
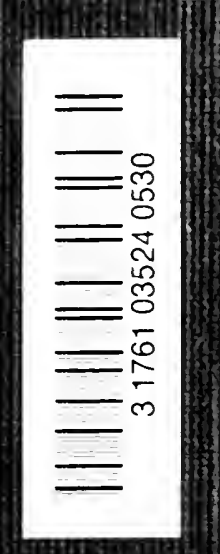


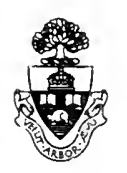

Presented to the

LIBRARY of the

UNIVERSITY OF TORONTO

by

Carleton University Library 


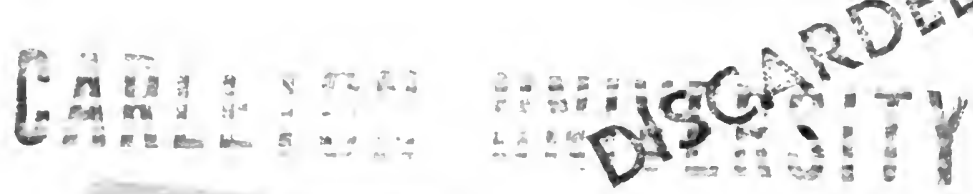

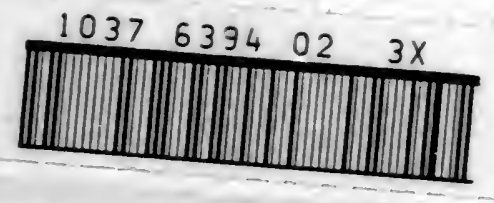




\section{CATTÁlOGO \\ DE LA \\ BIBLIOTECA DE SALVÁ,}

ESCRITO

POH D. PEDMo SALVi MaLLEx.

y cenriquccido

con la descripcion de olras muchas obras, de sus ediciones, elc.

\section{TOMO I.}

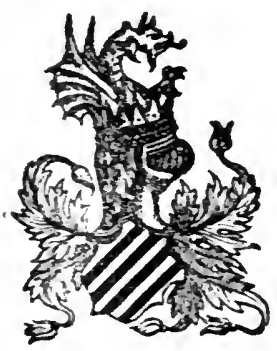

\section{HLENCIA,}

IYPRENTA JUE FERRER DE ORGA a cspaluas del Tealro Principal. 
5 


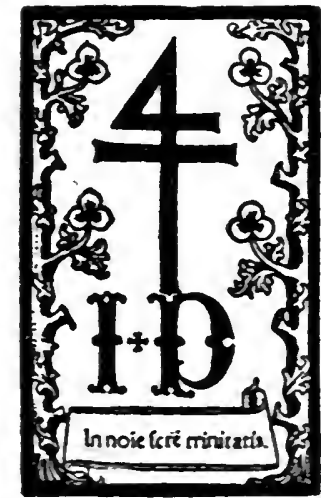

PORTER-LIBROS

EDITOR

Avda Puera del Angel, 9

BARCELONA-2 
Depósito legal B-28568-63 (I) 


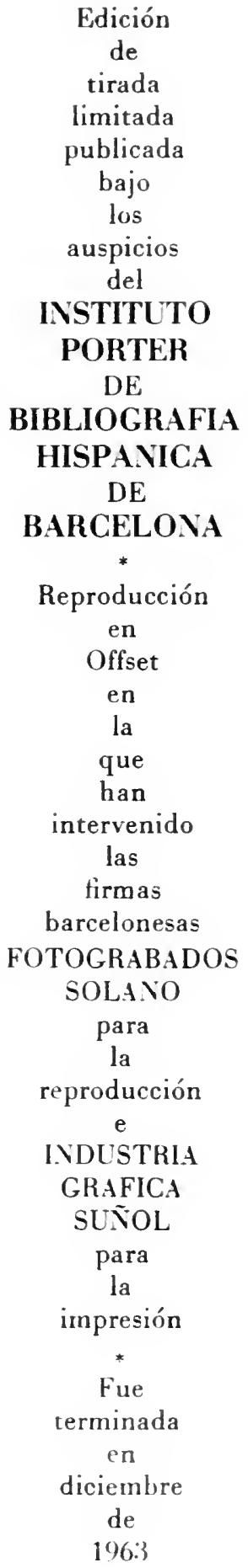




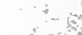

..

क्षे?

$-i=1$

(1)

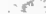

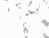

$\therefore$

2

?

$\therefore=$

$\therefore y^{2}$ 


\section{CATÁLOGO}

\section{DE LA BIBLIOTECA DE SALVÁ.}

TOMO I. 


\section{Salváy Pérez, Vicente

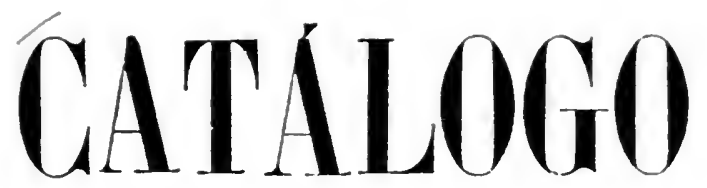 \\ DE LA}

\section{BIBLIOTECA DE SALVA,}

ESCRITO

\section{P0R D. PEDR0 SALVÁ Y MALLEN,}

EXKIOUECII) GOY LA JESCIRIPCION DE OTRAS MUCHAS ORKAS, DE SIS HIICIONES, HTC.

\section{TOMO $\mathrm{I}$.}

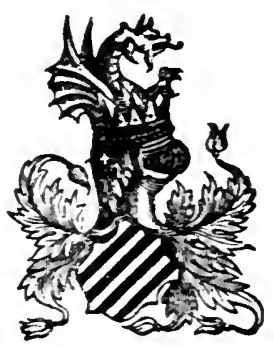

VALENGIA,

IMPRENTA DE FERRER DE ORGA, A ESTALDAS DEL TEATRO TRIYCIPAL. 


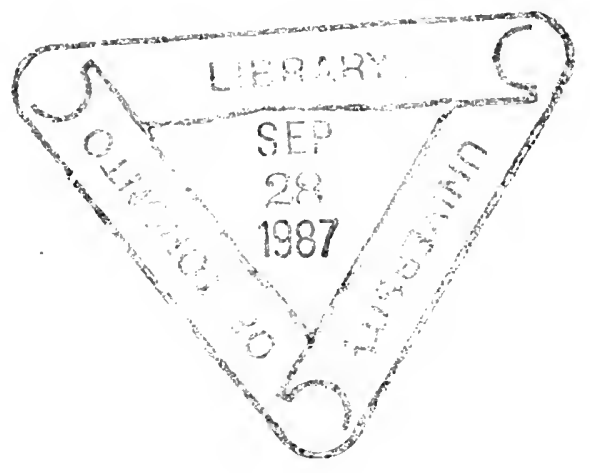




\section{PRÓLOGO.}

¡Cuán distante estaba yo en algun tiempo de pensar que llegase un dia en que tuviera que escribir el presente prólogo! Tal era lo difícil que me parecia el poder vencer el temor y aprension que de mi se apoderaban á la sola idea de acometer la coordinacion del presente inventario que, lo confieso francamente, no hubiera arrostrado esta empresa á no ser por las contínuas y reiteradas instancias de mis amigos, y por el deseo de dejar una memoria de las preciosidades que reunieron la inteligencia de un padre y la decidida aficion de su hijo. Perdóneseme, pues, mi atrevimiento, al ménos porque no me ha arrastrado el deseo de adquirir gloria; anticipadamente sé que no la merezco, y aseguro que me hallo mui ajeno á toda pretension literaria.

Los amantes de las letras sentirán con razon el ver que me ha tocado llevar á cabo un trabajo, que debia cerrar la lista de los muchos con que mi padre las ha enriquecido, sobre todo siendo este el que miraba con tanta predileccion, y al que se proponia dedicar los últimos años de su vida, cuando, desembarazado de ocupaciones mercantiles, pudiera consagrarle libremente su imaginacion. En efecto, al regresar á España hácia fines del año 1847 se trajo consigo su librería, la cual no quedó arreglada y en disposicion de poderse 
formar el índice hasta casi terminado el de 1848. Entónces dió principio á la redaccion de él, comenzando por formar las papeletas. Unos trescientôs artículos tendria hechos, cuando en mayo de 1849, huyendo de los rigores caniculares de nuestro pais, que tanto le agobiaban, y con el ohjeto de visitar algunas bibliotecas y verificar ciertos apuntes, que debian servirle para la redaccion de su apénas comenzado Catálogo, marchó á Paris en cuya capital murió el dia 5 de junio, cuatro despues de su llegada. Si á los bibliógrafos y bibliófilos fué indudablemente sensible esta pérdida, de mí sé decir que la llaga que abrió en mi corazon jamas se cicatrizará, porque con él dejó de existir no solo mi venerado padre sino mi idolatrado amigo.

Dos años se pasaron sin que yo me atreviera ni aun á mirar lo que habia dejado escrito del índice; y como por otra parte juzgaba que en los tres ó cuatro meses que á él se dedicó debia ser mui poco lo terminado de este trabajo, me decidí á condenar al olvido lo que solo padia considerarse como una lijera muestra, ó bien un pequeño ensayo de esta obra. Sin embargo, ántes de realizar tal determinacion examiné sus papeles y apuntaciones, $y$ al ver que la parte literaria no la habia comenzado mi padre cinéndose únicamente á la descripcion bibliográfica de los libros, es decir, á copiar los títulos, lugar y año de las impresiones, á fijar su tamaño y el número de hojas de que consta cada obra; cobré ánimo y me resolví á seguir el índice ó inventario de una Biblioteca que, por deberme su orígen $\left(^{*}\right)$, la miro con casi la misma predileccion que á mis hijos.

Para que no se crea aventurada esta ascrcion, copiaré lo que me decia mi padre en una carta suya que conservo, escrita en Valencia en 1843. Ne daba en clla instrucciones sobre la encuadernacion de ciertas obras, y al tratar del sello que debian llevar en las cubiertas, me decia: "Tendrá este dos manos enlazadas; la leyenda Bíblióteca de Salvá, yá un lado una $\boldsymbol{P}$ y al zotro una $V$, iniciales de tu nombre y del mio, porque á $t 1$ se debe primariamente el proyecto wde formarla: nunca olvidaré el dia en que me dijiste qne habias rehusado 550 fr. que te habian „ofrecido por el Romancero general de 1614, porque no querias que nos desprendiéramos de él "hasta tener otro ejemplar más hermoso. Eutonces te di facultad para que escogieras los que wmás te agradasen entre los libros raros que teníamos para vender; tú los recogistes y fur"mastes con ellos el primer cimiento de la coleccion. Ademas, has empleado tantas diligencias "y conatos para adquirir las obras con que la hemos enriquecido; te has ocupado á vezes wen trasformar un ejemplar, haciéndolo bello si era bueno, ó dejándolo decente cuando ántes „era malo, lavíndolo, quitando la tinta y las manchas, remendảndolo, añadiéndole papel al nmárjen, y hasta copiando portadas y hojas que se equirocan con las impresas. Nuestras zmanos deben estar unidas aquí como otro monumento de que esta Biblioteca es debida á wnuestros afanes comunes, y están unidas como lo están nuestros corazones.» 
Pero una vez engolfado en mi tarea, rellexioné que una nomenclatura tan árida no podia ser de utilidad alguna, ni tener el menor atractivo ni aliciente para los aficionados; y entónces determiné ampliar un poco mi trabajo, dándole mayor estension, bajo el sistema que voi á esponer.

Fruto de las investigaciones de mi padre y mias, y de las apuntaciones tomadas por ambos en las Bibliotecas públicas de España, Francia é Inglaterra, y en las particulares del honorable Thomas Grenville y las de los Sres. D. Pascual de Gayángos, D. Agustin Duran, D. Jacobo de Parga, Mad. Binns, Mr. Charles Nodier y otras varias que ahora no recuerdo; obraban en mi poder las descripciones de muchas obras raras, poco conocidas de los bibliógrafos, y cuya existencia continuaria tal vez ignorada si no se las diera á conocer por medio de la prensa. Decidí, pues, el intercalar la mayor parte de aquellas apuntaciones en mi Catálogo, aprovechando la ocasion de hacerlo al anunciar otra obra del mismo autor, ó tener que hablar de algun libro cuya materia estuviese relacionada con la del que me proponia dar á conocer.

Como todas estas adiciones van siempre embebidas en las notas, y solo forman cabeza de artículo y llevan numeracion las obras que yo poseo, es muy fácil hacerse cargo á primera vista de los libros que tengo, así como de los que cito para ilustracion ó complemento bibliográfico; poniendo, respecto de estos últimos, un cuidado especial en decir si los he visto, ó de dónde he sacado la noticia.

Estas indagaciones y consultas me han precisado á manejar con frecuencia la obra de Nicolas Antonio, y ver sus errores; por lo mismo se observará que mui á menudo rectifico, corrijo, y aun adiciono alguna vez á este autor, ya sea haciendo notar que una edicion le fué desconocida, que á tal ó cual autor no lo menciona, que equivoca la fecha de algun libro, ó su tamaño, etc. Sin enbargo, no se crea por esto que mi objeto ha sido rebajar el mérito de una de las mejores obras que en su género se han escrito, y que podemos citar con orgullo los españoles. Pocos harán ciertamente la justicia que yo al distinguido autor de la Bibliotheca hispana vetus et nova, porque pocos tambien son los que por práctica conozcan la dificultad que of rece la formacion de esta clase de obras; 
y la misma veneracion y amor con que la miro, me animan en mis observaciones para que, si volviera á reproducirse, contribuyan estas notas á hacer que desaparezcan los lunares que empañan tan brillante lumbrera.

Lo mismo debo decir con respecto á Mr. Brunet: cada vez que abro su Manuel dic libraire me lleno de asombro, por parecerme esfuerzo sobrehumano el que una sola persona haya tenido el talento, la constancia y hábilidad de recoger, ordenar y amenizar la inmensidad de noticias instructivas, y las indicaciones curiosas que en él se hallan reunidas, sobre todos los ramos de las ciencias y de la literatura. Si á cualquiera le arredra y atemoriza el deslindar algunos de la peculiar de un solo pais, ¿qué deberá suceder al que como cosmopolita los abraza todos? El poco miramiento y lijereza de los que han criticado tan útil recopilacion de datos bibliográficos, que confieso haber aprovechado en muchos casos, parece deben probar lo distantes que están ciertas personas de las condiciones necesarias para apreciar empresa tan gigantesca. Así, cuando circunscrito á la buena literatura española, noto alguma equivocacion de Mr. Brunet, ó insisto minuciosamente en advertir las que por casualidad se han acumulado sobre algun escritor, como sucede respecto á Tirso de Molina, debe creerse que solo es con la única mira de que no se sigan las inadvertencias de un libro que, por su exactitud, ticne el derecho á que se le considere como autoridad en todo lo que dice.

Aunque no pretendo que mi Catálogo sea mirado como una bibliografía completa española, pues sé que en esta clase de libros es mui fácil se deslice algun error, que falten muchas obras totalmente, ó la cita de algunas ediciones de ellas; habiéndome propuesto con especialidad el tratar de las obras de Caballerias, los Romanceros y Cancioneros, los Autores dramáticos, los Poetas y Novelistas, los tratados de Música y Refranes, ya parece que podrá indicarse ahora como una prueba de la rareza de un libro el que yo no tenga alguno antiguo que pertenezca á estas clases: no obstante de que esta regla puede ser falsa aun en ciertas ocasiones.

Los colectores de libros solemos tropezar con casualidades que parecen increibles. ¿Cómo podrá creerse que yo, que he reunido 
antas preciosidades, algunas únicas, de nuestro Parnaso, no he podido nunca adquirir las Poesias de Litala y Castelvi? Por eso es un absurdo el que se lıaya repetido mil vezes en Catálogos de Inglaterra, Francia y Alemania, que un libro era raro porque no lo citábamos ó mencionábamos en los nuestros de Lóndres; sin cuidarse de que esto era debido tan solo á que en tal época no lo teníamos de venta. Perdonable hubiera sido que alguien hubiese incurrido una vez en esta vaciedad; pero parece increible se repitiera con tanta frecuencia por los libreros de los tres estados de mayor ilustracion de Europa. ¿Arguye acaso en pró ó en contra de la rareza de un libro que lo tenga ó no lo tenga un librero? ¿Podrá nunca decirse que mi padre no conocia esta ó aquella obra, porque no se encontraba en el Catálogo de los libros que tenia venales? Si esta tontada, que así debe llamarse, solo puede servir para escitar el buen humor, nr debe empero decirse otro tanto de las imputaciones que parecen hijas de la mala fé, con el objeto conocido de arrancar mayor precio por los libros. Mr. P. Jannet al anunciar en 1847, en el núm. 101 del Catálogo de M. ${ }^{a}$ O. E. Van Hippe (personaje ideal), la edicion de 1539 del Cortesano, de Castellon, no tuvo reparo en poner la nota siguiente: Bel exemplaire d'une édition inconnue à Antonio, qui cite conme la première celle de 1559, et à $\mathbf{M r}$. Salvi', qui relève l'erreur de ce dernier, en indicant à son tour comme première l'édition de 1544. Sin embargo, mi padre no llamó primera á dicha edicion, ni la incluyó como tal en la lista de First editions, que se halla en la pág. XXVII de los preliminares, contentándose con decir, arreglado á la más estricta rerdad: This edition, which is of a very early date, was unknown to Antonio The older edition he mentioned is that of 1559. Sin salir de este Catálogo de Mr. Jannet, y para que se vea la lijereza de ciertas personas, hablando en el núm. 243 de Las cuatrocientas respuestas, de Escobar, dice: Ouvrage trèsrare, sur tout la seconde partie, que $\mathbf{M r}$. Salvá avvue n'avoir jamai, vue (Catalogue de 1826).

Yo mismo al leer esto, crei que en efecto mi padre hacia esta confesion, que ciertamente no probaba una gran cosa, porque al año de haberse dedicado á la libreria antigua, mui escaso de recursos pecuniarios y en un pais estraño, no debia parecerlo que no liubiese Том. I. 
¿11u caido en sus manos la segunda parte de Las cuatrocientas. Pero ¿quién podrá creer que la tal suposicion era gratuita, pues que mi paclé se limitó á prevenir solamente en el núm. 749 de dicho Catálogo, que no tenia de venta sino la primera parte (The first part only), y en el núm. 2915 de la segunda parte del mismo Catálogo, que redacté precisamente yo en 1829, espresé que ya teníamos las dos, lo que no debia ignorar Mr. Jamnet? Hago estas observaciones, no tanto para escusar errores en casos en que mi padre estuvo mui distante de cometerlos, sino para que el público esté prevenido contra la lijereza y charlatanería de personas que escriben y publican la idea que primero se les ocurre, sin curarse de la verdad de Jo que afirman, y sabiendo á vezes (lo que es infinitamente peor) ser falso aquello mismo que aseguran. El furor de la garrulidad insustancial ha llegado á tal punto, que en el Catálogo de que estamos. tratando, se alega al núm. 100 como un mérito el estar un libro lleno de pasajes borrados, y el que le falten por entero dos hojas. Reste à savoir (prosigue mui formalmente el redactor) si cette mutilation même ne lui donne pas un interèt particulier, en faisant connâ̂tre l'esprit qui a guidé le Saint-Office dans ces suppressions. Los compradores no debieron pensar que estas circunstancias recomendaban mucho el mutilado libro, cuando sé que no ofrecieron por él ni un franco.

Despues de lo espuesto chocará probablemente á algunos que yo aduzca á vezes como prueba de la suma escasez de un libro el que no lo turo Mr. Ricardo Heber, ó que no se encuentra en sus Catálogos. Esta estrañeza debe sin embargo dejar de serlo, si se reflexiona que aquel caballero fué sin disputa alguna la persona que ha reunido mayor número de libros raros españoles. Mui aficionado á nuestra literatura, que conocia perfectamente; dedicado por muchos años á recoger esta clase de preciosidades en Inglaterra, su patria, y en Paris, que son los dos mercados clonde se presentan todas las mercancias de grande estimacion; con medios pecuniarios para dar libre curso á su aficion favorita, y sin perdonar gasto alguno para ello, llegó Mr. Heber á juntar un número que sorprende de las obras más escasis, llevando su furor bibliómano hasta tener cuatro y seis ejemplares'de cada una de ellas. Brunet ha hecho perfectamente en 
estractar su Catálogo para completar el Manıel, sobre todo en la parte española. Puede mui bien afirmarse por consiguiente, que obra que no poseyese Heber, es mui difícil se presente nunca ocasion de adquirirla.

Algunas personas hubieran deseado que yo fijase precios á las obras; no lo he hecho por varias, y á mi modo de ver, fundadísimas razones. En los libros hai modas como en todo, y el gusto en este ramo raria tanto ó más que el de los trajes; así es que en época no mui lejana tenian un valor escesivo las ediciones Aldinas, las de los Estéfanos y los Grifos, miéntras que las de los Elzevirios andaban malparadas, vendiéndose á 6 y 8 reales cada tomo de los clásicos que imprimieron. Pues bien: en la actualidad hai muchos volúmenes publicados por los primeros, á los cuales casi no se da más valor que el que puedan tener para papel de envolver, interin que los últimos son buscados y bien pagados; debiendo notarse que aun entre estos podrá raler 3 ó 4 pesos la edicion genuina del César de 1635 , en tanto que fácilmentè se obtendrian 800 reales del Pastissier françois de 1655. Hai más, el César de 1635, de que acabo de hablar, con solo tener cuatro pulgadas y nueve líneas vale unos 30 francos, $y$ en la venta de Gouttard produjo 160 por tener una línea más de tabla. Puede asegurarse sin miedo de errar, que todas las obras que en la venta de La Vallière obturieron altos precios están hoi dia mui abatidas, miéntras que han subido á las nubes los. Misterios, y pliegos sueltos de poesía antigua francesa, por los cuales allí apénas quiso nadie dar arriba de 6 í 8 francos.

Esta es la razon por la cual considero las ventas públicas como una guia mui poco segura para conocer el valor de los libros. En el corto intérvalo de diez meses vi vender en Lóndres dos ejemplares de la Chronica de Muntaner, edicion de Barcelona, el primero por 10 guineas, y el segundo que era mucho más bello lo compró mi padre por un shellin. Cuando hai competidores sube á un precio fabuloso un libro, que lo obtiene mui reducido en otras circunstancias. Ademas, si en las obras antiguas y raras el valor es siempre relativo á su estado de conservacion, comparado con otro ejemplar, ¿como será posible en ese caso establecer el grado de aprecio pe- 
cuniario sin tenerlos ambos presentes? Una hoja manuscrita, una lijera polilla, la ẹscasez de márjenes, manchas ú otras imperfecciones, insignificantes muchas vezes á ojos inespertos, rebajan de una manera estraordinaria el valor de los libros. Es con todo innegable que no se hace el mayor gasto para llenar la parte principal de los estantes de una Biblioteca, aun de libros preciosos, si no para completarla con los de esta ú otra clase, ó de las varias ediciones de una misma obra. Aqui entran los mayores sacrificios, sacrificios à que se somete casi siempre el bibliómano, si los medios de que puede disponer guardan proporcion con su voluntad.

Debo añadir á las razones que llevo indicadas para no fijar precios á los libros, la de que en muchísimas ocasiones se pondria en terrible confusion al que se guiara por ellos, esponiéndole á vezes á desperdiciar lá adquisicion de un buen libro, ó haciéndole pagar una cantidad escesiva por otro de poco valor. Yo preguntaria á los que lanta aficion tienen á estas caprichosas tarifas, ¿de qué podría servirles el saber que la Poliglota, de Arias Montano, produjo unos 158 pesos en la venta de Sykes, y solo 30 en la de Bowtourlin? En vista de esta desproporcion, ¿podrán decirme cuál es su verdadero valor? 'Tambíen supongo que se guardarian bien de comprar el Currascon de 1633, que es uno de los libros castellanos más raros, si les pidiesen por él 30 reales, sabiendo que en la venta de Ja Serna Santander solo produjo 6, á pesar de llevar una nota mui curiosa de este bibliógrafo. Ejemplos parecidos á estos podria citar á centenares. Sin embargo, no quiero dejar compìetamente á oscuras á los neófitos y á las personas que se hayan dedicado poco al rebusco de ediciones antiguas, y les daré algunas reglas generales más seguras para conocer el valor intrínseco y permanente de ellas, lo cual creo preferible á saber el efímero y pasajero de la moda ó el capricho. Advierto ante todo que mis apreciaciones son puramente bibliográficas, $y$ de ningun modo se refieren al mérito literario de las obras, que suele estar muchas vezes en oposicion con su aprecio mercantil.

1. ¿ Son de primera rareza aquellos libros que se sabe de fijo ó se sospecha que han sido impresos, y sin embargo no se tiene noticia de qué exista ejemplar alguno de ellos, como sucede con la 
Biblia lemosina, del hermano de San Vicente Ferrer; el tomo primero del Viciana, y el Buscapié de Cervántes.

2. Entran en segundo lugar aquellos otros de que no se sabe exista más que uno ó pocos ejemplares, como Les òbres $y$ tròves de Mosen Fenollar; La Turiana, de Timoneda; el Tirant lo Blanc, impreso en Valencia (para mí todavía es más rara la edicion de Barcelona, que nunca he visto, y la traduccion castellana de que solo conozco un ejemplar en Lóndres); la primera edicion de la Crónica del Cid; la Rosa de romances, de Timoneda, y todos aquellos á los cuales llamo yo rarisimos ó escesivamente raros en el presente Catálogo.

$3 .^{a} \quad$ Vienen en tercer grado los libros de que solo mui de tarde en tarde aparece algun ejemplar de venta, ó que son mui pocos los aficionados que los poseen. Pertenecen á esta clase la mayor parte de los Cancioneros y Romanceros, los libros de Caballerías, muchos de los que tratan de Música, Caza, Juegos y Refranes, todas las Comedias en letra gótica, los Romances impresos en la misma letra $y$ en pocas hojas, por lo difícil que ha sido su conservacion, y las colecciones completas del Teatro de Lope, Tirso de Molina, Guillem de Castro, los Poetas valencianos, ó la Coleccion antigua de Comedias en cuarenta y ocho volúmenes. Respecto á estas obras y á las demas que se hallan en igual categoría, y pertenecen á otros ramos, he tenido cuidado de advertir en el presente Catálogo que son mui raras.

$4 .^{a}$ En cuarto grado de rareza deben contarse, porque efectivamente no se halla con facilidad ocasion de adquirirlas, casi todas las ediciones de nuestros Poetas, Novelistas y Autores dramáticos posteriores á 1560 y anteriores á 1610 . Sirva esta regla para todas las que se encuentran en el presente Catálogo, pertenecientes á este género, $y$ en las cuales he omitido la calificacion de raro por no repetir tan á menudo este adjetivo.

.5. ${ }^{\text {a }}$ Se reputan como escasos los libros cuyas ediciones, aunque más recientes, ó se han tirado en corto número ó se hallan del todo agotadas, $y$ de consiguiente suelen encontrarse por casualidad. A esta clase pertenecen los que habiéndose impreso en tiempos modernos, han sido destruidos en su mayor parte por alguna 
circunstancia fortuita, como sucede con las Obras de Gil Vicente, impresas en Hamburgo.

6. ${ }^{\text {a }}$ Tienen un valor ocho ó diez vezes mayor comparativamente los ejemplares impresos en vitela ó pergamino, y de un doble por lo ménos sobre dicho valor los de gran papel.

7. ${ }^{a}$ En todas estas clases, tambien respectivamente, gozan de mayor aprecio bibliográfico los libros en lemosin y vascuence, ó los escritos en algunos de los dialectos de América.

A pesar de la anterior clasificacion nunca se debe perder de vista, que el precio de un libro pende de su rareza respecto de otro de su clase, ó de su rareza combinada con el interes que inspire el contenido de una obra si la comparamos con otra. En atencion á lo primero, puestos en una venta el Tirant lo Blanc de la primera edicion de 1490 , el de la de Barcelona de 1496, ó la traduccion castellana del mismo de 1511, no sabria por cuál dar mayor precio, porque como he dicho ántes, del primero conozco tres ejemplares, miéntras que del segundo y tercero solo sé que exista $u$ ejemplar y ambos están faltos. Y en razon de la clase y contenido se aprecia más un tomo de Poetas, de mediana rareza, de 1620 por ejemplo, que el Regimiento de principes de 1494, los Cinco libros de Séneca de 1491, etc., etc., y acaso que el Carrascon, que indisputablemente pertenece á la segunda clase.

No ha faltado quien manifestara su opinion de que, al redactar este Catálogo, me hubiera limitado á dar á conocer la impresion más completa, de mayor correccion ó la más apreciable edicion de cada obra, y hasta ha habido quien se me ha burlado al ver mi afan por conseguir una edicion de algun libro del cual ya poseía más de veinte. A todos les diré que entiendo que no hai vicio en juntar muchos libros, si se leen y de ellos se saca algun fruto: Luciano en sús Diálogos se dirige contra el que los tiene por aparato, por lujo ó por vanidad. Hi padre en la Introduccion al Diccionario de la lengua castellana, hizo ver lo mucho que le habian servido para aquel trabajo las varias y antiguas ediciones de nuestros clásicos, y que es indispensable las consulte el que se dedica al estudio de las buenas letras. Yo mismo no hubiera podido indicar en este Catálogo qué ediciones eran las mejores y preferibles, como lo hago en varias ocasiones, si no 
hubiese podido cotejar unas con otras: tarea que solo puede practicarse cuando se hallan reunidas en una biblioteca propia. Pero como el hombre raras vezes se detiene en el medio virtuoso, es mui dable que decline en algun estremo que no le sea fácil justificar. Yo, por ejemplo, no me tengo por bibliómano en el hecho de haber reunido cuantas ediciones antiguas he podido allegar del Quijote, Guzman de Alfarache, Celestina, Ausias March, elc.; pero ¿cómo escusarme de pertenecer á tan ilustre cofradía cuando me afano igualmente por las de autores insignificantes, pago grandes precios por un ejemplar que tenga dos líneas más de márjen que el que poseo, ó gasto en su encuadernacion ó tanto más que lo que vale el libro? D. Ricardo Heber era poco mirado en el estado de los ejemplares, ni en la belleza de sus cubicrtas; en cámbio acumulaba, cómo ya dije ántes, una docena si podia de la misma edicion, capricho que tanıbien lo era de Gallardo, porque los bibliófilos todos han de tener una manía, así es que Dibdin llımó á esta pasion book madness. El uno solo quiere libros sobre vitela, el otro únicamente las ediciones llamadas incunables, ó sean las primitivas del siglo $\mathrm{XV}$, aquel se desvive por las de los Aldos ó los Elzevirios, este se afana en busca de las encuadernaciones antiguas de Grolier, Derome, Roger Payne, Padeloup, etc., miéntras que otro no quiere en șus estantes ningun libro que no haya salido de las manos de Douru, Bauzonet, Dusseuille, etc.; y mi amigo el amable é instruido Cárlos Nodier, habia desterrado de su biblioteca todas las obras cuyo tamaño fuere mayor que el de $4 .^{\circ}$, y solo quebrantó esta regla para dar cabida á la primera edicion de las Obras de Ausias March. ¿De qué, pues, hai que admirarse? Somos hombres, y con esto se ha dicha todo: Estos caprichos por fin dan de comer á los libreros, á los encuadernadores, á los que hacen las ventas públicas, y á nadic perjudican, como no los tenga un padrc de familias, ínterin deje perecer de liambre á sus hijos por el estravagante placer de comprar una edicion en letra gótica, ó un ejemplar en gran papel.

Tampoco falta quien haya censurado las espléndidas encuadernaciones de mi Biblioteca: con todo, el encuadernar lujosamente los libros raros y de mérico, no es una estravagancia caprichosa, sino una prudente precaucion para preservarlos de que perezcan. 
¿Cuántas vezes se les habrá empleado como papel para envolver o para encender la lumbre, por verlos manchados, apolillados, mal pergeñados ó rotos! Pero cuando un colector los hace recomponer, procura completarlos, los lava si lo necesitan,' $y$ les echa por fin una encuaderuacion de valor, hasta el más idiota los respeta; y si caen en sus manos, al momento dice: Este debe ser algun gran personaje, cuando anda tan bien vestido; y ya que no lo entienda, busca quien pagne lo que juzga debe ser una joya: y hé aquí salvado un. libro que de otro modo habria perecido. De consigniente, el que reprueba el gusto de las encuadernaciones costosas, reprueba tambien el de los literatos que reimprimen las obras apreciables de nuestros mayores, porque uno y otro tienen el objeto de perpetuarlas. Ademas, para mi es tan esencial ver el libro bien encuadeqrnado en mi Biblioteca, que liasta creo no pertenece á ella el que carece de este requisito, $y^{-}$manifiesta que el volúmen está falto, manchado ó corto de márjenes: circunstancias que disminuyen en gran manera el mérito de las obras raras. Por este motivo mi ánimo se esplaya cuando tiendo la vista por los dilatados eștantes que la componen, y veo al lado de las buenas encuadernaciones antiguas y orijinales que conservan algumos libros, como los de De Thou, Colbert, etc., las espléndidas ó únicamente sencillas de Lewis, Roger Payne, C. Smith, Derome, Mackenzie, Simier, Thoavenin, Purgold, Bedford, Busseuille, Muller, Kœhler, Ihrig,. Hering, Bauzonet, Bauzérian, .Closs, Thompson, Dourn, y las no menos bien acabadas de mi paisano Beneito y de mi buen tio Fr. Mateo Mallen, cuyos nombres perpetuará la duradera vestidura con que han engalanado las obras más buscadas por todos los literatos. Hablo aquí de la biblioteca que reunen estos parc consultar, pues los libros que se manejan de contínuo, los llamados de estudio, ya se sabe que basta estén encuadernados decente y fuertemente, á fin de que sirvan para el ohjeto á que se les destina.

Despues de lo que acabo de decir, puede que algunos estrañen que al describir las obras no haya mencionado casi nunca ni el estado del ejemplar, ni la clase de manto ó paludamento, permítaseme la frase, de que ra ataviado: estos detalles los he creido completamente inútiles para el literato y para el bibliógrafo, y á lo más solo 
podrian servir para satisfacer la vanidad de su dueño. Baste, pues, saber que en general los libros que contiene este Catálogo se hallan en el mejor estado de conservacion; que son poquisimos los tomos que no llevan una rica encuadernacion, y que en las cubiertas de todos ellos se halla el presente sello:

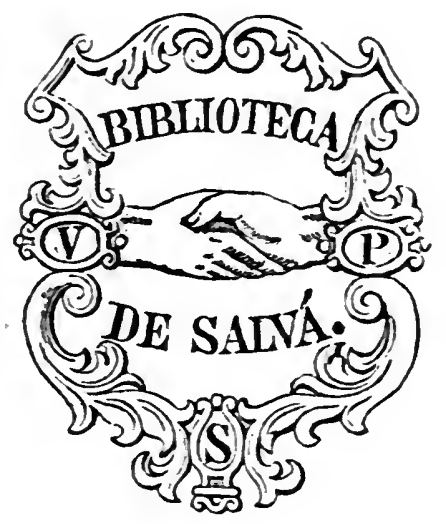

Si no hubiera esplicado ya el significado de este escudo, aprovecharia la presente ocasion para hacer ver que ni remotamente lo es de nobleza aristocrática, que no me pertenece ni ambiciono.

Es costumbre mui admitida, y casi necesaria, el que obras de esta clase vayan adornadas de facsímiles. He juzgado convenientemente que estos fueran de los retratos de los autores, escudos ó marcas de los impresores, y algunos que nos hicieran conocer los trajes de la época y el estado de las artes en los tiempos pasados. Los primeros son mui apreciables, porque habiendo sido sacados de ediciones contemporáneas los retratos de los sugetos que representan, hai una casi seguridad de la exactitud de su parecido. La utilidad de los segundos, ó sean las marcas y escudos de los impresores, es innegable, pues no pocas vezes se puede rastrear por ellos á quién se debe, $y$ la fecha aproximada de una edicion que carece de nombre de impresor y de año; y los otros son mui útiles y curiosos, porque algunos de ellos, como el escudo que lleva el Blancas Arag. rerum commentari, nos demuestran que el grabado sobre madera en el siglo XVI dejaba ya poco que desear en España.

Pasemos ahora á bosquejar el plan ó método que he seguido en la

Tox. I. 
coordinacion de esta obra, dando al mismo tiempo algunas esplicaciones para su mejor inteligencia y más fácil manejo.

Como al formar esta Biblioteca no nos propusimos hacerla general, si no que abrazase los nueve ó diez ramos más apreciados y buscados de nuestra literatura, me ha parecido tambien conveniente dividir la obra en secciones ó grupos, para que los aficionados á cada uno de ellos puedan encontrar reunidos al primer golpe de vista aquellos artículos que más llamen su atencion, ya sean como objeto de estudio ó de curiosidad.

Esta clasificacion, sin embargo, of rece alguna dificultad, porque hai ciertos libros cuyo contenido los llama á figurar en dos y á vezes en mayor número de las secciones; en este caso he descrito la obra circunstanciadamente en aquella seccion donde con más derecho le corresponde estar, y en las otras he indicado por medio de remisiones dónde debe buscarse.

Forma la primera parte como la más completa, notable y rara de mi coleccion, la de bellas letras, y en ella se encuentran los Pliegos sueltos de poesía popular, los Cancioneros, los Romanceros, Antologías y Poetas varios; los Autores dramáticos desde los primitivos ensayos del Teatro español, y las Novelas y libros de entretenimiento, á cuyo frente figuran los libros de Caballerias.

La parte segunda, que pudiéramos llamar científica y recreativa, encierra las obras pertenecientes á la Paremiología, ó likros de proverbios, refranes, etc.-Poligrafía.-Caligrafía.-Paleografía.-Bibliografía.-Música y Baile.-Juegos de suerte y de destreza.-Pintura. - Escultura. - Arquitectura. - Matemáticas. - Metalurgia. Agricultura.-Arte militar, Gineta, Albeitería y Esgrima.-Tauromaquia.-Cetrería y Caza.-Medicina, Cirujía y Farmacia é Historia Natural.

Comprende la tercera parte la Historia, y en ella he incluido, ademas de los autores que han escrito la Política y la Religiosa de todos los paises, las obras Biográficas, las de Heráldica, Genealogía, Numismática y Antigüedades._Lejislacion, Jurisprudencia, Economía política. - Astronomía. - Astrología. - Geografía. - Cosmografía.-Navegación, Viajes é Itinerarios; por la relacion que tienen todas estas materias con aquel asunto. 
Quedan solamente para la parte cuarta las obras Teológicas, Ascéticas y Morales; y las que llamo Misceláneos por no relacionarse con ninguna de las materias antedichas.

Se entiende que en toda esta clasificacion solo se da cabida á obras escritas en castellano ó en alguno de los dialectos de la Península ó de sus posesiones de Ultramar, así como á las escritas por autores españoles; aunque las hayan publicado fuera de España, y á las impresas en esta nacion á pesar de ser estranjeros sus autores y no haberlas escrito en castellano. Unicamente en los libros bibliográficos me he separado algo de estas reglas, pues he puesto aquellas obras que sin embargo de estar impresas en otros paises, y no ser sus autores españoles, traen sobre nuestros escritores noticias bastante considerables para que las consultemos con provecho.

En el encabezamiento de cada seccion he dado más estensos detalles acerca de las obras que he juzgado incluir en ella, limitándome aquí á indicar mui en resúmen el contenido de cada una. A continuacion de la Seccion Dramática he puesto un Repertorio alfabético de todas las composiciones de este género que poseo, bien sean en colecciones ó sueltas, con el objeto de fácilitar el busque de las piezas al que desee consultarlas. Me ha parecido ademas conveniente indicar á continuacion de cada una el tomo donde se encuentra, siempre que haya sido coleccionada ó incluida en alguna obra.

Cierra el todo una Tabla general de los nombres de los autores, y de las obras anónimas que con cualquier motivo se citan en el presente Catálogo, acotando el número del artículo donde se les menciona, y precediendo un asterisco $\left({ }^{\star}\right)$ á aquellos cuya cita debe buscarse en la nota del artículo; de este modo se encontrarán con mucha más facilidad.

Al designar los tamaños de folio, cuarto, octavo, etc., me he atenido al número de hojas en que está dividido cada pliego, el cual ha sido mui pequeño en España hasta nuestros dias, y lo fué generalmente en las demas naciones en los primeros siglos de la imprenta; por consiguiente, cuando les añado la calificacion de mayor (may.), ó marquilla (marq.), ha sido con referencia al grandor antiguo.

Llamo folios á las hojas que solo llevan numeracion en el blanco, y páginas cuando la tienen tambien en el reverso; y designo el nú- 
mero de las unas y de las otras con arreglo al último de la obra, sin hacer caso de las equivocaciones intermedias, á no ser cuando puedan inducir sospechas de que acaso el libro estê falto, hallándose completo ó yice-versa.

Siempre que cito á Nicolas Antonio me refiero á la última edicion de su Bibliotheca adicionada por Pérez-Bayer, y al mencionar el Manıel de Brunet es siempre á la impresion de 1842-44.

Cuando no espreso que las láminas están grabadas en madera, se entiende que lo son en cobre.

Las obras que llevan nombre de autor van al de este y nunca al del traductor, por ser el sistema adoptado entre todos los bibliógrafos modernos de alguna nota; ademas, el sentido. comun así indica que debe hacerse, porque si se colocasen al de los intérpretes se pondria en terrible aprieto á quien desease saber cuántas versiones españolas existen de las Obras de Tácito, de las Lusiadas de Camoëns, de las Metamórfosis de Ovidio, y otras muchas.

Si el autor tiene dos apellidos, va siempre puesto por el órden alfabético que corresponde al primero, y solo me he separado de esta regla en aquellos que son más conocidos por sus tíiulos de nobleza, como por ejemplo Mondéjar.

Las obras anónimas van colocadas en la primer palabra sustantiva $\dot{o}$ adjetiva del fróntis, y los libros de Caballerías en el nombre del paladin cuyas proezas relata el libro. En todos estos casos al principio del artículo he adoptado siempre la ortografía moderna, y con arreglo á ella se sigue dicho órden alfabético. Aquí observaré para inteligencia de los estranjeros que en castellano la $\mathrm{CH}$ va despues de la $C$; la LL española á continuacion de la $L$, y la $\tilde{N}$ tambien española, tras de la $\mathrm{N}$.

Digo que un libro está sin cortar ó intonso, circunstancia mui apreciable para los bibliómanos, cuando el ejemplar se encuentra con todas sus barbas; que tiene hojas sin cortar, cuando este hecho prueba que las márjenes son espaciosas por haber profundizado tan poco la cuchilla del encuadernador que ha dejado testimonios de su conciencia (sin duda por esta razon los franceses dicen: avec témoins); y por fin, cuando noto que está sin abrir, es que todavía conserva las hojas unidas, y por consiguientè mayor evidencia de su belleza. 
Nunca califico al ejemplar de gran papel, sino cuando me consta que los hai de dos clases, y no cuando todos se han tirado en uno mismo, aunque con grandes márjenes, como sucede en la primera edicion de los Análes de Zurita.

Al copiar las portadas de las obras he suprimido casi siempre los títulos, condecoraciones, pátria ó vecindad del autor, los nombres y calidades de los Mecénas ó personajes á quienes van dedicadas; el del sugeto á cuya costa se hacia la edicion ó el del encargado de su venta; la tasacion y precio del volúmen, y si se imprimia con privilegio. Tampoco he detallado el contenido de las hojas preliminares más que en ciertos y rarísimos casos, en los que lo he creido útil ó necesario $\mathrm{y}$ en aquellos en que convenia hacerlo para facilitar el ajuste ó colocacion de algun grabado. Todas estas nimiedades de poco sirven, y generalmente las han callado los bibliógrafos alemanes, ingleses y franceses, que han sido nuestros maestros. Lo preciso é indispensable es el relacionar todo lo que el fróntis diga relativo al contenido de la obra, su division, variantes, adiciones ó impresiones de la edicion de que se trata, guardando escrupulosamente la ortografía, $y$ hasta copiando las erratas tipográficas por groseras que sean; con espresion del número exacto de hojas de que consta el tomo en páginas ó folios, segun en él se indiquen, ó bien sus signaturas, si carece de aquella numeracion, no omitiendo el notar las hojas blancas cuando estas completan pliego.

He tenido especial cuidado en advertir si las obras están impresas en letra cursiva ó gótica; por lo mismo no se crea que solo son de la última los libros en cuyos títulos ó descripciones empleo esta clase de carácter, pues solo se han distinguido así algunos, ņo porque los demas no estuviesen impresos en carácter gótico aleman, sino porque los que se han señalado, son los que of recian ménos dificultad para ser imitados, y tienen las lineas más cortas para ajustarlas mejor al ancho de las colunas ó páginas; ya tambien por no hallarse en dichos títulos gran número de abreviaturas, signos, viñetas, orlas, adornos ó letras caprichosas, que de haberse grabado espresamente habrian tenido un coste exorbitante, siendo ademas práctica constante en esta clase de obras el dar solo alguna muestra ó facsímile de vez en cuando. 
Las crratas tipográlicas de los originales van anotadas de letra cursiva, para indicar que no es descuido mio cometido al corregir las pruebas.

Alguno me objetará tal vez que el intercalar algunas letras cursivas en nombres que están con caractéres redondos hace feo á la vista; peor efecto hace el poner en algunos títulos tres ó cuatro rezes (sic), y esto tendria ademas el inconveniente de interrumpir á cada paso la lectura. Y si alguno me dijere que cuando las erratas son evidente y claramente tipográicas debia haberlas corregido, me limitaré contestándole que entiende poco de bibliografía.

Cuando en el título de un libro va algo intercalado ó puesto entre paréntesis y de letra cursiva, debe entenderse que lo que así se encuentra está suplido por mi y no lo dice el original. Si al describir algun libro hai en un titulo puntos suspenşivos (...), indica que hai suprimidas algumas palabras que suelen generalmente ser de poca importancia, como los títulos del autor, su patria ó vecindad.

En los preliminares tambien he omitido especificar minuciosa y constantemente quiénes eran los aprobantes, si tienen ó nó privilegio, licencia y tasa, y las fechas de todos estos documentos. Esto sirve de mui poco en la generalidad de las obras; llena papel inítilmente, y es práctica inusitada por los maestros modernos de bibliografía. En obras escesivamente raras é importantes me he estendido algo más en aquellos detalles.

La aficion que toda mi vida he tenido á la bibliografía, las ocasiones de ver y manejar ediciones antiguas que me ha proporcionado mi asistencia contínua á la mayor parte de las ventas públicas de libros que ha habido en Inglaterra y Francia durante veintidos años, y los minuciosos y detenidos exámenes y rebuscos que he hecho en las principales bibliotecas conocidlas, han acostumbrado mi vista, $\mathrm{y}$ me han dado tal ojo para clasificar las impresiones, que me atrevo á fijar la fecha de las obras con tanta precision y certeza, que al marcarla en los libros que no la llevan, casi me atrevo á responder no me equivoque en diez años del en que se imprimieron, y hasta en ocasiones me aventuraré con buen éxito á indicar el lugar en donde se hicieron y hasta el nombre del impresor.

Higo esta advertencia para que no se crean caprichosos mis juicios 
cuándo en una obra que carece de año le asigno uno conjetural aproximado, y por esta razon no puedo de ningun modo convenir con Ticknor, en que son pocos los Romances españoles en pliegos sueltos impresos ántes del año de 15̃̃o. En el presente Catálogo se verá cuántas hojas volantes hai de esta clase anteriores á la publicacion de la Silva, que se dice impresa en Zaragoza. Tengo ademas una razon mui poderosa para creer que estos romances sueltos son anteriores á la época en que empezaron á reunirse en colecciones, pues en general su lenguaje es más anticuado, contienen infinitas variantes y están más completos. Aun supongo más, y es que una gran parte de las muchísimas glosas que hai de ellos, precedieron á la coleccion de este género de poesía, como lo prueban los testos que sirvieron para escribirlas, que son los de los pliegos sueltos. Y téngase presente, que si bien me figuro ser uno de los que mayor número han llegado á reunir de estas joyas de nuestra poesía popular, me consta existen muchísimos más diseminados en varias partes: el honorable Thomas Grenville al regalarme el de $D$. Gaiferos y el del Conde Claros, ambos impresos positivamente ántes de 1525, me franqueó para su exámen tres tomos donde habia por lo ménos otros veinte romances, todos anteriores á la fecha indicada por Ticknor; M. Debure poseía algunos, $y$ en poder de II. Turner, de Lóndres, ví tambien varios de principios del siglo XVI.

No deben buscarse en mi Biblioteca libros modernos, á no ser que los ejemplares tengan alguna singularidad de que carezcan los demas de la edicion, ó sean reimpresiones de otras obras antignas de importancia, publicadas por primera rez en nuestros tiempos. Entiendo por modennas las escritas de cincuenta años acá. Solo se esceptúan de esta regla los libros escritos y publicados por mi padre, que el cariño filial me ha inducido á incluir en casi su totalidad, $y$ por la misma razon se encontrarán algunas de las obras de Martínez de la Rosa, D. Angel de Saavedra (duque de Rivas), Lista, Jleléndez, Villanueva, etc., etc.

Al principiar este prólogo he confesado ya la lesconfianza que tenia en mis conocimientos para llevar á cabo con buen éxito la tarea que emprendia; ademas en 1852 me atacó una terrible dolencia hepática que me arrastró al borde del sepulcro en el 57 , y de la 
cual aun no me hallo del todo libre: esta doliente situacion que me impide abandonar á Valencia, me ha obligado á formar la obra, sin más ausilios que mi Biblioteca, porque las públicas de esta Capital, ricas en clásicos latinos, Santos Padres y obras teológicas, son sumamente pobres en libros castellanos. No he tenido por consiguiente con quién poder consultar las dudas que se me han ofrecido, que no han sido pocas, viéndome obligado á resolverlas segun mejor me ha parecido por inducciones ó conjeturas, escribiendo toda mi obra por mí mismo; y no ha sido poca fortuna la de haber encontrado para ella un buen impresor.

A pesar de todos estos antecedentes me lisonjeo de que en mi libro se encontrarán algunas noticias curiosas, aun cuando solo sean las uescripciones de ciertas obras tan raras que su existencia se habia puesto en duda por los bibliógrafos, y las, correcciones y adiciones que con frecuencia hago á los errores $y$ omisiones padecidos por estos. Bástame esta sola idea para dar por bien empleados los años que he dedicado á la formacion del presente índice.

Valencia, junio de 1869. 


\section{NOTA DE LOS EDITORES.}

Apénas terminada la impresion del primer tomo del presente Catálogo, vino la muerte á arrebatarnos al autor del mismo, nuestro querido padre.

Ajenos completamente á la bibliografía, y sin la certeza de que el original estuviera terminado y completo, decidimos acometer la para nosotros ímproba tarea de continuar la tirada de la obra; rindiendo así en cierto modo un cariñoso tributo á la memoria de aquel que despues de tantos años de afanes $y$ desvelos no logró la satisfaccion de ver coronada su obra.

Fácil será, quizá seguro, hayamos cometido errores mui disculpables en una impresion de esta índole. Cúlpesenos, pues, tan solo á nosotros., á nuestra ineptitud, si no hemos sabido interpretar debidamente los pasajes oscuros del original.-G.S.-E. S. 


\section{TABLA}

DE LAS

\section{SECGIONES Y DIVISIONES QUE CONTIENE ESTA ORRA.}

\section{TOMO I.}

$\sim$

Paginals.

Prologo.......................

Nota de los editores. .................. .

Tabla de las secciones y divisiones que contiene esta obra. . . . . sxvu

Esplicacion de las abreviaturas que se emplean en este Catálo:o. . . sxxı

Erratas notables. ................. Id.

\section{Seccion Pocitica.}

Primera division. - Poesía popular, Romances, Glosas, Villancicos. Cancioneros, Coloquios y Relaciones impresos en pliegos sueltos.. . 1

Segunda division.-Cancioneros y Romanceros, Antologías ó Colecciones de Poesias escritas por varios autores. Fiestas, Exequias, Certảmenes ó Justas literarias que comprenden producciones de diférentes poetas. ......................

Tercera division.-Poetas diversos. Comprende tambien esta division las obras que tratan del arte poética, y las relativas á la historia de la poesía..................... 177

\section{Seccion Dramática.}

Primera dicision.-Contiene las Comedias, Tragedias, Farsas, Autos, Colociuios, Diálogos, Entremeses, Sainetes, Loas, Bailes, Pasos, Mojigangas, Zarzuelas, Saraos, Fines de Fiesta, Operas, Oratorios 
sacros y de toda composicion representable, aunque lleve otra denominacion ó título, bien se haya publicado suelta ó en coleccion. se han incluido tambien las obras en las cuales se comprende alguna pieza de teatro, los escritos en pro ó en contra de las representaciones teatrales, las historias literarias del drama, y las relativas al histrionismo en España. . . . . . . . . . . . .

Segunda division.-Indice alfabético de los títulos de las piezas dramáticas. Farsas, Comedias, Tragedias, Tragicomedias, Novelas dramáticas, Pasos cómicos, Eglogas, Diálogos, Coloquios, Melodramas, Operas, Oratorios sacros, Dramas musicales y Zarzuelas. . . . . . - Alltos. Figuran en este índice los Autos sacramentales, los dialogados y más de ochenta, precedidos de Loa.. . . . . . . - Loas. Se comprenden en ellas las Loas sacramentales, dialogadas, entremesadas, alegóricas, criticas, famosas, cưriosas, $\mathbf{y}$ más de doscientas sin título. . . . . . . . . . . . .

Entremeses, Bailes, Jácaras, Sainetes, Mojigangas, Villancicos, Lnipersonales, Fines de tiesta, Saraos, Soliloquios, y alguna otra composiciou representable con distinta denominacion que no esté incluida en las secciones anteriores de este índice. . . . . . . .

Número de piezas de que consta el índice de esta segunda division. . .

\section{TOMO II.}

-

\section{Seccion Novelística.}

Primera division.-Libros de caballerías. . . . . . . . .

Segunda dicision. - Novelas varias. Comprende todas las que no pertenecen a la clase anterior, y ademas algunas obras que sin poderse Haniar propiamente novelas, contienen cuentecillos y anécdotas, 6 bien siendo su asunto entretenido, deben ser clasificadas como libros de pasatiempo y recreacion. . . . . . . . . . . . . .

\section{Seccion Paremiológica.}

Division unica. - Compónese de las obras que ex profeso ó de una manera incidental'tratan de los refranes, proverbios, adagios, senten- 
cias, máximas, apotegmas, emblemas, consejos, aforismos, enigmas, conceptos, avisos, empresas, problemas y dichos notables, senten-

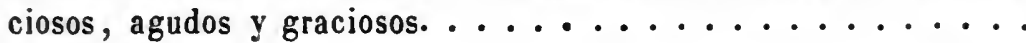

\section{Seccion Literaria, Cientifica y Artística.}

Primera division.-Filología, Poligrafía, Historias literarias, Caligrafía y Paleografía. Ademas del orígen, progresos y estado actual de la literatura, se incluyen en esta primera division el arte de aprender y retener en la memoria, correspondencias epistolares de hombres célebres, y miscelánea $\mathrm{y}$ variedad de escritos notables. . . . . . . .

Segunda division.-Bibliografía. Forman esta division los Catálogos y noticias más importantes para este género de literatura, como son el Catálogo de libros prohibidos en $\mathbf{1 5 5 9}$, y los Indices espurgatorios de 1707,1747 y hasta $1789 . . \ldots \ldots \ldots \ldots$

\section{Seccion Científica y Artistica.}

Primera division. - Música, Baile, Juegos de suerte y destreza.. . . . 329

Segunda division.-Pintura, Escultura, Arquitectura, Matemáticas, Metalurgia y Agricultura. ...............

Tercera division.-Arte nilitar, Esgrima, Gineta, Tauromaquia, Yeterinaria, Cetrería y Caza. Comprende esta tercera division la fortificacion regular é irregular, administracion y sanidad militar, la castrametacion ó arte de acampar, idea de los cañones rayados, y unos diálogos entre la milicia y las ciencias. Ademas, se incluyen en lemosin preludios militares, un tratado de artillería, otro de albei-

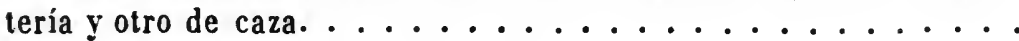

Cuarta division.-Historia natural, Medicina, Cirujía y Farmacia. Eu la Historia natural van dos catálogos en lemosin de todas las aves de la Albufera de Valencia y de los pezes de su Mar; en Cirujía tambien un tratado en lemosin; se incluye otro de la Sangría artificial, otro sobre Optica, y la Quiromancia ó arte de pronosticar.. . . . . . 394

\section{Seccion Histórica.}

Primera division.-Historia general, Cronologia. . . . . . . \$17 
Segunda division.-Historia antigna. . . . . . . . . .
Tercera division.-Ilistoria de España y Portugal, de sus posesiones
en el continente europeo, y las Crónicas y Biografias de sus reyes.

Cuarta dicision.-llistoria de otras naciones de Europa. . . . . . . .

Quinta dirision.- Ilistoria de las Indias orientales y occidentales, Africa y las Islas Canarias: . . . . . . . . . . . . .

Sesta dicision.-Biografía. Las Crónicas de reyes están en la tercera division de la presente seccion. .............

Sétima dicision.-IIeráldica, Genealogía, Numismática y Antigüedades.

Oclava dirision.-Legislacion, Jurisprudencia, Economía política, etc. En esta division se incluyen las Constituciones y Cortes de Cataluña, los Fueros y Cortes de Aragon, la Legislacion y Cortes de Leon y Castilla, los Furs (leves) de Valencia, y las Cortes españolas desde 1810 al 11 , de 1820 al 23 y de 1836 al 56 . . . . . . . . . .

Novena division.-Astronomía, Astrología, Geografia, Cosmografía, Navegacion y viajes é itinerarios marítimos. Ademas del cronómetro ó reloj de longitudes, tambien se incluyen en esta division el cuadrante ó reloj solar y la reprobacion de la astrología judiciaria. . .

\section{Seccion 'Tcológica, Ascética y Moral.}

Division unica.-Teología, Ascéticos y Moralistas. En esta seccion se incluyen los libros y epístolas de Séneca, obras de Epicteto, de Plutarco, doctrina de Calvino, cartas de Pascal, breviarios y misa mozárabes, y una porcion de autos de fe celebrados por el Santo Oficio.

\section{Miscclánea.}

Dicision única. . . . . . . . . . . . . . . 827

Indice de los autores, traductores y obras anónimas que se citan en el presente Catilogo. . . . . . . . . . . . . 


\section{ESPLICACION DE LAS ABREVIATURAS}

\section{QUE SE EMPLEAN EN ESTE CATÁLOGO.}

atlant. . . . Atlántico.

Bib. Colomb. . Biblioteca Colombina.

col...... Coluna.

cols...... Colunas.

Fol. ...... Folio ó foliacion.

fols. . . . . Foliadas.

Gr.. . . . . Grande.

Laám. ó lám. . Lámina.

Láms. ó láms. Láminas.

let. curs.. . . Letra cursiva.

let. gót. ... Letra gótica.

let. rom.. . . Letra romana.

marq. .... Marquilla.

may. ..... Mayor.

MS. ..... Manuscrito.

MSS.. . . . Manuscritos.

Núm. ó núm. Número.

P. ...... Parte.

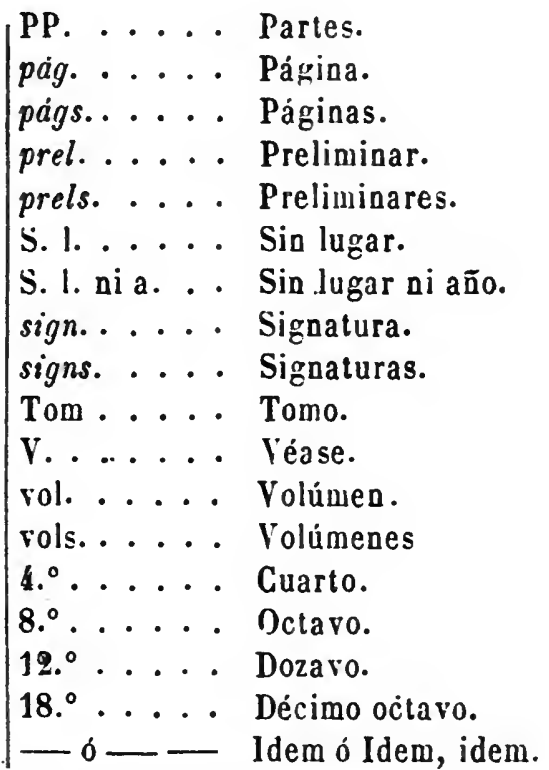

Ademas de las citadas abreviaturas se encuentran otras varias en la Seccion Dramática, cuya esplieacion va al principio de cada una de las dos divisiones de que consta aquella seccion.

\section{ERRATAS NOTABLES.}

La fecha del Núm. 27 debe ser 1665.

En la octava línea de la nota al Núm. 107 debe leerse Anunciacion en lugar de Encarnacion.

La última linea del colofon puesto en el Núm. 768 dice :

mes de Desembre. 8.

*

El $80^{\circ}$ debe separarse, pues no pertenece al citado colofon y solo significa el tamaño del libro. 
En la segunda línea anterior al Núm. 1180 dice estravagantzs en lugar de ESTRAYAGANTES.

En la primera línea del Núm. $\mathbf{9} 377$ dice PÉREZ (Antonio DR); debe decir PEREZ (ANTONIO).

El Núm. 2463 equivocadamente dice 1463 .

La fecha del Núm. 2878 debe ser 1806.

En el Núm. 3444, línea 31, dice partentizar. Léase patentizar. 


\section{BIBLIOTECA DE SALVÁ. \\ .}

\section{SECCIOX POETEC.}

\section{PRINERA DIVISION.}

\section{POESIA POPLLAR. ROMANCES, GLOSAS, VILLANCICOS, CANCIONES, COLOQUIOS Y RELACIONES IMPRESOS E.X PLIEGOS SLELTOS.}

Cun objeto de evitar frecuentes repeticiones, debo advertir, que de casi todos los pliegns en letra gótica, descritos en esta primera division, to se connce mas ejemplar que el de mi Bibliotera, $y$ aun de los que no sean únjcus, nn llegarin i tres lus citados como existentes en otras colecciones: en razon, purs, de tan singular rareza, el aficionado que llega á reunir media docena de estas joyas bibliograficas, se tiene por muy afortumalus vo posen iz.

\section{ALC}

1 ALCaldoete. (Alovso te). I Siguense dos glosas: la rna sobre el homãce que dizen. Buen conde Fernan gonçales el rey enbia por ros. I la otra sobre el Romance de. Yo me leuãtara madre mañanica de sant juan. E r nas coplas sobre las $\pi$ dizen. Al cauallero madre tres besicos le mande. Y otras sobre Llamaualo la donzella r diso el vil. Con vna desecha I vn villancico. Hechas agora nueuamente por Alonso de Alcaudete. S. 1. ni a. (hicia el 1:330). 4. ${ }^{\circ}$ let. got. rinet a de madera. 4 hojas sin fol. ni sign. Contiene:

Glusa subre el romance Buen conde Firnan Conzilez, que dice: Como debe de cumplir.

otra subre el romance Yo me tevantuia madre, que dice: En los (ticmpus) deleitosos.

Villancico que dice: De mi dicha no se es. pere.

Coplas que le pidió una señora sobre un cantar é lo que dicen las mugeres: Al cabulero madie.

Otras sobre las de Llamaibalo la doncella, que dicen: Llamibalo, di peredido.

Deshecha que dice: La dama que no mata 0 prenule.

Coplas de un gentil hombre i una señora, que diren: hecihme que buscris.
A

\section{ALC}

los romances ghosados estan en el Camcio.

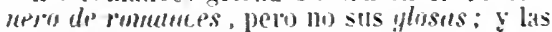

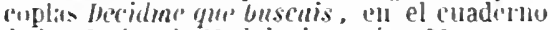

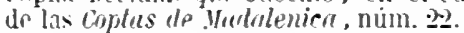

- El sr. lmaran no Lugrio rer este pliego de Alcaudete.

2 ALCALDETE (Alosso DE). C Glossa sobre el Romance que dizé Tres cortes armara el Rey, todas tres a rna sazon. Nuenamẽte compuesta por Alonso de Alcaudete, natural de Ronda. Con otras nuchas glossas y villancicos. Jmpressa con licencia en Burgos, por Juan Baptista Laresio, s. a. (hácia el 1590 ). 4. ${ }^{\circ}$ let. gót. Iineta de madera. 4 hojas sin fol. con la sign. A ij. en la segunda hoja.

Contiene:

Glosa del romane Tres cortes armara el rei, que dice: En el liempo de aquel sol.

Coplas subre la toma de-0re, que dicen: Llore el rei de' Trimecen.

Glosa del romanee lo me levantara madre. que dice: En los tiempos doleitosos.

Villancico de mi dicha mo se espera.

Coplas subre el rantar Aquel cubullero inaare, que dicen: Porque fue el namelo primero. Utras subre las de Lumibato la doncella, que dient I.lmmilnaln, di privlido.

Tos. 1. 
El Sr. Duran menciona una edicion de este pliego $s$. l. ni a. en $4^{\circ}{ }^{\circ}$ let. gót.; pero no conocio la presente de Bürgos. Iicho Sr. Duran cita otro pliego de Alcaudete que lleva el epigrafe siguiente:

Glosas nuerumente compuestas, por Alonso de tlcabdete, sobre los romances siguientes: Ya se salia el rey moro, etc.; y el ofro: Yo me adamara una amiga; $y$ el of ${ }^{2} 0$ : Ninno Vero, Nuño Vero. Y un villancico. S. l. mi $a$. 4. ${ }^{\circ}$ let. got. 4 hojas.

Conticue:

Glosa de Alcabdete al romance de ia se salia el rey moro, que dice: En cl tiempo que esta tierra.

Ilem de idem ul romance te yo me adamara una amiga, que dice: En el tiempo y joventud.

Idem de idem al romance de Nuño Vero, ele., que dice: De gran deseo lisiada.

Cancion de idem, que dice: oldme ros, senิora.

Idem de idem, que dice: Esperanza mia por quien.

Villancico de idem, que dice: Tus ojos sanan, señola.

El nombre de Alonso de Aleaudete no se encuentra en la Bibliotheca de D. Nic. Antonio.

Las dos coplas del pliego que tengo que comienzan:

A aquel caballero, matrey Llamábalo la doncella,

las ha reproducido Böhl de Fíber en la Floresta; pero se hallan harto desfiguradas.

3 APARICIO (PEnRo de). La vida y graciosos hechos de Antonico de Teuar. Compuesto por Pedro de Aparicio. Cuenca (sinimpresor), 1603. 4. Con una vinetita despues del epigrafe. 4 hojas sin fol. ni sign.

Como una tercera parte de este Romance es r.l asonantes, y lo demas en quintillas: principia: Nacio Antonico de Tévar.

Vo se halla el nombre de Pedro Aparicio en Nic. Antonio ni habla Duran de este opúsculo.

\section{ARGÜELLO (Fraycisco).}

(1) Chiste nueuo cõ seys Romances / y siete Villancicos viejos / agora nueuamente compuestos por francisco de Arguello / con va cancion y tres coplas a ella hechas por el mismo. (?) ?? (?) ?? (?) ? : . S. I. ni a. . $^{0}$ let. gót. Son dos hojas sin sign. ni foliacion. Copia literal mamuscrila de este pliego suello.

Contiene:

Villancico. Quitar me podeis la vide. Ronance. Los griegos entran en Troya.

Villancico. Pues no me quereis hablur.

Romance. Cala Francia, Montesinos.

Villanrirn. 'Todn. val de amor' heridns.
Romance. Muerto queda Durandarte. Villancico. Lleno de ligrimas tristes. Homance. En los campos de Alventosa. Villancico. Enemiga le soi, madre. Romance. Por aquel postigo viejo.

Villancico. Vos, señora, aborrescerme. lomance. ¡Ay, Dios! que buen caballero. Villaneico. Volveos por do venistes. Cancion. Nunca jamas dejaré.

No vió $D$. Agustin Duran este cuaderno, ni Nic. Antonio tuvo noticia de Franciseo Argiiello.

De los seis romances viejos que dejo anotados, solo se conserva la primera estrofa; los demas versos no tienen relacion alguna con el princlpio. Slrva de ejemplo el sigulente:

Muerto queda Durandarte Al pie de aquella montaña,

Tan malas lanzadas tiene

Que le atraviesan el alma.

Si mi lengua tiene calma

$Y$ vos dejais de me ver,

¿Qué vida podrè tener

Sino triste?

Al dolor no lo resiste

Mi querer, ni lo desecha,

Antes entra sin sospecha

De contrario.

Cuantas obras d' aversario

Me hará, le sufriri,

Porque vos, cuand'os miré,

Me 10 distes.

Pondrẻ comn muestras del estilo de Argủello un Villancico y la última Cancion.

\section{rillancico.}

Enemiga le soi , madre,

I aquel caballero yo,

Jal enemiga le so.

lues que nunca os ofendió

Mi corazon (triste del)!

¿.l'orfué le sois tan cruel

Eneniga?

El dolor porque lo diga,

Yo se amansa ni se muda,

Antes con pena mas cruda

Me amenaza.

Él me cita, él m' emplaza

Para delante la muerte;

A ir, pues quiere mi suerte,

Ne aparejo.

Cancion.

Nunca jamás dejaré De serviros con fé buena, Aunque se que por mercé Me dareis tormento y pena: olvidaros no es posible, Si es posible, no querria, Si quísiese, no podria, Que poder es imposible: Con firmeza os serviré De mudanza mui agena, Aunque sé que por mercé Me dureis tormento y pena.

pues vivo de solo veros No querais de mi olvidaros: Aquesto debe bastaros Que no puedo no quererns: 


\section{AVI}

Mil servicios os haré

Con fi de flrmeza llewa,

Aunque se que por mercé

Me dareis tormento y pena.

De penado juro y cuento

De olvidaros con rigor;

Mas no puedo, qu' el amor

Puede mas que juramento.

Olvidaros no podrè

Ni lo sufre mí fé buena,

Aunque se que por merce

Me clareis formento y pena.

Del mismo Argüello he visto otro opúsculo intitulado: Chisles mueus y galanes ugora nueuamente cōpuestos por Fräisco d' argueUu. Y este primero es cótra una muger enamorada ỳ le hizo vn gran enojo. cōotras coplus d'l mismo. S.l. ri a. $4 .^{\circ}$ let. gót. 4 hojas. Solo conservo nota del principio de la primera composicion que dice: Tan altiva $y$ des. deñosa.

5 AVE MARIA. C Aue maria glosada por vndeuoto de $n \tilde{r}$ a señora: $y$ va sobre cada rna palabra vna copla. La q] nunca fue impressa hasta agora. Con el magnificat: $r$ Nunc dimittis. Aue maris stella. Quem terra ponthus. 0 gloriosa domina. Memento salutis. Todo trobado. (Sigue una tiñetita en madera,$y$ á continuacion principia la obra, hallándose toda la página circuida de orla.) S. l. ni a. (hácia el 1533̈). 4. ${ }^{\circ}$ let. gót. 4 hojas, sign. Aij. solamente.

Contiene:

Glosa del Ave Maria: Ave sin pav en valor. -

Magnificat anima mea: La mi änima en. grandece. -

Nunc dimittis: Agora que ya cumpliste.ua. -

Ave maris stella: Dios te salve clara estre.

Quem terra ponthus: A quien tierra, cielos, mar.

0 , gloriosa domina: oh! gloriosa, señora.-

Memento salutis: Acuerdate qu' es verdad.-

Pliego desconocido á los bibliógrafos, y cuyas composiciones no se hallan en el Romancero de Duran.

6 ÁVILA (Frascisco de). Vinllancicos, y coplas curiosas al Nacimiēto del hijo de Dios, Saluador del mundo, y Señor nuestro. Aora nueuamente compuesto por Francisco de Auila. Alcala en casa de Iuan Gracian, 1606. 4. Viñetas del Nacimiento y la Circuncision. 4 hojas sin fol. ni sign.

Bơhl de Faber publicó en los números 25 y 32. del tomo I de la Floresta. Ia letra Portalirn
A YI

divino y las coplas Si lomais la posesion; pero siguiendo su sístema, en la primera desflguró enteramente ysin necesidad la última estrofa, y en las segundas suprimló una por entero y İlenó de alteraciones las demas.

Heproduzco las dos siguientes tales cuales se hallan en el original.

\section{coplas.}

Oh, que bien que baila Gil Viendo al niño entre las pajas, Bras repica las sonajas Y Antari toca el tamboril.

Gil viendo al nino en el heno

Salta y brinca de placer,

Y Bras comienza á taīer

De gloria y contento lleno;

Muéstrase el cielo sereno Con sus rayos celestiales. I en estos santos umbrales Porque baile y danze Gil, Bras repica las sonajas, $Y$ Anton loca el lamboril.

Todos alegres le miran, I él, en el baile picado, Tan lijero se ha mostrado Que se embelesan y admiran: Unos juegan, y otros tiran De aquelias flores del campo; Y porque baile Melampo Una mudanza con Gil. Bras repica las sonajas,

$Y$ Anton toca el tamboril.

Melampo con gran destreza

Bailó luego su mudanza,

Y Gil con nueva esperanza

otra mas pulida empieza,

Mostrando su lijereza

En el saltar y bailar,

Y porque torne á danzar

Con su donaire subtil,

Bras repica las sonajas,

Y Anton loca el tamboril.

Viendo pues, Melampo á Gil

Cómo baila, salta y danza,

Volvió á hacer otra mudanza

Mas gallarda y mas subtil.

Dando invidia á mas de mil

Que estaban al rededor;

Mas porque tome calor,

Mirando Melampo á Gil,

Bras repica las somajas,

Y Anton toca el tamboril.

Letra.

Este niño chiquito

que al mundo viene deja el alma contenta, dulce y alegre.

Este niño hermoso

da salud $\mathrm{y}$ vida

al alma afligida, con dulce reposo

siendo poderoso

y de real alteza,

nace con pobreza

$y$ en este pesebre

doja el alma contenta, dulce $y$ alegre.

Con mil maravillas

y allivas riquez.as, 
BEN

muestra sus grandezas

en pobres mantillas,

mostrando las sillas

del cielo divino,

que por tal camino,

il rei de los reyes

deja al almie comtenlu,

drilce $y$ alegre.

En este portal

el cordero manso.

dit vidia y dessansu

al lomble mortal:

rese tanto mal.

pues el poi sagrado

siendo disfrazado,

in este peseore

deja al alina contenta, dulce y alegre

I AVILA (Fancisco de). El Pirlo virginal de la Virgen santissimi, donde se contienen algumas letras, Villancicos, y Ronances curioso: sobre el misterio sacrosanto del Yacimiento de nuestro Śéñor lesu Christo, para cantar la nóche de Nauidad. Aora nueualiante compuesto por Francisco de Auila. Cuenca, en casa de Bartolome de Selma, s. a. poco despues del 1600). 4." Tinetilas ilel Facimiento y de la Aparicion del angel a los pastores. 1 hojas sin fol. ron la sign. A.

De las composiciones de este folleto se haIlan on el anterior del mismo autor la 1., …, $\therefore .{ }^{4}, 5 .{ }^{\circ}$ y 7.4 , que principian:

A la ciudad de Belen-
Zagalu si i Belen vas--

bl. que ii los justos corroma-

pues el rei de los cielos-

P'ortalico divino.-

De este pliego reimprimiré el siguiente Romance.

Salga el sul divino

dando al-mundo parti"

de sus rayos bellos
POESIA POPLIAA.

plles son agradibles:

ilégrese el campo,

y canten las aves

coil arpadas lenguas

Y picos suaves:

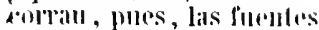

rllal puros pristales.

resmallatudo de owa

lodos sus lemales;

salte él curderitio.

ell viondu à su madre,

$y$ á sus blamens pechus

se allogue y regale:

pues al rei del cielo

tan humilde nafe.

sin tener mantillas

que abriguen sus carnes;

aqui está tembliusdo

$y$ sujeto al aire,

(fue el rigne del tiempo

es irrenirdialle.

une si mece' el sol que mace.

volnerase ln nache e'n luz ayradable.

El portal sagrado

con su luz radiante, deseubre í los hombres

um bien inefable;

Josef se enternece

viendo al nuevo Infante

verter de sus ojos

perlas orientiles,

Y la Virgen bella

con sus ajos graves

mira al Reidivino

que tiene delante,

y proesta en la tiejra

mil ofertas haee

al cielo sagrad",

al fin como madie.

Vienen con presentes

lodos los zagales

y ell vozes simoras

dicen los del valle:

Ulle si crece el Sol que nace,

volveruse la noche en lus agradable.

No hallo mencion de este antor en Nic. Antonio ni en Alvarez y Baena; aunque no puedo asegural si fué madrileño, pues los epigrafes de estos dos folletos solo dicen era vecino de Madri.l.-EI Sr. Duran no tuvo noticia de ninguno de estos pliegos de Franciseo de ivila, y harrera sulo menciona el primero.
8 BE.IVENGLT (Francisco). C Obra muy deuota sobre el sanctissitho nascimiento de nuestro Señor Jesu christo al tono dela golondreta: con utras al cabo Compuestas por Francisco Benuengut IIurciano. (Siguen dos riñetas de madera que representan el Nacimiento y la Adoracion de los reyps, ambas circuilas por una renefa.)
S. 1. ni a. (hácia el 1:300).4. ${ }^{\circ}$ let. gót. 2 hojas sin sign.

Contiene:

Alegraos genle crisliana.-

La cancion í S. José: Decia, vos sois, se. ñor.

Torna al Nacimiento: De ángeles mui cercedelo.-

Como vinicron los tres reyes: Los reyes vicnen d'oriente. - 
0tr

Mi Ciscáles, ni Yic. Antonio hablan de Franrisce Benvengut: tampere encuentro menrionl do semejante escritor on ningum otro biblicirafo.

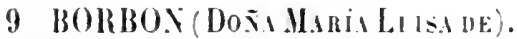
Composiciones poeticas eseritas con motivo de su muerte: todas en 1.", a saber:

Cantos frucbres de Ins cisues do Manzaniares a la temprana moerte de... Jwilit Variat l.visa do Borbon. Yhalrial. Seloastian de llmendariz, (1684?) 4." 28 peigs., inclusas las 2 de la linja de la porlade, if le alli adelandr. t's cherir, descle los segvindos cantus fromebres, comlinuir foliacion, que l'mina con el fol. as.

Carta de Don Intonin de Zamora , eserila i bon Francisco Candamo. Romance. ś hojus $\sin p(1 y$.

Estancias de you Intonia de Saravia, li linjus sill phly.

Endechas enderonasylabas. Pur of licenciado bon Pedro Antunio Bexarano. 8 migs.

Poemas funcbres a la temprana muerie de la regua. Escrivelos Don Ifanuel Vidal y s...]vador. It prirs.

Pomance de un lngenio forastero ì la muerte de la reyua. \& hijols.

Carta ell que el... (Ibispu de Mala;a... da no-

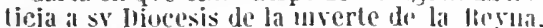
Madrid, Sebastian de Armendarie, list. lli peiss. Fil prosu.

Exequias Reales celdorindis en el Real Ginvento de he Encarmacion de csta Curte. Por' Juan Minnel de la Parra. Medrid., Sebatstian de Almendariz, 1689. 5 hojas prels. y 1.5 fols. En prosa.

Melrico canto i las Reales Exeqvias. Fscriviole l)on luan Franciseo Munoz de Vallelivis. so. 4 hojas sin pu!?.

A la teniprana muerte de la Reyua. I'vema de Fray Diego de tres. 1 hojas sin pag.

La transmigracion fvnebre. Elegia de Dum Pedro de la Camat] Garay. 4 linjas sin perg.

Romance a la temprana Vuerte di la Reyna. Por Dou Jiegu Perez de Villa-Real. 2 lwjus sin pa!j.

A la muerte de la Resina. velavas por Don Pedro Velasco. \& hojes foliadis.

Niveva relacion, y cirioso romance de la Enfermedad, Muelte, y Entierro de la Reyna.

2 hiojas sin pag.

A la acelerada mverte de la Reyua de Espitna. Romance de arte mayor de Don Antoniu dé Ascargorla.-Lyras de Don Diego Velazquez de la Cueua.-Oclavas del mismo.-S(1neto del misma.- Soneto de Don luan de Cor. doma y Cardonists li hrijas folindas.

A la muerte do lit liegma. Enderdits endecasylalms de Jon Mammel deosta y silva. 2 hojas sill paty.

Nomlmes y ministerios de las Pareas. Endeclias. Homance. 2 hujus siu paq.

Soneto en Laberinto del Vizconde de san

Higuel y de cleru. Cina hoju que se doblu.
Soncto del Maestro Thomas Manuel de Paz. ina hoja quis se dobli.

Sunelo acrostico de Inon luan de Cauiedes. lina hoju ill.

Sunelo de llon domso Antonio Sedeno. L̈no hijo idl.

Hecina acrostica de Diego Marcos latera. lilli hiju ill.

Ilecinas con glussa. Lna hoju id.

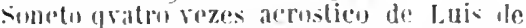
Silnduval y Malla. L'me hoja irl.

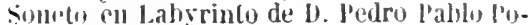
แIเar. Ema hoja id.

I.aberinto retrugrado. Cina hrija id. de neguro y colorarlo.

Sonclo acrostico do Don Raymundo Esa. late y ledesma. Lma hoja id.

Wrzinas acrosticas de Dou Pedro sagredn Manrique. Lna hoja $i d$.

soncto acrostico de Don Joseph ogazon All. grulo. Lna haja id.

feademica resolvcion de qvatro ingeniosos rayus palatimos. 16 paigs.

Irene viage a la truba... Que escrive Ivan Vaurol de la Parra. Madrid, Impreuta Real. lliv!! i hujas pe"ts. II I hojus fols. En juosu. Ifólos que respira vil corazon obseqviosı... fle Uni Juan llunoz de Valdiuiessu. (En ches rmutmres.) \& hojas sin pay.

bificilnente podrá reunirse otra culeccion tan completa de los pliegos sueltos. ('n verso. mulieados con motivo de la muerte de boña Iaria Luisil de Borbun.

in BRI\%LELA (MATEO DE) J.a bidis de la Galera, muy graciosa, y por ralan estilo sacada, Y conıuesta agra nuteuamente por Natheo de Bricuela, a pedimiento de don Iñigo de Illeneses Lusitano. Do cuenta en ella los trabajos zrandes que alli se padecen. Es obra de exercicio y no menos de exemplo. Siguentres figuritas grabadas en madera.) Barcelona: Por Sebastian de Cormellas, al Call. Año. II. DCIII. '." thojas sin fol. ni sign.

Fu lisimas de versos oclosilabus.

Xi fuc cunocidu este curiosisimo pliegro suedto por el Sr. Duran y Yic. Antonio tanpero menciona it Brizucla.

En el Eusayo de una bib. esp. se describe ")tra edicion de latu, por Pedro de la Cuesla. wino ste wil y spyscivios ! "'ynle y ocho (1628". 4. i hojats. - ritllardo ell dicho Finsayo dice: "l lenguaje indica ser lit ubrik mas antigua que del ano 1605: es castias.

$11 \mathrm{BLClI}(\mathrm{J}$ IXIJE). Relacioncierta de las nonedades del Rerno de Inglaterra, y del martirio que han dado a muchos catholicos por la fee de Christo: y entre cllos a rn Religioso Cons fessor de la lieval y otras cosas dig- 
nas de ser sabidas. I la famosa vitoria que el Rey de Francia ha tenido de la armada de Inglaterra, que en mumero de treynta Galeones, y otros nauios vino a cercar el puerto de Cales a los primeros del mes de Mayo deste presente Ano. Compuesto por Iuan de Buch. Cuenca, Saluador de Viader, 1626. 4. Lamina de madera. i hojas sin fol. ni sign.

12 CANCIr.v Canciõ heeha por luys del caunisu cõ su glosa y otras muchas cãciones glosadas: y villancicos y motes. Agora nueuamente imprimidos. (Al fin:) T Fue inpresso en La muy noble villa de Medina del campo en Corral de buyes. Iño de. M.D.x.xxxr. (1333.) 4. ${ }^{\circ}$ let. gót. Viñeta de madera. Son 4 hajas sin fol. con la sign. aij en la segunda hoja.

Contiene:

Glosa de la cancion Es tal la por quien yo siento, que dite: thue si de grolpe sufilese.

sdem de iden, oyan toilus mi tormento, an coplas que dicen: Es tul por quicu son mis miles.

otra glosa a la misma eancion, que dice: thl vosutros que s'guis.
Son cinco romances, que dicen:

El primero: Despues que justos respetos.

El segundo: llechas por entrambas parles.

El tercero: A los primeros de mayo.

El cuarto: Aqui, disereto lector.

El quinto: Vencielos por nar y tierra.

f.l Sr. Duran no menciona este pliego, ni se lialla en sil Rmancero ninguna de las courposiciones citadas.
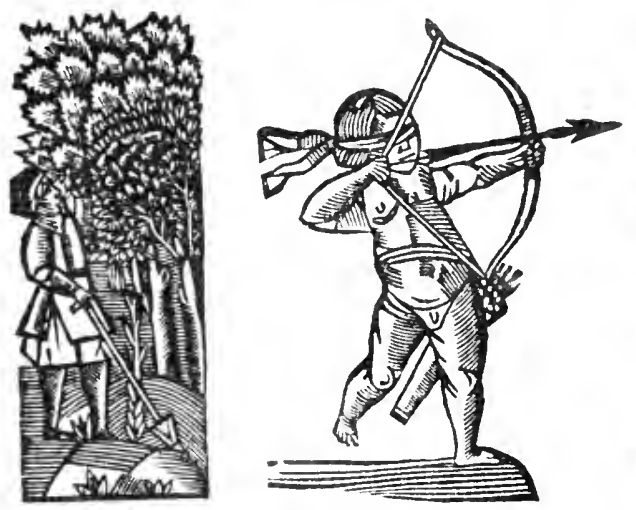

13 C.ITARES. Cantares de diuersas sonadas con sus deshechas muy graciosas ansi para bay lar como para tañer. S. I. ni a. (hicia el 1020 ). 1. ${ }^{\circ}$ let. got, Vineta de madera. 1 hojas sin fol. ni sign.
Sote que dice: Envilia de mi penar.

Cincion que dice: Tengo puesto el pensamiento.

Glosa á la inisma que dice: Qué ventura fuc aleanzar.

Xo se puede sacar por el contesto cuál es la cancion de Luis Castillo, autor desconocido i Nicolas Antonio, ni si son suyas todas las composiciontes de este pliego; yo presumo que no.

to vacilo en decir haber sido hecha la edicion yor l'edro Tovans, pues este inprimió tambien en Medina y en el Corral de buyes la Sezzundu Celestina y el Despertador de pecadoves ell 1534.

El Sr. Durall se equivoea en atribuir esta edicion al año de 1595; error nada estraño, pues arpuel literato 10 pudo examinar por sí este folleto.

La viñeta que va al prineipio del pliego es esta.

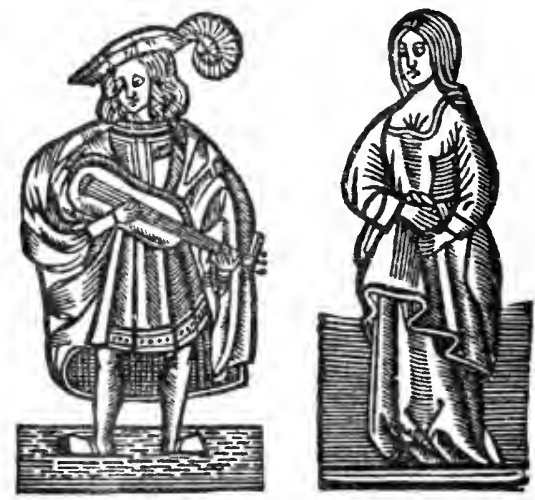

Contiene:

Cantar que dice: Si la nuche hace escuru. otro que dice: Enojustesos, señor'a. otro que dice: Descendid al valle la niña. veshecha que dice: Labradorcico amigo. Cantar que dice: Poder toneis vos, scñora. Deshecha que dice: Mis ojuelos, madre. Cantar que dice: Silos pastores hat amores. 
Deshecha que dice: Olvidar quiero mis anores.

Cantar que dice: Dicenme que el amor no fere.

Deshecha que dice: Encima del puerto. Cantar que dice: El que amores no sirve. Deshecha que dice: Aunque me vedes. Iden que dice: No deje mudie de amar. Cantar que dice: Dicemme que tengo amiga. Idem que dice: Llamiisme casada. Idem que dice: Ansi andando.
Deshecha que dice: La dama que no mata o prende.

Cantar que dice: Pues que no me quereis amar.

Deshecha que dice: A mi puerla nace una fonte.

Vo vio Duran este opusculo y las composi. ciones en él contenidas no se hallan en su Romancero.

Hé aqui la vineta del principio.
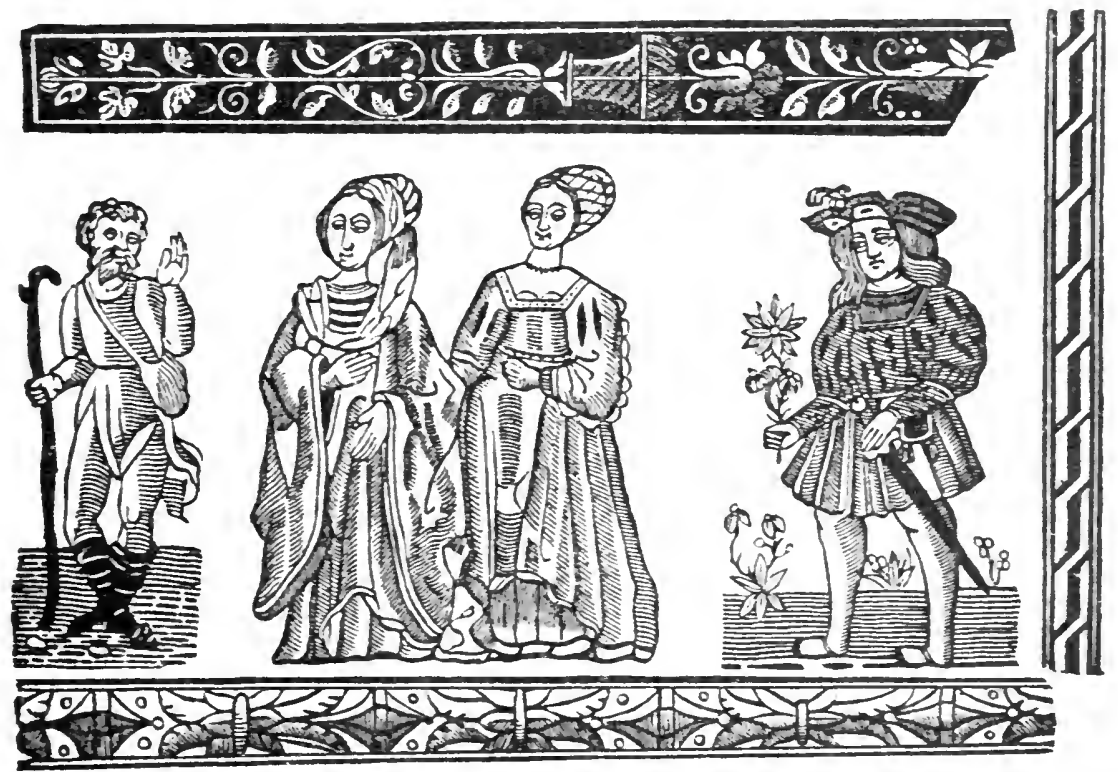

14 CASTILLO (Baltista del). Coloqvio de regoziios entre Minga y Fabio pastores, en alabancas de su Magestad, Yiniendo a verle a Barcelona. Por Batista del Castillo. Barcelona por Sebastian y Iayme Materad. Año 1626. 4. Dos hojas.

Es un romance que dice: Hinga $i$ la $\mathrm{Cin}$. dad Ulegamos.

No lo menciona Duran.

15 CASTILLO (ROdRigo del). I La gloriosa Resurrecion de nuestro Señor Jesu Christo / con las diez appariciones y sus Alleluyas: ra a manera de prégon en chiste. Hecho por Rodrigo del Castillo. (Este epigrafe ra precedido de dos viñetitas que representan el entierro de Cristo y su Resurreccion, todo circuido de orla.) S. 1. ni a. (hácia el 15010$)$. 4. ${ }^{\circ}$ let. gót. 2 hojas sin sign.
Rodrigo del Castillo y su composicion poéticia soll desconocidos á todos los bibliógra. fos--Principia asi:

$$
\begin{aligned}
& \text { Sepan todos los nascidos, } \\
& \text { Que se hace cridr y pregon } \\
& \text { ismo muestra sulvacion } \\
& \text { 'a es cumplida. }
\end{aligned}
$$

i6 CUSSEJO. Estees rn consejo que dio in Rufian a inas donzellas con las coplas del hueuo. S. I. ni a. (hacia el 1030). 4. ${ }^{\circ}$ let. got. Viñeta de madera. 4 hojas sin fol. con lasign. A.

Contiene:

Consejos del ruflan, que dicen: De las nutere villas.

Villancico que dice: Abajad, marido, las sienes.

Coplas que hablan de conjo las mujeres por una cosa de no nada dicen muchas cosas, en especial una mujer sobre un huevo con su criada: empiezan: Amarga de mi cuitada.

El Sr. Duran menclona esta edicion y supone, no sé porque, haberse becho en Vallado. lid: si funda semejante creencia en hacerse 
'll aquellis consejos, una descripcion de dicho pueblo, lo mismo podria alribuirse á Medina, pues tambien liabla larganente de psta cindad, y entre las cosas notables de clla menciona el corral de Buoyes donde vivia el impresor Pedro Tovans hácia el 1550 , eporal en que probablemente vió la luz pública este folleto.

Vinguna de las composiciones del presente plicura se encuentra en nuestros. Comcionceros: si 10 furran tan largas las reiniprimiria aqui; reproluciré tan solo el

\section{Villancico.}

Abajad, marido, las siemes

E 1 o deis oido á ruines;

los dejudmie ir i natines.

Marido pues que sabeis

Do se ganan los perdones,

Its suplico me dejeis

Ir andar las estaciones:

Pues cou santas intenciones

se gaman los buenus fines,

los dejadme ir cimatimes.

$$
\text { El. }
$$

Aquesas sautas pisadas

No ponen ell paraiso,

A doncellas ni casadas,

Vi el Senor tal cosid quisi:

pues que yo d' esto os avisu

(ime no perdais buemos times:

No cureis d'ir i mailines.

17 COPLA. Copla que hịzo tremir a vna alcahueta (que ania entranado ciertos caualleros travendolos cu traspassos engañosamente. S. 1. ni a. (hricia el 1330 ). $4 .^{\circ}$ let. gót. liñetita de madera. Son 2 hajas sinfol. ni sign.

Fista Copla desconocida al Sr. 1) uran prin* tipia asi:

\author{
oid, oid, amadores, \\ oid, siervos del amor \\ F. los que aldais (0)] herhor \\ Fazieminos mas servidures, \\ wh, seliores! \\ nid que (asil donosu \\ l de amores.
}

18 COPLAS. I Aquí se contienen tres maneras de coplas en loor del Vascimiento de Christo / y estas primeras son contrahechas a aque!las que dizen. Ilay de la ñiguiri ñigui. rc. Sigue una estampita del Nacimiento con una fugurita a cada lado, y a conlimacion principian tas coplas.) S. I.

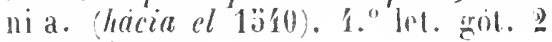
hojas sin sign.

comliene:

Conplas: Ai! le la niguiri, nigni.

ullas al luno de liali Miquel: Ml Gorict. otras al tono de Siempre que pienso en vos: Toda hora que pienso en vos.

No se halia citado por Duran ni ningun otro autor.

19 COPLAS. Coplas dela passion de nuestro señor / y de la passion que ouo nuestra señora estando al pie de la cruz que es la glosa de Stabat mater dolorosa. Con otras coplas de nuestra señora. (Siguen dos estamipitas en madera que son el Descendimientoy Cristo en la Cruz.J.S. 1. ni a. (hácic el 1540): $40^{\circ}$ let. gót. 2 hojas, sign. a y aij.

Pliego completamente desconocido que cuntiene:

Coplas à la Pasion: No me basta mi s'enticio A pensar sin dar gemidos.-

otras al lono de lastorcico, que hibedes, qué, di li fé, señora, vilestros imores he:

$$
\begin{aligned}
& \text { Ai, hijo bendito! } \\
& \text { Oue huiedes, que.- } \\
& \text { Hudre estoi llorando } \\
& \text { Del frio que he. }
\end{aligned}
$$

otras que dicen, Josef, al tomo de llescendjda al valle la niña no era de dia: No lloreis vos, vidu mit.

20 Coplas cõpuestas a modo de chiste de un clerigoque tenia amores cō vna labradora etc. (El titulo rntero ocupa siete lineas y esta cerrado con orla.) S. l. ni a. $10^{\circ}$ let. gót. Son 2 hojas sin foliacion ni sign. Copia literal manuscrita.

El Sr̃. Duran no vió este opúsenlo euyo titılo completo es el siguiente: Cuplas compuestas a manera de chiste de un clírigo que tenia amores con una labradora: y de como un dice, mientras fue su marido al arada, è eutró con clla, y viuromlo sus vecinas, y fuego se vinieron $a$ semlar i su puerfa: y siti no iwe remedio lle sacalls sino en un seron de estiercol, y llevinulolo fuera, topo cou su murich: y ansi hubo de llevar el ma. rido el estiercol junlamente con el clerigo, $y$ ella se roivio a su casa, y de lo que les acaescé.

\section{1 - C Coplas de Madalenica.}

C Otras de tãbué ganadico añadidas por Jaques normante. T Otros fieros que hizo vn rufiá en çamorá con vna puta. S. 1. ni a. $4 .^{\circ}$ let. gót. 4 hojas con la sing. A. Copia mantscrita de este pliego suelto.

Contiene:

Coplas que dicen : Tan buen grmalic').

Coplas hechas pur Alvaro de Solana; en qué cuenta cóno en Zamora vido hacer á un ru- 
Aan con una puta los Fieros siguientes: Yo te volo a Diss, Ximeria.

Villancico que dice:-Pucs ol fin de mi esperanza. Coplas de Madalenica que dicen: Abrisme, Madalenica.

Vlllanciro que dice: . vo le tardes que me muero.

El Sr. Duran no pudo ver exte folleto.

Los dos Vuluacicos son de Juan det Encina y se encuentran en su Cancionero: Ias demás coniposiclones creo que no se hallan reimpresas. Heproducire la que ue parece mejor.

Tan buen ganadico,

I mas en tal valle,

Placer es guardalle.

fanado precioso

De tanto ralor

Merece tener

E] valle vicioso,

Por ser deleitoso

Fil guarda tomalle:

Placer es guardalle.

No siento señor

Quien valle mirase

une no desease

Oficio pastor:

Con silbo de amor

Haber de silballe.

Placer es guardalle.

Con mui buen tempero

Entrase sirviente

A serle obediente

Del valle montero

Al lobo guerrero

Con rerba tiralle.

Placer es guardalle.

Pues vi los vaqueros

Andar mui gozosos

Con lns deseosos

Galanes frecherus

v tres montañeros

Oue salen del valle:

Placer es guardalle.

E mui atrevidos

Por me injuriar,

Me mandan prendar

Los cinco sentidos.

liciendo perdidos

sin ellos dejalle.

Plucer es guardulle. Con grande rigor

lo dije ser via

Al valle, y ponia

Nortable dolor

Por ser del señor

Que veda de entralle:

Placer es guardalle.

L.as guardas decian.

En valle cerrado

Quien entra sin grado

Herbaje perdian:

Monterus venian

Con saña prendalle:

Placer es guardulle.

con grande pasion

lo dije \& la hora:

Bendita quien mora

En tal posesion.

Por ser de varon
Que manda miralle:

Phacer es guardalle.

Ganado ian bueno

Que tanto Aoresce

Metello meresce

En prado mui lleno:

si entrase el ajeno,

l.a prenda quitalle:

Placer es guurdalle.

Ganado que pace

En tierra fragosa,

En cada bocado

Pace una rosa:

Kaiz ponzonosa

io puede enojalle:

Plucer es guardulle.

Pastor que se encierra

En valle seguro,

De lobo le juro

Que no le de guerra.

cianado de sierra,

$\checkmark$ mas en tal ralle.

placer es guardille.

De rosas y flores

Que cria el verauo.

rll campo está ufano

Con muchos olores:

lianad" y pastores.

$Y$ mas eil tal valle.

Placer es guarilulle.

iViste mi ganado

be azul y pardillo?

Purque he sospechad.

Que pace otro ejidu:

Coll mal Lin erescidu

Vo purdo sillablle:

Plucer es gunidulle.

Asi que gozoso

lo del me parti

En la hora que vi

El valle precioso:

Por ser nuy hermoso

Deje de enojalle:

Plucer es guardalle.

22 COPLAS. I Aqui comiençan las coplas de Madalenica. Con otras coplas dela reyna de napoles. Có rna

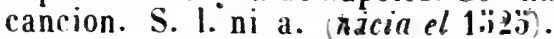
1. ${ }^{\circ}$ let. got. Fineta de madera. Son? hojas sin fol. ni sign.

Contiene:

Coplas que dicen: Abrasme, Madalemicu.

Romance de la reina de Xipoles, que dice: Emperalrizes è reinas.

Coplas de un gentil bombre á una senora, que dicen: Decidne, que buscais.

Cancion que dice: Donde amor su nombre escribe.

Otra que dice: Nunca pudo la pasion.

Hote que dice: Pues mi lida $y$ i'uestru trila.

El romance de Emperalrizes y reinus, se halla con muchas variantes en el Cancivicen: le ronnances, y copiado de este pliego en el Ronnancero de Duran; y las Cancíones Doude amor su nombre escribe y Nunca pudo la pa. sian, se cncuentran en el Canciumero generul 
y alli se atribuyen á Tapia. Las demas compusiciones del cuadermo, ignoro se hayan pu. hlicado en ninguna de nuestras antologias. Incluinc aqui la mas larga, que es las

Coplas de Madalenica.

Ibrasme, Madalenica.-

If Jesus! quim anda ahi?-

vo te enojes, hermanica,

A lu senora supliea

In galan, se llegue ali.-

ro es levintada cucara.

iluitu diré que vino aqui?-

vin ure hugas mala cara,

Di que el conde de Almenara

Uue la ama mas que á si. -

Vin la puedo despertar,

Selior, que asi vos lo digo:

sí que no ha de aprovechar,

Y que tomari pesar.

Y daril vozes conmigo.-

Mre, que traigo tristeza,

(iougoja, pena, mancilla

Que me causa su erueza:

Traigo querer $\dot{e}$ flrmeza

Coutiun para servilla.-

señor, ios en buen hora

fon "uestra pena e pasiones;

Vil pudeis cullar arora,

(vile llu eome mi senola

De palaloris ni razomes.-

Ihle, hor'mana Madalena,

Vu due (juirlas enojal,

Vu soas cansa de la peua

Ulie II seinola me ordena

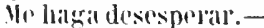

Vilia ifue lindo consuelo

Une me da de sil enijudo.

f. pluguiese á pios del tiels

Gile us diase tal desconsinelo

MIIr uriesdes desesperado.

Con el desamor que os tiene,

ligo que en balde afanais,

l'ur' mayor dolor que os pene,

Poco le va ni le viene

Que vivais ui que murais.-

Abre, Madalena hermana,

ieris que te mostraice-

Por mil fé, no os abrire

llasta tue sepa to cierto.-

Alorede buen curazon.

Uue le traign moas manillas

Labuadas con aflcion,

seda para un runon

Y grana para faldrillas.

Traigo i Framisco el joyero,

Ha que está en la Bolseria,

Yus le trae m almizquero,

$Y$ dos espejos de acero.

Y almaizares de Almeria.-

Y á llli, señol, dqué dlareis

Que te abra de bucna gana?

- Madalena, ya sabeis,

Tod', cumb vos quereis,

Como unien l" da i rma hermana.

- Enitad, señor, en buen hora,

Eutre vuestra senoria,

Que yo si de mi seĩora,

lue si sll pena le llora.
Que remedie su mancilla. Y en gozo convertirá

Toda su pena pasada,

Y con èl se alegrará,

Tanto que ella le dara

Más de lo que le demanda.-

Muchas gracias, Madalena,

Por tu buena voluntad:

Yo te daré buena estrena

Pues consolasle mi pena;

Pugarlelo he yo en verdad.

Fin.

Y toma esta cadenica, Hermana mia, por tu le,

$Y$ perdóname, hermanica,

Que en otra cosa mas rica

Te doi fé te pagaré.

Todo lo que va de letra cursiva son adi. ciones $\dot{v}$ variaciones, hechas con arreglo al testo del opúsculo descrito en el anterior articulo, N. 21 .

23 COPLAS. Coplas de vna dama y vn pastor sobre vn villancico que dize llamaua le la donçella y dixo el vil al ganado tengo de yr. Nueuamente compuestas: cõ vn Romance que dize quãdo el ciego dios de amor: $\mathrm{y}$ otro villancico que dize quanto mas nial me tratays. S. l. ni a. (hácia el 1530). 4. $^{\circ}$ let. gót. Viñeta de madera. a hojas sin fol. con la sign. a.

Conticne:

Cuplas que dicen: Llamibale la donzella.

Romance que dice: Cuundo el ciego dios de amor.

Villancico con su glosa, que dice: Mientre mus mal me tratais.

Lamentacion de amor, que dice: Resuenen mis alaridos.

Motete que dice: Ved cuan fuera de razon.

Las coplas de Llamábule la donzella son diversas de las de Alcaudete, más en número y mejores; el romance de Cuundo el ciego dios ile amor, se halla en el Romancero del Senor Duran, y la Lamentacion de amor, es la primera de Torres Naharro.

El Villancico y llotete no sé que se hayan reimpreso.

24 Coplas del Memento homo. I Coplas de memẽto homo quia cinis es $r$ in cinerum reuerteris. Hechas por Juan del Enzina. Y otras sobre la passion de nuestro señor Jesu christo. Con vn villäcico nueuo. Sobre el perdõ de la bienauẽturada santa maria magdalena. (Esta leyenda del fróntis va precedida de una gran viñeta que representa la crucifixion de Jesucristo, acompañado de su madre, las santas mujeres, los discípulos y los sayo- 
nes, y d los pies del Salvador un carbelon que dice Memento homo. S. 1 . ni a. (hácia el 1530). $4 .^{\circ}$.let. gót. Son 4 hojas sin fol. ni sign.

Contlene:

Coplas del Memento, que dicen: Acuerda, desacordado.

otras sobre la Pasion, que dicen: $E l$ rei de la gloria.

Villancico que dice: Dónde le dejas el tu amor.

No se halla este cuaderno en el Catailogo de Duran.

Las coplas del Memento están en el Curcio. nero de Encina: las otras no las encuentro reimpresas en ninguna de nuestras antologias, por cuya razon reproducire las de la Pasion de Jesucristo.

El rei de la gloria

la se muere y llama,

En la cruz por cama.

A Dios da querellas

Tan ronco y llorando,

Y la Virgen d'ellas

ruasi está espirando.

olı bios mio! y cuándo

El que más te ama

Terna cruz por carna.

En nudoso troneo

De ganchos agudos

Con un canto ronco

De tormentos cridos,

Con brazos desnudos

A su padre liama

En la cruz por calma.

El padre no cura

De le dar respuesta ,

Nas con muerte dura

Luego le requesta :

i Oh, riqueza presta

Para quien te llama,

Quien le dio tal cama!

Cuya roz tan triste

Llena de querellas,

De tinieblas viste

La lina y estrellas,

I el maestro d'ellas

Su sangre derraina

En la crus por' camu.

Vistes sus desmayus

Del dolor d'espinas;

Cubrió el sol sus rayos

Conj negras cortinas.

; Dios, porque te inclimas

A tam baja fama

(ui'es la cruz por cama!'

vel dolor tan puro

En que agola arudas,

Vo triste so el duro

Y las piedras blandas.

Dios, qu'el cielo mandas,

oye quien te llama

Por lu triste coma.

Rei de las naciones.

Gloria de batallas .

Entre dos ladrones

Vencido te hallas:
Del dolor que callas

Ha volado fama

A la mar que brama.

Cual dama de amores,

En esa persona,

De cardos por flores

Te puso corona.

Amor me apresiona

Que á vosotros ama

Y ine da lal cuma.

iOh venas corrientes

De sangre tan viva,

Que sanais las gentes

De la muerte altiva!

librad de cativa

Mi vida que os llama

Puesto en tal cuma.

A la nona hora

De lo ver defunto

Nuestra gran Senora

Nuere y vive junto;

En el triste punto

Al sol fué la fama

Y luz no derrama.

De costado abierto

Dolor que atormenta,

$r$ de lo ver nuerto

La Virgen lamenta;

Puesta está en afrenta

Porque más lo ama,

Llorendo su coma.

Alto rei de rielo,

De los cieln's arte,

En el templo el velo

De dolor sc parte

Para contempiartr:

Tii, señor, ne intlama

Y ell lu dura came.

La keina divina ,

Yadre del flnado.

De ver tanta espina

En su enamorado.

Cayó de su estado

De la vera rama,

Ou'es ln cruz jor colma.

El dolire la mata

Y el amor la aviva,

Y el padie relata

Su pena pasiva.

Coll vioz compasiva

st le queja y llima

il pie de in collum.

Por el dislue fiotio

Del vientro sagrado,

Puso el cielo linto

le su propin giadu.

¿ Uue dolir dobladı

Fu ti se derranna.

(th, preciusa dama : Heina de alto vinelo.

oh, mar de virtudes:

A verte en el cielo

Yis sentidos mudes.

I á morir me ayudes

Con amor de llania,

En la cruz por comia.

Las piedras , digades, Quisules ser duras

Porque novedades

Cobrastes blanduras. 
Porque á sus tristuras Nuestro bios nos llama En lu cruz por camu. Vosutras las gentes Suls lis duras eicltu, gue no parais mienles P(u) vos, Dios, ser muerto; su costido abierto

los quebranta y llama d s'ntir su camit.

Vinsotras las piedras (Is danus enjemplo ¿ Oh almas protervas. Duras en tal tiempo! Qiid rei vuestro y templo

l)e firl son os atma biie's la crna por camu. beo gracias.

El rej de la gloria

lia se muere y llama

fin la cruz por comat. Fin.

2.: COPLAS. I Coplas nueuamente heclias de vna señora yue pedia a su marido rna Saboyana y el escusisse todo loque puede. Có vn villäcico. S. l. nis a. (hicia el 18330). 4. Jet. got. Tinela do madera. Son 2 hojas sin fol. ni sign.

ionlicne:

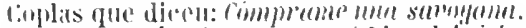

Villancice glie dice: Lomese a hios alel ciots.

son las de blas de dituma, is a lo menus se lonlau entre las suyas en al folloto impresu an Cuenca en 1605 , descritu il enntinuaciun.

El sl. Duran mo conoció la presente edipinn, pues ann cuando cita mal de las co-

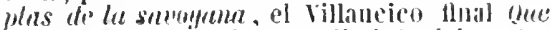
"fupress que os traigu, es distinto del conteuidu en la nuia.

26 Coplas agora nuewamente hechas, que dizen. Que quereys que os trayga delicada. Con otras. De comprame vola sabovana. Y otras contri los yue dizé mal de mureres. Agrora nueuamente nechos por Blas de Aytona: y con licencia impressas en Cuenca, en casa de Bartolone de Selma. Año de 1603. 4. Viñeta de madera. hojas sin fol. ni sign.

Contiene:

Coplas gre dicen: gue quereis yue os traigir, delicadu.

Otras que dicen: Los casados que querris. otras que dicen : Compn'ame nua savoyana. Villancico que dice: Loores al Dios del cislis.

beshecha que dice: Oue demundais mis, galumul.

Coplas moras comtan los que dieen mal de mujeres: huiph dice mal de mujeres.

vtra que dice: . Hnea mia, lomed amor.
El Sr. Duran no menciona este pliego; habla si de otro tambien en $40^{\circ}$ de 4 hojas en let. gót. comprensivo de las mismas composiciones que el presente ménos el Villancico y las Coplus Alma mia, tomal amor. Las últimas se hallan en otro folleto deserito por dicho Sr. l)uran, ol cual se intitula: Coplas de Camini, señora si quereis caminar, com sus villancicos sobre de cuso. E otras de Si que$r$ is comprar romero muy apacibles. Agora nueurmente fechas por Francisco de Monlemuyor. S. l. ni a. 4. let. gut. 4 hojas. Contitne: Duilogo pntre gulum y damu, en coplas y versos de enderhas que dicen: Caminá, senon. Villancico de la dama que diee: Quiera Dios por uni no digan. Ilem del caballero, juc dice: Ouedo de vos tan contento. Coplas $i$ modo de las de si quereis cumprar romero, une dicen: Alma mia, tomad anor.

He parece que Blas de Aitoma, eseritor desconocido á Vic. Antonio, será á lo más autor de alguna de las composiciones del follelo que yo posen.

Gallaido en el Ensayo de una bib. esp. describe el siguiente pliego cuyo contenido es casi igunl al al mio: coplas agora nuemmente hechas de una mujer colsuda que pedia a sul marido una saboyuma: y el marialo la responde quien son las yue an de traer, y las que wo. Com olras Coplas nuevas conlra los que dicen mal de mujeres. Van tambien otras Coplas que dicen: one quereis que os traigu grelum? com ofrus que diven: Que quereis que "s l"aiga delicula!" Es obra digna le ver. \&." let. grit. í hujas.

27 COPl.As. A Aqui comiencan muchas maneras de coplas y villancicos de muchos auctores. (Este es todo el epigrafe, incluido dentro de un cuadrilongo.) S. 1. ni a. (hacia el 1530). 1.0 let. gót. 1 hojas sin fol. con la sign a.

comticue:

Coplas rue diren: Quien vos aparto de mi. otras del comendador Escrivi, que dicen: ¿Que senlis cor'conn mio?

otras de Gartia sánehez de Badajoz, que diren: seciromus: los pesares.

otris de D. Pedro de Acuna, que dicen: si cumdo triste os mire.

Copla de viego de San l'edro, que dice: Nis hermosa que corles.

Villaneico hecho por Carasa, que dice: Dejuldos, mulre.

Otro del linism", que diec: Ya soi desposulin.

otro do Xicolas Núnez, que diee: Vevir yo $\sin$ ver ri wos.

otro de Quiros, que dice: aly! que yu movir no puedo.

otro del mismo, que dice: Nasci libre y soi cretien.

otro de Soria, que dice: Está tul mi vida, señora.

otro anónimo, que diee: Encubros el mal que siento.

otro del comendador Estuniga, que dice: como se puede partir. 


\section{(C)P}

PLIEGOS SIELTOS

Coplas de Perálvarez de Aillon que dicen: Con mi crescido cuideulo.

Copla alonina, que dice: Esle sayo vos entio.

Optisćulo desconocido á Duran y uno de los mas interesantes de su clase, pues la mayor varte de las composiciones en el contenidas, se hallan escritas por autores cuyas obras se encuentran en el Canciomero general, y á pesar de ello no se hallan en dicha coleccion siete de las coplas y villancicos que comprende este pliezo. Copiaré alguna de ellas, por no carecer de mérito.

Copla que hizo Diego de San Pedro a una seniora a quien rogo que le besase, y clla res. pondio que no tenia culo.

Mas hermosa que cortes, Donde la virtud caresce,

El culo no le neguẻs

Qu'en el gesto le tenés

si en las nalgas os fallesce.

Y si hai algun primor

Para no tener ninguno.

Yo digo que algun gordor

El cabo yel salvohonor.

os ha hecho todo uno.

Asi como Duraton

Pierde el nombre entrandi en Duero,

Asi por esta razon

Perdió el nombre el avispero

Cuando entró en el pozo Airon.

rillancico hecho por Carasa.

Dejaldos , madre,

Mis ojos llorar

Pues quieren amar.

Dejaldos llorar,

Itueran de pasion,

Que ansi han de pagar

Su ciega aficion:

Pues de su intencion

No pueden mudar:

Dejaldos Uorar.

Mejor es dejallos

Con su disfavor,

Que más consulallıs

Les dobla amor:

Su gloria es dolor,

su gozo es penar,

Dejaldos llor'ar.

tas causas sin suertes

De do s'encendieron,

Mis penas mui fuertes

Mis ojos lo fueron;

Llorando uascieron

Y ansi han de acabar:

Dejaldos Uorar.

Dejaldos vivir

Con sus fantasias;

Dejaldos seguir

Sus graves porfias,

Qu'el fin de sus dias

No debe tardar;

Dejaldos llorar.

Villancico.

Liss coplas son de Vicolas Núiez.

Vevir yo sin ver á vos,

in quipro, ni quiera lios.

\section{CHi}

Y puesto que yo pudiese

Quitarme de tal favor,

No me dejaria amor

Hacer lo que yo quisiese;

lines que otra dama sirviese,

sino a vos,

No quiero, ni quiera Diss.

Porque vuestra perflcion

Tiene tal virtud en esto,

Que nos paga en ver sil gesto

Cuando niega el gualardon,

I aunque pueda cl corazon

Vevir sin ros.

No quiero, niquiera Dios. Asi que lo qué valeis

No es razon tenello absente,

Porqu'el mal que vos haceis

Da herida y no se siente:

l'lles vevir sin ser presonte

ri) de vos,

No quirro, ni quiera Dios.

28 CosTa (José). El Cardenal prodigioso san Raymundo nonacido vída y portentos... Sacada de diversos avtores ... Recopilada ... por el Padre ... Fr. Ioseph Costa. Valencia, por Siluestre Esparsa, 1648.4. Lamina de madera. 8 hojas sin fol. sign. A.

Pliego y romance que no cunorii el scino Duran, y dice: Despues que del solin inpiret).

29 CRCZ (Fraxcisco de LA). Siguese un gracioso cuentoque seccedio en la villa de Madrid, a vn cauallero que se fue a la ciudad de Valladolid con la Corte, es de mucha curiosidad: trata de como en rna casa principal de la dicha villa, andauarn Ituéde que maltrataua a todos los criados, porque se yuan a Valladolid, $r$ de como se aparecio al cauallero en hauito de frayle, y de muchos coloquios que entre los dos passaron. Compuesto por Francisco de la Curz. Murcia, (sin nombre de impresor, $\lrcorner$ en este año de mil Y seyscientos y vno (1601.) $4 .^{\circ}$ Viñeta de madera. 4 hojas sin fol. ni sign.

Es un Romance que principia: Mientras ! $a$ Corte se parte, y unas Coplas, que dicen Dezi, dumas arreboladas.

No ereo autor de esta composicion á ninguno de los Franciscos Cruz, de quienes habla Nic. Antonio.

$\mathrm{El} \mathrm{Sr}$. Duran tampoco menciona este folleto.

30 CHISTES. Chistes de muchas maneras nueuamente compuestos: con vn villācico al cabo q̃ dize: no me demãdescarillo. S. I. nia. (hácia el 
1520 . 4." let. gót. Viñeta de madera. a hojos sin fol. ni sign.

Conliene:

Chiste que dice: Si quiero, no y puiern. thro que dice: tonituos allii.

loplas rne diecu: Agun, dulde agun.

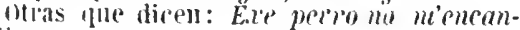
diles.

otras que diren: si lu patre to dijere mal. cuplas de ma mozil que no queria casarse.

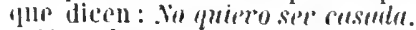

otras de como $\mathrm{mm}$ raballero y una dama ju. gaban al ajedrez, que dicen: Jugnemos ul ujpodrez.

Villaneico que dice: No me demandes, carillo.

Casí todas estas composiciones son mui libres.

El Sr. Duran no vió este pliego suelto. Büht de Faber ell su Floresta t. 1. p. 556 inserta las coplas No quiero sér cusculu, y en la pág. 276 del mismo tumo, el Villaucien No me demandes, cerrillo; pero de mil manera mui incompleta y modernizando el istilo.

La viñeta del priucipio es la siguiente.

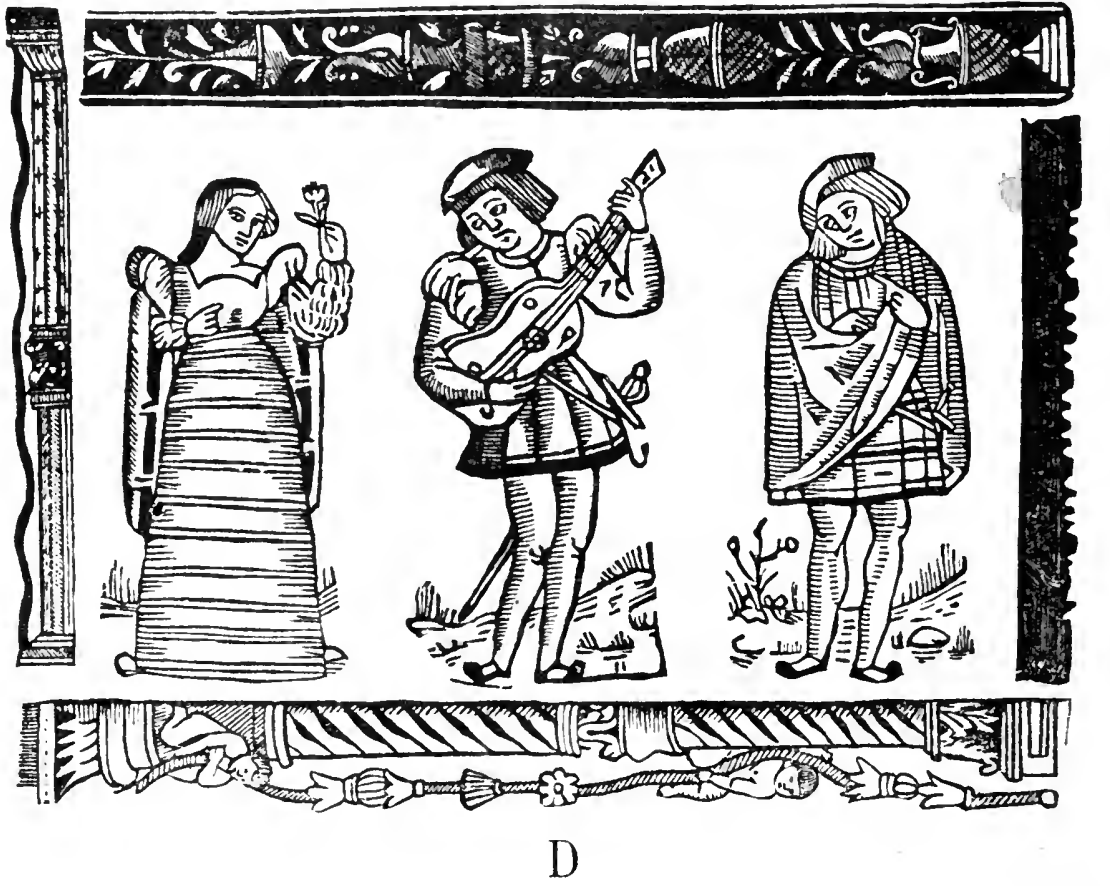

31 DÉOS (Roprifo DF.). Tratado do. Passos que se andam na Qvaresma, para rezarem, or cantarem os que os correrem. Por o P. Fr. Rodrigo de Pros. Lisboa, Domingos Carneiro, $1061.1 .{ }^{\circ}$ Con muchas viñetas de madeia. 2 's pags. inclusas las dos de la hoja de la portada.

En carla l'asso haj un himno en verso: lo demils estit eli prusil.

Cita Barbosa una edicion de Lisbon, 1618, y bu presimo las habri anteriores. Nire. Antoinio en la brevisima noticia de este eseritor, in tratar de sus obras, solo diee, que escribiii Motions spiritues: Tralado elos passos. misipone in $x$."

32 DESHECHA. Deshecha solipe lo acaescido $\vec{a}$ la sierra Bermeja 5 d'los lugares perdidos. Tiene la sonada d'los comẽdadores. S. 1. ni a. 4. 'let. gót. Son / hojas sin fol. ni sign. Copia manuscrita de este opusculo.

Contiene:

Deshecha que dice: jay sierra Bermeja!

Coplas te la reina de vípoles que dirent:

Emperulrizes yromas.

Villaneicu: No hai plucer en esta viele.

Idem: sul de muchos no comsuela.

Coplas fechas por Rodrigu de Reinosa a unas serranas, al tono del haile del villabo, que dicen: Mal enctramillo, millo.

El Sr. Duran no pudo ver este pliego surlto.

Rodrigo de Reinosa, nombre no meneionildo en la Bibliothere de Nic. Antonin, autor de la viltima composiciun arriba indirala, parece delié su ingenio á esta ('hase de litrintulá do pliegos follintes. mes yo be tertids 
DES

Pliegos sueltos.

ocaslón de ver los slguientes escritos por èl:

Comienza un razonamiento por coplas en que se cótrahaze la jermanta c feros de los rufianes $x$ Las mugeres del parlido: $x$ de $\mathrm{kn}$ rufian llamado cortauienlo: y ellu catalina torres altas. Fechas por rodrigo d' reynosa. S. $l$. ni u. $4^{\circ}$ let. gót. 2 hojas; el Sr. Duran dice que son 4. Comiençan vnas coplas d'vn pastor: \& vna hija de in labrudor. Cantanse al tono de vma amiga tengo hermano. Fechas por rodrigo de reynosa. S. l. mi a. 4. let. gót. Viñeta de madera. Son 2 hojas con la sign. $a$. Al fin van dos villancicos y otras coplas del mismo autor.

Aqui comieçan vmas coplas delas comadres. Fechas a ciertas comalres no iocando en tas buenas: saluo digo delas malas y de sus lenguas \& hablas malus: y de sus ufeytes $y$ de sus azeytes r blanduras a de sus trajes $x$ otros sus tratos. Fechas por Rodrigo l'reynosa. S. l. ni a. $4 .^{\circ}$ let. gót. Son en todo 12 hojas con las signs. $A-u v$; las siete restantes no tienen ninguna.

Comiéçan vnas coplas pastoriles para cantar de como dos pastores andando cō su ganado rogaua el vn pastor al otro le mostrasse rezar elpater noster que ellos en su lenguaje pastoril lluman palarniega. Fechas por hodrigo de reynosa. Ocupan una hoja y en la siguiente:

a Comiençan vnas coplas d' como el auctor que las fizo quiere loar a su amiga de todas las gracias que liene. El qual auctor es el dicho Rodrigo de reymosa. Utra hoja. S. l. ni a. 4. let. gót. Son dos hojas.

I Comienca in tratado hecho por coplas sobre पं vna señora embio a pedir por merced al autor que las hazo que pues estuua de parto le embiase algun remedio. el qual le responde por coplas. Han se de cantar al tomo de rezemos beatus vir qc. El qual autor es llamado rodrigo de reymosa. S. l. ni a. 4." let. gót. Viñeta de madera. 2 hojas sin sign.

De esta composicion cantable $y$ en dialogo conservo el estracto siguiente.

La mujer pide al marido que vaya á busear la comadre, pues anda de parto; viene esta, la enferma se queja de lo nucho que padece, y entre otras cosas dice:

\section{La preñada.}

Amarga de mi cuitada que ya me quiera finar, cierto no podre escapar comadre que soy cerrada : pienso que de esta vegada se acerca mi triste suerte de mi desastrada muerte, segun es mi afligir.

\section{La comadre.}

Ay hija! por vuestra vida no digais que sois cerrada, habes sido enamorada e de mas de tres parida; habes sido corrumplda de niña de doce años: para ml estos engaños no los quiero consentir.

A respuesta tan terminante la paciente se ve obligada á confesar sus flaquezas, despues que la comadre la promete
DIA

que tras de sicte paredes

vuestra honra será guardada ;

hlja porque seals crrada,

ya se bien estos aferes.

que fecho son de mujeres

que es con hombres dornir.

Animada con estas seguridades la preñada sigue abriendo su pecho.

Comadre, á vos la verdad

se os ha de conocer:

tiene conmigo que hacer

el sacristan $\mathrm{y}$ el abad,

que si le hago ruindad

á mi marido sabran,

que no me traen soliman,

ni arrebul, ni de vestir.

Para tranquilizarla y quitarle todo escrúpulo le dice la comadre:

Hija, digos sin embargos,

que es consejo sin falla.

dad con él en cornualla

é póngelos tan largos:

hija, todos esos cargos

vuestro abad al confesar

os lo quiera perdonar

rezandos el beautus vir.

El Sr. Duran nos da noticia del siguiente pliego que parece ser todo del mismo autor. Agui comienza un Pater noster trobado $y$ dirigidn a tas damas, y las coplas de la Chinigala, y un villancico que dize: Los cabellos de uni amiga-de oro son, con ofras te vil ventero y un escudero. Y' in villancico que dize: No tengo vida segura-en no ver tu hermosnra, frobado por Rodrigo de Reinost. S. l. ni a. 4. ${ }^{\circ}$ let. gót. 4 hojas. Y yo he visto otro pliego suelto, dónde 110 se leia el nombre de Reinosa; pero por su estilo y por hallarse encuadernado con otras composiciones de dicho autor, no vacilo en adjudicárselo. Hé aưui su descripeion.

Coplas de unos tres pastores. Iartin \& Mi. guel $₹$ Antō cōotras de Alegre fuy. ¿ otras de pusesme por dios bargro.

El diálogo, que es representable, empieza i colltinuacion y ocupa tres hojas; en la cuarta se hallan los dos viliancicos de Triste fui $e$ alegre vengo, y el de Pasame por lios barquero. S. l. ni a. $4^{\circ}$ let. gót. 4 hojas.

33 DIAS (Baltasar). Conselho pera bem casar. (Siguen cuatro figuritas grabadas en madera.) Obra novamente feita a qral he chamada Conselho pera bem casar. Porque em ella se tratāo as mais das causas que conuem ao tal conselho. Muito proueitosa pera homēs, \& molheres. Agora nouamente emendado, \& acrecentado por Baltasar Dias. Vay fingindo o Autor, que hum seu amigo lho mandou pedir pola maneira seguinte. E no cabo vay acrecentada hîa carta de hũa Senhora đ̃ queria aprender a ler. Em Lishoa. 
Por Intmio Aluarez. Anno 16i7. 1." 8 hojus sin fol. con la sign. A.

Ene virso ménos una corda que ocupa la iltima loja.

Barbusil cita una edicion de Lisbon, 1605.

34 DIAS (Burasili). Emperatri\% Poreina. Ilistoria novamente feita da Emperatri\% Porcina, molher do Emperador Lodonio de Roma. Ein a qual se trata como odito Emperador mandou matar a dita Senhora, por Im testemunho que the aleuantou $0 \mathrm{er}-$ máo do dito Emperador, \& como escapou da morte, \& dos muitos trabalhos \& fortunas que passon, \& de co:mo por sua bondade, \& muita limpieza, lornou a cohrar seu estado co mais hora $\vec{a}$ de primeiro. Lisbor, Antonio alures. 16iv. 1." Vinela de madera en la porlada. Son 12 hojas sinfol. conl ia sign.?

in llevil seto rumance nombre de antor en la presente edieion: Barbssir Machado io atribuye á Baltasa bias y sula mencinna otua impresinn hecha en Lisbur en lbtio.

$3:$ - Malicia das Molheres. Obra nomamente feita chamada malicia das molheres porque se tratam muitas sentencis, \& autoridades a cerca da malicia ij ha em algēus dellas, \& assi mismo trata como duas molheres enganarĩo a seus maridos muy graciosamente. Jisboa, Antonio
Aluares, 1637. 4.' C'm una pésima viñela de madera en la porlada. Son 4 hojas sin fol. con la sign. 9 .

Tampoeo lleva este pliego nombre de autor; se lo idjudien á Baltasiar Bias porque sin duda es lo que Barbosa N! lyat llama: Auto die. Mulu ita dus milheres, Lisi ' 'G0, y atribuye á dicho antur; sin embano mi opisenlo no es sinu mina especie de collentu en verso.

Brunet no habla de este iseritor portugues,

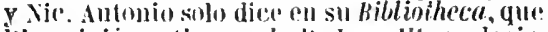
Ilias vivio en tiempo de ll. Jllall III, es decir, 'n la primera milad del siglo XVI; pero no" tuvo unticia de ningnena de las muchas obras publicadas pur el, pues fodis son á cual mas r'ara.

36 DISPARATES. I Disparates muy graciosos y de muchas suertes nuevamente heéhos. I vin aparato de guerra que hizo Mōtoro. Y vnos fieros que hace vn rulian contra otro. S. l. ni a. (hacia el 1320). 4. 'let. gót. Vinela de madera. 1 hojas sin fol. ni sign.

Contiene:

Romance: Cominamdo un viernes santo. Gissa primera: Chando Hector el valientr.

Idem sf'gunda: li portpe gritas y bramus. Iden tercera: Vi al talienle scipion.

Idem conarta: El rediunte Vulcano.

Idem quinta: Fin los M/pess de Alemano.

lilom sosta: cueme Ins apole daba.

Iden, que dice: tudrumat mil putas viryis.

A pillitu do gunerril, que dice: Oh, que pompay que arreo.

Fieros que hace mu rufian: pose a $t a l$, remiego de till.

Xin lingró ver este opíseulo el sr. Duian. Lal vinieta del principio es la sigutiente.

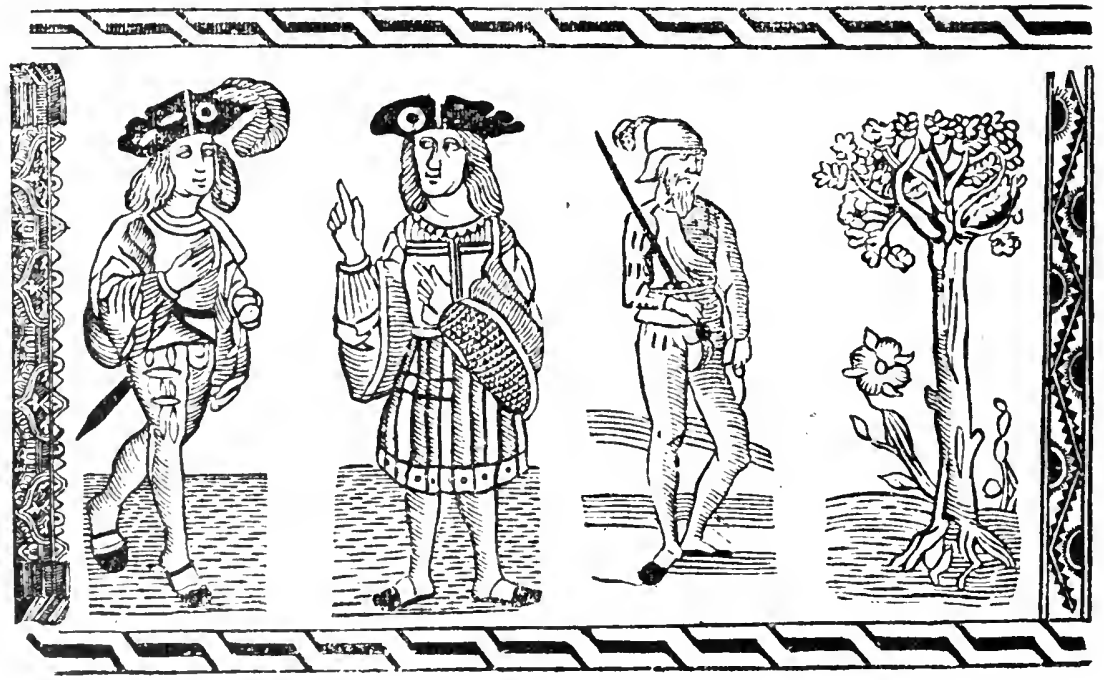


37 F.YCINA (JeAX deL). Disparates $y$ almoneda trobados por Juan del enzina. E vn villancico. S. l. nia. (hácia el 1330). 4. ${ }^{\circ}$ let. Éót. Viñeta de madera. 1 hojus sin fol. con la sign. aij en la segunda hoja.

En las notas al t. I de la Hist. de la lit. de Ticknor, se menciona una edicion hechã elı Snlmanca, 14975. 4. que tambien cita Bayer en las notas á la Bib. vet. y Diosdado Caballero.

Los Disparates y la Almoneda se hallan ell el Cancionero de Encina; el Villancico es el siguiente:

Por mul dichoso se tenga

Quien por vos sufre pasion,

Pues es harlo el galardon.

siendo vos la causadora

De la muerte que yo muero,

Qué mayor vituria quiero

Que morir por tal señora;

Pues con la causa se dora

Rien abasta la pasion.

Pues es harto el galardon.

A cuantos vencidos viven

So teneis que darles grado,

Pues en veros es forzado

Que de fucrza se cativen:

luestros ojos no me esquiven.

To quiero sino pasion.

Pues es harto el galardon.
Los aquejados sospiros De la pena que me dais

Harto lus galardonais

En que pene por servirns;

Sin otra merced pediros

Soi contento de pasion,

Fues es harto el gutardon.

A vis se debe el ditado

De más hermosura e gala,

$E$ a mi nadie se me jguala

En seros aflcionado:

Por ser tan bien empleado

io quiero sufrir pasiun.

Pues es har in ol galardion.

$E$ pues $s$ is tan linda e bella

Yi pasion he ro por buena,

Que à todo el nuundo dais pena

E á nadie remedio d'ella ;

xo puedo tener quorella

Con tan dichosa pasion,

Pues es harto el galardon.

\section{Fin.}

Aunque no janas vencida

E à tudios renceis en verus,

Nadie deje de quererus

Pues es deuda conocida ;

Con esperanza perdida

De esperar si nu pasion.

Pues es harto el gulardor.

Esta es la vineta que lleva bajo del epigrafe.

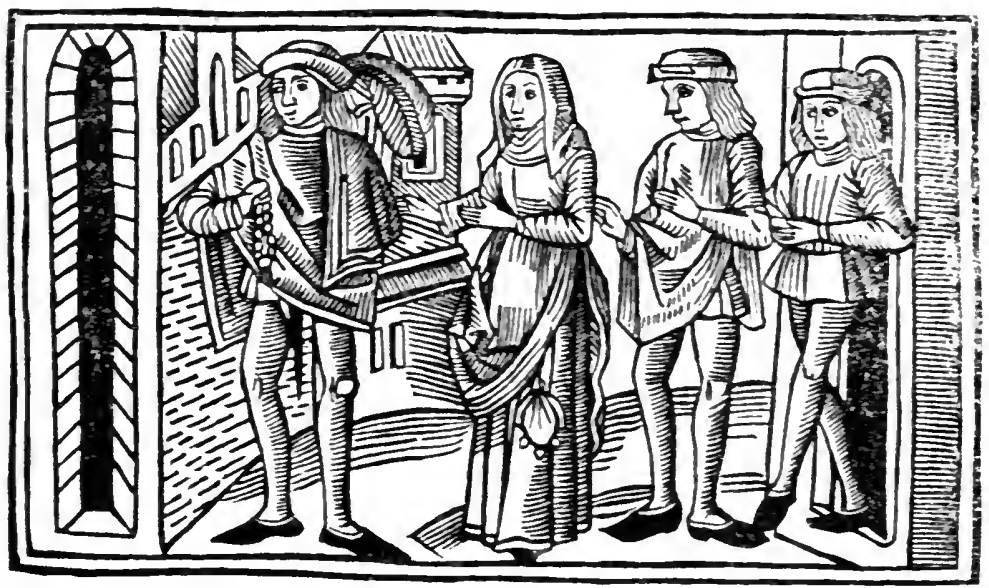

38 ESCA.IDON (IGXACIODE). Epoca Gali-cana, egira Gali-lea por el general D. Ignacio de Escandon. S. I. ni a. (Lima, 1763. 4. 4 hojas.

Es un romanee á la anertura de la cóso para las peleas de gallus en la capital del Perú.

Todas las obras impresas pll Anurica se ellcuentran con dificultad en Eumpa: pero un pliego de cuatro binjas, en relso, e's una veldadara coriusida! biblingratura.

Том. 1. 
39 FELIPE V. Miscelinca de 69 pliegos sueltos, en verso, sobre acontecimientos de su reinado y relativos á la Guerra de sucesion. Jupresos en varios pueblos de España y en diversos años. $4 .^{\circ}$

los papeles mas curiosos routenidos en esta coleccion son los siguientes:

Salve que reza un fldelisimo vasallo dando gracias, á X. S. de Atocha de la feliz Restanracion de Madrid al apacible dominio de sus reyes.

Carta que escribe deste Vitoria Magdalena li bea al Archiduque.

Relacion que al rey hace un Coromel de sus ejércitos de los felices sucesos y vitoria le Almansa.

Juan Soldado da la enhorabuena al pey Fe. lipo Y del feliz consoreio con D. Lnisa Maria de Saboya.

Quejas amorosas del monaguillu de la .11mudema.

El Patan de Caramanchel despierti á los gritos de tantos vapelones $y$ mete su eucharada contradiciendo á todos.

E.l Patan se quedo dormido otra rez, y sil hijo el Patancillo prosigue.

Carta que escribió D. Guindo al rey dandole la enhorabuena por haber heredado el reino.

Carta de Doña fininda al rey.

poema natalicio en celebracion del natal del Sunor D. Carlos Emamel de saboya.

Coloquio que tuvierou un Poeta, un Soldadi, un Sordo y un Ciego en las gradas de San Felipe.

Perico $y$ Marica vuelven di sus antignos coloquios censurando Malcontentos.

Segunda parte de Perico $y$ Marica.

Eniretenimientos de valor y juguete de la osadia. Romance jocoserio.

Coplas para coplas. Excrutinio recto.

Coplas para ciegos.

Bartolo y Pascuala, su conversacion camino de Foncarral.

Carta escrita en ítulos de comnedias, por t.uis Perez el Gallego.

Carta del amigo ausente á Luis Perez el Gallego en que lc noticia los sucesos de Cataluỉa, Valencia y Portugal. En títulos de comedias.

Epinicio métrico en la restitucion á la Conte de Felipe $V$. Por D. Antonio de Zamora. Romance en elogio de Felipe $r$, en titulos flo comedias.

sonoros ecos para advertir al desengaio, all el feliz regreso y progresos victoriosos de Filipe V. Por D. P. L. D. L. E. Y. R. (D. Pedro Luis de la Encarmarion y Rels.)

Peticion lamentable il Felipe $\mathbf{r}$. Sobre el salmo $15 f$ de David.

firmance romien en que se muenta di la reina lo que ha sucedido desde que SS. MI. se ausentaron de la Corte.

Justísimo elogio de Felipe $\boldsymbol{r}$.

Epistola á Luis Xiv y sumario de las hazaĩas, tuertus y derechos de las armas del Ar. chiduque Carlos.

learu y Dedalo, necedades de tontos y avi. sos de cuerdos.

Carta que escribió la Archiduquesa á su es. poso I. Carlos y la respuesta de este.

Carta que le escribe Geromillo de Parla d́ su amigu Bartolillo Cabrera, de lo que ha pasado en Castilla desde Agosti hasta Noriembre de 1710.

Carta de Perico el Tiñoso, para el cura de Oreajo su tio en que cuenta las hazanas del Conde de la Ataliya desde el 7 de 0ctubre hasta el 28 de Noviembre de 1710.

Carta de Estaremberg a Estanop hecho prisioncru en Brihuega.

Carta y respuesta que da Marica la Tonta á la que escribio Magdalena la Loca.

Proezas de Guido Estaremberg cuando pasó i Madrid á corouar al Arehiduque Cárlos.

Letrilla í la bienvenida í su Corte de nuestros reyes, segunda vez trimfantes.

Diversas puesías á la inconsiderada entrada y presurosa salida del Archiduque Carlos ell Madrid.

El Qne es? de la Corte. Escrito por un Gavacho nuevo.

Desengaño de la reina Ana, iristezas de Estanope y lagrimas de fistaremberg, a la perelida de su armada en 1710.

Tres romanres en Catalan relativos á acon. tecimientos de los años $1705,6 \mathrm{y} 7$.

40 FEY (Avroxiode LA). Tres romances, en la memorable, y triunfante victoria que tuvieron las Armas de la Catolica Liga, comandadas por el Señor Don Juan de Austria, contra la Armada Turquesca, en el Golfo de Lepanto, à siete de Octubre del año mil quinientos setenta y uno. Compuesto por Antonio de la Fev, \&. Valencia en la Imprenta de Agustin Laborda, s. a. 4. Viñeta de madera. 4 hojas sin fol. ni sign.

El primer romance dice: De Sicilia con poder La armada real salia.

Se halla en la Floresta de varios romances. El segundo dice: Yo el gran sultan Selim,

Yel tercero: Rei de reyes coromado.

A $i$, Celimo sultan, El que Gran Señor se llama. 


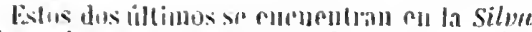

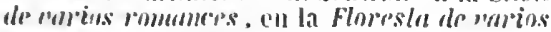

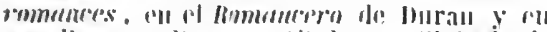

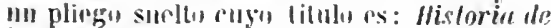

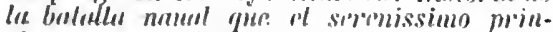

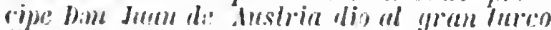

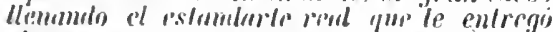

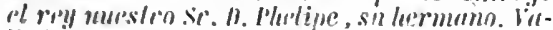

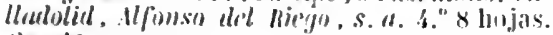
som 10 rumameses.

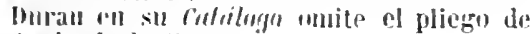
Antonio dle la frey.

41 FIGIEROA (LuSDE). Relaciō rerissima, de lo queha sucedido en la cindal de Scuillal, a rina honrrada señora, por no entenderse sil marido, que haziendose preñada, el primer año de su casamieto, vino a parir vo negrito, y cuetase lo que desto resullo, yue por ser largo no se puede saber, sin leer toda la obra. Compuesta por Luys de Firueroa, natural de la villa de Madrid. Cuenca en casa de Bartholome de Selma, 1603. 4." Viñeta en la portada. I hojas sin fol. ni sign.

Es un linmance en comsonantes, que principia:

$$
\text { El sacro Espivilu sumlu. }
$$

El Sr. Durau no turo noticia de este pliego: lampoen suena el nombre do Luis de rigio. roa en la Bibliothece de vic. Anturio ni Io memciona Alvarez y Baena í pesar de ser natural de la Corte.

Es cuenlo mui peregrino, como observa el Sr. Gallardo, y rarisimo como lodos los plieges sueltos de aquella cpoca.

\{Z FloRES (Bıtolomé) Y PARE.JO (Alorso). Relacion agora nueuamente compuesta. Del leuantamiento, I guerra del reyno de Granada. Cópuesta en verso castellano pur Bartolome de Flores colchero... \& por

13 GLOSA. C Glosa de llamaua lo la dōzella espiritualmente hecha. $\mathbf{S}_{\mathbf{i}}$ gue una estampita de madera, en la que hai un hombre con la palabra Pecador sobre el, $y$ un crucifjo.) S. l. ni a. (hacia el 1310).4. let. gót. 2 hojas al parecer completas, aunque la primera llev'l la sign. aiij.
Alonso Parejo el Blanco. (S. I. Mi nombre del impresor, año de nil : seyscientos y quatro $(1604) .40^{\circ}$ Vineta de maderia. a hojas sin fol. ni siyn.

lieflere el presente romance el levautamirutu de Istix.

Vic. Antunin no nombra en sn bibliothern

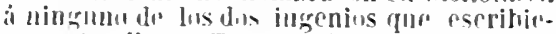
ron este plipgin. Tampuce lis mencinua el soกแल HuratI.

13) FlólRes (Rourigo de). Obra nue ra del nacimiento, vida, muerle. Y milagros del hermano frar Francisco del niño lesus... sacada a luz por Rodrigo de Flores. (.ll fin: Valencia. en casa de Pedro Patrieio Mey, 160:5. 1. ${ }^{\circ}$ 'on tres rinetilas despues del epigrafe. i hojas sin fol. ni sign.

E: una relacion ron fulma de romance: al fin de clla se Le": Viudese eil relsa de luan Bunlistu Timoneda junto u la lereed. Fste Timuneda era probablemente hijo del celebre escritor valeuciano del mismo nombre.

Vie. Inteniw nu habla de ledrigo flöres, $y$ el Sr. Buran no conveiu este pliego.

4 FOITELLAS (JUEAE DE). I la insigne r venturosa Ciudad de Barcelona Roniance. Por Insepe de Fontellas. Cuenca en casa de Cornelio Bodan, 1602. 4. ${ }^{\circ}$ Ina rineta de la Anunciacion en la porlada y otra de la Virgen de las Visericordias a su dorso.4 hojas sinfol. ni sign.

Son dis Romances con nintiro de la procesion del cuerpo de San Raimundo de Peñafort en 24 de Mayo de 1602. El primero principia:

En el suryrulo Orinn,

Ie el segundo: A la ciulud mas thehosen.

Sada dice de este escritor Nic. Antonio ni enenentro tal pliego en el Catrilogo del seños Duran.

\author{
Contiene: \\ (ilosa: Lluma nios al pecador, \\ Felijo el lil: \\ Al mundo quiero servir. \\ nesconoeido.
}

46 GLOSAS delos romances que dizen Cala Fräcia montesinos: 2 la de sospirastes raldouinos. E ciertas Co- 
Has hechas por Juan del enzina. (Esta heyenda va precedida de una laminita en madera, con orla arriba y abajo, que representa a un caballero y su escudero montados.) S. I. ni a. hicia el 1530). 4." let.got. hojas sinfol. ni sign.

i7 GLOSAS. Glosas delos romances que dizen Cata francia mōtesinos: $九$ la de sospirastes lialdoninos: E ciertas coplas hechas por Juā del encina. Sigue a este epigrafe la misma laminita que en el anterior sin la orla.) S. l. ni a. (hicia el 1030). 1. let. got. 4 hojas sinfol. con la sign. a.

El contenido, igual en ambas ediciones, es el signiente:

tilisa al romance, Cata Francia, que dice: Por siemas entristecirlus.

Cilosa al romance Suspirastes Valuovinos: cirrimilo ol amor lisonjero.

Juan del Encina en nombre de una dıeña i sll marido porque siendo yil vieju tenia innores con una criada suya, que diecoll Pnes glu' l'ss, señor, holgais.

Coplas hechas por el mismo, fue diren: oh, rustillo de Ifontunches.

Pur las descripciones bibliogrrifleas que anleceden cren que facilmente so reconoceri rmaluniera de las dos ediriones que poseo del prestente pliegn; anloas fureron desconoridas i lduran. quipen sulo rita utrat impresion s. l.

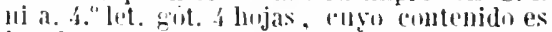
ignal al de las mias cun la íliejun de mas Cipplas de Juan del Encina, que dicen: Cumosrile desilirhudo.

Las composieiones de Juan del Encina restán en su Comeineme; las (ilosas no las encuentro m nuestras antologias.

48 GODOY JaA DE). Relacion mus graciosa, que trata de la vida y muerte of hizo la zarauanda, muger que fue de Anton Piniado, y las manlas if hizo a tudos aquellos de su jaez I camarada, Y como salio desterrada de la Corte, y de aquella pesadumbre murio, es obra de mucho guslo y entretenimiento. Compuesto por Iuan de Ciodoy. Impresso con licencia en Cuencil en casa de Bartholome de Selina, año de 1603. 1. ' Con una gran viñeta en la portada. I hojas sin fol. ni sign.

Es un liomance con un Villaneicu al fin. El jrineru forincipia: Desteriala de la corte, y (1) segundu: . Vadie canfe Zarabanda.

Hasta nuestrus dias han llecrado como cosa

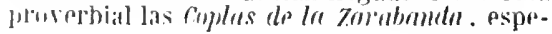

cie de baile bastante provocativo y obsceno, segun alginos autores. Se introdujo en España en el reinado de Felipe II, y se prohibió á principios del sigl XVII, sin duda, por lo que contra él declamaron varios autores, entre ellos el P. Mariana y Caro.-La presente Relacion, compuesta ci gran parte de los primeros versos de las coplas que acompaíaban á la mísiea cuando se danzaba, contienc su testamento y sus mandas antes de espirar.

De este raro y curiosísino opúseulo, no meneionido por el sr. Durall, hablan estensamente lo. Jinan Antonio Pellicer, en la Vida de Cervántes y notas al (uijote, y su hijo Don Casiant) en el Tratıdo listórico sobre el origen de li comedia.-El Juan Godoy, autor del presente oprisculo, parece diversu de los dos eitados por Nic. Antonio.

49 GONZILEZ DE FIGUEROA (Frascisco). TObra nueuamente compuesta por Frācisco Goncalez de Ficrueroa... dando (donde) se cuenta la vida, y el martyrio de vna santa muger Española: y fue, que la quemaron viua en la ciudad de Ilierusalē, en el monte Caluario, donde fue crucificado muestro Señor Jesu Christo. Valencia, (Sin nombre del impresor,) M.D.Lxxxj. 4. let. gót. Viñeta de madera, bastonte bien grabada. 1 hojas sinfol. ni sign.

La última pígina la llena una Glosa en alabança del sanlissimo Sacramento: Compuesta por vicente de Mirauet, componedor de la subtilissimu arte de la Emprenta, y natural de la ciudad de Valencia, la cual principia con el versi, En aquel pan celestial, escrita en quintillas. De la misina clase de metro es la relacion de González de Figueroa.

Nie. Antonio no da noticia alguna de estos dos eseritores, y á Vicente Miravet, á pesar de ser valenciano, no la encuentro en las $B i$ bliotecas de Rodríguez, Jimeno ó Fuster.

El Sr. Duran menciona este pliego, pero no pudo verlu.

50 GONZÁLEZ DE LEGARIA (Juix). Aqui se contiene vna obra graciosa, y muy gustosa, para reir, $\mathrm{y}$ passar tiempo, y es vn cuento que le passò a vn Soldado, con vn Gato, que le lleuaua la comida, y porque le lleuò vna libra de Ternera, y vn pedaco de Atun de hijada, las anenazas que le haze, al modo del Romance de Zayde: Iuntamente con la respuesta que dio el Gato al Autor. Con vn Villancico que las gatan le dan. Compuesto por Inan Goncalez de Legaria. Ma- 
drid, Carlos Sanchez, 1612. 1. ${ }^{\circ}$ Viñela de madera. 4 hojas sin fol. ni sign.

El romance principia: Miru, galo, que le aviso y es una imitacion $\dot{\theta}$ parodia del que. dice: Mira, Znide, que te ariso. Al fin va un Villancico que dice? Viemlo galo lan galan.

González de Legaria no ha lograd" un lugar en la Bibliwthera de Nic. Antonio, ni vio su folleto el Sr. D. A. Duran.

¿̈1 GL̈ETE (JIIME DE). Glosa nueua sobre aquel romace que empieça / Gritos daba de passion aquella reyna troyana / solo vn pie en cada copla hecha por Jayme de Guete cóforme alas traductiones $\tilde{q}$ hizieron Septimio romão d'dicto cretése y Cornelio nepote d" dares Phrigio d' la guerra troyana con otras obras al fin d'l mesmo author. S. 1. ni a. (hicia el 18.9.3). 1."

\section{$\mathrm{H}$}

32 IIISPANO (Bento). C Deuota contemplacio ordenada per lo Reuerent mestre Benet Hyspano... contemplant lo cors sagrat de Jesuchrist (en larbre dela vera creu. (Al fin:)

T Estampada enla insigue Ciutat de Mallorea per Ferrando de Cansoles. Acabas a quince dies d'l nies de Gener. Any de mil cinch cents y quaranta hù (13i1). 4. ${ }^{\circ}$ let. gót. La imagen de un Cristo crucificado en la portada, y en su reverso una estampa, igual a la que se halla en el Cancionero de burlas, impreso en Valencia, que representa $a$ un escritor sentado: ambas estan grabadas en madera. Son í hojas sin fol. con la sign. 1: las 3 primeras de cerso en dialecto mallorquin, y la última con una epistola latina, dirigida Nobili domino Frācisco Burguesio.

La parte poetica está toda en rstrofas de cinco versos del gẻnero de la siguiente, con que principia la dedicat oria a la semvora dona Johana d' Herill:

A vos quen la Spanya / tenin molta fama Molt nuble senyora / Johuma derill

Endresse ma obra / com a Real derna

De vir'tuls vestida ab que deu vos ana.

Per quen vastia vida / tingan r'n spill.

El presente ejemplar será tal vez el único que se conoce. let. gòt. liñela de madera. I hojas sin fol. ni sign.

Comtiene:

lilusa sobre el romance Grilns daba de pasion, que dice: Dispues de tuntos estragos.

A una s?îra quejandose en sn presencia ella le pidie que era li que sentia, empiezau: Vi sentido selilimiento.

[n despedimientu á nna seriora que dice: A biss, A biss, mi seniora.

Yemorial para una señora, que despues de haberle escuchado un rato to que le suplico le oyese, le dijo al fin, que pir su fe no le arordala nada de cuanto habia diclio: pero que se lo diese por memoria: principia: $A c o r^{*}-$ dius, seniora mia.

Muran no lugrij ver este fullelo, y ninguna d" Ias composiciones que contiene so hallan in sll Rouuncero. Basta con esto para probar la rareza é importancia de esta folosir.

Jame dis linete fuc autor de dos comedias. lease surticulo en la Seccion dramitica.

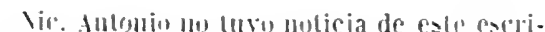
tur ni tampoco li menciona Buver.

Brumet se equivora cuamudice a! lıablar del presente libri an el artirulo Benel: $C^{\prime}$ est

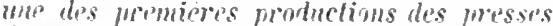
d: Yojoripue: pues en diefo punto se imori-

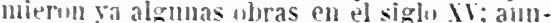
que Yindez no las cunocio. Io he visto una de ellas y's la siguiente:

meipit tractatus magistri Johinis de ger. sonn cancellarii parisiensis de regulis mall. dalorum qui stringil conclusionum proxessu: fere lolan theologiam practicam el voralem.

En el blanco de la uiltinı hoja se lee:

poctissini Magistri Joannis degersonm! presens opus: ofa "t impensis Renterenli kailholomei Caldenteii sacre theologie protfessoris Impressu est: arla lero et industria ingeniosi vicolon calafali batearici in maiori ex balearibus imprimentis fumn sn.

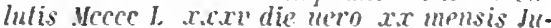
mii. 'Lueg 1 sigue: Jacobi olesie cinis Balenrici uice impressoris ad lectorem epmarama. Sin 8 disticus. Vol. en $4^{\circ}$ let. semigot. Sill foliacion. 30 hojas con las sign. $a-d$ todas de 8 ménos la viltima que es de 6 .

HISTOKIA del Marqués de .Mantua. Véase Romances del Haiques de Mantua, en la presente dirision.

J̈3 HISTURIA. Historia verdadera de la batalla naral, qre el serenissimo Principe Don Iran de Austria dio al Gran Turco, en la qual se hallarán 
POESIi POPLLAK.

L.OP

los mejores Romances, que sobre ella se han hecho. El romance primero, es, de como el señor rey Don Felipe Serundo entregò su Estandarte Real al Principe Don Iuan de Austria, y el acompañamiento que le hizo a la salida de la Villa de Madrid, y avisos que le diò sobre sei Cieneril de la liga. Midrid, por Francisco Sanz. s. a. (fues del siglo IVII). 1." Lamina de madera. 8 hojas.

El sr. Dmran no comocio esla edicion y si uma de billadolid, Ilfomso del Rígno, s. a. 1. 8 lugjas la cual coulleme los mismos dioz lomances de la plesento. que empiozan as:

De Habliat sule D). Junn-

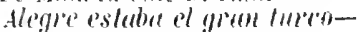

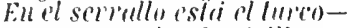
(o) gran poder de' SirilinFelipe , mastor clumpurdo.-

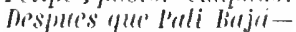

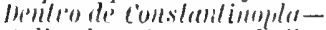

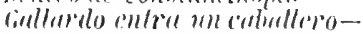
bin el groutele sullan sislinIli, Solimam sullan.--
54 HURTADO (Fanc:.). Relació verdadera de los daños Que hizo la creciente del Rio Pisuerga, en la ciudad de Ualladolid: Compuesto por Francisco Ilurtado Pineiano. Con dos Romances del sucesso de Salamāca, y camora S. l. ni a. (1597?) 4.0 let. gót. Con un Cristo crucificado entre los dos ladrones y carias personas al pie de la cruz. A lojas sin fol. ni sign.

son cualro Romume's y una Letrille que dicen:

\section{En la fribrica del mundo.- \\ En Valladolid la noble.- \\ Despues yur Pisucrya ! Duero.- \\ Nipltino lan enojoso.- \\ Ansi andrando.-}

Xo liabla el Sr. Durail de este pliegonsuelto, y itse palece ane el Finciseo llurtado menCiumado por Nic. Anlmin en su Bibliolhece, no es el antor de los Romanters. Congeturn la

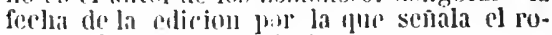
llance ál la arenida del Pisucroga. ö López (Aloxso). Glosa peregrina: la qual glosando nuchos Romancesantiguos/narra la eterna jerdicio de Lucifer / y slls sirfuaces: y la cayda y reparación del hombre; Ciópresta por. I loso Lopez clerigo. I Ian nueuamente añadidos sessenta y ocho nolables auisos/o códiciones ij ha de tener el höbre. Escle litulo ca precedido de dos estampilas en madera del arcángel San Higuel, y de Ldan y Era arrojados del Paraiso. Todo se halla rodeado de orla.) S. I. ni a. (hiscia el 13.00, . 4." let. got. 6 hojas com las signs. aii-aiiij.

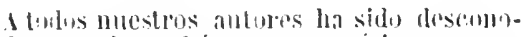

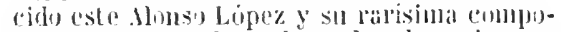
sicin, on lit cotal se glosill lus dos primer.us

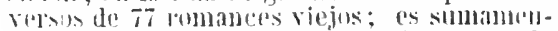

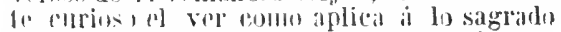
rosis sumburente profamas: sirva de cjemplo lis signimutr muestia:

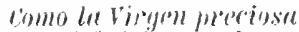
livi Jose fue diespusada,

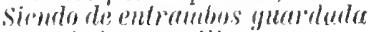

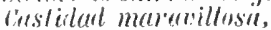

Essloba mi neromansa

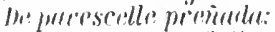

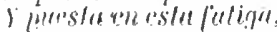

Combensolo, ansi a llevir:

No se lrisle tue.me digu,

(1)e me rece la barrigil

Y se me acorta el vestir.

36 LÓPEZ DE ĆBEDA (JUAN). Redondillas de los gloriosos Martyres san Sebristian, abogado de la peste, y de señor san Esteuan, juntamente con otras de san Augustin, y de san Iuan Evangelista mily deuotas. Y van al cabo otras de sarta Catalina martyr. Compuesto por el Licenciado luan Lopez de Vueda. Cuenca, Cornelio Bodan, 1602. 1. La imágen de San Sebastiun en la portada y la de Santa Calalina martir al fin, y dos ciñetitas. en lo interior. Son a hojas sin fol. ni sign.

Todas las composiciones de este cuaderno se hallan literales en el Virifel de flores del

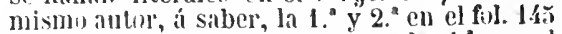
vta., la $50^{\circ}$ ent el full 149 itr., la $40^{\circ}$ en el fol. 1.20, la $50^{2}$ en el mismo i la vta., la 6. y la $7 .{ }^{a}$ en el fol. 121, la $8 .^{a}$ en el fol, 156 vta. y la ?.." en el fol. 172 vta.

57 - Romances de nuestra Señora, y de Santiago patron de Espa- 
ña: Compuesto por el Licenciado Iuan Lopez de Yueda. Cuenca, Cornelio Bodan, 1602. $4 .^{\circ}$ Con una viñeía en la portada de la Anunciacion y otra al fin que representa una procesion. Son 4 hojas sin fol. ni sign.

Las composiciones de este folleto se han copiado al pie de la letra del mismo lirrgel de fores, à saber: la 1." del fol. 98 , la 2. del 98 vta., la $5 . "$ del 99 , la $4 . "$ y $5 . "$ del 99 vta., la 6." del ful. 100 vta., la $7 . "$ del 102 , la $8 . " \mathrm{del}$ 119 vta. Y la 9." y 10." del fol. 120.

El Sr. Juran no trae en su catílıgo ninguno de estos dos pliegos.

38 LORA (Fravcisco de). Romāce del rey moro $\overline{7}$ perdio a Ualécia nueuamẽ te glosado por Frācisco de lora: dirigido a rn hr̃o suyo a comiēra. Helo helo por do viene: el moro por la calcada. S. I. ni a. (hácia el 1\%30). 4. ${ }^{\circ}$ let. gót. Viñeta de madera igual $i$ la que se halla en Romances cori sus glosas, la cual precede en la porlada al titulo antes copiado. Al dorso hai una dedicatoria en prosa. La glosa comienza:

Iquel sol de Castellanos.

Son i hojas sin fol. con la sign. a.
Al fin va una Cancion que principla: Para saberis loar, la cual tamblen tiene relacion con el Cid.

El Sr. Duran no menciona este rarisimo pliegu suelto.

Es mui singular la dedicatoria de Lora a su herimano, por el respeto con que le habla, y es notable la observacion hecha en dicha dedleatoria, de haber acordado glosar el pre. sente romance por ser el mas viejo que oi.

39 LORA (Frascisco de). CCoplas nueuaniente fechas por Francisco de Lora a este villancico que dize. Mariquita fue ala plaça mas ha d' yn hora: no puede mas la pecadora. Cõ rna glosa del mismo lora alas coplas de Desamada siēpre seas: ames y nunca te amen. E otras dos maneras de coplas. S. I. ni a. (hácia el 15203 ). $4 .^{\circ}$ let. gót. Viñeta de madera. 2 hojas sin fol. con la sign. a.

Contieue:

Villancico en dialogo, que dice: Mariquila fue a la plaza.

Glosa del romance Desamada siempre seas, hecha pir el mismo Lora, en coplas que dicen: Si en algun liempo supiera.

Inde si le faltarian dos hojas á nui ejem. plar; pero el $\mathbf{S r}$. Duran al describir este pliego tampinen le da mas de dos.

El nombre de Francisco de Lora no esta ell lis biblislluece de ric. intonio.
MALDICIONES DE SALAYA. Véase Salaya (illonso de), ea la presente division.

60 MarQLiNa (Fraxcisco). I Aqui comiēcan vnas glosas nueuamente hechas' glosadas por Francisco marquina. Las quales son las siguiêtes. Yna glosa de Tiẽpo bueno r otra de 0 belerina. Otra de rn romance it dize Descubrase mi pensamiēto: z otra glosa de Acordaos de quien se oluida : $x$ in romāce $\bar{i}$ dize Pues de amor fuystes dotada. del mesmo auctor agora nueuamente hechas. S. 1. ni a. (hácia el 15:30). $4 .^{\circ}$ let. gót. Vineta de madera. 4 hojas sin fol. con la sign. a.

Contiene:

Komance que dice: Tiempo buens, liempo bueno. libst del misun, que dice: Por let glorin untepresulu.

Cancion que dice: Fadie nis lenge en il mundo.

Glosa al romance de Oh Beler'ma! cu coplas que dicen: En los liempos que en la Francia.

Romance qne dice: Descibrase mi pensamienlo.

Gl isa á dicho romance, que dice: Scrlipndo de una pspesura.

ntra glosa del romance, Acordaos le quien so obvidu, en coplas que dicen: Serena luz delectuble.

Romance de Marquina, que dice: Pues di' amor fuisles dotude.

De todas las composiciones de este pliega s)lo encuentio en el Cancionero de ronumces el de Varquina y el de Describrase mi pensamiento. El unltim y lo reprodujo el Sr. Duran: per's cuu" no conocio el folleto de IIarquini no pulio completarlo como yo lo haré tuman. do del mio lo que falta al otro, y vice-versa. Tambien reimprmire literalmente los otros dos, al parecer antiguos, suprimiendo la glosa

E.] nombre de Francisco Marquina no se halla en la bibliolheca de Nic. Antonio. 
Romcances.

Tierupo bueno, tiempu bueno, Cuicin te apartú de mi, Oule solo en pensar en ti Todu placer me es agen!). (gnion no llora lo presente. Vicudo cual tice lo pasado; (luicu es aquel que nu) siente

lin que ventura ha quilado.

lo me vi sor bien amadi)

E. mi estadu en alta estima; Contemplande en lo pasado La memolia me lastima.

\section{otros.}

Acordans de quien se mitida

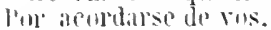
cordans pue os hizo plos

Par:a ruo no remedieis:

fracordá que me temeis

listivo on rusetra plision.

Arordins de la pasion

(III ros nesmal me ransais,

Acoldans yte me malais,

sia liabellumerecido.

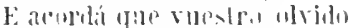

Ila deser mi sepulliti.

Arorida (fue moi remblura

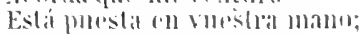

Aeordaus chan de tempratulu

Ye hecistes amanlon;

Acordans del grim dulor

(bive me dan vilostros immones,

Aendeis de los clammors

Gue go siompre os he alliado.

\section{$01 \% 0$.}

Descublase el pensamiento Jo alli secrerlo cullado.

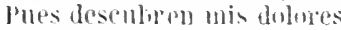

Ii virir apasiomadu.

lo esde aroma mi pasim,

loias ha quis sui perlandu;

Lila senura át quipll sirvo

$11 \mathrm{~s}$ servir lieme olvidado.

i dias me ha dado tristes.

Las nocles momea lee llolsado;

su beldan me hizo stryo,

IICritusura en allo srado:

E.) sil gesto tan polidir

En mi alma es it esmallatı.

il'ara glu paristes madre

In hijo Lan desdicharh"

i li le mi que la mire

l'ara virie listimalo,

l'ara llonar é planir

(iloria del tiempo pasado,

l'ues en armas s.ti dithoso

I en annores desdichadı!

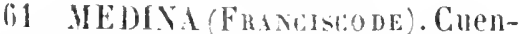
to muy gracioso rue sucedio a vn ar-

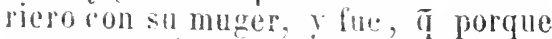
no se santiguaua de las mutreres, fuando ylla fuera, sll misma muger le lizo vina burla, dãdole vin mal rato, auiendole primero embriarado, $\mathrm{y}$ ra- pado la barua toda, y hechole la corona. Y de vna venganea que tomo el marido de su muger por la burla que del hizo. Compuesto por Francisco de Medina. S. 1. ni impresor, 1603. 4. 4 hojas sin fol. ni sign.

Las llena un solo Romance, que dice: En Falladislid fromosa.

Yingmo de los Franciscos Itedina traido por Nic. Antonio parrece pneda ser este. El si. Duran no habla del presente pliego.

62 MILA I FONTANALS (MAxter.). La Cansó del Pros Bernat fill de Ramon feta per En Manel Milá y Fontanals lo mes de Juny de l'any de la Nativitat del Senyor MiDCCCLXYII. Barcelona, En Celestí Yerdaguer, s. a. 8." mar. Son 8 hojas.

Lilldit rdirions. Ejemplar que une regaló el antur y lleva su antografo.

6:3 MONTALYAN (GoNzalo de). C Closa de espanca mia por quié. Fecha por rócalo d' mõtaluã estante enlas quadrillas del señor Pero lopez zacal. S. I. ni a. (hacia el 1025). 4." let. gót. Con dos figurities a los lados de la piimer copla. 4 hojas.

Contienc ocho estrofas de las quince que componen las Coplas del Morques de Aslorga, i su amiga, segun se hallan en el fol. 154 vla. del Cimeionero general de Anveres, 1573; además, la glosí de cllas en otras 32 estrofas: copiaré la primera.

Cansaio de pelear con tu conda condicion, gue me condena, delerniné de me dar á tu dichosa prision y cadena; y pues que me dó á rehen, da por libre el aftcion que te ha servido, esporanza mia, por quien pallesce mi corazon dolorido.

Nie. Antonia no cita a Gonzalo de Montalvin en sii Bibliolheca, ni tampoen encuentro nencion de este pliego en el Calailogo de Don A. Inran; habla si del siguiente, que contiene otras composiciones del mismo autor.

Closas de wos romances y cunciones, hechesis yon Gonsalo de Itonlalvan.-Entre Torres y Jinena. E Muril vos queredes, padre. $\vec{E}$ Domingu ra de kamms. S. 1. ni a. 4. let. gót. 4 loujas:

Comliene:

Cancion serromilla anomina, que dice: Entre Torres y jimena. 
Glośa de Monlatvan $a$ dicha cancion, en coplas que dicen: Caminando por la tierra. Glosa de idem al romance de Morir vos que. redes, padre, en coplas que dicen: Por menor y menos fuerte.

Romance viejo que dice: Domingo era de Ramios.

Glosu a Montaluan $a$ dicho romance, en coplas que dicen: Mirandi la gran constancia.

64 MORENO DE IA REA (PEDRo). La rida del sancto fray Diego... con algunos de sus milagros... Con vna breue relacion de su canoniza-

6.3 NUETA instruction $y$ ordenanca, para los que son o han sido Cofrades del Grilimon, o mal Frances, con las libertades $y$ essenciones a el necessarias. A do claro se conoceran los que deuen ser llamados a esta Hermandad y Cofradia. Cuenca, en casa de Corne!io Bodan, 1602. 4. Vineta de madera despices del epigrafe, y otra en la paig. tiltima de uns que van a ahorcar. I hojas sin fol. $\mathrm{ni}$ sign.

La Nucva instruction eș ell verso y está fechada, ii 22 de Septimbre de M.D.Ll., por lo tanto es probable exista alguna edicion anterior.-Al fin va un Rimance de v'n cofrade viejo, que se yua a cur ${ }^{\circ}$ cō el palo de las Indias, principia: Por la dolentia l'a el viejo; es una parodia del otro mas antiguo, Por li matanza va el viejo, que se halla en la Flo.

66 OBRA. I Sigue se vna obra muy prouechosa delos mandamientos. Agora nueuamente cōpuesta por in deuoto de christo. (A continuacion una estumpila de madera que represen!a a un clérigo en el púlpito, predicando a tres oyentes.) S. I. ni a. (hácia el 15000$) .40^{\circ}$ let. gót. 4 hojas sin sign.

Composicion de la cual no hare mérito uingun autor, y que principia asi:

Encaminn mi caminn,

Jesucrislo, muestra luz. cion, y con vnas coplas de $\tilde{q}$ hare para me saluar. Compuesto en verso Castellano por Pedro Moreno de la Rea. Cuenca en casa de Cornelio Bodan, 1602. $4 .^{\circ} 4$ hnjas sin fol. ni sign.

La vida de Fr. Diegn 'stá en décimas.-Las coplas de la íltima hoja las reimprimio Bōhl de Faber en el t. I. de la Floresfa; inutil es decir que en la reproduccion estạn lastimosamente mutiladas.

No da noticia de este escritor Nic. Antonio, ni de este pliego el Sr. Duran. resta de Lojpez de Tortajada, y glosado en el folleto gótico, que principia comiençu cirrtos romances con sus glosas.-Este misino romance Por la dotencia v'a el viojo. se halla en el Canciomero de romances y en el Romancern del sr. Duran, quien no conocjú este pliego.

Gallardo, que á pesar de sus vastisinos conocimientos biblingráflcos, pra mui descuidado en la ortografia de los titulos de las cbras que describe, y equivoca mui á menudo el número de las hojas de los libros, da el siguiente final á la viuera inslruccion y ordenanza:

De sctiembre áveinte dias Año despues del Mexias M.D.II.

Siendo la verdadera leyenda:

le Septienbre a veinte y dos Año despues del Mexias M.D.L.I.

Además nada diee del komance de un cofrade viejo.
67 Ol.IVA (Exrique de). T Coplas nueuas fechas por Einrigue de oliua: de la natiuidad de ñ̄o señor Jesu xp̄o, Y cătanse al tono de Abras me tu el hermitaño. S. I. ni a. hacia el 13̋30). 4. ${ }^{\circ}$ let. got. Son 1 hojas sin fol. con la sign. a.

Contiene:

Coplas que dicen: Una liija de Santa Ana.

Deshecha que dice: Mas lo prerin que pario. Coplas que dicen: Quien entrari por til puerta.

Deshecha que dice: Magüer un poro cansud". Coplas que dicen: Sepamos, señora. 
Deshecha que dice: Nuevas de gozar.

Coplas pasturiles, que dicen: Queda esa asuri Pascual.

ldem idem, que dicen: Hi de Dios, que trasnochada.

ldenr iden, que dicen: Cuando la Virgen prìió.

Iden idem, que dicen: Compuñero si te place.

Böhl de Faber no debio de lener noticia de estas composiciones, cuando no las incluyó ell su Floresta; tampoco las encuentro en el Cancionero general, y el Sr. Duran no menciona este pliego suelto en el Catalogo de ellos, que se lialla en su Romancero.

Sirva la siguiente Deshecha cono muestra del mérito y gracia de las poesias de oliva.

Nuevas de gozar

labemos sabido.

que Dios es nacido

para nos salvar.

Allá repastando

eı uuestra majada,

in angel volando

con gran relumbrada,

cun roz umi sonora

diju, aho , pastores

grandes y menores,

via levantar.

Catad gui es niacido

un claro luzero.

emýn apellido

es Dios verdadero;

soi su mensajern

que os vengo í derir,

que sin debatir

lic vais visitar.

Cun esta señal

á Belen ireis,

dentro en un portal

pobre lo rereis,

ende hallareis

la Virgen su madre

68 PERALTA (GREgORIO de). Aqui se contiene vna obra muy deuota de la sancta Conuercion de la gloriosa Magdalena. Mecha por Gregorio de Peralta. Cuenca en casa de Cornelio Bodan, 16002 (1602). 4. Viñeta de madera. hojas sin fol. ni sign.

Relacion on verso de consonantes con un villancico al fln.

Escritor desconocido á Xic. Antonio, y pliego no deserito por el Sr. Duran.

69 PERAlTA (Lis DE). Glosa nueuamente Irohada por Luys de Peralta: sobre el Romance de Fajardo. E siguese el Romance. S. I. ni a. (hi- con un viejo padre mucho de acatar.

Mia fé, el hato

del todo dejamos,

luego en aquel rato

a Belen llegamos,

$\mathrm{y}$ al nino hallamos

al frio sereno,

envuelto en heno,

en pobre lugar.

Una moza llana

estaba delante,

juro á diez, galana,

de lindo semblante,

nui mas relumbrante

qu'el sol, y hermosa,

fresca y graciosa,

para Dios loar.

Esta se sonaba

haberlo parido,

esta l'empañaba

con grande sentido;

yo lo vi asido

á los pechos d'esta,

y con faz honesta

le daba á mamar.

Conl esta jugaba

estando mamando, á esta abrazaba

aflcion mostrando;

juro á sant Fernando,

g'asmados venimos

de lo que le vimos

con esta pasar.

Cabo.

Pues en el ensai de su parto santo nunca dijo, ay, parió sill quebranto, y quedo tanto germosa y bella. virgen y doncella, entera y sin pas. cia el 1525). 4. ${ }^{\circ}$ let. gót. Viñeta de madera. Son 4 hojas sin fol. ni sign.

Contiene:

Romance antiguo que dice: Jugando estaba el rei moro.

Glosa al mismo de Luis Peralta, en coplas que dicen: De aquel que fite en los humanos.

otro romance que dice: Moricos, lus mis moricos.

Crlosa del mismo por el inismo Peralta, en coplas que dicen: Los que deseais seguirme.

otro romance que dice: Mis arreos son las armes.

Glosa al mismo del mismo, en coplas que dicen: Mi vida a todas las vidas.

Deshecha de Peralta que dice: Complid mestra voluntad.

Cancion de Peralta, que dice: Criada para dar pena. 
Cancion del adelantado D. Pedro Fajardo, que dlce: $A$ mis penas y lormento.

Glosa á la misma, probablemente del mlsmo Peralta, en coplas que dlcen: Señora hagoos saber.

En nuestras colecciones de canciones y romances no encuentro las Glosas ni la Cancion de Peralta, ni la del adelantado D. Pedro Fajardo.

El nombre de Luis Peralta se ocultó á las investigaclones de Nic. Antonio, y el Sr, Duran no hace mérito de este pliego, rarisimo como todos los de su clase.

70 PÉREZ (Herran). Recopilacion de los milagros y marauillas de san Ysidro de Madrid, sacados de su libro. Compuestos por Hernan Perez. Madrid, Miguel Serrano de Vargas, 1606. 4. Viñeta de madera. 4 hojas sin fol. ni sign.

Es una larga relacion en versos consonantados.

Desconocido á Nic. Antonio y á Duran.

71 PÉREZ (Martix). Relacion verdadera que trata de todos los sucessos y tratos de la Carcel Real de la Ciudad de Seuilla. Con rn romance nueuo, donde vn galan satiriza a las damas, Compuesto por el Licenciado Martin Perez, presso en la dicha carcel. lmpresas con licencia, año mil y seyscientos $y$ siete $(1607)$. S. 1 . ni nombre de impresor. $4 .^{\circ}$ A continuacion del epigrafe hai dos figuritas grabadas en madera, $y$ al fin otra ciñeta que representa una batalla. 4 hojas sin fol. ni sign.

Son tres romances, que dicen:

$$
\begin{aligned}
& \text { Despues de haber ya corriulo.- } \\
& \text { Aquesla curcel real.- } \\
& \text { Damas copeteras, locas.- }
\end{aligned}
$$

No lo menciona D. A. Duran ni Nic. Antonio.-El Sr. Fernández-Guerra habla de este pliego en la col. 1342 del Ensayo de una bib. esp. tom. I; aunque no conoció la presente edicion, $y$ solo cita como sumamente raros, los dos primeros romances impresos en Madrid, por Diego Flamenco, año de $1697,4 .^{\circ}$; pero en dicha impresion deben es. tar mui variados, segun se colige de los ocho versos que copia en la col. 15j7, los cuales en mi ejemplar dicen asi :

En habiendo estas pendencias, acude luego un portero con un baston en la mano, y al que es mas culpado poren en una reja de hierro.

Alli le ponen de pies elc.
72 PERQUÉ. T Sigue se vn perque: sobre la passion de Christo /que dize. Salid hijas de Syon. Y .rnas coplas / muy sentidas en alabança del glorioso sant Jaan Baptista. CSigue una laminita de madera de Cristo despojado de sus vestiduras.J S. I. ni a. (hacia el 1ว̌ŏ0). 4. ${ }^{\circ}$ let. gót. 2 hojas sin sign.

Contiene:

El Perque: Salid, hijas de Sion.

Coplas en loor de San Juan Baptista: Enlre todos los nacidos.

vo lo encuentro descrito por nadie.

73 - I Siguese vn perqué que dizen de veo veo. Y vna glosa nueua de: o mundo caduco y breue. Y vn derreniego a vnas damas. Y vn per $\tilde{q}$ d' nueua manera hecho a vna señora por Bartolome d' torres (Naharro). Y rna canciō $\bar{q}$ dize sola me dexastes. etc. S. I. ni a. (hacia el 1320). $4 .^{\circ}$ let. gót. Viñeta de madera. 4 hojas sin fol. ni sign.

Esti todo en verso. - I.as coplas de Sola me dejaste no tienen de. comun con las que puso Bôhl de Faber, ell la pág. J00 del tomo I de la Floresla, sino los tres versos primeros.

El Sr. Duran no inerrciona este Perque ni otro que vi, el cual decia: C Siguese vn per $\bar{y}$ : que dizé de veo veo. Con las cuplas de canta Jorgico canla y otras del vaquero de moraña. año. d. $x x x$ ij $15 \bar{j} 2)$. S. l. . $^{\circ}$ let. gót. Son 4 hojas que contienen ademas un villancico de Mas quiero morit por veros Que vivir sin conoceros.

y una Estrofa de ojos gar zos ha la niña.

74 - I Perque muy gracioso. Agora de nueuo sacado. Én que recuenta las tachas que teniarna Dama. Y va en manera de Hapiaha. Con vnas lamētaciones de amores. Y vn romance al fin de nueuo compuestas. $\boldsymbol{E}$ stos son los seis renglones de la portada, colocados bajo de tres figuras sueltas, que representan una dama y dos caballeros; todo circuido de orla.) S. I. ni a. (hácia el 1520). $4 .^{\circ}$ let. gót. 4 hojas sin fol. con la sign. A.

Contiene:

Perque que dice: Duna de tantos primores. Las tres Lamentaciones de amor de Bartolomé de Torres Vaharro, que dicen:

Resuenen mis alaridos. 
por hacer cinor tus hachos. Mete las armas traidora.

Romance del misino, que dice: Vivid, scñor, sin ruidado.

Las Lomentaciones y el Romance, aqui aninimbs, se hallan en la Propalatia de Naharro (oul algunas variantes.

El Sl". Duran no vió este pliego.

\section{T: PROCLAHACION DE FER-} IANDO VI.

Relacion descriptiva de los ohsequios con que la Ciudad de Barcelona ('n los dias 9, 10, y 11 de Setiembre de 1746. soleminizó el acto de la Proclamacion del key nuestro Señor Don Fernando sexto. Barcelona, Joseph Texidò, 1746, 4. 28 págs. en todo.

Fogosa activa llama del amor del Colerio de Pescadores de Talencia á la Proclamacion de nuestro Católico Monarea (Don Fernando sexto). (I lencia, 1746.) 4. 10 prigs.

Demostraciones afectuosas, conque el Gremio de Roperos celehrò en. Va!encia, en los dias 19. 20. y 21. de Arosto 17.66. la Proclamacion de D. Fernando sexto. Valencia, Geronimo Conejos, (1746). ¿. $^{\circ} 8$ hojas con la sign. $\mathrm{A}$.

El Pocta oculto, y español conocido, por el rozo explicado en el Romance heroveo a la exaltacion á el trono de Don Fernando VI. Valencia, Joseph Thomas Lucas, (1746). 4. ${ }^{\circ} 7$ págs.

$\mathrm{R}$

76 RaMiREZ (Axtosio). Relacion de la lestiva traslacion de la soberana Virgen de los Desamparados de la mry noble... Ciudad de Valencia, de su capilla à la sumtuosa nueva Maravilla que le fabrico la pia caridad de los devotos. Consagrasela... en dos romances, el teniente de general de la artilleria. Don Antonio Ramirez. Valencia, Benito Nace, 1667.4. ${ }^{\circ}$ hojas sin fol. ni sign.

fontiene das romances que dicen:

El primeru: De Maria immaculada.

El segrumdo: Euterpe, Talia, Apolo.

Yis se encueutra este pliego en el Catalogo de llirdu.
Coloqui nou, hon se referixen les Festes celebrades en Valencia à la Proclamaciò de nostron Fernando Sext. (Valencia, 1746.) 4. 1 hojas sin fol.mi sign. En vaienciano.

El representante de el catholico Colisè, representa por títulos de comedias la monarquia de España en este romance a su amado rey D. Fernando sexto. Valencia, Cosme Granja, y Agustin Laborda, (1746). 4. 2 hojas.

E] Cazador mas sabio del catolico Bosque, Apunta en este Romance las experiencias de la Caza Politica à su Antado Rey Don Fernando sexto. Valencia, Geronimo Conejos, (1746). $4 .^{\circ}$ Viñeta de madera. 4 hojas sin fol.

Relacion que haze una aldeana, dando cuenta de como la Ciudad de Valencia aclamó a Don Fernando el sexto. Valencia, Cosme Granja y Agustin Laborda, (17/6). 4. 2 hojas.

En elogio del Duque de Caylus, en ocasion de la proclamacion de Don Fernando VI. Ro!nance. (Valencia, 1746.) 4. 2 hojas.

Serundo coloquio nuevo, en que un cavallero valenciano explica las demonstraciones de la Ciudad de Valencia en la Proclamacion de Don Fernando el sexto. Ialencia, Geronimo Conejos, (1746). 1. Viñeta de madera. L hojas sinfol. ni sign.

7i RELACION de la enfermedad, testamento y muerte de nuestro Filipo Quarto, el Grande en dos romances. Valencia, por Geronimo Vilagrasa, 166.3. 4. "Lamina de madera. I hojas con la sign. A.

Lis romances dicen:

El primero: Aqui de lodo el dolor.

El segundo: Ya llega el postrer ahogo.

Pliego desconocido á Duran.

78 RELACION verdadera de la insigne vitoria qve sv alteza el serenissimo señor Infante Cardenal tuuo a veynte y vno, veyntè y dos de Iunio de 1638 contra los Estados rebeldes 
de 0lāda. Repartida en cinco Romances. Dase cuenta de la reñida batalla que cō ellos tuuo, del numero de soldados que traian, y de los muertos, heridos, y presos, y de los nauios, barcos grandes, y pieças de artilleria, vanderas, estandartes, bastimentos, $y^{\prime}$ pertrechos de guerra que se ganaron. Valencia, Syluestre Fisparsa, 16:38.4. ${ }^{\circ}$ Lamina de madera. hojas sin fol. ni sign.

El romance primero dice: Católico, al ar$m a$, al arma.

Idem segundo: Del mismo mes a catorce.

Idem tercero: ya los clarines resuenan.

Idem cuarto: De inastines tos ladrilos.

Idem quinto: ya que saben la vitoria.

Pliego y romances desconocidos á Duran.

79 RELACION verdadera del feliz srcesso qre Don Diego Cavallero, Gouernador del Presidio de hosas tuuo en el Coll de Pertus, donde prendio al Mariscal Fabuel, Maesse de Campo general de Francia, en 24. de Marco $1643 \%$. Valencia, Iusepe Gasch, 164 \% 4. Lámina de madera. 4 hojas sin fol. ni sign.

Plieg, en verso, desconocido a Duran, que principia asi: Sucesivas, senor, las ocasiones.

80 RESPUESTA. C Respuesta muy graciosa sobre las prerogatiuas y excelencias de nuestra señora la virge Maria / con quatro canciones al cabo. Sigue una laminita de la Purisima, rodeada de sus atributos, y á continuacion principia el texto.J S. I. ni a. 'hácia el 1030 ). $40^{\circ}$ let. gót. hojas sin sign.

Contiene:

Romance. La dama que preguntais.-

Canciones. Loores $a$ ti, señor.oh, santisimo cordero.Hijo mio, mis anores.Pues que jamas olvidaros.-

Duran no solo no trae ninguna de estas composiciones, sino que no habla del presente pliego suelto.

81 ROMANCE. C Romance del moro Calaynos de como requeria de amores ala infanta Sebilla y ella le demādo en arras tres cabezas de los doze pares. Có otras coplas. S. I. ni a. (hácia el 1530). 4..$^{\circ}$ let. gót. Viñeta de madera. 4 hojas sin fol. con la sign. a.

\section{Contiene:}

Romance que dice: Ya cabalga Calainos.

Coplas hechas por Juan del Encina, que dicen: Dos terribles pensamientos.

En el cap. IX de la II parte del Quijote se habla del Romence de Culainos: tambien se ocupan de este personaje fabuloso y del re. fran tan conocido á que han dado origen sus coplas, Clemencin y lellicer cn las notas á la obra de Cervántes, y el P. Sarmiento en las págs. 252 y siguientes de la Historia de la poesia; pero todos ellos se refleren al Cancionero de romances, ó á la Floresta sin haberlo conocido impreso en pliego suelto. El Sr. Duran no ignoraba haberse asi publicado, y sin embargo no logró verlı.

Las Coplas de Juan del Encina se encuentran en su Cancionero fol. $69 \mathrm{vta}$.

82 ROMANCE. I Romance d' la sacratissima virgen Maria: contrahecho a Emperatrizes y reynas: de los dolores que la virgen padescio. S. 1. ni a. (hácia el 1:3:30̈). 4. ${ }^{\circ}$ let. gót. 2 hojas sin sign.

Estas dos hojas, desconocidas á Duran, comprenden:

Romances. Emperairiz y seriora.En los mas altos confines.De Calcario sale el demonio.-

Ensalada. Ii serrana de Belmar.-

83 - Romance de la vitoria qre han alcanzado las armas de sv Magestad, governadas por el Marques de Leganes, del Conde de Ancurt, sobre el sitio de Lerida. Valencia, Claudio Macè, 1646. 4. 2 hojas.

Pliego no inencionado por Duran, $y$ que cumienza:

Mala la hubistes franceses

la noche de los ulaques.

81 - Romance de 0 belerma agora nueuamente glosado por Alberto gomez. S. l. ni a. (hácta el 1今30). 4. let. gót. Con viñeta bajo del epigerafe. Son t hojas sinfol. con la sigñ. a.

\section{Contiene:}

Romance que dice: Oh Belerina' oh Belerma' Closa al mismo de Alberto Gomez, que dice: oyenulo como salieron.

Villancico al fin de dicha glosa, que dice: oh Belerma, mi seriura!

Romance que dice: Los que habeis serivido anoires. 
Glosa del mismo por Alberto Gúmez Tizon, en coulas (qu) dicen : Caminemdo sin ervar.

Villaucieo al fiu de cllas, que dice: Amadores que athmais.

Vicolís Antonio no menciona á Alberto Gómez Tizon en su bibliotheca.-Los dos romances antignos se hallan en el Cancionero de romanres, mas no las glosas ni el Villancico del fin.

Eucuentro entre unis apuntes nota de un pliego suelto comprensivo de una glosa de ol Belerma!; pero no recuerdo si era la de Gómez Tizon. Sn descripcion es la siguiente:

(Orla y dentro:) Glosa meuamile compuresta sobro las dose coplas Moniales: ala mia gram pewa forte: moralizando la hystoria: p'm alos leclores no paresciesse ser el propusilo Honial conlra el esludo de la religion: comble mustiol cl contenlo désu penilencia dimida por su pecelo. Agma musurumente impresso. C Ua lambien ina glosa del romance te Belerma menammle echa. S. l. mi a. Son 8 hojas en $4 .{ }^{\circ}$, let. gút.

Además de la glosa de Belerma va al flu otra sobre una rancion que se dice: Tiemp? bueno, tirmpo burno.

El Sr. Duran trac en su Catrilogo un pliego donde se halla otra glosa dol romance de kelerma; el título y contenido de él es como sigrle:

Glosa del romunce de o Relerma, i Belerma zuevamente glosudo por Burtholome Santirgo; con olrats de Do tienes las mientes. con limos dos romamces menos, hechos por al mismo aurlor. Com of ras de Tanto me de-

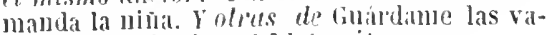
cas. ptc. S. l. mi. a. 1. let. gút.

contiene:

Glosa del romance ale oh Belerma, sn coplas que diren: Con mi mal no soi pagado.

Villancico que diee: Do tienes las mientes. Romance de Sanliayo, que dice: Oh princesa, linda dania.

Idem de idem, que dice: En el ticmpo que triunfaba.

Villamico que dice: Tanto me demanda la niı̀ลa.

Idem que lice: Gubirlane las vacas.

De este romance de Belerma hiza glosa Francisco Marquina; viase su articulo en esla misma division, y Gallardu en el Ensoyo le um bib. esp. trac noticia de las siguientes: Glosas de los Romances de "jOh Belerma!, y las de "Paseabase el Rey Moro:- y olra de - Riberas de Duero arvibu: todas hechas en disparates. '.' Iel. got. pliego suelto con nua estanpita en el fróntis que figmra dus gala. nes á fuienes sus damas están peinando.

La glosa dol romance de Belev'ma empieza:

El conde Partinuples

Y el obispo de Zamora.

La glosa del romance de Pasecibase el rei moro principia:

Sant Jines de Cartagena

Vi que conjuraba un dia.
La de Ribreses de Duero arriba dice:

La blancura de Guinea

E li obediencia de Adan.

Acaba el pliego con la cancion:

ÉL.

Háblame, señora mia,

Aunque sea de poco en poco.

\section{ROMANCE. Otro romãce} del conde claros nueuamẽte trobado por otra mancra. fecho por Jua de burgos. S. 1. ni a. (luciata el 102j). 4. ${ }^{\circ}$ let. gót. Tiñeta de madera. $\mathrm{Z}$ hojas sinfol. ni sign.

Principia Durmiēelo esta el cōde claros, y acaba Ventura no dio lugar. No lo halln en las colecciomes generales de tómances: el Señor Duran lo ha publicado en su Romancero, pero sácado de otro pliego en el cual se atribuye í Antulio de Pansac. Me parece que si hubiera visto el de Juan de Büros, le hubiera dado la preferencia, pues el de Pansac está mui mudernizadı. Gallardo que menciona en el Ensayjo de ma bib. esp. el Romance del Conde Claros, impreso por Varesio, deserituen el siguiente articulo, no hace mérito del mio, s. l. ni a., de Juan de Burgos. Tambien habla Gallardo de un pliego suelto en 4. let. gót., intituladu:

A qui se conlienen qualro romances viojos. Y csle primero es de don Claros de Monlalvan: el quat trala de las diferencias que hubo con ol emperalor por los amores de la princesa, su hiju.-Este romance principia:

A misa va el emperador

A sail Joan de la Montina.

Me regaló este precioso romance Sir Thomas Grenville.

86 - C Romance del Conde Claros de Moltauan. Con vn villancico pastoril al cabo, muy gracioso. Impresso con licencia en Burgos, por Juan Baptista Uaresio, s. a. (hácia el 1380). 4. ${ }^{\circ}$ let. gót. Viñeta de madera. 4 hojas sin fol. ni sign.

El romunce es el mismis del fol. 82 vLa. al 90 del Cancionero de romances, que principia: Melia moche era por filo, con mui lijeras variantes; el Villancico pastoril que dice: $D i$, Juen, de que murio breas, lo reimprimió Böhl en el num. 218 del tomu 1. de su Floreslu, suprinicendo dos estrofas.

El Sr. Duran no conoció esta edicion.

La viñeta del principio es la misma que conio en la Egloga de la Encina Placide y Vicloriano; pero carece de leyenda.

87 - Romance del Cõde dirlos: y de las grandes venturas que huo Nueuamente añadidas ciertas cosas que hasta aqui no fucrō pues- 
tas. I vna Cancion de nuestra señora. S. I. ni a. (hricia el 10330). 1. $^{\circ}$ let. gót. Viñeta de madera. Son 12 hojas sin fol. con la sig. A.

\section{Contiene:}

Romance que principia: Estubase cl conde Dirlos.

Cancion de Diego le Pegera, que dice: Oya tu merced $y$ crea.

Glosa a la misma, que dice: Consuelo de los nascillos.

Villancico de Juan dol Encina, que dice: Dos terribles pensamientos.

Duran $\mathrm{n}$ o menciona la presante edicion de este opúsculo: habla de otra que he visto, la cual lleva el ano de 15.78 y parece estar hecha con los caracteres de Jorge Coci. en cuya impresion se atribuye la filosa it la Cancim de Pegera. is un tal lliego farcia, autor de utras Coplas publicadas con las Maldiciones de Salayga. (Viuss dichn articulo en esta misma division.) Nic. Antonio no Inenciona a ninguno de estos dos escritores.

El Romance del Conde Dirlos se halla en el Romancero de romances y en el de Duran: la Cancion de Diego de Pegera, con la misma glosa, al fln de los Prolerbios en rimo do Salomon, y glosada por Tapia en el Cancionero general de Auveres, ful. xxij.

E.l Villancico de Encina está en el Cancionero de sus obras.

Gallardo en el Ensayo de una bib. csp. cita otra edicion de este rumance con el siguiente titulo: Hisloriu del esforzado raballero Conde de Dirlos y de las granles abenturas que hubo. Agora nuevamente arudidas ciertas cosas que husta aqui no fueron puestas. Y lleva una ginsa de . Yi libe'tu! en sosicgo.. Impresa... En Alcala en cosed de Andres Sanchez de Ezpeletu: ario de 16!1, 4. 12 hojas.

88 ROMANCE. A Romãce de don Gayferos que trata de como saco a si esposa que estana en tierra de moros. S. I. ni a. hacia el $1330 \%$. 1. let. gót. riñeta de madera. í hojas con la sig. a.

Es el mismo que principia assemtals esta gauferos en el cancionpro de kimances.

i.w encabeza esta viñeta.
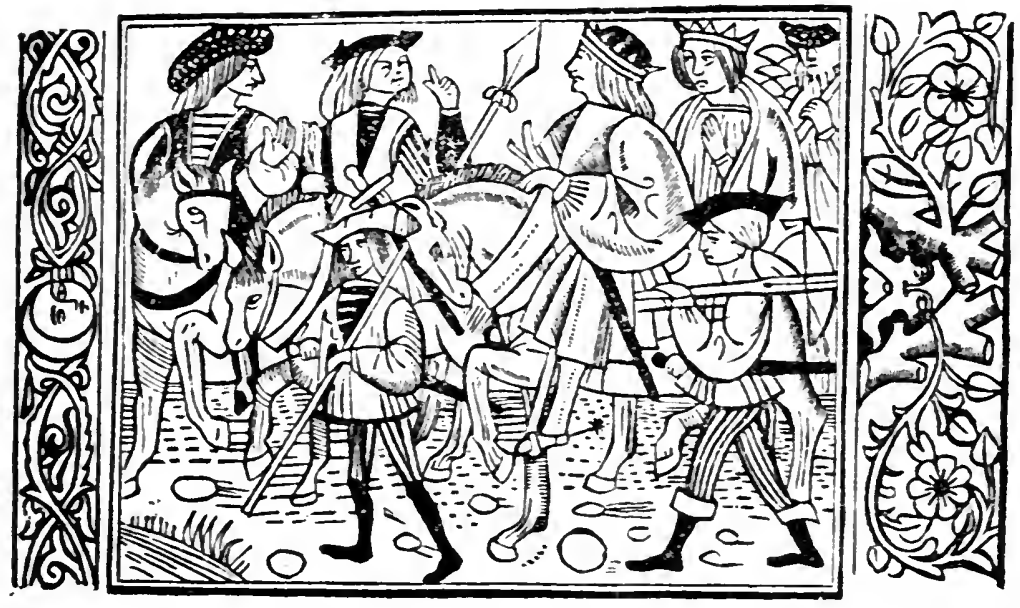

89 Romance de Don Gayferos que trata de como sacò a su esposa que estaua en tierra de moros. S. I. ni a. 'hácia el 1600). 4. 1 hojas sin fol. ni sign.

Igual al anterior.

He visto otra edicion de este romance. que decia: c Ronnance de don gayfervs que iralis de como saco asu espnsa que estauta en tierra de moros. S.l. ni a. Son dos hojas en fol. de let. gót. á ires colunas.

90 -Romance de D. Gayferos, trata como sacò a Melisendra su es- posa, que estaba en tierra de moros. Compuesto por Joseph Diaz, natural de Madrid. S. I. ni a .hicia el 1780!.1." Lam. de madera. í hojas con la sion. A.

Contiene In mismo que el gutien. Juse bial sera sin duda. unicamente ci cditur.

91 C Romäce dela rerma Trovana glosado: v vn Romance de Amadis: hecho por Alonso de salara. Con dos romáces de Gavferos: evilos quales se cótiene como mataron a don Galuan. S. 1. ni a. heirin el 13i3it. 
4." Jet. grot. Vineta de madera. 1 hojas sinfol. ni sign.

Contione:

Romance de la reina troyana, que dice: Trisle a'sluba i mui promesa.

Glosa al mismo, que dice: Con doloroso gemillo.

Romance de dinadis, que dice: En ren hermosn rergel.

lillaneici, que dice: onich servi que sét cobarde.

Romance de Gaiferos, que dice: Estribnse la comdisite.

Jem del mism:), que diee: Vimonns, dijo milii.

Todas las anteriores composioimes ménos los dos iltimos romances son de Salaya. El sr. Mutran ha reproducido en su homerancero la $2 . "$ 4. y $5 .^{2}$, pero las dos viltimas coll $\mathrm{mm}$ chísilias variantes, y creo que la leyenda del min! es preferible, pues tiente mayor sabor de antigüedad. Dicho sir. Dnt'an no conoció este plieg", pero cita lus dus signientes, en los cuales se comprendon tudas las poesias dol que yo lengo y algumas mas.

1. Glosu dir li royma troygma, y vm romance de Amudis, hechn per Alonso de Saluya; con otros romances y obras suyas. S. l. ni 1. 4. let. got. \& hıjas.

Cuntiene: Glosa del romance Triste estaba " mui penosa, en coplas de salaya que dicen: con doloroso gemido. Romance nuevo de Amadis, por Salaya, (que diee: En un hermoso retget. Villancico pur idem, que dice: ancien sera yue sea cuburle. Rimance por idem á una señosa, que diec: En mis pusiones prnsumds. Villancicen por idem: Gloriat me serit lo mererte. Rmmance por idem, que dice: Dormiemlus esti el pensamianto. Cuplas de idim, í uma señora que traia por colores ofl el tronzado, el verde y el pirdillo, que dieen: Esmalle de perfecrion. Cancion villancieni de ill'm, quo dice: Vis pasiones y lommentos. luem de idem á una señura que no le cumplió lo prometido, que dice: vuien podrit vivir mirundo. Villancico de idem, que dice: Contraria me fiue ventura.

2. Siguense dos romanees de Don Gayferos, ch que se contiene como mataron a Don Galuam. S. l. ni a. 4." let. güt. 4 hojas.

- Olra edicion del mismo pliego. S. l. ni e. 4. ${ }^{\circ}$ let gót. 4 lojas.

Contienen una yotra: Romance que dice: Eslibusc la condesa.

Iden que dice: Vimonos, dijo mi lio.

He Saliya he visto el pliego siguiente:

C. Romance' de dim Tristà muencumente glosado por Alomso de Salaya cō olras obras suyns. Sigue una laminita de un caballero que lleva í la gropa de su cabillo uma dama y un esenderu (eol dos caballos detrís, y á cuntinuacion til romance que principia:)

Al liempo que se alegraba
el campo con macus flores;
al tiempo que separaba
lan hermoso, que lanzaba
le si suaves olores;
cuando en esle tiempo estin
los amores en celadi,
con lrabujo y con afun,
ferid, está din Tristan
de una mala lanzada.

sigue otro romance que empieza: En nis pasiones pensando. de mis congojas cercalo, pensé mudu" ini deseo lel amor desesperado.

Vienc un Villancicon con solos estos versos: No quiero sino serviros, siempre yo meslro sere, annque quede con sospiros, climint, con vaestra merced.

Hai despurs un Dereniego $a$ una dama; unas Coplas en loor de ma clama, y por fin una composicion intitulada: Jutu del Encina despidicndo el umor. S. l. mi a. Son 4 hojas en fól. let. gót. á dos colınàs.

La vineta presta al principio de la edicion que poseo del Romance de li reina troyana, es la siguiente.

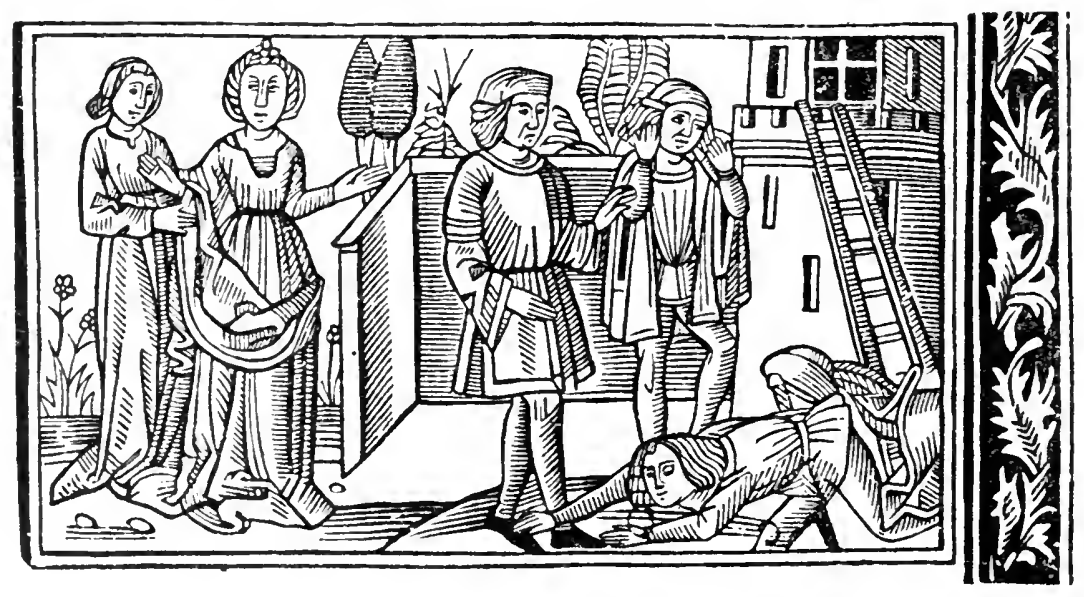


92 ROMANCE del Conde don Sancho Diaz padre de Bernardo del Carpio, como se caso con doña $\mathrm{Xi}$ mena hermana del Rey don Alonso: y como el mismo Rey lo mando echar en prisiones, y a doña Ximena mando moler en religion. I vnas lamentaciones di amor I in pregan de amor. cirigue una rineta de malera, y al fin selpe:) C Impresso con licencia en Burros, cn casa de Juan Bautista Carrio. (hricia el 1893). '.. let. git. i hojals sin fol. ni sign.

linuliene:

Romance que dice:

heinando el rei fom Alfonso, El que Custo se deciu.

Idem que dice: Andudos los anios trminta.

Idpm que dice: thusle sinc el rei ores.

lamentaciones de amor que dicen: anores de mis amores.

utras que dicen: Volloreis, mi madre.

El Sr. Duran no consiguio ver este pliego. En su Romancero reprodujo lus tres primeros romanes, segun lis trae la Rosa espumola de Timoneda; pero este lus mudernizó vercenó. sobre todo el primero y tercero, en tèminos de poder pasar por distintus. Böhl de Faber reimprimió en la Floresta las coplas de vo lloreis, mi mader.

93 ROMANCE que trata sobre la muerte que dio Prro hijo de Archiles a la mur linda Pol.cena. Compuesto por Francisco Sanchez de Guevar. Alcala de Henares, (sin nombre de impresor, ) tño de mil y serscientos y quatro (160'́). 4. ${ }^{\circ}$ Dos figuilitas en la portada. 4 hojas sin fol. ni sign.

Contiene:

Romance que dice: Oh, cruel hijo de. Irchiles. Glosa de dicho romance, hecho por V'illa. toro, que dice: Pues mis hados permitieron.

otro romance de Villatero, con canciones

intercaladas, que dice: Por las sal'ujes monlañas.

Cancion que se halla en el anterior romance: Cuando tal dolor sentis.

otra idem idem, que dice: La flaqueza que sentimos.

otra jdem idem, que dice: Huyamos de un tal dolor.

Otra idem idem, que dice: Loemos a Dios por siempre.

otra idem idem, que dice: Fenece mi triste vida.

Villancico: Madre mia, amores tengo.

Cancion que dice: Donde amor su nombre escribe.

El Sr. Duran no conocio esta edicion, pero rita otra, S. l. ni a. en $i^{\circ}{ }^{\circ}$ let. gót. 1 hojas, la

Tos. 1 . cual probablemente contendrá lo mismo que la de I60a, á pesar de no ser la última com. posicion la de Donile amor su nombre escribe. sino Mndre min, ammres tengo. He parece debe ser esto equivocacion, pres el primer verso del villaneico anterior es el mismo, y sin duda por inadvertencia, se repitió en vez de poner el que lleva en el mio.

Dicho Stenor luran reimprimió en su Romancero la mavior parte de los romances contenidos en este pliego, y Böhl en su Flaresta, ol Villancico Madre mí, amores lengo, aunque lo sacó de otro folleto.

Nic. Antonio no hace mérito de Sánchez de Guevar, el cual aparece unicamente como autor del romance oh cruel hijo de Archiles: en el pliego que deseribe el sr. Duran no se inenciona á semejante autor.

91 ROJlACE. C Romance de Don Cirgilios glosado con otros dos romances del amor. S. 1. ni a. Chicia el 1323$)$. 1. ${ }^{\circ}$ let. rót. Viñeta de madera. thojas sinfol. con la sing. a.

\section{Contiene:}

Romance antiguo, que dice: Yando el rei premeler rirgilios.

Glosa al mismo romance, en coplas que dicen: Por las mer'us que ha sabido.

Romance que dice: Oh amor, falso, mudable.

Idem que dice: Cuidulo de do zenis.

El primero y el último de estos romances se hallan en el Cancionero dr ronances, y tambien los ha publicado Duran. Yo men('iona este el prespute pliego smelto en el cor. frilogo de ellos, que precede á su Romanrero.

93 ROMAYCES. Comienzan sers Romances de Don Aluaro de Luna Conde-table de Castilla. Con la sentencia que le fue executada, por los doze luezes del Revno, $v$ las confirmaciones del Rer Don luan el II. Curiosaméte recopilados por el Bachiller Diego Perez, natural de Alcala. Impreso con licencia año $1606.4 .^{\circ}$ Vineta despues de! epigrufe y otra grande de San Jorge que llena toda la paig. última. \& hojas sin fol. ni sign.

\section{Contiene:}

Romance primero: En un tribunal supremn. Idem segnindo: Ilustrisimo señor.

Idem tercero: En un alto cadahulso.

Idem cuarto: Los que privais con los reyes.

Idem quinto: A don Aluaro de Luna.

Idem sesto: El segundo rei don Juan.

Idem sétimo: Aquella Luna hermosa.

Duran no conoció esta edicion: pero cita otra de balladslid. Alonso del Riego, $s$. $u$. del siglo . IVII $.4 .^{\circ} \&$ hojas, conteniendo los nismos romances que la mia. 
96 ROMANCES DE D. ALVARO DE LUNA. Segundo quaderno de varios homãces, los mejores que jamas se han cantado. Cópuestos por Luys, Cauallero. Impresso con licencia en Alcala de Henares en casa de lusto Sanchez Crespo, que sea en gloria, Año de 1607.

1 Los que seruis á los Reyes.

2 El segundo Rey don Iuan.

3 Illustrissimo Señor.

4 El Maestre de Santiago.

5 El testamento de don Aluaro de Luna. (Principia : Aquella luna hermosa.)

6 Tocauan las oraciones.

7 Ya don Aluaro de Luna haze de su vida examen.

4. 4 hojas, sinfol. ni sign.

Los romances: Illustrissimo Scrior, Aquella luma hermosa y El segundo rey don Ituan, son los mismos que los del primer cuaderno, descrito en el articulo anterior, con algunas variaciones, y la primera parte del otro, los que servis a los Reyes, es casi una repeticion del Romance Los que privais con tos Reyes; pero lo demás de él está variadisimo. Por lo mismo á Lilis Caballero solo se le podrian atribuir los otros tres, á saber: El Muestre de Santiago, Tocaban las orticiones y Ya don Alvaro de Luna: sin embargo, yo creo que ni Diego Pérez, ni Caballero sean autores de ninguno, sino meros colectores: Nic. Antonio no los menciona en la Bibliolheca.

bon A. Duran no conoció este segundo cuaderno; pero describe una Segunda parle, Vallalnlid. Alonso del Aiego, s.a. . $^{\circ} 4$ hojas, en la cual solo se hallan dos romances de la que yo tengo, como se verá por la siguiente lista de su contenido: bien.

Romance que dice Hagan bien por hacer

ldem que dice: Riguroso desengaño.

Idem que dice: La miserable tragedia.

Idem que dice: Eclipsada ya del lodo.

ldem que dice: Don Alvaro el Condestable.

Idem que dice: El Maestre de Santiago.

Idem que dice: Tocaban a la oracion.

Además dá noticia de una Tercera parle, lalladolid, Alonso del Riego, s. a. 4. 4 hojas que contiene:

Romance que dice: Fablando estan sobre mesa.

Idem que dice: En una oculta capilla.

Idem que dice: Iba declinando el dia.

Idem que dice: Sabed, señor Condestable.

Idem que dice: Debajo el siniestro bra $\approx$.

ldem que dice: Dividida de los hombres.

Y tambien describe una Quarla parle. Valladolid. Alonso del Hiego, s. a. 4. 4 hojas, give comprende:
Romance que dice: Atento escuchaba el rei. Idem que dice: La luna bella hermosa. Idem que dice: Hincadas ambas rodillas. Iden que dice: A los pies de la fortumu. ldem que diee: Los que a la mesi del mundo. Idem que dice: En una mulı enlutada. Idem que dice: Ya Don Alvaro de Luna.

Este último es sin duda el mismo romance contenido en mi Quadernu segundo.

97 ROMANCES. I Aquí comiëzan cinco romances muy notables. El primero de la salutacion. El segundo de sant Juã Baptista. El tercero de la Magdalena. El quarto de sant Juã Euangelista. El quinto del glorioso sant Fräcisco. Aora nueuamente impressos. (Sigue una imágen de la Virgen, dos figuritas á los lados y orla. Los romances principian en seguida.) S. 1. ni a. (hácia el 1560). 4. let. gót. 4 hojas sin sign.

Plicgo desconocido que comprende los romances siguientes:

De los cielos salia el angel.-

Cante la nacion cristiaria.-

Por las cortes de la gloria.-

Celebrando el rei la cena.-

Andavase San Francisco.-

Duran no trae ninguna de estas composiciones: la tercera, dirigida á Maria Magdalena, podri tal vez ser una de Juan Timoneda prohibida en el Indice espurg. de 1790 , cuyo titulo es: Un dirilogo de la Magdalena, y esta conjetura es tanto mas verosimil, cuanto estos lioinances están indudablemente impresos en Valencia, y se encontraban encuadernados junto con otros pliegos volantes, compuestos por el librero valenciano.

98 ROMANCES. I Aqui comiençan. iij. Romances Glosados: y este primero dize. Esta se la gentil dama. y otro / de Olorosa clauellina. y otro de Bodas se hacen en Francia. S. I. ni a. (hácia el 1525). 4. ${ }^{\circ}$ let. gót. Viñeta de madera despues del epigrafe, $y$ una pequeñita al principiar los Romances $2 .^{\circ}$ y $3 .^{\circ}$ hojas.

Contiene:

Glosa del romance, Estase la gentul dama, que dice: Los campos llenos de flores.

Glosa de Quesada al romance de Olorosa clavellina, que dice: Entrando por una huerta.

Glosa del mismo al romance de Bodas se hacen en Francia, que dice: Cuando mas el alegria.

El Śr. Duran no conoció este pliego, pero describe el siguiente: Glosa de olorosa Clauellina. Con ofra de Morir vos queredes, padre; 
con otras de Guárdame las vacas: y vnas requeslas de amores. S. h. ni a. 4. let. gót. 4 hojas. Contiene: Closa del romance Olorosa Clavellina, hecha por Quesada, en coplas que dicen: Entrando por una huerta.

Idem del idem de Morir vos queredes, padre, hecha por Gonzulo de Montalvan, en coplas que dicen: Por menor y ménos fuerte.

Villancico anónimo de Guardame las vacas, con coplas que dicen: Juri á mi qu'eres tan bella.

Los romances de Olorosa claveliina y el de Bodas se hacen en Francia, se encuentran en el Cancionero de Romunces y en el Romancero de Duran: el último bastante modernizado. No hallándose en ninguna de nuestras colecciones el de Estase la gentil dama, in reproducirć aqui, entresacándolo de la Glosa.

Estase Ia gentil dama Paseando en su vergel, Los pies tenia descalzos Que era maravilla ver. Desde léjos me llamara, No le quise responder: Respondile con gran saña, ¿Qué mandais, gentil mujer? Con una voz amorosa Comenzó de responder: -Ven acá, el pastorcico, Si quereis tomar placer. - Siesta es ya de medio dia
Que ya es hora de comer -Si quereis tomar posada Todo es á tu placer.

-Que no era tiempo, senora, Que me haya de detener; Que tengo mujer $\mathrm{y}$ hijos Y casa que mantener; E mi ganado en la sierra Que se me iba á perder, E aquellos que me lo guardan No tenian que comer.

- Vete con Dios, pastorcillo,

No te sabes entender:

Fermosuras de mi cuerpo

Yo te las hiciera ver:

Delgadica en la cintura, Blanca so como el papel, La color tengo mezclada Como rosa en el rosel, El cuello tengo de garza, Los ojos de un esparver; De mis fermosuras ricas Rogada habia yo de ser.

Las teticas agudicas

Qu'el brial quieren romper;

Pues lo que tengo encubierto, Maravilla es de lo ver.

- Ni aunque mas tengais, senora, No me puedo detener.

La vineta que lleva al principio es la si. guiente.

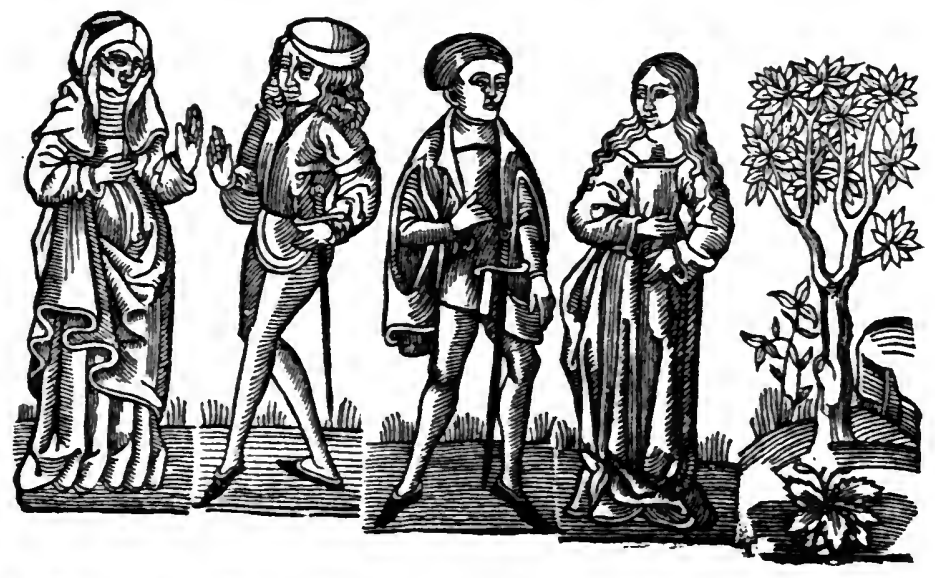

99 ROMANCES. I Comiencan ciertos romances con sus glosas nueuamente hechas: y este primero es. Por la matãca va el viejo: con su glosa: y otra. Que me crece la barriga $\varepsilon$ se me-acorta el vestir: cõ vna glosa nueua $\varepsilon$ nuy gentil mejor q otra $\bar{q}$ vino becha a este romãce con rna glosa de rosa fresca: assi mesmo nueua $r$ muy graciosa. Ninguna destas glosas trae el nöbre de quien las hizo porq̃ son de tales personas $\tilde{T}$ huelgan que se rean sus obras $r$ se encubran sus nombres. S. 1. ni a. (hácia el 1530). $40^{\circ}$ let. gót. Viñeta de madera bajo del epigrafe que va copiado. Son 4 hojas sin fol. con la sign. aij en la segunda hoja.

Contiene:

Glosa al romance, Por la matanza "'a el viejo, que dice: P'or' los valles de Iristura. 
filosa al romance, viu me cresce la barriga, que dice: oh, fortuma que enojada.

llewl de Rosa fresea, que diece: Culumdu yo os quise ple'ride.

\section{ROMANCES CON SLS GLO-} S.LS. Otra edicion hecha í plana renrlon sobre la anterior. S. I. ni a. 1." let. got. A linjas sin fol. con la sigmatura aiiij en la seyunda hoja.

Ediciom hecha á plama renglom solve la antorior y de mui pocos años posterior i ella: so distiugue por hacerse en el epigrafe mas iso de lia enujumbion $y$ que de la s, de modo gue 'n la presente se lee: la bar'igiga so me ucurtu, nueua y muly gentil, menu y muy graciosa, ubras y se pncubron; ademas la villimil palabra del epigrafe en lis utra dice nombies y en esla nomores; ell la ded nim. !y lleva orla la viùcla, y principian por letra mayusenla los dos versos del fin de eada estrufil, il silorr lus tomidos de los liomances intigums.

l.os romances solye que recaten las glosan, estim en el Camcionuryo de prometures coll algumas variaules: las ghosas ho las encuen-

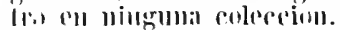

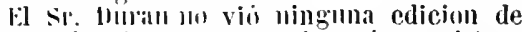

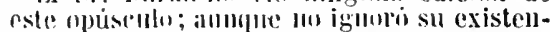

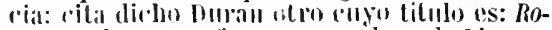

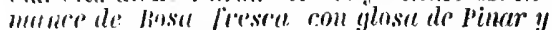
otros muchos romances. S. l.nit. a. 4. let. gü.

la glosa de lina principia eon el mismo vorso yue la mia, y no dudo serí igual en lo dolliks.

La limina de madera pllesta al principio de ambas impresiunes, os la eopiadi á conti. muariou, rinn la sola diferencia, como ya alviertu arriba, de liallarse circuida de una olla ell lit mis antigual.

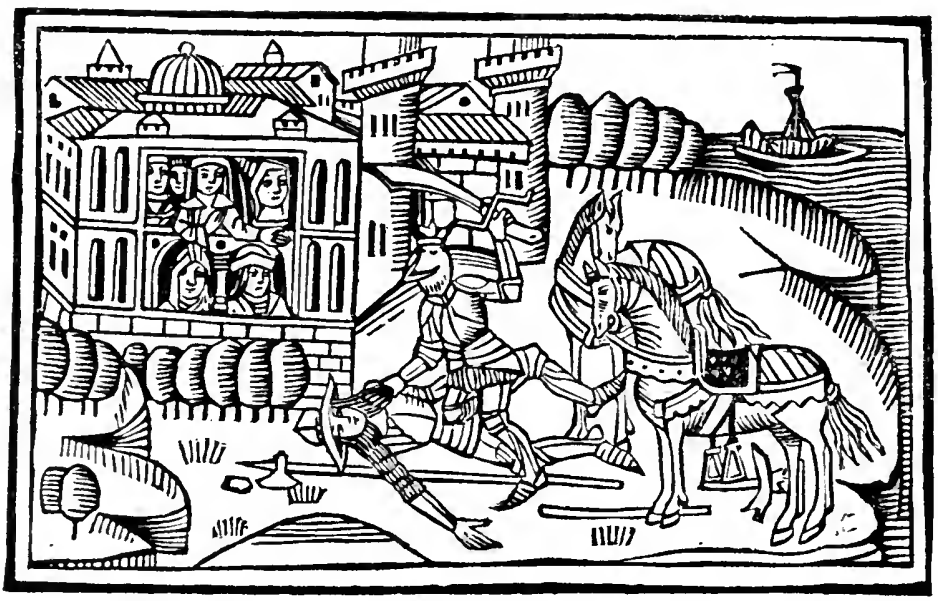

101 ROMA.YCES. I Aqui comienra rna glosa al romance de Amadis $y$ es de saljer que el romance es nuevo - la glosa assi mesmo mueua sentida Y muy gentil segun $\tilde{q}$ por ella vereys. Con ina glosa hecha ala mia gran pena forte tan biẽ nueuamête trobada: ia solamente la grlosa del romance sin el: porĩ quien lo quisiere hallar: le ha entos dos pies postreros delas roplas. S. 1. ni a. (hicia el 1330). 4." Jet. gót. Vrineta de madera. 4. ${ }^{\circ}$ i hojas. sin fol. con la sign. aij en la segunda lioja.

\section{Contiene:}

iilosa del romance, En la selva estii Amudis, glie dice:

\footnotetext{
Siguiendo ageno querer"
}

y' pregrmulu lie rilpa agrmu.
Cilosa de La mi gran pent forle, que dire: Tomiendome de perder.

En the sobrala hermosura.

El romince de Amadis, diverso del publiradi en el Concionero de rmannces, lo trae. Duran ell sil Romancero, sacado de un plie. gu cuyo 'pigrafo: es mui pareeido al del mio, y probablenente serí el mismo; pues lis lijelas variantes que en il se observan es ficil provengall de no haberse tenido al ticmpo de copiarlo toda la escrupulosidad indispensable en descripciones bibliográtlcas.- No se si reste romance de Amadis es igual al que se encuentra en otro pliego suelto, citado por dicho Sr. Duran, con el titulo siguiente: Romance de Amidis $y$ de Oriana, y olro del rey Malsin. Con otro del infunte Gayferos, et otro que dize: En Jaen está el buell ley; con otros dos romances. S. $l$. mi $u .4 .^{\circ}$ let. gót.

l.a viñeta de mi pliego es la misma que lleva la egloga de Ptcicida y Vicloriano, copiada al describir esta composicion dramática de Ju;u del Finciuli. 
$106^{\circ}$ ROMANCES. Octavas a la prision de Melisendra esposa de don Gayferos. I el romanze de cauallero si a Frãcia ydes, con su glosa, Y otro muy sentido de la cruda y sancrienta batalla que passo entre Mandricardo y Rodamonte, sobre quitalle a Doralice, Agora nueuamente impresas. Toledo en casa de luan Rurz, Año de. H:DCI. 4. ${ }^{\circ}$ Viñetas de madera. I hojas sin fol. con la sign. Aij. en la segunda hoja.

sin embaroro de ser este pliego de impre. sion mas modema que todos los que tengu en let. goit.. lo considern conto unu le lus mas raros y curiosos. En él se chenentran completas las sicte octavas enyos dos primrros versos eita cervintes ol ol rip. XVil. part. II del Qnijole; rommosicion (pur Pollicert

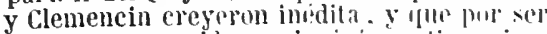
tas poco comocida copiare il romtimmandin; comprende ademis ma glusen al lommanco de Cubullero si a Francia ill's, lis rilal plill-

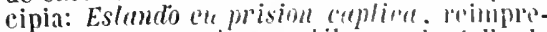
so en el Ensayo de lona bib. e'sy. do liallap.lo por no hallarse cl molestris anligllits antulogias, y el romance de Vambricildu y

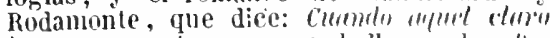

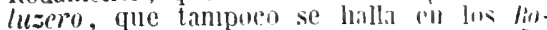
manceros, y es enteramonte distintal $h_{1}$ publicado por lourall, alln eluind: sll por-

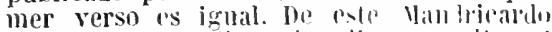

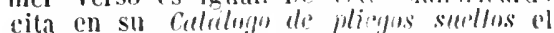

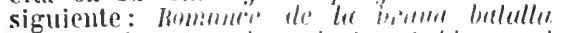

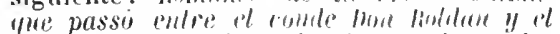

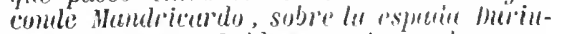
ilama, y como Rolelam so lorills loco por amores de lugraca la bella. Impresson com licelleia s. 1. ni. a. 4. ${ }^{\circ}$ lot. got. 4 hojas. Principia el romance: Helo, helo por do viene-t'd taliente Homdricardo.

\section{oclaras i la prision de Welisendru.}

Jugando esta í las Liblas lum tialiferos, 1) ye yo Melisenulea rsta olvidado, luandu el lamosu liblus y lliverus A ver el jue ro juntus hats entriulo Con otrus valerosios ialoalleros

be aquellos de los boce, que i su lado Jugaban, y á su mesa liss ponia,

Porque esto su valur lo merecia. Entrarido pues bon Cárlus el famoso

Y su persuna ya reverenciada,

Con rostro triste, airado y temeroso.

l'regunta á Dom Gaiferos por sil anıada, l)ieiendole: sobrino, mui ociosu

Estais siendo mi hija captivada,

Si fuérades valiente caballew,

los fuérales rescate y 10 el dinero.

Gaiferos deju el juego commenzadu,

$Y$ á Don Roldan sus armas le ha pedido, Las euales bon looldan no le ha negado Por ser d'el en estremo Lan querido; Y li!egir en sil caballo ha cabalgado, I i Dırindana al lado se ha cenide,
Espada que fué de Iletor el troyano, Ganada por Aquiles el greciano. Airado va Gaiferos á Sansueña, Ciudad donde sı esposa está captiva, $\mathrm{Y}$ al ciclo su palibra da y empena le no volver sin elli micintris viva; Al mumlo time es puco y le desdena Alzando esimulo y lanza en voz mul viva, I í ('uaustos topa y ve cou mano armadi En chlos probbat el fllo de sil espitala.

lil viemes a simsuneña llegú á limmpo t) ne todus ya on la mezquitil estaban, llaciendo la Zalí ("onl pissiliempor, Fiesta que en aquel dia se guardaba; Teniendu pracion de tan buen tiempo Oue lul ristiano captivas sa da daba, iviollun la crasion y roymulura, Entruse en la cindad pagina y dura. A vista del palario ya llegaba, sill ser do madie visto ni s(ontido, Conando de una ventana le llamaba Su exposa ron el rostro entristceido; tal rual inte el mil perlas dorramaba biccirludu: eahall'ru, dame vido porrefue eso csemelo y limza y esa seña, Xa sill de las que so usall ell samsuena. suplicuos me dienais si sois de Francia, Porque ese lorio, talle y gallardia, I aqulasa holli bólioil collstancia Co cale all la colbarde mireria. Cinfurus rospondic: ya es arrugancia, sibola, purreue en ni no hiri valentia,

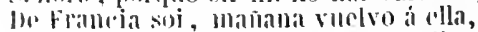
yirid ell ync os podré servir en ella.

\section{$10 \bar{T}$ ROMAYCES. C Ouatro Ro-} mãces d'la sagrada scriptura. O El primero d'l nascimiento. E El. ij. de sant Juã elāgrelista. I El. iij. del Annunciacion. El quarto del sacramento d'l altar. I Dos villācicos d'l nascimiēto. (Siguen dos estampitas, la una representa un Nacimienlo y la otra un sacerdote diciendo misa: ambas van circuidas de orla.) S. $\mathbf{l}$. ni a. (hácia el 10̈3̈̈). 4." let. zrót. 4 linjas sin sign.

to tengo sino las dos primeras hujas de este pliegro desconucido y en ellas se encuentran los tres romances:

Al Nacimiento: En Bellem esti cl infanle.-

A S. Juan Evangelista: A caza sale el buen rei.-

A la Encarnacion: Ricas dansas, ricas dem:as.-

$108-1$ Aqui se cõtienen dos romances glosados $\mathrm{y}$ tres canciones. Este primeroes d'la bella mal maridada. Y otro de catiuaron me los moros. Y una cancion $\bar{q}$ dize. Salgan las palabras mias. Y otra. Las tristes la- 
grimas mias: Y otra. Si en las tierras do nasci. todas glosadas. S. I. ni a. 4. ${ }^{\circ}$ let. gót. 4 hojas con la sign. aij. Copia literal manuscrita de este pliego suelto.

Los dos romances dicen :

Cuando amor en mi ponia.

y En mi jutentud pusadi.

El Sr. Duran no pudo ver este opiseulo: pero cita cirus donde se hallan algunas de las composiciones que ell él se conlienen, á saber:

Aqui connienzan qualro romances, y este primero dize: Cautiuaronme los morus, ! otro, De la bella mal maridada, y otro dis Caminando por mis males, con un villuncicy. S. l. ni a. $4 .^{\circ}$ let. got. \& hojas.

Aqui comienzan lres romances glosalos , y este primero dize: Desanada siempre seas: $y$ otro de La bella mal maridada; y otro de Caminando por mis males, con su villencico y in romunce. S. l. ni $a .40^{\circ}$ lel. got. 4 lirjas. Contiene este pliego:

Glosa de Melchor Llanes al romance de: Desamada siempre seas, en coplas que alicen: Pense que por bien amarte, con ilesheclut que dice: Perdonad, bien de mi vida.

Idem de Quesada al de La bella mal maridada, en coplus que disen: Cuando anisr en mi ponia.

Idem al de Caminando por mis males, en coplas que dizcn: Viendu que nui pensimiento.

Villancico de Dame acogida en lu latu, cun suś coplas que dizen: Esta noche en lu majada.

109 ROMANCES. I Tres romances del Cid. S. 1. ni a. (hacia el 1600). 4. Viñeta de madera que representa al Cid $a$ caballo. 1 liojas con la sign. a.

Principian:

Aquel sol de Castellanos.-

Si de morlules feridus. -

La que is nadie no perdona.-

El primero es la glosa de Franciseu de Loril al romance IIdo, helo por to viene, que teng" en una edicion gótica, los dos restantes se hallan en el Romancero de Duran y en otras colecciones.

110 Aqui se contien en seys Romãces del Cid Ruydiaz de Viuar, El primero cuydando Diego Layney El segundo, Ćonsolando al noble viejo. Ei tercero en los solares de Burgos. El quarto Pidiendo a las diez del dia. El quinto Yitorioso buelue el Cid. El sexto El vassallo desleal. Aora nueuamente inpresos con Licencia. S. 1. ni a. (kácia el 1600). 4. Viñeta de madera. 4 hojas $\sin$ fol. ni sign.

Dichos seis romances se hallan en rarias colecciunes y en el Romancero de Duran, a pesar de no mencionar en su Calatogo ninguno de estos dos pliegos suettos.

111 ROMANCES. I Aqui comiencan dos romances del marques de mãtua. El primero es de como andando perdido por vn bosque hallo a su sobrino baldouinos con heridas de muerte. Y el segūdo la embaxada ĭ el marques embio al enıpador demādādo justicia. Y otra agora de nueuo añadido que es rna sentēcia que dieron a Carloto: hecho por Hieronvmo tremiño de Calatavud. S. I. ni a. (hácia el 13̆30). 4. ${ }^{\circ}$ let. gót. Viñeta de madera sobre la portada que ra copiada. Son 12 hojas sin fol. con la sign. a.

Contiene tres romances que dicen:

De. Mrontue salio el Marques.

Dis Mantua salon apriesa.

En el nombre de Jesus.

so liallian en el Cancionero de romances, en la Silcel y en la Floresla. Duran los reimpri-

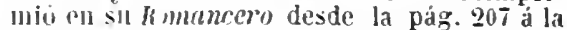
217 del lonno I, ¿ en el Caliolog' de plie'gos sultus cilit una edicion de Burgos, Folipe de Jintı, 1562. 4. let. got 12 hojus.

112 - Historia del Marques de Mantua (en cuatro romances). Córdoba, Rafaei Garcia Rodriguez, s. a. (hácia el 1730). 4. ${ }^{\circ}$ Lámina de madera. $\mathbf{2} 4$ paigs.

Contiene:

lomance I. De Montur sale el Marques.

II. De Mantua saten en posta.

III. En al numbre do Jesus.

IV. Sothre dinocente jouen.

Lus mimeros I, II y III son los contenidos en el articulo anterior; pero el primero y segundo estín tan variados que parecen distintos en alguinos trozos. á pesar de ser en el fondo los 111 ismos. El IV tambien relativo al Marques de Mantua, no lo encuentro reimpreso en los Romanceros.

\section{ROMANCES DE VALLADO-} LID. Qvaderno de diferentes obras y ronances y coplas diferntes. (Sigue una gran lamina que representa una fortaleza, y $a$ varios guerreros balallando fuera de ella. Bajo dice:) Inpresas Conlicencia. CLa hoja segunda 
lleva por epigrafe:) Qvatro Romances de la midanca de la Corte, y grandecas de Talladolid. Impresso con licencia en Salamanea esie presente año de 1606. Bajo hai ma vinetila con las armas de España y la letra AGRO DVLGE, y al fin de la cuarta hoja se encuentra olra de un butue a la re(a.) Son :̈ hojas en $4 .^{\circ}$, de las cuales solo la tercera y cuarta estan foliadas en la parte inferior. El fróntis se halla impreso en hoja separada.

Las primeros versos de los enatro romances soll:

- A li digo el pujezico.Magüer que !nto finurlo.-

- Trayganme papel y tiula.-Sulleulose a pusear.

114 ROMANCES DE VILLADOLII). Segrinco graderno de qvatro Romanees, en alabanca de lladrid Y Valladolid, y lespedida de los Cortesanos, Con licencia en Alcala este año. 1606. SSigue una rinela de un obispo sentado, y termina ol pliego por el escudo del impresor. Inan de Cinova.) Son 4 hojas en 4." sinfol. ni sign.

Los cuatro romanters prineipian ist:

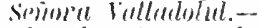

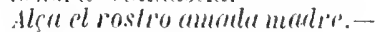
Francosa Folluerlolid. -

cou la buella veuturost. -

113 - El consuelo que in montañes haze a las Ciudades de Valladolid, y Burgos, y Montañas de Castilla la vieja en la ausencia de la Corte. Con rna Satrra a los poetas que han tratado mal la insigne y noble Valladolid. Impresso con licencia en Aleala, en casa de Iuan Gracian que sea en yloria. Año 1606. \&. ${ }^{\circ} 4$ hojas sinfol. ni sign. Despues del epigrafe copiado hai una vineta de madera y olrat al fin.

El Romance principia: y la sitira: I la gran Castillu vioju,

Toleruble fuera cl wurl.

116 - Dos Ronances de la partida y despedimiento de la lieal Chãrilleria, que reside en la ciudad de Burgos, que se torna a Valladolid, y los razonamientos de los Patrones y defensores de la dicha Ciudad. Iuntamente con vn casamiento de rna vieja de setenta años, con vn viejo de ochenta y quatro. Compuesto por luan de Cespedes. Madrid, Iuan Serrano de Vargas, 1606. $4 .^{\circ}$ i hojas sin fol. ni sign. con una ciñeta de madera en la portada y otra al fin. Al pic de esta se lee de letra gruesa gólica en dos renglones: Flor de x'tudes.

Los primeros versos de las tres composieiones sill:
Fomoso Cid compendor. -
Seviores medio proflas.-
l'usscand'sme en senilla.-

\section{ROMANCES DE VALLADO-} L.1D. Tres Romances. de Astrrias de Oriedo, gre tratan el primero de la eleccion del Rey don Pelayo. El segundo de vila querella que las mismas Asturias proponen, por que llaman a slis hijos de villanos. El tercero, de rna carta de consuelo, que el mismo Principado embia a Valladolid, sobre la mudanca de la Corte. Todo en su mismo estilo antigno de habla. Compuesto por Diego Suarez. Alcala, en casa de luan Gracian, 1607. 4. ' hojas sin fol. ni sign. con un escudo de un leon y las iniciales C F en la portada.

lus tres Romances principian de esta manera:

\section{Inturonse los Concejos.- Fidalyos som los mius fijos.- Fermoso lalledeolid.}

E.l sr. Duran an conocio ninguno de las pliegos sueltus descritos desde el num. 115, y estoi casi seguro de que no existe otro ejemplar tan completo de los rominees y otras composiciones poeticas, escritas con motivo de la Iraslacion de la corte á Madrid.

118 ROMLANCES. Romances populares impresos en varios puntos de España, durante la primera mitad del siglo XYIII. $4 .^{\circ}$ Casi todos llevan una lámina de madera al prineipio.

Relacion que lizo un patan í oton prino suyo, de las Fieslas, que los Padres I)ominicos de Sevilla hicioron á la canumizaciun del señor S. Pjo V, el año de 171.5. Primera y seguuda parte. s. l. ui a. \& fenjas.

Nueva relacion y romance de los martirios gue mando executar el Emperador del grall 
Cayro con novecientos Seglares y cien rellglosos de S. Francisco, en el ano de 1733. §. I. ni a. 2 hojas.

Romance trobado por el de ardiendose estava Troya, al sentimiento de la muerte del Rey (Carlos II). S. l. ni a. hojas.

Matraca en romance, coplas en verso, el Abate que voy, el coco de las Sardinas, y espantajo de los Pezes. A la derrota de la ar. mada inglesa. S. 1. ni a. 4 hojas.

Segunda relacion y trivnfo solemne que la Villa de Madrid tributá á la entrada de Felipe ovinto en 1701. S. l. ni a. 4 hojas.

Romance nuevo del sitio y toma de la Plaça de Belgrado, por el Principe Eugenio de Saboya, el 17 de Agosto de 1\%17. Compuesto por Pedro Ruiz de Gordejuela. Primera y segunda parte. Barcelona, s. a. 4 hojas.

Romance nuevo, en que se declara la horrenda y sangrienta tempestad que ha sucedido en Barcelona el dia 11 de Setiembre de 1717. Barcelona, s. a. 2 hojels.

Relacion histórica, y curioso romance, donde se declara la antiguedad de las flestas centenares que celebro Valencia en el primero, segundo y tercero siglo de su conquista por Don Jayme de Aragon. Compuesto por el Estudiante Yanuel Zuñiga. Primera parte. 2 hojas.

Segunda parte de la historica relacion de las fiestas centenarias que celebró Valencia en el quarto siglo de su Conquista año de 1758. Por Manuel de Zuñiga. Valencia, s. a. (1738?) 2 hojas.

Viage del mindo a la lnz de las estrellas, el presente añu de 1742. Compuesto por Don Antonio . Campillo y Mareo. Itadrid, Antonio Marin, y reinipresso en Zaragoza, por Francisco Revilla, s. a. 1 hojas.

Nuevo romance, en que se declara lo que les sucedio á dos fllos amantes llamados Bernardo y Constanza, que por quererse bien estubieron Cautivos. S. l. ni a. 2 hojas. - Verdadera relacion y nuevo romance, que declara, como vn Cavallero de Barcelona, sacó una Doncella de casa de su padre, forcandola en mitad de un monte, $y$ luego le dió de puñaladas, y se la dexó por muerta. S. 1. ni a. 2 hojas.

El uutor es Andres de Porras Trenllado, segun-dice el penullimo verso.-Sin embargo de ser el nombie de la heroina de este ro. mance el de Violante, la composicion parece dislinta de la que describe Duran con el título de Doina Violante: el v'erso primero de la obra de Trenllado dice: Atemoricese el mundo, y solo consta de una parte.

Nueva relacion, y curioso romance, en que se declara la muerte que tuvo Bigotillos en Nostagan este ano de 1733. y como fue la causa la pesadumbre que tomo por averle quitado una de sus mugeres los bigotes. Iladrid, 17j̄. 2 hojas.

Primera parte de los varios sucessos de Don Manuel de Contreras, y Doña Teresa de Ribera. S. l. ni a. 2 hojas.

Segunda parte de liona Teresa de Ribera. S. 1. ni a. 2 hojas.

Segun aparece por el final de esta parle. el autor se ltamaba Juan de Mendoza.
Curioso romanice en que se hace breve resumen de la portentosa imagen que se venera en el Real Ermitorio de las Beatas de Liria del Arcangel San Miguel. S. 1. ni a. '2 hojas.

Nuevo romance, en que se reftere un milagroso sucesso, que sucedió en Tolndo con un Devoto de la Santissima Cruz. S. 1. 1750. 2 hojas.

Verdadera relacion, y singular prodigio que obró Dios por medio de Santa Rita de Casia con dos devotos suyos el dia 51 . de Julio de 1751. S. I. ni a. 2 hojas.

Nueva relacion y curioso romance, en que se declaran las honradas travesuras y nobles hazañas de Don Pedro Peñalver, natural de Medina Sidonia. S. 1. ni a. 2 hojas.

Romance nuevo de Don Alonso de Granada. Cordoba, s. a. 2 hojas.

El penullimo verso declara que su autor es José Vonteroso.

Primera y segunda parte de la relacion, los Esclavos de su Esclava, y hacer biell nunca se pierde. Doña Leonor y Don Fernando. Malaga , s. a. 4 hnjas.

Relacion verdadera de los delitos, y causas de Igustin Florencio. S. 1. ni a. 2 hojas.

La muger que vivio con el osso. Cordoba, s. a. 2 hojas.

Este romunce es de Juan Garcia Valer, segun se ve por su final.

Caballero de Ronda y el Vegro. (Don Frmcisco de los Rios y Elvina.) Primera y segunda parte. S. 1. ni a. 4 hojus.

Primera y segunda parte de los amores de D. Carlos Moncarte, y Dona Blanca. Cordoba, s. a. 4 hojas.

Doña Clara y Don Manuel de Silva. Imse cuenta de los sucessos de estos dos amantes, su cautiverio, y el martyrio de la Doncella. Cordoba, s. a. 2 hojas.

Por el finul aparece que el aulor es Indres Porras Trenllado.

El Principe Transilvanio. Cordoba, s. a. 2 hojas.

El hijo del verdugo de Corduba. Primera y segunda parte. Cordoba, s. a. 4 hojus.

El cerso primero del printer romance es diferenle del que trae Durnn, pues en mi ejemplar dice: Atiéndame el Auditorio.

Vuevo, y curioso romance, en que se declara la desastrada vida, y admirable Conversion de la Hechicera de Cartagena, lla. mada Ana Maria de Prado. Primera y segunda parte. Cordoba, s. a. 4 hojas.

Curioso romance, en que se da cuenta, y declara el fln, y Cautiverio de estos dos finos Amantes llamados Bernardo, y Constauza. S. 1. ni a. 2 hojas.

Vueva Relacion y curioso romance, ell que se da cuenta, y declara la feliz victoria que consiguió contra los ingleses un Corsario Español, llamado D. Miguel Santos Cambronero, el año de 1742. Cordoba, s. a. 2 hojas.

Segun resulía del final, su autor se llama. ba Serrano; sin duda el Francisco, escritor de otros romiances.

Famosa relacion en que se decifra la antigua Fundacion de Granada y de algunas Excelencias suyas. Granada, s. a. 2 hojas. 
Verdadera relacion, y curioso romance, donde se refleren las valerosas hazañas, de Don Victorino de Lara. S. I. nl a. 2 hojas.

Don Antonio de Orellana, y Dona Josepha Caycedo. Cordoba, s. a. 2 hojas.

En el contesto se dice ser Mendoza su autor; supongo sera el Juan que compuso otros romances.

Don Francisco Cardona, y Doña Juana Ferrer. Primera y segunda parte. S. l. ni a. 4 hojas.

Simonanza, el Renegado de Francla. S. I. ni a. 2 hojas.

Duran lo trae sin nombre de autor: por el final consta que lo es Pedro Portillo.

Curioso romance de Joseph Canales. Cordoba, s. a. 2 hojas.

Juan de Gracia. Cordoba, s. a. 2 hojas.

Epilogo agradable, en que en un nuevo Romance se da noticia de la tragica, y admirable historia de Fenix Alva. Cordoba, s. a. 2 hojus.

Nueva relacion y curioso romance de los valerosos hechos, que hizo Bon Joseph Paula, por los amores de una Senora llamada Dona Flora de las Doblas. Primera y segunda parte. Cordoba, s. a. 4 hojas.

El aulor es José Francisco, como lo atestiguan los finales de los dos romances.

Nuevo romance de los hechos, y muerte del Sr. Marques de ia Algaba. Cordoba, s. a. 2 hojas.

Nuevo, y curioso romance, en que se reflere una lastimosa carta, que desde Argel escrivió á su muger un soldado llamadọ Francisco Hernandez. Cordoba, s. a. 4 hojas. Al fill del segundo romance dice que el autor es Pedro Saez.

Nueva relacion, y curioso romance en que se da cuenta y declara los afurtunados lances, y particulares sucessos que le sucedieron á una principal Doncella natural de Zaragoza: declarase las muchas muertes, $y$ atrocidades que executo en busca de un Capitan su amante. Malaga, s. a.

Este romance es de Juan de Mendoza, segun indica al fin.

Carta bvrlesca, escrita por lvan de Porcvna el Espeso... Alcayde Perpetuo del Burdèl de Valencia y de todas las demàs Casas, que sirven de Rediles, para guardar las Cabras, que saltando bardales, inquietan el Ganado. S. 1. ni a. 2 hojas.

Relacion y cvrioso Romance, en qve se da a los mortales noticia del Jvizio y Venida del Ante-Christo. Escrito por Lucas del Olmo Alfonso. Primera y segunda parte. Madrid, Francisco Sanz, s. a. 4 hojas.

Nuevo, y curioso Romance, en que se refieren los Desposorios de la hermosa Dionysia con un Potentado de Italia, llamado Alberto. S. l. ni a. 2 hojas.

Veridica relacion que maniflesta el memorable naval Triunfo, de los Curtidores contra argelinos Piratas quando robaron de Torreblalıca un Byril el año 1397. S. I. ni a. 2 hojas.

Relacion nueva del despedimiento de un galan para ausentarse por la esquivez de una D ama, en que pinta un Navio. Cordoba, s. a. 2 hojus.
Todos los romances descritos hasta aqui, - pertenecientes a la primera mitad del siglo XVIII, no se hallan en el Catálogo puesto en el Romancero del Sr. Duran. Lns siguientes, perteriecientes a la misma epoca, se encuentran en dicho Catálogo.

Dona Francisca la cautlva. Primera y segunda parte. Cordoba, Colegio de Nra. Sra. de la Assumpcion. S. a. 4 hojas.

Por los finales de ambas partes se ve que el nombre del autor es Pedro de Fuéntes.

Nueva relacion en donde se reflere la vida del Estudiante Tunante en particular algunos hechos de seis Estudiaites vagamundos. Sevilla, Joseph Padrino, s. a. 2 hojas.

Relacion en favor de las senoras mugeres. Sevilla, Joseph Padrino, s. a. 2 hojas.

Relacion contra las senoras mugeres. Sevilla, Joseph Padrino, s.a. 2 hojas.

Don Isidro, y Doña Violante, y el negro

Domingo. Primera y segunda parte.

El autor es Juan Miguel de Fuéntes, segun consta por el final de ambas partes.

Nuevo y curioso romance del cautiverio de dos finos anantes, llamados Belardo, y Lucinda. Cordoba, s. a. 2 hojas.

Espinela. Cordoba, s. a. 2 hojas.

Dona Ines de Castro cuello de garza de Portugal. Cordoba, s. a. 2 hojas.

Otra edicion, s. I. ni a. 2 hojas.

Curioso romance nuevo; en que se reflere, $y$ da cuenta de veinte $y$ seis muertes que hizo una Doncella, llamada Dona Teresa de Llanos, natural de Valencia. S. l. ni a. 2 hojas.

Verdadero, y curioso romance de la princesa lsmenia, hermana del Gran Turco osmàn, en que se declara la Embaxada que embio Osman à Felipe Segundo. S. l. ni a. 2 hojus.

Primera parte De los amores de Don Jacinto del Castillo, y Dona Leonor de la Rosa. S. l. ni a. 2 hojas.

Segunda parte De los amorosos sucesos de non Jacinto del Castillo, y Doña Leonor de la Rosa. S. 1. ni a. 2 hojas.

Testamento que ordeno el serenissimo senor Don Juan de Austria. Primera y segunda parte. S. I. ni a. 4 hojas.

Nueva relacion, y curioso romance, de la mas prodigiosa bistoria en que se declara la feliz fortuna de un Cortante de la ciudad de Cadiz, llevándoselo un Mercader à las lndias. Primera parte. Cordova, s. a. 2 hajas.

Prosigue la historia del hijo del Cortante de la cludad de Cadiz. Segunda parte. S. I. ni a. 2 hojas.

Nuevo y curioso romance del sacerdote de valencia. Audalla. S. 1. ni a. 2 hojas.

Romance del cautivo de Girona, que escribe á su Padre desde Argel los trabajos, que padece. l'rimera parte. Cordoba, s. a. 2 hojas.

Romance en que se reflere la' segunda parte del rescate de Lucas Perez Susvilla (el cautivo de Girona). Peregrinacion de sil padre y muger. Segunda parte. Cordova, s. a. 2 hojas.

Dun Juan de Aviles. S. I. ni a. 2 hojas. 


\section{ROM}

PLIBgOS SUELTOS.

ROM

Don Juan de Lara y Dona Laura. S. L. ni a. 2 hojas.

Primera parte en que se da cuenta de los hechos, y atrozidades del valiente Francisco Estevan.-Segunda, tercera, quarta y quinta parte del mismo romance. S. 1. ni a. 10 hojas.

Esta edicion es probablemente una de las mas antiguas del celebre romance de Fran. cisco Estevan, pues le tengo por anterior al año $1750, y$ observo que en ella y en otra posterior que tambien poseo, el orden de las partes es el siguienle, diverso del señalado por Duran en su Catálogo:

Primera: Tiemble de mi nombre el mundo.

Segunda: Esplique mi lengua torpe.

Tercera: Santo Cristo de la Luz.

Cuarta: $0 h$, Soberano Señor.

Quinta : Desde donde einpiezu Europa.

Admirable y gustosa historia del principc Filiberto de Esparta y la Princesa de Dinamarca. Primera $\boldsymbol{S}$ segunda parte. Cordoba, 3. a. 4 hojas.

En el final de ambas partes se lee el nnmbre del autor, Manuel Martin y no Vartir, comn dice Duran.

Nuevo, y curioso romance de la tragica Historia y Cautiverio de D. Luis de Borja. S. I. ni a. 2 hojas.

Duran trae este romance comn anonimn; sin embargo, lns dos villimos versos dicen: Y aqui la hija de olmo

Pide perdon de sus faltas.

119 ROMANCES. Romances populares. Impresos en varios puntos de España en la última mitad del siglo próxinio pasado, en $4 .^{\circ}$ Casi lodos llevan láminas de madera.

Veridica relacion del naval Triunfo de los Curtidores contra Argelinos piratas quando robaron de Torreblanca la Rica Joya de un Byril el ano de 1597 , cuya memoria recuerda este Gremio, á ocasion del nacimiento de los Infantes Gemelos. Valencia, 1784. 2 hnjas.

- Otra relacion sobre el mismo suceso hecha en 1789. 2 hojas.

El cautivo de Tarragona. Nuevo romance en que se declara como los Moros cautivaron á un principal Cavallero de la Ciudad de Tarragona, á su Esposa, y una hija, con otros: refierense los trabajos que padecieron, y como la Señora, y su hija, con algunos Cautivos, lograron la libertad, quedando allá el Cavallero. Primera parte. S. 1. ni a. 2 hojas.

Nuevo y curioso romance, en que se de. claran los trabajos que padeció el noble Cavallero, y cumo fué en rescate: tambien reflere como estando sil Esposa para casarse con otro, permitió-Dios que llegase la noche de las bodas á su casa. Segunda parte. S. I. ni a. 2 hojas.

Don Antonio Mellado y Osuna, y Dona Eugenia Lopez. Primera y scgunda parte. Malaga, s. a. 2 hojas.

Primera parte. De los varios sucesos de pon Bodrigo Zarzára: Cuentase el galanteo con una Dama, y. como fué cautivado de Moros, y despues se huyó con muchos Cristíanos a Espana, juntamente con una Cautlva, casada con un turco en Argel. Nalaga, s. a. 2 hojus.

Segunda parte. De Don Rodrigo Zarzára, reflerese lo que sucedió á la Cautiva, que se vino con èl á España, y como llegó á su $\mathbf{P a}$ tria, á tiempo que llevaban á su Padre al suplício, y de la forma que ella le alcanzó el perdon. (Málaga?) s. a. 2 hojas.

Verdadera relacion 5 curioso romance, en que se reflere el maravilloso Milagro, que ha obrado nuestra Senora del Rosario con dos devotos suyos, los quales por no haber querido renegar en Argel fureron cruelmente castigados de los Piratas. Don Alonso y Juan de fracia. S. 1. ni a. 2 hojas.

Primera parte del verdadero, y nuevo roinance, que da cuenta de la forma que cautivaron á un Cavallero natural de Llanes... y coino por una noble Mora se rescato, él y otro Cautivo, y se vinieron ellos, y otrow diez, y un Renegado, trayendose á la Mora á tierra de Christianos, donde se bautizo. S. I. ni a. 2 hoj $r s$.

De Don Diego, y Arlaja. Segundo romance, que refiere este verdadero suceso. S. 1 . ni a. 2 hojas.

Nueva relacion, en que se reflere el casn mas singular de dos Amantes, naturales de la Ciudad de Ronda: Declarase, como por una pendencia se auscnio el Galan, y havien. dose embarcado, lo cautivaron los yoros : y lo demas que verá el curioso lector. Primera parte. S. 1. ni a. 2 hojits.

Segunda parte, en que sr da cuenta, como saliendo Disūa Mariana ell trage de hombre en busca de su amante Luis Francisco. Ia cautivaron, y fue á parar á la misma Ciudad en que él estaba cautivo. S. 1. ni a. 2 hnjas.

Nueva relacion en dos famosos romances, en que se refiere, como un noble Cavalleri Andaluz, llamado Don Antonio Venavides de la Cerda, se enamoró de una Señora, llamada Dona Maria Teresa de Faro, Torres y Leon, natural de Palermo, por la qual tuvo una reñida pendencia, $\mathrm{y}$ haviendose enbarcado para venir á España, fueron cautivos: con lo demas que verá el curioso lector en esta Primera parte. S. 1. ni a. 2 hojas.

Nueva relacion, y curioso romance, donde se reflere lo que passaron en su cautiverio Don Antonio, y Dona Maria Teresa. Segunda parte. S. l. ni a. 2 hojas.

De Don Manuel Sanchez de Rueda. Nisevo y curioso romance, en que se declara la vida, y cautiverio de este mancebo, natural de la Ciudad de Valencia. Primera parte. S. l. ni a. 2 hojas.

De Don Manuel Sanchez de Rueda. Decla. rase como renego, y se caso en Argel, donde se mantuvo algunos años. 'Segunda parte. S. I. ni a. 2 hojas.

Primera parte, de Don Juan de Torres Cabrera, y Dona Yaria Teresa. S. 1. ni a. 2 hojas.

Segunda parte, donde se flhaliza la historia de Don Juan de Torres Cabrera. S. 1. ni a. 2 hojas. 
Primera parte, en que se reflere de la forma que Don Antonio Moreno, estando cautivo hlzo Christiana á una Mora llamada Zelinda, y á su Padre, y despues se vinieron á España. S. 1. ni a. 2 hojas.

Segunda parte. S. l, ni a. 2 hojas.

Primera y segunda parte de Don Juan Rosique. S. 1. ni a. 2 hojns.

Romance nuevo, donde se refiere el mas admirable, y prodigioso suceso, que hasta hoy han oido los vivientes, de un Cavalleri, llamado Don Leonido de S. Pedro,... el qual siendo Cautivo, renegó. S. 1. ni a. 2 hnjas.

Nuevo y curioso rumance, en que se da cuenta $y$ declara los amores mas constantes de min Cavallero llamado Don Cecilio del Villar, y Dona Manuela de Torres. S. l. ni a. 2 hojas.

Verdadero, y curioso romance, en que se declara, y da cuenta, como un Cautivo Christiano, natural de la Ciudad de Valencia estando Cautivo en la gran Constantinopla en el Palacio del Gran Turco, se enamoro de él la hija de el dichi key. S. 1. ni a. 2 hojas.

Verdadera relacion, y curios's romance, en que se reficre $\mathrm{y}$ declara el rigoroso castigo, que executaron los Iforos de Argel con un Cinvallero, Hamado Blas de Leon. S. l. ni a. 2 hojas.

Jueva relacion, y curioso romance en que se refieren los valerosos hechos de Don P'euro de Veraguas, el qual fué Cautivo por los Turcos... y se enamıro de la Princesa Lindaraja. Suredio el dia 15 de Septiembre de 1760. Primera y segunda parte. S. 1. ni a. 2 hojas.

Nuevo y curioso romance en que se refie-. ren los Amores, y Cautiverio de Don Juan de Flores y Doña Laura. S. 1, ni a. 2 hojas.

Romance nuevo, que reflere un caso sucedido á ur sacerdote natural de Gibraitar, tjue fué cautivo en Argel; y explicando á sil amo los Ifisterios de la Missa se convirtióa nuestra Santa Fé, y con muchos Cautivos se vinieron á Romn. S. l. ni a. 2 hojas.

Nuevo romance, en que se refieren los varius sucessos de dos enamorados de la Ciudad de Sevilla... Don Itanucl Gonzalez y Duna Teresa Enriquez. S.l. ni a. 2 hojas.

Relacion de la vida hechos, $y$ hazañas homrosas del valiente Natheo Benet y Vicente, natural de Benimaclet, Lugar en la linerta de Valencia. S. l. ni a. 2 hojrs.

Nueva y curiosis romance, en que se refieren los famosos hechos, y gallardas hazañas del valeroso Alfonso Nuñez, natural de la villa de Ledaña. S. 1. ni a. 2 hojıs.

Curioso y nuevo romance de la desastrada vida, fin $y$ muerte que tuvo un mozi) mancebu natural de la Villa de Zamarramala. Primera y segunda parte. S. 1. ni a. 2 hoj $t .5$.

Romance famost) en que se refleren las rrandes hazañas del valiente Yergo en Flandes, Ltamado Juan de Alva, y lo mueho que. el rey nuestro señur premió sus hechos. S. I. ni a. 2 hojrts.

Tengn otric eỉicion de Cordoba, s. a.; prorece mas anligua.

Nineva relicion y curioso romance, en que se declara, y da cuenta de treinta muerles que ha hecho una doncella, lla mada Dona Isa bel Gallardo natural de la Ciudad de Jaen. S. l. nl a. 2 hojas.

Curioso y nuevo romance en que se reflere İa Historia de los Vandidos que habitaron en los Montes de Toledo, executando en ellos notables atrocidades. Primera y segunda parte. S. 1. ni a. 4 hojas.

Famosa jacara, que hace relacion de los delitos, muertes, robos y atrocidades de Pedro Andres, Capitan de Vandoleros, que prendieron y ajusticiaron en la Ciudad de Valencia, S. 1. ni a. 2 hojas.

Nuevo y curloso romance, en el que se da cuenta de la vida, prision, y muerte de sie. te hermanos Vandoleros; $y$ en que se refleren las grandes crueldades, insultos, muertes, y robos que hizo Andrés Vazquez y sus hermanos. S. l. ni a. 2 hojas.

Primer"a y segunda parte de Don Juan Estevan de Argalia. S. l. ni a. 4 hojas.

Nuevo y curioso romance, en que se declaran las atrocidades de Sebastiana del Castillo. S. 1. ni a. 2 hojixs.

De Guillermo el ingles. Nueva relacion $y$ curioso romance, donde se da cuenta de una pesada burla que una muger hizo d́ un ingles, por liaverli enamorado. S. 1. ni a. 2 hojits.

El nombre del rulor, segun dice al fin, es Jerónimo Romero.

Famosa xacari nueva, graciosa y entretenida para reir, y pasar el tiempo despues de la panza llena y no de viento intitulada: l'iearus ay con fortuna. Alo ultimo va añadidı la del Dugue es muy cuerdo en todo. S. 1. 11 i a. 2 hojiss.

Nuevo romance á la prision, sentencia y suplicio de 111 piojo cogido en frangante delito. s. t. ni a. 2 hoj/cs.

sommilo romance curioso y entretenido en que se refieren las gracias, excelencias, preeminencias y libertades de las Pulgas y Piojos y los malos ratos que dan á todo viviente, fiados en su ligereza $y$ modo de veriltarse. S. 1. ni a. 2 hojits.

Iromance curioso, y chistoso, de la muzeer que engiñná siete galanes en la Ciudad ile Jien. Primera y segunda parte. Madrid, Andres de Soto, s. a. 4 hojirs.

Vlatraca de un estudiante d́ una dama. \$. l. ni a. 2 lojas.

Relacion burlesea del frances Juan Ferlaque. S. 1. ni a. 2 hojas.

Itatraca burlesca entre hombre y muger para reir, y pasar el tiempo despues de haver comido bien. Compuesta por el licenciado Chaffon, Poeta Gorron, y Visitadur de los Budegones, $\mathrm{y}$ Tabernas de esta Corte. S. I. ni a. 2 hojts.

Vueva relacion, flamante y curioso romance, jamas visto, ni oido, en que se refleren lis hazañas y atrocidades del Dios Baco; los puestos, y dignidades que reparte á los innumerables Cofrades de tan grande lermandad. Primera parte. Malaga, s. a. 2 hoj'ls.

seśunda parte. Curiosa xacara nueva de mucha graciosidad, dando cuenta del Deereto y Viando, que ha echado el Dios Baco, 
del gran Padre San Rorro, contra los Her. manus y Cofrades de las dos Cofradias, para que guarden las leyes: a instancia de un buen hechor de las dos Hermandades. Malaga, s. a. 2 hojiss:

Gracioso y nuevo romance, que refiere las habilidades del gran Palanquin, pariente de todo el mundo, vecino de tudas partes. comedor de todos manjares, y enfermo de todos achaques, que se puso á hacer testamento y lo dejó para otra vez. Compuesto por Andres de Porras Trenllado. Primera parle. Malaga, s. a. 2 hojiss.

Segunda parte del testamento del gran $\mathrm{Pa-}$ lanquin $\mathrm{y}$ las graciosas mandas que hizo. s. 1. ni a. 2 hojirs.

Relacion nueva, burlesca, de Don Francisco de Quevedo que declara un Cabildo que celebraron los gatos en el ala de un tejado. S. 1. ni a. 2 hnjiss.

Primera parte, de una carta, que un patan le embia í un amigo suyo llamado Ximon. dandole cuenta de lo que le habia pasadu $\mathrm{mn}$ la Ciudad de Sevilla, por los amores de una Zagala. s. 1. ni a. 2 hoj $\iota s$

segunda parte, donde el patan le explica por extenso á su amigo ximon, lo que le sucedio en la Ciudad de Sevilla con su querida Zagala. S. I. ni a. 2 hnj $/ s$.

Primera parte de los rumances de la graciosa burla que hizo á cierto galan un estudiante en la ciudad de Lorca. S. I. ni a. 2 hojas.

Segunda parte de los Romances del Estırdiante de Lurea, y como le hizo otra burla al mismo Galan. S. l. ni a. 2 hojos.

Relacion nneva y coloquio de un hombre amante y zeloso. Cordoha, s. a. 2 hojils.

Romance curiuso, en que se refleren, y declaran las quexas, y lamentos de un durnte, que se ve despreciadu de sil Dama. Explicandole las Virtudes del agua. Ifalaga, s. a. 2 hojils.

Rumance en que se refleren, unas amorosas quexas que un Galan da á sil Dama, por experimentar poca flrmeza en ella. Van al fin unas letras, que un amante afligido cantara á su Dama. Malaga, s. a. 2 hojıs

Guirnalda de coplas de la Jota por los nombres de mingeres. S. 1. ni a. 2 hnjus.

Coplas de la jota con estribilios y seguidillas, Coplas de la estopa, y utris diferentes cantatas. S.l. ni a.4hnjas.

Coplas de la Jota con estrivillos, y otras de los nombres de las mugeres, octavas y Quartillas, todas por el mismo tono, las Cuplas de la bella Peregrina, y respuesta del Pastorcillo. S. I. ni a. 2 hojiss.

Cartilla de casamientos, curiosas segnidi. llas nuevas y calidades que deben tener las señoras Mugeres con quienes se quieren casar los Mocitos solterus. Primera parte. S. I. ni a. 1 hnja.

Segunda parte de las festivas seguidillas en que se maniftestan las partidas, clausu. las $\mathrm{y}$ circustancias con que deben escuger á sus novios las señoras Duricellas. S. I. ni a. 1 hnja.

Coplas de la Jota con estribillos. y Quartillas, Coplas para casadas, viudas, y donce- llas, y Letras amorosas. Compuestas por Francisco Lecha. S. t. 1752. 4 hnjas.

Seguidillas nuevas, y curiosas por el A, B, C. Con otras à una Josepha. S. I. ní a. 4 hojas.

Romance nuevo, en que se da cuenta. y declara un portentoso milagro, que ha obrado con un Renegado de la Ciudad de Toledo. Primera y segunda parte de D. Juan Rosique. S. 1. ni a. 2 hojos.

Nueva relacion, y jocoso romance, en que se reflere el trágico casamiento de un desgraciado mozo llamado Marcos de Cabra. \$. I. ni a. 2 hijas.

Todos los romances hasla aqui comprendidos, pertenecientes a la segunda mitad del pasado siglo, no se hallan en el Catálogo, puesto por el Sr. Duran al principin de sil Romancero.

Los siguientes se encuentran todos en el citado Catálogo.

Primera parte, Relacion curiosa de un dulce tratado, de como una muger natural de Valladilid, siendo cautiva, negó la ley di: bius y casi con un ricu Voro. l.a kenegada de Valladolid. S. 1. ni a. 4 hnjas.

La vida, y penitencia que en el monte de Arsanio, junto á Ronia hizo una muger de Valladolid. la qual havia sido Renegada en Argel: Segunda parte. S. 1. ni a. 4 hojits.

San Antonio a 10 militar. Vuevo romance de dos portentosos milagros que ha obradı Sall Antonio en Don Francisco de Hermosilla y Valdepeñas, y la Sra. Doña Thomasa de iastilla y Cerezuela. Primera parte. Cordoba, Don Jinsef de Galvez y Aranda, s. a. 2 hлjı.

base crenta en este romance, como poir intercesion del señor san Antonio de Padıa se vieron libres D. Francisco y la Tul"a. segunda parte. Corduba, D. Josef Galvez Aranda, s. a. 2 hojis.

Ronuance que intitula: La Cautiva de Sevilia. Compuest" por Alons Murales. Primera y segunda parte. Malasa, D. Felix de Casas y yartinez, s. a. 4 hojas.

Primera parte nueva relacion y curioso Romance, en que se refiere un portentoso $\mathrm{Hi}$ lagro, que ha obradı la Virgen con una selimra Viul:ı quc mavegaba i Roma con tres hijos perueños a lis gue cautivarun los Turcos. S. l. ni a. 2 hojas.

Signnda parte. Dinde se da fin la empe. zada Hlistoria de Doña Francisca la Cautiva. s. 1. ni a. 2 hojiss.

por el final de la segunda parte constu sor de Pedro de Fuentes

El Renegado de Francia. Nueva relacion, y curiuso romance, en que se refiere la gintosa, y agradable Historia del Santo cristo de Santa Tecla de Valencia y la del céleture Simon Ansa. S. 1. ni a. 2 hojizs.

El nombre del autor, segun el finnl, es

Pedro Portilla I/ nn Antonio. cnmm dice Dur(m.

Nuevo y curioso romance, en que se dp. clara, y da cuenta de los arrojos, muertes, y valentias de Don Pedro salinas, natural de la Ciudad de Jaen. S. 1. ni a. 2 hojas.

Vinevo y curioso komance, en que se di cuenta, y dorlara los lrechos. arrestos 
valentıas de Don Juan de la Tierra, natural de la Villa de lllescas. Primera y segunda parte. S. l. ni a. 4 hojas.

Por los firule's le ambis partes constu es(a) compuesto por l'edro Salvador.

Primera parte, ell que se refleren los hechiss de un valeroso Manchego llamado Don Juan Lorenzo. S. l. ni a. 2 hnjas.

segunda parte, en que se prosiguen los valerosos hechos de Don Juan Lorenzo. S. I. ni a. 2 hojis.

P'n los fintles de ambus partes aprarece el inmbre de José Francisco comn aulnr.

liomance de las valentias de l'edro Cadenas, y de utros tres Soldados de las Galeras de Espania. S. 1. ni a. 2 hojits.

Doila Rafacla de los Arcos. Reflerese como haviendo muertı à un Caballero su amante, despues de muchas otlas aventuras, se entró en un Convento de Valencia. S. l. ni a. 2 hojas. finil.

Tumbien es de Jose Francisco, segun el

Vuevo y curioso romance del valeroso Juan de Arevalo, natural de la villa de ossuma. S. 1. $11 \mathrm{i}$ a. 2 hojots.

por el fintl se ve fie su aulor Cristobal Moricl, circunstancia que ignoro Duran.

Nueva relacion en que se refiere la disputa que tuvo el Trigo con el Dinero, sobre cual sea de mayor excelencia. S. I. ni a. 2 hnj $\iota s$. Segun el penuiltimn verso fuc sn aulor Sebastian Lopez: Durrall in die comn anonimo. Famosa historia y cuento mui gricioso, que sucedio a uln Harriero con su muger, porque no se santiguaba de las mugeres coint del diablo. Compuesto por el Bachiller lirogorio Carraseo. P'rimera parte. S. l. ni a. 2 hojics.

Segunda parte de los Romances de Juan prados donde declara el famosu despique que Jilan Prados executó con su muger. S. l. ni a. 2 hojics.

Estos dos rmmances contienen con algunas rariantes el. Cuento descrito en el $N .^{\circ}$ (i) the mesente calcilogo: alti se alribuye a Francisen de Nedina y aqui al. Bachiller Gregorio Carrasco: lal vez ni uno ni otro scan el verdlulplo aulor.

Homance de los amores, y tragicos sucesos de Don Isidro, y Dona Violante y el Ne. gro boming I. Primera y segunda parte. S. l. ni a. 4 livjus.

Por los finales de ambas parles se saca haber sido compuestas por Juan Miguel de Finentes.

We Antonin Montero. S. l. ni a. $2 \mathrm{hoj} h \mathrm{~s}$.

Vineva relacion del Gitano de Cartagena, por un ingenio cordoves. s. i. ni a. 2 hnjes. Relacion burlesca intitulada Las Desgrarias de Toribjo, y fracasos con los duendes. Curduba, Doina Maria de Ramos y Coria, s. a. 2 hijos.

Relacion jocosa de Ramon Úluferne. S. 1. ni a. 2 hojas.

Relacion nueva joco-seria. El amante mas perfecto pues tal sufrio por sil dama. Cordoba, D." Maria de Kamos y Coria, s. a. 2 lojirs.

Vinticias rieltas en que se eontiene el des- cubrimiento de una Isla lo mas rica y abundante de todo quanto hay en el mundo; descubierta por el aforlunado Capitan llamado lungares de Sellum, y de Gorgas. La Isla de Jalija. S. l. ni a. 2 hojas.

Relacion nueva de la Gitana. Por un ingenio cordoves. S. l. ni a. 2 hijas.

Relacion de los treinta reales. S. l. ni a. 2 linjas.

Relacion jocosa de la Calabaza, y el vino: Compuesta por un ingenio que se meneaba. S. l. ni a. 2 hojas.

Romance nuevo, en que se da cuenta de una sangrienti Batalla, que en los Campos de Arabiana tuvo el valiente, y esforzado Leon con el famoso, y alentado Grillo. s. I. ni a. $2 h$ jas.

El nombre del autor, segun dice al fin, es Jerónimo Romero.

Romance nuevo, del cliasco que le dió úlla vieja á un Mancebo, dandole una sobrina suya por doncella, hivia ya parido catorce chiquillos, sin otras faltas que tenia, como tuerta, tinosa, y calva. Compuesto por un capador de Grillos, y Cardador de lanta de tortugas. S. 1. ni a, 2 hojas.

El Testamento del Asno, donde se reflere su enfermedad, y las medicinas que aplico un Doctor de bestias, y las mandas que hizo en su testamento a todos sus amigos y parientes, con el llanto, que los Jumentos hizieron por su muerte. Y al fin un homance de la Mojigangi, que hicieron en Madrid un dia de Carnestolendas los Palànquines del Rastro. Malaga, D. Felix de Casas y Martinez. s. a. 4 hojas.

Contiene: Primer romance: Yo triste asno cansall .

Segundo romance: Era el tiempo de calores,

Testamento: Cutnis $i$ lo primern moulo, Tercer romance: Cintmomss y laureles. Cuarto romance: Marles de Carnestolendrs,

Nuevo y curioso romance, en que se declara la enfermedad y cura, que se le hizo duna Zorra: su inuerte y Testamento, con el llanto que por ella hicieron sus parientes y deudos. Malaga, Den Felix de Cosas y Martinez, s. a. 4 hojits.

\section{ROMANCES espirituales y} ascéticos, impresos en varias ciudades de España á fines del siglo último en 4. Todos van precedidos de una lámina de madera.

Nuevo y curioso romance, en que se ven, y declaran los grandes sentimientos, y bien fundadas quexas, con que Dios se esta quexando de todos los pecadores. Compuesto por Bernardo Delos. S. 1. ni a. 2 hojas.

Curioso, y nuevo romance, en enigma, como se saben las cosas que puede alcanzar la Oracion con Dios nuestro Senor. Compuesto por Lucas del olmo Alfonso. S. 1. ni a. 2 hnjas.

Romance à la mytra y pluma en la Cruz,... 


\section{ROM}

PLIEGOS SUELTOS.

ROM

San Casiano. Y van á lo ultimo los Documentos cristianos. Por D. Josef Blas Moreno. Malaga, s. a. \& hojits.

Prodlgios y martiriu de S. Casiano, Maestro de ninos: Compuesto por D. Josef Blas Moreno. S. I. 1782. 2 hoj $九 s$.

Fervoroso acto de contricion en un curinso romance donde se avisa á los mortales el modo con que han de pedir á Dios el perdon de sus graves culpas. S. I. ni a. 2 hojas.

Nueva y curiosa relacion, para contemplar en la hora de la muerte, y considerar el dolor que siente el alma quando se despide del cnerpo. S. 1. ni a 2. hoiss.

Romance nuevo, Del infernal Testamento, $\dot{o}$ declaracion que hizo el maldito Luzbel quando cayó arrojado del Cielo. S. 1. ni a. 2 hojas.

Komance nuevo, en que se refiere la decla. racion del Credo. Compuesto por Lucas del Olmo Alfonso. S. 1. ni a. 2 hojrs.

Devoto romance en que se refiere el santissimo Desposorio que celebró Christo Redentor con la preciosissima Cruz para la Re. dempeion del Linage humano. S. I. ni a. 2 hnjiss.

Verdadero romance espiritual, en que se declara el Desengano del Hombre. S. I. ni a. 2 hojas.

Verdadera relacion, y curioso romance, en que se da cuenta, y declara la descripcion y grandeza del Templo de Salomon. Primera y segunda parte. S. 1. $11 \mathrm{i}$ a. 2 hojas.

La vestidura del alma, romance en que se refieren las galas, y aderezos con que se ha de vestir y adirnar el Alma para desposarse con Jesu-Christo. S. 1. ni a. 2 hrjos.

Nueva relacion, y curiosn romance, en el qual por extenso va declarando la Historia del Prufeta Jonas y la Conversion de lis Ninivitas. Compuesto por Lucas del Olmo Alfunso. S. I. ni a. 2 hojas.

Romance de la vida, pasion y muerte de Christo, compuesto por Lueas del $0[\mathrm{~m} \prime \prime$ Alfonso. Cordoba, D. Maria de Ramos y Coria, s. a. 2 hojis.

Nueva relacion en que se refiere el dichoso transito y subida a lus Cielos de Miria sintima. S. 1 . ni a. 2 h j $\iota$ s.

Por el final uparece que el autor es Lucas del olmo.

Aqui se contienen dos obras muy contemplativas para todo Fiel Christiann: La prinera el Testamento, y Codicilo de Christo nues. tro Redentor: La segunda trata del Testamento, Transito, y Subida á los Cielos de la Madre de Dios: con un Romance de un Alma convertida. S. 1. ni a. \& hojiss.

Las tinieblas de Cristo. Primera y segunda parte. Malaga, s. a. 4 hojizs.

Segun los finules el autor es Lucas del olmo.

Coloquio entre dos niños, que van á la escuela, donde bay maravillosas preguntas, y respuestas á cerca de los principios de la Fé, y de los Mysterios de la Missa, con el Padre nuestro glosado y un Romance de un Alma en pecado, que desea convertirse á Dios. Compuesti) por el Licenciado Simon de Ro. xas. S. 1. ni a: i hojas.
Romance nuevo. Historla divina, en que se declara el Mysterio de la Santisima Trinldad, y otros articulos, y Mysterios de nuestra Sanla Fi, y en especial el Mysterio de la Encarnacion, y Vacimiento de nuestro Redemptor. Compuesto por Lucas del Olmo Alfonso. Primera parte. Cordoba, s. a. 2 hnjas

Nuevo romance, en que se prosigue esta sagrada flistoria declarando el Baptismo de nuestro Redemptor Jesu-Christo, su Ayuno y vocacion de los Apostoles, su predicacion milagros etc. Compuesto por Lucas del UImo Alfonso. Segunda parte. S. I. ni a. 2 hojas.

La pasion. Tercera parte. Compuesta por el mismo. Cordoba, s. a. 2 hojus.

La pasion. Quarta parte. Cordoba, s. a. 2 hojas.

La pasion. Quinta parte. Cordoba, s. a. 2 $h$ hijs.

La pasion. Sexta parte. Cordoba, s. a. 2 kinjiss.

Espiritual relacion en que se declara of Mysterio de los Desposorios del Sr. S. Joseph. y Yaria santisima; la Encarnacion del Diviın Ferro; y los Zelos del sr. s. Juseph. S. l. ni a. 2 hojas.

Nueva relacion, en que se hace presente a los ciudadanos de Cordoba el grande beneftcio que Dius les ha hecho, en embiarles al P. Fr. Diego de Cadiz. Primera y segunda parte. Malaga, s. a. \& hojzs.

El Contador espiritual. Compuesto por Lucas del olmo Alfonso. Primera y segunda parte. S. l. ni a. 4 hojizs.

El Sr. Duran mencima este romance; pern no lrae el nombre del uulor.

Romances del Juicio final y venida dol inte. Christo. Compuestos por Lucas del Olmo . 1 fonso. S. l. ni a. 4 hoj $t$.

Nuevo romance espiritual donde se refie. rell las muchas inlulgencias que han eoner. dido los Pontifices át tudos los que overen Misa. S. I. ni a. 4 hojus.

por ins fintes de ambas parles conslu ture el noulbre del autor es Juan Vlendoza.

Romances en que se refiere la prudigiusa vida de Santa losalia de P'alerm's. Primera. segunda y tercera parte. Cordoba, s. a. ti hวjhs.

Por el fin al de la minmo parle se up que el apellith del autor er' Idarbe, lo que in mencianz Durian.

Nueva relacion. en que se da cuenta del nacimiento del Glorios i San Albano. l'rimera parte. S. 1. ni a. 2 hnjas.

Nueva relacion en que se da cuenta del fin de los sucessos, y vida de el señor S. Albano. Segundil parte. S.l. 11 a. 2 lıjizs.

Consta por los finales tue el nombre lel autor es l'edro livarro. E' Sr. Durtun tablia de estos romances we S. Albann; pern Ins Irae coinn alonimns.

Vida y maravilloso martirio de santa Li. brada. Primera parte. S. I. ni a. 2 hnjas.

Segunda parte, en donde se refiere del modo que fueron martirizadas todas las Santas Virgenes hermanas de Santa Librada. S. 1. ni a. 2 hojius.

Pedro Ramirez es el nutor de estas in. minces, sigun nullece de su roulesto. 
Romanee espiritual en el que se refiete la grividad de los pecados moltales segun los mismos Comdenados con lorrorosos y espa!ntables gritus lo expliean. Primera y seyrunda parte. S.. 1. แi a. 4 hojzs.

Senmen so colije del fin de la seqund parle, ol aillor es Mondiza, que supougo sine el luall dintes citaito.

Ferdadera relacion, en que se declara la vidii. Y muerte de s. dlexo. Primeri, segumdi y lereera parte. Compuesta por ma herminta de Lucis del omo dlfonso. S. 1. ni a. $h \cap j u s$.

Durall lo trae rumoininn

Vida muerte y miligris de sau Antonio de ladua. l'rimeri y segunda parte. S. I. ni a. 4 hojits.

Por el final de ambas parles se ve que el. anior de allis es Pedro Portillo.

Nineva pelacion, y mystico jomanee, en que se da enentil y declaran en ensueno los guatro Vovisimos, o postrimerias del homlire, deseripeion del P'iliniss Terrenil del

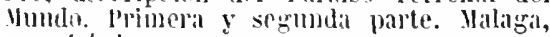
s. a. 1 hoj'ss.

Tirmbion enonsta al fin de estos rontences yme son del mism) Portillo.

Nuevo romanede do la prodigiosa vida de el seraphin de la lglesia. (S. Fromisen de.tsis). Primera y segurnda parte. Cordoba, s. il. hojas.

Los lillimos rersos ale ambns pontemes uns indiern que su auto" es Jose Diaz.

liwacion espiritual, en que se explica ol s.oberano Iysterio de la Santissima Trinidad, lis revelarioul de Luzhel; la Creacion del Vurnlo y pecado de unestros primeros Palres: llacimiento de Cilin, y sulescendeneia Janta el Diluvio. Compuesto pur franciseo Giallougs. Irimera parte. s. l. ni it. 2 linjus.

Expiritual relicion en que se refere las Elades que tirvo el Vumbin despues de sul lireacion, hasta la renida del Hijo de Dius; sll Encarnarion; su Vida hasla sn santisima Jasion. Compuestio pur Francisco Gallegos. segunda litrte. S. l. ul a. 2 hojits.

Ineva relacion y curioso romance de las l'lagas de Egipto. Cimpuresto por Lucas del Ulmu Alfulso. Primera parte. s. l. ni a. 2 hวjøs.

Nueva relacion y curioso romance donde se dreliara la explicaciun de los diez Vandimicntus. Compnesto por el mismi. Segunda barte. S. 1. ni a. 2 hojas.

Vineva relacion de los horrendos estragas gue en toda clase de Animales y fersomas ha (xecutadn en lus Ifontes de la [ugria supepinr el Monstruo de tres cabezas. Iurcia, s. a. 1 hoju en fil.

l'imeril y seguinda parte de la mejor triaca para itajar ol venemo con que la culpa pretende quitarle al Alma la gracia. Corduba, s. a. h hojas.

Primera y segunda parte del historial, curiuso romance, en que se refiere la Vida del (iIn]iosisino Labrad ir San Isidro y de la Bienaventurada Santa Maria de la Cabeza. S. l. ni i. I lowjus.

Romince espiritual en que se declara el Vystriou de la Enearnacion del IIijo de loius, y Visita de su Madre a Santa lsabel. Compuesto por Jucas del mino Alfonso. Primera parte. Cordoba, s. a. $2 \cdot j i s$.

IRomance espiritual, e que se declaran I: Zelos del Sr. S. Josef, $r$ el Nacimiento de mestro Redentor. Segur la parte. Cordoba, s. a. 2 hnjas.

Et Sr. Durin mencinna sle romance, pero ignora que sea segunda parte del anterior que no ha visto. Sujongo, ranque no se esprestl, que el rutor seivi el mismo olmo.

Ifectos de un pecador arepritido en mysticas décimas. Malaga, s. a. $4 h o j t s$.

Curios: romance, y manavillısos milagros que lia obrado Dios por intereesion de Santa Barbara. S. l. ni a. 2 hinjts.

Nueva relacion y curioso romance, en que se deelara y da cuenta del sucesso, que sucedió á un Cavallera de Xerez. Dase cuenta como le salio el bemonio en forma de muger diciendole emo su Esposa le era traidora: y coms por interessim de $\mathrm{S}$. Antonio de Padua se vieron libres. s. l. ni a. 2 hojas.

Durran trate este ininance con el titulo de San Intonio del doblon; pero un dice yue su "ailor es l'edro Saez, se'gim constit por el unteprmullims verso.

Romance muevo, en el qual se da cuenta de los prodigiosos Vilagrus, que en la Ciulad de Lisboa ha vbrido San Antonio de Padua con un Cavallero y una Señora devotos sugos. S. 1. ni a. 2 levjts.

Es d.stinto drel antorior.

Villevo $y$ curiosu romance, en que se da cuenta de la depravada vida del desventurado Ldo, Arzobispo de Sixomia y del tremendo eastigo que Dios executó en su cuerpo. Primera y segunda parte. S.l. ni. a. $4 \mathrm{hnj}$.

En ol find del segumilo romence se indica que el antor es un tal raredes.

Exemplar romance de uma Infanta de Inglateria, que se condenó por haber callado un pecado en la Confesion. Primera y scgumda parte. Valaga, s. a. 1 hajas.

Romance lastinroso de m caso sucedido en Teruel con un Cavaller, que por logrero y avarientı fue un Angel á pedirle limosna: dase cuenta como lo despreció y el castigo que tuvo. Primera $y$ segnuda parte. S. I. ni a. 2 hojes.

El Burlarlor de Sevilla, y combidado de piedra. Primera y segmida parte. Malaga, s. a. $\{$ hojıs.

Jardin ellganoso. Nucva relacion, y cllrioso lomance, en que se refleren los anpores de D. Fadrique, y D. Josef de Alvara, Doña Cumstanza y Doùa Teodora. Dase cuenta como D. Fadrique dió muerte á su hermano, y lo echó en un pozo, y le entregó el alma al demonio, par gozar de Doña ConsLanza, y como caso coul Doina Teodora. Primera y segunda parte. Cordoba, s. a. 4 linjas.

Vuevo y verdadero romance, en que se da cuenta del fin que tuvieron dos Amantes: Declarase como por anores del Galan dió muerte la Dama á su Marido y como muricron de alli í poco conf.'sadus pasando á las llamas del purgatorio. Primera y segunda parte. Valaga s. a. 1 hojos. 
Nicolas de vúntes Diaz es el autor de ambos ronninces, segun se desprende de sus finales.

Nueva relacion y curioso romance en que da cuenta y declara las quairo partidas del Mundo: y en particular de las ocho maravlllas del Mund ). Cuatro partes. Malaga, s. a. 8 hojzs.

Romance nuevo en que se declaran las excelencias de la Gente del Campo. Primera par: te. Cordoba, s a. 2 hijas.

Segunda parte, en que se prosiguen las excelencias de la Gente del Campo, declara los muchos Santos, y excelentes Varones que ha havido del Campo, y se les da saludable doctrina. Cordoba, s. a. 2 hnj,ls.

En los dos rominces se lee al fin que su autor es Francisco Serrano.

Nueva y curioso romnce, en que se refieren las Virtudes del Dia. Compuesto por Lucas del olmo. Primera y segunda parte. Cordoba, s. a. 4 hojus.

Las virtudes de la noche á lo Divino. Compuesto por Lucas del Olmo Alfonso. Primera y segunda parte. S. I. ni a. 4 hojis.

Duran mencionz estos cuutro rounances, pern no conoció el nombre de su autor.

Nuevo y curioso romance que declara las Virtudes de la Noche à lo Humano. Por Lucas del 0lmo. Segunda parte. S. 1. ni a. 2 hojizs.

No se si en la primera parle llevard el mismn titulo.

Romance de los Misterios de la Misa. Compuesto por Lucas del Olmo Alfonso. Primera y segunda parte. Malaga, Felix de Casas y Martinez, s. a. 4 hojins.

Duran wencima este roimance; pern no dice quich sea su nutor.

Nueva relacion, y ouriosa romance, en que se reflere la Creacion del mundo y fabrica del hombre. Compuesto por Lucas del 0lmo Alfonso. S. 1. ni a. 2 hojiss.

Duran omite èl nombre del autor.

Excelencias de la santisima Cruz en un mystico, y devoto romance. Compuesto por Lucas del Olmo Alfonso. Cordoba, s. a. 2 hojas. Duran lo cila anóniıno.

Nueva relacion, en que se da cuenta, y declara el admirable, portentoso, y maravilloso nacimiento del Glorioso San Albano. Primera y segunda parte. S. I. ni a. 4 hojas.

Pcdro Navarri es el nombre del autor, se. gun cousta por los finales de a!nbas partes; circusluncil que no inenciona Diran.

Nueva relacion, $\mathbf{y}$ curioso romance, en que declara, y da cuenta de un portentoso Milagri que ha obrado el Santo Christo de Burgos y su Madre la Virgen del Pilar, y los Santos Evangelios, con dos Devotos suyos. De Don Geronimo Morales. S. I. ni a. 2 hojas.

Todos los romances espiriluales y asceticos que preceden descritos $h \mathrm{in}$ sido des. comocidos d Duran y no se hallan por consiguiente en el Catálogo que precede $d$ su Homancero: cuando he puesto alguno citado ya por il, ha sish prara corregir algun exror ó suplir ounisiones comctidns en su descrijuion.

Tus. I.
121 ROMANCES Y COLOQUIOS VALENCIANOS. Romans, y coloqvi nou en que es declara el gran chasco, que han tengut els Pepos del Orta, en la bona venda de la fulla de $0 \mathrm{~m}$, y en la de Morera, en este any de 1719. S. I. ni a. $4 .^{\circ} 2$ hojas.

122 - Rahonament, que fan quatre llauradors de la Horta de $\mathrm{Va}$ lencia sobre la Funció, y Procesó del Corpus, en lo any pasat 1738 , en lo Misteri del Rey Herodes, ó de la Degolla.-Altre rahonament, que i fan los mateixos quatre llauradors a! Retor, presentantli tos Misteris de Sant Christofol, y el de la Creació del Mon. Valencia, Joseph, e Thomas de Orga, M.DCC.LXXII. 4. 24 págs.

$123-$ El mismo. Valencia, Miquel Esteran y Cervera, 1800. $4 .^{\circ}$ 24 pags.

121 Coloqui nou, curios, $y$ entretengut, hon se referixen la explicacio de les Dances, Mysteris Aguiles, y altres coses exquisites, tocants á la gran Festa del Corpus ques fa en Valencia. Compost per Carlos Ros. Valencia, Salvador Fauli, 177?. $4 .^{\circ} 4$ hojas.

$13 \ddot{2}$ - Junta general que han celebrat tots los pardals y peixos de la Albufera, pera representar al 0 ncle Don Suchet, queixanse dels cacadors. Valencia, s. a. $4 .^{\circ} 2$ hojas.

Estos romances y coloquios en dialecto valenclano, aunque de fecha bastante reclente, escaseall ya.

126 RUIZ DE VILLANUEVA (Alorso). Relacion verdadera de las grandes Fiestas $\bar{q}$ ha hecho la Villa de Madrid por la tan desseada salud y nueua rista de la Catholica Magestad del Rey... Felipe IY. En dos Romances, Pör Alonso Ruiz de Villanueua. Valencia, Iuan Bautista Marcal, 16그. 4. ${ }^{\circ}$ hojas sin fol. ni sign. 
Contiene dos romances que dicen:

El primero: Al mayos de los montrcas.

El segindo: Dando $i$ ios pasados lustros.

127 SALAYA. Maldiciones de Salaya, hechas a un criado suro que se llaniaua Misanco, sobre vna capa que le hurtò. Con vn romanre del Conde Fernan Goncalez. Y olro del Cid. S. 1. ni a. (hácia el 1390). 4." let. gót. 4 hojas sin jol. con la signatura Aij en la segunda hoja.

\section{Contiene:}

Maluiciones que dicen: Mucho quisiern apurtarme.

Romance del Conde Fernan fomzillez, que dice: Castollanos y leonesses.

lommance del cidd, que dice: P'm fimmlulquiviv" arvibur.

las tres composiciones estin reimpresils en el Romancero de Duran; pero lis dus primeras tienen variantes ronsiderables bli la edicion gótica que poseo.

Las Mildiciones de Salaya fueron lan cilebres en su tiempo que se pitaball (*) ll fre. ruencia igual á la de las Coplas de Culrinos. D. Adolfo de Castro no conocio nimgma impresion cuando no la cita al comeutar en las nolas al Buscrepie, el pasaje de la carta de Hateo Aleman alusivo a ellas.

IIe visto la signiente edicion distinta de la mia:

I. Maldiciones de Salanje conlra un criad. suyn llamado Misancho: sobie vina cripu if lis lurto. Con las lamenlariones de Gurcisanchez de Badajoz que comiencan. Lagrimus de mi consueln. (Sigue una laminita apaisada representando á un hombre coll corona de laurel escribiendo, a otro con lit espada al hombro y una casita por cilya ventani asoma una mujer.) $S . l$. ni a. Soll 4 hojas cn 4. lel. gót.

El Sr. Duran trae esta otra: Ciplas hechas por Diego Garcia, nalural de la ciudad de Berganza, con vnos amores de un caullero y una donçella, con las maldiciones de Selaya. S. l. ni a. 4 . $^{\circ}$ let. gúl. 4 hojas.

Contiene:

Coplas de Diego Garcia, que dicen: Vivo en tan triste penar.

Cancion villancico remitiendo á una dama las coplas anteriores; dice: Perdime por conoscer'so.

Romance de las maldiclones de Selaya, que dice: Mucho quisier'a apartarme.

Villancico en verso anacreóntico y su quebrado, hecho en diálogo entre una dama y su galan que le pide le abra la puerta, y dice: ih, hermosit.
Tambien es uno de lus pliegos desconocido á Duran.
128 SIN PEDRO (DIEGO DE). I Aqui se siguen las siete angustias de nuestra señora la virgen Maria / muy denotas i y contemplatiuas. Compuestas por Diego de sant Pedro. CSigue nua estampila de madera representando la Dolorosa.) S. I. ni a. (hicia el 1300). 1.' let. gót. L hojas sin sign.

Nir encuentro esta eomposicion de Sam Pedro entre las suyas true comprende el Canrimern gemeral, ni la menciona Nic. Antonin all ol alifulo de estr escritor. Principia asi:

Virllen diqua de alabams

lin quien loilo el mumedn arlura,

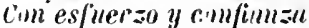

De lin preciosa esperranz"

Daré comienso, señor'n.

\section{SINCIEZ DE LA TORRE} (Juav). La vida y mverte del hernano Francisco de Alcala. Compuesta por Iuan Sanchez de la Torre... con vn liomance de nuestra Scñora al cabo. Madrid, Iuan Serrano de Vargas, 1606. 1. 'Dos viñelitas bajo del epigrafe y una del escudo de la Virgen del Cármen en la última página. Son 1 hojas sin fol. con la sign. 9.

Son tos romances que principian:

Dem? su aynda y favor.-

Maria de gracia llena.-

Antor desenonocido á Nic. Antonio; tampoco vii este pliego Duran.

130 SAYCHO (Jusepe). Dezima venida aora nvevamente de Madrid, y glossada por Iusepe Sancho Aragones... Donde se declaran los maravillosos prodigios, procedidos de la estrella del Principe Cardenal, su inuicto valor, valerosa vitoria, manifiesto estrago de la Francia, y general temor de todos sus enemigos. Valencia, Iuan Bautista Marçal, 1636. 4. 2 hojas.

Décima que dice: Francia en Italia vencida. flosa que dice: Cumpliose la profecia. 
Nio se haila mencion de este plicgo en el Caldlogo de Duran.

131 SOSA (LOPE DE). Villancicos para cantar la noche de Nauidad. Compuestos por Lope de Sosa. Imuressos con licencia de los Señores del Consejo del Key nuestro señor. (Sin lugar ni nombre de impresor.) Año de 1603. 4. ${ }^{\circ}$ Con una riñeta del Nacimiento de Jesus bajo del epigrafe. 4 hojas sin fol. ni sign.

Contiene:

Villancico que dice: Toulos los Cristinnos.

otro que dice: No vais le aqui, doncella.

Chanzonetas: Pastores, si habeis oulo.

Villancico: Pues Jesucristo ha nacido.

Idem: Mui amiga le soi, madie.

Idem: Que madre y doncella.

Nicolas Antonio no hace mencioun de I,0pe de Sosa en su Bibliolheca nova; tampoco conoció este pliego Don Arustin Duran, y no lo estraño porque yo nunca he visto otro ejcunpiar de las presentes composiciones.

Bōhl de Faher reimprimiu en su Floreslı dos de los villancicos; pero siguiendo su costumbre, introdujo muchisimas variantes y cercenó sin piedad: asi pues, del que principla: No vais de aqui, doncella, apénas dejó una mitad. Tanıpoco comprendo la razon de haber reproulicido aquellos dos $y$ de. jádolo de hacer con otros que son pir In ineuos tan buenos: sirvan de munslia lus siguientes :

Todos los cristianns habed alegria, tal noche como csla pario sanla Maríu.

Pario en Betleu en unos portales. puso á muestro bicu ron dos animales ; en pobres pañales segun convenia : lid noche como eslo jarió sanla Maríi.

El frio del invieruo ya veis conı es crudir; el niño mui tierno estaba desnudo: la Vírgen no pudo dar lo que queria: tal noche coino esta parió santa Maria.

El niño en el suelo cántanle canciones: de ángeles del cielo son doce legiones, con mui dulces sones y gran melodia : Ial noche coms esta parió santa Martí.

Cabe el arrabal

angeles llegaron, solire aquel portial luego se bajaron; la gloria cantaron con gran alegria: lal noche como esta paris sania María.

Vinieron pastores, para le adorar, todos los mayores biilar y cantar, y á le presentar lo que le traian: lal uoche como esta parió santic María.

Traenle presentes de chico valor, un queso reciente il tan gran sefior, y con mucho amor y grande alegria: inl noche como esta pariós santa Maria.

Están marvillados del hijo y la madre; del alto bios padre fueron consolados: para sus ganados viluelven ese dia : lill noche comn esta purió samla María.

olro.

Que madre $\mathrm{y}$ doncella lan bella.

Que madre grariosa, morema $y$ hermosa. de Dios generosa. csposa y doncella lan bella.

Monle de vision, ripres de Sion, V Vara de tarón. lie Jacob estrella l's!' bella.

Ay: llos influito. humbre pubrecilu. ('II III) portalito pariú rsla domeclla trin bella.

Fuera de la villa oslí que es maueilla. nu) liuno matlytla. 11 dis preale liabella, lan bella.

Sola con un riejo, so un portalejo,

Y lodo el conseju ilel cielo con rlla. lan bella.

Al niño que llır'a

la Virgen lo adora,

Josef lo enamora

y calla con ella. ian bella.

Con frio al sereno lu pone en el heno. yell su pobre seno le abriga ella tan bella. 
132 TIMONEDA (JOAN). I Les cobles de bella de vos en amoros: hara nouament trobades per Juan Timoneda: a suplicacio del interes y vulgo dela grent. Cllar i continilucion la figurita de un hrmbre tocando la guitarra delante de una lama, detras de la cual hai una casa.) S. I. ni a. (hácia el 1\%̈̈̈̈). 4." let. gót. luna hoja sin sign.

Esta rarisima $y$ descomocialit romposiovion en dialecto valencianu, prinripia :

Bella de vos so emmmoros

Ja foseu mia;

La nit y la jornt quaml pens'en tos Mon cor respiru.

lle visto otra edicion cuga deseripeism es la siguiente: cobles de bel! a dir ros cenrmmmros: contrafele's al spirilual: p't' Jum Timomeda a inuocacio dela mure dr dev dels desumparats. (Sigre mua mala límina de miulr. la circuida de orla que replesenta la liregent. S. l. ni a. 4. let. gü. Lna hoja.

133 TIMONEDA (JuM). I Les cobles de dali Hiquel portam a casa / cótrafetes al spiritual per Juan Timoneda / pera Nadal. I les cobles de Cercara Jorge cōtrafetes; a altra interpretacio. Sigue una riñeta del Nacimiento que encabesa la primera coluna y a continuacion las coplas.) 5. l. ni a. (haicia el 1533). 4. ${ }^{\circ}$ let. gót. lina hoja.

Contiene:

\section{Cobles: Dali Niquel}

Porlam « casa.-

otras al tono de buscari Jorge: para Navidad:

Yo sé à quien

De amores le fue mui bien.-

La primera de estas composiciones estí escriti en idioma valenciano $y$ ambas sul descunucidas á todos los bibliugrafos.

13 ' - Coplas del hōradissimo Gil Garcia. Compuestas por Iuan Timoneda. S. 1. ni a. (de fines del siglo XVI). IIoja suelta en $\mathbf{A}^{\circ}{ }^{\circ}$ con dos figuritas al principio.

13\% _- Diuersas y nueuas Canciones muy sentidas para cantar. Compuestas por Iuan Timoneda. S. I. ni a. Cile igual fecha que la anterior!'
IIoja suella en $4 .^{\circ}$ con mut viñela al principio.

Comtienen estas dos hi:jas:

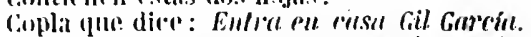

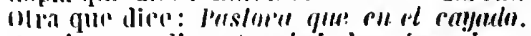

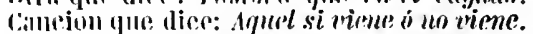
ofra que dice: Cummlo Menga quirve d bras.

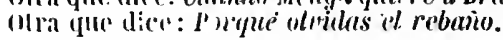

Tulas estas compasiciumes, eseepto la pemillima, lis reimprimici Boilil en el tom. l de lit Flomesle.

No mentiman estas hujas sueltas ni JimeI1), ni Fuster, ni I). Igustiu buran. Tampenco labli ninguno de cllus de las dos siguientes yue he tenidu ocasin de examinar.

(1) Fl Palor nos/er ylosalo sobre la saluta-

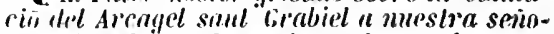
in / alosalo pur Jian Timonedu. Es obra muy sentilut y de muenu estito. Con dos chançonelas para cunlar la moche de Nanilisd.

sigue una lámina mui mala de madera que estí circuida de orla, y representa la Anunriacion le la Vírgen. la glosa esti en castellano y las chanz:metas on valenciano.) $S$. $l$. "i sign.

Q] Comliempuse dos conciomes deuolas / y comfeniplaliuas. La primera / es al lono drigurl caular que di:e. Si vos os lleuais lo.s besos. Commuluslas por Nofie Almudenar / con olru al lotio de mis nicj's hazen daño. Hechas por Jumi Timoneda.

(xigren d!s laminilas casi cuadradas de mideri, relilivas á la prision de Cristo, y lı10. vill á continuacion las coplas á la traicion de Judas, a la despedida de Cristo de su madre, $y$ a los padecimientos del Salvador.) $S . l$. iri $a$. Son dos h"jas en $4 .{ }^{\circ}$ let. gót. sin f.l. ni sign.

136 TIMONEDA (Juan). I Dãza spiritual de muchas mugeres señaladas dela sagrada scriptura. Ilecha en alabanca dela sacratissima madre de dios. Tañida por Juan Timoneda Agora nueuamente en el Año. M.D. Liij. (Sigue una viñetila en madera.) S. 1. (indudablemente de Valencia). $10^{\circ}$ let. gót. 2 hojas sin sign.

\section{Contiene:}

Danza: Pase la galana, pase.

Un chiste contrahecho á lo espiritual; para Navidad: Un chiste mui de notur.

Rarisimo como todo lo de Timoneda, y adenias desconocido á los bibliógrafos.

137 can el que sinfi hiuir va no querria 
contrahecha a lo spiritual por Juã Timoneda / en alabanca dela Concepcion de nuestra señora. (Sigue una laminila de la Purisima, y despues principia la Epistola.) S. I. ni a. (hacia el 1533). . 1. "let. gót. Una hoja.

Principia:

El que sin li vivi, ya no quarria

Ya muchn liempn que servir desea

A ti, madie de Dios, scñora mia.

Desconocida á todıs lus bibliögrafos.

138 TIMONEDA (Jus) Escriue Juan Timoneda natural La Eéciano en loor del glorioso sant Uicēte Ferrer d'uoto suyo las coplas signiētes. CSigue una laminita en madera de S. Vicente Ferrer, circuida de orler.) s. I. ni a. (hicia el 13̈3̈). 1." let. gót. Una hoja.

Pliegu volante completamente desenumeido: principia asi :

El que ya libre ha llergals

A prevto de sulverion.

139 - C La gallarda völrah:" cha a lo spiritual por Juã Timoneda / en alabäca de nuestro Reilemptor Jesu Christo. CSigue una viñelita en madera de la Virgen con el niina en los bruzos, circuida de orla.) S. I. ni a.

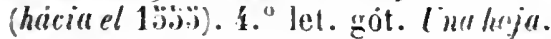

Vadir mencima exla rompusicion te Timuneda, la enal principia:

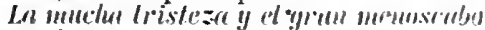

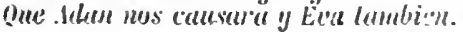

140 TIMONEDA (JuAs). Romance de là sacratissima passion de n⿳亠丷厂o Redemptor Jesu Christo / el qual comiēca de como Pilato dixo / Ecce Homo / y acaba hasta / quādo el hijo de Dios espiro enel arbul de la cruz. Es romăce muy contemplatiuo. Compuesto por Juan Timoneda. Siguen dos laminitas de madera; una es Jesus presenlad's a Pilatos, y la otra despojado le sus testidos.) S. I. ni a. (hacia el 1.jöö). 1. ' let. got. 2 hojas sin sign.

composicion deconocida que principia: Lurnd, devitos cristianos.

Uorad conmigo a la par.

1 i1 TORO COJO (Aloxso DE ). - Trabajo de vicios nueuamēte cõpuesto por Alonso de Toro coxo vezino de Auila. S. I. ni a. (hricia el 13330 ). 1. "let. gót. 1 hoj. sinfol. con la sig.a.

Es lndn en octaras, curos pies son de (M)lin silabas.

Si Ingró verlo el sr. lluran.

1'z- Coplas IIechas por Nonso de Toro coso/sobre la abundancia del vino que Dios ha dado enol año de. xisj. Y enel año de. xixij. S. 1. ni a. (hicia el 1333 3 ). 1." lel. enit. Iineta de madera. I lorjas sin fol. con la sign. a.

Tambien esli escrila en velavas $y$ lus versus sen octusilabos.

Xo lo encuentro cilado por al sr. Duran.

Fola es la vinelil rute lleva al principio.

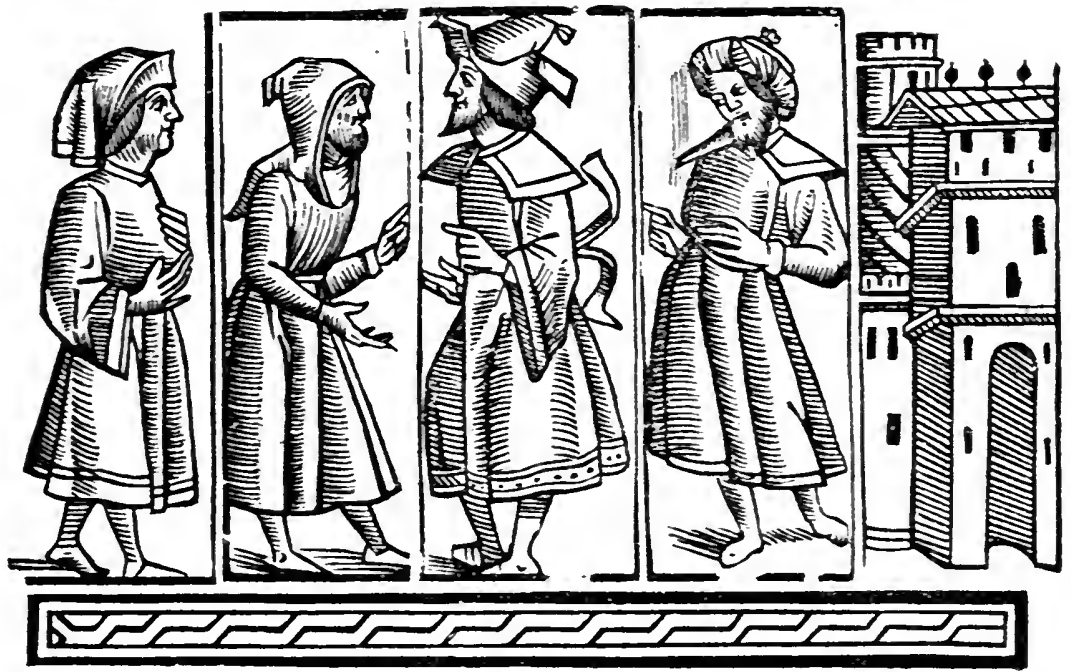


143 TURO COJO (AlONSO DE). I Coplas hechas por alōso de toro coxo vecino de Auila. Sobre la triste $r$ dolorosa nueua de Ungria. S. I. ni a. (hácia el 1530). 4." let. gót. Son 4 hojas sin fol. con la sign. a.

Escrito en el mismo metro que los dos anleriores.

Tampoco habla el Sr. Duran de este opiscullo.

Nic. Antonio no menciona á Alonso de Toro Cojo.

111 TROVAS da Menina fermosa. Cl este titulo siguen tres figuritas, y despues dice bajo de ellas:) Trouas feitas a cańtiga da Menina fermosa, a maueira $d$ Dialago \& va no caho outra caniga que diz $\mathrm{Na}$ i nte està Lianor, \& outra que diz Isabel, \& mais Francisca. Lisboa, Anonio Aluarez, 1610. 4. $0^{\circ}$ hojas sin fol. con la sign. A.

146 VEGA C.IRPIO (LOPE FÉLIX DE.). Segvnda parte del desengaño del hombre, sobre la octaua que dize: Larga cuenta que dar de tiempo largo. Con otra que dize: Yo para que naci. Con in Romance de Escarraman buelto a lo diuino. Compuesta por Lope de Vega Carpio, a pedimiento de vn Cauallero, Tercero de la Orden de San Francisco. Cuenca, Saluador de Viader, 1616. $8 .^{\circ} 16$ paigs.

opusculito de estraordimaria rareza: 110 si haberse reimpresu, ni mencionado en las listas dadas por los bibliógrafos de las producciones de Lope. Tampoco se hallan en su Colection de obrus suellas ninguna de las tres composiciones que comprende.

147 VEGA CARPIO (LOPE DE). Romance a las ventyrosas bodas que se celebraron en la Insigne Ciudad de Valencia. Ya rombrando todos los Grandes que se hallaron en ella debaio de nombres Pastoriles. Compuesto por Lope de Vega Carpio. Tendense en casa de Miguel Borras, a la puerta de los A postoles. (Al fin:)
Debe haber ediciones mas antiguas de las presentes Trovas, las cuales parecen escritas en el siglo XVI. No he podido encontrar ninguna noticla de ellas en la Bibliolheca lusilana de Barbosa.

\section{TROVAS DO HOLFYRO.} Trovas novamente feytas do Moleyro Por tres Auctores miyto graues em que se cōtam canseiras, \& trabalhos rue passou com sen querido pelote. Lisboa, Antonio Aluares, 1632. $4 .^{\circ}$ CViñeta de madera con tres.figuritas despues del epigrafe, y la última la llenan seis de igual clase.) Son 1 hojas sin fol. con la sign. A.

Por los epigrafes de las Truvas se ve que los autores graves son Anlomi? Leituo, Luis brochado y Ioaỏ do Couto.

Barbosa Machado no menciona á Antonio

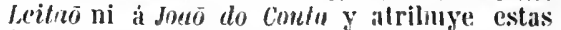
hoects esclusi vameute ál brochodo), autor yue floreció á mediados drol siglo X'T. lat rdicion de ellas de 16jo le fue descunncida; pero cila I11 a de Lisboa, 1602.

Valencia en casa de Diero de la Torre; a la placa de Vilarasa. Año de 1ว99. 8..$^{\circ}$ Viñeta de madera. 8 hojas sin fol. con la sign. $A$.

Además de lo que anumcia la portada, hai un soneto dirigido al rei y el romanace muriseo

Tirad, fidalgo, tirud, que se halla en el homancero generul.

Nic. Antonio no menciona estil olrita, y los editures de las $0 b^{2}(e s$ sueltas cle Lape reimprimieron en el tomis 17, el Bomanuce ii las bodas y el Soncto al rei, sacados de lill maunserito de la biblioleca mayansiana; pero ignoraron estuviesen impresos.

148 VEGA Y VERGADO (PEDRo JosQuin DE). Sonetos que aclaman la mejoríd de la Reyna nuestra señora Doña María Luisa Gabriela de Saboya, por arerse ocasionado de su Grandeza el riesgo de su salud en el sobrepalto del Infante D. Fernando de Castilla. Por el D. D. Pedro Jcachin de Vega. S. I. ni a. (Madrid, 1713?). $4 .{ }^{\circ} 8$ hojas.

Son dicz y siete sonelos y unas elicimus. 
149 VERDADERA relacion de vn admirable caso que ha sucedido en veinte de Setiembre deste año de.mil seiscientos cinquenta $\mathbf{y}$ vno en Cataluña, junto á Barcelona. Valencia, por Siluestre Esparsa, 16ə̈1. $40^{\circ} \mathrm{La}$ mina de madera. 2 hojas.

Duran uo habla de este pliego y tambien le fuè desconocido el romance que dice : Entre infinitos proligios.

150 VIDA (LA) y mverte de Anton Martin de Dios, Fundador del Hospital de Anton Martin, desta Villa de Madrid, y compañero de luan de Dios. Agora nuevanente cōpuesto à instancia de vn deuoto de su orden, y del dicho llospital. Alcala de Henares, en casa de Iuan Gracian, 1606. 4. 4 hojas sin fol. ni sig.

Son dos Ronances, intitulados por el antor, Caulos.

No se halla en el Culálogo de pliegos sueltos que precede al Romuncerv de Durall.

13 PID.lERRE (Axtovio BeNITo). Funestos ayes, Iragicos suspiros al fallecimiento de D. Fernando YF., de Don Intonio Benito Vidaurre de Orduña. Madrid, Gabriel Ramirez, 17.39. 1.0 8 hojas.

Es un r.mance, dos sonetos, una glosa y cuatro uclavis.

132 - Respelnosin obsequio, metrico epitalamio, a las bodas de Don l'asqual Benito Belris ele Moncada, Marques de Belgida con D. Florentina Pizarro, de Don Antonio Benito Vidaurre de Orduña. S. 1. ni a. (.Vadrid 17.jig?) 1. ${ }^{\circ} 16$ prigs.

lontiene un soneto y reintiucho octaras.

133 VILLAXCICOS. Coleccion de los villancicos que se espresall ia contiulacion. Todos son en '."

Lus de la Iglesia Metropolitama de Gramala ¿l la Natividad del señon de tobli. Lirallalat.

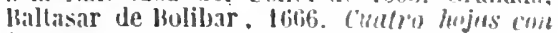
lu vign. . 1 .

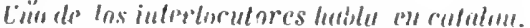

l.os de la farilla Keal de S. U. il lis Yimidiul

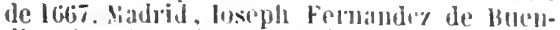
dia, (litit), \& hejols ewn lı sigh. A.

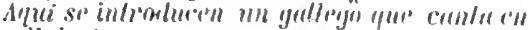

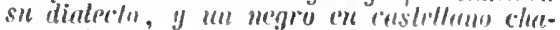
murredo.
Los de la Iglesia del Pllar de Zaragoza en los Maytines de los Reyes de 1674. (Zaragoza. 1674.) Cuatro hojas con la sign. A.

Los de la Metropolitana de Valencia á la So. lemnidad de la Virgen del Rosario en 7 de Octubre de 1674. Valencla, Geronimo rila. grasa, 1674. 2 hojas.

Letras que se cantaron en los Maytines de la Concepeion de $\boldsymbol{x}$. Señora en la Catedral de Malaga el año de 1675. Malaga, Mateo Lopez Hidalgo, 1675). \& hojas.

Los Villancicos de la Iglesia de los SS. Corporales de lyaroca en la noche del Tacimien. to de vuestro Senor de 1689 . S. I. nl a. 6 hojas con la sign. A.

Cnnta entre otros un negro chapury"undo el custellano.

Los de la l'rimada de Toledo en los Mayti. nes del Nacimiento del Hijo de Dios en el añ de 1696. Toledo, Agustin de Salas Zaço, 164 . 4 hojus con la sign. $\boldsymbol{A}$.

Lus de la Heal Capilla de S. M. en la nochu de Heyes de 1697. (Madrid, 1697.) 6 hojus con la sign. A.

Los de la Real Capilla de la Encarnacion en los Maylines de los Santos Reyes de 1697 . Maurid, Antonio de Zafra , (1697). La hoja de porlatlie y 10 pags.

Se introducen un negro que canta en espujiol chapurralo, y dos asturianos en sulengliaje.

Lus de la Toche de Tavidad de 1702 en la Real (:apilla de las Descalzas. (Madrid,) Itilinel liuiz de Murga, (1702). 16 págs.

El Villumico $7 .^{\circ}$ está en gallego, y el $90^{\circ}$ 'n la jerga de los negros.

Coplas que cantaron dos nifuas en $\mathbf{5}$ de $0 r$. tubre de 1709 á la lmagen de $\mathbf{X}$. Señora de Boma-Vìa, que estaba en la antigua puerta del Mar de Valencia, y se traslado al nicho rosteado por Mosen Joseph Canti. (Valenciu, 1709. Dos hojas.

Villaneivus de la Primada de Toledo en lis Milvlines del sitgrado Vacimiento en el ano de' 17.3.5. Tuledo, Pedro Varques, s. a. \& hisjus con lis signh. 1 .

l.os do la Ciathedral de Cartagena, de Mureial, ell los Yaylines del Vaciniento de $X$. S. lin de $175 \%$. Vurcia, Juan Vartinez Mesuier. 173\% . 8 prigs.

l.us ale la Catholral de Cordoba en los Yaylimes del sinnlu Vacimientu. de 175\%. Cordoha Antunio serrano, 17.5. 12 pags.

lin migro camle m caslellamo chnjumrado.

Lus de la salıta iglesia de Tuledo eu la liurlee dis Vavidad di 1755. Tuledo, Pedro Marqurs, 17.15.) li lonjas con lu sign. A.

los de la l'rimala de Toledu en la noche

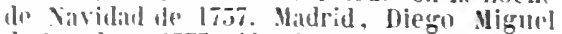
de l'orialtal, 17.7. 12 pags.

l.us dir lit flo:al Capilla de las spñulas de la

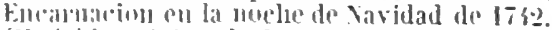
Yulivil.; otteilta de la calle Ingosta de Sall

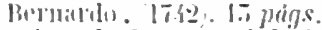

bas do la sillia ielesia de Toledn entus Vaylines del sagradu Vacimientu de IT.fo. Tololn, 17.8. 11 págs.

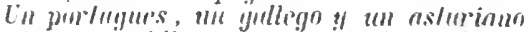
ranlan en su illiomen. "I un rizcainn lubla il restellemo chemurivelis. 
Los de la iglesia Real de San Cayetano en los Maytines de Navidad de 1742. (Malrid.) Calle de Cabestreros, (1742). 15 prigs.

Segunda”parte de los Villancicos para este presente ano. (Se ignora cual sea.) Valladolid, Andrès Guerra Nantilla, s. a. 2 hojas.

Tomadilla alegre pera eantar ou el dia del vaximent del Senor ell el portal de Belen. Valeneia, la Hija de Agustiu Laborda, s. a. 2 hojus.

Esle villanico en lemosin proces ser de époce mucho mas anligues.
Son innumerables lits commosiciones ch"esto genero que se han escrilo y publicado en España eu lodos tiempos, "y aunque no es ni ánimn dar nolicin ds: cillas, sin embargo por habev lenide ocusion dis verle nolare lu siguienle, que como lodas las anleriores al li20 es ru'cl: Clancometas placenteras con el santo nacinicuto di? mo'stro Senor Iesu Cliristo, en difornules lenguas.

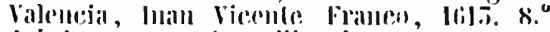

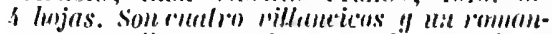

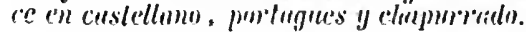

134 ZAFRA (ESTLM IE). Villancicos Para cantar en la Natiuidad de nuestro Señor Jesu Christo/IIechos por Estenan de cafra El primero al tono de 0jos morenicos. (Al fin:) Toledo, Juā knyz, M.I.XCr. $40^{\circ} \mathrm{le}-$ tra gòt. Viñeta de madera. I hojas sinfol. con la sign. A.

Contiene:

Villancico: Digas, presturion.

O(r.), que dice: Vumos, mming, juyumln. Cancinn que dice: Rile, ho, hr'.

Villanoieu: En la cimdorl de hrllon.

Oflo: Dime, dime, Gil linerguel's.

otio: Pascualejo, que luss lubirlo.

Otro: one le Uewis, di pulieln.

Cancion que dice: Bujo do lis peinn mar".

vie. Anton!o no hace merito de Estrivan de Zafray el Sr. Inuran tampicen romocio este opúseulo que es sumamente raro.

La cancion, Bajo de la peria nart, la reimprimio Böhl de Falver ('u la flurs's/a, aunque yo hubiera dado la preferencia il siguicute

\section{Villancico.}

i.Que le llevas, di, pulielu. al hiino recien Hicilli:

-Llivelo, jun' it simt peroln. u11 prllejo (a) sil pel]", que dicen ine esti en al such (ul III pesebre temdidu.

Lleve tambina 111 zilmarro, dos purlueriens y un jarrn, y si domde está mon minlon. dista viz lo he amriefureide.

I lambien le lleving: dos lomdas fone lo harre. y ull cillehirion le tiares fue cour el madic ha beluislu.

\section{Z}

barle lie un pedernal, la yesca y el material, por si fuere mayoral que esté bien apercebidu.

- Yo le mando un cucharon que the ha de hacer Anton, y un líerminso zamarron de rilletes bien cumpridu.

- jo llevaré uii rabel, el que compré de viiguel, y allá hablaré con èl lo mejor qu' es mia entendidı, -E yollevaré, por sall, rlatro luggazas de pan, y si zagales vernan sillaré con gran ruidn.

Luego le hice un calyado de sauz loeo, pintadu, por si guardare gaviado algun dia en el pjido.

- Yo le mando unos calzmes con senogis y botones. Ires $\dot{0}$ cuatro naterones, y un tasajo bien coeido.

Tamlien le haré unn zurrou de pellejos de cibrom, y un pico de un ansiron que ac tengo bien manids.

$Y$ cuandu allá, llegaré, hailaré y saltaré, y tantas cosas haré que le deje embolvecido.

Asmo, que si suena el sim jor sil buena proporeion, yo le diga una canejon por mui valiente sonido.

Porque arrojaré secenas rmartis, quintas y decenats. fuincenas, veinte durenas. la mui agrindo clibllidn.

Harci mils de mil sonctes, s'minintas y currluples,

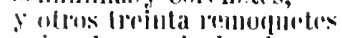
ifin ene la sregria be deprendide. 


\section{SEGUNDA DIVISION.}

CANCIONEROS Y ROMANCEROS, ANTOLOGIAS Ó COLECCIONES
DE POESIIS ESCRITAS POR VARIOS ILTORES.

Fiestas, Exequias, Centrimenes

i Justas literarias

que compremien producciones de difenentes poetas.

A

$\mathrm{ACA}$

13̈ IBAS Y NICOLAU (Gabriel Mandel. Narraciones de las fiestas en Laragoza el Setiembre de M.DC.LIX. a la Canonizacion de Santo Tomas de Villanueva. Refierelas el Lic ${ }^{\text {lo }}$. Gabriel Manvel Aliás y Nicołau. Zaragoca, Mliguel de Luina, 1660. 4. 6 hojas prels., 127 pigs. y una hnja en que termina la Tabla.

Contiene pnesias tatinas § castellanas de varios antures.

Latassa, en la páón. 519 del tonu $5 .^{\circ}$, advierte haberse equivocadi Tic. Antonio en decir que este libro está dedicado al Rector y Colegiales del Colegio de San Jerónimo) y ser su verdadero autor fr. José Enguita. Yo encuentro que vic. Antonio hable de rabriel Yanuel tbas y Yiculau ni de Jose Enguita, y asi ignoro donde menciona este libro, cuso auter por la portada, dedicatıria, aprobaciones y versos en su elogio, parece ser sin la menor disputa Abas y .ícolau.

\section{ACADEMIA DE LOS NOC-} TURNOS DE VALENCIA. Sus inslituciones, actas y composiciones leidas en las ochenta $y$ ocho sesiones que se celebraron désde el 4 de Octubre de 1391 al 13 de Abril de 1391. Manuscrito original de la misma Academia dicidido en tres tomos en fol. y encuadernado en un volumen que consta de 648 fojus utiles y 12 blancas.

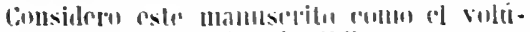
men mas previusu de mi liblinterea, yia pur ser un Camciuncro incelilo, como por conte-

\section{$\mathrm{ACA}$}

ner producciones de eincuenta autores distinguidos del siglo $\mathrm{xHT}$, todos ellos nat!lrales de mi patria y en cuvo dialecto escribio alguno de ellos. Por estas razones me estenderé algo en su deseripcion, empezando por dar una noticia de la Aceudemia de los Noclurnos, mas completa y detallada que la que nos dejaron Rodriguez, Jimeno, Cerdú y Rico y Tavarerte.

Segun Escolano, Hisl. de Valencia, tom. 2.․ col. 531 , D. Bernardo Catalan de Valeriola fué un sugeto, qque epilogando en si las - buenas prendas y loables inclinaciones de - sus pasados, en su mozedad y casa sustentio - con su diligencia la Academia llamada de los - Nocturnos, que como estrellas resplande- cieron en aquellas noches valencianas por -muchos años, en todas facultades de letras: -que si hubiera quien alentara la impresi . - de tantos y tan curiosos trabajos y los sa- carra á luz sin duda hubiera acaudaladı - mucha reputacion á la nacion españula c'(un - las estranjeras, que ciegamente la tienen - por desterrada de scmejantes ejercicios de - curiosidad. Deste caballero turo noticia la - real Majestad de Felipe III. y despues de - haberle homrado con un híbitó de santiagu. - le saco de presidente de la Academia pira - Corregidor de la ciudad y reino de Leon, en - la curona de Castilla: dende muriú dejandu -renombre de prudeste y virtuoso caballe. -ro."

Efectirantente, habienduse remido conn algunos amigos, pri:lablemente los diez que suenam ell has prumeras sesintues, a saber: el dicho D. Bpronardo, presidente (silencio), el

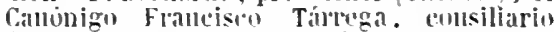
Miedo, D. Flatleisinu Desplugurs, secretari" (Descuido), Miguel Beseito, purtero (Sısiego: Caspar aguilar (Smmbra?. I). Franciseo Pacheen (Fiel). Hermamlo Pretri (Anevio), Maxi-

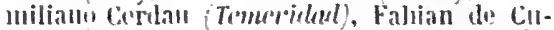
("aloul (Horror). Y liaspar de Villalun (Tinie. bless), redactaron las siguicules 


\section{"Instituciones \\ de Ia Meademia de los Mochuruos."}

" Yo está lan olvidada la vírtud en los corrazomes de los houblores, que en ol veramo de sil jurentud no produzgri alguma vez el foulo 1. los buenos cjereicios; y asi nosolros sien(lo los ingenios medianos desta rimdad, queremos imstiluir y fundar uma particular Acodemio, que hahido buen aruspdo y eomseju, dia

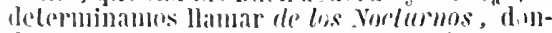
do so cultiven los entendiniontos do lodos, procuramlo asj en las ordinaciones como en al ejopioio dellas, mezclar lo dulee con bo proveluso: y asi para que este virtuoso enIratemimicuto hiya quielud y perpetuidad, (Holoummes lis cosis siguicules:

-1. Primerinuente, ordenamos que el pri- mer dia que nos hubiemenos de iuntar para comemzar el virtmoso rjereieio de la leademia, toulos immtos o cala coul de por si, oyamus misa y ell clla corl mucha derocium nos racinnendemis i bios; porque es bien que en principio de todas mostris cosis, acudamos al que es veriladerio principio dellas."

-ll. Item, updemamos que la deadenia se haya de celelorar en las easis del llustre I\%. Beruardo Cilalan. mestro mui caro y

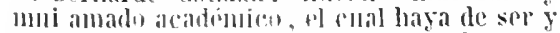

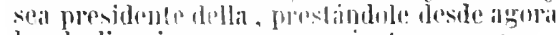
lit obediencial que "ll semejanle caso se loIfuicre.

-lll. Hem, milemamos que lodos los academicos hayan de tomar el nombre conforme al de la Acidemia."

- IfI. llem, ardemamos que ludus los academicos se iunten un dia cada semina, que? serí el miereoles, y que de tuna semana para otra este nombrado un lectors el cual sea obligado á lece ma licion de arfuclen que se le encomemdine, de la enal losidte i los

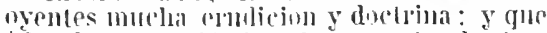

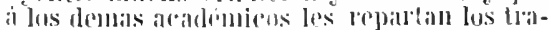

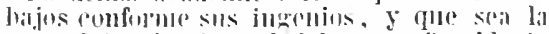

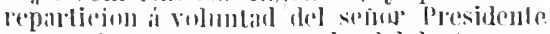

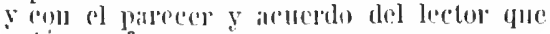
intuinces fircoe.

* ll, lem, omdenames pari el buen gobierno de la Acidemia, [ule re sentor Presidente layal de nombrar eonsiliario, com el cllal eomsulte lodis las cosas que hubieron de hacer, asi do lepallir las snjelos, comno do jecibir acaldemions, pomo de otras cualesfluiel posas treantes a la Ariulemia; y que il comsiliario so le de silla al lado del señor l'residente, $y$ al leedrer ni mas ni menos: pero enn rondirion, que la vez fue el consiliariu lea un havil de hialur mas do des sillas."

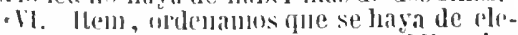

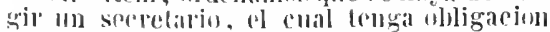
lo escrebir en ol libro de la Icadruia Lodas lis olydas fun on ellase hicieren, asi en prosa (r) cribir en la ciasil dumele se tiene la Acadomia y 110 en olpil parte, pordue no salya el libro ile poder ale sojum presidente.

- Vil. Itpun, ordendmos que ningun académino purala dojale de isistir an la Academia el dia y la hura que los denas se iuntaren,

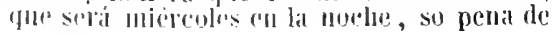

ser tenido por descuidado y de poca constancí; si ya no tuviere legitima escusa, la cual ha de ser á comocimiento del senor Presidente, y que aunque la troga sea obligado á enviar la ubra tole se le habri repartido."

- Vill. llem, ordenimos fue cualduiera persuna que pretendil cotrar cu la deademia, do mas de aquelus que somis instiluidures della, tenga obligaciun de hacer una petieion y dalia al porlero que será nombrado. para que la de il sciñor l'residente, el cual consullindula roul el c:msiliario y los demas academicos te reciba si lo mercciere y si us le despida con palahras de mucho comnediinienili.."

Villi. llem, ordenamos que para despedir ó recebir algon protondiente, lo hayi de proponer el senor l'pesidente y volamdo tudos ad aurem, se escopia el pareeer de los mas."

X. ltem, por coninto no sari bien que el seline lPresidente banal Jas cosas que son de menos importancia, como soll, mudar ex causa los dias de la Academia, nombrar consiliario, secretario y portero, lengar necesilad de consultallo con lis demias areadémicos; le otorgamos entero puder y facultad para fiuc lo puedil ordemar y hacer eomur sur gusto fuere, y mudar los dichos oflcitles á su volomtad sin romsulta ninguma y, faltando alšlumo dellos, poucr en su lugar á quien fuere s(crvido."

- Xl. Ilem, damos el mismo poder al señor Prosidente jitra que siempre ghe por alguma ocasion, asi bjen vista, fallare en alguna jurmirlis de lis lcademiar, pueda poner en su lnirar al caballerio que (quisiere, con tal que seal do lis andiomicos, al eulal se le teu-

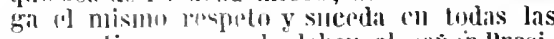
premogralivis que - lo deben al senor Presidemle."

*.il. Jem, ordenames para mejor regimiento de la leis!nuia, que ningun aeadémice ni ulla pers:suli de enalquied calidad

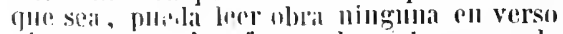

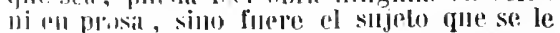
hubiere repintidi, sin que primero el señor Presidente, i) rujen sll orden tuvirre, pase los ojos por elli, $y$ dada por buena se puedis leer, y no siendo isi, el señor l'residente no dé linirar á que se liai."

- Xlil. Ilem, por cuanto tiene muels' trabijo el ariulémico que ha de leer el disenu'so, prira prevenisle conforme la ralidad de los "yentes, y que al pensar sujetos tales no es de minos consideracion, ni se lequiere ménos estudia; aliviambo de ba obligacion rue tenia el letor en el $4 .^{\circ}$ capilulo, mejorindole pll estil, ordenamos: que el s'jol l'residemte puedir ementmendar al acadimion er!e quisicre, el trabajo de pensar sujetis, conno no

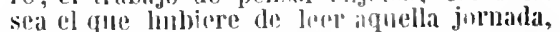
pl chal aradénico los hiva de traer al seimer Presidente un dia intes de la jumla, pira fue coll mas acuerdo I is reparta."

- Ilem, por cliant' se le ha ofrecido al sejus Plesidente precisa neresidad de ir a la Corte de S. M. para triltar negocios de muchlil ralidad e imporlancia, y por comsigniente mo prode asistir á los anlos y jornadas de la Academia, Instudo del poder á sut mereed 
ntorgado en el capitulo once de las Inslituciunes, numbra por Presidente al llustre l). Ciaspar Mercader al cual los académicos ljayan de prestar la obediensia y respeto, de li mesma mameri que al señor presidente hall acostumbrado, din'anel 1 el tiempo de la ilssencia del señur Presidente; el cual manda, que se escrila exta su determinacion y nombramientı al pié de las Instiluciones de la Academia, pues tiene la misma valididad y fuerzas que cllas.

Fl dia 1 de octubre de 1.591 se celebri la primera junta y en ella leyo el Presideute el siguiente

\section{Soneto en alubansa de ta Academia.}

Ya (que el silencio gratı) nos ayuda, V el reposo comum tan procurado, bel general afecto apıderado, obra con fuerzas de la unche muda.

la del ingenio con razinn acuda Al noble pensamiento, que alentado I)el general sosiego hallari vado

A la virtud purisima y desnuda.

F yos estrella nueva, que naciendo Pronueteis la riqucza que yozaron En el dorado sigio de siturno;

Creced con nueva luz, porque creciendo Se jlustren los alientos que os tomaroun lor noite de su nombre $y$ fln noclurnı.

Siguió á este Sonelo una Cancion de Tárrega il nombre de la Academia.

El 50 de Ortubre suena por primera vez el nombre de Estudia (El Dr. Jeronimo de ViInes); el 20 de Xoviembre el de Temeroso (1). Juan de Fenollet, y por eso Miguel Beneito, en un Elogio rilabanilo á liss fundadores de la dicalemia, leido el $2 T$ de Toviembre, enmmera dice. El 11 de Diciembre aparecen los de Triste $=0$ y Beconimionto Jaime Orls y Mamuel Ledesina con estos llegaba ya cl mumero de individıos á catorce, lo cual conflrma el canónigo Tárrega, el 25 de Diciembre de dicho año 91 , en un Soneto cuyo epigrafe dice, contiene todos los nombres alegoricos de los acudemicos; por esta lista aparecen ser efectivamente catorce.-Progresivamente fueron ingresando los siguientes.

Evaristo Mont (Soledad). 8 de Enero de 1592.

Licenciado Gaspar Eseolino (Luz). 15 idem.

Mtru. Antonio Juan Andreu (Vigilia). $5 \mathrm{Fe}$. brero.

Mtro. Gregorio Ferrer (Industria). 19 iden.

D. Caspar Mercader (Reldmpago). 5 Marzo.

D. Cirlos Boil (Recelo). idem.

D. Franciseo de Castro (Cmsejo). idem.

Iopez Maldonado (Sincero). 11 ideus.

b. Guillen de Castro (Sorreto). idem.

b. Tomas de Villanmeva (T)ampilidad). 25 ident.

Pelegrin Catalan (Cuidado). 8 Abril.

D. Matias Fajardo (Oscuriulad). 21 Octubre.

Mtro. Gaspar Gracian (Peliyro). 28 idem.

Tomas Cerdan de Tallada (Trueno). 15 Enero de 159.5 .

D. Guillen Ramun Catalan (Reposo). idem.
Capitan Andres Rel de Artieda (Centinelu).

13 Enero de 1593.

Pedro Vicente Gimer (Caulela). 20 idem.

l). Jaime de Aguilar (Niebla). idem.

Jerinimo de Mora (Serens). fi Octubre.

b. Guillen Belvis (Inviu). idem.

Estacio Gironella (Resplundor), 10 Noviembre.

D. Lois Ferrer (Norle).8 Jiciembre.

Iir. Juan Andres Nuñez (luzero). wey iden.

Hernando de Balda (Comula). 2 Febrero de 1594 .

Yicer Juan Jose Jarti (16eviniento). 16 idem.

D. Pedro Frigola (Espia). idem.

En la lista do los acalémicos que va al principio del volúmen se hallan

Juan de Valenzuela (Asmbro),

l.icenciad, Bartol.me Scbastian (Eslrellu),

l). Juan Pallas (olvido),

I). Franciseo de Villamova Recelo). yo

Ei Licenciad, Lurenz) de Valenzuela

(Timto).

De Jos cuatro primeros no encuentri) mencion en ninguna de las sesiones, y de Lorenzo de Valunzucla hai alyuma composicion hícia fues del año 1.5\% $\mathrm{y}$ principios del 14 ; pero no comn! imlividuo de la Academia, siii) como afleionalos.

Sin embarso. se ve gue al mismo tiempu que entriban nueves socius se ansentialsill o fallecian otros, pues en una de las rouniunes celebradas i fines de Abril de 159\%, diju Tárrega en un Diseurs.), que eran entunces diez yueve individius, cuando segum la lista que ántes lıe dadis de las admisiones, debian lleurar en aruella fecha á veinticinco: $y$ el 21 de netubre de aquel año un tal Simon Arias leyi una composicion donde elmumera solos catorce icadémicos.-Por el liscurso intes mencionado de Tírrega, vemus tambien que las tcadmuias en vez de ser mocturnas so tenian á medio dia, y pou utro que pronumciu el l'residente. a " 17 d"

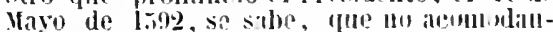
lua la generalidiu ol celchorse las sesiones í aquella hora, y sichulo por utril pirte las noches mui cortas, se deridio el silspenderlas desde aquel dia para seguirlas de uoche en el mes de octulire: dicist, pues, por flualizada ia primera temporidat y el primer tomnde dictis.

En efecto, reamidaron sus tareas el $T$ de dicho mes de Oetubre principianlo por la Academia 5i. El Presidente en uI pequeño Exordis, que precedo á sll bisturso de lis excellencias de la noche, se refiere i la suspension anteriog. l.a segumda temporida termino el de de Yarzo de 1.595. y lus trabajus en ella presentados forman el tomo 2. Coinesizo la tercera el bi de actmber do aquel año y conchlyio el lij de Abril del !4 alvirtienduse al remate, que ol señor presideml. mandé al académico tlorror, en lugar elel secrelario publicast la prarogacion de la tcademia para el primer miercoles de Ortubr'? dol año presente, pura cu!na jornada l'tepr': tio tos sujetos siquicentes: estos sujplos ò asuntos no se encrientran indieados y probablemente no se distribuirian, pnes no txist? 
dilto illgumo pana probar que llegara á celebrarse cuarla temporada.

bel eanlesto de la e.bra se desprende no haborse limilado la asisinucia a lis juntas a les miembros de la Sucialad, sinu que coneurlian á ellis afléirmades of lransemules; asi lo prttebil el permilir al l'lesidente il personas rstranias leer algumas poesias despues de termillulis varias sesimmes, y en vina ocasium, hasta mando que volviesou í sus asientos los arademicos para oir dichi lectura. Merecicron esia especie de defrencia o distincion los signientis:

Simull Arias, on las ICad'mias del 21 g 28 do (lidubre, 1 is de Tovicmbre y 2 de Diciomlite de 15 ?

Luis Tavarro, en la del 25 de voviembre del IIIsmu allo.

En fraile de lis ordon de S. Pilblo, primer rrmitano, cuyo nombre so calli, en las del ¿ 8 de Ocinbre y a de Noviemure del misino aili.

Pedro Tamayo, en las del 7 y 17 de Noviembre $y 15$ de liciembre de 159.5 .

El Doctor linoz, ol eual supongo seri quien despmes fue homibrido academien coll el momline de lusero, all lis del 17 y 29 de? Vovirmbre, 1. 8 y lo de liveiembre de dicho

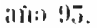

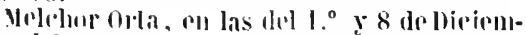

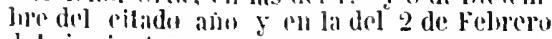
de I signienli".

Fit lonclor bux, en la del 8 de piciembre do 15.315.

Estevin Cortes, ell la del 2.2 del mismo IIIיs $y$ allo.

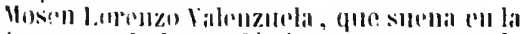

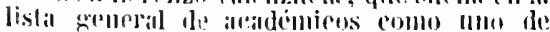

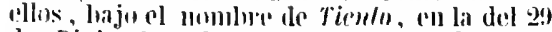
le Diciembro de 1.59, y by 15 de dlipil siguieule.

Cosmur laminian Tuflinu, en las del ga de

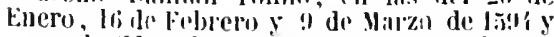
.....de Eduilulu, pu tis del lo y 2.) de Fe-

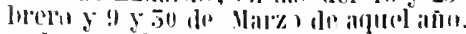

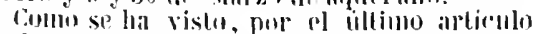

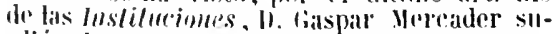
pliii al Prosidente durante su pesidencia pII

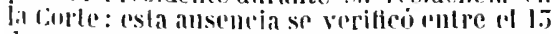

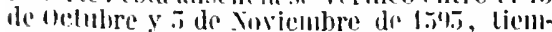
puen que so foviepon lis reminimes en easa

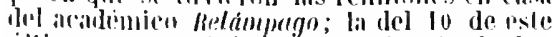
illimt, mes ye fue ell la pesidencia de dinll

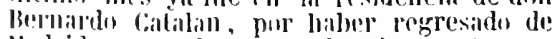
Madrid, segull lo espresal la misma acela.

Ilo dicho anteriormenter yue no hai distus flala probar existiese la dridemia mis que

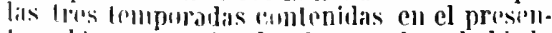

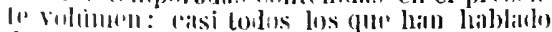

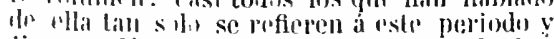

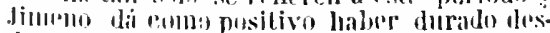

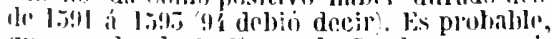

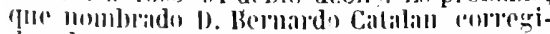
liol de Leril, dinde follecio en liox, se virra perecisindo i abillodonar las asambleas fulllialis y sosteniglas por él con un zelo infiligable, y que fillianilo cl alma y apoyo de cllas ilejiarin yil de reminise.

lin libli volviofun a renacer las Norformos it esfortens de lane de rllos; pero coul la de- nominacioin cambiada; asi lo atestigua la siguiente nota puesta por Yagie de Salas al fin de los Amantes de Temiel: :Despues de -impreso este pocma, me mindó la Acade- mia nuevimente resicitada en la insigne - rindad de Valcucia pur el conocido por de "superior ingenio 1). Guillen de Castru, de- liajo cl nombre de los Nomiañeses del l'ar- naso , reasumiese desnudo de episedios, en "lis octavis abajo eseritas; y se leyeron en , la segunda junta, habiendome favorecido - con admitirne por acadimieo della con "nombre de Pindaniru., - Lístima que solo nos haya quedado de estios Monlañeses la memoria de sil momlire, $y$ de que Guillen de Ciasloo fue su fundider, circunstancia que ni mencionan Rodrignez, Jimeno ni Fuster, al hablar de este eseritor.

Al principio indiqué que este Cancionero era inedito y por tal lo tengo, pues soln encucutro que on el Prado de Vulencia publico sil antor scis i ocho composiciomes de las dedieadis í los Yoclurnos, y aun estas las vario, adicionó, ó retocó en términos de no ser ficil reconocerlas. 'inede por lo mismo aserurarse qui madi de el ha visto la luz pirlliea, i jesar de existir pruebas en el cuerpo do lia wbia de que, ya fueril el mismo Presidente 0 alowno de los académieos, trató de, liar à luz simó el todo, alguna parte; pues mlemas de lis porreceiones. adicioues y sıpresiones, anotidas en muchas piezas, se lec "il los mirgenes cim algmua frecuencia: /o limeda no se ha de imprimis'; deleatur éu la. impresion: esto no es bume para impresu; resto as bueno para imprimis.

Terminada ya la parte? Listorica y deserip-

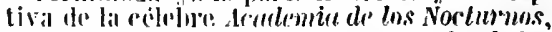
pissemos illoril il eximinar si sil fumdadur

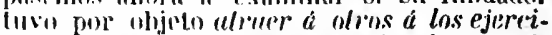
rios de lu vivlul, !l apurlar á los jóvenes de los tropipzos á qué andum espurstos, y tener-

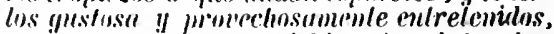
comin supome dimrno, i bioll si su intencion fue rulc'a y esclusivinueute la de pasar un rilo de soliz cadil weho dias, estimmando $\mathrm{y}$ cjepribando su ingenio y el de sus amigos. Vii opinion e's labber sido tal li mira que Ilevirull al comerrenarse: no negaré que D. Bo:lnirdo Catalin fue quien grucralmente dedilaba stes escrilus i ismutos de moral y santi-

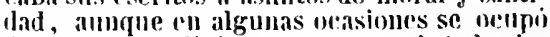
de (osis mis livianas; pero casi todos los demias comsingriron sis plumis á ubjetus amorosus, sittiricos y festivus, y sus conipm. sieimes i vezes flgurarian dignamenle al lidu del fleito rel mamlo; sobresiliendo en esta elase de literatura entre faceciusa y olssrena, ol camonigo Tírrega, Jaime orts, dim Fibian de cincalull, Inrnindo Pretel y aigun otro. L." mas chocinte que hai en esto is, que siemdo il l'residente (segun llodriguez y dimen' hombre tim religioso, devoto y esclison de la purisima Concepeiou, no solu permitiese desahogos lan poen deeentes en sus subordinados, sino que hallandose inveslido por las Instituciones con la facultad de distribuir los asuntos ó de examinarlos ántes le repartirlos, caso de no poderlos tar él, parere levia un enıeño especial en asignar 
ACA avtologias-y justas poéticas. ACA

á los escritores mas alegres aquellos argumentos en los cuales con mas facilidad podian deslizarse, comno por ejemplo: liras a una señora moza casada con un viejo: octavis alabando el cuerno: romance en loor de la zanahoria; redimdillas ó una damu enamorada de un capmi redondillas en aleban=a de la huba: relondillas d un sacristan que subia d repicar en cueros; discurso de lis escelencins de la breta; rodindillas d un gulan que bebió una loche creyendn que era de su dama; redondillas haciondo considera. ciones d una dama que en una enfermedad le dieron un serivio; redondillas d una mujer que malpario de deses de mondongo; redondillas daulo matraca d un copon etc. etc. Asi esque Jaime Orts (Tristeza), en una poesia, lejda en la última academia, pidiendo indul. gencia á sus compañeros por haber sido tan libre en sus composiciones, dice írunicamente:

Nuestro presidente amado, con honeslo y santo zeto, á Tristeza le ha mostrado tanta carne por seituelo, que de fuerza le ha tirado. Mui disculpadas serán mis obras, porque verin los que las quisieren ver, que me las hacen hacer el diablo y Calalan.

Esto no obsta para que mezclados con to mas tan poco edificantes, encontremos sme. Ins a la Fe de Nirr. Sra., al SSmo. Sacramen/n y duna porcion de santos; oclavas á la ins. lilucion de la cuarrsma; pelondillas $a$ lits pèus que se padecen en el infierno; estanzas Iraauciendo el salmo ilpl Miserere, romances al Nacimienlo ete. etc.: lo cual prueba la aberracion de ideas de aquellos himbres. que creian puder pasar como gènero licilu y inrriente, hodo aquello que no atacaba i lus dogmas del catolicismo, por mas que la in. moralidad y licencia reb:sara en todas sus partes. En vista, pules, de estos ditus y otrus muchos que podria alegar. he llegado í deducir, asiste poquisima razon a lus que para denigrar el r'stadu de cultura actual y los progresos de la civilizarion, nus estín cuntimuaneute preselltando cono inidelus i nuestros antu'pasados. Sin poseer, al decir de mestrus modernos redentores, sil decantada rirtud y religiosidad, nadie se atreveria hoi dia i publicar un Cancionero de obras te: burlas, parecido al que salio en Valpncia cu 1519. comedias del géner de la Tebaulu. Hipólila y Serafina, impresas en la mismi ciudad en 1.21, ni influidad de romances. glosas, fierus, dereniegos y letrillas que se dierun á luz eu varios puntos de la Peninsu. la en el sighy Xit. cuando se viria culdadosamente escudados por un tribunal de la Fé.- - kasten tambien estas lijeras rellexiours para hacernos mirar cun cierta prevencion las biografias y aun la historia de tiempos pasados, dindé á cicrtıs individuos se les pintil como intachables $\mathrm{y}$ perfectos; $\mathrm{i}$ que $\mathrm{ab}$ surdo! fueron hombres y por consigniente

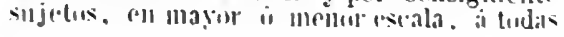

las fragilidades $\dot{e}$ imperfecciones del linaje humano, sobresaliendo acaso en ellos mas que ell nosotros la hipocresia, por razon de la ignurancia y el fanatismo, y en atencion a ta unenur tolerancia de su épora.

Para dar una muestra del contenido de este manuscrito, y para evitar se pierda totalmente lo que en él se halla, cosa muy fácil de suceder siendo unico el rjemplar, cupiare algun trozo de cada uno de los antores que con sus obras poéticas contribuyeron á antenizar las sesiones de esta Academia; advirtiendo. que si hai ciertas yiezas mal sonantes para oidos de doncellas. las he incluido, ya porque considero que ni Catálogo no ha de ser leido por ninguna de estas. cs)no por n) haber encontrado otra del autor de mas mérito ó de otro género.

El tom, comprende nchocientas cinco composiciones en verso y uchenta $y$ cinco en prosa, á saber, de

D. Bernardo Catalan, setenta $y$ una en verso y ocho en prosa.

\section{Suneto conlra la lumana iugratiliul.}

Rinde la tierra el ordinario fruto, Querifindose mostrar agradecida,

Y de una sementera recogida

Suele doblar cien veces el tributo.

Despoja el ciclo sul intricado luto

Por una lagrimilla bien salida;

Fen cambio de un regillo que se olvida.

se amansa el udio natural de un bruto.

Solo el pecho del hombre emponzmiado

Turnando mal por bien y por paz guerra.

l)e sus desdenes ásperos concibe:

A la tierra no sigue aunque es de tierrn,

Vi al cielo incita, ni al leon curado;

l'agando menus cuantu mas recibe.

A pesar de haberme propuesto publicar una sola compusicion de cada autor, en gracia de ser al l'residente de la Academia i. Bernardo Catalin. $y$ de parecerme bastante lindos los siguientes cuartetus, los cupiare.

A min pajarillo

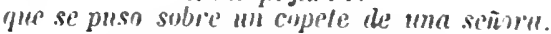

Al mejor nebli te igualas,

P'ajarillu, fun tu vuelo.

l'ues a la cumbre del cich

Han aleanzado tus alas.

Invidiell todos tu enipress,

Pues, volando lu candal,

lina garza tan real

fin tal parte hiciste presa:

bispretamente cull cllu

Instraste III proceder.

Qu'es urasion la mujer

I ha de asirse del eabell.

Más qu'el más rico trsoric

Vales, pajarillo ufino,

Plues ie has puesto de tu mano

Tall nubles piguelas de un!.

si los cabellus son ram!

Plantadu junto a la boca

Que con dulzuras provoca

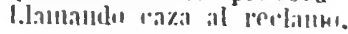


¿Quién habrá que no te dlga

Que al mejor sefiuelo has ído,

$Y$ il árbol mas florecido,

Y á la inas sabrosa liga?

No es, sirguerillo dichoso,

nueno de tan altos bienes,

El alcándara que tienes

De tórtola sin esposo;

pues llena de honesto fruto,

Si acnge cl regalo tierno,

Hard Nayo al seco invieruo

Y alegre esperanza al Iuto.

Vive mui asigurado,

Aunque habitas dinde miran

Punteros que al blanco tiran

De la caza que has tomado,

Qu'es blanco que deja en blanco

A la esperiencia $\mathrm{y}$ al arte,

Y asi no estarás en parte

Mas sigura que en el blanco.

Mas, si alguna vez se, doma

Nise y de ti se aconseja

Y le hablas á la oreja

Como el ave de Mahoma,

Te suplico que me valas

rraugeandoms favores,

Y pscribirć tus loores

Con las plimmas de tus alas.

El canúnigo Franelsco Tárrega, sesenta y cinco en verso y seis en prusa.

\section{Redondillas en alabanza de la haba.}

Ese buen Cid campeador Cuando el el siglo fablaba, Yos enseino que la faba Se deriva de favor;

Y en las juntas es sabido

Que si un pueblo no se avienc, Que aquel que mís habas tienr Queda más favorecido.

Asi la mujer procura

Antes las habas qu'el pal,

Pues todas cuantas le dan

Son votos de sil helıuosura.

Es una fruta cubierta

ne un cuerecillo delgado

oue con la mano apretido

Asoma el grano á la puerta.

I la mas tierna y mas clicica

Tanto procura medrar

Que sembrada y por sembral

Escriben que nultiplica.

Esta verdad se parece,

Cuando por mayor ganancia, Kecogiendo la sustancia

Je li olla, en ella crece.

Jicen los contemplativos,

Que solo de un haba ticrua

Hace la gente moderna

Frailes que parecen vivos:

$Y$ engañanse de manera

oue d'ella salen traslados

De cuantos hombres formados

Conoce la edad lijera.

Bien que con mas maravilla

Los frailes nos representan,

Porque las habas sustentan

sill rolnolit y sll capilla.
Las niñas juegan con estas

$Y$ al fin en sus reverenclas

Descargando las conciencias

Los hacen padres de flestas.

pero recogéd el vuelo,

Pluma, que en las habas fundo, Qu'ellas buscan el profundo

Y vos las subis al cielo;

Y alguno habrá que presuma, Segun la furia os llevaba, Qu'el favor puso la fab:1

En el corte de mi pluma.

En la Academia del 2 de Marzo de 159.1 leyó el mismo Tárı'ega, por labérsele distribuido, el signiente

\section{Soneto.}

A un pensauienlo.

Llevo tras si los pámpanos otubre,

$Y$ con sus muchas lluvias insolente

No sufre Turia márgenes ni puenté,

Mas ántes los vecinos campos cubre;

La sicrra, como suele, ya descubre

Corouada de nicve l'alta frente,

Y apéuis el sol vemos al oriente

citando la dura tierra nos lo encubre.

sienten el mar y selvas ya la saía

Del aquilon, y encierra su bramido

Gente en el puerto, y gente en la cabaña;

Y Fabio en el umbral de Tais tendido

Con vergonzosas lágrimas lo baña,

lebiéndolas al tiempo que ha perdido.

Ile copiado este precioso soneto por ser el mismo, que con algunas lijeras variantes, publicó diez años mas tarde Rel de Artieda en sus Discursos de Artemidoro, como de Argensola; que se incluyó el las Rimas de este en 16.34 , y que posteriormente han atribuido al poeta arigones cuantos lo han reimpreso.

Francisco Despliugues, diez y sicte en verso.

\section{Bedondillas}

o un limpiadientes que le dio su clamn.

En un limpiadientes bello que limpió la boca bella, line quis: sin mereccllo, favorecerme mi estrella cchando á mi suerte sello:

Anunciando á mí esperanza, pues tan rico premio alcanza, que gozarí la vitoria cun aqueste triunfo y gloria sin temer á la mudanza.

Pues qu'he llegado à gozar la prenda mas estimada que se puede imaginar, por haber sido tocada de aquella boca sin par.

Presea del alina mia, que me dais tal alegría, que ya no espera mi suerte sino tener vida ó muerte de aquella qlue os poseia.

$Y$ pues que con limpiadientes amor ine da estos favores, es bien que entipudan las gentes, 
ACA axtologías y justas poéticas. ACA

que sirvo yo mis amores no con cosas diferentes:

Y asi cierto me collviene, de quien tanto bien me viene, que le haya yo de dar con que se pueda limpiar la boca que 110 los tiene.

Miguel Heneito, cincuenta y ocho en $v$ ciso y tres en prosa.

oclavas á una dama que la vió bañando.

Entre tus aguas, regalado Turia,

Que corren por camino diferente,

londe menguando la temida furia

Con ronco son murmura til corricrite,

A tus ninfas haciendo eterna injuria,

Templan dos damas el calor ardiente:

Bellas entrambas, mas la una d'cllas

Corona puede ser de las más bellas.

Llega á bainarse, y con audazia poca

Quiere primero que su pié se moje,

Mas apenas con él las agnas toca,

Cuandu lijera con temor se encoje;

la teme, ya se anima y se provica,

Va se quiere atrever, ya se recoje;

Mas el agua que alegre se levanta,

Muja del blanco pié la bella planta.

Para defensa de alrevidiss ujus

Con un blanco cendal el cuerpo cubre,

Sirviríndole, á pesar de mis antojos,

De blanca nube que ini sol encubre:

Nas con todo me ofrecen mil despojos

Los pedazos de cielo que descubre,

Que á pesar de las aguas importunas

Viro del bello cuerpo las colunas.

Tus frescas aguas, qu'es razon que sientan

La ventaja que llevan á otros rios,

Mayures glorias alcanzar inteutan

cobrando nuevos y soberbios brios:

Y entre las dos colunas que sustentan

El claro ciclo de los ojos mios,

Como tan alto bien nerecen solas,

Alegres juegan con pequeñas olas.

Mas corren tan heladas tus corrientes,

Que porque no la ofeudas cual podrias,

Guiero llorando lígrimas ardientes

Templar el hiclo de las aguras firias;

Y cuandono bastaran, por mil fueutes

I.a roja samgre de las viuas mias

Dertramar quiero, porque d'esla suerte

Al méuns le dé vida con mi muerte.

Gaspar Agullar, diez y nueve on verso $y$ cuatro en prosa.

\section{Coplas contra los Bulnnes.}

Por solamente saber

cl bucu gusto quién le ensalza.

uin divorcio quicro hares

contre el calzon y la calza.

que son marido y mujer.

El dice que ella 110 es buena

porque las faltas n+) enr'ubre.

pucs de cuchilladas llena

todas las piernis descubre

y muchas d' ellas condema.

Ella viendo la aficion

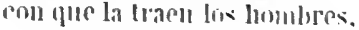

de su marido el calzon, prinero acuso los nombres de sivillano $\mathrm{y}$ balon:

$Y$ dice qu'el sivillano es mui bajo y baladi, pues tiene en su nombre ufano. dus letras que dicen si $y$ seis que dicen villano.

Del balon dice, que es lal que su origen y ralea es de gente tan bestial, que por guardar lo que mea lo lleva por orinal:

Y entre otras inuehas razones. dijo por verdad desnuda. qu' es traje de mariones. pues fácilmente se muda de faldetas en calzones.

I tal la mudanza es, que el que á ponérselos llega, parece puesto al reves, que saca atados los pies por dos bocas de talega:

I sus piernas desdichadas se afrentan de sustentalle. pues las lleva embarazadas (u) cosas que tienen talle de rejigas deshinchadas.

Y si por mayor decencia alguna vez aires tieneu, lablando con revereneia, serán de aquellos que vienen de tierra de pestilencia.

$A y$, de los que andan atados cou traje tan importuno. que si por nuestros pecalos vall las Inujeres con uno, ellos con dos verdugados.

Asi quejándose estáu las dos partes ofendidas. y para lestigos dan dos ligas, que por cumplidas servir de inedias yodrill.

Y el buen gusto, por hacer este divoreio de nombre, fué de voto $y$ parecer, que se de la calza al himbire, y cl calzon á la mnjer.

D. Francisco Pacheco, tres composiciones en prosa.

Mernando Pretel, cincuenta y tres pu versu y lres en prosa.

Cuartetas á una sej̃orn que querimoln mu. cho a su galan, sabienlo que te enojabu en

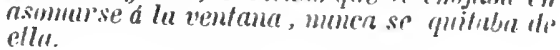

Si miafieint te da gusto y mi volmutad estimas. Lisbis, porque me lastimas roll uno yotro disgins(1)?

bices que me eres leal. y que me quieres Lambien, pues di, si me quieres bicu. para qué me haces nal:

Diome la batalla amor.

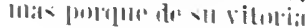


te eupiese a ti la gloria, me sujeta á tu valor.

Quisiste para ampararme que por tuyo nic tuvlera; quién sospechara que fuera el favor para matarme! Celehruse tan de veras el premio de mi ventura, que al templo de til hermosıra pude ofrecer mis banderas.

Nas porque mi vida ufana se convirtiese en tormento, celebras mi vencimientı por una y otra ventana.

Eres alcaide perjuro, pues cual lisonjero amigo descubres i mi enemigo la bandera de siguro.

bite el alma por rehcnes, mas si á la ventana sales, sacas á plaza mis males sacando á plaza tus bienes.

Pues como sirena cantas, con justa razun diré, que en vano te guardo fé, pues que la fé me quebrantas.

De suerte mis cosas van, que por mi fortuna avara, ser tu ventana estimara mas que no el ser tu galan:

I asi con esta querella ini flrmeza aventajaras, pues que por mí la enojaras (4) mo me enojas por clia.

Mas si quieres dar la palma de tus divinos antojos, pon los tilyos en mis ojos que s:m ventanas del alma.

Maximillano Cerdan, treinta y cinco eli vel'so y dos en prosa.

A un gralan que pedir zelos de su marids à uni seitora casadr.

Son los zelos hijos de la Invidia fleri, y asi lei no guardan ni razon esperall. Uniero con razon y vengo por ella, a tener invidia

de la hacienda ajena: Ajena la llamo. aumque por herencia es el mayorazgo que mi alma espera. Pero mi justicia está en no tenella, pues goza otra manı

la posesion d' clla. Mas conio el amor de injusto se precia, en injustas causas halla justas quejas.

Je mis propios bienes el amor ordena, que pague tributo á (puipul me da guerra.
Dè ini voluntad á una dama bella que vive casada con voluntad muerta:

Cligame de amores tanto, que me fuerza á que del inarido tristes zelos tenga: siendo el ofensor pongo la querclla. y justicia pílo de sil pripia ofensa. plues él no los pide yo pago la pena senibrando memorias para su cabezil.

Fabian de Cucalon, cincuenta y tres en verso y una en prosa.

Sonelo. A üinos ojos bellos.

Contra la fuerza det airado viento $Y$ entre soberbias ondas levantadas, Que cstán para matarine conjuradas, Navego coll mi triste pensamiento:

Del mar resisto el flero movimiento

Que, por verme las fuerzas tan postradas, Procura con sus aguas alteradas Anegarme en el golfu del tormento.

Tal vez pruebu á salir, y es escusado, Que con la nocbe oscura me retiro

Por uo dar al traves con mis enojos.

Mas con la tabla de la fé abrazado

Salgo de la tormentil, porque miro

El claro norte de uniss bellos ojos.

Gaspar de Villaion, cinco en verso. Redondillas. A unos njos.

Ser mandamiento me escusa lo que cmprende mi rudeza, pues quedará cualquicr musa, para contar tal belleza, arrinconada y confusa:

$Y$ asi con ni corto aliento, pues no puedo lo que siento, dirć de esos ojos bellos, que ha cifrado el cielo en ellos lo que aleanza un pensamiento. Son fenix en este suelo de la herumsura mayor, y para pechiss de hielo, fruego que envia el amor y claridad para el cielo.

Son la beldad albreviada de naturaleza dada, por dejar de si memnoria, porque levantó su gl oria en cusa tan sublimada.

Son dulces en el mirar, graciosos en el reir, temidos por el matar, afables para seguir y fuertes para esperar.

Por ser de tal compostura, son norte que me asigura en el mar de mis cuidados, y por ser tan estremadiss sion polos de la hermosura. 


\section{ACA Antologías y jtistas poéticas. ACA}

El Doctor Jerónimo de Virues, vein. te en verso $y$ seis en prosa.

\section{Liras en ulabanza de la libertad.}

El mas siguro puerto,

El mas alegre y apacible estado

Y el contento mas cierto,

Fs uunca ser mandado,

Nl estar un hombre á otro sujetado.

De tanta gloria es callsa

La libertad en esta vida triste,

Pues pone fin y pausa

A cuanto mal reviste

Al que de ajena mano come $\mathrm{y}$ viste.

Esta hace qu'el suelo,

Miéntras en él viviere libertado,

Le sea un otro ciclo,

Porque el bien alcanzado,

Sin ella queda de su ser privado. Ni por la plata y oro,

$\mathrm{Ni}$ las piedras preciosas del oriente, Renuncie este tesoro

El que libre se siente,

Porque en su mesmo daño y mal consiente. La libertad escede

A cuanto el mundo tiene de riqueza;

Ni á ella llegar puede

La fuerza o gentileza,

Pues en ella restriba su grandeza.

Es como una vislumbre

De la tartarea pena y su tormento

La triste servidumbre;

$\mathrm{Ni}$ bajo el firmamento

Hubo jamas serviciu sin lamento.

Matose con su mano,

Por no servir Caton gallardo y fuerte,

Mostrando cual romano

Tener por peor suerte

Vivir tal vida, que morir tal muerte. Y el esforzado Bruto

Por no servir, la muerte ha padecido, $Y$ dió por mejor fruto

La muerte que ha sufrido,

Qu'el tiempo q'ha sin libertad vivido.

$Y$ el vasu venenoso,

Que porque no le prenda sli enemigo, Bebio Anibal furioso,

Nos dió claro testigo

Que de la libertad fuè siempre amigo.

Pues à Pentesilea,

Del mujeril ejercito amazona,

Que porque no se vea

Cautiva su persona,

El arrancado pecho la corona.

Oh, libertad querida!

$\mathrm{Oh}$, libertad de todo el mundu amada!

lor ti pierden la vida,

Por ti se ticne en nada

Cualquier fuerza de fuego $\mathrm{y}$ dura espada. ¿EI soberbio ediflcio,

El monte, el prado, el rio, la floresta,

El bèlico ejercicio,

De qué sirve ni presta?

Todo sin libertad cansa y molesta.

Todos al fin procuran

Cobrar la libertad si la tuvieron;

$Y$ por clla aventuran

Cuanto bien poseyeron,

I pierden por ganar lo que perdieron.

Tos. 1.
Por esta, el que enlazado

En cautiverio está de piés y brazos,

Desea ser librado

Y cual Sanson los lazos

Por tener libertad hace pedazos.

Por esta el navegante

Ni teme el golfo, ni el austral furioso,

Ni hai Sirte que le espante;

Yeste vivir penoso

Le tiene por contento y gran reposo.

Y tanto á todos place

La vida libre, que cualquier fatiga

Su contento deshace,

De todos es amiga,

Y a padecer por ella nos obliga.

Tener el mundo todo

Sin tener libertad, don sobrehumano,

Es escoria, es lodo,

Es caballo Seyano

$Y$ poseer el oro Tolosano.

Por defender á Roma

Hizo en la puente Horacio gran matanza,

Y del contrario doma

El orgullo y pujanza,

Un lacerado hierro de su lanza.

La libertad pretende

Hasta el Olimpo santo alzar su vuelo,

No le estorba ni ofende

La distaneia del cielo,

Ni el viento, el mar, la tierra, el fuego, el Que aunque en la jaula rica

El dulce gilguerito está encerrado,

De uno en uno pica,

Por verse libertado,

Los juncos que le tienen cautivado.

Si los del alto cielo

vo tienen libertad, afirmar oso

Que no tienen consuclo,

ni gloria, ni reposo,

Porque sinlibertad, quién hai dichoso?

Pues, libertad amada,

Con este solo dicho al fin concluyo

Tu loa $\mathrm{y}$ mi jornada;

$Y$ quien no fuere tuyo

Jamás tengo esperanza de ser suyo.

D. Juan Fenollet, trece en verso.

cuartetas.

A un galan una dama pidièndole casamiento.

La que mas que á tu provecho

va publicando querer,

te escrile para saber

como se halla en tu pecho.

La ocasion del escribirte

te causará admiracion,

no ha sido sin ocasion

que ha nacido de advertirte.

Yas, pues, diciendo que mueres

herido de mis amores,

y á mi me parece flores

cuanto d'eso más dijeres;

Publicas que consumido

estás en fuego de amor,

y es esa para mi, flor

que pucus l'han conocido;

Dicen que te estás muriendo, que lo eausa mi acedia, 
y que la noche y el dia pasis lus aires bebiendo.

Todo eso es invencion mostríndome que te quejas, porque incline nis orejas a tu fingida aflcion.

pero porque nu te quejes de los escoge nu partidi. í el de serme á mi nuarilu $\mathrm{y}$ si llo el de que me dojos.

si le quieres admitir seril de mi mal remedio, si 110 serviril de medio para dejarme y vivir.

Con eualquier ternás reposo y podrás nutucho obligarme, 1) con dejar de cansarue ú con querer sel mi esposo.

si salyo con esta mupresa echaré in ello de ver que juntos decir y liacer tienen asiputo if to mesa.

Si 110 es tu volumtad estit dejaris de persuadirme y nu teruás que escrebirue que no aguardare respuesta.

Iaime Orts, cincuenta y tres en verso y'dos ell prosia.

\section{Glosa de eslos versos.}

Duma del bel aculer. duma del cueryo gensm. que hayudes dichu en amor si hubedes subor de amur.

Para que finque mi mal ell vos plute sois nui folgallza, dima bella e primeipal, temgo foda mi membranza pursta en el virestro hrial:

I á llu ser pur el pecar, gu' el buen lume ha de resousar, bien fleiera algumos dias con ros las barraganias, drma det bel acalar.

Magüer que estoi en prisiun por ciertos desaguisadis, unn mo afinca lia pasion de lus flerios y candadıs que acuitan mi corazon:

la) (que me causa dulup* es que como à malfechor soterrado en esla calina, non vos puedo dar el alma, llama del cuerpo gensor.

De mal talante miro mis aventuras quiza quien aqui me engarlafi; ved, señura, que farí III pellastro cullin, yo.

- Vinllureis, mi buen señur, raballero de valur. (fu' el demoniu del socos lárí ratando por rus. que hryades decha en amor.

Ia si vos un lne alvidarles en Iriza o en Cordenia, ó por do quiera que vades, la memoria de esta dueña

logrará vuestras edades;

Mas si habedes de olvidar mis cuitas y mi pesar, permita el ciclo que amedes ini asno Silta-paredes. si habcoles sabor de aman.

De este autor no he podido dar otra mues. tra, purque tolas sus composiciones son en demasia atrevidas.

Manuel Ledesma, diez y nueve en vers:) y seis en prosa.

Recogrimiento, cualro eslanzas á su nombre.

El puerto mas seguro de esta vida Y el que levanta el ánimo hasta el cielo Es el recogimiento, en quien se anida I.a quietud y la gloria d'este suelo. Ia vida bulliciosa es desahrida, Llena de confusion y de rezelo; l'ero la recogida es quich encierra Los descansados gustos de la tierra.

Los sabios qu'esta vida conocieron, Las grandezas y cortes olvidaron Y á los desiertos a vivir se fueron, A donde mil secretos alcanzaron;

I aum otros muchos príncipes que vieron Los peligrosos trances que pasaron, Cansados de adquirir cosas tan caras, Remunciaron lus cetros y tiaras.

Lidliades su reino desampara

Y en un lugar pequeño se arrincona; Augusto su corvona renunciara, Si alguno mereciera su corona; Aténis á Allaxilo curonara,

Si ell minos estimara su persona; pero vicudo que todo es desconcierto Acabaron sul vida en el desierto.

Todos tienen invidia al recogido $Y$ el á uinguno invidia sus estados; Vive sin ser de nadie perseguido, A jeno de disgustos y cuidados;

$\mathrm{Ni}$ es de los invidiosos perseguido, Que no mora la invidia en despoblados, Autes sucle alijior el que está ausente. Cun su recoginiento al maldiciente.

El Licenciado Gaspar Escolauo, cincu composiciones todas en prosa.

Evaristo Mont, treinta y cinco en verso. Sonelo.

A la muerle de su dama.

Ai de mi! que la muerte me ha quitado Con mano ailada toda mi alegria:

Ai de mi! que aquel sol que cscurecia Al de aqueste enisferio es eclipsado.

iUnicu me dijera, triste, que í un estado Tan dnlee para mi, la suerte mia tin sola aquella noche escura y fria, Diera fln y principio á mi cuidado?

Aquel divino rustro y claros ojos, Anul mirar tan dulce y tan honesto, Qui's's d'rl? á donde está que no lu v'eu? 


\section{$\mathrm{ACA}$}

l.a memoria eruel que mil enojos Me causa me quedó de todo aquesto, Con la cual $y$ conmigo aqui peleo.

EI Maestro Antouio Juan Andreu. cuatro conposicjones en prosa.

EI Maestro Gregorio Ferrer, ocho en verso y ucho en prusa.

Liras en que traluce ol himno: Christe redensptor ommium.

Cristo, que todo el mundo

Redemiste con precio inestimable,

Del Padre sill segundo

Por un modo inefable

Nacido ántes de tienıo deleznable:

Y tú, cuya luz pura

Es del Elerno padre un fiel traslado,

Esperanza sigura

De todo lo criado.

oid lo que tu pueblo ha suplicado.

Hecuerde la memoria.

Alitor de la salud, de aquel instante

Cuando llena de gloria

La Virgen $y$ triunfante,

De nuestro ser mortal te dio el semblante.

Ansi lo testifica

Aqueste dia alegre cada un año,

Por la salud que aplica

El cielo á nuestro daino,

otorgándole al suelo uil bien tamaño.

Cuanto el cielo y la tierra

Comprende dentro su estendido ruedo

Y el ancho mar encierra,

Despedido ya el miedo,

Tu fled venida alaba con denuedu.

Con este sentimiento

los que la sangre vuestra ha redimido,

A vuestro nacimiento,

Con pecho agradecido,

Hemos este nuevo himno dirigido.

Dénle al recien nacido

De la Virgen y madre omnipotente,

Al Padre y procedido

De entrambus, juntamente

Là gloria que se debe eternamente.

Don Gaspar Mlercader, treinta y siete en verso y cuatro en prosa.

\section{Estancias.}

A un galan mui favorecilo de dos damms.

No hai en la tierra cosa que te espante, No hai en el mar borrasca que te ofenda,

No hai suerte que á la tuya se adelante.

$\mathrm{Ni}$ hai bien que se te ausente ni deflenda;

Eu los hombros no iuvo cosa Atlante

Que no te ofrezca párias y pretenda

Ser de tu sujecion, ya todo es tuyo.

Ilasta yo con invidia contribuyo.

A la escasa fortuna debes tanto

Que ha tmmado á su cargu el defenderte,

Y del tiempo imagino que entretanto

l'iensa sus piés atados prometerte.
ACA

El cielo en los matizes de su manto Quiere dos nortes juntos of recerte, Y entretanto que estés en esta esfera, Dos sules que te alumbren su carrera.

Dos almas á tu gusto están rendidas, Cuyos divinos rostros enamoran. Y esperando que el llanto les impidas La competencia tuya entrambas lloran:

Yo quieren que el contento les dividas, Purque son los estremus con que aduran De impusibles de amor un imumsible,

$Y$ asi pretenden remio indivisible.

Quisose esaminar naturaleza

Y saco de la estampa uma figura, Y tanto se pagó de su bellezá, que en un puntu formó segunda hechura;

Estas, dos damas son que tu tihieza

Procuran abrasar ioh, suerte dura!

iComo permites, cielo, pueda un hombre

Cun dos damas tener de ingrato nombre:

Cualquiera de las dos tiene de bella

otro tanto que tii de renturoso.

V darí porque quicras escogella

Su pechı en quien se anide ta reposo:

si como tu pudiera merecella,

En ocasion cual esta afirmar oso. Que quisicra partirme en dos mitades Para admitir tan bellas voluntades.

D. Gaspar Vercader, vice-presidente de la Acadenia y antor del célebre y rarisino tumito intitulado Prado de Valencia , merece el que copie una segmnda composicion suya, desviandome le la regla que he seguido con casi todos sus compaúeros.

\section{carta}

de un galan ausente á una dama mudable.

A Belisa la mas bella que hai del uno al otro polo, de porte un suspiro solo y dese en sus manos della.

Dama tan hermosa $y^{*}$ bella cuanto mudable y cruel, la silud te envia aquel que i tu causa esta sin ella.

Perosi por esta via á conocer no me doi quiero que sepas quién soi el que ser tuyo solia:

Li) soi, mas no soi, menti, porfuc soi tan diferente del que era, que solamente soi lástima del que fui:

Soi quien ha sido alma tuya de tu boca, $y$ fué tan tuyo, que se olvido de ser suyo por tenerte á ti por suya: Soi el quie en pena ecedi las fuerzas del sentimiento, recibiendo por discuento no mas de penar por ti;

soi, si para te acordar estas señas no son parte, una sola quiero darte que no la podrús negar:

Io soi, dama varia $y$ bella, ui] limubre que tu olvidaste, 


\section{aCa cancioneros, romanceros, ACA}

sefa es de olvido, esta baste

para que te acuerdes della.

Que quien poco ó muclı amo

y luego quiso olvidar,

para no volver á amar,

no ha de olvidar que olvido.

Bien es verdad que imaginı

qu'el tiempo de mís favores

le pasé conligo ell flores

por no ser del fruto dino;

Y aun loi el alma con lulo

tengo de que se sccasen

tantas llores y quedasen

marchilas sin lievar fruto.

Para condenar mi intento

conflesn que culpa sobra,

pues si me falti de obra

me sobro de pensamicnlo.

Vite algun dia, Irıidora,

lágrimas por mi Horar, mas sirvieron de engendiar

las que por ti lloro agoria;

Porque entónces lus enojus

haber dado á mi alma hallo

mil mar de gloria, por dallo

agora de agua mis ojos.

Llora mi alma el bieı pasadı, siente y llora el mal presente y lo que mas lloria y siente es haberla lu engañado;

De cuyo engaño sacaste mui pequeño Iriunfo y palma, pues si me engañaste el almia

á una alına tıya engañaste:

ofuscando mi sentido

me la engañaste mejor, cubriendo el fuego de amor

con las cenizas the olvido.

Itas por no cufadarte tanto

ni eslarte agora cansandn, no más yo quedo rogamu

al cieln piadoso y santo

Que si Fideno presente

ofende tus ojos bellos,

intes de volver á vellos

te sirva muriendo ausente.

D. Cárlos Boli, duce en verso.

Bomamce. A uru dama que quis're à uno por inleres y á olro por uficion.

Dos aflciones unidas

en desiguales balanzas, del amor y el interes

us tienen cautiva el alma.

pide el amor corazones

y el interes prendas allas,

que munca tuvo instrmmento

tantu fin: $\mathrm{y}$ tantas falsas.

ioh, retrato verdadero

de la condicion humana, donde del honor la mingua

está á mui poca distancia!

solo en pecho de mujer

se pueden hallar cifridas,

las esperinzas mas nobles,

y las que soll mas villanas.

Unereis, señora, en efecto

III hombser jorluur us agrada, y un otro para que supla

d' este Narciso las faltas; uno mantiene el contento, y otru inantiene la gala, y entre los dos se sustentan la mentira y la mudanza: que mal siguras y libres fuieren con tretas voltarias, jor los pulgares al rico, $y$ al hermoso por lic cara. ioll, bolsa, (quinto elemento). d! las senoras mirladis, que con las prendas compites que soll de mas imporlancia! (1) belleza vagamumda,

con los cuer.os empatada (li: un escogido aposentu del metal que rinde Araloia ! ¿Quién vencerá de los dos en el pecho de mi dama? pero al tiempo lo remito. escribano d' esta causa. El rico y el galan medran porque en su comun posada, pari iılólatras, hai piezas, y para gentiles, salas: todos caben, Lodos viven, Lutos obran, todos ganall, y lo mas malo de todi, es ver que tidus se gastan. - Vos sola llevais en esto con manus diferenciadas, del lindo, los alfiteres, del dadivoso la capa.

Don Fullien de Castro, veiulieinco en verso y enatro en prosa.

Romance.

Poco despues qu'el aurora tras su enemiga llegase, parte febu del Oriente y Gazul furioso parte del Alhaizin de Gramada; y no furioso de valde, pues con ajenas mentiras eseurecen sus verdades: en un caballo morcillo, á quien mandó que adrezasen de monte, porque en los montes piensa reparar sus males. No sale como otras vezes galan, porque fiero sale, sin gallardele en la lanzi, sin plumas en el turbante, sin guarnecer la marlota, y el capellar semejante; sin lazo los boreeguies, sin dorar los acicates. ia tan colérico el mozo, que por los ojos le salen vivas centellas de fuego, entre lágrimas de sangre; de Zaida se va quejando $y$ de Zulema el alcaide, de sus parientes $y$ amigos, de todos cuantos le valen y le ayudan con las lenguas, y quizi porque no saben, 
ACa antologías y jestas poéticas. ACA

que para cortarlas tudas

trae afllado sil alfanje.

A vozes iba diciendo,

tan bravo como arroganle:

ya se acabó mi paciencia,

ya no hai paciencia que baste,

guárdense ho que me ofenden. y digoles que se guardeı, porrue a mas de ser quien soi, no liai ofendido cobarde.

Bien sabes, morillo triste,

ciumo te igualo en linaje,

y que en valor de personas

hal mui pocos que me igualem:

bien conoces lo que valgu,

y sabes que sé vengarme,

y que ne ufendes tambien,

y que he de matarte sabes.

Fu parcces á mis ojos,

inagino que lo haces

wirue cun mirarte soly

fuera posible acabarle;

pero advierle, muro triste,

qu' es imposilile escaparte,

que ya te busca Gazul,

huye lejos, guarte, guarte:

huye con liempo si puedes.

y mira no acuerdes tarde,

y advierte que huyan tambien

ins consejerus infames,

que pues rue ofendieron todos,

laré porque no se alabeu

que nii mengua con sus vidas

a un mismo tiempo se acillus.

Que si el fuego de mi pecho

se lleva volando el aire,

lia de ser segunda Troya

- Ciranada y sus arrabales.

¡il, Zaida, infame eneniga!

nuejor dijera mudable,

mis pues me infama tu guslo

bien puedo llamarte infanc.

Gue te ha movido, cruel,

il quererme $\mathrm{y}$ adorarme

palla midalue tan prestı,

afrencirte $y$ afrentarme?

Vo siento el ver que nie lejis,

pues me honras cull dejalnue,

nias que falsa te perjures

y fenuentido me llames.

Esto el alma me lasiini

y ell mis entrañas esparce

IIn rejalgar, un veneno.

compuesto de mis pesares.

- Esis dijo, y un suspiro

acabó sus libertades:

y en un campo del camin!)

nui puco espacio distante,

lijeru se auea y sienta

entre verdes arrayanes,

porque descanse el caballi,

y persamientos le cansen.

ki) celebirrinu D. Fuillen de castro. el conocido autor de las Mozedades del Cid nu debe ser menns que D. Bernardo Catalan, el canonigo Tárrega o D. Gaspar Vercader: pul lo misıno tanibien daré cabida á dos de sus composiciones.
Cuartetos.

A lina dama en boca de un ga'an que le tomó una cinla de los chapines.

A lal gusto me provoca este subido interes, que porque le vi en tus piés uo le aparto de mi bocd,

biciendi con vivo ardor elevado el pensamiento, quẻ dichoso atrevimiento! unc gustos tiene el amor?

Oue venturosos despojos! qué gloria que me ofreci! quien, sin quitarle de alli, pudiera darle los ojos!

Que de milagros que viera ! qué buend suerte alcanzara! qué de penas olvidara! qué de gloria que sintiera !

l'ero en tan felize bien, annque fueran ojos buenos, la boca se hallara ménos y aun otra cosa tambien: (jue tanto gusto alesora In que vellgo à imaginar, que la quisiera gozar como la contemplo agora.

Con estas quimeras cuyas snn, Flora, mis alegrias, y con estas glorias nias porque son memorids tuyas, Vivo contento, pues es cierta opinion de amadores, que anuncian bien los farnres que cumieuzan por los pies:

I llu es vano pensamiento Inie la dama por ser palma, si los quiere dar del alma lis pida al entendimiento;

l csle en la cabeza vive $y$ los favores que asoma inn la vislunted le toma y los da á quien lu recibe. Cuandis por los pies empieza

i dar un favor crecido, (ları) estil que halorá venido á los piés de la cabeza;

Y el dichosin enamorado the il reccbille vendri, llas el favor subirá lı mismon quíl ha bajado, I rom gusln peregrino gustari sin intervalos, (l)éctar de sus regalos ell las benlas del camino:

Cuyas dulzuras no cuente si ii iupnsibles no se obliga, Iengua humana que lo itiga cmino en el alma se siente.

Dichnso yo pues llegue i un bien din ni bien consiste, Ine aunque tii nn me le diste simo que yo le tomi,

Del recelir al tomar

diferencia no he de hacer, porque favor suele ser el consentir romo el dar.

$Y$ asi de contenlu ltopo nis glorias adevinando, 
y esta cinta estoi besando de los chapines que adoro.

Y bien puedo sin rezelo esperar sabrosos flues, porque serán tus chapines la escalera de tu cielo.

D. Francisco de Castro, dos en verso. Glosa.

El mayor mal por la mayor bellesa.

Hasta poner los ojos en tu ciclo, sin temer que tu luz me cegaria, Me levantó con altanero vilelo

Con alas de esperamza la fí mia.

Y pues á levantarme desile el suelo

A mirar tu belleza dió osalia,

Tambien para sufrir dará flrmeza

El mayor mal por la mayor bellesa.

Que sea el mayor mal está probado, pues me viene a probar la nuyor gluria, Que ni el gusto de estar bien empleado Ne atrevo á revolver en la menioria;

Porque mi merecer, considerado Con ser tu gentileza tan notoria, Me trae á padecer por lu aspereza, El mayor mal por la muyor bellezas.

Mas aunque es como digo ni tormento Tan grande como fuere tu hermosura, No me podrá impedir aquel contento Qu' el haberte mirado me asigura;

$\mathrm{Y}$ pues eres del bien y mal que siento la causa, favorece á mi veutura, Que lograrás, si ablandas tu diréza, El mayor mal por la mayor belleza.

Pero si solo atormentarme tienes, Ruégote mis tormentos sean tales Que muestren proceder de tus desdenes, Llegando á ser con tu hermosura iguales:

Que pues no he de esperar mayores bienes, Tendré por grande alivio de mis males, Ver que me viene á dar naturaleza El mayor mal por la mayor belleza.

Lopez Maldonado, nueve en verso y una en prosa.

\section{Salira contra las mujeres flacas.}

Mandar satirizar á quien condena Las sátiras á eterno y vivo fuego, Rigor es nuevo de tormento y pena, Y más si alli perdio su fuerza el ruego; Mas quien lo manda ha puesto tal eadena Sobre mi voluntad, que á mi me niego Mi propia inclinacion, y en sacriflcio ufrece la oberliencia del servicio.

t'erdonadme por Dios, señor as mias, Las que de flacas pareceis lanzetas, Las que de vivás servis de anatomias, Y de nowe de hierros de saetas; Ias tule Leneis las tripas tan vacias Gue se han lomado thacas lurjolelas, ifui buenis para huesos de catvario, Sirviendo el espinazo de rosario.

Sabe lios lo que siento en este paso

bo mo ha traido mi fortuma fiera,

Nas la cubediencia y la verdad del caso
Me fuerzan á que hable aunque no quiera.

El somético A polo y su parnaso

Contra vos veo levantar bandera,

Y la lasciva vénus os contrasta

Con todos sus secuazes, véd si basta.

Dice la bella vénus, que no es justo

Que unos huesos sin carne ú carne poca.

ocupar quieran el venereo gusto

Que á la rolliza y dulce carne toca:

Jípiter lo reprueha por injusto,

Pues nunca ocupó manos, piernas, boca, Sino en mozuelas tiernas garrofales

Inyendo de palotes de atabales.

I sin esto, si bien consideramos

El nombre de flaqueza entenderemos, Oue cuantas cosas malas confesamos

Con este nonbre discurrir podremos;

Si por cobarde á un homlire reputamus, Que tiene flaco el corazon diremos,

I. carne flaca el apetito quita

Y íntes á vomitar que á gusto incita.

Si el año es malo, luego alli decimos

Que la cogida flaca fué y lijera,

Y á las que hablar en la fantasma vimos,

Mui larora y flaca nos predican que cra;

Si porfiar á algun idiota oimos

Con algun docto, pena dura y flera,

Al sabio le decimos, dale, dale,

Qu' es flaca la razon de que se vale.

I aquel que de pobreza es oprimido Y por ella de todos desechado,

Decimos que va flaco su partido,

Por mas que sea discreto y muy honrado;

Este por su flaqueza es abatido

De todos y anu de si desestimado,

Que flaqueza de bolsa es cáncer fuerte,

Que da mil muertes no una sola inuerte

Reniego, pues, de la señora flaca

Y de quien quiere ser su prisionero, Que es lo mismo que serlo de una haca

Criada á la dieta del buldero,

Y conı estar atado de una estaca

De seco minbre ó palo mas ligero,

Que al tiempo de la dulce coyuntura

Temeis que ha de quebrar por la cintura.

Pues ver unas cavernas escondidas

Entre dos tlacos postes puntiagudos,

Que os dan si alli llegais fleras heridas

Aunque lleveis de acero los escudos;

las fuertes lanzas con razon temidas

Funca tuvieron hierros tan agudos,

Ni pusieron á nadie en tal trabajo

Comno una pierna que es toda zancajo.

Qné es ver una señora muy compuesta, Que solme los vestidos los cuadriles silen á hacer á nuestros ojos flesta,

Sin que ropas lo encubran ni monjiles;

Pueden hacer cureñas de ballesta

ne los momdados huesos mujeriles,

$Y$ es Io misino que ver una azagaya

Vestida, en el solaz, de cuera y saya.

Señorias tlacas, las que atentamente

A mi pesar leyéredes mis versos,

Yo os demando perdon humildemente,

Bien que no son de la verdad diversos:

Un tiempo fui cofrade y penitente

I) vuestros casos prósperos ó adversos,

Teniéndolos en dulce y sumo precio

$U$ de inui sensual ú de mui necio. 


\section{ACA antologías y jestas poéticas. ACA}

Don Tomas de Villanwera, diez y seis en verso y una en prosa.

Sdira al desden de una señora.

A dỏnde piensas llegar,

Belisa, con tus desdenes

si son cansa de mis bienes

tu melindre $y$ desdcnar?

Si desdeñosa te adoro

y te ofendes adorada,

no te muestres enojada

porque d' eso me enamoro.

Refrena el desden severı.

bella ingrata, y considera,

qu' el hacer que no te quiera

es por donde más te quiero.

Tienes tal rostro enojado

para mi qu'es mi consuelo.

qu'en estando alegre el ciclo

es su perfeto traslado.

Con acciones zahareñas

tan de veras me enainoras.

que imagino que me adoras

al tiempo que me desdeñas;

$Y$ aunque pudiera vivir

contento con este engaño, quicro tanto huir tu daño que te lo quiero decir.

Aviso qu'es mi regalo

desden que nunca me ofende, y que ini volcan enciende

esu que tienes por malo.

Mira si te quiero bien.

$y$ si es bien que me destruyas,

pues en alabanzas suyas

hago sálira al desdeı.

Pelegrin Catalan, cuatro en verso y una.en prosa.

No me parece digna de imprimirse ninguna de las composiciones puéticas.

Don Mallas Fajardo, cinco ell verso. Bomence.

En alabanza de la avellane.

Eutre las cosas criadas

es conucida certeza,

que las de mayor valor

son las que mas sr nos vedan.

li ansi para que se gozen

uro, plata, perla o piedras.

e's menester se penetren

las entrañas de la tierra;

y no solo en los metales.

pues en las plantas y yerbas, guarda este mesmo concierto

la sabia naturaleza:

pues zelosa de los frutos

que mas virtudes encierran.

mostrando querer guardallas,

les da mas recia corteza.

Y asi viendio en la avellana

tan sin número escelencias,

porque esté ménos á mano,

la cubre con tres cubiertas;

y para que unas con otras

se aconıpañen y dellendan, las produce de ordinario

muchas juntas de conserva:

y sin esta, hay de su parte

otra más bastante prueba,

y es á lo que están sujetos

los frutos de mas flneza:

pues el membrillo á un gusano,

y á un pájaro la cereza,

y ansi todos los denás

tieneu quien se les atrera.

solamente la avellana,

conno mucho de más cuenta,

tan solo para el servicio

de los humbres se reserva;

dice alguno que la zorra

supo gustalla y comella,

y si es asi, por aquesto

tan buen renombre le queda

I cuando estas alabanzas

no sean de subsistencia,

diganlo debilitados

pues saben para que presta.

El Uaestro Gaspar Graclan, solo tiene seis composiciones en prosa.

Tomas Cerdan de Tallada, diez $y$ ochts en verso.

Me habia propuesto dar como muestra una sola conposicinn de cada autor; pero respec(i) a 0 . Tumas Cerdan me separo de esta recla, insertando cuatro en rez de una, porque nuestros bibliografos no solo no citan ningurl escriti suyo en verso, sino que ni alll menciollan fuera poeta. Creo sin embargo, que lus tres romances y el romaneillo siguieutes, darán il conocer no haber sido indigno de alternar con Gaspar de Aguilar, Guillen de Castro, Rei de Artieda y los demas.

\section{Roinance.}

A una gloria perdida.

$A$ las templadas riberas qucel alegre Turia baña, pur el cielo defendidas de las menudas escarchas, coil destemplado rabel y con pasion destemplada, sale kiselio, un pastor que entre los hielus se abrasa. sale a llorar, mas no sale, intes la pasion le saca de la choza el cuerpo triste, y del triste cuerpo el alma; * sacando á vueltas d' ella sus mal furmadas palabras, dice con acentos tristes salidos de las entrañas: bella Tirse de mis ojos, pues la furtuna me aparta de lus regalados bienes que en tu presencia gozaba, quiero con lágrimas tristes sulemnizando mis ansias. llorando bienes perdidos sentir la pena ganada. Pace sin dueño el rebano por las dehesas vedadas, 
y pues pierdo lo que gano perdido el ganado vaya. Miraba tus bellos ojos; pero la fortuma ingrata mudó mi suerte dichosa con su ordinaria mudanza. Para ol ros desdichados Son vanas las esperanzis, mas para mi, p'u mas pend, las posesioues soll vanas. Dejome en tinjebla escura, pues á ui pesar les falta i los tristes ojos mios el bello sol de tu cara. -Esto dijo, y arrojando cayado y rabel al agua, se volvió á sus mudas quejas porque del hablar se cansa.

\section{Romance.}

A un pensumienlo.

Fiado en lubregas sombras que la ausencia de los rayos del rubio Apolo causaba, por las selvas y los eampos con el traje diferente la negra noche alabando, entra en Gramada cubierto el desterrado Albayaldos, huyendo las anchas plazas angostas calles cruzando a la calle va de Zajua con prestos y largos pasos; la Mora que le conoce con gozo y con soliresalto de verle y que no le vean le habla con tono bajo. - Albayaldos de mi vida. bien logra Tarfe su engaīn pues tiene á Zaida enterrada y á Albayaldos desterrado. Mas ay! como te asiguras teniéndole por contrario, qu'es Tarfe alcaide y podria costarnos caro este rato. - For Nahoma, dice el moro que de mi flema me espanto, porque siento tu temor y doblados mis agravius. No temais, mi bien, que vengo de cristiano disfrazado, $y$ yo se bien que ese moro teme de ver los cristianos; aunque, por Alá bendito, que en lo que digo me engaino, que no puede temer nada el que no teme á Albayaldos. Pero pasen sus trajciones, que yo espero con mis manos el rebelde corazon sacarle del pecho falso; pues agravia á moros nubles en sus poderes confiado, y con engaños sustenta su mal adquirido corgo. Si no temiera el perderte, para mostrar lo que valgo, iria luego á topalle y hacelle luegro pedazos: mas si quieres encubrirme esconde tus ojos claros, ó á los que vengan coll il deslumbralos con mirallos; y recógeme en tu cielo, que si vivo desterrado, bien cumplo el destierro mio cstando en tu cielo santo. -Esto dice el moro apénaș, cuaudo por la calle abijo rondando baja el Aleajde, por ver si puede encontiallo; y la bella Zajda al punto, sin que lo estorbe el desmayo que le causa el conocer el tropel de sus contrarios, dando de mano al decoro, para tenerle celado, le da acogida en su casa y luego en su pecho casto. Y amor á los dos amantes concede tiernos regalos, para mostrar que no sienupre es, como dicen, ingrato.

\section{Romance.}

A unı Clama que un capilan la llevaba por fuersa d la gueria.

Un otro sigundo Páris, qu' en otra apacible noche pudo robar otra Elena, al mar con ella se acoge, y aunque forzada la embarca en sus galeras velozes y sin tocar leva manda il los forzados que voguen, y clla en la popa arrojada se queja con roncas vozes del capitan que la tiene por miedo que no se arroje. - ¿Dónde me llevas, le dice capitan de sin razones, á la guerra de mis gustos y á la paz de tus favores? ¿Porque fuerzas voluntades, pues por mi daño conoces qu'el forzar la voluntad no es de hidalgos corazones? ¿No miras que no estará eternamente conforme, la terneza del amor, y la dureza del bronce? Sin duda, trajdor, que tengo razon, pues tanto te encojes: ¡Mal haya mujer que amor en advenedizos pone! No imagines, fementido, que podrás llevarme á donde, sin rezelo de perderme, al gusto tuyo me gozes; que solo por agraviarte, aunque deshonre mi nombre, con tu mayor enemigo he de hacerte más, traiciones: y ruego al cielo en castigo, que cuando las armas tomes para cobrar honra y fama, deshonor é infamia cobres; y que á vista de los tuyos si á empresa famosa corres, 
- temas do suerte al coutrario que avergonzado te tornes; y que por hechns infames a tu linaje deshonres, con viles tratus de cuerda tus lascivos brazos dohlen; y permita el ciclo santo que á tus delitos atrozes, amotinadus suldados. les den castigos enormes. Tú, mar, que tus fuerte ulas en los altos riscos rumpes. ¡porqué esta frágil galera cual otras muchas no sorbes? iporqué no das sepultura ¿ este, infamia de los humlıres? Mas no querrá ser tu centro sepoltura de traidores: y si por esto le dejas no hai porque á mi me perdones, haz que me ahogiten tus aguas $\dot{o}$ que mi llanto me ahogue. - Eslo rabiando le dice, mas como ya la conoce, el mudo capitan deja que su colera desfingue.

\section{Konnancillo en boca de un galan derdichulu.}

Nina de mi alma, pues llamarte mia no puedo por ser tanta mi desdicha, llamareme tuyo, por unas que lo impida contraria influencia de estrella enemiga. Presta tus oidos $\dot{a}$ las quejas mias, seris menos flera si llegas à oirlas. - Tuyo he sido siempre despues que vi un dia de tus bellos ojos las azules niñas; el amor ingrato entro por la vista, porque como es niño entra por las niñas. lo te vi en la flesta que los de la villa, cun varios disfrazes, sus penas alivian: y aunque al ver tus ojus, dos caras traia. agura en la propia traigu el alma escrita. Segui tus pisadas con varias fatigas, porque el alma adora la tierra que pisas. Persiguiome amor que tu pecho entibia con largas ausencias que acortan mis dias: y tú con tormentosmudarme porfias porque es tu flereza cual la suya misma. Pero no pudrás, aunque me persigas, apagar la llama que quedo encendida: que ántes de los rios irán hảcia arriba las recias corrientes de sus aguas frias, $y$ el sil, que ell su ciursy lijero camina, pararí priwern que no la fé nlia. Y en efeto, Tirse, primero la vida perderé, si ag:ra nı está ya perdida, intes que se apaguc el fuegi) que atizan in mucha belleza y mi poca dicha.

Don Gulllen Ramon Catalan, once en verso.

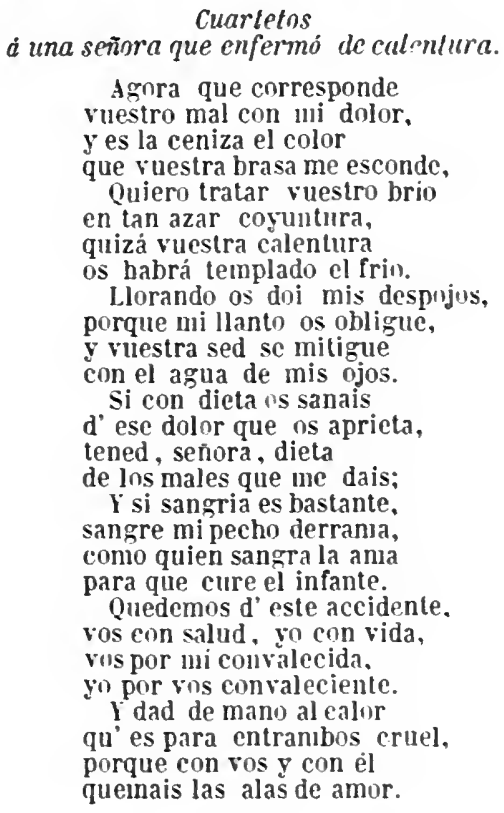

EI capitan Andres, Hei de Irtieda, doce en verso y una ell prosa.

Glosa.

Criando ho desdichas min pienso que se han de ucubur. se ruelien à comenzar.

Con tantas veras me entreg,

á tu potencia y rigor.

que al último estremin llego

de los martirios de anm, que son fuegu sobre fuego. 
Crece el fuego con los dias, con tu desden mis porfias, con tu libertad mis danos, y acuden los desenganos cuando las desdichas miats.

Este es el mayor despecho, y la pasion mas aguda que lile descompone el pecho, ver que el desengaño aculat ('uandi) ya no es de proverho.

Modérase esle pesar. cuando juntos a la par yo y las pasiones que digo, il abiando yo commigu, pienso que se han de acubur.

Eutretanto, puesto caso) que eontra toda lei vivo, ('s el placer tan escaso y el pesar tan escesivo, file lin sé como lo paso;

pues conno ondas que en el mar van y vienen sin parar, si se consumen algunas, mis desdichas y fortumas se vituten á comenzar.

Don Jalma de Aguifar, mal ch verso que es la siguienle:

Cuarlclis de wil. galan ausente: quejas.

Tan insufrible dolencia con vida que tanto tura, es vivir en scpoltura el piciligo de una ausencia.

Tantos daños se me ofrecen $\mathrm{y}$ á mis cuidados combaten, que cual milanos se abaten cuanto esperanzas feriecen.

En zelos se convirtieron cuando de ti me ausentaron, pues mis bienes se volaron trats el gustı que tuvieron.

I cono tan agradable sea a lis dimas lo nuevo, respel de que lo priebo tino mi fin niserable:

(une como me veo ausente de ti, mi cruel ingrata, el no mostrárteme grata llevo en los ojos presente.

Teligin zelis con razon, pues cuando presente estaba, de ti un se asiguraba si pulial el rorizon.

iQme hare, triste de mi, si mi diado ha permitidn (que muera yo consumido, y nunera ausente de ti!

Sospecho que estás nujada y esto vive en mí de sucrte, qui: we entreticne la muerte for darme pena doblada.
Pedro Vicente Giner, treinta y una en verso y dos en prosa.

\section{Cuartetos.}

A un galan que envió d una scñora un ranillete de violetas.

Viuletas venlurosas, si llegáredes á manos de la que entre los lumanos es de las mis poderosas;

Ya que indignu de guzarlas es cualquicra criatura, si cupiere en ni ventura tal dama quiera aceptarlas.

Reina de uni pensanientı, á quien tinlo ha que yo adoro, en cuenta de incienso y oro reccbid ni atrevimiento:

Nirra $n o$ os osı of recer que á los mortales se ofrece, el corazon que padece os doi si no ha de ofender.

Dedicome todo á vos denlro d'ese ramillete, que el que se humilla y somele, justo es que le ayude Dios.

Mucho tiempo ha, Diosa, os miro y trasportado en miraros par'a en mi alma retrataros, toula la vida suspiro;

I' no sé si sé entenderme cuando me volveis el rostro, pienso, pues que no, soi monstro, es querer fivorecerme.

cual César eché la suerte, conflado en mi ventura, pstes seria gran locura darme yo mismo la muerte: Sill estar desengañado de que vos querais matarme, pues las muestras son de amarme ellalldo mas soi desechado.

P'rimero da el árbol flor (que no el fruto que se espera, y primero desespera IIIC da esperanza el amor.

P'ues lo que de mi os espanta, mis suspiros son bramidos en que fueron convertidos los del otro y Atalanta.

Ramo suave, oloroso, Ileno de fragancia y flores, los poelas y pintores os celcbren por dichoso.

Don Gullien Relvis, cinco $e^{*}$, erso.

Redomdillas á unu señora pue se levanló mui lrisle dè lólumo.

No sć que causa tuviste, ¡ai, señora malograda! para levantarte tristc, descontenta y enfadada del tálamo en que dormiste. 
No puedo clerto pensar en este caso y lugar, sino que de tu belleza alguna casta limpieza tu cuyo quiso guardar.

V esta no yor perflcion que dar quisiese á su vida, que es otra mi opinion, sino por falta escundida de su floja complicion;

D' esto se me allena el pecho y aquesto solo sospecho, que cuando otro sucediera, tu semblante amaneciera mas alegre y satisfecho.

I si csta fué tu querella, con gran razon la tomaste. y aun puedes siempre tenella, porque lii no te casaste para quedarte doncella.

Antes por poder saber que es un licito placer: mas hallaste, segun creo, al reves de tu deseo

un perpetio desplacer.

Ia figuro desde aqui el discurso que hacias la noche intes ;ai de ti! y como entre ti decias: ¿sin suerte porqué naci?

Pensábame yo adquirir con casarme un buen vivir ó á lo ménos un buen año; mas he adquirido un mal añ que me entregará al morir.

Hallabas de cien en cien varias imaginaciones. y acordabaste tambien, de los ruegos y estaciones que hiciste por casar bien.

Véyaste despues presente, ¡ai, hado duro inclemente! al hermoso lado tuyo, solo una sombra de cuyo, que no es más un impotente.

Dábasle tu blanca mano viendole estar tan marchito, mostrábasle el pecho humano por movelle el apetito; pero todo te era en vano:

Y asi en esta coyuntura, qué unucho que tu cordura trocada no te trujese, a desear que te fuese el tảlamo sepoltura.

Causa, pues, tuvo bastante tu tristeza desigual, y la tendrá semejante siempre y cuandi monstro tal se te ofreciere delante.

El que con él te casó ten pur cierto que lo erro, y aunque á tu parte algo caya con razon diras: mal haya, quien aqueste tal amó.
Derónimo de Mora, siete en verso.

\section{Cuatro eslanzas a un galan que dejaba de visitar d su duma para amartelalla.}

Tus amigos, Artemio, me han contado Que sigues con amor fllosofia, I de suerte el sujeto me ha brindado Que te escribo, y es ln mas que hacer podia: Tinta, pluma y papel hoi he tomado, Pur recordar la musa que dormia Dus años ha en brazos de Morfeo:

Nuta la fucrza de ini buen deseo.

Dijéronme, que adrede te retiras De tu Leonarda porque asi pretendes Amartelalla; mas si bien lo nuiras, Sufístico remedio es el que emprendes si el puntio que sin ella estás suspiras, IIuvendo d'ella nueva llama enciendes, Y lias que si mujer alguna ama Es al que tiene al lado en mesa ó cama.

Porque en ausencia son antojadizas, Frágiles de memoria, y si las dejas, Al gusto le espoleas y le atizas A darte de Moisen dis sobreorejas; I además de que á ti te martirizas, Haces que olvide tus costumbres viejas, Que te pierda el respeto.y preste aidu A huesped qne despues sea preferido.

Andar con privaciones de apetito Con gente que lo tiene tan dispuesto, Es vano proceder en infunito,

Para quedar al fin, humbre, becho un cesto: Todo lo que Aristuteles ha escrito, Vale, Artemio, una paja para esto: Lu que has de hacer, es ir y risitalla, Que no se vence huyendo la batalla.

Estacio Gironella, catorce en vers!y y una en prosa.

\section{Estancizs.}

Despidiéndose de la Acadernia y de Florisa.

Menalio el sin rentura y sin contento, En quien probó fortuna sus rigores Creciendo de contino su tormento, Haciendole gustar mil sinsabores, perdido ya del todo el sufrimiento, I del todo olvidados sus amores; Por no volver á la pasada pena Deternina partirse a tierra ajena.

I porque no se aparte de estorballe Vada si pretension y justo intento, Y de su buen propósito apartalle Itudando su acertado pensamiento; Porque puede Florisa retiralle ne aqueste provechoso apartamiento, Determina partir sin que le vea, Qu'es lo que mas le importa y mas desea.

I hubiera ya partido, mas espera D'esta ilustre Academia y compania Licencia para entrar en la carrera Que á su perdida libertad le guia: Piensa gastar la dulce primavera 
(inl crecidu contento y alegria,

pues fenceieron sus pasados males,

Sus torinentos, y penas desiguales.

licencia y perdon pide juntamente A este colrtiave insigne, do se encierra Todo el saber que enitre la humana gente hepartio el crialder de cielo y tierra; cayo valor la fama laulo ammenle, (Que anuque quiera el ulvido dalles guerra, Nu pueda escurecer sul nombre y gloria, Vas quede para siempre su menuria.

Quede com bios tambien Florisa bella (iuc solia ser humlure de mis ujos. Gile ya murio en mi pecho su centella Y acibo sulesden y mis enojos: QIIC ('I mi cimazon hacen poca inclla sts osadas quineras, sus anlujus, the tencr libertad me alabo y precin, lues es quien no la lienc ó luco ó necio.

Ya acabarou mis penas y cuidados Por haber sido mal agradecidos, Ia mis amores quedan ulvidados, la vuelvo í ser señor de mis semlidos; Itucho liempo los Iuve enajenalos Y Iras su gis(i) y volumlad perdidos, llas ya coble la libertin perdidil Colmando mevo ser y meva vida.

\section{Luls Ferrer, once en verso.}

Cuurtetos.

Ourjus de un galan a quien no correspondiu su damere.

Pues se acaban ya mis dias gidıle, senora, un poro, mo querais que muera loco, pues lo fui de fantasias;

Con cllas muero gozoso

porque deciros podré, une no ume faltó la fé aunque no fui venturoso.

si es viestro gusto que muera, qué mayor bien que morir, pues no alcanze con vivir que me eseuchasen siquiera.

I pues se allega la hora, quiero ser cisne en mi muerte, porque fortuna me advierte que me escuchareis agora.

Sojs ingrata cuanto bella, $y$ al ciclo santo le ruego, que cual me enciendo en mi fuegu, prenda en vos otra centella:

$Y$ aun de vuestra crucldad slli ulla razon dirć, que no ha aprovechado fc, amor, ni importunidad.

$Y$ si en alguna ocasion lwiste de nil un rezcli, porngo por tesligo al cielo de mi sencilla afleion;

Si os engañaron divisas, seinora, tened por cierto, yoe soi cual el fenix muerto une vivo entre mis cenizas.
Séd en mi muerte piadosa, considerad que habeis sido la luz que me lia consumido, cual suele a la mariposa.

Solo os quiero suplicar, que si us acordais de mi, que mireis que me perdi por do me pensé ganai:

Y coumo ell vuestra memoria tenga vivo acogimiento, mueri con mayor contento coll esperanzas de gloria.

No nie temgas, muerle, un calma, déjame luego partir, á ver si podré vivir donde vivirí uni alına.

Vere si vilestras durezas, aunque son lan de diananle, en fe de mi amor ennstante se ablindan con mis teruezas.

El Doctor Juan Andres Núñez, trece en verso y dos en prosa.

\section{Romance á un pensamienio.}

Un moro gallardo sale en unas fiestas que ordena, por las pazes de Beichite, Mule-Azen rei de Valencia. No solemniza las pazes, ni deja cl traje de guerra hasta que Zelinda trate de sus pasiones la tregua. Sale el gallardo Alatior en un caballo a la vega hista donde el manso Turia con sus claras aguas ricga, que quiere ver à Zelinda ánles que vaya á la fiesta, que suele mirar el rio desile un balcon de la reina. Zeloso el rei la entretiene donde Alatar no la vea, que de qu'cl moro la adora le lastima una sospcelia. Ni alza al balcon los ojos, ni mira si alli la deja, que contemplándola el alına sienpre prisente la lleva: hista que el caballo pára, $\mathrm{y}$ aunque le aflige la espuela entretiene el pensamiento del moro que al ciclo vuela. Ivelto en si, vuelve los ojos y dice: bien es que vuelvan y que te miren, Zelinda, los ojos que tuyos eran; $y$ pues los que son del aima siempre cl retrato contemplan, hagan, si es l'original, conforme el retrato prueba; porque estos que ves delanie en tu servicio se emplean, y con lágrimas sin fin mi triste ausencia celebran. Sé que te adora mi rei, scnora, y de mi te ausenta 


\section{ACA antologias y uUstas róticas. ACA}

sin pensar que crece amor

más sin mudanza en ausencia;

escondate que mis ojos

lo más secreti) poneiran,

J el alma que te entregué

ni te olvida ni te deja.

SI verde marlota visto, siendo mi esperanza muerta, es porque esperando plenso nırir o rer que me quleras. L'Almaizar azul y pardo te darán bastante iniestra de la pena que padezco y mi zelosa sospecha; pl cielo en tu numbre llevo ell uni adarga por empresa, y por letra he de gozallo, aunque el rei cierre la puerta. Armas no pienso dejallas, pues en mi tura la guerra, cue el rei que concierta pazes la de los dus desconcierta. A Dios, hermosa Zelinda, que mi desgracia me muestra señas, que ofenden al rei mi atrevimiento y sus quejas. Con esto parte rolando Poruue no empiezen la flesta, donde le esperan sus deudos y sus desdichas le esperan.

El siguiente romance del mismo vủinez ln inserto por ser continuacion del anterior.

Empezada ya la fiesta y ordenadas sus cuadrillas, viselve el gallardo Alatar al balcon do vió á Zelinda; in porque esperaba vella pues se la encubre la envidia del zeloso rei que quiere que ausente sin ella viva: llegado mira el balcon que sil pena pronostica, y á las zelosas paredes que el sol de Zelinda eclipsan, les dice cada hora:

puredes hisles, qu'es ile mi señora?

Sepulers del bien que invidio y el rei de invidia me quita, en contemplaros paredes mis ojus su gloría cifran; c'erraís á mi bien las puertas, priváisme de mi alegria, derribais el pensamienti de la cumbre de su silla; y pues callsiis tanto mal daisse ocasion que me aflija, y el pensamientó á los njos que de lu serreto os pidan, les dice calla hora: paredes tristes, qu'es de mi smĩm?a?

Fin esto calló Alatar, y aunque enmudece suspira, sobreserito de la pena que lleva en el alma escritn: mira cual la triste Herı, unil linz que resincita que la eclipsan las paredes, aunque es el sol de Zelinda; nira una belleza en ellas. que á la de Zelinda Imita, y por aquesta ocasion con que de nuevo le obligan, les dice cuda hora: paredes lristes, qu'es de mi señora?

A pénas tiende los ojos cuando tristes los retira, de miedo que ffende al rei aun si las paredes mira: $y$ asi pues que cun miraris del reí se ofende la vista, de la presencia el temnr me hace que me despida. Y íntes de partirse á vozes, dujala el alma ofendida. à las que su bien encubren y de Zelinda le privan, les dice cada hora:

paredes trisles, "lu'es de mi seniora?

Iernando de Balda, diez en verso. Glosa.

Mi porfia hastu la muerle.

vinea el premio de gozarte dió, bella Laura, valor í la fuerza de adorarte, no cupn en suerte de amor la que yo tuve en amarte.

vunca entendi de mi suerte que pudiese merecerte, y como premio no espera, amindote persevera ini porfia hasta la muerle.

Aunque sospecho, señora, que comn la voluntad es del alma que te adora, gozará en su eternidad lo que á tu causa atesora:

I aunque el cielo descincierte las ocasiones de verte, muerto te vendré á adorar. quie no solo ha de durar mi posfü haslu la muerle.

$r$ el corazon afligido que tanbien por til ocasion vive sujeto y rendido, de l'alına la sinrazon llora y teme su partido;

Que si muerto ha de perderte no quiere que el alma arierte, ni que on tu hien se eternize. ansi gne me basta, dief. imi porfía hasta la muerle.

Pero el alma aficionada de tII diviua hermosura, ni este concierto le agrada, pues en tu imagen procura ver su gloria levantada;

r dice, que es caso fuerte pretender que ha de ofenderte, que eterno amor te asigure, annque solamente dure mi porfin haslu la muerle. 
Pero tu, ingrata, no sientes de guerra tan desigmal lus giaves inconvenientes, pues procurando mi nual ell mj gloria no consientes;

Y ani yo por oluedecerte profmo mi mal, y advielte, jue si amone tamto te ohliga, i. para cluc quibes que siug mi jorfiu lusta la mu'rte?

\section{Micer Juan José Martí, seis en verso.}

\section{. Mebunza de la tcademia en esurrijulos.}

Retumben ecos de sonoros dictilos Medidus versos con flmal trisilabo, Rompa de mi sonoru acento el impetu Los elementos purns y difíanos: l.legue mi voz, dejandu el suelo espérico, A lo el crespo aleman, el negro etiope I el orbe ciño cour redondu circulo. Justre, sibin y generuso conclave, ormato y gloria de la antigua máquina, Ante cuyo valor mis versos himiles son cual delante al sol menudos itumos; Para complir con lo que dice el titulo, Refonociendo yo mis fuerzas débiles, solo me anima vuestro ser magnamimo, Purque en tan ancho mar y largo pielago" Teme mi rota nave escollo o remura; Y pues emprendo cosas tam difieiles, El nombre de atrevido es í propúsito. Con mas velozidad la fama aliogera Esparce vuestris glorias, tam sin limite losele donde el planeta mas tianifero Tumala posta pur camino imróguito, Ilasta donde da fin al curso ripido, Mostrando esta deademia ser mas cilebre (Vu' el cámopo de Atenas tan heruico, Ni el pritimeo y licen fimosisimos, Vi el celebrato críneo corintiaco. Aqui florecen singulares juvenes, QII' exceden sumamente en l' arte comico Al estremado en él llamado Euripides, En raciocinacioues á Aristóteles, En filosofia natural á Empédocles, F en la divina sciencia al grave irigenes. Aqui de Clio esti el narrar histiorico, Y de la sabia Euterpe matemáticas, be Polimnia facumdia en verso exámetro, lle Molpumene azucarada música, be Lrania astrolugia, $y$ de Caliope l.a cousonancia $y$ el furor poctico, V de las ofras musas lo mas únice. le Helicuna y Parmaso ocupa el termino Esta jumta dichosa, cuyo espiritu Ireju del orle todis el resto atónito: Quien esto no conoce es un sacrílego, lor no llamarle de una recua acémila, Aunqu'este nombre í él l'es mas sinónimo. Vo llegará á alıbar ningun relórico J' esta congregacion la parte minima, si bien en arudeza es un Calímaco; Virád que pudrá hacer el que es un bárbaro, ()ne atufue me sobra atreviniento y injmu, Fillan razomes a mi verso bético Que muestren de mi pecho lo mas intimo,
Y asi parezeo bachiller de estómago.

Soi cual ante kilipo el gran bemistenes, Que habiendo de orar quedò cual rústico

Hecho bien del silencio 11 mudo simbolo;

Este delante un rei mui poco plático,

Mas yo ante muchos de lis sciencia epilogos

A qujen debajo el estrellado comeavo

Nadic iguala del ártico al antírtico.

Más digno cada cual de rica estátua

Que Armudio ni hemelrio, el mo bélico

Y el otro aventajado en lo politien,

A quien dió estaluas de luzidos mármoles

La ateniense singular república:

Librola el umo del rigor tibílice.

y' gobernola el utr* el año décimo

Desule el primero que caluenzó al número.

Vusutros de la patria sois carbínculos

Y ell eonfederacion y liga uminime,

poncis su numbre en el estradu olimpico.

Feliz Valencia, pues en el catílogo

De sus hijos os pune cual fllosofus,

Con estremado gozo y mevo jubil.

Dijera mada, anuque escribiera un código,

Y asi usando de mi usada prítica,

Que se rogula aỉ tirmino jurídico,

lo cifraré mejur con un etcétera.

Mnerdan si pneden las livosas viboras,

Y rabie de envidinsu el qu' es satirico,

(u) en esta impresa supla ol viento pröspero

Favorecido del Tridente $y$ Eolo,

I no temo malicias de algonn páparo;

Recilias el intentu heneneírito,

Ammque cn tan largo y estendido páramo

Se me haya rendido cl toseo cílamo.

Don Pedro Frigola, cuatro en verso y una en prosa.

Redonalillas de un galan que con seña contrahecha gosi de los favores de su dama.

Sin razon os enojais, señola, cou mi ventura, porque si bien lo pensais, fué mi engaño gran cordura y ros sin ella os quejais;

Pues viendu que no aprovecha mi firme anor verdadero a dejalos satisfecha, hice el asalto primero con la seña contrahecha.

I asi no debeis culpar la jornada que prosigo, la seĩa supe robar, culpa fué de vuestro amigo que no la supo guardar.

No pidais tanta venganza por lal pasada ucasion, pues curriendo mi bonanza, ros con la imaginacion lograsteis vuestra esperanza.

Para el mundo y para bios gozasteis de ruestro flel, y nos holgamas los dos, vos pensaudo,estar con él yo sabiendo estar con vos;

Y si el gusto se imagina, cl vilestro fuè el verdadero. porque la opiniom si es fina, 


\section{ACa antologias y justas poéticas. ACA}

bace gallina al carnero

que se come por gallina.

Olvidad vuestra querella,

pues sin deshonra os divierte,

y si quereis guzar d'ella,

dád la seña de tal suerte

que llegne siempre á sibella;

$Y$ podreis con esta flor

regalaros y no mal,

guzaremos del favor,

el galan por principal,

y yo por coadyutur.

El Llcenelado Lorenzo de Valenzuela, tres en verso.

\section{Romance.}

En alaban:a de San Juan Evrmyslisla.

En este dichoso dia relebra li santa Iglesia al sagradı Evangılista, mueva pascua y uneva flesta: es providencia del ciplo, que lo permite $y$ ordena, que habiendo Jesus nacido su coronista esté ceren: que para escribir tal vida plimua es menester tan buena, y para tratar de Cristo. quién en tantu le semeja. No sois Iins, apóstıl sinto, porque eslá la diferencia en lener padre en el cielo y vos tenellu en la tierra. A lo menus sois su bermano, y èl por hermany us conflesa dándoos por, hijo a su madre, y á vos dindoosla por vuestra. I si a vuestro amigo Predro le dió su esposa la Iglesia, á vos, por ser sul querju, su madre y espusa us deja. Sitis el amado de Cristo ýá quiem su pech, revela. pues recustaduen el suyou los secretos de ẻl os muestra. ve águila temeis la pluma y tantu os alziis cuis ella, que de los rayus del sul los dais en nube las nuevas: pedidle, pues tantu os ama, que nos muestre su clemencia para que con vuestra ayula consigamos gloria eterua.

\section{Den Francisco de Villanova. \\ Don Inan Pallas. \\ Juan de Valenzuela.}

El licenciado Hartolonié Sebastiat.

A pesar de hallarse estos cuatro nombres en la lista de los académicos, no encuentro uinguna composicion suya en las Acliss.

Las siguientes poesias estan escritas par sugetos á quienes, no perteneciendo á la Acridemit, se permitio leerlas en ella.
Simon Arlas, cinco en verso.

En alabanza de la Academia.

Academia valentina

tan ilustre y soberana que solo tienes de hormana el no llamarte divina:

De nohles ingenius palma, de los euriosos escuela, azute del orio, tela

para las justas del alma;

Luna contra el negria manto, lengua de malos resaljos, admiracion de los sahius, y de los simples espanto:

Tienda donde á justus prepius se dan manjares perfectos, cormena de lus diseretos y confusion de los necios.

Académicos fommsos, que atosigados de vicius escogeis los cjercicios tau nobles y virtumsos;

Daudo alivio á vuestras penas, pherto i vuestras tempestades, honor á vuestras riudades,

y amn envidia á las ajenas:

Yo que infinitas he andadi, deseoso de saber.

$y$ las de más fama $y$ spr

he conocido g guzado;

lie venido á reposar eu esta lielicona fuente. de cuya dulce corriente mi sed no puedo saciar.

Porque de mi buena estrella guiado á tales venturas, vi una noche, que andil a esemus desde que me aparto de ella;

Como lo andará en efeto quien dejare de gozaila, qu'es noche donde se halla

sileucio, laz y secreto.

Miedo, indastria y soledud, sosiego, estudio, temor. relcimprgo, sueño, horror, cuidedo yremeilidud.

Ini bien puedes hacer guerra al dia que mas lo ha sido, nuche. pures has convertido en Indias aquesta tierra;

Porque cuando el sul se va á descubrir minas de oru, otro más rico lesoro tú nos revelas acá:

Que en las Indias de Valencia ill noble merecimiento conn el sol de entendiniento descubre minas de sciencia.

¿Pues quién, noche, no se asombra del valur que en ti se emplea? i. quien, noche, no desen ser de tí siquiera sombra?

Fi) lo deseo en estrem:, y aunque lo vengo á pedir, la verdad he de decir, mil contraditores temo.

firande ha sido ni arrogancia, vo propio ine hago el priveses, 
y en él declato y comfeso

que no pequé de ignorancia;

Que conozco que hice mal, y que propongo la enmienda, ijue no es bien que yu pretenda ser sombra y de noche tal:

I si otro juez no hubiela me condenara mi miedo, qu'el me dice que no puedo ser sombril del que lo era.

Mas con todo serí bueno mi pretension abonar, que no he de desesperar amine veis que me condeno:

Puesto que suy forastero, de valor é ingenio escasi, y quue no es bien que de paso goze tan honroso empleo.

Yas no me tengais por loco ni creáisme descomido, que, atendiendo aquesto, pido, sombre porque dura poco;

Y eum esta liumilde muestra la peticion no me asombra, que si pretendo ser sombra es por estar í la vuestra.

prestidme pues vuestra ayuda, y si mi intento aprobais, aceptadle y no pongais cn mi poco valor duda;

Que d'ese saber profundo, como testigo de vista, pretendo ser coronista en la redondez del mundo:

l' si este valor derrama en uni tau honrosos cargos, hurlare lıs ojos á Argos,

y las lenguas á la fama.

Y asi aunqu'es alta la historia para mi bajis talento. suplir'í á ni entendimiento mi voluntad y memoria.

Bien veo qu'es mucho darme lugar de tanta opinion, uist por humilde es razon lonrarme para animarme;

Y aun si lo quereis notar, al que falta castigais

y harto castigo le dais

endarme á mi su lugar.

Pues verá cuan mal se ocupa el lugar que suyo fué,

y solo le veuparé

mientras él le desocupe:

Que si se mostrare fiel,

y reducido viniere,

y solulura como era fuere,

seré yo su sumbra de él,

porque me pondré detras

de quien tall atras me deja

y no podrá formar queja

de mi ni de los demás.

Asi, que mientras él falta, podeis،darme este favor, aunque on mi no haya valor para una nerced tan alta:

Keciloa yo este regalo de aquese discretı senn, que inuque el lugar es mui buenı, sil dileino eil dejalle es malo.
Ya mi ventura une dice In que mis diseos pueden, eallando me lo conceden, niugruno li) contradice. Conmiencen mis alegrias. y acábrense vuestras dudas, que pues el que falta es Júdas, bien predo yo ser Matias.

Y si un bien tan deseado, porque al fin no lo merczco, no alcanzo, tambien me ofrezco por vuestro humilde criado;

Que cuando para aleanzallo no baste mi buen intento, me cousuelo y me contento con la gloria de intentallo.

Por la anterior composicion se colige que Gaspar Aguilar (Sombra), se habia ausentado, y efectivamente diste el dia $10^{\circ}$ de Abril de 1592 , hasta el 15 de octubre de 1593, nada se encuentra suyo en ninguna de las sesiones; sin embargo Sim m Arias, que parece se presentaba como sil suplente, solo escribió desde el 21 de 0etubre al 2 de Diciembrè del año 92.

Un fralle de la órden de $\mathbf{S}$. Pablo, primer ermitaño, tres sonetos, de los cuales ninguno merece copiarse.

\section{Pedro Tamayo, tres en verso.}

\section{Soneto.}

Crezca y aumente el tiempo cada dia El flero ardor que en mis entrañas slento, $Y$ el dulce $y$ amoroso pensamiento Vaya por donde $\mathrm{mi}$ dolor le guia.

Y desta triste ausencia la porfia Dé fln amargo á su ordinario intento, $Y$ el hado injusto con rigor violento, Consuma y seque la esperanza mia;

Y en la bárbara playa, en el arena, Dé al traves mi bajel despedazado, Roto el timon y la pesada entena;

Que yo en la avara tierra ó mar airado, Puesto en mi libertad, preso en cadena, Amo y adoro mi inmortal cuidado.

\section{Melehor Orta, cuatro en verso.}

\section{Soneto.}

Del imperio del cuerno.

Con fleros una vez y otra mui tierno, Pidiij zelos de un clerigo í una dama Un fraile, y dijo: al calso oh, flera llama! Que aun no perdonará á la Iglesia el cuerno. $Y$ ella dijo: esta furia del inflerno Es como pesadilla de la cama, Que con tenerla el hombre más la llama, Y al más zeloso da combate cterno:

kincon no se le eseapa en todo el mundo, Es mas temido que el del rei su nombre, Cualquier fuerza se rinde á su pujänza,

Mina las peĩas, sulca el mar profundo, Al fin, conno la sombra es en el hombre, Que a quiell más huye d'ella más lo alcanza. 
El Doctor Bux, una en verso, que es la sigulente:

\section{Estancias d Santa Lucta.}

lna águila grandiosa $\mathbf{y}$ mui pintada ne varledad de plumas y colores, Al libano ha llegado apresurada

Y el Cedro ha conocido por las flores;

Y por hacer mas alta su morada.

Desteje con su vuelo las labores

De sus doradas plumas y belleza.

Mostrando por el aire su graudeza.

Y lleva la medula que ha cortado nel Cedro, y en el pico se la ha asido I en tierra cultivada la ha plantado A dó por uno ciento ha producido: El dueno de la huerta no ha faltado De cobijar las plantas que han salido, Regándolas con sangre de su pecho, Mostrarido ser su esposo en dicho y hecho.

Esta águila es Lucia, luz y estrella. Sol, luna, resplandor, hacha encendida Que vuela por el cielo cual centella, Por sus luzientes ojos conocida;

Graciosa niña, vírgen y doncella, Posada del mui altn enriquezida, Tan llena de virtudes $\mathrm{y}$ despujos Que á Dios le parecieron bien sus ojos.

Carrera de la luz de las estrellas, Estrella radiante, sol hermoso.

Luz que por no escurecer tus niñas bellas Echaste por tinieblas á tu esposo,

Y sol que á las tinieblas todas huellas Bajándolas al más caverno fos?: Siguiendo tus pisadas quiero irme subiéndome contigo al lugar firme.

Estevan Cortes, una en verso, que es este

Soneto.

\section{Al Sr. Presidente D. Bernardo Catalan.}

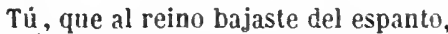
La citara suspende y tu son baste, $Y$ tú, que á Arion en el delfin libraste Del mal presente $y$ del eterno llanto;

Tú, que al tebano muro, con espanto. Las duras piedras con razon juntaste Y en proporcion igual le fabricaste, oid de un nuevo Apolo el dulce canto; Y vereis un retrato soberano

Del sumo bien, que el bien muestra del cielo En el pecho mas noble y mas gallardo.

Espiritu divino en cuerpo humano Debeis de ser, que andais en este suelo Con solo el nombre de houbre Dou Bernardo.

Cosme Damian Tofiǹo, tres en verso.

Cancion al desden de una damu.

1.a suave armonia y dulce canto Del músico y poeta el grande orfeo, No pudo enternecer ni ablandar tanto A la gente del reino del Leteo,
Cilanto la pena mia

Al corazon mas duro ablandaria,

A ser de otra que vos ménos hermosa,

Mẻnos inexurable y rigurosa.

Pagar con tal desden el amor mio, Estar hecha un penasco á mi ternura, A mis quejas y llanto un mármol frio, I á mis servicios zahareña y dura, llesdice $\mathrm{y}$ degenera

De lo que del valor vuestro se espera;

Y es desconcierto á quien nınguno iguala,

Tener en tan buen cuerpo alma tan mala.

El haber dicho mala no os altere, l)igolo, porque no hai vicio ó pecado Que tanto con razon se vitupere, Cumo la ingratitud que en vos he hallado Y en vuestri pecho fuerte, Que paga un bien con mal, y amor con ii sé porqué encerró naturaleza, [muerte: En hermosura tanta tal dureza.

Fo mirais á Anaxárate, señora,

En piedra por los dioses transformada;

to aborrezeais á una alma que os adora,

Guardíd la diosa Némesis airada,

Yirad la estrecha cuenta

Que toma amor á una alma dura esenta,

Mirád qu'el ser cruel es de tiranos,

I siendis en lei de amor es de villanos.

Pero no sois ingrata, no sois dura, No puede haber en ros ninguna falta, Débela haber en mi $y$ en mi ventura; Tal vez á mi valor valor le falta, I si esto os ha ofendido.

léd tambien que la muerte y dios Cupido Al mayor y menor de los nuortales, inn su flecha mortal hacen iguales.

Luis Tavarro, un sonet, de poquisinn mérito.

.....de Eduardo , cuatro en verso.

\section{Romance.}

Cuando ya de la gran Céres vemos al ojo el tributo, liumidu radical nuestro, que sun lis mieses de Junio; cuando el aljofar sereno qu'es de la mañana anuneio, consenzando i evaporar se resuelve en aire puro; cuando á los verdes pimpollos les viste de color rubio aquel dorado planeta, que rige $y$ da luz al mundo; cuando sus luzientes rayos encima del mar profundo hacen galanes reflejos que á la vista dan gran gustu: se descubrio, de alto borde, un bijel con tan gran rumb. que parece de Belen ol alto y soberbio murn: al muelle barcelones 
encaminaba sus sulcos, ayudando al espolon el grueso timon siguro. La mercaduria que trae, seméjase á la que trujo el enamorado Páris por aquel árbol tan sumo: trae una preciosa perla, que vale mas que un carbunclo, engastada en la firmeza de un espanol sin segundo; es piedra en fin de quilate $y$ de un saboyano fucaro. que las piedras peregrimas siempre el hombre estima en mucho. $Y$ viéndose ya cercanos del patrio suelo que pudo sustentar tal gozo y gloria, ansí le dijo aunque mido: luziente perla del sur, no tengas temor alguno que siempre serás quieu eres, mi corazon, alma y gusto; yo seré lo que en Turin, y si en la tierra que ocupo me guardares la firmeza que pide de amor el mudo, mi querer, serí adorarte, mis suspiros, serán hılıu que anuncian el sacrifleio que ofrece un cristiano tuyo. I no te espantes que tema, que quiero esas niñas mucho. y en fin temo no se muden dando al tiempo lo que es suyo. -Ella , enlazándole el cuello. con su aliento le deturo los amorosos acentos que brotaban fuego puru.

$1 \ddot{3} 7$ ACADEMIAS celebradas en varias ciudades de España durante el siglo xvil, y primeros años del xvili, á saber:

Sol de Academias, o Academia de Sules. En los lvcidos ingenios de Valencia. Sv Presidente el señor Don Ivan Andies Coloma, Conde de Elda. Sv poeta para la Introdvecion Don Francisco de la Torre. Valencia, Ivan Lorenzo Cabrera, $1658.40^{\circ}$ \& hojas prels. y 67 págs.

Repetida carrera del Sol de Academias, 0 de la Aeadenia de Soles. Sv Presidente cl señor Don Felipe Foleh de Cardona, Conde de Buñol. Valencia, Iuan Lorenẹo Cabrera, 1659. 4. 7 hojas prels. y 76 págs.

Academia que se celebró en Madrid en veinte $y$ dos de mayo, siendo presidente Don Matias Diego de Villanueva. (Madrid). M.UC.LXI. 4. 43 hojets foliadas, inclusos lis mels. y una blanca al fin.

Academia qve se celebró a diez y ocho de enero de 1668 ). en casa del Señor Don Franciseo de Adda Conde de Salas. Siendo presidente. D. Diego Ferıandez de Carvajal. Año M.JC.I.XVHI. Salamanea, Antonio de Cossio. \{. 1,7 prigs. en torlo.
Real Academia celebrada en el Real de Valencia... á los Años de Carlos segvndo... Siendo presidentes, y protectores...los S. S. R. R. Carlos, y Mariana. Valencia, Geronimo Vilagrasa. 1669. 4. 4 hnjas prels. y 150 pags.

Academia (a) los felizes anos de su Mag. la Reyma N. Señora D. Maria Ana de Austria, el dia 22. de Diziembre de 1672. Que presidió Don I)iego de Contreras. (Al fin:) Cadiz, Juan Vejarano, 167.j. 4. ${ }^{\circ}$ hojas prels. y 80 foliadas. Lamine.

Academia qve se celebró en dia de Pasqua de Reyes, siendo presidente Don Melchor Feriandez de Leon. (Madrid), M.DC.LXX.IIII. 1." ' hojas prels., of foliudas y una blanca.

Academia que se celebró en la Real Advana desta Corte. Siendo presidente Don Melchor Fernandez de Leun... Año de 1678. Madrid, Imprenta del Reyno, (1678). 4. \& hojas prels. 95 págs. y 16 hojas sin fol. para el. Vexamen.

Academia que se celebró en el convento de los Padres clerigos Reglares, Ministros de los Enfermos, vulgó Agouizantes, en 25 de Mayo... de 1681. siendo Presidente el Padre cieronimo Perez de la Morena. Madrid, Atanasio Abad, M.DC.LXXXI. 4. 5 lojas prels. $y$ 111 págs.

Trivnfos christianos del Mahometismo vencirlo. En cinco Disevrsos academicos. Pvbliealos I). Diego Vincencio de Vidania. Madrid, Incas Antonio de Bedmar y Baldivia, 1684 . 4." 3 hojas prels. $y$ SI fol. El Discurso segundo está en verso.

Academia, a qve dio assvmpto la religiosa, y catholica Accion, que el liey muestro señor (Dios le guarde) executó el dia 20 de Hener: de este Año de 1685 . Celebróse el dia 5 de Febrero en casa de Don Pedro de Arce. Fve presidente Don Andrés Sanchez de Villamayor. (Malrid, 1685.) $40^{\circ} 48$ hojas fol., inclusos los prels. que nu llevan folios y una linja al fin yue se dobla.

Academia qve se celebro en la. Ciudad de Valencia. En la Alcaydia del Real Palacio... En 5 de Febrero dẹ 168.. Valencia, Vicente Cabrera , $16854 .^{\circ} 75$ págs. inclusas las dos de la hoja del frónlis.

Academia que se celebró en Palacio, En la Real presencia de sus Magestades, estando en publico el dia veinte de Febrero de este Aino de 1700. Siendo presidente de ella Don Antonio de Zamora. (Madrid, 1700.) 4. 27 hojus fol. en lodo y una blanca.

Icademia de Valencia. En celebracion de la gloriosa entrada en los dominios de Espaîa y feliz cvmplimiento de años del Rey nvestro Señor Don Felipe IV. de Aragon, y V. de Castilla. Execvtada en la casa de la Diputacion del Reyno de Valencia, el dia 2. de Febrero 1704. (Al fin:) Valencia, Vicente Cabrera, 1704. 4. 94 págs. en todo.

Festivos obsequios en que acreditó su fidelidad la Acadenia de Valencia celebrando los augustos Años y feliz entrada del Rey nuestro Señor Don Felipe IV. de Aragon y V. de Castllla, executados en la Casa de la Diputacion de la misma Ciudad, y Reyno en 22 de Enero de 1705. (Asi Jimeno en la paigina 512 del tomo $\mathrm{H}$, pues d mi ejemplar le 
AGU

fultan las primeras hajas. Al fun:) Valencia, Vlcente Cabrera, $1705.4 .^{\circ} 80$ pags. en todo.

Academia que se celebró en Granada el ano de 1707 al nacimlento del Principe Luis Fernando. (Ignor'o el verdadero tilulo de la obra, las seizas de la impresion y el numero de las hojas prels., porque faltan estas á mi ejemplar.) 4.'... hojas prels. y 128 pdgs.

Academia qre se celebró en Madrid el dia 51. de Diziembre de 1718. siendo presidente de ella Don Licurgo Bradamante. (Madrid, 1718.) 4. 80 pdgs. comprendidas las dos dé la porlada.

En el siglo XVI existieron ya en España algunas de estas Academias literarias; pero solo tenemos noticias ciertas de trez de ellas: fué una, la que se reunia en casa de Hernan Cortes, conquistador de Nueva España, de la cual nos habla D. Pedro Navarra en su Carta dedicatoria de los Diálogos de la preparacion de la muerle; era la otra La Imilatoria establecida en Madrid en 1586; á ella se reflere Juan Rufo en los Apotegmas, y dice chistosamente el Jurado de Cordoba, que en razon í hallarse presidida por un muchacho murió mui joven de alferecia; la tercera instalada en 1591 es la de los Nocturnos de Valencia de la cual doi estensos pormenores en el numero anterior (156). El siglo siguiente Xill fué mucho mas fecundo en esta especio de. reuniones, $y$ desde mui á principios de èl sabemos, haberse formadi) en Madrid algunas que pronto se mandaron disolver sin duda por sugestiones del sto. oflcio ó de la clerigalla; asi lo indica suárcz de Figueroa, en la Plaza umiversal de las ciencias, 1615 , cuan. do alega como motivo probable de su conclision el que olvidudos de lo principal frecuentaban solamente los ver'sos aplicados á dife. rentes asuntos.-En $1616^{\circ}$ renació en Valencia la de los Nocturnos con la nueva denominacion de Montañeses del Parnaso, y desde aquella época fueron numerosisimas, las que ya con cierta regularidad periodica; ya con algun plausible motivo se tuvieron en varias ciudades.

Pueden reputarse estas Academias comn Cancioneros y Romanceros del siglo xill, por encontrarse alli juntas las producciones en verso de los mas distinguidos poe. tas de las épocas y pueblos donde se celebraron. En las de Yalencia suelen hallarse algunas composiciones en el dialecto del pais. -Es mui dificil el reunir una coleccion tan completa como la que aqui se describe.

AGUilar (Gaspar). Fiestas de Valencia á S. Luis Bertran. Yéase en la Seccion dramática, al nombre de este autor.

1 ö8 AGUIRRE Y ÁLAVA JOAQUINDE). Honores frnebres qre hizo el Real Consejo de Navarra a la piadosa memoria del Rey N. S. Philipuo IV. (Por) D. Ioachin $\mathrm{Fr}^{\circ}$ F) (de)
AL.M

83

Agvirre y Alava.-Oracion frnebre. Dixola el R. P. Juan Garcia Marin. Pamplona, Gaspar Martinez, $1666^{\circ}$. 4. ${ }^{\circ}$ Portada grabada, 3 hojas prels. 62 paigs., frontis de la Oracion fúnebre y 34 pags.

El volumen se compone en casi su totalidad de poesias castellanas, latinas, italianas, francesas, vascuences y portuguesas escritas por diferentes autores.

EI nombre de Joaquin de Aguirre y Alava no se encuentra en la Bibtiotheca de Niculis Antonio.

139 AlarCON (Alorso DE). Corona sepvlcral Elogios en la mverte de Don Martin Suarez de Alarcon. Escritos por diferentes Plumas. Sacados a lvz Por Don Alonso de Alarcon. (Madrid, 16033). 4. ${ }^{\circ}$ Portada grabada y retrato del heroe á quien se dirigen los elogios. 20 hojas prels. y 13 ö foliadas. La portada del Panegirico del P. Fr. Diego Niseno ra fuera de la foliacion despues del fol. 144.

La mayor parte del volúmen se compone de pocsias de varios autores; cuentanse enIrcellos D. Pedro Calderon de la Barca, el principe de Esquilache, D. Diego de Silva y Guzman, D. Juan Frrnainlez de Heredia, D. Luis de Liloa, D. Hipolito Pellicer de Ossan. D. Nicnlas Antonio, D. Gabriel Bocállgel y Lnzaeta, D. Gaspar Ibánez de Segovia, D. Jérónimo de Cuellar, D. Juan de Zavaleta, el Vtro. Gabriel de Roa, el lic. Juau Bautista Diamante, D. José y D. Juan Pe. llicer de Tovar, D. Iuan Gonzălez de Salcedo, D. Sebastian de Oliváres, D. José Córdova y Figuerua, D. Imbrosio irze de los Reyes y D. Kodrigo de Herrera.- De D. Gabriel Bernaldo de Quiros hai un Soneto. latino congruo y puro castellano.

Ni) menciona Vic. Antonio á D. Alonso de Alarcon ni la corona sepulcral á pesar de hallarse en csta ubra un Someto de aquel distinguido bibliografo.

160 ALMELA (JuAY Alorso DE). Las reales exequias, $y$ dóloroso sentimiento, que la...ciudad de Murcia hizo en la muerte del muy Cathólico Rey, y Señor Don Philippe de Austriä, îr. Con dos de los celebres Sermones Lugubres de ellas. Collegidas por el Doctor Ioan Alonso de Almela. Valëcia, Diego de la Torre, 1600. 8. 8 hojas prels. y345̆ págs., la última numerada por equirocacion 54 :. 
Contiene poesías castellanas y latinas de los siguientes autores: D. Alonso de Puxmarin y Soto, D. Juan Bernal y Loaisa, Doctor Juan Pérez de Tudela, lic. Juan Lozano, Dicgo Beltran, Doctor Juan Yanez, lic. Juan Castejon, lic. Ramirez, Baltasar de Cepeda, Alonso Cano, estudiante, lic. Camerino, 'Tomas Perez de Evia, Doctor Jerónimo de Alcald́ Yánez, Juan Diaz, Gines Hernaindez Azorin, Doctor Martinez, lic. Felipe del Rio, [oetor Jirall Alonso de Almela, Diego Funes. Juan Amoros de Salinas, Gines Pérez de Hita, Enrique Núñez, y varios escritores de la Compañia de Jesus que no pusieron sus nombres.

Nic. Antonio no solo olvida el titulo de esta obra rara en su Bibliotheca, sino que hasta omite el nombre de Juan Alouso Almela.

161 ALONSO (Juan.) Festividad gloriosa. que consagro la...villa de Alzira a la nueva feliz del Decreto de su Santidad, por el objeto de la liesta de María Inmaculada a su primero instante. Por el Dotor lvan Alonso medico. Valencia, Geronimo Vilagrasa, 1663. 4. ${ }^{\circ}$ Lna hoja con una Purisima Concepcion en la primera cara y las armas de Alcira en la segunda, a la que siguen 8 prels. $y$ 202 págs. en mi ejemplar; annque es probable le falte alguna al final.

Conticne diferentes composiciones anúnimas en verso: sin duda son de varios antores.

\section{AMADA Y TORREGROSA} (José Felix de). Palestra nvnierosa avstriaca. En la victoriosa civdad de Hresca. Al Augustissimo Consorcio de los Catholicos Reyes de España, Don Felipe el Grande, y Doña María-Ana la inclita. Publicala... el Licenciado Ioseph Felix. de Amada y Torregrosa. Hvesca, Iuan Francisco de Larumbe, M.DC.L. 4. 6 hojas prels. y 167 foliadas.-Sermon a la Prrificacion de la Virgen Señora nvestra. Fiesta... a las reales bodas de nvestros Catolicos Reyes. Predicòlo el P. M. F. Joseph A bbad. Una hoja de portada y 22 pags.

Este volumen se compone casi por entero de poesias de diversos autores que concurrieron al Certámen literurio; entre ellos se encuentran D. José y D. Martin Abarca y Bolea, D. Miguel. Mateo Diez de Aux, D. Gabriel Bocángel, D. Juan Francisco Andres, I). Manuel de Sillinas y Lizana, I). Pedro Bal- daji, D. Francisco Djego de Sayas, el licenciado Jiran Nadal, D. Antonio José Amada, D. José Pellicer de Tovar y Abarca, el licenciado Blas Pérez de Rua, D. Alonso Sotomayor, D. Juan Lorenzo Ibáñez de Aoiz, Don José de Slerra, el lic. José de Tarazona, D. Gabricl Fernández de Rózas y un número crecido de señoras poetisas.

\section{ANDRES DE UZTARROZ} (Juan Franc). Certamen poetico. De Nvestra Señora de Cogvllada con vna breve chronologia de las imagenes aparecidas de la Virgen... en... Aragon. Del Doctor Ivan Francisco Andres de Vztarroz. Zaragoca, en el Hospital de nuestra Señora de Gracia, M.DC.XL.IIII. 4. ${ }^{\circ} 6$ hojas prels. ý 2.10 págs.

Comprende este Cerlámen poesias de Juan Nadal, Jusepe Falqués, Juan Lorenzo Ibáliez de Aoiz, cl lic. Jerúnimo Jiménez, el lic. Márcos farcia, Martin Artabia y Bolea, D. Pedro Beltran, D. Miguel de Urrries y NaVarra, Alonsi) de Bátres, el lic. José Alberto de Medrano, el lic. Jian Löpez, el licenciado Martin Ezquerra, I). Jerón. Cáncer de Velasco, D. Jaime Latre y Látras, Fr. Djego González y otros. Jlai tanıbien composiciones de nulchas señoras.

\section{ANGULO Y VELASCU (Don} Isidro). Trivnfos festivos que al crvcificado redemptor del mundo, erigiò la Real Congregacion del Santo Christo de San Gines desta Coronada Villa de Madrid, en-la Colocacion a su nueua Capilla de su Santa Imagen. Dedicalos en sv nombre a sv dignissimo prefecto. D. Isidro de Angvlo y Velasco. En Madrid, Por Gregorio Rodrigvez, $1636.4 .^{\circ} 4$ hojas prels., una lám. que representa el Cristo de $S$. Gines y 208 págs.

Contiene muchas poesias de varios autores siendo los ménos desconocidos D. Fernando Bazan y Heredia, D. Cárlos Magno, D. Francisco de Velaseo, D. Isidro de Angulo y Ve. laseo, D. Alonso de la Maza, D. Juan Montero, Juan Navarro, D. 'Francisco de Avellaneda, D. Ambrosio de Arze; D. Agustin de Palacios, D. Juan Zavaleta, D. Manuel de la Peîa, D. Juan de Zamora, D. Juan de Ávila, D. Alonso de Zarate y la Hoz, D. Tomas de Oña, D. Francisco Duran, D. Rodrigo de. Herrera y D. Luis Nieto.

APLAUZOS ACADEMICOS o rellaçao da victoria do Ameixial. Véase en la Seccion dramática. 
16ə̈ AVISOS PARA LA MUERTE. Escritos por algvnos Ingenios de España. Recogidos, y publicados por Don Luis de Arellano. Zaragoca, Pedro Lanaja, y Lamarca,. $16 \% 8$. 12. 6 hojas prels. y 92 fol.; aunque las dos últimas tienen errada la foliatura.

He visto una edicion de V'alemeie, Inan Bautista Marcal, 16.54. $12^{\circ} 12$ lujas prels. \& 90 fols.; otra de Caragoça, Iuan Larumbr", M.DC.XXXX. 12.0 6 hojas prels. y 90 fols., y Alvarez y Baena se reflere á la de Malrici, 1648. $8.0^{\circ}$.

166 _L La misma obra. Añadidos en esta sexta impresion. Madrid, Imprenta Real, 1652. 8. 12 hojas prels. y 124 fols.

Contiene efectivamente nłás que la de 1618: cualro romances, unas déeimas yum acto de contricion.

Tickuor, tnmo Ili, pág. 266, habla de una edicion de Zaragoza, 165.'. 12. $\mathrm{y}$ yi he visto utra en la cual, por hallarse el ejentplar falto del frontis, no pude sacar el año y lugar de la impresion, aunque presumu que seria de Lisboa, pues todas las licencias estaban fechadas en dicha ciudad en 1658 y 59 . Era en $21 .{ }^{\circ}$ y solo tenia II hujis prels. y 14.4 fuls.

En el frontis de la edicion de I65"2 se liana al recupilador Luis Ramilez de .Arellano.

\section{7} La misma obra. Añadidos en esta septima impression. Madrid, Andres Garcia de la Irlesia, 163̋9. 8. 12 hojas prels. I 193 fols. con una al fin que no liene foliatura.

Igual contenido que la de I 652.

168 La misma obra. Añadidos en esta septina impression. Madrid, Viuda de Melchor aleare.
1672. 8. 12 hojas prels., y 152 fols.: hai error en la foliatura de las dos ulltimas.

Contiene lo mismo que las dos anteriores y ademas un romance de Martinez de la liente.

Sienda sélima la edicion de 1659, debs: ser por lo menos octava la presente de 1672 .

En el Diccionario de bibliografia españolı de Hidalgo se cita una edicion de Valencia, 1772. 8. ${ }^{\circ}$ y otra de Madrid, M. de Burgos, 1832. 16.

Debe clasiflearsceste tomito entre los rumanceros ó antoloyias, pues se compone de romances y otras poesias eseritos por 57 autores á saber: Lope de lega, Fr. Dieg"॥ Niseno, Antonio de Mira de Amescua, José de Valdivielso, Juan Pérez de Montalvan, Fclipe Gudinez, Francisco Quintana, Gaspal. de la Fuente y Vozmediano, Gabriel de Roa, Alons: de Alfaro, Miguel Jeróninı, Sanz, Antonio de Leon, Gabriel de Henao y Mnnjaraz, Pedro Calderon de la Barca, Luis Vélez de Guevara, Franciseo de Rójas Zorrilla, Intonio de Huerta, Garcia de Salcedo Cormel, Antonio de Medina y Fonseca, l'e. dro de Bolivar y' Guevara, Gabriel Bocán. gel y Unzueta, Antonio Pellicer Tovar $y$ Âbrea, Pedro Rosete Nino, Martin de Figueroa Sarmiento, Alonso de Bátres, Juau Navarro de Espinosa, Francisco de Oliváres y Figueroa, Luis Ramirez de Arellano, Josi de Villalóbos, José Pellicer de Tovar, Juau de Ayala Fajardo, Francisco Bernardo de Uuirus, Antonio de Castilla, Francisco l'érez de Amaral, Álvaro Cubillo de Aragon, Bartolomé de Salazar y Luma y José Martinez de la pliente,

Tickuor indudablemente solo turo presen. te la impresion de Zaragoza de 1648 , la cual es li ménos completa, así en la página 15 del tomo III, supone que la obra únicamente contiene versos de treinta poetas, y en la pág. $266^{\circ}$ del mismo tomo vuelve ii repetirser el núnero de romances tambicu de treinta. Debo nolar de paso que en el lugar últimamente citado menciona Ticknor una edicion de Zaragoza de 165.1, y aqui sin duda quiso referirse da valenciana de igual fecha, de que he liablado al principio.
169 BERILUEZ DE LA TORRE Y SOLIER (Pedro José). El Sol en el Zodiaco. Certamen poetico en el solemne. triunfal recibimiento del Excelentissimo Señor Don Carmine Nicolas Caracholo... en la Real Ýniuersidad de San Marcos de.. Lina. Escribiale El Señor Doctor D. Pedro loseph Bermudez de la Torre y Solièr. Lima, Francisco Sobrino, 1717. 4. ${ }^{\circ}$. Son dos partes con diversa foliacion, la primera tiene dos hojas con portada y anteportada y 64 folios; la segunda $10 \mathrm{o}$ folios, y acaso le falta alyuna hoja blanca al fin. 
La segunda parte contiene el Certimen poélico en que hai poesias de varios autores.

170 BIBLIOTECA. Bibliotheca (astellana portuguesa y proenzal por I). G. Henrique Schubert. Segunda edicion. Leipsique y Altenburgo, J. C. Hinrichs, socicix. 2 vols. $8 .^{\circ}$ may.

Comprende esta antologia el poema del rid, poesias de oclienta y move anlures anteriores al 1500 , y algunos romances ancnimos de la misma epera; ademis la plecede una larga introduccion solore muestra literatura hasta el siglo X\%, escrita en illeman, y lleva dos glosarios de las palabras poen usadas ó dificiles de entender, eou las correspondencias en el mismo idioma.

Es obra enteramente distinta de la Bibliothecot espanola impresa en Cotha, por Stoudel y Keil, 1805-11. 11 vols. 12. puesto que los tratados contenidos en esta son: Ia Primera y segunda purle de las Guerras ciriles de Gromala de l'irez de Itita, las tres partes de la Arancuna de Ereilla, las Vovelas de Cervántes, la Historia det grmm Tacrño de Quevedo y la Viela de Lazivillo le Tórmes de llurtado de Mendoza.

171 BOCANGEL UYZUETA (G.1BRila). Relacion panegyrica del norenario celebre con qre el orden ilvstrissimo, inclita cavalleria y Capitulo General de Alcantara solemnizò en San Bernardo de Madrid, su quarto voto de professar, $y$ defender el purissimo misterio de la Concep-cion de Nuestra Señora, Concebida sin pecado original. Lncluye los elogios del institrto $y$ antiguo lustre desta Religion sacro-sanla; de sus valerosos Maestres y Reales Adn:inistradores perpetuos. Escriviala Don Gabriel Bocangel Inzveta. Madrid, Imprenta Real, 1633. 4. ${ }^{\circ} 16$ hojas prels. 9a fols. y una para repetir el lugar y año de la impresion.

lina parte del volumen consta de virias poesias al mismo asunto compuestas por buringel, D. Luis de blioa Pereira, D. Antonio de solis. II. Gristoval te Giviria, bon Tomas de Aguiar, b. Luis Pallavesin, 1). All(1)llo Ramirez, y otrus escritores anonimos.

172 BolX (D. Vigexta). Fiestas que en el siglo IV de la Canonizarion de San Vicente Ferrer se celebraron en Valencia. Relacion es- crita por Don Vicente Boix. Valencia, José Rius, 185ّ̋. $4 .^{\circ} 4$ láminas litogrificas.

Ina buena parte del volimen lo ocupa el Albun poético-religioso que se compone de presias castellanas, valencianas $y$ latinas de vilios autores naturales de Valencia.

17: BREVE ELOGIO, y ceñida relacion de la vida, enfermedad, y muerte del Serenissimo Señor Francisco Farnesio... padre de la Reyna N. ${ }^{a}$ S. ${ }^{a} . . . y$ de las exequias, que... se celebraron en el Real Convento de la Encarnacion de esta Corte. Madrid, Miguel de Rèzola, 1728. 4. ${ }^{\circ}$ Lamina del túmulo. 119 págs. todo comprendido para la Relacion; $56 \mathrm{pa}$ ra una Oratio funebris del $\boldsymbol{P}$. Antonio Maria Piscatori; 61 para la truduccion castellana de la misma, y 6 hojas con varios versos y el final de las exequitas.

Fjemplar del papel fucrte.

Cuntiéne algunis poesias castellanas e italianis, anonimas: pero que prubiblemente serín de virios ingenios.

174 BREVE RELACION de las. Exequias yre la mry noble y mry leal Cirdad de Sevilla dedico a sv Reina la Señora Doña Maria Lvisa de Borbon. Sevilla, Juan Francisco de Blas, (H.DC.LXXXIX). . $^{\circ}$ marq. Lim. que se pliega del túmulo. Anteportada grabada, 4 hojas prels., la lim. del catafalco, 13 hojas sin foliacion, con las signat. A-D, 18 del Sermon, sign. A-E, 48 de Inscripciones, Elogios y Ilieroglificos, sign. 1-3 y 1-9, y una de Érratas.

Este ejempiar es del papel grande y fuerte. Coutiene el volúmen unas cincuenta hojas de puesias latimas $y$ eastellanas eseritas por diferentes antores.

\section{BRITTO $E$ MENEZES} (Fraxcisco). Argrstissimo Hispaniarum Principi recens nato Balthasari Carolo Dominico Phelippi hoc nomine III. Lusitanix Regis Filio expectaissimo Natalitium Libellum dedicat Academia Conjmbricensis. Ivssv Francisci de Britto.e Menezes,... citusdem Academiae Rectoris. Conins- 
bricæ, Didacus Gomez de Loureyro, 1630. $4 .^{\circ} 2$ hojas prels., 84 fols. y 6 con la signat. Aa para el Genethliacrm.

Es una coleccion de poesias de varios autores en diferentes clases de metro, escritas en latin, portugues, castellano, frances é italiano. Entre varias cosas notables de este libro, no deben olvidarse los dos sonetos en latin del fol. $37, y$ el que está en cuatro idiomas en el fol. 61 vta., es por el estilo de las composiciones que cn varias lenguas muertas y vivas nos ha regalado Mor de Fuéntes.

BRU DE LA MAGDALENA (Juar). Véase Excellentias de Santa Maria Madalena, en esta misma division.

176 BUENDIA (José ve). Parentacion real al... Señor Don Carlos II. Fvnebre solemnidad... en sus reales exequias en la Iglesia Metropolitana de Lima. Escribiala... el R. P. M.

177 Campos (Mavoel de). Relacam do solenne recebimento que se fez em Lisboa ás santas reliquias q̃ se leuáram á igreja de ${ }^{-} \mathrm{S}$. lloque da companhịa de Iesr aos. 20 . de Ianeiro de 1388. Pello Licenciado Manoel de Campos. Lisboa, Antonio Ribeiro, 1588. $8 .^{\circ} 4$ hojas prels. y 192 fols.

Comprende poesias de varios en portugues, latin y castellano.

Se conoce que Nic. Antoniu no vio esla obra, pues ademas de equivocar el apcllido del autor, copia con poca exactitud la portada y omite el nombre del impresor.

178 Relacion Del solēne recebimiento que se hizo en Lisboa a las santas Reliquias que se lleuarõ a la vglesia de San Roque, de la Compañia de Iesus, a veynte y cinco de Enero 1588. Compuesta primero en Lengua Portuguesa por... Manuel de Campos, y agora traduzida en Castellano, por Aluaro de Yeancos. Alcala, Iuan Yñiguě
Ioseph de Bvendia. Lima, Ioseph de Contreras, 1701. 4. ${ }^{\circ}$ Retrato, 2 hojas prel.s., 180 fols. y la Oracion fvnebre dicha por el P. Rodrigo de Castro y Mena; que tiene 6 hojas prels. y las sign. A-F, careciendo de foliacion.

Entre los autores que escribleron pnesias para estas exequias se encuentran D. Pedro Peralta Barnuevo. D. Diego Vallejo de Ara. gon, D, Ignacio de Hijar, D. Pedru Urquiza, D. Juan Jacinto Guerrero, D. Miguel Saenz Cascante, D. Pablo Jiménez Caja, D. Fer. nando Carrillo de Cordova, D. Francisco Maldonad,, D. Bernardo Romero, D. Francisco lzquierdo, D. Juan de Zapata, D. Martin Dávila, D. Bernabe Guerrero, D. José de Segovia, D. Francisco Flores, D. Manuel de Bañuclos, D. Ballasar de Eyza, D. Juan de Lujan y Bedia, D. Agustin Montero de la Aguila, D. Fernando Bravo de Laguna, José de Contreras y Alvarado, D. Pedro Sánchez de Zamora, D. Prudencio de Musaurieta. Diego de Zarate, D. Juan de Santiago Concha y otros muchos ménos conocidos que ins anteriores.

Tudas las obras impresas en las antiguas culonias hispano-americanas hasta mediados del siglo Xifll, son por lo menos escasas. de Lequerica, 1389. $\mathbf{8}^{\circ} \mathbf{2}$ hojas prels. y 4030 págs.

Nicolas Antonio no hace mérito de esta traduccion ni menciona en su Bibliotheca i Alvaro de Veáneos.

Mas de 160 págs. al fin del volúmen conlienen poesias en latin, portugues, castellano è itatiano, escritas por Simon Borja Cardoso, Felipe Tomas, Diego Bernárdez, Pedro de Andrade de Camina, Gaspar Freire, Andres Falcon, Luis Franco, Simon Machado, Virgilio Rosetti, lic. Fernando Rodri:ruez Lobo, lic. Ytanuel de Cảmpos, Pablo de la Vid, Antonio d'Acosta, Antonio de Casiro, Mauricío Crastíni, Manuel de Sosa Cuutiño yotros anónimos.

\section{CANCIONEIRO GERAL DE} GARCIA DE RESENDE.

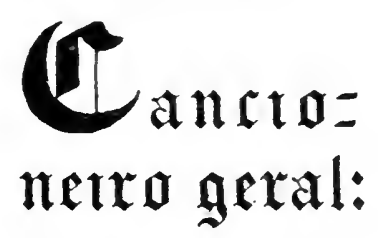

Enm prrailegir. 
(Ile aqui todo lo que se halla en la portada, á cuyo dorso principia la Tauoada, que concluye en el reverso de la hoja lercera. Tres chartas partes de el las llena el T Prologuo de garcia de rresende deregido ao princeje nosso senhor, el cual termina en la heja suarta. Ocupa todo su dorso el escudo de las armas de Portugal. La folha I empieza despues por una Pregunta que fez Jorge da silueira a Nuno perejra elc. Ina hoja que ra al fin despues del fol. CCXXYll, está destinada para el remate, del que estracto lo que sigue:

Acabousse de empremyr o cancroneyro geerall. Com prenilegio do muy to alto $x$ muvto proderoso Rey dom Manuell nosso senhor... Foy ordenado 2 emẽdado jor Garcia de Reesende fidalguo da casa del Rey nosso senhor $r$ escriuam da fazenda do principe. Comēcose em almerrym $\checkmark$ acabousena muyto nobre $r$ sempre leall cidade de Lixhoa. Per Hermã de cãpos alemã hôhardeyro delrey nosso senhor a emprenijdor. Aos xxviij. dias de setébro da erade nosso senhor Jesn cristo de mile. quynbeut ${ }^{9}$ r xri (1516) anos. fol. mari. let. gót. A tres cols. it escepcion de las pocas vezes en que lo largo del metro las hace resheir a dos. De las cuatro hojas prels. Ia segunda líeva la sign. AdA y la tercera AAAA, sin que pueda adivina" la razon. Las CCrTYll de la obra están foliadas, y a mas hai una en cuya sura esti el remate de que se ha hablado, llenando todo ci dorso un escudo de arimus, diverso del de los prets.

Liloro rarisimo de que mo conozen mis ejemplar completo yur el presente, al cual adenlas se lialla porfertanlente comservallu: el que rita lirunet en puder de Mr. Tepmanx es defertuosin, pues le faltan algumas bujas. Durante veintidus an̂us de pesielnucia co l'aris ? Londres no he visto ningume de ventil.

Xie. Antunio, en el artieulo de Garcia de Resenda, trie mua olura que intitula: Das

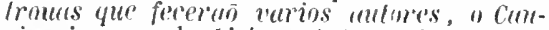
cimpiro geral. Lisbor, $1510 \mathrm{y}$ cita ma se.

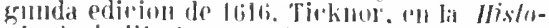

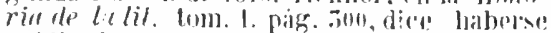
publicady esta obra en list. In roncean. ni se haya visto nadie, otra impresiun que la que yo tengo de 1516 , y la publicada por la Snciednd de bibtiofilos de Stultgarl en $1816-72$. 3 vols. 8. Lirada á un número mui limitado de ejemplares.

- El Cancionero portugues tiene mnchos - mas poctas que cl castellano. Este contiene -solos las del siglo décimoquinto: pero - aquel á vista de las poesias que pone del - rei 1). Pedio, que murió en 1565, tambien - eoloca, ó contiene algunas del siglo dí. - cimocuarto." Sumiento. Hist. de la poesía. pák. 325.- Hl misıno ell la pág. 360 ascgura que el comcionero general portugurs contiene mas de eient" y eincuenta poetas que vivierull en el sigla $\mathrm{XV}$.

Intercaladas en el volimen se hallan más de un centenar de poesias en eastellano. algunas escritas por españoles; pero la mayor" parte son de autores portugueses: entre estus el infante D. Pedro, hijo del rei Don Juan, tiene una composicion en 12.5 octavas de arte mayor, o scan mil versos, sobre el memosprecio de las cosas del mundo, que adiejonala con uma glosa ell prosil se inprimió por separadio y yo lengo. De Juan lin IIena se encuentran unas poesias dirigidls í dicho infante que principian:

Principe, todo valiente,

En los fechos mui medido etc.

\section{CANCIONERO GENERAJ:} que contiene mvebas obras de Diuersos Autores antiguos, con algunas cosas nueuas de modernos, de nuevo correcido y impresso. Anvers, en casa de Philippo Nucio, M.D.LXXIII. 8. ${ }^{\circ}$ may. 4 hojas prels. $y$ ccclaxavifol. Ila $i$ un salto desde el fol. cxcij al cciij, de modo que el mimero cerdadero de las hojas es solo de 376.

Amnque en esta edic:ion se suprimierun las obrus dr burlas que tiene la de 1557 desde el fol. coclvij al ccclxxiiij, se le añadieron al fin algunas compusicjumes que no se liallan en aquella: por lo mismo las dos son igualmente buscadas y tienen el mismo valor por ser amloas le estlaordinaria rareza.

Hallindose en igual caso todas lis edicio. nes del Cancioncro generul y habiendo tenido yo la suerte de poder examimar In mayijr parte de ellas, diré aqui ma nota hilliogriflea. de lis varias impresinnes hechas de un libro que goza de celobridad tall tulivesal. Los que desien enterarse mas á fondo de las varianles, supresiones y adiciones que eutre ellas existen, podrí cousultar el Culátogo de documentos que trae el sr. Duran al fin de su Romnuncero.

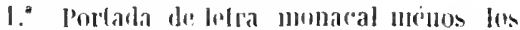
dus illtimos rengromes qur dice: 


\section{$\mathrm{CAll}$}

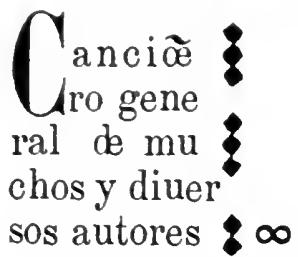

\section{Cum pre uilegio.}

(Al dorso está el prólogo que prmeipia asi:

c Cupilacin cancionero de abras en metro instellano de muchos y diuersos auctores dirigida al muy espectuble / y magnifico se. ĩor / el señor côde de Oliua.

\section{( Protogo.}

Todos los ingenios etc.

Concluye poco íntes de la mitad del blanco de la hoja siguiente que tiene la sign. F, en seguida cmpieza la Tabla que termina á la mitad del recto de la huja octava, y desunes principia la lista de lus antores que se hatlan en este Cancionero, In cual concluye con dicha hoja octava. En la que sigue que es fol. $j$ sign. A hai un epigrafre coloraduque dice:)

Cancionero genmal de muchas y rimersas obras de todos / o d'los mas principales trobalores despriña en légua custellina assi antiguos como modernos / en denociō / en moralidad / e'n amores / en burlis / romances / villancicos / cäciōes / letras de imuēciōes / motes / glosas pregūtas res. puestas / copilado y marauillosamèle ordenado por Hernuido d'l castillo Pricipiato pn obrus de nuestia señora / sin cujo faunr ningü pricipio / medin ni fin mede s's' dicho bueno / en näbre d'la santa trenidad comiēca.

(Las hojas están fuliadas hasta la ccxxxiiij illclusive, $y$ las sign. I hasta $\mathbf{C}$ C lodas de 8 hojas, menos la $c$ G qur es de 10 . En el blanco de la última (la 254 ) se lee:)

La presente obra intitulada cíciomernge. neral copilado por Fervadulo a'l castilto." E im presso en la mu isigne ciblad de lulicia de Aragö por xjofal hofmi alemá de basilea con preuilegis. Renl y por espacio de canco años en castilla / y de diez en aragö no pueda ser imprimilo todn ni purte ilel ni traydo de ofra parle a ser venclido por otras personas / q por aïllas por cuyjas desprensas pslu vez se imprimio snlas penus infra escriles Es a saber de diez mil maranedis enlos rmynos de castilla y de. Aragó cle ciè ducados y perder todos los libros. Acabose a. $x u$. dias d'l mes de Enero enel año de nia salud de Mil y guimin̈tos y on:ce (1511). A lom y glia d'l of biup y remna. $\dot{c}$.

Fol. Ict. gót. Está generalmente á Ires colunas, menos las pocas vezes que el ver. so 110 permite sino que liaya dis. Esta edi('jous no lipuse el Ploilo drel momlo; pero or licne la heelia en Valencia en 1:14.- Bruliet no ha vistu sin duda ningun ejemılar conl-
$\mathrm{CAN}$

pleto de esta primera edicion por cuan(1) el título que Je da no es el verdadero, el dla de la fecha In equivoca y no cita el número de hojas del volimen. El ejenıplar descrito por él de la Biblioteca de I)resde, falto de la última hoja, es sin disputa de la edicion de 1511 .

2."Cancinnero generul d' muchos y diwer. sos auclores otra vez ympresso emendado y corregido por el misnio uutor cō rulicion do' muchas y muy escogillas obrus: l's tuales quien mas presto q̈rì rer vaya a la lubla.

La presente obra intitulada cäcionero general copilado por Fernando elel Castillo. F. impresso segunilu vez en... Valecia de Aragon por Jorge costilla... Acubose $u$. xx. dias del mes de Jurio en el añn de... Mil y quiniētos. $y$ xiiij (1514, años. ful. let. gott. Láns. de madera. 8 hojas prels. y CC.II fols

Asi describe Brunet esta edicion, muchn mas completa que la de 15ll; en ella vin noLadas con 11 asterisco * las composiciones que se han aumentado entre las cuales cres estí el Pleito del manto.

3." Cancionern general muelumïte añaliclo, olra vez impresso con adicion de muchess $y$ muy escogidus obras.

La prescutr obru... fue impressn terervil vez pu la imperial ciudur de Toledo a custa. y mission de Juan de Villatuiran impressor de tibros. Acabose a powtrern dia clel mes ate agosto año... ale mil yquinientos y die: ! siol" (151T) años. fol. let. gott. vill hujàs prels. y CCIII. fols.

Brunet es quicn describe esta edicion.

\section{4. (Orla y dentro:)}

$$
\begin{aligned}
& \text { Cancione } \\
& \text { ro general } \\
& \text { nuewamete } \\
& \text { Ainadido }
\end{aligned}
$$

otra "es ympresso con adicion de nu chas y muy escugidus abrus: las yun les quien muts presto ylurrart ver: z'dyn ula tabta: y todus aguellis que terman exta siñal .+. son las muenamente añalidas.

(A la vucita principia el Prologo que cou. cluye cii la mitad del blauco de la siguiente loja + ij. en seguida empicza la tabla que ncupa 6 hojas: en el fol. I sign. A se lee: Cancionero general de muchus y diuersus obrus de todos: o de los mas principales lrobadores despañ! : unsi antignes como mo. dernos: en dewocion: en morulislad. en unn. res: ch burlus. romanres. villuncicos cullcinnes. letras de inuencimes. motes. glosus. prequntas. respuestas. Otra vez ympress" copilado enmídado y corregido por al mis. nto fornando del castillo. Cä adición de' mu. chas y may e'sirgidas obrus cinde une e'll sil lugur por gretil anden muelislos.

sigue la ubra gencralincnte en tres colu. 
nas hasta el fol. CCIII en cuyo reverso se lee:)

La presente obra iulitulada cancionero general copilado por hernádo del castillo. Fue impresso en la impcrial cibdad de Toledo lor Juan de villaquiran impresor de libros. leabose a veynte dias del mes do Enero Año lel macimienlo de nuestro saluador Jhesu christo de mil r quinientos \& v'ynle (1520) linos. Fol. let. gót.

Esta edicion contiene el Pleito del manto.

$\therefore$." (Portada circuida de grande orla $y$ denlro de colorado:)

Cancimero general Agora mouanēte anadiulo. Otra ve: impressu con adicion de mu'has y muy escogilas obras Las quales qui" mas presto ÿrra ver taya ala tabla: y Iwlas aỹllas ỹ ternà esla señal. +. son las muenamente añadiclas.

Al dorso del fróntis principia el prólogo liricido al conde de Oliva el cual concluye en el hiluco de la hoja siguiente; al reversi de ella comienza la tabla que ocupa seis lojas más, es lecir, que en todo son ocho que solo Jlevan las signat. +iij, +iiij y despues fol. $j$ sign. A.

La ubra concluye al dorso del fol. $C X C V$ y luego hai una hoja la cual contiene el registro de la obri que va de $A$ á $C C$ Todos son chadernos salvo. BB. que es terno. En seguida so halla este final:)

(I La presente obra intitulada cancionero feneral copilado por hernando ilel castillo. En el qual van agora nueuamente añadidas muchas obras muy brenas y quien las ynisiere buscar las hallara al principio y al fill alel libro. Fue inpresso en la muy noble \& Imperial ciblad d'Toledo por maeslre Ramon lle pelias / imprensor de libros. Acabose a doze dias del mes de ma!jo. Año d'l na'imicuto de nuestro saluador señor jesu c'misto d'mil \& quinientos \& veynte y siete 15.27) Años.

(Escudo de Petras copiado al desiribir l.l Cirnica de D. Prello, Vease la Seceion listorica.-Historia de España.)

Viol. en fol. let. got. 8 linjas prels., $195 \mathrm{fol}$. y ulia para el registro y feclia. La generaliilad del tonno estí á tres colmuas y á vezes a ress, cuando el metru no permite aquella disuribur(i)u.

Couliene las Obias de burlas entre las que istá el Pleito det manto.

li. a (Dentro de una grande orla de negro $y$ (o) orado dies:)

(ancionero general: enel qual se han añadidh ayora de mueun eñsta vitima impression muchas cosas buenas: ha sido cō dili"ricia correryido y cmidado. M.d. xxxy.(A) dorso principia la tabla que ocupa 4 hojas más. bespues en el fol. $j$ sign. a princi'ipia li nbra y acaba á la vuella del cciiij. '*ul el siguiente final:) Aqui haze fin el canrimero general. El cual enesta vltima immession ha sivlo con liligencia reuisto 2 . corregielo / culresacando del algunas obras deshonestass \& muy profanas : \& añadiendole "lvas muchas \& mu! bnenas / como por la labla paicece. Fuc impresso cn senilla en la imprenta de Jican cromberger. Aĩo de la encarnacion del Señor de mill $v$ quinientos $v$ treynla r cinco: (1535) a dos dias del mes de Abril. Fol. let. gót. á dos, y tres colunas. Esta edicion no tiene el Pleilo del manto.

7." (Portada flgurando una capilla, y dentro de negro y encarnado:) Cancionero general: en el qual se han añadido agora de nuewo eñsla vllima impression muchas cosas buenas: ha sido cō diligécia corregído y emédado. M. d. $x l$. (Al dorso principla la Tabla, compuesta de cinco hnjas más. Viene luego el fol. $j$, signt. $a$, y sigue hasla el fol. ccvij, en cuyo dorso se lee:) (I Aqui haze fin el cancionero general. El qual en esta vltima impression ha sido con aligencia reuisto $y$ corregido: entresacando del algunas obras lesonestas $x$ niuy profanas: $\&$ añadiendole otras muchas \& muy buenas: como por la labla se vera. Fue impresso en Seuilla enlas casas de Juan cronberger. Año dela encarnacion de nuestro saluador Jesu christo de mil \& quinientos \& quarenla (1540) a veynte dias del mes de Nouiembre. fol. let. gót. á 3 colunas. Tambien se suprimió en esta edicion el Pleilo del manto.

Depping se equivoca, en las notas á la Introduccion de su Ronancero citando una edicion hecha en Valencia por Jorge Costilla en 1545; este impresor solı publicó la de 1514 ; tambien menciona tres reimpresiones de Valencia de 1517, 1526 y 1568, una de Sevilla de 1527 y dos de Amberes de 1568 y 1678 en $8 .^{\circ}$ Pongo mui en duda la existencia de estas seis ediciones, que nunca he. visto, y solo Nayans, en la vida de Virgilio, pág. 1j1, menciona la de 1678.

8. Canciomerogeneral: que contiene mvchas obras de diuersos autores antiguos, con alyunas cosas nuenas de modernos, de nueuo corvegido y impresso. (Sigue el escudo del impresor y dehajo dice:) En Anvers, En casa lle Martin Nucio, à la enseña de las dos Cigueñas. M.D.LVII. Con Priuilegio del Rey. 8. ${ }^{\circ}$ marq. ceccij hojas fol. y 8 de fróntis y tabla. A dos culunas.

Fsta edicion contiene más que la de 1575 todo lo que se halla desde el fol. ccclvij vta. hasta el ccelxxiiij, bajo el epigrafe de obras le burlas; pero ell cambio á la más reciente se le añadieron ciertas composiciones que

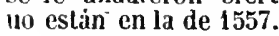

181 CANCIONERO de obras del Marques de Santillana, Fernan Pérez de Guzman, Juan de Mena, Juan Rodríguez del Padron y otros distinguidos poetas del siglo décimo quinto. fol. MS. de hermosa y gruesa ietra roja y negra, mui parecida á la que copia el P. Merino al principio de la lámina 30, pág. 283 de su Paleografía, escrito hácia el 1450. El papel es fuerte y bello y lleva la cono- 
$\mathrm{CiN}$

iNTOLOGIAS Y JUStas POÉticas.

CAN

cida marca de la sortija. Está completo y va desde el fol. I hasia el cxciij, a más de la hoja de portada, en que solo dice, de letra abultada gótica

\section{Cantionero.}

Aunque su principal valor viene de las poesias que comprende iueditas, no es inferior en las ya jublicadas, por estar en todas uás anticuado el lenguaje que en lo impre. so, y por las muchas y notables variantes que suministra. Haré una reseña de las obras que conliene.

\section{$1 .^{2}$}

La Consolatoria de yñigo lopes de mendoça marõs de santillana v conde del Real al Conde de alua.

ocupa desde el fol. $\mathrm{j}$ al xxxiij, $\mathbf{y}$ principia:

Que es lo que piēsas fortuna.

E] Sr. Llagıno la intitula coplas de Bias $a$ la Fortuma, y copia la dedicatoria en 'a página 224 y siguientes del Centon epistolario etc. Madrid, 1775. 4. Esta dedicatoria no se halla en el MS.; pero sí la tïla de Bías. Llaguno dice que están impresas en euarto, sin espresion del año, del lugar, ni del nombre del inpresor. Sánchez (pág. XllI del tomo I de la Coleccion de poesins castellanas, rnteriores al siglo $X V$ ) sospecha que es de Sevilla y de Estanislao Polono; de lo que él no podia cerciorarse, por esiar inconjpleto al fin el ejemplar que logró ver. Ic da (en la pág. XLI) el titulo de Bias conlra Fortuna, y dice que es un diálogo entre Bias y Fortuna, de ciento y ochenta octavas de pié quebrado. Bayer en la nota de la pág. $27 b^{\circ}$ del tomo II de la Bibliot. Vet. de Nic. Antonio, las reduce á CLXX. Acaso sea errata: yo puedo asegurar que en mi MS: hai 175. Bơhl de Fáber ha entresacado solas ochenta en la pig. 97 y si. guientes del tomo lll de la Flor'esta.

\section{2. ${ }^{2}$}

Diuersas virtudes $\varepsilon$ vicios $\varepsilon$ himnos rymados a lohores diuinos enbiados al muy bueno et discreto aluar garcia de santa maria del consejo del rey ñ̄o. señor.

\section{Prologo.}

Amigo sabio 2 discreto ete.

Desde el fol. xxxjv al exvij.

- Estas son las Sietecientas de Fernan Perez de Guzman, segun se hallan desde cl fol. j. vta. hasta el verso del blanco de la sign. diij de la edicion de Lisboa, 1541,

\section{que non con manif̧̧̧ençia.}

Lo que sigue en las hojas cxijj á cxvij del MS. no lo hallo en dicho volúmen de las Sietericulas, lli si que se laya publicado ell otra partc.

\section{3. ${ }^{\mathrm{a}}$}

I Johan de mena.

Argumento breue de toda la obra к julocacin catholica.

Canla lu xp̈iana musa ete.

Folios cxviij al cliiij.

Estas son las Coplas de Mena contra lus. pecados mortales con la continuacion di Gómez Manrique, impresas en lus fóls. CIX a CXVIll del Cancionero de Mena y otros, de Zaragoza, 1506 y 1509 , pues ambas ediciones contienen lo mismo. En las que comprenden solamente las obras de Mena $y$ se Lallan estas Coplas, la continuacion es de rai Jerónimo de oliváres, distinta de la de Gúmlez Manrique. EI MS. no pasa de la estrofa que principia:

E sy bueno ser quer'as,

que está en el fol. CXVII del impreso, en èl aun continúan cuarenta coplas más.

\section{4.}

los siete gosos de amor que fiso Juan Rodrigues del padron.

Ante las puerlas del templo etc.

Desde el fol. clv hasta el clvijj.

Hállanse en el Cancinnero general de Almbéres de 1575 , al fol. 121 y siguiente.

\section{$3 .^{2}$}

Nao de mosen Juan de dueñas al Key de aragon.

En altas ondas de amar.

Fol. clix á clxij.

Es diversa de la Nao de anmer del Conne'ldadur Escrivá, que está ell el fól. $527 \mathrm{~d}$ d Cancionero general de Amberes. 0elow la I"cimprimio en el tomo de Rimas de Sanlillana: pero el testo de mi MS. es preforible al unue él siguió.

Tanto Nic. Antonio como su anotador II" ticen una sola palabra de suan de lluenas. y Latassa que habla de il ell la pág. lon reil tomo Il de: la Biblinleca anligna, tno conns. ciú esta obra.

$$
6 .^{2}
$$

lope de astuñiga denos dios señora mia ele.

Folio clxiij. No estat en el Cancionero groureral.

$$
\begin{gathered}
7^{2} \\
\text { gonez manri } \\
\text { quardo Roma conijstaua ele. }
\end{gathered}
$$

Folios clxiv, clxv y elxvj.

Tanto en el Cancionero general, fol is via., conno en el lonno I, pig. 145 de la Florres/a de böhl de ráber falla la copla del ys. yute dice: 
Es peligjo navegar ell galea sin los renıs, mas mayor es conversar con quien sigue los estremos; pues si la conversacion is cou los tales dinnosa, por cierlo la sujebeion undeluo será peligrusa (provechosa).

\section{$8 .^{2}$}

lope de astuñiga a la señora suya esta mal

(donsella culya bollesa elc.

fol. ('Axrij y concluye en el reverso del mismun.

Io la hallo en el Cancione'ro gemeral, ni la simnicmle, que va del ful. clxvii vta. al c'lxix vila.

$$
\begin{gathered}
9 .^{a} \\
\text { lope de astuñiga } \\
\text { (0 sy mis llagas morlales rete. }
\end{gathered}
$$

\section{$10 .^{2}$}

desir ij liso Juã de vlloal a don sancho

sabed señur virlunso ele.

$$
\text { 11. }
$$

respuesta de don sancho

Hegre siempre y gasoso.

Las dus se hallan en el foll. clxix vta., y III" en el cancisncers gencral.

\section{2. ${ }^{2}$}

dierro de Ribera

El diu se va pasando ete.

Eil el fol. clxx, y en su dorso

$$
13 .^{2}
$$

\section{diego de Ribera}

En peliyno esla mi villa ets.

que conclnge con la cara del fol. elxxj.

Faltan en el Cancionero general, ignalmente que las seis que van á continuacion.

\section{$14 .^{\mathrm{a}}$}

lope de astuñiga

acabo de mis dolores etc.

fol elxxj via, al clxxiij.

$$
\begin{gathered}
15 .^{2} \\
\text { cancion }
\end{gathered}
$$

nonn se do raya lan lexos cte.

Fi)l. elxxiij.

$16 .^{\mathrm{a}}$

$$
\text { gomez manriō }
$$

the tal guisa vío deseo elc.
$17 .^{\mathrm{a}}$

condestable

quexense de la fortuna etc.

\section{8."}

mōtoro al marĩs cancion

i obra lan descusar etc.

Ambas en el fol. clxxiv.

$$
\text { 19. }{ }^{2}
$$

Francisco de miranda quant brauas som en ferir etc.

En el ful. clxxiv vla.

\section{$20 .^{2}$}

Proucrbios de ferrnāt ps de gusnan qu: conneras para cras ete.

Fol, clxxv i clxxxiij.

poeos tenian noticia de esta obra de pérez. de Guzman, Jiasla que ochoa la publico en Paris en 18.1 copiíndola de un Ms. de aquella Biblioteca imperial, $\dot{e}$ incluyendola en el loIIII de Rimas inélilas de don lñigo Lopez at, Mundoza etc. En el presente MS. se hallan seis pronerbigs' más que en el de l'aris.

\section{$21 .^{2}$}

Coronacion de juan de mena al señor marques de santillana. bespues jil pintor del müdo etc.

Folins elxxxiv al elxxxix.

sin las cincuenta coplas tantas vezes impresas.

\section{2. ${ }^{2}$}

Sancho de villegas pues no conosceyss a vos etc.

\section{3. ${ }^{2}$}

glosa de alfonso basurto de la gracia de vos doncella allende de ser muy bella etc.

Fol. clxxxix.

$$
24 .^{2}
$$

Al señor marōs de sãlillana ya la grant noche pasaua etc.

Folios clxxxix vta. y cxc.

\section{5. ${ }^{\mathrm{a}}$}

Coplas de diego de valera uraldigo por vos el dia etc.

Fol. exc.

\section{$26 .^{2}$}

otras de diego valera por las penas q̃ pase elc.

Fol. exc. vta: 
27.

Cancion de sancho de villegas

En el līio ù pense ete.

$28 .^{2}$

otra cancion suya sabe dins con ïnto enojo etc.

29. ${ }^{2}$

memorial de diego de valera a su amiga q̃ndo ptio de castilla acuerdate agora del trisle de mi etc.

Todas tres en el fol. cxej.

$300^{2}$

Otra suya

o triste vida penosa etc.

$31 .^{2}$

despedimi $i^{\circ}$ de diego valera

pues por bien seruir yo peno ete. Ambas en el fol. cxej vta. y cxeij.

$32 .^{2}$

Cancion $\bar{q}$ fiso gomes de rrojas.

por muy grït desdicha mia etc.

$33 .^{2}$

otra suya a braçeyda I a la Reyna.

dos tienen poder agora etc.

Las dos en el fol.cxcij.

\section{$34 .^{2}$}

coplas $\bar{T}$ enbio en

estrenas a braceyda

estrenas estrenas meresçe ete.

3.े. ${ }^{2}$

otra a vn mote filla traya

प dise o si yo nũca naciera

mi vida plagada trisle etc.

$36 .^{2}$

otra poniẽdo al cōtrario el mote $\dot{q}$ diga $\bar{y}$ no he sofrido etc.

$37 .^{2}$

otra en $\tilde{q}$ torrno a poner

el mote de braceyda

por $\tilde{q}$ le dixeron $\tilde{q}$ non las

avia el fecho.

quien dixn fue descortei etc.
$38 .^{2}$

glosa $\tilde{q}$ fiso goms de Rojas a

va canciõ $\bar{q}$ dice ros sereys toda mi vida.

por dina de ser seruida etc.

Las cinco en el fol. cxcij vta.

$39 .^{2}$

la copla

mas dame graue pasym etc.

$40 .^{2}$

otra suya a no me

place nin consyente

Aun ỳ ya males syn cuèto etc.

41. ${ }^{2}$

la copla

mas por aver alegria etc.

42. ${ }^{2}$

vn cantar ô fiso gomes

de Rojas ptiendo de la corte

ya mis ojos vercys ğndo ete.

Las cuatro en el fol. cxciij.

43. ${ }^{3}$

glosa ỹ tanbien fiso a vna cancion de aluaro de mendoca.

quando mi visla a vos ver ete.

Las dos en el fol. cxciij vta.

Las 22 composiciones mencionadas desde la 22." inclusive se echan de ménos en el Cancionero general.

182 CANCIONERO DE FRAI ÍṄIGO DE MENDOZA.

CUita $x$ pi fecho por coplas por fre y yñigo de mẽdoca a peticiõ dela nu y virtuosa señora doña juana de car lagena.

Con este epigrafe principia la primera coluna de la lioja sign. a, concluyendo el colimen en la octava de la $\mathrm{m}$; hai despues una hoja en cuyo blaneo se lee: Las coplas $\bar{q}$ ay en este cãcionero son las siguiêtes. De esta especie de tabla se saca que casi todas las composiciones son de Fray Iñigo de Mendoza, a saber, la Vita Christi, El Sermon trobado, Coplas en vituperio de las malas hembras en loor de las buenas, otras en que declara como por el advenimiento de los Reves Católicos es reparada nuestra Castilla, El dechado, Ia Justa de la razon contra la sensuali- 
dad, los Gozos de nuestra Señora, la Cena de nuestro Señor, la Pasion de nuestro Redentor, á la Veronica y al Espíritu sancto. Llenan las 21 hojas úllimas del volumen las Coplas de Jorge Manrique á la muerte de sil padre, una Lamentacion á la quinta angustia de nuestra Señora, las Coplas de Juan de Mena contra los pecados mortales, la Pregunta de Sancho de Rójas á un aragones, con la respuesta de este, sobre que es amor y las Coplas de Jorge Manrique sobre el mismo asunto.) S. I. ni a. (Zamora, Centenera, hácia 1480?)

El vol. es en fol. de let. gót. á dos cols. Sin foliacion; tiene las sign. $\mathrm{a}-\mathrm{m}$, todas de 8 liojas, ménss la última que es de 9 , y tal vez le falta una blanca al fin. Son en todo 89 hojas útiles, porque no se halla la $\mathrm{k}$ en lus sign.

Aunque no suena en parte alguna el lugar y año de esta rarísima impresion, no me cabe duda estar hecha en Zamora por Antou Centenera, hácia cl 1480 ; efectivamente, ell la biblioteca de $\mathrm{D}$. Pascual de Gayángos $\mathrm{vi}$ in tomito impreso con los mismos tip: is cuya descripcion es como sigue. Principia por la sign. $a$ de este modo:

C Vila xp̃i fecha por coplas por frey yñ go de médoça a peticiō dela muy v'tu sa señora doña iuana de carlagena.

Sigue esta obra hasta el reverso de la sign. eii y en la siguiente eiij principia el

Sermon trobado que fizo frey yñigo de. médoça al muy allo $y$ muy poderoso prinçipe rey y señor el rey dō fernádo rey le castilla y de aragon sobre el yugo y coynmdas que su alteza trahe por deuisa.

Llena este sermon cinco hojas y en el reverso de la última que es la $6 . "$ de li sign. $e$, se lee:

i Fecha en camora a veynte y cinco de henero año de lxxxij(1482). Centenera.

Viene á continuacion en $\gamma$ hojas con la sign. A de la misma letra que el tratado anterior una

( Cöposyçiō fecha por goinez manrrique enderescaila alos serenissymos señores priçipes de los reynos de castilla $x$ de arafjon ? reyes de cecilla.

4. ${ }^{\circ}$ let. gót.

siendo evidente, como arriba he indirado, que el tomo de composiciones de Inill Inigo de Irendoza y otros poetas que poser. está publicado ántes de 1492, se equivoci Ticknor al suponer que el impreso en Zaragoza cu dicho año, descrito en el siguiente articulo, es la antologia más antigua dida il liz en Fspaña. Tampoco anduvo acertildo en derir, que el camrionero de Caslillı de 1511 fue la primera ubra con este títula, pues tanto en el epigrafe de la labla de la impresa por Centenera como en el de la ejecutada por lablo Hurus ya se les dió á ambas esta denominacion.

D. Fermando Colon en el Registrum de su biblioteca cila una edicion de solas las $\mathrm{Co}$ plas de Vita Christi fechas por fray Iñigo de Mendoza. Sevilla, 1506. 4. á dos cols. con láminas.

183 Cancionero. Cancionero De Obras de Burlas Provocantes a Risa Cum privilegio, En Madrid, Por Luis Sanchez, s. a. (Londres, 1841). (En la pág. 203 se halla copiada la fecha de la primera edicion; Valencia, por Juan Viñao a xxii de Febrero. Añc M.D.XIX.) 8. ${ }^{\circ}$ mar(. esp. El fróntis es de let. gót. negro y colorado.

Desde la pig. 207 á la 246 se compone de poesias recogidas de nuestros antiguos poetas por el edilor de esta edicion, de quien son las interesantes Advertencias que la preceden y el Glosariu puesto al fin. La impresion es bellisima y segun se me ha asegurado, solo se tiraron 200 ejemplares de ella sobre papel y 4 o 6 sobre vitela.

He visto en el Museo Británico el único ejemplar conucido de este libro, acaso el mas cínico $\mathrm{y}$ obsceno que ha producidi la prensa española. He aqui su descripcion:

(Un personaje cseribiendo sobre una mesilla y delante un jarro con flores. Es la misma lámina ó una mui parecida á la que se halla al principio del Itispano, devaía contemplacio: bajo en dos líneas:)

\section{UTamionera de}

\section{Iltras ì haclas pronarätes a Risa.}

(Todo lo descrito hasta aquí circuido de Ima orla. A la vuelta: Comiença vn nposento que se hi:o enla corte al papa alixadre, ete. ete.

En la sign. E: Siguese vna especulatiua obra intilulada caragicomedia etc. - En el blanco de la octava hoja de la sig. $G$ se lee cl siguiente final:)

$$
\begin{gathered}
\text { Aqui se acaba el libro llamado cancio } \\
\text { nero de obras de burlas: el qual fue } \\
\text { impresso enla muy noble cibdad } \\
\text { de valencia por Juan Uiñao } \\
\text { a xxij. de febrero. año. M. } \\
\text { D. xix. }
\end{gathered}
$$

4. ${ }^{\circ}$ let. gót. Todo el volúmen está á dos coluuas escepto la Caragicomedia que está á ren. glon tirado $y$ las notas al rededor de las páginas. Signs. $A-G$ todas de 8 hojas. Este cancionero solo comprende las composiclones que contiene la reimpresion de Londres 
hasta la pág. 205. y son las mismas que en el Cancionero de Castillo se intitulan obras de burlas; con la adicion del Aposento de Juvera y la Caragícomedia; por consiguiente está tambien el Pleito del manto, produccion, que segun une dijo D. Bartólome Gallardo, suspechaba sèr parto del ingeniı) del $P$. Iñigo de Mendoza que tantas $y$ tan devotas coplas hizo en su vida.

184 CANCIONERO (el) de Juan Alfonso de Baena (Siglo XV). Ahora por primera vez dado á luz, con notas $\mathbf{y}$ comentarios. Madrid, M. Rihadeneyra, 183̈1. 8. may. 2 facsimiles del códice original.

Este ejemplar tiene una precinsa y singular encuadernacion inglesa en tafilete encarnado, imitando perfectamente las hechas por Derome á flnes del siglo pasado.

\section{CANCIONERO DE RAMON} DE LLAVIA. Principia en la hoja sign. a j, sin frontis por no haberlo nunca tenido, dél modo siguiente:)

Prologo fecho ala señora doña francisquina de bardaxi mujer d'l magnifico señor mossen joan fernandezde heredia gouernador de arago por ramon dellabia en $\tilde{q}$ le endereca el presente libro. Ocupa poco mas de la mitad de la primera pág. y á continuacion:)

\section{Tabla del presente libro}

Coplas de fernan perez de guzman de vicios: e virtudes: e ciertos hymnos de nuestra señora dirigidas al muy magnifico: $\varepsilon$ virtuoso aluar garcia de sancta maria coronjsta del rey don joan de castilla: $\longleftarrow$ de su consejo . a cartas. ij

De los. vij. pecados mortales que fizo joan de mena para la emienda de la presente vida a cartas. Xxxxiij.

Confession de fernan perez de guzman delos. x. mandamientos: e. vij. peccados mortales: e las. vij. obras de misericordia temporales : e otras. vij. spirituales a car. xlviiij.

Del mismo fernan perez contra los que dizen que dios en este mundo $\mathrm{nj}$ da bien por bien: nj inal por mal a cartas. lxj

Del mismo fernan perez dirigidas alas nobles y tuosas mujeres para su doctrina dando les. v. consejos los quales son honrra tus suegros / ama tu marido / gouierna tu casa rige tu familia / viue sin reprehension a cartas. lxv

Dechado $r$ regimiento de principes fecho por fray ynyou de médoca dirigido ala serenissima $\tau$ muy alta señora doña ysabel reyna de castilla de aragon a cartas. lxiiiij.

Obra de don jorge manrique por la muerte de su padre en menosprecio del munclo a cartas. lxxiij

Coplas de fray ynygo de mẽdora alas mujeres en loor de las truosas $\tau$ reprehensiõ delas ī no son tales a car. lxxyj.

Otra obra de don jorge manrique dādo diffiniciõ de amor que cosa es a cartas. Ixxriij.

Otras dos esparcas de joan aluarez. en la rna se despide del mundo: la otra faze por vnos compases que. trahia el duque de alua a cartas. lxxviij.

Obra de joan de mena jntitulada la flaca barquilla de mis pensamientos a cartas. lxxviiij.

Coronacion d'las. iiij. virtude: cardinales fecha por fernä perez de gilzman enderecada al marques de santillana a cartas. lxxx.

Obra de eruias en loor de nuestra señora a cartas. Ixxxiiij.

Los. vij. cuchilos $\bar{q}$ firieron an nuestra señora fechos por gonuez. manrique a cartas. lxxxy.

La coronació de nuestra señora fecha po: el bachiller fernã ruyz de seuilla a cartas. lxxxrj.

En decir de goncalo martinez de medina contra el mundo a carras. lxxxviiij.

Otro del mismo goncalo a cartas. xe.

Un otro dezir de fornā sáches talauera a vna dama fecho por draloyo: z concluye en virtud a cartas ic.

Razonamiento de fray gauberte d'l mõge con el cauallero sobre li vidi venidera a cartas. xcj.

Son las obras en el presente volnmen contenidas. xriiij.

Principia la obra en la hoja siyuremle sign. aij y rmmrluype en el 
blanco de la octava de la $\mathrm{n}$ sin fecha mi lugar de impresion, aungue esta es pridentemente del siglo $X V$.) Vol. en fol. de let. gót. á dos colunas. Sin foliacion sign. a-n todas de ocho hojas ménos la d, I y m, que solo tienen seis.

Bello papel y edicion la cual me Inclino á creer hiberse hecho en \%aragoza.

El Cancioncro de Llavia es una verdadera joyia biblingráflca por su insigue rareza; mi padre lo clasiflcaba entre los volumenes mas preciosos de su Biblioteca, y Ticknor, en la Ilisloria de la lileralura, no sulo no lo menciona sinn equirocadamente supone que el unico libro de este gémero publicado en Espaina ántes del Cancionero de Castillo del aîn 1511 , fué la coleccion de nueve poetas impresa en Zaragoza en 1.492.

El Cancionero de Llavia debe ser anterior i csta fecla por cuanto D. Juan Fernández de Heredia era ya gohernadur de Aragon en 1 is1, segun Zurita.

\section{CANCIONERO Coplas de} Vita Christi. de la Cena cōla pasiō. $y$ de la Veronica cōla resurrecciō de nuestro redêtor. E las siete anguslias e siete gozos de nuestra señora. con otras obras mucho provechosas.

(En la misma hoja de la portada á la vuelta, coloca el siguiente catalogo con este epigrafe:)

Las coplas e obras que en este cãcionero se contienen son las siguientes

Primeramente el Vita Xp̃i $\tilde{q}$ fizo fray yīigo de mendoza...

Otras coplas fechas por el dicho fray yinigo en que pone la cena it nuestro salvador hizo con sus discipulos...

Otras coplas de la passion de nuestro redēptor trobadas por diego de sant pedro.

Otras coplas que fizo fray vinigo a la veronica.

Otra obra de la resurreccion de nuestro redẽptor jesu $\mathrm{X} \tilde{p} 0$ que fizo pero Ximenez.

Otras coplas de las siete angustias de $\| \tilde{r} a$ señora fechas por Diego de sant pedro.

Otra obra de los siete gozos de nuestra señora fecha por fray yīigo.
Otras coplas en loor de nFa señora fechas por ervias.

Coplas de la hysturia de la sacratissima virgẽ maria del pilar d'zaragoza fechas por medina.

Coplas que fizo el famoso juã de mena contra los siete pecados mortales.

Otra obra de los diez mandamiētos e de los siete pecados mortales cõ sus virtudes cõtrarias y las catorce obras de misericordia temporales e spirituales fechas por fray juã de ciudad roùrıgo...

Las coplas de justa de la razon cõtra la sensualidad fechas por fray yñigo de mendoza.

Las coplas de Jorge manrique por la muerte de su padre.

Un decir gracioso e sotil de la muerte, hecho por fernan perez de Guzman.

(Al fin:) Fue la presente obra emprentada en la insigne Ciudad de $\mathrm{Za}$ ragoza de Aragõ por industria e expensas de Paulo Hurus de Cõstancia aleman. A. xxvij. dias de Noviembre M. cccc.xcij.

Fol. let. got. á dos colunas. Láms. de madera. Papel grueso y buena edicion.

La descripcion que precede de este rarisimo volúmen la he sacado de Méndez por hallarse mi ejemplar falto de las primeras y últimas lıojas.

\section{CANCIONERO DE JUAN} DE MENA Y OTROS.

Las ccc. del fanosissimo poeta Juan de mena con sIl glosa : $ช$ las cinquẽta cõ su glosa: r otras obras.

Principia la hoja Aij por estas palabras: Las coplas y obras que en este presente tractado estan copiladas son las siguiētes $A l$ dor'so empieza la Tabla, que ocupa cinco páginas más. En el reverso de la hoja quinta está el Prologo ó dedicatoria de la G'losa, que lermina en la hoja siguiente. IIállase al dorso de esta la lámina, que representa á Juan de Mena ofreciendo su libro al rei Don 
Juan. Viene despues el fol. I de la obra que concluye asi en el blanco del fol. CX.X. despues del escudo de Coci:)

I Fue imprimida la presente obra a instācia del discreto y virtuoso rarõ Loys malferit enla nuy inclita y noble cibdad de caragoca: por industria del virtuo:0 varo George coci: y acabo se a. v. de mavo del año de mil q'njētos y sers (1306.) fol. let. gót. Lams. de madera. 6 hojas prels. y CXXX fol.

\section{CANCIONERO DE JUAN DE MENA Y OTROS.}

Las. cce. cō. xxiiij. coplas ago

ra nuevamēte añadidas:

del famosissimo poeta

Juan de Mena con

su glosa : $r$ las cin

quenta con su

glosa: e o

tras 0

bras.

(Este titulo de letra gruesa como el de la edicion anterior. Al dorso principia el Prologo y al pié se halla el indice; ambas cosas ocupan hasta el blanco de la hoia segunda. a cuijo recerso va la limina representando al autor en acto de ofrecer su obra al rei. En la lercera hoja fol. I Comiença el labyrinto elc. Sigue á plana renglon con la de 1006 hasta el blanco del fol. CX.Y. donde se lee despues del escudo del impresor:)

Acaban se las treszientas del famoso poeta Castellano Juan de Mena : con xxiiij. por el añadidas: las quales fasta agora nunca han sido impressas: y otras obras suyas. y de otras notables personas muy prouechosas: segū por orden del libro se demuestra. Fue impressa enla muy inclita y noble cibdad d'caragoca: por industria y costa de Georgi (sic) coci Aleman. y acabose a. xxiij. de Septiêbre. año de mill y quinientos y nueue (10009.) fol. let. gót. Lams. de madera. 2 hojas prels., y CXXX foliadas, intercaladas 6 despues del fol. LXXXVIII, que no llevan foliacion.

TOM. 1. fulicion hecha i plana renglon en el cuerpo le la obra sobre la anterior, de la que es diversa sin embargo. Las diferencias reales $y$ visibles se hallan todas en los princlpins y el colofon, pues esla aunque lleva un título de la misina letra gruesa que la de 1506, va dividido de dístinto modo, segun lo deinuestran las copias exactas que de ellos doi, y al principio solo tiene dos hojas de preliminares para el Prologo y un breve indice del contenido de la obra, mientras en ld anterior se llenan seis por ser la Tabla mui difusa: por lo demás ambas edieiones $s \backsim n$ tan parecidas que dificilmente se las distingue siendo iguales hasta en los folios, pues las 24 coplas añadidas por primera vez, se encuentran intercaladas en 6 hnjas despues del fol. LXxxill sin numeracion ni signaturas, de modn que ninguna de las dos cosas se altera ell el resto del tomo y van acordes ambas impresiones hasta el tinal ì sea fol. C.XXx.

Las obras que contiene este rolumen son las signientes:

Las trezientas de Juan de Vena. Con xxiiij otras suyas agora mevamente añadidas. (Estas 24 no se encuentran en la edicion de 1506.)

Coplas del mesmo poela inlituladas la Coronacion.

Otras suyas que fizo de los siete pecados morlales Con la continuacion de Gómez Yanrique.)

Coplas fechas por fray Juan de Ciudad Rodrigo de los diez mandamientos.

otras coplas, de dicho fraile, de los siele pecados mortales.

otras, de dicho fraile, tle las siele obras de misericordia espirituales.

otras, del mesmo fraile, de las siete obras de misericordia temporales.

Coplas fechas por frai hingo de Mendoza intitularlas la Justa de la ra:on contra la sensualidal.

Coplas fechas por Diego de S. Pedro inlitulailas desprecio de la fortima.

Coplas ordenatas por Fernan Pérez de Gusman por contemplacion de los empera. dores reyjes y princijes.

Vi Vr. Ticknnr ni sus traductores conncleron la enntinuacion $y$ terminacion del tritado de los siete pecados mortales de J. de Iena hechn par Gumez Manrique, y es la que se encuentra en las dos ediciones anteriores, debiendi arlvertir se hallan en el impreso, al fln, cuarenta coplas más que en el Cancionero del yarques de Santillana el cual posen en un bell , códice del sigls $x \%$. (V. el $\%^{\circ} 181$.)-Los Sres. Gaýáng us Y Yedia se equivocan cuando suponen que las $24 \mathrm{co-}$ plas añadidas al Laberinto ó Trezientas, se imprimieron por primera vez en sevilla en 1517 habiendose publicado yd en 1509 en la coleccion arriba descrita.-Segun remos por la lista de las composiciones contenidas en este volimen, el Desprecio de la fortuna de Diego de S. Pedro se imprimió con las ubras di. Wrind murlon intes de 1666 , fecha 
la más antigua en que Mr. Ticknor.supone se juntaron estas obras.

En Londres tuvimos una edicion comprensiva de los mismos tratados que las de 1506 y 9, la cual decia en el fróntis en seis rellglones: Las. cec. del famosissimo poeta Juan de mena con su glosa: ₹ las cinquenta cè su glosa: $<$ olvas obras. Al dorso: Glosa sobre las Irezienlas etc. Prologo. En el blanco de la hoja siguiente: Las coplas y obras que en esle presente tractado estan copiladas etc. (Son las que dejo indicadas.) Viene luego el fol. $I, y$ concluye cu el blanco del CXXX con el gran escudo de Coci y este colofon: Fue imprimida la presente obra por indistria y espensa de George coci cn la muy inclita $y$ noble ciudad de Caragoça: y acabose $a$. $v$. de oclubre del año de milt \& quiniètos $\leftarrow$. $x v$ (15l5). fol. let. gót. Coll algunas láms. de madera.
Los traductores de Bouterwek citan, en la pág. 217, tom. I., el Cancionero de Juan de Mena impreso en 1520. Ignoro sl aludirán á otra edicion de la antologia descrita ántes, $\dot{o}$ á alguna impreslon de las obras de Mena.

Existe una reimpresion, que he visto, de los tratados publicados en 1506, 9 y 15, la cual salio á luz en Alcala, Iuan de Villanueua y Pedro de Robles, 1566. 8. 12 hojas preliminares, principia la obra al fol. 9 y sigue hasta el 520 ; en 86 fols. mis se hallan, las Coplas de los siete pecados mortales y las otras composiciones que llevan al fin las ediciones zaragozanas.

Como muestra de algunas de las láminas que adornan ambas ediciones le 1506 y 1509 , se copia la siguiente, colocada frente al fol. LXXXIX, reducida á ménos de la mitad de su tamañio.

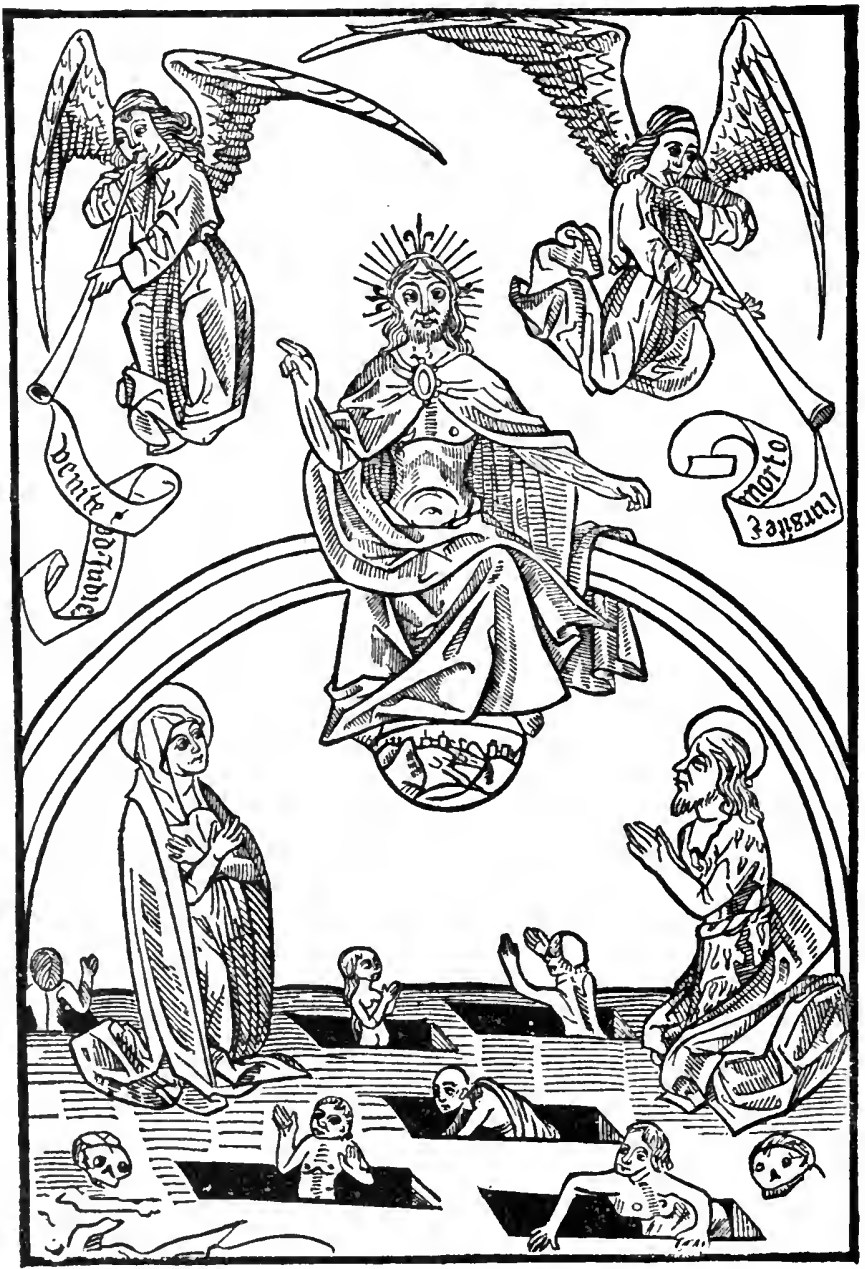


Y esta otra, que ha sidn coplada de su verdadero tamano, precede al tratado De los

siete pecados mortales $\mathrm{y}$ se encuentra frente al fol. CIX.

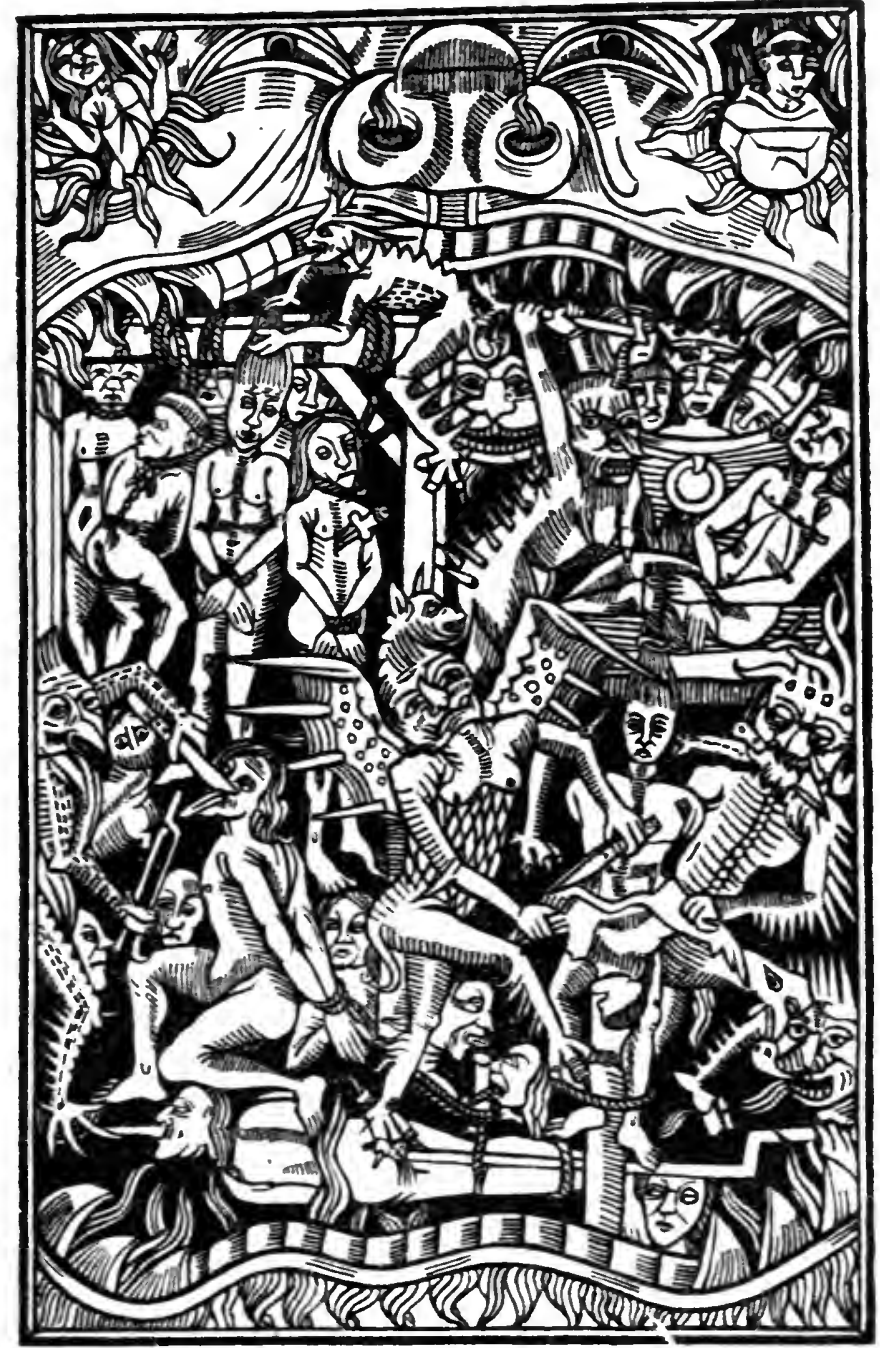

189 CANCIONERO. C Cancionero de nuestra señora: Enel qual se contienen muchos romances / canciones / villancicos / \& chistes / Agora nueuamente Jmpresso. (Va precedida esta leyenda por una lámina de madera que representa la salutacion angélica y el lodo se halla circuido de orla. Al dorso: Siguese el cancionero: enel qual se contienen muchas obras en loor de nuestra señora / y de otros sanctos. Y este primero que se sigue: es de la sancta Encarnacion del hijo de Dios.) S. 1. ni a. (hácia 13̈10.) 4. ${ }^{\circ}$ let. gót.

Desgraciadamenle solo poseo la primera hoja de este precioso libro y una parte de la segunda, en cuyo trozo termina la compo. sicion á la Encarnacion del hijo de Dios, a que se reflere el epigrafe arriba copiado.

Ignoro cuántas hojas componen este Canlcionero; pero sospecho que tal vez no pasen de ocho a doce. - El Sr. Duran no lo mellein. 
na en los Calulogos de su Romancero general, ni encuentro en esta ohra el ínico romance que se conserva en mi fragmento, el cual principia:

De los cielns sale l"angel A la tierra lescendia. Cartas llev'a á una doncella. De noble mensagería.

190 CANCIONERO de Nrestra Señora: en el qual ay muy buenos romances, Canciones v Villancicos. Aora nueuamente añadido. Impresso en Barcelona, con licencia del Ordinario, en casa de la biuda de Hubert Gotart, Año. 15091. 12. ${ }^{\circ}$ 81 hojas fols. inclusa la portada.

Volúmen precioso y deseonocido á todos los bibliografos: contiene una porcion de lindisimas composiciones que no hubieran desdeñado de incluir en sus antologias Böhl de Faber y D. Justo Sancha si hubieran logrado adquirir $\dot{0}$ ver esta alhaja.

Con dos nuevas especies de portaditas en las que hai una intagen de la Virgen: pern siguiendo la misma foliacion, se hallan: $E l$ rosario de Nuestra Señora la viryen Ifaria, y la manera de rezar los quinzi .ysterios del Rosario. Ay en esle Hosario oraciones muy deuolas y contemplatiuns, con ias coplas de cada Mysterio.-Comiençan los yozos de meslra Señora del Rosario. có olrals coplas muy dewolas del Rosario. tyui tam unas coplas menamète cópueslus por lı sol fa mi re, con un milagro de in religioso muy deuoto de mestra señora del Rosurio.

lghoro si esta obra seri la misina del Catálogo de Sora, pág. 112, intitulada: Thomas Garcia, Cancionero de nuesiru Señora, Burcelonu, $1606.16^{\circ}$

191 CANCIOYERO llamado Dança de galanes, en el qual se contienen inumerables canciones para cantar, y baylar, con sus respuestas, y para desposorios, y otros plazeres. Recopilados por D̆iego de Yera. (Figuritas de un galan y una dama, grabadas en madera.) En Barcelona. Por Geronymo Margarit en la calle de Pedritxol, delante $\mathbf{Y}$. S. del Pino, Año 1620. 120.60 hojas sin fol. con las sign. A-E, cada una de doce hojas.

llermoso ejemplar, prefinsamente encuadernado por Duru en tafllete encarnado. cortes dorados y jaspeados; perteneció á la Biblioteca de Cárlos Nodier.

Varios autores citan una edicion de Léri. da, 1612. 12.0, y acaso será la printera.

Contienc este volumen entre otras varias eomposicionos mas cancinnes sobre diwer. sas colores y las significaciones dellas, que sin duda son de Timnneda. Véase el articulo de este en la presente division, entre los opúseulos descritos por Wolf.

Brunct corrige con razon á Nic. Antonlo, quien denomina Vega á Vera, y no sé de donde pudieron sacar dicho Antonio y Barrera que el recopilador de este Cancionerito rarisimo, fué Don Diego de Vera y Ordóñez de Villaquiran, á quien supnngo diverso del hmmilde Diegu de Veril. En la relacion a lis flestas hechas ell Barcelona en 1601 á li callonizacion de $\mathrm{S}$. Raimundo de Rocafort, publicada por Fr. Jaime de Rebullosa, enenentro í un Don Diego de Vera entre los que escribieron para la Justa puética, y tal vez sca el mismo.

Xi Duran ni Barrera han lograd, ver este libro, por lo mismo no estraino se equivoquen ambos en el mimero de sus hojas. y que el primero no haya incluido en su Romancero ninguna de las poesías comprendi das en él: tampoco se encuentran en el Romancero general de Cuesta, í pesar de liaberlas mui lindas y picarescas. Sirvan de muestra las dos siguientes:

\section{Cancion.}

Cuando í Juana toparé otra vez bajo la haya, a fé, a fé, que le daris cosa que no se le cayle.

¿Es verdad, dime Bartolo. que Juana allá en tu rełaĩo, por verme con ella solo. diz que fui de los de antaño? Dile, que euando veré qué aforro tiene la saya, i fé, a fe, que lo dart' cosa que no se le cayr.

bice la falsaria perra, que platicando en soidz, para apaciguar la guerra no fui para darle paz. cuando yo la besaré, purque quejarse no vaya, a fe, á fé, que le daré cosa que no se le caya.

Por callar y tener miedo bajo de la liaya umbrosa, Juana agora en hablar, quedo yo afrentado, clla quejosa. Ilable Juana y dejeme llegar do tiene la raya, a fé, a fé, que le daié cosa que no se le cayja.

Calle Juana y sufra, pues que si yo le do mis vezes, haré que venga íl los piès el mal de los nueve meses. Cuando dormida hallaré su vergonzosa atalaya, d fé, d fé, que le ditré cosa que no se le caya.

La mujer tengo entendido, que de los medios diftere, y eon un hablar tingido que pregona lo que quiere. Plles Jualla, segun se vé, lo mismo á defir se ensaya. 


\section{CAN antologías y justas póticas. CAN}

d fé, d fé, que le clare cosa que no se le caya.

\section{Lelrilla.}

Serrana, si vuestros ojos tuatan con solo mirar, mui rica debeis de esla. rubando lantos despojos. Al basilise imitais con el mirar que teneis pues á cualqujera que reis con la vista le inalais; y asi pues de vuestrus ujos 's el ufleio natar, miti rica debeis de eslar robando lantos despojos.

Itecib). gloria en milarus y mucha pena ell no verus, pues lemu tambien perderus cuandu mas pienso ganalis: y si matan vuestrus ojos, i sualar cus el miras, mui rica debeis de esstar robando tantiss despujos.

Aunque mirandi matais, quiero mis que me uateis gue no que nu ine mireis pues muertio vida lle dais; y pues vuestros bellos ujus inatan con solis milar. mini rira debris de estar. robando lanlos despojos.

En el Museo británico vi un librito, que pur tence su tilul, alguma relaciun cons el de Vera, lo deseribire aqui:

Orla negra que circuye el fruntis y dentro casi tirlo de colocido:

\section{Cancionero de Galanies}

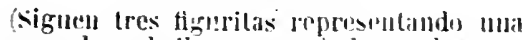
dama y dus calalleros, nuo de los conales luca la gritarra, y bajo:

1 Cancionev de quanes menamente i.ngresso: enel pual si confiue muchos romumces y glosus: y muchus canciones: Cilluncicos: Chistes y Cálures para buylar: clareşar y lanien'.

Empicza la obra a la vuelta del fruntis del modu signtuiente:

C Cànuneror Herenumète hecho En el qual

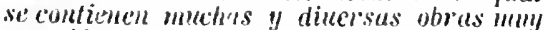
apdisibles. Y en este primur pliego s' contienen tres mumeras dromances glosado y dos cancinnes, el primero d'passcauasse el buen coide, !n olio if dize riberas de duero arriba. y olro gre dis' buen conde ferman gonçalez. s. l. vi a. $4^{\circ}$ let rút.

Efectivamente tales son las anmpusiciones que se hallan en estas cuatro hijas, siento las dos cancines:

Anuel cubullero, mudre.

tres besicos le mandé elc.

y la utril

he mi dicha no s'espera

the alcuse' cosa yue quitra. clc.
Tambien se halla en el Catálogo de Grenville el Cancionero llamado guirlanda esmal. tada de galanes y eloquentes dezires de diversos autores / copilado y recogido por Juan Fernandez de Constantina. S. l. ni a. 4. let. gót.

IIace ya algunos años lo vi en Paris, ántes de adquirirlo su viltimo poseedor, y conservo idea de ser aquella cdicion de principios del siglo Xll.

\section{CACCIONERO de romances} en que estan recopilados la inayor parte de los Romances Castellanos, que hasta agora se han compuesto. Tueuamente corregido, emendado, $\checkmark$ añadido en muchas partes. (Esc. de Ias dos cigieñas.) En Anvers Ea casa de Martin Nucio, a la enseña de las dos Cigueñas. M.D.LV. 12. ${ }^{\circ} 300$ hojas fols. inclusos los prels., que no llevan fol. y contienen la Tabla.

lagnifl:o ejemplar preciosamente encuadernadis por Bauzonet cul taflete verde, corles diorados $\mathrm{y}$ jaspeados. Lleva una nota aulugrafa de su anteriur poseedor itr. Charles Viodier, en la que dice: rendu plus de 240 firmes (a l. 15 s. st.) Solheb! a Londres, 1siT. Bepertorium Biblingraph. Brunet, nouvelles hech. Tom. 1. 202. La encuadernacion se le ha agrogado despues.

Ocius es el que tratánduse de esta obra y sobre linlu de la presente edicjull, observe yo el que Clemencin en el tom. I del oxijote. pag. 19!, la califlca de libro rurisimo.

19.3 La misma obra. En Anvers, En casa de Philippo Nucio, II.D.L.XVIII. 12. 300 hojas fols. inclusos los prels. en los cuales esta cmmprendida la Tabla.

Reimpresion à plana renglon de la anterior de 1.5.5 \% tall parecida a ella que se necesita colejarlas cun mucho cuidado para ca morel une sonn dislintas. Es ionalmente rara.

bil culcetor de este tancioner $u$, dice en el próluci), haher recogidu ('uantos romances riejos le habian venido a las manns, faltando solo los completamente desconocidos ó aque. llus cuyas copias estaban nuui desflguradas 0 incompletas. Advierte al mismo tiempo, que sin duda se olservarán faltas en los inclui. dos. las euales deben atribuirse i lo mendiso de lins uriginales $j$ á la flaqueza de la menoria de los sugetus que se los dictaron. que no se podian arordar dellos perfectamente-Despues añde: "Tambien quise que luviesen algun órden. Y puse primero los que hablan de las cosas de Francia $y$ de los Wore l'ares: ciespues los que cuentan historias cuslullanas, 5 despues los de Troya, y illimamente lus que Iratan cosas de amores. Pero esto no se pudu ba:er tanto a punlu. 
que al fin no quedase alguna mezcla de unos con otros.:

Depping en la Introduccion á su Coleccion cita un Cancioner'o de romances en que están recopilados la mayor parte de los romances castellanos que hasta agor'a se han compuesto. En Envers, en casa de Martin Nucio, s. $t$. 12. 275 hojas. El nismo Depping observa no sir esta edicion tan completa como la hecha por Nucio en $1550,12 .^{\circ}$, de 300 fojas, Ia cual probablemente sirvió de original para las de Anvers, Philipo Nucio, 1554 y $68,12 .^{\circ}$; para las publicadas en el mismo pueblo por Marlin Nucio, el dicho ano 54, 15.55 y 1575 ; la de Lisboa, Hamel de Lyra, 1581, 12. , la cual, segun Brunel, contiene $1 \$ 2$ romances; y para las de Barcelona, de 1587. y 1626. 12.

otra coleccion del mismo género he visto, intitulada: Romances varios de diversos avtores. Añudidos y emendados en estu tercera impression. En Caragoça, Por Pedro Lanaja, Año 1643. Sigue la Tabla en cuatro hojas y despues la ubra en 432 págs. No recuerdo si cra en $8 .^{\circ}$ it $12 .^{\circ}$

Romances varios de liversos aulores. Aña. didos, y enmendados en esta vitimu impres. sion. Madrid, por Pablo de Val. Año de 1655. 12. 12 hojas prels. que contienen: frontis, tabla, licencias $y$ aun algunos romances $y$ despures 477 págs.

L L L misma obra. Sevilla, Nicolas Rodrigues, $1655.120^{\circ} 12$ hojas que comprenden los preliminares $y$ algimos romances, y 477 págs.

No sé què razon hubn para poner fuera del cuerpo de la obra los romances que se hallan al principio entre los preliminares.

Nogues, 166. 12.

Ignoro si este será el mismo libro que el citado por bepping en las nolits á la Inlio. duccion de su Romuncero con el titulo de:

Romances varios de aliversos anlores agora nuevamente recogidos por el Licenciado Antonio Diez. Zaragoza, 1663. 8.

\section{CANCIONERO VALENCIA-}

No. Libre deles dones, mes verament dit de consells profitosos y saludables, axi per al regiment y orde de la vida humana, cố pera aumẽtar la deuocio de la... Concepcio de... Maria, fet per lo magnifich mestre laume Roig. Ara nouament corregit $y$ esmenat de moltes faltes, y de nou affegit la disputa, o proces de víndes y donzelles: Fet per los Magnifichs mossen laume Siurana generos, $y$ mestre Lloys Ioan Valenti, doctor en Medicina, ab rna sentencia del honorable y discret Andreu Marti Pineda Notari. En Valencia. Per Ioan de Arcos, 1501. 8. ${ }^{\circ}$ Fróntis de negro y colorada. 130 fols., inclusos 6 de prels., y 18 que contiene la Disputa de Viudes y Doncelles, sin foliar. -Lo proces de les oliues y somni de Ioan Ioan, ordenat principalment per lo Reverent mossen Bernat Fenollar, y lo discret en Ioan Moreno Notari, E apres per lo magnifich mossen Iaume Gacull caualler e altres amplificat... Corregit, y affegit la Brama dels pagesos, 0 vocables bandejats escrita per mossen Gacull al dit mossen Fenollar. (Al fin: j Fon estampat lo present libre en la insigne ciutat de Valencia, en casa de Ioan de Ar$\cos$, a les espatles del estudi general, Any M.D.LXI. 8. ${ }^{\circ}$ Láms. de madera. 2 hojas prels. y 40 fol. el Proces; el Somni y la Brama carecen de paginacion, son 60 hojas con las sign. A - Il todas de 8 hojas, ménos la última que es de 4.

Todos estos tratados deben reunirse y encuadernarse juntos, no solo por hallarse impresos en el mismo año y pror Juan de Arcos, sino porque el editor de cllos Onofre Almudever, en el prólogo al Proces de les olives advierte, daba á luz como continuacion de las obras de Jaume Roig, publicadas tambien por il, dicho Proces, el Somni de Joan Joan y la Brama dets pagesos, juntando asi las composiciones de Ios mejores poetas valencianos. Por la misma razon doi cabida á este volumen en la presente division, siendo indudablemente un Cancionero ó antología de los principales autores lemosines de fines del siglo II $y$ principios del XVI. En èl se encuentran producciones de Jaume Rolg, Mossen Jaume Siurana, Mestre Lluys Joan Valenti, Andreu Martí Pineda, Bernat Fenollar, Joan Moreno, Mossen Jaume Gaçull, Ificer Verdancha, Mossen Nareis Vinyoles, Baltasar Portell, Micer Artes y Micer Sabater; cuatro de ellos, Valenti, Portell, Artes y Sabater, desconocidos á Fuster y á Jimeno.

Sin duda por ser estas poesias mui populares y mui leidas, los ejemplares completos son rarisimos y casi imposibie de encontrarlos limpios y con buenas márgenes.

como probablemente no volveré á tener ocasion de hablar de Andres Martin Pineda, imo de los poetas de quien se encuentran. composiciones en este Cancionero, aproveclaré la presente para describir tres opus. culitos escritos por él, que he visto, y son raros: Escriu Andreu Marli Pineda Notari, a va son gran amich nuuament casat. (Sigue una lamínita de uno que escribe y otro que le está hablando, y bajo:) vense en casa Ioan Balista Timoneda, junl a la Merce.s. a. 8. hojas en verso.

Comsells, y bons auisos, lirigits a vna noble senyora Valenciana nouament casada. l'er Andreu Man'li Pineda Nolari. (Una lanji. 


\section{CAN ANTOLOGias Y JUSTAs poÉticas. CAN}

nita que representa á una senora que va acompanada de un caballero y seguida de varios otros, y bajo:) Venense en casa Inan Batista Timoneda, junt a la Merce. 8. ${ }^{\circ} 4$ hojas en verso.

En cuatro renglones: Coteplacio en honor y Reuerencia dles set vegades quel nostre redemptor Jesus escampa la sua preciosissina sanch ab tes propietals de cascumi feta per Andreu marli pineda notari. En seguida principia la obra que ocupa dos hojas signaturas $A j, A i j$. Al concluir las coplas se en. cuentra la fecha de 1521 , que es sin duda la de la impresinn. $4^{\circ}$ let. gót. Lleva á las márgenes unas láminas de madera representando el asunto de la conteinplacion.

193 CANCIONERO de la Academia de los Nocturnos de Valencia, estractado de sus Actas originales por D. Pedro Salrá. Valencia, Ferrer de Orga, 1869. 8. ${ }^{\circ}$ Fróntis de negro y encarnado.

De esta linda edicion solo he tirado un cjemplar sobre hermosa vitela y veinticin. co sobre papel bueno y fuerte, numerados.

Cumprende todas las noticias y puesias de la Academia de los Nocturnos, incluidas en el artículo Núm. 156 del presente Catilogo, y sobre una cuarta parte más de las úllimas que no be querido insertar en esle Indice para evitar el que salga demasiado volumi. noso.

\section{CANCIONEROS MAYLS-} CRITOS, Cancionero. de alqunas obras de Silvestre, Padilla, Espinel yotros poetas de aquel tiempo. 1." Manuscrito de 71 fojas de fines del siglo XVI.

Varias de las composiciones de este tono son ineditas, hallándose entre ellas una larga sátira de Espinel que principia:

Un vivo César, Hėrcules famoso,

Espejo y luz de valerisos hechos. etc.

y la siguiente Glosa del mismo á un romance antiguo que tampoco veo en la edicion de sus Rimas.

Sin dineros y sin brio, lleno de malencolia, un amante se salia riberas de un fondo rio que de una pena salia: y como perdió el caudal, siento formento mui flero solo enl haberte perdido, pues cuando tenia dinero, unca fuera cabaltero de danias tan bien servido.

la me traen al estricote. echan por otro camino, pues nadie pagó el escolc, como fuera Lanzarole

cuando de Bretaña vino.

Está mi corazon flel con cuanto mal padecia. que podrán decir por èl, en liempo estaba Espinel de hacer caballeria.

Hai muchas composiciones misticas y no pocas que por demasiado libres no reimpriino: sun notables en este género un romance que principia:

Una dama está en Sevilla mui discreta y mui hermosa; pero la mas melindrosa que debe de haber nacido.

y una Epistola de Yórcos de unas monjas, que dice:

De tindas las religiosas

mal sabidas indiscretas servi de un Yárcos Redondo in diebus meis.

197 CANCIONFROS MANUSCHITOS. Cancionero de composiciones en varias clases de metro de la nejor época de nuestra poesía. Manuscrito en $4 .^{\circ}$ de unas 170 hojas de los primeros años del siglo XVII.

Abunda este volumen en asuntos espirj. tuales por el estilo de los Conceplos de Le. desina, y acaso sean suyas todas o la mayor parte de las composiciones de este género cuntenidas en él. Tambien hai dos o tres romances del Cid que no encuentro en el $R o$. mancero de Duran.-Para dar alguna idea del mirito de las poesias que forman el volumen, prescntare las siguientes muestras: Al Nacimiento.

Dile Pascual á Isabel, que tiene un niño Maria, que Juan el de el otro dia, wo liene que ver con ell.

Pascual, si vuelves al hato por él te preguntarán, pues di á mi cuenta, que Juan aun no le llega al zapato: Y que un sol, nino, clavel, Dios, Jesus , tiene Maria. que Juan el de el otro dia. no tiene que ver con el.

No hayas miedo que lo niegue Juanico en sabjendo hablar, que más lo ha de confesar cuando el mundo más se ciegue.

Yo he visto á Jesus y á él y dije luego á Maria, que Juan el de el otro dia, no tiene que ver con ét.

Di si alguno quiere hacer cumparacion de los dos: Juan es hombre, y Jesus Dios, y no sabrá responder.

A este niño, á este clavel, solo iguala el que le envia, y Juan el de el otro dia. no tiene que ver con el. 
Letrilla.

Bien podeis, ojos, buscar nuevas trazas de vivir, que ya no os puedo sufirir. si tanto habeis de llorar.

Nu es razon que el fuego licve consigo tantas corrientes, no sufren ascuas las fuentes, ni cl cuaru elemento nieve.

No me querais allegar norque he tardido en decir, yue ya no os puedo sufrir, si fanto habeis de llor(t).

Mal declarais mi pasion con tam lloroso torment, siendo luz del pensamiento y lengua del corazon. Tan cerca estais de acabar lo poco que he de vivir, que ya no os puede sufrito si lanlo habeis de lloral.

\section{Romance.}

Bullicioso vientecillo, poderoso con las hojas, que de envidia secó el sol, porque verdes daban sombri; deja del oro las hebras, porque nuuestra que se enıja . del humilde Nanzanáres. la zagala mas hermosil. vo lumilles las florecillas que invidiosas unas de otras, porque las corten sus labios con más abundancia lsrotan: de las humildes corrientes no las inquieten sus olas, que en espejos de cristal es mejor que mansas corríl. Ni quieras de ajenos biences mostrar que olores te sibran, burtando i los verdes campos Io que sus flores arrojan. Ti quieras del ruiseñor sus quejas ni sus congojas por esos aires, i dumde apénas mi bien los viga. Templa los soplos uII poeo. $y$ sin merecerln, gozi ile la voz de mi lmarilis. que canta desdichas propias.

\section{Endechas}

Vo duran mas las tlores en el verano alegre, que dura la firmeza que la mujer promete. No es más lijero el rayo de Jove omnipotente, ni la luz que despide mis presto desparece; Ni tiene más eonstimcia hoja qu'el viento mueve, ola qu'el mar levanta, o niebla qu' el sol hiere. Es eomo el verde ramo de almendro que tlorece, gute una llor arrebilta cada soplo que viene. Nil vezes amenaza. si alguha favorece, y no siempre desdeìa, por ser mudable siemure.

Romance.

ojos, cuyas niñas bellas esnaltan mil arreboles, inuchos sois para ser sules, pocos para ser estrellas. No sois sol aunque abrasai. al que por veros se encumbra, qu'el sol todo el mundo alumbra y vosotros le cegrais: no estrellas aunque serena luz mostrais con Lanta cipia, que en vosotros hai luz propia y en las estrellas ajena. No sois lunas á mi ver que belleza tan sin par no es posible en si menguar ni de otros ojos erecer: no sois ricos donde estais ni pobres donde yo os canto, pobres no, pues podeis tanto, ricos no, pues que robais. No sois muertes rigurosos, ni vidis cuando alhagais, vidas no, porque matais. inuertes no, que sois hermosos. No sois fuego ni os conviene el nombre que d'èl gozais, pues con rayos no abrasais al mismo lugar que os tiene: no sois agua, ojos traidores, que me robais el sosiego, pues nunca matais mi fuego y siempre encendeis ardores. No sois cielos, ojos raros, ni inflerno de desconsuelos: cielos no, que sois pequeños, ni inflerno, pues sois mui claros; $\mathrm{y}$ aunque ángeles paresceis no mereseeis tales nombres, qu'ellos guardan á los hombres y vosotros los perdeis. No sois diablos aunque andajs dando pena á los que os vieron, que los del cielo cayeron, vosotros en él estajs.

pero en haceros de modo naturaleza echó el resto, que no siendo nada de esto paresce que lo sois todo.

198 CANCIONEROS MANUSCRITOS. Cancionero recogido de vadios poetas del buen tiempo, señaladamente de Lope de Vega, Gaspar Aguilar, Góngora y Quevedo. Volumen en $4 .^{\circ}$ de 180 fojas escrito con mucha nitidez en los primeros años del siglo XVII. Las iniciales y algunos cersos son de letra encarnada. 


\section{CAN} Tiené su indice al fin, como suelen
lenerlo los Romanceros y Cancioneros impresos.

Contiene, además de las composiciones de los autores ántes indicadus, un gran núner, de anỏnimas y á mi parecer inuchas inéditas. A esta clase pertenecen casi todas las de Agullar, hallándose entre cllas la célebre Fibula de Endimion y la Luma, atribuida equivocadamente d́ Tärrega por Gracian en el Arte de ingenio. Dicho poema, segun Rodriguez, ncasionó á su autor graves disgastos y consecuencia de ellos la muerte. Tamhien son del misino Aguilar el Mistrere en rumance, que consta de 21 octavas, un Soneto, ocho cuartetos d una firmeza y las octavas que despues copiaré.-Encuéntrase una Sátira escrila por un valenciano, la cual principia:

A buen tiempo el ay! ay! ay!

nos ha llegadú á Valencia,

pues que le cantamos todos

por diferentes maneras. Ay ! ay ! ay!

Jel mismo pocta será problamente otra Suilira á continuacion de la anterior, en lénqua morisca y trata de la traicion que leuitu los moriscos ordenada conlra valencia; comienza asi :

Todax lax cuxax del mondu tener xex altaix e baxax que combu el mondu ex modable todax lax coxax xacaban. Ay!

Tambien se hallan dos Someios, uno en catalan y otro en valenciano.

lle entresacado de las composiciones anonimas las siguientes que juzgo dignas de ser repruducidas y creo pertenecen al numeru de las inciditas.

Unos bellos ojos

adoro madre,

ltórolos ausentes

v'erelos tarde.

Adoro unos ojos

de estraña belleza

do naturaleza

partió sus despojos;

ay bios : qué de enojus

mie cuestan, madre:

ubrolos ausentes

ver'clos tarde.

Nace un nuero dia

tras su dulce alba

y háceles la salva

in que el cielo envia;

dan nueva alegria

á Guien miran, madre:

llorolos unsentes

verelos taride.

si el amur les mirn

cobran nuevo alicuto.

y con el contento

sarlas de oro tira;

su hermusura admira

á quien los vé, madre:

llórolos uusente

verelos larile.
CAN

Las palomicas del palomar ellas se yienen y ellas se van.

Madre, si las aves

buscan libertad,

por el aire alegres

dan d'ello senal;

la qu'está diez años

en cautividad,

qué mucho que salga

a llorar su nial!

No me priveis d'esto, que si me privais, tambien por el aire ne saluré á volar.

De estar apretada

viene á reventar

la granada, madre,

si bien lo notais;

miéntras encerrada

me querais guardar

corre más peligro

mi honestidad:

el ave que vuela

más sigura está

de que no la maten

si le han de tirar.

Tras de los deseos va mi voluntad qu'esta nasciú libre, aunque no querais: cual llaves al lado me quereis llevar, al lado se pierden, señora, las más:

como hallé este mund lo quiero dejar, libertad os pido, dádme libertad.

\section{Al amor.}

Tirano amor que con iguales viras Al cetro apuntas y al arado corvo, F no te hacen estorbo

Alcáares ni chozas cuaudo tiras

A tudos de mina suerte,

Que en esto te pareces a la muerte.

Sienten las fuerzas de tu imperiu injustu

Las cornnas que pisas de lus reyes,

Y al paso de los bueses

Llora un desden el labrador robusto;

Que quien tu bien escoje.

Lágrimas siembra y desventuras eoje.

Qué manso corderillo ó tlera tigre

Puede evitar cruel tu ardiente fragua?

0 qué pez on el agua

Habri que de tu finego no peligre?

() qui avecillas dejas

Que de ti, flero aumn , no canten quejas?

Las vides en lus árbules enlazas,

Haces trepar la yedra pur el nuro,

inista el cielo siguro

De tus hurtus, amor, ni de tus trazas,

Que lo dificil buscas

Y con engano su rezelo ofuscas.

obedicete el tiempo y la firtuna.

Qu'eres inui poderuso en inuestros daños, i tus tiros estraños 
Causaron sus mudanzas á la luna, Heriste al sol, y luego

Los rayos de su luz fueron de fuego.

\section{Endechas.}

Mallıyan mis carnes, morena de perlas. si no diera un dedo por veros las vuestras.

Que no soi de aquellos que de ver se elevan una blanca mano de cuajada fresea .

El carbon me abrasa, la nieve me hiela, li blanco deslumbra, lo moreno alegra.

I) cabellos de oro, dicen los poetas, que vencen al sol y que al oro afrentan:

Que ni el sol los tiene ni se ha visto tienda donde los cabellos corran por moneda: Que sifueran de oro la vez que los peinan, 110 dieran las solbras para hacer munecas.

oh, trigueño rostro! hl, manos triguenas! oll, gallardo brio! oh, liermosa morena! Quicin no espera fruto de tan bnena lierra? Bien haja el diclıoso que la riega y siembra;

Que como es cada año aquesta cosecha, pide su calor un Mayo que llueva.

liumo de mi fuegro! tinta de mi letra! luto de uni alma! noche de mi pena! Si aquello que falta eso se desea, lencidme por blanco y séd vos mi negra.

Tal sea mi ventura aunque me anochezca en medio del dia tan buena tiniebla; Que como en el sol la noche me cerca, que estoi en las Indias se me representa.

Decid, bellos ojos, á cuantos me vean, aquel es el blanco de mi ceja negra. IJagamos las almas á los cuerpos sean Lablas de ajedrez de tan rica mezcla; lase á vuestra casa una blanca pieza y un peon que corra inflnitas leguas:

Y á mi casa blanca pasaré la vuestra que era dama libre y está agora presa. Si es verdad que dicen que el deseo fuerza suerte he dado'n blanco pues que sois ajena.

Oclavas de Gaspar de Aguilar.

Caduco tiempo que la culpa tienes le inis pasados juveniles brios, si tan lijero pasas por mis bienes Como pesado por los males mios; Asi tus blancas y nevadas sienes Se vean por las ninfas de estos rios Coronados con himnos y cantares, Que siempre vucles ó que siempre pares.

Cuando miraba el bello rostro hermoso

De Vénus, á quien tuve de mi parte, Corrias tan alegre y presuroso Que solo tú pudieras alcanzarte, I agora que en estado peligroso Miro el aspecto de Satırno y Marle Envuelto en saña, cólera y braveza, Tropiezas con tu misma lijereza.

Si con tu mano vengativa vuelves La rueda más eruel que de navajas, I la ocasion fatal que la revuelves Los lyajos subes $y$ los altos bajas; Pnes en darme desdichas te resuelves, ¿Porqué en darle otra vuelta no trabajas? Que si estoi á desdichas condenado Nejor es caminar que estar parado. fo soi aquel que tuvo tal ventura Que pudiera gozar de los despojos De la mayor belleza y hermosura Que ver pudieran los humanos ojos; Nas como la inujer sicmpre procura Seguir la vanidad de sus antojos, Perdi nil bien, perdi mi conflanza, Que su mayor firmeza es la mudanza. luego me vi anegado y consumido En el profundo mar de mis enganos, Cuyas hinchadas olas me han traido A que padezca daño y cause daños; Y dellas acosado y perseguido, Quedo en mis verdes y floridos años, Como la verde planta á quien despojas be sus tempranas verdinegras hojas.

Y pues tienes el mando y el gobierno De los fuertes influjos celestiales, Y en primavera, otoño, estio, invierno, Padescen por tu causa los mortales, lerriba, ó tiempo, con olvido eterno EI soberbio edificio de mis males, Pues el más principal de tus oflios Es derribar los fuertes ediflcios.

199 CANCIONEROS MANUSCRITOS. Cancionero que comprende poesías de los escritores de la primera mitad del siglo XVII. Manuscrito on $4 .{ }^{\circ}$ de 196 fojas escrito hácia el 16300. 
Contiene este volúmen composiciones de los autores slguientes, muchas ineditas $\mathrm{y}$ otras con variantes de consideracion:

D. Antonio Coello, D. P'edro de la Pena, D. Jerónimo Cáncer, Gaspar de Ávila, Don Francísco Galante, Juan Delgado, Juan de la Barreda, D. Juan Martinez, D. Jacinto de Herrera, D. Francisco de Clavijo, D. Francisco de Mendoza, 0 . Pedro Calderon de la Barca, Dr. Francisco de Quintana, D. Juan Pèrez de Montalvan, Lic. Jerónino de Ribera, D. Antonio de Herrera, Luis de Benavente, D. Luls de Góngora, D. Francisco Campuzano, D. Antonio de Silva, D. Francisco de Quevedo, D. Francisco Galarza, Anastasio Pantaleon de Ribera, el Mtro. Alfaro, D. Juan de Horozco, D. Juan Cuello de Arias, Dona Isabel de Aguiar, D. Antonio de Mendoza, D. Jerónimo de Villaizan, D. Gabriel Bocángel, Antonio Martinez, D. Juan de Andosilla, D. Pedro de Mendoza, D. José Pellicer de Tovar, Lic. Crespin, D. Antonio de Solis, D. Diego de Silva, D. Gabriel de Roa, Luis Vèlez, D. José Camerino, Lope de Vega, Don José González, D. Juan Vélez, D. Diego del Rincon, el Conde de Salinas , D. Roman Yontero, Pedro Méndez de Loyola, Céspedes y el Varques de Alcanizes.

\section{CANCIONEROS MANUSCRI-} TOS. Cancionero de poesías escogidas de nuestros poetas del siglo XVII. Volúmen en 4. ${ }^{\circ}$ de 218 fojas escrito poco antes del año 1700.

Principia por algunas composiciones de Quevedo, Gongora, D. Nelchor de Fonseca, D. Francísco Candamo, Calderun de la Barca, el P. Yalentin de Céspedes, D'. Gabriel l'ellicer y D. José Solis : siguense varias contra los privados, ministros y gobierno de Felipe III y Felipe if, en que se hallan 117 composiciones, la mayor parte inéditas, del conde de Villamediana, de las cuales 65 no se encuentran en el códice de sus poesias satíricas, descrito en esta misma seccion ( $r$. Vill $c_{\text {- }}$ mediana: en los Poetas diversos.) siendo de notar que aun en las repetidas son tantas las variantes $\dot{0}$ adiciones, que deben consultarse ambos manuscritos. Vall á continuacion muchas de las poesias que salieron contra la menor edad y el reinado de Cárlos 11 , ocupando un mui principal lugar las de Perico y Marica; y hácia el fin se halla una sátira en prosa $y$. verso contra el gobierno de la monarquia en la menor edad de dicho rei.

201 Cancionero de muchas poesias anónimas relativas á los sucesos y desconcierto de España desde 1691 á 1693 y señaladamente las varias que salieron á nombre de Perico y Marica. Vol, ex $4 .^{\circ}$ escrito en $\mathrm{Li}$ ma hacia el 1700 y pocos años despues.
En este volúmen se hallan además varias obras en prosa, mereciendo menclonarse las siguientes: Obra de caridad que D. Jerónimo Monforl ejercila con la obstinacion de Don Matias de Escobar de gloriosa sálira.-Car. tas que mediaron entre el arcediano de Cuenca D. Ballasar de Moscoso y un cura del arzobrspado de Toledo.-Tizon de la nobleza de España y fuera de ella por D. Francisco de Mendoza y Bobadilla.-La Gigantomaquia, diseverso académico.-Hisloriı del Buho ga. llego con las dernas aves de España.-Sueños le un predicador.--Memorial del Duque de Arcos a S. M. del 22 de julin de 1701.-Pronósico general para el uño 1695 y los demas que se sigan.-Poder y fuerzas de las dos Coronas de España y Francia, para contrastar ambas d lodas las Polencias juntas de Europa.-Vejámen que dió á los ingenios de la Academia, como su fiscal, El Emo. Seĩor Marques de Caslelldosrius, virei del Peru el 19 de diciembre de 1709.

Entre las composiciones poéticas he escogido un soneto y una satirilla, a mi juicio ineditas, como la mayor parte de las comprendidas en el volimen.

\section{definiendo á los Grandes de España.}

Las que pretenden culto de adorados, Sicndo de cielo y tierra aborrecidos, Que en lugar de valer á desvalidos Ann no piensan pagar á sus criados;

De letras $\mathrm{y}$ armas viven dirorciados, En todo lo indecente mui lucidos, Si ellos han menester, his más rendidos. Si los han menester, embelesados:

Contra cl rei y el gobierno los primeros Y contra aquellos que aplaudió su maña; Vanos de cascos, duros de sombreros,

Valor de cobre, vanidad de caña, $Y$ en todo el mundo grandes majaderos: Esos dicen que son Grandes de Espana.

\section{Bomance.}

Juanilla, aunque todo el numdo te venga á ver no es por bien, porque segun es til trato con todos tienes que ver.

Si es fraile el que te visita, dices que tu tio es, $y$ affrnando la mentira, en sus trece estás con èt.

Si es clérigo es tu compadre, y si cura llega a ser.

tú eres la benefliciada dándote la cuarta èl.

Cuando hace una baquia $\left({ }^{\circ}\right)$

el gramático, es por que

lleva de memoria el cuarto

en que conjugas con él.

Como es pobre y estudiante, aunque ves su inendiguez, si te lo plde lo das

por si tuviere despues.

A tomar un matecito

van el conde $y$ el marques, 
y haciendo tí el agasajo pllos te hacen la mereril.

A cuncertar la costura

va el caballero cortes,

y ajustarla la gonlilla

vilye aleure su nerced.

El letrado trae un pleite

que te plisio n!: se (juibll, y en mis punto de derechor con del lluviste gue ver.

El casero no le dejia

enbrindole ol alquilor:;

porque lien! por astumber

alzirle en pasindo ol mes.

lil merrider trine la ruenta

dis dibene $y$ lat de haber: poryur yo le lable ma tarde Imoliplicando rom il.

En las puntas y aldules

que ol thitle le va á vender

lo clivas, y to la pera

$y$ rll cl encaje timbien.

El sultado a todis lon'as

de respola entra, perculue

inn III trabueu de a vara

il Lorlus da que temor.

Alma, vida y cinazun

rimla al mísieo que es,

loma lorla par natura

abricindela tio al pape!

Al fill cont todus. Juanilla.

lo valde is pot inleras

lienes cuentu comenzallo,

y el curntis de crentos is.

\section{C.INCIONEROS MINUSCRI-}

TOS. Cancionero do noesias escritas en la primera mitad del siglo XVIII. 1. Hanuscrito posterior al año de 1780 .

l'rincipia por poesias a la muerte do folipe $\mathrm{V}$; y algunas dirigidas í Fermando il, pasando luega a la estincinn de lus Jesnilis, í la caida de Esquilache y á otras corsas del reinado de Carlos III. Contiene fuera de lo indicado varios tralados en prosa, á saber: Tesfameuto de Esjañas por yacanni, el Munilomio grneval, secreto y ponlicular de la Compañin de Jesus, una Relacion de los lémimlamienlos de Nadrid !) Zaragos a en 1760. Tison de España. Discurso te alqunos linayes que el caldenal Bubadilla dio al rei 1). Filipe II pos haber hallado obstacalo en la: Informacimn's para el hubilo de su sobrino al Conde de' Chinchon: con ma adicion distinla del Iniscurso de Pedro Gerónimo iponte en un libro de linajes; poryue en él no liza relarion de alpminas personas que rum drelirailas aljui. ia fambzen de contimurinn ol anledicho Discurso de Aponle.origen d. los rillams ele España, gne dicen. cointmmonteristanos viejos por el Cardenal yendosa.

203 - Cancionero que abraza poesiats huchits en la cillima milad del siglo XVIII. 1. ${ }^{\circ}$ Manuscrito de 640 págs. escrilo en los últimos años del mismo.

Casi todas las composiciones son relativas i los adornos de las casas y carrera de Madrid ell varias flestas reales, a las Comedias re. presentadas y premiadas cin molivo de haberse celebrado cl nacimiento de los dos Gemirlos, á los bailes de la Nueva Union, y á la dosgraciadi espedicion contra Argel, que mando el conde 0-Reilly. Algunas composiriones son evidentemente de Benegasi, Salas, D. Tomas de Iriarte y D. Alvaro María Gucrrero. La ubri mas larga que hai en prosa es ima Relucion de lo acaecido desde el follecimiento de Curlos III, con la proclamaciom de Cárlos IV. y el juramenlo del prin. cipe su hijo D. Fernando. Un tercio del tomo lo Henan las sátiras contra 0-Reilly, de las cuales no se ha podido estractar una capaz de escitar ahora algun interés : tan pegadas suelen estar í las circunstancias en que se escribieron, las debidas á motivos especiales y pasajeros. Respecto de las otras poesías es scusible que lo sobrado lúbrico o sucio de algunas, las cuales por otra parte no carecen de mérito, impida su publicacion.

\section{CANCIONEROS MANUSCRI-} TOS. Cancionero formado de las composiciones mas bonitas de nuestros mejores poetas del siglo XVI y principios del XVII. Mamuscrito en 8. ${ }^{\circ}$ hecho hiria el 1825.

La mayor parte de las poesias que conliene estin sicadis del cancionero de Romunces, de las dos pirtes del Romancero general de lís Flore's de poclas ilıstres de Espinusa, de las Poesias rarias publicadas por Alfay, de alyrums plicgus sueltos de ediciones antiguas en letra gotica, y tambien de varios manus. critos generalmente inéditos.

200̈ CAÑIZÁRES (JosÉ DE). ÉSpaña llorosa, sobre la funesta pyra el augrsto mausoleo, y Régio T'unulo, que a las... Cenizas de... Luis de Borbon Delphin de Francia... mandò coustruir... D. Phelipe Qvinto. Por Don Joseph de Cañizares. Oracion funebre de Monseñor Luis Delfin por el P. Mtro. Agvstin de Castejon. Madrid, 1711. 4. Con una gran lám. del túmulo. Lna hoja para el fróntis, 80 págs., una hoja que se dobla, y 51 págs. en todo para la Oracion fúnebre.

Contiene algunos versos de diferentes au(1)r'es. 
206 CARTEL del Certamen Templo del honor, y la virtud. En el plausible triinfal recibimiento del Ex.mo S.ar Don Agustin de Jauregui y Aldecoa. En la Real Universidad de San Marcos de... Lima. (Lima, 1783 ?) 4. $^{\circ}$ Retrato y escudo grande de armas, que ocupan dos hojas fuera de las tres prels., 244 xags., corren sin ellas las Presias del Certamen bajo las silys. Q3-T4, y despues sigue el Elogio hecho por el D. D. Joseph, Baquijann y Carrillo, que tiene portada y 82 paigs.

Contiene poesias de varios autores en castellano $y$ latin.

A pesar de que el recibimiento se hizo á D. Agustin de Jauregni, en Agosto de 1781, y de llevar el mismo año el escudo de armas colocado tras de la portada, el retrato que la sigue está fechado en Lima en 1785.

207 CARRION Y MORCILLO RLBIO DE AUNON (Alforso). Nlagnifica parcntacion, $\mathbf{y}$ frnebre pompa, en la ocasion de trisladarse... la sepvltvra... del Cuerpo de... D. Fr. Dieg , Morcillo Rrbio de Arñon. Sacala a lvz... èl Dr. D. Alfōso Carriō y Morcillo Rubio de Auñon. Lima, Antonio Gutierrez de Zeballos. A. de 44 (1744). $4 .^{\circ}$ Lám. del tímulo. lina hoja de portada y despues las signs. $\mathrm{A}-\mathrm{Gg}$, pues carece de foliacion.

Contiene poesias de varios autores.

208 CASACONCHA (Mates DE). El nuevo heroe de la fama. Certanen poetico con que la Real Lniversidad de S. Marcos de Lima... celebró el feliz, y fausto recibimiento, en sus Escuelas, del Excelentissimo Señor Don Manuel de Amat y Junient. Escribiole el Marqués de Casaconcha. Lima, Imprenta de los Niños Huerfanos, 1762. 4. ${ }^{\circ}$ hojas prels. (una de ellas con un escudo de armas) y 167 págs. - Oracion panegirica. Dixola el Doct. D. Miguel de Yaldivieso y Torrejon. (Lima, Inprenta Nueva de la Calle de Coca, 1762$)$. 2 hojas prels. y 26 hojas sin fol. con las sig. A-N.-Proclamacion a las Musas, o introduccion a la letura de las Poe- sias. 68 hojas sin fol. con las sig.s. A-LI, y una hrja de Fe de erratas.

En el Certamen que va al fin y ocupa casi una mitad del volimen, se encuentran pu"sias en varios metros y de diferentes au. tores.

209 CaSta ̃éd (Fraxc. Javifa DE.) Relacion de los solemnes aparatos... con que en la Inserial Ciudad de Toledo... se celebró la colocacion de Christo sacramentado, Hecha el dia nueve de Junio de el Año de 173 2... La da a luz Don Francisco Xavier de Castañeda. Toledo, Pedro Ilarquès, (1732). 1. marif. Retralo. 22 hojas prels., a mas del retrato, y 152 fol.

Ejemplar al parecer de papel fuerte.

Cuntiene poesias de varius antores cuyos noinbres no se publican.

210 CERTAMEN POETICO, JUSta literaria. Palestra conceptuosa, que se celebrò... en la Iglesia de los Padres Trinitarios Descalcos. En las solemnes fiestas de la Colocacion de el Sagrado Cuerpo de el gran Patriarcha San Juan de Mata. Madrid, Antonio Gonçalez, 17 z $2.4 .^{\circ} 16$ hrjas prels. y 202 pigs.

Contiene poesias de varios antores.

I11 Cespedes (Baltasar de). Relacion de las Honras, (Ive hizo la Vniversidad de Salamanca a la Magestad de la Reyna doña Jlargarita de Austria nuestra Señora, que se celebraron Miercoles nueue de Noniembre del Año M.DC.XI. Ordenada por el Maestro Baltasar de Cespedes. Salamanca, Francisco de Cea Tesa, M.DC.XI. 4. ${ }^{\circ}$ ö hojas fol. inclusa la porlada, y 38 de nueva foliatura para el Sermon de honras predicado por Fr. Andres de Espiusosa, y la Oracion frnebre hecha por Don Fernando Pimentel 4..$^{\circ}$.

Contiene poesias latinas, portuguesas, italianas y castellanas: los autores que escribicron las últimas sın: D. Diego Gaitan de Vir’gas, Lic. Pedro de Pantoja Fr. Benitı de la Serna, Lic. Miguel de Cárdenas, Ventura Pintn, Sebastian de Acosta Pereira, Alonsı 
de Cabrera Silva, Pedro ortiz de Sahagun, Pedro Pimentel, Juan Simon de Garlbay y Dona Antonia de Alarcon.

\section{CLARIN (CANORO) CELES-} TIAL, cryas canciones son Romances Espiritrales contra los vicios, y a favor de las virtudes, repartidos en dos tomos. Tomo I. que dedica a los padres de familias... para destierro de cãtares perniciosos Estevan de Cabrera... quien a sv costa los saca à luz, aviendolos adquirido con toda instancia de varios Autores Capuchinos. (Cordova, Estevan de Cabrera), 1720. 12. 6 hojas prels., 332 paigs. y una hojita mas, en que tiene fin la Tabla.

Las composieiones de este romancerito son de varios autores, aunque anonimas.

i pesar de decir eu el fróntis tomo I y hablarse en alguna de las aprobaciones de que la obia consta de dos volúnienes, es posible no se haya publicado el segundo, pnes por el prólogo del editor é impresor se ve que el presente salió suelto, prometiéndose para mas tarde el otro.

CLARIN (EL) de la fama y Cítara de Apolo. Véase Butron (José) eu la Seccion dramática.

213 COLECCION de las mejores coplas de Seguidillas Tiranas y Polos que se han compuesto para cantar á la guitarra. Por D. Preciso. (Al fin:) Tercera edicion, corregida y aumentada. Madrid, la Hija de Don Joaquin Ibarra, MDCCCV. 2 vol. $12 .^{\circ}$ Los fróntis son grabados.

He visto otra edicion de Madrid, 1816. 2 vols. 12. ${ }^{\circ}$ fróntis grabados, $\mathrm{y}$ he tenido una Coleccion de seguidillas impresa en Madrid, Villalpando, 1799. I tomo en $12 .^{\circ}$ que no sé si será igual á la publicada en Barcelona, Agustin Roca. $s . a$. en un volumen en $12^{\circ}$ que tambien posei.

214 COLECCION de los mas célebres romances antiguos españoles, históricos y caballerescos publicada por C. B. Depping, y ahora considerablemente einendada por un Español refngiado. Londres, M. Calero, 182:3. 2 vol. $8 .^{\circ}$

Mi padre fué el editor de esta impresion. La presente obra se reimprimió mui all- mentada en Leipsique en 1844 con el titulo de Romancero Castellano. Véase en esta division.

\section{COLECCION DE OBRAS} POÉTICAS españolas: unas casi enteramente perdidas, otras que se han hecho muv raras, y todas ellas merecedoras de ser conservadas en el Parnaso Español.

Contiene : Los Doze Triumphos de los doze Apostoles, fechos por el Cartuxano (D. Juan de Padilla): Canticos entresacados de las tres Tablas del Retablo de la vida de Cristo, compuesto por el mismo. Descripcion del Aula de Dios, cartuja de Zaragoza, en dos silvas, por Don Miguel de Dicastillo. A pendice. Poesías varias, póstumas de Don Eugenio Antonio del Riego Nuñez y el Romancero de Riego, por Don Benito Perez. La publica Don Miguel del Riego. Londres, Carlos Wood, 1843. $4 .^{\circ}$ nıy. Láms.

La impresion y papel son muibellos y al principio hai dos grabados que quieren ser facsimiles del frontis de la edicion original de los Triunfos y de la lánina que representa cl signo de Aries.

El eanónigo Riego hubiese hecho mucho mejor en imprinir en un volúmen aparte, las poesías de su padre y el Romancero que nos relata los hechos gloriosos y patriótieos de su hermalno, pues bajo ningun concepto debian haber ido unidas estas composiciones á las de Padilla y Dicastillo. El amor fllial y fraternal podrá escusarle en una pe. queña parte; pero la culpa principal de esta mezcolanza debe atribuirse al caracter original y estrambótico, peculiar del editor.

216 COLECCION de poesías castellanas anteriores al siglo XV. Preceden noticias para la vida del primer marques de Santillana, y la carta que escribió al condestable de Portugal sobre el origen de nuestra poesia, ilustrada con notas por Don Thomas Antonio Sanchez. Madrid,. Antonio de Sancha, M.DCC.LXXIX, LXXX, LXXXII y XC. 4 vols. 8. marq.

Ejemplar del gran papel.

El tomo primero de esta coleccion contiene las Noticias para la vida de D. Iñigo Lopez de Mendosa, Proemio al Condestable de Portugal, por el Marques de Santillana; Notus al 
Proemio os carta precedente (por D. Antonto Sánchez) y el Poema del Cid; el tomo segun. do, Poesias de D. Gonzalo de Berceo; tel tercero, el Poema de Alejandro, por Juan Lorenzo Segura de Astorga: y el cuarto, las Poesias del Arcipreste de Hila. Cada tomo lleva al principio un prólogo que contiene curiosas y eruditas noticias sobre el autor en él comprendido, y al fin van copiosos glosarios para facilitar la inteligencia del testo.

217 COLECGION de poesías castellanas traducidas en verso toscano, é ilustradas por el Conde D. Juan Bautista Conti. Madrid, Imprenta Real, MDCCLXXXII- XC. 4 vols. 8. ${ }^{\circ}$ marq.

El ejemplar, ademas de ser en gran papel y estar tirado en $4 .^{\circ}$, tiene la particularidad de haberse conservado en él Ias páginas XLV, XLVI, CCXXV, CCXXVI, 125 y 126 del tomo $1 .^{\circ}$ suprimidas, y las que deben reemplazarlas.

Contiene esta coleccion trozos escogidos de nuestros mejores poetas castellanos desde el siglo XII hasta fines del XVII, precedidos de noticias biográflcas y literarias y seguidos de notas. - El testo castellano va al frente de la version italiana.

EI Sr. Conti se habia propuesto sin duda seguir publicando otros volúmenes, pues en los fróntis de los cuatro que existen se lee: primera parte, $y$ en el úlimo tomo se ofre cen para el quinto composiciones de los au. tores del siglo XVIII.

218 COLECCION de poetas españoles, publicada por D. Ramon Fernandez. Madrid, Imprenta real, $1789-1820.20$ vols. $8 .^{\circ}$ marq.

Coleccion que recopiló D. Pedro Estala bajo el seudónimo de D. Ramon Fernández; comprende los poetas siguientes, impresos ó reimpresos en los años indicados á continuaclon de cada uno:

Tomo I. Rimas de Lupercio Leonardo de Argensola. 1805 .

II y III. Rimas de Bartolomé Leonardo de Argensola. 1805.

IV y V. Rimas de Fernando de Herrera. 1805 .

VI. Rimas de Don Juan de Jauregui. 1819.

VII y VIII. Farsalia ( $y$ el Orfeo) de Don Juan de Jauregui. 1789.

IX. Poesias de D. Luis de Gongora y Argote. 1820

X. Poesias del Mtro. Fr. Luis de Leon. 1808.

XI. Rimas humanas y divinas del Licenciado Tomé de Burguilios. 1792.

XII y XIII. Obras de Cristobal de Castllle. jo. 1792 .

XIV y XV. Conquista de la Bética: poema heroyco de Juan de la Cueva. 1795.
XVI \& XVII. Poesias escogidas de nuestros Cancloneros y Romanceros antiguos. 1796.

XVIII. Poesias Inéditas de Franclsco de Rioja, y otros poetas andaluces (Arguijo, Céspedes y Alcdza'). 1797.

XIX. Las Heroydas de Ovidio traducidas en verso castellano por Diego Mexia. 1797.

XX. (Aunque no lo espresa la portada.) Poesias de Francisco de Figueroa, llamado el Divino. 1804

Varios tomos llevan Prólogos con noticias biográflcas y literarias sobre el autor ó autores que contienen, $\mathrm{y}$ de algunos existe mas de una edicion.

219 COLLADO (Francisco JERósimo). Descripcion del túmulo y relacion de las exequias que hizo la ciudad de Sevilla en la muerte del rey D. Felipe segundo por el licenciado Francisco Gerónimo Collado. Sevilla; D. José María Geofrin 1869. 8. ${ }^{\circ}$ Lám.

opúsculo publicado por la Sociedad de bibliófllos andaluces; tirado á $\mathbf{3 0 0}$ ejemplares, el mio lleva el núm. 68.-Curiosa Descripcion sacada de la Historia de Sevilla, escrita por Collado, obra todavia inédita.

Al fin del volumen hai algunas composiciones poéticas, entre ellas una de Cervántes, publicada por primera vez en el Yuseo universal de 18 de Julio, de 1868.

Un escelente amigo mio que ha tenido la original ocurrencia de bautizarse de nuevo, teniendo ya completo uso de razon , tomando el nombre del Dr. E. W. Thebussem, ha escrito é impreso una Carta bibliogrdfica $d$ D. Francisco de B. Palomo, sobre la Descripcion del tumulo y exequias del rey Felipe If. Sevilla, Antonio Izquierdo, $1869.8^{\circ}$ marq.

\section{CORDOVA Y CASTRO} (Francisco De). Festivos crltos Celebres Aclamaciones qre La sïempre triumphante Roma dio a la bienaventrrada Rosa de S. Maria Virgen de Lima en sv solemne beatificacion Los escriue... D. Francisco de Cordova y Castro. Roma, Nicolas Angel Tinas, 1668. 2 hojas prels. y 222 págs. con una hoja blanca al fin.Sermone in lode della B. Rosa di S. Maria detto Dal Reuerendissimo Padre Gio. Paolo Oliva. Roma, Nicol' Angelo Tinassi, 1668. 36 págs. comprendida la portada. - Oracion panegirica qre el M. R. P. M. Fr. Antonio de Vergara Dixo en la Fiesta anual de la B. Rosa de Sancta Maria. 
4." 12 hojas sin foliucion con las signs. a-c.

El ejemplar parece en gran papel.

Contiene muches poesias ifalianis y latimas y alominas castellamas de diversos autores.

Nic. Antonio omite el lugar y año de la edicion.

221 CORONA FÚNEBRE en honor de la Exma Sra. Doña Maria de la Piedad Roca de Togores, Duruesa de Frias y de Uceda. Hadrid, Husebio Aguado, 1830. $\% 0^{\circ}$ mart.

Ejemplar del papel flno.

Los antores que formaron esta Corona fueron el duque de Frias, D. Variann Juse de Larra, 11. Frameises Martinez de la Rosa, D. Juan Nicasio billeron, D. Engenio de Tapia, I. Ramon Lopez Suler, D. Yanuel Jose Quintama, D. Yontura de lil Vega, D. Alherto lista, 1 Angel de Siavedra, I). Juan Ion: so Cortes, D. Dirgo Colon, D. Jose Waria Cambrunero, D. Juan Bautista Arriaza $\mathrm{y}$ en el presente ejmplar se eneuentrá de D. Fulgrencio Igrillon un soneto ineidito.

La enumeracion de los nombres que precele es sufleiente para prohar se hallan en esfe volimen eomposiciones de mucho mérilo.

\section{CRELIILDES (Juan Nic.).} Solenes, y grandiosas fiestas que la... Civdend de Valencia ha hecho por el nuevo Decreto que la Santidad de Gregorio $\mathrm{XT}$. ha concedido en fauor de la inmaculada Concepcion de Maria Madre de Dios. Con el Decreto de su Santidad, y el Certamen poetico. Por Iran Xicolas Crevhades. Yalencia, Pedro Patricio Mley, 1623. $8 .^{\circ} 8$ hojas prels. y $29 \ddot{3}$ págs.

Nic. Antonio llama al autor creusnades, acaso por errata de imprenta.

Los poetas que concurrieron al Certimen, son: Gaspar Aguilar, Juall Niculas Creuhádes, 1). Jimen Pérez Desplígues, Lope de Vega, Vartin Villorado, Vicente lzquierdo, Abdon Clavel, Vicente fascon, Maximiliano Cerdan, Luis Cavaller, lo. Onofre Fúnes de Muñoz, Jerónimo Yartinez de la Yega, Juan Bautista Polo, Marco Antonio Ortin, D. Baltasas Laflon, Fr. Ilernando de Santa Maria, Fr. Gregorio Alegria, Francisco Cros, Joaquin Sala, Antonio de Ponti, Vicente Vignel Cid, José Higuel Berlomeu, Vicente Font, Dr. Juan
Moria de Agnirre, Vicente ruri, Vicente Sanz, José Oriola, Mr. Antonio Pablo Serrano, Joaquin Sala, Matias Morla y Juan Bantista Bervegal.

Contienc este rarisimo libro muchas composiciones pacticas escritas en el dialecto valenciano.

Timbien he visto mna Insla poelica En drefonsa le la pureç" de la inmacvlada Concencion de la Virgen Samlissima Mantenida y premiada por $D$. Sancho Capula. Zaragoca, Diego de lie To:\%e, I6I?. $4 . " 4$ hojas prels., incluso el froutis grabillo, 22.2 hijas fols. $y$ una de erratas y fuch:ı. Contiene poesías de diferentes antures.

223 CIRUZ (Juñ Ines). Fama, $y$ obras posthmmas del Fenix de Mexico, decima Musa, Poetissa americana, Sor Juana Ines de la Cruz. Madrid, Angel Pasqual Rubio, 172:3. 4. ${ }^{\circ}$ may. Diez hojas sin paginacion, y desdè la undécima principia la pág. 1 y llega i la 352. IIai despues dos hojos de Tabla.

Ejemplar en papel grande.

Esle tomo que forma tel tercero de las obras de la puetisil nejicani, parece haberse publicado con intencion de venderlo por separado: contiene alguna composition postuina de Sor Juana; peru lo forman en su mayor parte poesias que en su clugio eseribieron varios antores.

221 CUE.TCA (Victoriano). Parentacion solemne, que al nombre augusto, y real memoria de la Catholica Revua... Doña María Amalia de Saxonià, mandò hacer en esta santa Iglesia Catedral de los Reyes. Lima, Corte del Perú, el dia $2 \%$. de Junio de 1761. el Ex.mo Señor Don Joseph Manso de Velasco, y la escribe el Padre Victoriano Cuenca. Lima, Pedro Nolasco Alvarado, (1761?). 1. $^{\circ}$ Lámina en fol. del calafalco, que se dobla.

260 páginas de este volímen las ocupan las poesias que los escritores residentes en Lima compusieron con motivo de la muerte de Dıña María Amalia de Saxonia ; la mayor parte son en castellano, pero las hai tambien en latin, vascucnce, italiaun, frances, aleman, portugues, húngaro, ingles, catalian, en lengaa índica generil $y$ en la de bos xos llamada Nlobima. 
$\mathrm{D}$

Q2.) Di VILA (Tomas). Epinicio sagrado, Certamen olympico arreo, en la solemne dedicacion de la insigne Capilla que al Glorioso Apostol S. Andres... erigiò el Eminentíssimo Señor D. Francisco Pacheco. Dispuesto Por el P. Fr. Thomas Dauila. Salamāca, Lucas Perez, 1687. 4. ${ }^{\circ} 17$ hojas prels. (quizi falta despues una blanca) y 492 paigs.

Contiene poesias de diferentes autores escritas para el Ceridonen.

Sin duda será de este mismo autor la obra siguiente que turimos en Londres: IIistorin y vida del admirable, y exfatico Sin Fursen, Principe heredero de Irlanila. Fscrivela Fr. Thumas Davila. Nudrid, Lucas Anlomi" le bedmar, y Narvaes, [6!\%. 1." El pjemplal" parecia en gran papel.

226 DELICIAS DE APOLO, Recreaciones del Parnaso, por las tres Mrsas Vrania, Euterpe, I Caliope, hechas de varias poesias, de los Mejores Ingenios de España. Recogidas, y dadas a la estampa por D. Francisco la Torre y Sevil. Madrid, Melchor Alegre, $1670.40^{\circ} 4$ hojas prels. $17 i$ pág. (Entre la 174 y 17 s hai una hoja suelta, que es el titulo de la Euterpe.) y 4 hojas sin paginar.

Las cuatro hojas de preliminares comprendeu: la portada, aprobacion del vicario general de Madrid, fechada el 8 de Yayo de 1669, la licencia del Consejo, del mismo dia, el Prólogo al lector, firmado por I. Franciscu de I.a Torre, una composicion poética cuyo epigrafe dice: Contempla de la esfera lucientes as/ros, del señi marques de Legar. da, una Décima que hizo el autor para que precediese al romance $\mathrm{y}$ una especie de antefróntis á Urania, musá V'II.

Como se verá por el siguiente articulo, Alfay reimprimió los preliminares de está edicion en el mismo año, omitiendo el nom. bre del verdadero colector y sustituyéndolo con el suy0. Por no haber visto la edicion de Madrid ignoraron esta circuustancia los traductores de Ticknor, D. Aglistin Duran y Gallardo, asi es que atribuyen á Alfay un trabajo que no le pertencee.-Esh es sin duda la obra denominada por Vic. Antonio: Poesias varias in $4 .^{\circ}$ Vatrili, en el articulo de Frunciscus de la Torie et Sebil.
Zaragoca, Ivan de Ybar, 1670. $4 .^{\circ}$ Número de hojas igual al precedente.

Es la misma edicion que la descrita en el articulo anteriur, variadas solo las $4 \mathrm{~h}$ jas de preliminares; pn ellas va una dedicatoria de Ioseph Alfay al Ilustr. S. D. Fernando Ilvarez de Toledo, la aprobacion del Dr. D. Jacin- to Alvarez, fechada en Zaragoza á 10 de Junio de 1670, el mismo prólogo que en el ejemplar ántes descrito sin el nonbre de D. Fran. cisco de La Torre, puesto al pjé de él, y con la supresion de la composicion Contempla de la esferu y de la Décima para que precediese al rornonce; ademas la portada que es identica á la anterior tampoco hace merit!) de dichn I.a Torre.

En la dedicatoria falsamente se da Alfay por colectur de estas poesias ; no siendo es:traño pur lo mismo que le adjudique la ubra Latasa, si no habia visto la edicion ron lus preliminares de Jadrid.

Cintiene esta antulogia poesias de los me. jol'es autores del siglo fill y se furmó, como ubserva el sr. Duran, á imitacion de las Flores de poplus ilustres de Espinosa. Algnuos suelen unir las Delicius de Apolo al volimen que publicu Alfay intitulado: Poesfas mirias de grandes ingenios espoñoles, cumo una segunda parte i continuacion.

Los traductures de Ticknor observan, qup tanto las Delicius de Ipoly como las Poestas rarias de grandes ingenios, son consideradas con razoll, conno una especie de Cancioneros, $y$ ambas obras son mui raras.

DIA $\left(E_{L}\right)$ del Seminario. Véase en la Seccion dramática.

228 DIE7, DE ALI (Lus). Compendio de las tiestas que ha celebradu la imperial Cirdad De Caragoca, Pol auer promovido... Filipo Tercero de Castilla... al lliustrissimo Señor don Fray Luis Aliaga... en el Olicio ! Cargo Supremo de Inquisidor General de España. Ordenado... Por Lurs Diez de Aux. Con la rersion de tres hvmnnos... (de) Aurelio Prudencio. Zaragoca, Iuan de Lanaja y Quartanet, $1619.4 .^{\circ} 8$ hojas prels. y 30 ' págs. Sigue luego meera porlatla para la Tradrccion de los himnos qre hizu Avrelio Prrdencio a los martires San Laurencio, San Vicente, Santa Engracia, San Lupercio, etc. Zaragoca, 
Iuan de Lanaja y Quartanet, 1619. 12 hojas prels. y 63 págs.

A muchos de los ejemplares les suelen faltar los himnos que van al fin, y á esto sin duda se debe el no haberlos podido examinar Latasa, puesto que nos da en su Biblioteca como inédito, cl dirigido á $\mathrm{S}$. Lorenzo que principia:

Antigua madre de los falsos Tımplos, siendo asi que es el primero impreso, segun se ve por la descripcion del volimen que antecede.

La mayor parte del tomo de las fiestas contiene poesias latinas y castellinas de diversos autores que concurrieron al Certámen poético y cuyos nombres son: Gaspar Aguilar, D. Pedri de Sessé, Lic. Domingo Miguel, Diego Jerónimo Diez de Aux, Dr. Juan Sala, Lic. Sebastian Navarro de Garces, Donal Aldonza de Aragon y Gurrea, D. Antonio Manrique y Luna, D. Francisco Dicgo de Sayas y Urtubia, Lorenzo de Santistevan, Pedro Pouce, Valeriano Aznar, Jerón. Hernando de Tarazona, Vic. Blasco de Lanuza, Vic. Bissé, Gabriel Ripol y Villanueva, José Salinas, Mig. Jerón. Castellot, Raimundo Anglada, Jerón. Salas Malo, Juan Salas Malo, Vic. Calvo, Mig. Anjel de Onate, Mig. Antolin, Juan de Córdova, Damian Marti, Jerón. Miguel, Martin Miguel, Domingo Garces, Jerón. López Villanova, Franc. Luis López de Villanueva, D. Tomas Lombart, Lic. Juan Nequesa, D. Luis Diez de Aux, Gaspar López de Fúnes, D. Juan de Fúnes Villalpando, Doña Leonor de Bardaji, Martin Jinćnez, Doña Ana Teresa de Rozas, Doña Varia Paez de Pantoja, Douna Catalina Meléndez, Dr. Agustin Vengochea, Mig. Luis Tafalla, Ant. Ibáñez de Aoiz, Jerónimo Zamulano, Pedro Francisco Provenzal, Francisco Español, Felipe Giner, Pedro Sánchez, Dr. Juan Cercito, Díonisio Pérez Manrique, D. Manuel de Sessé, Cita Canerol, Doña Juana Ventura Español, Susana Vengochea, el marques de Tórres; D. Pedro de la Cerda y Granada, Miguel Samper, Dr. Bartolomé de Castro, Doña Luisa de Agullera, Juan Bta. Felices de Cáceres, Jai-

230 ELOGIOS de el Ilvstrissimo, y ervditissimo varon Don Honorato Ivan, gentil hombre de la S. C. C. M. del Señor Emperador D. Carlos Quinto, Maestro del serenissimo D. Carlos principe de las Españas, obispo de Osma. Sacados de varios escritos de Autores gravissimos, avtorizados Con diversas cartas Pontificias, y Reales. - Parafrasi que tradvze dos fragmentos del libro IV de Retorica de Benedicto Arias Montano. En que trata de me Alberto, Jerón. Navarro, Dofia Maria Clemente, Doña Isabel Laporta, D. Juan Francisco Aparicio, Dr. Juan López Galvan, Vicente Izquierdo, Lic. Juan Franc. Serrano del Castillo, Pascual Martinez, Lic. Arascu, Doña Maria de Sessé, Dr. Bartolomé Colomi. na y Lascorz, Ant. Sanz de Broto, Juan Jerónimo Malo, Hernando de Sala, Alonso Ribero, Franc. Madrid y Bárcenas, Petronila de Aragon y Gurrea, D. Raniro de Peralta, I. Pedro de Lumbier, Juan Ripol y el Licenciado Franc. Gregorio Fanlo.-De esteúltimo autor he visto otras composiciones poéticas en un tomo cuyo titulo es: Gestamen a las fiestas de la lvaslacion de la reliquia de San Ramon Nonat. Hecopilado por cl Padre Fr. Pedro Martin. Y su vida en rimas por Francis. co Gregorio de Fanlo. Zaragoza, luan de Lanaja y Uuartanet, 1618. 4. 6 hojas prels. 43 fuls. del poema de Fanlo y 90 (la última dice equivocadamente 60) del Certamen.

229 Dighero (Juan Antonio.) E'l Pantheon Real, Fvnebre Aparato A las exequias, que en la Ciudad de Santiago de los Caballeros de Guatemala se hicieron por el alma... de nuestra Catholica Reina, y Señora, Doña Maria Amalia de Saxonia. Dispuesto por el Dr. Don Juan Antonio Dighero. Guatemala, Sebastian de Arebalo, 1763. $4 .^{\circ}$

Contiene diferentes poesias, que por no llevar nombre de autor ignoro si perlenecen á uno solo.

Al fin del volúmen, con nuevas signaturas, pues no hai paginacion ni foliatura, se encuentra el Sermon que predicó el P. Fr. Joseph Til, y como muestra del buen gusto con que está escrito, copiaré su fróntis que dice: Silenciosos gemidos, sangrientos llantos, cordialtsimos trenos, que en las Reales exequias de la augustisima reina Dona Ma. ria Amalia consagró la audiencia de Guate. mala el 27 de Sepliembre de 1761. el Ilvstrissimo Honorato Ivan. Por el botor Roqve Iason Verja.-Tradvccion de la Epistola de Nicolas Nicolay Grvdio. Por Don Francisco de la Torre. Valencia, Geronimo Vilagrasa, M.DC.LIX. fol. 3 hojas prels., 74 págs., 1 hoja de Erratas y 10 de Parafrasi $y$ Traduccion.

Hai una primera edician hecha en Valencia, por Silvestre Esparza en 1649; pero la segunda de 1659 está mui aumentada.

A pesar de no sonar en parte alguna el 
nombre del recopllador de estos panegiricos, lo fié, segun Jimeno, D. Antonlo Juan de Centelles, sobrino de D. Honorato.

Algunos-de los Elogins y la Pardfrasi de Arias Montano y Epistola de Nicolal y sus traducclones están en verso.

A mi ejemplar se ha agregado una lámina grabada en cubre que representa una medalia, al parecer bastante antigua, en la cual se halla el retrato de Hnnorato Juan á la edad de 49 afios. y una flgura emblemática: va firmada la estampa $F$. Pesca $F$; pero no encuentro el nombre de semejante grabador en Cean Bermúdez.

\section{ENCINA (JUAY DEL).}

\section{Ualliollero de todas las}

obras de Juan Jel enina: son otras co,

\section{sas meuamente airadisas $\therefore$}

(Eslo dice la porlada bajo de un gran escudo de las armas imperiaies con el TA.NTO MONTA. Empieza al reverso la $\mathrm{Tabla} y$ concluye en el blanco del fol. II, principiando al dorso de este el Prohenio ó dedicatoria á los reyes cáólicos, a quienes da el tratamiento de vuestra real magestad. Terminado este en la cara de la hoja III, se halla: Al muy esclarecido $y$ bienauêturado principe don Juan. Llama á este unas rezes alteza, otras Vuestra muy alta Señoria, tambien Vuestra Real Magestad, $y$ por fin Vuestra real Señoría. Comiencan el prohemio en vna arte de poesia castellana: compuesta por Juan del enzina. Esta Poética es toda en prosa, está impresa á dos colunas y llena poco mas de tres hojas. A la vuelta de la VI se nos ofrece la dedicatoria de sus obras poéticas à los duques de Alva, comenzando estas con el fol. VII. Al recerso del XCI se halla el siguiente remate:)

I Fue imprimido el presente libro: llamado Cancionero: por Jorge Coci: en çaragoça. Acabose a. xr. dias del mes de deziembre. Año de mill $\varepsilon$ quinientos $x$ deziseis (1516) años.

Continuando los folios y signaturas, encontramos unas Coplas en loor del apostol sant Pedro, una Egloga trobada y una Representacion, que da fin en la cara del fol. YCYIII, úl- timo de la obra, pues este número tiene toda ella con inclusion de la portada. En mi ejemplar van despues de esto seis hojas sin foliacion con la sign. A, cuyo título de letra encarnada dice lo siguiente:)

A la dolorosa muerte del Prineipe Don Juan de gloriosa memoria: hijo delos muy catolicos reyes de Esp?ña. Don Feriando el quinto: v Doña Isabel la tercera deste nōbre. Tragedia trobada por Juan del enzina. (Son cien coplas de arte mayor, un romance $y$ un villancico dirigidos al mismo objeto.J fol. let. gót. A $3 \mathrm{cols}$. ménos cuardo lo largo del metro no permite sino dos.

Esta bellisima edicion contiene las piezas dramáticas citadas por Moratin en los Origenes del teatro bajo los núm. 5, $6,7,8$, $9,10,11,12,14$, y 16 ; se ve por consiguiente que faltan la Egloga de Fileno y Zam. bardo y el Aulo del Repelon: en cambio se hallan en ella mayor número de poesías que en las otras, y en mi ejemplar se encurntra la Tragedia trobada á la muerte del principe D. Juan, que no he visto en ningun otro.

Böhl de Faber reprodujo en su Tealro anterior á Lope los números $5,6,10$, 11 , parte del 12 y el 16: síguiendo su costumbre introdujo variantes considerables y suprimió, sin advertirlo, una mitad por to mén os de la composicion núm. 12. Yoratin reimprimió los números 9 y 11 y Gallardo en el quinto cuaderno del Criticon publicó la del núm. 14.

Los Ss. Zarco del Valle y Sancho Rayon, en el Eissayo de una bib. esp., son los únicos que citan la composicion dia dolorosa muer. te det Principe D. Juan, $\dot{e}$ indudablemente tuvieron presente, segun su descripcion, un ejemplar de igual impresion que el mio, pero falto de las dos hojas últimas: por eso suponen consta de 78 octavas clatando son $100, y$ omiten el hacer mérito del Romance y Villaneico puestos á slu continuacion y escrí. tos al mismo asunto. Dichos SS. Zarco y Rayon pretenden que la letra empleada en este opúsculo es la del Cancionero de Encina, impreso en Salamanca en 1496, y conjeturan que debió publicarse el año de 1497 , en el cual murió el Principe. Mi ejemplar pur lo tanto es el único que se conoce compuesto de seis hojas y completo.

Todas las ediciones del Cancionero de Juan del Encina son tan estraordinariamente ra. ras que Nicolas Antonio creyó existia solo manuscrita esta obra, á pesar de haberse hecholas siguientes impresiones que he visto o he encontrado citadas:

1. Cancionero de todas las obras de Juan de la Encina con olras añadidas.-Finaliza: Fue impreso en Salamanca a veynte dias del mes de Junio de M.ccc r xcvi. años. fol. letra gót. Hasta aqui esıá copialo de Méndez. 
y en mis apuntes hallo notado que esta edicion consta de 2 hojas preliminares y exvj folios.

Duran se equivoca ell suponer que la fecha es de 1476.

2." - - Sevilla, Juanes de Pegnicer y Magno Herbst, 16 Enero 1501 fol. Brunet.

3. - - - Burgos, Andres de Burgos, a xiii de Febrero 1505 . fol. let. gót. Inrau.

4." Portada con las armas imperiales que tienen orla arriba y en una parte de los lados. Bajo dice en tres renglones de letra gruesa:

\section{Cancionero de todas las obras}

de Juan del encina cōotras co

sas nueuamente añadidas.

-Al dorso del fol. xej dice: Cue esta presente obra emprimida por Hans gysser ale. mã d'Silgèstat enla muy moble \& leul cibdad le Sulamanca: la qual acubose $a$. v. de enero del año de mill quinienlos \& siete (1507). fol. let. gòt. ados y tres colunas. El ejemplar do que he tomado esta descripcion llega al fol. xcrij hoja nona de la $m$ y uo concluye.

5." Cancionero de todas las obras de Juan del Encina con las coplas de Zambardo: e con el auto del repelon en el qual se introdusen dos paslores Piernicurlo e Johan para elc. P. con otras cosas muevamente añadidas. (Al fin:) fue esla presente obr $a$ emprimida por lians Gysser aleman de Silgenstat en ta muy nuble e leal cibdad de sillamanca: la qual dich obra se acabo a vil del mes d'Agosto del año d'mil e ymirientos e mueve añ's (1509. fol. let. gót. 104 hojas. Adiciones $y$ nolas á Ticknor. T. I. pág. 528.

Esta parece ser la edicjon mas completa en las producciones dramáticas: pero la de $\mathrm{Za}$ riguza de 1516 , tiene mayor número de poesias, segun Duran.

6. ${ }^{2}-$ El mismo Cancionero, Zaragoz 1512. for. let. gót. Mayaus, Fida de Virgilio.

Las Eglogas de este autor impresas por separado se encuentran en la Seccion dramáti. ca al nombre de Encina.

Del mismo he visto el siguiente folleto:

Documento \& inslrucció prouechosa para las dozellas desposadas y rezien casadas. Có unajusla d'amores: hécha por Juan del encina a vna dócella i mucho le penaua. M.D.Lvj. 4." let. gót. 12 hojas sin fol. con la signat. $A$.

232 ENRÍQUEZ (Alorso). Honras y obsequios que hizo al... Rey Don Filıpe Tercero... su... Ciudad de Mrrcia. Por Alonso Enriqvez. Mur- cia, Luys Beros, M. BC.xxII. (1622). 4. 8 hojas prels. y 312 pags. La hoja que corresponde $\dot{a}$ las págs. 123 y 124 es blanca.

Contiene poesias de D. Pedro de Castro y Anaya, Fr. Pedro de Hojeda, Lic. Juan López, D. Diego Beltran Hidalgo, Lic. Don Juan Bernad Loaisa y Sandoval, Dr. Francisco Yánez, Lic. Nicolas de Avila, Hernando Chavarria Velaseo, Fr. Agustin Muñez, D. Franrisco Artiz, Lic. Juan de Salinas. Mig. Aznar Pardı y Juan Cano Irargui.

Ilai tambien una composicion anónima latina y castellana á la vez, escrita en sáflcos y adónicos.

Nic. Antonio no habla del escritor murciano Alonso Enriquez.

233 EXCELLENTIAS de Santa Maria Madalena. Recogidas de la Fiesta que le hizo en Roma el P. F. loan Bru de la Madalena su sieruo. El año de M.D.XCI. En Roma, Bartholomeo Bonfadino. 1591. 8. 77 págs. inclusa la portada. La pág. 7 la ocupa una lamina en cobre que representa a Santa Magdalena; lai ademas dos en madera.

No recuerdo haber visto otro ejemplar del presente cancionerito.

Esta justa literaria cuyo Carlel va al principio contiene composiciones en varios metros de Baltasar de Escobar, Dr. Antonio de la Parra, Miguel López de Aguirre, Andres Vázquez, Gil Yanégos de Mesa, Fernando Pérez, Otaviano Pastorello, Lic. Hierónimo d'Acóris, D. Alvaro de Laserna, Diego Valderrama, Fr. Juan Palermo, Juan de Aguilar, Luis Fernández de Córdova y la Cerda, Dr. Diego Diaz de Soria, Diego Pizarro, Castro Julio, Giovan Doninico Cozgiano d' Úrbino (en ila. liano y latin), Gonzalo Ponce de Leon (en lalin), Julio Rosci Hortini (idem), Antonio de oquendo, Lic. Pedro Fernández Navarrete y Pedro Pastor de Medina.

Los premios adjudicados, segun el cartel, fueron: Un Cancionero general Español, estampado en Anvers. - Un Horucio, con galana encuadernucion de Paris.-Una Hierusalem del Tasso con fiquras y anolaciones.-Unas Epistolas de Ovidio, de curiosa encuadernaciun.-Un Marcial.-On Juvenal de Planlino, encuadernado en Paris.-Un Virgilio.-Una corona de laurel y Un Agnus Dei, guarnecido.

Ademas de esta ubra cita Nic. Antonio la siguiente cuyo titulo demuestra estar escrita con igual objeto que la que yo poseo:

obras espiriluales de diversos en prosa y verso en la fiesla de la Madalena que se hizo en Roma. En casa de Dominico Bassam, 1591. $8 .^{\circ}$ 


\begin{abstract}
Q34 FAJARDO Y AZEVEDO (ANToNio). Varios romances escritos a los sucessos de la Liga Sagrada, desde el Sitio de Viena, hasta la Restauracion de Buda, y otras plaças, conseguidas en tres añ̃os, en que se celebran doze Heroes Insignes de estos tiempos. Por el Hermano Antonio Faxardo y Azevedo. Valencia, Iayme de Bordazar, 1687. 12. 10 hojas prels. y 336 págs.

El tener solo 10 hojas preliminares $y$ haber una llamada $\mathrm{VA}$ - en la última, no acorde con lo que sigue, pareceria indicar la falta de alguna huja ; sill embargo, cotejándolo con la edicion on $40^{\circ}$ se ve estar completo, y que sill duda dicha llamada se pondria pensando encabezar la primera pagina coll el titulo de varios romances, que es el de la portada.
\end{abstract}

$23 \mathrm{z}-$ La misma obra. Valencia, Iayme de Bordazar, 1687. 4. ${ }^{\circ}$ 4 hojas prels. y 80 págs.

Esta edicion hecha en el mismo año que la anterior, tambien por Burdazar $y$ a espensas de José Rudrigo comı aquella, contiene igual numero de rumances.

El Sr. Duran confiesa no haber visto este libro conociendolo únicamente por una nota que le comunico mi padre: 110 es plles de estraîar se cquivoque creyendu haber sido Fajarlo solamente el colector, siendo asi que es el autor de los treinta $y$ un romances en el eontenidus.

El sr. Barrera, ademas de no haber visto uinguna de las dos ediciones intes citadas, se equivoea ell suponer que las 356 págs. de la impresion en $120^{\circ} \dot{0}$ las 80 de la ell $4 .^{\circ}$ se hallabiu reproducidas ell in pliego suelto que tuvi presente, cuyo litulo era: Siccesos de la Liga, por et hermano Ántonio Faxardo y Acevelu, ermitaño de S. Antonio de Pudua en la villa de Carcaxente. Este plicgo se describe mui delalladamente en el Ensayo de una bib. esp. y se ve por su mismo titulo que contiene solo Tres romances, que comprehenden los suressos de la liga sagrada, desde el Sitio de Viena, hasta la toma de Buda; impressos en Valencia ! en Yadrid con licencia del Comsejo. Escriviolos el hermano Antonio Fisxarilo y Azevedo Hermitaño de San Antonio de Padiuz de la Real villa de Carcaxente. (Al fin:) Hallaranse estos Romances en la Puerta del Sol en la Librería del Rey juntumente con bus versos, que Don Jodoco Buker a ísic escrito, vltimamente a la muerte del Excolentissimo buque de Bejar. S.l. ni a. 4. 4 hojas.
Existen varias comedias escritas por Antonio Fajardo y Azevedo y Antonio Azevedo, los cuales ignoro si serán ambos un soln sugeto. Tambien se conoce un Resúnen historial de las edades del mundo, y Geneulogin real y origen de las Religiones eclesiásticris "f militares, por el P. Maestro Antomio Faxardis y Acevedo. (Madrid, 16i1.) que es el mism: autor, segun una Genealogí, origen y nolicias de los comediantes de España, manuscrito de la Bib. Nac., en la cual se dice tam. bien haber sido Fajardo apuntador cn lit compañia de Esieban Yúnez (El Pollo), quien estuvo en Valencia el ano de 1657, y haber hecho segundos barbas en Granada en 1680 . Si no hai equirocacion en la última fecha no puede ser que el histrion del ano $80 \mathrm{y}$ her'mano del 87 cuando salieron á luz los lio. mumces de la liga, fuera el Padre Maestro del 71 .

Sobre los treinta y un komances de la liga, dice Gallardo. son una especie de gacetas en verso. El autor escribe con facilirlud $y$ solturn: sn lenguaje es llano y corriente, pero sin rudeza ni barbarismo.

\section{FELICES DE CACERES} (Juax Bact.). Irsta poetica por la Virgen santissima del Pilar. Celebracion de su Insigne Cofradia. Sacada à luz, por el Licenciado Iuan Bautista Felices de Caceres. Carayoca, Diego de la Torre, 1629. 4. $^{\circ}$ Dos hojas prels. $y$ 14 págs.

Este ejemplar perteneció a la Biblioteca de D. Vincencio de Lastanosa.

Contirne producciones poeticas de Pedrn Virgas Yachuca, el Lic. Jilan Vadal. D. Vi:" de figueria y Cordova, el Lic. Juan Bautista de Cáceres, él Stro. José de Valdivielso. Don Diego de Vera, D. Juan Fernández de Heredia, P. Fr. Yiguel Dezpeleta, Fr. Ingelo Hermitaño, Lic. Franc. Lopez de la Torre, Dona Vartina Teodora Palavesino y Moreno. Pedro Gaudioso Hernández, Fr. Niguel Sánchez, Melchor de Talavera, Juan Franc. de Aguillur, Cristoval Molviedro, D. Pedro Carceller, Lic. Vitorian, Lic. Domingo de hoa, Dr. Bartolome de Castro, Dona Catalina Ali. tonia de Castro, Juan Delgado. Pedro IIongay de Espes, Jilan Orencio Lastanosa, Dnetor Bartolome de Castro, D. Diego de Vera, Yicolas de Liane, Jusepe Martinez, Lic. AsuiIon, mosen Pedro Plazas, Fr. Juan Cetilia, D. Miguel Vallejo de Salazar, Lic. Luis Pallas, Lic. Juan Franc. Serrano, Lic. Judu Franc. Arguillud, Juan Baulista Felices de caceres. Vicente Lastanosa, luis López, Luis Diez de Aux y Agustin de Yagüe.

- El autor de la Justa poética y su obra fueron desconocidos á Xic. Antonio g el Sr. Bar. 
rera se equivoca en suponer ser su tamaño el de $8 .^{\circ}$

Segun I,atasa, Felices de Cáceres escribio adenas: El Caballero de Avilr. Por la Samla Madre Tiresa de Jesus, en las Fiestis, y Torneos de la imperial Ciudal de Zaragozu. Poema heroico. Zaragoza, Diego la Torre $1625.8^{\circ}$

Corlamen poelico pm. la Cofrodiu de la Sangre de Christo de la liudad cle Zaragoza: Accion del mismo Caballero dr: Avila. Zar'aguza, Diegn La Torre $1625.8 .^{\circ}$ Va unida á li obra anterior.

Tornen de à cabrllo en cumpus abiv'lo, que celebró la ciudad de Zar'ago:a en la menida re la Serenissima Reyna ile Ungria. Zaragoza, Diego La Torre, 1630 . 4..$^{\circ}$ En prosa y verso.

biferentes comedias y Poesias que se encuentrall ell certámenes.

Lope de V'ega en el Laurel de Apolo hizo un cumplido clogio de Felices de Cáceres.

\section{FESTIVAS DEMONSTRA-} CIONES y magestvosos olsegrios, con que la Excelentis. Civdad de Barcelona celebró la accion de gracias à su Divina Magastad, por el singular beneficio de aver restituido à la perfecta salud, à nuestro Catolico monarca Carlos II. Serrinda impression. Barcelona, Thoinas Loriente, (1696). 4. 92 prigs. en lodo.

llai en este vulumen algumas paesias de varios aulores.

238 FESTIYO APARATO, con que la Provincia mexicana de la Compañia de Jesrs cclehrc... los immarcesibles lauros... de S. Franciseo de Borja... en la gloria de Canonizado. Mexico, lvan Rvyz, 1679. '." is hojas prels., 130 folicadas y al Sermon del P. Lr. Sebastian de C'astrillon sin fol. con las siyns. $\mathrm{A}-\mathrm{I}$, todas de 4 hojas, menos la Ǹ que solo tiene dos.

Yo nerecen menciomarse los nomlires de los cisnes mejicanos que? entraron en la Jies/u poélica; su merito lilerario es mui inferiur i la rareza de este libro.

239 FESTIYOS, Y MAGESTYOSOS evltos, que la... Ciudad de Bascelona en 23. y 30 . de Octubre 1686. dedicò à su Inclita llija, Patrona, Virgen, y Proto-martyr Santa Eulalia. Barcelona, en cása Cormellas, por Iayme Cays, (1686). 1." 139 paigs. in todo.
Contiene algunas composiciones poeticas latinas, castellanas y catalanas de diversos antores.

FIESTAS que celebró la Iglesia parrochial de S. Maria la Blanca de Sevilla. Vease Torre Farfan enire los Poetas diversos.

240 FLORES DE POETAS. Primera parte de las flores de poetas ilvstres de España, Diuidida en dos Libros. Ordenada por Pedro de Espinosa natural de la ciudad de Antequera. Dirigida al señor Duque de bejar. Uan escritas diez y seis Odas de lloracio, traduzidas por diferentes y graues Autores, admirablemente. En Valladolid, Por Luys Sanchez. Año M.DCV. 4. 8 hojas prels., 204 foliadas y 4 de Tabla con la sign. 999.

El presente ejemplar no solo es apreciable por su estraordinaria belleza, pues hai en él muchas bojas sin cortar, sino que tiene la singularidad de contener los primitlvos y genuinos folins 126 y 127,202 y 203 , como el ejempler del Sr. Cañete descrito en el Eusayo de una bib. esp. de Gallardo; comprendiendo ademas los fols. 126 y 127 que sustituyerull á los ántes citados y en los cuales se omitieron un soneto de Lope de Vega, otro del Lic. Juan de Valdes Meléndez (inserto ya ell el fol. 20) y dus de Góngora, poniendo en sil lugar dos sonetos de Juan Jeronimo Serra y dus del dicho Juan Valdes.-En las otras dus hojas $(202$ y 203 ) la única variacion que lubo fué la de suslituir con un soneto del mismo Valdes el siguiente de Quevedo, stlprimido al parecer por un remate un tanto impio, segun la opirsion de los adieionadores del Sr. Gallardo.

Llegó á lus piès de Cristo Madalena ne todo su vivir arrepentida, Y viéndole á la mesa enternecida

Lágrimas derramó en copiosa vena; Soltó del oro crespo la melena, Con orden natural entretejida, $Y$ deseosa de alcanzar la vida

Con lágrïmas banó su faz serena.

Con un vaso de ungüento los sagrados

Piés de Jesus ungió, y él dilijente

lial perdonio por paga, sus pecados.

Y pues aqueste ejemplo veis presente, Albrieias, b.ticarios desdichados,

Que hoi da la gloria Cristo por ungüente.

Debo notar que las 4 hojas de la Tabla cuyo papel. y tipo indican haberse impreso al misino tiempo que las 4 hojis canbiadas de que ántes he hablado, raltail en muchos ejemplares.

P'edro de Espinusa, distinguido poela, recogió con delieado gusto y escelente criterio 
esta coleccion de poesias eseritas por sus contemporáneos, muchas de las cuales estaban ineditas y no se han vuelto á reimpri. mir. Es la primera y mejor antología publi. cada de la época clásica de nuestra lifteratura: Sedano se equivoca cuando dlce que hasta 1768 no habla aparecldo en Espana ninguna olra obra de este género, pues Alfay publlcó las Poesias varias en 16.54 , y Torre y Sebll las Delicias de Apolo en 1670.

observa Ticknor, con razon, que en la presente antologia se encuentran poesias de autores que nos son completamente desconocidos, y de otros mui oscuros cuyas composiciones están llenas de mérito y hubieran quedado ignoradas á 110 haberlas publicado Espinosa. Su libro ofrece ademas curíosos materiales para escribir la historia de la poesia castellana á fines del slglo XVI y principlos del XYII.

Gallardo, en el Ensayo de una bib. esp., lla. ma á esta obra libro de oro y el mejor tesoro de poesía española que teneinos.

Sabido es que las Flores de poetas ilustres compiten en rareza con nuestrns romanceros; Ticknor supone ser unn de los librus más raros en la poesia española.

A pesar de decir en la portada primera parte ninguna otra ha visto la luz pública: algunos quieren lo sea la segunda del Romancero general impresa en el mismo pueblo $y$ ano; pero el titulu de la obra, la naturaleza de su contenido $\mathrm{y}$ la combinacion tipográflca hacen ver claramente que dicha segunda parte es la continuacion del que se habia publicado en Madrid en Itios, y no de las Flort's de Poelas.

La lista de los autoris yue forman este delicioso ramillete de flores es la siguiente:

D. Juan de Arguijo,

Lupercio Leunardo de Argensola,

Pedro de Espinosa,

Conde de Salinas,

D. Luis de Göngora,

Luis Martinez de la Haza,

D. Francisco de vue. vedo,

Luis de Suto,

Juan Valdes y Melèndez,

Doctor Tcjada,

Baltasar de Escobar,

Juan de Aguilar,

Diego de la Chica,

Juan Bautista de Mesa

Juan de Muráles,

Marques del Aula.

Dona Hipolita de Narvaez,

Viego de Mendoza,

Juan de Vera y Yár. gas,

... Ceperla.

Paltasar del Alcizar,

lijego de lienavides,

Bartolomé Yartinez,
Lope de Vega Carpio, ' 'edro de Liñan,
D. Fernando de Guz- Vicente Espinel, man,

D. Leon Espinet,

Luts Manuel de Fl. D. Cosme de Salinas gueroa,

Mariscal de Alcalá,

Andres de Perea,

y Borja,

Antonio de Caso,

Pedro Rodriguez,

J. Francisco de Fi- El Doctor Mescua (Mi. gueroa,

ra de Amescua),

$\checkmark$ ademas nueve composiciones de poelas inciertos.

211 FLORESTA de Rimas Antiguas Castellanas ordenada por Don Juan Nicolas Böhl de Faber. Hamburgo, en la imprenta de la Viuda de F. G. Langhoff, 1821-23 los to$\operatorname{mos} 1 .^{\circ} y 2 .^{\circ} y$ Leipsique, imprenta de F. Brockhaus, 1825 el $3 .^{\circ}$ Son 3 vols. 8. ${ }^{\circ}$ marq. El $1 .^{\circ}$ lleva un fróntis grabado.

Tengo una idea vaga de haberse hecho del primer tomo por lo inénos reimpresion. La obra completa ya escasea.

El Sr. D. A. Duran hace un merecido elogio de esta nbra cuando dice es una rica, copiosa y bien escogida antologia; en lo que me parece que no anduvo tan acertado fué en suponer, que su. .colector nos presenta la literatura española tal como ba sido en todas las edades $\mathrm{y}$ bajo todas sus fases $\mathrm{y}$ aspertns. sin tratar de rebajar el mérito del Sr. Böhl de Faber, ni entrar ahora á discutir sí fué feliz o nu en su sistema de eleccion, puedo asegurar que ninguno de los que han reimpreso producciones ajenas, se ha tomado la libertad del autor de la Floresta, el cual á su antojo ha suprimido estrofas enteras, sus. tituido otras de su propia cosecha, variado versos y hasta modernizado el lenguaje, cuando bien le ha parecido: y no se crea hà usado de esta licencia con timidez y parsiInonia, pues apénas hai composicion donde no se encuentren trascendentales variaciones si se compara con cl original. Me parece, pucs, que nu es esta la manera mas conve. niente de hacernos cunocer la marcha progre. siva del lenguaje, ni el gusto peculiar de los diferentes periodos de nuestra poesia, y come. te una profanacion literaria, quien se permite semejantes alteraciones. ¿rodria tole. rarse ni consentir á ningun pintor, por so. bresaliente que fuera, el corregir ó retocar algun lieuzo de Velázquez u de Murillo?

\section{理 FLORESTA de rarios roman-} ces, sacados de las historias antiguas de los hechos famosos de los doce Pares de Francia. Agora nuevaniente corregidas por Damian Lopez de Tortajada. Valencia, Imprenta de Antonio Bordazar, s. a. 12.0348 páginas: la 2 esta al dorso de la portada, donde principia la obra. 
213 FLORESTA de vários romances, sacados de las historias anliguas ete. (ut retro). Valencia, Imprenta de Antonio Bordazar, s. a. 12. ${ }^{2}$ Viñeta. 3506 paigs. inclusas las elos de la portada, y ademas 2 de $\mathrm{Ta}$ bla. La obra principia en la 3.

Esta ediejon hocha á plana renglon con la ie Madrid de 776:, contiene más que la auterior de Bordazar ocho romances antiguus; fiero tiene de menos unas redimdillas cuyo isumta no corresponde efeetivamente al Iitulo de la obra.

El Sr. lumran menciona una tercera edicion valenciana s.a. en $16 .^{\circ} \mathrm{y}$ las de Mulrial, 1611 , 1615,1646 y 1664 en $12{ }^{\circ}$ pero no emocio las que se hicieron tambien en Malliel por Jum Gurcía Infanzon en $171 . \bar{y}$ y por Josiph dlonso l'udilla en 174ti, ambas en 12." Ticknor, tomo $3 .^{\circ}$ pág. 268 , hace refprencia í otra edi"ion de Madril, 1728. 12.0 y inade que la primera se publico en 160s; pero no dice ilonde.

\section{$244-L a$ misma obra.} Madrid, Doningo Fermandez de Arrojo, 1764. 12. 350 págs., inclusa I a hoja de portada , y 2 hojas de Tabla.

El Sr. Duran no menciona esta ediciun.

Los romances que contiene la presente Floresla están saeados del Cancione?o y la silva, ammque algo modernizados.

Thomas Rodd la trilujo en ingles y la insorto inceglid en su IItstory of Clumbles the Great and Orlando, Loudon, 1812.2 vols. $8 .^{\circ}$

\section{Q保 FOMPEROSA Y QUINTANA} (Aybrosio De). Dias sagrados, y geniales, celebrados en la canonizacion de S. Franciseo de Boria. Por el colegio imperial de la Compañia de lesis de Mladrid. Y la Acadenia de los mas celebres ingenios de España... Por Don Ambrosio de Fomperosa y Quintana. Madrid, Franeisco Nieto. ก̃̃o de 1672. $4 .^{\circ} 10$ hojas prels., 232 fols. y 30 con nueva numeracion de los Panegíricos en verso.

suelen faltar en algunos ejemplares los $P t^{-}$ negíricos, en verso, del P. Francisco de Alriraz Pardo y del P. Antonio Noreno, y el loena a la conversion de S. Francisco, de II. Djego Calleja, que se lallan con foliacion separada al fin del volúmen; estos opúsculos deben precisamente ir unidos á los Dias sayrados, segu una advertencia puesta al prineipio.

En el Ensayo de una bib. esp. de Gallardo se da detailada nota de los 79 poetas que contribuyeron al Cerlámen eon sus compo. siciones, yo me limitaré á citar los más conocidos que son:

J). Pedro Calderon de la Barea, Juan Vélez de Guevara, D. Francisen de la Torre, Don Antonio de Solis, D. Juan de Mátos Fragoso, 1). José Figueroa y Córdoba, el Mtro. D. Manuel Leon, I. Juan de Vera y Villaroel, Don Juan J Lorente Aguado, I). Juan L,ipez do Cuéllar y Vega, D. Melehor Ferníndez de Leon, D. Frane. Pinel y Monroi, 1). Frameiseo de Bustos, D. Leonardo del Castillo, li. Agristin de Salazar, D. Juan Antonio del Rei, Don Diego Pellicer y D. Ambr. Fomperosa.

\section{FUÉNTES (Alonso De) Li-} bro de los quarenta cantos pelegrinos $\tilde{q}$ compuso el magnifico cauallero Alonso de Fuêtes, natural de la ciudad de Seuilla, diuididos en quatro partes. La primera es de listorias de la sagrada scriptura. La segũda de hechos Romanos. La tercera de casos de diuersas naciones. La yuarta d'historias d'Christianos, có las cosas $\pi$ acaescierō enla cõquista de Malaga y Granada.. I En caraguea, cu casa de Juan Millan... M.D.LXIII. C La porlada va circuida de orla que fugura una capilla. Al fiu se lee, despues del escudo de Pedro Hardoyn que lengo copiado, con la variacion de las iniciriles que son J II:) ( Fue inpresso este presente libro enla muy noble cindad de caragoça, en casa de Juan Millar... acabosse a. xxvij. de Ocbre del año de mil quinientos sesenta y quatro (1:5ici) años. $4 .^{\circ}$ let. gót. \& hojas prels., 22:3 fols. Iy una con el colofon.

247 - Libro de los qvarenta cantos, que compuso rn Canallero llamarlo Alonso de Fuentes, ete. (ut supra). Agora nueuamente corregido y emendado, y con licencia impreso. En Aleala. En casa de Iuan Gracian que sea en gloria. Año. II.D.LXXXYII. 8. 8 hojas prels., 415 fols. y una para repetir las señas de la impresion.

Nie. Antonio no meneiona las edieiones de 1564 ni 1587 y se equivuea por yerro de imprenta ạt citar una de Alcalá, 1557. La primera inpresion, que he visto, dice en el fróntis: Quarenia Cälos de diuersas y peregrinas historias, declarados y moralizados, por el magnifico cauallero Alonso de Fuenles. $\mathrm{Y}$ al tin: Fuc impresso el presenle libro en.. 
Seuilla... En casa de Dominicn de Robertis... Acabose a quatro dias del mes de Abril Año de mil y quiniètos y cincuèla (1550). 4. ${ }^{\circ}$ let. got. cexxxviij hojas en todı, Hal otra ediclon de Granada, Antomio de Lebrija y Garcia de Briones, 156j. 8. ${ }^{\circ}$ Wolf supone haberse reimpreso en el mismo pueblo en $156780^{\circ}$ y se. gun Duran salió á lız por uiltima vez en Burgos, $1579.12 .^{\circ}$

Contiene esta obra cuarenta romances coil sus glosas ó esplicaciones en prusa, divididos en cuatro partes o clases, segun se espresa ell el fróntis arriba copiado al describir la edicion de 1564 .

. Todas las impresiones de este Romancero se encuentran dificilmente; pero las de Sevi$11 a, 1550$ y Zaragoza, 1564 son mui raras.

Ningun autor que yo sepa, menciona mas obras de Alonso de Fuentes que la presente y la Suma de filosofia mutural; sin embargo, lic visto un ejemplar de la siguiente de $\mathrm{A}$ pu. leyo, en cuya purtada se leia en mua nota manuscrita: Alumso de funtes es el traduclor del Asilo de uro:
Portada circuida de grande orla y dentro una lámina que representa á una mujer conducicndo á un asno del ronzal y á un hombru y otra mnjer desnudos, él con caheza de pollino; debajo de negro y colurado se lce:

c Lucio Apuleyo del asmo de oro / currogido y añadido. En al fual se tractun michus hyslorias / y fubulus alcgres / ! de cumo vina moça su amign por lo burnar ane cor mo se ania lornado su señora / yue era jrait hechicera / erro la buxela / y (ostenn io do honbre en "ssno: " amdando hecho asm"। riuly / ! oyo las maldarles / y lrayciones ynit las malas mugeres hazen a sics maridns. Y ansi anduns hesla que acubo de v'll año comio de vias rosas y torno se humbre: s'inut

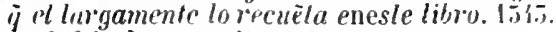

A] fol. lxxy vuelta sa lec:

C Fue impresia la presente obra / culn muy moble ville de Vedina del caumpin pop. I'odro de custro impresor "onsla de sumi de

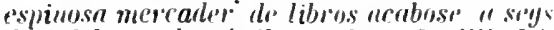

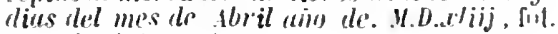
let. gül. di dus colls.
GADEA Y OTIEDO Sib. Irt. DE). Triunfales fuestas a la canonizacien de $\mathbf{S}$. Juan de Dios. Vease en la Seccion drimática.

248 G.LRCIA (Nicolas). Sacra plausible diadema, vistosamente tcxida de jas mas selectas flores del pensil ameno del Parnaso,... con la que... la Religion de Clerigos Reglares... Cerona, à su Patriarcha, y Fundador el B. Canilo de l.elis, éi el... dia... de su Beatificacion. Delineada por el Padre Nicolas Garcia. Maidrid, Juan Muñoz, 1712.4." Limina con un grande escudo, otra del sanlo, que se pliega, y ctra de un laberinto de letra coloruda, que tambien se dobla. A mas de las dos hojas del escudo y el santo hai 10 prels. y 248 págs.

\section{Contien: algunas poesias anúnimas.}

249 GáRIGó (Fraxisco). Panegyrico frnfral en las exequias de la Catholica Magestad la Serenissima Reyna Mladre Doña Yariana de Avstria, que celebrò la Excelentissima Civdad de Barcelona en su Iglesia Cathedral dia 19. de Junio de 1696. Disola el Doctor Franciosco Garrigò.
Dase a la imprenta con un lireve resimen de dichas llonras dispursto por el mismo Grador. Barcelona. Thomas Loriente, (1696). 4." 32 prigs. y 28 pare el Panegrico, un Soneto y la Protesta del Predicador.

Tiene a'gumas poesias latimas $\mathrm{y}$ castclliulls de diversos antores.

\section{GODI.IEZ DE ZARAGOZ,} (dxues). Irsta literaria... Nonenalio de Fiestas, que hizieron los dos Yumeros desta ciudad de Malañal, a Maria Santissima, En sus Desiglauius... el nes de Mayo del Año de 1610. Por Indres Gollinez dr \%aragoza. Mlalaga, Iuan Serrano de lirgas y Vrueña, 1611. 4. 10 hojus preliminares y 86 foliadas.

Los amtores que contribuveron con sus poesias à esla Jusla liferarü fueron: D(111 Francisco de Miracle, el Lic. Juis sinchez de Melo, D. Fernando Suárez. Frai Cristival de Astorya. D. Jeronimo Cipriano Santa Cruz Zurita, D. Diego de Ribas Pacheco. D. Fraspar de la Plaza, D. Marlin de Aldamia Maldo. nado, Gabriel del Aguila Sánchez, D. Rodrigo de Miranda, D. Antunio de Paz, D. I.eunardu de Salazar, D. Juan de Velasco, Fr. Juan de Prádus Igarte, D. Alunso Benituz, il lic:. Escalante, D. Juan Nuñez Fajardo, I). Vacariı Fariuas, D. Liego Caravajal, D. Luis di. IIderote, D. Clemente Lopez, D. Jorenzo Yindiela, D. Juan de simliren, frai bedro finn. 
zález de Alva, Frai Diego de Aviles, Don Francisco Becerra, Juan Isidro de Bustamante, D. Juan Bernardo Salamanca $\mathrm{y}$ Acevedo, D. Juan Serrano de Várgas, D. Fran. cisco de Molina, Frai Andres Terréros, Don Baltasar Bastardo de Cisnéros, D. Juan Alonso de Moscoso y Pozo, I. Estévan Santaren ovaudo, D. Juan de Rójas Centéllas, D. Juan de Silva Menéses y Frai Juan de Molina.

No se encuentra el nombre de Andres Godinez de Zaragoza en la Bibliolheca de Niculas Antonio.

\section{GÓNEZ (VICENTE). Relacion} de las famosas fiestas que hizo la civdarl de Valencia, a la canonizacion del bienauenturado S. Raymun:lo de Peñafort, en el Conuento de Predicadores. Por el Padre Fr. Vincente Gomez. Valencia, Iuã Chrysostomo Garriz, 1602. 8. ${ }^{\circ} 4$ hojas prels., 494 págs. y una hoja al fin que contiene un soneto de D. Carlos Boyl, para llenar la uiltima hoja de la sign. .Hh.

La mayor parte de este volimen se compone de poesias en toda clase de metros esrritas pur los antores mas distinguidos de aquellit époea, tanto valencianos como pertenecientes a utras provincias; citare sus nombres, debiendo ubservar que á varios de 'llos no los mencionan nuestrus bibliugrafos valencianos: Luis Reyes Mejia de la Cerda, 1). Jerónimu Mereader, 1 . Franciseo Giron de Rebolled,, D. Cárlos Boil, Vicente Mariner, Juan Tafalla, Micer Rejaule, D. Gaspar Mercader, D. Agustin Gutiérrez de Cháves, Maximiliano Cerdan, Luis Cavaller, D. Francisco Belvis, Cristoval Virues, Guillen de Castro, I. Alonso de Rebolledo, Felipe Mey, Gaspar Gil Polo, Niguel Ribéllas, bachiller Juall de Salinas, Lic. Blas Marco, Luis Parra, Cristoval Martinez, el Dr. Martin, Fr. Jacinto de Castro, Jérónimo Muñoz de Peregrina, Blas Soria, Dr. Juan Duarte, Jeronimo Ferritil, Lic. Jerónimo de Alagon, Pedro Mártir Martin, Dr. Vincente Corella, Jaime Nloncayo, Gaspar Roca Togóres, Jerónimo Tristañ, Bartolomé Lozano, Jerúnimo de Amaya, Guillen Auris, Pablo de Cáceres, Sor Bernarda Romero, Jusepe Pérez, Alonso Garcia de lujan, Lorenzo Valenzuela, Antomio Clavel, D. Bernardo Antist, Leonardo de Castro, Estevan Martinez, Roque López de l'erona, Gaspar Garcia Ortiz, Sebastian de Sálas y Jaime orts.

\section{Los sermones y fiestas} que la Civdad de Valencia hizo por la Beatificacion del glorioso padre san Luys Bertran. Por... fray Vicente Gomez. Valencia, Iuan Chrysostomo Garriz, 1609. 8. 8 hojas prels. y al dorso de la úllima el re- trato de $S$. Luis grabado en madera: 496 págs.

Los escritores que celebraron esta beatiflcacion en versos castellanos, latinos, valen. cianos, portugueses, é italianos fueron: Don Jerónimo Mercader, Dr. Juan Núnez, Don Miguel de Ribéllas, D. Jerónimo Martinez de la Yega, Lic. Pareja, D. Gaspar Escrivá de Romani, Lorenzo Asóris, Jacinto de Castro, Pedro Rosellon, Pedro Juan de Ochoa, Sor Angela Sánchez, Joaquin Colomar, Abdon Clavel, Vicente Tristaî, Pedro Luis Curtes, Lic. Domingo Felipe, D. Pablo Castelvi, Felipe Mey, Luis Caballer, Vicente Gascon, Lorenzo de Valenzuela, Vicente Mariner, Jusepe Rastrojo y Gaspar Aguilar.

Es sorprendente el que habièndose propuesto Jimeno y Fuster comprender en sus Bibliotecas á todos los valencianos que han escrito poco ó mucho, no hayan examinado con mas detencion todos estos tomitos de Relaciones de fieslas de los cuales hubieran sacado lluchisimos nombres de autores, de quiencs no hacen mencion alguna en sus bibliografías.

233 GÓMEZ (Vicente). Verdadera relacion de la vida, muerte y he'hos milagrosos del bendito P. F. Domiugo Anadon. Yan añadidas cosias muy notables, cō vna Iusta Poelica, que en su alabança se tuuo el año 1606 . Valencia, junto al molino de Rouella, M.DC.VII. 8. 16 hojas prels. y:51 pigs. El retrato del $\mathrm{Pa}$ dre Anadon va en la portada y al fin de la obra.

Contiene la Jusla poética composiciones de varios escritures, entre ellas las hai del I)r. Rejanle, Maximiliano Cerdan, Lorenzo de Valenzuela, Fr. Jacinlo de Castro, Miguel de Ribellas, Jusepe Rastrojo o Rastojo, Jeronimo Nartinez de la Vega, I). Juan Cervellon, Sor Beruarda Romero, Jerónimo de Espejo, Fr. Francisco de Castro, Roque Lo pez de Perona, Dr. Virues, Alonso Garcia de lujan, Estévan Ortiz, Vicente Gascon Frai Vicente Gómez.

234 GÓMEZ TONEL (Juan). Relacion de las Exeqvias que hico la Real Audiencia del Reyno de Galicia, á la Magestad de la Reyna D. Margarita de Austria. Descriptas, y puestas en stilo por loan Gomez Tonel. Sanctiago, loã Pacheco, 1612. 4. ${ }^{\circ}$ Sin fol. con las sign. A-X de 4 hojas, menos la $\mathbf{C}$ y $\mathbf{D}$ que tienen $\square, y$ despues 8 hojas más.

Contiene poesias castellanas, latinas y gaIlegas de D. Alonso Ordónez Sejjas y Tovar, 
el P. Fr. Luis de Tapia, el Lic. Pedro Váz. quez de Neira y Juan Gómez Tonel.

No hallo en Nic. Antonlo mencion alguna de esta rara relacion, ni de su autor.

Q5̆ GONZÁlLZ (Franc. Rayox). Sacromonte Parnaso, de las Mvsas catolicas de los Reynos de España, qve vnidas pretenden coronar sv frente, y grarnecer sus faldas con elegantes poemas en varias lengras. En elogio de... S. Franciseo Xavier... Qve Recogidos, y disprestos con veinte $\mathbf{y}$ vna Lamína del Santo, da à la Estanıpa el Licenciado Francisco hamon Goncalez. Valencia, Francisco Mestre, 168i. 4. 21 Viñelas grabadas en cobre. 12 hojas prels. una que se pliega con la vida en verso y la imágen del santo, 267 págs. $y$ dos hojas más con unas Octavas y un Romance.

La lámina que se pliega falta en muchos ejemplares.

Contiene este libro poesias del R. P. José Butron y Mojica, D. Francisco Basurto, Juse de Villaran, D. Pedro Nayor Descals, Don Manuel de Contrèras, D. José Lupercio Panzano, Vicente López, D. Marco Antonio Orti, Francisco Guardia y Belvis, Pedro Luis Cor. tes, D. Antonio de Zamora, D. Manuel Losada y Quevedo, D. Fernando José de Sada y Antillon y otros. Hai algunas composiciones en valenciano.

No sẻ por qué razon supone Fuster, en el articulo de Francisco La Guardia, ser esta obra del P. Vicente Claudio, uiéntras por la portada y dedicatoria aparece escrita por Francisco Ramon González, y á este se la atribuye tambien Jimeno. En Io que indu. dablemente se equivoca Fuster es en asignar el ano de la edicion á 1686 .

206 GONZALEZ DE VARELA (José). Pyra religiosa... que la mry santa Iglesia Primada de las Españas erigio devota... las sepvlcrales memorias... de Sr + teza el Serenissimo Cardenal Infa. e... D. Fernando de Arstria. Por el icenciado Ioseph Gonzalez de Varela Madrid; Diego Diaz de la Carrera, 1612. 4..$^{\circ}$ marq. 10 hojas prels. inclu a la del retrato de S. A., gran lámina tel catafalco y 19 págs.

Nic. Antonio equivnca el a, a de la impresion, pues supone ser el de $1: i 4$.

Contiene poesias de varios, intre ellas las hai de D. José de Herrera, D. J rúnimo Malu de Molina, el Lic. Francisso Nieto, b. Miguel Pantoja y D. Francisco López de Zarate.

Si Cean Bermúdez hubiese conocido este libro, sin duda habria citado en el articulo de Juan de Foort, el bellisimo retrato del Cardenal infante, $\mathrm{y}$ el catafalco erigido al mismo, grabados anbos por aquel artista.

20 GRANDE DE TENA (Pedro). Lagrimas panegiricas a la tenprana mverte del gran Poeta, i Teologo Insigne Doctor Iuan Perez de Montalban. Lloradas i vertidas por los mas Ilustres Ingenios de España. Recogidas i pvblicadas por... el Licenciado don Pedro Grande de Tena. Madrid, Imprenta del Heino, M.DC.XXXIX. 4. 12 hojas prels. Cla segunda es un relrato de Montalvan, grabado) y 164 hojas foliadas. - Elogio erangelico fvneral... del Doctor Iuan Perez de Montalban. Por F. Diego Niseno. Madrid, Imprenta deI Reino, M.DC.XXXIX. 4 hojas prels. y $\mathbf{3 1}$ folzadas. - La Poesia defendida, y ditinida, Montalban alalıado. Por el Doctor Don Grtierre Marques de Careaga, 18 hijas foliadas._Oracion panegirica, o sernion frnebre. Honores extremos del Doctor Iuan Perez de Montalban. (Por) el Doctor Francisco de Quintana. 14 hojas foliadas.

No son frecuentes las Lagrimns panegíricas; pero ofrece una gran difinultad el reunir todos Ios tratados comprendidos en el voiumen aqui descritu.

Sobre 180 puetas son lus que escribicrum en loor de Pérez de Muntilvill condoliomilusis. de su prematura nuerte, $\mathbf{y}$ este voliumin comprende sus composicjonies: pur lo nismo, poseyendi) la presente antologia y lil Justa a S. Isidro de Lope, se tienen remindus los nombres y muestras del ingruio, de casi todus los autores de alguma valia que florecicron ell la primera mitad del siglt ivil.

En esta obra se halla lo visto en mui pncas de sul clase de aquella epoca. es decir. un indice alfabético de los escritures quis contiene: de dicho indice he entresacado los numbres siguientes por ser lus mas (ounocidos. D. Agustin Moreto, raloriel Tillez (Tirso de yolima), Luis de Belmonte Bermúdez, D. Alonso de! Castillo, D. Anturion Coello, D. Ant de Sutis, $b$. Bermaldo Abarra de Bolea, D. Bernardiuo Gonzalez de Mendo. za, D. Cristoval de Monroi y Silva, el 'Princjpe de Esquilache, D. Feruandu de Suto y Berrio, Francisen Pachern, Fraurisco Bey. nardo de Quiros, I. Francisca de Rojas, D. Gabriel Bocángel y Unzacta, 1). Cirezurio de Tapia, Gaspar de ivila, el Mdestru 
Ciil González Dávila, D. Gutiøre Marques de Careage, D. José Camerino, D. P'edro Calderon de la Barea, In. Antonio de Tassis, D. Franeiseo Vélez de finevara, D. Luis Abarea y Bolea, Fr. Fernando Camargo y Salgado, n. Gareia de Salzedo y Coronel, I). Luis Vélez de Guevara, D. Luis Ramirez (ie Arellanu, Vicente sifariner, el Lic. l'edru Cirande de Tena, Francisco Jimenez Sedenu, I. Diego Sínchez Purtocarrero, 1). Jnan Mitos Fragoso, 11. lliego de Luaisa, Doña Maria de Záyas Solumayor, el Dr. Juan Andres de
Uztarroz, D. Pedro Rosete Niño, Francisco Moreno Pórcel, Pedro de Castro y Anaya, 1). Ant. de Pellicer y Tovar, D. Diego de Mojica, Jacinto Polo de Médina $\mathbf{y}$ el Lie. Luis Tribáldos de Toledo.

Nic. Antonio menciona las Ldgrimas panégivicas en el artículo de P'érez de Montalvin; pero ni alli ni en articulo particular micila á crande de Tena.

El retrato que se encuentra al principio del tono es ell siguiente.

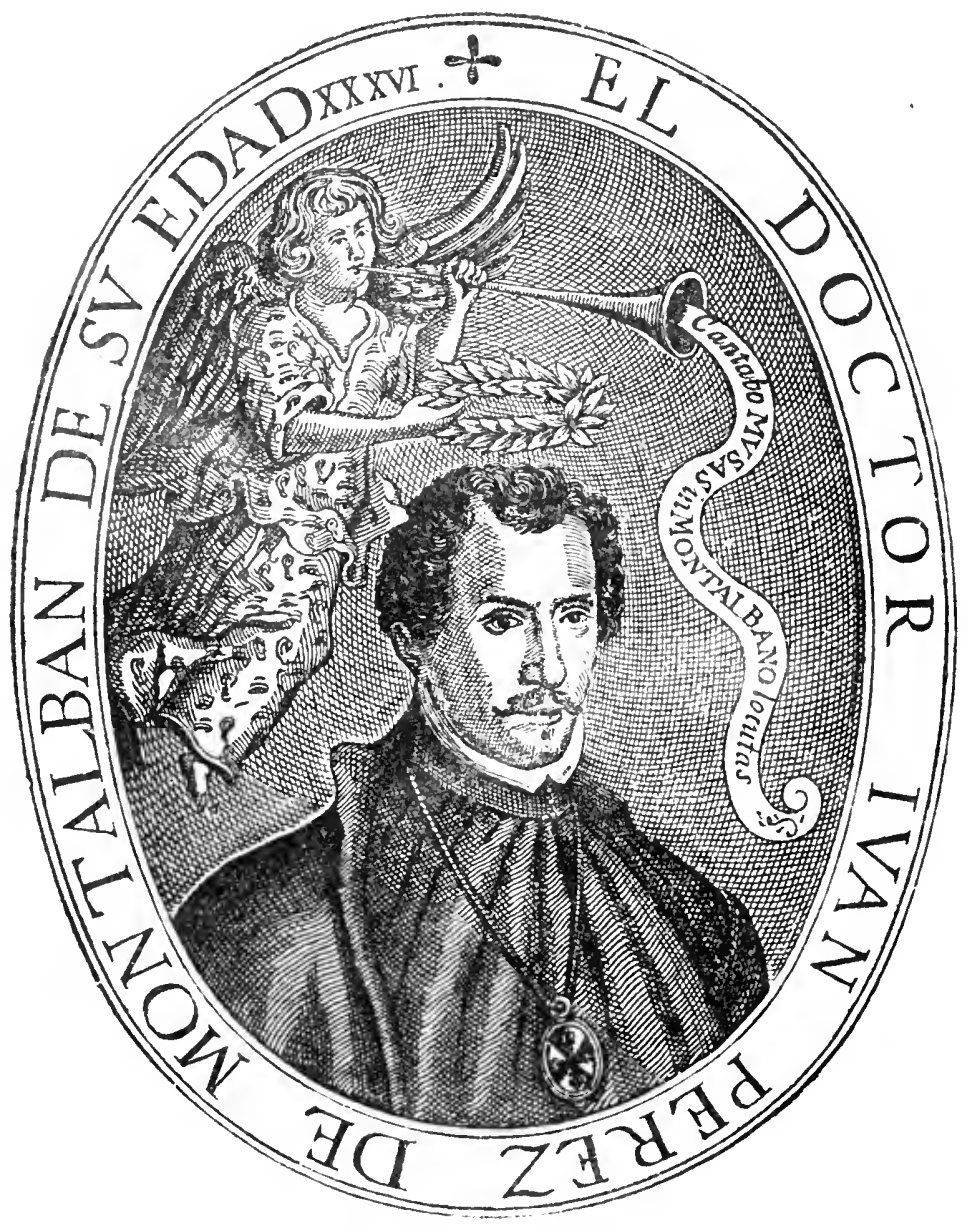

258 GUERRA (D. José Cálos). Clarin armonico, descripcion sagrada á la sumptuosa colocacion del Sacramento en la nueva Capilla Mayor de la Basilica de Padres Dominicos. Su autor Don' Joseph Carlos Guer- ra. Madrid, Joachin Sanchez, s. a. (1735้?) 4. '๋ hojas prels. y 32 págs. Contiene composiciones de varios poetas.

2o\%9 GUIRNALDA POETICA, legida de las mas fragrantes Flores, 
que ha producido la fertil Carpentana Athenas. Academia serijocosa, que se celebrò en esta Corte el dia 2 . de Novienbre de 1733. Dala a la estampa Don Joseph Rodriguez. Madrid, (1733?). $8 .^{\circ}$

Contiene poesias delos autores mas distinguidos de principios del siglo XVIII.
2G0 HERRERI (Pedro de). Descripcion de la capilla de $\mathbf{N}^{a}{ }^{\text {S. }}{ }^{a}$ del Sagrario qve erigio en la S.1a Iglesia de Toledo el 1ll.mo S.or Cardenal D. Bernardo de Sandoual y Rojas. Por el Lic.do Pedro de Herrera. Mladrid, Luis Sanchez, 1617. 4. ${ }^{\circ}$ Una hoja de portada grabada, 4 de prels., 98 foliadas, 126 de segunda foliacion con ocho Sermones, 28 de tercera foliacion para el Sermon del $P$. Jerónimo de Florencia, 141 de cuarta foliacion para el Certámen poético, que es todo de letra cursiva, y una al fin, en que se repiten las señas de la impresion.

Hállanse en este voliumen poesias de muchos autores, entre ellos flgurall D. Luis Ramirez de Arcllano, D. Jose de Salas, Francísco Francia, Francisco de Salzedo, el Doctor Juan de Cararajal, D. Fernando de Ludena, el Lic. Pedro de Herrera, el Lic. Sebastian de Céspedes y Venèses, D. Antonio Hurtado de Yendoza, el Dr. Engenio Narbona, Jacinto de Ledesma, el Capitan Juan González de Sepúlveda, el Dr. Cristóval Suarez de Figueroa, Gonzalo de Ayala, Juan Quevedo Villègas, Pedro de Värgas Vachuca, Martin Chacon, el Lic. Luis Hurlado de Écija, el Dr. Agustin Collado del Hierro, D. Pedro de Céspedes, el Lic. Gaspar de la Fuente, D. Juan de Valladáres, Frai Juan Centeno, D. Juan de Jáuregui, el Htro. Jusé de Valdivielso, D. inis de Góngora, Cristóval de Mesa, el Lic. Gabriel Garcia de Corral, Don Rodrigo Fernández de Ribera, el Lic. Cosme de los Reyes, el Mtro. Narcos Yèpes Bolános, el Lic. Pedro Tumas Aibar, el Dr. Agustin Collado del Hierro, Alunso de Bonilla, Don Biego de Vera y ordónez de Villaquiran y Francisco de Herrera. Tambien contribuyeron al Certamen poético con sus composiciones varias señoras, descollando entre ellas Dona Cristovalina Fernández de Alarcon tan justamente celebrada por Gallardo en el núm. 2 del Crúicon.

El Lic. Pedro de IIerrera publico, segun Nic. Antonio, otras dos obras intituladas: Truslacion del Sanlissimo Sacramento $a$ la Iglesia de S. Pedro de la villa de Lerma. M :drid, 1618. 4. y, Jornada del Duque de Alcala d dar la obediencia en nombre de su Magestad d Urbano VllI. Roma, Geronimo Mascardi, 1625. 4.

\section{HEERTA (ANTONIO DE).} Trivnfos gloriosos,... y ostentosas fiestas, que se celebràron año de M.DC.LXIX. ell... Madrid, y en el Keal Conuento de San Gil... A la canonizacion de... San Pedro de Alcantara. Escrivelas el Padre Fr. Antonio de Ilverta. Madrid, Bernardo de Villa-Diego, M.DC.LXX. 4. ${ }^{\circ} L a-$ mina del santo. 12 hojas prels., hï paigs. y 11 hojas de Tabla é Indice.

Entre los autores que concurrieron al certámen literario están $D$. Jusé de Vátus Fragoso, U. Sebastian de Oliváres, D. P'edro IIejia y D. Jose de Eguizabal. Hai ademas diez y scis sermones de varios predicadores, escritos con motivo de la canonizaciun.

Vic. Antonio no trae en su Bibliolheca á Antonio de Huerta.

262 HURTADO (Lurs). La philipica oracion, historico frneral, ell la muerte de... D. Phelipe Qvarto el Grande... Breve descripcion del trmvlo, Que la Imperial Ciudad de Toledo erigiò... Para celebrar sus solemnes Exequias. Con algrnos de los gerogliphicos, y epitaphios, que estuvieron en sus liencos, $y$ vavetas, v otros escritos En la muerte, $\because$ para la sepultura del... Señor Don Baltasar de Moscoso y Sandoval... Ofrecialos... Don Lvis Hurtado. Madrid, Iuan Noguis, 1666. 4. Thojas prels. cacaso falla alguna de la primera signat.), y 108 foliadas.

Contiene varias pocsias que supnngo seriu de diferentes antores aunque no se espresa. Nada se pierde por ignorar sus nombres, pues solo con copiar una especie de portada que precede á sus producciones, se cunucerii el gusto con que están eseritas: Nolas sugrıdas, letras egipcias, geroglificos flebiles, simbolos funebres, emipresas tragicas y $\mathrm{mm}$ dos poemas; concebidos y formudos... pur decir en los lienzos, para escribir en las bayetas... de la Iglesin de Toledo, el solemme dia de los solemnes oficios y gran parentacion de los manes pios, buenos, amables, poilp- 
rosos, regios y grundes del Rey... D. Felipe IV.
Nin tuvo noticia Nic. Antonin de este Luis Hurtado.
263 JESUS (José DE). Cielos de fiesta Mrsas de Pascra, en fiestas reales, que a $S$. Pascval coronan svs mas finos, y cordialissimos devotos los mvy esclarecidos hijos, de la... Ciudad de Valencia, que con la magestad de la mas luzida pompa, echó su.gran derocion el resto, en las Fiestas de la canonizacion de San Paseval Baylon. Retratalas en mal formados rasgos, en el vistoso lienco de los cielos, el tosco pincel de la menos diestra pluma del Padre Fray Ioseph de Iesvs... Valencia, Francisco Mlestre, 1692. 4. ${ }^{\circ} 16$ hojas preliminares, una estampa del sanlo y З33̈ pigs.

Ilai en este volímen algunas poesias de diferentes autores, que miti pludentemente callarion sus nombres: por fortuma el número es corto, pues todas participan del misuno gusto literario que descuella desde la portada.

26' JIMENEZ DE EXCISO Y póRRES (José Est.). Relacion de la Nemoria frneral gue en $27 . y 28$. de Nouienibre de 16/4. la my noble y mry leal Ciudad de Logroño hizo a la mrerte de la catolica D. Y sabel de Borbon nuestra Rerna. Escrita Por D. Ioseph Esteuan Ximene\% de Enciso y Porres. Logroño, Ivan IDiez de Valderrama y Bistida, 16\%. $40^{\circ} 6$ hojas prels., ij 188 págs.

Casi la mitad del volumen lo componen las poesias de varios autores que escribieron vara el Corlámen, hallíndose entre ellos : el Lic. 1). Antonio Vázqnez de Acuña, U. Juan de Dicastillo y Azedo, D. Antonio de Nallclires, D. Lucas de Ilardui y Eguiluz, Don ledro de Arbierto, Doña Josefa Maria de Albelda y Zapata, Lic. D. Juan Cantero y Grtega, D. Juan Lorenzo de Ribera, D. Migruel de Eguia, Doña Josefa de Puelles y Silllieron, D. Franc. lopez de Zarate y D. Luis Moreno Ponce de Leon.

263 JUSTAS POETICAS hechas a devocion de Don Bernardo Catalan de Valeriola. Valencia, Iuan Chrysostomo Garriz, 1602. 8. 4 hojas prels., 267 págs. y dos hojas, en que termina la Tabla.

Primera y mui rara edicion: Nic. Antonio y Jimeno citan una segunda hecha en Madrid en el mismo año de 1602, por Luis Sanchez. $4 .^{\circ}$

Valencia es una dé las ciudades de España en que inás obras de esta clase se imprimieron hasta mediados del siglo XVI, y esto sin duda se debe i lo privilegiado del pais, en la gran copia y sobresaliente mérito de los poetas quie ha producido. La obra en cuestion es sin disputa la que contiene composiciones de mayor número de autores, hallándose entre ellos los nombres de los vates mas distinguidos. Ia categoría elevada de I). Bernardo Catalan, y el haber sido fundador y presidente de la célebre Academia de los nocturnos, influiria no poco en que contribuyeran todos los hombres mas notables de aquella épica, ofreciendo algunas flores para formar la corona poetica que aquel señor reunia. Sirva como muestra la siguiente lista de algunos de los escritures de quienes hai producciones en el volúmen: El canónigo Tárrega, D. Miguel de Ribéllas, D. Alonso de Rebolledo, el Doctor Jerúnimo Virues, Fr. Francisco Diago, D. Gaspar Escrivá de Romani, Gaspar Escolano, Faspar Aguilar, Miguel Beneito, Don Guillen de Castro, D. Francisco Crespi de Valldaura, D. Cárlos Boil, López Maldonado, D. Gaspar Mercader, D. Felipe Catalan, Don Fernando de Moncada, D. Joaquin de Calatayud, Vicente Joaquin de Miravet, Marco Antonio Pintor, Francisco Juan Pintor, Hernando Pretel, el Dr. Juan Andres Núnez, D. Guillen Catalan, D. Bernardo Tallada, Maximiliano Cerdan, Enrique de Castro, Jaime García, Feliciano Adrian, Gaspar de Arellano, Leonardo Castro, Eugenio de la Cueva, Francisco Desplúgues, Jusepe Gascon, Frai Antonio Juan, Francisco Julian, Manuel Ledesma, Pedro Marañon, Juan Mendoza, Evaristo Mont, Fr. Lázaro Moya, Frai Juan Núnez, Jaine orts, Ant. de Padilla, D. Francisco Rebolledo, Lic. Reyes Mesia de la Cerda, Sor Beruarda Romero, Constantino Salort, Pedro Juan de Tapia y Pedro Juan de Villanueva.

JUVENTUD (LA) triunfante, representada en las fiestas del Colegio de la Compañía de Jesus de Salamanca. Véase en la Seccion dramática. 
266 LASO DE LA VEGA (GABriel). Elogios en loor de los tres famosos varones Don Iayme de Aragon, Don Fernando Cortes Marques del Valle, y Don Aluaro de Bacan Marques de Santacruz. Cōpuestos por Gabriel Lasso de la Vega. En Caragoça por Alonso Rodriguez, $1601.8 .^{\circ}$ 4 retratos grabados en madera. 8 hojas prels. y 144 fols.

He colocado este tomn, que es mui raro, entre las antologias porque contiene poesias de los autores siguientes: Vicente Fspinel, I. Luis Zapata, Juan Castellanos, Francisco de Guzman, D. Jerónimo de Lrrea, D. Alonso de Ercilla, lone de Vega, D. Luis de Váráns Manrique, el Dr. Alonso Lupez, Lic. Luis Alonso Maldonado, el capitan i. Jerónim, Cortes, D. Juan Duque de Portugal, Jerónimo Hamirez, Cosme de Aldana, el Maestro
Francisco Sánchez (el Brocense), Jerüimo de Corte Real, Gaspar Garcia de Alarcon, Juan Ochoa de la Salde, Laurencin Flóres, el alfẻrez Francisco de Segura, y tambien las hal del mismo Gabriel Lasso de la regit sacadas muchas de ellas de su obra intitulada: Romancero y tragedias, con otras abras que intitulo el Manojuelo. 1. parte, Aicala. 1587. 8. Asi Alvarez y Baella, tom. 2. " página 265: los traductures de Ticknor mencio. nan otra edicion de este Romancero, hecha en Barcelona, Sebastian de Cormellas, 1601. $16 .^{\circ}$, que segun parece es tambien la primera parte; y en el Catálugo de la venta de Taylor encuentru el Manoivelo impresi en Zaragosa, Niguet Fortunn Sanchez, 1601. 8. sin irage. dias, siendo posible fuese la segunda partr. la cual dice en el fol. 24 via. de lns Elorios, publicados tambien en la nisma riudad $y$ año, se quedabu imprimimulo.

El retrato de Laso de la liega que neupa el reverso de la líltima hoja de los preliminares es el siguiente:

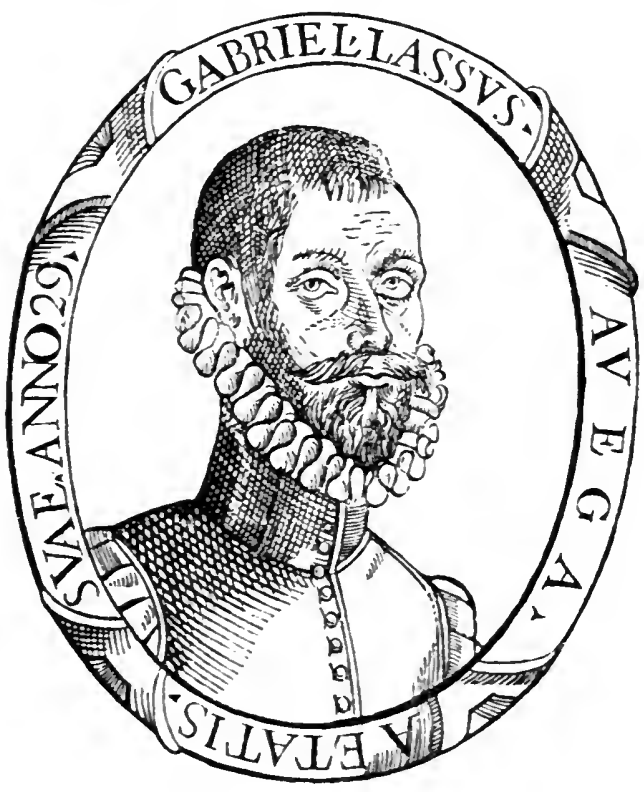

267 LAZARRAGA (Cristóv. DE). Piestas de la Vniversidad de Salamanca, al nacimiento del Principe D. Baltasar Carlos. Refierelas el M. F. Christoval de Lazarraga. Salamanca, Iacinto Tabernier, 1630. 1.
4 hojas prels. Cocupa la una un grande escudo de armas), 301 paigs. y una linja para las erratas.

Contiene un Sermon que predicó el P... Fr. Angel Yanrique y poesias latinas, griegas rastellanas y una en lengua sayngipsa seguli 
¿ liablaba ou algunos ligares cortos de Caslilla la vieja. - De los autures que escribieron rersos jará estas Fiesias solo citaré á Don Juan de Andusilla, el Dr. Cespedes, D. Juan de liscovedn Altamirano, el Lic. Felipe Malag'(on, 1). Juan (Chacon Salinas, el P. Fr. Alonso P'irez, 1). Diego de Leon Pinelo y D. Gaslitr del Arco.

Vu enementro memoria de Cristoval Lazarraga ell Nic. Antomio.

268 LEDESMA (AloNso DE). ROmancero y monstro imaginado. Compresio por Alonso de Ledesma. Madrid, por la viuda de Ilonso Martin, $1613.8 .^{\circ} 8$ hojas prels., 187 foliadas y 4 de Tabla.

Esta edicion es indudablemente la primera, segun se rolige de las licencias y lasa. Los llaductores de Ticknor, tom. 5. ${ }^{\circ}$, pámilli 508, parece duden do sı existencia. Nicolís Antonio cita solo el Vonstruo imaginado sin mencinnar el Romancero y lo supone inpreso en Madrit par Franeisco Martin. liti. tn euyo nombre evidentenente hai equivoacion. Ifo visto ma inmpresion de B areplont, s'bast. Commllas, lol6. 8. 7 hojas prels., 181 fols. y a de Tubla, y otras dis del inismo ario, una de Mablid, viuda rle Alonso Marlin, 8 hujas prels. 187 fols. y 5 o 4 de Tubla (el rjemplal no las tenia lidas), y la otra de levilu, luis Hanescal. 8 linjas prels., 187 firlios $y$ i de Tabla, ambas en 8 .

El Romancero de l,edesma, esclusivamente compuesto de pıesias suyas, cuntiene murhos villaneieus, de imas, endechas, jerogriticos y hista soundillas. - Vo desmiente en "sta obra el autor su gran reputacion enmal poeta y nos hice ver en ella, que con igual facilidad y maestria cantaba las ilabanzis de lis santus que empuñaba el lítigu de la sátira, empleando además ul lengrinje picareseo y fostivo ell los asuntos amorosos. - El Monstruo imaginalo es una especie de uovela en equirucos, escrita en prosa; el autor la intitula romica y pretende haberla traducido de la lelgua siria.

Idemas de lus Conceplos espiriluales, he visto dos obras más de Ledesma; la una rxiste en ol Iluseo Británico, y es la intitulada: Epigramas y Geroglyficos a ta Vida de christo, festivitarles de Vuestra Señora, Excelcucilis de? Sanclos, y grandesas de Segobitt. segrn Vic. Antonio, pues el ejemplar de londres estaba fallo del fróntis y aun de tres hojas mas de preliminares, contando solo 1'u!atro, y yo ereo que deben ser nehu; al fin del tomm se leia: Vulrid, Ium Goncalez. Año V.WC.XYV, yel vulumen se componia de 104 fílios. La segunda obra á que me refiero es la de los loegos de noche bvena moratizados "l le vida de Christo, marlyrio de Santos, y reformacion de cosiumbres. Barcelona, Sebastian Cormellas, Ario M.DCYI. ช hojas preliminares, 167 fols. y 7 de dos Tablas.Ambos tratados son en $8 .^{\circ}$ y están escritos il el estiln de los conceptos.
269 LIBR0 de las honras que hizo el Colegio de la Cōpañia de Iesvs de Madrid, à la M. C de la Emperatriz doña Maria de Austria... a 21. de Abril de 1603. Madrid, Luis Sanchez, M.DC.III. 4. $^{\circ}$ Con emblemas y jeroglificos grabados en madera. 6 hojas prels. y 138 foliadas.

Contiene muchas poesias latinas y castell:nas y algunas hebreas y griegas ; lambien hai varios jeroglifleos en ver'so.-Ninguna de las eomposiciones lleva el nombre de su autor, y por ciertn es sensible, pues se enementrin algunas de mucho mérito y dignas de la época en que se escribieron.

\section{LISACA DE MAZA (Bautis-} TI). Los grados del amor de Dios, en theorica, y practica, Sobre el opusculo 61. de Dilectione, del Angelico D. S. Thomas. Recopilada, y compuesta por el P. Fr. Bavtista Lisaca de llaza. En prosa, y versos diferentes. IIuesca, Pedro Bluson, 163̈. 8. 8 liojas prels. y 128 foliadas.

Primera edicion; la segunda la hizo en Mairiul, D. Joaquin Ibarra en $1782.8 .^{\circ}$

los Grarlos del umar de Dios los escribió el P. Fr. Diego de Fúnes, segun lo apunta Latasa, en el tom. II de la Bublioteca aragiomesa píg. 310 ; la Practica de dichos Gralus es produccion del P'. Lisaca, y el EstimuIn del divino anlor, que tambien se lialla en este tomito, se sujone ser obra de Frai luis de Lemn; asi lo indica el prólogo de la presente edicion, y lo supone Sedano en el Parnaso espuñal, t. V. p. XXVI.

Nic. Antimio no menciona este volúmen ni al nombre de Diego de Fúnes ni al de Lisaca, y Latisa en el articulo de este escritor, tom. 1II. pág. 144, se equivoca en suponer que la edicion primera de los Grados del amor de Dios esta hecha en Huesca, por Pedro Bluson, $1636.8 .^{\circ}$

271 LOPEZ DE HÓYOS (JUAN). Hystoria y relaciō verdadera de la enfermedad felicissimo transito, y sumptuosas exequias funebres de la Serenissima Reyna de España doña Isabel de Valovs. Con los sermones, letras, y epitaphios a su tumulo. Cópuesto y ordenado por.el Maestro Iuan Lopez. Madrid, Pierres Cosin, M.D.LX.IX. 8. ${ }^{\circ} 16$ hojas prels. 218 foliadas, y 16 sin foliar, que comprenden: Dec laracion y armas de Madrid, precedidas de un grabado en 


\section{LOP}

madera de las mismas, Las erratas, Tabla, dos Sonetos y una Copla.

Contiene este rarisimo tomo algunas con1. posiciones poéticas de varios y entre ellas hai tres de Miguel de Cervántes a quien el Ntro. Juan Lopez llama caro y amado discipulo.

La Declarucion de las armas de Madrid que se halla al fin de este volúmen es quizá la obra que supone inédita Alvarez y Baena en los Hijos de Madrid; alli menciona del mismo autor el

Rucibimiento que hizo la Villa de Madrid á Doña Ana de Auslria, con una breve relacion del triunfo de D. Juan de Austria, el parto de la Reyna, y solemne Bautismo dil Príncipe D. Fernando. Madrid, 1572. 8..$^{\circ}$ y en Lóndres tuvimos la

Relacion de la mverle y honras funebres del SS. Principe D. Carlos, hijo de la Mag. del Catholico Rey D. Philippe el segũdo nues. tro Señor. Marlrid, Pierres Cosin, 1568. 8. escrita tambien por Hóyos.

En ninguna de sus obras se le llama mas que el Naestro Juan López; sin embargo tanto Alvarez y Baena como Yavarrele y Pellicer le añaden el apellido de llóyos, por constar asi en un documento que existia en el archivo de la villa de Madrid, fechado el 29 de Enero de 1568, dia en que salió electo por voto de lodos, eatedrático de gramática y letras humanas del Estudio püblíco.

272 LOPEZ DE ĠBEDI (JCAN). Vergel de Flores Diuinas. Compuesto por el Licenciado Iuan Lopez de Tueda... En el qual se hallaran todas y qualesquier composturas apropriadas para todas las fiestas del año, assi de nuestro señor como de nuestra señora, $Y$ de otros muchos sanctos. Alcala de Henares, Herederos de Iuan Gracian, 1588. 4. 12 hojas prels., 210 foliadas, 9 de Taibla, $y$ una al fin en que se repiten las señas de la impresion.

Libro de estraordinaria rareza y dudo exista otro ejemplar tan hermoso como el mio.

En los titulillos de las 65 hojas primeras y en el Prólogo, se le da á esta obra el nombre de Cancionero, y los traductores de Tick. nor, tom. Ill pág. 520 , pretenden que es el mismo libro publicado con este titulo por el autor en 1579 y 1586 , en $8 .^{\circ}$ yo en $4 .^{\circ}$, aunque corregido y aumentado. En esto se equivocan, el vergel contiene efectivamente muchas de las composiciones del Cuncinnero; pero ademas de haber en este gran número de poesias no incluidas en aquel, se omitieron por entero las comedias, el auto y el coloquio de que hago mencion al tratar de la obra de López de lubeda en la Seccion dramá. tica.

Tом. 1.
En el Prólogo del Vergel dice su autor: cancionero d lo divino, hasla agora no acuerdo, ni lengo nolicia haber visto alguno, sino es el de frai Ambrosio Monlesino que debe de haber más de ochenta años que se imprimio. - En esto hai dos equivocaciones; la primera en suponer que solo Montesino habia hecho un Cancionero espirilual, cuando existen los siguientes:

1. ${ }^{\circ}$ El de Fr. Iñigo de Mendoza, impreso probablemente en Zamora por Centenera en el siglo XV.

$2 .^{\circ}$ El dado ả luz en Zaragoza, 1492, ambos descritos en este Catálogo. (Nums. 182 y 186.)

3. Otro impreso tambien en Zaragoza, 1495 , que trae Héndez.

$4{ }^{\circ}$ El Cancionero de Jnan de Luzon. Za. ragiıza. 1508 que describiré á su nombre en esta misma division. (Núm. 277.)

Y 5. visto por mi: (Portada circuida de orla y bajo una pequeña imágen de la lírgen con un niño en brazos, se lee de negro yencarnado:)

C Cancimero Espiritual, en el qual se tratà muchas y mu! excelèles obras sobre la concepcion de la gloriosissima virgè nuestra señora sancta Maria: y de las lelras de su nöbre, cō un passo d'i nascimiēlo, y olras muchas cosas en su loor. Y assi mesmo se tralá muy excelentes marauillas de la passion de $x$ p̃o $y$ del combale del coraço espiritual y del ansia del anor de dios. Y otros muy marauillosos dichos y cäciones del mundo buetlas a lo diuino todo en metros diferètes. Hecho por v'n religioso d'la orden del biécus̃unado sant Hieronimo

(Al dorso empieza cl prólogo ó dedicatoria que concluye en el blanco del fol. ij sign. Aij cuyo reverso lo llena la tabla por la cual se ve son treinta $y$ una las composiciones de este Cancionero. En el fol. iij sign. Aiij Comiença la obra, y concluye en la octava hoja de la sign. G. foll.lvj de esta manera:)

C Fue impressu la presenle obra inlitula. da cancionero espiritual : en la muy noble villa de lallatolil, en casa del homrado varon Jum de lillaquirun impressor acosta y mission del auctor... Acabose a qualro dias de hebrero de mil y quiniétos y. xlix (1549). años. $4^{\circ}$ let. gót. a dos colunas. Todas las composiciones son del mismo autor, segun se advierte en el prólogo, pero el nombre de este no consta en parte alguna.

No pude eueontrar á que se daba el titulo de Paso lel Nacimiento, sin duda será uno de los villancieos para la noche de Tavidad que ocupa como unas dos páginas, en el cual hablan Bras, Mingo, Llorente, Frutos, Gil, la lirgen y uno que solo dice Be. y cuyin nombre no me fue posible adivinar. Tambien liai entre las composiciones de este tomo una intitulada: Obra ltumada combate de coraçon en que se introduzen seys capilanes que le gnerrean y faligan que son Ansia. Trisleza. Cuydado. Temnr. Dolor. y Passion. Es un diálogo en décimas entre todos estos 
personajes y otros varios como la Temperanza, el Libre alvedrio, la Fortaleza, elc. y ocupa cerca de siete págs.

La segunda equivocacion cometida por López de Ubeda es la de suponer, en 1588 , que el Cancionero de Montesino se habia publicado hacia más de ochenta años, cuando la primera edicion conocida es ly siguientc, que describiré pues no lo la luecho ininuciosamente ninguno de nuestros bibliografos. Brunet y el Sr. Juran copiando a Nic. Antonio han equivocado el tamaño.

(Bajo de un escudo de armas cardenailicias se lee en cinco renglones:)

(I Cancionero de diuersas obras de nuevo trobadas: todas compueslas: hechas \& corregidas por el padre fray Ambrosio montesino de la orden delos menores.

En el fol. LXXIII, despues de la tabla, dice:

Aqui acaba el cancionero d'todas las coplas del veuer èdo padro fray Ambrosio montesino dela ordẽ d'l señor sant Franoisco. Las quales el mesmo reformo y corrijo: estando presente a esta impresion que fue fecha en la imperial ciudad de Toledo. a. xvj. del mes de Junio. d'l año de nuestra reparació de Mill \& quinientos \& ocho (1508) años. Laudelur $x \bar{p} s$. Amen.

Haj una hoja despues con el escudı de las armas de Espana. 4. ${ }^{\circ}$ let. gót.

De este Cancionero creo que se hizo otra edicion en Toledo, Jum de Ayala, 1547, 4. let. gòt.

LÓPEZ DE ÚBEDA (Juas). Cancionero general de la doctrina cristiana. Véase en la Seccion dramática.

273 LUJan (Marano). Relacion funebre de las Reales Exequias, que a... la Señora Doña Maria Barbara de Portugal... mandò celebrar en esta capital de los Reyes el dia 4 de Septiembre de 1759... Don Joseph Manso de Velasco... La escribia el R. P. Fr. Mariano Luxan. Lima, Pedro Nolasco Alvarado, $1760.4 .^{\circ}$ Lámina del túmulo, y dos hojas con dos laberintos: todas tres se pliegan. 2 hojas prels. 216 (dice equivocadamente 116) págs. y una hoja con una décima del impresor Alvarado.

Al fin se halla una oracion funebre del P. P. Fr. Juan Antonio de Tagle y Bracho con 12 hojas prels. y 136 págs.

Contiene este tomo poesias de varios autores, pero no vale la pena de menclonar aqui ninguno de sus nombres.

274 LUll (Ramundo). Coleccion de piezas relativas á su canonizacion y escritos, á saber:
Memoriale collationis, sev comprobationis centvm articvlorvm Lvllianorvm per F. Nicolavm, limeric in suo olim Directorlo compilatorum, factæ cum ipsis archetypis libris Magistri Raimundi Lull, Per Consules Iuratos Regni Balearium, iuxta mandata accepta a Sacra Congreg. Patrii Cardenalium Sancta Generalis Inquisitionis Homanæ, nec non \& Legat. Hispaniaril Romæ residentis: quorum recentiores litteræ, data ad Consules Baleares, sequenti folio describuntur. Palmæ Balearlvm, Typis Emmanuelis Bodriguez. s. a. (hacia 1614.) 6 hojas prels. y 90 pags.

Memorial de Fray Alltonio Busquets ál rei para la canonizacion de Raimvndo Lull. S. I. ni a. 10 hojas.

Proces original de les Hobres fetes per diuersos Trobadors en lehor de la vida Doctrina e mort del Egregi e gran monarcha Mestre Ramon Lull Doctor illuminat nat en la Insigna ciutat de Mallorca. Duimenge a $\mathrm{xv}$ de Maig any de nostre Sor. Deu Jesuchrist festa gloriosa de Sincogesma MIll sinchcents e dos . dich M.D.ij. Manuscrilo del siglo XVI en 28 hojas.

Letra feta per lo Rnd. mestre Clapes a alguns amichs seus de la ciutat de Mallorques en lehor del gran teolech Mestre Joan Lobet. Manuscrito de principin del siglo XVII.

Copia de acte audtentich de coses conteses en fauor de les obres y doctrina del benaventurat mestre $R$. Lull y concessio de Chathedres en fauor del Dor. Villeta. Manuscrito de principio del siglo XVII.

Copia de acte autentich de la bencdictio de la cambra del Beato R. Lull en capella a ont se selebre missa. Manuscrito del siglo XVII.

Copia de las cartas escritas por el rei en 1611 al Papa, á los cardenales Pindo y Panphilio y á su embajador en Roma relativas á la beatificacion de Raimundo Lull.-Informatlo verdadera sobre lo linatge dels Lulls. Con un árbol genealógico.-Copia de la carta ambiada per els Jurats al Inquisidor general asirca lo impediment que feren al Regna en la impresio del llibre intitulat Apologia en defensa de la causa del V. Dor. y Martyr Ramon Lull. Manuscrito de la misma época.

Transvmtvm memorialis In cavsa pll eremitæe, et Martyris Raimundi Lulli, quæ nunc. Romæ vertitur coram Sanclissimo, per Ad. modum Reverendum Fr. Iohannem Riera. S.l. ni a. (Parece edicion de koma hecha ha. cia fines del siglo XVI.) \& hojas prels. y 162 págs.

Los tratados que preceden descritos se encuentran reunidos en un vol. en fol.

Todos estos documentos y opúsculos son curiosos; pero llama principalmente la atencion la Justa pnetica celebrada en 1502. El Sr. Bover, en su Memoria biografica de los Mallorquines, la menciona $\mathrm{y}$ da a entender no ha conseguido verla; á esto se debe sin 
duda el ser tan lacónlco en las noticlas que nos da de Antonio Masot, Juan de Menorca, Jorge Alber, Gaspar Veri, Ramon Lull y Gaspar Calaf, justadores que tomaron parte en ella, presentando composiciones poeticas en dialecto mallorquin. Como complemento á estos versos, escritos en alabanza del gran Raimundo, el curioso copilador de este volúmen agregó al fin de dicho certamen una Obra fita en lanr de Mestre Ramon Lull Malorqui Per hun trobador nomenat mossen Fransesch Prals prewera, que Bover no vió y supone Impresa el P. Paseual en su Aguja ndutica.-Tampoco parece que tıvo Buver presente el Transumitun memorialis del $\mathrm{Pa}$ dre Juan Hicra.

Coino considero que el tratado mas inuportante contenido en este tomo es el Proces de les obres fetes per diversos trobadors, coloco esta miscelánea en la presente division.

El tratar aquí de Raimundo Lull me in. duce á describir una obra suya que he visto, y no es frecuente.

Empieza:

Jhesu christe gloriose etc.

Al dorso de la liltima hoja se lee:

Ad laudem r honorè inlemerale virginis marie : liber de ei $i^{9}$ cóceptu ab oini labe originali imuni : ab egregio viro magistro Raymundo lull doctore illuminato compilutus (qui profide catholica lapidĩ ictibus orcubuit apud tunicem ciuilatem agarenor foliri numine est cxplicilus. Jmpressus hispoti impensis religiosi liri fratis marlini almodo"ur militie de calatraua opera v'ero e ige. nio magistri pauli $d^{\prime}$ colonia « sociorü ei ${ }^{9}$ alemanur ${ }^{2}$ duodecima dic martii. Anno ab incartione dñi. 1991 .4. let. semigót. á rellglon seguido. Son 28 hojas, con las signaturas $a-d$ todıs de 8 hojas, ménos la última que es de 4 .

273 LUQUE FAJARDO (Fraxcisco DE). Relacion dela tiesta que se hizo en Sevilla a la Beatificacion del Glorioso S. Ignacio. (Por) El Lic. du Francisco de luque Fasardo. Sevilla, Luis Estupiñan, 1610. 4. ${ }^{\circ}$ Una hoja con la portada grabada, en la que esta el retralo de S. Ignacio, 2 hojas prels. y 26 foliadas. - Cartel de Ivsta iiteraria. 12i hojas foliadas. Sermon gre predico el P. M. Fr. Pedro de Valderrama... En la fiesta de la Beatificacion de... San Ignacio. Sevilla, Luys Estupiñan, 1610. 2 i hojas foliadas inclusos los prels.

$276-O$ Ora edicion. Sevilla, Lvys Estupiñan, 1610. 4. Igual numero de hojas que la anterior.

Fsta impresion es tan sumamente parecida á la ántes descrita, que aun cxaminada con la mayor escrupulosidad apénas se conoce sea distinta; las diferencias más marcadas consisten, en estar impreso el fróntis de la presente, siendo el de la otra grabado, y en que el nombre del impresor y señas de su casa, puestas en la última página, son en esta de letra redonda $\mathrm{y}$ en la precedente de cursiva.

A pesar de poderse ya calcular el mérito de esta Justa, que llena cl libro en su mayor parte, por la fecha de él, citaré los nombres de varios de los autores que á ella concurrieron, entre los cuales se hallan a'gunos de los poetas más esclarecidos de nuestro par. naso:

El Lic. Lucas de Valdes, D. Luis de Gongora, Pedro de Soto, D. Pedro Fernández de Salinas, Francisco Pacheco, el P. Fr. Simon de Gainza, Miguel Cid, el P. Fr. Luis de Fuzman, D. Juan de Jaúregui, Damian Saluzio del Poyo, el Lic. Juan Bautista de Mesa, D. Alonso de Ribera, Diego Camargo, Dun Francisco de Villalon, Rodrigo Caro, el licenciado Felipe Godinez, D. Juan intonio del Alcázar, el Lic. Gonzalo de Padilla, Sebastian Muñoz, Francisco de Luque Fajardo, Sebastian de Alfaro, el marqués de Algava y Ardales, el P. Fr. Luis ingeles, Antequera, Simon Areas de Valdivieso, IItro. Francisco de Bosmediano, D. Alonso de Busto y de Bustamante, el P. Fr. Alonso Cabeza de raca, Bernardo Luis de Cárdenas, Diego de Cuencá y Avalos, Lic. Estéran de Espinosa, Pedro Fernández y Peñalver, Francisco Fernández de Cordova, Rodrigo Fernández de Ribera, cl P. Fr. Pedro Fromesta, Cionzalo de la Fuente, Lic. Juan Gómez, Lic. Gúmez del Rio, Lic. Sebastian González, Francisco del Grado, D. Juan Guzman, D. Luis de Guznan, Prudencio Huarte, Pedro de Jesus, Bartolome Leon IIontero, Sebastiall de Lizana, Don Ant. López de Calatayud, Lic. J. Bta. Martinez de Ylata, Lic. Alonso de Yedina, Lic. Baltasar Yéndez, el P. Fr. Alouso de Mesa, el P. Fr. Franc. Millall Lic. Felipe de Mora, Sebastian Muñoz. Lic. Felipe Iavarro, el P. Fr. Juan de ortega, Antonio Ortiz Yelgarejo, Lic. Nartin Perez de la Mata, Don Luis I'once de Lewn, Itro. Igustin Quijada de Carvajal, I. Juan Rúbles Rivadeneira, el P. Fr. Juan San Martin, Dr. Franc. Silva dolivera, Pedro de Turres Escobar. bachiller Lorenzo Vallinas, cl P'. Fr. Felix de Vera, Fr. Juan de Vera, i.ic. Aut. de Villagran, Lic. Pedro de Villagran, D. Juan Villamarin y muchos ingleses colegiales de los jesuitas que eseribieron todos en latin.

Al principio de la Justa se encuentra un Acto en castellano y latin, que se representó por seis niños $y$ está dividido en seis escenas.

Nic. Antonio describe otra obra del género de la presente publicada por el mismo Luque Fajardo. cuyo titulo es: Relacion de las fuestas que la Cofiudria de Sacerdotes de S. Pedro clebró en su Parroquial Iglesia de Sevilla $a_{4}$ la Purisima Concepcion. Sevilla, $161644^{\circ}$

El siguiente escudo del impresor Estupi. oan se halla al fin de la Fiesta d $S$. Ignario 
debjendo advertir es el mismo usado por Diego Pérez elı la Christiada de Hojeda.

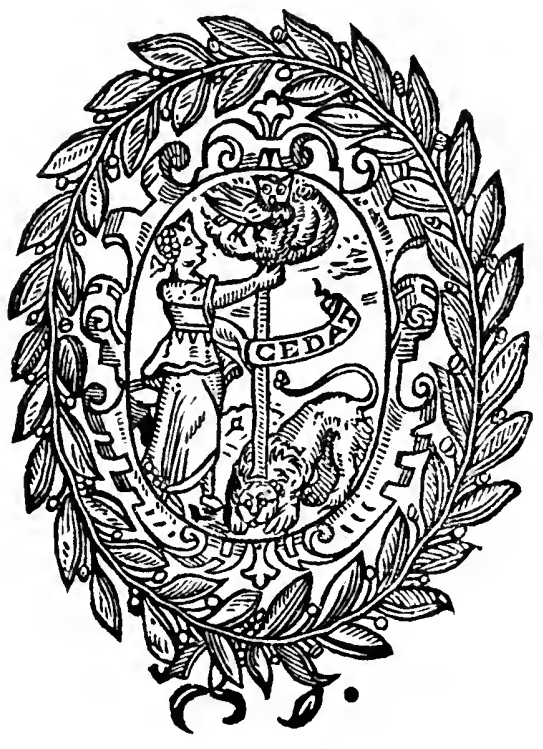

277 LUZON (Juan de). Cancionero de Juã de Luzen. Epilogacion dela Moral Philosophia: sobre las virtudes cardinales: cõtra los vicios y pecados mortales: prouada cõ razones y

278 MADRE DE DIOS (Lúcas DE LA). Noticias de la aclamacion festiva, que celebro en... Toledo el Colegio de Carmelitas Descalzos a la Beatificacion de San Jvan de la Crvz. Escrivelas el Padre Fray Lvcas de la Madre de Dios. Madrid, Lucas de Bedmar, 1679. $4 .^{\circ} 8$ hojas prels., 400 págs. y una hoja de Indice.

Se encuentran poesías de varios, aunque la mayor parte no tienen nombre de autor: esta falla es poco sensible si se atiende al escaso mérito de las producciones y al mal gusto que reina en todas ellas.

279 MALDONADO (López). Cancionero de Lopez Maldonado. Impresso en Madrid, en casa de Guillermo Droy. Acabosse a cinco de Febrero. Año de 1386. 4. 12 hojas prels., 189 fols. y una blanca. actoridades diuinas $\mathbf{y}$ humanas / y cõ exêplos antigos y üssentes: glosada cnlo necessario: aprouada por muchos theologos: cõ las cõtēplaciones d'san Bernardo sobre la passion: el Salmo Misere / de pfundis / o gloriosa domina rc. (Al dorso principia el Prologo ó dedicatoria a Doña Juana Daragon que concluye en el blanco de la sing. a ij, cuyo reverso lo llena la Epilogacion ó tabla de la obra; comienza esta en la tercera hoja y concluye en la quinta de la sing. n con cste colofon despues del escudo de Coci:)

I Acabada fue toda la p̃sente obra el postrero dia d'l mes de julio: de mil quinientos y seys años: en la ciudad de Burgos... Y fue hecha y glosada por Juan de luzon... Y fue imprimida enla muy noble ciudad de caragoca: y acabose a. xij. dias del mes de octubre del año d'mill quiniētos y ocho (1508). 4. ${ }^{\circ}$ let. gót. sin foliacion, sing. a-n de 8 hojas ménos la n que solo tiene seis siendo la illima blanca.

Este tomo mui raro, solo contiene composiciones de Luzon; sin embargo lo coloco en la presente division por el título que lleva.
He puesto í este autor hajo el nombre de Maldonado pues el de López tomado por algunos como apellido, no lo es, segun lo maniflesta Clemencin en la pág. 1/8, tom. I. del Quijote.

Nic. Antonio no pudo, sin duda, alcanzar á ver este rarisimo libro pues al hablar de él no scñala el lugar ni año de la impresion.

De Vicente Espinel, Lope de Vega, Juan de Vergara, Gonzalo Gómez de Luque, Pedro de Padilla, y otros varios hai composiciones laudatorias al principio del volúmen; Miguel de Cervántes hizo dos y ademas en el escrutinio de la biblioteca de D. Quijote encomia á Maldonado, y no solo perdona al Cancionero de ir á las llamas, sino que dice debe guardarse con los escogidos.

El Sr. D. A. Duran formó de la obra el siguiente juicio: El autor de este raro y precioso libro se propuso formarle de poesías suyas, escritas en todos los géneros y metros que se usaban en su tiempo, sin excluir las canciones $y$ villancicos, cuyas formas precedieron a la metrificacion italiana. 
I) Lopez Maldonado hai tambien varias composiclones en la Academia de los nocturnos cle Valencia.

280 MANRIQUE (ÁNGe). Exequias. Trmvlo y ponpa fvneral, que la Vniversidad de Salamanca hizo ell las honras. Del Rey... don Felipe III. en cinco de Iunio de mil y sevscientos y veynte y vilo. Salamanca, A-n tonio Vazqvez, M.DC.XXI. 4. ${ }^{\circ}$ marq. 1 hojas prels. y 252 págs.

Ejeniplar de gran papel.

El nombre del autor consta del ftnal de la dedicatoria.

Comprende este volumen poesias caste. llanas, latinas y algunas griegas escritas por varios ingenios; sobresalen entre ellos: Don Luis Brochero, D. José P'ellicer y Sálas, el Lic. Pedro de Avendaño, D. Jerónimo de Arostigui, el Lie. Cionzalo de Correas, Don Fernando Gallo, el VItro. Blas Lopez, el Liceneiado Álvaro de Pantoja, el Lic. Juan Roáles, Alonso de Ledesma, el P. Fr. Julian Mannel, lic. Gómez de Záyas y Fuéntes, Fr. Pablo - Martinez, Fr. Juan de la Negra, D. Luis Sors de Peramato, Lic. Francisco González, Diego de Oquet, Lic. Mateo Alvírez, D. Luis Mendoza, Iona Antonia de Alarcon, Fr. Julian Hanuel, Fr. Angel del Águila, Pedro de Vírgas Machuca, el P. Fr. Juan de Herrera, dil itro. Márcos López, Lic. Simon Felipe de Quirus, Lic. Diego Gutierrez, Lic. Juan de Aguilar, Fr. Antonio de Nomroi, el P. Fr. Tomas de san Vicente, Fr. Julian Manuel, D. Francisco de Ifendoza, Lie. Bartolome Ilonorato de Ribera, D. Liris Antonio de Silva y Barahona, Lic. Pérez de Soráles, Lic. Pedro Bello de Herrera y D. Inimo de Avendaño Idiáquez.

\section{MANRIQUE DE LUJAN} (Fernano). Relacion de las fiestas de la Cirdad de Salamanca, en la beatilicacion de la $\mathbf{S}$. Madre Teresa de Iesus. Por D. Fernando Manriqve de Lvxan. Salamanca, Diego Cussio. Año de M.DC.XV. 4. 4 hojas prels. y 300 pags.

Desde la pág. 96 á la 199 se encuentra un centdinen poético donde hai composiciones castellanas y latinas: concurrieron á él los siguientes autores: Fr. Andres de Moráles, Lic. Juan Navarro, D. Claudio de Tejeda, D. Sebastian de Guevara, D. Rodrigo Godinez Cabeza de Vaca, D. Pedro Allvarez de Toledo, el Lic. Matienzo, Alonso Tavira, Don Baltasar de Zuniga, I. Francisen Heredia, Francisco de Francia, Fr. Gabriel de Santa Cruz, D. Antonio de Viera, Fr. Leandro Vadillo, D. Pedro Navarro, D. Garcia Bravo, Fr. Lorenzo de Andrade, Fr. Miguel Infante, D. Francisco de Ayala, $\mathfrak{D}$. Rodrigo de $\mathbf{A}$ lava,
D. Francisco Bravo, José Sánchez, Diego Fernández de Paz, Pedro de Molina, Pablo Verdugo, D. Pedro de Andrada, D. Leandro de Andrada, D. Diego de Cabrera, D. Ventura Pinto, D. Francisco Lucio, Lic. Pedro Alvarez, D. Jerón. Pueyo, D. Diego de Frias, D. Gregorio Pareja, D. Rafael de Heredia, lic. Carvallo, Franc. Martinez, D. Laurencio de Guevara, D. Alvaro de Zúñiga, Don Juan Orozco, Mtro. Blas Lopez, Antonio Álvarez, D. Cárlos de Heredia, Estévan Mongenet y D. Lnis Luprel.

Nic. Antonio omitió á Fernando Manrique le Lujan en s!l Bibliolheca.

282 MANUEL (DIEGo). Ivsta poetica, que hizo al Santissimo Sacramento en la villa de Cifventes, el Dotor Ivan Gvtierrez. Recopilada por Diego Manuel. Madrid, Imprenta Real, 1621. (Al fin se repiten las señas; pero en lugar de Imprenta Real dice Tomas Iunti.) $\mathbf{8}^{\circ} \mathbf{8}$ hojas prels., 66 fols.y dos despues sinfoliar.

Contiene esta Jusfu poesias de Fr. Diego Lopez, Cristóval Gutiérrez, el Lic. Antonio de Alcázar, Doña Isabel de Ribadeneira, el I.ic. Alonso de la Peña, el Lic. Diego de En. zinas, Doña Ines Baptista, Diego Manuel, el Dr. Luis de Lzedo, el lice. Pedro de liuigarcia, Hernando de Hita Salazar, Fr. Luis Aceituno, el Lie. Juan de Orozeo, Juan Bta. Diaz de las liasas, el Licenciado Helchor de Ion. te Relond y Juan Bautista de los Rios.

vic. Intonio no hace inencion de Diego Yanuel ni de Juan Gutiérrez de Solorzano, como se le denomina varias vezes en los preliminares; habla si, de un Juan Gutiér. rez de Gudoe que conviene con este en ha. ber sido medico de S. M.

283 MárMOL Manel Maria DEL). Romancelo ó pequeña coleccion de romances, tomados de las poesias impresas é inedilas del Dr. D. Manuel Maria del Marmol. Serilla, Hidalgo y Compañia, 1834. E vols. $16 .^{\circ}$

28. MARTEL (Jerónimo). Relacion de la fiesta que se ha hecho en el convento de Santo Domingo de la Ciudad de Caragoca a la Canonizacion de San Hvacintho. Caragoca, Lorenzo de Robles, M.D.LXXIXY' $8{ }^{\circ} 6$ hojas prels. y 418 págs.

Latasa al hablar de este libro dice haberse hecho raro. Se halla en él la glosa de Niguel Cervántes á uma redondilla propuesta en el corlamen, la cual mereció el primer premio: 
Navarrete la reinprimió en la vida de aquel autor. Los demas poetas que escribieron para la justa, son: Fr. Juan Blay, Juan lúcas Itarcuello, Juan Ripoll, Diego Felizes, I.ic. Sebastian Navarro, Fr. Dicgo Murillo, el capitan Alberto de Cuévas, Jerúnimo de Mora, Fr. Juan Sánchez de Ezpeleta, Fr. Juan Calderon, Juan Miguel de la Era, Martin Gratal, Jerónimo lidal, el I)r. Juan Sala, Luis I)iez de Iux el lic. Niguel Martou y Marlin Perez de olivan.

Por la licencia, aprobaciones y dedicatoria consta que el recopilador de estas flestas fué Jerónino Marlel.

283 MARTINEZ (Fravcisco). Las exequias y fiestas funerales qre hizo la santa İglesia de Origrela, y svs Parroquias, a la dichosa muerte de... Mossen Francisco Geronymo Sinō... Coa rn tratado breue de la Antiguedad de... Origuela etc. etc. Por el Dotor Francisco Martinez. Origuela, Agustin Martinez, 1612. 8. 8 hojas prels., 208 fols. y dns al fin sin foliar con Advertencias al Letor y las Erratas.

El Breve tratado de la fimblacion !| antiguedad de Origuela: y de su Iglesia Calhedral, ocupa 65 hojas al fin y lleva nuevo frinlis, á pesar de segitir la foliacion dal Iratado de Las exequias.

Obra rara en la eual liai poesias de bun Pedro Rocamora, Gines Visdes, Barlolonıi Gil, Jusepe Alenda, Juan Trenciòı, Antoniı Bellot, D. Francisco Sans, mosen yignel Gali, Fr. Teófilo Masearos, Dr. Bartulonı (iil, mosen Fernando de la Fasa, Gitspar Gil, mosen Hárcos Armero. mosen Andres Valles, mosen Francisco Ochoa, Francisco Leon, mosen Miguel Balagner, Fr. Aguslin de Mendoza, Dr. Serafln Buenaventura de Cozar, mosen Roque Beneito, mosen Baltasar Sober, mosen Bartolomé Terres y el Doetor Juin Martinez.

286 MARTINEZ (José). Exequias Reales, qre a la mverte de svar-grstissimo Monarca, y Señol, I). Carlos de Avstria ,... Cèlebrò la Ciudad de Lerida. Cria relacion escrive El Padre losef Martinez. Lerida, Domingo Simon, 1701. 4. ${ }^{\circ}$ Lna hoja con el escudo de las armas de Lérida, 8 hojas prels. y 203 piigs.

Contiene poesias latinas y cistellanas anonimas de yarios: nada ha peraido la posteridad por ignorar los nombres de sus autores.

287 MARTINEZ (JUAN). Relacion de las solemnissimas Exequias, que la Ciudad de Caragoça ha hecho por cl Rey Don Philippe nuestro señor primero deste nombre en estos Reyues de la corona de Aragon por el Doctor Iuan Martinez, Racionero de dicha Ciudad. Caragoca, Lorenco de Robles, M.D.XCVIIII. $40^{\circ} 8$ hojas prel., 318 pags., una hoja blanca, págs. para el Sermon del P. Fir. Diego Murillo, y 3 hajas de Tabla, $i$ mis de una de Erratas, en que se repiten al fin las señas de la impresion.

El no ver citado por Latasa en su Biblioleca a este Racionero de Zaragoza, pudiera hacer creer a alguno que no era aragones: sin embargo no.pucde dudarse de ello, porque dedicando la presente obra á los Jurados de aquclla ciudad, les dice: "si el respeto que "deno a los que son padres tan benemeritos "de mi propia palria no me huuiera obliga'do. - y eli el Próogo al letor, la principal razon que aduce para componer el libro,es, el amur de mi palria, a la qual, como dijo Plalon, denemos parle de meslro nacimien. to. A lo mismo parece aludir el Maestro José Salímas en los versos laudatorios de la obra, emando dice:

\section{Citsarece Auguste refereliam Doctus alumnus.}

Contiene el volumen composiciones poétieas lle Vartin P'érez de olivan, lic. Juan Franciseo de Lezan, Lie. Miguel Cortes, Bachiller Almendro, D. Miguel Moneayo, bein Jilan Sala, Gregorio Juan Palacio, Martin de Valdelvila, Valerio Fortuno de Agreda, Lirenciado Lucas Mareuello, Miguel Lorenzo de Lubera, Luis Escatron, Juan Ripol, Juan Valero de Allóbras, Juan Valero Palácios, Lic. Juan Bautista Alzamora, Fr. Juan Sánchez Ezpeleta, Lic. Miguel Marton, Antonio Frances, lic. Jerónimo Gutiérrez, Fr. Diego de Benso, Dr. Miguel de Ezpeleta, Lic. Antonio Tóres, Antonio foces, Lic. Pedro Sigues, Juan Valerio, Dr. Braulio Pilíres, Gas. par Mesa, Lic. Gregorio Ganaverro y Lo. renzo Juan Mompaol.

288 MARTÍNEZ DE IA VEGA (Jeróx.). Solenes, i grandiosas Fiestas, $\pi$ la... Ciudad de Valencia $a$ echo por la Beatificacion de su Santo Pastor, i Padre D. Tomas de Villanueva. Por Geronymo Martinez de la Yega... Con un discurso de los Obispos, i Arcobispos, desde el dia de su cõquista por el hey don layme, i otras cosas memorables. Valencia, Felipe Hey, 1620.8. Viñetas de madera. 8 hojas prels., 580 págs., dos hojas de Indice y una en fol. que se. dobla, de un Laberinto en latin. 
MEN ANTologias y JUStas poéticas. MIL

Hai en este volúmen setenta y dos jerogliflcos ó emblemas y un Certámen poético donde se encuentran muchas poesias castella. nas, latinas $\mathrm{y}$ valencianas de D. Pablo de Castelví, Don Gaspar Mercader, D. Gaspar Escrivá de Romaní, D. Baltasar Ladron, Juan Ribalta, Vicente Esquerdo, Jusepe Bertomeu, Vicente Mariner, Vicente Gasco de Slurana, Vicente Bise, Vicente Espinosa, Juan Bta. Roig, Antonio Medina, D. Juan Sigler Cardona, Jerónimo Nartínez de la Vega, Fr. Lam. berto Espejo, Juan Tremino, Pedro Salinas, Fr. Cristoval de Espejo, Miguel Antolino, Juan Luis Fababulx, Jaime Juan Bertomel, Jose Miguel Bertomeu, Marco Antonio Orti, Leonardo, Juan Alfonso, Jusepe Rostojo, Vicente Valterra, Maximiliano Cerdan de Tallada, Luis Caballer, Vicente Font, Lamberto Ortiz y Gaspar Aguilar.-Observo que Jimeno y Fuster cn sus Bibliotecas omitieron Ios nombres de la mayor parte de estos autores á pesar de ser casi todos ellos valencianos.

Es este tomo curioso ademas, por sus descripciones de los torneos, canas, toros, saraos, etc. celebrados en las flestas a Santo Tomas.

289 MatA (F. Gabriel de). Vida, mverte $\mathrm{y}$ milagros de $\mathrm{S}$. Diego de Alcala, en otaua rima, por F. Gabriel de Mata... Con ios hieroglificos y versos que en alabāc̣a del santo se hizieron en Alcala, para su procession y fiesta. Madrid, en casa del Licēciädo Castro, 13̈98. 8." 8 hojas prels. y 247 fols.

Hermoso ejemplar de este libro raro, en el que hai algunas hojas sin abrir.

Nic. Antonio menciona una edicion de $\mathbf{1 5 8 9}$ en 4. ; pero no dice el lugar dónde se imprimio: la de 1598 le fué desconocida.

La vida de S. Diego, escrita en octavas se divide en diez y seis cantos y ocupa 137 hojas, las 110 restantes comprenden las fiestrus de Alcala en donde están los jeroglificos y certánenes, y se hallan poesias de muchos autores cuyos nombres no constan.

Gabriel Mata escribio tamhien dos poemas caballerescos ascéticos y se hallan descritos en la seccion correspondiente del presente Catálogo.

290 MFNÉZES (D. LUIS DE). Compendio panegirico da vida, e acçoens do Excellentissimo Senhor Luis Alvarez de Tavora. Escrito por Dom Lvis de Menezes, Conde da Eryceira. Oraçam funebre, Que prégou nas suas Fxequias Dom Frey Luis da Sylva. Varios versos. Dédicados ao mesmo assumpto. Lisboa, Antonio Rodriguez d'Abrev. Anno 1674. 4. 4 hojas prels. y 19 págs.
Desde la pág. 51 á la 167 se encuentran poesias portuguesas, castellanas y latinas escritas por unos cincuenta autores Iusitanos.

291 MERCADER (D. GASPaB). EI Prado de Valencia. Compvesto por Don Gaspar Mercader. En Valencia, por Pedro Patricio Mey. 1601. 8. ${ }^{\circ} 8$ hojas prels. y 3 ว̆2 págs.

Jimeno no conoció mas edicion de esta obra que la que yo poseo de 1601: sin embargo el Sr. D. Agustin Duran en el Catdlogo de documentos de su Romancero cita otra del mismo Pedro Patricio Mey de 1600, la cual consta de solas 168 págs. (serán 168 hojas?).

Aprovecho esta ocasion para advertir que en varias obras copio el juicio de ellas emitido por dicho Sr. Duran, considerando haber sido la persona mas idónea para formarlo con acierto, tanto por su gran instruccion, como por la vasta lectura que hizo de nuestros poetas. Del Prudo de Valenciu dice: - Es un "raro y precioso libro, donde en una nove. x la pastoril semihistórica se describen fles. - tas, se intercalan buenas $y$ artisticas poe- sias del autor y de los mas célebres poetas - valencianos, que como Aguilar, Guillen de - Castro, Boil y otros florecieron desde las - últimas décadas del siglo XVI y las primeras - del XVII. Las composiciones todas son liricas "Y subjetivas; pero no se desechan de ellas - los metros antiguos de arte menor, ni los -romances.

- Puede considerarse este libro como un - inestimable Cancioneru que conserva las - obras de escelentes poetas que existian - cuando se imprimió, y que se distinguieron - no sol" como liricos sino tambien como - dramáticos contemporáneos de Lope de - Vega."

Para completar la precedente reseña, aña. diré á los tres nombres citados por el Sr. Duran los de los otros poetas de quienes se encuentran composiciones en la obra de Mercader: Miguel Beneito, Lopez Maldonado, Fernando Pretel, el Capitan Artieda, D. Leudomio Mercader, D. Miguel Ribéllas, D. Baltasar Centéllas, D. Francisco Crespi, D. Juan Fenollet, D. Jeroninı Mercader, Masimilia. no Cerdan, Jaime orts y Francisco Tárrega.

Los traductores de Tícknor, tom. liI página 541 , dicen ser esle libro sumumente raro, y tanto es asi que no sé exista en Valenciá otro ejemplar completo y bello como el mío.

292 MILA Y FONTANALS MANUEL). Resenya histórica $\mathbf{y}$ crítica dels antichs poetas catalans. Per $\mathbf{M a}$ nel Milá y Fontanals, premiada ab la medalla d'or del Ateneo Catalá en los Jochs florals de 186. Barcelona. Lluis Tasso, $1863.8 .^{\circ}$ may.

Regalo del autor con su autógrafo: contiene este tratado innumerables trozos de poesia antigua catalana de diversos autores. 
293 MIRANDA Y LA COTERA (José DE). Certamen angelico en la grande celebridad de la dedicacion del nvevo, y magnifico templo qve sv grave Convento de Religiosos de la esclarecida Orden de Predicadores consagro a Santo Tomas de Agvino... el Octubre de M.DC.LVI. Porj D. loseph de Miranda y la Cotera. Madrid, Diego Diaz de la Carrera, M.DC.LYII. $4 .{ }^{\circ} 28$ hojas prels. y 204 foliadas.

Contiene composiciones de más de ochenta. poetas, siendo entre ellos los 1uils conocidos D. Ambrosio de Arze, I)r. Felipe Godinez, i). Juan Francisco Dávila, l). Mermardo Verdugo, D. Antonio de Miranda, I). Antonio López de Vega, D. Rodrigo de Iterreri, Don Bernardo Piña, D. José Félix de Allada, Din Luis de Villamarin, D. Juan Vélez de liuevara, Juan Navarro, D. Jual de Zamora, el Lic. Miguel Jiménez, D. Mamuel Núñez, loon Juan de Salzedo, el Itr. Diego B3dı. de Quiros, D. Isidro de Angulo, D. Gabriel Boćálgel Unzueta, D. Fernando Niñez de Castro, D. Alvaro Cubillo de Aragon, I). Jeronimo de la Cruz, D. José Miranda de la Cotela y D. Francisco de Quinones.

Está omitido D. José de Mliranda y la (i)tera en la Bibliolheca nova de D. Nic. Alltonio.

294 MONFORTE Y IIELRERA (Fers. De). Relacion de las fiestas que ha hecho el Colegio Imperial de la Compañía de Iesus de Madrid en la canonizacion de San Igliacio de Loyola, y S. Francisco Xauier. Por Don Fernando de Monforte y Ilerrera. Madrid, Luis Sanchez, 1622. 4. ${ }^{\circ}$ hojas prels., 74 foliadas y otras 103 de nueva foliacion para el Certámen poético.

Pocos libros de esta clase contienen composiciones de tan gran minnero de distinguidos poetas como el presente: sirvil de prueba la siguiente lista de lis que tomaron parte en la Justa poética:

D. Juan de Jáuregui, I). Franciseo Lojez Zarate, D. Alonso del Castillo, el Dr. Juan Pérez de Montalvan, Guillen de Castro, Don Pedro Calderon, el Dr. Mira de Ameseua, t)on José Pellicer de Sálas, Atanasio Pantaleon de Ribera, D. luis de Belmonte y Bermidez, D. Diego de Villégas, D. Jacinto y D. Rudrigo de Herrera, D. Franeiseo de Francia y Acosta, Juan de liña, Pedro Váuras Nachuca, el P. Juan de Ávila, Scbastian Franciseo de Medrano, Lic. Jeronimo Marlinez de Castr., Pedro de Avendaño, Dr. 1). (iabriel de Airolo, Lnis Vélez de Guevara, Loje de Vera, Alonso ylartinez, Alonso Góntez de Toledo, Don
Diego de Benavides $\mathrm{y}$ de la Cueva, Mtro. Blas López, P. Antonio del Valle, Lic. Hernan Suarez, D. Francisco Fernández de Azagra, 1). Francisco de Tapia y Leiva, D. Juan Hurtado de Castilla, el P. Cosme Zapata, Don Juan Ramirez de Peralta, Fr. Douningo Vélez, I). Diego Núñez de Bracamonte, Lic. Felipe del Castillo, D. Matias de Urosa, Juan Franciseo de Prado, Doña Manuela Pardo de Monzol, D. Fernando de Aguilar, Jerónimo de la Fuente, Márcos González, Joña Antonia de Alarcon, José Ruiz de Antable, D. Antonio Martinez y Meneses, el P. Franc. Verdugo, D. Pedro Bravo y Urosa, Antonio de Silva, Lic. Francisco de Quintana, Gonzalo de Ayala, D. Luis Falier, Lic. Alonso Gutiérrez, el P. Antonio de Valle, D. Francisco Pedrosa y Ávila, Luis Tribaldos de Toledo, Sebastian Matienzo, D. Juan de Córdova, Lic. Matias Aberle, Fr. Ambrosio de Herrera, el P. Pedro Ponce, Marcos Jiménez, D. Francisen Lucio de Espinosa, D. Juan Velázquez, D. Luis de Tovar, D. Juan Bejerano, Don Martin Urbina, D. Berrardo Arias de Toledo, Alfonso Ribciro Pegado, Pedro de Benavente y el Bach. Juan Portillo.

293 MONTEMAYOR (JoRGE DE). Las obras de George de Monte mayor, repartidas en dos libros, y dirigidas a los muy altos y muy podelosos señores don Iuã, y doña luana, Príncipes de Portogal. En Anvers. En casa de Iuan Steelsio, Año de M.D.LIIII. ( $l l$ fin:) Fuc inipreso en Anvers, en casa de Iuan Lacio. $10 ̈ 54$. 12. 12 hojas prels., $2: 7$ fols. y una blanca.

Volúmen de estraordinaria rareza que produjo siete libras y diez chelines en la venta de Ileathcote en 1808 .

Es la primera edicion de sus obras poéticas dada á luz por Montemayor. Hasta el fol. 74 comprende las producciones profanas; en el 75 , con nuevo fróntis, aunque siguiendo la foliatura, comienzan Las obras de Deuocion, dirigidas como las de la primera parte á Don Juan y Dona Juana de Portugal, las cuales ocupan el resto del volumen hasta el folio 257. En esta segunda parte se encuentran tres Autos que fueron representados al serenisimo principe de Castilla en los mailines de la noche de Navilau, á cada nocturno in auto, y ademas hai una buena Gtosa d las coplas de Jorge Manrique, que, por ser tan poco conocido este libro, no se insertó en la edicion de dichas coplas hecha por Sancha. A esta misma razon se deberí indudablenrente el que Barrera no ponga á Montemayor entre los autores dramáticos, á pesar de reclamar de derecho las tres piececitas arriba citadas un lugar para él en el calálogo del teatro español.

He colocado el presente volúmen en la clase de los Cancioneros, no purque sea una 


\section{MON antologílas Y JUStas poEticas. MOR}

verdadera antologia, sin embargo de contener algunos versos de Juan Vázquez de Ayora, Gutierre de Cetina y D. Juan Hurtado de Mendoza, sino porque en todas las ediciones posteriores de la primera parte se le dió aquel título, y D. Rodrigo de Mendoza en una Eptstola dirigida al autor lo denomina por dos vezes Cancionero.

En el Indice espurgatorio de D. Fernando de Valdes, arzobispo de Sevilla é Inquisidor general, publicado en 1559 , se hallan ya probibidas las Obras de Montemayor, en lo que loca de devocion y cosas crislianas.

Segun se verá por el articulo siguiente en 1558 el autor dividió sus Obras en dos vo. lúmenes, intitulando el uno Segundo cancionero de Montemayor y el otro Segunds cancionero espirilual; no he visto el último, y por lo mismo ignoro si será reimpresion al pié de la letra de las 360 págs. poco más ó ménos. que en el de 1554 se dedican á esta clase de obras, $\dot{0}$ bien sucederá como con el de las de humanidad á las cuales añadió muchisimas y suprimió no pocas.

296 MONTEMAYOR (JORGE DE). Segrndo Cancionero de George de Monte mayor. Anvers, en casa de Iuan Lacio, M.D.LVIII. 12.0 let. cursiva. 9 hojas prels. (quizá debe haber una blanca despues) y $202 \mathrm{Z}$ (0liadas.

Dice Montemayor en el prólogo de este volúmen: : Ln libro mio se imprimió habrá - algunos años (. sin duda Las obras que dió d - luz Juan Steelsio en 15ă) con muchos yer- ros, asi de parte mia cono de los impréso- res; y porque la culpa toda se me ha atribui- do á mí, á este segundo libro junté las me-jores cosas del primero y las enmendé, y lo - mismo se hace en el segundo de las de devoscion que ahora se imprimió."

El tomito contiene efectivanente una buena parte de las composiciones comprendidas en la primera de las obras de 1554 ; pero como faltan en él otras muchas que se encuentran en aquellas, es preciso reunir ambos volúmenes para tener completa la coleccion de las poesias del escritir lusitano.

Segun Duran y Brunet el otro tomo, impreso tambien por Juan Lacio en Amers en $1558, y$ al cual se reflere Montemayor en el prólogo del nio, se intitula Segundo cancionero spiritual; pero ninguno de aque. llos dos distinguidos bibliógrafos conocio la edicion que yo poseo del Cancionero de obras profanas, hecha en el mismo año.

Sedano, en el tom. t. del Parnaso español, se equivoca suponiendo ser primera la edicion hecha en Zaragoza por Barlolome de Nagera en $1561.8 .^{\circ}$ sin duda por haber sido la más antigua que encontró mencionada en la Bibliotheca de Vic. Antonio: por lo mismo se ve no haber citado ninguno hasta ahora el Segundo cancionero (de obras de humani. dad) de 1558 .
Brunet trae una tercera edicion de Alcala, 156.j. $8 .^{\circ} \mathrm{y}$ la cuarta, que tengo, es la si. guiente:

\section{MONTEMAYOR (JORGE DE).} Cancionero del excellentissimo poeta George de Monte mayor: de nueuo enendado, y corregido. Salamanca, Domingo de Portonarijs, á costa de Simon de Portonarijs, 1371. 8. 173 hojas foliadas, inclusa la portada, y 1 hojas de Tabla.

Comprende las mismas composiciones que la impresion del Segundo cancionern de 15.58 , ménos la Historia de Alcida y Silvann. Nó sé si esta se encontrará tambien suprimida en la quinta edicion que vi de Alcala. Iuan Gracian, 1572. $8 .^{\circ} 8$ hojas prels., 190 fols. y dos más de Tabla; y en la sesta hecha en èl mismo pueblo en $1573.8 .^{\circ}$, citada por Duran. Sospecho que la sétima, vista por mi, impresa en Coimbra, por Inan de Barrer $\iota .1 .59$. $12 .^{\circ} 12$ hojas prels. y 222 foliadas, está completa $y$ tal vez sea reimpresion exacta de la primera, pues en mis apuntes dice que el fol. 1 empieza por un epigrafe igual al de esta, que es el siguiente: Comicnca la Segunda Parle de las Obras de Iorge de Montema. yor. En la edicion de Salamanra, 15i1, se varió de este modo: Comienca el Cancionero de las obras de humanidad de George de Montemayor. - Brunet habla de utra impresion (la octava) dada á luz en Salamanca por Juan Perier, $1579.120^{\circ}$ y yo he tenidu presente la novena, última tal vez pubticada, impresa en Madrid, viucla de Alonso Gomez, $1588.8 .^{\circ}$ 8 hojas prels., 177 fols. $y 5$ de Tabia; en ella no recuerdo si estaba la intes mencionada IIistoria de Alcida.

\section{MÓNTES DE OCA (Fraxis-} co). Del doctissimo Reverendo P. M. F. Basilio Ponce de Lenn, honor de España... Fama postrma. Affecto suyo. Francisco Montes de Oca. Salamanca, Diego Cussio, 1630. : $^{\circ} 18$ hojas con las signs. A-E.

Francisco Ilóntes de Oca, matural de la ciudaul Real de las Pulmas en la Isla te la Gran Canaria, como il inismo dice en el fróntis, no está mencionado en la Bibliotheca de Nic. Antonio. Ignoro si ln omitiria pur no baber visto esta obrilla, 0 bien porque dicho Móntes de oca no tuvis inas parte en ella que la de liaber recogido las composiciones puci. ticas de unos veinticuatro autores, quienes escribieron en elogio de Fr. Basilio l'unce de Leon.

299 MORILES (Anвrosio wE). La vida, el martvrio, la inuencion las grandezas, y las translaciones de los 
gloriosos niños Martyres san Iusto y Pastor. Y el solenne triumpho con que fueron recebidas sus santas Reliquias en Alcala de Henares en su postrera translacion. Que escreuia Ambrosio de Morales. Alcala, Andres de Angulo, 1568. 4. 1 hojas de prels., la villima en blanco, 146 fols., aunque le falta numeracion a la última, una de Tabla y otra de Errores.

Comprende este volinuen varias poesias latinas y vastollinas de diferentes autores; peril solo llevan nombre algmus de luis liálvez de Montalvo, Simon de Ribera, Den Bernardino de Mendoza, Juan de Vergara, Fiai Diego Hurtado, el barthiller Antonio Gilerra, el Dr. Budriguez y el Dr. Frarcisco sinchez.

Munoz y Romero dice que esta obra contiene, ademas de lo referido en el titulu, nuticias curiosas de la poblacion $\mathrm{y}$ antigrïedades; y observa con razon que es libro bastanto raro y curiuso.

En Londres luvimos 111 tono manuscrit, en 4. que contenia lo siguirute:

La vida de La Cond'ssa Malildic de Canossa y sits grandes hazañas ron que autprio y ueffrulio, La sede Appostolica y los sũmos Ponlifices de su tiempo. Sucada de los mejores uriginales if d" aqu"llos liempos st hallan poi Ambrosio re Motales natural de Condona Coronisla elel Re!l Don Plitippe 2." clesle n.e N. S.-l'ersona que conocia bien la letra de Moráles, por haberla visto muchas vezes, me aseguro que el Ambr. ${ }^{\circ}$ de morales puesto al fin de la delicatoria y algunas correceiones que en este MS. se hallan, son de mano del mismo. No conoció esta obra Nic. Antonio; pero se habla de ella en la pág. XXl y XXIl de la vida de dicho Moriles, escrita pur el $\mathrm{P}$. Flures, que precede al Viage á los r'ynos de Leon etc.
En una hoja que al parecer quedó blanca entre este tratado y el descrito despues se encontraba el Sonelo al lumulo del Rey P. H. 2. que hizo la ciudad de Seuilla.-Era al parecer de mano del mismo Cervántes, segun li evidenciaban la letra $y$ Ias variantes que se observan respeto del publicado por Alfay, Rios y Pellicer, pues decia asi:

Vive Dios que me espanta esta grandeza Yque diera un doblon por descrebilla, Porque ¿ á quién no suspende y maravilla Esta máquina insigne, esta riqueza?

Por Jesucristo vivo, cada pieza Vale más de un millon, y que es mancilla Que esto no dure un siglo, ó gran Sevilla, Roma triunfante en ánimo y nobleza.

Apostaré que el ánima del muerto, Por gozar de este sitio hoi ha dejado La glorla donde vive eternamente.-

Esto oyó un valenton, y dijo: Es cierto Cuando dice voacé, señor soldado;

Y el que dijere lo contrario, miente.-

Y luego incontinente

Caló el chapeo, requirió su espada,

Miró al soslayo, fuese, y no hubo nada.

Venia á continuacion un opúsculo denominado: Virtudes de mugeres. Al fin: Bher. Ferñz de Castro (seguia su rubrica) aetalc. 17. annor. faciebal Grannale. Empezaba por IIn soneto bastante bueno, y habia otros versos intercalados en el tratado, que parecia escrito á fines del siglo XVI.

MORILES (Luis). Fiestas del Corpus en 1610. Véase Morales (Luis), en la Seccion dramálica.

MORILES (Penro). Carta en que se da relacion de la festividad que en Méjico se hizo en la colocacion de las reliquias. Véase Moráles $/ \boldsymbol{P e}_{\text {- }}$ dro), en la Seccion dramática.
300 NEBRISSENSIS (AEL. ANToN). Libri minores de novo correcti per Antonium Nebrissensem. S. I. n. a. $1 .^{\circ}$ let. gót. Sin fol. ni paigs. con las signs. a-h, todas de 8 hojas: la última es blanca.

Las obras eomprendidas en los Libri minorés son las siguientes y todas están en hexáinetros, ménos la última.

Liber Calonis.

Liber de contèplu mundi.

liber florelus.

Liber Quinque clauium supienlie.

\section{Fubule esopi. \\ Lectiones inb.}

Esta es probahlemente la edicion mencionadi por Mayans en la pág. 32 de su Specimen. La portada que falta á uni ejemplar la he copiado de otra impresion del mismo libro hecha en Compluli in aedibus Michaelis de Eguia. Anno milsesimo (sic) quingentesimo vigesimo nimo (1529). Kal. Marlias. 4. ${ }^{\circ}$, descrita tambien en dicho Specimen.

NÚÑEZ SOTOMAYOR (JuAN). Descripcion panegírica de las fiestas de la Catedral de Jáen. Véase en la Seccion dramática. 
301 OBRA A LLAORS DE S. CHRIST OFOL. (La siguiente lamina es un facsimile de la portada copiado con escrupulosa exactitud.)

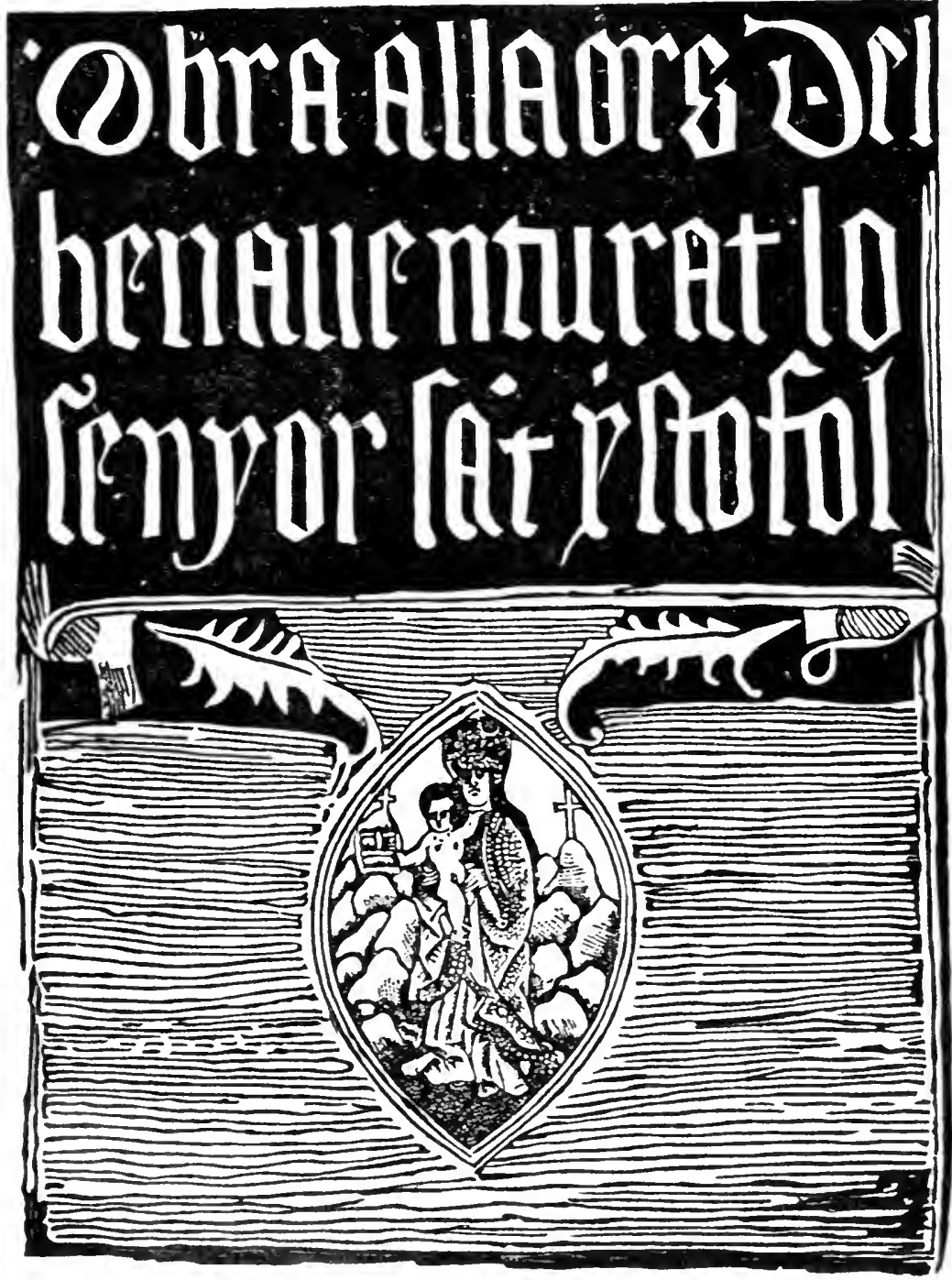

En el reverso de este fróntis hai una imágen de $\mathrm{S}$. Cristóval, no del todo mala, festoneada con una orla bastante graciosa. Comienza la obra en la hoja de la sign. aij, con el epiyrafe siguiente: 
Lo darrer jorn del mes dagost del any Mil. ccec. Ixxxviij. dins la parroquial sglesya de sent johan en la ciutat de Ualềcia fon aparellada insigne plasca axi ornada de tapesceria com de diuerses presones donor enla qual se porta vna siugular y bẽ feta praderia de molts ramellets excelents peucts y olos suauissimes per honrrar en la sua ymatge o figura al benauenturat martir caualler de jesus mon señor Sant Cristofol en or pur maçis marauellosament obrada Lo qual estimat joyel fon donat per lo magnifich kn pere Gisquerol menor de dies al qui millor en cobles diria laos del predit glorios sant satisfent a la molta deuocio quel sobre dit li porta e jat sia $\tilde{q}$ de aço alguns dies abans fossen fets y possats per los loclis publichs de la ciutat ben ordenats libells / empero aquell dia del consistori en semps ablo libell per part dels Reuerents e magnifichs jutges fon lesta $i$ e presentada la preposicio del tenor seguent. Sigue la Preposicio en verso; despues el Libell; a conlimuacion Segueixense les obres dels dehidors; al fin de estas las Gracies de los jueces; en seguida la Sentencia dada el ocho de setiembre; una Apelacion de Mosen Pere D'anyo: la Replica de Luis Roig y la Provision de los juezes denegando la apelacion. Vienen despues ocho composiciones más de los yue aspiraban al premio del mazapan y nueva Sentencia para adjudicarlo. Il reverso de la octava hoja de la signatura f. se lee:)

I Ahonor e gloria dela santissima trinitat : y lor del bien aventurado sent Cristofol font acabat de emprentar la present obra per pere tringer libreter En la molt insigne enoble Ciutat de Ualēcia aiij·de febrer Any dela natiuitat de nostre senyor deu Jhesu christ Mil. $\mathrm{y} \cdot \mathrm{cecc} \cdot \mathrm{Ixxx}$ viij. (1498.) CVa despues un pequeño crucifijo á cuyos lados están la Virgen y santa Maria Magdalena.) $\mathbf{4}^{\circ}$ let. gót. Son 48 hojas sin fol. con las signs a-l, de 8 hojas cada una.

Vinguno de muestros bibliografos ha conocido este precioso libro: solo Fuster ha

hablado de èl, refiriéndose á la nota que le mandó Gallardo, sacada de este ejemplar, único conocido y el mismo que se vendió en la biblioteca de Croft, despues en la de White knights, por $29 l .10 \mathrm{~s}$. st. y posteriormente en la de Heber, donde lo compró Thorpe, de quien lo adquiri.

Los nombres de los poetas que eseribieron pari esta Justa son los siguientes:

Lois Roiz.

Pere D'Anyo.

Pere Nartinez.

lois Garcia.

Jolian Balaguer.

Miquel Miralles.

Ausias de Sant Johan.

Ferrando Diez.

Es mui singular que habièndose celebrado esta Justa poética en el mes de Agosto de 1488 no se imprimiera hasta Febrero del 98 , es decir, casi diez años despues: si los meses tuvieran un órden inverso sospecharia que quizás lubliese error en uno de los dos aũos: pero asi no sé como espliear esta diferencia tan grande de fechas. En lo que positivameute hai yerro es en suponer Brunet que la edicion es del $1 / 488$.

Me parece propio de este lugar el dar noticia de algunas otras justas poélicas celebradas en Valencia á fines del siglo XV y principios del XVI; limitándome á las vistas por ni. Es la primera en importancia la siguiente :

1." Les obres o trobes dauall scrites les quals lractende lahors de la sucratissima verge Marin foren feles $e$ ordenades p los $(r)$ badors deig $e$ en cascuna deles dites obres scrils ísponeuls a una senlécia o seria d'l mes prop inserlal libel o carlell ordenal $p$ lo ueneruble mos $\$$ Bernal fenollar... de mamament $e$ ordinatio del Spectable senyor frare Luis Despuig... Lo qual senyor posa en la dita Ciulat de Valencia una Ioya a tols los lrobadors a onze dies del mes de Fobi Any d'la natiuilal d'nìre senyor Mil.CCCC.Lxxiiii... qui mils lohara la uerge Maria en qual seuol lengua lo qual Ioya per adir en aquella fonch lo dil diu prada en la casa d'la cótraria de sant Iordi de la dita Ciutal e Ingada a. $x . c v$. del mes de Mars del dit any. S. $l$. ni $a$. $4 .^{\circ} 58$ lojas sin pag., fol. ni signs. Habiendo Villarroya descrito tan larga, minuciosa y exactamente este libro en su $D i$ serlacion sobre el origen del arte tipográfico en Vulencia, no me estenderé en dar más detalles sobre su contenido, limitándome á observar que difiero de la opinion de dicho Villarroya en suponer falta al único ejemplar conocido, la úllima hoja con la fecha: encuentro que las cincuenta y ocho hojas del volímen forman seis cuadernilios de ocho y uno de diez, sin haber traza ni senal de imperfeccion alguna.-La inexactitud, vaguedid y laconismo con que Rodriguez y Ji meno dan el titulo de la obra, me prueban lo poco que hai que flar en que ellos seneilla- 


\section{OBR antologías Y Justas poéticas. OBR}

mente anoten En Vulencia, 1474, advirtiendo ya el primero, carece de nombre de impresor: por lo mismo estos testos aducidos por Vlilarroya para justiflcar su creencia, me parecen de poca valia. - Yo, aunque valenciano, no me atreveré hoi á suponer que existen ó hayan existido impresiones de mi pais con el ano de 1474 , por inás que tenga una casi seguridad de que en 1475 se trabajaba ya en la impresion del Comprehensorium, volúmen gruesísimo en fólio, terminado el 25 de Fe. brero de 1475.

Quede, pues, sentado que este Comprehensorium es, hasta ahora, el primer libro de fecha flja é incuestionable dado á luz por las prensas españolas, y el segundo el Salustio del 16 de Julio del mismo año, deserito en la Seccion historica.-Historia antigua, del presente Catálogo.

2. La segunda Justa poética que conozco, hecha tambien en loor de la Concepcion, es la siguiente:

Falta la primera hoja: la a.ij. lleva el siguiente epigrafe de letra encarnada, que ocupa doce renglones.

Comenca ta obra dela sucratissima cöcep. tio d'la intemerada mare de deu examinada $e$ dignumèt appunda $p$ molts mestres en sacra theologia / diuulgadis e publicadi en la isigne ciulat d'valètia dins la casa dela loable 2fraria d'ella gloriosa senyora nía. En lo any de nostre senyor deu jesu crist fill seu. mil.cccc.lxxxvj. jorn dela sua purissima 2ceptio. A instätia d'l noble mof p Ferrädu diec puere affectat fuilor d'sa majestad. p qui foren donades quatre joyes segons se mostra $p$ quatre zolechs cascu $p$ son orde. E coméça lo p'mer.

Siguen doce versos en la misma página, Y despues de la Justa y por remate se halla el siguiente en el reverso de la última hoja, octava de la sign. $i$ :

A laor e honor dela purissima cỏceptio dela verge maria / E a instantia del noble mossen Ferrando diec preuere: foren emprëntades e acabades les psents obres per lambert palmart aleinany en la insigne cintat le valétia En lany d'la natiuitat de nie senyor deu mil.cccc.lxxxvij. a. xiiij. dies dabril. vespra d'pasqua de resurrectis 4. algo menor que el ordinario, de buen papel y letra gótica mui clara, por ser poco angulosa y bastante gruesa. Sin foliacion, con las signs. $a-i$, todas de ocho hojas.

Las composiciones del Certámen son de los poetas que se espresan á continuacion: Ferrando diec preuere.-mossen jeronim Fuster. -mossen pere de anyo preuere-el honrat en vilaspinosa notari-vinyoles-vallmanya -miquel miralles-Arnau d'cors-jaume de olesa mallorqui-Mossen Ramon vinot caualler mallorqui. - Luys cathala-johan tallante -Franci johan-Lois roic-mossen . Fenollar preuere.-Hieronim de vich-George centeles-mestre balaguer mestre en sacra theologia e en medeçina-mossen Guillem mercader-Baltasar johan balaguer-franci de vilalba-blay assenci-y al fin oratio guiller. mi raymundi centelles. Hai una composicion en italiano que lleva este titulo: Respon vinyoles tiranl al inarçapa: las demás son en lemosin.

Aunque Jimeno cita esta obra en el articulo de Ferrando Diez, es evidente que no la vió, y tanto él como Méndez se refleren unicamente á las escasas noticias que da vic. Antonio. A esta circunstancia se debe sin duda el que no mencionen aquellos bibliografos, ni tampoco Fuster, á varios de los trovadores que contribuyeron á este Certámen.

5." He visto un pliego suelto, que voi á describir porque en èl se hace mencion de una Justa prética que debió celebrarse en los últimos años dei siglo XV.

Salve regina feta $p$ lo discret en Pere vilaspinosa notari dvalencin la ōl el mateix to honor du loable cósistori lo dia g̃s publica la devall scrita sentẽcia d'la d' mül dita joya d'les lahors dela verge maria aj̈lla spädi e. publica e dieça ajulla ul molt spectable e reuerèt sèyor frare Luis d'puig mestre d'l orde e caualleria d'mũtesa $e$ d'sant jordi... la ì' fóch fela... p manamèt e consolacio del dit spectable senyor visrey. S. l. ni a. Parece indudablemente del siglo $\mathrm{X} F$, sin embargo de lo que dice ortiz, segun Fuster. Estas cuatro hojas en $4 .^{\circ}$, let. gót. no llevan ninguna signatura $y$ al fin de ellas se lee: Finis, pero no se encuentra en ellas ni Ia joya ni la sentencia á que se reflere el epigrale.

4." Fr. Tomas Vessach tradujo y publici: La Vida de la serafica sancta Catherina de. Sena ara nouament per un deuot affectat religios della cumplidainent arromançarla / $\rho d e$ moltes istories istoriada; en cuyo flnal (blanco del fol. CCXXXiliI) dice: A honor / lahor / e gloria d'nostre senyor d'u ihù xp̄í: e dla intemerada / e sacratissimu łge tostēps maria mare sua / e senyora nos. tra: $e$ D auguèt d' deuncio d'a seraphica $e$ benauèturada scà catherina d' sena fon acabada destãpar ab priuilegi la present hystoria d'lla en la noble / e insigne ciutat de Valencin to Johan inffre de briäso dimecres a xuij d' setembre d' An! d' la nati. uital M.D.xj. Sigue el escudo del impresor. Al dorso principia la Tabla que ocupa diez hojas más y en la siguiente comienza el Libell qui millor dira a la ioya en lahor. dela seraphica senta catherina de sena ordenat por lo semyor mossē iheroni fuster. mestre en sacra theologia (y despues: obres feles en lahor de la seraphica senta Calherina de Sena en lo seu sagrat Monestir dc. les monges dela insigne ciutat de lalencia per diuersos trobadors narrades to dix de sen Miquel det any M.D.XI... Viene despues la Justa a la cual contribuyeron: Vicent Ferrandis. Narcis Vinyoles, Pere Marti, Pere Sorivella, Miguel Garcia, Andreu Pineda, Jheroni Fabra y Pere Gómis.-Este Cerlaimen, en el ejeluplar que tengo á la vista, tiene diez y nueve hojas; Fuster dice consta de seis pliegos que suponiendolos de cuatro hojas cada uno componen veinticuatro hojas; sin embargo presumo no sean tantas. 
5." He tenido ocasion de examinar un tomito comprensivo de varias composiciones poéticas en dialecto valenciano, cuyo contenido describiré, no solo por ser opísculo de gran rarezi, sino porque en él se nos da nolicia de una Justa poślica celebrada en la iglesia de Sinta Cruz de Valencia, hácia el 1515.

I Obres contemplatiues y de molla denocio nouameul liobades en lnors de la sanclissima cr'lu ab allrps piadoses cobles dela inlem(')ada verye Maria d' les dolors $y$ dela soledal moll ulils y profitoses alu salui deles animes y consciucies nostres ab vns versos latins loant al sacratissim arbe dela vera creu $\therefore$ En el blanco del fol. signiente, sigrnatura $A i j$, hai una lámina de madera que representa un crucifijo con lit Vírgen, San Juan y la Magdalena, y al dorso principia por un Preambol en el que se dice, que habiendo sometido esta olna, trovadi por Jaume Beltran y Vicent Ferrandis, al juicio del Sr. D. Francisco Fenollet, este caballero les suplicó que la dedicasen á su hermana Sor Doña Elionol de Fenollet, monja de Sta. Catalina; electiramente í contimuacion de esta corta adverteucia: I Començu lo prolech Bellian ala moll Renereni prioressa.

Aquell fenoll lendre / ab rames moll belles precla don francisco / poela stimat \&c.

Siguen dos estrofas de diez versos de arte mayor y un pareado de Beltran y dos de Ferrandis, y luego: C Beltrun als legidors. que son tres estrofas más, dos de Beltran y una de ferrandis: concluyendo en el blanco de la cuarta hoja del libro, sig. Aiiij, al dorso de la cual hai ma cruz rodeada de todos los atributos de la pasion. En la quinta hoja principian las

a Cobles en honor y gloria a' iesus saluador nostre y a la sia santissima crou: en les quals se recilen molles excellecies / $y$ laors de aquella / fotes per Janme bellran if Uicent Fer'iandis. Concluyen en el hlanco de la sexta hoja de la sig. $C$. hallíndose en su reverso repetida la límina de la cruz; la sétima hoja por el primer lado la llenan unos (I Uersus (latinos) demelissiins a la creu contemplant los sagrals misleris de aquella, $\mathrm{y}$ por el segundo una límina grande y grosera que representa un descendimiento de la cruz, y en dos renglones bajo: I Ala sacratissima verye maria deles dolor's contemplacio feta per lo mateix Jaume belIran. La contemplacion ocupa el blanco de la siguiente lıja, cuyo reverso por entero lo llena una imágen de la Soledad; en la sig. D: I Estrams fets plo maleix jaume Bellran en vna joya ques dona a qui millor ajudaria aplayer / y plorar / ala sacralissinu e innaculada verge maria dela soledat, \&c. Concluyen en el blanco de la sig. natura Diiij, que no la lleva, y á la vuelta se repite el erncifijo del principio; en la sig. Dv. I Dona fi ala obra ab aquesta deunta contèplacio al crucifix, acabando en el blanco de la hoja siguiente $\mathrm{y}$ á continuacion: laors al moll suauissim y dolc nom de Jesus fetes per Jaume Bellran / en vna Joya ques dona en la parrochial resglesia de sancta Cren / ahon molts bons trobadors / $y$ digueren loant lo caila hu de aquella millor manera o estil que sabe y pogue... Conclnyen en el blanco de la hoja siguiente, que es la sétima de la $D, y$ á la vuelta, en letra gruesa, hai un privilegio concedido á Beltran y Ferrandis para que deste el dia 12 de Febrero de 1515 , hasta pasada Pascua de resurreccion de 1516, no las pueda imprimir nadie dins la contribucio de dila ciutal de Valencia). E aço a peua de los cenls floris e perdre tot lo que dell's seru estumpal e foren impresses e acabades de impremir enla ciutat de Ualencia por Johan Joffre $a$. xv. de Febrer an! M.D.exv. 4. ${ }^{\circ}$ let. gót. Signs. $A-D$ todas de ocho hojas ménos la últina que solo liene siete por filtarle sin duda una blanca.

6. ${ }^{a}$ Rodriguez en la Bib. valent., art. de Andres Martí Pineda cila un Certumen Poelich, en Lahor de la Cmcepcio. Principia: En lo present lractat, eslani kepilogades; moltes obres de diversos trobudors; a lahor, y gloria le la Imaculada Concepcio, de la Purissima Ifrre rle Deu. IIe manejado un ejemplar falto del fróntis, el cual principia por la sign. aij y con el siguiente verso:

$Y$ vint que la verba / de lots contenia, \&c. hai cinco versos finales de una estrofa $y$ sigue otra de diez. Despues en prosa:

I La causa lela impressio de les seguèts obres.

Se espone el motivo de la convocacion de este Certámen ell loor de la Purisima $\dot{e}$ inmaculada concepcion de la Vírgen, celebrado en la parroquial iglesia de santa Catalina de Valencia el 15 de Diciembre de 1532; se habla de los premios ofrecidos á los concurrentes á él; se espresa que el promovedor de esti Justa fuć el Iaureado poela Jerónimo Sent-pere, mercader, siendo los juezes él mismo y el maestro Luis Zapater, Joan Ferrandis de Heredia $y$ el notario Andres Martín Pineda, quien dice, publicaba ó daba á la preusa esta obra á ruegos del devoto que costeó el Certímen.

En el blanco de la líltima hoja del volúmen se lee:

Se acaba de imprimir lo present traclat ben examinat : ennendat y corregit tostemps ala correctio dela sancla mare esglesia sols mes. A.xxv. del mes de Abril dela salulifera natiuilal $d$ noslre senyor deu jesu crist. any. M.d.xxxiij. Fonch inpromit enla insigne y corouada ciutal de Ualencia per Fräcisco romano al moli dela rouella. 4. ${ }^{\circ}$ let. gót. Deben ser 32 hojas con las signs. $a-d$. Los poetas de quienes contiene composiciones son: Andres Martin Pineda (una de las suyas es en castellano).-Juan Solivella. - Miguel Juan Gómis. - Tomas Real.-Frare Enco.-Vicari de Sant Pere.-Garci Álvarez (en castellano). - Antonio Blanch.-Juan Sebastian, alias de Jérica.-Luis Ferrandis.El Hospital general.-Luis Galiana.-Pedro Marti, médico.-Jerónlmo sent Pere (de 
quien hai una composicion interpolada de estrofas castellanas y valencuinas). - Andres Honorato PIneda. - Pedro Gómis. - Estrada (en castellano.). - Francisco Pastor y Juan Miquel.

302 OCAÑA (Francisco de). Cancionero para cantar la noche de $\mathrm{Na}$ uidad, y las fiestas de Pascua. Fecho por Francisco de Ocaña. Agora de nueuo añadido de muchos villancicos y chançonetas. Alcala, en casa de luan Gracian, 1603. 4. ${ }^{\circ}$ Con la viñeta del Nacimiento del Niño Dios en la portada. 16 hojas sin fol. y con la sign. A, que no puede sercir de gobierno.

Bōhl de Faber ha reproducido nueve composiciones de las treinta $\mathrm{y}$ cuatro de este Canciumero en el tom. I de su Floresta, y es de estrañar como ha omitido algunas de tan. to ó mayor mérito que las que ha reimpreso. Sirvan de muestra las siguientes:

Anda acá, amigo Bras, mira que cosas verás: anoche fui al lugar con mis amos á cenar, y cosas oí contar que te maravillarás.

Dicen que Dios es venido como era prometido, de una doncella nacido mui hermosa ademas.

Con aquestas nuevas tales han ido alli mil zagales, pastores y mayorales, y tủ descuidado estás. Yo, $y$ Benito, y Pascual, el hijo del nayoral, le vimos en el portal que nunca tal vi jamas.

Los ángeles en Betlen, dó es nacido nuestro bien, canticaban y tañien que en velios te hoigarás.

Yo le dije un cantarcillo al mozuelo $\tan$ bonillo, y respondiole Minguillo, cantando por contrapas.

Allí está tambien un viejo, que estaba en el portalejo, y aunque dijo un cantarejo, mla fé, yo cantaba más.

Anda acá, vamos priado, no estés tan encaperuzado, dejemos aquí el ganado, que presto te volverás.

Y en llegando que lleguemos, juro á san, luego ballemos y un cantar tambien diremos, y tú me responderás.

Llevaremos ml barril

y tambien tu tamboril, porque ballemos yo y Gil, que tú nos le tanerás;

Yo bailaré con Juanilla tú tambien con Antonilia, juro á mi, que aunque es en villa que no me quede yo atras.

Y lievaremos á Mingo, porque es dia de domingo, y daré salto y respingo, tú veremos qué harás.

Yo haré la revellada la caperuza quitá, altibaja zapatada, que en verme te espantarás.

Anda, toma tu cayado, no seas tan empachado, que te vernás espantado de lo que pasar verás.

Dice un pastor á otro, Migallejo, hermano, qué te contaré ! -que no me lo digas que bien nue lo sé.

A la media noche, esta madrugada, vino Gil Peloche á la mi majada; entre la manada viene vozes dando y á todos llamando:

levantád ahé! Luego levantamos yo y mi compañía, Bras y Mingo y Ramos, Pascual y Yaria; tal prisa traia el loco atronado, que espantó el ganado, no sé por dó fué.

Llegó placentero, cansado, corriendo al apriscadero dó estaba durmiendo, á vozes diciendo: venid al lugar si quereis hallar lo que yo ballé: Sabéd que parió la Virgen Maria, y lo que parió dicen qu'es Mesia: par Dios, que diria que cierto es aquel el que en Israel de venir habia.

Cuando esto pasamos aun no era de dia, luego caminamos á ver qué seria, todos a porfia por valles, por cerros, la honda y los perros todo lo llevé.

Fuimos al liıgar

para preguntar
donde el niño estaba.
oh! qué trisca andaba
toda de pastores,

(') Falta este verso ea el original. 
chicos y menores

que mís no cabia.

Como allá llegamos

en 111 porlalejo

Ia madre hallamos,

$y$ al uiño, y al viejo.

iiriades al viejo,

zagales cantar,

por los ayudar

coll ellos cante:

De los que cantaban

grande Irulla andaba, cuando no acertabal

yo los entomalia;

mís prisa me daba,

yo te juro i sall,

ylue no el saclislan

ammque presimmia.

Aquellos zarales

á quien yo ayulala, cantos palanciales

rada lue cantaba;

Pasemal se pensaba

que yo mo sabia,

mas lambien deeia

la sol, fa, mi, re.

Ilartos de cantar

luego lo dejamos,

saque de almorzar,

y litego almorzamos:

alli les guisamos

ahoulo de migas,

$y$ aun con sus faligas

el vicjo comia.

Gilisamos tasajos

il la maravilla

v un barreño le ajos

ileno liasta arriba:

toda la cuadrilla

se jumlo í comer;

rimales sorber

it quien mís podia.

Cinando tolos fuimos

liins repantigados,

III rito rsturimos

en ri sinelo echados;

i nuestros ganados

de alli mos tormamos,

mas no los hallamos

donde Jos deje:

lespues de buscallos

pol valles y prados

frumos i topallos

"n umos vedados;

auncue bien cansados

ací los Irajimos

mala tarde hubimos

mas bien almomé.

\section{Fillancico.}

Dejidlos mi madre mis ojos lloral,

pues fueron á almar.

()h madre sagrada, no os inaravilleis de ver tan regada mi cara cual veis; pues que bien sabeis que vengo á pagar. el primer pecar.

El hombre pecó

por inobediencia,

por él lloro yo

y tomo peritencia:

amor y clemencia

me hacen penar.

dejidme llorar.

Lloren mis ojos

más que lian llorado,

por quitar de emojos

al hombre criado;

porque su pecado

se pliede llevar.

Por sanal' í Adau,

IIn amigo mio,

llorú cou afau

y muero de frio:

lágrimas le envio

por lo refrescar

dó estí en el penar.

Al hombre perdido

vengo í redimir,

tomo por partido

llorar y gemir,

para lo guarir

$y$ gloria le dar,

dajádme llorar.

De Dios sempiterno

me quise hacer hombre,

para que se escombre

el profundo inflermo,

y mí reino eterno

se torne i poblar;

dejádme llorar.

Porque seau llenas

lis primeras sillas, estas lagrimillas

tengo yo por buenas;

fatigas y penas

tengo de pasar;

dejaidme llorar.

Nic. Antonio y D. Agustin Duran no conocieron ninguna de las varias ediciones que deben existir de este Cancionero, y ni siquiera meucionan el nombre de su autor.

303 OÑA (Tomas De). Fenix de los ingenios, qve renace de las plavsibles cenizas del certamen, qve se dedico á la venerabilissima imagen de N.S. de la Soledad en la celebre translacion a sv svmptrosa capilla, con vn epitome de su sagrada historia... A diligencias de el licenciado Don Tomas de Oña. Madrid, Diego Diaz de la Carrera, 1664. $4 .^{\circ}$ marq. Lam. 8 hojas prels. entre las que se cuenta la lámina, 170 fol. y una al fin en que se repiten las señas de la impresion.

Contiene una comedia intitulada el Divino calabres de Vátos Fragoso y poesias de cincuenta y cuatro autores. Son entre ellos los 
mas notables dicho Fragoso, D. Manucl de la Pena, I). Luis de Ulloa, D. Juan de Zamo1’a, D. Ambrosio de Arce, D. Antonio de Mendoza, D. Alvaro Cubillo de Aragon, D. Juan Vélez de fruevara, D. Diego Pellicer y Abarca, D. Juan de Zavaleta, D. Juan Bautista Diamante, D. Manuel de Leon, D. Inan Francisco Mártir Rizo, El Marques de Mondejar, D. Diego de Córdova. y Figueroa, D. Francisco de Quiros y D. Antonio de Espinosa.

Nic. Antonio llama oñes al Lic. Ona y no logró ver la obra el Fenix de los ingenios. Mi ejeinplar es en papel grande.

301 ORTI (Marco Antonio). Segvido centenario de los años de la canonizacion del Valenciano Apostol San Vicente Ferrer, concluydo el dia de San Pedro, i San Pablo, 29. de Iunio, del año 1655. Celebrado por la insigne, noble, leal, i Coronada Ciudad de Valencia. Por Don Marco Antonio Orti. Valencia, Geronimo Villagrassa, $16306.4^{\circ} 18$ hojas prels., 340 págs., 6 hojas de Tabla y una blanca.

Contiene este volúmen, ya raro, poesias anónimas de diferentes autores entre ellas varias en valenciano; hai tambien un ser- mon escrito en el mismo dlalecto, por el Ir. Antonio Buenaventura Guerau, y otros dos en castellano del P. Fr. Pedro Pascual de lbarra y el Dr. Meichor Fuster.

ORTI (Marco Ant.). Siglo cuarto de la conquista de Valencia: Véase en la Seccion dramática.

30马̈ ORTIZ (ANTovio). Relacion de la venida de los Reyes catholicos, al Collegio Ingles de Valladolid, en el mes de Agosto Año de 1600. Y. la collocacion y fiesta hecha en el mesmo Collegio, de vna Ymagen de Nuestra Señora maltratada de los hereges. Por don Antonio Ortiz. Madrid, Andres Sanchez, 1600. Cal fin: 1601.) 4. 4 hojas prels. y 60 foliadas. - Recebimiento que se hizo en Valladolid a vna imagen de nuestra Señora. Madrid, En la imprenta de la Tina, M.DC. $4 .^{\circ} \mathrm{52}$ hojas foliadas inclusa la portada.

En ambos tratados se encuentran poesias latinas y castellanas de varios autores, pero todas anónimas.
306 PADHLLA (PEDro de). Iardin espiritval. Compresto por F. Pedro de Padilla. Madrid, en casa de Querino Gerardo Flamenco, $1308 \%$. 4. ${ }^{\circ} 8$ hojas prels., 252 fol. y 5 de Tabla.

Colócase esta obra en la clase de los Cancioneros y Romanceros por comprender poesias de muchas y mui variadas clases de metro y sobre todo por haberlas de varios autores como son el Dr. Campuzano, Pedro Laínez, López Maldonado, Lope de Vega, Gonzalo Gómez de Luque y Miguel de Cervántes, de quien se encuentran tres composiciones.

Los tradıctores de Ticknor, tom. III, página 505 , citan una edicion hecha en Madrid en 1584. 8. No la he visto y á no tener tan absoluta conflanza en las noticias bibliográficas de aquellos literatos me atreveria á dudar de su existencia.

Brunet no menciona la presente obra de Padilla, una de las más raras de este autor: los pocos ejemplares que he visto de ella eran generalmente malos; el mio es tan bello que la mayor parte del tomo está intonso con barbas.

Toм. 1.
307. PAdLlla (Pedro de). Romancero de Pedro de Padilla. En el qval se contienen algunos successos que en la jornada de Flandres los Españoles hizieron. Con otras historias y poesias differentes. Madrid, en casa de Fraucisco Sanchez 1083. 8. 8 hojas prels., la última de las cuales está en blanco, 347 fols., 5 de Tabla y una para repetir las señas de la impresion. Hai al fin una hoja blanca.

Parece que el Sr. Duran no consiguio ver este rarisimo libro por cuanto duda si es una antología ú obra únicamente de Padilla: tambien tuvo de él una noticia mui inexacta Nic. Antonio, pues supone que la edicion es de Sevilla y su tamaño en 4."

A pesar de intitularse en el fróntis este volumen Romancero, contiene, ademas de unos setenta romances históricos, caballerescos, moriscos $\mathrm{y}$ amatorios, más de cincuenta villancicos, muchas glosas y varias canciones, redondillas, tercetos, ensaladillas, sonetos, etc. Fstas composiclones son todas 
de Padilla, i escepeion de unas pocas que hai de D. Cárlos Arellano, el alférez Lizardo, Gabriel de Arriaga y algunas anonimas. - Entre las poesias de los clogiantes, quc se encuentran al principio, se halla III soneto de Niguel de S('ruuntes, y alli mismo va una aprobacion do Inan Lipez de lloyos, maestro de aquel, donde dice que este volimen comprende ma tercera parte de las obrits de sil autor.

308 Padilla (Penro ne). Thesoro de varias poesias. Compuesto por Pedro de Padilla. Madrid, Francisco Sanchez, 1580. 4. 8 hojas prels. y 482 fols.

Nic. Antonio menciona ma elicion licella

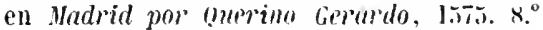
En esto hai positivamente error. poreme las licencias para la impiesion estin fochadas on 1579 y 80 ; ademas yo he visto dicha edicion de Gerardo y su año es el cle list. s." 8 hojas prels., a 68 foliadas y 8 do Tulla.

Clasificase esta rarisima obria elltre Ios Cancioneros y Romanceros, sin luslis jor ser, como la llama el sr. Durall, umu roleccion de poesias artisticas do toilas rlusis, entre ellas v'arios romances de' igual arlificio, que pertenceen it la poesiu arlistica popularisada que couserida las formas micionales.

He visto un poema de Padilla intitulado: Grandezas, y excelencias de la lïn'lu señma mestra. Compuestas on lifana Rima. Madrid, P. Maclifinul, 15xi. 8." 8 hojas preliminares, 15.1 fols. 5 dr Tubla y ima pala repellr la fecha; lleva al principio min soneto de Cervánlos. - Vie. Antonio se eguivoca en decir que es ell $4 .^{\circ}-\mathrm{Tengo}$ ma idea vaga de que se reimprimio en lsol.

De Pedro de Padilla se dice on el Discurso puesto al principio de las obras de Gregorio Silvestre, que era habilidal rara y unica ch decir de improviso, y a pocos inferim" on escribir de pensado, y Cervintes rn al Canto de Caliope se espresa en los lérminos siguientes:

Admireos un ingenio en quien se encierra Todo cuanto pedir puede el des'sos),

Ingenio que anque vilua aca en la tierra,

Del alto cielo es su caudal y arieo:

ora trate de pas, ora de guerra,

Todo cuanto yo mirro, escricho y tis

Del celebrado Pedro de Padill"

Mc causa nucvo gusto y maravillu.

309 PANTIIERON, ó Red castalida de varias plumas congregadas En Buelos Metricos de Composiciones Latinas, y Españolas, de Epigramas, Elogios, Anagramas y otras Erudiciones. $\Lambda$ celehrar ol Dia de la posession de Don Andres (iuerrero, y Torres, Del Puesto de Lilgartenien- te de la Camara de la Summaria. Napoles, Domingo-Antonio Parrino, M.DCC.III. 4. ${ }^{\circ}$ marq. Anteporlada grabada y una limina frenle la página 90, la cual se supone formar las pagiuns 9I y 92. 10 hojas prels., a más de la poitada grabada, 114 paigs. y 4 sin payinar con larias poesías.

Contiene poesias latinas, jtalianas y eastellamas de varios anloles, la mayor plarte ancinimas; pero lodas de pésino gusto.

PARACUÉLLOS CABEZA DE YACA (LuIs ve). Elogios a María santisima. Vease en la Seccion dramática.

PARNASO ESPAÑOL. Coleccion de poesías escogidas de los mas célebres poetas castellanos. Véase en la Seccion dramatica.

310 PERALTA (Frinciscio De). Copja de rna carta, yve el Padre Franciseo de Peralta... Eserinio al Padre Rodrigo de Cabredo Pronincial de la Nueua España. En que se da quenta Dela dichosa muerte que tumo en Londres la sancta señora doña Luysa de Caruajal... Y de las lonras, Que se le hizjeron... Fin el Collegio Ingles de Seuilla, en 11 de Mayo de 1614. (Serilla, 1614.) 1." Dos hojas prels. I 12 foliadas; viene luego una con la dedicaloria del Sermon funelore, olra del epilafio y $\ddot{36}$ de nueva foliacion, en cuyo mumero estcin comprendidas dichas dos hojas y la portada del Sermon funcbre predicado por.el P. Juan de Pineda.

llai poesías latinas y castellanas de varios autores cuyos nombres no se espresan.

En el tílulo que dá Nie. Antonio de esta obri, hai mna mui notable errata, pues diee: Carla del Palle Rodrigo, rte., cn lugar de Carla al Padie Rodrigo, etc.

\section{PERALTA BARNUEVO Y} ROCHA (PEDno DE). El cielo en el Parnasso, Certamen poctico. conque la Real Yniversidad de San Marcos de Lima... celcbro el favsto feliz recibimiento de S. E. en sus Escuelas... que describe el Doctor Don Pedro de Peralta Barnuevo y Rocha. 
PER antologias y justas poḱticas. PIN

Lima, Imprenta Real, 1736. 4. Grande escudo de armas. $4 \mathrm{hnj}$. prels. y una con un escudo grabado. La obra carece despues de páginas, y lleva las sigs. A-Zzz y A-Aa.

Esciso.

Contiene poesias de diferentes antores, cuyos nombres por ser completamente desconocidos, y varecer sus obras de mirito literario, me abstengo de citar aqui.

\section{PERALTA BARYLEVO I} ROCHA (Peoro). Fincbre pompa... en las altas exerquias, y tumvlo erigido en la santa Iglesia Metropolitana de la Ciudad de Lina... al Serenissimo Señor el Señor Francisco Farnese, Drqve de Parma, y de Placencia. Crva relacion escribe... el Doct. D. Pedro de Peralta, Barnuevo y Rocha. lima, Imprenta, de la Calle de Palacio, 1728. 4." Gr. lamina del ralafalco. Lna lioja de portada, 132 foliadas, y la Oracion frnebre, dicha por el $P$. Francisco de Rotalde, que no esti foliada ylleca las sign. Ll-Rr.

Casi todas las ponsias de este volimen son anónimas, y si en alguna se lıa prefijado el nombre de! autor, ,es este tan poco renotido $\dot{o}$ de mérito Lan escaso que no merce $\mu$ mencionarse.

Este libro como impreso en Anerica es dificil de enconllai.

\section{PERALTA BARNEEYO Y} ROCHA (PEDro José DE). Lima T'rirmphante, glorias de la America, jregos pythios, y jubilos de la Minerua peruana en la entrada qre hizo S. Exc. en esta mry Noble, y Leal Ciudad, Emporio, ${ }^{*}$ Cabeza dè Pe$r v, y$ en el recibimiento con que fre celcbrado por la Real Vnirersidad de S. Marcos. Prblicalas el Dor. D. Pedro Joseph de Peralta Barnuevo y Rocha. Lima, Joseph de Contreras : Alvarado, MDcciliI. 4. ${ }^{\circ}$ oे hojas prels., inclusa una con un escudo de armas que precede al antefronlis, signs. A-Z, Aa-Tt, lodas de 1 hojas ménos la $\mathrm{Bb}, \mathrm{Cc}, \mathrm{Dd} y$ Ee que lienen 2 y la T t que es de ö.

Fl Cerfámen poélico ocupa casi una mitad del volumen, $\mathrm{y}$ contiene composiciones de valios autores.
PEREZ DE MONTALVAN (JuAN). Fama póstuma á la vida y muerte de Lope Félix de Vega Carpio. Véase Vega Carpio. Comedias, en la Seccion dramática.

314 PINTO (JORGE DE). Llantos imperiales de Melpomene regia. Llora la mverte de... Doña Maria-Ana de Austria, Madre de Don Carlos II... por.las vozes, y por las plrmas de los Padres de la Compañia de Iesrs... Refiere (las honras) Don Jorge de Pinto. Madrid, Antonio de Zalra, (1696?). 4. ${ }^{\circ} 8$ hojas prels. y 13 it paigs.

Hai poesias latinas $ঘ$ castellanas de diver. sos: todas son anónimas, y obraron con juicir los autores ocultando sus nombres a la posteridad.

313 PIÑO ó PINHO (NANEL DE). Villancicos, y Romances, a la Nauidad del niño Iesu, nuestra Señora, - rarios Sanctos, Compuestos por Manuel de Piño. Lisboa, Pedro Craesbeeck, 161\%. $8 .^{\circ}$ Muchas laminilas de madera. 124 hojas foliadas, comprendidos los prels.

Iic. Antouio le llama Pino por crrati de imprenta.

Es libro mui raro que se clasifica general. mente entre los kounceros y Cuncioneros. Contiene mui lindas composiciones castellanas portuguesas: sirvall de inuestra las dus siguientes:

rillancico.

In seriann, madie mia.

hoi bajo del alta sinrra.

y amique al uso de la tierra, al miswo rei pareria.

Blinco rostro $y$ Jindo talte?

tenia ol rubio pastor.

y captiviabd do anor.

i las zirralas del rialte.

Dulces palabras decia

el serrano de la sierra,

y aunque al uso de lil liesra

al mismo rei parecia.

Ligrimas de mi niùo

son 111 aleyria.

pues llorando ui muerte

une da la vida.

Nino que llorais

por quitill mis milps.

y. en ligrimas tales

la vida me dais,

l'ertas derinan: .

que dan alegria:

pmes llorando mi murle III. " latı Lil Silli 
Romance.

Del aldea salen

por el verde prado,

a ver á Jacinto,

todos los serranos.

Del sacro Betlen,

dicen que ha llegado,

de ver tantos bienes

de III diclioso parto.

If́cenle que cuente.

si hai poder contarlı,

$y$ él coll altas vozes

tliee así cantando:

Grandes mucvis, zagales,

de Bellen os traigo,

que el portal de la gloria

yi) no estíl cerrado.

Uuiso fll mll portal

Dios niōon naveอ".

por dal it rutendiry.

que es al rielo igual:

Alssí mi zagal

nos muestra inui claro

que el portal de la gloria

ya no estí cerrado.

Del cite las puertas

el celeste bando

bien lo está mostrando

conlo estín abiertas:

Sus vozes dispjertas

nos muestran mui claro

que el portal de la gloria

ya $n o$ está cerrado.

316 POESÍAS ERÓTICAS de varios autores de fines del siglo XVIII y principios del XIX. Manuscrito en $4 .^{\circ}$

Comprende este legajo composiciones de diferentes poetas modernos: entre ellos des. cuellan D. Tomas de lriarte, D. Juan Helendez Valdes y D. Leandro Fernández Moratin. La mayor parte son ineditas y dificilmente verán la luz pública por ser demasiado obscenas.

317 POESIAS ESCOGIDAS de varios autores castellanos. Manuscrito en $4 .^{\circ}$

Todas las composiciones comprendidas en este legajo son de nuestros autores de prineipios del siglo XVl, y algunas ineditas: las copjó In. Juan de triarte de varios códices de la Biblioteca real.

318 POESÍAS escogidas de nuestros Cancioneros y Romanceros antitruos. Continuacion de la coleccion de D. Ramon Fernandez. Madrid, Imprenta real, IDCCXCVI. 2 vols. 8. "marq.

son los tomos XVI y XVII de la Coleccion de fermindez.
319 POESIAS ESPIRITUALES escritas por F. Luis de Leon, Diego Alfonso Velazquez de Velasco, $\mathbf{F}$. Paulino de la Estrella, Fray Pedro de Padilla y Frey Lope Felix de Vega Carpio. Madrid, Andres de Sotos, M.DCG.LXXIX. 8. ${ }^{\circ}$

Comprende este volúmen el Estimulo del amor de Dios atribuido al Mtro. Leon; las odas de Velázquez de Velasco, las Poestas de Estrella, sacadas de las Flores del desierIn, I y II parte, coyidas en el jardin de la rlausura Minoritica de Londres. Lisboa, Antonio Craesbeck, M.DC.LXXV. 16. ${ }^{\circ}$; algunas composiciones estractadas del Jardin espiritual de Padilla y los 7 Soliloquios de un alma á Diss de Lope de Vega.

Publicó este tomito D. Francisco Cerdá y Rico quien puso al principio una noticia de los autores de estas poesias, que se habian hecho sumamente raras.

320 POESÍAS selectas castellanas, desde el tiempo de Juan de Mena, hasta nuestros dias. Recogidas y ordenadas por D. Manuel Josef Quintana. Madrid, Gomez Fuentenebro y Compañia, 1807. 3 vols. 8. ${ }^{\circ}$ marq.

Primera edicion.

\section{POESIAS SELECTAS CAS-}

TELLANAS desde el tiempo de Juan de Mena hasta nuestros dias, recogidas y ordenadas por Don Manuel Josef Quintana. - Segunda parte. Musa épica: ó coleccion de los trozos mejores de nuestros Poemas heroicos. Madrid, M. de Burgos, 1830-33. 6 vols. 8. $^{\circ}$

La primera parte encierra el contenido de los tres tomos en $8 .^{\circ}$ marq. de la anterior edicion de 1807, y ademas muchas composiciones de los poetas de fines del siglo pasado y principios del presente; la segunda parte, o Musa epica, es nueva y contiene largos fragmentos de La Araucana, de Ercilla, de La Bética de Juan de la Cueva, de La Cristiada de Hojeda, de La Invencion de la Cruz de Zarate, de La Jerusalen de Lope, del Monserrate de Virues, y de El Bernardo de Balbuena.

D. Eugenio de ochoa incluyó estos seis tomos en su Coleccion de aulores españoles publicada por Baudry.

322 POESÍAS SELECTAS de varios avtores latinos, tradvcidas en verso castellano, e illvstradas con notas de la Erudicion, que encierran 
por'el Padre Ioseph Morell. Tarragona, Ioseph Soler, 1683. 4. 8 hojas prels', 188 págs. y 16 hojas de Indice.

El testo latino, que va siempre de letra cursiva, precede á la traduccion.

Los autores de quienes hai composiciones eu esta antologia son: Belnajdo Baulusio, Franclsco Remondo, D. Jaime Falcon, Itarco Antonio Murcto, Sulpicio Cartagines, Ausonio, Alciato, Pantano Joviano, Pamfilio, Bentio, Guinisio, Vaninjo, Ovell, César Scalígero, Enrique Heer, José Morell, Marco Valerio Marcial, Quinto Inracio Flaco.

323 POESÍAS de varios autores del siglo XYI, recogidas y copiadas por 10. Gregorio Mayans. 4. ${ }^{\circ}$ Manuscrito autógrafo de 45 fojas.

Contiene este volúmen canciones, octavas y glosas, comunmente del género féstivo, y algunos romances de las clases de moriscos y caballerescos: entre estas composiciones las hai ineditas, y aun en las ya impresas se observan variantes de mucha consideracion. Tambieu se halla un traslado de unos gozos en Llaors del beneit Sunt Roch advocal contra la pestilencia, que se dice fueron impresos en Valencia en 1597; y una copia de otro opusculo tambien en lemosin, escrito en la clase de metro que usó Jalme Roig, euyo titulo es: Breu Descripcio dels Mcsires de Valencia que anaren á besır les mans á la Magestal del rey D. Felip, segon de aquest num, en lo primer de Febrer del any mil cinch. 'ents huilanta sis, feta per to venerable Mestre Gaspar Guerau de Montmajor. Fuster supone ser inédita esta siltira, que tantos disgustos ocasionó á su autor; sin embargo al flu del manuscrito se Ice: linprimis la present loscripcio en casa ilel botor lineses, "luit de Febrer mil einch cents huitomla e sis. Vense cu casa de Viccul Garrigue sa muller.

324 Poesías de veinte i dos autores españoles del siglo decimo sexto Traducidas en lengrua Italiana por D. Juan Franc. de Masdeu. Roma, Mdcclxxxi1. 2 vols. 12.

Acompaña el testo castellano.

$3 \nexists 3$ POESIAS VARIAS, de grandes Ingenios españoles. Recogidas por Iosef Alfay. Zaragoca, Iuan de Ybar, 1634. $4 .^{\circ} .4$ hoj. prels., 160 paigs. y 4 hojas con la sign. A para dos xacaras. El papel é imirresion son delestables.

Este ejemplar ofrece la particularidad de contener las pígs. I1 y 12 que fueron suprimidas y las que las reemplazan: dicha hoja se vario sin duda, por haber en ella unos Consejos a Juanilla, los cuales se juzgaron probablimente demasiado libres, para darlos al publico; sin embargo cncierra aun bastantes composiciones picarcseas dignas de competir en frescura con los antedichos Consejos. Ilai otra singularidad en mi ejemplar y es la de llevar al fln dos Xacaras que no he visto en ningun otro.

Son muchas las poesias anonimas de la antologia de Alfay y entre ellas el Soneto:

Voto d Dios que me adnira estagrandezu etc. generalmente atribuido á Cervántes, y el siguiente, que no me parece deseabellado adjudicar al mismo autor, por su paridad y scmejanza con el anterior.

Un valenton de espátula y gregūesco, Que á la muerte mil vidas sacrifica, Cansado del oflcio de la pica, Aunque no del oflcio picaresco;

Retorciendo el mostacho soldadesco, Y viendo que la bolsa le replica, A un corro se llegó de gente rica

I en el nombre de Dios pidió un refresco.

Den voacedes por Dios, ó por cien santos Que hago lo que sueio sin pereza;

Mas uno que á sacar la espada empieza, i Y sino se la dan al pica cantos, Preguntó, qué ha de hacer en la querella? Respondió el Bravonel, irme sill ella.

Ifállanse tambien en el presente volimen trece décimas saliricas á un pocla corcobado (1). Juan Ruiz de Alarcon) que se valio de lrabajos ajenos; escritas por otros tantos poetas dramáticos de aquella época.

Los nombres de los autores que forman este Canciorre son los siguientes: D. Antouio de Ifendoza, D. Francisco de Quevedo, J. Luis de Gongora, P. Pineda, D. Francisco de la Torre, 1). Gabriel Bocangel, D. Garcia de Pórras, Leonardo de Argensola, Pérez de Montalyan, 1). Francisco de Sáyas, Lope de Vega, Céspedes, Orozco, D. Diego Morlanes, el Dr. Mira de Amescua, Luis Vélez de Gueva. ra, el P. Fr. Gabriel Téllez. D. Alonso de Salas Barbadillo, Fr. Juan Centeno, D. Alonso de Castillo Solorzano, D. Alonso Pérez Marino, 1). Diego de Frias, D. Gaspar Sotelo, Villaizan, I. Pedro Calderon, I. Jerónimo Cincer, D. Juan Fernandez, D. Battasar del Aleázar, D. Jusepe Zaporta, 10. P'edro l'anzano, I). Alberto Diez, I). Antonio Coello, Don Antonio de Solis, Anastasio Pantaleon, Don Gaspar de Figuera y D. Antonio de silva.

Sedano, en el Parnaso español, toll. IX, página Xix, pretende que Alfay publico si obra con el titulo de Flores de varias Poesias de los mejores Ingenios de España y que la imprimio en Zaragoza ell 1608: en anibas cosas se equiroca.

Las Pocsias varias de grandes ingenios, es obra mui rara.

Algunos suelen agregar á este tomo, como si fuera su segunda parte, las Delicias de Apolo, publicadas por I. Francisco de la Torre en Madrid en $1670, y$ por Alfay en Zaragoza en el mismo ano. 
Segun los traductores de Ticknor la pre. sente coleccion está hecha con mucho tino, observando, que lo que en ella domina es el género burlesco.

326 POMPA FESTIVA, en la solemnidad de la translacion del Santissimo Sacramento à la Iglesia Nueva de San Luis,... que se celebrò en esta Corte el dia 19. de A gosto deste año de 1689. Descripcion de la solemnissima procession qve se hizo dicho dia, con el Ornato de Calles, y Altares. Noticias de los principios, y antigvedad de dicha Iglesia... Con dos sermones, qvie... predico... El Señor Doctor D. Ioseph Martinez de Casas. Madrid, Antonio de Zafra, (1689?). 4. 8 hojas prels. y 163 págs.

Hai varias poesias casi todas anúnimas.

327 POMPA FYNERAL. IIonras y Exequias en la muerte De la muy Alta y Catolica Señora Doña Isabèl de Borbon Reyna De las Españas y del Nuevo Mundo Que se celebraron en el Real Convento de S. Geronimo de la villa de Madrid. Madrid, Diego Diaz de la Carrera, 1643. 4. $0^{\circ}$ marı. 171 hojas foliadas, ademas el fróntis grabado, y dos lams. que se pliegan.

Se encuentran poesias latinas, castellanas, italianas y portuguesas de varios aulores; los mas conocidos entre ellos son: D. Autonio López de Vega, D. José de Bolea, D. Ciabriel Bocángel y Unzuela, D. Francisco López de Zarate, Gaspar de Ávila, Mamuel de Faria y Sousa, D. José Micheli y Marquez, D. Juan Mátos Fragoso, D. Garcia de salcedo y Coronel, D. Jerónimo Cáncer, 1). Sehastian de Villaviciosa, b. Pedro losete Niño, b. Manuel de la Peña, el Lic. Luis Sánchez de Melo y el Lic. Antonio de Leon linclo.

328 POMPA fvneral, y real mavsoleo, que erigio el... Conde de Salvatierra, y la Audiencia Real de esta Ciudad de Mexico a las memorias de... Doña Y sabel de Borbon. Mexico, Iuan liuyz, 1640. 4. 3 hijas prels. y 39 foliadas.

rolúmen raro, en el ellal hai muchas poe. sias todas anónimas, aunque parecen de varios autores.

329 PÓRRES (Francisco IG v. de). Ivsta Poetica zelebrada por la Vin- versidad de Alcala Colegio Mayor de S. Ilefonso: en el Nacimiento del Principe de las Españas. Pvblicala el Dotor Francisco Ignacio de Porres. Alcala, Maria Fernandez, 1658. 4. Porlada grabada y una gran lámina plegada como dedicatoria de los Juegos sacros Megalenses. 8 hiojas prels. y 184 paigs. inclusa la lámina.

Difieilmente se encnentran los ejemplares como el presente cou una anteportada impresa que dice: Aclamucim de las Musas al Nacisiento del Principe de tas Españas Nuestio scrior, y sobre todo con la lamina plegada, que forma las págs. 39 y 40.

Contribuyeron á formar esta antología entre otros varios poetas D. Llvaro Cubillo de Aragoll, D. Andres Pellicer Abarea, D. José Figueroa y Córdova, el Dr. 1). José de Villaroel, D. Manuel de Leon Narchante, D. Fernando Aguiar, el Nitro. Baltasar de los Reyes, el Bachiller Juan Rodriguez del kincon $\mathrm{y}$ D. I)iego Calleja.

Eutre las obras de Pórres citadas en la $B i$ bliothera de Nie. Antonio no está la Justa poélica.

Segun los traductores de Ticknor, tom. III, píg. 529, la universidad de Saldmanca celebro fiestas con igual motivo, las cuales pu. blicó, en el mismo año 1658, Sebustian Pérez en $4^{\circ}$ con el titulo de Retacion de las. demonstraciones festivas de religion y lealtad, ete.

330 PRADO UGARTE (JUAN DE). Desagravio congrvo, sino condigna satisfacion, en la mayor ofensa, que a la suma Bondad pudo la mayor ingratitud, obstinada preuenir, y sacrilega executar. Escriuiolas el P. F. Iuan de Prado Vgarte. Malaga, Iuan Serrano de Vargas, y Vrueña, 1636. 4. 12 hojas prels. $y 102$ fols.

Hai en este libro poesias del Lic. Bartolome de la l'eña, el Dr. D. Bernabé de Godoi, Pedro de Araujo Salgado, D. Franciseo Mirácles Sotomayor, el Dr. Lorenzo de Silva y Menéses, 1). Francisco Calderon Ocampo, Frai Juan de Prado Ugarte, D. Diego de Mendoza y Acevedo, el lic. Matias Guerrero, el Licenciado D. Martin de Aldama Maldonado, D. Luis de Córdova y Cueva, I). Nicolas Bied. ma Ugarte, el Dr. D. Alejandro de Vontoya, Fr. Juan Serrano, el Lic. Rodrigo de Eslava, el alférez D: Juan Agustin, el Lic. Alonso de Ocaña, D. Diego Laso de la Vega, D. Álvaro Núnez, el Mtro. Cosme Charcuélos, Juan Ser. rano de Várgas y Urueñ, D. Fernando Suárez de S. Nartin, y Fr. Alonso de Padilla.

No encuentro en la Biblintheca de Nic. Antonio el nombre de Juan Prado de Ugarte ni mencion de la obra Desagranio compruru. 
331 PRIMAVERA, y flor de los meiores romances qve han salido, aora nueuamente en esta Corte recogidos de varios Poetas. Aora nueuamente añadido, y corregido, por el Licenciado Pedro Arias Perez. Madrid, Juan de la Cuesta, 1623. 8. 8 hojas prels. y 140 fols.

En cl fol. $120 \mathrm{vta}$. se lee: Fin de lo impresso hista aqui. Siguen diez y nueve romances, sátiras y letras, olvidadas por el editor en la Tabla del principio.

La edicion mas antigua que trae el Sr. Duran en su Catalogo es la de Vadrid, Alonso Marlin, 1621, y del usismo impresor menciona otra de 1622; asi pues, la mia podrá ser la tercera, y la cuarta la que vi hecha en $\$ / /$ urid por la Viuda de Alonso Martin, I623. 8. 8 hojas prels. y 120 fols. El mismo Duran, nos da á conocer la quinta de sfadrid, Juan de la Cuesta, 1626, y la sesta y sétima impresas en Sevilla en el misıno ario de 1626; á Brunet debemos la noticia de la octava edicion en Lisboa, Malh. Pinheiro, 1626; he visto la novena dada á luz en Barcelona, por Lorenco Deu, $1626.8^{\circ} 4$ hojas prels. 9.5 fols. y una sin foliar en la cual concluye la Tabla; se reflere á la decima de Madrid, por la riuda de Alonso Marlínez (supongo será Marlin), 1626, la licencia de la impresion descrita en el siguiente articulo num. $352 ; y$ liepping habla de la undécima publicada en Sevilla en 1627. A propösito de bepping, observaré se cquivoca cuando dice, en la Introduccion de su Romancero, que la cdicion princra de esta obra se publico en el siglo XV: no conozco ninguna anterior at XVII.

Pasemos á describir la duodécima ediciou, que poscoy es la siguiente:

\section{2} ejemılar; pero las aprobaciones están fechadas en Valencia el año de 1628. 19.0 6 hojas prels. inclusas la portada y Tabla y 216 págs.

Ningun bibliografo menciona esta edicion. En la licencia dice hallars? esta obra ya impresa ántes en Madrid, por la Viuda de Alonso Murtine' (será Martin') en el año 1626. Lleva al fin cl romance de las Unciones de Marica y otro que principia: Los pedazos de un retrulo, composiciones que no están en la de 1623 de Cuesta.

Tengo la decima tercera impresion cuyo titulo es:

333 — Primavera, y flor de los meiores romances, $y$ satiras, que nueuamente han salido en la Corte recogidos por el Licenciado Pedro Perez Arias: Añadidos en esta im-pression muchos, cõ el famoso delas inciones de Marica en el Hospi- tal. Barcelona, Esteuan Liberds, M.DC.XXXII. 12. 6 hojas prels. y 215 págs.

No está en esta edicion el romance, Los pedazos de un retralo.

El Sr. Duran nơ cita la edicion, probablemente publicada en Valencia en 1628 , y tam. bien omitió la de 1632 de Barcelona. En el frintis de esta se denomina al autor Pedro Perez Arias; pero en la Licencla se le llama Pedro Arias Perez.

Figura igualmente en mi Biblioteca la décima cuarta impresion, que dice:

\section{PRIMAVERA, y flor de los} meiores romances, $y$ Satiras, que se han cantado en la Corte. Recopilados de varios Poetas. Por el Licenciado Pedro Arias Perez. Zaragoza: Por Pedro Verges. 1636. A costa de Pedro Alfay, y Tomas Alfay, mercaderes de libros. 12. 9 hojas prels. y 123 fols.

Yo se encuentran en esta edicion los romances de Las inciones de Marica y Los pedazos de un relralo; pero en cambio se añadieron siete composiciones que principian:
Zelosa estaba de Anfriso.-
Inasco, el de Talavera.-
Sinti, contigo, y sin mi. -
Con sits trapos Inesilla.-
si al la guerra mi lindo amor.- iimo bien y trabajo poco.-
Con unas blancas ovejas. -

En el mismo pueblo imprimió Iuan de Larumbe en 1659 en $12 .^{\circ}$ la décima quinta edi. cion: he examinado el tomito $y$ consta de 6 hojas prels. 122 fols. y tres más sin numeracion en las que concluye la Tabla, repitiéndose al fin la fecha.

Las quince ediciones anotadas creo que contienen solo la primera parte; de esta, unida á la segunda, he nianejado ejemplar de la siguiente: Irimavera y for de los mejores Romances y Sutiras que se han canlado en la Conte. Añadialas diuersas Poesius. Y aora nueuamente añadido el Romance que se hizo à la entradu de Galicia en Portugal, en esia Primera, y Segunda Parte. Por el Licenciado Pedro Arias Perez. Marllid, Pablo de lal, 1659. - dl folio 125 se halla un nuevo fróntis que dice: Primavera y flor de Los mejores Romances, Canciones, y Letrillas curiosas, que ha salido agura nueuamète hechas à diferenles proposilos. Segunda parte. Recopilado De diwersos Aulores, por el Alferez Francisco de Segura, criado de su Mugestad. 12.012 hojas preliminares, 225 fols., ambas partes juntas, $y$ j hojas al in sin numeracion para terminar la tabla.

La segunda parte lleva unas aprobacio. nes fechadas en Zaragoza en 16.29: esto parece indicar que debe haber alguna edicion de dicha ciudad hecha hácia aquel año.

Todas las ediciones de este romancerito son raras. 
335 PRIMAVERA y flor de romances ó coleccion de los mas viejos y mas populares romances castellanos publicada con una introduccion y notas por D. Fernando José Wolf y
D. Conrado Hofmann. Berlin, Gustavo Lange, 18506. 2 vols. $8 .^{\circ}$ marq.

Liuda edicion de este escelente romancero, precedida, como ya lo indica la portada, de IIIna interesante y erudita introduccion.
336 QUiÑóNES (JuAN DE). El monte Vesvioio, aora la Montaña de Soma. Por el Doctor D. Iran de Quiñones. Madrid, Inan Gonzalez, 1633 . 4. ${ }^{\circ} 16$ hojas prels. y 56 fols.

El aulor se propuso dar ma noticia de las principales erupciones que liabia tenido el Vesubio, y al fin del tomo reunió las composiciones de varios poetas castellanos dirigidas a aquel volean; son estas en número de viintitres, y entre sus autores se hallan: Lope de Vega, Valdivielso, Quevedo, Montalvan, Esquilache, Lopez de Zarate, Villaizan, Silveira, Luis Vélez de Guevara y Ruiz de Alarcon: de este hai un bello soneto que $\mathrm{D}$. Adolfo de Castro ha reproducido recientemente.
33T RAJaS (Pablo albiniano de). Lagrimas de Caragoça en la mverte de Filipo Rey II. de Aragon deste apellido. Y exeqvias. Que... d su memoria celebró. Recogiolas EI P'. Paulo de Rajas. Caragoea, Juall de Lanaja, 1621. 4. ${ }^{\circ}$ Fróntis grabado $y$ una lamina del túmulo. lna hoja de portada, 4 de prels., 261 paigs., una hoja blanca, y dos grandes que se doblan y no forman parte de la paginacion.-In obito Philippi tertii... oratio. Dixit Pavlys Albinianvs de Rajas. Casaraugusta, Ioannes à Lanaja et Quartanet, 1621. Una lioja de portada y 32 págs. - Sermon que predico... el P. Geronymo de Florencia... en las IIonras... al Rey Felipe III. Zaragoza, Iuan de Lanaja y Quartanet, 1622. 3 hojas prels., 20 paigs. y una hoja blanca al fin.

Contiene poesias de varios: pero todas son anonimas. - Nic. Antonio mejciona esta obri sin citar el lugar ni aî́o de la edicion.

238 RAMÍREZ (José GIJ). Esphera mexicana... leales aplausos, que al feliz Nacimiento del Serenissimo Señor Infante D. Philippe Pedro... consagrò... la... Ciudad de Mexico. Escrita Por el M. R. P. F. Ioseph Gil Ramirez. Mexico, Viuda de Miguel de Ribera, 1714. 4.0 \& hojas prels., 61 fol. y una al fin para dos composiciones poéticas.
Contiene varias poesias anonimas que supolngo serán de diferentes autores.

339 RAMÍREZ PAGAN (Diego). Floresta de varia presia. (Sigue un escudo de armas, probablemente del daque de Segorbe, y bajo de él se lee:) I Contiene esta Floresta $\tilde{q}$ componia el doctor Diego Ramirez Pagan, muchas y diuersas obras, morales, spirituales, y temporales. Y esta primera es vna elegia en la inuerte del Emperador nuestro rey y señor. Dirigrida al Excelentissimo señor duque de Sogorbe. zc. (Al dorso se halla un Lipigramma de Fr. Miguel Carranza, en la siguiente hoja, a $\mathrm{ij}$, principia la dedicatoria que llena dos hojas más, la quinta la ocupa una Epistola á Doña Juana de Austria, y en la sesta comienzan siete Elegias dirigidas al emperador D. Cárlos a Doña Guiomar de Aragon, duquesa de Alva, al Mariscal de Leon, á Miguel Ramirez, padre del cutor, á D. Juan Fernández de Heredia, a D. Francisco .Buil, y á D. Juan de Mendoza; luego hai ravios Tumulos ó sonetos $i$ algunas personas notables y una Lamentacion en la muerte de liartholome de Torres Naharro. En ia primera hoja de la sign. gr viene olro fróntis parecido al primero; pero con diferenle escudo, pues sin duda seri el del principe de Melito, á quien va dirigida esta parte, 
advirtiéndose que la primera obra en ella contenida es vn Encomio en la passiō y martyrio de los Cartuxos de Jngalaterra. Despues de este encomio se encuentran una composicion en quintillas en ioor de S. Juan Evangelista, un Villancico á S. Juan Bautista, un Sermon en la festiuidad d'l glorioso santo Thomas Arcobispo de Cantuaria, tambien en verso, y varios sonetos. En la primera hoja de la sign. n se halla un tercer fróntis con diferente escudo, tal vez el de Doña Leonor Guálvez a quien se dedica; pero el contenido igual al de aquellos en su primer parte. Al reverso esti el retrato de Ramirez Pagan, copiado á continuacion. Esta última division de la obra, contiene composiciones en varias clases de metro y sobre diferentes asuntos, terminando en la octava hoja de una tercera sign. caprichosa que sigue al alfabeto, de este modo:) I Acabosse de imprimir la presente Floresta de varia poesia, vista y examinada, en la insione ciudad de Ualencia, en casa d' Joã Nauarro a . xjx . de Deziembre. año. 1562. 8. ${ }^{\circ}$ let. gót. Viñetas de madera $y$ retrato del uutor. No tiene foliacion, sino signaturas, que comprenden un alfabeto completo y tres signos arbitrarios: cada una es de 8 hojas.

Además de lo ya indicado se encuentran en el presente volümen poesias de D. Fadrique de Toledo, Alonso fiarcia, Juan Lezcaun, Felipe Catalan, Antonio de Padilla, .0. Juan Hurtado de Mendoza, Jorge de Montemayor, D. Sancho de Londoîn, 1. Manuel Ferrando y Pedro IIurtado de Guevara.

Dice el autor en una epistola á Ios lectores, que si el presente trabijo les funse arradable, saldria luego á Inz la segunda parte, la cual ya estaba en poler de los impresores, y contendria una deseripeion del espantoso terremoto de Iurcia, todas las epístolas de ovidio tralucidas en rerso español, una apologia é invectiva contra los hereges. otras cosas dignas de ser tenidas eil algo. A pesar de este of recimiento, dicha segunila parte no Ilegú á publiearse.

En concepto de D. J. B. Gillardo, este libro es 11110 de los mis raros que existen en la literatnra pocitica española, y de la misma opinion son Ios traductores de Ticknor; efectivanente. Mr. Heber 110 In tuw en su Biblioteca, ni brunet comsiguii verlo; Cerdí y Rico solo descubrio un ejuuplin", segun dice en. sus Adiriones a las hoits de lil Diana de Gil Polo. El min es de ma helleza tan singular que tiene varias luojis sin abrir.

D. Agustin Duran, sin duda por mu yemu de implenta, supone ser ijis el ano de la impresion.

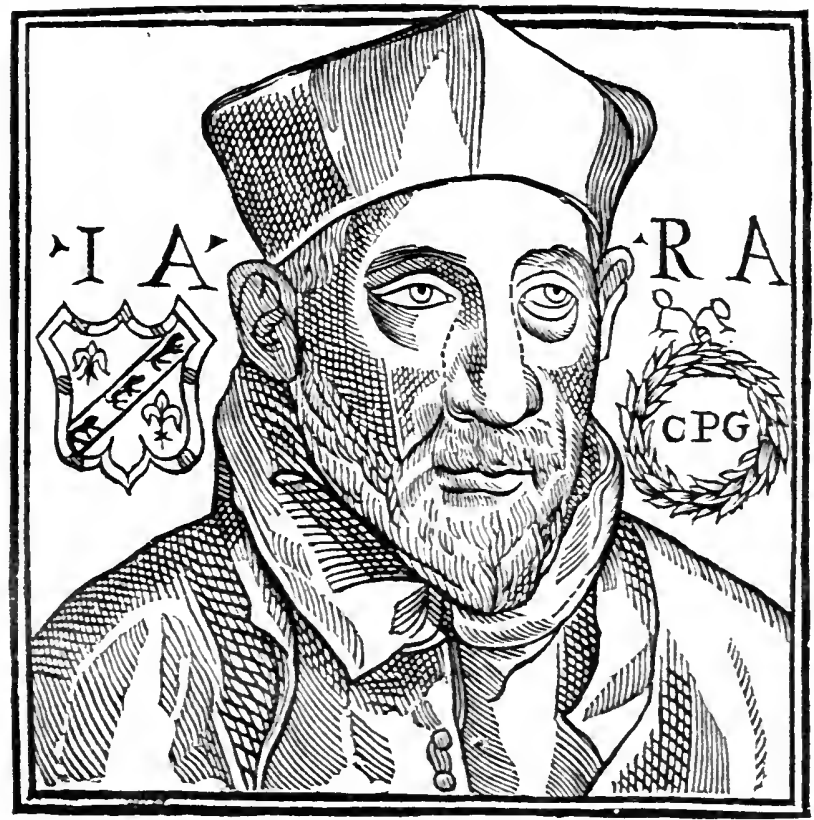


340 REALES EXEQUIAS que a su augusta Soberana $D^{a}$ Mlaria Amalia de Saxonia Reina de España consagró... la mui ilustre ciudad de Barcelona. Barcelona, Maria Teresa Vendrell, y Texido (1761?). 4. ${ }^{\circ}$ laminas que casi todas se pliegan, y vinetas de madera. lina hoja de portada, 110 paigs., y dos hojas prels. y 34 pags. para la Oracion funebre que dixo el P. Ramon Foxá.

Se hallam varias poesıas castellanas, lemosimas, latimas, hebreas $y$ griegas escritas por varios, segun se colige, á pesar de ser todas anonimas. Tambien haj algumas empresas $\dot{0}$ emblemas.

311 REBUllosi (Jame). Relacion de las grandes fiestas que en esta Cirrlad de Barcelona se han echo, à la Canonizacion de su hijo San Ramon de Peñafort. Con vn Sumario de su Vida, Muerte y Canoniracion; $\mathrm{y}$ siete Sermones... Por F. layme Rebrllosa. Barcriona, Iayme, Cendrat, M.DCI. $4 .^{\circ}$ inojas prels. y 170 pags.

Eucucintranse es este tomo la descripeion de un Paso dr' armas llamado el Venlaroso, 'Il cl que hubo varios mantinedores; un desafio y combale do dos caballeros, y una Justu yal'ida entre algrmos paladines. - llai tambien poesias castellanas, calilamas $y$ latinis de muchos autores, sicndo los mas notables: Visel Fructuoso Bisbe y Vidal, Felipe Fontellas, Rafacel Cordellas, D. Jeronimo P'ujailas, Ausias Yarch (descendiente del gran porta de este nomble , D, Juan Dorla, Diego de Ribadencira, Juin Dessi, D. Jerinimo de Heredia, D. Cílos fillillen, Bermardo Aimerich, D. Alejandro Iluseida, Dona Catalina Cardona, 1). Pedro Casina. Yiguel Clanxet, Jusipe Fontellas, Ranın Harem, Jaine Lopez, Jeronimo Monoray, D. Cárlos nlivon, Jaime Rebullosa, Rodriguez de Madrid, Jum ltubert, Raimundo Toralla, Itro. Juan Xiran y b. I) iego Vera. iserí este el compilador del Cuncionero llamado banza de galanes?

312 RELACAM GERAL das festas que fez a Religiaō da Companhia de Iesus na Prouincia de Portugal, na canonizaçā dos gloriosos Sancto I rnacio de Lovola... \& S. Francisco Pauier. To anno de 162. Lisboa, Pedro Craesbe'eck, 1623. 4. 4 hojas prels., 223 foliadas y una al fin con el escudo de la Compañia de Jesus.
Comprende varias poesias anónimas en portugues y castellano, $y$ un largo análisis de una tragi-comedia en cinco actos, intitulada S. Ignucio, que con motivo de estas flestas se represcnto en Evora.

343 RELACION. de la fiesta que en la Beatificacion del B. P. Ignacio fundador de la Compañia de Iesvs, hizo su Collegio de la Ciudad de Granada, en catorze de Febrero de 1610. Sevilla, Lvis Estupiñan, 1610. 4. ${ }^{\circ} 4$ hojas prels. y 96 fols.

El escudo del impresor que lleva al fin lo tengo ya copiado al hablar de la Relacion de la fiesta, publicada con igual motivo por Franciseo de Luque Fajardo (Nún. 275).

Contiene el volúmen produccioncs de va. rios poetas; pero todas son anónimas.

344 - Relacion de las exequias qre en la mrerte del Rey... Don Felipe Qvarto el Grande... hizo la Vniversidad de Oriedo. Madrid, Pablo de Yal, 1666. 4..$^{\circ}$ marq. Diez hojas prels., 292 págs. y una hoja al fin en la que se repiten las señas de la impresion.

Ejemplar en gran papel.

Se encuentran en este tomo muchas poesias castellanas en varios metros, algunas latinas y una ó dos griegas; entre sus autores flruran: D. Dionisio, D. Franciseo antonio y I). Falipe Berlialdo y Quiros, D. Juan Gonzillez de Parédes, el br. D. Francisco la Polia Argüitles, D. ilvaro Dasmarinas PuInarino, el Lic. I). Jualn Contréras, D. Antonio de Valdes Ramirez, Francisco de Argüelles Lorenzana, P. Fr. Jerónimo Bazan, G Lic. Juan Ordunez, el Lic. José de Solis Valdes y D. Tomas de la Cruz llerrera.

313 - Relacion de las festivas aclamaciones, con que celebrò la siempre Fidelissima Ciudad de Valencia la noticia de los Augustos Desposorios de el Señor Don Carlos Sebastian de Borbon y Farnesse, Infante de España con Doña Amelia Mlaria Christina, Princesa de Saxonia. Executaronse en diclia Ciudad en los dias 23. 26. 27. 28. 29. 30 y 31 de Julio, y primero de Agosto de 1738. S. 1. ni $\because .4 .^{\circ} 40$ páys.

Tiene algunas poesias.

346 - Helacion de las fiestas que la Vniversidad de Salamanca ce- 
lebro, desde 27. hasta 31. de Octubre, del Año de 1618. Al juramẽto... de que todos sus graduados defenderan la pura, y limpia Concepcion de la Virgen. Salamanca, Antonia Ramirez viuda, M.DC.XvilI. $4 .^{\circ} 111$ págs. inclusas las dos de la hoja de la portada.

Encuentranse varias poesias que por no llevar nombres de autores no sé si son de uno solo, probablemente procederán de diversas plumas.

347 RELACION de las reales exeqvias, que se celebraron por el Señor D. Luis primero, rey de España. Madrid, Miguèl de Rèzola, 1720 . 4. Lamina en fol. del túmulo. 180 págs. inclusa la portada, y luego sigue un sermon de honras sin pag. con las sings. A 2-H.

Los versos comprendidos en este tomi, aunque anónimos, supongo seráı de varios autores.

348 - Relacion verdadera del recebimiento, que la muy noble $\mathrm{y}$ muy mas leal ciudad de Burgos... hizo a la Magestad Real de la Reyna nuestra señora, doña Anna đ̊ Airstria, primera de este nōbre: passando a Segouia, pa celebrar en ella su felicissimo casamiēto cõ el Rey dô Philippe nuestro señor, segūdo de este nōbre. Burgos, en casa de Philippe de Iunta, M.D.LXXI. 4. ${ }^{\circ}$ Dos hojas prels. liiij fols. En el blanco de la última se repiten las señas de la impresion, y en el reverso esta eí esculo del imprescr.

Relacion curiosa y rara en la cual hai va. rias poesias y la deseripeion de un tornco de una jusla y de una comedia y brtullı naval que se répresentó en la plaza de Bürgos, tomado su argumento del romance de Amadis de Gaula.

El escudo que va al fin de Felipe Junta es igual al del Juan, hecho copiar por mi, con la sola diferencia de que las iniciales I'A de aquel, se han cambiado en este en una $\mathrm{F}, \mathrm{y}$ de que la leyenda Nichil sine causa lia sido suprimida.

349 REMON (Alonso). Las fiestas solemnes, y grandiosas que hizo la sagrada Religiō de N. Señora de la Merced, en este su Conuento de Ma- drid, a... san Pedro Nolasco este año de 1629. Por el Padre Maestro Fray Alonso Remon. Madrid, Imprenta dél Reyno, M.DC.XXX. h. $^{\circ} 10$ hojas preliminares rentre ellas una con un escudo de armas), 114 foliadas, una sin foliar y una grabada.

Contiene muchis poesias latinas y castellanas, entre ellas las hai de D. Antonio Copllo, D. Andres Alarcon y Rójas, el Dr. Pi. rez de Montalvan, D. Pedro de Váreas Yachuca, D. Gregorio de Mojica y Sepuitveda. D. Antonio de Tapia, D. Luis de Zarate, "I Mtro. Alonso dlfaro. D. Diego Ramirez, Francisen de llerrera, D. Antonio de Fignerna y Albarategui, Doĩa Maria Diez, D. Andres Círlos de Balmaseda, Doña Victoria de Leiva, D. Juan belgado, D. Juan de draujo, Dona Maria de Medrano, Dona Maria Jimenez de Castro, D. Alejandro ortiz de Va]des, D. Simon Alonso de Arteaga, D. Franciseo ortiz de Montesa, Dr. Ormero Bonifac, D. Diego de Mojica y Sepúlveda, Benito Lojpez Remon, D. Juan de Tamayo, D. Juan de Castro, Dona Ana Vallejo y Araque, el P. Franciseo de Santiago, Fr. Serafin de Freitas, Francisen Pralo, Gregor. Altamirano, Franciseo Carrillo, Pedro Correa de Silva, Fr. Igllacio de Caona, D. Juan de Andosilla, D. Antonio ile: IIaro, Doìa Lorenza de Aragon, D. Jacinto de Herrera y Solomayor, $\mathrm{n}$. Alejandro Orti\% le Valdes, D. Juan de liebolledo, Fr. Juin de Castaliazor, D. Riabriel Bocingel y Iuzuela, yel Dr. Antonio Mira de dmesella.

No encuentro fll Nic. Antonio autor que se llame IIonso Remon, hai si ull .l/phonsus. lirmon, á quien atrimuyo varias oloras, entre ellas las Fieslas a S. Pedro Polasen los Geroglificos de la vida de] mismo sinto". los evales no me cabe duda son los Discursox rlógiros y apolongéticos que deseribn en li Seccion paremiológiea: sill pubarero en allbas obras se le apellida positivamente Remon.

RESENDE (Gancii be). Véan Cancioneiro geral en la presente division. ( Núm. 179.)

300 RIBERI (Joix Axt.). Pollpa funeral en las exequias del catholico rey... Don Fernando VI... en esta Iglesia Metropolitana de Lima it 99 de Julio de 1760. (Por) el P. Jian Antonio Ribera. Lima, Pedro Nolasca Alvarado, 1760.4. ${ }^{\circ}$ Dos hojas piels., 38 2 págs. Clas ocho últimas estun erradas); y Oracion funebre dicha pon el P. Juan Bantista Sancher, que tien" 10 hojas prels. y 8 Z prigs. con unu hrja al fin de Fe de elratas, y una lamina en fol. del timmulu. 
Se encuentran en esta obra poesias de varios autores.

\section{RIBERA FLÓREZ (DIONISIO} DE!. Relacion historiada de las Eaequias fvnerales de la Magestad del Rey D. Philippo II... hechas por el T'ribrual del Sancto Officio de la Inquisicion desta Nueua España... Por a) Doctor Dionssio de Ribera Florez... Donte Irata de las virtudes es. clarecidas de su Magestad, y transito folicissino: declarando las Fignras, lar ras, Hierogliphicos, Empresas, y Diuisas, que en el Tumulo se pusierom... Mlexico, en casa de Pedro Balli, 1600. 4." Al mincipio can dos hojas de Erratas deste libro, cn que estiu casi las mismas que en la hoja del fin de él. 16 hinjas prels., 187 fols., una blanca, 3 de Talila y una de Erralas.

Arlomis de la gran rareza de esle libro

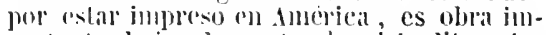
fortante bijo el punto de visla literario, purs comliene poesias de varios anlores del hilen tiempo, ritlo los gue ementramos at I. Dipere oville de Rizman, el Dr. lliepolimo de llemeral y sll hijo I.orenzo de ller. lët, el Lic. Silltiago Esquirel, el Canningo Berualdo de lis Yeara, Pedro de Iledina Vacis, Fr. Luis Vadillo, 1). Franciseo de Solis, el laclı. Antonio Branvila de Arriaga, lodrigo livila, l). Valeo de aquendo y de muchos olros cuyos mumines no coustim.- Idemas

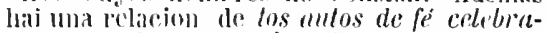
tus por of santo Tribumat despues que se

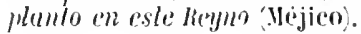

$3 \dddot{2} 2$ RIMAS INEDITAS de Don Iñigo Lopez de Mendoza marqués de Sintillans de firman Perez de limzman señor de Batres y de otros poetas del sigrlo XV. Recogidas i anotadas jor Engenio Ochoa. Paris, imprenta de Fain y Thunot, MDCCCXLIV. 8. ${ }^{\circ} \mathrm{fr}$.

l.us otros poetis de los cuales hai composirimes y enyos mombres no se mencionim in la porianla sous loiego dol Cislillo. Juhan de Andijall, Juan dgraz, Suero de libera y dianli tle Hurî̀as.

3ii) MiOS IIETII CERON (MiNEL DE ros). Fiestas que hizo la insigne Cirdad de Talladolid, con l'oesias y Sermones en la Beatificacjon le la Santa Madre Teressa de
Iesus. Por Don Manuel de los hios lleuia Ceron. Valladolid, Francisco Abarca de Angulo, 1615. 4. 10 hojas prels. y $2: 2$ foliadas: la última no liene fol.

Comprende esta obra poesias latinas, castellanas $y$ porluguesas del mejor tienipo $y$ de los anlores siguienles: el Dr. Martin Her. nando Ezquerra, el Dr. Martimez Polo, cl Lic. Pedro de Avendaño, D. Andres de Calatayud, Luis Mejia, D. Juan de Céspedes, liego de Baeza, D. Manuel de los Rios, el Lic. Juan Jordan, el Lic. Bernardo de Rozas el Lic. Domingo Ezquerra, Hernando Manojo, el P. Fr. Jerón. Gracian Danlisco, el I.icenciado Manuel de Tórres, D. Antonio de Carvajal, Gabriel Gareía del Corral, Lorenzo Lobalo, D. Pedro Quejada Mota, Juan Baulista de Garnica, Miguel Mulsa, Francisco Zamorano, el Lic. Pajáres de la Torre, e] l'. Fr. Bartolomé de Segura, el Lic. Pedro de Villagarcia, el P. Fr. Juan de Mayorga, el Lic. Cristóval de la Vega, el P. Fr. Jeronimo de Valdenegro, Benito Quijano, Manuel Campo de Gama, l)iego Basurto, Fr. Juan de Salazar, l). Juan de Zamudio y algunos alumnos ingleses del Colegio de Valladolid, que todos escribieron en latin.

Conticne ademas cinco sermones del P. M. Fr. Ballasar Navarrete, Fr. Alonso-de Herrera, lir. Cristoval de ovalle, el P. Francisco Lavala y Fr. Anlonio de Sagrameña.

El nombre de llios llevia Ceroul se oculti i las investigaciones de Nic. Antonio, asi es que no eslí con su Bibliolheca.

3̈̈. RIOLELME DE MONTALYO (Ronm(go). Las reales exequias, qve la... Ciudad de Murcia... celebrò en su Yylesia Cathedral, A la muerte de la Serenissima Doña Margarita de Austria. Dispuestas en trescientas y treynta Octauas, Por Don Rodrigo Ripuelne de Montaluo, Con dos Sermones que en ellas se predicaron: y Versos que en el sumptuoso Tumulo se pusieron. Origueli, Iuan Barcelò, M.DGXiI. 8. 8 hojas mels. y 200 fol.

Es libro raro cuyo antor no menciona Nicolas Antonio, y Cascảes al hablar de Riquelme le Ylontalio en su Discurso de los linajes de Murcia, no dice haya eserito obra alguna.

Al fln del volúmen, en 60 hojas, se encuenIran mnos. cerlámenes poélicos que contienen composiciones cast ellanas, latinas y portugnesas en distintas clases de metros de fermando de Chavarria Velizco, Gines Camso, lic. Bartolomé lerrer, D. liodrigo Biquelme, Enrique Nünez, Lic. Juan Ramirez, Doctor Francisco Yánez Tomas, D. Bernardo Pedri- 
nan y Mercader, D. Francisco Pérez de Tudela, Cristoval Belchid, Juan Bernal y Sandoval, Diego Beltran llidalgo, Alonso Fer. nández, Lic. Gines Melgáres, José de Aguilera, Lázaro Pérez, Lic. Sálas, Diego Alvarez, Juan de Espejo, Jerónimo Bienvengud y Lizana, Fr. Diego de Fúnes, Lic. Juan de Salinas, Dr. Juan P'érez de Tudela y Doña Luisa Beltran de Guevara.

3̋̈3 ROCABERTI (JosÉ). Lagrimas amantes de la Excelentissima Ciudad de Barcelona... en las Magnificas Exequias, que celebrò a... su difunto Rey y Señor, Don Carlos II. Descrivelas el Padre Ioseph Rocaberti. Barcelona, Ivan Pablo Marti, 1701. 4. ${ }^{\circ}$ Lleva siete hojas que se pliegan y tienen duplicada la numeracion de la paigina en que se colocan. 1 L hojas prels., 272 págs. y la Oracion fu. .bre del P. Ioseph Rocaberti sin pag. con las signs. i-D.

Hai poesias de muchos autores en castellano, latin $\mathrm{y}$ catalan.

356 RODRÍGUEZ (José). Sacro y solemne novenario... à... San Ivan de Mata, y San Felix de Valois... por la felize Declaracion, que de su antigua Santidad hizo Nuestro Santissimo Padre Alexandro VII. Sr avtor el P. P. F. Iosef Rodriguez. Valencia, Benito Macé, 1669. 4. 10 hojas prels. Cla segunda la llena un escudo de armas grabado), 681 págs. y una hoja al fin en que está el Breve de S. S., que parece añadida despues de hecha la impresion. Se encuentran varias laminas en el volimen; pero van contadas como páginas de testo.

Ademas de algunas poesias intercaladas en la obra, hai al fll un Certámen al que con. currieron los principales antores valencianos de aquella desgraciadisima época de nuestra literatura. El epigrafe de dicho Cer. tómen será sufleiente muestra del gusto con que está escrita la obra, dice asi: Poética palestra, délfica batalla, en plumas de dos corles, en letras de dos rasgos, que se erigen aludas, que se dirigen ardientes á la es. fer'a de dos polos, al volumen de dos pumtos, los insignes prodigios S. Juan de Mala y Sun Felix de Valois elc. elc.

337 RODRÍGUEZ LOBO (FraNcisco). Primeira e Segvada parte dos Romances. De Francisco Rōiz Lobo, de Leiria. Em Lisboa. Por Manoel da Sylua. anno 1634. 12. 2 hojas prels. y 88 fols.

Todas las composiciones de este raro romancerito escepto tres ó cuatro son en castellano. El Sr. Duran no lo inenciona en su Calálogo y Nic. Antonio no cita edicion alguna de esta obra. El Sr. Barrera Leirado dice que la primera edicion del presente libro se hizo en $\mathbf{1 5 9 6 .}$

3 S39 RODRÍGUEZ LOBO (Fraxcisco). La Iornada qve la Magestad Catholica del rey Don Phelippe III. de las Hespañas hizo a sı Reyno de Portugal; y el Triumpho, y pompa con que le récilió la insigne Ciudad de Lisboa el año de 1619. Compresta en rarios romances por Francisco Rodriguez Lobo. Lisboa, Pedro Crasbeeck, 1623. 4. 2 hojas prels. y 92 fols.

Es una relacion de este recibimiento escrita en cincuenla $y$ seis romances, y por consiguiente pertenece il la presente division.

Obra rara de la que he risto pocos ejemplales.

359 ROMANCERO castellano, coleccion de antiguos romances populares de los españoles, publicada con una introduccion $y$ notas por $G$. B. Depping. Nueva édicion con las notas de Don Antonio Alcala-Galiano. Leipsique, Brockhaus, 1811.-Mosa de romances, ó romances sacalos de las "Rosas" de Juan Timoneda que pueden servir de suplemento á todos os Romanceros, asi antiguos como modernos y especialmente al publicado por el señor Don G. B. Depping, escogidos, ordenados $y$ anotados por Don Fernando José Wolf. Leipsique, F. A. Brochaus, 1816. 3 vols. gr. 12. ${ }^{\circ} \mathrm{fr}$. que equirale a el $8 .^{\circ}$ marq. esp.

El último volúnen ó sea la Rosa de Roman. ces tiene dos frontis, el primero al que se copia el del Romancero de Depping y se denomina tomo tercero, y el otro tal cual queda arriba descrito, sin duda para los ejemplares que se deseen encuadernar suellos.

La unica edicion antigua que existe de esta Rosa de Romances es de tal rareza, que solo se conoce el ejemplar qne sirvio al senor de Wolf para su reimpresion. 
168

ROM

CANCIONEROS, HOMANCEROS,

ROM

360 ROMANCERO GENERAL. I deber dar una copia, ó mejor dicho (De este libro tan precioso he creido $\mid$ un facsimile de la portada.)

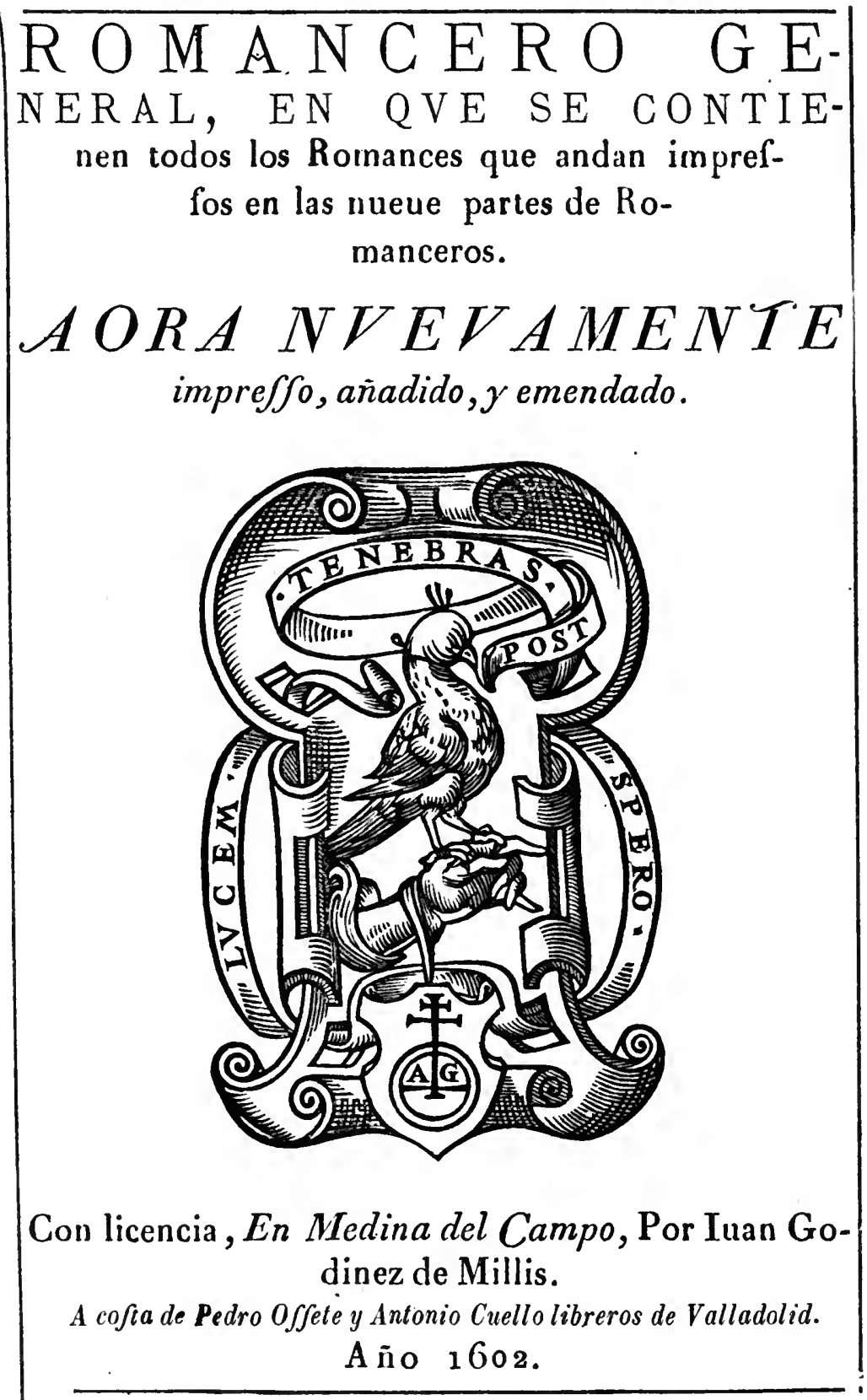

(En la última página de la Tabla, | con que termina la obra, dice:) Fin 
del Romancero General: en que se contienen las nueue partes que hasta aora ban sido impresas. $4 .{ }^{\circ} 8$ hojas prels. y 362 fols.

Bellisimo, con muchas hojas sin cortar. Generalmente se cita esta edicion, sumamente rara, como la primera del Romancero general; sin embargo, yo he visto en la libreria de Gámez, una en $4 .^{\circ}$, con la portada y final MS. y en aquella dice ser publicado por Miguel Martinez y estar impreso en Madrid por Juan de la Cuesta en 1599. La licencia, se halla en la segunda hoja y se concedio á Martinez en Madrid, á 4 de setlembre de dicho año, para poder imprimir y vender un libro que otras vezes... ha sido inpresso, intitulado las nueue partes de los Romäceros. El volúmen en efecto las contiene en 361 hojas foliadas, despues de 8 preliminares. Los Romanceros de 1604 y 1614 son una reimpresion á plana renglon de este hasta el fol. 73 inclusive: luego hasta el fin hai ya alguna variacion de lineas, aunque no creo la haya en los Romances. La Tassa colocada al principio lleva la fecha de 16 de diciembre de 1599 .

Las señas que preceden convienen perfectamente con las dadas en el Ensayo de tuna bib. esp. de Gallardo, al describir la edicion hecha en Madrid, En casa de Luis Sanchez. Año de $1600, y$ por lo tanto debe ser error lo que dice el fróntis manuscrito, de estar impresa por Juan de la Cuestu en 1599 ; ademas no recuerdo ninguna obra ejecutada por este tipógrafo en la corte en el siglo XVi: en Segovia es donde trabajaba en aquella época.

Las nueve partes del Romancero de 1602 son las nueve primeras del impreso por Cuesta en 1604 y 1614 , de modo que estas ediciones son una copia á plana renglon de aquella hasta el fol. 24 inclusive: despues van ya ganando algun renglon por página las publicadas por Cuesta, asi es que al fin de la novena parte hai 7 hojas nrénos en ellas que en la edicion de Medina, aunque la foliacion solo presente la diferencia de 2 hojas. Proviene esta singularidad de saltarse en la de 1604 del fol. 288 al 299 y en la del 1614 de estar equivocados los fols. 325 y 326 y al lle. gar á la hoja siguiente pasarse tambien por alto una decena, poniendo 337 ; error que dura hasta el fin del volúmen.

Por la descripcion ántes hecha se ve la equivocacion padecida por los traducctores de Ticknor, tom. IV pág. 406, al suponer que la edicion de Medina del Romancero, comprende no solo las nueve partes primitivas, sino las cuatro agregadas por primera vez á la impresion de Madrid de 1604 .

Brunet no logró ver la edicion de 1602 y la cita refiriéndose al Catálogo de la venta de Stanley donde obtuvo el precio de 63 lib. est. No conozco otro ejemplar completo, pues el que vi en el Museo británico está falto de 4 hojas.

En el fróntis, como se ha visto, lleva el escudo usado por Godinez, sucesor sin duda de Adrian Ghemart, segun lo indican el pa. recido de los sellos y las iniciales que van al pié, correspondientes á las del nombre del ulitimo.

361 ROMAYCERO GENERAL, en que se contienen todos los Romances que andan impressos. Aora nvevamente añadido, y emendado. Madrid, Iuan de la Cuesta, .1604. 4. $^{\circ} 4$ hojas .prels, 499 fols. (deben ser solo 489, pues del fol. 288 salta al 299) y 7 de Tabla.

Esta edicjon y la siguiente de 1614 contienen integras las nueve partes de la anterior con la adicion de otras cuatro; por lo mismo no es exacto lo dicho por los traductores de Ticknor, tom. IV pág. 406, que el contenido de la impresion de 1604 es igual al de la de 1602 .

\section{2} El mismo. Aora nveramente añadido, $y$ emendado por Pedro Flores. Madrid, Juan de la Cuesta, 1614. 4. 4 hojas prels, 499 fols. (no son sino 489, puesto que desde el 327 hai una decena de más) y $\bar{I}$ de Tabla.

Es una reimpresion del de 1604 .

Se equivoca Depping ellando dice, en la Introduccion á su Romancero, que Flores publicó en 1614 en dos volúmenes en $46^{\circ}$ la primera y segunda parte. De esta liltima nn conozco mas edicion que la de Valladolid de 1605 .

ocioso es encarecer la estraordinaria rareza de todas las impresiones del Romancero general: baste decir, se considera feliz el que posee cualquiera de ellas comlpleta, contentándose muchos con tener trozos ó fragmentos. Asi es que los adicion:dores al Ensayo de una bib. de Gallardo suponen carecer de Tabta la impresion de 1604 ; prueba de que, á pesar de liaber era. minado muchas $\mathrm{y}$ selectas bibliotecas, no han conseguido tener presente un ejemplar completo de dicha impresion de $160 \%$.

\section{3} Segunda parte del Romancero general, y flor de diuersa Poesia. Kecopilados por Miguel de Madrigal. Valladolid, Luis Sanchez, 160弓. $4 .{ }^{\circ} 4$ hojas prels. y $2 \mathrm{Q} 4$ fols.

Edicion mas rara que cualquiera de las de la primera parte por ser la unica que existe de la segunda. Contiene unas $360 \mathrm{com}$. posiciones poéticas, entre ellas quizá no hai una mitad de romances.

Anotaré para inteligencia de los curiosos los varios Romancerilos de que se formaron las nueve primeras partes del General. 
Ftor de varios, y nuevos Romances, Prime. ra y Segunda parte. Aora muevumète copilados, y puestos por orden, por Andres de Villolla nutural de Valencia. Añadiose á ora nuevamente la tersera Parte por Felipe Mcy mercadel de libros. Valencia por Miguet Pralos. 1595. 12. ${ }^{\circ}$ Son 221 hojas fols. inclusa la portada, y á más 4 de Tubla.-Segrm nota del Sr. Parga hai una edicion de Burgos de 1595, que en su primera y segunda parte contienc los mismos rọmances quic este; pero los de la terceril son diferestes, y se dicc compilado por el Br. Pedro de Moncayo. La feeha de la edicion solo consta del lomo del libro pues le falta la portada. El Sl. D. Agustin Duran dice ser de 1591 la edicion ralenciana, y en ello me parece se equivoca, y añade que siendo la licencia de 1588 debe haber edicioues anteriores; en esto último puede tener algo de razon, pues yo opino la hai anterior all 95 , pero solo de las dos primeras partes de Villalta, y asi es como se espliea haberle anadido min téreera .Honcayo al mismo tiempo que IIcy, segun la nota del Sr. Parga á que he hecho referencia.

- Flor ile ulirios romances nueuos, y Canciones. Agor'u nueuamête recopilados de diuersos autor's, por el Bachitler Pedro Mnncayo, natural de Borja. Siguen dos flguritas de un hombre tocando la guitarra y una mujer que le mira, y bajo: En Inesca, Impressos con licencia, por luan Peres de Valdiuielso, Impressor de la Lniversidud, 1589. Acosta de ledio Ibaira libiero. La obra principia en la hoja siguiente, folio 1 , y concluye en el blanco del 150 , al dorso comienza la tabla que llena dos hojas mís. Segun esta, contiene el volumen 85 romances y 25 canciones. $12{ }^{\circ}$ Sigus. $A-L$.

- La misma obra. Perpiñan, 1591. 12. ${ }^{\circ}$ Nie. Antonio.

—_ La misma obra. Alcala de Henares, 1595. 12. ${ }^{\circ}$ Wolf.

$\rightarrow$ Hlor de varius romances nueuos. Pri. mera, Segunda, y Tercera prarte. Añadidos muchos homizces que se han cantado des. pres de la primera imp'ession. Y corvegidos por el Bachiller Pedro de Moncayo. Madrid, V'iuda de $P$. Yadrigal, 1597. 12." Contiene 215 romances. Lo tuvimos en Löndres.

Los romancerillos de Villalta, Mey y Mon. cayo formaron la primera y segunda, una porcion de la tercera parte del Romancero general.

Itomancero, primera y segunda y tercera Parte. Por Sebastian Velez de Guevara. 1594. $8 .{ }^{\circ}$ Xic. Antonio.

Quarta y quinta parte de Flor de Romances. Recopilados por Sebastian Velez de Guenara. Burgos, Alonso y Esteuan Rodriguez, 1592. $12^{\circ}$ Lo he visto.

Flor de romances. Quinta parte, re. copilarla por' Sebastian Vetez de Gucvara. Burgos, 1594. 18. ${ }^{\circ}$ Ticknor, tom. I. pig. 190.

La recopilacion de Guevara formó la cuarta y quinta j,arte del Romancero general.

Ramillete de flores, quarta, quinta y sexta partc de Ftor de romances nuevos, hasta agura munca impresos, llamado Flores: de muchos graves y diversos autores. Recopilaclos, no con poco trabajo, por Pedro Flores, librero, y u su costa impreso. Y demas va al cabo la tercera parte de la Araucana en nue. ve romances, excepto lic entrada de este reino de Portugat, que por ser tan notorio a todos, no se pone. Lisboa, Antonio Alvarez, 1595. 12." Duran.

- Flor de romances. Toledo, 1594. 12. Segun Ticknor, lom. I. pág. 142, están recopilados por Pedro Flóres.

Sexta parte del Romancero. 1594. Tambien la menciona Ticknor en el tom. I. pág. 155, y atribuye á Pedro Flóres la recopilacion. Por esta razon los coloco á continuacion del citado por Duran.

El Ramillete de flores de Pedro Flóres forma sin duda la sesta parte del Romancero general.

Septima parte de Flor de romances nuevos, recopilados de muchns autores por Francisco Enriques. Madrid, Viuda de Alonso Gornez, 1595. 12. Durall.

El misino. Emendado y corregido de muchos yerros que en la primera impre. sion tenia. Toledo, Pedro Mndriguez, 1596. 12. ${ }^{\circ}$ Duran. Los traductores de Ticknor, toin. 4. ${ }^{\circ}$ pág. 406, dicen que el año es el dé 1595.

Septirna parte. Alcala, 1597.18. Ticknor, sin mencionar el nombre del compilador Enriquez.

Forma la sétima parte del Romancero general.

Flores del Parnaso. Oclava parte, re. copilado por Luis de Medina. Toledo, Pedro Rodriguez, 1596. 12. Duran. No sé si será libro igual al que inenciona Ticknor, Historia de ia literat., tom. I. pág. 149, intitillado Flor de romances. Octava parle. Aleala 1597 .

Las Flores del Parnaso se incluyeron en la octava parte del Romancero.

Flor de varios romances diferentes de todos los impresos. Novena parte. Madrid, Juan Flanenco, 1597. Duran.

Esta fué despues la novena parte del Romancero.

Las cuatro añadidas á la edicion de esta antología publicada en 1604, no sé de dónde se tomaron, tat vez la duodéciona seria la

Dozena parte de romances. Recopilados de graues y diuersos Autores. Con licencia. En Valladolid, por Sebastian de Cañas Año de 161. (Debe ser 1604, segun se ve por la Tasa.) $12 .^{\circ} 6$ hojas de prels. y 144 fols.

364 ROMANCERO GENERAL, ó coleccion de romances castellanos anteriores al siglo X VIII, recogidos, ordenados, clasificados $y$ anotados por D. Agustin Duran. Segunda edicion. Madrid, M. Ribadeneyra, 1831. 2 vols. 8. marq. 


\section{R0M antologías Y JUSTas poéticas. ROM}

Estós dos tomos forman el X y XVI de la Biblioteca de autor'es españoles de Ribadeneyra.

E1 Sr. Duran publicó la primera edicion de esta obra en Madrid en los anos de 1828, 29 y 32 , en 5 tomos 8. may., divldidos del modo siguente: Romancero de romances moriscos. 1 vol.-Cancionero y romancero de coplas y canciomes de arte menor, lelras, lelrillas, romances cortos y glosas, anteriores al siglo XVIII, perlenecientes á los generos Docirinal, Amalorio, Jocoso, Satírico etc. 1 volúmen-Romancero de roniances doctrinales, amatmios, festivos, jocosos, salíricos $y$ burlescos. I vol.-Romancern de rumiances caballerescos é históricos anteriores al siglo XVIII, contiene los de Amor, los de la Tabla redonda, los de Carlo Magno y los Doce Pares. los de Bernardo del Carpio, del Cid, de los Infantes de Lara etc. 2 volumenes. En la segunda injpresion de 1851 , la obra ha sido considerablemente aumentada, $y$ el número de las composiciones que comprende llega á 1887; se han ilustrado la mayor parte de los romances con notas mui importantes; lleva un erudito é interesante prólogo, $\mathrm{y}$ va adicionada con dos curiosísimos catálogos, el uno de los pliegos sueltos que se han impreso de romances, canciones $\mathrm{y}$ villancicos, y el otro de los Romanceros, Cancioneros y poetas que tuvo presentes el Sr. Duran para la formacion de su preciosa antologia de poesía popular.

363 ROMANCERO DEL CID. Romancero, e historia del mvy valeroso cavallero el Cid Ruy Diaz de Biuar, en lenguage antiguo. Recopilado por Iuan de Escobar. Caragoca, Por Iuan de Larumbe. Año 1618. 12.0 4 hojas prels. y Tabla, 163 fol. y una al fin en cuyo blanco hai una laminita que representa un caballero montado y al reverso se repite el lugar y año de la impresion.

\section{Contiene 102 romances.}

Ademas de la edicion de Alcala, Juan Gra. cian, 1612. 12. ${ }^{\circ}$, descrita por Brunet, se menciona en el Ensayo de unu bib. esp. de Gallardo otra tambien de Alcala, en casa de Iuan Gracian, que sea en gloris. Año de 1614. (Al fin: M.DC.XV.) 8..$^{\circ}$ y Depping en la In/roduccion al Romancero, habla de la de Lisboa, 1615. 12..$^{\circ}$ Yo he visto la de Segnuia por Diego Flamenco. 1621. $12 .^{\circ} 165$ fols. inclusos los prelims. y 3 de Tabla, y tambien la de Madrid, Iuan Delgado, M.DC.XXY. 12. con número de hojas igual á la anterior. En mis apuntes encuentro anotada una de $v a$ lencia, Mey, 1629. 12. La de Segovia, 1629. $12 .^{\circ}$ y Madrit, Marin Quiñones, $1650.12 .^{\circ}$; las trae Brunet. En una apuntacion de mi padre se menciona otra de Lisboa, $1650.12 .^{\circ}$ advirtiendo que solo contiene 96 romances; $y$ Duran habla de las de Madrid, Maria Qui.

Tон. 1. ñones, 1661. 12. y Francisco Saez (iserá Sanz?), 1685. 12.

366 ROMANCERO DEL CID. Romancero e historia del muy raleroso cavallero el Cid Rvy biaz de Bivar. Recopilado por Iuan de Escobar, en lengua Antigua. Madrid, Antonio de Zafra, 1688. 12. 156 hojas fols., inclusos los prels., una hnja blanca antes de la portada, $y$ dos hojas en que concluye la Tabla.

Duran no menciona esta edicion en su $\mathrm{Ca}$ lálogo.

367 - Romancero, e historia del mvy valeroso cavallero Don Rodrigo de Bivar, el bravo Cid campeador. En Lenguage antiguo. Recopilado por Juan de Escobar. Madrid, Francisco Sanz, s. a. (La licencia y Tasa son de 1695.) 12. 142 hojas fols. inclusas las prels., $y 2$ de Tabla.

Se advierte al fin que en esta impresion uan añadidos muchos romances que hasla ahora no han sido impresos; pero no encuentro sino los 102 contenidos en casi todas las publicadas desde la de 1618 que tengo.

Reguero y no Roquero, como le llama Duran, editor de la edicion de 1818, cita una de Madrid, 1695 , que tal vez sea la ántes descrita, y otra de Burgos, s. a. $12 .^{\circ}$

368 La misma obra. Cadiz, Pedro Ortiz, 1702. 12. 142 hojas fols., inclusos los prels., y 2 mas de Tabla.

Sigue á esta la edicion de Pamplona, 1702. $12 .^{\circ}$, que encuentro en Depping.

369 La misma obra. Én esta rltima impression vàn añadidos muchos romances, que hasta aora no han sido impressos, ni dirulgados. Pamplona, Martin de Zavala, 1706. 19. ${ }^{\circ} 36$ hojas fols. inclusos los prels., y desde la 37 son ya págs. hasta la 292. Al fin van 2 hojas de Tabla.

Tampoco contiene más que los 102 romances, á pesar de lo indicado en la portada.

Edicion desconocida á D. Agustin Duran; yo he visto la de Madrid, Joseph Alonso $y$ Pudilla, 1726. 12. ; Duran cita otra del mis. mo pueblo de 1746: la segunda edicion hecha yor el dicho Padilla, en 1747. 12. 1.42 fols., inclusos los prels., ${ }^{2} 2$ hojas al fin para terminar la Tabla, la tavimos en Lún- 
dres, y Depping cita la de Barcelona, 1757. 8. dividida en dos partes.

370 ROMANCERO DEL CID. Nueva edicion reformada sobre las antiguas, añadida é ilustrada con varias notas,... Y adornada con un epitome de la historia verdadera del Cid. Por D. Vicente Gonzalez del leguero. Madrid; Cano, 1818. 12.

A pesar de adrertirse en varias de las ediciones anterioles i la presente estar anadidas $\dot{0}$ aumenladas sobre las precudentes, ninguna contiene mas que 102 rominces. Ja de lsts es la mas incomplela pues le faltan 2: romances, anmglle aldrunos trozos de ellos se reproducen en las notas, para completar la lisstoria del Cid.-D. Juan Antonio Vuller publico este romancerito adicionado con una vida do liui Diaz de Vivar y 10 imprimió en F'ancoforto en 1828. 12. , habiendo tirado ejemplares en papel vitela superior. Alsuna otra edicion se ha hecho en el presente siglo.

Cerraré la entimeracion de las impresiones de esta biografia poetica con otras dos obras que tratan del mismo asunto, á saber: Tesoro escumlido de todos las mas famosos romances, asi antiguos commo modernos del Cid, reeroiludos ninevamenl' y's Frencisco Metge, con romances d" los sicte infumles de Lar i. Barcetonn. Sibustian Cormellus, 1626. 12. Creo que contiene 40 romances del Cid y 7 de los infuntes; y al Rumamero del Cid. mb'icalo por A. holler. Slutlgart, 18\%0. 12. mas. Consta segum el sr. Duran de 154 romanees y es la mis completa coleccion antolugica especial de los del Cid.

371 R0MANCES a la vida de Nvestro Señor Iesv Christo, y a sv santissima Passion. Escritos a la instancia piadosa de rna gran derota srra. Dedicados a la meditacion de in corazon catolico. S. l. ni a. (Madrid, 1666?) 4. 3 hojas prels. y 93 foliadas.

Son en todo treinta y siete, Romances, á saber: veiutiuno á la Vida de Cristo, y los diez y seis restantes de la vida y muerte de santa Catalina y de otros varios asuntos derotos. Van mezcladas algmnas Endechas, Coplas y Estribillos. Es volumen raro y mui poco conocido.

37? ROMAYCES UE GERMANIA de rarios artores con su Bocabulario al cabo por la orden del a, b, c, para declaracion de sus terminos y lengua. Compuesto por Iuan Hidal- go. (Siguen dos figuritas de un hombre y una mujer, el primero lleva sobre la cabeza el nombre de Garrancho y la segunda el de La Mendez.) Barcelona en casa Sebastian de Cormellas, Año, 1609. 12. 'Sin foliacion, signs. A-I todas de 12 hojas, incluyendo en la última una que solo contiene la laminita de uno que toca la guitarra $y$ lleva el nombre de Malariros.

Primera edicion, segun Nic. Antonio, y tan rara que yo nunea lie visto otro ejemplar de clla: hizo la seguitia en Zuragoca, J. de Larumbe, 162'. 12. ${ }^{\circ}$ segun Brunet, $y$ he tenido ocasion de examinar la tercera impresa lambien en Crragoça, Por. Iuan de Larumb', Año l6;4. 12. ${ }^{\circ}$ sig. A-I, lodas de 12 hojas, incluyendo las dos de prels., y una del fin en que se repite la fecha : el mismo Rrumet habla de la cuarta de 1654 ; pero no dice dúnde está impresa, y me inclino á creer se equivoca al citar una edicion de Madrid, Suncha, 177i, no siendo probable que el mismo publicara dos años despues la siguiente:

\section{ROMANCES JEE GERMA-} IIA de varios autores, con el Vocabulario por la orden del a. b. c. para declaracion de sus términos y lengua. Compuesto por Juan Hidalgo: el viscurso de la expulsion de los gitanos, que escribió el Doctor Don Sancho de Moncada, y los Romances de la gerniania que escribió Don Francisco de Quevedo. Madrid, Don Antonio de Sancha, I.DCC. LXXIX. 8. ${ }^{\circ}$ may.

Las ediciones antiguas solo contienen los Romances de germanía y el Vocabulario, por lo mismo aunque bibliográflcamente hablando no sea esta la edicion de más precio, es sin embargo la más completa $\mathrm{y}$ útil para el que desee adquirir la obra con el único fin de estudiar el dialecto de los gitanos.

César oudin al flnal de la primera parte de su Tesoro de las dos lenguas francesa y españolı, Paris, 1616, publicó el Vocubula. rio de Juan llidalgo; tambien lo reimprimió D. Gregorio Mayans en el tom. Il. de lis origenes de la lengua caslellana.

374 ROMERO DE CEPEDA (JOAQuiv). La antigva memorable, y sangrienta destruycion de Troya. Recopilada de diuersos autores por Ioachim Romero de cepeda vezino de Badajoz... A imitaciō de Dares Tro- 
yano, $Y$ Diclis Crethẽse Griego, los quales la escruierõ y pelearon en ella. Toledo, en casa de Pero Lopez de Haro, 10̆83. (Al fin:) Acabose este libro á diez y siete del mes de Marco, año de 10ั81. 8. 10 o hojas foliadas en todo.

Dice el Sr. Duran en el Catilogo de dxcumentos que se halla al fin de sij Romancero, al hablar de esta obra, lo siguiente: -Cons- la este raro e interesante libro, 1. De lu - narraciones en prosi, en que el antor con- ciliando las opiniones de los historiadores - que cita en lil portada, refiese la guerra y "destruccion de Troya. 2." De 20 romances - de la clase artistica media y precursora de - la completa, precculdos cada uno de ina - declaracion en prosa. .." Ln resimen histu. - rico de lo que acaecio despues de la rui- na de Troga a los personajes que inturviuje-ron en eila. Fl autor de todo el libro, in-
- clusos los romances, es el cilado Romero - de Cepeda y sit obra se considera como un - Rounancero.

Debo añadir á las advertencias del Sr. Du. ran, que en el tomo de las Obra.s de Cepeda impreso en sevilla on $\mathbf{1 5 8 2}$, se encuentra otro poema en diez cantos, intitulado: El infelice robo de Elena reyna de Esparta por Paris Infante troyano; del qual sucedis ta sangrienta destruicion de Troyu, y aunque el asunto tiene gran relacion con el de la Anti. gui memorable !/ sangripnta destruycion de Troyu, la composicion es enteramente distinta. Ticknor sin duda no conoció esta ùltima, pues solo incuciona la primera en el tom. lill. pás. 16\%.

El Sr. Barrera despues de describir $L u$ an. linua memorable y simgrienta destruicion de Troy $a$, aỉade que este libro es rarisimo como todos los de Cepeda.

Al reverso de la portada de la obrita se encuentra cste escudo del impresor Pedro l.upez de Ilaro.

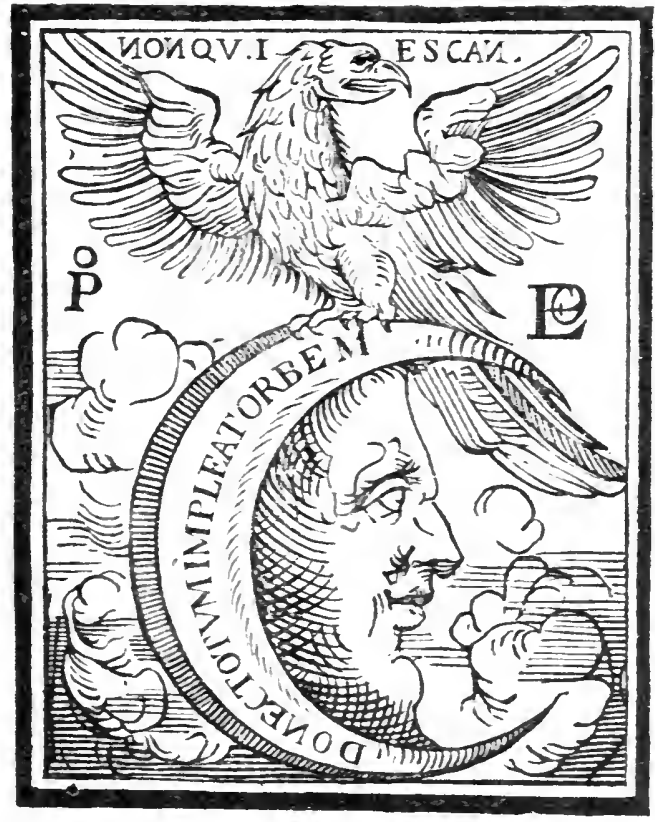

373 ROYS (Fraxisco DE). Pyra Real, qre erigio la maior Athenas a la maior Magestad; La Vniuersidad de Salamanca, A las immortales ceniças, â la gloriosa memoria de su Rey y Señor D. Phelipe IV. el grande. Refierela... El $\boldsymbol{M F}$. Francisco de Roys. Salamanca, Melchor Estevez, $1666.4 .^{\circ}$ marq. 2 hojas prels.
Cla una con un escudi, de armas renles) y 472 paigs.

Ejemplar de papel grande.

Contienc poesias de muchos autores cuyos nombres no laan llegado á la posteridad. sin duda por el pésimo gusto que los distingue: sin embargo, como en cisi lodas las obras de esta clase be hecho mell " in do los escritures mas sobresaliontes he quines ses eneuentra alguna produccioll. rilaréde l.t 
presente aquellos que no son completamente desconocidos, como D. pedro Calderon de la Barca, el Lic. 1). Juan Francisco Rámos del Manzano, el P. Fr. Alonso Pérez, el P. Fr. Alonsı Cortes, D. Gabriel de Narvaez y Aldana, el P. Fr. Plácido Gómez de Vera, 1). Manuel de Otalora Arze y Astete, el Licenciado 1). Estévan del Puerto Alvarez, D. Nanuel Pérez de Araciel y Rada y el P. Fr. Crisóstomo Manuel Enriquez.

376 ROYS (Francisco de). Relacion de las demostraciones festivas de Religion, y Lealtad, que celebrò la insigne Vniuersidad de Salamanca. En el... nacimiento del Principe nuestro Señor D. Felipe Prospero, Escriviola... El Maestro F. Franeiseo de Roys. Salamanca, Sebastian Perez, 1638. $4^{\circ}$ Una hoja para la portada y 472 pags.

Entre las poesias griegas, latinas, eastellauas y vascuences contenidas en esta rela. cion, las hai de D. Matias de los Reyes Valenzuela, D. Antonio de Guevara, D. Alonso Garcia de Aponte, D. Iliego de Vera y Tasis, I). Baltasar de liosáles, D. Gabriel de Leon, el P. Gaspar de Cruzat, D. José de Ribera, el P. Antonio de Lodisa, D. Juan Vontero y el P. Fr. Manuel Guerra.

En la Bibliolheca de Nie. Antonin no encuentro noticia alguna del Maestro Fraucisco de lioys.

Sobre este mismo asmuto pullico el Doctor Francisco lgn. de Púrres una Justa poética. Véase à su nombre en la presente division, Núm. 599.

377 RUEDA MARIN (ANTONIO DE). Justa poetica, celebrada en el

379 SAAVEDRA (Angel de). Romances históricos de D. Angel de Saavedra, duque de Rívas. Paris, II. Fournier y C. ${ }^{2}$, 1841. 12. ${ }^{\circ}$ may. Viñetas de madera.

Publico mi padre estos Romances en 12. may. frances, para formar juego con los dos volumenes del Moro expósito.

380 SAGRADAS FLORES del Parnaso, consonancias metricas de la bien templada lyra de Apolo, que a la reverente, eatholica accion, de a ver ido acompañando Sus Magestades al SS, mo Sacramento,... el dia insigne Colegio de la Compañia de Jesvs... de Murcia, el dia 17 de Noviembre del año de 1727. en cvlto de S. Lvis Gonzaga... y de S. Estanislao de Kostka. Por Don Antonio de Rveda Marin. Murcia, Jayme Mesnier, s. a. (1728). $4 .^{\circ} 20$ hojas prels. y una que se pliega, á las que siguen 388 págs.

Son muchos los poetas que concurrieron á esta Jusla; pero todos de escaso mérito.

378 RUIZ (Francisco). Relacion de las fiestas que hizo el colegio de la Conpañia de Iesvs de Girona. En la canonizacion de sv patriarca San Ignacio, i del apostol de la India San Francisco Xavier, i beatificacion del angelico Lvis Gonzaga. Con el Torneo poetico mantenido i premiado por Don Mlartin de Agvllana... Por Francisco Rviz... Barcelona, Sebastian i laime llatevad, Año CI') IDC XXIII (1623). $4 .^{\circ}$ "s hojas prels., incluso un fróntis grabado, 139 fols. y una blanca.

Raro.-La relacion de estas flestas solo ocupa 1.4 hojas; hasta la 48 se encuentran poesias anonimas en varias clases de metro, y en el fol. 49 principia el Torneo poélico, el cual encierra composiciones de unos setenta poetas, que no enumero por ser poco conocidos sus nombres, escritas la mayor parte en castellano, muchas en latin, y no pocas en catalan.

Nic. Antonio no menciona este libro ni á su alltor Francisco Ruiz, natural de Loja.

28. de Noviembre de 1722. Cantàron los mejores Cisnes de España. Madrid, Juan de Ariztia, (1723.) 4. ${ }^{\circ} 14$ hojas prels., 176 págs. $y 3$ hojas para unas Lyras de Don Diego de Tórres. Quizá falta una hoja blanca al fin.

Este volúmen contiene composiciones de muchos poetas; pero entre todos cllos solo hai dos cuyos nombres son conocidos en la república de las letras, á saber, D. Diego de Turres y D. Antonio de Zamora.

381 SAINZ DE VALDIVIESO TORIEJON (Miguel). Parentacion real. Luctuosa pompa. Sumptuoso 
cenotaphio,... Al Augusto Nombre, y Real Memoria del Serenissimo Señor Don Phelipe V. Cuya Relacion escribe el Doct. Don Miguel Sainz de Val. divieso Torrejon. (Lima, 1748.) $4 .^{\circ}$ Gran lám. del catafalco. Una hoja de fróntis, 119 foliadas, luego portada para la Oracion funebre del $\boldsymbol{P}$. Mtro. Diego Joseph Merlo, que no lleva paginacion, y si las signs. A-D y por fin dos hojas de Fee de erratas.

Contiene poesias de varios autores en cas. tellano, latin í italiano.

$38 Z$ SAN JOSÉ (DIEGO DE). COMpendio de las solenes fiestas qre en toda España se hicieron en la Beatificacionde N. B. M. Tere sa de Iesrs ... enprosayverso. Por Fray Diego de San Joseph. Madrid, Viuda de Alonso martín, 161\%̆. 4. ${ }^{\circ}$ Lna hoja de fróntis grabado, y otra con el retrato de la santa, 4 hojas prels., 98 foliadas ren las dos últimas se lee 61 y 62 por errataJ para las Fiestas de Madrid, y 2932 de nueva foliacion para las de otros pueblos de España y para la Tabla.

Asi como en otras obras de esta clase he dicho importaba mui poco el ignorar los nombres de los poetas en ellas incluidos, en la presente es sensible que la mayor parte de los versos sean anónimos, y por consiguiente desconocidos sus autores. Las composiciones en general tienen uérito, é indudablemente son debidas á las plumas de nuestros mas distinguidos escritores; asi lo prueban los nombres siguientes, sacados de cntre los pocos que constan en el libro: Lope de Vega, Vicente Espinel, Hiruel Cervántes, Francisco de Céspedes, el Mtro. Josẻ de Valdivielso, el Lic. Porreño, Antonio Ló: pez, D. Pedro de Orozco, J'an de Pina, Collzález (el estıdiante), el Dr. Ezquerra, el Licenciado Pablo Verdugo, Vicente Olsina, Alonso Palomino, Andres de Quiros, el Licenciado Francisco de Aguilar, Cristóval Ferreira de Sampayo, Fernando Alvarez, Agustin Collado del Hierro, Dr. Campezo, Juan de Ribas, Pedro Luzon de Pasamonte, Lic. Cristóval de Montoya, Jacinto de Piña, Jerónimo Pérez Garcia, D. Dlego Vera y Ordonez, Dona Mariana de Ciria y Veteta, Mateo de Tavira, Dona Clementa de Pina, José Sánchez, el P. Fr. Pedro de Cardona, Juan Jerónino de Tórres, el P. D. Gonzalo de Fúnes, Doria Luisa Zapata, Doña Jacinta de Heredia. Don Gaspar Bárbara de Guzman, D. Alvaro Vique, el P. Fr. Pablo de Arellano, Manuel de ledoya, Lic. Vicente, D. Juan Cazcarro, Dona Ana de Urrea, Lic. D. Franc. Fernández de
Peralta, Soror Ana Ramirez Ateza, el P. Hernando Orio, el P. Fr. Bartolomé Navarro, el P. Fr. Martin de Recarte, Lic. Luis Martin de la Plaza, el P. Fr. Roque dé Vera, Pedro de Vergara, $\mathbf{D}$. Juan de Ciria y Veteta, Juan Ruiz de Sta. Maria, el P. Fr. Simon de Vega y el Lic. Jerónino González.

Las composiciones poéticas son en castellano, portıgues, latin, jtaliano, á lo vizcaino, á lo guineo ýá lò sayagūes.

A pesar de hablarse en el libro del P. S. José de las fiestas que en casi todos los pueblos de España y Portugal se celebraron con mo. tivo de esta beatifleacion, vieron la luz pública otras descripciones parciales de las hechas en algunas ciudades, asi el Sr. Gallardo, en su Crilicon núm. 2, pág. 46, cita una Relacion de las fiestas de Córdoba á la beatificacion de Sunta Teresa, con la Justa literaria etc. por el Lic. Perez de Valenzuela. Córdoba, por la viuda de Barrera, 1615. En este volúmen es donde se encuentran las preciosas quintillas de Dona Cristovalina Fernández de Alarcon, reimpresas por dicho Ga. llaruo.

Vic. Intonio olvido al P. Diego de San José.

383 S.ACHEZ DE ESPEJO (ANpRES). Relacion historial de las Exeqrias... qre el Arcobispo, Dean y Cabildo de la Santa, y Metropolitana Iglesia... de Granada hizieron en las lonras de la Reyna nuestra señora doña Ysabel de Borbon... Al Rey nuestro señor... el M. Andres Sanchez de Espejo. Granada, Baltasar de Bolibar, y Francisco Sanchez, M.DC.XLY. 4. Gran lamina del catafalco. Ina hoja de portada, otra con un escudo de las armas de España grabado en madera, 4 hojas más de prels. y 92 foliadas.

Contitene poesias del Lic: Alonso Hidalgo, D. Juan de Trillo y Figueroa. el IItro. Ca. Iriel Rodriguez de Escrabias, el lic. Ramon de Moráles, D. Dipro Carrillo de Mendoza, 11. Rodrigo de Avila Ponce de Leon, D. Luis de Zepedd, l'edro López, D). liegn de Fuṕntes Manrique y urtiz, D. Jose de Coraleda $y$ Aguilar, D. Alonso de Vargas, (1 Lic. Tomas lorez de linga y otros.

El nombre de Sánchez Espejo, no se en. cuentra en la Bibliolheca de Xic. Antonio.

381 S.NTA MARÍA LUTS DE). Octava sagradanente crlta... Festira aclamacion: poinpa sacra, celebre, religiosa. Centenario del rnico nillagro del mrindo San Lorenzo Real del Escvrial. Escrito Por el P. II. 
Fray Luis de Santa Maria. Aplardido Este primer Centenario, de la edad de este Real Monasterio en ocho Sagradas Oraciones Euangelicas. Coronado, Vltimamente, con in Sacro Certamen Poetico. Madrid, Imprenta Real, 1664. fol., 11 hojas prels. y ámas una con el retrato de Felipe IV y dos de la vista del monasteterio del Escorial: 367 pags. Cla hoja que corresponde á las paigs. 339 y 340 , se pliega) una hoja que respresenta un castillo y 20 para los Indices.

El Cerldmen poélico ncupla 142 pigs. y enntiene composiciones de muchos ingenjos: ninguno de ellos goza de gran celebridad en la republica de las letras, siendo la mayor parte colegiales del Seminario de S. Inrenzo y monjes del monasterio, ó de la órden de S. Jeronimo.

38ว SARAVIA (ANTonio DE). Justa literaria, certamen poetico, o sagrado influxo, en la solemne, qranto deseada Canonizacion del Pasmo de la Caridad, el Glorioso Palriarca, y Padre de Pobres Sin Juan de Dios, Fundador de la lieligion de la Hospitalidad. Celebrose en el claustro del Convento Hospital de Nuestra Señora del Amor de Dios, y lenerable Padre Anton Martin de esta Colte, el Domingo diez de Junio del Año de mil seiscientos y noventa y vno... la descrive Don Antonio de Sarabia. Madrid, Bernardo de Villa-Diego, M.DC.Lxxxxir. 4. ${ }^{\circ}$ La portada de negro y colorado. 12 hojas prels., inclusa una lámina grabada en madera del santo, que precede á la portada, y 370 paigs.

Casi todo el volúnen comprende poesias de diversos autores dignos de Ia época phl que escribieron: los dos unicos nombres cunocidos entre todos ellos son el de 1). Antonio de Zamora y el de D. Francisco Candamo.

386 SEGURA (Franciscode). Primera parte, del Romancero historiado, Trata de los liazañosos Hechos de los Chrisianissimos Reves de Portugal. Compresto por el Alferez Francisco de Serrura. Lisboa, Vicente Aluarez, 1610. 8. 16 hojas prels. ra iltima bläca) y 182 foliadas.
Rarisima edicion; la primera es de Cara. goça, Angelo Tavano, 1605. 8. y là tercera, como diee D. Agustia Duran, es tambien de Lisboa, 1614. 12. y parece está anadida. Nic. Antonio no senala el lugar ni ano de la impresion de este libro, al cuisl da el titulo de Romancero historiador. - La segunda parte no llegó á publicarse.

De cste mismo autor es el Rosario sacratissimo de la serenissima reina de los Angele's Nueslra Señora la Virgen Murí. Compuesto por cl Alferez Francisco de Segura. Ziragoça: Por Iuan de Lanaja y Quarimet, $1615.8 .^{\circ}$ i6 hojas prels. y 156 fols. Poema en quiuce cantos, divididos en tres séries; la primera de 4 , la segunila de 6 y la tercera de

No estoi cicrto si será del mismo Segura la Segumda parle de la Primavera ? flor de romances que acompaña en alguua edicion á la primera de Arias p'érez.

La obra de segura nada tirne de comun con el Romancero historiado con mucha variedal de glosas, sonetos y ul fin una foresta pistorit, hreho y recopilado por Lucas Roilriguez. Alcala, Herian Ramirez, 1579 o $1581.8^{\circ}$ y Alcata, Querino Gerardo, 1582. 12.", secoun burau: he visto de esta obra mua tercela impresion tambien de $A^{\prime}$ :ala, Hernan Ramizez, $15 \mathrm{~K}$ ). 8. 275 hojas fols. inclusas las ij de prels.-De Lícas Rodriguez menciona Nic. Antonio otro libro intitulado: Conceptos de divina poesiu. Alcala, Jum higuez de Lequerica, $1599.8 .^{\circ}$

387 SEPÚLVEDA (Lorenzo de). Romances nvevamente sacados de historias antiguas de la cronica de España compuestos por Lolenço de Sepulueda. Añadiose el Romance de la conquista dela ciudad de Africa en Berueria, en el Año M.D.L. y otros diuersos, como por la Tabla parece. Anuers, Pedro Bellero, M.D.Lxxx. 12. 238 hojas foliadas, comprendidos los prels. y dos de T'abla.

Esta impresion, desconocida á Nic. Antonio, tiene las mismas composiciones que la de 135t: lo fillan veintiona de la de $1566 \mathrm{y}$ comprende ocho no incluidas en exta.

He visto las dos ediciciones que acabo de mencionar y su descripcion es la siguiente: la primera dice en la portada lo mismo que la de 1580 , con la sola diferencia de leerse al pie de ella: Amvers, En casa de Tum Steelsio. H.D.LI. 12. ${ }^{\circ}$ semigót. 2 hojas de Prólogo, 259 fols. 3 hojas para terninar la Tabla y una con cl escudo del impresor.

La leyenda del fróntis de la segunda es: Roinances mevamenle sacados de historias antiguas de la Cronica de España por Lorenco de Sepuhueda vezino de Seuilla. V'an añadidos muchos nǘca vis!os, compuestos por vu cauullero Cesario, cuyo nombre se guurdu para mayores cosas. En Anvers. En casa Philippo Nicio. $1566.120^{\circ}$ semigót. 276 fols. incluso el 
fróntis. Contiene velntiuna composiciones más que las ediclones descritas anteriormente, pero le faltan ocho que aquellas comprenden.

El Sr. Duran colige de una advertencia puesta por Nilcio en 1551 que debe haber alguna edicion de Sevilla anterior á esta fecha. No comiprendo como esto pueda ser cuando Nucio no publicó la obra en este año sino en el de 1566 .

Wolf en la Advertencia á las Rosas de Timoneda describe la obra siguiente: Cancionero de Romances sacados de las Coronicas antiguas de España con otros hechos por Sepulveda. Y algunos sucados de los quarenta cantos que compuso Alonso de Fupntes. Impressa (sic) en la noble villa de Medina del canno, por Francisio del Canto. Año 1570. 16. let. gót. ménos la portada que es de redonda, CCII hojas fols. inclusis las cuatro primeras que no están numeradis.-De esta misma obra he visto en el Museo británico otra edicion hecha en Valladolid, en casa de Diego Fernundez de Cordoua. Año de M.D.Lxxvij. 12. 4 hojas de Tubla y prels. y 199 fols. Me parece será el mismo libro el que cita Nic. Antonio en el articulo de Se. púlveda, con el titulo de olros Romances sacados de la Historia y de los quarenla Cantos de Alonso de Fuenies. Burgos, Felipe Junta, 1579. 12. : y aun sospecho como el $\mathrm{Sr}$. Duran que los Romances sacados de la Historia de España del Rey D. Alonso. Medina del Campo, Francisco del Canto, 1362. $8^{\circ}$ mencionados por dicho Autonio en el mismo articulo, son la primitiva edicion del Cancionero de Romances impreso tambien por C.anto en $15 \% 0$, obra enteramente distinta del Romancero de Sepúlveda, escepto cn las composiciones sacadas de él, y tambien del Cancionero de Rontances impreso en Auvers en $1555 \mathrm{y} 68$.

Brunet describe una Recopilucion de romunces viejos, sacados de las coronicas españolas, romanas y troyanas. Agoro (sic) nueuamente: pur Lorenco de Srpulueda. Alcaln, Fr. de Cormellas y Pedro de Robles, $1563.120^{\circ} 4$ hojas prels. y 169 fols. v observa que de los 112 ronuances alli contenidos solo unos pocos se hallan en la edicion del $\mathrm{Ko}$. mancero de Sepútiedn de $\$ .51$ y 1580 . Parece que en el Repertoris hilingráfico ingles se habla de una edicion de esta Recopilacion impresa ell 1.5.5, lo cual podrá ser un error tipográflco en lugar de 1505.5.

Ticknor en el tom. $\mathbf{3}^{\circ}$, pág. 261 , refiriélldose á Ebert, cita una edicion de 1584: pero no dice donde está impresa. y marca al mismo tlempo que comprende ciento cincuenta y sels romances.

388 SERRANO (Tomas). Fiestas seculares, con que la coronada ciudad de Valencia celebrò el feliz cumplimiento del tercer siglo de la $\mathrm{Ca}$ nonizacion de su esclarecido hijo, y angel protector $\mathbf{S}$. Vicente Ferrer.
Escribialas el R. P. Thomas Serrano. Valencia, Viuda de Joseph de Orga, M.DCC. LXII. 4. ${ }^{\circ}$ marq. Lámina que precede á la anteportada y dos al fin que se pliegan.

La impresion es mui bella $\mathrm{y}$ el frontis $\mathrm{y}$ viôtetas estín grabadas por Galceran $y$ dibujadas por 0. José lergara. - Iti ejemplar es en papel grande.

Tiene el volúmen muchas poesias, entre ellas algunas en valeneiano, escritas por varios ingénios; la mayor parte son anónimas.

Fuster al tratar de esta obra ha formado su titulo uniendo la anteportada con la portada.

389 SEVILlA (Feliciaxo). Segunda y tercera parte de Romances espirituales $y$ Canciones devotas. (Madrid ó Sevilla, 1699?) @ vols. 8.

No puedo fljar el lugar y año de la impresion ni el numero de hojas de que constan estos dos tomos, pues en mi ejemplar ambos están faltos al principio $\mathrm{y}$ al fin.

He visto una Primera parte de romances espirituales, y canciones dewolas, acerca de la obligacion del Christiano. I otras devociones para destiorro de olros inalus. y per. niciosos, que ha introducidn la ma'iciz. Dis. prestos por $F)^{2}$. Feliciamo de Sevilla... Añadida en rstu tercera Impression. En Sevilla, por Francisco de Lecfdacl. Añ de 170j. 8. 8 hojas prels., 4.30 pázs. y una hoja de Tabla.

Es obra del genero de los Conceplos de Ledesma.

390 SILVA. Sylva de varios romances. Agora de nueuo recopilados los miejores Romances de los tres libros de la Sylua, y añadidos los de la Liga. I en esta vitima impression van añadidos, el de la muerte del Rey D. Felipe II. y el despedimiento, $y$ embarcacion dè la infanta Doña Ísabel de la Paz Archiduquessa de Austria, Y los quatro de D. Aluaro de Luna. I ures Romances de la enfermedad y muerte del Rey Don Felipe Tercero. Barcelona, Sebast. $\mathrm{y}$ Iayme Materad, 1636. 12. 168 fols. incluso el frontis y una hoja sin foliacion para terminar la $\mathrm{T}$ abla.

D. Agustiu Durau en el Catálogo puesto al fin de su Romancero supone ser ta edicion de 16.56 más copiosa que la de 167.5 , y en ello tiene razon, pues esta no contiene los ro. mances de la liga, los de lat muerte de Felilipe II, el despenimiento, los de U. Alvaro de Luna ni los de la enfermedal de Felipe 11: en canibio ell la de Zararoza se ellcuentran al fin algunos Villancicos $y$ canciones $y$ los romances de Piramy y Tisbe, del Infanle 
Troco, el de Moriana y el de Leandro que no tiene la de Barcelona.

\section{SILVA de varios romances.} Aora nuevamente recopilados por grares Autores, de los tres libros de la silva, con ciertas canciones, y chistes nuevos. Zaragoca, Ilerederos de Pedro Lanaja, 16 3 . 12. 2 2 hojas prels., 111 foliadas y una de Tabla.

Al fin del tomo hai varias hojas intituliudas cancionero de enmmorados, que contienen villincicos y Canciones.

Esta colicion lienc al principio ma licenaia dadi a los libreros Círlos de Labayean y Julm de Lartumbe, para poder imprinir la obra, fichada en Zaragoza en lió, y adenlas hai ntro permis, para el nismo efectu concelido pll Ituesea en 162\%. Esto coufirma la existencia de las ediciones de dielos pumtos heclias en los anos indicados, descritas por Juran en el Catiloyo de sir Romancero.

Brmet en el Yamuel du libraire mencinna la edicion siguiente, la cual he visto annque no tome su deseripcim biblígrafien. Silna de rorios romances, en que estan recopilalos la mayor parte de los romances custellanos que hasta ayora se han compm:silo. hay al fin alymas cunciones: cophlas fritciosas y sentidas. Impressa en laragisa por stevan $G$. de Vager'a, en esto iño ile M.L.L. 2 vols. 2i. ${ }^{\circ}$ let. got. Iims. de madera. I.a furmera parte tiene 5 lojas plels, y cixis fols., la segunda cciij fols. y le sin toliateinn.

El sabio aleman D. Foruamdo Jose IV inl,

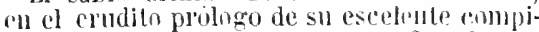
lacion intitulala: Primatera y f $w^{2}$ de romances, habla estensamente de esla dicion, y al mismo tiempo cila otri de barcelonu, inapresa por ledro Borin, en el mismo aibo de 15.50 , la cual solo contiene la parte pri. mera de la zaragozana.

Silua de varios romances: En llus eslan reopilados la muyor purte de los romances castellanos, y afora muezanente añadides en esta segunda impresion que munca "un sido estampados. Hay al fin Hymas coiriones v'llacicos y coplas, y lambien se an añudido chesta imomeston algunas rosus semlidas, sucades de dinersos anctores. (Iiarenlona, Jamme Cortey, 15.57. 12. let. gúl. 210 fols. y i hojas de Tabla. Brmet.-Segun el indicado sr. Walf es leimpresion cxacta de la de Barcolona, 155t, y pur consiguiente copia de solo la mimera parfe de Ia edicion principe, con algunas supresiones $\mathrm{y}$ adiciones peculiares de ella.

Silua de varios romances recopilados, !) con diligencia escogidos de los mejores romanes de lo: lies libros de la Silla. y agor't mevanuente añadidos cinco romances de la

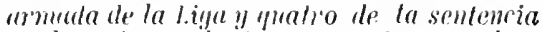

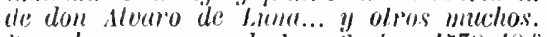
litrecelona, ch asa de Jom Corlen, 1578. 12." En todo 192 hojas. Brumet.
Wolf menclona la de Barcelona, Jayme Sendrat, 1582, y Duran dice ser on $12 .^{\circ} y$ que tiene 172 fols. de testo.

Silva de varios romances. Agora de nuevo recopilados los mejores romances de los lies libros de la Sylva, y añadidos los de la Liga. Barcelona, 1602. 12." Brunet.

En el Calálogo de la Biblioleca real de Pa. ris y en las notas á la Introduccion del Romancero do bepping se menciona una edicion de Barcilona, Sebaslian Cormellas, 1611. 8. añadiéndose en la noticia dada en ( Catílogo, que su editor es Jilan Tiar!e, lo cual me hace suponer serí el contenido de esta edicion jugual al de la de 1617 que describiré despues siguiendo el úrden cronoló. gico de las meneionadas por Brunet.

Sylla de varios romances. Agoru de nuevo recopiludos los mejores romances de los tres libros de la Sylua, y añadidos los de la liga. $Y$ 'n esta última impressimn van añadidos $\mathrm{cl}$ le li muerle del Rey D. Felipe II. Barcelona, Gabriel Graells, 1612. 12." 168 hojas en todo.

La misma obra con la advertencia: $Y$ en esta villima impression van arialidos el de la muerte del rey, y el despedimionto y deseubarcacion de la Infanta doñu Isabel le la Pas; compuesto jor Juan Tia'te. Barcelona, en casa de Sebastian de Cormellas, 1617. 12.

Wolf nenciona otra tambien de Barcelona, por Juan de Larumbe, 1617 ; pero me choca el nombre de este impresor en Barcelona; y efectivamente Duran dice que la edicion es de Zaragoza.

- Igora de muno recopiladis los mejomes Romáces de los bres lifros de la syluı, y añalidos los de la Liga. Barcelona, Iosef Foreula, 167. 12." 167 hojas fols. y 1 de tabla. Iicimpresion de la de 1636 que poseo.

Depping en las Nolas á la Introduccion de su Romancero menciona otra edicion de Jaen, 1696 , en $12 .^{\circ}$, la cual dice tambien en su titulo: En esta uillina impresion van añadidos el de la muerte del rey Felipe II. ete.; y yo he visto una de este mismo año, $169 t ;$, impresa en Barcelona por Iosef Casararhs en 12. ${ }^{\circ}$ de $16{ }^{\circ}$ fols. inclusos el fróntis y la rillima hoja que es de tabla y no está numerada. En la portada de la edicion se leia: añadidos ol de la muerte del rey D. Felipe II y el despedimienlo y embarcacion de... Doña Isabrl ile la Paz... y los quatro de D. Alvaro de Luna y tros romances de la enfermedal y muerle del Rey Don Fulipe II. (deberia decir III pues á él se refieren y no al Il de este nombre).

Duran en su Calálogo cita ademas la edicion de Jaen 1636 . 12. ${ }^{\circ}$ que probablemente serí la de 1696 indicada por Depping.

En el Cancionero de romances se hallan algumos de los que rontiene la Silva; ammque con muchas variaciones y ménos completos; pero los más no estáll en aquel ni en el Romancero general. 
392 SOLA (Raimundo DE). Llanto fvnebre, con que la nobilissima Civdad de Barcelona,... llorò la mverte de la Serenissima Señora, y Keyna nuestra, Doña Maria Luysa de Borbon. Sacale a la lvz de in desenga. ño e] Dotor Raymuŕdo de Solà. Barcelona, Imprenta de Cormellas, por Iayme Cays, (1689). 4. ${ }^{\circ} 6$ hojas prels., $116^{\circ}$ pags. $y$ al fin 8 hojas sin foliar para los Sentimientos devidos etc. Dixoles el Dotor Raymundo de Solà.

Tiene muchas poesias latinas $\mathrm{y}$ castellanas de varios.

SOLEMNES obsequios de la Com- pañía de Jesus y su Colegio de San Pablo de Granada. Véase en la Seccion dramálica.

393 SOLEMNIDAD funebre; $y$ reales exeqvias, qve executó la Ciudad, y Gran Puerto de Santa Maria, por la muerte del... rey Don Carlos 31. Celebrados en los días 28 . y 29 . de Noviembre de 1700. Cadiz, Christoval de Requena, 1701. 4. ${ }^{\circ}$ Lamina en fól. del túmulo. 6 hojas prels., una de Erratas y 121 págs.

Comprende poesias de varios, aunque la mayor parte son de D. Juan Francisco de Enciso y Monzon.
394 TírRega Francisco). Relacion de las fiestas qve el Arçobispo y Cabildo de Valencia hizieron en la translacion de la Reliquia del glorioso $\mathbf{S}$. Vincente Ferrer a este santo Templo. Sacada a luz por su devocion y mantenimiento, por el Doctor y Canonigo Francisco Tarrega. Valencia, Pedro Patricio Mer, 1600. $8 .^{\circ} 330$ págs. inclusas las dos de la hoja de la portada, y al fin una para las Erratas y repelir las señas de la edicion.

Este tomo es todo èl un Cancionero i coeccion de poesias castellanas y valcncianas de los poetas nuás célebres de aquella épnca, segun lo deniuestra la siguicnte nota de sus nombres: 1). Jerónimı y v. Gaspar Mercader, J. Bta. Asoris, Estévan Burgués, Antonio Juan Ferrảndiz, Bautista Ferrer, Gregorio Ferrer, Estacio Gironella, Francisco Juan, J. Bta. Insa, Fernando Ixsar, Lozano, Blas Marco, Vicente Martinez, Estévan Martínez, mosen Muñoz de Peregrina, Juan oliver Pinero, Jaime orts, Andres Pérez, José l'crez, Jaime Ponce, Pedro Ralfes, Juan Tafalla, Vicente Tristan, Dr. Virues, Cárlos Boyl, Melehor Orta, Miguel Ribéllas, el canónigo Tárrega, Gaspar tguilar, Jerónimo de Ileredia, Gaspar Escolaro, Luis Caraller, Jusepe Rostojo, el l)r. Nủnez y Lorenzo balenzuela.

Nic. Antonio omitio en su Biblintheca í Francisen Tírrega, autor de nuturbs y mi buenas obras, celebrado por Cervántes en el prólogo de sus connedias y en el cap. 48 de la parte primera del Quijote, al bablar de la
Enemigu fannable. Tambien lupe de Vega en su Laurel de Apolo dice:

Al siempre claro Turia

hiciera Apolo injuriu,

si no ciñera de oro justamente.

del Canowigo Tírrega la frente;

Que ya con su utemoria ulargu el puso.

Paru subir' al Palin y "l'arnas",

Com Gaspar Aguilur, que competia

Con él en la dramiálica poesia.

sobre el mismo asunto que trata el toun publicado por Tárrega he visto un oprisculo, compuesto de dos rumances, cuyotitulo es: Recibimito do la santissima reliznia del glorissu sint Vicenie Frorer. que se linxo ph la venturosu cindnd de falencin: con intor't noticiu de las nuchas lominurios, fieslas, galas, inlenriones. $y$ solene mroressim que se hi:'s en dicha ciuclud. Faléria, junlo al molino de Rouella, $1600.8 .{ }^{\circ} 8$ liujas.

TERRALLA Y LAN])A Estéras DE). El sol en el medio dia. Yéase en la Seccion dramatica.

395 TESORO DE DIYIXA POESIA. Primera parle del tesoro de divina poesia, donde se contienen varias obras de deuocion de diuersos autores. Hecopilado por Esteuan de Villalobos. Madrid, Luys Sanchez, M.DC.H1I. 8. 8 hojas prels., 167 foliadas y una al fin para repelir el lugar y año de la impresin.n.

Comprende los tritimlos siguiontis:

Sumbe de la vida tes. Finncive en estancias, por 1 . Lope de salinas. 
Breve suma de la comersinn y vida de la. gloriosi Madalena, en estancias, de incierlo anlor.

La sugrada pasion de Jesu Christo, en redondillas, por Fr. Pedro Juan Micon.

El llanto de S. P'ello, compursto en estanrias italiomas por Luis Tansillo, raducido en redondillas, for Luis fílvez de Vontalvo.

Sátiras morales en arte ma!nor y redondillas, por Alvar liomez. (Som siole.)

Rominnce de la mutrete de Cristo, d manera de teslumento.

Volumen lim escesivamenle raro que Mayans, eu el Prólogo del l'astor' de Filidat, al hatblar de la version de las Jayrimas de S. Pr(l), de llomtalvo, menciona lit edicion de ellas hecha en Toledo, l.587: pero nada dice de li presente por no haberla conocido; y al terminar el ciladı Prólogo, anade: $y$ s si se lograse la dicha te descubrir lus poesias que publicó Montalvo de las Lágrimas de San l'edro y de la Paslon de Jesucristo señor unestro, tendria mi trabajo por remunerado colmadamente.

No he visto vingun ejemplar de la edicion le Toledo, 1:887, cilada por sedano en el tomo I. del Painaso español, y mencionada lambien por vic. Antonio en el artículı de P'edro Juan Micos o Mico, como le llama Hodriguez, cul su Biblioleca, donde deseribe ulia wilicion de la Pusion cle Crislo hecha rll lalentia, por Jllatl Vitrillorn, 1582, en $x^{\circ} .^{\circ}$

Tuve ocasion de ojear ripidammle la edicion del Thesoro de divina jo:'va, impresa en Lishoa, Por lorge Rodrighes. Iitg. 8. 8 lojas proliminares y 125 fols. y in: parece no contenia el Romanse á la maerte de Cristo.

\section{Elillete de Amor.}

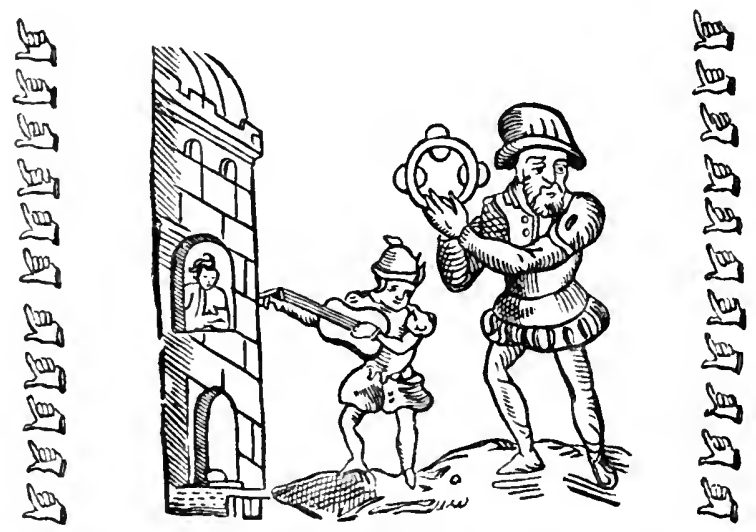

\section{TiLancionero llamado Tille re oe Zamoz:cōpuefto por 3Baptíta 4 on tidea.E्Enel qual fe contienen Tanciones, Cillancicos,p otras obas biuerfas.}

\section{[Dirigio al mun experto, y anisado lo- fo fang Onirosillo đruban exalliuado ell Gorte. \\ đ[ Hende $\mathfrak{s e}$ en casa de Toan Timoneda, Allercader de libros.}

Copia dé la portada de este opuisculo: en el recerso de la viltima hoja se lee: Fin del primer quaderno.) 8 hojas sin fol. con la sing. a. 
Uillete de amor. (Sigue una laminita que representa $\dot{a}$ un hombre de medio cuerpo.) I Enfados de muy grandes auisos, y prouechosas sentencias, nunca ímpresos, ni vistos hasta agora. Puestos a gesto por Montidea (Timoneda), grande amigo de Diamonte (Timoneda). I Dirigidos al muy experto etc. (Como en el anterior.' 4 hojas.

I Coplas en que se trata como Diego Moreno el $\bar{q}$ otro tiempo tuuo tanto descuydo de su muger: agora la mata de celos. SSigue una laminita que representa á.Diego Moreno y su mujer y á un caracol que con los cuernos mui erguidos se le sube por la pierna al pacientisimo marido.) \& hojas. Estos dos últimos folletitos llevan la sig. b. En todo son 16 hojas. S. I. ni a. Pero indudablemente impreso en Valencia hácia 10̈65̆.) $8^{\circ}$ let. gót.

El primer cuaderno contiene nueve canciones y un villancico, y el segundo los enfados, composicion ell tercetos, y de ellos copio los siguientes como muestra:

Enfádome del viejo que se casa

Con moza de quince años, y no entiende,

Que pone hambre y sed dentro en su casa.

Enfádame mujer arrebozada,

Que vielve y se revuelve á cada paso,

Por llevar el bobillo á su posada.

Enfádome que veo unos galanes

Casarse con sus madres por el dote,

$Y$ andarse papavientos holgazanes.

Enfádame una falsa lagrimita

De viuda que llorando está al marido,

Miéntras que-otro maridi) solicita.

Enfádanme las duenas y doncellas,

Que están á media noche á las ventands.

Y no sé si coiljuran las estrellas.

Enfádame un viejazo enamorado

Que tizna su cabello, y con nlores

A todo hombre de bien tiene enfadado.

Enfádame el galan de amor llagado,

Que dice de su dama, por jactarse;

Aquelln que no hizo, nl alcanzado.

Enfádame el capon ó mazacote,

Que quiere sustentar contino amiga,

Y slempre sin comer paga el escote.

A los enfados siguen otros tercetos de Montemayor que principian:

Pasaba amor, su arco desarmado, Los ojos bajos, blando y mui inodesto. Dejándome ya atrás mui descuidado.

A continuacion vienen las Coplas de Diego Moreno; despues otras quejondose su mujer y termina con una cuncion que comienza:
Gózate de tu hermosura, Zagala, y date á placer, Que lugar, tiempo y ventura Siempre falta al menester.

Obras todas desconncidas á Nic. Antonto, Jimeno, Fuster y Cerdá, en las Nolas á lá Diana de Gil Poln, y mi ejemplar, bellisimamente conservado, es el único de cuya existencia tengo noticia.

Notaré aqui porque son del mismo génerı c igualmente raros los siguientes folletitos descritos por el Sr. Wolf en su advertencia á las Rosas del misino Timoneda.

Cancioner" llado (sic) Enredo de Amor. Agora nuevamente compueslo por Joan Timonedr en el qual se conlienen Canciones Villancicos. y otras obras no vistas. Año. 15̄̄õ. Vende se en casa de Joan Timoneda.

(Este titulo se halla bajo una lámina en madera que representa un pescador, circuido de la leyenda: Con sofrimienlo y callar suelo pest:ar. - Al blanco de la hnja Xil dice:)

Impresso en Valencia, en casa de Joan vauarro.

(La tabla ocupa el reverso.) 12. ${ }^{\circ}$ let. got.

Cancimero llado'sic) Guisadillo de Amor. Agora nueuamenle compueslo y guisudo por Juan Timoneda de diuersos Auctores, para los enfermos y desqustados anadores: en el qual se continen (sic) Canciones y eslraĩisimas Glosas. Vende se en casa de Joun Timoneda.

(Lo que precede bajo de una lámina igual á la que lleva el Cancinnero llamado Enredo de Amor, ántes descrito, y en la pág. 1 de la hoja XII se lec:)

Impresso en Valencia, en casa de Joan $\mathrm{Na}$ uarro. s. a. (probablemente de 1573 ).

(El reverso de la última hnja lo llena la Tabla.) 12..$^{\circ}$ let. gót.

El Truhanesco copilado por Jian Timone. da, en el qual se conlimen apazibles, "I araciosus Canciones, para canlar. Con loilas las obras del hourado Dipgo Moremo, que. hasta aqui se han compuesto. dro 1573. Ven. de se on casa de Jnan Timoneda.

(A este títılo precede la misma limina ym. llevan el Cancionero llamado En'edo sle Amor' y Guisalilln de Amor.-Signen Xll hojas f.liadas conteniendo el reverso de la última la Tabla, al fin de la cual se lee:)

Impresso en Valencia, en casa le Joan Nauarro. 12. ${ }^{\circ}$ let. gót.

Este Diego Moreno es sin duda un ente imaginario con el cual se queria denotar un marido paciente, $y$ así lo indica el verse en la laminita que lo representa en las Coplas puestas al fin del Cancionero llamalo villele de amor, in caracol con los cuernos mui erguidos pareciendo querérsele subir por una pierna.

Debn observar que si dice ser en $120^{\circ}$ ios tres tratados acabados de mencionar y el descrito á continuacion, es por haberles asignado Wolf este tamano, en la ddvertencia á la 
Rosa de romances, de donde yo he sacado la descripcion; sin embargo, sospecho se equiroea el autor aleman, pues lo probable es que sean en $8 .^{\circ}$

Falla la primera hoja que probablemente contendrá el froutis y el principio de la materia; llevan las píginas el epigrafe siguiente: Derchado de conlures.

Concluye la obra en el blanco del fol. Xll, donde se lee:

Iminesso ch Vulencia, en casa de Joan $\mathrm{Na}$ uavo.s.u.

(1l reverso se halla la tabla.) $12 .^{\circ}$ let. gót. Comprende doce villancicos dirigidos á olras timtas danias que salen restidas en hilitios de diforentes colores, cuyas signiflcaciones simbolicas se explican: romo p. e.: si sule la dlma de lmarilto, denota desespróacion.-Anidense í estos villancicos un Pomante de amores, agor'a mu'uantente compuesto, sobre aquel subgecto que esta cn la Fontuna de anmo, do se quexa la lengua de los njos, y los ojos del corecon: comi las delicalas sentencias que les du cupido. Una: Cancion por descrlu, y un mote glosado que dice: Esle Wole se 'gluso, por'ine que-

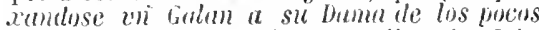
funores gur le las:ia, le respondio esle Wole. bomde las toman las dom.

llasta aqui la desopipeion de esle opieseulo hecla por Wolf, dobjendo yo añalir que si lo altibuyo á Timonodil es por halliuse enenalepradi, con los lolletitos anteriores del misme remera, compuestos pol dich $r$ antor é impresos tambicn por lavarro.- En el Cancior ntro de' Jaían's lecopilarlo por biege de Vera encuentro mas: Canciones sobre diuersos colores, y las significaciones dellas. Son quince villancicos al sermmio de los enales lieva el vimuiente epigafe: si sule la dama ar finarilo, denota ilesesperacion, ilentico al citidlo por Wolf, y esto me hace creer que sorá reanpesion del tratadito de Valmeia con la adicion de alsun villancico ú color.

nialiue como complemento á esta mota de Cancioneritos de fimmedil el siguiente riLado por Jimeno: El Cabañera Camrionero. En ralencia, por l'ello Inele, 1570. 8."

397 TIIONEDA (JaA) . Rosa de Ronances, o Romances sacados de las Rosis de Juan Timoneda. Escoridos, ordenados, y anotados por Don Fernando José iVolf. Leipsique; F. A. Brockhaus, $1816.12 .^{\circ}$ fr. marq. Portada de negro y colorado.

Lus ejomplares llevan una segunda portada dinde se copia el titulo del Romancero castellome de Depping g se le llami Tomo tercero de diclio Romancero.

precole a este tomito ma advertencia del cdilur Winf y pul alla se ve que Timoneda

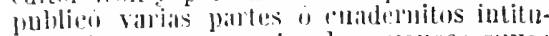
lados Roses, complestos de romances shyos y ilnumos ajems de los cuales el literato ilentan entresaco los a su parecer mejores y dejo de publicar una gran parte, ya por hallarse en otras colecciones, ya porque los juzgó de poquisimo interes ó mui inferlores en mérito literario.

Copiaré aqui la descripcion dada por dicho $\mathrm{Sr}$. Wolf de la edicion original, siendo un libro tan raro que solo se conoce de él un ejemplar en la Biblioteca imperial de Viena.

Rosa de amores. Primera parte de Romances de Joan Timoneda, que tralan diuersos, y muchos casos de amores. Dirigialos al discroto Leclor.-Impressos con Licencia. Año 1573. Veuden se en casa de Joan Timoneda.

(En el fol. LXX vuelta se lee:)

Fue impressa esta mimera parte de Romances en Ia Insigne Cindad de Valencia. En casa de Joan Valuirro. Año MDLXXII.

Rosa Española. Segumda parte de Romanees de Joan Timouedn, que Trulan de Hystorias de Españu. Dirtigidos al prudente Lector.-Inpressos con licencia. Año. 1575. Venden se cn casa de Joan Timonedis.

Esla segunda parte ocupa 95 hojas foliadas. En el blanco de la XCV priucipia la $\mathrm{Ta}$ bla, que abraza una hoja mas sin foliatura. Vin lleva fecha ni nombre de impresor al fin, pero no eabe duda es del mismo que la anterior.

Rosi. gentil. Tercera parte de Romances de Joan de Timoneda, que Iratan hystorias Rolilanas y Troyanas. Dirigidos al curioso Lector.-Impressos con Liechicia. Año. 1573. Venden se en rasa de Joun Timoneda.

(Eu el reclo del fol. L.XXl dice:)

Imprimiosse en Valencia, en casa de Joan Namaro. 1575.

En el reverso de dicho fol. 71 comicnza la Tabla que neupa una hoja mas sil foliacion. Rosa Real. Guartu parte de Romances de Jom Timomedr, que h'utan de casos señalados de Rryjes, y otras personas que han teni(b) curgas imporlanles: assi como Principes, risurreyes, y drcobispos - Impressos con licencin. dĩo. 1573. Venden se en cașa de Jomin Timoneda.

(Il fin se lee:)

Imprimiose esla quarta y vllima parte de Rosa de Romances en Valencia, en casa de Joan Nalutroro. Año 1573.

Coinsta csta parte de 83 hojas foliadas y una de Tabla sin numeracion. 12. ( Tal ves $8 .^{\circ}$ ) let. goil.

398 TOMAS (Miguel). Certamen poetico, en honor de la Venerable IIadre Sor Catharina Thomasa... mantenido en la isla, y Civdad de Mallorca... Sacado a luz por sv sobrino el Dotor Miguel Thomas. Barcelona, Gabriel Nogues, 1636. $40^{\circ} 9$ hojas prels., la segunda es la imágen de la Venerable; ademas de un retrato en marlera, que va al reverso de la novena, $y 133$ hojas foliadas, seguidas de otra, en que concluye el Indice; al fin vuelve á repetirse el retrato. 


\section{VAL ANTOLOGIAS Y}

No llevan los nombres de sus autores las varias poesias castellanas, catalanas y latinas de que se compune esta obra, no conocida por Nic. Antonio.

TORRE Y SEBIL (Francisco de LA). Luzes de la Aurora y Reales fiestas á la imágen de la Virgen de los Desamparados. Véase en la Seccion dramática.

399 TORREJON (Tomas ne). Parentacion Real... en las Reales Exe-
VAL

quias del Serenissimo Señor Don Lvis I... en la Iglesia Metropolitana de Lima. Escribiola... el R. P. Thomas de 'Torrejon. Lima, Imprenta de la Calle de Palacio, por Ignacio de Luna y Boborquez, $172 \%$. $4 .^{\circ}$ marc. 3 hojas prels. 160 fols. y 31 hojas sin foliar con las signt. Ss hasta Ccc para la Oracion fúnebre del $\boldsymbol{P}$. Alonso Messia.

Contiene poesias latinas y castellanas de varios autores, todas de pésinno gusto.
400 VAlda (Juan Bautista de). Solenes fiestas, gre celebro Valencia, a la immacrlada Concepcion de la Virgen Maria. Escrivelas Ivan Bavtista de Valda. Valencia, Geronimo Vilagrasa, 1663. 4. ${ }^{\circ}$ Liminas $y$ viñetas de cobre. lna hoja de anteportada grabada, 17 hojas prels., 632 págs. y 112 de nueva paginacion para el Sermon del Doctor Melchor Fuster. Las láminas son contadas para la paginacion.

Contiene poesias castellanas y valencianas; todas anonimas.

Nic. Antonio no espresa el lugar ni año de la edicion.

VAldes (Pedro Clemexte). Amphitheatro sagrado. Véase en la Seccion dramática.

401 VALDIVIELSO (José DE). Primera parte del Romancero Espiritual, en gracia de los esclauos del santissimo Sacramento: para cantar quando se muestra descubierto. Por el Maestro Ioseph de Valdiuielso. Valencia, luan Chrysostomo Garriz, 1613. 12. 10 hojas prels., 279 poigs. $y$ b hojas, en que terminan las Tablas.

Debe ser segunda edicion, la primera lleva el mismo titulo, y está impresa en Toledo, viuda de Pedro Rodriguez, 1612. 8. 12 hojas prels. 165 fols. y 7 de Tablas. La tercera será probablemente la de Lerida, Luys Manescal, 1616. pequeño $180^{\circ}$ y se halla en el n. $1578 \mathrm{del}$ Catálogo de la venta de Taylor; Brunet la describe $\mathrm{y}$ dice que es pequeño 8.
402 VALDTVIELSO (JoSÉ DE). Primera parte del Romancero Espiritual, en gracia de los esclauos del santissimo Sacramento: para cantar quando se muestra descuhierto. Por el Maestro loseph de Valdiuielso. Añadida y enmendada en esta impression por el mismo dutor. Toledo, Diego Rodriguez, Año 1618. 8. 12 hojas prels., 28 fóls. y 8 de Tablas.

Lo dicho en el fróntis acerca de estar añadiula esta ruarla edicion es positivo; sus catorce primeras composiciones y las sicte últimas no estim en la segunda de Valencia que posen, í imorn si se hallarín en la de Lérida.-Al principio de estas dos inprosiones de Valencia y Toledo, entre otras comprsiciones laudatorias en verso, hai una de Elisio de Medinilla.

La quinta edicion la trae Brunet $y$ es de Madrid, Vinda de Alonso Marlin, 1627. 8. ; la sesta, segun Böhl de Faber, se hizo tambien en Madrid en 16:s; he visto la sélima de $\mathrm{Al}$ cala, Maria Fernandes, 1655. 8. ${ }^{\circ}$ \& linjas prels. y 192 fols.; y los traductores de Boulerwek, en la päg. 218 del tum. 1. ${ }^{\circ}$, hablan de la octava de 1659 .

403 - Romancero espiritval, en gracia de los esclavos del Santissimo Sacramento, para cantar, quando se muestra descubierto. Por El Maestro Ioseph de Valdiuielso. "Añadido y enmendado en esta vltima inpression por el mismo Autor. Madrid, Melchor Sanchez, 1663. 8. 8 hojas prels., 183 fols. y una con las señas de la impresion y la fecha. 
No debe ser exacto lo de estar adicionada la presente novena edicion por el mismo autor; pero lin cierto es que al fin de ella encuentro euatro composiciones que no están en la de 1618, y mucho ménns en la de Valencia, 1615; miéntras en ambas se hallan al principio poesias laudatorias de varios, omitidas en la de 1665 .

Llevamos ya nueve ediciones descritas de esta obra: he visto la décima de Alcala, Muria Fernandez, 1668 . 8. 8 hojas prels., I8\% fols. y una hoja al fin con la fecha, la cual tal vez sea reimpresion á plana renglon de la de 1663 , pues tiene igual numero de hojas. La undécinia y última la he tenido presente, es de Valencia, Juan Lorenço Cabrera, 1680 ú 89 , pues no estaba claro en el ejemplar, $8 .^{\circ} 3$ hojas prels. y 559 págs.

Todas las impresiones de este Romancero son mui laras, sobre todo las cinco primelas; no es por lo mismo estraino, el que no se halle citado en el catálogo de dncumentos puesto al fin del suyo por el Sr. Duran en donde dici cabida á los de Ledesma y Padilla, y que el sr. Barrera Leirado solo mencione una de Madbid, 1612. 8. , euya existencia se me hace sospechosa por no mentar el nombre del impresor, y la única descrita por Böhl de 1648 .

\section{VALDIVIESO Y TORREJON} (D. Miguel DE). Oracion panegirica con que la Real Universidad de San Marcos de Lima, celebrò en su Recibimiento al Exmo. Señor Don Manuel de Amat y Junient. Dixola el Doct. D. Miguel de Valdivieso y Torrejon, el dia 26. de Junio de 1762. (Lima,) Imprenta Nueva, s. a. $4 .^{\circ}$ Portada de negro y colorado. Sin fol., signaturas A-Ll y una hoja de erratas al fin.

Despues de la oracion hai una justa poética y en ella se lcen composiciones de varios autores.

\section{0马 VARIAS, HERMOSAS FLO-} RES, del Parnaso. Qve en quatro floridos, vistosos qvadros, plantaron ivnto a sv cristalina fvente: D. Antonio Jurtado de Mendoza; D. Antonio de Solis; D. Franciseo de la Torre y Sebil; D. Rodrigo Artes y Mvñoz; Ifartin Ivan Barcelo; Ivan Bavtista Agvilar, $y$ otros ilvstres poetas de España. Valencia, en casa Francisco Mestre, 1680. $4 .^{\circ} 8$ hojas prels. y $\mathbf{2 1 6}$ páginas.

Ademas de los autores indicados en la portada, contiene composiciones de $\mathrm{D}$. Onofre Vicente de Ixar y de algunos anónimos.

El Sr. Duran al hablar de esta obra dice:
-Es una buena antología de poesias de todas - clases, de aquel tiempo, mul parecida á la - de Flores de ilustres poelas, que recogió - Pedro de Espinosa á principlos del siglo aXVII.,

406 VEGA CARPIO (Lope Félix DE). Romancero espiritval, para recrearse el alma con Dios. Y redempcion del genero humano. Con las Estaciones de la Via Crucis. Compuesto por Lope de Vega Carpio. Han se añadido en esta impression tres Estaciones y en cadavna delas quinze, quatro Consideraciones muy deuotas. Pamplona, luan de Oteyza, 1624.16. 136 hojas fols., inclusos los prels.

Edicion no mencionada por los editores de las Obras suellas de Lope, ni por Álvarez y Baena, Hijns de Madrid, tom. III. pág. $\mathbf{3 6 8}$.

407 Romancero espiritual, para reglarse el alma con Dios. Y redencion del Genero Humano, con las Estaciones de la Via-Crucis. Compuesto por Lope de Vega Carpio. Quarta impression. Madrid, Pedro Joseph Alonso y Padilla, 1720. 8. 4 hojas prels., 126 fols. $y 2$ de T'abla.

Al fin del tomo se advierte haberse únicamente impreso 250 ejemplares de él, y ser esta edicion la lercera á pesar de decir en el fróntis cuarta.-En cuanto á ser tercera $\dot{0}$ cuarla puede ponerse en duda habiendo datos para sentar la existencia de las siguientes:

1." Pamplona, 1619, segun lo demuestra la aprobacion puesta al principio de la de 1624 .

2." Zaragoza, $1622.160^{\circ}$ La citan los editores de las 0bras sueltas de Lope al principio del tom. XIV, y Brunet.

5." La que tengo de Pamplona, 1624.

4." Madrid, 1625. 8. ${ }^{\circ}$ Segun Álvarez y Baena, tom. HII. pảg. 368.

5." Una que vi sin portada y en cuyo final decia: En Madrid, por Andres Garcia de la Iglesia. Vendese en casa de Iuan de S. Vicente, enfrente de San Felipe $s$. a. (hácia $1680) .16{ }^{\circ} 126$ hojas fols. incluso el fróntis y 2 de Tabla.

6..$^{3}$ Otra, que tambien he tenido presente, impresa sin duda en Madrid, aunque no lo espresaba, $s, a$. en cuya portada se leia: $\boldsymbol{A}$ costa de Iuan de S. Vicenle, Librez"o, en frente de S. Felipe. $240^{\circ} 258$ fols. (quizá fueran páginas) y'uno más para terminar la tabla. Esta impresion y la anterior, publicada por el mismo, debe pertenecer á la última mitad del siglo XVII.

Por consiguiente la edicion de Padilla es por lo ménos la sétima. 
Este Romancero espiritual, obra no men. cionada por Nic. Antonio, se reprodujo en el tom. XV de las Obras sucltas de Lope publicadas por Sancha.

\section{VEGA CARPIO (Lope FÉLIX} DE). Ivsta poetica, $y$ alabanzas ivstas Que hizo la Insigne Villa de Madrid al bienauenturado San Isidro en las Fiestas de su Beatilicacion, recopiladas por Lope de Vega Carpio. Madrid, viuda de Alonso Martin, 1620. 4. 8 hojas prels. y 140 fols.

Reimprimiose la presente Jusla en el tom. XI de las Obras suellas de Lipe de Vega publicadas por Sancha. Comprende composiciones de muchos autores: mencionaré aqui unicamente los nombres de los que no flguran en la lista dada por mi de los contenidos en la Relacion de las fiestas de S. Isidro del mismo Lope, para hacer más completo el catálogo de los poetas españoles que florecieron á principios del siglo Xitt. Los he arreglado por órden alfabético para facilitar su busca, por ser el número algo crecido.

Aguiar y Acuna (Don Manuel).

Almeria (Francisco de ).

Alvarado (D. Francisco).

Arbizo (El Doctor).

Barbosa (El Lic).

Barretı y Mendoza (Domingo).

Botello (Miguel)

Calvo (EI Mitro.).

Campezo (El Doctor).

Castro (Frai Gonzalo de).

Castro y Bermúdez (D. Francisco).

Cordova y Campofrio (D. Juan de).

Cordova y Contréras (El Lic. D. Tomas de).

Cruz (Fr. Jerónimo de la).

Espinel (El Mtro. Vi. cente).

Figueroa (Fr. Loren. zo de).

Garcia (El Bach. Pedro).

Gómez de Salazar (E) Doctor).

Guat (El Dr. Ant.).

Herrera (Jacinto).

Herrera Maldonado (E

Lic. D. Francisco).

Herrera y Sotomayor (D. Jacinto).

Ledesma (Alonso de).
Vega (Fr. Francísco). Vlliamediana (El ConVega Carplo (Lope de de).

de), el mozo. Zenoz (Juan de).

Zúniga (D. Pedro de).

VEGA CARPIO (LOPE FÉLIX DE). Relacion de las fiestas á la canonizacion de San Isidro. Véase en la Seccion dramática.

409 Velasco (Francisco de). I Cancionero de coplas del Nacimiento de nuestro Señor Jesu Christo, para cantar la noche de Nauidad. Compuesto por Francisco de Yelasco... Agora nuevamente con licencia impresso en Burgos, en casa de Juan Bautista Laresio: Año de M.DC.iiij. 4. ${ }^{\circ}$ let. gót. Una viñetita de la Anınciacion y otra del Yacimiento de Jesus. 4 hojas sin fol. con la sig. A.

Contiene:

Coplas que dicen: Oh, cuan lindo es el doncel.

otras: Quien perdio, y yo hallé.

otras: Romerico, tú que vienes.

otras: Alleluya, que es nacido.

otras: Buenas noches, pecadores.

otras: Noche mas clar'a que el dia.

Otras: Hoi ha bajado el pastor.

otras: Bien le lo dije yo, alma.

Dtras: Del inundo y sus flores.

otras: Yira que le mira, mira.

Otras: Guárdame mis mandamientos.

otras: Al mundo ha salido.

Yo menciona Nic. Antonio á Francisco de Velasco ni el Sr. Duran describe este Cancionerilo en su Catdlogo de pliegos sueltos.Cinco composiciones de las doce contenidas en él, las reimprimio Böhl en la Floresta; pero con las variantes y supresiones acos. tumbradas: yo reproduciré una segun se encuentra en el original:

Noche mas clara que el dia
quién la vio?
mi fé, yo no la 2 , no.
En noche caliginosa
tan ilustre arrebol:
de noche salir el sol!
quién nunca vido tal cosa,
loche tan iluminosa:
quién la vio?
mi fé, yo no la vi, no.
De noche el sol de justicia
nace con tal clariddd,
por fugir la escuridad
de aquella vieja malicia.
Noche de tanta leticla,
quién la vio?
mi fé, yo no la vt, no.


Desta noche, sin segunda, el P'salmista nos decia;

que la noche mas que el día daria luz santa y fecunda.

otra noche tan jocunda, quién la vió?

mi fé, yo no la vi, no.

En esta noche nupcial,

el mesmo que la formo,

tanquam sponsus, succedió

de tílamo virginal.

Tal noche en un portal, quién la rio?

mi fé, yo no la vi, no.

410 VILlalta Y NúṄeZ (Francisco Javier). Plausibles fiestas, que en la Provincia de Guaylas Consagró abCatholico Rey de lás Españas el
Señor D. Fernando el Sexto, el Amor, y lealtad del General D. Bartholomé de Sylva. Por D. Francisco Xavier de Uillălta, y Nuñez. Lima, Imprenta de la Calle Real de Palacio, 1749. $4 .^{\circ}$ Una hoja de la portada y 86 págs.

Se encuentran en este volúmen algunas poesias de diversos autores.

VIÑERTA (Tomas DE). El nuevo Sol de la Francia. Relacion de las tiestas que celebró la Compañia de Jesus en la Canonizacion de S. Juan Francisco Regis. Véase en la Seccion dramitica. 


\title{
TERCERA DIVISION.
}

\author{
POETAS DIVERSOS.
}

\section{Comprende tambien esta division las obras que tratan del arte poética, y las relativas á la historia de la poesia.}

\section{$\mathrm{ACU}$}

411 ABREU (Avores nE). Vida del serafin en carne, y vera efigies de Christo San Francisco de Assis. Conipuesta por el Reverendissimo $\mathrm{Pa}-$ dre Mlaestro Fr. Andres de Abrell. Madrid, M. DC. LXXXXII. 4. ${ }^{\circ}$ 20 hojas prels., inclusa una que solo contiene un escudo de armas, y 8í fols.

Poema en ochocienlas reintisiete cuartetas.

412 ACUX̃A (Hersardo De). Yarías poesias, compuestas por don Hernando de Acuña. En Madrid, en casa de P. Vadrigal. 1591..$^{\circ} 8$ hojas prels. y 20 ' fols.

Primera $\mathrm{g}$ bella impresion, smmamente rara.

El editor de la reimpresion de 1804 , descrita en el siguiente articulo, dice, que le Labia servido de original una copiu mamus crila hecha de la edicion de Salumanca de 1591: á la misma se reflere vicolas Antonio sin mencionar el nombre del impresor. $y$ tambien la cita Sedano en el Parmaso español. tom. Il, aunque del dicho de este hai pocó que flar; pero nadie hace mencion de lil de Madrid del mismo año, única antigua en mi opinion pues sospecho que la de Salamanca no es cierta. Sin embargo, aun cuando realmente hava una de esta ciudad. no cabe duda en ser la madrileña la primiliva, porque en ella se encuentran los privilegios para Castilla $y$ Aragon fechados en 1589 y 90 en los cuales se concede licencia á la viuda de Acuĩa para dar á la estampa las Poesias de su marido $y$ el Caballero determinado, hallándose iguales documentos al principio de esta última obra que tambien imprimio $P$. de Madrigal en 1590 : parece, pues, lo más natural que el mismo tipógrafo à quien empleo Doủa Juana de Zúñiga para la ejecucion de aquel

TOM. 1
A $\mathrm{AGU}$

libro, publicase las Poesías de órden de dicha señora.

113 ACUÝa (Herraxdo de). Yarias poesias. Segunda edicion. Madrid, Sancha, sidcccIr. 8. ${ }^{\circ}$ narq.

Si realmente hubiese una cdicion de Sula. manca de 1591, la presente no seria segunda sino tercera.

41 ADA.VE DE MONTE.HAYUR (Fraxcisco). Tacimiento, rida, I inverte del Apostol S. Pedro, Principe de la Iglesia. Por el Licenciado Francisco Adame de Montemaror. Toledo. Pedro Rodriguez, M.D.xcriII. 4. 4 hojas prels. y 298 foliadas.

poema raro en reinticuatro cantos, escrito en octavas.

1130 AGLIL.AR (Gaspar). Exprlsion de los moros de España por la S. C. R. Magestad del Rey Don Phelipe Tercero. Por Gaspar Aguilar. Valencia, Pedro Patricio Mey, 1610.

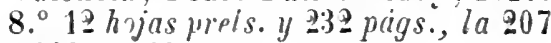
y 208 son blancas.

Poema eu octaras dividido en ocho cantos.

Libro mui raro $y$ tan difieil de encontrar completo que de los dos i tres ejemplares que he risto solo el unio está perfecto. lie. comiendo por lo tanto la cuidadosa colacion del numero de hojas, pues gemeralmente suelen faltar, la hanca que se halla despues de la pág. 206, í que corresponden las $20 \overline{7}$ y 208 y todas las siguientes basta la pig. 252. Contienen estas liojas ocho composiciones latinas $y$ una griega en loor de Felipe III, con motivo de la espnlsín. is están eseritas por 
D. Antonio Coloma, Vicente Mariner, Felipe Corvi, Miguel Antolin y Fr. Juan de Mayorza. Ni Jimenn ni Fuster citan las de Antolin y Mariner, al hablar de las obras de estos, y no encuentro en sus Bibliotecas los nombres de D. Antonio Coloma, Felipe Corvi y Frai Juan Mayorga.

A propósito de la obra de Aguilar mencionaré aqui un folletito en verso, descrito en el Catálngn de Grenville cuyo título es: Rela. cion verdadera de las causus que su Magestad ha hecho aueriguur, par'a hechar los Moriscos de España y los bandos que se publi. caron en el Reyno de Andaluzia, por el Marques de San German: y de los moros que auia en Seuilla para leusntarse. Caragoça, por Lorenco de Robles, 1611.4."4 hojas.

416 AGUilar (Gaspar). Fiestas nvpciales que la civdad y reyno de Yalencia han hecho en el félicissimo casamiento del Rey don Phelipe nuestro señor III. destè nombre, con doña Margarita de Austria. Por Gaspar Aguilar. Valencia, Pedro Patricio Mey. 1599. 8. 4 hojas prels., $13 \ddot{3}$ págs., la última dice equivocadamente $333, y$ dos más sin numerar que contienen tres sonetos y las señas de la impresion.

Poema en octavas, dividido en cuatro cantos.

Obra tan rara que no la mencionan Gallardo ni sus adicionadores on el Ensayo de uma bib. esp. al hablar de las producciones de Aguilar; y es libro curiosu por la minuciosa descripcion que da de los trajes que ostentaron, $\mathrm{y}$ las justas y torneos que mantuvieron los principales caballeros de Valencia, con motivo de las fiestas celebradas al casamiento del monarca espanol.

Vense en este tomito algunos sonetos de Guillen de Castro, Maximiliano Cerdan, Franclsco Juan Pintor, D. Carlos Boil y el Doctor Virues.

\section{AGUIRRE Y SANTACRUZ} (IÑao DE). El heroe sacro español Santo Domingo de Guzman. Elogios a $\mathrm{sv}$ vida, y prodigios cifrados à Numeros de lietro Castellano. Afectos no emprendidos del Genio, sino inuentados del Amor. Clausulas si no atentas à las urbanidades poeticas, Felices en el sagrado riesgo del Assumpto. Consagra este culto Religioso Don Iñigo de Aguirre y Santacruz. Madrid, Diego Diaz de la Carrera, M.D.C.XLI. $40^{\circ} 8$ hojas prels., inclusa la que precede al fróntis con las armas dominicanas, $y 34$ fols.

Poema en cuartetas, dividido en dos estu. ciones $\dot{0}$ romances.

La simple lectura de la portada hará conocer el pésimo gusto con que estí escrita esta obra.

Precede al fróntis una hoja la cual solo contiene el escudo de la orden de Santo Domingo, grabado en madera. Suele este faltar en los ejemplares, y sin duda por esta razon Gallardo en el Ensayn de una bib. esp., solo da á este tomo 7 hojas prels. en vez de 8 que son las que le corresponden.

418 airolo Calar (Gabriel DE). Lavrentina Poema heroico de la victoria naval que tuuo contra los Olandeses don Fadrique de Toledo Osorio, Marques de Villanueua de Balduesa, Capitan General de la Armada Real del Mar Occeano, y gente de guerra del Reyno de Portugal, en el Estrecho de Gibraltar, el año de 1621 - dia del inclyto Martyr Español San Laurencio. Cadiz, Iuan de Borja, 1624. $8{ }^{\circ} 8$ hojas prels. y 75 fols.

Poema en octavas y en nueve cantos, des. cnnocido á Nic. Antonio, á Gallardo, Zarco del Valle y Rayon, pues no lo mencionan en el Ensayn de una bib. esp. al hablar de este autor y de sn Pensil de Apolo.

Airnlo Calar fué natural de Méjico y su libro está escrito en octavas fáciles.

419 - Pensil de Principes, y Varones Ilustres. Por el Doctor Don Gabriel de A yrolo Calar. Sevilla, Fernando Rey, 1617. 4. $^{\circ}$ El verso de let. curs. 8 hojas prels. y 52 fols.

\section{Libro raro.}

Entre las varias compnsiciones en verso que contiene este tomo, hai una cuyo titulo es: Al Rey Don Felipe nuestro señir, dandole quenta de la inundacion de Mexico, desague, $y$ discrepcion de su laguna; y más de la mitad del olimen lo ocupa la Descripcion del Tumulo Letras, $y$ Geroglificos $\tilde{q}$ en onrras de nuestra serenissina Reyna Doña Murgarita de Austria fueron hechos en la ciudud de Mexico. En esta relacion hai muchas poesías todas del inismo autor.

I.ope de Vega, en el Laurel de Apolo, al hablar de Cádiz dice:

\section{Aqui Gabriel Airolo}

es de las Mirsas celebrado Apolo, porque de las colunas de su genio no ha pasado jamas mortal ingenio. 
420 ALARCON (ARCíngel DE). Vergel de plantas divinas en varios metros espirituales. Por el P. F. Archangel de Alarcon. Barcelona, Iayme Cendrat, M.D.ICIIII. (15094). 8. ${ }^{\circ}$ 8 hojas prels., 387 fols., 4 de Tabla y una de Erratas y señas de la impresion.

Libro mui raro y del cual es casi imposible conseguir un cjemplar perfectamente. completo $\mathrm{y}$ bien conservado, como el que yo tengo.

La mayor parte de las composiciones comprendidas en rl lergel de ptantas divinas pertenece al género de los Conreptos de Ledesma, hai alginnas de mayor estension y lle. gan á ser verdaderos poemitas, divididos ya en capitulos ya en cantos; los siguientes son sus titulos:

Epistola a D. Alliaro de Mendoza on que se escribe la Pasion y muerle del Señor.

Tratado compuesto en varios metros de las siete palabras que el S'ñor dijo en la Cruz.

Triunfo virginal de ta gloriosisinu Vadre de Dios.

Liras en alabanza del glorioso S. Juan Bau. tista do se contiene su vida.

Vida de la Bienaventurarla Santa Ann, madre de la Virgen, dividisla en cuatro cuillus.

Piscaloria, en la cual se comtiene el glorioso martirio de Sta. Eulalia de Burcelona.

Cunto (dividido en dos compuesto en atabanza de las stagradus estigma! as de S. Francisco, de las cuales fué et autor Jesucristo.

El lenguaje de este autor es castizo y su versiflcacion siempre fácil, como ya 10 observaron los traductores de Ticknor ell cl tom. 5. de la Hist. de ia lit. esp., pàg. 525 .

\section{ALCALA I HERRERA} (Alovso DE). Iardim anagrämatico de divinas flores lvsitanas, hespanholas, e latinas contem seiscentos e oiten!a \& tres Anagrammas em prosa $\&$ verso, \& seis flrmnos Chronologicos Dividise em seis oprsculos nas tres linguas. Avtor Alonso de Alcala-y Herrera. Lisboa, Officina Craesbeeckiana, 16.34. 4. 13 hojas prels. incluso el fróntis grabado, las dos hojas de Index y una especie de portada que lleca el Primeiro Opriscrlo, 274 págs. y 2 hojas añadidas despues de concluida la edicion.

Nic. Antonio no logró rer esta obra: por consiguiente no designa el lugar y aĩo de su edicion.

De el mismo Alcalá y Herrera son las cinco novelas sin una de las vocales que pu. blicó con el titulo de Farios effectos de amm. lisboa, 16:1. 8. Vièase la Seccion novelistica, articulo de varios prodigios de amor.)

42 ILDANA (Cosme de). Sonetos y octaras de Cosme de Aldana: Gęntilhombre de su Magest. Cathol. en lamentacion de la IIuerte de su Hermano el Capitan Francisco de Aldana, Alcarde de san Sebastian, que murio peleando en Ifrica. Milan, juan Baptista Colonio. 1387. 8. ${ }^{\circ}$ let. curs. Sin foliacion. Las 8 prims. hojas sin signat. y las siguientes con las sign. A-II, de 8 hojas cada una. ménos la L que solo tiene cuatro, y ademas despues de la $\mathrm{A}$ hai 4 hojas con la sig. a.

Segrnda parte de octavas, y sonetos de Cosme de Aldana... Sobre la muerte de su hermano el Capitan Francisco de Aldana... Adonde inçdentemente, y cón brenedad se trata la causa, y sucessos de dicha jornada. Florençia . jorje Mariscote 1387. $8 .^{\circ}$ Iet. curs. 8 hojas prels. y 96 paigs. Estin erradas las 16 del pliego uiltimo por hallarse repetida la 80 . Vienen despues 28 hojas de sonetns, tercetos y redondillas sobre el mismo asunto, y una Corona al vrlgo con !as signs. * y $\mathrm{A}-\mathrm{C}$, de 8 hrjas, sino la $\mathrm{C}$, que solo tiene 4 .

En las dos partes se hallan composiciones poéticas de Pedro Ferrer, Francisco Cueras, Agustin Enriquez, D. Juan Velasco, D. Pedro Maldonado, Jerunimo de silva, otavian Pastorello, el Auditor Arzeo. Diego de Andrada. Bermardino de salas, Jian de Tello, Padre Alonso de Aguilar, Francisco Baldi. Enriquez de Cartajena. Francisco de Pareja, el Comendadur Jian liuiz de Herrera, Bernardo de Figuerna, Julian Betrada, Luis Arana $y$ otros.

La segunda parte es tan rara que no la veo mencionada por bibliografo alguno. Ji meno y los Ss. Zarco del falle s sancho Ra. yon hablan de nuà version italiana de Rime di Cosimo Aldana... in morte di suo Fratello. It Capitano Francesco d' $A^{\prime}$ dana. Milans, Giacomo Picaglia, M. D. L.X.YH. 8."

ric. Antonio no convció ninguna obra de Cosme de Aldana en castellano.

$423-$ Reconocimiento y $110-$ ro de pecados a Dios Niestro Senor. De Cosme de Aldana. En Florencia, Por Antonio Padouani, 13087. 8. let. 
cursiva. 4 hnjas prels. y $\mathbf{2 4}$ sin foliar con las sig is. A-C.

in veo citad. por ningun autor la presente obrita de Cosme de Aldana, que es un poenua en octavas.

424 ALDANA (Cosue DE). Invectiva contra el vrlgo y sr maledicencia, con otras Octauas, y Tersos de Cosme de Aldana. Madrid, Luis Sanchez, 1531. 8. 11 hojas prels. y 33 foliadas.

Desconocido á casi todos los bibliógrafos.

Nic. Antonio solo menciona de este autor al Discorso contra il volgo. Florencia, Jorge Marescolti, 1578, que no sé si será el original o traduccion de la ubra castellana ántes descrita con un titulo casi igual.

Aunque el privilegio colocado al frente de la obra solo se dirige á perinitir la reimpresion de las publicadas por el autor en Italia, este asegura en el prólogo que nunca habian sido impresas las comprendidas en dicho volúmen.-El tratadito en cuestion se reimprimió, como una Curiosidad bibliográfica, ell el tom. 36 de la Biblioteca de aulores espanioles, publicada por Ribadeneira.

42. ALDANA (Fraxcisco De). Todas las obras que hasta $A$ gora se han podido hallar del Capitan Francisco de Aldana... Agora nveramente Puestas en luz por Cosme de Aldana su hernano. Madrid, Luys Sanchez, M.D.XCII. 8." 8 hojas piels., 101 foliadas, y otra, en cuyo dorso se repiten las señas de la impresion, si bien dice: en casa de Luys Sanchez.

Segvnda parte de las Obras, Que se han podido hallar del Capitan Francisco de Aldana... Sacadas á luz por su hermano Cosme de Aldana. Nadrid, P. Madrigal, 1591. 8." 16 hojas prels. y 104 foliadas. La dedicatoria de Cosme Aldana a S. M. está fechada en Madrid, á 3 de Julio de 1591 .

Ambas partes son de estraordinaria rareza.

El Sr. D. Pascual de Gayángos ha tenido la bondad de comunicarme la descripcion de una Primera parte de las obras que hasla agora se han podido hallur Del Cipilan Francisco de Aláana Alcayde de San Sebastian. El qual murio peleando en la jormala de Africa. Agora mevamcnle puestas en laz por su hermano Cosme de Aldana, gentilhombre dol Rey Don Phelippe. Dirigidas a su sacra catholica Real Ifigestad. En Milan. Por Publo fotardo Poncio. Con lirencia de los su- periores. $8 .^{\circ}$ let. cursiva. Segun parece esta pirte se conforma en un todo con la de 1593, antes descrita, con la única diferencia de que en lugar do las Oclavas suellas del Author puestas al fin de ella, en la de Milan se encuentra la Obra del Capilun Francisco de Aldana intitulada Parto della (sic) Virgen, composicion que se reimprimio en la segunda parte del año 1591 . El ejemplar del $\mathrm{Sr}$. de Gayáugos parece falto al fin $y$ solo tiene 104 hojas no foliadas: pero yo sospecho sea de la impresion de 1589 que describe D. Adolfo de Castro en las Notas al Buscapié pág. 31. - A propisito del impresor Pablo Gotardo Poncio, debo observar fué sin duda hijo ó hermano del que imprimió el siguiente poemita en octavas: El sitin y toma de Anvers, De Miguel Giner. En Milan, Por Pacifico Pon: cio. II. D. Lxxxvit. $8 .^{\circ} 46$ fols. y una hoja al fln en que dice: Estampado en caragoça de España, el Año de M.D.LXXXVII. y restãpado en Mían, el propio Año. Por Pacifico Poncio. Nic. Antonio cita efectivamente la edicion de Zaragoza y una de Antuerpia de Plantino, pero no habla de la de Vilan; tampoco hace mérito de la segunda parte de las obras de Aldana publicadas por su hermano Cosme en 1.591, de que he hablado al principio de este articulo.

Los SS. Zareo del Valle y Sancho Rayon describen una edicion de las dos partes, de cuya impresion ignoran el año y lugar, por carecer de preliminares y final el cjemplar que tuvieron presente; pero dicen terminantemente ser distinta de las de $1593, y$ 1591 .

426 AlECIO (Adriano de). El Angelico. Fscrivelo con estilo de poeta Firico el Padre Fray Adriano de Alecio. Murcia, Esteuan Liberos, 1645 . 4. ${ }^{\circ}$ let. curs. 4 hojas prels.y 182 fols., la última numerada por equivocacion 178.

sospecho si habrá alguna edicion hecha en Lima anteriormente, pues la presente lleva las aprobaciones fechadas en dicba ciudad en 1642 y 43 .

Nic. Antonio no conoció la impresion de Mureia y solo menciona una de Madrid, s.a. con el titulo de Vida de Sto. Tomas de Aquino, en quintillas: efectivamente tal es el asunto de que trata, y la clase de metro de este poema, dividido en diez cantos.

427 ALMACEN de chanzas y veras, obra original escrita en metros diferentes para instruccion y recreo por D. E. A. P. Corregida y aumentada en esta segunda edicion. Madrid, Imprenta de la calle de la Greda, 1807. 12.

la primera parte es toda de seguidillas. 


\section{AI. V}

428 ALMADA (A POLINAHIO DE). Despertador del alma, al sueño de la vida. Fin voz de un advertido desengaño. Dale a la estampa Apolinario de Almada. Lisboa Manuel Lopes Herrera, M.DC.Xcr. 1. 11 hojas prels., inclusa una lámina rmblrmalica que precede a la porlada y 1.000 priginas.

\section{P'oema de Irescienlas octavis.}

l'or algunas espresiones de los preliminn. res ya se comprende que Apolinario Almada no es el verdadero antor del libro; en efecto la que lo escribió fuci Dona Juana Josefa de Menéses, tercera marquesa de la Ericeira, de quien era criado dicho Almada.

429 ALMRES SOARES (ANT0Nio). Rimas varias, de Antonio A!vares Soares. Primeira parte. Lisboa, Matthe us Pinheiro, M.Dc.xxvill. 8." 6 hojas prels. y 72 foliallas.

Todas las composiciones de este volúmen son castellanas ménos una $\dot{0}$ dos que estan eseritas en portugues. Es obrita rara.

Nic. Antonio no indica el tamaño del libro.

430 ALVAREZ (AvTovio). Trirmpho de la virtrd, dibriado en la admirable Yida, y peregrina muerte de el Inclyto Martyr de España, San Victores, hijo . de la anligra, como noble civdad de Cerezo, y patron de la ilvstrissima Villa de Belorado. Tradvcida de latin a romance, $y$ compvesta por el $\mathrm{Br}$. Don Intonio Alvarez. Valladolid, Antonio Fizueroa, s. a. (169̈̈?). 4. 10 hojas prels., 160 piigs. y 1 lioja para terminur la Tabla.

Eu la primera parte de esta obra hai varias ponsias; pero la segunda es loda en verso.

831 iLVAREZ (GaRC1). Contenuytus minli que hazia Garci aluarez capellan dela serenissima señora: doina liermana reyna de Aragon... S Sigue un gran escudo de armas del duque de Calabria y bajo:) Cou preuilegio del muy ecelente señor don Fernădo de Aragon duque de Calabria mi señor. TToda la porlada va circuida de orla.) S. l. ni a. $4 .{ }^{\circ}$ let. gót. 11 hojas con la sig. A; en el reverso de la úllima hai una gran lámina de madera tue representa el juicio final.
ALV

Aunque no lleva el lugar ni fecha de la impresion no me cabe duda es de Valencla y hecha hácia el ano 1530.

To encuentro noticia en ninguno de nues. tros escritores de Garci Alvarez ni de su rarisimo poemita religioso-moral, escrito en metro ifrual al de las coplas de Jorge Manri. que. IIé aqui una muestra:

No pienses que has de durar que solo habrá, sola la fé que tendrás,

pues todo se ha de acabar, y sino en los que dirć lo verás.

Dó la potencia de Asuero? qués de Crecio y su riqueza, qué dirán?

'iues de Veron el severo? (1) llejandro y su grandeza, liiml. están?

une fur d' Hercoles forzoso? ques dol limpmoso Absalon i) de Hlolona?

dó Cleopalra. sil aınoroso aquel calualliro linon, i) sll pena?

¿Qués de la maguificuncia de Julio César augusto, que 110 veo?

lii Alistotil y su cieneja?

dó P'itágoras robusto

y Tolomen !

Busca, búscane á Platon j) todo cuanto escribieron jara vellos;

i.qu'es del gran Tulio o Maron. inude están ó que se hiciernn. Ifue fur d'ellos?

Que ann si salomon no hiciera penitencia yad despues yuc se viu,

lambien ereo se perdicra p'ro en el Eclosiastes so lloro.

Todo volo como un ave do no se puede hallar senda $\mathrm{y}$ tino:

lodo paso comn nave. sobre las ondas del mar sill camino:

todo fué un claro error. lodo deshecho á deshora collio miasa :

lodo fue sombra de amor. huésped de sola wla hora que se pasa.

\section{ALVAREZ DE TOLEDO} (D. Gabriel.). Oliras posthumas poeticas, con la Burrumaquia: De Don Gabriel Alvarez de Toledo Pellicer : Tobar. Sacalas a luz el Doctor Don Diego de Torres Villarroél, el que escrive al principio un resumen de 
la Yida, y Virtudes de este Author. Madrid, Imprenta del Convento de la Herced, 171 $4 .{ }^{\circ}$ 1I hojas prels. y 13 z prigs.

En Löndres tuvimos un tomo manuscrito que se intitulaba: Virrias Poesits de D. ${ }^{n}$ Gabriel Alutere de To'edo y Pelliern. Jumlolas D. Niguel Joseph Vimhufel. Año 1719. Ignoro si el contenido seria ignal al del tomo pub!icado por Tórres.

133 ANACREON I MLSEO. Odas de Anacreon. Los Amores de Leandro y IIero, traducidos del griego $y$ el Beso de Abibina por $6 . A$. v. de C. Puerto-Rico, Dalman, 1838. $8 .^{\circ}$ marq.

Tiene este ejemplar un recúerdo autórraso dirigido á mi padre.

\section{ANGLERIA ó ANGLUS} (Pedno Martir). Poemata: in quibus supreme laudes Catholicorū Regum continentur: que sunt. Pluto furreus Janus Jnachus Equestria Satyra Uictoria Conuiuium regium Uaria item ad diuersos epigrāmata lectu sapidi q rtilia.: Author Prothomotarius Petrus martyr Regius senator. Cliste frintis va circuido de orla; al dorso principia un prólogo al lector en latin de Alfonso Ordónez, y terminado este, sigue la dedicatoria del Pluto a Alejandro VI. La obra termina en el reverso de la última hoja de la sig. J con el siguiente colofon:) Excussit Ualētiae Joannes vignaus. Nonas februarias. Anno a xpi Natali vigessi$m$ o supra quingentēgessimū c llillesimum (1520). SSigue una hoja de erratas.) 4. let. gót. Sin foliatura, signs. A-J, todas de ocho hnjas.

l.a mayor parte de estas composiciones se inmprimieron al fin de la edicion de sevilla de 1.511 de la Legatio bubilonica y occeani decas: no sé que ningun eseritor mencione la impresion valenciana de los poemas separados; yo no lie visto mas ejemplar que el de ni biblioteca.

13\%̈ ANGLLO Y PLLGAR (MAnTIX DE). Egroga frnebre a Don Lyys de Gougora. De rersos entresacalos de sis obras. Por Don Martin de Angrilo y Pulgar. Seuilla, Simon Fajarii, 16.38. 1. 12 hinas prels. y 20 fols.
Va en la portada un lindo medallon con un retrato, que si es el de Góngora, debió ha. cerse siendo todavia mozo; supongo estará grabado por el mismo artista que ejecutó el escido de armas del mecenas D. Fernando Pélez del Pulgar, puesto en los preliminares, Y se llamaba F. Heylan, belga.

Como ho indica el fróntis esta Egloga no es otra cosa que un centon de versos de Góngora apticados á su elogio.-Vic. Antonio invo noticia de la obra: aunque debemos presumir no la vió, cuando no cita ni lıgar ni año de impresion.-El mismo Antonio y los traductores de Ticknor, tom. 5.”, págima 511 , se refleren í otra produccion del mismo Angulo intitulada : Epislolas salisfactorias a las objecciones que opuso $d$ los poemas ale D. Luys de Gongora el licenciado Francisco Cascales. Granndr, Blas .Iarlinez, $1635.8 .^{\circ}$

436 ANTONIO (LuIs). Nrevo Plato de varios manjares. Para divertir el ocio. Por Luys Antonio, Lego del Parnaso. Zaragoça, Ituan de l'bar, 1638. $80^{\circ} 7$ hojas prels. y 93 prigs.

- Coleccion lindisima de versos en el gé- nero jocoso y burlesco, entre los cuales hai - 110 pocos romances y letrillas de singular - mérito. Nada dice de este autor II. Nic. An. - tonio, y Latasa no hace mas que mencio. - llar el título de la obra.. Aádiciones a Tick. nov, tom. 3. ${ }^{\circ}$, pág. 531 .

IIe visto una obra por el estilo de la de Luis Antonio intitulada: Tropezon de la risa. Compuesto por Jacinto Alonso de Maluenda. nulural de la ciudad de Valencia. Valencia, por Sylvestre Esparza, s. a. 12. 3 hojas prels., 104 fols. y 2 de Tabla; y los Iraductores de Ticknor, tom. $3 .^{\circ}$, pág. 550 , hablan de otro tomilo compuesto tambien de poesias satiricas y burlescas del mismo Malvenda, que se llama La Cozquilla del Gusto, impreso igualmente en Valencia por dicho Esparza en $1629.12 .^{\circ} 8$ hojas prels., y 61 más de testo.

ARBOLANCHE (JERÓNiMO). LOS nuere libros de los Havidas. Yéase en la Seccion novelística.-Libros de caballerías.

ARGENSOLA (LUPERCIO Y BARTOlomé Leonando DE). Véase Leonardo de Argensola en esta misma division.

437 ARGUIJO (Juan DE). Sonetos de D. Juan de Arguijo: Sevilla, Francisco Alvarez i compañía, 1841. $40^{\circ}$

De este distinguido poeta sevillano solo se conocian: una cancion impresa por Sedano 
en el tom. 9 del Parnaso español, tres sone. tos que dióá luz Gracian en su Agudeza y arle de ingenio, y veintinueve incluidos por Fernandez en la Coleccion de poetas. El Scfor D. J. J. Colon, encontró un códice anotado por el Maestro Francisco Ycdina, que comprende $n o$ solo los treinta y dos sonetos $3 \mathrm{r}$ riba indicados, sino veintiocho más inéditos; por consiguiente siendo el tomito que forina el asunto de este articulo copia de aquel manuserito, conticne scsenta.

\section{8 Ális (Gónez). El Clarin} armonico de las glorias, y milagros del minimo maximo thaumaturgo $\mathrm{S}$. Francisco de Paula. Por su autor Don Gome\% Arias. Madrid, Joseph Gonzalez, 1749. 8. 34 hojas prels. y 118 paigs.

Poema compuesto de tres cantos y precedidn de un Resumen (tambien en verso) te algunos milagros siugulures obridos por el santo, cscrito por el aprobante de la obra Fr. Agustiu Antonio. A pesar le ser este resuinen bastante estenso, debemos suponer que su autor se dejio muchas cosis estupendas en cl tintero, porque unị nota, puesta ell li pior. 115 del poema de Arias, nos asegura que el nuimero de milagios hechns por S. Francisco, segun el cálculo te todos tos sabios, es de dos cuentos trescientos y nov'nta y un mil doscientos y ochenta. Lástima no añada uno mas a esta respetable cifra, haciendo desaparecer por completo todos ins cjcmplares de su biografia, escrita ell versos tan detestables.

ARIOST0 (Luis). Orlando furioso. Véase en la Seccion novelística.-I. $i$ bros de caballerías.

439 ARISTÓTELES. Compendio de toda la Philosophia Natural de Aristoteles, traduzido en metro Castellano, segun la intencion de los mas graues interpretes del mesno Aristotil: por in Collagial en el Colegrio de nuestra señora la Real de Hirach. Fue Impresso en la muy noble Ciudad de Stella, por Adrian de Anuerez. M.D.XLVII. 4. ${ }^{\circ}$ Sin foliacion; pero con las sigs. $\mathrm{A}-\mathrm{G}$ todas de $\mathbf{8}$ hrjas, inclusos los prels., y una blanca al fin.

Bella y rara edicion.

Todo cstá en coplas de artc mayor. Al principio se enculentran unos versos latinos de Jian Ferrer ell elogio del autor, que ternuinan:

o decus, 0 generi decus immortale Canales, He precor accipias in tha iussa vale.
De aqui vlno, sin duda, el que Nic. Antonio coloque este libro en el tom. II. de la Bibl. nova, pág. 340, al art. Anonymus de Ca. nales. Fue cste prubablemente aragones: pero Latasa no menciona la presente obra en uinguno de los cinco cscritores de este apellido á quienes cita; aunque por la época en que los clasiflca, acaso á duras penas podria atribuirse á unı cuyo nombre era Sebastian, poeta nada vulgar, autor en 1595 de una Copiosa glosa del Himno: lste confesor Domini etc.

440 ARISTÓTELES. La Poetica de Aristoteles dada a nvestra lengva castellana. Por Don Alonso Ordoñez das Sevjas y Tobar. Madrid, viuda de Alonso Martin, 1626. 8. 8 hojas prels. y 80 fols.

Primera edicion: á la segunda que he visto, hecha en Madrid, por Don Antonio de Sancha, 1778. 8. may. retrato de la cual se tiraron ejemplares en gran papel), se añadió cl testo griego. la version latina y notas de Ileiusio y de Batteux: y se suplió y corrigió la traduccion eastellana por el Lic. D. Casimiro Flórez Canseco. Haj otra Arte poetica de Aristoteles en caslelluno. Por D. Joseph Goyu y Muniain. (Madrid) D. Benito Cano, 1798. 4. marq. Retrato. Existen algunos ejempla. res de ella tirados en papel grande. Esta cdicion lleva el testo griego.

Vic. Antonio menciona otra traduccion hecha por Ordónez das Seijas de El Tralado de el Gobierno de los Principes, de Sto. Thomas de Aquino. Madrid, Juan Gonzalez, 1625. 4."

111 ARIIENDIRIZ (JULIAX DE). Patron Salmantino de Ivlian de Armendariz. Salamanca, Artus Taberniel, M.DC.III. 8." it hojas prels. y 432 pags.

Hermoso ejemplar cou la firma del autor ell la portada.

Poeina en cuartetas y en diez cantos.

Vic. Artonio trac como primera edicion uni de Ro..1a, $1611.80^{\circ}$ y el titulo que da í la olora cs el de rida de S. Jum de Sahagun.

142 Patron Salamantino 0 Vida de San Iran Fecundo del Orden de San Augustin. Compuesta por Iulian de Armendariz. Barcelona, Esteilan Liberos, $1629.8 .^{\circ} 8$ hnjas prels. y 343 paigs.

- Armendariz es cscritor puro, propio, - castizo, y uno de nuestros mas aventajados ingenios. Gallardo, Ensayo de una bib. esp. 
ARTFAGA (Félix DE). Obras póstumas divinas y humanas. Véase en la Seccion dramática.

$\$ 43$ ARTIGA, olin ARTIEDA (Francisco José). Epitome de la eloquencia española. Arte de discririr, y hablar con agudeza, y elegancia en todo genero de assunptos, de Orar, Predicar, Arguir, Conversar, Componer Embaxadas, Cartas y Recados. Con Chistes, que previenen las faltas y Exemplos, que muestran los aciertos. Comprsolo D. Francisco Joseph Artiga olim Artieda. Segunda impression. Pamplona, Alfonso Brrgvete, 1726. 19. 16 hojas prels. y 418 páginas.

Recuerdo laber vlsto algun ejemplar enn el fróntis grabado; el mio lo tience impresı. Ignoro el ano le la primera edicion; todis las aprobaciones de la segunda soll de 1725.

La obra está eserita en metro de romance y dividlda en cinco diálogos.

144 ARZE SOLORZENO (JUAN DE). Historia Euangelica, de la vida, nilagros, y Muerte de Christo, nilesIro Dios y Maestro. Obra de Arce Solorzeno. En Madrid, En la Imprenta Real, M.DC.v. 8. ${ }^{\circ} 12$ hojas prels. y 136 págs.; en la illima se repile la fecha y sepone el nombre del impresor Iuan Flamenco.

obra dividida en cilueo partes y escrita en octavas cada una de las cuales lleva una laminita de madera.

Nic. Antonio no consiguiú ver esta obra, pues ademas de no citar el lugar de sil in!presion, supone ser en $4 .^{\circ}$ : sin duda es la mís rara de Arze Solorzeno.

otro poema he visto sobre el mismo asunto, escríto tambien ell octavas $\mathrm{y}$ dividido en siete cantos, que se intitula:

Grandezas divinas. Vida, "I muerle de Nvestro Saluador Jesv Chrislo, yue dexo escrilas en ver'so al Licenciudo Francisco Du. ran Viuas, en varios papeles. Aora nueva. mente reducidas al lengnaje, y esti'o comatu deslos liempos por el Licencindo Don fer. nando Viuns de Comtreras, su vielo. Malvid,

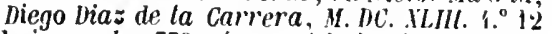
hojas prels. 339 págs. y 1 hoja al flu coll el lugar, nombre del impresor y fecha de II. DC. XLIl.

445 A VALOS Y FIGUEROA (DieG0 DE). Primera parte de la miscela- nea avstral de Don Diego D' Avalos y Figveroa, en varios cologuios. Interlocutores, Delio, y Cilena. Con la Defensa de Damas. Lima, Antonio Ricardo, M.DC.II. 4." 23 hojas prels., 219 fols. y 8 de Tabla.-Defensa de Damas de Don Diego D' Avalos y Figveroa, en octaula rima, diuidida en seis cantos, donde se alega cō memorables historias. Y donde florecen algrnas sentencias, refutando las que algunos Philosophos decretaron contra las Mugeres, y prouando ser falsas, con casos verdaderos, en diuersos tiēpos succedidos. Lima, Antonio Ricardo, M.bcir. 1. $\ddot{3}$ hijas prels. 80 fol. $y 1$ de Tabla.

I.ibro de mucha rareza: Nic. Antonio se conoce quie no lo vió, pues ademas de no lacer mérito de la Defensa de damas, no flja lingar ni año á la primera parte del volúmen.

Lí Micelanea austral está en prosin, con bastintes poesias intercaladis, y se divide en cuarenta y cuatro coloquios. Su coutenido corresponde perfectamente al titulo, siendo IIII verdadero eajon de sastre. Ademas de cien mil cosas, que en obsequio de la brevedad numito, se trata en ella del amor, de las cualidides que debe tener un amante, de los zelos, de la música, de las calidades de los cabillos, de la verdad, de la vergiienza, de la perfeceion de la dama, del origen de las sortijas ó anillos, de la conversacion, de las intágenes y templos de vénus, de los suefios $y$ del sueño, de las ventajas de la lengua toscinla pira la música, del uso de las estampas $y$ daños de la ociosidad, del ave fénix, del pelieano, del cisne y del ágnila, de los mitierales, verctales, animales y cosas notables lel l'eri, de las propiedades de la piedra Vezahar, de los edificios antiguos de aquel pais, del origen de los Ineas y de sus leyes y ritos, de los sacriflctos que los indios usaban, de la antigna riqueza de España en oro y plata, elogio de la ciudad de Eeija, un frag. mento de una traduccion en verso de las lagrimas de S. Pedro de Tansillo ete. ete.

por lo tocinte í la segunda purte su portadil dice ya el objeto del tratadn, metro en que está escrito y cantos en que se divide.

446 AYALA FAJARDO (P. Fr. JUax DE). Epithome De las quatro Postrimerias de el. homtre. Por el P. Fr. Joan de Ayala Faxardo. Van a ñadidas vna cancion al transito suaue y gloriosa asumcion de la V. M.a N. ${ }^{a} S^{a}$ y una Palestra espiritual de el mismo auctor. Madrid, Imprenta del Reyno, 1638. 8." 8 hojas prels., incluso el fróntis yrabado, $y \mathbf{b} 6$ fols. 
Cási todo cl volúmen está escrito en versos octosilábicos asonantados, ménos la Cancion heroica al tránsito de la Virgen.

447 AYALA FAJARDO (P. Fr. JUAN DE). . Oracion panegirica Christo desagraviado de los Oprobrios que unos Hebreos le hizieron en su Sa- crosanta Imagen. El P. Fैr. Ioan de Ayala Fajardo. Madrid, Maria de Quiñones, 1639. 8. 3 hojas prels. y $17 \mathrm{fols}$.

Nic. Antonio no conoció este poemita en octavas, que debió haberse recitado al rel en el convento de la Trinidad; pero estorbolo cl hallarse enfermo S. Il.
448 BACALLAR Y SANNA (D. VICENTE). Vida de los dos Tobias, historia sagrada, escrita en 500. octavas ritmas castellanas 1 or D. Vicente Bacallar y Sanna, Marquès de San Phelipe. Tomo tercero de la Monarquia bebrea. Segunda edicion, Que nuevamente corregida, e. ilustrada con Notas marginales, la saca á luz Gabriel Ramirez. Madrid, Gabriel Ramirez, 1746. $4 .^{\circ}$

Tengo una apuntacion segun la cual existe en el Musen Británico un Catalogue de la bibliolheque de fen son Exceltence D. Vincent Bacallar y Sunna. Haya, 1726. 8.; pero no he logrado verlo.

\section{BALBI DE CORREGGIO} (Fraxcisco). Pasada del sereniss. S. D. Vilicenzo Gonzaga, y Arstria Dvq' de Mantiva, y Monferato, por el Estado de Milan, para yr à tomar el poseso del su Estado de Monferato, con los recibimientos que en el dicho viaje le han sido bechos, en todas partes. Recogido por Francisco Balbi de Corregio. Mantoua, Giacomo Ruffinello. H.D.LXXXVIII. $4 .^{\circ} 119$ págs.

Poema en octavas, dividido en seis cantos. vic. Antonio no conoció esta obra de Balbi ni la Hisloria de los umores del valeroso Moro Alimle - Arvaez, y de la hermosa Xarifa Aben-Cerases; y la balalla, que hivo con la gente de Roditigo de Norbciez a la sacon Alcayde de Antequera y Allora. y con el mismo Rodrign, "ueltos cn verso. Milan, $P a$. cifico Porzio, 1595. 4. Poema en oclavas y en diez cantos citado por Quadrio en el tomo 4. pág. 450. Trae si dielıo Antonio la vida de Oclavio de Gonzaga Capilan general de la Cavalleria ligera de Milan, en verso. Barcelona, Huberlo Gotardo, 1581. 4.; y yo he visto $L a$ verdader 1 relacion de todo lo que el anno de M.D.LXV. ha succedido en la Isla de Halla, de antes que llegase l'armada sobre ella de Soliman gran Turco. Por Francisco Bulbi de Corregio. Segunda Impresion. Barcelona, Pedro Reiyner, 1568. 4. La primera edicion, segun los traductores de Ticknor, tom. III, pág. 547, la hizo en Alcala, Juan de Villanucva, 1567 . 4.

Balbuena (Bersardo De). El Bernardo. Víase en la Seccion novelistica.-Libros de caballerias.

450 BANZES Y CANDAMO (FraYcisco). Oloras Luricas de Don Francisco Antonio de Bances y Candanio. Que saca a luz D. Jvlian del Rio Marin. Madrid, (1729.) a costa de Francisco Martinez dhad. $160^{\circ} 32$ hojas prels. y 264 págs.

La primera edicion de estas poesias debio hacerse en Madrid hdcia 1720, segun parece por las aprobaciones.

BANZES I CANDAMO (FraNCISco). Poesías cómicas. Véase en la Seccion Dramática.

BALAHONA DE SOT() (Luis). La Angélica. Véase en la Seccion nocelística.-Libros de caballerías.

451 BARRIOS (MIGLEL DE). Imperio de Dios en la harmonia del mundo. Escritor Don Miguel de Barrios. S. 1. ni a. $4 .{ }^{\circ} 4$ hojas prels. y 32 págs.

Peema en ciento veinticinco octavas.

obra mul rara desconoeida il Vic. Alstonio y la eual no logru ver Rodriguez de Castro. El Sr. Barrera y Lcirado la supone inédita.

452 - Symbolo de la buena eleccion. Por el Capitan Don Miguel de Barrios. S. l. ni a.-Trimpho cesareo en la descripcion universal 
de Panonia, y Conquista de la Ciudad de Buda, a 2. de Septiembre de 1686. Por el Capitan Don Miguel de Barrios. S. 1. ni a.-Augusto Carro Triumphal de Don Mignel de Barrios. S. I. ni a.- Poesias al Duque de Bexar. De Don Miguel de Barrios. S. 1. ni a. $4 .^{\circ}$

las precednules obras fuerou desconocidas a Xic. Antonio, a liodriguez de Cistro, á Barl'ra ý ć lolos los bihlicigrafos que he consultikto: solo poseo trozos ó fragmentos de allas; pero los considero como reliquias de gran valor. l'or las 270 págs., de que consian aproximadamente, se dedıce que estas romposiciones eran en verso, mezcladas de prosa y estahan adornidas con bonitas líminis bien grabadas en cobre.-Ninguna de lielıas obras fija el lugar y año de su publiricion: pern yo prosmmo fueron impresas en Anstridan por los años de $1682,85,8.1,86 \mathrm{y}$ sis. que es donde y cuándo estín fechadas pur allor valias epistolas o dedieatorias rompremdidas cu cllas; y lambien se dedure le sll contcuido estin escrilas despues de haber vilelfo barrios a abrdzar la religion julaica de sus padres.

lle poseido un tomito intitulado: Epitulamio rejes a la l'niom do lonn l'edro se'gundo Rey de Posluyal com Varia Sophia Princesa de viendurig a cuyas plamlas lo consagran El

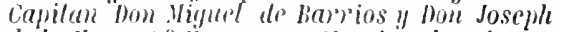
ele la lega. 8. En verso. - He visto igualmen. fo olra ubrita eserita por Barrios, criyo título ela: llegrias, o pinluras lucientes de Itymeneos. 'or Hanid Levide Burrios. Amsterdam. 1680. 8. ${ }^{\circ}$ - E.l Sr. Barrera refiriendose i lo. Jose Amador de los Rins, cita ademas el Aplauso thelricn por las dos celebres viclorias que hovo a 7 y la de jumio de 1675 la armuda de los eslados de Flandes mandula por el prinripe de biange. Austerdam, s. a.; y A)bol. forido de nochr. Ansterdam, David Tolas, Ifisis i. ${ }^{\circ}$

En la colra de Esquemolingr, Piralas de Imerica, V. la sorectun hislórica-IIstoria de las tmlias.) Hai al principio una romposion poetica en eincuenta y cinco octavas inlitulata: bescripcion de las islus del rnur allántico ys de Anerica, $11 \mathrm{l}$ Eplgrama y un Armónicu ryilogo, eseritos por nuestro Barrios: llamilulosele en li cabezal del Epigrauna insigne poela; "ecino de Ansterdan.

B.ARRIOS (Migena). Coro de las Iusas y Flor de Apolo. Véase en la Seccion dramática.

13) BEAEGASI Y LLJAN (D. Jo¿É Jo.locix). Poesias Lyricas, (y enIre estas la rida del glorioso San Damaso. Escrita en Redondilias jocoserias.) Su autor Don Joseph Joachin Be- negasi y Luxan. Madrid, Juan de Zuñiga , M.DCC.LII. $4 .^{\circ} 21$ hojas prels., inclusa una lam. que representa á San Dámaso, 160 págs. $y 2$ hojas de Tabla.

En algunas de las aprobaciones y licencias se intitinla el tomo el IV de las obras de este autor; sin embargo parece completo por si solo y en el frontis nada se menciona para indicar que pertenezca á ninguma serie de tomos.

4 B̈4 BENEGASI Y LUJAN (D. J0SÉ Joa QUIN). Obras métricas, que a distintos assuntos, assi serios como festivos, (aumentadas en mas de la mitad en esta segunda impression) escrivia Frey Don Joseph Joaquin Benegassi y Luxán. Madrid, Miguel Escrivano, s. a. $40^{\circ} 6$ hojas prels., 218 págs. y 8 hojas de Tabla.

Es ejerlo lo de la portada de comprender esta impresion una mitad mas de poesias sucltas que la descrita en el nimero anterior; pero en ella lalla por entero el poema de San Dilllaso.

$43 ̋$ - Poesias Lyrïcas, y jocoserias. Su autor Don Joseph Joachin Benegasi y Luxin. Madrid, Joseph Gonzale\%, M.DCc.xum. 4. 10 hojas prels., 28I paigs. y 3 hojas de Indice.

Segun parece conliene composiciones diversas de las de los dos números anleriores.

436 - El fiambre de quantos papeles han salido con motivo de las reales fiestas, asi por tardo como por frio; el que sin sal, ni pinienta compuso en prosa, $\because$ metros distintos Frey Don Joseph Joachin Benegasi y Lujan. Marlrid, Antonio Marin, $1766^{\circ}$. $40^{\circ} 67$ págs.; aunque las tres últimas por equivocacion están numeradas 63, 64 у 630.

Inai en esle cuaderuo muchas pocsias $\mathrm{y}$ una Loa.

407 - Vida del portentoso negro, San Benito de Palermo, descripta en seis cantos, Joco-serios, del reducidissimo Netro de Seguidillas, con los Argumentos en Octavas. Por Don Joseph, Joachin, Benegassi, y Luxàn. Madrid, Juan de San Mar- 
tin, M.DCCL. $4 .^{\circ} 13$ hojas prels. inclusa la lám. de S. Benito

Poema conceptuoso, lleno de equivocos que generalmente tienen gracia. Hai otra edicion de Indrid, 176.5 , tambien en $4 .^{\circ}$

458 BENEGASI Y LUJAN (D. JosÉ JoaquiN). Vida del glorioso San Damaso, Pontifice Maxino, martillo de la heregia, dianante de la fe, crysol de la castidad. Escriviola en Redondillas Jocoserias, Frev D. Joseph Joachin Benegassi y Luxan. Sale aumentada, $y$ corregida en esta segunda impression por el mismo dutor. Madrid, Miguel Escrivano, 1763. 4. ${ }^{\circ} 10$ hojas prels., inclusa la lám. de $S$. Dámaso y el relrato del aulor.

La primera edicion so hizo en 1752 junto con sus l'oesias liricas. $r$. el nim. 4.5.

Poema escrito en el mismo estilo que ul anterior de S. Benito y revela lambien el ingenio y gracia de su autor, quien compuso algunos bailıs, una loa y mna comedia.

439 - Carta, en respuesta de otra, que le havia escrito un amigo, noticiandole cierto desengaño de una parienta. S. I. ni a. (174t?) $4 .^{\circ} 8 \mathrm{ho-}$ jas, la illima blanca, sin paginacion ni sig.

Papel volante no mencionado por Bacma y cuyas dos uiltimas cuartetas diecn:

Loja y Agosto... á veinte y dos, parece Que un poquito de dudase me ofrere.

dün de setceicutos y cuarenta,

Que con un siete mis sale la cucula.

Tuyo siempre con todo mi albedrio, I tan tuyo que ya no sere mio, Don Jose Benegrasi el infelice, l'ues procura decir $y$ janas diee.

\section{0 - Descripcion festiva de} la suntuosa carrera, y reales funciones con que esia impérial, ! coronada Villa ha celebrado la plausible entrada, y esaltacion al trono de nuestros catholicos monarcas los señores Don Carlos III . y Doña Maria Amalia en los dias 13. 14. 13. y 19 le Julio de este año de 1760 escriviala én segruidillas, y con la introduccion en Octavas Jocosas Don Joseph, Joachin, Benegassi, ! Lujan. Madrid,
Miguè Escrivano, s. a. $4 .^{\circ} 6$ hojas de prels. é introduccion, 46 págs. y 1 hoja con una nota subre las erratas, nombre del impresor, que aquí sellama José Matias Escriluar o, y un cal ilogo de algunos escrilns de Benegnsi.

461 BEÑ (Cirlos de). Fabulas politicas de D. C. de B. Londres, S. II.c Dowall, 1813. 12.0 marr.

Son notables istas fábulds por la facilidad de su versiflcacion.

462 BERMARDE\% (DIOgo). Virias rimas ao bom Iests, e at Virgem gloriosa sra may, e a sanctos particvlares. Com outras mais de honesta \& proveitosa licão. Por Diog̣no Bernardez. Em Lisboa. Em casa de Simão Lopez. II. D. XCIIII. 4. ${ }^{\circ}$ let. curs. 4 hojas prels. y 108 fols.

primera edicion mui rara.

403 - La misma abra. Lisboa, Pedro Craslieeck, 1608. 1. ${ }^{\circ}$ i hojas prels. y 108 fols.

segunda edicion que tampoco es frecuente.

Eu pl Ensayn de ma bib. esp. de fallardo. se diee equiroendimente que ei presente vir. limen colnsta de solas div hojas. - En el mis. mo Eusayo se deseribe la terera edicion de esta obra lecha en Lisbou, pur Pedro cirnes-

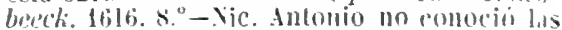
impresiones de 1596 y bus; pero si eilia unas Rimns denolas. Lisbum. Jisez. Itue tal vez sean al mismu libru.

Las buries rimns pontirmen algunas colilposiciones porticas en confollanu.

101 - O Lrma, de Dingo Bernardez: em o qral se contem as suas Errlogas a Cartas. Lishoa. c'm casil de Simálo Lopez, 1596. 1." let. curs. 4 hojas prels. y 173 fols.: pero del 100 salta al 111.

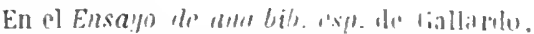

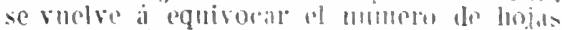

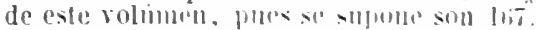

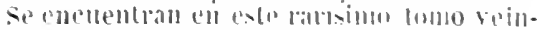

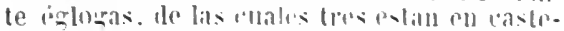

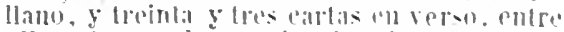

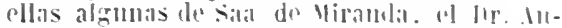

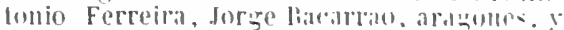

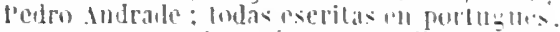
menos tres que lo eslin ell cavinlino.

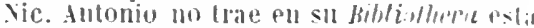
ubra de Bernardez; en eI Ensayo le uru hih. 
esp. se describe la segunda edlcion liecha Fill Lisbora. Por Lorenco Crasbeerk, 1653. 12. y l3runet cila otra de Lisboa, 1761, 12. ${ }^{\circ}$ por i). Slvaro d' Allemicaslro.

463 BERNARDFZ (Diogo). Rimas varias Flores do Lima. Composta por Diogo Bernardes. Em Lisboa. Impresso por Manoel de Lrra. Inno I).M.XCVII. (15̋97.) 8..$^{\circ}$ la primera larte de let. curs. 8 hojas prels. y 181 fols.

lua buena parle de este larisimo volumen está ell castellano y compreude poesias en loda rliso de metro: las hil entre ellis dol Dortor Antonio Ferreira, Pedro de sudiade de Caminha, Francisco de Andrade, lic. Gonzalo Fernández y biogo Fernández.

Vic. Antonio equivoca la fecha de esla elicion, pues supone ser de 1697, y mencioni unas Rimas portuguesas y castellanas. lisbmu, Jorye Hodrigues, 1601 . f. que iguoro si serál cl mismo libro con diferente titulo. scymm Brmuel existen mna edicion de 0 limu y tarills rimas. publieada en lisbra, craesbeeck, $16.52 .52^{\circ}$, y otril de la misma ciulul, $1771.12^{\circ}$ i la que se anadierou Vurras pre. sias de Agosl.da Crus, se'u irutaio. - Bermardir. es imo de los poelas portugueses de printer mola, y la Academia de Lisboa le cita como lesto de lengrraje.- lo es ménos digno de elogin como pseritor cisslellano, pues eutre sus composiciones en este idioma las hai de mui lindas; sirvilu de ejemplo las siguientes

\section{Canligas.}

Di. zrguleja cruel, her'urosu por mi do!or., si lii no sirutes amor", inciél te dio las armas de dl?

i. Milen to dio sus duras flechas rlavidis ron punlas de oro, quic por dumle sale el lloro vinima al alına derechas: iouien te alii vivir sin él porduc yo viva en lolor? ¿Quiril lisdo el poder le Amor, sin. solo el pouder de (il?

iquicin a tus njos aquellıs rayns dii con que me chl iende? IIiina los lazos con que pronde fabrici do lus cabellos? (IIIicu sil dulzmra y su hiol, sil flacer y $\$ 11$ didur?

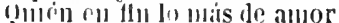
sillo los allowes le ril?

binn mones!ra sep niñu y viegro Allur a quilou piral mientes, puls a $1 \mathrm{i}$ qur no lo sientes lineliss diu. lazos y fuegor. si lo liza do eruel jor sue doblial el dolın, els sa mi velugador que lii me reugarás ule el.
BOC

olra.

No se lo tengan a mal que olvide: Blas su ganado, pues Renita le ha olvidado por anor de olro zagal.

Tiénelo por sin raznn, anda para enloquecer, y no mira qu'es mujer que todas mudables son. Disculpa tiene su mal, remedio no su cuidado; il olvida su ganado, clla no su natural.

Mientras de olvido se queja en Benita embebecido, no mira que pnr olvido. sıl ginado perder deja. Conformies son en su mal el pistor y el ganado, el ganado desdichado, 110 tiene dicha el zagal.

Ya ningun consmelo quiere, suspirandn, lloril y gritil, muérese porque Benita de ajenos amores muere. vio solo llora su mal, el pastor mal fortunado, mis tambien mal del ganado cont el bien de otro zagal.

466 BOCANGEL Y UNZUETA (Gabriel.). Al invicto y Serenismo. Señor Don Fernando de Avstria...Don Gabriel Bocangel y Inçueta,... Dedica la Lira de las Musas, de hvmanas, y sagradas vozes; junto con las denas obras Poeticas antes divulgadas. Madrid, Carlos Sanchez, s. a. $4{ }^{\circ} 12$ hojas prels., 197 jols. $y$ una para repetir el lugar y nombre del impresor.

Por las Erratas y Tasa aparece que la edicion es de 1637.

Adellís de una grill porcion de composiciones mucris, comprende casi todas las que se halliu en al tomito de Rimas y prosas, junpreso en $16 ; 27$.

Dudo exista la edicion de $16 \overline{55}$, citada por Nic. Autonio, pues allu cuando el Privilegio y aprobiciones llevan la fecha de este año, lias Erratas y Tasa son de 1637 , como ya 10 he indicillo arriba, y entre los sonetos hai 11110 i los eccesivos calores deste verano de .7. Los traductores de Ticknor, tom. $3^{\circ}$, prig. 114, citan otra impresion de Madrid, Cárlıs Sánchez, 1652. 4.0

Rimas y prosas. Véase la Seccion dramilica. 
BOE

DIYERSOS.

BOE

$18 y$

467 BOECIO (Severino). (He I aqui el facsímile de la portada.)

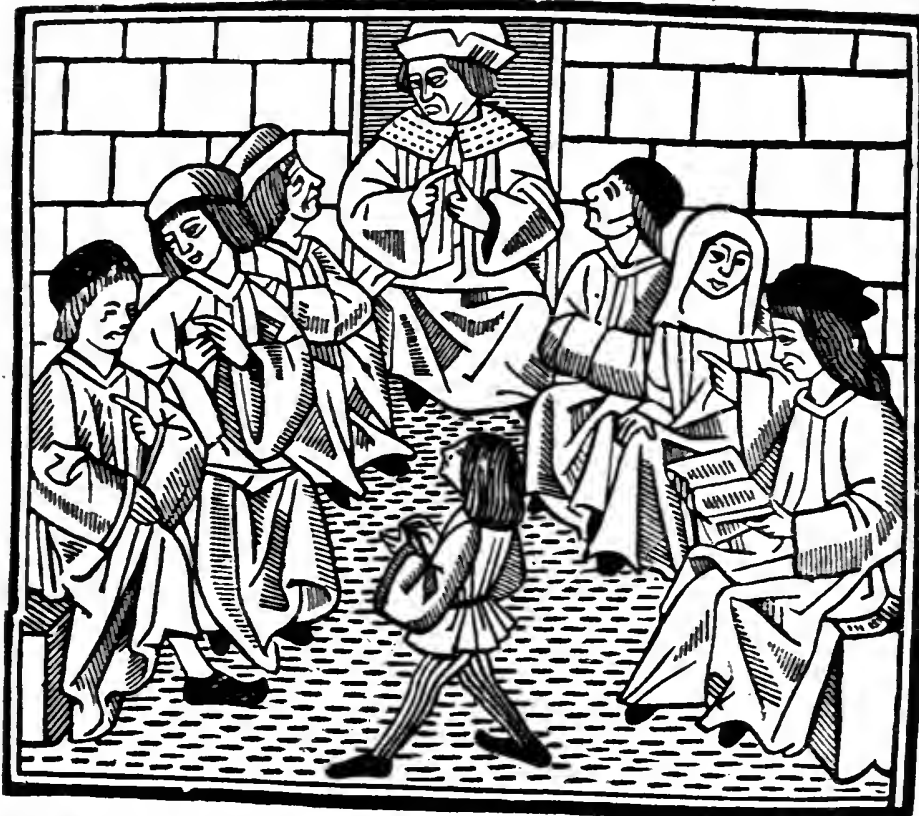

fibso de boecio feuerino inti tulato dela cōfolation decla philofophia: agoza nue wamente tradujito de latĩ en caftellano po: $\mathfrak{e f t i l o ~} \mathfrak{n \mathfrak { u }} \mathfrak{c} \mathfrak{a}$ ante $v \mathfrak{i}$ fto $\overline{\mathfrak{e}} \mathfrak{e} \mathfrak{p} \mathfrak{p a} \overline{\mathfrak{n}} \mathfrak{a}, \boldsymbol{v a}$ $\mathfrak{e l ~ m e t r o ~} \overline{\mathfrak{e}} \mathfrak{c o}$ plas y la $\mathfrak{p}$ fapo: me dida.

Al dorso dice: Prologo. C Comien- $\mid$ nador romano, intitulado dela conça el libro d' boecio... cauallero ý se- $\mid$ solaciõ natural: traduçido d' latin 
en castellano por fray alberto de aguayo frayle dela ordē delos predicadores. dirigido al illustre $\varepsilon$ muy magnifico señor el señor don juan tellez giron conde de vreña: señor de peñafiel $x c$. Al reverso de la hoja lxiij se lee:) Fin del quinto $x$ vltimo libro de boecio seuerino cauallero y senador romano dela cõsolacion natural. deogratias. Anno domini vniuersalis redēptoris. M. d. xvj. xx. iılij. etatis mee. xlvij.

\section{El interprete al libro.}

\section{A pues estas ya traslado}

a boecio seuerino

corre toma tu camino

mira no pierdas el timo

ve do estas va dedicado

$y$ si tueres preguntado

por carta palabra o seña

a do vas encaminado

di que a ser examinado

del señor conde de vreña.

Fue impreso el pisente libro de boecio seuerino por Jacobo crōberger aleman enla muy noble y opulétissima cibdad de Seuilla: en el mes de junio. Año del señor de. a. d. xviij. 4. 'let. gót. Tiene lxviij hojas inclusa la portada.

Nic. Autonio, en su Bibliotheca y Pellicer, en el Ensayo de una biblioteca de traductores, solo conoeierol una edicion hecha tambien en Selilla, por Juan Varela, 1530. 4. ${ }^{\circ}$ Tampoco menciona la de $1518 \mathrm{D}$. Vic. de los Rios en las Memorias de Villégas; pero cita una impresa en Sevilla, 1521 y otra de Medina del Campo, 1542.

Esta traduccion, mui celebrada por Ambrosio de Norales y por el autor del Dialogo de las tenguas, tiene la singularidad, que ya se advierte en el fróntis, de estar la prosa eserita ell verso ó con medida.

En Lóndres tuvimos tambien el Boecis de consolacion. Traduzido y comentado por el Padre Fray Agustín Lopez, y enriquecilo con aduertencias sentenciosas, y tritados espirituales. Valladolid, Iuan de Bostillo, 1601. fol.
468 BoEcio (Severino). Los cinco libros de la consolacion, que compuso Seuerino Boecio, Varon Consular, y Patricio Romano. Tradvcidos en lengva castellana, por Don Esteuan Manuel de Villegas. Con las vidas del mismo Boecio, y del liey Theodorico, y vn apoyo de la Philosophia en Tercetos. En Madrid, por Andres Garcia, 1665. 8. 16 hojas prels. y 108 foliadas.

Los melros de Boecio están traducidos en verso castellano. El final del libro $V$ quedó sin interpretar por las razones que apunta D. Vicente de los Rios en las Memorias de Viltégas, que van al frente del tom. I. de las Eróticas impresas en Madrid en 1797. En el II tomo de las misinas se reimprimió el tratado de consolacion, sustituyendo la parte del libro $V$. que faltaba con la traslacion de Aguayo.

Ni Nic. Antonio, ni Pellicer tuvieron noticia di esta version de Villégas: Sedano solo menciona una edicion de ella hecha en $M a$ drid, 1680 , que no creo exista, y anade que es obra tan rara, que apénas se conice.

La traduccion en prosa de Boecio hecha por Ginebreda se encuentra en la Seccion teologica.

469 BOLEA (D. IÑIgo). Tratado de vnion del alma con Dios mediante entẽdimiẽto y amor de su perfeccion por via de soliloquios compuesto por dō Yñigo de Bolea. (Al fin:) Fue impressa la presente obra... enla leal ciudad de Caragoca en casa de Pedro Bernuz Año. 1570. 8. ${ }^{\circ}$ No tiene foliacion, signs. A-D todas de 8 hojas.

Segun Nic. Antonio y Latasa el verdadero nombre del autor de este libro es el de Don Inigo Abarca y Bolea. La manera vaga con que aquellos dos bibliógrafos hablan del Tratado de la union del atma, poemita escrito en quintillas, indica no consiguieron ver esta obra, en mi concepto mui rara.

Escribió $D$. Iñigo tambien en verso, el Baculo de nuestra peregrinacion, en que se trata coms se ha de unir nuestra voluntad con la Divina. Zaragoza, $1550.8^{\circ}$; y en prosa, un Tratado y suma de Oracion mental. Zaragoz $a, 1552 . .^{\circ}$; ademas hai de él uno ó dos tratadillos citados en la Biblioteca de escritores aragoneses; mas al parecer quedaron inéditos.

El volumen lleva al fin el siguiente escudito de Pedro Bernuz, que se encuentra tambien en los Soliloquios de S. Buenaventura, impresos por el mismo: guardo idea de haberlo visto en alguna edicion de Coci, cuya inicial lleva, lo cual nada tendria de estraño hablendo 
sido aquel sucesor de este, segun se dice en el cololon de la primera edicion de los Anales de Zurita.

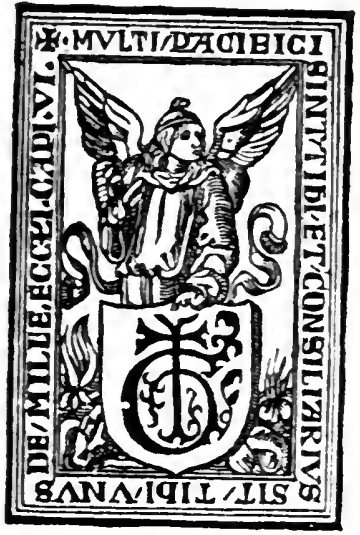

BOLEA Y CASTRO (MARTIN). Orlando determinado. Véase en la Seccion novelistica. - Libros de caballerías.

470 BONILla (Alovso DE). Nirevo jardin de flores divinas, en qre se hallarà variedad de pensamientos peregrinos. Compresto por Alonso de Bonilla, rezino de la Cludad de Baeca. En Baeça, por Pedro de la Cuesta. Año. 1617. 8. 8 hojas prels. 431 fols., 1 para repetir el lugar y año de la impresion y \& de Tabla.

Este volúmen consta de composiciones poéticas on varias clases de unetro por el estilo de los Conceplos espiriluales de Ledesma. En una nota al fin promete el autor una obra cuyo titulo debia ser La sin mancha concebida y ntras muchas obras compuestas al mismo proposito; sin duda este tomo será el que he visto, intitulado:

Nombres y atribvios de la impecable siem. pre virgen Maria Señura Nuestra. En Octauas. Con olras riinas a diversos Assumplos, y Glossas dificiles. Pur Alonso de Bonilla. Baeça, Pedro de la Cuesta, 1624. 4. 22 hojas prels., una con la Suna de io que contiene este libro, etc., luego el $\mathbf{f}(\mathbf{l}$. $\overline{5}$, que acaso deberá ser 7 , pues continúa el 8,9 , etc., hasta el 105 , todo de cursiva, una hoja despues Al lector, y por fin 129 hojas, con foliatura nueva, que contienen olras rimas.

471 - Peregrinos pensamientos, de mysterios diuinos, en varios Versos, y Glosas dificultosas. Com- pvestos por Alonso de Bonilla. Baeca, Pedro de la Cuesta, 1614. $4 .^{\circ} 6$ hojas prels., 227 fols., la última dice 217 equivocadamente, 11 de Tabla y una al fin para repetir la fecha.

Este volúmen $\mathrm{y}$ el Nuevo jardin son por el estilo de los Conceptos de Ledesma, y ambos dificiles de encontrar limpios y coinpletos: los mios son bellos y tan perfectos, que el tomo de los Peregrinos pensamienlos tiene hasta la singularidad de contener, ademas de las 6 hojas de los preliminares que todos llevan, 4 hojas de otros que se suprimieron, en culya portada hai una imágen de santo Domingo, y no tienen fe de erralas.-Gallardo no consiguió ver mas que un ejemplar falto.

En el Ensayo de una bib. esp. los Sres. Zarco del Valte y Rayon citan de Bonilla $\mathrm{el}$ siguiente pliego suelto: Glosas a la Immacula. da y pura Concepcion de la siempre Virgen Maria, Madre de Dios : y Señora nuestru: en forma de Chançonelas. Glosando este Verso ì comummente canlan los viños.

Todo el mundo en general

A vozes Reyna escogida

Diga, que soys Concebida Sin pecado original.

Baeça por Pedro de la Cuesta. Año 1615. 8." 8 hojas, sig. A. Segun los mismos hai otra edicion de Seuilla por IIlias Clauijo, $161 j$. $4 .^{\circ} 4$ hojas, sig. $a$.

- Fue Bonilla poeta no rulgar, como lo - prueban sus elegantes y armoniosos $1:$ isos, - ý á no ser por el estudio que pone en !nitar -a sil afectadisimo maestro Leclesma. no - Vacilariamos en colocarle al lado de unes- tros mejores poetas liricos." duiciones a Ticknor, lom. 5. , pdg. 509.

\section{BOSCAN Y GARCILASO. Las} obras de Boscan valgrnas de Garcilasso de la Yega repartidas en qvatro libros (Sigue el escudo de las armas de España, y bajo de colorado se lee:) Crm privilegio imperiali ( $\mathbf{L} a$ portada esta rodeada de orla ancha y fuera de ella á la parte inferior dice:) Carles. Amoros.

(A la vuelta principia el prólogo, que concluye en el blanco de la hoja segunda, en cuyo reverso principia la Tabla que llena tres hojas más. Las dos siguientes contienen el Privilegio, y en la octaca solo hai un Soneto de Garcilasso que se olvido de poner al fin con sils obras. Vienen luego CCXXXVII hojas foliadas, rlos fols. $X I X, X X, X X I, X X I I$, y $C X V I I I$ 
se repiten sin corregirlos despues) $y$ en.el dorso de la úllima se halla este final:)

tcabaron se de imprimir las obras le Boscã y Garci Lasso de la Vega: en Barcelona en la officina de Garles Amoros a los xx. del mes de Marro: Año. M.dxum. 4. ${ }^{\circ}$ Buen papot i inilpresion.

lrimera relicion de suma rareza y gran precio, drseonocida i la mayor parte de los hiblicigmafos. La licencia de Cuirlos r. á li viluda de lioscall, Hoña lna firon de Rebolledo, esti fechadil en Madrid el is de febrero Ir $15,15, y$ de consiguiente un mes y dos dias sules do trrminarse la impresion.

473 BOSCANYGARCILASO. Las obras de Boscã y algunas de Garcia lasso d' la lega. lieparlidas en Ttro Libros. 1513. Cla portada tambien va circuida de orla ancha y esta impresa de negro y colorado. Liena el dorso el mríngo C 1 lins lectores, ocupando las otrus lies hojus de prels. la Tabla. Principea la obra con la sign. $\mathrm{A}$; pero mi esta hoja ni la segunda llevan folios. los cuales empiezan en la A iij, y con mui frecuentes equirocaciones, llegan al cij, en cuyn recersoleemos:) C Acabaron se de imprimir las obras de Boscan Y Garci lasso dela Lega. Año del nascimiento de Jesı christo. II. D. xliij. Iños \$. ${ }^{\circ}$ let. gót.

sorunde plicion aun mis para y menos ronocilla duc lis prinera: el no llevar nombre le lugar. pirece que indique haberse hecho furtirimente apenas salió í luz la de Barcelona.

Brunet reflieindose i Bonterwek y al Catálogo de P'ijot d' Ouscnbray, cita mna, tal vez l. leverra, impresa en Lisbna, 1545. 4. lle vislo la cuarla que es la más antigua mencionada por Yic. Antonio y Barrera Leirado, cura descripeion es la siguiente:

(P'ortalia rou orla grande, dentro un esendo de almas imperiales, y bajo de negro y colurido:, Las obras del Boscan y alguna: de Garcilaso de la rega: reparlidas en qua. tro librys.-Al fin: C Fueron impressas las obras de Boscrn: y de Gaveilasso de la vega: en Nedina del caipo: por Pedro de castro immessor, A cosla de luci Pedro museli mercaler le libros vezino de medina del campo: Acubaronse a siete dias de agosto. Añode. M.b.xliiij. $1^{\circ}$ ' hojas prels. y CCXXXlll foliadas.

Los traductores de Ticknor, pig. 484 tomo 2. dicen ser esta la primera edicion donde se incluyo la Comersion de Boscan. Tam- bien tuvimos en Lóndres la quinta de $A n$ vers, Martin Nucio, M.D.XLIIII. 12. ' la cual, scgun los mismos, contiene igualmente la Comversion, y la recomiendan coino más completa que las anteriores.

\section{BOSCAN Y GARCILASO.} Las Obras de boscan y algrnas de Garcilasso dela Vega repartidas en quatro libros. De nueno enmendadas y en mejor orden delo que hasta agora han do impresas. En Enveres. En casa de Martin Nucio, s. a. 12.0 6 hojas, : $:$ els. y 982 foliadas. Es de las ediciones que tienen la y gótica.

En la presente impresion, tal vez la sesta, se lialla el Mar de Amor, la Conversion, las Respuestas al A/miranle, y otras composiciones que no están en las primeras.

473 L Las obras de Boscan y algrnas de Garcilasso dela Yega. Repartidas en qvatro libros. Ade meteque ay mvchas anadidas uan aquí mejor corregidas, mas cóplidas y en mejor orden que asta agora han sido impressas. Año M.D.x LVII. (Al fin:) I Estampado por. M. Antonio de Salamanca el Anno de 1347. 8. ${ }^{\circ}$ narq. 271 hojas fols., inclusos todos los preliminares, y una hoja blanca al fin.

Esta edicion romana, probablemente la selima, es toda lle letra cursiva, y á pesar de Ins aumentos anmeiados en la portada es copia de las primeras sin adicion alguna.

No pude verificar el contenido de otra que vi de Toledo, Iuí Ferrer, s. a. $12 .^{\circ} 12$ hojas prels., 298 foliadas, y una al fin en que se repiten las seîas de la impresion de la portada, la cual está de negro y encarnado.Brinet trae otra de Leon, Iman Frellon, 1547, $12 .^{\circ}$, que no he visto; pero tal vez sea la misma que la siguiente.

\section{0} La misma obra. Leon, Iuan Frellon, M. D. XLIX. gr. 12. 12 hojas prels., 766 págs. $y$ una hoja, en cuyo blanco se halla la nota que copio despues.

Lleva las adiciones de la impresion ántes mencionada de Envers, s. a.

En la venta de Yemeniz obtuvo el precio de $150 \mathrm{fr}$.

Como la presente impresion sufrió un cambio de portada en 1658 , habiéndolo ya tenido probablemente en 1618 , no estrañaria que esta de 1549 fuese la misma que trae Brunct lecha por Juan Frellon en 1547.

La nota final ántes citada diec: - Fstas 
-obras de Juan Boscan, y àlgunas de Garćl- Iaso de la rega, y muchas otras nuevamen- te añadidas, que hasta agora nunca fueron - Impresas, son lambien corregidas y emen- dadas de muchas faltas que por descuido. de - los oflciales en las impresiones se hallaron; - de unaneri que van agora niejor corregi- das, mas colmplidas y en mejor orden que -hasta agora lan sido."

477 BOSCAN Y GARCILASO. Las Obras de Boscan y algrnas de Garcilasso de la Vega repartidas en quatro libros. A de mas ( sic) que ay mxchas añadidas, uan aqui mejor corregidas, mas complidas y en mejor orden que hasta agora han sido impresas. Yenetia, en casa de Gabriel Gilito de Ferrariis y sis hermanos, ID LIII. (Al fin dice que se acabó a XIIII. de Agosto de M D LIII.) 12. ${ }^{\circ}$ let. curs. 300 hojas foliadas.

La presente edicion y la de Medina, 1544 son las únicas conocidas por Nic. Antonio.

Contenido igual al de la anterior $y$ ademas lleva una composicion poética de incierto autor Sobre la troba hespañola e ilaliana.

En el num. 1456 del Ensayo de una bib. esp. de Gallardo se describen: Las noras de Boscan y algunus de Garcilasso de la vega. Reparlidas en quatro libros. En Valladolicl. Año. M.D.L.III. lan en este libro muchas obras añadidas, y mejor corregidas. Y en mejor ordè que hasta agora fuer'on impressas. Por Iuá maria de terranuua, Ilacome de liarcary. En Mcdina del cäpo. Lleva la nota final de la lionesa de 1549 con la siguiente adicion:) Esto que aqui se promete no es fabula, poró qualquiera curioso vera la diforencia $\bar{q}$ ay de esta comeccion a las otras. En Vulladolid en casa de Scbastiun Martinez. Año de 15.5. $12^{\circ}, 289$ fols., 12 hojas prels. y una al fin con las seinas de la impresion. liebe ser esta cdicion copia de la de Lion de 1549 , segun lo indica el contesto de la portada y la advertencia del fin que es iguàl.

En el Catálogo de Gancia hai una edicion de Anvers en casa de Iuan Steelsio, 155.5 . 1.2.

478 La misma obra. Barcelona, 10̆3̆4. (En la portada; y en el blanco del fol. cclxviij:) En Barcelona, enla ofticina de la viuda Carles Amorosa Año 10̆0ّ4. 12. ${ }^{\circ}$ Siete (no seis como sienta Brunet) hojas prels. cclxviij foliadas y 26 con las signs. aa-bb para la Conversion de Boscan, el Mar de Amor y otras varias composiciones del mismo.

Encierra las adiciones de la de Envers, s. a.; pero en vez de intercaladas en el volúmen van reunidas al fin.
879 BOS̈CAN Y GARCILASO. Las obras de Boscan y algunas de Garcilasso de la Vega... De nueuo enmendarlas y en mejor órden de lo que hasta aora han sido impressas. Anvers, Iuan Steclsio, M.D.LIIII. 12. ${ }^{\circ} 6$ hojas prels. $y 288 \mathrm{fols}$.; empezando la foliatura por el fol. 3 despues de la hoja en que concluye la Tabla.

Testo como la de Envers, s. a.

Tuvimos en Londres otra impresion de Allvers, Marlin Nucio, M.D.LF. 12. , que supongo seria igual á la ántes descrita.

480 Las mismas. Emendadas agora nueuamente, $y$ restituidas en su integridad. Anvers, en casa de Philippo Nucio, M.D.Lxix. 12. 300 hojas fols. en todo; las 8 primeras notienen impresa la foliatura.

Igual en el conteuido á la anterior de Juan Steelsio de 1554 .

Al núm. 14.t? del Ensayo de una bib. de Gallardo, se describe una edicion de Alcala do Inenares, por Sebustian. Hartins:. Fuera de la puerta de los sanclos Marlires. Año. 1575. $8 .^{\circ} 500$ hojas. No detalla el contenido.

481 La misma obra. Anvers, en casa de Pedro Bellero, M.D.Lxxr. (Al fin: Antverpiae, Typis Gerardi Sinits, 1ji6.) 19. 6 hojas de prels. y

Comprende lo mismo que las impresas anteriormente en aquella ciıdad. - Vo sé si serji ignal la pubticada en Caragoça, $157 \%$. $12 .^{\circ}$, descrita por Brunet, y tambien en el Catilogo de Sora donde diec que es en $16 .^{\circ}$

432 - La misma obra. Anvers, en casa de Martin Nucio, M.D.XCVII. 12. 189 hojas fols. inclusos los prels. , dos de Tabla, 68 foliadas para Las obras de Garcilaso de la Vega, que llevan nuevo frontis y nueva foliatura, una en que concluye la Tabla de las mismas y tres blancas.

En algunos ejemplares se lee en ambas portadas: En casu de Pedro bellero, j la primera tiene su eseudo: lo que prueba que la presente edicion fué costeada pol los dos impresores. Véase el siguiente articulo.

483 - La misma obra. Anvers, Eu casa de Pedro Bellero, 1097. 12. 
Es la misma edicion que la precedente con sola la diferencia de la portada, segun lo indico en la nota anterior.

Contenido igual al de las puestas ántes.

\section{BOSCAN Y GARCILASO.} Los Amores de Ivan Boscan, y de Garcilasso de la Vega. Donde van conocidos los tiernos coracones de nuestros Abuelos. En Leon, Por Ivan-Ant. Ivgretan, y MarcoAnt. Ravavd, H.DC.LVIII. 12. 12 hojas prels., 766 págs. y una hoja al fin en que se recomiendan las ventajas de esta edicion.

Es la misma de 1549 con la sola diferencia de haberse reimpreso el pliego de los prelimi nares: esta circunstancia me induce á sospechar que la anunciada en el num. 39 del Catálogo de la venta de Conde, como hecha en Leon, en 1618. 12. ${ }^{\circ}$, con titulo idéntico al de la de 1658 , sea otra metamórfosis de igual especie.

\section{BOTELlO DE CarVallo} (El capitan Miguel). La Filis. Del Capitan Migvel Botello de Carvallo. Madrid, luan Sanchez, 1641. 8. 8 hojas prels., inclusa una que solo contiene un escudo de armas y precede al fróntis, y 124 foliadas.

Novela ó poema en octavas dividido en seis cantos, donde enenta el autor sucesos de su vida bajo el nombre de Fabio.

En el Ensayo de una bib. esp. de Gallardo se describen las Rimas varias y Tragicomedia del marlir delhiopia. Por El capilan Miguel Botello de Carvallo. En Rean, En la inprenta de Lorenço Mavrry. Año M.DC.XLIT, 8. may. 136 hojas.

Barbosa Machado cita de este autor un Soliloquio de Cristo nuestro Señor en la Crus. Paris, Viguel Blagearl, 1645. 8. menciona unas Rimas divinas y humanus. Parte segumela; pero no dice si llegaron á imprimirse.

El mismo Carvallo dió á luz, tambien en

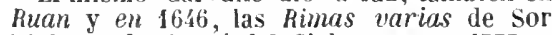
Violante do Ceo o del Cielo, que en $173 \overline{3}$ se reimprimieron en Lisboa, aumentadas y con el Lítulo de Parnaso lusitano; á pesar de ser en castellano la mayor parte de las composiciones que comprende. Asi lo dice Barrera.

Nicolas Antonio y Gallardo no vacilan en adjudicar á este Miguel Botello de Carvallo La fabula de Piramo y Tisbe y las Prusas y versos del Pastor de Clenarda, sin embargo de llamarse el autor de ambas obras únicamente Miguel Botello, y de haberse publicado veinte aîos intes.
486 BOTELLO DE MORAES Y VASCONCELOS (FrancISCO). El A1phonso Del Cavallero Don Francisco Botello de Mforaes, y Vasconcelos. Paris, chez Estienne Michalliet, MDCCXII. 12. 365 págs. comprendidas las 6 de las tres hojas prels. Al fin va una hoja para anunciar la próxima reimpresion de El Nuevo Mundo del mismo autor.

Poema en octavas.

487 - El Alphonso ó la fundacion del reino de Portugal, assegurada, i perfecta en la conquista de Lysboa. Poema epico dél caballero Francisco Botello de Moráes i Vasconcélos. Salamanca, Antonio Villargordo, II.DCC.XXX1. 4. 12 hojas prels., 284 págs. $y 2$ hojas al fin que contienen una noticia biográfica del autor.

La primera edicion de Paris lleva una de. dicatoria de $\mathrm{D}$. Francisco Botello dirigida á D. Rodrigo Annes de Sa y en ella dice, que publica este poema por no poder tolerar el que corra divulgado en copias imperfectas. De consiguiente no sé como esplicarme el que al publicar la impresion de 1731 el mis. mo Botello, pues hai en ella dos dedicatorias suyas, la una á Doña Clara de Solis y Gante, y la otra á li Princesa de Asturias Doña Maria, fechadas en 1751, advíerte en el Prologo, que todas las ediciones anteriores son furtivas y publicadas sin anuencia ni consentimiento suyo. Ademas observo ser enteramente distinta la obra dada á luz en Paris, no obstaute de llevar casi igual título, ser el asunto el mismo, y constar de 12 libros que comprenden mil cuatrocientas trece octavas, juiéntras la de Salamanca abraza únicamente diez libros y mil ciento cuarenta y seis octavas.

488 El nuevo Mundo. Poema heroyco de D. Francisco de Moraes y Vasconcelos; con las Alegorias de Don Pedro de Castro, Cavallero Andaluz. Barcelona, Ivan Pablo Martí, 1701. 4. 16 hojas prels. y 476 págs.

Poema en diez libros escrito en octavas.

No conozco otra edieion de esta obra; sin embargo al fin de la del Alphonso hecha en Paris en 1712, se dice: El otro poema epico de nuestro Author inlitulado El Nuevo Mundo, ya impreso ha algunos años, brevemente volverá á imprimirse concluido y limado.

Ile tenido otra obra de este autor intitula. 
da: IIistoria de las cuevas de Salamanca. Salamancz, Joseph Villargordo, 1737. 8. 16 hojas prels., 426 págs. y al fin 16 págs. de una composicion latina.

489 BOTELLO DE MORAES Y VASCONCELOS (Francisco). Panegyrico historial, genealogico, de la familia de Sorsa. Cordoba, Diego de Valverde y Leyva, s. a. (haicia 1696.) $4 .^{\circ} 6$ hojas prels., inclusa la del escudo de armas de los Sousas, y $4 \mathrm{~b}$ págs.

Escrito en octavas.

490 BOTELLO DE IORAES ET VASCONCELOS (Fraxciscus). Satyræ equitis domini Francisci Botello de Moraes et Vasconcelos, cum notis et argumentis Joannis Gonzalez de Dios. Salmanticæ, Nicolaus Josephus Villargordo, 1739. 4. 4 hojas prels. y 115 págs.

boyardo (Mateo Maria). Los tres libros de Orlando Enamorado. Véase en la Seccion nocelística. - L ibros de caballerías.

491 BRAVO (Fr. Nicolis). Benedictina de F. Nicolas Bravo... En que se trata la milagrosa vida del glorioso S. Benito, Patriarca de los Monges, con vna breue recapitulacion de las Religiones, que le reconocen por Padre, assi monasticas como militares. Salamanca, Artrs Taberniel. M.DC.IIII. 4." 12 hojas prels., 481 págs. y 17 de Tablas.

Poema en octavas y en diez yocho cantos. Primera y acaso única edicion, rara.

492 BURGUILLOS (TOMÉ DE). Rimas hrmauas y divinas, del Licenciado Tome de Burguillo:, no sacadas de Blibioteca ningrna, (que en Castellano se llama Libreria) sino de papeles de amigos y borradores suros... por Frey Lope Felix de Vega Cärpio. Madrid, Imprenta del Reyno, 1634. $4 .^{\circ} 8$ hojas prels. (enire ellas un retrato grabado) y 160 foliadas.
Las licencias, aprobaciones y tasa de $\mathbf{1 6 3 4}$ prueban ser esta la primera edicion, y no existir la de 1618 citada por Sedano, en el toll. II. del Parnaso español.

493 BLRGUÍLLOS (TOME DE). Rimas hvmanas y divinas, etc. (Como el anterior.) Madrid, Imprenta Real, 1671. . $^{\circ} 8$ hojas prels. y 160 fols.

Reproduccion á plàna rengIon de la primera, de donde ha copiado hasta las erratas y la Fé de ellas, que por consiguiente le es nécesaria.

494 La misma obra. Paris, Julio Didot mayor, 18z8. 32. Con anteportada grabada.

Fernández reimprimió estas Rimas en el tom. XI. de su Coleccion de Poelas, y alli trata de sostener que Burguillos es un poeta real, diverso de Lope de lega, anunciando demostrarlo en una disertacion, que jgnoro se haya impreso. Las pruebas de lo contrario se hallan indicadas en el tom. XIX. de las Obras suellas de dicho Lope, en el que se reprodujeron las Rimas de Burguíllos. - La Gatomaquia, que forma parte de ellas, se reimprimió en el tom. II. del Parnaso espanol y varias vezes suelta.

Ticknor al hablar del presente poema forma de él este exacto y acertado juicio: :Es un - poema heróico-ecónico en verso suelto, di- vidido en seis cantos ú silvas, pinta la lucha - de dos gatos que pretenden los favores dc - una gata... Si no es el priner peema espa- ñol de su genero en el orden de antigüe- dad, lo es indudablemente en el mérito: las - dos silvas últimas, particularmente, están - escritas con tanto brio como gracia y lije- reza, parodiando unas vezes al Ariosto y á - otros poetas épicos, y otras imitando los - ronances autiguos, aunque siempre con la - mis.ua facilidad y soltura: asi es que desde - su primera publicacion fué mui leida $y$ - apreciada en Espaila, y aun en el dia puede - asegurarse que es la más conocida de las - obras sueltas de su autor.,

49:3 BLTRON Y IIUJICA (JosÉ Avroxio). Harmonica vida de Santa Teresa de Jesrs, fundadora de la reforma de Carmelitas Descalcos. y Descalças. Por el Padre Joseph Antonio Butrón y Muxica. Madrid, Fran-

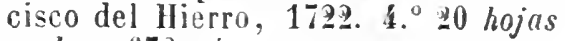
prels. y 672 paigs.

Poema de pésimo gusto escrito en mil novecientas sesenta y una octavas, $y$ dividido eu dicz y ocho Rasgos ó sean cantos.

He visto otra biografia poética de esta mis- 
ma santa cuyo título es: Vida, invicta, milagros, y fondaciones de la B. Madre Teresa de lesvs. Compuesto en quintillas, por Pablo Verdugo de la Cueua. Barcelona, Sobastian
Matevad, 1615. $8 .^{\circ} 8$ hojas prels., 205 fols. y una con una carta de Lope y las señas de la impresion. Es un poema dividido en veinte cantos.
496 CABRA (Teodoro José de). Historia dolorosa, dividida en siete cantos, en que se ve la acervísima pasion y muerte de Nuestro Redentor Jesu Christo, v la compasion de su Dolorosísima Madre. Por el Padre Fr. Teodoro Josef de Cabra. Córdoba, Don Rafael Garcia Rodriguez, s. a. 4. ${ }^{\circ}$ Lim. de madera.

Poemita escrito en romance octosílabo.

497 CADALSO (José ne). Poesias del Coronel D. José de Cadalso. Madrid, Sancha, 18叉1.18.

Edicion positivamente francesa.

La mejor impresion de las Obras de D. José Cadahalso es la de Madrid, Repulles, 1818. 3 vols. $8^{\circ}$. Iróntis grabados.

Por separado se han publicado las Cartas marruecas. Vadrid, Sancha, MDCCXCIII. 1. - Barcelona, Piferrer, MDCCICVI. 4. ${ }^{\circ}-C_{8} e^{\circ}$ rona, A. Oliva, 181\%. 12. - Tulosa, 1820. $120^{\circ}$-Paris. J. Sillill. 1827. $180^{\circ}$

Los Eruditos a la violeda. Paris, J. Smith, 1827. 18. Debe haber alguna edicion anterior española.

Las Noches hugubres. Valencia, (Estevan) 1817. $160^{\circ}$-Aüadidas con los Anales de cinco dias, y la Guia de Hijos de lecino etc. Barcelona, J. F. Piferver, 1818. $40^{\circ}$-Seguidas del Delinqüente Honrado, drama en prosa, por D. Melchor Gaspar de Jovellanos. Rurdess, Lawalle joven, $1818.18 .^{\circ}$

\section{CAIRASCO DE FIGUEROA} (Bartolouí). Templomilitante trivmphos de virtrdes festividades y vidas de santos Compresto por Bartolome Cayrasco de Figueroa ( $\mathrm{Al}$ fin:) En Valladolid, En casa de Luys Sanchez. Año 1603. 4. 13 hojas prèls., incíuso el fróntis grabado y otra lamina que representa la corte celestial y la vida de Jesu-Cristo, 293 priys. y dos hojas blancas la primera parte; y 376 paigs. y 3 hojas de Tabla la segunda.

En ejemplares de sta misina impresion he observado algunas variantes hasta el folio 9 , siendo las mis chorantés á primera vista las siguientes: en el que yo tengo principia la obra por póg. 1, la hoja segunda no lleva signatura, y en la tercera, fol. 7 , el segundo verso termiua por Geminis,; en otros comienza la obra por la Paig. 3 , la hoja siguiente lleva la signat. A 3 y en la tercera, fol. 7 , el verso ántes citado acaba por Gemini,.

La primeta edicion de la primara parle se publicó en Valladolid en $1602.8^{\circ}$; de la segunda no hai ninguna anterior á la de 1603 , arriba descrita.

\section{CAIRASCO DE FIGUEROA.} Templo militante Flos santorvm, y trivmphos de svs virtvdes. Por Don Bartolome Cayrasco de Figueroa. Primera y segvnda parte. Lisboa, Pedro Crásbeeck. Año. 1613. (Al fin: 1612.) 6 hojas prels. y 331 pags.-Tercera parte del Templo militante. Madrid, Luis Sanchez, 1609. 4 hojas prels. y 3509 págs.-Templo militante Flos sanctorvm, y trivmphos de svs virtudes. Quarta parte. Lisboa, Pedro Crasbeeck. 1610. hojas prels. 289 paigs. y una hoja blanca. 4 tomos en 3 vols. que generalmente se encuadernan en 2 . fol. Viñetas de madera.

Hai ejemplares de la presente edicion de las dos primeras partes cuyos fróntis llevan el año de 1615 .

Nic. Antonio no solo ignoró la existencia de todas lits impresiones deseritas ya de esta obra, sino que no supo lubiese una cuarta parte: como dice, la prinera y segunda se imprimieron en Lisboa en 1614 y la tercera en la misma ciudad en 1628.

Al fln de los preliminares de la 1.", $3 .^{\circ}$ y 4." parte se encuentra el retrato de Cairasco á los 60 años, que copio á continuacion; va precedido de un corto elogio biográfico-literaric. en latin, $y$ en él se supone que el autor del Templo mililanle fue el inventor de los versos esdrújulos. Sin duda el panegirista no conocia la Diana de Gil Polo escrlta mas de medio siglo ántes, pues de lo contrario liubiera recordado que en el libro $\mathbf{j}^{\circ}$ hai una composicion en Terços esdruccioles, que principia:

Tauriso, el fresco viento que alegrdndonos. Murmura entre los árboles allisimos, I.a uista y los oidos deleilándonos; etc. 
Los traductorcs de Ticknor, en sus Adiciones á la Hisloria de la lit. dicen, hablando de los escritores de principios del siglo XVII: - Asimismo merece ser cilado entre los poe. - Las de este tiempo Bartolomé Cálirasco de -Figueroa, matural de la Gran Canaria, lla. - mado por algunos al Divino... Vic. Autonio - hace grande elogio de él, llamándole Forlu-
- natarum insularum decus... Dicen que fué - tan diestro en la música, que cuando tanla - la guitarra dejaba suspensos á los oyentes. - Escribio Templo mililanle, especic de Flos - Sancloruin en verso, obra verdaderamente - colosil pues consta de más de quince mil - octavas, aparte de otros muchos metros cn - ella intercalados.

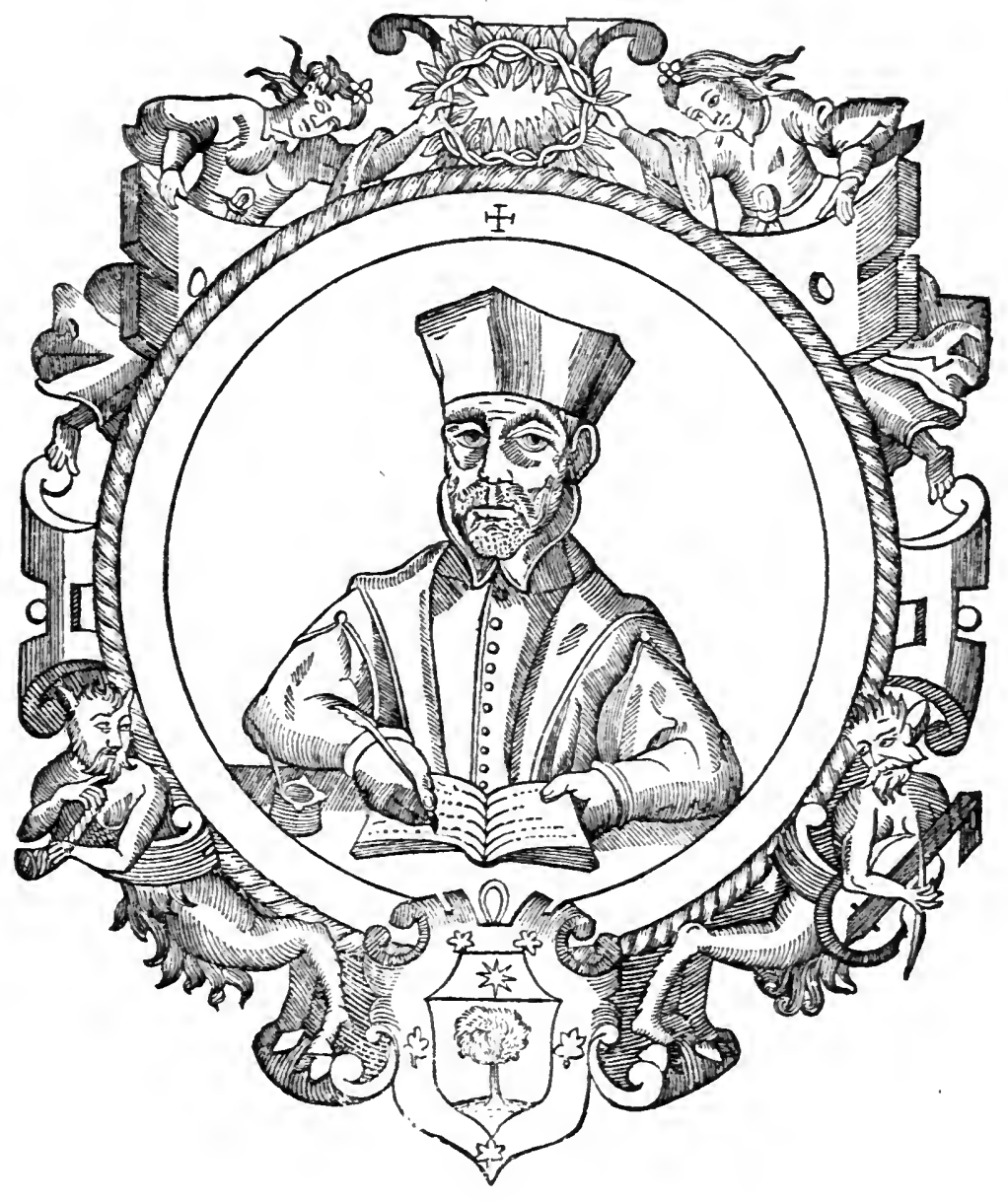

500 CALVETE DE ESTRELLA (Juan Crist.). El trmvlo Imperial, adornado de Historias $y$ Letreros $y$ Epitaphios en Prosa y verso Latino Por luan Christoual Caluete de Estrella. Valladolid, Francisco Furnandez de Cordova, M.D.LIX. 1. ${ }^{\circ}$ i hojas prels. y 36 foliallas. En cl blanco de la viltima se repilen las señas de
Ia impresion y al dorso esta el escudo del impresor; despues viene la lámina del tímulo tirada en fol.

Todas las poesias contenidas en este raro tomito sou latinas, como ya lo indica lá por. tada, y están escritas por Calvete de Estrella.

Mi ejemplar tipne la lámina que sp pliega, la cual suele faltar. 
501 Camargo (Hernando de). Mverte de Dios por vida del hombre dedvzida de las Postrimerias de Christo Señor nuestro. Primera parte. En que se tratan los mysterios de nvestra Redencion, con variedad de conceptos diuinos, y humanos, principalmente las de la semana Santa; hasta la institucion, y excelencias del santissimo Sacramento. Poema en Decimas. Por el Padre F. Hernando de Camarco. Madrid, Iuan de la Cuesta, 1619. $0^{\circ}$ Tiene 12 hojas prels. con las cuales parece nada falta a pesar de no corresponder exactamente la llamada de la cuarta al principio de la quinta; 137 fols., una hoja de Tabla y otra para repetir las señas de la impresion.

Dudo llegara á publicarse la continuacion; á pesar de suponer Nic. Antonjo que la Primera $y$ Segunda parte se imprimieron en Madrid, Juan de la Cuesla, 1619. 4.0

Este poema se divide en treee cantos y va precedido de algunas poesias escritas en elogio de su autor, entre otros por Luis Vélez de Guevara, el Maestro Espinel, l). Fernando de Lodena, el Maestro Jose de Valdivielso, Lope de Vega, Nira de Anescua y Guillen de Castro.

Los Iraductores de la Hisl. de li lit. de Ticknor (tom. 111. pág. 182) eitan un poema inlitulado: El santo milagroso aynstiniann, San vicolas de Tolenlino, sus excelencias, vida, merte y milagros. Madrid, 1628. 4.' el cual dicen estar escrito por Fr. Fermando Camargo y Salgado, aunque suena como autor D. Francisco de Salcedo Camargo. No me cabe duda ser dicho Fernando Camargo el mismo que compuso la Muerte de Dios por vida del hombre, y el no citarse por los mencionados traductores esta produccion, prueba no tuvieron noticia de su existeneia, y es un dato mas de la rareza de ella.-El ejenpiar de Gallardo mencionado en el Ensayo de una bib. esp. estaha falto de la hoja de la Tablı y la de las señas de la edicion: puesto que no las menciona al describir el contenido del volúmen.

Camargo fué uno de los poetas del buen tiempo de la literatura, $y$ de él formó Lope de Vega el siguiente juicio en su Laurel de Apolo:

Con mil laureles en la sacra frenle por estilo tan puro y elocuenle, con tus rimas y tu patria honraste, dulce Camargo, á Nicolas cantaste, despues de haber cantado en verso triste la sagrada E'egia,

muerte de Dios y llanto de Maria, que de tu nombre fuiste dulcésima ironia.
502 CAMOENS (LUIS DE). OS LVsiadas de Lvis de Camōes. I Polo original antigo agora nouamente impressos. Em Lisboa, Com licenca do Santo Offisio \& Priuilegio Real Por Manoel de Lyra. 1597. $4 .^{\circ}$ let. curs. 2 hojas prels. y 186 fols.

Brunet asegura que esta rarisima edicion se copió de la primera cuya descripcion es la siguiente: os Lvsiadas' de Luis de Camóes. Com privilegio real. Impressos em Lisboa, com licença da sancta Inquisição, \& do Ordintrio: em casa de Antonio Gốcaluez Impressor. 1572. (Este título va circuido de orla; en la hoja siguiente está el permiso del rei, fechado cn Lisboa el 24 de setiembre de 1571 , y la aprobacion de Frey Bertholamen Ferreira. La obra principia en la tercera hoja que no lleva foliatura; pero debe ser 1 sign. A, y concluye á la vuelta del fol. 186.) 4. ${ }^{\circ}$ let. curs. Existe otra impresion del mismo año ejecutada tambien por Antonio Gonzalvez con igual número de hojas; pero segun parece tiene algunas variantes o correcciones en el testo.

La tercera edicion, que tambien he visto, dice en el fróntis: 0 s Lvsiadas de Lvis de Camões. Agora de noun impresso, com algũas Annotaç̃es, de diuersos Autores. (Sigue el escudo de Lira que representa á Orfeo tocan. do el violin y bajo:) Com licença do Supremo Consello da Sancta \& Geeral Inquisição, por Manoel de Lyra. Em Lisboa. Anno de 1584. (En la hoja siguiente la licencia, á la vuelta la $T a$ voula, que ocupa nueve hojas más, una hoja despues con solo el escudo del impresor, $y$ en la siguiente, fol. 1, empieza la obrd que va hasta el fol. 280.) 8.

La cuarta edicion que encuentro citada la trae Ebert, núm. 3398 y es de Lisboa, Manoel de Lyra, 1591 , llamada por él en $80^{\circ}$ y á mi juicio es $4 .^{\circ}$ pequeño español.

La quinta es la de 1597 que forma el objeto de este artículo, y la sesta, es la descrita en el siguiente. Nic. Antonio solo menciona en su Bibliotheca la de 1572 .

503 CAMOENS (LuIS DE). Os LVsiadas de Lvis de Camoẽs Principe da poesia heroica. Em Lisboa, Pedro Crasbeeck: Anno 1609. $40^{\circ}$ la mayor parte de let. curs. 2 hojas prels. y 186 fols.

Brunet no menciona esta edicion. Tampoco conoció la sétima, que se halla en mi biblioteca, $\mathrm{y}$ es la siguiente:

504 Os Lvsiadas de Lvis de Camoẽs Principe da Poesia heroyca. Em Lisboa. Por Vicente Aluarez. Anno 1612. $4 .^{\circ}$ let. curs, 2 hojas prels. y 186 fols. 
Habiéndome propuesto dar notlcia de todas las ediciones antiguas de este poema, aun cuando no estén en mi poder, para seguir el órden cronológico corresponde colocar aqui la que trae Brunet de Lisboa, 1613. $4 .^{\circ}$, con un comentarlo de Manuel Correa. En El Catálogo de Conde, núm. 49, se anunció una edlcion de Lisboa, 1626. 8. ${ }^{\circ} \mathrm{y}$ Brunet habla de otra tambien de Lisboa, Craes. beek, $1631.24 .^{\circ}$, que creo confunde con la de 1651 , cuya descripcion daré despues.

50J CAMOENS (LUIS DE). LVsiadas de Lvis de Camoens, Principe de los poetas de España. Comentadas por Manvel de Faria i Sousa. Contienen lo mas de lo principal de la Historia, i Geografia. del mundo; i singularmente de España: Mucha politica excelente, 1 Catolica: Varia moralidad, i doctrina; Aguda i entretenida satira en comun à los vicios: I de profession los lances de la Poesia verdadera i grave: I su mas allo, i solido pensar. Todo sin salir de la idea del Poeta. Madrid, Ivan Sanchez, 1639. 4 tomos en 2 vols. fol. $E l$ primer tomo consta de 12 hojas prels., la ultima de las cuales tiene los retratos de Camoens y Faria y varios elogios en versoá los mismos, y 552 colunas; el segundo nunca tuvo portada y contiene $63 \mathrm{Z}$ colunas al fin de las cuales se lee: Madrid, Antonio Duplastre, MDCXXXIX.

$E l$ tomo tercerotiene portada y $328 \mathrm{co}$ lunas; el cuarto carece de fróntis, como el segundo, comprende 670 colunas y 17 hojas para terminaria Tabla. $C a$ da canto lleva al principio una viñeta grabada en cobre é intercalados en el testo hai algunos retratos en madera.

Son raros los ejemplares del papel ordina. rio, bastante malo por cierto: del papel grande $\mathrm{y}$ fuerte no he visto más que el mio.

Este copiosisimo comentario en castellano á las Lusiadas es mui apreciado. Se halla al principio de èl un largo Elogio escrito por Lope de Vega al trabajo de Faria, y una Vida de Camoens y un Juicio de su poema de di. cho Faria.

Dice Brunet que al tin de la cuarta parte suele unirse un follete intitulado: Informacion en favor de Manuel de Faria y Souza sobre ta acusacion que se hizo en el Tribunal del $S$. Oficin de Lisboa a tos comentarios que escrivio à las Lusiadas.

506 Os Lvsiadas de Lvis de Camōes. Lisboa, Paulo Craesbeek,
163ั1. 24. ${ }^{\circ}$ hojas prels. y 141 fols.

Creo que debe encuadernarse este tomito con las Rimas, impresas tamblen por Craesbeek en el mismo año, segun está en mi ejemplar.

En el Ensayo de una bib. esp. los SS. Zarco del Valle y Rayon describen una edicion de os Lvsiadas com os argumentos do Ldo. João Franco Barreto. Com hum Epitome de sua vida. Lisboa, Anlanio Craesbeeck d'Mello. Anno $166 \overrightarrow{3} .12{ }^{\circ}$-Cuatro ediciones posteriores á esta se hallan en el Manuel de Brunet; pero no las he visto, á saber: la de Lisboa, 1720. fol., copia de la de 1613 y por consiguiente con el comentario de Manuel Correa. - Lusiada, poema epico ... com os argumen. tos de Joaõ Franco Barielo, illuslrado com varias $\&$ breves notas... por Ign. Garcez Ferreir Napoles y Roma, 1751-32. 2 vols. $4 .^{\circ}-$ Os Lusiadas. Coimbra, 1800. 2 vols. $180^{\circ}$ - Os Lusiadas, poema epico, nova edizẵo correcta, e dada á luz, por Don Joze Maria de Souza-Bstelho. Paris, F. Didot. 1817. gr. $4 .^{\circ}$ pap. vitela. Magniflca edicion que solo se tiro para regalos, ilustrada con diez hermosas láminas y el retrato de Camoens. He tenido la impresion que se hizo conforme a la de Souza-Botelho, ejecutada tambien en Paris, por F. Didot. MDCCCXIX. gr. $80^{\circ}$ con solo el retrato. Ile visto una edicion segundo o legilimo texln. Avinhaõ, Francisco Seguin, 1818.2 vols. $16 .^{\circ} \mathrm{y}$ otra de Paris, Teofilo Bar. rois hijo, 1820. 2 vols. $18 .^{\circ}$; en ella se siguió el testo de la de 1S19. Terminaré el articulo de Las Lusiadus con la siguiente impresion que tengo, suponiendo se habrán hecho otras despues, sill embargo de no haberlas visto.

อ̈0T CAMOENS (LUIS DE). OS LYsiadas. Poema Epico de Luis de Camōes. Nova edicaó correcta e dada á Iuz conforme a de $181 \bar{T}$, in $4 .^{\circ}$ por Joze Maria de Souza - Botelho. Paris, Fermin Didot, 1823. 32. ${ }^{\circ}$ Fróntis grabado y retrato.

Preciosa edicion de la que se tiraron dos ejemplares sobre vitela.

Pasemos ahora á tratar de las traducciones castellanas.

כ08 La Lvsiada de el famoso poeta Luy's de Camōes. Traducid en verso castellano de Portugue:, por el Maestro Luys Gomez de Tapia. Salamanca, Ioan Perier, M.D.LXXX. 8. 16 hojas prels. y 307 fols.

Raro.-El Prólogo y unos versos latinos de los prels. son de Francisco sánchez de las Brozas; tambien hai poesias en alabanza de la obra escritas por el Dr. Diego de vanégas, D. Luis de Göngora, D. Luis de Valenzuela y Pedro de Yega.-Al fin de cada canto vañ puestas algunas breves anotaciones. 
509 CAMOENS (LUIS DE). LOS Lvsiadas de Lvys de Camoes, Traduzidos en octaua rima Castellana por Benito Caldera. Alcala de IIenares, Iuã Gracian. Año de M.D.LXXX. 1. ${ }^{\circ}$ No tiene foliatura; signs. $\mathrm{A}-\mathrm{Z}$ y A. 2, todas de 8 hojas ménos la última que tiene diez.

Raro.-Ejemplar hermoso con muehas hojas sin cortar--Brumet dice que la presente uraduccion fue reimpresa en Salamanca en $1580 \mathrm{en} 8 .^{\circ}$, y en Vadrid en 1591 en $4 .^{\circ}$ : en esto se equivora pues la de Salamanca, es la version de Gómez de Tejada, descrita en el articulo anterior, y la de Madrid la siguiente, que he visto: Los Lvsiadas de Lays de Camoes, Tradusidos de Porlugues en Caslellano por Henrique Garces. Mallial, Guillermo Droul, 1591. 4. 4 hojas prels. 185 fols. y una al fin de Erralas. Es en verso como las dos anteriores y la hecha por D. Lamberto fil, unida á las poesias ó rimas del mismo Camoens, impresa en Madrid, por D. Miquel de Burgos, 1818.3 vols. $8 .^{\circ}$ : de esta edicion se tiraron algunos ejenıplares en un papel mís flno y algo azulado.

De Caldera dijo Cervíntes en el Canlo de caliope.

$T \dot{u}$, que del usu el singular tesoro Trujisle en murua forma a ln riber" Del fértil rio, a quien el lecho de orvo Tan famoso le hace adonde quiera; Con el debido aplanso y el deroro Debido á li, Benilo de Caldere, $Y$ d lu inginio sin par promelo homrarle, $Y$ de lauro $y$ de yedra coronurle.

C.MHOENS (Luis de). Rimas. Vease en la Seccion dramática.

3̈10 CAMPILLO (TORIBIO DEL). Ensayo sobre los poemas provenzales de los siglos XII y XIII. Leido al Claustro de la Ciniversidad central por D. Torihio del Campillo. Madrid, M. Campo-Redondo, 1860. 8. ${ }^{\circ}$ may.

̈11 C.IMPOAMOR (RanON BE). Colon. Poema por D. Ramon de Campoamor. Valencia, J. Ferrer de Orga, 1833. 8. ${ }^{\circ}$ may. Retrato.

Poena en octavas, dividido en cliez y seis

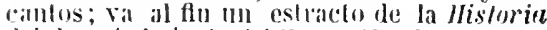

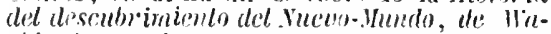
shinglon Irein!.

Créo que solo se tipi un enrto mimero de ejemplares y entre cllos unus pocos de papel superior para regalar.

̈̈12 CAMPOREDONDO (Mania). Tratado philosophi-poetico esçoti- co, Compuesto en Siguidillas por Doña María Camporredondo. Madrid, Miguel Escrivano, s. a. (1757?) 8.

\section{CÁNCER Y VELASCO (JERónimo} ఐE). Obras varias poéticas. Véase en la Seccion dramática.

513 Canton (Jerónimo). Excelencias del nombre de lesvs, segrn anbas naturalezas. Por el M. F. Geronymo Canton. Barcelona, en la En-prenta de Iayme Cendrat, 1607.8. 8 hojas prels., 323 foliadas y 29 de Indice.

obra escrita por el estilo de la Conversion de l's Magdalenu de Malon de Chaide, en la cual se encuentran muchas composiciones en varias clases de metro.

314 - Vida y miliagros del B. P. y Señor Don Thomas de Villanveva. Con algunos Tratados concernientes a la misma Vida. Compresto por el P. Maestro Fr. Geronymo Canton. Barcelona, Sebastian y Iayme Matevad, 1623. $4 .^{\circ} 8$ hojas prels., 196 fols. y 6 de Tabla.

Poema en quintillas dividido en doee libros y en euarenta y seis cantos.

3̈13 CARRILLO Y SOTOMAYOR (Luis). Obras de Don Lyys Carrillo y Sotomayor. Madrid, luan de la Ciuesta, M.DC.XI. 4. 21 hojas prels. y 2 i2 fols., inclusa una al fin en la que solo están las señas de la impresion.

Contiene esta primera edicion las mismas poesias de D. Luis Carrillo que la siguiente de 1615 , y entre ellas la traslacion en verso del tratado De remedio amoris de ovidio. Se hallarf ademas varias composiciones poéticas de su hermano D. Alonso Carrillo y Lasó, y las tradueciones en prosa hechas por el mis. mo de los libros De fuga sceculi y De bono morlis de S. Ambrosio, los cuales se suprimieron en la segunda impresion. No es por lo misino estraño que Nic. Antonio á cuya noticia solo llegó esta, y nada supo de la de 1611 , no menoinene entre las obras de dicho Alonso Carrillo sus versiones de S. Ainbrosio.

$3016-$ La misma obra. Madrid, Luyz Sanchez, 1613. $40^{\circ} 25$ hojas prels., incluso el frónt is grabado, y 239 fols. 
Segunda edicion donde se han corregido algunas faltas de que adolecia la anterior, y hasta se han variado algunos versos, como ya se advierte en el prologo al lector; pero si por un lado tiene estas ventajas, por otru no es tan completa como la primera, pues le faltan los dos tratados de S. Ambrosio, traducidos por D. Alonso Carrillo y Laso, herinano del $\mathbf{b}$. Luis.

\section{CARYAJAL Y RÓBLES} (RoD. DE). Fiestas que celebro la Civdad de los Reves del Pirv, al nacimiento del Serenissimo Principe Don Baltasar Carlos de Austria. Por el Capitan D. Rodrigo de Caruajal y Robles. Lima, Geronymo de Contreras, 163\%. 4. ${ }^{\circ}$ ว hojas prels. y 104 foliadas.

Al fin hai un Sermon al mismo asuntu del P. Juan de Zarate.

Mui raro.-Nic. Antonio no menciona este poema dividido en quince silvas; habla si de otros del mismo autor intitulados: Conquista de Antequera. Limn, 1627, y la Balalla de Toro. Ibidem. No he visto ninguno de los dos.

518 CARVALlo (Luis Alronso DE). Cisne de Apolo, de las excelencias, $y$ dignidad y todo lo que al Arte Poetica y versificatoria pertenece. Los nietodos y estvlos que en sus obras deue seguir el Poeta. El decoro y adorno de figuras que deuen tener, y todo lo mas a la l'oesia tocante, significado por el Cisne, ynsignia preclara de los Poetas. Por Luys Alfonso de Caruallo. Medina del Campo, Iuan Godinez de Millis. Año. 1602. 8. 16 hojas prels., la última blanca, $y$ 214 fols.

Raro.-Este arte poètica está dividido en cuatro diálogos y no cinco, segun se dice en el Ensayo de una bib. de Gallardo; comprende como muestras de versiflcacion muchas puesias en varias clases de metro.

CASASUS Y NAYIA OSORIO (JosÉ). Viage del Parnaso. Véase en la Seccion dramatica.

ö19 CASCALES Licenciado Fraxcısco). Tablas-poeticas, del Licenciado Francisco Cascales. Murcia, Luis Beros, M.DC.XviI. 8. $10^{\circ}$ hojas prels., la ültima blanca, $y$ \$18 págs.
Publicó una reimpresion en Madrid, Suncha, en 1772.2 vols. $8 .^{\circ}$, en la cual anadió su editor Cerdá y Rico, la Epistola 9 Horatii Flacci de arte prética y un discurso de la cinudad de Cartagena, el cual escribio Cascáles cuando estaba aun libre de los vicios contraidos desde que dió crédito á los falsos crónicones. A pesar de este lunar como his. toriador, Cascáles es reputado uno de los buenos escritores de nuestro siglo de oro; asi es que Lope de Vega le tributó el sigulente elogio:

ya por los allos montes, que mirundo eslán las claras aguas de Segura, que la leal ciudad de Murcia baña $y$ de Guadulatin, que desperlando del sueño que te lleva en linfa pura, se espanla de mirarse mar de España; la voladora Fuma desengaña a los ingenios de mayor decoro en el verso y la hisloria, que pretcude Cascriles con justa presuncion las hojas de oro, haciendo memorial de su memoria, sin los esludios à su nombre iguales en limlas facultades generales, el arle de escribiv versos que arguye, que quien perfeclamenle constiluye cómo ha de ser un célcbre poeta, el mismo serí el arle más perfela.

3̈ํㅜ CASTAX̃IZA (D. JCAY DE). Descripcion de la ivnta, en qre el mvy noble, y nuvy leal señorio de Vizcaia eligio por Patron y Protector suio al Glorioso Patriarca San Ignacio de Loyola; y de las vistosas fiestas, con que celébrò la Eleccion, ... tocanse breuemente los elogios de esta Naciō inuicla... Cancion real dividida en tres cantos. Ufrecela... Don Iuan de Castañiza... al... Señorio de Vizcava. Bilbao, Nicolas de Sedano, 1682. 4. 3 hojas prels. y 91 paigs.

Al fin del tercer canto va un Romance en que se dan las grucias al Señorio por esla eteccion, y por li grandeza de tas fieslus.

\section{CASTELLAYOS (JUAX DE).} Primera parte, de las Elegias de varones illrstres de Indias. Compuestas por Juan de Castellanos. Madrid, Alonso Gomez, 10̈89. 4. 10 hojas con parte de los prels. y 38 zágs.

Primera edicion mui rara, de esta parte: la segunda y lercera quedaron incditas y no 
vieron la luz publica lasia 1847 en que se publicaron en el tom. V. de los Autores españoles de Ribadeneira.
El retrato de Castellános, que se encuentra en la pág. 5 de la edicion de 1589, es el siguiente algo reducido.

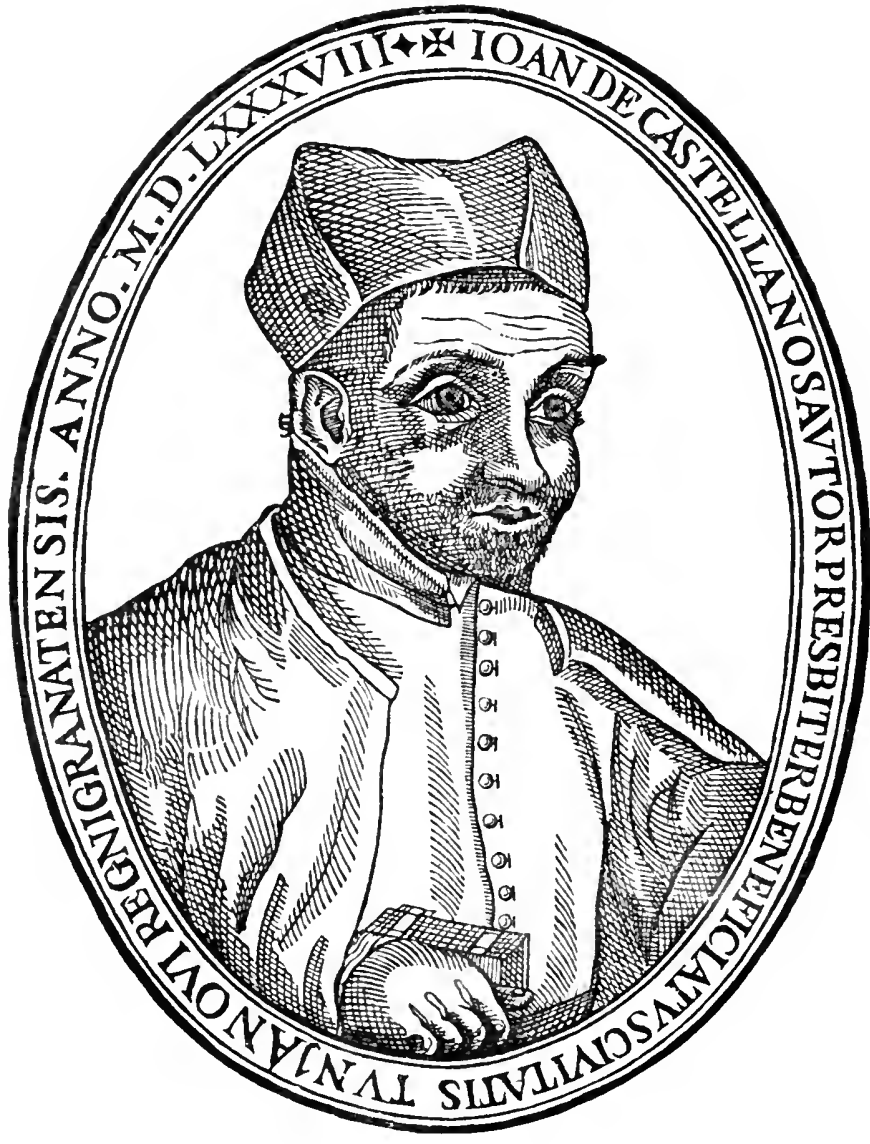

苂2 CASTILLA (D. Francisco DE). T Theorica de virtudes en coplas / y con comẽto. Compuesta por don Francisco de Castilla. Y otras obras suyas en metro / $\tilde{q}$ son las que enla siguiente hoja se contienen. (Esto de negro y colorado. Sigue el escudo de las armas imperiales y bajo el de las de C'astilla, y Leon: todo circuido de orla. En el blanco del fol. xxxiiij de la Practica de las virtudes de los buenos Reves de Despaña, se lee:)

i Fue impresso el presente libro enla muy noble y real ciudad de $C a$ ragoca por Agostin millan impressor de libros. Año de M.D.L.II. $4 .^{\circ}$ let. gót. lxx fols. inclusa la portada, 4 hojas de Tabla $y$ lierrores que a huuido enla impression, $y$ xxxiiij fols. incluso el fróntis y Prologo de la Practica de las virtudes de los buenos Reyes.

Los tratados comprendidos en este volúmen son los siguientes:

Térica de virtudes, en coplas con comento.

Tractado de amicicia, en coplas de arte mayor.

Sutirica lamentacion de humanidad y su consuclo, en didlogo, en coplas de piéquebrado.

Inquisicion de feliridad, por metafora.

Proverbios para con Dios y para con et mundo. 
Trátado de la preservacion del pecado original en la Concepcion de Nuestra Señora.

Práctica de las virtudes de los buenos reyes de España.

Edicion nuui rara.

\section{CASTILLA (D. Francisco} DE). Theorica de virtvdes en coplas y cō cōmento. Cópuesto por don Francisco de Castilla. Y otras obras suvas en metro. Alcala, Francisco de Cormellas y Pedro de Robles. 10̈64.8. 8 hojas prels. 192 fols. y 6 de Tabla.

El librero Luis Gutiérrez, editor de la presente impresion, advierte en el prólogo, que á pesar de baberse impreso esta obra pocos anos hacia no se encontraba ya ningun ejemplar de ella, por su estraordinario exito, debido á lo docla $y$ discretamente que estaba escrita: habiéndole instado varios sugetos á que la reimprimiera, procuró con mucha diligencia el propin original corregido de la mano del Señor D. Francisco de Castilla, su autor, y hallado la reprodujo con toda fidelidad $y$ cuidado.

Hai ejemplares de esta edicion en cuyo fróntis va la fecha de $156 \overline{3}$.

El autor de estos tratados era tercer nieto del rei $D$. Pedro; asi pnes, al hablar de aquel monarca trata de vindicarle del dictado que generalmente se le da de cruel. La primera copla á él dedicada nos hace ver ya los co. lores con que pinta el retrato de su héroe.

El gran rey don Pedro quel vulgo reprueua por selle encmigo quien hizo, su historia fue digno de clara y famosa memoria por bien quen justicia su mano fue seua: No siento ya como ninguno se atreua decir contra lantas vulgares mentiv' daquellas jocosas cruezas y yras que su muy viciosu coronica prueua.

Ademas de las dos ediciones ántes descritas, que poseo, existen las siguientes:

Gran escudo de las armas imperiales y bajo:

ब Theorica de virtudes en coplas de arte humilde con cõmento.

a Practica delas virtudes de los bue nos reyes despaña en coplas re arte maym dirigidas al esclarecido rey don carlos nuestro señor.

(Bajo un escudo pequeño con un castillo y un leon. Hai XXXIIl hojas foliadas, inclusos los prels., y despues 4 con la sign. a sin foliacion, al dorso de la última dice:) Fue impresso el presente tratado enl $r$ muy nobley leal ciudad de murcia. por el honorable Gor. ge costilla Acabnse a. iiij dias del mes de Agosto año de mil $y$ D. y xuiij (1518) años.(Sigue el escudo grande del impresor. Viene nueva portada con los eseudos grande y pequeño de la primera, y entre ellos se lee:)
Pratica delas virtudes de los buenos reyes despaña en coplas de arte mayor dereçadas al esclarecido rey do Carlos nuestro señur.(Son XVI hojas en todo. Al dorso de la viltima se lee:) Acabose cste tratadn en valladolid: a. $x x$. dias de dizièbre del año de mil D.xvij. estando en aquella villa el catholicn rey don Carlos - nuestro señor. A honor $y$ gloria de dios lodo poderoso: y dela sucraiissima vigren maria madre suyuy señora nusstio. Fue impresso el presente tratado enla muy noble y leal ciudad d'Mu'cia. Por el honorabte Gorge costilla. Arabose $a . x x$. (dias d'l mes de Enero año de mil !. D. y. xuiij 1.518). años. fol. let. gót. i dos colunas. sigue el escudo del impresnr. En esta fecha ó en la delprimer tratado hai equivocacion, á no ser que se imprimiera este el primero, y pensando despues agregarle la Theorica del misino Don Francisco de Castilla se hiciese la portada, segun ántes la he copiado.

Ticknor, tom. II. pág. 11. cita una edicion de 1516 ; pero no dice el lugar de la im. presion ni el tamaño.-En el Catálogo de Sora se menciona otra de Caragoça, 1570.

Portada que figura una gran capilla y dentro dice: De los trafados de philosophia moral en coplas de dó Francisco de castilla. Los siguientes. El prohemio de su thenrica devir. tudes Los prouerbios Inquisicion te la felicidad en mptaphora. La satirica lamentacion de humanidad. otras cosas de deuocion trobalas y algmmas on latin.

Concluye la obra en el blanco de la $6 . "$ hoja de la sign. $D$ con este colofon:

c Fue impresso en Siuilla en casa de andres d'burgos año de. M. D. xlij. fol. let. giot. son en todo 28 hojas y por lo nilismo creo no puede contener los trat ados que se hallan en las otras ediciones: no me ha sido posible cotejarlo.

Velázquez en los Origenes de la popsta, dice, hubiera sido Castilla el primern que escribio versos latinos con rima y consonancia igua les á lns castellanos, á no haberle precedido el Doctor Luis González. Sin duda se reflere á las composiciones latinas de la edicion de Sevilla que no encuentro en las otras.

524 CASTILLEJO Cristóval de). Las obras de Christoval de Castillejo. Corregidas, y emendadas, por mādado del Consejo de la Santa, y General Inquisicion. Madrid, Pierres Cosin, M.D.LXXII. $12{ }^{\circ} 8$ hojas prels. la última blanca, y 91 I págs.

Primera edicion de todas las obras de Castillejo reunidas; nuni rara.

El editor Juan López de Velasen hizo un gran servicio á la literatura rejmprimiendo la Propaludia de Torres Vaharro y las obras de Castillejo, á pesar de haberle oblimalo el Santo ofleio á mutilar ambas producriones, porque la primera se habia hecho mui rara y las segundas andaban diseminadas unas on manuscritos y otras en impresiones dificil.simas de encontrar. 
Gallardo en el Ensayo de una bib. esp. cita otra edicion de estas mismas obras tambien espurgadas por mandado del Consejo de la santa, y General Inquisicion, Impresas... En Madrid, por Francisco Sanchez. Iño de 1577. $12 .^{\circ} 404$ pigs. ds. inis 6 de prels. y otra al flu con el escudo del impresor. Debe ser reimpresion de la de $15 \% 5$, pmes lleva liasta el privilegio de esta fecha dado á favor de Juan lópez de Velasco.

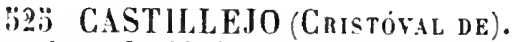
Las obras de Christoval de Castillejo. Corregidas, y emendadas, por mandado del Consejo de la Santa, y General Inquisicion. En Anvers. En casa de Martin Nutio. 1598. 12. ${ }^{\circ} 6$ hojas prels. y 372 fols., principiando la obra por el fol. 3 .

Segun frunct hai ejemplares de esta misma impresion que llevan el nombre de Pedro Bellero en hurar del de Nucio.-Citan otra cdicion de Anvers, $1582.12 .^{\circ}$

$326-$ Las mismas obras. Madrid; Por Andres Sanchez. Año 1600. 8. 7 hojas piels., 438 fols. y 2 blancas.

Esta edicion y la de 1598 son mui lindas y ambas copiadas de la primeris de 1575.

Fernández reimprimio las obras de Casti"lejo ell los tomos .ill y Xlll de su Coleccion de postas.

Varias producciones de este autor, como ya lie indiondo arriba, se habian impreso por separado iutes de 1575: yo conozco las siguicules:

El llialugo lle las condiciones de las muje-

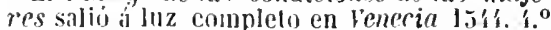
let. grot., en Toledo, Juan de Ayala, 15.65. 4. y junto con el frocesn dre carlas de amore's eu lenecia, 15\%. . 8. : me tiguro estari ya castrada la edieion publicadi en Vulenciu, 1600. 16: ${ }^{\circ}$, como sucede con la de Alcala, Iudres Sanchez Ezpeleta, 1615. 12.0 y con lodas las ediciones de las obras reunidas de liaslillejo. En la Seccion nomelisticu.-Libios le caballerias, articulo de Segura (Juan), reproduzco la parte suprimida de dicho Dialogo.

lle visto el siguicute tratado cuyo autor me aseguró Gallardo ser Castillejo, añadiéndome eri un trozo de la Constansa del mismo:

C Sermon de anores del maestro buéta. live llamado fra!l videl de la molen dil fris. lil. Agora nupurainente Corregido y enmédado Año de. M. D. xlij A la vuella empieza con un dialogo introductorio que termina al re. verso de lit segunda lioja, sign. aii, donde - Comiensa el surmon di amores, que con(dize al reverso de la vigésima hoja con li laninita, que suele hallarse en las Celestillis, de dos homlores que recojen del suclo i ollo que la cinido de una esedlera.) S. $l$. $n i$ a. $44^{\circ}$ let. gót. á dos colunas. Son 20 hojas sin foliacion con la sign. $a-a x$.

En el mismo Ensayo de una bib. esp. de dicho Gallardo se cita el Sermon de amores, mevamente compuesto por el menor Aunes, a los galanes \& damas de la corle. S. l. ni a. 4. $^{\circ}$ let. gut. 12 hojas, y se alribuye á Castillejo.

Tambien se imprimieron por separado los signientes opusculos de los cuales habrí sin duda ediciones anteriores, aunque no las he visto ni conozeo: Hisloria de los dos leales amadores Piramo y Tisbe. En li qual declara la grande fuerça qut' haze el amor, pues pierde su villa por cl amado, como por esta obra se dectara. Por Christoual de Castillejo. En Alcala, Andres Sranche 12. 2 hojas prels. y sig. $A-F$, todas de 8 hoj.

Dialoqo entre la verlarl y la lisonja. En el qual se hallarà como se pueden conocer los aduladores y lismjeros, que se meten en las casas de los Principes, y la prudencia que se dewe tener para huyr dellos. Interlocutores. Verdad, y Lisonja. Con olro lralado de la vidu de Corte. Por Christoual Castilleji. Aleala, Andres Sanchez Ezlolela, 161.4. 12. ${ }^{\circ}$ liojas prels. y 88 fols.; ademas 44 fols. del Diálogo y discur'so de la vida de Corle.

3227 CASTILLO MAN'TLLLA Y COSIO (Gabriel de). Laverintho poetico, texido de noticias natrrales, historic ss, y gentilicas, ajvstadas a consonantes Para El Exercicio de la Poesia, Por l)on Gabriel de Castillo Mantilla y Cossio. Madrid, Melchor Alvarez, i.DCxcl. 4. 25 hojas prels., inclusa una lim. con un escudo de armas, T6ö paigs. y una hoja en que se repiten las señas de la impresion.

Es un Diccionario de la rima.

\section{ร28 CASTILLO SOLURZANO} (D. Alonso de). Donayres Del Parnaso. Por Don A lonso de Castillo Solorcano. Madrid, Diegro Flamenco, 1624. 8. 8 hojas prels. y 128 fols., la ultima dice por error 118.

Ademas de muchas otras poesias, entre ellas no pocos romances, comprende las $F a$ bulas de Acteon, de Varte y Vénus, la de Pan y Siringa, la de Polifemo y la de Adónis.

Ni por las licencias, las aprobaciones o el Prölogo aparece sea esta una primera parte; sin embargo, tanto Vic. Antonio como los traductores de Ticknor, tom. III. pág. 550 , y los SS. Sancho Rayon y Zarco del Valle en el Ensayo de una bib. española, se refleren á una Segunda parle impresa En Madril, Por Diego Flamenco, Año 1625 , la cual supongo seril en $80^{\circ}$ á pesar de decirse en dicho Ensayo es en fol. 


\section{CAT}

DIVERSOS.

Otro tomito he visto escrito por Castillo Solorzano que contiene varias poesias $\mathrm{y}$ se intitula: Sagrario de Valencia, en quien se incliyen las vidus de los Illustres Samtos hijos suyos, y del Reyno. Valencia, Siluestre Esparsa, $16.55 .80^{\circ} 4$ hojas prels. 159 fols. y una blanca al fin; y en el Ensayo de una bib. esp., se describe un pocma en nueve cantos del inismo, intitulado: Patron de Alsira el glorioso Martir San Bernardo, de la Orden del Cistel. Zaragoza, Pedro lerges, $1636.8 .^{\circ}$

\section{ö29 Castro (Fraic. Antonio} DE). Laureola sacra de la vida; y martyrio del Venerable Padre Diego Luis de Sanvitores, primer Apostol de las Islas Marianas. Por Don Francisco Antonio de Castro. Madrid, Gabriel del Barrio, M.D.CC.XX.IIj. 8. 12 hojas prels. $y$ $\mathbf{2} 36$ págs.

Es un poema en octavas, en ocho cantos.

530 _ Vida de la gloriosissima Señora Santa Ana, madre de Maria santissima, y abuela de Jesu Christo, segun la humana naturaleza, por Don Francisco Artonio de Castro. Bilbao, Antonio de Zafra, ubcc.xxin: $8 .^{\circ} 8$ hojas prels. y 133 págs.

Poema en romance de ocho sílabas.

531 CatalaN (Blasco PeleGRIV). Tropheo del oro, donde el oro mvestra sv poder, mavor que el del Sol, y la Tierra, con Allegaciones de todas las tres partes prelendientes, auiendo cada rno contado su ralor. Compvesto por Blasco Pelegrin Cathalan. Çaragoça, Domingo de Portonarijs y Vrsino, 1j79. 4. 2 hojas prels., 138 pags. y una hoja para repetir la fecha en el blanco y con un escudo de armas en el reverso.

Mui raro.- Mi ejemplar es tan hermoso que parece en gran papel.

Del fróntis, licencias y dedicatoria resulta claramente ser el nombre del autor Blasco Pelegrin Catalan; no sé esplicarme cúmn en presencia de un ejemplar de esta misma edicion, Jimeno no solo atribuye una equivocacion á Nic. Antonio, por llamarle Blasco Pelegrin, y no Alonso, como él pretende; sino que estrana sobremanera incurra Rodriguez en el mismo error, habiendo tenido el libro a la rista.-- En la Acolemia de los nocturnos, donde hai alguna composicion de Catalan, no lleva más denominacion que la de Pelegrin.
CEL.

El poema en cuestion está en octavas y dividido en tres cantos.

332 CA UDIBILLA Y PERPIÑAN. La historia de Thobias, sacada de la Sagrada Escritura, v compuesta en Octaua rima: Por el licenciado Caudibilla y Perpiñan... natural de la Jmperial Ciudad de Toledo. Barcelona, Sebastian Matevad, 1610. 8. hojas prels. y 2003 fols.

Poema en once cantos, raro.

A pesar de que en el fróntis el nombre del autor es Caudibilla y lerpijian, en ta licen. cin $\mathrm{y}$ en la firma de la dedicatoria se llama cl licenciado Crudibilla Sanlaren y A clorga: ni bajo una ni otra denominacion encuentro $\dot{d}$ este escritor en Vic. Antonio.

333 CELESTIAL (LA) JER.IRQUIA. Comienca el libro de la celestial jerarchia $y$ inffernal labirintho metrifficado en metro castellano en verso heroyco graue por vn religiosso de la orden delos minimos dirigido al illustre v muY magnifico señor don Juan dela cerda duque de medina celi conde del puerto de Sancta maria rc: (Al dorso comienza el Prologo ó dedicatoria, que concluye con la hoja segunda. Principia la obra por el fol. I sign. a, omitida en esta hoja, del modo siguiente:

\section{Jnuoca el autor.}

A] mur propotente supremo monarcha aỹl que los cielos y tierra esclaresce.) S. l. ni a. Chricia el 1:30). fol. let. gót. I hojas prels, y XXII foliadas. IHai al fin otra con la Tabla de faltas.

Libro de estraordinaria rareza que no pudo conseguir IIr. Heber.

Segun aparece del Prólogo o dedicatnria. el autor desconocido de este poema se decidió á escribirlo esrandalizado de haber oido leer las lecciones de Job, que habia trobado Garci Sánchez de Badajoz, apropiadas á sus pasiones de amor.

El argumento de la obra y la clase de metro en que está escrita lo harán conocer suflcientemente las siguientes coplas:

Cantaré yo la gloria sublime, ensalzada, De los cortesanos mui altos del cielo, I d' hombres mortales que abajo en el suelo Vivieron con vida heroica acabada Por lumbre divina á ellos mostrada; La cual les dio esfuerzu por ella hollasen, Asi que por ella pasadu volasen 1 la casa de Dios mas alta sagrada. 
Aquelios son estios que jamas se quejaron De la movible y ciega fortuna, Nunca sufriendo dormir en su cuna, Engaños mortales del todo evitaron; A si con lo adverso alegres quedaron, Sus falsos halag:ıs mui léjos huyendo, rel todo tan libres d' aquella riendo, Que á sus miradores envidia dejaron.

En uuas montañas mui altas estaba n' escuras tinieblas del todo cercado, le sueĩo pesado asi sujetado, Que asi como muerte la vida privaba; Cuando el aurora corriendo buseaba Aquel claro Febo, luziente, dorado, Con sus crines de oro, asi nui pagado, Que alegre y riendo los mundos miraba.

Yo que dormia con tanto reposo Una voz alta hablome dieiendo: Despierta, despierta ¿qué haces durmiendo Eil tiempo tan dulee, alegre y gracioso? Abri, pues, mis ojos asaz temeroso, Para mirar á quien me hablaba, Y vi claridad tan grande, que estaba Todo aquel monte con rayos lumbroso.

Era aquel tiempo alegre y temprano, Cuando los campos se visten de flores, Cantan calandrias, cient mil ruisentores, Aquel mucho dulce del lindo verano, El toro potente, valiente, lozano, Abrie las puertas del todu potentes, Para que alegres mirasen las gentes Con gran hermosura el mundo galano.

CEO (Maria do). Obras varias. Véase en la Seccion dramatica.

534 CERTAMEN epithalamico, Publicado na Accademia dos Generosos de Lisboa: Ao Felicïssimo Cazamento Do sempre Augusto, \& Inuicto Monarcha D. Affonso Vl. com D. Maria Franc. Izabel . Pello Academico.Ambicioso . Lisboa, Ioam da Costa, M.DC.Lxvi. 4. 3 hojas prels. $y 27$ págs.

\section{CERVANTES SAAVEDRA} (Miguel DE). Viage del Parnaso, compresto por Miguel de Ceruantes Saauedra. En Madrid, Por la viuda de Alonso Martin, 1614. 8. 8 hojas prels. y 80 fols.

Primera edicion, mui rara y desconocida á Nic. Antonio.-En el presente ejemplar la últina página de los preliminares la ocupa un Soneto de $E l$ autor a su pluma; pero poseo otro de la misma impresion (V. el siguiente articulo.) con esta composicion suprimida y reemplazada por un gran floron. Sin duda era asi el que sirvió á Sancha de original al reproducir la obra en Madrid en
1784, (V. la Seccion dramdtica, art. Cervaintes.) pues carece de dicho soneto.

Ei Privilegio del rei está fechado en vento. silla, á 18 de octubre de 1614 y la impresion ya concluida en 10 de noviembre siguiente, segun aparece por la fé de erratas.

\section{CERVANTES SAAVEDRA} (Miguel de). Viage del Parnaso. Madrid, Viuda de Alonso Martin, 1614. $\mathbf{8}^{\circ} \mathbf{8}$ hojas prels. y 80 foliadas.

Igual edicion í la anterior con sola la difereneia de llevar floron en la última pág. de los prels. en lugar del soneto de El autor a su pluma.

537 - La misma obra. Milan, Ituã Bautista Bidelo. 1624. 12. 2 hojas prels. y 107 págs.

Magniffco ejemplar intonso y lodo él sin cortar. Esta edicion, mui rara, lleva una dedicatoria de Juan Bantista Bidelo dirigida á 1). Antonio Rodriguez de Freehilla, en lugar de lia de Cervántes á D. Rodrigo de Tapia, que se encuentra en la primera, y se ha suprimido el Prólogo al lector y el Epigrama latino de Agustin de Casanate hójas, contenidos en la de 1614; pero se halla en ella el Soneto del, autor a su pluma, que por faltar á la mayor parte de los ejemplares de la edicion principe, y no haberse reimpreso en los modernos copiaré aqui:

Pres veis que no me han dado algun soneto Que ilustre de este libro la portada, Venid vos, pluma mia mal corlada,

Y hacédle, uunque carezca de discreto.

Hareis que escuse el temerario aprieto

De andar de una en otra encrusijada

Mendigando alabanzas, escusada

Faliga é impertinente, yo os promelo.

Todo soneto y rima alla se avenga

Y adorne los umbrales de los buenos, Aunque la adulacion es de ruin casta;

$Y$ dádme vos que este viaje tenga De sal un panecillo por lo ménos, Que yo os le marco por vendible, y basta.

El Viaje del Parnaso se encuentra en la edicion de las obras de Cervántes, publicada en Madrid por D. Joaquin Ibarra desde 1803 á 1805 en $16^{\circ}$ vols. $8 .^{\circ}$

538 CLARAMONTE Y CORROI (ANdres DE). Letania moral... Piadoso travaxo De Andres de claramonte y corroi. Sevilla, Matias Clavijo, 1613. (Al fin:) M.DC.XII. $8 .^{\circ} 8$ hojas prels. incluso el fróntis grabado, 532 págs., y 7 hojas para la Svma de los Cantos y el Inquiridion.

No sẻ si algunos ejemplares llevarán en la portada la misma fecha que al fln, á saber: 
1612, pues en el catálogo de la venta de Conde se anuncló uno de este ano.

Fue Andres de Claramonte poeta, famoso representante $y$ autor de varias comedias: su Letania, compuesta ántes del ano 1610 , es en verso y del género de los Conceptos de Ledesına. Al fln de ella se halla el Inquiridion que es un curiosisimo catálogo ó breve noticia de los hombres célebres" de fines del siglo XVI y principios del XViI ; sobresa. len entre ellos los actores $\mathrm{y}$ autores dramáticos, y se citan muchos escritores valencianos. Al hablar de Cervántes le Ilama dignisimo poeta español y autor de D. Quijole, 10 que me prueba más y más cuan errados an. dan los que creen haber sido desconocido el mérito de esta novela en un principio, y preciso escribirse el imaginario Buscapié para sacarla de su oscuridad.

El Sr. Barrera dice con sobrada razon que la Lelania moral es rarisimo librito; y sin duda por esta razon tambien, da Gallardo en el Ensayo, estensos estractos de él.

En dicho Ensayo se dice que el numero de pảgs. de las Tublas puestas al fin, es I8 siendo solas 13; y allí se hace mérito de otras dos obras de Claramonte, á saber:

Fragmento d la Purtsima Concepcion de $\mathrm{Ma}$. ria sin pecado en su primer instante. SeviUa, por Francisco de Lira, 1617. 4. 10 hojas. Dos famosas loas d lo divino. La primera de la Assuncion de la Virgen representada en competencia por los doze meses del Añn. La segunda, Sacrainental, de las calles de Sevillu, tan celebrada de todos. Sevilla, Francisco de Lyra. Año $621.4 .^{\circ} 4$ hojas.

539 CLaUdiano (Caro Locio). Robo de Proserpina, de Cayo Lrcio Clavdiano... Traduzido por el Doctor Don Francisco Faria. Madrid, Alonso Martin, $16088 .^{\circ} 8$ hojas prels. y 64 fols.

Poema en octavas dividido en tres libros.

Edicion primera, mui rara, de esta version buena y celebrada por Cervántes y Lope de Vega ; la segunda la hizo en Madrid, Sanchu, MDCCC VI. 8..$^{\circ}$ arq. con una Introduccion escrita por Capmani, segun dice Gallardo, quien habla tambien de otra tercera impresa en dicho pueblo y año, por Repulles, que lleva un prólogo de El editor, compuesto por dicho Gallardo.

540 CLIMENTE (FaBIO). Amor enamorado, Fabvla de Psiques, Y Crpido por Fabio Clymente. Zaragoca, Diego Dormer, 165 5̆5. 8. 4 hojas prels., 268 págs. y dos hojas blancas.

poema en octavas y en ocho cantos.

Este ejemplar perteneció á M. Heber.

El verdadero autor del libro fué D. Francisco Jacinto Fúnes de Villalpando, Marques de Osera. Nic. Antonio no vió esta obra pues no cita nl el lugar ni el ano de su impresion, y Latasa no turo más noticia de ella que la que el mismo villalpando da en el prólogo de su Vida de Santa Isabel, Infanta de Ungria, impresa en Zaragoza, Diego Dormer, 1655. 8. ${ }^{\circ}$, publicada tambien bajo el seudóninin de Fabio Climente. Segun el mismo Latasa habia escrito una Fabula poetica de Psiques y Cupido, que eslando para estamparse la ras. go el autor ¿Xo seria esta composicion la misina que forma el objeto del presente articulo?

Parece fué autor de una comedia intitulada: Mrs pueden celos que amor. Zaragoza, 1647. $4 .^{\circ}$ representada en el teatro de dicha ciudad.

541 COBLES fetes en laors de diversos sants. 4. $^{\circ}$ Manuscrito del siglo $\mathrm{XV}$.

Este códice que perteneció á la biblinteca Mayansiana está perfectainente conserrado y se compone de 91 fojas. Comprende veinticuatro composiciones á varios santos escri. tas en diversıs géneros de metro y todas en el dialecto valenciano.

Como carece de portada, y al parecer nunca la tuvo, no se sabe si su contenido es de uno ó de varios autores; lo que no vacilo en aflrmar es ser inédito cuanto comprende.

\section{J42 COLODRERO VILLALÓBOS} (Miguel de). El Alpheo, y otros assuntos, en verso, exemplares algunos. Por Don Miguel de Colodrero Villalobos. Barcelona, Sebastian $y$ layme Mateuad, 1639. 8. 8 hojäs prels. y 130 fols.

La fábula de Alpheo ncupa poco más de 9 hojas, el resto del volumen se compone de otras dos fabulas, la de Fiteton y la de Mentir'a pura de Bacn y Erigone. más de cincuenta sonetos, muchos epigramas y décimas, y varios ronances.

Gallardo, pregunta si el hallarse en blanco en el ejemplar que tuvo á la vista, la pảgina que solo lleva el epigrafe de prólogo, será descuido de la tiracion ó del impresnr; pero encontrándose el mio en igual caso debe su. ponerse sucederá lo mismo en todos los ejemplares y por consiguiente cosa hecha intencionadamente por el autor.

Nic. Antono no conoció la presente obra de Colcdrero, y sin duda los traductores de Ticknor tampoco tuvierou noticia de ella, cuando no la citan al hablar de las otras dos fábulas del mismo autor, comprendidas en sus Rimas.

En el Errsayo de una bib. esp. de Gallardo se describen las dos siguientes producciones del mismo autor:

Golnsinus del ingernio. Don Migvel Colodre. ro de Villalobos. Se las embia para algun rato. A Don Alberto Pardo... En Zaragoça, Por Pedro Lanaja. Año 1642. 8.

Divinos versos o carmenes sagrados. Donde el que elyere (sic) sintiendo, no el que sintiere leer, podra coger frutn $y$ flores, que 
tambien la fragancia sabe aprovechar. En Zaragoca, por los Herederos de Pedro Lanaja, y Lamarca. Año de 1656. 4.

\section{COLODRERO DE VILLA-} LÓBOS (D. Mrguel). Varias rimas de Don Migvel Colodrero de Villalobos. Cordova Salvador de Cea Tesa. M.DC.XXIX. $40^{\circ}$ let. curs. 8 hojas prels. y 175 fols.

Entre los versos en elogio de la obra, que van al principio, los hai de Lope de Vega, Pérez de Montalvan, el Maestro Valdivielso, D. Pedro Soto de Rójas, el licenciado Luis de Aranda y Sotomajor y D. Diego de Silva. Y entre las composiciones de Colodrero se hallan las Fabulas de Teseo y Ariadna, la de Hipomenes y Atalanta y varios romances.

Nic. Antonio no espresa el tamaño de este libro raro, y la fecha la da de un modo dubitativo, pruebas evidentes de que no consiguio verlo. -Gallardo lo describe en el Ensayo de una bib. esp.; pero se equivoca en decir que son 16 las hojas prels. pues solo lıai s: sin audi quiso decir páginas.

344 COLOMA (Eugenio). Obras posthumas de poesia, escritas por el señor Don Evgenio Coloma. Madrid, Imprenta de la Mvsica, 1702. $4 .^{\circ} 20$ hojas prels., inclusos el antefróntis, el romance intitulado Fabula de Narciso y una hoja en blanco, $19 \ddot{3}$ páys. y 2 hojas de Indice.

540 COLOMA (D. Juan). Decada de la Passion de Nvestro Redemptor Iesv Christo; con otra obra intitvlada Cantico de sv gloriosa resvrreccion; Compvesta por el illvstrissimo Señor Don Iuan Coloma. En Caller, MDlXxvi. Por Vincencio Sembenino, Impressor del Reuerendo Doctor Nicolas Cañyellas. $16 .^{\circ}$ let. curs. 6 hojas prels. y 166 fols.

Supone Ticknor, tom. III., paig. 157, que esta primera edicion es de 1579 y que en ella se dice ser el primer libro impreso en Caller: en ambas cosas se equivoca, pues el ano es positivamente el de $1576, y$ lo único indicado en el privilegio es que su editor Nicolas $\mathrm{Ca}$ nyellas era el introductor de la imprenta en aquella ciudad.-Es libro raro.

546 _ Decada de la Passion de nuestro Señor Iesu Christo. Con otra obra intitulada Cantico de la gloriosa Resurrection. Compuesta por el Illust. Señor Don Iuan Coloma. Madrid, Que- rino Gerardo, $1586.8 .^{\circ} 82$ hojas inclusos los preliminares.

Edicion tan rara como la anterior, descono. cida á Nic. Antonio, Rodriguez, Jimeno $\mathrm{y}$ Fuster.

El primer poema está en tercetos y divi dido en diez libros, el segundo consta de solo ill canto, y es en octavas.

De este distinguido escritor dijo Cervántes en el Canto de Calíope en Ia Galaten.

oh' tú, D. Juan Coloma, en cuyo seno Tanla gracia del cielo se ha encerrado, Que a la envidia pusisle en duro freno, Y en la fama mil lenguas has criado, Cim qué del gentil Tajo al fériil Reno

Tu nombre y lu valor va levantado;

$T \dot{u}$, Conde de Elda, en lodo tan dickoso,

Haces el Turia más qu' el Po famoso.

otro poema he visto sobre la pasion cuyn titulo es: Proceso y contemplaciones de la Pasion de N. S. Iesu Christo. Compveslo por Iayme Guiral. Caragoça, en casa de Lorenço y Diego de Róbles hermanos 1588. 12. 18 hojas, prels., 196 fols. y 8 más sin foliar. El poema consta de nueve cantos y llena casi todo el volúmen, agregándose al fin varias poesías espirituales.

347 CÓRdOVA SAZEDO (SebasTIAN DE). Las obras de Boscan y Garcilasso trasladadas en materias Christianas $y$ reliriosas, por Sebastian de Cordoua vezino de la ciudad de Vbeda. (Al fin:) Impresso en Granada en la emprêta de Rene Rabut a sant Francisco año de, 1575. 12. 12 hojas prels., 302 fols., 5 de Tabla, $\mathrm{y} 3$ blancas.

A] principio hai una aprobacion de 1567; pero el privilegio para la impresion no se concedió hasta 1575 , y esto me prueba ser esta la primera edicion, desconocida á los traductores de Ticknor.

马ั48 La misma obra. (Al fin:) Impresso en Caragoça en casa de Iuan Soler impressos de libros junto el pesso de la Harina año 1577. 12. 12 hojas prels. 297 fols. (la última dice mal 267), 5 de Tabla y colofon, una con un floroncito y 2 blancas para completar el pliego.

Heber no poseyó ninguna de estas dos edlciones ni Brunet las menciona y Nic. Antonio hace confusion de ambas pues, cita solo una de Zaragoza, 1575, tomando el lugar de la segunda y el año de la primera. Sedano tampoco anduvo mui acertado en decir, tom. VII. del Parnaso, que Sebastian de Córdova intituló su obra: Conceptos espirituales. 
D. Juan de Andosilla y Larramendi, segun Alvarez y Baena, toın. lil. pág. 200, imprimio otra obra por el estilo de la íntes descrita, la cual intitulo: Cristo N. Sr. en lu Cruz, haLadio en los versos del Principe de mu'stros Poelas Gaicil'so de la vegu, sacados de di. ferentes parles, y unidos con ley de Centones. Madrid, 1623 . $4 .^{\circ}$

z̈19 CORNIZANO (AvToxio). Las Reglas militares de Autonio Cornazano; traduzidas en Romance Castellano, por Lorenzo Svarez de Firveroa. Venecia, Ioan d' Kossi, 1308. \&. let. curs. 213 hojus foliadas, comprendidas las 4 prels. y 6 de Tabla $y$ una carta de Alonso de Ulloa al traductor. Va al fin una hoja, en cuyo reverso hai un escudo con un Mercurio, que parece ser del impresor.

obra mui rara escrita en endecasilabos $y$ dividida en nueve libros.

ว̈ö0 CORONA ilvstre del gravissimo y real convento del Carmen de Valencia. Enrriquecida de nuchas piedras preciosas de Hijos suyos, y en especial de las vidas de los lenerables Yarones Fray Iuan Sanz, y Fray Angelo Ceinuliquio. Comprestas por el lieverendo P. M. Fr. luan Pinto de Viloria y del V. P. M. F. Roca en sy libro de oro de Lilz del Alma para la hora de la nuerle. I del flustr. Señor D. Fr. Arastasio lives de Hocamora, cura Vida exemplarissima está contenida en el Sermon que predicú en sus Exequias e] R. P. M. Fr. Andres Capero. Dalo a la estampa el R. P. M. Fr. Ilatheo Maya. Zaragoca, herederos de Agustin Verges, $16^{\circ} 9.4^{\circ} 2$ hojas prels. $y$ 312 pags., aunque la última dice equivocadamente 3 ㅍ.

Ademas de lo espresado en la portada contiene este volumen la Relacion de vn sucesso nolable en apoyo de la Tercera Ordi de N. S. del Carmon que cmbio al P. H. F. Ritymundo Lumbier, el P. Audres Cupero y uni Encominstica carmelitice. Aragonum prouisciae declamulio. l'er $\mathrm{Fr}$. Elistetim, Garcia.

No solo es en verso toda la obra intitulađa Luz del alma, sino que hili varias poesias en la vida de Fr. Juan Sanz.

5̆1 CORTE REAL (Jeroximo). Srccesso do segrndo Cerco de Jir. Estando Dom Joham Mazcarenhas Toss. I por Capitam da fortaleza. Anno de $1: 46$. Lisboa Simam Thaddeo Ferreira, M.DCC.LXXX1111. 8.

El nomlire del autor consta por algunos de los versos que van al principio en su elogio, y por el epigrafe del poema.

Bento José de Sousa Farinha reimprimló este poema portugues de la primera edicion hecha en Lixboa, Anlonio Gonçalvez en $1574.4^{\circ}$

Corte Real cscribió tambien el Naufragio $e$ laslimnso sucesso da perdiçam de Manoel de Sousa de Sepulueda e Dona Liudor de Sâ sua molher e fithos vindo da India... "ls cabo de Boa Esperançu na lerra do Nalal: o a peregrin'tçän que liucraó rodeando terias de Cafries mais de $\mathbf{3 0 0}$ legors lè sua morte; composto ein verso heroico el oclaua rima por I*ronimo Corle Real. (Lisbua), na officina de Simaó Lope:, 1594. 4. 4 hojas prels. y 206 fols. Asi lo describe Brunet quien menciona una segunda edicion de Lisbua, 1785. 8. y la traluccion castellana impresa en Madrid, 1644. $4^{\circ}$

ว̈ว้2 CORTE REAL (Jenóvimo). La verdadera historia, y admirable svcesso del segundo cerco de Diu, estando don Iuã Mazcarenhas por Capitan y Gouernador de la fortaleza. Compresto por Geronimo Cortereal Tradvcido en Lengua Castellana, por fray Pello de Padilla. Alcala de Henares, en casa de Iuan Gracian, M.D.xCril. 8. 8 hojas prels. y 360 foliadas.

Pocma en verso suclto: ticne veintiun cantos. Es la traduccion del anterior y tan rara como la primera edicion del original portugues.

333 - Felicissima victoria concedida del cielo al señor don Iuan d'Austria, en el golfo de Lepanto de la poderosa armada Othomana. En el an̄o de nuestra saluacion de 10 วิ. Compuesia por Ilieronymo Corte Real, 1578. (Al fin:) Fie impresso en Lisboa por Antonio Rivero. Año de M.D.Lxxvil. 4. ${ }^{\circ}$ let. curs. 8 hojas prels., 217 fols. y una con las señas de la edicion. Lains. de madera.

Ejemplares tan hermosos como este se encuentran rara vez.

Corte Real escribio este pnema en verso suelto castellano y lo dividio en quince cantos: al principio de cada uno hai una gran viñeta grabada en madera. La hoja 217 la ncupan seis octavas en portugues de Corte Real á D. Juan de dustria.

Ticknor se equivoca en decir no lleva lugar de impresion, y en califlcar sll tainallo de $x$ ? 
El escudo del impresor Ribero que se halla en la ưltima hoja es el siguiente.

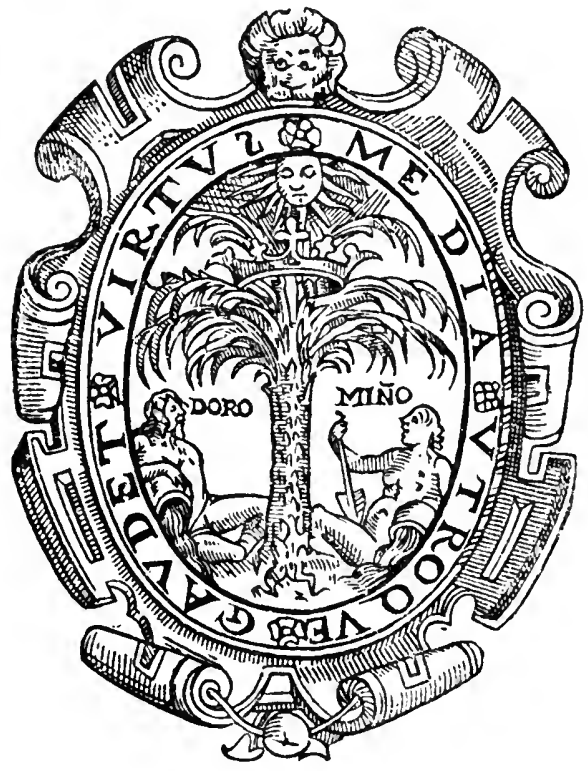

554 COSTIOL (Jerónino De). Primera parte de la Chronica del muy alto y poderoso principe Dou Iuan de Austria hijo del Emperador Carlo quinto. De las jornadas contra el gran Turco selimo. II. comencada en la perdida del Reyno de Cipro: tratando primero la genealogia de la casa Otomana. Copilada por Ifieronymo de Costiol. Barcelona, En casa de Claudes Bornat, 10̈72. 8. ${ }^{\circ}$ sin fol. con las sign a-q de 8 hojas, ménos la $\mathrm{q}$, que tiene 4.-Canto Al modo de Orlando, de la memorable guerra entre el gran Turco Selimo, y la Señoría de Venecia. Con la felicissima Victotoria del Serenissimo Señor Don Iuan de Austria General de las armadas de la confederacion Christiana. Traduzido por Hieronymo de Costiol. Barcelona, En casa de Claudes Bornat, 1572. 8. Sin foliacion, signs. A-H de 8 hojas: la última es blanca. Tienen las dos partes viñetas de madera y una lám. de la posicion de ambas armadas en la célebre batalla de Lepanto.

Este Canto forma en cierto modo la conti. luacion de la Primera parle, y va casi siempre unido á ella. Costiol ofrece la segunda de la Crónica; y tambien la traduccion de los consiguientes cantos que se aguardan; lo que no llegó á cumplir, ni ha perdido mucho por ello el Parnaso español. Esta traduc. cion la hizo del italiano y eslanza por estan. za, esceplo algunas que añadió fuera de la suslancia, como él mismo dice.

La presente obra nos prueba cuan distinto sucle ser el valor biblingráfleo de los libros del que tienen en la república de las letras; miéntras en csta la produccion de Costiol no goza de reputacion, como ya he indicado, para los biblióflos merece un grande aprecio por su estrcmada rareza: Brunet no conoció este libro, Heber no pudo conseguirlo, y Nic. Antonio sill duda no llegó á verlo completo, pues no menciona el Canto á mocio de Orlando, que va al fin del volúmen.

ว̋̋̋ CRUZ (Gerardo de la). Christo Señor nvestro padeciendo como refieren Los Quatro Evangelistas. En versos De Romances Castellanos. Por Gerardo de la Cruz. Madrid, Don Francisco Nieto y Salcedo, 1660. 8. 128 págs., inclusas las 4 de prels., circuidas de fletes.

No se encuentra el nombre de este autor en la Bibliolheca de Nic. Antonio: su obra es efectivamente de dificil adquisicion.

306 CRUZ (Juan de La). Sonetos sacros, politicos, y morales. Su autor el Licenc: D. Jvan de da Cruz. Madrid, M.DCCI. 8. ${ }^{\circ}$ a hojas prels. y 101 págs.

CRUZ (Sor Juana Ines de la). Poemas. Véase en la Seccion dramatica.

357 CRUZ (LUIS DE LA). Historia del glorioso martir San Vicente, en otaua Rima. Compuesta por el Licenciado Luys de la Cruz. En Toledo , Pedro Lopez de Haro, 1585. 8. 8 hojas con parte de los prels. sin foliar y 64 fols.

Está dividido este poema en tres partes.

Van al principio algunas composiciones en verso encomiando el mérito del libro y las hai entre ellas del Vtro. José de Valdivielso, Luis Hurtado y Luis Gaitan.

Tomito tan raro que Nicolas Antonio no solo no lo conoció, pero ni siquiera trae á Luis de la Cruz en su Bibliolheca.

CÜBILlo de aragon (Álvaro). El Enano de las musas. Véase en la Seccion dramática. 
533 CUEVA (JUAx DE LA). Conquista de la Betica, poema heroico de luan dela Cueua, en que se canta la restauracion y libertad de Seuilla, por el Santo Rey Don Fernando. Sevilla, en casa de Francisco Perez, 1603. 8. 28 lojas prels. Cla segunda es un escudo de armas a cuyos lados están Marle y Apolo y bajo la leyenda: Gesta cano y la fecha 18990 , y la ullima el reirato del autor.) y 453 foliadas.

Poema en veinticuatro libros que reimpri. mio Fernindez en los tomos XIV y XY de su Coleccion de poetas.

Sedano observa en el tom. IIII del Parnaso español, que todas las obras de este poeta se han hecho ya rarisimas.
Juan de la Cueva publlcó ademas de sus Comedins y lragedias, descritas en la Seccion uranálica del presente Catálogo, las dos obras siguientes que he visto:

coro febeo de romances historiales, Compueslo par loan de la cueva. Sevilla, loan de L'on, 1588. (Al fll: 1587.) $x .{ }^{\circ} 15.5$ hojas fols. y 11 de Labla.

Obras de Juan de la Cueva. Serilu, Andres Pescioni, 152. 8. 15.j hojas fols inclusas las prels. $y$ de Tabla. se componeu de sone. tos, canciones y elegias.

En el tom. Mlll del Parnaso español se dii a luz su Ejemplor poślic», ó Arle poética española, y en el IX, Los qualro librts de los inventores de las cosas. Poema; ambas produrciones ineditas.

La siguiente es copia del retrato que esti entre los prels. de la Conquista de la Bélica de $160 . \overline{5}$.

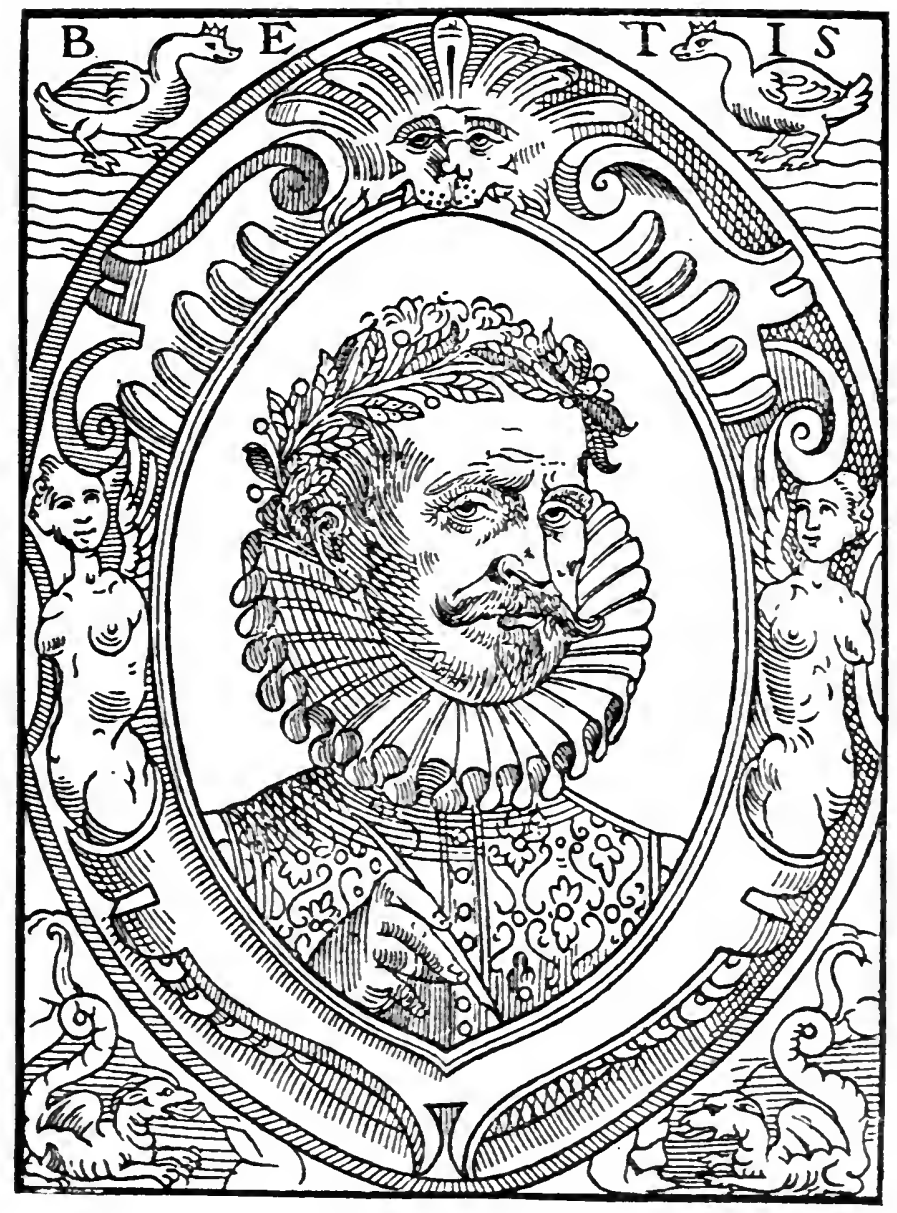


539 DANTE. (Dice la portada:)

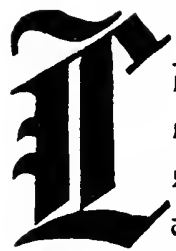
Con prenilegio real: $\overline{\mathfrak{q}}$ no se imprima por ocho años. v estátas sado en oche reales. a traduciō. Jel dante De lengua toscaua en verso caste llano: por el Renerèdo don po fernāde; de villenas areediano de burgos: $\mathfrak{p}$ por el comentado allende d'los otros glogadores por mādado d'la mụ excelente señora doña Inama de aragon duquesa de frias $\mathfrak{p}$ Condessa de hato fifa d'l min poderoso hey don fernàdo de castilla p ide ara gon. Ilantado el catbolico Coa otrog Dos tratados. vno $\bar{y} \mathfrak{s e ~ d i ~}$ ze querella dela fe notro avergi

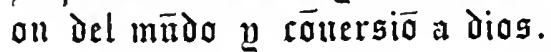

CLos cuatro mimeros renglones de este fróntis son de negro, y los restantes de bermellon: en la loja siguiente signatura (ij principia la Suma de lo contenido enlos. xxxiiij. capitulos desta cantica y obra asy enel testo del dante como enla glosa y materias enello tratadas. fecha por dō po fernãdez de villegas arçediano de burgos: traduzidor y glosador della $\tilde{T}$ mucho a clara todo el libro. Cuya tabla a indice ocupa las cinco sigurentes; en la otra hoja, que es la ectaca de la obra, sign. a, comienza el Prohenio dirigido ala dicha señora doña juana. al cual sigue la vida del Dante, viene en seguida una introduccion, $y$ al terminar esta, principia el Canto primero de la prima cantica y comedia del diuino poeta florentino dante aligero. El poema concluye en el blanco de la hoja octava de la 0. En el recto de la primera de la $\mathrm{P}$ hai una especie de fróntis que dice:)

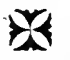

Brene đratado fecloo por el dicho don pero feruãdes de villegas arçediano de Burgos intitula io. Anersion del $\mathfrak{m} \overline{\mathfrak{n}} d \mathfrak{o}$ y $\mathfrak{c} \overline{\mathfrak{o}} \mathfrak{u} \mathfrak{e r}$
sion a dios.

(Este tratado, que empieza ci la vuelta, llena cuatro págs. y luego se encuentra las Querella de la fe comẽcada por diego de burgos y acabada y añediédo entre sus versos lo que conuenia y prosiguiêdo la adelante por dõ pero fernādez de villegas arcediano de burgos (Terminada esta composicion, que es en verso como la anterior, se halla la) Satira dezena del juuenal en ã reprehêde los vanos deseos y peticiones delos hombres... Traduzida por dō geronimo de villegas... hermano del dicho dõ pero fernandez de villegas... (Acaba en la cuarta hoja de la sign. Q; en la siguiente hai unos dísticos latinos, al pié de los cuales se lee el siguiente colofon: / Jmprimiose esta muy prouechosa y notable obra enla muy noble y mas leal cibdad de Burgos por Fadrique aleman de Basilea acabose Lunes a dos dias de Abril del año de nuestra redempciō de mill y quinientos y quinze (1515) años. (Viene el escudo de este impresor igual al que se halla en ei Fasciculus mirrhe con la orla suprimida.) fol. let gót.

Hai algunos ejcmplares donde se lee al fin la Suma ó índice, y en lugar de esta at principio tienen una hnja con un gran escudo y dos lineas bajo que dicen: Tradució del dante, por don pero fernandez de villegas dirigido a la señora dona Juana de aragõ.

be esta traduccion del Infiernn de Dante 
dicé Ticknor con sobrada razon ser libro ra. rsimo y en eslremo apreciable.

Sánchez, en la Vida del Marques de Santillana que precede á la Coleccion de poesias anieriores al sig'o XV, pág. XXVII, y Clemencin, en el Elogin de la reina $D .{ }^{*}$ Isabel, pág. 477, hablan de una obra lemosina cuyo titujo es: Senlencias catolicas del Div' Porlu Dant compilalas per Mosen Jaine Ferver lle Blancs, impresas en $1545.8 .^{\circ}$

560 DAVILA (Juar). Passion del Ilombre-Dios referida $y$ ponderada En Decimas Españolas. Por el Maestro Ivan Davila. Leon de Francia, A Costa de Horacio Boissat y Gorge Remers. Clardio Bovrgeat y Nigrel Lietard, M.DC.LXI. $4 .^{\circ}$ may. 4 hojas prels., incluso el antefrónt is grabado, libro I. 72 paiys.-II, อ̈7.-III, 82. -IV, 44.-V, 33̈ y VI, 81 y 16 lams.

Tengo dos ejemplares de la misma cdicion; pero entre ellos se observa la diferencia de hallarse en la portada impresa, en el primero, una viñeta representando un mavio con la letra Ingenivm siperal vires. Despues del Ingenium, lıaj t:na cifra de lus impresores con las iniciales B. I. En el otro, en lugar del barco, aunque del misno tamano, se halla una laminita de la Anunciacion de lit Virgen y en la parte inferior una cifra diferente de los misınos impresores; pero con las letras B. L.

Este poema eslá dividido en seis libros, cuarenta y tres estancius y ciento veintiires cantos.

Las liminas están perfectamente grabadas y suelen faltar en algunos ejemplares.

561 C DESPERTADOR DE PECCADORES. SSigue lu viñela de que pongo el,facsímile. Bujo de ella principia la Carta del auctor al señor alınirāte, la cual concluye en el dorso de la segunda hija, llenando lo reslante de la paigina el Irgumento de toda la obra. Esta comienza con la hoja tercera asi:) CDespertador de peccadores inuentado por vno dellos. (Al fin, en el blanco de la última hoja, se lee:) Esta obra llamada despertador depecadores Fue impressa enla muy noble villa de Medina del campo: Por Pedro Touans impressol de libros que biue a corral de bueves. Mil.D.xxxiiij. 4. ${ }^{\circ}$ let. gót. Son 16 hojas sin fol. con las signs. A y B. de 8 hojas cada una.

Para dar una ligera idea del contenido de este tratadillo, desconocido á todos nuestros blbliografos, copiare el Argumenlo de todu la obra, puesto al principio de ella.

Un hombre mancebo en edad, sano en fuerzas, valienle en esfuerzo, claro en lina. $j e$, curnplido en gracia, abundante en riqur. $z$ us, contento en pensamienlos, y por lanlo gozoso de la vida y descuidado del morir: se durmito en su voluntad paresciéndole nin. guna cosa ser conl ruria d ella. Y como, segun 'er'lader'a filosofir, el tiempo mida al movimient", y jainas en un estulo pueda alguno durar mas de un inslante ó punto, vió el aposento de su repos" lo conlrario de su de. seo, así en el edificio y adereszo de la casa. como en el lemeross aviso que le dió un ar's the lis despertó, la cual para meterle en aruerlo y probarle el rposilo des su fantasia, lo mostri un desperiador en emyas ruedas y "rrlificin los diferencindos estados de genli's y vintuoso curson, of culpable pausa y desor. den se ilsclarabu; guarmescido de generali.

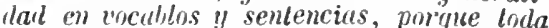
su doclinin asiblanda como rigurosa no toque parliculures personas: mas si.fuere res. celyida con la curidad que se escribe, rofor. mo y concierle sus estados y oficios; cmmo por lo siguiente parescera.

La obra está casi por entero en coplas, comn las célebres de Jorge Vanrique á la muerte de su padre. Véase una muestra:

primera rucelu de religiosos.

En esta y sus aparejos

van limados, conio nuevos, los tres votos

que guarda con los mas viejos de los cuales los mancebos

van remotos:

que los otros estatutos, y consejos, y doctrina qise fuitaron; comenzados y destructos por falla de disciplina lus dejaron.

1) uc temple el de los primeros! ivtic ayuno, qué devocion. qué pureza:

¡iuan contentos, cuán enteros, cuan alta contemplacion, que pobreza!

ilue estremada caridad, qué palabras, qué sermones, que eflcatia!

i)ué probada sanctidal, que curaban inil pasiones coll su gracia!

Estos eran paraiso, estos alcáz,lr dirino, estos templo,

eslos nos dieron aviso de la gloria y su camino. l'or ejemplo desta soberana enjambre, futroullenos de panares los desiertos,

los cuerpos secos de hambre $y$ en las almas los manjares eneubiertos.

¿Cuántos millares de Elias enlas montañas morarun! 
DES

¿Qué biliseos,

qué zelısos Hieremias

en los pueblos predicaron

sus deseos!

¿Qué valientes Gedennes

en vencerse y en vencer

todos vicjos!

¡uui sabios, qué Ciccroues ell regir s conoseer los oflioios!

Balsilio, y sant Auguslin, santo Domingo y el pobre sant Franciseo:

limpiado todo el orin d'aquesta rucla de coble, y aun el eisco.

Mas, despues de acecalida vinieron otros perlados, mémos buenos, que catsan que este parada; pues los puntos mal limados pasin menos.

l.os mus siguen las cortes prorirando ennfesiones de los grandes; otros buscan sus deportes tlanando negociaciones para Flandes:

otros quieren ser esentos por dar á sus voluntades suelta rienda:

otros se muestran contentos porque el fin de sus maldades 110 se entienda.

listos la hipocresla, las pasiones, las codicias y lisonjas, sobormos y fantasia,

los doblezes y maticias;

y en las monjas.

los linajes $y$ favores,

las rartis y lus servicius

$y$ presentes,

los estraños pundunores. el glangear los oticios comparientes.

¡oh que cosas, qué mistrrios celebran eu sus clatssuras y hospitales!

¿Que ermilas, qué monasterios

fiundaron con sus lucuras estos tales:

que dejaron lo del mundo

y tomalnon por emplesa

lo del cielo:

y perderín lo segunda porque su rolante fresil con el suelo.

pues miren eslos su ruedit y vuelvan con sus cilieios a pulilla,

y en la vida que les quteda ofrezcan sus sacrifleios sill mancilla; porque yo sin duda temo, pues siendo los apartados deshonestus,

de los malos son estremn, y lins hombres mas burlados soll alpuestus.
Segunda rueda de eclesiásticos.

\section{Luego la rueda segunda descubria por entero \\ su mudanza, \\ porque su fuerza se funda en la sangre del Cordero, que con lanza}

fuc vertida, y es guardada en los santos sacramentos por tesoro;

inis li rucda estaba alada, pues atan sus movimientos los de el coro.

Eran mohosos sus guijos, sus barras y sus piñones de fruslera;

porque ya vau por litijos las prebendas y elecciones d'esta eria;

y por frutos y regresos que prometen y retienen sill derecho, vall Ios puntos más espesos, y el cereo en que se contienen es estrecho.

lloa esta rueda tallada de Concilios y decretos y de indultos;

mas la talla está gastada, porque ya no son secretos los insultos

que cometen los perlados, lis colegios, dignidades, y los curas, śiendo los ménos letrados, $\mathrm{y}$ asi las elaras verdiades son escuris.

l)e aqui nasce la zizaña, aqui se frigua y caldea ed cauterio, de que Dios guarde la España, que es la herejia mui fea de Lulerio: que siendo de herejes monstro, y del cabo del infierno la hebilla, a bios encuenlra en el rostro y á su esposa del Eterno da manzilla.

Signe despues una terrible invecliva contra Lutero, escrita en los términos más ofensivos : sirvan de ejemplo estas dos estrofas:

ouieres ser reformador de la lglesia y hicrarqufí de eristianos:

oh, cruel perseguidor, capitan de artilleria

de paganos:

biell se parece tu zelo, cometicudo cada hora sacrilejo con sacras monjas de velo, que disfama y que desdora II consejo.

Hal ravo te despedaze fuego como aquel de lilías te derrilit, pues tal seta de ti nasce 


\section{DES}

que en Sajonla en nuestros dlas se permita;

hldra de siete cabezas,

lucifer trasflgurado

en agustino,

yo te vea hecho piezas,

y tu cuerpo rastrillado

comolino.

Viene despues una Oracion en la que pide el autor a llitos, que imitando á los apostoles y primeros prineipes de la lglesia, para confusion y ejemplo de la herejia, haga abando. nar á los papas y prelados de su ticmpo, los vieios en que yilcian enecnagados; y' ('ntre otras cosas dice:

Pues ya las cusas de lloma en España sin debate se contratan, que si posesion se toma y hai dinero que rescate las rescilan;
DIVEBSOS.

DES

los curados á docenas,

las otras slmples prebendas

redobladas:

sus trojes y cuevas llenas,

sus riquezas y haciendas

bien colmadas.

yucran los pobres y niños, las viudas y donzellas

siendo buenas,

y estos forrados de armiños,

las menos remedian dellas

en sus penas:

que si no es por aflcion

id deshonesta manera

de mundanos,

apẻnas darán racion

iij tal limosna se espera

de sus manos.

La viñeta que lleva este tomito al principio es la siguiente.

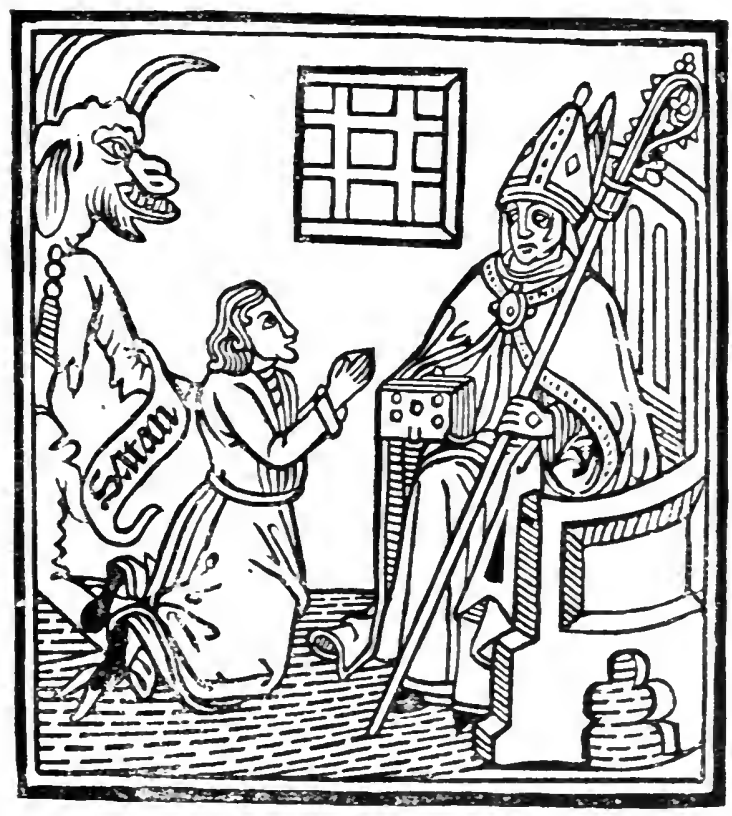

b62 DESSI (Juan). La Divina Semana, o sicte dias de la creacion del myndo en olara rima Por loan Dessi. Con vna declaracion de nombres y figuras poëticas. Barcelo. (sic), Sebastian Matheuad, y Lorenzo IVen. 1610. 8. 12 hojas prèls. y 218 fols.

Pocma en octaras dividido en sie!e dias ó iantos.
Pur el prolugo de Vessi sabemos que su propisilo primitivo fue lraducir la obra franips, iulitulada La semaine de Guillermo Sa. llusl 10. asi h hizo en el primer dia; pero viendo ilespues las diffcultades de una version prelica, se decidio a solo una imitacion de aquella, y asi lo veriflé en el resto de la obra.

segun parece, por lo que dicen los Iraductores de Ticknor, tom. III. pág. łs।, hai otra Iraduccion ell prosa castellana hecha por un judio llamado Jose cáceres con el titulo 
de: Los siete dias de la semana, sobre la creacion del muudn. Amslerdain, Alberlo Boumeester, 5372 (1612). 4.

DIAS (Dearte). La Conquista de Granada. Poena. V. Gómez (Alvar). Seccion listórica. - Historia de España.

\section{DIAZ CALLECERRADA} (Marcelo). Endimion. De Marcelo Diaz Callecerrada. Madrid, Yiuda de Luis Sanchez, M.DC.xxrif. 4. 4 hojas prels. y 51 fols.

Poema en octavas dividido en tres cantos. - Esla obra se recomienda por la buena - versiflcacion, y mís que todo, por cierto - estudio en evitar el casi general contagio - del culteranismo que á la sazun reinaba sin - rival. Notas de los lraduclores de Ticlinor, tom. III. pág. 495.-Baena, no menciona estil edicion; pero cila otra de 1624, de cnya existencia dudo, porque le tasa, er ratas, licencia y aprobaciones de Lope $\mathrm{y}$ Jáuregui están fechadas en $162 \bar{i}$.

El Sr. de Rosell ha reimpreso esta obrita en su coleccion de Poemas épicos de la bibliole. ca de Autores españoles de libadeneira.

364 DIAZ RENGIFO (JUAX). Aite poetica española, con ro fertilissima sylua de Consonanles Commes, Proprios, Esdruxulos, r Reflexos, y in dinino Estimulo del inor de Dios. Por Ivan Diaz Rengifo. Madril, Iman de la Cuesta, M.DCrI. 4." 6 hojas prels. y 364 paigs. Entre la 68 y 69 se halla una hoja plegada que contiene un Laberinto.

Nic. Antonio cila una celieion de Saltemmuca, $1592.4 .^{\circ}$ y serí la prime'il porque tales son el lugar y año de li dedicaloria.

Brunel se reflere á la de .Madrid, 160.5. 4.'; pero lo hace de mua manera bastante vaga.

:0 La misma obra. Madrid, Francisco Nartinez, 161'. 4. ${ }^{\circ} 7$ hojas prels., inclusa la queva plegada con el Laberint $0, y 36$ págs.

La aprobacion de D. Alonso de Ercilla, In prólogo al lector $y$ dos sonetos lindalorios de D. Pedro de linzman, que se encuentran en la edicion de 1606, vall silstiluidos on la presente por uma aprobicion del l'. Josi ll: Valdivielso, feelada en 1620 , y olra de bon Juan de Júuregui de $16 \%$ s, cuya cireunstancia me induce á suponer que hahri otra impre. sion hecha hacia este illo.

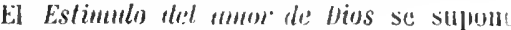
escrito por cl Maesilo l.con.
Segun Nic. Antonio y Velázquez, el verdadero antor del Arte poflica es el l'. Diego Garcia Rengifo de la Compania de Jesus, quien disfrazó su nombre con el de Juan Jiaz Rengifo.

Jle visto una edicion en cuyo frintis dice estar Aumputada con dos Trutarlos, tuno de Alisos, "licglas, otro de Asturant"s, con un Compendio de toda el Artr loelica, y casi cinco mil Consonanles. Barceluna, Maria Angelt Mat li, s. à. (17.58). 4. y otra de BarceloHa, $1759.4 .^{\circ}$

En mis apuntacionrs encuentro utra obra portnguesa del mismo género intitulada: Arte po'tica, e da pinlv'n, esymellin rom mincipios' die Perspectiva. Cimuposla por Plitlippe Nunes. Lisbou, Pedrn Crasbeecli. Aunn 161 . $40^{\circ} 6$ hojas prels. $y$ Tó fols. Entre el 57 y 58 hai umi hojal grantle que se dolla y conliene un laberinto poético. líms. de maderit. il dile da pialur" lleva mevo frontis, amuque sigue la foliacion. la primera mitad del vohimen es casi loda en vorso.

366 DICASTILLO (D. Miguel DE). Arla de Dios, Cartuxa real de Zaragoza, fvndacion del Excelino Principe Don Fermando de Aragon sy Arcolispo. Descrive, la vida de sus monges, acrsa, la vanidad del siglo, acverda, las memorias de la mverte. En las desengañadas Plumas de 'Teodoro, y Siluio. Consagrala a la vtilidad Publica Don Mliguel de Mencos. Zaragoca, Diego Dormer, M.DC.XXxvil. 1. 14 hojas prels., inclusa una que solo contiene un escud) de armas y 139 paigs.

Eutre las poesias laudatorias que van al príncipio las bai del boctor Pedro Agnilon, Francisco l.opez Zarate, l). Francisco I)iego de Siyas y Juan Franciseo lzarroz.

Contiene este volimen dos Silvas, la una dirigrila por Teodoro á Silvio y la otra la contestacion de este; y tres canciones i S. Bruno, de Tomas Andres Cebrian, el licenclado Juan Yadal y D. Miguel de Meneos.

En el problogo de esta cdicion se advicrtc que hai una anterior de la Primera silua.

D. José Pellicer dic Ossan en la prefacion pueslit al fiente de la impresion de $\mathbf{1 6 7 9}$, lescrita í continuacion, dice, que el Aula de Dins la compuso el padpe I). Mtiguel de ni- eastillo adoptando el apellido de su intimo amigo (1. Trabriel de .lencos. bicho Pellicer cheareces la rireza de las dos ediciones he. chis ántes de li cilada del 79; y serín, sill dumla, la gur? yo poseo del 37 , y uni mencionala por Ticknor do 167\%. Xic. Antonio indica la impresion le J 6.5 ; pero ignoro que Migruel de Mencos fuera un sendunimo.

:67 - Avla de Dios, Cartuxa real de Zarisoza, frondacion etc. (ut 
supru. Antes'descrita por el Pédre Don Migvel de Dicastillo, y aora nvevamente añadida, y armentada Por otro Monge de la misma Cartra. Con vna Selva de las penas de Christo. Zaragoça, por Pasqual Bucno, 1679. 4. ${ }^{\circ}$ it hojas prils., que comprenden la Silva de la vision, y 217 páys.

No solo por la portada se ve hiber sido el verdadero autor de este poema el P. Miguel de Dicastillo, sino que cono ya he indicado en el articulo precedente, cu una Prifucion de D. José Pellicer y ossau, colocada al principio del tomo, se prucha que dicho Dicastillo, apropiándose el apelli lo de su amign D. Gabriel de Véncos, lo liıbia publicado antériormente con este scudrinimo.

La presente edicion contiene adicioncs mui considerables, hechas en las mismas Silias del primitivo antor, por el tadie non Agustin Vagore $y$ ademas una nueva Sill'a donde describe una vision maravillosa, que declara la Gloria que tienen en el Cielo los Carluxos; una Erormucion metrich a la Sima de las penas del Redimplor que essrivio Ivun Lansuergio; 111 Sonefo y una Cancim real d S. Bimino, lodo compuesto por ol dicho $P$. Nagore; se balla tambien la Cancion de Djeastillo al mismo santo que en la rdicion de 1657 está a nimbre del indicado Méncos, y termina el tomo con otra Cancion del P. Dicgo de Fúnes il la dicha de le ruca. cion carluxa ; pero no se cucuentran los versos laudatorios que preceden í la primitira edicion, ni las Canciomes de Tomas Andres Cebrian y Juan Xadil puestas al fin.

La última rez que sc ha publicado el lula de lins ha sido en Londres en I845, á continuacion de los Trimfos del Carlujum: h'zt) la reimpresion el munca bastante ponderiulo, por sus rarezas y estravagancias, callinign D. Miguel del Riego. Aprovechare esta ocasion para refular una advertencia inserta por aquel clérigo al final de la obra : censura en ella la nota de mi padre al num. 1572 de sil Catálogo de Lóndres de 1824 , al anunciar al libro de Dicaslillo, porque supone que alli se ataca injustamente la reputacion do este cartujo y la de Nic. Antonio. Bicn se ve que á pesar de su Jarra residencia enl lnglaturra, no conprendia mucho la lengua de aquel pais el buen canonigo, pues a haberia eutendido no hubiera sentado aquellas falsas supnsicinnes. Vi padıe dijo con muchisima razon: "el monge adicinnador sı" llamaba, - comosr por la dedicatoria y por otros - varios lumares. el P. D. Agustin lagme, el - cual no condinto con los versos compuestos - por otros en rlogio suyo, sa alabo i símis" Jlo bajo nombres supuestos ell dos somplos. - dos octavas y un romance que se hallan al - Jirincipio del rulúnen. Por estas poesias se - descubre que el P. D. Agus/in nu cuconiala - Ian de corazon la soledid y la vida cartuja- ma y dedicabi algumos rulos á jueas mejos - ibstractas. Ileinause sino las primeras le- tras de dichas poesias, y se vera que las del "primer soneto dicen: Augustin Fausla; las -de las octavas: Mi Aguslin lu fausta; lds rlel romance: Fausla y Agustin son una - alma sola en dos cuerpos; y el último sone- to: Mi esposa Futusla. Io sé si algun otro - lialirá hecho anteriorinente esta observa. rion. Si ella no es importante para la bi- bliografia, lo será para convencerse más y - muis de lis supercherii de los humbres. que - bajo la capa de austeridad y rigidez se lian - freconizado esentus de las pasiones y debi- liblatrs de los demis limulires, á quipnes lian - callsado cuantos inaliss se origiman de la - irnorancia, ha supersticion y ol fanatismo.

- Vo liallo que viculas Antonio haga uren. - cion de bicastillo ni de Ningori..

liga ahora eualnuiera jujparcialnente si en lo que precede se alaca lis reputistion d: lus intores del dule de bios y de la biblisllura hispuna.

lle visto un solo rjemplar te la redicion de

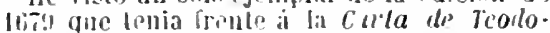
in a sileio píg. I Ima limini, repressutan.

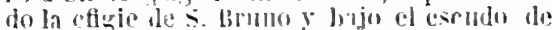
la Cartujal con la inseripeion al redodor do Carlusia bialc Vurit? Aula b's.

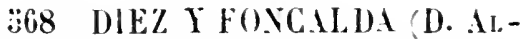
berto'. Poesias varias de Don Alberto Diez. i Foncalla. Primera partc. Zaragoca, Iuan de Ybar. M.DC.LII.

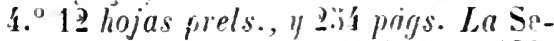
gunda parte principia ci la pain. 192.

vic. Antonio dedica a este autor en su $\mathrm{Bi}$ bliollieca poro más de dos líneas, $y$ en ellis dire sireamente que eri matural de Zaragoza y que llabia escrito Rimas l'arius: no sı!. pues, cimn I.atasa, tom. III. pág. T41, califica de alabanza el dicho de aquel bibliórrafo, pues ni conorio el verdadoro titulo de las obras de liez, ni supo donde ni en que ano se hizo la edicion de rllas.

DOLCE (Lcoovico). El nascimiento y primiras empresas del Conde Orlindo. Viase en la Seccion nocelistica.-Libros de caballerias.

g69 DOMISHIEZ CAMARGO (Itersixdo). S. Ignacio de Lovola, frndador de la Compañia de Iesss. Poena herovco. Escrivialo el Doctor D. Ilernando Douringuez Camargo. Obra poslruma. Wala a la estamua el Maestro D. Antonio Savarro de Navarrete. Madrid, Inseph Fernandez de Buendia, 1666. 1." 8 hojas prels. y $\mathbf{1 0 0} p a ́$ ágs.

Pucma en octavas dividido en cimco libros

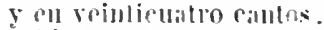

Vic. Anlunio no menciousa i este autur na. tural de santa fí de buguti. 
DURAN (Agustin). Leyenda de las tres toronjas del vergel de amor. Véase en la Seccion novelística.-Libros de caballerías.

3̋70 ELISIO DE MEDINILLA (Baltasar). Limpia Concepcion de la Virgen señora nvestra. Por Baltasar Elisio de Medinilla. Madrid, Viuda de Alonso Martin, 1617. 8. 16 hojas prels. 89 fols. y 7 más que contienen algunas poesias en elogio de la obra, $y$ el Indice.

Nic. Antonio nos habla de una edicion de Moulvid, Alonso Marlince, 1618. 8. : en esta noticia me parece hai dos equivocaciones, la primera, en la cual podria mas bien no haber error, es ell la fecha; pero nuuca he visto otra edicion que la mia, en realidad Inui rara. En lo que sí hai evidente inexac. litud, es en llimar al impresor Alonso Marlincz, quien siu duda deberá ser, caso de existir aquella impresion, Alonso Harlin, ó mas cierto la vinda de este.

La limpia Concepcion, poema en octaras F en cinco libros o cantos, es la única obra isupresa que nos ha quedado del desgraciado cilinto célebre poetil Elisio, de quien dijo sll lliaestro Lupe en el Latrrel de tpolo:

Ins y a las santas Yusas apercibs Aquel que muerto en mi memoria vive, Y'simple vivira con dulce canto, oute me deshace el ulma en lierno llanto:

\section{Elisio Medinilla,}

A quien l's verdes seluas lastimadas liciendo estón por ma y obra orilla: Iqui por eslas peñus enramalas Cantó la Concepcion en alto estilo, Hientras que yo del parlo de María La noche fulicisima escribia.

El Tajo que à los dos nos escuchaba, I' agoru eorre conuerlido an vilo,

En v" de murmarar lambien conlaba, l' para más exagerar' su pena Aun loparece que e's pequeño ris, I' lrislemente suena:

Elisio, Elisio mio;

Pero pues no respo:liles,

la mis voses y lagrimas le escondes, Descansa en puz, que por las verde's ramas Di? esle land hista th nombre ingredo, Co'garin "is pastores evirromas

A lin infoliz relrato.

Infaniando I lesporia,

Ii: lu sangre' y mis layginas buñudu.

I en la Elrogia escrita por el mismu lope al desgraciadi lledinill' se lee:

l'ues lneyo que del coro pegaseo Al Angélico vi que lrasl udabas Et alulce plectro, á ser divino orfeo,

Y que decir, Elisio, comensabas: Je lil malre del sol cándida Allrol'a, iseja divina concepeisn can!abas:
Bien puedo, dije, eslar conlento ahora, Pues bordan ya lu liva inás estrellas, Que la que Apolo junto al cisne dora.

571 ENCINA (JuAN DEL). Viage y Peregrinacion que hizo y escribió en verso castellano el famoso poeta Juan de la Encina en compañía del Marques de Tarifa. Madrid, Pantaleon Aznar, MDCCLXXXVI. 8.

Nic. Antonio supone que la primera cdicion con el titulo de Tribagia, o via sacra de Hicrusalem por Juan de li Encina se hizo en Roma en 1521. $8^{\circ} \mathrm{y}$ Brumel dice ser del año 1528, segun Velázquez, en cuyos Orígenes no hallo semejante noticia.

El liagpe de Encina se reimprimió con el del Marques de Tarifa en Lisboa, 1580. 1. ${ }^{\circ}$ : yo he visto esta edicion cuyo titulo es el siguiente: Esle libro es del visje î hize a lorusalem. de todas lus cosas que en el me pasaron desule que salide mi casa de Bornos mior. coles 21 de Nowiembre de 518 . Lasla 20 le Olubre de 520 que entre en SBuilla. YO DON FADRIOVE EVRIOVEZ DE RIVERA HARO.S DE TARIFA. En Sevilla año de 1606.-Se. villa, por Francisco Perez: En las Casas del Duque de Alcala, 1606. 4..$^{\circ}$ Fróntis grabado. Desde el fol. 187 hasta el 237 , que es el último, se lialla el viage de Jerusalem en verso por Juan de l'Encina.-Los traductores de Ticknor citan una segunda de Lisboa, Antonio Alvarez, $1608.40^{\circ}$ y otra de Madrid, por Francisco Martinez Abad, 1733. foll: Mayans en la Vida de Virgilio habla de la de Mredrid, 1748. fol.

En Bimet lasi und errata de imprenta cmando se dice, que la útima impresion es de 1586 , siendo de 1786.

3̈72 ENCISO Y MONZON (Ju,N Fravcisco). La Christiada poenua sacro, y vida de Jesv Christo Nuestro Señor, que escriuiò Don Jvan Francisco de Encisso y Moncon. Cadiz, 1694. 4. 4 hojas prels. y 2200 págs.

Poema en octavas, dividido en diez cantos.

3773 ENRIQUEZ BASURTO (DIEGo). Fil Trivmpho de la virtud, y Paciencia de Iob. Por Diego Henrigrez Basurto. Roan, L. Mavrry, 1619. 1. ${ }^{\circ}$ may. let. curs. y redonda. 4 hojas prels. ì 198 págs.

Poema escrito en varias clases de metro y distribuido en seis visiones.

No encuentro en Nic. Antonio el nombre de Enriquez Basurto, hijo de Antonio Enriquez Gounez, segun Barrera; tampoco lo cit: Rodriguez de Castro en su Biblioleca, a pesar de ser acreedor á una honoriflea niencion. 
oั71 ENRIQUEZ GÓMEZ (AxT0Nio). La crlpa del primero peregrino. Por Antonio Henrriquez Gomez. Roan, Lavrens Mavrry, 1614. 4. ${ }^{\circ}$ let. curs. 4 hojas prels. y 14 págs.

Primera edicion de estr poema no mencionado por Rodriguez de Castro.

373 _ La culpa del nrimer peregrino, y el Passagero. Su autor Antonio Énriquez Gomez. Madrid, IIerederos de Juan Garcia Infanzon, 1733̈. 4. 12 hojas prels. y 176 páys.

Segunda edicion aumentada al fin con unos souctos y el poemila intitulado El Pasugero, producciones de Enríquez liomez, que el rditor Pedro Reboredo dice habel sacado de otras obras del autor: ígnoro si será de la Acadenia de las musas ù del Sansoí nazaremo.

\section{- Academias morales de las Musas. Véase en la Seccion dramática.}

576 ENZINAS (Pedro de). Yersos espirityales, que tratan, de la cōuersion del pecador, menos precio del mundo. I vida de nuestro Señor. Con rnas Sucintas declaraciones sobre algunos passos del libro. Comprestos, por el R. Padre Fray Pedro de Ezinas. En Cienca. En casi de Vigruel Serrano de largas, Año, $19 y$. $8 .^{\circ} 20$ hojas prels., 1 I 2 fols., una con dos sonelos en elogio del auror, y dos para repetir las señas de la impresion, con la fecha de 1396, y la Tabla.

Castro en las págs. 19, 21) y 2! del Bustapi s y en la 29 de sus nolas, dice siempre $E=i n u s$ porque así está en el fiuntis del libro doude evidentemente falta sobre la $\mathrm{E}$ la ravita qut suple la $n$; pero si Inubiera examinado la Tusa, las infinitas composiciones latudatorias, el privilegin, la aprobacion, las licencias la dedicaloria de Chrisliano Bernabé. on lodas partes labiese ancontrado el apellido rscrito Enzinas sin f,llarle ningma letra. Isi le Ilamal Lambion Vicolas dntonio cuantos han hablado de la presente obra.-Esta equivocacion de Castro es para ni una de lis pruebas mas convincentes aducidas contra la legilinidad del Broscupie de Corvintes, pues es mui dificil de creer qur rste ignorinse el nombre de un sugeto á quien se dice cono. cia, miéntras es mucho más nalulab creer turo á la vista el Sr. D. Adolfu, cuilldo se re. firiu ai este libro, algun ejemplar fallo de los preliminares y cu el cual solo se conservase

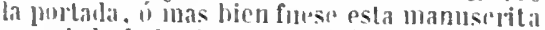
y copiada de la impresa donde se lialla omilida aljuclla letra y cl signo que la represen- ta; sobre todo siendo rarisimos los ejem. plares con los princlpios perfectos.-Ye confirma más en esta idea el suponer el Sr. de Castro qué varios religlosos recogieron las obras de Enzinas y las dieron á luz despues de su muerte para evitar quedaran ineditas; cuando el privilegio, las licencias y aprobaciones se dieron al misuno Enzinas en 1595, y el editor Bernabé, librero sin duda, dice en la dedicaloria ántits citada, dirigida j D. Diego de Váráas Carvajal, que de mís de un año atras tenia el libro impreso: pero hibia retardado su publicacion la muerle del autor, quicn no lo habia podido dejar com. pletamente terminado, razon por la cual erd èl quien le enderezaba la obra. Eslas circuns. tancias esplican bien porque la fecha final del rolúmen es la de 1596

Fallardo dice de Pedro de Enzinas, es ingemio de rira vena y z'ario coloridn pó́lico. Conocia á fondo la lengna castilluma.

37i EPICTETO, Y PHOCILIDES en español con consonantes. Con el origen de los Estoicos, y su defensa contra Plutarco, Y la defensa de Epicuro, contra la comun opinion. (Por) Don Francisco de Quevedo Villegas. Madrid, Maria de Quiñones, M.DC.xxxr. $160^{\circ} 8$ lojas prels. y 120 fols. Al principio eran ademas un frintis y el retrato de Ouccedo grabalos.

He visto la elifion de burcelona, Sobarliomy

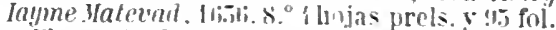

El retrato de Querido aribih rilado es este.

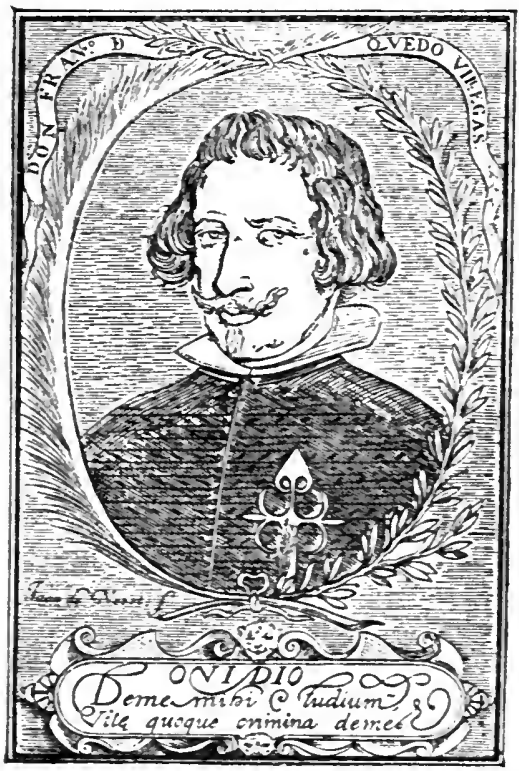


378 ERCILLA (APolinar). Juicios atados y jensamientos sueltos, ó jugneles de imaginacion. En joco-serios versos, romances, y lelrillas de algunos acaecimientos. Pेor Apolinar Iircilla, fillalgo sin D. Tomo I. Madrid, Yillalpando, 182i). 8.

Xis salio probahlomente ntro rolumen, ui se hat pordido murto con ello.

379 ERCHLA Y ZL TILA (ALONso NF.' Lal Ilareana de Don Dlonso le Erzilla y Cuñira. En Anvers, Fn rasa d. Pedro Bellero, 137\%. (Al fin: Tipis Theodori Lyndani.) 12." T hojus mPls. 333 fols.y't sin fo! iar que conlieven dos romposiciones poéticas en elogio d" Ercilla, la Tabla, una aprobacion de Juan Gimez, un foron y la illima blanca.

\section{Nui raro.}

Ferrer lin Itio en la Imtrotucciom á esta obra. edicion abidemina lo Istili, dice, omitimulo nombre als impresol y limlinto, quo silio í laz por prinera vez all Madrill, 1570;

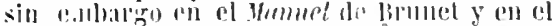

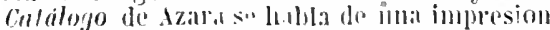

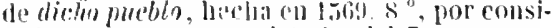

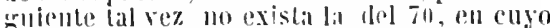

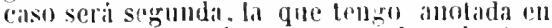
mis apmutes de salımanca, brimingu de' P'orlonarjis, 157'. 8. ${ }^{\circ}$ lo hojas prols. al revelso

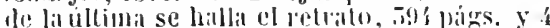
lojas Illis; y tercera la intes deseritil de Allrers liog la cual contiene despurs de la portadil li de licitoria á Felipe II, feelsadil En .Ma. drill $i$ dos de Maten de 1 .60 como la edicion principe descritit por Brunet y unos elogios da Juan fermindez de licbana y de l). Flaneisen Hamírez de Mrndoza; al fin llevia otros de Cristival Baldominlo, el indiann, biego de Morillas osorio, l). Pedro de Cílulenis, y una "iprobarion de linan libuez, quirn esturo seminn al mismo llire, mis de reintisiete años "il Americil, siendo uno de sus primeros conquistadores. Lin las edieiones posteriores il fa publicacion de la segunda parte se vario la dedicitoria, se suprimierom los antedichos versos en alabanza de la obra, y lit aprobilcion de Gomez. - Alvarez y Bacha halsa de mnil edicion de Zarag $5 a, 1.57 .5$; ell el Ensayo de ma bib. esp. de Gallardo, se describs otra tambien de Calongocu. en casa de luan Sulpo dño 1577. S. 176 hojas; ambas comprenden solo la primera parte pues la sore ymmila 110 sallió á luz hista despurs, es decir, en bis, de cuyo ino he visto tres edicionos distintis, i saber: Primera y soynda parle de la sraverma, de don Alonso de Ereilla y çuñiga, Cauallero de la Ordende Stanliago, genlil hombse de la ramara de la Nugesiud dirl Emperarlor. En Madrid, En casa dr Pines (i) in, mingessor. Año. Iรis. i. ${ }^{\circ}$ hojas prels., en la última de las cuales se halla un re. lrato igual al que copio de la edicion de $1.590 ; 195$ hojas fols. y una en blanco para los quince cantos de la primera parle, y 169 fols. para los catorce de la segunda, inclusa la nueva jortada y prels. Hai despues tres lojas, una ron el privilegio csclusiyo para liss Indias, (pules los insertos al principio, som para los reinos de Castilla y Aragon, segrin en la nortada se espresa) y dos para la Tublu, i cuyofin se repite el lugar, fecha, otc.-Primera y sequnda parte de la Araue'unu, de don Alomso de Ercilla y cuñiga. Muhirl, lierres cosin. 1578. 8. 16 hojas de prels., inclissa la del retrito de Ercilla, igual al de la interior, 729 fols. y por fln 4 hojas con poesias laudatorias $\mathrm{y}$ fé de erratas. $-S e$ cioula parle le la Arateana de Don Alomso cle Er zilla y Cuñiga, gue lrala la porficda greron rmlire los Españoles, y Araucanos cò algumus cosas nutubles grue en aquel liempo suredieron. En Caragoca, en casa de hian Solve, 1.78. 8. 2 hojas con parte de los mels. sin foliar, 555 hojas numeradas y dos al fin con unos elogios de la obra en versn. El ejemplar no tenia la primera parte ; pero scril la intes indicada del mismo pueblo hecha el año de 1577. - He visto ademas la l'rimer'a parte de' la Arancana etc. Lisboa, Antonio Ribero, 1582. - Stovenda parle de la Arancuna... Que Irala de la porfiada gueria pulre lo: Españnles y Arauranos. S. l. (Lisb) Ja, Inlmi, kibero M.D.LILX. 12. La prime$r^{2} /$ purte ticue 12 bojas prels., 149 fols. y una hoja con 111 escudo; la sragunda 130 hojas fols., inclinsos los prels., y al fin dosó mass hojas, pues el ejouplar que tuve á la vista se liallibil fillo. lits culites contienen una aluobalcion y vitios elugios en verso. La ferlar de estal sénuma parle debe estar equirulialil, yil porune no recuerdo haber visto rdiciones tin antiguas de Antonin Ribero, (a)mo porque la edicion de Madrid de 1578 rs la mis antigua de ella.-En Lóndres tilrimos utla jimpresion de lil Primera y segunla parte le la Aravcana, etc. Anvers, Pedro Bellero, 1586. 12."

\section{ERCILLA Y ZLNIGA (Alon-} so DE). Primera, segvida y tercera Partes de la Araucana de don Alonso de Ercilla y Cuñiga. Madrid, Pedro Madrigal, 1590. 8. 32 hojas prels., inclusa una con el relrato que va copiado á continuacion, 436 fols. y 12 de la Declaracion de algunas dudas que se pueden ofrecer en esta ol)ra, y tres Tablas.

primera edicion del poema de Ercilla completo, y en ella se incluyó, probablemente por primeril vez, el Elogio del autor hecho por el lic. Christóval yosquera de Figueroa y fechado en 1585.

En ol Ensayo de uma bib. esp. de Callardo se menciona li l'rimera seyunda, y lercera 
partes de la Araucana. Barcelona en casa Sebastiä de Cormellas, 1592. (Al fin:) Barcelo. na, en casa de la buula de Hubert. Gotart. 1591. 12. ${ }^{\circ}$ prolongado: y en el Catálogo de Croft, en el de la venta de Conde y en el de Sora, se anuncia unn impresion de las lres partes de Barcelona, loan Amello, $1592.8^{\circ}$ El retrato de Ercilla que lleva la edicion de 1578 y la presente de 1590 está abierto en inadera por cl célcbre Juan de Arfe y Villafañe y la siguiente es una reproduccinn de él.

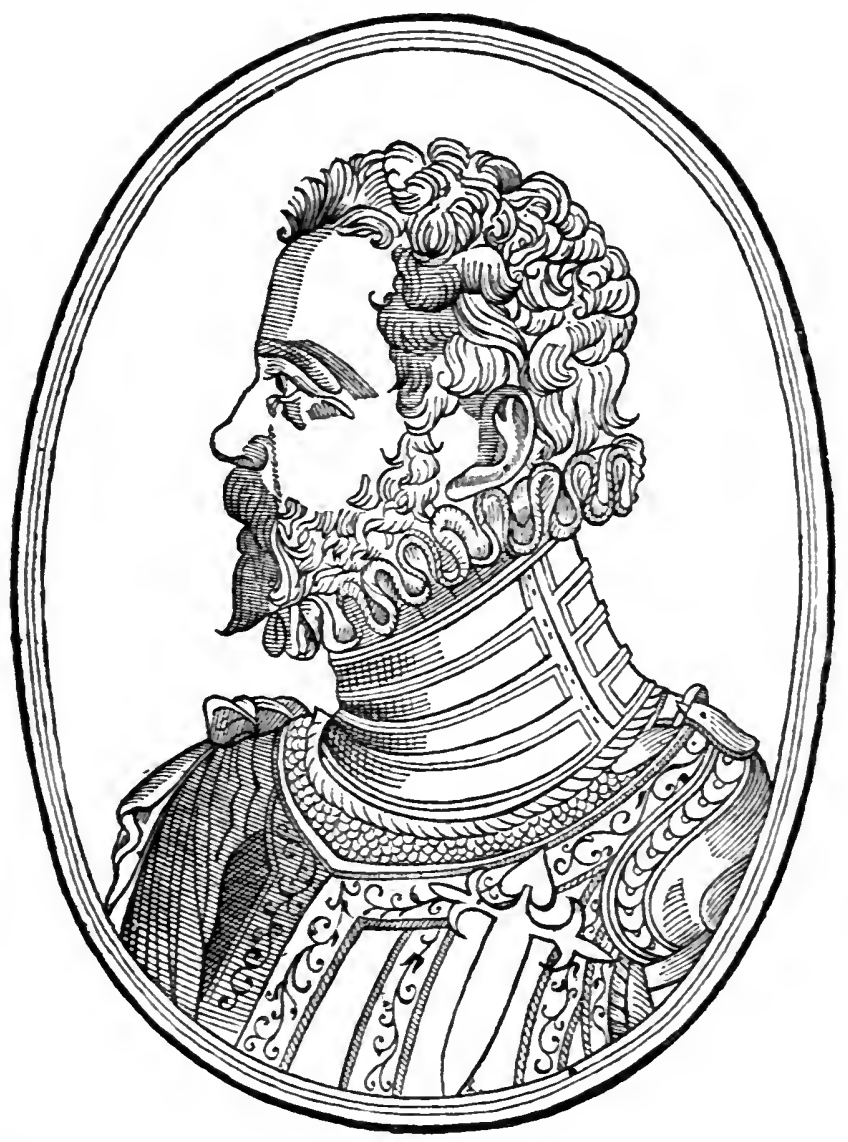

381 ERCILLA Y ZUÑIGA (ALONso DE). Primera Segrada, y Tercera parte de la Araucana de dõ Alonsa de Ercilla y çuñiga. Perpiñian, Sanson Arbus, 15y6. 17 hojas prels. $3 \nexists 3$ fols. y 2 sin foliar en las que termina la Declaracion de los vocablos oscuros.

382 - Primera, segvnda, y tercera partes de la Aravcana, De don Alonso de Ercilla y cuñiga. Anvers, en casa de Pedro Bellero, 13597.
(Al fin: Antrerpiæ, Typis Andree Bacxij Typographi iuratí. 1ว997.) 12. ${ }^{\circ}$ I. ${ }^{2}$ pte., 12 hojas prels., 116 fols., 4 de Tabla sin numeracion y una blanca; II. ${ }^{2}$ pte., fróntis, una hoja Al lector y fols. 149-273; III. ${ }^{2}$ pte., frointis, fols. 270-3 29, una hoja con una tprobacion del Maesiro Ocando y el colofon al reverso, con dos hojas blancas despues para terminar y completar el pliego.

Ferrer del Rio en la llustracion $d$ lib Araucana cita una impresion de Madrid, 
Licenciado Castro, 1597, que dice ser mui correcta.

583 ERCilla Y ZUÑiga. Primera, segrnda, $y$ tercera parte de la Araucana. Madrid, En casa de Iuan de la Cuesta. Año $1610.8 .^{\circ} 16$ hojas prels., 405 fols. y 13 de la Declaracion de algunas dudas y Tablas. C'ada una de las partes tiene su portada; pero la foliacion es solo una desde el principio al fin de la obra.

Habiendo enumerado lodas las ediciones que conozeo publicalas hista esta fecha, continuaré dando noticia de las posteriores, aunque no estén en uji biblioteca, así completare la parte bibliogriflea del poema más célebre que tenemos en muestro idioma.

Madrid, Imprenla del Reino, 1652. 8. Ensayo de una bib. esp. de Gallardo.

Malrid, Francisco Martinez Abad, $175 \tilde{3}$. fol. La he tenido.

Madrid, Antonio Sancha, M.DCC.L.Y.YI. 2 vols. 8. may. Láms. Hai ejemplares en papel azulado y más fuerte. La he tenido de aubos papeles.

Lion, Cormon, 1821. 4 vols. 18. ${ }^{\circ}$ Brunet.

Paris, Rignoux, 1824. 4 vols. 18. La he visto.

Madrid, D.M. de Burgos, 1828. 2 vols. $16 .^{\circ}$ Hai ejemplares en papel superior azulete. La he tenido de ambos papeles.

584 ERGILLA Y ZLÑ̃IGA (ALONso DE). La Araucana de Don A!onso de Ercilla. Edicion de la real Academia española. Madrid, Imprenta nacional, 1866.2 vols. $80^{\circ}$ may.

En los antefrontis llevan los tomos el título de Biblioleca selecla de autores clásicos españoles. Contiene esta linda edicion mua Introduceion biogrifica de Ercilla, é ilustraciones í sil poema, escritas por 1). Antonio Ferrer del lío. Es de cstrañar que habiendo cuidado de la impresion sugeto tan entendido, se hayan tambien suprinido en ella la dedicatoria á Felipe II, puesta en la primera edicion y en la de lijis, documento interesante por los detalles biográfleos de Ercilla que encierra; los elogios de la obra hechos por varius poetas y la aprobacion de Juan Gómez, er la cual se confliman por un testigo ocular los hechos relatados en la Arallcana.

Se incluyo este poema en los tomros IV., V. y VI. de la Biblioleca española inípresa en Gotha, por Steudel y Keil, 1805-11. 11 vols. $12 .^{\circ}$; en el Tesoro de tos poemas españotes épicos, sagrados y burlescos, publicado por IBaudry en su Coleccion lle aulores españoles. Paris, 18:0. 8." $y$ hai algunos fragmentos de ella en las Poesias seleclus caslellanas de Quintana, Segunda parte. Musı épica.

I.a continuacion del poema de Ercilla hecha por Santistevan 0sorio, busquese en el articulo de este autor en la presente division.

383 ESCANDON (D. Ig NaGio DE). Poema que en celebridad de Don Manuel de Amat y Junient, Virrey del Peru y Chile escribio el General D. Yonacio de Escandon. (Lima, 1762?). 4. 11 hojas.

ESCOBAR (Luis). Las cuatrocientas respuestas. Véase en la Seccion paremiologica, al nombre de este autor.

386 ESCOBAR CABEZA DE VACA (Penro de). Lvzero de la Tierra sancta, $y$ grandezas de Egypto, y Honte Sinay agora nueuamête vistas y escriptas por Pedro de Escobar Cabeça de Vaca. Valladolid, Bernardino de Sãcto domingo õ en gloria sea. Año de. (1087.) (sic) 8. 16 hojas prels., 201 fols. y 7 de Tabla.

Primera edicion rara y desconocida á Nic. Antonio; la segunda que he visto se imprimió Lambien en Valladolid, Diego Fernand'z de Cordona y ouiedo, 159.4. 8. 16 hojas prels., 167 fols. y 9 de Tubla sin numerar.

Dice el autor estar su obra escrita en verso suetto, y tal que de verso liene solo ta medida, poryu" en su cluridad y llaneza y el poco adorno de polabras galanas, ni regalan el oidto ni ofenden la verdad: y es esto tan cierto, que a no haber renglones cortos $\mathrm{y}$ largos, dificilmente se adivinaría ser un poema en veiulicinco cantos 10 contenido en el presente volúmen.

387 ESCOBAR Y MENDOZA (ANTonio DE). Nveva Gervsalen Maria. Poema heroyco. De Antonio de Escobar, y Mendoza. Fundase en los doze preciosos cimientos de la mystica Ciudad la vida, y excelencias de la Virgen Madre de Dios. IV. impressio enmendada por su autor. Valladolid, Iuan Bantista Varesio, 1620. 16. ${ }^{\circ} 8$ hojas prels., 262 fols. y 2 más para terminar la Tabla.

Ticknor, tom. IlI. pig. 155, dice, que este poema con el título de Historia de la Virgen, inadre de lios, se publico en 1608; por el privilesrio y aprobacion de la edicion que yo tengo, fechados en 1615, se puede creer ha- 
berse reimpreso en dicho año $\dot{0}$ el siguiente, y Nic. Antonlo habla de una impresion de Valladolid, Geronimo Murillo, 1618. 8.

He visto otra composicion poética al mismo asunto intitulada: La mejor muger, madre, y virgen. Sus excelencius, vida y grandezas, repurtidas por sus fiestas todns. Poema srucro del Licenciado Sebaslian de Nieua Calıo. Madrid, Iuan Gonçalez, 1625. 4. 12 hojas prels. y 256 fols.

\section{ESCOB.R Y MENDOZA} (Axtovio De). San Ignacio. Poema heroico De Antonio de Escobary Mendoza. Valladolid, Francisco Fernandez de Cordoua, 1613. 8. 22 liojus prels., 201 fols. y 4 de Tabla.

Poema en octavas, dividido en siete libros y en veintiun cantos.

Ademas de la Historia de la Virgen en ver. so este autor escribió en castellane, segun Nic. Antonio, Exumen y prarticu de confesores y penitemles. 1647. 12. Sus tratados en latin son mui numerosos y podrán verse en la Bibliolheca no:'a, tom. I. pág. 11.

\section{ESPINEL (Vicexte). Diver-} sas rimas de Vicente Espinel... con el Arte Poetica, y algunas Odas de Oracio, traduzidas en verso Castellano. Madrid, Luis Sanchez, M.D.XCI. $8 .^{\circ} 16$ hojas prels. $y 166$ fols.

Entre las poesías encomiisticas las hai de Lupercio Lennardo de Argensola, l'edro Montesdoea, el indiano, D. Luis de Contréras y Lope de Vega: tambien se lualla un Prolngo en alabanza de la Poesía por Alonso de Valdes.

El privilegio del rei está fechado en el año de 1591 , y en él espresaınente se dice que anı cuando et antor tenia vermiso anterior para publicar la obra, no habiu hecho uso cle él: esta circunstancia unida i la de no citar escritor alguno impresion mís antigua que la de 1591 , prueban la equivocacion padecida en el Catálogí de la renta de Conde, num. 2-js, al anunciar una de Madrid de 1.887 ; verdad es que á aquel ejemplar le faltaha el frontis y algunas hojas más de las preliminares, y solo se conservaria la hoja comprensiva de. la aprobacion de Ercilla, la cual efectiramente es de dicho año 1587 .

El presente tomo es mui apreciado, pues ademas de su rareza no ba vuelto í publicarse en más de dos siglos y uedio, y inicamente en alguna de nuestras antologías, como la de Sedano, se ha dado cabida á muestras mui cortas de las composiciones de Espinel, á pesar de gozar de una buena reputacion como poeta. Su nombre, sin embargo, es mas conocido por la novela: Relaciones de la vida del Escudero .larcos de Obre. gon.

A Vicente Espinel se Je ha considerado siempre comn inventor de las decimas llamadas de su nombre espinelas y como intmductor en la guitarra de la quinlu cuerda, segun unos, y de la sesta segun otros. por lo tocante á las décimas ya han hecho ver algunos autores, que ántes de haber nacido aquel se eseribió en esta clase de metro, como lo prueba el Cancionero general; pero no sé que hasta ahora le haya nadie disputado su mejora en la vihuela, y sin embargo, yo poseo varias obras anteriores al ano 1350 , donde se trata de este instrumento, y en todas ellas se describe y pinta con seis cuerdas: hai mis, Bermudo en su Declaracion de instrumentos, publicada cuando Espinel apenas tenia cuatro años, propone ya la adicion de ina sélima cuerda ú órden, y con ello supone ganaria mucho en vozes y armonia.

כ̋90 ESPINOSA (PEDRo). Elogio al retrato del Excelentissimo Señor don Manuel Alonso Perez de Guzman el Bueno, Duque de Medina Sidonia. Avtor Pedro Espinosa. Malaga, Iuan Rene, $1623.5 .^{\circ}$ Sin foliacion, signs. A-Q todas de 8 hojas ménos la última que solo tiene 4.

He colocado este tratado en la presente seccion por sus unnchas composiciones poéticas en varias clases de metro.

391 Psalmo de penitencia importantissimo para alcançar perdon de los pecados. Al Excelentissimo Señor dun Manuel Alonso Perez de Guzman el Bueno... Pedro Es. pinosa. Sanlucar de Barrameda, Fernando Rey, 16z\%. 8. 8 hojas.

Yic. Antonio no menciona esle rarísimo salmo, el cual. segun sudann, tom. II, págima Xix, está escrito en clequnle verso. Tampoco lo conocieron Gallando ni sus adicionadores.

Pedro ale Fspinnsa recopilador de la conocida intologia intitulada: Flures de poelas iluslies, fut uno de ellos y merecio que lope en sil Laurel de tpulo le dedieari el signiente elogio:

\section{Y la fienle espaciosa \\ Ceñida de lawel tenga Espinosa.}

Tambien escribió segun Mnñoz y Rmuero, un Panegiricn de la ciudat de? Anterpun'a, con las medallas halludas en ella. Je'pez de la Fruntera, 1626. 8.

592 ESQUIL.LCHE (El Príxcipe DE). Obra: del Principe de Esquilache. (Al fin:) Madrid, Diego Diaz de la Carrera, M.DC.xLvitr. 4. 6 hojas 
prels., 684 págs., 11 hojas de Indice y una con el lugar y año de la impresion.

Segun el Catálogo de la venta de Conde, nim. 288, esta es la primera edicion, y Nic. Antonio no menciona ṇinguna anterior á la de 1654; sin embargo, Sedano en el Parnaso español, tom. IX. pảg. XXXVI, y Barrera en su Catálogo, se refleren á una de Madrid, 1659, que probablemente existiri, pues de esta fecha son las censuras y aprobaciones de la del año 48 , de la cual ninguno de ellos tuvo noticia.

593 ESQUilacile (El Principe DE). Obras en verso del Principe de Esquilache, que no se imprimieron. S. T. ni a. (Madrid, hacia 1650?) 4." 27 hojas impresas y una blanca al fir.

Todas las composiciones de este tomito, bastante raro, faltan en la edieion de 1648 . Barrera no hace mérito de esta especie de adicion á las Obras del Principe.

894 Las obras en verso de Don Francisco de Borja, Principe de Esquilache. Edition Segunda reuista y muy añadida. Amberes, Emprenta Plantiniana de Balthasar Moreto, M.DC.LIV. $4 .^{\circ}$ may. 8 hojas prels. inclusa la anteportada y el fróntis grabado, 692 pags., una hoja con un Epitafio latino y una décima, 8 de Indice, al fin del cual se repiten las señas de la impresion: pero con la pecha de 1653 , una hoja con el escudo del impresor y dos despues que contienen $\mathbf{4}$ sonelos entregados á baltasur Moreto despues de terminada la edicion, y que por lo misms no pudieron incluirse en el cuerpo de la obra.

Esta bellísima edicion, inica conocida por Nic. Antonio, comprende no solo todas las poesías de la de 1648 y las del tomito descrito en el artículo antelior, sino unas ochenta composiciones uuevas no publicadas en ninguna otra parte: Sedano al citarla nada dice sobre sus considerables adiciones. - Gallardo en el Ensayo de una bib. esp. describe la siguiente edicion de Las obras en verso do Don Francisco de Borja, Principe de Esquilache... Edicion postrera, revista y muy axadida. A Amberes, en la emprenta Plantiniana de Baltasar Moreto, $1663.4 .^{\circ} 736$ págs., 16 de prels. y 20 de Tabla. Lleva al principio una adrertencia del impresor Moreto ell la cual dice: - Aqui tienes, amigo lector, la postrera edicion - mul añadida, de las excelentes obras del - Exmo. D. Francisco de Borja. En esta edi- cion muchos versos se añadieron que en la
- precedente no se imprimieron, es á saber: - los que despues de la muerte del autor (que - Dios tenga en glnria) se me han entregado: -25 de Agosto, 1663.:-No dice Gallardo si efectivamente esta impresion es mas rica en composiciones que la de 1654 , la eual tambien vjó. Ticknor pretende hai una edicion de 1652; pero no menclona el lugar donde se cjecutó: pongo en duda su existencla.

593 ESQUILACHE (El Príncipe DE). - Poema heroico, Napoles recvperada por el Rei Don Alonso, qve dedica a la Magestad del Rei nvestro señor Don Felipe quarto el Graode Don Francisco de Boria, Principe de Esquilache. Caragoca: En el Real, y General Hospital de nuestra Señora de Gracia, M.DC.LI. 4. ${ }^{\circ} 17$ hojas prels., inclusa la anteportada, fróntis grabado y portada impresa, 398 págs. y una hoja de Erratas.

Primera edieion del presente poema, dividido en doce cantos.

3̈96 La misma obra. Amberes, Emprenta Plantiniana de Baltasar Moreto. M.DC. I.VIII. $4 .^{\circ}$ may. 12 hojas prels., 398 págs. y una hoja para repetir el lugar y año de la edicion.

Ilermosa edicion desconocida á Nic. Antonio, y bellisimo ejemplar en gran papel.

Sedano, cuyo fuerte no era la exactitud biblingráflca, cita ell el Parnaso español, tom. IX., pág. XXXVl, dos ediciones solas . de este poema, una de Zaragoza, 1661, y olra de Amberes, Emprenta Plantiniana, 1685; en ambas feehas hai equivocacion, pues es evidente quiso referirse á las de 1651 y á la de 16.58.

Los traductores de Ticknor, tom. III., página 514 , hablan de una produceion de Es. quilache, impresa por separado, incluida despues en sus Obras, euyo titulo es: La Pas: sion de N.S.Jesu-christo en tercetos, segun el texlo de los santos quatro evangelistas. Madril, Francisco M trtinez, 1638. $4 .^{\circ}$; y Barrera meneiona las Oraciones y meditaciones de la vida de Jesu-Chiisto por el B. Thomas de Kempis, con otros dos tratados: De los tres Tabernáculos, y Soliloquios del alma. Bruselas, Foppens, 1661. 4.

597 ESTAZ0 (Baltriar). Sonetos, cançoẽs, eglogas, e ovtras rimas. Compostas per Baltezar Estaço. Coimbra, Diogo Gomez Loureyro, M.DCiIII. 4. ${ }^{\circ}$ let. curs. y redonda. hojas prels., 200 fols. y 5 de Taboada. 
Raro. Contlene algunas poesias castellanas; pero la casi totalidad están en portugues.

Nic. Antonio menciona vagamente unas Rimas sacrus $y$ morales de este autor, sin citar edicion de ellas.

EVIA (Jacinto DE). Ramillete de varias flores poéticas. Véase en la Seccion dramálica.

\section{EXPOSICION Parafrastica} de las Lamentaciones del Santo Profeta Ieremias. (1638?) $16^{\circ} .^{\circ}$

No sé de quién es csta version de las Lamentaciones, faltándole la portada á mi ejemplar. El titulo y año los he sacado de una aprobacion puesta al principio.
El Mtro. Hernando Jarava tradujo las Lamentaciones, en prosa y se publicaron con los siete salmos penitenciales, y los quince del Canticumgrado en Amvers, 1556 . 12."

599 EXPRESIONES de reconocimiento y gratitud, que al Señor $\mathbf{D}$. Manuel de Amat y Junient, Virey del Perù y Chile: tributa el vecindario del Valle de Lurigancho, en accion de gracias por la apertura del Camino de la Piedra liza, que conduce de Lima à aquel Valle. Lima, Oficina de la Calle de la Encarnacion, 1767. $4 .^{\circ} 18$ hojas.

Poema anónimo en cien octavas.
600 FALCó (Jaime). Opervin poeticorvm Iacobi Falconis valentini. Libri Quinque. Ab Emmanvele Sousa Coutigno Lusitano anici fama studioso collecti. Mantuæ Carpentanorum, Petrum Madrigalem, M.DC. 8. 16 hojas prels. y 118. fols.

Esta primera edicion y la hecba en Valencia, por Felipe Mey, en el mismo año, contienen unicamente las obras que pudo recoger Manuel Coutinho.

\section{1}

La misma obra. Noua editio, quâm plưrimis eiusdem Auctoris operibus, quæ nondum lucem viùerant, locupletata. Barcinone, Stephanum Liberòs, 1624. 8. ${ }^{\circ}$ let. curs. 16 hojas prels., 127 fols. $y$ una para repetir las señas de la impresion.

Hai otra edicion de Valencia, José Gasch, 1647. $80^{\circ} \mathrm{y}$ se han hecho varias posteriormente; todas ellas contienen las adíciones de la de 1624 .

Nic. Antonio se conoce no vió ninguna de las varias impresiones de las obras de este célebre poeta latino, pues solo menciona la de Mey sin fljarle fecha.

Gil Polo en el Canto del Turia dice de Falco:

A $t i$, que alcanzards tan larga parte

Del agua poderosa de Pegaso,

A quien de poesia el estandarte

Dardn las moradoras de Parnaso.

Noble Falcon, no quiero aquí ulabarle,

Porque de ti la fana hard lal caso, Oue ha de tener particular cuidado oue desd' el Indo al Mauro estes nombrado.

Toy. I.
Y Cerdá y Rico, en las Nolas á dicho Canlo, añade: -Múchos elogios pudiéramos recoger - de este célebre valenciano, que pueden - verse en las Bibliotecas de D. Nicolas, Ro- driguez, Jimeno y Vayans ; pero nos atre- vemos a asegurar que entre todos los poetas - latinos que han florecido en España desde - el siglo XVI hasta el presente, apénas halla- mos alguno que se aventaje á Falco, espe- cialmenie en las Odas y Epigramas. La lds- lima es que sean lan raras sus obras."

El escudo puesto por Estevan Liberos en el fróntis de su edicion es el siguiente:

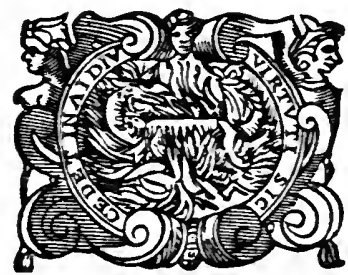

602 FARIA Y SOUSA Manuel DE). Divinas y hvmanas flores, Primera y Segvinda Parte. Por Manuel de Faria y Sousa. Madrid, Diego Flamenco, 1624. 8. 8 hojas prels. y 158 foliadas (y no 168 como se dice en el Ensayo de una bib. de Gallardos. Para la Parte segunda hai nueva portada, que lleva el fol. 107.

Fvente de Aganipe. Tercera Parte. Por Manuel de Faria y Sousa. Madrid, Andres de Parra, M.DC.xxviI. r $A l$ 
fin: Iuan de la Cuesta, M.Dc.xxviI.) $16 .^{\circ}$ let. curs. 8 hojas prels. y 224 págs.-Qvarta Parte. (Al fin:) Madrid, Andres de Parra, 1627. $16 .^{\circ}$ let. redonda. Va desde la paig. $220 \ddot{3} a$

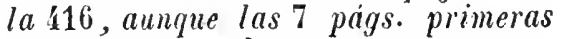
no estín mumeradas.

Ni Nic. Antonio, ni Yoreno Poreel en el Retrato de Manuel de Faria y Sousa, tuvieron noticia alguma de esta primera elicion de las cuatro partes de la Fuente de Aganipe de Faria. Segrin me aseguró el Sr. D. Jacobo de Parga se hizo otra en Madrid on los años de 1644 y $46 \mathrm{y}$ los tomos V., Vf. y Vll. se publicaron en Lisboa. Yo solo he podido ver las dos siguientes: Fuente de Aganipe ó rimas varias de Mamuel de Fanin $i$ Sonsa. Dindidas en siele parles. Paile segund. Nadrit, Inan Sanchez, M.DC.XLIIII. 8. 8 hojas prels. 215 (dice 115 equivocadanente) foliadas y 3 para completar la Tabla. - Fuenle de iganine etc., etc. Parte quarla. Madril, Inan Sanchez, M.DC..ILIIII. $80^{\circ} 12$ hojas prels. y 216 fols.

603 FARIA Y SOUSA MaNel DE). Nenia. Poema acrostico a la clarissima Reyna de España Doña Isabel de Borbon. Madrid, Imprenta Real, M.DC.XLIV. $4 .^{\circ}$ may. 2 hojus prels. y signs. a-g de 4 hojas cada una.

El nombre del autor de la presente obra solo consta por la dedieatoria de Manuel Cor. tijos de Villasante, pues en ella dice, haber solieitado de Manuel de Faria se lia compusiera y este habia convenido en escribir el presente poenia.

Nic. Antonio no lo pone entre las producciones mencionadas por él de este autor; ni se encuentra en los catálogos de las obras de Faria, que se hallan en su Relrato eserito por Noreno Porcel y en el Nobiliario de Barceos; á no referirse á el, cuando dice en este illimo: Un libro de cierta hisloria, de que no se dice el tilulo, porque la escribió á ins. tancia de quien la quiere imprimir en su nombre.

604 FARIA Y SOLSA (PEdRo de). Poema nrpcial, de Pedro de Faria, i Sousa, Al Señor Don Nuño Alvarez de Melo Pereira, Duque de Cadaval, Marques de Ferreira, Conde de Tentugal, etc. Lisboa, 1661. 8. ${ }^{\circ}$ cuadrado. Manuscrito autógrafo fechado y firmado por él en Lisboa, à 11 de febrero de 1661.

Creo inedito este poema, que consta de doscientas doce redondillas.

Fné D. Pedro de Faria hijo del célebre.Don Manuel, como se ve por el Retrato de este, escrito por Yoreno Porcel, en el \$ XVI, donde dice al hablar de su descendencia: . Pedro - de Faria, el mayor de los que viven, siendo - estudiante se dio á las armas, dejo los estu- dios y fué capitan de infanterfa española, - para pasar á Italia; hoi se ejercita en buenas - letras y en buenas artes.,

D. Pedro hace una alısion á su padre en las dos siguientes redondillis, últimas del Poeina:

l'ero como á tanto asunto

Mi instrumento no es bastante, Me darí de allá constante

Mi padre su contrapunto, De lira ó tuba elegante.

l'orque d'él, Duque, la tuba, l'ues es la misina de apolo, Quisiera para t1 solo, Que es bien que tu gloria suba lesde 111 pillo al otro polo.

603 FEBRER (Mosex JAME). Trobes de Ilosen Jaume Febrer, caballer, en que tracta dels llinatges de la conquista de la ciutat de Valencia $\dot{e}$ son regne. Valencia, Imprenta del Diari, M.Dcc.xcvi. 4. $\boldsymbol{X X I V}$ págs. prè's., 296 de testo y 14 láms. con 588 escudos de armas.

Esta olira empezó á ver la luz pública en ol Dirl'io de Vulencia del $10^{\circ}$ de Setiembre de $1791, y$ el editor de aquel periódico la reunio èmprimio en un tono $y$ es el que forma el objeto de este artículo.

Inchos hin pretendido que las Trobes de Iosen Febrer son apocrifas: el P. Fr. Bartolonn libelles escribio unas observaciones his/ndir-criticas sobre ellas, y solo publicó cl Quuderno I, en Vulencia, Joseph Orga, MDCCCIV. 4. En este opúseulo se sostiene aquella opinion; pero otros no participan de clla: sin abrizar resueltamente ninguno de los dos pareceres se puede asegurar, que si existió Jaime Febrer en el siglo XIII, y eseribio las Trobes; 0 su obra se ha perdido, ó la hoi conocida se hilla desfigurada en términos de no haber quedado rastro del lenguaje y es. tilo del tiempo en que se supone compuesta, pues contiene palabras $y$ frases pertenecientes casi á nuestra época.

Porteriormente se ha reimpreso con el sl. guiente título:

Trol'as de Mossen Jaime Febrer, que tratan de los conquistadores de Valencia, nueva edicion hecha con presencia de la primera y de un manuscrito antigun, e iluslrada con notas po' D. Joa'fuin Maria Bover. Palma, Jose Gelabert, $1818.4 .^{\circ}$ Retratos y láms. litográlleas.

606 FERNÁNDEZ (Blas Franco). La vara de Iese, y sv divino frvto. Vida de Iesvs, y Maria. Poema heroico. Con discursos Historicos, Politicos, Morales, y Misticos. Por el 
Doct. D. Blas Franco Fernandez. Madrid, Iulian Paredes, 1674. 17 hojas prels., inclusa una lámina que representa a Jesus y María: entre las pags. 372 y 373 hai otra portada que dice ser Tomo segvndo de la primera parte, y una lamina igual a la del principio; el volumen consta ademas de 638 págs. y 13 hojas de Tabla é Index.-La vara de Iese etc. (ut supra) Tomo primero de la Segunda Parte. Madrid, Iulian Paredes, 1678. 17 hojas prels. inclusa una lamina igual a las del otro tomo y 469 págs. Son 2 vols. $4 .^{\circ}$

Por la precedente descripcion se ve que el volumen primero forina los dos tomos de la primera parte, y el segundo, el primero de la seguilda. Sin duda fué lo úmico publicado y Nic. Antonio lo confirma diciendo estar la obra dividida en tres partes. Este bibliografo se equivoca cuando supone ser la edicion de Madria, de 1670 , porque las aprobaciones del primer volumen son de 1673 y su dedicatoria de $1674, y$ las del segundo de 1677.

obra cserita en prosa y verso.

FERNANDEZ DE IIEREDHA (JUAN). Las obras. Véase en la Seccion diramática, al nombre de este autor.

607 FERYANDEZ DE MARMANiLlo (Fraxcisco). S. Pedro Arbves. Sol de Inqrisidores. Logroño, Año de 1663. 4. ${ }^{\circ} 13$ hojas prels. sin mumeracion y $6 \mathbf{4}$ págs. principiando por la $\overline{7}$.

En la tercera hoja de los preliminares se halla una especie de portada; de ella haré un estracto, pues alli se encuentra el nombre del autor y se da una idea del contenido de la obra: Vida de S. Pedro Arbues. Escribela Primero en verso heroyco latino, y luego en Oclauas sacada al pie de la letra de su historia, el Licenciado D. Fruncisco Fernandez de Marmanillo, y assi mismo describe las fiestas a su beatificacion en la Ciudad de Logroño, Año de 1664 .

No encuentro en Nic. Antonio mencion alguna de Fernández de Marnanillo ni de su libro.

608 FERNÁNDEZ DE MEDRANO (Sebastiax). Breve descripcion del Mundo o Guia geographica de $\mathbf{H e -}$ drano. Lo mas principal de ella en Verso. Brusselas, Lamberto Marchant, M.DC.LXXXVIII. 12. 108 págs. inclusos los prels. que las llevan impresas.
Por los prellminares se ve ser el autor Don Sebastian Fernández de Medrano, el cual dicc en el prólogo, que la parte en verso de su obra la escribió, bajo su direccion, D. Manuel de Pellicer y Velasco, discipulo suyo.

\section{FERNÁNDEZ DE MORATIN} (LEANDro). Obras líricas de D. Leandro Fernandez de Moratin, entre los Arcades de Roma, Inarco Celenio. Segunda edicion conforme en todo á la que el autor acaba de publicar en Paris. Londres, M. Calero, 1825. 8. ${ }^{\circ}$ esp.

Esta edicion la costeó mi padre.

FERYANDEZ MORATIN (LEANDro). Obras poéticas. Véase en la Seccion dramática.

FERNANDEZ DE MORATIN (NIcolas). Obras líricas. Véase en la Seccion dramática.

\section{FERNiNDEZ DE RIBERA} (RODRigo). Trivnfo de la vmildad en la vitoria de David. Por Rodrigo Fernandez de Ribera. Sevilla, Luys Estupiñan, 1620ั 1. ${ }^{\circ}$ 2 hojas prels., 19 fols. y una para repetir las señas de la impresion. Todas las págs. están circuidas de orla.

Poema en octavas y en un solo canto.

Vic. Antonio no inenciona esta obra de Fernández Ribera ni ninguna de las impresas del mismo autor.

Los traductores de Ticknor, tom. III., pág. 541, se refleren á un poemita de esté autor, imitacion de Las Lágrimas de S. Pedro de Tansillo, impreso en Sprilla, Alonso Rodriguez Gunurra, $\{609$. 8. Segun parece, en el ejemplar que tuvieron á la vista se hallaban:

Dos canciones, tas mejores que se han im. preso, la primera al apostol S. Pedro: su autor el licenciado Pedro Rodriguez. La segunda á la Asuncion de la Virgen N. S. compuesta por el Dr. Tejeda. Sevillu, Simon Faxardo, 16.50 .

Cancion del gloriosissimo cardenal y Doctor San Geronimn. Compuesla por Fr. Adrian del Prado. Sevilla, Pedro Gomez Pastrana, $1637.80^{\circ}$

En el Ensayo de una bib. esp. de Gallardo se citan ademas las obras siguientes de este autor:

Esquadron humilde, levanindo A deuncion de ta Immaculada Concepcion de la Virgen muestra Señora. Sevilla, por Alonsu Rodri. guez Gamarra, 1616. 4.017 hojas. 
Cancion al Santo Monte de Granalla. Gra: mada, Bartolome de Lorenzana, 1617. 8." 8 hojas.

Elogin. Al altar que en onor de sus gloriosos Prolomartyres del lapon lpianto la Orolon de $N$. Seraphico P. S. Framicisco. En su insigne Convenlo Mayor. MC Criblll. h. 6 hojas.

Lil Asinuria, poema in treces chrlos. Manuscrilo.

\section{FERXINDEZ DE RÓZAS} (Gabriel). Noche de invierno. Conversacion sin naypes. En varias Poesias Castellanas. De Don Gabriel Fernandez de Rozas. Divididas en dos partes. La primeral de assumptos graues, r sacrus. Lal segunda, de assumptos de burlas. Madrid. Francisco Nieto, 1662. $10^{\circ} 16$ hojas prels. y 161 fols.

Enlrr las poesías bulleseas se encurenlan sesenta $y$ siete epigramas.

FERREIRA Axtoxio. Poemas lusitanos. Véase en lil Seccion dramritica.

(1) FERREIRA DE LA CERDA Berrarda. Suledade de Bregaco Por Doña Bernarda Ferreira de la Cerda. LisLoa, Mathias Rodrigues. 1631. 8. 8 hojas prels. Cla primera es un friutis grabado y la $8 .{ }^{3}$ blanca), 121 foliadus, $y$ Thojas mis, que completon la sign. Q.

Poema en cuarletas de asomanles y varias ulras poesías. - Es libro raro.

Gallardo al deseribir la presente obra en sul Ensayo de una bib. psp. dice: . Fste libro "propiamente es mu Romancero; comsta de - veinte romances que acaban en la pín. 80 . - Desplies hai otros cualto, uno de f'llos ell - esdrijulos. -Trar timblen alguna romposi- cion portuguesa, y dos latinas enl conso- nautes.

lle visto olro poema de esta escrilora inLitulario: Hesputia libertarta. Lisbou, Pedru crapsbeli, lois. 4. Y uma f'arte seglinda del mismo publicadia despues de li murete de lia autora, por sil hija boña Berustrda, intrpresal cin Lisboa, Ivan de la Costa. M.l)C.L.XXIII. 4.

Yic. mutomiorlice compuso ademas alermas Comedias; pertu segull filloce 110 vio el lomito de liss Soledartes, pures no menciona el lugarl si el año de la impresion, ni su taInaก̃o.

Lope de lega en el Lauret de apolo hace el signieute elogio de musito literario de dicha sinutur.
Si puliera tener la fana aumento y gloria Lusilana,

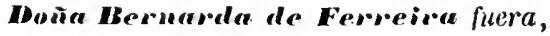
á cuyo portugues entendimiento

? pluma corsteltamu

la Espoña libentada España debe:

porque sola pudiera

partir entre los reinos esla gloria;

lan poderosa inteligencia mueve

estos tos orbes com su dutce listoria, con lanta erudicion, con tanto lnstre, que cllu queda imnortal y Espuña itustre.

613 PIgUEROA (Francisco de). Obras de Francisco de Figveroa. Lavieado Pindaro hespañol. Prblicadas Por el Licenciado Luis Tribaldos de Toledo. Lisboa, Pedro Craesbeeck, 162.7. 8. ${ }^{\circ}$ Sin foliatura ni paginacion, signs. A-K, todas de $\mathbf{8}$ hojas ménos la $\mathrm{k}$ que solo tiene 4 .

Primera edicion y en mi opinion la única antigua: sin embirogo en el Catálogo de la venta de Conde se anmeio una de tisboa, Pedro crapsbeck, li26: de la misma habla Tickinor, en el loun. Ill., pág. 188; de ella hatce mirito Fermindez, en el Prologo del lom. XX. de sll toleccion de poetas, en el cual roimprimici estas obras, $y$ allí poudera la liteza del lihro: supongo que á la misma edicion se retlere sedino al mencionar una de 1526, elur tipogrifflco evidente, pues el divino Figneroa nacio hicia el año 1540. El liecho es que ninguno de todos estos allores conocio la inipresion que poseo de 1625

Lope de Vega le tributó el siguiente elogio en el Laurel de Apolo:

¿.Hs cómo tu Academia
no propone al divino Figueroa,
si con verde laurel sus hijos premia?
Pero dirás, que el atribulo loa
cuanlo decir pudisle,
dichoso rio, que decir le oiste
con lan süave acento y harmonia,
que los nobles espiritus eleva:
de paso cu paso injusto amor ne lleva,
cuando dejarme descansar debia.

614 Flores (El Geveral). Ocios poelicos del Jeneral Flores y una Oda en su obsequio por J. J. Olmedo. Paris, Appert, 1846. 12. ${ }^{\circ}$ marq.

Ejemplar regalado á mi padre por el autor con una dedicatoria autógrafa.

613 FONSECA (Melchon). Sueño politico. S. I. ni a. $12 .^{\circ} " 33$ págs. 
Satira en verso contra Felipe IV y sus ministros.

La presente obra no tiene portada y probablemente nunca la ha tenido: tampoco consta por parte alguna el nombre del antor; pero ul ejemplar lleva una nota mamuscrita en la hoja de guardas que dice: $D$. Melchor de Fonseca es el intur" le este libro. Ho listo el original.

616 FoNTINELLA (Fracisco). Occident, eclipse, obscrredat, frneral. Panegirica alabanca del molt lllustre Doctor Pau Claris. Per lo doctor Francisco Fontanella. Barcelona, Gabriel Nogues, 1611. $4^{\circ} 30$ hojas con las signs. A-li.

Contiene este tomo varias composiciones poéticas en cittalan.

Franciseo Foutanella no se encuentra citado por vic. Autonio.

617 FORAER (1). JCAX PABLO' Discursos filosóficos sobre el hombre: de Don Juan Pablo Forner. Madrid, Imprenta real. 178\%. $8 .^{\circ}$ marq.

Ni ejemplar es del papel fucrte $y^{*}$ azulado del cual se tiraron jounisinmos.

Ponena dividido en cineo disenrsos.

618 Fortoll (Hiprolyte). Essai sur les poëmes et sur les images de la Danse des morts; par Hippolyte Fortoul. Paris, Bourgogne et llartinet, s. a. $160^{\circ}$

kin estr librito, entre otras rosas curiusis, se trata Hel poema español atribuito al habef 11. Santo intitulado La dom:a gever?ml de la Huerle.

619 FRAGMETTOS DEL OCIO, yye recouro rna templada atencion. Sin mas tin que apartar estos escritos de el desaliño; poryue no los empeoras se el descuido ordinario de la pluma en los traslados. S. I. Año de 1668. 4. ${ }^{\circ} 162$ hojas foliaders, inclusos los preliminares, y la última hoja de la Tabla.

Todo este tomo se compone de poesias en varias clases de metro, escepto unas Riglas part torear, que se hallall al plincipioy dos papeles en prosa, puestos al fin diricidos el uno it Felipe $1 \mathrm{~V}$. y el otro a la reina Doña Mariana de Austria.

En el Catálo:ro de la venta de comle: nui- mero 304 , se anuncio un ejemplar de esta obra y alli se indica ser libro mui raro, y al parecer impreso privadamente con el ún. co objeto de regalarlo.

El Sr. Duque de Veragua tuvo la bondad de commnicarme la nolicia le una edicion de este libro que poseia hecha en MDCLXXXII, sin lugar ni nombre de impresor; lleva el unisuo tínlo que la mia, y el contenido es igual con la sola aiferencia de ir al fin las Reglas pren torear y ocupar los fols. It5 al llis vuelto, que es èl ullimo. Tiene el cjem. plar dol buque en el frontis ta siguiente nota manuscrita:

$$
\text { - Por el Almirante de Castilla.. }
$$

- Esta noticia lel verdaderi autor de este - libro se ha hallado on las Pnessus de D. Luis - le Cllor sll amigo, al fol. 5.5; ven las Presias - de Francisco Trillo impresas en firauada, - año llive. ell el fol. 11. hai un Soncto a la - mucrte de li. Jiran Alfonco Enríquez, Al- mirante de Castilla. que es el misumo: $y$ así - queda averiguado el nombre. apellido $y$ comploo de cote gran poeta anuimimo.

Efpetivamente en el fol. $\mathbf{5 3}$ de las poesums de flloa se encuentra un simplo del Almirmble de cuslilla, y le precode uma cuarléa que principia:

\section{Cieulifico Ajolo muestion.}

Y ambas composiciones con alzunas varian. tes se hallan "ll los fols. 24 t2' de los Fing. menlos del Orio. Yo cabe, pues dida ser el autor anunimo de esta obra nuo que lle. vaba el título de Almirante de Castilla: pern 11) "s exarto el fue este fuera D. Juan difonso Emiqum. yuien sugm parece habia muerto

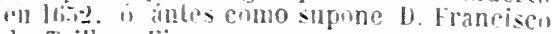
di: Trillo y riguteroa, en cuyo caso no es probable cine ba rarla en contestacion à Dou dutuil, Touan. donde pilio se eseribieran los precentos de torear. esturiera fechada ef su dersio del mismo año iz, y es mate. rialunemle impasille que mo du los papeles en Fosa, imeluidn támbion en los Frongenlos. fueral digrigido pure il a boña Yariana de Alsetria lutorn y gobernadore all la memor mlinel de Carlus il. " asto no pudo suceder hasta despues de bibjo ell cuyo año murie lolipe $10 .-E$ ln probablo s easi sezuro que el Almirante de castilla. aintor de lus Frag. meulos del orio. fuera 1). Juan liaspar Enríquez de labrerit. il quien hrando y santarem dirigio su ocins de Costaliel on lobis: y disipa toda duda "I clocio leecho de el como poeta en la dedicaturia : In mucho que ellsalza sll lisilreza para torear a caballo:

Tu rijon entre los brulos, per to humalo galones, "icme a sus planias de' molde. purs simpre teucllos les atre.

620 FRA.CCIA I ACOSTA Fraxcisco DE). Iardin de Apolo. De Francisco de Francial ! Icostal. Madrid, 
Iuan Gonçalez, M.DC.XXIIII. 8. ${ }^{\circ} 4$ hojas prels., 51 fols. y una para repetir el lugar y año de la impresion.

Primera edicion desconocida á los traductores de Ticknor, quienes únicanente mencionan la segunda, tambien vista nor mi, hecha En Coimbra, Mumuel Dias, 1658. 8. ${ }^{\circ} 4$ hojas prels., 51 fols. Y Ina al fin donde se repite la fecha, pero con el año de V.DC.I.Vll.

Hai en esta obrita veinte sonetos, cinco silvas, un poema en octavas intitulado: el Peñasco de las lágrimas, catorce rominces y doce epigramas.

Adquirí este libro raro en Lóndres y estaba encuadernado con las Rimas de D. Anlonio Paredes. Cordoua, saluador de c'a, 1625. $8 .^{\circ}$ 4 hojas prels. y 48 fols., volimen tambien poco comun.

Del autor del Jardin de Apolo dice Lope de Vega en la Relacion de liss fieslas á S. Isidro, fol. 151:

Ya de Framcisco de Franciu el lucido entendimiento viene con su pompay lustre, causa a.tan dulces efectos.

621 HREGOSO (Fileremo). Rissa y planto de Democrito y Heraclito Traduzido de Ytaliano en nuestra Lengua Vulgar, por Alōso de Lobera. (Al fin:) Fve impresa en Valladolid En casa de Sebastian Martinez Acabosse a. VII. de Iulio de. M.D.L.IIII. Años. 4. $^{\circ}$ liii hojas foliadas, inclusas las 4 de preliminares, y una al fin con año, lugar y nombre del impresor.

Poema bastante raro, dividido en quince cantos y traducido en tercetos.

Al principio hai un soneto de Jorge de Montemayor en elogio del traductor.

El nombre del autor de la obra original 10 menciona Lobera en la dedicatoria.

El libro en italiano se intitula : Riso di Democrilo, e pianto di Heraclilo. Modiolani, Pelrum Marlyrem de Monteyatiis, 1506. $4 .^{\circ}$

622 FRÍAS (ANтоNio DE). El LIIzero mejor del Sol divino: vida de San Juan Baptista: que dedica al... Señor D. Juan del Rio... Don Antonio de Frias. (Al fin:) Madrid, Lucas Antonio de Bedmar, y Narvaez, M.DCCXviI. 8. ${ }^{\circ} 16$ hojas preliminares, lo demas son las signaturas $\mathrm{A}-\mathrm{Q}$, de 8 hojas: la última es blanca.

l'oema en romance endecasilabu.
623 FUENTES (AloNso DE).

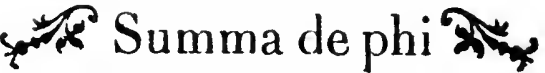

lotophia natural, enla qual alfi mismo fe tracta de ASTRVLVGIA Y ASTRONOMIA, $\varepsilon$ otras fié cias. En eftilo nūca vifto, nueua mete facada. porel magnifi co cauallero ALONSO DE FVENTES. Diri gida ala.S.C.M.del Jrincipe $\mathrm{DON}$ PHELIPE ñ̄o leñor.

Con priuilegio Imperial. ओ 1547 \&

(El fróntis va circuido de orla; el prologo ocupa la segunda hoja y en la tercera fol. I, principia el Argumento; sigue la foliatura hasta el cxxvir no llevando mumeracion ninguna las 46 hojas que quedan hasta terminar el tomo. Al fin se lee:) Fue impresso en la muy noble $r$ muy leal ciudad de Seuilla siendo primero examinado por mandado delos muy magnificos \& muv rellerēdos señores inquisidores. Én casa de Juā de Leõ impressor de libros. Acabose a tres dias del mes d' octubre. Año d'lnascimiento de n ro redēptor Jesu xp̄o de. 15̆17. Años. 4. ${ }^{\circ}$ let. gót. Láms. de madera y las págs. cerradas con rayas. 2 hojas preliminares, CXXVIII fols. y $\mathbf{6} 6$ hojas sin numerar.

Nic. Antonio se reflere á una edicion de Sevila, 1545, la cual no ereo exisla; pero no menciona la del 47 que es muir rara.

En el fol. Vl y no alfin del volúmen, como dice Brunct, hai esta singular advertencia: Nota lector el artifirio de cista obra, que loda la prosu: en que pregunla / y habla Ellirusco, es verso surlto Ylaliano. Y in prosa en que responde y habla Landalio / es verso suelto castellano.

FÚNES DE VILLALPANDO (FrANCisco Jacinto). Véase Climente ( $\mathrm{Fa}$ bio), ell esta division. Núm. 340 . 
624 GALERIA (LA) DE LA OIINIPOTENClA. Cartel del Certamen poetico conqve celebra... la Santa Iglesia Metropolitana de Lima... la sagrada apotheosis, y Divina Canonizacion del glorioso Santo Thoribio Mogrovejo. (Lima........) 4. ${ }^{\circ}$ Lna hoja de portada, 62 sin fol. con las sign. A-Ith para esponer el objeto y condiciones del Certamen.

No pueden sacarse las señas de la edicion ni el nimero de hojas del volimen, por faltar á mi ejemplar la parte ultima, donde deben estar las poesias. Io que resinlta del final de este Cerlámen es ser su autor $\mathrm{b}$. I'tedro de Peralta y Barnuevo.

620 GALIANO DIEZ PJATAS (Tomas José). Coleccion de varias poesias, dividida en dos partes. La primera por Don Tomas Josef Galiano Diez Platas. La segunda por Don Francisco Clemente. Murcia, Viuda de Felipe TL::ol, 1783. 8. ${ }^{\circ}$ Dos partes en un volúnıen.

Son puesias sagradas de ninguu mérito.

626 Gallegos (Maxel de'. Gizantomachia de Manvel de Gallewos. Lisboa, Pedro Cirasbeck, 1628. $4 .^{\circ}$ 20 hijas prels., incluso el fróntis grnbado y una blanca, y 86 fols.

Al fin de la Giganlomnquia, poema en netavas dividido on ciuco libros, se encuentra otra composicion intitulada Araxarete.

lone de Vega en el Laturel de Apolo elogio así á esle autor y su poema.

Cuando en tu liru lusitann Orféo

Fannel Gallégos las bulallas cantes

De Encélado is Tifeo,

No adnire el allo premio lu deseo:

une alcrmarin con ver'sos ele'gantes

Estrellas por laureles tus gigmutes.

Los traductores de Ticknor citan otro poema intitulado Lambien Gigrntmuquia compuesto por D. Franciseo de Sandoval, impreso en Zarigoza, Juan de Lumaxa. $1650,80^{\circ}$ y del mismo autor es un tomo de poesias denominado Rasgos del ocio. S. l. ni a. 8.

627 GALLEGOS (MaNel DE). Obras varias al Real Palacio del
Bren Retiro. Avtor Manvel de Gallegos. Madrid, Maria de Quiñones, 1637. 8. 8 hojas prels. y 32 foliadas.

Son poesías dedicadas á describir el pala. cin, pinturas, jardines y otras preciosidades del Buen Retiro en tiempo de Felipe IV.Tomito raro.

Ile vist" de este autor otra obra intitulada: Teinplo de memorin. Poema epilhalamirn, uns folicissimas bolas dn Excellentissinı Sinhor Imique de Bargança, \& de Burcelos. I.isboa, Lou'enco Craesbeeck, 1655. 4. 12 hojas prels., 126 fols. y 6 para terminar el Indire de los nombres propios que se hallan citados en este poema portugues.

Tambien escribio el mismo un Discurso moptico e cançao "L Llyssen de Gabriel Pereyra le Caslro, que se halla al frente de este poema: y Barrela menciona como suya, aunque no lleva nombre de autor, la kelaçao do que passme ma felice aclanıçāo (llel nuebo rei (li) Porlugal, luque de Bragança). Lisboa, Lourenso de Anveres, 16.1 . 4.

628 GARCiA (Gaspar). Primera parte de la Mrrgetana del Oriolano, guerras, y conquista del Reyno de Murcia poŕ el Rey don layne primero de Aragon. Con la redempcion del Castillo de Origuela. Donde se illustra casi toda la nobleza de España. Compuesta por Gaspar Garcia Oriolano. Valencia, I uan Vicente Franco, $1608.8 .^{\circ} 8$ hojas prels., 100 foliadas y 8 sin foliar.

Tomito de estraordinaria rareza.

El poema ronsta de nueve cantos en octavas ve halla comprendido en los 100 folios; lo que sigue despues, es una Ineclaracion de los numbins antiguos contenidos an este compendi", y fumlacion de la ciulad de origuela "l antiguederd dr la rilla de o'iua. - El Doctor Francisco Martinez tambien puso al fin de las Ereruins funerales a Yissin Frenc. Ger. Simon, un Breve trotado de la fundacion y unliguedad de origuelit.

Se equivoca Rodriguez en suponer que Gispar iarcia era natural de oliva. pues èl mismo espresil en la portada, despues del apellido, ser orjolano; en la Epislola al lec. ton', nsegura a fé de minlano bien nucido. y on la Decluracion do los nombres antiguos, colocadi al fin, observa, ser orchelis, hoi oribuela, la elimmlogía d'esta mi patrúc. Tambien ignoro Rodríguez cual habia sido su profesion y por el Carlel de los Fiestas a S. Raymundo de Peñafurl del P. Gómez, sabemos fue la de sastre. Yle pareee que la 
propagacion de esta noticia ignorada de muchos, me la agradecerán los que pertenezcan á dichn arte, pues mayor gloria y honra les cabe de contar entre sus compañeros de profesion á un poeta épico, que á otros llenos de orgullo por sus timbres de nobleza, aun cuando pretendan descender del rei Chico.-Gaspar García promete al fin una segunda parte que no llegó á publicarse.

GARCía (Vicente). La armonia del parnas, poesías varias. Véase en la Seccion dramática, al nombre de García (Vicent).

629 GARCÍA DE ALEJANDRE (Juan Bautista). Cancion real al Altissimo Misterio de el Ave Maria en la Sacratissima Encarnacion de el Verbo Dios Eterno, principio de nuestra feliz, y final Redempcion. Romance. Chaos de el mundo en la muerte de el Fenix Christo Señor nuestro, y alegria vniuersal en su Resurreccion. Por el Licenciado Ivan Baptista Garcia de Alexãdre. Lisboa, Antonio Aluarez, 1635. 4. Sin foliacion, signaturas A-I, tudas de 4 hojas, inclusos los prelininares.

No encuentro en Nic. Antonio noticia ni de tste autor ni de su poemita.

GarRido de Villent (Franc.). El verdadero suceso de la batalla de Ronce;valles. Véase en la Seccion novelíbica.-Libros de caballerías.

630 GAZULL (JAIME).
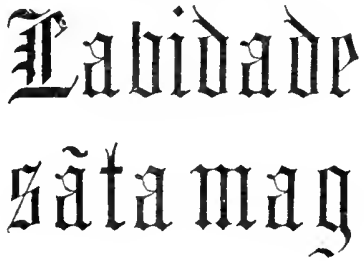

dalemant

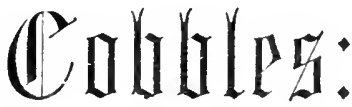

(Estos cuatro renglones de letra mui gruesa, van seguidos de un escudo de armas, probablemente las de Cardona, sostenido por dos angelitos con una rodilla en el suelo y circuido todo por una orla. Al reverso hai una lámina que representa al autor sentado escribiendo, y enfrente de él á santa María Magdalena. En la tercera página principia la obra en verso, por una especie de dedicatoria a la santa. En el blanco de la última hoja, que es la sexla de la sig. H, se lee:) A lahor y gloria de nostre senyor deu y dela gloriosa intemerada mare sua fon feta la presẽt obra per lo magnifich mossen iaume gaçull caualler lāy mil quatrecents noranta e sis / ia qual a fet estāpar frare gabriel pelliçer ermita dela ermita dela benauenturada Santa maría magdalena de mocoro la qual esta en la baronia den têça enlo terme de la vila de mara de Ebro del molt illustre Sẽyor duch de cardona $E$ stampada en la insigne ciutat de valencia per ioan iofre acabada a xy. de mars Any. m. d. e cinch (1505.) $4 .^{\circ}$ let. gót. Son 62 hojas sin fol., con las sings. A-II, todas de 14 hojas ménos la última que solo tiene 6.

Ni Nic. Antonio, ni Jimeno, ni Fuster, ni ningun bibliógrafo español tuvieron noti. cia de este libro, del cual no conozco otro ejemplar, en biblioteca alguna pública ó particular, y es el misno que se encuentra descrito en el catálogo de la venta de Croft. De dicho catálogo sacó Brunet la incompleìsima é inexacta descripcion que de él da, y así no es de estrañar copie la equivocacion de su. poner autor de esta obra á Ciabriel Pellicer, que fué únicamente quien la hizo imprimir. Para ponderar su estremada rareza bastará saber que Mr. Heber no logró tener este tra. tado en su selecta y copiosa librería.

No he visto volumen alguno de aquella época, donde haya tal profusion y lujo de grabados como en el presente.-Todas las estampas y páginas de testo van circuidas de orlas variadas; en las pares lleva una copla relativa á lo que representa una gran lámina colocada en la página del lado ó impar: así por ejemplo, en el pasaje donde se cuenta que el soberano del pais habitado por la santa, no teniendo sucesion y admirado de los prodigios que de ella habia oido relatar, la hace conducir a su presencia; se halla la siguiente estampa esplicada en los versos copiados al pié, los cuales en el original van puestos al frente. 


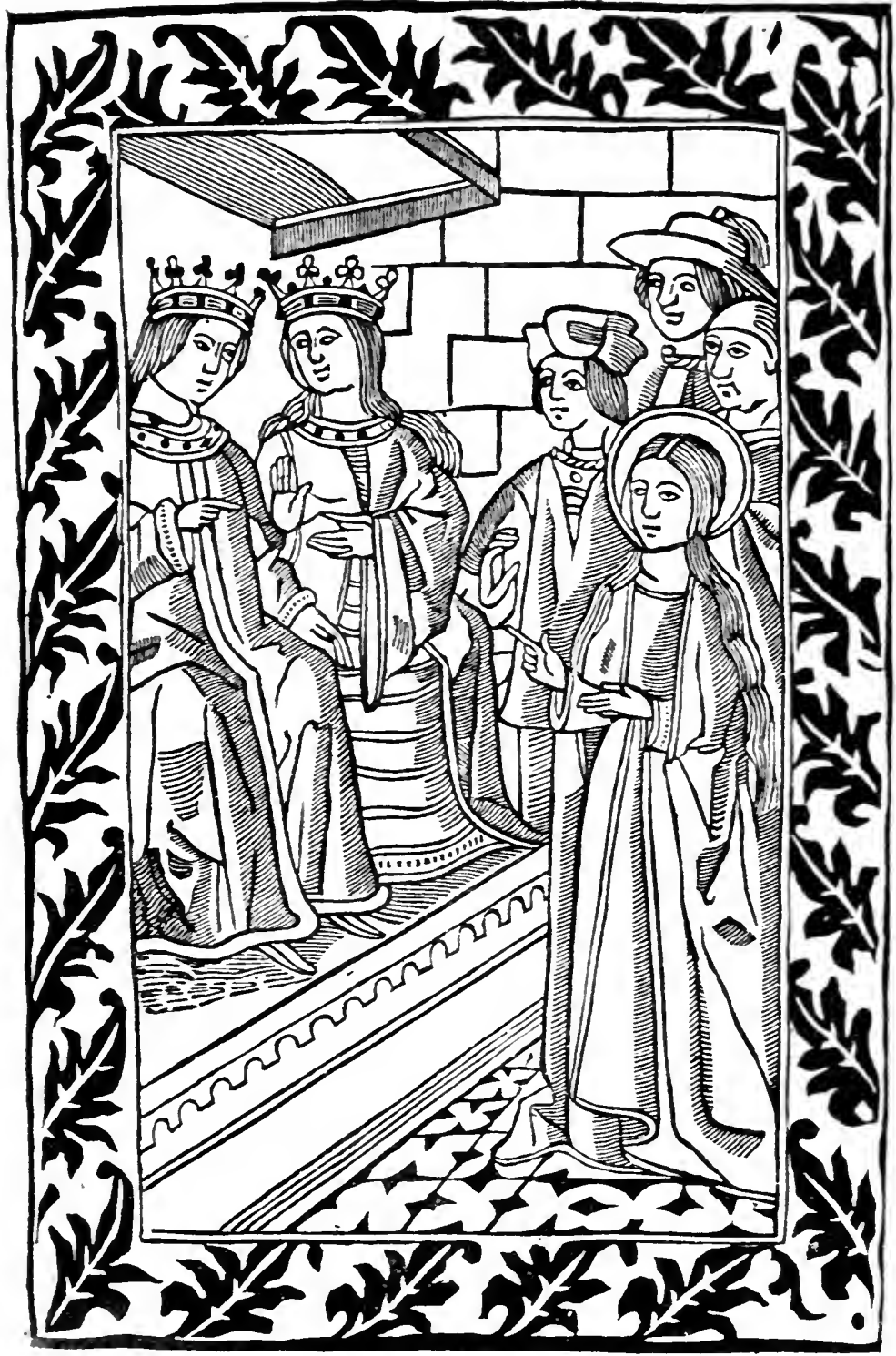

E segons que la storia recita,

Tan gran senyal feren vostres paraules Y tant bastá esta santa vesita,

Que sa muller ne restá molt contrita; Puix no cregue fossen burles ni faules. Y iorn apres manant que us acollissen, losferen dar posada y vitualles;

Manant á tots sos vassalls qu' y servissen,
I com tots iorns rostres sermons oi ssen La de la fe s'encenien les falles.

Y soplicaus al vostre deu pregasseu, Que d'aver flls merce li recaptasseu.

Gazull es uno de los poetas valencianos mas distinguidos del siglo XV; Cospar $\mathrm{Fil}$ Polo en sul Diana, le dedica eslos cuatro versos: 
Mirando estoi ariucel poeta raro

Jaime Gazall, que en rima valentina Mucistrit el valor del vivo ingenio y claro, One á las más allas mubes se avecina.

631 GAZILLA De URSINO (Cár3.0s). Relacion dilusa, recopilada con varios metros de las fiestas sexcenales, Que la Villa de Morella, y sus individuos dedican à su Patrona Maria Santissima de Vallivana, en el sexcenio de M.DCc.XxxvilI. Compuestas for 1). Carlos Gazulla de Ursino. Valencia, Esteran Dolz, 1739. 4. ${ }^{\circ}$ 3hojas prels., inclusa ma lamina de la líryen, y 8 it paigs.

GERARDO LOBO (EvGENio). Obras poélicas. léase en la Seccion dramitica.

632 - Reo convicto en el tribrnal de sy conciencia, con apellacion al de la Misericordia, por medio de Maria Santissinli. Fre ociosilad de Don Erigenio Gerardo Lobo. Toledo, Aguslin de Salas Zaço, 1710. 4. 12 hojas fols.

Romance incluido en las ediciones de sus obras.

633 GILBERTE DE MAJARRES (liigtel).

\section{Lth chofuresio del mü}

do y conof cimtiēto de fus engaños berho por ftliguel ailberte de majarres deregivo ala unm magnifira feñora la G. Doña Joäna dela cana lleria feñora de Aleara; mifeñora.

Sigue un globo con una cruz encima, y bajo de él se lee:)

\section{[tlenofpreciemos el mundo} que el que eluel pone el candado ala fin queda burlado.

CA la ruelta está el Prologo ó dedisatoria en prosa, la obra principia en
POETAS

GIR

el blanco de la sign. aij, y al fin bajo de una calavera hai este terceto:)

\section{【 Si. degta nog acor Damos quanto asa enla vida eftemos haremos lo que denemos.}

S. I. ni a. hicicia el 1330.$) 4^{\circ}$ let. gót. Sin fol. con la sign. a, siete hojas impresas y una blanca.

Es en quintillas, y como muestra pondré las cuatro primeras.

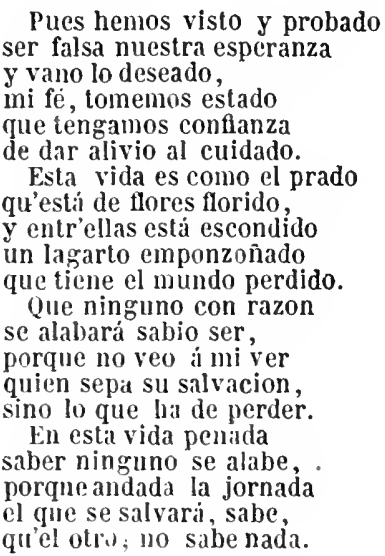

Esta ifltima quintilla recuerdo haberla vis. to copiada cisi litcralmente en otra, atribuila segun creo á Stis. Tercsa, la cual concluye:

Porque al fin de la jornada solo el que se salva, sahe, que el qule no, no sabe nada.

vic. Antonio no conoció este rarisimo opúsculo, ni ınenciona á Gilberte de Majarres.

\section{GIRON Y DE REBOLLEDO} (D. Alovso). El Ochauario Sacramētal de las obras de don Alonso Giron y de Rebolledo, en alabãça de aquella ineffable marauilla dela Eucharistia, por contemplaciō del... señor don !uă de Ribera... en su fiesta del Año. 15̆̈1. Con mas vil Paradoxo, de amar los enemigos... Tambien una glosa,... del padre nuestro por differente estilo que hasta hoy: trobado todo por el mismo. Válencia, Pedro de Guete, 1572. 8. ${ }^{\circ}$ let. curs. 64 hojas fols. inclusos los prels. 
Está escrito en varias clases de metro y contiene dos sonetos laudatorios, uno de Don Luis Fermández de Heredia y otro de Micer Cosme Clemente.

Es un tomito raro no conocido de Nic. Antonio.

Otra composicion poetica sohre el Sacramento be visto, tambiru impresa en Valencia, intitulada: Ifymmolias de loas divinas en ulabanga dol srintissin" Sacramunto y de la Virgen sautissinu. Anlur Pedros de Herreros Cupali. Falentia, Itian Bullista Mrrcal, $1629.8 .^{\circ} 16$ hojas prels., I!) fols. y una con un jeroglffico $y$ repeticion del lugill y aก̃o.

\section{GIION Y DE REBOLLEDO} (D. Alovso). La Passion de nuestro Señor Iesu Chrysto segun S. Iuan. Compuesta por D. Alonso Giron y de Rebolledo. Valencia, Inan Mey, 1303. 8. ${ }^{\circ}$ let. curs. 38 hojas fols.

Primera edicion, rara: en ella se encuen. tra al principio un soneto de fill Polo.-No respondo de la exactitud del título pues mi ejemplar tiene la portida manuscrita:

La segunda impresion es de Valencia, Juan Navarro, 1579, segun Fuster, y 1.574, segun Jimeno, en $8 .^{\circ}$ : parece ser reimpresion de la anterior con la adicion de algumas läminas grabadas en madera.

636 _ La passion De nuestro Señor lesu Christo segun \$. loan. Compuesta antes por dô Alonso Giron y de liebolledo, y aora corregida $\mathbf{y}$ añadida por el mesmo Auctor. Yalencia, herederos de Iuan Tauarro, Año 10̈88. 8. ${ }^{\circ}$ ö hojas fols. inclusos los prels.

Raro.-Bello ejemolar que perteneció i onofre Esquerd" y llewa su firna.-Edicion desconocidil í vie. Antonio.

Rebulledo anduvo mui modesto en anotar en el frontis, que esta impresion la habia corregido $y$ añdido, cuando en realidal se puede decir hizo una obra nueva, pues alemas de las numerosas variantes introducidas, su libro de 1.51 .5 se comprne de dos. cientas sctenta quìntillas, y el de 1588 consta de unas cuatricientas ocho. El soneto de fil Polo, inserto en lit primera cdicion, se susti. tuyó en la presente por otro de D. Baltasar de Centéllas

En el Libro de la vida y obras maravillo. sas del siervo de bios y biemmu'nlurado pudie fray Pedro Nivolas Failor... Compnu'slo pri... fra! Chrislonal Moreno. Valencire, viuct ile Pedro de. Huete 1586. 8.0 20 hojas prels. y 590 pilgs.; hai adcmis do unas Lirus de Vicente Joaquin de Miravet diez y nueve decimas de limon y de tieloollolo cn alabarzi del t'. Paetor, quien fuc liabil pintor cu tabla, lienzo, cristal, etc.
Sobre la Pasion de $\mathrm{N}$. S. Jesucristo he vis. to otro poema cuya descripcion es la siguiente: Fróntis grabado: Trutado de la Passion de nuestro Señor lesv Christo. Dedicado à N.ra Señora Monte Carmelo. Compuesta por Gabriel Lopez de Mendoça, Tesorero at sı Mag.d Por Fran.co Heylan Jmpressor de la Real Chancilleria de Granida A. 1629. 8. 16 hojas prels. y $142 \mathrm{fols}$, en el viltino se re. pite la fecha y se pone el escudito del impre. sor.- Está dividida la obra en noventa y ocho romances, llamados cantos por el autor. Tanto en las aprobaciones como en la licencia se intitula este libro: Rmnancero espiritual de la sagrada Pasim de.N. Srñor Jesu Cristo. - En el Indice espurgatorio se prohiben las obras en verso de Gabriel López de Ien. doza.

No quiero terminar este artículo sin copiar los siguientes versos del Canto del Tirin de Gil Polo, en alabanza de Giron de Rebolledo:

Tendreis un don Alomso que el renombre De iluslres Rebolledos ditatando

En todo el universo, ira su nombre Sobre Maron famoso levantando:

Mostrará no lener ingenio de lombre, Antes con verso allísimo cantando, Parecerá del cielo haber robado La arte sutil y espirilu elev'udo.

Y Cervintes en el Canto de Caliope le con. sagrú estos otros:

Verece bien en este insigne valte Luga' ilus/re, asiento conocirlo. Aruel á quien la fama quiere' dalle El nombr' que su ingenio ha nerecido: Tenga cuilado el ciels de loalle. Pues es del cielo su virlor crecirlo, El ciuln alabe lo (que ! $/$ ) no puedo Del sulio Don Ilonso thebolledo.

\section{GODOY (Fraxisco DE). Apo-} logo membral, Discrrso jocoserio moral, y politico. Contiene eficacissimos remedios para que Dios nos quite la peste, y el Rer nuestro señor por nuestro medio los tributos. Escrivialo Don Francisco de Godor, Sevilla, Juan Vejarano, 1682. 8. 11 hojas prels., inclusa la que contiene el escudo de armas del Harques de Jamaica que precede al fróntis, y 89 prigs. de testo.

Apülogo escrito en verso.

GOME\% (ilran). Teológica descripcion de los misterios sagrados. Y. Günez (llwar). Seccion histörica. - Historia de España. 
638 GOMEZ (JUAN). Trihumpho dela immaculada concepcion de nuestra señora. Compuesto por el Reuerendo mossen Juan Gomeç maestro en sacra theologia y predicador famosissimo: dirigido al muy eçelête señor el señor infante don Enrrique de Aragon y de Sicilia duque de Segorue y conde de Ampuries. (Este título va precedido de la misma laminita de la ioncepcion que se halla en el fróntis del Jaume líoig de 1531: todo está circuido de orla. Al dorso principia el prólogo ó dedicatoria que termina en el reverso de la siguiente hoja signatura Aij, en la tercera Jnuoca el autor el diuino auxilio y despues comienza la obra que acaba en el reverso de la novena hoja.) S. l. ni a. $4 .^{\circ}$ let. gót. Sin fol. signs. A-A rj.

El tipo $\mathrm{y}$ la viñeta de la portada indican, á un dudarlo, ser la edicion de Valencia y de Francisco Diaz Romano, hecha hácia 1550.

Yingın bibliógrafo menciona á Juan Gówez, a quien tengo por valenciano.

Esle poemita, cuya rareza no hai necesidad de encarecer, está escrito en verso de arte mayor. Pondre como muestra la última copla del tratado:

\section{Conlra los maldizientes.}

Si nadie presume, mi obra mirando, Inzar que no debo estar miui ufano liel don d'esta reima que voi pregonando; (ine muchos dolores no son de mi bando, De mui más saber, de seso más sano: lues yo mu pigmen, no saben que gano Con graudes gigantes venir á cabellos; Ventaja me tienen mano por mano, Y puesto a la pac parezco ser nano, Eucima sus hombros descubro más que cllos.

Sobre este mismo asunto encuentro citados por Gallardo, Zarco del Valle y Rayon en el Ensayo de whe bib. esp., las siguientes composiciones poeticas:

Bomance d la limpia Concepcion de nuestra Señora. S. l. ni a. fol. 1 lioja suelta impresa por uua sola pág. Enpieza:

\section{Ior san que vengo enojailn Senora la de José...}

Redondillis a la santa, e Immacvlada Concepcion de la Madre de bios. (Al fin:) Impressas' en Senilla, por Gabriel Ramos Vijarano, Año lijl6. 4. 18 liojas á dos cols.

Canciom a la purr y limpia concepcion de la samlissima Virgen Maria Madre de Dios, y señora nuestra. Compuesla por vn devoto su!yo, nulural de balencia. Sevilla, Francisco le Lijru. Año 16]6.4. 4 hojas.
Gozo de España por la nueva calidad que la Santidad de Paulo V, Pontifice Maximo ha dalo a la sentencia pia de la Concepcion limpisima: y gracias que hace a su invicto Rey Filipo III. por la heroica piedad y afecto con rue la asistido a este decrelo santo. Sevilla, Juan Serruno de Vargas. Año de 1617. 8. 8 hojas. Son cuarenta y cinco octavas, con notas marginales en prosa.

GÓNEZ DE LUQUE (Gonzalo). Libro primero de los hechos de Celidon de Iberia. Véase en la Seccion nocelísica.-Libros de caballerías.

639 GOMEZ D' OLIVEIRA (ANToNio). Idylios maritimos, y rimas varias. Primera parte. De Antonio (iomez d' Oliveyra. Lisboa, Pedro Crasieeck, $1617.8 .^{\circ} 8$ hojas prels. y 116 fols.

Ignoro se haya publicado segunda parte. Los seis Idilios ocupan poco más de 21 hojas, ("l resto son las rimas varias, y en ellas se encuentran composiciones en casi todos los géneros de metro. Gomez d'oliveira es pocta bastante bueno, y libre por de contado de todo resabio de mal gusto.

640 GÓNGORA (LuIS DE). Obras en verso del Ilomero español, que recogió Iuan lopez de Vicuña. Madrid, Viuda de Luis Sanchez, I.DC.xxin. 4." "o hojas prels. y 160 fols.

Primera edicion, mui rara, en la cual no se encuentran las comedias ni unas ciento cincuenta romposiciones poéticas de la de 165.5; cn cambio hai en ella quince que no se hallau en esta ni en la de 1654 , y son: en los Sometos satiricos, el II, al fol. 20 ; el III, al mismo fil. vta: el $\mathrm{V}$, al 21; y el XXIV, al 25, vta.: en los Sonctos burlescos, el V, alfol. 27; cl 11 , al mismo; el Vll, en igual fol. vta., y el $\mathrm{X}$, al $2 \mathrm{~s}$ : en las Decimas saliricas, las que principian: Cortes asi os guarde Dios, al fol. 58, y Cantemos á la jinela, en el mismo fol.: en las Derimas burlescas, la que dice: De puños de hierro ayer, al fol. 62 ; y en las Letrillas, las de Que tenga el engaño asiento, fol. 15.5 vta.; Cual más cual ménos, fol. 156; Dulce musa picaril, fol. 159, y Si d gastar y pretenter, en el mismo fol. vta.

041 - Todas las obras de Don Lvis de Gongora en varios poemas. Recogidos por D. Gonzalo de Hozes y Cordoua. Madrid, Imprenta del Reyno, 1634. $4 .^{\circ} 14$ hojas prels. $y 232$ fols.

En I.ondres tuvimos otra edicion con igual portada, inpresa tambien en Malrid, Im- 
prenla del Reyno, 163j. 4. Supongo será la primera hecha por Gonzalo de Hozes y su contenido igual al de la del año siguiente, antes descrita. Esta, como ya he observado arriba, comprende unas ciento cincuenta poeslas que no ran cu la de 1627; ademas se han pucsto epigrafes i la mayor parte de las composiciones, con lo cual se facilita cl saber a quiea se dirigen y el objeto del antor al escribirlas: se ha añadido la comedia de Las firezas de Isabela y los fragmentos del Doclor Carlino y la Comedia venatoria. Tambien se han introducido algunas variantes en el testo, no siempre acertadas 'n mi sentir.

Por los detalles dados di!l contenido de la impresion de 1634 se ve fué desconocida á los traductores de Ticknor (tom. III. página 510) quienes despues ile describir la de 1627 publicada por Lope\% Vicuña, añaden: Pro-metió el editor otro tomn con algunas más - poesías y las dos romedias de Las fine- zas de Isabela y el boctor Carlino que no -sabemos se llegire: á imprimir.,

\section{GÓNGORA (Luis de). Las} Obras de 1). Lvis de Gongora. Coinentadas por Ion García de Salzedo Coroncl. Madrid, Imprenta Real, 163i (el lomo primero), Diego Diaz de la Carrera, 1644 (la primera parte del segundo y) Diego Diaz de la Carrera, 1618 (la segunda parte del segundo). 3 vols. $4 .^{\circ}$ El primero no llevil el título que los otros dos, sino el de Soledades de D. Lvis de Gongora, y se compone de 12 hojas prels. Cuna de ellas un fróntis grabado), 312 fols. y 8 de Indice alfabetico. Portada grabada para El Polifenıo, 8 hojas prels. del mismo, una lámina que representa a Poliferno tocando una zampoña, $y$ a unas Vereides que le estain escuchando, y luego cuelce á continuar la foliatura interrumpida, desde 313 hasta 420 , hallando por fin 4 hojas de Indice. El tomo segundo tiene un antefróntis, una portada grabada, 8 hojas prels., 784 págs. y 9 hojas de Indice. El tercero un fróntis grabado, 4 hojas prels. Cla primera es otro fróntis impreso), 501 paigs. $y$ 19 de Indices.

No comprende esta edicion las Comedias, y falta en ella casi una mițad de las poesías contenidas en Ia anterior: pero encuentro los ocho sonetos omitidos de la primera en la de $1654, y$ hai ademas doce composiciones que no están en ninguna otra, a saber:

Ave real de pluma lan desnuda.

Tom. 1l. píg. 76.5.

\section{* Ausente de mi vida.}

Tom. III. pág. 116.

De la merced, ser̃ores, despedido. Tom. II. p. 639.

El conde, mi señor, se va a Charta. Tom. II. p. 601.

Es el Orfeo del Señor D. Juan.

Tom. II. p. 619 .

Huésped sacro, Señor, no peregrino. Tom. II. p. 663.

- La bella tira muda yace uhora.

Tom. Ill. p. 177.

Mis albercoques sean de Toledo.

Tom. II. p. 602.

Palos del agua, chirle castellana.

Tom. I1. p. 632.

Señor, aquel dragon de ingles veneno.

Tom. II. p. 610.

Ser pudiera la pira levaniada.

Tom. II. p. 768 .

* Sobre lrasles de guijas.

Tom. lII. p. 75 .

En los tres que llevan * ya observa Sal. cedo haberlos sacado de eiertos manuscritos, pues estaban inciditos.

En las notas a Ticknor se cita una edicion popular de las nbras del poeta cordobes que con el titulo de Varias pnesias y Delicias det Parnaso se publico en Z'uragnzr, por Pedrn Verges, $164 \overline{5} .5$ tomitos en $16^{\circ}$ : y eutre los apuntes de ni padre se encuentra el siguiente: -Obras de D. Lvis de Gongora. Primera - parte. Sacadas a luz de meuo, y enmenda- das en esta ultima impression. Lisbua, Pan- (1) Critesbeck, 1646-7.2 vols. 12. Esta edi- cion, que he tenido, me parece era reimpresion de la de Hózes: en ella se hallaban -de positivo las mismas comedias..

613 GÓNGORA (Lets de). Todas las obras de Don Lris de Gongora en varios poemas. Recogidos por Don Gonzalo de Hozes y Cordoua. Madrid, Imprenta Real, 1634. 4. ${ }^{\circ} 10$ hojas prels. y 234 foliadas.

Contenido igual al de la de 1654 , con la adicion de tres poesías que van al tin y llevan la nola de que fallaban.

\section{1} Las mismas. Madrid, Imprenta Real, 1634. 4. ${ }^{\circ} 10$ hojas prels. $y \geq 34$ foliadas.

Esta reimpresion furtiva, hecha en Zaragoza, segun puede inferirse de su basto $y$ negro papel, se distingue fácilmente de la otra por esta circunstancia, por no llevar escudo alguno grabado en la portada, ser de letra cursiva la Adeertencia que va al fin de los preliminares, tener equivocada la foliacion de la última hoja, que dice 154 en lugar 
de $234, y$ por no repetirse las señas de la impresion al dorso de dicha hoja, como en la genuina.

\section{GÓNGORA (Lurs DE). Obras} de Don Lvis de Grongora. Brusselas, Fancisco Foppens, M.DC.LIX. 4. ${ }^{\circ}$ may. 8 hojas prels., 658 págs. y 10 hojas de Tabla.

Es indudablemente la edicion más bella de las obras de Góngora; pero no se hallan en ella las Comedias y le faltan varias poesias de las que contiene la edicion de 1654 .

\section{6 - Las obras de Don Luis} de Gongora. Manuscrito del siglo XVII de 5038 hojas foliadas, ademas de las del Indice.

Fué este códice de $\mathrm{D}$. Juan de Iriarte, quicn lo cotejó con otro manuscrito antiguo, anotando en este todas las diferencias de aquel, segun lo certiflea èl mismo al fin en Madrid á 22 de Setiembre de 1745 . Seria notable aun cuando solo fuese por la pulcritud con que está escrito y por la importancia de las variantes que lleva apuntadas a las márgenes; pero es precioso por hallarse en èl varias piezas que no encuentro en ninguna de las ediciones y por consiguiente me parecen inéditas. Para no privar de ellas por más tíempo á los aflcionados las copiaré aquí.

\section{Soneto.}

En una fortaleza preso queda Quien no tuvo templanza, y desplumado Cual la corneja morirá enjaulado infanıando sus plumas la almoneda. oh qué bien está el Prado en la Alameda! Mejor que la Alameda está en el Prado, Y en un cofre estuviera más guardado, oue esta es carcel de gatos de moneda. - Porqué le llaman Prado, si es montaña De Jaca $\mathrm{y}$ aun de fénova, que abriga Bandoleros garduños en España?

Su nomble á cada cosa se le diga:

Si es Prado, laca sea su guadaña;

Si es Montaña, Madera le persiga.

\section{Decimas.}

Pues es lunes, con que empieza el año, el mes, la semana, más hueca que una campana se levanta ni cabeza.

Mi lengua, aunque con flaqueza

bien puede á tercia llamar

las damas de este lugar;

mas crea cada señora,

si la mintieren la hora que lenguas todo es hablar.

¿Qué servirá hacer señal y quitarles el sosiego,

si llamare á tercia y luego

llorare completas nial?

Cera se ha vuelto el metal

\section{GON}

á los que el cáñamo crece en las manos de contino, que los hallareis en pino a las doce y álas trece.

Bigardos, en cuyos lechos profesando teología, los mas flojos noche y dia ojeais vuestros derechos, cruzados de amor los pechos $y$ de zelos con fervor, salís derramando amor, $y$ volveis como unas brasas seguros que en vuestras casas hallais vuestro Redentor.

Señor marques Trinitario, pida vuestra reverencia que le dé su omnipotencia quien le dió su escapulario y profeso Sagitario; salga armado y no de acero, creyendo que en un terrero cualquiera de esas coronas hará como tres personas, que es un fraile verdadero.

\section{Otra.}

Dicho ue han por una carta, que es tu cómica persona sobre los manteles mona, y entre las sábanas marta. Agudeza tiene harta lo que me advierten despues, que tu nombre de el reves, siendo Lope de la Haz, en faz de el mundo y en paz pelo de esta inarta es.

\section{otra.}

En vuestras manos ya creo el plectro, Lope, más grave, y aun la violencia suave, que á los bosques hizo orfeo; pues cuando en vuestro museo por lo blando y cebellin cerdas rascais al violin, no un árbol os sigue ó dos, mas descienden sobre vos las piedras de Balsaín.

\section{Letrilla.}

La publicó Gallardo en el núm. $10^{\circ} \mathrm{del}$ Criticon con algunas variantes.

A toda lei, madre mia, (lo demas es necedad) regalos de Señoría, y obras de Paternidad.

Aunque mui ajenos son, señora, mis verdes años de maduros desengaños y perfecta discrecion; oid la resolucion que me dio el tiempo, despues que me distes al marques, y yo me di á frai Garcia. A toda lei, madre mia, elc. 


\section{GON}

Narcisos, cuyas figuras dan por paga a los pobretes que libran en moginetes mi hierro en sus herraduras, Ganimédes en mesuras, enamorados y bellos: yo creo que para ellos vuesa merced no me cria. A toda lei, madre mia, etc.

Orlandos enamorados, que despues dan en furiosos, en las pazes belicosos, y en las guérras envainados, de bigotes engomados y de astróloga contera: ¡Nunca Dins me haga nuera de la hermana de su tia! A toda lei, madre mia, etc.

Canỏnigos, gente gruesa, que tienen a una cuitada entre viejas conservada, como entre paja camuesa; dan poco y piden apriesa, zelan hoi, zclan mañana: mui humilde es mi ventana para tanta celosía. A toda lei, madre mia, etc.

Almidonados poetas por quien la beldad acaba de ser nido $y$ ser aljaba de amor $\mathbf{y}$ do, sus saetas, dánme canciones discretas: y es darme á mí sus canciones, gastar en Guinea razones, y cruzes en Berbería.

A loda lei, madre mía, etc.

Basta un señor de vasallos, y un grave y potente fraire; los demas los lleve el aire, si el aire quiere llevallos. Hagan riza sus caballos, acuchillen sus personas, rezen sus tercias y nonas, celebren su poesia.

A todu lei, madre mia, etc.

Solo á estos dos mi amor y wis contentos aplico, madre, al uro, porque es rico, al otro, porque es hechor. Llévame el fraile el humor. el marques me lleva en coche, démosle al uno la noche, y al otro démosle el dia. A lola lei, madre mia, etc.

Otra.

Caracoles pide la niña, y pidelos cada día, etc.

Esta composicion se publicó en el Roman. cero general.

otra.

Cura que en la vecindad vive con desenvoltura, ¿ Para qué le llaman Cura, si es la misma enfermedad?
El cura que seglar fué, y tan seglar se quedó, y aunque órdenes recibió, hoil tan sin órden se re; pues de sus vecinas sé, que perdió la continencia, no le llamen Reverencia que se haze Paternidad. Cura que en la vecindad, etc.

Si es una y otra comadre, de cuanta: ,ecinas vemos, de hoi más su nombre mudemos de cura en el de compadre; $y$ si le llamare padre algun rapaz tiernamente, la voz de aquel inocente misterio encierra y verdad.

Cura que en la vecindad, etc.

Cura que á su barrio entero trata de escandalizallo, ya no es cura sino gallo de todo aquel gallinero. Si enfermó por su dinero á las más que toca el Preste, ya no es cura sino peste por tan mala cualidad. Cura que en la vecindad, etc.

\section{Romance.}

Busqué para enamorarme las damas que se usan hoi, * del más seguro estado no poco dudoso estoi. Si sois doncellas, hai riesgo, si sois casadas, inayor, si sois solteras, sois charco de los sedientos de amor; si viudas, pareceis urracas, y si no os doi paga, cual dice la urraca, decís que soi ruin señor. Si sois darmas de más de uno, no es perfecta la aflcion, I si lo sois de mí solo, pago al doble, y no lo sois.

Peor rue peor, si sois del Prior:

Sois tan diestras en mentir, que no hai engaño $\dot{0}$ traicion que no lo desculpeis luego con aparente razon:

y si os cogen en las manos con el hurto cual ladron, porque os den luego por libres, buscais falsa informacion.

Si es mozo, decis que es primo, si es anciano, que es tutor, y si es fraile por ventura, que es padre de confesion. si él es primo, á la prima no le faltará bordon, el anciano, no es tan malo, mas del fraile os guarde Dios.

Peor que peor, si sois del Prior. 
No hai lince como vosotras con no ser hijas del sol, mas sois de la luna hermanas mudables en condicion. Si ella se muda por cuartos, por cuartos hai más de dos, que saben hacer mudanzas mas que tiene el Esturdion. Para mi bolsa en menguante tales lunas quiero yo, que quiero verme en sus cuernos a cuartos y no à doblon. A la mejor de vosotras yo le echo mi bendicion, que si sois buenas, sois malas, $\mathrm{y}$ si sois malas, peor.

Peor que peor. si sois del Prior.

Resulta, pures, del minucioso cotejo que he hecho de las varias ediciones de las obras de Gongora, que se necesita remir, para tenerlas completas, las impresiones de $162 \bar{i}$, 1636 y 16\%. a das cuales se pueden ahora agregar las composiciones que acabo de copiar, sacadas del manuscrito existente en mi biblioteca.

Bueno serí notar por liltimo. que la mayor parte de las noesias de este antor, tan sobresaliente, cuando no se le autojaba delirar, han sido reimpresas en el tom. IX. lle la Coleccion de Fernindez, y que pu las eliciones de Hizes va la siguiente advertencia: en ta Comedia de las Firmezas de Isılbela, los fines della no son de. Dim Luis. porque la acabo don lian de frgole su herinans. Y las olvas dos de Carlino y la Venatoria, tambien las dejó por acabar' en arpet eslado.

647 GÓNGORA (LUIS DE). El Polifemo. De Don Lvis de Gongora. Comentado Por Don Garcia de Salzedo Coronel. Madrid, Iuan Gonçalez, 1629. 4. ${ }^{\circ} 12$ hojas prels. en las que se incluye el fróntis grabado y la lam. que representa a Polifemo, y 124 fols.

Primera edicion.

648 Delicias del Parnaso, en que se cifran todos los Romãces Liricos, Amorosos, Burlescos, glosas, y decimas satiricas del regucijo de las musas el prodigioso don Luis de Gongora. Recogido todo de sus originales. Barcelona, Pedro Lacavalleria, 1640. 12."6 hojas prels. y 1850 foliadas.

Especie de romancerito de Gingora sacarlo de sus obras; es raro y no lo mencionan Nic. Antonio, li inran en el Cátalogo de docurnentos. Conliene todas las composiciones ?ll versos cortos publicadas en la edicion
POETAS

GON

hecha por Gonzalo de Hozes; por consiguiente no están los sonetos, las octavas, la Fábula de Polifemo, el Panegírico, ni las Soledades: tampoco se encuentran las Comedias.-Pedro Lacavallería, habia hecho otra edicion en igual tamaño y el mismo número de hojas en 1634 .

intes de cerrar el arlículo de este autor debo mencionar un centon de sus versos intitulado Egloga funebre, y una vindicacion de los mismos con el título de Epistolus salisfactorias, publicadas por V. Martin de Allgulo y Pulgar. Vèase su arlículo en la presente division.

\section{GONZALEZ DE CRITANA} (JUAN). Manual de Jesus Maria, con una carta de Christo nuestro Señor al alma devota. Por Fr. Iuan Gonzalez de Critana. Valladolid, Andres Mendez, 1604. 12. 3 ? hojas prels. y 238 fols.

Aunque la mayor parte de esta obra es en prosa, contiene bastantes composiciones en verso, algunas mui buenas.

\section{GONZALEZ DE CUNEDO} (Miguel). Silva panegirica a la Marestad Catholica de Felipe IIII el Grande, en defensa de España, y contra sus emulos. Compresta, por el Alferez Miguel Gonzalez de Cunedo. Murcia, luan Fernandez de Fuentes, $1614.8 .^{\circ} 8$ hojas prels. y 20 fols.

.io conocio esta Silva vic. Antonio.

Dice el autor en el Prólogo, dirigidoá su amigo Francisco Dardalla, que de la milagrosa victorin que sobre Lérida consiguio muestro ejércilo, alentado por su Majestad, habia sacado asunto y principal accion para esta pequeña obra. Tambien sabemos por el nismo prefacio haberse representado dos comedias suyas intituladas: Al riesgo mayor 't rei y Hacer de los piés cabeza, y estár escribiendo otra de la descendencia del Conde de Alba; anuncia ademas como terminados: El Pirámide en el cielo poema en octa. vas, Los crepuscrulos de Febn, La vereda peregrina, Las tres Dianas de Aurora, $\mathrm{Ha}$ cer de la iierra cielo y La Aurora desde abeterno. No sé que ninguna de estas obras se haya publicado, a pesar de designar hasta los nombres de los sugetos á quienes dedicaba cada una de ellas.

Nic. Antonio solo menciona de González de Cunedo Los triunfos de S. Miguel. 1628. $8 .^{\circ}$ á cuyo tratado se reftere en el Prólogo de su poema el Honstruo españot.

El Sr. Barrera Leirado, equivoca el apellido de este autor, y no tuvo la menor noticia de la Silva panegirica; por lo mismo no es estraño no haga mérito de las comedias de Cuncdo, citadas en el prólogo. 
GONZALEZ DE CUNEDO. Monstruo español. Véase en la Seccion novelística.-Libros de caballerías.

\section{GONZALEZ DE MADRID} (Fernanoo). Versos en reverencia de Dios nuestro Señor, v de Maria Señora nuestra, Concebida sin malit!, de pecado original, su Santissima Madre, yde el Glorioso Patriarca San Ioachin, y à su festiuidad. De Don Fernando Gonçalez de Madrid. Madrid, 1664. $4 .^{\circ} 3$ hojas prels., 80 págs. y 6 láms. a las págs. 1, 4, 10, 22․, 38 y 32 .

Obra escrita toda en romances.

Nic. Antonio omitió en su Bibliotheca á .ernando González de Madrid.

Algunas láminas son bastante buenas.

6ว̈2 GONZALEZ DEL TORNEO (Cristóval). Vida, y penitencia de Santa Teodora de Alexandria. Por Christoual Gōzalez del Torneo. Madrid, Diego Flamenco, 1619. 8. 8 hojas prels., $20 \ddot{\mathrm{J}}$ fols. y una para repetir las señas de la impresion.

Primera edicion, poco frecuente, de este poema en octavas y en veinte cantos: Vic. Antonio cita tambien una segunda hecha en Cordov' $\iota, 1646.4^{\circ}$

Don Alonso del Castillo y Solorzano dirige al autor de esta biografia poética el siguiente soneto:

\section{Anciano Ducro, tú que é Tordesillas}

Bañas el fuerte muro y hermoseas

Florido de Nayades y Napeas,

$Y$ celebrado de las dos Custillas:

Un Cisne que has criado en tus orillas,

Honrado de tus claras semideas;

A pesar de las márgenes leleas

Nos canta de Tcodora maravillas.

No teme al vulg?, fiero cocodrilo

Que atrae al ignorante d su deseo,

Pura que esté gozosa Alejandría.

Duero aqueste presente ofrece al Nilo,

Tordesillas a España este Torneo,

sutil ingenio que d siss pechos cria.

\section{GONZÁLEZ DE LA TORRE} (JUaN). Dialogo llamado Nrncio Legato Mortal, en metros redondos castellanos. Compuesto por Iuan Gonçalez de la Torre. Madrid, en casa de Francisco Sanchez, 1580. 8. ${ }^{\circ}$ Con muchas láminas de madera 105 hojas foliadas, inclusos los prels. que no lo estan, y una hoja al fin, en cuyo blanco se repiten las señas de la impresion, y en el recerso está un escudo, que parece distintivo de impresor, pues es igual, aunque menor $y$ sin iniciales, al de Martin de Montesdoca, copiado en el artículo de Luis Miranda, Comedia pródiga.

Poema fantástico-ascético-moral í historico de tal rareza que no he visto otro ejent. plar en mis viajes: Brunet se reflere á Nic. Antonin al citarlo, $y$ Heber no lo pudo conseguir para su biblioteca.

Para dar una -4ra del estiln del autor $y$ metro que usa en la obra, presento el siguiente trozo, ó sea una segunda dedicatoria en verso, que l!eva al principio:

Iui reverendo señor, el autor pide y suplica que su servicio menor le reciba $y$ dé favor, pues la voluntad no es chica.

Si sentencia ó conclusion en mi verso lubiere falta, sílaba ó larga diccion, lo inclino da la correccion de su prudencia tan alta.

Si doi tollo mi talento no debo ser imputado, si buena cosa yo cuento, vuestra merced diỏ el intento por habérmelo mandadn.

La falta de claridad atribuir a mi se puede: mas la sentencia y verdad del saber \& autoridad, de vuestra merced procede.

Cierto está, que si no diera á un su siervo sustancia para que en esto entendiera, que de mí jamas pudiera salir cosa de importancia.

Ansí que lo bueno suyo se diga, pues de el depende, y lo no tal, atribuyo á mí, lo cual constiturio a su merced que lo enmiende.

$Y$ con tal contemplacion doi principio á mi carrera, y con indigna oracion comienzo la invocacion en la siguiente manera.

Las láminas grabadas en madera no carecen de mérito ; la siguiente es copia de la que se halla al fol. 80 . Como el autor dice 
en su dedicatoria al Doctor Salamanques, | que esta obrecilla la escribia en Bruselas, abiertas en aquella ciudad.

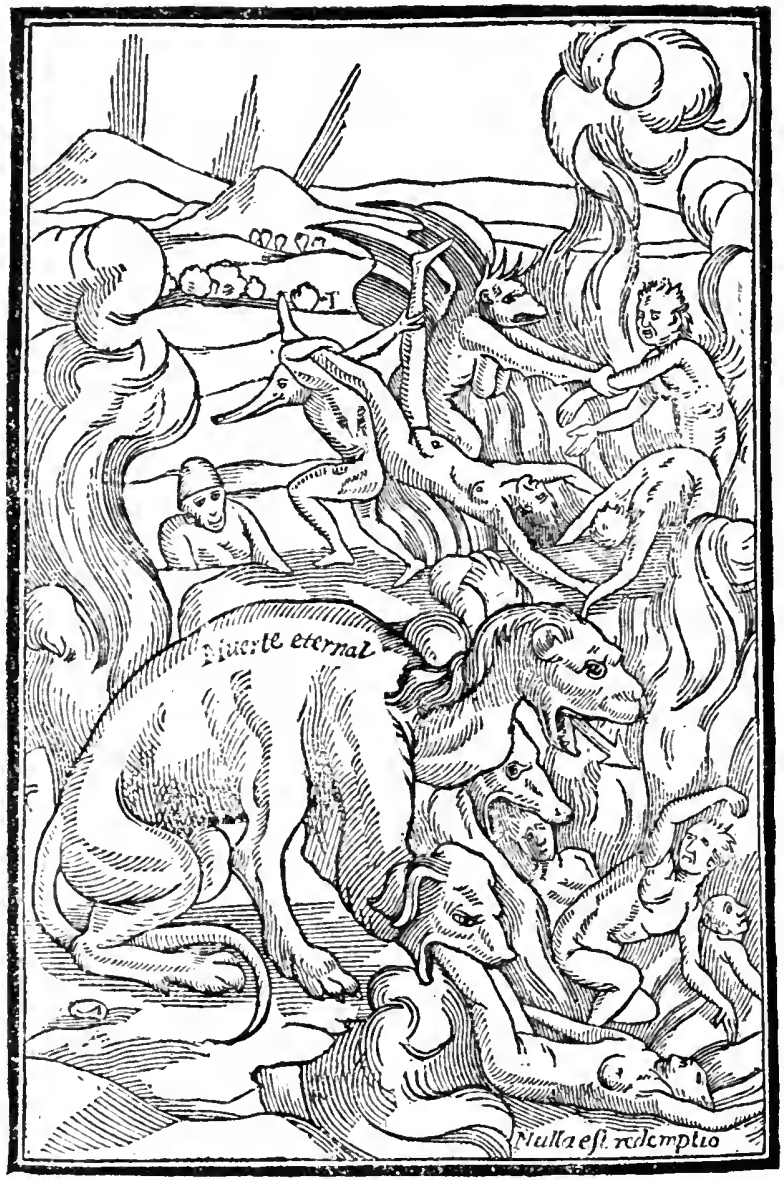

6344 GUAL (Doctor Axtorio). El Cadmo del Dotor Antonio Gral. Neapoles. Egidio Longo, 1639. 4. ${ }^{\circ}$ let. curs. 6 hojas preis., incluso el frimtis grabado, y 17 con las signs. A-E.

poema eu cien octaras, mui raro y des. conocido à Borer en sus Escritores mallorquines.

Fine este ejemplar sin duda el que regaló el autor i b. Himiro Felípez de Guzman, a quien dedica bil obria, Jues lleval el fruntis minialo y todas las letras capitales son de oro.

$65 ̋ 0$ - La Oronta, del Dotor Antonio (iual. Napoles, Egidio Lon- go, s. a. 4. ${ }^{\circ}$ let. curs. "3 hojas prels. y 21 hojas, la ultima blanca, con las signs. A-F.

Poema ell ciento treinta y cuatro octavas, raro.

La fecha de la dedicatoria de la Oronta es de 165i, y Bover en sus Escrilores mallorquines, no sé porqué, da esta fecha como la de la impresion.

Nic. Antonio menciona ell el indice de su Bibliotheca a Antonio Gual; pero no puedo dar con su artículo en cl cuerpo de la obra.

$60 ̈ 6$ GUERRA (Teresa). Obras poelicas, que a diferentes Assuntos ha escrito Doña Teresa Guerra. Ma- 
drid, s. a. (1725). 8. ${ }^{\circ} 16$ hojas prels. y 137 págs.

637 GUERRERO (D. Savcmo). Gloriosos dolores de Maria. Por Don Sancho Gverrero. (Así dice el antefróntis en el que hai una Dolorosacircuida de grande orla. En el fróntis se lee:) Hetrico encomio, fvnebre canto, Lyrico elogio, descripcion numerica, gloriosas, fatigas, angrstiadas glorias de la heyna de los angeles Maria SS. de los Dolores. etc. Malaga, Juan Vazquez Piedrola, 1718. 4. 27 hojas prels., inclusa la anteportada y una lám. de un escudo de armas que la precede, 130 paigs. y una hoja de Erratas. Todo el voliumen va circuido de orla.

El principio del fróntis arriba copiado da suffeiente idea del gusto y estilo de este poema.

638 GUERRERO DE FIGUEROA (Francisco). Vida, y martirio de los Santos Martires Vicente, Sabina, y Christeta Por el Licenciado Francisco Grerrero de Figueroa. Madrid, M.DC.LXVII. 4. ${ }^{\circ}$ hoj. prels.y 59 paigs.

Pocma en octavas diridido en reinte pálrafos.

No eneuentro í este autor en la Bibliolle. ca de Nic. Antonio.

GÜerta (Jerósimo DE). Florando de Castilla. Véase en la Seccion nocelíslica.-Libros de caballerías.

639 GUZMaN (Fraxcisco DE). Triumphos Morales, de Francisco de Guzman. Alcala de Henares, Andres de Angulo, 10̈6̆. 4. ${ }^{\circ}$ Láms. de madera. 201 hojas fols., inclusas las 4 de prels., y una al fin para repetir las señas de la impresion.

Edicion bella y rara.

La obra está en octavas y dividida en ocho triunfos.

\section{$\mathrm{H}$}

HEREDIA (Jeróximo). Guirnalda de Vénus casta. Véase en la Seccion rovelistica. - Novelas varias, al nombre de este autor.
Sl Nic. Antonio no mencionase una ediclon de Anveres, $1557.80^{\circ}$ no titubearia en llamar. primera á la de 1565 , porque los dos privilegios que lleva son de este año y en uno de ellos dice: - lor cuanto por parte de vos el - amadi nuestro Francisco de Guzman, nos - ha sido heclia relacion, que con mucho - trabajo de vuestra persona y gasto de vues- tra bacienda, habeis compuesto un libro -intitulado: Triunfos morales del cual se es- p:ra notable fruto para los que le leyeren; - suplicándonos, nos fuésemins servido daros - licencia para que por tiempo de diez años 'podais imprimir el dicho libro etc."

660 GLZMAN (Fraxcisco DE). Triumphos Morales, de Francisco de Guzman. Seuilla, Alonso Escriuano, 13̈\%. 8. Lams. de madera. 8 hojas al principio sin foliacion con la sign. A, empieza en seguida por el fo!. 5 signatura B ij termina en el 196.

xic. Antonio no conociú esta edicion. En el Catíloyo de sora hai una de 15i7. $8 .^{\circ}$; pero no dice dünde está impresa : he visto la de Senilla, Andrer Pescioni, 1581. $80^{\circ} 195$ hojas fols., inclusos los prels., y una blanca al fin.

\section{1} La nisma obra. Nuettamente corregidos. Medina del Campo, Fraucisco del Canto, M.D.Lxxrrij. 8. ${ }^{\circ}$ Láms. de madera. 19:̈ fols., inclusos los prels., y atlemas una hoja blanca al fin.

Licra en el fruntis el escudito pequeño de Francisco de Canto, mui parecido al grande, copiado en el presente Catílogo al hablar de la impresion di. la Ayjicultura de Herrera, hecha por ol mismo jupresor en 158$\}$.

En esta mismli dieisimn al artículo de yanrique (Jorg"), sc habla de la Glos" rue hizo Guzman a las Coplas de aquel, $y$ c'n la Secciun paremiológica se triala de la flor de senten. cias y Derrelo de sabios.

Gozo este poeta de nucha reputacion y Cervintes lo ellsalza osi en ol Cimlo de $\mathrm{Ca}$. liope:

De aquel que la crisliunu por:siz Tan en supunlo ha pueslo, cll linla gloria, Haga la fana y la memosia mili Famosa jara siemple su nemnria: De donde race á llonde muere el dia La ciencia sea y li bondad noloria

Del gran Francisco de Guzman, que De Febo sabe asi como el de Marle. [el arle

HERYiNDEZ (Alosso). Historia Partenopea. Véase Crónicia del Giran Capitan. Seccion IIistórica. - Historia de España. 
662 HERNÁNDEZ BLASCO (Francisco). Vniversal Redempcion, Passion, Mverte, y Resvrreccion de nuestro Redemptor Iesu Christo, y angustias de su santissima Madre, segun los quatro Euangelistas, con muy deuotas contemplaciones. Compuesto por Francisco Hernandez Blasco. Toledo, Pedro Rodriguez, 1598. 4. ${ }^{\circ}$ Lams. de madera. 12 hojas prels. y 200 fols.

Primera parte dividida en cuatro libros, $y$ toda en octavas.

Nic. Antonio cita la primera edicion de $\mathrm{Al}$ cala de Henares, Juan Gracian, 1584.4.\% pero no conoció la de 1598 , sin diıda la tercera, pues en sil Prólogo se advierte que las láminas puestas en ella y grabadas en madera por el mismo autor, se estamparon por la vez primera en la segunda impresion, no mencionada tampoco por Antonio, hecha en Toledo en casa de la viuda d' Juan Ptaza, 1589. En dicha segunda edicion y en la de 1598 se añadiu, segun se indica al principio del volúmen, lo siguiente:

Un prólogo al benévolo lector.-Una derocion en que el Christiano puede hacer un grato servicio á Dios. - Al principio de la historia valu añadidos lis cuatro primeros cantos.-Van por toda la obra añadidis y enmendadas mutuchas cosas. - En compendio de todos los cíntos de los cuatro libros $\dot{0}$ tratados en que se lıalla dividida la obra Un abecedario ó declaracion de todos los rocablos oscuros de la listeria.-Van tambien añadidas unas Eglogias á la muerte de Cristo.

663 La misma obra. Aora nueuamente corregido y eme $u$ dado. Madrid, Imprenta Real, 1602. 4. 'Lams. de madera. 12 hojas prels., 424 págs. y 8 de Tabla.

Al repetir las señas de la edicion en la última página, se pone el nombre de Iuan Flamenco como á inpreson: lo mismo sucede en el Sigüenza Historia de la órden de S. Jerónimo; lo cual prueba que dicho Juan dirigia ó tenia por su cuenta la Imprenta Real. Sin duda le sucedió Tomas Iunti, pues la Justa poélica de Diego llanuel, salió de aquel esta. blecimiento en 1621 con el nombre del espresado lunti. - Ambos tipógrafus merecen un recuerdo honorifico por haber sido los mas aventajados de su tiempo en Madrid, así como en Valencia lo eran sus contemporáneos los Mey, y poco átes Io habian sido Claudio Bornat en Barcelona y Hernando Diaz en Sevilla.

La edicion de 1602 de la Universal reden. cion es reimpresion de la de 1598 il 89 , pues ambas son iguales, con la única diferencia, de que no siendo las laminitas que lleva las grabadas por Hernández, se hubo de suprimir el prologuito á que me reflero en el artículo anterior, donde habla de esta circunstancia.
Antonio omitló la ediclon de 1602; menciona si la de Madrid, Imprenta Real, 1609. 4.

664 HERNANDEZ BLASCO(FraNcisco). Vniversal redencion, ete. (ut supra). Aora nvevamente corregido y emendado. Madrid, Luis Sanchez, I.DC.XII $4 .^{\circ}$ Viñetas de madera. 12 hojas prels., 424 págs. y 8 de Tabla de vocablos.

Reimpresion exacta de la de 1602.-He visto una edicion de Alcala, 1621. 4.

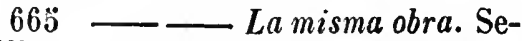
villa, Francisco de Lyra. Año de M.DC.XXIII. 4. Viñetas de madera. 4 hojas prels., inclusas las 2 de Tabla de los nombres escuros, y $\mathbf{4 2 4}$ págs.

Impresion desconocida á los hiobliógrafos; se han seguido en ella las de $1: 589,98$ y 1602 ; pero faltan al principio, una corta advertencia al lector, la dedicatoria al lic. Ramfrez de Prado, los versos laudatorios dirigidos á Ilernández Blasco y el Prólogo al benévolo lector.

Recierdo haber pasado por mis manos otra edicion de Sevilla, 1628.4..$^{\circ}$

666 HERNA NDEZ BLASCO (LuIs). Segvnda parte de la vniversal redencion, en la qual se contienen los hechos de los sagrados Apostoles, sus persecuciones, y varios sucessos de la Iglesia Militante. Compresta por Lvys Hernandez Blasco. Alcala, Iuan Gracian, M.DC.X11I. 4. 6 hojas prels., 581 págs. y 5 hojas para terminar la Tabla.

La tengo por primera edicion de esta segunda parte, a pesar de ser la licencla $y$ aprobaciones de 1611. Está en octavas dividida en cuatro libros y en ochenta $\mathrm{y}$ seis cantos.

Luis Hernández dice en el Prólogo, haber escrito la continuacion, porque á su hermano que se proponia hacerlo, le habla sobrevenido la muerte.

Nicolás Antonio no solo ignoró la existencia de un segundo tomo de la Universal redencion, sino que le fué desconocido su autor.

667 HERRERA (FERNANDo DE). Algvnas obras de Fernando de Herrera. Sevilla, Andrea Pescioni, M.D.LXXXII. 4. 4 hoj.prels. $y 56$ fols.

Primera edicion rarisima, hecha por el mismo Herrera.

Impresion mènos completa que la segunda pues solo contiene setenta y ocho sonetos, siete elegias, cinco canciones y una Egloga venaloria; sin embargo, es preciosa no solo 
por la difleultad de encontrarla, sIno por contener en los preliminares und dedicatoria de Hertera al Marques de Tarifa, un soncto laudatorio de este, otro del Mtro. Francisco de Medina, otro de D. Diego GIron y una aprobacion en prosa de D. Alonso de Ercilla, y en el cuerpo de la obra un soneto de Herrera que principia:

Yo voi por esta solilaria lierra, y una Egloga venaloria, del mismo, en ciento cincuenta y seis versos, todo lo cual se suprimló en la edicion de 1619 , y por consiguiente en la reproduccion becha de ella por Fernández, en los tomos IV. y V. de la coleccion de poetas. Dicho Fernández publicó un fragmento de siete versos de la Egloga tomados de los Comentarios à Garcilaso.

668 HERRERA (FerNaNdo DE). Versos de Fernando de Herrera. Emendados i divididos por el en tres libros. Sevilla, Gabriel Ramos Vejarano, 1619. $40^{\circ} 15$ hojas prels., incluso el retrato, 447 pags. y 10 hojas de Tabla.
Edicion mui bella y rara, que contiene sobre trescientos ocho sonetos, treinta $\mathrm{y}$ tres elegias, diez y ocho canciones, cuatro sestinas y dos estanzas, que es lo que Fernández reimprimió en los tomos IV. y V. de su Coleccion; pero suprimió los largos prólogos de Rioja y Enrique Duarte, un soneto laudatorio y la decticatoria de Francisco $\mathrm{Pa}$ checo, publicador de la edicion. Lleva ademas un retrato del divino Herrera, dibujado por aquel pintor scvillano, cuya copia es la puestá á continuacion.

Segun Sedano y Ticknor es de Herrera una iida de Tomis Moro, por la escrita en latin por Stepleton. Sevilla, 1592.

Cervantes hizo un digno elogio del escritor andaluz en la siguiente octava, en el lib. V1. de la Galatea:

En punto estoi, donde por mais que diga En alnban:a del divino Herrera, Será de poco fruto mi faliga. Aunque le suba hasta la quinta esfera: Mas si soi sospechosa por amiga Sus ubras y su fama verdadera Dirán que en ciencias es IIernando solo Del Gange al . iulo, $y$ de uno al otro polo.

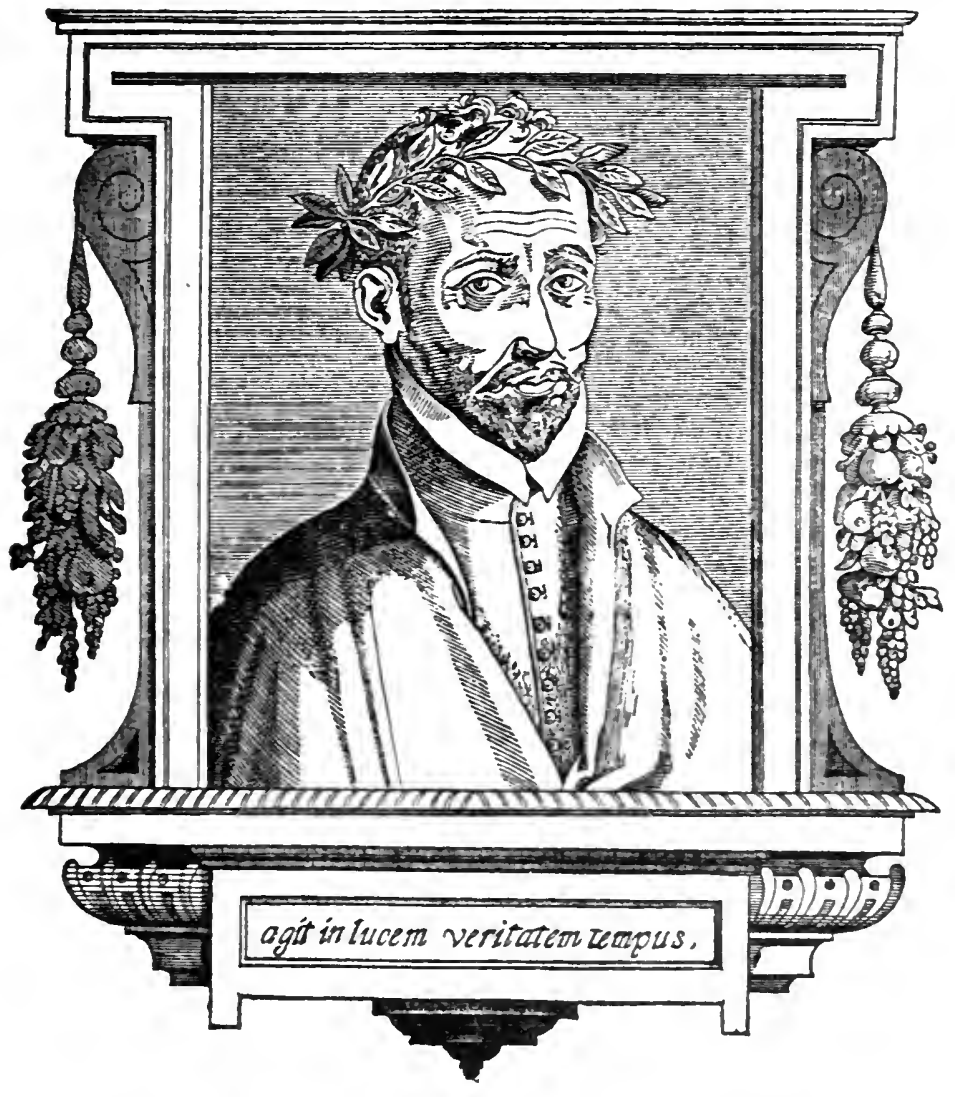


669 Herrera (D. Rodrigo de). Silva fvnebre a la muerte de don Aluaro Iacinto Colon y Portugal, Duque de Veragua. Por Don Rodrigo de Herrera. (Madrid, 1636?) $4^{\circ}{ }^{\circ} 8$ hojas.

No mencioua Nic. Antonio á este antor cuya Silua lleva al plincipio ma décima landitoria de D. Francisco de Röjas, y una aprobacion en prosa de l'érez de Nontalvan.

Vo tieme feclia la elicion; el lugar y año que le scĩalo se halla en los preliminares.

\section{IIIERRO (BALtISIR DEL).}

\section{Aibsa y prime}

ra parte, Jelos victoriofos lje cljos del uny valerofo $\mathfrak{c a}$ tallero don Aluaro de

Baçä: feñor delas vi llas d’l Hisa, y färta

Crmj. Capitã

gelleral del mat $\operatorname{Ble} \sim$

atlo.

\section{Dirigido al mun illufter feñor} don fung Cyatat. Se nor delas villas de $\mathfrak{A l}$ buñol, y Torbifín, con fus partidas. Cópuefto por Baltbafăr d’! Gierro.

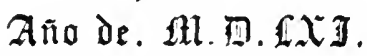

(Este frontis se halla circuido de orla. Al dorso hai un soneto á Don Luis Zapata, y en la siguiente hoja uno á D. Lirancisco Zapala y otro al antedicho D. Luis por Giregorio Silcestre; en la tercera hoja sign. Aiij esta la dedicatoria, y la cuarta la rcupan dos sonetos, uno de Hierro à
D. Álvaro Bazan y otro de Silvestre al autor. En seguida principia la obra en la sign. Av, terminando en la octava hoja de la sign. J con el siguiente final: $\mathcal{C}$ Aqui haze fin el presente tractado. El qual fue impresso cō licécia, en la muy noble ciudad de Granada: en casa de Rene llabut junto a los hospitales del corpus Christi. 8. ${ }^{\circ}$ let. gót. Sin foliacion, signs. A-J todas de 8 hojas.

Hermoso ejemplar de un libro de tan estre. mada rareza, que no recvier'so haber visto ofro. Ni Nie. Antonio ni ningun bibliógrafo mencionau á Baltasar del Jiierro y $\mathrm{Mr}$. Heber I10 tuvo esta obra en su biblioteca.

Ell contenido del presente volúmen es mui interesante para los que buscan obras relativas á Inglaterra ó âlas Indias, por hallarse un cinto en el cual hablit del viaje hecho por D. Alvaro Bazan acompañando al rei D. Felipe í Inglaterra, ofro en donde da cuenta de los gramles rescibimienlos que se hicicron al "uleroso D. Alvaro y su armada en Canaria: y cómo despues pai lió de alli y fué limpiando ios puertos y hariendo marivillas hasla to. par cont el ar'madtu de Indias: y un tercero relatando cómo D. Álvaro salió de Caliz y Irujo un armada de Indias a Barrameda, $y$ (le (o) que en la ida le aconteció.

El poema está en octavas $\mathrm{y}$ se halla dividido en seis cantos, terminando al reverso de li hoja sign. Iij donde se lee: Fenece la primera parle de los gramdes y virtuosos hechos del valeroso cauallero don Aluaro de Buçan y comiença sonetos, y coplus de difereules autores. Con efecto siguen dos sonetos, uno de Hierro y otro de Silvestre, dos grlosas de este, otra de D. Juan de Borja; otra de llierro, una cancion que dice: $D i$, pastor, quistresine bien? y una glosa de ella nor el mismo.

La de Silvestre es la siguiente hecha á la

Cancion del Duque de Sesa.

Si os pesa de ser querida, yo $n$ o puedo no os querer; pesar habeis de tenar miéntras yo tuviere vida.

De Silvcslre sobre la camcion del Duque.

Señora, podeis creer que el que una vez pudo veros, imposible es no quereros, annque no os quiera querer; y si no tomais placer de ser amada y servida, pesar habcis de tener mientras yo luviere vida.

Yo no sé hallar manera, despues que amor me prendió, para no quereros yo 
aunque no querais que os quilera; si no se muda $\mathrm{ml}$ ser ó el vuestro va de vencida, pesar hubeis de tener mientras yo tuviere vida.

Pesar de vuestro pesar me turba el placer de amarns, y más que vengo á enojaros con lo qu'os debia agradar: mas si vos tomais placer del pesar de ser querida, por fuerza os he de querer miénlras yo tuviere vida.

\section{HINOJOSA Y CARVAJAL} (Alvaro de). Libro de la vida, y milagros de S. Ines con otras varias obras a lo Diuino. Compuesto por el P. F. Aluaro de Hinojosa, y Caruajal. Braga, Fructuoso Lourenço de Basto, M.DC.XI. 4. ${ }^{\circ} 12$ hojas prels. y 407 págs.

El poema de Sta. Ines es en octaras y va dividido en dicz cantos: las Obras á lo divino, que son por el estilo de los Conceptos de Ledesma, están escritas en una gran variedad de metros, abundando especialmente los romances y villanciros.

Nic. Antonio equiroca el tamaño de este libro raro y poco conocido, pues dice ser en $8 .^{\circ}$

672 HOJEDA (Diego DF). La Christiada del Padre Frai Diego de Hoieda. Sevilla, Diego Perez, 1611. 4. 8 hojas prels. y $3 \mathbf{1 0}$ fols.

Precioso ejemular. Se me ha asegurado existen algunos con un retrato del autor.

Poema en octavas, dividido en lote libros.

Recuerdo que I. Juan Manuel de Berriozibal publicó en Paris, hácid $18.5 \overline{5}$, un tomito que contenia los trozos de este poema que juzgó de mayor mérito, y segun creo lo re. produjo en Madrid en lis. Quintana en la Musa épica, tum. II., tambien incluyii largos fragmentos, $y$ alli advierte que los ejemplares de la edicion de 1611 se han lieclio rarisimos, porque sin duda sc llevaron á América donde el autor residia.

La segunda edicion de la Christiada completa la ha publicado Ribadeneira en el tom. XVII. de la Biblioteca de Autores espunoles.

Sobre este mismo asunto escribio Juan de Quiros otm poema en siete cantos , intitila. do: Crisloputhiu o Passion de Chrislo. Tuestro Señor, impresa, segun los traductores de Ticknor, toin. III. pág. 480 , en Toledo, Juan Ferver, 1552. 8. ; sin embargo Vic. Antonlo dice ser de 1555 .

El libro de Hojeda lleva al fin este escudo del impresor Liego Pèrez, usado el año an. terior por Luis Estupiñan: tal vez fué aquel sucesor de este.

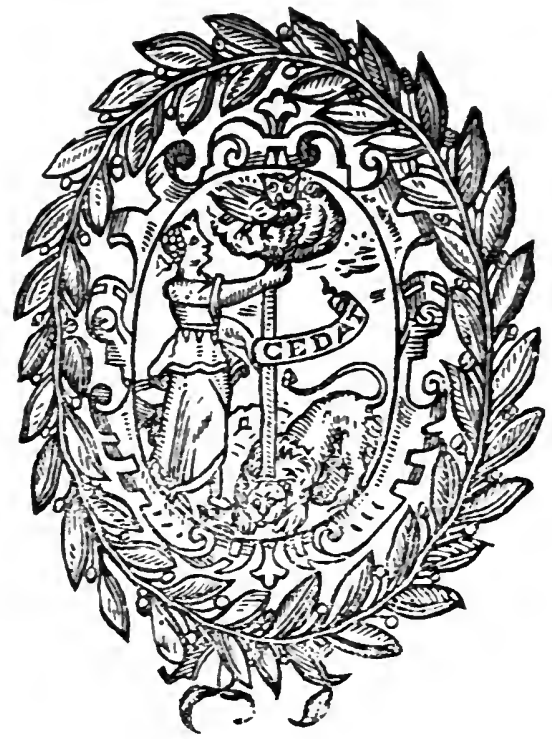

6 i3 HOMERO. La Vlyxea de Homero. Repartida en Xill. Libros. Tradvida de Griego en Romance castellano por el Señor Gonçalo Perez. Fenetia, en casa de Gabriel Giolito de Ferrariis, y srs hermanos, IDLLII. 12." let. curs. 209 hojas foliadas, inclusos los prels. y una al fin, en cuyo reverso se repiten las seias de la impresion.

He vislo la primera olicion, eon el siruiente lítulo: th" la lyxea de Homero. IIII. libros. Mulusidos de Griego en Romance Castellaino por loncali Per's. Amuers, on casa de Innm sletsin, 1550. 8. ${ }^{\circ}$ let. cursiva. 4 hojas prels. $y 295$ fols.

Vic. Ańtonio menciona otra tambien de Anvers, $1555.120^{\circ}$

674 La Vlyxea de Homero, tradrzida de griego en lengua Castellana, por el Secrelario Gonçalo Perez. Anuers, Iuan steelsio. 13 š6. 8. ${ }^{\circ}$ marq. let. curs. s hojas prels. y 140. fols.

De la nueva dedicatoria inserta en la presente edicion, se deduce ser esta la primera completa de la Llixea, por haberle añadido Pérez los once libros que faltaban para compietar los veinticuatro de que debe constar. 
673 HOMERO. La Vlyxea de Homero, tradvzida de griego en lengua Castellana, por el Secretario Gonçalo Perez. Venetia, en casa de Francísco Rampazeto, MDLXII. 8. ${ }^{\circ}$ let. curs. 8 hojas prels., 795 pags., una hoja con un adorno grabado y la leyenda $\mathrm{IN} \mathrm{s} 1-$ I.ENTIO ET SPE $y$ otra blanca.

A pesar de decir en la portada de la presente impresion Nuenamente por el mesmo (autor) revista y emendada, reo es copia de la anterior de 1556 .

Brunet habla de dos ediciones de Madrid de $1767 \mathrm{y} 1785$, ambas en dos volúmenes $8 .^{\circ}$

Miéntras de la Ulixea de Homero no conozeo mas version que la de Gonzalo Pérez, tengo noticia de tres traduceiones de la lliada y son las siguientes:

Portada: und estampa de madera que re. presenta una ciudad murada con torreones, y á su pié varias gentes que al parecer salen perseguidas y llorando. Debajo se lee: Esta es la lliada di' Himero en romance traducida por Juan de Meme. A la viselta: El presenle tibin se nombra la Iliada de Homero, historiadm muy antigun y principe de los Poetas. Traducidu del griego y latin en lengua vulgar castellana por el famosn Poeta Cástellano Juan de Mena: cmbiola el Licenciadn Alonso Hodriguez de Tudela al ilustre y muy magnifico Señor el Sr. D. IHernundo Hen'riquez com la presente carla. (sigue esta. En la hoja siguiente: Comiença la Yliada de Homero traducida en lengun mulgu' por el famoso Juan de Mena. Proemio de Jum de Mena al Rey Don Juan el segumdo. riene despues el proemio en el cual dice el autor haber dispuesto no interpretar los veintieuatro libros, que son el volimen de la Eneitla, sino formar una breve sunca de ellos. Despues del proemin se halla la suma mencionada en treinta y seis capitulins en prosa, y concluye el libro:) Aqui se acaba la lliada de Homero listoriador muly excelente: traducida dol brieg" y lalin en lengua vingure por el Po'tu Castellanu Juan de Mena. Embiola el Liremiado Alonsu Rodriguez de Tidela al ilustre !l uny magnifico Señor Don Her'nand") Henrriquez para que lean sus hijos los que han de exercitar la disciplina y aclo mililar. Fue imprimida en la villa de valladolid por Arnao Guillen de Brocar á 25 dias del mes de Abril. Año de 1519. Contiene 30 hojas.

A continuacion se halla en el inisino volúmen otra obrita impresa en octavas de arte mayor, titulada: Contienda que ovieron Ayas, Telamon y Ulises unte los principes y pueblo de Grecia delante de Troya, y sobre seguro en el templo de Aprilo delante de Troya. (Contiene este impreso 11 hojas de tamaño y letra iguales al anterior; consta de setenta y seis octavas, y concluye:) Aqui se acubu la conlienda pue ovieron dyax, Telamon y Ulixes sobre las armas de Aquiles.
La qual embio el Licenciado Alonso Rodriguez de Tudela al ilustre y muy magnifico seitor el Sr. D. Hernando Enrriquez juntamente con la Iliada de Homero para en quo lean sus hijos los que han de exercitur el acto mili. liir. Fue imprimida por Arnao Guillen de Brocar en la muy noble villa de Valladolid a 29 de Marzo: año de 1519.

lat precedente notleia la saqué de unos apuntes comunicados por el Sr. de Parga, en ellos no se menciona el tamaño del libro ni la clase de letra; pero los traductores de Ticknor dicen, que esta obra es en $40^{\circ}$ y de let. gót.

La Iliada de Homero, traducida del griego en verso castellano por Ignacio Garcta Malo. Madril, 1788 . 3 vols. $8 .^{\circ}$ Se reimprimió en 1827 , en igual numero de tomos y tamaño.

La Iliuda de Homero, traducida del griego al. castellano (en verso) por D. José Gomez Hermosilla. Madrid, imprenla real 1831. 3 vols. $4^{\circ}$

676 HORACIO (Q.) FLACO. Q. Horacio Flacco poeta lyrico latino. Sus obras con la declaracion Magistral en lengua Castellana. Por el Doctor (Iuan) Villen de Biedma. Granada, Sebastian de Mena, 13̈99. fol. 10 hrijas prels., 330 foliadas y 8 de Indice.

Traduccion en prosa, no mencionada por Pellicer en el Ensayo de una bib. de traduclores.

677 Horacio español, esto es obras, de Q. Horacio Flacco, traduzidas en prosa española, è ilustradas con Argumentos, Epitomes, y Notas en el nismo idioma. Parte primera. Poesias liricas. Por cl R. P. Vrbano Campos. Van al fin la declaracion de las especies do los Versos. v Udas, I Ires Indices. ol primero illabetiro de bas Odas, el segundo Cosmogratico, y el tercero de las cosas notables, que se explican en las Notas. Leon, Anisson y Posuel. M.DC.LXXXII. 12. 6 hojas prels. $y$ 360 págs.

Debe ser la primera edieion á pesar de llevar al primcipio una licencia del P'repósito provincial de la Conıpañía de Jesus, fechada en Valencia á 10 de Abril de 16\$0. Hai una segunda de Barcelona, por Antonio La Cavalleria, $1699.8 .^{\circ}$

No liace mencion Nic. Antonio del P. Urbano Cámpos.

En el Catílogo de Morante se llena página y media para repetir cuatro vezes el título de 
la verslon de Bledma, y tres el de la de Cám. pos sin darnos más noticias bibliográflcas o iterarias sobre ellas, sino que un ejemplar de la prluera, estaba encuadernado en pasta, con fletes y cortes dorados, y adornado con las armas del buen marques, habléndole costado 120 rs.; otros dos en pasta valian á 64 rs., y el cuarto a la holandesa 60 . De la de Cámuos tambien se encuentra uno en pasta fina, con el consabido escudo, cuyo coste fué de 50 rs. miéntras el siguiente solo vale 3 rs. y el último á la holandesa con la querida divisa 16 . De este modo y acumulando ademas notas traducidas de Brunet ó del Bulletin du bibliophile, fácilınente se forma un Indice de ocho tomos, y se hace subir á muchos miles el número de las obras que se poseen.

\section{HORACIO (Q.) FLACO.} Las Poesías de Horacio traducidas en versos castellanos con notas y observaciones criticas por Don Javier de Búrgos. Paris, H. Fournier y C. ${ }^{2}$, 1841. 4 rols. $12 .^{\circ}$ may.

Ejemplar del papel de color de rosa de que solo se tiraron tres. - Esta edicion la publicó mi padre.

He tenido las Odas de Horacio, traducidas en verso castellano por Don Felipe de Sobrado. Corıña, en la Caxa typographica, 1813. $80^{\circ}$

679 Traduccion de la Arte poetica de (Q. Horacio F. Principe de los Poetas liricos i de los tres discursos sobre el Poema heroico de Torquato Tasso. Por D. ${ }^{\mathrm{n}}$ Thomas Tanayo de Vargas, Toledano. 4. Manuscrito de principios del siglo Xlll de 81 fojas incluso el fróntis.

Hanuscrilo que pertence io à la bibliuler.d if 1). Tomas ule Iriarte. y it él debe ser ulli nota puesta al fln que dis:o: Trafurerion nriginal de Bon Thunas Tamayn de l'w'gas. Lonarman esta aserelon las inuchas correcciones Interlineales puestas al princlpio, pues variantes de tanta innnta solo sc atreveria d hacerlas el nisuio autor.

La portada, annque bastante antiguä, debe ser por lo inenos un siglo posterior al resto del codiec, § esto esplica porque en clla se sup'rne a Virgas tilcedmo, habiendo nacido en Madrid, seyun li conflrman Nic. Autonio y Alvarez y Bitenit. Alubos autores tracil istensos catílogus de los escritos de Tamayu de Virgas: pero 110 incluyeron la traduccion inedita del Arte poelica y Discursos de Tasso. ni tuvicron noticia de que hubiese versificado en castellano, sipullo así que el Art, pélica de lloracio arriba descrito, esti en verso.
680 HUBER (V. A.). De primitiva cantilenarum popularium epicarum (vulgo Romances) apud hispanos forna ad professoris ordinaril locum in facultate philosophica universitatis litterariae Berolinensis rite capessendum scripsit V.A. Huber. Berolini typis Academicis. MDCccxliv. $4 .^{\circ}$ may.

Tiene este ejemplar la siguiente dedicato ria autografa: Viro doclissimo humanissimo perillustris $V$. Salvd auctor.

Se imprimió en corto numero para regalar.

681 HURTADO DE MENDOZA (Axtonio DE). Vida de Nuestra Señora Mlaria Santissima de Don Antonio de Mendoza. Obra postrma, Que sale à gozar repetidos aplausos de la turguesa de mas legitimos, y correctos Originales. Napoles, Iuan Francisco Paz, 1672. 8..$^{\circ}$ marq. 4 hojas prels., ademas de un retrato de D. Juan Montero de Espinosa, y/ 159 págs.

Se reimprimió este poenita de. D. Antonio Hurtado de Mendoza en las ediciones de sus Obras hechas en 1690 y (1728?) y suelto en Valencia por Antonio de Borda:ar, 1710. 24. advirtiendose en la portada que la impresion está Anra nuevamenle uñadida, y enıendaula; tambien salió á luz en Milan, J. Moreli, 1725. 12. ${ }^{\circ}$, segun el núm. 6 del Boletin biblingrdfico de 1864 .

He visto un tomito curo titulo es: Vida de Ninestra Señora. Escrivinla Don Antonio Hurlado de Yendo:a. Comtinembala Don Agustin Lopez de Refa. Panplina, Marlin Gregorio de Zabala, J680. 8. 25 hojas prels. " 210 párs. Ye parece quic $\mathrm{ni}$ en la edicion jo lil rida heeha en xapolos. ni en las reimpresoncs includas on las obras de Hendo-

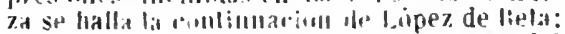

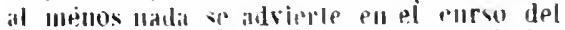

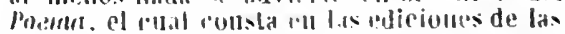
o'ras de setecientas udient. y ocho cuartetas, de seteclentas noventa y una en la Vida impresa en .ápoles, y de nihocientas cuatro en la de Valencia.

Barrera se equivincil en suponer que este poema se reimprimio linicinnente en la se. gunda edicion de las Obrots de Mendoza, pues se halla tambien en li primera; en decir que consta de ocluocientas redondillas, no teuiendo mis que setecientas ochenta $\mathbf{y}$ ochn, $y$ en dar colmo edicion principe li de Nápoles, cuando en la adedicateria d. rí. Jina Antonio Garéa, dirigida al ilustre. 0 . Juan Montero de kspinnsa y kelmonte, dice, se resolvia á dar esta obrilla à li cstampa por sı adiniracion al sabe" que de dié mil tomus (untrque fallos $y$ luenos de errores) quo 
se imprimieron en Sevilla quatro años ha, (1668) no se hallaban ejemplares. Ademas en la aprobacion del Mtro. Fr. Nicoforo Sebasto, dada en Agosto de 1671, tambien se habla de la impresion hispalense.

IIURTADO DE MENDOZA (ANT0Nio). Obras líricas y cómicas. Véase en la Seccion dramática.

\section{HURTADO DE MENDOZA} (DiEgo). Obras del insigne cavallero Don Diego de Mendoza, Embaxador del Emperador Carlos Qvinto en Roma. Recopiladas por Frey lvan Diaz Ilida lgo. Madrid, Iuan de la Cuesta, 1610. $4 .^{\circ} 8$ hojas prels., 109 fols., Cla viltima dice 1505 por equivocacion), y una en que se repiten las señas de la impresion.

Entre los versos laudatorios del principio hai un soneto del Doctor Mira de Amescua, otro de D. Antonio Hurtado de Mendoza y un tercero de Miguel de Cervántes Saavedra, que dice:

En la memoria vive de las gentes,

Vhon famoso, sig!os infinitos, premio que le merecen lus escrilos

Por graves, puros, castus y excelcntes.

Las ansias en honesla ltuma àdienlc

Los clnas, los estigios, los cozitos,

oue en ellos su'vemente van descritos:

Mira si es bien, oh fama! que los cuente.

Y aunque los lleves con lijero vuelo

Por cuanlo riñe el mar y el sol rodea,

Y en ldminas de bronce los esculpas:

Gue asi el suclo sabrá que sabe el cielo one ol renomibre inmortal que se desea,

Tal v'? le alcimzan amojosas culpas.

Lnica edicion de las poesías de este célehre escritor. Tickuor, ton. II., p. 72 , observa mui fundadamente, ser libro raro y notable.

Es sensible que el editor Diaz Hidalgo nos haya privado de las obras satíricas y jocosas de Mendoza, por escrúpulos mal entendidos.

\section{HURTADO DE MENDOZA} (Juas). I Buen plazer trobado en treze discãtes de quarta rima Castellana segun imitacion de trobas Francesas, compuesto por don Juan Hurtado de Mendoça: cayo es Frexno de Torote: y dirigido a la muy insigne v llena de nobleza, $y$ de buen lustre la cortesana villa de Madrid su muy amada patria: con algunos metros antes: $y$ despues de la obra princi- pal. Al fin de la qual sobre los discantes ay treze argumentos hechos por el padre fray Francisco Tofiño a instancia del autor: $\tau$ sobre examen ecclesiastico y seglar.

I Con licencia y priuilegio Real por diez años.

(Este itiulo en docc renglones es todo de bermellon, ménos los dos calderones y un iscudo de las armas de Madrid puesto sobre él, que van de negro. Al reverso se encuentra el privilegio real; siguen siete hojas sin foliar con composiciones poéticas del autor a dicho privilegio, á la villa de Madrid, á los examinadores, á los comentadores, á los impresores, etc., tambien hai algunos versos ajenos en loor de la obra; la novena hoja del libro sign. A fol. j. comprende el final de los prels. y en ella hai un soneto de Ambrosio de Moráles. La obra comienza en el fol. ij y termina en el xlvij vuelta con el siguiente colofon:) Fve impresso en la muy noble Villa, y florentissima Vniuersidad de Alcala en casa de loan de Brocar, a ocho dias del mes de Mavo, Año del nacimiento de nuestro saluador lesu Christo, y de nuestra redencion de M.D.L. sobre examen ecclesiastico y seglar con licencia y priuilegio Real. SSigue en otra hoja è gran escudo de Brocar que copio a continuacion.) 8. ${ }^{\circ}$ let. gót. 8 hojas sinfoliar al principio, 47 fols. y una con el escudo.

Magniflco ejemplar que casi puede llamarse único, pues á pesar de haber hecho las más esquisitas diligencias para descubrir la existencia de otro, no he podido encontrarlo ni en bibliotecas públicas ni en las de particulares.

D. Bartolomé Josė Gallardo dice en el Criticon núm. 3., pág. 11, al hablar del autor de este precioso libro: 'Era D. Juan Hurtado - de Mendoza, caballero mui conocido y hon- rado de los poetas y sabios de aquella edad, - porque lo era él todo; y tanto que á virtud - de su aplicacion á todn linaje de saber, y - porque vivia como enbebecido en sus estu- dios, por festivo apodo le llamaban sus - amigos el Filosofo. He alcanzado á ver su- yas dos obras de poesia, que son mui rarus: - la una titulada Buen plazer, trobado en - trece discantes, impresa en $80^{\circ}$ Alcala, - 1550. La otra El' Caballero Cristüino. Anle- quera, por Andres Lobalo, 1570. 8. 
gun veo por Nic. Antonio, Gallardo se equivocó en suponer era esta última obra del Juan Hurtado de Mendoza, madrileño, pues parece que su antor, sin embargo de llevar gual nombre, fue natural de Granada.
Por eso sin duda, Alvarez y Baena no Incluye El Caballero cristiano entre los escritos del Mendoza de Madrid.

El siguiente escudo de Juan Brocar se halla al fin del Buen plazer.

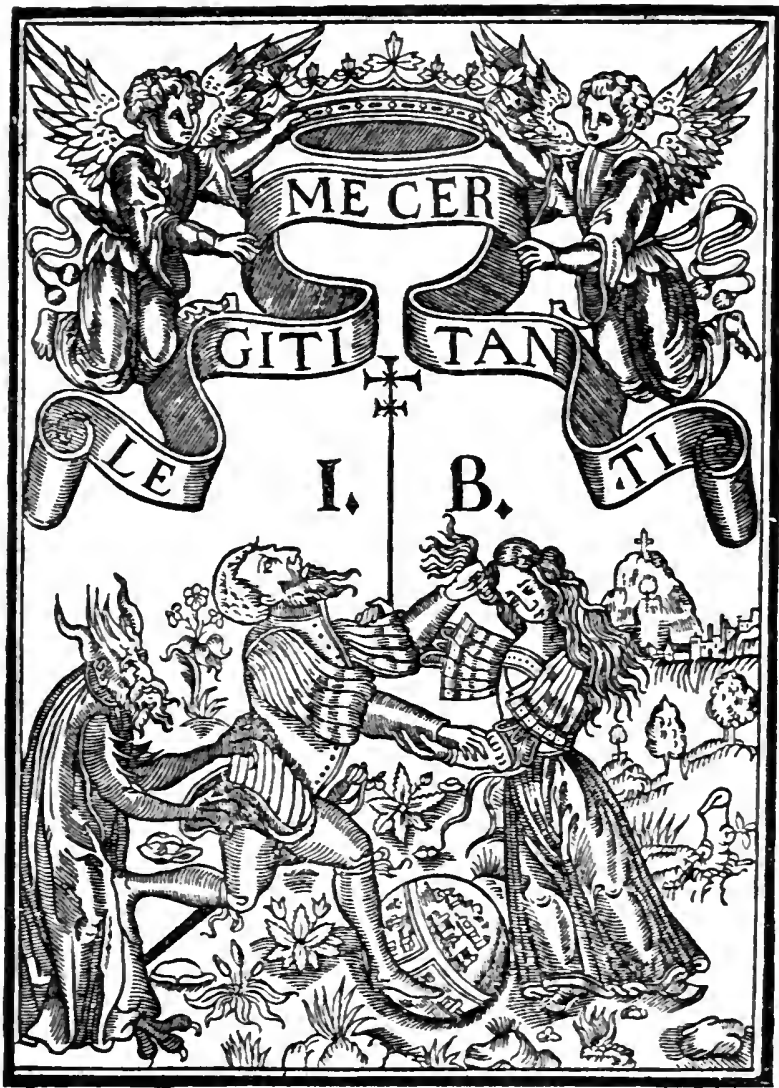

684 IMAGEN poètica de la filosofia moral, ó retrato christiano-politico de un buen Cortezano. Reinipreso en Lima, oficina de la Calle de la Encarnacion, $1767.8 .^{\circ} 14$ hojas.

Es un romance.

68ว IRIARTE (D. TOMAS DE). La Música poema, por D. Tomas de Yriarte. Tercera edicion. Madrid, Imprenta real, MDcclxxxix. 4. Láms. finas.
He visto otra edicion hecha tambien en la Impienla real en MHCLCXIX, probable. mente la primera; ignoro el año de la segunda. I.a cuarta es de Burdeos, Pedro Beaume, MDCCCIX. $18 .^{\circ}$

686 IRIARTE (D. TOMAS DE). Obras poeticas de D. Thomas de Triarte, entresacadas de algunos de sus manuscritos. Madrid, 1780. 4. Manuscrito mui inteligible de 3 hnjas sin numerar y 253 numeradas.

to puedo decir si hai en este tomo algu. 
na composiclon incidita no habiéndolo cotejado con sus obras impresas.

687 IRJARTE (Tomas DE). Poesias inéditas de este autor: hai entre ellas muchas festivas, jocosas, satíricas y lubricas. Manuscrito autografo en $4 .^{\circ}$

688 JAUREGUI (JUAN DE). Discrrso poetico De don Iuan de Iauregui. Madrid, Iuan Gonçalez, M.DC.XXIIII. 1. $^{\circ}$ hojas prels. y 40 fols.

Ćnica edicion.-Nic. Antonio al parecer rita esta obra de oidas, pues ademas de variar su título, no neenciona lngar ni año de impresion; Sedann en el tom. IX. del Parnaso le copia; Tickmor la intitula Discurso sobre cl esilo culto y oscuro y observa que nunca ha podido verla, tal es su rareza; Barrera se 'imita a dar la misma noticia.

689 - Orfeo de Don Ivan de Iavregui. Madrid, luan Gonçalez, M.DC.XXIIII. $4 .^{\circ} 4$ hojas prels. y 34 fols.

Primera edicion.-Este poema en octavas $\mathrm{y}$ en cinco cantos, lo publicó en Madrid, hácia 1684, Lorenso García junto con la Frorsalia; lo mismo hizo Fernández en el tom. Vill. de su Coleccion de poctas; se incluyó con algunas variantes en el tom. I. de la Cítara de Apolo de Salazar y Tóres como si fuera obra de este; y por fin Quintana dió algunos frigmentos en sus Poesíns caslellanas, advir. liendo no haber podido numsa ver in ejemplar de la enlioion de log:i.

690 L Rimas de Dou Ivan de Iavregri. Sevilla, Francisco de Lyra Varreto, M.DC.xvill. 4. ${ }^{\circ} 16$ hojas prels. 307 paigs. y 6 de Tabla.

I'rimera cdicion, rara.

Entre los versos en elogio de la obra que se hallan al principio los hai de Antonio ortiz Melgarejo, D. Nelchor del Alcázar, Francisen Pacheco, D. Lúcas de dilluregui, 1). Juan Antonio de Vera y Zuñiga y D. Juan de. Argnijo.

Eu esle tomo de Rimas se reprodujo el Aminla impreso anteriormente en Roma; pero sufrio considerables retoques $y$ alguluas supresiones; Scdano al publicarlo en el toiI. 1. del l'urnaso Español, siguio cl testo
Es un legajo reunido por su hermano D. Bernardo, quien se conoce habia ldo entresacando varias composiciones, las cuales debian formar el tom. IX. de las obras de D. Tomas, publicadas en 1805; pero no llegó á ver la luz pública. - Tambien hai algunas poesias de D. Nic. Fernández Moratin, Don Francisco Duran y algun otro literato, dirlgidas á Iriarte.

de la edicion sevillana, y el contenido de la de 1607.

Las poesías de Jáuregui, segun la edicion de 1618 , las reimprimio Fernandez en el tomo Vl. de su Coleccion.

691 JESUS (Diego DE). Conceptos espirituales $y$ en particvlar de la contemplacion, y negacion propia. Comprestos por el Padre Fray Diego de lesvs. Recogidos por D. Martin de Vgalde. Madrid, Doña María Rey, Viuda de Diego Diaz de la Carrera, 1668. 8. 8 hojas prels. y 247 fols.

El titulo de esta obra póstuma indica ya suflcientemente pertenecer al género de la de Alonso de Ledesma. Su autor debió eseribirla en los primeros años del siglo XVII, pucs aun se eucuentri bastante libre del mal gusto que dominaba á mediados de dicha centuria.

Los Conceplos de Fr. Diego de Jesus se cscaparon á las investigaciones de Nic. Antonio.

692 JIMÉNEZ (Fernando). Libro de la Restavracion y Henovacion del hombre Compvesto por Fernando limenes. Lisboa, Pedro Crasbeeck. 1608. 4. 8 hojas prels., incluso el frontis yrabado y las Erratas, y 7) hojas foliadas.

Poema dividido en dos tratados, en los siete dias de la semana, y en varios capitulos.

Nic. Antonlo llama á este autor Ferdinandus Ximenez de Aragaon, y se conoce no viỏ la presente obra, cuando supone estar escrita en portugues: tambicn menciona otro tratado del mismo, del cual nos da el título en dicho idioma, á saber: Doutrina catolica pera Instrucçaõ e confirnıaçã dos Ficis. olisipone, Petrum Crasbeeck, $1625.4 .^{\circ}$

JIMENEZ AILLON (DIEGO). LOS famosos hechos del Cid. Véase en la 
Seccion novelística. - Libros de caballerias.

693 JIMÉNEZ PATON (BARTOL.). Declaracion magistral destos versos de Irvenal. Sat. 6. Por el Maestro Bartolome Ximenez Paton. Cuenca, Saluador de Viader, 1632. $4 .^{\circ} 4$ hojas sin fol. ni sign.

Declaracion Magistral de la Epigrama de Marcial 29. libro. 3. Por el Maestro Barlolone Ximenes $\mathrm{Pa}-$ ton. S. I. ni a. 6 hojas con la sign. A. Admodvm ervdito viro... Magistro Bartholomæo Ximenio Patonio. Licentiatus Michael Diaz, Castellanos ...hunc hymnum in laudem diuæ Mariæ Magdalenæ ase elucubratum dedicat. S. 1. nec a. $40^{\circ} 4$ hojas con la sign. A.

Nic. Antonio no hace mérito del opúsculo de Diaz Castellanos.

694 JOVIO (Padlo). Elogios 0 vidas breues, de los Caualleros antiguos y modernos, Illustres en valor de guerra, $\tilde{q}$ estan al biuo pintados en el Museo de Paulo Iouio. Es autor el nismo Pavlo Iovio. Y traduxolo de Latin en Castellano, el Licenciado Gaspar de Baeça. Granada. En casa de Hugo de Mena. 1568. fol. La prosa en letra redonda y el rerso de cursiva. 4 hojas prels. y 222 fols.

Despues de la biografía ó resumen de los hechos notables de cada varon ilustre, hai por lo ménos un elogio en verso, á vezes son dos y hasta tres, escritos por diferentes autores en varias clases de metro: como estos elogios poéticos forman casi una mitad de la obra me ha parecido que debia colocarla en esta division.

695 JUÁREZ (D. Diego). Historia del Principio sitio y fundacion y cosas memorables de San Juan de la Peña. $4 .^{\circ}$ Manuscrito mui nítido $\dot{e}$ inteligible de fines del siglo $X V I$; consla de 148 fojas numeradas, el fróntis y una blanca que le sigue.

Poema inédito, escrito en octavas y dividido en diez cantos. No lleva nombre de autor; pero la dedicatoria dirigida á D. Beltran de la Cueva, Duque de Albuquerque, está flrmada por El Abad y Monjes de San Juan de la Peña, y en el frontis se encuen. tra una nota de letra de $D$. Joaquín de Traggia que dice: El autor de esta obra fué Don - Diego Xuarez, abad de Sn. Juan de la Peña, - aunque nada dice Latasa en su Biblioteca dé -escrilores aragoneses.,

Es cierto que no menciona Latasa esta produccion poética: pero en el artículo de Francisco Xuarez (t. I., p. 615) da algunas noticias que pueden servir para corroborar la suposicion de Traggia: pues dice: Her- mano de nuestro escritor (el Francisco) fuè ,el Ur. D. Diego Xuarez, Abad que fué del , Monasterio de la 0 en 1590 , y en 1593 del - de San Juan de la Peña, y Diputado Prelado - del reino de Aragon, que murió en 11 de - Junio de 1607 en Zaragoza y fué sepultado - en su Parroquial de Santa María Magdalena, - quien tambien compuso Versos lalinos y es- pañoles, y nereció el que el Cionista An-dres lo alabase en su Aganipe, diciendo:

- Entre las altas peñas,

- nobilisimo honor del Pirinen,

- de Don Diego Xuárez doclo Orfeo, - se descubren las señas

- de su grave Talia,

-y las fuentes risueñas

- agradecidas a su noble en!.

'repilen su dulcisima armn:

- cuando el sol muere, y cuando nace el dia.,

Nic. Antonio no trae en su Bibliolheca á ninguno de los dos hermanos Juárez.

696 JUVEXAL. Declaracion magistral sobre las Satiras de luuenal. Por Diego Lopez. IIadrid, Diego Diaz de la Carrera, M.DC.XLII. $4 .^{\circ} 8$ hojas prels., 538 págs. y 3 hojas de Tabla. Luego siguen 130 págs. y 2 hojas de Tabla, que contienen, sin nuevo fróntis, Las seis satyras de Avlo Persio Flacco con declaracion Magistral en lengua Castellana Por Diego Lopez.

Tanto vic. Antonio como Mayans en su Specimen, ouniten hablar de esta edicion en 4. del Persio de López, limitándose á la primera de Burgos, 1609 en $80^{\circ}$ La en $4 .^{\circ}$ esti hecha con toda probabilidad en Madrid, por el mismo Diego Diaz de la Carrera, aunque en ninguna parte se indica.

En cl título de esta obra liai exactitud llamándola Declaracion magislral; no sucede asi en el Persio del mismo López, edicion de 1609, donde se la califica de traduccion castcllana de las Sdliras, siendo solo un es. tenso comentario como el del Juvenal. 697 I Esta es la sexta de satira de Juuenal poeta muy famoso: en la qual se reprehenden algunos vicios y costumbres d' mugeres: en coplas de arte mayor. (Este título va 
precedido de una laminita que representa á dos personajes discutiendo y el todo ra circuido de una orla. Al dorso comienza el Prologo y argumēto blanco de la hoja sign. cij se lee:) I Aqui se acaba la sexta satira del juuenal. Traduzida por don Jeronimo de villegas prior de cuebas ruuias: el qual assi mesno traduxo dezena satira. (Al reverso principia:) I Satira dezena del junenal: en que reprehēde los ranos desseos y peticiones delos hombres que hazen a dios / no mirando $\bar{T}$ lo que pide y dessean las mas vezes les es dañoso. Tradızida por don Jeronimo de villegas prior de cuebas runias hermano de don Pero fernandes de villegas arçediano de burgos. (En el reverso de la sign. diij se encuentra el siguiente colofon:) U Aqui fenescé la sexta y dedela sexta satira del Juuenal, y en el

cima satiras del juuenal. Traduzidas por don Jeronimo de villegas prior de cueba ruuias liue imprimida enla villa de Ualladolid por Arnao guillen de brocar. A. xv. de abril. Año de mil $x$ quinientos rdiez y nueue (1519). años. $4 .^{\circ}$ let gót. 28 hojas sin foliacion con las sign. a-d, las tres primeras de ocho hojas y de cuatro la $\mathrm{d}$ siendo blanca la última.

Rarísima edicion, y precioso ejemplar intonso.

Nic. Antnnio no hace mérito en su Bibliolhéca de Jerónimo de Villegas: en el artícu. lo de sil hermano Pedro atribuye á él la traduccion de la decima salira, publicada al fin de la version de Dante, á pesar de que allf ya se dice ser del Jeronimo. La sátira sesta ignoro se haya reimpreso en parte alguna.-Inútil es anotar que Pellicer nada dice de la presente obrita cuando omite hasta el nombre de Juvenal en su Ensayo de una biblioleca de lraductores.

LA MARCHA (OLIVER de). El caballero determinado, traducido por llernando de Acuña. léase en la Seccion nocelística.-Libros de caballerías.

Discurso de la vida humana $\mathbf{y}$ aventuras del caballero determinado, traducido por Jerónimo de Urrea. Véase en la Seccion novelislica.-Libros de caballerías.

698 LAMARTINE (Alforso). Poesías entresacadas de las obras de A. Lamartine, traducidas por D. J. M. de Berriozabal, marques de CasaJara, entre los árcades Cintio Elimeo. Paris, H. Fournier y C. ${ }^{2}, 1840$. $18 .^{\circ}$ Retrato.

Edicion publicada por nuestra casa de paris.

699 LANCINA (Francisco DE). Vida de S. Francisco Xavier Apostol de las Indias. Assuntos políticos, y morales de Poesia. Por Don Francisco de Lancina. Madrid, Melchor Aluarez, 1682. $4 .^{\circ} 7$ hojas prels., inclu- so un retrato de $S$. Francisco Javier, .3:3 hojas fols. y una para terminar la Tabla.

Poema escrito en romances y dividido en diez y ocho asuntos.

Nic. Antonio no menciona á Lancina.

700 LARA (Francisco de). El Sol Maximo de la Iglesia. S. Geronymo. Poema heroyco en octavas rithmas. Sv artor el MI. R. P. Fr. Francisco de Lara. Sevilla, Francisco Sanchez Heciente, 1726. $4 .^{\circ} 34$ hojas |prels., 421 págs. y 2 hojas de Indice.

Consta de mil doscientas trece octavas.

El presente poema, aunque lleva al principio numerosos elogios y aprobaciones en verso y prosa, puede citarse como modelo del estilo más pervertido y detestable.

701 LASO DE LA VEGA (GABRIEL). Primera parte De Cortés valeroso, y Mexicana, De Gabriel Lasso de la Vega. Madrid, Pedro Madrigal, M.D.LXXXviII. 4. $^{\circ} 8$ hojas prels., inclusas las dos que contienen los retratos de Cortes y de Laso de la 
Vega, 193 fols. y 7 sin foliar que comprenden el Privilegio, seis sonetos laudatorios y la Tabla.

Primera edicion, mui rara.

En el catálogo de Sora se cita una edlcion de Madrid, 1587, que nunca ha existido; sin duda el ejemplar del cual se tomó la descripcion estaria falto del fróntis, y se coplo el año de la fé de erratas impresa al fin y fechada en Madrid, à 18 de viciembre de 1587.

702 LASO DE LA VEGA GABRIRL). Mexicana de Gabriel Lasso de la Vega, emendada y añadida por su mismo Autor. Lleva esta segvinda impression treze cantos mas que la primera. Madrid, Luis Sańchez, $1594.8 .^{\circ} 8$ hojas prels., en las que van incluidos los dos retratos de la edicion anterior, y $301 \mathrm{fols}$.

Se proponia Laso de la Vega al imprimir la Primera parte del Corles valeroso publicar una segunda, y D. Martin Cortes le indica en la epístola colocada al principio de la edicion de 1588 , en vista de la mucha narracion que quedaba, seria conveniente el añadir dos partes mús. To siguiou el autor ni su primera idea, ni los consejos del hijo del Conquistador de Ifijico, pues refundió, o por mejor decir, escribió de nuevo los doce cantos ya impresos, $y$ añadió trece para completar la obra, formando una série seguida de veinticinco.

Al fin del volümen, $\dot{0}$ sea desde el fol. 295 , se halla una Apología en defensa del ingenio y forlaleza de los Indios de la mueua Españu, conquistados por don Fernando Cortés. Por el Lic. Geronino Ramirez: opisculo mui curioso que revela el alto grado de cultura y civilizacion de los mejicinos en la época de la conquista. - Por consiguiente esta segunda edicion á más de ser lan rara como la primera es mucho más completa.

En ambas se encuentra un soneto laudatorio de Francisco de Aldana, y en la segunda hai una aprobacion en prosa de Don Alonso de Ercilla, quien elogia mucho lo añadido $\mathrm{Y}$ mejorado en dicha impresion.

La obra de Laso de la Vega. intitulada Elogios en loor de Don Jaime de Aragon, Don Fernando Corles y don Alvaro de Bazan, se describe en los Cancioneros, romanceros, antologías, etc. (V. el Nưm. 266.)

703 LASO DE LA VEGA (GARC1). Las obras del Excellente Poèta Gar. cilasso de la Vega. En esta postrera impression corregidas de muchos errores que en todas las passadas auia. Madrid, Alonso Gomez, 1570. $8^{\circ} 78$ hojas foliadas inclusos los prels.

Raro.-Contiene únicamente las poeslas sin anotaciones: en el mismo caso se encuentran las siguientes ediciones: la que trae Nic. Antonio de Venecia, Giolito, 1553. 12. , la anunciada en el Catálogo de Conde de Lisboa, 1626. $12 .^{\circ}$, la de Lisboa, Lorenzo Craesbeeck, 1632. $16 .^{\circ}$ de la cual se habla en la pág. 24. de la edicion de Paris, 1828, y la de Madrid (Paris), Sancha, 1821. 18. - Ignoro si la que se halla en el Catálogo de Sora de Madrid, 1600 . 8..$^{\circ}$, tendrá ó no las notas.

704 LASO DE LA YEGA (GABC1). Obras del Excelente Poeta Garci Lasso de la Vega. Con Anotaciones y eniendas del Maestro Francisco Sanchez Cathedratico de Retorica en Salamanca. En Salamanca Por Pedro Lasso. Y en Napoles Por Iuan Batista Sotil. MDcirir. 12. ${ }^{\circ}$ let. curs. $12 z$ hojas fol., inclusa la portada, una blanca que va al fin de las poesías y el frontis de las Anotaciones, y dos mas de erratas y licencias.

Por la fecha del privilegio dc esta linda edicion se conflrma la cxistencia de la de: Salamanca, Pedro Lassi), 1574. 16. 'mencionada por Nic. Antonio, aunque por el flnal de ella se ve es copia de otra que he tenido hecha tambien en Salananca, pol el nuismo Pedro Lasso, en 157\%. 12.0 Hle visto la tercera de Salamanea, Lucas de Iunta, 1581. 16. 11 i 12 hnjas prels. y $12 j$ foliadas: pero 110 he podido examinar la do Salamanca, Diego Lopes, 1582. 12. ${ }^{\circ}$, de que habla .iic. Antonio, ni la de 1589 , citada por Brunet. sin decir el lugar de sil inıpresion ni el tamaño; tal vez sea la descrita en el Catálogo de Gancia hecha en Salamancı Diego Lopez y Pelbo de Adurca, 1589. 12.

La última publicada con las notas del Brocense probablemente es la siguiente:

$70 \breve{~-~ O b r a s ~ d e l ~ E x c e l e n t e ~}$ poeta Garcilasso de la Vega. Con anotaciones, $y$ emiendas del Maestro Francisco Sanchez. Madrid, Iuan de la Cuesta, 161 . $80^{\circ} 8$ hojas prels. y 140 fols., inclusa la portada de las Anotaciones.

He visto una impresion de Madrid, por Ri. polles, s.a. $12 .^{\circ}$ Retrato, en ella se ha puesto el Prólogo de Azara y las Anolaciones del Brocense, que son las que más aceptacion han tenido $\mathrm{y}$ lo prueban las varias ediciones que de ellas se han dado á luz.

706 - Obras de Garci Lasso de la Vega con anotaciones de Fernando 
de Herrera. En Sevilla, Alonso de la Barrera, 1080. 4. 6 hojas prels., 691 pags. y dos hojas para terminar la Tabla.

Debo olsservar que en los dos $\dot{0}$ tres ejemplares veriflcados por $\mathrm{ml}$, de la pág. 60 pasa a la 65 sin faltarles nada. El ejemplar que poseo parece en gran papel, por lo marginoso y bello.

Libro doblemente apreciable por su rareza y por su mérits literario. El célebre Heırera no solo dió en él una muestra de su gran erudicion y profunda príctica en el lenguaje castellano, sino que nos hizo conocer, citándolos comı modelos y ejemplos, trozos mui escogidos y algunos inéditos de los siguientes poetas: Cristoval Mosquera de Figueroa, de quien cita un libro intitulado: El enamorado Eliocrisio, Luis Barahona de Soto, Franciseo de Medina, Pedro biaz de lierrera, Fernando de Cángas, Diego de Ilendoza, Gutierre de Cetina, Juan Saez Zumeta, Jerónimo de los Cóbns, Francisco de Figueroa, el Doctor Francisco Saa de Miranda, el Doctor Pedro Gómez, Jorge de Resende, Juall Sánchez Burgurllos y Diego Giron. Tambien hai inuchas composiciones del mismo Herrera, las cuales no encuentro en el tomo de sus Versos, impreso en 1619, y curiosíshmas noticias biogrifleas de Garcilaso.

707 LASO DE LA VEGA (GARCI). Garci-Lasso de la Vega natvral de Toledo Principe de los Poetas Castellanos. De Don Thomas Tanaio de Vargas. Madrid, Luis Sanchez, Año 1622. 16. 8 hojas prels., incluso el fróntis y una hoja blanca, 116 fols. que contienen la Vida, las obras poéticas de Garcilaso, la tabla etc. Hai ademas $87 \mathrm{fol}$. con el Comentario de Tamayo de Vargas, y una hojita al fin de fé de erratas en la que se repite la fecha.

liecomiendo el eximen del número y órden de las hojas de que consta este tomito, pues con mucha frecuencia ó faltan algunas o se hallan tergiversadas en la colocaciun.

708 - Obras de Garcilaso de la Vega, ilustradas con notas. Madrid, Imprenta Real de la Gaceta, M.DCC.LXV. 8. ${ }^{\circ}$ may.

Primera edicion publicada con las anotaciones de D. José Nicolas de Azara.

$709-$ La misma obra. Madrid, Don Antonio de Sancha, M.DCC.LXXXVIII. 12." Retrato.
Segunda edicion de las poesias de Garcilaso con las notas de Azara: la sigulente es la tercera.

710 LASO DE LA VEGA (GARCi). Obras de Garcilaso de la Vega, ilustradas con notas. Madrid, Sancha, M.DCC.XCVI. 12. ${ }^{\circ}$ Retrato.

A esta tercera edicion con notas de Azara, siguió una de Madril, 1805. 12.', que encuentro entre los apuntes de mi padre; una de Barcelona, Comipanín de Jordi, Roca, y Gaspar, M.DCCC.IV. 8. Retrato, que he tenido y la de Madrid, Sanchu, 1817. 12. Retrato, que se llıma Segunda edicion sin duda por serlo de las publicadas por aquef impresor. La viltima que poseo es la descrita á continuacion.

711 Paris, Imprenta de Julio Didot mayor, 1828. 32. Retrato.

Costeó esta edicion el Sr. I). Joaquín María Ferrer: tambien lo hizo con el Quijole, Melo, Guerra de Calaluña, Burguillos rimas, Lazarillo de Tórmes, etc., etc. - Nada dejarian que desear estas ediciones, pues son sumamente correctas y están preciosamente impresas; pero por desgricia el papel continuo o mecánico empleado ell ellas tiene mucha cal y con el contacto del aire infinitas hojas se han llenadı de manchas, ó vuelto pardas.

En la advertencia à la presente impresion se indica haberse formado de las publicadas por Sánchez el Brocense, Hernando de Herrera y Azara; pero despues de bien cotejada y examinada, veo en ella simplemente una reproduccion de la que dió á luz el último en 1765.

Al nombre de Boscan en la presente division, se encuentran descritas las ediciones de lis obras de Garcilaso, publicadas juntamente con las de aquel poeta. (V. el Núm. 472 y sigs.)

712 LECCIONES DE JOB. Las leciones d' Job 'Trobadas por vn reuerendo $x$ deuoto religioso: dela orden delos predicadores. Con vn Infierno de dañados Es obra muy deuota y cōtemplatiua. Agora nueuamente impressa. (Esta portada está bajo de una gran viñeta, formada con tres pequeñas. Al fin se lee:) I Fue impresso este tratado enla imperial ciudad de Toledo por Remon de petras impresor de libros. Acabose a dos de setiēbre: Año de milr.d.xxiij (1524). años. 4. ${ }^{\circ}$ let. gót. Son 8 hojas sin fol. con la sign. a. 
Ohra diversa de la de Garci Sánchez de Badajoz, que se halla á fojas 161 del Cancionero gener $u l$ de Anveres. Tampoco encuentro el Infierno de dañados reimpreso en ninguna de las colecciones generales. - Esta composicion está escrita en la misma clase de metro que las Lecoiones.-Supone el autor que arrebatado de este mundo, y acompañado de la Fè y la Esperanza, baja á los inflernos donde le van esplicando los varios padecimientos de los condenados:

Estos soll Ios lujuriosos

que quemaban sin quemarse, estos son los orgullosos, estos son los deseosos de en vano fuego abrasarse; $y$ pues bien les pareció el fuego que los quemó cuando el fuego no sentian ; aquel fuego meresció este fuego á do venian.

Despues que estos vi arder, vi penar los avarientos, bien hambrientos por comer, bien hartos en padecer, bien vestidos de tormentos: vi desnudos los vestidos, vi los ricos ser venidos á ser la misma pobreza, vi los grandes abatidos, vi caer su fortaleza.

Vi que aquestos se quemabau con los bienes que guardaron, perdidos porque guardaban, caidos pues levantaban los bienes que aquí adoraron; vi los ricos que quisieran ser pobres si ellos pudieran, pues pobreza es buena amiga; vi que su riqueza dieran, pues esta les fué enemiga.

Horrorizado de tantos tormentos, ruega it sus guias le saquen de aquel sitio, y termina exhortando á los cristianos á que reformen su conducta para no hacerse acreedores á tan duros castigos.

Tratadito de estremada rareza.

713 LEDESMA (ALONSO DE). Conceptos espiritvales de Alonso de Ledesma. Madrid, Imprenta Real (al fin Iuan Flamenco), $1602.8 .^{\circ}$ Bellas viñetas y läms. de madera mui bien tiradas. 16 hojas prels., כ̋1ว̆ págs. y 6 hojas en que concluye la Tabla.

Nic. Antonio no conocio esta edicion; pero menciona una de Madrid, 1600, fecha que lleva la Tasa de la presente.

Тон. 1.
714 LEDESMA (ALONSO DE). Conceptos espiritvales (ut supra.) $\mathrm{Na}$ drid, Imprenta real, 1604. 8. $\mathrm{Vi}$ netas de madera. 16 hojas prels., 500 págs. y 6 hojas de Tabla. Al fin se repiten las señas de la impresion; pero en lugar de Imprenta Real se lee Iuan Flamenco:

Tambien fuẻ desconocida esta edicion á Nic. Antonio.

\section{3} La misma obra. Lisboa, Antonio Aluarez, 160 . $.8^{\circ} 16$ hojas prels., 258 fols. y 6 en que termina la Tabla.

La omitiỏ Nic. Antonio.

716 La misma obra. Madrid, Imprenta Real (al fin Iuan Flamenco), 1609. 8. Viñetas de madera. 12 hojas prels., y 423 págs.

Yo la menciona ric. Antonio.

\section{7} La misma obra. Madrid, Irlian de Paredes, 1660. 8. ${ }^{\circ}$ 4 liojas prels. (la primera es blanca), 380 paigs. y 3 hojas de Tabla.

ric. Antonio, que tampoco cita esta edicion, describe una de Barcelona, Sebast. Cormellns, 1605, otra hecha en ta misma ciudad por Geronimo Yargarit, en 1612, y dos de $\mathbf{M a}$. drill de 162.5 y 29 . Brunet habla ademas de otra de Barcelona, del'misino Seb. Cormellas, $1606 ;$ y nosotros tuvimos la de la misma ciudad hecha por Iayme Cendrat, Y.DCVI. Todas en $80^{\circ}$

718 _ Segrnda parte de los Conceptos Espirituales, y Morales. Compresta por Alonso de Ledesma. Barcelona, layme Cendrat. $160 \mathbf{T}^{\circ} .8^{\circ}$ Viñetas de madera. 8 hojas prels. $y$ 383 pags.

Nic. Antonio dice haber visto una edicion de esta parte, hecha en Yadrid en 1600 .

719 La misma parte. Barcelona, Sebastian de Cormellas, $1607,8{ }^{\circ} 10$ hojas prels., 396 pags. y 4 hojas de Tabla.

720 La misma parte. Valladolid, Iuan de Rueda, $1613.8 .^{\circ}$ Viñetas de madera, 16 hojas prels. y

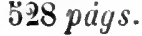


721 LEDESMA (ALONSO DE). Tercera parte de Conceptos espiritvales. Con las obras hechas à la Beatificacion del glorioso Patriarca Ignacio de Loyola,... para el Colegio de la Ciudad de Segouia. Compuesto por Alonso de Ledesma. Lerida, Luys Manescal, 1612. 8. 8 hojas prels., 154 fols. y 14 de Tablas.

No encuentro haya tenido ningun escritor noticia de esta tereera parte: el único que indica algo sobre ella es Nic. Antonio, y lo hace en los siguientes términos: Tertia pars, quce Romances continet. Matriti, 1616. Me parece por la manera de describirla, confunde este tomo con el Romancero del mismo autor. En primer lugar porque el tercer volúmell de los Cunceptos no solo contiene romances sino muchas otras clases de poesías, y ell segundo porque cono he dicho al hablar del Romancero, (Num. 268.) existe de èl en efecto una edieion madrileña de 1616 , fecha citada pirl Antonio.

Los Conceptos de Ledesma, sin duda por el género de composiciones contenidas en ellos $\mathrm{y}$ por la infinita variedad de su metrificacion, han solido clasiflearse entre los cancioneros y romanceros. El tomo primero comprende ademas 111 Diálogo pastoril representable.

En punto á la rareza de la obra observaré, que de la primeral parte, por haber lo menas doee ediciones de clla, suelen encontrarse algumos ejemplares; poeos poseen la segunda, pero ignoro que tenga alguno la tercera.

Los traductores de la Historia de la lit. esp. de Ticknor, tom. III., pág. 508 , se equivocan cuando suponen ser la Tercera parte de los Conceptos la misma obra que los Juegos de noche buena.

Varias son las obras publicadas en España á fines del siglo XVI y principios del XVII en el género de los Conc'ptos de Ledesma: en la present division se hallarán descritas algunas que $i$ go $y$ ademas he visto las siguientes:

Conceptos de divina poesia, en alabança del Rosario de la Reyna de los Angeles, Nacimiento de su benditissimn hijo nuestro Señor, y mysterin del santissimo Sacramento. Con un tratado en loor de la Cruz de nuestro Redemplor lesu Christo, y de muchos Sanctos. Compuesto y recopilado por Lucas Rodriguez. Alcala de Henares, han Iñiguez de Lequerica, 1599. 8. 8 hojas prels., 132 fols. y 4 de Tabla.

Discursos del varon ivsto, y conversion de la Mudalena, con otras Flores Espiriluales. Cöpuestos en Verso por Diego Cortes. Madrid, P. Madrigal. Año de M.D.XCII. 8. 8 hojas prels., 376 págs. y 4 hojas de Tabla.
Nvevos conceplos espirituales, en vario genero de verso. Por el Licenciado Gaspar Lozano Regalado. Valladolid, Iuan de Rueda, 1624. 8. 8 hojas prels. 174 fols. (Al fin se repiten las señas de la impresion; pero el año es el de 1623.) 7 de tabla y una blanca.

Sacro plantel de varias si (sic) divinas flores: Fertil primavera del supremo jardin y celestial floresta. Precioso material de fragantes y olorosos ramilletes, para recreo espiritual de las almas. Sv avtor el M.F. Fruncisco Ballester. Valencia, Clandio Mace, $1652.8^{\circ} 16$ hojas prels. y 480 págs. Cada concepto va precedido de una introduccion en prosa.

\section{LEON (LUIS DE). Obras pro-} pias i traducciones de latin, griego, i toscano, con la Parafrasi de algunos Salmos, i Capitulos de Job. Su autor el P. M. Fr. Luis de Leon. Tercera impression nuevamente añadida. Valencia, Joseph Thomás Lucas, $1761.8^{\circ}$

Precede á esta edicion de las Poesias del Mtro. Leon una Vida del autor, escrita por D. Gregorio Mayans; en ella da notieia mui cireunstanciada de las varias obras del poeta granadino.

Mi ejemplar lleva un retrato añadido, el cual positivamente no debe pertenecer á esta edicion.

La primera que he visto, salió con el tItulo de Obras propias y tradvcciones latinas, griegas, y llalianas. Con la parafiasi de atgunos Psrlmos, y Capitulos de Inb. Avtor el dnetissimo, $y$ Reuerendissims Pudre fray Luis de Leon. Sacadas de la libreria de don Manuel Sarmienlo de Mendoça. Dalas a la Impression don Fräcisco de Quebedo Villegas. Mudrid, Imprenta del Reyno, M.DC.XXXI.16. 22 hojas prels., 203 fols. y otra para repetir el lugar y fecha de la impresion. Siguió á esta la de Milan, Phelippe Guisolfi, 1631. 12. 6 hojas prels. y 312 pags. que tambien he visto: segun Mayans, en el prólogo de la de 1761, esta edicion es mui incorrecta.

En el año 1785 salió á luz, si no me equivoco, cuarta impresion, y Fernández las reimprimió en el tom. X. de la Coleccion de poetas.

\section{3 - Poesias. Madrid, Ibar-} ra, $1816.8 .^{\circ}$ may.

Forma este tomo el VI. y último de las obras del M. Fr. Luis de Leon, reconocidas y cotejadas con varios manuscritos por el $P$. $M$. Fr. Antolin Merino.

Edicion de las poesias indudablemente la más correcta y completa; el editor hombre mui estudioso y erudito, tuvo presentes al formarla tidas las impresiones publicadas hasta aquella fecha y diez ú once códices antiguos mui apreciables. 
He tenido un tomito intitulado: Poestas escogilas de Fray Luis de Lenn, Francisco do la Torre, Bernwdo de Bulbuena y olros varios. Madrid (Paris J. Sinith), Sancha, 1823. $18 .^{\circ}$, y en la presente seccion (segunda division, Nim. 319), en un tomo de Poesias espiriluales las hai tambien de nuestro autor.

724 LEON Y LUNA (Gabriel DE). Sacra y humana lyra. Poemas de Don Gabriel de Leon y Luna, que ha podido adquirir, y saca á luz Don Juan Manuel de Palacio. Malrid, Juan Muñoz, 1734. 4. 10 hojas prels. y

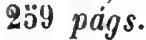

LEON MARGHANTE (MaNuel DE). Obras poéticas póstumas. Véase en la Seccion dramática.

72. LEON TAPIA (Fructos DE). Poema castellano qre contiene la vida del Bienauenturado San Fructos, Patron de la ciudad de Segouia, y de sus gloriosos hermanos San Valentin, y S. Engracia. Por Frvetos de Leon Tapia. Madrid, Tomas Iunti, M.DC.XXIII. $4 .^{\circ} 4$ hojas prels. y 104 fols. tos.

Poema en cuartetas dividido en diez can.

Nic. Antonio trae otra obra de este autor intitulada: Elogin en las fiertas de la lrans. lacion de Nuestra Seriora de la Fuencisla, Madrid, 1614.

726 LEONARDO DE ARGENSOLA (Lupercio y Bartolomé). Rimas de Lipercio, i del lotor Bartolome Leonardo de Argensola. Zaragoza, Hospital Real, i General de nuestra Señora de Gracia, 1634. 4. ${ }^{\circ}$ 13̈ hojas prels., incluso el Indice, $y$ 502 págs.

Lleva este ejemplar la firma autógrafa de J. J. Debure.

\section{7} Zaragoza, Hospital Real i General de nuestra Señora de Gracia, 1634. 17 hojas prels., inclusos el fróntis grabado, el impreso y el Indice, y 502 pág.

Es mui fácil distinguir estas dos ediciones del 34 , completamente distintas, aunque mui parecidas y sin duda hechas ambas por el mismo impresor. La que tiene el frontis grahado ademas de la portada impresa, se co. noce desde la primera hoja, pnr declr en el año de la fecha de la aprobacion de $D$. Lorenzo Vander Hammen, solo $\mathbf{3 4}$, mientras en la que únicamente lleva el frontispicio impreso se lee 634; siempre que en los preliminares se repite este año se escribe cuatro con $q$ y no con $c$; lleva un. soneto de D. Francisco Diego de Sáyas, dirigido é los dos insignes Leonardos, del cual carece la otra; y las págs. 268 y 269 estủn numeradas por error 262 y $26 j$.

Sedano dice equivoçadamente en el tom. VI. del Parnasn espuñol, que la primera edicion se hizo en Zaragoza en $161 \mathrm{j}^{\circ}$, contra lo sentado por él misino al principio del tom. III. de dicha obra. P'or los preliminares y por el Prólugo de D. Crabriel Leonardo de Albion, hijo de Lupercio, se ve claramente no haber impresion anteriol á las de $\mathbf{1 6 3 4} 4$, las cuales son ya bastante difíciles de encontrar; sobre todo en buen estado.

\section{LEONARDO DE ARGENSO-} La (Lupercio y Bartolomé). Versos de Lupercio Leonardo de Argensola. - Versos de Bartolome Leonardo de Argensola. $4 .^{\circ}$ Manuscrito de unas 300 hojas útiles.

Al ver la antigüedad de este IS., sin duda de los primeros años del siglo XVil; al observar en la mayor parle de las poesias variantes de las impresas, siendo en muchos casos de tal importancia que preden considerarse como composiciones distintas; al encontrar ademas infinitas correceiones interlineadas, $y$ barralas las pallabris $\dot{0}$ versos que debian cambiarse: y al descubrir por tin no estar ni en las ediciones de Zillayoza ni en la reimpresion adicinnada de formandez, quince sonețos y ocho dicimas de Bartolomé, y un soneto, un dístico, un propmin al $\mathrm{Cer}$. támen del Simo. Sucramento. Innas estamzas y treinta tercetos de cierta cartil principiada del Lupereio para su hermano, habia creid? que este codice ela auliugrafo: pero una nola

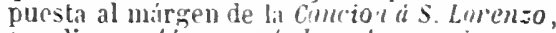
que dice: está enmomiluda esla cancim contfurme al original alel antior, del cual se suro esta quinta estanza. I no hizo mas, me demuestra que aun cuando no sea exacta mi sospecha, esie volimen es aprocialilisimo y de gran autoridad, pues apirece estar confrontado con el original autigrifo, de donde se anotaron las diferencias.

Tanto el presente minuserito como el que describire en el siguiente artículn, son mui inteligibles y ambos proceden de la librería de D. Beruardo de Iriarte: al más antiguo se refiere sin ducla Pellicer en su Biblioleca de traductores espaíules, página 8 .

729 Libro de todas las obras que se han podido recoger de los dos hermanos Lupercio y Bartolome Leo- 
nardo. $4 .{ }^{\circ}$ Volúmen manuscrito de 392 hojas de las cuales hai unas 46 en blanco.

Este manuscrito parece estar hecho hácia la iltima mitad del siglo XVll y debe ser copia del anterior ó sacarlo del original, pues se ha seguido el mismo testo y adoptado casi todas las colrecciones interlineadas en el precedente. Por lo mismo, aun cuando no tenga tanto mérito como aquel por ser algo más moderno, es sumamente apreciable $\dot{e}$ interesante, pues ademas de contener todas las composiciones inéditas, indicadas arriba en el anterior, compren. de al fin de los Versns, el Diálogo de Mercurio y la Virlud que publicó Pellicer en el Ensingo de una biblioleca de traductores, y los de Menipo y Demócrito que no han visto la luz pública. Tambien se hallan los Adverlimientos á los Dipulados del Reyno de Ara. gon, de las parles que ha de tener el perfecto chronista de Bartolomé Leonardo, opúsculo joualmente inédito, denominado por Latasa Discurso hislorial. Cierran el tomo los Af $\mathrm{n}$ rismos de las Primerus carlas de Anlonio Perez; pero no se espresa el nombre de su autor, y sin duda por esta razou dicho Latasa, que vió el presente ifs., los atribuye malamente á Argensola.

Fernández reimprimio las presías de los dos hermanosen los tom. t. il Itl. de su Coleccion, copiándolas de la edicion zaragozana, y añadio dice sonetos y una $\dot{o}$ dos composiciones más, que efectivamente están incluidas en mis códices como escritas por ellos. - Sin embargo de decir Ferníndez en una advertencia, al principio del tom. HII., que los versos no publicados por el hijo y sobrino de los Leonarilos, deben mirarse com apocrifos, porque debiendo este poseer los papeles de sus parientes no hubiera dejado de darles cabida en su impresion ; 10 puedo participar de su opinion, pues ademis de no lener duda acerca de la autenticidad de mi manuscrito más antiguo, en donde hai muchas cosas ineditas, el mismo D. Gabriel Leonardo de Albion observa en su prólogo habia tratido de restituir estos papeles a la verdad de sus originales, favorecidos de sus autores tan poco, que hu silo casi igualmente dificil para mi que pudier'a serlo para un estraño el recojerlos; porque como nunca aspiraron á ganar aplauso, poco inás ralo conservaron sus papoles del que era necesturio para exprinir con la pluma lo que habian coscebido interiormente; y usá salen en publico sin hubelles dudo la última mano.

vo necesitan los Argensolas el encarecimiento de su inérito literario, pues es demasiado conocido de todos; sin embararo, no puedo resistir al deseo de copiar lis tres octivas que les dedica el autor del quijote en el li lib. de su Galatea:

Tu verde y rico márgen, no de nebro $\mathrm{Ni}$ de cipres funesto enriquecido, Claro, abundoso y conocido Ebro,
Sino de lauro y mirto florescido; Ahora como puedo te celebro, Celebrando aquel bien que ha concedido El cielo a tus riberas, pues en ellas Moran ingenios claros mds que estrellas.

Serdn tesligos d'esto dos hermanos, Dos hiseros, dos soles de poesia, A quien el ciclo con abiertas manos Dió cuanto ingenio $y$ arte dar podia: Edad temprana, pensamientos canos, Maduro trato, humilde fantasia, Labran eterna $y$ dina laureola

A Lupercio Leonardo de Argensola. Con santa envidia y competencia santa Parece qu'el menor hermano aspira A igualar al mayor, pues se adelanta Y sube do no llega humana mira: Por esto escribe y mil sucesos canta Con tan suave y acordada lira, Que este Burtolomé menor, merece Lo que al mayor Lupercio se le ofrece.

730 LePanto (Batalla de). Poema catalan en ciento ochenta y cuatro octavas en el que se da una relacion de la batalla de Lepanto. S. 1. ni a. $8 .^{\circ}$ may. 66 págs.

Al principio hai una nota manuscrita de letra del eélehre impresor frances Mr. Joseph Tastı y firmada por él en ia que dice: Poème inédit en langue Cataline sur la Bataille de Lepanthe, Composé et liré à 4 exemplaires pat J. Taslu ancien Typographe. C'est une eprewe en altendant la publication. Dicha publicacion no llegó á hacerse y por eonsiguiente aun cuando el libro está impreso, puede considerarse como inédito todavía.

Mr. Tastu al regalarme el presente ejemplar, que estí sobre papel fuerte y sin ubrir, me aseguró era al parecer del siglo XVI el manuscrito que le habia servido de original, y carecia de título, razon por la cual él ḥabia dejado la obra sin portada.

731 LIAÑO (IsABEL DE). Historia de la vida, mverte, y milagros de santa Catalina de Sena, diuidida en tres libros. Cõpuesta en Octaua rima por doña Isabel de Liaño. Valladolid, Luys Sanchez, 1604. 8. 16 hojas prels., en las que está el retrato de la autora, y 328 foliadas.

Poema dividido en tres libros $₹$ veintlsiete cantos.

Nic. Antonio menciona la yresente obra, pero se conoce nu la vió, cuando no supo dónde se habia impreso. 
El retrato de la autora puesto al principio del vulumen es el siguiente.

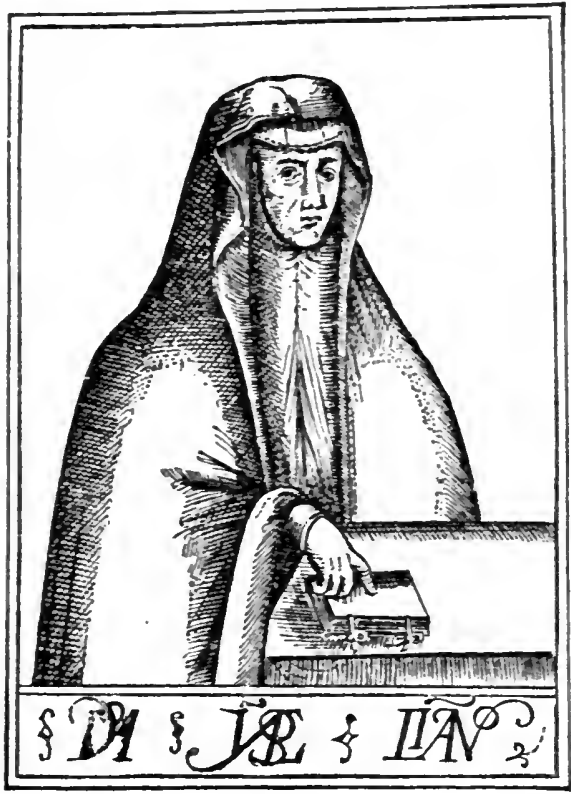

732 LIBROS (Los) poéticos de la santa Biblia, traducidos en verso castellano por D. Tomas José González Carrajal y reimpresos de la edicion española jor D. Vicente Salvá. Paris, Moessard, 1838. 2 vols. $18 .^{\circ}$ Láms. de madera.

Mi padre suprimió las notas de la edicion española, asl es que estos dos lomitos comprenden la castiza y elegante traduccion en verso de los Libros poélicos de la Biblia, esparcida en los doce volúmenes impresos en Valencia y Madrid.

El tomo primero contieate los Salmos y los Conticos suellos del antiguo y nuevo Testa. mento, y el segundo el Libro de Job. el Cántico de los cánticos, la Profecia de Isaías y los Trenos de Jeremías.

733 - Los Salmos. Paris, Moessard, 1838.-Los libros poéticos de la santa Biblia. Paris, 1833. 2 vols. $32{ }^{\circ}$

Estos dos volumenes contienen lo mismo que los anteriores: mi padre al publicarlos en tamaño tan pequeño se propuso fuera mas fácil llevarlos consigo.

734 Lista (Alberto). Poesías de Don Alberto Lista. Edicion ajustada á la de Madrid de 1822, y aumentadá con una composicion del mismo autor. Paris, Herhan, 1834. 18. may.

Edicion publicada por mi padre.

73̈. LÓMAS CANTORAL (JERóNIMO DE). Las obras de Hieronimo de Lomas Cantoral, en tres libros diuididas. Madrid, Pierres Cosin, 1378. $8 .^{\circ} 16$ hojas prels., 243 fols. y yे de Tabla.

Buena y rara edicion. Mi ejemplar lleva la firma del antor al reverso de la portada.

Nic. Antonio se equiroca sin duda, en citar una impresion de 1ร̌̆, yo no conozco sino li del año siguiente.

El Maestro Juan López de Hóyos en una aprobacion puesta al principio dice, que será libro vilil para lu diferencia de canciones, octavas rimas, redondillas, sonetos, sextinas y otros modos de versos que a imitncion dr la porsin italiuna los psfañoles han inventado. Y efectivamente de lodas estas clases de metro usa Cantoral con exilo bdstante feliz: ademas entre sus obras se hallan in. tercaladas algunas produccinnes de Hernando de Herrera. Crisloval de Vendoza, Fran. cisco llontános. Pedro de soria. Iic. Hernan Garcia, Juan de uña y el lic. Lope de Molina.

Cerrintes en el Canln de Caliope dedicólos siguientes versos al autnr:

Si vuestras obras son tan estimadas,

Famoso Cantorab, en toda parte.

Serán mis alab unas escusadas,

Si en mevo modo no os alubo y arte:

Con las palabras mas culificadas,

Con cumbo ingenio el cielo en mi reparte, os admiro y alabo arui callando

Y llego do llejgar no pueso hablando.

736 LOORES en alabança de la santissima Assumpcion de la sacratissima Virgen Maria, para cantar por jornadas. Valeucia. junto al molino de Rouella, 1599. 8. ${ }^{\circ}$ Sin foliacion, signs. A-D. las tres primeras de 8 hojas y de 1 la ulltima.

Libro raro, dividido en catorce jornadas y escrito en diferentes metros: una de las poesias es en valenciano.

La versificacion es fácil, como lo prueba la siguiente composicion:

Sagrada Marfa, hoi es vuestra flesta, que os suben al cielo $\mathbf{v}$ dejais la tierra. 
Subireis vestida de pírpura y seda, toda recamada de oro con perlas ;

Pondrín os corona sembrada de estrellas, chupines labrados de la luna bella;

Tambien os pondrán a la mann derecha los tres que us formaron tan pura y perfeta;

Díros han la silla sobre todas puesta, de todos juriulis por naturial reina.

La celestial corte que veros desea, saldrá á recebiros alegre y contenta;

Sereis recolyida de las castas dieñas, ángeles y sintos, de virgenes bellas:

Entonarin juntos coll vozes perfelas. cantando $\mathrm{y}$ tiñendo flautas $\mathrm{y}$ cornetas.

I d'ellos mirando vuestro ser y alteza, diros han loores en esta manera:

Subid, gran senora; Finix verdadera, que volais tan alto do ningruno allegra;

Subid, linda esposa, en quien Dios se cumplea cual blanca paloura cuya vista alegra;

Subid del desierto á la region nueva, subid, digna madre del que nos gobicrna.

otros admirados de vuestra belleza entre si dirin: quién puede ser esta?

¿Quiṕn es la que sube rual aurora amelia, cual escuadron fuete que un canıpo atropella?

;Quién es la que sube con tantil grandeza que el brazo del liei la tiene y sustenta?

Mostrádnos la cara, celestial princesa, y vuestra voz suene en nuestras orejas.

- Yo soi flor del campo

y blanca azicena, bálsamo oloroso, y mirra y canela;

Soi el cipres alto, palma verde inliesta, plátano apacible, nardo que consuela;

Soi pebete fino, soi ramo de haleña, soi incienso puro y oro que herinosea.

Cual sol fuí escogida, aunque soi morena, hermosa cuil luna sin manclia nj mella.

Soi graciosa oliva, fuente de las huertas, soi cedro ensalzado de firuc madera;

Soi bucrto cercado do Dios se recrea, soi ciudad de Dios y del cielo puerta;

Soi rosa fragante $y$ del mar estrella, cristalino espejo y vara jesea.

Soi la fuerte lorre de David profeta, soi lirio entre espinas pozo de agua elerna;

Soi la zarza ardiente, clara vidriera, area del tesoro, la luz más serena.

Soi la más hermosa de toda judea, cuya dulce boca de miel está Ilena;

Soi la Virgen madre, casada y doncella, soi toda agraciada humilde y honesta.

Soi quien á Satan quebro la cabeza, soi llena de gracia de pecado ajena;

Soi de pecadores la esperanza cierta, el bien de su vida, la paz de su guerra.

Ifoi me da mi hijo la cindad superna, do por siempre goze de su rica lierencia.

737 López (Francisco). Versos devolos en loor de Nvestra Señora, dirigidos a la muy alta y muy pode- 
rosa señora Doña Catherina de Austria Reina de Portugal. Hechos por el doctor Francisco lopez: van dirididos en tres partes, en diuersos generos de cõposicion Italiana T Impressos en Lixboa en casa de Antonio gonsalez, acabaronse de imprimir a xv dias de Setiembre de 157 ó 76 . Años. $4 .^{\circ}$ let. curs. 288 págs., inclusas las dos hojas de prels., y 4 hojas sinfoliacion que contienen una Dedicatoria a la reina Doña Catalina, la fe de erratas y dos sonetos que se omitieron en el cuerpo de la obra.

Poema no mui cornun, dividido en tres partes y escrito en diferentes clases de metro.

Mi ejemplar es mui bello; pero la parte inferior de la portada está un poco recortada $\mathbf{y}$ apénas se puede leer la fecha, por eso la designo de una manera dubitativa, pues sin embargo de parecer 5 el último número de ella podia tambien ser 6 , llevando la tasa del mes de Diciembre de 1574, y un privilegio del rei de Agosto del 75 .

Vic. Antonio se refiere sin duda á la primera edicion de esta obra en la citada por è con el título de Loor de Nuestra Señora en diversos géneros de metros. Lisbna, Antonio Gnsalez, $1573.8 .^{\circ}, \mathrm{y}$ se inflere de sus nismas palabras, que la edicion en $4 .^{\circ}$ de los Versos devolos, úntes deserita, no consiguiọ verla.

Fủe este Francisco López médico de Doña Catalina, reina de Portugal. Hubo otro poeta de igual nombre $\mathrm{y}$ apellido, natural de Lisboa y librero que escribió, segun el mis. mn Antonio, un poema en quintillas intitu. lad): Santo Antonio de Lisboa, primeira $e$ segunda parte, de seu nacimento, criaçaó vida, morte, $e$ milagros. Listoa, Pedro Craes. beck, 1610. 4. Brunet, aunque de una manera incierta, cita una edicion de 1682 , y hace mérito de otro libro de este Lopez que se llama: Ferdadera y santa historia dos cinco murtyres de Marrocos. Lisboa, 16190 1682. $4 .^{\circ}$

738 LÓPEZ PINCIANO (Alosso). El Pelayo del Pinciano. Madrid, Luis Sanchez, M.DC.v. 8. 4 hojas prels., 310 fols., dos blancas y 4 que contienen una Alegoria y la lista de los Vocablos peregrinos.

Poema escrito en octavas y dividido en veinte libros.

Las seis últimas hojas faltan á la mayor parte de los ejemplares, pero se hallan en el mio.

Al parecer Nic. Antonio no llegó á ver esta ubra, pues no menciona ni el lugar ni el año de la impresion.
739 LÓPEZ PINCIANO (AloNso). Philosophia antigra poetica del Doctor Alonso Lopez Pinciano. Madrid, Thonas Iunti. M.D.XCVI. $4 .^{\circ}$ hojas prels. y 536 págs.

Buena edicion.

Montiano y Luyando, en el Discurso sobre las trugedias, cila á la pág. 65, una edicion de 1559 , trasponiendo equivocadamente los dos últimos guarismos.

\section{LOPEZ DE RÓBLES (AX-} DREs). Tarios discrrsos, en qre se declara lo svcedido en la cirdad de Cordora y tierra de su comarca, en los años iue estuuo lastimada de enfermedad de peste, y modo de curalla, y otras cosas que en ello sucedieron. Compresto por Andres Lopez de Robles. Cordoua, Biuda de Andres Bırrera, 16il3. 8. 8 hojas preis. y 144 fols.

Poema en octavas dividido en nueve cantos; su asunto st: colige fácilmente con solo la lectura del tíulo.

La rareza de esia obra escele de mucho it su merito literario. Vic. Antonio no solo no tuvo noticia de ella, sinn que ni aun se halla en la Bibliothec noi a el nombre de Andres López de Robles.

741 LÓPE\% DE VEGA. (xтоvio). Lirica poesia. Por Antonio Lopez de Vera. Madrid, Bernardino de Gilzman, M.DC.xx. 8. 8 hojas prels., 190 foliadas, una para reputir ! as señas de la edicion, y otia blanca.

La treera parle de esta obra contiene esclusiramente porsias jortuguesas.

Vo conocieron el presente volumen ni Ticknor ni sus traductores.

712 El Perfeto Señor. Sueño politico. Con otros varios discresos, i rltimas poesias varias, De Antonio Lopez de Yega. Madrid, Imprenta Real, 1632.406 hojas prels. y $20 \%$ págs.

El Perfeto señor y los Discu'sns son en prosa yocupan una mitad del volumen. El autur advierte en el prólogo que estas obras se habian impreso anteriormente; pero en mui corto numero de ejemplares: á esta edicion probablemente se referirá Vic. Antonio como hecha en Madrit on 1626. $8 .^{\circ}$ Las poesfas del resto del tomo. dice en el mismo prefacio, son las mas selectas de las postreras compuestas por el autor. 
743 LÓPEZ DE YANGUAS (HER- $\mid$ portada está admirablemente ejecuNAN). (El siguiente facsimile de la

\section{Triumplos oe loaña mueuamẽtecompue ftospozllarman lopes deyan guas;:}

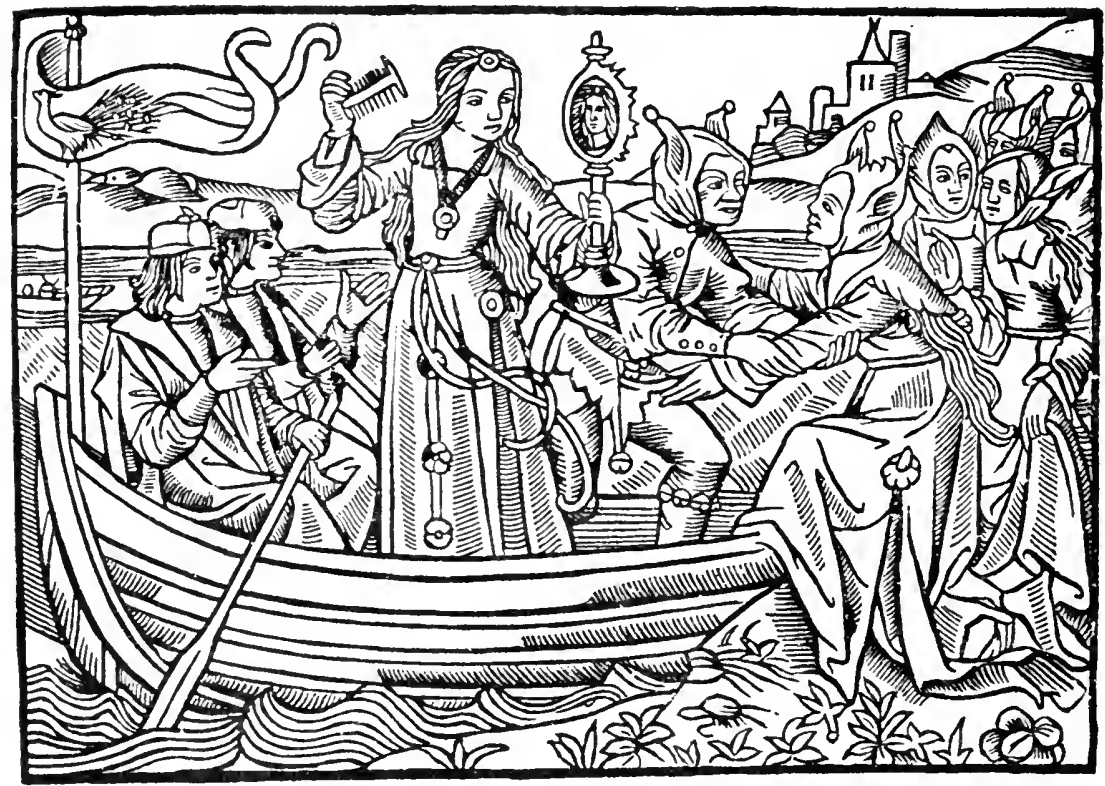

Al dorso principia el prologuito ó epígrafe de que luego hablaré.) S. 1. ni a. (hácia el 1530). 4. ${ }^{\circ}$ let. gót. 12 hojos sin fol. con la sign. a.
Nic. Antonio dice haberse impreso en 152. Acaso habrá otra edicion con esta fecha. El Sr. Duran no logró ver el folleto.

El presente opúsculo de Yánguas es una imitacion de la obra latina de Brandt siul- 


\section{LOP}

DIVERSOS.

tifera navis, traducida al frances con el tItulo de La grand nef des fols, y en ingles con el de The Shyppe of fooles, habiendo ediciones del siglo XY en estas tres lenguas. Yánguas advierte en una especie de prologuito ó epigrafe colocado al frente del poema que lo compuso sobre un dicho latino del sabio que dice:-Stultorum infinitus est numerus, y que su intencion era la de mostrur que cosa es locura y cual prudencia.-Al principio del tratade el autor introduce un diálogo entre él y la locura y esta le obliga á escuchar las hazañas ô triunfos que ha conseguido sobre personas de varias edades $\mathrm{y}$ estadus; se hallan entre ellas la infancia, la adolescencia, los enamorados, los zelosos, los holgazanes, los codiciosos, los escurieros pobres, los cantores, los jugadores, los rústicos, los parásitos, las mujeres, las viejas, los artistas, los gramáticos, los retóricos, los poetas, los lógicos, los astrólogos, los médicos, los juristas, los teólogns, los grandes, los cazadores, los perlados, los clérigos, los religiosos, las monjas, etc.

Como muestras del estilo y rersiflcacion de este autor (tan encomiado en el Didlogo de las lenguas, pág. 150, por su diccion, como de escritor que habia bebido en las fuentes latinas) copiare los siguientes trozos:

Triunfo de médicos.

Los secuazes de Galieno $y$ de Hipocras y Avicena. de mi mano los ordeno, yo les doi muj bien de cena por virtud de mal ajeno. Cuando matan, cuando sanan, siempre medran, siempre ganan, sus trabajos bien se emplean; los enfermos devanean y los médicos devanan; con dos pasos que pasean dos mil presentes les manan.

\section{Prosigue.}

Hago que los más idiotas sean tenidos por Apolos; d'estos hai trescientas flotas, que no tres ni cuatro solos: no hablo en persunas doctas. Pero nota una verdad que te digo de amistad, qu' el peligro y aventura, procede más de la cura que no de la enfermedad; porqu' el más necio procura tentar mayor necedad.

\section{Triunfo de leólogos.}

En la sacra teología bien sé que hai varones doctos, que con prudencia y porfia de mí viven mui remotos y de mi capitania. Mas hai otros principiantes que de nuevo calzan guantes, gue causan admiraciones á todos los circunstantes.
Dice algunas.

Quiero ponerte presentes algunas en que los meto: buscan como hai accidentes en la hostia sin subyecto, con estas otras siguientes. Si san Pedro consagrara en el altar sobre el ara cuando Cristo en cruz pendia: Ł̨qué consagrara aquel dia, o su misa en qué parara? Item, si entónces podia ser hombre Cristo á la clara?

Prosigue.

Mueven más alteraciones, yo soi la que los insisto, si habrá muchas fliaciones en el nismo Jesucristo, con no sé que probaciones. Item, procura saber si en los muertos de comer, despues de resucitados y los cuerpos ya gastados, de qué suerte podrán ser unidos y conformados, sin un pelo fallescer.

\section{Prosigue.}

Luego procuran volar sobre los púlpitos todos, para esgrimir y mostrar las manos hasta los codos, y por los dedos hablar. Buscan nueva introduccion ton tema y salvacion, algunas vezes soñada otras vezes forgicada, y dividen su sermon cada cual como le agrada, para dar prosecucion.

\section{Prosiglie.}

El Evangelio sagrado, que Dios manda declarar, déjanselo entreverado, no lo saben bien mascar porque nunca lo han usado. Es su más principal voto nombrar al subtil Escoto, Y luego á santo Tomas y muchos doctores más. No hablo yo en varou docto porque lleva otro compas que los de mi bando noto.

\section{Prosigue.}

Luego en la parte primera mueven cuestion nui profunda si Adan fue luás, si no fucra, y pásanse à la seguuda, satírica y lastimera. Sudan y lanzan saetas. no acaban hasta completas de decir null de lins vicios hasta que salen de quicios; despues traen dos fabuletas causantes riso y bullicios: este es el fin de sus iretas. 
Triunfo de perlados.

A los notables perlados tambien les manda cordura que siempre estèn ocupados en la sagrada Escritura, curando de sus ganados; pero yo tengo mis mañas y mis cautelas estranas: hágoles poner vicarios y jüezes arbitrarios que pelen bien sus cabañas, porque sean mis tributarios anejos á mis hazañas.

\section{Triunfo de clerigos.}

De los prestes bien podria darte inui largo proceso tal que nunca acabaria; aunque tambien te confieso que muchos dejan mi via. Rapan los quesos y lana y cuanto la Iglesia mana; en los pueblos do residen huélganse que los conviden, más si estí la oveja sana $\dot{o}$ con roña 110 lo piden por tenerme por hermana.

\section{Prosigue.}

Por huir de lo ferial rezan flestas rezagadas, y si rezan bien ó mal o van las horas mascadas no hacen mucho caudal. Desto soi la causa yo cuando con ellos estó, la culpa no me la quites; y quieren más dos ardites que de pitanza les dó, o dos pares de confites que pronunciar bien ó no.

744 LÓPEZ DE ZARATE (FRANcisco). Varias poesias de Francisco Lopez de Zarate. S. I., Viuda de Alonso Martin de Balboa, 1619. 8. ${ }^{\circ}$ 4 hojas prels., 99 foliadas y una blanca.

Primera edicion rala.

Se equivoca Barrera en decir que solo tiene 3 hojas de preliminares.

Supone Sedano, Parnaso españnl, tom. VIII., pág. XXV, copiando á Nic. Antonio, que hai una edicion de Alcald, 1619: la mia creo sea la única existente de este año, y aun cuando no se menciona en ella el lugar de la impresion, debe ser de Madrid, punto donde ejercia su profesion la Viuda de Alonso Martin.

Se reimprimleron estas poesias, mui aumentadas y añadida la tragedia de Hercules furcnte Oeta, en Alcala, 1651.4. Véase en la Seccion dramática, al artículo de Lopez de Zarate.
745 LÓPEZ DE ZARATE (FraNcisco). Poema heroico de la invencion de la Cruz por el Emperador Constantino. Dedicalo al rey nvestro señor Francisco Lopez de Zarate. Madrid, Francisco Garcia, 1648. 4. 2 hojas prels. y 268 fols.

Primera edicion.

Poema en octavas dividido en veintidos libros.

Se tiene á I.ópez de Zarate por uno de los buenos poetas de nuestro siglo de oro, y asi le juzgó tambien Lope de Vega cuando dijo de él en su Laurel de Apolo:

Qué segura que pide la Rioja
para el famoso Zirate su hijo,
con justo de las musas regocijo,
todis un laurct, sin que le falte hoja;
tan bien debido, cuanto dulce suena
la pastoril avena,
que Erato cntre bucolicas aluba
en los bosques sombrios:
árboles compañeros de estos rios.

746 LOSA (Andres de la). Verdadero entretenimiento del Christiano, en el qual se trata de las quatro postrimerias del Ilombre, que son: Muerte, Iuyzio, Infierno, Gloria. Compvesto en verso de Otaua Rima por Andres de la Losa. (Al fin:) Fve impresso en Sevilla en casa de Alonso de la Barrera impressor de libros Año de. 1584. 4. ${ }^{\circ}$ iz hojas prels., 119 fols. y una con la fecha y demas señas de la impresion.

Primera edicion, mui rara, de este poema dividido en cuatro cantos.

Buen ejemplar que perteneció al laureado poeta ingles Robert Southey, cuya firma lleva en la portada.

Entre las poesias laudatorias del principio hai una cancion de Juan de la Cueva.

Andres de la Losa escribió otro poema as. cético-caballeresco, intitulado: Batalla $y$ triunfo del hombre contra los vicios. Véase Losa. Seccion novelística.-Libros de caballerias.

$747-$ La misma obra. Pamplona, Cárlos de Labèyen, 1617. 8.' 8 hojas prels. 98 fols. y una para repetir las señas de la edicion.

En la portada de esta impresion y en una de las aprobaciones se llama al autor equivocadamente Andres de la Losada.

Tambien es rara la presente edicior

748 LOZANO DE CORDOVA (Sebastian). Poema tragico a la 
passada ocasion de la Peste de Napoles. Compuesto por el Doctor Don Sebastian Lozano de Cordoua. Cosençia, Iuan Bauptista Ruffo, 16:5. 4..$^{\circ}$ hojas prels. y 51 págs. circuidas de orla.

Consta de cien octavas.

vic. Antonio no menciona en su Bibliotheca á Sebastian Lozanı de Córdova.

\section{LOZANO Y REGALADO} (Gispar). Loores de los Santos de quien reza $\mathbf{y}$ hace comenoracion la Yglesia de L̆oma, y las de España, con los Santos, que en particular celebra la de Leon, por los meses del año. Por el Licenciado Gaspar Lozano y Regalado. Valladolid, Iuan de liueda, 1619. 8. 8 hojas prels. $30 \stackrel{ }{0}$ fols. y 8 de Tabla.

Obra del género do los Conceptos de Ledesma, escrita en toda clase de metros $\mathrm{y}$ de un mérito más que mediano.

Nic. Antonis no logró ver esta obra y Ia cita de oidas.

El mismo Lozano publicó en Valladolid, 1624, unos Nhev'ns Conceptos espirituales que describo al hablar de los de Ledesma, Núm. 721.

750 LUCANO. La liystoria que escriuio en latin el poeta Lucano: trasladada ẽ castellano por Martī Lasso de Oropesa secretario dela excellête señora marquesa d'I zenete cōdessa de Nassou.: (Este título de negro y colorado se halla dentro de una especie de capilla; siguen despues del fróntis nueve hojas sin foliar; en la undécima principia el fol. j., y la obra termina en el reverso del cliiij con el siguiente colofon:) I Aqui se acaban los diez libros de las guerras ciuiles que compuso en verso heroyco el famoso poeta Lucano traducidos en romance castellano por Martin Laso doropesa... Jmprimierōse enla insigne ciudad d' Lisbona a . xx. d'mayo. d' inil c quniētos y quarēta y vn años (10̈41): por Luys Rodriguez librero del Rey nosso sēnor. $40^{\circ}$ let. gót. 10 hojas sin foliar y cliiij fols.

Es probablemente la primera edicion de esta traduccion en pros: de la Farsalia de l.ucano desconocida á Nic. Alıtonio y á Pellicer. Este dice que el Sr. Lorga vió una en cuya segunda hoja estaba el escudo de armas de Cárlos V entre las dos colunas, al plé de él se leia: Apud Guillictmum Millis, $\mathrm{y}$ en las bases de las colunas, en una 1 . V. (acaso Impressum Vallesoleti), y en la otra MDXLItII. fol.

Se cita, no recuerdo donde, una tercera cdicion de Colonia, 1:50.

7 L LCAYYo. Lvcano poeta, y historiador antigro: Én que se tratan las guerras Pharsalicas, que tuuieron Iulio Cesar y Pompeyo. Traduzido de Latin en Komance Castellano, por Martin Lasso de Oropesa. Anvers, Pedro Bellero, 1585. 8. $^{\circ} 8$ hojas prels. y 397 págs.

Edicion copiada de la primera de Lisboa, y desconocida tambien á Yíc. Antonio y á j'ellicer. Este cita otra inıpresion de Anvers, Juan Cordier, $158580^{\circ}$ la cual parece contiene el testo de la de Bcllero ántes descrita.

792 Lrcano tradvido de verso latino en prosa castellana, por Martin Laso de Oropesa. Nueuamente corregido y acabado con la Historia del Triunuirato. Dirigido al Illustre Señor Antonio Perez, Secretario del estado del rey don Phelippe Segundo. Bvrgos, Phelippe de Iunta, MDLxxxvil. ( $\mathrm{Al}$ fin 1078.) fol. 9 hojas prels. inclusa una de $\mathrm{Fe}$ de erratas y 411 pags.

La rerdadera fecha de esta edicion es la de 1578 como lo demuestran las licencias, aprobaciones y dedicatoria que van al principio; sin embargo la coloco despues de la de 1585 , porque esta es una inera reimpresion de la primitiva, mientras la de Burgos contiene muchas variaciones y correcciones y la adicion de los tres libros del Triunvirato. todo locual dejó manuscrito á su muerte Martin Laso y lo publicó, por primera vez, su heredero Juan Bautista Bonello, en dicha edicion burgense. Como Nic. Antonio no conoció ninguna más antigua, comete la equivoca. cion de suponer que la traduccion de Lucano es obra póstuma.

733 - La Farsalia, poena español, escrito por Don Ivan de Iavregui y Aguilar. Sacale a lvz SebasLian de Armendariz. Madrid, Lorenzo Garcia, (1684?). 2 partes en un volúmen 4. "La primera parte 18 hojas prels. y 239 fols., y la segunda 111 fols. 
Edicion primera de esta traduccion ó imitacion hecha en octavas.

Desde el fol. 82 al flin de la segunda parte se halla el orfeo, poema de D. Juan de Jáuregui ya impreso por separado en Madrid en 1624 é incluido más tarde, no sé porqué, entre las obras de Salazar y Tórres como produccion de este.

Fernández reimprimió ambas nbras en los tomos VII. y vilI. de sil Coleccion de poetas.

LUQUE (JUan DE). Divinas poesias Y varios conceptos. Véase en la Seccion dramática.

734 LUZAN CLARAMUNT DE SUELYES Y GURREA. (IGNac10). La
Poetica, ó reglas de la poesia en general, y de sus principales especies, por Don Ignacio de Luzan Claramunt de Suelves y Gurrea: corregida y aumentada por su mismo Autor. Madrid; Don Antonio de Sancha, HocclxXXIX. 2 vols. $80^{\circ}$ may.

Se tiraron algunos ejemplares en gran papel ; el mio es uno de ellos.

La prinera edicion se publicó en Zarago. $\approx a, 1757$. fol. : la de Sancha comprende todas lds adiciones y correcciones hechas por el autor en un ejemplar que poseia Llaguno $\mathrm{y}$ Aunirola, y además lleva al principio una noticia biográflca de Luzan, escrita por su hijo D. Juan Ignacio.
73̋ MALON DE CIIAIDE (PEpro). Libro De la conuersion de la Magdalena, en que se ponen los tres estados que tucio de pecadora, y de penitente y de gracia... Cópuestō por el maestro F. Pedro Maló de Chaide. Alcala en casa de Iuan Graeian que sea en gloria, $1393.8 .^{\circ} 4$ hojas prels., 346 fols. y 14 de Tabla.

Tuye una edicion de esta obra hecha tambien en Alcala, por Jurun Iñiguez de Lequerica en 1.592. 8. 'o la cual, ignoro porque, suponen primera Capmany y Ticknor, cuando Nic. Antonio trae otra de Barcelona, 1588. s. $^{\circ}$ cuya existencia confirman las cuatro aprobaciones que llevan al principio las de Alcalá de 1592 y 9.3 y tambien la siguiente.

736 - La misma obra. Alcala, Iuan Iñiguez de Lequerica, $1396.8 .^{\circ}$ i hojas prels., 346 fols. $y$ 14 de Tabla.

Edicion hecha á plana renglon con la anterior de 1592; aunque perfectamente distinta.-Capmany cita cuarta y quinta impresion complutenses de 1598 y 1605 y una sesta de Barcelona, 1598, en mi concepto dudosa. La última será la de Madrid, 179\%. 4. ${ }^{\circ}$ mencionada por Böhl en la Floresla.

La Conversion de la Magdalena es tan apreciable pur su prosa como por sus versos; asi es que el citado Capmany en el Teatro de la elocuencia dice: :es preciso confesar, que su - estilo por lo general es brillante, pintores-co, y donoso, y que en algunos lugares - abuida de rasgos sublimes. A las vezes - hermosea y realza las cosas mas estériles -y comunes con una energia incomparable, -así por la grandeza de las ideas, como por "la viveza de las imágenes de que están, ha-blando cols propiedad, esmaltadas algunas ade sus frases.,

737 MANRIQUE (JoRGE). Glosa Famossisima. Côcupan el resto de la portada, circuidos de orla, el escudo de armas de los Estúnigas y los si. guientes versos:)

1 La vanda y cadena son ciertas señales D)e armas y gloria de hechos nombrados be stuñiga fueron los antepassados Que aquesta dexaron por ser immortales Fineron fundadas jor cosas reales l) igosas de toda perpetua alabança (ive acrora se hallan no menos mas tales En este que es quito de no transuersales En quien tienen puesta muy firme su estancia.

(Al reverso del frontis principia el Prologo de la obra hecha y cōpuesta por el licenciado Alonso de ceruantes: sobre las coplas de don Jorge mãrrique : $\bar{q}$ hizo sobre la muerte de su padre...). S. I. ni a. (hácia el 1525). 4. ${ }^{\circ}$ let. gót. 20 hojas sinfol. con la sing. a.

758 Glosa famossisima $(E s-$ ta leyenda se halla en la presente edicion á la parte inferior de la portada precedida del escudo de armas y lo: versos copiados al describir la anterior. El Prologo tambien principia al reverso del fróntis y consta como la 
anterior de 20 hojas con la sign. a.) S. 1. ni a. (hácia el 1525). $4 .^{\circ}$ let. gót.

Ademas de la notable contraseña de llevar la presente edicion el titulo de Glosa famos. sisima en la parte inferior de la portada, hai tamblen gran diferencia en el escudo de armas, pues no tiene como el de la anterior un ángel á cada lado, y la banda que lo atraviesa va en esta de derecha á izquierda y en la otra es al contrario.-Ambas ediciones son rarisimas.

En la biblioteca del Hon. Th. Grenville vi otra edicion tambien de 20 hojas, sin fecha ni foliacion en $4 .^{\circ} \mathrm{y}$ de let. gót.; pero llevaba las signs. $a-b$.

Tambien he tenido ocasion de examinar un ejemplar de la primera edicion de esta Glosa de Cervántes, impresa en Lisbua, Valen/in Fernandes, 1 5̆o1. fol.; no doi aquí su descripcion bibliográflca porque-Brunet la trae con bastante exactitud.

En el Ensayo de una bib. esp. cita Gallardo la impresion de Cuenca, Por Juan de Canona, M.D.Lij. . $^{\circ}$ let. got. 16 hojas con las signaturas $A$ y $B$.

Nic. Antonio no habla en su Bibliotheca de Alonso de Cervántes.

Las coplas de Manrique sin glosa se imprimieron: en el Cancionero de D. Inigo de Mendoza, edicion $s$. $l$. ni a., pero sin duda de Zamora, Centenera, hácia 1480 ; en los Cancioneros impresos en Zal'agoza en 1492 y 94 en Sevilla sueltas en 1494, segun Nic. Antonio, lo que dudn; en el Cuncionero de Ramon de Llabia, edicion del siglo XV; en la Vision deleilable del Bachiller la Torre de Ferrura, 1554; con el Centon epistolario de Cibdareal, Madrid, 1775, y compendiadas ó mas bien cercenadas, las publico Bartolomé Rodríguez al fin de su vida de $S$. Roque. Bruselas, 1657.

759 MANRIQUE (Jorge). Glosa sobre la obra que hizo Don George Manrrique a la muerte del Naestre 'de Santiago don Rodrigo Manrrique su padre. Con otro. Komance $\mathrm{y}$ su glosa. (Anvers, Martin Nucio,) M.D.XCIIII. 12. ${ }^{\circ}$ Carece de foliacion.

Es la edicion de la Glusa de Francisco de Guzınan unida á los Proverbios de López de Mendoza impresos en 1594 por Nucio, asi es que sus signaturas son: seis hojas de la $\mathrm{M}$, doce de la $\mathrm{N}$ y 0 y seis de la P. - La primera impresion es probablemente la de Martin Nucio, 1558 puesta á continuacion de dichos Proverbios y la última la hecha por Villalpando en Madrid, 1799. 12..$^{\circ}$, unida Lambien al Cenliloquin del Marqués de Santillana. Al principio de la obra se encuentra un Prohemio de ella en trece octavas, doce de las cuales encierran el acróstico siguiente: $A$ la muy alla y muy esclarescida pryncesa madaina Leonor reyna de Francia su muy umilde servidor Francysco de Guzman.
760 MANRIQUE (Jorge). Glosa famosa sobre las coplas de don Iorge Manrrique. Compuesta por el protonotario Luys Perez. (Al fin:) Se imprimió... en Valladolid en casa de Sebastian Nartinez. Acabosse a doze dias de mes de Abril. De M.D.LXI. 4. ${ }^{\circ} 63$ hojas foliadas, incluso el fróntis y preiiminares, y una al fin sin numerar, con.la fecha y lugar de la impresion.

No comprendo cómo al describir Brunet la portada de esta edicion añade á lo que yo he copiado: con otru obra muy contemplativa a la virgè nuestra señora, pues en mi ejemplar no se lee semejante cosa y tiene la portada perfecta. Donde se leia lo dicho por Brunet es en otra edicion examinada por $\mathrm{ml}$, hecha por el mismo Sebastian Martinez en Valludolid el año de M.D.L.XIII. $44^{\circ}$; a pesar de tener solo como la de 1561,65 hojas foliadas y una con un largo cclofon. ¿Si será la obra contemplaliva una especie de dedicatoria á la Virgen, en verso, puesta al fol. 62 que se intitula Loores a Vuesira Señora!

761 Las coplas de Don Jorge Manrique, con una glosa muy devota y christiana de un religioso de la Cartuja. Ya juntamente un caso memorable de la conversion de una dama. Con las cartas en refranes de Blasco Garay. Con un Dialogo entre el amor y un caballero viejo. Compuesto por Rodrigo Cola. (Al fin:) Impresso en Alcala en casa de Francisco cormellas y Pedro de Robles año 1ว̋64. 12. 4 hojas prels., una sin numeracion con que principia la obra, 103 folios hasta el primero del Dialogo inclusive, y 12 hojas mas sinfoliar, comprendida la de la fecha.

A mi ejemplar le falta el fróntis y por lo mismo no respondo del que yo he formado en vista del contenido del volumen.

Brunet menciona otra edicion del mismo lugar impresa por Andres Angulo, 1570.12. ${ }^{\circ}$ de 209 hojas; y he visto una en cilyo título dice: Coplas di Don Iorge Manrique. Con vna glosa muy deuola y chrisliana, de un religioso de la Carluxa. Van añadidas las Coplas de Mingo Reuulgo, glosadas por Hernando del Pulgar... Asimesmo las cartas, en refranes de Blasco de Garuy. Huesca loan Perez de Valdiuielso, 1584. 12. Sin foliar, signs. $a-n ;$ y otra de Alcala, Hermun Ramirez, $1588.12 .^{\circ} 222$ fols. Me parece el contenido igual al de la otra edicion del mismo pueblo de 1564 . 
762 MANRIQUE (JoRge). Las Coplas de Don Iorge Manrique, con vna glossa muy deuota y christiana de vn Religioso de la Cartuja. Va juntamente vn caso memorable de la conuersion de vna dama (enverso). Assimismo va aora nueuamente añadida la glossa de Mingo Reuulgo, y las cartas en refranes de Blasco Garay...Con vn dialogo entre el Amor, y vin Cauallero viejo. Compuesto por Rodrigo Cota. Va tambien la Doctrina del Estoyco Filosofo Epicteto, traduzido de Griego por el Maestro Francisco Sanchez el Brocense. Madrid, Yiuda de Alonso Martin, 1632. 12. 6 hojas prels. y 246 foliadas.

El cartujo autor de esta glosa es Fr. Rodrigo de Valdepiñas. Brunel se reflere á una edicion hecha en Alcala de Henares, Andres de Anoulo, $1570.12 .^{\circ}$ euvo contenido es igual al de la mia ménos la Doclrina de Epicteto. En el Prólogo de la edicion de las Coplas de Nanrique, hecha en 1779 , se cita otra impresion de la presente glosa de Sevilla, por Alonso picardo, $1577.12 .^{\circ}, y$ su licencia, fechada en $15 \% 2$, hace presimir existe una de este año; Barrera mencinna varanente la de 1588 , y en el Prólogo álıtes indicado se habla de la de Madrid, Juan de la Cuesla, 161.1. 12.0

763 Glosa sobre las coplas de don Jorge manrrique. (Ignoro el verdadero título de esta obra, pues le faita la primera hoja á mi ejemplar. Al fin de la última selee:) Impressa en Ualencia / en casa de Joan Nauarro. A ño. 1วั76. 4. ${ }^{\circ}$ let. gót. 14 hojas sin fol. con la sign. a.

Edicion rarisima y desconocida á nuestros bibliografos. Esta glosa es la de Jorge de Montemayor que se halla en sus obras impresas en Anvers, 15ắ. Como no la incluyó en su edicion el editor de las Coplas de Manrique, Madrid, 1779, copiaré á enntinuacion las cuatro primeras coplas y por ellas se verá que puede competir en mérito literario con las de Alonso de Cervíntes, Guzman, Pérez y el Cartujo.

Despierte el alma que osa estar contino durmiendo, y luego irá conosciendo que no pulede esperar cosa que no se pase en viniendo. No fle tantio en su vida mire que dice la inuerte vozeando: recuerde el alma dormida, avive el seso $y$ despierte contemplando.
Contemple el entendimiento lo que ha sido y podrá ver, lo que es, como ha de ser, -y entenderí el fundamento de su ganar ó perder: imagine su caida, tema aquel juicio fuerte, no olvidando,

cómo se pusa la vida, como se viene la muerle tan callando.

Mira pecador por ti, hazte á ti obra de amigo, entra ya en clionta contigo que quien se olvida de si de sil alma es enemigo. I si esto quieres hicer, has de mirar con cuidado $\mathrm{y}$ aun temor, cuán presto sé va el placer. como despues de acordado da dolor.

Porque si ves el pasar ternás en poco el venir, y aborrescerás subir si en llegando á aquel lugar te has por fuerza de partir. Pues si no hai cosa en un ser ni bien que no haja dejado más dolor, ¿cómo á nuestro parescer cualquiera tiempo pasado fue mejor?

764 MANRIQUE (JoRGE). Coplas de Don Jorge Manrique, hechas a la muerte de su padre Don Rodrigo Manrique con las glosas en verso á ellas de Juan de Guzman, del P. Don Rodrigo de Valdepeñas, monge cartujo, del protonotario Luis Perez, y del Lic. do Alonso Cervantes. Madrid, Antonio de Sancha, M.DCc.LXXIX. $8 .^{\circ}$ marq.

Es la mejor edicion por contener todas las glosas heehas á las preciosas coplas de Jorge Manrique, ménos la de Jorge de Montemayor, impresa en Valencia en 1576 , deserita en el art. anterior, y la de Gregorio Silves. tre que se balla en las obras de este poeta.

intes de terminar el presente articulo anotaré una Glosa de moral senlido a las famosas y muy excilentes Coplas de Don Jorge Manrique, en prosa, euyo autor es Luis Aranda, la eual concluye en el fol. Ixiiij vuelta con estos versos:

I Aqui se acaba la glosa ques de sentido moral hecha en elerante prosa vlil $y$ muy prouechosa con priuilegio Real.

En Ualladoli imprimida a su costa del auctor por el mesino corregida lela offecina salida de Cordoun el impressor. 
Sigue el escudo del Angel de que usaba este impresor. $4^{\circ}$ let. gót.

Segun el Prólogo de la edicion de 1779 de las Coplas de Manrique, el privilegio para esta impresion es de 10 de Abril de $1552 \mathrm{y}$ sin duda se hallará al reverso de la portada que faltaba en el ejemplar visto por $\mathrm{ml}$. Nic. Antonio dice terminantemente Pincice apud Didacum Fernandez. 1552.

Tambien se menciona en dicho prólogo otra obra de Luis Aranda que se denomina: Glosa intilu'ada segunda de Moral sentido, a diferencia de otra de este nombre, a los muy singulares Proverbios del Ilustre Señor D. Iñigo Lopez de Mendoza, Marques de Santillana Contienese yas en este libro olra Glosa a $X X I V$. Coplas de las CCC. de Juan de Vena. Granada, Hugo de Mena, M.D.L.XXY. . $^{\circ}$

Antonio menciona otra edicion de 1578; no sé si será equivocacion de fecha.

En el Ensayo de una bib. esp. sc anota la siguiente obra de este Luis de Aranda: Obra nuevamente hecha, inlilulada Glosa Pcregri$n \boldsymbol{~}$, purque va glosando pies d'diuersos Romàces. Va reparluda en cinco Canlicos. É primero de la Cayda de Lucifer. El segunds de la desobediencia de Adã. El tercero de la encarnacion de nuestro Redemplor. El quarlo de su muerte y pasion. Et quinto y vltimo de su Resurreccion. Seuilla, Alóso de la Barrera. Aino de M.dcuij (1607) ó quizás falta una $\mathrm{x}$ entre la $d$ y la $c$ y sea $1597.4 .^{\circ} 8$ hojas, let. gót.

763 MANSILLA (Cristóval). Jnuectiua contra el heresiarcha Luthero. Cōpuesta por el mur reuerẽdo padre fray Christoual Másilla / de la orden de los predicadores. Dirigida al muy Jllustre señ̃or dó Pedro Fernãdez de Cordoua / cōde d' Feria. rc. M.D.L.II. (Este tílulo va precedido del escudo de la órden de Santo Domingo y todo circuido de orla ancha. Al dorso principia el Prologo ó dedicatoria que termina en el blanco de la hoja siguiente sig. Aij; el reverso y casi todo el recto de la Aiij lo llenan unos versos latinos de Andres Bonilla en elogio de la obray su autor: en seguida Comiençan las maldiciones conira el heresiarcha fray Martin Luthero, que concluyen en la segunda hoja de la signatura $\mathrm{C}$ verso, con el siguiente colo/on:)

(I Jmprimio se la presente obra en la muy noble y mas leal ciudad d'Burgos i en casa de Juã de Jüta. Acabo se a veynte dias del mes de Agosto / año de mil y quinientos y cinquenta $y \operatorname{dos}\left(15 \mathrm{~J}^{2}\right)$ años. 4. ${ }^{\circ}$ let. got. Sin foliacion, sign. A-C de $\mathbf{8}$ hojas las dos primeras, y de 2 la última.
Ni Nic. Antonio ni ningun otro bibliografo que yo sepa mencionan á este autor ní conocieron su rarisimo tratadito.

Como muestra del metro en que está escrito y de la mansedumbre evangelica, piadosa indulgencia, y caridad cristiana que animaban al reverendo Padre Mansilla, copiaré un par de estanzas, tomadas al acaso, pues en todas respira igual templanza y moderacion. 'Se dirige á Lutero:

I al olor inflcionado de tus carnes maculosas mal olientes, salga cuanto se ha criado de las cosas ponzoñosas y serpientes: y dejando escondedijos, $\mathrm{y}$ las cuevas abrigadas $y$ latebras,

vengan parientes é hijos, ejércitos $\mathrm{y}^{-}$manadas de culebras.

No venga el escorpion, ni la víbora cerrada no te viese, porque no es justa razon que serpiente tan honrada te comiese:

mas esotras más villanas, como escuerzos y lagartos pintadillos, con sus bocas inhamanas, te hagan partes y cuartos menudillos.

766 MARCH (Mosexínias). CLas obras del famosissimo philosofo y poeta mossen Osias Marco cauallero Ualéciano de nacion Catalan / traduzidas por don Baltasar de Romani / y diuididas en quatro Cantares: es a saber: Cantica de amor / Cantica Moral / Cātica de Muerte / y Cantica Spiritual. Dirigidas al excellentissimo señor el durue de calabria.Anno. M.D.XXXIX. (Este título de negro y colorado ia circuido de una hermosa orla, y precedido de un escudo de armas. Ai dorso: Epistola. E Epistola de don Baltasar de Romani al excelentissimo señor el Duque de Calabria. etc. En la hoja sig. que es fol. II sign. aij empieza Cantica de Amor. En el blance de la hoja cxix dice:)

\footnotetext{
¿ Ha sido impresa la presente 0 bra enla muy noble ciudad de Ualencia Por Juan Nauarro. Acabosse á diez del mes de Marco Año M.D.xxxix.
}

Fol. let. gót. Sign. desde a hasta la 
sétima hoja de la p; hai despues una hoja en blanco. Cada página contiene cuatro estancias, dos del original y dos intercaladas de la traduccion castellana en verso.

Primera edicion.-Rodriguez, en su Biblioteca valentina, habla de haber visto otra edicion hecha tambien en 1.59 por el mismo impresor, en letra ciceroniana ó redonda, en cuya portada se llamaba al autor Ausias March, Poela valenciano, en lugar de Osias Marco, caballero valenciano de nacion catalan; pero observa que la que él poseia era la gótica. Jimeno copió lo dicho por su antecesor Rodriguez, y Cerdá en las notas á la Diana de Gil tolo, repitió el aserto de ambos. Nada tiene de estraño el que Brunet participe de la misma opinion, al verla repetida de una manera tan terminante por escritores valencianos. Sin embargo pues, de la seguridad con que Rodriguez publica la noticia, y la minuciosidad en deseribir las va. riantes de las portadas, me atrevo á ditdar de su exactitud, ya por parccerme imposible que en un año imprimiese Navarro dos vezes la obra, como por no conocer ninguna edicion de este tipografo hecha en letra redonda. siendo tantas las obras que imprimió. Por lo tocante a Brumet, este se apoya en un hecho inexacto, pues supone de letra romana el ejemplar de la venta de Gohier, siendo el mismo descrito en el ním. 700 dé nuestro catalogo de Paris de 18.5 , que era positivamente de impresion gótica. La prueba para mí más fuerte contra la existencia de las dos ediciones es, la de que todos los ejemplares que he consultado pertenecen al uma misma sin haber encontrado quien haya visto ninguno de la otra.

in entra en mi plan el estenderme muclio para rebatir la calificacion de calılan dada en el fróntis de la cdicion de $\mathbf{1 5 5 9}$ á Ausias March; Cerdi, Jimeno, Fuster, sarmiento y sobre lodos Burrull prueball de una manerd indudable que fue valenciano, concediendo i lo más ser de estirpe catilana. El canónigo Tárrega, en la Lou á su comedia La fundacion de la Merced, llama á Jarch valenciano á boca llena.

Notaré aquí para terminar, que la edicion de Valencia viene á contener poco más de un tercio de las poesias comprendidas en las de Barcelona y Valladolid; $y$ aun en las incluidas faltan las Tornadas del fin, y los pareados que suclen agregarse al remate de las octaras, los cuales solo se hallan en el cap. I de la Cánlica de muerle; que ademas los cantos puestos estín á vezes faltos de estrofas enteras: $y$ que si bien el cap. XXIII del fol. XL vuelta, el IX de la vuelta del fol. CII y el III del fol. CXVll vuelta, tienen unos principios diversos de los anotados en el Indice atfabético de la edicion de Barcelona, es de creer que aquellos tres capitulos compondrán alguna parte de los muchos que esta tiene $\mathrm{y}$ faltan á la primera valenciana.
Nada advertiré sobre la estraordinaria rareza de la impresion de 1559 ; es demasiado conocida de todos para detenerme en acumular pruebas justiflcativas.

\section{MARCH (Mosen Áusias).}

\section{LES OBRES DE MOS SEN AV SIAS MARCH}

AB VNA DECLARA TIO EN LOS MARGES.

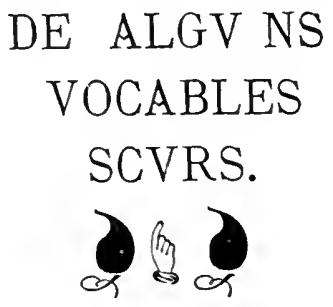

(A esto se reduce toda la portada. Sigue al dorso la Tavla que tiene dos hojas más y despues hai una en blanco. En la 5. $^{\text {a }}$ fol. I sign. A principian Les obres etc. que concluyen en el blanco del fol. CLXXII. asi:)

Foren Impreses y acabades les obes del extreu caualler mossen Ausias March en la insigne Ciutat de Barcelo

na p mestre Carles amo ros Prouençal Lany

M.D.XL.III. A.XXII.

del Mes De desembre.

4..$^{\circ}$ Signs. A hasta $\mathrm{Y}$, segun se espresa en la última hoja, en el registro, 
donde se añade: Totes estes letres son quaderns excepto $Y$ grega qu's duern.

En la toja LXXXij se ha repetido por equivocacion la estrofa

Yo conlrafac, nau, en golf perillant

y la que le sigue

Ma voluntal ab qu'en la mar fuy mes

y su Tornada

Plena de seny nos pol ben sofferir, pues ya se habian puesto en el fol. XLII.

Primera y hermosa edicion de las obras complelas de este autor.

Los ejemplares bien tratados y sobre todo si conservan sus bellísimas márgenes, se encuentran con suma diflcultad. El mio por su estado de conservacion tal vez sea único.

768 MaRCH (Mosex Áusias).

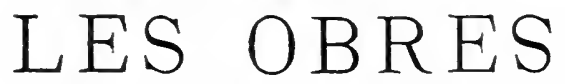

DEL VALEROS Y EXTRE

NV CAVALLER. VIGIL

$\mathrm{Y}$ ELEGANTISSIM PO

eta Aufias March. Nouament

reuifles y eftampades ab

gran cura y dili=

gencia. $\mathrm{Po}$

Sades

totes les

declarafions

dels uocables Scurs

molt largamèt en la taula.

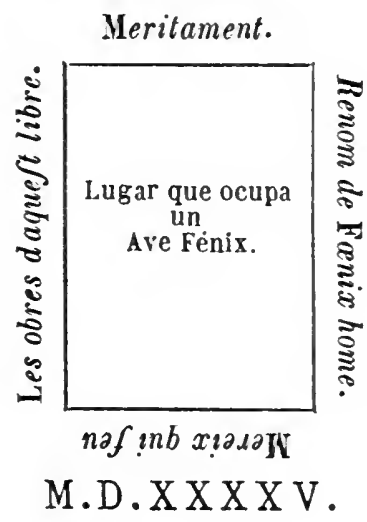

Toy. I.
(Al dorso la Taula que tiene otras tres hojas con t por sig., y en la $5 .^{2}$, fol. j sign. A, empiezan Les obres que concluyen al dorso del CLxxij con el siguiente colofon:)

Foren impefes y acabades les obres del extrēu caualler mosse日 Ausias March en la in signe Ciutal de Barcelona per Car les amoros Prouencal en lany

M.D.xxxxy.a. xxij. del mes de Desembre. $8 .^{\circ}$

\section{标}

En el prólogo puesto por D. Luis Carroz en un MS. de las obras de Yarch, fechado en 156 , que cita Jimeno, dice que para copilar aquella copia se habia valido de varios códices antiguos, $y$ de las dos ediciones hechas en Barcelona, por órden del almirante de Nápoles D. Fernando de Cardona, la primera del 22 de Diciembre de 1545 y la segunda de igual dia y mes de 1545. Effectivamente el editor de la de 1560 , Claudio Bornat, al dedicar su impresion al dicho Cardona conflrma la asercion de Carroz, y añade, que sin embargo de ser bastante considerable el numero de ejemplares tirados, ya habia falta de ellns. Si esta escasez se hacia sentir á los quince $\mathrm{y}$ diez y siete años de publicadas i cuánta no sera su rareza tres siglos despues!

La edicion de 1545 es una reimpresion de la publicada dos años ántes, con la única diferencia de que la interpretacion de las palabras oscuras ú dificiles, puesta al márgen de la primera, en esta va colucada por órden alfabético, tras de la tabla.-Jimeno equiroca el tamaño de la presente edicion, pues dice ser el de 4.0

769 March (Mosey Acsias). - Las obras del poeta Mosen Ausias March, corregidas de los errores $\bar{q}$ tenian. Sale con ellas el rocabulario de los vocablos en ellas contenidos... Impresso en Valladolid, Año de. 1 วัว̆ว̆. CEste título va precedido de un esculo de armas. En el blanco del fol. 210 acaban las Obras $y$ al dorso se encuentra la fé de erratas; en el $\$ 16$ principia la Tabla y al recerso del $218 \mathrm{em}$ pieza el Yocabrlario para las obras del poeta Ausias March: cópuesto por Ioan de Resa capellan de su Magestad, el culal va precedido de algunas reglas para su uso y de dos octacas de Jorge de Montemayor en elogio de dicho Resa. En el blanco del fol. 276 termina el Diccionario y la obra de esta manera:) 


\section{FUE IIPRESSO EL}

\section{PRESENTE TRACTADO}

en la muy noble villa de Valla dolid. Iúto a saut An dres. En casa de Se

bastiā Martinez, im pressor. Acabose de Imprimir a rernte dias d'Febrero

Año. De. 1333 ว. Años.

8. ${ }^{\circ}$ Signs. A-MIII, incluyéndose en ellas las 6 hojas de fróntis y prels.

En un ejemplar de esta edicion en poder de D. Manmel de Bufirmull, se tee al fin del epitome de la vida de Varch. que va al principin, en una nita us. al partecer de flues del sign XVI: Frameres Hirrouly Ramo a de. mandu de serta soñor nubte intençiana escrigui molt alifusmment la uila det mugnific y estrem caualler mosen Atsins Maroh.No encuentro en Jimen ni Fuster mencion algma de este frameisco Jeronimm Ramon, chya biografía de llarch seria un feliz hallazgo.

llabiemln coteiado la presente culcion con la de Barcelma de lisis. me parere igual en cuanto allesto de Jaroh, com la difereucia c. llevar los cantos mumeridos: se la ha adicimado cum mos preguntas hechas por el autor á Diña tuacleta de Borja, ntra de Hosen Fenular a dusias Vareh y lus contestacinnes de este y un tal Roullign Diez; va añadido el Vicabrilario do Juan de Resa, y se han dividido de diferente modo las compor anos variando la colocacion de considerable numero de strofas. Por esta razon he dicho de ma s mera dubitativa que el testo lo creia imual al do la de 15.55 pues presentanelu tale cambios en sin orden es casi imposihle el sderlo asegurar

Jimeno pretende, que al oririn utilizado por hesa para hacer su impresion fué el IIS. de "1). Luis Carroz, mencionado antes al hablar de la edicjon de 15.5.

70 MABCII (Mosex Ádosias). Les obres del valeros cavaller, y elegantissim poeta Lusias March: Ara nouament ab molta diligẽcia reuistes y ordenades, $v$ de molts cãts aumẽtades. (Sique el pscudo de Bornat.) Imprimides en Barcelona en casa de Claudi Bornat. 1:660. 8. 4 hojas prels., 207 foliadas y 3 mas en quo concluye el índice y se halla una Tarlay alphabet dels rocales scurs.

Rodriguez sospecha que la Taula y alphabet dels rocables scurs, puesta al fin de este volúmen, es el Vocabulario de Honorato Juan, citado vagamente por algunos. La tal Taula es simplemente reproduccion de la que lleva tambien al fon la edicion de Barceloura, 1545. 8. , con la sola adicion de seis ú ocho vozes.--Dudo mucho haya nunca existido el Diccionario de Honorato Juan, tal vez el origen de esta suposicion procede de que alouno, con dentasiada lijereza, le haya atribuidı el de Hesa, por el mero hecho de decir en la licencia real de la edicion de Valladolid, 1555, que la habia examinado el maestro del infante D. Cárlos.

Hojeada superficialmente la edicion de Bornat la tomé por reimpresion de la de Valladolid de 15.55 por hallarla conforme en la distribucion de los cantos y porque sus epigrafes en catalan son traducciones literales de los castellanos de aquclla, pero culando me fijé más y las comparé con mayor detencion observé repetidas variantes en el testo.

Los traductores de la obra de Mr. Ticknor dicen ser la edicion de 1560 la más completa y quizá tambien la más correcta; me inclino a pelisar como ellos en este último punto; pero por lo tocante al primero evidentemente se equivocan, pues la edicion de Valladolid tiene todo lo comprendido en la de Barcelnna y ademas se incluye una corta bingrafía de March y un estenso Vocabulario de Juan de Resa. Recomiendo pir lo tanto al que desec estudiar las obras del poeta lemosin, trate de adquirir ambas ediciones, pues en la uma encontrará un testo correcto, miéntras la ntra le proporcionará un excelente diccionario que le facilite en gran inanera su inteligencia.

El escudito de Bornat que se encuentra en la portada de esta impresion es el siguiente, puesto tambien en el Ariosto Orlando furioso, publicado por el mismo editor en 1564; aunque alli va circuido de una orla mucho mayor.

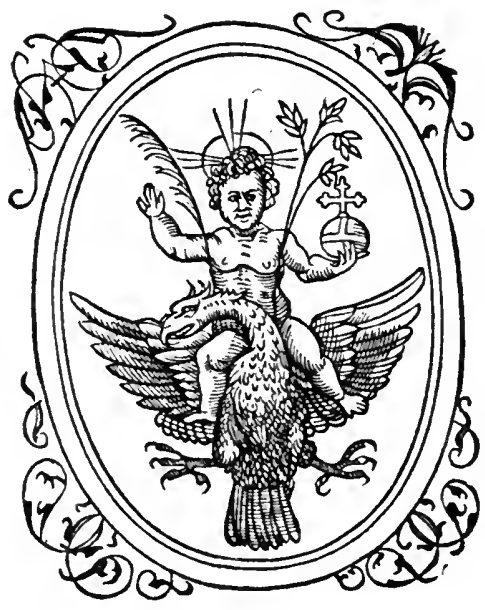


La última edicion de este libro publicada en su Idionia original es la siguiente: Alssias March, Obras de aquest poélu publicadas, tenint al devant las ediciorts de 1513, 1545, 1555 y 1560 , por Francesch Pelayo Briz, acompanyadas de la vida del poeta, éscrila per Diego de Fiuentes, de una mostra de la Iradicció castellana que d'ellas féu lo poéta Jordi de Mintemayor, $y$ del Vocabuluri que, pera aclarir lo original, publicd Joan de Ressa. Barcelona: E. Ferrando Roca, 1864. 4. Antefrontis litografiado en colores y oro. - A pesar de lo dicho en la portada creo que solo se tuviernn presentes para esta reimpresion las ediciones de Valladolid, 1555, y la de Barcelona, 1560.

771 MaRCH (Mosen Áustas). Primera parte de las obras del excellentissimo Poëta y Philosopho mossen Ausias March cauallero Valenciano, Traduzidas de lengua Lemosina en Castellano por Iorge de Montemayor, y dirigidas al muy magnifico señor mossen Simon Ros. (Sigue un gran escudo de armas.) S. 1. ni a. 8. ${ }^{\circ}$ let. curs. 4 hnjas prels., 130 foliadas rla úllima sin numerar) y 3 de Tabla.

Preciosa y curiosisima edicinn desconocida á todos, y la cual nos suministra datos mui interesantes para corregir alsnnas equivocaciones cometidas por los bibliogratos al bablar de esta traduccion.

Vi ejemplar se halla sumamente recortad) por el encuadernador $y$ u) estrañıria que en la parte inferior del escudo de la portada se hallen el lugar y año de la impresion.Procedamos pues á probar haberse hecho en Valencia, sin duda por Juan Mey y tal vez ántes del año 1560.-En primer lugar todos los tipos empleados en ella s in los usados en la primera edicion de La.Diana del mismo Montemayor, la cual espresa terminantemente estar hecha en dicha ciudad, y aunque sin nombre de impresor, ya daré al hablar de esta obra mis razones para atribuírsela á Mey. Hasta el escudo de armas del fróntis, probablemente el de Mosen Simon Rus, tiene cierta semejanza en el grabado con el de D. Juan Castelá de Vilanova Tue se encuentra en el de La Diana.-El apellido del sugeto á quien se dedican las Obras de March pertenece á esta provincia y los dos unicos sonetos en elogio del libro, colocados al principio de èl, son de Micer Cristóval Pellicer, escritor conncido de nuestro pais y de un anónimo caballero valenciann.-El prólogo del traductor, que voi á copiar por su interes y por no haberse reproducidn en las ediciones posteriores, suministra otr.s dito para corroborar mi upinion, pues al men- ionar á D. Luis Carroz, le llama baile geveral de esta ciudad.
-Al lector.

- La segunda prte deste libro dejé de tra- ducir hasta ver como contenta la primera - en la cual tambien deje algunas estanzas - porque el autor habló en ellas con más - lijertad de lo que ahora se usa. Cinco orl- grinales he visto de este poeta y algunos - difleren en la letra de ciertas estanzas, por - donde la sentencia quedaba confusa en algo: - yo me he llegadn mas al que hizo trasladar - el señor don Luis Carroz, baile general - desta ciudad, porque segun todos lo aflrman - él lo entendió mejor que ninguno de los - de nuestrios tiempos. - Yo he hecho en la - traduccion todo cuanto á mi parescer pue- de sufrirse en traduccion de un verso en -otro: quien otra cosa le paresciere, lıme - la pluma y calle la lengua que ahi le queda - en que poder mostrar su ingenio.,

Con lo espuesto pueden ya sentarse los siguientes hechos: $10^{\circ}$ Que la impresion ántes descrita, y de la cual me ocupo, es la primera de esta version. 2. Que en ella sol. se encuentra el trabajo de Montemaynr, es á saber, la traduccion de los Cantos dé amor, seis Esparsas, una Pregunta hecha por Hosen Ausias March d la señura Veleta de Borja, sobrina del Padie sanlo, la Respues. ta de dicha señora, una Epistola de Sireno $a$ Rosenin, otra de Rnsenio a Sireno, y una composicion de Jorge Montemayor contra el tiempn. 5.० Qne este prometió para más adelante la scgunda parte, ó sea la terminacion de la obra, y $40^{\circ}$ que la impresion del libro debio hacerse hácia el 1560 óntes.

Algunos autores citan una edicion de Zara. $g \circ=a, 1562, y$ suponen ser version de Romani, miéntras Nic. Antonio, Fuster y Brunet, aseguran ser la de Montemayn: no he tenido ncasion de verla; peco calculi que ha . biendo muerto Montemayn en el Piamonte en Febrero de 15'jl. dejaria sin concluir la obra $y$ el editor zaragrzano suplió aquel vacio con las cinticas moral, de muerte $y$ espiritual, anteriormente vertidas en castellano par D. Ballasar de Romani, siendo la edicinn madrileña descrita en el siguiente artículo una reimpresion de la araginesa y llamada por eso sin duda segunda. aun cuandu en realidad sea la tercera. De este modo quedan conciliadas en parte las diversas aserciones de escritures mui respetables: pues serm se ve enciema las traduc. ciones de Youtemayor y Romaní.

77 MarCH (Mosex Ánsias). Las obras del excelentissimo poeta $\mathrm{Ar}$ sias March, Cauallero Valenciano. Traduzidas de lengua Lemosina en Castellano por el excelente Poeta Iorge de Monte Mayor. Agra de nvero corrigilo $Y$ emendado en esta segunda iunpresion. - lupressas en Madrid, en casa de Francisco Sanchez. Año de. 13̈79. (Des- 
pues de la portada sigue una hoja con la Tasa, la cual no está incluida en las 12 de preliminares, y en la 133 hai una nueva portada que dice:) $\mathrm{Si}-$ guense tres Cãticas, es a saber cantica Moral, Cantica de muerte, y Cantica spiritual. Compuestas por el excelentissino Poeta Mossen Ausias March, Cauallero Valēciano. T'raduzidas por Don Balthasar de Romani. (En la hoja 134 esti la dedicatoria de Romani al Duque de Calabria $y$ el volúmen termina en el fol.183: hai ademas una hoja al fin en la que se repite el lugar y año de la impresion, siendo digno de notarse que la fecha aquí es la de 1578.) 8.

Edicion tambien mui rara.

Mayans en los Origenes, Jimeno en su Biblioteca y Cerdá en las notas al Canto det Turia, dan á entender haberse apropiado Montemayor en la edicion de Zaragoza, burtolomé y Pedro de Najer'a, 1562. 8. , la traduccion de Romani publicándola comn suya. Hemos visto por mis observaciones hechis á la edicion deserita en el artículo anterior, que el poeta lusitano solo dió á luz la primera parte de las Obras de March prometiendo para mas adelante la segunda, y que aun cuando en la edicion de Zaragoza se lubbiera cometido aquella superchería, lo cual no creo, nunca podria achacarse á Montemayor quien habia nutuerto casi dos años ántes. Ademas insisto en tener á la edicion madrileña por reimpresion de la de 1562 , y aquella comprende, cumo ya se ha visto en sı descripcion, desde el fol. 133 en adelante las eánticas moral, de muerte y espiritual, con nuevo fróntis anunciando ser la version de Romaní y hasta se copio la dedicatoria de este al duque de Calabria.-Cotéjesc todo lo traducido por Romaní cou lo hecho por Montemayor, y sc advertirá fícilmente ser obra diversa y superior á la del intérprete valenciano.

Es indispensable hacer esta justicia al célebre autor de La Diana y vindicar su buen nombre de la nota con que Mayans, Jimeno y Cerdá lo habian tildado, sin duda por no baberse tomado el trabajo puesto por mi en aclarar la verdad.

Jimeno comete ademas otra equivocacion y es la de suponer que la edicion de 1579 solo contiene la traduccion de Romani.

773 Marin (José María). Vida inimitable, en carrera incomprehensible, de Santa Juana de Valois Reyna christianissima de Franzia,... fundadora de la sagrada, mistica, singular Religion de la Anunciada. Que saca à la publica luz en metricas cadencias por seguir tan espirituales consonanzias su Fiel Devoto D. Maria Joseph Marin Perez de Suelves, Gurrea de Rosendi, y Franzia, Claramunt, y Luna de los Condes de Bureta. Palermo, Angelo Felicella, MDCCXLVII. 4. ${ }^{\circ}$

Poema dividido en doce Estanzias ó cantos, y aunque en general está escrito en octavas, se hallan intercalados trozos en otras clases de metro.

774 MÁRQUES (Antonro). Vida de N. Serafico Patriarca San Francisco de Assis. Compvesta por Fr. Antonio Marqves. Alcala, Julian Garcia Briones, 1710. 8. 24 hojas prels. y 202 págs.

Está en cuartetas asonantadas de ocho stlabas.

775 MARTíneZ (Drego). Docvmentos a vn hombre avariento, que con vsuras, y logros hizo vn caudal crecido. Adviertesele la obligacion de restituir lo $\bar{q}$ ha vsurpado à los pobres y que vse de caridad con ellos. Sacalos à luz. Diego Marlinez. Segovia, 1710. 9 hojas prels., inclusa una que contiene solo la imágen de la Vírgen de la Fuencisla, $\mathbf{5 4}$ págs. $y$ una hoja blanca.

Los Documentos se encierran en treinta y dos décimas. En mi ejemplar la hoja blanca fnal la ocupa una Dezima manuscrita, De el autor á quien impugnare los Documentos por suyos.

776 MARTÍNEZ (Éugenio). Libro de la vida $\mathrm{y}$ martyrio de la divina virgen y martyr Sancta Ines. Compvesto por Fray Eugenio Martinez. En Alcala de Henares, en casa de Hernan Ramirez, 1592. 8. 8 hojas prels., 305 fols. y 7 de Tabla.

Poema en veinte cantos. Advierte el autor al fin haberlo acabado el 18 de Set. de 1584 á los veinticinco años $\mathrm{y}$ dos meses de edad.

Al hablar del poema escrito por este autor con el titulo de La Discreta Toledana, ya advierto que está tan lleno de patrañas, encantamentos y sucesos inverosimiles, que con razon se le colocaba entre los libros de caballerias: por respetos al asunto tratado en la presente vida de Santa Ines no la he dado igual clasiflcacion, aunque en rigor la correspondia. 
MARTÍNEZ (EUgrio). Genealogía de la Toledana discreta. Véase en la Seccion novelíslica.-Libros de caballerias.

777 MARTÍNEZ GUINDAL (José). Poema sagrado de Christo paciente, primera vez introdvcido en el mundo, en las Sombras del Viejo Testamento, desde el genesis basta los Machabeos, segun San Pablo, 1. à los Hebreos. Por el Licenciado Ioseph Martinez Guindal. Madrid, Francisco Nieto y Salcedo, 1663. 8. 16 hojas prels., 116 foliadas y 4 de Indice.

778 - Soliloquios a Christo sacramentado, para los siete dias de la semana. Y a la hermosvra de la Vir. gen del Bven Consejo, y camino que esta Señora hizo à Belen. Madrid, Francisco Nieto. $1663.8 .^{\circ} 16$ hojas prels. y 91 fols.

Todo el tomo está escrito en romance.

Et nombre del autor consta del fin de la dedicatiria y del epigrafe de la Hermosura corporal de Maria.

Nic. Antonio no trae el nombre de Martínez Guiudal, á pesar de ser autor de las dos obras descritas anteriormente.

779 MARTINEZ MONTERO (GABriel). Paraiso espiritval de las almas amigas de Dios. Tesoro Patente a las codicias espirituales. Tratados Siete en todo genero de verso Español. Ofrecelos A... Maria Santissima. D. Gabriel Martinez Montero. Madrid, Alonso de Paredes, M.DC.LI. 4. ${ }^{\circ}$

Nic. Antonio no vió sin luda este libro, porque ademas de ignorar el primer apellido de su autor, nos da el título de una manera mui incompleta é inexacla.

La presente obra está escrita en diferentes metros y es del género de los Conceptos de Ledesma.

MARTÍNEZ DE LA ROSA (FAANcisco). Poesías. Véase en la Seccion dramática.

Mata (Gabriel de). Cantos morales. Véase en la Seccion novelistica.Libros de caballerías. i80 MaUry (Joan María). Estero y Almedora, poema en doce cantọs, por Don Juan Maria Maury, autor de la Espagne poètique. Paris, H. Fournier, 1840. 12. ${ }^{\circ}$ may. Retrato.

D. Juan Vlaría Maury, aunque español, tradujo al frances en su Espagne poetique, varias composiciones de nuestros mejores pnetas con tal felizidad que se adquirio una bien merecida reputacion en la república de las letras. No estuvo á la altura de aquellas producciones literarias, en su Esvero y Almedora; asi es que mi padre no quiso que su nombre flgurase como editor de esta obra, sin embargo de haber él costeado la impresion.

781 MAUSINHO DE QUEYEDO (VAsco). Affonso africano. Poema Heroyco: da presa d'Arzilla \& Tanger. Autor Vasco Mausinho de Quebedo Natural de Setubal. Lisboa, Antonio Aluarez, M.DC.XI. $8 .^{\circ}$ let. cursiva. 8 hojas de prels. y 196 fols. : al fin se repite la fecha.

poema portugues en octavas $y$ en doce cantins.

Nic. Antonio menciona esta rara edicion; pern como no la vió, no es estraño ignorase su tainan̄o.

782 - Trivmpho del Monarcha Philippo Tercero en la felicissima entrada de Lisboa. Author Vasco Mansino de Queuedo. Lisboa, Iorje Rodrigues, 1619. $4 .^{\circ} 4$ hojas prels. y 66 fols.

Poema castellano en seis cantos del cual dicen los traductores de Ticknor, tom. III. pág. 534: es olra de buslante ingenio, escrita en octavas faciles $y$ armoniosas.

783 MEJÍA (Dıgo). Primera parte del Parnaso antartico, de obras amatorias. Con las. 21. Epistolas de Oridio, i el in Ibin, en tercetos. Por Diego Mexia. Sevilla, Alonso Rodriguez Gamarra, 1608. 4. ${ }^{\circ}$ ö hojas preliminares $y 268$ fols.

Las Heroidas de Ovidio que llenan casi todo el volumen las reimprimió Fernández en el tom. XIX. de su Coleccion de pnetas; pero suprimió el largo Discurso (en verso) en toor de la Foesia compuesto por una seniora principul, el cual se encuentra cn la primera edicion. En dicho Liscurso se da noticia de muchos escritores naturales de America.

Várgas Ponce, en su Declamacion contra los abusos introducillos en el castellann, llama preciosa y rara á la traduccion de las Heroidas de Diego Mejía. 
784 MELÉNDEZ VALDES (JoAN). Poesias de Don Juan Meléndez Valdes, reimpresas de la edicion de Madrid de 1820 por Don Yicente Salvá. Edicion completa con el prólogo y la vida del autor, que falta en casi todos los ejemplares de la de Mastrid. Paris, J. Smith, 18:2. 4 rols. 18. may. Retrato.

La edicion de las poeslas de Melindez hecha en Madrid el año de lN20, lue ejecntada sobre el mamuserito del atutor; uma mitad casi de las composiriones que comtine un labian visto ántes la luz publica y las otmas silieron comsilerallenente bariadas y corregidas. Parece que la reimpresim hechil cu Frincia el año de lsol m tres tomitos en 18. debiena biabri sido ma copia de la edicion de I8:0; pern mu lof fue simo le la dimimuta de Vulluiblid de 17!7.-La venta de la de lladrid, publicada durante el regruen constilucional, esturo suspendida pur más de tres años. y solose la volvió á poner en circularion suprimiendo el probgo de llelendez y tambin su vida, escita por D. Manuel Jose duintana, es decir, 77 pigimas del tomo primero. En la presoute calieis de laris se ajustó mi padre con la mis escrupulnsa exactitud a un ejemplar mo castrido de la matritense, si hien se lia iñididn el retrito del autor, eolocido al frente de los cjemplires que ahora estim de rentil. Yo se ha de huscar pues en lis librerías olra edicion completal simo esta parisicuse de cuya correccion tipográfica se cuido con particular empañ.

Melendez es sin disputa unn le los mejores betas españoles del sigh pasallo. y ninsuno la avontiojo en la dolzura y ficilitad de sus composicines croticas. Hlibia estmulialo á

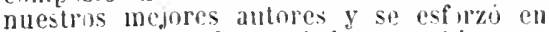
imitarlos; piro desoraciadanente hizu uso alirunas vezes de areaismas, galicismos y construcciomes ajemas de nuestro idinna, cuyos defectos empleados con demasiada profusion pior Cienfuegos y otros escritures, produjeron in mevo gongorismo. Los zelosiss defensures de la pureza y majestad de li lengual castellana demminaron á esta meva secta literaria escupla sulumalina, piryme Neléndez y sus imitadores ( $\dot{0}$ mejor diclo los imitadores de sulos sus defectos) estudiaron en la universidad de Salamanca.

783 IIELO (D. Finacisco Mlaxule DE). Las tres Mrsas llel Melodino. llalladas por Jou lianciscu Hanvel. ()ue por su industria recogio y publica, Ilenriquie Lalente de Olliuera. Lisboa, Officina Craesbeeckniana: lol llenrique lalente de ()]imera, 1619. 4. 8 hojas prels. y 131/ols.

l'rimera edicion do lis Tres Yusas lo Dum Francisco Manuel de Melo publicada bajo el seudónimo de Melodino. Va al fin el fragmento de ma Tragelia intitulada La impossible. Todis las poesias de este tomo están en castellatlo.

Nic. Antonio no conocio la presente edlcion y Ticknor cita otra de 1665.

Melo. (D. Frangisro Maneel de). Obras métricas, y Las tres Musas del Melodino. Véase en la Seccion dramitica, al nombre de Melo.

\section{G MENA (JUAN DE).}

\section{Toronacion de Inan de Atlena at $\mathfrak{f l l a r q u e s}$}

\section{CEsta es toda la portada. Al dorso de} la hoja 7 . $^{a}$ de la sign. n leemos:)

Acabun se las obreng de jun

de Ettena sobre ln coranació de viit,

ao lopes de mentoca.

Aco grations.

S. 1. ni a. $4 .^{\circ}$ let. gót. Sin foliacion con las sign. a-n, lodlas de $\mathbf{8}$ hnjas: la biltima es blanca. En el recto de la hoin bij hai unt gran figura grabada en madera. La marca del papel es la mano sosteniendo una flor do tres hojas en forma de cruz.

En el Calilogo de la Biblioflueca Grenvilliana se liabla de esta edicion, descunacida á llénilez í pesar de pertenecer indudablemente al simln $\mathrm{Xr}$; per, por la deseripcion le aquel Catílngo se ve le faltaban al ejemplar el frontis y acaso la haja blanea del fin, prosel tomon debe tener ciento cuatro y no eirnto dos como alli se dice.

l'anzer cita utra edicion, la cual segun mis apuntrs vi en Londres, tambien sin fecha cn 4. y de liel. gol., compuesta de ochenta y una hojas cori las signaturas y numeracion en el centra de la parte superior dol márgen. laruce carecia le frontis $\dot{0}$ de alguna otra luia, pues smpone dicho lanzer principiaba por las palibras Mnchas vegadas, que son las que comicnzan el Preambilo primern, al cual debe preceder el Pró!ogo y un Exmidio.lle visto li descrita por Mendez con bastante firlta de exactitud, en cuanto á ortografla, impresa jubablemente en Sevilla, u cinco

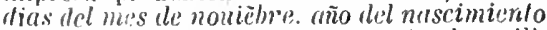
del nuestio saluador Jhesu cristo de mill. ccc.x.cix. (199). años. fol. let. gót.; y adeinas una desconocida al citado Méndez, la cual decia en cuatro líneas en la portada:

$$
\begin{aligned}
& \text { Coronacion Del famoso poe } \\
& \text { ta } 3 \text { unn de ttlena: Dirigisa } \\
& \text { 11 Inigo lope; de mendoct } \\
& \text { Htarques de sontillanir. }
\end{aligned}
$$


(A la vuelta empleza la obra que concluye en la octava hnja de la $K$ :) I Aqui se acaba la coronacio del famnso poeta Jua de mena. Fue emprimidu enla muly nuble $x$ muy leal ciudad de Seuilla por maestre lançalıo polono "xij. del mes de Nouièbre enel año de mill.cccc.x.xcix (1499). $4^{\circ} .^{\circ}$ let. gót. sin fol.

Finalmente, Nic. Antonio cita una impresion de Toledo, MDIV. en $4 .^{\circ}$, probablemente la última publicada de este tratado suelto, pues posteriormente siempre se ha unido a las otras obras de Mena.

Sarmiento, en la Historia de la poesia, página 373 y 74 , da una noticia exacta del presente poema.

Pues me ocupo de Juan de Vena y he suplido algunas (minisiones de Méndez, anotaré aqui otra obra del vate cordoves, la cual he tenido presente, y no se cncuentra en la Tipografia española de aquel.

(orla y dentro una lámina que representa un mónstruo con siete cabezas y bajo en tres lineas se lec:) Coplas. d'los siete peculos mortales hechus por el famoso poeta. Juan de mena. (Empiezan á la vuelta y yan hasta la tercera hoja de la signatura d donde dice:) Impreso en salamäca año d' mill \&. d (1500). Deo gias. (Despues me parece que deberia encontrarse una hoja blanca pira completar las cuatro del último cuadernillo.)

No recuerdo el tamaño ni la clase de letra que indudablemente seria gótica.

787 MENA (JUAX DE).
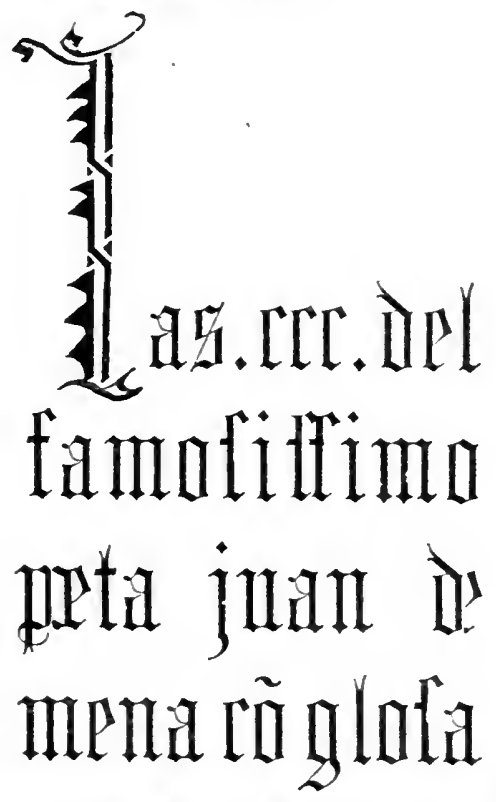

(Esta leyenda, forma la portada; en la hoja siguiente fol. ij sign. aij prin- cipia el Prologo, y en la otra fol. iij la obra que termina en el blanco del cx xxvj con el siguiente colofon:) Acabanse las trezientas del famoso poeta Juan de Mena: glosadas por Hernand nuñez de Toledo Cauallero de la orden de Santiago: y emendadas enesta segũda ympision por el mismo Comendador quitando el latin que no era necessario $Y$ añadiendo algunos dichos de Poetas en el coniento muy puechosos para entender las coplas. Junpssas con grandissima diligencia por Juan Uarela de Salamanca en/a muy nombrada y grand ciudad de Gránada. Enel año de Mill y quinientos y cinco (1300) años: a siete dias del Mes de Nouiembre. (Sigue el esculo del impresor que ra copiado al hablar del Vocabulista arábigo del $\boldsymbol{P}$. Alcalli.) fol. let. gót.

Edicion mui rara.

.Nic. Antonio atribuye la glosa de Las trescientas á Fernan viñez de Guzman porque la edicion mís antigua de estil obra descrita por èl es la de Sevilla 1528. donde solo dice en el epforafe del Prólogo haberla compuesto Fernan Viñez.

Bayer al adicionar la Bibliotheca noua no cita ninguna anterior á la impresion de 1505 y ünicamente supone que la Labrá por lo dicho en el colofon de ser segunda.- He visto la primera de este libro sin la glosa y su descripcion es la siruiente:

(1)ebia faltarle el frontis al ejemplar pues principiaba por la sign. a ij:) Comiéca el labirintho de Jum de mena po'te castellann: intitulado al muy esclirrecido y podernso principe don Juan el segrids Rey de caslilla y le leon \& $\bar{c}$. etc.

Al muy prepotente don Juan el segundo:

(En la 4." boja de la sign. $f$. vuelta dice:)

Acaban se las. cce. lle juä de mena enpremidas en Seuilla a insticiu y espèsas de juan th omas funario de litmelo del comludo de Pauia e nel año di" Mill. cecc xevj (1496). a. xij. de Enmo. 4. let. giot signs. $l-f$ todas de 8 hojas ménos la viltima qui tiene 4.

Contiene solo el Laberinto.

Tambien he examinado la segunda en cuya portada hai un rei en sı trono y delante un personaje con una rodilla en el suelo; bajo en dos renglones:

$$
\begin{aligned}
& \text { fas. fec . de } \\
& 3 \mathfrak{a} \bar{a} \text { de menii. (sic) }
\end{aligned}
$$

(A la vuelta: Comienca el labyrintho de juin de mena poela castellano... (Concluye este en el blanco de la cuarta hoja de la 
slyn. f como sigue:) a Acaban se las. ccc. de Juan de mena empremidas on Seuilla enel año de Mill. ccec. y. xiix. a. vij. dius d' olubrio: por Johänes pegnizer de nurenberga y magno herbst compañeros alemanes. $4 .^{\circ}$ let. gót. Tampoco tiene glosa.-La tcreera impresion, segun Méndez, reflriéndose al Indice sevillano MS., dice: Las cce die Juan de Mena con la glosit de Hernando Niñez de To'edo. Sevilla pior Juan Pignizer, Maimo y Thomas e'n rrviij. de agesto de MCD.XCIX. fol.

Como se ve, it la edicion de Granada de 1505, precedieron tres del Laberinto ó Tres. cimins: pero solo mu contiene la glosa de Niñez de Toledo: así se esplica porqué se llama segunda á la granadina en su final, pues realmente lo es de la obra adicionadi con el comentario. En 1506,1509 y 1515 salieron á luz en Zaragoza Las trescienlas, l.u Coromacion y las Coplas de los siete preailos morlales y se les agregaron ademas algunas composiciones de varios pretas; por eso los bibliourafos intitulan este tom cancinnero de Mena y otros. Véase en lit division de los Cancioneros y Romanceros (Iums. 187 y 18'). Segun Brunet existe una cdicion de Serilla, Jac. Cromberger, 1512. fol. let. grot., y los editores de la de lladrid, is:0 lo conflrman, añadiendo que comprende los tres tratados de Mena. De la impresion de 15l2 unicamente poseo La Coronacion encuadernada al fin de Las trescientas de 1517.

788 MENA (JuAn de). Las. cce. del famosissimo poeta Juã de mena: cõ otras. xxiiij. coplas y su glosa y la coronacioa del mesmo poeta: 2 ot ras cartas: c coplas r cãciōes. Agra nuenamente añadidas. (Al reverso del fol. ciiij se lee:) Fueron empremidas las ccc. del famoso poeta Juan de mena ela muy noble cibdad d'Seuilla: por Jacobo crōberger alemã año de mil $\varepsilon$ quniêtos $r$ dezisiete $(10 \% 17)$ a veynte $r$ quatro de setiembre.-La coronacion cópuesta por el famoso poela Juan de Mena: cõ otras coplas añadidas ala fin fechas por el mesmo poeta. (Este título va precedido de cuatro vineetas y circuido todo do orla ancha. En el blanco del fol. $x$ xij dice:) Fue e:IIpremida la presente obra delas cinquenta o coronacion... en la... cibdad de Seuilla por Jacobo cronberger Aleman año... de mill $x$ quinientos $r$ doze (1512) años. A ocho dias del mes de Febrero. (Lo que queda de blanco en esta paigina (1) llenan unas Coplas sobre vn macho que compro de vn frayle.) Fol. let. gót.

sin ninguna dudi existira una edicion de la Coronucion de 1517; pero al presente ejemplar le han suplido este tratado, que probablemente le faltaria, con uno de la de 1512. En el mismo caso se encuentra el siguiente.

789 MENA (JUAN DE). Las. ccc. del famossisimo poeta Juã de mena: (ut supra.) Sevilla, 10̈17.-La Coronacion compuesta por el fanıso poeta Juan de mena: al illustre cauallero don yñigo lopez de Mendoça marques de Santillana: cõ otras coplas añadidas ala fin fechas por el mesmo poeta (Al fin:) Fue empremida... enla muy noble $x$ muy leal cibdad de Seuilla por Jacobo cronberger Aleman año... de mill $r$ quinientos, $q$ veynte $(\mathbf{1 5 2 0})$ años. A ocho dias del mes de Março. fol. let. gót. La Coronacion no lleva foliacion; signs. a-c las dos primeras de 8 liojas y la úllima de $\mathbf{6}$.

En la cdicion de 1517 se alumentaron algunas poesias á continuacion de las veinticuatro coplas añadidas i tas Trescientas.

La impresion de la Coronacion de Sevilla, 1520 , indica que debe haber alguna del $L a$ berinto hecha en el mismo año.

790 Copilacion de todas las obras del famosissimo poeta Juan de mena: cōuiene saber. Las. ccc. con otras. xxiiij. coplas y su glosa: y la corōació y las coplas de los siete peccados nortales có otras cartas $y$ coplas y Canciones suvas. Agora nueciamête añadidas. M.D. xxviij. CEste título de negro y colorado, va metido dentro de una especie de capilla. Al reverso del fol. ciiij se lee:) Fueron empremidas las Trezientas del famoso poeta Juan de mena: en la muy noble Cibdad de Seuilla: por Juā varela. Año de mil r quinientos r veynte $r$ ocho (1528). a $\mathrm{xx}$. del mes de Mayo. - La coronacion... con otras Coplas añadidas ala fin fechas por el mesmo poeta. (Este nuevo fróntis va circuido de grande orla y a la leyenda la precede una viñeia que representa á un rei sentado en el trono, y rarios personajes que le rodean. En el blanco del fol. xxij está el siguiente colofon:) Fue empremida la presente obra... enla muy noble $\varepsilon$ muy leal 
cibdad de Seuilla por Juan varela. Año... de Mil $\varepsilon$ quinientos $\varepsilon$. xxviij (1528) años. A diez y seis dias'del mes de Mayo. (El blanco de dicho fol. 22 lo llenan las Coplas sobre vn macho que compro de vn frayle, $y$ en el reverso comienza el Tratado de vicios y virtudes que termina en el fol. xxvj vuelta.) Fol. let. gót.

Despues de esta edicion, á mi juicio la más completa de todas cuantas hasta entỏnces se habian publicado, salió una en Sevilla, por J. Varela, 1554. fol. let. gót., de la cual habla Brunet.

791 MENA JCan de). T Copilaciõ de todas las obras del Famosissimo poeta Juan de mena: Fróntis con orla casi igual al de 1328, y á la vuelta del fol. ciiij se lee:) Fueron empremidas las treziettas del famoso poeta Juan de Mena enla muy noble Uilla de Ualledolid en nuestra señora de prado por Juã de Villaq'rã. Año de. M.D.y'xxx y vj (1036). años. a.j. d' junio 'Sigue un nuevo fróntis para la Coronacion con la misma orla que el anterior $y$ en el blanco del fol. xxij se lee:) Fue imprimida la presente obra... en... Ualladolid en nuestra señora de Prado por Juan de villaquirā... Año... d' mil ๘ q̄niētos treynta y sers (10̈36) años. CSiguen despues las Coplas sobre vn macho $y$ el Tratado de vicios y virtudes, y todo termina en el reverso del folio $x x v j$.J Fol. let. gót.

El contenido de esta cdicion es enteramente ignal al de la de sevilla de 1525 : por lo mismo se ve que Ticknor no conocio aque. lla.cuando supone ser la de $15 \overline{5} 6$ la más completa de las publicadas."

\section{2} de la anterior edicion, con la unica diferencia de alguna cariacion ortográfica y que en aquella el año puesto en la parte inferior es el de 1536, y en esta el de 1530. A la vuella del fol. ciiij no ha quedadolugar para poner ningun colofon; sigue la porlada de La corronacion casi idéntica tambien a la de la precedente, observaindose en ella igualmente la variacion de fecha. En el blanco del fol. xxij se halla un final por el que constan las señas de la impresion; pero como lo esencial de él se repite en el reverso del fol. xxuj lo copiaré de este:) Fueron empremidas las trezientas del famoso poeta Juan de mena enla muy noble villa de Ualladolid. Por Juan de villaquiran. A costa de Cosme Damiā A. ix. de deziēbre. Año. M.D.y.xl. Fol. let. gót.

Está casi á plana renglon con la de 1.536 . por consiguiente contiene lo mismo que la de 1528.

He visto otra edicion, la cual por el nimero de fólins y demas señas, conceptuo abrazaria las mismas composiciones que las tres anteriores: hẻ aquí su descripcion :

(Portada con grande orla y dentro de negro y colnrado:) C Copilarion d todas las obras ilel Famosissino poela Juä de mena... Agora nueuamente añadidas \& Jmpuimidas. dño. M.D.y.xlviij. Añns. - (Al fll1: Toledo en cusie de Fernando de sancta calalina defunto que dios rya. C Acabose a quince dias del wes de Dizienbre. Año del nucincienlo de mestro saluador Jesu christo. Del mil z quinientos 2 quarinta y siete $15 \hat{5}$ ). Años. Fol let. givt. Ciiij fols. inclusa la pertada. Sigue una nueva y xxvj fols. para la Coronacion.

793 MENA (JCAN DE). Las Trezientas etc. Añadidas de nueuo dos tablas, vna de las Coplas, otra de las materias principales, declaradas por todo el discurso de los Comentarios. Anvers, Iuan Steelsio. M.D.hII. $8{ }^{\circ} 16$ hojas prels., 830 pags. y 17 hnjas de Tabla.

El contenido de esta edicion, dedicada it Gonzalo Perez, es igual al de las cuatro הuteriores ý más lleva dos Tablas sumantute ítiles: esta circunstancia, la bondad de la impresion y lo manejable de su tamaño, la hacen mui apreciable y buscada.

ro he visto Todus las obras del fomosissmo poeta Juan te Mina, con la glosin det comendudor Fervan vines: agnin meramonte corregiulas y pumendidas. Amer's, en casa de Martin vucin, $15.92 .80^{\circ} 850$ piigs.. que menciona Brunct y que supongo seri igual á la de Steclsio, pues tiene el misino numero de páginas. Tampoco he lozrado ver otra edicion tambien de Am'ers, 1554. 8.", citada por el mismo Brunct, y yo he lenido la de Atcala. Iutan de Villamipun y Pedr" sle Robles, $15666^{\circ} 8^{\circ}$, que no solo comprende las obras del poeta cordoves sino las composiciones de otros antores como en las impresiones de Zaragoza de 1506,9 y 15 . Vicase sil des. cripcion en la division de los Cancioneros, romanceros, etc. Núm. 188.

Debo notar aqui, intes de hablar de las obras de Ylena corregidas por Francisco san- 
chez, que en las tres ediciones de Zaragoza que acabo de citar y en la de Alcalá de 1566 , lis Coplas snbre los siele pecados morlales las reformó y conchuyo Gómez Manrique; miéntras que en todas las demas, desde la de 1517, llevan por titulo: Tratado de vicios $y$ vivtudes, adicionadas y acabadas por Fr. Jeroninıo de óliváres sin alterar el testo primitivo.

794 MENA (JUAN DE). Las obras del famoso Poeta Juan de Mena. Nueuamente corregidas y declaradas por el Maestro Francisco Sanchez. Salamanca, Lucas de Iunta, 1382. 12. 8 hojas prels. y 148 fols.

Contiene estc tomito el Luborin/o, La Coronacion, Lo claro oscuro, Sobre un macho que ('ompró de un arcipreste, Cancion del rei $D$. Juan, Al mismo criando sulio de Vadrigal y Coplas contra los si'l" pecudos morlales sin ninguna adicion, continuacion ó terminacion.

Ignoro si la edicion de linvers, 1582. 8. citada por Brunct, s'rá yo copia de la dé sinchez a reimpresion de las anteriores: me inclino más á lo ìllimo.

79.3 Las obras del famoso poeta Juan de Mena. Corregidas y declaradas por " Maestro Francisco Sánchez. Madrid, liepulles, 1804.8.

$796-$ La misma obra. Madrid, Agualo, 1810. Fol.

Reimpresion de la edicion de Franciseo Sánchez, aumentala con varias composiciones sacadas del Camcioner" general y de algun otro lihro no indicado. - A contimuacion de las Obrus de IIena va el Centon epistolario de Ginnez de Cibdareal, y el lítulo que lieva este tomo i su frente es el de Coliccion de aulores clásicos evpañules. Tomo I, úuico publicado.

l.a impresion es mui bella, como lo son en gencral to las las publicadas por Aguado, y ganaria no poco si se le supriniera el Ensayn $f^{\prime} \prime$ sófico que va al principio: esta produccion es sill duda de algun fraile y cuando no, lo es positivamente de uil limatico. Sin tratar yo de vindicar á la escuelie romántica, í la cual acomete sin compasiou, ni atacar á la clísica, de la que se muestra parcial por creerla más catúlica, apostulica, romana; diré únicamente que las mejores causas se pierden cuando al esponer las razones en su favor, se usa de tauti virulencia é iutolerancia, y se ganan mais prosélitos si se revisten los arumiunentos de formas más arreglindas á los principios de educacion y buena crianza.

l’arodiando o imitando á Juan de Meua se pilblicaron Las docientres del Caslillo de la F(ima, compuestas por el. Iicenciado Alfonso Alvarez Guerrero. Valencia, á 4 dias de Enie- ro... ¿ casa de Juan Jofre... Año de $1520.4 .^{\circ}$ Láms. 33 hojas sin fol.; y del mismo autor Las Cincuenta del Laberinto contra Fortuna. No se sabe el año de la edicion por estar falto el ejemplar visto por Gallardo, que es quien cita ambas producciones en el Ensayo de una bib. esp.

MÉNCOS (Miguer DE). Aula de Dios. Véase Dicastillo, en la presente division. Núm. 566 .

797 MÉNDEZ (Gregorio). Arte para conseruar el dinero enla bolsa conel qual en gran manera se remedia lo mucho $\tilde{q}$ se gasta conel Orinal: el qual por otro nombre es llamado Regimiento de salud. (Al fin:) Salamanca: por Pedrode castro. Año. M.D.xlj. 4. ${ }^{\circ}$ let. gót. 19 hojas foliadas, sin que haya ningun folio a derechas, con las signs. a-c, de 8 hojas las dos primeras y de tres la última. En el fróntis lleva una laminica de madera que representa a san Cosme y san Damian, tan usada en nuestros libros de medicina del siglo $\mathbf{X V I}$.

Nic. Antonio omitio el nombre de Gregorio Méudez y ningun bibliógrafo ha visto este curioso y rarisimo tratado. Contiene reglas higienicas para preservarse de las enfermedides y csplica las buenas y malas cualidades de muchas sustuncias alimenticias. Sirvall de muestra del metro y rudeza con que está escrito este poemita los siguientes trozos:

Limpio, claro é mui sereno el aire convien que sea, porqu'engendre espirto bueno, será de alegría lleno, quien quisier aquí lo vea; que si es inflcionado de algunos malos olores, cualquier que lo haya tomado mui presto será enfermo de mui diversos dolores.

El ejercicio templado es mui bueno en conclusion, cualquier que lo hubiere usado será bien sabio llamado sin tener contradicion. En ayunas debe ser hecho aqueste bollicio, que haga el calor crecer no siendo recio el oflcio. Que despues de haber comido es dañoso trabajar ántes de ser digerido el manjar é ser cocido, pues hace piedra criar. Las ropas se han de traer 


\section{MEN}

que deflendan frio e calma, y no para desplacer a nuestro bios y ofender destruyendo cuerpo y alma.

FI nombre del autor y su profesion de médico constan por el principio del prologo $\mathrm{y}$ por una singular aprobacion que va al fin fechada en 1513.

798 MÉNDEZ DE VASCONCELOS (Juax). Liga deshecha, por la expvlsion de los Moriscos de los Reynos de España. Compuesto por Iuane Mendez de Vasconcelos, Cauallero Portugues. Madrid, Alonso Martin. Año 1612. 8. 12 hojas prels. y 207 fols.

Poema raro, dividido en diez y siete cantos $y$ escrito en octavas.

Aunque Nic. Antonio cila esta obra, probablemente no consiguió verla, ya por no decirnos nada sobre la patria del autor, que apareee en la portada misma del libro, como por omitir el lugar de la impresion.

799 MENÉZES (Fraxcisco Javier DE). Templo de Neptuno, Epithalamio No felicissimo Casamento da senhora D. Joanna Perpetua de Bragança com 0 senhor D. Luiz Joseph de Castro, Marquez de Cascaes: Escrito pelo Conde da Ericeira D. Francisco Xavier de Menezes. Lisboa, Officina Sylviana, M.DCC.XXXVIII. $4 .^{\circ} 8$ hojas prels. y 37 págs. - In nuptiis Domini D. Francisci Xaverii Menesii, et Dominæ D. Mariæ A'Gratia Norognia, Epithalamium. Pangebat D. Franciscus Xaverius Leitam. Ulyssippone, Antonii Pedrosi Galrain, s. a. $4 .^{\circ} 4$ hojas prels. y 19 págs.-Plausus Tagi, quo D. D. Didaci de Almeida Portugal et D. Francici de Almeida Mascarenhas sanctæ ecclesiæ occidentalis Principum Triunphum, et possessionem loci in ipsa Sancta Ecclesiæ celebravit poetice' descriptus a Francisco Josepho Freire. Ulissipone, Antonius Isidorus da Fonseca, 1739. 4. 8 hojas prels. y' 38 págs.

El poema del Conde da Ericeira está en portugues: El Epilulamio de Francisco Javier. Leilaó y el Aplauso del Tujo de Freire, son dos composiciones poéticas en latin.
MES

MESA (Caistóval De). Las éclogas y geórgicas de Virgilio y Rimas. Véase en la Seccion dramcitica.

800 MeSA (Cristóval De). Las Navas de Tolosa. Poema heroico De Christoval de Mesa. Madrid, biuda de P. Madrigal. M.D.XCIIII. 8. 8 hojas prels., 324 fols., 2 hojas con cuatro Sonetos laudatorios y una hoja en la que se repiten las señas de la impresion.

Primera edicion, rara.-Nic. Antonio y Sedano hablan de una becha en Mallid, 1598. $8 .^{\circ}$; pero no conocieron la primitiva.

El poema es en oclayas y está dividido en veinte cantos.

Encierra el volúmen tres cosas notables: una aprobacion en prosa de D. Alonso de $\mathrm{Er}$ cilla y Zúñiga, un soncto en italiano, escrito desde Mantua, por Mesa, dirigido á Torcuato Tasso, y otro de este en el mismo idioma, en el que hai el siguiente clogio:

Saggio .rese cosi gli huomini lira

L'allo vostro Poema, e due corone

D'valor l'unn, ha l'altra di raggione

ond'il suo nome a gtoria etterna aspira.

801 - El Patron de España. De Christoral de Mesa. Madrid, Alonso Martin, 1612. - Rimas de Christoval de Mesa. Madrid, Alonso Martin, 1611. 8. ${ }^{\circ}$ Los dos tratados llevan una sola foliacion y conslan de 8 hojas prels. y 232 fols., el úllimo por equivocacion 231.

El Patron de España es un poema en netavas dividido en seis libros, y ocupa norenta $y$ Ires folios: el resto del tomo lo llenan las nimas varias.

Navarrete en la Vida de Cerrántes, paigina $48 \bar{j}$, menciona una edicion de Mudjrid, 1611. Supongo se flju unicamente en el año de las Rimas, que positivamente era este; pero la portada general y prelininares, que se imprimieron despues de terminado el tomo, deben pertenecer al siguiente porque las Erratas están fechadas el 16 de Diciembre de $1611 \mathrm{y}$ la Tasa el 28 de dicho mes.

802 - La Restavracion de España. De Christoval de Messa. Madrid, Iuan de la Cuesta, 1607. 8. 8 hojas prels. y 180 fols., el último marcado equivocadamenle 186.

Poema en octavas dividido en diez libros.

Entre las poesias que tiene al principio encomiando la obra, las hai de Barahona de 
Soto, del Doctor Agustin de Tejada y Paez, Y D. Francisco de Quevedo.

Nic. Antonio equivoca el tamaño de este volúmen pues supone ser en 4.

803 MeSA (Caistóval de). Valle de lagrimas y diuersas Rimas de Christoual de Messa. Madrid, Iuan de la Cuesta, M.DCriI. (Ál fin: M.DCVI.) 8. ${ }^{\circ}$ 8. hojas prels. y 163 fols.

El Valle le lágrimas es un poema en octavas dividido en seis llantos que son los de bavid, Nuestra Señora, S. Pedro, la Magdalena, S. Francisco y S. Aguslin.-Entre las Rimas vuelven i repetirse el soneto en italiano dirigido al Tasso y la contestacion de este en otro soneto en el mismo idioma, publicado ya en los preliminares de las Navas ce Tolosa como queda indicado al hablar de aquolla obra. Lis relaciones de Mesa con el autor de la Gerusalemme liberala fueron sin duda bastante estrechas, pues en una especie de ppistola á su amigo Luis Barahona, que se hilla entre las Rimas impresas en 1611 , dice al hablarle sobre su estancia en Roma:

"dilí gruste del agua del Pegaso, Comunicando la gentil persona

I la doctrina lel Torcuato Taso.»

Nic. Antonio no menciona el ralle de ldgrimas ni tampoco Barrera al enumerar las obras de Hesa.

Cervantes en el Canto de Caliope hace el siguiente elogio:

De Cristóvul ale Mresu os digo cierlo, que puede hom'ar vinestro sagrado valle No solo en vida, mas despues de muerlo Podeis con justo tilulo aliballe:

De sus heroicos versos el concierto, Su groue y allo eslilo meden clalle Alto y honroso nombre, aunque callur a La fama del, y yo no me ucordara.

Estas obras de llesa son raras; pero es casi imposible el reunirlas, sobre todo en tan hermoso estado de conservacion cono el de los ejemplares de mi biblioteca.

801 MEY (Felipe). Del Metamorfoseos de Ovidio en otava rima tradvzido por Felipe Mey Siete libros Con otras cosas del mismo. Tarragona por Felipe Mey, 1386., 4 hojas prels., 412 fols. y 10 de Tabla de las cosas nolables.-Rimas de Felipe Mey. Tarragona por Felipe Mey. 8.
4 hojus prels., 62 págs. y una hoja al fin, en que está el escudo de este impresor. Las Rimas forman parte del volúmen, asi es que continuan las signaluras, aunque no la paginacion.

Tomo sumamente raro, y la mayor parte de los ejemplares que se encuentran están faltos de las diez hojas de Tabla, colocadas al fin del Metamorfoseos.

Nic. Antonio se equivoca en decir son en 4..$^{\circ}$ las fimas, y que en ellas hai unas octavas en loor de la fuente de Alcevez; pues el tamaño es el de $80^{\circ}$ y la composición poéti. ca á la cual se refiere, va dedieada al manantial de Alcover: Jiıneno no vió el libro, y Brunet no lo menciona: tampoco lo tuvo Heber en su biblioteca.

Velázquez en el Orígen de la poesía, observa, que la traduccion de ovidio hecha por Mey compile con la de Sigler, sino la escede en la puntnalidad y hermosura.

Al tratar del tipógrafo y literato Mey (hijo de Juan Mey y no de Tomas, como dice Jimeno) ne parece oportuno notar, que aun cuando Garcta de Villanueva, pág. 294, supone imipresos en Va'encia en 1585 por el Felipe, cinco tomns en $4 .^{\circ}$ intitulados: Jardin de comedias de Poetas Valencianos los cuales, tambien, segun el mismo, se reimprimieron en Jaen en 1605 , me rezelo no hai en esta noticia cxactitud, ya por no mencionar ningun otro escritor semejantes ediciones, como porque Felipe Mey inprimia todavia en Tarragona, como hemos visto, en 1586 y de consiguiente no habia trasportado aun su casa á Valencia en la fecha indicada por Garcia. Esto no lo verifleo hasta despues de la muerte del docto Antonio Agustin, su favorecedor, acaecida en 31 de mayo de 1586; y entónces no fué inmediatamente, pues el Tratralo de medallas de dicho Agustin está impreso por Mey en Tarragona el año de 1587.

El escudo que usó y se halla estampado al fln del presente tomo es el siguiente.

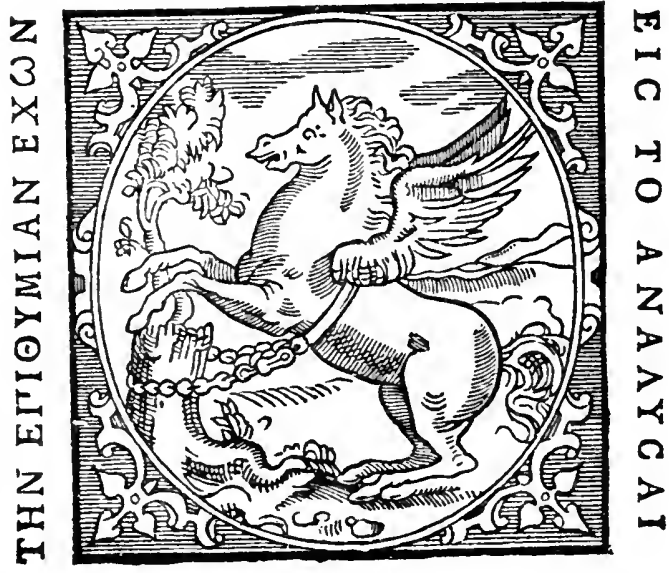




\section{MIN \\ 805 MING0 REVULGO.}

Glosa delas coplas del theuulgo fecha por fernando de pulgar para el señor conde de haro condestable de castilla

CEstas tres líneas de tinta encarnada principian la obra en el blanco de la sign. .A.) S. l. ni a. (hácia el 148ら̈). La edicion carece de folios y llamadas y lleva las signs. A-D, la primera solo de 7 hojas, porque a mi ejemplar le falta probablemente un fróntis ú hoja blanca al principio, la B y C de 8 y la $\mathrm{D}$ de 6 , aunque le faltan dos, que la una podia ser blanca y la otra la portada del tratado siguiente:

Letra de fernando de pulgar de los males dela vejez.

(Por estos dos renglones principia la hoja primera de la signatura .a.) S. l. ni a. (hácia el 1485). Sin folios ni llamadas con las signaturas .a. y b. de 8 hojas la primera y de 7 la segunda aunque regularmente deberá llevar alguna blanca al fin. Contiene quince letras de las treinta y dos de Pulgar que posteriormente salieron a luz. Ambos tratados son en $4 .^{\circ} \mathrm{y}$ de let. gót.

La edicion es positivamente de la época que le señalo, y sin ninguna duda ambas obras están hechas por el mismo impresor, pues los tipos son idénticos y exactamente iguales á los empleados en la Vision deleitable de Alfonso de la Torre, s. 1, ni a. que poseo. Tienen alguna semejanza con los de Centenera de Zamora, solo que este no usó del signo fl por $r$ empleado unicamente por los impresores de Tolosa y Fadrique de Basilea en Búrgos.

No sé si D. Eugenio Llaguno, en la Vida de Pulgar que precede á los Claros varones, aludirá á esta impresion de las letrus ó á la de que hablare en el artículo siguiente. Si se reflere á la presente sp equivoca en decir consta de 16 hojas, pues mi ejemplar tiene 17, aun suponicndo que no lleve portada, y ademas el número de las Car. tas no es 14 sino 15, á saber: la 1, 2, 3, $4,5,6,9,10,11,12,13,14,15,17$ y 32 de la edicion de dicho Llaguno. - Ya notó este literato que aun cuando la edicion príncipe de las letras, no llega á comprender la mitad de las contenidas en las posteriores, hai sin embargo en las incluidas algunos pasa. jes cercenados en aquellas, los cuales él reprodujo en la suya de 1775 .

El P. Méndez no menciona ninguna impresion del siglo XV de las Coplas del Revulgo
MIN

ni de las primitiyas Letras de Pulgar; Brunet solo hace una indicacion incierta de las primeras en la pág. 875 del tom. Ill.

806 MING0 REVUlgo. Coplas de mingo revulgo glosadas por fernādo de pulgar. $\varepsilon$ otras sus cartas. (Esta es toda la portada en cinco renglones de letra gruesa. En ta hoja siguiente sign. aij se hallan la dedicatoria al conde de Haro y el principio de la Glosa.) S. I. ni a. Chacia el 1000 ). $4 .^{\circ}$ let. gót. Sin fols. ni llamadas, con las signs. a-g, todas de 4 hojas, fuera de la $\mathrm{g}$, que tiene cinco impresas y una blanca al fin.

La edicion es del siglo $\mathrm{XV}, \mathrm{y}$ acaso hecha por Stanislao Polono de Sevilla en 1500, pues mi ejemplar se hallaba unido en su encuadernacion primitiva con el tratado intitulado Los claros varones de la edicion de 1500 , y asi lo he conservado. Ia letra, aunque de un grado más chico, es mui parecida á la de los Claros varones, y tambien el papel, que no lleva marca alguna. Las unicas diferencias notables son en favor de la mayor antigūedad de las Coplas, las cuales no tienen foliatura ni mayúsculas floreadas como los Claros varones. Presumo falta á este ejemplar toda la parte última, comprensiva de las Letras que acaso serian las mismas quince de la edicion ántes descrita, por eso be dicho alli, no sabia si era aquella o esta la aludida por Llaguno en la Vida de Pulgar.

D. Fernando Colon en el Kegistro de su Biblioteca menciona una impresion de las Coplas de Vingo Revulgo, glosadas por Fernando del Pulgar hecha en Sevilla, el 25 de Julio de 1506. 4.

\section{MINGO REVULGO.

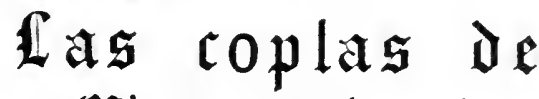 ftlingo ramlgo glo fadas por fier- mando de} pulgar.

(Esto ra precedido de dos figuritas que segun las leyendas que tienen al lado, son El pastor mingo reuulgo y El profeta gil arriuato: todo circuido de orla. La obra principia al dorso de la portada y termina en el 
blanco de la hoja 20, donde solo hai siete líneas y una para el Deo gratias.) S. I. ni a. (liácia el 1520 ). $4 .^{\circ}$ let. gót. 20 hojas sin foliar con la sign. a.

He visto otra cdicion donde tampocu existia iudicacion de lugar ni año y cuya descripeion es la siguiente: Orla y dentro dos flguritas y un arbolito, al lado de uno de los personajes dice: El profeta Cil arriuato, y al del otro: El pastor Mingo reuidgo. Bajo se lee: L Las coplas de Mingo reuulgo. Glosailıs por Hernado de pulgar. A la vuelta: Glosa de las coplas dil Reuulgo. Hechr por Hernando de pulgar: para el señor Conde cle haro. Condestable de custilla. $4 .^{\circ}$ let. got. Son 20 hojas sigus. a. - a xj y 9 hojas sin sign.

\section{MINGO REVLLGO.}

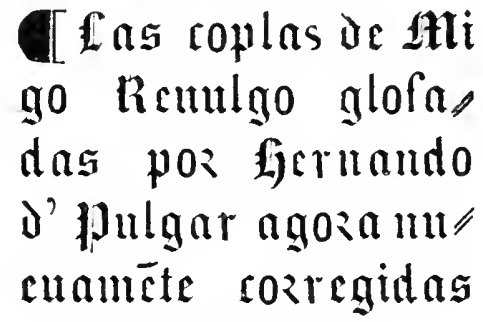

y ementidad as.

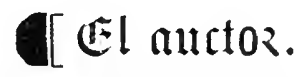

CPreceden á esta leyenda dos figurilas separadas por un arbol; solure la primera dice: El propheta Gil arribato, y sobre la otra; El pastor Migo reuulgo. Al fin:)

\section{Aqui fe acaban las coplag de}

Aningo licunlgo: Con la gloga que les hizo Gernando de junlgar. Fis quales fueron impressas enla muy noble $x$ umperial sindad de Toledo por tha mon de Jetras impresgor. Alabaron se a vevinle y seug dias del mes de Junio de mille quinientos $x$ vepnle y cinco Anos.

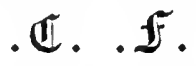

4. ${ }^{\circ}$ let. gót. Sin fol. con las siys. a-c de 8 hoj. las dos primeras y de 4 la íltima.

Signicron á esta edicion, una en cnyo final se lee: Fue impressa la presente obra en Medine d'l campo por Pedro de Castro. A costa de Juan de Espinosa mercader de libros. Año mil.d.xl.ij. 4. let. gót. 20 hojis con la sign. $a$, sin fol.; y otra que dice al fin: Fue impresso en Seuilla en casa de Iuan de Leon. A sancta Maria de Gracia. Año de 1545. 8. let. gót. signs. $a-e$; se publicaron con los Proverbios de D. Iñigo López de Mendoza en Anvers, 1558. 12. ${ }^{\circ}$ : se imprimieron en $V \boldsymbol{~} \boldsymbol{\text { s- }}$ lladolid, Adrian Ghemart, MDLXIII. 12. 47 fólios, inclusos los preliminares; con las Co. plas de Jorge Manrique salieron á luz en Alcala, Francisco Gormellas y Pedro de Robles, 1564. 12. ; segun Brunet, de éllas solas hai una edicion de Toledu, Fr. de Guzman, $1565.8^{\circ} 40$ hojas; y otra vez con las Coplas de Manrique, en Alcala, Andres de Angulo, $1570.120^{\circ}$; yo he visto las que hicieron en Huesca, Ioan Perez de Valdivielso, 1584. $12 .^{\circ}$ y en el mismo Alcala, Hernan Ramirez, 1588. 12. , tambien acompañadas del Manrique; y la publicada en Anvers, pur Nucio, 1594, con la obra de D. Jorge y los Proverbios de Mendoza. Dicho Brunet habla de la de Madrid, Luis Sanchez, 1598. 16. ${ }^{\circ}$; yo tengo la de Madrid, Viuda de Alonso Martin, 1652. 12. , que se hallit á continuacion de la antedicha obra de Manrique, y por fin se encuentran despues de la Crónica de D. Euriqu"IV, impresa por Sancha en 1787, con el título de Coplas de Hingo Revulgo, compueslas por Rodiigo de Cola (el tio), natural de la ciudad de To!edo. Glosadas por IIernando del Palgar, y seguidas de otra glosa á las mismas hecha por Juan Martínez de Barros en el año de 1564 .

Eu el Essayo de una bib. esp. se han publi. cado las Glosas sobre el trat zdo de Domingo con las Respuestus, dirijidas al muy magnifico Señor don diego furlado de mendoça, mar'ques de Sanliltan conde del Real: Acabado por metro $y$ prosa. Siguc á cada copla de Vingo otra del glosador anónimo y luego vienc la glosa en prosa. Las estancias no valu por el orden conocido, y son 35 , es decir, tres más de las que comentó Pulgar.

Sobre el objeto de estas Coplas y su autır, podrá consultarse í Sarmiento, Memorins para la listoriı de la poesia pígs. 397 y 598 , y á Gallardo, Criticon, N. 4 pág. 24.

809 MOLINA (Luis de). Descripcion del Revno de Galizia, y de las cosas notables del... Compuésto por el Licenciado Molina. El qual tratado, va en cinco partes. La primera, tracta de los cuerpos sanctos $\tilde{T}$ aqui se hallã. La segunda, de las cosas notables. que ay en este Reyno. La tercera, de todos sus puertos y costa de la mar. La quarta, de todos los Rios, y pueblos, por do passan. La quinta, de los linajes, y solares, y armas $\mathbf{y}$ blasones, de donde proceden muchas señaladas casas en España. 133̈1. (Al fin:) Fue iumpresso el presente tratado llamado Discrijucion del reyno de Galizia en la ciudad de Mondoñedo en casa de Augustin de 
Paz Acabose el segundo dia del mes de Agosto. Año mil quinientos y cincuêta (1530). 4. ${ }^{\circ}$ Todo de let. gót. ménos los prels. que son de redonda. 4 hojas prels. y lxij fols.: al reverso de la última va el escudo del impresor y el colofon.

Primera edicion mui rara.

Brunet supone conshi dicho volúmen de 6 hojas de prels. 5 que se lee en el frontis ser de 1550; sin cinbargo en mi ejemplar, al cual parece no faltarle nada, solo hai 4 hojas al principio, y la fecha de la porlada es positivamente de 1.jol, debienulose observar lleva el mismo año al fln del Prologo siendo la tasa del 25 de noviembre de 1550 .

810 MOLINA (Luis DE). Descripcion del Reyno de Galizia (ut supra). Madrid, Roque Rico de Miranda, 1675. 4. 6 hojas prels. y 160 págs.

He visto olra edicion S. $l$. ni $a .4 .^{\circ} \mathrm{y}$ parecia hecha hácia 1620 . en ella tambien el verso era de letra cursiva y lo demás de re. donda, como en la de 1675. Mıño\% s Rome ro cita una de Malrid, $1650.4^{\circ}$ la cual ignoro si será la de este aĩo impresa en bulla. dolid, que trac Nic. Antonin. El mismo coloca á Molina entre los anónimos en la pag. 311 , tom. II. de la Biblinth. nov'a, pues efectivainente en su obra se le llama tan soln Liccn. ciado Molina. Ignoro el fundanento de relázquez para decir en los Orígenes de la poesia, pág. 157: De gengrafia lenemos la bescripcion del reino de Galizia hecha en verso de arte mayor por Luis rle Molina, natural de Málaga publicada en .Mondoñedn en 15.70, que en su linea es un poema dialáclico bien escritn. Lna manera tan terminante de aseverarlo me ha inducido á aceptar la asercion; á pesar de que Muñoz y Romero le llama Francisco.

La obra está en octavas como las de Juan de Mena y cada una de ellas lleva una especic de comentario en prosa para esplicarlas. Trata del cuerpo del apustol Santiago $y$ de los de otros simtos que hai en Galicia, de los romeros, de las cosas notables, del hospital de Santiago. de la torre de la Coruña, de algunos monasterios, montes, puertos, puentes, elc.; y concluye dando noticia de las familias nobles y distinguidas de Galicia.

El escudo de Agustin de Paz, impresor de la edicion de 1550 , es este.

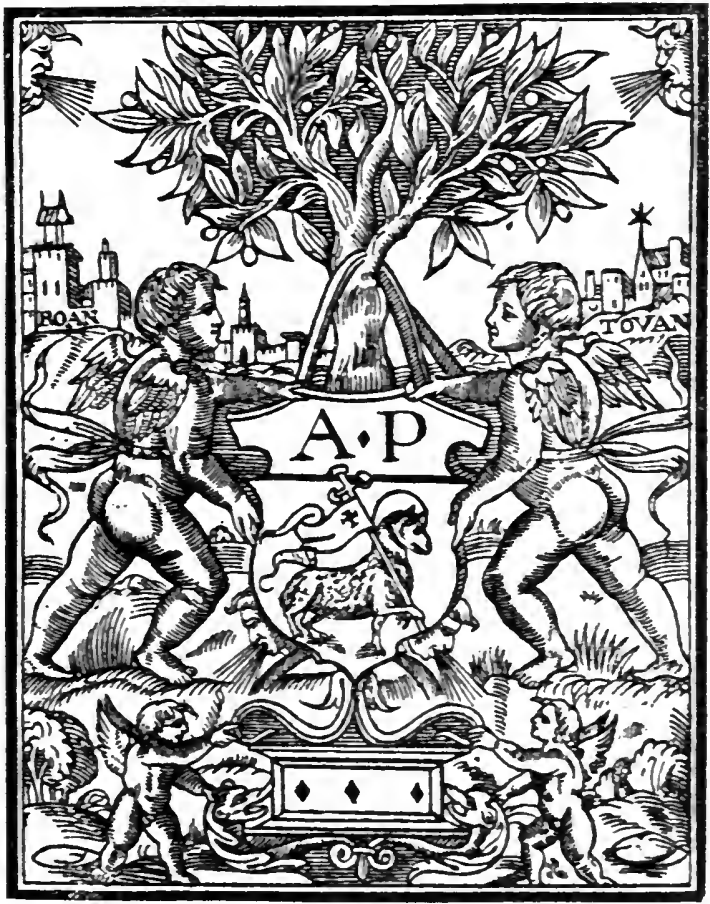

811 MONCAYO I DE GURREA (Juan de). Poema tragico de Atalanta
Y Hipomenes. Por Don Iran de Moncayo y de Gurrea, Marques de Sąn 
Felices. Zaragoça, Diego Dormer, 1636. $4 .^{\circ}$ let. curs. 23 hojas prels., 360 paigs. y 2 hijas de erratas.

Poema en octavas $\mathrm{y}$ en doce cantos: se trata en èl de los reyes y linajes ilustres de Arigerull, y de los varones distinguidos, literatos célebres y noticias históricas mui curiosas de este reino.

\section{MONCAYO Y DE GURREA} (Juan De). Rimas de Don Ivan de Moncayo, i Gurrea, Marques de San Felices. Caragoça, Diego Dormer, M.DC..LII. 4. 18 hojas prels., 31. págs. y una hoja de erratas.

He visto pocos libros que tengan al principio tautas pocsías laudatorias como el presente: entre ellas las hai de D. Juan Francisco Anures, D. Miguel Leonardo de Argensola, D. Francisco Diegro de sáyas Rabanera, 1). Alberto Diaz, D. Manuel Salínas y Lizana, D. Juan Antonio kodriguez y Martel, El Doctor Juan Orencio de Lastanosa, D. Antonio de Funes y Villalpando y D. Luis Abarca de Bolea.

La princra edicion de las Rimas de IIoncayo, segun Latasa, es de Lerida, Enrique Castum, $1656.16 .^{\circ}$; sin embargo en el prologo al lector de la impresion de 16.52 dice: olra lez espongi di tu censura mis obras.. si bien enlonces fué la corle clonde te debi los aplausos... ahora to eres li Zaragosa, patria uira: Esto indica la existeucia de aloruna edicion de lladrid desconorida á los bibliografos.

\section{MONDRIGON (JERóNiMO} DFe. Arte, para componer en metro Castellano diuidida en dos partes en la Primera se enseña ĩ cosa sea Verso, i en quantas maneras se halle, i como se cóponga: en donde se traen para exemplos, tratados i cosas de mucha curiosidad, i entretenimiento. En la Segunda se pone el Modo de cõponer, qualesquier obras de Poesia. Con la Prosodia Latina, cõpuesta en esta mesma vulgar lengua. C.aragoça, Lorenço de Robles, 15393. $8 .^{\circ} 4$ hojas prels. y 48 fols.

Como muestra de las varias especies de metro castellano quc existen, copia el autor, cuyo nombre aparece por la dedicatoria, composiciones poéticas suyas y de otros escrilores.

Mayans en el Specimen de su biblioteca dice de esta obra: hic libellus Hieronymi de Mondragon, eo uestimabilior est, quo pauciores fuerunt in Hispania, qui de arte metrica scripserunt.
Nlc. Antonio cita dos obras de este autor, intituladas: Universal y artificiosa ortogrufia de Latin y Español. Zaragoza, 1594. 8. y Prosodia Lalina en Castellano. Zaragoza, Lorenzo de Robles, $1593.8^{\circ}$

814 MONER. Obras nueuamẽte imprimidas assi en prosa como en metro de Moner las mas dellas en lengua castellana y algunas en su lengua natural Catalana compuestas en diuersos tiemposy por diuersos y nobles motiuos: Las quales son mas para conoscer y aborrescer el mundo $\bar{q}$ para seguir sus lizonjas y engaños. CEste título, todo de encarnado, se halla dentro de una especie de capilla con orla ancha. Al dorso de la portada hai una II Carla de Miguel Berenguer de barutell. Dirigida y endereçada al muy illustre señor don Hernando folch duque de Cardona / y marques de pallas. etc., la cual concluye bastante al principio de la primera página de la hoja siguiente, quedando en blanco lo restante de ella. Llena todo el reverso una lámina representando una especie de fortaleza, y por la puerta de la torre más alta va a entrar un hombre: bajo de él hai otro conversando con una mujer. En la tercera hoja, sign. aiij, comienza la Obra intitulada la noche de moner mas propiamente llamada vida humana endressada por el mesmo actor ala muy illustre señora dueña Joana de Cardona que oy es Duquesa de Najera, yesta concluye en la quinta hoja de la sign. B; viene en seguida un discurso sobre la paciencia, seguido de una Glosa (en prosa) de una cancion del mismo autor, y en la sétima hoja de dicha sign. B, principian las obras en verso castellano. Al reverso de la Fij dice: đl Las obras que se siguen son del mismo auctor y son en lengua Catalana es la primera vna obra muy prouechosa y aguda $\tilde{q}$ se llama Lanima de Oliuer porã finge Moner que lanima de aquel cauallero le aparesce reprẽdiendo su vida y desputãdo los dos del libre aluidrío... etc. $E l$ volúmen termina en la cuarta hoja de la sign. G vuelta, con el siguiente colofon:) I Aqui acabã las obras đ̃ se 
han podido hallar de Moner en prosa y en Metro assi en lengua Castellana como las que cópuso en su lēgua natural Cathalana: emēdadas cō harto trabajo por ser enlos trāslados $\bar{q}$ se hă hallado dellas corruptas y unuy mal escritas Jmprimidas enla insirgne ciutat de Barçelõa por Carlos amoros a gastos de quyen hoy mas ama y d'ue al autor dellas. "Laño dela natiuilat de nuestro Redemplor. M.D.xxviij. fol. let. gót. Sin foliacion, signs. A-G de 8 hojas ménos la última que solo tiene 4 .

Yolủmen impreso con lujo, pıes las márgenes son espaciosas y la impresion y papel dignos de una edicion de Cárlos Amoros.

La obra intitulada La nuche es una especie de novela alegórica-moral, en prosa, cuyos protagonistas son el misno autor y personajes como el odio, el deseo, la pasion, el deleite, la tristeza, la esperanza, la descsperacion, el temor, el descuido, la ira, la mentira, la pobreza y otros vicios y virtudes.

Me he datenido tanto en la descripcinn de este tomo por ser indudablemente uno de los más raros que salieron de las premsas harcelonesas en el siglo XVI: por csta razon y por Ia de ser Yoner desconocido á todos nuestros cseritores doi á continuacion una muestra de su metrificacion.

\section{Coplas}

¿ Ntra. Sra. á ruegos de su madre.

$$
\text { -. }
$$

Tú me guia, reina mia, tis ne guia.

Reina del cielo bendita, alabada, aquel cuidado me quita que m'agrada, aquel que yo olvidaria si me via; tü me guin, reina mia, tiv me guia.

Ah señora! yo te pido m'aconsuele, sáname el triste sentido que me duele, que la mujer que servia le desvia: tú me guia, reina nia, tú me guia.

Una mujer c'adorć, inal pecado me concierta el dolor que hẻ tan sobradi, todo cuanto Je servia mal queria; tus me guia, reina mia, tú me guia.
Panidad y desconcierto es seguilla, porque el vivo torna muerto por servilla; si a vos me convertia medraria; tù me guia, reina mir, tù me guis.

Tarde ine vuelvo, señora, pero más vale algrun hora que jamas;

porque eres dulce ẻ muí pía, todivia;

tú me gub, reina mia, tú me guia.

Tủ no eres desconocida á ninguno, ni es cualquiera que te pida importuno, quien te sirve no desvia ilalegria;

tí me guia, reina mia, tú me guia.

Tú nunca juzgas con ira las personas, á aquel que por tí sospira gualardonas,

tú no siglles fantasia

ni porflit:

tú me guia, reina mia, tí me guia.

Reina de Dios toda llema, qué os diré?

á quien concierta mi peua no le erré;

mas porque a vos deservia, padescia;

lú me guia, reina mia, tù me glia.

Sin zelos son tus amores escogidos

por ser tus altos valores intinidos,

cuautos siguen esta via van de dia

tú me guia, reina mia, tú me glita.

Tu fuiste Virgen y inadre para nos. inadre, esposa de tu padre, unestro Dios, en tu alta mejorín 110 hai contía;

tí me guia, reina mia, til me guia.

Madre de nuestro Meslas, Dios y hombre, iquién dirá las primerı́as de tu nombre? yo, señora, si sabia las diria: tú mé guia, reina mia, tú he gria. 
Eres à Dios tan cercana por amarte, que la presumpeion es vana d'alabarte; mas servirte convenia pues podia:

tú me guia, reina mia, tú me guia.

Entle Dios y mi te pone, reina pura,

haz que tu hijo perdone mi locura

porque si más la seguia hundirme hïa:

tú me guia, reina mia, tú me guia.

Corta, reina, mi trálla de codicia, haz que pueda más maneilla que justicia,

que si lo justo se hacia mal me iria:

tú me guia, reina mia, tú me guia.

Sáeame, lírgen, d'aquí d'esta selva, haz quel que murió por mt que m'absuelva, destruye la idolatría que tenia;

tit me guia, reina mia, tu me guia.

Iloi comienzo, te sirviendo, libro nuevo.

en tus manos encomiendo lo que llevo:

mi alma que se perdia

tú la gulia,

tì me guia, reina mia, tii me gria.

A dónde ireis á posar Aguililla caudal?

Polla zahareña, quién detras te corre? deja la cigüiña del nido en la torre; mas por tu volar que las nubes pasa, mi vista es eseasa no puede alcanzar dónde irás á posar.

Las alas al cielo no temes pihuelas, es gran desconsuelo que siempre más vuelas; por ver dónde tiras yo ne hago mal, tú mui bien lo miras mas piensas en al, aguililla caudal.

Agrililla gentil por quien se sospira, tu vista sotil de léjos me mira; mas si se complia lo que no es d'esperar, qué gloria seria poderte cebar, donde irds á posar.

Reina de las aves en todas maneras, mis pasos son graves, tus alas lijeras, cá provecha correr pues cierto eres tal? que no quieres comer de ningun animal, aguililla caudal.

Aguililla ajena, qu'en las nubes luces, no hai carne tan buena que no la rehuses; no espere ninguno que quieres bajar, pues si vas de yuno, quién puede acertar dónde irás á posar.

Entre las hermosas tú sola hermosa, si en cumbre te pones no sea fragosa, posades donde era el verde predal, si fuere ribera no sea arenal, aguililla caudal.

Aguililla squiva, posarás en poblado, miéntra que yo viva terné este cuidado; no spero que vea cuíl querrás tomar, mas cualquier que sea, bendito el lugar clonde irás a posar.

\section{Ella.}

\section{Déjame volar} Cazador de mal.

En valde te quejas por cosas que sueñas, ui es mucho si dejas por nıí las cigüeñas; mas de mi vida no cures pensar que llevo por guia mi vista sin par, dejame volar.

EI.

Bien es que t'alabes que vas do no veo, y yo del deseo mayor que no sabes; mas si tu sintieses mi pena mortal, de priesa vinieses al son del tabal, aguililla caudal. 
Ella.

Eucubre rodeos de tantos amaños, que vuestros deseos son todos engaños; sol suelta aguilllla, no me he de trabar, nl te tengo inancilla pues vas á engañar: déjaine volar.

i.l.

Pollerte volar sin dar apellido, morir y callar es cuanto te pido; este es el engaño, cruel, desigual, tủ bien, á mi daño sin ser criminal, aguililla caudal.

\section{Ella.}

Cetrern dudoso, que mal fantaseas, tú estás peligroso si más me deseas; segun vas atranco y a más más andar, el llano es barranco poidrás tropezar: dejume volar.

\section{É1.}

No puedo olvidarte despues que te rí, caer por mirarte es bien para mi; si estás ellojada de mi portlar, no pierdes tú nada, dejame mirar. donde irás a posar.

\section{Ella.}

Si tú ves tan poco y yo voi tan alta, dirán quieres loco que miras en falta; en tal cetrería no hai buena señal, deja la porfía qu'es negro cabal, cazador de mal.

\section{É.}

Aguililla ufana, cuant más alta vas me pone más gana de irte detras: gu'en sola flanza d'en ti contemplar mayor bien s'alcanza que de otra gozar: uonde irás volar.
Aguililla que vuelas traves de las bravas, si no sé dỏ vuelas correré dó volabas; amansa altivez tan descomunal, y miucra despues por serte leal aguililla caudal.

81ว MONTANES Y MONIEALEGRE (Maxiel). Poesias lvricas, que escrivia Don Manvel Montañes y Monte-Alegre. Madrid, Manuel Martinez, 1735̆. 8. 8 hojas prels., 2003 págs. y una hoja más en que concluye el Indice.

\section{MONTEMAYOR (JORGE DE).} SCExpoficion mozal fo, bee el pralmo. laxioj. Del real propheta 国aaid, Dirigido a la may alta $y$ may poderofa fo nosa la infanta dosia stlaria po: Geoge de moute mayos cătos de la capilla de fa alteza.

CEste título va precedido de un escudito con las armas imperiales, y el todo se halla circuido de una orla ancha. El reverso lo llena una lamina de la Purisima C'oncepcion con S. Joaquin y Sta. Ana a la parte inferior; el blanco de la siguiente hrija conliene la dedicalorin; y á la vuelta comienza el Argumento. Concluye la obra en el blanco de la décima hoja ('on el siguiente colofon:)

\section{CEfta pisscute obià fue}

vifta y-cxuminata po: el muv reacredo y magni fico ferios al vicario general en efta metropoli de Toledo y só fu licencin imperffa en la uninerfioas de Alcula po: Joan de B:oenr: psimera Del mes

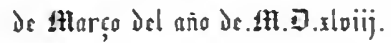

4. ${ }^{\circ}$ let. gót. Sin folialura, signaturas A-Ar. Sondiez hojas.

Aun cuando mi ejemplar estuviera impreso sobre papcl no dudaria el clasificar este volúmen como una de las joyas de mivor valía de mi biblioteca por su estremadi rareza; pero estando tirado sorre pERGayiro no vacilo en llamarlo cistios. 
La traduccion del Salmo principia as1:

Hizo Dios una ciudad sobre santo fundamento, siendo efeto el pensamiento, y obra la voluntad del divino entendimiento.

El pensar Dios de hacella no es pensar sino saber, y la voluntad bacer; pues para morar en ella véd qui tal fué menester.

Cuáles fueron las comarcas sobre que Dios la fundó, Abraham, Isaac y Jacob, por sacal de patriarcas el area do se encerró.

Montes sintos parecieron en ser á Dios allegados, santos, en ser sus privados, $\mathrm{y}$ tan altos cuando fueron en prudencia señalados.

El Sr. Gallardo conocia esta obra del arrtor de la Diana y me encarecio sobremanera su estraordinaria escisez: él ha sidn el unico bibliugrafo con quien he labliado sobre Ia Exposicion del sulmo 86 que hayat temidn noticia de ella.--Vic. Antonio diee, (fue 'sta jroduccion se atribuye á uno limmado Yontemayor, quien ell su sentir debia ser diverso sugeto del célebre poeta lusitimo de este nombre: por aquí puede colegrirse no vio la obril pues a laberla tenido presente, el líntis y lit dedicatmia hubieran disipitu sils do. das. Sedano en el P(r)naso espuñol toin. II. pag. $\mathrm{xliv}$, se concreta á repetir lo dicho por Nice. Autonio.

La traduceion del Salmo es en verso y la exposicion en prosa.

En el tomito de las Obras de Iontemayor impreso en Anvers, 15J.', no se iucluyú esta pruduccion suya.

\section{MONTERO DE ESPINOSA} (Rом.s). Sicte Meditaciones sobre la oracion del Padre nvestro. E-critas por la Seráfica Madre S. Teresa de lesus, y glossadas en verso por D. Roman Montero de Espinosil. Gritnada, Baltasar de Bolibar, 16t:8. 8. 68 hojus foliadas en todo.

Las 28 hojas últimas de esta impresion las ocupan Los Psalmos penitenciales, I'arafrasis en romances Castellanss. Por lon Luis de Hllot. Estos Psalmos se cncuentran ya en una edicion de las Veditaciomes de Yontero, que he visto, hecha en Amberes, Imprentit Plemlinima de Ballesar Morelo, M.DC.LVI. $40^{\circ} 8$ hojas prels. y 50 fols., la cual no debe ser la primera. Barrera no conoejó la de
Granada existente en mi biblioteca; pero cita una de Roma, 1658, que jgnoro si contiene el tratadito de Ulloa.

818 MONTERO VAN COMPOSTELA (PABlo). Reverente obsequio metrico epitalamio en las felices bodas del Conde de Altamira con Doña Bentura Fernandez de Cordova, por Don Pablo Montero Van Compostela. S. l. ni a. (hácia 1731). $40^{\circ} 16$ págs. En outavas.

819 MORA (José JoAquin DE). Leyendas españolas. Paris, II. Fournier y C. ${ }^{\mathrm{a}}, 1840.120^{\circ}$ may. Viñetas de madera.

Las compnsiciones de este tomo, publicado por mi padre, no ceden en fluidez, gracia y pureza de lenguaje a ninguna de las muchas con que su autor se habia grangeado fa un nombre distinguido en el orbe literario.

820 MORADELL (Vicente Mim GUEi be). Ilistoria de $\mathrm{S}$. Ramon de Peñafort Fravle de Predicadores en coplas Castellanas. Por Vicente Migilel de Moradell. Barcelona, Sebastian de Cormellas, M.Dciri. 8. ${ }^{\circ}$ 10 hojas prels., 213 fols. y una que contiene un Soneto de el autor á Nra. Sra.

Poema en ouce eantos, el último se intithla : De la Sifrena.

Scymn parece, el autor sacó su poema de la Historial Latima de Francisco Peña, y de la castellana del P. Diaro, y lil compuso á los diez y nueve años de edad.

MORATIN (Leandro Fernández je). Víase Fernández de Moratin, en esta division. Núm. 609.

8?1 MOSQUERA DE BARNUEVO (Fiscisco). La Nvmantima De el Licen.do Don Fran.co Mosquera De Barnueuo. (Al fin:) Sevilla, Luys Estupiñan, M.DC.XII. 4. ${ }^{\circ} 12$ hojas prels., inclusa la portada grabada y el retrato que se copia á continuacion; un árbol genealógico que se dobla, 371 fols. y 29 hojas de Tabla ò Repertorio.

Debe fljarse la atencion en las hojas preliminares, pues he visto algunos ejemplares fal- 
tos de las dos que conticnen la Tassa, un soneto de D. Antonio II urtado de Mendoza y otro de D. Diego de Barnuevo (hijo del autor, á quien pertenecii este ejemplar y lleva su autograto en el fróntis) y la Fé de erratas. Tambien sucle echarse de ménos el árbol genealógico.

Poema que trata de la destruccion de Numancia y fundacion de Soria; está dividido en quince cantos comprensivos de inil y dicz octavas; y va acompañado de una glosa en cincuenta y siete capitulos donde se ilustran varios puntos histórícos y beráldicos con copia de documentos y escrituras antiguas.
Cervántes dijo de este autor en su Galalea:

olrn vereis, en quien vereis cifrada Del sacro Apolo la mds rara ciencia, Que en otros mil sugetos derramadis, Hace en lodos de si grave aparencia; Mas en esle sugeto mejorada

Asiste en tantos grados de excelencia, Que bien puede. Vlosguera el Licenciado Ser como el mesino apolo celebradu.

El retrato del autor puesto al principio del libro es este.

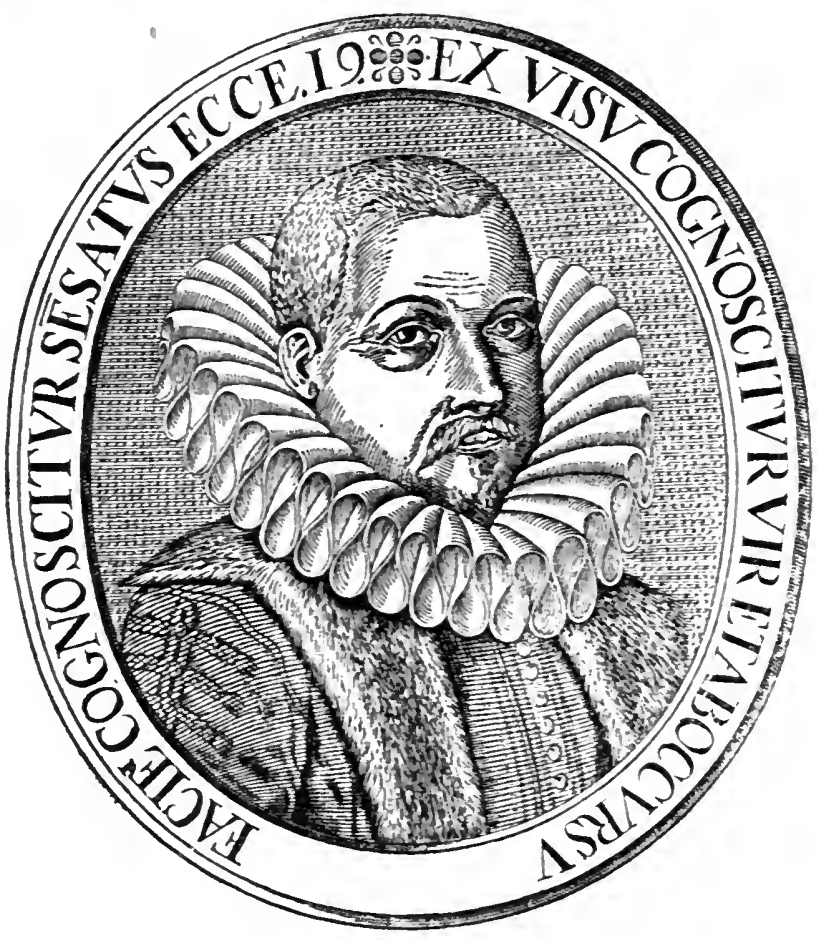

822 MOLSINHO DE CASTELBRANCO (Yasco). Discyrso sobre a vida, e morte, de Santa Isabel rainha de Portugal, \& outras varias Rimas. Por Vasco llousinho de Castelbranco. Lisboa, Manoel de Lvra, 1396. 1. let. curs. 1 lojas prels., 138 fols. y 3 de Tabla.

Nic. Antonio se reflerc á una edicion de esta obra hecha en Lisboa en 1594, dc cura existencia dudo, y no menciona la de $\mathbf{5 9 6 ,}$ bastante rara.

kil poema de la vida de sta. Isabel es en octaras, se divide en seis cantos, ocupa como una tercera parte del rolúmen; y es en portugues: el resto soll limas en varias clases de metro escritas enl dicho idioma y en castellano.

8æ3 Mlirillo (Diego!. Divina, dvlce. y provechosa poesia, Compuesta por el P. Fray Diego Murillo. Caragoça, Pedro Cabarte, 1616. 8. 16 hojas prels., ademas del retrato del autor grabado, de que doi el facsímile, $y \geq 6$ foliadas.

Raro.-Obra del genero de Ios Conceptos de Ledesma.

ro sé si será de la misma clase otro libro, cuyo titulu es algo parecido al de Murillo 
compuesto, segun Nic. Antonio, por Fr. Jaime de Torres, y se llama: Divina y humana poesia. 1579. 8.

El cronista Andres en su Aganipe, dice:

"Fr. Diego de Murillo desalando Los rindales copiosos de su vena, En dulce estilo hablando.

La conversion canto de Madalena,
$Y$ en sutil $y$ dulce poesta

Se vió la variedad de su armonia.

En los dnclos escrilos

Sus conceptos se admiran erudilos, Y por su pluma goza

Noble honor en su historia Zaragoza;

$Y$ d su liru y pinceles

Se deben dupticados los laureles.

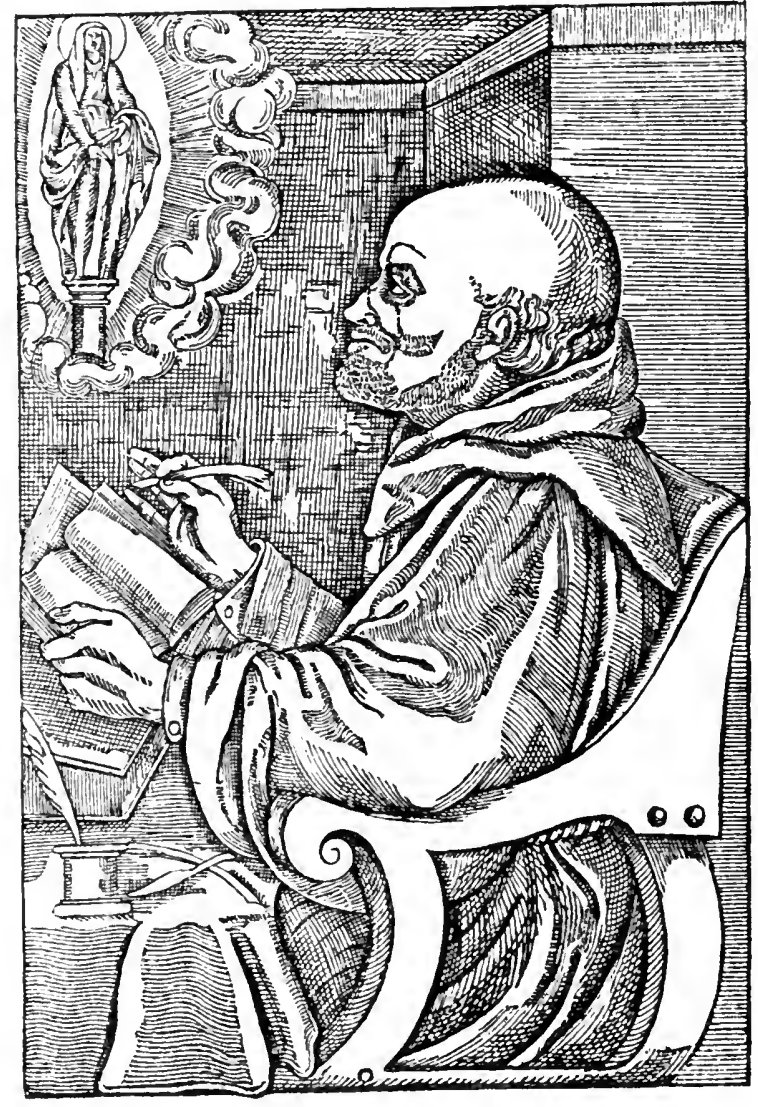

$\mathrm{N}$

8.4 NAVARRO (D. JoIqUIN). La hermosura sin lunal, qual es la del alma, y cuerpo de Maria santisima, significada en su vida, cscrita en estancias de cancion real, y segun la reveló la Señora a su sierva la $\mathbf{M}$. Maria de Jesus de Arreda: su autor el P. Doctor Joachin Navarro. Madrid, Joachin Ibarra, 1762. 4.

Está dividida en veintidos canciones.

82:) NaVarRo (Martin Miguel). Obras Poeticas del Licenciado Martin Miguel Nauarro. Mandadas sacar 
à luz. Por el Illustris. Sor. Don Antonio de Aragon. $40^{\circ}$ Manuscrito mui inteligible de mediados del siglo XVII, de unas 500 fojas.

Este códice es el mismo, adquirido del librero Mena en 1749 por D. Juan de Iriarte; segun Latasa, pasi luego á su sobrinn Don Tomas, y á uni me lo regalaron los herederos de este. Se conoce estiba preparado para la imprenta, pues ya tenia puestas al priucipio algunas aprobaciones, varios versos laudatorios y la vida del autor; y al fin lleva una noticia sumanente curiosa é interesan. te, en 18 fojas, sobre los principales poetas aragoneses, cuyo eplgrafe es ol siguiente: En la elivinn de lus obras del Cmonign Martin Miguel Savarro de Turaznna. A su lllmo. Mecenas rl Sor. D. Anlo:io de Aragon ete. D. Francisco Diego de Sáyas de Rabuncela (sic) y Ortubia.

Segun el ya citado Latasa, D. Ignacio de Asso publicó en Amsterdam en 1781 algunas poesias selectas, saciadas de este manuscrito.

Barrera llama á. Navarro elegante poeta latino y espiñol, y dice fue grande anigo de ambos Argensolis.

El marques de San Felíces le tributa en su Atalanta el signiente elogio:

La luz lanto en dos inclitos varones Empeños de sol hizo, que pudieron En siempre venpradis locuciones, Conseguir lo que insignes merecieron; Del doc: or Juan Fiancisco Andres blasones, Sus dulces vos's di'l Parnaso furon; Regir. det sol pulieva ardiente el carro, Al lado del Ductor Miguel Tararro.

\section{NICANDER COLOPHONIUS.}

Nicandri Colophonii Poetæ, et Medici antiquissimi: clarissimique Theriaca. Interprete et enarratore Petro lacobo Stere. Valentiae, Ioannes Mer, 1552. 8. ${ }^{\circ}$ let. curs. 4 hojas prels., 93 foliadas y una en que se halla el escudo del impresor.

Acompaña el testo griego á esta version en verso latino.

Al fin va el siguiente escudo ale Juan Mey, del cual usó alrumas vezes Pedro Patricio, sin el cuadro ni los cuatro florones de los angulos, segun se halla ell el Thesaurus puc- rilis de Povlo, edicion de 1615. Tamblen empleó el Juan uno inucho mảs pequeño que el presente, sin el cuadro ni florones y se encuentra en cl Oronli Finei de mundi sphera.

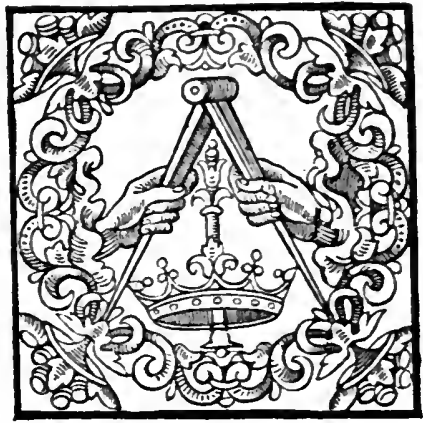

827 NIETO MOLINA (Francisco). El Fabulero: por D. Francisco Nieto Molina. Madrid, Don Antonio Muñoz, 1701. 4. ${ }^{\circ}$ ö hojas prels. y 121 paigs.

Son varias fabulas mitológicas, escritas en diferentes metros.

$8 \geq 8$ - La Perromachia. Fantasia poetica en redondillas, con sus argumentos en octavas, por Don Francisco Nieto Molina. Madrid, Pantaleon Aznar, $1763.8 .^{\circ}$

$8 \geqq 9$ NUÑEZ DA SILYA (ANDRE). Hecatombe sacra on sacrificio de cem rictimas, Em Çem Sonetos, Em que se conthem as principaes acçoēs da Vida do glorioso Patriarcha S. Caetano Thiene. Eseritos Por Andre Nunez da Sylva. Lisboa, Miguel Deslandi, 1686. 8. ${ }^{\circ}$ II hojas prels., 100 págs. y dos hojas más, la una contiene un Soneto final y la otra una corta advertencia sobre las fuentes de donde se sacó esta obra.

Son ciento un sonetos en portugues.
830 OX̃a (Pedro de). Araveo domado. Compresto por el Licenciado Pedro de Oña, natural de los Iufantes de Engol en Chile. En Madrid, por Iuan de la Cuesta, $1603.8 .^{\circ} 16$ hojas prels., 342 fols. y 2 de Tabla.

Edicion bastante rara.-La primera se publico con el siguiente título, segun Brunet: 
Primera parle de Arauco domado, compuesto por el Licenciado Pedro de oña, natural de los Infantes de Engol en Chile. En la ciudad de los Reyes (Lima) por Antonio Ricardo de Turin, primero impresor en eslos reynos año de $1596.4 .^{\circ}$ Con el retrato del autor.

Nic. Antonio no cita las ediciones ántes descritas; pero menciona dos de Madrid de 1596 (no 95 como dice Brunet) y 1608: me figuro se cquivocó en el lugar de la primera y en la fecha de la segunda y que las únicas existentes son la de Lima y la madrileña de 1605. Nada tendrá de estraño semejante error, pues se debe presumir no vió la obra, cuando dice hablando de su autor: Chilensis natu forsan, de lo que se hubiera desengañado con solo tener presentes las portadas $\dot{0}$ las aprobaciones del libro.

Es un poema épico en oetavas, divididn en diez y nueve cantos: el asınto el mismo de La Araucana de Ercilla y aunque mui inferior en mérito literario la versiflcacion es fácil.

Los traductores de la Historia de la literatura de Ticknor, tom. Hl., pág. 472, dan noticia de otra obra que trata tambien de la guerra de los arancanos, cuyo título es: Compendio listorial del descubrimicnto, conquista y guerra del Reino de Chile, con otros dos discursos. Compuesto por cl Crtpitan D. Melchor Xufré del Aguila. Lima, Francisco Gomez Pastrana, 1630. 4. Está el verso.

Nic. Antonio habla de una produccion de oña, intitulada: Temblor de Lima en cl año de MDCIX. Lima, 1609.

831 OÑA (Pedro de). El Ignacio de Cantabria. 1. ${ }^{a}$ P.te Por el Lic.to Pedro de Oña. En Sevilla Por Francisco de Lyra. Año de Mocxxxix. 4.' 4 hojas prels., inclusa la portada grabada, y 214 fols. C'ada libro lleva una viñeta bastante bien grabada en cobre.

Pocma en octavas dividido en doce libros.

Nic. Antonio no conoció esta obra poco comun.

Ignoro se haya publicado la segunda parte.

832 OSORIO DE CEPEDA (JUAN). Tesoro de Cristo y Rescate del mvndo. Sonetos morales. A todos los passos, y misterios particulares de la Sagrada Passion di nuestro Señor Iesu Christo, y a los dolores, y penas de Maria Santissima su digna Madre, segun la letra de los Euangelistas, y Dotrina de los Santos. Por Don Ivan Osorio de Cepeda. Madrid, Catalina de Barrio y Angulo, 1645. 4. ${ }^{\circ}$ 16 hojas prels. y 36 fols.

Consta esta obra de setenta sonetos.
Nic. Antonio no trae en su Bibliotheca á Juan Osorio de Cepeda.

833 OVANDO SANTAREY (JUAN DE). Ocios de Castalia, en diversos Poemas. Comprestos por D. Jvan de Ovando Santaren Gomez de Loaysa. Malaga, Mateo Lopez Hidalgo, 1663 . $4 .^{\circ} 18$ hojas prels., inclusas dos láms. una con un escudo de armas y otra que representa $a$ Sanson, 231 hojas fols. y otra de Tabla; hai ademas 4 láms. tan detestables como las dos antedichas, que van colocadas delante de las fojas $5,177,178$ y 183.

Desde el fol. 186 al 217 haj una Descripcion panegirica de Malag't, en oclavas', y la quinta parte, de las cinco en que estí dividida la obri, son Poesíus latinus $d^{\text {'l }}$ Lic. Don Diego Maldinado, autor no mencionado por $\mathrm{Nico-}$ Jas Antonio.

Ticknor cita (tom. IlI. pás. 143) otra obra de Ovando Santaren, intitulada: Oיfeo melilal, en dos partes, impresas en Mataya (1688). 4.

834 OVEN (Juan). Agviezas de Jvan Uven, tradvcidas en metro castellano, ilvstradas, con adiciones, $y$ notas, por Don Francisco de la Torre. Madrid, Francisco Sanz, 1674. 8 hojas prels. y 346 paigs.-Segrnda jarte. Madrid, Antonio Gonçalez de Reyes, M.Dc.LxxxII. 8 hojas prels., 316 paigs. y 3 hojas de Tabla. 2 rols. en $4 .{ }^{\circ}$

La traduccion de la segunda parle, que contiene el libro llamado Uno y los Disticos politicos " morales de Migucl Verino, es obril póstuma; Nic. Antonio so'o menciona la primera.

Las adicimes tambien en verso, hechas por I. Francisco de la Torre y Sebil, componen otro tanto ó más que la obra de oven.

833 OVIDIO (P.) NASON. Heroyda ovidiana: Dido a Eneas. Con parafrasis española, y Morales Reparos Ilvstrada. Por Sebastian de Alvarado y Alvear. Bovrdeos, Gillermo Millanges, M.DC.XXvir. $40^{\circ} 20$ paigs. de prels., 333 la obra y 3 hojas de Indice.

Alvarado y Alvear trae ejemplos numerosos, sicados de nuestros buenos poetas, en apoyo de sus reparos á la Heroilla ovidiana. o sea la Epistola Vil de ovidio. 
ñetas de madera al principio de cada libro. Las transformaciones 20 hojas prels., la última blanca, 179 fols. $y$ olra blanca; Las anotaciones 314 hojas fols., inclusos los prels., y $\mathbf{4}$ de Tabla sin numeracion.

Los ejemplares suelen tener las márgenes recortadas y faltan generalmente las 4 últimas hojas de Tabla: el mio es hello y completo.

811 OVIDIO NASON.
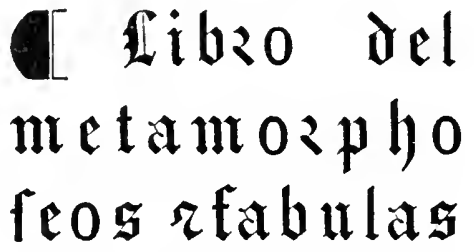

del exelente poeta y philofo, pho Onidio noble caualle

ro patricio liomano:

tradujido de latin en

romalice. Agoza

nutuamēte coz

renido y alia

dido elle

fta ter.

cerat

impzeffion.

Año. . ftl. .⿴囗十. . C.

CEsta leyenda, toda de colorado, ménos el calderon y el año, va circuida de orla, y al fin del tomo se lee:)

Ine impzeffa la piefente obza s̈lamuy noble may leal cibdad d' feuiblla en cafa d' Sebar

tiā erujillo imp?effo? ’’ libses: a une

ftra fertoza d' Gracia. Arabofe a quimze dias d'l mes d'abzil

Año de tht.․․…

8. let. gót. ccciij hojas foliadas inclusas las preliminares, 7 sin numeracion para concluir la Tabla, y una blanca.

Esta traduecion en prosa de las Melamor. fosis, a pesar de no llevar al principio las coplis de que bablaré despues, es la misma de. Jorge Bustamante; es rara y no niencionada por Nic. Antonio nl Pellicer.-En Lóndres tuvimos una edicion, sin duda la primera, cuya descripcion es la siguiente: Libro del Matamorphoseos y fabulas del excelète poeta $y$ philosofo Ouidio noble cauallero Palricio romano: Traduzido de latin en romance. (Esta portada va circuida de varias flguritas de cuerpo entero. Al dorso empieza una Eprstola del impresor á D. Alonso de Azevedo, Conde de Monterey. Por ella aparece ser este impresor estranjero, tener casa en Paris, y que pensaba establecer otra en Medina ó Salamanca; pero como no consta por parte alguua el lugar de la edicion, es difícil atinar su nombre. Dicha Epistola ó dedicatoria ocupa ademas el blanco de la otra hoja, signatura aij, y al dorso empieza el Prólogo y argumento, el cual llena tambien las hojas 3. 4. $^{\mathrm{a}}$ y 5 . $^{\mathrm{a}}$; en el blanco de la 6. . van cuatro octavas, cuyo acróstico leido al revés dice: Jorge de Bustamante nalural de Syl(i)os. Vieue ya luego en la hoja 7 , $^{a}$, sign. $b$. I $\mathbf{L i}$ bro primero del chans etc. y concluye la obra con la hoja excij. Se hallan por fin seis de Tabla.) S.l. ni a. $40^{\circ}$ let. gót. bastante buena á renglon tirado. Como no conservo copia de lis cuatro octavas comprensivas del acróstico y estas se suprimieron en la edicion que poseo de 1550 , no sé si serán las mismas del Justino de 1542 , traducido tambien pir Bustamante. (Véase el artículo de Justino en la Seccion histórica.-Historia gencral.) be esta misma version he visto: Las Metamorphoses, o Transformaciones del muy ceccelente poela ouidio, repartidas en quinze libros y tradusidas en Caslellano. Anver's, En casa de Inan Steelsio. M.D.LI. 8. 20 lıojas prels. y 236 fols., y Las transfor. maciones de ovidio en lengua española, reparlidas en quinze libros, con las Allegorias al fin dellos, y sus figuras, para prouecho de tos Artifices. Anvers, En casa de Pedro Bellero, M.D.XCV. 8. ${ }^{\circ}$ láms. de madera. 18 lojas prels. y 2/1 fols. En Inglaterra examine otra jmpresion cuyo titulo decia: Las Melamorphoses, ó transformacimes det excelt :te Pocta Ouidio, en quinze libros buelto en Cuistellano. Madrid, Alomso Marlin, MDCXXII. 8.': en esta edicion ocurren variaclones mui esenciales respecto de las anteriores. El Sr. de Gayángos en su folleto sobre Palmerin indica que esta última edicion de. Las Melamorphoses de ovidio, la ántes deserita de Bellero, 1595, y otra citada por él de Toledo, Francisco Guzman, s. a., encierran la version de Luis Hurtado: sospecho, sin embargo, son reimpresiones de la de Jorge Bustamante; pero no puedo asegurarlo porque no las poseo y no ine es dado cotejarlas.

842 OVIDIO NASON. Metamorfóseos 6 Transformaciones de Ovidio, traducidas al castellano, con algunas notas pará su inteligencia, por Don Francisco Crivell. Madrid, Imprenta Real, 1805. 4 vols. 4." Muchas y bonitas lams. grabadas cn cobre. 
Traducclon tambien en prosa.

Hai un Restumen en prosu de las Melamorfosis. Madrid, Hija de Ybarra. 1807. $80^{\circ}$

En esta misma division y en el artículo de Fellpe Vey (Nún. 804), se encontrará la descripcion de la traslacion en verso de la obra de Ovidlo unida á las Rimas de aquel.

\section{OVIDIO NASON.}

\section{Tanla dels quinie libres d’ tranfformaciong Del poeta onidi partida per libres : $e$ capitols com fe fegneix}

(Así principia la hoja primera signatura a. i. y a continuacion de este epígrafe comienza la labla, que ocupa 6 hojas; sigue una blanca y luego la a ij. Cartas i, empieza:)

Ala illnftriffina fenyora la fenyora dona Ioalla d' Ara go filla del molt alt e potel tiffium fenyor don ferrando fegon :noftre hey e fenyor $a b$ humil affecrio francefth alegre befa les dignes mās.

(Llena la dedicatoria hoja y media, pues el dorso de la a. iij. es blanco. En la a iiij, mal foliada Carta. i., debiendo ser iii., principia la obra, que concluye en el blanco de la cclxviiii, la cual está señalada por errata cclxvii, con estas palabras:)

Acaben los quinze libres d’ tranfformacions del poeta onidi:e los quilize libres de allegories e morals expofici ons fobre ells eftapats en barcelona per pere mignel. Benanenturadanent $\mathfrak{e n}$ ef panya e enlog regnes $d$ ' ara go regnāt los innictiffimg.e preclariffinis don ferralldo e dona yfabel. any .eft. frcrlexxxiii: a xxiiii d'abril
Sigue el registro que indica las signs. a-z, A-E, advirtiendo que la r y la $\mathrm{E}$ son ternos y todas las demas cuadernos.)

Fol. let. gót. á dos cols. Buen papel.

La última hoja es impar, no obstante completa el cuaderno; esto proviene de estar la foliatura disparatadísima, pues el volúmen realmente solo tiene 250 fojas en todo.

En Paris vi un ejemplar que tenia la singularidad de contener duplicalas con variantes dos hojas, á saber, la đe la dedicatoria á Juana de Aragon y la sesta del testo.

Comprende este volúmen no solo los quince libros de ovidio sino ntros quince, los cuales principian á la sign. . $i$. con la siguiente leyenda: Prolech de francesch alegre enles allegories: e morals expnsions dels libres d'transformacions del poela ouidi difinint poesia faula: e allegoria.-Es en prosa la presente version lemosina de 0 ridio.

Clasifico este libro entre los más precio. sos de mi biblioteca. Méndez ni Brunet no lograron verlo, y en 1825 vendió Sotheby en Lóndres un éjemplar encuadernado en pergamino por 59 lib. est.

Cerraré el artículo de este autor describieudo la siguiente obra, que he visto, por tener alguna relacion con las Metamórfosis del poeta latino: El Varcisso Flor traducida del Cefiso al Betis. Por El Liccnciado Inan Bermudez $i$ Alfarn... Lilio cultiuado en cadencias rimis, sino tan oloroso como en sus palernos exametros. Imitaciun Dol dulce Poeta latino en las transformaciones quinta $i$ sexla de su tercero libro. En Lisbor por lorge Rodriguez. 1618. 8. 54 fols., incluso el fróntis. Todo en octavas.

814 OVIEDO HERRERA Y RUEDA (Lis Antonio). Poema sacro de la Passion de N. S. JesuChristo, que en in romance castellano, dividido en siete Estaciones, Escribia Don Lvis Antonio de Oviedo Herrera y Rueda. Lima, Francisco Sobrino, 1717. $4 .^{\circ} 6 \geq$ hojas sin foliacion hasta la sign. Il inclusive; la $\mathrm{N}$ principia porla foja 25 y termina en la 128; despues en dos hojas hai cuatro sonetos á la muerte del autor.

El fróntis indica ya el mptro en que está escrito este poema y su division.

845 Vida de Sta. Rosa de Santa Maria, natyral de Lima y Patrona del Peru. Poema heroyco de 
Don Luis Antonio de Oviedo y Herrera. Madrid, Juan Garcia Infançon, 1711. 4." 41 hojas prels., inclusa una lámina que representa á Santa Rosa y al autor escribiendo su obra, y $\mathbf{4 8 4}$ paigs.

Poema en octaras dividido en doce cantos.

846 OYANGUREN (IÑgo DE). Quaresma poctica. Distribuida por todos los dias de la Quaresma, en un Soneto, y veinte Coplas de Romance Castellano cada Feria, desde el Miercoles de Ceniza, hasta el Domingo de Pasqua inclusivé. Por D. Iñigo de Oyanguren. Madrid, Joseph Gonzalez, 1739. 4. ${ }^{\circ}$ L' hojas prels. y 183 paigs.

84t OZFjo (Ploro Nolasco de). El Sol de los anacoretas, la Luz de Eingto, el Pasmo de la Tebayda, el Assombro del mindo, el Portento de

819 P.DILIA (D. JUAN DE).

\section{Cos do 0 e triūphos}

delos doje Apoftoles: ferhos pozel cartuzauo: pfeffo eu fea ftlaria d’las cueuas en fenilla.

\section{$\mathfrak{T} \overline{0} \mathfrak{p} \mathfrak{e} \mathfrak{u}$ illegio.}

CEste título, lodo de encarnado, va precedido de doze viñetilas que representan á los Apistoles, y el todo se halla circuido de una grande orla. Al dorso hai una caboza de S. Juan Baulistu, y las tres hojas siguientes las ncupa la Tabla; la quinta y sesta las llena el Argumento, una lámina del Cielo estrellado, la dedicaloria y otra lámina alegórica del signo de Aries. La obra comiensa en la selima hoja fol. jy concluye en el lxij asi:) la Gracia; la milagrosa vida de San Antonio Abad. Puesta en octavas por Don Pedro Nolasco de Ozejo. Madrid, 1737. 8. 20 hojas prels. y 200 págs.

Poema dividido en cinco cantos y el presente ejemplar lleva al fin la firma del autor. Es obra de pésimo gusto; contra ella se publicaron algunas críticas á las que contestó ozejo en el siguiente folleto.

848 OZEJo (Pedro Nolasco de). Los Impressores y Plumistas de la Corte, en busca dell Diario Apologetico de las murmuraciones. Prossa corriente, y vulgar, para que todos lo entiendan. Escrito por Don Pedro Nolasco de Ozejo. Madrid, Alonso Balvas, (1738). 8. 4 hojas prels., 37 págs. y una hoja para el anuncio de varias obras del mismo autor.

Contiene algunas poesías en varias clases de metro.

\section{Q Aqui fe acaba el trim} pho de funt filathias apoftol: y poftrero delos doje lriüphos. Acabofe la obsa de sō poner voninga en.xiiij. de febero de mill Y. quinientos. xuiij.años dia de fant balers: tino martyr. Eue empsemida enla may no. hle y mny leal cibdad de Sentila: po: Inan varela.n.n.dins d'l mes d'Otubse: año d'ñ̄o folundo de mill y quiniêtos y.xxj. años.

Fol. Bella edicion en let. gót. á dos cols. 6 hojas prels.y 62 fols.

obra rarisima desconocida á Nic. Antonio. la Serna cita una edicion de 1529 que nunca he visto. iLa confundirá acaso con la del Retablo de la vida de Cristo hecha en Alcalá en dicho año?

Los Triunfos de los Apóstoles los reimprimió el canónigo Riego en el tomo que publici en lóndres en 1843 con el título de Coleccion de obras poelicas españolas (Véase dicho artículo entre los Cancioneros, Romanceros, etc. Núm. 215.)

830 PADILLA (D. JUAN DE). Retablo dela vida de Christo: hecho en metro/ por el deuoto padre don 
Juán de Padilla mōje Cartuxo. I Jmpresso con licencia en Alcala de Henares / por Sebastian Marlinez. Año. M.D.Lxxvij. (Esta es la leyenda del fróntis encima de la cual hai un gran crucifijo, y el todo va rodeado de orla. Al dorso se encuentra una aprobacion; en el blanco de la hoja siguiente la licencia, $y$ al reverso principia la Tabla que ocupa por entero la tercera; el blanco de la cuarta es el Argumento y á la vuelta comienza la obra que termina en el dorso del fol. Ixviij con este colofon: $)$ Fue impresso con licencia la presente obra en Alcala de Henares / por Sebastian Martinez. Año de mil y quinientos y setenta y siete (1377). Fuera de la puerta de los sanctos Martyres. Fol. let. gót. á dos cols. Viñetäs de madera. 68 fols. inclusos los prels.

Ejemplar tan bello que tiene muchas hojas sin cortar.

Nic. Antonio no vió esta obra y se reflere á Teodoro Petreyo al citar la edicion de $\mathrm{Se}$ vitta, Juan Vela (será Varela?), 15l8. Fol. Brunet menciona la de Alcala de henares a ocho dias de nouiēbre. año d'mil z ãniètos y $x x i x$ (1529). Fol. let. gót. á dos cols. Viñetas de madera; y tambien una segunda de Scvilla, Juan Varela, 1550 Fol.

Yo be visto una fdicion en cuyo frontis se lee estar Impresso con liccncia En Toledo. Por Francisco de Guzman. Año de. 1570 , á pesar de decir al fin del tomo con todas las letras que es de 1567 . Fol. let. gót. á dos cols. Láms. de madera Ixx fols. inclusos los prels.

El P. Sarmiento en la Historia de la Poesía (p. 385), encarece la rareza de esta obra, sin embargo de haberse reimpreso tantas vezes, y añade no haber conseguido verla, si bien sabia la existencia en Paris de un cjemplar de Valladolid, 1582. Fol. He tenido ocasion de examinar la publicada en Alcala de Hcnares / en casa de Sebastizn Marlinez que sea en gloria. Año de M.D.XCiij. Fol. let. gòt. táms. de madera; $\mathrm{y}$ he visto la del mismo pueblo de 1605. Fol., aunque no me fuè posible tomar nota más circunstanciada de ella.

En el año de 1843 publicó en Lóndres el canónigo Riego algunos cortos estractos de este libro, á continuacion de su reimpresion delos Triunfos de los apóstoles del mismo Padilla (Véase Coleccion de obrus poélicus españolas, en los Cancioneros y Romance. ros, Núm. 215.). Tambien se formó en su mayor parte, con coplas sacadas del Recablo de la vida de Cristo, el testo puesto á las láminas de Julio Fontana que representan la Vida de Nuestra Señora bendila Maria (Véase este articulo en la presente division.) Méndez y La Serna Santander describen otro tratado de este autor cuyo titulo es:
El laberinto del Duque de Cadiz Don Rodrigo Ponce de Leon. - Las ciento y cinquenta del laberinlo compueslas por fray Ju in de $P a$. dilla, Cartuxo, antes que retigios? fuese. (Al fln:) Aqui se acaban las ciento y cinquenta coplas por fray Juan de Padilla Cartuxo pro. feso de las Cuebas de Sevilla. Inpresas en Sevilla en el año de mill e quatrocientos $e$ novenla e tres (1495). $4 .^{\circ}$ let. gót.

851 PAdilla (Pedro de). Eglogas pastoriles de Pedro de Padilla y ivntamente con ellas algunos Sonetos del mismo Auctor. Serilla, Andrea Pescioni, $1582.40^{\circ} 4$ hojas prels. y 246 foliadas.

Por errata o error menciona Yic. Antonio una edicion de 1581: tengo por primera $\mathrm{y}$ probablemente por única a la de 1582, siendo de este año la fecha de la dedicaloria.

Todas las obras de Padilla se encuentran con diflcultad; sin embargo Romancero y Eglogas sobrcpujan á las demas cn rareza.

Contiene el presente volúmen muchas muestras de poesia nacional, tales como villancicos, lctrillis, glosas, elc.

Cervántes en el Canto de Caliope formó de este autor el siguiente juicio:

Almireos un ingenin en quien se cncierra Todo cranto pedir puede el deseo,

Ingenis que aunque viva acá en la lierra, Del allo cielo es su calldid !f ariono;

Ora lrate de pas, ora de gumra, Torlo cuanto yo mivo, escucho ylen De' cetebrado Pedro de Piadilla Me causa nuevo guslo y mavavilla.

En la portada deI tomo se cucuentra el es. cudo del impresor Pescioni copiado i continuacion. El mismo circuido de una orla mayor está en las obras de Romero de Zepeda.

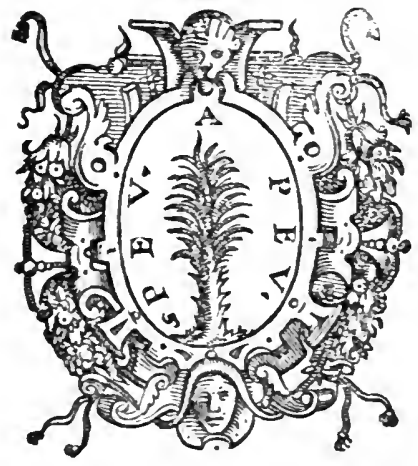

852 PALAFOJ (JuX DE). Gria, y aliento del alma riadora... Compresto en metro, por el llistrissimo Señor D. Jvan de Palafox. Bruselas, 
Juan Baptista Verdussen, s. a. $8^{\circ} \mathbf{8}$ hojas prels. y ̈̈68 paigs.

La aprobacion y licencia para la impre. sion son del año 1682.- - No encuentro esta obra citadi en la Bibliolheca de Nic. Antonio, en el artieulo de Palafoj.

8 8̈3 PANEGIRICO por la pocsia. Sigue un gran escudo de armas de los Teras sostenido por un águila, y al fin del volimen se lee:) Impresso en Montilia, Por Manuel de Payua. Año de $1627.8 .^{\circ} 59$ hojas fols., inclusos los prels., y $\ddot{j}$ de Tabla sin foliar.

En la censura dada al principio de este librito por el P. Juan de Vitoria se dice, que años pasalos lo aprobo Lopre di Vega !t se dis al molde con nomlre del autor, sibien no laro efelo por la desconfiansa del acierto...Pero hoi com alenciones parliculu'es no se ha podidi negar a salir enteramente; aumque sin el ariffice. l)e aquí se deduce existirán probablemente ejenplares de una edicion inís antigua, y sin duda teudrian presente alorino de ellos los traductores de Ticknor, segun se ve en la píg. 565 del tom. Il., donde resueltamente dicen ser el autor del P'unegirico D. Juan Antonio de Veral y huñiga. Sin ('mbargo Nir. Antonio lo atribuye a $D$. Fernamlo de Vera, quien escribio otra ohra intitulada: Explicacion y nolas al libro quarlu del Arle commen. Granada. 16.51. $8 .^{\circ}$ y al mismo se lo atribuyen Ifontiano $\mathrm{y}$ Luyando, Barrela y D. Aurelimo FernandezGuerra en su Sulicia de un códice de la biblinl'ce colombina, que va al fill del Ensaij" de una bibliolecu española de Gallardo, donde dice, se publico en Momtilla, 1620.

El Pane'firico por la poesia es un libro tan difícil de encontrir que Barrera lo llama verdarler: ruriosided bibliografica y los traductort. 's Tieknor lo calliflean de obre rara y curver. Conticne ademas noticias interesantísimals de muchos poetas castellanos, dando algumas muestras de sus composiciones, entre las cuales hai el siguiente soneto de Felipe IV.

Es la unuerte un efelo poderoso

Firme en su proceder mal entendido,

Ámdda de Mitrídates rencido,

Temida de ['ompeyo victoriosi).

Es la muerte in antídoto dudoso

Al veneno del misero lendido,

Que de propias desdichas sacudido

Libra en eterno sueño su reposo;

pluerto donde la nave combatida

De la saña del mar contrario y fuerte,

Piensa tener propicia la acogida.

Es un bien no estimado, de tal suerte,

Que todo lo que vale nuestra vida

Es porque liene necesaria muerte.

Lástima es que on un tratadito tan apreciable se encuentren ideas tan estrambólicas como las de querer probar, haber sido alumnos de las musas Jesu Crislo, su madre la Vilogen y tanbien Luzbel.
834 PEDRO DE PORTUGAL (EL INFANTE D.).

\section{$\mathbb{C o p l a s} \quad \mathfrak{f} \mathfrak{c}(\mathfrak{l}) \mathfrak{s}$ por $\mathfrak{s l}$} muty illuftre Ser̃oz in. fante dō pedzo de poz. togal :enlas quales ay Atlil uerros coll fins glo. fas/contenientes del meenefpzesio: e contempto delas rofas fermofás del mundo:e deinoftrando la fax vana:e feble beldad.

\section{辺}

(Este es el eprgrafe que lleva la primera hoja, que debia ser sign. a, aunque el impresor la olvidó, pues no tiene fróntis ni nunca lo tuvo. Al fin en el blanco de la última hoja se lee:)

\section{Acabã fe las coplas} fecl) $\mathfrak{a} \mathfrak{s}$ po el muy illustre feñoz infante don $\mathfrak{p e d r o}$ de postogal.

\section{国e gracias.}

Esta edicion es sin duda la descrita en la Tipografía española; sin embargo de que si se comparan las octavas copiadas por Méndez con las de mi impreso, casi podia sospecharse ser distinta. Véase como muestra de las considerables variantes la última, que en mi ejemplar, copiada literalmente, dice:

Si veys a los malos / ser muy enxalçados Y a los buenos / venir afticciones Ni por aqueso / sed vos aparlados De guiar al bien / vuestros coraçones Por ȳ los puersos / cõ sus falsos dones Al fin in elerno / sosternan tormentos Los buenos cobrädo / v'os galardones Serä féchos dioses / de bienes cờlêtos.

Hain indica de una manera vaga y sin fljar el tamaño de ellas, la existencia de otras 
dos ediciones de estas Coplas, una de las cuales dice al fin: Jmpr'rssas seis annos depnis yne em Busilen fol"u uchuda a famosa arle le imprimission, y la otra: linpressas nove annos depois de inventada a famosa arle da imprimissào.

Mí impresion la conceptuo hecha en Portugal hácia el año de 1490.

Sarmiento no cita ninguna edicion ni co. nocii) estil composicion. sino por haberla incluido Reseude en su Cancionero y Labla de ella y ue sil autor en Ia píg. 380 de la Hisloria de la poesia. Pero Resende en el fol. $73 \mathrm{y}$ signientes puso uinicamente las $C_{0}$ plas y no la glosa, la cual, segun Barbosa Machado, es de Anton Inrrea.

Las oetavas de que consta estit nbia, ni aqui ni en el Cancinnero de Resrnile son ciento veinticuatro, ni cisnto veintise is, como supnnen el citado Barbosa y llendez, sino ciento veinticinco, y así es necesario sea para haber mil versos como se dice en el epigrafe.

8ä3̈ PELLICER DE OSAU (IIpólito). Genetliaco del serenissimo Principe Don Fernando Wenceslao, Rey de Vngria, y de Bohemia, Archidure de Arstria. Por Don Hipolito Pellicer de Ossar. Madrid, M.DC.LXVII. $4 .^{\circ} 4$ hojas prels. y $1 \ddot{\partial}$ paigs.

830 PELLICER DE SALAS Y TOVAR (José). El Fenix y sv historia natural escrita En reinte $y$ dos Exercitaciones, Diatribes, o Capitulos. Por don Iosepli Pellicer de Salas y Tobar. Madrid, Imprenta del Reyno, CID l'J XXX (16:30). 8. 20 hojas prels., 20 del pooma El Fenix, 260 de Diatribes y 16 de Tabla.

El poema del Fenix de Pellicer que ra al principio consta de 1150 versos; ademas ha $i$ composiciones inétricas al mismo asunto del Conde de Villamediana. Anastasio Pantaleon de Ribera, D. Gabriel de Corral, D. Francisco de Quevedo y del mismo Peliicer.

\section{3̋7 PELLICER DE TOVAR} ABARCA (José). La Astrea safica, Panegirico Al Grā Monarca de las Españas, i Nuevo Mundo. En que Recopila los Mayores Sucessos de su Felicissimo Keinado, hasta el Año M.DC.XXXv. Don Ioseph Pellicer de Tobar Abarca. Serunda edicion, mas añadida, i emendada. Çaragoça, Pe- dro Verges, M.DC.XLI. 8. 2 hojas prels., 94 paigs. y dos hojas más sin paginar. En la úllima se pone como fecha de la impresion M.DC.X. $\mathbf{L}$.

D. Nic. Antonio cita una edicion de este poema de 1640 , sin lugar de impreslon, la cual será probablemente la prinera; pero no supo el año de la publicada en Zaragoza.

Los traductores de Tieknor-mencionan otra obrita dada á luz por 1). José Pellicer con el enfítico titulo de Anfileatro de Felipe el Grande, impresa en 16.31; se compuso en celobridad de la muerte dada por el rei á un toro en la plaza Nayor, disparándole un arcabuz desde el balcon de la l'anaderla. Contiene el tomo poeslas de ochenta y seis ingrenios de lo mis florido $y$ aventajado que i la sazon habia en la corte.

838 PERALTA (JEAX DE). Las tres jornadas del Cielo. Via Purgativa, Iluminativa, i Lnitiva. Significadas en Gemidos, Deseos, i Suspiros. Ordenadas en inetrica consonancia, para mas suave armonia al corazon, Por el R. P. Fr. Juan de Peralta. Lima, Imprenta de la Plazuela de San Christoval, 1739. 8. ${ }^{\circ} 16$ hojas prels., XXX de una Breve noticia del P. Peralta y 171 pags.

Poema escrito en liras y dividido en quince gemidos, quince deseus y quince suspiros.

839 PERALTA BARNUETO ROCH.I Y BEXAYIDES (PEDRO DE). Lima fundada. 0 Conquista del Perú. Poema heroico en que se decanta toda la historia del Descubrimiento y sugecion de sus Provincias por Don Francisco Pizarro. I se conline la serie de los reves, la Historia de los Virreges y Arzobispos, que ha tenido; y"la memoria de los Santos, y Varones ilustres, que laciudad y Reyno han producido. Por el Doctor D. Pedro de Peralta Barnueuo Rocha y Benavides. Lima, Francisco Sobrino y Bados, 1732. 2 vols. $4 .^{\circ}$

Pocma dividido en diez cantos y escrito en oetavas. Al pie de las piginas y en las mar. genes de cllas se cncuentran muchas notas históricas.

PEREgRINO (Axgea . La mejor guirnalda de Apolo. Véase en la Seccion dramática. 
860 PEREIRA BRACAMONTE (Domingos). Banquete que Apolu lizo a los Embaxadores del rey de Porlugal Don Ivan Quarto. En cvyos platos hallaran los señores combidados, mesclada con lo dulce de alquna poezia, y politica, la conseruacion de la salud humana. Por el Licenciado Jomingos Pereira de Bracamonte. Lisboa, Lourenço de Amberes, 1642. 4. ${ }^{2}$ hojas prels. y 164 págs.

Se describen en estil obra, en varias clases de metro, las calidades de ciertasfrutas, verduras y legumbres, $y$ luego en prosa se esplican sus propiedades medicinales, ingiriendo de paso algunas reflexiones politico-morales.

No encuentro en Nic. Antonio mencion alguna de Pereira Bracamonte.

801 PEREYRA (Luis). Elegiada de Lurs Pereyra. (Lisboa,) Manoel de Lyra. Anno 1588. 8. ${ }^{\circ}$ i hojas prels. y 286 fols.

Bellisimo ejemplar con muchas hojas sin cortar.

Poema portugues escrito en oclavas, divillido en diez yoch"s cantos. llai al principio alounos versos en alabanza de lia obra, de l'edio de Andrade, Frincisco de Andrada, D)iegn Beplnildez y Jerónimo Corte Real.

Brunet encalece la loaza de esta primera edicinn y añade, se volvio i publicar con el título de Jornada da Africa, poema. Lisboa, $1755.8 .^{\circ}$

862 - Viuiendo el Rey Don Sebastian de Africa para Lisboa el año de Setenta y quatro disgustado por no auelle succedido la jornada como el quisiera, con aquella melancolia pide que le quenten lo succedido a una naue que uiniendo de la India se perdio Junto al Cauo de Buena Esperança. Es sacado de la Elegiada de Luys Pereyra que en lengua Portuguesa hizo a la perdida del dicho Res. Manuscrito de principios del siglo XVII en letra mui inteligible y de 33 hojas en 4.0

Hai al principio una especie de prólogo ó dedicatoria que dirige A Doña Maria de Porres st prim" y seruidor, en la cual dice, que salbicudo era esta siñora aficionada á cuentos trisles, se decidii á ocuparse en la traduccion del rpisodio comlado por pereira, durante uni convalecencial que le tuvo encelrado en su aposento.
El manuscrito que poseo contiene hasta ciento veintisiete octavas; ignoro si están todas las que trasladó el intérprete español.

863 PEREYRA DE CASTRO (GAbriel). Vlyssea ov Lisboa edificada. Poema heroico, Composto pelo Doutor Gabriel Pereira de Castro. Lisboa, Lourenço Crasbeeck, 1636. 4. 10 hojas prels. y 207 fols.

Primera edicion rara.-Lleva al principio un elogio en verso y uni biscurso poctico de Manuel de Gallégos.

El poema es en octavas y va dividido en diez cantos.

864 La misma obra. Lisboa, Miguel Rodrigues, M.Dcc.XLy. 8. 21 hojas prels. y 413 págs.

Segunda edicion; reimpresion exacta de la anterior.

865 PÉrEZ (Juan). Ioannis Petreii toletani Oratoris eloquentis. nec nõ \& poëtæ ingeniosis. libri quattuor in laudem diuæe Marice Magdalenæ, vná cum alijs eiusdem opusculis in fine adiectis. Ad sereniss. Principe Hyspaniarũ Philippvm, nunc primum in lucē rediti, \& diligenter excusi. (Sigue un escudo mui parecido al de lus Grifos.) Toleti. Apud fratres Ferrarienses. (Colofon:) Excusum prasens opus, apud Fratres Ferrarienses, Toleti. Anno Domini. M.D.LII. 8. 93 hojas fols., incluso el fróntis, una más de Errata $y$ otra con el mismo escudo de la portada.

Segun el índice que va al dorso de la primera hoja este tomito contiene ademas de los cuatro libros del poena de Santa María Magdalena:

Genelhliacum sercniss. Principis Philippi.

Epithalamium eiusdem et sereniss. Principis Marice.

Eulerpe seu de musica.

Carmen in laudem D. Christophori.

Epigrammalon liber unus.

Lo único en castellano que se encuentra en la obra es el Privilegio del Príncipe concedido á Antonio Pérez, vecino de Toledo $\mathrm{y}$ hermano del autur, ya defunclo, para poder dar á luz todas estils composiciones poéticas.

El presente tomito es de gran rareza: Nicolas Antonio no supo que estos tratados se hubiesen impreso, y al mencionar el poema de la Magdalena se refiere á un MS. de la bib. del conde de Villaumbrosa. Barrera en el 
artículo del Mtro. Juan Pérez se limita á citar sus cuatro comedias latinas: Necromanlicus, Lena, Decepti, Supposili, impresas en Toledo, en 1574 .

866 PÉREZ (Sebastian Pedro). Hospital general de el Tiempo, donde el desengaño cura las interiores dolencias de los Hombres. Primera parte. Su autor D. Sebastian Pedro Perez. Calatayud, Joaquin Esteran, $1701.8 .^{\circ}$

Casi una mitad de este folleto está escrita en verso de varios metros.

867 PÉREZ DE CÉLIS (IsIDoRo). Filosofia de las costumbres, Poema. $\mathrm{Su}$ autor el Padre Isidoro Perez de Celis. Parte primera y segunda. Madrid, Benito Cano, Moccxcis. 8. marq.

Ejemplar al parecer de papel fuerte.

Poema diridido en once silvas, precedido de una dedicatoria del vicario de los Agonizantes Matías Saavedra, al Príncipe de la Paz, escrita con la más estúpida $y$ vil adulacion.

868 PĖREZ DE CCLLA (YICENTE). Exprlsion de los moriscos rebeldes de la Sierra, y Mrela de Cortes. Por Simeon Zapata Valenciano. Compvesta por Vicente Perez de $\mathrm{Cu}-$ Ila. En Valencia, 'Por Iuau Bautista Marçal, junto a S. Martin. M.DC.XXXY. $4 .^{\circ} 10$ hojas prels. y 72 fols.

Poema mui raro escrito en octavas $\mathrm{y}$ dividido en cinco cantos.

\section{PÉREZ DE GUZMAN (FER- Nis). \\ đ $\int \mathfrak{a s}$ ficteričtas del do}

to $x$ noble eauullero fernam pere; de gn;mă:

las quales fon bien frientifieas y de grādes

$\varepsilon$ diuerlas materias $\varepsilon$ may prouecholas:

poz las quales qualquicr bóber pue-

de tomar regla soctrina y exé-

plo de bien binir.

\section{Agora nuenamēte ìpffas sinl} año de mil y quinis̄tos y quarenta y vno..

Tом. I.
PER

(Lo que antecede se halla bajo de una viñeta en madera que representa á un personaje escribiendo y todo ménos las tres últimas lineas está circuido de orla. Al fin en el dorso de la úllima hoja se lee:)

fueron impieffas las fetecientas del noble canallero ferria perez de guizman enla may noble \& muy leal sindad d' fífbo po: Enys hodrigne; libzero del kiey naeftro ferios. Acabarōe eñl año Del nacimiēto de ñ̄o feño: Đefa xp̄o de.ftt.尹.xij. 4. ${ }^{\circ}$ let. gót. Sin foliacion signs. a-f, todas de 8 hojas.

Ademas de la obra en octaras de pies de ocho sílabas, que se anuncia en la portada $y$ flnal del libro, contiene las siguientes del misno autor: Exposicion del paler noster y del aue maria, en prosa y verso, loores di. uimos alos maylines, en octavas como las dichas, la Cófession rimada, en octavas de versos endecasilabos, 10 más, y una parte en estrofas de ocho versos octosílabos, Los sie. le pccados mortales en décimas de pies de once silabas, Lus siete obras de misericor. dia, en igual clase de metro, y en la misma se halla por fin una Relucion alas señoras grandes dueñas dia doctrina que dieron a Sarra muger de Thobias cl moro su padre y sumadre.

Las coplas del Páter noster. y Ate Maria se hallan en el Cancionero gemeral de Anvers, fol. $14 \mathrm{vta}$. Las variantes que tiene el folleto de Lisboa, hacen preferible su testo. Al fln del Cancionero de Juan de Ilena esta la obrilla que principia: Tú hombre que eslás leyen. do, y todos los demas tratados se encuentran en el Cancionero de Ramon de Llavia con alteraciones de consideracion.

Ticknor, en el t. l. págs. 426 y signs., al ha blar de las obras de P'érez de l uzman, no men. ciona las setecientas, que es sin duda la com. posicion poetica de este autor de mayor estension. Cita si los Prouerbios de los.cu-les, supone habla el Varques de Santillana en el Prulogo de su Centiloquio: pero se equivoca, pues en ninguna de las edicinnes de este li. bro que tengo á la vista bice semejante mencion. Donde se reflere à ellos es en la Carta al Condestable de Portugal publicada por Sinchez, y los terminos en que lo hace inducen á creer no son dichos Protrerbios sino las Selecientas; asi lo siente tambien el P. Sarmiento, quien conflesa no haber visto esta obra: de la misma opinion es el Sr. Llaguno en la ríla de Guzman. Alli, refliéndose á D. Vic. Antonio, cita uma impresion de las Setecientas hecha en Lisbou en $1512.4 .^{\circ}$. pero tal rez hai equirucacion en esta fecha. Brumet menciona Las coplas de Fernan Perez de Guzman.-Fueron inpressas estas co. plas en... Seuilla por maestro Yenardo lingut aleman e Lançalao polono companteros a viii. dias del mes de Junit). año... de mille 
qualrocientos e nouenta $e$ dos airos (1492). 4. let. gót., las cuales son Las selecientas i El ejemplo de bien vivir.

Yo he visto: Portada con orla y dentro un personaje eseribiendo, bajo del cual se lee: Las sietecièlas d'l docto \& noble caull'o fer$n \tilde{a}$ perez de guzmã: las q̄les son bit . : ficas \& de grädes \& diuersas mater muy puechosas: por las cuales ğlger hod. puede lomar regla $x$ doctrina y exéplo de bien biuir.-Ai dorso de la hoja nona de la sign. f. se lee: C Fueró impressas las. dcc. d'l noble cauallero ferman perez de gusman en la muy noble r muy leal cibdad de seuilla por Jacobo crōberger Alemã E acabarõ se Año del nuscimièlo de nīo señor Jesu $x$ p̈u: de mill \& quiniètos $x$ seys años (1506). a.xxij. dias del mes de deziembre. A dios gias. $4 .^{\circ}$ let. gót. á dos colunas sin fol. con las signaturas $a$-f todas de 8 hojas ménos la $f$, que tiene 9 impresas, y acaso habria una blanca para completar las diez. Brunet trae otra edicion del mismo Jacnbo Cromberger, 1516. 4. let. gót. refirièndose al Catálogo de Heber. ¿No podrá haber equivocacion en esta fecha $y$ que deba ser 1506 ?

He examinado tambien la siguiente edicion:

Exemplo pera bien biuir. (De colorado.)

(Sigue una laminita que representa la fuente de la sabiduria $y$ dos personajes que se llegan para hacer acopio de sus aguas; y bajo de negro y coloradn:) Las sietecientas del Docto r noble canallero Fernan Perez de Guzman, las quales son bien scienlificadas $y$ de grandes $x$ diuersas materias $x$ muy prouechosas: por las quales qualquier hombre puede tomar regru y doclrina $y$ exemplo de bien biuir. anno. 1564. (11 dorso del fróntis principia el Indice, que Ilena la hoja siguiente sign. $a i j, y$ en la tercera comienza la obra, que concluye al reverso de la sign. $K$ iiij con el siguiente colofon: - Fueron impressas las siele cienlas del noble cauallero Fernan Perez de Guzman, en la noble y muy leal ciudad de Lixbon, en casa dela viuda que fue muger de German Gallard. Y acabaronse enel. añ's de M.D.Lxiiij. Aos vinte $y$ uno de Março. $4 .^{\circ}$ let giot.

Nic. Antonio se reflere á una edicion de Lisboa, 1612. $4 .^{\circ}$ acaso la última.

PÉREZ DE MONTORO (JosĖ). Obras póstumas. Véase en la Seccion dramática.

PÉREZ DE OLIVA (Ferman). Obras. Yéase en la Seccion dramática.

870 PÉREZ PERICON (FERNANDo). Descripcion de la mry noble, y mas antigva civdad de Gibraltar, y de sv celebrado monte ilamado Calpe. Compvesto por Fernando Perez Pericon. Madrid, Imprenta del Reyno, 1636. $4 .^{\circ} 6$ hojas prels. y 8 fols.

opúsculo mui raro.-Al principio hal algunos versos laudatorios de D. Luis Pacheco de Narváez, Juan Espejo, Gaspar Dávila y D. Juan Aldrete; tambien se encuentra una aprobacion en prosa de D. Pedro Calderon.

El Sr. Muñoz y Romero no tuvo más notlcia de este romance que la dada por Nic. Antonio en su Bibliulheca; por esta razon copia el título bastante abreviado y omite el segundo apellido del autor.

\section{PEREZ VALDERRÁBANO} (Manuel). La Angelomaquia, ó Cayda de Luzbel, poema de ensayo para merecer el premio prometido y suspenso por la Real Academia Españoa. Por D. Manuel Perez Va!derrabano. Palencia, Xavier Riesgo y Gonzalorema, MDCCLXXXVi. $8 .^{\circ}$

872 PERSIO (Aulo). Avlo Persio Flacco, tradvzido en Lengva Castellana, por Diego Lopez. Con declaracion Magistral, en que se declaran todas las Historias, Fabulas, Antiguedades, Versos difficultosos, y moralidad que tiene el Poeta. Burgos, Iuan Baptista Varesio, 1609. 8. 8 hojas prels., 228 foliadas y 4 de Tabla.

Esta más bien que una traduccion, es un estenso comentario á las seis sátiras de Persio. Pellicer no la menciona en su Biblioteca.

Se reimprimióal fin del Juvenal, ilustrado por el mismo López edicion el 1642. (N. $\left.{ }^{\circ} 696.\right)$

El testo latino va intercalado en el comentario.

873 PETRARCa (Francisco). Los sonetos y canciones del poeta Francisco Petrarcha, que traduzia Henrique Garces de lengua Thoscana en Castellana. Madrid, Guillermo Droy, 1091. $4 .^{\circ} 13$ hojas prels. y 178 fols.

Se divide el volúmen en primera y segunda parte.

Este mismo Enrique Garces es el traductor en castellano de LoS Litsiadas de Camoens, de quien dijo Cervántes en el Canlo de Caliope:

De un Enrique Carces, que al Pirceano Reyno enriquece, pues con dulce rima, 
Con sulil, ingeniosa y facul mano

A la mas ardua empresa en el dis cima; Pues en dulce español al gran Toscano Nuevo lenguaje ha dado y nueva estima: ¿Quion serd tal que la mayor le quite Aunque el mesnis Petrarca resucite?

Del Petrarca he visto otra version que lleva por título: De los sonelos, canciones, mandriales y sextinas det gran poela y Orador Francisco Pclrarca. Tradusidos de toscano Por Salomon Vsque Hebreo. Parte primera. Con breves sumarios, i Argumenlos en lodos tos Sonetos y Canciones que declaran ta intencion del aulor. Compuesta por el mismo. Con dos tablas, una castellana. y la olra Toscana y Castellana. Venecia, Nicolao Beuilaquia. M D LXVII. $4 .^{\circ} 8$ hojas prels. y 164 págs. En el ejemplar que tuve á la vista no encontré las Tablas, sin duda irán al fln del volúmen.-En un prólogo de Alonso de Ulloa, dice, ser el verdadero nombre del traductor Salusque de nacion portugues.

874 Petrarca (Fraxcisco). Francisco Petrarca con los seys triunfos de toscano sacados en castellano con el comentoque sobrellos se hizo. Con preuilegio Real. (Esta leyenda en cuatro renglones, va precedida de un magnífico escudo de las armas del almirante de Castilla D. Fadrique Enriquez de Cabrera, á quien está dedicada la traduccion.-En la hoja fol. ij, va encabezada con siete líneas de bermellon la dedicatoria del traductor Antonio de Obregon, capellan del Rey, la cual solo ocupa una cara: llena la otra y $\mathbf{5}$ páginas más La vida del auctor. El capítulo primero del primer Triunfo principia con el fol. vj, y al fin del volumen se lee este remate:)

a Fue ympressa la psente obra delos seys triumphos del petrarca enla muy noble y leal cibdad d'logroño por Arnao guillen de brocar acabose lunes a reynte dias del mes de deziembre año del nascimiento de nuestro saluador Jesu cristo de mil $\varepsilon$ quinientos y doce años (1512). (Sigue el escud̆o del impresor.) Fol. let. gót. á renglon tirado, ménos los cortos que hai para el verso. Frente del principio de cada Triunfo se halla una lámina, no mala de madera, que coge por entero la paigina. El volumen tiene en todo clxiiij hojas foliadas.
Primera edicion $\mathbf{y}$ una de las más bellas que salieron detas prensas del célebre Arnao Guillen de Brocar. Nlc. Antonin no tuvo noticia de ella ni de ninguna de las hechas de la traduccion de obregon, á quien llama capellan de Felipe II: por el epigrafe de la dedicatoria se ve que lo era de Carlos V, pues el hijo de este no entró á reinar hasta 1556 , es decir, 44 años despues de la publicacion de los Triunfos.

Pellicer en la Biblioleca de traductores no solo omite esta version de 0 bregon, sino que lo más estraordinario es no hable de ninguna de las varias obras de Petrarca vertidas en castellano.

\section{7ö PETRARCa (Francisco).} Triumphos de Petrarca. (Sigue una lámina de madera, que es la misma que precede al Triunfo de la dicinidad, $y$ despues en siete renglones casi todos de colorado, como el tituiillo de la parte superior, se lee:) Trãslacion d'los seys triumfos de Frãcisco petrarca de toscano en castellão: fecha por antonio de obregō capellã d'l rey Dirigida al Illustrissimo señor Almirăte de castilla $\varepsilon c$. Agora de Nueuo emēdada. (En el reverso se encuentra la carta dedicatoria, en la hoja siguiente, fol. II, principia La vida del auctor que termina al IIII vuelta, $y$ en el Y comienza el Capitulo Primo. La obra acaba en el reverso del fol. CLY con el siguiente final:) Fue impressa esta excelente y artificiosa obra delos seys triumphos de micer Francisco peirarca en castellano: enla... cibdad de Seuilla en casa de Juan varela de salamanca corregida y emendada de algunos deffectos que ante tenia. Acabose a.xxx. dias del mes de Agosto d'l año de nuestra reparacion de mill $\gamma$ quinientos y vernte y sers años (1526). Siguen 6 hojàs dé Tabla sin foliatura.) Fol. let. gót. á renglon tirado ménos los versos que ran circuidos del comentario en prosa.

Hermosa edicion y papel.-Rara.

876 L La misma obra. Al reverso del fol. cl se lee:) Fue impressa esta excellente I artificiosa obra... enla... cibdad de Seuilla en 
casa del jurado Juã varela:... Acabo se a cinco dias del mes de Setiembre: del año... de mill $\varepsilon$ quinientos $r$ treynta $r$ dos años (1532). Fol. let. gót. cluj fols. inclusa la portada de negro y encarnado, y seis hojas de Tabla que van al fin.

Esta cdicion es tan bella y rara como las dos anteriores y el papel igualmente bueno.

IJe tenido ocasion de ver la que sin duda deberí ser cuarta impresion, tambien mui bien ejecutada, y su descripcion es la siguiente: en la portada se encuentra una límina igual 0 mui parocida á la de la de 1520 y bajo se lee: Translacion de los seys triumjhos de Francisco pefrarca: de liscano en castellano: fecho por Antonio de obregio... Agora de nur.un cmendalit. M.I).xxx.x.j. (Al reverso del fol. clij se lee: Fue impresu estu... obra... en la... villa de Valladolid en casic de Jumn de villarquiran... Acabssi' el postrero cle Mayo. Año de westra reparacion de mil r

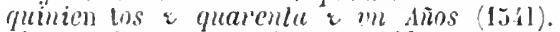
siguen despues 6 hojas de Tubla. Fol. let. sot.

En la nota puesta í la culeion de 1,12 ya nbservo que Xic. Antonio no conncio otra de los Trimfos s:ano la liechi en Salumanca, 15St. 8. ${ }^{\circ}$, enga thablerion atribuge equivocalamente il Antonio de obregon. Vease el siguiente artículo.

877 PETRARCA (Fraxisco). Los Trirmphos de Franciseo Petrarcha, ahora nuevamente iraduzidos en lengua Castellana, en la medida y numero de rersos, que tienen en el Toscano, " con nueua glosa. En Medina del Campo por Guillermo de Millis. 13ï. (Il fin: u.D.LIII.) 4. ${ }^{\circ}$ let. curs. Ios versos y redonda la glosa. 8 hojas prels., inclusa La vida de Francisco Petrarcha, 189 fols. y 3 hojas de Tabla.

La presente edicion es la misma que en algmos ejemplares lleva en el fimtis el año de Y.D.LIIII. con la inica diferencia de haberse reimpreso la portuda, la hoja siguiente con el Prologo ó dedicatorial y el principio de la vida de petrarca. Los ejemplares de fechil más antirna tienen timbien dos hojas mis de prefiminares cuyo contenido isnoro.

Esta tratuccion es la que generalmente se comore por la de Hernando de flozes, á pesar de uo eomstar ceto nombre an parte algrma

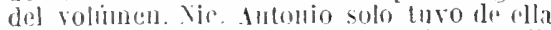
y de sil autor lit signionte noticia: Fordinumbe d" II"zes scripsisse divitur: Sobre los Triunfos de Francisco Petrarca; y en (l artículo de Automits Obregon de la kibliollera nown, da como la traduccion de los Triunfos, que este hizo, la publicada en Salamanca en 1581. 8. que anda errado, pues es la de Hózes, segun se verí por el siguiente articulo.

En el fróntis hai un escudo con las iniciales G. M. igual al de Tomas Porralis, estampado en la portada de El Secrelario Aguilon con las letras T. P.; y al terminar el volumen se encuentra otro grande, copiado í continuacion, que es el mismo puesto al final del Libro de música de pisador, el cual suena como impreso por el autor.

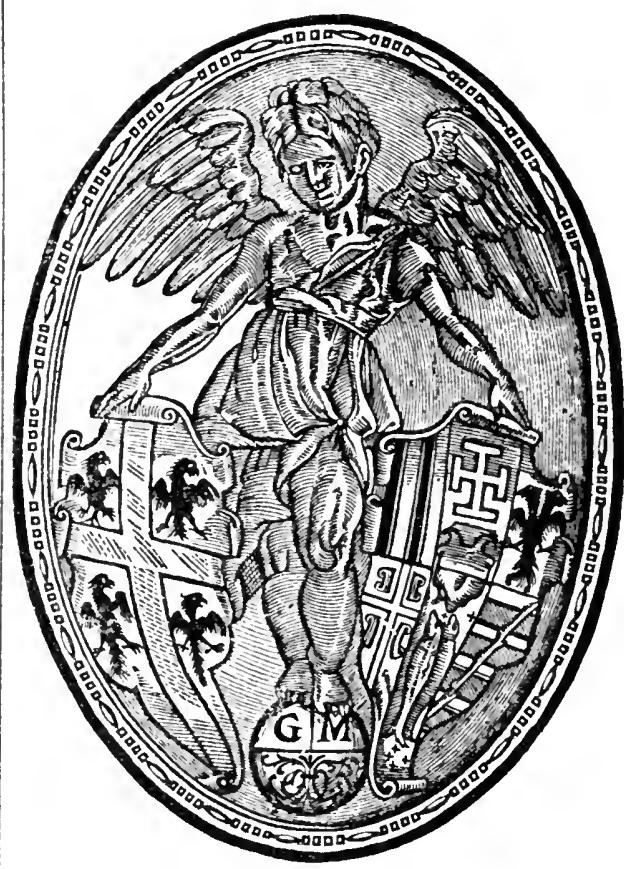

878 PETRARCA (Francisco). Los Triunphos de Francisco Petrarcha (ut supra). Salamanca, En casa de Iuan Perier. Año 1581. 8. 16 hojas preliminares, en las cuales va incluida la Vida de Petrarca, 487 fols. y 8 hojas de Tabla.

Una minuciosa comparacion con la anterior de 15.55 me ha hecho ver que la presente es reimpresion exacti de ella y por lo mismo no anduvo acertado Nic. Antonio al suponer, ell altículo de Antonio obregon, era esté el antor de la version.

l'ar completar la lista de las traducciones castellamas del poeta florentino, mencionaré uni Tirsilucion de los Triunfos hecha por Alvar Gomez de Ciudareal, citada por dicho Nic. Ait tonio. 
879 PETRARCA (Fraxcisco). (La | bastante bien imitada, sobre todo la siguiente copia de la porlada eslá vinela que es un verdaderofacsímile.)

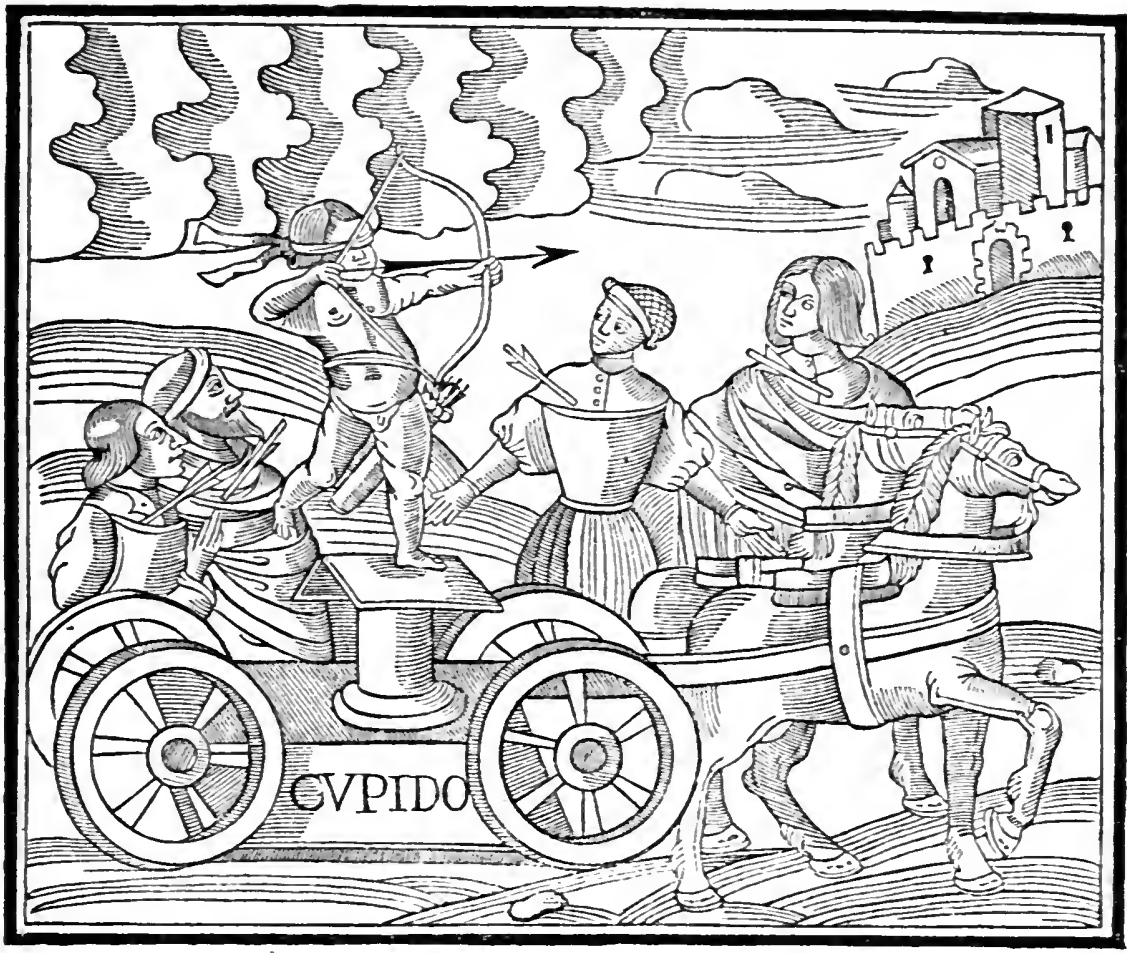

\section{Triumpho de amoz de petrar" cha facado y trobado $\mathfrak{e n}$ romantce $\mathfrak{c a f t e l l a n o}$ por $\mathfrak{r a f t i l l o .}$}

S. 1. ni a. Chricia 13030). 1. ${ }^{\circ}$ let. sót. Sin fol. y con las signs. a-b, de 8 hojas la primera y de a la segunda.

Se lalla en estancias de diez versos octo. sllabos.

Ignoro quien sea el Castillo traductor de este Triunfo. Yo han tenido noticia de il ni Nic. Antonio ni Pellicer: verdad es que ro no he visto otro ejemplar en ninguna biblio. teca.
880 PINED. JuIX DE'. Libro de la vida y eacelencias maravillosas del glorioso sant luan Baptista, diuidido en tres Liliros. Compuesto por c) Padre liay Inau de Pineda. Barcelona. Sebostian de Cormellas, M.D.XCvi. 3 rol.. 8. ${ }^{\circ} \mathrm{El}$ primerotiene 8 hojas prels. y3i3 paiginas: el segundo 45 paigs. en todo. y el tercero 318 
págs. y despues 8 hojas para la Censura del Author $y$ una composicion poética.

En el tomo primero se halla un soneto de El Libro al Lector, una octava y otras ocho de Imuocacion del Author a la Virgen Maria, y al fin del tercero una obra docta y deusta sobre la salutacion Angelica, que ocupa seis hojas. Se conocen mul pocas poesias de este escritor, contado con razon entre nuestros clásicos.-Nic. Antonio se equi voca en llamar 4. al tamaño de esta edicion.

881 PINTO DELGADO (JuAN). Poema de la reyna Ester Lamentaciones del Propheta Ieremias. Historia de Rut, y varias Poesias. Por Ioan Pinto Delgado. A Roven, chez Dauid du Petit lal, M.DC.xxvir. 8. ${ }^{\circ}$ marq. 6 hojas prels., incluso el fróntis grabado, y 368 pógs.

Al hablar de este autor dice Ticknor, tomo II., pág. 182 : «Pinto Delgado, judío por. "tugues, vivió mucho tiempo en España, „abrazo la religion católica, volvió á la lei mde Moises y huyo por temor de la Inquisi»cion á Francia, donde murió por los años nde $1590 \ldots$ En sus coplas antiguas, sonetos "y otros versos al gusto italiano, hai trozos sllenos de ternura y de una rersiflcacion marmoniosa y delicada." Me parece se equivoca el citado Ticknor en suponer su muerte liácia 1590 , pues la dedicatoria dirigida por Pinto á Richelieu, ministro de Luis XIII, es contemporánea de la fecha de la edicion (1627).

Vo conoció Rodriguez de Castro esta impresion de Rouen, pues en su Biblioteca española, tom. I. píg. 510, leemos: "Por este mmismo tiempo, en que se dieron á luz las "Conjeturas sagradus de Yshac de Acosta s(1729), se publico en un tomo en $\delta^{\circ}$ con „366 págs., sin nota de lugar, ni año de la mimpresion, el l'oema de la Reyna Ester, Lamnentaciones de Jeremits elc., que escribio wen verso Juan Pinto Delgado. Estas precio. msas obras, que por lo sublimè de su estilo, "por la variedad de sus metros, y por la melegancia de sus locuciones han merecido "la aceptacion de los doctos, están dedicadas mal Cardenal de Hichelien y por ser obras mmui raras y únicas en sú linca, será agra"dable el espécimen de ellas." Siguen esten. sos estractos.

El Sr. D. Adolfo de Castro al hablar del Poeina de la reina Ester se contenta con decir que estas poesías se dieron á la estam. pa en Paris. No tengo otra noticia de semejante edicion; pero se ve haberle sido des. conocida la primera de Rouen.

882 PIRENO (Contador). Fabulosa Tragedia de la Elisa Dido. Al
Excelentissimo Sr. Marques de Fuentes. Dedicada Por su Contador Pireno. 1629. Manuscrito mui inteligible en fol. de 31 hojas.

Poema en octavas que creo inédito: va repartido en cuatro divisiones ó sean cantos.

883 PLAUSIBLES alborozados festejos con que la villa de Alcira acreditò su gozo en la proclamacion de Fernando VI._Oracion panegirica gratulatoria en las fiestas de Alcira à la proclamacion de Fernando VI.; que dixo El M. R. P. Fr. Antonio Salanova. Valencia, Viuda de Geronimo Conejos. S. a. $4 .^{\circ}$

El primer tratado contiene algunos versos.

884 PONGE (Felipe). Historia, Milagros, y admirables cosas, y peregrinas, de la excelsa sancta Catharina, nobilissima Reyna de Egypto, virgen, martyr, predicadora, y esposa de nuestro Señor Iesv Christo... Compuesta en octaua rima por Phelipe Ponce. Valencia, junto al molino de la Houella, 1585. (Al fin: Por los herederos de Iuan Nauarro.) $8 .^{\circ}$ 180 hojas foliadas, inclusos los preliminares y 4 de Guia para saber las cosas notables del libro. El fol. 9 lo ocupa el retrato del autor, y el 11 una imágen de la Santa dibujada por Felipe Ponce.

Poema en octavas y en trece cantos. Al principio lleva unos sonetos laudatorios de 1). Juan Quintana y Ponce, D. Jerónimo Mercader, D. Alonso Giron y de Rebolledo, Honorato Joan Ülzina, y de D. Pedro de Rójas y Ladron, que dice:

No de Orlando y Angélica ficciones, No la navegacion del sagaz Griego, No el incendio de Troya y grande fuego, No d'España y Aruuco las quisliones:

No de Beatriz, ni Laura perficiones, No de la de Carlago el triste ruego, - No sátiras que alaba el vulgo ciega, No dioses falsus, ni transformaciones; Canta con verso grave $y$ elegante

El Ponce, a quien doto naturaleza De ingenio que d mayor cumbre se empina.

De reina sabia, martir y constante Nos muestra en tiernos años la belleza, De Cristo esposa, virgen Catarina. 
I.Ibro muliraro que citan, sin baberlo visto, | El retrato del autor, puesto entre los prellJimeno y Nicolas Antonio.

minares de la obra, es el slguiente.

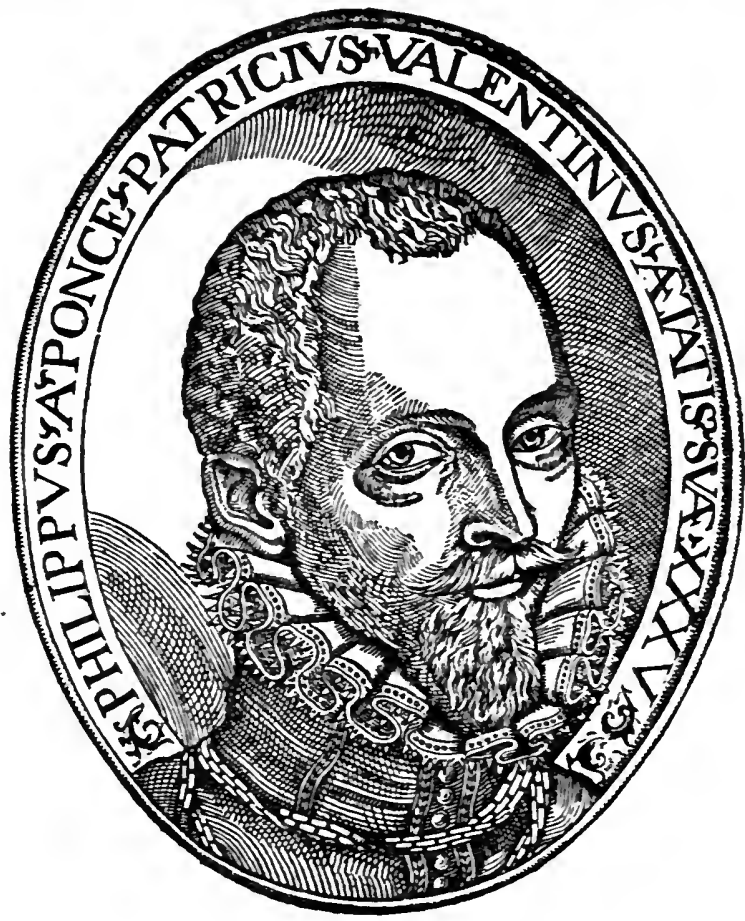

88ว̆ PóRRAS (Jeróximo). Rimas varias, de el licenciado $\mathrm{D}$. Geronimo de Porras, natvral de Antequera. Antequera, Juan Bautista Moreira. Año de 1639. 8. 16 hojas prels. y 104 foliadas.

Contiene algunas composiciones de Pérez de Montalvan, Doña Cristovalina Fernández de Alarcon $y$ de Pedro de Espinosa.

Nlc. Antonio probablemente no logró ver este tomito, pues omite el lugar de la impresion.

886 PORREÑO (Licenciado BalTASAR). Uraculos de las doze Sibilas Profetisas de Christo nuestro Señor entre los Gentiles. Por el Licenciado Balthasar Porreño. Cuenca, Domingo de la Iglesia, 1621. 4. ${ }^{\circ} 6$ hojas prels. y 72 fols.

No carece de rareza este volúmen: pero la edicion y papel son detestables, y peores si cabe, los retratos de las doce sibilas grabados en maitera é intercalados en el testo. Cada una de estas lleva dos octavas en castellano, traduccion de los versos latinos que se hallan al pié de dichos retratos, y á continuacion un discursito en prosa en el cual se relatan la vida $y$ virtudes de la heroina.

887 PORTUGAL (Fraxcisco DE). Ao Principe D. Theodosio Nosso Senhor. Divinos, e hrmanos versos, de Dom Francisco de Portvgal, por D. Lrcas de Portrgal Seu filho. Lisboa. Officina Craesbeckiana. Anno 163르. 10 hojas prels. y 167 pags.Prisoens, e soltrras de hrma alma. Por Dom Francisco de Portvgal. S. 1. ni a. $4{ }^{\circ} 5$ ge págs.

A pesar de llevar las Prisoens e solturas de humu alina nueva paginacion y signaturas, el papel y tipo indican deber ir unidas á las Poesias anteriores: sin embargo, Nico- 
las Antonlo no menciona aquel tratado al hablar de los Versos de D. Francisco de Portilgal.

La mayor parte, ó mejor dicho, casi todas las composiciones de este tomo raro, están en castellano.

888 PORTUGal (Manuel De). Obras de Doin Manoel de Portvgal. Lisboa, Pedro Crasbeeck, M.DCV. 8. ${ }^{\circ}$ let. cursiva. 8 hojas prels., 489 foliadas y 8 hojas al fin sin foliar.

Llamo la atencion de los bibliciflos á las 8 hojas sin foliar que van al flu, pues filtabain it uno ó dos ejemplares más que he visto.

Todas las composicioues comprendidas en el presente volumen están en castellimo y en muclia diversidad de metros, á escepcion de un Tralado breve da oraçam en prosa portuguesa, el cual ocupa desde el fol. 459 al 481, y 6 hojas sin fol. que le siguen tambien en prosa, de uni Addiçam de comn de. vemos de offrecer o filho de Deos a seu pay eterno.

No sé si por la rariedad de metros en que están escritas las poesías contenidas en este tomo ó por ser una gran parte de ellas canciones, endechas, spar'sas y odas, muchọs lo han

QUEVEDO VILLEGAS (Fraxcisco). El Parnaso español. Véase en la Seccion dramática.

891 QUINCÓCES (Gaspar Fraycrsco Dli). Glorias de Castilla, tvmhres de Valledolid, santissima vida, feliz transito, y admirables portentos de S. Pedro Regalado, su autor el Doct. D. Gaspar Francisco de Quincoces. Valladolid, Imprenta de los Figueroas, s. a. $(1747 ?) \cdot 40^{0} 6$ hojas prels. y $\mathbf{4 0}$ págs.

Poema en octavas, dividido en tres cantos.

QUINTELA, LEDESIIA Y BRACAIIONTE (Lic. JUAx DE). Letras divinas. Véase en la Seccion dramatica.

\section{QUIROS Y BENAVIDES (FE-} LIPE Bennado). Timbre asturiano. Historia de la vida, y martyrio de la llamado Cancionero de D. Manuel de Portugal; no entraré á disculir si este título está bien ó mal dado, en lo que no cabe duda es en que por su rareza puede compelir con muchas de aquellas antologías.

Ticknor, tom. Ill., pág. 198, equivoca el tamaño, pues dice ser en $4 .^{\circ}$

889 POVOAS (Manoel das). Vita Christi, de Manoel das Povoas. Lisboa, Pedro Crasbeeck, M.DCXIIII. $4 .^{\circ} 3$ hojas prels. y 253 fols.

Poema castellano en tercetos, dividido en treinta cantos.

Es libro bastante raro.

890 PRVEVASE, que es mas fineza amar por eleccion, gve por inflvxo. Romance Lyrico. Offrecido Al Marques de los Velez, en el Festillo dia de sus años. S. l. ni a. (haicia 1630). 8. 16 hojas, la última blanca. rito.

Es major su rareza que su interes y mé-

gloriosa Sta. Evlalia de Merida, y de las traslaciones de su cverpo, y reliquias. Con el poema sacro, y descripcion panegyrica de las que se veneran en la Santa Iglesia de Oviedo. $Y$ vn romance à la Passion de Christo. Por Don Felipe Bernardo de Qviros y Venahides. Madrid, Francisco Sanz, 1673. 4. 8 hojas prels. y 101 fols.

He fljado el año de la impresion segun lo pone Nic. Antonio porque a mi ejemplar le falta justamente la esquina del fróntis donde debe hallarse.

La edicion y papel son tan detestables como todas las producciones del establecimiento tipográfleo de Franeisco Sanz, á pesar de intitularse Imprenta del reinu.

La Historia de Santa Eulalia es en prosa y ocupa hasta el fol. 48; sigue despues el Poema sacro de las reliquias, que consta de cien nctavas; á contimuacion está el Romance a la Pasion, de 27 fojas ; viene despues un Epicedio á la muerte de Felipe IV., en veinticuatro oetaras, y termina el tomn con ilgunas poesias á varios asuntos. 
893 RAFELS Y GARCİ (José). Muerte, Lauros y Gloria. Poema por D. José Rafels Garcia. Valencia, J. Ferrer de Orga, 18.58. Fol.

Es notable cste volimen por el gusto $\mathrm{y}$ belleza de su ejecucion tipogriflea.

Solo se tiraron treinta ejemplares.

894 RATOS ociosos de D. F. H. R. Dedicados al vulgo. En Brvsselas Por Ivan de Yeerbeeck, 1630.8. ${ }^{\circ}$ 6 hojas prels., inclusa la Tabla, y 27 르 fols.

Obra poco frecuente escrita en versos de varios generos.

893 REBOLLEDO (EL CoNde DoN Bernardino de): Ocios del Conde Don Bernardino de Rebolledo. Tomo primero de sus obras Poeticas. (Contiene tambien Las selras Dánicas.) Amberes, Officina Plantiniana, 1660. 50 pags. prels., 4 hojas sin numeracion que comprenden: nuevo frontis grabado, retrato de una dama y dedicatoria; ademas 674 págs. de testo.Selva militar y politica. Tomo segundo de las obras Poüticas. Segunda Edicion. Amberes, Oficina Plantiniana, M.DCLXI. 6 hojas prels., in. cluso el antefróntis grabado, y 496 págs. - Selua sagrada. Colonia A grippina, Antonio Kinchio, 165̄. 3 hojas prels., una de las cuales es el antefróntis grabado, y otra una limina que representa un cisne con una lira y la leyenda Candidus et canorus, y 306 págs.-La constancia victoriosa Egloga Sacra. Colonia Agripina, Anlonio Kinchio, 163\%. 4 hojas prels., que comprenden el fróntis grabadn. el retrato do la reina Cristina de Suecia. una espiecie de anteportada y la Dedicatoria, y ademas 174 págs. y 1 hoja de Erratas. - Idilio sacro. Amberes, Officina Plantiniana, 1660. 2hojas prels., una de las cuales es el retrato de Rebolledo, y 88 pígs. En todo z̈ tomos en $4 .^{\circ}$ que sueleu encuadernarse en 4 vols. reuniendo las dos últi- mas obras. El tom. 2..$^{\circ}$ liene al fin varias láms. grabadas en cobre y tiradas como págs. de testo.

El tomn de Ocios contiene el entremes intituladn: Los maridos conformes y la tragicomedia: Amar despreciondo riesgos; segun Barrera Leirado dichas composiciones dramáticas no se incluyeron en la edicion de este volumen, hecha en imberes. 1656, que dicho Barrera llama primera equirocada. mente.

896 REBOLledo (El Corde Dor Bermardino de). Ocios del Conde Don Bernardino de Rebolledo (ut supra). Madrid, D. Antonio de Sancha, $17 i 8$. 4 rols. $8 .^{\circ}$ marq. 3 retratos.

He visto una edicion de los Ocios del Conle de Rebolledo. Amberes, $16.50 .2 \AA^{\circ} 2$ hojas que contienen un fruntis grabado y otro impreso, 55 fols. de Promemin, 155 de testo 515 hojas sin numeracion de Indice y errata.

897 REBOLLEDO DE PALAFOJ (Beryabé). Metrica historia sagrada, profana, $v$ general de el mundo; sus tres primeras edades, sobre el libro de elGenesis. Su autor Don Bernabe Rebollido de Palafox. Zaragoza, Jian Malo, 1734. 4. ${ }^{\circ}$-i hojas prels. y $201 \mathrm{fols}$.

Poema en octaras diridido en reintidos Argumentos.

893 REI DE ARTIEDA (ANDRES). Discrisos, epistolas y epigramas de Artemidoro. Sacados a luz, por Micer Andres Rey de Artieda. Caragoça, Angelo Tauano, 1603. $4 .^{\circ} 8$ hojas prels. y 128 paigs.

Se eneuentran al principin sonetos encomiásticos de Inpereio I.conardo de trgensola. D. Martin de Castro y Bolea, D Migmel libellis de Villanuva, d alferez Francisco de Segura, D. Mareantonio Aldana y el alferez Alonso Télles de buevira : $y$ en el cuerpo del volumen composiciones de los dos primeros que acabo de cilar $r$ del sargento Antonio Vizquez, el Dr. Tomis Leomalo. cl Dr. Jerunimu tsuris y ele un tal Cascajares.

Inai ciclos antores curas obras ticuen la cuilidad de ser toulas litras, así slleede con las de Timoneda. Juan de lit Cueva. Lope de Rueda, Rei de artiedia y otros : de este ullimo 
supone Rodriguez haberse impreso ciertos libros que ya no se encuentran; de su tragedia los amanles no se conoce más ejemplar que el que yo tengo; y pocos poseen los Discursos, eptstnlas y epigramas de Artemidoro de los cuales ignoro exista sino li edicion de 1605 , á pesar de ser libro de mucho merito y ue gozar su autor una bien mereeida reputacion literaria, segun lo prueba el siguiente elogio que hace de él Lope de Vega ell su Laurel de Apslo:

\section{$Y$ al Capitan Artieda,}

Aunque Valencia lamenlarse pueda, Pondra en sus cuairo Zaragoza el dia Que de lu numerosa monarquía Apolo nombro un senador supremo, une como aquel celeste Polifemo Unico dé su luz d los los polos

Pues no es un siglo para dos Apolos.

El escudo de Angelo Tavano que Ilevan en la portida los Discursos de Artieda es el siguiente.

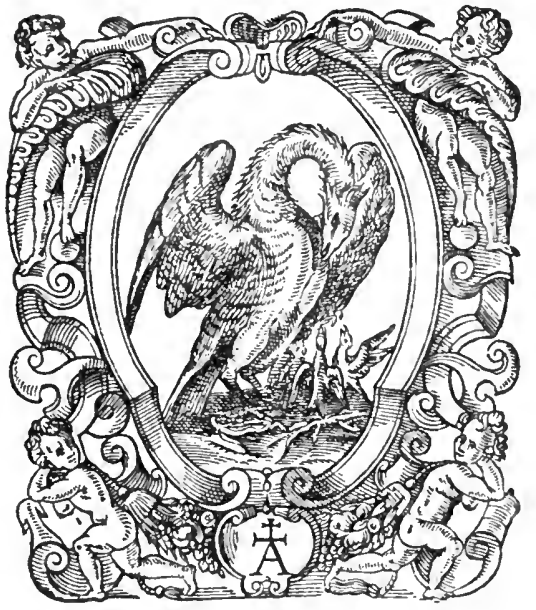

899 REI Y LARA (GABiAEL DEL). El Tifèo siciliano, Y Guerra de los Gigantes contra lupiter. Poema heroico. Del Dotor 1)on Gabriel del Rey, y Lara. Napoles, Françisco Benzi, 1696. $4 .^{\circ} 1$ bojas prels., páginas 3 a 70 y 6 hojas que contienen la Prueba, que huwo Gigantes.

Poema en ciento treinta y cinco octavas. Ilai al fln una disertacion en prosa, intitulada: Prueba, que huno Gigantes, y que oy los ay, y por cierto para mi soln prueba que el autor era sumamente cándido o tenia mui grandes tragaderas: sea esto dicho con perdon de los varios testos bíblicos y de sautos Padres que aduce en confirmacion de sus ideas gigantescas.
900 REMÍREZ DE LA TRA PERA (Albanio). La Crvz, por Albanio Remirez de la Trapera. Madrid, Iuan de la Cuesta, 1612. 8. 8 hojas prels. $y$. 199 fols.

Poema en quintilias, consta de dlez cantos. Entre las poesias en alabanza de la obra, insertas al principin, las hai de Lope de Vega, Pedro soto de Rójas, D. Francisco de Silva, Mignel Silveira, Gaspar Dávila, Luis Vélez de Guevara y Gabriel de Vega, que supongo será Laso de la Vega.-El volúmen termina por una composicion en varias cla. ses de metro, intitulada: Flores de la Cruz y por un Soliloquio.

Nic. Antonio equivoca el apellido del autor, pues le llama Ramírez de la Trapera.

RESENDE (Garcia De). Miscellanea ẽ trovas. Véase Resende /García de). Seccion histórica.-Historia de España.

901 REYES (Fr. Gaspar de lOS). Tesoro de Concetos divinos, compvestos en todo genero de verso por el $\mathbf{P}$. Fray Graspar de los Reyes. Sevilla, Clemente llidalgo, 1613. 8. 8 hojas prels., 238 fols. y una para repetir las señas de la impresion.

Obra mui rara, de la misma clase que la de Alonso de Ledosma, en la cual abundan sobre todo los romances.

Nic. Alltonio trae de este autor una Obra de la Redencion, ó sea De la pasion de Christo en volavas. Sevilla, 1613. 8. , y otra intitulada: Romances de las IIstorias antiguas de la que no cita edicion alguna.

902 RIBERA (Anastasio PantaLEON DE). Obras de Anastasio Pantaleon de Rihera. Ilvstiadas con la proteccion del Illustrissimo i Excelentissimo Señor Don Rodrigo de Silua, i Mendoça... Por Don Ioseph Pellicer de Tovar. Madrid, por Francisco Martinez, Año de M.DC.XXXIV. 8. 16 hojas prels. y 292 ? fols. Lo ignoro por faltar el final a mi ejemplar.

Sedano, en el tom. VII. del Parnaso, llama á esta primera edicion; sin embargo me pone en duda el ver llevá la Aprobacion, la Censura, el Privilegio, la Fe de erratas y la Tasa fechadas en 1631. Por otra parte tambien puede ser cierto lo sentado por dicho Sedano, pues D. José Pellicer, al principio de su introduccion biográflco-literaria, observa que salen ya a lus pública, despues do 
casi, tres años de embarazo, las deseadas Obras de Anaslasio Pantaleon.

Al fol. 212 principla la Fabula, en verso, de Ecco del Lic. Tamayo Salazar.

En estas obras de Ribera solo hai unas $\mathbf{4 0}$ hojas de sus Prosas, lo demas son poesias entre :as cuales se halla una Relacion para una corr dia y el fragmento de una Loa para otra.

903 Ribera (Anastasio PantaLEON DE). Obras de Anastasio Pantaleon de Ribera. Ilvstradas etc. (ut supra). Çaragoça, por Diego Dormer, Año M.DC.XL. 8. 16 hojas prels. y 192 fols.

Es una reproduccion de la cdicion anterior.

Nic. Antonio no conoció más impresion que esta de 1640.

904 Obras de Anastasio Pantaleon de Ribera. Dedicadas á D. Gregorio de Tapia i Salcedo, Cavallero de la Urden de Sant-Iago, i Fiscal Cavallero del Consejo Realde las Ordenes. Madrid, Diego Diaz de la Carrera, 1648. 12. 10 hojas prels.y 162 fols.

En ld presente impresion se suprimió la introduccion ó prólogo de Pellicer de Tovar y en vista de unos MS. de la libreria de Don Lorenzo Ramírez de Prado, se le añadieron tres romances, una décima y un soneto.

905 Obras de Anastasio Pantaleon de Ribera. Dedicadas a Don Iuan de Gayoso y Mendoça señor de Oca, etc. Madrid, Andres Garcia de la Iglesia, $1670.8 .^{\circ} 8$ hojas prels. y 172 fols.

Copia de la anterior de 1648.

Segun se ve son tres las ediciones que poseo posteriores á la de $\mathbf{1 6 3 4}$, Io cual prueba el error de Sedano cuando afirma solo exis. ten dos hechas despues de aquella.

906 RIBERA (Luis DE). Sagradas Poesias de Don Lvis de Ribera. Seuilla, Clemente Hidalgo, 1612. 4. $^{\circ}$ 5 hojas prels., iricluso el fróntis grabado, 221 págs. y 13 hojas más de Tabla y de la Cancion de Ćristo puesto ex el sepulcro con su esplicacion.

No conozco otra edicion de estas poesias.

907 ROCA Y SERNa (Ambrosio DE LA). Lvz del alma para la hora de la muerte. Compvesta por el Hermano Gerardo de lesus Maria. Y en esta vltima impression muy añadida y aumentada. Valencia, Iuan Bautista Marçal, 1644. 16. ${ }^{\circ}$ Sin foliacion con las signs. A-S de 8 hojas. Van á continuacion: Clamores arrepentidos latinos, en metro castellano. Compvestos por el Hermano Gerardo de Iesus Maria. Valencia, Claudio Macè, $\mathbf{1 6 4 5}$. $16 .^{\circ} 8$ hojas con la sign. A.

La primera edicion, dice Jimeno, se imprimió en Valencia, por Juan Baulista Mar. zal, 1634. 24.0: y segun el mismo, la hecha en dicha ciudad en $\mathbf{1 6 5 5}$, es la primera publicada con el nombre de su verdadero autor Fr. Ambrosio de la Roca y Serna.

908 RUCA Y SERNA (Ambrosio DE LA). Lvz del alma para la hora de la muerte. Por el Venerable Padre Maestro Fr. Ambrosio de la Roca. Madrid, Andres Garcia de la Iglesia, 166 ö. $8 .^{\circ} 8$ hojas prels. y 218 págs.

Jimeno menciona una edicion de Valencia, virenle Cabrera, $1682.16 .^{\circ}$

$909--L a$ misma obra. Por el P. M. Fr. Ambrosio Gerardo Roca de la serna. En esta vitima impression muy añadida, y aumentada. Valēcia, en el Real Covẽto del Carmẽ, 1683. 16. 6 hojas prels. y 3 五1 págs.

910 L L misma obra. Su autor Fr. Ambrosio de la Roca y Serna. Con unas addiciones devotas. Por el Doctor Don Diego Suarez de Figueroa. S. I. ni a. (Madrid, 1786?) 8. 308 págs. en todo.

obra del género de los Conceplos de Ledesma.

La Luz del alina se incluyo en la Corona ilustre del convento del Cárinen de valencia, impresa en Zarayoza en 1679 , $y$ en la dedicatoria de este libro se habla estensamente del P. Roca y Serna y se dice de un modo terminante, existian más de quince ediciones de su obra.

911 RODRIGUEZ (BARTOLOME்). La vida y milagros del glorioso S. Roque: Con algunos Remedios espirituales contra la Peste, y otros exer. 
cicios de devocion. Por el Licenciado Bartholome Rodriguez. Brusselas, Juan Mommatre; M.DC.XXX VII. 12. 226 págs., ̈̈hojas de Tabla y una de aprobacion.

Hai al fin de este tomito varias poesías rcligiosas y moriales, entre ellas se hallan las Coplas de Jorge Manrique compendiadas.

\section{RODRÍGUEZ G.ILAN FraN-} crsco). La Primavera en Febrero, escrita ell octavas rithmas y symbolizada En los Festejos con que İa Primada Iglesia de Toledo dio la Possesion de sil Arzolispado al Infante Cardenal D. Luis Antonjo Jarme de Borbon. Compuesta Por el R. P. Fr. Francisco Rudriguez Galan. Toledo, Pedro Marqués, 1736. 4. 8 hojas prels. y 17 fols.

son cien octavas.

913 RODRIGLE? LOBO (Francisco). 0 Condestabre de Portrgal D. Tino Aleres, Pereira. De Francisco Rodrigres Lobo. Lisboa, Pedro Crasbeeck, 16010 (1610). 4. 3 hojas prels., incluso el frintis grabado, y 31 ' fols.

Primera edicion mui rara.-Jorse Rodriguez, editor de la impresion deserita en el signiente artículo, decia ya en 1627 , era obra mui dificil de encontrar por no existir ejemplares de la edicion anterior.

914 La misma obra. Lishoa, Iorge Rodrigues, 1627. 4. 2 hojas prels. y 237 fols.

Vic. Antonio ignoró la existencia de esta edicion.

Poema portugues dividido en veinte cantos y escrito en octavas.

913 - As Eqlogas de Franciszo Rodrigres Lobo. Lx. ${ }^{2}$ (Lixboa), por pedro Crasbeeck, 160 วั. $^{4} .^{\circ}$ G hojas prels., incluso el fróntis grabado, ! 11' fols.

niez églogas en portugues.

Esta obra y la Primavera son las más raras de este autor.

916 RODRÍGLEZ DE FiRGAS (Damiay). La Yerdadera hermandad de los cinco martyres de la Arabia. Por el Licenciado Damian Rodriguez de Vargas. Toledo, Diego Rodriguez, 1621. 12 hojas prels. y 84 fols.

Poema mui raro en octavas, dividido en nueve cantos: contiene las vidas de los santos Cosme, Damian, Eupremio, Leoneio $\mathrm{g}$ Eutimio.

\section{ROIG (JAUME).}

C[ fibse de côfells: fet per lo ma gnificl meftre Jaume roig/log quals fon molt profitofos y falm dables axi peral regintent y 02, de d’ bē viure com $\mathfrak{p}$ augmētar la d’nocio ala puritat y färeprio dela facratiffima verge ftlaria.

(Este título, de negro y colorado, se halla rodeado de orla y precedido de una laminita que representa una I'urisima Concepcion circuida de un lema latino. Al dorso empieza el prolech que sigue liasta casi el fin de la hoja. siguiente. A continuacion hai unas eslancias de diez versos cada una, de arte mayor, despues otras de diversos metros, y la obra empieza al reverso del. fol. iiij diciendo:

\section{Comença lo libie deles} dones:o zdenat per lo magnifich en Iaume roig boctos famos dela fereniffuma fenyoza reyma dona fllaria.es exemplar:e de confells per ell inonats afõ nebot en Bal thafar bou senyoz d' callofa qui molt amana.

Sigue la obra hasta la hoja exxxx, en cuyo dorso se lee:; 
usónch ftampat lo pzefent libze enla infigne ciutat d' Halēria per frā, ciffo diaz Rontano al ftndi

\author{
general a.xix. ð’ Jnny

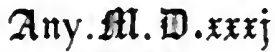

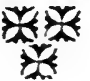

(En el blanco de la hoja siguiente $y$ última se encuentra una Vírgen sentada con el niño en brazos y una santa á cada lado.) 4. ${ }^{\circ}$ let. gót. á dos colunas, cxxxx fols., inclusos los prels., y una hoja con la estampa antedicha.

He becho una descripcion tan detallada de esta primera edicion porque no recuerdo haber visto sino otro ejemplar tan completo como el mio; pero ninguno tau bello. El fróntis o la lámina final faltan en general á los poquísimos existentes. Como una prueba de lo diffcil que debe sel hoi dia su adyuisicion, bastará observar que onofre Almudever, en el Prólogo del Proces de les olives, impreso en 1561 , decia ya, haber reproduciuo tambien las obras de jaime Roig por no encontrarse ejemplares de ellas, y Cárlos Ros en 1725 , hubo de valerse para hacer su edicion, de fragmentos $\dot{0}$ trozos de la de 1561 .

Jimeno menciona una de 1552 , la cual nunca he visto y dudo exísta. Tal vez copió á Nic. Antonio quien trae como primera una de este año.

918 ROIG (JACмE). Libre de cõsells fet per lo magnifich mestre Iaume Roig, los quals son molt profit?sos etc. (ut supra). Estampat en Barcelona per Iaume Cortey. 1061. (En la hoja siguiente fol. II, principia el Prolech y despues de él las estancias que tiene la primera edicion; la obra comienza en el VI tuelia y concluye en el CXLIX, terminando tambien allíla foliacion; perocontinuando las signs.: en la hoja siguiente en una especie de portada se lee:) Comença lo proces, o disputa de viudes y donzelles, ordenat per los Magnifichs mossen Iaume Siurana Generos, y mestre Lirs Ioan Valenti doctor en Medicina, àb vna sentencia ordenada per lo Honorable $v$ discret Andreu Marti Pineda Notari. CEn el reverso de la octava hoja de la sign. Y se lee: $\mathcal{E}$ Estampat en Barcelona en casa de Iaume Cortey. Any. M.D.LXI. 8. algo mayor que el ordinario.

Edicion mui rara.-Jimeno equivoca el tamaño pues le llama en $4 .^{\circ}$; y á ni modo de ver Fuster comete un error al sentar bai una impresion de Barcelona, Jaime Cendrat, 1561. $8^{\circ}$, por no parecer probable se hicieran dos ediciones en un año y en el mismo pueblo; es mui facil haber confundido el apellido del impresor, siendo igual el nombrè al de Cortey: ademas los libros hechos por Cendrat que conozco, fueron publicados desde 1587 á 1607 .

Tengo otra edicion dada á luz en Valencia, Jorun de Arcos, $1561,80^{\circ}$ que va unida al Proces de les olives al Somni de Joan Joan y á la Brama dels pagesos, la cual se describe en el artículo Cancionero valenciano, en la division correspondiente (Iúm. 194). -Jimeno habla de otra impresion de Valencia $y$ de Juan de Arcos de $1562.8 .^{\circ}$, que no he logrado ver, y como nadie la menciona sino él, sospecho que dicha edicion, como la de 1.52 , solo han existido en la imaginacion del autor de los Escritores del reino de Valencia.

919 ROIG (JACve). Lo libre de les dones e de concells donats per Mosen Jaume Roig, a son nebot en Balthasar Boil. Uuarta impressió. Traula a nova llum Carlos Rós. Valencia, M.DCC.xxxi. 4. 4 hojas prels. y 281 paigs.

Dice Ros en la dedicatoria al Conde de Carlet, que para formar un cuerpo par reimprimirle, ha sillo preciso viulersa de fiammenlos, que á custa de especial cuid la de ${ }^{\circ}$. S. se han logrado. Y en vistil $d^{*}$ esta" todo su contexto integro y perfecto. utc. Luego en la adrertencia proenial añde: y siendo así que con haberse h: cho dos impresiunes en esta ciudal, apénas se encuenIra un libro, ni noticia de esta obra... me motivo... á dar cuarla v'ez à la prensa csla impresion que ofresco, la que ha sidocopiada de la segunda qu" en esta ciudad se hizo en octneo, sin añadir ni quitar cosa alquna. - Como yo supongo apócrifas las ediciones de 1552. la de Jaime Cendrat de $1561, y$ ln de ralencia de $1 . t_{12}$, tengo or exacto el llamar Ros cuarta á la suya y cinjeturo haber sido la valenciana de 1561 la que tuvo presente, aunque ol ejemplar pudo estar formado de fragmentos donde faltarian probablemente el fruntis, las poesfas proliminares $y$ acaso los trozos relativios á las monjas que por csla raznu nu se hallan en la impresion de Ros: $y^{*}$ anu de tales ciremstancias pudieron provenir las variantes del tilılo.

Jaime Boig descuella como prinucl pocta lemosin del siglu . $\mathrm{r}$. y por l., mismo merece 
hien el que Gil Polo dijern en el Canto del Turi?.

Pues, ninfas, esparcid hierbas y flor'es Al grande. Jaime Roig agrudecidns, Coronárl con laurel, serpillo y apio El gran siervo de Apolo y de Esculapio.

Sils poesias son en estremo dulces, y en el Libre de les domes se encuentran cuentecillos $y$ anecdotas, narrados con tal gracia $y$ sal, que no desdeñaria Boccaccio flguraran en su célebre Decamerone.

Los traductores de Ticknor, en el tom. I., prig. 559 , dan noticia de otra obra algo parecida á la de Jaime Roig, intitulada: Libre de Fra Bernal, composl per Francesch de La via per pendre solac. Al fln de la obra se lee: Es estat fet lo present tractat per pendre solac; en lo qual se descobren des enganys e burles que les dones males e no les bones, solen fer. $4 .^{\circ}$ let. gót. 41 hojas. No tiene lugar ni año; pero parece impreso hácia fines del siglo XV.

920 ROLLIM DE MOURA (Fraxcisco). Dos Novissimos de Dom Francisco Rollim de Moura.. Qvatro cantos. Com os argumentos de hum amigo em cada Canto. Lisboa, Pedro Craesbeeck, 16⒊ 4. ${ }^{\circ}$ let. curs. 2 hojas prels. y 90 foliadas.

Poema portugues escrito en oclavas y como ya lo indica la portada va dividido en cuatro cantos.

BOMERO DE CEPEDA (JoAqUIN). Obras. Véase en la Seccion dramátitit.

92 I RUFo GUTIÉRREZ (Juas). La Avstriada de Iuan Rufo, jurado de la ciudad de Cordoua. En Madrid en casa de Alōso Gomez (que aya gloria) impressor de su Magestad, Año de mil y quinientos y ochenta y quatro (1584).8. 18 hojas prels. y 447 fols.

Entre los preliminares se halla el retrato del autor, copiado á continuacion, unas estancias de Lupercio de Argensola, un soneto de Góngora y otro de Cervántes.

Esta primera edicion es mui rara y no la conoció Nic. Antonio. He visto la segunda, tampoco mencionada en la Bibliotheca nova, hecha En Toledo, En casa de Juan Rodriguez, Impressor y mercader de libros, Año de mil y qainientos y ochenta y cinco (1585). 8. ${ }^{\circ} 16$ hojas preliminares, 447 fols. y una en la cual se repiten las señas de la impresion: poseo la tercera descrita en el número slguiente.

Brunct se equivoca en suponer que el asunto principal cic este poema es la batalla de Lepanto: de los veinticuatro cantos de que consta, diez y ocho se dedican á la rebelion de los moriscos en el reino de Granada, y lances de guerra ocurridos, y solo tres ó cuatro tratan de aquel célebre combate naval y acontecimientos que le prece. dieron.

El soneto liudatorio de D. Luis de Góngora que lleva al principio es el siguiente:

Canlaste, IRufo, tan heroicamente De aquel César novel lı augusla historia, Que está dudosa entre los dos la gloria $Y$ a cual se deba dur ninguno siente;

Y asi la fama que hoi de gente en gente Quiere que de los dos la igual memoria Del tiempo y del olvido haya victoria, Ciñe de lauro á cadi cual la frente.

Debeis con gran razon ser igualados, Pues fuisteis cada cual único en su arte, Él solo en armas, vos en letras solo;

$Y$ al fin ambos igualmente ayudados, Él de la espada del, sangriento Marle, Vos de la lira del sagrado Apolo.

\section{El de Migruel de Cervántes es este:}

o venturosa, levantada plumı, Que en la empresa más alta te ocupasle oue el mundo pudo dar, y al fin mostraste Al recibo y al gasto igual la suma;

Calte de hoi más el escrilor de Numa, Que nadie llegará donde llegaste, pues en tan raros versos celebraste Tan raro capitun, virtud tan suma.

Dichoso el celebrado y quien celebra, Y no ménos dichoso todo el suelo Que de lanto bien goza en esta historia;

En quien invidia ó tiempo no harán quiebra, Antes hará con justo zelo el ciela, Eterna más que el tiempo su memoria.

\section{RUFO GUTIERREZ (JUAN).} Ja Avstriada de Iuan Rufo, 'ut supra). Alcala, Ivan Gracian, $1586.8 .^{\circ}$ 4 hojas prels., 447 fols. y una para repetir el lugar y año de la impresion.

Ademas del retrato faltan en esta edicion las poesías laudatorias que lleva la primera.

He aquí el juicio, algo exagerado, que formó de esta obra Cervantes en la P'. I. cap. VI. del Quijote: Aqui vicnen tros juntos: La Iraucana de D. Alonso de Ercilla, La Austriada de Juan Rufo y EI Monserrate de Virues, poeta valenciano. Todos estos tres libros, dijo el Cura, son los mejores que en verso heróico en lengua castellana están escritos, y pueden competir con los más famosos de Italia: guárdense como las 
mas ricas prendas de poesta que tiene Es- | El retrato de Rufo puesto en la primera paña. impresion es el siguiente:

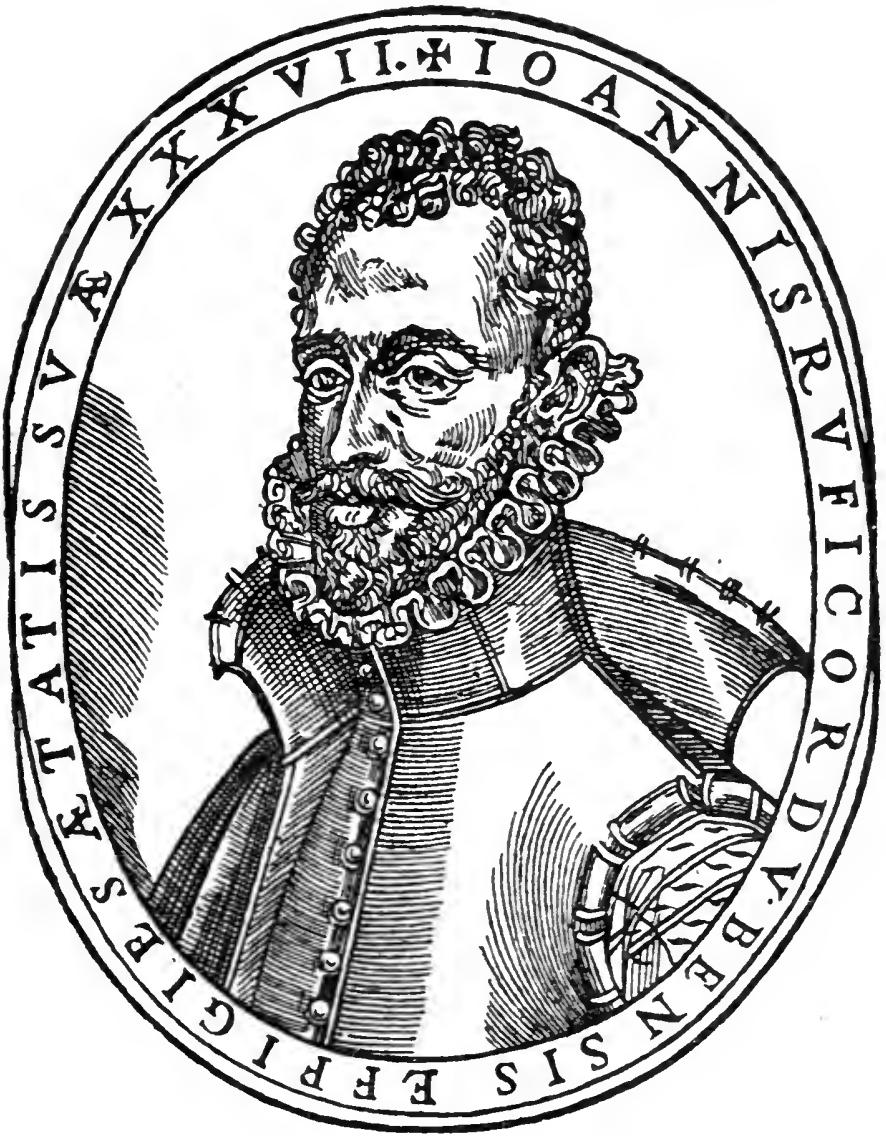

923 RUIZ DE LEON (FrAYcisco). Hernandia. Triuniphos de la fe, y gloria de las armas españolas. Poema heroyco. Conquista de Mexico, cabeza dèl imperio septentrional de la Nueva-España. Proezas de Hernan-Cortes, Catholicos blasones militares, y Grandezas del Nuevo Mundo. Lo cantaba Don Francisco liuiz de Leon. Madrid, Viuda de Manuel Fernandez, 1750. 4. 10 hojas prels. y 383 págs.

Poema en octavas dividido en doce cantos.
92' RLIZIUS VILLEGAS (FERDINands). Ferdinandi Ruizii Villegatis Burgensis qua exstant opera; Emmanuelis Martini studio emendata, et ad fidem Castelviniani codicis correcta: a Bernardo Andrea Lama iterum recognita ac recensita nunc primum prodeunt. Venetiis, Joannes Baptista Albrizzi, MDccxxxiv. 4. may. Frontispicio grabado.

Unica edicion de las poesías latinas de este español que floreció en el siglo XVI. 
920 SAA DE MIRANDA $\{$ FranCisco DE). As Obras do Doctor Francisco de Saa de Miranda. Agora de nouo impressas conı a Relação de sua calidade, \& vida. (Lisboa,) Por Vicente Aluarez, 1614. 4. ${ }^{\circ}$ let. curs. 12 hojas prels. y 160 fols.

La primera edicion, segun el Catálogo de Grenville, lleva el siguiente título: As obras do celebrado Lusilamo o doulor Francisco de Sa de Wiranda, collegidas por Mamuel de Lura. (Lisboa,) Inmressas com licensa do supremo consellon da sumla Geral Inquisiçao 'l Ordinario. 1595 . 1.

La edicion de lifí́ es la más correcta, y como tal la eita la Academia de Lisboa ; lleva una Vida del autor, y al fin de la Tabla se cncuentra una lista de las composiciones que se ban acrescontudo nesta segunda impressaĩ. 0 aqui hai equivocacion, ó la eomete sedano cuando en el Parnaso español, tom. VIll., pág. XXIl, mencioma una de Li.sbou, 1605; pues ell este caso la mia deberia ser lercera.

926 - Obras. do Doutor Francisco de Saa de Miranda Lisboa, Pedro Craesbeeck, 163 ?. 쁘. $0^{\circ} 1 \mathrm{hrja}$ prel., 173 fols. y 2 de Tabla.

Edicion microscripica donde no se halla la vila nj el someto lauditorjo de D. Mammel de portugal contenidos en la de 161 i; pero estín todias las poesias de saa que esta encicrera y hai ademas dos composiciones repetidas por el gran numero de variantes de entre cllas.

Brunct cita ntra edicion de estas obras tambiell en 24. ${ }^{\circ}$ heeha en Lisbna, 16.51, y sesmin el misino, si no lo entiendo mal, se leimprimieron en dicha ciudad en 1781.2 volimenes. $8^{\circ} .^{\circ}$ junto con las comedias del mismo alltor.

Ifuchas de las composiciones de saa de Milanda están en castellano.

927 SAAVEDRA (INGEL dE). El Moro Expusito, ó Córdoba y Búrgos en el siglo décimo. Lerenda en doce romances por Don Angel de Saavedra. En un $A$ péndice se añaden la Florinda y algumas otras composicione: incitas del mismo autor. Paris, J. Smith, 1834. 2 vols. $12 .^{\circ}$ may. $\mathrm{V} i$ netas y retrato.
Ejemplar de la primera edicion y del papel flno, del que se tiraron pocos; ademas se han intercalado los borradores autógrafos de El sueño del proscrilo y de El Faro de Malla.

928 SAAVEDRA (AंNGEL DE). El Moro Expósito, ó Córdoba y Búrgos en el siglo décimo. Leyenda en doce romances por Don Angel de Saavedra. En un apéndice se añaden la Florinda y algunas otras composiciones inéditas del mismo autor. Paris, J. Smith, 1834.2 vols. $12 .^{\circ}$ may. Vinetas y retrato.

Edicion distinta de la anterior, aunque lleva el misino año y está hecha á plana renglon con ella; sin embargo, se las puede reconoeer mil fieilmente, porque la primera tiene al pie de la pág. XV del Prólogo tres linuas completas de la nota que principia en la Xir; mientras en la posterior solo son dos y media.

Vi padre fue el editor y corrector de esta obra y suya es la Adluerlencin que precede á la Florinda; el Prólogo general, puesto en el primer tomo, lo escribió D. Antonio Alcalá Galiano.

929 SALVEDRA GUZMAN (AxToNio DE). El Peregrino indiano. Por D. Antonio de Saavedra Grzman. Madrid, En casa de Pedro Madrigal, 1ذ99. 8. 16 hojas prels. Ocupa la illima un retrato del autor, grabado en madera.J 347 foliadas, 4 hojas sin foliar, y una en que se repiten las señas de la impresion.

To he visto nunca otro ejemplar de este poema eserito en oetavas y dividido en veinte cantos: trata de la Conquista de Nueva España por llernan Cortes. - Entre los elogios en verso que se encuentran al principio los hai de Vicente Espinel, Lope de Vega y Gonzilo de Berrío.

Saavedra Guzman en el Prólogo advierte que habia gastado siete años en recopilar su liistoria; pero añade: la escribi y acabé en selenta dias de navegacion con balanzas de nan. A pesar de este corto tiempo tiene, como alice Ticknor, tom. 111., páyina 1 it, poesía y veruad, pues el antor, como hijo de lrejico, estaba fanniliarizado con las escenas que deseribe, y eonocia los hábitos de aquella infeliz raza cuyo desgraciado fin relata. 
El ejemplar de mi biblioteca tiene la singularidad de estar encuadernado en taflete y cortes dorados, por el cèlebre Roger Payne.
El retrato del autor puesto en los preliminares de la obra es este:

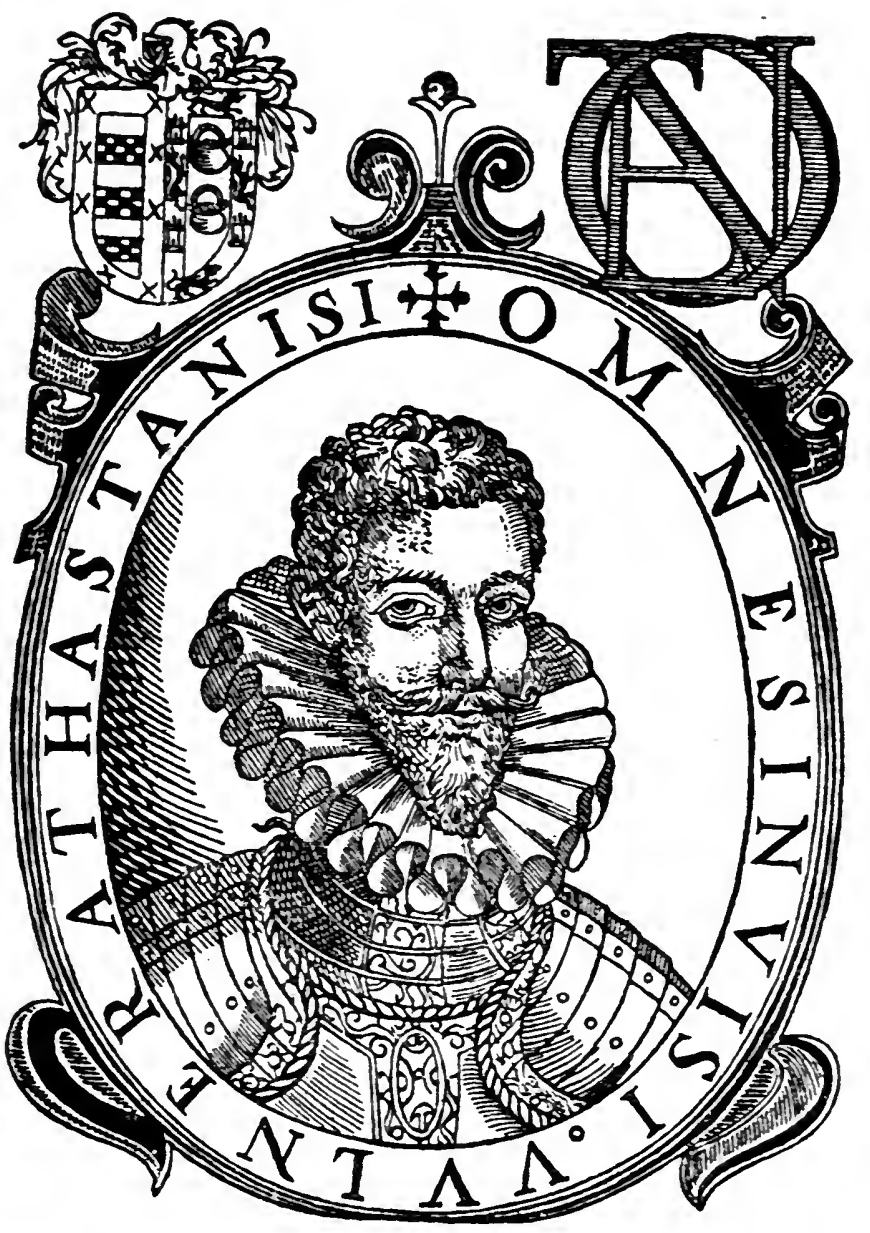

\section{SAAYEDRA Y GLZNIAN} (Martin DE). Ocios de Aganipe dirididos en diferentes poesias de Don Martin de Saavedra y Grzman. Trani, Lorenzo Valerij, M.DC.xxxiv. 4. 3 hojas prels., incluso el fróntis grabado, y 260 págs.

En el fróntis y en los titulillos de las páginas suenan"ser estas poeslas de D. Martin Saavedra y Guzman: no comprendo. pues, porque en la dedicatoria de este á D. Luis Méndez de Haro, dice: en que es V. S. quien los ha de amparar, ha dado fuer:a d este atrevimiento imprimir esle libro, que es- cribió mi padre; y en la pág. 225 se halla un soneto A la muerte de Don Consalo de Saavedra su padre y a sus obras. Pluede que al enviar D. Martin sus composiciones i su mecénas, le acompañase Los Pastores del Betis: prosas y versos, que compuso D. Gollzalo $y$ se imprimeron tambiell en Trani en 16.5 .5 .

Vic. Antonion no conoció los ocios de Aganipe, obra bastante rara, y solo cita otra del mismo autor, intitulada: Discursos de razon de estado y guer'ra. Trani, 1655. \$.

931 SAE.IZ OYECLRI (Diego). Thomasiada al sol de la Iglesia. y sr Doctor Santo Thomas de Aquino.

Tor. 1. 
Por el Padre Fray Diego Saenz Ovecuri. Guatemala, Joseph de Pineda Ibarra, 1667. 4. 30 hojas de prels., 161 fols. y 34 de Tablas y Fe de erratas.

Poema escrito en varias clases de metro y dividido en move libros, el primero de los cuiles es una dedicatoria en verso al capitan 1. Pedro de Sadaválles.

Nic. Antonio no menciona í este antor $y$ no lo estraño por ser la Thomasiada libro mui raro.

932 SAGRAD0 culto, respiracion festiva; desahogo de amor; y expressivo rasgo de la piedad; En las solemnes fiestils de la translacion del Santissimo Sacramento, y Fundacion del nuevo Colegio, y Templo de las Escuelas Pias, dedicado al Sol, Santo Thomas de Aquino, erigido en Zaragoza. En el dia 20 de Febrero de 17\%0. Zararoza, Joseph Fort, (1740?). $4 .^{\circ}$

\section{Son seis villancicos.}

933 S.ILAS B.ARB.IDILLO (ALOXso Jeróx. de). Patrona de Madrid restituida. Poema heroyco, de Alonso Geronimo de Salas Barbadillo. Serunda impression añadida. Madrid, Antonio Marin, 173̈0. 8. 12 lenjas prels. y 31 í paigs.

Las adiciones hechas a esta impresion consisten en haber añadidu al fin los Eloyios de varios ingenios, en alabanza de algunis prodigios de lira. Sra. de Alocha, en verso, los cuales ocupan las 56 pígs. últimas. He risto la primera edicion hecha en Madrid, Alonso Nurlin, fiog. $8 .{ }^{\circ} \&$ hojas prels. , 152 fols. y utra en cusco hauro se advierte, que arreglados por su irden los duscientos cincuenta y ocho versos numeralos en la obra se forinari un tratado pocitico de la esfera. Esta misma adrertencia se halla en la pag. 258 de la inpresion de 1750 .

Brunel dice se imprimio tambien esta obra en 16:20; no tengo de ello otra noticia. Lo contradice el llamarse seguuda edicion la de 1750 , existiendo positivamente la primera de 1609, y no 1608 , como supone equivocadanente IIvarez y Baena.

\section{3. - Bimas castellanas. Por} Alonso Geronimo de salas barbadi11o. Madrid, viuda de Alonso Martin, 1618. 8. 9 hojas prels., incluso el fiontis grabudo, y 136 fols.
Nic. Antonio y Brunet cltan ntra edicion de Mludrid, viuda de Alonso Marlin, 1616. 8.; cuya existencia se me hace mui dudosa, pnes la fecha de la licencia, privilegio $\mathrm{y}$ aprobaciones es de 1618 en la que yo tengo.

933 SÍLAS BARBAI)ILLO (ALONso Jilónimo DE). Los trivifos de la Beata Soror Ivana de la Crva En verso heroyco. Avtor Alonso Geronimo de Salas Barbadillo. Madril, Viuda de Cosne Delgado, 1621. 8. 8 hojas prels. y $\mathbf{8 0}$ fols.

Poema en octavas, dividido en cuatro libros.

Algunos cjemplares suelen flnalizar en el fol. 77 donde termina el poema; sin embargo les faltan tres hojas que contienen una Silva dedicada A la religion del Serafico Páriarca San Francisco.

Es una de las obras de Sálas Barbadillo más dificil de encontrar.

936 SALAZAR (Fr. Juan de). Ramillete de Cardeña compvesto de varios poenas en loa de sus docientos Monges Martyres. Recogidos por el muy Rdo. P.e Fray Iuan de Salazar. Bvigos, Pedro de Huydobro, 1628. 8. 11 hojas prels., inclusos el fróntis grabado, una lamina represen!ando a liclipe IV puesto de hinojos, recibiendo un libro de S. Estéran, y olra con una especie de sol, en cuyos rayos van puestos los nombres de las posesiones de ultiamar que tenia España en tiempo de aquel monarca, 252 fols. y 8 hojas de Tabla.

obra escrita con suma variedad de metros.

Es libro raro y cuya existencia ignoró Nic. Antonio á pesar de haber conocido otras dos obras del mismo antor intituladis, la una: Arte de anndar a disponer a bien morir a todo genir'o de personas. Roma, 1608. $4 .{ }^{\circ}$ y la otra: Polilica Española, que conliene un discurso cerca de su Monarquia, materias de eslado, aumento y perpeluidad. Logroño, Diego Mares, 1619. 4.

\section{SALAZAR Y HONTIVEROS} (Juar José). Poesias varias en todo genero de assumptos, y metros, con vn epilogo al lin de noticias, $y^{\prime}$ puntos historiales, sobre la provincia de la Rioja y sucessos de España, con la Chronologia de sus Reyes, hasta nuestro Don Phelipe Quinto. Su autor. El Licenciado Don Jvan 
Joseph de Salazar y flontiveros. Madrid, s. a. (hácia 1732). $4 .^{\circ} 18$ hojas prels. y 316 paiys.

El Epilogn de nuticias y punlos historiales, en prosa, ocupa más de la mitad del vo!úmen.

En unos apmutes de mi padre encuentro anotada como del inismo autor l' Cylhara de Apoln, varios pnesius divinas y humunus. Madrid, 1681. 4.

938 SALAZAR MARIONES CRISTóval. Ilvstracion y defensa de la Fabrla de Piramo y Tisbe. Compresta por 1). Lis de Gongora y Argote. Escrivialas Christoual de Salazar Mardones. Madrid, Imprenta Real, M.DC.XXXVI. $4 .^{\circ} 8$ hojas prels. y 19z fols.

I.a fabula de Piramo y Tisbe ocupa las 4 hojas primeras, las 188 restantes se invierten eul la ilustracion y defensa de ella.

SALAZAR Y TÓRRES (Agustin). Cítara de Apolo. Véase en la Seccion drainatica.

939 S.ILGADO Y CABARGO Dor Ferrayde). El santo nuilarroso argrstiniano, S. Nicolas de Tolentino. Sus excelencias, vida, muerte, $y$ milagros, Poema heroveo, repartido en veinte libros. Por Lon Fernando de Salqado y Camaryo. Madrid, Imprenta Real, 16 $28.4 .^{\circ} 12$ hojas prels., inclusa una que solo contiene una lamina grabada por Courbes que representa i $S$. Nicolas, y 140 fols.

Al principio del volúmen hai versos laudatorios de Lope de Vera, Mira de Amescua, Sálas Barbadillo, Valdivielso y del lic. Juan Magaña y Zevíllos: tambien va al frunte de la obra un Soneto de Salgado en lutin con. grtuo y puro castellano, ef mejor que he visto de su clase, pues son en él mémos perceptibles las trabas que siljetaban al autor en su composicion.

Nic. Alltonio en el artículo de Fcrnando Camargo y Salgado, trae una porcion de obras eserilis por cste, y entre ellas el poeuna a S. Nicolas; pero se conoce que no lo vion, pues no flja ni el lugar y año de la impresion, ni su tamaño.

940 S.LIINAS Y LIZANA (D. MANeEl). La Casta Srsana, parafrasi poetica de sy sagrada historial. Por El Doctor Don Manuel de Salinas i
Lizana. Huesca, Iuan Francisco de Larumbe, 165̆1. 8. 13 hojas prels. y $47 \mathrm{fols}$.

Poema en cuartetas nada frecuente.

Hai al principio un soneto del Doctor Juan Francisco Andres.

941 SALMOS (Los) DE DAVID. Exposicion paraphrastica del Psalterio de Dauid, en diferente genero de verso Español, con exposiciones varias, de varios y grauissimos Autores. Con la tabla de todos Ios Psalmos y sus Autores. Por el Padre Maestro Fr. Iuan de Soto. Alcala, Luys Martinez Grande, 1612. $4 .^{\circ} 16$ hojas prels., siendo blanca la última, 398 fols. y 4 de Tabla.

Las licencias, censuras y aprobaciones de la presente edicion, fechadas en 1611 , hacen suponer es la primera y que no existe la única mencionada por Nic. Antonio de Alcala, 1602. - La unás antigua de que habla Barrera es la siguiente de $162 \vec{j}$.

91느 - Exposicion parafrastica del Psalterio y de Los Canticos del Breuiario Por el M. Joseph de Valdiuielso. Madrid, viuda de Alonso Martin Año. $16 \geqq 3.4 .^{\circ} \mathrm{T}$ hojas prels., inclusa la portada graballa, $220 \mathrm{fols}$. $y$ I de Tabla.

Tanto los Salmos como los Cúnticos de breviario estiul traducidos en verso.-Hai una reimpresion hecha en Fulenria, por Joscph y Thomus de Orga, H.DCC.L.Y.X. 2 rols. en $8 .{ }^{\circ}$

Leva al principio en la primera edicion, y al fin en la segunda, algumas pocsias laudatorias de Lope de Vega, francisco de Francia y A costa, Juan Pérez de Montalvan y el Doctor Vlila de Amescua.

943 - Sagrada Eratos y meditaciones Daridicas de I. Alonso Carrillo Laso de la lega. Napoles, Lucas Antonio Fusco, M.DC.LVII. 3 tomos 4. ${ }^{\circ}$ may. 6 hojas prels., incluso un antefróntis grabado y el retrato de Don Juan de Austria, 18- paigs. y una hoja de erratas, el primer tomo; 4 hajas prels. conel mismo antefrontis yrabado, y 172 prigs., el segundo; 4 hojas prels., conlando tambien un ante froutis igual a los otros, 170 pays. y una hoja de emmiendas, el incer: 
Esta version de los clento clncuenta Salmos de David la publico el hijo de su autor D. Fernando Carrillo y Manuel.

Los tres tomos generalmente van encuadernados en uno.

\section{SALMOS (Los) DE DAVID,} Espejo fiel de vidas Que contiene Los Psalmos de David En Verso Obra Devota, Vtil, y Deleytable Compuesta por Daniel Israel Lopez Lagvna. Londres, 3480 (1720). $4 .^{\circ}$ may. 26 hojas prels., inciusas dos lams. en jeroglíficos, 286 pags. y una hoja con varias décimas.

Contiene la traduccion en verso de los ciento cincuenta salmos del rei profela.

He visto: Los Psalmos de David con sus sumurios en que se declara con brenedad lo contenido en cada Psalmo, agor a muena y fielmente traduzidos en romançe Caslellano por el doctor Iuan Perez, conforme a la ver. dad de la lengua Sancla. En Venceia en casa de Pedro Daniel, M.D.LVII. 8. ${ }^{\circ}$ Precrden á la obra dos pliegos, signs. $A$ y $B$, de 8 hojas el primero y de 7 el segundo; siguen 118 fols., 2 de Tabla y una al fin con una advertencia sobre el tercer salmo.

Tambien he tenido ocasion de ver otra traduccion en verso del salterio, la cual describiré por ser poco conocida: Los CL. Psalmos de Dauid: in lengua espannola, en varias rimas, conpuestos por Dauid ABenatar melo, conforme ala uerdader a Tracduccion ferv'uresqua: con algunas aleguorias Del Autor. En Frunqua Forte Anho De 5386(1626). $4 .^{\circ} 7$ hojas prels. y 268 págs.

otra version tuvimos en Inglaterra, cuyo título era: Las Alabansas de Santidad, traduccion de los Psalmos de David, Por la misma Phrasis y palabras del hebrayco. Ilustrada con su Paraphrasis que facilita la inteligencia del Texto, y Anotaciones de mucha dotrina. Por Yahacol Yehuda, Leon Hebreo. Amsterdam 5451 (1671). 8. Acompaña el testo hebreo. No menciona esta version $\mathrm{Ni}$ colas Antonio en el artículo de Jacob Yeliuda Leon.

La última traduccion de todos los Salmos es la hecha al custellano en verso y prosa conforme al sentido literal y d la doctrina de los Santos Padres con notas sacadas de los mojores interpretes, y algunas disertaciones. Por el Dr. D. Tomás Gonzalez Carvajal. Valencia, D. Benito Monfort, 1819. 5 vols., $80^{\circ}$ marquilla.

Mi padre reimprimio la version castellana de Carvajal sin testo ni anotaciones, en un tomito en $32^{\circ}$, y la publicó en Lóndres en 1829: en Paris volvió á darla á luz en 1848 en $32 .^{\circ} \mathrm{y}$ en $18 .^{\circ}$
945 SALMOS (LOS) DE DAVID. Los Psalmos de David. Metrificados en lengua Castellana Por Iuan le Quesne. Conforme a la traduccion verdadera d'el texto hebreo. M.DC.VI. $8 .^{\circ} 4$ hojas prels. y desde la signatura A á la $\mathrm{K}$ todas de ocho hojas.

La edicion parece hecha ell los Paises Bajos. Nic. Antonio no vió este libro, el cual no comprende todos los salmos, sino unos setenta saltados.

946 Lo que en este libro esta tradvzido de latin en lengua Castellana con vna breue exposicion es lo siguiente. Los siete psalmos penitenciales. Los quinze psalmos d'el canticumgrado. Las lamentaciones de llieremias. Lo qual todo la muy poderosa y christianissima señora Leonor Reyna de Francia mando assi traduzir y componer al maestro Hernãdo Iaraua su capellan. Anvers, Martin Nucio, M.D.LVI. 24. ${ }^{\circ}$ Tirado en negro y colorado. Sin foliacion, signs. A -S todus de $\mathbf{8}$ hojas.

Ejemplar rayado. Nic. Antonio no conocio esta obra de Jarava, ni supo ser este capellan de la reina cristianisima, ni que habia cstado en la Iniversidad de Paris, segun todo consta por la portada y dedicatoria del presente libro.

En el Catálogo de Gancia, tal vez equivocadamente, se anuncia una edicion hecha tambien en Anvers, en casa de Martin Nucio, $1546.160^{\circ}$ y allí se advierte ser libro mui raro, por haberse impreso para el uso particular de la reina, y tirado por consiguiente en corto número de ejemplares.

947 - Exposicion de los siete Psalmos Penitenciales Escriviala el Excelentissimo señor Don Antonio de Peralta Croi Velasco Hurtado de Mendoza, Marquès de Falces, etc. Madrid. Por Pablo de Val. Año de M.DC.LXII. $4 .^{\circ} 6$ hojas prels. y 199 págs. Al reverso de la última se repite la fecha.

Los salmos están traducidos en cuartetas y se repiten al fln, entresacados de la Esposicion.-Este tomo debe ser bastante raro; Nic. Antonio no hace mérito de D. Antonio de Peralta Croi, ni conozco su obra citada por bibliógrafo alguno.

948 Salzedo (Mateo de). Postrimerias del hombre, y enemigos del 
alma, y a labanzas del santissimo $\mathrm{Sa}$ cramento. Por el Licenciado Mateo de Salzedo. Madrid, Iuan de la Cuesta 1610. 8. 16 hojas prels. y 91 fols.

Las cuatro postrimerfas están en octavas, los tres enemigos del alma en quintllias, y las alabanzas al Sacramento en varias clases de metro como son romances, villancicos, letrillas, etc.-obra rara.

Nic. Antonio babla de otra de este autor, intitulada: Luz de la oracion menlal. Madrid, Cosme Delgado, 1619.16. y pone en duda si será el mismo Salzedo ú otro quien escribió las Mercedes de la Beyna del Cielo y Excelencias del nombre de Maria. Madrid, 1629.8.

949 SALZEDO CORONEL GARcía DE). Rimas de Don Garcia de Salzedo, Coronel. MaDrid, Por Don Iuan delgado, Año de 16 27. 8. ${ }^{\circ}$ Fróntis grabado, 16 hojas prels. y 162 fols.

Nic. Antonio cita una edicion de esta primera parte de las Rimas de Salzedo, becha en Madrid, 1624, $\mathrm{y}$ en ello se equivoca, pues las licencias, aprobaciones, erratas y tasa todo está fechado en 1627, prueba evidente de no haber edicion anterior á la de este año, la cual èl no menciona.

El P. Fr. Diego Niseno dedicó al autor de estas Rimas las dos siguientes décimas:

Corone el Betis sus sienes det siempre verde laurel, oh famoso Coromel, pues lal valor le previenes. ivué le glorias, qué de bienes ha merecido alganzar. por lu musa singular! pues si de ánles fugitivo, y a podrd correr alitivo con presunciones de mar.

El sucro plectro aplaudido del dulee canoro orfeo. por más glorioso trofeo d tus pies yace rendido; y la uro lan merecido si magnánimo no emprendes, tu honor, tu valor ofendes, que Orfeo cuando cunto los infiernos suspendió, mas tii los cielos suspendes.

950 - Cristales de Helicona Segunda parte de las rimas de Don Garcia de Salçedo Coronel. Madrid, Diego Diaz de la Carrera, 1649. 4. ${ }^{\circ}$ 32 hojas prels. que comprenden el fróntis grabado, la portada impresa y la composicion intitulada: El circo espanol que consta de $\mathbf{4 6}$ octavas; hai ademas 138 folios, 3 hojas de Indice y una blanca.
Algunos citan una edicion de 1630; esto se debe á haber muchos ejemplares faltos del fróntis grabado que es del año 49 \& solo con. servan el impreso que lleva el de 50 , el cual fué realmente el de la publicacion, como se ve por parte de los preliminares. La supresion tan frecuente de la portada grabada consiste sin duda, en que como en esta se espresa ser segunda parte, y en la otra nada dice, los líbreros le arrancaron aquella para quitarle la apariencia de una obra incompleta.

9 Sa1 SaMaNiego (Félix María). Fábulas en verso castellano por Don Félix Maria Samaniego. Paris, Bacquenois, $1833.18 .^{\circ}$ may.

Edicion hecha por mi padre.

952 SAN ACGUSTIN (Fr. JUAN DE). Trivnıpho panegyrico. Aplavso real, y sagrado; celebracion festiva; que al nvevo crlto qve a S. Fernando III. rey de Castilla, y Leon, concedio nvestro mvy Santo Padre Clemente decimo. Corisagro la Metropolitana y Patriarcal Iglesia de Sevilla. Poema heroyco historial, en que la describe el P. Fr. Ivan de S. Avgustin. Sevilla, Thomè de Dios Miranda, 1671. 1. ${ }^{\circ} 13$ hojas prels., 41 fols., una con dos epígramas de $\boldsymbol{D}$. Jose Roman de la Torre y Peralta, y olra con las Erratas y las señas de la impresion.

Poema en tres cantos, de cuyo autor no encuentro naticia en vic. Antonio.

9 9̈3 SAN MARTIN (GREgORIO DE). El Trimpho mas famoso que hizo Lisboa a la entrada del Rey Don Phelippe Tercero d' España, y Segundo de Portugal. Compuesto por Gregorio de San Martin. Lisboa, Pedro Craesbeeck, 1624. 4. 6 hojas prels. y 10 sols.

Poema en siete cantos y en octavas.

En el canto quinto describe la tragicomedia representada por los Padres de la Compañía en su convellto, cuya Relacion publico Juan Sardina Yimoso, con el título de Retacion de la real tragicomedia con que los Padros de la Compañia de lesv's en su colegio de S. Anton de Lisbon recibieron a Felipe II. de Portugal, y de su enlrada en esle Reino. Re. cogido todo verdaderamente. Lisboa, Iorg Rodrigue $=1620.4 .^{\circ} 10$ hojas prels., 163 fols. $y$ una de erratas.

No encuentro á Gregorio de S. Martin en la Bibliotheca de Nic. Antonio. 
$9 \breve{4}$ SAN PEDRO (DIEGO DE).

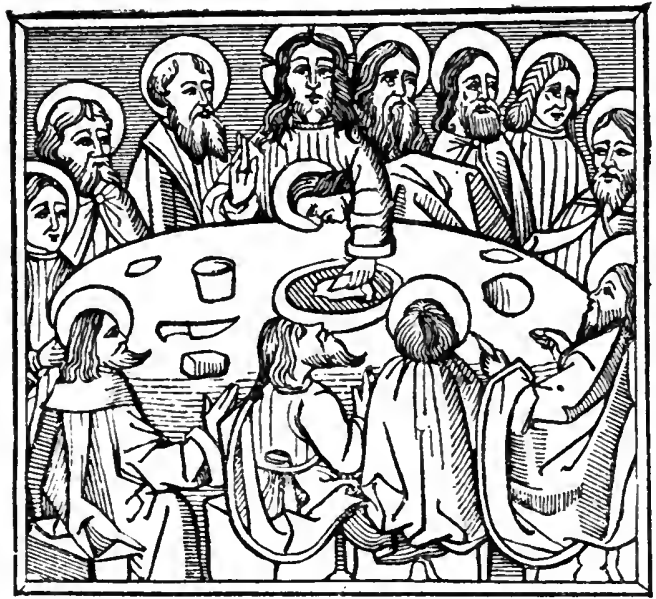

CLa paffió de ñ̄o re

\section{de $\mathfrak{e}$ to: : y faluador $\mathfrak{I} \mathfrak{e}$}

\section{fur $\mathfrak{x p} 0$. Trobadta por} diego de fant pedtro.

(Esto va todo circuido de orla ancha en cuya parte superior s? lee:

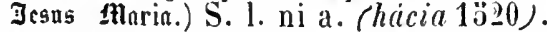
4. ${ }^{\circ}$ let. gót. Viñetas de madera. 20 hojas sin foliacion, con las signs. a-c de 8 hojas las dos primeras y de 4 la última.

En el catálogo de Heber, P. IX. número 1032 , se deseribe una edicion en $40^{\circ}$, letra gót. diversa de la presente, pues en aquella las Coplas á una devola momja principialuan en la sign. Aii y la Pasion en lia diii, micintras en la mia las unas comienzan al dorso del fróntis y la otra en el riverso de la sign. aij. -En el mencionado catálogo se comete el dispárate de decir que este pocmita estil es. crito an proveluzal y $\mathrm{Mr}$. Brunet en sı $\mathrm{Ma}$ muel, to repite inadrertidamente. El primer antor de este desatino fuc $\mathrm{Mr}$. Thorpe, de Londres, quien al anumciar por la primera vez en uno de sus catilngos ol mismo ejem. plar, perteneciente despnes i Heber, le pasi por las mientes el ballizar como dialecto lemosino el lenguaje cistollano del siglo XV: verdad es que el librero londinense ela tan puco versado en idionas como en conoci- mientos blbliográficos; sin embargo de no haber habido persona en el mundo por cuyas manos hubieran pasado tantos y tan preciosos libros. Esto prueba que el hom: bre ha de circunscribirsc á las facultades concedidas por la naturaleza, y él por lo mismo un debió haber abındonido su ocupacion de hornero para la cual se conoce esliba predestinado.

Nic. Ántonio hab'a de Diego de San Pedro en la Bibliolheca vetus y en la nova; pero en ambas partes se olvida de esta obra, y tambien Bayer la omite en las notas á la velus.

95: SAN PEDRO (DIEGO DE). La Passion de Christo, Redentor, y Salvador nvestro, trovada por Diego de San Pedro. Madrid, Francisco Sanz, 1699. $4 .^{\circ}$ Viñetas de madera. $\mathbf{4 0}$ págs. inclusas las dos de la hoja de la portada.

Esta edicion va bastante acorde con la de letra gótiea, pero tiene algunas variantes: se han suprimido del principio las coplas enviadas a una monja, y se ha añadido al fin como una hoja de coplas del Bachiller Buirgos á la Resurreccion.

956 La Passion de Nvestro Señor Jesv-Christo. Compuesto por Diego de S. Pedro. Sevilla, Lucas Martin de llermosilla, 1700. $4 .^{\circ}$ Viñetas de madera. 16 hojas sin foliacion con la sign. A.

El contenido es el mismo que el de la edicinn en let. gót.; pero tiene muehas variantes y principia desde la copla de la hoja segunda: Grandes cosas nos dixeron.

9:7 SÁNCHEZ (ÁNGBL). Titiada compuesta en doce libros por Don Angel Sanchez. Madrid, viuda de D. Joaquin Ibarra, MDCCLXxxxIII. 2 vols. $8 .^{\circ}$ marq.

Precede á este poema un Discurso sobre la epopeya.

9038 SÁNCIIEZ (PEdRo). Arrepentimiento que el alma tiene de auer ofendido a su Criador: con una inuocacion a nuestra Señora. Y cinco puntos del verdadero examen de conciencia, con algunas oraciones de grandissimo prouecho para el alma. Por PedroSanchez. Valencia, Syluestre Esparsa, 1630. $160^{\circ}$ Sin foliacion, signs. A y B de 16 hojas inclusos los prels. 
Este tomito es todo en verso. - Nic. Antonio no solo no lo menciona sino que omite en su Bibliotheca el nombre de Pedro Sanchez, natural de Quintanar de la órden.

SÁNCHEZ (Vicente). Lira poética. Véase en la Seccion dramática.

SANCHEZ DE BADAJOZ (DıEGo). Recopilacion en metro. Véase en la Seccion dramatica.

959 SÁNCHEZ DE LIMA (MIGCEL). El arte poetica en romance Castellano. Cõpuesta por Miguel Sanchez de Lima Lusitano. Alcala de Henares, Iuan Iñiguez de Lequerica, 1680. 8. 71 hojas fols., inclusos los prels. y portada, y una hoja para repetir las señas de la impresion.

Está dividida esta obra en tres dicilngos en prosa, y en ellos van interealidas muchas poesias puestas como muestra de las varias maneras de metriflcar que tenemos en castellano: al fln se halla La historia de los amores que vuo entre Calidonio y la hermosa Laurina, en verso.

Ademas de lo diclın en la portada sobre el nombre y la patria del autor de este libro, en un soneto landatorio dirigido al mismo por D. Francisco Valdonado, que se encuentra en los preliminares, leemos:

\section{Levanta Lusitamia lu soutido}

Verás un nicuv Apolo, me ha estado

Su claro resplandor como cclipsau,

F agora por ct orbe se ha esparcido.

Que alinjue en li, Lusitania, fré nacido, Le vimos sumdo niño deslerrailo,

$Y$ acd se hizu varon sabio y prudeule.

Estos datos nos prueban que ric. AnInnio no vió la presente obra, pues á labuerla tenido á la vista ni suponuria estar eserita por un tal Sánchez de viana, ui que este era natural de Lima en el reino del l'erú. Tam. bien se cquivoca en el tamaĩo del volúmen, pues dice es el de $4 .^{\circ}$

960 SiNCHEZ DE MELO (LUIS). Invectiva pnetica, contra cinco vi. cios, Soberuia, Inuidia, Ambicion, Murmuracion y Ira. Elogios 1 las Virtudes quie se les oponen. Discrrsos morales, En que en epilogo se trata lo juridico y politico, que toca a cada rno de los dichos Vicios y Yirtudes. Por el Licenciado L uis Sanchez de Melo. Malaga, Iuan Serrano de Vargas y Vrueña, 1611. 4."10 hijas prels., 95 fols. y una que contiene una décima dirigida al autor y al impresor y las señas de la edicion.

Poema en uctavas, dividido en cinco Discursns á cada uno de los cuales acompaña und Alegucion jurídica y moral en prosa.

llice el autor en el Prólogo al lector, haber escrito esta obra en miénos de un mes y añade, quedaba preparando una segunda parte, la cual debia comprender la Gula, la Sensualidad y la Negligencia. Ignoro si llego á publicarse dicha continuacion; pero sospecho que no: tambien me parece no existe la edicion de 1644 de la primera parte, citada por Tickror, tom. III., pág. 43.3.

961 SANTAZARO (Jacobo). Arcadia de Jacobo Sanazaro gētil hombre Napolitano: traduzida nueuamente en nuestra Castellana lengua Hespañola / en prosa y metro / como ella estaua en su primera lengua Toscana. CEsta leyenda ta precedida de un escudo de armas, circuido de orla, proballemente el de Gonzalo Pérez, á quien se dedica la obra; las dos hojas siguientes, signs. aij y aiij, las ocupa la dedicatoria y la obra principia en la cuarta lioja con el Prologo de Sanazaro, terminando en la hoja norena -de la h, así:) Fue impressa la presente obra en la imperial cibdad de Toledo / en casa de Juan de A yala. Acabose a reynte dias del mes de Otubre. Año de mil! quinientos y quarenta y siete (lăli Años. (Al dorso principia una advertencia al lector de Blasco de Garai que termina en el blanco de la hoja siguiente.) $4 .^{\circ}$ let. gót. la prosa y de redonda los versos puestos en dos colunas. Sin fol. signaturas a-h, todas de ocho hojas escepto la h que tiene 10.

962 - Fróntis iqual al de la anterinr edicion con sola alguna variacion en la distribucion de las líneas, y con la unica diferencia ortográfica de decir gentil en vez de getil. El resto del columen esta impresn a plana renglon con la edicion del $\mathbf{i} \bar{T}$, teyéndose comn en aquel en el recto de la novenu hoja de la li el siguiente colofon:) Fue impressa la presente obra enla imperial cibdad de Toledo: en casa de Juan de Ayala. Acabose a 
quatro dias del mes de Nouiēbre. Año de mil y quinientos y quarẽta y nueve (1549) Años. (Sigue la misma hoja que en el anterior.) $4 .^{\circ}$ let. gót. la prosa y los versos de redonda distribuidos en dos cols. Sin fol. signaturas a-h, de 8 hojas ménos la última que tiene 10.

Ambas ediciones son perfectamente distintas é igualmente raras. - Nic. Antonio en el artfélo de llego de SaIazar solo mencioma la del $17, y$ en la pág. 3.38 del tom. II. de la biblioth. nova, entre los anonimos. se refiere á una de Salantanca, 1578, que. los editores de las obras suctlas de Lope, prólogo del tom. Vl., dieen es de Simon de Portonariis.

En la dedicatoria de Blaseo de Garai y en la advertencia del mismo, inserta al fin, se encuentran noticias curiosas sobre los co. antores de esta version. Segun parece, la prosa es de 1). Pedro López de Ayala, canónigo de Toledo y traduetor tambien del Laberinto de amor de Boccaccio, y los versos son det capitan Diego de Salazar, lombre singular, que despnes de haber militado muehos años bajo las banderas de Círlos $V^{\circ}$, murió ermitaño. Era, segmn parece, intimo amigu de dicho Garai, y por ello se permitio este hacer algunas correceiones y hasta variaciones en la parte poitica.

Vada prueba cuan puco conocida es este libro en castellano, como el que Gallardo en el num. 3 del Criticm, al ocmalse de biega de Salazar y al cmmmerar sils eseritos soto cita la Coronica del Emmeralm Carlos V. en la qual se brata de la justisima guerio que $S$. If movio contra los Luter rmos y robeliles de Alemania, y tos sucesos que turo. Tapoles, 1548 y Sevilla, 15.52 , y no dice mia patalord de la presente tratuccion de sannizitro, ni de la de Apian', ni tampoco del Traludo de re militari que eseribio. Bronet tambien jgnoro que existiesen en español lit $A r$. cadit y el Parto de ta Firgen del mismo Silnnazaro.

seguin Latasa, Bibl. aragon., tom. I., página 267 , [). Jerónilllo Jiménez de Urrea tradujo La Arcudia dé Jucobo Sanazaro, Poela insigne de Ilalia. en el mismo género de ver. sos que to escribii su Aulor; pero quedo inédita à pesar de estar ya muri adelantada para darse a la imprentil, como lo justificil una aprobacion de 6 . Ilunso de Ercilla puesta en ella.

963 SANTIZARO (Jacuno DE). El Parto de la Virgen, đ̃ cõpuso el celebre Iacobo de Sinazaro. Traduzido en octaua rima Castellana : por el Licenciado Gregrorio Hernandez de Velasco. Salamanca, Mathias Mares, 13้69. 8. 76 hojas fols. inclusas las 7 de prels.

Nic. Antonio meneiona una edicion de
Toledo, 1554, y otra de Madrid, 1569, ambas en $8 .^{\circ}$; pero nada dice de la de Salamanca. Sedano reprodujo la traduccion de Hernández de Velasco en el tom. V. del Parnaso es. pañol, y observa en los preliminares de dicho tomo, pág. XXX, que la obra se habia impreso valias vezes y en diversos tiempos, en Toledo, Madrid y Sevilla, sin mentar á Salamanca. Lope de Vega en el Laurel de Apolo hace un elogio mui grande y merecido de esta version $\mathrm{y}$ los editores de las obrus suellas de dicho Lope de Vega en el Prólogo del tom. VI. se contentaron con copiar á Nic. Antonio al mencionar á Hernández de Velaśco.

964 SANNAZARO (JACOBO DE). Sanazaro español. Los tres libros del Parto de la Virgen nuestra Señora. Tradvecion castellana de Verso Heroyco Latino. Por el Licenciado Don Francisco de Herrera Maldonado. Madrid, Fernando Correa de Montenegro, 1620.8. 16 hojas preliminares y $\mathbf{7 9}$ fols.

Vic. Antonio no menciona la edicion de 1620 y si una de Madrid del misino Fernando Correc de 1621. 8. , lo rire puede mui bien ser erratia. Los editores ite las obras sueltas do I ope de Vega, en el prólogo del tom. VI., se ciñen á repetir lo que se dice en la Bibliollecen nor'u.

Jerrera Valdomado fué uno de los buenos poetas que florecioron á principios del siwlo Mrll, por eso dijo de él Lope en el Laurel de Apolo:

Preciada de las musas oropesa dijo, que en el parnaso graduado

Ion Frumcisco de Herrera Maldohabia de ser el héroe de esta cmpresa: [mado porque si España de alabar no cesa sus u'ersos y su prosa, ellos thitees y gruces, $y$ clla hermosa: a ninguno mejor le compelia.

963 SANS (Hı́ólto). La Maltea. En que se trata la famosa defensa de la Religion de sant Ioan en la isla de Malta. Compresta en octava rima por Hippolyto Sans, Cauallero, natural de la Ciudad de Xatiua. En Valencia Se imprimio en casa de Ioan Nauarro, Añu 1382. 8. 4 hojas preliminares, clxiij foliadas, al reverso de la última se rexiten las señas de la impresion.

Poema en doce cantos y tan raro que álpesar de estar impreso en Valencia y ser su au- 
tor natural de este pais, Jimeno lo cita refriéndose á Rodriguez, y este copiando á Nicolas Antonio.

D. Hipólito Sans, caballero del háblto de S. Juan, natural de Játiva, en la provincla de Valencia, se hallo en el sitio de Malta el año de 1565 , y con este motivo y como testigo ocular escribló el presente libro.

Van al principio dos sonetos laudatorios, unn de Miguel Jerónimo de Armingol y el siguiente de D. Jerónimo Sans:

Sant-Elmo dicen que es al navegante Gran muestra de bonansa y de reposo, Cuando con resplandor claro y lustroso Le quieta con su rayo penetrante: De aquella clara luz y radiante Seitala sosegado el mar bravoso, Y el viento que con impetu furioso, Turbaba al marinero y al tratante.

$Y$ nuestro claro aulor en este vaso De versos dignos de inmortal memoria, Cotmado del licor mas consumado;

De Agamipe, Castalia y de Pegaso, De Malla y de la Cruz la gran victoria Nos muestra y d́ Sant-Elmo sosegado.

966 SANTA MARIA (Artorio DE). La vida, y nilagrosos hechos del glorioso S. Antonio de Padva... en verso: nueuamente compuesta por Fray Antonio de Sancta Maria. Salamanca, Guillelmo Foquel, M.D.LxxxviII. 8. ${ }^{\circ}$ let. curs. 8 hojas prels. y 288 foliadas.

Poema en treinta y cuatro cantos; al fin va un Dialogo espirilual (en verso) que trala quan datuso es perder el tiempo y ocuparse en leer libros profanos.

Nic. Antonio al parecer no vió este libro rari) pues omite el pueblo donde se imprimió.

\section{SANTISTEVAN 'OSORIO} (Diego de). Primera y segvada parte de las guerras de Malta, y toma de Rodas. Por Don Diego de Santisteuan Osorio. Madrid. En la imprenta del Lic. Varez de Castro. MDxcix. 8. ${ }^{\circ} 8$ hojas preliminares, 297 fols. y 2 de Tabla.

Las dos partes en un volumen: la primera contlene doce cantos $\xi$ ! a segunda trece, todos en octaras.

Nic. Antonio se equivoca en decir que esta edicion es en $4 .^{\circ}$ y que el nombre del impresor es Suárez de Castro.

Es libro raro.
968 SANTISTÉVAN OSORIO (Diego DE). Quarta parte de la Aravcana. De don Diego de Santisteuan Osorio. Barcelona, M.D.Lxxxxviij. 12. 6 hojas prels., 246 fols. $y 4$ de Tabla.

Al fol 117 principia la quinta parte del mismo autor, con nuevo frontis, en él se espresa que el impresor es Ioan Amello, lo mismo se repite al fin del tomo.

Nic. Antonio cita una edicion de estas dos partes hecha por Juan Renaut, 1597. 8. y yo he tenidn la de Madrid, Francisco Marlinez Abad, 1755. fol. que forma juego con las tres partes de Ercilla que imprimió el mismo Abad en 1733 .

969 SARMIENTO (MARTIN). Obras posthumas del Rmo. P. M. Fr. Martin Sarmiento. Tomo primero. Memorias para la historia de la poesia, y poetas españoles. Madrid, Joachin Ibarra, MDCCLXxY. 4.

\section{Ejemplar en papel fino.}

Dice Sánchez en el Prólogo de su Coleccion de poesias anteriores al siglu $\mathrm{XV}$, al hablar de este libro, que es tan abundante de exquisila y recóndita crudicion perleneciente d la materia de que trata. y aun d o/ras muchas, que bastaria esta so'a obra para acredilar el gran caudal de tarin literatura que poseiu su autor, aun cuundo no le turie'se bien acredilado en toda la nacion y fuera de ella.

970 SAYARIEGO DE SAXTAYA (GASPAR). Lioro de la lberiada de los hechos de Scipion Africano en estas partes de España, donde se da cuenta de sus viclorias, y de muchos famosos españoles. Compuesto por Gaspar Sauariego de Santana. Falladolid, Por Luys Sanchez. Año 1603. 8. $^{\circ} 8$ hcjas preliminares y 298 fols. tos.

Poema en octavas dividido en veinte can-

Nic. Antonio no tuvo presente este libro, pues dice ser el nombre del impresor Juan Sánchez; Brunet no lo cita y tampoco lo encuentro en el Catálogo de la biblioteca $\mathrm{He}$ beriana: Ticknnr, tom. III. pág. 180, confiesa que nunca ha podido verlo.

SCOTTI DE ARGAOIZ (PEdro). Obras poéticas. Véase en la Seccion dramática. 
971 SERAFIN (Prdro). (Sigue el | facsímile de la portada de la obra.)
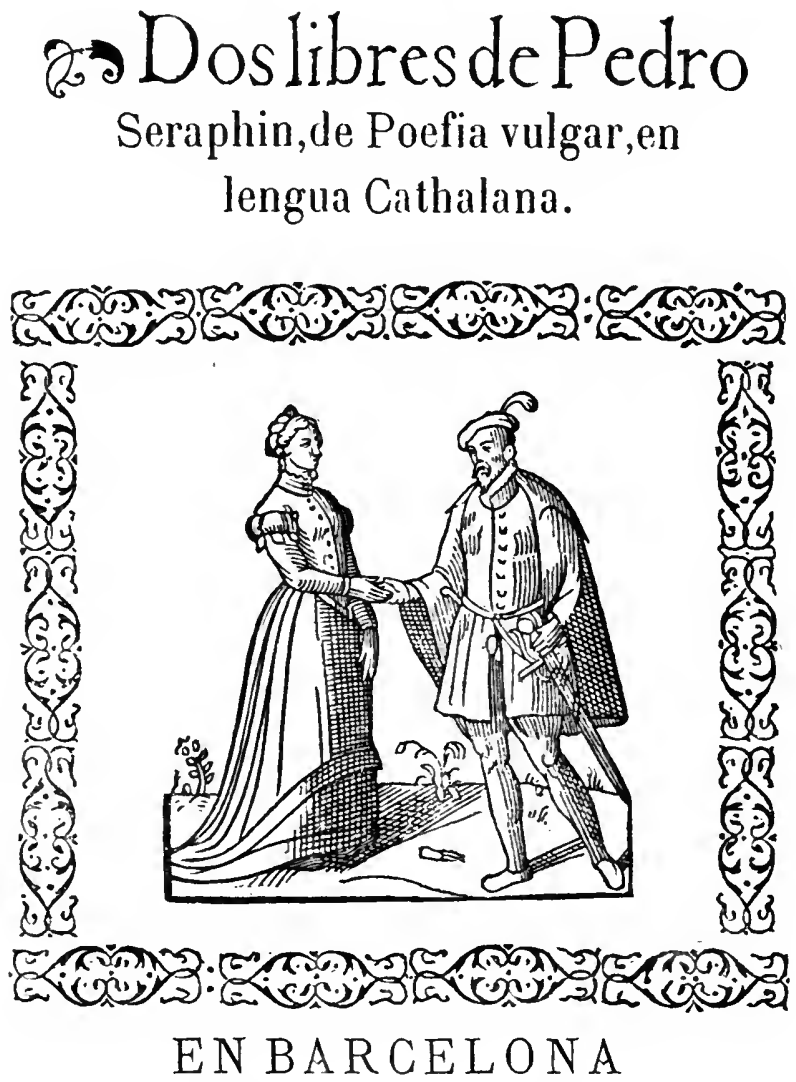

En cafa de Claudes Bornat. 1565 .

\section{Ab priuilegi Real per deu anys. $\vartheta_{9}^{29}$}

(Al final de la úllima hoja se encuentra el siguiente colofon.)

Fon eftampat en Barcelona en cafa de Claudes Bornat libreter, a coftes del Autor, acabas a dos de Agoft del any. I $j 6 j$.

\section{8 hojas prels. y 124 fols.}

Edicion rarisima y tan nitida como todas las de Claudio boruat. He visto una reimpre- sion moderna de esta obra hecha en Barcelo$n \dot{n}$, creo que en el año de 1840 , es en $4 .^{\circ} \mathrm{J}$ me parece tiene alguna lámina.

Pedro Serafln fué pintor á la par que poeta; ignoro si se mostró tan diestro y suave en el manrjo del pincel, como en la ciencia de trovar.

Hé aquí una prucba:

Cansó.

Bella, de vos som amoros, ja foseu mial. sempre sospir cuant pens on vos la nil y dia. 


\section{SIE}

Bella, mirant vostra valor y gentilesa

sent en lligams de vostr'amor ma vida presa,

hon tinch mon cor trist, doloros

sens alegría:

sempre sospir cuant pens en vos la nil y dia.

Bella, del jorn que you's miri, me te lligat en fins ast

ab cruel pena,

vos me llevau tot lo repos

que yo'm moria;

sempre sospir cuanl pens en vos la nit y dia.

Bella, cuánt mal yo per vos pas, no's pot compendre;

puix vustr' amor es tan escas

qu' es de rependre;

estich de penes congoxos,

ple de agonia;

sempre sospir cuanl pens en vus

la nil y dia.

Bella, mirant no teniu par

pensí de amarvos,

que sols un punt no puch estar

sens dezijaryos;

Y ella cruel des ses amos

tant me desvia!

sempre sospir cuant pens en t'os

la nit $y$ dia.

Bella, sens vos no sé que fer ni com aidarme,

y vos tots temps preneú plaer

de maltractarme,

y yo trist no so venturos

en ma porfia;

sempre sospir cuant pens en vos la nil y dia.

Bella, si vos ma voluntat

sabeseu certa,

no'm mostrarieu crueltat

tant descuberta;

y yo per vostre gentil cos

y galanfa,

sempre sospir cuant pens en ros la nil y dia.

972 SIERRA (Licerciado Alonso LA). El Solitario poeta. Compresto por el Licenciado Alonso la Sierra: El qual trata de los Mrsterios de la vida de Christo, y de lä l'irgen Santissima por el orden de las Fiestas
SIL

DIVEASOS.

solemnes que canta la Santa Madre Iglesia. Con vn Elogio a la muerte del Rey Phelipe. Zaragoza, Angel Tauano, $1605.8 .^{\circ} 8$ hojas prels., 117 fols. y tres sin numeracion para terminar la Tabla. Cada canto lleva una laminita de madera.

Poema en treinta y scis canlos, escrito en octavas con algunas redondillas intercaladas.

Al principio se ballan poesias laudatorias de D. Martin Bolea y Castro, el capitan Andres Rei de Artieda y Francisen de Segura.

Latasa no conoció el presente libro y supone á Siera hijo de Zaragoza, siendo asi que él mismo espresa en la portada ser natural de Barbastro. Dicho Latasa, menciona de este autor: Exeyuias Augustas en la muerte de Don Felipe segundo. Zaragoza, 1615. 4. y observa que vic. Antonio habla de está obra: yo solo encuentro citado en la Biblio. theca nnva un Elogio a la muerte de Filipo II. Zaragoza, Alonso Taciano, $1615.80^{\circ}$, el cual tal vez sea el que se balla al fin del Solitario poeta.-Aun cuando Nic. Antonio trae el titulo de este poema y el año de su impresion, el nn decir el lugar dónde se hizo es una prueba de no baberlo tenido presente.

973 SILVA MASCARE.IHAS (AxDRE DA). A destruiçam de Espanha, restauraçam summaria da mesma. Por - Doutor Andre da Sylra Hascarenhas. Lisboa, Antonio Craesbeeck de Mello, 1671. 4. ${ }^{\circ} 6$ hojas prels., 304 fols. y una al fin de Licenças.

Poema portugues en nueve librns prece dido cada uno de ellos de un argumento en prosa. El asunto como ya lo indica el título versa sobre la bistoria del malhadado $\mathrm{D}$. Rodrigo y la restauracion de la inonarquia por Pelayo.

No menciona Nic. Antonio á este autor.

974 SILVEIRA (MIGCEL DE). El Macabeo. Poema heroico de Migrel de Silveira. En Napoles por Egidio Longo, 1638. $4 .^{\circ}$ let. curs. Cada canto lleva una lam. grabada en cobre. 6 hojas prels., inclusas la de la portada grabada, la del retrato del autor y la de erratas que tambien lleva una lämina al reverso y 6 를 págs.

Poema en octavas dividido cu veinte cantos.

970

La misma obra.

Nuera impreșion. Malrid, Francisco Martinez Abad, 1731. $8 .^{\circ}$ let. curs. 8 hojas prels. y 611 paigs. 
Nic. Antonio cita otra obra de Silveira in- $\quad$ El sigulente retrato es el que se halla en titulada: Vida de Elio Seiano. los prels, de la edicion del Macabeo de 1638.

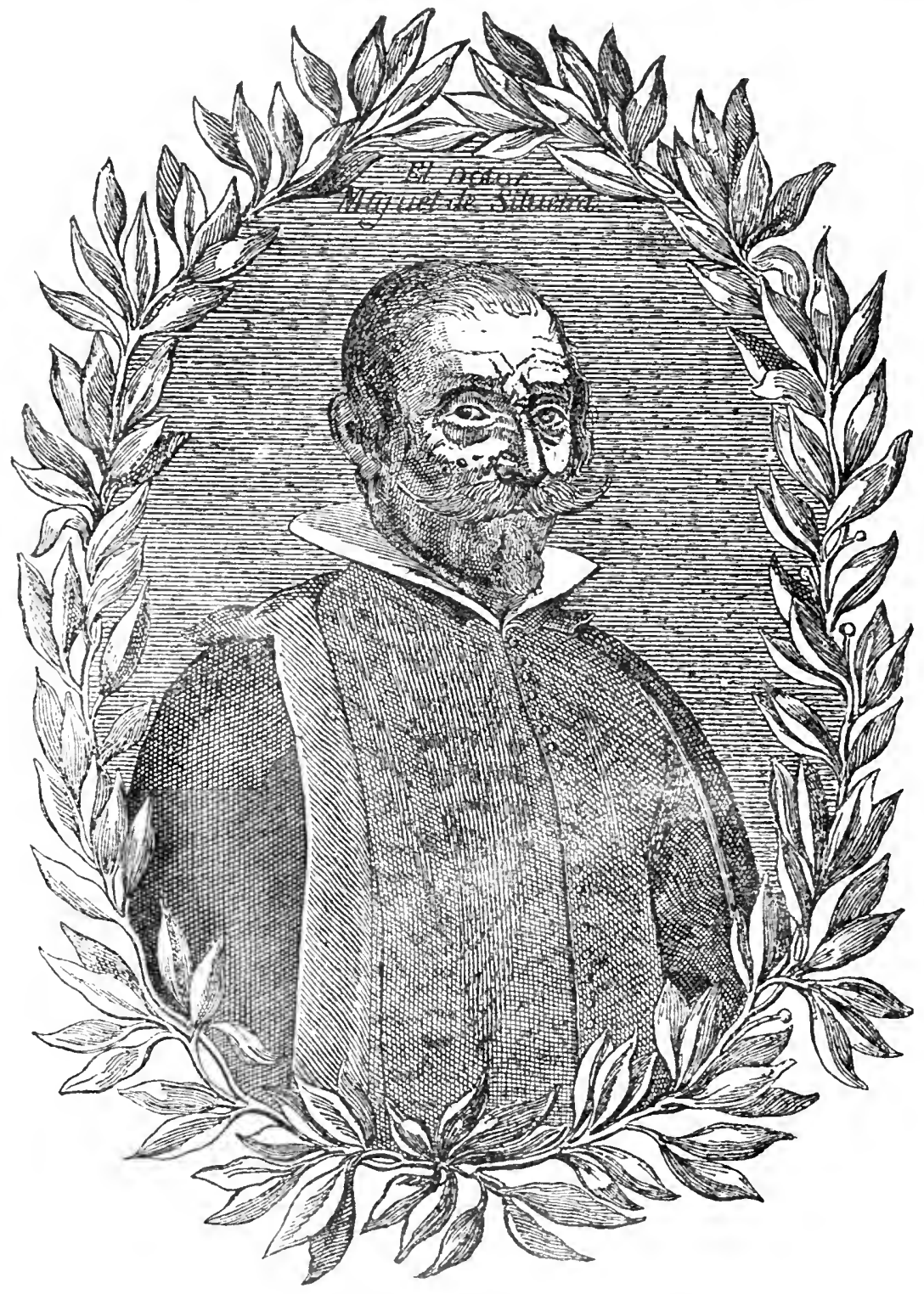

976 SILYEIRA (Miguel DE) E! Sol vencido Poema IIeroico del Dotor Migrel de Silveira. Sapoles por Eridio Longo, 1639. 1. ${ }^{\circ}$ let. curs. 2 ho- jas prels., incluso el fróntis grabado, y 28 paigs.

Herutoso ejomplar sin cortar por delante. Ni Nic. Intonio, ni ninguno de nuestros 
bibllógrafos, mencionan este raro poemita, compuesto de ochenta y dos octavas.

977 SILVESTRE (Gregorio). Las obras del famoso poeta Gregorio Sylvestre. Recopiladas por diligencia de sus erederos. I corregidas conforme a sus mas verdaderos originales. Lisboa, Manuel de Lvra, 1592. 12. ${ }^{\circ} 432$ hojas fols. y no sè cuantas de prels. por faltar algunas a mi ejemplar. 1599

El fróntis lo he copiado de la edicion de

En la biblioteca de Moratin vi la primera edicion cuya portada dice: Las ohras del filmoso poeta Gregorin Sylvestre. Recopiladus, y corregidas, por diligenc1a de sus erederos: y de Pedro de Caçeres y Espinosu. Impresso. en Granada, en el Carmen de Lebrixa. Por Fernando de Aguilar. Año de. Y.D.LIXYII Vendese en casa de Pedro Rodrigues, librero. 8. 24 hojas prels. y 376 f ils. - Los adicinnadores y traductores de la Hist. the la lit. de Ticknor mencionan tambien otra de Grallada de 1588 .

$978-$ La misma obra. Granada, Sebastian de Mena, 1399. 8. $^{\circ} 24$ hojas preis., $38 i$ fols. y una blanca. Al fin del libro lercero, despues del fol. 296, se halla una hoja que se dobla, impresa a cinco colunas, que principia: A la larga y al traues.

La hoja que sc dobla rara vez se encuentra en los ejemplares.

Al principio del volúmen se halla un Discurso sobre la vida de Silvestre escrito por Pedro Cáceres y Espinosa; en el da interesantísimos detalles biográficos de aquel distinguido poeta y noticias mui curiosas sobre algunos de sus contemporilleos; tambien se ocupa de la lucha que entónces existia entre los partidarios de la escuela poética española, y los adictos á la italiana.

Entre las poesias de silvestre hai una Glosa d las coplas de Jnrge Manrique. y me sorprende no encontrarla ni aun citada, en la Advertencia puesta á dichas Coplas en la edicion madrileña de 1779.

Todas las impresiones de las obras de Silvestre son mui raras.

979 SiL VeSTRE (Pedro). La Proserpina poema heroico jocoscrio. Dedicalo al Exmo. Sor. Marques de Crellar Dn. Pedro Silvestre sy arthor. Madrid, Francisco del llierro, M.DCC.XXI. 4. 12 hojus prels., incluso el fróntis grabado, y 366 págs. tos.

Poema en octavas, dividido en doce can-
Brunet supone haber sido escrito este libro por el Narques de Cilélar bajo el seudonimo de José Silvestre: rio sé de donde se sacó esta noticia pues no consta de ninguna parte de la obra; pero sl se equivoca en decir que el nombre del seudoniıno es José siendo positivamente Pedro.

SOLIS (Antovio de). Poesias. Yéa. se en la Seccion dramática.

980 SOT0 (JUAx DE). Alabanças de Dios, y de srs Santos, con alvsion a los canticos de la Yglesia, y Hymnos que por el discurso del Año canta mas comunmente, en diferente genero de verso Español. Por el Maestro F. Iran de Soto. Alcala, Viuda de Andres Sanchez de Ezpeleta, 1610̈. 8. 8 hojas prels. y 136 fols.

Com ya In indica el frontis, la presente obra esti eserita en muchas clases de metro.

[lol mismo autor tuvimos un liliro en prosa intitulatalo: Vuromitus preciosus de la I!jesir, la Virgen "I Murtir. La Llamada Pelagio Vmmp La Serenissimi Rema de Escociu. En lres lihros c cada qual del Texto de su vidis. Alc dla, Aneli'es Sanchez Ezpeleta, 1617.4.

\section{SOTO DE RÓJAS PEDRO'.} Desengaño de amor en rimas. Del Licenciado Pedro Soto de Rojas. Madrid, Viuda de Alonso Martin, 16ə3. 8. 12 hojas prels., 189 fois. y tres para lerminar la Tabla.

Al principio del tumo se encuentran composiciones purticas ensalzando el mirito de Ja obra escritas por D. Luis de Giongora, el Doctor Mira de Amescua, Francisco López de Zarate. D. Diego de Tovar Valdermama, el licenciado Francisen de Cuenca, Albanin Ramirez de Arellano y un Elogin en prosa do Lope de Vesa. Tambien se halla mn Discurso sobre la poritica, leido por soto de Rójas al alrirse en 1612, en rasa de D. Francisco de silva. la Academia setéaje, do la que era in. dividin con el nombre de Artiente.

sedano en el Parnaso español, tom. IV. pás. xlvii, enearece con razon, la suma rareza de este libro: Nie. Antonio sin duda no ligró verlo elıado dice ser su tamaño el de i.

Advierte el autor en la dedicatoria al Conde-duque, no hiberse atrevilo i estampar intes sus poesias, a pesar de tener el privilegio para ello lacia ya nueve años.

932 - Pararso cerrado para mrchos, lardines abiertos para pocos. Con Los fragmentos de Adonis. 
Por Don Pedro Soto de Roxas. Granada, Imprenta Real, Por Baltasar de Bolibar, 1632. 4. 90 hojas foliadas, inclusas las prels.

La obra va precedida de una Introduccion $a$ lis Iardines, por D. Francisco de Trillo y Finneroa.

Libro de gran rareza y que Nic. Antonio y Sedimo omitieron entre las obias de soto de Rójas.

983 SOTO DE RÓJAS (PEDRo). Los ravos del Faeton. De Don Pedro Soto de Rojas. Barcelona, Pedro Lacanalleria, 1639. 6 hojas prels. y 4ö fols.

Poema en octaras dividido en ochn Rayos, í sither: Crepusculo, Clareciente, Matutino, Lnziente, Meridiano, Ardiente, Estivo y Elementar.

Tambien encomia Sedano la rareza de esla obla.

981 SUIRE7 DE CHIVES (LoRexzo). Dialogos de varias qrestiones en Dialogos y metro Cástellano sobre diuersas materias, con vn romance al cabo del dia final del jurzio y de sus seinales Compnesto por Lorénco Suarez de Chaues. Alcala de IIenares, en casa de luan Gracian, $137 \% .8 .^{\circ} 8$ hojas prels., 316 foliadas, $y$ ' en que concluye la Tabla.

Volimen raro y apreciable al cual se ha dado cabida algunas vezes entre los cancio-

TAFALLA NEGRETE (Josí). Ramillete poético. Véase en la Seccion dramálica.

988 TAMarlz (Lic. Cristóval). Ilistoria de los sanctos martires de Cartuxa, que padescieron en Londres. Ilecha por el Licenciado Christoual Tamariz. Sevilla, Alonso la Barrera, 1ว84. $8 .^{\circ} 8$ hojas prels., una de ellas blanca, 86 foliadas y otra para repetir las señas de la impresion.

Raro.-Mi ejemplar es tan bello que tiene alguna hoja sin abrir. neros, sin duda por la diversidad y clase de netros en que está escrito.

985 SUÁREZ DE FIGUEROA (Cristóval). España defendida, poema heroyco, de Christoual Suarez de Figueroa. Madrid, Iuan de la Cuesta, 1612. 8. 4 hojas prels., 247 fols. $y$ una blanca.

Primera edicion de este poema escrito en octavas y dividido en catorce libros ó cantos.

986 La misma obra. En esta quinta Jupresion pur su Aulor reconocido, y de las erratas enmendado. Napoles, Egidio Lon:o, 1644. 4. ${ }^{\circ}$ let. curs. 4 hojas prels., inclusa la portada grabada, y 499 fols.

No he visto ni encuentro mencion en autor alguno del lugar y año de la publicacion. de la segunda, tercera y cuarla edicion de la presente obra; por lo mismo ignoro si fué únicamente en esta quinla en la que el autor hizo las variaciones y adiciones que observo en ella respecto á la primera.

987 SUÍREZ DE YÁRGAS (DoN Cristóval). Descension de Nvestra Señora. De Don Christoval Suarez de Varcas. Toledo, loan Ruiz de. Pereda, M.Dc.Xxxvi. 8. 6 hojas prels. $y$ 31 foliadas.

Poema en ciento treinta y dos octavas.Raro.

Poema escrito en octavas y en seis cantos. ¿Será este Licenciado Tamariz el autor de las seis novelas en verso, descritas en el número 2507 de nuestro Catálogo de Lóndres, en un manuserito del sirrlo XVII y se hallaban al fin de la Chronica de Don Frances de Zuniga?

989 TANSILLO (Luis). Lagrimas de San Pedro comprestas en italiano por Lvys Tansillo. Tradvcidas en español por el Maestro Fray Damian Alvarez. Napoles, Iuan Domingo Roncallolo, 1613. 12. ${ }^{\circ}$ let. curs. 4 hojas prels., 379 págs., la última numerada 279 por equivocacion, y una hoja para terminar la fé de erralas. 
En el Tesoro de divinu poesía de Villalóbos se incluyó la traduccion de Las Lagrimas de S. Pedro, hecha por Luis Gálvez de Montalvo, la cual, segun Ticknor, tom. III., página 489 , se habia publicado por separado en Toledo, 1587. 8. Tambien las vertió en castellano Luis Marlínez de la Plaza; pero su traduccion quedó inédita. Nic. Antonio supone que D. Martin Bolea y Castro las dió a luz en español, $\mathrm{y}$ hasta menciona una edi. cion de Lerila de 1578; sin embargo pingo en duda su existencia : por fln los traductnres de Ticknor, tom. III., pág. \$\$1, hablan de una Imitacion del poema de Tansillo hecha por Kodrigo Fernández de Ribera, inn. presa en Scvilla, Alonso Rodriguez Gamarra, $1609.8^{\circ}$

990 TANSILLO (Lus). Lagrimas de S. Pedro. Poema sacro, en qve llora svs escarmientos Frey Iacinto de San Francisco. Professo en la orden del Señor Santiago. Pamplona, por Martin de Labayen y Diego de Zabala, 1653. 8. ${ }^{\circ} 10$ hojas prels. $y$ 94 fols.

Aunquc no se espresa en parte alguna del volúmen, solo contiene la version de ocho llantos de los trece, que encierra el original de Tansillo.-Nic. Antonio no conocio esta traduccion.

Al ver que Latasa en su Biblioteca atribuye á D. Francisco Jacinto Funes de Villalpando Las Lagrimas de S. Pedro impresas en Zaragoza, por Diego Dormer, 165.5. 8. empezé á pensar si el Frei Jacinto de San Francisco seria el uismo: el llorar en la portada sus escarmientos, me hizo eutrar aun en mayores sospechas, pues recordiba que Villalpando escribió una novela intitulada Escarmientos de Jacinto; casi ine decidi á creerlo al leer en el prólogo al lector, ocultaba el autor sil nombre por no escanda: lizar; pero se destaneció por completo mi duda cuando encontre unos versos que dirige dicho D. Francisco Jacinto Fúnes de $\mathrm{Yi}$ llalpando, marques de Osera, al autor su mayor amigo.

La edicion de Pamplona debe ser la prinera pues lleva al principio aprobaciones y licencias dadas en dicha ciudad al mismo autor en 1652 .

Nic. Antonio menciona una traduccion de las Lagrimas de S. Pedro, hecha por Juan Sedeño; pero no cita impresion ninguna de ella.

Las versiones castellanas de las Lagrimas de $S$. Pedro son todas dificiles de encontrar, por eso Mayans en el Prólogo del Pastor de Filida, 1792, se espresa en estos términos: Es cosa lastimosa que habiendo tenidn este poema de Tansillo lanlas tradicciones, sean tan raras, que apénas se sabe poco mós, que la noticia del trabajo que emplearon en propagarle.
TELL

991 TASSO (Torcuato). Iervalem libertada, Poemá heroyco de Torquato Tasso. Traduzido al sentido de lengua Toscana en Castellana por Iuan Sedeño. Con los Argumentos al principio de cada Canto, y las Alegorias al fin de todos los Cantos. En Madrid, Pedro Madrigal, 1587. $8^{\circ} 8$ hojas prels., 311 fols. y 17 de Tabla y Erratas.

Edicion rara.

Se reimprimio esta traduccion en Barcelona, viuda e hijos de Gorchs, 1829.2 vols. $8 . .^{\circ}$; pero se suprimieron la licencia, aprobacion, los elorios á Sedeño y las Estuncius de esté en lnor del Tasso, que van al principio de la edicion original, y la Alegoria del poema y copiosa Tabla que lleva al fin.

Juan Sedeño el traductor del Tasso, es el mismo que hizo una version de las Lagrimas de S. Pedro de Tansillo; pero es distinto del autor de li Celestina en verso y la Suma de varones iluslres: Nic. Antunio opina de otro modo y atribuye á uno las cuatro obras.

992 La Giervalemme liberata de Torquato Tasso. Tradvzida por Don Antonio Sarmiento de Mendoça (en octaras). Madrid, Diego Diaz de la Carrera, 1649. 8. 8 hojas prels., la una con el esculo de las armas reales de España grabado, y $33 \bar{i}$ fols.

La licenci, y aprobaciones fechadas en 16.36 , parecen indicar que hai alguna edicion auterior; sin embargo. no encuentro men. cion de clla en parte alguna, y Xic. Antonio solo conoció la del 49.

993 TÉLLEZ DE AZEVEDO (AxTovio). Lira misteriosa para el camino de la passion. Dispuesta en verso A contemplacion de 30 . la minas: por D. Antonio Tellez de Azevedo. (Madrid, 1727.) 8. 32 hojas prels., incluso el frintis grabado, 2 hojas foliadas, que contienen 30 láminas, y otra de Jesus atado a la coluna, que se halla frente la portada; pero que no pertenece à la obra.

El testo es en verso.

Cean Bermúdez no tuvo noticla de esta obrita cuando al hablar de las producciones del buril del P. Irala no hace merito de las treinta y una liminas contenidas ell ella $\mathrm{y}$ grabadn en cobre por este Padre. Indica dicho Cean que el cenobitico artista se dedicó principalmente á copiar estampas es- 
tranjeras, y efectivamente muchas de las de la Lira misleriosa, aunque no lo estén exactamente, son imitaciones bastante serviles de los grabados en madera publicados ántes en un librito intitulado: La perpetva cres o passion de Iesv-Chrislo Nuestro Señor Desde el principio de su Encarnacion hasta su mucrte. Representada en quarenta estampas gue se reparten de balde, Y explicadt con differentes ruzones y oraciones de denocion. Amberes, Cornelio Wooms, 1650. 12. Estas preciosas láminas llevan el monngrama A-S., quizás sean de Antonio Sultzer.

994 TERAY (Francisco Manuel). Laurel del sol español, en cuyas lucientes hojas se escrive puntualmente la proclamacion de Don Carlos III, por D. Francisco Manuel Theran. Madrid, Gabriel Ramirez, s. a. rhácia 17รั9).

Poema en sesenta y siete octavas.

99ว TERRIN (BUENaVENTURA). San Raphael, custodio de Cordova. Eutropelia poetica, sobre la historia de su patrouato; que en siete centurias heroycas escrivia el R. P. M. Fr. Buenaventura Terrin. Madrid, Miguel Francisco Rodriguez, 1736. 4. ${ }^{\circ}$ let. curs. 18 hojas prels., 238 paginas y $1 \ddot{3}$ hojas de Indice.

Poema en octavas, dividido en siete cenLurias.

Difícilmente podrí presentarse otra muestra nús evidente de la depravacion á que llegó el grusto poético de principios del siglo Xilli.

996 TOLEDO (FADriQUE DE). Relacion del Hijo Prodigo al llegar a los pies de su Padre, tan arrepentido, como pobre, i Respuesta del $\mathrm{Pa}$ dre al Prodigo con su comento al fin, del Padre Frai Fadrique de Toledo. Manuscrito ejecutado con suma nitidez, de 91 fojas en $\mathbf{1} .^{\circ}$

Este poema, que creo inédito, está escrito en dos romances; el primero comprende la Relacion del hijo y el segundo la Respuesta del padre.

El MS. parece ser de mediados del siglo XVII; pero en un prólogo que precede á la obra, escrito por un amigo del autor, se supone haber este ya fallecido.

997 TORRADO DE GUZMAN (Pebro). Trivnfo immacrlado de la
Emperatriz de Cielo, y Tierra, Maria, concebida sin mancha de culpa Original, en el primer instante de su Ser. Compvesto por Don Pedro Torrado de Guzman. Sevilla, Jvan Francisco de Blas, $1669.4 .^{\circ} 8$ hojas preliminares, inclusa una lamina de la Concepcion, $y 36$ fols.

Poema en octavas y en cuatro cantos.

Nic. Anionio en su Bibliotheca solo menciona de este autor la siguiente obra.

\section{TORRADO DE GUZMAN} (Pedro). Trivnfo de Iesvs. En quatro cantos de octava rima. El primero, el ser divino, y hvmano. El. segvndo, la vida. El tercero, la mverte, y passion. El quarto, la resvrreccion, y gloria. Compuestos por Don Pedro Torrado de Guzman. Seuilla, Iuā de Ossuna, 167\%. 4. ${ }^{\circ} 5$ hojas preliminares, inclusa una lámina del Niño Jesus que precede á la portada, y 36 fols.

Pocos poctas habrá de esta época en quienes se encuentre ménos afectacion y gongorismo que en Torrado de Guzman.

999 TORRE (FRINCISCO DE LA). Obras del Bachiller Francisco de la Torre. Dalas a la impression 10. Francisco de Queuedo Villegas. Madrid, Imprenta del Reyno, M.DC.XXXI. 16." 16 hojas prels. y 144 fols.

Primera edicion, rara.-Sedano equivoca la fecha, pues dice ser de! año 1630.

1000 Poesías, que publico D. Francisco de Quevedo Villegas, Con el nombre del Bachiller Francisco de la Torre. Añadese en esta segunda edicion un discurso, en que se descubre ser el verdadero Autor el mismo Don Francisco de Quevedo: por Don Luis Joseph Velazquez. Madrid, Eugenio Bicco, 1753. 4.

Signiendo Sedano su costumbre de errar la mayor parte de las fechas, dice ser esta cdicion de 1757 .

Velázquez en su Discurso intenta probar que el Bachiller Francisco de la Torre no es otro que D. Francisco de Quevedo. y del mismo parecer.es Sedano; pero Quintana en la Coleccion de poestus castellanas opina de distinto modo, y en Lóndres tuvimos un 
ejemplar de esta segunda impresion, con una porcion de nolas y observaciones manuscritas de D. Juan Antonio Mayans; en ellas tambien probaba que Quevedo no es el autor de las poesías publicadas á nombre de la Torre.

1001 TORRE FARFAN (FERN. DE LA). Fiestas qre celebro la Iglesia Parrochial de S. Maria la Blanca... de Sevilla; en obseqvio del nvevo Breve concedido por...Alexandro VIJ. en favor del purisimo mysterio de la Concepcion sin Culpa Original de Maria. (Al fin:) Sevilla, Ivan Gomez de Blas, $1666.4 .^{\circ}$ Lamina. 8 hojas prels., 191 foliadas y una para las Erratas y señas de la impresion.

En el cuerpo del volúmen hai varias poeslas, y al fin una descripcion en verso de estas flestas, por cuyo epigrafe aparece que el autor de toda la obra es D. Fernando de la Torre Farfan.

1002 TORRE Y SEBIL (FrascisCo DE LA). Entretenimiento de las mrsas, en esta baraxa nvera de versos. Dividida en qratro manjares, de asvntos sacros, heroicos, líricos, y brrlescos. Compresta por Feniso de la Torre natrral de Tortosa. Charagoça, Iuan de Y bar, M.DC.LIHI. 4. 8 hojas prels. y 160 págs., la última dice equivocadamente 260 .

Mala impresion y peor papel.-A pesar de llamarse el autor en el fróntis Feniso de la Torre, las aprobaciones, los versos laudatorios, un Elogio que lleva al principio, y el decir la portada que era natural de Tortosa, prueban positivamente fué Don Francisco de la Torre y sebil de quien hablan Nic. Antonio y Rodriguez; pero ni uno ni otro bibliografo citan la presente obra entre sus escritos.-Barrera la menciona y observa ser hoi sumanenle rara.

Ticknòr, no sé porqué, supone á Torre natural de Murcia.

1003 TORREBLANCA (Cristóval DE). Amnon, y Thamar, svcesso qre refiere el Sagrado Texto en el segundo de los Reyes, cap. 13. Repetido en octavas... Por Don Christoval de Torreblanca. S. I. ni a. $4 .^{\circ} 19$ hojas, inclusa la portada.

Tом. 1.
Son cien octaras.

La edicion parece de la última mitad del siglo XVlI.

1004 TÓRRES (ToMas). Llave interior, que abre la pverta del $\mathrm{Pa}$ lacio hrmano. Qve saca a lvz, el R. Padre Presentado Fr. Thomàs Torres. Zaragoça, Manvel Roman, s. a. (1706?). 12. 11 hojas prels., 125 págs. y una hoja en que concluye el Indice.

Poema en tercetos, dividido en veintiun capitulos.

$100 弓$ TÓRRES Y VILLARROEL (DIEGo DE). Conquista de el reyno de Napoles por su rey D. Carlos de Borbon. Escrita en octavas por el Doct. Don Diego de Torres y Villarroèl. Madrid, Juan de Moya, (1730̈?). 4. 10 hojas prels. y 78 pägs.

Consta de doscientas treinta $\mathrm{g}$ una octavas.

1006 Ocios politicos, en poesias de varios metros de el gran Piscator de Salamanca D. Diego de Torres Villarroel: las recogio, $y$ saca a luz su mayor amigo Don Isidro Lopez del Hoyo. Impresso en Madrid, y por su original en Sevilla, Diego Lopez de Haro, (hácia 1740). $4 .^{\circ} \mathrm{Q}$ hojas prels. y 88 págs.

De este autor he visto las Obras complelas. Madrid, liuda de Ybarra, M.DCC.XCIY-IX. 15 vols. $80^{\circ}$ - Analonia de lado lo visible $e$ in. visible: compendio universul de ambos mundos: viaje fantastico: jornadas por una $y$ otra esphera: descubrimiento de sus Entes, Substancias, Generaciones, y Producciones. Salimanca, Antonio Villarroel, (1738). 4. ${ }^{\circ}$ Sueños morales, visiones $y$ visitas de Torres con D. Francisco de Quevedo, por Madrid. Madrid, (Paris) libreria de Rainos, 1821. $18 .^{\circ}$ $8 .^{\circ}$-lida, ascendencia, nacimiento, crianza y aventuras del Doctor Don Diego de Torres Villaroel. Escrila por el mismo.-El Ermitaño y Torres. Aventura curiosa en que se trata de la piedra fllosofal. Parle II. Madrid, Benito Cano, HDCCLXXXIX. 2 vols. $4 .^{\circ}$

1007 Exequias mentales y tristes sentimientos, que en la muerte de Phelipe Quinto, hizo el Doctor Don Diego de Torres Villarroèl. Madrid, s. a. (hácia 1746). 4. 31 pägs. 
Hai poesias en latin, español, portugues y frances, todas de Tórres Villarioel.

1008 TRATADO copioso y verdadero, de la determinaciō dèl gran Monarcha Phelipe II. para el casamiento del 11I. có la Serenissima Margarita de Austria: y cutradas de sus Magestades y Grandes por su orden en esta ciudad de lalencia: con las libreas, galas y tiestas if se hizieron. Impresso en Valencia: junto al molino de Rouella. Año II.D.Lxxxxix. (Al fin:) Valencia en casa de Iuã Grysostomo Garriz... tĩo 13̆99. Vendese en casa de Iuã Bantista Timoneda, junto a la Merced. 8. ${ }^{\circ}$ Sin fol. sign. \$-O todas de $\mathbf{S}$ hojas ménos la última que solo tiene $\mathrm{T}$.

Relacion mui lara y enriosisima por su minuciosidad y estemsion en detallar los lanjes usidos en aquellis tiestas por lis damas y caballeros que i cllas asistiem. y las variadas $r$ vistosas libreas ostentadas por sus numerosos pajes y criados; sp describun mui prolijamente jos saraos, justas g tormeus con que so festejó a lus recien casidos, y al hablar de los bailes nos da a ronocer la nomenclatura de los usados en aquella época.

Rodrfyuez dice ser esta obra de Inin Ezquerdo yor haberle comunicado la noticia su nieto onofre. Este solo dato es algo vigo, y no parece probable que en el mismo ano y en la imprenta de Garriz, hubiese publicado dicho Ezquerdo el presente lomi to yotro igualmente anonimi que tambien le atribuyesu nieto. intitulado: Relacion verissima, de las Fieslas, que so hizieron, en la Cimdall de Valencia, d la Entrada del Rey D. Folipe III. $y$ de lá Serenissima keyma D. Margarila de Auslria. Ademas el autor del Tralado copioso supone en varias partes de el ser poeta, y no se que ol tal Juan hay eserjto madia an verso. ¿Seria aventurado supones, atendida esta última circunstancia, la de venderse el libro en casa de Timoneda, y la de contener muchas poesias, el que sca más bien produccion del librero valenciano?

to comprendo como habiendo visto Rodriguez la relacion que go poseo, la supone toda en prosa conteniendo tauta poesía, y como dice que los doce primeros capitulos deseriben las fiestas celcbradas en Denia cuando solo tratan de ellas los nueve del principio.

El ya citado Rodríguez nos da noticia de un tercer anónimo que dió á Juz una Relacion de la Solemne Enlrada, que hizo la Magestad de la Beyna... Doña Mrargarila de Austria, en la... Ciudad de Valencia: en la yual ayuarda$v a$, la S. C. R. Magestad, del Rey mestro Senor, Ion Felipe" III. su inirido. Y por exlenso se relata lodo el Acompañamiento, que se le hizo, con los Nombres de lodos los Gran- des, y Tilulados, y muchos Caualleros; con las diferencias de las Libreas, yue calla uno traia: y los Aparalos, ! Regnzijos, yue hizo la Cindad en la dirha entrada. Val'ncia, Diego de la Tor' ${ }^{\prime}$, 1599. 8. cuyo contenido, segun li descripeiun dada por aquel hibliografo, es tim senejante al del Tratado copioso que parece la misma obra.

Jimeno eita el Libr" del felicissimo Casamiento y boda en Valomria celobrato, de Felipe Tercero con Doña Mn'yarila de Alistria, escrito por Felipe Gaona, y quedó manuscrito.

Rodríguez menciona $m$ romance suelto en castellano intituladn: Verlader'l descripeion do Las Gramelesus, y Markillas, de la Imsigne,

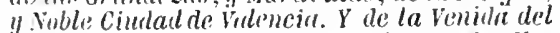
Polentissimo D. Felipe IIJ. Rey de España. Valencist. junto al molina de Rovella, 1600. 12. Y tambien habla de otro

Romance, en que se glosa rl letrero, que se muso en el Arco Triunful, peho en el Her'"ulo de balencia, en la entrada de la Reyra Dona Margaritade Austria, que decia: Pura mas si mus hevieror. Valencia jumlo al Molino de la Rovella, 15!9. 12. ${ }^{\circ}$, el cuill es sin disda el mismo que se halla en el Tratado copioso y verdadero y llena ocho piginas.

A la descripcion de estas bodas consagró Gaspiar de Aguilar un poema, el cual esti en el presente Catálogo, Núm. Al6; y lope de leca escribió tambien en verso sobre el mismo asunto, véase el Nüm. 1050.

Mi amigo el Sr. D. Jnan de la Cruz Vartí ha tenido la brimilad de franquearme ol siguiente opusculito que debe tambien ser mui raro.

Reliecion del aporalo que se lizo en la civdal de Valencia para el recibimiento de la Seremissima Reyna Doña Maryarita de Auslria desposadic con el Calholico y polentissimo Rey de España Don Phelipe Tercero deste nombre. (Sigue el escudo de Felipe Vei que copio en el articulo Trilles, Institutiohes sacrae linguae hebraicae, y bajo:) Vendese en casa de Francisco Miguel a la calle le Caualleros. Al dorso de Ja portada se halia una advertencia de dicho siguel al leclor rn la que declara ser el autor de este tratadito el Ductor" Inan Bullisla Confuloniero Secretario del Illustrissimo... Don Camilo Gaetamo Putriurea de Alexandria. Al dorso de la hoja 16 que es la última se lee: En Valencia, En casa de Pedro Palricio Mey junlo a S. Martim. 1599. 8. ${ }^{\circ}$ Sin foliatura, sign. A.

Tengo ademas varjos pliegos sucltos relativos a estc mismo sucesn, los cuales se describen en la Seccion histórica.-Historia de España, artículo Papeles voluntes y reluciones que tratan de acontecimientos nolables ocurridss de 1517 a 1665 .

1009 TRIGUÉROS (CÁNDIdO MAnía). La liiada. Por D. Candido M. Trigtteros. Describese la terrible 
inundacion que molesto a Sevilla en los ìltimos dias del año $1783, \mathrm{j}$ los primeros de 1784. Sevilla, Vazquez, MDCCLXXY. 4.

No respondo de la exactitud de] año de la impresiou, porque en mi ejemplar se encuentra estropeada la parte del fróntis donde se halla.

Este poema se divide en seis cantos.

De Triguerus he visto dos obras más, una intilulada: Wis pasaliempos Almacen defins-

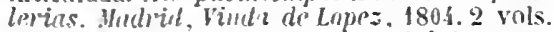
8." y la otra Los Enamorados $\delta$ Galulén ys sus bodics: historia pustoral concriaata p'or Migivel le Corvdules Siluvedra. Abreriala des. pues, y contimala y illimaniente concluida. Jadrid, inprenta reul. MDCCICFIII. 4 vols. $8 .^{\circ}$

1010 TRILLO Y FIGUEROA (DON Frascisco DE). Neapolisea, poema heroyco, y panegirico; al Gran Capitan Gonzalo Fernandez de Cordova. Por Don Francisco de Trillo y Figueroa. Granada, Baltasar de Bolibar, F Francisco Sanchez, 1651. 4. 138 hojas fols., inclusas las 3 de prels.

Poema en octavas y en acho libros que vale poco,y cuyo prólogo y notas rebosan una pcdanterla y y anidad insufribles.

En unos apunies que tomé en la biblinteca de D. Jacobo de Parga, encuentro tambien anotada una edicion de franada, hecha por los mismos impresores, y con igual numero de hojas; pero con el año de 16.j2: no sé si seria la misma con la sola diferencia de la fecha del fróntis.

Segun Yic. Antonio cxiste un tomn de Viariıs poesías de este autor impreso tambien en Granada; pero no flja el año de la impresion.
1011 ULLOA PEREIRA (LUISDE). Versos que escrivio D. Lvis de Vlloa Pereira, sacados de algunos de srs borradores. Madrid, Diego Diaz, M. DC. L. IX. $40^{\circ} 8$ hojas prels., 210 fols., la última estii numerada equivocadamente 203 , una hoja sometiendo la obra a la Doctrina de la Iglesia, y 4 más de Tabla.

Primera edicion desconocida á Sedano y a Ticknor.

A la foji 190 , con nuevo fróntis, pero siguiendo la foliatura, principia la Defensa de libros fabulosos, y pocsias honestas, y. de las comedirs ate ha introducido el vso, en la forma que oy se ropresenlan en España, cun pxlremos diferenles de las antiguas, acesudas por sunlos, y aulores graius.

1012 - Obras de Don Lvis de Vlloa Pereira, prosas, y versos, añadidas en esta vitima impression recogidas, y dadas à la estampa por D. Ivan Antonio de Vlloa Pereira. Madrid, Francisco Sanz, 1674. $4 .^{\circ} 8$ hojas prels. y 386 pigs.

En esta segunda cdicion. cuyo panel é iuspresion son detestables, aumentu su editor, el hijo de Llloa, algmmas poesias y dos opisculos en prosa intitulados: el uno Apulogia por los

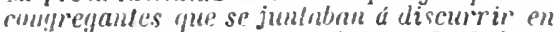
milerias de dewncion; y el otro: D. Luis de Lllort a D. Juan, su hijo, del Consejo de S. H... "slandn para ir" al Corregimiculo de la ciudad de Ecija; pero tambien es cierto suprimió muchas de las amatorias o fesitias, por un esceso de escrupulo mistico. liesulta, pues, del exámen comparativo de ambas impresio. nes, que para tener más completas las obras de este autor, es preciso poseer las dos y caso de no poderlas conseguir, deberá darse la preferencia á la primera.

Vic. Autonio en su Biblintheca, habla de vlloa y sus escritos; pero no cila edicion alguua de ellos.

A pesar de no haber conocido Sedaun la edicion de 1659 , unica en que se hallan algunas bellisimas composiciones de los generos festivo $y$ amatorio, dice al hablar de Llloa, fué sir ingenis) sublime, que junto con su erulicion. le hicioron un poefa celebre, sentencioso y cullisimo.

El Sr. Barrera le encomia igualuente y observil, que su opísculo en Defensa de libros fribilosus, es uno de los mejores escritos sobre la debalida cuestion de las comedias: y el papel dirigido í su lijo sobre el corregimiento de Écija es nolable.

Escribio asl mismo Clloa una Parafiacis de los simle pralmos Penifenciales. If solibrquios en Romances casle!lantos. que se imprimió en Hadrid, añu de' lijis, lit cual se reprodujo al tin de algmuas pelieiones de las siefe

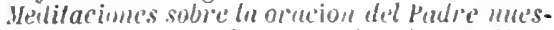
fro de Sta. Teresa de Jesils, glosalas port Mon(ulo de. Espinosia. 
1013 VACA DE ALFARO (ENRIQue). Lyra de Melpomene a cvias armoniosas rozes y dvlces arnive frnestos ceos oye atento el Doclor D. Henrique Vaca de Alfaro La tragica metamorphosis de Acteon, y la escribe. Corloba, Andres Carrillo, M.DC.LXVI. 8." Sin paginacion ni foliatura, signs. A-ll, todas de 8 hojas ménos la B que tiene 10, una de ellas blanca y la otra con el relrato, y la $\mathrm{II}$ tambien de 10, incluyendo una Annotacion y la Correccion de erratas que van al fin.
Ejemplar al parecer en gran papel $\dot{o}$ por lo ménos en papel fuerte.

El poema trigico de Acteon escrito en $l i$ ras ocıpa casi uma mitidd del volúmen y está dedicado en un romance, í D. Diego de Silva y lelázque ol celebre pintor de Felipe IV: el resto comprende Sondes varius con otras poesias a diwersos asumplos del Doclor D. Hemique Vaca de Alfar'o. - El retrato de este puesto al principio es el copiado í continuaciou, habiéndole suprimido únicamente una inscripeioil latinil colocida al pié en la cual despnes del nombre dice ser cordoves, medico de Salamanca, y que tenia en 1664,29 años de edad.

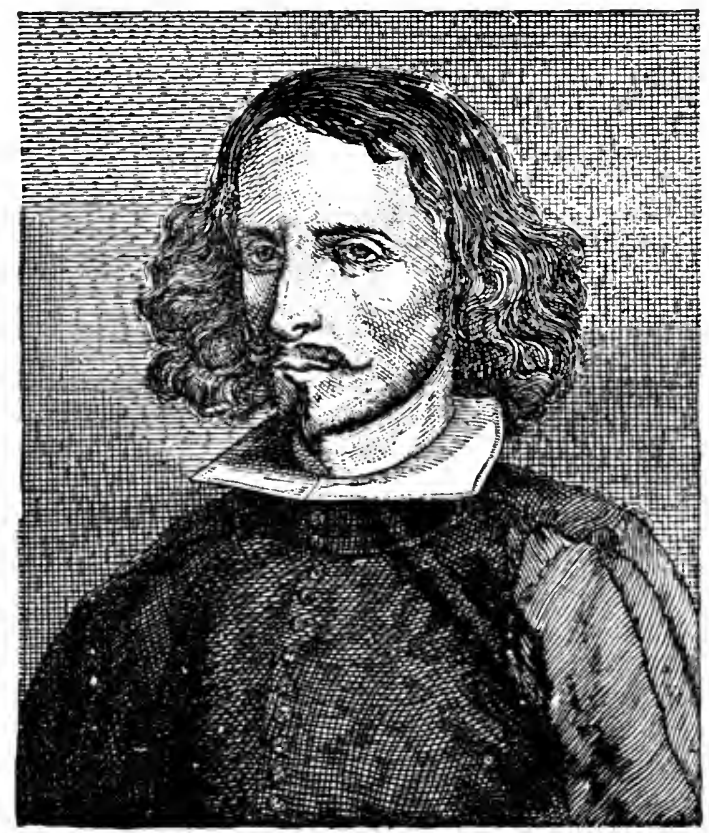

1014 VALDES (Rodrigo de). Poema heroyco hispano-latino panegyrico de la frndacion, y grandezas de la mur loble, y Leal Ciudad de Lima. Obra Postvina del M. R. P. M. Rodrigo de Valdes. Madrid, Antonio Roman, 1687.4. ${ }^{\circ} 56$ hojas prels., 184 pags. y 4 hojas de Indice.
El artificio de este poema, compuesto de quinientas setenta y dos cuartetas, consiste en que estando en español, parece escrito en latin con solo la variacion ó adicion de una que otra letra.-De este género existen varios ensayos; pero este es el mús largo pues los otros se reducen á algun soneto ó composicion de mui pocas estrolas. 
1015 VALDIVIELSO (José DR). Elogios al Santissimo Sacramento, a la Crvz santissima, y a la Prrissima Virgen Maria Señora Nvestra. Por el Maestro Ioseph de Valdiuielso. Madrid, Imprenta del Reyno, M.DC.XXX. 8. ${ }^{\circ} 8$ hojas prels. y 60 fols.

Poema en octavas, dividido en tres partes dedicadas á los tres objetos que indica la portada.

Entre el Romancero espirilual, los Aulos y el presente libro, no me atreveria á decidir cual de estas tres obras de Valdivielso es la más rara.

1016 - Sagrario de Toledo. Poema heroico por el Maestro Ioseph de Valdiuielso. Madrid, Luis Sanchez, $1616.8 .^{\circ} 8$ hnjas prels., inclusa la portada, que es grabada, 491 foliadas, y una despues con un floron.

Primera edicion no citada por Ticknor en el tom. IIl., pág. $15 \overline{5}$.

1017 La misma nbra. Barcelona, Esteuan Liberòs, 1618. 8. ${ }^{\circ}$ hojas prels. " 493 fols., la última de las cuales la ocupa una imagen de la Vírgen y las señas de la impresion.

1018 - Vida, excelencias, y mverte del gloriosissimo Patriarca y esposo de nuestra Señora san Ioseph. Por el Maestro loseph de Valdiuielso. Van enmendadas en esta impression algunas cosas por el mismo anttor. A costa de Martin Yazquez de la Cruz. Año 1608. (Al fin:) En Toledo. Por Pedro Rodriguez, M.DC.ViII. 8. 16 hojas prels., 331 fols. y 2 hojas más con tres sonetos !audatorios y el colofon.

Ejemplar tan hermoso que parece de gran papel; tiene varias hojas sin cortar.

Poema en octavas, dividido en reinticuatro cantos.

Las aprobariones y licencias estain fechadas en 1603 y 1604 ; sin embargo, la edicion más antigua deserita por Nic. Antonio es de Toledo, 1607. 8. Brunet se refiere it ntı de Barcelona, Honofre Anglade, 1607. 8. ${ }^{\circ}$; pero ni uno ni otro conncieron la de 1608. Tam. poco la cita el Sr. Barrera Leirado.

$1019-$ La misma obra. Barcelona, Hieronymo Margarit,
$1610.8 .^{\circ} 16$ hojas prels., 354 fols. $y 2$ más con los sonelos en elogin de la obra y la repeticion de las señas de la impresion.

Solo Brunet menciona esta edicion. En lóndres tuve la de Lisboa, Pedro Crasbeeck, 1611. 8..$^{\circ}$ y Barrera se reflere à una de Madrid, 1612. 8.

Las únicas citadas por Ticknnr en su His. toria de la lil., tom. IlI. pág. 15j̃, son una de Lisboa, 1615 y otra sin lugar de 1617, ambas supongo serán en $8 .^{\circ}$ Tambien he visto la impresinn de Valencia, Iuan Vicente Frä. co, $16^{\circ} 21.8^{\circ} 16$ hojas prels:, 306 , numeradas 307 , de testo y dos más de sonetos laudatorios.

1020 VALDIVIELSO (JoSÉ DE). Vida, excelencias, y mverte del gloriosissimo Patriarca y Esposo de nuestra Señora, San Ioseph (ul supra). Madrid, Viuda de Alonso Martin,

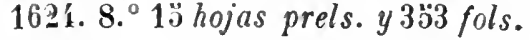

$1021-L a$ misma obra. En Seuilla, Nicolas Rodriguez, 16 亿2. 8. 4 hojas prels., 354 fols. y 2 con tres sonetos laudatorios y la repeticion del lugar y año.

Brunet $y$ Yic. Antonio traen otra impresion de Sevilla. P. Gonez Pastrana, 1647. s. ${ }^{\circ}$ pero il ambos les fué desconocida la de liti2. comn tambien la de Madrid, 1624.IIt risto una de Lisbua, Anionio Aluarez, $16.14 . s^{\circ}$ lo hujas prels. y 554 fols., y Barrera se reflero í la de yallid, Francisco del Hier. ro, 17: j. j yols. i."

102 2 - La misma obra. Reimuresa é ilustrada con 2 ö estampas por un Devoto quien la dedica al IIIismo Santo Patriarca. Valencia, Joseph i Thomas de Orga, 1774. 8. may. Frontis grabado y 14 lams.

Sin embargo de carecer de conocimientos artisticus, juzgo que estas estampas no hacen mucho honor ni al dibujante Camaron, ui á Ricarte que las grabo.

Ribadeneira ha incluido este poema en el tom. XXIX. de su Bibtioleca de tulores españoles.

Por pertenecer al unismo asunto, anotaré aqui un canto en octaras que he visto, intituladn: Mverle' y transito del palriarchas. Ioseph, y de si enterranimito, y Sepultura. con los priullegins que Dins le concedio a la hora de su muerle: y de algunos milagros que christo obri con sus dinotos. Valencia, luin Chrysostomo Gurriz, 1605. $80^{\circ} \cdot 12$ hojis. 
1023 Valeria (Gaspar alonso DE). Engaños desengañados a la lvz de la verdad. Poesias Sacras, Misticas, Morales, y Funebres, Escritas con la clara tinta del Santo Desengaño. Por Gaspar Alonso de Valeria Aragones. Añadense tambien alǧunas otras, que estandose imprimiendo las sobredichas, Hegaron a manos del Impresor, y ha sahido, que sen de Don Manvel Garcia Brsiamante. Napoles, Carlos Porsile, 1681. 8. 8 hojas prels. y 312 paigs.

Hai varias poesias italianas.

To sé si lo de Arayones es apollido i inulica la patria del autor. Io cierto es que Litasa no lo nuenciona en su Bibliolecr.

En innchas de las composiciones pocticas comprendidas eu esta obra, alvierlese ofectivamente en sus epigrafes, ser de Rustamante.

1024 VANlÈR (Eu P.). La casa de campo, Poema castellano, traducido del latino, intitulado Predium rusticum del P. Vaniere. Por D. Santos Diez Gonzalez. Madrid, Blas Roman, M.DCC.LXXXY. 8. ${ }^{\circ}$

\section{ViRG.IS MANRIQLE (Dox}

LuIS DE). Christiados o libro de los hechos de Christo. Compresto por don Luys de Vargas Manrique. Madrid, Pedro Madrigal, M.D.LXX.x. 8. 30 hojas foliadas, inclusos los preliminares, 3 de Tabla y 3 blancas.

Volumen raro; Vic. Antousio no lo conocio ni trae en su Bibliolheca el nombre de Luis de lárgas.

Los Chrisliados es una coleccion de SoneIns á la Encarnacion, Nacimiento y Vida de Christo y ocupan hasti el fol. 30 ; el resto del lomo son Canciones á Ira. Señora de Montserrate, á la Magialena, í S. Laurencio, á la eleccion de sixto $V$, á un llisacantano $y$ á la profesion de Fr. l'edro de Padilla.

1026 VARGAS Y PONCE (D. JosE). Proclama de un solteron á las que aspiren á su mano; por Don José Vargas y Ponce. Marsella, Camoin, 1827. 8..$^{\circ}$ marq.

Esta composicion poética se pulitico en Madrid, 1808 , sin nombre de autor y con las iniciales L. K. A.
1027 VEGa CARPIO (Lope Félix DE). Coleccion de las obras sueltas, assi en prosa, como en verso, de D. Frey Lope Felix de Vega Carpio. Madrid, Antonio de Sancha, M.DCc.LXXVI-LXXIX. 21 vols. 4. may. Retrato.

Fjemplar del papel grande.

Cuido de esta cdicion D. Francisco Cerdá y Rico y puso ademas algunos prólogros.

Los veintiun tomos comprenden las obras anotadas al pié : como se veri, y ya lo da á entender el fróntis, no hai ell ellos ninguna de lis composiciones dramiticas que contienen los reinticinco volúmenes de la coleccion publicada á principios del siglo XV'll.

\section{Contiene el tomo 1.}

El Lamrel de Apolo. Poema.

La selva sin amor. Egloga pastoral.

Catálogo de los poetas celebrados en cl Lau. rel de Apoln.

Veinle Epislolas, on verso, de las cuales nueve estan tomadas de la Circe y once de la Filomena.

\section{Tomo II.}

La Hermosmin de Angelica. Poema. Rimas. Segunda y tercera parte.

La Filomena, con otras diversas prosas y versos.

Tomo III.

La Circe. Porma, con otras Rimas y prosas. La Dr'agont'a. Poenia.

Las fiestas de Deniu á Philipo Ill, en dos cantos.

roesius vurias. otrus poesias.

Rimas humanas. Primera y segunda parte. Arle de hacer comedias en este timpo.

Tone V.

El Peregrino en su palria. En prosa y verso.

Tonı VI.

La Arcadia. Prosas y versos.

\section{Tomo VII.}

La Dorotea, accion en prosa. Al flin se ha añadido un Indice de los adigios que contiene esta obra, en numero de ciento cuarenta y ocho.

\section{Tomo vill.}

Cinco unvelas en prosa que se publicaron una con la Filomena y las otras cuatro con Ia Circe.

La tragedia El Castigo sin venganza.

Tome XX.

La Vega del Parnaso. Primera parte. 


\section{VEG \\ Tomo X.}

La Vega del Parnaso. Segunda parte.

\section{Tomo XI.}

Isidro. Pocma castellano.

Justa poelica da la bealificacion de S. Isidro.

\section{Tomo XIE.}

Relacion de las fiestus d la canonizacion de S. Isidro.

\section{Tomo XIIt.}

Triunfos divinos y qurias rimas sacrus.

Rimas sacras.

Conlemplativos discursos.

Cuatro sotiloquios.

Forma breve do resar.

\section{Tome XI:}

Jerusalen conquisfadu. Los dnee libros primeros.

\section{Tonmo XV.}

Jerusalen compuisluda. Los ocho libros últimos.

Le Virgen de la Almudena. Poema histórico. Romancero espiritual.

\section{Tomo KII,}

Pastores de Beten, prosas y versos.

\section{Tomo IVIt.}

Solilounios anorosos de un alma do bios. Trinnfo de la fé en los reinas del Jinnom.

Varios verso" " prosas, que se hallue es. parcidos en algunos libros.

Dris sonetos II dos crivlas inéditas.

Romance de lins bodns yue se celebraron en Vulencia

Romances que se hallan en el Homancero general.

\section{Tomo XVII.}

Fu'slas del Sintisino Sacramento.

\section{Tomo XIX.}

Rinces divinas y humanas del Mecestro Tomé de Burguillos.

Oracion eclesióslica funcrat del P. F. Frinncisco de Permlla.

Sermon finebre del Doclor Francisco de Quinlana.

Oracion functal manegiricu, hecha por el P. Mapstro F. Ignacin de Vitoria.

Oricion fünebre, por el Ductor Fernanilo Cav. doso.

Egloga da Frry Lope Felix de Vega Curpio, del Doctor Jian Antonio de la P'eña.

\section{Tomo Xx.}

Fuma póstuma à la rida y muerte de Lope, por el Ductor Juan Péres de Montaluan.

\section{Tome $\mathbf{X I}$}

Exequias que consagraron á Lope los ingenios de llalia.
Suplemento d los varios versos y prosas de Lope que se hallan esparcidos en alginos libros en alabanza de eltos $y$ de sus au. tores.

Indice alfabetico de los autores que escribieron en las exequias de Lope en Italia.

indice general de las obras contenidas en los 21 tomos de esta coleccion.

Indice general por orden alfabetico de todas las composiciones y demas obras que crimprenden los mismos.

Indice ulfabélico de los aulores que escribierou on elogio de Lope ó de sus obras.

indice alfubetico de autores de quienes se hatlin alyunas piezas incluidus en esta coleccion.

$10 \geqq 8$ VEGA CARPIO (Lope FELIX DE). La Circe con otras Rimas y Prosas De Lope de Vega Carpio. (Matrid,) Biuda de Alouso Martin, 1624. 4. ${ }^{\circ}$ let. curs. el verso. 5o hojas prels., incluso el fróntis grabado, y 236 fols.

Primera edicion.

Contiene este volúmen: ill Circe, poema pll oetaras y en tres cantos; La mañann de S. Juren de "Yarbitl y Lut rosa blienca; dos composiciones en la misma clase de metro; irrs Vurelus intituladas: La desdicha por la ho't"l, La prudente venganza y Gusman el Brer'u: mnere Epistolas y Rimas varius. Todo se ruimnrimio en las obras suellas, á saber: Lin Cire en el lom. III., las vovelas en el 1ill, F los Epislotes y Rimas en el I.

1039 - Coronat tragica. Vida y mverte de la serenissima Keyna de Escocia Maria Estrarda. Por Lope Felix de leara Carpio. Madrid, Viuda de l.uis Sanchez. M.uc.xxvi. ${ }^{\circ}$ 8 hojas prels., incluon ol relrato, y 127 lowjos, fols.

El hellu retrato de Yaria Estuarda, grabado por combes inc vit al prineipio suele faltar it muchos ejemplares.

Lil Commin Tribigere y otras noesias que se hallan al flu se reimprimieron en el tom. $l$. de las abress sueltas de Lope.

1030 Fiestas de Denia, al Rev Catholico Felippo III. deste nombre. Por Lope d. Tega Carpio. Valencia, Dierro de la Torre, 1399. 8. ㄹ hojas mels. y 7 I paigs., la úllima sin numerar. que es la que contiene el Soneto acrustico de D. rarlos Boil.

Edicion original, rara.

El conde de Saceda reprodujo hicia el año de tícista obrita, poniéndole la feeba de la primera colicion de ling; sin embargo es 
fácll reconocer la Impresion contrahecha. Posteriormente se ha incluido en el tom. III. de las Obras suellas de Lope.

Yo he tenldo otras Fiestas en la traslacion del santissimo Sacramento, d la iglesia mayor de Lerma, Por Lope de Vega carpio. En Valencia, Joseph Gasch, 1612. 8. ; de cuyo tratado he visto una impresion contrahecha á flnes del siglo pasado, en $8 .^{\circ}$ marq. y consta de 78 págs. y la hoja de la portada.

1031 VEGA CARPIO (Lope Félix DE). La Filomena con otras diuersas Rimas, Prosas, y Versos. De Lope de Vega Carpio. Madrid, Binda de Alonso Martin, 1621. $4 .^{\circ}$ i hojas preliminares, incluso el frontis grabado, y 220 fols.

Primera edicion. Alvarez y Baena babla de otra de Barcelona, del mismo año en $8 .^{\circ}$

Tengo anotado en unos apuntes tomados por mí mui á la lijera, que hai una edicion de Madrid de 1622 , tambien en $4^{\circ}$

Contiene este volúmen: La Filomena, la Andróneda y La Descripcion de la Tupada, reimpresas en el tom. II. de las 0bras suellas; las Epistolus y el Jardin de Lope, reprodıcidas en el tom. I. de las mismas; varias poesias y el Discurso sobre la nucva poesin, publicadas en el tom. IV. y las Fortunas le Diana, novela en prosa que se encuentra en el tom. VIll. de dichas Ooras sucllas.

- La hermusura de Angélica $y$ La Dragontea. Véase á Vega Carmio, en la Seccion novelística.-Libros de caballerias.

1032 - Isidro. Poema castellano de Lope de Vega Carpio, en que se escrive la Vida del bienauenturado Isidro, Labrador de Madrid, y su Patron diuino. Madrid, Pedro Madrigal, 1603. 8. ${ }^{\circ}$ let. curs. 16 hojas prels., 250 fols. y 9 hojas despues sin foliar.

No se distingue bien la fecha del frontis; pero me parece ser la de 1603.

1033 - - La misma obra. Barcelona, en casa de Honofre Anglada, 1608. 8. 8 hojas prels., 203 foliadas (dice 103 por errata), 10 sin foliar y una blanca.

Ambas ediciones son de letra cursiva.

En el prólogo del tom. XI. de las Obras sueltas de Lope donde se reimprimió este poema se describe la primera edicion liecha $e n$ Madrid por Luis Sanchez, M.D.XCIX, una tamblen de Madrid, Pedro Madrigal, MDCII, Y otra de Madrid, Imprenta del Reyno, M.DC.XXXVIII, las tres en $80^{\circ}$ Nic. Antonió cita ademas la de Alcala, Juan Gracian, 1607, Y una de Madrid, 1613 , en $8 .^{\circ}$

\section{VEGa CarPI0 (Lope Félix} DE). Iervalen conquistada, epopeya tragica. De Lope Felis de Vega Carpio. Madrid, Iuan de la Cuesta, M.DC.IX. 4. ${ }^{\circ} 16$ págs. prels. y 536 fols.

Primera edicion y una de las mejores de Cuesta. En los preliminares hai un retrato pequeñito de Lope, grabado en madera, sacado de la pintura de Pacheco y bastanté parecido al que yo he hecho coplar de la Ar'radia: tambien hai en dichos preliminares otro retrato de Alfonso VIII de cuerfo entero.

Nic. Antonio no conoció esta edicion.

1035 La misma obra. Barcelona, a costa de Raphael Nogues, M.DC.IX. (Al fin:) Emprenta de Gabriel Graells y Giraldo Dotil. Any 1609. 8. ${ }^{\circ}$ let. curs. 16 hojas prels. y 536 fols.

He copiado el nombre del editor puèsto en el fróntis y el del impresor en el fin, para hacer ver que quizá Nic. Antonio confundió á ambos, al referirse á una impresion de Nogues de 1609, y á otra de Gabriel Graells de 1619 .

He visto la edicion de Lisboa, vicente Alvares, $1611.4 .^{\circ}$ citada por irunet; pero no tomé su descripcion bibliográflca.

Esta obra se reimprimió en los tomos XIV. y XY. de las Obras sueltas.

El escudo de Sebastian Cormellas que lleva en la portada mi ejemplar es el siguiente.

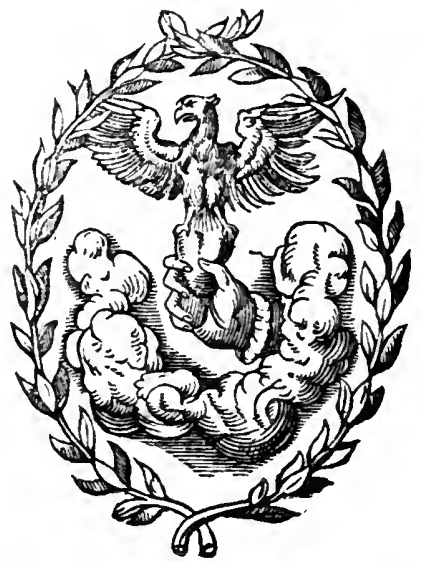

Igual es el que emplé laume Cortey en el Jaime Roig impreso en 1561 y en el Muntaner de 1562, con la sola diferencia de que este le colocó á los lados sus iniciales $I$. $C$. 
VEGA CARPIO (LOPE PÉlIX DE). Laurel de Apolo. Véase en la Seccion dramálica, al nombre de Vega Cärpio.

1036 Poesias escogidas del Doctor Frey Lope Felix de Vega Carpio. Con un discurso sobre la oda por Marmontel. Madrid, Villalpando, $1796.8 .^{\circ}$

Estas poesias, entre las cuales se encuentra La Galomaquia, están entresacadas de varias obras de Lope.

1037 - Rimas de Lope de Vega Carpio. Aora de nuevo añadidas. Con el nvero Arte de hazer Comedias deste tiempo. Madrid, Alonso Martin, 1609. 16. ${ }^{\circ} 8$ hojas prels., 210 fols. y 8 más sinfoliar que contienen dos sonetos y la Tabla.

Va dividido este tomito en dos partes, aunque ambas llevan una sola foliatura; la primera contiene los doscientos sonetos que se publicaron antes al fln de la Hermosura de Angélica, y la segunda se compone de poesias en varias clases de metro, entre ellas tres églogas, y el Arle de hacer comedias. Todo se reimprimio en el tom. IV. de las obras sueltas de l.ope, en cuyo prólogn se habla de una edicion de Huesca , Pedro Bluson, 1625. 16." ilvarez y Baena, tom. Ill. píg. 366, menciona otla de. Lisbon, $1605.4 .^{\circ}$ y efectivamente he visto una de dicha ciudad y de igual año; pero ademas de ser en $8 .^{\circ}$ marq. estaba á no dudarlo coutrahecha á mediados del siglo pasado: probablemente la mandaria tambien hacer el conde de saceda, pues lleva en el frontis igual adorno al que se puso en las Varias rimas sacras, reimpresas de órden de este noble. Debo observar que si cl contenido de la edicion original de Lisboa es jgual al de la reproducclon, sclo comprenderá las composiciones de la segunda parte del volúmen de 1609 , d pesar de espresarse en la portada ser Primera parte.

1038 - Rimas sacras. Primera parte de Lope de Vega Carpio. (Madrid,) Viuda de Alonso Martin. Año de 1614. 8. ${ }^{\circ} 12$ hojas prels. y 188 fols.

l'rimera edicion. Alvarez y Baena mencio. na una segunda de Lerida, 1615. S. $^{\circ}$

1039 La misma obra. Em Lisboa. Por Pedro Crasbeeck,
M.DC.XYI. $8 .^{\circ} 8$ hojas prels., 188 fols. y 4 de Tabla.

Tercera edicion, copla exacta de la anterior.

1040 VEGA CARPIO (LOPE FĖLIX DE). Rimas sacras, Primera parte de Lope de Vega Carpio. Con cien octauas a la vida de la Madalena. (Madrid, $\mathcal{}$ Viuda de Alonso Martin, 1619. $8 .^{\circ} 16$ hojas prels., inclusa la Tabla, y 184 fol.

Detestable edicion $y$ papel: el contenido es igual al de las dos anteriores, á pesar de anunciarse en el fróntis comn una novedad el que comprende las cien oclavas a la vida de la Marlalena.

Aun cuando se dice en la portada que esta es la primera parte, ignoro se haya publicado segunda, si no se considera como tal las fimas sacras que van á continuacion de los .Triunfos publicados en 1625: unas y otros se imprimieron juntos en el tom. XIll. de las Obras suellas. Los editores de dicha coleccion no conocieron la cuarta impresion de 1619; pero hablan de una de Lerida, Luis Manescrl, 1626 , de otra de Lisboa, Henrique Valente de olivera, 1658, y de la que contrahizo el conde de Saceda hácia mediados del siglo Xrill, copiando hasta el fróntis de la madrileña de 1619.

1011 - Varias rimas sacras de Lope de Vega Carpio. S. l. ni a. $8 .^{\circ}$ marq. Una hoja de fróntis y 22 pags.

se reimprimieron como las precedentes en el tom. XlII. de las Obras sucllas de Lope, publicadas por Sancha, y los editores pretenden que la edicion arriba anunciada s. I. ni a. la mandó hacer el conde de Saceda por Ios años de $17\{\tau$; sin embargo la encuentro cierta apariencia de mayor antigūedad.

1012 Soliloqrios amorosos de vn alma a Dios. Escritos en lengra Latina por el muy R. P. Grauiel Padecopeo, y en la Castellana por Lope de Vega Carpio. Barcelona, Sebastian de Cormellas, 1626. $16 .^{\circ} 16$ hojas prels. y 128 fols.

Con el nombre anagramático de Graviel Padecopeo trato de ocultar el suyo Lope de Vega; sin embargo, en la Egloga á Claudio, dijo:

Y en neclar soberano

Bañado disfraze con anngrama

Los Solilor wios de.mi ardiente llama.

Son estos Snliloquios siete, en vérso, que estiende despues en prosa: van ademas cien jaculalorias á Cristo y el Llanlo lle la Vir gen. 
Este librito se reimprimió en el tom. XVII. de las obrus sucllas de Lope y sus editores cilan como primera una impresion de $\mathbf{M} / \mathbf{l}$ drid, riula de luis Sanchez, 1626. 16. ${ }^{\circ}$; tambien se pefleren a una de Roan de 1646 , i otra de 16:17, la cu,l no dicen de dónde es, y á la hecha en Madrid, Juan de S. Miguel en 16.36. 8. : añaden debe hiber otras ediciones gue no han portido averigull por su rareza (efeclivamente la mia de Barcoloma es ma de plias, y ilrarez y Bacua, Lnm. Ill. pagina 5fit, nuenciona la de Madrial, 1701. s.०.

\section{VEGa CARPIO (Lope Félix} DE. Soliloquios amorosos de vn alma a Dios. (ut supra.) Madrid, Juan de San Miguel, M.DCC. I.Vi. 8. Marq. 14 hojas prels. y 121 paigs.

Ejemplar en gran papel.

Secrul se vé son conocidas por lo ménos meve ediciones de este libro, y estraño como un peribelien, al auunciar la impresion hechal en yadrid en $1865, \mathrm{~b} j \mathrm{j}$, la direceion de D. Vicente Bilrrintes, diga; es obra rarisina en España, por laberse impreso por cuenta de lie ditquesa de Oliváres, solo par'u regalar a sus amigas.

1011 Trivnfos divinos con o! ras rimas sacras. Por Lope de Yega Carpio. Madrid, liuda de Alonso Marlin, 163.). 4. 8 hojus prels. y 127 fols.

Primera cdicion. Al f:l. 105 con nuevo fruntis, annque signiendo la foliacion y sig. naturas, cunpieza cl Poema de Lat Tirgen de la .1murdena.

lus trimufos se reimprimiernu en el to-

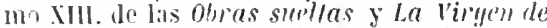

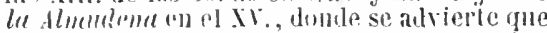
de este poema snelto hai otra impresinn hecha en Yadrid, por \%. Aulmio Senz, 17.51. $4 .^{\circ}$ y ilvarez y bacua menciona una timbien de Matid 1726. 3.。

YÉGA Duman de). Libro de poesia cristiana. Véase en la Seccion drameitica.

\section{TELIZQUEZ DE VELASCO}

(Diego Alforso). Odas a imitacion de lus siete salmos penitenciales del Real Propheta Darid, por Diego AlConso Velazquez de Velasco. Anvers, Emprenta Plantiniana. M.D.XCHI. 8." marq. Dos escudos de armes y una lámina del rei David, grabados en cobre y tirados con el testo, 67 págs., inclusos los prels., un soneto con que ter- mina, $y 2$ hojas más al fin con un Previlegio $y$ tres aprobaciones.

Va al principio una escelente oda d la conversion del pecador, escrita por D. Bernardino de Mendoza, hermano del célebre Don Diego.

Reimprimiéronse estas Odas con otras varias obritas en verso en un tomo publieado cu Madrid en 1779 con el título de Poesías rspiriluales ( $\boldsymbol{V}$. la division de Cancioneros, Núm. .319) y en sul prulogo dice el editor moderno que la unica edicion de las Odas hecha cll Anteres, 1595, por ser tan rara no la habia conocido Nic. Alltonio.

Diego Alfonso Velázquez de Velasco es el autor le la Lena, á pesir de que en esta solo se le llama D. Alfonso Velízquez de Velasco. Ambas obras las dedicó á D. Pedro Enríquez, conde de Fuéntes.

1046 VELAZQUEZ DE VELASCO (LuS José). Origenes de la poesia castellana por Don Luis Velazquez. Malaga, Francisco Martinez de Aguilas, IIDCCLIV. . $^{\circ}$

\section{VÉLEZ DE GUEVARA} (Luis). Elogio del Ivramento del serenissimo Principe Don Felipe Domingo, Qvarto deste nombre. De Luys Uelez de Gneuara. Madrid, $\mathrm{Ni}$ guel Serrano de Uargas, $1608.8 .^{\circ} 6$ hojas prels. $y 28$ hojas fols.

poema en octavas, compuesto por el autor del Diablo cojuelo.

lleva al principio algunos elogios de la obra en verso, eseritos por lope de Vega, 1). Frauciseo de Quevedo, D. Sebastian de Cécpedes y Meneses, D. Francisco Coronel y Sillcedo, Pedro Soto de Rújas y D. Antonio de Mendoza.

Es librito raro y Barrera lo llama precioso.

1048 VERA Y FIGUEROA (JUAN A vToxio DE). El Fernando o Sevilla restavrada Poema beroico escrito con los versos de la Gervsalemme liberata del insigne Torqvato Tasso. Por D. Ivan Antonio de Vera y Figveroa, Conde dela Roca. Milan, Henrico Estefano, 1632. 4. $^{\circ}$ let. curs. "̌ hojas prels., incluso el fróntis grabado, una lámina emblemática en la que está Felipe IV. y $6 \ddot{3} 4$ págs. Cada canto lleva una lam. en cobre tirada con'el testo.

Me parece que Nic. Antonio comete tres cquivocaciones al hablar de este libro: la primera, en atribuírselo á D. Juan Antonio 
de Vera y Zuiniga, sugcto que ereo distinto y probablensente padre ó ascendiente del Figueroa: la segunda, en suponer que hai una edicion de Sevilla anterior á la de Milan siendo asi que las dedicatorias, fechadas en esta ciudad en Julio de 1632 , no dejan casi duda de haber sido allı $\mathbf{y}$ en aquel año, donde se publicó por primera vez; y la tercera, en suponer que se imprimio en Milan en 1625 , siendu de 1652 la edicion más antigua, como acaba de decirse. En esto último es fácil se deslizase una equivocacion tipogrifica, por la cual se hayan traspuesto los dos últinios guarismos.

\section{VERA Y ORDÓÑEZ DE} VILLAQUIRAN (DIEg0). Heroydas Belicas, y Amorosas. Por Don Diego de Vera, y Ordoñez de Villaquiran. Barcelona, Lorenço Déu, M.DC.XXII. 4. 4 hojas prels., 108 pigs., comprendido un nuevo fróntis que forma la 1 y $2, y$ una hoja at fin para lerminar el Prólogo hecho a un sermon.,

Son ocho heroidas en tercetos.

$10 \ddot{0} 0$ - De Don Diego de Vera y Ordoñez de Villaquiran, a la Magestad de Felipe Quarto. Instando a su Magestad el castigo de los Iuezes injustos; como el premio a los buenos. Que alivie de trihuto a sus vassallos; la conquista de Flandes, y la de Ierusalem; con baticinio que ha de señorear el Mundo. Heroyda Belica. Barcelona, Lorenco Dei, 1629. 4. 16 hojas sin folialura, signs. A-D de 4 hojas cada una, la tercera de la B es blanca.

Consta de una Cancion dedicatoria, y de la Heroida en tercetos.

Esta herojda por sı tipo, tamaño y demas circunstancias parece estar hecha para ir unida á !as anteriores, y asi se halla en mi ejemplar; pero el llevar distinta portada $y$ signaturas, nuevas aprobaciones y dedicitoria, $y$ el no continuar la foliacion, todo esto me inclina á creer se publicó por separado: efectivamente el Sr. Barrera solo habla de las ocho heroidas comprendidas en el artfculo anterior, $y$ nada dice de la que forma el asunto del presente.

Brunet y Barrera supenen ser Don biego de Vera Orduñez y Villaquiran el viego de Vera á secas, recopilador del Cancionero llamalo Dansa de galancs: no participo de la opinion de estos bibliografos.

1051 VERGARA SALCEDO (SEbastian Venturi de). Ydeas de Apolo y dignas tareas del ocio cortesano.
De Don Sebastian Ventura de Vergara Salcedo. Madrid, Andres Garcia, 1063. 4. 12 hojas prels. y 226 fols.

Contiene este volúmen poestas en difrrentes inetros, escritas por Vergara Salcedo.

10302 VEZILLA CASTELLANOS. (Pedro de la). Primera y segunda jarte de el Leon de España, Por Pedro de la Vezilla Castellanos. Salamanca, Iuan Fernandez. 10̈86. 14 lojas prels., inclusas dos de inscripciones halladas en Valdecésar, 369 fols., 5 de Tabla $y$ una de Enmiendas.

-Poema en octavas y en reintinueve cantos divididos en dos partes, la segunda de las cuales lleva nuevo fróntis, aunque incluido en la foliatura general.

Este libro es mis apreciable bajo el punto de vista bibliográlfeo que bajo el literario; se le busca enn cierto empeño por forinar parte de lo que algunos curiosos llaman $\mathrm{Bi}$ blioteca de D. Quijote, y esta es una de las razones por la cual los ejemplares son raros y casi nunca se eneuentran en buen estado. El mio es mui bello y tiene la firma original del autor al reverso de la portada.

10 3 VIDA de San Antonio A hbad. kn octavas. Caller, Imprenta de Santo Domingo, Por Fray luan Batista Cannauera, 1700 . $10^{\circ} \geq$ hojas prels. y 103 págs.

Poema anoulimo, dividido en cuatro can. tos.

Existe otra vida de $\mathbf{S}$. Antonio tambien en verso eserita por Ozejo, V. su arliculo en esta inisma division. Yim. 847 .

1034 IIDA (LA) de Nrestra Bendita señora Maria virgen emperatriz de los cielos en la qral tambien se cōtienen el Nascimiento, Passion, y miverte de Nvestro Dios y Salvador Iesv Christo... Obra de Irlio Fontana pintor y vezino de la mry noble cividad de Verona. Con algunos versos, hechos parte yor vn de roto cartrano, y parte por Irsepe de los Cerros de Trento. (Venecia?) Apud Lucam Guarino, 1360. "rol. Son 10 lams., incluso el frointis.

Libro rarlsimo, y del cual no recuerdo haber visto otro ejemplar.

Sus precinsas liminitas, grabadas con mucha delicadeza y naestría al agua fucrte, llevin rada una de ellas a la parte superior $y$ a la inferior versus alusivos al pasaje 0 acontecimiento que representali: la mayor 
parte de estas poesias están sacadas del Relablo de la vida de Cristo del P. D. Juan de Padilla, autor tambien de otras obras en verso, y las restantes las escribió Jusepe de los Cerros de Trento, segun dice Fontana en su dedicatoria.

He visto otro libro cuyo titulo tiene alguna analogía con el de Fontana, y aunque es perfectamente distinto, lo describiré por ser tambien silmamente raro.

Gran lamina que representa In Concepcion y bajo: La vida y excelencias dela sacratissima virgen Maria nuestra señora vista y examinadu. Con Prinilegio Jmperial.- Al dorso está el permiso para la impresion dado á Francisco de Trasmiera, el culal ocupa la hoja siguiente. En la tercera sign. i iij principia el Prólogo que concluye ell el blanco de la quinta; al reverso: Comieça un psulmo, aplicado ala côcepcion de muestra Señora. es de montemayor.

đ Furudamenta eius in mötibus sanctis.

(1) Hizo dios vna ciudad sobre sancto fundanento etc.

ocupa esta composicion las tres hojas siguientes. En la novena del vol., sign. A, principia la obra que concluye en la octava de la $T$, asi:

I En alabäça d’ nīo spñor, y de sugloriosa madre. Fenesce la presente obra llamaila la vida y excelencia de nuestra señnra. Fue ympressa enI muy ynsigne villa de Valladolid (Pincia otro tiempollamarla) En cası d' Francisco fernandez de Cordona Junto alas es. cuelas muyores Acabose enel mes d' Jilio d' $1546.8^{\circ}$ Iet. gót. Puema en varios metros.

Relativa à la Virgen he tenido ncasion de examinar otra obra, la cual no cede en rareza á las anteriores: he aquí su descripcion:

Lna lảmina que representa á la Vírgen á quien está coronando la Trinidad y bajo se lee:

Triumpho de Maria.

Este es todo el fróntis, detras hai otra lámina de un fraile con una cruz en la mano derecha y un libro abierto en la izquierda, todo circuido de una orla. En el blanco de la hoja siguiente $a i j$, se lee:

Por alabança de la preciosa virgen y madre de cristo ihesu: comiéça el libro intitulado triũpho de maria: por marlin marlinez de ampies compueslo: $y$ er emienda de sus delictos a el otorgada: por el reuerendo doctor fray gonçalto de rebollcda friyle menor como por padre de su cofessio sigue una especie de prólogo que concluye al re. verso, y a continuacion hai una advertencia de las autoridades que se citan, la cual concluye al principio de la hoja siguiente signalura aijj. Despues

Comiença el prologo dirigido al frayle por este metro.

Sigue una límina igual á la que se encuentra $\dot{a}$ la espalda del fróntis y bajo:
Reuerendo señor la cruz imitante: del viuo seraphe del fuego de amor: deuoto constante del merecedor. del quino rosario de grả mananie: mandays me dezir dela imperante:

loores algunos: en su reuerencia. $y$ en cosa tan grande por ni sufficiencia: tan infima ruda razon que me spante.

Sigue una como glosa $\dot{o}$ notas en prosa á la copla anterior y en la sign. a iiij.

prosigue la razon de la copla susodicha.

Es otra octava y bajo de ella:

- Adreça la fabla a nuestra señora.

Una límina de la Virgen del pilar con San lioque y otros santos arrodillados,

Humille mas alta: humana: diuina. etc.

Siguen las octavas y las glosas en prosa hasta cerca del fin del reverso de la quinta hoja de la sign. $b$ en donde

Comicucan las cãciones delos chorosceles. ies: en alabunça de muesıra señora.

Los pireos serafines

ya comiencan con los tronos:

los de medio y jerubines

con todos siguen sus lonos etc. etc.

Las coplas y glosas de los coros celestes concluyen en la sétíma hoja vuelta de la misma sign. b y allí

Comicnçun las canciones de los justos y sanctus.

Despues de estas vienen las dirigidas $d$ los religiosos y sacerdotes. -Cancion del linage femenino de la glorin-Varias octavas y glo. sas.-Prosiguiendo to començado buelue a nía scñora la copla siquiète con vna cöparacion en su alabī̧̧a.-Varias oclavas sobre los pecudos mortales.

En el blanco de la hoja octava de la f:

Acabado el romance comiecça en lalin vna oraciõ a nueslra señora por metro examelio la qual sera por los latinos.

Concluyen estos versos en el dorso de dicha hoja y en la siguiente sign. $g$

Comienç el prologo en los amores de la madie de diss a su gran alteza encomendado por Marlin dampies.

Lámina que representa una Virgen de medio cuerpo con el niño en brazos y dos ángeles que le sostienen la corona. Sigue el prólogo que acaba en la sign. $g i i j$ y á continuacion

Comienca la copla en el tratado con nuestra señola.

La copla y glosas van hasta el blanco de la sétima hoja de la misma sign. y en el reverso

Comiença el primero amor dela virgen

El amor madre primero

que todo saber inclina tuuo dios por muy entero con $1 i$ cierlo y verdadero pura nuestra medicina yuando su mente diuina 


\section{VID}

te scogio y ante scogio

$y$ scogida clarecio

iu persona y alma fina etc.

Siguen despues los amores del mundo, de salutacion, de nacimiento, de la adoracion, en la resurrection, de la ascension, del espiritu santo y de la asumpcion; llevando todos ménos el prinero una lámina de madera.En el blanco de la última hoja sign, $i$ iij se lee:

El triūpho y los ainores d'la preciosa madre de dios aqui si acaban: y emiprèlados con las expensas de Paulo Hurus aleman de Conslanciu en la noble ciudud de Car'agoca: enel año de nuestra salud Mil.cccc.lxxxxv (1495).

Vol. en $4 .^{\circ}$ let. gót. sign. $a-i i i j$ todas de 8 bojas menos la $i$ que solo tiene 3 por faltarle
VILL

qulzas alguna blanca al fin. Las págs, șon de trelnta líneas cada una.

10 อ̈̉ VILLAGRA (GAspar DE). Historia de la Nveva Mexico, del capitan Gaspar de Villagra. Alcala, Luys Martinez Grande, 1610. 8. 24 hojas prels., en las que se halla el retrato del autor y la Tabla, 287 foliadas, y una al fin para repetir las señas de la edicion.

Poema en treinta y cuatro cantos y en verso suelto.-Libro raro y no reimpreso.

El retrato incluido en los prellminares es el siguiente.

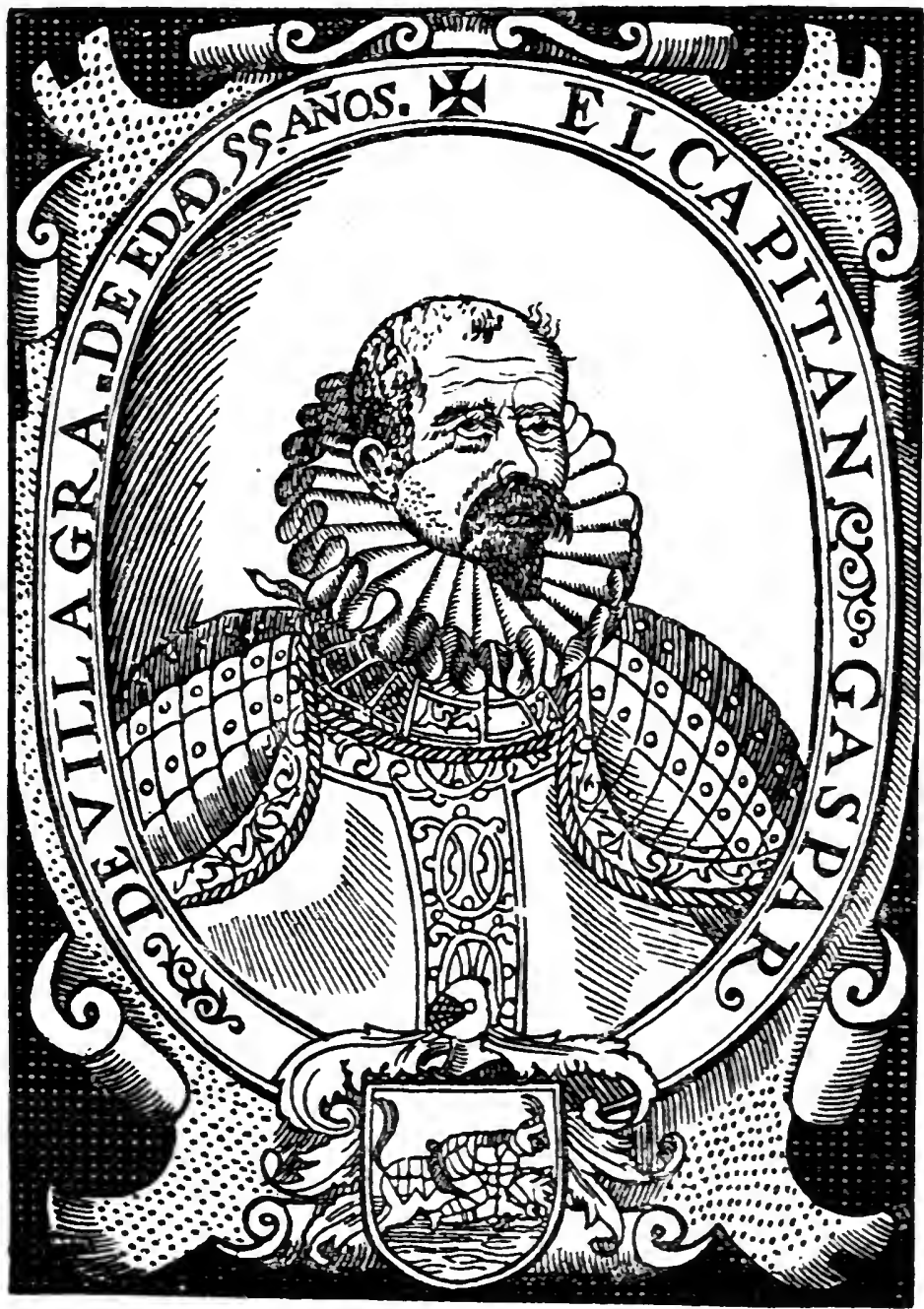


VILLALÓbOS (Fraxgisco DE). Los Problemas. Véase en la Seccion dramatica.

1030 Villamayor (Pedno de). Primera parte de la poesia espiritval, en la qual (con la frciente Doctrina del Sol de la Inlesia Santo Tomas de Aquino) se alumbra al Christiano en todo lo que deve creer, y obrar para conseguir la perfeccion; gulardanda el orden de toda la Doctrina Christiana. Por el P. Fr. Pedro de Villamayor. Madrid, Domingo Garcia Morràs, $1663.4 .^{\circ} 8$ hojas prels., 191 paigs., 53 de Indices y una en que repite las señas de la impresion.

En la Fe de erralas, fechada en Mabrid, el año de 1665 , sc intitula esta obra Mislevios le la $f e$, y en los titulillos de las páginas del Libro primero tambien se denomina así: sin duda vic. Antonio tuvo presente algun ejemplar fallo de las primeras hojas, y por eso no mencinna la Poesia espiritual y sílos Mislerios de la fé, diciendo estar impresos cll 1665 .

1037 VILLAMEDIANA Fi CoNDE DE . Ohras satiricas del Conde de Villa Mediana que no estan ympressas. $40^{\circ}$ Manuscrilo mui inteligible de 93 fojas útiles y de unos dos siglos de antigiiedail.

Contiene este rolimen las composiciones poéticas de Villamediana, algmas de las cuales por denasiado libres, y lis mayor parte por ser sumimeute ofensivas a sugetos de alta categoría en la corte de Felipe III, no pudicron imprimirse con sus demas obras; por esta razon casi tudas lian quedado ine. ditas: I'ellices, eli el Origent de ta comedia, il llibblar de la Josefa Vaca y de la Amarilis, cupia dos de estas composiciones; pero 110 sill hiberlas mutilado.

Tambien comprende este manuserito una porcion de poesías escritas contra el Conde, en justo desquite de sus injuriosos versos, y ademas lis producciones de Gongora, J.ope, Jauresui, Alarcon, Quevedo, el Conde de Salínas, Jira de Amescua y D. Autonio de Vendoza, dedieadas a la muerte del malogrado Villamediana; en todas ellas se revela algo de enemistad hicia el, y se hice una anarga censura de su carácter maldieiente y procaz.

El nimero totil de composiciones es de ciento quince, de las cuales solo sesenta y una se hallan en el Cancionero descrito al Nim. 200 de este Catílogo. Contiene í su vez aquella antoloria sesenta y tres poesíns que no están en cl presente manuscrito, y aun entre las repetidas en ambos códices las variantes son tan considerables y de tal importancia, que conviene consultarlas y compulsarlas.-En el tom. It. de Poctas liricos de la Bibliolec'a de Ribadeneira ha publicado Castro mas cuarenta y tres poesias del desgraciado Conde: pero entre ellas quizás no lleguen á veinte las que hai de las comprendidas en este manuscrito.

Sus obras liricas, jmpresis, se hallan en la Seccion dranática al nombre de Villamediana.

1038 Vlllareal (IIErnando). Emblema o scriptura de la justicia donde se tocia las maneras pordöde. El justo juizio se tuerce cōpuesta por Hernãdo de villa real estudiante dirigida al muy Magnifico Señor Iuã razquez de Molina secretario de su.

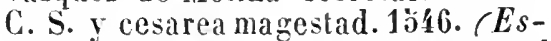
te es el conténido de la porlada, la cual va circuida de una orla, en cuya parte inferior se halla un tarjetoncillo sostenido por dos ángeles y en él las iniciales I. A. que parecen ser las de Junta. Al fin solo dice:) I Fue hecha en Salamãca. $8 .^{\circ}$ let gót. Sin foliacion, sign. 1-C de 8 hojas.

liarísimo volimeneserito en ignal metro al de las Coplas de Manrique. Ile aquí como principia:

\section{Irégumla el lector.}

;Cuya es aquesta flgura

que tiene tan grave aspecto.

y soberano?

No es de liumana criatura, que aquel color tan perfecto no es luumano;

ya está esquiva y espantosa, ya ticne mui agradable

todo el gesto,

ya está torva y temerosa,

ya blanda y mui deleitable.

Qué es aquesto?

\section{Responde la Juslicia.}

Yo soi la sacra justicia hija del Celsi-lonante dios supremo, enemiga de nequicia, siempre muj frme y constante en estremo;

yo distribuyo igualmente su derecho a cada cual con razon;

castigo al que es muj potente $y$ al que es de pobre caudal sin pasion.

Nic. Antonio no logró ver este tratadito $\mathrm{y}$ 10 cita refiriéndose a Tamayo de Yírgas. Al fin de èl van a'gunas emblemas de Alcialo traducidas (en verso) de latin en romance. 
Escribio Hernando de Villareal otra obra cn metro Intitulada Imagenes de la muerte, citada por Antonio y descrita por mi al hablar de la Danza de la muerle. V. este articulo en la Seccton dramdica.

1059 VILLARROEL (JosÉ). Poesias sagradas, y profanas, que en varios metros compuso Don Joseph Villarroel. Madrid, Andres Ortega, 1761. $4 .^{\circ} 8$ hojas prels. y 264 págs.

1060 VILLAYICIOSA (José DE). La Moschea poetica inuentiua en Octaua Rima. Compresto por Ioseph de Villauiciosa. Cuenca, Domingo de la Iglesia, 1615. 8. 16 hojas prels. y 174 foliadas.

Primera edicion.-Nic. Anlonio no pone el lugar ni año de esta edicion, ni el nombre del impresor; prueba de no hiberla visto. La segunda me parece es de Madrid, 1652.

1061 La misma obra. Tercera impression. Madrid, Antonio de Sancha, M.DCC.LXX.viI. 8. ${ }^{\circ}$ marq. Retralo.

1062 - Otro ejemplar de esta misma impresion tirado sobre papel fuerte y azulado.

1063 VILLÉGAS (ANToxio DE). Inventario. De Antonio de Viliegas. Medina del Campo, Francisco.del Canto, M.D.LXV. 4. ${ }^{\circ}$ hojas prels. y cxxxij fols.

Primera edicion mui rara: el título de la segunda es el siguiente: Inventario de $\mathrm{A} n$ tonio de Villegas... Va agora de nvevo añadido vn breue retrato del Excellentissimo Duque de Atra. Y vna question y disputa enlre Ainx Telanon y vlixes, sobre las armas de Achiles. Medina del Cäpo, Francisco del Canto, 1577. 8. 8 hojas prels. y 144 fols. - Me parece no es cierto lo dicho en las notas á la Historia de la lit. de Ticknor (to. mo IV., pág. 437) sobre haber una edicion anterior à la de 1565 ; en lo que si hai equivocacion evidente es en suponer á esta en $8 .^{\circ}$

Contiene el volúmen muchas cancimes y glosas y ademas una Historia de Piramo y Tisbe, en verso, una novela pastoral intitulada: Ausencia y soledad de ainor, en prosa y verso, y otra de los amóres de la linda Jarifa, y el moro Abencerraje, en prosa. Ticknor, en el toın. IIr., Ilama á estas, primeras novelas españnlas. $\mathrm{J}$ supone que Montemayor tomó de villégas la illtima; uucho lo dudo por cuanto he vlsto una edicion de la Diana de Valladolid, 1561 y otra de Lisboa, $1565, y$ en ambas se halla ya la historieta del abencerraje. Más fácilmente podria suponerse la saco de otro librillo, mencionado por Callardo en el Ensayn de una bib. esp., intitulado: Parte de la Coronica del inclito infante D. Fernando que gand d Anlcquera: en la qual trala comn se casuron a hurto el Abendaraxe Abindaryaez con la linda Xarifa hija de Alcaycle de Coin, y de la gentileza y liberalidad que con ellos uso el noble caua. llero Rodrigo de Narbaez, Alcaide de Ante. quera y Alora y ellos con él. S. l. ni a. $8 .^{\circ}$ let. gút.; o bien de otra obra que igualmente se cita en dicho Ensayo, y tal vez sea la misma, cuyo título es: El moro Abindarraez y la bella Xarifa: novela. Toledo por Miguel Ferrer, 1 562. 12.

Antonio de Villegas es uno de los poetas que como Castillejo, tratarnn de desterrar de nuestra poesia el gusto ilaliano introducido por Boscan y Garcilasio.

\section{VILLÉGAS (Estévay Ma-} NUEL DE). las eroticas o amatorias de don Esteuan Manuel de Villegas. Parte Primera. (Al fin:) En Naxera por lvan de Mongaston. Año de 1618. 4 hojas prels., incluso el front is grabado, 160 fols. y una para las señas de la edicion.-Las Eroticas de Don Estevan Manrel de Villegas. Qve contienen. Las Elegias. lib. I. L.os Edylios, lib. II. Los Sonetos lib. III. Las Latinas, lib. IIII. Segvnda parte. En Najera por luan de Mongaston, 1617. Acosta del autor. i por el corregida la ortographia. 87 hojas fols., aunque realmente son 88 porque la 82 está duplicada. 2 partes en un volúmen en $4 .^{\circ}$

Primera edicion, mui rara.

En el fróntis que lleva la parte primera se ve un sol naciente con el lema: Me sur. gente quld istae? A este esceso de amor propio, que no tiene escusa en un hombre del mérito literario de Villégas, aludio Lope de Vega en el Laurel de Apolo en los siguientes versos:

Aspire luego de Pegaso al monte Et dulce traductor de Anacreonte, Ciyos estudios con perpetua gloria Libraron del olvido su memnria; Aunque dijo, que todos se escoudiesen Cuando los rayos de su ingenlo viesen.

Ménos se le puede perdonar al autor de las Eróticas el que zahiriese al inmortal Cerviutes, aplicandole el epíteto de quijolisla: no vacilo en asegurar que cualquicr autor daria la mejor de sus composiciones, y aun el inis. 
mo villégas, despojado de la pasion que le cegaba, hubiera renunciado con facilidad á su preciosa cantineta:

Yo vi sobre un lomillo etc.

por la gloria de poder llamar suyo cualquier capitulo del Ingenioso hidalgo.

1063 VILLÉGAS (EstévaN MaNuel DE). Las Amatorias de Don Estevan Manvel de Villeras. Con la tradvcion de Horacio, Anacreonte, y otros Poetas. En Naxera por Iuan de Mongaston Año M.DC.XX. (Al fin: 1618.)-Segrnda parte. (ut supra.) Numero de hojas igual al anterior. 2 partes en un vol. 4 .

Esta edicion, no citada por ningun bibliografo, es la misma que la de 1618 , descrita en cl numero anterior, con las únicas diferencias de haber sustituido el fróntis grabado de li primera por el impreso que acabo de copiar, y ser blanca la cuarta hoja del tomo, que en los primilivos ejemplares contiene la licencia y una especie de anteportada al libro primero. Sin duda al ver Villégas el mal cfecto producido por su escesiva pe: tulancia, suprimió el frontis en ol cual se hallala el malhadado cmblema, y fuc este reemplazado por Ima viñetita en madera, representando la djvisa caida por llurtido en el Bnen plazer trobado, fol. 58 , de dos eslavones que hiriendo un pedernal arrojan abundantes chispas, y las leyendas : Con el oclo lo lucla se desluce, y Rompe y Ince.

\section{Las Eróticas y traduc-} cion de Boecio de Don Estevan Manuel de Villegas. Segunda edicion. Madrid, Sancha, II. DCC.XCVII. 2 vols. 8. ${ }^{\circ}$ may. Retrato y fróntis grabado.

Ademas de la traduccion de Los cinco libros de la Consolacion, que se imprimieron por separado en 1665 , comprenden estos dos volumenes algunas poesias inéditas de Villégas y una noticia biográficn-literaria de este autor, escrita por D. V'icente de los Rios.

Tuve otra impresion hecha tambien en $M a-$ drid, por Sancha, M.DCC.LXXIV. 2 vols. $80^{\circ}$ may., de la que hai ejemplares en papel fuerte azulado.

\section{Virgiliu (Publio) MA-} RON. Las obras de Publio Virgilio Maron, traduzido en prosa Castellana, por Diego Lopez, con commento, $y$ annotaciones. Valladolid, Francisco Fernandez de Cordoua, 1601. (Al fin: M.DC.) 4. 8 hojas prels. y 378 foliadas.
Primera edicion.-Lleva este ejemplar la frma del traductor bajo de la Tassa.

Nic. Antonio menciona la de Madrid, Cuesta, 1614. $40^{\circ} \mathrm{y}$ he visto citada una tercera de Valladolid, Francisco Fernandez de Cordoba, $1620.4 .^{\circ}$

1068 VIRGILIO (Publio) MARON. Las obras de Publio Virgilio Maron, (ut supra.) Alcala, María Fernandez, 1650. 4. 4 hojas prels. y 548 págs.

1069 La misma obra. Madrid, Imprenta Real, 1668. $4^{\circ}$ hojas prels., $\ddot{3} 18$ págs. y dos hojas de Tabla.

Estns dos últimas ediciones fucron desconocidas a Nic. Antonio.

La impresion mis reciente de la traduccion de Lopez, creo debe ser una que se cita de Valenciu, $16984^{\circ}$

Pellicer, en su Biblinteca de traductores, no habla de esta version de virgilio, ni dé Diego Lopez, quien tantos autores latinos clásicos tradujo y comentó.

1070 Obras de Publio Virgilio Maron. Concordado. En latin artificial, en latin natural, en lengua Castellana, de prossa y verso, y en notas latinas. Por el Lic. Abdias Ioseph. Tomo primero de las Eclogas. Madrid, Domingo Garcia Morràs, 1660.-Obras de Pvblio Virgilio Maron (Como el anterior.) Por D. Antonio de Ayala. Tomo segundo de las Greorgicas. Madrid, Domingo Garcia Morràs, 1660.2 vols. $8 .^{\circ}$ El $10^{\circ} 4$ hrjas prels. y 238 págs.; el $2 .^{\circ}$ hojus prels. y 408 págs.

No cabe duda en ser Abdias Joseph el misino D. Antonio de Ayala que concordó el tom. il., por cuanto este dice en la dedicatoria dirigida á D. Alonso López de Rio: "Tal "parnce que le hemos padecido (el sentimien(o) estos dias con la muerte del Señor „D. Francisco hermano de v. m. d quien yo shabia dedicado todo mi trabajo;" $\mathrm{g}$ efectivamente el tomo primero lo encuentro dirigido a dicho D. Francisco por el supuesto Ảbdias Joseph. Pero tampoco es D. Antonio de Ayala el verdadero concordador ó editor de este Virgilio, sino el P. Antonio Lúcas de Moya, scgun lo aflrma Álvárez y Bacna y se confirma por otro volumen intitulado: obras de P. Virgilio Maron, Elogias (sic) Georgicas $y$ Eneida. Concordado explicado é ilustrado por el P. M. Fr. Antonio de Moya. -Tomo tercero de la Eneida. Madrid, Pablo de Val, 1664. 
8. . Eń cuyo prólogo dice Moya: aFstos tres wlomos que tengo publicalos sobre Virgilio y wel último que falta para reınate de esta obra, spiden alldar en un tomo grande con un in. wdice de todas sus palabras... y otros dos wtomos que tengo de notas escogidas sobre weste autor.w-i)tra controversia se ha suscitado entre los literatos, y es la de saber, si la prosa y metro castellanos son de este reverendo Padre, ó del Mtro. Fr. Luis de Leon: la mayor parte están contestes en atribuir Ins versos al vate granadino, y Mayans, en la Vida de Virgilio, pretende que tambien lo es la prosa; Alvarez y Baena, concediendo lo prlimero, se resiste á creer lo segundo. No es de mi incumbencia el deslindar esta cuestion, baste indiearla dejando el ocuparse de ella á los que tengan más tiempo $\mathrm{y}$ capazidad que yo para dilucidarta.

\section{Virgilio (Publio) MA-} RON. Bucolicas de Publio Virgilio Maron, con la Egloga à la Muerte del Poata Jayme Vanier, y Esplicacion de su primer Libro. Traducido toda en lengua Castellana Por Pedro Bes, y Labèt. Gerona Miguel Brù, (1771). $8 .{ }^{\circ} 18$ hojas prels. y 288 paigs.

Las licencias son de $|7 \pi|$, año probable de la edicion.

Traduccion en prosa cie las Eglogas de Virgilio: Juan del Enzina las trasladó en verso y se hallan en su Cancionero.

$10 i z$ Los doze libros de la Eneida de Vergilio Principe de los poetas latinos. Tradvida en octava rima y verso castellano. En Anvers En Casa de Iuan Bellero. s. a. CAl fin: En Anvers. En casa de Gerardo Smits, a la costa de Iuan Bellero.) 12. ${ }^{\circ}$ let. redonda. 399 págs., la última sin numerar, inclusos los prels.

Sin duda es la primera edicion de la Eneida, traducida por Hernández de Velisco; pues diciéndose en la licencia de la de Toledo de 1574, que hacia casi veinte años que la habia traducido y por no haber tenido l'rivilegio la liabia impreso muclias vezes en diversas partes entiendo quiere decir fuera de España); debemos suponer es la edicion principe la de Juan Bellero sin fecha, pues la tengo por anterior á la que he visto de la misma ciudad de Anvers y del antedicho Iuan Bellero, hecha en Y.D.LIII. $12 .^{\circ}$ let. curs. 8 hojas prels. y 6.48 pags.

La tercera impresion conocida por mi es la siguiente:

1073 - Los doze libros dela Eneida de Virgilio... Tradvida en Том. 1. octava rima y verso castellano.-En Anvers, luan Bellero, M.D.LXVI. (Al fin: Typis. A. T.) $12 .{ }^{\circ}$ let. curs. 8 hojas prels. y 648 pags., la última va numerada equivocadamente 641.

IIe visto citada una edicion hecha tambien en Anvers, por el mismo Bullero en 1572. $12 .^{\circ}$; pero me son desconocidas las otras tres que debieron salir á luz ántes de publicarse la siguiente.

1074 VIRGilio (Perlio) MARoN. La Eneida de Virgilio... traduzida en octaua rima y verso Castellano: ahora en esta vltima impression reformada y limada con mucho estudio y cuydado, de tal manera que se puede dezir nueua traduccion. Ha se añadido en esta octaua impression lo siguiente. Las dos Eglogas de Virgilio, Primera y Quarta. El libro tredecimo de llapheo Veggio... Vna tabla que contiene la declaracion de los nombres proprios, y vocablos, y lugares difficultosos. Toledo, Iuan de Avala. 1374. 4. ${ }^{\circ} 8$ hojas prels., 127 fols. y 13 de la Declaracion ó tabla.

Es probablemerite la primera edicion en la cual refundio Herı́ndez de Velasco su traduccion y añadio las demas cosas indicadas en la portada.

Ignoro si una impresion de Anvers. 1575. 12. ${ }^{\circ}$, mencionada en el Francofurt. imumpinae, contendrá Io misno.

1075 - La Eneida de Tirgilio..., traduzida en uctaua rima y verso Castellano: ahora en esta rltima impression reformada ! limada... Ha se añadido a la primera impression, lo siguiente: Las dos Eglogas de Virgilio. Primera, y Quarta. El libro tredecimo de Maptieo Veggio... La moralidad de Virgilio sobre la letra de Prtagoras. Ina tabla... La rida de V'irgilio. Toledo. Diego de Avala, $137712.0^{\circ} 10$ hojas prels., 3 피 foliadas y 39 de Tabli.

Es copia de la anterior edicion de 15:4, con unil mueva adicion de L/6 morulidal dé Virgilio y la vida de este: por lo mismo puede llamarse la mas completa.

En unas apuntaciones de mi padre encuentro anotadas una impresion de Alcala, Juan lniguez de Letfuerica, 15si-6, yotra de Taragoza, Lurenzu y Diego de Robles, Her- 
manos, $1586.8^{\circ}$ Esta última contiene positivamente lo mismo que la de 1577. Sedano supone se imprimió tambien en Madrid; pero no dice el año. Mayans reimprimió la traduccion de Velasco en las obras de Virgilio, lalencin, Hermanos de Orga, M.DCC.XC'V. 5 vols. $8^{\circ} \mathrm{may}$.

Varios son los autores que han ensalzado el merito de esta version del poeta latino; me contentaré con copiar lo que dice sobre ella Lope de Vega en el Laurel de Apolo.

Acudiendo el primero, el Titiro español, nuevo sincero, cuya divina Musa loledana

dió poder \& la lengua castellana,

Gregorio Hermámdez, d quien hoi le deaunque otros muchos prueben, [bcn, ¿ querer igualar su ingenio raro, Virgilio y Sannazaro

hablar con elegancia, y no con vana pompa inúlil la lengua castellana, como diciendo en fácil melodía:

Ai dulces prendas cuando Dios queria!

1076 VIRGILIO (Poblio) MARON. La Eneida de Virgilio. De Christoval de Mesa. Madrid, Viuda de Alonso Martin, 1615े. $8 .^{\circ} 8$ hojas prels. y 356 fols.

Barrera califlca la presente version de mui rara: dudo haya otro ejemplar como el mio el eual es magniflco $\mathrm{y}$ liene algunas hojas sin abrir.

Mesa vertió en castellano las Églogas y Geórgicas y las publicó junto con sus Rimas y la Tragedia El Pompeyo. Véase el artículo de Mesa en la Seccion dramatica del presente Catálogo.

\section{7 - Tradvecion poetica} castellana de los doze Libros de la Eneida de Virgilio Maron: sv avtor Don Jvan Francisco de Encisso Monçon. Cadiz, Christoval de Requena, 1698. 4. 8 hojas prels. y $20 ّ 3$ pảgs.

Está en octavas.

Existe una version de Los diss primeros libros de la Eneida, traducidos en oclavas caslellanas por D. Francisco de Varyas Machuca. Alcala, Imprenta de la Universidad, 1792. $4^{\circ}$

1078 ViRUES (Cristóval de). EI Monserrate segundo, del Capitan Cristoval de Virves. Milan, Gratiadio Ferioli, 1602: 8. '马ّ hojas prels., 220 fols., y 6 que contienen la Tabla, ocho sonetos y las Enmiendas.
Et autor hizo tales variaciones y adiciones ell esta rari impresion que por eso intitulo la obra El Monsevrate segundo, así lo aseguran el editor de la publicada en Madrid, en 180.5, y Barrera y Leirado en su Catalogo del teal'o español, á pesar de que Quintana, en las Poestins selectios caslellanas, diee no se difer"ncia en nada de la primera. He visto ejenplar de esta, sin haberlo podido comparar con ninguno de la segunda, y la siguiente es su descripcion: El Monserrale de Cristoval de Virues. Mttdrid, Querino Gerardo, $1588.8 .^{\circ} 8$ hojas prels., 192 fols., y 4 de Tabla sin numeracion. Al fin se repite el luar y nombre del impresor; pero la fecha es de 1587. Llevando en el colofon este año mo liene mada de estraño diga Jimeno haberse lieclio en él la plimera impresion, pues pudo mui bien fijarse er la fecha final, sin reparar era distinta de la que lleva la porLada.

El editor de la edieion de 1805 y Barrera mencionan, refiriéndose tal vez á Jimeno, una impresion de Madrid, $1601.80^{\circ}$, y caso de existir, la hecha por Sancha debio llamarse quinla y no cuarla.

1079 VIRUES (Gristóval DE). El Monserrate del Capitan Cristoual de Virues. Tercera impression añadida y notablemẽte mejorada. Madrid, Alonso Martin, 1609. 8. 8 hojas prels., 191 fols. y cinco más para completar la Tabla y para cinco de los ocho sonetos que pone la de Milan.

La presente edicion sirvió de testo para la siguiente por ser la más correeta y completa. Brunet no la cita y Heber no la tuvo.

El designar en la portada que es tercera impresion me hace dudar si existirá la ántes citada por Jimeno, de Madrid, 1601.

$1080-$ La misma obra. Quarta impresion añadida, y notablemente mejorada. Madrid, Sancha, MDCCCV. 8. ${ }^{\circ}$ marq.

D. Agustin Bonacasa revisó $\mathrm{y}$ dió á luz esta edicion, que ha servido de testo para la reimpresion de este poema en el tom. XVII. de la Biblioleca de Ribadeneira; en ella se añadieron dos composiciones de Virues que se encuentran en las Jornadas para el cielo de Moreno, y otra tomada de sus obras tragicas y liricas.

Tieknor ensalza estraordinariamente el merito literario de este poema, y termina diciendo que "EI Monserrate es aun leldo "y admirado en una époea como la presente, "poco dispuesta á dar fé á leyendas de esta "especie."Tambien Cervántes le consagró este elogio: 
Cristóval de Virmes, pues se udelanta

Tu ciencia y lu valor tan a lus años, Tu mesmo aquel ingenio y virlud canla Con que huyes del mundo los engaños: Tierna, dichosa, y bien nacida planta, Yo hare que en propios reinos y en estraños El fruto de lu ingenis levanlado Se conozca, se udmire y sea estimado.
ViRUeS (Cristótal de). Obras trágicas y liricas. Véase en la Seccion dramática.

1081 VOLTAIRE. La Enriada en verso castellano, por D. José Joaquin de Virues y rispinola. Madrid, Miguel de Burgos, $18218 .^{\circ}$ marq.

\section{Y}

1082 YAGÜE DE SALAS (JUAN). Los Amantes de Tervel, Epopeya tragica: Con la Restauracion de España por la parte de Sohrarbe, y conquista del Reyno de Valencia. Por lvan Yagve de Salas. Valencia, Pedro Patricio Mey, 1616. 8. 30 hojas prels. Cen la última hai un retrato del autor grabado en madera), 722 págs. (la postrera dice 700 por errata), 20 hojas de Tabla o Dictionario poetico, y dos hojas con un resumen en octavas del poema, y unas quintillas de Fray Leandro Vadillo.

Libro raro.-Recomiendo el exámen minucioso del número de hojas ántes indicado pues hai pocos ejemplares que contengan las dos últimas, las cuales se aîadieron despues de concluida la tiracion de la obra, y son interesantes pues por ellas solamente se sabe que disuelta la Acalemia de los nocturnos, volvió á renacer con el título de Montañeses del Parnaso, presidida por D. Guillen de Castro, siendo Yagüe de Salas uno de sus miembros.

Este poema consta de veinte $\mathrm{y}$ seis cantos y está escrito en verso suelto, aunque al finalizar de cada parte suele hallarse un pareado.-La historia de los desgraciados amantes termina en realidad en el canto diez y siete: los nueve restantes tratan principalmente de dos santos religiosos patronos de Teruel, llamados Fr. Juan y Fr. P'edro, y de la conquista de Valencia y sucesos pertenecientes a dicha ciudad de Teruel, patria del autor.

Entre las varias composiciones laudatorias que van al principio del tomo se encuentran de Lope de Vega, Ricardo de Turia, Jerónimo de Sálas Barbadillo, D. Pablo de Castelvi y los dos siguientes Sonclos, el primero de Miguel de Cervántes Saavedra, y el segundo de Guillen de Castro.

De Turia el Cisne mds famoso hoi canla Y no nara acabar la dulce vida,
Que en sus divinas obras escondida A los liempos y edades se adelanla.

Queda por él canonizada y santa Teruel, vivos Marzilla y su homicida, Su pluma por. heroica conocida, En quien se admira el cielo, el suelo cspanla.

Su dolrina, su voz, su estilo raro, Que por tuyos, oh Apolo, reconoces, Segun el vuelo de sus bellas alas,

Grabadas por la Fama un marmol paro $Y$ en ldminas de bronce, hardn que gozes Siglos de elernidad, Yagie de Silas.

El que tragedia infausta aunque amorosa Te viere, siendo causa de que lubien'a Quien para eternizarte te escribiera, Volivendo el oro d nuestra edad famosa;

Si el almu más altiva que piudosa Tan heróicus resultas considera, La encogida piedad hara severa Y la desdicha llamará dichosa.

Y aun si los infelizes dos amantes Al lierno pretender de aquella dicha, Vieran lo venidero de esta historia,

Hénos enamorados que arrogantes

Pienso que no escusardn su desdicha, Por ver lan celebrada su memoria.

Los traductores de Ticknor, en el tom. III. pág. 496 , dan noticia de otro poemita mui raro sobre el mismn asunto, que se intitula: Hisloria laslimosa y senlida de los dos tiernos amanles. Marcilla y Segura, naturales de Teruel, ahora muevamente copilada y dada d luz por Pedro de Alventosa, vecino de dicha ciudad. S. l. ni $a$. hácia 1555). 4.0 let. gótica 16 hojas. I los mismos añaden que la berisima historia de los Amanles de Teruel se introdujo por Bartolomé de Villalba y Estaña en la obrita de Los veinte libros del pere- 
El siguiente retrato de Yagüe es el colocado en los preliminares de su obra.

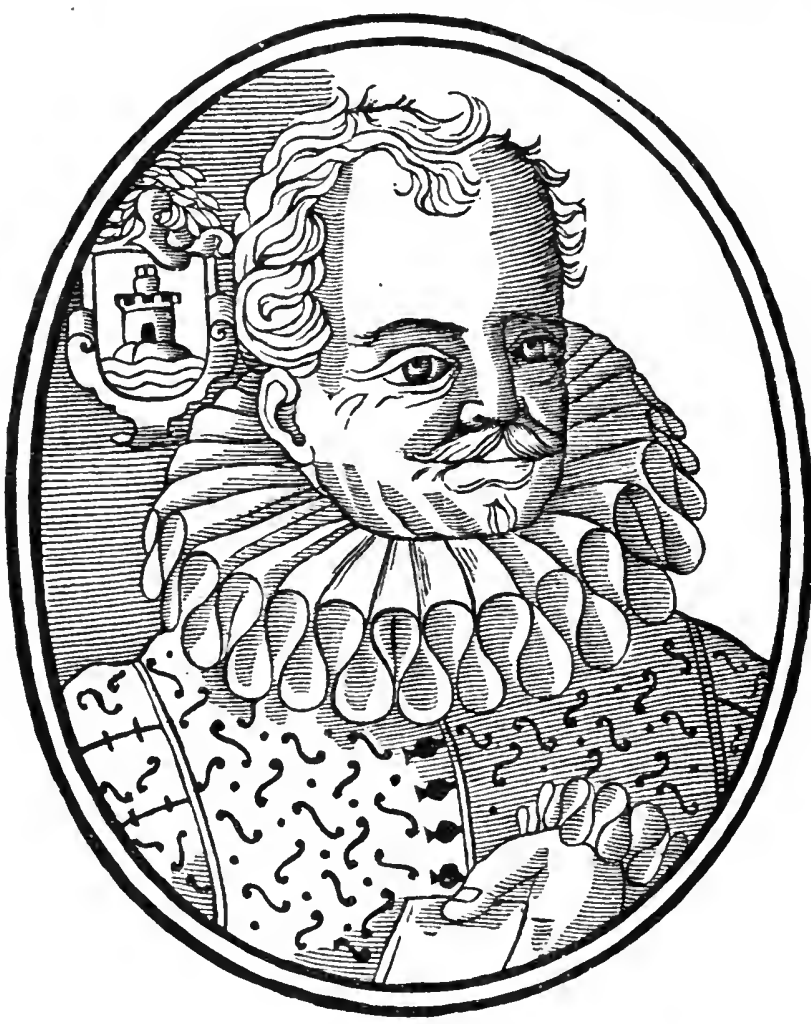

1083 ZAMORA (D. Antonio de). Breve descripcion reverente de los hyeroglificos, epitaphios, y demas obras fvnebres, que sirvieron en las exequias que a la memoria de Lvïs XVI. Delfin de Francia, y sv digna Esposa Maria Adelheida Ënanvel, Consagrò la villa de Madrid el dia 20. de Agoșto de 1712. A quien exorna, la Oracion funebre, que dixo el M. R. P. Agvistin de Castrejon. Y oy saca a lvz D. Antonio de Zamora. S. l. ni a. $40^{\circ} 42$ págs., inclusa la hoja de la portada. - Sermon fvnebre del Principe Monseñor Lvis Delfin, y de la Princesa Maria Adelayde de Sabo- ya. Predicòle a Madrid el Rmo. P. M. Agustin de Castejon. Madrid, Diego Martinez Abad, S. a. $\mathbf{4} .^{\circ} \mathbf{4 0}$ págs. y una hoja para la portada.

Las endechas dirigidas á la villa de Madrid $\mathrm{y}$ algunas poesias que contiene la primera parte, me parecen todas de Zamora.

1084 ZAMORA (LoREncio DE). Primera parte de la Historia de Sagrnto Numancia y Carthago. Compvesta por Lorencio de Zamora. Alcala, Iuan Iñiguez de Lequerica, 1589. 4. ${ }^{\circ} 4$ hojas prels., 244 fols. y 3 de Tabla.

Primera edicion, mui rara.-Nic. Antonio $\mathrm{y}$ 
Brúnet, sin duda copiándole, cltan equivocadamente una de Alcala, 1587, que no existe y no menclonan la del 89. - En la Bibliotheca nova, tom. II., pág. 11 y 12 , se encuentra la notlcia de varias obras ascéticas que escribió Zamora.

1085 ZAMORA (LORencio DB). Primera parte de la Historia de Sagvnto Nvmancia y Cartago. (ut supra.) Madrid, Por Iuan de la Cuesta, 1607. 8. 8 hojas prels., 214 fols., 7 de Tabla y una con el escudo grande de Cuesta.

Poema en octavas $\mathrm{y}$ en diez $\mathrm{y}$ nueve cantos, cuyo título en las cabezeras de las páginas pares es La Numantina.

El autor dice en el Prólogo, que cuando escribió esta obra apénas tenia diez y ocho años, habiéndola compuesto en ménos de unn, y debiendo dedicar á otros estudios seis horas diarias; advierte haberse ceñido á la verdad histórica, aunque de vez en curando recurria á alguna ficcion para amenizar la lectura; efectivamente tanto abuso de este recurso que su poema nias bien pertenece al género caballeresco que al histórico; previene por fin no publicaria segunda parte, sin embargo de prometerla en la última oc. tava del canto XIX.

La segunda edicion no es tan buena, tipográflcamente liablando, como la primera; pero es casi de igual rareza.

1086 ZAPATA (Juan). Tratado de nuestra fe Christiana y ley verdadera. En el qual vã glosadas todas las oraciones que se encierran devaxo del comun nombre de doctrina Christiana en diuersas maneras de versos valcabo de cada oraciō su alabança ansi mesmo la venida del juez con la materia del juzio final en mur graciosas octauas y las penas del İnfierno y el gozo déla gloris con la eternidad della $y$ al cabo del tratado vna glosa alo diuino sobre aquel romance que dizen al humano en las salas de paris en el palacio sagrado $r$ al fin d'l libro vn verso muy notable có su glosa sobre el amor grande que dios tuuo al hombre todo nuelamente compuesto por el illustre poeta Iuan çapata natural de Guadalıortuna enel reyno de Granada. Lerida, Lorençio de Kobles año de $1376.8 .^{\circ}$ 112 fols. rel viltimo numerado equirocadamente 1012) inclust :la hoja del fróntis.
Contlene muchos sonetos, romances, villancicos, octavas y glosas.

No recuerdo haber visto otro ejemplar de este raro volúmen.

1087 ZAPATA (Leis). Carlo famoso De don Luys Çapata. Valencia, en casa de Ioan Mey, M.D. LXYI. 4. may. esp. let. cursiva. 4 hojas prels. y 289 foliadas.

Hermoso ejemplar de un libro mui raro.

Ticknnr, tom. IlI., pág. 1.j6, se equivoca en decir que el año de la impresion es el de 1565 .

“Por acudir á este ruido y estruendo, no se "pasó adelante con el escrutinio de los de. "mas libros que quedaban, $y$ asi se cree que wfueron al fuego sin ser vistos ni oidos, La "Carul'a y Leon de España, con los hechos wdel E.llperador, compuestos por Don Luis nde Avila, que sin duda debian de estar en"tre los que quedaban, y quizá si el Cura los "viera, no pasaran por tan rigurosa senten"cian Quijote Parte I., cap. Vil.

Cervántes poco exacto en copiar titulos de libros y que generalmente los citaba de memoria, forjó, por su asunto, el de Hechos del Emperador, y' equivocó el apellido de su autor, pues indudablemente se refiere al Carln famoso y confunde á D. Luis Zapala con D. Luis de Avila, escritor de unos Comenlarios de la guerra hecha por Cárlos 1 á los protestantes de Alemania; pero esta es una nbra seria $y$ en prosa, que desdice de todas las demas inencionadas en el escrutinio de la bibl:oteca dol hidalgo manchego, y se conoce que el autor del Quijote se referia á los tres poemas escritos sobre las hazañas del Conquistador de Alemania; el Leon de Espainn dir Vecilla Castellanos (Véase en esta division Yín. 1052, el Carlo famosn de Zapata $y$ cl simulente di sompere que he visto:

Primera jarle do la Carolea, Irata de las

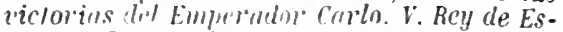

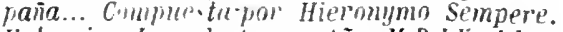
Valencia, Imm de Aleos. Añn. M.D.L.Y. \& hojas prels. cxlix fols. y una hoja al fin que contiene un soneto de Marco Antonio Aldana y un colofin dinde se repite la fecha.-Segunda parle de: Lu Crrolin, trota las victorius Del Emperador Carlo, V. Re!l de' España... Cumpmestu por Hirnmyno Semperc.Al fin: Fne impiressu lil presente obra en ba. levia, en case de luan w' trens, Año. 1560. 8. Yo ticne foliacion : signs. A-r.

En la primel'iparto lia sonetos laudatorios de Jerónimo oliver. D. Alonso de Rebolledo, Irontemavor $: r_{3 i l}$ Polo.

La composicion de Zapata es un poema en nclavas dividido ell cincuenta cautos: los hechos listurices se encuentran mezciados con una infinidad de aventuras fabulosis, habiendo tenido cuidado el autor de señalar con un $*$ los acontecimientos que perlene. cen ál esta viltima clise. En el canto cuarenta $\mathrm{y}$ uno da cuenta de la desgraciada muerte de Garcilaso de la Vega. 
La edicion; como todas las de Juan Mei, es buena y el escudo de este impresor, puesto al fin del volúmen, es el copiado í continuacion, que usó tambien como distintivo en

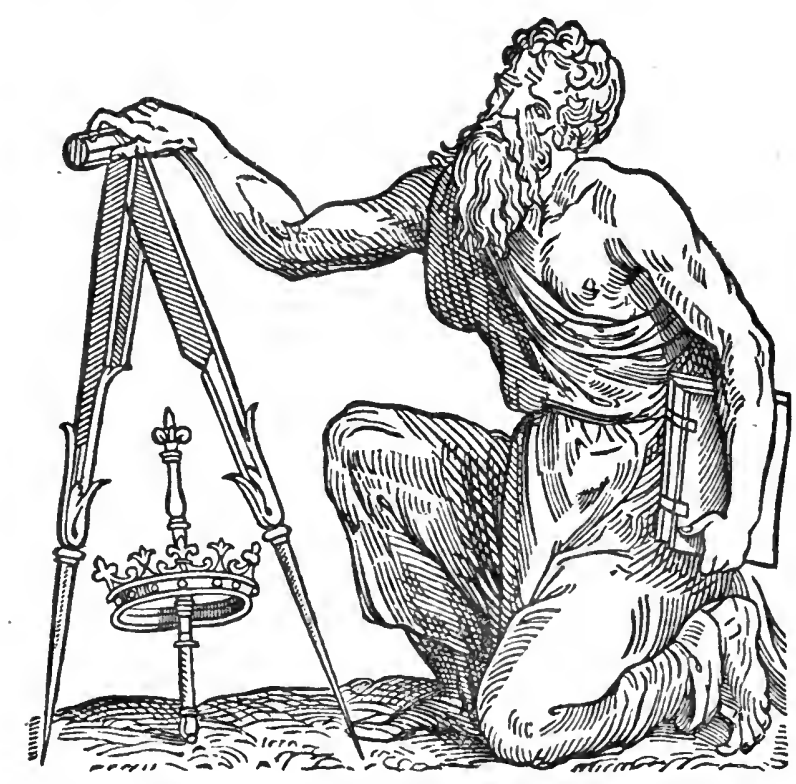

1088 ZERNADAS Y CASTRO (Diego Avtovio). Obras en prosa y. verso del Cura de Fruime Ion Diern Antonio Zernadas y Castro. Tomo 1. Segunda edicion. Madrid, Joachin Ibarra, MDCCLXxxII. - Tomo II. Segunda edicion. Madrid, Benito Cano, MbCcLxxix.-Tomo III y IV.
Madrid, Joachin Ibarra, MDCCLXxIx. - Tomo Y y VI. Madrid, Ibarra MDCCLxxx. - Tomo VII. Madrid, Ibarra, MDCCLXXXI. 7 vols. $4 .^{\circ}$

Ignoro el año de la primera impresion de los tomos I y II.

La mayor parte de las obras del Cura de Fruime son en verso. En el ültimo volúmen liai una Loa y un Coloquio entremesado. 


\section{SECCION DRAMÁTICA.}

\section{PRIMERA DIVISION.}

\section{CONTIENE LAS COMEDIAS, TRAGEDIAS, FARSAS, AUTOS, COLOQUIOS, DIÁlOGOS, ENTREMESES, SAINETES, LOAS, BAILES, PASOS, MOJIGANGAS, ZARZUELAS, \\ SARAOS, FINES DE FIESTA, ÓPERAS, ORATORIOS SACROS \\ y toda composicion representable, aunque lleve otra denominacion ó titulo, bien se haya publicado suelta ó en coleccion.}

SB HAN INGLUIDO TAMBIRK LAS OBRAS EN LAS CUALES SE COMPRENDE ALGUNA PIEZA DE TEATRO, LOS ESCRITOS EN PRO Ó EN CONTRA DE LAS REPRESENTACIONES TEATBALES, LAS HISTORIAS LITERARIAS DEL DRAYA, 7 LAS RELATIYAS AL HISTRIONISMO BN ESPAÑ̈.

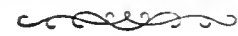

Lista de algunas abreviaturas usadas en esta division:
A. ... Auto.
A. S... A A to sacramental.
B. . . . Baile.
E. C. . Entremes cantado.
$F$. de $f$. . Fin de flesla.
J. ... Jácara.
B. E. . Baile entremesadı.
L. . . Loa.
C.... Connedia.
L. E. . Loa entremesada.
E. . . . Entremes.
L. S. . Loa satramental.
M.. . Mojiganga.
P.... Paso.
S.... Sainelc.
$S . C . y R$. Sainete cantado y re-
Z. ... Zarzuela. presentado.

\section{A}

\section{ACA}

1089 ACADEMICI (GL') INTRONATI. L'Hortensio, comedia de gl' Academici Intronati. Rappresentata in Siena alla presenza del Sereniss. Gran Drca di Toscana. Siena, Luca Bonetti. 1576.12. 236 páginas, incluso el frontis, il ademas una hoja con un escudo que puede ser el del impresor, y otra en blanco.

Esta comedia se representỏ en presencia del fran Duque de Toscana el dia 26 de Enero de 1560 .

\section{$\mathrm{AGU}$}

El autor de ella es Alejandro Picrolomini y contiene varias escenas en las cuales Lablan en castellano los interlncutnres He creido que esta cireunstancia la daba derecho á flgurar en la libliografía é historia de unestro teatro; sin elubargo, ó el Sr. Barrera juzara de distinto modo, ó no loori ver las varias composiciones derste generu salidas á luz en Italia en el siglo Xif, pues no les da cabida en su Contálngo.

Hai otra edicion del Horlensin, impresa tambien en Sicna en 15i1. 8.

1090 AGUILAR (Gaspar). Fiestas que la insigne civdad de Valencia ha 
hecho por la beatificacion del Santo Fray Luis Bertran. Iunto con la Ciomedia que se representó de su uida y muerte, y el Certamen Poetico que se tuuo en el Conuento de Predicadores, con las obras de los Poetas, y Senteucia. Por Gaspar A guilar. Valencia, Pedro Patricio Her, 1608. 8. 8 hojas prels. y 392 págs. En los preliminares se halia el retrato de $S$. Luis grabado en mudera, copia del que pintó Ribalta y existe en el Colegio del Patriarca de Valencia.

La descripcion de estas Fiestas por Aruilar es un poema cuyo primer canto trata de la Proceion y lominarias: el segundo In liena la Comedia de la vida y muerte alel santo froi Luis Berlran, precedida de una Loa; el tercero describe los toros, cañas y fuegos artificiales; y el cuarto el certámen poético, en el que despues de aloumas romposiciones latinas hai muchas en castellamo escritas por los siguientes autores:

Esperanza Abarca. Bírbara Abarca. Adrian Abella.

Miguel Antolino. Lorenzo Asoris.

Círlos Boil.

Luis Caballer.

Gabriel Capella.

Jacinto Castro.

Maximiliano Cerdan.

Luis Cortes.

Felipe Corv1.

Juan Dorda.

Gaspar Escrivá de Ro. manl.

Luis Ferrer de Cardona.

Pedro Gregorio Font. Arcis Frexi.

Alfonso Jimeno.

Jerónimo de Leon.

Lozano

Vicente Mariner.

Jerónimo Martinez de la rega.

Nic. Antonio no conoció esta obra de Gas. par de Aguilar, distinguido poeta valenciano á quien elogia Cervintes en el Prólngn de sus Comedias y de quien dijo Lope de Vega en la Filomena:

Retrata en blanco marmol de Liguria A Gerpar. de Iguiler, dquien ha hecho Avaro el siglo, con no premiarle injuria.

1091 Al VAREZ (Afronso). Avto de Sancto Antonio (Sique una laminita de S. Antonio de Padua y bajo:) Avto do bemaventrado Senhor Sanc- to Antonio. Feito por Affonso Aluarez a pedimento dos muy honrados, $\&$ virtuosos Conegos de S. Vicente. Muy contemplaticuo \& em partes muy rracioso tirado de sua mesma vida. Em Lisboa. Por Antonio Aluarez. Anno de 1642. 4. 8 hojas sign. $\sin$ fol.

Barbosa Machado en su Bibliothera no menciona esta mui rara edicion, ni otra que probablemente debe existir de Lisboa de 1619 , segun parecen indicarlo las fechas de las licencias de la de 1642; pero cita las siguientes: Lisbna, 1613; Evora, 1615, y Lisboa, 1639 y 1659 .

1092 Allare7 (Afrosso). Avto de S. Babora. (Sigue una limina de Sta. Bárbara y bajo:) Obra da vida da bemanenturada S. Barbora Virgem, \& Martyr filha de Dioscoro Gentio. Em oqual entrāo as figuras que no comeco da obra se seguem. Lim Lisboa. Por Aatonio Aluarez. Anno 1634. 4. 12 hojas sign. $\mathrm{sin}$ fol.

Barbosa Nachado atribuye este rarísimo auto anónimo á Alfonso Álvarez, poeta que lloreció á principios del siorlo XVI, y cita las siguientes ediciones de él: Lisbor, 1613 y Fnora, 1615; la de 1634 no la conoció, ni otra que pribablemente cxistirá de Lisboa, 1621 , como lo indica la fecha de las licencias de la que $y^{\circ}$ poseo. - Los pastores en esta composicion hablan en castellano.

Barrera y Leirado no solo no menciona ninguno de estos dos autos; pero ni aun trae en su Catálogo el nombre de Alfonso Alvarez.

\section{APARICIO (Bartolomé). 0 [Obza del percadoz}

Sigue circuida de orla una laminita que representa un Vacimiento $y$ bajo:)

\section{(1)bia del fantiffimo} nacimiēto de nueftro Seños Jefu Chrifto, llamada de! jecradoz. Compuefta pos Bartholome Aparicio.

Ocupan el reverso ocho figuritas, que representan á otros tantos inter- 
locutores, y los nombres de los que salen en esta comedia que srm quince; en la hoja siguiente sign. Aij, principia el Jntroyto que concluye en el reverso donde Comiēça la obra que termina en el blanco de la undécima hoja: van á continuacion dos canciones á $\mathbf{N}$. Sra.j

S. I. ni a. (hícia 1530 ). $40^{\circ}$ let. gótica 12 hojas sing. A.

Ningun bibliografo ha conocido esta rarisima edicion: Barrera solo menciona una de Sevilla, Fernando de La $a, 1611.4 .^{\circ} 10$ hojas, y aunque Gallardo en el Ensayn de una bib. esp. cita otra sin lugar mi $a .4^{\circ}$, no debe ser la misma porque ademas de no corresponder el título exactamente al de la mia, no está impresa en letra gót. y solo consta de 10 hojas.

Si el Sr. D. Manuel Cañete hubiera tenidn presente la que yo posen al escribir su Discurso sobre el dirana roliginso español sin vacilar habria colocado á Bartolome Aparicio entre los eseritores de principios del siglo XVI.

No necesito dar análisis de esta pieza dramática por cuanto se ha reimpreso en el Ensayo ántes citado, tom. ।., col. 222 y siguientes.

\section{APLALZOS ACADE.IICOS} e rellaçao do felice sucesso da celebre victoria do Ameixial. Pello Secretario da Academia dos Generosos (D. Antonio flearea de Acuña). Amsterdam, Jacob van Velsen, 1673. 13 hojas prels., inclusos el fróntis grabado y el retrato a caballo del conde de Villaflor, y 381 págs. - Aplauzos Acidemicos. Oraçaó Panegririca Na cellebridade do Certamen. Pello Academico Saudozo. - Certamen Academico Em onze Combates Na Palestra Dos generosos de Lishoa, A memoravel Victoria do Canal. 236 paigs. $4^{\circ}$ may.

La primera parte de este raro y bello volimen comprende la Relacion en prosa de la campaña de Portugal en la provincia del Alentejo, en la primavera de 1663 , escrita por 11. Anlunio Alrares da runha. segun se ve por los Elogios del P'. Frey Jelunimo Vahia, y muchis poesias latiuas al mis. mo asunto. L.a segunda parte contiene gran numero de pocsias nortuguesas y casiellanas, compuestas por varios autores, cuyos nombres no se espresan, y una zar. zuela en castellano de Higuel de Bárrios, intitulada: Palacio de la sabiduria, la cual va precedida de una lámina que forna las páginas 209 y 210 . Barrer 2 no la menciona.
1095 ARCALIA DE ENTREMESES, escritos por los Ingenios mas Clasicos de España. Primera parte. Pamplona, Juan Micòn, 1691. 8. ${ }^{\circ}$ 173 págs. (comprendidas las dos de la hoja de la portada, y una hoja al fin, en cuyo blanco termina la Tabla.

Comprende este tomo las siguientes piezos:

Los siete dias de la semana. L. S. -De D. Pedro Calderon.

El Zahori. B.-Anónimo.

Las naciones. E. -ld.

El nigromántico. E.-Id.

Lns buñuelos. E. - I $i l$.

El Arrufaifa. B. $-I d$.

La guitarra. E.-Id.

La universidad de amor. $B-I d$.

Juan Rana, comilon. E.-IL.

Los arambeles. E. $-I d$.

El gato y la montera. $E .-I /$.

Los amantes de Teruel. M. - Ill.

Las pintas. B. - Ill.

Candi! y garavat?. E.-Id.

Lo que puede la intercesion. $B,-I d$.

El boetor soleta. E.-Id.

Lanturulu. B. - I $d$.

Los gansos. E. - Id.

El difuntn. E.-ll.

Barrera y Leirado no conoció esta edicion.

1096 La misma obra. Pamplona, Juan Micòn, 1700. 8. 163 pajgs., contando las dos de la hoja de la portada.

Comprende las mismas composicinnes que la anterior ménos el baile intitulado Lns pin. tas, que no sé la razu de haberse suprimido.

A pesar de decirse en la portada de ambas impresiones, que este volumen es la primera parle, ignoro se haya numca publicado la segunda á no ser la signiente obra.

\section{ARCADIA DE E.TTREME-} SES. Escritos por los ingenios mas clasicos de España. Madrid. Angel Pasqual Rubio, 17æ33. 8. ${ }^{\circ}$ i hojas prels. cor la anleportada y 264 págs.

Quizas sea esta la segumla par/e de la obra anterior $y$ asi parece probario su diferente contenido escepto en dos entremeses que se encuentran en ambas.

Comprende las piezis siguientes:

El reloj. L. S.-Calderon.

El alcalde villano hablando al rei. E.Anóniinn.

I.os buñuelos. E. - Id

F.l mothiselo. E.-Id.

Los ciegos apaleados. E. $-I d$.

El pésame á la duquesa. $E .-I d$. 
Quijada y el alcalde. E.-Anonimo.

El novio de la aldeana. E.-Id.

Los osos. E. $-I d$.

Los linajudos. E.- Id.

Las sordas vocingleras. E. $-I d$.

El espejo y burla de Pablillo. E.-Id.

El cilsado de por fiuerza. E.-Id.

El presente del romano boloñes. $E-I d$.

La negra lectora. E.-It.

El alfanje y estudiantes burlones. E.- Id.

El astrologro embustero y burlado. E. $-I d$.

El botero Mastranzos. E. $-\mathrm{Il}$.

los ridiculos enamorados. E.-Ill.

El rejete enamniado. E. $-I l$.

El lijo del zapatero y estudiante salmanquitro. E.-Il.

El muerto vivo y el vivo muerto. E. $-I d$.

El nigromántico. E. $-I d$.

\section{ARMESTO Y CASTRO (GIL} DE). Verdores del Parnaso, en diferentes Entremeses, Vayles, y Moriganga escritos por Don Gil de Armesto y Castro. Painplona, Juan Micòn, $169 \% .8^{\circ} 8$ hojas sin paginacion que comprenden la portada y una Mojiganga, y 130 paigs.

Contiene diez y siete entremeses, cuatro sainetes, una mojiganga y ma loa cuyos títulos y autores son:

Los invencibles hechos de D. Quijote de la

Mancha. M.-Anómima. (Franciseo de Avila.)

Los títulos de las comedias. L.-Lope de Vega.

Los muertos vivos. E.-Moicto.

Los órganos y sacristanes. E.-Bcnavente.

El persiano fingido. E.-Ammesto y Castro.

El Sacristan Berengeno. E.-El mismo.

El sacristan Bonami. E.-El mismo.

El cantarico. S. C. y R. $-E l$ mismo.

El agujetero fingido. E.-Et mismo.

Las vendederas el la puerta del Rastro. $E$. -El mismo.

El pajarillo. S. C. y R. El mismo.

Los forzados de amor. E.-El mismo.

La competencia del porturues $\mathrm{y}$ frances. E.-El mismo.

La burla de los capontes. E.-El mismo.

Los baladrones. S. C. y R.-El mismo.

Oye usted. E.-El mismo.

El zagal agradecido. E.-El mismo.

Guarda corderos. E. S.-El mismo.

Pan y Siringa. E.-El Misino.

Los maricones galanteados. E. - El mismo.

La reliquia. E.-El nismo. (Es de Malo de Molina ó de Noreto.)

Entremes que cantaron Bernarda Manuela, la Grifona y Mamuela de Escamilla, en flesta de sus Majestades.-El mismo.

otro entremes que cantaron las mismas con igual motivo.-El nismo.

Barrera y Leirado cita unos Sainetes $y$ entremeses representados y cantados compuestos por bon 'Git Lopez de Arinesto y Castro. Hudrid, Rorue Rico de Miranda, 1674. 8. Contiene dicho tomo todas las composi- ciones que á nombre de Castro se encuentran en los Verdores $\mathrm{y}$ en lugar de las piezas de los ántes citados, Ávila, Lope, Benavente $\mathrm{y}$ Moreto ó Molina que van en la última impresion, hai en la primera una loa de Las tres potencias del alma, otra de Los cinco sentidos del hombre y los entremeses $E l$ desterr'tr los sagales, Lus tonadas grandes del Retiro y El negro valiente y enainorato, escrito todo por Castro. El citado Barrera men. ciona otros V'rdores del Parnaso en veinte y seis entremeses, baytes y saymetes. De diversos avtores. Madrid, Domingo Garcia Morras, 1668. 8..$^{\circ}$ pero como no ha logrado verlo é ignora su contenido, no sé si tendrá algo de comun con el mio, aunque sospecho sea obra distinta.

1099 ARTEAGA (Félıx DE). Obras posthrmas, divinas, $y$ hvmanas, de Don Felix de Arteaga. Madrid, Carlos Sanchez, $1611.80^{\circ} 8$ hojas prels. y 192 fols.

El editor del Parnaso español no conoció esti primera edicion de l.s 0bras de Arteaga, pues al principio del tom. V. solo dice se imprinierou en Lisboa, en 1615 y en Madrid el año de 1650.

$1100-$ Las mismas obras. Alcala, Maria Fernandez, 1650. 8. 8 hojas prels. y 192 fols.

Una tercera parte del volúmen on ambas impresiones la ocupa la comedia intitulada: La Griblonia o Ciclo de anor vengado.

D. Félix de Arteagra era el P. Fr. Hortensio Félix Paravicino y arteaga, que se disfrazó as tomando su segundo nombre y apellido.

1101 AUTO. Avto de la soberana virgen de Gradalvpe, y svs milagros, y grandezas de España. Son Interlocutores. Benhalamar, Moro. Abenamar, Moro. Aliatarfe, Moro. Cegrimo, Moro. Alarico, Godo. Sisibuto, Godo. Theodoreto, Godo. Rosimunda, Goda. IIonorio, Godo. Vn pastor de Caceres. Aurelia su Muger. Francisquito su hijo. Dos ciudadanos de Caceres. E'l cura de Caceres. Marcelo pastor. Nra. Señora de Guadalupe. Seuilla, Clemente llidalgo, M.DC V. $4 .{ }^{\circ} 8$ hojas, siendo blanca la última. Sign. A.

Ignoro si la edicion de esta pieza que poseia 1 . Justino Matute y Gaviria, hecha en Sevilla, por Barlolomé Gómez, año de 1615, llevaba el nombre de Mighel de Cervántes, como autor de ella; lo cierto es, que ni en la que volvió á hacer en la misma ciudad, 
dicho Barlolomé Gomez Paslrana, en 1617. $4 .^{\circ}$, en poder del señor de Barrera, ni en la mia, aparece semejante noubre. Observo si que en las impresiones le 1615 y 1617 se intituli Comedia, mintras en la de 1605 se la llauna Alío, á nii parecer con más propiedad.

El Sr. Barrera califica con razon de rarisimas las ediciones de los años 15 y 17 ; bajo este punto de vista la que se encuentra en mi biblioteca lleva rentaja, ya por ser una de las mis antirnas, si no es la primera, va por haber escapalo íl las investigaciones de los bibliugrafos; es tamlien más completa, pues á las ciladas por Matute y Barrera debe faltarles la Lna que lleva al principio, careciendo de ella la siruiente reimpresion, copia de aqueilas ediciones.

1102 ACTO. Comedia de la Soberana Virgen de Guadahne, y sus milagros y grandezas de España. Seuilla, Por Bartoloinc Gomez de Pastrana, 1617. (Al fin:) Fue reimpresa... en... Sevilla en la imprenta de Don José Maria Geofrin,... Acabose á veinte y ntieve dias del mes de Abril del año 1868. 8.

Esta linda edicion, Lirada á 500 ejemplares, la publico la Sociedad de bibliviflos andiluzes, y lleva un prüloril del erudito D. José Maria Isensio, en el que con sumo ingenio pretende probar ser esta produccion de cervintes.

1103 - Aretonvero. Del Transito y Assumpcion de la purissima, immaculada y gumilde girgen Maria madre de Dios Señora y anngada nuestra, Son interlocutores Vuestra Señora, El Arcancel sant Gabrie, Los doze APostoles. La roz de nuestro Señor Iesu Christo. Dos Angeles que con el vienen. (Sigue una laminita de la Vírgen con dos aingeles à los lados.) Impresso con licencia de los señores del consejo Año 1403 (1603). (En el reverso de la hoja 11. ${ }^{2}$ se lee:) Acabose de imprimir al presente Aucto del transito y Assumpcion de la Virgen santa maria. En el mes de Abril de 1903 (1603) 4 4. $^{\circ} 12$ hojas, la última solo contiene en su reverso una lam. de madera. Sin foliacion, sign. A.

sumamente raro y desconocido ì Barrera y l.cirado.

Et lenginaje do este Aulo perola gue esti escrito en la primera mitiud del siglo Xll, y el indicar en alguno de los cánticos cn el contenidos, que deberán ir acompañados por el organo, prueba ser de los que primitivamente se representaban en los templos; por 1o tanto me inclino á creer deberá haber alguna edieion anterior á la de mi biblioteca.Joration no solo no lo vio sino que no hace inencion alguna de este drama en sus origene's del tentro.- Yo lo analizo por reducir. se todo su argumento á lo indicado en el fruntis.

A proprisito del presente Auto de la Virgen daré la descripcion de otro que vi en el yuseo britúlico, el cual tiene tambien relaciun con Vuestra Señora.

Ln crucifljo y á un lado varios discipulos y al otro lis santas mujeres y bajo: Aulo agora meuamente hecho sobre la ouinla Angustia yue muestra. Señora passo al pie de la cruz muy deunto y conlemplutiun: en el qual se introdusen lns personus siguientes. Ku'stra seño / Sant Juan / ylas /res Murias. Joseph Abarimaita / Nicodemus / Iylal') / Page / Cenlurio. M.D.L.II. (Al dorso del frontis principia el auto, que rstá en décimas y concliye al reverso de la sesta hoja en donde se encuentran tres viñetas que representan la Vírgen al pie de la cruz con su lijo delante, la Circuncision 5 Cristo crucifleado. En la sétima hai una linina que renpa casi toilo cl blanco, creo que es la cena, y bajo se lee:) C Romance mny deunto en conlemplacion de la passion do nuestion Redemplar" IJ saluador Jesu Cloristo. Esta composicion principia á la vuelta yocinpa ademas la primer coluna de la octava hoja: la segumela roluna la llena L'uu cancion fure dise / si me admmiere madre, y el signiontefinal: C Fue immressa la presente obra en la muy notle 1) Was leal Ciudal de Burgos : en casa de Jum de Juan. 4. ${ }^{\circ}$ let. gut. al dos colunas, en todos hujas.

In habiendo rouncido Moritin esta composicion dramática hare de ella el siguiente estracto:

Jose Abarimatía va á casa de pilato 5 entra diciendole:

Nui magniflco Pretor,
o como antigro criado
tanto vucstro servidor.
ros pilo me liaras señor
merced del crueifieado.

Despues de 1 un diálingo bastante largo. en el que se informa l'ilato de un Centurinn. si habian dejalo de existir ya los crucifleados, le dice:

Justo desio temeis, hágase lo que mandais, yo os le doi, que le guitcis, y lleveis, y sepulteis donde vos mejor veais.

En seguida Jose y Xirmamus se concier. tan solire del molu de lle rillo il cabo.

La escena sizuiente pasa cu el cilliario entre s. Juan, la Vírgen, Jose, Nicudemus y 
la Magdalena. Desclavan á Cristo, y al bajarlo de la cruz Nicodemus se desmaya jor lo que diee José:

Señor esfuérzese ya

pres en esfuerzo le alabo, amigos, tomád alla, dídme esa tovaja a cá, tencd, señor, de ese cabo.

Despues de dar sepultura al cuerpo, San Juan invita á la rirgen a dejar aquel sitio.

Justo es, señora, que vamos a nuestro triste aposento y al lusar donde cenamos, ya que il salvador dejamos en su postrer movimiento.

Vuelven sin embargo al Calvario, donde eada uno de los circunstantes dirjge algunos versos á la eruz; pero José, que es en toda esta pieza sumamento atento con las damas, los sae.a de su éxtasis espiritual dieiendo:

Señores, mucho tardamos
en ir i nuestra posada,
llorando el tiempo pasamos,
y esta señora llevamos
mui llorosa y angustiada.
Que despues de haber perdido
ella y lis santis Varas
su amor, amparo y querido,
estain sin haher comido
easi eerea habri tres dias.

S. Juan, acompañante de Marí, les agradeee los servicios que les han prestado y el cortes José contesta:

Primo del rei escelente, consolid í esa señora, servilla mui humilmente, que en tener su bijo ausente sentiı́í más eada hora.

Itirí qué cargo os quedó, y quien es la encomendada, $\mathrm{y}$ quien os la encomendó, y acordais de mi, que so uno de vilestra manada.

Se hallaba encuadernado este Auto al fin de una traduccion castellana hecha por el bachiller Juan Jolina de la Yida de la Sanclisima Verge Maria que escribió Miguel Perez y se imprimió en la insigne ciulat de valencia per Nicolau Spindaler Alemamy $\iota x x v$ del mes $d$ joliol any Mil. cccc. Ixxxxiiij. (1494). 4. ${ }^{\circ}$ lel. yot. La version se intitula Verget de nuestra Señora y se imprimió en Sevilla, por Dominico de Robertis, a xuu dias del mes de Abril de Me DLXII. (1562). 4. ${ }^{\circ}$ letra güt.

1101 AUTO. Arto do dia do Irizo. Sigue una limina mui mala de madera que parece representar á Jesucristo apareciéndose a unos apóstoles.) Em (quál se contell as figuras seguintes conuem a saber, S. João,
Christo, nossa Senhora, S. Pedro, S. Miguel, hũ Serafim, Lucifer, Sathanas, Dauid, Absalam, Vrias, Caym, Abel, Sansam, Dalida, hũ Vilam, hũ Escriuão, hum Carniceiro, hūa Regaleira, hum Moleiro. Em Lisboa. Por Antonio Aluairez. Anno de $1625.40^{\circ} 12$ hojas sign.

Mui raro.

No eneuentro mencion de esta farsa portuguesa en la Bibliotheca de Barbosa Machado; tampocola cita Barrera y Leirado en su Calálogo.-Las licencias para la impresion que lleva al fin, fechadas en 1619 , hacen conjeturar existe alguna edicion de aquel año, li cual sospecho no sea aun la primera, pues el estilo y lenguaje parecen de mayor antigüedad. La composicion es del género de las de Gil Vicente, y no deja de tener facilidad y dulzura en la versifleacion; sirva de ejempio la siguiente Cantiga que el autor pone en boea de Abel:

Doloroso gado
de tanto primor,
dóate o fudo
do lriste paslor.

Lembraivos cordeiros da minha tristura, ovelhas, carneiros, que pastais verdura; Abel sem ventura de vos apartado, meu gado amado, de min eom amor: déale o fulo do triste pastor.

Doeiros de quem de vos se duía, fembrevos tambem minha companhia, ja quem ser sola sam outro tornado, flcais so deixado sem ter guardador: doeivos do fado do lriste pustor.

1103 AUTO. Avto do Esgudeiro svrlo. (Siguen tres figuritas.) Auto do Escudeiro Surdo. em q' entram as figuras seguintes, $s$, IIum villão Representador, hum Escudeiro Surdo, hum seu moço, hum Castelhano \& hüa Padeira, \& hum Pastor uamorado, \& hum Doudo. Feito por hum nouo Autor da Cidade de Beja. Lisboa, Antonio Aluarez, $1634.4 .^{\circ} 8$ hojas. La porlada va rodeada de orla.

Mui raro.

Las licencias para la impresion que lleva al fin, fechadas en 1619 , prueban que hai 
edicion de aquel año ó del siguiente. Yo creo que aun debe existlr alguna más antlgua, pues el lenguaje y estilo de la composicion pertenecen á la primera initad del siglo Xiv. - Barbosa Machado ni siquiera menciona este Auto, ó más bien farsa, en su Bibliotheca, y Barrera comete la misma omision.

El Castellano y Pastor enamorado, citados en el fróntls, hablan constantemente en castellano.

\section{AUTO. Avto dos escrivaens} do pelovrinho. Siguen cuatro figuritas en madera y bajo:) Arto dos escrivaens do Pelourinho relho, em que entraō as figuras seguintes, $s$. dous Patifes, dous Escriuaēs, \& hum negro \& hun Villāo, hūa Velha, hum Atafoneiro, hum Ratinho, \& hum Paruo. Em Lisboa por Antonio Aluarez. Anno 1620. 4. 8 hojas, signatura A, sinfol. La última hoja tiene en el reverso seis figuritas grabadas en madera.

Farsa portuguesa de gran rareza que no menciona Barbosa Machado en la Bibliotheca lusitana, $\mathrm{y}$ de la cual probablemente habrá ediciones más antiguas. Tampoco encuentro ninguna noticia de ella en el Catálogo de Barrera.

1107 Dom Andre. Siguen cuatro figuritas en madera y bajo de ellas una licencia para la impresion fechada en Lisboa à 10 de Julio de 1619 y despues:)

Avto de Dom Andre: no gral entram catorze figuras. Dõ Andre, sua molher, \& hũa Irmaā da Senhora chamada Dona Belicia, hüa Criada chamada Ilaria hũ Veador, hũ Paje, hū Ralinho seu Irmão, hũ Vilāo, \& sua Molher, hum filho do mesmo $\mathrm{Vi}$ lāo chamado Fernando, hum Fidalgo que anda de amores com Dona Belicia, por nome Dum Belchior, hum Escudeiro chamado Anrique Leitāo, outros dous Escudeiros, hum por nome Bras Taueyra, \& outro Antam Colaço.

(Empieza el Aulo á continuacion y concluye en el reverso de la décima hoja donde se lee:) Impresso com licença. Por Antonio Aluarez. 1620. 4. 10 hojas sign. A.

Mui rarn.

Por la licencia puesta al principio parece debe existir otra edicion hecha en 1619 , y yo sospecho no sea esta aun la más antigua.
En la Bibliotheca lusilana de Barbosa Machado no encuentro mencion alguna de este Auto, ó farsa portuguesa, ni tampoco en el Catdlogo de Barrera.

AUTO de S. Barbora. Véase Alvárez (Affonso). Número 109 z.

\section{AUTOS SACRAMENTALES.} Avtos sacramentales, y al Nacimiento de Christo, con srs Loas, y Entremeses. Recogidos de los maiores Ingenios de España. Madrid, Antonio Francisco de Zafra, $167 \% .40^{\circ} 4$ hojas prels. y 390 págs.

Raro.

Contiene:

El galan discreto $\mathrm{y}$ valiente. A.-D. Francisco de Rójas.

El gran palacio. A.-Yorén.

Las pruebas de Cristo. A.-yira de Amescua.

Los obreros del Señor. A.-Rójas.

El Vacimiento de Cristo. A.-Luis Vèlez de Guelara.

El Nacimiento de Cristo y pastores de Belen. A.-Godine:.

El Nacimiento de Cristo. A. - El mismo.

El Nacimiento de Vuestro Señor. A.-Yira de Amescua.

El heredero. A.-El mismo.

La Vírgen de Guadalupe. A.-Felipe Godinez.

Seis loas de Felipe Sinchez, Jeronimo Cáncer, Guillen de Castro, Mira de Amescua y un anónimo.

La burla de Pantoja y el doctor. E.-Moreto.

El hambriento. E. $-E t$ mismo.

La fábula de Orfeo. B.-Cáncer.

El miserable y el dotor. B.-Benatente.

El alfler. B.-El mism.

Los gitanos. E.-Cáncer.

El Abantal. E.-Benavente.

El libro de Qué quieres boca? E.-Cancer.

El ayo. E.-Morelo.

Los sacristanes. M.-Mira de Amescua.

El portugues. 1 .-Cancer.

Las galeras de la honra. E.-Yoreto.

Los toros. B.-Anónimn.

Las brujas. E.-.Horeto.

Nuestra Señora del Pilar. A.-Felipe Sánchez.

Loa á Nuestra Señora.-Jiban de S. Antonin.

Tres autos sacramentales. - Diego Rámos del Castillo.

Al Vacimiento del hijo de Dios. A.-Antonio de Castilla.

Al Nacimiento de Cristo. L.-Anónima.

La burla mas sazonada. E.-Cáncer.

Los árboles. A.-Rújas.

Roinance à S. José.-Felipe Sánchez.

1109 AUTOS, COMEDISS, E:TREUESES Y LOAS. Avtos sacramentales, con qratro Comedias nrevas, $y$ srs Loas, y Entremesses. 
Primera parte. Madrid, Maria de Quiñones, $16330.4 .^{\circ} 4$ hojas prels. y

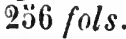

Contiene este volúmen lo siguiente:

\section{Comedias.}

La Vírgen de Guadalupe.-Felipe Godinez. El prodigio de los montes y mártir del cielo. -Guillen de Castro.

El gran rei de los desiertos.-Andres de claramonte.

El rico avariento.-Mira de Amescua.

\section{Autos.}

El reino en cortes y rei en campaña.Anl. Cocllo.

Las plantas.-Calderon.

El patio de palacio.-Rójas Zorrilla.

Los obreros del Señor.-Del mismo.

El pleito matrimonial del euerpo y el alma.Calderon.

Gialan, discreto y valiente.-Rójas.

El cubo de la Almudena.-Calderon.

El heredero.- Mira de Amescua.

Las pruebas de Cristo.-Del mismo.

El Nacimiento.-Luis l'éliz de Guevara.

El teatro del mundo.-Calderon.

\section{Entremeses.}

La fregona.-Anónimo.

El borracho. - Id.

Las visiones. $-I d$.

El alcaldito. $-I d$.

El sordo y Periquillo en Madrid.-Jerónimo Cdncer.

El portugues.-Del mismo.

EI sí.-Del mismo.

Los sacristanes.-Mira de Amescua.

\section{Baile entremesado.}

El rei D. Pelaso y la Cava.-Morelo.

\section{Coloruios.}

Los pastores de Belen.-Fel. Godinez.

Segundo coloquio de los pastores de Belen.Del mismo.

El Nacimiento de X. S.-Mira de Amescua.

\section{Loas.}

Nueve unónimas.

Una de Cincer, una de Lope, dos de Mira de Amescua y und de Guillen de Caslro.

Fste tomo es estremadamente raro: el senor Barrera y Leirado dice que no habia podido verlo ni hallar noticia de su contenido.

Ticknor (tom. III., pisg. 121), sin duda por error, cita una edicion de Madrid, 1665. 4.

Ile visto en la biblinteca del Duque de osıma un volúmen manuscrito de Aulos y comedius en 4. que al principio dice Año $1590 \mathrm{y}$ al fln Año 1585. Fi último guarismo no esti bien claro; pero el manuscrito es indudablemente anterior al $\mathbf{1 6 0 0}$.

Contiene Ios doce dramas siguientas:
1. Aulo de la degollacion de sant Jhoan. Inlerloculores. Sant Jhoan / el Rey herodes ; dos criados del Rey / Herodias. / su hija / Un carzelero / Un Cupitan. / La tentacion / y la inspiracion. (Tiene dos jornadas.)

2. Segunda Comedia que trala del Rescate del alma. / Son interlocutores / dios padre y $x$ po el Spiritu Sanclo / El demonio / . El mundo. / La carne. / El alina / El chor diuino / Un Angel / La esperanza.

5. Tercera Comedia y aulo sacramental. Ynlerlocutores Virlud. / Ociosisad / y la justicia / Tiberio / y ambrosio. / Un angel / .dos truhanes. / Un porlugues.

$4^{\circ}$ Quarta Comedia y auto sacramental. de la combersion de Sanl pablo. / Son jnterlocullores. Suulo / dos capilanes / un paxe / el pontifice / Xjo / Ananias / y unos soldados.

5. Quinta Comedia y aulo sacramental de los amores del alma Con el principe de la luz Sm ynterloculores. / La Gracia / El de. leyte / El pensamiento en abito de villano. I La fee / . dos porleros el uno llamado Si / y el otro llainado no / . Lil sensualidad El perturbador sagaz / . El albedrio / . El temor / .La esperanca /. El entendinienlo /. La nolicia.

6. Comedia sesta y auto sacramental del Castillo de la fee. I En el qual representan las personas siguientes La fee / El cuydado / y la Oracion / Un soldado herelico / dos o ires soldados Calolicos.

7.' Comedia selima y aulo para Representar del marlirio de Sani Lorencio. son ynler. loculores. / Sanl Lorencin / Vn heletor / El Emperador deçio y baleriano Adelantado / - Vn soldado llamado partemio / dos bealas / ypolito carzelero / dos o tres Criados del Emperador.

8. Conedia octaba y auto sacramental del teslamento de Xj̄o. hecho a debocion de la Sancla Yglesia de Toledo. que la inando componer en el año de 1582: son ynterloculores. En la primera escena. vn lijo de la ley vieja y otro de la tey nueba que piden la herencia por el lestamento. In simple de la ley natu$r$ al que pille de comer. / La fee anle quien se causa el pleyto. Dos letrados el vno theologo de Gracia / y el olro Jurista de Scriptura que ynforman. El pontifize que haze la deçision del pleyto.-Las figuras son de esta suerte. El hijo de la ley de Gracia enlra muy Gralan al tiempo-El hijo de Scriplura sale a lo antiguo. mity gallardo.-El de la ley nalural sale de simple. - La fee sale de blanco y con un caliz en la mano y dos Grucias con tunizclas blancas y con alas de angeles-El pontifice con capa $y$ tiara de tres coronas sobre vn Roquete y un libro en la mano y dos Cardenales a su lado-El abogado de Gracia. con sus insignias de doctor theologn.-El de Scriptura. con bestido fariseo. de masiro de la ley.

9. Comedia nobena de la historia y adoracion de los tres reyes magos. quando bi- 
nieron dc las partes orientales. a adorar al niño dios Reciennacido / a li cibdad de bellehen. Ynterlocutores. I El Rey herodes. I Nicodemus. / Leui / Sineon sacerdotes / Gaspar / ballhasar / mclchor. Reyes magos. Melelo / pare del Rey Herodes / Joseph. / y la vtrgen. y el niัs.

10. Auto sacramental y Comedia decima delicado y muty Subillo de buena y santa dnctrina. Son ynterlocutores / La diuina fee / y el cuerpo en abito de Labrador / el alma en abito de donzella / el mundo / la Razon / La Curiosidad / La Opinion / y la Justicia. (En cuatro jornadas.)

11. Comedia Vndecima. del nacimiento y Vida de Judas. Entran las fiquras siguientes. Cesareo Rey. La Reyma Elisı Su muger ; - Heralo cauallero / . Celia y Claudia damas / Tindoro principe. / Simon Hebreo. / y Z'borea su muger padres de Judas / y Judas / Lucifer / Embidia / Yra / Cudicin / Xjo / nueslra Señora / Pilalos / Zenlurio / Herisdes y gabaln y Zelaso galileo / Sant Pedro / Sant Joan / Sant Philipe / Sant andres / Varon Criado del Rey. (En cuatro jornadas.)
12. La gran comedia de los famosos hechos de mudarra. En la qual entran las figuras siguientes. mudarra / el Hey almançor / .El Rey de Segura / Axa / Zayda mora / Ruy belazquez / Doña Lambra / Gonzalo buslos / y sus criados / dns criados del Rey almanzor. dos pastores. (En tres jornadas.)

Consta este vol. de 211 fols. Todas las plezas son en verso con variedad de metros.

\section{A VELLANEDA (Lorenzo).} Comedia de la Vida Comberssion $\mathrm{y}$ muerte de Agueda de açebedo Dama de Valladolid.-Glosa sobre la oraçion del Pater noster. Manuscrito original en $4 .^{\circ}$

Al fin de la comedia, que es en verso $y$ de seguro inédita, se lee: Por Lovenç de abellaneda Soldado año de 1605. La Glosa puesta á continuacion aunque es de la misina letra, me parece de otro autor quien versiflcaba algo mejor que el soldado Arellaneda, no mencionado por Barrera en su Católogo.
1111 BANZES CIINDAMO (FraNcisco). Poesias comicas, obras posthumas de 1). Francisco Banzes Candamo. Madrid, Blàs de Villanueva, 1722 el tomo primero, y el segundo por Lorenço $\mathbf{F}$ rancisco Mojados, 17 ?2. 2 vols. $40^{\circ} \mathrm{El} 10^{\circ}$ de 8 hojas prels. $y$ ठ30 págs., y el 2. ${ }^{\circ}$ de 8 hojas prels. $y$ 507 págs.

El tomo primero contiene los dramas siguientes:

El primer duelo del mundo. A. S. precedido de una Loa y seguido de un Entremes y una Mojiganga para cl mismo.

Quien es quien premia el amor. C. precedida de su Loo.

La restauracion de Buda. Va precedida esta comedia de una Loa.

Como se curan los zelos y Orlando furioso. Z. que lleva ánles su Loa.

Duelos de ingenio, y fortuna. C. con su Loa.

La Vírgen de Guadalupe.

La piedra fllosofal.

Cual es afecto mayor, lealtad, ó sangre, ó amor.

Por su rei $\mathrm{y}$ por su dama.

El vengador de los cielos, y rapto de Elias.

En el segundo se hallan estos dramas:

El gran químico del mundo. A. S. con una $L$. $y$ un $E$. intitulado, Las visiones.
La Jarretiera de Inglaterra, el mayor aprecio del descuido de una dama.

El Austria en Jerusalen.

Fieras de zelos, y amor. $z$. Barreru añade al lílulo: ó cuál es la flera.mayor entre los mónstruos de amor.

El esclavo en grillos de oro.

El sastre del Campillo. Barrert añade al tituIn el úllimo verso de la comedia que dice: Duelos de anor y de zelos.

Yás vale el hombre que el nombre.

El duelo contra su dama.

San Bernardo Abad. Las dos primeras jornaclas de Cándamo y la tercer'a de D. Juun de la Hoz Mota.

El español más amante $\mathrm{y}$ desgraciado Mazias. De Cándamn y otrus dos ingenios.

Las mesas de la fortuna. $A$. $S$.

1112 BANZES CAXDAMO FRAXcisco). Conedias escojidas de Don Francisco Bances Candamo. Tomo primero. (To salió otro.) Madrid, Ortega, 183 2. $8 .^{\circ}$

\section{Abraza estas cuatro comedias:}

El sastre del Campillo.

Por su rei y por su dama.

El duelo contra su dama.

El esclavo en grillos de oro.

Edicion que solo tiene de bueno el Exámen puesto al fin de cada pieza. 
Fste antor escribio ademas las comedias siguientes:

Inclinacion (La) española.

Imposible (El) mayor en amor, le vence amor.

Invicto (El) Luis de Baden, y primer triunfo del Austria.

Reina (La) Cristina.

Sungre, valor y fortuna.

1113 BARRIOS (Miguel De). Coro de las Musas. Por el Capitan Don Migruel de Barrios. Brusselas, Baltazar Fivien, 1672. 12.0 21 hojas prels. $y$ 618 páys.

IIai en este tomo algunos Epilalámios representibles.

vic. Antonio no hace mencion de esta obra diversa de la flor de apolo, y más rara.

En la Aderertencia del editor, colorada al principio de la Itistorie de los movimirntos, separrecim!n guerra de Calaluna, escritil por Helo y fublicatia por D. J. Y. Ferrer en P'a. ris el ait, de $18: 26$, se menciona otra edicion del Coron de lies mesas impresa en Amster'drum, Juan Lnis de Paz, 1672, en la cual se hatlia el retrato de dicho yelo, il quien Barríos dedicio su obra: la de Bruselis, a pesar de estar dirigrida al mismo no lo theria.- El

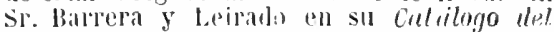
teutro cital ma impresion de tmbires, llig! 4. ${ }^{\circ}$, la cual segun parece tiene tambien el retrato de yelo.

Ticknor (1. III. p. 92), se equiroca en su. poner que el corro de las musus lleva al fin las comedias; donde estas se encuentran es chl la Flor de apolo.

\section{Flor de Apolo. Por el} Capitan Don Miguel de Barrios. Bruselas, Baltazar Virien, 166.3. 4. marq. 12 hojus piels., 250 prigs. y lo restante del volumen, segun se diri al describir las comedias, las cuales no guardan el mismo irden en todos los ejemplares. Il fin hai una hoja con la Aprobacion y Privilegio, y otra en que se repiten los nombies del lugar y del impresor, más no el año. Bellas viñetas en cobre intercaladas en el testo.

En el presente ejemplar despues de la portadia, van un magniflen retratio de D. Antonio de Cirdoba, a futien se dedica la obra, y su escodo de armas: estas dos hojas tal vez no pertenezcin a la micion, al ménos no las he viste en otro ejemptar.

En Nic. Antonio se señala por errata el año de 1565 i esta impresion.
1115 Bí RRIOS (MIGUel DE). Las poesias famosas y Comedias de Don Miguel de Barrios, Segunda Impression enriquescida con lindissimas Estampas. Amberes en casa de Henrico y Cornelio Verdussen, 1708. $4 .^{\circ}$ marq. Viñetas.

Esta impresion es exactanente la misma de 166.5, con la sola diferencia de haberle variado la hoja de la portadil, suprimiendo la final, en la cual se repetian los nombres del impresor y lingar donde se hizo; en igual caso se halla la de Amberes, por Verdussen en 1674. 4..$^{\circ}$, con el mismo titulo de Poesías famosas $y$ comedias.

Contiene el rolumen las siguientes comedias:

Pellir fuvor al conlrario. 5.5 pigs. en todo.

El Canto junto al Euranto. 4 hojas prels. y 42 págs.; pero ha paginacion sigue ya hasta el flin del volimen.

El pspañol eri 0ran. Va desde la pág. 43 has-

ta la 107; pero lias tres hojas primeras no

Heran impresa la paginacion. Hai tambien III

Diálogo amoroso, represent able.

En la obra intitulada: Aplauzos academi$\cos$ (V. el Ním. 109\%.) hai una especie de zalrzuela de Barrios cujo titulo es: Palacio de la subiduria.

nel mismo se citan otras dos comedias impresas sueltas, cuyos titulos son:

Nuhes no ofenden al sol.

Conlra la verdad no hai fuersa.

El nombre primitivo de este escritor fué el de Daniel Levi de Bárrios, habiendo adoptado el de Viguel de Bárrios mientras vivió como cristiano. Temeroso probablemente de las persecnciones de la Inquisicion huyó á Amsterdam; así es que todas sus obras se publicaron en el estranjero.

\section{BELMONTE BERMÚDEZ} (LUIS DE). Aulo Sacramental. Las fiestas de los Martires. De Luis de Belmonte. $4^{\circ}$ Manuscrito.

Parece original y lleva la fecha de 1639. Barrera, al citar el presente auto, se refiere á este mismo ejemplar anunciado en nuestro Catálogo de Paris.

He tenido una comedia en la que este escritor lluvo por colaboradores á Nira de Amescria, el conde del Basto, Ruiz de Alarcon, Luis Yélez de Guevara, D. Fernando de Ludeña, D. Jacinto de Herrera, D. Diego de villègas y 1 . Guillen de Castro; dicha pieza se incitula: Algumas hazanus de las muchas de Don Gurcia IIurlado de Mendoça, Marques do Cañele. Por Luis de Bel- 
monle Bermudez. Madrid, Diego Flamenco, 1622. $48^{\circ}$

En el Ensayo de una bib. esp. de Gallardo se inencionan del mismo autor: La Avrora de Crislo. Lisboa, Francisco de Lyra, 1616. 8..$^{\circ}$ Pema en octavas sobre la Concepcion; y La solenissima fiesla y procession, que hace la lluslre Cofradia de la Pura y Limpia Concecion a su Imagen, llevandola de el Monasterio de Regina coeli, a la iglesia major y de alli al Convenlo de San Francisco. Y el ornalo y colgaduras eslraordinarias, que no perdonando suntuosos gastos, los vezinos desta ciudad por las calles, y pasage de la Procession hazen. (Sevilla,) Francisco de Lyra, 1616. 4. $0^{\circ}$ Se cita ademas en dicho Ensayo otro poema de Belmonte, nianuscrito, intitulado La hispdlica, cuyo asunto es la conquista de Sevilla.

\section{BERMÚdEZ (Jerónimo).} Primeras tragedias españolas de Antonio de Silua. Madrid, en casa de Francisco Sanchez, M.D.LXXvir. 8. let. curs. 8 hojas prels., 106 foliadas y una al fin en que se repiten las señas de la impresion.

El verdadero nombre del autor resulta de un soneto de Diego González Duran que está al principio, en el cual dice:

"Derónimo Bernudez, ha compuesto Las tragedias de Nise lastimosa, En su pasion y en muerte laureada."

Para probar Montiano y Luyando la equivocacion padecida por Bermúdez al suponer que sus tragedias eran las primeras españolas, cita las traducciones ó imitaciones de Sófocles y Eurípides, hechas por el Maestro Oliva á principios del siglo XVI, y no dice una palabra de la Tragedia Serafina de Alonso de la Vega, publicada por Timoneda en 1566.

Nic. Antonio ignoró que el nombre de Antonio de Silva era supuesto $y$ admitio como cierto lo que en el frontis se decia, sobre no haber aparecido anteriormente en castellano otras producciones dramáticas del género trágico.

Segun parece, Jerónimo Berınúdez escribió un poema latino que intituló La Hesperoida, el cual tradujo en verso suelto castellano, y se imprimió en el tom. Vll. del Par. naso español.

Sedano habla sobre la estremada rareza de la primera edicion de las Tragedias de Antonio de Silva y las reimprimio en el tom. VI. de dicho Parnaso español; tambien las dió á luz por tercera vez Baudry en el tom. I. del Tesoro del lealro español.

1118 BISBE Y VIDAL (Froctuoso). Tratado de las comedias en el qual se declara si son licitas. Y si hablando en todo rigor sera pecado mortal el representarlas, el verlas, y el consentirlas. Por Frvetvoso Bisbe y Vidal. Va añadido va sermon de las mascaras, y otros entretenimientos por el P. Diego Perez. Barcelona, Geronymo Margarit, 1618. 8. 16 hojas prels. y 113 fols. La Platica del $P$. Diego Pérez de Valdivia tiene $\mathbf{4 9}$ hojas foliadas incluso el fróntis.

"Libro curinsisimo, pues ataca al teatro wespañol con más discrecion é ingenio que sningun otro tratado antiguo de cuantos whan llegado á nuestra noticia... Bisbe Y „Vidal es un seudónimo de Juan Ferrer.» Tick. nor, Hist. de la lit., tom. II., pág. 358.

Gallardo en el Ensayo de una bib. esp. se equivoca en suponer que el número de las hojas preliminares es $\mathbf{1 5}$, pues bien repasadas encuentro 16.

El tratado de las máscaras del P. Diego Pérez de Valdivia lleva lâ siguiente portada: "Platica o lecion de las mascaras, en la qual wse trata, si es pecado mortal, o no, el enmmascararse: y se ponen en ella principios y wreglas generales, para juzgar de semejantes mobras si son pecado mortal: como con yr a „representaciones, flestas, saraos, paseos, "bayles, galas, pinturas, juegos combites, "y todas reereaciones, en las quales suele nser Dios offendido.

1119 BOCÁXGEL UNZUETA (GABRIEL). El nvevo Olimpo, representacion real, y festiva mascara a los felicissimos ānos de la Reyna Nuestra Señora. Escrivialo D. Gabriel Bocangel Vnçueta. Madrid, Dieğo Diaz de la Carrera, (1649). 4. $0^{\circ} 13$ hojas prels. y 62 /oliadas.

Es una zarzucla.-Barrera y Leirado babla de esta composicion y dice se publicó por separado; pero supongo no vió ningun ejemplar de ella, cuando no copia su verdadero título ni da las seúas de la impresion.

1120 - Rimas y prosas, junto con la fabvla de Leandro y Ero. Por Don Gabriel Bocangel y Vnçueta. Madrid, Iuan Gonçalez, 1627. 8. 16 hojas prels. y 136 fols.

Hai en el presente tomito una Églnga representable, que estraño no mencione el Sr..Barrera, y la Prosa cuarla, ó discurso descriptivo, en que se compone un annante cortesano; es una especie de novela en prosa y verso.-Se incluyo en la tercera parte de la Lira de las Musas, el contenido de este volúmen, ménos unas dẻcimas de Bocángel, Las prosas que van al fin, y diez octavas de Juan Andosilla. 
No mencionan esta edicion de las Rimas los traductores de Ticknor.

\section{BUTRON (JosÉ). El Clarin} de la Fama, y Cithara de Apolo. Con metricos rasgos a las Reales Fiestas, que en el felicissimo nacimiento de el Principe N. Señor D. Luis Jacobo Primero el Deseado. ejecvtò la... Ciudad de Orense. Santiago, Antonio de Aldemunde, 1708. $40^{\circ}$ 10 hojas prels. $y 218$ págs.

1122 CALDERON DE LA BARCA (Pedro). Primera parte de las Comedias de D. Pedro Calderon de la Barca... Recogidas, y sacadas de sus verdaderos originales por D. loseph Calderon de la Barca su hermano. Madrid, Viuda de luan Sanchez, $1640.4 .^{\circ} 2$ hojas prels. y 200 páys.

Contiene estas conredias:

La vida es sueño.

Casa con dos puertas nala es de guardar.

El Puratorio de San Patricio.

La gran Zenobia.

La Devocion de la Cruz.

La Puente de Mantible.

Saber del mal y el bien.

Lances de Amor y Fortuna.

La Dama duende.

Peor estí que estaba.

El sitio de Buda.

El Príncipe constante.

La primera edicion es de Madrid, 1656. 1.

1123 - Segunda parte de las Comedias de Don Pedro Calderon de la Barca... Recogidas Por lon Ioseph Calderon de la Barca su hermano. Madrid, Por Maria de Quiñones, Año M.DC.xxxVII. $4 .^{\circ}$ i hojas prels. y 282 fols.

Primera impresion rara, desconocida á Barrera.

$1124-$ La misma parte. Madrid, Carlos Sanchez, 1641.4. ${ }^{\circ}$ i hojas prels. $\quad 286$ fols.

I a componen las . . yuicnte comedias:

El mayor encanto amor.

Árgenis y Poliarco.
Contiene poesias de varios autores en el Certámen poetico y esparcidas por el cuerpo del libro; ademas se halla una Loa.

El nombre del autor de esta obra se saca de un anagrama contenido en las décimas que preceden al prólogo, el cual dice: $D$. Diego Cosío at Padre Joseph Butron.

El Sr. Barrera no menciona al P. Butron en su Caíalogo, ni se encuentra la Loa, cuyo primer verso es: Cese ya el gemir, en la lista del Sr. Fernández-Guerra.
El galan fantasma.

Júdas Macabeo.

El médico de su honra.

orígen, pérdida y restauracion de la Vírgen del Sagrario.

El mayor monstruo del mundo.

El hombre pobre todo es trazas.

A secreto ayravio, secreta venganza.

El astrulogo fingido.

El amor, honor y poder.

Los tres mayores prudigios. Con loa.

La existencia de una edicion de la Primera parte del año de 1650 y de la seguncla del 37 , evidencian la equivocacion de Ticknor, en sı Hist. de la lit., tom. IIl., pág. 14, donde supore que el hermano de Calderon habia publicado algunas de las comedias de don Pedro entre el 1640 y 1674.

1120 CALDERON DE LA BARCA (Penro). Tercer'a parte de las comedias de D. Pedro Calderon de la Barca. Madrid, por Domingo Garcia Morràs, 1664. 4. ${ }^{\circ}$ i hojas prels. y 272 fols.

Abraza las siguientes comedias :

En esta vida todo es verdad y todo es mentiri.

El maestro de danzar.

Mañanas de abril y mayo.

Los hijos de la Fortuna, Teágenes y Cariclea.

Afectos de odio y amor.

La hija del aire. Primera parte.

Ni amor se libra de amor.

El laurel de Apolo. Fiesta de la Zarsuela.

la pürpura de la rosa. Representacion mis.

tica de zarzuela precedida de una Loa.

La flera, el rayo y la piedra.

T'ambien hai duelo en las damas.

Prinera edicion de la tercera parte, recogida y publicada por D. Sebastian Ventura de Vergara y Salcedo, y dedicada al marques de Astorga por D. Pedro Calderon. 
Hal una ouarla purte, comprensiva de las mismas comedias que la de Vera Tásis, la cual lleva un prólogo del autor y salió á luz hảcia 1675 ; la reimprimió en Madrid, Ber. nardo de Hervadi en 1674. La Quinta parle hasta la Novena, las puhlicó dicho Vera Tásis y Villarroel. Tambien habla Calderon en el prólogo al tomo de Autos, dado á luz en 1697 , de una Quinta parte de Comedias furtiva, que solo contiene diez, cuatro de elias no suyas y las demas enteramente desfiguradas; segıu Hartzenbusch, en la páy. 709. y en el Indice del tomo de Comedias escogidus de Tirso, está impresa en Midrid. aunque suena como hecha en Barcelona, lleva el año de $167 \overline{7}$ contiene entre otras la cousedia El rei D. Pe. dro en Marlrid. Por eso denominó Vera Tásis á la suya Vertadera quinla parle.

1126 CALDERON DE LA BARCA (Pedro). Primera parte de Comedias del celebre poeta español, Don Pedro Calderon de la Barca,... qre nvevamente corregidas prblica Don Ivan de Vera Tassis y Villarroel, sv mavor amigo. Madrid, Francisco Sanz, 1633 . 4..$^{\circ} 14$ hojas prels. (entre ellas el retrato de (alderon) y paigs.

A pesar de que la primera y scgunda parte habian sido sacadas por el hermano de Calderon de sus verdaderos originales, dice Vera Tásis, que su autor las habia désconociulo por desfiguradas. Témoine sin eınbargo, que las reloco el desvelo de este editor, acaso en demasía, como puede verse en los dos tomos prinieros. señaladamente en la jornada tercera de El mayor mónstruo lıs zetos, título que se da en el tom. II., a El mayor mónslruo del mundo.

La edicion príncipe de esta primera parte, publicada por Vera, es de Madrid, 1652.4."

Comedias las mismas y con el mismo órden que en la edicion de 1640.

Parte segunda de Comedias etc. Madrid, Francisco Sanz, 1686. 4. 8 hojas prels., comprendida la del retrato, y 3 iz paigs., á las que siguen una de Tabla de las Comedias verdaderas de D. Pedro Calderon, otra con la Tabla de los Avtos sacramentales, y por fin una en que se repiten las señas de la impresion.

Esta comprende las mismas comedias que la de $16 \bar{\jmath} \bar{i}$, pero no con el mismo órden.

Tercera parte de Comedias etc. Madrid, Francisco Sanz, 1687. $4 .^{\circ} 8$ hojas prels., comprendido el retrato, ä86 págs. y 3 hojas finales destinadas á lo mismo que las del tomo segundo.

Publicó estas doce comedias, si bien orde. nadas de otro modo, en 1664 D. Sebastlan Ventura de Vergara Salzedo, y dirigiéndolas al autor le dice. que las habin recogido $y$ daba d la eslainpa, por eximillas del riesgo que las de'mas habizn padecido, saliendo di. minulus y llenas de errores de imprenta. El mismo Calderon parece reconocer este zelo de su más apasionato amign; y aun darle el sello de su aprobacion, al dedicarlas al marques de Aslorga. Sin embargo ningunas sa lieron más defectuosas que estas doce, en particular el Laurel de Apoln, Tambien hui duclo en las Damas y las dos partes do la Hija del airc, si hemos de dar crédito al editor de la Coleccion que al presente nos ocupa. llaya ó no exazeracion en lo que afirma, es indudable que Calderon no perdia mucho tiempo en examinar las cdiciones que se hacian de sus Comedias, cuando en la dedicatoria habla como de ofdas del trabajo puesto por Vergara Salzedo. Ha procurado, segun dice, (copio sus palabras) restaurarlas de los achacados errores que padecen otras en la estampa.

Quarta parte de Comedias etc. Madrid, Francisco Sanz, 1688. 4. ${ }^{\circ} 8$ hojas prels., comprendido siempre el retrato, y 606 parginas.

La forman las siguientes comedias:

El postrer duclo de España.

Eco y Narciso.

El Ionstruo de los jardines.

El gran Principe de Fez, Don Baltasar ae Lušola.

El Encanto sin encanto.

La Viña de Gumez Arias.

El Hijo del Sol, Facton.

La Aurnra en Copacabana.

El Conde Lucawor.

Apolo y Climene.

El Golfo de las Sirenas, Egloga piscaloria.

Fineza contra fineza.

Hai dos ediciones de esta cuarla parle de Vera, hechas en Madrid en $168: 2$ y 84.

Verdadera quinta parte de Comedias etc. Madrid, Francisco Sanz, 1691. 4. 31 hojas prels. Cpues se halla en ellas la larga Aprobacion del Maestro Fray Manuel de Guerra y Ribera, probando que la Comedia es indiferente en lo cristiano, y convemiente en lo político,) y 3 İ paigs.

Comprende las corvedias siguientes:

Hado y divisa de Leonidn $\mathrm{y}$ de Marflsa.

Los dos Amantes de! cielo, Crisanto y Daría. Ilujer, llora y venceras. 
Acradecer y no amar.

De mua causa dos efeclos.

Cinal es mayor perfeceion.

El Jardin de Falerina.

La Sibila del oriente, y gran reina de Sabá.

No hai burlas con el Ninor.

Gustos y disgustos son, no mis que imarinacion.

Amigo, amante y lcal.

Basta callar.

Barrera no menciona esta edicion de 169.4 y solo habla de la primera hecha en Madrid, en $1682.4^{\circ}$

CALDERON DE LA BARGA. (PEdro). Sexta pante de Comedias etc. Madrid, Francisco Sanz, 168:3. 4. ${ }^{\circ} 34$ hojas prels., inclusa la del retrato, 579 págs. $y$ dos hojas mas para completar la lista de las Comedius rerdaderas y las supuestas de Calderon.

Repitese al principio la difusa aprobacion del Naestro Guerra que va en el tomo precedente.

Este contiene lis comedias siguientes:

Fortumas de Andromeda y Perseo.

El Josef de las mujeres.

Los Empeños de un acaso.

Primeru sai yo.

La Estatua de Prometeo.

El Secreto á vozes.

Dar tiempo al tíempo.

El IIájico prodigíoso.

Mejor está que estaba.

Fieras afemina $A$ mor.

Dicha y desdicha del nombre.

Para vencer á Amor, querer vencerle.

Segun Barrera hai una cdicion anterior de Madrid, 1682.

Septima parte de Comedias etc. Madrid, Francisco Sanz, 1683. $4 .^{\circ} 8$ hojas prels., inclusa una que ncupa un escudo de armas, "36? paigs., dos hojas para la lista de las comedias verdaderas y supuestas de Calderm, y otra para repetir las señas de la impresion.

La componen las signicntes comedias:

Auristela y Lisidante.

Fuego de Dios en th querer bien.

El Segundo Seipion.

La Exaltacion de la Cruz.

No hai cosa como callar.

Zelos ann del aire mistan. Fiesla conlada.

Mañana será olro dia.

Darlo todo y no dar mada.

La Desdicha de la vriz.

El Pintor de su deshonru.

El Alcalde de Zalamea.

El Escondido y la tapada.
Detava parte de Comedias etc. Madrid, Francisco San\%, 1681. $4 .^{\circ} 8$ hojas prels., comprendido el retrato, 570 págs., 2 hojas para la nota de las comedias verdaderas y supuestas de Calderon y otra para las señas de la impresion.

Esta parte abraza las comedias siguientes:

La Cisma de lnglaterra.

Las Vanos blancas no ofenden.

Los Cabellos de Absalon.

No siempre lo peor es cierto.

Las Cadenis del demonio.

Los tres afectos de Amor.

La Banda y la flor.

Con quiell vengo vengo.

Guirdate de lil agrua mansa.

El Aleilide de sí inismo.

Luis Pérez el gallego.

intes que lodo es ni dama.

Wovena parte de Comedias etc. Madrid, Francisco Sanz, 1691. 1. 8 hojas de prels., en las que está incluido el retrato, 561 págs. y una hoja de Tabla de las Comedias verdaderas de Calderon.

Comprende las que siguen:

Las Armas de la hermosura.

Alilato y aborrecido.

La Señora y la criada.

Nadie He sil secreto.

Lis tres justicias en inna.

Amar despues de la muerte.

in Castigo en tres venganzas.

Duclos de amor y lealtad.

Céfalo, y Pócris. Comedia burlesca.

El Castillo de Lindabridis.

Bien vengas mal.

Cada uno para si.

Al fin de este tomı presenta Vara Tásis la Tabla de las comedias veriluderas de Calderon, que componen cada una de las nueve Partes, y designa como para la décima las que siguen. We ellas reconocio ya como suyas, en la Carla al duque de Veragua, las que llevan un asterisco al márgen.

* La Vírgen de Madrid.

* El Carro del cielo, San Elias.

Sall Francisco de Borja.

El Triunfo de la Cruz.

* La lír ren de la Almudena, parte primera y segunda.

* Niestra Señora de los liemedios.

* Desagravios de llaría.

* El acaso y el error.

* Don Quijole de la Mancha.

* El Condenado de Auror.

* El Sacrilleir de Eflerenia.

* Cerínen de amor y zelos. 
Debio de prevenirle la muerte ú otra causa que ínoro, pues no llegó á sacar à liz la Decima parfc. De las comedias que habian de componerla, unas han sido impresas $\mathrm{y}$ otras no.

Añade al fin de la Novena haber compuesto Calderon una jornada en estas comedias:

La flngida Arcadia, La tercera jormada.

Enfermar con el remedio, la primera.

El Pastor Fido, la lercera.

Circe y Polifenı, la tercera.

I. Margarita Preciosa, la tercera.

El Mónstruo de la fortuna, la primera. .

El mejor amigo el muerto, la tercera.

El Privilegio de las mujeres, la tercera.

1127 CALDERON DE LA BARCA (Penro). Primera parte de comedias verdaderas del celebre poeta es pañol D. Pedro Calderon de la Barca... Qve nveramente corregidas publicó Don Jvan de Vera Tassis y Villarioel su mayor amigo. Marlrid: Viuda de Blàs de Villanuera (1726?). 12 hojas prels., incluso el retrato, y $50 \mathrm{1}$ paigs. Tiene 8 paigs. mais que el de 1683 por tener este repetida la paginacion desde ö80 a :87.

Parte sromida (ut supra). Nadrid, Viuda de Blas de Villanuera, $17 \$ 6.8$ linjas prels., inclusoel retra!o, $\$ 70$ prigs:, una hoja de Tabla de las comedias verdaderas'de Calderon, otra de Tabla de los Autos y acaso falla ma al fin para repetir las señas do la impresion. Si este tomo lieno dos jraginas ménos que el misma dle 1686, es por sallarse alli de la prig. 330 a la 33.3 , lo que se ha reclificado en ! a reimpresion.

Tencerar parte (it supra). Vill. da de Blas de Villanuera, 17-26. 8 linjas prels. que comprenten el relialo, ̋so págs. una lioja de Tabla de las Comedias, otra de los Autos y acaso fallu al fin una para las señas de la impresion.

Quarta parde (ut supirt). Madrid, IIerederos de Juan Garcia Infanzon, 1731. 8 linjas mels. y 618 págs. En la edicion lle $168 \mathrm{~s}$ eslain repelidas las prigs. "is' y "88, y por eso resultun aqui dos mais.
Verdadera quinta parte (ut supra). Madrid, Herederos de Juan Garcia Infanzòn, 1730. 34 hojas preliminares y $3 \mathbf{z z}$ págs.

Sexta parte (ut supra). Madrid, Juan Sanz, 1713. 32 hojas prels., inclusa la del retrato, 579 pags. y dos hojas más para completar la lista de las Comedias de Calderon.

Septima parte (ut supra). Madrid, Jvan Sanz, $171 \%$. 8 hojas prels., una de ellas con el retrato, öju paigs., Z hojas para la iista de las Comedias y otra en que se repilen las serias de la impresion. La edicion de 1683 tiene 8 págs. ménos, por duplicarse en ella las $267-269$ y las $3 \exists 1-3 \nexists 4$.

Detava parte (ut supra). Madrid, Vilida de Blàs de Villanuera, 1726.8 hojas prels. con la del retrato, $\$ 70$ parys. , 2 hojas para la lista de las Comedias verdaderas de Calderon, y una blanca.

Cocena parte (ut supra). Madrid, Juan Garcia Infanzon, 1695. 8 hojes prels. que comimenden el retrato, 366 pirys. y unn linja de las tomedias de Calderon. Tirne 2 prigs. menos la edicion de 1691 a causa ide es!ar duplicadas la $\ddot{3} 31$ y $y$ :

Son en todo 9 rolimenes f. $^{\circ}$

lislas varias reimpresiones de ln anterior edicion de Vera Tisis. s' hicieron con tal

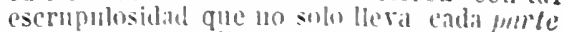
las mismas comedias plologos. privilegros

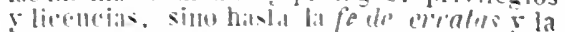

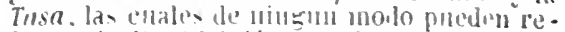
ferirse a ella Dirigio eslat cedicion 1). Juseph

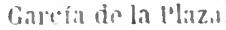

bialora un rondio lis cinco primerens parfess le la presente leimpresion, ni tamponen la octurit.

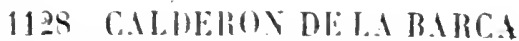

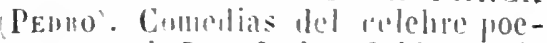
ta español Don Pedro Calderun de lal Barra, que saca a luz. Don Juan Fernandez de Apontes. Madrid, Yinda de Don Manuel Fernandez, 1760- 
63. 4. 11 vols. en 10. Ejemplar intonso.

En esta edicion no se ha seguido cl irden dado á las comedias por Vera 'Tásis, sin indicar el motivo, y de consiguiente vamos á señalar las que llenall cada tomo:

El priniero: Cada uno para sí.-Las armas de la hermosura.-Amado y aborrecido.-La señori y la criada.-Nadie fle su secreto.Las tres justicias en nua.-Amar despues de la muerte.-Cun castigo en tres venginzas.Dnelos de amır y lealtad.

El scgundo: Céfalo y Pócris.-El castillo de Lindabridis. - Bien vengas mal.- La vida es sueño.-Casa con dos puertas.-El purgatorio de S. Patriein.-La gran Cennbia.-La devocion de la Cruz.-La puente de Mantible.-Siber del bien y del mal.-Fincza contra flneza.

El lercero: Lances de amor y fortuna.La dama duende.-Peor estí que estaba.-El sitio de Breda.-El príncipe constante.-El pristrer duelo de Espiña.-Eeo y Vareisn.-El mónstrun de los jardines.-El yran príncipe de Fez, D. Ballasar de Loyola.-El encanto sin encanto.

El cuarlo: La nina de Gomez Arias.-EI hijn del Sol, Faeton.-La aurora en Copacabana.-El Conde Lucanor.-Apolo y Climene.El golfo de lis sirenas.-La Cisna de Inglaterra.-Las manos blancas no ofemiten.-Los eabellos de Absalon.-Xo siempre lo peor es ciertı. - Las cadenas del demonio.

El quinlo: Los tres afectos de amor.-La banda y la flor. - Con quien rengo, vengo.Guáldate de la agua mansı. - El aleaide de sí mismo.-Luis Pérez el gallego.-iutes que todo es mi dami.-El mayor encanto amor. -El galan fintasma.-Jidas llacabeo.-El mayor müstruo los zel os.

El sesto: El médico de su honra.-Argenis y Poliarco.-orígen, perdida y restauracion de la lirgen del sagrario.-Hombre pobre todo es trazas. - I seereto agravio secreta venganza.-El astrólogo fingido.-Amor, honor y poder. - Lns tres mayores prodigios, con toa.-El laurel de Apolo.-Tambien hai duelo en las damas.-La flera, el rayo y la piedra.

El sélimo: En csta vida todo es verdad y todo mentira.-El maestro de danzar.-Mañanas de Abril y llayo.-Los hijos de li fortuna.-Afectos de odio y amor.-La púrpura de la rosa, con Lon.-La hija del Aire. Primera y segunda parte.-.Vi anor se libra de amor.-Pari vencer ál Amor querer vencerle.

El octavn: Fortunas de Andromeda y Perseo.-El Josef de las mujeres.-Los empeños de un aeaso.- Primero soj yo.-La estatua de Prometeo.-El secreto á vozes.-Dar liempo al tiempo.-El migrieo prodigioso.-Nejor está que cstaba.-kieras afemina anor, con Loa.
El nono: Dicha y desdicha del nombre.Hado y divisa de Leonido y de Marfisa.-Los dos amantes del cielo.-Nujer, Ilora y vencerás.-Agradecer y no amar.-De una causa dos efectos.-Cuál cs mayor perfeccion.-El jardin de Falerina.-La Sibila del Oriente y gran reina de Saba. - No hai burlas con el amor.

El décimn: Gustos y digustos son, no más que imaginacion.-Amigo, amante y leal.ỉasta callar.-Auristela y Lisidante.-Fuego de Dios en el querer hien.-El segundo Escipion.-La exaltacion de la Cruz. - No hai cosa comn callar.-Zelos aun del aire matan.-El escondido y la tapada.

El undécimo: Mañana será otro dia:-Darlo todo y no dar nada.-La desdicha de la voz. - El pintor de su deshonra.-EI alcalde de Zalamea.

\section{CALDERON DE LA BAR-} CA (Pedno). Las Comedias de Don Pedro Calderon de la Barca, cotejadas con las mejores ediciones hasia ahora publicadas, corregidas y dadas á luz por Juan Jorge Keil." Con un retrato del poeta grabado por un dibujo original. Leipsique, publicado en casa de Ernesto Fleischer, $1827-30.4$ vols. en mui grande $8 .^{\circ}$

Contiene las ciento ocho comedias de la edicion de Vera Tásis por el mismo orden que en ella guardan.

ofrece el editor, al principio del tom. IV., publicar otro con la comedia San Francisco de Borja y las demas que logre reunir de Calderon, con sus copiosas observaciones sobre la suerte (verdaderamente fatal) que las obras de uno de nuestros primeros autores dramáticos han sufrido en manos de los impresores, con las variantes de las principales ediciones, con notas suyas sobre ciertos lugares difíciles y algunos nombres propios, y por fin con la indicacion de las fuentes de donde saco Calderon los planes de sus comedias, y del tiempo en que probablemente las escribio. Pero el píblico carece todavía del fruto de tan útiles trabajos.

Antes de esta edicion, que no deja de ser esmerada y lujosa, habia principiado Keil otra de menos boato, que debia constar de diez volúmenes en $12 .^{\circ}$, o pequeño $8 .^{\circ}$, de la que se publicaron en Leipsique por $F$. A. Brockihaus en 1820,21 y 22 los tres tomos primeros, comprensivos de 31 comedias.

1130 Comedias escogidas de Don Pedro Calderon de la Barca. Madrid, A. Fernandez, $1826, y$ Ortega y Compañía, $1828-33$. 4 vols. $8 .^{\circ}$ 


\section{Comprenden las comedias siguientes:}

No hal burlas con el amor.

La dama duende.

No siempre lo peor es cierto.

Mañanas de abril y mayo.

El astrỏlogn fingido.

Dar tiempo al tiempo.

El mayor monstruo los zelos, y el Tetrarca de Jerusalen.

Cuál es mayor perfeccion.

Los empeños de un acaso.

Casa con dos puertas mala es de guardar.

Amigo, amante y leal.

La cisma de Inglaterra.

Pcor está que estabil.

Mejor está que estaba.

La impresion y cl papel son malos, las erratas abundan, hai algunos pasajes suprimidos por ta censura, y así solo merece cierto aprecio el Examen que va al fin de cada comedia.

Principiaron á publicarse las Comedias de Calderon en la IIabana, por R. Oliva, 1859: pero solo salieron dos tomos que comprenden treinta y dos piezas.-La mejor coleccion de las obras dramáticas de cste autor es la que ha dado á luz el Sr. D. Juan Eugenio Hartzenbusch en Madrid, 18i8-50,8 $0^{\circ}$ atlánt. y forma cuatro tomos de la Biblioteca de autores españoles de Ribadeneira.

\section{CALDERON DE LA BARCA} (Pedro). El Lucero de Castilla y Privado perseguido. Comedia en tres actos inédita de D. Pedro Calderon de la Barca: Madrid, F. Grimaud de Velaunde, 1837. 12. ${ }^{\circ}$ Con una laminita.

Forma parte del Antigun teatro español, que einpezó á publicarse ell Madrid.

Lista alfahitica de las comedias impresas con el nombre de D. Pedro Calderon de la Barca, que n' son suyas, segun D. Juan de Vera Tásis y Villarroel.

A in que obliga un agravio.

Amante (EI) inudo.

Amazonas (Las).

Amor con amor se obliga.

Amor (El) hace discretos.

Amor (El) hace prodigios.

Amor, ingenio y mujer.

Ángel' (El) de la guarda.

Aristoménes Mesenio.

Bárbara (l.a) de los montes.

Batalla (La) de Sopetran.

Blason (EI) de los Mendozas.

Caivallo (EI) vos han muerto.

Cada cual á su negocio.

Cada cual lo que le toca.

Canas (Las) ell ol papel.

Casamenteru (EI).

Casamiento (EI) en la muerte.

Castañar (El) de Toledo.
Castigo (El) del penseque.

Cena (La) del rei Baltasar.

Codicia (La) rompe el saco.

Cómo se comunican dos estrellas contrarias.

Conde (El) Don Sancho Niño.

Del rei abajo ninguno.

besdichados (Los) dichosos.

Despreciar lo que se quiere.

Dia de san Blas en Madrid.

Dicha (La) del retraido.

Dios hace justicia á todos.

Donaires de Mengo.

Duelo de honor y amistad.

Empeños (LOS) de seis horas.

Empeños (LnS) de un plumaje.

Encantos del marques de Villena.

Engañar para reinar.

Enseñar à ser buen rei.

Escándalo (El) de Grecia.

Esclavo (El) de Varia.

Española (La) de Florencia.

Fè (la) de Abrahan.

Fénix (El) de España.

Galan (El) sin dama.

Haz bien, y guárdate.

Hermanas (Las) bandoleras.

Honor (EI) contra la fuerza.

Ilonra, confusiun y amor.

Huyendo vence el honor.

Imposibie (El) más fácil.

Industria (La) contra el poder.

Lígrimas (Las) de David.

Lo que hace un manto.

Lo que merece el valor.

Lizzero (El) de Castilla.

Mal (EI) pagador en pajas.

Vareo Antonio y Cleopatra.

Nayor (La) fineza.

Mayor (El) rei de los reges.

Mojor (La) luna africana.

Nejor (EI) padre de pobres.

Mejor (EI) testign.

Ilejor (El) testigo el rei.

Nejor (EI) testigo es Dios.

Muchos indicios sin culpa.

Mudanzas de lit fortuna.

Nujerts (Las) cuando quicren.

Obrar bien, que Dios es Dios.

Paciencia La de Job.

Paje (El) de Don Alvaro.

Palabra (La) en la mujer.

Petir El con mal intento.

Perdon (El) eastiga mis.

Polifeno (EI).

Porfiando vence amor.

Premio EI añade al valor.

Prondigi, El de Alemania.

Prudente (I.a) Abigaíl.

prueba de amor" y amistad.

Qujen calla, otorga.

liej (El) ángel.

Rei (El Don Pedrn en Yadrid.

Respuesta La rstí on la mano.

Riessos los que tiene un coche.

Ricror El de las desdichas.

Roea $\mathrm{La}$ del honor.

Rollo El de Feija.

saber ilesnuentir sospechas.

Saco (EI) de Ambéres.

sencea y verou. 
Sucesos del príncipe Lisardo.

Tejedor (El) de Segovia, 1." ₹ 2." parte.

Tercera (La) de si misma.

Tres (Las) edades de España.

Triunfos (Los) de Josef.

Tuzani de las Alpujarras.

Vencerse es mayor valor.

Vencimiento (El) de Turno.

Venturoso (EI) por fuerza.

Vísperas (Las) sicilianas.

Vitoria (La) de Fuente-Rabla.

Yo me entiendo.

Zelos (Los) hacen estrellas.

Zelos no ofenden al sol.

Comedias que se han impreso con el nom. bre de Calderon, á más de las que anteceden y de las comprendidas en las nueve Partes.

Como padre y como rei. (Índice general de Medel.)

Conquista (La) del alma. (Sera auto?)

Infanzon (El) de Illéscas.Es la misma que $\mathrm{El}$ rei D. Pedro en Madrid.

No son todos ruiseñores.

Teagénes y Clariquea. (Indice general.)

\section{CALDERON DE LA BAR-} CA (Pedro). Artos sacramentales, alegoricos, Y historiales. Comprestos por Don Pedro Calderon de la Barca. Primera parte. Madrid, En la imprenta Imperial, Por Ioseph Fernandez de Buendia, 1677 (no 1676, como dice Alcarez y Baena). 4. ${ }^{\circ}$ La portada es de letra negra y colorada. Tiene 8 hojas prels. á más del retrato de Calderon, grabado por Villafranca, bastante diferente del que se lialla en las dos ediciones de Vera Tásis, y $40 ّ 9$ págs.

Esta es la única parte de los Autos que publicó Calderon de la Barca; pero viviendo èl todavla se imprimieron tomos sueltos con algunos autos suyos recogidos por la aficion de sus apasionados ó por la codicia de los cspeculadores. El presente contiene los que siguen, precedido cada Auto de una Loi.

Las órdenes militares.

El santo rei don Fernando, primera parte.

La vida es sueño.

El Divino Orfeo.

El primero y segundo Isaac.

la nave del mercader.

La viña del Señor.

La vacante general.

Quién hallará mujer fuerte.

No hai instante sin inilagro.

El nuevo hospicio de pobres.

1133 - Avtos sacramentales historiales, y alegoricos. Compuestos. por Don Pedro Calderon de la Barca.
Que dedica vn su Apasionado, a cuya costa se han impresso. a Santa Theresa de Jesvs. Barcelona, Sebastian de Cormellas, 1701.4. 2 hojas prels. y 319 págs.

\section{Loas.}

Contiene los doce autos siguientes sin

El Pleitn matrimonial.

Ia Divina filotea.

El verdadero Dios Pan.

El Jardin de Falerina.

La Inmunidad de el Sagrado.

A Marta el corazon.

A llios por razon de Estado.

El Diablo mudo.

Los encantos de la culpa.

Los Misterios de la misa.

Las rspigas de Rutl.

El primer refugio del hombre, y probática piscina.

Fajardo dice en la disertacion que precede a las dos partes recorilas pur él de los Autos de Calderon, no incluidos en las seis impresas, que cierto D. Isidro de Ilaro, indiano perulero, dió á la estanupa sueltas en Madrid y Alcala el año de 1716 , hasta setenta composicinnes de este género, bien ó mal atrihnidas á dicho Calderon, formando despues algunos volúmenes en los cuiles remió hasta doce, poniéndoles el fróntis copiaulo al priucipio de este artfeulo, usando la supercherfa de supmorlos pubdicados en Barcelona quince años ántes de que se imprimieran; y en apoyo de esta viltima suposicion +ñadiré, que positivamente Sebastian Cormélas no existia ya en aquella fecha (1701).-Este tomo es tan raro, que Barrera no lia logrado verlo.

\section{CALDERON DE IA BARCA} (Pedro). Avtos sacramentales, alegoricos, y historiales del insigne poeta español Don Pedro Calderon de la Barca. Obras posthumas, que del Archivo de la Villa de Madrid saca originales a Ivz Don Pedro de Pando y Mier. Madrid, Manuel Ruiz de Murga, 1717 (no 1716, como dice Brunet). 6 vols. $4 .^{\circ}$

La Purte primera, compuesta de 17 hojas prels., incluso un antefróntis grabado en que está el relrato de Calderon. y 399 pdginas, abraza estos doce Autos precedidos de Loa.

A Dins por razon de estado.

El viático cordero.

A María el corazon.

Las ordenes militares.

El grail teatro del inundo.

Amar y ser amado, y divina Filotea.

la cena de Baltasar. 
La nave del mercader.

Psiquis y Cupido.

Llamados y escogidos.

La inmunidad del Sagrado.

El pintor de su deshonra.

El retrato de Valk que Ileva este tomo falta en muchos ejemplares.

La Parte segunda, de 2 hojas prels. $y$ 413 pdginas, comprende cstos doce Autos con sus respectivas Loas.

La serpiente de metal.

Psiquis, y Cupido.

El indulto general.

El nuevo hospicio de pobres.

La primer flor del Carmelo.

El año santo de Roma.

EI año santo en Madrid.

El árbol del mejor fruto.

Los misterios de la misa.

Primero y segundo Isac.

Los alimentos del hombre.

El nuevo palacio del Retiro.

La Parte tercera es de 2 hojas preliminares y 457 págs. que contienen estos doce Autos con sus correspondientes loas.

Lo que va del hombre d Dios.

El verdadero Dios Pan.

La piel de Gedeon.

El lirin y la azuzena.

La derocion de la misa.

El santo rei D. Fernando. Primera parte.

- Segunila purte.

Sucños hai que verdades sou.

La semilla y la cizaña.

El pastor Fido.

La torre de Babilonia.

El Maestrazgo del Toison:

La Parte grarta, de 2 hojas prels. y 597 pdginas tiene doce Antos, cada uno con su Loa, y son los que signen:

El segundo blason del Austria.

El valle de la zarzuela.

La lepra de Constantino.

La hidalga del valle.

No hai más fortuna que Dios.

La viña del Señor.

El veneno y la triaca.

Andrómeda y Perseo.

La vacante general.

El cubo de la Almudena.

El gran mercado del mundo.

El tesoro escondido.

La Parte griula es de 2 hojas prels. $y$ 422 páginas, y tiene dnce Autos y doce Loas. Los titulos de los primeros son:

El sacro Parnaso.

El arca de Dios cautiva.

La humildad roronada de las plantas.

Los encantos de la culpa.

Quién hallará mujer fuertc.

El jardin de Falerina.

Fl cordero de Isaias.

MIstica y real Babilonia.

No hai instancia sin milagro.
El órden de Melchisedech.

El sncorro general.

La redencion de cautivos.

La Parte sexta, que consta de dos hojas prels, y 454 pdgs., abraza doce Autos, cada uno precedido de su Loa, á saber:

La vida es sueño.

El pleito matrimonial.

El dia mayor de los dias.

El primer refugio del hombre, s probática piscina.

El diablo mudo.

La cura y la enfermedad

El divino orfeo.

La siembra del Señor.

La segunda esposa, y triunfar muriendo.

A tu prójimo como a tí.

Las espigas de Ruth.

El laberinto del mundo.

He visto un ejemplar con la misma portada $\dot{e}$ igual contenido; pero algunas de las partes se diferenciaban en el número de las páginas. Tambien he tenido ocasion de examinar la impresion hecha en Madrid en $1759 y$ 60.6 vols. $4 .^{\circ}$ que es una reproduccion de la anterior de pando, hecha por D. Juan Fernández Apóntes, con la diferencia de que las composiciones del tom. II. de este son las del I. de la edicion de 1717; el II. contiene las del I.: el III. las del IV.; el IV. Ias del II.; el $\checkmark$. las del III. y el $\mathbf{r}$. las del $\mathbf{V}$. con la adi. cion de una Loà intitulada; Fabrica del narín y un autn que se llama la Prolestacion de la fé.-Ademas he comprobado los Autos sa. cramentales etc. inédilos recogidos en 1718 por D. Jurn Isidro Fajardo. Manuscrito de más de un siglo de antigūedad en dos volilmenes en $4 .^{\circ}$, preparado á lo que parecia para la impresion, que no se verifleo. Hai al principio un prólngo mui erudito sobre los Autos y Conedias de Calderon y se habla es. tensamente de sus diversas ediciones.

Comprenden cstos dos tomos los diez y sicle que se ponen aqui.

El Aqua de mejor vida.

Las ilos estrellus de Francia.

El divina Jason.

La Escuela divina.

La nueva moneda, y junta de Cortes.

La rida es sueĩo.

El Segundo David.

La prudente Abigail.

La Cruz donde murio Cristo.

Gedeon divino y humano.

La Iglesia sitiada.

Ll universal Redencion.

El Convite general.

Ecoy Narciso, primera parte.

El - Segunda parte.

El Divino orfeo, segunda parte.

Acto de Contricion.

A los Autos de Calderon les ha cabido me. jor suerte que a sus comedias, pues mulchas de estas se imprimieron por las copias mendosas que andaban en uanos de los cómicos, 
lniéntras los Autos, tanto los de Pando como los de Fajardo, se han copiado de los origillales que dejo su autor en manda al ayuntamiento de Madrid.

Es digno de advertirse que de los Autos impresos y manuscritos, de que he dado nolicia, se hallan omitidos oclo en la Tabla de los de Calderon, publicada por Vera Túsis, quicil nos da en cambio los títulos de los diez y ocho siguientes:

El primer blason del Austria.

Fortunus de Andrómeda.

la Fé del Auslria.

canlinerio y liberlad.

Los Mu'os ile Jericó.

La Fe sitiada.

Los Desugravios de Cristo.

La Iglesia silinila.

To hai plazo tue no se llegue.

El rescale del gémero hamano.

Triunfar muriendo.

J. a nuevi l'sposa.

El Juicio final.

La protestacion de la fé. Esta se halla en la edicion de los Autos de 1760 .

Las plantas. (Impreso.)

El minjor din de los mejores.

Los sicte planeta.s.

La peste del pan dañado, y Junta te la salud.

Se han impreso por fin, como de Calderon de la Barea, los pocos Autos, Loas, etc. que se notan il enntinuacion:

noña Muta. Entremes.

Jirlugonzillo $(E l)$. id.

lonelo (El) de los pastores. Suclto.

Juego (El) de la polotil. Loa.

for Sin tílulo especial.

Murrte' (Lu). Mojizanga.

l'ésume El de la vimila. id.

biloj til). I. oa sacramental.

siete lis) dias re la semante. id.

Siete Los) subios de Grecia.

Para cerrar el articulo de este autor me parce oporinno colocar aquí ha siguiente obra que conviene agregall á las de Calderon.

1133 C.ILDEROY DE LA BARCA (Peuno). Apelacion al tribunal de los dortos, Justa defensa de la Aprohacion a las Comedias de Don Pedro Calderon de la Barca, impressa en 11. de Abril del año de 1682. Impurnacion eficaz de los papeles, rue salieron contra ella hasta el año de 168:3. Apolocria que dexó escrita el Rmo. P. II. Fr. Manuel de Guerra y Ribera. Madrid, Joseph de Orga, incCLIY. $40^{\circ}$

Y comos complemento a la reseña bibliográ fica del célebre dranátiéo español, mencionare la siguicnte obra que describe Barrera:
Funebres elogios a la memoria de D. Pedro Calderon de la Rarca. Escrilos por algunos apasionados suyos del Alcacur. A instancias de D. Ioseph de Cactelvi y Alagon, Marques de Villatorcas... que es quien saca d luz eslos pipeles. Valencia, Francisco Mestre, 1681. 4. Comprende corto nimero de composiciones. Fueron sus autores: el conde de Buñol, D. José Ortí, el Marques de Villatórcas, Don José Coloma, Vicente dol Olmo, D. Marco Ant. Orti, Jacobo Fuster y D. Francisco Figuerola.

\section{CAMOENS (LUIS DE). Rimas} de Lvis de Camōes. Acrescentadas nesta Terceyra impressaõ. Em Lisboa. Pedro Crasbeeck. Anno 1607. A custa de Domingos Fernandez. $4 .^{\circ}$ La mayor parte de let. curs. 8 hojas prels., 202 fols. Cla última está numerada por equivocacion 102) y 5 sin foliatura para terminar la Taboada.

Raro, especialmente si liene las ochn hojas preliminares. Entre Ios sonetos laudatorios hai uno de Torciato Tasso y otro de Lconardo Turricano.

He visto la primera edicion cuya descripcion es la signiente: Rhylmas de Lvis de Camoes. dinididas em cinco parles. Lisboa, Munnel de Lam $a$, M.D.Lxxxxv. $4 .^{\circ} 9$ hojas preliminares (quizi faltase algmma), 169 foliadas, la última mal marcada $160, \mathrm{y} 4$. de Tabonda. Casi todo de let. curs.

La segrunda, que tambien he visto, dice mo el frintis, Accrescentadas nesta segunda impressaó. Lisboa, Pedro Crasbeeck, segun mis apuntes, y Manoel de Linra, segun Brunet, M.I.XCVIII. $4 .^{\circ} 8$ lojas prels., 202 fols. $\mathrm{y}$ J de Talla. let. curs.

Del Prólogo puesto por el librero Domingo Fernández il lá edicion que yo tengo, se desprende ser èl quien publico la de 1595 , y quich al reimprimirla en 1598 acrecentó la obra con varios sonetos, cinco odas, algimos tercetos y dos cartas en prosa; al hablar diclo Ferníndez de la impresion de 1607 advierte, no la adicionaba con todo lo que tenia recogido, porque lo reservaba para hacer una segundu parte, que luego publicó ell lifti; sin embargo, algro debio de añadir, pues en el Catálogo de Grenville se olsserva cncontrarse en esta tercera edicion, ademas de las composiciones que Fernández previene habia aumentado en la segunda, veinte y dos redondillas que no están en la primeru.

Brnnet trae como quinla la de Lisboa, $P$. Craesbeel, 161\%. 4. , ignoro cual pueda ser la fecha de la cuartic edicion.-He visto las Rimas de Lvis de Camões. Primeira parle. Lisboa, Antonio Aluurez, 1621. 4. 8 hojas prels., 202 fols. y 5 más para completar la Taboaila. Varece reimpresion de la de 1614 .

En el Catálogo de la venta de Conde se 
anuncló una de Lisboa, P. Craesbeek, 1629. $24^{\circ}$, y Brunet cila otra del mismo punto $\dot{e}$ impresor de 1641 , tambien en $240^{\circ}$ ambas las supongo iguales a la siguiente, la cual, como todas las descritas hasta aquí, solo contiene la primera parte de las Rimus.

\section{CAMOENS (LUIS DE). Rimas} de Lvis de Camōes. Primeira parte. Lisboa, Paulo Craesbeck, $1651.24 .^{\circ}$ 2 hojas preliminares y 18 fols.

Este tomito debe sin duda ir unido á las Lusindas, impresas en el inisnıo año por Craesbeek, 5 descritas al Núm. 506.

Brunet se refiere a las bimas varias, comentadas por Manuel de Furia y Sovsa, Lisboa, 1655-89. J partes en 2 vols. en fol. El comentario es en español. Como no he visto este libro no se si contiene todas las rimas i) solo la primera parte.

1138 - Rimas de Lris de Camōes Segrnda parte. Agora nouamente impressas com dinas Comedias do Autor. Com dous Epitafios feitos a sua sepultura, que mandarāo facer Dom Gonçalo Coutinho, N Narlim Gonçaluez da Camara. E hum Prologo em que conta a vila do Author. Em Lisboa, Pedro Crasbeeck. 1616. A custa de Domingos Fernandez. Siguen $1 \geq$ hojas prels., en que se comprende una que contiene la lista de los Liuros que Domingo Fermandez tem impressos deste Autor, y 40 folialas; viene lnego mevo fromtis en el que se lee:) Comedia dos Enfatrióes. Composta por Lris de Camōe.. Em Lisboa, Vicente Aluarez, 1613.--Comedia de Filodemo. Composta por Lris de Camóes. Em Lisboa. Vicrnte Aluarez, 1613 . CAmbas piezas llenan :0 folios sin contar las dos postadns.jOhra do grande Lvis de Camoés, principe da poesia heroyca. Da creação, c composiģ̃o do Homem. Em Lisboa, Pedro Crasbecek. Inno 1613. Froutis y 3.: hojas folindas.) 1. Las Rimas y la creacno do homem de let. curs.

I'rimera edicion, smmamente rara.

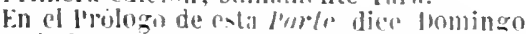
Fernindez, que a prsar do luabre promotido en el de la primera la prontil [ublic cine de La segumda, le liabia costado mus de sifot? años el remuir los matrialrs para formarla, pues muchas do: las romprosiciom las luabia mandado recoger eu la lulia: tambien pre. viene podria suceder que algunas de ellas no fuesen de Camoens. -las dns comedias se connce habian sido impresis sueltas ante. riormente, como ya Io indica la fecha de ellas, y quedindole sin duda rasi integra la edictinn las unio á las preslas para hacer saliese el volumen regularmente abultarlo. En la intitulada Filodemn haj dos personajes que hablan en castellann: lo misnuo sucede on los Anfilriones, traduccion libre de Plauto. Tambien debe agregarse la Creaçōo do homem, impresa por separado, pues aunque esta obra no va mencionada en el fruntis general del volumen, es evidente-que al darla d la estampa se tuvo la intencion de incluirla en èl. ast es que en todos los litu. lillos de las páginas se lee: Rimls de I. de Camoès. 2. parte.

Este tomo segundo de las poesias del vate lusitano debe formar juego con el primero, publicado tambien por Ferníndez en 1607. Viin. 1156.)

Nic. Antonio no conocio ninguna edicion de las Rimas de Camnens, inicamente indica haberse impreso en Lisboa.

Habiendo dado en este artículo una lista bastante completa de todas las frimcipales edicinnes de las nbras suclas de Camoens, mo: parece, que para completar la moticia biblingrifica. seril ronvenieuto indirar las impreviones de todis ellas reunidas: pero no habiumlome sido posilule coupulsarlas no puculo detallar con exactitud su costcuido, y por lo mismo ignorn cuates son mas o murnos complatios.

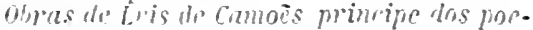
Ins mplugurses. Con as unqumentos do lecenceado Juin Fruncon lienriplo. Lisbon. An-

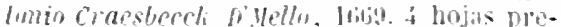

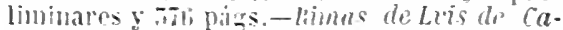

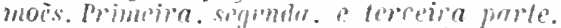

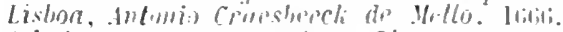

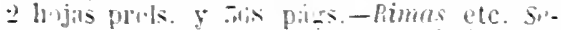

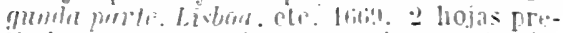

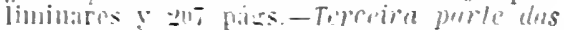

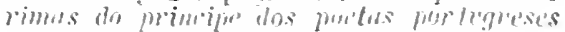

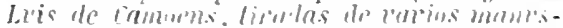

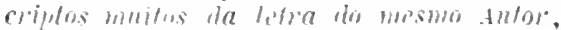

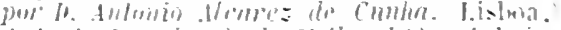

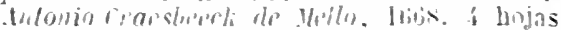
proliuninare. flis pos. II hujas sinfoliar

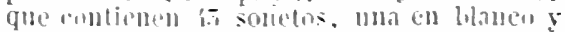

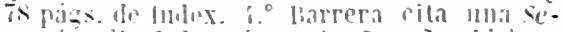

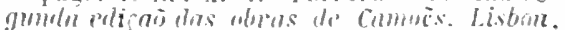

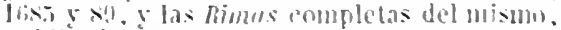
publicada fur Vantel de Faria y somsa : pero

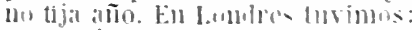

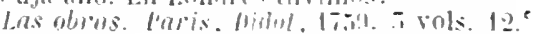

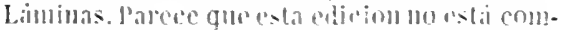
pleta.

Las ahmas. Lisbone 17.2 inols. 1200 Lami-

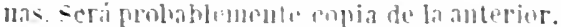

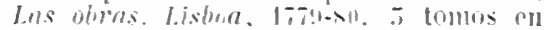
5 buls. s. Edicion mas rompleta que las anteriores: ha servido de oricinal para lis

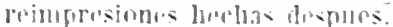

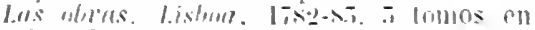

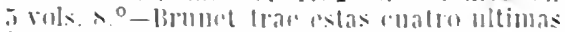
impresiones, yo le visto: obrus do grande 
Luis de Camōes. Terceira ediç̄ò da que se fez em Lisboa nos annos de 1779, e 1780. Paris, P. Didat senior, MDCCCXV. 5 vols. $18 .^{\circ}$ Retratos y láminas.

\section{CAMPILLO DE BAILE (Gt-} NEs). Grstos y disgrstos del Lentiscar de Cartagena. Svcessos varios, a modo de novelas, ilvstrados con sentencias. Avtor el Licenciado Gines Campillo de Bayle. Valencia, Francisco Mestre, 1691. 4. ${ }^{\circ} 6$ hojas preliminares y 387 págs.

Contiene varias poesías y un Baile cantado, que es una especie de zarzuelita.

Ticknor, tom. III., pág. 344, cita otra edicion de Valencia, $1689.4 .^{\circ}$, cuya existencia confirma una aprobacion de 1688 que se encuentra en la del 91 . El Sr. Barrera solo menciona la del 89 ; pero dudo la haya visto porque á tenerla presente no hubiera dejado de mencionar el Baile cantado.

Parece existe una comedia de Campillo, impresa en 1691 , intitulada El mejor des. calıo, San Pascual Bailon.

1140 CANCER Y VELASCO (JE nónımo DE). Obras varias de D. Geronimo de Cancer y Velasco. Madrid, Diego Diaz de la Carrera, M.DC.LI. $4 .{ }^{\circ} 6$ hojas prels. y 98 fols.

Esta es sin duda la segunda edicion hecha en el mismo año que la primera, segun Barrera, en la cual se dejo el prólogo de Zavaleta $\mathrm{y}$ la comedia burlescil La muerte de Baldovinos; pero se suprimió el entremes de La Garapiña, que se halla en la anterior.

1141 . Obras varias poeticas de Don Geronimo Cancer v Velasco. Madrid, Manuel Martin, $1761.4 .^{\circ} 6$ hojas pre's. y wöz̈ págs.

Tampoco se encuentra en la presente edicion la dedicatoria de Cáncer al duque de Nedinasidonia, ni el entremes de La Garapiña; pero está el prólogo de Zavaleta $\mathrm{y}$ la comedia.

El Sr. Barrera no menciona la edicion de 1761 y sí una de Lisbor, Antonio Rodriguez, 1671. $12^{\circ}$ en la que tambien falta el entremes.

Escribió este autor varias comedias en las cuales casi siempre tuvo por colaboradores á D. Juan ó D. Luis Vélez de Guevara, Moreto, Mátos, Villaviciosa, Zavaleta, Martínez de Menéses, 0 . Antonio Huerta ó Rosete Niño; y la mayor parte se publicaron en la - Coleccion antigua de comedias, impresa en el siglo XVII en 48 vols. Tambien compuso Cáncer algunos entremeses $\mathrm{y}$ bailes.

1142 CAÑIZÁRES (José De). Comedias escogidás de Don José de Ca- ñizares. Madrid; Ortega, 1829-33. 2 vols. $8 .^{\circ}$

Estos dos tomos forman parte de la coleccion de Comedius que publicó dicho Orlega y comprenden:

El dómine Lúcas.

El honor da entendimiento y el más bobo sabe más.

El picarillo en España.

De los hechizos de amor la música es el mayor.

Por acrisolar su honor, competidor, hijo $\mathrm{y}$ padre.

Abogar por su ofensor, y Baron de Pinel.

La más ilustre fregona.

La heroica Antona Garcia.

Creo hai una edicion de las Comedias de este autor hecha en Madrid, hócia 1754 . 2 vols. $4^{\circ}$; pero no la he visto ni tampoco el Sr. Barrela.

\section{CAÑIZÁres (José DE). El} Sol de el Occidente S. ${ }^{n}$ Benito de D. ${ }^{\text {Joseph Cañizares. Manuscrito en }}$ $4 .^{\circ}$

En él encabezamiento de este manuscrito se-espresa haber pertenecido á Carlos Ballejo Aulor de Comedias pr su Mag.d Año de 1697.

El Sr. Barrera cita otro manuscrito, al parecer autógrafo, del mismo año, existente en la Biblioteca nacional, y observa hallarse en el Catálogo de lluerta como anónima; en ello se equivoca porque tanto este como Medel atribuyen esta comedia á Cañizáres. Nunca la he visto impresa.

\section{CARDONA Y BORJA (AN-} Tovio DE). Lo mejor, es lo mejor. Fiesta, qve se escriviò para celebrar el dia del nombre de la reyna madre, nuestra señora, D. Mariana de Avstria. Y se represento a svs magestades, en el salon de palacio. Dia de svs reales años veinte $y$ dos de diziembre de mil seiscientos y ochenta y dos. Escriviola con Loa, \ Saynetes D. Antonio de Cardona y Borja, Marques de Castelnovo. S. 1. ni a. 4." may. La portada circuida de orla.

El no llevar esta impresion lugar ni año, sus espaciosas márgenes, buen papel y lujo con que parece ejecutada, indican no se hizo para vender sino para regalar ó distribuir privadamente. Estas circunstancias son de algun peso para suponerla primera edi. cion. Jimeno y Barrera no la han conocido y solo citan otra de Madrid, por Bernardo de Villadiego, 1683. 4..$^{\circ}$, la cual será probableinente la que se espendió al püblico, $y$ en ella el título se adicionó del modo sigulente: 
lo mejor es lo mejor ó untes que amar es la patria y primer cerco de Homa. Los sainetes se intitulan: La entrada de la reina.-La pragmatica de amor.-La Ronda de palacio.

1145 CARRILlO (D. Josè). La sinrazon impugnada, y beata de Lavapies. Coloquin critico, apuntado al disparatado prologo que sirve de delantal (segun nos dice su autor) a las Conedias de Miguel de Cervantes. Compuesto por Don Joseph Carrillo.. Madrid, MDCCL. 4.

\section{CASASUS Y NAVIA OSO-} RIO (JosE்). Viage del Parnasso y descubrimientos nuevamente hechos en este Monte, y sus Colonias. Su autor Don Joseph de Casasus, y Navia Ossorio. Valencia, Joseph Estevan Dolz, 1749. 8. ${ }^{\circ}$ marq.

Contienc una composicion dramática en verso, intitulada: El gran poema del mundo.

\section{CASTILLA MUÑIZ (JER.} Man. De). El Principe de los Sabios. Poema comico... en las solemnes fiestas de Santo Thomas de Aquino. Formabalo D. Geronymo Manvel de Castilla, Mvñiz. Sevilla , Joseph Navarro, (1735). $4 .^{\circ} 2$ hojas prels. y 42 págs.

Composicion dramática que no menciona en su Catalogo Barrera y Leirado.

\section{CASTILLO SOLÓRZANO} (Alorso DE). Los alivios de Casandra. Por Don Alonso de Castillo Solorçano. Barcelona, Iayme Romeu, 1640. 8. 3 hojas prels. y 191 fols.

Contiene este tomo cinco novelas $y$ una comedia intitulada el Mayorazgo figura.

Es una de las obritas más raras de Castillo Solórzano, así es que Nic. Antonio no la conoció, ni la menciona D. Pedro Padilla en su Catálogo de libros de entretonimiento.

1149 - Aventrras del Bachiller Trapaza, qvinta essencia de Embusteros, Y Maestros de Embelecadores. Por Don Alonso de Castillo Solorzano. Caragoça, Pedro Verges, 1637. 8. 4 hojas prels., 157 fols. $y$ una de Tabla.
Las fechas de las licencias y aprobaciones son de Zaragoza de 1655. - Nic.. Antonio no conoció esta novela de Castillo Solórzano, y Barrera y Leirado no hace mérito de esta edi. cion; pero cita una de Valencia de 1634.

\section{CASTILLO SOLÓRZANO} (Alosso De). Las aventuras del $\mathrm{Ba}$ chiller Trapaza. Escritas por Don Alonso de Castillo Solorzano. Segunda impression. Madrid, D. Pedro Joseph Alonso y Padilla, 1733. $8 .^{\circ} 8$ hojas prels., 314 págs. y 3 hojas de Tabla.

Contiene algunas poesías esta novela $\mathrm{y}$ el entremes de La castaĩera. El autor promete al fin de ella una segunda parte intitulada: La hija de Trapaza, que segun una advertencia del librero Padilla, es La Garduita de Sevilla.

Barrera y Leirado tampoco babla de la impresion de Padilla, la cual debe ser cuurta $y$ no segunda, si existe una de 1655 .

Creo hai impresion de Madrid, A. Yenes, 181\%. : $^{\circ}$, adicjonada por el licenciado Lanceta.

Gallardo, en su difuso artículo de Castillo Solorzano en el Ensayn de una bib. esp., nada dice de las Aventuras del Buchiller Tra$p a=a$.

11 - Hverta de Valencia, prosas, y rersos en las Academias della. Por don Alonso de Castillo Solorzano. Valencia, Miguel Sorolla, 16 29. 8. 7 hojas prels., 286 págs. y signs. a-g para la comedia.

Esta obra es una imitacion del Prado de Valencia de D. Gaspar Mercader: contiene una comedia en verso intitulada: El agraerio satisfecho y varjas poesias.

Si fuese cierto lo que dice el Sr. Barrera, al describir este libro, de que lleva en la portada los escudos de Valencia, esto supondria, ó haber dos ediciones del mismo año, ó por lo ménos, que son distintos los frontis en los ejemplares; pero recelo sean los tales escudos unicamente un adornito que encierra un águila con las alas abiertas, del cual usó Sorolla en rarias de sus impre. siones, $y$ es el que se encuentra en el mio.Gallardo al describir este libro en el Ensayo de una bib. esp. tambien dice lleva en la portada escudos.

11 光 - Varios y honestos, entretenimientos. En Varios Entremeses, Y pasos apasibles; que dio a LuzDon Alonso de Castillo Solorzano. Mexico, Juan Garses, $1620.8^{\circ}$. hojas prels. y 162 pays. 
Mi ejemplar, únlco que be visto, es tan hermoso que tiene muchas hojas sin abrir. El papel, letra y clase de erratas, particularmente en la hoja preliminar, todo concurre á haccr sospechar que esta edicion es de Ambéres, ó de alguna otra ciudad de fuera de España.

No hallo mencionado este rarisimo libro ni en Nic. Antonio ni en el Catálogo de las obras de Castillo Solorzano que formó D. Pedro de Padilla; tampoco ha logrado verlo el Sr. Barrera y Leirado.

Las composiciones dramáticas que contiene son las siguientes:

Coloquin de los amigos y competidores. En lves jornadas.

Diálogo de las ausencias del amor.

Las Bodas de Mengo y Camacho. E. En dos jornadas.

El Borracho. $E$.

El decreto del cielo. Especie de paso.

Las dos amigas. $E$.

Gallardo al describir el contenido de este tomito en cl Ensayo de una bib. esp., no hace mérito del Entremes de las Bodas de Mengo y Camacho; tal vez faltaria á su ejemplar. Y a propusito de Gallardo, aprovechare esta ocasion para observar que liabiéndole sido desconocidas tantas y tantas obras raras y preciosas, y habiendo descrita con suma concision olras mui curiosas ć interesantes, llena mada ménos que diez págiuas de dicho Ensayo copiando aprobaciones, licencias, prólogos, dedicatorias y estractos de las producciones de Castillo Solórzano, las cuales, escepto la presente y una ó dos más, no pasan de ser libros de mediana rareza.

\section{CASTRO (Fraxcisco de).} Primera parte de Alegria comica, esplicada en diferentes assumptos jocosos, compuesto por Francisco de Castro, Representante de vna de las Compañias de la Corte. Zaragoça. Año de 1702. 4 hojas prels. y 1038 paginas._- Segunda parte. Zaragoça. Año de 1702. 4 hojas prels. y $190 ̈$ págs. -Tercera parte. Zaragoça. Año de 1702. 4 hojas prels. y 152 págs. 3 volúmenes 8.

\section{Contienen estos tres volúmenes:}

\section{La Primera parte.}

El novio miscrable. $E$.

Francisco, qué tienes? $E$.

Los cuatro toreadores. $E$.

La visita y pleito de la liebre. $E$.

La burla del talego. $E$.

Ia boda y los violines. $E$.

El anor buhonero. $B$

El pésame de Medrano. $E$.

El enfermo y junta de médicos. $E$.

Ir á ver partir la vieja. $M$.
El estudiante marques. $E$.

La noche buena. $E$.

El ingrles hablador. $E$.

El reto. $E$.

La casa de posadas. $E$.

\section{Segunda parte.}

Quièn masca ahı? $E$.

El vejete enamorado. $E$.

El organo y el mágico. Primera y seaunda patrte. E.

La burla del sombrero. $E$.

La almoncda. $M$.

Los gigantones. E.

Los niños de la inclusa. $E$.

Las figuras. $M$.

Tres introducciones para la Comedia, Sarao y Fin de flesta que se hicieron á los años del conde de Salvatierra.

El amor sastre. $B$.

La fantasma. $E$.

El Dengue. $B$.

El figuron. $E$.

\section{Tereera parte.}

El ropero alquilon. $M$

Los diablillıs. $E$.

La burla del papel. $M$.

El harrendero. $M$.

Doña Parva materia. F. de $f$.

Lus negros. Introduccion y entremes.

La novia burlada. $F$. de $f$.

La casa puntual. $E$.

Lns burlados rle Carnestolendas. $E$.

Los titanes. $M$.

El paseo deI rio. $F$. dle $f$.

La burla de los titcres fingidos. $E$.

El cỏnico José de Rivas publicó una colcccion de entremeses de varios antores en 2 vols. en $8 .^{\circ}$; el primer tomo conticne uinicamente composiciones de Francisco de Castri). Véase Cómico festejo en la presente Division.

Fué conocido Francisco de Castro con el apodo de Far'ruco, y dice de él una Genealogía, origen y noticins de los comediantes de España, MS. en la Bib. nac., que hizo graciosos en las compañías de Madrid y fue mui aplaudido por las chanzas y gracejo que tenia, y añadia en las representaciones y sainctes. Los papeles de vejetes los hizo con particular gracia, y compuso buenos versos, particularmente en lo jocoso... En su conversacion fuera de las tablas era mui chistıso), y gustaban de él las señoras y señores, con los cuales tenia mucha cabida... Estuvo de gracioso en Valencia en 1692 .

Es mui difícil el reunir los tres tomitos de la Alegria cómica.

1134 CaStro (Gullenen de). Primera parte de las comedias de Don Gvillen de Castro. Las Comedias que van en este libro, son las siguientes:
1 El Perfecto Cauallero.
2 El Conde Alarcos.
3 La Humildad soberuia. 


\section{CAS}

4 Don Quixote de la Mancha.

5 Las Mocedades del Cid. 1.

6 Segunda de las Hazañas del Cid.

7 El Desengaño dichoso.

8 El Conde Dirlos.

9 Los Mal Casados de Valencia.

10 El Nacimiento de Montesinos.

11 El Curioso impertinente.

12 La de Progne, y Filomena.

\section{Dirigidas a Doña Marcela de Veg̀a} Carpio.

Valencia, en casa de Felipe Mey, 1621. 4. ${ }^{\circ}$ Varias viñetas de madera. 2 hojas prels. y el volumen carece de foliacion. Las signaturas y numero de hojas de cada comedia son estas: la primera tiene $\mathbf{2}$ hojas con la signs. A-C, la última es blanca. La segunda 20 , signs. A-B, la última de 12 hojas. La tercera 26, signs. A-C, la viltima de 10. La cuarta 24 , signs. A-C, la última hoja blanca. La quinta 2 ? , signaturas A-C, esta solo liene 6. La sesta 24 , signs. A-C. La sétima 20 , signaturas $\mathrm{A}-\mathrm{C}$, la última de 9 . La octava 26, signs. A-C, esta de 10 hojas. La nona 21 , signs. A-C, la última de ग̈. La décima 21, signs. A-C, la última es blanca. La undécina 24 , signaluras $\mathrm{A}-\mathrm{C}$. La duodécima 26 , con las signs. A-C, esta de 10 hojas.

Segrinda parte de las comedias de Don Gvillem de Castro. Dirigidas a Doña Ana Maria Figuerola y de Castro. En Valencia, Por Miguel Sorolla, Año 162ö. 4. 4 hojas prels. y כ้ว้6 págs.

Los titulos de las comedias de la segunda parte, son:

El engañarse cngañando.

El mejor esposo.

Los enemigos hermanos.

Cuanto se estima el honor.

El Narciso en su opinion.

La verdad averiguada, y engañoso casamiento.

La justicia en la piedad.

El pretender con pobreza.

La fuerza de la costumbre.

El vicio en los estremos.

La fucrza de la sangre.

Dido y Eneas.

Garcia de villanueva en el Orígen del teatro españul, pág. 294, dice, ser Castro mui poco conncido en sus compusiciones, que se han hecho mui raras; y Montiano y Luyan-

do, tom. II., pág. 10 , no tuvo más noticíd de la tragedia de Didn y Eness, de la Parte segundu, que la dada en el Discursn apolng ético de ta Poesía de Vera; con lo cual prueba no vió nunca ningun ejemplar de las comedias de Don Guillen : siempre be tenido á este libro por uno de los mís dificiles de conseguir de nuestra literatura dramática, y en efecto Mr. Heber solo logró dar con una Primera parle.

Barrera, en su Calálogo, apunta dubitatlvamente una edicion de la Primera parte hecha en Valencia por Felipe Mey, 1618.4. tomando probablemente de Jimeno esta no. ticia; yo pienso no existe semejante impre. sion, porque el autor en su dedicatoria á Doña Marcela de Vega Carpio, fechada el 23 de Abril de 1621, dice: Un mercader de libros, más curioso que corles, estando yo ausente, imprimió eslas doce comedias, añadiendo a sics yerros los del impresor. Para que eslo tenga (ya que n's enmienda) disculpa, suplico av. m. qur las admila, tea y acre. dite. Hai ademas un aviso al lector en que se le advierte que el lihro salia con muchas erralas y corrige dos de las más garrafales: la aprobacion de D. Juan de Jiuregui y la Tasa son tambien del mes de abril del mismo año 1621. Ifucho mènos, por consiguiente, creo en la impresion de 1614 de dicha Primera parle, apuntada por Ticknor. - Dice este al bablar de Castro y de sus Mocedrales rlel Cid, que esta comedia es la que le diú á conocer en Europa, así por ser la mu.jor de cuantas escribió, comu porque su contemporáneo Corneille se valio de ella para cscribir su mag. nifica tragedia del $C i d$, drama que determino y fijo durante dos siglos el carácter del teatro moderno europeo. Pero aunque Corneille, endoctıinado sill duda por las reñidas disputas que bajo la influencia de Richelieu se movieron sobre las unidades dramáticas, hizo en el plan de la comedia algunas alteraciones acertadas $y$ fclizes, es evidente que el principal interes de su tragedia consiste en la lucha entre el deber y el amor de la heroína, creacion primitiva del ingenio de Guillen de Castro.

Lope de Yega en su Laurel de Apolo le tributó el siguiente elogio:

Ninfas del sacro Turia, ya Pactolo, tejéd verdes guirnaldas

de flores de oro y hojas de esmeraldas, que son las de Helicona d́ lanlo vencedor breve corona; pero sea desmayo de los opositores en armas y en amores, el vivo ingenio, el rayo, el espirilu ardiente

de Don Guillen de Custro, á quien de su ascendente fué lan feliz el astro, que despreciando jaspe y alabastro, piden sus versos uro !y bronce elerno, ya se enoje narcial, ó endulce lierno. 
$11: 3 ̈$ CaXESI (Juan). Auto Famosso de Los desposorios de la Virgen Compuesto Por el Liçençiado Jü Caxesi. 4. Manuscrito autógrafo firmado por el autor.

No habla Nic. Antonio de este eseritor, ni sll auto, que es ineditn, se halla mencionado en el Índice de Medel. Barrera lo cita reflriéndose á nuestro catálogo de Paris y á este mismo ejemplar. Las licencias para su representacion dol vicario general Dr. Futierre de Cetina están fechadas en 11 y 15 de agosto de 1609.-La versificacion es bastante buena.

1156 CAYORC Y FONSECA (RAMiro). Triumpho sagrado de la conciencia. Ciencia divina del humano regocijo. Bienaventuranza de los pueblos, ciudades y reinos, cifrada en aquellas palabras celestiales Beatus populues, crei seit jubiletionesse. Psalm. 83. v. 16. Obra utilissima para el bien de las almas y acertada eleccion de las conciencias. Compuesta por D. Ramiro Cayore, y Fonseca. Salamanca, Antonio Joseph Villargordo, 1731. 4.

No esfácil adivinar al leer la portada de este libro ni su indice, que la obra del pres. bitero Cayorc es uma furibunda eritica de las comedias y una terrible reprobacion de que se pongan en escena. Casi todo el tratado está dirigido contra el P. Nammel Guerra por la defensa que lizo de las producciones dramáticas de D. Pedro Calderon.

\section{CELESTINA (LA). Oranicomedia}

de Califto y Atldibea nucuamēte reui, fta y cmendada fó addicion Delos argu métos de sada un anto en psillsipio. La qual ētiene de mas de fa agradable $\mathscr{c}$ Jules eftilo muchas fentéciag filofofa les: : $と$ auifos may neceffarios ‘pa māace bog:moftrādo les log engaños $\bar{q}$ eftan encerrados en firuiz̄tes $と$ alcahuctag.

(Esta leyenda circuida de orla va precedida de una lámina de madera que representa varias escenas de la comedia. Al dorso se halla la carta del autor; ocupan la hoja 2. ${ }^{\text {a }}$ las nueve primeras estrofas del continuador, en la $3 .^{2}$ están las dos restantes $y$ el prólogo, que concluye al principio de la 4. ${ }^{a}$ llenando lo restante de la pág. los argumentos de la comedia y de su primer auto. Principia este en el blanco de la $5 .^{2}$ hoja de la $\mathbf{A}$ con una viñeta, como sucede en todos los veintiuno, escepto el $19 .^{\circ}$ que lleva dos. Al fin estan en 2 hojas las tres estrofas con que remata el autor, y las siete del corrector Alonso de Proa$z a$, copiadas a lo que parece de la edicion de Salamanca de 1500 , pues concluyen diciendo:

c Descriue el tiempo y lugar en que la obra primeramente se imprimio.

I El carro phebeo despues de auer dado mill r quinientas bueltas en rueda ambos entonçes los hijos de Leda a phebo en su casa tenien possentado: quando este muy dulce y breue tratado despues de reuisto $r$ bien corr egido con gran vigilancia puntado y leydo fue en Salamanca impresso acabado.

$Y$ a continuacion va el siguiente remate:)

[Tragicomedia de Clalisto 5 me libea. Agoza unenamente reni;

fta $\mathfrak{\imath}$ cosregida conlog arga mentos de cada anto en pzincipio acabaffe con diligencia ftudio im pzeffa enla $\bar{i}$ figna cindad de valétia poz $\$$ uã joffre a.xid.de febze ro de. Al . $y \cdot d . y \cdot x i i i j$ años. 
4..$^{\circ}$ let. gót. Viñetas de madera. Sin foliacion, con las signs. A-J, todas de 8 hojas, ménos la $\mathrm{J} q u e$ tiene seis.

Hai que notar que en la presente impresion de 1514 son siete las estrofas del rorrector Proaza, mientras en otras su numero es solo de scis, por fallar la penúltima, la cual dice:

\section{Toca como se deuia la obra llamar Tragicomedia $थ$ no comedia}

\section{Penados amantes jamas conseguieron dempresa tan alta tan prompta victoria como estos de quien recuenta la historia ri sus grandes penas tan bien succedieron: mas como firmeza nunca touieron los gozos de aqueste mundo traydor supplico que llores discreto lector el tragico fln que todos oujeron.}

La edicion valenciana fue probablemente hecha plana por plana sobre la saliumanquina de 1500 , pues la dada i lnz en dicho punto en 1.502 debió ser copia de la anterior, constando tambien de 70 hojas. y llevando jguales signaturas á la de Valencia, de la cual no se conoce mís ejemplar que el bellísimo de mi biblioteca, procedente de la de Mr. Nodier.

Habiendo reunido bastantes impresiones de esta obra y recogido $11 \mathrm{n}$ mimero erecido de apuntes sobre otras varias . vistas por mí $\dot{0}$ mencionadas por los bihliografos, las iré describiendo intercalíndolas por su cirden cronológico.-Principiare por las anteriores á la de 15l4, que es la más antigua de mi coleccion.

Se ignora el título de esta obra en su primera edicion, por faltar el frontis al inico ejemplar que de ella conozen. Este en la hoja sign. aij (no ai comn dice Brunct) tiene la viñeta copiada del Plácida y ricto. riano de Encina, y encima de ella se lee lo siguiente:

\section{If Argumèto del primer auto desta comedia. Mclibea Culisto}

La obra concluse al reverso de la hoja tcr. cera de la $m$ con las palabras parque ne dxaste triste e solo in hac luchrymernm valle. En la hoja siguiente solo se encnentra el escudo de Fadrique de Basilea, impresor de Búrgos, que va copiado en el presente Catilogo al artículo Fasciculus mivrer y en la faja de su leyenda, en el blaneo bajo la palabra cavsa, se ha puesto 1499 ,

Tоу. 1. de modo que solo por este dato se sabe que la edicion está hecha en Búrgos, por Fadrique aleman de Busilea en 1499. 4. ${ }^{\circ}$ let. gót. Láminas de madera, sin folios, con las signaturas $a-m$, todas de 8 hojas fuera de la uittima que solo tiene 4. No sé de dónde se sacó el editor de la impresion hecha por Hibade. neira, que la edicion principe es de Medina, 1499.

En la primera y rarísima de Búrgos no se hallan los autos XV á XIX, ó sea el Tra. tado de Cenlurio, que añadió el barhiller Fernando de Rójas en la de Salamanca de 1500 ; de modo que solo tiene XVi autos, correspondiendo el XV y XVI al XX y XXI de las ediciones posteriores. Tampoco se encuentran las estrofas del adicionador $\mathbf{y}$ sil prologo, puestos al principio de las otras, ni las del corrector Alonso de Proaza, con las cuales suele cerrar la obra. La carta del autor nombre que toma el adicionador con fundamento á un su amigo pudiera estar al dorso de la portada, de que carece el ejeniplar.

El P. Yéndez no turo ninguna noticia de este libro.

Por de contado se ignora saliera á Iuz ninguna edicion con solo el aulo primero, que es el de la primitiva mano, pues los quince restantes de esta edicion de Bürgos, forman la primera de lis tres adiciones que turo sucesiramente esta obra.

La edicion que parece siguió á la de Burgos. es la publiedda en Salmmunca, 1500, segun el testimonio de Yoratin, y lo prueba el final de ella copiado en la de valencia de 1514. Probablemente será en $4^{\circ}$ y en let. crot.-Se imprimieron aqul por primera vez los actos 15, $16,17,18,19, \dot{0}$ sea el Tratado de Centurio que fue la segunda adicinn hecha por Rójas al primer fragmento de la comedia.

Amarita en el priltego de la edicion de la colestiun di lses. habla de una hecha por

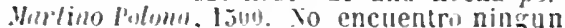
iunpresor de aste mumbre entre los que ejerrierou la profesion en España en ol siglo $\mathrm{xl}^{\circ}$

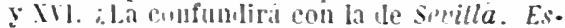
innistwo polounn, 1501. io Iet. grit.. citada por Brunet y Yoratin 5 mencionada tambien eII el Catulingue des licres du Duc d'Estrees al $11 \mathrm{~m}, 1066 \mathrm{i}$ ?

Tragicomedia de Calislo y Meliben en la qual se conliene de mas de su aqrailoble dulce estilo muchas semtencits filnsofales: ? anisos mi hecesurins per"a mancebns: mostrundo le's los enumios io cstan encervados en seruimtes: itcalnurlas: a muruemente'

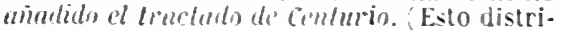
buido en nueve Ineals bajo de nua limina de madera izual il la gue se halla pll la porta-

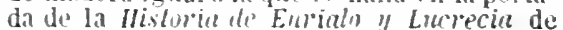
Eneas silvio .11 dorso principia: El Auctor a z'll sil antigo. Desptles de esle prologa vienen has once oetilvis, por enyo acróstico ste saca cl nombre y uatria del continuados de la 
obra, principla esta en seguida, y en el blan. co de la uiltima hoja dice:)

\section{Descriue el tiempo que la obra se imprimio}

El carro de febo despues d' auer dado mill $\times$ quiniètas dos buellas è rueda... fue en Seuilla impresso acabado

4. ${ }^{\circ}$ let. gót. $\sin$ fol. signs. A-U, de 4 hojas todas, menos la $\mathrm{U}$ que es de 6 . Viñetas de madera. Brunel la menciona; pero la descripcion la he tomado original del libro.

Puede inferirse ser esta impresion dis dacobo ó Jacome Cromberger, porque la viñeta del fróntis, como ya lo he indicado, es la misma puesta por este en 1512 á la Historia de Eurialo y Luerecia.

\section{La misma obra. (AI fin:) \\ Mil \& quinièlas dos buellas... \\ fue en Salamãca impresso acabadn.}

4.' let. gót. Viñetas de madera. 70 hojas con las sigus. $A$-J. $\sin$ foliacion. (Brunet.)

En el Catálogo de Gancia se anuncia una edicion de Sevitla, 1504. 4. "let. gót. Láminas de madera. Dudo sea cierta la fecha porque nadie la menciona, y estando falto ol ejemplar de las tres últimas hojas, indudablemente le faltaria el colofon que es donde debia constar el añn. En dicho catálngo se comete ademas el disparate de llamarla primera impresion.

Principia el ejemplar de otra edicion, que he visto, por la hoja sign. $a v$, con el siguiente epigrafe:

C Siguese la Comedic o Tragicomediu de Calisto y Melibea: compuesta en reprehension delos locos enumorados que vencidos en su desordenato apetilo a sus amigas llaman I y dizen ser su dios. Assi mismo hecho en auiso delos engaños delas alcaluzetas / y mulos / lisonjeros siruientes.

\section{Argumenlo.}

Concluye la obra en el blanco de la novena hoja de la sign. $i$, principiando en seguida los versos que ocmpan liasta el blanco de la décima; la última estrofa dice:

\section{- Descriuc el liempo en q̃ la obra se imprimio.}

- El carro de Phebo despues de auer dado mil quinjentas y siete buettas en rueda... fue en çaragoça impresso acabucto.

4. let. gót. $\sin$ fol., signs. $a-i$. La vi en poder de ini amigo $\mathrm{U}$. Manuel de Bofarull.

Estas son las ocho ediciones que conozco anteriores á la de 1514 de mi biblioteca. Las de Milun, 1514 y Venecin, 1515, que cita Barrera están en italiano. La primera que siguio en castellano fue
1158 CELESTINA (LA).

\section{Uragicomedia De Clalifto y Atle"}

libea: enla qnal fe cotiene de mas de sa agrada/ ble $r$ dalce eftilo: muchas fentécias filofofales: $\checkmark$ anifos may neceffarios para mārebos: mo/ ftrandoles los engaños que eftan encerrados en feruientes $x$ alcahnetas; $\varepsilon$, nucamente aña dido el tractado de Centurio.

Principia al dorso de la portada la. carta del autor; los prels. concluyen con la hoja 5." de la $\mathbf{A}$, empieza la Comedia en la $6 .{ }^{\mathrm{a}}$ y acaba tolalmente en la 7. ${ }^{2}$ de la M., diciendo la última estrofa de Proaza.

\section{Defrine el ticmpo en que la obza fe impzimio.}

El carro de febo defpaes de haner Jado mill $\varepsilon$ quingentas veynte y tres bneltas ambos entortes los hijos ie leda a phebo en fa safa tienen pofertado quando efte muy inlec y becue Iratado defpues de renifto y bien cozregido con gran vigilancia puntado y lcydo fue en Seuilla impzeffo acnbado.

\section{Finis.}

8. ${ }^{\circ}$ let. gót. Portada de negro y encarnado. Viñetas de madera; sin foliar y con las signs. A-H, todas de $\mathbf{8}$ hojas, la última blanca. Se omiten al fin las escrofas antepenúltima y penúltima de las 7 de Proaza puestas en la edicion de $15 \mathrm{14}$.

Primera edicion hecha en el tamaño de $80^{\circ}$

Nadie, que yo sepa, ha suscitado hasta - ahora dudas acerca de la legitimidad de esta impresion de 1525 , que es para mi veneciana. Así lo evidencian la jentidad de sus láminas y letra con las edicinnes hechas por Juan Bautista Pedrezano y Estéfano de Sabio; su tamaño, que es algo mayor que el $8 .^{\circ}$ español, y más que todo la frecuencia de erratas y la clase de estas, pues desde las primeras líneas de la cartadel autor se lee: a vn suo amigobeneficio recebito-pera en vez de paravostra-nostra-galenes por galanes, ete., algunas de las cua: ss se conservaron en las cdiciones de Venecia; onnque la mayor parte se corrigieron.-Aqui vu ive el Sr. Barrera á intercalar una traduccí:il italiana impresa en Venecia en 1525. Siguió, jues, á la impresion de 1523 la citada por Brunet, en el blanco de cuya últinı hoja se lee: 
Impresso (en Sevilla) por Jacobo cromberger uleman y Juan cromberger. Añn del seĩor de M.D.XXV. en fin de Nouiembre. $4 .^{\circ}$ Iet.-got. Láms. de madera: sin fol. conl las signs. $A-H$ de 8 hojas cada una.

D. Jaime Villanueva, en su Viaje literario, tom. XVI., págs. 50 y siguientes, describe otra en cuyo final se lee:

El carro de Febo: sus vuellas ha dado mil y quinientas: $y$ XXV en rueda ambos los hijos: enlonces de Leda a Phebo en su casa: lienen posentado cuando esle muy dulce : $y$ breve tratado despues de revislo: $y$ bien corregido dentro Barcelona : puntado y leido por Carlos Amoros: impresso acabado.

No da más señas sobre la edicion; pero supongo será en $4 .^{\circ} \mathrm{y}$ en lel. gút.-He visto otra intitulada:

Tragicomedia de Calislo y Nelibea, ěc., etc. y nueuamète añadido el tratado de Cèlurio y el aulo de Trasso r sus cöpañe. rus. Nueuanèle hystoriado. (La parte superior del fróntis la ocupd una lámina igual á la que luego copiaré al hablar de la edicion de $1538 \mathrm{y}$ a la vuelta de la portada se halla c El aulor a un su amign; siguen los versos con el acrósticn y el prólogn. La obra principia en la hoja sign. a $i$ iij vuelta, y concluye en el blanco de la octava de la $H$ : el reverso lo llena una grande orla dentro de la cual dice:) Impriminse la presene Tragico media de Calisto y Melibea: Nucuamèle corregita hystoriada) enla Yupprial ciudad de To!edo: en casa de Remon de Petras. Acabose a. xxiij del mes de Junio. Año de Vil $x$ quinienlos $x$ $x \boldsymbol{x} \boldsymbol{i j}^{\mathrm{j}}$ (1526). Anos. (Sigue el escudo de Petras copiado en el art. de López de Ayala. Cronica del rey D. Pedro. Seccion histórica.-Historia de España.) 4. $0^{\circ}$ let. gót. sin fol. Tiene láminas de madera, las mismas á mi parecer que las de la impresion de 15.58.-Esta es la primera donde encuentro añadido el Auto de Trasn e sus compañeros, intercalado entre el 18 y 19 de las anteriores, de modo que tiene veintidos autos.

En el Catálogo de la venta de White knight hai una edicion de Sevilla, 1528; y en el nianuscrito del tom. Il de la Tipografia española de Mèndez, anunciado en nuestro Catálogo de Lóndres, se describia una en cuyo final dice:

Tragicomedia de Calislo y Melibeáa agorn. nueuamente revisla e corregida con los r.r. gumentos de cada auto en principio. Accosose con diligenle esludio. Impresso en a in sane ciudad de Valencia. Por Iuan Viño. ." $\rightarrow i j$. de febrero. M.D.xxix. 4. ${ }^{\circ}$ let. göt-iv: : dicion debe de estar copiada de la de Sainnanca de 1500, ó bien de la de Yheisia de 1514, pues repite en la última ístruía de Proaza la fecha de aquella

sigamos la noticia de las que esisten en mi biblioteca.
1159 CELESTINA (LA).
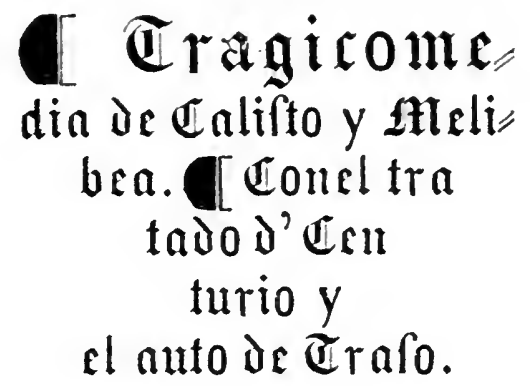

(Este título va precedido de dos figuritas de lombre y mujer y se halla circuido de una orla, dentro de la cual se lee en la parle inferior: CAROLVS V. IMPERATOR. El dorso y blanco de la hoja aij lo ocupa la carta del autor a su amigo, de letra rontana, siendo lo demas ael volumen de letra gotica. Siguen despues en el recerso de esta hoja y las otras ä los versos de Fernando de Rójas, su prólogo y los argumentos, por manera que la Comedia principia en la mitad del blanco de la 8. ${ }^{2}$ de la sign. a. En la 3̈. ${ }^{a}$ de la q se lee á la vuelta: Esle auclo. xix. fue añadido en la presente obra que hasta aqui no estaua. Sin embargo, dichn Auto es el de Traso, anunciadn en la portada de la edicion de Toledo, 10:6. Al reverso de la hoja $4 .^{2}$ de la sign.s, hai un renglon que dice:)

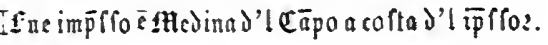

(. To suena el nombre de este ni el año; pero yo presumo es de hácia 1530. 8. - let. gót. Vinetas de madera: sin foliacion, signs. a-s, todas de 8 hojas, ménos la $\mathrm{s}$, que tiene 4 .

io van al fin las estrofas que en las otras ediciones.-Es impresion mui rara.

\section{CELESTINA (LA).}

\section{Cragicomedia de Califto y}

Entelibea: enla qual fe sötiene de mas de fa agradable $x$ julce eftilo: muchas fentēerias filofofales: $r$ auifos may neceffarios para mácebos: moftrūdoles los engaños $\bar{q}$ efta encerrados en feraisnteg $v$ alcahnetas; $\tau$ nuearaéte artadido el Iractado de Cestario 
(Al fin en el blanco de la hoja $3 .^{2}$ de la 0 dice, distribuidos los renglones de diferente manera:)

El libzo pzefente agradable a todas las eftranas naciones fue enefta inclita ciudad de Uenesia. Keriup zeffo poz mifer Inan ba" tifta pedrezanto mercader de libzos que tiene pos enfeña la êse: iut" to al puente de hitalto... fo acabo efte año del señoz de. 1533. a dias

\section{De ODtobre...}

El co2etos gุue es iela peña de murtos folamente co:rigio las letrus que maleftanan.

finis.

8. ${ }^{\circ}$ let. gót. Portada de negro $y$ colorado. Finetas de madera; sin fol., con las signs. $\mathrm{d}-\mathrm{O}$ de 8 hojas cada una ménos la 0 que tiene tres, debiendo haber alguna blanca al fin.

La lámina de la portada, viñetas y letra de esta impresion, son idénticas á las de la que se dice hecha en Sevilla en 1525; pero se hat corregido muchas de las erratas de esta.

Fo es le estrañar sea el contenido del frontis innal al de la edicion sevillana de 1502, por cuanto en las estrofas de Proaza, puestas al fin, se ha dejado subsistir lo de

El carro de Febo despues te haber dado vil e quinientas dos vucllas en rueda

Cuando este mui dulc: y breve tratado

Fué en Sevilla impreso acabado.

En poder de la Sra. Doña Antonia de Sojo ví otra edicion, al fin de li cual se leia:

Acabase ln tragicomedia con el tratado de Centurio: con diligencia correyido y emendado. Fue impreso enla mity uoble y mas leal ciudud de Burgos: por Juan de Iunta impressor de libros: y acabos? a. xii. dias del mes de seliembre año det nacimionto de mestro redemptor y satuador Jesnchristo de mil y quinienlos y treinta y un (15.51) años. 4. let. grit. Vinetas de madera y el fróntis de letra color,ada.
1161 CELESTINA (LA).

Tragicomedia de Calisto y Melibea: enla qual se cõtiene de mas de su agradable $\varepsilon$ dulce estilo: muchas sentẽcias filosofales: (ut supra). (Portada igual a la de la anterior de Venecia, y en la cuarta lioja de la sign. 0 se lee lo siguiente, distribuidas las líneas de distinto modo:)

El libzo pzefente agradable a todas las eftrañas naciones fae enefta inclita cindad de Denecia. Reimp $\bar{p} f 0$ poz maeftro effephano da $\mathfrak{s a b i o}$ imipffoz d' libsos griegos latinos y efpañoles nuy cozregi, dos con otras dimerfag obzas is libzos... To arabo efte año del Señoz de. 1534, a dias die; de $\mathfrak{J}_{\mathfrak{H}}$, lio...

(El folye dicho inaeftro ó ftampa todas las obzas efprinolus en quarto follo efta a fan Eantia in Lencria.

rinis.

8. ${ }^{\circ}$ let. gót. Viñetas de madera. Porlada de negro y colorado.

Edicion hecha hasta el fin de la hoja se. gunta de lia sign. 0 á plana renglon con la de Venecia de 1551 , y aunque diferente de ella en todas sus pácinas, se emplearon para inıprimirla la misma letra y viñetas. La dirersidad principia en la tercera hoja de la sisuatura antedicha, donde hai una Introduc. cim is muestra el Delicalo a pronunciar la lenque española. Al fin, como sucede en la de 15.51 , se ha suprimido la penúltima estrofa de las de Proaza que trae la de Valencia de 1.51 ; pero contiene la que prueba ser las dos impresiones venecianas copias de la de Sevilla de 1502 .

Tilmpoco tiene mís que veintiun autos, faltándole por consiguiente el de Traso.

lor tercera vez vuelve á ingerir el señor Barrera en la série de las Celestinas castellanas una version italiana, impresa en Venecia en 1555 .

D. Antonio Nayans, segun el teslimonio de García de Villanueva, pág. 71 del Orígen del Teatro español, tuvo una de Sevilla, 1534.

Panzer habla de otra hecha tambien en Sevitla, Domeniro de Robertis, 12 de Mayo de 1556. $40^{\circ}$ let. gót.

L.ampillas se refiere á la de Genova, 1538. 
CEL

PRIMERA DIVISION.

CEL

389

1162 CELESTINA (LA). (El siguien- | te es un buen facsímile de la portada.)

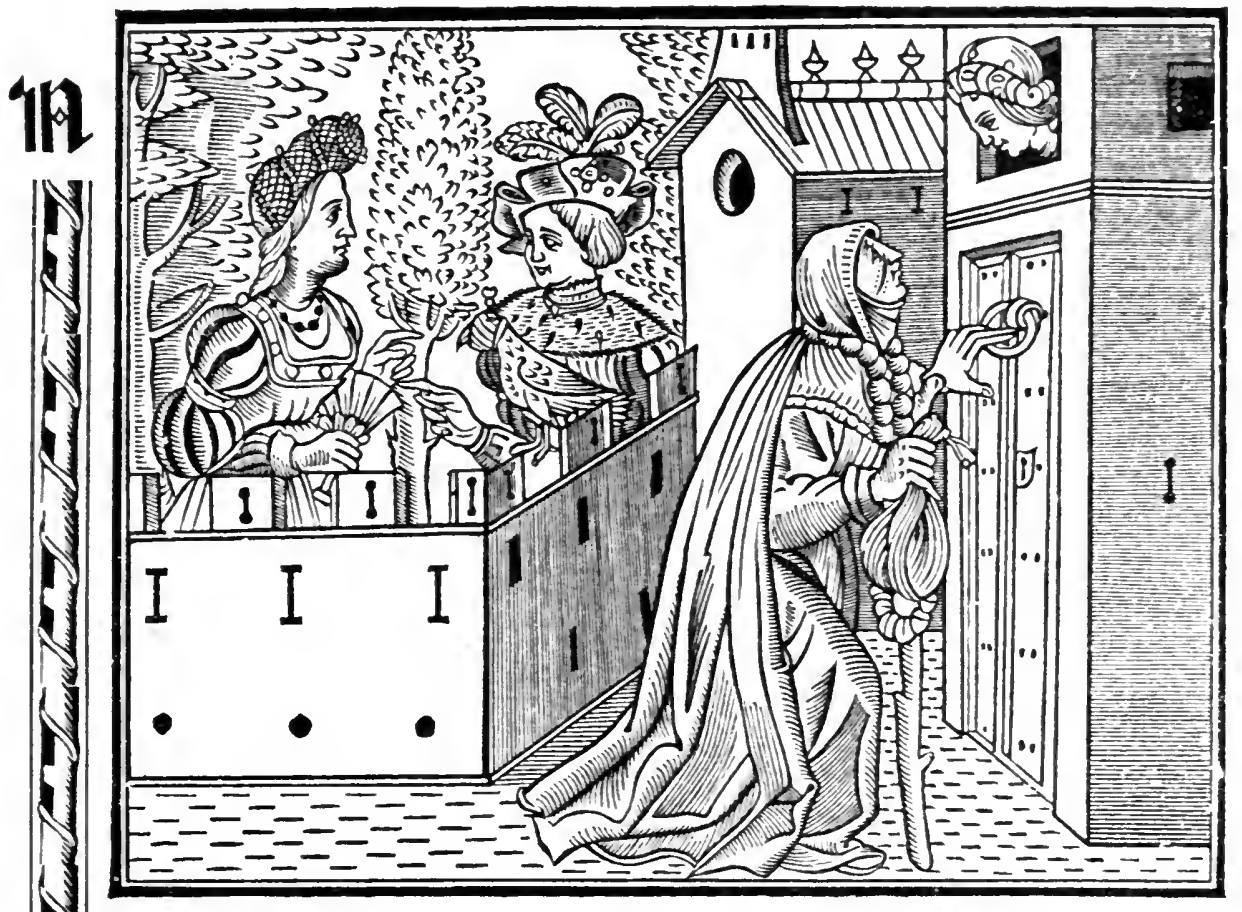

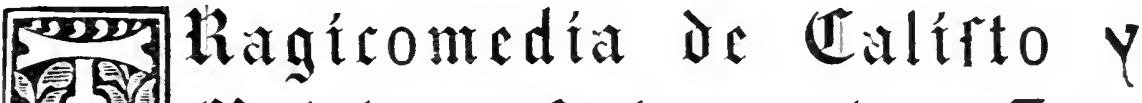

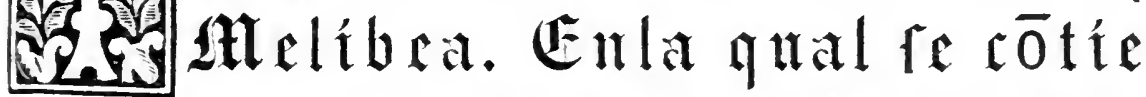

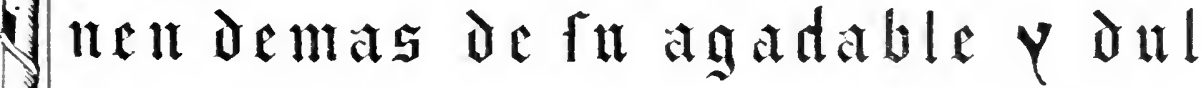
Nie eftélo muchar fentēétar philofo Gales yantfos muy necefartor pa

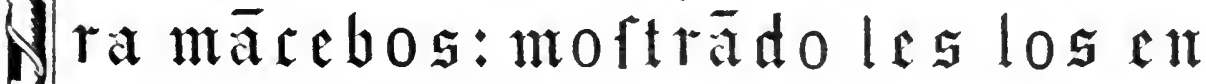

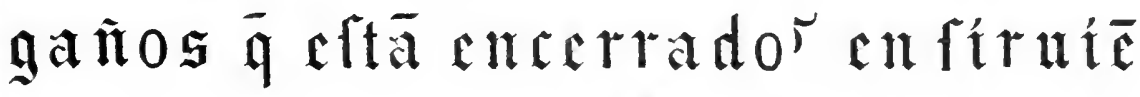

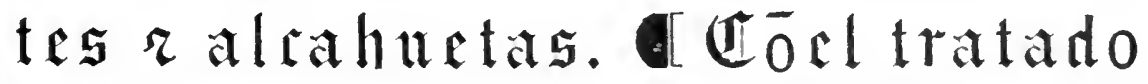
Nate $\mathfrak{C}$ enturio yel anto de erafo. 
(Al dorso: El autor a rn su amigo: esta carla concluye mui al principio de la hnja segunda, y la siguen las estrofas, prologo y argumen(1)s, empezanilo la Comedia en el reverso de la hoja 5. " En el blanco de la
$8 .^{a}$ de la $\mathrm{h}$ se repite lo de la edicion de Medina, y con lanta verdad como en clla, que el auto $\mathbf{X} X$ fué añadido en la presente obra que hasta aquí no estalsa; y a la vutella de la hoja úllima se lee este final:)

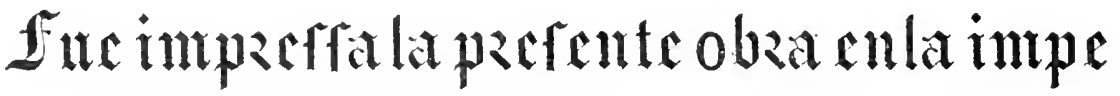

\author{
rial cindad de Toledo en rafa de $\mathbb{I}$ llan de ayala. Aca \\ bofe a veynte y ocho dias del mes de fehzero. \\ Ano de mil aquiuirtos atreyuta y ocho \\ Añog.
}

4. ${ }^{\circ}$ let. gát. Virirtas ile madera, sin foliacion con las sigus. $a-i$, lodeles de 8 hiojas.

Se parece esta rarisima y completa edicion a la de Medina en tener veintidos antos y en no llevar al fin los versos del correcior proaza. Siemdo tan poco conocida, me lat parceido romveniente presentar los facsímilies de la limina de la purtada $y$ de la viñota que se lialla poco despues del prineipio del aulo caloracro.

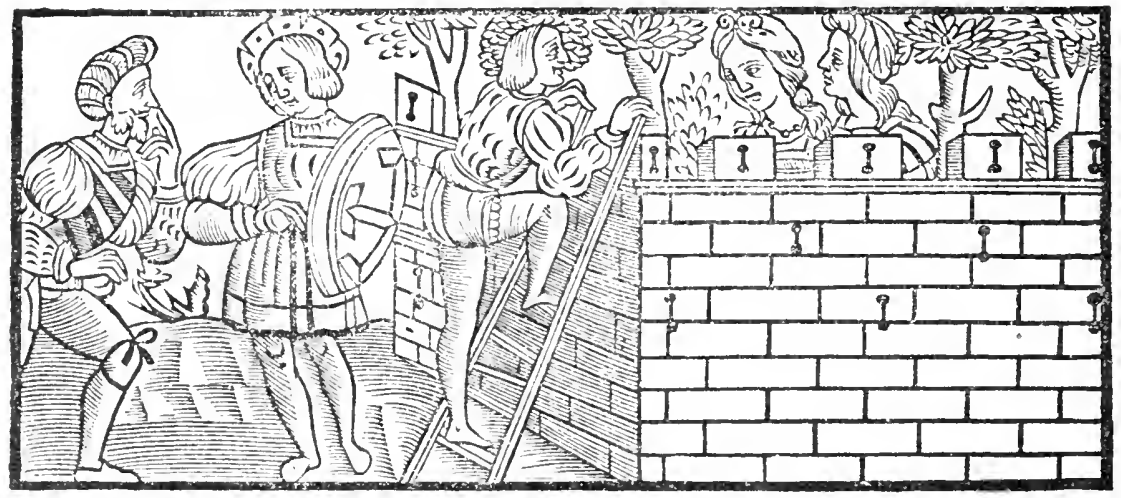

Antes de describir ba edicion de 1.555 de mi bibliotera, corresponde hiblar arni de seis edieiones anteriores á esta fecha que no tengo, á saber:

Tragicomedia de Calisto y Helibia. (Al fln:) El libro presente... fu? enesta rindal Euberes... ?empresso por mass(ro) Guillome Wonlano impressor de libros ariorgos lolinosy cspañoles... lo acabo este año l.s.s?, alins re!mete y octaun de Jurio. $s 0^{\circ}$ sin folios ni viüetas, con las signaturas A-Oij. (Brunet.)

Sevilla, 1559. (Indice espurgatorio de 1610, Vie. Antonio y Vontiann Luyando ('n el Discurso subre las (ridyolins, pín. $7,1.1$.

En Lixbou, Luys Rorlriquez, 15.40. 1. (Ca-
Lílngo del Sr. Marques de Morante.) Ignoro si estarí en let. got. porque esta circunstanria sucle omitirse a vezes en dichn Catá$\log 0$.

(Brumet.)

Carayoça, Diego Hernandez, 15行. . $^{\circ}$

- Emers, on casa de Yartin Nucio, 1545. 12. lel. semiguticat, sill folios, sions. A-O, todas de 8 hojas, la ńltima es blanca (Brunet; y otradicion dal mismo.

- Nucio, s. a. que se halla er el Catálogo de Teschuer.

1163 Cellestixa (La). Tragicomedia de Calisto y Melibea En la qual 
se contienen etc.... IIa se le añadido nueuamente una Grammatica, y un Vocahulario en Ilespañol, y en Italiano, para mas introduction de los que studian la lengua Castellana. Nveramente corregida por el S. Alonso de Vlloa. Impressa en Venecia en casa de Gabrel Givlito de Ferraris y svs hermanos, en el anno del S. MD LVI. (Al reverso del fol. 152 dice:) Inpresso enla inclita ciubdad de Venecia, acosta de Gabriel Giolito de Ferrarijs, e sus hermanos. Acabose a xx. dias de llenero del año del nascimiento de nuestro Saluador. M.D.LIII. (Sique sin foliacion en 2.3 hojas) Introdutione del Signor Alphonso V'glioa, nelia quale 's' insegna pronunciare la lingva spagnvola. Venegia, Gabriel Giolito de Ferrari e fratelli. MDLIII. $8 .^{\circ}$ let. curs.

Los ejemplares primitivos de esta impresion llevan la siguiente portada: Tragienmediu de Calisto y Meliber en la quml elc... Dirigida al llust. y mui Magnif. S. el S. Juan Micas, y con suma diligencin corregida por Alonso de Lllor: e impresa on quisa husta aqui nunca vista Es mevamente aũaristo el lratado de Cmiturio con una esposicion d'al. gumos vocablos en lengua thosrama. Iupresa "n Venecia en casa rle Gabriel Ginlelo de Frr. rari y suls hermanos en el amo del S. HDI.III. Tienen efectivamente la dedicatoria dirierila al S. Juan Yicas, mićntras que á los de 1556 se les mudó á nombre del S. Juan de Civallo, fechada en dieho añก วิf.

Lo que dire en el fróntis más antiguo de estar ingleses en guisa hasta aumi unnca visla, se reditce a haber sacado al margen los anmbres de los interlocutores y hallarse impresos de versalitas los refranes $y$ frases proverbiales.

En un catilogo del liburo Teschner he visto anuncialla una edicion en cuyo fiual se lee: Impressu en la muy nohlo: y leal ciudad de Curagoça pro Augustin Miltan impressor de libros. Acribose a quinze dins del mes de Ma!̣o del año de mil y quiniontos cinquenlu $y$ cinco (1555). 16. ${ }^{\circ}$ let. gót. Lám. de madera.

En el Indice espurgatorio de 1640 pág. 948 y en Vic. Antonio encuentro otra de sala. manca, Herederos de Iuan de Im/a, 1558.

Mnratin cita la de Cuenca, Iurn de Canowa, 1561, debiendo yo observar no tenia noticia de haber impreso nada en Cuenca dicho Ca. nova.

Teschner da noticia de la de Sevilla en casa de Sebastian Trugillo impressne, junio a las casas de Pedro de Pineda. mil et quinienlos y sesenla $y$ dos (1562). $8 .^{\circ}$
1164 CELESTINA (LA). Tragicomedia De Calisto r Melibea. En la qual etc. (Despues de tres figuritas en madera.) Agora de nuevo corregida $y$ emendada, y con licencia impressa. Alcala, en casa de Francisco de Cormellas, $y$ Pedro de Robles, $1 \vdots 63$. $12 .{ }^{\circ} 4$ hojas prels., 1530 foliadas y una despues en que se leen las estrofas de Proaza.

En la presente edicion y eu las posteriores se suprimió la iltima estrofa de P'roaza que rontenia el lugar 8 año de su publicacion. Tambien nolaré agú, qur ningual de ellas tienc mis de reintiun autos, ye consigrien. te les falta el de' Truso; esta circunstancia dobe sin duda atribuirse á la casualidar de haberlas reimpreso de las que carecian de ćl, verdad es que son casi todas. Volviendo á hahlar con particularidad de la de 1.56 .5 , nbvervaré no haher en ella otra viñeta sino las tres figmritas aisladas de la portada, y que lo anunciado acerca de su correccion $y$ enmienda, significa à mi modo de ver cl haber omitidn o varialo algun pasajc. Con todn roto subsisten todaria los minchos cspurgados mis tarde por la Inquisicion, si bien se encuentra alguno modifleado.

Garcla de Villanueva pág. It, dice que D. Cárlos Andres poseso una impresion de Baicelona, 1560 .

1163 - [Celestina] Tragicomedia de Calisto y Melibea, en la qual se cōtienē de nias de su agradable $y$ dulee estilo murhas sentécias philosophales, etc. Con licencia impressá en Aleala Fn casa de Iuan de Villanueua. 1969. 12. ${ }^{\circ}$ Con tres figuritas en la portada. 12 hojas prels. Cla última es blanca y se corta) y 192 fols.

Fs la primera cdicion donde he visto denominar cota obra celestina, titulo que casj conslantemente se le dio en las rarias im. presiones herhas despues.-Eu la presente aun se encuentran los muchos pasajes que despues se mandaron espurcar; sin embargo de estar ya alsunos corregilos.

Moratin cila otra cdicion de Salamanca, Marlin Mares, 1569.

En el Indice espurgatorio de 1640 encuentro la de Salommenca, Matius Gast, 1570. $160^{\circ}$ Segun el prólogo de la edicion de Amarita de 1822 . liarece se hicioron en ella las son. satas correcriones, semialadas por su cditor simon Bolgoñon. librero, en la dedicatoria á b. Sancho de irila.

Brumet nos da i conocer la Celcstina, tragicomediu de culisto y Melibira. Toledo, Francisco de Guzman, 1575. 12.0 180 hojas foliadas. 
1166 CELESTINA (LA). Tragicomedia de Calisto etc. Agora nueuamente corregida y emendada de muchos errores que antes tenia. Salamanca, Aluaro Vrsino de Portonarijs, 15̆ $73.12 .^{\circ}$ Vinetas de madera. 200 hojas fols., comprendidas las 11 que no llevan foliatura en los prels., una al fin sin foliar, y otra en que se repiten las señas de la impresion.

El testo de la presente se conforma aum con las de Alcalá de $156 j$ y 69.

1167 - Tragicomedia de Calisto / y Melibea. En la qual etc. Igora nuevamente corregida y emendada de nuchos errores que antes tenia. (Al fin:) En Ualencia, En casa de Jvan Navarro, 1370̈. 8. ${ }^{\circ}$ let. gót.
Signaturas A-Q. Tiene una lámina en el fróntis y otra en la sesta hoja de la sign. Q que es la copiada despues.

He tenido presente la edicion de Alcala, Inan de Lequerica, $1575.12 .^{\circ} 211$ hojas foliadas, inclusos los prels., y unir para la fecha.

En el Catálogo de la venta de Solcinne, vúmero 480 ', se lialla Agora nucnamenle corregida y emendada de muchos errores que anles temia. Salanaca, Pedro Lasso, 1577. 12.0 156 hojas foliadas, inclusos los piels. Láminas de maderá. Para el testo se siguió el de Salamanca, 1570 .

Barrera se reflere á la de Ambcres, Planli110, 1590. 12. ${ }^{\circ}$

Tambien he visto la que hizo en Alcala de IIenares, Herman Ramirez, 1591. 212 fols., inclusos los prels.

El siguiente es el facsinile de la lámina final de la valenciana.

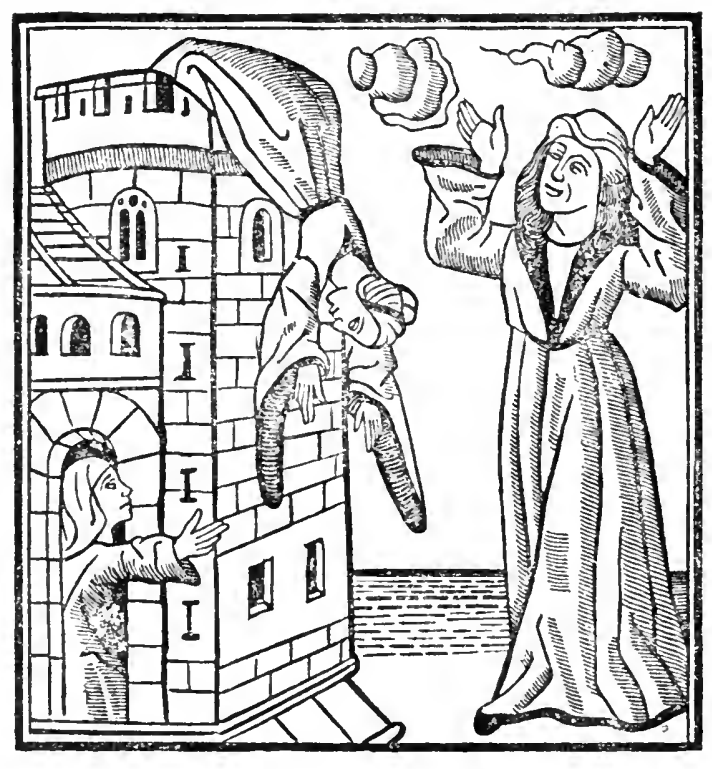

1168 CELESTINA (LA). Celestina. Tragicomedia etc. (Imbéres) En la olicina Plantiniana, $1393.8 .^{\circ} 352$ paigs., comprendidas las dos de la hoja de la portada.

El testo, con las pocas variaciones que se observan eli las ediciones de Alcalí de 1563 y 69.-Preceden descritas diferentes ediciones publicadas ya con el nuevo título de celes. lina: de consiguiente, no es esta la priniera que lo adoptó, como nos lo asegura el re- dactor del Catálogo de la venta de Solcinne al núm. 1805 .

1169 CELESTINA (LA). Tragicomedia de Calisto etc. Agora nueuamente corregida y emendada de muchos errores que antes tenia. Tarragona, en casa de Felipe Roberto, 159ว. 12. No tiene más viñetas que las figuritas de Calisto y Melibea que se hallan en la portada. 20 ? hojas fo- 
liadas, comprendidas las 11 de preliminares que no llevan foliatura, una para los versos de Proaza y otra en que se repiten las señas de la impresion.

Testo como la plantiniana anterjormente descrita.-Drsconocida á Barrera y á todos los bibliógrafos.-Precioso ejemplar que pertenecio a M. Ch. Nodier.

\section{CELESTINA (LA). Celesti-} na. Tragicomedia etc. (Ambéres,) En la olicina Plantiniana, 1099. 12. ${ }^{\circ}$ 311 págs., inclusas las 2 de la portada.

Testo el de la edicion de la misma imprenta de 1595 .

En el Indice espurgatorio de 1640 se encuentra la de Sevillic, 1599.

Moratin, en Ios Orígenes, trae uni tercera de (Anbères) En la oficina Plantiniana, 1601 .

Entre los libros que habian pertenecido í dicho Moratin vi la Tragienmedia de Culisto etc. Agora nevermente corregiala y emendata de muchos errores que antes teria. Madrid. Andres Säches, 1601. 12.0 202 hojas fols. ! 2 $\sin$ fol.

1171 - Tragicomedia de Calisto y Melibea. En la qual etc. Caragoça, Carlos de Lauaven y Iuan de Larumbe, 1607. 12. Con las figuritas de Calisto y Melibea en la portada. 9 hojas prels., $173 \mathrm{fols}$. y dos para los versos del autor y corrector y para repetir las señas de la impresion.

\section{Testo como las anteriores.}

Yi amigo D. Pascual de Gayángos en su rica y selecta biblioteca posee un ejemplar de la impresion de Madrid, Inan de la Cuesla 1619 . 12. 212 fols. $y \&$ hojas más sin nu. merar.

En el Catilngo del Sr. Marques de Morante se describe la de Milan lizz. 12.0

\section{2 - Tragicomedia de Calis-} to, y Melibea, viltarmente llamada Celestina: en la qual se contienen etc. Por el Bachiller Fernando de Rojas. Aora nvevamente corregida $y$ emendada, y impressa conforme al Expurgatorio nueuo de 1632. Madrid,
Viuda de Alōso Martin, 1632. 12. 6 hojas prels. y 196 foliadas.

Aqul, á más de suprimirse los versos del fin, quedó el testo espurgado á gusto de los inquisidores. Basta cotejar el principio de la uhra con las anteriores ediciones, para conncer cuán castrada está la presente.Barrera no la menciona.

He tenido la Tragicomedia de Calislo y Melibea, vulgarmente llamada Celestina. Por el Bachiller Fernando de Rojas. Cor. regida y cmendada nuevimente y tradu. zidn de Castellano en Frances. Rvan, Charles osmont, 16.5. en la portada española, y M.DC.YYYIIII. en la francesa. $8 .^{\circ}$, á dos colunas. ia una en castellano y la otra en fran. ces. 4 hojas prels., 578 pags. y dos hojas al fin sin paginacion.

Moratin tambien dice existir una edlcion en español y frances, impresa eu Pamplona, Carlos Labayen, 1ri.j. 8.

1173 CELESTINA (LA). La Celestina, o tragicomedia de Calisto $\mathrm{y}$ Melibea, Nuera edicion con las rariantes de las mejores ediciones antiguas. Madrid, Leon Amarita, 18?z. 8.

En esta edicion no se hace mérito siquiera de tener varias de las antiguas el auto de Traso, que es en ellas elliez y nueve, y aun. que al fin se pone lil estrofil de Proaza, hecha para la edicion de sevilla de 1502 , se onite ha penultima, donde toca como se dcuia la obra llamar Tragicomedia $x$ no comedia. la cual estii rn la de Salamanca de 1500 , de donde la copió la de ralencia de 1jlí. Del prologo y las notas no se infiere se hayan tenido presentes otras ediciunes, que lia de Venceia de 15.5, mna de la Vinda de Yartin lincio, que me es desconoeida, la de salmanea de 1570 , mma de lis de Toledo yotra de las de Plantinn.- Ma rampreso al fin el bialogo entre un riejo y cl Amor, de lindrigo Cota, el tio. -El nisino Allarila parece volvio a reimprimirla en $1855.80^{\circ}$

En el Tesoro del Tealro español, Paris. 18.53 , tom. I., desde la rig. 225 á la 255 , solo reimprimio por cntero D. Eugenio ochoa los acios $30^{\circ} 4^{\circ}$, contentimilose con poner los argumentos de lus diez y nueve restantes. Por no añadir un par de pliegos mis al tomo, prefirio el librero editor presentar tan en esqueleto el trozo mis bello de la prosa castellana del siglo $\mathrm{Ar}$, y el primer ensayo dra. mático cue poseemos, đigno de estudio y. ventracion.

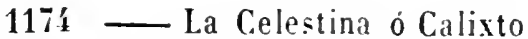
* Velirea. Por Juan de Mena y por Rodritro Cotta, y concluida por Fernando de Rojas. Adornada con cuatro 
láminas finas. Barcelona, Tomas Gorchs, $1842.8 .^{\circ}$ marq. 4 láms.

Esta impresion lleva al fin algunas Notas del editor y el Diálogo entre un virjo y el amor de Cota. Segun parece sirvió de testo la edicion de Zaragoza, 1507 y tal vez el mismo ejemplar de mi amigo Bofarull de que ántes hablé, falto de la portada: á esta circunstancia probablemente se deberá la originalidad de su título donde se supone, sin ningun fundamento, fueron coautores del primer auto Juan de Mena y Rodrigo Cota (no Cotla).

fulurdo illea de haber visto otra edicion moderna, tambien de Barcelona, cuyo tituli) ela aun mís estrambotico que el de la ántes descrita, pues nie parece decia: Los polvos de la madr"e Celestina.

La viltima impresion la hizo Aribau en el tom. Ill. de la Biblialeca de autores españoles.

Antes le terminar la historia bibliogriflea de esta obra debo advertir, que las siguientes ediciones, tomadas romo reinipresiones del testo español por Gareia de Villanueva, Moratin y al sr. Barrera copiándoles; son traducciones italianas de la Celestina:

Milan, Zanotti da Castione, 1514. 4.

Venceia, 1515.4 .

Venecia, $1525.8 .^{\circ} \mathrm{y}$

Venecia, 15.5. 8.

Y para completar la noticia de todas las obras que tienen alguna relicion fulima con ella, anotaré las siguientes:

1."

\section{A N C I O NER O DE LAS OBRAS DE DO PEDRO MA U - EL DE URREA :}

Estos cuatro renglones de letra monacal lienan la portada. Sigue la tabla en una hoja, y despues en el fol. I., dice de letra encarnida: A la e'gregia \& muy inagnifica señora Doña Callutina de: Yxar y de Lrrea Códesa de Arandu. Comiensa el Prologo compuesto por Don Pedro Mamue! de Urrea.

\section{Prólogo.}

\section{Si los hijos ctc.}

Siguense varias canciones y villancicos, y d algunas precede un prólogo o dedicatoria del autor í diferentes personajes. En el dorso del fol. Xliijij dice: Egloga de la Tragicomeslit de Calisto y Melivea do prosa trova. da en metro por dö Pedro de Urrea dirigida a la Condesa de Aranda su madre elc. Esta E. signiente que no tiene fol. dice: Fue la pre. sente obra emprentali en la muy noble $y$ inuy leal Ciudad de Logroño a costa y espen- sas de Arnao Guillen de Brocar maestro de la emprenta en la dicha Ciudad. E se acabo en alabanza de la santissima lrinidad a siele dias del mes de Julio. Año del nascimiento de nuestro Señor. Jesu cristo Mil y quinientos $y$ trece (1513) años. Fol. let. gót. Esta descripcion la he sacado del MS. del tom. II. de la Tipografia de Méndez. la Egloga arriba mencionada no es sino el primer acto y aun no entero de la Celestina: asi como se ha dicho solo ocupa desde el fol. 44 al 49.

2." Siguese la lragicomedia de calisto y Melibea: nuenamente trobada y sacada de prosa en metro castellano: por Juã sedeño: vezino y natural do Areualo... 1540. (Este titulo de negro y colorado se halla circuido de orla aucha en la que se hallan representados pasajes de la comedia en la parte superior é inferior. Al flu en el blanco de la hoja 114 , carece defoliacion, dice:) Acabose la tra gicomedia de Calislo y Melibea: impressa en Salamanca: a quinze dias del mes de deziembre: por Pedro de castro intpressor de tilsros. tî̃o le mil y quientos y quarenta (1540) años. $4:{ }^{\circ}$ letra gơt. Sin foliacion, signs. $a-0$. Está toda en estrofas de diez versos octosilabos.

5." Farsa en copless sobre la Comedia de Calixtoy Melibea. Por Lope Ortiz de Stuñiga. Empieza

"IIi de san, y quẻ floresta

y qué floridos pradales...»

Así In cila D. Manucl Cañete en el Prólogo á las Farsas de L. Fernández, sin decir si es impresil.

4." Romance menamète hecho de Calisto y Melibea que lrain de torlos sus amores $x$ delas desastradas mut 'les suyas r dela muerte de aquella desasionaia muger celestina intercessora en sus umores. (Sigue la misma lánina que se encuentra cn lit Celestina de Sevilla de $1,102, y$ á continuacion en cuatro colunas empieza el romance:)

Un caso mu! señ'ilado qniero, scũres, contar, como se iba Calisio para la cas a castur; en huertas de Metibea una gar:a vido estar, echado le habic el falcon que la hobiese de tomar etc.

(Terminado el romance se halla el villancico que principia:)

Amor, quien de tus placeres
é deleiles se enamora
d la fin cuitado llora.

(Y concluye con otro romance cuyos cuatro primeros versos son los siguientes:)

De la luna lengo queja e del sol mayor pesar, siempre lo hobievon por uso de no dejarme folgar.

S. $l$. ni a. No estoi seguro si son dos ó cuatro hojas en fol. let. gót. 
5." Calisto y Melibea. Comedia de Mendoza, segun Ticknor tom. I. pág. 284.

6. Lá Celestina. Comedia de Calderon de la Barca, segun lo dice él mismo al Duque de Veragua, la cual pensaba Yera Tásis incluir en lá décima parte y no llegóó á publicar.

7. Comedia Selvaje de Romero de Cepeda. Los dos primeros actos están tomados de la Celestina. Yéase en la presente division, al nombre del autor.

8." La segunda Celestina de Feliciano de Silva. Vẻase al nombre del autor en esta division.

9." La segunda Celeslina. Comedia de Salazar. Véase el Indice general de comcdias en la siguiente division.

10." La tercera Celestina de Gaspar Gómez. Véase en esta division, al nombre del autor.

11:- Tragicomedia de Lysandro y Roselia llamada Elicia y por otro nombre quarla obra y tercera Cellestina. 1542. (El reverso lo ocupa el escudo de Junta que tengo grabado y se balla en el Covarrubias, Remedin de jugadores de 1543 , y bajo de èl una Agurita de la Muerte con un ataud bajo del brazo y una especie de azadon al cuello, seguida de dos versos latinos. La carta dedicatoria que principia al fol. siguiente $i j$ sign. $a i j$, concluye en el blaneo del $i i j$ al dorso del cual comienza el prölogo al lector, que toma tres hnjas más: la obra empieza en el folio vij $\mathrm{y}$ concluye en el lxxxix vuelta, signatura $n$.; el blanco del folin siguiente que debia ser el $90 \mathrm{~g}$ por error esti numerado $C$ (100) lo ocupa el siguiente colofon:) (Aqui se acaba la tragicomedia de Lysandro y Roselia: llamala Elicia y por ol ro nombre quarla obray lercera Celestina: nueuamete in. pressa. Acabose a veynte lias d'l mes de desiembre. Año del nascimiento de nuestro saluador Jesu christo de mil \& quinièlos y quarèta y d's (1542) Años.

(A la vuelta pi incipia una carta de un amigo del autor en la que le pide perdon por haber hecho imprimir la obra sin su licencia : sigue la respuesta del autor y una réplica de su amigis sobre los motivos que le movieron á darla á luz: por estar fechada esta carta en Madrid á 7 de linviembre de 15 \{́, ha habido quien ha supuesto haber sido es. tampada la obra en dicho pueblo ; pero á mi no me cabe duda es de Salamanca y de Juan de Junta. Se hallan despnes quince octaras en la última de las cuales dice:)

Si el nombre glorioso quisierdes saber Dal que esto compusn: tomdi el trabajo

Cual suele tomar et escarabujo

Cuando su casa quiere proveer, Del quinto renglon debeis proceder.

Donde notamos los hechos ufunos

De uquel que por nombre enlre los humanos, Vengudor de lu tierra pudo lener.
No me fué posible dar con el acertijo. Los versos concluyen en el blanco del fol. cvj. 4. ${ }^{\circ}$ letra gót. Láms. de madera apaisadas.

12. La ingeninsa Elena hija de Celeslina de Sálas Barbadillo. Es una novela. Vẻase en la seccion de ellas en el presente Catálogo, al nombre del autor.

13. La Escuela de Celestina, y el hidalgo presumido. Comedia del mismo Barbadillo. Yadrid, Andres de Porras, 1620 , segun Nicolas Antonio.

1.." Tragedia Policiana, en la qual se traclan los muy desgrnciados amores de Policirno e Philomena, execulados por indusIria le la diabolica vieja Claudina, madre de Parmeno y muestra de Celestina. (Al fin:) Aca. bose esta tragedia Policiana, a xx dias del mes de lioviembre, a costa de Liego Lopez librero vezino de Toledo, añ's de nuestra redencion de mill e quinientos el quarenta $y$ siete (154T) años. 4. ${ }^{\circ}$ let. gôt. 80 hijas.

Asi se halla descrita en las nolas y adiciones á la obra de Ticknor, tom. 1. pág. $525 \mathrm{y}$ siguicntes, donde se di un largo análisis de clla, y se deduce, por un acrostico al principio del volúmen, que es produccion del bachiller Sehastian Fernández; pero el señor D. Fernando Wolf en su tratado Sobre una Coleccion de romances españoles nos da noticia de otra edicion de esta tragedia tambien de Toledo, en casa de Fernando de Santa Cathatina: ncabose al primero dia del mes de Varço añ') de... 154s, en cuya penúltima hoja hai in epilogo de Luis Hurtado de Toledoj Al lector, cn el que este se declara autor de la obra.

\section{5." La Escuela de Celestina por Andres} Parra.

16." La ingeniosa Elena de Juan de Herrera.

Estas dos últimas las cita Moratin tomando la noticia sin duda del Prólogro de la Celestina de 182.2; yo mo las conozeo ni las menciona ric. Antonin. Serin indudablemente las misunas que casi con identicos titulos escribij Silas Barbadillo, la uma impresa por Andres Póricas y la otra por Juan de Herre. $r a$, descritas en los numeros 12 y 15 de esta lista.

La Celestina mereció por su castizo y hermoso lenguaje, que el sabio autor del Didlı. go de las lenguas la tributase el cumplide elogio de que ningun libro habia escrito on castellano, adonde lit leigrut estuviese más nutural, mais propin ni mds elenante (página 167). Gaspar Barth (el licenciado Vidrier. de Cervintes, segun algunos' la tradujo en latin con el título de Pornobnscodidascalus $\mathrm{y}$ la llama libro verdaderamente divino, coincidiendo con el epiteto que ántes le habia dad" Cerrantes, al principio de la ubra que ha llevado sil nombre á la inmortalidad. Todos la admiran unanimes cumo un singular modelo por la fiel pintura de las costumbres 
de aquel siglo, por la propiedad de los caracteres, la viveza del diálogo y la ingeniosa disposicion de las escenas, en una época en la cuil Italia y Francia no conocian mís que sus Farsils sagradas y sus rudos Misterios. lil primer acto precedio de bastantes años á las tentativas dramáticas hechas entre nosotros por Juan del Encina por cuanto el misino que con lanto acierto la continuo, ignoraba í flnes del sigln XY quien fuese suautor.

En vano lian redoblado los eruditos sus investigaciones para averiguarlo, y se han divididi al lln sus parcceres, en no encontrall los unos bastante rancio el lenguaje lara que pudiera ser de Cota, y mucho menos de Yena, erryendo por esta callsa Ioralin en sus origenes det Teutro espuñol) que es de un escritor coetinen de kojas; y (an sostener los ntros ser la ob)a loda, desde el principio al fn, de mna misma mimn, empeño desenvirelu con líbiles razones por 11. Josi Blaneo en el nim. 5 de las liarieta-

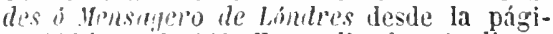
na 2 . hasta la 2 if. En medio de esta diversidai de opiniones, espondré sencillamente la mia. funtando mi eximen tan solo en los datos que arroja el linro, y tejiendo la hishiria de su formacion sucrsiva, en la cual madie ha herho el alebido hincapié, por no ser fícil tener acasion de consultar las principales edieiones intes descritas.

El bachiller Rijas, en la carta ó dedicatoria $a$ un su a rigo. dispues de cubrir de sinceros y clevados elogios el primer anto de la Comedia de Calisto !l Melibea, añade, que un lenia suf firma del auclor, el que, ségun alfmuos dicen, fué Juan de' Mena, $\dot{e}$ segun ntros, Rodrign cota; y cuando un juez tan idoneo se abstiene de fillar sobre ambas suposiciones, seriamos mui temerarios en lesechar ninima do cllas como absurda. Vinelve en seguida á deshacerse en alabanzas de la nlira, tanto en la Curta, como en las estrofis $60^{\alpha}$ s. ${ }^{a}$ y $1 .^{a}$; alabanzas que respiran ingenuidal y que nunca sollaria en jartancia propia un sugeto del saber manifestado for kijas cn la gran parte, que es indiulablemente fruto de su trabajo. Para uniformar con ella la que ya existia, y no dejar á sus contemporámeos, en un libro de plicer y entretenimiento, frases rancias y palabras anticuadas, es regular hiciese desaparecer todas las que de esta clase ocurrian en el anto primero. Faltan de consiguiente los distintivos para negarlo á llena, como li hace .ic. Antonio, y no debiera estrañar Yloratin que se lea ahora todo el libro, como si fuera produccion de una solu pluma. Si cuando estaba intacto el testo primitivo, y. unicamenle habian trascurrido cincuenta ó soscnta años desde su formacion, no se atrevio Ríjas á señalar el autor, ni á decidirse por alguno de los dos designados por la fama: seria vano empeño quererlo averiguar tres siolos y inedio más tarde, y ningun resiltado podiamos prometernos de que un "piscula de prosa desligurada sufriese el colejo con las composiciones pocticas y gemilinas de Hena, 0 , con las breves que nos ban quedado de Rodrigo Cota, el tio. Del sobrino, caso que fuese el autor, nada exlste para servirnos de hilo en tan intrincado laberinto. Me contentare pues con decir; que el carácter del Did́logo entre un viejo $y$ el Amor hace inclinar la balanza á favor de Rodrigo Cota; que á este se la adjudica Alonso de Villégas en 1554 en la dedicatoria de la Selvagia caando dice :

\section{sabemos de Cota, que pudo empezar obrando su sciencia la gran Celestina; labróse por Rojas su fin, con mui fina ambrosia, que nunca se puede eslimar;}

que bien estudiada la Tragicomediu de Calisto, se encuentra en su printer acto un dejo de antigüedad, que no se percibe tan claro en los demas; que dicho acto es cinco vezes mis largo que los otros, los cuales guardan entre si una regular proporcion, y que de él solo no conocemos ningun ejemplar, mamuscrito ni impreso. Pero nos prueba circulaba ya entre los curiosos la obra primitiva, fuera dol testimonio irrefragable de Bojas, el que anunciándola trobala en metro Don Pedro yammel de Urrea, escritor que floreció á fines del sigro $\mathrm{XV}$, solo metriftcó el primer acto. Sin embargo, como su Cancionero no se pulblicú hasta el año 1513, y entónces ya se habian multiplicado las ediciones de la Celestina con los quince, y aun con los veinte antos añadilos por Rơjas, ya se denomina alli Trayicomedia de Calisto y Melibea. Que fuese su primer título Comedia de Calistin !y yibra lo evidencia el prólogo de Riijas, siss yersos, el acrostico de los mismos y la estrufa pentiltima le Proaza en la edicion de Salamanci de 1500 , en la del mismo pueblo de 1502 y en la de Vialencia de 1514 , copiada al describirla al Vum. 1157.

si la dedicatoria á um su amigo se halla en la de 1499 , lo que no puede siberse hasta descubrir su portada, debe estar suprimido este miembro de la peníltima cláusula : para discutpa de lo cual lodo, no soto a vos, pero d cumilos lo leyeren, ofrezco los siguientes metros: por scr imposible que en el reverso del frintis se hayan metido tambien las once estancias. En la suposicion de estar allí la dedicatoria, en los quince dias de vacaciones, destinados á completar la comedia, no se tribajaron los veinte actos restantes, como lo han repetido cuantos han locado esta inaleria, sino quince, á saber, desde el segundo hasta el catorceno, 8 los que se denominan XX Y XXl en las más de las ediciones. La príncipe de Búrgos no tiene más que diez $y$ seis autos: los catorce primeros son los mismos de las otras ediciones, y el $\mathrm{XV}$ y XVI corresponden á los dos últimos de las que comprenden veintiuno. Pero si la Carta no salió sino en 1500 , cuando se añadieron al principio y fin los versos del autor, los del corrector Alonso de Proaza, que nos descubrió el secreto de aquel, y el Tructado de Centurio, es decir, los autos XV í XIX, ya nos veremos algo embarazados para resolver si los quince dias sirvieron para componer ios quince actos, de que arriba hemos hablado, ó los cinco nuevamente aña- 
CEL

PRIMERA DIVISION.

CEL

didos. Me inclino siempre á creer que se reflere á los quince primeros, así como indudablemente habla de los cinco segundos, cuando dice al fin del prólogo: Viendo estos... disonos y varios juícios, miré d donde la mayor parte acoslaba, y halle que querian que alargase en el proceso de su deleite destos amantes. Sobre lo cual fut mui importunado, de manera que acorde, aunque contra mi voluntad, meter. seguda vez ia pluma en tan estraña labor é lan ajena de ni facultad, junlando algunos ratos d $m i$ principul estudio con otras horos destinadas para recreacion, puesto que no han de faltar nuevos detractores á la mena adicion. Esto ya se escribia en Salananca, donde se hizo la segunda edicion, aumentada con el Tractado de Centurio, inientras Ios versos se trabajaron fuera de ella, como claramente lo denota la estancia sétima :

Yo vi en Salamanca la obra presente; Novime d acaballa por eslas razones:

Es la prinera que estó en vacaciones etc.

Tal vez se escribia en Burgos, lugar de la primera edicion, en la que no tuvieron sin embargo cabida los versos. 6 el bachiller liojas no asistió á su publicacion, ó la voluntad del impresor prevaleció sobre su dictimen, pues hácia el fil del prülogo dice: Aun los impresores han dalo sus prinluras pmiendo rubricas o sumarios al principin de cala aulo, narrando en breve lo que dentro conte. nia: una cosa bien escusalla segun lo que los antiguos escriptor'e's usaron.

Pasemos ya á tratar del tercer acrecentamiento que turo la obra. Queda dicho que despues del anto XIV. se introdiljo un nuevo personaje, el rufian Centurio, que directa ó indirectamente hace su papel cn los cinco

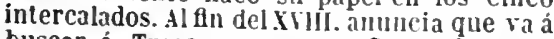
buscar á Traso y sus compañeros, los cuales, dice Tristan en el acto sigujentc, habian tratado de incomodarlos; pero que se habian ido. Este Traso es el introducido en el nuevo acto XIX. como interlocutor con Centurio, Areusa, Elicia, Terencia y Tiburcia: Terencia era la amiga de Traso y Tiburcia tia de aquella. Se dice que el auto está sacado de la Comedia que ordenó Sanabria, que ignoro cual sea. Se puso por primera vez en li edicion de Toledo de $1526, \mathrm{~g}$ solo se ba repetido, que yo sepa, en la de Medina, hecha hácia el 1550 , y en la de Toledo de 1538 . I. c copiaré aquí por su singularidad, por ser tan pocas comoraras las ediciones que lo tienen. y para que pueda juzgar por si mismo el lector, si lo debemos al bachiller Rójas, ó es de otra mano, como yo creo.

\section{Este anto xix fué añadido en la pre-} sente obra que hasta aquí no estaha."

\section{"Argumento del XIX auto."}

antre Centurio e Traso, públicos ruflanes, se concierta una levada por satisfacer Areúsa é á Elicia; yendo Centurio á ver á su amiga Elicia. Traso pasa palabras con Tiburcia, su amiga, y entreviniendo Terencia, tia de Tiburcla, mala é sagaz mujer, entre ellos traiciones é falsedades de una parte é otra se inventan : como parce en el proceso deste auto, el cual fué sacado de la Comedia qué ordenó Sanabria."

\section{«Centurio. Traso.}

Areúsa. Elicia. Terencia. Tiburcia.»

"Cent. Las adargas é corazas tengamos apercebidas porque á boca de noche yendo encubiertos, más á nuestro salvo podamos, Traso hermano, hacer lo levada que concertado tenemos.

$T r$ Vamos presto, porque me parece mala aquesta tardanza, aguardando tiempo de buscar lo que conviene, do más estcrvo tengamos que lugar desocupado para que en este negocio tuyo mejor se pueda entender."

"Cent. Recaudo hai.»

"Tr. Cómo?"

"Cent. Ciemon el tuerto é su compañero á mi casa irán esta noche, segun ellos me prometieron.w

nTr. Cuantos más fueren en el ruido será hacer más en nuestro favor, será hacer en nuestro partido: porque como dicen, á más moros más ganancia, é más que deste camino es incierto lo que suceder se nos puede.,

"Cent. E hablastes con Ciudelia”»

"Tr. Que quiere que le rueguen: á dineros contados brazos quebrados.

"Cenl. Por mejor tengo ir solo que mal acompañado; bien me pagu lo que por el he hecho. medrare con la ganancia. por él me he puesto en hill peligros. por su causa me dieron este rasgonzillo de oreja á oreja, Ia uıa manotengo puesta en la picota é dos vezes he ya pasado carrera por la cilt. dad y el mercado, cada dia en desafíos, corrido de las justicias. corrido de los alguaciles. corrido tambien de porquerones: siempre ando á somblora de tejados, la capa caida, la adirga einbrazada que broquel ya sabes que traer no le puedo): mas si viro todo junto me lo pagara como el perro los palos.m

"Tr. Pues que asi es, pongrimonos i punto porque sa sabes. que hombre apercebido medio combatido.»

"Cent. Mlientra lora se hace el gestn alte. rado, las armas en orden, el paso cre. cido, la malla crujendo, los ojos en arco. Ia espada sin vaina quiero pasar por casa de mi Areúsa porque vea lo que tiene en míla gana que de contentalla tengo, porque esotro dia en un poco de camino que le iba mucho, le dije de no.n

* Tr. Kazon es de contentalla, andalle al sabor de su paladar, cuanto tiene e no tiene es todo tuyo, cosa no le conozco propia que contigo no lo reparte: las camisas de dos en dos te cnvia, cuando te vido en necesidad capa e sayo te saco de la pieza, quel rei se lo vistie. 
ra; pues dadivas quebrantan peñas, cuanto más á ti que lo entiendes: no me loaré yo de mi Tibureia aungue me quiere tanto comoá tí tu Areúsa.,

"Cent. Por mi amor, que tengas cargo de este hecho que otro dia hablaremos despacio, porque estoi ocupado en otro negocio e hazeseme tarde para la cena, y en tal caso vale más anticiparse que pospiner; más quiero estar al asentar de la mesa que venir al levantar de los manteles; por mejor tengo hallarme al henchir de las escudillas que despues venir al fregar de los platos é tambien huésped con sol...)

"Tr. Huesped dices? que me maten si no es la que viveá la Madalena: por ti se diria, tresquílenme en concejo, mas no se que te diga salvo que ojos hai que de lagañas se enamorin.»

"Cent. De lagañas! Cuando vino el embajador lo vieras cuán mirada era, que desotras de almacen no cale, salvo hazellas del ojo que tras mí se vieuen á docenas; 10 que peor reo, es no poder ir á menudo á su casa por no atraresar por el mercado y cacr en mines de quien los pecados viejos me hagian purgar en la prision, é más que los algruaciles de ogaño, como bien liabrás visto, por llevar li capa a 111 compañero no drermen cinco maches; en lugar de ayudar al miserable. en lagar de farorecer al que poen puede, no liv dejan cera en lis oreja, saben bien tresquiliar a cruzes: mas por ventura los tomarc en parte do escapar no se puedan de mis manos.n

"Tr. En lo bien dicho no cale, polpue tu veris que no sol. tengo gana de poner en obra el negneio, mís ant que no me falta inimo para acometer aquella gentecilla. e no vengas manvacío por cansid de lus que sibes,

"Cent. Tunso muehos enemigos en esta cindad é por esto no me oso embirazar las nanos por estar apercebido, por estar mejor apnnto oyendo algun repiquete de broquel, eque quiera no tengo, asi que bicn verís que el rei me hace fratleo,"

"Tr. Pues ve con Dios."

"Cent. Ese quede contigo é te dé buena manderecha."

"Tr. Ylal me va de esta compiñía de mi amo; pues i su causa mil ratos de placer que tomar podia me estorrit; allende, como dicen que la libertad no se precia por ningun tesoro, y que pin ajeno poeo engrorda. Buena tardanza hacen aquellas mis mujeres á tal tiempo, no se contentan con haber jlo á casa de aquel vellaco cariacuchillado, como me his dirho, sino que en chalquier lugar habrin entrado de doude no álres tiurones silgan; birll parece que no estu ya en el mmmilo, que yo no soi el que ser solia é cada muse me atleve, cada mno se lile iguala, con mal va mi honra, perdida es mi fama: mas yo juro que de que Dlos andaba por la tierra no se burlaban asi conmlgo; empelo con mal va quien mala fama cobra, la maldicion más comun que por boca de todos se usa. A manos de Traso mueras $\mathrm{y}$ en el su poder fenezcas."

"Terencia. Landre mala me mate, hija, si no está allí aquel loquillo de Traso, si la vista no me sngaña, con su espada haciendo rayas en el suelo, paseándose de una parte á otra como hombre eno. jado, la mano puesta en la barba, dando paladas en tierra, asiendo del pu. ñal de rato en ralo, escupiendo de cara el ciclo.n

"Tiburcia. Anda, madre, siempre has de estar de burlas: está el otro en casa de su amo é quicresme espantar.”

"Ter. Vistas somos."

"Tib. Como?"

"Ter. Hícia acá viene."

"Tib. Yluerta soi mayormente si sabe la casa de donde venimos.n

"Ter. No nos paremos pues es por demas, no solevantemos humo do no hai quiza memoria de lizesno, que un bobillo destos presto es engañado: á un traidor dos alevosos, è mas vale á tales tiempos saber que haber.n

"Tra. No me digais más, no me hableis más, tal cosi ha de pasar ya : ya muerto es po: quien tañian."

«Tib. Qué dices, vios mío? qué hablas, ángel mio?

"Tra. Oué dices, me preguntas? oh! descren del padre que no me parió, con quien tal uye is no hace algo de lo que hicer acostumbri, á su biazo poniendo tanta paciencia.»

"Ter. Calla por tu vida, señor Traso, no seas de tal mantera, gota de sangre no tracmos en todo el cuerpo por mi ánima á tı causa, y tú malquejoso ć malcontento.n

"Tra. A mí causa! só yo el que estoí aqui? só yo el que esto oye?"

"Tib. El diablo nos ha traido en poder ye este desvariado loco, sin seso ninguno; por mi salud! d' altericion en las piernas tener no me puedo, no me dé algun porrazo; Jesú! Jesú! qué flero que está.»

"Ter. No paro mientes á sus cosas, no hagas caso de sus vozes; porque, como dicen, gato maullador nunca buen cazador; del rio manso me guarde bios: en los que mas ferozes se demuestran con quien no tienen manos para responderles, inui pocas vezes decir é obrar juntos se hallan.”

«Tib. Habla bajo, tia señora, no nos oiga que será peor."

"Tra. Bien lo barruntaba yo, á casa de Claudio, bien lo sabia yo no podia ser aosadas otro vuestro caminō."

"Ter. S1, no podia ser otro, como solemos ir mui amenudo, no es maravilla que digas eso. Por la lierra que come á los muertos é a nosotros espera, que se 
pasa lo más del año que dos vueltas no damos por su calle: hallado habias las visitaderas, hallado habias las que se precian de ir á casa de otros sin primero bacerlo saber. Aquí donde estabamns nos dijeron que Claudio é tú habrades corrido lins criados del Arce. diano e cierta gentecilla que vino al ruido á echaros la mano: si bien les supo vuélvanse al regostn; y á esta causa, harto medrosas, pasamos por su casa á informarnos de la verdad pensando que algo te hobiese acaescido."

"Tra. No queria mas saber! esto esperaba yo oir! no guardaba yo otra cosa! Ayudele Dios si le encuentro, imposible es que de inis manos se escape; haga cuenta que tiene su vida jugada al tablero.w

"Tib. Detenlo, por Dios, no haga tal cosa como dice seyendo el otro sin culpa.z

*Tra. Ni por eso dejaré de hacer lo que digo, ni menos por vosotras ine detendré de no le ir à buscar.,

"Ter. Vaya si querrá: no te cures, hija; en fin palabras son, ja sé en qué cae: de los esperimentados, como suelen decil, se levantau los arteros. Abre esa puerta y entremos en casa que es vergüenzi de los que á tal hora nos vieren puestas en la calle, que á tu Traso segun va enojado, por demas esta noche será esperalle."

«Tra. No so dúnde ir me pueda para que ponga en obra aquellu que por centurio me fué rogado: pues todo este hecho de mi lo contla. Si vamos, luego seriamos conocidos", é seria dar materia que cualquier entendiese este nuestro calnino: á su casa me roi á esperar á Cremon é á los otros porque con inénos trabajo nos juntemos, en lo demas contento voi porque tan bien me ha sucedido. Yo dejo aquellas innjeres bien amedrentadas. pir donde pienso que otro dia no parecerán de temor para bacer la estada que boi han hecho, allende de esto no ignoran para cuanto soi ; empero qué órden buscaré para salir de lo que dicho tengo; en ninguna manera pensar puedo porque el otro siendo avisado, no es inénos que se pondrá á punto é tendrá manera para hacerme pagar lo dicho; eulpero viniendo á su noticia yo le harè entender que lo habia con Claudio el criado de Caldorio è no con él, poniendo algunas ofertas delante é d' esta manera antes amistad tendrá conmigo que no gana de reñir, é yo podrè más a salvi) hacer lo que a este mi negocio è honra conviene tomándolo más des. cuidado.w

Se inflere de cuanto llevo espuesto, que de los veintiun autos que comprenden casi todas las ediclones de la Celestina, el pri. mero es de un antor que floreció á mediadns del siglo XV, que unos suponen ser Juan de Mena y otros Indrigo Cota, inclinándume yo más á la opinion de estos últimos; que á flnes del mismo siglo El bachiller Fernondo de Roús acabó la conedix de Calislo y Melybea y fue nascido en la Puebla de Moníalvan, segun dice el mismo en las once estrofas acristicas puestas al principio, aumentándole los actos II. á XIr. y los dos uiltimos; que el año de 1500 añadió los que son abora en casi todas las rdiciones IV. Xil. Xill. XVIII. y XIX. $\mathrm{g}$ forman el llamado Tractado de Cenlurio, y que en 1526 se agregó como $\mathrm{XIX}$. el Alito de Traso sacado de la Comedia de Sanabria, resultando por consiguiente veintidos autos, sin que sepamos quién fué el que introduji esta última adicion.

Ticknor en su Hisloria do fit. esp., tom. I. pág. 282, dice, que á las impresiones de la Celeslina, posteriores al año 15.j4, se unio una continuacion de un tal Domingo de Castega, la cual no conozco ni he visto en ninguna de las ediciones publicadas despues de dicho año j4.-Tambien supone el mismo Ticknor que la Tragelia Policiuna, Toledo

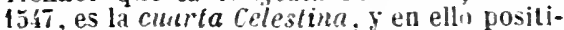
vamente anda errado, pues ya en 1545 habia visto la luz publica la Tingedia de Lisandro y Roselia, cuarta obra !" l.rerra Celestina.

Convienc hacer merito aquí de la singular especie que se halla ell el viscurso 56 de la Agude $=$ y arte de ingenio. donde dice Lorenzo Gracian: el enclibicrio ardyones en su ingmiosisima Traricr.urdia de Calisto y Meliben. Copiale Latasa en la pag. J! del tomo It. de sll Bibliofeer muev'a, añadiendo al desatino de hacel aragones al autor de la Celestina, el de colocarle entre los anonimos al fin del siglo Xrll; con lo cual probo estar tan al corriente de nuestra bibliografia como de la historia de la literatura española.

Así cono hemos recorrido los sucesivos aumentos de la Celestina, justo será que contrapongamos las mermas que sufrió por el caprich de los impresores, o por la voluntail de los gobiernos. Desde luego en las ediciones de veintilos autos, se suprimieron los versos del autor $y$ los del corrector, que cerraban la de Salamanca de 1500 á lo ménos asi lo observo en la de Iledina, s. a. y en la de Toledo de 1.jis. que lengo á la vista. En las demas se omitio la penúltima estancia de Proaza, que estit inui aenrde con el deseo manifestado por el contimuador al fin del prólogo, la cual he reproducido al describir la edicion de Valencia de 1514 , copiada, como queda dicho, de la de salamanca de 1500 .

Desde la edicion de Amberes de $1545 \mathrm{em}$ pezó á omitirse la última estamcia de Proaza, en la cual descubre cl liempo y lugar en que la obra primeramente se inprimiu acabada. r quedo como úitima la que sienupre habia indicado que hai un acrustico en los versos del principio. Mr. Lacroix dice sin embargo, en el num. 4502 del Catilogo de $\mathrm{Mr}$. de soleinne, que ell dicha edicion de 1545 se sustituyó por primera vez la estrofa, aclaratoria del acrustico, á la que designaba el lugar y 
año de la impresion. Más ecrtero anda en asegurar, que tanto en aquella como en las dentas que saliepon en los Estidos sujetos á Felipe II, se iba corrigiendo el testo de algunas proposiciones anticatólicas, iunque se dejaban subsistir otras ménos mal sunantes. Por fln la luquisicion trmó á su cargo el espurgo, y salio, con ar'rero í su gristo por entonces, la pdicion de Viadria de 1632 , pues pocos años despues se prohibio por entero la reimpresion y circulacion de un libro que tanto honraba à España, de modo que ya no vulvió á ver la luz entre nosotros hasta el año de 1822.

1173 CEO (Mania do). Obras valrias, y admirables de la Madre Maria do Ceo... Corregidas de los muchos defectos de la edicion Portuguesa, è ilustrada con breves Totas por El Doct. D. Fernando Settien Calderon de la Barca. Madrid, Antonio Narin, 1744. 2 rols. $8 .^{\circ}$

El primer tomo contiene ma novela alego. rica en prosit y rerso, dividida en dus partes, intituladia: La Perergina. Engañas del bosque y desengañus del rio, y valias poe-

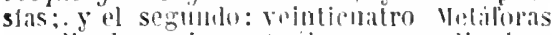

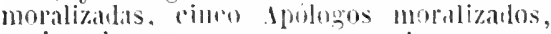
valias obrils pll prosa y verso, y tres composiciones drandicas relativils is s. Alejo, inti-

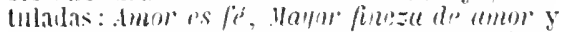

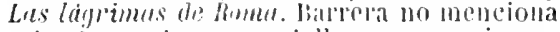
estos ires alltus an castellano y es mui raro que ill vitar los lifulus en pertughes slpongat quedaron mamuspritos, sienlo así que el traductor seltien dietese lablaban en la impuresion portuguesa de la cual el hacia li version.

1176 CERYANTES SAATEDRA (Migcer De). Ocho Comedias, y ocho Entremeses nuevos, Nunca representados. Compuestas por Migvel de Ceruantes Saauedra. Madrid, Yiuda de Alonso Martin, 161̈. 4. ${ }^{\circ}$ hojas prels., 237 foliadas y una en que se repiten las señas de la impresion.

Yagnifico ejemplar con hojas sin cortar.

El editor de lin sogunda edicion de 1749 dice, pudia considerarse como obra mueva la que remprimia por ser la primera rarísima y desconocida.

\section{Comedias, y Entreme-} ses de Migruel de Cervantes Saavedra. Con una dissertacion, ò prologo (de D. Blas Vasurre) sobre las Comedias de España. Marlrid, Antonio Marin, 1749. 2. vols. 4. ${ }^{\circ}$ El primero consta de 4 hojas prels., 26 ile Prologo con las signs. $\Lambda$-D 2 y 2 sö págs. El segitudo de 2 hijas prels. $y 326$ págs.

Reimpresion exacta de la anterior cuyo fróntis se copia tambien.

Las composiciones dramáticas que comprende son las siguientes:

\section{Conculias.}

El galiardo español.

La casa de los zelos.

Los bitĩos de Argel.

El ruflan dichoso.

La gran Sultana.

El laberinto de amor.

La Entretenida.

P'edro de Lidemalas.

\section{Entremeses.}

El juez de los diroreios. En prosa.

El rufian viudo, llanito Trampagos.

La eleceion de los alcaldes de lyaganzo.

La gollatlal énidadosa. En prosa.

El vizcaino fingrido. En prosa.

El retablo de las maravillas En prosa.

La curva de Salmmanca. En prosa.

El viejo zeloso. En prosa.

En Sevilla se publico en 162' otro entremes all prosa intitulado Los habladores, que lia sith reimpreso en lomn $10^{\circ}$ y ultimode las oiras esconflus de este antor, Paris, 1s.2t, y an el iom. I. ded Trsoro alel Teutro espuñil. en ambis partis con el título de Los dos hablublores. Ilabia ya salidu dutes en 1617. anuquesin mombre de antor, en la Parte Vil de lits Commlias de Lope.

Tambien se supome ser de Cervántes el anto anonimo de Vuestril Sra. de Guadalupe. vease en esta division. Numero 1102.

\section{CERYINTES SAIVEDRA} (Miguel de). Viage al Parnaso, com. puesto por Miguel de Cervantes Saavedra. Publicanse ahora de nuevo una tragedia $Y$ una comedia inéditas del mismo Cervantes: aquella intitulada La Tumancia: esta El trato de Argel. Madrid, Antonio de Sancha, M.DCC.LXXXiv. 8. ${ }^{\circ}$ may. 3 láms.

La descripcion de las otras ediciones del Viage al Parnaso se encuentra en la Seccion poélica.-Nímeros 555 á 557 .

1179 COLECCION ANTIGUA DE COMEDIAS de los mejores ingenios de España, publicada en Madrid desde 1632 á 170 '. 48 vols. $4 .^{\circ}$

\section{Parte primera.}

Primera parte de comedias escogidas de los meiores (sic) de España. 


\section{COLECCION ANTIGUA DE COMEDIAS ETC., 48 VOLÚMENES.}

Madrid, Domingo Garcia y Morras, 1632. 4. 4 hojas prels. y 266 foliadas.

Tiene estas comedias:

La Baltasara. - Tres ingenios, á saber, Luis Velez de Guevay'a, Coello y Rójas.

Nunca lo peor es cierto.-Calderon de la Barca.

Lo que pucde el oir misa.-Vira de Amcscur.

La exaltacion de la Cruz.-Calderon.

Chico Baturi, y siempre es culpa la desdicha. - Antonio de Huerta, Cancer y Rosete.

Mejor está que estaba.-Calderon.

San Franco de Sena.-Voreto.

El Hamete de Toledo.-Bclmonle \& Anlonio Marlinez.

La Renegada de Valladolid.-Belmonte Bermidez.

Luis Pérez el Gallego. - Calderon de la Barca.

El trato muda costumbre.-Antonio de Mendoza.

Con quien vengo vengo.-Calderon de la Barca.

\section{Parte scaunda.}

Segrnda Parte de Comedias escogidas de las mejores de España. Madrid, Imprenta Real, 16ว2. 4. 4 hojas prels. y 280 foliadas.

Las comedias de esta Parte son:

No guardas tú tu secreto.-Calderon de la Barca.

Juan Latino.-Jinénez de Enciso.

Zelos, Amor y Venganza.-Luis Vëlez de Guevara.

La flrme lealtad.-Diego de Solis.

La sentencia sin firma.-Gaspar de Átila.

Fingir lo que puede ser.-Ruman Monlero de Espinosa.

El inobediente, $\dot{o}$ la ciudad sin Dios.-Claramonte.

La Rosa de Alejandría.-Luis Vélez de Guez'ara.

El blason de D. Ramiro, $\mathrm{y}$ libertad del fuero de las cien donzellas. - Luis de Guzman.

No hal contra el honor poder.-Enriquez Gómez.

La obligacion á las mujeres.-Luis relez de Guevara.

Amor $y$ Honor. - Belmonte.

\section{Parte tercera.}

Parte tercera de comedias de los meiores ingenios de España. Madrid, Melchor Sanchez, 1653. $4 .^{\circ} 3$ hojas

Tor. I. prels. y 261 foliadas con una blanca al fin.

Se compone de las comedias signientes:

La llave de la honra.-Lope de vega.

Irás pueden zelos que amor.-Del mismo.

Engañar con la verdad. - Jerónimo de la Fuenle.

I.a discreta enamorada.-Lope de Vegu.

A un traidor dos alevosos, y á los dos el más leal.-Miguel González de Cunedo.

La portuguesa, y dicba del forastero.-Lope de Vega.

El maestro de danzar.-El mismo.

La Fénix de Salamanca.-Yiru de Amescua. Lo que está determinado.-Lope de lipga.

La dicha por malos medins.-Gaspar de Arila. San Diego de Alcalá.-Lope de Vega.

Los tres señores del mundo.-Belinonte.

\section{Parte cuarta.}

Lavrel de comedias. Qvarta parte de diferentes Antores. Madrid, Imprenta Real, 16.33. 4. ${ }^{\circ} 4$ hnjas preliminares y 2033 foliadas, segun apare-

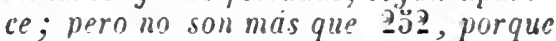
del fol. 249 salta al 251 .

Forman esta Parte las comedias siguientes: Amigo, amante r leal.-Calderon de la Barca. obligar con elarravio. - Francisco lle liloria. El lego de Alcalí.-Luis belez de Guevara.

To hai mal que por bien no venga.-Ruiz de Alarcon.

Enfermar con el remedio.-Colderon. Luis lélez de Guevara y Cancer.

Los riesgos que tiene un coche.-Antonio de Vendo $=a$.

El respetio en el ausencia.-Caspar de dirila.

El Conde Partinuples. - A $a$ a C(t)

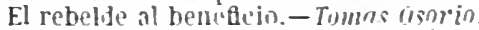

El cspañol Juan de [rbina.-Yamel Gomstéte.

Ln que puede uma sospecha.-Yira de Awies. cua.

EI negro del mejor amo.-Del mismo.

\section{Parte quinta.}

Quinta parte de comedias escogidas de los meiores Ingenios de España. Madrid, Pablo de Val, 1633..$^{\circ}$ 6 hojas prels. y วัँ̈

Comprende estas comedias:

oponerse á las estrellas. - Vilos, Anlonio yartines s.llne'to.

Aman y Yardoquen.-Felipe Godime.

Estados mudan costumbres. - Malos Fragoso. 


\section{GOLEGCION ANTIGUA DE COMEDIAS EtG., 48 VOLÚMENES.}

El Conde Alírcos.-Mira de Amescua.

Donde hai agravios no hai zelos.-Rójas.

EI narido de su hermama.-Juan de Villégas.

El licenciado Vidrieri.-Moreto.

Nuestra señora del Pilar.-Villaviciosa, Mátos y Moreto.

El cmbusle acreditado, y el disparate creido. - Luis Vélez de Guevara.

A gradecer y no amar.-Calleron de la Barca.

Ni hai burlas con las mujeres, ó casarse $\mathrm{y}$ vengarse.-Nira de Amescua.

Los anotinados de Flándes.-Luis vélez de Guevura.

Segrun Barrera hai otra edicion hecha por cl mismo impresor en 165.. 4.

\section{Pante sesta.}

Faltan á mi ejemplar las tres primeras hojas de los preliminares por lo mismo no sé ni el lugar ni el año; supongo será Madrid, 1634 . 4.

Pertenecen á la Parte sesta las doce comedias que signen:

No hai ser padre siendo rei.-Rójas.

El burlador de sevilla y convidadı de piedra. - Tirso de Molina.

Progne y Filoumena.-Ríjas.

Obligidos y ofendidos, y Gorron de Salamanea.-Rójas.

La banda y la llor._Caldron de la Barca.

El pleito del Demonio con la Vírgen.-Tres liggenios.

El cselavo del Demonio.-Mira de Ainescala.

Los trabijos de Job.-Felipe Godines.

El Principe constante.-Calderon de la Barca.

Los Médicis de Florencia.-Jiménez de Enciso.

A un tiempo rei y vasallo.-Tres Ingenios.

Cada cual à su negrocio.-Cuellar.

La estremada rareza de este tomo la atribuye el sr. de Barrera á la prohibicion de una de las piezas que contienc, intitulada: Et pleito del demomio con la Virge'n. Siegun el mismo, existe mna leimpresion ile Zaragoza, herederos de t'edio Lamaju, 16.5'. 4. ${ }^{\circ}$, y otra sexla parle con diferentes comedias, hecha tainbien en Laragosa cu 1653.

\section{Parte sétiman.}

Teatro poetico, en doze comedias nvevas, de los mejores Ingenios de España. Septima parte. Madrid, Domingo Garcia y Morràs, $1654.4 .^{\circ} 4$ hojas prels., 164 foliadas y 80 de nueva foliatura rla última hoja dice $\mathbf{7 8}$ por errata) para las cuatro comedias del fin.

Las de esta Parte tienen los títulos siguientes:

Para vencer á amor querer vencerle.-Calderon.

La mujer contra el consejo.-Nálos, Anlonio Marlines y Zabaleta.

El buen caballero maestre de Calatrava.Juan Bautista de Villégas.

A su tiempo el desengaño.-Mátos.

El sol á media noche, y estrellas á medio dia. - Juan Baulisla de Villégas.

El poder de la amistad. - Morelo.

Don Diego de Noche.-Rójas.

La Norica Garrida.-Juan Bautisla de Villegas.

Cumplir dos obligaciones.-Luis velez de Guevara.

La misma conciencia acusa.-Moreto.

lil mónstruo de la fortuna.-Tres Ingenios.

- La fuerza de la lei.-Morelo.

\section{Parte octava.}

Comedias nvevas escogidas de los meiores Ingenios de España. Parte octava. Madrid, Andres Garcia de la Iglesia, 163̈7. 4. 4 hojas prels. y 270 foliadas.

Componen la Parte octava estas comedias:

Darlo todo y no dar nada.-Calderon de la Barca.

Los empeños de seis horas.-El mismo.

Travesuras soll valor.-Anonima.

Gustos y disgustos son no más que imaginacion.-Calderon.

Reinar por obedecer.-Diamanle, Villaviciosa y Málos.

El Pastor Fido.-Solis, Coello y Calderon.

La tercera de sí misma.-Calderon de la Barca.

Amado y aborrecido.-Del mismo.

Perderse por no perderse.-Cubillo de Ara-

Del cielo viene el buen Rei.-Rodrigo de Her. rera.

Agua mansa.-Culderon de la Barca.

El marques de las Navas.-Mira de Amescua.

En la licencia fechada en 1656 , se dice que esta es segunda edicion; no conozco la anterior. 


\section{GOLECCION ANTIGUA DE COMEDIAS Etc., 48 VOLÚMENES.}

\section{Parte nona.}

Parte nona. De Comedias escogidas de los mejores Ingenios de Fispaña. Madrid, 1637? 4. 2 hojas preliminares y 465 ? págs.

Constituyen esta Parte las comedias siguientes:

Las man's blancas no ofenden.-Calderon.

El mejor amigo el muerto.-Belmonle, Rójas y Calderon.

Las Amazonas. - Anónima.

Vida y muerte de San Lázaro._Mira de Arnescua.

El escondido y la tapada.-Calderon de la Barca.

La vitoria del Amor.-Manuel Morchon.

La adúltera penitente.-Cáncer, Moreto $\mathrm{y}$ Milos.

El Job de las mujeres. - Málos.

El valiente Justiciero.-Moreto.

La razon busca venganza.-Hanuel Morchon.

Gravedad en Villaverde.-Pérez de Montalvan.

El rei Enrique el enfermo.-Scis Ingenios.

Los preliminares de ini ejemplar se componen de portada y tabla de las comedias; pero como aquella está rota jor la parte donde debe hallarse la fecha, no puedo saber si esta es la edicion de Madrid, Gregorin Rodriguez. A cosla de Muleo de la Bastida, 1657, 0 una, que segun el Sr. Barrera, debio salirántes, segun se colige de la licencia dada para la impresion á dicho Bastida.

\section{Parte décima.}

Nvevo teatro de comedias varias de diferentes Avtores. Dezima parte. Madrid, Imprenta Real, 16:38. $4 .^{\circ} 4$ hojas prels. $y 238$ foliadas.

Títulos $\mathrm{y}$ autores de las comedias de esta Parte:

La vida de San Alejo.-Moreto.

EI ermitaño galan.-Zabalela.

Contra el Amor no hai engaños.-Diego Enriquez.

El hijo de Marco Aurelio.-Zabaleta.

El nieto de su padre.-Guillen de Castro.

Osar morir da la vida. -Zabaleta.

A lo que obliga el ser Rei.-Luis Vélez.

El discreto porflado. - Tres Ingenios.

La lealtad contra su rei.-Juan de Villégas.

La mayor venganza de honor.-Cubillo de Aragon.

Sufrir más por querer mẻnos.-Rodrigo Enriquez.

Los inilagros del desprecio.-Lope de Vega.

\section{Parte undécima.}

Comedias nvevas escogidas de los mejores Ingenios de España. Onzena parte. Madrid, Gregorio Rodriguez, 1639. 4. 4 hojas prels. y 232 foliadas.

Comprende las comedias que se ponen á continuacion:

El honrador de su padre.-Diamante.

El valor contra fortuna.-Andres de $B a z a$.

Hacer remedio el dolor.-Moreto y Ćancer.

El robo de las Sabinas.-Coello y Arias.

El loco en la penitencia, y tirano más impropio. - Un Ingenio.

Contra su suerte ninguno.-Malo de Mulina.

Vencerse es mayor valor.-Calderon de ia Barca. En la Tabla se corrige diciendo tue es cle los Figueroas.

El más ilustre frances san Bermardo.-Moreto.

El escíndalo de Grecia contra las santas inıígenes.-Calderon.

No se pierden las finezas.-Andres de Breza.

La silla de San l'edro.-Antonio Martines.

La mís constante mujer. Burlesca. - Juan Maldonado, Diego la Dueña y Jerónimo de cifuéntes.

Segun Münch Bellinghausen existe otra edicion de esta Parte becha en Mallid, l65s. en 1. $^{\circ}$

\section{Parte duodécina.}

Comedias nveras escogidas de los meiores Ingenios de España. Drodezima parte. Madrid, Andres Garcia de la Iglesia, 16058 . 4. ${ }^{\circ}$ i hojas preliminares y 218 foliadas: la última no lo está.

Títulos y autores de las comedias de csta Parte:

La dama corregidor.-Zubaleta g l'illaviciosa.

La estrella de Monserrate. Cristúcal de Moráles.

Amor y obligacion.-Morelo.

Vencada ílites de ofendida.-Jerónima de cifuentes.

La española de Florencia.-Caldernn.

Servir para merecer.-Diamanle.

Prudente, sabia, y honrada-Cubillo de Arezgon.

El vencimiento de Turmo.-Calderon ele lil Barca.

El Hercules de Lingria.-Ambrosio de dree.

Los desdichados diebosos - Calderon.

Más la amistad que la santre. - Andres de Bae $\approx$. 


\section{COLECGION ANTIGOA DE COMEDIAS Etc., 48 VOLÚMENES.}

El mariscal de viron. Burlesca con Loa.-
Juan Maldonado.
Fl Sr. Barrera y Ieirado supone que hai una reimpresion de esta Partc hecha en el año 16.9, con algunas diferencias mui accesorias; yo tengo un ejemplar de ella y confleso que á pesar de haberla examinado, registrado y cotejado, encuentro es idénticamente la misma con la sola variacion de frinlis, en el cual tampoco se cambio sino el íltimo nimero de la fecha.-Por lo que dice el mismo Barrera parece tuvo aull esta portada posteriormente una tercera metamórfusis, aunque en ella el cambio fue mis completo, pues dice: Primavera nemerosa de muchas armonias lusiente's en doce Comedias fragrantes. Parte duodesima, impressas fielmente de los borralores de los mas celebres plausibles ingenios de España. Madrid, A cosla de Francisco Samz hupressor del Reyno, 1679.

\section{Parte décimatercera.}

De los mejores el mejor, Libro nvern de comedias varias, nvnca impressas, compuestas por los mejores Ingenios de España. Parte treze. Madrid, Mateo Fernandez, 1660. $4 .^{\circ} \cdot 4$ hojas. prels. y 004 págs.

Abraza las comedias que se espresan aqui:

Pobreza, amor y fortuna.-Dicgo y José de Figueroa.

segunda parte del Conde de Saldaña, y hechos de Bernardo del Carpio.-Cubillo de Aragon.

Triuntos de amor y fortuna-Antonio de Solis. Con Loa, et cntreme's de El Niño Caballero, el de El Salta en banco, y otro entremes y un sainete que no llevan litulos especiales.

Fuego de Dios en el querer bien.-Calderon.

Julian y Basilisa.-Antonio de Inerta, Rosele y cáncer.

Los tres afectins de amor, piedad, desmayo y valor-Calderon de la Burca.

El Josef de las mujeres. - Del mismo.

Cegar para ver mejor.-Ambrosio ie arce.

Los bandos de Vizcaya. - Rosete Niño.

El amante más cruel, y la amistad ya difunta.-Gonzalo de Vlloa y Sandoval.

No hai reinar como vivir.-Mira de Amescua.

A igual agravio no hai duelo.-Ambrosio de Cuenca.

\section{Parte catorec.}

Pensil de Apolo, en doze comedias nvevas de los meiores Ingenios de Éspaña. Parte catorce. Madrid, Do-
Està Parte se compone de las slguientes comedias:

No puede ser.-Horelo.

Leoncio y IIontano.-Diego y José de Figueroa.

El delincuente sin culpa, y bastardo de Aragon.-Mátos Fragoso.

Mentir y mudarse á un ticmpo.-Diego $\mathbf{g}$ José de Figucroa.

poco aprovechan avisos cuando hai mala inclinacion.-Mátos Frugoso.

El valiente Campuzano.-Zarale.

El Príncipe villano.-Betinonte Bermúdez.

Las canas en el papel y dudoso en la venganza-Calderon.

La hija del mesonero.-Diego de Figueroa.

La fuerza de la verdad.-Francisco de $\mathrm{Ma}$ laspina.

El galan de su mujer.-Mátos Fragoso.

La mayor vitoria de Constantino Magno.Ambrosio Arce de los Rejes.

Hai una edicion de Madrid, Domingo Garcia y Norvàs, 1661.4. igual á la anterior.

\section{Pante quince.}

Parte quinze. Comedias nvevas, escogidas de los mejores Ingenios de España. Madrid, Melchor Sanchez, 1661. 4. 0 hojas prels. y 260 foliadas.

Tiene esta Parte doce comedias, cuyos tItulos son:

El Conde Lucanor--Calderon de la Barca.

Fingir y aunar.-Moreto.

El mejor padre de pobres.-Calderon.

La batalla del honor.-Zarale.

La fuerza del natural.-Moreto.

Los empeños de un plumaje, y orígen de los Guevaras.-Calderon en el título; pero ta Tabla to corrige, diciendo que es de otro Ingenio de esta Corle.

El tercero de su afrenta.-Antonio Martinez.

El Eneas de Dios.-Moreto.

Las tres justicias en una.-Calderon de la Barca.

El obispo de Crobia, san Estanislao.-Zarute.

Cada uno para sí--Culderon.

Los Esforcias de Milan.-Antonio Martínez.

\section{Parte diez y seis.}

Parte diez y seis de comedias nvevas, y escogidas de los meiores Ingenios de España. Madrid, Melchor 


\section{COLECCION ANTIGUA DE COMEDIAS ETC., 48 VOLÚMENES.}

Sanchez, 1662. $40^{\circ} 4$ hojas prels. y cada comedia tiene las que se espresarán a continuacion, pues todas llevan nueva foliatura.

Están comprendidas en esca Parte las siguientes comedias:

Pedir justicia al culpado.-Anlonio Marlinez. 16 folins.

Solo en Dios la conflanza. - Rosele. 16 folios.

Cada uno con su igual.-Blas de Mesa. 18 folios.

El desden vengado.-Rojas. 16 folios.

El diablo está en Cantillana.-Luis velez. 18 folios.

El diciembre por agosto.-Juan Vélez. 16 folios.

Allá van leyes, donde quieren reyes.-Guillen de Custro. 16 folios.

El servir sin lisonja.-Gaspar de Ávila. 20 folios.

El verdugo de Málaga.-Luis Vélez. 18 folios.

El hombre de Portugal.-Yaestro Alfaro. 20 filios.

No es Amor como se pinta.-Tres Ingenios. 16 hojas.

Castigar por defender. Burlesca.-Rodrigo de Hervera. 16 folios.

\section{Parte diez y siete.}

Parte diez y siete de comedias nuevas y escogidas de los meiores Ingenios de Eiropa. Madrid, Meichor Sanchez, 1662. 4.

No la tengo; pero be sacado el titulo de Barrera y segun el misno comprende el vo-. lúmen estas comedias:

Dar tiempo al tiempo.-Calderon.

Primero es la honra.-Ioreto.

La sortija de Florencia.-Sebastian de rillaviciosa.

Antes que todo es mi dama.-Calderon.

Las dos estrellas de Francia.-Mres/ro Ma$\because$ lel de Leon y Lic. Diego Calleja.

Ca para levantar.-Malos Cáncer y Moreto.

La ierdad en el engaño.-Juan léles de Guevara, Cáncer y Murlinez de Menéses.

Tambien da amor libertad.-Marlinez de Menéses.

Amor hace hablar los mudos.-Scbastiun de Villatiriosa, Málos y Zabalein.

La ofensa y la venganza en el retrato.-Juan Antonio de Mnjica.

No hai cosa conıo callar. - Calderon.

Yujer llora y vencerás.-El mismo.

\section{Parte diez y ocho.}

Parte diez y ocho, de comedias nvevas, escogidas de los meiores Ingenios de España. Madrid, Gregorio Rodriguez, 1662. 4. 4 hojas preliminares, 160 foliadas y 76 de segunda foliatura.

Sus comedias se ponen á continuacion.

Dicha y desdicha del nombre.-Calderon.

Euridice y 0rfeo.-Anlonio de Solts.

Séneca y Neron.-Calderon.

La paciencia en los trabajos.-Felipe Godinez.

Los Médicis de Florencia.-D. Diego Jiménez Enciso.

El lindo D. Diego.-Moreto.

L.as niñezes del Padre Rojas. - Vega Carpio.

Lo que son suegro y cuñado. $-D$. Jerúnimo de Cifuentes.

El amor en vizcaino y los zelos en frances, $\mathbf{y}$ torneos de vavarra.-Luis velez de Guevara.

Amigo, amante y leal.-Calderon.

Firmeza, amor y venganza.-D. Antonio Francisco.

El rei D. Alfonso, el de la mano horadada. Comedia burlesca.-Un Ingenio.

\section{Parte diez y nueve.}

Parte diez $\mathbf{y}$ nvere de comedias nvevas, $y$ escogjdas de los meiores ingenios de España. Madrid, por Pablo de Yal. Año de 1663. 4. 4 hojas prels. y 212 fols.

Titulos de las doce comedias que se hallan en este Parte:

El alcázar del secreto. -D. Anlonio de Solis.

Travesuras de Pantija.-Mureto.

S. Froilan.-Ln Ingenin.

Ei Caballero. - Yor'elo.

El rei II. Sebastian.-Francisco de Villégas.

En el sueño estíl la muerte.-D. Jerúnimo Gupdeja Ouiroga.

Los sietedurmientes.-yoreto.

Los dos fllosofos de Grecia.-D. Fernando de Zarate.

La lealtad en las injurias.-D. Diego de Figuerna y Cirtola.

La reina en el Buen-Retiro.-D. Antonio Marlinez.

Mudarse por mejorarse.-D. Fernando de Zarale.

Zelos aun del aire matan.-Calderon.

Parece que hai una cdicion de Madrid, Pablo de val, 1662. 4. 


\section{COLECCION ANTIGUA DE COMEDIAS ETc., 48 VOLÚMENES.}

\section{Parte veinte.}

Parte veinte de comedias varias nvnea impressas, comprestas por los meiores ingenios de España. Madrid, Imprenta Real. 1663. $0^{\circ}$ G hojas preliminares, $\mathbf{3} 26$ págs. y una hoja para repetir la fecha.

Contiene esta larte las siguientes comedias:

El májico prodigioso.-Calderon.

Cillar hasta la ocasion.-D. Juan Ifurlads y cisuerros.

Auristela y lisidante.-Calderon.

Guardar palabra a los santos.-D. Sebastian cle olináres.

La difunta pleiteada.-Rójas.

El rigor de las desdichas y mulanzas de fortuna.-Calderon.

Don Pedro Viago.-Rójas.

El mejor alcaile el rei y no hai cuenta con Serrános. $-D$. Anlonio Marlinez. Iliferente de la de Lope.

Siber desmentir sospechas.-Calderon.

Aristómenes Mesenio.-El Vaestro Alfaro.

El hijo de la virtud, S. Juan Bueno. Priniera parte.-El capitun D. Francisco de Llúnos " Valdes.

El hijo de la virtud, elc. Segunda parte.El mismo.

\section{Parte veintiuna.}

Parte veinte $\mathrm{y}$ va de comedias nvevas, escogidas de los mejores inzenios de España. Madrid, Ioseph Fernandez de Buendia, 1663. 4. $^{\circ}$ a hojas prels. y 492 paigs.

Comedias que contiene:

Cuál es mayor perfeccion.-Calteron.

Fortimas de Andrómeda y Perseo. - Calderon. Quererse sin declararse. $-D$. Fernando de Zarate.

El Gobernador prudente-Guspar de ivila.

Las siete estrellas de Frameia.,Luis Belmonte.

El platero del cielo. - Lntonio Marlinez.

La conquista de Cuenca, y primer dedicacion de la Virgen del Sagrario.-D. Pedro kosete.

La hechizera del cielo.- - . Antonio de Nancláres.

La razon hace dichosos.-Anlonio Marlinez, Zabalela y cinarer.

Amar sin ver.-J). Antonio Murlines.

La Margarita preciosa.-Zabaleta, Cancer y Cuideron.

El más herujco silencio.-D. Anlonio Cardona.

\section{Harte veintidos.}

Parte veinte $\mathrm{y}$ dos de comedias nvevas, escogidas de los mejores ingenios de España. Madrid, Andres Ciarcia de la Iglesia, 1665. $4 .^{\circ} 4$ hojas prels. y 234 fols.

Títulos de las comedias que comprende:

Los españoles en Chile.-D. Francisco González de Bústos.

Elegir al enemigo.-D. Agustin de Salazar $y$ Torres.

El area de Noe. $-D$. Anlonio Marlinez y Don P. Rosele.

La luna de la Sagra, vida y muerte de la Sta. Juana de la Cruz.-D. Francisco Bernardo de Quiros.

Lavar sin sancre una ofensa.-D. Roman Moulero le Espinosa.

Los dos monarcas de Europa.-D. Bartolomé de Salazat y Luna.

l.a corle en el valle.-Auellaneda, Málos Fragoso y Villaviciosa.

Amar y no agradecer.-D. Francisco Sulgado.

La santa Olalla de Mérida.-Francisco Gonzilez de. Bustos.

Nerecer de Ia Fortuna ensalzamientos dichosos.-D. Diego de Vera y D. Jósé de Ribera.

Muchos aciertos de un yerro. $-D$. José de Figueroa.

Antes que todo es mi amigo. $-D$. Fernando de Zarate.

\section{Parte veintitues.}

Parte veinte y tres de comedias nveras, escritas por los mejores ingenios de España. Madrid, Ioseph Fernandez de Buendia, 166o. 4. ${ }^{\circ}$ a hojas prels. y 507 págs.

Esta Parte contiene las comedias siguientes:

Santo Tomas de Villanueva.-Diamante.

Los dos prodigios de Roma.-Málos Fragoso.

El redentor cautivn.-Málos y Villaviciosa.

EI parecido.-Moreto.

Las misas de S. Vicente. $-D$. Fernando $Z a$ rate.

No ammar la mayor fineza.-D. J. Zabraleta.

Hacer fineza el desaire.-D. Diego Calleja.

Encontríronse dos arroyuelos. -D. Juan Velez.

La Vírgen de la Fuencisla. - Villaviciosa, Mátos y Zabalela.

El honrador de sus hijas.-D. Francisco Polo.

El hechizo inaginado.-D. J. Zabalela. 


\section{COLECCION ANTIGUA DE COMEDIAS ETC., 48 VOLÚMENES.}

La presumida \& la hermosa.-D. F. de Za. rate.

Tengo otro ejemplar de la misma edicion con el año 1666 en la portada.

\section{Parte veinticuatro.}

Parle veinte y qualro de comedias nuevas, escogidas de los mejores ingenios de España. Madrid, Mateo Fernandez Espinosa, 1666. 4.

Me falta csta Parte; pero segun Barrera, contiene:

El mónstruo de la fortuna. (La lavandera de

Nápoles.)-Cnlderun, Monlalvan y Röjus.

La Vírgen de la Saleeda.-Leon Marchante y Calleja.

Indistrias contra finezas.-Moreto.

La dama Capitan.-Los Figueroas.

Tambien tiene el sol menguante.-Tres Ingenios.

Lo que purede amor y zelos.-Un Ingenio de esia corle.

Los amantes de Verona.-Crislóval de Rózas.

El soldado nas herido y vivo despues de muerto.-Estenoz.

El maestro de Alejandro.-Zarate.

San Pedro de Arbués.-D. Fernando (es Don Franeisco) de la Torre.

Solo el piadoso es mi hijo.-Ndtos, Villaviciosa y Avellimeda.

La Rosa de Alejandria: "la más nueva.»Roscle.

\section{Parte veinticinco.}

Parte veinte y cinco de comedias nvevas, $y$ escogidas de los mejores Ingenios de España. Madrid, Domingo Garcia Morràs, 1666. $4^{\circ} 4$ hojas prels., 243 foliadas y una para repetir la fecha.

Títulos de las comedias de esta Parte:

El letrado del cielo.-Málos Fragoso.

La más dichosa venganza. $-D$. Anlonio de Snlis.

La flngida Arcadia.-Morelo.

Cuantas veo tautas quiero. - D. Sebastian villaviciusa y D. Francisco de Avellaneda.

La condesa de Belflor.-Morelo.

No hai contra el amor poder. $-D$. Juan Vélez de Guevara.

Sin honra no hai valentía.-Morcto.

Amor vencido de amor.-D.J. Vélez, Zabalela y D. Anlonio de Huerla.

A lo que obligan los zelos. $-D$. $F$. de Zarale. Lo que puede la crianza.-D. Francisco de villéyas.
La esclavitud más dichosa y Virgen de los Remedios. - Francisco villégas y Jusepe Rojo.

Lorenzo me llamo.-Málos Fragoso.

\section{Parte veintiseis.}

Parte veinte $y$ seis de comedias nvevas, escogidas de los mejores ingenios de España. Madrid, Francisco Nieto, 1566. $40^{\circ} 4$ hojas prels. y Q:3ว foliadas; la última por equivocacion está numerada 20 ŏ.

Este tomo se compone de las siguientes comedias:

El vaquero de Granada.-Diamante.

La dicha del earbonero, y Lorenzo me llamo. La nueva.-Mátos Fragoso. Es la misma que la ultima de la Parte 25.

Haí culpa en que no hai delito.-D. Roman Montern de Espinosa.

El mancebo del camino.-Dimnante.

Lns sucesos de tres horas. - D. Luis de Oviedo.

Fiar de Dios. $-D$. Antonio Marlínez $\mathrm{Y}$ D. Luis Belnionle.

Desde Toledo á Nadrid.-Tirso de Molina.

El amor puesto en razou. $-D$. Sebaslian de Villavicinsa.

S. Luis Bertran.-Horeto.

La piedad en la justicia.-D. Guillen de CasIro.

Resucitar con el agua.-D. José Ruiz, D. Jacinlo IIurlado de Mendoza y Pedro Francisco Lanini Vatencia.

Todo cabe en Io posible.-D. Fernando de ivila.

\section{Parte veintisicte.}

Parte reinte $y$ siete. De comedias rarias nrnca inipressas, comprestas por los meiores ingenios de España. Madrid, Andres Garcia de la Iglesia, 1667. 4. 4 hojas prels. y 436 paigs.

Titulos y autores de las comedias:

Los sucesos en oran por el inarques de Ardales.-D. Luis Vélez de Guevara.

Los bandos de Ravena y institucion de la Camáudula.-Málos Fragoso.

La cortesana en la sierra.-Tres Ingenios.

Reinar no es la mayor suerte.-Un Ingenio.

El labirinto de Creta.-Dianante.

La ocasion liace el ladron.-.yálos Fragoso.

Nuestra Señora de Regla. - Ambrosio de Cuenca.

Amar por señas.-Tirso de Molina. 


\section{COLECCION ANTIGUA DE COMEDIAS Etc., 48 VOLÚMENES.}

Las auroras de Sevilla.-Tres Ingenios.

La cruz de Caravaca.-Diamulle.

La ventura coll el nombre.-Tirso de Molina.

La Judía de Toledo.-Diamante.

\section{Parte veintiocho.}

Parte veinte y ocho de comedias nveras de los mejores ingenios desta corte. Madrid, Ioseph Fernandez de Buendia, 1667. 4. 4 hojas prels. y 478 paigs.; la última está numerada por equivocacion $\mathbf{4 8 \pi}$.

\section{Comedias que contiene:}

El principe D. Cárlos.-Pérez de Montalvan. S. Isidro Labrador de Madrid.-lega Carpio. El sitio de Breda.-Calderon.

Los empeños de un engaño. - D. Jian de Alarcon.

El mejor tutor es Dios.-Luis de Belmonte.

El palacio confuso.- Mira de Amescua.

Victoria por el amor-Dacinto Cordero.

La victoria de Torlingent.-Al'mso del Castillo Solór:ano.

La ventura en la desoracia.-léga Carpio.

S. Naten en Etiopia.-Felipe Golinn:

Mira al fin.-Un Ingenio.

La corte del demonio.-Luis vélez de Guevara.

\section{I'arte veintinueve.}

Parte veinte y nvere de comedias nvevas, escritas por los mejores ingenios de España. Madrid, Ioseph Fermandez de Buendia, 1668. 4. 4 hojas prels. y $\mathbf{1 6} \mathbf{1}$ paigs.

Contienc esta l'arte las siguientes:

El iris de las pendeucias.-Gaspar de Avila. La razon vence al poder.-Yátos Fragosn.

El vaso y la piedra.-D. Fermando de Zarale. Píramo y Tisbe. - D. P. Rusele.

La defensora de la reima de Hungría. $-D, F$. Zarale.

El mejor representante, S. Gines-Cáneer, Rosele y D. Antonio Marlinez.

Ganar por la mano juego. - Cubillo de Aragon. El primer conde de Flándes.-D. F. de Zarate.

El hamete de Toledo. Burlesca.-Tres Ingenins.

Tétis y Peleo.-D. José de Bolea.

Nuestra Señora de la Luz.-D. Francisco Salgado.

Cómo se vengan los nobles.-Horclo.

\section{Parte treinta.}

Parte treinta. Comedias nvevas, y escogidas de los mejores Ingenios de España. Madrid, Domingo Garcia Morràs, 1668. 4. 4 hnjas prels. y ¿63 págs.

Títulos de las comedias:

El Bruto de Babilonia.-Málus Fragoso, Morelo y Cáncer.

La montañesa de Astúrias.-Luis Vélez de Guevara.

El premio en la misma pena.-Mirelo.

Cuerdos bacen escarmientos.-D. Francisco Villégas.

Hacer del anor agravio. - Un Ingenin.

El mancebon de los palacios. $-D$. Juan vélez de Guevara.

La conquista de Véjico.-D. Fermundo de Zarale.

El príncipe viñador.-Luis Véles.

El valeroso español, y primero de su casa.Gaspar de Alita.

La negra por el honor.-Morelo.

No está en matar el vencer.-Málos Fragoso.

S. Antonio Abad.-D. Fernando de Zarale.

\section{Parte treinta y una.}

Parte treinta $\mathbf{y}$ vna de comedias nvevas, escritas por los mejores ingenios de España. Madrid, Ioseph Fernandez de Buendia, 1669. 1. $^{\circ}$ a hojas prels. y ö01 págs.

Comprende las siguientes comedias:

Querer por solo querer.-D. Anlonio de Mendoza.

Sufrir más por valer más. $-D$. Jerónimo Cruz.

Mentir por razon de estado.-D. Felipe de Milan y Aragon.

No hai gusto como la honra.-D. Fernando de Vera y Mendoza.

El cabaliero de Gracia.-Tirso de Molina.

El pronóstico de Cádiz.-D. Alonso de Osuna.

La trompeta del juicio. $-D$. Gabriel del Corral.

Prodigios de amor.-Villaviciosa.

El amor enamorado.-Zabaleta.

El esclavo del más impropio dneñn. - Rna.

El socorro de los mantos. $-D$. Cárlos Arellano.

La traicion en propia sangre. - El Mastro Ribera. 


\section{COLECCION ANTIGUA DE COMEDIAS ETC., 48 VOLÚMENES.}

\section{Parte treinta y dos.}

Parte treinta y dos de comedias nvevas, nrnca impressas, escogidas de los mejores ingenios de España. Madrid, Andres Garcia de la Iglesia, 1669. 4. 4 hojas prels., 438 foliadas y una para repetir el lugar y nombre del impresor.

Títulos de las comedias que contiene:

La culpa más provechosa.-D. Francisco de villégas.

El bandolero Solposto.-Cáncer, Rosele y Rójas.

La vida en el ataud.-Ríjas.

Los muros de Jerico. - D. Sebastian de oliváres.

Las cinco blancas de Juan Espera en Dios.D. Antonio de Huerla.

La Vírgen de los Desamparados de Valencia. - Marcos Anlonin Orliz. (Debe ser Morco Antonis Orli. Jimeno dice, que la tercera jornada es de Jacinlo Alonso Malvenda.)

Duelo de honor y amistad. $-D$. Jacinlo de Herrera.

Selva de amor y zelos.-Ríjas.

El más piadoso troyano.-D. Francisco Ville. gas.

Pelear hasta morir. $-D$. Pedro Rosele.

El legitimo bastardo. $-D$. Crislóval de Mordles.

Afamador el de Ctrera.-Luis Belmonle.

\section{Parte treinta y tres.}

Parte treinta $\mathrm{y}$ tres de comedias nveras, nvnca impressas, escogidas de los mejores ingenios de España. Madrid, loseph Fernandez de Buendia, 1670. 4. 4 hojas prels. y 4 כั1 páginas; en el reverso de la última $\mathrm{nu-}$ merada lleva la fecha de 1669.

Comedias que contiene:

El sabio en sul retiro.-Wálos Fragnso.

Cuerdos hai que parecen locos.-Zabnleta.

La romera de Sanliago. - Tirso de Molina.

Las niñezes de Roldan.-Jose Rojo y Francis. co villégas.

Vida y muerte de la monja de Portural.Mira de Amescua.

El voto de Santiago y batalla de Clavijo.D. Rodirigo Herrera.

Pérulida y restauracion de la bahla de Todos santos.-Jurn Antonio Correa.

El casamiento con zelos, y rei D. l'edro de Aragon.-Burtolumé de Anciso. (. En Enciso como dice Barrera.)
Mateo Vizconde. $-D$. Juan de Ayala.

El más dichoso prodigio.-Un Ingenio.

El fénix de Alemania. Vida y muerte de Santa Cristina.-Watos Fragoso.

La más heróica flneza, y fortunas de lsabela. - Mátos y D. Diego y D. José de Córdoúa y

Figueroa.

\section{Parte treintan y cuatro.}

Parte treinta y quatro de comedias nrevas, escritas por los mejores ingenios de España. Madrid, loseph Fernandez de Buendia, 1670. 4. ${ }^{\circ} 4$ hojas. prels. y 446 págs.

Titulos de las comedias:

El lazo, banda s retrato. $-D$. Gil Enrique=.

Rendirse á la obligacion.-D. José § D. Diego de Figueroa.

El santo Cristo de Cabrilla.-Yorelo.

Pocos bastan si son buenos, y crisol de la lealtad.-Yálos Fíagoso.

Verse y tencrse por muertos.-D. Hannel Freire de tudiende.

El disparate creirlo.-D. J. Zabals la.

La renganza en el ilespeño. - Yálos Fragoso.

La Virgen de la Aurora. - Vurelo y Ceineer.

El galan secreto.- Mirna de Amesciuz.

Lo que le toca al valor, y príneipe de orange.-El mismo.

Allor de razon rencido. - Ln Ingenio.

El azote de su patria.-Yoreto.

\section{Parte treinta y cinco.}

Parte treinta $y$ cinco. Comedias nuevas, escritas por los mejores Inrenios de España. Iladrid. Lueas Intonio de Bedmar, $1671.4^{\circ}$ i lotojas? prels. y ḯli paigs.

Forman esta Parte las comedias signientes:

El defensor de su arravio - y,melo.

l.a conquista de Gran.-Luis leles de Gue. "ara.

To hai amar como flngir.-Yaesho Loon.

En ladrid y en mua casa.-Rójas. (Se cree con fundamento es de Tirso.

l.a hermosura y ha desdiclia.-Réjus.

A lo que obliga el desden. - D. Francisco Satgado Garces.

Telos son bien y venlura.-Fitipe Gndiues.

l.a confusion de Hungria. - Mira de Amescunt.

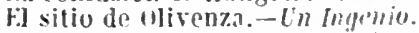

Emprzar a ser amizos.-Morelo.

El dutor Cirlinu.- - Anturio do sotis.

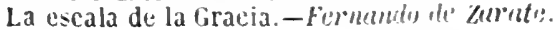




\section{COLECGION ANTIGUA DE COMEDIAS ETc., ¿8 VOLÚMENES.}

\section{Parte treinta y seis.}

Parte treinta y seis. Comedias escritas por los mejores ingenios de España. Madrid, Ioseph Fernandez de Buendia, $1671.4 .^{\circ} 4$ hojas preliminares y 307 paigs. dias:

Esta Parte consla de las siguier.'s wme.

Siuta Rosa del Perú.-Moreto y ianini Sagredo. En el título de esla comedia se dice que sus dos primeras jornadas fuerón las bllimas que escribio Morelo en el discurso de su vida.

El mosquetero de Flándes.-D. Francisco Gonzllez de bixilos.

El timano castigado.-Diamante.

Arúspas y Pantea.-D. Francisco Salgado.

El prodigio de Polonia.-D. Juan Delgado.

La Fénix de Tesalia.-El Maestro Roa.

El mullcio falso de Portugal.-Tres Ingenios.

La dicha por el agravio.-Diamante.

El dichoso bandolero, Fr. Pedro de Nazara. -Crmizáres.

El sitio de Betulia.-Ln Ingenio.

Darlo todo y 110 dir nada. Burlesca. D. Peclro Francisco Lanini y Sagredo.

Las barracas del Grao de Valencia.-Tres Ingenios.

\section{Parte treinta y siete.}

Parte treinta y siete de comedias nvevas escritas por los mejores Ingenios de España. Madrid, Melchor Alegre, $1671.4 .^{\circ} 4$ hojas prels. y 438 paigs.

Los sirruientes son los titulos de las comedias que contiene:

in bobo hace ciento.-Antomio de Solis.

liesgos, amor $\mathrm{y}$ amistad.-Juan Vélez de Guevar'a.

Salisfacer callando.-.yorelo.

El nuevo mundo en Castilla.-Málos Fragoso.

Los prodigios de la vara, y capilan de lsrael. - Mira de Amescua.

El amor hace diseretos. - Un Ingenio.

Todo es enredos amor. $-D$. Diego de Córdova y Figueror.

Poder y amor compitiendo.-Juan de la Calle. La gitanilla de Iladrid.-D. Antonio de Solis.

Escarraman. Burlesca.-Moreto.

El mejor casamentero.-Málos Fragoso.

La desgracia venturosa. $-F$. de zarate.

Hai ejemplares do la misma impresion que llevan en el frontis el escudo de armas de b. Jacinto de Romarate, á quien va dedicado ul tomo, y atros que no lo tienen. En el mio se encuentran ambas portadas.

\section{Parte treinta y ocho.}

Parte treinta y ocho de comedias nvevas. Escritas por los mejores ingenios de España. Madrid, Viuda de D. Francisco Nieto, 1673. 4. \% lojas prels. y 448 págs.

Conliene las comedias notadas á continua. cion:

El águila de la iglesia, S. Agustin.-D. Francisco González Bústos y D. Pedro Lanini sagredo.

Las niñezes y primer triunfo de David.-Don Manuel de Várgas.

Tambien se auna en el abismo.-D. Agrstin de Salazar.

Los Mozárabes de Toledo.-D. Juan Hidalgo.

La grala del uadar es saber guardar la ropa. - Morelo.

Olvidar a nando.-D. Francisco Bernardo Quiros.

Las tres edades del mundo.-Luis Velez de Guevara.

Del mal lo ménos.-Un Ingenio.

Vida $\mathrm{y}$ muerle de $\mathrm{S}$. Cayetano. $\rightarrow$ Seis Ingenios.

El hechizo de Sevilla.-D. Ambrosio de Arce.

Enmendar yerros ajenos. -D. Francisco Jiménez de Cisnéros.

El cerco de Tagarete. Burlesca con un enl'e' mes intitulado: El malcontento.-D. Francisco Bernardo de Quiros.

Barrera menciona otra edicion de esta Parle hecha en Madrid, por Lucas Anlonio de Bedmar, $1672.4 .^{\circ}$; pero no tuvo nolicia de la de 167.5 , que yo poseo.

\section{Parte treinta y nueve.}

Parte treinta y nveve de comedias nvevas de los meiores ingenios de España. Madrid, Ioseph Fernandez de Buendia, 1673. 4. $^{\circ} 4$ hojas preliminares y $4 \mathbf{4 2}$ págs.

Comprende esta Parte las comedias siguientes:

El mejor Par de los doce.-Málos Fragoso y Morelo.

La mesonera del cielo-Mira de Amescua.

La milagrosa eleccion de Pio V.-Moreto. Este es el título yue lleva en el indice. en la comedia. solo dice, Lil milagrosa eleccion.

La dicha por el desprecio.-Mátos Fragoso.

El veneno para sl.-Un Ingenio.

El vaquero emperador--Málos Fragoso, Diamanle y D. dndres Gil Enriquez. 


\section{COLECCION ANTIGUA DE COMEDIAS Etc., 48 VOLÚMENES.}

La cosaria cdtalana.-Mdtos Fragoso.

Las mozedades del Cid. Burlesca.-Cancer.

Los carboneros de Francia.-Mira de Ames. cua.

Cómo nació S. Francisco.-D. Roman Monlero y D. Francisco Villégas. Esle es el titulo con que se la designa en la Tabla : pero la comedia lleva el de Nacimiento de San Francisco.

La discreta venganza.-Morelo.

Contra fé no hai respeto.-D. Diego Guliérrez. A este aulor se la alribuye la Tabla; pero la comedia unicamente dice que es de un Ingenio.

\section{Parte cuarenta.}

Parte quarenta de comedias nvevas de diversos avtores. Madrid, Iulian Paredes, 167\%. 4. 2 hojas prel:minares $y \mathbf{2 4 4}$ foliadas.

Comedias que contiene esta Parte:

De médico pintor, s. Lucas.-D. Fernando de Zarute.

El rei D. Alfonso el Bueno.-D. Pedro Larini Sagredo.

El fénix de la Escritura, el glorioso S. Jerunimo.-González de Bústos.

Cuando no se aguarda.-D. Francisco de Leiva Ramitrez de Arellann.

No hai contra lealtad cautelas. $-E l$ mismo.

Amadis y Niquea.-El mismo.

Las tres coronaciones del Emperador Cárlos V. - D. Fernando de Zarate.

Los hermanos amantes, y piedad por fuerza. - El misino.

El dichoso en Zaragoza.-Pérez de Montalvan.

Los bandos de Luca y Pisa.-Antonio de Ace. vedo.

La playa de Sanlúcar.-Barlolomé Cortes.

Orígen de Nra. Sra. de las Angustias y rebelion de los moriscos.-Anlonio Fajardo y Acevedo.

\section{Parte cuarenta y una.}

No se conoce la verdadera de esta Coleccion: Barrera la sustituye por una estravagante ó de las de á fuera que se dice impresa en Pamplona, s. a.; pero que segun todas las apariencias, es un tomo donde un aficionado reunió doce comedias, la mayor parte ya incluidas en los otros rolúmenes, y les hizo imprimir una portada desígnándolo como $\$ 1$ de la serie.

\section{Parte cuarenta y dos.}

Parte quarenta y dos de comedias nvevas, nvnca impressas, escogidas de los mejores ingenios de España. Madrid, Roque Rico de Miranda, 1676. $40^{\circ} 4$ hojas prels. y 004 págs.

Contiene las comedias que siguen:

Varios prodigios de amor.-Rójas.

S. Francisco de Borja.-D. Melchir Fernández de Leon. Este es el tílulo de la Tabla, en la comeliu se le añade: Duque de Gandia.

Dios hace justicia á todos.-D. Francisco de Villégas.

lo por vos y vos por otro.-Yorelo.

El luzero de Vadrid, Nra. Sra. de dtocha.D. Pedro Francisco Lanini Sagredo.

La mejor flor de sicilia, Sta. Rosolea.-Don Agustin de Salazar.

Como noble y ofendido. $-D$. Anlonio de la Cuevu.

Endimion y Diana.-D. Melchor Fernández de Lean.

Será lo que Dios quisiere.-D. P.F. Lanini Sagredo.

El hijo de la molinera.-D. Francisco de Villégus.

El gran rei anacoreta, S. Onofre.-D. P, F. La nini Sagredo.

El Encas de la Vírgen y primer rei de Vavarra.-D. Francisco dé tillégas y D. P. F. La. nini Sagredo.

\section{Parte cuarenta y tres.}

Parte qrarenta $y$ tres de comedias nveras, de los mejores ingenios de España. Madrid. Antonio Gonçalez de lieves, 1678. 4. ' hojas prels. y 169 prigs.

Las siguientes comedias forman esta Parte:

Cueva y castillo de amor. $-D$. Francisco de Leivă.

Porcia y Taucredo,-D. Luis de Clloa.

ira. Srá. de la lictoria y restauracion de Yálaga.-D. Fi'ancisco de Leiv'u.

El Fenix de España, S. Francisco de Borja.Un Ingenio.

El cielo por los cabellos, Sta. Ines.-Tres Ingenios.

El emperador fingido.-I). Gabriel Bocángel y inzueta.

La dicha es la diligencia.-D. Tomas osorio.

Cual es lo mis en amor el desprecio o el favur.-Salvador de la Cuev'a.

La infeliz Aurora, y tilleza acreditada.-Don Francisco de L'iva. 


\section{COLECCION ANTIGUA DE COMEDIAS Etc., 48 VOLÚMENES.}

La nueva maravilla de la Gracia.-D. Pedro Lanini Sagredo. Estos son el tilulo y nombre de antor que se le da en la Tabla; pero cu el encabesamichto de a comedia añude al anterior lilulo Juana de Jesus Maria y la alvibuye a D. Francisco Lanini Sayredo. Nerecer pira alcanzar.-Moreto.

El principe de la Estrella, y castillo de la vida.-D. Antonio Martines, Zabaleta y Don vicenle Suárez.

\section{Parte cuarenta y cuatro.}

Parte quarenta y qratro de comedias nvevas, nveca impressas, escoridas de los mejores ingenios de España. Madrid, Roque Rico de Miranda, 1678. . $^{\circ}$ thojas prels. y 492 páginas.

Las comedias que componen esta Parte son las que siguen:

Quien habla más obra ménos.-D. F. de Zarale.

El apostol de Salamanca.-D. Felipe Sicardo, Dejar un reino por otro y mártires de Madrid-Cáncer, Villuniciosa y Moreto.

Ciuco venganzas en una.-D. Juan de Ayala.

Santa Peliagia.-D. Fer'nando de Zarate.

La confesion con el demonio.-D. Francisco de la Torre.

La palabra vengada. $-D$. F . de Zarale.

El ellyaño de unos zelos.-Roman Nonlero de Espinosa.

la prudencia en el castigo.-Rójas.

La sirena de Tinacria. $-D$. Diego de Córdova y) Figlteroa.

l.as lises de Francia.-Wira do Amescua.

El sordo y el montañes. - D. Melchor Fernández de Leon.

\section{Parte cuarenta y cinco.}

Comedias nvevas, escogidas de los meiores ingenios de España. Parte qrarenta y cinco. Madrid, Ioseph Fernández de Buendia, 1679. $4 .^{\circ} 4$ hojas prels. y 434 págs.

La forman las siguientes comedias:

I,os bandos de Verona.-Rojas.

La sirena del Jordan.-D. Cristóval de Monroi y Silva. En la Tabla se da desla comedia el tílulo de La sirena del Jordan, San Juan Bautista.

los trabajos de Llíses.-Luis Belmonle.

Ni hai dichil hasta la muerte.-Un Ingenio. El lílulo de esla comedia en la Tabla es el de llastit la mucrte no hai dicha.
La mudanza en el amor.-Montalvan.

Ingrato á quien le hizo bien.-Un Ingento.

El gran Jorge Castrioto y Príncipe Escandarbec.-Luis velez de Guevara. En la Tabla se alribuye a Belmonte.

El fln más desgraciado y fortunas de Seyano. -Montalvan.

La traicion en propia sangre. Burlesca.-Un Ingenio. El título de la Tabla es: La traicion contra su sangre.

Dejar dicha por más dicha.-D. Juan Kuiz de Alarcon.

Quièn engaña más á quiẻn.-El mismo.

El amor más verdadero. Burlesca.-Mosen Guillen Pierres. En la Tabla se alribuye d un Ingenio de esta Corle.

\section{Farte cuarenta y seis.}

Primavera numerosa de mrchas armonias lvzientes, en doce comedias fragantes, parle quarenta $y$ seis. Impressas fielmente de los horradores de los mas célebres plausibles ingenios de España. Madrid, Francisco Sanz, 1679. $40^{\circ} 6$ hojas prels. y 20 2 foliadas.

Títulos de las comedias:

La mitra y pluma en la cruz, s. Casiano.El Maesiro Tomas Mamuel de Paz.

Cuanto cabe en hora y media.-D. Juan de Vera y Villarroet.

Al noble su sangre avisa.-El Maestro T. $M$. de P'as.

El patron de Silamanca, S. Juan de Sahagun, con Monroyes y Manzanos. $-D$. J. de Vera y villartoel.

Las armas de in hermosura.-Calderon.

Perico el de los palotes. - Tres Ingerios.

La señora y la eviada.-Calderon.

La cornna en tres hermanis.-D. J. de Veray Villarroel.

La conquista de las Malucas.-D. Melchor Firnándes de Leon.

Más nerece quien más ama.-D. Anlonio de Mendozi y D. J. de Vera y Villarroel.

El veneno en la guirnalda, y la triaca en la fuente.-D. Meichor de Leon.

El marques del Cigarral. $-D$. Alonso del Cas. tillo Solor'zano.

\section{Parte cuarenta y siete.}

Parte quarenta y siete de comedias nvevas escogidas de los meiores ingenios de lispaña. Madrid, Melchor Alvarez, 1681. 4. 1 hojas 


\section{COLECCION-ANTIGUA DE COMEDIAS Etc., PARTES DE A FUera.}

\section{prels., 382 págs. y una hoja para repe- tir la fecha.}

Todas las comedias de esta Parte son de D. Antonlo de Solis y sus títulos los siguientes:

Triunfos de amor $\mathrm{y}$ fortuna; precedida de Loa y seguida de los enlremeses del Niño caballero y Salta en banco $y$ un sainete. Euridice y Orfeo.

El amor al uso.

El alcázar del secreto.

Las amazonas.

El Dotor Carlino.

Un bobo hace ciento. Precedida de Loa.

La gitanilla de Madrid.

Amparar al enemigo.

\section{Parte ewarenta y ocho.}

Comedias nvevas, parte quarenta v ocho, escogidas de los mejores ingenios de España. Madrid, Francisco Martinez Abad, 17.04. 4. ${ }^{\circ}$ 亏 hojas prels. (puede que alguna deba ir al fin del volumen) y 494 pags.

Las comedias que forman esta última Parte son las siguientes:

El Austria en Jerusalen.-D. Francisco Bän. ces cdindamo.

El sol obediente al hombre.-D. Garcia $A z$ nar vellez.

El duelo contra su dama.-D. Francisco Bánces Caindamo.

Qué es la ciencia del reinar.-D. G. Aznar Vélez.

Venir el amor al mundo.-D. Helchor Fer. nóndez de Leon.

Cuál es afecto mayor, lealtad, ó sangre, ó amor.-D. Francisco Bánces Gdindamo.

Por su rei y por su dama.-El mismo.

Tambien hai piedad con zelos.-D. Garcia Aznar Vélez.

El español más amante y desgraciado Macías. - Tres Ingenios.

El valor no tiene edad. $-D$. J. B. Diannante.

İcaro y Dédalo; precedida de Loa. $-D$. Melchor Fernández de Leon.

Los aficionados à nuestra literatura dramática han supuesto casi siempre que la obra más rara de este género era la coleccion de las comedias de Lope de Vega ; sin embargo yo considero la de los 48 vols. de autores varios de adquisicion mucho más dificil; esto tiene una esplicacion mui sencilla: pues ademas de ser el número de'tomos que la componen casi de un doble, como estos contienen producciones de diferentes escrito. res, los libreros los han deshecho por encon. trar mayor ventaja y lacilidad en vender las piezas sueltas. Tres de las partes que posen las salvé por casualidad de semejante destrozo.

A mi ejemplar le faltan por entero las partes 17, 24 y 41 (de esta última no se conoce ejemplar alguno) y á pesar de estos defectos le tengo por el más completo de los pocos que se citan.

Desde principios del siglo XVIl hasta 1652 se publicó otra coleccion de comedias cuyos tomos se imprimieron en varios pueblos de España. Segun supone D. Agustin Duran, en una apuntacion suya que conservo, y en la lista dada por el Sr. Barrera, llegan estos á 44 , los cuales anotaré á continuacion, intercalando los que yo tengo en los lugares don. de corresponda.

Estos volúmenes se conocen con la denominacion de

PARTES ESTRAVAGASLES $\dot{O}$ DE $\dot{A}$ FUERA.

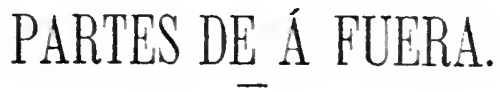

11801 1. $^{2}$ Flor de las meiores doce comedias de los mayores Ingenios de España, sacadas de sus verdaderos originales. Madrid, Diego Diaz de la Carrera, $1632.4 .^{\circ} 4$ hojas prals. y 261 foliadas. Apénas hai fol. que no esté errado. son:

Contiene las doce comedias, cuyos títulos

La luna de la sierra.-Luis lélez de Guev'ara. No hai amor donde hai agravio.-Antonio de Yendozl.

Los empeños del mentir.-Del mismo.

Zelos no ofenden al sol.-Anlonio Enriquez Gónc:.

No hai bien sin ajeno daño.-Antonio Siglet de Huerta.

El pleito que turo el diablo con el cura de Madrilejos.-Tres Ingenios, Luis rélez de Guevara, Rojas y Mira de Amescua.

Competidores y amigos. - Antonio de Huerta.

El familiar sin demnnio.-Gaspar de ivila.

Las inaravillas de Babilonia.-Guillen de Castro.

El Señor de noches buenas.-Antonio de Men$d o=a$.

Castigar por defender.-Rodrign de Herrera.

A gran daño gran rernedio.- Villai=an.

Volümen tan raro que $\mathrm{D}$. Agustin Duran solo poseia de él un fragtaento, segun nota 


\section{COLECGion antigua de COMEdias Etc., PARTES de a fuera.}

\begin{abstract}
- 刃o
suya. Dicho señor y Barrera suponen ser este tomo el primlero de las Parles de á fuert: yo no puedo conformarme con esta opinion, ya por su fecha posterior á casi todos los que se dice pertenecén á esta scrie, como por no haber en su portada indicacion alguna de formar parte de coleccion. ¿No podrian contarse como I. y II. los de Poetas valencianos, como HI. cl de Lope y otros, impreso en Valencia, bícia 1611, Barcelona, 16I2, Madrid, 1613 y Barcelona, 1614 ; como IV. uno desconocido y $r$ el de diferentes autores

1181 - Parte treynta vna, de las meiores comedias, que hasta oy han salido. Recogidas por el Dotor Francisco Toriuio Ximenez. Y a la fin va la Comedia de Santa Madrona, intitulada la viuda tirana, y conquista de Barcelona. En Barcelona; Iaime Romeu, Año. 1638. 4. 4 hojas preliminares y 277 fols.
\end{abstract} de Madrid y Alcalá, 1615 y Madrid y Barcelona 1616?-De la parte $60^{2}$ describe el señor Barrera una cuya portada dice: Parte sexta de Comedias escogidas de tos mejores Ingenios de España. Zuragoza, por los herederos de Pedro Lanaja, 1653. 4. - Desde esta Parte basta la 21 inclusive no se tiene noticia cicrta de ninguna; la 22 será sin duda la qute describo en el artículo de Lope de Vegi al hablar de este tomo de sus comedias, y está impresa en Zaragoza, 1650 ; de la 25 nada se sabe; la 24 puede sea la que lleva esta numeracion como de Lope, inpresa en Zarguza en 16.52 y $16 \overline{5}$, descrita en cl artículo de las comedias de dicho autor. Sirue la parte veynte y cinco de comedias recopiladas de diferentes dutores, e Illustres Poetas de Españit. En el Hospilal lieal y General te nuestra Señoit de Gracia de la ciudad de Zaragoça, 1632 y $354 .^{\circ}$ en la cual se encuentran, segun el sr. Duran que la cita, las comedias siguientes:

Cómo se engañan los ojos, y el engaño en el anillo, de Villegas. - No hai vida como la homra, de Montalvan.-Amor, leallad, $y$ amislad, de Montalvan.-El cripitan Belisario, y ejemplo mayor de la desdicha, de IIonLalvan.-Los zclos en el caballo, de Enciso.El gran Séneca de Españu, Felipe segundo, de Avila.-La más constante mujer, de Mon. talvan.-Sufirir mas por puerer más, de Villaizan.-De un castigo dos venganzas, de Montialvan.-El astrútogo fingido, de Cálderon.-El muriscal de Viron, de Montalvan.El discreto porfiado, de Villégas.

Las Partes 26 y 27 no las conozco: Barrera presume sean las estravagantes de Lope que llevan esta numeracion, impresas en Barcclona, 1655 y Zaragoza, 1645.-La 28 , segun Duran y Barrera, dice: Parte veinle y ocho de Comedias de varios Aulores. En Huesca por Pedro Bluson, 1634. 4. - La 29 tiene el siguiente titulo: Parte veynte y mueve de comedias de diferentes autores. Valencia, Silvestre Esparsa, 1636. 4. 0 - La 30, Parte treinta de Comedias famasas de varios Aulores. Zarayoza, $1636.40^{\circ}$ y otra de Sevilia, Grande, $16 . j s .4 .^{\circ}$ que ignoro si será reimpresion de aquella. Estos tres tomos los describe Barrera en las págs. 684 y 685 de su Catálogo.
Títulos de las comedias que contiene; ninguna lleva nombre de autor.

Darles con la entretenida.-Belmonte.

Con quien vengo, vengo.-Calderon.

Zelos, honor y cordura.-Anónima.

Contra valor no hai desdicha. - Lope.

El sileneio agradecidø._Anónima.

El Conde de Sex.-Coello.

Valeroso Aristómenes Mesenio-Málos Fragoso?

El valiente negro en Flindes.-Claramonte.

Los amotinados en Flándes.-Luis vélez de Guevara.

Santa Isabel, reina de Portugal.-Rojjas Zorrillia.

Los trabajos de Job.-Golinez.

La vida y muerte de Sta. Madrona, intilulada: La vinda tirana y conquista de Barcelona.-Anónima.

Esta Parte es tan rara que el Sr. Duran solo poseia un trozo de ella, segun dice en su nota, y me figuro no la ha visto Barrera pues supone que nueve de sus conedias llevan nombre de autor no teniéndolo ninguna.

Barrera describe la Parte treinta y dos, con doce comedias de diferentes Autores. Zaragoza, Diego Dormer, MDCIL. $\mathbf{4}^{\circ}$, y da la nota de las comedias que comprende (página 685 de su Calal.) Tambien trae la Parle treintay tres de comedias de diferenles autores. Valencia, 163̄j., refirièndose á Fajardo, y habla de otra Parte treinta y lres de doze Comedias famosas de varios Autores. Valencia, Claudio Macé, $1642.4 .^{\circ}$ (V. dicho Catalogo, páo. 686 .)-De la 34 á la 38 nada se sabe: en el catálngo de Croft encuentro anunciadas: Doce comedias de Lope de Vega y otros grandes poetas. Parte treynla y nueve. Zara. goza, 16ว̃. $4 .^{\circ}$; la 40 no se conoce; la 41 será una de Villencia, s.a. citada por Barrera en dicha pág. $686, \dot{0}$ la $4 \mathrm{I}$ impresa en Pam. plona, $s$. $a$. con la cual alguno ha sustituido la desconocida de la verdadera Coleccion en 48 Partes.

1182 - Parte quarenta y dos de comedias de diferentes avtores. Zaragoça, Iuan de Ybar, M.DC.L. 4.

Solo tengo de ella las 4 hojas de los preliminares en las cuales se encuentra la tabla comprensiva de los títulos de las comedias 


\section{COLECCiON ANTIGUA DE COMEDIAS Etc., PARTES DE A FUERA.}

contenidas en el tomo y son las siguientes. No trae los nombres de los autores.

No hai burlas con el amor.-Calderon.

El secreto á vozes.-El mismo.

El pintor de su deshonra.-El mismo.

Manases, rei de Judea.-Juan Horozco.

Del rei abajo ninguno.-Rojas.

La hija del aire.-Calderon.

Transformaciones de amor.-Villaizan.

Lo dichn hecho.-Luis Coello?

El mayor desengaño.-Ttrso de Molina.

El prisionero más valiente.-Cristóval de Monroi.

El labrador más honrado.-Rójas.

Los zelos de Carrizáles.-Anónima.

\section{3 - Parte quarenta y tres} de :omedias de diferentes aviores. Zaragoça, luan de Ybar, M.DC.L. 4. ${ }^{\circ}$ hojas prels., y cada comedia con nueva paginacion.

Titulos $\because$ las piezas que comprende.

Los mártires de Córdova.-Antonio de Castro. 40 págs.

El demonio en la mujer, y cl rei ångel de Sicilia. Primera parte.-Juan de Mojica. 46 págrs. y una hoja blanca.

El rei ángel de sicilia, y príncipe demonio y diablo de Palermo. Segunda parte.-D. J. Mojica. 48 págs.

La desdicha de la voz.-Calderon. 48 págs.

Hacer cada uno to que debe.-D. Jerónimo de Cuellar. 44 pảgs.

La más hidalga hermosura.-Tres Ingenios. 47 pågs.

Palmerin de 0liva.-Montalvan. 40 págs.

Lo que merece un soldado. - Moreto. 36 págs.

Amparar al enemigo.-D. Antonio de Solis. 44 págs.

Las academias de amor-D. Cristóval de Moráles. 38 págs. y una hıja blanca.

El padre de su enemigo.- Juan de rillégas. 40 págs.

A un tiempo rei y vasallo.-Tres Ingenios. 32 págs.

Barrera refiriẻndose à Fajardo menciona otra Parte cuarenta y tres de Comedias de diferentes Autores. Vulencia, $1660.4 .^{\circ} \mathrm{y}$ comprende la mayor parte de las piezas que se hallan en la de Zaragoza de 1650 .

1184 - Parte qvarenta y quatro de comedias de diferentes artores. Zaragoça, Pedro Lanaja y Lamarca, 16כ2. 4. 2 hojas prels. y cada comedia nueva paginacion.

Contiene las siguientes:
Los amantes de Teruel.-Montalvan. 40 págs. No hai vida como la honra.-El mismo. 40 págs.

La mảs constante mujer.-El mismo. 40 págs.

El mảs impropio verdugo.-Rójas. 44 págs.

El divino portugues, S. Antonio de Pádua.Montalvan. 36 págs.

Las fortunas trajicas del duque de Memoransi.-El Doctor Martin Peiron y Queralt. 40 págs.

De un castigo dos venganzas.-Montalvan. 40 pảgs.

El mariscal de Viron.-Montalvan. 40 págs.

Sufrir más por querer más.-rillaizan. 48 págs.

ofender con las flnezas.-El mismo. 44 págs.

El juramento ante Dios y lealtad contra el amor.-Jacinto Cordero. 36 págs.

El villano en su rincon.-Lope de Vega. 56 págs.

El tomo intitulado: El mejor de los mejores libros de comedias, que se publicó en 165̃ , quizá debe formar la Parte 45 de las de á fuera.

1183 COLOMES (Juan Bactista). Adoracion de los Reves. Drama sagrado. Con un interniedio. Composicion de D. J. B. C. Valencia, Viuda de Martin Peris, udccc. $8 .^{\circ}$.

El autor de esta especie de zarzuela fuć D. Juan Bautista Colomes, como lo indican las iniciales de la portada y lo confirma Fuster en su Biblioteca. Al fln van tres poesías del mismn autor; la primera se escribiu con ocasion de vestir el habitn religiosn Doña Juana Maria Pallares en el convento do sinta Ana de Murviedro; la segunda ra dirigida dun amigo en el dia de S. José; y la última es una Paráfrasi del salmo 127.

1186 COLOQUIO de Fenisa nueuamente compuesto en muy gracioso estilo y muy apazible a los oventes son interlocutores las personas siguientes. Valerio Marfirio. Siluio. Bouo. Fenisa. Inıpresso con licēcia en Valladolid por los herederos de Bernardino de santo Domingo, Año de M. D. Lxxxviij $4 .^{\circ} 4$ hojas sin signs.

Hai una cdicion de Setilla de,1540. V. Moratin, origenes del tealro.

Esta pieza curiosa y rarísima ha sido reim. presa en el num. 7 del Criticon de Gallardo. 
1187 COMEDIA famosa y nova de cent anys, Secret de peixcar tellines y traza de agafar rates. Manuscrito en $4 .^{\circ}$ may.

Ia presente comedia es más conocida entre Ins valencianos con el título de La Infanta Tellina y ell Rei Halarol: 110 se ha llerado a imprimir por estar escrita con bastante libertad $y$ contener espresiones nu del todo honestas.

Esta produccion se ha atribuido por muchos á un tal Padre Vulet, que otros suponen no haber munea existide: sin embarign parn desengiñar á estos últimos copiari $\mathrm{l}_{1}$ siguiente notil sacada del Necrologio original del P. Teixidor:

«El P. Fr. Francisen Mubet nacio en San "Ylateo, de Blas llulet y Honserrada yurrol; "siendo de diez y sicte años y des unest's lomó wel hibito en el convento de la misma villa en "9 de junio de 16.41 , y profesir en Valencia, por mhijo de San llateo, en lá de junio de 16:2, men manos del r. ''. M. Fr. Gilspar Catalan de "yonsonís... Graduado de Marestro en artes "por la universidiud de Valuncia, obturo por moposieinn la caltedra de artes por nityo de mliji. A has primeros de charrsma de liost

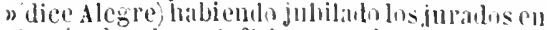
"lit eitcedra de metafísiea munal al pr. maestro "Fl. Acacio March: se opuso i clla el P. lec. utor Fr. Francisto Vulct, y la obturo con "grandisimo lneimiento. l.nego immediatamuente, dejamdo procura pari tomar posewsion de la cátedria, se partió á Roma para wener las cuuclusiones en el capillulo gene. mal por esta plovincia de Arapour.. Todas mas memorias Mss. que he leido aseguran nque el .1. .tulet lue uno de lus marores sumetos que en su tiempo turo la Reliyion, sde profundo entendiniento, claro y asudo mingenio, grimule filosofo $\mathrm{y}$ humanista, $y$ en "la cátedra tan clleáz en argumentos, que mara rez dejaba de coneluir... Fué mui samado y agudo en la poesía, como manifiestin malgunos llss. que conservill alonmos re. nligiosos, especiahnents al Destumepio... of gualmente rouservin alinnos la memoria nde algumos chistes graciosos y dichns arrl"Wos del P. Mulet. De este grincru es su pes"puesta al dean Frigola, que hallíndose de "rector de l: universidad, ar nteatro Mulet, le dijo eon poea cortesanta: n. lcabe, $P$. Hulet, $y$ este cun agudeza le res. "pondió sacudidamente: Ya mo deixe, mo"sen Frigola."

Murio en Valencia a 25 de setiembre de 1675.

1188 CONEDIAS ANTIGUASESPAÑOLAS. Análisis de 174 piezas de nuestros autores de principios del siglo XVII. Manuscrilo en $4 .^{\circ}$ may. de unas 3000 fojas.

Comprende pste volumen el resúmen de setenta y nueve comedias de Lope, ocho de
Cervintes, slete de Rỏjas, scis de Tárrega, tres de Gaspar de Aguilar, nueve de Solis, seis de Mátos, euarenla y einco de Moreto, mini del Lic. Mlejía de la Cerda, tres de Salistio de Poyo, una de Mira de Amescua, dos de Luis Vélez de Guevara, dos del Lic. Juan Grajal o Grijáles, una de Miguel Reneito y dos de fuillen de Castro; en muchas ocasiones se forman juicios eríticos sobre el mérito de algunas piezas, $y$ suelen darse hasta estractos de varias.

COMLDIAS ANTIGUAS ESPAÑOLAS, escogidas de varios autores. Madrid, Ortega y Compañía, 18634.33 vols. $8 .^{\circ}$

Esta Coleceion no lleva cl título que le doi, sino una portada peculiar para eada autor de lus diez $y$ siele tjue abraza, á saber, tomo.

D. Francisco Bínces Cándamo. 185̄2. Un

D. Pedro Calderon de la Barea. 1826-53. Cuatro tomos.

D. Jose de Cañizires. 1829-52. Dos tomos.

1). Alvaro Cubillo de Aragon. 1826. Un lomo.

I). Francisen de Leiva. Is.5. Un Lomo.

1). Antonio Yiril do Amesema. 1850. Untomo.

i). Juan de Mitos Fragoso. 1828-53. Dos tomins.

I). Agustin Moreto y Cabaña. 1826-31. Tres tomos.

1). Juan P'erez de Montalvan. 1827-31. Dos tomos.

[). Francisco de Rójas Zorrilla 1827-31. Dos iomos.

I). Juan Ruiz de Alareon y Mendoza. 1826-29. Dos tomos.

U. Antonio de Solis y Rivadeneira. 1828. Un tomo.

El Maestro Tirso de Molina. 1826-34. Cuatro tomos.

Frei lope Felix de Vega Carpio. 1826-32. Cualro timos.

Luis lielez de Guevara 1852. Un tomo.

D. Antonio de zamora. 18.3I. Un Iomo.

D. Fernando de Zarate. 183̈2. Un tomo.

Como lie colocado las comedias que comprente la Colcecion, al nombre de eada autor, all han de buscarse y por eso no pongo numeracion al presente artienlo.

En cuanto a li impresion, todo ha eoncurrido para hacerla indigna del noble objeto á que se destinaba. Pésimo papel (pues aun el llamado fino vale poeo), frecuentes erratas y supresion de muehos pasajes por la ridicula censura, que á la sazon reinaba. Lástima es que contenga el Exámen de cada comedia, escrito, si bien á la lijera, con bastante impareialidad $\mathrm{y}$ juicio.

1189 COIIEDIAS. ESCOGIDAS de differentes Libros. De los mas Celebres, è Insignes Poetas. Brusselas, Manuel Texera Tartaz, 1704. 4. 
marq. 2 hojas prels. y cada comedia lleva los folios, que se espresan á continuacion:

El defensor de su agravio.-Moreto. 17 folios.

El conde de Sex.-Mátos Fragoso. 16 folios.

El alcázar del secreto.-Solis. 16 folios.

El desden con el desden.-Moreto. 16 folios.

El maestro de Alejandro.-Zarate. 18 folios.

El valiente Pantoja. - Moreto. 12 folios.

La misma conciencia acusa.-Moreto. 17 folios.

Casarse por vengarse. - Rójas. 21 hojas desde el fol. 18 al 38.

Lorenzo me llamo.-Mátos Fragoso. 19 folios.

El esclavo en grillos de oro.-Bánces Cándamo. 20 folios.

El luzero de Castilla, y luna de Aragon.-Luis Vélez dé Guevara. 14 folios.

El más impropio verdugo, por la más justa venganza. - Rójas. 18 folios.

1190 COMEDIAS de los mejores y mas insignes poetas de España. Lisboa, 1632. $4 .^{\circ}$

Mi ejemplar solo tienc las 242 hojas foliadas, faltándole por entero las preliminares, asi pues, ignoro el verdadero tifulo quic he puesto por los apuntes del Sr. Duran. Contiene el volúmen las comedias siguientes:

El principe constante.-Calderon.

El conde Alárcos. - Guillen de Castro.

El perfeto caballero.-El mismo.

La batalla del honor.-Lope.

Reinar despues de morir.-Luis vélez.

Lo que puede la porfia.-Antonio Coelto.

Lo que son juicios del cielo.- Montalvan.

Errar principios de amor.-P. Rosele.

La mayor hazaña del emperador Cárlos V.Jiménez de Enciso.

Lances de amor y fortuna.-Calderon.

Envidias vencen fortunas.-Cristóval de Monroi y Silva.

El ejemplo - lliayor de la desdicha. Tragicomedia lastimosa.-Lope.

Tomo tan raro que el señor de Gayángos, á pesar de sus esquisitas y eflcazes diligencias, solo ha adquirido un ejemplar falto de los preliminares como el mio, $\mathrm{y}$ ademas de la primera y última comedias.
1191 COMEDIAS NUEVAS de los mas celebres Autores, y realzados Ingenios de España. Anistardan, A costa de David Garcia Henriquez, 1796. 4. ${ }^{\circ}$ marq. Dos hojas prels., 5006 paigs. y una hoja blanca.

Comprende este volumen las siguientes comedias:

La Judla de Toledo.-Diamante (es de Mira de Amescua).

Los trabajos de David, y flnezas de Michol. - Gaspar Lozano Montesino.

Manases rei de Judea.-Juan de Horozco.

La creacion de el mundo, y primer culpa de el hombre.-Lope de Vega Carpio.

Júdas Macabeo.-Calderon de la Barca.

El sol obediente al hombre.-D. Garcia Aznar Vélez.

El sitio de Bctulia.-Un Ingenio de esta Corte.

El Bruto de Babilonia. - Mátos, Moreto y Concer.

Los cabellos de Absalon.-Calderon de la Barca.

La prudente Abigall.-Antonio Enriquez Gomes.

El divino Nazareno Sanson.-Pérez de Montaluan.

La fnerza lastimosa.-Lope de Vega Carpio.

Ademas de los tomos de esta clase que acabo de describir en los anteriores artículos, todos mui raros, y de Las doze comedias mas grandiosas. Lisboa, 165.5.-Autos sacramentales, con quatro Comedias nuevas. Madrid, 1655.--Mejor de los mejores libros. Madrid, 16.5.-Flor de las mejores doce comedias. Madrid, 1652. 4. -Comedias de los uulores valencianns. 2 vols. $4^{\circ}$, que tambien tengo, mıchos de los cuales no conocio el Sr. Duran; este caballer ne comunicó la noticia de los siguientes que no poseo.

$1 .^{\circ}$ In volimen impreso en Barcelona cuya portada y año ignoraba, pero que vió contenia: Tragedia de la hija de Jephtie.-El santo sin nacer.-La privanza desleal.-El primer conde de orgaz.-El cerco de Túnez.La isla Bárbara.-El renegado de Zanaga.El corsario Barbaroja.-Lns zelos de Rodamonte.-Sta. Teresa de Jesus.-El cerco de Tremecen.-El fuero de las cien donzellas.

2. Comedias de los mrjores y mas insignes poctas de España. Colonia, $1697.40^{\circ}$ Colltiene: Verse y tenerse por muerto, de $\mathrm{An}$ drade.-Ejemplo mayor de la desdicha, de Mátos.-La venganza en el despeño, de Yó. tos.-No hai ser padre siendo rei, de kijus. - Antíoco y seleuco, de Morelo.-Estindos mudan costumbres, de Máfos. - La vida es sueño, de Calderon.-Los Médicis de Florencia, de Enciso.-Reinar despues de morir dc Vélez de Guevara. - io puede ser, de Moreto. - Cuando no se aguarua, de Leiva.-Tambien la afrenta es veneno, de vélez, coello y Rojas. 
3. Comedias escogidas de los mas insignes poetas de España. S. l. ni a. Contiene ocho comedias que son: Los cngaños de un engaño y confusion de in papel, de Moreto. - Los encantos de Medea, de Rójas.-Cegar por ver mejor, de Moreto.-La vida es sueño, de Calderon.-No hai burlas con el anor, de Calderon.-liiesgos que tiene un coche, de Calderon.-El desden con el desden, de Moreto.-El príncipe de los montes, de Monlalvan.

Ile tenido tambien $11 \mathrm{n}$ tomo intitulado: Ameno jardin de comedias, de los insignes aulores Dom Anlonio de Zamora, D. Juan Batstista Diamante, y D. Alvaro Cubillo de Aragon. Madrid, $1754.40^{\circ}$ Contiene cuatro de Zamora, seis de Diamante y cuatro de Cubillo.

1192 COMEDIAS VARIAS. Manuscrito en $4 .^{\circ} \mathrm{de}$ principios del siglo XVII.

Se lo regali í mi padre D. Pedro García y Latasa. sobrino y heredero del autor de la Biblinleca de escrilores arajomeses, y contiene las siguientes composiciones dramáticas:

Los caulinos de Anlioquia. En tres jornadas. Esta fechada en Salamanca en 51 de oetubre de 1615.

En la Biblioteca mueva de dicho Latasa, tom. II. al núm. Cill, se supone escrita por un Inónimo aragones. No la encuentro citada en el Indice generul de Medel, y sospecho sea inédila.

La esproñola y enredos de Lemiardo. En tres jornadas. Anónima.

Tampoco se menciona en el Indice, ni la cila Barrera, y me inclino á creer que no se la impreso.

La serrana de Tórmes.

No tiene nombre de autor, pero se halla en la Parte XVi de las comedias de Lope de Vega, y de ella dice este en la dedicatoria á D. Antonio de Córdova Cardona, era la $e n$ que probe la pluma en el principio de mis esludios. No estrañaré que este manuscrito contenga la pieza tal cual salió de las manos del antor primitivamente, pnes ademas de no estar dividida en actos sino en jornadas, tiene infinidad de versos, suprimidos en el inpreso, variantes sin numero y hasta los nombres de algunos personajes son distintos, como por ejemplo, el de la heroina que en el manuserito es Damiana en vez de Diana.

La obligacion de las mujeres. Anónima.

Es la que con el títılo de La obligacion a las mujeres se publicó á nombre de luis Vílez de Gnevara en la Parte III de la Coleccion unligua de comedias, en 48 vols. Hai en el mannscrito infiuitas variantes del impreso, donde tambien se suprimieron versos.

Comedia de la Ysla Baruara. Compuesta por Miguel Sánchez. Én tres jornadas.
En el Indice general de Medel se menciona una pieza con el mismo título; pero no se dice quien sea su autor. Se imprimió como de Lope en las Doce comedias de varios autores. Tortosa, 1638.

Latasa, en el tom. I. de la Biblioleca nueva, núm. CCLXXVili, habla de este manuscrito al fin del cual en una hoja blanca se encuentra un autógrafo del historiador Bláncas y una inscripcion de letra antigua que dlce: El autor es Miguel Sdnchez Vidal Aragones.

Comedia del Tao de Sın Anton. En tres jornadas.

No lleva nombre de autor pero eu el Indice de Medel se cita una de $\mathbf{D}$. Andres de Claramonte con este título; como no la tengo no me es posible cotejarlas para ver si son las mismas.

Pertencció esle tomo al señor de Berbedel.

Creo que Latasa procedió algo de lijero al hacer á Iliguel Sínchez, aragones, guiado sin duda unicamente por lo que un antiguo poseedor del volimen dijo en la nota que se halla al fin de la Isla búrbara. Tampoco me atreveria á ascgurar que su segundo apellido fuese Vidal, por cuanto esta noticia la dd el mismo antor de la mova patria de sánchez en su citada nota y lo intercaló entre lineas al principio porque el manuscrito original no lo traia.-lliguel sánchez, segnn parece, fue natural de liedrahita de Pisıerga y mereció, ademas del título de divino, los mayores elogios de Rojas Villandrando, el Doctor Antonio Navarro, Cervíntes y Lope de Vega, quien dijo de él en su Filomena:

\footnotetext{
El dulce cristalifero Pisuerga

Que, como centro del sagrado Apolo,

Tantos ingenios delficos alberga,

A uquet en lo dramático tan solo,

Que no ha tenido igual desde aquel punto

Que el coturno dorado fue su asunto;

IIiguel Sámchez que ha sido

El primero maestro que han tenido

Las mitsas de Terencio,

Propuso, aunque con trágico silencio;

Matole el sol de la inclemente Vera,

Porque le anticipo la primavera,

Y con la variedad de los calores

Pensó que los concetos eran flores.
}

1193 CÓNICO FESTEJO. Libro nuevo, de Entremeses, intitulado: Comico festejo, su autor Francisco de Castro. (Al fin:) Madrid, Gabriel del Barrio, 1742. 2 vols. $8 .^{\circ}$ El primero tiene 20 hojas prels., 195 págs. y 2 hojas para el Indice y señas de la impresion; $y$ el segundo 8 hojas prels. y 144 págs.

Publicó éstos dos tomos, que son raros, el representante José de Ríbas, sucesor en su parte, del comico Francisco de Castro.

El Sr. Barrera y Leirado trae en la pág. 719 de su Catdlogo, la noticia de una coleccion 


\section{COP}

de entremeses Intitulada, segun un indice MS. de faltardo: Chistes dicl gusto en 2 volúmenes. Indudablemente el ejemplar estaba falto y el célebre biblióflo de la Alberquilla sacó el titulo del enigrafe puesto en cl tomo I., á un Soneto que un apasionado del musson corn, $y$ amigo del que suca d tuz estos dos libritos de comico festejo y Chistes del gusto, escribe en atabanza de ellos. Por lo mismo la obra descrita por Gallardo no era otra que los dos tomos asunto de este arlículo.

En todas las licencias y aprobaciones que lleva el tom. 1., se dice terminantemente, que solo los entremeses de él son de Castro; pero que los contenidos en el II. están escritos por varins autores. Es estraño por lo mismo que el dicho Sr. Barrera, á pesar de no haber visto el tomo Jl., pero teniendo presente el I., omita esta circunstancia y por consiguiente no coloque este libro entre las colecciones entremesiles.

No dol los títulos de las piezas comprendidas en la presente coleccion porque las del $\mathrm{i}$. se ballan en el artículo de Francisco de Castro, en el Catálogo ántes citado, y las del II. en la pág. 719 del mismo, al hablar de los Chistes det gusto, y yo los detallo en el Indice alfa. betico de las piezas dramiticas españolas.

1194 CONSULTA Que se embio al consejo de Portugal, por la qual Su Mag. fue seruido mandar boluer las Comedias que se hauian quitado en aquel Revno. Fol.

Manuscrito original; fechado el 9 de Ene. ro de 1598 , y segun resulta de una nota quin va al fln, escrita el año de 1601 , el autor de este papel es el P. Fr. Jerónimo de Tieura.

\section{COPLAS.}

Coplas dela macrte como llama a un poderofo Canallero. y otras coplas ala muerte. y otras co. plas bzethas po: Bnan Iol Enjina.

(A continuacion de este epigrafe principia la obra.) S. 1. ni a. Chicia 1530 J. $4 .^{\circ}$ let. gót. 4 hojas signatura a.

Escesivamente raro, tal vez único.

Las coplas de la muerte son un diálogen re. presentable en verso. El lenguaje parece del siglo XV y por lo misno debe colocarse esta composicion entre los primeros ensayos dranáticos hechos en nuestro pais. Como Mora. tin no lo menciona en los Origenes del tealro daré una idea de su argumento, el cual aunque sumamente sencillo, no carece de interes.

Llama la muerte á la puerta de un caballero rico y inanda al portero que haga salir á su amo; se resiste aquel á ejccutar seme.
COP

jante órden, alegando entre otras razones la de hallarse en un convite con varios amigos; pero insistiendo la muerte en que le haga comparecer, obedece el criado y entra anunciando que un hombre de oculto busca al caballero; incombidase este de verse interrumpido en los placeres del festin, y dice:

Quien es ese que me llama?

váyase en hora buena,

hombre soi rico y de fama,

él viene de tierra ajena:

él no seria tan osado

de hablar tal contra mí,

que será mal destrozado

si no se parte de aquí.

La muerte a quien no parece arredran estas bravatas, le amonesta para que se prepare á seguirla: el paciente se opone y alega como razones poderosas para no ser dócil á tan inesperado mandato, el poseer inuchas riquezas y tener relevantes lítulos de nobleza; le anuncia el mensajero serlo del rei mayor de justicia y entónces el rico le ofrece hos. pedaje y vino, y hasta le brinda á ser medianern con èl en sus heredades; pero la inexorable muerte insiste y le añade:

Qu'el rei alto soberano

te manda luego partir.

y que serás con los justos

èn su santo paraíso;

con tan alhagineĩa perspectiva se resigna á su suerte despidicindose de sus hijos y su mujer, á quien dice entre otras cosas:

Fid, mujer, si es gran duclo

cuanto en uno trahiajamos, que no nos pone consuelo

para que no nos partamos:

il la nuerte prometi

heredalles con buen viso

y en todo consentı,

ella jamas, nunca quiso.

Las llaves de mis areas

yo gelas puse en puder,

que fuese por las comareas

mis bienes á recoger:

dijo. que no osiria

en esta vida dejarme,

y que no consentiria

sino consign levarme.

Pard esto. amiga mia. el remedio que aqui vor. pues el ditelo ros castiga. vos ponclite buen aseo y rosid, como yo hago. al Señor nios piaduso que comigo hagais pago por el su nombre precioso

Hace despues oracion y acaba la pieza con esta octara:

Pues eres tu poulerosa murle que a levarme vienes. yo hice llua fea cosa en levar á tantos bienes; que jamas desde pequeño trabaje por mis subir. que jamas tomze engaño para poder bien vivir. 
A continuacion de este Didlogo se hallan otras coplas d la muerle en diez octavas que comienzan:

Muerte que á todos convidas ete.

un Villancico que principia:

No hai placer en esta vida sin dolor;

busquemos otra mejor.

otro Villancico que dice:

Mal de muchos no consuela mi dolor,

pues es mi pena mayor

y las Coplas de Juan del Encina:

Razon que fuorza no quiere me forzó

a ser vucstro como so.

Estas últimas se encueutran en el Cancionero de Enzina las otras ignoro se hayan reimpreso.

Barrera y Leirado nn lace mérito de esta composicion en su Catátogo det teatro esp.

1196 COPLAS DE UNA DONCELLA I UN PASTOR.

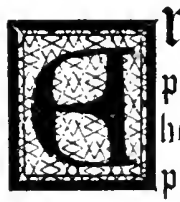

Mlas piefentes co, plas fe trata como vna hermofa dojella andādo perdida poz vna mōtaña encōtro cō vin paftoz: $\mathfrak{e l} \overline{\mathfrak{q}} l$ vifta fu gétileza fe enamo20 della y con fins paftosiles rajones la requirio de amozes. $\mathcal{A}$ snya req̄fta ella no quifo côfentir: $\mathfrak{r}$ d’fpues viluo $\mathfrak{v}$ faluaje a pllog r todos tres fe tō, certaro de yr a pua denota her" mita que alli cerca eftaua a hazer ozacion a nueftra feñoza: $\{$ co miença dezir la donzella enla foz" ma figniente.

(Despues de este encabezamiento, distribuidas las líneas de distinto modo, hai una viñeta con la Vírgen y 'a donzella arrodillada haciendo oracion.) S. 1. ni a. (liácia 1530). 4. ${ }^{\circ}$ let. gót. 4 hojas sin foliacion ni sign.

Rarísima edicion, y magniflen ejemplar con barbas.
1197 COPLAS DE UNA DONCELLA Y UN PASTOR. En las presentes coplas etc. (ut supra.) Vistas $\mathrm{y}$ examinadas, y con licencia impressas en Alcala de Henares año de mil y seys cientos y quatro (1604). (Sigue una viñeta de la Vírgen, la doncella y el pastor.) $4 .^{\circ} 4$ hojas sin foliar $y$ sin signatura.

El autor de esta composicion dramática fué Eugenio Alberto, segun el indice ùs la bib. de osuna al describir una edicion de Cuenca de 1619 , que existio en aquella biblioteca; pero Gallardo, con inás ingenio que razon, presume es obra de Lúcas Fernández, y aun si podrá ser justamente la pieza que faltaba á su ejemplar de las Farsas del escritor salmantino. Tambien parece participar de esta opinion D. Manuel Cañete en el pról. á las diclias Farsas.-Moratin cita una impresion de Valladolid, 1540 y observa que en esta piezecita la pintura de los afectos $y$ el estilo e'n que está escrita no carecen de mérito. El sr. Barrera la menciona; pero sin duda no la vió.

Omito su análisis ya porque en el epigrafe antes copiado lo hace bastante estenso, como jor haberse reimpreso en el Ensayo de una bib. csp. de Gallardo : debiendo sin embargo notar, que ha servido de original la edicion de Alcalí, en la cual el lenguije se halla algo modernizado, y hai variautes las más vezes inoportunas y desacertadas.

1198 Cornellle (Pedro). Cinna. Tragedia, de P. Cornellio, traducida del idioma frances en Castellano. S. I. ni a. (Madrid, 1713?) 8.

En una nota manuserita de nui ejemplar se dice que está traducida por D. Francisco Pizarro de Aragon, marques de S. Juan.

1199 CORTES (Pedro Luis). Demostraciones festivas, con que la... villa de Almansa celebro la Canonizacion de... S. Pascual Baylon. Escriviolas el Doct. Pedro Lvis Cortes. Madrid, Imprenta Real, por Mateo de Llanos, 1693. $4 .^{\circ} 12$ hojas preliminares y 207 págs.

Contiene poesías del Dr. Pedro Luis Cortes, D. Francisco Bueno, el hermano Antonio $\mathrm{Fa}$ jardo, D. Manuel Pellicer y Velasco, D. Diego de Najera y Segri, D. Vicente Tejedor y Belvis, D. Pedro Andres de Bustamante y otros. Hai tambien una piececita dramática en la pág. 42 llamada Competencia entre la Villa, la Parroquia, la Religion, la Juslicia, un Pastor y la Música.-Barrera no la menciona en su Catdlogo y yo sospecho que su autor es tambien P. L. Cortes. 
Rodriguez y Jimeno no mencionan á Pedro Luls Cortés, sin embargo de ser el autor de las Demostraciones festivas y de muchas composiciones poćticas que se hallan en el Sacromonte parnaso de Francisco Ramon González.

1200 CRUZ (Sor Juana Ines de LA). Poëmas de la vnica poetisa americana, musa dezima, Soror Juana lnes de la Cruz... Que en varios metros, idiomas, y estilos, Fertiliza varios Assumptos: con elegantes, sutiles, claros, ingeniosos, vtiles versos: para enseñanza, recreo, y admiracion. Sacolos a luz Don Juan Camacho Gayna... Tercera Edicion, corregida, y añadida por su Authora. Barcelona, Joseph Llopis, 1691. $4 .^{\circ} 8$ hojas prels. , 406 págs. y 5 hojas de Tabla.

Lo añadido en esta cdicion principia en la pág. 327 y concluye en la 406 , que es la iltima.

La primera impresion de este tono, segun Barrera, lleva el título de Inundacion Cas'álida de la vnica pnclisa Nusa decima Soror Juana lnes de la Crvz, y se imprimii ell Malrid, por Jean Gurcia Infun:0n, $168 !)$. 1. Tuve la que se llama segunda cdicion liecha tambiell en Halrid por el mismo Garcis Infuszon, 1690. 4.

1201 - Poemas de la vnica poetisa americana; Mrsa dezima. Soror Ivana Ines de la Crve, etc. Como la edicion de 1691.) Tercera impression. Corregida, y añadida en diferentes partes debajo de esla señal $\because \rightarrow$ Va al fin vn Romance de D. Ioseph Perez te Montoro. Zaragoza, Manvel Roman, Año de M.DC. Lxxxxir. 4. 10 hojas prels., 330 paigs. y 4 hojas de Tabla.

A esta impresion le correspondia llamarse cuarta pues ya llevo citadas tres anteriores á ella. No la eirnoció Barrera y por cierto es apreciable porque aun cuando uo comprenda las obras añadidas en la de Bareelona de 1691 , contiene, desde la pág. 202 á la 210 , varias composiciones no reproducidas en las ediciones posteriores que be examinado: sin duda por ser demasiado profanas y picantes para una señora nionja. Fil romance de $\$ 1011 \cdot$ toro tampoco se ba reiuspreso.

- Segumdo tomo de las obras de Soror Juana Ines de la Cruz... Añadido en esta segunda impression por su autora. Barcelona, Joseph Llopis, 1693. 4. 4 hojas prels., 467 págs. y 2 hojas para terminar el Indice.

La primera ediclon de este tomo es de Se. villa, 1691, segun Barrera. Las adiciones que se anuncian cn la portada serán probahlemente desde la pág. 456 á la 467 y llevan por tItulo: Mas pocsias lirico-sacras.

CRUZ (SoR Juana INes de LA). Fama y obras posthvmas, Tomo tercero, del Fenix de Mexico, y dezima Musa... Sor Jvana Ines de la Crvz... Recogidas y dadas a luz por el Doctor Don Juan Irnacio de Castorena y Ursua. Lisboa, Miguel Deslandes, MDCCI $4 .^{\circ} 60$ hojas sin foliar de prels. y de composiciones laudatorias, 212 págs. de Obras postumas y más versos en elogio de Sor Juana.

De este tercer lomo recelo hai alguna edicinn de 1698 ii 99 , à no ser realusente priniera la citada por algunos, hecha en Madrid cl ñ̃o de 1700.

1202 - Poemas de la unica poetișa americana, IIusa dezima, Soror Juana Ines de la Cruz. Tomo primero. Madrid, Joseph Rodriguez y Escobar, 1714. 8 hojas prelininares, 33' i paigs. y ว̆ hojas de Tabla.Segundo tomo. Madrid, Angel Pasqual Rubio, 172. A hojas preliminares., 438 paigs. y 3 hojas de Indice. -Fama yobras posthvilias, Tomo tem-cero... Recogidas, I dadas a lvz por el Doctor Don Jvan Igrnacio de Castorena y Trsta. Barzelona, Rafiel Fignerò, ì. DCCI. Gib hojas de preliminares y composiciones landatorias, 21? piigs. y 2 hojas de Tabla.

Parece deben existir los tres lumos impresos en . Wadril, 17lí; sin embargo Barrera solo menciona el primero, igual al que teugo: tambien es probable Ins haya de ralenciu,

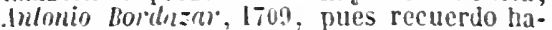
ber vistu al mismo tomo impreso en dicho punto y año por este tipurgato, y espresilldose en lit portadia ser lenera álicion. El toin. I. de lití no conticne las adiciones hechas en la impresion de Bareelona, 1691.

1203 La misma obra. Quarta impresion, completa de todas las obras de su Authora. Madrid. Francisco Lopec, 17. marq. 
Hermoso ejemplar en gran papel.

El tom. I. es reimpresion del de Barcelona, 1691 con las adiciones.

He colocado esta obra en la presente seecion, porque contiene diez y scis loas, dos autos, una comedia, dos saineles, un sarao y um poema encomiastico representable.

Algunos bibliografos citan una impresion de los tres tomos hecha en Zaragoza en 1725.

1204 CRUZ Y CANO Ramor DE LA). Teatro, ó coleccion de los Saynetes y demas obras dramaticas de D. Ramon de la Cruz y Cano. entre los Arcades Lanisio. Madrid, Imprenta Real, 1786-91. 10 vols. 8.

Contiene las composiciones dramílicas siguientes; que sun todas sainetes, minos aquellas en que se espresa otra cosa.

\section{Eu el tomo primero.}

Las superfluidades.

La falsa devota.

Las señorias de moda.

La presumida burladi.

La oposieion í cortejo.

Los picos de oro. Comedia.

La embarazada ridienla.

El dia de campo. Comedia.

\section{En el segundo.}

Los maridos engañados y desengaĩados.

Los lombres con juicio.

El cortcjo escarmentado.

Los pobres eom mujer rica, ó el picapedero.

Lal devocion engañosa.

El almacen de novias.

El estranjero. Connclia con misical.

\section{En el tercero.}

La prueba feliz. Comedia.

El sombrerito.

Las frioleras.

El petimetre.

El malidos sofoeado. Trajedia burleséa.

La midja majada.

Eugenia. Comedia.

\section{En el charto.}

La espigadera. I'rimera parte. Comedia. _ Segruma parte. Comcalia.

La discreta y lil bobil.

Manolo. Tragedin pare reir, o suinele parı llorar.

\section{Enel quinto.}

Clementina. Comedia de misica.

El tio y la tia. Zarzuela.

La feria de la fortuma.

Los novios espantados.

Las dos viuditas.

Los hijos de la paz.

Los impulsos rel plarer.

\section{En ol sisto.}

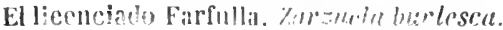

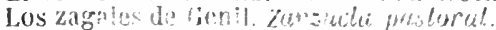
El eareo ite igs 11 ia!?
I.as daınas apuriadas.

La amistad, $\dot{0}$ el buen amigo. Connedia.

Zara. Tragedia en ménos de un aclo.

\section{En el sétlumo.}

El divorcio feliz. Comedia.

Los vaqueros de Aranjucz. Loa.

lias castañeras picadas.

La viuda hipóerita.

lil sarilo.

li reverso del sarao.

\section{En el oetavo.}

Elfénix de los hijos. Comediu.

El padrino, y el pretendiente.

El cortejo fastidioso.

La india. Comedia.

li) sueño.

los hombres solos.

Las tertulias de Madrid.

Lal visita de duelo.

El agente de sus negocios.

\section{En el nono.}

Lit Briseida. Zarzucla heróica.

La fuerza de la lealtad. Comedia.

Enc:asa de madie no se meta nadie : ó el buen urarido. Zarzuela jocosa.

El triunfo del interes.

Las liestas itiles $\mathrm{y}$ de repente.

\section{En el déclmo.}

la Pelra y la Juana, ó el casero prudente. Caprichis drannalico.

El hijito de vecino.

El burlador burlado.

El entierro de la compañia de Ribera.

Las eseofieteras.

El VIñ̃uelo. Tragedia por mal nombre.

El maestro de la niña. Comedia de música.

\section{CUATRO COMEDIAS FA-} MOSAS. Qvatro comedias famosas de Ion Lvis de Gongora, y Lope de Vera Carpio, recopiladas por Antonio Sanchez. Madrid, L. S. (Luis Sanchez al fin), $1617.8 .^{\circ} 4$ hojas preliminares, 269 foliadas y una despues para repetir las señas de la impresion.

Ilé aquí los títulos de las euatro comedias: Las firmezas de Isabela.-Góngora.

Los Jacintos, y zeloso de sí mismo.-Lope de Verie.

Las burlas, y enredos de Benito.-Lope ì Góngora.

El lacayo fingido.-Lope de Vega.

Los Jacintos es la misma comedia ajue con el Lifulo de til pustoral de Jacinto se halla en la parte XVIll de lope; Las firmezas de Isabela estí en las obras de Gongoria, y alli se advierte la acabio lo. Juan de Arote, herma110 te b. L.uis: las otras dos no las encuentro en mingruna coleceion. 
Por algunos de los preiliminares, fechados en Madrid en 1612, se puede conjeturar debe haber alguna edicion hecha alli, hácia aquel añı; sin embargo, yo no encuentro más noticia que la de una impresion de cordnva, por Francisco de Cea, $1613.8 .^{\circ}$

1206 CUBILLO DE ARAGON (ÁLvaro). El Enano de las Mrsas. Comedias, y obras diversas, con vn poema de Las Cortes del Leon, y del Agvila, acerca del Bro gallego. Sv avtor Alvaro Crbillo de Aragon. Madrid, Maria de Quiñones, 1651. 4. 8 hojas prels. y 478 paiys.

Tengo por yerro de imprenta el que Brunet inencione en el num. 15280 del tom. $I$. una edicion de 5651 que no existe, pres la descrita aqui es la prinera, úlica y rara.

Comprende estos dramas:

La honestidad defendida de Elisa bido, reina, y fundailora de Cartiga.

Los triunfos de Son lliguel.

El rayo de Anilalicia. Primera parte.

Et rayo de Andalucla y genizaro de España. Sequnda parlc.

Los desagravios de Cristo.

El invisible príncipe del Baul.

Las muñecas de Marcela.

El señor de noches buenas.

El amor conin ba de ser.

El duque de Verranza. Tingedia.

1207 Comedias escogidas de Don Alvaro Cubillo de Aragon. Tomo primero. (To se publicí otrn.) Madrid, Ortega y Compañia, 1826. $8 .^{\circ}$

Comprende las siguientes:

Las mıñecas de Yarcela.

La perfecta casada, prudente sabia y lonradi.

El Señor de noches buenas.

El antor como ha de ser.

Si esta edicion no tuviera un Faxmen bastante juicioso al fin de cada pieza, no mere. ceria inencionarse.

1208 El mayor desenpeño Arto sacramental. 6. ${ }^{\circ}$ Ianuscrito autógrafo.

Está firmado al fin: En Gramada « jl de abril de 1657 a.s Albaro Chuillo le aran $n$ Es casl todo de letra del autor y ni se halla incluldo en las obras impresas de cubillo, ni mencionado por Vedel: Barrera al citarlo se reflere vinicamente à este manuscrito. I.0 considero por lo mismo inédito.

1209 CUESTION DE AMOR. Qvestion de amor (Asi se lee en un renglon de letra encarnada a la parte superior del frontis, despues hai una viñela por el estilo de las que se hallan en las Celestinas de Venecia, y debajo, la mayor parle tambien de encarnado, dice:) C Qvestion de amor: de dos enamorados: Al vno era muerta su amiga: el otro sirue sin esperança de galardon. Disputan qual delos dos sufre mavor pena. Entrexerése en esta 2trouersia muchas cartas y enamorados razonamiētos. Introduzense mas vna caça. In juego de cañas. Ina cgloga. Ciertas justas : \& muchos caHall'os $\&$ damas cõ diuersos 2 ricos atauios: có letras \& inuẽciores. Cōclıye cō la salida del señor: Visorey de Tapoles: donde los dos enamoralos al presente se hallauan: para socorrer al sanclo padre. Dóde se cuéta el numero de aífuel luzido exercito: y la cotraria fortuna de Rauena. C La mayor parte de la obra es hystoria Ferdadera. 10̈33. (Al fin se halla una hoja, impresa solo en la primera página, que dice: C Estampada enla rnclita ciudad de Venecia hizo lo estimpar miser Iuan Batista Pedrezano mercader de libros: por importunacion de muy muchos señores a quien la obra: yestillo y lesua Romance castellana muy mucho plaze. Corecta delas letras que tras trocadas estananse a calio año del señol. 1.i3:3. 8. ${ }^{\circ}$ let. semigrot. Vinetas de madera.

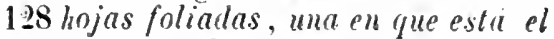
remate que se ha copialoy una blanca.

Ile descritu tan ciremstanrialanente esta edicion pur su escesiva ratezal: He!ere mo la

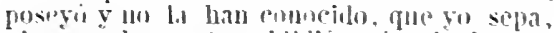
ninguno de nuestros bibliogratios, inchuso el sir. Harreria.

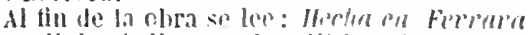

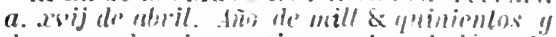
dose: por lo mismu, si ur) se imprimin on lí misma cindiul te Ferrara is en Vipoles en este aĩu). lat primera edicion serai probablonumbe la siruiente, citala en el in. del tomo II. de la Tilungrofice rspañola de slendez que tuvimos en Londres:

Question de amor le los cnemoralos: al

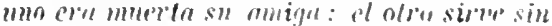

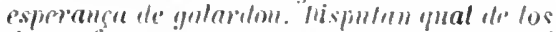
dos sufie mayor pena. Al tin: temere el libro llamado quesfion di amm. Finprimiose

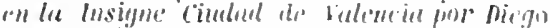

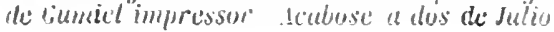


año de mil $x$ quinien los y trece (1513). (Sigue cl escudo del impresor.) Fol. let. gót. 39 hojas.

En el Regislro de la bih. Colomb. se cita la ouestion de amor, en castellano, cujus Prologu.s I. "Muchos son los que." El argumento del libro: I. "El aufor "n la obra." La obra: I. "Acaesció pues, que al tiempo." D. fecha en Firvara, rino de 1512. Dividese en capilulos epilh. Est in fol. 2 col. Inpreso Salmantica, anno 1519, 10 Febrero.

En la bib. imp. de Viena exisłe una edicion sin fecha que el señor de Gayíngos cree anlerior á la de Salamanca, 1559: he aquí su descripcion:

Queslion de Aunor De dos encinorados: at uno era muertu su aniga. El otro sivue sin esperança de galardon. Dispulan qual de los dos sufre mayor pena. Entrexerense en esla conlrouersia muchus carlas y enumoradus razonamienlos. Introducense mus una caca, un juego de cañas, una egloga. Ciertas juslas y muchos calual!eros y ilamas con diucrsos e ricos atavios: con letras r ymvençiones. Concluye con la salida del scñor Visorvey de Nápoles, donde los dos enamorailos al presente se hallutan, para socorrer al sancto Padie, donile se cuenla el numero de apuel lucilo ejercito, y la con/raria forluna de Rancena. La mayor parle de la obra es histo. ria rerdadera. Commuso esta obru un gentil hombre que se hallo presenle d lollo cllo. S. $l$. ni a. Fol. let. gót.

En el catálogo de Sora se cita una impresion de Sevilla, 1521 .

Ticknor en la llist. de la lit. esp. t. 1., pigina 457, supone equivocadamente, ser la primera edicion una de 1527 á la que 110 flja lugar ni nombre de impresor.

En la bib. Colomb. se cncuentra la

Questiö de amor. Agora muenamente impressa: con algunas cosas ruñalidas. (Al fln:) Emprimiose en la muy noble ciudad le camor'a en casa de Pedro Tovans: a xxviii dias atel mes de Julio. Año de mill y quinientos \& treynla nucue (1559). Fol. let. got.; y yo he visto esta otra:

Question de amor. Aqor"u menamente impresso: con algunas closas añadidas. Año. M.D. $x l v$. (Este título va precedido le una viñeta que representa a un caballero tocando la guitarra, acompañado de un escudero y á una dama en una ventana : el prologo principia al reverso y la obra concluye en el blanco del fol. Ixxiij de este modo:) Fortese el libro llamado Queslinn de Ainor. Jimpresso en la muy noble villa de .Hedina del Campo por Pedro de Caslru: impressor le libros. A costa de Jum de Espinosa mercader de libros. Acabose a siete dias de Mayo. Añn de mil y quinientos y quarenla y cinco (15/5). 4. ${ }^{\circ}$ et. gót.

\section{CUESTION DE AMOR.} Question de amor, de dos enamorados: al vno era 'mverta sv ami- ga, el otro sirve sin sperança de galardon... Assimesmo se ha añadido a esta obra en esta ultima addition treze quistiones del philocolo de Iuan Boccaccio. Venetia, en casa de Gabriel Giolito de Ferrariis, y svs hermanos, MDLIII. (al fin MDLiIII.) $8 .^{\circ}$ let. curs. 158 hojas foliadis, inclusas las 4 prels. que no lo estän.

Las Treze quesliones de Boccaccio que contiene, son las mismas ya publicadas por separado ell Sevila en 15/6, con el título de Laberinto de amor. (Véase en el presente $\mathrm{Ca}$ tílogo, Seccion novelislica.--Libros ile caballerias.) El corrector de la reimpresion veneciana Alfonso de viloa uos descubre, en una advertencia á dichas Questiones, que el traductor de la prosa era 1). liego l.opez de Ayala, canónigo de Toledo, $y$ el autor del sumario en metro, que precede í cada una de ellas, Diego de Sillazar, que primern fué capilan y al fin ermitaño. Tambien observa Uilna haberse hecho furtivamente la edicion de Sevilla y sin el consentimiento de Ayala, por cuya razon adolece de errores que habian sido corregidos en la presente edicion.

Al fin del villumen va una lulrodutione che moslru il sigunr Alfonco di vlioa a proferire la lingun castigliuna.

\section{CUESTION DE AMOR.} Qvestion de amor, y Carcel de amor. Invers, en casa de Martin Nucio, M.D.LVI. 12. ${ }^{\circ}$ Sin fol. sign. A-H, de 12 hojas: las dos últimas son blancas.

Desconocida í Barrera.

1212 Las mismas obras. Anvers, en casa de Philippo Nucio, 11.D. LXxvi. 12. Sin foliar, signaturas $\mathrm{A}-\mathrm{R}$ de 12 hojas cada una: son blancas las dos últimas de la $\mathrm{R}$.

Ni en el Ensayo de una bib. esp., He fallardo ni en el Culálogo de Barrera se cita esta edicion á no ser que por equivocacion sea la mencionada en el último como impresa on Amberes, Marlin Nucio, $1586.8^{\circ}$ - La de 1576 está hecha á plana rengron sobre la anterior de 1556; pero es completamente distinta, conteniendo ambas al fin una composicion poética intitulada: Verso elegiaco sobre la inuerle de la Forluna, dada por la Virlud.

Brunet cita la de Salamanca, 1580, con la carcel de amor.

He visto una lercera impresion de Anvers, Marlin Nucio, M.D. YCVIII. 12. 221 pígs. para la Question de amnr, 155 párs. para la Car. cel y 6 hojas sin numeracion con el Verso elegiaco. 
DAM

PRIMRRA DIVISION.

DAM

425

Barrera describe otra de Lovaina, Roger Velpius, s. a. $12 .^{\circ}$

El autor del Dlálogo de las lenguas habla con elogio de la Cuestion de amor: Moratín ensalza el mérito de la hermosa Egloga representable, en coplas de arte mayor que contiene, y Ticknor dice: "Toda la obra wrespira el espiritu de la época, describién. mose minuciosamente en ella pasos de cawballeria y flestas públicas en Nápoles, cawcerias, justas, torneos y juegos de cañas, usin olvidar los trajes, armaduras, motes y wdivisas de lins principales personajes que en »dichos pasatiempos tomaron parte. Hállanse wambien mezcladas en ella michas poesias, "villanclcos, motes $\dot{e}$ invenciones como las wque se encuentran en los cancioneros."

\section{CUEVA (JUAN de La).}

\section{PRIMERA PARTE}
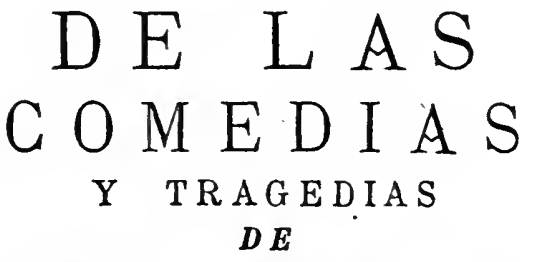

IOAN DE LA CVEVA, Dirigidas $\dot{a}$ MOMO. $*$

VAN A NADIDOS EN ESTA

fegunda iuprefsion, en las Comedias, y Tragedias Arrumentos, y en Iollas las lornatlas,

\section{ENMENDADOS MVCHOS yerros, fallas de la primera Iimprefsion.}

\section{CON PRIVILEGIO.}

TiEstá tassudo a cinco bluncas el pliejo.

I MPR E S S O E N SEVILLA en cafa le luan de I.eon. 1588.
4. ${ }^{\circ}$ let. curs. todos los argumentos y el verso oct osílabo. 330 hojas foliadas, inclusas las dos preliminares.

Comprende las diez comedias y cuatro tragedias, cuyos titulos siguen:

La muerte del rel D. Sancho, y reto de $\mathrm{Za-}$ mora por Don Diego Ordóñez.

El saco de Roma y muerte de Borbon, y $\mathrm{Co}$ ronacion de nuestro invicto emperador Carlos Ouinto.

Los siete infantes de Lara. Tragedia.

La libertad de España por Bernardo del Car. pin.

El degollado.

La muerte de Ayax Telamon, sobre las armas de Aquiles. Tragedia.

El tutor.

La constancia de Arcelina.

La muerte de Virginia, y Appio Claudio. Tra. gedia.

El príncipe tirano.

El príncipe tirano. Tragedia.

El viejo enanırado.

La libertad de Roma, por Mucio Cévola.

El infamador.

Lo que se lee en la portada, y el estar fechado el Privilegio cuatro años ántes que se hiciera esta impresion, parece no dejar duda sobre la existencia de ntra anterior. Sin embargo no he podido hallar el menor rastro de ella, ni la encuentro citada por Nic. Antonio, lloratin, Sedano, Ciarcía de Villanueva, Velizquez, duintana $\dot{0}$ Barrera quienes unicamente hablan de la de liss, encareciendo alguno de ellos su escesiva rareza. Es posible que varios de los dramas se publicasen intes sueltus, y aun esto solamente lo conjeturn, pues ningruma certeza tengo de ello.

Fs mii singulir que el sr. de Barrera, guien generalmente deseribe con nimia prolijillad los preliminares de casi todas las olnas, dira micamente de la presente thold in "noloyo clel antor, siendo así. que adeuns de este prefacio, intiluliulo Episilola dediratoria a yomn, se encuentra el Privilerio fechado, como ya he dielıo. ell 1.isí, lis Talna de las Comedias y Tragedias, y lumos versos landatorios de Virnel biaz de Alareon. Tampoco dice ina pulabra sobre el tamaño del volimen.
1214 DAMA (L.) IOCTORA. Comedia famosa, intitulada: Ia Dama Doctora, o la Theologia carda en la rueca, Traducida del Idioma frances en Castellano. Aviñon, Francisco Girardo, Chácia el año de 1750). 8.
187 pags., comprendidas las dos de la hoja de la portada.

Fs traduccion en prosia de la comedia yue

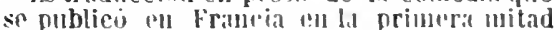
del siglo pasado, para ridiculizar á lus jansenistas. 
1215 DANZA (LA) de la Muerte, poenia castellano del siglo XIV, enriquecido con un Preambulo, Facsímile y Esplicacion de las voces mas anticuadas, publicado enteramente conforme con el Códice original por Don Florencio Janer. Paris, D' Aubusson y Kugelmann, 1856. $8 .^{\circ} \mathrm{ma}-$ yor. Facsímile.

Moratin en sus origenes, Martinez de la Rosa en la Poclica y Barrera en su Catálogo, hablan de esta pieza dramátiea impresa por la vez primera en el tom. III. de la Historia de la literalura de Ticknor.

Con más ó menos probabilidades de acierto se ha supuesto por cuantos han tratado de la presente composicion, ser obra del rabí I). Sem-Tob, conocido por rabi D. Sancho, judio de Carrion: es por lo tanto estraño que ni aun sobre este hecho se liaga la mís lijera mencion en el preambulo español-frances con que va emiquecilu la edicion parisiense.

En casi todos los paises se han escrito poemas ó piezas dramiticas relativas a la muerte y gremeralmente acompañan á estas conposiciones laminas alusivas al asunto; no conozco en español sinn mma olma que se encrentra en este caso la cull deseribiré por ser rara: Imeyines deld moerte tradusidas en metro caslellomo con via broue declu'eciò subre calez vian. In sermon vitilissimo y de mucha doelrina para sabmse exprcilar en la memoria de la muerle. Con otros tractados vtilissimos, cuyo lilulo vera el lector ila buclta dela hoja... Compucstas por Hernando de villa real cleriyo nalural de Vbeda. En Alcala. En casa de Ioan the Brocar, 1557. 8. Nuchas y preciosas lamiuitas grat. badas en madera. sin foliacion, signs. $A-V$ todas de 8 lojas menos la niltima coll solas

Ademas de lo que reza el frontis contiene el lomito, todu en verso, Esprojo interior del conocimiento de bios y de si mesmo, sobre un verso del saráfico P. S. Franciseo.-Lu himuo de Pedro namicmo bradusido en veluéa rima.

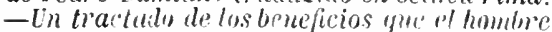
ha recebido de lios, sobre' un rerso que csta

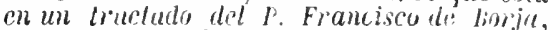

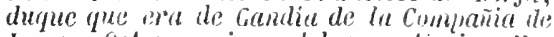
Jesus.--octaves rimas del sacratissimo Vacimiento sobre me versir inlerecolite im otros metros y son'os derolos y jurivectersos.

Es obra de bastante merito literario. Las láminas de origen germínice y otras circunstancias de la implesion, me liacen sonpechar sí serí esta alemana a pesar de sunal como de Alcali.

Vèase en la presente seccion Coplas de la muerle. Xúm. I1!5.

1216 DÁVILA Y IIEREDIA (1NDres). Comedia sin musica. Por D. Andres Davila y Ileredia. Valencia,
Benito Macè, $1676.8 .^{\circ} 4$ hojas preliminares y $\mathbf{8 0}$ foliadas.

No es drama que pueda representarse, sino un diálogo en que se discuten algunas materias poltticas entre varios escritores $y$ personajes distinguidos, como Juan Bodino, Machiavelo, Bocilini, el Cardenal Richelieu, el Conde Dnque, Mazirino, ete. etc.

Mc inclino á creer que el Sr. Barrera no habril tenido presente este librito, ya porque segun se ve, no es una satira de las representaciones musicales; como porque, a haherlo tonido presente, hubiese observado en sı portada que en 1676 era ya Dávila Heredia capitan de caballos, ingeniero militar $\mathbf{y}$ profesor de natemitieas, y no hubiera sacado estos datos biográflcos de la obrita del mismo antor, intitulida: lunta de animales cmilin el hombre. Zaragosa, herederos de tooningo la Puyada, $1686.12 .^{\circ}$

1217 DIA (EL) DE LIMA. Proclamacion Real, Que de el Nombre Allgrusto de el Supremo Señor D. Fernando el VI Hizo la muy Noble, y muy Leal Ciudad de los Reyes Lima. C L $i$ ma, .I.IICCXLVIII.j4. ${ }^{\circ}$ Una hoja de portada, ctra con un escudo de las armas reales grabado, 268 págs. $y$ Q 1 hojas con las signaturas A-K, que contienen la Loa que para la coronacion de el Señor I). Fernando el VI Compnso el Lic. D. Felix de Alarcoll.

En las inlimwas gruardas de este ejemplar mabia mal mota manuserila que decia, ser el antor le esta olna D. Jose Eusebio Llano Zapita.

Lil inica poesía que contiene el volumen es la Lon llnal.

to encuentro esta obrit en el Catálugo de Barrera y l.eilado ni mencion alguna de bon Félix lo llarcon.

1218 DIA (EL) de el Seminario en el mas lucido sol. Festejo, con que en ocasion de honrar sus Magestades, y Altuzas (Carios III y sil familia) cl liral Seminario de Nobles con sus Reales presencias, manifestaron los mismos Caralleros Seminaristas su agradecimiento. S. I. ni a. $0^{\circ}$ a págs.

Contieme una esporie do zarzuola y varias poraías cu latin y castallanu.

1219 DHahante (Juan BautisтA). Comedias de F. Don Ivan Bavtista Diamante. Madrid, Andres Gar- 
cia de la Iglesia, 1670. 4. 4 hojas prels., 283 pigs., 138 de nueva paginacion y una hoja blanca al fin.-Comedias de Fr. Don Ivan Bavtista Diamante... Segunda parte. Madrid, Roque Rico de Miranda, 1674. $4 .^{\circ}$ hojas prels., 38 de nueva pág. para Lides de amor y desden, y una blanca por remate.

Comprende las siguientes comedias la Parte primera:

El defensor de el Peñon.

El remedio en el peligro.

Santa Juliana.

Pasion vencida de afecto.

El sol de la sierra.

Más encanto en la hermosura.

Triunfo de la paz y el tiempo.

No aspirar á merecer.

Santa Maria del monte, y convento de san Juan.

El Hércules de 0caña.

Jupiter y Seniele. Zarzmela.

Santa Marfa Magdalena de l'azzi.

La segunda abraza estos dramas.

Loa á las bodas del condestable de Castilla. Alfeo y A retusa. Zar zirela.

Ir por el riesgo à la dicha.

Cumplirle á Dios la palabra.

Cuanto mienten los indicios, y el ranapan de desdichas.

El Jubileo de Porciuncula.

El cerco de Zamora.

El Nacimiento de Cristo. Zur zuclu.

El negro mis prodigioso.

Amor es saligre, y no puede engañarse.

Santa Teresia de jesus.

La reina IIaría Estuarda.

Lides de amor y desden. Zarzuela.

El Sr. Barrera y Leirado observa que esta coleccion es ya diffcil de encuntrar completa.

Nic. Antonio se equivoca en suponpl que ambas partes se publicaron en 1670.

12 g0 DIAS Baltasar. Arto de S. Aleixo. Signe unalamina de madera que representa a este santo bijo de una escalria, y lespurs:) Obra novamente feita da vida do bemauenturado S. Aleixo, filho de Eufemiano, Senador de Hona Feito por Balthezar dias. Interlocutores. Eufemiano, \& Aglais sua molher, Aleixo seu filho. o Emperador Honorio, $\mathrm{E}$ a Emperatriz, \& Sabina sua filha, tres Embaxadores, hum Camareiro de Elilemiano, \& o Papa, \& quatro Cardeates, \& hum Pobre, \& lium Injo, \& 0 Diabo. E entra logo o Emperador fa- lando com Eufemiano, \& diz. (Al fin: L Lisboa, Antonio Aluarez, 1925 $(1625)$. 4. ${ }^{\circ}$ Son 12 hojas sin fol. con la sign. A.

Mni raro.

Las licenclas para la impresion son de 1620 y 1621:-Barbosa Yachado no lace mérito de esta edicion; pero trae las de Lisboa, 1615, Evora, 1616 y Lisboa, 1638.

12 Zl DIAS (Baltasar). Arto do nacimento. (Sigue una lámina que representa el Vacimiento y bajo:) Nouamente feito por Balthesar Dias, enı 0 qual entraõ as figuras seguintes, coul $m$ a saber. Dous Pastores, hum chamado Benito, \& outro Bartholo, \& de pois outro que se chama Llorente, - Einperador Augusto Cesar, Serino Embaixador, el Rey Ilerodes, dous Iudeus hum Vilão, hua relha, s. Ioseph, nossa Senhora hum Anjo \& os tres Rers Magos, E entra logo Benito cantando. Em Lisboa por Antonio Aluarez, 16 20̈. $10^{\circ} 8$ hojas signalura A sin foliacion.

Mui raro.

l.os pastores de esta pieza dramática ba. blan en castcllano.

Recelu debe luaber alyma edicion nuás an. lífua: sin embargo, Barbosa lachado no cita ninguna anterior is la de Lisboa, 1615.5, unica de que habla: tambien se limita Barrira i coniar lo que trac sobre este auto la bibliutheca lusitanu.

$1222-$ Marruez de Mantra. Sigue una laminila que representa dos caballeros montalis con la lunza en ristre y en el acto de arometerse.)

Trasedia do Marıve\% de Vantra do Emperador Carlo Ilagno. A qual trata como o Marquez de Mantua andando perdido na caça achou a Valdominos ferido de molte, ed da justiça que por sua morle for feita a Dom Carloto litho do Emperidor. (.I contimuacion se halla la lista de los interlocutoies.) Em Lisboa. Por Domingos Carneiro Anno de 1661. 4." 12 hojas, sign. A.

Mini raro.

liste drami portugurs no llova nombre rle antur en la presente edicion: prin Barbosil

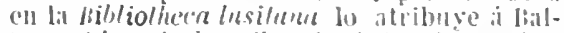
tasar bias al describur la imica impresion que conocio, hecha en tisbese col loitis.-bist. 
rera y Leirado se limita á copiar al bibliógrafo portugues.

1223 DIAS Baltasar). De sancta Catherina, (Sigue una lámina de madera que representa a esta Santa y bajo:) Obra nouamente feita da vida da Bemauenturada Sancta Catherina virgem, \& martyr, filha del Rey Costo de Alexandria. Em aqual se conta seu martyrio, \& glorioso fim nuyto deuota, \& contemplatiua. Feita por Balthesar Dias. Em Lisboa. Por Antonio Aluerez. 634. (1634). 4. ${ }^{\circ} 16$ hojas sign. A.

Cumposicion dramática portuguesa mui rara. de la cual cila Barbosa Machado las siguicntes ediciones: Lisboa, 1616, $165.5 \mathrm{y}$ 16ie?; pero omite la que yo tengo. Las noticias de Barrera se limitan á lis dadas por dicho Barbosa.

Baltasar Dias o Diaz escribio durante los peinados de 1). Juan III y I). Sebastian de l'ortugal, es decir, en la segunda milad del siglo frl: pero ni Barbosa Machado, ni otro libliórafo á mi conocimiento, hacen merito de ninguma edicion de sus obrits anterior al Xril. Todas ellas son sumamente raris y pocos habrin conseguido remir tantas como yo: me faltim sim embarm para temerlas completas, cl Auto del Rey Salmario. Enora,

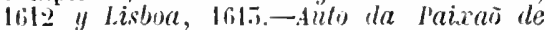
chrislo. Lisbna, 1615, 1617 y 1653, y Aulo da firir da Ladra. Lisbist, 1619.

1221 DLIZ TANCO DE FREJENAL (Visco).

\section{Errilo comsdiario nul}

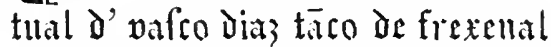
Dirigido al muy mugnifico. 5. Do Inall de Aragō aftellano de anl" polta pzioz dela Camalleria de fan Juall ellel inclito reyno de Ara" gon. .ic.

(Este titulo, con distinta distribucion, va precedido de un ingel sosteniendo el escudo de armas de Aragon, mui parecido á los que se encuentran en algunus ediciones de sus Fueros, el cual llena la mayor parle de la pagina. En la hoja síguiente aij esti el Prefacio missiuo ó dedicatoria, y en la Aiij el Exordio introductional, donde dice que el Terno autual come- diario contiene tres comedias, $\dot{a}$ saber, Potenciana que trata de la Resurreccion de Cristo, nuestro redentor. (En el Jardin del alma dice el autor, que trata de las brujas.) Dorothea, que habla en loor de Santiago, patron de España, $y$ Justina, que introduce un casamiento acontescido por todos los modos de composicion que yo he podido quimerizar e conlprehender, segun dice el autor. ¿Aludirá con esto á los cuarenta modos de metrificar, que en ella habia, como lo refiere en el ya citado Jardin del alma? La hoja cuarta y última, tiene una Epistola en verso, dirigida al mismo caballero.) S. 1. ni a. 4 hojas.

\section{Eernofarffario autual ô} vafto diaj tallco de frexenal: en" deref̧ado al illustre or ratholico feñor do Juan puerto carrero $\mathfrak{f l a r} \bar{g} \mathfrak{s}$ d'villa mueua d’l frefno it d' moguer feñoz.rat.

(Este título esta en cinco líneas y va precedido de un escudo de armas imperiales; todo se halla dentro de una especie de capilla en cuya parte inferior y dentro de la orla hai una cifra que es la que se encuentra on el centro del escudo de Pedro Mardowin, copiado en el articulo de Don Florindo. ( $V$. Seccion novelística.-Libros de caballerías.) Ocupa las tres hojas signientes, todas de la sign. a, la Epistola prologal ó dedicatoria, y en ella anuncia que este Terno farsario autual abrazatres farsas, llamadas Beneslita y Aretina, que tratan de la Tatividal de Cristo nuestro redento:", y Patricia, que habla de la cuaresma etcétera, segun en sus principios se dice.) S. 1. ni a. 4 hojas.

T Trrmo 国ialogal autual de Hafto diaz timco ite frezenal Jedicado al Jlluftriffimo $\mathbf{s e n ̃ o z}$ Jon pedro de Ulelafeo Có̃oeftable

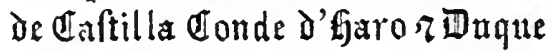
Je friag. $\mathfrak{a}$. 
DIA

CTambien ncupa esta leyenda cinco renglones, se halla colocada dentro de una capillita y va precedida de unas armas imperiales, todo idéntico i la portada del anterior; igualmente lleva la cifra de IIardouin al pié. Al dorso del róntis principia la Introducion prohemial ó dedicatoria, la cual termina en la mitad del blanco de la lioja tercera, sign. aiij, cla segunda no lleva sign.) y viene en seguida el Exordio introducional, que llena lo restante de la hoja: en el blanco de la cuarla se encuentra una Epistola en verso, que es otra especie de dedicatoria. El Terno dialogal comprende el Dialogo real, donde se da cuenta de todos los reyes de C'astilla; el Dialogo imperial habla de todos los emperadores que en el mundo ha habido, y el Dialogo pontifical trata de todos los pontifices romanos, desile Sall Pedro hasta nuestro máximo Clemente septimo. Eslos Divilogos se hallan puestos por copla en modo representalivo alltual, por valerme de las propias palabras del autor.) S. I. ni a. \& hojas.

Son en todo 12 hojas en $\mathbf{~} .^{\circ}$ letra gótica.

No me rabe duda en quic la impresion es de Zaragoza y de l'edro IJardouin, hecha hicia 1.50 , pues ademas de ser el ínjel de la portada del primer Terno, el usido, como ya lu he indicado arriba, en algumas ediciones de los Fueros de Arayon, las cifras de las portadas de los otros dos son de aquel implesor, y la P unyuscula con que camienza el Exordio del illimo Termo. e's exachamente la misma puesta al priucipio de la segunda par. te del Don Florinito.

El ballarse reunidos estos tres preliminares, y encontrarse en igual caso otro $y$ único ejemplar conocido de ellos, me jriteba que las conjposiciones á las cuales parece estabau destimados no llegaron í imprimirse. Fué costumbre de algunos autores en varias épocas el dar á la estamja cl fróntis, dedicatoria, próloges ó indices de sus obras al dirigirlas à ciertos sugetos á quienes debian favores ó cuya bencrolencia tratabun de prangearse; así lo nbserva tambieu Sedano, en cl tom. Vill. del Parnaso españxl, al hablal del Ejemplar poélico de Juan de la Cueva. Yo he visto Las trecientas de Intis Hurtado con solos los preliminares impresos, y del mismo modo tengo El Paraiso en el Vuevo Mundo de Leon Pinelo.

Nuestros escritores, incluso Moratin, no han tenido noticia alguna de estos preciosos preámbulos; solo los citan los traductores
DIA

de Ticknor, tnm. II. pig. j22, y Barrera en su Catílngo.

Puesto que me ocupo de Diaz Tanco, y que i la presuite seceion corresponde mas bien da lista de sus composiciones dranniticas, copiaré la que nos da en el prólogil de el Jar. din del alma, (y no se mencionan en los Ter. nos) siendo lo más estraordinario el no conocerse cjemplar de ninguna de ellas ni impreso ni manuscrito.

El coloquio de la violencia, de cosas vistas cn nuestros tiempos.

El coloquio de esfuerzo bélico, de hazañas de españoles.

El coloquio de loca osadía, de cosas estrañas acrescidas.

La tragedia de Absalon, mui sentida y dolorosa.

La tragedia de Amon, mui estraña y mui al natural.

La tracredia de Saul y Jonatas en el monte de Gelbot.

La cmbajada del ángel Gabriel á Ninestra Seĩora.

La combajadal de los cierigos pobresal l'apa en lioma.

Lil cmbijada de los Concejos al rei estando ansonte.

La destruccion de Jertisalian por Nabucodonosur.

La captura de Jerusalen por liespasiano y Titn.

La cmpresis de Jerusalen por Constantiuo el Magno.

La entrada en Jerusalen por Godofredo de Bullon.

El anto del haplismo celcbrado en el rio Jordiul por $x$.

Tambien el auti) de la Temptaciou en el ale. sicrto.

El allo de Abrahau cuando llevó á su hijo á sacriflcar.

Tambien el auto de la Cananca que pidic salıd por su hija.

El auto de santa Sissana cumo fuć acusala falsameule.

Tambien el auta de cumo Jesucristo sani al cicyo.

El anto de cmando llerudes mando degollar i sant Juan.

Tambien el auto de la samaritaun que estaba al poz).

El anto de la liesurleceion de Lizare como Cristo le resuriti.

Tambien el anto del conscio de los judios sobre la pasion de cristo.

El auto de comm Jesucristo entru en Jerusalen con clanures.

Tambicu el anto de cino cristo ceho los canbiadores del templo.

El antu de la cena postrera die Cristo con sus discipulos.

Tambien el auto de la prision de Cristo en el huerto.

El auto de coino Jesucristo fue acusato $y$ crucificado.

Tambien el anto de cunno Jindas desesperadı se alsurco. 
El aulo de la Resurreccion de Jesucristo mui complido por estilo mui estraño $y$ mui regocijado.

1225 DISCURSO de la entrada, Riçibimiento y fiestas que se le içieron al exmo. Señor Duque de Lerma en su villa de Tudela y lo que en ella yco su exa. desde que entro asta que salio de ella o. fue a ocho de sep. de 1609 años. Fol. Manuscrito de 21 fojas a dos cols.

Contiene varias poesías entre ellas algun romance y un didlogo represenlablc en verso.

1226 DOZE COMEDIAS las mas grandiosas que hasta ahora han salido, De los mejores, v más insignes Poetas. Aora de nueuo impressas. Lisboa, Pablo Craesbeck, 16333. 4. ${ }^{\circ}$ hojas prels. y 498 págs.

Contiene las comedias que signen:

El Cain de Calaluña.-Rójıs.

El principe perseguido.-Uloreto, segun se lee al principio de ella; pero de tres antores, segun el indice que precede al volúmen.

El príncipe prodigioso.-Málos en el titulo di la comedia, y de clos autores en el indice.

El garrote mís bien dado.-Calderon de la Barea.

L.a lima de la sierra.-Luis Vilez de Guevara.

A grin daño gran remedio.-Villaizan en el tilulo, y de Rodrigo de Herrera en el indice.

El caballero de Olinedo. Burlesca.-Monteser.

El pleito que puso al diablo cl cura de Madrilejus.-Tres Ingenios.

El pirvado perseruido.-Luis Veles de Guerara.

Zelos no ofenden al sol.-Antonio Enriquez Gómez.

Competidores y amigos.-Antonin de Huerla.

El gliardarse a si mismo. (En el indice: La guarda de sí mismo.)-Calderon.

El Sr. Barrera dice que este libro es raro y apreciable, $y$ lo cila como una de las obras singulares traidas de Porlugal por el señor D. Pascual de Gayángos.

Los traductores de Ticknor, tom. IV., págima 415 , con referencia á Von schack, describen un tomo cuyo título, algo parecido a este, dice: Doce comedias de varios aulores, los ttulos de las quales van en la signiente oja. Torlosa, en la emprenta de Francisco Marlorell, año de 1638. $4 .^{\circ}$

Contiene las siguientes:

La tragedia de la hija de fiepten. Anónima.
-El santo sin nacer, y mártir sin morir, que es San Ramon Nonal. Anónima.-El primer conde de Orgaz y servicio bien pagado. Anónima.-El cerco de Túnez y ganada de la Goleta por el elnperador Cárlos V. Licenciado Sanchez.-la isla Birbara. Lope.-El renegado Zanaga. Licenciado Bernardino Rodriguez.-El corsario Barbaroja y huerfano desterrado. Segunda parte. licenciado Juan Sánclsez.-Los zelos de Rodamonte. Mira de Amescua. - La bienaventurada madre Santa Teresa de Jesus, Luis Velez.-EI, cerco de Tremecen. Guillen de Castro.-El espejo del nunndo. Luis Vélez.-Doña Ines de Castro. (Tragcdic). Licenciado Mejía de la Cerda.

Barrera describe ademas las siguientes:

Doze Comedias nuevas de diferenles Autores, lus mejores que hasta ahora han salido, cuyos títulos van á la vuella. Parle xxxxyii. Año 16ł6. En Valencia, á costa de Juan Sonzoni. 4. Contiene:

A un tiempo rei y vasallo. Tres Ingenios.San Antonio de Paula. Montratvan.-No hal culpa donde hai amor. Juan de Vega Beltran. - No hai amor donde hai zelos. Monroi.-los trabajos de Tohías. Rójas.-La moza de cíntaro. Lope.-Frrar principios de amor. Rosete.-Los defensoris de cristo. Tres ingenios. - Los dos Fernandos de Austria. Antonio Coello.-Entre los sueltos eiballos. Cubillo.Entre bobos anda el juego. Rójas.-La firmeza en la hermosura. Tirso.

Doz c comedias de las mas famosas que asla nora han salido de tos meiores $y$ mas insignes Poetas. Tercera parte. Lisboa, Alonso Aluarez, Anmo 16.99. 4. Contiene:

Más valiera callarlo que no decirlo. Villaizan.- -lludanzas de la fortuna y firmezas del amor. Monroi.-Lo más priva lo ménos. Diego Anlonio de Cifuéntes.-Engañar para reinar. Enrique Gómes.-Todo sucede al reves. $R 0$ sete. - Babilonia de amor. Fadrique de la Cámara.-Don Florisel de Niquea. Montalvan.-Por el esfuerzo la dicha. Antonio Coello.-Amor, ingenio y mujer. Mira de Amescua. - Galan, tercero y marido. Alonso de Sonsa.- No hai culpa donde hai amor. Juan de Vega Bellran.

Doze comedias nueuas de Lope de Vega Car. pia y olros Avtores. Segunda parte. Barcelona, Geronimo Margarit, $1630.4 .^{\circ}$ Contiene:

Más merece quien más ama. Mendoza.Las dos bandoleras y fundacion de la Santa Hermandad de Toledo. Lope.-Olvidar para vivir. Miguel Bermúdez.-El hijo por engaño y Loma de Toledo. Lope (dice).-La locura cuerda. Juan de Silva Correa.-Los Médicls de Florencia. Enciso.-El Burlador de Sevilla. Tirso.-Marina la Porquera. Con loa al fin. Andres Martin Camona.-La desdichada Estefania. Primera parte. Lope.-El pleito por la honra. Segunda parte. Lope.-Desta agua no bebere. Claramonte.-Lucidoro Aragones. Juan B. de Villegas. 
ENC

PRIMBRA DIVISION.

ENC

131

E

1227 ENCINA (JuAN DEL). (Dice 1 el fróntis de la presente obra:)

plactoa. Gitoriano.

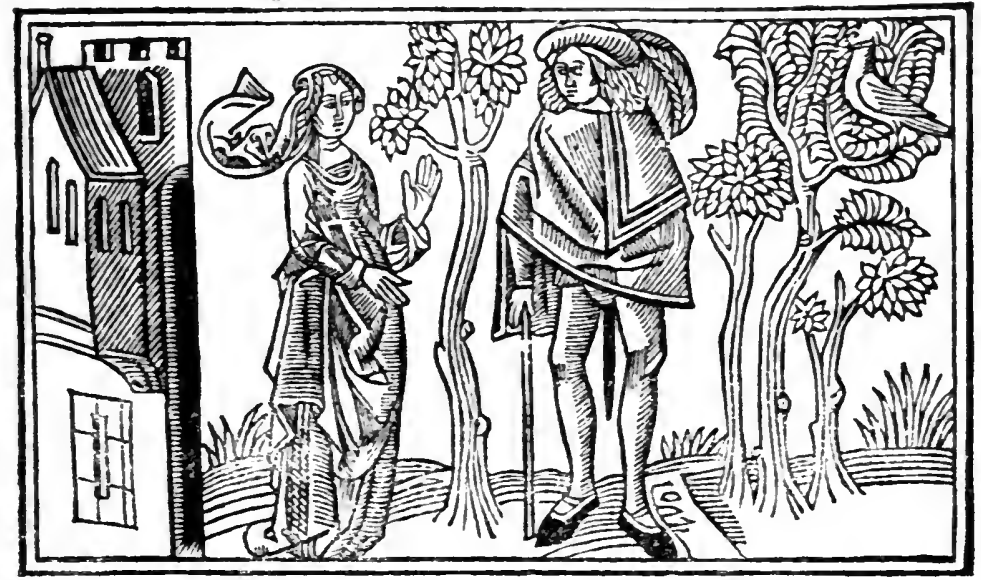

Egloga mueuamète trobada po: juan d’l enjüa. Enla qual fe intro duzen dos chamozados llamtada

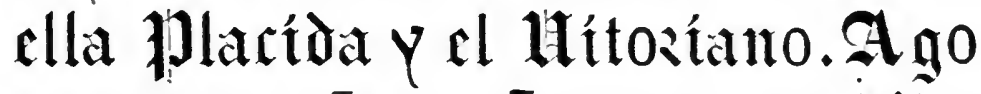

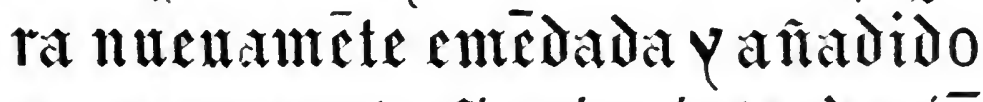
vin argamento fíquter íntrodurio de toda la obsa cu coplas: $y_{\text {mas }} 0$ tras do 0 e coplas $\mathfrak{\mathfrak { q }}$ faltanam $\mathfrak{c}$ ulas otras que de antes erā intpeeffas.

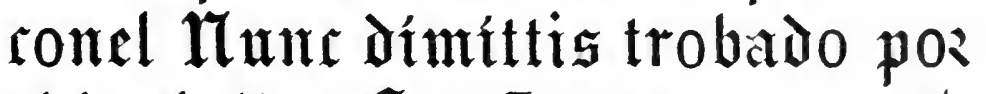
el bachíller $\mathfrak{F}$ ermādo de yangarar.

(Al dorso de la portada principia el argumento que concluye en el blanco de la sign. a ij, y a continuacion comienza la Egloga, la cual termina en 
la sign. c.) S. 1. ni a. (Búrgos, hácia el 1:20?). 4. ${ }^{\circ}$ let. gót. 20 hojas con las signs. a-c: las dos primeras de ocho hojas y la última de cuatro.

Los tipos de la impreslon ya indicall ser anterior al 1520 y lo confirma el hecho de haberla comprado en Medina en 1524, Don Fernando Colon por oclio maravedis, segun lo dice en el Registro de su bibioteca. He supuesto tambien estar heeha en Burgos, por haber visto la siguiente obra, en cuya porta. da se encuentra la misma lámina que en esta Egloga, y el pájaro de ella tiene igual imperfeccion en la cabeza: La ystoria d'l noble cauallero Paris \& d' la muy hermosa donzella Uiana. (Al reverso de la octava hoja de la sign. $c$ se lee:) Fue impresso el presente libro de paris r viana enla muy noble leal ciudud de Burgos por Alonso de melgar. Acabose a viij dias del mes de Nobiembre Aüo de nuestro saluador jesu christo de mil \& quinientos r. xxitij (1524). Años.: $40^{\circ}$ let. got. - Téase una prueba de la utilidad de los facsímiles, sobre todo cuando están flelmente copiados, para poder conjeturar, coul alguna probabilidad, el lugar y año de ciertas Iınpresiones que no los espresan.

La égloga de Prieida debe clasiflcarse entre las de primera rareza, y me atrevo á asegurar que mi ejemplar es úmico en su estado, pues se lualla todo él intonso.

Moratin en los Origenes det leatro, y Tieknor (tom. l. pág. 2ss) suponen que la primera edicion se hizo en Roma en 1514 (siendo esto mui posible por lo que dice el autor del Diálogo de lits lenyuns, y porque en el frontis de mi ejemplar ya se indica haberse impreso anteriormente); pero los mismos Noratin y Ticknor la dan como perdida, por suponer no queda ejemplar ilguno de ella. Los traductores de la IIstoriu de la lileratura esp. en sus notas, tambien participan de la misma errada opinionl.

Gallardo en el Criticon, nu்m. 4., encarece Io raro de esta pieza dramática, que no se halld en ninguna de las cdiciones del Cancionero de su autor, y Moratin, en los Orígenes del leulro, no tuvo de ella otra noticia, sino la dada en el Indice espurgalorio de 1559 donde se prohibio in lotum.

El Sr. Barrera, en su Calálogo, píg. 130, dice: En aquella capital (Roma) compuso $y$ publicó, año de 1514 su celebrada Farsa de Plácida è Victoriano, que prohibida luego por el santo oficio, no parece haber llegado á nuesiros dias; y luego en la pág. 151, añade: De esta pieza... no se conoce ejemplar ulguno. - Sin embargo de no pertenecer el mio á la edicion primera, es mas apreeiable por llevar añadida un argumento, doce coplas y el Nunc dimittis de Yanguas.

En prueba de ser esta Egloga igualınente apreciable para el literato que para el bibliofllo, baste copiar lo dicho por el entendido critico Juan de Valdes, en el Diálogo de las lenguas, pág. 149: Juan del Encina escribió mucho, y asi tiene de todo. Lo que me con- tenta mds, es la Farsa de Plícida y de Vletorjano, que compuso en Roma.

Siendo tan completamente desconocida, creo se me agradecerá el dar aquí noticia de su argumento copiando el que va al principio:

\section{Entra Gil Cestero y dice:}

Dios salve, compaña nobrc, nora buena estais nucstro amo; merecéis doble y redoble; palma, lauro, hiedra y roble, os den por corona é ramo. Ya ací estoi, mas vos no sabéis quien soi; pues Gil Cestero me llamo.

Porque labro cesterla este nombre nila fé tengo; soi hijo de Juan García y Carillo de Mencia, la mujer de I'ero Luengo. Vos miráis, yo magino que dudáis, que no sabés á que vengo.

Por daros algun solacio, y gasajo, y alegría, ahora que estoi despacio me vengo ací por Palacio, y aun verlut más compañia; sabèis quién? gente que sabrá mui bien mostraros su fantasía.

Verní primero una dama, desesperada de amor, la cual Ilicida se llama, encendida en viva llama, que se va con gran dolor, y querella viendo que se aparta della un galan su servidor.

Entrará luego un galan, el cual es Vitoriano, lleno de pena y afan que sus amores le dan sin poder jamas ser sano; porque halla que l'es forzado, y dejalla no es posible ni en su mano.

Y él ınismo lidia consigo, y con él su pensamiento. Sin sentir ningun abrigo; mas con Suplicio, su amigo, eslinda su pensamiento, por hallar remedio para aplacar el dolor de su tormento.

Y aconséjale Suplicio, que siga nuevos amores de Flugencia y su servicio, porque con tal ejereicio se quitan viejos dolores; mas aqueste hiriole de mortal peste, que las curas son peores. 


\section{ENC}

Y no se puede sufrir sin á Plicicida tormarse, alunquis se esfluerza il partir toroando pur la servir, halli que fou a camboscarse; IIII pastor, le dis nievas de dolor diciendo que fué á inatirse.

Y con e̊l en busca della va Suplicio juntanente; yendo razonando della lialla quiesta dama bella sc mali cabe una fuente; y él as sc quiere matar allí y Vinus no lo consiente.

Mas ántes hace venir á Mercurio desd' el cielo, que la venga á resurgir y le dé nuevo vivir de modo que su gran duelo se remedia.

Y asi acaba esta comedia con gran placer y consuelo.

Yo me quiero aqui quedar, que seremos dos pastores, y con ellos razonar: inandád callar y escuchar, Estád atentos, scñores, que ya vienen, si al entrar no los detienen; venid, venid, amadores.

\section{ENCINA (JUAN DEL).}

\section{PGloga trobads por Juan del enjina. Enla qual repsefenta el Amoz de como} andana a tirar en vna felna. 11 de como falio vit paftor llamado 引es layo a dejille que pos $\bar{q}$ alldaua a tirar en lugar Jemedado. 11 defpues como lo hirio el amoz: 1) de como vino otro paftoz llamado Bzas aro folallo: r otro paftoz llamado $\Xi_{\mathfrak{u} a}$ nillo:y on efendero $\overline{\mathfrak{q}}$ llego a ellos.

(A continuacion de este titulillo, distribuido en seis líueas en el original, principia la Egloga que termina en el reverso de la $4 .^{a}$ hoja.) S. I. ni a. (hacia 1320$)$. 4. ${ }^{\circ}$ let. gót. á dos cols. 4 hojas, sign. a.

IIillase la presente Representacion de Juan del Encina en el fol. 96 de su Cancionero, edjcion de Zaragoza de 1516, y la reimprimió
ENC

Gallardo con el titulo de El triunfo de Amor en el uum. 5. del Criticon.

l.leva esta rarisima ellicion al an, cl Villanrien de Ojos gar'sos lu la niñu: tamblen se chenentra el mistuo villancico en otra linpresion que he visto y vol á descrlbir.

Egloga trobaula por Juan del enzina. Enla quil ripresenlit el Amor de coino andanct at lirar en una selua. Fo de rnmo salio un pastor llamado peluyo a vlezille y por tue anda. ua a firar int lugar denedado. E despintes comn lo firio el ainor. Eromo tinu otro passlar llamado. Brus a ciosnlulln: a otro paslor llammin Juanillo: r lambien u'n ssculero.

(0eupa 4 linjas, incluso el Villancleo del mismo Encina Ojos garsos ha la niña, que va al fin.) S. I. ni a. 4. ${ }^{\circ}$ let. gót. Solo en la segunda hoja se encuentra la sign. aij.

Ademas de estas Eglogas he visto las siguientes del mismo autor impresas por separado.

Bajo de cuatro flguritas que llevan los nombres de Fileno, Zambardo, Cardonio y Zefira se lee en cuatro líneas:

Egloga de tres pastores mueuamente trobudu por Juan del ensina.

(Al dorso del fróntis principia con este encabezamiento:)

Egloga trobada por juan del ensina: enla qual se inlroduzen tres pailores. Fileno. Zambardo. Cardonio donde se cuenla como este fileno preso de amor de v'nu muger' zefir a de cuyns amor'es viendo se muy desfun'nrecido cuenta sus penus a zambardo y cardonio. El qual no fallíto e'nellos remedio: por sus propias manos se mato

(Sigue la Egloga en once hojas más.' S.l. ni $u .40^{\circ}$ let, gul. Carece de fol. signs $a \cdot a v j$.

Tambien le cxaminado otra eilicion que en la pirte superior de la primera pia. tenia cuatuo flguritas circuidas de orla estrecha $y$ en secruidil:

C. Eyloga Trobarke por Juan dil Ensina ! en la muil se introdusen l'es' pastores. Filenn. Zambardo. Cardonin... S. l. ni a. . $^{\circ} 1 \mathrm{let}$ gotica 12 bojas sill fol. sign. $a$.

Esta es probablennute la edicion sin fecha de que hablan Ios fraductores de lit llistoria de lit lit. de: Tickinor, Ins enales citan uta de

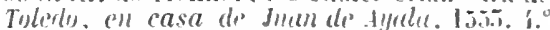

I. a pieza de Zumbardo y Fileno se añadio en la edicion del comidmero de l.sug y Vloratin la inaliza al minn. 1. nel Calcilog" que precedé á sus Orige'stés del letalro.

Egloga represesdonla en la noche postrera

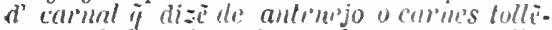
das: a diolde se introllnzen jitru pustores lla.

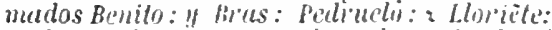
\& pimero benito cutro èlu sala a donder el

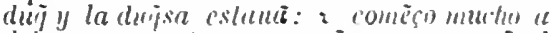

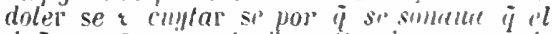

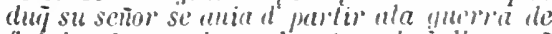
fraciat. Lueng tras rl entro el if llumenta Bras: primintáto le la cansib de su dolor. Y despues llamaron a Pedruelo: el öl les dio 
nueuts de paz: y en fin vino Iloriente que les ayndo a cantar.

(A continuacion de este encabezamienlo principia la égloga que conclnye hicia la initad de la primera coluna de la quinta página y en seguida principia la)

Egloga rep̃sentada la misma noche d' antruejo o carnes tollendas: a dõde se itrodu$z \tilde{e}$ los mismos pastores d' arriba llamados benilo y bras: lloriète: pedruelo. ₹ p'inero beneyto entro èla sala a dóde el dữ r dug̃ sa estauã: y lëdido eñl suelo d' grã reposo comézo a cenar. ₹ luego bras à ya auia cenado entro diziédo camal fuera: mas inportũada d' beneito torno otra vez a cenar conel. ; estädo cenädo \& razonädo se sobre la vehida de àresma: entraró lloriête y pedruelo. $\checkmark$ todos àtrojũtamẽte comièdo \& câtădo cõ mucho plazer dieró fin a su festejar.

(Acaba al reverso de la cuartil hoja con un villancico.) $S$. $l$. ni a. $4 .^{\circ}$ let. gót. sin sign. á dos colunas. Las dos églogas ocupan 4 hojas y aunque no llevan nombre de autor son de la Encina y se encuentran en su Cancionero. Moratin las analiza eu los nums. 9 y 10.

Egloga mouamenle trobada por Juan del ensina a domde se introduz? vn pastor it co otro se acoseja querièrlo d'xar este mũdo \& sus vanilades por seruir a dios el äl despues de auer se retraydo a ser hermitaño: el dios d'amor muy enojado por'j sin su ticécia lo auia fecho. una nipha ébza a le tétar d' tal suerle à forçalo d'l amor d'xa los abilos y la religió.

Interloculores.

Cristino. Justino. Feber. Amor.

(Sigue una laminita que ocupa la cabezera de la primera coluna, pues está dividida en tres cida página, la cual representa i dos pastores y una mujer, todos con cayados; a continuacion dice Cristino:)

En buen hora estes, Justino.

J. Cristino,

tú vengas tambien en tal,

amigo mio leal,

fasta do llevas camino?

I.lena la igloga dos hojas y acaba por el Villancico:

Torna ya pastor en ti,

dime quien te perturbo:

no me lo preguntes, no.

S. l. ni a. Son dos hojas ell fol. let. göt.

$\mathrm{Ni}$ se laalla esta composicion dranditica de Juan del Encina en sil Cancionero, ni encuentro mencion de ella en ninguno de los que han hablado de las producciones del pocta salamanquino.

Egloga interlocutoria : en la qual se introduzen tres pastores \& vna zugala: llamados p'ascual: \& Benito: \& Gil verio: y Pascuala. En la qual recuíta como pascual estaua en la salı del duque \& la duquesa recontảdo como y a la sela de mahoma se auia de apocar: \& olras muchas cosas: y entra Benito y le traua de la capa: y el dize como quiere dexar el ganado y entrar al palacio: \& Benito le empieça de contar como dios era nacido: y Pascual por el gran gasajo que siente le manda vna borreca en albricin.s. Y estädo lo tâto alabädo dize Pascual que nazca quien quisiere que le dexen la suyo r oyendo esto Gil verlo: como tomo un cayjado para dar le conel: 4 Benito los puso en pas: hasla que ya vienen a jugar a pures y a nones. E acabando de jugar empiezan de alabar sus amos: $\varepsilon$ assi salen cantando su villancico.

(Sobre este largo titulo hai cuatro figuritas colocadas entre una casa y un árbol. La égloga principia al dorso del fróntis y ocupa tres hojas más. Solo la segunda hoja lleva la sign. aij.) S. l. ni a. . $^{\circ}$ let. gót. A dos colunas y í vezes á línea tirada.

El titulo precedente y la circunstancia de hallirse encuadernada esta composicion con otras cuatro églogas de Juan del Encina, no deja casi duda de que esta pieza es del mismo; sin embargo no se halla el nombre mencionado en ella, ni la encuentro en su Cancionero. Moratin tampoco la cita en los origenes del teatro español.

Las varias cdiciones del Cancionero de este antor, en cl cual se incluyeron tambien sus Eylngas, pudrán verse en la Seccion poélica, Niim. 231 .

1229 ENRIQUEZ GÓMEZ (ANToxio). Academias morales de las Mvsas. Por Antonio IIenriquez Gomez. (Al fin:) Estāpado en Bourdeaux, por el Señor Pedro de la Covrt, 1642. 4. may. 13 hojas preliminares, inclusa la portada y un retrato del autor perfeclamente grabados en cobre, 478 pags., 2 hojas de Yndice y una con las Erratas y señas de la impresion. El fróntis y retrato grabados, se repiten al principio de la segunda, tercera y cuarta Academia.

Primera y bella edicion no mui frecuente. - EI Sr. D. Adolfo de Castro, en su Historia de los judios, no la cita, ni tampoco la siguiente de Valencia.

1230 La misma obra. Valencia, Claudio Macè, M DC XLVII. 4. 8 hojas prels., 470 págs. y una hoja de Indice.

Parece ser la segunda edicion. Contenido igual al de la primera; pero no lleva retrato. El Sr. Barrera no ha logrado verla.

Ticknor, en el tom. IIl., pág. 9I, cita una impresion de Madrid, $1660.40^{\circ}$ y Brunet habla de otras dos tambien de Madrid, Jos. Fern. de Buendia, 1688 y $1690.4 .^{\circ}$

1231 La misma obra. Barcelona, Rafael Figueró, 1704. 4. 
4 hojas prels., 466 págs. y una hoja de Indice.

Reimpresion de la de Valencia, 1647, con la única diferencia de estar dedicada á San Francisco Javier y no á la reina de Francia Doña Ana de Austria, como las dos primeras, y de haberse sustituido a la Apologin de la obra, hecha por el capitan Manuel Fernảndez de Villareal, que llevan estas, la dedicatoria al Santo de liafael Figueró.

Barrera no menciona esta edicion y cita otra de Barcelona, 1701.

Brunet descrilie la de Madrid, 1734. 4. ${ }^{\circ}$, que es probablemente la viltima.

Nic. Antonio tuvo noticia de esta obra; pero no conoció otra edicion sino la de 1660: es mui singular por lo mismo. que Rodrí guez de Castro al enumerar las producciones de Enríquez Gómez, omita la Academiı de las musas, de la cual dejo descritas siete ediciones.

Dividese este libro, que es todo en verso, en cuatro Academins, cada una de ellas contiene nna introduccion, v'arias poesias y una comedia: hai por consiguiente cuatro de estas, cuyos títulos son: A lo que obliga el honor. - La prudente Abigail. - Conlra el amor no hit engatios, $\mathrm{y}$ dmor con vista y cordura.

1232 ENTREMESES varios, aora nvevamente recogidos de Jos mejores Ingenios de España. Zaragoza, Here. deros de Diego Dormer, s. a. 8. 2 hojas prels. Las págs. van seguilas hasta la 128, y cada uno de los seis entremeses que vienen despues tiene nueva numeracion.

Contiene:

Loa sacramental de los siete sabios de Grecia. - Calderon.

Mojiganga del rei D. Rodrigo y la Caba.Morelo.

Entremes de la pedidora.-Cancer.

Entremes de la reliquia.-Jerónimo Malo de Molina.

Entremes de Pelícano y Raton.-Calderan.

Entremes de la campanilla.-Morelo.

Entremes de la hidalga.-Monteser.

Entremes de las lenguas._Calderon. (En esta pieza hai un personaje que habla en italiano, otro en latin, uno en gallego, un valenciano en su dialecto y un negro en su jerga.)

Baile entremesado de los carreteros.-Málos.

Mojiganga de la manzana.-Maestro Lenn.

Entremes de la tranca.-Jose de Figueroa.

Entremes del niño de la Rollona.-Francisco de Avellaneda.

Baile de la Niña hermosa. - Alonso de olmedlo.

Entremes del degcii: ').--Anónimo.

Entremes de la tia.-Wonteser.

Entremes de la melindrosa.-Luis Benavente.
Entremes de la Mariquita.-Borelo.

Entremes del frances.-Cancer.

Entremes cantado. El soldado.-Anónimo.

Ile visto otro tomito intitulado: Flor de enIremeses, bayles, y Lnas. Éscogidos de los mejores Ingenios de España. Zaragoça, Dieyo Don'mer, M.DC.LXXVI. 8. 4 hojas prels., 233 foliadas y una repitiendo la fecha etc.; y Barrera y Leirado cita:

Enlremeses nuevos de diferentes aulores. Zaragoza, Pedro de Lanaja, 1640.8.

Enlremeses nuevos de diversos aulores para honesla recreacion. Alcria de Henares, Francisco Roper'o, $1645.8 .^{\circ}$

Tealro poetico. Reparlido en veinte y un Entremeses nuevos. Escogidos de los mpjores ingenios de Esparia. Zaragoça, Iuan de ibar. $1658.8 .^{\circ}$

Livrel de entremeses varios. Repartidos en diez y nueve Entrineses nuevos. Escogidos de los mejores ingenios de España. Zaragoça. Iuan de Ybar, 1660. 8.

Rumillele de Sayneles escogidos de los mejores ingenios de España. Zaragoça, Diego Dormer, $16,0.8^{\circ}$

Vergel de eiilremeses y conceptos del donaive, con diferentes bayles, Loas, y Moji. gangas. Compuesto por los mejores ingenins destos liempos. Zaragoça, Diego Dormer, $1675.8 .^{\circ}$

kimillete de entremeses de diferenles AVlores. Pamplona, 1700.8.

Migajas del ingenio y apacible entrenimienlo en Entremeses. Zaragoza, Diego Dor. mer, (t675.) $80^{\circ}$

Gallardo en el Ensayo de una bib. esp. trae el Pensil ameno de Enlremescs, escrito por los Ingenios mas clasicos de España. Pamplona, Juan Micon, 1691.8.

1233 ENTREMESES varios V Loas. Impresos casi todos en Madrid, Antonio Sanz, s. a. 8. Cada uno llera nueva paginacion.

Contiene este volúmen los siguientes:

Entremes de la petimetra.-Un Ingenin alegre. Entremes famoso del zapatero sordo.-Ano. nimo.

Entremes nuevo del alcalde por fuerza.Anónimo.

Entremes del Corta caras._Aninimo, es de Moreto. Impresion de Sevilla, Diego Lupez de llaro.

Entremes de los pajes golosos.-Anónimo; pero es de Leon Marchante.

Un baile ó entremes cantado del cual, por faltarle el fruntis, ignoro el título: ui padre lo llamaba Los Bamboches: pero Fermandez fuerra no ln trae con este nombre. verdad es, que tampoco encuentro cite ninguno cuyo primer verso diga: Ayui sin dulla ha de ser.

Entremes de las cortesias.-Anonimo. Impre so en Sevilla, por Diego López de Ilaro. 
Entremes nuevo de los gurruminos.-Antonio Zamora.

Entremes muevo de las guruminas.-inio. nin \% amnira.

Entremes nuevo de los linajudos. - Aminimo.

ocho loas entretenidas y breves para re. presentar ell cualquiera tiempo y funcion. -Aninimas.

Loa al santlsimo misterio del Nacimiento de X. S. Jesu Cristo.-Ambinima.

Loa breve en melifolat de Palifemo y Galatea para cualquier fumcion y liempe y principalmente para el de Yavidad.-Anouimu.

1234 ENTREYESES varios (31) impresos todos en Sevilla por IIanueí Nicolas Vazquez, José Pidrino y uno solo por Diero López de Ilaro. $8 .^{\circ}$ Cada uno lleca su paginacion peculiar.

Denominare este tomo Nim. 1 de En/re-

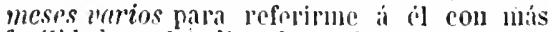
facilidad en el intice le títulos.

Contiene los siguientes enlremeses:

El sacristan lechizero.-Anónimo.

El duetor Borreiro.-Anónimo.

La Mariquiti.-Yheto.

Los rintro galanes. - Anómims.

La codicia lompe el saco.-Jian de Tapia $y$ Ballisteros.

El lilriseo.-Anónimn.

La joringa.-Welyurojo.

El soldadillo.-Aumimo.

El novio y el sueño del carnero.-Francisco Jerónimo de Tóres.

Los buĨuclos.-Anónimo.

Los cirgos apalcalos.-Anómino.

Guardídure lis espaluas.-Anomimo.

Los ciegos Candil y liarahato.-Anonimo.

La casa de posada.-Anónimo. Es de Francis co de Castro.

Chirimfas o la tadrona.-Ansnimo.

La torda.-Anónimo.

La guitarra.-Amómimo.

Trullo. Añidido. Inomimo.

Los cornudos y Juall de Ipricta. -Anónimo.

El bobo casado,-Anónimo.

El Zaborí.-Anónimu. Es de D. Francisco de Bene'fasi.

Lus Matachines. - Anómimo.

El Mnlinero.-Inúmimo.

El hijo del zapalero y estudiante salmanquino.-Anómino.

La Duca.-Anónimo.

Escandarbcy.-Velgarejo.

Los qúnicos fingridus.- Juan de Tapia y $B a$ llestéros.

La porflada sangria y discrecion de un harher(.-Un Inquio de Seyovia.

El Niño de la Rollona.-Francisco de Avellaneda.

El doctor Soleta.-Anónimo.

El hombre solo.-Anónimo.
1233 ENTREMLSES varios $(49$ y una loa) impresos casi todos en Sevilla y algunos en Valencia y Córdova hảcia el año de $1730.8 .^{\circ}$ Cada entremes con paginacion especial.

Este tomo es al que llamo Entremeses varios, vium. 2 en el Indice gener'ul de títulos de comedias.

Contiene:

La muerte de Bigotillos.-Un Ingenio de la Corle.

La tranca.-José de Figueroa.

El uedico sordo y el vecino gangoso.-Diego Tiimes $y$ Villarroel.

El lesafio de Juan Rana.-Anónimo. Es de Calderon.

El sacristan hechizero.-Anónimo.

El soldadillo.-Anónimo.

El derecho de los tuertos.-José Julian de Castro.

Los buñinclos.-Anónimo.

El cindil y garabato.-Anónimo.

Loil crítica y sucinta en que se elogia mujer de cualquier estado, nombre ó otra circumstancia.-Anómima.

El mochuelo.- trónimo.

Las locis caseras. - Anónimo. Es de Alonso de olunedo.

Los cuatjo galanes. - Animimo.

El melonar $\mathrm{y}$ la respondona.-Anónimo.

F.l hombri solo.-Anónimo.

El pleito del borrico.-Anónimo.

1. reliquia.-Jerimimo Valo de Molina.

Escaudarbey.-16lyarejo.

El cuero ó bitero Mastraiuzos.--dnónimo.

El carristan Bonamí.-Anónimo. Es de Arin y Castro.

El in y el letrado, y pleito del cebadal. - inóninio.

El gori, grori.-Anónimo. Es de Quiñones.

La gulitaria.-Anónimo.

Las cortesias.-Anónimo.

El molinero.-Anónimo.

l'erico y Marina, por otro título los golosos. -Anorimo. Es de Quiñones de Benavenle.

Las clirimías, $\dot{o}$ la ladrona.-Anónimo.

El amigo verdadero.-Anónimo. Es de D. Andres Gil.

Los ciegos Candil y Garabato.-Anónimo.

El Sacristan encantado.-Jerónimo de Tórres.

Los matachines.-Anónimo.

Los sacristanes burlados.- Francisco Bernarlo Quiros.

La codicia rompe el saco.-Juan de Tapia $y$ Ballesiérus.

La casa de posadas.-Anónimo. Es de Francisco de Castro.

El novio y el sueño del carnero.-Francisco Jerónimo de Tórres.

El farisco.-Anonimo.

La moreilla.-Ilem.

Trullo, añadido.-Idem.

La sombra.-Ilem.

El coehino de S. Anlon.-Idem.

El hambriento.-Idem.

Las senteneias.-Idem.

Tembleque.-Idem. 
FAM

Los alcaldes enharinados.-Anónimo.

El capitan D. Samuel.- Idem.

El sacristan cojete.-Idem.

El plelto del gallego.-Idern.

El tribunal con uñas.-Idem.

El inlco.-Idem.

No habla reparado. - Idem.

1236 EVIA (JaC!NTO DE.). Ramillete de varias Flores poeticas, recogidas, $\mathbf{y}$ crltivadas en los primeros Abriles de sus años. Por el IIaestro Xacinto de Evia. Madrid, Nicolás de Xamares, 1676. (Al fin:) Alcala de Henares $1675.40^{\circ} 9$ hojas prels., 406 págs. y una hoja al fin con las señas de la impresion.

No menciona Nic. Antonio á estr escritor gunyaquileño, ni tompoco lo cita Barrera y Lcirado, á pesar de conurender sil knmillic doce loas, algum de cllas larbia y dialusala, y una Introduccion on forma ile cololuin, para la festividad de Sun Iynacis de Loyola.
FAM

1937 E7QLERD0 (VICENTE). El frerte, animoso, sagaz $r$ valiente, Martin Lopez de Ayuar Valenciano, Teniente de Macse de campo general en los Estados de Flandes. Conedia famosa Por Vicente Ezquerdo Ingenio Valenciano. Representola en $\mathrm{Ya}$ lencia la Compañia de Baldes, Autor de Comedias por su Mag. muchos dias con grande concurso de gente, el primero del mes de Junio del diño 1620. Hanuscrilo en 4.

Manuscritn inéditn: es el original, y fué sin duda el que tuvo presente fuster.

Al flu de lit comedia se halla $1 \mathrm{~m}$ romance anninisio y dos strmefos de lonis riblez de santaniarfa chcomiando a Vartin bopez de Aivar. Eil rilado Fuster da notiria de otras cuallo rmucelias del mismo autor, las cuales, come la presioute, quediron ineditas, y se lithlan: Marte y remus en Paris. La iluslre fregonu.

- La lolclana ch iladrid y La mina de antor.

El sr. Barrera no ha logrado ver uinguna Je ellas ni la que yo tengo.
1238 FAMOSA (LA) COMEDLA de la entrada del Margres de los Velez en Cathaluña, rota de las tropas castellanas, $y$ asalto de Monivich. Barcelona, Iavme lomeu, 1641. $\mathbf{1}^{\circ}$ 星 hojas prels. y 96 folindas. - Entremes de los Labradores, y soldados castellanos, con rn bayle al rso de Ciathaluña. $4 .^{\circ} 8$ hojes con la sign. 1. La primera lleva por erruta la E. II Ia ulltima es blanca.-Loa ic la comedia de Vonivich. $4{ }^{\circ}$ a lojas con la siynatura!

En el catremes hal varios personajes que Lablan el catalan.

1239 La misma obra.

Barcelona, Iayme Romeu, 161z. h. Q hojas prels. y 26 foliadas.

Fs edicionll diversa do la anterior, y 110 liene el Enliomurs ni lis Lure.

Aunque Barrera y ledirado cita el tílulo do esta romedla ril ol indice gioneral the chlos, no menciona ninguna de estas dos edicionis: y lo que es mis, el entremes demominado:
Los lubradine's il soldailos caslellinos no 10

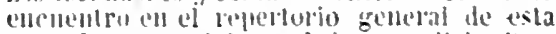

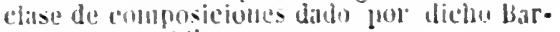
red"a en sil culaloyu.

$1 \geq 10$ F.IIOSO romance del artificio de la sedil. Y grandezas de la Ciudad de Murcia, I su fertil Vesa. Con vna Loa en alillianera de las Millereses en melaforil de lodals las Flores, liantas, yerras: l ro lillancico en forma de oracion de ciemo. Valencia, Francisco Mustre, s.a. rlacial 16j0\%. a." laminilus de madera. 1 hojas sinful. ni signs.

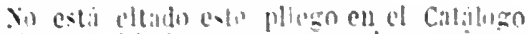

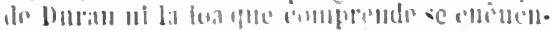

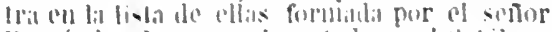

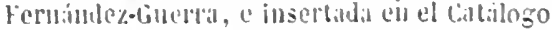
de liallerea

Contiene: Romance que dice: En mestion ed jardin diel mmarlo

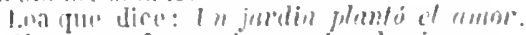
chanz:1 en forma do Hracion de ciego que

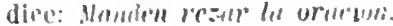

Uuintillas que dicen: En ugledla nocke bivillu. 


\section{Comiença la far}

fa llamada Del Sozdo. En la qual fe introdnien las perfonas figuie tes. Hur paftoz. y vuir mora. y Bartholome loco. An hermitaño. y vil galan. y vil page. y vu viejo fozdo. y wn bobo. fa qual $\mathfrak{s}$ dyra siofa y apajible a todos los oyen" teg.

(A este epígrafe, dividiuln on seis líneas, siguen cuatro figurilas que re.presentan los actores, y a contimuacion comienza la farsa, que concluye en el reverso de la octava hoja com un villancico y el siguiente colofon:)

IJmperfo con liscusin de los feñoses del sonfejo

heal, en Llalladolid, en snfa de Bermardino de Sancto Bomingo.

S. a. Chicia 1560 ). h. ${ }^{\circ}$ let. gót. 8 hojas sign. A.

Escesivamente rara.

1242 FARSA DEL SORDO. COmiēça la farsa llamada del Sordo. Én la qual se introduzen las personas :iguientes. Vn pastor. X vna moça. Y bartholome el loco. Vn hermitaño. Y in galan. $Y$ in page. $Y$ in viejo sordo. Y vn bobo. La qual es muv graciosa y apazible a todos los oyentes.

eSiguen cinco figuritas que renresentan los interloculores, cuyos nombres llevan encima, y en seguida principia la farsa que ocupa ocho hojas con la sign. A.) S. l. ni a. 4. ${ }^{\circ}$

Rarisima.

A pesar de no llevar la presente edicion ni lugar ni año, la creo hecha en Alcalí por Sebastian Martínez, en 1565 , por lo menos esta es la fecha de la licencial dada en Madrid á aquel impresor, puestil all fill de la farsil.

Si pudieramos flarnos tle las deseripeiones bibliogrifleas de fiallirdo, (II el Ensay') de' una bib. esp., deberfamos suponer, al notar las diferencias ortografleas le la portada y el ser gútico el carácter de la impresion de que el habla, existe otra en la cual tampoco suena el lıgar ni año; pero el advertir que el cjemplar examinado por èl tenia cinco flguras al principio, que estas llevaban encima los nombres de Moza, Bartolomé, Galan, Ermitiño, Paje, que al fin se encontraba la licencia dada á Sebastian Martínez en 5 de noviembre de 1568 , y el constar de 8 hojas, circunstincias que reune la que tengo, me induce a pensar sea la misma.

Segun Moratin, en los Orígenes del lealro, y segun la edicion de esta pieza descrita á coutinuacion, hecha en Alcalí en 1616, el autor de ella es Lope de Rueda: bien podia haberlo indicado así dicho $\mathrm{Sr}$. Gallardo, sobre todo díndomos una reproduccion total de esta farsi en su ya citado Ensayo.

El sr. Barrera posce un ejemplar en cuya porlada se lee: Firsa llamada del Sm'do, la yeal es muly agradable. Compuesla por Lope de Ruedla, represenlanle. Son interloculores. In Pastor. Vme Moca. Vin Galm. Vn viejo Sordo. I'n page. In Bobo. Bartolome el loco. Vn Hermilaño. (Aquí cuatro flguritas en made. ra.) Colofon: Impressa... En Alcala de Henares, en casa de dmilies Sanchez de Eznelela: y por su originul en Seuilla en casa de Bartolome Gomes, a la esquina de la carcel Real. Año de $1616.4 .^{\circ} 7$ hojas.

Las ediciones de mi biblioteca no las conocieron ni Moratin ni Barrera.

1243 FELIPE V. Composiciones dramáticas publicadas en varias ciudades de España y en diversos años, relativas á acontecimientos de su reinado y á la guerra de sucesion. $4 \mathbf{6}^{\circ}$

Comprende esta coleccion las siguientes:

IIacer cuenta sin la huéspeda. Zaragoza, 170.4. Zurzuela precedila de una Loa inlitulada: i mis tinieblas mis luzes, al llanto más alegrfa y Matachines nuevos.)

Serrunda jornada de llacer cuenta sin la lluespeda. (Zarzuela precedilla de un Sainete I/ $\mathrm{th}$ Entremes ilulado: Los valieutes de la Alupa y fanfarron de la Europal, fechados en Zaragoza, 1704.)

Sueño del lerro. S. l. ni a. Comedia precedida de una Loa, que es la lercera parte de llacer la cuenta sin la huéspeda y al freir de hos hincros.

Comedia semunda del Sueño del perro, competencia de animales terrestres y voláiiles. S. l. ni a.

La vida es sucño, y lo que son juicios del cielo. Zarzuela espinosa, historia verdadera, representada en el gran coliseo de la Pacier. cia de Mitdrid. Zaragoza, s. a.

Sueños hai que son verdades y Felipe $V$. en Estremadura. Comcdia. Lisboa, s. $\pi$.

A] freir de los huevos. Comedia. (Van intercalados en ella el enlremes intilulado: No hai tiempo que no se lleyue; el sainele: Dime con quien andas direte quién eres, y una Ifojisanga para fin de flesta.)

Sainete cur iorma de danza a los felizes sucesos de Felipe $V$. 
siempre vence la razon. Coloqulo. Es una especie de zarzuela.

Quien bien tiene y mal escoge. Coloquio (represenlable) en la sublevacion de Barcelona y Valencla. Madrid. 1706.

besaflo entre un filipense y un calvinista. Didlogo representable.

Alcídes alegórico. Idea con que cclebró el Colegín de san l'ablo de Búrgos la vicloria de Villa.Viciosa. Por D. Francisco Antonio de Castro. Bürgos, s. a. (Conliene un romance, la mascara y la Representacion que se ejecutó sobre un carro triunfal.-Xio menciona Barrera d este autor.

Coloquio alegórico entre siete persunajes. S. l. ni a.

1244 FERNANDEZ (Lécas). Farsas y églogas al modo y estilo pastoril y castellano, fechas por Lucas Fernandez, salmantino. Edicion dc la Real Acadenia Española. Madrid, imprenta nacional, $1867.8 .^{\circ}$ mayor esp. Facsímile fotográfico.

Este tomo forma, segun su antefróntis, el tercero de la biblioleca selecla de autores clásicos españoles, publicada por la Academia española. La edicion es inui nitida y el papel bueno.-El editor $\dot{0}$ encargado del presente volumen ha sido el Sr. D. Manuel Cañete, quien lo ha ilustrado con un copioso glosario.o Declaracion le rocablos oscuros y con un Prólogo lleno de noticias curiosísimas, escrito con copia de datos y mucha erudicion: lástima grande es que el $\mathrm{Sr}$. Cañete haga en ćl intencionado é insistente alarde de las tendencias rancias e intolerantes del apologista de Felipe II.

fiallardo poseia un ejemplar de la primera edicion de estas Farsas, el cual tuve en mi poder para lavarlo y restaurarlo, pues se hallaba en bastante mal estado; á la mmerte de D. Bartolomé pasó á la bib. de osuna, y ha servido de original para la cdicion académica.-llé aqui su deseripciou.

El fruntis lo ocupa casi por entero una límiua que ropresenta a la Virgen poniendo la casulla á San Ildefonso, v a Sun Francisco recibiendo los estigmas: é, mui parecida d la que se halla en la portada del comentario de Eusebio sobre el Toslado, y abajo en tres renglones:

Farsas y Eylogas al modo y estilo pastoril: y castellano F'chas por lucas fernundez Salmantino Nucuamenle impressas (Todo circuido de una orla. En la segunda hoja principla la obra que concluye en el blanco de la sesta de la sig. a con el signiente colofon:)

C Fuc impressa la presenle obra en Salamanca por el muy honrrado varon Loréç te liom dedei $a$. $x$. dias del thes d' nouiçbre de M. quinipntos qualor ze (1514) uños. Fol. gút. signs. A-B-C-D-F-a. Cada sign. comprende una comedia, farsa o auto. La pitimera en hojas iflcluso el fróntis, la segunda en $\mathbf{4}$; li tercera en 6 ; la cuarta en 4 ; la quinta tambien en 4 y la sesta y ullima en 6 .

No sé si la sign. $E$, que no se encuentra, fallará efectivamente, y si contendrá alguna otra farsa; cl ejemplar parecia cosido mui di: antiguo y no aparentaba falta de hojas; sin embargo, en el Registro de la bih. Colomb. se encuentra descrito asl: Lucae Ferdinanlez, fursas y églogas. n. 7 en español. Sa, 1514. lo cual prueba que deben ser siete las piezas.

\section{FERNÁNDEZ Y ÁVILA} (Gaspar). La infancia de Jesu-Christo. Poema dramatico, dividido en diez coloquios. Su autor. D. Gaspar Fernandez, y Avila. Malaga, D. Felix de Casas, y Martinez, s. a. Chicia 17830 . $40^{\circ} 0$ lenjas prels., inclusa una que lleva el escudo de armas de D. Luis Irostegui i quien se dedica, 162 págs. y una hnja de Indice y Erratas.

Contiene esta obra diez coloquios represenlubles cuyos tilulos son:

La Encarnacion del Hijo de Dios.

1.a expectacion de Yaria Santisina.

El Vacimiento de unestro señor Jesucristo.

La manifestacionde unestro señor Jesncristn.

La adoracion de los santos reyes í Jesucristo.

La presentaciun de nuestro señor Jesucristo en el temph.

La huida á Esipto de nuestro señor Jesucristo. La decrillacion de los Inocentes.

La perdida de Jesucristo nuestro señor de doce años.

La invencion de nuestro señor Jesucristo en el templo.

\section{FERYIXDEZ DE CASTRO}

Y BOCiNGEL (Jeroxino). Elisio Pervano. solemnidades heroicals. festivas demonstraciones de ivhilos, que se han logrado en la muy Yoble, y muy Leal Ciudad de los Reres Lima. in la Aclanacion de Don Lris Primero N. S. Las resine. Don Geronimo Fernandez de Castro, y Bocantel. Lima, Francisco Sobrino. 1720. 4. Sin fol. con las signs. $1-0$ de 4 hojas carla una, y despres $\mathrm{A}-\mathrm{H}$ de a hojas cuda una: la ultima es blanca.

Comtiene al fill una Loa de D. Pedro die l'p. ralta para la Cousedia con quec celebret la familia del marques de Castelfuerte la Asmmpcion ála corona de Lnis I.; 111 setimele de b. Jeronimu Monforte y lera para la misma,

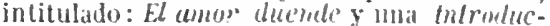
cion, zarzucla, baile o fin de ticsta al Sarue 
de los planelas, escrita por Fernandez de Castro - Bocángel.

1247 FERNÁNDEZ DE HEREDIA (JUAN).
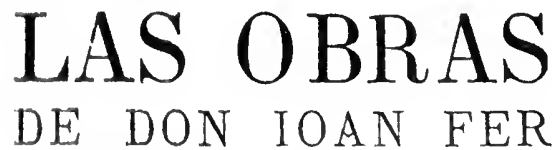

NANDEZ DE HEREDIA. ofsi têporales, como efpirituales

\section{Dirigidas al illuftrifsimo feñor don} Francifco de Aragon.

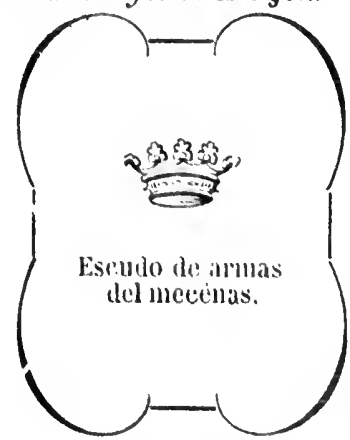

EN VALENCIA,

Con gracia y Priuilegio por diez años. 1562.

(En la ullima hoja llera el siguiento colofon:)

\section{¿̧ Impreflo en Valencia en} cafa de Ioan Mley.

$$
\text { Año. } 1562 \text {. }
$$

8. ${ }^{\circ}$ hojas prels. , la villima blanca, äs0 foliados, ï de porsius sin foliar, I de Tabla y una con las señas completas de la impresina.

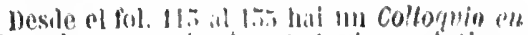

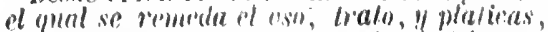

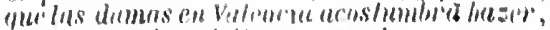
y lener en las visilas gure se hasen vmos a olras. Algillos interimulores hablan al va= lenclann, y un porturnes sirumpe su lenina.

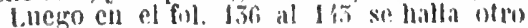

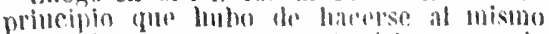

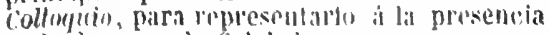
de la diequesa de: Calibiria.

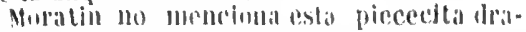
millicit.

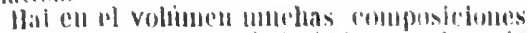

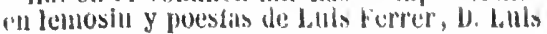

Mllan, Martin Pineda, Mosen Pedro Roda, MIcer Hierónimo Oliver, Jaime Segarra, Don Juan de Borja, Diego Ramírez (Pagan) $\mathbf{y}$ Francisco Garrido de Villena.

Considero el presente libro como uno de los más raros de mi biblloteca : Jimeno no logró verlo completo, pues observa carece de nombre de impresor, constando este como hemos visto, en una hoja al fln; Fuster se contentó con copiar lo que dice Cerdá en las notas à la Diana enamorada; Brunct no 10 menciona, Ileber no consiguió tener un ejemplar y Barrera no habla de este autor.

b. Juan Fernández de Heredia fué uno de los poetas más distinguidos que tuvo Valencin a principios del siglo XVI; en al Cancionero general hai varias composiciones suyas y tambien en El Cortesano de Milan.

(iil l'oto en el Canto del Turia le dirige el siguiente elogio:

Ninfus, huced el resto, cuando el cielo Con Juen Feruéndez os hard dichosas, Lugar no queile en loclo aqu'sle suelo

Do $n$ sembreis los lirios y las rosas:

Y lú lijera Fana, ularga el vuelo,

Emplea aqui ins fuersas poderosas,

$Y$ diale auluel renombre soberano,

Uice diste al celebrado mantuano.

He creido debia eolocar el presente tomito ell esta seceion mis bien que entre los cancioneros, donde tambien podia flgurar por contener composiciones de varios conocidos poclis, ya indicados ántes.

1248 FERNANDEZ IORATIN (Leaxino). La Comedia nueva. Comedia en dos actos, en prosa. Su alltor Inarco Celenio poeta árcade. Parma, J. Juan Baustista Bodoni, Mucclxxxxvi. 1. " may, 6 hojas preliminares y 128 págs. Ejemplar intonso.

Preciosa edicion y una re liss más diffeiles de hallar del célebre impresor Bodoni.

1249 FERNANDE\% DE MORATIN (Nucolis). La Petimetra. Comedia nuéva: escrita con todo el riror del arte. Midrid, Yiuda de Juan Mluñor, 1702. 8. ${ }^{\circ} 136$ prigs. en todo.

Desengaño al Theatro español, respuesta al Momance liso, y llano, y defensa del Pensador. Su author Don Nicolas fernández de Moratin. S. 1 . ni a. $8 .^{\circ} 80$ págs.

Egloga a Velasco, y Gonzalez, lanosos español is. Madrid, Miguel Escrivano, s. a. 8." XXXII paigs. en todo.

Lucrecia. Tragedia. (ll fin:) Madrid, Joseph Francisco Martínez, Abad, 1763. 8." 99 paigs. 
El Poeta . Libro primero. Madrid, Miguel Escrivano, $1764.8^{\circ} 160$ páginas en todo. Publicado en diez entregas.

La Diana, o Arte de la caza: poema. Madrid, Miguèl Escribano, 1765. 8. Sin paginacion, signs. A-H, de 8 hojas.

Hormesinda, tragedia. Madrid, Pantaleon Aznar, (1770). 8. 12 hojas prels. y 94 págs.

Al piadoso augusto, y catholico Monarca Don Carlos III. por el perdon concedido à los Reos el dia veinte de Septiembre de este año de 1762. Cancion. 4." 4 hojas.

Estas-obras se hallan encuadernadas en un volúmen y es mui dificil el poulerlas reunir.

1250 FERXINDEZ DE NORATIN (Nicolís). Obras postumas de Don Nicolas Fernandez de Moratin. Entre los Arcades de Roma: Flumisbo Thermodonciaco. Barcelona; Viuda de Roca, Mocccxxi. 4. ${ }^{\circ}$ Retrato. Ejemplar del papel superior.
1251 FBRNANDEZ DE MOHATIN (Nicolís). Obras póstumas. Segunda edicion. Londres, M. Calero, 1825. 8. ${ }^{\circ} \mathrm{esp}$.

Estas dos ediclones, de igual contenido, comprenden ademas de las poesias postumas, fraginentos de las tragedlas la Lucrecia, la Horinesinda, el Pelayo y Guzman el Bueno. La segunda impresion la costeó mi padre.

1232 FERREIRA (A vTonio). Poemas lusitanos do Doutor Antonio Ferreira. Lisboa, Pedro Craesbeeck, M.D.xcviri. 4. ${ }^{\circ}$ Casi todo de let. cursira. 4 hojas prels., 240 fols. y 4 de Taboada.

Todas las composiciones son en portugues. Al fin va la Tragedia intitulada castro y dos eleglas na morle de Anlonio Ferreira, la una de Diogo Bernarues y la otra de Pero d'Andrade Caminlia.

Libro raro, y asi lo reputa Brunet.

He visto la Segundu impressão Emendada, $e$ acrescenlada com a Vida, e Comedias do mesmo Poeta. Lisbna, na regia officina typographica, MDCCLXXI. 2 rols. $12 .^{\circ}$

El cscudo de Craesbeeck, puesto en el frontis de la primera impresion, es este.

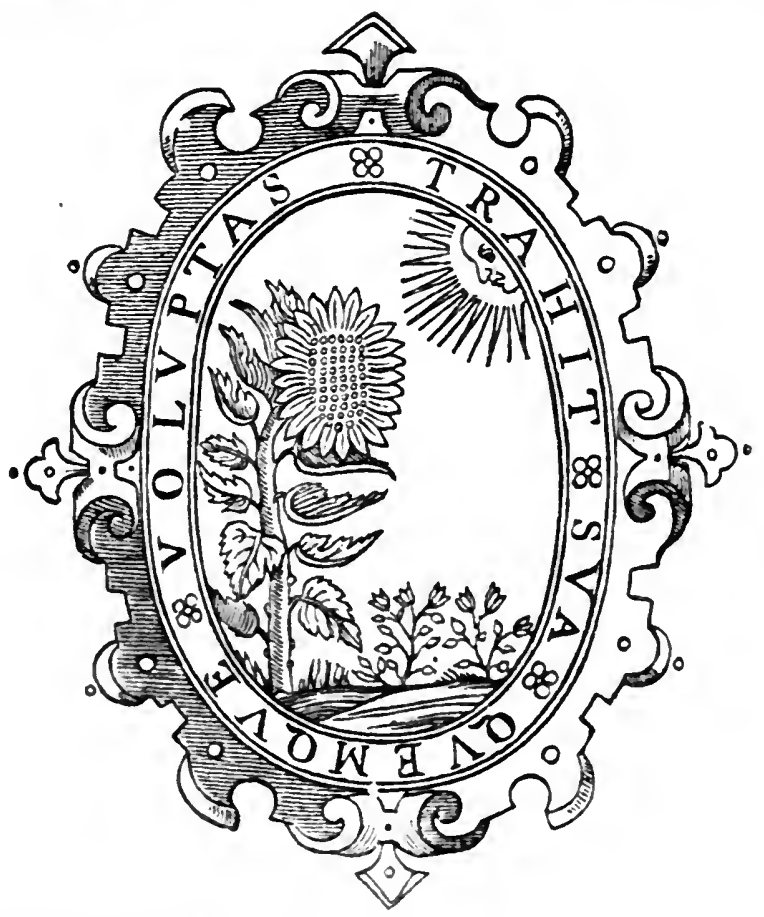

$123 ̈ 3$ FERREIRA DE VISCONCELLOS (JohGe). Comedia Avlegra- fia: feilia por Iorge Ferreira de Vasconcellos. Agora novamente impressa 
a custa de Dom Antonio de Noronha. Lisboa, Pedro Craesbeeck, 1619. 4. $^{\circ}$ 4 hojas prels. y 186 fols.

Brunet se equivoca al decir que este libro es en $8 .^{\circ}$

Velázquez, en los origenes de la poesia, págs. 99 y 100, y García de Villanueva, co. piandole en el Origen del tealro español, pág. 252 , hacen tal mescolanzá de esta comedia y las de Olisipo y la Eu,rosina, que no se puede sacar en limpio si quisieron decir hiberse hecho de las tres comedias una edicion en Evora en 1566 , o solo de la viltima; a esto me inelino más. Ningun bibliografo menciona impresion más antigua de Aulegrufir que la presente de 1619 , publicada por el yerno del autor Antonio de Noronba; al principio lleva un Epigrama latino de Santiago Tevio en el que dice, que Ferreira siemple dió á luz sus obras anónimas.

Al fin del tomo va una Carla que se achou chtre os prupeis de lorge Ferreira de Vasconcellos: es una composicion en verso que consta de cuarenta y tres oclayas.

Eno de los interlocutores de la Aulegrafia habla en castellano.

12马\% FERREIR. DE VASCONCELLOS (JORGE).

Zelotypo.Eufrofina. Siluia de Soufa.

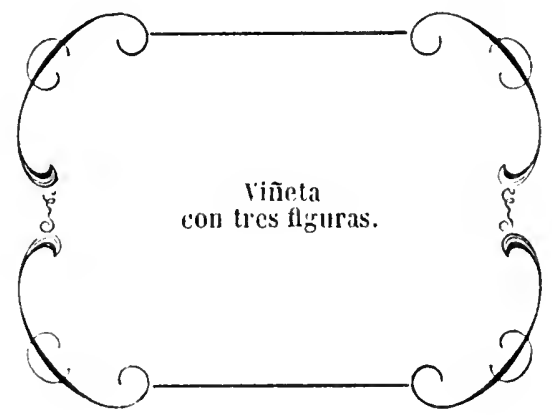

\section{ComediaEufro}

fina.De nouo reuifta, \& $\mathrm{cm}$ partes acrecētada. Impreffa em Coimbra.

Por Iō̄ de Barreyra Imprefsor da V́nịuerfhade; Aos dez de Mayo.

M. D. LX.
(En el reverso principia el Proemio ao Principe. N. S.; en la pagina siguiente 3 se hallan las Figuras da Comedia, y al reverso principia el Prologo que termina en la página 12; en la siquiente comienza la comedia que concluye en la 347 ; la vuelta la llena una lamina con varios personajes, y en el blanco de la hoja siguiente se lee:)

T Foy impreffa a prefente obra,em a muy nobre \& fempre Real cidade de Coimbra,por Ioā de Barrey ra empreffor da vniuerfidade. Com priuilegio Real que nenhũa peffoa

a poffa imprimir, nem vender

nem trazer doutra parte impreffa, fob as penas conteudas no Priuilegio.

Acaboufe aos dez dias do mes de Mayo.

De M. D. LX.

8. Láminas de madera. Solo la lista de las Figuras da Comedia es de let. gót.

Esta edicion, escrsivamente rara, es la más antigua citada pol los bibliógrafos. En el Iuseo britinico ví otra enteramente distinta cuya fecha no se siabe por lallarse incom. pleto al fin el ejemplar; pero podria ser la de Evora, Andres de Burgos, 1566, que se cita ell la version castellana de 1735 . He aquí su descripcion:

Zelotypo. Eufrosina. Siluia de Sousa. (Esto en una línea y bajo una límina de midera que representa á un caballero y una dama conversando y bajo de negro y colorado: Comedia Eufrosina. De nono reuista, \& em partes acrecenlada. Agora nouamentc impressa. Dirigida a muilo allo \& poderoso principe dom Joann de Portugal. Al reverso del fróntis conuienza el Procinio que concluye al principio de la hoja siguiente aij, y en seguida viene la lista de las Figuras da comedia; á la vuelta empieza el prólogo que acaba al reverso de la octava hoja del volúinen, donde principia el acto mimeiro. El ejemplar solo llega á la sceria décima del quinto acto, sign: $G$ iij. No sé por lo mismo si al fin llevará la fecha. 8 . $^{\circ}$ let. gót.

1235 FERREIRA DE VASCONCELLOS (Jonge). Comedia Evfrosina. Nouamente impressa \& emmendada. 
Pór Francisco, Roïz Lobo. Em Lisboa, Antonio Aluarez. 1616. $80^{\circ}$ hojas prets. $y$ 223 fols.

Rodríguez Lobn, ademas de retocar la obra, debió suprimir algunas cosas de clla, cuando el santo oflcio permitio la circulacion de esta edicion, teniendo prohibida la de las anterlores.

1230 FERREIRA DE VASCONCELl.OS (Jorge). Comedia Eufrosina. Traducida de Lengua portuguesa en castellana, por el Capitan Don Fernando de Ballesteros y Saavedra. Madrid, Antonio Marin, 17.35. 8. ${ }^{\circ}$ 12 hojas prels., 422 paigs. y una hoja blanca.

La primera edicion de esta traduccion se publicó en Madrid, en la imprenta del Reino, $1631.8 .^{\circ}$

Dice D. Francisco de Quevedo en la aprobacion que lleva al principio, que Ballestéros y Saavedra con suma diligencia la ha truducido, de suerte, que hablando castellano no deja de ser porlugues, ni deses de verse como nacio, donde empieza ahora à vivir.

$120 \%$ - Comedia Vlysippo de lorge Ferreira de Vasconcellos. Nesta segvada impressaó apurada, correcta de algūs erros da primeira. Lisboa, Pedro Craesbeeck, M.DCXVIII. 8. ${ }^{\circ}$ a hojas prels., 278 foliadas y dos blancas al fin.

Brunet dice se ignora la feeha de la primera edicion, yo tampoeo la ennozco y solo encuentro en Velízquez, orígen de la poesia, págs. 99 y 100, una indicacion confusa de si se publicu en Evor'i en 1ajbi, junto con la Eufrosina y la Aulegraphia. Barrera no cita ninguna anterior it la que yo poseo de 1618 .

FLOR de las mejores doce comedias. Véase en esta division, Coleccion antigua de comedias en $\mathbf{1 8}$ volúmenes entre las Partes de a fuera de la misma. Núm. 1180.

1258 FLORES DEL PARNASO, cogidas para recreo del Entendimiento Por los mejores Ingenios de España: en Loa, Entremeses y Yuurigangras. Zaragoza: Por Pasqual Bueno, s. a. (1708:). 8. 4 hojas prels. y 190 paigs.
Contiene:

Loa sacramental del Reloj.-Calderon de la Barca.

Entremes para la flesta de Todo lo vence el amor.-Anlonio de Zamora.

Baile, y Sarao que se cantó y representó en la misma flesta.-Del mismn.

Entremes del Dragoncillo.-Calderon de la Brarca.

Mojiganga de la Negra.-Anónima.

Entremes de las Visiones.-Francisco Candamo.

Entremes de los Amantes à escuras.-Anonimo.

Entremes de las Locas caseras.-Alonso de olmedo.

Entremes de la Dama toro.-El mismo.

Entremes del Sacristan Chinchilla.-El mis. mo.

Entremes del Aicalde villano hablando al rei. -Vicenle Suárez.

Baile de Paracumbe, á lo portugues.-Anonimo.

Entremes del Yochuelo.-Anoniño.

Entremes de los Coches de Sevilla. - Ano. nimo.

Entremes la Renegada de Vallécas.-Anónimo.

Mojiganga de la Inerte.-Calderon.

Entremes de la Rueda y los buñuelos.-Juan Francisco de Tejera.

Mnjiganga de las sacas.-Anónima.

Sin duda el ejemplar de este libro que tuvo i la vista el Sr. Barrera estaria falto, porque al detallar el contenido del volumen omite las dos viltimas pirzas que en él se encuen. tran, $y$ al describir los preliminares solo habla de la licencia, siendo así que lleva una dedicatoria í 1). Gregorio Espir de Vilanova, y la Tabla. Dicho Sr. Barrera cita otra obra cuyo tflulo tiene alguna relacion con el de la presente y es: Flor de saineles. Compuesta por Francisen Sararrete ! Ribera. Madrial, Crilalina del Barrio y Anguilo, 16:0. 8. ${ }^{\circ}$ Contiene diez Entremeses. dos Bailes, un komance y las dos novelis tambien de Yarar. rete intituladas: Los lies Hermmos, sin la a Y El cuball'ro invisible.

19:39 FLOREST.I DE F.XTREMESES, y rasgos del ocio, a diferentes assvimptos, de Bayles. y Mogigangas. Escritos. Por las mejures plumas de nuestra España. Madrid. Por Anlonio de Zafra, 16y1. 8. 4 hojas prels. y 168. paigs.

Contiene:

Entremes de la Reliquia.-Jer. Vulo de Molina.

Entremes de pelieano y Ratou-Cáncer.

Entremes de la Campanilla.-yorelo.

Entremes de la llidalguia.-Ytonfeser.

Entremes de las lengruis. - Cancer'.

Baile entremesado de los Carreterus.-Juan de Yálos. 
Mojiganga de la âlzana.-Mtro. Leon.

Entremes de la Tranca.-José de Figueroa.

Entremes del Niño de la Rollona.-Francisco de Avellaneda.

Baile de la Niña hermosa.-Alonso de olmedo.

Entremes del Dia de compadres.-José de Figuerva.

Entremes de las Tajadas.-Anónimn.

Eutremes de los Rábanos y el dia de toros.Franc. de Avellenedu.

Entremes de lo lo vi.-Cáncer.

Entremes de la Hija del dotor.-José de Figueroa.

Entremes de li Boda de Juan Bana.-Cinere.

Entrenses de Juan Rana.-Franc. de Avellaneda.

E! Sr. Barrera y Leirado cita ntro tomito on el inismo tetulo, impreso en Madrid, Por la rinule de loseph Fernandes di Burndia, fise; pero las piezas que comprente diez y nueve (ntremeses y una moji rangai) son distintiss de las que se hallin en el de 1601 , antes des crito.
1260 FORNARIS (FABRITIO DB). Angelica, comedia de Fabritio de Fornaris Napolitano detto il Capitano Coccodrillo Comico Confidente. Parigi, Abel l'Angelier, M.D.LXXXV. 12. ${ }^{\circ}$ let. curs. $40 j a s$ prels., 61 foliadas y una al fin con un floron.

1261 La misma obra. Venelia, Francesco Bariletti, II DC VII. 12. let. curs. 14'́ prigs., comprendidas las $\ddot{3}$ hojas primeras que no lienen paginacion.

Ini] de los interlocutores de esta comedia liabla constantemente en castellano y por 10 misino la juzgo en ignal caso que el imor constante de Stordilo el Horlensio de los Aceadrmici intronati y il' Inlricali puslorute de l'isqualigo.
1262 Gadea Y OYIEDO (Sebastian A.Tonio DE). Trivifales fiestas que a la Canonizacion de San Jran de Dios... consagro la... Ciudad de Granada. Las describe D. Sebastian Antonio de Gadea y Oviedo. Granada, Imprenta Real de Francisco de Ochoa, 1692. 4. ${ }^{\circ}$ In $u$ hoja de portada yrabada, 8 hojas prels., la imágen del santo y 3 בzo págs.

Conliene este lomo nna Jasla poélica en la que se enconentrim composionomede

\footnotetext{
b. Franciseo de Viedma y Alostegui,

1). Jorge de Avellan y Córlovit,

I). Jedro de soria y sittiblia,

1). Peilro Kafited Zalpitis.

I. blugo lltgrol de prido,

ע. Ferinindo de la Peñit,

l). Jose dle Reina,

J. Iulis de Espinosa,

J. Antonio lopez de Mendoza,

b. Cristoval Günez de la legra y otros.
}

se halla ademas un Aulo sarra nental piecediulo de Loa, intiluliton: la imágen dol

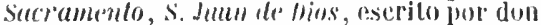
seb. Ant. de Gindea y oviedo; pero á vesial de sur mi rjemplar mui bueno y estar imdulat. blemente completo, no tiene el otro yni: dice Barrera, intitulado: El lesoru de la Iglesia, it no denominar asi la lon que el no men. ciona.

126:) G.LLARDO (B.IITOLONÉ JosE. Cil Criticon, papel volante de Libcritura y Bellas-artes: por Don Bartolome Jose Gallardo. Madrid, 1. Sancha, $183 \ddot{3}-39.8 .^{\circ}$

solo se lian publicado ocho numeros ó

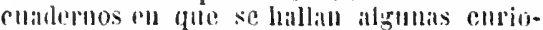
stsimats reflieas literarias del autor, villias

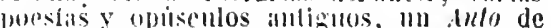
Jana del Eucina que intitula: Trimfo de "tmor, Ina Egluga inlertaculoriu, graciosa y

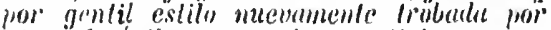

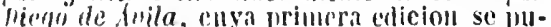
hivio en Aliald de Henuris, s. a.; pelo inites lel 1512; "l Colngui' de Fomisa y una Farsa y una Comedia de Juicas lernández.

\section{Garcia (VICent). La Ar-} monia del Parnás, mes nvmerosa en las Poesias varias del Atlant del cel poetic lo Dr. Vicent Garcia. Recopiladas, y emendadas per los Ingenis de la Acidemia dels desconfiats. Bareelona, Rafael Figveró, 1700. $4 .^{\circ}$ 28 hojas prels., 201 paifs. y una hoja inás en la que termina la Taula. 
Esta es á mi parecer, la primera edicion de las obras del cillelore Rector de Vallfogona, poeta catalan de pincipios del siglo XVII. En la fecha del fruntis debe haber equivocaclon, $\dot{0}$ es incxacta la referencia al año de 1703 que se hace en el prólogo de los reclor's del Banys y de Pilalluga.

Todas las composiciones del tomo son en lemosin y en verso, inclusa la comedia intltulada: Glariosa verge y marlir Sanla Barbara.

En la veuta de Conde, nim. 312 , s's lescrlbe una edicion de Barcelona, $1703.40^{\circ}, \mathrm{y}$ en Londres tuvimos la de Burcelona, Josep) Torner, 1820. 4. ${ }^{\circ}$ con el titulo di! Por'sias jocnsas y scrias del Dr. Vicens Gav'cia. Nova edicis numentala, corregiula y arreglasta a la orlografia moilerua: y otra impresion tambien de Barcelon $\iota$, Josef Rulbin, $1 \times 20.4 .^{\circ}$ con portada igua] i la de $[700$, y parece estar conforme cri todo con clla, pues en la ántes citada del mismo año 1820 , se variu y suprimio algo de los preliminares.

las dos primeras culiciones son escasas, sin duda por hiber merecido el anatema del Santo oflio.

\section{GARCIA DE VILLATEET}

(Mavel. Origen, epocals y prouresos del Teatro español: discurso his. torico. Al que acompaña un resumen de los Espectáculos Fiestas y Recreaciones, que desde la mas remota antigüedad se usaron en las naciones mas célebres: y un compendio de la historia general de los teatros hasta la era presente. Por Manuel Garcia de Villanueva Ilugalde $\mathbf{v}$ Parra. Madrid, Gabriel de Sancha, 1802. $4 .^{\circ}$ Frontis grabalo y dos liminas.

Ya al principio del tomo nu Poema de D. José Julian de Castro, en que da noticia de la mayor parte de los escritnres dramáticos españoles, desde Juan del Encina hasta flnes del siglo XYIIl.

1266 GERARDO LOBO (ELGENIO). Selva de las Mrsas, qre en elegante construccion Poëtica prorrumpe la facundia de D. Ergenio Gerardo Lobo... y reimprime en Cadiz, con las licencias concedidas á sus Originales. Gerónymo de Peralta, Impressor en la dicha ciudad. Quien la dedica, y ofrece al mismo Autor. S. I. (Cadiz?) M.DCC.XviI. 8. 3 hojas preliminares. , 326 fols. y 2 de Indice.
Esla será tal vez la primera cdicion de las obras reunidas de fierardo I,obo: cu clla se cncuentra ya la Ina intitulavla: Fl triunfio de las mujeres. - lle visto las Obras poelicas, de Don Euginis Gorardo Lobo... Driliculas, cn esla segunda Elicion al mismo Aulor. Y uña. dillas de vna lereera parle, y con'regilas, y enunendadas. Cadiz, por Geronimo Peralía, s. a. 4. Solo pude darle una rípida njeala. y me parece contenia este tomo casi todas las composiciones de la anterior edicion gaditana $y$ ademas una Adicion al fin que or: $r^{2}$ a 32 págs.

1267 GERARDO LOBO (E CGENIO). Obras poeticas de Don Eugenio Gerardo Lobo. Dedicadas en esta segunda edicion al mismo autor. Y añadidas vna tercera parte $\mathbf{y}$ corregidas $\mathbf{y}$ enmendadas. Pamplona Joseph Ezquerro, 17 I. $4 .{ }^{\circ}$ thojas preliminares y 243 foliadas.

Esta que debia llamarse tercera impresion es desde el fróntis una copia i plana renglon de la segumla gallitana descrita en la nota del articulo anterior: so me hace mui es. traño, por lo timto, el no haberse incluido en ellil la delicim. que debia principiar en la pis. 2i.s. solure todo advirtiendose en la portada que v'a añadida de ma lercera parte.

En el Catilingi de la venta de Conde se anunciaron las obrus poelicus y liricas. IIadrid, $1755^{2} .4^{\circ}$

1268 Obras poeticas del Exmo. Señor Don Eugenio Gerardo Lobo. Nueva edicion, aumentada con muchas Piezas posiumas. Nadricl, Joachin Ibarra, 1758. 2 rols. 4.0

El primer tomo es reimpresion del de Pam. plona; $y$ el segundo debian ser, spgrm su misma portada: lierius posesias y enlré ellas muchas del Finmo. Señol Don Eugenio Ge'rarilo Lnbo. Con muchns Piezas pos/numas, en verso y prosa, y olras inedilus de diuer: sos Aulores: pero por hads vilueltas que le doi al tomo no encuentro hava en ét ninguma composicion que no sea de Gerardo Lobo.Comprende la loa Triumpo de las mujeres y un oratorio mistico, y alegoricn, que en el cullo de varia smilssina del Pilur, canló la capilla de lin catedral de Rarcelona: entre la Fe, la Esperanza, la Cariula y Jacob y Coro de rirludes, composicion no men. cionada por el Sr. Barrera al hablar de este autor.

Hai una reimpresion de la anterior edicion de las obras, hecha tambien en Madrid, por Miguel Escribano, 1769.2 vols, $4.0^{\circ}$ 
1269 GÓMEZ (GASPAR).

\section{đUerceraparte dela tragínontedía}

de. Celeftina: $\mathfrak{n a}$ pfigniendo enlos amrozes de felides/y poládria: cōolnyenfe fag deffeados defpofozios y la muer te y defdichado fin que ella wno: eg obra dela qual fe pue denfarar dichos futitiffunos / fentencias admirables: poz muy slegante eftilo dichas agoza nuenamēte compne ftas poz Goafpar Crome; natural dela mny infigne cibdad de. Toledo: dirigida al mlagnifico canallero feliciano de silna.

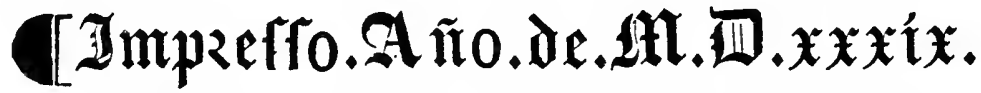

(Este título, va impreso en negro y colorado: la parte superior de la porla. da la llena una viñeta de madera, que representa el acto de ahorcar á uno, lo cual no sé que tenga relacion alguna con la obra. Al dorso principia la dedicatoria al noble cauallero Feli- ciano de Silva, que concluye en la $p \dot{a}-$ gina siguiente. Al reverso de la segunda hoja, Aij, comienza el Primer auto y el Aucto l (50), que es el último, lerrina en la hoja $6 .^{2}$ de la $\mathrm{Q}, \dot{a}$ la vuelia, con el siguiente remate:

Acabofela pzefente obza enla muy noble

¿ Imperial tinbdad d' Toledo. A veynte

dias del mes de lloniembze. En tafa

de. fiernādo de fanta catalima. Año

de nueftro feños Iefur chzifto:

de mil / Muniuientog

y treynta y $\mathfrak{m}$ me

Anog.

4. ${ }^{\circ}$ let. gót. á renglon tirado. Sin foliacion con las signs. A-Q, todas de 8 hojas, fuera de la última que es de 6 .

Brunet copiando a Panzer describe asi la primera edicion: Tercera parte de la Lragicomedia de Celeslina... agora nuevanente compuesla por Gaspar Comez. (Al in:) Acabose la presente obra en la muy noble villa de Medina del Campo. A seys dias del mes de Julio. Año de mil y quinientos y treynla $y$ seys $(1556) .4 .^{\circ}$ Iet. gót. ; pero no conociú la segunda de 15.59 y Ileber no tuvo ni una ni otra.
Al hablar de la segunda y tercera Celestina, tanto García de villanueva, en la pág. 72 del Orígen del tealro español, comn Amarita, en el prólogo á su edicion de la Celestina, se refleren á Mayans. Este no parece pueda tratar de semejante libro en ninguna de sus obras impresas á no ser en el prólogo del Pastor de Filida; pero alli ni siquiera lo mienta. Por si era equivocacion mia he registrado de nuevo la vida de Cervántes, el Specimen Bibliolhecae majansianae yi el tom. I. de los Origenes y en ninguna de estas partes hace mérito D. Gregorio Mayans de la edicion sevillana de 1.534 de las tres Celestinns reunidas, segun indica García de Villanueva. 'asemos à ver si es posible que cxistan. 
La segunda celestina no salió á nombre de s:u autor: nos lo declara su corrector Pedro Ue Mercado, como Alonso de Proaza, corrector de la primera, nos dió tambien á conocer á quien deblamos dicha parte. Este Pedro Mercado era vecino y morador de Medina del Campo; luego la ediclon que alli se conclilyó á 29 de octubre de 1534 , fué la primera, y no pudo salir una reimpresion en Sevilla aquel mismo año, del que solo quedaban dos meses.

Gaspar Gómez, autor de la tercera, pudo mucho ménos componerla en tan breve tiempo, 7 más entónces que no se escribia á destajo $\mathrm{y}$ por oficio como al presente. No es tampoco probable hiciera la primera edicion en Sevilla, sino en su patria Toledo. Por esto yo me hubiera Inclinado á creer que la edl. cion de esta ciudad del 1539 era la primera, á no darnos Panzer las señas tan circunstan. cjacias de la hecha en Yedina el año de 1536 , año en que pudo ya ver la luz la continua: cion de Gómez á la obra de Silva ; más no en 1534. - Ticknor cita una edicion de 15.57; pero como no dice ni donde se imprimió ní su tamaño, me atrevo á poner en duda su existencia. El Sr. Barrera, que no ba visto esta obra, tal es su estraordinaria rareza, trae una impresion de Tolcdo, 15539 , sacada de la Junta de libros de Tamayo de Várgas; aunque sospecho hai equirocacion, y que se refiere á la mia de 1559 .

1270 GÓMEZ TEJADA UE LOS REYES (Cosme). Noche buena. Avtos al Nacimiento del Hijo de Dios. Con sus Loas, Villancicos, bayles, y saynetes para cantar al proposito. Por el Licenciado Cosme Gomez Texada de los Reyes. Madrid, Pablo de Val, 1661. 8. 4 hojas prels. y 328 págs.

Comprende cuatro autos con sus loas, intitulados: Triunfo de la virlud. - El Soldado. -Adivina quien te did. - Inocencia y mulicia. Ademas hail varios himnos y villancicos para bailar: pero no los sainetes indicados en la portada y que nunca ha tenido.

Con razon llama el Sr. Barrera a este tomo coleccion peregrina, y su rareza es tal, que hasta él ningun bibliografo lo habia mencionado.

Dudo exista edicion anterior, á pesar de llevar la aprobacion fechada ell 1649. ¿Será error tipogrifleo por $165 \%$ !

De este autor he tenido una novela satirico-moral intitulada Leon prodigioso. Apolo. gia moral entrclenida y provechosi a las uuenas costumbres. tralo virlusso y politica. Malrid, Fruncisco Marlinez, lij.jt. Fróntis grabado.-Segunda parle de Leon prodiginso. Alcala, Francisco Gurcia Fernandez, 1675.2 vols. $40^{\circ}$ De la primem parte menci, ua Nic. Antonio una edicion tanbicn de $\$ / a$ drid, 166.5, Böhl en su Floresta otra de lilencia, $\mathbf{1} 66 \overline{5}$, y Barrera la de Madrid, 1670 y Sevilla, 1752. En dicha primera parte se cn- cuentrs un poemita Intitulado La nada, y en la segunda otro con el titinlo de El todo.

GONGORA (LUIS DE). Sus composiciones dramáticas. Véase en la Seccion poélica. Núms. 641,643 y 644 .

1271 GONZALEZ DE GARCIGONZALLZ (Artovio). Comedia famosa. Sin honor no ay amistad. De Don Antonio Gonzalez de Garci-Gonzalez. S. 1. ni a. 4. ${ }^{\circ} 18$ hojas signaturas $\mathrm{A}-\mathrm{E}$.

Barrera nn menciona á este autor dramático en su Catajlogo, ni se encuentra el tilu. lo de esta comedia en los Inulices de Medel y Huerha: sin embargo de que la edicion parece de fines del siglo Xill.

127 GONZALEZ DE SÁLAS (JtSepe Axt.). Nueva idea de la Tragedia antigua 0 llustracion ultima al libro singrlar de Poetica de Aristoteles Stagirita por Don Jusepe Antonio Gonçalez de Salas. Madrid, Francisco Martinez, cIo IoxxxI11. $4 .^{\circ} \mathrm{An}$ teporlada, fróntis grabado por loort, 3 hojas ademas prels., 363 paigs., 29 de nueva paginacion para $\mathrm{El}$ Theatro scenico a todos los hombres, $y 12$ hojas para la Bibliotheca escripta. Tiene los retratos de Aristóteles y Séneca, y la imagen del siervo cómico (pág. 1033), mui bien grabados para aquella época.

Primera edicion.-Decia D. Fregorio Yayans en el año de 1761 hablando de este libro en la rida de Leon uobra dignísima de que la simprenta la haga mis fúciluente legible. sporque se ha hecho mui rara.s

\section{3}

La misma obia. Madrid, Antonio de Sancha, 17i8. 2 rols. 8. ${ }^{\circ}$ marq. Con frontispicio. el retrato de $L$. .1. Séneca y la imaigen del sierro cónico.

Fsta obra contiene Lus Troimas, tragedia latina de Luc. An. Sincea, puesta culerso castellano pup Gollzilez de sillas. it in segunila cdicion se lia agreurado el testo latillu de dicha tratedia.

Tiekunl, tomo [1]. pày. 11?, cita mun e.li-

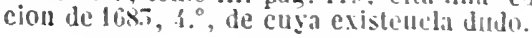

\section{7a GLARISI Batresta) El} Pastor Fido. Tragicomedia pastoral de Battista Givarino. Tradupida de 
Italiano en verso castellano por Chrisloval Srarez. Tapoles, 'Tarfuinio Longo, $1602.8 .^{\circ}$ let. curs. 'i hojas prels., 286 prigs. y una hoja al fin sin paginar, con un Soneto.

Primera edicion mui rara, desconocida í Clemencin, Pellicer y Nic. Intonio: los traductores de Tickinor no han podido verla.

1273 GUARINI (Batrista). El Pastor Fido, tragicomedia Pastoral.
De Baptista Guarini. Traduzida de Toscano en castellano por Christoval Suarez de. Figucroa. Valencia, en casa de Pedro Patricio Mey, 1609. $8 .^{\circ} 8$ hojas prels. $y$ 278 págs.

Fin vista de la diversidad del testo de una yolra colicion, no debu llanarse la presente. segunda impresion, sino mua nueva traduc. cion dol l'rstor fielo, dodir:ada al cluque de Yintua, mientras la anterior lo está á Baltasar Suirez de la Concha.

Como prueba de la completa diferencia entre mua y otra coniari el principio de ellas, debiendo observar que en toda la obra hai igual disparidad.

Testo de la calicion de 1602.

Pastores, los que cucerrado habeis la terrible flera. partid a dar con cujdido de la caza que se espera el aviso acostmmbrado.

pues Cintia it su estudio inclina de lodos las iulenciones, despertid por los rantones los ojos con la locina, con vinzes los coriazomes. sigame todo pastoj del campo y selias amigo, que si es zeloso de honor, hoi en la ocasjon commigro podrá mostriar sıl valor.

limos donde reengido en espicio limititlo. mas para pecho atrevido ancho y largo demasiado. está el javalí temido.

\section{Testo de Ia clicion de 1609 .}

Id vos los qu' encerrastes

la holrible fiera, á dar la seña usada

De Ia futura caza; id despertando

Con cl cuerno los ojos,

I con la roz los corazones. Si hubo En Arcadia jamas pastor de Cintia

Y su ejcreicio amigo,

A quien el generoso pecho, glori;

0 cuidado de selras incitase,

lloi to muestre y ne siga

Vasta donde encerrildo

Esti cn pequeño ceren,

llas campo al valor nuestro dilatado, Aquel teribible javalí, aquel mónstruo De la naturaleza y de las selvas.

rez, Henrico y Cornelio Verdussen, M.I.C.XCIV. 8. ${ }^{\circ}$ mary. 293 páginas, inclusas las dos de la hoja de la porlada, y una al fin que contiene las Erratas.

Hespucs del clogio que hizo Cervántes de la traduccion de Fi irueroa no deja de admirar la modestia de Doña Isabel Correa cuando dice en la dedicatoria: hoi que? on los ociss que me dispensa la tarea de la aquja (no parezca vanidad, lo que es ocitpacion honesla) to Iraduje melrificado en español, no celiendo en aseo y pompa a los dos sus predecesores (sc refiere á las traslaciones francesa y castellana); anles permilume la modestia el decirlo, los supero en parle, por haberlo ilustraulo con alyunas reflexiones. Y despues en cl Prólogo añade: aumifue Cristóval Snarez de Figueroa se aldelantó en el intento, y lo consiguid, no por rso desmayé on la irabajosa euipresa, dntes me puso espuclas a la ejecucion, el ver eslaba con michas quicbras de valor por carecer de lo dulce y grave del rilmo, esmalle que tuvo por imposible dar a Español, y illustrado con Reflexio-
nes por Doña Isabel Correa. Ambe- 
su traduccinn rste autor, y que yo le di d la min venciéndola con metrificadas cadencias, lisonja que utrae at más insipido oido... Per. mila me la osadiu, sin que me riña la modestia, et que me atreva d decir que escedo et original cn parte (si no me engaña el serlo en juicio propio) por haberto ilustrado con algunas refleximes etc.

A pesar de la estremada presuncion de esta señora no puede negarse á su trabajo bastante mérito, sin embargo del mal gusto que domina en su version: sirva de ejemplo el principio de la obra que podrá compararse con el ya copiado anteriormente de la version de Figueroa.

Andád vosotros, que teneis cercada La horrible flera, á dar la seña usada De la caza vecina:

Andád, $\mathbf{y}$ despertíd con la bozina Los ojos perezosos,

Y con la roz los ánimos briosos. En la leccion que sigo,

Si hai en la Arcadia algun pastor amigo De Cintio y de su estudio venatorio, Cuidado de la selva, vasto emporio De cuanto bruto cria formidable, A mi ejemplar hoi muestre infatigable El generoso pecho, y con robusto Ardor ine siga por el bosque arbusto, Donde en breve lugar, mins dilatado Campo á nuestro valor, está infestado Aquel terrible javall cerdoso.

Ticknor, en el tont. III. pág. 285, dice, era judia Doña Isabel Correa y que la edicion de $169 y^{\prime}$ de su obra es la tercera: no sé de donde se sacó lá últina noticia, pues ademas de ignorar que nadie haya citado otra más antigua, el hallarse fechada la Dedieatiria en noviembre de 1695 , me parece bastante prueba de ser primera la Impresion publicada al siguiente año.

1277 GUERRA Y RIBERA MANUEL DE). Apelacion al Tribunal de los Doctos, justa defensa de la A probacion a las Comedias de Don Pedro Calderon de la Barca, impressa en 14. de Abril del año de 168:. Impugnacion eficaz de los papeles, que salieron contra ella hasta el año de 168:3. Apologia, que dexò escrita el R.mo P. M. Fr. Manuel de Guerra y Rihera. Madrid, Joseph de Orga, MoccLIr. $4 .^{\circ}$

La Aprobacion orjoinal de 1682 se halla reimpresa por entero en este tomo. Véase el articulo de Puente Hurtado de Mendoza (Don Anlonio), en la presente division.

1978 GUERRERO (Haxcer). Respuesta á la resolicion que el Padre Gaspar Diaz, dio en la consrlta theologica acerca de lo ilicilo de representar. Y ver representar las Comedias, como se practican el dia de oy en España: donde se prueba lo licito de dichas Comedias, y se desagravia la Còmica Profession. Sr artor Manvel Gverrero, comico en la Corle. Zaragoza, Francisco Moreno, 17i3. $4^{\circ}$

\section{GïETE (JAIME DE).}

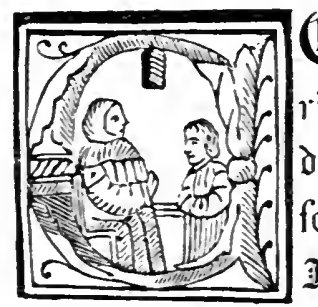

(Dimedíántútulada Tefo rina la materia dela quales $\mathfrak{x}$ nos amoses de vol peltado pos vita feñosal / y otras per" fonas adherentes. Esecha nuentamēte po: Iayme de Eanete. jero fi/po: fer fir natto ral lengua Aragonefa / no fuere pos muy cédrados termí nos / quäto a efto merece perdon fos Interlocntoses fon los infrapueftos / y es de nota que fl fravle ss catsados.

(Siguen diez figuritas que represenian los personajes del drama. llecando cada una encima su nombre.Al dorso del fróntis principia la obra que ocupa quince hojas más.) S. I. ni 'ооу. 1. a. Chacia 1323j. 4. ${ }^{\circ}$ lei. sót. Son 16 hojas con las signaturas a $y \mathrm{~b}$.

Xo habla L.atasa en sil Biblintere de Jaine? de Huete ofinete, y Yoraliu no turo mis conocimicntu de esta pieza qu lit lijel'al ill- 
dicacion hecha por el Indice espurgatorio de 15.59, tal es su estremada rareza. Para completar pues, las escasas noticias que existon de esta composicion daré un anilisis de ella.

Son interlocutores: Lucima, dama; Cite-

ria, su criada; Timbreo, padre de Lucina; Tesorino, caballero; Pinedo, su criado; Fr. Vegecio, Pero frillo, pastor; Gil Iraeho, pistor le Timbreo; Sireelo y Margarita, criado y escliva del mismo, y Juanieo, mozo del fraile.

Está dividida la comedia en cinco joruadas y precedida de un Introito.

Jornada prinera. Reprende Tesorino á Pinedo porque no le trae nuevas de Lucina; se eseusi el criado con no haber podido ver á Citcria para entregarle la carta de su amo, y le maniflesta que li ha hecho pedazos para evitar estravios. Tesirimo se incomoda; pero le promete un escudo para la sirvienta de lucina y tres para èl, si consiguen poner cu manus de sil querida otra carta.-En la escena siguiente sile Citeria con un pedazo de queso que habia agarlado, y al presentarse Lucina trata de esconderlo; lo advierte esta y la oblima i deseubrir su robo, le quita un pilo, con el cual Cileria acababa de sacudir un mantor, y se sirve de el Lucina para lacer ignal operacion con las espaldas de su eriada, quien la teja suli y se ví despiles lamentimblose de la desgracia del que se ve obligado á servir á otro.-Llega en esto fil Iracho y pide í Citeria li cena ; exige esta en cambio un requesin, èl le promete dos para otro dia: se marcha á busear la colacion para el pastor, y mientras está solo, dice entre otris cosas:

Anda que aquí me recacho, no te hari mal en el cajo el requeson,

válale la maldicinn

á l'acuella lacañosa,

creo busca guariñon,

oh, como qu'es laminosa

por tragir;

Dios que la quiero tentar, pellizcarla de las zancas, procuralla he de bresir

por ver si consiente ancas:

si viniere,

y en ello me consintiere,

yo la tomaré en la red,

y os voto á san, si quisiere, de arrimalla í li pared.

A la vuelta de Citeria pone por obra su propisito de darla un heso: pero la púdica doncella le vuelve un bofeton y lo llena de injurias, terminando la jornadia con una sarta de improperios soezes que la dirige Gil Iracho.

Jornada secrumia. Fr. Vegecio, que habla ceccando, manda i su criado Juanico saque pan, queso, miel y leche; pero este le contesta, se lo ha comido todo; el fraile enfurecido le obliga á desatacarse y le da un solenme vapulamiento; le envia despues á la ciudad para que vea de recoger pan para cenar, miéutras él se entra en casa de Timbreo: encuentra á Citeria y la pregunta por su hija de confesion Lucina, á quien desea ver con objeto de pedirla una limosna; la criada le responde que su ama no se ha levantado aun por ser mui temprano, y el padre se despide prometiendoli volver tan luego como concluya la misa.- Se presenta Tesorino paseíndose por bajo el balcon de su dama, y allí echa un largo soliloquio en el que trata de hacer ver, que Sanson, Amnon, Jacob, Polifemo, orfeo y uira porcion más de enamorados, fucron niños de teta comparados con èl. Lucina desde su ventana le ve y quiere entrarse para evitar sus miradas; pero Citeria la induce á quedarse y entabla con su amante III disilorro, en el que principiando la Señora por mostrarse algo esquiva, concluye diciendo á Tesorino:

Baste, baste, sei flime en lo que empezaste y mi ingratitud se escluya; pues con fé tan fiel amaste, si eres mio yo soi tuya. Pero quicro que sepas, que si fué fiero liasta hoi mi pensamiento, fué por proburte primero si amabis con fundamiento; que en verdid tuya es mi libertad aunque to he disimulado, $\mathrm{y}$ en ver tu fidelidal del todo me has caltivado.

Tesorino.jEs insomnio i algum hechizo emonio que engaña mi sentimiento, o ilusion del demonio, $\dot{o}$ fantasma hecha en el viento?

Lucina. lesa espina

te dieril la medicina

si el lugar diera camino: yo soi tu sierva Lucina, lii mi señor Tesorino.

Tesorino.0h, señora; pues en ti piedad ya mora, labé lástima de mí, y dame licencia agora de estar mús propinco á ti.

Lucina. Deja andar que si el tiempo da lugar, í fi, señor, te prometo de presto te contentar, con que vengas mui secreto.

Tesorino.Sea así, pero...

$$
\begin{aligned}
& \text { Lucina. } \\
& \text { vete que aquel no te vea. }
\end{aligned}
$$

Deseando, pues, Tesorino hallar algun medio para centrar en casa de su querida, y viendo al fraile que volvia de decir la misa, le ocurre el arrojarse á sils piés pidiendole fivor y socorro pues acababa de matar á un hombre en una pendencia y huía de la justicia; le pregunta el Padre, por qué medio podria librarle, y Tesorino le propone el cam. bio de trajes: asl se hace metiéndose cl 


\section{GÜE}

amante, favorecido por el disfraz, on casa de Lucina quedando el frajle en la calle. - l.lega rinedo, y viendo á un hombre vestido con las ropas de su amo, le toma pur 111 ladron y le da una terrible paliza redoblando los golpes cuanto más Fr. Vegecio protesta de su inocencia.

Jornada tercera. Se reduce casi lodi ella á un grosero y suzio diálogo entre l'ero Grillo y Gil Iracho, en el cual se encuentra alguno que otro chiste, y hácia el fin salen lucina y Tesorino despidiéndose; el galan se muestra agradecido á los favores que le ha dispensado su dama, $\boldsymbol{y}$ esta le recuerda haga venir í su confesor Fr. Vegecio para legitimar su union. Suplica Tesorino it los pastores le acompañen a la ermita en busca del fraile, y ellos acceden despues de recibir una gratiflcacion del amante.

Jornada cuarta. Pinedo viene á encargar á Citeria avise á su señora que el cunfesor se ha convenido en desposarla con su amo; llegan rste y Fr. Vegecio el cual rucga di Lucina baje al callejon, $y$ alli al aire tibre se hace la ceremonia para ia que emplea cl fraile la siguiente fórmula:

Zuz, puez zuz, hagace cl rezto, cea aci,

allegaoz loz doz aquí, dad aca loz doz laz manoz y dezta zuerte deci, con corazonez mui zanoz: yo fulano, como zan Pedro romano lo manda, oz tomo en ezpoza, plegue il Crizto zoberano nz concerve en ezta coza. Yo fulana,

tomo de mui buena gana à voz fulano en ezpozo. Nueztra zeñora y zanta Ana oz hagan vivir en grozo; voz zenิor,

didle paz con mucho amor.

$110 \mathrm{nz}$ ezteiz Ioz doz paradoz, aqueztoz del derredor cepan que zois dezpozadoz do precente:

doz palabraz zolamente me oid con atencion. quicro hacermz bievemente una breve colaciou.

IIijoz. II)ioz,

griardanz de los dezvarioz

dezte mundo iranzitnrio, no eztejz para coll Dioz frioz y penzil que liai purgatorio con ardid:

puez que unezlra vida ez lid, cada cual con lioz ze aprete que azl lo reza David, en cl zalmo trenta y ciete: Ia ocazioll no $\mathrm{ez}$ ciun una confucion y un ezcuro laberinto, y czto dive Zalomon, proverbiorum cuarto é quinto. O Deuะ quantum

peccatum in Zpiritum sanctum,
GüE

dize Dioz, no lo perdono,

legitur hoc quod est tantum, exzondn capite nono.

En fin, fln,

mi padre zan Aguzlin

y olinz trenta mil doctorez no dezmarchan en un brin deztoz zotilez primorez.

El Toztado

y otro doclor ceñalado, loan con lengua zabroza, la paciencia en el cazodo cer una mui gentil coza; que annque rea que zu mujer ce le emplea con otro por ranagloria, que tenga por cierto y crea cornu ciuz cxallabitur in gloria ad quam noz perducat elc.

Tesorino propone á Lucina, puesto que ya están casados, se vaya con él á su posada, enrargando á Fr. regecio haga saber a Timbreo el enlaze de su hija: al marchar'se encuentran á Gil Iracho, quien no quiere per. milir se lleven a su señorita, y les amenaza con dar vozes; Pinedo se encarga de apretarle el gaznali :ra evitar grite mientras todos los demas electuan la fuga.

Jornada quinta. Llega de un largo viaje Timbren, padre de Lucina, acompañado de su criado sircelo, y hallando la casa desierta pregunta i la negra Yarcarita pır el paradero de su hija: la esclavia contesta en un lenguaje tan chapurrado que no pueden entender lo que quiere decir. sin embargo de lo largo del dicílogo: entra fill Iracho, $y$ por alguna espresion que i este se le escapa sospechan está cuterado del paradero de la furitiva; le alan y le interrogan; pero nada sacan en limpio: afortunadamente aparece Fr. Vegecio, el cual se retira aparte con Timbren. consigne no solo calmar al irritado padre, sino glle llega este hasta mos-

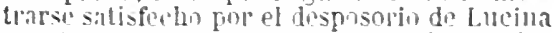
con Tesoriso, y concluse la comedia sendose tolos en busca de los nuvios.

L.7 versificacion en general es fícil: pero adolece Inda la composinion de nul lengajaje mui gunsero ge de un sinmintero de proriucialismos por los cualles ra pide el antor induluencia desle el frintis do sll obra.

bi so. barrera y ledirido sin disda no ha

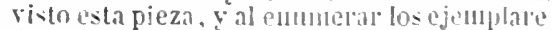
de clla que connce principia por de de the ber, signe el de Teruaux y acaba por el de la biblinteca de Munich: pries bien, pl te tle-

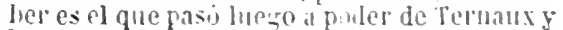
hace diais de veinticinten años rstit en el mio: de modo que en resimien solo lata los, uno ell Junich y el spgnndo sis nini libería.

Esta pieza y la siguiente de Ginete están indudablencule cjecutadas por un impresur: asi lo prueba el ser igual el papel en ambas, identicos los tipos y las mismas las viñtetis de varios de los interlocintores y hasta la $c$ adornada con gue principial "litulo en las dos, segun lo demuestra el facsimile que de clla via puesto al principio de cste y ul siguiente numero. 


\section{GÜETE (JIME DE).}

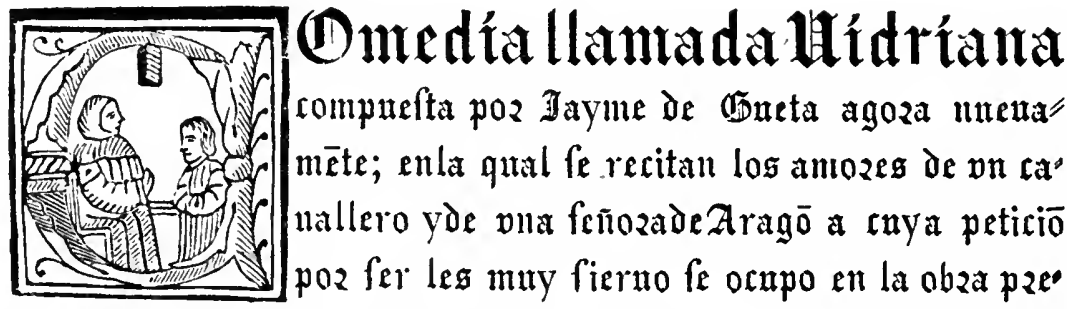
fente: el fucceflo y fur de cayos amozes va meataphosicame te tocado jufta elpzoceffo y execucion de aquellos.hay log in terlocntozes fignyentes.

\section{(Siguen diez figuritas grabadas en} madera con el nombre impreso sobre cada una de ellas.) S. l. ni a. Chácia 13̈23). 4. ${ }^{\circ}$ let. got. Son en todo 18 hojas con las signs. a $y \mathrm{~b}$, la segunda de 10 hojas.

Más rara aun que la Tesorina, pues no se conoce otro ejemplar. - No encuentro mencion de esta pieza en ninguno de nuestros bibliógrafos; Noratin ni siquiera cita su título. -Ticknor, tom. II. píg. 134, menciona este ejemplar que fué de Irr. Ternaux.

La presente comedia, como la Tesorina, estí dividida en cinco jornadas y tambien lleva un Introilo donde se espone mui lijeramente el argumento.

. Son interlocilores: Lepidano y Modesta. padre y madre de Leridana: Cetina y Oripesta, criadas de estos; Perucho y Gil Lanulo, hortelano y pastor de Lepidano; Vidriano, caballero; Secreto y Carmento, sus criados.

Jornala primera. Vidriano se lamenta del amor que profesa á Leriana y confla su pena á Secreto: le promete este, por medio de ciertas relaciones que tiene con una sirvienta de casa de Lepidano, poder lograr hable con su amada. Vidriano le bace grandes promesas si lo consigue, y manda ensillar su cabillo marchándose á distraer su dolor.Sale Carmento, á quien Secrelo da cuenta de lo acontecido con su amo, y le confiesa, que sin tener conocimiento con las criadas de Lepidano, se ha vendido í Vidriino como anigo de una de ellas; Carmento le recoInienda no se apure, porque èl conoce una doncella de la casa, pur enyo conducto podrín introdncir al pretendiente en ella.

Jornada segunda. El pastor Gil Lanudo pide la comida a Cetina, $y$ al terminar su coloquio sale Carmento. Suplica este á la criada de Leriana interceda en favor de vidriano para con su señora; Cetina presenta varias diflcultades para que sea correspondido; pero por fin ofrece poner de su parte cranto pueda con objeto de facilitar la empresa.-En la escena siguiente aparecen Leriana afligida y pesarosa, y su doncella Oripesta tratando de averiguar la callsa de su quebranto: despues de mil protestas de guardir secreto, le declara la dama procede su tristeza de habérsele acercado la víspera á hablarla cierto galan que por alli pasaba, y sin oir sus razones se habia retirado cerrando la ventana. Asegura Leriana que su pena no la causa el tener amor al tal caballero, sino el haber faltado con su proceder á la buena crianza. Oripesta la consuela y aconseja que para reparar esta falta se ponga á bordar en una reja del jardin por donde acostumbraba pasar varias vezes al dia $\mathrm{Vi}$ driano, el cual viéndola allí sola, sin duda se acercaria á hablarla y entónces, aprovechánclose de esta coyuntura, podria disculparse por su falta de atencion.

Jornada tereera. Cerca de la ventana deljarlin de Lepidano encuentra Secreto á Gij Lanudo de quien trata de inquirir el nombre de las criadas de su casa y algunas otras cosas; pero el pastor le contesta de una inanera evasiva, dejando á su interrogante en la misma ignorancia. Llega Vidriano en compañia de Carmento y viendo á Secreto le preguntan si habia adelantado en el encargo relativo á Leriana; contesta que nada, y cuando el desventurado amante empieza á que. jarse de su malhadada suerte, aparece la dama en la ventana acompañada de oripesta. Se acerca Vidriano y entabla una conversa. cion amorosa, en la cual la scñora principia mostríndose tín desdeñosa como lo hizo Lucina en la Tesorina y acaba tambien como aquella por ablandarse, aunque no llega al estremo de introducir al galan en su cuarto, sin duda porque estorbaron el diálogo los dos criados que cansados de esperar, empiezan á dar cuclilladas fingiendo riñen con seis hombres, los cuales trataban de incomodar á Vidriano: al ruido de las espadas se atemoriza Leriana y cierra la reja, terminando asi la jornada ó acto.

Jornada cuarta. Salen al jardin Lepi- 
dano y su mujer Modesta $\mathbf{y}$ discurren sobre el modo de casar á su hija, pues siendo ya viejos desean verla establecida ántes de su muerte; la madre observa que tal vez haya diflcultad en obtener el consentimiento de Leriana, pues ha renunciado i tres buenos partidos que se la han proporcionado: esta conversacion la interrumpe Oripesta, quien viene á avisar á su ama que la encajera la aguarda. Márchanse y queda solo Lepidano examinando las flores y su cultura, de la que no está satisfecho, segun se colige del largo y fastidioso coloquio entablado con el hortelano Perucho, cuya terminacion es el ccharle de sil casa.- Aparecen despues en la escena Cetina y Carmento: este requiebra á la moza en un sempiterno diálogo que concluye pidiéndola un beso, rehusa aquella dárselo, y acaba la jornada arrojando de su boca el desairado pretendiente una sarta de espresiones poco limpias.

Jornada quinta. Mndesta trata de convencer á su hija á que acceda á los deseos de su padre tomando estado; pero I.criana se imagina quieren darla por marido á uno á quien ella no ama, y rehusa complacer á su madre, prefriendo meterse mnnja.-Perucho y Gill lanudo ocupirn gran parte de la jornada on una conversacion insustancial sin relacion alguna con el cuntesto de la comedia - Oripesta hace saber a Vi. driano que á su señorita la van á encerrar en un convento, porque amándole á è se opone á unirse con otro; el juven enamrorado decide presentarse en casa de lepidann efectuándolo en el momento de llevarse a su querida à la claısura. Al ver lecrianá á su imante conflesa á su padre que sulo con Vilriano se casaria. Lepidano indaga las cualidades del novio y consiente en la bruda.

l'or el anilisis que precede se puede for. mar una idea de lo sencillo dol plan de esta comedia. El autor ha teniulo que intercalar en tndas las jornadas, con el objeto de alargarlas, interminables diálogns ajenos al asunto del driına. - La versificacion comlo en la Tesorima es fácil y fluida; adulece como aquella de provincialismos aratroneses; pero el lentruaje es menos grosero y algo más decente.
1281 HOLLAND (HENRY Richard LorD). Some account of the life and writings of Lope Felix de Vega Carpio. By Henry Richard Lord IIolland. London, Bicliard Taylor and C. ${ }^{\circ} 1806$. 8. ${ }^{\circ}$ may. Retrato.

Primera edicion.

1282 Some account of the lives and writings of Lope Felix de Vega Carpio and Guillen de Castro by IIenry Richard Lord IIolland. London, Thomas Davison, 181'. 2 volúmenes $8 .^{\circ}$ marq. Retralos de Lope y Jovellanos y tres facsímiles de la escritura de ambos.

Ia segunda edicion contiene más que la primera, lo relativo á Guillen de Castro, es decir, casi todo el tomo segundo.

He incluidn esta obra, aunque escrita en ingles, en cl presente catálogo, portratar esclusivamente de nuestra literatura, y la coloco en este lugar porque la mayor pal. te de su contenido son estractos y juicins crilions sobre las composiciones dramiticas de Castro y Lope e indices de sus comedias.

1283 IIOROZCO (Sebastian). Noticias y obras inciditas de este autor dramático desconocido. Por D. José
María Asensio : Toledo. Sevilla, José María Geofrín, 1867. 8. ${ }^{\circ}$

Contiene este precioso tomito la Represen. tacion de la narabola de sant buluto i los ve!nte copinnlos de su sagrado "ramprlio.

liepresentacion de la historia e'ranjolira del capilulo de Saurt Jomm, que comirnan, et praeteriens Jhs. vidit hominen concrim.

Siguese un ontremess que hiso cl anctor $\dot{a}$ ruequ de ma monja.

Glosmin de las l'r.ces anticualas nscuras y de ductosa aromeim the so momentran on

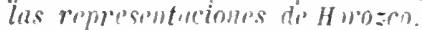

Todio va precedido de lla elouljto a intere. sante prolo:n, escrito por el ilustrabin cult ir

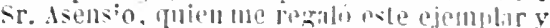
puso al principio un afectuoso recuerdo in. toiralo.

\section{IILRTADO DE MEYDOZA} (Axтово). El Fenix caslellano D. Antonio de Irendoga. renacirio de la gran Bibliotheca d'el Iluslrissimo Señor Luis de Sousil. Lisbua. Miruel Menescal, M.Mc.xc. 1. ' thojus preliminares y 164 pays.

Barrera calitica de mui escasa esta primera fucion y advicite no laber conseguido rer 1111 solo rjomplar de ella. Yir se liallan en l.t posentis juplesion la comblia

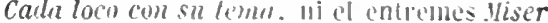
Palomo que comprende la segunda.

1983 - Obrils liricils i comicas, divinas y humanas, cou la celes- 
tial ambrosia del admirable poema sacro de Maria Santisima, ultimo divino suave aliento de... D. Antonio Hurtado de Mendoza. Segunda impresion. Añadidas algunas obras, que se tienen por ciertas, y verdaderas del Autor. Madrid, Juan de Zuñiga, (1728). 4. 8 hojas prels., 91 paiqinas pura la Vida de Nra. Sra., 174 págs. y una hoja de Tabla.

Les:

Este tomo contiene las comedias siguien.

Querer por solo querer.

No hai amor donde hai agravio.

El marido hace inujer, y el trato muda costimmbre.

l.os empeños del mentir.

Más merece quien mis ama.

Cada loco con su tema. Ariadida en esta se. gunda edicion.

Miser Palumo. Entremes. No está en la primera edicion.

El poema de la Vitla de Nuestra Scñoril que se halla en ambasediciones se imprimio por separado. Víase en la Seccion poélira al articulo de esle autor. Ninm. 6si. El entremes de Niser Pelomo sulo comprende la Parte primer'e.

1286 IIURTADO DE HENDOZI (D. Avrovio). El ingenioso entremes del examinador Miser Palomo. Compuesto por Don Antonio de Mendoça. Talencia, junto al molino de Rourlla. 1620.-Servida parte del entremes de Mliser Palomo y Medico de Espiritu. Compuesto por don Antonio de Menduca. En Valencia, por Svluestre Esparsa, 16⒏ 8. Líminas de marlera en las portadas. Cada una de las partes de 8 hojas.

Edicion mui rara-Barlera y Leiralo ma la mencioua ni al hablar de este entremes bace

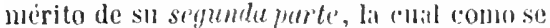
ve, lleva una adicion en el título. Si diulus sr. Barrera hubiese tenido presente estil edicion de Miser Palomo, no se bubjera coulenlado con decir fue Mendoza paje tel conde de Saldaña, pues mís tarde llegi a ser su gentil-hombre, como lo espresan las portadas de ambas parte's del entreuses.

En la edicion de las obras luecha en Ma-

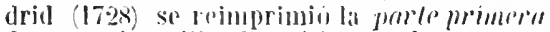
de esta piezecilla dramilioa; de la seymula no conozer más gue la de lizes, ni he visto mas ejemplar que el mio.

1287 IIURTDO DE MENDOZA (ANTONIO). Qverer por solo querer, comedia que representaron las señoras meninas, a los años de la reyna nvestra señora. Escriuiola D. Antonio de Mendoça. En Madrid, Por Iuan de la Cuesta, 1623. 4. 6 hojas prels., inclusas una blanca que precede $\boldsymbol{i}$ la portadla y las dos de la Loa que va al frente de la comedia, y 38 hojas fols. -Fiesta que se hizo en Aranivez a los años del rey nvestro señor $\mathbf{D}$. Felipe IIII. Escrita por D. Antonio de Mendoca. Madrid, Por Iuan de la Cuesta, 1623. 4. 26 hojas fols., inclusa la portada.

Raro.-Despues de la descripcion en prosa de la flesta, hai una relacion dialogada de la inisma.

\section{IUURTADO DE LA VERA} (Penro). La Doleria del sveño del Mlundo. Comedia Tratada por via de Ihilosoph. Moral. luntamente van aqui. Los Proverbios morales Hechos por Alonso Guajardo Fajardo. Paris, Ivan Foiiel, H.D.C.XIIII. 12. 6 hojas preliminares y 193 fols. Luego viene meva portada para Los Proverbios morales, los cuales tienen seis hojas preliminares clas dos últimas blancas), $\mathbf{1}$ foliadas rla última dice $\mathbf{4 6}$ por errata) y una blanca.

Existen de esta comedia, segun Brunet, dos pdiciones de Allvers, ILerederos de Inan Steelsio, 1572 y 1579 , ambis en $8 .^{\circ}:$ Barrera y Leirado menciona otra tambien de Amberes, en casa de Guslenio lansens, 1595. 16.': ninguna de ellas contiene los Proverbios; pero sin duda llevan el nombre de IInrtado de la Vera, que en la de Paris un comsta jor parte alguma. Nic. Antonio en el artíenlo de dicho aubor le alribuye esta obra y menciona all la edicion de 1572 ; entre los Auonimos se encuentra la Doleria y cita la impresion de Jaris, I61/4; y al hiblitr de Alonso Guajardo, supone ser suya esta produccion dramítiea y que salio á lız en l'aris por Juan Fouci (supongo querrá decir Foüet); pero no le fija año.

De la Carta dedicaloria de Sebastian Leon que precelle á los proverbios, aparece los

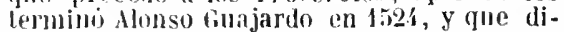
cho Leon los publicabi por primera vez en Cordova: asi es que Nic. Antomio trae una Plicion de aquella ciulad heclia por Gabriel Bejurano en 1585. 8. ${ }^{\circ}$ y efectivamente al fin de la impresion que yo lengo de Paris, se lee: Impresso en Cordova. En casu de Gabriel Ramos Vejarano. 
Los Proverblos de Fajardo son dosclentos ochenta; cincuenta de los cuales acompañados de la verslon francesa publícó César oudin al fin de sus Refranes.

Todas las ediclones de la Doleria son raras.
D. Pedro Hurtado de la Vera tradnjo del italiano la Historia lastimera of el Principe Erasto, hijo del Emperador Diocleciano. Anver's, Buida y herederos de Iuan Stelsio, 1573. $12^{\circ}$
1289 INDICE GENERAL ALFABETICO de todos los títulos de comedias, que se han escrito por varios Autores, antiguos, y modernos. Y de los Autos sacramentales, $y$ alegoricos, assi de Don Pedro Cálderon de la Barca, como de otros Autores clasicos. Madrid, Alfonso de Mora, M.DCC.XXXV. 4. 136 págs. en todo.

El presente volumen es ya escaso.

Al pié de la portada se advierte que todas las comedias $y$ autos comprendidos en este Índice se hallaban en pnder de los Herederos de Francisco Medel del Castillo, y de aquí le viene el ser conocido por Indice de sedel.

He visto un tomo en $4^{\circ}$, manuscrito, denominado:

Coleccion de tilulos de comedizs, formada por D. Francisco Nieto de Molina. Madrid, 1774, y otro inupreso, intitulado:

Catalogo de Comedias de los mejores ingenios de España. Madrid, 1681. 4.", diversos del Indice publicado en 1735.

1292 JUVENTUD (LA) TRILYFANTE. La Juventud triunfante, Representada en las Fiestas, con que celebrò el Colegio Real de la Compañia de Jesus de Salamanca la Canonizacion de San Luis Gonzaga, y San Stanislao Kostka. Obra escrita por un Ingenio de Salamanca. Salamanca, Eugenio Garcia de IIonorato y San Miguel, (1797). 4. $0^{\circ} 10$ hojas préliminares $y \mathbf{1 1}$ pags.

$$
1293-\text { La misma obra. }
$$
Valencia, Joseph Estevan Dolz, 173̈0.
1290 INTRODUCCION al drama, que ha de representarse en el teatro del Real Seminario de nobles de esta Corte, á los serenisimos Príncipes de Asturias é Infantes de Éspaña, por los caballeros seminaristas. Madrid, Joachin Ibarra, MDCCLXXXIV. 4. marq.

Ejemplar en gran papel de una obra impresa solo para regalos.

Comprende una zarzliela ó égloga pastoril representable, la tragedia Joseph vendido y una pieza en un acto intitulada: Academia de música y poeria.

1291 IRIARTE (Bernardo). Papel que estendió para el teatro de la Corte. MS. orininal en $4 .^{\circ}$

Contiene nbservaciones sobre los defectos de ciertas clases de composiciones dramáticas, y propone algunas reformas que debian introducirse en las representaciones teatrales de los coliseos de la corte.

4. 10 hojas prels., 407 págs. y una hoja en que termina el Indice.

Esta edicion se hizo di plana renglon por la de Silamanca; pero resulta al fin que tiene dos páginas minos, porque la des silamanca saltal de la 145 i 146 , sin rectiticar esta eriata.

Ademas de las varias poesias que compren. de el volimén, hai en cl los siguientes dramas:

Gradn de San Luis fionzaga. Zarzmelu. Grado de Sall stinislao hustha. Zur:zuclu. Dos colnquios entre los ermitaĩos Alberto $y$ Roque.

Diálogo éutre el Bueu gusto y el Mal gusto.

Barrela y Leirado no menciona esta obra ui sus composiciones dramdicas. 
1294 LAMARCA (D. Luis). El teatro de Vilencia desde su orígen hasta nuestros dias. Por D. Luis Lamarca. Valencia, J. Ferrer de Orga, 1840. $8 .^{\circ}$

obra mui escasa, llena de noticias curiosísimas sobre el teatro de Valencia y en la que se encuentra un catálogo mui completo de los autores drantáticos de este pais y los títulos de las comedias que escribieron.

Aprecio en mucho el ejemplar que me re. mitió el Sr. Lamarca á Paris por llevar al principio la siguiente nota autografa: "Al "Sr. D. Pedro Salvá, como recuerdo de la "patria, su anigo L. Lamarca."

\section{9: LEIVA RAMIREZ DE ARE-} LLaNO (Francisco de). Comedias escogidas de Don Francisco de Leyba. Tomo primero (y uinico). Madrid, Ortega, $1833.8 .^{\circ}$

Comprende estas comedias:

Cuando no se aguarda, y príneipe tonto.

La dama presidente.

Edicion mala y castrada; pero merece leerse el Exámen de cada comedia.

1296 LEON MARCIIANTE (MANUEL DE). Obras poeticas posthumas, que a diversos assumptos escrivio el Maestro Don Manuel de Leon Marchante, divididas en tres classes, sagradas, humanas, y comicas. Madrid, Gabriel del Barrio, M.DccxxIIxxxiII. 2 vols. $4 .^{\circ} \mathrm{El}$ primero tiene 12 hojas prels., 468 pägs. y 2 hojas de Indice, $y$ el serundo 10 hojas preliminares cla viltima lleva el retrato del autor grabado en madera), 384 paiginas y 4 hojas de Indice.

Por las aprobaciones del tomo serundo, por el privilegio y prologo del misino, es evidente se pensaba publicar el terecro con poesias líricas y cómicas; pero yo no lo he visto.

El tomo primero, ademas de varias poesías, contiene las siguientes composiciones dranáticas:

Loa al patriarca s. Pedro Nolasco.

Planctas y signos. $L$.

El relij. $L$.

Virgen de la Salceda. C.-En colaboracion de b. Liego Calleja.
Las dos estrellas de Francia. C.-Escrila con el mismo Calleja.

Los dos mejores hermanos, san Justo y Pastor. C.-Tambien con Calleju.

No hai amar como fingir. $C$.

El gato y la montera. $E$.

Las barbas de balde. $E$.

la estafeta. $E$.

Dia de compadres. $E$.

Refugio de los poetas. $E$.

El abad del Campillo. E.

los pajes golosos. $E$.

Los alcaldes. $M$.

Los espejos. $E$.

l.a pulga y la chispa. $B$.

Borracho y Talaveron. $B$

Gargalla. Jácara entremesada.

1297 LISTA (Alberto). Lecciones de literatura dramatica española, esplicadas en el Ateneo Científico, Literario y Artístico por Don Alberto Lista. Tomo I. $^{\circ}$ Madrid, Nicolas Arias, 1839. 4. $^{\mathrm{a}}$

Son en todo quince lecciones: la décima quinta pertenece ya al tomo segundo. No se publicaron más.

\section{LÓPEZ RANJEL (Pedro).} 河) A farea figuicute no2 'i renerécia del gloziofo nafei miento de nueftro redéptos $\mathbb{J} e f_{\mathfrak{u}}$ chzifto $r$ dela virg $\overline{\mathrm{e}} \mathrm{gloziofa}$ madre fuya. Eu la $\bar{q} l f_{\mathfrak{e}}$ introducē quatro paftozes. los nōbzes delos $\bar{q}$ les fon / Juall / Domingo bzas / benito / y $\mathfrak{v n}$ faluaje $\bar{q}$ los viene affombzar. 11 entra Inan diziédo.

(Esta leyenda solo ocupa cinco lineas en el original. Sigue una laminita de madera que representa el $\mathrm{Na}$ cimiento y bajo principia la pieza.) S. l. ni a. (hicia 1330 onterior). $4 .^{\circ}$ let. gót. 4 hojas con solo la sign. aij.

Unico ejemplar que se conoce el cual perteneció a Mr. Ternaux Compans hace veintisicte $\dot{o}$ veintiocho años, y ál se refleren Ticknor, en la Hist. de la lit. esp. tom.I. 
pág. 15j5, y Barrera en su Catdlogo: pero me iguro que ninguno de los dos lo ha tenido presente al describirlo.

El título de esta farsa, no conocida por Moratin, ya indica suflcientemente su argumento, que es en estremo sencillo.

Aparécese un ángel á Juan y le anuncia el parto de la tirgen; reune aquel á sus compañeros Domingo, Bras y Benito y les propone vayan à ver ai recien nacido: Benito opone algo de resistencia á alejarse de all porque ha perdido su burra, segun lo espone en el siguiente diálogo:

Benito. ¿Viste por allá mi burra, que se me ha ido perdida?

Juan. Oh, Dius praga con tu vida, y á tal recaudo la posiste.

-Bras. Si es de lobos ya comida.

Benito. A dora mala veniste.

Bras. Pues qué quieres que te diga, do al diabro tu cordojo; quieres que te di una higa?

Benilo. Para tí y para tu ojo.

Bras. Pues, juria sant, si me enojo que te dé un palo mui huerte.

Juan. oh, do al diabro tu antojo que se le achacara muerte: siempre huste mal criado.

Bras. Eso no lo ha de agora.

Juan. Ves que está ahı la señora y haste desmesurado.

Bras. Calla que estoi enojado que no es mucho que me aburra, porque se perdió la burra de Benito cl desposado.

Juan. Oh, Dins! praga no te aburras por una burra pelada, ui aun que fueran dos burrias.

Benilo. In al diabro tus bandırias, nunca te costi a ti nada.

Juan. Calla triste dolorido, no tienes saber de nada, quizás Domingo la vido por allá por la cañada.

Benito. Ah, Domingo, y de Bras?

Domin. Acá tras csta balranca.

Benito. No viste alla mi burranca?

Domin. Vídela yo cara atrás; y cómo se te perdio? Si sabes, di, dolorido.

Benito. Oh, Dios praga y qué sé yo

Domin. Por mi fé yo no la he vido: oh, lii de puta, y que scutido quc tienes tú de nu nada.

Bras. Si se te quedó perdida por olvido en la majada.

Benito. Dende agora esta mirada, cuanto ha que la lie mirado, que buscando la he andado toda esta madrugada.
Por fin se conforma y marcha con los otros entonando los cuatro este Villancico:

Hoi parló la luz del dla, hoi parió; gran gasajo y alegría tengo yo.

Hol parió una doncella tan hermosa, tan esmerada, y tan bella, y tan graciosa, que nunca tal se veria ni se vió; gran gasajo é alegria tengo yo.

Hoi grande gozo se hace en el cielo, por este quis ahi haze en el suelo: hoi luz nuera nos envia que nos dió; gran gasajo é alcgria tengo yo.

Para cobrar fuerzas sin duda, ántes de cmprender la jornada almuerzan, $y$ aquí hai el siguiente diálogro animado y fácil en que unos á otros se achacan su descomunal apetito.

Benito. Daca, Bras, almorciquemos, saca pan de tu milocha.

Domin. Pues que canticado habemos, comamos la miga cocha.

Bras. Praceme de lo hacer: yo eucharas sacaré

Juan. Y el ganado?

Benito. Ahirquenle. pucs es noche le pracer.

Juru. Hincarancho! Hincarancho! coniamos a imucrie y sorbe, hasta que este lleno el pancho uno it otro no se estorbe.

thmin. Que nos prace lal jormada.

Benito. Comannos todos it tanto.

bras. Echa. Juan, la sontiguada.

Juan. Xombre del l'Espirto sinto! como estís arrpllanado.

Benito. Pues, qué quieres li que haga?

Juan. Due vayas í tı ganado.

Bras. Oh, hi de puta, y cumn traga!

Benito. Hago bien mientras me vaga.

Domin. Nunca vi tan gran tragar.

Benito. Pues ros no me vais en zaga. don hí de pula. rapaz.

Juru. Esteunos açora on piz. siquiera mientra almorzanos: no mires ese rapaz. por comer, munca riugamos.

Benito. Ujo, ojo, que bastaje que vien entre aquellos ramos, que quieres, Bras, que hagamos:

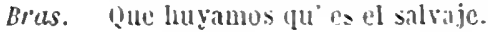


Se introduce efectivamente este nuevo interlocutor sin otro objeto que cl de asustar á Juan, quien se conoce estaba algo apartado de sus amigos; se reune con estos y se van á Belen hablando por el camino, $y$ ántes de llegar dice:

Benilo. D1, Juan, ¿qué le llevaremos, tú que sabes más que nos?

Juan. De lo que mejor tenemos, pues que es madre de Dios.

Domin. Yo le entiendo de llevar, porque por suyo me haya, un labrado cucharal y una barreña de haya.

Benilo. Yo le andonaré al chiquito un gran don, que ese no 's nada.

Bras. Qụe, Benito?

Benito. Un corderito de mi oveja la preñada: Quẻ esperanza de manada! Qué le llevarás tú, Bras?

Bras. In presado de cuajada que, juria sant, vale más.

Domin. Et tu Juan, ¿no llevas algo á este bello garzon?

ruan. No quiero llevar embargo más de un mondo corazon.

Domin. Soncas, soncas de nacion, lo tuvo siempre y de coro: Dios es limpio corazon más que montones de oro.

Benito. Pues vamos no nos tardemos, cata que estas espacioso.

Juan. Viamos luego, quẻ hacemos?

Bras. iDí, Juan, cómo le diremos á este rei glorïoso?

Jian. Ln cantar sea gracioso.

Fntonan este villancico en presencia del Xiño y se van despues cantando otro.

liuiha, huiho, pues nasció el que el inundo redimio.

Nasció de una doncella tan hermosa y tan bella, relimbrante como estrella, y sinta y lirgen parió al que el mundo redimio.

lino para nos salvar este rei celestïal, váınoslo, Mingo, adorar que: diz que en Belen nasció el que el mundo redimió.

vamos todos en buen hora. veremios á la señora (ju* es del cielo emperadora, y santa y víroren pario el que el mundo redimió.

Là versificacion es buena y los pensamien. tos adecuados á los personajes del drama.
1299 LÓPEZ DE ÚBEDA (JUAN).

CANCIONERO.

General, de la Doctrina

Chriftiana, muy vtil y prouechofo,

en todo genero de verfo Caftellano.

HECHOPORELLICEN CIA de Iuā Lopez de Vbeda,natural de To ledo, fundador del Siminario de lcs ni ños de la Doctrina de alcala de Henares, cō otras muchas obras, recogidas de muy graues autores. (.?.)

DIRIGIDO ALILLVSTRE SEnor Licenciado Salas, Vicario general de la Corte de Madrid. (.?.)

CON PRIVILEGIO REAL. En Alcala de Henares, en cafa de Hernan Ramirez Impreffor y mercader a $\rightarrow$ de libros.Año de. 1586 .

8. 12 hojas prels. y 244 fols.

La mayor parte del volumen se compone de romances, villancicos, octavas, canciones, sonctos, motetes, coplas, letras, ctc., de López de Übeda, el Mtro. Arce, el Mtro. Jiménez, el Mitro. Marco Antonio, el Mtro. Cámara, Lic. Kul López de Zúñiga, Fr. Pedro de Mendoza, Lic. Vergara y el Lic. Braujos; el resto del tomo lo forman las siguientes piezas dramáticas escritas tambien en verso.

Colloquio del sancto naciniento de Nuestro Señor lesu Christo, entre tres pastores, llamados, Discrecion: Cequedad y Rude $\approx$.

Comedia de San Alexo agora nueuanète lraluzida, de vn libro de prosa suyo, en diuersidud y variedal de verso Castellano, por el Licenciado luan Lopez de Vueda, y por Cornejo de Rajas, son interlocutores, el Emperador, y Sabina su hi.ja, Alejo y Eufemiano su padre, y su madre, vn Anget, vs demonios un camarero, un peregrino, y olras persona, que se contienè en la obra.

Comedia de virludes crintra los vicios, en la qual ay los interlocutores que se siguen. El Mundo. Soberuia. Luxuria. Regalo. Apetito. Cupido. Demonio. IIombre. Fe. Esperanç. Caridud. Fortaleza. Iusticia. Amor de Dios. Memoria Entendimiento. Es nueuamenle hecha, de grá doctrina y erudicion, assi para recreacion del entendiniento, como para prouecho del alma. 
'Auto de la Esposa en los Cuntares, entran las personas siguientes. Tl La Esposa. El Genero humano. La Grucia. La Confession. La Contricion La Penitencia. Christo. La Hipo. chresia. El Demonio. Don de Forla'eza.

Moratin y Barrera no solo no mencionan ninguna de eslas composiciones, sino que omiten los nnmbres de lopez de libeda y cornejo de Rójas entre los autores dramáticos: la rareza del libro hace disimulable esta omi. sion; yo no he vistn otro ejemplar.

vic. Antonin cita und edicion de este Cancionero de 1579, cuya existencia demuestran las aprobaclones y privilegio de la de 1586, fechados en 1578.

El Vergel de fores divinas, del mlsmo au. tor, descrito en la Division de Cancioneros $y$ Romanceros, Núm. 272 , comprende muchas de las poesías contenidas en el presente cancionero; pero ademas de que una buena porcion dejaron de incluirse en aquella obra, se omiticron el Coloquio, las Comedias y el Auto.

1300 LÓPEZ DE YANGLAS (FEB$\mathbf{N A} \mathbf{i})$.
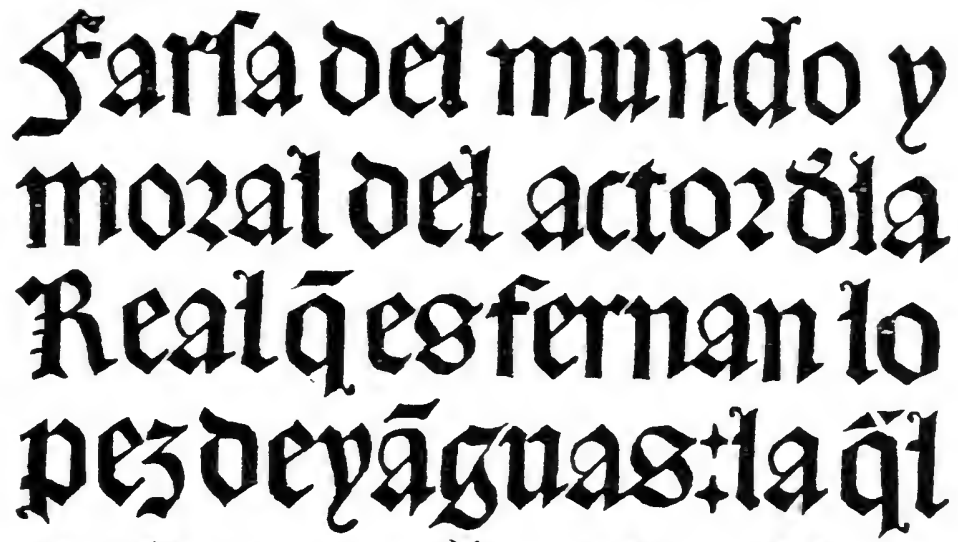

yadritgidaalaylluí

treyanfimagnifica

reñozatareñozado:

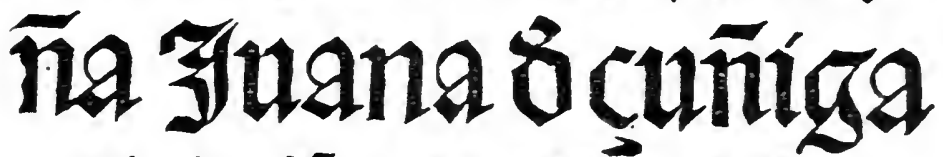

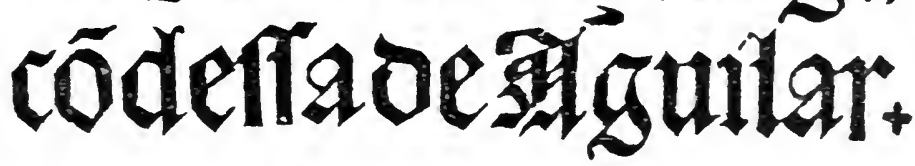

Tyanguas+

$1524++$ 
(Al dorso se halla el Prólogo y dedicatoria, de que hablaré despues; en la hoja siguiente aij, principia la obra que concluye al reverso de la 16.) S. 1. 4. ${ }^{\circ}$ let. gót. 16 hojas con las signs. a y b, sin foliacion.

Edicion rarisima desconocida í todos nuestros bibliógrafos: Cañete en el prólogo á las Farsas de I. Feruández menciona una de 1528 y el Sr. Barrera se reflere al ejemplar existenic en la biblioteca de Nunich, de otra impresion en cuya portada se lee: Fin'sa del mundo y moral del autor de la real que es Fernan Lopez de Yanguas: la gual va dirigida a la illustrissima y magnifica señora, la señora doña Juana te Cuñiga, Condesa de Aguilar. M.D.L.I. (1551). S. l. 4. ' let. gót. 16 hojas con signatura.

Para dar alguna idea de su argumento, de la clase de metro en que está escrita, y hasta algunos apuntes bingrífleos del autor, copiaré una especie de prólogro y la dedicatoria, puestos al principio:

- Farsa del mundo y moral del auctor dela Real. Esta presente drama es nueuamète cópuesta por Hernan lopez de yanguas sobre este dicho del Apostol que dize. Hec est victoria jo vincil mundum fides nostra. En la qual se introduzi qualro Jnterloculores. Él primero es el mismo müdo. El segundo es vn pastor llamado Apetilo. El tercero vn. Hermilaño. El quario es la. Fe: es la Jntenció del anclor magnifesta. las cautelas det mudo. Como engañan a calla uno de nosotros á se enliédle por el apelito. Junto cõ este. Como por el hermilanio ì es la prenlicació e religió nos arvimumos ala fe y có plla le vécemos como la obra declara Relala se en fill la Assumpció de nuestra señma: enla qual a!y biè ij ver i no ver porrue no alcican los ojos. Acaba con su musica cicertadamente: dirigida ala muy illustre \& ansi magnifien señora: la señora doñu Juana de Cuñiga Códesa de aljuilar: el müdo se ha de vestir. como rey apelito como pastor. El hermitaño como 10 eś la fe como Dama: a un ramo verde en la mami.

\section{El ariclor aquiè divige la obra.}

C Jlhslre señora: caulal rio sin vados en rutien la belle:a: del mutulo se pncierra qumilo fortma: mo tumo on su tierra solian nor sevilla: volar mis cuydalos mas despue prisirron: sacarne mis hados a lierress 'slinaña': cesso mi exercicio pero an queser tardr: no es tarde el servicio resciba estos metros: assi dedicados.

De este mismo autor debe ser la siguiente pieza que se halla on la Biblioleca imperial de Viena:

Eqloga nueuctmente Trobada por IIernando de Yangunas, en lore de la natiuidarl de mostro señor: En la quat se introdusen quatro prstores. Cryos nombres son. Mingo subido. Gil pata. Benitillo. Pero punça. Los quales irformados de los angeles como chrislo era y a nacido vienenle adorar y ofrecen sus do. nes y nuestra señora da las gracias y llega mingo sabido tunendo una gayla, $y$ dice... etcétera. S. $l$. ni $a$. $40^{\circ}$ let. gót. 8 hojas. Está en estrofas de arte mayor $y$ concluye con un Villancico.

Cañete en el pról. á las Fursas de L. Fernández menciona del mismo Yánguas:

Farsa de genealogia.

Farsa de Natividad.

Drama. Empicza: "Mas ba que guardo rebaños.»

Farsa turquesca.

Farsa sacramental, en coplas.

Ignoro si se han impreso.

Dicho Sr. Cañete en el mismo lugar pretende que la Farsa reul á la cual se alude en la portada de la del mundo, es la siguiente, en poiler del señor de Gayángos:

Fu'sa nuenamente compuesta por Hernan lopes de Yanquas: sobre la felice nueua de la concordia y jaz e concicr to de nuestro felicis. simo Emperadm semper augusto: y del crislianissimo key de Francia.

A mi entender se equivocó el señor de Cañete en suposicion semejante: la pieza que posee cl scñor de Gayángos se reflere indudablemente á la capitulacion de paz entre el Emperador y el rei de Francia Francisco, celebrada en Madrid á 14 de enero de 1526 , y por consiguiente mal podia hacerse referencia d ella en la portada de la composicion dramitica que yo poseo, fechada en 1524.

1301 LÓPEZ DE ZARATE (FraNcIsco). Obras varias de Francisco Lopez de Zarate. En Alcala, Maria Fernandez, 1651. 4. ${ }^{\circ} 30$ hojas al principio sin foliar que comprenden: 6 de prels., 23 con tres Silvas $y$ un Epitalamio y una blanca; ademas 339 foliadas.

En esti edicion mo solo se han incluido las poesfas contenidas en el tomito impreso en 1619 , sino tambien se aumentaron otras muchas y se añadio la Tragedia le IIércules furenle y Oeta, con todo el rigor del arte.

L.os tradnetores de Ticknor, tom. III., página 515 , supmen que en esta impresion se espresi haberse concedido la licencia al alltor en 1622; en ello hai crror, pues dice ser en 162!), y anln esto es una equivocacion tipografica, pues deberia Ieerse 1619.

El editor de la edicion de 1651 , Tomas Alfay, pide en un prólogo dirigido al lector, indulgencia por las erratas que puedan hallarse en el volímen, las cuales provenian de no haber atendido el autor á la correccion por el estado delicado de su salud.

1302 LOZano (Cristóval). Persecvciones de Lvcinda dama valenciana; y tragicos sucessos de Don 
Carlos. Por el Dotor Christoval Loçano. Valencia, Siluestre Esparsa, 1611. 8. 8 hojas prels. (inclusas dos blancas y una con un escudo de armas) $y 288$ paifs.

Las aprobaciones de esta obra están fechadas en Valencia en 1656 , cuya circunstancia me hace creer existirá probablemente alguna edicion anterior; sin embargo la presente es tan rara que Barrera no turo noticia de ella.

1303 LOZano (Cristóval). Persecrciones de Lvcinda, dama valenciana, y tragicos sucessos de Don Carlos. Valencia, Benito Macè, 1664. 8. 3 hojas prels. y $283 \ddot{~ p a ́ g s . ~}$

Nic. Antonio no habla de esta obra de L.o. zano. Es una novela la cual contiene algunas poesías y la comedia intitulada : Darse zelos por ventarse.

Se halla esta novela, sin la comedia, al fin de algunas de las ediciones de las Soledades de la vida, del mismo Lozano.

En una advertencia al lector dice el autor, que hacia ya seis años tenia detenida lá publicacion de otra novela titulada: Las $S e-$ rafinas; la cual conflaba dar pronto á luz: no tengo noticia de que jamas se haya impreso.
1304 LUQUE (JUAN DE). Divina poesia y varios conceptos á las fiestas principales del Año que se ponen por su Calendario. Con los santos nueb os y todo genero de Poesias. Ponense al fin en verso los dias en que caen las fiestas de guardar. Y la quenta para saber de memoria las mouibles Por el Licenciado Iran de Luque. Lisboa, Iuna (Iuan) de Lira, Año de $16088 .^{\circ} 8$ hojas prels. y 560 págs.

Se hallan en este volúmen composiciones en todo género de metros; pero abundan especialmente los romances y villancicos, algunos en diálogo y uno en lenguajc guineo.

Al fin hai varias piezas dramalicas, entre ellas una A la Redencion del género humcho. Pleito ejeculivo entre el Genero humano y el Casligo. Son interlocutures: Justicia, Razon, Relalor, Misericordia, Abogado del Genero humano y Rigor, abogado del Castigo.-La Pasion de Cristo, turien. Interlocutores: La Juslir:iu y la Fe, una Lna y cuatro Autos.

Nadi prueba Lanlo la singular rareza de este libro como el que el Sr. Barrera no haga en su Calálugo ld más lijera mencion del licenciado Juan de Luque, ni de su obra.
1305 MaCIIADO (Simā̃). Comedias portuguezas, Fertas pelo excellente Poeta Simaó Liachado Conedias do Cerco de Dio, primerra, \& segunda parte. Comedias da Pastora Alfea, primeyra, \& segunda parte. Nesta terceyra impressāo emendadas, \& acrescentadas, dous Entremeses \& quatro Loas famosas. Lislboa, Antonio Pedrozo Galram, 1706. 4. $^{\circ}$ Q hojas prels. $y$ 2912 págs.

Las counedias del Cerco de bin y las de Alfea están en portugues y castellano.

Los dos entremeses coll que va acrecentada esta edicion son: La endemoniuda fingida y chistes de Bricallas, de D. Francisco de Quevedo y La Infunta Palancona, Anónimo: las cuatro Loas dice sun de Lope de Vega; pero Barrera lo nieza.

Nic. Antonio y Birunet cilan una edicion de Lisbou, Alvares, 1631.4. ${ }^{\circ}$ no sé si scrí la primera 0 la segunda.-Serun Barrera y Brınet, Simāo Machado es el l'adre Buenaventura Machado, a quien vic. Antonio solo atribuye La Vidu del P. Pedro Diuz y sus Compañeros, impresa en Barcelona, $16.524^{\circ}$

\section{M}

1306 MANOGITO DE ENTREMESES, a diferentes assumptos, de Bayles, Y Mogigangas. Escritos Por las mejores plumas de nuestra España. Pamplona, 1700. 8. 133 págs. en todo.

Comprende las mismas composicinmes que la Floreslit le enlieme'ses, impresa en Vadrid cil $] 691$, inénos al entremes intitulado: La Relifuia.

Barlera y Leiradu no menciona esta coleccion de entremeses; prueba de no encontrarse fácilmente.

\section{MARTINET DE LA ROSA} (Fraxcisco). Porsias y las dos comedias, los Zelos infundados, \&o que puede un empleo! de Don Francisco Martinez de la Rosa. Paris, Bacquenois, $1836120^{\circ}$ niay. Retrato.

Al reimprimil ni palre ol tomito con las Poesias y los Zelos infmudalos ile Vartinez de la Rusa, publicado intes él Mindoid cu $8 .{ }^{0}$ marq. , no solo uniformo ambas producciones con el tamañn desus obrils lilerarius 
impresas en Paris, en 1827 , en 5 vols., sino que añadio, para commpletarlas, la comedia Lo que puede un empleo! no reproducida por su autor, á causa de circunstancias particulares $\dot{0}$ cousideraciones políticas, las cuales mi padre jamas tuvo necesidad de guardar.

1308 Mártir RiZO (Juan Pablo). Historia tragica de la vida del Dvque de Biron, con sv Comedia a la fin. Sv avtor Ivan Pablo Martyr Rizo. Barcelona, Gabriel Nogues, 163 . 8. ${ }^{\circ}$ hojas prels. y 137 fols.

La comedia que va al fin es la de Pérez de Montalvan titulada: El mariscal de Biron, la cual ocupa desde el fol. 88 vta. hasta el 157 . Barrera no lo advierte en el articulo de Montalvall.

Nic. Antonio no conoció esta edicion de la obra de Mártir Rizo y solo cila la anterior de Barcelona de 1629, descrita en la seccion Histórica.-Biografia, del presente Catílogo.

1309 IIÍTOS (José Felife de). Acto de conclusiones en que se defiende que el Señor Santo Thomas de Aquino es Angel.-Otro en que se defiende que es Sol de la Iglesia. Por Ioseph Phelipe de Matos. Sevilla, Diego Lopez de IIaro, (1733-4). $4 .^{\circ}$ El primero de dos hojas prels. y 20 prigs. El segundo de dos hojas prels. y Qi págs.

Son dos composiciones dramáticas que no encuentro citadas por Barrera en su Calálogo.

\section{MáTOS FRAgOSO (Juan} DE). Primera parte de Comedias de Don Ivan de Matos Fragoso. Madrid, Iulian de Paredes, 163̈8. 4. ${ }^{\circ}$ Cuatro hojas prels., 118 foliadas y 104 de nueva foliatura.

No se publico mis I'arte que esta, la cual abraza las doce comedias siguientes:

El hijo de la piedra.

Amor, leallad y ventura.

El traidor contra su sangre.

La devocion del ángel de la guarda.

La tia de la menor.

El marido de su madre.

Los indicios sin culpa.

El jenízaro de Hungría.

Callar siempre es lo mejor.

El yerro de! entendido.

Con amor no hai amistad.

El amor hace valientes.

Barrera dice ser libro ya mui raro da la presenle fecha.
1311 MátOS FRAGOSO (Joan DE). Comedias escogidas de Don Juan de Matos Fragoso. Madrid, Ortega y Compañia, 1828-33. \& volúmenes en $8 .^{\circ}$

Comprende estas comedias:

El yerro del entendido.

El galan de su mujer.

Callar siempre es lo inejor.

La dicha por el desprecio.

Ver y creer, segunda parle de Reinar despues de morir.

Lorenzo me llamo y carbonero de Toledo.

Nada hai mediano siquiera en esta edicion más que el Exámen de cada comedia.

\section{$\therefore$ MEJOR (EL) DE LOS ME-} JORES LIBROS DE COMEDIAS. El meior de los meiores libros qve han salido de Comedias nvevas. Madrid, Maria de Quiñones, 1653 . 4. 4 hojas prels. y 456 paigs.

Comprende estas comedias:

El Caili de Cataluña.-Rójas.

El príncipe perseguido.-Luis de Belmonte, Vorelo y Anlonio Marlinez.

El príncipe prodigioso.-La mitad de Mátos y la otra de Morelo.

El garrote mís bien dado.-Calderon.

El galan sin dama.-Anlonio de Mendoza.

El privado perseguido.-Luis Vélez de Guevara.

Mañana serí otro dia.-Calderon.

La guarda de sí mismo.-El mismo.

la tragedia más lastimosa de amor.-Antonio cocllo.

Los empeños que se ofrecen.-Calderon.

Los siete infantes de Lara. Burlesca.- La mitad de Cáncer y la otra de Juan Vélez de Guevara.

El caballero de Olmedo. Burlesca.-Monteser.

Voltimen publicado por Tnmas Alfay.-El Sr. Barrera cita, con igrual lítulo, una edicion de Alcula, María Fernandez, $1651.4 .^{\circ}$ : contiene las mismas comedias; pero sin espresar los nombres de sus autores.

1313 MEJOR (LA) FLOR DE ENTREMESES. La meior flor de entremeses, que hasta oy ha salido. Recopilados de varios Autores. Zaragoça, Herederos de Diego Dormer, M.DC.LXXIX. 8. 4 hojas prels. y 112 fols.

A pesar de decir en la portada que estos entremeses están recopilados de varios aulores, y de asegurar lo mismo el editor en una advertencia puesta al principio del tomo, encuentro que todos son de Luis Quiñones de Benavente y están copiados de la obra 


\section{MEL}

PRIMERA DIVISION.

MIL

publlcada por este en 1645, Intitulada: Jocoseria burlas-veras.

Contiene los entremeses siguientes:

La paga del mundo. $E$. $C$.

Las civilidades. $E$.

La muerte. E. C.

El tiempo. E.

El talego niño. $E$.

Los cuatro galanes. $E$.

El murmurador. $E$.

Turrada. $E$.

El talego. Segunda parle. E.

Jácara que se cantó en la compañía de 01medo.

Loa que represento Antonio de Prado.

El licenciado y el bachiller. $E$. $C$.

La dueña. $E$. $C$.

La Maya. $E$.

El doctor Juan Rana. E. C.

La capeadora. Primera y segunda parte. E.

Los planetas. $E$. $C$.

El borracho. $E$.

Las dueñas. $E$. $C$.

Las manos y cuajares. $E$. $C$.

El retablo de las maravillas. $E$.

La verdad. $E . C$.

El doctor. E. C.

Los muertos vivos. $E$.

Barrera y Leirado no menciona este tomito en su Critalogo; pero trae otra Flor de entremeses, bayles y loas. Escogidns de los mejores Ingenios de España. Zaragoza, Diego Dormer, M.DC.LXXVI. $8 .^{\circ}$

1314 MELO (D. Francisco MANUEL DE). Obras metricas de Don Francisco Manvel, y segundo tomo de sus Obras. Contienen La Tres Musas. El Pantheon. Las MIusas Portuguesas. El Tercer Coro de las Musas. Qvare? (Asídice el antefróntis y en la portada que le sigue se lee:) Obras metricas de Don Francisco Manvel. Leon de Francia, IIoracio Boessat, y George Remevs, M.DC.LXV. $4 .^{\circ}$ Ias Tres Musas del Melodino, 6 hojas prels., 358 págs. y una hoja blanca; Las segundas tres Musas, 8 hojas prels. y 283 págs. siendo la última (numerada por error 185) una lámina que representa una Pyramide solenne; y el Tercer coro de lás Musas, 4 hojas prels. y $17 \grave{j}$ págs.

Tengo otro ejemplar de la misma edicion con algunas pequenas diferencias en los preliminares; tales como no espresarse en el antefrontis ser segundo tomn, ni enumerarse en él las obras que contiene: estos detalles se hallan en la portada, la cual lleva ademas un escudo de los inıpresores Boessat y Remeus; y la quinta hoja en vez de ser una especie de antefróntis, como en el otro ejemplar, es un verdadero fróntls, repltiéndose el lugar y año de la impresion, pero no el escudo de los impresores.

Sc colige de la dedicatoria que el tomo primero contiene las obras en prosa, y será probablemente el intituladn por Nic. Antonio: obras morales. Tom. I. - Votare de pasn no haber conocido este bibliógrafo el año de la impresion de Lion de las obras métricas.

La primera parte de estas, ó sean las Tres musas, es reimpresion del tomo descrito en la Seccion poética. Num. 785 , con la adicion del Panlheon d la inmorlalidad que no se halla en aquel; la segunda, contiene Lits Musas porluguesas, y como lo indica el título están escritas en esta lengua todas las poesias que comprende; la ullina parte, es decir, El lercer coro, o sean las tres musas restantes, es tambien en verso y en castellano. - Se hallan diseminadas por el volúmen las piezas dramáticas siguientes:

El fragmento ya citado de La imposible.

Cazamento. Égloga moral.-Pastures Andre e Gil.

Temperanza. Égloga moral.-Inlerlocutores: Afoulo, Medrozo, Mediano.

Egloga rustica.-Clemenle, Gabriel.

Antiloquio, ou Loa a hüa Comedia de $I 0 b$.

0 fldalyo aprendiz. Farça.

Todas estas composiciones son en portugues mènos el primer fragmento.

Conocida cosa es que D. Francisco Manuel no es otro que D. Francisco Manuel de Melo, autor de la Guerru de Calaluña en tiempo de Felipe IV.; así lo sientan Vic. Intonio y Barbosa Machado, y lo conflrma un apasionado de dicho Melo, quien escribió una Epistola que precede al Tercer coro de las Mfusus: en ella dice, ponderando la celebridad de Melodino, preguntaselo al aplauso y d́ la ulilidad no solo de Espaĩa mas de Italia y aun de Francia, donde pocos tiempos ha se tradujo con elegancia su Cataluña, etc.

1310 MESA (Cristóval de). Las Eclogas y Georgicas de Virgilio, Rimas, y el Pompeyo, tragedia, De Christoval de Mesa. Madrid, Ramon Ruiz, MDCCXCIII. 8.

La primera edicion que he visto lleva cl mismo titulo y esti impresa en Madrid, Iuan de la Cuesta, 1618. . $^{\circ} 8$ hojas prels, y 191 fols.

1316 MILAN (LCIS DE). (Al dorso de lo que debia ser portada, pues no la tuvo nunca la obra, empieza la dedicatoria con este epigrafe:)

Libro intitulado el Cortesano, dirigido a la, Catholica, Real, Magestad, del Inuictissino don Phelipe por la gracia de Dios Rey de España nuestro señor, \&ic. Compuesto por 
Donluys Milan. Donde se vera lo que deue tener por Reglas y pratica. Repartido por lornadas. Mostrādo su Intinciō por huyr prolixidad debaxo esta breuedad. Siruiendo de Prologo, y Diriction, y Vtilidad, E. ta presente Carta. CConcluye el libro, en el recerso de la última hoja, asi:) Fue impressa la presente obra en la insigne ciudad de Valencia, en casa de loan de Arcos. Corregida a voluntad y contentamiento del Autor. Año M.D.LXI. 8. ${ }^{\circ}$ Carece de foliatura $y$ lleva las signs. A-g de segundo alfabeto, todas de 8 hojas.

Jimeno vagamente cita una edicion de 1565 , que dudo exista; ni la menciona ningun escritor, ni la ha, visto yo.

Los traductores de la Hist. de la lit. de Tlcknor, tom. Il., pág. 486, dan algunas nolicias de esle precioso libro y ebservan es obra tan rarísima que no habian alcanzado d ver sino un solo ejemplar en la biblioleca de D. B. J. Gallardo. Dicen ademas: "entre sus mjornadas hai algunas referentes á saraos, worneos, justas poéticas y otras flestas y re"gocijos, describiéndose con la mayor punntualidad las armis de los caballeros, los "vestidos y arrens, cmpresas y motes de dawmas y ralanes. En este punto es libro preweioso y mís interesante que ol de Castiglio"ne en que se describen costumbres que no wllegaron nunca á generalizarse en España.» - Y yo añadiı́ que es un continuado dílogo, en prosa y verso, y ell castellano y valenciano, para poner en accion las costum bres, trato y jovialidad de las reuniones que solia haber en el palacio del duque de Calabria; pol lo mismo debe considerarse como un verdadero drama desde el principio hasta el fln. Conviene mís señaladamente tal dictado i las dos farsas, en verso, Los Comendadores y La monteria de las damas y cabulleros de Troyja. que se intercalan en el volúmen. Por lo tianto es mui estraño que el Sr. Barresa 110 haya inclitido á Luis Milan en su Calálogo, y mincho ménos á su singular y apreciable Corlesano.

Comprende tambien este muchos refranes y gran numero de composiciones poéticas de $\mathrm{b}$. Juan Fernandez de Heredia, D. Franciseu Fenollet y D. Diego Ladron, ademas de las intercaladas por Milin, escritas por él; se encuentran algunos romances caballereseos y mitulúgiros de Grecia, recordando por su sabor de antigriedad los contenidos en nuestros Romanceros.-Como el Sr. Duran no los conocio copiari el siguiente:

\section{Romance}

\section{del valeroso troyuso Eneas.}

La noche que Troya ardia partiose Eneas troyano navegando por los mares á Cartago es llegado; ciudad de la reina Dido, que fué bien aposentado, él y todos sus troyanos por su puerto han entrado. En llegar delante d'ella á sus piés arrodillado: apiádate, señora, d'este Eneas desdichado. Esta reina piadosa dijo, bien seas llegado, cuéntame, troyano Eneas, de Troya lo que ha pisado. - Reina Dido, pues que mandas renovar dolor llorado yo te contaré llorando Troya como ha quedado. Djez años tuvieron griegos guerra sobre nuestro estado, y á la fin de los diez años su real fué levantado; fingiendo volverse á Greciá en sus naves han entrado, dejaron un hombre en tierra que sinon era nombrado: dijo que la griega armada ya se habian einbarcado, yo huí li noche ántes y escondime en este prado; porque me cupo la suerte que fuese sacrificado, por placar al dios Neptuno y el mar no estuviese irado. Dejaron este caballo de madera bien labrado po: el Paladion de Pálas, que de Troya os han liurtado. Creimos Sinon el griego, de sus griegos consejado para darmos á entender todo lo por él contado. Yo les dije que quemasen el caballo, que era engaño; por su mal no me creyeron y á la ciudad fué llevádo. Haciendo flestas de Baco los troyanos se han turbado, y quedáronse durmiendo, que el placer es descuidado; y pasada media noche salieron los del caballo ; los griegos desembarearon y por Troya s'han entrado. Dieron fuego á toda Troya, nuestro rei fué degollado, y delante de sus hijos solo yo soi acampado. Entre tanto fuego y sangre, de Héctor fuí aconsejado, que volvió del otro inundo de los dioses enviado. Dijome, vete, Eneas, i buscar nuevo reinado, lleva los dioses de Troya que por esto t'han guardado; lleva tu padre y tu hijo y entra en mar aconsolado, que los dioses te dirán dó serás bien fortunado. Que si el ciclo no quisiora derribar á nuestro estado 


\section{MIR}

i Irajcion no me matara

Aquiles falsiflcado.

Por la muerte de Patroelo,

sul anigo mui anado,

que mate delante Troya

con las armas d'él armado:

pensando que fuese Aquiles

derribcle del caballo,

y cortele la cabeza,

y enviele mui honradi);

Jo que yo no ful de griegos

que inuerto ful deshonrado,

fuera los murns de Troya

siete vezes arrastrado.

Abrizcmonos, Eneas,

cn lugar tan desdichado,

donde yo perdí mi reino

y tú te vas desterrado.

D. Luis Milan no solo fué un buen escritor en prosa y verso, sino sobresaliente nuúsico, habiendo compuesto un tratado sobre el arte de tocar la vibucla.-Gil Polo en el Canlo del Turia le consagró la siguiente octava:

A Don Luis Milan recelo y lemo Que no podré alabar como deseo, Que en musica estard en lan alto esirem? oue el inundo le dira segundo Orfeo;

Tendrá estado famoso y lan supremo

En las heróicas rimas, que no creo

Que han te poter nombrórsele delante

Cino Pistoya y Guido Catalcante.

1317 MINATO (Nicolas). La Prosperidad de Elio Serano Drama poetitico en el dia de años del... emperador Leopoldo... año de M.DC.LXXI. Puesto en Musica por Antonio Draghi.
MIR

465

Tradvcido de italiano por el Licenciado Jvan Silvestre Salva. Viena de Austria, Mateo Cosmerovio, s, a. (1671). 8. ${ }^{\circ} 6$ hojas prels. y 72 pags.

1318 MINATO (Nicolas). La competencia de genios. Festejo comico para en mrsica. En el dia de años de la... emperatriz Margarita... Año de M.DC.LXXI. Pvesto en Musica por Antonio Draghi. Tradvcido de italiano Por el Lic. Jvan Silyestre Salva. Viena de Austria, Mateo Cosmerovio, s. a. (1671). 8. Signs. A-D, de 8 hojas, ménos la última que tiene 4.

El nombre del autor aparece por el final de las dedicatorias en ambas composiciones.

Barrera no hace unérito de ninguno de estos dos dramas, ni de su traductor silvestre Salvi.

1319 MIRA DE AMESCUA (ANToxio). Comedias escogidas del Doctor D. Anlonio Nira de Mescua. Tomo primero (y único). Madrid, $1830.8^{\circ}$

Abraza dos comedias, que son:

Galan, valiente y discreto.

La Fénix de Salamanea.

La edicion es mala $y$ el testo castrado; pero no es malo el Exámen que va al fil de cada comedia.

1320 MIRANDA (LUIS DE).

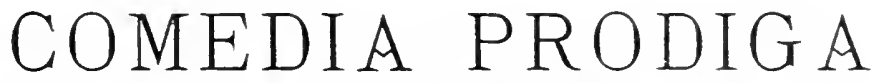

Dirigida al mny magnifico feño: Inan d' billalıa de la ribdad de planjencia. C Cōpuefta y ftlosaliza da pos fuis de flliranda plajentino. En la qmal fe cōtiene, demas d' fuagradable y dulce eftilo, muchas fentencias y auifos muy neceffarios para mance bos que van poz $\mathfrak{e l}$ mundo: moftrandolos $\mathfrak{s}$ gaños y burlas, que eftan encubiertos en fungidos amigos, malas mugeres, $y$ traydozes firmientes. EnSeuilla.Año deM.D.L.iiij.

CEsto va precedido de un gran escudo de armas y al reverso de la hoja

Toy. I. vigésima cuarta se halla ol del impresor y colofon asi:) 
fflartin de fflontefdoca. Atrabofe a die; diag de 2 izizientbze. Año de. Mt. 四. I. iiij.

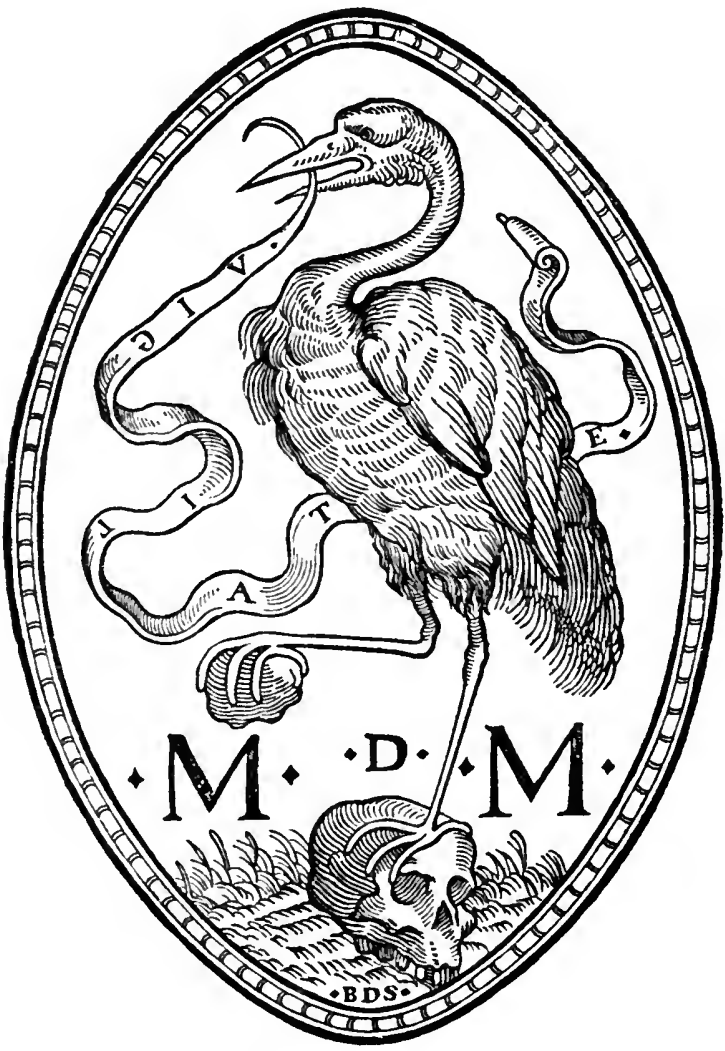

Spernere vis mortem? Vis puram viuere vitam? Vis fierifapiens, vir q; bonus? Vigila.

4. letra gót. Sin foliacion, con las signs. a y b, de 12 hojas cada una.

Comedia de tan gran rareza que no conozco otro ejemplar en biblioteca alguna; la reimpresion de 1869 se hizo de una copla manuscrita sacada del mio.

Nic. Antonio solo menciona á un Luis Miranda, natural de Valladolid, autor de una porcion de tratados teológicos $\mathrm{y}$ ascéticos; pero no habla de nuestro placentino.-Barrera al parecer no ha visto ningun ejemplar de esta comedia y por tanto copia el título con la ortografia moderna tal cual lo trae Muratin.
1321 IIIRANDA (LuIs DE). Comedia pródiga, compuesta por Luis de Miranda, Placentino. Sevilla , Don José Maria Geofrin, 1868. (Al fin: 1869: $8^{\circ} .^{\circ}$

Lindisima edicion publicada por la Socledad de bibliófilos andaluzes; solo se han tira. do 300 ejemplares $y$ seis ú ocho en papel superior, de los cuales es el que yo poseo.

Horatin analiza largamente esta comedia en el núm. 85 del Catálogo que precede á sus Orígenes, y dice de ella ser sin duda una de las mejores del antiguo teatro español, bien 
pintados los caracteres, bien escritas algunus de sus escinas: las silunciones se suceden unas d oiras, aunque no con particular arlificio dranalico, siempre con verisimiliiud $y$ rapidez.

MONTEMAYOR (JoRGE DE). Tres autos. Véase Monlemayor (Jorge de). Las obras. 1j̈̈̈, en los Cancioneros y romanceros. Núm. $29 \ddot{3}$.

\section{MONTIANO Y LUYANDO} (Agustin DE). Discurso (primero y segundo) sobre las tragedias españolas. De Don Agustin de Montiano $y$ Luyando. Segunda impression. Madrid, Joseph de Orga, 17ä0-5̈3. vols. $8 .^{\circ}$ marq. Los prels. del primero comprenden 8 hojas y una de la signatura A. La paginacion empieza en la 3 y acaba en la 2ŏ3. El segundo tiene en todo 203 págs.

Los dos discursos contienen noticias literarias sobre nuestro teatro antiguo: á continuacion del primero va la tragedia de Virginia, y al fin del segundo la de Athaulpho, ambas escritas por Montiano.

He visto un opúsculo en $8^{\circ}$ intitulado: Examen de la carla que se supone escrita por Don Jayne Doms, contra el Discurso sobre las tragedias españolas, y la Viroinin de D. Agustin de Montiono y Luyjando. Le ofrece al juicio de los inteligentes D. Domingo Luis de Guetara Madrid, imprenta de Musica, Calli, del Desengaño, (175.5). Yo creo que este tratadito es de Nontiano.

1323 MOR DE FUÉNTES (JosÉ). Poesias varias de D. Joseph Mor de Fuentes. (Primera parte.) Madrid, Imprenta heal, 1796. - Segunda parte. Zaragoza, imprenta de Miedes, $179 \overline{7}$. - Mercera parte. Madrid, Cano, 1800. 8:

Tres partes en un volúmen. En la última hai una zarzuela intitulada: La presumida.

1324 MORALES (LOIS DE). Fiestas del Corpvs que el año de $\mathbf{1 6 1 0 .}$ hizo el illvstrissimo Señor Don Antonio Venegas de Figueroa, Obispo de Pamplona, con rn Dialogo, Cartel Poetico, y poesias premiadas. Escritas por el Licenciado Luys de Morales. Pamplona, Nicolas de Assiayn, 1610. 4..$^{\circ} 10 \mathrm{~h}$ hajas foliadas en todo.

Llb̧ro mui raro.
Hal composiclones poétlcas en latin, latln macarrónlco, castellano, una en vascuence y otra en portugues: sus autores son: el bach. Alonso Cutiérrez, Hernando Labad, Miguel Ferrer, Martin de Alvarado, frai Pe: dro de Otalora, frai Frarcisco Salgadn, Baltasar Medrano, Ramiro Jiménez de $0 \cdot \cdot 0$, el lic. Pedro Yicto, el l’. Sảlas, Antonio de Escobar, Enrique Ponce, l'edro de Sálas, don Pedro de I.umbier, D. Jartin Marin, Josẻ Velázquez, Iñigo de Briviesca, Gaspar de Her. rera, el lic. Avendaño, frai Alonso de Riero, Antonio Venégas de Figueroa, Juan Pérez de Azcona, el cap. Yelasco, Martin Portal y fral ledro Lnigarro.

Se encuentra ademas el Didlogo del Santisimo Sacramento, anónimo; Aulo Sacramental no mencionado en el Catálogo de Barrera.

13Zu MORÁles (Pedro de). Carta del Padre Pedro de Morales de la Compañia de lesus,... en que se da relacion de la Festiuidad que en esta insigne Ciudad de Mexico se hizo este año de setenta y ocho, en la collocacion de las Sanctas Reliquias que nuostro muy Sācto Padre Gregorio XIII. les embio. Mexico, Antonio Ricardo $1579.8 .^{\circ} 191$ hojas foliadas en todo.

Hai varias poesias en el volúmen, y desde el fol. 109 al 18 una tragedia intitulada: Triumphn de los Sanclos. En que se representa la persecucion de Diocleciano, y la prosperitad, que se siguio con el Imperio de Constantino, la cual fué representada por los estudiantes de los colegios de jesuitas mejicanos.-Yoratin no la conocio pues no hace mencion de ella en sus origenes del leatro. Es un libro de estremada rareza y no se halla en ninguna de las bibliotecas públicas que conozco: el Sr. Barrera al califlcarlo de rarisimo, cita otro ejemplar existente en la librería del Sr. Sancho Rayon.

MORATIN (Fervández de). Véase Fernandez de Moratin, en esta Division.

1326 MORETO Y CABAŶA (AGCStiv). Primera parte de las comedias de Don Agrstin Moreto. En Valencia, en la Imprenta de Benito Macé, Ā̄o de 1676. Acosta de Francisco Duarte. 2 hojas prels. Cportada y tabla) y cada comedia principia por nueva signatura, no llevando fólios ninguna de ellas.

Segunda parte de las comedias etc. (ut supra). 2 hojas prels. (porta- 
da y tabla) y como el rolúmen se ha formado de comedias sueltas, todas llevan nuevas signaturas y alguna hasta paginacion separada.

Verdiadera tercerar parte de las comedias de Don Aguslin Moreto. En Valencia en la Imprenta de Benito Macè, Año de 1703. A costa de Vicente Cabrera. 2 hojas prels. (fróntis y tabla); cada comedia principia con nueva signat. y las pocas que tienen paginacion, la llevan pecuculiar a ellas.-Son 3 vols. $4 .^{\circ}$

\section{Contenido de las tres partes:}

\section{La primera.}

El desden con el desden.

El poder de la amistad.

Antíoco y Seleuco.

De fuera vendrá.

El mejor imigo el rei.

Hasta el fin madie es diclioso.

La fuerz.l de lia liej.

la vida de san Alejo.

La misma conciencia acusa.

Sall Franco de Sena.

Trampa adelinte.

Lo que puede la aprensión.

La segurida.

No puede ser.

Santa liosa del Perú.

La fuerza del natural.

Primero es la lonra.

El licenciado Vidriera.

Industrias contra fluezas.

El caballero.

El parecido.

La fingida arcadia.

El Eneas de bios.

lil valiente justicitero.

El lindo D. Diego.

\section{La tercesa.}

Yo por vos y vos por otro. Las Iravesuras de Pantoja. La ocasion hise el ladron.

Como se vengan los nobles.

Sin honra nu hai valentia.

En el mayor imposible nadie pierda la esperanza.

Todo es enredos amor.

El marques del Cigarial.

Los juezes de Castilla.

El defensor de su agravio.

Nuestra Señora de lit Aurora.

La confusion de un jardin.

No me cabe duda en que no es genuina esta edicion de las tres partes: entiendo que algun librero reunio las comedias que encontró sueltas de las publicadas primitivamente por Yace, formandu tomos y poniendoles las portidas que arriba he copiado, las cuales van clrcuidas de una orla de que carecen las legitimas. Viene en apoyo de mi opinion el haber alguna diferencia en el contenido de los tomos, el diverso órden que guardan las piezas, las variaciones en sus tItulos y el no llevar más preliminares que la hoja del fróntis y la del indice. Sin embargo, aun as1 es diffcil el adquirir reunidas estas tres partes espureas.

\section{MORETO Y CABAÑA (Agus-} tiN). Promen'a pante de comedias de D. Agvstin Morelo y Cabaña. Dedicado a Don Joseph de Cañizares. Madrid, Andres Garcia de la Iglesia, Año 1677. 4. 4 hojas preliminares, 253 foliadas y una para repetir las señas de la impresion.

Comprende once comedias de las doce án. tes indicidas en la primera Parle de Valencia, con diferente órden y hallándose LoS juezes de Castilla en lugar de La vidu de $S$. Alejo; tambien el titulo de S. Franco de Sena es en esta El lego del Córmen.-No habiendo visto la edicion original de Nacé, ignoro si en ella habrá estas variaciones; pero sospecho que estirí tal cual se halla cn la cdicion matritense.

Poseia don A gustin Duran fragmentos de uma impresion de la Primera parle de Comedias de D. Agustin Mor to y Cubañu. Madrid, Diego Diaz de la Carrera, M.DC.LIV. $4^{\circ} .4$ hojas preliminares y 270 foliadas. Al parecer su contenido es igual al de la edicion de $\mathbf{1 6 7} 7$, segum Barrera y un apunte puesto por Mr. Heber al principio de uno de los tomos que poseo.

\section{Segvuda parte de} las Comedias de Don Agrstin Moreto. Dedicadas al llvstre señor D. Franciseo Idiaquez Butron Muxica Borja. Valencia, en la Imprenta de Benita Macè, Año de $1676.4 .^{\circ} 4$ hojas preliminares y 496 paigs.

Indudablemente esta es la edicion original de Mace, en lit eual lleva el titulo de El caballero del Sacramenlo, la comedia que se denomina El Eneas de Dios en la otra que tambien dice ser publicada por dicho Macé.Como ya he observado ántes, la portada no tiene orla. Va al principio una aprobacion de Tomás López de los Rios, fechada el 20 de febrero de 1676 , en la que dice: estas comedias de D. Agustin Moreto corren ya impresas en diferentes lomos, lo cual prueba sea esta tal vez, la única y primitiva impresion que existe de la Parte segunda: Barrera tainpoco menciona otra.

De lia Verdadera lercera parte hai edicion de Valencia y de Benilo Macé del año de 1676, con aprobacion de López de los Kios; contiene las comedias que dejo anotadas al hablar de la reimpresion de 170.5 . - Barreri 
describe en la pág. 278 de su Catdlogo, una Tercera parle de comedias de don Agusfin Morelo y Cabaña. Malrid, Antonin de Zafra, 1681. 4..$^{\circ}$ que tiene, ademas de los preliminares, 412 pigs., y solo comprende dos comedias de las del tonI. III. de Valencia: Ias demas todas son diferentes.-Tambien habla Barrera de una Tercera parle que se dice iupresa en Valencia, por la viudu de Josef de Orga, s. a. 4. ; pero este tomo se formo de comedias impresas por separado hácia fnes del siglo anterior, poniéndnle un fróntis y tabla, con el objeto sin duda de suplir en algunos ejemplares el antiguo de que estarian faltos. Contiene las mismas piezas que la edicion de Macé, ménos: lo por vos $y$ vos por olro.-Cómo se vengan los nobles. En el ma!nor imposible nadie pier Ia la esperanza y Nueslra Si'l. de la Alirora, que ban sido sustituidas con los siele durmiuntes.La negra por el honor.-Travesuras son valor y ringir $y$ amar.

1329 MORETO Y CABAÑA (AgusTIN). Comedias escogidas de Don Agustin Moreto y Cahaña. El tomo I. Madrid, D. A. Fernandez, 18*6., el II. Imprenta de Ortega y Compañia, 1828, y el III, en la imprenta de Ortega, 1831.3 vols. $8 .^{\circ}$

Estos tres tomos, que solo deben tenerse por el Exámen que acompaña cada comedia, conlienen las siguiestes:

El desden con el desden.

El lindo D. Dicgo.
El valiente justiciero $\mathrm{y}$ el Rico-hombre de Alcali.

Trampa adelante.

jo puede ser.

De fuera vendrá quien de casa nos echará, o la tia y la sobrina.

Fl caballero.

I.a ocasion hace al ladron.

La confusion de un jardin.

El parecido en la corte.

El defensor de su agravio.

El licenciado Vidriera.

1330 MUXET DE SOLIS (DIEgo). Comedias hrmanas y divinas, y Rimas morales, comprestas por Diego Mrxet de Solis. Brrßselas, Fernando de Hoeymaker, $1624.4^{\circ}{ }^{\circ}$ hojas preliminares, $30 \ddot{4}$ pags. y 64 de nueva paginacion para las Rimas.

Contiene estas seis comedias:

Cómo ha de ser el valiente.

La igualdad en los sugetes.

El cazador más dichoso.

El generoso en España.

La venganza de la duquesa de Amalf.

El ermitaño seglar.

Nic. Antonio dice equivocadamente estar impreso en Francfort, y Garcla de Villanueva, Origen del teulro español, supone es de Amberes, sin mencionar el año; esto prueba que ni uno ni otro han podido consultarlo por ser difícil de encontrar.

\section{NIVIDAD Y córpus} ChISTI. Navidad, y Corprs Christi resicjados por los mejores Ingenios de España, en diez.y seis Irtos a lo divino, Diez ! scis Loas, y dicz ! seis Entremeses. Representados èn esta Corte, y nunca hasta aora impressos. Recogidos por Isidro de Robles. Madrid, Ioseph Fernandez de Buendia, 1664. 4. 4 hojas prels. y 373 págs., segun la ultima; alinque la numeracion esta llena de equivocaciones.

Conticne este raro volúmen:

\section{Lòas sacramentales.}

I De los tltulos de las comedias.

2 Sacramental. Albricias salyo d pecliros.

.j Sobre las cinco reglas de contar.

4 Del Nacimierto del lliju de Dios. Entre dos pastores y un ángil.

J Entre cl dia y la noche $\mathrm{y}$ un galan. b Del alma cnferma.

7 lle los tres sentidos corporales.

$s$ Del Sacimiento.

9 Eulro Lres galanes.

10 Entre un galan llamado D. Cárlos, que representa la sabiduria, y entre Bris, villano, que representa ha iznorancia.

11 Sacramentil. Beso a vursurce las manos.

1.2 Del Rosario. Kin alabanza de Nuestra Senora. Entre los doce nueses.

15 De ta Vírgen del Rosario. Entre un pastor y un galan.

14 De Yuestra Sra. del Rosario.

15 Del Vacimiento de Kuestro Señor.

16 Del Naciniento de Cristo, nuestro bien.

Todas anónimas.

\section{Autos.}

1 El divino Jason.-Calderon.

2 La llayor soberbia humalla de Nabucodonosor. - Vira de Anescha.

3 La mesa redonda.-Luis Véles de Guevira.

4 El tirano castigado.-Lope.

5 El prenio de lí linsusna y rico de Alejandria.-Folipe Godines. 
6 El caballero del Febo.-Rsjas.

7 Las santisimas formas de Alcalá.-Monlalvan.

8 El Nacimiento de Cristo, nuestro bien, y sol á media noche.-Mira de Amescua.

9 La gran casa de Austria y divina Margarita.-Morcto.

10 Entre dia y noche.-Valdivielso.

11 La cena del rei Baltasar.-Calderon.

12 Nuestra Señora del Rosirio, la madrina del cielo. - Tirsu de Moliur.

13 Nuestia Señora del Rosario, ciento por uno.-Cubillo de Aragom.

14 La Vírgen del Rosario, la amiga más verdadera.-Anlonio Coello.

$1 \leftrightharpoons$ El Nacimiento de Nuestro Señor. - Valdiviclso.

16 El Nacimiento de Nuestro Salvador Jesucristo.-Lope.

\section{Entremeses de Luis de Fbenarente.}

1 Los mariones.

2 Los sacristanes Cosquillas y Talegote.

3 El convidado.

4 El doctor y cl enfermo.

5 El nerrito hablador, y sin color anda la กีกิก.

6 El sacristan y viejo ahorcados.

7 Von Gaiferos y Busconas de Madrid.

8 Los sacristanes burlados.

9 Las burlas de Isabel.

19 El marido flemático.

11 Los ladrones y moro hueco, y la parida.

12 El enamoradizo.

$13 \mathrm{El}$ anor al usn.

14. El juegu del hombre.

15 El zeloso Turrada.

$16 \mathrm{El}$ állogulo.

latasa en su Biblinteca, dice poseia un

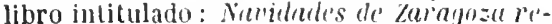
parlidas en qualro roches, compunshn por D. Natías de Aguirre y Sebastian, impreso en dicha ciudad de Zaragoza, por Juch de

\section{OCIOSIDAD ENTRETENI-} DA, en varios Entremeses, Bayles, Loas, y Jacaras. Escogidos de los mejores Ingenios de España. Madrid, Andres Garcia de la Iglesia, 1668. $8 .^{\circ} 8$ hojas prels., 127 foliadas y otra al fin en que concluye un Romance á san Jerónimo.

Tomo raro, dirigido a $\mathrm{D}$. Pedro Cilderon de la Balca por Juan Marlin Iterinero, y contiene las piezas siguientes:

I'utos (Los). E- -Jeroncimo Cáncer.

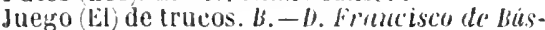
tos.

El abad del Campillo. E.-Haestro Leon.

El médieo de amor. B.-Franciseo Avellaneda.

La batalla. B.-El mismo.
Ibar, 1634. 4..$^{\circ}$ de 389 págs. Contiene este tomo cuatro comedias intituladas: El engaño en el veslido, La induslria contra el peligro, Cómo se engaña el demonio y El principe dé su estrella.-He visto esta misma obra con el siguiente t1tulo: Navidad de Zaragoza. Repartida en qualro noches. Compuesta por Dun Matias de Aqvirre, del $P(0=0$ y Felizes. Gıraqoca, Illan cle Ybar, (1654?). El año estaba añadido de mano, porque no sitio de imprenta: pero las aprobaciones son con efecto de $165 \%$. $40^{\circ} 6$ hojas prels. 385 pírs. y 2 hojas mis para terminar el Indice, que principia il dorso de la pág. 385 . Son novelas y cada noche contiene una de las comedias arriba indicadas. - No sć esplicarme la rizon que lumbo parat suplantar el nombre de sn verdadero antor en esta serunda edicion; ni cómo ciliundo Nie. Antonio lin de lizís se la atribuye i V. Natias Aruire del l'ozn y Felizes, quien, segrin Lalasi, naciu en 16.5 .5$.

13:32 NÚỶEZ SOTOMA YOR (JOAN). Descripcion panegyrica de las insignes fiestas que la $\mathbf{S}$. Irrle sia Catedral de Iaen celebró en la translacion del Ss. Sacramento a su nuevo y sumptuoso Templo, por el mes de Octubre del año de $1660 \ldots$ Disprsola Jvan Nvñez Sotomayor. Nialaga, Hateo Lopez IIIilalgo, 1661. 4. Anteportada, con un grande escudo de armas, y portada, y otras 8 hojas prels. , 880 pags., una hoja con un soneto y otra blanca.

Contiene uua Lna del P. Fr. Juan Alegre, dos autos de D. Pedro Calderon intitulado el uno El sacro parnuso, y el otro El maesirazgo del Tuson, y un certámen poético donde hai composiciones de los autores más distinguidos de aquella époea.
La manta. E-Francisco de Quiros.

La ronda de amor. $B .-$ Avellaneda.

El Quero. E.-Quiros.

Los estravagantes. B.-Francisco Monleser.

El sastre. E-D. Juan vélez.

El hilo de Flándes. B.-Pedro Francisco Lanini.

Descuidese en el rascar. E.-Munleser.

Los gallos. B.-Luis de Benavente.

Sacadora (La). E. -P. F. Lanini.

La casa al reves y los vocablos. B.-Benavente.

La castañera E-Monteser.

El tilbaco. B.-Avellaneda.

Ins locus. E-Monteser.

lil herroro de vicjo. $B_{t}-J u a n$ de Zubaleta.

Los valientes encanisados. E.-Francisco de la culle.

El gusto loco. B.-Monleser.

Las calles de Madrid. E.-Benuvente. 
Ralle para Francisco Ponce.-Monteser. En el Indice lleva el titulo de $E$ loco de cmor.

\section{El cómo. E.-Ouiros.}

I.os esdrujulos. B.-Monteser.

El enfermo. E.-Benavente.

Mucho te qulero Marica. B.-Peñaroja.

El ensayo. E.-Andres Gil Enriquez.

El mudo. B.-Monteser.

La miclindrosa. E.-Benavente.

El letrado de amor. B.-Monteser.

El Santísimo Sacramento. L.-Sebastian de Villaviciosa.

I.a plemática. J.-Benavente.

Lna entre la iglesia y el zelo.-Benavente.

El mellado. J.-Culderon.

El jucgo de la pelota. L. - El mismn.

Loa con que entro en la Corte Bernardo de Prado.-Benavenle.

Romance que se cantó á S. Jeróninı año de 1667.- Juan Malos Fragoso.

1334 ÓPERAS. Artaxerxes. Drama en musica del celebre abate Pedro Metastasio para representarse en el nuevo teatro de la sala del Duque de Gandia en la ciudad de Valencia. En este año de 1769. Valencia, Francisco Burguete, s. a. $8 .^{\circ}$

El Charlatan. Drama jocoso en musica para representarse en la sala del Duque de Gandia en Valencia. El año de 1769. Valencia, Viuda de Joseph de Orga, s. a. 8.

Primera y segunda parte de la Buena muchacha. Drama jocoso en musica para representarse en la sala del Duque rle Gandia. Este año 1769. Valencia, Francisco Burguele, s. a. 8.

Motezuma. Drama en musica para representarse en la sala del Duque de Gandia, este año de 1768. Valencia, Viuda lle Joseph de Orga, s. a. 8.

Estas operas llevan al frente de cada página de la traduccion castellanil, el testo italiano.-Las tres primeras estün en verso.

1335̆ ORATORIOS SACROS. A fectos de una alma reconocida al beneficio de su justiticacion, en el exemplar de Sta. Maria Magdalena. Oratorio sacro segundo, que se cantò en la Real Congregacion del Oratorio de San Felipe Neri de la Ciudad de Valencia, año 1716. Reducido à concento musico por Don Joseph de San Juan Maestro de Capilla de las Descalzas Reales de Madrid, Valencia, Antonio Bordazar, s. a. (1716?). 13 pags., inclusa la porlada, y una hoja blanca.
Desengaño de la mundana felicidad, y conversion de un Pecador; simbolizado en la parabola de el hijo prodigo. Oratorio sacro, que se cantò en la real Congregacion del Oratorio de San Felipe Neri de Valencia año de 1732. Reducido à consonancia Musica por el Lic. Mos. Joseph Pradas, Maestro de Capilla de la Metropolitana Iglesia de la misma Ciudad. Valencia, Antonio Bordazar, s.a. (1732?). 16 págs., inclusa la portada.

La primera flor del Peru, entre penetrantes espinas; y la Inocencia atribulada. Expressivos simbolos de la vida de Sta. Rosa de Lima: Oratorio sacro primero, que se canto en la iglesia de la Real Congregacion del Oratorio de San Felipe Neri de la Ciudad de Valencia, Año 1i34. Reducido a concento Musico por el Licenciado Mosen Vicente Cervera Presbitero, Maestro de Ceremonias, y Organista del Real Colegio de Corpus Christi de la misma Ciudad. (Falencia,) Por Antonio Bordazar, s. a. (17349). 12 págs., inclusa la hoja de portada.

El exemplar de la devocion al Smo. Sacramento S. Pasqual Baylon. Oratorio sacro, Que se canta Én la Real Casa, y Congregacion del Oratorio de S. Felipe Yeri de la Ciudad de Valencia. Puesto en Musica Por D. Pedro Furió. Maestro de Capilla de la Irlesia Cathedral de la Ciudad de Guadix. Valencia, Salrador Fauli. Año 170.16 pags., inclusa la hoja de portada. Todos en $80^{\circ}$

Estas nperetas u piezas musicales están des. empeñadas entre cualro personaje correspon. dientes á lasvozes de Tiples, primero y segundo, Alto y Tenor 8 correspinden indudablemente al repertorio dramático: es singular por lo mismo no las mencione el señor de Bar. rern; sin duda no las babrá conocido yor ser raras en razon de constar cada una de solas ocho hojas y no haberse vuelto á imprimir.

Como hemos visto ninguna de las cuatro lleva nombre de nutor; pero yo quizás ine atreveria á atribuir, por lo ménos las tres primeras (aunque la última parece reproduccion de edicion más antigua), á D. José Vicente orti y Mayor, quien supone Jimeno, eseribii muchos poemas ingeniosos en forma de dialogo, sobre diversos asuntos y con el litulo de oratorios sacros: los cuntes reducidos a conceto músico por los mas ilustres maestros de capilla de esta ciudad (Valencia) 
ORT

El titulo ántes coplado indica ya el número de jornadas en que está dividida y el nombre de los interlocutores.

Dornada primera. Redúcese á un diálogo entre l.ireo y Ricreto en el cual el prinero se lamenta de la pérdida que ha tenido con la muerte de su esposa, miéntras el criado procura aliviar su dolor haciéndole algunas reflexiones.

Jornada segunda. Cleriano informa á Turpino del amor que profesa á Radiana, y se duele de no haber poulido comunicar á esta su pasion: el eriado se ofrece á enamorar á la sirvienta Marpina, para lugrar por este medio el que su amo entre en relarinnes cin la dama. Al divisar de líjos á la criada, Cleriano se ausenta para dar ocasion a Turpino de llevar su plan adelante: empieza este por requebrar a Marpina, segun costumbre esta se muestra esquira en un principio y despues accede i proteger los amores de Ra. diana. Vuelve a presentarse Cleriano y pregunta á Turpino.

\section{Di, qué tal?}

Turp. Quedú el amnr tan igual,

que si me echaba á empujones,

me prometio en lo final

de remediar tus pasiones

si pudiese;

aunque pensase y supiese

que las tocas la insorase,

le dirá cuanto quisiese,

escuchase io 110 escuchase.

En esto ven llegar i Lirco y se marchan, termiluando el acto.

Jornada tercera. Lireo sale desesperado porque ha oido á Marpina aeursejar á su hija que tomase chamorado, y temiendo el presentarse por no eausar dolur i Radiana envia i kicreto en el objeto de que le avise cuando este pronta la ceur. Imorante la ansencia del criadis aparecen pinto y firado (no Lirado comose lee en el frontis, dis pastores il quienes Lirro suplira lo den muerte para qute cesen die ma ro\% sus doln-

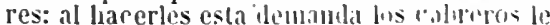
interrogia sobre su enfermedal, y le ufrean varios medicamentos y unturis, sin poiler comprender la angustia del alligrido friblet, pues no cabe en sil juicio el qui! las dolencias morales pongan il un hombre en iquel estadn: llegra Ricreto y dice al su amo habol oido á Marpina que hablando con Radialla,
Decia que se perdia
Cleriano en sils alloles,
más decia, que le cmuplia
que li mostrase favoles
ladïılli.
y que viuiendo mañana
coneinclún de te dejar;
la bellaca muli ufana
no hacie simn (amar.

L.e insta para que vinya í eumer, l.ireo accelle y se vill.

Quedan solos los pastores dialogando y jugandu.

\section{ORT}

Jornada cuarta. Segun se deduce de la conversacion entre Turpino y su señor, Radiani ha consentido en recibirle en el jardin entre las dos y las tres; conciertanse sobre el modo de hacerlo con mayor seguridad, y se marchan decididos í sacarla de casa de su padre. - Salen Lireo y licereto que sin duda habian estado escuchando el diálıgo anterior, pues el primero dice:
Malcriado,
oh, Cleriano malvadn:
unira que tu mala suerte
y la firtuna ha ordenado
que yo te de cruel muerte;
tu procura
de conseguir tu locura
y sacar a Radiana:
mira que hai gran estrechura,
gnarte no dejes la lana:
luego, luego,
habliba el triste lan ciego
jurando que Radiana
ha de costar sansre ó fuego,
y la ha de sacar mañana
a las tres:
escucha bien y veris;
cria hijos con regalo.

Ffectivamente convienen en esconderse de un modo oportuno piara siorprender al raptor.-Se presentan despurs l'into, firardo y Juan $y$ charlin lin roto en lenguraje ristico o pastoril, sin que rsta escena tenga ninguna relacion con el argumento de la comerija.

Jornada quinta. Entran en el jardin de Ia casa du Liren, Vidriano y Turpino, y ellcuentran aguardándoles à Radiana y Marpina. La dania hace jurar al galan que su anior es verdatero y con eslat seguriuld se lisponon a efectuar la fusil: prestutase en esto l.ireo mui enojado y com animo le op unersi: pero un sacerdote que jol illi pisa inter.

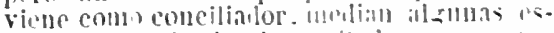
plicinioncs, siento al risultidu and reeon-

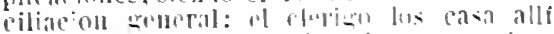

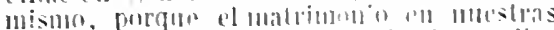

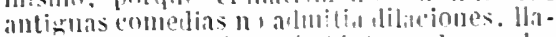
man!l, eoum lestiens a liblo y Juall. Ins cuales terminam la flesta cantando un villancieo.

l'or el anterior anilisis se ve que ol arom-

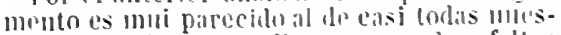
tris primilisis comedias: un pluden faltar

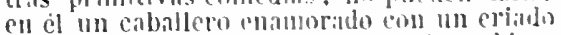

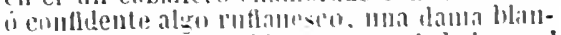
dal de corazon dirisidir por stl criada la collal siompretiene sus puntios de alcalusela. Hu padre ó llondre que se upone i los amoles de sll lija, dos i tres pastores, para llenar el

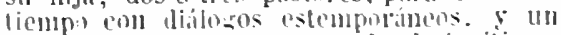
clerien is ermitaño encirrend, de lowitimar

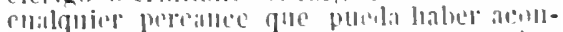

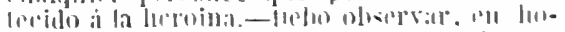

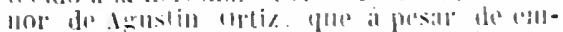

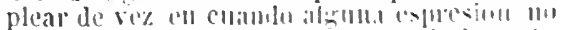

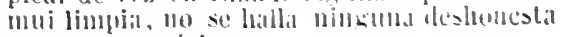
(ull sll composicion 
1338 PALMIRENO (LORENZO). Phrases Ciceronis, Hypotyposes clariss. virorum, Oratio Palmyreni post reditvm, eiusdem fabella Aenaria. Valentiae, Ex officina Pet. à Huete. $1374.8^{\circ} 64$ hojas, inclusa la portada.

Tomito de estraordinaria rareza y curlosfsimo por contener una pieza dramática hispano-latina, escrita por Palmireno. Ocupa esta composicion 19 hojas, pues principia al reverso de la $\mathbf{4 6}$ con el sigulente título é introduccion:

"Fabella Aenaria Laurentii Palmireni acta in Academia valentina, 6 idus Februarii, 1574.n "Autor. Di, Eco, què tal parecerá á esta ilustre compañía lo que yo compongo?

Eco. Hongo.

Aul. Luego flojos $\mathrm{y}$ de poco valor te parecen mis trabajos?

E. Ajos.

Aut. Para eso más vale callar é irme á otra parte.

E. Arte.

Aul. Qué arte quieres que siga, pues si hoi viniesen Menandro y Terencio cansarian? E. Rian.

Aul. ¿Cómo quieres que rian si la buena comedia no obliga á decir gracias? Cómo me echas tan crudamente en la boca del lobo?

E. Bobo

Aut. El bobo es siempre más escuchado; pero icómo lo harán ó representarán niños, pues ni la edad ni el cuerpo les ayuda en alguna cosa?

E. Osa.

Aut. Osar donde no se espera suceso, parece dislate de modorro, por tanto dame alguna cosa con que á tan sábia congregacion contente.

E. Tente.

Aut. No está en mi mano porque me lo han mandado, y detenerme no puedo, desviarme no me es concedido; creo será unás fácil camino ayuntar el lenguaje latino con cl castellano.

$E$. Llano.

Aut. Pues esto te parece llano seguiré tu consejo consolándome que si es fria mi comedia no es este mi oflcio, y que por divertir á mis discipulos del naipe en estas vacaciones, les he ejercitado la accion $\mathrm{y} \mathrm{voz}$ en esto que ni es comedia ni farsa, sino entretenimiento. Y porque me quitaron la joya de terciopclo carınesí habrá seis meses, di. ciendo que toda mi obra iba latina, pongo en esta mucho romance; no sé si habré acertado."

Al terminar la comedia se encuentra la siguiente nota: Ni mili vitio verlat benignus leclor non servatas csse Comedice leges, quando quidem Farsas hispanicas, non Terentii gravilatem in graliam vulgi imilatus sum.
El no Incluir esta obra en su Catálogo el Sr. Barrera, ni hacer mencion de Palmireno como autor dramático, es la prueba más evidente de ser mui poco conocido el presente librito.-Latasa cita de èl una segunda impresion hecha en Vatencia en $1578,80^{\circ}, \mathrm{y}$ ademas habla de la Comedia de la Seo, en Agoslo, tambien de Palmireno; pero no acota edlcion de ella.

\section{PARACUELloS CABEZA} DE VACA (LUIS DE). Elogios a MA Sãtissima consagrolos En suntuosas celebridades devotamente Granada ala limpieça pura de su conçepcion. Disprsolos D. Luis de Paracuellos Cabeça de Vaca. Granada, Fran.co Sanchez y Baltasar de Bolibar, 1651. 4. Una hoja de portada grabada, de prels., 444 foliadas y dos para las Erratas, que faltan frecuentemente.

Contiene poesias de D. Garcia Salzedo Coronel, D. Matías Guerrero, D. Juan Bermúdez de Castro, frai Gaspar de Monterubio, D. Laureano de Moráles, D. Diego de Rójas Carvajal, D. Francisco de Trillo y Figueroa, el P. Pedro de Cóbos, P. Fr. Cristóval de Ortega, frai Luis de Bocanegra, D. Juan Pedro Vivaldo, D. Juan Antonio de Ibarra, el doctor D. Luis de Padilla, D. Fernando de Salzedo, Gabriel Martínez del Aguila, el Dr. D. Juan Martin, Felipe Orena y Valdes, Juan de Santa Maria, D. Alvaro Cubillo de Aragon, el licenciado Francisco de Sevilla, el P. José de Ocampo, D. Vicente Crespo de Moya, el P. Fr. Juan Amador y el lic. Felipe de Mena.

Ademas hai en el volúmen las composiciones dramáticas siguientes:

El valle de lágrimas convertido en risas, por la Aurora María. Auto compuesto por el P. Fr. Anlonio Amador. Va precedido de Loa. Las venlas del Puerto. Entremes. Por el p. Fr. Niguel de Molina.

La Concepcion sin mancilla. Auto en ale. goria de Diego Fernandez Solana.

Las fiestas del Padul. EnIrenes. Compuesto por el P. Fr. Miguel de Molina.

Como Nic. Antonio da á entender no haber visto una obra cltada por él de Luis Para. cuéllos, no puede asegurarse si quiso designar la presente, cuyo título es mui diverso.

El Sr. Barrera no tuvo presente este libro, pues el título del Valle de lágrimas de Amador lo da de un modo mui incompleto; equivoca el nombre de su autor; omite el de Miguel Molina, y por consiguiente no menciona los dos entremeses arriba citados, y al detallar las composiciones dramáticas de Fernández Solana solo trae noticia de otra produccion suya intitulada: Lo que vale un español. 
PAR

PRIMRRA DIVISION.

PAR

475

1340 PARIS (JUAN DE). (Facsi- | miles de los grabados del fróntis.)

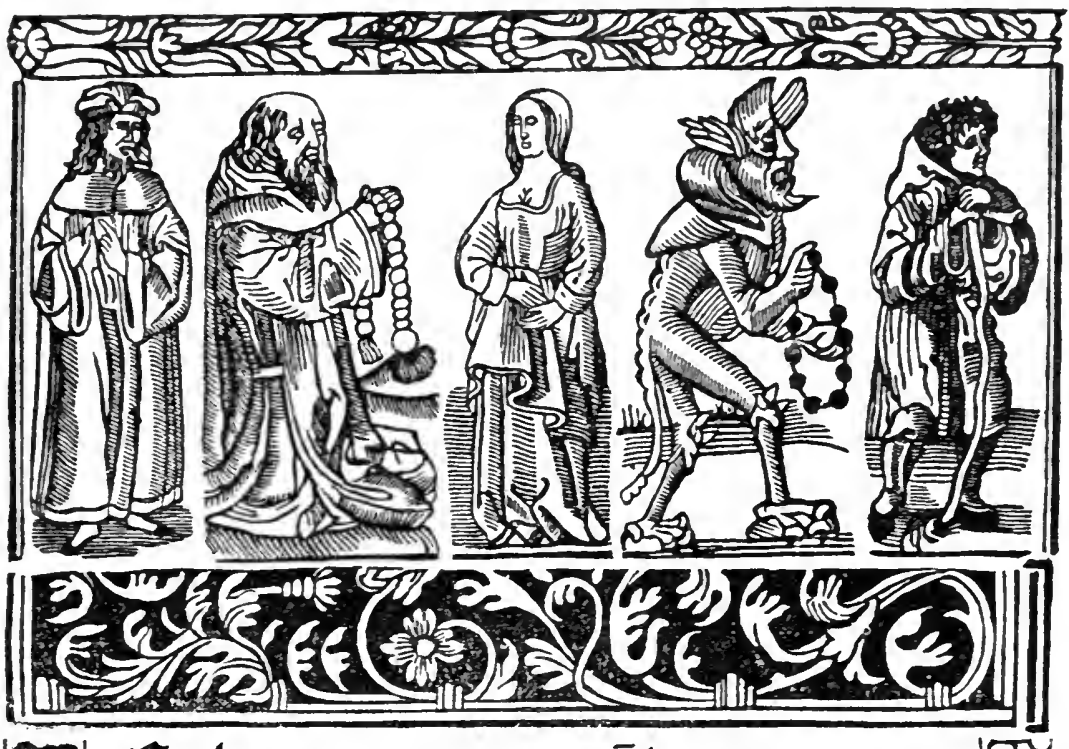

政 ge fta pozjuā de partís enla qual

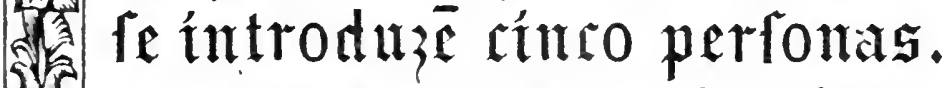

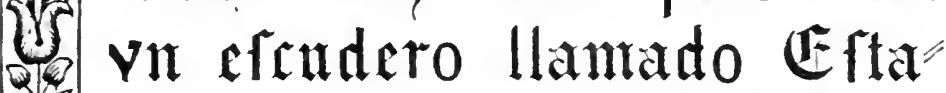

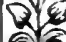
ริ

(5.)

Yi.

00

T)

ío $Y$ vil hermitaño $y$ vina motad Y Yul díablo: $Y$ dos pas ftozes:el yno llamado Hicen te: y el otro Uremon.

$$
1536 .
$$
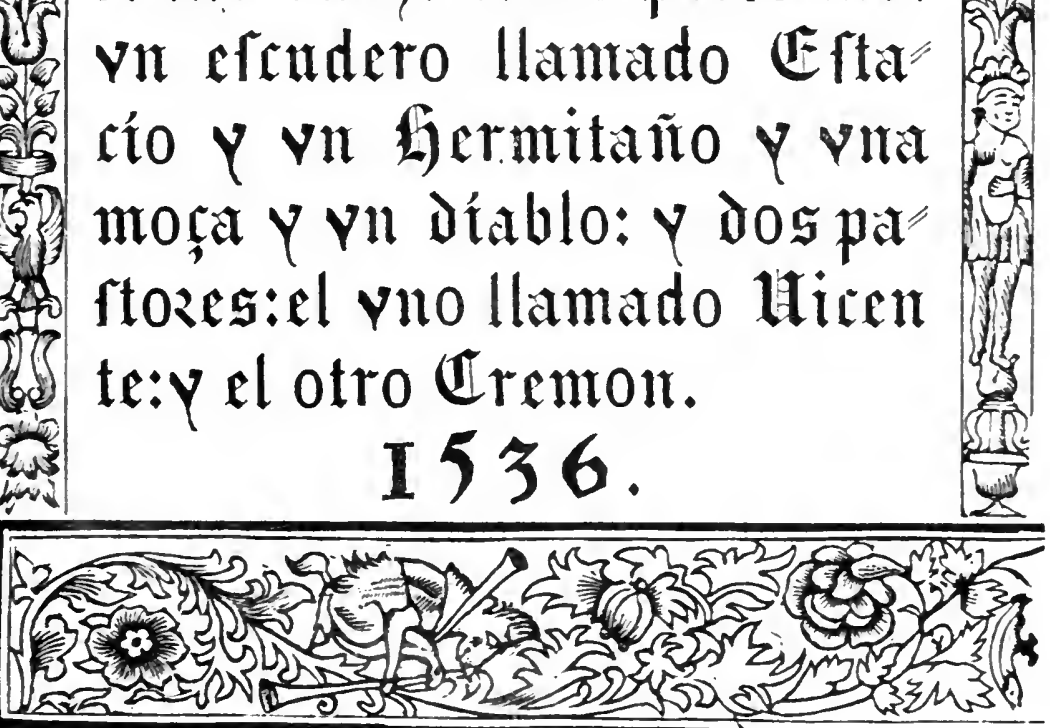

(Al dors' principia la Egloga.) | S. 1.4. ${ }^{\circ}$ let. gót. 12 hojas, sign. a. 
Como Moratin no menciona esta rarisima égloga me permitiré dar de ella un sucinto análisis.

Aparece en la escena un Ermitaño lamentándose de los trabajos y penalidades de la vida terrenal, y dirige una oracion a Dios y á la Vírgen María para que le libren de las tentaciones del espíritu malo.-Sale por otro lado un Escudero quejándose, en siete octavas, de las crueldades del amor, y el Erınitaño que le ha oido dice:

Por las palabrąs que aqueste ha liablado

De tanto tormento, de tanto dolor,

Yo pienso que debe venir del amor

El su corazon con pena llagado;

A él quiero ir , pues está tair penado,

Porque yo sea su cinnsolador.

-Dios os consuele, mui noble señor.

Esc. Padre bendilo, seais bien llegado.

Sigue un diálogo entre los dos en el cual el mancebo le da razon de sus cuitas reasu. midas en estos versos:

Habeis de saber que el bravo Cupido

Es causador de mi pena $\mathrm{y}$ tormento;

Aqueste Dios ciego, mochacho sin tiento,

Hizo que ainase a quien me aburriese

E de la su vista me despidiese ;

Aqueste Dios ciega el mi entendimiento.

El padre le aconseja no piense en devaneos y tenga continuamente ocupada su imaginacion en cosas santas y virtuosas; el escudero Estacio queda tan convencido con estos consejos, que promete al fraile abandonar el mundo y retirarse á hacer una vida austera y religiosa; y el Ermitaño, viéndole tan bien dispuesto, se lo lleva á su vivienda con el objeto de que realize sus laudables propósitos.

Se presenta en la escena el Diablo, quien en un monólogo de tres octavas, se queja de Dios no solo por tenerle prohibida la entrada en el ciclo, sino porque le arrebata sus victimas, como le acaba de suceder con el Escudero, mas se propone reparar esta perdida haciendo que la mujer á quien amaba Estacio busque á su querido hasta encontrarle, con la esperanza de que á su vista cejari aquel de sus santos propósitos.

En la escena siguiente aparece un pastor llamado Vicente, lleno de miedo por haber visto al Demonio, y dice en la primera octava:

Defléndame Dios y cuan crecentado

Traigo el temor y la pena conmigo, Que una fantasma é un mal enemigo

Me han por el monte mui mal medrentado

Ehan, par Dios, tal miedo se me ha levantado Mirando estas cosas á tan denodadas, Qu'al rabo yo traigo las bragas pegadas, Segun qu'hora vengo de miedo cagado.

Se oculta luego entre las breñas para no ser hallado, aun cuando vuelva el Demonio, y miéntras está en su escondite sale una dama llamada Numida, que es la querida de Estacio, quejándose tambien de su suerte en varias octavas, la primera de las cuales nos declara ya suficientemente el motivo de su dolor:

0 pena mui dura, dolor mui crecido Que ansina penetras mis tristes en trañas, Sabiendo qu'es ido á morir por montañas, Por sola mi causa, mi bien mui querldo; Agora yo triste á buscallo he venido Por esta espesura de valles y sierras, Porque su amor me da tantaz guerras

Cual nunca mayores jamas las he vido.

Vicente desde el escondrijo cree que aquella mujer es Satamas con disfraz femenil y le conjura para que se vaya; pero Numida calula sus recelos y se entabla entre ambos un diáloğn, del cual copiaré testualmente el principio:

Don.No tomes espanto ni ménos pavor, Mas mira conosce mi estado é honor E no te ausentes, pastor, por tu vida. vic. Olı, Dios os mantrulla, la dama garrida. Don. Estés en buen hora tambien tú, pastor.

Vic. A Dios m'encomiendo, señora lluziente, Que sos mui chapada de gran perflcion, De gran gestadura, de huerte facion, Y todos los bienes teneis juntamente: Mas dizule señora, ipor qué incon veniente Estades llorando con huertes pasiones? ¿Tenés mal de madre, dillor de riñones, 0 quizas del bazo, tambien de la frente: 0 estais empreñada de mala manera $Y$ estais en puntillos de haber de parir? E si es de esta guisa debeislo decir, Iré yo corriendo á llamar la partera.

La dama le desengaña, sin ofenderse de sus suposiciones gratuitas, y le cuenla el verdadero motivo de sus penas; le pregunta si ha visto á Estacio, y Vicente le responde negativamente: esta contestacion la desespcra; pero el compasivo pastor la consuela ofreciéndose él á suplir el puesto del Escudero perdido. Llega en esto Cremon, amigo de Vicente, se entera de lo ocurrido y no estraña haya la señora rechazado los ofrecimientos de Vicente, siendo este tan necio, bobo $\mathrm{y}$ grosero. Esto da lugar á un diálogo mui re. ñidn entre los dos pastores, siendo Numida medianerd para evitar lleguen á las mąnos. - Terminada la contienda, propone vicente ir á buscar á un Ermitaño que mora cerca de alli, y los tres se marchan con este objelo. Por el camino Cremon brinda á la doncella con su amor y es desairado como su compañero: -llegados á la ermita el cenobita inquiere la causa que ha traido alli á la dama, y esta se la declara dándole las señas de su amante; al oirlas el fraile ie hace saber está en el santuario aquel sugeto, $\mathrm{y}$ le manda salir:. Estacio queda sorprendido al ver á Numida, y arrojándose en sus brazos renuncia á los propósitos que habia hecho, en estos dos versos:

\section{Agora reniego de mala frailía}

Ní quiero ermitaño, ni fraile más ser.

El Padre les aconseja se casen y Cremon añade, que aprovechen la presencia del religioso para desposarse. Estacio preflere se 
celebre la boda en la cludad; el pastor insiste en que se den las manos y pronuncia una especie de formula matrimonial.-llaciendo. se ya tarde $\mathrm{y}$ acercáldose la noche dice el

Erm. Suplicoos querais, señor escudero, Quedar, pues es noche, aqul reposado Yos é la dama.

ric. Cremon repicado, oteas la habra del padre e consejo! l'rometo por san, que quirri el puto vicjo Tener esta noche la moza á su lado.

crem. Heñego, Carillo, de mala razon Qu' el padre ha habradn, è de tal consejar Par diez te lo juro, que debe de andar Mui bien alterada la su comprision.

Vic. Hi de cornudo! que mal frailejon E como quirrie con la moza rezar. Es este el santo?

Crem. Será de pajar, inon. Que estase él ardiendo é las pajas aun Consejoos, señores, que no vos quedeis Con fraile tan malo de mila manera, So irse ha. par diez, á la cabecera A'n que a los pies de la cama lo echeis.

El Escudero se indigna al oir este coloquio; pero se conviene á marchar en seguida, y todos le acompañan cantands un Villancico con que termina la pieza.

Este ejemplar es el unico que se conoce y perteneció á Mr. Teruaux-Conpaus; de él habla Ticknor en el tom. II., pág. 152 á 154, y Barrera en su Cralálogo; el último menciona otra edicion de la misma farsa existente en la biblioteca de Munich, cuyo tftulo es: Farsa muevamente cumpue ila, por Juan de faris, en la qual se introduzen cinco personas: un escudero llamado Estacio, y un Hermitaño y una Moça, y un Diablo y dos pastores. El vno llamado vicenle, y el otro cre. mon. M.D.L.I.S. l. de impresion. 4. (Supongo será en let. gót.) Encima del título un grabado. 12 hojas signadas cada dos.

1341 PARNASO ESPAÑOL. Coleccion de poesias escogidas de los mas célebres poelas castellanos (por D. Juan José Sedano/. Madrid, Joachin Ibarra y Antonio de Sancha, 1768-78. 9 vols. $8 .^{\circ}$ Láms. y retratos.

El tom. VI. comprende los siguientes dramas:

Nise lastimosa. Tragedia de Fr. Jerónimo Bermúde:.

Nise laureada. Tragedia del mismo.

La venganza de Agamemnon. Tragedia de Sófocles, traducida por Pérez de oliva.

Hécuba triste. Tragedia de Eurípides, traducida por el mismo.

Isabela. Tragedia de Lupercio Leonardo de Argensola.

Alejandra. Trugedia del mismo autor.

Al principio de cada tomo se hallan noticias biográflcas de los autores contenidos en (i), y al fin unos Juicios crilicos de las com. posiciones que se incluyen.

1342 PARNASO NUEVO. Primera parte del Parnaso nvevo, y amenidades del grsto; en veinte $y$ ocho entremeses, bailes, $y$ sainetes. De los nejores ingenios de España. Madrid, Andres Garcia de la Irlesia. Año de $16 \overline{10.8} .^{\circ}$ i hojas prels. y 220 págs.

Conticne los siguientes entremeses, bailes, sainete $\mathrm{y}$ niojiganga:

El cortacáras. E.-Yorelo.

Ecos. B.-Yinleser.

El refugio de los poetas. E-Vtro. L.con.

El borracho y Talaveron. E.-Anónimn.

El amigo verdadero. E- Audres Gil.

La Zamalandrana hermana. B.-Voreto.

Los einbusteros. E.-Franc. de Quiros.

El alcalde del corral. B.-Benavente.

La sorda. E.-Fillaviciosa.

El matulero. B.-Yonleser.

Diña Mata. E.-Caleleron.

Para la noche de Sin Juan. E.-yoreto.

Dos íspides trae Jacinta. B.-Monteser.

El sar.rento bauchillos. E. Franc. de Ave. llanedit.

Los zaparrastrones. B.-Bennvente.

Las manos negras. S. - Im mleser.

El cerco de las hembras. B. Vorelo.

El muerto, Eufrasia y Tronera.-Fl' de omiros.

Periquillo non durmas. B.-El mismo.

Las patas de raca. E.-Benatenle.

Morena de Manzaníres. B.- Villaviciosa.

Doña Esquina. E. -Yorcln.

Los pájaros. B.-Malvenda.

Los registros. E.-. Yonteser.

Yo me muero y no sé cómo. B. -J. Vélez

Los sacristanes burlados. E. - Moreto.

Enjuga los aljofares. B. - Diamante.

El pésame de la viuda. M.-Calderon.

Sin duda el Jacinto Malvenda, autor del baile de Los pajaros, será el autor de una coleccion de poesias algo libres y picarescas que he visto y se intitula: Tropezon de la risa. Compuesto. Por Jacinlo Atonso de Valuenda, natural de la ciudad de balencia. Ialencia, por Syluestre Esparza, s.a. 12. hojas prels., 104 fols. y 2 de Tab'a.

El Sr. Barrera y Leirado isnora el titulo del Parnaso nuevo y supone ser este libro el llamadu Migajas del ingenio y apacible entretenimiento en entremeses. Zaragoza. Diego Dormer, (1675?) 8. , porque solo habin visio dos fragmentos de èl en poder de los seĩores Duran y Fernindez-Guerra, faltos de lis preliminares y del entremes de El corlacdras.

1313 PARRAGA MARTEL DE LA FUENTE (Francisco). Historia de Lisseno, y Fenissa. Dividida en seis 
discrisos. Sv avtor Don Francisco de Parraga Martel de la Fuente. Madrid, lulian de Paredes, 1701. $4 .^{\circ} 10$ hojas prels. y 313 prigs.

Es una novela en la cual sø eucuentra una Loa paru licmpo de Carnestolendas, que es más bien una especie de zarzuelita representada entre varios persouajes.

\section{PaSQUaligo (Alvise).} Gl' Intricati Pastorale del clariss. Sig. Aluise Pasqualigo. Non più posta in luce. Venetia, Francesco Ziletti, $31 \mathrm{D}$ LXXXI. 8. ${ }^{\circ}$ let. curs. 71 hojas foliadas, inclusas 9 del principio que no lo estrin. Al fin va una blanca.

En la presente comedia italiana, el gracioso Calabaza habla constantemente en cas. tellano; por esta razon he ereido que tanto esta pieza como dos ó tres más, impresas tambien en ttalia, las cuales tienen aquella particularidad, debian flgurar en la seccion Uramática española. El Sr. Barrera ó no npina como yo, o no ha conocido estas composiciones, pues no las hl incluido en su catálogo del tealro español.

134: PASTOR (JUAN). Avelonvevo del sauto Nacimiento de Christo nuestro Señor. Compuesto por Iuan Pastor. Siguen dos laminilas de mudera.) Son interlocutores de la obra. Burguñon moço. Pero Gomez ciego. Martin Aluarez ciego. Ril Emperador Octauiano. Yn Secretario suyo. Vn pregonero. Vn viejo llamado Blas Toçuelo. In bobo. Su hijo dicho Perico. San Ioseph. Santa Maria. Pastores. Miguel recalcado: Anton Morzilla. Iuan Relleno. In Angel. Impresso, en Alcala de IIenares, en casa de luan Gracian que sea en gloria. Año de 1613.3. 4. 12 hojas, signatura A.

Mui raro.--Los tres primeros interlocutores mencionados en el fróntis 110 lo son del Auto, sinn de Vn passo de dos ciegns mu! gracioso pai"e la noche de Naltidad, que le precede, escrito por Juan de Timoneda, scgun se ve en los Origenes del leatro de Moratin, donde se ha reimpreso.-En el nim. $3^{9}$ de dichos orlyene: encuentro citala una edicion de la nbra de Jian Pastor, hecha en Sevilla el año 1.i28.

De este mismo autor he visto otra composicion dramitica cllyo título era: Farsa cle Licrecia. (Siguen dus flguritas y una especie de ediftcio, y bajo:) Tragedia dila castidad de Luerecia. Agora nuevamenle cöpuesia en metro por Juan pastor natural de la villa d'morala... (La portada está cịrcuida de orla estrecha.) S. l. mi a. $4 .^{\circ}$ let. gót. 12 hojas sin foliacion, sign. A. Tiene algunas flguritas al principio de las escenas.

El Sr. Barrera copia á Moratin al hablar de este aulor, y por consiguiente tampoco menciona la edicion del Aulo que yo tengo.

Al tlin de la farsa le Lucrecia, ántes deserita, dice Pastor habia compuesto otras dos llamadas Grimallina y Clarinna: es la única noticia que de ellas se tiene, ál no ser esta iltima la siguiente pieza deserita en las adiciones y notas á la IIist. de la lil. de Ticknor: Comedia llamada Clariana nucvamente compuesta, en que se refieren por heroyco estilo los amores de un cavallero moço ilamailo Clareo, con una dama noble de Valencia dicha Clariana. Assi mismo una Egloga pastoril entre dos paslores, Ju'io y Leuzinio, a la muerle de una pastora llamada Julia, compucsta por un vezino de Toledo, y por el dirigida al duque de Gandia.-Valencia, por macstro Juan Jofre, al moli de la Rovella; acabosse a ix de mayo del año de nuestra reparacion MDXXII. $4 .^{\circ}$ let. gót. 22 hojas $\sin$ foliatura.

1340 PeLlicer (Casiano). Tratado historico sobre el origen y progresos de la comedia y del histrionismo en España: con las Censuras teologicas Reales Resoluciones y Providencias del Consejo Supremo sobre Comedias: y con la noticia de algunos célebres Comediantes y Comediantas asi antiguos como modernos. Con algunos Retratos. Por D. Casiano Pellicer. Madrid, Imprenta de la Administracion del Real Arbitrio de Beneficencia, 1804. 2 vols. $8 .^{\circ}$ Con los retratos de Lope de Vega, Lope de Rueda y María Ladvenant.

Ademas de ma historia mui interesante de la literatura dramática española, contiene una completisima noticia biogrifllea de todos los principales actores y actrizes que más se lian distinguidı en nuestra escena.

Vo comprendo por qué en un Catálogo bibliogrifico-biogrifico del teatro español, como intitula el suyo el Sr. Barrera, no ha incluido indas las obras que lienen relacion directi con esta parte de nuestra literatura, como por ejemplo, la presente de Pellicer, las Recreaciones publicas de Garef́a de Villanueva, los Origenes le, Moratin, las Lecciones de Lista y aun casi los Origenes de la poesia de Velízquez. Ménos concibo todavía, el que no se dé noticia de las colecciones de nuestros antiguos dramíticos publicadas á flnes dẹl siglo pasado y durante el actual, en cuya clase entran la de García de la IIuerta, la de Ortega y Compañía cu cincuenta y oeho cua: 
dernos, el Tealro antiguo espaitol, Impreso por frimaud Velaunde, el Tesoro de ochoa, La Talia españolu, \&., \&. En producciones de tanta Importancia y estudio como la del Sr. Barrera, no solo les corresponde un lugar á los libros citados, sino á todos aquellos que por cualquier incidente hablen sobre nuestro teatro: ası deberian estar las censuras y apologlas escritas sobre él, los tratados que se ocupan de nuestros escritores dramáticos y todo lo relativo al histrionismo en España. Esla falta es tanto más sensible cuanto que se ha dado en dicho Cutalogo suma estenslon á noticias, Interesantísimas y curiosas si se quiere, pero estrañas al objeto de la obra: v. g. el largo artículo de Feliciano de Silva, lo Ilenan casi por entero juicios y descripciones de libros caballerescos, miéntrás en el de D. Gabriel del Corral y el del P. Fr. Juan de la Concepeion apenas se dedican dos líneas á las producciones dramáticas de ambos, verdad es que estas se reducen á haber escrito una comedia cada uno de ellos; y por el estilo hai otros muchos.

Estas observaciones me he permitido hacerlas porque sé apreciar como merece el interesante y erudito trabajo del Sr. Barre: ra, y porque deseo ayudar en cuanto esté de ni parte á su mejora y perleccionamien. to. No se crea, pues, que en mis reparos hai la menor lendencia á una indigna é injusta hostilidad: si á vezes he corregido algunas equlvocaciones $\dot{o}$ llenado varias de sus lagunas, no he tenido otra mira sino la de contribuir á que desaparezcan ciertos pequeños lunares que afean tan escelente obra; $y$ sin querer parangonar en mérito é importancia mi humilde nomenclator bibliografico con el Catálogo razonado del teatro y otros ramos de la literatura española del Sr. Barrera, suplico á este señor y á los demás bibliófllos, se sirvan rectificar pủblica ó privadamente las faltas que tal vez pululen en este inventario, seguros de que aceptaré gustoso $\dot{\mathrm{y}}$ agradecido cuantas justas enmiendas se me hagan.

1347 PEREGRINO (ÁNGE). La mejor guirnalda de Apolo, y corona del monte Parnaso, que de varias flores poeticas, Sagradas, y Profanas, Serias, y Jocosas, (esparcidas en diversos Assumptos) labra, y texe su autor Don Angel Peregrino. Tomo primero. Madrid, 1742. 8. 16 hojas prels., 406 págs. y dos hojas de Indice.

Contiene ademas de varias poesias un Paso cómico, una Zarzuela con su Loa, un Sainete $y$ un Entremes.

El Sr. Barrera y Leirado se equivoca en suponer es el año de la impresion el de 1746 , á no ser exista una segunda, Io cual no parece probable, o bien que el segundo toino se halle así fechado. Dicho $\mathrm{Sr}$. Barrera da el titulo de dos comedias comprendidas en la obra, y sin duda estarán en dicho tom. II. que no tengo; pero se me hace mui estraño no diga una palabra del Paso cómico, de la Zarzuela real Intitulada: $E$ l veneno en la hermosura, y el Entremes las niñas de la maestra, Incluidas en el primero.

\section{PÉREZ DE MONTALVAN} (JunN). Primero tomo de las Comedias del Doctor Ivan Perez de Montalvan. En Madrid, En la Imprenta del Reyno, Añ̃o 1635. A costa de Alonso Perez de Montalvan, Librero de su Magestad, y padre del Autor. $4 .^{\circ} 6$ hojas prels., 209 fols. y una en que se repiten las señas de la impresion.

Primera edicion. El Sr. Barrera y Lcirado, despues de describir la edicion de Alcalá, 1638, pregunta si existe alguna anterior a ella, á pesar de que todos ios bibliografos la dan como primera. ¿Qué mayor prueba se quiere de la escesiva rareza de la impresion príncipe de 1635 , de la cual nadie ha Lablado?

1349 - Primero tomo de las Comedias del Doctor Iran Perez de Montalvan. Alcala, Imprenta de Antonio Vazquez, 1638. 4. 6 hojas prels., 20 9 fols. y una para repetir el lugar y año de la impresion.

Esta segunda edicion, reimpresion á plana renglon de la anterior, es casi tan rara como aquella. El Sr. Barrera se equivoca cuando supone ser el año de la portada el de 1659 ; á la verdad, dicho señor no solo no ha visto el libro, sino que aun pone en duda su existencia.-Brunet equiroca el tamaîo, pues dice es en $8 .^{\circ}$

- Segundo tomo de las $\mathrm{Co}$ medias del Doctor lvan $\Gamma$ :ez de Montalran. Madrid, Imprenta del Reyno, 1638. $4 .^{\circ} 6$ hojas prels. y 974 fols.

Primera edicion de este tomo, mui rara. Brunet menciona una Segunda purte de $M a$ drid, 16j9, y Nesonero otra de Alcal $i, 1641$.

$13 \breve{50}$ - Tomo primero de las Comedias del Dotor Ivan Perez de Montalvan. Valencia, Claudio

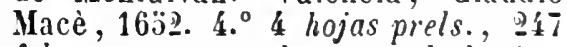
fols. y una para las señas de la impresion.

Las comedias comprendidas en este tomo, en las tres ediciones descritas, son las siguicntes : 
A lo hecho no hai remedio y príncipe de los montes.

El hijo del selafln, San Pedro de Alcímtara.

Cumplir con sli obligacion.

Los tomplinios.

Lal doncella de labor.

El mariscal de Viron.

La toquera vizcaina.

Alnor, privinza y eastigo. Tragedia.

oliuspa y Vireno.

I.0 que son juicios del ciclo.

El si. 1). Juan de Austria.

Los amantes de Termel.

Observo falta cu la edicion de Valencia la dedicatoria que lleva cada comedia en las dos anteriores, y el nombre del aclor cuya compañía las represento.

\section{PEREZ DE MONTALYAN (JUAN).} Segrudo tomo de las. Comedias del Dotor Ivan Perez de Montalvan. Valencia, Claudio Macè, 16ว̈2. 4. $^{\circ}$ 4 hojas prels. $y 272$ fols.

Las comedias comprendidas en este segundo tomn, en las dos ediciones que tengo, son las signientes:

como amante $y$ como hourala.

Sermulit parte del séneca de España, Dou

Felipe segumdo.

Don blorisel de Niquea.

L.a keshome homlosi.

El valiente vizareno.

Teitgenes y Clariquea.

bespreciar lo que se quicre.

El divino polturues, san Antonio de Pidua.

Amor, lealtad y amistad.

la ganancia por la mano.

il valiente mis dichoso, D. Pedro Giral.

El sufrimiento preciado.

Tamhien es mui dificil encontrar en buen stado las dos lartes de lit edicion de Valencia.

$13 \dddot{31-C o m e d i a s ~ e s c o g i d a s ~ d e l ~}$ Doctor Don Juan Perez de Montalvan. Madrid, Ortęa y Compañia, 1827-31. 2 vols. $8^{\circ}$

Pésima elicion que solo se puede tener por el Examen puesto al flin de cada comedia.

Contiene las siguientes:

Cumplir con su obligacion.

L mis constante mujer.

No liai vida cono la lionra.

ser pridente y ser sulrido.

Como í padre y como í rei.

la loquera vizcalna.

1320 Para todos, exemplos morales, humanos, y divinos. En que se tratan diversas ciencias, materias, y facultades. Repartidos en los siete dias de la seniana Por el Doct. Juan Perez de Montalian. Sevilla, Gomez, 1736. 4. 4 hojas preliminares y 536 págs.

Comprende las comedias y autos sacramentales que se espresan á continuacion:

El segundo Séneca de España, ó príncipe D. Cárlos.

No hai vida como la honra.

be un castigo dos venganzas.

El Polifemo. $A$.

Escandarbech. A.

La más constante mujer.

Tambien hai tres novelas distintas de las ocho que comprenden las primeras ediciones de los Sucesos y prodigios de anor.

Del Para lodos se conocen varias ediciones de las cuales he visto ó encuentro citadas las siguientes:

\section{- Madrid, 1652. Barrerd.}

- Huesca, Pelro Bluson, 1653. 1.0 Brunet. Con algunas adiciones nuevas en esta uinla impression. Madrid, Imprenla del Riyno, M.DC.X.XYV. 4. 8 hojas prels., 295 fols. yuna para repetir la fecha. La tuvimos en limilres.

- Madrial, 1640. 4. Nic. Antonio.

Matrid, 16:5. Barrera.

Oclava impression. Mudrid, Sánchez,

16.1. Brunet. Alcala, Fermandez, 1661.4. Brunet. Lisboa, Domingo Carnero, 1691. 4. La he visto.

Por lo que dice el mismo Montalvan en el prólogo al tomo primero de sus comedias, doben existir ediciones del Para lodos hechas en Barcelona, Zaragoza o Valencia y de Bruselas, anteriores al año de 1655.

He visto manuscrita una crítica anónima de este libro, hecha al parecer poco despues de sul pulicacion; como muestra de lo acremente que está escrita copiare el siguiente pasa : "Ahi tienen V. Ids. (dijo D. Blas) el "libro Para todos, que es del llr. Joan Perez de Montalvan que su nombre es verso y "de arosa.-iEse, dijo la Pelinegra, no es uno "prosa. fue muchos años retazillo dè Lope de "que fue muchos anoduras de sus comedias "re dió en escribir "se sustentaba, hio? iPoeta de la calle de los media con limpio? ¿Pocta de la cara hacer megros, juntándose con otros para hacer "pasos á escote? ¿Ún estudiantitlo eon encaje mde lechuza, hijo de un librero de alcala? "-Ese propio, respondio D. Blas, y para ha wcerse copia de l,ope se ordeno no quilarle "presto se echarí el frei; por no quilarle upinta hízose doctor por equivocarse del "Vescua; y está graduado pós dineros á mal 
no trajo graduada la mula de alquiler. A weste, pues, llaman hominieacu, por chico, ay por los hurtos; que se le averiguo que marrıño una comedia entera de Villaizan; y uprimer testigo mayor de toda escepcion "fué lo que habia escrito ánles y lo que eswcribio despues y abora; para enmendarlo wy ostentar su ciencia, ha compuesto este "libro que se intitula: Para lodos, y en el whai novelas, autos, sacramentales, sitiras, wdeclaracion de la misa, comedias, instrucwcion de predicadores, almanaques, repor"torios, lunarios, amores y cuestiones teolowgicas; junta los santos á los bergantes, cila "batidos los idiotas y los tlósofins; Ios chan. mzeros y los padres de la Iglesia; alaba al waulor de la Niaqueracuza como al de la tlia. wda ó Eneida; celebra al autor de los fórligos wmórligos, chichirimallos, forisimollos, trimbulicallos, mucho más que al penandro, y "con palabras que aun arrastraran á Aristoweles, de manera que este no es libro sino wcoche desde Alcaláa Madrid.»

133̈3 PÉREZ DE MONTORO (JosÉ). Ubras posthumas lyricas humanas de D. Joseph Perez de Montoro, recogidas, $y$ dadas a la estampa por Juan de Moya. Madrid, Antonio Marin, 1736. 2 vols. $4 .^{\circ}$

Ademas de las poesias conticnen dos loas, la una representada en celebridad de los años de la reina Doña Itaría Luisa, y la otra con motivo de la llegada á la corte de la misma, un entremes y baile en dicha flesta, y utro baile intitulado: Del Abrunino.

Es mui singular que el Sr. Barrera no haga mencion de Pérez IIontoro en su Culillogo. á pesar de pertenecer este autor al siglo Xili, pues murió en Cadiz en 16:44: pero lo más estraordinario es no conociera Jimeno la edicion de sus obras hecha en 1736 , y suponga en 17.49 que estaban inéditas. Fuster no ha reparado este descuido del autor de los Escritores del reino de Valencia.

13:4 PEREZ DE OLIVA (FERnav). Las obras del Maestro Fernan Perez de Oliva... Con otras cosas que van añadidas. Cordoua, Gabriel Ramos Bejarano, 10̈86. Al fin, M.D. LXXXY.) 4. 21 hojas prels., inclusas dos de fe de erratas que faltan casi siempre, 283 foliadas y una blanca.

Primera edicion.

En el fol. 283 rta. se lee la siguiente advertencia del impresor, que esplica por qué algunos ejemplares llevan la fecha de $\mathbf{1 5 8 5}$ en la portada, la diversidad que se observa en los preliminares y el coneluir estos con la llamada LAS, que no va acorde con el priacipio del fol. 1.

Том. 1.
"Al Leclor, Gabriel Ramos Bcjarano."

"Fste libro se començo a imprimir en Samamanca, y despues fue necessario passarlo wa Cordoua, auiendose impresso alla no mas sque lasta el argumento de la dignidad del whombre en quatro pliegos. Todo lo demas „se acabis en Cordona. Yas porque on Salamnanca no se imprimieron mas de quinienmlos, se inmprimierno otros mil enterus en "Cordoua. P'or esto tendrin vnos libros difwerentes principios de otros, y podrlase penusar que fuessen dos impressiones, y no es "sino toda vna misma, como por lo dicho se wentiende.

El volumen contiene algunas pneslas del ytro. Pérez de oliva, y lus tres dramas en prosa que van á continuacion:

El nacimicnlo de Hercules, o Conedia de Amphitrion, tomando el argumento de la latina de Plauto.

La Venganca de Agumenon. Tragedia cuyso argumento es de Sófocles, poeta griego.

Hecuba Triste. Tragedia, cuyo argumento está tomado de Euŕpides, aunque se han mudado inuchas eosas.

Sedano reimprimió en el tom. VI. del Parnaso español, la Venganza de Agrmenon y la Hécubu lrisle; pero ni dirho tedann, ni yontiano y Luyanilo ell el biscur'so de las lragedias espuñdas, pág. 11. ni yoratin en los origenes del lealon español, ni . Yic. Intonio, ni Ticknor, ni Barrera supicron que tanto la primera ile aquollas produrbiones dramáticas como el Anfilrim se habian publicado por separadn antu's del ding list, en que salieron á luz tudas las obres reunidas alel Maestro Perez de Oliva. rianse los artículos de Plauto y Sófocles en esta misma Division.

Contiene este volíuren ademas de las antedichas obras de uliva las signientes de su sobrino y editor Ambrosio de Horiles:

Un Discurso sobre li lengua castellana.

Quince discursos sobre varios asunlos.

La devisa pura el siñor D. Juan de Auslria y un discursn sobre ella.

La Tabla de Cébes y su derlaracion y

Un discurso del licenciado Pedro de valles.

A proposito de estos escritos dice el P. Flires en la pig. XX de las. Folicins pura la vida de Mordes, que preceden á su Viaje: "Hoi no mgoza el publico de estas obras, por estar nimpresas en el lihro del tio, que la Inquisiweion tiene recogidn, hasta que se inuminwden: y no ha llegado el dia de quien logre "la enmiendio." A esta cireunstancia se uelieri en gran parte la rareza de esta primera edicion, tan encarezida por el editol le la reimpresion hecha en Mallid. por Bellilo Calno, Y.DCC.LYY.YVII. ? vils. \&. ${ }^{\circ}$ " confirmada pni el hecho de que el Sr. Barrera y Leirado, a pesar de su particular empeño en recoger todis lo concerniente at nuestro teatro. sulo posee un ejemplar con los preliminares ma. nuscrilos. 
PLA

SECCION DRAMÁTICA.

PLA

$133 ̈ 5$ PLAUTO (H. Accio). Esta | es aproximadamente la portada.

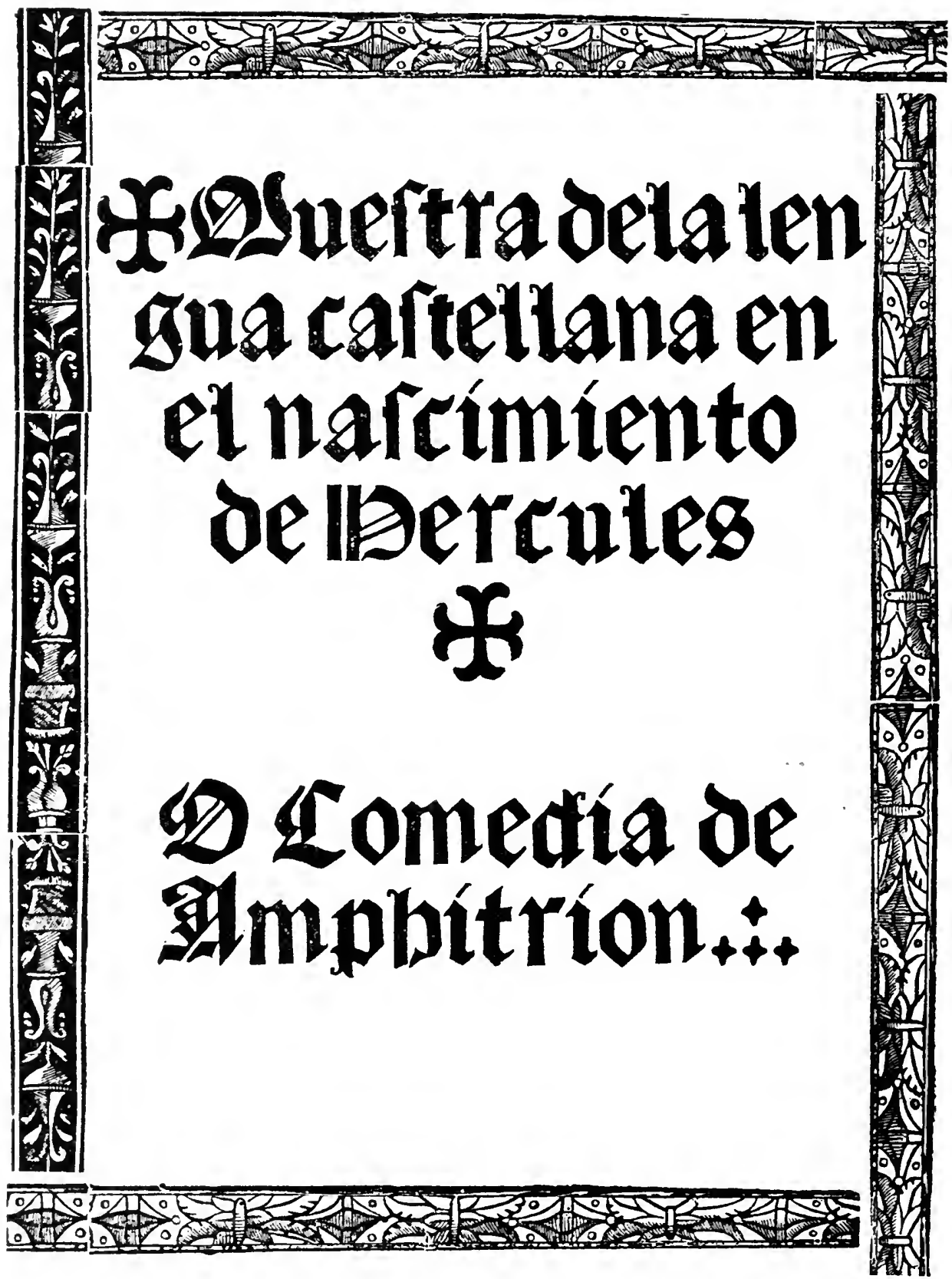

(Al dorso principia la dedicatoria $\mid$ no, y la obra concluye en el reverso de Ferman Pérez de Oliva i su sobri- $\mid$ de la vigésima hoja con las palabras 
Mispania Plaude.) S. l. ni a. rhácia 1523̈). $4 .^{\circ}$ let. gót. á renglon seguido de 34 líneas en la página; $\sin$ foliacion, con las signs. a y $\mathrm{b}$, la primera de 8 hnjas y la última de 12.

Rarisima edicion.

Dice el Mtro. Fernan Pérez de Oliva á su sobrino Augustin, en la dedicatoria, que esta es initacion y no traduccion de la comedia de Plauto.

Prueba ser mi edicion del año 1525 ó anterior, el que despues de describirla D. Fernando Colon en el Registro de su biblioteca, observa se la dió el mismo autor en Sevilla, el 27 de noviembre de dicho año 1525 .

Moratin, Ticknor y Sedano se equivocan en decir que ninguna de las obras de Pérez de Oliva se publicó hasta 1585 ; porque ademas de esta jınitacion de Plauto, tengo La venganza de Ayamenon, traducida por el mismo é impresa en 1528. Barrera tampoco dice una palabra sobre baber visto la luz pública estas dos comedias ántes de verificarse la im. presion de todas las Obras de Pérez de Oliva.

1356 PLAUTO (M. Accio).

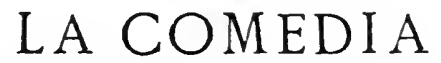

de Plauto, intitulada Mili

te gloriofo, traduzida en lengua. Gaste

Ilana.

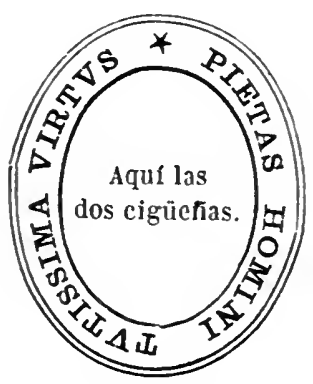

EN ANVERS

En cafa de Martin Nucio. M.D.LV.

Con Preuilcgio Imperial.

Esta comedia llega hasta el blanco del fol. 53: sigue despues
L A COMEDIA de Plauto, intitulada Me" necbmos, Traduzida en len gua Gaftellana por el mif mo Autbor.

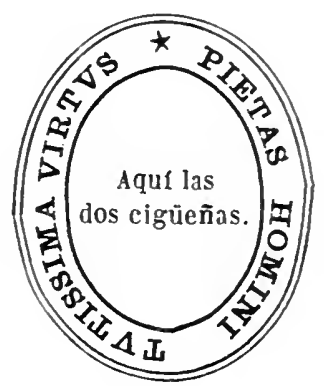

$$
\begin{gathered}
\text { En Anuers, En cafa de } \\
\text { Martin g̃ucio. } \\
\text { M.D.LV. } \\
\text { Gon Preuilegio Imperial. }
\end{gathered}
$$

12. 92 hojas foliadas, una en que hai unos versos latinos y el escudo de las dos cigiieñas, y tres blancas. La primera comedia como ya he dicho, llega hasta el blanco del fol. 53: la segunda, termina en el 92.

"En estas dos traluccioncs merecen ala"banza el lenguajc y el estilo." Yoratin. Origenes del lealro español.

Es singular que hablando los traductores de la Hist. de la lit. de Ticknor, en la pín. $520 \mathrm{del}$ toul. Il., de la traslacion casteIIana del Viles gloprosins de planto, no mencionen lit te los youechuos.

liel tradnctur aninimn solo se sabe que dedico sll obra á Gonzalı pérez, secerctario de Felipe II. . que hizo su version eall Lila, y que cstaba empleado en la hacienda renl.

Este tomito es mui raro.

Entre mis apuntes encuentro uma nota que dice:

Comedia de plauto llamada Amphitrion tradusida de lutin en lengua Castollana. Agora nucurumenle impressu en mucy dulce / apacibte y sentencioso eslito. 15j.4. (1I fin:) Fue impressa la jresinte obra en la impe. rul ciudud de Toledo: en casa de Juan de Ayala: en cl año de M.D.L.iiij. 4. let. gút. 
Sin fol., signs. $a-c$, las dos primeras de 8 hojas y de 11 la última. Es una taracea formada de las traduceiones de Villalobos y de Oliva, tomado un trozo de una y otro de otra.

Tambien guardo otra apuntacion que sin duda tome mui de prisa, pues solo dice: Anuphytrion. Alca (sie) de henares, Arnao guillé de brocar, m.y.d.y xvij (1517). 4.0 let. gótica sin fol., sign. a-e. Ignoro, pues, si seria la version de Oliva ó la de Villalóbos, aunque me inclino más á creer era la de este último.

\section{POETAS VALENCIANOS.} Doze Comedias famosas, de quatro poetas natvrales de la insigne y coronada civdad de Valencia. Valencia, Aurelio Mey, 1609. (Algunos ejemplares llevan 1608.) $4 .^{\circ}$ 4 hojas preliminares. En cuanto á lo demas del volumen, es necesario describirlo comedia por comedia, pues cada una tiene nuevas signaturas, $y$ todas carecen de foliacion.

En mi ejemplar dice en la portada: Venulese en casa de Iusepe Ferver; en otros se lee: Ventese en casa Pilicinali. son:

Las comedias que comprende este tomo

El Prado de Valencia. Con una Loa al principio y otra al fin.-Tárrega.-Tres floroncilos bajo el litulo. 28 hojas con-las signaturas A-D, de 8 hojas, ménos la D que tiene 4.

El fingido Esposo.-Tárrega.-Viñela. 20 hojas, signs. A-C, de 8 hojas, sino la C, que solo tiene 4. (Al fin diee:) Impressa en Valencia, en casa de Pedro Patricio Mey, junto a San Martin. 1608.

El cereo de Rodas.- Tárrega. - Viñeta. 20 hojas, signs. A-C, de 8 hojas las dos prineras y de 4 la $\mathrm{C}$.

La persegvida Amaltea. Preedida de Loa.Tárrega. - Varias viñelas de animales, plantas y árbotes en la porlada, y seis más al dor'so de la hoja segunda. 22 hojas, signs. A-C; la última solo tiene 6 .

La Sangre leal de los montañeses de Navarra. -Tírrega.-Viñeta con cuatro figuras. 22 hojas, signs. A-C; de 6 hojas la ultima. (Al fill dice lo mismo que El fingido Esposo.)

Las Svertes trocadas y Torneo ventvroso. Preeedida de Loa.-Tárrega.- $\mathbf{3 4}$ hojas, signs. A-D; la úllima tiene 10.

La Gitana melancolica. Con Loa al prineiplo. -Gaspar Aguilar. 24 hojas con las signaturas A-C, de 8 cada una.

La Nvera hvmilde. Lleva Loa al principio y diez decimas al fin.-Gaspar Aguilar. Viñela compuesla de tres en ta portada, así cumo lleman nueve todo el reverso de la segunda hoja. 24 hojas con las signaturas A-C, de 8 cada una.

Los Amantes de Cartago. Con Loa al fin.Gaspar Aguilar.-Viñeta con cualro figuras. 20 hojas con las signs. A-C; la ulltima tiene 4.

El Amor constanle.-Guillen de Castro. Va al principio una $L o a, y$ al fin dos composiciones poéticas intitulada la una Disputa entre $E l, y$ Tu, y la otra Boda pastoril. Viñeta con 4 figuritas bajo del titulo. 28 hojas con las signs. A-D, todas de 8 ménos la $\mathrm{D}$ que tiene 4.

El Cavallero Bovo.-D. Guillen de Castro.Viñeta de cuatro figuras. 20 hojas, signaluras A-C; esta solo tiene 4.

El Hito obediente. Con Loa.-Miguel Beneito. -Viñeta bajo del título y dos figurilas ul fin de la Loa. 24 hojas con las signs. A-C, de 8 cada una. Al fin va un enlremes inti. tulado: El maestro de escuelas, en prosa.

1338 POETAS VALENCIANOS. Doze comedias famosas de quatro poetas natvrales de la Insigne $y$ Coronada Ciudad de Valencia. En Barcelona, en casa de Sebastian de Cormellas, 1609. Vendese en la mesna Emprenta. $40^{\circ} 4$ hojas prels. y signs. A-Qq, todas de 8 hojas, ménos la $\mathrm{D}, \mathrm{G}, \mathrm{K}, \mathrm{Ff}, \mathrm{KK}$ y $\mathrm{Nn}$, que son de 4, la $\mathrm{N}$ y $\mathrm{Q}$ de 6 , y la $\mathrm{V}$ de 10. Tiene viñetas al principio de algunas comedias.

Hai ejemplares de esta edicion en cuyo fróntis dice: Vendese en Caragoca en casa de Jayine Gotart Mercader de libros, en vez de to que se lee en el mio.

1359 - Doze comedias famosas, de quatro poetas natvrales de la insigne y coronada civdad de Valencia. Las quales van en la segunda hoja, con sus loas y entremeses. Madrid, Miguel Serrano de Vargas, Año de 1614. 4. ${ }^{\circ}$ Carece de foliatura. 4 hojas prels. y las signs. A-Tt, de 8 hojas ménos la $\mathbf{D}, \mathbf{K} y \mathbf{T t}$, que solo tienen 4. Viñetas mui toscas al principio de todas las comedias y tambien al fin de algunas.

la segunda parte que describlré á continuacion no sè que se reimprimiera en Madrid.

Soi de la opinion del Sr. Barrera y Lelrado en creer que las variantes en las portadas de las ediciones de Valencia y Barcelona, pendian de la distribucion de ejemplares hecha entre los libreros que mancomunada. 
mente costeaban los gastos de la Impresion. Por lo tocante á la diversa colocacion de las comedias, notada en algunos, nada tiene de particular, pues careciendo de follatura $y$ siendo las siguaturas (que sf las tienen ambas partes, por más que diga en contrario el Sr. Minch Bellinghausen) independientes en cada pieza, podian colocarse como más placiera á cada librero copropictario.

\section{POETAS VAleNCIANOS.} Norte de la Poesia española. Illvstrado del sol de doze Comedias ique forman Segunda parte) de Laureados Poetas Valencianos: y de doze escogidas Loas, $\mathbf{y}$ otras Rimas a varios sugetos. Sacado a luz, aiustado con sus originales por Aurelio Mey. Valencia; En la Impression de Felipe Mey... A costa de Filipo Pincinali, $1616.4 .^{\circ} 8$ hinas preliminares; para lo demas hai que recorrer las doce comedias, pues cada una tiene muevas signaturas, y el libro carece de fcliacion.

El Cerco de Pavia y Prision del Rey de Francia.-Tárrega. Yan al fin unas Cuplas para cantar. - Viñela con cuatro figuritus. 28 hojas con las signs. A-D, de 8 hojas, ménos la $\mathrm{V}$, que solo liene 4.

El Marido asigurarlo.-D. Cárlos Boil Vives de Canesmas, olinı de Arenos. l'recede una lona donde se nombrum lodrs lats damus the Valenciut. - riñela con cuntro fuymrilus. ¿s hojas con las signs. A-C de 8 ; le ullima liune 12 hojas.

El Nercader amanle.-Gaspar Agllilar. Pre. cedida de Lina y seguida de umas Coplas

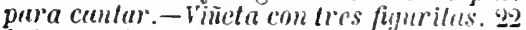
hojus con las sijnes. A-i; la ullima es tle ij.

La Burladora burluda. Precedida de uni loa confrand" "'n estruno suceso.-licitrilo le Turia.-Vineta con tres figuritas. 26 hojits con las signs. A-C; esta the 10.

La fuerzu del Interes.-Gaspar Aguilar. Va al principio una Loa $\mathrm{g}$ al flu Octueus a un desden y un Soncto.- Iincta con 4 figruritus. 24 hojus con las signs. $A_{-} \mathrm{C}$ de 8.

La Belligera española. - Ricardo de Turia. La precede una Lut para el primer dia que represento la Compañia de lorras en Valencia, y ya al fin una carta De vn Gulan a vinu Damu Corfesana, que pur sej'lo sin recelo de la lusticia se caso con l'n Puge llamado Leon.-Escudo del impresor, que representu el caballo Pegaso, bajo del litulo. 28 hojas con las sigus. A-C: la ullima ticne 12.

La Duquesa conslante.-Tirrega. Con I.na al principio, y al fin un soneto intitulado: Laur cola de los Poelas Bomancislas luezes de obras agenas por autoridad propia. - Vi. neta con tres fiyuritas. 2\% hojas con las signaluras $\mathrm{A}-\mathrm{C}$ de 8 .

La Sverte sin esperança.-Faspar Aguilar. Con Loa.-Vinelu con cuatro figurilus. 22 hojas con las signs. A-C; la última de 6.

La Fe Pagada.-Ricardo de Turia. La precede una Loa, cerrandola Tri's fimosus Chuconas para canlur. - Viñela de tres figurilas. 28 hojas con las signs. A-C; esta de 12.

La Fundacion de la Orden de Vuestra Señora de la Herced, por el Re!l Don layme.-Tárrega. l.leva loa al principio, y dus sone$t o s$ al fin, el segundis con estrambote. bejo del tilulo el escudo de X. Señora de ta Merred. 26 hrojus con las signs. A-C, pues la ullima tiene 10.

El Gran Patriarcha Don Iunn de libera, Arcobispo que, fue do esta insigne Ciurdid de

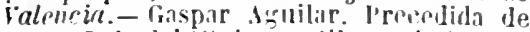
Lure - Rajo del Litulo un edilizcon la lustia, sigun lo ucrstumbruba i usur en su sello dicho palriarcu.

El lrivmfante murlirin !" gloriosa memete de Sun Vieconte, hion de Horsca, y l'alsonle le Belonciat.-Ricardo de Turia. Con lon al principin y dos composirimues pnétiras al fln.-Lamina les. l'iepnle márlir bujo del tllulo. 26 hojas con las signs. A-C; le illima es de 10.

IJai cjemplares en cuỹa portada dice eslar hecha la impresion a cosla le Insepe fierer. Tulas las talicioues ule la primera parte, y la inica que conozco de la seguluda, son escesivamule ramas.

El nombre de Ricarilo de Turia, de quien hai cuatro comedias en la sogumla parte, es indulablemente supuesto: pero quirin era el que se nemltaba lojo "ste sembunimo, no aparees claramenti" aroriguade. Virintras

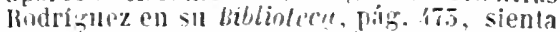
con razouss bastante suliulas, haber sido 1). luis ferrer la Cordona: Jinmono, apovalo en la antoridad de mofro fequerdo, supoue

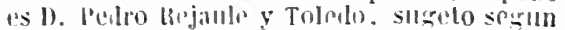

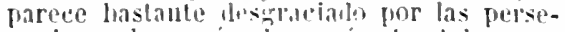
cuciones do sus ímulus, if plas tall rez se refleril 11. lírlos lioil, an 111 Romamre colocalo al principio de la sogmuda parte, cu el cual lecunis:

\section{El verso conceptuso y las quintillas perfetis lel culto Ricurdo busque: pero no afecle su estreda.}

Fusler tambien es do la opiuiun de Reder.

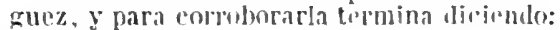

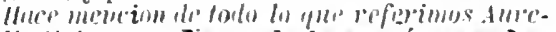
lio Mri, ensu Vorte de Ia poesía espanola, pdif. li. Solo hai el love riparo de undecir ni indicar Mei mada de lo que aquí afimma, constando imiramouto por los proliuminares de diclat olra, que un tal liearulo de Turia es autor de cuatro de las doce compdias del tomo y del prologo intitulado Apologetico. 
Por lo que valga en estas dudas apuntaré dos especies que no ereo haya nadie mencionado; la uni es, que cl tomo de comedias que comprende las de Ricardo de Turia, y del cual il aparece como cditor ó recopiladur, va diriorido a Doña Blanca ladion y Carilona, parienta sin duda de $\mathrm{D}$. Luis lerrer y Cardoma, y cu la dedicaloria de Aurelio Vyei se encomia el guslo que dicha siñon lemia por lodo gemero do z'ros, principalmentr ('n el de connedias (escelencia si nil dericudu de ascenditemtis, participiala de tris. versales): el secrumlo dato es, que en la

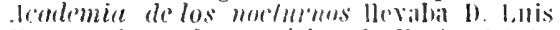
Ferrer el nombre peritico de Norle, tílulo que se dió á dicho tomo de comedias.
1361 POETAS VALENCIANOS. La famosa comedia del Prado de Valencia, compresta por el Canonigo Tarrega, Poeta Valenciano. S. l. nia. 4. Vineta con tres figuritas despues del título. 28 hojas signs. A-D de 8 hojas, ménos la última que tiene 4.

Es edicion diversa de las tres que preceden descritas en la primera parte. ¿serí acaso del Jardin de comedias de Poelas valencianos, publicado en Vulencia, por Felipe Mel, 1585. 5 vols. $4 .^{\circ}$, reimpreso en Jaen ('n 1605 , que jamas he visto í pesar de citarlo García de Villanueva, pig. 29.4 del Origen del leairo español?

\section{PRAD0 (ANDRES).}

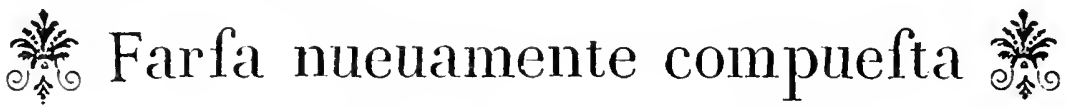

llamada Cornelia, en la qual fe introduzen las perfonas figuientes. Vn paftor llamado Benito, y otro llamado Anton, y vn rufian llamado Pandulfo, y vna moga llamada Cornelia: y vn efcudero fu enarnorado. Donde ay cofas bien apazibles para oyr. Hecha por Andres prado Eftudiante.

Imprefsa con licencia, en Medina del campo: por Iuan Gudinez, de Millis. Año 1603.

(Siguen cinco figuritas que representan los interlocutores, con sus nomlres encima, y en seguida principia la farsa.) $40^{\circ}$ let. gót. ménos el título arriba copiado rue es de redonda. 4 hojas signs. A y $\mathbf{A} \mathbf{2}$.

Nui rara. Barrera babla de esta farsa reflriéndose il Moratin, quien, en el num. 59 de los Origenes, menciona esta pieza, pero de otra cdicion hecha por cl inismo Juan Godinez en 15.5\%; en ello debio parlecer equivocacion, pues no creo que dicho impresor pudiera ejercer su prufesion en época tan remola; Lodas las obras que yo he visto publicarlas por él, lo fueron il fines del siglo Xrl i principios lel Xill. Sin embarro debe existir algum improsion lecha hicia el año que indica Voritin, pues su lenguaje revela pertenecer it aquella ruoea.

Nic. Antonio no menciona a este Andres de
Prado: el antor del mismo nombie traido por él es el que un sigló despues escribio las Meriendas del ingenio $y$ entretenimientos det guslo. Zaragoza, 166j. 8.'; que son seis novelas.

1363 PRATICA de tres pastores. A saber Rodrigo Loirenço e Sylvestre Os quaes aparecendollie o Anjo a noite do Natal, espantados chamāo hum a outro dizendo. (Sigue una laminita de madera que representa el Nacimiento y lajo principia la pieza. Al reverso de la duodécima hoja que es la última se lee:)

Com lodas as licenças necessarias. Em Lisboa Por Antonio Aluares. 1626. 4. 12 hojas, sign. 


\section{QOE}

No mencionan Barbosa Machado ni Barrera este rarísimo Auto al Nacimiento, del cual habrá sin duda ediciones más antiguas, pues sulenguaje prucba que debió escribirse en la scrunda mitad del siglo XVI, ó quizís ántes. - La versificacion en general es flufda y fácil, y como muestra copiaré de él la siguicnte

\section{Cantiga.}

Virgem antes do parto, no parto e scmpre; bendilo seja o fruito do vosso ventre.

Nove mezes trnuxestes encuberto

o fruito que hoje destes manifesto :

Rezīo tendes por certo

estar contente:

bendilo seja o fruito

do vosso ventre.

O que Eva nos tirou

vos nos lo destes,

á os que clla matou

vivos fizestes:

á vila nos trouxestes

em vosso ventre,

Virgem antes do parlo,

no parto e semipre.

Paris o Criador, vos criatura,

sem corrupeīo nem dor,

ficando pulla:

i glurin futura

e paz presente, nos destes com o fruilo

de vosso ventre.

Criais quem vos crion, Vis'ren silyrala ;

vistes qucm vos formou

e fez de nada :

entre todas eriada

mais excelente.

bendilo seja o fruito

do vosso eventre.
QUE

Dais de mamar a quem

sustenta o inundo ;

maitendes a quem mantem

e cria Ludo:

misterio profundo

tendes presente:

Dros $e$ homem fruito

de vosso ventre.

Virgrm antes do parto, no puito e sempre;

bendito spja o fruilo

(i) vosso ventre.

\section{PIB UEBAS (LAS) DEL LINA-} JE HCMANO. Auto Saçramental nuebo de las Pruebas del linaje umano yen comienda del hombre. Mams.sciio en $1 .^{\circ}$ de 28 hrjas vitiles.

Fste manuserito es origimal y Hera al fiu la iprobacion del lie. Juan Hurtado de cetima, y la licuncia del Dr. Futierre de Cetina, ambas fochadas el í de junio de 160.5, espro. sánulose en la viltima que estil dada en Aicalí.

Amune Vedel, que seneralmente citi pieziss publicadas, inenciona este auto, gonunca In he visto impreso. Barrera no parere habor tonido más noticia de el que la que da Ifilel.

El nombre del autor no aparece por parte alımutis.

136.j PUENTE IICRTADO DE MEN1)0\% (INrovio). Discurso Terlowico, y politico solire la Apulogra de las Conelias, que ha sacinlo a luz el P. Manuel Gurra, cĩ nombre de aprobacion de la ruinta. I - cala parte de las Comedias de Don Pedpo Calderous. Por Jon Intunio preaste IIvirado de Ilendozel. S. I, ni a. ".." 83 prigs.

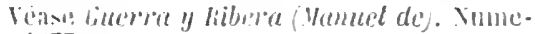
$101.27 \%$
1366 QUEVEDO VILLÉGAS (Francisco de). El Parnaso español, y Mrsas castellanas de D. Francisco de Qvevedo Villegas... Correridas, i enmendadas De nuevo en esta inspression, por el Doctor Aumso Cultifragio, Academico ocioso de Lolaima. Malril, Ilelehor sallehez. M.DC.Lxira. Acosta de Mateo de la Bastida. 4." "bojas prels., inclusa una lamina que representa a buevedo an el Parunso, y otra ci la Musa Clio, ̈02 prigs. y ! hojas de Sumarios ó Ju-

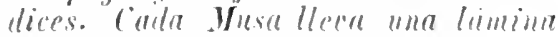
que ra contada en la paginacinn.

Yateo de la biastida principia ast sll dedi-

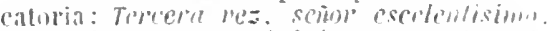

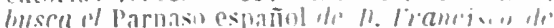

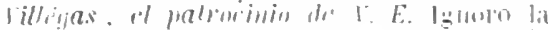

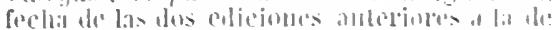

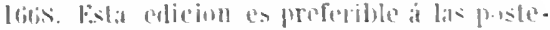

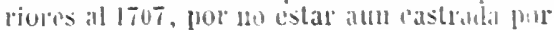
". Santo oticio. 
Tengo idea de haber visto una impresion de este tomo hecha en Madrid, 1729. 4.

\section{QUEVEDO VILLÉGAS} (Frarcisco de). El Parnasso español, monte en dos cumbres, dividido con las nveve mvsas castellanas. Donde se contienen Poesias de Don Francisco de Qvevedo Villégas. Sale a ora añadido con adorno de unas Dissertaciones à cada vua de las Musas, y nuevamente correcridas, y enmendadas en esta vltima impression, segun el Expurgatorio del año de 1707. Madrid, Juan de Ariztia, 1729. 4. ${ }^{\circ}$ Laminas de madera. 8 hojas prels., อ̋ว̋8 pags. y 9 hojas de Sumarios ó indice.

Las láminas de madera que preceden á eada una de las Musas, sun detestables.

Este volúmen lo mismo que el anterior de 1668 , solo eontiene sois de las nueve Musis. be unas prevenciomes que llova al principjo se colige forma el tom. 111. de lis obrus de Ouevedo; supongn que el primero y segunilo serín los dos de lis produreinnes en prosa, impresos an 1650 , lleseritos eu la Seccim movelistica del presente. Catílogo, y el cumrto rl cilado por Fornámdez-fiuerra, intitulaulo: Las tres ynsus vltimas castellanus. Segunda crmbre del Parmaso Español te Don Fiancisco de puevedo !I rillegas,... sacadas de la Libreria de don Pedre Aldrie ouenedo y vi-

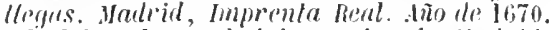
4. , tel cual creo hai impresion de Mallid, 17.4. $40^{\circ}$

El tom. III. contiene diez bailes $y$ al $1 Y$. secun dicho sr. Feruández-buerra, ciatro entremeses.

\section{QLINTELA LEDESMII Y} BRICAMONTE (JUAX DE). Letras divinas. Del Licenciado Iran de Quintela Ledesma y Bracamonte, natural de Segouia. (Madrid,) Tonıs Iunti, 1623. 8. 16 hojas prels. y 180 fols.

Entre las poesías en elogio del libro, puestas al principio, las hai del lic. biego de Colmenáres, el doctor Jerunimo de Alealá Yiñe, I). Gabriel de Belmonte, y la signiente dicima de

\section{Alonso de Ledesna Butrago,} tio del antor.

Tener coloquios con Dios por estilo dulce y grave, es yracia yue nadie sabe con tal gala conno vos. A no spi deudos los diss, dijerr: pue rovules dino de: primio y luuro dirino, mas dirato obon del arle, no) diym nue yo soi jarle en fé que sois mi subrina.
Casi todo el volumen, se compone de Villancicos, Romances y otros géneros de poesía en diálogo; hai ademas once Loas á varios asuntos, \& muchos coloquios, siendo notable uno con este encabezamiento : Coloquio en que se introduce el Himbre, que a lílulo de hijo de Dios, pide d la Iglesia su madre $y$ d los dos principes delli S. Pedro y $S$. Pablo, los bienes de gracia que son los sicle. Sacramentos. Cánlase esla lelra.

El volúmen es tan raro que el Sr. Barrera so lo menciona, ni tampoco á su autor, en el Calálogo del teatro español.

\section{QUIÑÓNES DE BENAVEN-} TE (Lurs). Ioco seria. Burlas veras, o reprehension moral, y festiua de los desordenes publicos. En doze Entremeses representados, y veinte $y$ quatro cantados. Van insertas seis Loas, y seis Iacaras, que los Autores de Comedias han representado, Y cantado en los teatros desta Corte. Comprestos por Lvis Qviñones de Benauente. Recopilados por Don Manvel Antonio de Vargas. Madrid, Francisco Garcia, 1615. 8. 16 hojas prels., 243 foliadas y una para repetir las señas de la impresion.

$1370-$ La misma obra. Valladolid, Iuan Antolin de Lago, 1653. $8 .^{\circ} 8$ hojas prels., 243 foliadas y una en que se reproducen las señas de la impresion.

Esta se diferencia solo de la anterior en los preliminares, estando heeha á plana renglon sobre ella por lo que toca al testo de la obra.

Nic. Antonio llama á este autor Luis Benavente, da el tílulo de su obra truneado y no menciona la edicion de 1653 . El Sr. Barrera y Leirado cita una impresion de Barcelona, 16.5. en $8 .^{\circ}$

Los her'ederos de Diego Dormer, impresores de Zaragoza, publicaron en 1679 La me. jor flor de cntremeses, y aunque en la portada espresa estar recopilailos de varios autores, no es sino una reimpresion de veintitres Entremeses, una Jácara y una Loa de l.nis Quiñones de Benavente, sacados de la Jocoseria, burlas veras.

De este autor dice el Sr. D. Aureliano Ferníndez-Guerra y orbe: "El licenciado Luis »niñones de Benavente fué, por su gracejo "y donaire, por su agudeza y florido ingenio, vel más hermost adorno y gala de niestro mantigno teatro con sus incomparables lois, mbailes y entremeses. En todos hai, por lo "comun, un gran pensamiento filosofico; 10 martifleioso del contesto es adinirible, los ea"racteres delineados con prodigiosa verdad, 
- lás sales y rasgos más fellzes de Cervántes wy Quevedo, de Lope y Góngora, y de los cláuslcos antlguos abrillantan el diálogo."

\section{QUiros (D. Francisco Ber-} nardo De). Obras de Don Francisco Bernardo de Qviros. Y a ventrras de Don Frvela. Madrid, Melchor Sanchez, 1650 . 4. 12 hojas prels., 123 foliadas y una para repetir la fecha.

La major parte del voliumen la ocupa una novela que contiene algunas poesias, y en la cual van intercalados los siguientes entremeses:
El toreador don Bablles.

El poeta remendon.

Mentiras de cazadores y toreadores.

Los viudos al uso.

El marido hasta el Infierno.

La burla del pozo.

Di)n Estanislao.

Ir por lana y volver trasquilado.

L.as flestas del aldea.

Los sacristanes burlados.

El resto es una Arademia en la que se representó la comedia $E l$ hermuno de su hermana, la cual va al fin del tomo y suele faltar en algunos ejemplares.

No sé si la rareza de este volumen procede. rá de haber sido prohibido por la Inquisicion.
1372 RASGOS DEL OCIO, en diferentes Bayles, Entremeses, y Loas. De diversos Avtores. Madrid, Ioseph Fernandez de Buendia, 1661. 8. ${ }^{\circ}$ hojas prels. y 263 págs.

Conticne las piezas siguientes:

El aguador. E.-Agustin Noreto.

El zapatero. E.-Fernando Zarate.

Baile para los años del príncipe.-Naestro Leon.

Hidalgo de Olías. E.-Juan de Zabaleta.

Los sones. B.-Sebastian de Villaviciosa.

Alcalde de Mairena. E.-Fernando Zarale.

I.a fregona. E.-Juin de Mdos.

El rico y el pobre. B.-Del mismo.

El figonero. E.-Juan Baulisla Diamante.

Las noches de invierno y perdone el enfermo. E.-Francisco de Avellaneda.

Las carnestolendas. E.-Pedro Calleron.

El gato y la montera. E.-Scbastian de Villaviciosa.

La burla del ropero. E.-Francisco de Avella. neda.

La casa de recindad. E. $-S$. de Villariciosa.

Las casas de placer. E.-F. de Avellanida.

Los testimonios. E- Benavente.

El reo. E.-Jerónimo Cancer.

La plazuela de Sta. Cruz. E.-P. Calderon.

El retiato vivo. E.-A Morelo.

El loco. E.-Juan velez.

El dormillon. E.-J. Nátos.

El casado por fuerza. E.-S. de Villaviciosa.

La flema. E.-F. de Avellaneda.

Cuatro loas de Diamante, Villaviciosa, Diego de Cordova y Figuerua y Moreto.

El Sr. Barrera cila unos Rasgos del ocio en diferentes bayles, enlremeses y loas, de diversos autores. Segundiz purle; dirigida á D. Diego de Córdova como la primera, é impresa en Madril, Domingn Garcia Jirras, 1664. $8^{\circ}$; pero advierte no haber Ingrado ver ni esta segunila parté, lii la mia de $16(i 1$.

Los traductores de Ticknor, tom. Ill. página 495 , dicen que D. Francisco de Sando- val publicó un tomo de poesias intitulado: Rasgos del ocio. S. l. ni $a, 8^{\circ}$, el cual debe ser obra distinta.

REBOLLEDO (Bernardino). Ocios. Véanse los Núms. 895 y 896.

\section{REI DE ARTIEDA (Ax- DRES).}

\section{LOS AMANTES.}

TRAGEDIA, COMPVESTA POR MICER ANDRES REY DE ARTIEDA.

Dirigida al Illuftre Señor DON THOMAS DE VILANOYA, Mayorazgu y leyitimo fuccerfor cu las Baronias de Bicorp y Quesa,\&c.

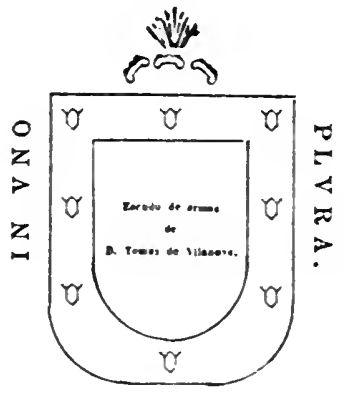

En Volëcia,en cafa de la Viuda de Pedro de lluele, 1581. 
8. 4 hojas prels. y $\mathbf{3 6}$ sin foliar con las signs. A-E, todas de 8 hojas ménos la ultima que solo tiene 4 .

El presente ejcmplar de esta comedia es el unico que se conoce en la actualidad, y su estado de conservacion es tan perfecto que muchas hojas estín sin cortar y con barbas.

En prueba de la singular rareza de esta comıosicion dramática, citaré aquí lo que varios antores han dicho al hablar de ella.

En cl año 1581, pone D. Nic. Antonio en su Bibliotheca, lı impresion en Valencia de la Tragedia inlilulada Los amantes, de Andres Rei de Artieda... No he conseguido ver aque. lla obra, anmpe to he solicilado diligentisimamenite. Montiano, Discurso pág. 25 y 24.

La tragedia de Los amantes, de Rei de Ar. ticula, que se imprimió en 1581 y no se encuentra ya. Velazquez, origencs de la poe. sia, pajg. 121 .

De la tragedia de cos amantes, impresa en Valencia año de 1.581 , solo hu quedacto la no. ticia. Moratin, Ca!álogo de piezıs, nủm. 154.

(Rei de Artieda) publicó en Valencia en 1481 (debe lcerse 1581) la tragedia de Los amantes; de que solo ha quedado la nolicia. Parnaso español, tom. II. pág. 20.

Los amantes de Teruel, Iragedia, empieza: Como de aquí á Ternel no hai media milla... Se imprimió en Valencia, año 1581, en $8 .^{\circ}$ : es alabula por Velazquez (en lo que se equiroca, pues no pudo elogiar lo que no vio en el origen de la poesia, donde dice que dicha tragedia no se encuentra ya. Fuster, tom. I. piảg. 212.

Posee un cjemplar de esta obra rarisima (Los amantes de Teruel) el Sr. D. Vicente Salvá. Hartzenbusch, Catáloyo de las obras dramaticas de Tirso, pág. XX.xill.

liodriguez ni Jimeno no lograron verla, y Ticknor equivoca la fecha de la impresion pues silpone ser de 1551 tom. 11. pag. 156): lo eiral prueba no la tinvo presente: por in nismo es mui singular que nos diga en el tonl. 111. pág. 165, ser un clrama insulso y pesado. llas raro se me hace el gue siss traductores en las Viotas al tom. III. pàg. 'alli, supongan llamarse el autor Francisco sicmelo Andres; que es aragones habiendo nacido en Valencia, y que la fecha de la obra es de 1599 cuando es del año 1581 .

Como Moratin solo conocio el título de esta obra no pudo dar el análisis de ella en los origenes del teatro español; copiaré aquí el que publicó el ya citado Sr. Hartzenbusch, puesto que es el mismo que formo y le cominnico mi padre, y del cual tomis una parte e) Sir. de Barrera para su Catálogo, donde tambien encarece la peregrina rareza del libro.

AXÍLISIS DE LA TRAGEDTA

$$
\text { I.OS A M A TES. }
$$

Los principales personajes son Hareilla, chyo criado se llama Perafan y su paje Layu, Sigura, dama, á la que se le da al- guna vez el nombre de Isabel de Sigura, y se ignora el de los padres de los dos aman. tes, aunque el de Marcilla se presenta tambien en la escena.

Principia el drama á media milla escasa de Teruel, lugar de la accion que dura poco más de veinticuatro horas.

Se dirige á dicha ciudad Marcilla, acompañado de sus criados $\mathrm{y}$ de su camarada Here. dia, á quien cuenta en la escena primera cómo, habiéndose criado juntos de niños él é Isabel fué creciendo con la edad el cariño que se tenian, de modo que el padre de Marcilla pidió al de Sigura la mano de esta. El viejo era tan marrullero como avaro, y pretestó para dilatar la boda la poca edad de los dos amantes, dilacion que les pareció insoportable; $y$ asi determino Marcilla ausentarse y seguir la carrera de las armas, aprovechando la ocasion de estar

\section{«... por órden de su Alteza}

En Palamos la armada y gente lista.»

Poco despues añade:
Aunque primero me ofreció sigura
De no casirse, hasta pasar siete años:
Con esta fé partí í probar ventura, Do sabes, si entre bárbaros y estraños Mi nombre (aunque merece poco) dura: Tras que de perlas, oro, seda y paños
Traigo cincuenta acémilas ó cargas.”

Los combates fueron en Túnez, $y$ de allí trae el botin, por más que al princlpio dé á entender que viene de Milan.

Al llegar a Ternel encuentra que su amada, obedeciendo la voluntad paterna, se habia casado aquel lia, dos horas despues de cumplirse los siete años, con una persona cuyo nombre se calla, no obstante que figura eu li escena.

Marcilla disimula su pesar; pero rehusa asistir a las justas y fiestas de la boda, y se esconde tras la cama de los novios, con el designio de dar un beso á sigura cuando duerma su marido.

Isabel ignora tener tan cerca á su amante, mas ocupada en è su fantasía, se resiste á Ins ruegos de su marido, of reciéndole acceder i ellos en la noche proxima. Viendo el marido que no puede emplear mejor la presente se duerme. A todo esto Eufrasia, prima de Sigura, está en acecho por pura curiosidad: oye que está porflando un hombre, que ella supone ser el novjo, por dar un beso á lsabel, y . Marcilla despide un ay de muerte.

En el tiempo que media entre el tercero $y$ cuarto acto, la mujer habrá contado al marido sus antiguos amores con Marcilla, la pretension de este y su repentina muerte, culando en la primera escena de dicho acto cuarto estan los dos tratando con bastante trançuilidad sobre el modo de sacar el cuerpo de la alcoha, para evitar toda sospecha $\mathbf{y}$ habladuría. Sin émbargo ella principia medio á desvariar, y resuelve ir á la iglesia á darle el beso que ántes le negó, y con efecto l) ejecula, muriendo en el acto. 
El desenlaze se da mucho la mano con el de la comedia de Tirso que lleva el mismo título y se halla en el tomo segundo de sus obras; la trama está mal urdida y la versiflcacion es gencralmente floja. Se usa de la octava de endecasílabos en la escena primera del acto primero, en la primera y segunda del tercero y en la segunda del cuarto. Lo oemas está todo en quintillas de piés de ocho silabas, ménos las de la escena segunda del acto segundo, que tienen eptasílabos los versos primero, tercero y cuarto, y de once s1labas el segundo y último.

Antes de la tragedia se encuentra un soneto de D. Miguel Ribellas y de Vilanova, al autor, y una epistola dedicatoria de este al ilustre señor D. Tomas de Vilanova, mayorazgo y legitimo sucesor en las baronias de Bicorp y Quesa, etc. En ella esplica por que dividió esta tragedia en cuatro autos ó actos, en los tërminos siguientes:

"Por elln, y porque mil ejemplos tuve,

Siguiendo el uso y plática española,

De mi tragedia hacer dos partes hube..

aPero porque cualquiera de ellas sola

Cansar pudiera, la razon y el uso

(Digo español) en otras dos partióla...

Expone luego algo del plan; mas sin indicar de dónde ha tomado siquiera el asunto, suponiéndolo hecho histórica ó que pasaba por tal entre sus contemporáneos.

Siguen á la obra cuatro octavas de Miguel de Ribellas al lector, la aprobacion de frai Juan Baptista Búrgos, consultor del Santo oflcio, y un soneto de Pere Juan Stornell, en alabanza del autor, composicion de grande interes porque en ella se tija la debatida cuestion de si Rei de Artieda fué valenclanu ó aragones. He aquí los cuatro primeros versos que lo declaran:

"El hijo del gran Turia se ha mostrado En nuestra noble patria valentina, Mui caballero en su arte y diciplina, De rosas y de lirios coronado.."

1374 RELACION de la famosa comedia del Premio de la hermosura y amor enamorado, que el Principe ñro sor. La Christianissima Reyna de Francia y sermos. Infantes don Carlos y doña Maria sus hermanos, y algunas de las sras. Damas representaron en el Parque de Lerma lunes, tres'dias de nobiembre de 1614 . Fol. Manuscrito original en 7 hojas.

En esta relacion coetánea se encuentran curiosisimos y estensos detalles sobre la distribucion de papeles, y trajes, y aparato que se emplearon en la representacion de la comedia.

1375 RELACION que pueden representar dos niños, explicando los principales Mysterios de nuestra Santa Fé. Primera, segunda, tercera, quarta, quinta, sexta, septima y octava parte. Cordova, Doña Maria y D. Luis de Ramos y Coria. S. a. 'hacia 1750). 1. ${ }^{\circ} 16$ hojas sin fol. ni signatura.

Es dificil el poder reunir estas ocho partes impresas y vendidas por scparado.

1376 REYES (Matías de :0s). Para algvnos de Matias de los Reres. Madrid, Iuan Sanchez, 1640. 4. 10 hojas prels. y 218 fols.

Obra bastante rara, escrita á imitacion del Pura todos de Montalvan. Contiene varias poesías y una comedia intitulada: El agravio agradecido.

EI Sr. Barrera y Leirado nos da noticia de un tomo de Seis comedias de este autor, impresas con pritilegio, en Iaen, por Pedro de la Cuesta, año de $1629.4 .^{\circ}$ Cada pieza lleva su dedicatoria, portada y paginacion separadas; por lo mismo sin duda se vendieron sueltas, y no es estraño sea ahora dificil ol lograrlas reunidas.

Los titulas de estas piczas son:

Enredos del Diablo.

Di menlira, sacurds verdad.

Dar al tiempo lo que es suyo.

Donaires de Pedro Corchuelo, y el qué dirdn. Elías, su vida y rapto.

El agravio agradecido.

1377 RÓBLES CORVALAN (JUAY DE). Misterioso aparecimiento de la santissima Crvz de Caravaca, por crva rirtud los enfermos alcanzan salud, los afligidos consuelo, las tempestades de Mar y Tierra, y los incendios de fuego se han visto aplacados, las maldiciones pierden su fuerza. Recopilados por el Lic. Iuan de Robles Corralan. Madrid, Francisco Sanz. S. a. (hücia 168\%). 1. Lám. de madera. 4 hojas sign. A.

Pliego omitido en el Catálogn de Duran: tampoco menciona Barrera á Robles Corralan, ni Fernández-Guerra incluye la Loa en la lista de ellas.

\section{Conticne:}

Romance que dice: Sanla Crus, pues sois ta nluma.

ld. Lna mujer en Bur!illos.

Id. En Cáliz, ciudail fromosa.

Id. No solo de la sin par.

Loa curiosa del diero del hombre (lialoga. da), que dice: In suldimo mellralado 
Sigue una viñeta de dos mujeres y un árbol en medio, $y$ despues la lista de los interloculores. La comedia principicl al dorso y concluye en el reecrso de la hoju octaca así:)

No resta más que escucheis pues aquí, si habcis memoria, fenesció ayuesta historia, bieu ó mal eual visto habeis ; lo que resta es que enmendeis, os suplica el autor,

si cu sul obra ha habido error, y con esto á Dios quedeis.

\section{Fin.}

S. 1. 4. ${ }^{\circ}$ let. gót. 8 hojas sin fol. con la sign. A.

Magniflco ejemplar con hojas sin cortar: es el innico conocido y fué el que tuvo presente Noratil.

$$
1379
$$
La mis:a obri. CEl título de la portada es de letra redinda, y dice lo mismo que la anterior hasta la palabra parescera. Continía despues:) Los interlocutores son los siguientes.-Impressa con licencia, en Medina del campo: por luan Gudinez de Millis, año. 160̋̈. rViene en serjlida una viñeta con tres fuguritas, y bajo de ella estan los nombres de los interlocutores de letra gritica como toda la comedia.) $4 .^{\circ}$ letra gót. Sin foliacion, sign. $\Lambda$, de ocho hojus.

Esta debe ser mua de lis iftimas obris que se imprimieron en España con caracteres góticos.
Nic. Antonio no menciona á este escritor, y Moratin no conoció la segunda edicion de sil rirrísima comedia, de la cual dice tiene interes dramulico, siluaciones y afectos, enredo, solucion y moralidad.

He visto de clla otri edicion cuya descripciun es la sigriente:

I Comedia hecha por Juan Rodrigo Alonso, que par olva nombre es tlamudu de pedraza / vesino d'll ciudaul de Segouia / en la qual por interlocucion de diuersas personas / en metro se declara la hystoria de sancla Susaña a la letra / quat en ta prosecucion claramente parescera. Hecha al tonr de dios nuestro señor. Añu de mil y quinientos y cincurnta y acho (1.5is) años. (Siguen dos figuris de mujer y en medio una torre, circuido todo por nila ancha, y bajo se pone la noticia de los inlerlocutores. Al fln:) Impressa en Alecala de Hentri's en casa de Salzedo librero, uño U.D.Lviij. $4 .^{\circ}$ let. gót. 8 hojas sin foliacion con la sign. $A$.

El si. Barrera no ha visto ejemplar impreso de cite libro, pues el título de la edicion de isis lo tomo de Moratin, el de la de 1.558 de ma repia manuserita que posela Duran, y la impresion de 1605 le fue desconocida.

Thil mismo autor es indudablemente la siguicute pieza, cuya edicion original existe ell Ji Liblioteca de Munich ; la reimprimio en Viena en 18.12 el Sr. Wolf, y la han reproducido los Sres. Salvá y Sainz de Baranda en el tom. XXll. de la Coleccion de documentos inéditos:

Farsa llamada Dança de la muerle, en que se declara como d todos los morlales, desle et Papa hasta e: que no tiene capa, la muerte haze en este míscro suelo ser yguale's, y d nadie perdona. Contiene mas como qualquier biuiente humano deue amar la razon, teniendo entendiniento della: considerando el proucchn que de su compañia se ronsigue. Va dirigida d loor del Santissimo Sicramento. Hecha por Juan de Pedraza, tundidor, vezino de Segovia. Son interlocutores de ta presente obra las personas de suso contenilas. M.D.L.I. S. $l$. $4^{\circ}$. $^{\circ}$ et. gót. 8 hojas sin foliatura. 
1380 RODRÍGUEZ (JUAN). (Así | va distribuida la leyenda del fróntis.)

\section{Comedia llamada}

\section{Florinea:quetracta de losamo-}

res del buen duque Floriano, cö la linda y muy cafta y generofa Belifea, nueuaméte hecha:muy graciofa y fentida, y muy prouechofa para auifo de muchos necios.

Vifta y examinada, y con licēcia impreffa

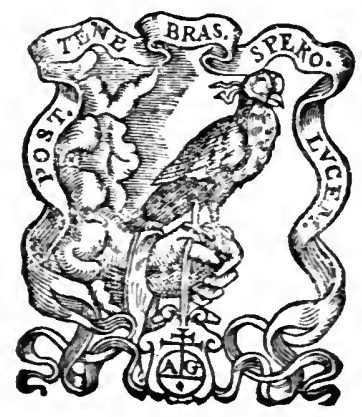

Hendenle en Aledina Del Campo en cala de Adrian Ghemart.

\section{4}

(Esta portala casi toda de colorado, esti rodeada de adornos y forma

una especie de capilla. Al reverso del (ol. clvj va este remate:)

Q Acaba la comedia no menos vtil

que graciofa y compendiofa; llamada flozi'

nea; nuenamente compnefta. Impsef

fa en Elledina Jel campo sul ca

fa de Enillermo de flillis,

trag la iglefia ma

y02. Año de

1554 
4. ${ }^{\circ}$ let. gót. 4 hojas prels. y clvj foliadas, y no 160 como dice el señor Barrera.

Sumamente rara. No la tuvo lleber, y Moratin no la menciona en los origenes del teatro, quizá por no entrar en su plan.

Ignoro el fundamento de García de villa. nueva para decir. en el origen del tealro, pág. 251 , que el autor de esta comedia, escrita en el género de la Celeslina, quiso ser conocido con el nombre de Bachauro, y tampoco sé de dónde se ha sacado Ticknor (tomo 1., pág. 283) que se llamaba Rodriguez Florian, pues en la única parte donde se lialla su nombre, al principio de la dedicato. ria, dice secamente Iuan Rodriguez.

Al fin del Proemio al lector, en verso, advierte que

Las bolas del buen Floriano esperando

Para olro año de mas vacacion,

A donde la historia tendrá conclusion,

A Dios dando gracias allá nos llegando.

La continuacion aquß anunciada no llegó à publicarsc.

Esta composicion dramitica es en prosa con algunos yersos intercalados, y se divide en cuarenta y tres scenas ó actos.

El Sr. Barrera solo cita un ejemplar de esta pieza en la Rillioteca de Munich.

El escudo de Adrian Ghemart que va en el frontis, es el mismo puesto en el Sacrobusto de la sphera. Valludolid, $156 \mathrm{~s}, \mathrm{y}$ mo mui parecido a este, con igral letra, en el que no pueden distinguirse bien las iniciales de bajo, está en la Parte .III de las Comedias de Lope, la cual dice en la portada haber sido impresa en Valladolid en 1627 , por Jerónimo Horillo, y al flu por la Viuda de Francisco de Córdova.

\section{RÓJAS VILLANDRANDO}

(AGUSTIN DE). El viaje entretenido de Agustin de Rojas, natural de la villa de Madrid. Con vna exposicion de los nombres Historicos y Poeticos, que no van declarados. Madrid, Imprenta Real, M.DC.III. 8. 32 hojas prels. y 749 págs. En el dorso de la última hoja se repiten las señas de la impresion, y alli está el nombre de Iuan Flamenco.

Nic. Antonio, y Alvarez y Bacna y Brunet, sin duda con referencia á aquel, citan una edicion de este libro hecha en Madrid, por Alonso Gómez, $15 \$ 3$. Dicha impresion no puede existir por varias razones; la primera y principal, por haber nacido kojas hácia 1577 ; la segunda, porque las licencias y aprobacion son de 1602 y 1603, y la tercera por evanto en la Loa al dia de mièrcoles de ceniza, habla el autor de que en el misino dia del año 1601 , la reina de Inglaterra haj)ia mandado dego. llar á varios grandes de su reino: fecha como se ve posterior de 18 años á la preten. dida edicion. Queda pues sentado ser la priinera la de 1603.

\section{ROJAS VILLANDRANDO} (AGUSTIN DE). El viaje entretenido de Agustin de Rojas, (ut supra). Madrid, Emprenta Real, M.DC.IIII. 8. ${ }^{\circ}$ 32 hojas prels. y 749 págs. En el dorso de la última hoja se halla tambien el nombre del impresor Iuan Flamenco.

Esta segunda edicion, desconocida á los bibliografis, está hecha á plana renglon con la anterior, aunque es perfectamente distinta. Ambas son mui raras y apreciabilísimas como unicas completas, sin tener ninguna de las grandes supresiones que sufrier on las posteriores por mandado de la Inquisicion.

1383 La misma obra. Lerida, á costa de Luys Menescal, 1611. (Al fin: Hieronymo Margarit y Luys Menescal.) $8 .^{\circ} \mathbf{1 0}$ hojas preliminares y 264 foliadas, aunque las 8 del último pliego est.in todas erradas.

\section{4} La misma obra. Lerida, Luys Manescal, $1615.8 .^{\circ} 16$ hojas prels. $y 264$ foliadas.

Ambas ediciones, aunque hechas á plana renglon, son completamente diversas; en las dos está cl testo algo castrado; pero no tanto como lo desea el Indice espurgatorio de 1747. Ignoro si otra que vi de Madrid, Viuda de Alonso Mrortin, 1614. 8. 16 hojas preliminares y 288 fols. estará mutilada; supongo que si, puesto que la de 1611 ya habia sufrido algunos recortes.

La impresion de 1615 fué desconocida á Nic. Antonio, á Álvarez y Baena, al editor de la de 1793 y á Barrera.

$\mathrm{El} \mathrm{Sr}$. D. Pascual de Gayángos me dijo haber visto una de Barcelona, $1619.8 .^{\circ}$ con el retrato del autor, que no se encuentra en ninguna de las anteriores; tambien se halla en la otra edicion hecha en Barcelona, 1624. 8. ${ }^{\circ}$ segun Barrera, Catal. del tealro esp.

Ticknor babla de una impresion de $\mathrm{Ma}$ drid, 1640 .

1385 - La misma obra. Quinta edicion, corregida y emendada segun el expurgatorio del año de 1747. Madrid, Benito Cano, 1793. 2 vols. $8 .^{\circ}$

Esta edicion, por lo ménos la novena y no quinla como se supone en el fróntis, puede considerarse como la peor por hallarse mi. 
scrablemente mutilada: en clla ademas de supresiones en el testo, faltan dos loas por completo, asi es que solo contiene treinta y ocho.

Pellicer dice, en la P. ll. píg. 6, del Tralado del origen de la comcdia, al hablar de la obra de Rujas, ser libro mui curioso y ver. daderamente entretenido, y mui necesario para enlender la hisloria de la comedia en España: y yo añado estar escrito en dílugn, que contiene varias poesias en diferentes clases de metro, y treinta y cuatro loas en verso y seis en prosa.

Por ser tan raras todas las impresiones antiguas de la presente obra, el Sr. Barrera confiesa no haber visto ninguna de ellas; asi al hablar del número de loas que contiene el libro, dice ser el de treinta y neho, mientras las primitivas ediciones conticnen cuarenta; en la de 1793, unica que dicho Sr. Barrera tuvo presente, se suprimieron la de un chasco que le sucedió ul aulor con una mujer fea, y otra en alabanza de los ladrones.

\section{RÖJAS ZORRILLA FraN-} cisco DE). I'rimerar parte de las Comedias de Don Francisco de Rojas Zorrilla. Madrid, Haria de Quiñ̂́ones, 1640. 4. 4 hijas prels. y 300 foliadas.

Segrnda parte, Madrid, Francisco Martinez, 1645. 4. 4 hojas preliminares, 269 foliadas y una.en que se repiten las señas de la impresion.

Primera edicion mui rara. He visto otra de Madrid, Lorenço Garcia de la Iglesia, 1680.2 vols. $4 .^{\circ}$, y Brunet menciona ina de la Parte primera de Scvilla del mismo año cn $4 .^{\circ}$

La Parte primera abraza estas comedias:

No hai amigo para amigo.

No hai ser padre siendo rei.

Donde hal agravios no hai zelos.

Casarse por vengarse.

Obligados y ofendidos.

Pérsiles y Sigismunda.

Peligrar en los remedios.

Los zelos de Rodamonte.

Santa Isabel, reina de Portugal.

La traicion busca el castigo.

El profeta falso Mahoma.

Progne y Filomena. tes:

La Parte segunda comprende las siguien.

Lo que son mujeres.

Los bandos de Verona.

Entre hobos anila el jilego.

sin houra no hai antistid.

Nuestra Señora de Atocha. En lenguajc antiguo.

Abrir el ojo.

Los trabajos de Toblas.
Los encantos de Medea.

Los tres blasones de España.

Los aspides de Cleopatra.

Lo que queria ver el marques de Villena.

El Inás impropio verdugo por la mas justa venganza.

En el prölogo de la Parle segunda se queja amargamente de los libreros de Zaragoza y Sevilla, quienes recortaban las comedias sin compasion, con el oljeto de que entraran en cllatro pliegns; dice no ser suya Los desalinos de amor, impresa á su nombre, y promete una Parte tercera que no se publicó.

\section{RÖJAS ZORRILLA FraN-} CISCO DE). Comedias escoridas de Don Francisco de Rojas Zorrilla. Madrid, Ortega y Compañia, 1827-31. 2 vols. $8 .^{\circ}$

\section{Contiene estas ocho comedias:}

Del rej abajo ninguno.

londe hai agravios no hai zelos.

Entre bobos anda el juego.

Don Dierson de Toche.

l.o qu!e son mujeres.

linlil ui ojo.

El clesden rengando.

Progne y Filomena.

Edicion pesima, llena de erratas y lagunas. que solo debe tenerse por el Fxamen, pllesto al fin de cada pieza.

1388 ROMERO DE CEPED. (JoAQcis). Obras de loachin Romero de Cepeda. Serilla, Andres Pescioni, 1382. $4 .^{\circ} 140$ hojas foliadas, inclissos los preliminares.

Se hallan en este volumen las dos comedias siguientes:

Comedia Salvage.

Comedia llamada Iclamorfosea.

Ambas las reimprimio nchoa en el tom. I. del Tesoro del Tintro espriñol. A la segumia la supone anonima Moritin en los Origenes, nun. 151; y de lus terminos con que describe la primera, se colige fue ínpresa por separado de las obras, como tambien debiu suce. der con la Metamorfosea.

Los dos primeros actos de la Comedia Sal. vage estín tomados de la Celestina.-Veliz. quez en los Origenes de la poesia, pig. 98, llama Selvagia i la composicion de Rimero de Cepeda, tiluln de la escrita por İillegas Selvago, y Barresa la denomina, equirocada. mentr lambien. Sillatyr.

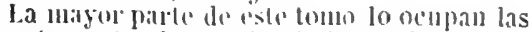
poeslas entre lis culales liai cinciones. viilancicos, glosis, romances, motes, sometos y el poema intitulado: El infelice robo de 
Elena, Reyna de Esparta, por Paris Infanle Troyano Diel qual sucedio la sangrienta destruyjcion de Troija. Reparlida en diez cantos. Está en quintillas. Sobre este asunto escribio el mismo autor otra obrita que se halla en la Seccion de los Romanceros y Cancame. $\because 0 s$, Nim. 374, por pertenecer á los de esta clase.

Segun Xic. Antonio, Romero de Cepeda compuso un libro llamado: Conserva espiritual. Medina del Canipo, Francisco del Canto, $1588.8^{\circ}$ y Las fabutas de Esopo y otros. Sevilla, Juan de Leon, 1590. 8.

Todas las producciones de Romero de Ce. peda son raras; pero del tomo de sus obras son contados los ejemplares conocidos.

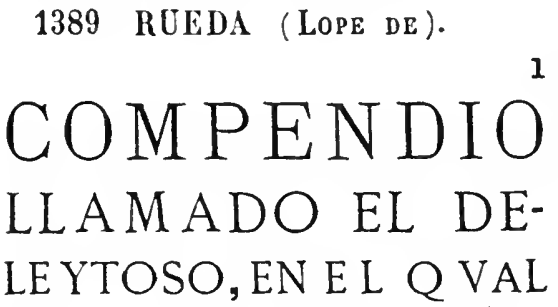

SE CONTIENEN MVCHOS PAS-

fos graciofus del excellente Poeta

y graciofo reprefentante Lope

de Rueda,para poner en prin

cipios y entre medias

de Colloquios,y co

medias.

\section{Recopilados por Iuan Timoneda.}

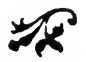

CON LICENCIA.

Impreffo en la muy noble y muy leal ciudad de Logroño por Mathias Mares Año de, 1588 .

8. 38 fols. incluso el fróntis, y una hoja ademas sin numeracion al fin con el siguiente colofon:

\section{Con licēcia impreffo en la muy noble y muy leal ciudad de \\ Logroño,por Mathias \\ Mares. I588.}

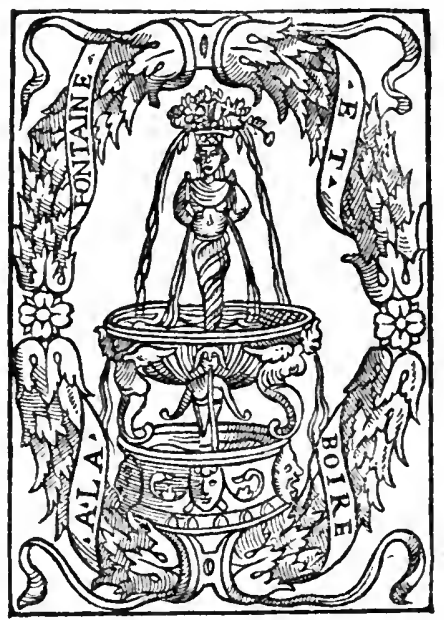

El presente volimen tiene la singularidad de llevar la foliatura numerada desde el unismo fióntis.

El título de la primera edicion, segun los traductores de la Hist. de la lit. de Ticknor, es casi igual al de la de Logroño, y en su colofon se lee: Impressos con licencia en la yuclita ciudad de Valencia en casa de Juan Mey. Año MDLVII. $8 .^{\circ}$ de 32 hojas sin foliacion. Gallardo, en el núm. 4 del Criticon, se equi. voca cuando dice ser el nombre del impresor Joaquin Mey; ninguno de los tipógrafos que llevaron este apellido se llamo así. Dicho Gallardo encarece la rareza de este libro, y Böhl de Faber conflesa que ninguma diligencia le bastó para conseguir un ejemplar de cualquiera de las ediciones del Deleiloso.

Moratin reimprimió en sus Origenes del tealro español, seis de los ocho pasos comprendidos en este volúmen: los que dejó de publicar fueron el primero y el quinto.

Barrera y Leirado da á los dos pasos omi. tidos por Noratin los títulos de Los criados y La tierra de Janja.

El mismo Barrera nos comunica la siguiente noticia de las otras obras dramáticas de Lope de Rueda:

Las primeras dos eleganles y graciosas comedias del excellente poela y representante 


\section{RUE}

PRIYRRA DIVISION.

ademas un tomlto Intitulado: Rrgistro lle vepresentunles. Valenctu, 1567, el cual, segun l). Juan Colon y Colon, comprende Codos los Pasos de lupe de kueda.

\section{RUIZ IDE ALARCON Y} MEYD0ZA (JCAN). TParte primera de las Comedias de IJon Tran Riviz de Mlarron y Ilendoça. Mfadrid, Iuan Gonçalez, M.DC.xxvir. 1 hojas prels. y 179 foliadas, con una mis al fin para repetir las señas de la impresion.

Parie segunda de las Comedias del licenciarlo Don Iran Rryz de Alarcon y Hendoca. Barcelona, Sebastian de Cormellas, 1634. 4 hojas prels. y 269 fols. 2 vols. $4 .^{\circ}$

Es mni raris el encontrar cjemplares buenos y complutos de ambas Partes - lic. Anto nio no menciona ningma elicion de ellas. y Brunet rita una de la Sigumila Parle' do har. colona, 162s. de euya existencia me hacen dular las aprobaciones y liceneias de la do 16.if. fochailas en 16.5: ademas lo dicho al principio nor $\mathrm{Fr}$. Crisistomn Bonamith, en barcelmall ol 2 de abril de 16.5. de que habia Ieido con atencion Ias doce Commerlias,

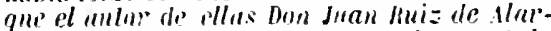
con. quit" imprimir. sncur it lus y i la

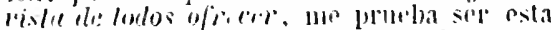
la primera edicion de dicha soumda Pintr, ₹ qur 110 pudo por consisnimite jublirarse en $162 \mathrm{~s}$, como sujene Jrinct.

La Parte primera abraza estas ocho enmedias:

Ins favoles del mumulo.

l.a iudustria y la sluerte.

Las paredes oren.

El splutrjante í sí mismo.

la curva de salimmanea.

Dllitillse por inejoralsos.

Tould resutura.

li drsichado en fingir.

J.a Earte segumda islas doce:

l.ns cumpeños di un emgaño.

EI dueñun de Jas estrellis.

La amistad eastigarla.

L.a mancanilla de Yelilla.

L.a rerdidd sispechosa.

liallar anligos.

E.I Intichrislo.

El lejedhe de segoria

la prucloa di las promesas.

Los perdess privileyiados.

l.a rruelulad por el lonor.

Eximell de maridos.

1391 Comedias escogidas de Don Juan Ruiz de Alareon y Ilendoza. Madrid, Ortega y Compañia, 1826-29. 2 rols. $80^{\circ}$

Toy. I. 
Comprende las siguientes comedias:

Canar amigos.

la veridid sosplechosa.

El eximen de maridos.

Las pilredes ovell.

Los ('mlneños de un engaño.

Uuicul cllyañi más à quién.

rimea micho ensti poes.

El lejedor de segovia. Sc'yunde parle.

so ha dielo varias vezes al tratar de olros autores combicos incluidos en la presente co-

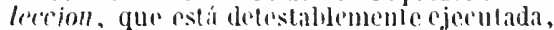
F que no dideria denerse at 110 ser por el Exáme'n en que se analiza cada pieza.

\section{3:9 RULZ DE ALARCON Y} MFADOZA (Jun). Comedias escogidas de Don Juan Ruiz de Mlarcon. Edicion de la real Academia espanola. Madrid, 1867. 3 vols. $8 .^{\circ}$ may.

Llevan islos lomnos en el antefróntis el título de Biblioleca silecta te antores clisicos españoles.-La adicjon es nutidia y el papel bueno. Precede al primer tomo nin disvillso

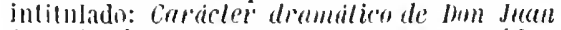

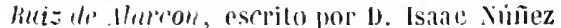
de Alemas, de quien son tamhien los duicios

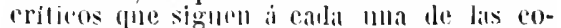
melias.-l.as publicalis luasta el dia son las signininles:

l.os pechos privilugiados.

Vo hai llal fule: pol biem no reuga.

diallill illuges.

Muliuse por mejoriarse.

l.us farofes del inmodo.

tas palredes oypen.

Ell lejulor de surovia.

El eximen de matidos.

La verdad sospechosa.
Original es el haber sido Perez de Montalvan 1110 de los poetas que tan desapiadadamente lrataron á Alarcon en las composicioues pullicadits por Alfay, en el tomo de poesins l'arias de grande's ingenios, despues de luaber dicho de él en el flual del Prore Codos: Dim Juan Ruiz de Alureon las dispone con ta! novealul, ingenio y eslirnezrt, yne no hat contedi's sulyu que no tenya mucho que almirar y nalli que reprenul'r, que clespmes d' luberse escribu truilo, es gran muestra (le su cautial ferlilisimo.

D. Iose Pellicer y Tovar en los Avisos pablicados en el Semanario ermdilo, tom. XXXI, pitir. 57, dice al apuntir tos acontreimientos notables del dia !) de agosto de 1659: Murió Don Juan de Alarcon, poela fumoso, asi por sus tontelius, como por sus corcobas, y r'clalor (lel Cousejo de Indias. - En el Penegirico ale la Paesia, impreso en Montilla on 1627 , fol. 5 i vtit., al hablar de los eseritores mis celcbres "n este grincro, se lee: Don Jllan te dlarcon es el cresililo de Mesjico; y en los meliminares del Desenyetion de forlutua, de Gulierre Harques de Curraga, impreso en $\left.16\right|_{2} ^{2}$, so ancuentra ma decima lauditoria be vilicencialo lum Ruyz de Alarcon y Mendoģ $\ell$, natural de Mexico. Apunto estas especies, porque ellas antorizan la opinion de que ol atulor le la Verlaul sospechosa era lijo de la capital de Nueva-España.

\section{RUIZ I)E GORDEJUELA} (Pevko). Comedia nveva. El Trivnfo de las Flores. Sta. Evlalia, y Jvlia. Escriviola D. Pedro liuiz de Gordejuela. 4. ${ }^{\circ}$ Manuscrita.

Mamuscrito que parece ser de fines del siglo Xi'll $\dot{a}$ principios del Xillt. Iglloro si se ha impreso: Barrera la trae como anonima, y cus su catilogro de antures no se halla el nombre de Ruiz de Gordejuela.
1394 SAA DE MIRANDA (FRANCISco ne) y FERREIRA (ANTONIO). Comedias famosis portyovesas. Dos buclores Francisco Sia de Miräda, \& Antonio Ferreira. Lisboa, Antonio Aluarez, Lishoa, 1622. 4. ${ }^{\circ} 4$ lojas prels. y 13 í foliudas.

Las comedias de San de Miranda son:

os Vilhalpindos. Fil prosa.

(Is Estrangeiros. Lu Mismus.

Las de Autonio Ferreira: ·

Brislo. En prosa.

0 Cioso. Lo mismo.
Barrera y Leirado describe una edicion de la comedia Villatpandos de Coimbra, 1560 . $12 .{ }^{\circ} \mathrm{y}$ de la $0 s$ Es'rirtingeiros. Coimbra, 1569. $8 .^{\circ}$; Brunct solo cita de la primera una de Coimbra, y de la segunda otra de la mismu cindal de 1580 .

En el Catálogo de la bib. Grenvilliana sc describe así la primera edicion de las obras de este autor: As obras do celebrado Lusila"o 0 doulor Francisco de Sa le Miranda, collegidas por Hanlel de Lyra. (Lisboa,) Impressas com liçença do supremo constllio da santa Geral Inquisiç̄o et Ordinurio. 1595. 4. Barrera observa que en esta impresion se incluyi da comedia os Vilhalpandos, y esta y la de 0 s Estrangciros en las de Lisboa, $1614,1632,1651$ y 1677 . Tambien parece se 
incluyeron ambas en la edleion hecha de las obris poélicus de Saa en dicha ciudad de Lishon, en $178 \mathrm{i} .2$ vols. $8 .{ }^{\circ}$

be las dos comodias de Ferreira no sé haya micion nimeruna mis antigua que la de f6i2-, hoi dia nui rara. El Sr. Harrera se conote no haberta visto, amuque la menciona en los irtferilos de Antonio Ferreira y de Sail de Nirandi, pues si la lubiese tunido presente, parece mui natural hubiera copiado la por. tada y observado que las cuatro comedias forman un volimen eon su foliacion seguida desde el principio hasta el fin.

El esinlo del impresor Antunio ilvarez, que se enenentra en el frontis, es mui parecillo al usado por Couesta, del halcon con la inseripcion Post tenchras spero lucem, y es casi el mismo puesto en las Vouelas de Cervintes, que se suponen falsamente impresas por dicho Cuesta en 1614.

13930 SÁLAS BARBADILLO (ALONso Jeróximo de). Casa del plazer honesto. Avtor Alonso Geronimo de Salas Barbadillo. Madrid, En casa de la viuda de Cosme Delgadn, 1602 (1620). 8. 8 hojas prels. y 180 fols.

Primera edicion. La fecha del frontis esta evidentemente equirocada por una trasposicion tipogrática de los dos viltimos guarismos. il año de lis aprobaciones, licencias, etc., es el de 1620 .

\section{6}

La misma obra. Barcelona, Sebastian de Cormellas, 1624. $8 .^{\circ} 8$ hojas prels. y 180 fols.

Edicion que nn citan Nic. Intonio, Alva. rez y Baena, ni Barrera y Leirado.

Contiene csta obra seis movelas intercala. das de varias poesias, Ia comedia on prosa El busca-oficios, otra en verso intitulada: El caprichoso e'n su guslo, y la Damia setenlona y dos dicilogos, Los mirones de' la corte, ell prosa, y El tribunal de los Majuderos, en verso.

Tambien hai composiciones dramáticas de este genero en otra obra del mismo Barbadillo que se denomina: Firslus de la boda de la incasable mal casada. Madrial, Viutula de Cosme lietgato, 1622. $8 .^{\circ} 8$ hojas preliminares y 167 fols., y sus títulos sou: El Descasaméllero. Comedia en prosa.-El Comisario conlra los malos guslos. Comedia en verso.-El Remendon de li naluraleza. En prosa.-El Cocinero del amor. En verso.Las Avenlureras de la corte. En prosa.-El Malcontentadizo. En prosa.

1397 - Coronas del Parnaso, y Platos de las Mrsas. (Por) Alonso Geronimo de Salas Barbadillo. Madrid, Imprenta del Reino, 1633. $8 .^{\circ} 8$ hojus prels. y 310 foliadas.
Contiene ademas de algunas novelas y varias composiciones poeiticas sueltas, cuatro entremeses intitulados: loña Venlosa, El Caballiro bailurin, El frado do Mudrid y baile de la Caponn y Et l'ulrazo y lus hijazas; y las dus comedias Viloria de Espana y Francia y Et galan lramposo y polire.

l.os ejemplares bien conservados son raros.

1398 SALASBARBADLLIO (ALONso Jeróxiyo DE). La sabia Flora malsabidilla. Avtor Alonso Geronimo de Salas Barbadillo. Madrid, Luis Sanchez, 1621. 8. 8 hojas prels., 16.3 foliadas y dos en que se termina la Silva. Albanio a Laura.

I'rimera edicion.-Es una especie de comedia en prosa y verso, ó más bien una novela puesta en dialogo; siu embargo, está dividida en tres actos.

Al mismo zénero pertenece otra obra citada por los traductores de Ticknır, tom. IlI., pig. 348 , escrita por Barbadillo $\dot{e}$ intitulada: el Cortesmo descortes. Madrid, Cosme Delgado, 1621. $12 .^{\circ}$

1399 El Sagaz Estacio Marido examinado. Autor Alonso Geronimo de Salas Barbadillo. Madrid, Iuan de la Cuesta, M.DC.xx. 12. 12 hojas prels., $10 ̈$ fols. y una para repetir que la impresion es de Nadrid, Por Iuan de la Cuesta Año M.DC.xx.

El títuln de la obra lo he copiado de la edicion de luis Sinchez que describire en el siguiente numero, por faltar i mi ejemplar la portada.

La fecha de los privilegios $\mathrm{y}$ aprobaciones es de 11013 y 14 , prieba al parecer de la cxistencia de impresion anterior á la de 1620 ; sin embargo la Tisa y Erratus son de 1620 .

$1400-$ La misma obra. Madrid, Por Luis Sanchez, Año M.DC.xxi. (Al fin: M.DC.xx.) 12. ${ }^{\circ}$ Igual nümero de hojas a la anterior.

Estas dos ediciones son mui parecidas, aunque perfectamente distintas; ambas son raras.

Comedia en tres actos en prosa, intereala. da de algunas poesías.

1401 El svbtil cordoves Pe. dro de Vrdemalas. Artor Alonso Geronimo de Salas Barbadillo. Con vn tratado del Cauallero Perfecto. Madrid, Iuan de la Cuesta, $1620.8^{\circ}$ hojas prels. y 267 foliadas, aunque 
solo dice 167, porque desde la 2110 hai in centenar de ménos. Al fin se encuentra una hoja, en que se repilen las señas de la impresion. Viene despues nueca portada que dice así:

El Cavallero perfecto. En crvos hechos, y dichos se propone a los ojos in exemplo moral y politico, digna imitacion de los Nobles, y necessaria para la perfeccion de sus costumbres. Por Alonso Geronvmo de Salas Barbadillo. Marlriu, Luan de la Cuesia, 1620. 8. ${ }^{\circ}$ it hojas prels. folialas. (Iri ejemplar llega solo i la 136.)

I.a plimera r's ma novela en verso y prosa, que tiene al fin la eomedia do $1: 1$ gullomedo

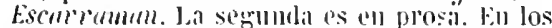
titulillos de ambas se lee Promer"l parle; mas no lan sido rontimualas.

Debo olservar que he visto varios ejem-

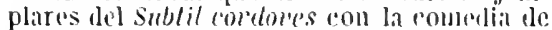
Escarrmman; pero en ninguno de ellos se hallaba El caballero perfeclo.

Otra obra existe de silas Barbadillo intilulada: El Caballero prulual. Primer" parle. Misdrid, Miguel Serrano, 161.1.-Segmulie parte. Com la comeline de Los prodigios de Ausor. Mallid, 16I!! 2 vols. $8 .{ }^{\circ}$

1'02 S.ILAZAR Y TÓRRES (AGTSTry ne). Cythaza de Apolo, varias Poesias divinas, y hrmanas, fre escrivio D. Igustin de Salazar y Torres; r saca a luz D. Iran de Vera Tasis y Villarroel, sr mavor amigo.

Priniera parte. Madrid, Francisco Sanz, 1681. Ignoro cuantas hojas prels. tiene, en mi ejemplar solo hai 24, 306 prigs. y 3 hojas de Tabla. - Crithara de spolo, loas, y comedias diferentes yre escrivio J). Inrstill de Salazar y Torres; y saca al lvz D. Iran de Vera Tasis y Villarroel, ov mayor amigo. Segunda parto. Madrid, Francisco Sanz, 1681. 2 hojas prels. y 446 prigs. 2 vols. $4 .^{\circ}$

El tomo segrmudo de esta clicion es tan laro que Barrera supone baber salidu imicamente el primeru on lisi, y que el otro no vio la luz publica hista hió.

\section{3} La misma obra. Madrid, Antonio Gonzalez de Reves, 1694. 2 vols. 4. ${ }^{\circ} \mathrm{El}$ primero tiene 2 ' lojas piels., 301; fols. y: 3 hojas de Tabla, y el segundo, - hojas prels. y 424 peigs.
Ilai dos ediclones distintas, tipogrificamente hablando, que llevan ei mismo año: pero su contenido es exactimente igual. Como he nolido esta circunstancia cn varias obras que no debieron espenderse con tinta rapide\%, me inclino á creer si los impresores o libreros las reproducirian furtivamente, repiliendo el año de la auterior edicion, bicn para no pagia al autor algun derecho, o para no solicitar nueva licencia. I as Obras de Salizar me confirman en esta ill ima idea, pnes se ve por el permiso, puesto al principio, habiascle concedido este al impresor para publicarlas una sola vez.

El contenido de las ediciones de 1681 y 9.4 es el mismo. El tomo primero comprende alguntis loas y bailes, y el segundo las comedias siguientes:

Elegir al enemigo. Con lor.

El almor mits desgraciado, Zefalo y Pócris. Conlina.

La mejor llor de Sicilia, Sta. Rosolea. Con loa. Timbien se ama en al abismo. Con loa.

Jos . megos olímpicos. Con loa.

El incinto es la hermosura. Con loa.

El merito es la coroma, y encantos de mar y amor. Con Ior.

Titis y Peleo. Con loa.

Triunto y venganza de amor.

In comprendo por que se incluyó en el tomo primero como prodnccion de Silazar $y$ Tirl'tes el poema de orfeo, publicado ya en 1621 , coll el nomlore de su verdidero autor I). Juth de Jiul'egut.

1404 Si.YCIIEZ (1). José). Examen imparcial de la zarzuela intitulada: Las labradoras de Murcia, c incidentemente de todas las obras del mismo Autor; con algmas reflexiones conducentes al restablecimiento del Theatro. Por Don Joseph Sanchez. Madrid, Pantaleon Mznar, $1769.4 .^{\circ}$

190:3 SiNCILEZ (VICExte). Lyra poetica de Vicente Sanchez. Oliras posthvmas que saca a lvz in afieionado al avtor. Zaragoça, Manvel Boman, II.DC. LXXXVIII. $40^{\circ} 17$ hojas preliminares, 312 pás. y 2 hojas de Indices.

Contiene, ademas de poesías en varios gineros, una lou, un baile y el fragmento de una especic de: zarzucla intitulada: Fabula de apolo y Dafire.

Nic. Antonio no menciona í Vicente Sínchez.

Lallasi cila moil ulicion de Zaragoza, 1 li68, y Tickmor, tom. Ill., paig. 120, olra del mismo meblo, 168i; ambos se equivocall á mi entemler, pues no conozco mís impresion que lit de 168s, y la dedicatoria, aprobacion $y$ censurit focliadas en junio, julio y agosto de dicho año, prucban ser la primera. 
1406 SiNCHE'\% DE BADAJ()\% (Divao). (Bajo de un escudo de armas, probablemente del señor don Giómez

Suárez de Figueroa, conde de Feria, a quien va dedicada la obra, y rodeado todo de una orla bastante ancha, dice:)

\title{
Gheropúlacion en metro \\ Del Bachiller Diego fanche; de badajoz sula qual pos araciofo Costefano y paftosil eftilo fe cuentan y de claran muchas figmas yanto sidades dela fagrada effriptusa Agoza nuena mente ympeffo y Diriaido al ylluftriffimo $\mathfrak{s e}$ noz Dou Some; farar de figurroa Conde d' frita fí. \\ Compsiullegio
}

(Al dorso principin la licencia dada a Juan de ligueroa, sribrino del autor, fechada en $130 \mathrm{i}$ ?, la c:lal concluye en el blanco de la hoja siguiente sign. Aij. En el reverso se halla la dedicaloria al Duque de Ferilt, que ocupa tambien el recto de la hoja tercera, y a la vuella comiensa la Tabla que llena casi toda la sign. Aiiij. La oura principia en la quinia hoja y termina en la signatura Xij con el siguiente colofon:)

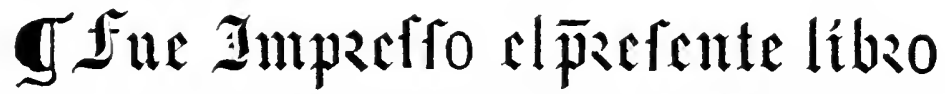

\author{
enla muy aoble y leal riudadde senilla \\ junto al mefondela caftaina acabo $f_{e}$ \\ aocho dias Del mes de Otu \\ bse Ano de mily quini \\ entos y cinquenta \\ y quatro

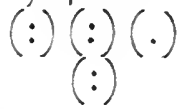

(Siguen dos hojas de fi de erratas.) 4. ${ }^{\circ}$ let. givt. á dos colunas.

Sin vacilar califlen ln Rernpilacion de Sinchez de biadajuz como el libro mis precioso c intcresante de todos los que contiene la prescule seceion, tanto por sul importaucia literaria comb por su rareza. lo flimdome en mis conociunicutos, il pesal' de que mua nflcion de muchos añus me ha dirlo ya alsmma inteligencia prictica, me dicige pillicudo mis nolieis al conocido biblinllo $1 \%$. Misellal the liayilleos, al distinguido lierato 1. Formanulo Wulf, de Vienta il los bibliote. carios do la lomperial de Francia, do satuta

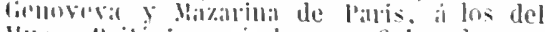

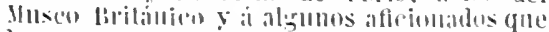
buscall ?

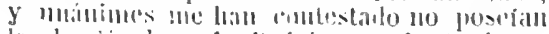
la do sinclue\% de Bathioe, y latstal igno- raban su cxistencia: me parece pues no scrá ayenturalo ol decir que uni cjemplar es cl solo conocido ('n la ictualislid.

lil inico de nuestros biblinglus que hace mirito de este cscritur dramiti(co, sin cmbargu de ser quiell mayor mimero de piezas publico intes del año de lliov, es Vic. Autnnio, y allu este solo le cita de oidas al pare. cerr, pilles allemas de omitir el sugundo ape. llido clol autor. el titulo daclo por el de la olira apeillas tiene mada del veriadero, cquivolando el tamaño que designa comb s.o

lie la lionucia dada i Juan de finueron, sobrimo del alltor, y le la dedicatoria de esté sessea, gue biego Sincliez chil ya difumto en

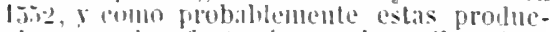
ciuns squall foutu do sus jurenilos anos.

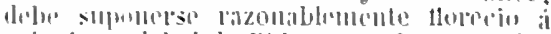

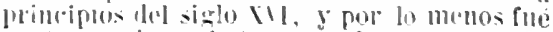
contemporinco de Tomes Vabarm ? inn su 
rlval, como to indica dlcho sobrino al deeir, que las composiciones del bachiller de Badajoz eran las mejores que hasta entonces se habian sacado á luz, sin injuria de Nahurro.

Aunque Moratin no analiza ninguno de es. tos dramas, porque el inico que menciona refriendose à Pellicer, es la Farsa del matrimonio, no me es posible el llenar tan gran laguna, por ser un trabajo demasiado prolijo dar una idea algo completa de las veintiocho piezas que cucierra esta hecopilacion; me contentaré por lo misno eopiando literalmente sus eplgrafes, y linicamente de la Farsa del moliner'o, inpresa por separado, presentaré un lijero estracto.

\section{LIST A}

de las Farsas ó composiciones representables que cricierra el volumin.

1. Fursa theologal en que principalmète se iralan algunas razones dela encarnacion: y natiuidal de nío señm jesil cliristo: son interlocutores vn pastor que pregunta: $y$ ? $: n$ theologo ô responde : ? vina negra: y vn Sol-dado: y in maestro de sacar muelias : y r'n cut?u. (L.a negra liabla. el castellano chapurrado.)

2. Farsa de la naliuidad en'a qual principalmềle se dispula qual (ue mayo" gnzo ala virgen muestra señora en a ineffinble conception o en la gran natiuided de su glmioso hijo mestro saluador ihesu chrislo con otras incidenies quistione's ansimorales comn thenlogales: son interlocutores vn clerigo que sustenta la parle de la encarnacion: y ${ }^{\prime \prime \prime}$ flayre que habla por la nalinidad: II vin villano que se nombra Juan : ? via figura de donzella honesta que se llama la cienria: entra primero el clerigo ys viene Juan como por su crindo y asientase el clerigo en su silla : y el Juan comiença a dezir.

3. Farsa de sancla barbara en como fue lleuada en juyzin anle Dios: snn mnterlocutores: cimen figures i'n xin asentado en v"na silla como juez con romu cruz en la momo sobre in mundo: sancla Barbara delante din bien atauiada: in Angel deln grardia que lit lleua por lu mano a jusgar : 'n Diablo abras que la vu acusar: in paslor yue comienca primero ha a hablar el qual a de llouit ires currones : vno aldelanle : y olvo alras : y vno muy pequeño a un lado.

1. Farça de Salomon son ywterlncutores nueve figuras un puslor ij entra primero: dos mugeres rraneras: y un niño de tete

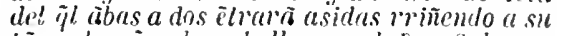
tio sobre jen lo a de lleuar el Rey Silomion. quelus oyra de Justiçiu y derra su sentensia el pual " de pstar deste el principio en pun silla asantado con vina con'ona !l mill celro rreal : yn page del hey que estera on pie y destwraido dilunte del / ima ventera / an houn crialn suyn: y ũ fruyle: los ijtss mliuran a su lino el pustor hublu com lodos el it culva comièdo de z'nas vellotas y dise ansi las coplas siguiētes : este añ ino mu! gran falla de pà. Pieza bastante libre é indecorosa. x. Farca moral en que se rrepresenlan las qualro viriudes cardinales como enderecan los actos humanos. son ynterloculores. Jislicia . Prudencia : Fortaleza Temperanca: Nequiciu: el palriarca Job con su paciencia : y vn moço suyo : el rei Nabuco donosor con su soberuia : nuesira Señora Rezien parida con su niño en braçs : enlra primero nequicia vestido como siuple pastor $y$ dize la gual csta añedida y emendada por el anclor. Eu esta farsa se da una nomenclatura bastante estensa de los juegos que estaban en uso en aquella época, y de las fullerias empleadas en ellos por los tihures.

6. Farsa del colmenero son ynterlocutores un pastor que se hizo colmenero:y un frayre :y un labrador: y a de lezar el pastor puesia una mascara de castrar colmenas : yl vna castradera è la mano : y vna pa!lla có panales en la olra y a de lleuar la payla a la parle de fuera cierlas munchas de lechada y dize el pastor. En esta pieza dramática, lo mismo que en casi todas las otras, las miximas de moral y religion van mezcladas con diseursos y frases bien poco edificantes: asi por cjemplo, en la presente, un habradır y el colmenero (mui centritos y arrepentidos al fll de la farsa) empiezan por llenar de inproperios á todos lus clérigos, y partichlarmente al fraile, quien para defenderse les dice:

Oh! cuán claro se parecen

I.as bestiales intenciones;

clérigos y religiones

Son los que el inumdo esclarecen.

A cuya observacion replica el pastor:

Esclarecen d' esque erecen

Los vientres de algunas ducñas.

ว. Farsa de tamar : en qu entran siete figuras : vn pastor : y lomer : $y$ judas $: y$ opilo su criculo : alquazil: fiscnl : escriutuno: entra primeramenle el peslor y dize.

8. Fursa dicha mililar en que principalmente se alaba la sacra penilencia. representase en ella comn los tres enemigos que lenemos : Carne: :tundo : y el Diablo: Balallan contra las persnntes espirilunles : son ynlerloculores: hacifer en forma de bestia fiera : el mundo en abilo de un viejo négocia. dor : la carne en abilo de muger poco honesta: vn frayle con su Anyel de la guarda. vn ciego : y u cu coxo que lo adiestra: y vn manco de inu mano todns tres mendigantes. al fin enlra on sordo. y un pastur el que al principio dixo el argumento : meuamente emmendada ys anedida por el Bacliiller Diego sanchez de lalauera.

9. Farsa kncional del libre alueirin en ij se represonta la Batulla que ay entre el spiviluy la carne son ynterlocutores : el libre aludrio armado de todas armas: el ruerpo como pastor : el anima como Angel. aladit con el : lie sensualidad como vma mala muger : el Descuydo como pastor. El entendimiento como doclor : la razon como lieyna: culva ante lodess vn paslor que se lenanla de dormir disicndo. 
10. Farsa d' malitimonio : es para repre. sentar en bodas Son seys figuras: un pastor: y su muger : y su hiju mencia : y un frayle : y su mozo marlin : y vn maestro de quebraduras. De esta farsa tengo una reimpresion, descrita despues, la cual contiene variantes de consideracion; aunque no alteran el argumento.

11. Farsa del santissimo Sacramenlo son ynterloculores dos pastores : wo ò se dize Juã : y otro pablo: y un frayle que les declüu algunas de las sinificaciones y misterios de la missa. Cópucsle y hordenuda por el bachiller Diego Sanchez de Budujoz: es una de las Farsas i entran en su recopilacion. Con priuilegil.

1.2. Farsa de los Doctores en que sc representa como el niño Jesus de edud d' do:e años fue halludo ch el tépto cn medio de los doclores de ta ley rieja: Gamaliel : viendemus :y Rabi Sammel : sentados cu lres sillas en Iriangulo y en medio el niño Jesus semlailo en cl sucla: is un pastor ij entre lodos dize gracias para royr: y la maria gue snbre viene : y al fin vn diablo que lucha ci el Pastor: ante lolo entrin bos loctores cullados con sus libros en las manos ! sienlanse: y luego entra el paslor. Cipuesta y ordenala por el bachiller biego sächez de Ballajoz: es vna de las fursas que conlran en su recopilacion

13. Far'su de la fortuna o hudo : sij inlerloculores lres figuras: un pastor: y in cauallero: $y$ 'n negro. Este uiltimo personaje habla el castellano chapurrado.

1- Farsa de jsate: son interlaculores cinco figuras : Ysuac: " Rebeca su mugur : y sus ulos hijos Jacub: y Esau : y un pastor el qual dize lo siguiente.

15. Fursa alel molinero en que enlran quatro figuras: in molinero que sirne de

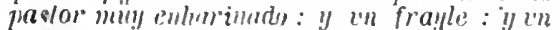
ciego : I su muchucho que lo adieslru: habla del senr'lissimo sucrumenlo ded corpus Chrisii. Fsta firsil es la misma que uleseribipe $y$ analizare mis abajo, reinupesa í principios del siglo Xill., en lenguaje algo madernizado.

16. Farsu en tue entran cinco figuras: in pastor y Hoysen : y sant Pablo : y un Negro. IInbla del sanclissimu sucramento del conpus cluristi: culra primero el pustory dize. En los titulillos de las páginas se denomina: Fursa de Moysem.) El negro habla cn su algarabía.

17. Farsa de sumea susaña cn que cullan seys figmeas a de yr lu rairela hecha b'a "ergel y u la l'na perrle ascondidas dos riojos con sus yarus comn juese's: y ala olla piarle una muger mu! udereçada qu' t's suseña : !l

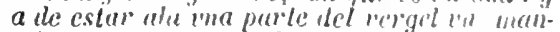
cebo clerigo que o's el profodu clanial : !n m angel mubierlos :y t'll Orloluno : rn jetstor. "l "fual romiensu a desir.

Es distimla de la que sobre el mismo asuntu escribiu Juan de lodrigo dlonso.
18. Fursa del rey dauid son inlerloculores seys figuras : in pastor : !y cl rey Saul: y su hijo jonutas : y el rey llauid como pastor : y el ginante golias armado.

Segun el Ensuyo de uria bib. esp., Gallardo vió una edicion suella $y$ anónima de esta Farsa, sin nota de lugar ni año. $40^{\circ}$ let. giot. 4 hojas: de olla se hizo la reimpresion que se halla en dicho Ensuyo; pero esti tan cercenada que solo contiene unos trescientos noventa $y$ dos versos, mientras que en la lie. copilacion de Sinchez le Badajoz llega á seiscientos sicte.

19. Farsa de abrahum en que entrā siete figuras : a Bralian : y Sarra sumuger : lres Angelcs : y in piastor: Sarra a de eslar debaxo de in pauc!lon y Abrahan ala pllerla sentado en vint silla y el moço de lante leuanlado: Ins lres angeles cncubiertos hasla q salyun usu itewipn: ade eslar purde el paudion una ensina : cl prastor dise primero: $e$ te año secriso cl sol las ance jutrles.

20. Farsa de la yglesia son ynterloculores quatro fimuras : ina muger tirja tures la sinagnga cubierla con lula. is twre muger it es la !ylesin muy linda y honestisimammle alcuiaila: In morn is esta encubierlo:y 'n pastor que que sic comienç aluablar leuanlandose de dormir.

21. Farsa del herrero en que entran tres figuras : un herrero marlillidilo jumlo a su fragua: $y$ un pastor:y un Ramero: corniença ahablar el pastor

22. Farsa en que se reprisenli lu saluInciom de nia señma son lies fijuras: la marta : y el angel : y el pastor.

23. Farsa tle sanpledro en que enlran qualro figuras une son: en vin :y son pe-

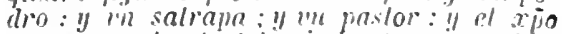

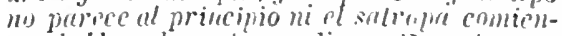

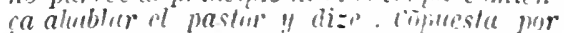

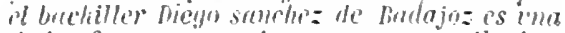
de les fursas ane cutran en su redopilacio. Cumbrimilegio.

21. Fursu te la hechizera son ynterloculores siele figuras l'n pasior : it entra al principio : y z'n galun yles se prexa de su

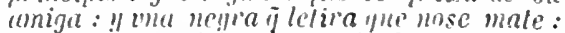

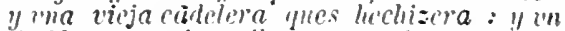
diablo, y z'n alg!nzil. La negra habla el cas. tellano chapuriado.

3.5. Farsa de la ventera son interlocutores seys figuras : ima venlera : y in pas.

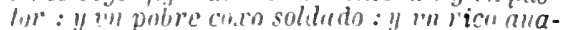
rienlo : y ina neqra : y in ulguasil: comiençn ahoblar pl prestor. Tambien llsa la nespa de su habilual algaribia en el lenguaje.

-3. Farsu de li muerles son ynterloculo-

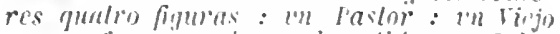

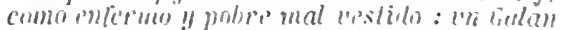

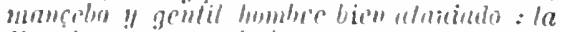

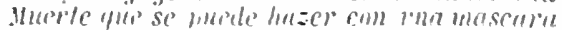

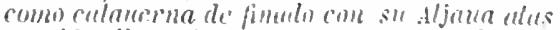
espuldes llena de surlus y inn aron en la ma. iij con su arpon : conizença ahablar el pastor. 
el yutroylo siguiente que fue hecho para los canonigos de badajoz porque se quexaro que les dixo en rina far'sa dios mälengu. Cópuésta jow el bachiller Diego sumehe (sie) de badajos es rina d' las fursas que entran en su recopilacion Compriuillegio.

2. Farsa en que se represenla un juego de cuñas espiritual de virludes contra ii. cios son ynterloculores : vn pstor (sic): Y vma pastora que an de estar en vn lablado en marle if todo el avdilorio lo vea yt wha sibilu on figura de andet que asu timmpo se asentara en rma silla que a de cislar puesla en parte alla de manera que so juzgue atrodos y que todos la veran delanle de la qual estara un blando o hacha ariliendo pendicle de z'n hito de hierro can su hoja de lalu meima de arle que paresca ò se time cut el ayre todas las de mus finguras ande eslar y represenfar en parle ascondida donde nadie las pueda ver saluo la sibilu porque a de dar razon ale to que hizieren el pastor habla primero $y$ dize. Pieza sumamente curiosa porque todos los personajes deben desempeñar sus papeles cantando, asi es que estí llena de villancices, coplas, folíis, himmos y coros, acompañados de atabales, frompetis yo urgano, y mezclados de diversos bailes: es por consiguiente una verdalera zarzuela ú opereta, quizí la más antigua que cxiste en castellano.

28. Dança de los pecados désta manpra guia atai siguense snberuiuryra: ynuidia: unaricia : gula : luxwria : arilia : pl paslor z'a delavile aparlando la gonle co su cuyudo haziédo corro y quario salen a buylar aprarluse a vn lado y desile alli hablia.

Ademas de los lramas que acabo de enumerar contiene esta Reropilacion las siguienles composiciones pocticas :

Momteriu espiritual gue los hombres deuen en si hazer : en que la razon caça a la lolinntad : ci) rua ghosa para mayor declaracion.

Yatraca de Juga:ores compuesta d" miesa con protestacion que sera emendada antes yuellos.

Romances a lnestra señora "l la l'asion.

Estando el auctor enfermo de sarna le embin l'n su amigo muchos principios dle romances antiquos rogandole se los juntase è copla el qual los aplico a la sarina.

In yumitatorio y otro cantar para los muchachos el dia de Corpus.

bos Introytos el uno de pescadores de tierra de badajoz y el otro do los siete pecalos.

Coplas a sant junt baplista.

Coplas a rua monja ya antigna enla relizion níbrada santispirilus.

\section{SINCIIEZ DE BIDAJOT}

(D)ego). Farsa sobre el matrinionio es para representar en bodas. En la qual se introduce, vn pastor y su miger, ! su hija Mencia desposada, rll frayle ! vil moro Martin, y in maestro de quebraduras. Es obra muy apacible y prouechosa. Inpressa en Medina del Campo con licencia en casa de Juan Godinez de Millis aก̃o, $13 ั 30$.

(Siguen tres figuritas y una torre, $y$ principia inmediatamente la farsa que concluye en el blanco de la octaca hoja con este final:)

In presso con licencia en Medina del Campo. año de MDCiij.

4. ${ }^{\circ}$ let. gót. sign. A.

Esta farsa no lleva nombre de aulor en la presente impresion.

segun se ve por et titulo arriba copiado es de suponer cxiste otra edicion hecha en Hedina del Campo en 1530 , aunque no pudo imprimirla Juan Godincz de Millis; Pellicer la cita ; pero no sé si la apuntacion la sacaria de alonn ejemplar de la de 1603 , el crial examlnaria superficialmente sil fljarse en la fecha del fin.- Horatin no turo más noticia de esta nieza que la dada de su titulo por el citado Pellicer en el Tratado de la comedia, y de la uisma fuente lia sacado sus apuntaciones Barrera y Leirado.

observo que esta coniedia en la presente edicion difiere bastante de la que se encuentrit en la Recopilacion de Sínchez de Badajoz, pues hasta el orden de las escenas se halla invertido. En el Ensayo de una bib. esp. se ha reinipreso, pero copiada de la edicion de Medina del Campo de $160 \tilde{5}$.

\section{SiNCHEZ DE BADAJOZ} (Diego). Farsa del Molinero, que trata del santissimo Sacramento del Corpus Christi. Agora nueuamente Impressa con licencia en Cuenca, aĩo de mil y seyscientos y tres (1603). Sigue una lám. de S. Juan Evangelista.) Compuesta por Diego Lopez de Orozco, vecino de la ciudad de Toledo. 1." thojas sin fol. ni signs.

Diego Lipez de Orozco no es el autor de la preseite farsa, á pesar de lo dichn en el fróntis, sino Diego Sánchez de Badajoz, pues se halla en la Recopilacion de sils ubras ántes discritil. - La ellicion pareee de principios del siglo xill: observo algunas variantes entre ella y la de lox́, consistiendo principalmente en estar modernizadas muchas palabras.

Por ser bastante corta daré el análisis de esta pieza.

\section{ARGLMF.XTO}

de Ia FAPSA DEL MOLINERO.

Ln molinero cansado de serlo y aburride de ver qur á pesar de empeñarse en obrar como hombre honrado, nadie le tiene por 
tal, deja su profesion $₹$ quiere hacerse pastor: encuéntrase con un fraile al cual pregunta por qué está la gente tan regocijada: le contesta, que por ser el dia del Corpus, y continuando en su interrogatorio, sin venir mui á pelo, pide esplicaciones sobre el misterio de la Eucaristía y el de la omnipresencia de Dios: á ambas contesta el padre con argumentos por el estilo de este:

Has notado tu figura en un espejo al mirarte, si aquel espeju se parte, til figura tal cual era, en cada parte va centera toda en todo y toda en parte.

A tan palpable y acertada esplicacion no puede resistir la ilustracion del molinero, así es que esclama:

lo vos juro a los planetas, qu'es la via verdadera, andar con fé mui entera camino de las carretas.

Sin saber por qué ni para qué se aparece un riego guiado por su lazarillo of reciendose á rezar

La oracion de la emparedada, y los versos gregorianos, las Angustias, la P'asion, las almas del purgatorio, la oracion de S. Gregorio, la santa Resurreccion,

la mui devota oracion,

la beata Catarina,

y la cristiana Doctrina,

la misa y su devocion, la vida de san Hilario, comienda de san Anton, la uracion de san Leon, la devocion del Rosario, la vida de san Macario trobada.

Y cuando el pordiosero desgraciado se apercibe que su guia le ha colocado cerca de un fraile, le da un garrotazo observándole:

iNo te tengo dicho ya

que me alejes de quien pide?

El muchacho temeroso huye, y el ciego ra dándose golpes por todas partes: al verse así perdido vuelve á llamar a su conductor y se reconcilia con él. De aquí saca su moraleja el fraile para advertir que en este mundo todos nos perdemos si no tencmos quien nos dirija, y termina la Farsa con un villancico y sil copla.

El Sr. Barrera no la conocio, aunque reimpresa por separado y en época más reciente que la Recopilacion de Sánchez de Badajoz.

\section{SANCHEZ TÓRTOLES AN-} Tovio). El Entretenido. Repartido en catorze noches, desde la de la rispera de Navidad, hasta la del dia de los Reves. Celebradas en metafora de Academias, de verso, y prosa, en que se obstentan varios assumptos, muy provechosos, y entretenidos. Por Antonio Sanchez Tortoles. Zaragoca: Por Pasqual Bueno. Año de 1701. 4. 4 hojas prels. y 404 pags.

Contiene este tomo muchos romances, letrillas, relaciones y otras varias composicinnes en verso, algunos cuentos y novelitas, una comedia intitulada: El Nacimiento de Nuestro Ser̃or Jesu-Christo con Loa, y el entremes denominado: El valiente.

Segun se ve por el prólogo de la sequnda parte hai ura edicion de la primera hecha en $|6 \overline{1}|$ : debe ser de Madrid, segun aparece por las aprobaciones. Nic. Antonio hace tambien mencion de otra de Walrid de 167.5 . 4. y cita una obra de Sánchez Tortoses intitulada: Segundo ramillete de divinas flores. Madrid.1671. 12.

El Sr. Barrera y Lcirado solo describe una impresion de Vadrid 1729 . ..$^{\circ}$; pero no habla nada de la $L o a$, y dice se titula el entremes Las Gurruminas. Observo ademas equivocado el nombre del autor á quien llama Alonso.

1410 SíNCHEZ TÓRTOLES (AxTorio). El Entretenido, segunda parte, miscelanea de varias flores de dirersion y recreo, en prosa y verso: adornada de diversas relaciones serias, burlescas, y seri-jocosas, Entremeses, Novelàs, Seguidillas, y ot ras muchas noiicias curiosas para el gusto de los aficionados. Compuesto por Don Joseph Moraleja. Madrid, Gabriel Ranirez, 1741. $4 .{ }^{\circ} 8$ hojas preliminares y 2 2.' paigs.

Ademas de las muchas poesias y cuentos que contiene, hai en este tomo cualro en. iremeses intitulados:

El alcalde médico.

Perdone la enferma.

El alcalde haciendo audiencia.

l.os cestos.

Y una Loa al Patriarca S. José, y un Solilo. quio, de cuyas dos composiciones no bace inérito el Sr. Barrera.

SÁNTOS (Frascisco). Otros hai mas locos que nosotros. Entremes $i$ sainete. Véase en la Seccion nocelistica al nombre de este autor en el articulo de Los Gigantones de Madrid.

1411 SCOTTI DE AGOIZ PeDro). Ohras poeticas postlumas, 'que a diversos assumptos escrivio Don Pedro Scotti de Igniz. Tomo primero. Madrid, Imprenta de Lorenzo Francisco Mojados, M.DCC.xxxy. 
4. 8 hojas prels., 268 págs. $y 2$ hojas de Indice.

sin embargo de espresarse en el fróntls que este es el tomo I., el Sr. Barrera aseguri no haberse publicado otro y asi lo prueba cl ferminar el rolumen con la palabra fin, y el decir en el cncabezamiento del Indice, que lo es, de las poesias que contiene cste libro.comprende ademas de varias poestas cuatro composiciones dramáticas, dos comedias, intilulita una El mime' blason de Isract, y la otra Los juicios det cielo, no examinarlos y obedecerios. y dos zarzijelas enyos títulos son: Filis y Demofimte y Apolo y Lencotea.

publico este volúmen el hijo de sil antor 1). Francisco Scolli Fernindez de Cordova quim lambien escribió algunas piezas dramáticas.
1412 SEBA STIAN Y LATRE (ToMaS). Ensayo sobre el Teatro español. Por D. Tomas Sebastian y Latre. Reimpreso en Madrid, Pedro Marin, 1773. $4 .^{\circ}$ marq. Todas las págs. circuidas de orla.

Esle volimen contiene los dos dramas que siğtuen, refundidos libremente ó más bien imitados por el autor del Ensayo:

Progne y Filomena. Tragedia.-Rojas. El Parecido en la Corte. Com edia.-Moreto.

La primera edicion se hizo en Zaragoza, neal Imprenta, en el mismo año 1772 , en $4 .^{\circ}$ : la segunda arriba descri ta, la costeo el conde de Aranda y í esto sin duda se debe el ser tan lujosa.

1413 SEgURA (Juan DE).

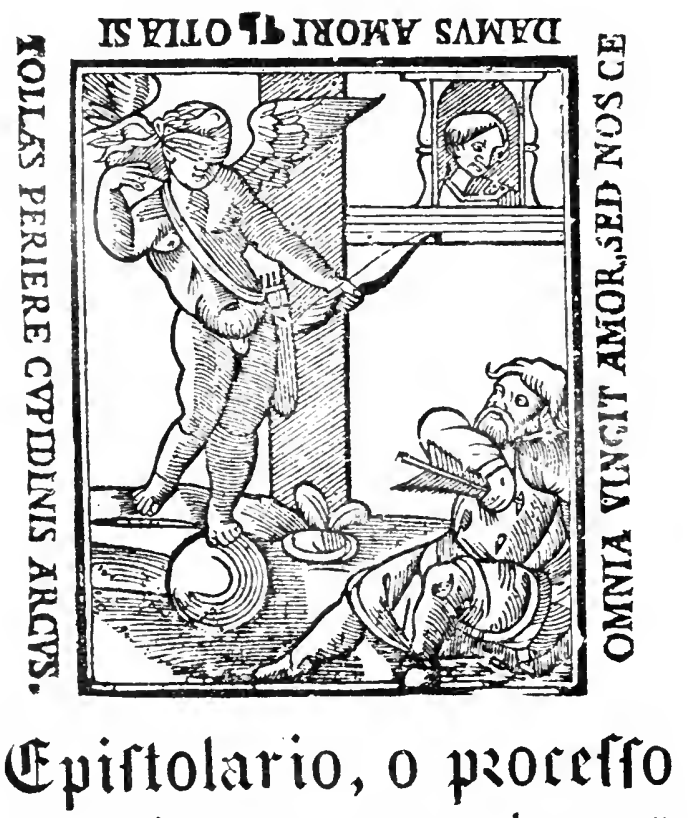

de fartat de amozes: fom vna carta para va amigo fayo: y pna qnexa y anifo contra a mo2. Uruduzido Jel eftilo Grieno el Mro politico Uaftellano: p02 $\$ 0 a n$ de Gegnra. Affe añdido en efta impzeffion mata enlos far:en $\bar{q}$ poz fabtil eftilo el poeta oraftella"

no fuis fourtado tracta dol gura

lardon v pacmio id Allos.

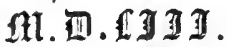


8..$^{\circ}$ let. gót. 96 hojas fols. en la totalidad.

La ćgloga representable en cuatro aclos ó escenas, que ncupa desile el fol. 85 rta. hasta el blanen del 96 , donde se lialla el remate ya copiado, tienc este eplgrafe:

I Egloga Siluiana del galurdon de amor: por Luys hurlıdo commuesta y acabada: son aclores. Siluano Quirino: Lusciun: pastores. Siluia!y Rosedo su esposo. Año M.D.LIII.

Aunque Yoratin no conoció la presente composicion Irambitica, no hago el análisis de ella por haberlo dado ya los traductores de la Hist. de la lil. de Ticknor, en el tom. It. pág. 553 ; alli mencionan una impresion que se encuentra á continuacion de la Coinedia de Proteo y Tibaldo, llamada Dispula y remedio de annor. Coinpuesta por el conendador Peralvarez de Ayllon, agora de nueuo acnbada por Luys Hurlado. Valladolid, Bernardino de Sullo Domingo (1552?) 8.0 let. gót.; pero no se halla en otra edicion de esta mis. ma Comedia hecha en Toledo en 1552.

La impresion que so tengo del Epistoluris ha sido descomocida á todos los bibliógrafos.

Ya que hago mérito en pste articulo de Luis Hurtado de Toledo antor de Palmer in de lilglaterra;, describire detalladamente dos obras que he visto escritas por el mismo, en ohsequio de los curiosos $\mathbf{y}$ por merecerlo su estremada rareza.

(Bajo de un gran eseudo de armas reales se lee de uegro y colorado:)

II Cortes d' casto amor: y corles d' la muerte con algunas obras en metro y prosa: delas que coinpusn Luys Hurlado de Toledo Por el dirigidas al muy alto $y$ muy poteroso señor Dó Phelippe, Rey de España x Jnglalerra su señor y Rey Añu. 1557.

(En cl blanco del fol. ij se halla la Dedicatoria a Felipe 11, y al dorso el siguiente in. dice de Las obris que se conlienen en este lraclado.)

Cortes de casto amor hechas on la flureciente vibera de Tajo donde se determina por la reinu Dianay el principe de Custo amor su hijo lo que se ha de guardiu en sus lejes. Esta es la única composicinn que hai en prosa y verso, las demas son tolas en versu.

El coloquio de la prucba de léules entre Leundroy Ero.

El hospilal de galanes cnamorados con el remedio y cura para nueve enfermos que en el están.

$E^{\prime}$ hospital de damas de amor heridas, domule son curadas otras nueve enfermas de amorosa pasion.

Espejo de genlileza para dumas y galanes corlesanos, con las condiciones de la mujer hermosa.

Ficcion deleilosa y triunfu de amor, cmpuesla para recreacion de los dnimos fatigados y irudicion y consuelo de los leales enamorados.

Las cortes que hizo la muerte con lodos los estados donde se represenlan en melro 24 cenas de las causas que pidieron los mortales, es obra notable $y$ delicnda.

Van al cabo lres epistolas amorosas contrahechas por Luis Hurlado en sentido espirilual.

(En el blanco del fol. Ixij se lee:)

Impresso en Toledo en casa de Iuan Fer. rer, Año Y.D.L.VII.

Sigue despues nuevo fróntis con las mismas armas que el primern. y lajo:)

Corles de lu Vuerle tias quales vienen todos los eslados: y por via de representacion: dan aniso alos binientes y doclrina alos oycnles. Lleuan gracioso y delicudo éstilo. Dirigidas por Luys Hurlado de Tolodo. Al inuictissimo señor don Phelipe clc. elc. Año de M.D.L.vij.

Concluye esta parte al reverso del folio Ixvij, y sigue despues una hoja sin numeracion que contiene las erratas y el siguiente final:)

Aqui se acuban las cories d" la muerte que compuso Michael de Carumajal y Luys Hurlado de Toledo. Fueron impressas on la Jmperial Cibdad de Toledo. En casa de Juan Fcrier. Acabaronse A. $x$ v de Olubre. Ano. de. M.D.L.vij. 4. let. gót. Láms. de madera. La primera parte consta de lxij fols. $y$ la segunda de lxvij $\mathrm{g}$ uno sin numeracion.

De este Miguel de Carvajal, primer autor de las corles de la mucrl', sc conserva en la Biblioteca lmperial de Vicua. segun el señor Wolf, la siguiente composicion drambitica:

Tragedia llamada Jospphina, mberumente sncaila de la profundidad to la Sugraila Escriplura "l toobala por Vichael de Carnajal, de la ciuluet de Plastenci九. Al fin: Fu' impre's. sula presenle obru en lic ionperial cilculal de Tiledo, en casa de hun de Ayalu. Atomse a dos dius del me's de Julio año... de 1jíti. 4.0 let. gót. 32 hojas. 
Las cortes de la muerle es un drama no representalue por lo bargin, y su argumento rs smmatmente seneillo: ina percion te persomajes de valias condiciones y edades lratibll do llegnciar con la morerle para gine esta lus liberto do su groadaña; pero ella inesorable. á tollos advierte que se preparen porque

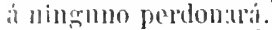

Por ulutice qur he eopiado de las corfes de Casto antor, se ve que contienen dos tratados, el uno inlituledo: El hospilal ele galames enamormins, g al ofro: El hospilal te damus de amme. Sin dulla se reflere it estiss compusiciones Pedro de Cíceres y Espinosia ell al liscurso sobere la viela de Gorgorio

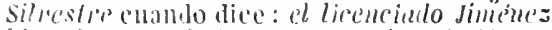

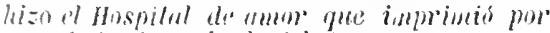
sumo Luis Horrado de Toledo.

L.a sermuda ohra de este, que le tenido ocasion de ver, es la signiente:

Las hereirmlas de bulys Murbulo Porta Cas-

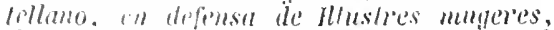

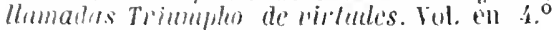
de 200 hujas folialas, escrito en ljs2, segun aparece de varias fechas que hai esparcidas por la obra. Solo está impresa la portada y las cuatro oetavas primeras del Triumpho de virludes, lo que no pricha que estic obra haya sido impresa por cntero, pues como observa Sedano en el tom. VIII. del Parnaso español, hablando del Ejemplar poélico de Juan de la Cneva, esta costumbre se ve usada en ajgunos manuserilos de célebres escritores inligrus. Lo mismo hizo Diaz Tanco de Frexemal imprimiendo solo los preliminares de sus Ternarios, que tengo, y leon pinelo en El paraiso en el. Nuevo Mundo que tambien posco. - El volimen comprende otris cinco oblas de Luis flurtado en verso, ménos El thealro pustoril que está en prosa y verso.

bel rooceso de carlas de amores hai otras ediciones que se hallarín descritas al artfenlo de Jurn le Sogura, en la Seccion novelislica.-Libros le cabullerias, del presente Catálogo.

1114 SHAX (Felituxo de). (Dentro de una ancha orla se le'e:)

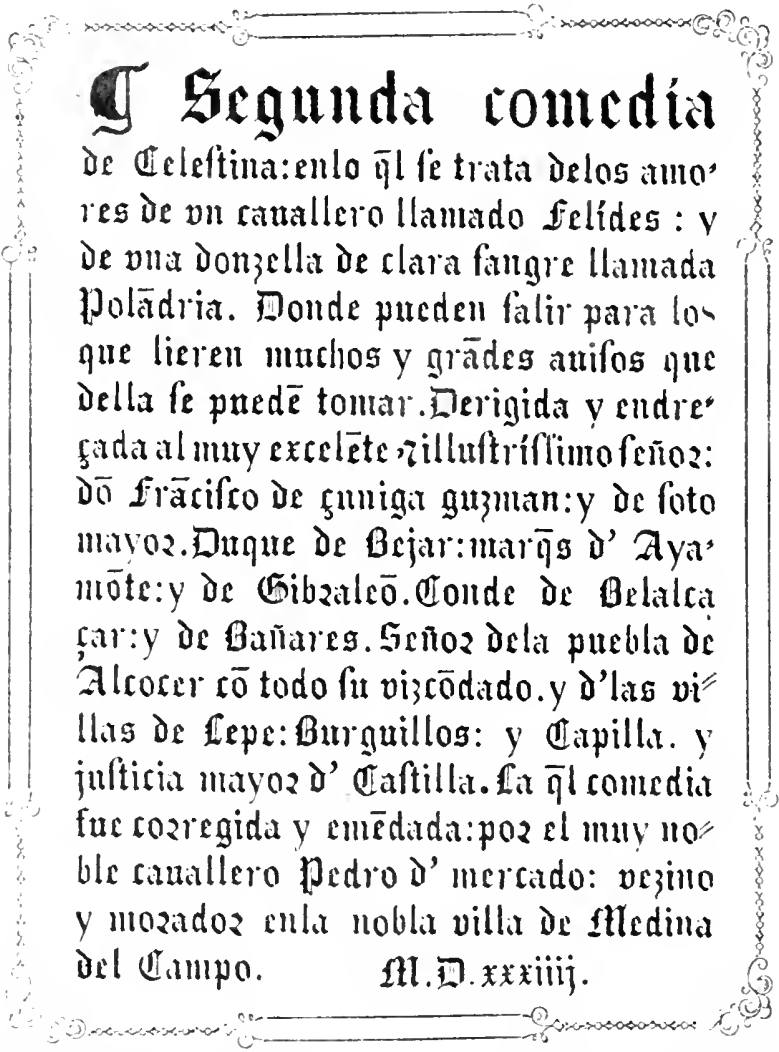

C.ll derion re la Carla prominel, on I la serjunda hoja las Coplas de Pedro 
Mercado, y la obra principia en la tercera. En el blanco de la última se lee:)

Acabore la p:efenta ob:a rila may noble villa de sttedina del campo / En safa de Jes dro tollās encl co:nl de bocy s. Año

de. Itt. …xxiiij.a.xix. de Urtobie.

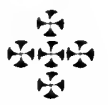

4. ${ }^{\circ}$ let. gót. Sin foliacion, signs. a-q, cada una de 8 liojas.

La presente edicion, desconocida á todos los bibliografos, á pesar de las erratas que se notan en la portada y colofon, es espaniola y del impresor Tovans, pues la orla del frontis es la misma que se halla en la Tragedia de Mirva, dada tambien a luz por este impresor.

La edicion es anterior it ha de 1.5.5, que os la más antigua citada por Irunel: este bibliografu ya sospechaba sin rmbirgo la existencia de olra anterior.-linber no lusero tenerla.-Si debicramos dar criblito á Galcia de Villanueva, pirg. T2 del Origen del terlio españul, hai otra edicion de Sirvilla flol in ismo año 1554 , que dice, se imprimio junto enll la primera Celestima de kijas y la Tircera de limez; pero me parpee que sus noticias som mui vagas y equirocadas. como lo pruebo mis estensamente en el artículn de Gispar Gümez. Ním. 1219.

El Sr. Barrera cita ma clicion de 1.5.5. otra de 1-55; pero como no dice haberlas visto, ni fija el lugar de ha impresiou, ni el tamaĩo, pongo en duda la exactilud de la nolicia.- io he tenido la siguiente:

Esendo de armas que representa min castiHo, á cuyos lados se lec: domingo-riquztelic. Bajo del escido dice de letra colorada lndo, menos el primer renglon:

Segunda comedia de la famosa edestima on la qual se rrala de la desturenefion de led dicha Celestina: I de los amomess do Folides !" poladeria corregida y cmemlende por bomingo de Gastelu secrelario dol Illnstriscine surim.

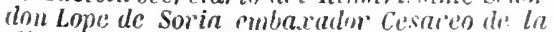

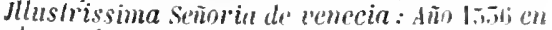
el mes de Junio. Al fin en el blanco de la vittima hoja se ler: Col libro presunte ayrulaUl' a todas his estrañas nacione's fue en estu inclila cindad de lenccin. Reiumesso por maestro Estephrino de Subin immin'ssor de $1 i$ bros griegos latinos ! espuñoles mun corregidos co olras dinmsas cobras \& libres. Ln

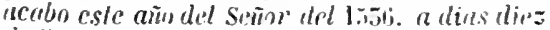
de Znìn. $8 .^{\circ}$ let. gut. Vintelas de madera, sin foliacion y cun las signs. A-I, de s hojas cada una.

Desde la portada se dessubren yo las correceiones y emmienlas que se permilio fiaztchı, quien sustituyio una dediealoria suya á la que lleva la princra edicion. Es portanto preferible la siguieute que la reprodujo con
Lola fluclidad, sergun ol testo de la colicion orisillal.

\section{SILVA (FELITINO UE).}

\section{Segunda Come-}

\section{DIA DE CELESTINA EN-}

laqual fe trata delos amores devu cauallero

llamado Felides: y de irna donzella de cla

ra fungre Llamada Polandria, Donde pueden fulir paru los iy leyer mu cloos y gräles anifos que della

fe pueden tomar Agora nueuamète imipresfay

corrigida: Dirige-

da al mus

illuftrifsimo fen-

nor: dun Francifio de

cuniga guzman. y le foto

mayor. Duque de Beiar: narques

de Ayamonte: y de Bibraleon

Conde de Belalcacar

y Damnares dic.

Vendefe la prefente obra cnla cindad de Anuers, ala enfeña clela polla graffa, y en paris ala cnfeña dela famaritana, cabe

fanct benito.

\section{CImpreso hacia el año de 1:30.) 16.} Sin foliacion, signs. a-F de sequmilo abecedario, codirs de slojas, monos la $\mathbf{F}$, que tiene $\mathbf{1}, y$ la ultima de estas es blanca.

Vic. Intonio nu hahla do esla obra ru ol

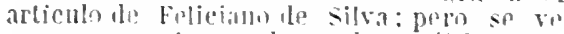

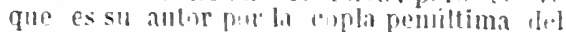
corrector pedro de Vercadu gue dire:

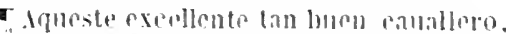

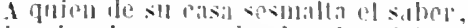
l.a ciencia os millolle de tal pusioler.

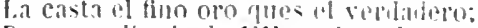
De casa y linajo de silsa. Lrepelope. Folice en liss ubros, pues es Faliciano. Al qual vos suplico. (que mi (oppo mant) Perdone, gniada p ir seso grosero.

Alemas raspar Frimez dodica i Foliciann

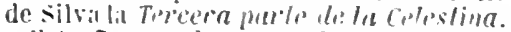

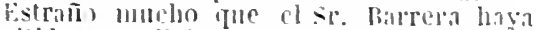

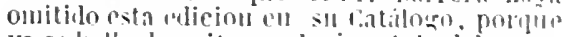

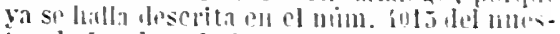
tro de I.midies d, lis:?

Estí casi por domas el abrertir (qu) la mi.

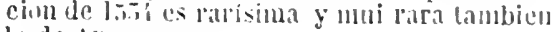
lit de Anvers, s. a. 
b10

SOF

SECCION DRAMÁTICA.

SOF

1416 SÓFOCLES. (Dentro de una | va distribuida tal cual aquí se pone, orla ancha como esta, aunque diversa,

la siguiente leyenda:)

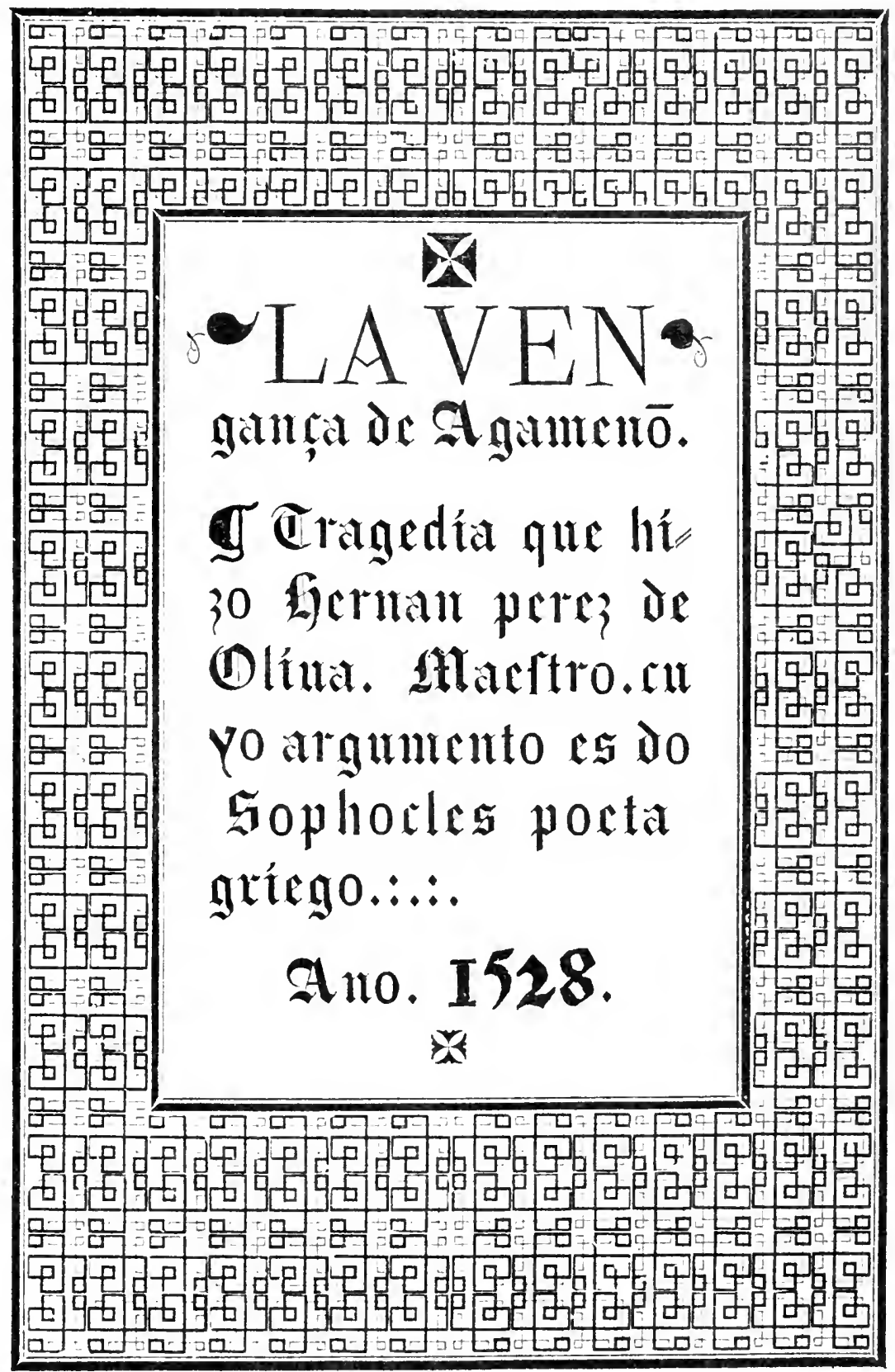


(Al dorso se describe La muerte de. agamenon, y la hnja décimasesta lleva el siguiente colofon:)

\section{to}

fue impzeffo enla mny noble y

mas leal cindad de Burgos : acabo fe a.xiiij.

dias del mes de stluyo. Ano del feño:

de mil y quinientos.y.xroiij.años.

\section{赵}

4. ${ }^{\circ}$ let. gót. á renglon tirado. Sin foliacion, con las signs. a-b, de 8 hojas cada una.

Esta rarfsima edicion y la del Anflrion de Plauto, descrita en la presente Seccion, (Número 135j), nos hacen ver el error de Moratin en el Catálogo que precede á los Orígenes dél tealro, de Sedann en el tom. Vl. del Par. naso, y de Tícknor en la Hisloria de la literalura, cuando suponen que las obras de Pérez de Oliva permanecieron manuscritas hasti que Ias publicu su sobrico en 1585 . Tampoco conoció Barrera estas comedias separadis.

Sedano reimprimio La vengansa de Agamcnon en el tom. VI. del Parnaso español, píginas 191 y sigs.

1417 SOLEMIES, $y$ afectuosos obsequios... con que la Religion de la Compañia de Jesus, y su Colegrio de San Pablo de la Ciudad de Granada; acompaño la publica aclamacion... de... San Jran de Dios ,... canonizado por la Santidad de Alexandro Vill. Madrid, Mateo de Llanos, M.DCxcir. 4. 8 hojas prels. con la anteportada, y 88 págs.

Contiene una pieza dramatica cu un acto, titulada: Dispula sagrada, geslosu, y moral Question, en loor de S. Juan de Dios y muchas poesias que aunque anónimas, estin escritas por diferentes autores. Barrera y Leirado no hace mérito de la composicion dramática.

1418 SOLIS (D. Antovio DE). Comedias de Don Antonio de Solis. Madrid, Melchor Nivarez, 1681. 4. ${ }^{\circ} 4$ hojas prels., 33ะ págs. y una hoja en que se repiten al fin las señas de la impresion.

Me parece ser esta la primera edicion que se publico de las Comedias de Solis reunidas. El presente volúmen, con la sola variacion de la portada y dedicatoria, sirvió para constituir la Parle quarenla y siete de la Coleccion untigua de comedias, compuesta de 48 tomos en $4^{\circ}$
1419 SOLIS (D. Astonio DE). Comedias de Don Antonio de Solis. Madrid, Melchor Alvarez, 1681. 1. $^{\circ}$

El presente volumen comprende las mismas cumedias que el anterior; pero aun cuando las cuatro hojas de los preliminares son copiadas de él, forman el tonı piezas impresas sueltas ó por scparado; as1 es que las hai de Nadrid, Salamanca y Barcelona, y una de ellas lasta lleva la fecha de 174.j; por consiguiente se eucueutran trozos con loliacion, trozos con paginacion y utros qule carecen de ambas cosas. L'or esta sola circunsLancia es lácil de reconocer la edicion genuima; ademas la original lleva en el frontis. el escudito ovalado de yatías Gast, que va en el interior del que copio al hablar del Saltnas, De musica, mientras que el tomo foljado tiene una especie de ave fénix grosera. mente grabada.

Brunet cita una edicion de Malvill, Melchor Alvares, $168 \overline{1} .4^{\circ}$ y Barrera otra tambien de Madrid, Anlonio de Reyes, 1716. 4."

Contiene este tomo las composiciones dramáticas siguicutes:

Triunfos de amor y firluna. Precedida de Loa y seguida de los Eulremeses El niño caballero y salta en banco, y de un Sainete sin titulo.

Eurfdice $y$ orfeo.

t.l amor al uso.

El alcizal del secrelo.

Las alluizonis.

El dotor Carlino.

Ln bobo liace ciento. Precedirla de L.oa.

La gitanilla.

dimparar al enentigo.

En el Indice de comedias de Yedel s! allibuyen ciuco de estas piezas a D. Vieso de Sluxet $\mathrm{y}$ solis.

1420 Comedias escogidas de D. Antonio de Solis y Rivadeneira. Madrid, Oriega y Compañia, $18 \geq 8$. 8.

Comprende estas cuatro comedias:

Un bobo hace ciento.

El amor al uso.

El doctor Carlino.

La gitanilla de Madrid.

Merece leerse el Exdmen que va al flu de cada una, pues por lo demas vale puquisiun esta reimpresion.

1421 - Varias Poesias Sagradas, Y Profanas, que dexó escrilas (avaque no juntas ni retocadas) Don Antonio de Solis y Ribadenevra. Recogidas, y dadas a liz Por L̈on Jian 
de Goyeneche. Madrid, Antonio Roman, M.DC.LXXXXII. 4. 22 hojas prels. y 328 págs.

Ejemplar liermoso intonso y sin abrir de esta primera cdicion.

1422 SOLIS (D. ANTONio DE). Varias Poesias Sagradas, y Profanas, (ut supra). Madrid, Manuel Fernandez, ir.pcc.xxxil. $1 .{ }^{\circ} 6$ hojas preliminares, inclusa la anteportada, y 3 ŏ0 paigs.

Barrera no mencinua la presente edicion.

En el tonto de larias Poesias salieron á luz estos diamas:

Representacion panegírica en alabanza de Jon Duarte de loledo, conde de ()ropesa.

I.oa para la flesta que hicieron unas seglares en un convello de monjas.

Loa para la comedia de lin bobo hace ciento.

Loa para la consedia de tas amazonas.

Ina para la comedia de Euridice y orfeo.

Fiestas bacanales. Sainete con que se acabo la comedia de Euridice y Orfeo.

Loa para la comedia de Calderon Darlo todo y no dar nala.

Loa para la comedia de Pico y Cantente, de b. Luis de Llloa y D. Rodrigo bivila.

Sainete, con que se dio flu il la comedia de Pico y Cumente.

Fraguento de lusa comedia intitulada: Antor es arle de amar.

Lod para la comeda de Hipoménes y Atulanla (le 1). Francisso Antonio de Vonteser.

Loa para la comedia La cautiva de Valladolid.

Loa para la comedia de Euridice y Orfeo. (Es la segunda.)

Dialogo en que se celebra la salud del conde de Uropesa, despues de libre de un garrotillo.

Representacion graciosa. El retrato de Juan kana.

I.oa para nna comedia doméslica que se representó en casa de los condes de oropesa.

El Baile yerdido. Representacion graciosa.

Loa para la primera comedia que representaba en cada ciudad la compañia de Prado.

\section{STORDITO, ACCADEMI-} CO INTRONATO. Amor Constante Comedia del S. Stordito Intronato. Composta per la uenuta dell' Imperatore in Siena, l'anno $\mathbf{M} \mathbf{D} \mathbf{X X X I}$. Venetia, Altobello Salicato, MD LXX. $12 .^{\circ}$ let. curs. 82 hojas fols. y dos hojas blancas al fin.

$1424-L a$ misma obra. Venetia, Giacomo Cornet ti, M D LXXXVI. 8. ${ }^{\circ}$ let. curs. 79 hojas fols. y una blanca a! fin.
Esta comedia de Alejandro Piccolomini se represento á presencia del Emperador Cárlos V, cuando pasó por Siena el año de 1531 . Para Iisonjearle se introdujeron en ella tres persomas, que hablan siempre el español. Ya he dicho, en el artículo Accademici introna$t i$, que en $m i$ sentir les corresponde á esta clasc de composicioues ocupar un puesto en la bibliogrilía y aun en la historia literaria de nuestio teatro.

Brunet citi una edicion de Venezia, 1540. $8 .^{\circ}$ del Amor constante-Barrera no habla de la obra.

\section{SUÁREZ DE DEZA Y ÁVI-} LA (Vicente). Parte primera de los Donayres de Tersicore, compvesta por D. Vicente. Svarez de Deza y Avila. Madrid, Melchor Sanchez, 1663. 4. 12 hojas prels. y 216 fols.

Nic. Autonio no menciona à Suárez de Dezil.

La segunda parte no llegó á publicarse; la primeri, que es rara, contiene:

Los amantes de Teruel. Comedia burlesca.

El Nundi nuevo. $M$.

Jas inozas de la galera. B. E.

El cocinero sordo, fingido por el interes. $S$.

Los títeres. $S$.

El juego del a jedrez. $M$.

El corcovalo de Asturias. B. E.

El milagro. E.

El pintor. B. E.

Mojirganga de personajes de lítulos de comedias.

El l'ara todas. $E$.

Los casanientos. $M$.

El platero de amor. B. E.

El uiño y la mujer que acomoda anas. $M$.

El antojero. B. E.

La burli de la inocencia. $E$.

La ronda. $M$.

La casa de los genios, y la dama general. $E$.

Las estafas en metífora de flores. $B$.

La encantada. $M$.

I as bandoleris del Prado. $S$.

El mal casado. E.

Don Gaiferos, con tftulos de algunos romances antiguos y modernos. $M$.

El alcalde hablando al rei. $E$.

Lo que pasa en el rio de Madrid en el mes de Julio. $M$.

El matemático. $S$.

l.os novios. $E$.

El galeote mulato. B. E.

El barbero. $E$.

Los borrachos. $B$. E.

La burla del miserable. $E$.

Gila y Pascuał, zagales. $\boldsymbol{B}$.

El caballero. E.

Añasquillo. B.E.

El poeta y jos matachines. $E$.

La casa de dueñas. $S$.

Los gorroncillos. $E$.

Los esdrújulos. B. E.

La tabaqueria y las pazes. $E$. 
Mojiganga que se hizo para flesta de su Majestad la reina por criadins suyos.

In retrato de la señora illfanta M̆argarita. $B$. Amor, ingenio y mujer, en la discrela venganza. Comedia famosa entre burlas $\mathrm{g}$ veras, de titulos de comedias.

\section{SUAREZ DE RÓBLES (PE-} Dro). Danza del santissimo Nacimiento de nuestro Señor Iesu Christo, al modo Pastoril. Compuesta por Pedro Suarez de Robles Clerigo de Euangelio, natural de Ledesma. Son interlocutores. Yn Angel, $y$ ocho Pastores, el primero se llama Anton, : el segundo Rebanado, y el tercero Pasqual, el quarto Toral, el quinto Pelejon, el sexto Pelayo, el setimo Rebollo, el ortaun Tereso, y S. Io- seph, y Nuestra Señora, y el niño lesus. Y otros quatro Ciriales junto al Nacimiento y a su ticmpo cantaran in Villancico. Y lo que mas se ha de hazer, a la buelta desta hoja se vera. (Sigue una laminita que representa un Nacimiento.J Madrid, Miguel Serrano de Vargas, 1606. $4 .{ }^{\circ} 4$ hojas sin fol. ni sign.

Edicion mui rara.

Cita Yoratin una edicion hecha en Madrid en 15i,1, y observa que esta composicion es mui curiósa por cumlo en ella se ve la dis. pusicion de estus drumas sagrados. cuyo uso dưó lanlos años en lus iglesias de España.

El sr. Barrera sin duda no ha tenido oeasion de ver esta pieza, y se limita d estractar la noticia que trae Moratin ; por consiguiente, tampoco menclona mi impresion de libt.
1497 TAFALLA NEGRETE Jo$\mathbf{s} \dot{\mathbf{E}})$. Ramillete poetico de las discretas flores, del amenissimo. delicado Nrmen del Dotor D. Joseph Tafalla Negrete. Sacalas a lvz llanvel Roman. Zaragoça, Manuel Roman, 1706. $4 .{ }^{\circ} 8$ hojas prels. y 332 paigs.

Conliene ademas de las.poesias de Tafalla dos Loas del mismo.-Barjera $n 0$ menciona i este antor

Aunque entre mis apuntes encuentro anotada otra edicion de Zaragu:a de $1707.4 .^{\circ}$, no respondo de la exactitud de la noticia.

1428 TAPIA (ETGEYIO DE). El Museo literario. Periodico mensual, for Don Eugenio de Tapia. Madrid, Antanio Yenes, 1814. 8. " frances.

Sou los tres numeros primeros, en los cuales hai dos Autos antiguos, y una noticia de los otros noveuta y tres que se hallan en un códice de la Biblioteca nacional de Iradrid. Los titulos de aquellos son:

Auto de los desposorios de Moisen. En prosa,

fuera del argumento yue está en verso.

Auto de la Residencia del Hombre. En verso.

1429 TARDES apacibles de grstoso entretenimiento, repartidas en varios Entremeses, y Bayles entremesados, escogidos de los mejores ingenios de España. Madrid, Andres Garcia de la Iglesia. Año de 1663. Tox. 1.
$8 .^{\circ} 8$ hojas prels. Cla primera es blanca) y 132 fols.

Contione lus siguientes entremeses, bailes, jicaris. mojigantras y loa:

Las mozas de la galora. E.-Juan biaz de la Call' dice en la Tabla, y de la Fuerile al principio do la pieza.

Fil toreador. E.-Calderon.

El sacammelas. B. E.-Sibestirn de billaviciisa.

El bodegnn. E-Juan letrs de fuevara.

Lo que es Madrid. E.-Francisco de Alellaneda.

Ia chillona. B. E.-Selastian de Villuriciusa.

El corlesano. E.-Jerón. Cáncer.

El desafio de Juan Rann. E. - Calderon.

El melladi. B. E-Woreto.

El hambricnto. E.-S'b. de, Villariciosa.

I.as visitas. E.-El mismo.

Vengil y Bras. B. E.-Jerin. Cincer.

La pretpudida. E.-Juan Véles.

El retrato de Juan Rana. E. - S. de rillaui. cinsa.

Mariguela. B. E-Juan leplez.

El alcalde de Aleoreon. E- - Vorelo.

La pedidora. E-Calderon.

Los negros. B. E.-Fruncisco de deellaneda.

Las tlestas de palacio. E-Yoreto.

Las reverencias. E. - Udos Fragoso.

Los of cios. B. E.-Yoreto.

El galan llevado por mal. E.-ydtos Fragoso.

Los galanes. E-Horelo.

El juego del hombre. B.-Jum Vélez.

El reloj y genios en la venta. E-Calderon.

El trepado. E.-Yátos Fragoso.

L.a rubilla. B. E.-Franc. Al'cllaneda.

Guảrdame las espaldas. E.-Calderon.

La bota. E.-Yorelo.

Los trajes. B.-Juan Vílez. 
L.as flores y el zurdillo. J. E.-Franc. Avellamilla.

Los sitios de recreacion del rei. M.-Calderor.

El mellado, cn jácara. B.-Málos Frayoso.

I.a antojadiza. E-Luis de Benturenle.

El premendeca. E-Morelo.

los sones. B. - Seb. de Villaviciosa.

Los instrmmentos. E.-Cildrion.

El sacristan Chincla. E.-Seb, de Villneiciosa.

Loa de Nuestra Señora. L.-Culderon.

1430 TASSO (Tonetato). Aminta de Torevato Tasso. Traduzido de Italiano en Castellano, por don luan de lauregui. Roma, Fisteran Paulino, mDcrir. 8. ${ }^{\circ}$ let. curs. S hojas precliminares y 87 paigs.

Al hablar del Aminta puesto en castollano por Jámregui, y del Pastur Fílo trasladido en li unisma lengua por Fjorueprob, dice Cervíntes que, ferlizmente pone'n en dudu cunl es la traduccion ó cual el originul. Todos lan conrenido en que con respecto al primero anduro acertado el autor del tuijote' pero mui exagerado en cuanto al segundo; sin duda i este accrtado juicio del publico se debe el que existan solo ellatro edieiones de lil reasion de: lit obra de linarini, mientras de la de Tasso hai muchas más: yo he visto las siguinutes:

Sevillı. Francisco de I.yra, lois s. ${ }^{\circ}$, junto

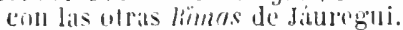

Mathil, lsón. s. P'riner ensigo esterentipico herho on Esplañia, y ealicion publicidda pur la seanemial españolis.

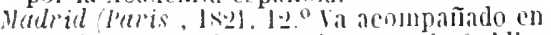
esta impresion del trte de amar de ovidio.

Ademas so encuentra en la colecrion de

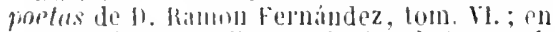
lis ropsias restellanas deste el tiempro de Juan de. Hewa, recogidas por Quintana, y en el l'armaso épañol, trim. 1. donde so adrierte lis simma ritreza de la ellieion de Romal, $y$ se nota hiber límregui corregido y limado muchisims su tualuceion en lin impresion de Sevilla. llik; si bien es verdad que suprimiij algumos trozos de la de 1607. En dicho l'arnaso y cull una impresion due creo se hizo ch Burcelona en 1820 , se adiptaron las correccinnes de la sevillana, y se incluyeron lus pasijes que en estil se habian omitido de la pijulera de koma.

\section{TEATRO ANTIGUO ESPA-} NoL. Madrid, D. F. Grimaud de Velaunde, 18:37. 16. Lims.

Solo se publicaron cstas ocho comedias:

El lucero de Castilla y privado perseguitlo.Calderon. (Amngur: se supone aqul inédilu, es lia mismli que con el tItulo de $E l$ lucero de Castilla y luna te Aragon y á numbre de Luis Velez de Guevara, se halla en el volumen de Comedias escogidas. Bruselas, 170.4.)

Desde Toledo i Madrid.-Tirsn de Molina.

l.os corredos de Celauro.-Lope.

En Madrid y en una casa.-Rójas y Zorrilla.

Los balcones de Madrid.-Atrihuida á Tirso.

La doncella de labor.-Pérez te Montalvan.

El pretendiente al reves.-Tirso de Molina.

El rufian Castrucho.-Lope.

1432 TEATRO ESPAÑOL. Theatro hespañol. Por Don Vicente Garcia de la IIuerta. 15 vols.-Catalogo alphabetico de las comedias, tragedias, autos, zarzuelas, cntremeses y otras obras correspondientes al theatro hespañol. 1 vol. Madrid, Imprenta real, MDCcLxxxy. - La escena hespañola defendida en el Prologo del Theatro Ilespañol de D. Vicente Garcia de la Huerta y en su Leccion Crilica. Segunda impresion con Apostillas relativas á varios folletos posteriores. Madrid, IIilario Santos, MDCClXXxir. 1 rol. Son en todo 17 vols. 8. Retrato.

Esta coleccion, ya mui cscasa, se divide del modo signiente: Comedias de figuron. a rols.-Comedias de capa y espada. 8 vols. -Comedias heruicas. 2 vols.-Entremeses. 1 vol. - Catílogo de titulos de comedias. 1 vol.-Reimpresion adicionada del p'rúlogo de lluerta que va en el tom. I. 1 rol.

1433 TEATRO ESPAÑOL anterior á Lope de Vega. Por el editor de la Floresta de Rimas antiguas castellanas (Don Juan Nicolas Böhl de Faber). II amburgo, en la libreria de Frederico Perthes, 1832. 8. ${ }^{\circ}$ frances.

Comprende los siguientes dramas:

De Encina.

Figloga de la noche de Navidad.

Égloga de la pasion y muerte de nuestro Redentor.

Égloga de la noche postrera de Carnal.

Egloga del escudero tormado pastor.

Fgloga de los pastores vueltos palaciegos.

Egloga de las grandes lluvias.

\section{De Gil Vicenle.}

Auto del Nacimiento.

Auto de los Reyes Magos.

Auto de la sibila Casandra.

Auto de los cuatro tiempos.

Esecna de Rubena.

Comedia del viudo.

Un paso del triunfo del invierno.

Un paso de los físicos. 
TEA

De Torres Naharro.

Comedia Imenea.

Comedia Jacintit.

Comedia Calamita.

Comedia Aquilana.

De Lope de Rueda.

Comedia Eufemia.

Comedla Armelina.

Comedia de los engaños.

Comedia Medora.

Algunos pasos del coloquio de Timbria.

Algunos pasos del coloquio de Camila.

Bōhl de Faber se equivoca en el prólogn cuando dice, que las ocho composiciones illcluidas, son todas las que se hallan en castellano en las obras de liil vicente, pues hai ademas en ellas el Auto de la Barca de la Gloria, Aulo da Fé, Aulo de S. Marlin, Comedia sobre a divisa de la cidade do Coinbra, Dom Duardos, tragicomedia, y Amudis de Gaula, tragicomedia, sin otras que están en español cn gran parte.

1434 TEATRO MODERTO ESPANOL. Coleccion de varios dramas de autores modernos. Madrid, en las imprentas de Repulles, Jordan, Sancha, Yénes y los Hijos de Ioña Catalina Piñuela, 1836-38. 4 volúmenes, $8 .^{\circ}$ marq.

Contiene varias piezas de García rulierrez, IIartzenbuseh, Bretun de los IIerriros, Angrel de Saavedra, linea do Togures, Cil $y$ Zarate, Patricio de la Escosura, Castro y Orozeo, Eugenio Ochoa, Muñoz Maldonado, Gaspar Fernando Coll, Pedro Gorostiza y Garela de Villalla.

\section{TEATRO NLEFO ESPA-} ÑL. Madrid, Benito Garcia, y Compañia, $1800-1.6$ vols. $8 .^{\circ}$ marq.

Contienen estos seis tomos los dramas siguientes:

\section{Tomo primero.}

Gombela y Suni-Ada. Tragetia.-D. Juan Franciseo del Plano.

Cecilia y Dorsan. $-D$. Vicenle Rodriguez de Arellano.

Pablo y Virginia.-D. Juan Francisco I'aslor. El abate de L'Epée, y su discipuln el sordo mudo de nacimiento, conde de Harancolır. Comedia de $M r$. Bouilly, traducida en proSa castellana por D. Juan de Eslrada, y D... Laus-Litzos.

\section{Tomo segundo.}

El avaro.-Moliere: traducida libremente en prosa castellina por D. bámaso le lsus. quiza.

La reconciliacion o los dos hermanos. - Kol:bue, traducida en prosa por $D$. Hicenle Rodrinuez de Arellorio.
TEA

La Acclina.-D. E. T. (Eugenio Tapia.)

El preso, o el parecido. Nelodrama, Iraducido del frances en prusa y verso por D. E. T. (Eugenio Tapiu.)

Agamenon. Tragedia de Lemercier, traducida por D. E. T. (Eugenio Tapia.)

Tomo tercero.

La orgullosa. Formada sobre la que con el misno título escribiu Mr. Destouches, y acomodada al teatro español por D. Francisco del plano.

El amor y la intriga. Traducida de la de Schiller en prosa castellana.

El chismoso.-D. Francisco lleseguer.

El solteron y su criada. Formada sobre la que escribio en frances.$/ r$. Collin l'Harleville por D.T.G.S.

Tomo cuarto.

El duque de Viseo. Tragediu.-D. Wanuel Josef Quintarka. El asunto está sacado d.l drana ingles intitulado: El espectro dei cristillo.

El espectro del castillo. Rasgos $y$ trozos traducidos en prosa castellana de esta tragedia inglesa.

La Fulgencia.-D. Vicente Rodríguez de srellano.

Clementina y Desurmes. - Ir. Vontel : tradicida en prosa castellana por $D$. licenle liodriguez de Arellano.

Los amantes generoins. Compuesta en fiances, sobre un molelo alemian, por $\mathrm{Vr}$. Hochon de Chribannes. Y traluejda en prosa castellana por D. G.F. F.

\section{Tomo ruinto.}

La virtud en la indigencia. Traduceion del frances, en prosa, pir D.J.E. $G$.

Ali-Bek. Tragelia.-Doña Vuria Rosa de Gilvez.

La ópera comica. Traducida en prosa y verso

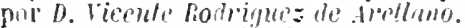

Catalina, ola bella lisbralobil. Traducida on prosa del franees por boña lluria Iusa cle Gill'e:

Ln loco hace ciento. En un acto y ell prosa. - La misma.

El califa de liggdad. opera cumica en un acto yell prosa.

\section{Tomo sesto.}

El conde de Olsbach. Comedia en prosa, del teatro alcman. aresclada al español.

La prucba capriclosia. Trablucida kel ingles al frances por yma. Riccobmi, y del frances en prisa castellana por D. Frencisco cle Paulir Villonjo.

Adolfo y Claria o Los dos presos. Connclia enn intermedios de musica. Tradurida en pusa y versi por D. E. T. Fumplla Tapia

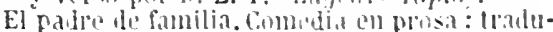
cida libremente del framees por H.J. I. E.

La mujer zelosa. Comcdia en prosa: tmmada de la de $M r^{2}$. Desformers. y traducida en Castellano por D. Julian de belasco. 
516

TEB

SECCION DRAMÁTICA.

TEB

1436 TEBAIDA ( LA ) Y LA SERAFINA. (Las dos figuriläs y la ancha distinta de la que aquílleva.)

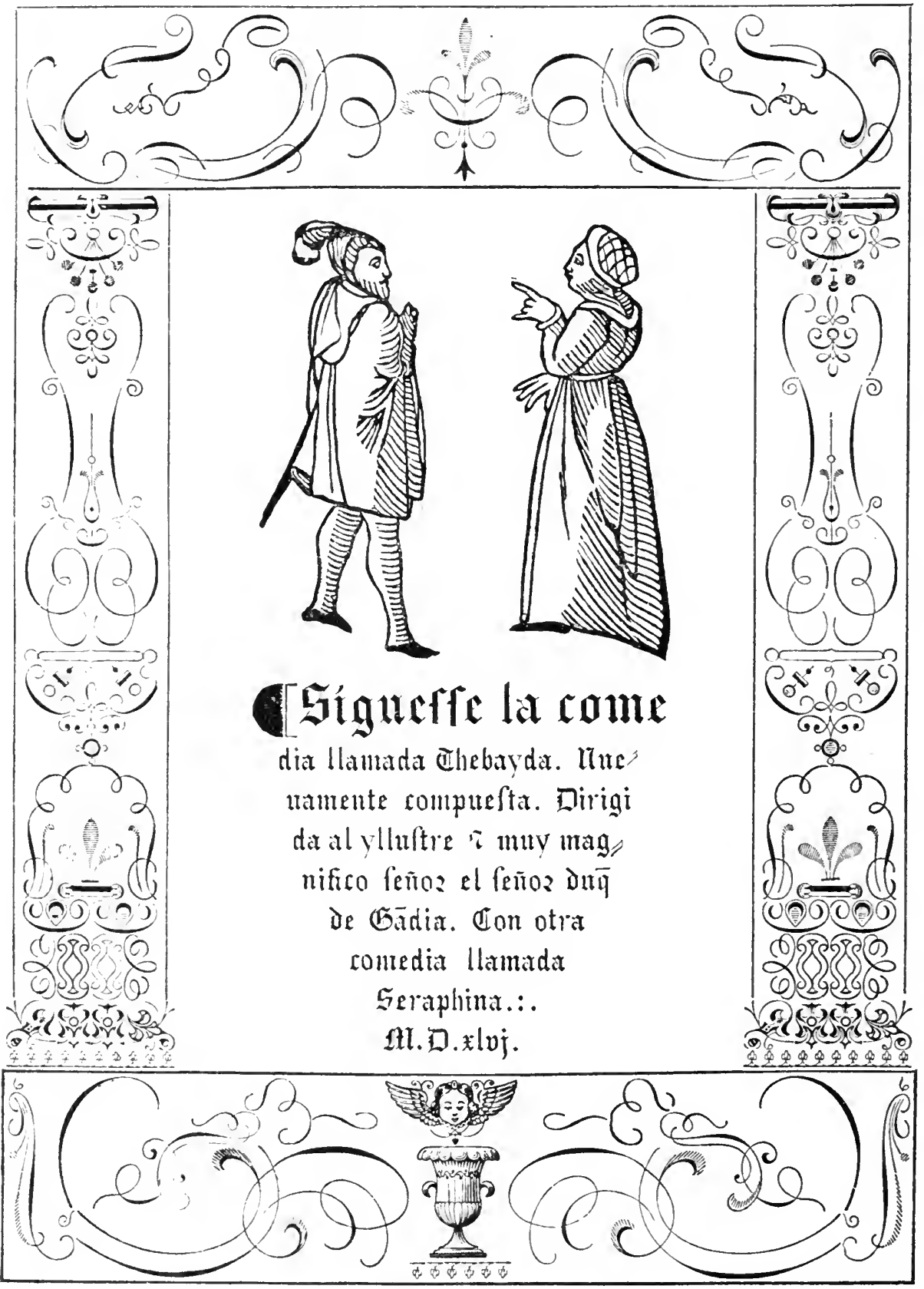


COcupan el dorso de la portada y las dos hojas siguientes el Prefacio, la dedicatoria en verso y el argumento de La Thebayda. Principia la comedia con la hoja de la sign. aiiij y concluye en el blanco de la oij. En esta impresion no se encuentra la Hipólita, y por consiguiente la Serafina principia en seguida al reverso de dicha hoja con el siguiente epígrafe:)

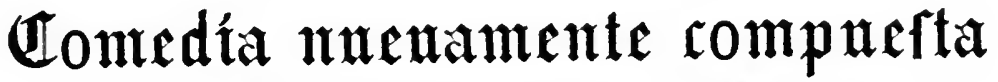

\author{
llamada Geraphina/ en que fe introdnjen nuene \\ perfonas. Las quales en eftilo comienco ya vejes \\ en metro van razonādo hafta dar fin ala comedia.
}

\section{CAcaba lavbra en el blanco de la} hoja sétima de la r; á continuacion rienen las sentencias en pareados, las cuales terminan al principio de la hoja que sigue, $y$ se halla por fin este iemale:)

\section{I fue impzeffa la pzefente obzalla/} mada Thebayda en Scrilla en cafa de Andres Je Burgos. Alabofe a Die; Dias de Atla yo. Aีno de mil y quinienlos y qua renta y feys años...

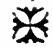

4..$^{\circ}$ let. gót. Con figurilas en la portada y al principio de las escenus seyun el facsimile que acompaño. Carece de foliacion y tiene las signs. a-r, lodas de 8 hojas.

La presente edicion de la Thebayda y Serafina es de una rareza estraorilinaria ; Brunet solo vió el ejemplar incomplefo que está en la Biblioteca imperial de Paris, $y$ en el inismo caso se encontrará el de Viena, pues Barrera, refriendose á él, dice que carece de lugar, cuyo hecho no es cierto, pues se halla indicado en la últina hoja. A yoratin le fué enteramente desconocida, y supone solo existe de estas comedias la impresion que voi á describir circunstanciadamente y examiné en la Biblioteca de Grenville.

(El fróntis tiene una ancha orla por sus cuatro lados, y dentro hai un grande escudo de armas del duque de Gandia. En la parte superior de la portada se lee: Con preuilegio, y debajo del escudo:)

Siguese la Comedia llamada Thebayda nueuamēte compuesla dirigida al illustre y muy magnifico señor el Señor Duque de Gandia. $\therefore$.

(Al dorso se halla la dedicatoria, titulada Prefaction, y en el fol. Il otra dedicatoria en verso, despues de la cual viene el argumento de La Thebayda. Esta comedia en prosa, con algo de verso, principia en el fol. III, y con. cluye al fin del XLY. En el blanco del XLVI se lee:)

Siguese la comedia llamada ypolita muena. mète compuesta en metro.

Esta termina en el fol. LlI vta. Signen despues foliacion y signaturas nuevas para la Compdia nuevamète compupslu llamada Seraphina en que se introulurm nueue personus. Las quales en estilo comien co ya vezes en metro van razonädo hasta dar fin ala co. media.

(Finaliza esta en el reverso del fol. Xill, marcado por errata, como si fuera el Xili. 1)espues leemos: C Aunque compuesto por el mismo aulor. Sigue á esta especie de eptgrafe una coleccion de sentencias en pareados de ocho stlabas, las que principian a la vilcla de la penúltima hoja y ncupan casi todo el blanco de la última, dejando solo lusar para lo que copio á continuacion:

Fue impresa la presente obra en la insigne cibdad de valencia por matre George costilla impresor de libros acabose a. xv. del mes $d$ hebrero del año mil y . D.y.x.rj (1521).

C Olorgo si cesarea magestad al presite libro arucia y Prenilegio/que ninguno lo pueda ipremir en torlos los réphos de Castilla ni arugó ni traer de olra purle ipremido por liempn de diez años so las penas en el contenitas. Fol. y no $40^{\circ}$ como dice el Cildalogo de la Biblioth. grenv., let. gót. con unas flgurilas, al principio de cada escena, de los interlocutnres de ella. Tiene foliacion que sc renueva al principio de la Serafina, y las signs. A-l iij. Viene luego aj hasta Cij. Cada cuaderno es de 6 hojas.

Barrera, copiando el Catálogo de Pont de Fesle, cita una impresion de las tres comedias hecha en Valencia, por George Costilla, 1524; sin duda habrá equivocacion en el ujltimo guarismo, como tambien creo la hai en Gallardo. Ensayo de una bib. esp. cuando menciona, ast como de memoria, otra edicion de l'alencia, Jorge Costilla, 1552. Fol.

Hacen mérito de estas comedias Nic. Antonio en la pag. 558 del tom. II. de la $B i b$. nov., rareía de Villanueva en el Origen del teatro esp., pág. 251, y Pellicer en la $16 \mathrm{del}$ origen de la comediu; pero sin indicar nin. 
guno de cllos quitin sea su autor, lo que tampoco puede iraslucirse de su contenido. D. Leandro Fernindez de Ioratiu, en carta escrila á mi padre, que posen, prelende era ralenciano: pero yo le creo andaluz por lo mui instruido que parece estar en cosas pnrticulares de aquella provincia, y solo comscderia que pudo resillir en Valencia

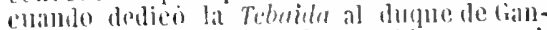
día. Vlasta que la serafina lambion se escri-

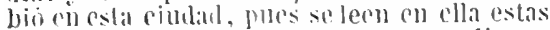
dos alusiomes do cusas que lo som peruliares: iv al tilamo rirgen amo el portal de cuarte... coloñate. calalazate, cilromate.

Ei estilo es bistante anlietado y mui puro; pero difuse y derlamatolio. I,os proverthos

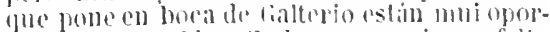
[manemte trablos. En los persomajes so filla

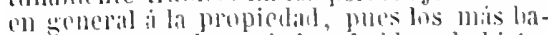
jus, pombo som les crialos, hablan de histo.

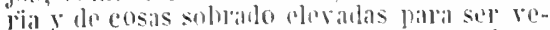

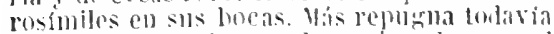
la mezelit ridienda you hate i calla paso el aulor, de Dios, las Eseriluras y relleximes mui morales, con las cosils mis profinas $y$ imin imlerentes.

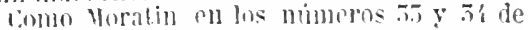

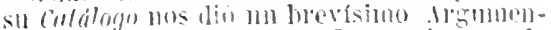
i1) de la llipulita y la serafina y mimouno de

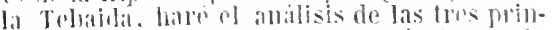

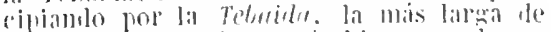

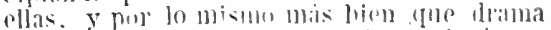
penpesentallo, novela dialugala en el genero dela celcstina.

$$
\text { de la TEBAind. }
$$

Las persomas de lit comedia son:

IBoriuto , caballero amante de

Cautativa.

Clambina domcella rica que vive con CanLilliat.

Menenlemo, criado bastante instrinido de Berinto.

Galterio, criado del mismo, baladron $\mathrm{y}$ srincioso.

Pamlina . manceba de fialterio.

Sinaco. criado juven del diclio Berinto.

Evaristo, criado del mismo, hallia poco.

Animtas cliado del mismo, joven imstruido.

Framuila. mujer de um mereader, que habia sido crialia de Canlaflra.

Tiburuba, madre de Fianquila.

Sorria, crialita a lo fuce parece de Tiburnilin.

Veluriua , criada antigna de Cantaflva.

El IPalle de la mancelia.

Cua recina de Franguila.

Escena primera. Estando enfermo [). Berinto bijo del duque do Trbos. deliva en

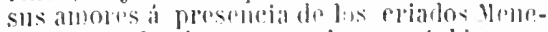
demo y liallerio, eon quidues entibla mo curjusi y sulil controversia acercal de la esenuia y males del amor. los otros dos criados simaco y muintas estan á la puerla, ha- ciendo unas vezes burla y otras admirándo. se de lo que dentro pasa. Los criados consue. lan á su amo exhortandole á que no desespere de la consecucion de sus deseos, mediando Franquila, de quien él no se acuerda, á pesar de las repelidas vezes que le ha favorecido en ser mensajera de sus amorosas allsias. Mićnlras Gallerio sale para buscarla, Menedemo dispone recado de escribir á Berinto.-Esta escena dura seis horas, segun en ella se espresa.

Escena segunda. Tienen una entrevisLa Venedemo y Galterio, quipn cuenta largamente su vida, como lia adquirido fama de valiente sin serlo, y lo que piensa hacer por servir á su amo. Proponese corlejar á Frinquila, cuyo marido está ausente. Toda esta cecena la oyen all paño Sínuco y Amíntas.- Tiene solo una hoja, miéntras la primora liene más de cuatro, y su duracion se supone de un par de horas.

La escena tercena, que consta de dos hojas, y durit mas dos o tres boras hasta preo inis de las diez de la noche, se reduec í presentarse Gallerio dolante de la casa de frimculila y i ser introdncido en ella. En seguida de desechar con aspereza los requie. bros de fialterio, se le rinde casi do improviso, y le ruega permanizea allí mis lirgo rato, pon frases que no tienen todas la debida decencia. Hecho lo eual, se dirigen i easa de biprinto, domele Galterio da cuenta île. nedemo de su conquista y de haber traido á Franquila.-Como los actores no si: meven de la rscena, y regrularmente olmarín con arreglo i lo que resulta de sil diálogo, los espectatores deberian estar prevenidos para presenciar lo mís escaudaloso que á los ojos del publico pueda of recerse.

Escena cuarta. Despues de haber llegavlo Franquila, ni clla ni los criados se atreven á interruminir í Berinto, el cual glosa en su delirio el romance Caminando por mis mules, echando por la boca nada ménos que treinta y dos estancias de diez versos cada ma, en cuyo nimern ninguma hai que descuelle por su boudad. Entran á continuacion tolos: Franquila le da buenas esperanzas, y él habla sobre la eternidad y los estravíns de los lombres, sin venir mui á pelo, concluyendo por dar una carta á Franquila para que la lleve á Cimtafiva. En esto han dado no solo las dos, sino que empieza ya í alborear, Y Franquila pide espresamente que la acompañe i su casa el jóven Amíntas, en unos términos que harín ya sospechar í cualquiera sus designios, alendida la facilidad con que á Galterio se ha prestado.

l.a escema quiutu es cual puede presmmir el lector por el final de la cuarta. Franquila frincipia por hablar mal de Galterio, ereyendo no sucedo fechorla aleuna en que no - tellga (i una parte mui primeipal; y de ello Aurntas la desengaña, dicicndole es mn baladron coharde. Elli da á en tender mui á las elaras su pasion á Amı́ntas; pero dil como joven inesperto, solo piensa en dormir, y se retira 
á la cama que le destina Franquila, quien devorada de sus lascivos deseos, no tarda en buscarle pretestando cierto ruido, se acuesta con él, y se presenta de nuevo á los espectadores el escándalo de la escena tercera. Si los hechos no son los más honestos, lo son ménos las espresiones, pues Franquila no cesa de ponderar la valentia y buenas parles de Amíntas, quien despues de quedar solo en la canna, advierte la mucha sangre que ha dejado Franquila. Tiburnina, madre de esta, llama de mañana á la puerta, le deja los relieves del almuerzo que sn hermano ha dado a dos $\dot{o}$ tres amigns, con lo que se desayuma nucstra pareja sobre la nueva cama. Refiere Franquila á su novel querido que el trato amoroso de Cantafira y Berinto cuenta Fa tres años; que arden entramhos en el mis vivo fuego: que se ren y hablan, pero que no sabe liasta dinde han Ĭlegado, no obstante ser desde un principio la lercera de estos amores. ia en seguilla d buscar á Cantafiva, despidiendo ántes á dmintas, que estí mui retozon á la puerta misma de la calle.

Escena sesta. Cogido Amintas en contradiccion al escusarse de su tardanza, conflesa á sus compañeros lo que con Franqnila ha pasado. Galterio se resiente y principia con sus bravatas, que intimidan poco á Amintas, y mudando entónces de tono cuenta cómo se maneja para bacer del ruflan $y$ valiente. Con tal motivo reflere particularidades bastante ruriosas, $y$ dice que esti bien con la justicia, siendo el denunciador rde algunos que juegan jurgos de redados, "y de al frmas mincebas de casados, ifrailes, "o clérigos pobres, que de los demas otro mnorte se signe... procuro por todas las for"mas y maneras que puedo de saber quien wes el amiga del provisor, del vicario, del "prior, del dean, del arcediano, del tesore"ro, del clantre, del camoniteo, del raciune. "ro; e no picuses que se me olvida la del mmacstre escucla: e sabido esto, luego prowuro que venga á su noticia de como yolo wsé, pues como ellas, y aun ellos, sabell ya sque vịro de dar arisos, luego cada nua macude con su eslafa, $y$ asi procuran de ncontentarme hasta mandar al despensero yque para commigo ni hay cuenta ni tasa, "y desta manera vienen las cosas a tal estamdo, procurindolo yo, que si es memester ulas acompaño hasta casa dellos ; otras vezes mlas llevin algunas mensajertas, ya que licmen alguna conversacion conmigo.) [u hombre de esta caladura pronto ajusta sus resentimientos con Amintas, y este por su parte, como jovell, cree ser vina pura baladrunada de (ialterio que Franquila le haya acordado ningun favor.

La escena sétima empieza por un soliloquio de Franquila, ponderando cuin perdida la ticne dmintas, hasta que llega i la emin. ta de santa Isabel dorde encuentra con Clandia y Velurimit. Ellas la informint de los desvarios $y$ desconertindis imaginacion de Caulafiva de resullas de sus aurores, como lo presencia la inisma Franquila. Entrega esta à la enamorada joven la carta de su amante, le aconseja que tengan ambos una cntrevista al dia siguiente en la ermita, y Cautafiva convienc en ello, á más de responder á la carta de su querido. Asomase por fin á una ventana, atraida del ruido que de la ermita sale, originado de hallarse alli Galterio cargado de armas. - Esta escena dura desde la mañana hasta la tarde.

Al principio de la escena octava está Galterio conversando con el l'adre de la mancebla sobre el modo de vengarse de cierta persona que le habia ofendido. Jlega en esto Amintas a asegurar a Gallerin que puede ya rolver i casa sin temor alguno; y tomo entre tanto se han remuido Franquila : Clandia, se estiende Gallerio en ponderar delante de ellas ctlánto hai que temer de la justicia, y que no deben andar en chanzas con plla los mismos instrumentos de que se sirve, mezclado todo esto con las luravatas acos. tumbradas y con una retahila de refranes. Franquila hace que Claudia $y$ Amíntas se conozcan, se desespera de la frialrlad que en este nbserva. y entra en casa de Berinto a quien halla en un mortal desmayo.-La escena empieza al caer la tarde y dura hasta entrada la nuche.

La escena nona da principio por las dos. esperadas esclamaciones de Berinto que echa por la boca diez coplas, bastanie tole. rables algunas de ellas. Cambia de tomo as1 que lee la respuesta de Cantafira, crevindose ya el hombre mis foliz del unirerso. Ilenedemo se propone demostrarle que no rs asi. diciendnle cosas mui subidas sobre al hien supremo. Sill saber comn, se sllsita nueva y lara cuestion acerea de la verdadera aunistad, y lo dificil que es hallar un amigo sincero. Franruila anumeia i solas a Berinto que tendri una eutrevista con su querida en la emita. le reconviene de que sil amor le obligne i comeler lales dosiaríos. le ruega qui disponira la acompañe Amfntas, y despidicndose de los demas eriafos, que no so olvidan de murmurar de su conducta, se ra esta pareja.-Toda la escena es de nuche.

La escena dreina es de las más impidicas de esla comedia. Principia Franquila por dar quejas ammosas i Imfutas de su esquivez, reconcflianst pll breve, vinse i la cama, vel juven mantiene su puesto con tal valentra que obliga i decir a Franquila a la madrngada: "i bnena fi mas de cuitlo ho. "ras lo he terido encima que no pensaba "sijo que era juro de beledad o rasa do por "rida." Llama despues i su madre que esta en ol vecindario. para que adereze almuer. 20 i 111 antigo de su marido, y Tiburnina manda i sorria, criada slly. con este objeto. Ifientras Franquila amtia ocupada en dis. poner el desavuno. Amíntas destlora it ser. gia, muchacha de loce años, la cual se que. da medis mmerta. Virne Galterio il participar del almuer\%o que presume tendria dispuesto. repite con Franumila la escona que con Amin. tas ba precculdo, pasa a vir á cste, tranqui- 
liza á Sergia por lo que le ha sueedido, y se sientan todos eн seguida á la mesa disertando largamente sobre la escasez de hombres virtuosos, y tragando y bebiendo sin consuelo. Levantados de mesa, llama Tiburnina á su liija, y falterio aconseja á Amintas que aproveche esta ocasion de renovar el ataque a Sergia, que no queda mui descontenta del segundo envite, pues empliza á su amante para la noche. Franquila los despide flltal. mente por ser más de las doce del clia, y la escena termina hacienilo ver fillerio que las mujeres son todas unas en buscar el dinero y su gusto.

Eseena undécima. Espera Berinto la horia de la cita. que es i las dos, y Galterio se pone á contar ce por loe al los eriados cuanto pll casa de Frampuila ha pisado. Sale fuego Berinto á caballo, acompanitdo de Amíntas, se va í casa de Cantafiva, il quien espeta una arenga pesada y de mal gusto, espresando sus ansias y deseos. Cantiflva le contesta menos mal, atuque no enn mis brevelad, y remata por decirle que haga de ella lo que guste: consejo que no echa en saco rotio el ambate apasionado. Las crialas que presientorl ya en lo que va a parar la flesta, los dejall solos, g thos consuman el matrimonio antes siquiera de dirse palabra de esposos, pues estu no se veriftea hasta mís adelamle. Entre tanto Amsntas empieza i enamoras a Clamdia, yo con tanto recato que drje de ohligarla a decir: "lormi fi, señu Amintas, utirnes mala crianza, que no abastaba meter na milno én los peehos, sine Limulien hater motra mayor descortestion La buena mucliapla penetraba de su ador ofrece recibirle fur la moche, y el da entumees gracias il hios de rom ha inspirabo este permsaniento a Clan-

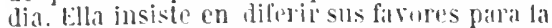
urehe, ymas acuando va algo satisfecho y Ma bulli no pase a mis de tomalle las tetas. "y jural m lito." Berinto se despide de sil quelida, y dejalas las cusas en al termino á

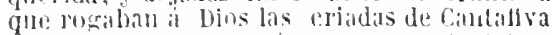
que llerasen, regresa a su casi cou dmíntis, y alli dice a sus eriadus que "Dios ha puesto ula conclusion y torminu que habeis visto í mui tan demasiado y desenfrenalo apetito." f'or esto, le replica llenedemo, que en todn es necesaria mucha constancia, citindole ejemplos de grrieros y lomanos, y a renglon segriblo de habla de la virtud de la templanza, sin que se adivine con que oljeto. El amo y los criados se retiran á descansar; pero lialterio y simalo se van á atompañar i Amintas a sli esjedieion nocturua.

Escena duodicima. Entra Veturina á ver a clandia, y la halla en un delirio amoroso pensando al la cita dada, que confiesa á Ja vieja. Esta dice qua pues ya no hai remealo, icuda di clla y se despose allí con Amintas. Nientras los dos anlintes huelgan liista binll ambuecido, como se infiere de tpur liallerio dice á Amfntas: cmunu"i pensames le pu"diela erhar de chrima, la vieja y los dos cumpañeros del juvell llevan bonitamente la resta. Claudia queda perdida de amores,
Amintas no le va en zaga, y se vuelve á su casa donde almuerza con sus amigos. Entra en esto Paulina quejándose de uno que le ha dicho que no era la mís honrada de las mujeres, con lo que se alborota Galterio y empieza á fleros, hasta que sabiendo que el insulto viene departe de nn hermano suyo, se tranquiliza, diciendo despues, que ha metido toda aquella bulla solo para contentar i Paulina. Berinto se cutera de este suceso y se dispone á repelir su visita á Cantaflva.

En la escena trece empjeza Cantaflva por hacer esclamaciones sobre la corta duracion de los gozos terrestres, y termima por desear con ansia nueva visita de Berinto. Llega este, $y$ despues de haberle reconvenido su amante por haber profanado la ermita haciendo las cosas que hiciera la víspera en sus inmediaciones, se acuesta con ella, y Améntis con Claudia, aparejándolo todo la rieja Veturina. Las dos mujeres suelen quejarse de la valentía de los atletas con quie. nes combaten, sin huir por eso el cuerpo á la lid. Amlutas y Claudia se desposan con toda furmalidad estando solos. Viene el dia desparciendo los abrazos de los amantes, que se repomell de sus fatigas almorzando. Berinto vulve á su casa y Cantafiva á la suya, pues parece no es esta ocasion de continuar las novenas á la Virron.

Escena eatoree. Loeo Berinto de colltelito, quiere dar muestras visibles de él; pero Menedemo lo ealifiea de imprudente. (IIedase dormido, y Menedemo echa entretanto por su boca contra las mujeres, cuanto mal puede decirse de ellas. Despierta Berinto y da ordenes para que se regale marnificamente á sus criados y á los de Cantifiva, no menos que á Claudia y á Franquila. Se presemta esta da sazon con humor de decir verdides, y asi espeta i berinto que no tiene. razon de estar tan ufino, pues las mmjeres torlas vienen á ser lo misno que Cantafiva: "aili lo tiene donde las otras, que de cinta mahajo no hai mujer fea," ctc. etc. No tarda en mover una disputa con Nenedemo acerca de la nobleza, de la que tratan mui por estenso. Amintas que tenia mis necesidad de dormir que de escuchar tan doctas discusiones, se hallaba retirado en in cuarto donde Galterio introdnce í Sergia que ha venido con Franquila. El autor nos hace formar sin necesidal el peor concepto de Amíntas, por la facilidad con que vilelve a las andadas, divirtiéndose con la pobre muchacha, y acaso acaso con Franquila, con la que tambien se queda solo al fin de la escena. Se anuncia en ella la llegrada de Veturina.

En la escena quince Veturina dice á Berinto que dos tios de Cantaflva, sus deudos mis cercanos, le han hablado sobre su casamiento; que están acordes en elio y desean se realize, de lo cual se alegra no poco el novio. Pasa despues al cuarto de Amintas, quien le da una cancion escrita para Claudia. se reunen allí luego los demas criados, entre ellos Ienedemo, que á instancias de Veturina se pone á referir en compendio la 
Historia de la Biblia desde Adan hasta el Antecristo, y se estiende por fin á hablar de la confesion $y$ de los frutos de la penitencia. Todos se despiden mui satisfechos del sermon ó plática de Menedemo, y veturina dice: "yo he acabado de representar la connedia; pero sin que se hable una palabra de las bo: das de Berinto y su criado Amfntas, que si bien se presumen, no seria malo que los espectadores las viesen realizadas.

El lugar de la accion es en Andalucia, que un breve arsumento puesto al principio denomina con el nombre de Castilla.

\section{A.ILISIS}

de la HIPOLITA,

comedia en verso, que se halla en la edicion de Valencia de 1521.

Personas que en ella hablan.

IIpólito, caballero, amante de

Florinda, doncella huérfaura.

Solento, criado de Hipólito.

Jacinto, idem.

Carpento, idem.

Solisico, paje de Florinda.

La escena primsera se reduce a esponer llipólito á sus eriados que está perdido por Forinda, para cuya consecucion le da solento buenas esperanzas. En la segunda hace florinda igual declaracion respecto de su anor hacia llipilito. Aprovechia lis ocasion Solento para hacerla convenir en que venga su amo il verla, lo cual repugua solisico haciendo presente á sn señora, que

"no amaneces con el virgo,

si eutras con el en palabras...

Despues de tragar y beber de lo lindo, Solento en la esrena tercera da parte a lijujlito del buen estado de su negociacion. En la cuarta se verifiea la entrevista de los dos amantes y cuanto es consiguiente á ella. por lo que en Ia quinta poudera llipólito su ventura, y regala lindos vestidos de seda á sus criados.-El lingar de la aceion seri regularmente Andalucla, porque si bien Hipolito es aragones, Florinda es del Andulucla, como se ve por el argumento.

\section{Axilists}

de la SERAFINA, comedia en prosa.

\section{Los interlocutores son:}

Evandro, caballero, amante de

Serafina, inujer de

Fllipo.

Artemla, inadre de Filipo.

PInardo, paje de Evandro.

Volante, doncella de serafina.

Popilla, criada de Evandro.
Davo, criado de Evandro.

Crátlno, secretario de Evandro.

Escena primera. Crátino diserta largamente sobre el amor divino y humano á presencia de Pinardo, Davo y Popilia, y la conversacion viene á parar en el que Evandro tiene á Serafina. Evandro espresa di solas su pasion ell una larga glosa de inceliano merito, y la oven desde la puerta sus crialos que entran á distraelle.

Escena segunda. Encarece Erandro las partes de Seraflua y su antor, que l'opilia opina no ha de llegar al témino deseado, mientras pinardo piensa de mui distinto modo, y se propone facilitarlo vistiendose traje de mujer y llevando una carta á serafina.

Eseena tercera. Se introduce Pinardo, vestido de mujer y con el unubre de llia en casa de Serafina, so pretesto de haberse indispuesto con un tio suyo. y le recoge Artemia. Lee Serafina la carta de Evandro en prosa $y$ en verso. $y$ dice á sl! doncella, que no obstante hallarse casida seis meses, aun no la ha tocado su marido por ser impotente.

Escena cuarta. Artemia dispone que Pinardo se acueste a sus pies: pero el principia á retozar, y la vieja se manifiesta al momeuto tan descompuesta de palabras comm de acciones, quelando satisfecha en tales teruinos que le regala treinta doblas, y le ruega que vuelva. Antes de irse cincirta conserullua que admita i la nocle i Evandro, a quien el procurará introducir. se clltra en el cuartu de Violaste. Ilamadi por esta. la pone cono nueva. serum de la busena disposicion le entrambos es die presumir, y le da palabra de ser su esposio.

Escena quinta. Cuenta Pinardo a su amo el feliz estado del nezocio y cllanto en casa de seraflua le ha pasadu. licgilale cumplidamente Evamdro. "s so va con il disa de su querida, donde lis intruduce Viulante. Es donoso el pasaje en que bavo pinta lo que es la vieja Irtemia. sus torpes collexiones con el provisor del ohispo. ren el vieario, con el guardian, con el que pite por las inimas del purgatorio, y cimlo malinstaba su catudal en regalarles aves, rontluras y los mejores bocados, todo lo cual es descrito mui por menor.

Escena sesta. seraflua. it quien Frandro halla inopimadamente virgen, deja de serlo entre sus brazos, mientras limalibo $y$ Violante pasan la noche divirticindose potentemente á buena cuen ta del matrimonio que ha de celebrarse. Sin embargo. l'inardo entra despues resuelto it satisfacer los torpes descus de la vieja Artemia, y ann parcec que la enamuradia biolante no lo rephrolla: puro por fortuma llega Filipo. Y Irtemia informada ya de la oeupacion en que sil numra so halla, baja á derio al hijo. que no millo en el cuarto de aquella, porque hoi he lace l'e'mido su costumbre mas desordenaila ipue utias 
vezes, y será bien que no la vec. Con lo que el bondadsso é impotente marido se recoje en otro cuarlo ó en el corral, pues ambos parajes se indican. 11 amanecer llama Pinardo à su amo, quien se va á casa mui gozoso de su conquista, aunque el criado l)avo teme no sea el virgo postizo por hacelle creer que truena. le dan tados el parabien por el feliz exito, y para no hablar de casamientos ni de cosa que lutrela á algun flu moral, no se illlica siquirla cuindo serin las bodas de pi. rardo con liolanto.

El luear de la accion parece ser en Castilha, pues aumque frandro es de portugal, seratina es dol reino de Castilla, segum se declara en el arobumento.

Como muestra de algrmos de los grabados con que van encibluadas las pscenas en la

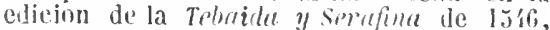
pondri el siguicnle facsimile de dos fimurilas que ch ellas se representan, ademis de lis dos que se encuentran en la portada, las cuales se usun tambien á vezes en el cuerno de la obra.
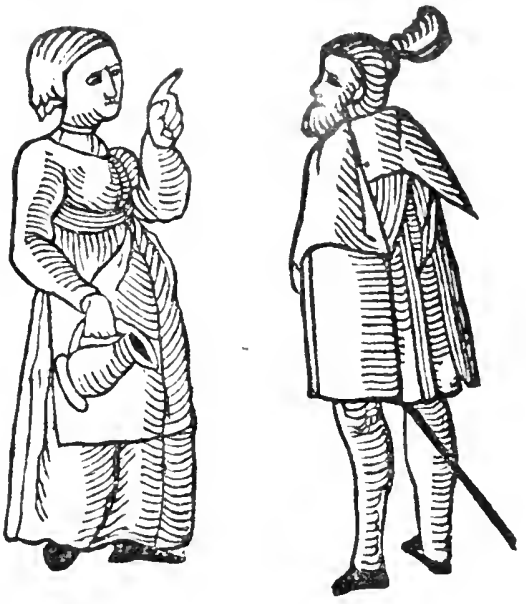

1 137 TElLEZ (Gabriel). Doze comedias nrevas del Maestro Tirso de Molina. A D. Alonso de Paz, Reridor de la ciudad de Salamanca. Proinerar pante. Sevilla, Francisco de Lyra, a costa de Hanuel de Sandi, mercader de libros, 1627 (no 1626, como dice Duran). 4. 2 hojas prels. y 2966 foliadas, aunque suenan 300 en lo impreso. Como no he visto otro libro que tenga tantos y tan garrafales yerros en la foliacion, estableceré minuciosamente sus signaturas, para que pueda por ellas compro- barse la integridad de los ejemplares. Van desde A hasta Qq inclusive, y son de 8 hojas, ménos la D que solo tiene 2, la $\mathrm{H} \mathrm{4,} \mathrm{y} \mathrm{la} \mathrm{P}, \mathrm{Dd} y \mathrm{Gg}$ 6 calla una. La última de la $\mathbf{X}$ es blanca. En cuanto á las preliminares mi ejemplar, que fué de Mr. Ileber, solo liene la hoja de portada y otra, en cuyo blanco estí la dedicatoria a 1). Alonso de Paz, suscrita por El Maestro Molina, y en el reverso los Nombres de las comedias. No he tenido ocasion de ver otro para comparar si falla al mio alguna hoja, en que se hallen el Privilegio, Tasa etc.

Comprende esta Parte las comedias sigruicntes:

\section{ralabras y plumas.}

El pretendiente al reves.

El ilinol del mejor fruto.

l.a villara de Vallécas.

El melancilico.

El mayor desengaño.

Fil castigo del penséque.

Seguida parte del penséque, que es: Quien caila otorga.

La gallega Vari-Hernäudez.

Tanto es lo de más como lo de ménos.

la zelosa de sí misma.

Amar por razon de estado.

Torin el mundo sabe que el P. Mitro. frai rabriel Tíllez disfrazi con el de Tirso de Molina su nombre verdadero al publiear sus olyas, por parecerle que el eseribir comelias yovelas, un tanto libres, se compagiJaba mal con su estado de religrioso mercenarin. l'ero pocos tienen noticia (á lo ménos yo lo iguoraba) de que se llamase ya Molina, ya Molino, como lo sienta Brunet, sin apunLar el fundamenio de su asercion.

Al formar la lista de sus dramas, hai que tocar tantas especies diversas acerea de algunos de los tomos que los contienen, que me veo obligado á separar los cinco de la prinniliva colcecion de sus comedias.

El Sr. baron Schack dice haber visto una rdicion de esta Parte hecha en Madrid on 1627 , diriglda á l'érez de IIontalran, con el privilegio fechado el 12 de marzo de $1626, y$ la Tasa y Erratas el 20 y 22 de novicmbre del mismo año.-Mi edicion de Sevilla no tiene estos documentos, pero si lleva nua dedicatorla á D. Alouso de Paz, regidor de Salamanca, firmada por Ei Maestro Molina, en la que advierte no hiber querido enderezar cada una de sus piezas a diferente sugeto, pues de hacerlo asi, solo quedaria para el mecenas del volúmen el pergamino de la encuadernacion $\mathrm{y}$ lis preliminares del liliro, y por esta razon añade: Tollas estas loce (comedias), salen á su nombre sequias, ó á lo ménos ejerciladas al sufrimiento, pues habiendo 


\section{TELL}

PBIMBaA division. pasado libres por los infortunios del tealro, maliciado ya de envidiu, y ya maliciado por la ignorancia; comn soldados viejos gozarán la plaza muerta del soslego $y$ pax que les promete el nombre y agrado de $v . m$. Es por consiguiente aun muy dificil el poder decidir si es primera la impresion madrileña $\dot{o}$ bien la sevillana.-La tercera es la de Valencia, Pedro Palricio Mey, 16.51. 4. ${ }^{\circ}$, citada por D. Juan Eugenio Hartzenbusch en el Caldlogo razonado de las obras dramáticas de Tirso, que ha prefljado al tomo de las $\mathrm{C} 0$ medias escogidas de este autor, Madrid, 1848. - Alvarez y Baena indica una impresion de Madrid, $1616^{\circ}$, y Duran y Mesonero han copiado este error; pero nadie asegura haber visto semejante edicion, cuya fecha está en abierta contradiccion con los preliminares de la de Madrid, descrita por Schack, con lo que dice el autor en el prólogn de Los Cigarrales, dados á luz en $\$ 621$, de haber entregado á la imprenta las doce comedias que debian formar la Primera parte; y inás aun con la fecha del 25 de marzo de 1620 , que se halla en la carta de la Villana de Vallécas, hácia el fin del primer acto. Se presume por tanto haber escrito el P. Téllez esta comedia en 1620 , y haberse publicado la Parte que la comprende, á poco de tasarse y sacarse sus erratas, es decir, despues del 22 de novienbre de 1626: lo cual coincide aproximadamente con lo que afirmo D. Francisco Licas de Avila, al publicar en 16.34 fa Purte tercera, sobre que sı tio el Maestro Tirso, en fe de la buena faina que adquirio (con las co. medias de la Parte primera), se habia echado adormir no unénos liempo que el de diez años. No eran diez sino ocho, pues en esta clase de cuentas, ni entónces ni despures, han sido mui escrupulosus los editores y prologuistas.

Segunda parte de las comedias del Maestro Tirso de Molina. Recogidas por SF sobrino don Francisco Lucas de Auila. Madrid, Imprenta del Reino, a costa de la Hermandad de los Nercaderes de Libros desta Corte, 1635. 4. 4 hojas prels. y 300 foliadas.

Comprende estas comedias:

La reina de los reyes.

Amor y zelos hacen discretos.

Quien habló pagó.

Siempre ayuda la verdad.

Los amantes de Teruel.

Por el sótano y el torno.

Cautela contra cantela.

l.a mujer por fuerza.

El condenado por desconflado.

Próspera fortuna de D. Alvaro de Luna y adversa de Rui López de Avalos. Primera parte.

Adversa fortuna de D. Alvaro de Luna. Segunda parte.

Esto si que es negociar.

\section{Ademas estos doce entremeses:}

La venta.

Los alcaldes. "rimeru parle.

- Segunida parte.

- Tercera parte.

- Cuarta parte.

El esludiante.

El gavacho.

El negro.

Las viudas.

El duende.

Los coches de Benavente.

La malcontenta.

Es infundada la suposicion de Brunet $\mathrm{y}$ del baron Adnlf $F$. de schack, afirmando debe existir otra edicion anterior de esta Parte, pues no cabe duda la publicó por primera vez en 16.55 el IItro. Téllez; as lo evidencian las aprobaciones y su dedicaloria, aunque por el bien parecer puso en el frontis que estas comedias las habia recogido su sobrino. Hallarlase este á la sazon en Tortosa, é instrúdo por su tio de estarse imprimiendo en Madrid la Segunda parte, 7 recibidas las comedias para la tercera intituló as la que dió á la estampa; la cual salió ántes que la segunda, porque lá Hermandad de libreros de la corte, como todas las compañias en que el interes pierde sil actividad por estar mui dividido, no sobre. saldria por la brevedad de sus empresas. Esplfease con esto la inversion de feebas de las Partes segunda y tercera, hechas tan de acuerdo entre tio y sobrino, que no repiten comedia alguna, a pesar de haberse impreso ambas simultáneamente.

Esto se entiende en el supuesto de no ser una pura farándula la persona del tal sobri. no, y de que el nombre de Tirso de Iolina no eñeubra í los dos. porque es mui singular que al mismo tiempo se publieasen en Yadrid y Tortosa las Partes segunda y tercera con comertins escogirlas por el dichoso sabrino. Como mis sencilla se presenta la esplicacion de haber Téllez enviado i Martorell, con sn beneplicito, las doce contedias de la Trecesa parte, mientras el agenciaba que la Hermandad de S. Jeronimo costease la Segunda; diligencias en que perderia algun tiempo. y 110 activaria mui solicita aquella, tratindose de un libro el cual no le prometia un lucro cirrto. Asl debia de ser por lo que el mismo Tirso conflesa paladinanente en la dedicatoria, agradeciendo í la ller. mandad hubiese redimido del Argel de la penuria sus trabrios, pues si no custeara su estampa, murieran balbuciontes e'n las mantillas de' sus cortapacios.

Tampoco tomo mui il lo serio lo añadido por Tirso, pocos reuglones despues. s bre no ser suyas ocho de las doce comedias. Que motivo podia impeler à imprinir producriones ajenas, y no bien acabadas. i quien catorep anos intes lenia escritas más de treseientas comedias, que habion tiverti. do melancolias y honesliulo ociosidales. y ahora se hallaba ya con $11 n$ eaudal de cuatro: cienlas y más, segun cl testimonio de su so- 
hrino en la dedicatoria de la Parte tercera? cogeria del rimero las doce primeras que le vinieron á la mano (estravagancia disimmlable en los grandes ingenios) y saldrian muas limadas, otras en el primer borrador, y algunas con el todo o algo del plan repetido, como sucede en las demas p'trles. Hartzanbusch reconnce con efecto que cuando 110 sean do Tirso por entero las ocho comedias almoldds por il, hai en lodis pasajes y alsum acto que le reclaman por su autor.

Wa se comoce olra edicion sino la arriba ritida de esta Parle, pues la de 1616 supmesta por Alvarez y Baena, munca ha existido por ilammas de lis mismas razemes adueidas para denostrar que la primera no pudo publicar-

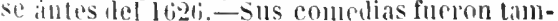
livell recosidas por ll. Francisco lucas de drila, si liemos de dir crédito a la portada; cirromstancia que Brunel señalil como peculiar de las tres partes diltimas.

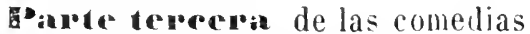
del Maestro Tirso de Molina. Recosridas por Don Francisco Lreas de Auila, sobrimo del Autor. Tortosa, Francisco Matorell, 1631. 1. 4 hojas prels. y 213 foliadis.

Brunel pita ma edicion de esla misma

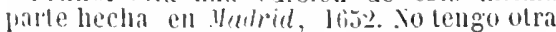
molieia de sll existromia.

Eulicha l'arti se hallan las siguientes coInedias:

lel enemizo el primer consejo.

Vi) hai peor soldo.

lia mejur espiesulera.

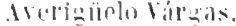

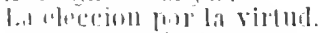

bemluma to di loins hijo.

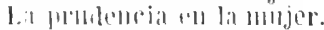

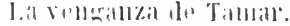

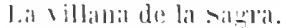

Elat alol y el andistal.

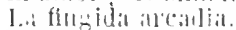

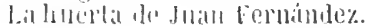

Qunetal pane le las comedias dol Maestro Tirso de Molina. Recogidils pol don Francisen lucas de Auilat solurino del Autor. Madrid, llaria de (Mniñones, 163:3. 1. 1 hojas m\%ls. y 308 /mliadas.

Es la linica cdicion te esta Parte, y abrazil lis doce comedias que siguen:

l'rivall rontra su groto.

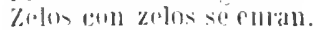

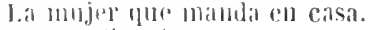

dutuma liarcial.

lit : intor encilico.

Joña lieglri\% de silva.

Tudo es dar ro mola rusa.

dunzomas en las ludias.

lal leallad contra la envidia.
La Peña de Francia.

Santo y sastre.

Don Gil de las calzas verdes.

No sé de dónde ha sacado el Sr. Barrera que este tomo se ejecutó en la Imprenta del Reino.

Qvinta parte de comedias del Maestro Tirso de Molina. Recogidas por Don Francisco Lucas de Avila, sobrino del Autor. Madrid, Imprenta Real, 1636. $4 .^{\circ} 4$ hojas prels. y 268 foliadas.

No conozco otra cdicion de la Parte quinta.-l). Nic. Antonio no la menciona, ni tampoco la cuartia.

Contiene las once comedias siguientes:

Amar por arte mayor.

Los lagos de sall vieente.

Escarnientos para el cuerdo.

lat republica al reves.

El Aquíles.

Marta la piadosa.

Quien no cae no se levaute.

La vida de. Herodes.

La clima del olivar.

la santa Juana.

Segunda parle de sanla Juana.

Es smmamente difícil llegar í remir eslos cinco tomos, sobre todo completos y bien conservados como estín los mios; dudo se conozcan lies en este estado.

1338 TEllez (Gabriel). Comedias escogidas de Fray (iabriel TeHez (el Macstro Tirso de Molina), juntas en coleccion e ilustradas por Jon Juan Eugenio Hartzenbusch. Madrid, Imprenta de la Publicidad, 18.18. Un vol. en mui gran $8 .^{\circ}$ que forma el quinto de la Biblioteca de Autores españoles, publicada por Ribadeneira.

Este volumen, bastante bien impreso, y cu cuyo arroglo y correccion ha trabijado el editor com 11 esmero singular, contiene las cumedias que se espresan á continuacion:

Palabras y plumas.

El pretendiente al reves.

La villana de Vallicas.

El ristigo del penséque.

Quien cilla otorga: segunda parte de El cas-

tigro del peuséque.

La gallega Nari-Hernández.

la zelosa de st misma.

Amor y zelos hacen diseretos.

Amor por razon de estado.

El condenado por desconflado.

El vergonzoso en palacio.

'or el sulano y el torno. 
Esto sí que es negociar.

No bai peor sordo.

La prudencia en la mujer.

La villana de la Sagra.

El amor y el amistad.

Privar contra su gusto.

Zelos con zelos se curan.

El amor médico.

Don Gil de las calzas verdes.

Amar por arte mayor.

Marta la piadosa.

Anır por señas.

Desde Toledo á Madrid.

Cautela contra cautela.

La ventura con el nombre.

En Madrid y en una casa.

Los balcones de Madrid.

El burlador de Sevilla y convidado de piedra.

El rei don Pedro en lladrid y el infanzon de Illèscas.

El zeloso prudente.

La huerta de Juan Fernandez.

Del enemigo el primer consejo.

A verígūelo Várgas.

Los amantes de Teruel.

Jornada tercera de la comedia Lo que hace un manto en Madrid.

Fragmentos de la titulada: El rei Don Pedro en Madrid, segun la edicinn de $167 \%$.

Existe un Tealro escogislo de fray Gabriel Téllez conocido con el nombre del . Vaestro Tirso de Molina. Madrid, 1 \$59-42. 12 vols. 8. ${ }^{\circ}$ marq.

1439 TÉllez (Gabriel). Comedias escogidas del Maestro Tirso de Molina. Madrid, Ortega y Compañia. $18 \geq 6-34.4$ vols. $8 .^{\circ}$

Abrazan cstas comedias:

El vergonzoso en palacio.

Por el sótano y el torno.

Zelos con zelos se curan.

Don Gil de las calzas verdes.

El amor y la amistad.

La mujer por fuerza.

Amar por razon de estado.

La huerta de Juan Fernández.

Amar por señas.

No hai peor sordo, que el que no quiere oir.

Escarmientos para el cuerdo.

La eleccion por la virtud.

Todo es dar en una cosa.

La romera de Santiago.

Mala impresion, incorrecta y mutilada, con un regular Exámen de cada una de las co. medios.

\section{Talía española, ó Co-} leccion de dramas del antiguo Teatro español, ordenada y recopilada por Don Agustin Durañ. Tomo I. Madrid, Eusebio Aguado, 1834. 8. marq.
Esta correcta y bien impresa Coleccion se suspendio, quizá por haberse preferldo publicar el Teatro escogido we fray Gabriel Té. llez, 1839-42, del que ya he hablado. Solo salio a luz el principio del tomo primero, el cual abraza tres comedias de Tirso, cuyos títulos son:

La prudencia en la mujer.

Palabras y plumas.

El pretendiente al reves.

1411 TÉLlez (Gabriel). Cigarrales de Toledo. Compuestos por el Maestro Tirso de Molina. (Madrid,...

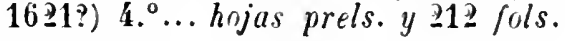

Primera edicion, rarísima $₫$ desconocida a Barrera.

Este ejemplar que fué de $\mathrm{Mr}$. Heber, se halla falt de los prels., que deben llenar 4 hojas por lo menos.

He tljado el año de $\{621$ a la presente impresion porque siendo enteramente distinta de las dos descritas á continuacion, únicas mencionadas por los bibliigrafos, no lue cabe duda que mi ejemplar, incompleto, pertenece á la hecha en Yadriden $\{10 \mathrm{~T} \mid$, de la cual habla Duran al principio de la Talia esprinola. Esta fecha li confirman las aprobaciones que tiene la de liz't datadas en octubre de aquel año, y el privilegio real concedido en noviembre de! inismo.

1412 Cigarrales de Toledo 1. ${ }^{\text {a }}$ parte Compuestos Por el Maestro Tirso de Molina Natural de Madrid. En Madrid por Luis Sanchez... Año de 1624. 4. ${ }^{\circ} \bar{i}$ hojas prels., incluso el frontis grabado, y 363 paigs., la ulltima sin numerar.

Barrera cita esta rara edicion como prinera, $y$ o no la ha visto bien, 0 el ejemplar que tuvo presente estaba falto, pues ademas de onitir el nombre del impresor, dice constan los preliminares solo de las aprobaciones de frai lliguel sinchez 50 . Juan de tillregui $y$ del l’rúlogo del autor, siendo así que en ellns se unchentran tambien la Tass, el Privilegio del rei, las Erritas, versns landatorios de Lope de lega. Castillo solorzano y doña laría de san Ambrosio y l'iña, y la dedieatoria dirigida á $\mathrm{L}$. Suero de Quiกิ่ones y่ Acuña.

1443 La misma obra. Barcelona, Gerony mo Margarit, 1631. $4 .^{\circ} \ddot{3}$ hojas prels., la guiuta es la primera de la sign. $\mathrm{A}$, y $21 \mathrm{~b}$ foliadas.

Los que suponen ser la edicion de 1024 la primera, suelen fundarse, en decir el P. Mi. guel Roca, en sll aprobacion fechada el 3 de octubre de 1650, que los Cigarrales se im. primierm seis años ha en yadrid: pero esto 
sin lejar de ser cierto, no prucha de ningun muto que anteriommente no hubieran visto la luz fublica, fel obsurvar en la Tasa de la ya rita impresion de lt2., yue los señores lel eomsego habian risto un tilno que? con su lieneria fue immerso. conflrma mas y mis la existencia de la edicion de l621.

1.os Cigar'ales comprenden tres de las mejores comedias de Tirso, a saber:

El vergonzoso en palacio, precedida de Loa. En el cigarral primero).

Como han deser los amiriss. (En el cuarto.) El zeloso prudente. (En el quinlo).

En el probogo de la olra ofrece el aulor Serymela parle de la misma, lis primere de doe eomedias, sateidis de entre las lpescientas suyas que se dadidin representado on

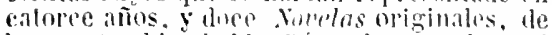
las que lambien habla Pirez de Muntalvan al fin del Pare todos. Solo complio sll afertil en lo treante i la primera perile de las comedias. Las trescicutas 100 las liahia escrito antes de cutrar en la religion el año de lligo, como piensi Brmet, pues en el chímstró continuo ibasteriendo la escena española con el mismo arilor que cuando era seglar. Eu la Biblioteca dol ducue de Ostma existe el original de las tres partes de Samla Juana, y r'll linja viltima se lee de mano de $\mathrm{Te}$ llez: En Toledo á 50 de mayo de 1013 ... Frai Gabriel Telles. El año de ligo era ya Presen-

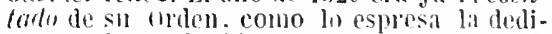
catoria de Lo fingidn verelentero. enmedia de Lupe de lrega ques halla on si becimusexla parte, la enal quetio aprobada por el llaestan lirente Espinal a lí de seliembre de diclun ano. si pues en los catorce anteriores

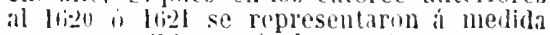
que se rescribian. mis de treseientas comedias do Tollez, y esle alrazii la vida cenobit. ca intes del biti, como parece mui probahle, no sirit arenturado suponer que trabijo mal mitad for lo minos de aquel numero en el retiro do la celeli.-lil sobrino volvio a oliecer col la Tercera prorte de lis comedias, que ell hreve saldria la segunda de los $\mathrm{C} i$ garrales $\mathrm{y}$ las dince Novelas; pero esto $\mathrm{mm}$ ca llegro à realizalse.

\section{LIST. ALFABÉTIC.}

de las comedias ciladas como impresas á nombre de Tirso de Molina, fuera de

las que precelen mencionadas.

Al lunen callar llaman Sancho.

Caballero $(\mathrm{El})$ de ciracia.

Cobarde $\mathrm{El}$; mats valiente.

Condesa (La) bandolera, ó la ninfa del cielo.

Conquista de Valencia por el Cid.

Firmeza (La) en la herniosura.

llablidine en entrando?

Honroso (El) atrevimiento.

Joya (La) (de las montañas.

Mejor (El) desengaño. (Puede haberse confun. dido con El mayor desengaño.)

Quien da luego, da dos vezes.
Quinas (Las) de Portugal.

Rico (El) avariento, segun el Indice genera. de Vedel.

Iomera (lii) de santiago.

Sinta (La) Julma, tercera parte.

sutilezas de amor y el marques del Camarin. (Es la misma que Amar por razon de es. lado.)

Fida y interte le llércules. (Puede mui bien ser errata del Indice general.)

144 ' TELLEZ (TABRIEL). Deleytar aprovechando. Por el Maestro Tirso de Molina. Madrid, Imprenta Real, 163\%. 4. 8 hojas prels. y 334 foliadas.

Primera edicion, aluque la Licencia sea del año de $16 \overline{2} 2$.

\section{0} Madrid, Iuan Garcia Infançon, 1677. 4. 6 hojas prels. y 337 fols., el último dice 328 .

Al fin se repiten las señas de la primera edicion, de la que la presente es en un todo diversa, contra li que sientan Brunet y Barrera.

\section{6} La misma obra. Madrid, Antonio Marin, 1765̆ (no 1775 , como por errata se lee al fin de los Apuntes biográficos de Tirso por Duraii). 2 vols. $4 .^{\circ}$

En las tres ediciones se lee el nombre de Fr. Gabrial Téllez al pié de la dedicatoria, mas no en las portadas donde se prefirio conservar el sendónimo de el Maestro Tirso de Molina.-Al fln se ofrece Segunda parte, la culal no vió la luz pública.

Esta obra contiene los antos sacramentales y demas dramas que van puestos á continuacion:

El colmenero divino, con Letra $y$ Loa. En el doming" por la larde.

Diallogo entre Simon Mago y el apostol san Pedro. En el línes por la mañana.

Los triunfos de la verdad. Dí́logo en el línes por la mañana.

Los hermanos parecidos. Precedido de Loa $y$ Romance. En el lúnes por la tarde.

No le arriendo la ganancia. Auto precedido de Letra y Loa en el mártes por la tarde.

Noticia de otros autos impresos del mlsmo autor.

Laberinto (El) de Creta.

Locura (La) por la honra.

Nuestra Señora del Rosario la madrina del cielo.

Oso (El) y la colmena. 
1417 TERENCIO (Poblio). Las seis comedias de Terencio eseritas en Latin y tradvzidas en vulgar Castellano por Pedro Sinon Abril professor de letras humanas y philosophia, natural de Alcaraz. "Caragoça, en casa de Iuan Soler, 13̈\%. (Al fin: Caesaravgrstae aprd Ioannem Soler, et Vidvam Ioannis a Villanova Idibus Quintilis. M.D.LXXVII.) $80^{\circ} \mathbf{8}$ hojas prels. y 396 fols.

Va acompañada esta buena taduccion del testo latino; y la presente primera edicion, es tambien la úniea que contiene la vida de Terencio, escrita por Elio Donato, y un breve tratado sobre la tragedia y la comedia.

\section{8}

dias de Terentio conforme a la edicion del Facrno, Impressas en Latin, v traduzidas en Castellano por Pedro Simon Abril. Alcala, Iuan Gracian, 10ั83. 8. ${ }^{\circ} 8$ hojas prels. y 344 foliadas.

El testo latino va de letra cursiva.

1449 La misma obra. Barcelona, en la Emprenta de Iayme Cendrat, M.D.XC.IX. 8. ${ }^{\circ} 10$ hojas prels. y 344 foliadas.

Aquf el original latino se ha puesto tambien de letra cursiva, por ser una reimpresion a plana renglon de la de Alcalí, onitidas las dos hojas de prólogo.

Las ediciones de Aleali de 158; y de Barcelona de 1599 , son preferibles a la anterior de Zaragoza por estar mís correridas que esta, y arreglado el testo latino al publicado por Gabriel Facruo en Florencia: ade. mas Abril se valió de algunas observaciones comunicadas por su amigo Francisco Sán. chez de las Brozas.-Segun Moratin, en los Origenes del leatro, esta traduccion siempre se estimará como una de las mejores entre las pocas hechas en España de Ios clásicos latinos.-Mayans fué el último que la reimprimió y publicó con un erudito prỏlogo, en Valencia, Benito Monfort, M.DCC.L.XII. 2 vo. lümenes 8 . $^{\circ}$

Antes de terminar el artículo de Terencio, daré noticia de runa bella edicion españolá del testo latino, rara y desconocida á Brunet:

Orla ancha y dentro está el epigrafe casi todo de colorado, que empieza:

Terètii aphri conicorum eleganlissime comedie: a Guidone Jutuenale per"̄o litterate familiariter explanule ete. Bajo está la cifra de Coci. En la sesta hoja de la sign. G se halla el colofon que termina: cesar auguste summa opera insup \& expèsis Gorgii coci theulonici excusse. Anno nato messis. xxiij. post willesimù̃ quingülesinù. (1524) sexto hal.'s Junii. 4.0 let. got. sin fol., signs. $a-G$. Los comentarios van por el lado del testo.

Velizquez, til los origenes de la poesía, cita una traduccion de la Mrodire de Euripides, hecha tambien por simon Abril, y dice se imprimio en Burcelona, 1599. To la he visto.

\section{TERRALLA Y LANDA (Es-} TÉvir DE). El sol en el nedio dia: Año feliz, $y$ jubilo particular con que la Tacion Indica de esta muy noble Ciudad de Lima solensniso la exaltacion al trono de Carlos IV. Su autor Don Estevan de Terralla v Landa. (Lima) Casa Real de Niños Expositos, 1790. $40^{\circ} 8$ hojas preliminares, incluso el relrato de D. Bartolomé de .Mesa, signs. 1-3Z, a-r, todas de dos hojas menos la ullima que solo tiene una; $\mathrm{A}-\mathrm{E}, 1-\mathrm{J}$, todas de dos hojas escepto la última que es de tres; y 1-3 de dos hojas las primeras y de cuatro la tercera.

La lolaciou de las fiestas es en verso, y las pousias culncalas en la iglesia, edificios", fuentes. ete. parecell ser tudo obra de Terralla. Il fill vall cualro Loces.

\section{1'ï1 TESORO DEL TEATIO} ESPAIOL, desde su orizen año de 13006 , hasta nuestros dias; a rieglado y dividido en cuatru partes, por D. Eugenio de Ochoa. Paris, imprentas de Casimir y Crapelet, 1838. 3 rols. en $8 .^{\circ}$ frances. Con retratos.

Conticnen los Origenes del Teatro español, por D. L. F. de Yoratiu, y los dramas siguientes:

\section{Tomo primero.}

Diálogo entre el amor y un viejo.-Podrigo de cola.

Dos églogas.-Juan del Encina.

Egloga.-Anónima:

Comedia himenea.-Tóres taharro.

La carátula. P. - Lope de Rueda.

El ruflan cobarde. P. - El mismo.

Enfemia. C.-El mismo.

El convidado. P. - El mismo.

Las aceitunas. $P .-E l$ mismo.

Los engaños. C.-El mismo.

Cornudo y contento. P.-El mismo.

Pagar y no pagar. P. - El Mismo.

Prendas de amor. Coloquio en verso. $-E l$ mismo.

Amor vengado. P.-Alonso de la lipqa.

Los ciegos j el mozo. P.-Timoneda. 
Los lenemmos. C.-Timonille.

Celestina.-Rodrigo Cota y Fernando Rójas.

Escena primera de la comedia Rubeua.-Gil licente.

El viudo. C.-El mismo.

Auto pastoril del Xacimienlo. $-E l$ mismo.

El saco de Roma. C. Juan de la Cuever.

El Infamados. C.-Elmismi).

Comedia salvaje.-Joaquin Romero de $\mathrm{Ce}$. meder.

Combdia llamada melamorfosea. - kl mismo.

Xise listimosa. Tragedia-Jeromino Bermade:

Yise laureada. Trazedia.-It mismo.

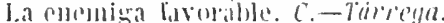

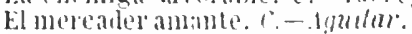

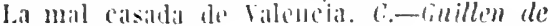
custio.

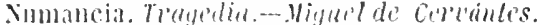

La entrelinida. $(-E l$ mivimo

La guarda roldiadosit. E-El mismo.

L.os dos hablitulores. E.-KI misima.

lsabelis. Trugédia.-Lup. lononardo de Argensola.

El zeluso.-Alfmso Velizquez de Velusco.

El touo segrumb ablaza las sigujentes commenlias de Loph the legu:

l.os milagros del desprecio.

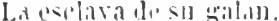

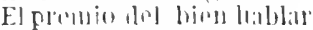

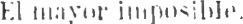

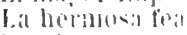

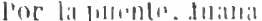

Al prasil diel aloporo.

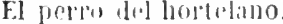

Las thres do dou luan, y rion y polore tro. citlos.

si un vieran lis mnjeres!

J.a lobbat paral los ubos y discrola para sí.

Las lizalyas li lielisa.

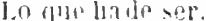

El nolimo.

Lil dama molimilosa.

los buens do Valogeja.

lil lontalo hermants. Tranicomedia.

El acoro de Vialjid.

Ill Vievo Nomelo, resculierto por Crislival Colon.

Jos emreflos de Colattro.

I:l tomo tercero petos dramas de Culileron:

\section{Comedias.}

J.a vila es sueño.

Casa rom lox puertas mala es de guardar.

La devocinu de lit cruz.

El medico de su homra.

Mañinas dualril y mavo.

A secruto agravio secreta venganza.

La cisma le Jnemiateria.

Jivba y disdicha dol nombre.

Hl mavou momstrun los zelos.

Eljindin de talerina.

Agrimlecer y no amar.

El illoaldr de Zalamea

El Jocief de lissmujeres.

Fieras afemina amor.

l.as armas do la hermosura.

El mustrico prodigrioso.
I.os dos amantes del cielo.

buelos de amor y lealtid.

No siempre lo peor es cierto.

La niña de Gómez Arias.

Hado y divisa de Leonido y Marflsa.

Autos sacramentales alegóricos.

La cena de Baltasar.

La nave del mereader.

La primer flor del Carmelo.

La viña del Seffor.

Fin cl tomo cuarto se hallan estas comedias:

La prudencin en la unujer.-Tirso de Molina.

Ion Cille las calzas verdes.-El misino.

El bullitur de Sevilla, y convidado de picdra.-El mismo.

La beata enamorada, Marla la piadosa.-El mismo.

Galin, valiente y disereto.-Mirade Amescua.

. Io Jaj vida como la honra.-Perez de Montalran.

La loquera vizcána.-El mismo.

koinar despues de morir.-Luis Vélez de Guev'ar'a.

El desden con el desden.-Morelo.

El valiente Jusliciero, y el ricohombre de Alcalli.-Et mismo.

El limlo dou bie.go.-El mismo.

nul pi abijo, ningumm, y labrador más honlallo lialrelia del Castañar.-Rójas.

boulde lial agratrios no hai zelos, y amo criallo.-El mismo.

Eutre bulos indal al juego.-El mismo.

Lil rerdiul sospechosa.-Ritiz de Alarcon.

Ciallily amiuros. - El mismo.

J.as paredes oyen.-El mismo.

E) tejerlor de Segovia, priniera parte.-El mismo.

El tejedor de segovia, segunda parte.-El mismo.

l.orenzo me llamo, y carbonero de Toledo.Matos Fragoso.

La dicha por el desprecio.-El mismo.

En el tomo quinto se hallan eslos dramas:

El honrador de su padre.-Diamanle.

El castigo de la miseria.-La Hoz Mola.

El diablia predicador y mayor contrario amigo.-Luis de Belmonte.

La tragedia más lastimosa, el conde de Sex. -Felipe IV.

Cuando 110 se aguarda, y principe tonto.Fruncisco de Leiva.

Las muñecas de Narcela.-Cubillo de Aragon.

Pobreza, amor y fortuna.-Diego y José de Figueroa.

Mudarse por mejorarse.-Zarate.

jor su rei y por su dama.-Bánces de cándamo.

El amor al uso.-Solis.

El hechizado por fuerza.-Zamora.

El dómine Lúcas. - Cañizdres.

El picarillo en España.-El mismo.

El delincuente honrado.-Jovellanos.

Raquel. Tragedia.-Garcia de la Huerla.

Mamolo, tragedia para reir, ó saincte para llorar.-Ramon de la Criz. 
Zoraida. Tragedia.-Cienfuegos.

Ei st de las niñas. - L. Ferndndez de Moratin. Pelayn. Trayedia.-Quintanu.

La niña en casa y la madre en la máscara.Marlinez de la Rosa.

indulgencia para todos.-Gorostiza.

Muérete, y verás!-Breton de los Herreros.

TIRSO DE MOLINA. Véase Téllez (Gabriel). Nủm. 1437.

1432 TORQLENADA (ANTONIO DE). (La portada de negro y bermellon, circuida de orla, dice:)

\section{Los colloquios}

fatiricos, son vn solloquio paftozil y graciofo al cabo Dellog hechos pos Antonio de ofor quentada fecretario del Jllnftriffimo feños don Antonio alfonfo pimétel $\mathbf{c} \overrightarrow{0}$ de de Benabente Tirigidos al may 3llaftre y miny exce lente feños, 田 đlōopimies, tel, pzimogenitor faceffor enfu rafa y eftado if,

Ala buelta d'fta hoja frhalla rälas materias que fe tractā eneftosfiete collognios.

Con priuillegio.

Efta tafado a

$$
I 553
$$

(Al dorso del fróntis principia efectivamente la Tabla que llena la siguiente hoja; la tercera contiene en su blanco la aprobacion del Mtro. Alejo Venégas, en la que se lee:)

Del Coloyulo pastoril, digo, que el es. stlio sube no solamente de pastores, sino de wmui lefdos cludadanos, en el cual, aunque wal agunos avisos contra el amor... hal "muchas celadas que enseñan á amar á los wignorantes; por donde no se les debria dar warte para osar emprender lo.que su Igno. srancia no emprenderla."

(Este Coloquio à que se refiere el aprobante comienza en el blanco del

Tos. I. folio clij, despues de una hoja blanca sin foliacion; pero que es la última de la sign. t., con esta portada, tambien de negro y colorado y rodeada de orla:)

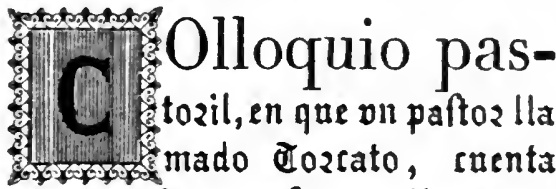
a otros dos paftozes llamados filonio, y Bzifaldo los amozes que tuno coll vna paftoza, llama" da Belifia, Da compnesto en efti lo apajible, y graciofo: y contie" lie en $f t$ avifog pzonechofos para que las genteg hnyan de dezarfe velleer del aunor, tomalndo en"

xemplo suel fin que tuniero eftos amozes, y el pago que dall alog que rie gamente los figne $\bar{e}$,

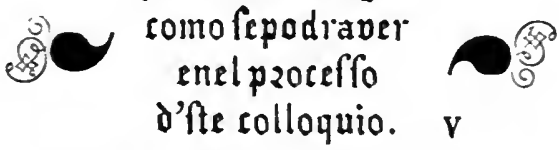

(Al reverso del fol. ccxxxvj se encuentra el siguiente final:)

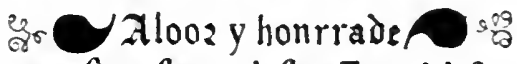

uneftro feños jefu xp̄o y d' fu bendita inadre fanta ma ría nueftroāparo y gnía fueron impzefos losfie te colloguios en la rindad de ftlon donedo en ca fa de $\mathfrak{A} \mathfrak{n}$ gnftin

de paj imprefor Acabofe a $x$ o.diag Del mes de ortubze del anto de All $\mathbb{C} \mathbb{i}$ iij. 
8. ${ }^{\circ}$ algo mayor que el esp. let. gólica. 8 hojas prels.y cexixvjfols.

lil cologrio quinto, cuyo frintis va intes ropiado. es representable y eslí en prosa y verso: no lo anallzo, pues yal lo lian liecho cour bastantc rstension los tradnctores de la IItsl. de la lit. 'ssp. de Tickmor, tom. II., pigs. 5.57 y 558 . Los olmos seis coloquios tratim: el $l^{\circ}$ de los diños curporales del juego; el 2. dr lo que lus medicos y boticarios estim abligados i hacer para cumplir con sus ofleios (En dos parles à diálogos;) el $5 .^{\circ}$ de Ias escelencias $y$ perfeccion de la vida pistoril; el $40^{\circ}$ del desúrlen en el eomer \& beber: el jo del descirden en los vestides; el 6.o de la lomia del momelo.

Nic. Antonjo no tmanoticia de la primera edicion de Mondoñodo, cugos éjempliares son muy risos, sobre todo en el magntero estado de conservacion en que el mio se encuentra, pues aun tiene hojus sin contor; pero cita una que carece de lnorar le impresim, hecha tambien en 1555. . 8 - $1: 1 \mathrm{Sr}$. Birrera y Leirado llama à esta oljra libro perégrino.

1453 TOROLEALDA (AxToxio DE). Los culloquios pastoriles (ut suprol. Billsao, Por Malhias Mares, 138i. 8." 8 hojas prels. 20̈́ fols. y una en que se repite el lugar, nombie del impresor y año.

Contiune lomismo que la edicion préncipe. Barrera no mencionil esta impuesion pero trae. (gujzis molusveidamente, whis hecha tambien ell Bilbuo por el mismo Mares en $1580.8 .^{\circ}$

\section{5:' TORRE Y SEBIL (FrixcIS-} Co DE L.1). Luzes de la avrora, dias del sol, en fiestas de la que es sol de los dias, y avrora de las lices, Maria santissima. Motivadas Por el nuero indulto de Alexandro Septimo... Las escrive, Don Francisco de la Torre, y Sebil. Valencia, Geronimo Villagrasa, 1665. 4. ${ }^{\circ}$ Fróntis grabado, 10 hojas de prels. que principian por otrofróntis impreso, retrato del marques de Astorga, 612 paigs., 8 hojas sin paginar, que contienen un romance, un soneto, la Tabla y las Erratas, y 4 lims. que van delante las priginas $346,3.00,3322$ y $3 \ddot{3}$.

Contiene una comedia intitulada: La azucena de Eliopia, cuya primera jormala y Loa que la precede, son de D. José Bolea; la segunda jornada y la Mojiganga defiestas y fiesta de Mojigarigas, que la sigue, escribio D. Francisco de la Torre: y la tercera es parte de este y parte de dicho $\mathrm{D}$. Jose
Bolea.-IJai ademas en el volúmen muchas poesfas castellanas y valencianas de diversos autores compuestas para la Jista poélica.

I.os traductores de Tickunr, toin. Ill., pigima 529 , mencionan unas flestas al mismo asunto celebradas en Sevilla, cuya relacion publicó en $166 \overline{3}$ (Juan Gomez de Blas, 4. ${ }^{\circ}$ ) D. Feruando de la Torre Farfan, con el titulo de Teuplo panegirico, etc., con poesias de muchos ingenios sevilianos, la mayor parte poco conocidos.

\section{0: TORRE Y SEBIL (Francis-} co DE LA). Reales fiestas a la soberana imagen de la Virgen de los Desamparados, de la Civdad de Valencia, en sv translacion a la nveva capilla. Las escrive, Don Franciseo de la Torre. Valencia, Geronimo Vilayrasa, 1667. 4. 6 hojas prels. y 390 págs. IIai tres láms. y algunas vinelas.

Esta primera cdicion solo contiene la relacion de las dos fiestas mandadas celebrar por la reina Doña Mariana de Austria.

14006 - Reales fiestas que disprso la... Ciudad de Valencia a honor de la milagrosa Imagen de la Virgen de los Desamparados, en la Translacion a su nueva sumptuosa Capilla. Escrivelas Don Francisco de la Torre. Valencia, Geronimo Vilagrasa, 1668. $4 .^{\circ} 7$ láms. $y$ algunas viñetas. 4 hojas de prels. diversos de los de la edicion de 1667, 38 paiginas que tampoco se hallan en esla, las 390 páginas de ella, no reimpresas, sino las mismas, sin otra diferencia que tener 4 lams. más en las paigs. 5ّ, $\mathbf{5} \mathbf{4}$, 56 y 58 y la llamada falsa el en la pagina 390 , fallando la palabra Fin, $y$ llega despues à la paig. 5038 , que debia ser 658, porque el centenar $300 \dot{a}$ 400 está repetido.

En esta segunda edicion se agregó la descripcion de otros festejos que con igual motivo hicieron algunos particulares y corporaciones.

En ambas impresiones hai muchas poesias de diferentes autores, y una Loa representable de D. Francisco de la Torre.

Nic. Antonio y Barrera no mencionan esta obra, y Savall, en la continuacion á la Biblioteca de Rodríguez, no habla de las grandes diferencias que se observan en los ejemplares de las Reales fiestas.

1457 TÓRRES (CONDr DE LAS). Decio, y Eraclea, Opera. Para reci- 
tar en Musica, segun estilo, y metro Italiano, en celebracion festiva del primer año, que cumple el Serenissimo Señor Principe de las Asturias. Madrid, Gabriel de Barrio, hácia el 1708). 8. 11 hojas prels. y 52 páginas.

El nombre del autor se halla al fin de la dedicatoria. La ópera va precidida de una Loa.

1438 TÓRRES NaHARHO (BarTOLOMÉ DE).

PROPALADIA

DE BARTOLOME de Torres Naharro,

\section{$\mathrm{Y}$ \\ L A Z A R I L L O de Tormes,}

Todocorregido yemendado per mandado del confejo de la fanta. "general Inquificion.

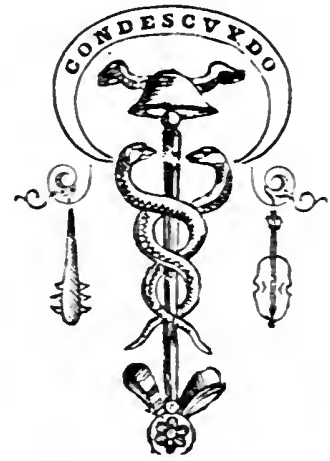

IMPRESSO CON LICEN cia y privilegio defu Mageftad para los reynos de Caftilla y Aragon.

En Madrid, por Pierres Cofin. M.D.L.XXIII.

8..$^{\circ}$ pequeño. 12 hojas prels. y 417 foliadas. (El escudito que hai en el frón- tis que dejo copiado no es el mismo, aunque mui parecido.)

Contiene varias poesias $y$ las siguientes comedias en verso:

\begin{tabular}{l|l} 
Serafina. & Ilimenea. \\
Trofea. & Jacinta. \\
Snldadesca. & Calamila. \\
Tinelaria. & Aquilana.
\end{tabular}

El editor de esta rara edicion, Juan I.opez de Velasco, hizo un señalado servicio il las letras, reimprimiendo, amnque algo mulilalas, La Propaladia de Turres Iaharro, El Lazarillo de Tóme's y las Obras de Cristivial de Castillejo (Tum. o.'i del presente Culälojo). Ilallibanse estos libros prohibidos en varios yasajes por la luquisicion, y hacia va algunos años que nadie se habia atrevido à reproducirlos: Velasco los volvio á ofrecer á Ins aflcionados á nuestra buena literatura, suprimiendo o variando con sumo acierto los lugares tachados por el inexorable tri. bunal del Santo oficio.

Dare una noticia de las impresiones que he visto o he encontrado citadas, pues no es fácil hacerse con ninguna de ellas.

Portada de negro y colorado: Propalladia Do Barlholnme de' Torres Vuharro. Divigida al Jllustrissimo Señur: el S. Hon Fernando Daualos de dquino Mar'iqu's de Pe'scara. Conde de Lorito: gran Camarlongo del le'mo de Sapoles ctc. Con gratia y Prinilegio : Puljal . y thal. (Sigue un escudo cun torres y lennes metido dentro de una especie de capillita sostenida por cuatro columas, al un lido se halla un hombrc escribiendo §al otro una mujer. y bajo: Contientuse eula Propulla. dia. Tres lamentationes de Amor lina saty. ra Onze Cupitulos Sicte Epistolas. Comedie. Seraphinu Comedia. Trophea Comedia. Soldadesca Comedia. Tinellaria Comedia yme. nea Comedia. Jacinta Dialıgo . del Tacmiélo. Lna. Contemplation L'na. Exclamation Al hierro de la lança A la L'ronica Relracto Romances. Cuncimies. Sonctos.

Al fin: Eslampada en Fipoles. Por Ioan pasqueto do Sallo. Innto ala Ámunciada... Acavosse. Ineues. XYI. de Março. M.D.XIII. (Signe el escudo del impresnr.) Fol. let. gut. De 94 hojas inclusa la portada sinfoliacion con las signs. desde la 1 hasta la $z$. luego la \& $(\mathrm{ct}, \mathrm{y}$ por último ?. Esta de 3 hojas las demas de 4 .

Moratin dice en una nota del Discurso histórico que precede à los Origenes. que él turo una edicion de limma de 1517 . en fol. let. gut. $y$ despues ln repite. Creo que escribiendo de memoria, la confundio con la anterior de Nápoles, $y$ lo mismo opina Gallardo en el número 4 del Criticon.

Propalladia De Bartholome de Torres Nizharro... (Hai despues un grande escudo de armas de Castilla y Lcon, al cual sigue de negro $:$ colorado:) 
Contienense en la Propalladia. Tres lamen. latiom!'s de Amor.-Una Sal!ra.-Onze Capilulos.-Sirle Epislolas.-Comedia. Sormphine.Commedia. Trophea. - Comedia. Soldridesca.Commilia. Timellaria-Comedia. Ymeneu-Comedia. Jacinla.-Dialogo. del Nuscimièto.Imu . Coulemplncion. - Una . Exclamacion.Il hicr'ro de' lu lança. - A la Veronica.-Retracto.-Romances. Cancimes. - Sonelos. Comedia Aquilama. Fol. let. gút.

- Este ejemplar que esli incomplelo al fin, liene las signs. $A$, inclusos los pielinuiuares, liasta $Z, x, 2, z, a$ y $b$ comprendiendo solamente ít hojas de la Comedin Ápuilatia. Böhl de Faber creyó ser esta cdicion li de Sevilla de 1.i20 por contener la Aquilann, y que en la que so lizo ell la misma ciudad en 15.5. se drbe cneontral li Culamila. Amhas comedias filtan en la de Nipoles hecha pur Juan P'asquelu de sallo.- bus traduelores de Ticknor, quirnes deseriben este mismo ejemplar, se incliuan i creer que esta es una serunda edicion heehn on Nápoles pot cuanto lu clase del papel y letra en unu y otra pal'ece ser la misma.

Bruset cita una edicion de Sevilla, $J$. Cromberger, 1520. 4. ${ }^{\circ}$ que dice contiene la Aquilana.

Los traductores de Ticknor describen una edicion numi risa, al fin de la cual se lee:

Femesce la propalialia ele Ravlholome de Torre's Sirharvo. Impressu en serilla pur Ja-

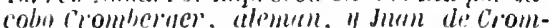

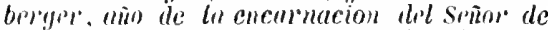
mile yuinicutos e vinte y seys (1526) añus $a$ 5 ale octubre. Fol. let. sot.

Contiene esta edicion a mas de la Aquilana la Colnumila que no se halla en las ediciones anteriores.

Propalalia de Bartoloine de Torres nuIarro. Cólienese enla I'ropalinlia. Tres lamenlaciones de amor. Una salira. Onze capilulos. Sicte epistolats. Comedirt S'raphina. Comedira Trophea. Comedia Soldadeseu. Comediu Tincllaria. Comedia ymenea. Comnedia Jucinlu. Comedia calamila. Comedia aquilana. Dialogo d'l nascimièln. Una contemplacion. Lina exclanacion. Al hierro deI a lanza. Ala veronica. Retracto. Romances. Caciones. Sonnellos. E olras olmas añrdidas del dicho auclor. (l.a obra termini en la decima hoja de la sign. $\varphi$ en el recto de li cual se lee: Fue implessu en Seuilla: en casa de Juan cromberger a. $x$. de Selietre de. M. a.xxxiiij. años. En la otra hoja nuevo fróntis circuido de orla y en el centro en cuatro renglones de letra bastante gruesa:) Comedia llimada aquilana fecha por Barlolone de torres naharro. Sigue dentro de un rículo una grande águila. Al dorso principia el Introilo y argumento de la contedia que ocupa 19 hojas mis, y en el reverso de la filtima dice:) Impressa en Seuilla por Juan cromberger: enel Año de Mil e quinicntos e treynta y tres (1533). 4. ${ }^{\circ}$ lel. gót. Sin foliacion signs. $a-1 \mathrm{y} a$; $\mathrm{i}$ dos colunas ménos cl Dialogo del nacimiento. I.o ví en la Bihlioteca imperial de Paris.

Me parece que no me equivoqué al copiar la feclia do la primera parte M.d.xxxiiij; sin embargo Hrunet pone N.d.xxxiij. En lo que no hai duda es en que su tamaño es $4 .^{\circ}$ y no fol. como supone Ticknor.

\section{Brunct cita la siguiente edicion:}

Tolcdo, acabose d veynte et quatro dias del mes de enera, año... de mil et quinientos el treynta ct cinco (1535) annos. $4 .^{\circ}$ Barrera dice equivocadamente ser del 4 de enero.

(Portada con orla ancha y en el centro se lee de colorado y negro:) ol Propaladia de Barlalome de Tinres Naharro. Contienen se' en la propuladia. Tres lamentuciones de amor. Una salyja. Onze copitulos. Siels enl'as. Comedia Serophina. Comedia Trophea Comedia Soldulesca. Comedia tinctlariu. Comédia Yunenea. Comedia Jucinta. Comerdia Calimilu. Comedia Aqnilana. Dialogo del nascimiento. Una contéplacion. Una exclamacion at hierro de la lanca. A la veronica. Retracto. Ronnäces. Cä́ciones. Sõnetos. E olras obras añadidas del dicho auctor. M.d.xlv.-Ún el blanco de la uiltima hoja de la Calamita se lee: $a b c d e f \| h i k l m n$ op $q$ Todos sum quadernos: excepto el primero que es duerno: y este de lu q que tiene dos pligos y medio. Fue inapressa en Seuilla: en casa de Andies de Burgos a. ij. de agosto de. M.d.xlv. añus.-Sigue nueva portada para la Aquila$n a$ que ticne 20 hojas con la sign. A. 4. gritica. Sin foliacion. Sin embirgo de que en el hegishro dice que el primer pliego es duerno se equiroca, pues consta de 8 liojas como los que le siguen. He visto esta impresion.

Propaladia de Bartolome de Torres Nahar. ro / uneuamenle corregida y enmendada. (1) Lo que enella se conlienc se vera en la pagina siyuienle. (Sigue el escudo de las dos cigüeñas.) I En Anvers en casa de Marlin Nucio. S. a. En el fol. Aij principia: Parle la peregrince naso \&c. La obra comienza en la 9." hoja del vol. y concluye en la 8." de la sign. $Y$. Despues con nuevo fróntis y nuevas signaturas siguen las comedias Calamila y Aquilana, que concluyen en la hoja 12 de la $h$ á cuyo reverso se repite el escudo del impresor. 12. ${ }^{\circ}$ let. gill. Sin foliacion. Esta edicion debe estar completa, pues en la Soldadesca se halla el diálogo del fraile. La he tenido á la vista.

El Sr. Duran da noticia de una de Anvers, 1573, espurgada como la de Madrid.

Propaladia signiflca primer parlo del inge. nio, con arreglo à la csplicacion que da en el prólogo el aulor, que es quien inventó la voz.

Noratin ha reimpreso casi por entero en sus Origenes la Himenea, Ja cual se halla tambien en el Teatro anterior d Lope de Vega. En el mismo están la Jacinla, Calamila y Aquilana. 


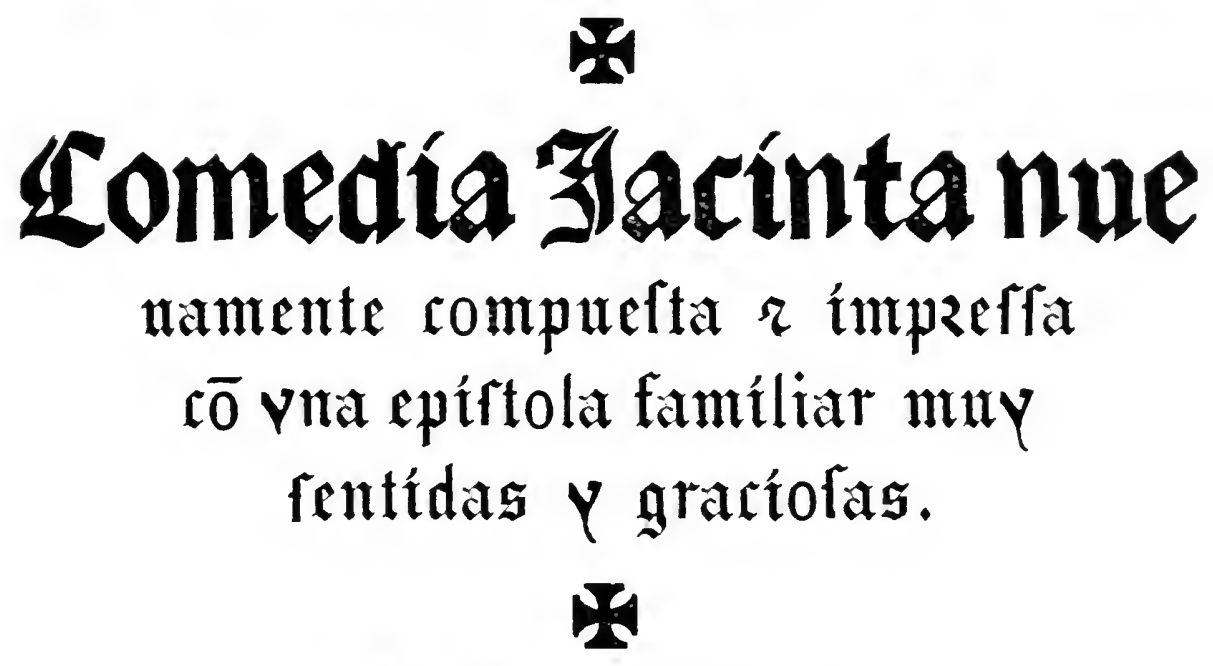

\section{Interlocutozes.}

Dinina. E0ztaleza. Hillano. Jacinto. や̧zeriofo. 引agano.

CSiguen los interlocutores representados en cinco figuritas grabadas en madera y ademas unia fortaleza. Al dorso de la portada principia el $\mathrm{Jn}$ troito: y Argumento y conclinye la pieza al reverso de la hoja undécima con un Villancico; sigue despues la Epistola que termina en el blanco de la siguiente.) S. l. ni a. (hicia 1530 ). 4. ${ }^{\circ}$ let. gót. 12 hojas con la sign. a.

Siendo este cjemplar el de Mr. Ternaux, no comprendo como pudo decir Ticknnr, en cl tour. II., pág. 155, refiriendose à è, que era obra distinta de la escrita por Naharro con igual titulo: yo encuentro ser exictanurnte la inisma, comprendida en la Propaladia y analizada por Moratin on cl nuim. 26 del Caldogo que precele á los oriyenes. Schack, Barrera y Cañetc, este en el priol. d las Farsas de l. Fernández. han comelido el misulo ertor que Ticknor.

Despues del Villancico puesto á rontinuacion de la cumedia, hai una Eptslola, que ignoro de dúnde está sacada, la cual principia:

Manos mias que temblais, Msisegad un poco agora, Y escribamos si mandais a la mi diosa é señora.
Tambien se imprimio suelta, y existe en un tomo de farsas españolas de la IBil. real de Yumicln. segun Wolf. la Comedia llumalu

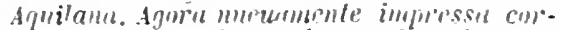

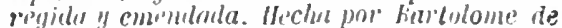

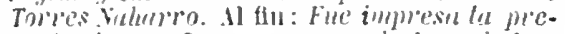

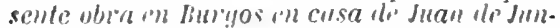
la, ha dezi-srys dias del mes ate deciemhe. Aino ale mill !f quinienlo: y cincuenta y dos

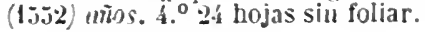

1460 TRICYFO de la lealtad. Elogio politico, y moral. Al excelentissimo seĩor D. Antonio Alvarez de Toledo. Duque de Alla... A cuvas sienipre excelsas plautas D. 0 . Y. C. Yn rendido Afecto, y fervorosa passion. Madrid, Imprenta de Lucas Antonio de Bedmar y Baldiuia. S. a. Khicia 1680) $40^{\circ} 48$ prigs. inclusas las 4 de prels.

Es una picza dramática representable, en verso, en ha cual nu consta por parte alguta el nombre del autor. Barrera y Leirado, ell el Indice general de comedias, cita una con este utulo que atribuỵe i un ingcnion; no sẻ si será la inisma por no dar has señas de la impresion. 
1461 VALDES (Pedro Clemente). Amphitheatro sagrado,... para aplavdir, en su canonizacion, a... S. Lvis Gonzaga, y S. Estanislao Kostlia. Le da a la lvz publica Don Pedro Clemente Valdes. Cordoba, Juan de Ortega, y Leon, (1728?). 4. ${ }^{\circ}$ Lamina con un grande escudo de armas: á más de esta hoja 10 de prels., 136 págs. y 300 por último para el Certámen.

Contiene poesias de varios en un Certámen poético y una comedia intitulada: Los des jovenes de Ignacio, composicion de D. Francisco Isidoro de Molina, segun consta por la pág. 101.-Barrera no tuvo noticia de este eseritor, y al mencionar á Clemenle Valdes, dice: "Citado vagamente como autor dumávtico. No he ballado noticia de él ni de sus wobras."

1462 VALDIVIELSO (JosÉ DE). Doze actos sacramentales y dos comedias divinas. Por El Maestro Ioseph ${ }^{-}$de Valdiuielso. Toledo, Iuan Ruyz, 1622. 4. 4 hojas prels. y 183 foliadas, con una blanca al fin.

Los títulos de estas catorce composicioncs dramáticas, son los que siguen:

\section{Autos sacramentales.}

El villano en su rincon.

El hospital de los locos.

Los cautivos libres.

El féuix de amor.

La amistad en el peligro.

Psiques y Cupido, Cristo y el alma.

El hombre encantado.

Las ferias del alma.

El peregrinn.

La serrana de Plasencia.

El hijo prỏdigo.

Árbol de la vida.

\section{Comedias divinas.}

El nacimiento de la Mejor.

El Ängel de la guarda.

Esta es la obra más rara de Valdivielso; he visto uno ó dos ejemplares, pero faltos de las dos comedias que van al fln : el mio está completo y es magnífico.

Nic. Antonio menciona otra edicion de Braga, 1624. $4 .^{\circ}$

Se publicaron en otras colecciones ó sueltas las siguientes piczas dramáticas del misno autor:
Autos.

Entre dia y noche.

El nacimiento de Cristo Nuestro Señor.

La escuela divina.

La locura.

Los locos de Toledo. $B$.

No le arriendo la ganancia. $A$.

\section{Comedias.}

El loco cuerdo.

La flor de lis de Francia, y conquista del Santo Sepulcro.

\section{VALEDORA DE LOS HOM-} BRES. La gran Comedia de la baledora de los hombres. $4 .^{\circ}$ Manuscrito.

Tiene las licencias para su representacion fechadas en Madrid el 22 de mayo de 1675, y en Lisloa á 15 de mayo de 1689. No encuentro rastro de esta comedia inedita en el In. dice de Medel; y Barrera la menciona refriéndose á este ejemplar que es el que se halla anunciado en nuestro Catálogo de $\mathrm{Pa}$ ris de 1834 .

No consta el nombre del autor por parte alguna.

1464 VAZ DE GUIMARÃES (FrancISCo). Obra novamente feita da muyto dolorosa Morte, \& Payxā̃ de nosso Senhor IESV Christo, conforme a escreueram os quatro Santos Euangelistas. Feita per hum deuoto Padre chamado Francisco Vaz de Guimarães. Precede a este título una mala lámina de madera que representa un Crucifjo.) Em Lisboa. Domingos Carneiro. Anno 16\%9. $4 .^{\circ} 20$ hojas sign. A. Con muchas laminitas de madera.

Mui raro.-Barbosa Machado clta ademas las siguientes ediciones de esta pleza dramática portuguesa en verso; dos de Evora, la primera de 1593 y la segunda sin fecha; una de Braga de 1613, y dos de Lisboa de 1617 y 1639.-Se me hace mui estraño que hallándose este auto descrito en la Bibliotheca tusilana, no lo esté en el Calálogo de Barrera; tampoco lo menciona Nic. Antonio.

Drama que parece compuesto á mediados del siglo XVl, y no estrañaría fuese la misma obra puesta entre las anónimas por Nic. Antonio, refiriéndose á Cardoso, con el titulo de Tratado da Paixaõ de Christo. Evora, 1556.

El argumento de esta pieza dramática portuguesa, en verso, se reduce á una relacion dialogada de los últimos momentos de Cris- 
to, désde la Cena con sus disclpulos hasta 12 colocacion en el sepulcro despues de cruciflcado.

\section{VEGA (ALONSO dE LA).}

\section{Clas tres famofteffí}

mas Couredias del Jllnftre poe taly araciofo repsefentāte Alou fo de la Ueya. Agoza nuena mente facadas a lm; poz Joan Cimolleda. En $\mathfrak{e !}$ Año. I 566

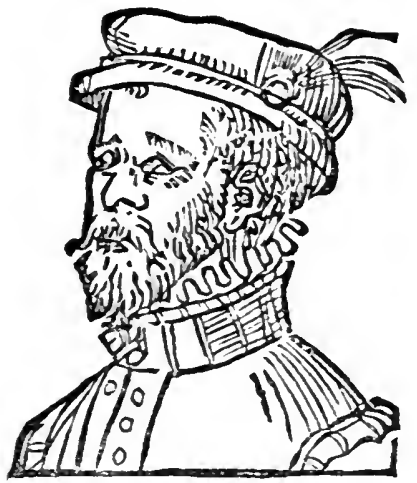

Con pziuilegio heal poz quatroaños.

[Dendenfe, en fafa de
Joan einromeda.

(Al fin, en el reverso de la última hoja:)

\section{đIntpreffas en la} cindad de balencia. Año. I 566

8. ${ }^{\circ}$ let. got. Sinfoliacion, signs. A-I, todas de 8 hojas. La Serafina y La du- quesa de la Rosa llevan nuevas porladas con el mismo retrato.

Las tres piezas dramáticas de este volú. men son en prosa; $y$ sus titulos los siguien. tes:

Tholomea.

Seraflna. Tragedia.

La duquesa de la Rosa.

Si Pellicer y Moratin vieron este rarisimo volumen, no comprendo crimo pudiernn decir que el soneto de Timonedia á la muerle de Alonso de lit lega va al principio, puesto que se halla lúcia la mitad del libro, al fin de la comedia Tolomea: el que encalieza la obra es el copiado a continuacion juntimente enn la Epistola de Timoneda, por la cual se ve claramente que su profesion era la de librero, circunstancia que niega hodriguez y que supone dubitativamente Jimeno: prueba de que á ambos les fue desco. nocido el tomito de Vega. Tampoen me parece li vió el Sr. Barrera, pues á haberlo tenido presente no diria que el Paso publicado por Joratin, en sus Origenes del tealro, con el título de El anor verigado, no se sabe de dunde lo saco; no siendo sino el In/roilo y Argumento de la comedia La duquesa de la Rosa, con alguna perqueña supresion.

"Epistola de Joan de Timoneda

al pio lector."

" 50 por via de presuncion y jactancia, b. - lierinano lector, ni mostrarme reprehensor de obras ajenas, sino por ser mi arle librero y buscar sin perjuiclo de madie de dis me pueda resultar alguna mamnancia, be querido con mi poen habilidanl y "poble caudal, sacar al luz y poner en el moimde de la emprenta estas tres presintes comucdias del ilustre poeta y gracioso repreusentante Alouso de hrega, con lodil la "perfeccion que ba sidn posible, dichas la "Tholomea, yla Seraphina, ýla dic la Disquesa mie la Rosa; las enales te suplico que las maceptes con aquclla voluntad que el autor ulas compuso y mi mano te presenta. Vale."

\section{"Soneto de Juan Timoneda."}

"En una lega vi que concertaban Tres ninfas tres coronas de mil tlores, p'oetas, recitantes y oradores

De aquellas tres coronas coronaban:

Jui pocos dos coronas alcanzaban, En esto ví asomar. puesto entre antores, Alonso acompañado de cantores,

$Y$ á este tres coronas le asentaban.

Mlonso de la Vega ya salido

De manu de las ninías coronado,

En Corte esecutaba sus deseos;

Despues en allegarse á Turia ha sido

Lo que más y mejor nos ha mostrado,

Duquesa, Serafina y Tholomeos. „

Ticknor dice, que Alonso de la Vega y Cisnéros escribieron farsas en prosa lan popnlares y propias de su tiempo, que apenas ha 


\section{VEGa CARPIO (Lope Félix de).-SUS OBRAS DRAMÁTICAS.}

llegado d las muestros mu de ellas.-Brmuet no las enocio, y lleber no pulo jamas hacerse con un ejemplar.

Navariote, eu la liela de cervdules pági-

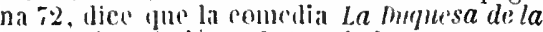
Rosa so implimio cu lisio: dullu sea exacto.

El relialo que va en lil porlada supengo seri el de. Alunso de lit reora.

1466 YEGa C.ARPIO (Lope FriLIS DE). Auto de la natiuidad de Fira S.ra De lope de Yega Carpio. Manuscrito en $4 .{ }^{\circ}$ Coetuneo del aulor.

Barrera die que es incilito.

\section{l'tia — Luto del Principe de} la l'az y transformaciones de Celia del a. ${ }^{\circ}$ ie 16:9. para lis fiestas de Madrid de Lope de Teza Carpio. Hamuscrilo en 4.".

Ta] os el chrabczamienlo del manuscrito fric poseo, el enal parece ser de lis fecha cilimla.

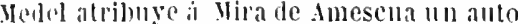
con el mismon lítulo; pero llada dice del de Lope.

1'608 - Auto famoso sacramental del vino de Xijo, de lope de rega Carpio. Iamuscrilo en $4 .^{\circ}$

lina de las apolnationes gue lleva al fll

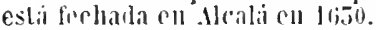

Vedel cita mu atulo cour el missmo título; pero no ticne nombre de antor.

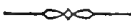

1969 VEG.A CABPIO /LOPE FÉLIX DE) COLECCION DE SUS OBRAS DMAMITICAS.

\section{Pinte primera.}

Las comedias del famoso peeta Lope de Vera Carpio. Recopiladas por Bernardo Grassa. I fora nveramente impressas y emendadas. Amberes, Martin Pricio, cIs. Iocru. 8. 622 prigs. en torlo.

Conliene ademas de once Loas las Comedias siguientes:

Los domajres de Ilatico.

Círlos el persegruido.
El cerco de Santafe.

Villa y pullerie de Bamba.

Ia traicion bien acertada.

El hijo de Reduan.

Naciuicuto de Urson y Valentiu.

El casimiento en la muerte y licchos de Bernardo del Calpio.

La escolística zelosa.

l. amistad pagada.

l.a comedia del molino.

El testimonio vengado.

Me han asegurado hai uma edicion de esta larle liecha ell Valencia on 11,04 y otra de Fulludolid de la mismn ficha. La existencia de la primera estí conflmada por uma aprobacion de Giracian Pantisco, que lleva la de Amberes, dada en Valladolid el 17 de febrero do aquel añn, en la que dice: Fislus duze co. medias que han sido impresns en Valencia.

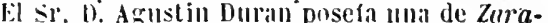
gnsa, Angelo Tanano, M.DCIIII. 4..$^{\circ}$, con la

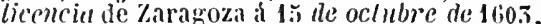
cuya circunstancia indince á sospechar bai aloma jupresion anterior i la de Valencia arriba cilada.-El Sr. Barrera y lecirado hace merilo le la de Madrill, lijof. 4. ${ }^{\circ}$ y de la de Vialladolid, 1605. $44^{\circ}$ : y yo he tenido ocasion de examinar la signicute que dice en la portada: lan añtulidis él esla impression muchos emlremeses. Valencia, en cusa de Gaspar Leget, 160.. 4. 4 bojas prels., mina de ellas blanca, 16 de la Primera parle de entremeses sin pagiual, 3tít pígs. liasta la conedia del Te'stimmio vengado inclusive, 258 písts. de mineva mmmeracion hasta el Hijo de Reduon inclusive, y por flus hojas sin foliar para las Louts.-Los Entremeses de asla edicion son Ios cineo primeros de la de Valladolid, 1609 , y las Commedias guardan otro irden segin se ve pur la deseripeion que precede.

- Las. Comedias del famoso poeta Lope de Vega Carpio. Recopiladas por Bernardo Grassa. Agora nveramente impressas y emendadas, con doze entremeses añadidos.... Las que en este libro se contienen van á la buelta desta hoja. En l'alladolid, luan de Bostillo, 1609. 1.' 1 hojas prels. y 366 fols. El ultimo dice 363 por equivocacion, pues hai más folios errados que acertados.

Esta edicion es la más completa, porque fucra de lis once Loas y loce Comedias de la de Amberes, contiene los signientes Entreineses:

Melisendra, con Loa mui graciosa.

El padre engañado.

El eapeador.

El doctor simple. 


\section{YEGa CARPIO (Lope FÉlix DE)._SUS OBRAS DRAMÁTICAS.}

pedro Hernández y el corregidor.

I.os alimentos.

Los negros de sancto Thome.

El indiano.

La cuna.

Los ladrones engañados.

La danıa flngida.

La endemoniada.

La uprobacion que va al principlo es la de Gracian Dantisco de 1604 , que se encuentra en la edicion ántes citada de Anvers.

- Las comedias del famoso poeta Lope de Fera Carpio. Recopiladas por Bernardo Grassa etc. (ut supra). Talladolid Iuan de Bostillo, 1609. 4. ${ }^{\circ}$ hojas prels., $366 \mathrm{fols}$.; la última dice equivocadamente 365 .

A pesar de ser esta edicinn del mismo im. presor, pueblo y año, tener igual mimero de hojas y las mismas crratas de finliacion, es perfectamente distinta $\mathrm{y}$ se conoce con mucha facilidid desde el frontis, porque ademas de no llevar punto final despues del articulo Las, en el primer renglon, dice más abajo: Las ã en este libro ctc., cn lugar de Las que en este libro etc. El Sr. Barrera ignori que hubiese dos impresiones del mismo pueblo y año.

He oido hablar de una edicion de Vilan, 1617; pero no la be visto: la que tengn de aquicl punto es la siguiente:

La misma Parte. Milan, Iuan Baptista Bidelli, 1619. 8. 62 z paiginas en todo.

Edicion hecha á plana renglon con la de Amberes, y por consiguiente conticne solainente las Comedias y Loas, y no los Entremeses, como dice Barrera: en los preliminares observo algunas diferencias, y la inayor consiste en ir aquella dirigida al liceneiado D. Antonio Ramirez de Prado y la presente a D. Juan de Figueroa y Villégas; siendo notable se advierta en la dedicatoria á dicbo D. Juan, que cstas comedias de tope, aun. que impresas cn Madrid anteriormente, están llenas de errores.

El Sr. Barrera y Leirado, reflriẻndose á Schack habla de la impresion de Milun, 1617, que no creo existia : la mia, conforme con la de Mr. Chorley, dice claramente 1619.

La misma Parte. Caragoça, Iuan de Larumbe, 16ə26. 4. 4 hojas prels., 8 con la sign. S para las Loas y $\mathbf{2 8 9}$ fols.

No comprende los Entremeses; pero si el prólogo de Bernardo de Grassa, que no está en la edicion de Valladolid, 1609, nl en la de Milan.

Fl Sr. Barrera y Lcirado no trae esta cdicion en su Calálogo; y refiriẻndose á Ticknor, describe otra de Zaragoza, Juan de Lrrumbe, 1624. 4. ${ }^{\circ}$, en lo que creo hai error.

\section{Parte segunda.}

Segrnda parte de las Comedias de Lope de Vega Carpio. En Brrsselas, Roger Velpio, y Huberto Antonio. 1611. 8. 3 hojas prels. y 669 priginas. La última dice 613 por equicocarion. Ia despues una hoja que contiene el Privilegio, y en el recerso se lee: Antrerpia. Excudebat Andreas Baex, 1611.

Contiene este volumen las siguientes co. medias:

La fuerza lastimosa.

La ocasion perdidd.

El gallardo catalan.

El mayorazgo dudoso.

i. a condesa Malilde.

Los Benavilles.

Los comendadores de Cúrdova.

la bella malmaridada.

I.ns tres diamantes.

La quinta de Florencia.

El padrino desposado.

Ferias de Yladrid.

La primera edicion de esta Parte es de ./a-

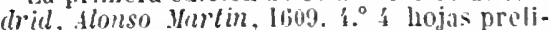
minares y $5 \%$ foliadas: creo cxiste una de Valladolid, del mismo añ, segmn Schack. y Barrera cita la de Ifallrid, lbto, tambicin en $4 .^{\circ}$

La misma Parte. Barcelona, Sebastian de Cormellas, 1611. 4. ${ }^{\circ}$ hojas prels. y las Comedias llevan las signs. A-Xx, sin foliacion.

En la biblioteca de Mr. Labouchere existia la edicion de V'allarlolid. 1611. s. $^{\circ}$

La misma Parte. Lisboa, Pedro Crasbeeck. 1612. 1. 1 hojas prels. y 312 foliadas.

En una advertencia ó prólogo en portugues que precede i esta impresion, se dice, eran ya mis de quinientas lis comedias de Lope represcontadas. - Edicion desconocidil á Barrera y Leirado.

La misma Parte. Madrid, Iuan de la Cuesta, 1618. 4. 


\section{VEGa CARPIO (Lope Félix de).-SUS OBRAS DRAMÁTICAS.}

hojas prels., 313 fols. y una al fin con una advertencia del editor.

La advertencia final supongo es del editor Miguel Martínez, aunque no lo dice; en ella se queja de los perjuicios irrogados í él de poderse introducir en Castilla libros impresins en la Corona de Aragon, Valencia, Calliluña y Navarn. Por dicha adrertencia sabenos, que pago á Espinel por la autorizacion de imprinir el Várcos de Obregon, teien estelldos de oro. Al dorso del fol. 5ly copia el Auto de los señores del Concejo de 19 de octubre de 1617 , para que n! se intuduzeau en Castilla, siu licencia, los libros impresos fuera de ella.

Tengo El gallardo catalan, La quinta de Florencia y El pallino desposado de una Purte segrinda diversa de la que poseo. La primera pieza ocupa los folios 65 á 98 , y la segunda y tercera los folios 285 al 5.11. Puede que estos fragmentos pertenezcan a la cdicion de Valladolid, 1609, ó á una de Pamplona del mismo año, que encuentro citada.

\section{Parte tercena.}

Parte tercera de las comedias de Lope de Vega y otros avtores, con sus Loas y entremeses. Barcelona, Sebastian de Cormellas, 1611. 4. ${ }^{\circ}$ hojas prels. y 310 fols.

Las comedias de este tomo son:

Los hijos de la Barbuda.-Luis Velez de Gue. v'ar'e.

La adversa fortıua del caballero del Espiritusamu.-lic. Juen Grajal.

El espijo del mumlo.-Luis Vélez de Guevara.

La noche toledanit.-Lope de Vega Curpio.

La trayedia de doña Ines de Castro.-Licenciudo Mejía de la Cerda.

Las mudanzas de fortuna, y sucesos de D. Beltrall de Aragon.-Lme de Vega.

La privanza y caida de D. Alvaro de Luna.Damian Salustrio de Poyo.

La próspera fortuna del caballero del Espiritu-santo.-Lic. Juan Grajal.

El esclavo del demonio.-Doclor Mira de Amescua.

La prospera fortuna de Rui López de Ávalos. - Damian Salustrio de Poy's. Primera parte.

Segunda parte. La adversa fortuna.-El mismo.

El santo negro Rosambuco de la ciudad de Palermo.-Lope de Vega Carpio.

\section{Entremeses.}

El sacristan Soguijo.

Los romances.

Los huevos.

Loa en alabanza de la espada.

Loá de las calidades de las mujeres.
Loa de la batalla naval.

Loa de las letras del A, B, C.

Loa del sumptuoso Escurial.

La presente edicion lleva una aprobacion del 5 de diciembre de 161.j. En ella se dice que este volúmen habia ya sido impreso en Sevilla. No he visto semejante edicion; pero si una que con titulo casi idéntico al de la de Barcelona se público en Madrid, en casa de Mignel Serrano de Vargas, $1613.4 .^{\circ} 4$ hojas prels.; las Comedias, que carecen de foliatura, van desde las signs. $A-T t$, y luego hai is lojas con las signs. $A, B$, para los Entrein'ses y Loas, á las que sigue una para repetir la fecha.-La portada de este libro nos dice que Miguel Serrano hizo la impresion A costu de Miguel Marlinez, como lo verifico tambien al año siguiente con el tomo de Poetas valencianos, en el que hai seis co. medias de Tírrega; por eso dijo en la advertencia final, puesta á la Segunda parte de Lope de 16t8, que los libreros aragoneses y valencianos habian reproducido indebidamente entre otras obras la Tercera parte de comedias y las Comedias de Tárrega publicadas por èl. Sin embargo, por las noticias bibliogrífteas que actualmente tenemos, esta acusicion, con respecto á ambas obras, es mui infuudada, pues de la primera se conoce otra edicion de Barcelona hecha tambien por Sebastian de Cormellas en 1612. 4..$^{\circ}$ cuyas aprobaciones demuestran debe laber una de $V a$ lencia de 1611, y lo conflrma completamente el estar dirigido el tomo á D. Luis Ferrer de Cardona, y firmada la dedicatoria por Aurelio Mey; y por lo que hace á la segunda, sabemos se publico en Valencia por dicho Ney en 1608 , y en Barcelona en 1609. Así, mientras no se pruebe que Miguel Martínez dió á luz la Tercera parle de varios ántes de 1611 , y las Comedias de Tärrega en 1608 ó precedentemente, debemos decir no tuvo razon para quejarse, siendo él al contrario el usurpador de la propiedad ajena.

Esta Parte y la quinta son tal vez las más raras de la coleccion.

\section{Parte cuarta.}

Doze comedias de Lope de Vega Carpio ... sacadas de svs originales. Qvarta Parte. Madrid, Miguel Serrano de Yargas, 1614. 4. 4 hojas prels. y 296 foliadas.

Primera edicion.-Contiene las comedias siguientes:

Laura perseguida.

El Nuevo Mundo, descubierto por Cristỏval colon.

El asalto de Mastrique por el príncipe de Parma.

Peribáñez y el comendador de ocaña. 


\section{VEGa CARPIO (Lope Félix de).-SUS ObRAS DRAMÁTICAS.}

El genoves liberal.

Los torneos de Aragon.

La boda entre dos maridos.

El amigo por fuerza.

El galan Castrucho.

Los embustes de Zelauro.

l.a fi rompida.

El tirano castigado.

Doze comedias de Lope de Vega Carpio... Qvarta parte. Pamplona, Nicolas Assiayn, 1614. 4. ${ }^{\circ}$ hojas preliminares y 996 foliadas.

En el catálogo de la venta de Tieck se cita una edicion de esta Parte hecha en Barcelona, 16!4. 4.

\section{Parte quinta.}

Flor de las Comedias de España, de diferentes avtores. Quinta Parte. Recopiladas por Francisco de Auila, vezino de Madrid, Barcelona, en casa Sebastian de Cormellas, 16i6. $4^{\circ} \mathrm{Q}$ hojas prels. y 334 foliadas.

Este volumen comprende las siguientes co. medias:

El cjemplo de casadas y prueba de la paciencia.-Lope de rega Carpio. Con Loa y el Baile del $A y, a y, a y$, , "Lillo.

Las descracias del rei 1). Alfonso el Casto.Doclar Mira de Amescua. Con Loa y Baile del Amor y el inleres.

Los siete infinte's de Lara, ell lengraje antigun.-Ihurlado Vilarde. Tragrdia con loa y un Baile eurioso de Pello ele Brita.

El bastardo de Cellta.-Lic. Juan Grajules. Con Loa y Baile del Sofillo de Hanzmuires.

La rengranza honrosa.-Gaspar ele Aluular. Con Loa famosa de La lenyua : Baile de Ia Boda de Foncarral.

La hermosura de Raquel.-Luis Vélez de Guevara. Prinera parte. Con Loa y Baile de La colmeneruela.

Segunda parte.-El mismo. Con Loa curiosa y de artiflcio (en prosa), y Ba'le de Los mis. riscos.

El premio de las letras, por el rei D. Felipe el Segundo.-Damian Salustio de Pomo. Con Loa En alabanza de los dedos, y Baile pas. toril.

La guarda enidadosa.-El divino Miguel San. chez. Con l.oa Én alabanza de los males, y el Baile de La Maya.

El loco cucrdi.-Maestro Joseph rte bialdivielso. Con l.oa En alubanzu det liabajo, y Baile de Los locos de Toledo.

La rueda de la fortuna.-Doctor Hiril de Amescua. Con Loa y un Baile curioso y grave.
La enemiga favorable.-Lic. Tárrega. Con Loa En alabanza de las mujeres fcas y el Baile de Leganilos.

La primera edicion de esta Parte, con igual titulo que la de Barcelina, se imprimió en Mudrid, Vuula de Alrmso Vurlin, $16154 .^{\circ} 2$ hojas prels. $5 . j$ f foliadas; en la VII parte del Catilugo de Hober hai una de Alcala, riuda de liuns Marlinez framele, 16i1.). 4.\% y Yr. Chorley se refiere á la de Madrid de 1616. 4. : yo no la he visto.

Siin embarso de contener este tomo una sola comerlia de Lope. forma la Parte quinta de las obras dranálicas le este autor en todos los ejemplares que conozco. Creo efectivamente no existe semejante tomy quinto conupuesto esclusivamente de producciones de Veara Carpio, a prsar que Barrera refiriendose i Fajaruo cita uno de Yadrial, 1t5ji: se halla por consiguiente en igual caso que el volimen tercero: ambos pertenecen tambien á una colpecion gencral de comedias principiala í publicar en los primeros años del siglo Xil, y esta circunstancia, sin duda, ha contribuido i que sean los mis raros y dificiles de encontrar de toda la serie.

El escudo de sebastian Cormeillas estampadi) en la portada de la cdicion que tengo de Barcelona es el siguiente.

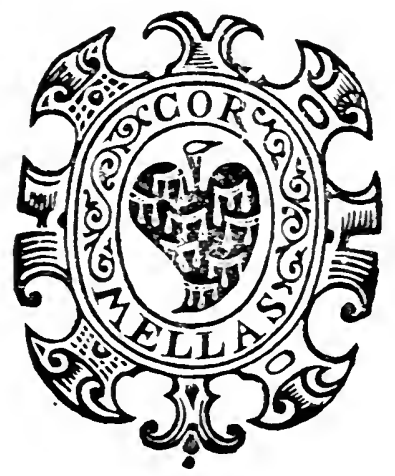

Parte sesta.

El Fenix de España, Lope de Tega Carpio. Sexta parte. Barcelona. Sebastian de Cormellas, 1616 . f. $^{\circ}$ hojas prels., 2:3 foliadas rel fol. 16 eslá repetidos para la priniera comedia, 21 parc la se:unda, 26 y una blanca para la tercera, 9.4 para la cuarta, 14 para la quinta y sesta, \& para la setima, 24 para la octava, ə8 para la nona, 24 para la décima, 


\section{VEGA CARPIO (LOPE FÉlIX de).-SUS OBRAS DRAMÁTICAS.}

24 para la undécima y otras tantas para la últina.

Este tomo tlene las comedias siguientes:

l.a batalla del lonnor.

Lin olodiencia lamreada, y primer cárlos de Ilıiluría.

Ell lombre de hien.

El servil con mali estrelli.

El cucrdo en sll casa.

La feina Juanil de Ninoles.

Trimieomerlia listimosa del duque de riseo.

E.l secretario de sí mismo

El llewar ch ocasion.

El testign contla sí.

El milunol de Fulisilrdo.

El mejor maestro, el tiempo.

En Nic. Antonio y en la parte ril del Catálogo de lleber se menciona una edicion que con lítulo irual al de la de Barcelona se im. primio en Mulrid, riuda de Alonso Marlin, 6615. 4. ${ }^{\circ}$ que seli prubablemente la primera: y yo volra en el Museo Britínico hecha ell Vindrid, Iman de la Cuesta lol6. 4. 4 ho. jas prels. y 2xie fols. de la rual solo tenero un fragrnento con la iltima comedia y la lecha.

\section{I'arte sćtima.}

El Fenix de España Lope de Yega Carpio. Septima parte de svs Comedias. Con Loas, Entreneses, y Bayles. Madrid, Viuda de Alonso Mlarliii, liiti. 1. 4 hojas mels. y 306 folialav. is omilen los fols. 218, 219,

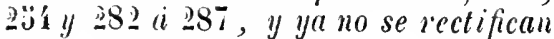
estos siltos.

La misma Parte. Barcelona en Casa Seluastian de Cormellas, 1617. 4. \& hojas prels. y 302 folialas. Desde et fol. 209 salta al 214, sin que se rectifique ya este error.

Contiene este tomo lo que sigue:

\section{Comedias.}

Fl rillano en sll rinenn.

El castigro del disereto.

las pobrezis de teinalidos.

El gran duque de lloscovia, y emperador personilido.

Las pazes de los reyes, y Judía de Toledo.

los Pirceles de Nurcia.

La hermosura aborrecida.

t.l primel lajardo.

La viula casada y donzella.

El príncipe despeñado.

La serrana de la Vera.

San Isidro labrador de Madrid.

\section{Entremeses.}

los habladores. (En prosa, ménos el final.) Se supone de Cervántes.

La cirreel de Sevilla. (Casi lodo en prosa.)

El hinspital de los podridos. (En mosa, menos el fin.)

\section{Loas.}

Ell alabanza de la humildad.

(Comparacion de la mujer buena con ta abeja yl de la mala con la araña.)

(El Firscro.)

En vituperio de la mala lengua.

\section{Balles.}

El duque de Humena.

Don Jime.

El caballero de Olmedo. (Dice ser de Lope).

\section{Parte octava.}

El Fenix de España Lope de Vega Carpio. Octava parte de svs Comedias: con Loas, Entremeses, y Bayles. Barcelona, Sebastian de Cormellas, 1617. $4 .^{\circ} 4$ hojas prels., 268 foliadas, $y 20$ sin foliar para los Entremeses, Loas y Bayles con las signaturas $0_{0}$ y Pp de 8 hojas cada una, y Qq de 4 .

Este tomo, que es mui dificil de encontrar, annque no taito como el tercero y quinto, contiene lo siguiente:

\section{Comedias.}

El despertar í quien dıerme.

El allzuelo de Fenisa.

Lus locns por el cielo.

El más galan portıgues, duque de vergauza.

El ángel fingido, y renegado de amor.

El postrer godo de España.

La prision sin culpa.

El esclavo de Roma.

La imperial de oton.

El raquero de Morana. Las pasa por alto $\mathrm{Ni}$. Angélica en el Catai. colas Anlonio.

El niño inocente de la Guardia.

\section{Entremeses.}

I.os invencibles hechos de D. Quijole de la Mancha.-Francisco de ivila.

El trius fo de los coches.-Barrionucvo. (En prosa, ménos el final.)

El mortero, y chistes del sacristan.-Francis. co de Avila.

\section{Loas y Bailes.}

En alabanza de la vanidad.

Tres loas sin titulo.

Baile sin tilulo. 


\section{VEGA CARPIO (LOPE FÉlIX DE).-SUS OBRAS DRAMÁTICAS.}

Baile de la unesonerica.

Baile de pásate acá, compadre.

He visto en el Museo Británico una edicion de esta octava parte, probablemente la primera, hecha en Madricl, Viuda de Alonso Marlin, 1617. 4. 8 hojas prels. y 288 foliadas.

\section{Parte norena.}

Doze Comedias de Lope de Vega Sacadas de sus originales por el mesmo. Nouena parte. Barcelona, Sebastian de Cormellas, 1618. $4 .^{\circ}$ i hojas prels. y 300 foliadas.

La Parte nona coinprende cstas comedias:

La prueba de los ingenios.

La donzella Teodor.

El Amete de Toledo.

El ausente en el lugar.

La niña de plata.

El animal de llungria.

Del mal lo ménos.

La hermosa Alfreda.

Los Ponces de Barcelona.

La varoua castellana.

La dama boba.

Los melindres de Belisa.

La edicion mas antigua que he examinado se publico con igual título en Mabrid, riuda de Alonso Martin, 1617. 4. 4 hojas prelinunares y 300 foliadas, $\mathrm{y}$ he visto citala otra tambien de Madrill, $1618.4^{\circ}$

Primera parte publicada con anuencia del autor, quien dice en el Prologo que la prece. de: «Viendo imprimir cada dia mis Comedias mde suerte que era imposible llamarlas mias... nme he resuelto a imprimirlas por unis origiwnales... Este será el primer tomo, que 60mienza por esta novena parte, $y$ ası irin uprosigniendo los demas, en gracia de los wque hablan la lengua castellana como nos la wenseũaron nuestros padres. *

\section{Parte décima.}

Decima parte de las Comedias de Lope de Vega Carpio, Sacadas de sus originales. Barcelona, Sebastian de Cormellas, 1618. 4. ${ }^{\circ}$ hojas preliminares y 298 foliadas.

Contiene estas comedias:

El galan de la Membrilla.

La venganza venturosa.

Don Lope de Cardona.

El triunfo de la humildad, y soberbia vencida. El amante agradecido.
Los guanches de Tenerife, $\mathrm{y}$ conquista de Canaria.

La otava maravilla.

El sembrar en buena tierra.

El blason de los Cháves de Vỉllalba.

Juan de Dios, y Anton Martin.

La burgalesa de Lerma.

El poder vencido, $\mathrm{y}$ anor premiado.

La primera edicion de csta Parte la imprimió en Madrid, la Viuda de Alonso Marlin, 1618. $4 .^{\circ}$, la menciona Nic. Antonio y se ha* lla en ta VIl parte del Catilngo de Ileber. Yo he visto otras dos impresiones tarmbien de Madrid, la primera hecha por Fernando $\mathrm{Cm}$. rea cle Nontenegro en $1620.4^{\circ} 4$ hojas preliminares, 299 hojas fols., y otra para repetir la fecha; y la segunda impresa por biego Flanenco, en $1621.4 .^{\circ}$ hojas prels. y 249 fols.

El siguiente escudo de Sebastian Cormellas es el que lleva en la portada la edicion de Barcelona.

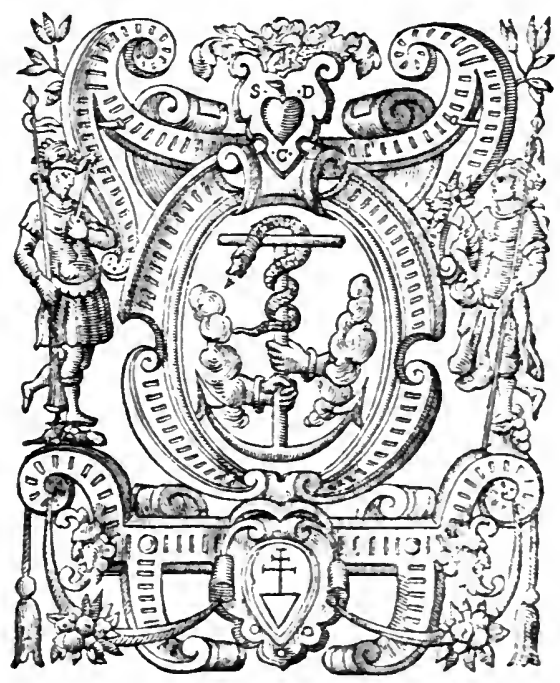

\section{Parte undécima.}

Doze Comedias de Lope de Yega Carpio: sacadas de sus originales. Onzena parte. Barcelona, Sebastian de Cormellas, 1618. $4 .^{\circ} 4$ hojas preliminares y 29 zoliadas.

Sus doce comedjas son:

El perro del hortelano.

El azero de Madrid.

Los ramllletes de Madrid. 


\section{VEGa CarPIO (Lope FÉlix de).-SUS OBRAS DRAMÁtiCAS.}

nbras son amores.

Servir á señol discreto.

El prineipe perfeto.

EI amigo hasta la muerte.

la lociura por la henra.

EI mayordomo de la duquesa de Amalf.

EI arenal de Sevilla.

La fortmona merecida.

El bautismo del príncipe de Marruécos.

En el Museo Britínico ví la primera edicimn que lleva el mismo título, y esti lueeha en Madrid, riuda de Alonso Mortin de Batboa, 1618. $4 .^{\circ} 6$ lojas prels. y 295 foliadas, coll una al fin para lepetir las señas de la impresion. Io solo tengo un fragmento de ella que contiene cuatro de sus doce comedias.

Tambien es este tomo de los más raros de la coleccion.

\section{Parte luodécima.}

Dozena parte de las Comedias de Lope de Vega Carpio. Madrid, Viuda de Mlonso Martin, 1619. 4. 4 hojas prels. y 30 foliadas.

La misma Parte. Madrid, Viuda de Alonso Martin, 1619. 4. 4 hojas prels. y 280 foliadas.

Edicion parecidisima íla otra hecha en igual año por el mismo implesor: estíll copiadas á plana renglon; pero son perfectamente diversas. Barrera imnoro esta circunstancia y solo vio al rumo de los ejemplares que llevan en la portida las armas del conde de la Puebla, d quien va dirigida esta l'arte. los otros tienen en lugar de la citada inues. tra nobiliaria el siguiente escudito.

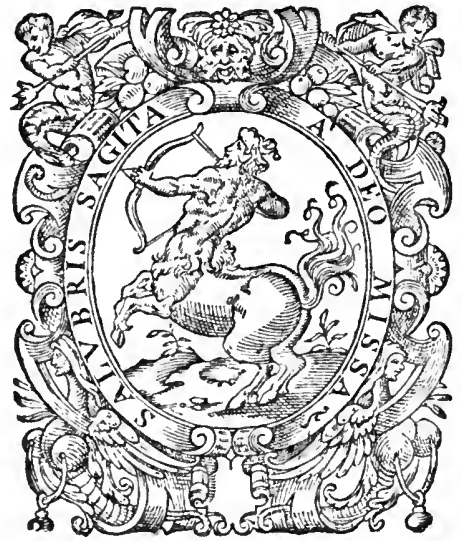

Sin gran reflexion habia yo tomado esta viīeta como marea del impresor Alonso Martin, porque li usó tambien en la Parte diez $y$ seis y en las dos ediciones que ejecuto de la veinle; pero al verla empleada por Fer. nando Correa de Montenerro en las quince y diez y siete, y por Juan González en las dicz y ocho y diez y nueve, me parlece más biell un emblema adoptado por Lope, alusivo quizá á la inspiracion que tuvo para mudar de estado. Confímame en esta idea el encuntrar el mismo esendo en la Jerusalen de este autor, lublicada en 1609 por Juan de li Cuesta.

Pertenecen a esta Parte las comedias que siguen:

Ello dirá.

la sortija del olvido.

Los enemigos en casa.

La cortesía de España.

Al pasar el ar'oyo.

Los hidalgos del aldea.

El marques de Nantua.

Las flores de Don Juan, y rico y polore trocados.

I.o que hai que flar lel mundo.

I. a tirmeza en la desdicla.

la desiliclanda Estefimía.

Fuente ovejuna.

\section{Pante décimatemcera.}

Trezeua parte de las Comedias de Lope de Veca Carpio. Dirigidas, cada vna de por si, a diferentes personas. Madrid, Viuda de Alonso Martin, 1620. 4. ${ }^{\circ}$ 4 lojas prels. y 152 foliadas hasta $\mathbf{E} 1$ Cardenal de Belen inclusive. IIai despues 189 folios para las seis Comedias ultimas, siendo de notar que del fol. Đ̋3 se salta al 94,y que la hoja postrera dice 33 bै en lugar de 189.

\section{Primera edicion.}

- La misma Parte. Barcelona, en casa Sebastian de Cormellas, $1620.4 .^{\circ} 290$ hojas foliadas, comprendidos los preliminares.

Componen dicho tomo estas comedias:

La arcádia.

El halcon de Federico.

El remedio de la desdicha.

Los esclavos libres.

EI desconflado.

El cardenal de Belen.

El alcalde mayor.

Los locos de Valencia. 


\section{VEGa CARPIO (Lope Félix de).-SUS OBRAS DRAMátICAS.}

Sanliagn el Verde.

La francesilla.

El desposorio encubierto.

Los españoles en Flándes.

La tercera está dirigida por Lope á Doña Marcela del Carpio, su hija.

Esta Parte es de igual rareza que la octava $\mathrm{y}$ la undécima.

\section{Parte catorce.}

Parte catorze de las comedias de Lope de Vega Carpio. Madrid, Yiuda de Fernando Correa Montenegro, 1621. $4 .^{\circ} 4$ hojas prels., 313 foliadas y una al fin con las señas de la edicion repelidas.

Es una errata estar fechado el privilegio el año de mil $y$ scyscientos nueue: ha de leer. se: mil y scyscienlos diez y nueue.

Abraza las comedias que aquí se espresan:

Los amantes sin amor.

La villana de Jetafe.

La gallarda toledana.

La corona merecida.

La viuda valencianla.

El caballero de Illéscas.

Pedro carbonero. Tragicomedia.

El verdadero aminte.

Las almenas de Toro.

Et bobo del colegio.

El cuerdo loco.

La ingratitud vengada.

El verdadero amanle cslá dedicado á su hijo Lope de Yega. El autor denomina esta comedia la primera sulya, y dice á su hijo que a la sazon (en 1620) hubia escrilo novecientas comedias, y esta á los aĩos que èl tenia, que eran catorce, pues le tuvo de Doña Maria de Lujan en 1606.

Poseo un trozo de la primera edicion de esta Parte, que hizo en Madrid, Juan de la Cuesta, 1620. \&. ${ }^{\circ} \&$ hojas prels., $31 \mathrm{j}$ fols. y una para repelir la fecha.

\section{Parte quince.}

Decima quinta parte de las Comedias de Lope de Vega Carpio. Madrid, Fernando Correa de Montenegro, 1621. 4. 4 hojas prels. y 304 foliadas.

Esta Parte comprende las comedias que siguen:

La mal casada.

Querer la propia desdicha.

la vengadora de las mujeres.

El caballero del Sacramento.
La santa liga. Tragicomedia.

El favor agradecido.

La hermosa Ester.

El leal criado.

La buena guarda.

Historia de Toblas. Tragicomediu.

El ingrato arrepentido.

El caballero del Milagro.

En el Museo Británico vi otra edicion de Madrid, Viuda de Alonso Marlin, 1621. 4. 4 hojas prels. y 296 foliadas.

El autor se vuelve á quejar en el Prólogo de esta Parte, de que en las primeras que salieron á luz se intercalaron en las combdias versos de autores desconocidos, y se agregaron loas y entremeses que él no imaginó en su vida.

\section{Parte diez y seis.}

Decimasexta parte de las Comedias de Lope de Vega Carpio. Madrid. Viuda de Alonso Martin, 1622. 4. 6 hojas prels. y 281 foliadas.

El último nínero de la fecha en el fróntis parece corregido de imprenta porque primitivamente decia 1621: lo misno sucede en otro ejemplar que hai en el Ilıseo Britinico, y Nic. Antonio señala tambien el aña 11022 . He visto otra edicion positivamente distin. ta, hecha en Madrid por la misma rinde de Alonso Marlin en 1621 , en $40^{\circ} 6 \mathrm{~h}$ ojas preliminares, 285 foliadas y la liltima siu nume. racion, aunque nada tendria de estraño haberse publicado esta Parte por primera vez en cl 22 ; sin embargn de que la diez y siete salio à luz en el anteriol, puesto que en el Prólogo Dialogislico que lleva al principio, dice que la parle die $y$ scis de las Counedias de Lunc "o sc acubó de imprinti por su ausencia, y asi viene despues de lu décima sétina.

Barrera y Leirado no mencioua la edicion de 1622 .

Esta Parte se compone de las comedias siguientes:

El premio de la hermosura. Tragicomedia.

Adonis y Vénus. Tragedia.

Los prados de Leon.

Mirád í quién alubais

Las mujeres sin hombres.

El Persen. Tragicomedia.

El laberinto de Creta. Tragicomedia.

La serrana de Túrmes.

Las grandezas de Alejandro. Tragicomedia.

I.a Filisarda.

La inocente Laura.

Lo fingido verdadero. Tragicomedia.

En el título de La serrana de Tórmes se la denomina comediu antigna de Lope, porque en ella mobó la pluina en el principio de sus estudios, para valerme de la idéntica frase que usa èl en la dedicatoria. 


\section{VEGA CARPIO (Lope FÉlix de).-SUS OBBAS DRAMÁTICAS.}

Parte diez y siete.

Decima septima parte de las Comedias de Lope de Vega Carpio. Madrid, Fernando Correa de Montenegro, 161: $4 .^{\circ} 4$ hojas prels. y 312 foliadas. A las 8 últimas falta un centenar por errata.

La misma Parte. Nadrid, Viuda de Fernando Correa, 1622. $40^{\circ}$ Chojas prels., y 312 foliadas. Ta á plana renglon con la anterior; pero las dos son enteramente diversas.

Componen esta Parte las comedias que siguen:

Con su pan se lo coma.

Quien inis no puede.

El soldado amante.

Muertos vivos. Tragicomedia.

El primer rei de Castilla.

El dónine Lucas.

I.ltcinda perseguida.

El ruiseñor de Sevilla.

El sol parado.

La madre de la mejor.

Jorge toledano.

El hidalgo bencerraje.

Entre mis apuntaciones tengo anotada otra edicion de Madrid, Viuda de Alonso Marlin, 1622. $4 .^{\circ} \&$ hojas prels. y 312 fols.; dice está hecha á plana reiglon con la de 1621 , pero se observa que en aquella la última hoja está equivocadamente numerada 212.

Barrera y Leirado, con referencia á tres bibliotecas de Lóndres, cita una impresion de Madrid, Viuda de Alonso Martin, 1621. $4 .^{\circ}$; pero nada dice de la que yo tengo del nismo año, hecha por Fernando Correa de Montenegro.

\section{Parte diez y ocho.}

Decima octava parte de las Comedias de lope de Vega Carpio. Madrid, Iuan Gonçalez, 1623. (Al fin: M.DC.XXIrr.) 4 hojas prels., 309 foliadas y una blanca.

Primera edicion.

Hai ejemplares de esta misma edicion, y yo tengo uno de ellos, que llevan en la última hoja el año de M.DC.XXII.

Las doce comedias que comprende, son:
Segunda parte del príncipe perfecto. La pobreza estimada.

El divino afrlcano. Trugicomedia.

La pastoral de Jacinto.

El honrado hermano. Tragicomedia.

El capellan de la Virgen.

La piedad ejecutada.

Las famosas asturianas.

La campana de Aragon.

Quien ama no haga fleros. (Nic. Anlonio la omite.)

El rústico del cielo. Tragicomedia.

El valor de las mujeres.

Sebastian Medrano, editor al parecer de esta Parte, dice en el Prólogo, que veĺa á Lope de Vega con poco dnimo de proseguir la publicacion de sus Comedias, ya porque deseaba dedicar el ti'mpo que le ocupaba la correccion de ellas d estudios de más instruccion, como por haber visto tantos librillos de romances $y$ olros versos ast divinos como humanos con su nombre, que no le ha pasado por el pensumiento escribirlos.

\section{Pante diez y mueve.}

Parte decinveve y la meior Parte de las Comedias de Lope de Vega Carpio. Madrid, Iuan Goncalez, 1624. $40^{\circ}$ b hojas prels. y 280 foliadas.

Nic. Antonio cita otra edicion de Madrid hecha por el mismo Juan Gonzdlez en 1623. $4 .^{\circ}$ Ia cual indudablemente existe puesto que el Sr. Barrera dice estả en el Museo Britá. nico.

La misma Parte. Madrid, Por Iuan Gonçalez. Año 162 . 4. ${ }^{\circ}$ hojas prels. y 280 foliadas.

Edicion desconocida á Barrera, hecha a plana renglon con la de 1624 , aunque completamente distinta. Dicho Barrera menciona otra impresion de Madrid, 1626.

\section{La misma Parte. Valla-} dolid, Geronimo Morillo, M.DC.XXVII. $4 .^{\circ} 6$ hojas prels. y 280 foliadas. Al dorso de la última suena como impresora del tomo la viuda de Francisco de Cordoua. tes:

Contiene esta Parte las comedias sigulen.

De cosario á cosario.

Amor secreto hasta zelos.

La inocente sangre. Tragedia.

El serafln humano.

El hljo de los leones. 


\section{VEGa CARPIO (Lope FÉLIX DE).-SUS OBRAS DRAMÁTICAS.}

El conde Fernan González. Tragicomedia.

Don Juan de Castro. Primera parle.

Don Juan de Casiro. Segunda parte.

La linipieza no manchada.

El vellocino de oro. Con Loa.

La mozedad de Roldan.

Círlos quinto en Francia.

Esta Parte tiene al principio un Prólogo dia. logistico entre el Pocla y el Tealro, en el que se dan noticias curiosas para la historia dramática española. Se ve por ellas que el Tea. tro se arrendaba por veintiseis mil ducados al año, y que el representante llevaba tres partes y el arrendamiento siete, sin contar los aposentos y bances; se aboga por que vuelvan los precios de entrada á lo que cran en tiempo antiguo, es decir, a un real, el cual se distribula, medio para el autor $y$ el otro medio para el arrendamiento; se dan quejas de que habiendo aumentado el precio la gentc se relrae de concurrir, y el repre. sentante no puede vivir con la poca parle que le loca, siendo tanto el esceso de los gaslos: proponiendo se suspendan las repre. sentaciones durante los nreses de junio, julio y agosto, por el mucho calor y ser poco saludable el reunir tanta gunte en el verano. Tambien parece era entonces el publico tan poco tolerante como el de nuestros dias, pues como alli se dice, si un representanle yerra una letra, pierie el poeta el Paso y la Comediu el gusto... Como si por decir uno Arcadia dijere Arcada, o por escritura, es criatura... yo he uislo por un defeclo que el latin llaina lapsus linguæ, parur la comedia un hora. - Se babla de que empezaban á usarse las upariencias que se llaman lra. woyas.

Al mencionar á Cisneros el cómico, observa era nombre cuyo donaire no tuvo igual en el mundo, y se cuenta de èl, que babiẻndole preguntado á un alcalde por qué estaba preso un estudiante, le contesto el escribano, que por una sátira.-Quẻ es sátira: replicó el actor. - Sátira es, decir las faltas del lugar.-il'ues en ese caso, repuso Cisneros, no seria mejor prender á los que tienen las faltas?

\section{Parte veinte.}

Parte veinte de las Comedias de Lope de Veqa Carpio...Dividida en dos partes. II adrid, Yivda de Alonso Martin, (Al fin: Iuan Gonçalez.) 16 ¿ö. 4. ${ }^{\circ}$ hojas prels. y 298 foliadas.

Primera edicion.

La misma Parte. Madrid, Yivda de Alonso Martin, 16 26. (Al fin: Iuan Conçalez, M.Dc. xxvIr.) 4. ${ }^{\circ}$ hojas prels. y 298 poliadas.

Toy. 1.
- Parte veynte (ut supra). Barcelona, Esteuan Liberos, 1630. $10^{\circ} \&$ hojas prels. y 299 foliadas.

Comedias que contiene este tomo.

La discreta venganza.

Lo cierto por lo dudoso.

Pobreza no es vileza.

A rauco domado. Tragicomedia.

La rentura sin buscalla.

El valiente Céspedes. Tragicomedia.

El hombre por su palabra.

Roma abrasada. Tragedia.

Virtud, pobreza y mujer.

El rei sin reino. Trugicomedia.

El mejor mozo de España. Tragicomedia.

El marido más firme. Tragedia.

En el nủm. 1571 , pte. VII del Catálogo de Heber, se cita una edicion de esta Parte, becha en Madrid, por Juan Gonçalez, 1629.4.

Es digno de notarse que en los fróntis de las Partes Xi y XVil, impresas por Fernando Correa de Montenegro, en 1621; en la XII $\mathbf{S} X X$ de la Viuda de Alonso Martin, 1622 y 2.5; y ell la XYIII y XIX de Juan González, 1625 y 24 , se usó del escudito qule be copiado al describir la Parte duodécima: alli espongo mis razones para suponer era este un emblema escogido por el mismo Lope.

\section{Parte veintiuna.}

Veinte y va Parte verdadera de las Comedias del Fenix de España Frei Lope Felix de Vega Carpio,... sacadas de sus originales. Madrid, Viuda de Alonso Martin, 163\%̆. $40^{\circ}$ hojas prels. y 260 foliadas.

primera edicion.

Consta esta Parte de las comedias siguientes:

La bella Aurora. Tragedia.

Hai verdades que en anıor.

La boba para los olros, y discreta para si.

La noche de san Jiran.

El castigo sin venganza. Trajedia.

Los bandos de Sena.

El mejor alcalle el rei.

El premio del bien hablar.

La vitoria de la houra.

El piadoso aragnnes.

Los Tellos de Ŷlenéses.

Por la puente Juana.

La dedicatoria del tomo es de Doña Folicia. na Felix del Carpio, hija de Lope de Vega, por haber fallecido este el 27 de agosto del mismo año $165 j$, de mudo que el turo bastante ticupo para cuidar de su impresion, la cual estaba terminada el 4 de setiembre, segun consta de la FC de erratas. 


\section{VEGA CARPIO (Lope FÉlix de).-SUS OBRAS DRAMÁTICAS.}

El editor de esta parte el lic. Ortiz de Villena dice que el quiso yue esle libro fuese la veinte y una parle verdadera de las Come. dias de Lope, que las demas que se han impreso en Sevilla, Zaragoza, Valencia y otras parles todas son de diversos poclas, y aunque eslán con su nombre no son suyas... Despues de estas saldrá tambien la parle veinle $y$ dos verdadera $y$ luego ofrezco la rega del Parnaso con otras comedias $y$ varias Rimas.

\section{Parte veintidos.}

Ventidos Parte perfeta de las Comedias Del Fenix de España Frey Lope Felix de Vega Carpio,... sacadas de svs verdaderos originales, no adulteradas como las que hasta aqui han salido. Madrid, Viuda de luan Gonçalez, $16303.40^{\circ} 4$ hojas prels. y 251 foliadas.

Primera y única edicion de este tomo que es el término de la série de la verdadera coleccion.

La dedicaloria de la Parte ventidos está suserita por Luis de Usátegui, yerno de lope de Vega, y este pudo corregir casi todo el volúmen, habiendo quedado impreso ántes del $2 x$ de setiembre, á lo que se colige de la Fe de crratas.

Las comedias que abraza, son:

Quien todo lo quiere.

No son todos ruiseñores.

Amar, servir y esperar.

La vida de san Pedro Nolaseo.

La primera informacion.

Nadic se conoce.

La mayor vitoria.

Amar sill saber á quién.

Amor, pleito y desafio.

El labrador venturoso.

Los trabajos de Jacob, sueños hai que verdad son.

La carbonera.

Parte veynte y dos. Caragoça, Pedro Verges, $1630.4 .^{\circ} 4$ hojas preliminarcs, 20̈1 fols. y una para repetir la fecha.

Mi ejemplar está falto de varias hojas al principio $\mathrm{y}$ al fin; pero el tomo debe comprender las comedias siguientes:

Nunca mucho costó poco.

Di mentira sacarás verdad.

La carbonera.

La amistad y obligacion.

La verdad sospechosa, y por otro título, el Mentiroso.
Ouien bien ama tarde olvida.

Amar sin saber á quién.

El marques de las Navas.

Lo que ha de ser.

La lealtad en el agravio.

En los indicios la culpa.

La intencion castigada.

Este volúmen debiera más bien llamarse de diversos, pues contiene dos comedias de Lope, reproducidas más exactamente por la edicion de Madrid de 1635, seis del mismo, que no se hallan en ninguna de las Partes; Nunca mucho costo poco y La verdad sospechosa, que son de Alarcon, aunque la primera lleva el título de Los pechos privilegiados en la Parte ll. de este autor; Dí mentira, sacarás verdad, es de Matías de los Reyes, segun Ảlvarez y Baena y el Indice general de Comedias, y El marques de las Navas se publicó á nombre de lira de Amescua en el tom. VIII. de la Coleccion antiqua de comedias en 48 tomos en $40^{\circ}$ Indudablemente esta es una de las partes espurias á las cuales so reflere ortiz de Villena en el prólogo de la XXI.-Segun Barrera y Leirado, refiriéndose á Fajardo, hai otra parte veintidos impresa en Zaragoza, 1636; pero no sabemos si su contenido es igual al de la de Madrid de 1635 , al de la zaragozana del 30 , o bien distinto del de ambas.

\section{Parte veintitres.}

Parte veinte y tres de las Comedias de Lope Felix de Vega Carpio. Madrid, Maria de Quiñones, 1638. 4. ${ }^{\circ} 8$ hojas prels. y 304 foliadas.

Primera y única edicion.

El privilegio está concedido á Luis de Usástigui (asi se le llama), el yerno de Lope, y la dedicatoria va flrmada por Manuel de Faria y Sousa. tes:

Componen esta Parte las comedias siguien-

Contra valor no hai desdicha.

Las Batuecas del duque de Alba.

Las cuentas del Gran Capitan.

El piadoso veneciano.

Porflar hasta morir.

El robo de Dina.

El saber puede dañar.

La envidia de la nobleza.

Los pleitos de Ingalaterra.

Los palacios de Galiana.

Dios hace reyes.

El saber por no saber, y vida de san Julian de Alcalá de Henares.

En el catálogo de L. Tieck citan una edlcion de esta Parte hecha en Madrid en 1634, lo que es indudablemente falso. 


\section{VEGA CARPIO (LOPE FÉLIX DE).-SUS OBRAS DRAMÁTICAS.}

\section{Parte veinticuatro.}

Parte revnte y quatro. Madrid, 1640?) 4. No estoi seguro ni del título, ni del añn, pues á ni ejemplar le faltan los prels. y solo llega al fol. 132.

Abraza estas comedias, segun Nic. Antonio: (las marcadas con una ${ }^{*}$ están en el trozo que tengo).

* La despreciada querida.

* La industria contra el poder, y el honor contra la fuerza.

* El labrador venturoso.

* El palacio confuso.

* La porfía hasta el temor.

* El Juez de su causa.

El ingrato.

La tragedia por los zelos.

La primer culpa del hombre.

La cruz en la sepultura.

El honrado con su sangre.

El hijo sin padre.

Barrera y Leirado llama rarisima á esta Parte con mucha razon: yo no la tengi completa, y ciertamente no diria el trozo que poseo pur dos de las otras, aun cuanilo fueran de las más dificiles de encontrar. Ignoro se ha. lle en ninguna biblioteca, ni be hablado con nadie que la haya visto.

Parte veynte $y$ quatro de las Comedias del Fenix de España. Y las mejores que hasta aora han salido. Caragoça, Diego Dorner, 1633. 4. ${ }^{\circ}$ hojas prels.y 236 foliadas.

Contiene este tomo las comedias siguientes:

La lei ejecutada.

Selvas y bosques de amor.

Exámen de maridos.

El quẻ dirán.

La honra por la mujer.

El amor bando:ero.

La mayor desgracia de Cárlos $\mathrm{V}, \mathrm{g}$ hechicerías de Argel.

Ver y no creer.

Dineros son calidad.

De cuando acá nos vino.

Amor, pleito y desafío.

La mayor vitoria.

Segun Barrera y Leirado esta es segunda edicion porque supone que hai otra tambien de Zaragoza por Diego Dormer, $1632.4^{\circ}$

Ventiqratro Parte perfeta de las Comedias del Fenix de España Frey Lope Felix de Vega Carpio. Sacadas de svs verdaderos originales, no adulteradas como las que hasta aqui han salido. Zaragoza, Pcdro Verges, 1611. 4. 4 hojas prels., 239 foliadas (falta la foliatura en la última) y una blanca. tes:

Componen esta Parte las comedias siguien-

Guardar y guardarse.

La herinesa fea.

El caballero de Olmedo. Tragicomedia.

El bastardo Yludarra. Tragicomedia.

La ilustre fregona.

El nacimiento de Cristo.

Los liamirez de Arellano. Tragicomedia.

Don Gonzalo de cordova.

San Nicolas de Tolentino.

Los peligros de la ausencia.

Servir á buenos.

Barlan y Josafí.

\section{Parte veinticinco.}

Parte veintecinco, perfeta, y verdadera, de las Comedias del Fenix de España Frey Lope Felix de Vega Carpio. Sacarlas de srs rerdaderos originales, no adulteradas como las que hasta aqui se han publicado. Caaragoça, Viuda de Pedro Verges, 1617. 4. 1 hojas prels. y $30 ّ 6$ paginas.

Primera y única edicion.

Contiene las comedias que se espresan aquí:

La esclava de su galan.

El desprecio agradecido.

Las aventuras de don Juan de Alúrcos.

El magor imposible.

La nueva vitoria del marques de Santa Cruz. Tragiconedia.

Los cautivos de Argel.

Castelvines y Monteses. Tragicumedia.

l.o que ha de ser.

El uiltimo godo. Tragicomerlia.

La necedad del discreto.

El juez en su causa.

Los embustes de Fabia.

Aquí termina la llamada coleccion de las Partes de comedias de lope, y mis propiamente debe cerrar la série la veintidos de Madrid, pues lis posteriores fuernn ya espurias y formadas al cipricho de los editnies; por esta razon se elicuentran en ellas composiciones en las cuales nimguma parte tiro el Fenix de Fspaña. Sin embargo, para completar este artículo tial cual lo pueda desear el bibliufilo mis antojadizo, he puesto lus tomos 25, 2i y 25. yescribire aluunos otros que poseo o de que teugo noticia, publicados como de Lope, aunque ya se advierte en sus portadas que contienen piezas de otros in. genios. 


\section{VEGA CARPIO (Lope Félix de).-SUS OBRAS DRAMÁTICAS.}

Parte veintiseis.

No la tengo. El S.r Barrera y Leirado supone ser de Zaragoza, $1640.4^{\circ}$ si bien cree que su fecha es de 1632 ó 33. ('V. su Catálogo, pág. 682.)

\section{Parte veintisiete.}

\author{
Es de Barcelona, $1633.4^{\circ}{ }^{\circ}$ segun \\ Barrera.
}

\section{Tengo de ella}

El sastre del Campillo. . . fols. $59-62$

Alli darús rayo. ..... fols. 65- 80

Julian liomero. ...... fuls. 101-122

Eu la biblioteca del duque de osuna vi de. la Inisma larte:

Lanza por lanza de Luis Almanza. fols. 21 - 38 La selva confusa. . . . . . . fols. 81-100 Los Värgas de Castilla. . . . . fols. 125-146

Y Barrera trae ademas como del mismo tollo

El méalico de su honra.

Los milayros del iesprecio.

Por la pacmle, Jumina.

El gran cardenal de Esprina D. Gil de Albornoz. Primera y Segunda parle.

El infanzon de Illéscas.

Zelos con sclus se curin.

\section{Parte veintiocho.}

Debe ser de Zaragoza, 1639. $4^{\circ}$ No la tengo. El S.r Barrera describe su contenido en la pág. 683 de su $C a-$ tálogo.

\section{Parte veintinueve.}

Doce comedias de Lope de Vega Carpio, (y otros autores.) Parte veinte y nueve. En IIuesca, por Pedro Bluson. Año 1634. 4. ${ }^{\circ}$ No la tengo; pero la cita Barrera y Leirado (V. su Catálogo, pág. 683).

No encuentro en ningun hibliografo indicacion de más lartes de Lupe que lleven espresa numeracion de orden; daré sin em. hario lit descripcinn de piezas sueltas que tengr $\dot{0}$ he visto, las cuales evidentemente pertenecen á tomos de comedias; pero ignoro si se componian únicamente de las de este autor 0 de varios.
La estrella de Sevilla.. . . fols. 99-120

La paloma de Toledo.... fols. 121-140

Amar como se ha de amar. fols. 214-233

La primera de estas dos piezas es rarísima; más tarde se publicó refundida con el título de Sanchn Ortiz de las Roelas. No puedo encontrarla bajo ninguno de estos dos títulos en el Indice de Barrera, y causa tanta estrañeza semejante omision que me inclino á creer es torpeza mia el no poder dar con ella.

Zelos con zelos se curan.

Está á nombre de Lope, á pesar de ser de Tirso, en una edicion antigua perteneciente á una Parte, que no conozco, y la precedia Por la puente Juana. No tiene foliacion $\mathrm{y}$ va desde la sign. C3 hasta la sesta de la $E$.

Lo cierlo por lo dudoso. Brusselas en casa de Huberto Antonio Velpio, 1649. 4. ${ }^{\circ}$ De 14 paigs.

De cosirio á cosario. Ibid. 1649. De 45 páginas y una hoja blanca.

Del mal lo menos. Ibid. 1649. De 48 págs.

Qverer la propia desdicha. Ibid. 1649. De 44 págs.

El vaquero de Morana. Ibid. 1651. De 48 paigs. La vengadora de las mvgeres Ibid. 1649. De 4 pãgs.

Aunque estas seis comedias impresas por Velpio, lleven cada una su portada y paginacion peculiar, parecen destinadas a formar "u volümen de comedias de Lope. No mencinna estas ediciones el Sr. Barrera.

Pondré aquí por remate las noticias que he recogido de la existencia de tomos diferentes de los que anteccden mencionados.

En la biblioteca del duque de osuna hai los siguientes fragmentos de algunas Partes, distintas de todas las descritas hasta aqui, $\mathbf{y}$ son:

Un trozo de un volúmen que principia al folio 95 y llega al 145 , que contiene: $E l$ Conde $D$. Pedro velez y Forluna adversa del infante D. Fernando de Portugal.

otro trozo desde el fol. 171 al 270 , com. prende: Nuestra Sra. de la Peña de Francia. - Leon aposlólico y cautivn coronado.-El esclavo fingido.-Don Manuel de Sosa y nuufragio prodigioso y El príncipe lrocado.

otro trozo al que apénas se le ve la foliacion por eslar borrada; parece ser desde el folio $176 \dot{o} 177$ al $203 \dot{0} 204, y$ contiene $L a$ vicloria de la honra y el principio del Piadoso aragones.

otro fragmento cuya foliacion no se distingue, y es la comedia El Prodigio de Eliopia.

Y por último los folios 315 á 400 de un tomo, que conlienen Fernan Méndez Pinlo. Primera parte, á nombre de Lope en el título y al de Gómez en las cabezas de las págs., y Peregrinaciones de Fernan Méndez Pinto. Segunda parle, de D. Antonio Enríquez Gómez. 


\section{VEGA CARPIO (LOPE FÉlIX DE).-SUS OBRAS DRAMÁTICAS.}

La coleccion de comedias de este autor debe terminar con los dos volúmenes que se ponen à conlinuacion:

1470 La Yega del Parnaso. Por el Fenix de España Frey Lope Felix de Vega Carpio. Madrid, Imprenta del leyno, 1637. 4. ${ }^{\circ}$ i hojas prels., y 292 foliadas.

Ademas de varias poesias, contiene estas comedias:

El guante de doña Blanca.

La mayor virtud de un rei.

Las bizarrías de Belisa.

Porflando vence Ainor.

El desprecio agradecido.

El Anor enamorado.

La mavor vitoria de Alemania de don Gon. zalo de Cordova.

Si no vieran las mujeres.

Diálogo militar. Pieza representable en un acto.

Este tomo se balla reimpreso en los $1 \mathbf{x}$. Y X. de la Coleccion de obras suellas de Lope.

1471 - Fama posthrma a la vida y mrerte del Doctor Frey Lope Felix de Vega Carpio. Y elogios panejiricos a la inmortalidad de $s r$ nombrę. Escritos por los mas esclarecidos Ingenios. Solicitados por el Doctor Iran Perez de Montalran. Madrid, Imprenta del Rerno, 1636. 4. 12 hojas prels., 211 foliadas Cla uiltima dice 2:31 por errala) y una al fin en que se repiten las señas de la edicion.

Este volumen, que es un verdatero Canciouern, por reunir enmposiciones de los mejores poetas de aquella epoea cn elosrio de Lope de Vega, acaba con ina councdia cuyo titulo es Honras a lope de lega en el l'urna. so. Puede agregarse á este tomo la

1472 - Oracion frneral panejirica... (en) las Piadosas Grandes Exeqvias... de Lope Felix de Vega Carpio. Dixola el P. Maestro Fr. I nacio de Vitoria. Madrid, Imprenta del Reyno, M.Dc.xxxy. 4. 4 hojas prels., Ė foliadas y una blanca.

Con mayor fundamento debe formar parte de esta Coleccion cl tomo, que he visto ylle. va el título de

Ficstas del Santissimo Sacramento, repartidas en do:e avlos Sacramentales, con sus
Lous, y Entremeses, Compuestas por el Phenix de Esprña Frey Lope Fclix de Vega Carpio; recogidas por el lic. Ioseph Orliz de Villena. Caragoça, Pedro Verges, M.DC.XXXXIIII. $40^{\circ} 4$ hinjas prels. y 142 fols.

La edicion de Madrid del mismo año, que menciona Vic. Antonio, debe ser la primera.

Hillase reimpreso este rarisimo tomo en el Xlill. de la Coleccion de olras suellas de este autor.

Conticne los dramas que vall aqui espresados:

\section{Autos.}

El nombre de Jesus.

El heredero del ciclo.

Los acreedores del hombre.

Del pan y del palo.

El nisacantano.

Las arenturas del hombre.

La siega.

El pastor lobo.

La vuelta de Egipto.

El Xiño pastor.

I.os cantares.

I. a puente del mundo.

El letrado.

\section{Entrenieses.}

El soliadillo.

El poeta.

El robn de Elcna.

I.a hechizera.

El marques de Alfarache.

El degnllado.

l.a muestra de los carros.

l.osorganos.

El remediador.

[aca mi uuujer.

Las comparaciones.

Contiene igmaluente doce Lous sin títul, especial.

Agut termina propiamente la Coleccion de las obras dramitieas del gran line

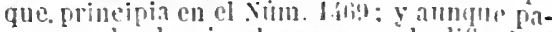
rezca redundancia el encarecer la dificullad que hai para remirla. pules harlo conocida es de todos los aficionidos á uueslros libris y literatura. quiero notar que siendo tudavia mui joven. y por ennsiguiulle algumos años dutes de haber peusado en formar mi liblioteca, me dedique il coleccionar todas las composiciouses teatrales del Woinstrun de lin noturaleza, Y despues de muplear curerenta años "n recoger todo lo relativo á nui propesito, viajando unuebo y gastando sobre rino pesos fucrtes. aun no he logrado posear la sirie completa y en un estado de conservacion perfecto é intachable: sill embargo, puedo ramaghlnriarue le que es la que mayor niunero de Folumenes y ediciones diversas remne, y la más bella ý bien tratada de cuantas he visto en liblintecas publicas y particulares, deutro y fuera de España. 
Hista mafabética de varias comedias yne tengo, publleadas como de Lope, y no se hallan en los tomos que preceden descritos.

Animal (El) Profeta, san Julian. 4. (Edicion de fines del siglo XVIII.)

Anticristo (El).

Bella (La) Andrómeda. Tragiconedia. (Ediciun anligua.)

Boba (Li) discreta. (Edicion del siglo XVIII.)

Burlas (Las) veras. (Ellicion antigna.)

Caballo (EI) vos han muerto. (Édicion anligua.)

Capilan (El) Belisario. (Edicion anligna que ller'a al fin el enlremes de El Médico del tabaco, sin nombre de autor.)

Cerco (El) de Vicna por Cárlos V́. (Edicion anliqua.)

Ciudind (La) sin Dios. (Edicion antigua.)

Defensa (La) en la verdad. (Edicion anligua.)

Desprecios (Les) en quien ama. (Edicion antiguta.)

Discreta (La) enamorada. (En la Parle III. de la Coleccion antigua de comedias.

boncellas (Las de Simúncas. (Elicion de mediados del siglo . XIII.)

Engañar á quien engaña. (Edicion antigua.)

Fernan Véndez Pinto. Segunda parle. (Edicion antigua.)

Fianza (La) salisfecha. (Edicion antigut.)

Guerras de amor y de honor. (Edicion antigua.)

Hermanos (Los' bandoleros. (Elicion antigua.) Infanzon (EI) de Illescas.

Juventud (La) de S. Isidro. En la Relacion de las flestas á su canonizacion. Vadrid, 1622. $4 .^{\circ}$ al fol. 19. La precede ma Loa.)

Labrador (El) de Túrmes. Elicion antigna.)

Lacayo (El) fingido. (En ol tomo en $\mathrm{s}$. $^{\circ}$ intilulado: Cuatro comedias fimmosas.)

Lo que esti determinado. (Parle III. de la Coleccion antiuna de comedias.)

Lhave La de lil lomra. (En ta misma Parle.)

Maestro 'El de damzar. (En la misma Parte.)

Nírtires Los de IIadrid. (Eolicion antignut.)

Más pesa.el rei que la sangre. (Edicion chliquia.)

Más pricden zelos que amor. (Parle III. de lu Coleccion antigna de comedias.)

Mayor (EI) rei de los reyes. (Indice de Medel. No la tengo.)

Merced (La) en el castigo. (Edicion antigua.)

Milagro (El) por los zelos. (Edicion antigua.)

Milagros (Los) del desprecio. (Parte X. Coleccion antigua de comedias.)

Montes (Los) de Gclboé y David perseguido. (Edicion antignu.)

Mozedades Las) de Bernardo del Carpio. (Edicion antigua.)

Nacimiento (El) del alba. (Edicion antigua.)

Niñez (La) de S. Isidro, con su Loa. (En la Relacion de sus flestas ántes mencionala.)

Niñez (La) del P. Bójas. (Purle XVIII. de la Coleccion antigua de comedias.)

No liai más saber que salvarse. (Edicion anliyua.)

Novios (Los) de Ilornachuélos. (Edicion anli. gua.)
Pleito (El) por la honra. (Edicion an(igua.)

Portuguesa (La) y dicha del forastero. (Parte III. de la Coleccion antigua de comedias.)

Príncipe (El) D. Cárlos. (Edicion antigua.)

Púsoseme el sol, salione la luna. (Edicion antigua.)

San Diego de Alcalá. (En la Parle III. de la Coleceion antigua de comedias.)

Satisfacer (El) callando y princesa de los montes. (Edicion antigua.)

Sierras (Las) de Guadalupe. Edicion anligua.)

Sin lıonra no hai valentra. (Elicion antigua.)

Valiente (El) Juan de Heredia. (Edicion anligur.)

Valor, fortuna y lealtad. (Edicion antigua.)

Valor, lealtad y ventura de los Tellos de Menises. Segunda parte. Valencia, Viuda de Joseph de Orga, 1769.

Ventura (La) en la desgracia. (Purle XXVIII. de la coleccion antigua de comedias.)

ventura y atrevimiento. (Edicion antigua.)

Hist Alfanética de varlas comedias, cuyos duplicados tlenen alguna especialidad.

El acero de Madrid. Madrid, Imprenta de la Real Compañía, 18356. 4."

Antes que te cases mira lo que haces, y exámen de maridos. Madrid, MDCCCIII. $4 .^{\circ}$

Buscona (La) ó el anzuelo de Fenisa: refundida por 1). Cíndido Marla Trigueros. Madrid, $1803.4 .^{\circ}$

Creacion (La) del mundo, y primera culpa del hombre. (Edicion antiguu.)

Dama (La) melindrosa. Nadrid, (hácia el 1780). 4.

Ejemplo (El) mayor de la desdicha, y capitan Belisario. Barcelona, 1771. 4. $0^{\circ}$

Ilijo SI de los leones, comerdia de un Ingenio de lia Corte. Sevilli, Yiuda de Francisco de Leffitacl, (hácia 1780).4. (Es la que se halle en la l'arte XiX de Lope.)

Melindrosa (La), o los esclavos supnestos: refundisla por D. Cándido Marfil Trigueros. Ifadrid, $1803.4^{\circ}$

Mentiroso (El). (Edicion mui antigua.)

Moza (La) de cántaro: refundida por D. Cándido Naría Trigueros. Valencia, Joseph de Orga, 1803. 4.

Reina (La) Juana de Nápoles, y marido bien ahnrcado. (Edicion hechu hácia et 1770.) 4.

Sancho Ortiz de las Roelas, tragedia arreglada por I. Cándido Mara Trigueros. Valencia, 1818. $4^{\circ}$

Tellos (Los) de Menéses. (Primera parle.) Representóla Avendaño. (Edicion antigua.)

Gista MLARÉTica de varios antos y otras composielones dramáticas, que no están en los tomos hasta aquí niencionados.

Nacinienlo (EI) de nuestro Salvador Jesucristo. Auto. (En el tomo inlitulado Navidad $\mathrm{y}$ Corpus Christi. Madrid, 1664. pág. 346.) 
Natividad (La) de Nuestra Señora. Auto. (Ma. nuscrito en $4 .^{\circ}$ coeldneo de Lope de Yega Carpio, y que lleva su nombre.)

Príncipe (E) de la paz, y trasformaciones de Celia Del año de 1629 para las flestas de Madrid. De Lope de Vega Carpio. (Asi estó encabezado el anliguo manuscrito en $4 .^{\circ}$ que lengo en mi libreria de este Auto.)

Selva (La) sin aunor. Egloga pastoral. (Al fin del Laurel de Apolo.)

Tirano (El) castigado. Auto. (Se halla en la pag. 95 del lomo Navidad y Corpus, poco hace citado.

Yugo (El) de Cristo. (Manuscrilo en $4 .^{\circ}$ con el permiso para su representacion, dalo en Alcald el año de 16.50.)

\section{MISTA de algunas Ioas que se hallan en otros voliumenes, diversos de los hasta aqui indleados.}

Memorables (Los) hechos de los romanos. (Al fin de las Comedias porluguesas de Simaō Machado.

Titulos (Los) de las comedias. (En los Verdores del Parnaso por Armesto y Cuslio, paig. 1.a)

LOA SIN TíTULO PARTICLLAR.

Una que se halla en el fol. 211 vla. del toino dutos sacramentales, con quatro comedias nuevas etc. Madrid, 1655. $40^{\circ}$, la cual principia:

Perdiose en un monte un rei.

Otra que puso Simon Machado al fin de sus Comedius porluguesas, cuyo primer verso es:

Suclen del formado campo.

Ademas de las ediciones antiguas hasta aqui descritas, tengo de çpoca más reciente los siguientes:

1473 YEGA CARPIO (Lope FELIX UE). Coleccion de las mejores Comedias de Lope de Tega. Tonno primero. (És el único que se mublico.) Madrid (sin nombre de impresor), 1803 . 4. ${ }^{\circ}$ Fronti, 314 páginas para las 9 comedias primeras, una hoja en que se repiten el lugar, año (aquí es el 1801) y puntos de despacho del tomo, y 31 paigs. más para la última comedia.

Las diez de este tomo son:

Las bizarrías de Belisa.

Servir a luuenos.

Las doncellas de Simancas.

El molino.

I.o que ha de ser.

El perro del hortelano.

l.a arcadia.

Los locosde valencia.

El premin del bien bablar.

Obras son amores.
1474 VEGA CARPIO (LOPE Fél.IX DE). Comedias escogidas de Frey Lope Felix De Vega Carpiu. Madrid, D. M. Urtega, 1826-32. 4 vols. $8 .^{\circ}$

Contienen estas comedias:

Los milagros del desprecio.

La esclava de su tralan.

El premin del bien hablar.

El mayor imposible.

La hermusa fea.

Por la puente Jnana.

Al pasar del arroyo.

El perro del hortelano.

Jas flores de Inon Juan.

¡Si no vieran las mujeres!

la boba para los otros y discreta para sí.

Las bizarrias de Belisa.

Lo que ha de ser.

El molino.

La danta melindrosa.

los locos de Valencia.

Fstit edicion es tan mala comn incorrecta, con el notable defecto de haberse suprimido algunos pasajes por la censura. Solo debe tenerse por el Examcn que va al fin de cada comedia.

1173̈ La Dorotea, accion en prosa, de Frey Lope Felix de Vega Carpio. (Al fin:) Hadrid, en la 1 mprenta real. $1634.8 .^{\circ} 8$ hojas prols. Q2.2 fols. y una con las señas de la impresion.

Segun los editores de las obras surllas de Lope. ell cuyn tom. MIl. se reimprinini ésta produccion suya, la primera edicion se hizo cn Marliel. en la Imprenta del lieino en M.DC.X.YII. $\mathrm{s}^{\circ}$

1176 La misma olita. Madrid, Nelchor Sanchez, 1673. 8. 8 hojas preliminares. ․ㅡㄹㅡ fols. y una en que se repite el lugar y añ.

\section{7} La misma ohra. Añadidos en esla impression el Arte nuevo de hacer comedias, in Catilogo de las obras que este Autor escrivio, y otros de varios Libros de diversion. Oetara impression. Madrid, D. Pedro Joseph dlonso y Padilla, 1736. vols. $8 .^{\circ}$

1478 - Larrel de Apolo, Con Otras Rimas. Por Lope Felix de Vega Carpio. Madrid, Iuan Gonçalez, 16:30. $4{ }^{\circ} 8$ hojas prels., entre las que se cuenta un bucn retrato de Lnpe de I'ega, 123 foliulas. y una en que se repiten las señas de la impresion. 
Va al fin una égloga pastoral intitulada: La sclva sin amor, que se reprisento cantada ell presencia de S. M.; cosa mueva en Espann, como advierle el autor; ademiss se inclujo una Sili'a, una Epistola y algunos Sonetos.

El Laured de Apolo y las deunas composiciomes que le siguen st: publicaron en el tomo 1. de las Obras suellas de Lope impresas por Sancha.

1479 VEGA CARPIO (LORE FÉLIX ne). Laurel de Apolo (ut supra). Londres, Richards, 182\%. 2\%."

Fn esla reimpresion no se incluyo La Selva sill amm ni las otras poeslas que van al tln de la primera edicion.

1180 El Peregrino en sv patria De Lope de Veca Carpio. Barcelona, Sebastian de Cormellas, M. DC. V. 8. 12 hojas prels., 211 fols., 2 de poesias laudutorias y una blancu.

Conliene esta obra cuatro antos sacramenlilit's.

La primera edicion la cilan ilvarez y Batena y Brunct hecha en Sevilla, Clem. Hidalgo, $160 \%$. $4.0^{\circ}$; hai otra de Madrid del mismo año en 1..

$1 / 81-$ La misma obra. En Brrsselas, Roger Velpius, 1608. 12." 8 hojas prels., 588 pigs., la ultima sin numerar, $y 6$ hojas con los titrlos de las comedias de Lope $y$ versos laudatorios.

Esta reimpresion parece haberse lecho sobre la de Barcelona, pues time al principjo las aplubaciones diudis en apuella ciudid. para la edicion le Ibos.-Barrera trae odra edieinn de Matrid, Vinda de Alomso Jartia, 16ls. s: ${ }^{\circ}$ y en ella se adiciono el catílogn de las comedias.

1482
Tercera Impresion. Aamisma obra. corregida, con una Tabla de lo que trata. Madrid, Francisco Martinez Abad, 1733. 4." 12 hojus prelimires, una de ellas contiene un retrato de Lopie, 200 prigs. y 8 hinjas de Tabla.

Como se veri por las ediciones que he deserito de cesta obra, a la presente de $17.5 . j$ le correspouderia llimarse sista y no lercera.

l.a impresion es mala; pero mi cjemplal esta tirado en papal superior y rrande. y ast aparece í la vista mocho mejor.-Fin esti edicion se anadio mna Tabla, die las cosas y vozes más notables que contiene la obra, y lia lista de las comedias eserilas jor lope r's inuchomás completa, conıo cupiallit de la de 1618 .

El l'erefrino se inclnyí en el tom. V. de las obras suellas de esle autor.
1483 VEGA CARPIO (LOPE FÉlIX DE). Relacion De las Fiestas que la insigne Villa de Madrid hizo en la Canoniçacion de su Bienauenturado Hijo y Patron San Isidro, con las Comedias que se representaron y los Versos que en la Iusta Poetica seescriuieron. Por Lope de Vega Carpio. (Al fin:) Madrid, Villda de Alonso Nartin, 1622. 4. ${ }^{\circ} 28$ hojas prels., inclusa la portada que es grabada, y 156 foliadas.

Se reimprimió esta Relacion en el tnm. XII. de las Obras suellas de Lope de Vega.-Contiene dos comedias de cste intituladas: La niricz de S. Isidio y Juventad del mismo.

Concurrieron á la Jusla lilerarin los más dislingridos escritores de la mejor ćpoca de nuestra poesia, y es una antologla en la cual se hallan reunidos los nombres de casi todos Ios autores que florecieron á pricipios del siglo Xill, jor cuya razon daré la siguiente

\section{Lista alfabética}

\section{de rumellos ale quienes hui composiciones.}

Aibar (Doña Catalina de). I Alarcon (Doña Anlonia de.

Belmonte Bermidez (D. Luis de). I Bermidez Carvajal (Fermando). I Briviesca y ivila (1). Juan de).

Calderon y Riaño (I). Pedro). I Casanate (Don Agnstin de). I Castillo(El I)r. Felipe Bernarlo del). I Castillo solorzamo (1). Mlonso,. Castrí(D. Guillen ile). / Cullado(El Doctor). ( Cuadros (D. l)iego).

Encarnacion (Fr. Jiego de la). | Enrfquez Pesoa (Antonio).

Fernimdez de Ażara y Vírgas (D. Francisco). | Francia y Acosta (D. Francisco). | Fuente (Jerónimo de la).

Gaona (Fr. Ignacio). I Garcia Ponce éEl licencíldo Pedro). I fircía Veléndez (bil lic. l'edro). I Garte (Vicente). | Gavia Ponce (1). l'edro). I Gómez de Nora (El lic. Andres). I Gómez de Opego (D. Juan). I Gómez de Zuritil (El lic. Alonso).

Jáuregril (D. Juan de).

Lima (I). Jorge de). I López de Viga (D). Antonio). | López de Zarale (Franciseo). | Lucio Espinosa (D. Francisco). I Ludeña (D. Fernando: I lugo y liibera (l). Antonio de).

Manuel El lie. Diego). I Medrano (Schastian Franciseo de). I Mendez Testa (Franciseo Manuel). ( Mira de Amescua (El Doctor).

Navarro (El lic. Juan).

Ochna (Fr. Domingo de). I Osorio (El Macstro Juan). | Osorio de Zepeda (D. Juan).

pantaleon de Ribera (Alanasio). I l'érez de Montalvan (El lic. Juan). | l'iña (El lic. Jacinto de). I Piña (Juan de). I Ponce (Ilanuel). I Prado (Juan Francisco de). 
Quintana (El lic. Francisco).

Hasura (EI Dr. Pelayo). I Hibeiro Pegado (Alfonso). | Ribera (Atanasio Pantaleon de). Róbles (Jtrónimo de). Rodrı́guez (Fẻlix). i Rodrlguez de Monroi (D. Gaspar).

Sálas Barbadillo (D. Alonso Jeronimo). I San Cirilo (Fr. Juan de).

Silva (Diego de). I Silva (D. Fernando). I Silveira (El Dr. Miguel).

Tapia y Leiva (U. Francisco). I Tẻllez (El presentado Cabriel). | Tovar (U. Iuis de).

Ugarte y Hermosa (El Mtro. Juan). | Urbina (D. Martin).

Valencia (D. Juan de). I Várgas Machuca (Pedro). I Vega Carpio (Lope de) I Vejarano de Caravajal (U. Juan de). Vélez (Fl presentado Fr. Jerónimo). I Venégas (1). Miguel). I Villegas (D. Diego). I Vique (D. Alvaro).

Ziyas (Doña lnes). I Zepeda y Ayala (Don Luis!

\section{VÉGAS (DAMIN DE). Libro} de poesia christiana, moral, y divina. En que mry de principal intento, se trata de la Immaculada Concepcion de nuestra Señora. Compvesto por el Doctor Frey Damian Vegas. Toledo, Pedro Rodriguez, 15̈90. 8. 8 hojas prels., 503 foliadas y una al fin para repetir las señas de la impresion.

Contiene este volumen ademas de las poeslas sueltas en que hai muchos villancicos, romances, motes y glosas, un Dialogo cutre vua Donzclla Lonesta, y m Mancebo lasciuo cunante; un Colloquin entre un Alma y sus Ires potencias, y la Comedia llamada tucolit. na, o Bendicion de lruac: cuyas tres composiciones son representables.

La couluclia Jacobina mirca perfectamente la transicion que sufrio el gusto dramitico cspiñol de los tiempos de Rueda it los de Lope. Eserita hácia 15,0 y siendo su argumento religioso, participa mucho por su forna del primitivo drama; pero el hallarse dividida en tres jormadas, el tener prulogo y epilogo, el contener coros, y el estir compuesta en varias clases de metro, la liacen inui senejante á las escritas en los primeros años del siglo Xril.

No me detendré á hacer el anảlisis de esta pieza, por hallarse reimpresa con las otras dramáticas y gran parte de las poeslas, en el Rimunncero y Cancioneros sagrados, tomo X.XXl. de la Bibliołeca de autores espaìoles, publicala por M. Ribadeneira; basta decir que el frlan es sencillo y la accion marcha con bastinte desembarazo; en cuanto á la versifleacinn, en general no pasa de mediana, sin embargo de encontrarse a vezes trozos de bastante mirito.

En cllanto a la parte bibliográfica esti reputado el presente volúmen por mui raro.

\section{VELASCO (Axronio ABAD).} Aleluyas jocosas que se echaron en el templo de Apolo, a la restitucion de las Musas comicas en este tiempo de Pasqua, distribuidas en tres festivas noches. Delineadas por Don Antonio Abad Velasco. Madrid (sin nombre de impresor), 1730.8. 19 hojas prels., 148 págs.y dos hnjas de Tabla.

Contiene este volńmen las siguicntes composiciones, todas representables:

Relacion jocosa.

El duende fingido y vejete burlado. $E$.

Trova de un paso de la comedia: Vo hai amar como fingir.

Si el abad juega á los naipes, ¿no harain lo mismo lins frailes? $B$.

Relacion.

Relacion jocosa pintando una batalla.

L. a burla de los lisiados. $E$.

Paso burlesco de la comedia el besden con el desden.

Trova burlesca de una relacion de la comedia de Lorenzo me llaino.

Los bandos de Lavapies. $B$.

Relacion del desacomodado.

Paso trovado del Tercero de su afrenta.

F.l duidas por fuerza. $E$.

Fl amor es sin razon. $B$.

Relacion trovada de la comedia to hai ser padre siendo rei.

\section{VELAZQCEZ DE VELAS-} CO (Diego Alronso). El Celoso por D. Alfonso $\mathrm{Vz}$, de Velasco. Barcelona, Sebastian Cormellas, 1613. 12.0 4 hojas prels. y 13 i fols.

Comedia del ginero du la celestinn, dada á luz por primera vez con el título sisuiente:

La l.em por D. A. V. D. V. Pincimo Vi. lam, Herederos del quon racifico Poncio. E Inum baplista Picnlia rompaieros , 1002. il:." 276 pícrs. 5 . 5 hoins prels. divididns del molo siguiente: Portada, en la sermula la dedirn. toria ot llust. " Excellem. S. D. Pedro Emri-

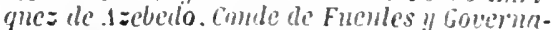
dor de Yilın y está ferbada cu dicha ciudad a 1. de Abril 16io2. por $D$. Alfonso lelazi de relasco; en la huja terceri se hallan lis Eirores de la Immoession: en la cuarta un prilingo A los lectores, I en la quinta la nolicia de los interloculore's. I.a reinpresion de Barcelona va dirigida it 1. . Iurm fermanles de Velasco Condesluble de Custilla y Lcon, Duque de Frias: Presidente del Consejo de Ilulia: su fecha Milan, a los quinze le setiembre de 1612 , por $D$. Alfonsu $r$. de relas ro. En esta dedicatoria repite varias clóusu. las de la primera, y zurce otras al principio del Prúlog, al lector. l, levande la ticion calalana una aprobacion del '?'. Fr. Thomas Roca del 20 de noviemble de dicho año 1612 , se ve que la impresion se ejcculó sin perrlidá de tiempo.

El Sr. D. Pascual de Gayíngos posee El Ccloso. Por D. Alfonso $V z$. de Velasen. A luan 
Fernandez de Velasco, Condestable de Caslilta... En Milan. Por los herederos del q. Pacifico Poneio y Ilian Baplista Picalia, compañeros, 1602. 16. - Como no me ha sido posible cotejarla con La Lena del mismo impresor y año, no puedo decir si son dos impresiones distintas ó la misma con solo la variacion del frimtis.

Ignoro de dinde se sacó Nic. Antonio llamarse el nutor del presente libro Alphonsus $V a z$ de Velasco ; verdad es que no tuvo noticia de la edicion príncipe, al fin de cuya dedicatoria se declara esto, ni logró ver la de barceloua.

Bandry, en el tom. 1. del Tesoro del tealro español, nos dio nua reimpresion de esta comealial. $y$ sin saber por qué llamó al autor 1). Alfonso Iz de Velasco: el mismo apellido le dio Velazquez, en los Origenes de la poesia, pilcima $99 . \mathrm{y}$ allf menciona ma impresion de Milan, 1612, que no he visto.

So complendo cumo han hecho todos tanta confusion en el nombre de este autor, pues en lis odas a imitacion de los siete salmos penilenciales (1. la Seccion poélica, Nimero lún se le denomina Diego Alfonso Velázquez, de belusco, y 0 . Alfonso Veláquez de relasco se firma en la dedicatoria que puso en el comenturio de la guerra de Frisa de Veringo, lechada en vápoles, 1.० de mayo, le 1610 .

1487 TELE\% DE GUEVARA (Lris). Comedias escojidas de Luis Velez dis (iverara. Tomo primero. (In salio otro.) Madrid, Ortega, 1832.8.

Edicion que solo tiene de bueno el Exdmen puesto al tim de cada comedia. El volumen ibliza estis los:

leinar despur's de morir.

El ollero de (unina.

Conselvo ma molicia ragra de que en Serilla se pulnicu en 17.50 un tomo en $4{ }^{\circ}$ con algrumis coniedias de este autor, gue suponiso serin diez ò doce, á pesar de huber escrito mis de culloncienlas, lodas ellas de pensamientos sutilis, arrojumientos poéticos, y versos escelentisimos y bi :arras, en que no admile comparacion su valiente espirilu, usando de las propias espresiunes puestas al final del l'ara tolus' de Pérez de Montalvan, juez umui abonido yenteudido en esta materia.

Fue D. Luis de Guevara padre de D. Juan escritor tambien dramático de quien hai algumas coniedias en la Colccion antigua ell 48 Volumenes, y unos Entrcmeses publicados en Madrid en 'tóf, segun Barrera.

1488 VEXCER a Marte sin Marte, Fiesta real que para celebrar la memoria de la Entrada de D. Maria Lvisa de Borbon, y sis felices bodas, representaron los estudiantes del Colegio Inmerial. Representóse Martes once de Febrero de 1681. Madrid, Iulian Paredes. S. a. $4 .^{\circ}$

Contiene la pieza intitulada: Cadmo y Har. monía, fábula, y los dos sainetes $L a$ visila de los locos.

Barrera, refiriendose á Fajardo, dice que el autor de Vencer a Marle sin Marle ó Cadmo y Armonia es el P. Pedro de Fomperosa y Quintana.

1489 VICENTE (GIL). Obras de Gil Vicente, correctas e emendadas pelo cuidado e diligencia de J. V. Barreto Feio e J. C. Monteiro. Hamburgo, Langhoff, 1834.3 vols. $8^{\circ}$ frances.

Comprende las obras dramáticas siguientes:

\section{Tomo primero.}

Auto pastoril castellano.

Auto dos Reis Magos. Castellano.

Auto da sibila Cassandra. Id.

Auto da $\mathrm{Fe}$. La Fe es el único personaje que liabla en poriugues.

Auto dos cuatro tempos. Caslellano.

Auto da Mofina Mendes.

Auto pastnril portuguez.

Auto da feira.

Auto da alma.

Auto da barca do inferno.

Auto da barca do purgatorio.

Auto da harea da gloria. Castellano.

Auto da Ilistoria de beos. Contiene un romanre en castellamo.

niálige sobre a llesurreiço.

Aut ila Canamea.

Auto de S. Itartinh. Castellano.

\section{Tomo segundo.}

Comedia de Rubena. Parte está en español. Comedia do viluvo. En castellimo.

Comedia solure a divisa dir cilade de coimbrn. Toda está cn cxpañol, menos el argnmento y el final.

Floresta de enganos. Casi loda esta comedia eslá en español.

Tragiconedias.

Dom Duardos. Española por cnlero.

Amadis de Ganla. Lo mismo.

Nas d'amores. Gran parle de ella esld en español.

Frasoa d'amor. Casi toda en castellano.

Exliortaçāo da guerra.

Templo d'Apollo. Todos los personajes hablan en español, ménos un villano.

Cortes de supiter. Solo hai un Romance en español.

Serra da Estrella.

Triampho do inverno. Lo más de ella en caslellano.

Romagem de aggravados. Remata con una Cinliga en cspañol.

Tomo tercero.-Farsas.

Quem tem farelos. El criado Ordonho habla en español. 
Auto da India. El Castethano habla siempre en su lengua.

Auto da faina. Tambien hai un Caslelhano que nunca olvida su lengia.

o Velho da horta. Hai un cunlar en esprñol.

Auto das fadas. Uno de los dos frailes hablic el castellano.

Inez Pereira. Un ermilaño que se introduce hácin el fin, habla en español.

o Juiz da Beira. Hai un zapalero que se produce siempre en español.

as ciganas. Toda eslá en castellano, como ln hablaban tos gilanos y gilmas de aquel liempo procedentes de Custilla.

os Alnocreves.

0 clerigo da Beira.

Auto da Lusitania. Vémus, Verecinta y Jumo representan en español, y tambien hai algunas Cantigas en est' lengua.

os fisicos. El Clérign, Meslie Altrique y ol Confesor hablan et castellano.

Poesias en varios metros. Algunas están en cuslellano.

La primera edicion, si hemos de dar crèdito al Prologo de la de 1854, se intitula : Copilaçam de toulalas obras de Gil bicente, a qual se reparte cm cinco livrns. 0 primeiro he de todas suas obras de detaçam. o segundo as Comedias. O terceion as Tragicomedias. 0 guarto as Farças. No quinlo as obras meudas. Lisboa, Joäo Alt'ares, 1562 . Fol. todo de letra gót. mẻnos los argumentos. Yo tengo una breve apuntacion tomada de un ejemplar que vi, no me acuerdo dinde, $\$$ soln dice: Obras de Gil Vicente. Lixboa, loain $A l$ varez, M.D.LXII. Fol. let. göt. 4 hojis prels. $y$ CCLXII foliadas.

Gallardo dice en El Criticon, nüm. 4́. pîgina .5 , que segun algunos el hijo de (iil vicente, luis, las habia publicado sa en 1557. Moratin lo da como positiro.

En la segunda edicion, siempre segun la de $1 \$ \tilde{3} 4$, se advierte que Vom ememelndns peln Sancto officio, como se manla no Cathalogn deste Regmo. Lisbon, Andre Lobuto, 1585. i. (Brunet y Gallardo dicen 1586.)

Las ediciones antiguas son mui raras $\mathrm{y}$ lo es bastante la de Hamburgo, por haber destruido un incendio la mayor parte de los ejemplares.

Es mui estraño que tanto lns editores de la impresion de 1834 , como cuantos han escrito la biografia de Gil vicente, ignoren dinde nació, $y$ supongan fueron sus padres personas ilustres, cuando en el Azto da Lusitania dice el Licenceado, argumentador da obra:

Gil Vicente o aulor me f's seu embaixador, mas eu lenho un menoria que para läo alta historia Naceo mi baixo doutor.

Creio que he da Pederneira neto d hum tamlorile iro, sua mae era parteira c seu pac era albardeiro.

D. Idolfo de Castro ya hizo esta observacion en las Notas al Buscapié.
Bōhl de Faber reimprimló en el Teatro español anlerior d Lope de Vega, ocho de las piezas dramáticas, escritas en castellano, que se encuentran en estas Obras.

1490 VICENTE (GIL). Avto da Donzela da Torre chamado, do Fidaligo Portuguez. (Sigue una laminita de madera que representa dos hombres, una torre y un arbol.) Auto feito por Gil Vicente da Torre, no qual se representa que andando hü Fidalgo perdido num deserto achou hūa Donzella fechada nunia lorre, a qual tirou có hĩa corda que tomrou a hum Pastor, \& despois vem hum Castellhano, que atinlia fechada, ¿ foy a poz o Fidalgo. \& ficou o Castelliano vencido. Em Lishoa, por Antonio Aluarez. Anno 1632. $4 .^{\circ} 8$ lojas signatura A. En el recerso de la villima hoja hai varias figuritas grabadas en madera.

Rarisimo.-Los persnnajes hablan en castellano, minos el Fidalgo que lo hace en portugues.

To puedu dar con esta composicion de Gil Vicente en la edicion de sus obras lurcha en Hamburgo, copiada de la primera de 1.502 , a pesar de suponer barrera que esta pieza se halla en ella.-Sin embargo de intitularse Auto. es una verdadera Fursa.

Barbosa Vachado describe un ejemplar impresi) en el año de 1643 .

1191 - Iviz da Beyra. Sigue una lamina de madera que representa cuatro figmitus.): Auto ferto jor Gil Vicente, Representado a muito poderoso Rey Dom Ioão em Almeyrin. Em que entrito as figuras seruintes. Ilum Iuiz da Beyra. hum Porteiro, hum Ferrevro, \& hĩa velha por nome Inna Dias, Calcado velho, hĩ escudeiro, hü mogo \& assi rem quatro irmāos demandando hum asno, que ficou. de sen pay. He obra mui graciosa. Em Lisboa, por Intonio Aluarez, 1613. . $^{\circ} 8$ hojas sign. $\mathbf{A}$.

\section{Snmamente raro.}

Este auto ó mejor dicho farsa, dinnde hai un personaje que habla ell castellano, se ha. lla en las olinas de cill vicente: pero la edicion arriba deserita conticne mumernsas va. riantes y algunas adiciones. Barbosa Machado cita una edicion de 16.50 , y la de 161 j contiene un permisn para sil impresion fechado en 1619 , lo enal pricba que Isai edicio. nes sueltas anteriores a aquellas dos. 
556

VILL

SECCION DRAMATICA.

VILL

1492 VILlaLOBOS (Francisco $\mid$ colorado, es una imitacion de la oriDE). (La siguiente portada de negroy $\mid$ ginal:)

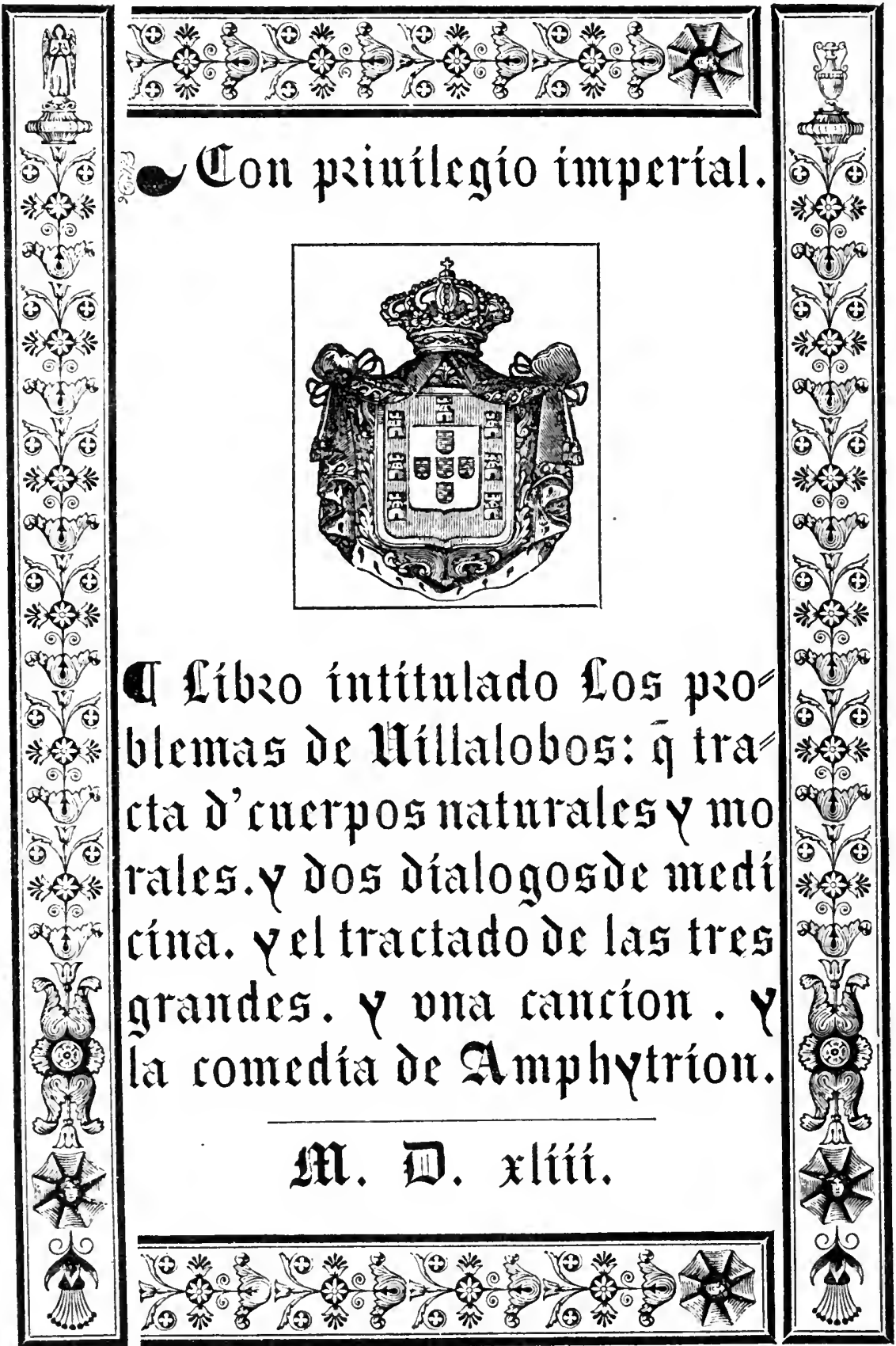




\title{
T fae impzeflo el pzefëte libzo d'l doctoz Hillalobos. Conuiene faber los p 20
}

\author{
Hemas. W los dialogos. "l cl traclado J' las tres grandes. "y la comedia de Amphytri \\ on - Araduso el ذicho ancto:ecrla magnifica/noble/y antiquiffima ciudad J' Eamo \\ ra. Ho: el honrrado varō Juan picardo imp:effo: de litros vejino d’ la dicha \\ ciudad.A colla y efpenfas del virtnofo varon Juan pedro maffetti mer \\ cader de libsos:vesino de fflledina Jel säpo. Accobofe a nueue di \\ as iel mes it febero. Ano delnafcimiéto d' nueftro falua \\ do: Jefu ch:ifto ذe.Atl.D.xliij.Arios.
}

Fol. let. gót. á dos cols. Tiene lxxrriii hojas foliadas en todn; pero hai tantas equioncaciones en ellas, que se hace indispensable examinar los ejemplares por las signs., para cerciorarse de si estín complelos. La hoja $7^{3}$ de la II es la portada de La comedia del Planto llamada Amphrtrion que traduzia el doctor Uillalobos. La qual gloso el en algunos passos obscuros. Agora nueuaniente impressa.

Primera edicinn, mui rara.

Brumet tomando la uoticia del catálogo de IIeber cita una edicion de Medina del Campo de 1545: probablemente no existe semejante inmresion, y el error provenuri de hiber tomado por cl lugar donde se publicu, el de la residencia del librero Iussetti, que fue el que costeo la de Zamora.

Ticknor menciona una impresion de Cura. goşa Gcorge Coci, YDILIIII. Fol., y en los A pulltes biograficos que preceden al tom. X.XIVI. de la Biblioteca de aulores españies publicada por Ribadencira, el cual lleva por título Curiosidades bibliogrdficas, se habla de otras dos hechas en 1550 , la una en Sevilla y la otra en Ziragiza.

La comedia el Anfilrion se publico sucth ántes del año 15.13. Moralin cita una edicion de Zaragoza, 1515; y una que yo vi de Alca. la, Armao guillen de brocar m. g. d. y $x v i j$ (151\%). 4. let. gót., me parece era del nismo traductor.

\section{VillalobOS (Fraxcisco} DE). Los problemas etc. (ut supra.) Sevilla, En casa de Hernando Diaz, M.D.LXXIIII. 8. 181 hojas fols. inclusos los prels. Para la comedia el Amphytrion hai nuevo frontis y nueva foliatura, que llega hasia 87, y despues una hoja en que concluye la $\mathrm{Ta}$ bla.
D. Adulfo de Castro, en las notas a su Buscapié, dice no habia podido ver la primera edicion de Zamora, y la presente de sevilla le fué del tndo desconocida.

Lns problemas estiun en mrtro.

Todos los tratados comprendilos en estr. vo. limen se reimprimieron en el tom. XIXVI., autes citada, de la Biblislecu de autores es: pañules, que se intitula: Curiosidales bibliogroficas.

A propusito de Villalobos, dare aquí la des. cripcion de uma obra de este autor bastante conocida; pero de una rareza nstranrulinaria.

La portada dice en tres renglones;

\section{El sumario dela medicina. con un tratado sobre las pe sliferas buuas.}

Al dorso principia el prohemium en latin $y$ concluye d la nitad del blanco de la hoja segundr aij, y despues se lee: El surnario dela medicina en romançe troualo por el licencurdo de lillalobos estudiante enel estudio de? Sulantica . hecho a cölemplacion del muy maqnifico y yluslre señor el marymes ile Astorga segundo al qual dize. - sigue la dedicatoria, que concluve a poco nuis de la mithd del dorso, y d continuacion: Comiença la obra trouada.- - ll dorso de la viltima hnja se lee: Fenesce el Sumario dela medecina hecho por el licéciudo lopez d' villalobns emédalo y corregido por el mismo Jmprimidn en la cibdad de Salamiaca a sus expèsas de Anlo. nio de barreda librero. Año del nascimiculo de nueslro saluador de mill.cccc.xc.t.viij (1498). Deo gracias.-Fol. letra gótica a dos colunas, menos la prosa de las dos primeras hojas. Sin foliacion con las signaturas $a-d$, la primera $y$ la última de 8 hojas y la $b$ y $c$ de 6. La obra está toda en estrofas de diez rersos de á doce sílabas con cesura en el medio. Denomina al mal venereo bubas, habla de los ercordios, y reprueba el sistema de los que curaban con azogue; pero en las dos recetas que pone despues, tambien mezcla el azogue. 
1494 VillaloN (Bacmillen).

CSítgucrelatragedia

De ftlirrha:enla qual fe recuentan

los infelices amozes $\bar{y}$ ono só

el rey Bintray fn padre. Có puefta pozel Barliller

Uillalon: dirigida al

licenciado Diego

fltartine; fin

may grall"

de anlii

go.

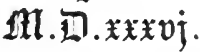

(Esta portada ra rodeada por una orla llena de figuritas en todos los cuatro lados. Al dnrso: Carta del auctor dirigida al licēciado Diego martinez sı muy grã señor y amigno. En la paigina siguiente sign. Aij, princepia: C Siguese la historia etc. y al dorso de la sesla hoja de la sign. B se lee:) C Fenesce la Tragedia de Mirrha: enla qual se recuentan los infelices antores que ouo con el Sey (sic) Ziniras su padre.

\section{Ofme impzefo en flledina del campo poz $\mathrm{j}^{\circ}$ dro Tonanis.}

4. ${ }^{\circ}$ let. gót. Sin folincion y con las signs. A de $\mathbf{8}$ hojas y $\mathbf{B}$ de 6 .

Nic. Antonio no tuvo noticia de este rarí. simo libro, y en un artículo que trae de Anonymus Villalon solo menciona Gramimali. ca caslellana. Anveres, Guillemo Simon, 1558. $8^{\circ}$

He colocado esta obra en la presente seccion porque Barrera le da lugar en sul Catálogo dramático; sin embargo, no encuentro sea otra cosa sino una novela dialogada, tomada del libro $\mathbf{X}$ de las Nelamórfosis de ovidio.

En e! Museo británico existe ntra obra in. titulada: Ingeniosa cōparacio entre lo antigno y lo presenle. Hecha por el Bachiller Villaló... Año M.D.XXXIX... E impressa por maestre Nicholas tyerri impresor è la muy noble villa de Valladolid. Acabose a q'nze de Enero. El Sr. Cañete que la cila, no dice cuál es su lamaño ni su tipo.

\section{9o VILLAMEDIANA EL CoN-} DE DE). Obras de Don Ivan de Tarsis Conde de Villamediana. Recogidas por el Licenciado Dionisio Ilipolito de los Valles. Caragoça, Iuan de Lanaja y Quartanet, 1629 . $10^{\circ} 4$ hojas prels. y 403 págs.

En el nuiur. 2245 de muestro Catálogo de Lóndres se anuncio esta cdicion como hecha en Madrid, chya equivocacion ha dado lugar á que Brunel y el sr. de Barrera hayan creido en la existencia de semejante impresion. Qneda pues sentado ser la zaragozana la primera y acaso la única hecha en $\mathbf{1 6 2 9}$, porque me parece dudoso haya otra de Alcald del mismo año, segun pretende Barbosa.

En el niim. 2245 del citado Catálngo tambien hallo una edicion de Madrid, 1634. iPero 110 podria ser este otro error en los dos últimos grlarismos de la fecha, debiendo leerse I6 35 ? Ilago "'stil observación por encontrar mui estraordinario nl que se publicasell dos rdiciones en Madrid eu dos años comsermliros: gue se llama seqmalre la de I6.5 cuande se advierte en ella que la primera es la de Zaragoza; y sobre todo el decir mi padre en sus apuntes manuscritos que diclia elicion de l6jón está ejecutada por Diego Diaz de la Carrera, quien efectivamente. pullici una en 1645, como dire luego. l'ongo, lunes, lambien en duda la edicion de 16.5 y las de Zuragoza y Alcala de este mis. mo año de que hablan Antonio y Barbosa en sus Bibliolhecas.

$1 / 396$ La misma obra. Añadido en esta segunda Impression. Madrid, Maria de Quiñones, M.DC.XXXV. 4. 9 hojas prels., incluso el fróntis grabado que precede á la portada impresa, y $\mathbf{4 3 7}$ págs.

Si existiesen las impresiones de Nadrid, Zaragoza y Alealá de 1634 no seria exacto lo de decir en la portada de la presente ser esta la segunda edicion; lo posilivo es lo de haber sido añadida, pues ademas de las pnesias sueltas, la comedia de la gloria de Yiquea, y descripcion de Aranjues, las fubuias de Faelon, Dafne y Apolo, la Fenix y la de Europa, y una Silva que compreude la de 1629, hai en la de 1655 al fin, 29 págs. de varias composiciones que no contiene aquella.

He visto la cdicion de Malrid, Diego Diaz de la Carrera , 16.43. 4..; el Sr. Barrera menciona una de Barcelona, Antonio Lacavalleria, 1648. 8..$^{\circ}$ y Ticknor (t. Ill., pág. 209) otra de Madrid. 1654. 4. 
VILL

PRIMERA DIYISION.

VILL

559

1497 VILLÉGAS SELVAGO (ALON- | so DE). (De negro y bermellon dice:)
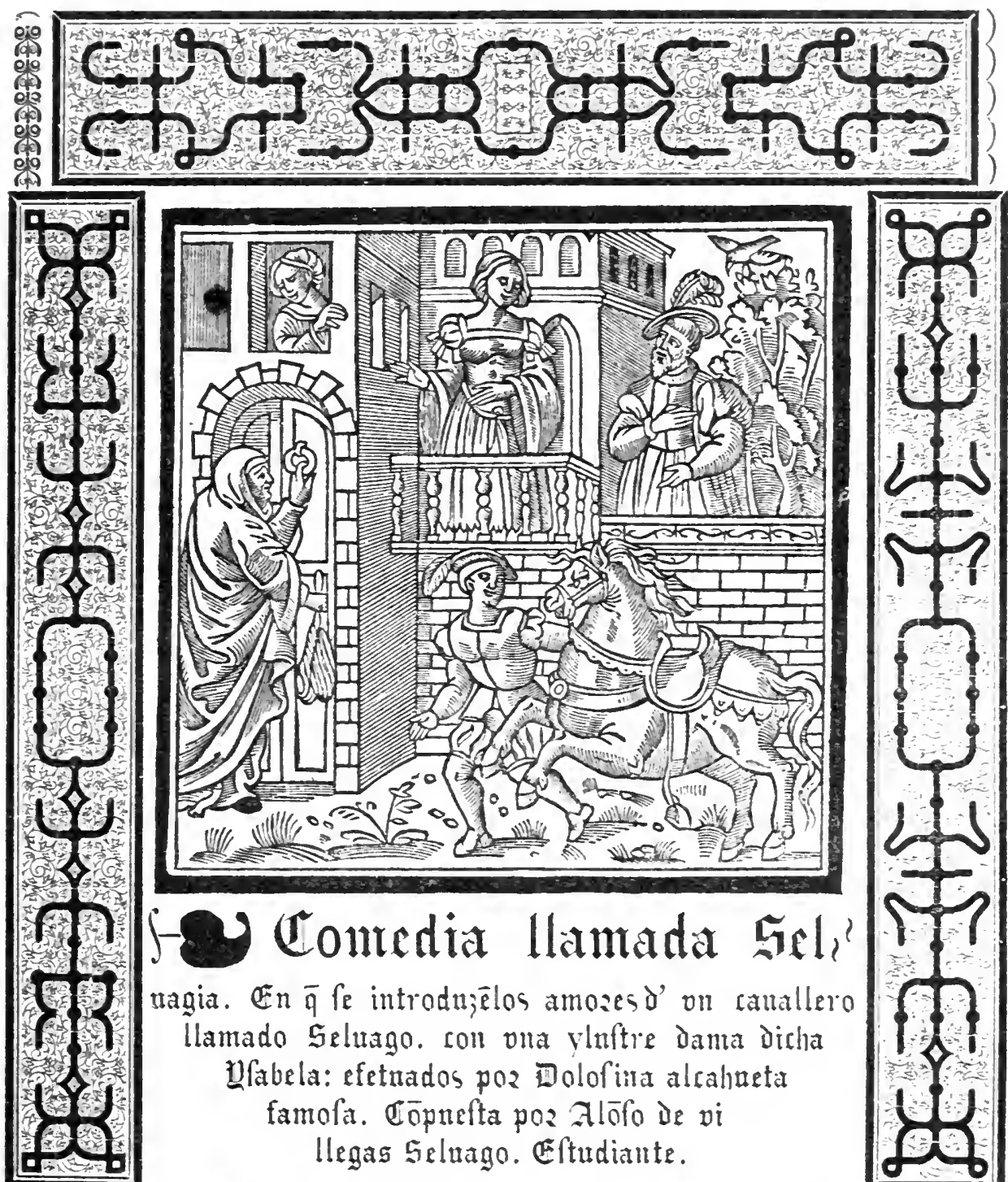

magia. En $\bar{q} f_{e}$ introdnjétos amoses d’ on cauallero Llamado Seluago. con vila ylnftre dama dicha 1) fabela: efetuados poz Dolofira alcahneta famofa. Cōpmefta pos Alōfo de vi llegas Seluago. Eftudiante.
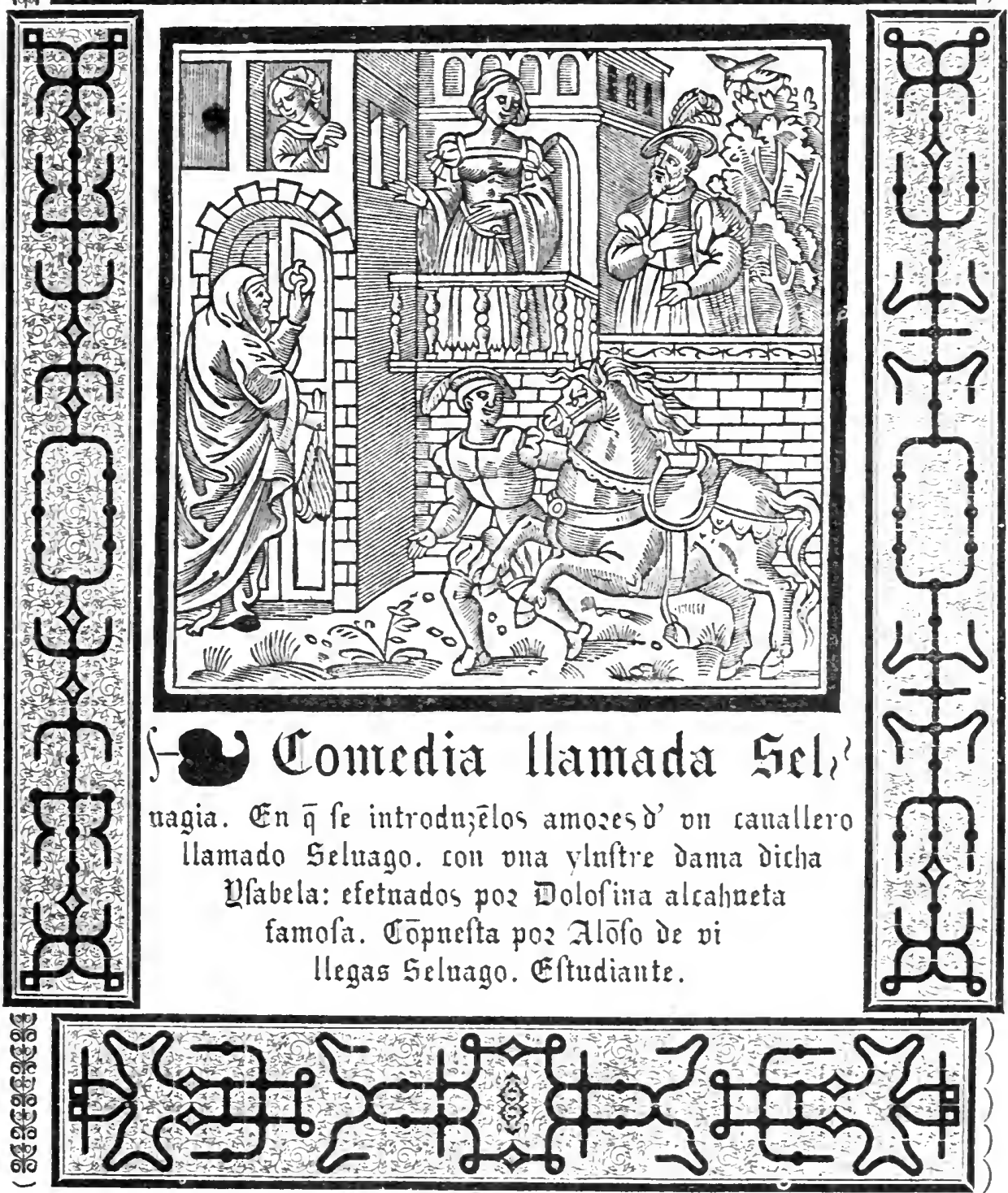

(La orla puesta aquí es diferente de | la quelleva el original.-Al fin se lee:) 


\section{Jane impacfa la paefente obza}

enl la Imperial êindad de coledo: en cafa de Joan ferrer. Acabofe a diez y feys diag del

meg. de Allayo. Año de

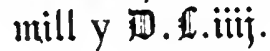

(:.)

4. ${ }^{\circ}$ let. gót. lxxuj hojas fols. en todo, aunque las dos primeras no tienen impresa la foliatura.

Antes de principiar se hallan diez y seis octavas en las que dirige el aulor su obra, las cuales contienen un acróstico que dice: Alonso de Villegas Selvago compuso la conte. dia Selragia en servicio de su semnora Ysabel de Varrionuevo siendo de edad de veynle anmos en Toledo su patria.

¡De culin distinto modo pensaba y escribia Villegas en 15\%, de lo que pensaba y escribia veinticuituo años mis tarde cuando principio it publicar su Flos sanctorum! Ouien habia de decir que cl antor de una imitacion de la Celestina, compondria algun tiempu despmes una obra que ha sido y es aun el deleite y pasto espiritual de lis personas mits misticas y timoratas!! Tal es la condicion del genero humano, y esta la carrela que remos seguil à la mayno parte: juvcutudes licenciosas y depravadas, casi de fljo nos ofrecen a la rejez los tipos del nads ciego $\dot{e}$ intolerante fanatismo religioso; observándose mis commnmente esta metamorfosis en los individuos del sexo femenino, siu duda por su debilidad ý consiguiente timidez. Verdad es que estos cambios suelen veriflcarse cuando la falta de fuerzas y atractivos físicos, hace que se busque el modo de sustituir los deleites corporales por los de la imaginacion.

Horrorizado sin duda Alonso de Villégas de su primera produccion, procuri durante los últimos años de sı vida, segun loos lo dice D. Nicolas Antonio (quien no connció la fecha de esta ubra), recoger y destruir cuan. tos ejemplares le vinieron á las manos de la Selvagia, y á esto se debe indudablemente el que sea hoi una de las comedias más raras de nuestro antiguo teatro.

Como Moratili no conoció la Selvagia, que aunque algo larga es representable por sus dimensiones, me estenderé algo mís en describirla : está en prosa intercalada de algun pequeño trozo de poesia; se halla dividida en cinco actos y estos en cenas ó escenas, y el argumento es el siguicnte, copiado al pié de la letra del que el autor lc puso al principio:

"Un caballero llamado Flerinardo, genero"si) y de abundante patrimonio, vino de la "Nueva España en esta cibdad, donde un dia upor clla ruando, como acaso pasase por easa wde un caballero anciano llamado Polibio, de. „una fenestra della vido o fermosa doncella »de la cual escesivamente fué enamorado: "pues como le fue dicho el tal Polibio tener "una mui apucsta hija cuyo nombre era Isasbela, y la tal femestra fuese de su aposento, „creycndo ser la mesma Isabela la que vistó "habia, por caballero de su amor se intitula„ba. Donlle dando parte á un gran amign sı"yo, caballero de ilustre prosapia, llamado "Selvigo, de su crecida pena, sueedió que el mmesmio Selvago teniendo deseo de ver quicin mí su amigo tan subjecto y captivo tenia, "cumpliendo un dia su propósito y viéndola, "no puliendo su libertad someter á lo que á nla verdadem amistad de Flerimardo debia, "grandes cuitas y mortales deseos á su causa "p.tesce, tanto que fuc puesto en grave en. "fermedad. l'ues veniendo su grim amigo "Flerinardo en presencia de su hermana. „losiana llamida, á visitarle conociu que "la tal Rosiana era la que en la fenestra de "P'olilio habia visto y no Isabela como se "pensaba; porque acas!) como hubiese amisntad cutre las dos doncellas aquel dia se hambien juntas recreado; lo cual como a Scl"vago fuese dicho, con escesivo placer, "porque abiertamente osaria anuar á Isabela, „de su tan grave enfermedal fué sano: donde "poniendo en el negocio una vicja astuta, "cuyo nombre era Dolosina, cumplieron ennteramente sus deseos, siendo primero des"posados por palabra de futuro, lo que de "á voco con licencia de sus padres se puso "por obra, pasando lo mesmo de Flerinardo „con Rosiana. Pues estando cl dia que las mbodas se solemnizaban con gran rcgocijo, wvino un macstro de la Nueva España, que nhabia sido de Flerinardo, el cual declaro "cómo el mesmo Flerinardo era hijo único »de Polibio, padre tambien de Isabela, que wde chico con un tio suyo en aquellas tieruras se habia partido: con las cuales nucvas stodos mui gozosos, quedando dos hermanos "con dos hermanas juntos en matrimonio, "se dari fin á la comedia."

El Sr. Barrera y Lcirado no vió sin duda ningun ejcmplar impreso de esta pieza, pues nos da de clla una descripcion bibliografica mui mezquina.

1498 ViñertTa (Tomas DE). El nuevo Sol de la Francia. Relacion de las solemnes fiestas, que celebró el 
Colegio imperial de la Compañía de Jesus en la Canonizacion de S. Juan Francisco Regis. Escrivióla Don Thomas de Biñerta. Madrid, Herederos de Francisco del Hierro, M.DCC.XXXVIII. $4 .^{\circ} 6$ hojas preliminares, 108 págs. para la descripcion. de las liestas, 132 para varios poemas y 232 para algunos sermones.

Contiene poesias de diferentes autores al parecer ; aunque anúnimas.

Lo que se intitulan Poemas varios y ocupan 152 pígs., son cuatro zarzuelitas ü operetas que se recitaron y cantaron con motivo de estas flestas. Es mui estraño que el Sr. Barrera no mencione á Tomas de Viñerta ni á su obra, á pesar de pertenecer tan de lleno á la bibliografía dramítica.

\section{Virues (Cristóval de).}

O B R A S

\section{TRAGICAS Y LIR I C A S D E L CA PIT A N CRIS- toual de Viruês.}

Las Tragedias que cn este libro fe contienen, fe veran on la boja Siguiente.
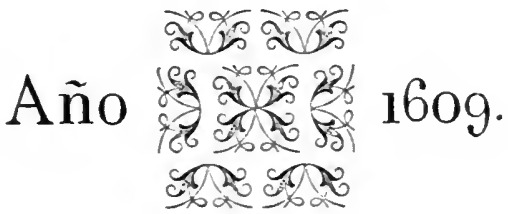

CON PRIVILEGIO.

En Madrid. Por Alonfo Martin.

A cofla de Efleuan Bogia, Mercader de Libros.
8. 8 hnjas prels., 277 rdice 278 por errata) foliadas y una blanca.

Comprende estas cinco tragedias:

La gran Semíramis.

La crilel Casandra.

Atila furioso.

La infelize Viarcela.

Elisa Dido.

Las obras líricas principian al fol. 204.

Nic. Antonio, Montiano y Luyando, Velázquez, Kodríguez, Jimeno, Fuster, Moratin, böhl de Faber, Ticknor y Barrera y Leirado, citan esta edicion como la primera y única de las Obras trd́gicas y líricas de Virues; sin cmbargo, sospecho debe haber otra de vilan hecha en el año 16040 poco despues, porque preceden á la de Madrid una Aprovecion Y Licencia fechadas en aquella ciudad en dicho año.-Rarísina debe ser la impresion milanesa, si existe; pero no le va en zaga la madrileña.

vic. Antonio $y$ Jimeno se equivocan en suponer que el impresor de la edicion de 1609 se llamaba Luis Martin.

Dice Virues en el Prologo que precede á la primera pieza del volúmen de sus obras.

Hoi en su traje trdgico se ofrece La vida y muerle de la gran Semíramis, Tirana reina de la gran Asiria; Y soiamente, porque importa, advierlo Que esta tragedia con estilo nuevo Que ella introduce, viene en tres jornadas, Que suceden en tiempos diferentes.

La misma innovacion pretende Cervintes haber hecho él por vez primera, y bai quien supone les precedió Rei de Artieda. Sin embargo la tragedia intitulada $L o S$ amantes, única composicion drannítica conocida de este autor, está en cuatro actos.

yi compatriota Virues fué uno de los poetas más sobresalientes de su tiempo: al hablar del Monservate, en el Nim. 1078 del presente Catílogo, copio el elogio que le tributó Cervíntes: aquí trascribire el de Lope de Vega en su Laurel de Apolo:

En la hermosa ciudad que baña el Turia, Esta memoria finebre y glorinsa Al cupitan Virues hicier'a injuria, o ingenio singular! en paz reposa, A quien las musas cómicas debieron Los mejores principios que turieron. Celebradus tragedius escribiste, Sacro parnaso d Monserrate hiciste, Escribiendo en la guerra aquella suma, Tomando ya la espada ya la pluma. 
1300 ZAMIOR.I (Axtosio IDE). Comedias de Don Antonio de Zamora. Maldrid, Joanuin Sinnche\%, 1714. 2 vols. 4. " lil printero de 1 to hojas preliminares ila villima blancas y $\mathbf{3 9}$ paiys., y el segundo de 2 hoijas prels. y 370 prigs. con ma hoja blanca por remale.

E.jemplar intonso.

El tomo primero abraza estas comedias:

Tolo lo vence amor.

Mazalliegos y Mlumsalves.

El hechizido por fuerzat.

f.l ellstodio de la Ilmurria, sill Juan Capistrallo.

La Poncella de orlears.

Aspides hai basiliseos. $Z$.

Jidis lscariote.

Pur oir misa y dar cebsada, mune'a se perdic jortualia.

Siempre hai que cnvidiar amandi.

En el segundo se hallin estas othils:

Amar es saher remer, $y$ el arte cuntril d joler.

Viento es la dichal de imor. Zatrande mixica.

Duendes son lis allahuctes, y el espritutu foldo. Irrimere parle.

_- Semumb parte.

El Juzero de Viddid sill Isidro I.abrador.

So hai lenlla que no se pagrle, I' conridado de piedra.

Carla uno es limajr aparte, y los Vazas de Aramon.

Ser flno y no parecerto.

El editor D. Felipe Medrano ofrece en el priblozo del primer tomo, publicar uno de Poesíns liricas de Zamora, que no llegó a salir á lız.

1 0̆01 Comedias escojidas (de)

Don Intonio le Zamora. Madrid, Ortega, 18:32. $8 .^{\circ}$

Comprende las cuatro siguientes con un breve Examen al fin de cada una:

El hechizido por fucrza.

El convidado de piedri.

No hai mal que por bien no venga.

Mazariegos y Monsalves.
El Sr. Barrera y Leirado labbla de las Comedia: mervas, com los mismos Sammele's con que se cxecularmin assi ene colliseo del Silio

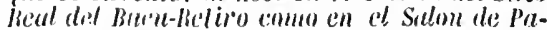
lacio y Tentros de Maltrid . Escriatiolas don An/onio de Zetmor'a... Tomo prime'o. Madrid, Diego Murlinez Abad, 1720. 4. '0 Segun su deseripcinn este volumen contiene lis mismas connedias que el primero de 17.1, ménos Por sir misa y dar cebudu nunca se perdió jormada; pero en ćmbio todas las piezas llevan entremes y baile suprimidos en la edicion mis moderna. El citado St. Barrera supone: que sulo se imprinio entonees dicho Lonl. I. no biabiéndose diado í luz el II. hissta 17íi: me pilreec no debe ser eierto, y me induce il ereerlo así el tener yo mat impresion de lis dos partes de la comedia Duendes son los alcrathutes, y el espirilu folelo, ma de lias del indicido segundo tomo, la eual primeifia o la pig. 95 y concluye en lis 207, síniendo en la ¿os la pieza El liverro de Madrid y divino lubrador. Esta paginacion no es la que gulardan en la edieion de 171.; ademils los tipos y papel parecen ser mis antisuos.

Eu una advertencia que va al principio lel tom. l. se prometen las poesias líricas de Zilmora, las cuales no llegaron á publicilrse.

1302 ZARATE (Fernando de). Comedias escojidas de Don Fernando de Zarate. Tono primero (Único publicado.) Madrid, Ortega , 1832. 8.

Abraza estas cuatro comedias:

Quien habla más, obra menos.

IIndarse por mejorarse.

El maestro de alejandro.

A lo que obligan los zelos.

Ya se ha repetido varias vezes en el presente Catilingo que la Coleccion a que pertencée este tomo, únicamente es digna de alomua consideracion por el breve Exámen agregado il cada comedia.

7ERNADAS Y CASTRO (Diego Anrovio!. Obras en prosa y verso. Véase en la Seccion poética. Número 1088. 


\section{SEGUNDA DIVISION.}

\section{INDICE ALFABETICO \\ DE $1.0 S$ \\ títclos de las piezis draniticas.}

FARSAS, CONEDIAS, TRAGEDIIS, TRAGICOMEDIAS, NOVELAS DRAHITICAS,

PASOS CÓMICOS, ÉGlogas, Dillogos, COLOQUís, MELOdRAMAS, ÓPERAS, ORATORIOS SACROS, DR.MIIS MLSICALES Y ZARZUELAS.

Cuando despues del título y nombre del autor no se cita la obra ó coleccion donde se halla la pieza, debe suponerse está fimpresa suelta.

Siempre que siguen á la Parte citadá las iniciales C. A. signiflcan estas la Coleccion antigua de comedies en is vols.

Si dispues del nombre del autor snlo se cita la Parte $(P$. $)$ ó Tomo donde se encuentra, me reflero al de las comedias í obris, de aquel autor.

En lins casos en que menciono il yedel entiẻndase lo hago con referencia al Indice general alfabético de comculias recopilado por èI.

si a continuacion del titulo no se espresa si es tragedia, farsa, paso, etc. se sobreentiende que es comedia.

Ademas de las abreriaturas usadas y esplicadas ya al principio de la Primera division, las que se encuentran en esta son las siguientes:

F. . . . Fábula.

o. . . ópera.

O. S... . Oratorio sacro.
P. . . . . Parte.

PP. . . . Partes.

T. . . . Tragedia.
T. ... . . Tragicomedia.

Tom.. . . Tono.

V. .... . Véase.
A

\section{A}

A buen padre mejor hijo, Antioco y Seleuco.-Moreto.

Es el Anlioco y Sclcuco de su P. I.

A cada paso un peligro.-Ux I.vaesio.

Con este titulo, dice el Sr. de Barrera, se imprimió una de los hermanos Figue. roa, que ignoro si será distinta.

A cual mejor confesada y confesor, San Juan de la Cruz y Sta. Teresa de JeSUS.-José Cax̃zizes.

A España dieron blason las Asturias y Leon, y triunfos de D. Pelayo.-Josk Cosicui.

A falta de hechizeros lo quieren ser. los

\section{A}

gallegos, y Asombro de Salamanca.Axóxiyo.

A gran daño gran remedio.-Jezóviuo DE Villaizay. Flor de las mejores doce comedias, y en las Doce comedias las mas grandiosas, donde se atribuye al mismo en el título. y á Rodrigo de Herrera en el índice del volúmen.

Barrera trae otra con igual titulo. y dice que es de un tal licenciado Francisco Fernández de Várgas.

A igual agravio no hai duelo.-Ambrosio DE Corrica. P. XIII. C. A.

A la Natividad del glorioso Precursor San 
Juan Bautista. O. S.-José Yic. OrTí Y IIAYoR. Valencia, 1722.

A to hecho no hai remedio, y príncipe de los montes.-Mostalyax. Tom. I.

Segun mota de Durau, con el titulo de El primeipr de los momles se publica en la

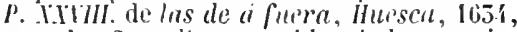
Y on las Comedias escogidas de los mas insignes poetas. S. l. ni $a$.

Batrera observa que so ha impreso suelta como de Calderon.

A lo que obliga el desden.-Fravcisco S.llado G.rrces. P. XXXY. C. A.

Medel cita tambien otra de Rojas con este tftulo, en lo que till vez se equivoea.

A lo que obliga el honor.-A.тtosio ExríQtez Gónez. Academias de las Musas.

A lo que obliga el honor, y lluelo contra su padre.- Y. Por acrisolar su honor, competidor hijo y padre.

A lo que obliga el sel rei.-Lus VELEz de Glevari. P. $\mathrm{I}$, C. A.

A lo que obliga un agravio, y las hermanas bandoleras.-Dos Irigesios.

Estos son yites y S. Villaviciosa, segun se ve por el flual que dice:

Y aqui ponen fin dichoso

i lo que un acravio obliga,

Vulos y Villueicusu,

que agridiros solicitan.

lle visto ellicinnes con el tilulo de 1 lo

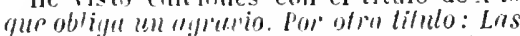
hermunacs bandolerns. Nedel la trae tambien it nomlu'e de Caldelon sin mís titulo que $\mathrm{A}$ lo que oblign an ngratio, pero el nombre de Calderou se ha usulpado indebidamente, á lo que pretende Vera Tásis.

A lo que obligan los zelos.-Ferxisoo Zakate. P. $\boldsymbol{X} \boldsymbol{X V}$. C. A., y Comedias escogidas de este autor, Madrid, 1832.

Antonio Enriquez Gímez, en el prulogo de su Samson Vazareno, dice que escribio una comedia con este lítulo; de cusa circumstiucia y de la de decir el lndice espurgntorio que Don Fermando de Zarate es An. tonio Enriquez Gomez, prohibiéndose su comedia El capellan de li Firgen. S. Illeforiso, dedise el sir. D. Adolfo de Castro que Fernando de Zarate es un semdúnimo di: Gimez. Barrera y llesonero parpee son de distinta opinion. y el primero de estos dos antores no menciona está picza como de Zarate.

A pícaro, pícaro y medio. En un acto.Áónisio.

A secreto agravio, secreta venganza.Caluerox, P. II., ediciones de 1637 , 1641, 1681; y 1726, en el Tom. VI. de la de Fernàndez Apóntes, en el $\boldsymbol{l}$. de la de Keil, y en el III. del Tesoro del teatro español. En la $\boldsymbol{P}$. $\boldsymbol{V I}$. de Comedias escogidas de los mejores in- genios de España. Zaragoza, 1653, 1654, se pirblicó con el título de Vengarse en fuego y en agua; y Barrera le da tambien el de El gran don Lope de Almeida.

A ser rei enseña un ángel.-Uv İigexio.

A su tiempo el desengaño.-Mítos Fagoso. P. VII. C. A.

A un tiempo rei y vasallo.-Tres IxGEvios. P. VI. C. A., XLIII. de las de a fuera, Zaragoza, 1630, y en la XIXXXVII. tambien de $\dot{a}$ fuera, $V a$ lencia, 1646, segun Barrera.

Ignoro porque añade este al titulo: $y$ villomo moulinjuson.

A un traidor dos alerosos y á los dos el más leal.-Mhiuel Goxzílez de CuxeDo. P. III. C. A.

Abate (El) de L'Ejéc, y su discípulo el sordo mudo de luacimiento, conde de Harancour.- Bocilly, y la traduccion cil prosa castellana de D. Juan de Estrada y D... Laas-Litzos. Tom. I. del Teutro nuevo español.

Abindarraez y Narvacz.-V. Remedio de la desdicha.

Abogar por su ofensor, y baron del Pinel. - Ciñzires. Tom. II. de sus Comedias escogillas, Madrid, 1833, y ell la Coleccion de dramáticos de la Biblioteca de Ribadencira.

Barreril lo da tambien el título de El gran burwh del Pincl.

Abrahan (El) castellano y blason de los Guzmanes.-Juax Cladio de la Hoz.

Abre el ojo, ó sea el aviso á los solteros. -Rósas Zornilla, refundida por Castrillon.

Este es positivamente el título que lleva en mi ejemplar; í pesar de que Barrera dice que el de esta refundicion es Abre el ojo, o aviso a los casados.

Abrir el ojo.-Rójas Zormilla. P. II. de sus Comedias y Tom. II. de las Escogidas, Madrid, 1831.

Mellel la denomina Abre el ojo, y asi se let? en los titulillos de las píginas en la riaicion original de 1645 . Tambien se coinoce con el título de Abre el ojo y aviso de los cusculos.

Tengo un ejemplar, que sin duda pertenece a la impresion de 1680 , con muchos pasajes tachirdos, el cual lleva al fin una censura autografa de D. Pedro Francisco J.anini Sagredo, fechada el 10 de febrero de $16 ; 16$, y el inlorme del flseal, poco favorable i que se permita su representacion, dado et 15 de dichos mes y año.

Abuelo (El) y la nieta. Comedia de música.-Luciano Francisco Coyella.

Academia de música y poesia.-Axóximo. 
Pieza en un acto que se halla en la $I n-$ troduccion al drama que han de representar en el Seminario de nobles, 1784.

Moratin cita uma pieza de D. Ramon de la Crrz intitulada: Acudemia le músice; no sé si sera la misma que la que tengo anunima.

Academias (Las) de amor.-Cristóval DE Moríles. P. ILIII. de las de áfuera, Zaragoza, 1650, y segun Barrera, en otra $\dot{P}$. XLIII. de las mismas. Valencia, 1660 .

Acaso (EI) de un anillo, y confusion de una noche.-Ux lvievio gadrTivo.

Aceitunas (Las). - LOPE DE ReED..

Asf istitula Moratin ol l'(len sflimo del Deleiloso, que reimprinio cu sus origenes del lealro cspañol.

Acelina (La).-E. T. (Eugenio Tapia.) Tom. II. del Tealro nuevo español.

Acertar de tres la inna.-Felipe Godísez. Acmet el Magnánimo.-Axóxino.

vo la mencinna Voratiu, sin embaráo de hiber sido ya represelltada en $(i !) \cdot 2$.

Acrisolar el dolor en el más filial amor.Antosio Rezaxo Iypehill.

Acrisolar la lealtad á la vista del rigor, por fama, padre y amor: Cósdroas y Siroe. T.-Axósiyo.

Acto de conclusiones en que se defiende que Sto. Tomas de Aquino es Sol de la Jglesia.-Jose Feupe de Mitos.

Acto de conclusiones en rue se deliende que Sto. Tomas de Aquino es ángel.José Felipe ne Mitos.

Adlelfos (Los).-Telievcio . tratlucilla por A isril. Comedias de Terencio.

Adeliua (La). Segumia parle.-Astovio Valladires de Sotomiaror.

La mrimere mole se intilula: El cmpe-

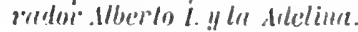

Adolfo y Ciara, ó los dos presos. Comedia con inlermedios di musica.-Traducida en prosa v verso por D. E. T. (Eugenio Tapia.) Tom. VI. del Teatro nuevo español.

Adónis y Vénus. T.-Lore. P. XVI.

Adoraciou de los Reyes. Drama sacro con un intermerlio.-D. J. B. C. (Don Juan Bautista Colomes.) Valencia, Viuda de Marlin Peris, 1800. 8.

Fs una esprecie de zarzuela.

Adoracion (La) de los santos Reves á Jesucristo. Coloquio.-Gaspar Fersididez Y Avila. Infancia de Jesucristo.

Adriano en Siria.-Gaspar Zabala y Z 1 MORA.

Adúltera (La) penitente.-Cáxicer, More- to y Mátos. P. IX. C. A. y no $X V I I$. como dice Barrera.

Fste añade al tilulo: Santa Teodora. Medel la cila como de tres ingenios.

Adversa fortuna de D. Álvaro de Luna.Tirso de Molisia. $\boldsymbol{P}$. II.

Es la sequndis purle de Próspera fortuna de thon Alvurn de Luna, y una de las ocho conredias que se incluyeron en dicha $P$. II. de Tirso, il pesar de no ser enterimente sllyas, cono lo sienta Hartzenbusch.

Adversa (La) fortuna de Rui López de Ávalos. Segunda parle de la Próspera fortuna del mismo.-Dinlax Sillestrio nE Poro. Como se halla eli el tomo lldmado $\boldsymbol{P}$. III. de las Comedias de Lope, no es de admirar que le atribuyan la presente Nic. Antonio y Medel. - Se ba reimpreso en la Biblioleca de Ribadeneira.

Barrera la intitula: Adversa forfune del mui nuble crabullèn Rui López el Bumo.

Adversa (La) fortuna del caballero del Espíritu Santo.-Lic. Jeay Griall (Grajales?). P. III. de Lope, á quien indebidamente la atribuyen Nic. Antonio y Medlel.

En el mismo tomo se halla La próspera forlunu del cerballero del Esplrilu Santo que debera ser la segundu parle; aunque III lo dice.

Afanador (El) de Ltrera.-Lis BenyorTE. P. IXIII. C. A.

Afectos de odio y amior. - Cilveror, P. III. de $1664,1687, y 1726$, en el Tom. VII. de la de Fernández de Apóntes, ven el $I I$. de la de heil.

Afectos de una alma reconocida al beneficio de su justilicacion. ell el ejemplar de Sta. María Magulalena. O. S.-Relucido á concento musico por D. José De Sir Jux. Valencia, Antonio Bordazar, s. a. 8.

Guizils sea la letra de D. Jnsé lic. Orte

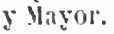

Agamenon. $T$. Levercier traducida por D. E. T. (Eugenio Tapia.) Tom. II. del Tealro nuevo español.

iseril esta la citada por Voratin como de un aminimo de la segunda mitad del si"slo Xint:?

Agradecer y no amar.-Calneror. $P, \boldsymbol{V}$. C. A., en la misma de las Comedias de Calileron. ediciones de 1694 y 1730 , Tom. IX. de la de Fernández de Apóntes, en cl III. de la de Keil, y en el III. tambien del Tesoro del teatro espaitol, por Orhoa.

Agravio (El) agradecido.-Matís de Los ReYes. En el Para algunos. 
Se habia impreso en Jaen, por Pedro de la Cuesta, 1629, segun apuntes de Duran.

Agravio (El) satisfecho.-Castillo SoLORzANo. Huerta de Valencia.

Agua mansa.-V. Guárdate de la agua mansa.

Aguila (El) de la iglesia S. Agustin.linixisco Goszalez Bústos y Penro linicisco Lavisi Sagedo. P. XXXVIII. C. $A$.

Aguila (El) del agua, y Batalla nayal de Lepanto. T. Hijo (El) del iguila.

Al buen callar llaman Sancho.-T. Zeloso (El) pridente.

Al freir de los huevos.-Axóxiyo.

Barrera dice que es de $2 m$ ingenio; no sé si se espresarí así en alömm otra rdieinn-Yan intercalados en estil colluedia, escrita durante la guerra de sucesion, a mincipios del siglo pasado, el entremes intitulado: To hai liempo que no se llegme, ni denda que no se pague; el saincle: Dime con quién rmalas direle quilueres, y una Mojigangi para fin de fiesta.

Al noble su sangre avisa.--EL Miestro Tomis Maxel de Pız. P. XLVI. C. A.

Al pasar del arroyo.-Lope. $P$. $\boldsymbol{X} I I .$, en el Tom. II. de sus Comedias escogidas, Madrid, 1828, y en el II. del Tesoro del tealro español.

Alba (El) y el sol.- Lx IxGexio.

Ni Hedel ni Barrera memeionan esta $e_{0}$ media como de un lngenio; citall otra con isual lítulo de Luis Vilez de Guevari, que probablemente seril la misma, y que segmu dicho Barrera, se ennace tambien r:or Le reslamacion de Españu, ó el alba y el sol.

Alcaide (El) de sí mesmo.-Cillerox. P. VIII., ediciones de 1684 y 1715 , en el Tom. T. de la de Feruández de Apontes y en el $\boldsymbol{I} \boldsymbol{V}$. de la de Keil.

Es La quarda de si mismo, que se halla en El mejor de los mojores libros de crmmedirts, y sesun Barrera timbien se intitulit: Alcaide en propia guardu.

Alcalde (El) de Zalamea. - Cilnerox. P. VII., ediciones de 1683 y 171 J̈, en cl Tom. H. de las de Fernández de Apóntes, en el IV. de la de heil, y ell el III. del Tesoro del teatro español.

En la bib. de Lord Holland, se hallaba una comedia impresi con este títulu it nombre de Lope, de la cual existe copiis Ms. en la de Duran. La de Calderon se cincuentra lambicen en El mojor de los mojores libros de comedias y en lis Daze comedias las mas gramliosus, donde el título es $E l$ gurrole más bien dado.

Alcalde (El) mavor.-Lore. P. XIII.

Alcázar (El) del secreto.-Axroxio DE Solis, en el tomo de sus Comedias
PP. XIX. y XLVII. C. A., P. XLIII. de las de á fuera, Zaragoza, 1650, en las Conedias escogidas, Bruselas, 1704 y en cl Theatro hespañol de Ifuerta.

Alcides alegórico. Idea con que celebró la Escuela de estudiantes del Colegio de S. Pablo de Búrgos la vicloria que consignieron las armas de $D$. Fclipe $V$ en los campos de Villa-Viciosa el 10 de Diciembre de 1710.-Fraxcisco AxToxio dE Cistro. Impresion suelta de Burgos, Juan de Biar, s. $a$.

Es una especie de zarzuela que no mencional el Sl. Barrera.

Alcídes (El) de la Mancha, y famoso Don Quijote.-Lx INGEsio.

Alejandra (La) $T$.-Lupercio Leosirdo DE Argessola. Tom. VI. del Parnaso español.

Alcjandro en la Sogdiana.-Gaspar Z.1BALI Y ZiMORA.

Alejandro eu las Indias.-Axó viyo. Esta pieza será probablemente la que citil Barrela como original de Metastasio, tralıeida por I), Jerónimı del Val.

Alfeo y Aretusa. $\boldsymbol{Z}$.-Dindaxte, $\boldsymbol{P}, \boldsymbol{I}$.

Alfonso de Navarra.-V. Venganza (La) en cl despeño.

Alfonso el Batallador ó el émperador de España.-Juan de Ver.i y Villaroel.

Trítulo de la segunda jornada de su comedia $L a$ corona en tres hermanos. Medel trate una anónima con solo el título de $A l$ fiulso el Bulallador.

Alfonso octaro en Alárcos.-José YillaVIRUE FerYíxDEz.

Ali-Bek. T.-Miríi Rosi de Galyez. Tom. V. del Teatro nuevo español.

Almenas (Las) de Toro.-Lope. P. XIV.

Almocreves (Os). Farsa portuguesa.Gil Vicente. Obras.

Allá darás rayo.-Lope. P. XXVII. esIravagante, Barcelona, 1633.

Allá se verá.-V. Tia (La) de la menor.

Allá van leyes donde quieren reyes.Gulles de Castro. P. $\boldsymbol{X} \boldsymbol{V I}$. $\boldsymbol{C}$. $\boldsymbol{A}$.

Medel dice que hai otra de Lamini con el mismo título.

Amadis de Gaula. $\boldsymbol{T}$. c.-Gil Vicentв. Obras.

Amadis y Niquea.-Francisco de LeIva Rayírez Arellayo. P. $\boldsymbol{X}$ L. C. A.

Toda en castellano.

Amado y aborrecido.-Calderon. $\boldsymbol{P} . \boldsymbol{I} \boldsymbol{X}$. de 1691 y 1698 , en el Tom. I. de la de Fernández de Apóntes, en cl IV. de la de Keil y en la $\boldsymbol{P}$. VIII. C. A.

Aman y Mardoquẹo. - Felipe Godínez. P. V. C. A. 


\section{AMA}

INDICE DE TITULOS.

AMA

yo la he tenido con la adicion al titulo de la horca para suduciono, y Barrera añade alun: ó la litina Ester.

Amando siempre hai envidias.-V. Siempre hai que envidiar amando.

Amante (EI) agradecido.-LOPE. P. $\boldsymbol{X}$.

Amante (El) astrỏlogo.-V. Astrólogo fingido.

Amante (El) generoso.-Ux IvaEsio.

Ture una pieza con este mismn título á nombre de Is. Caspar Zabala y Zamora; iggnoro si era ia misula.

Amante (El) honrado.-Axóxiyo.

Mratin cita una pieza con este título de D. Ciaspar ie Zabala y Zumora, till vez sea la presente.

Amante (El) más cruel, y la amistad ya difunta.-Gosz.r.o IE Lllor Y SisnoVAL. P. XIII. C. A.

Amante (El) mudo, la fuerza de la sangre y amor hace hablar los mudos.Tres Irgenos, que son: S. ne Villaviciosı, Mítos y Zibileti, srgun se ve por la $\boldsymbol{P}$. XFIÍ. $C$. A. donde esta comedia lleva el título del dimor hace hablar los mudos : tambien la tengo con el de Fuerza de la sangre, y amor hace hablar los mulos.

Barbosa yachado la at ribuye equivocadamente á solo Mátos Fragnso. - fu alıbuna impresion se ha adjudicado á Calderun.

Amantes(Los). T. -Rei de Artied. Falencia, $1581.8 .^{\circ}$

Amantes (Los) de Cartago. Con Loa al fin.-Gispir de Agcilir. P. I. Poetas ralencianos.

Amantes (Los) de Salerno. - Toyss DE A.jorbe y Corregfi.

Amantes (los) de Teruel-Mosturir. Tom. I. y P. XLIV. de las de a fuera, Zaragoza, 1632 .

Es un: rofundicion de la que so halla ell la P. Il. we las ale Tirso: segun llartzenluisch.

Amantes (Los) de Teruel.-Tirso. P. II., y en el tomo de Comedins escogidas de este antor (Biblioteca de Riballeneira) lit incluyó Hartzenbusch, ynien observa que no es por entero de Tirso.

Amantes ílos: de Termel. Burlesca.-Suínez te Dez.. Donaires de Tersicore.

Es ma parollia de la que escribio con el mismu tílulo Prerez de Jontalvall.

Amantes (Los) desgraciados ó el conde le Comingr.-D. Arrien, traduccion de D. Mivuel ne Bellosírtes.

En el cjemplar que tengo dice lereera parte; tal vez la primera sea: Los amores del conde de Cominges, y la segunda: Cominge perseguido, ó sea los umores del concle de Conninge.

Amantes (Los) engañados, ó falsos recelos.-Aróximo de la segunda mitad del siglo XVIII.

¿Será acaso loos amuntes mgañados de D. Antonio lsidro de la lobrega que trae Barrerat?

Amantes (Los) generosos.-Mr. Rocuor de Chibuives, traducida en prosa castellana por D. G. F. R. Tom. IV. del Tealro nuevo español.

Amantes (Los) portugueses.-Gaspir Loziso Mostesivo.

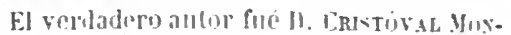
TEno, tio del linspar. kl cejemplar que tengo es de una edicinn shelta de Sevilln, limprealn real, s. a.; pero se publici en las Soledad's de lin vidh. Hadrid. lfjos, segun Barrerit, y alli parece que el tiluto que lleva es: Los amumle's jortunueses y ruerere hista morit.

Amantes (Los) sin amor.-Lope. P. XIV. Amar ántes de nacer. La Paloma dominiea, Sta. Columba de Reati. Primera parte.-Ait. Télez de Azevedo.

La Spgrmila parle se intitula Foloma (Lor) dominier. Vease.

Amar como se ha de amar.-Lope.

$\therefore$ vir por la soliacion que pertunece a alentra Parto de comedias de lopo.

Imar despreciando riesqos. T. c. - EL COYNe ne ReBOLleno. Obras.

Amar despues de la muerte - Cuneros. P. IX. celiciones de 1691 × 1698. Ell al Tom. I. Le la de Fernánile? de Ipóntes, y en el IF. de la de heil.

sogum lina Tás es la misma que la ennocidar ron el lítuln de E.T Tusuri de lus Aipujarias.

Amar es saber vencer, y el arte contra el poder. Drama con música.-A.T. UE ZIYOR I. TOM. II.

Comsta aninima co ye lo!.

Amar por arte mavor.- Tirso. $P$. $V$. y en las Comedias escogidas de Tirso. Biblioteca de Ribadeneira.

Amar por fuerza le estrella y un portugues en llungría. -Jicivto Cornero.

Burrera dice que hai primpla y semmula narlis: rul la qur yu tenizu nada se esprest. ₹al conchure en fugar de prometer ilsil continnacion, dice:

"l aquil tel somadı da fin culre zelus y purfías.

Aimar pur firerzal de estrella, y portugues en llunglia, w 
Amar por razon de estado.-Tirso. P. I., en el Tom. II. de sus Comedias escogidas. Madrid, 1829, y en las Comedias escogidas de este autor publicadas por Hartzenbusch.

Dice este que vió en la biblioteca de 0su. na esta pieza mamuscrita coll algunas rariaciones adoptadas por el autor con mejor acuerdo, y mudándole el lítulo en el de Sutilezas del amor, y el maingues det Camarin. Medel la trae con el mismo y con sola la denominacion de El marques ald Camarin.

Amar por señas. - Tirso. P. XXVII. C. A., y en el Tom. III. de las Escogidas de este autor, Madrid, 1831. Tambien se halla en el tomo de Comedias escogidas de Tirso por Hartzenbusch (Biblioteca de Ribadeneira).

Amar por ver amar.-V. Perro (El) del hortelano.

Amar servir y esperar.-Lope. P. XXII. Madrid, 1635 .

Medel atribuye equivocadamente á Calderon una pieza con el mismo titulo.

Amar sin saber á quién.-Lope. P. XXII. Madrid, 163\%, y tambien en la edicion de Zaragoza.

Amar sin ver.-Ant. Martisez. P. $\boldsymbol{X X I .}$ C. $A$.

Amar y no agradecer.-Fraticisco S.ILGADo. P. XXII C. A.

Amazonas (Las).-V. Mujeres (Las) sin hombres.

Amazonas (Las).-Axt. DE Solis. Comedias, 1681, y en las PP. IX. y XLVII. C. A.

En la P. IX. no lleva nombre de autor. Vera Tásis dice que salió indebidamente al de Calderon. La he tenido suelta con el titulo de Las Amazonas de Escilia.

Amazonas en las Indias.-Tirso. $P$. $I V$.

Se reimprimió en el siglo XVlll con el título de Segunda parte de las Amuzonas de las Indias y hazañas de los Pizarros. Vèase Todo es dar en uma cosa, y leallad contra la envidia.

Amfitrion. En prosa.-PÉrez de Oluva, tomando el argumento de Plauto.

Se incluyó en sus obras, despues de haberse impreso suelta varias vezes, con el titulo de El nacimiento de Hercules, o comedia de Anfitrion.

Amfitrion.-Plauto. Traducida por el licenciado Francisco López de Villalobos.

Impresa suelta en 1515 y 1517 , se incluyo en el tomo de Problemas del mismo autor y se halla en la Bibliol'ca de Ribadeneira, tomo de Curiosidudes bibliográ. ficas.
Amigo; amante y leal.-Calderon. $\boldsymbol{P}$. $\boldsymbol{V}$. ediciones de 1694 y 1730 , en el Tom. $X$. de la de Fernández de Apóntes, en el III. de Keil, en el III. de las Comedias escogidas de este autor, Madrid, 1831, y en las PP. IV. y XVIII. C. A.

Amigo(El) hasta la muerte.-Lope. P. XI. Amigo (El) por fuerza.-Lope. $P$. IF .

Amigos (Los) y conipetidores. - Coloquio en tres jornadas. - Cistillo Sol.orzaxo. en sus Varios y honestos entretenimientos.

Aminta.-TAsso, traducida por D. JuaN de Jíuregul.

Ademas de lis ediciones suellas se halla en el tomo de las Rimus del tiaduetor.

Amistad (La) castigada. - RuIz DE ALARcos. P. II.

Amistad (La) ó el buen amigo.-Rayon de la Cruz. Tom. VI. de su Tealro.

Amistad (La) pagada.-LopE. P. I.

Amistad y obligacion.-Lope. P. XXII. Zaragoza, 1630 .

Esta conledia con algunas variantes se publicó á nombre de lérez de Montaivan, bajo el título de Lucha de amor y amistall.

Amor al uso.-Ant. de Solis. Comedias, en las Escogidas, Madrid, 1828, en el Tom. V. del Tesoro del teatro español, en el Thealro hespañol de Huerta y en la Biblioteca de Ribadeneira.

Amor, astucia y valor.-Penro de LeIva y Pedro Correa.

Amor (El) bandolero.-Lope. P. XXIY. Zaragoza, 1633.

Amor (EI) cómo ha de ser.-Curiluo oE Aragon. El Enano de las Musas y en el tomo de Comedias escogidas de este autor, Madrid, 1826.

Amor con vista y cordura.-Ant. EnríQuez Gónez. Academias de las Musas.

Amor (El) constante. Precedida de Loa.Gulleev de Castro. P. I. de los Poetas valencianos y en la Biblioteca de autores españoles de Ribadeneira.

Amor (El) constante. Drama en un acto. -Gaspar Zabala y Zamora.

Tuve á nombre de este autor una comedia con el titulo de El amor constarte ó la holandesa; no sé si seria la misma.

Amor costante. - Stordito Intronato (Alejandro Piccolomini).

Comedia en prosa italiana en la que representan tres personas que hablan siem. pre el español.

Amor de razon vencido.-UN INGenio. P. $X X X I V . C . A$. 
AMO

INDICE DE TítULOS.

AMO

369

Amor destrona monarcas, $y$ rei muerto por amor.-UN INGENIO VALENCIANO.

Segun Fuster es del P. Fr. Luis Ballester.

Amor (EI) dichoso.-GASPAR DE ZABALA Y Zis moRA.

Amor (El) en vizcaíno y los zelos en frances, y torneos de Navarra.-Lus Vél.ez de Guevira. P. $\boldsymbol{X} \boldsymbol{V I I I}$. C. A.

Amor (El) enamorado.-Lope. Vega del Parnaso, en el Tom. $\boldsymbol{X}$. de las Obras sueltas, y en la $P$. $\boldsymbol{X X X I}$. C. A. á $110 \mathrm{~m}^{-}$ bre de D. Juan de Zabaleta.

Es indudablentente de Lope, $y$ por eso hace mal Yedel en atribuirsela á dicho Zabaleta.

Ignoro si será esta la misma comedia que se representó en Lerma, eı 1614, por la familia real, con el título: $E l$ premio de la coustancia $y$ amor enamorado, segun una Relacion MS. que poseo.

Barrera la intitula: Amor enamorado (Jupiter y Dafue).

Amor es arte de amar. - Ast. DE Solis. EI fragmento de esta comedia que dcjó el autor á su muerte, se halla en el tomo de sus Poesías.

Amor es más labirinto. - Jeava INES DE LA Gruz y el Licesciado D. Juay de Guevára. Tom. II. Obras de Soror Juana.

Amor es naturaleza.-Movialys.

Amor es sangre y no puede engañarse. --DhMAste. P. $\boldsymbol{I I}$.

Amor es todo invencion, Júpiter y Anfitrion. Melodrama musical. Precedido de Loa.-Axósino.

El Indice de Yedel trae una de Cañizáres intitulada Anor es todo invencion, y segun se ve por el Catálogo de Barrera, es la que yo tengo.

Amor (El) filial. En dos actos..-D. * * Impresion de Madrid, 1794.

Amor (El) hace discretos.-U. Isgesio. P. XXXVII. C. A.

La tengo tambien suelta á nombre de su autor Calderon. Verd Tásis dice que no es de él, sin duda por ignorar que era la misma que con el título: De una causa dos cfectos se publico en la Verdadera quinta parle de sus Comedias.

Amor hace hablar los mudos.-Sebastias DE Villaviciosa, Mítos y Zabaleta. P. XYII. C. A.

Es la misma que $E l$ amante mudo, la fuerza de la sangre, y anor hace hablu. los mudos, que tengo como de tres inge. nios y Fuerza de la sangre, y anor hace hablar los mudos.

Amor (El) hace valientes.-Míros Fratoso. P.I.

Barrera añade: Y toma de Valencia por el Cid.
Amor, honor y poder.-Cal.derov. P. II. ediciones de $1637,1641,1686$ y 1726 , en el Tom. FI. de la de Fernáidez de Apóntes, y en el $I$. de la de Keil.

Se publicó como de l.ope en su Parte $X X I V$. edicion de Madrid, y segun Barrera en la XXVIII. de las de d fuera, Huesca, 1634 , en ambas con el título de La industria contra el podir, y el honor contra la fuer. za. Es mui singular que rera Túsis con este titulo la dé como supuesta de Calde. ron, mientras que en la $\psi$. II. la publico como suya con el de Amor, honor y poder.

Amor, ingenio y mujer.-Mira ne AyescuA. V. Tercera (La) de sí misma.

Amor, ingenio y mujer en la discreta venganza.-Sídez DE DEZA, Donaires de Tersícore.

Esta comedia tiene la singularidad de estar compuesta en gran parte con los títulos de otras.

Amor, lealtad y amistad.-Mostalvax. Tom. II. Segun nota de Duran se encuentra tambien en la $\boldsymbol{P}$. $\boldsymbol{X} \boldsymbol{X} \boldsymbol{F}$. de las de $\boldsymbol{a}$ fuera. Zaragoza, 1632.

Amor, lealtad y ventura.-Mítos Fragoso. P. $I$.

Amor (EI) más desgraciado, Zéfalo y Pócris. Con Loa. - Stlazar I Tórres. P. II. Cítara de Apolo.

Amor (El) más verdadero. Burlesca.Mosex Gullex Pierres. P. $\boldsymbol{X} L \boldsymbol{Y} . \boldsymbol{C} . \boldsymbol{A}$.

En la tabla de dicha I'arie se atribuye a un Ingenio de esta Corte.-La tengo suelta con el título de El amor más v'eldadero, Durandurte y Belerma.

Amor (El) médico. - Tinso. P. IV. La incluyó Hartzenbusch en el tomo de $\mathrm{Co}$ niedias escogidas de Tirso.

Amor (El) perseguido y la virtud triunfante. Con Loa alegórica.-G.isp.ip DE Zibali i Zisopa.

Anor, pleito y desafío.-Lope. P. XXII. Madrid, 1630े, y P.XXIV. Zaragoza, 1633.

Es el Ganar amigos de Alarcon, que se halla en la Purte il. de este autor. Duran tenia un manuscrito autografo de Lope de la presente comedia.

Amor, privanza y castigo. T.-Mostalvix. Tom. $I$.

Es la misma que con el titulo de $E l \cdot f i n$ mds desgraciado y fortunas de Seyano se reimprinivi en la $P$. $I L F$. $C$. $A$.

Amor (El) puesto en razon.-SEBAstiay de Villaviciosa. P. XXVI. C. A.

Amor secreto hasta zelos.-Lope. P. III. Amor vencido de amor.-JUAY VÉLEZ DE Guevara, Zabaleta y D. A.t. de HeerTA. P. $\boldsymbol{X X} \boldsymbol{Y}, \boldsymbol{C}, \boldsymbol{A}$. 
El viltimo de estos autores debe ser Don Antonio Sigler y lluerta. - Medel cita una comedia anónima con el mismo títuln.

Anor vengado. P.-V. Duquesa (La) de la Rosa.

Amor (El) y el amistad.-Tinso. P. III. y en el Tom. II. de las escogidas de este autor, Madrid. 1829, coll el pesado título de $\boldsymbol{E l}$ Amor y la amistad, y prueba real para conocer los verdaderos amantes y amigos. Tambien la incluyó Hartzenbusch en el tomo de $\mathrm{Co}$ medias escogidas de Tirso.

Amor y honor--Belyoste. P. II. C. A. Barreri añade á este titulo: ó respilo, homor y valor.

Amor (El) y la intriga. - Schiller, traducida en prosa castellana por D. N. Rebolleda, segun Moratin. Tom. III. del Teatro nuevo español.

Amor y obligacion.-Moreto. P. XII. C. A.

Amor y zelos hacen discretos.-Tirso. $\boldsymbol{P}$. II. Incluida en el tomo de las Comedias escogidas de Tirso por Hartzenbusch.

Es segun el mismo, la unica de Tirso que guarda las tres unidades, y una de las cuatro que son indisputablemente suyas en la Parte segunda.

Amores (Los) del conde de Cominges.Acóxiso. La tradujo del italiano Lociaso Francisco Comela.

La segundu parle, que tengo, se intituIa: Cominge perseguido ó seu los amores del conde de Cominge, y la lercera será probablemente los amantes desgraciados, ó el conde de Coninge.

Amotinados (Los) de Flándes. - Luıs Vélez de Guevara. P. V. C. A. y XXXI. de las de á fuera, impresa en 1638.

Amparar al enemigo.-ANT. de Solis. Comedias, P. XLIII. de las de áfuera, Zaragoza, 16300 y XLVII. C. A.

Amphitrioẽs (Os). - V. Enfatrioès.

Ana Bolena. T.-Lorenzo Maria de VILLARROEI.

Andria (El). - Terencio, traducida por A bril. En las Comedias de Terencio.

Andromaca (La): por otro título, Al amor de madre no hai afecto que le iguale. T.-A vósimo.

No sé si será esta nisma la que cita Moratin con soln el titulo de La Andrómaca y atribuye á D. José Clavijo y Fajardo.

Ángel (El) de la Guarda.-JosĖ DE VALDIvielso. Actos y comedias, y $\boldsymbol{P}$. VI. de Comedias escogidas de los mejores ingenios. Zaragoza, .1655-54.
Medel menciona ademas de la de Valdivielso la que salió á nombre de Calderon, quien no la compuso, segun Vera Tásis.

Ángel (Fl) de las escuelas Sto. Tomas de Aquino.-Pedro Francisco Lanini I SaGREDO.

Ángel (Fi) lego y pastor, S. Pascual Bailon.-Ant. Pablo Fernández.

Angelica.-Fabricio de Fornaris. Parigi, 1585 y Venetia, 1607.

Comedia italiana en la que uno de los interlocutores habla constantemente en castellano.

Angélica en el Catai.-Lope. P. FIII.

Anillo (El) de Gíges y mágico rei de Lidia. Primera y segunda parte.-José dE Cañizáres. Tercera parte. UN INGEXIO.

lgnnro si esta parte scrá la que Barrera atribuye á Herrera Barrionuevo con el titulo: La union es mui poderosa, y Lidio mágico Gíges. La parte cuarta escrita por Manuel vicente Guerrero quedó inédita.

Animal (El' de Hungría.-Lope. P. IX. Animal (El) profeta.-Lope.

I.a tengo tambien con el título de $E l$ animal profeta, S. Julian. En la bib. del duque de Osuna existe un MS. fechado en 1651 , en el que se atribuye á Nira de Amescua.

Ántes de nacer muriendo, S. Emeterio y Celedonio, mártires de Calahorra. -V. Tres (Los) blasones de España.

Ántes que amor es la patria, y primer cerco de Roma.-Francisco de LeIva.

El manuserilo que poseo no tiene nombre de autor al principio, pero este consta por el flnal de la comedia. Medel y Barrera la traen como anónima.

Antes que te cases mira lo que haces, y exámen de maridos.-Lope. Edicion suelta , Madrid, 1803.

Esta comedia con algunas variantes es la misma que se halla en la Parte XXIV. de Lope edicion de Zaragoza de 1633, bajo el título de Exdmen de maridos, que es el que le habla dado su verdadero autor Ruiz de Alarcon en la Parte II. de sus Connedias. -Yo la tengo tambien suelta con el título de intes que te cases mira lo que te haces, y exdmen de maridos, á nombre de dicho Alarcon.

Antes que todo es mi amigo.-Franando ne Zarate. $P$. XXII. C. A. y en una $X L I$. estravagante de varios.

Ántes que todo es mi dama.-Caldrron. P. VIII., ediciones de 1684 y 1726 , en el Tom. $\boldsymbol{F}$. de la de Fernández de Apóntes, en el IF. de la de Keil, y en la P.XVIII. C. A. 
Anticristo (El).-Roiz de Alarcos. P. II. Debe haberse impreso tambien á nombre de Lope de Vega, prsesto que Hedel le atribuye una de este tilulo.

Antíoco y Seleuco.-Moreto. P. I. y en las Comedias de los mejores. Colonia, 1697.

La tengo suelta con el titulu de $A$ buen palle wejor hijo, Autiveo y Sclcuco; y IIedel irae una de tres Ingenios con el primer liftulo.

Antona García.-Tirso. P.IV.

Anzuelo (El) de Fenisa.-Lore, P. IIII. V. Buscona (La).

Apolo y Climene.-Calderos. P. IV. de las ediciones de 1688 y 1731 , eir el Tom. IV. de la de Fernández de Alóntes, y en el II. de la de Keil.

Apolo y Dafne. F.-. Vicevite Síviciez. Lira poélica.

Es un fragmento de una especie de zarzuela.

Apolo y Leucotea. Z. - Pedro Scorti Arcolz. Obras póstumas.

Apóstol (El) de Salamanca.-Felipe SICARDO. P. XLIY. C. A.

Barrera añade al tftulo: San Juan de Sahagum.

Aquilana.-Tórenes Ninıro. Propaladia, y reimpresa en el Teatro español anterior á Lope de Vega.

Aquíles (El).-Tirso. P. V.

Aragon restaurado por el valor de sus hijos.-Gispin $Z$ ibila y $Z$ iyori.

Arásplas y Pautea. Z. -lirtycisco S.llg.lDo. P. XXIVI. C. A.

Arauco domado por el escelentísimo señor D. García Hurtado de Nendoza. T. C.-LOPE. P. XX.

Arbol (El) del mejor fruto.-Tısso. P. I.

Arca (El) de Noe.-Axt. Mirtíxez, RoSete y Cíxcer. P. XXII. C. A.

La he tenido suelta como de tres Ingenios.

Arcadia (La).-Lope. P. XIII, y en la Coleccion de las mejores comedias de este autor, Madrid, $180 \mathrm{3} .4^{\circ}$

Arcadia (La) fingida. - F. Fingida (La) arcadia.

Ardid (El) militar. Pieza en un acto.Luchiso Frascisco Coyella.

Arenal (El) de Sevilla.-Lope. P. XI.

Argel (El) fingido y renegado de amor. -LOPE. P. VIII.

Argelan, rei de Alcalá.-Y. Padrino (El) desposado.

Árgenis y Poliarco.- Cilderor. P. II. de las ediciones de 1637 (?), 1641, 1686 y 1726 , en el Tom. YI. de la de Fernáudez de Apóntes, y en el $\boldsymbol{I}$. de la de Keil.

Aristómenes el griego. V. Aristómenes Mesenio.

Aristómenes Mesenio.-El Miestro Alf.ro. Así dice en la $\boldsymbol{P}$. $\boldsymbol{X} \boldsymbol{X}$. C. A.; sin embargo, en la XY.TI. de las de ci fuera, 1638 , se encuentra anónima con infinitas variantes, y con el tilulo : $E l$ valeruso Aristómencs Mesenio.

la tengo suelta intitulatil: Ouilar el foudo $d$ su protria, Aristomenes Vosmin, atribuida í látos Frasost : psta enlicion n." tiene las variantes que se observan en la de la $P$. FYY. Barrera no la minciona con esle ultimntínlo, ni indica flue se la ţa supuesto á Jútos alutor do ella; 10 que si dice es, que se la conoce timbien pon Aristómenes el qrieqo. Medel liabla de otris dos con el misino ítulo, la unin de yoretu y lit otra de Caldemen: no las he visho: peri Fera Tásis nicga que este illtimo la haya escrito.

Armas (Las) de la hermosura.-Cilneros. P. I.Y., ediciones de 1691 y 1698 , en el Tom. I. de la de rernándéz de Apóntes, en el $I V$. de la de Kéeil, en la P. XLII. C. A., y eu el Tom. III. del Tesoro del teatro espanol.

Armelina. En prosa.-Lope de Riedi. Comedias, y en el Tealro español anterior il Lope de Tega.

Armengoles Los). Primera y segunda parte.-Cirsióril de Moniles.

lo mencinna Barrera cota romedia eomn im!prese, y sulo cila mn lfs. de la bib. del duque de Osmua en el que ileva por titulo:

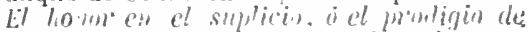

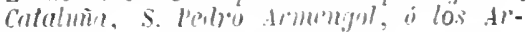
me'ngoles.

Artajérjes. Drama en mísica para representarsc en el nuevo lealro de la sala del duque le Gandiu en Valencia; en las carnestolendas de 1769.- PEDno Metistisio. Talencia, Francisco Burguete, s. a. $8 .^{\circ}$

El tesin italiann se halla al freute: de la traduccion cistellimil.

Asalto (EI) de Mastrique por el prílcipe de Parma. T. c.-Lope. P. IV.

Asombro (El) de Jerez, Juana la Rabicortona. Primera y segurda parte.Li INGEvo.

Asombro (El) de Jerez y terror de Audalucia, D. Agustin Florencio.-Gullite Scirez.

Asombro (F.l) de la Francia, Marta la romarantina. Cuarta parte.-W INéL H!DALGO. 
Segun Barrera se ha impreso tambien anónima.

A sombro (El) de Palermo.-V. En el sueño está la muerte.

A sombro (El) de Turquía y valiente toledano. -Luis Vélez de Gueyara.

Barrera añade al título: Francisco de Ribera.

Áspides (Los) de Cleopatra.-Rósas ZonRILL.A. P. II .

Aspides hai basiliscos. $Z$.-Arт. of $Z_{\text {ano- }}$ R. Tom. I.

Astrólogo (El) fingido.-Calderox. P. II . de $1637,1641,1686$ y 1726 , en el Tom. VI. de la de Fernández de A póntes, en el I. de Keil, y en el $\boldsymbol{I I}$. de las Comedias escogidas de este autor, Madrid, 1828.

segun nota de Duran, se halla tambien en ld farle XXY. de las de á fucra, Zarago$\approx a, 16.52$; pern creo que lleva el título del Amanse astrólogo.

Fue refundila por D. Pablo Mendibil, quien la publico en tóndres con el titulo de El astrólogo fingido.

Astucias del enemigo contra la naturaleza. Marta imaginaria, segundo asombro de Francia.-Jose Coxcils.

Tambien se conoce cont solo el título de Marla inaginaria.

Asturianas (Las).-Lope. P. XVIII.

Esta comedia é historia, como dice en su titulo, está escrita en lenguaje antiguo.

Asturiano (EI) en Madrid, y músico por amor.-Y. De los hechizos de amor la música es el mayor.

Asturiano (EI) en Nadrid y observador instruido.-Axóxıyo.

Atahualpa. T.-Cmstóval Maris Contes. Ataulfo. T. - Mostlivo i Lurixdo. Discurso II. de las Tragedias españolas.

A tila azote de Dios.-Luls VÉLEz DE GueV.SR.

Barrera añade al título: $\dot{o}$ la silla de S. P'ello.

Atila furioso. T.-Ceistóval de Virues. Obras trágicas y líricas.

Iledel la cita anónima.

Atolondrado (El). Picza en un acto.-Yiceste Ropríguez Arellayo.

Aulegrafia. Comedia portuguesa en prosa.-Ferreir.a de Yascoycelios. Lisboa, 1619.

Aun de noche alumbra el sol.-FELIPe Godíxz.

Se ha reimpreso en la Biblioleca de Ribadeneira.
Auristela y Lisidante.-Calderon. P. VII. impresa en 1683 y 1713 , en el Tom. $X$. de la cdicion de Fernández de Apóntes, en $\boldsymbol{c} l \boldsymbol{I I I}$. de Keil, y en la $\boldsymbol{P} . \boldsymbol{X X}$. C. A.

Aurora (La) del sol divino.-Francisco Jinéxez Sedex̃o.

Tengo dos ediciones bastante antiguas con el nombre de este autur.

Aurora (La) en Copacabana.-CiLderon. $P$. $I V$. ediciones de 1688 y 1731 , en el Tom. IV. de la de Fernández de Apóntes, y ch el II. de la de Keil.

Auroras (Las) de Sevilla.- Tres IxgeNos. P. XXVII. C. A.

A usencias (Las) del amor. Diálogo.-Cistillo Solorzaxo. Varios y honestos entretenimientos.

Ausente (EI) en el lıgar.-Lope. P. IX.

Austria (La) en Jerusalen.-Bínces Can-

- Dayo. Poesías cómicas, Tom. II. y en la P. XLVIII. C. A.

Auto da Fama (Farça chamada).- GIL Viceste. Obras.

Todil en portugues, ménos el papel del Castethano que emplea su lengua.

Auto da Iıdia ( Farca chamada ). - GIL VICENTE. Obras.

Esti toda en portugues, meinos un CasteIlano que habla siempre en su idioma.

Auto da Lusitania (Farça chanada).GiL Viceste. Obres.

lin esta farsa portuguesa Vẻnus, Verecinta y Juno representan en español; tanbien liai ilgmas cantijus en esta lengua.

Auto das Fadas (Farca chamada).-GIL Vicente. Obras.

Esti toda en portugues, menos uno de los fritiles que habla en castellano.

Avaro (El).-Montı́ne : puesta librcmente en prosa castellana por D. Dímaso DE Isusquiza. Tom. II. del Teatro nuevo español.

Avaro (El). En prosa.-Moliére, traduccion de Orchard-old. (Es Huerta?)

Aventuras (Las) de D. Juan de Alárcos.LOPE. P. XXV.

Es la Segunda parte de Don Juan de Castro de la P. XIX.

Aventuras de Grecia.-V. D. Florisel de Niquea.

Averígielo Yárgas.-Tirso. P. III. y tomo de las Comedias escogidas de Tirso por Hartzenbusch.

Tengo la reimpresion de dona Teresa de Guzman con el titulo: Del mal el ménos, y averigüelo várgas.

Ayo (El) de su hijo.-Luciano Francisco Comella. 
Azero (El) de Madrid.-Lope. P. XI. y en el Tom. II. del Tesoro del teatro español.

Se intitula Primera parte; mas ignoro que baya segunda.

Azote (El) de su pa! ria, y renegado Abdenaga.-Moreto. P. XXXIV. C. A.

Con el titulo de El esclavo de su hijo se
Balcones (Los) de Madrid.-Tirso de Mouxis. No está en las Partes; pero se ha incluido en el Teatro antiguo español, $183 \bar{i}$, y en el tomo de Comedias escogidas de Tirso, por Hartzenbusch.

Debe de haber alguna edicion bastante antigua con el nombre de Tirso, pnesto que ya se la atribuyc el Indice de Nedel cn la pág. 116.

Baltasara (La). - Luis Vélez, ANtosio Coello y Rósas Zorrilla. P. I. C. A.

Banda (La) de Castilla, y duelo contra sí mismo.-José de Ca⿳亠丷iZáres.

Barrera añade al título: $\delta$ el privado perseguido.

Banda (La) y la flor.-ChLDeror de Lt Birca. P. VIII., ediciones de 1684 y 1726 , en el Tom. $V$. de la de Feruảndez de Apóntes, en'el IV. de la de Keil y en la $\boldsymbol{P}$. VI. $\boldsymbol{C}$. $\boldsymbol{A}$.

Se publicó con el titulo de Hacer del amor ugrowio, $y$ comn de un Anúnimo en la P. XXY. C.A.

Bandido (El) más honrado y que tuvo mejor fin, Mateo Vicente Benet.-A sósimo.-Segunda parte.-Gabriec SuaiREZ.

La primera parle es sin duda del mismo autor.

Bandolera (La) de Italia y eneniga de los hombres.-Ux IsGevio.

Bandolero (El) de Flándes.-Álvaro CuBILLO dE ARAgOY.

Bandolero (El) Sol-Posto-Cávcer, RoSete Ni⿱̃o y hójas Zorrilla. P. $\boldsymbol{X X X I I . ~}$ C. $A$.

Bandos (Los) de Luca y Pisa.-Ast. DE AZEveno. P. XL. C. A.

Bandos (Los) de Raveua y fundacion de la Camándula. - Mátos Fragoso. P. XXVII. C. A.

Es la misma que tengo suelta á nombre de Antonio Enríquez Gömez.

Bandos (Los) de Sena.-Lope, P. XXI. halla, segun Barrera, en la P. III. de este autor, Malrid, 1681 .

Azucena (La) de Etiopia,-José Bolea y Frixcisco de cl Torar. Precedida de una Loa de Bolea. Va intercalada una Mojiganga de fiestas y fiesta de mojigangas. En las Lvzes de la Aurora, de Torre y Sebil.
Nedel trae ademas una aninima con ol mismo título.

Bandos (Los) de Yerona.-Rósis Zorrilla. P. II. de sus Comedias, y $\boldsymbol{X} L \boldsymbol{V}$. C. $A$.

La tengon suclta con el título de Lns Rundos de Verona, Honlestons y Cupeleles, asi supone Duran que se halla en la $P$. $Y L i$. de liss de á fuero. Valencia.

Bandos (Los) de Yizcava.-Pedro Rosete Nis̄o. P. XIII. C. A.

Barrera añade al titulo: ó los Oñez y Gamboas.

Baños (Los) de Argel.-Cervíxtes SiAvenRt. Comedias y Entremeses.

Se imprimiú suclta er 161.5, sczum lo dice sancha en la adrertencia il su euliciou del Viaje del Parnas!). Vedel trai; ademis otra anunima con cl mismo lítulo.

Barlan y Josafá.-Lope. P. XXIY. Zaragoza, 1641 .

Barrera dice que tambien se conoce por Los dos soldalos de Cristo.

Baron (El).-Irinco Celeyio. Leandro Fernindez de Moratin.

Barracas (Las) del Grao de Valencia.Tres Ivignios. P. MTYFI. C. A

Basta callar.-Gilberos. $\boldsymbol{P}$. $\boldsymbol{V}$., impresa en 1694 y 1730 , en el Tom. I. de la edicion de Fernández de Apóntes, y en el III. de la de Keil.

Bastardo (EI) de Ceuta. Precedida de una Loa y del baile del Sotillo de Manzanáres.-Licexicudo Jut. GrisiLES. Flor de las mejores comedias de España. Se ba reimpreso en la Biblioteca de Ribadeneira.

Bastardo (El) Mudarra, T. c.-Lope. P. XXIY., Zaragoza, 1641.

Barrera le da tambien por título: Los sie. te infuntes de Lara.

Batalla (La) de las Návas, y el rei D. Alfonso el Bueno.-Pedro Lixisi StgreDo.

Medel cita con solo el título de Batalla de las vóvas una anónima. 
Batalla (La) de Pavía, y prision del rei Francisco. - Cristóval DE Mosroi $Y$ Silvi. Coleccion de dramálicos de la Biblioleca de Ribadeneira.

Barrera la iutitula tambien El prisionero mis valiente.

Batalla (La) del honor-Lope. P. VI. En la XV.C. A. se reimprimió á nombre de D. Fernando Zarate. Se lialla tambien en el tomo de Comedias de los mejores y masinsignes ingenios de España. Lisboa, 163̈2, y 1). Salustiano de Olózaga la posee mánuscrita, autógrafa de Lope.

Batalla (La) Naval. - V. Santa (La) liga.

Batuecas (Las) del duque de Alba.-LoP'E. P. XIIII.

D. Juan de la Inoz y Mota refundio esta comedia con el titulo de El sol c'n el vinero

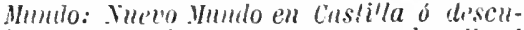
briminio de las Bulnecas, y Lord Hollumd la poscia Ms. To la tengo con el título de El Tuet'o Inudo en Custilla, refundicion de viltos.

Bautismo (EI) del príncipe de Marruécos. -Lope. P. XI.; pero allí se titula: Tragedia del rei D. Sebastian y baulismo del principe de Marruécos:

Beala (La) enamorada.-V. Marta la piadosa.

Belerofonte en Licia.-V. Bellorofonte.

Beligera (La) española. Con Loa.-Ric.irno uE TlRil. (Es D. Pedro Juan de Rejaule?) P. II. Poetas valencianos.

Bella (La) Andrómedia. T. c.-Lope.

Es El Perseo del misuo autor y así lo prueba el final que dice:

La Bella Andrómela atabe y fábulin de Perseo.

Bella (La) Aurora. T.-Lope. P. XXI.

Bella (La) inglesa Pamela en el estado de soltera. Primera parte.-GoLdos.

No tiene el nombre del traductor.

Bella (La) inglesa Pamela en el estado de casada. Segunda parte -Goldow.

Tampoen tiene ul nombre del traductor. Creo que hai ma tercer'a parte.

Bella (La) mal maridada.-Lope. P. II.

Bellorofonte en Licia. Drama en un acto. -D. G. Z. Z. (D. Gaspar Zabala y Zamora.)

Benarides (Los).-Lope. P. III.

Bernardo del Carpio en Francia.-Lope DE LLasc.

Se cree con fundamento que este D. Lope de Llano es el Dr. Lope de Liaño citado por Montalran; corrobora esta opinion el conservarse en el Iluseo britúnico, segun Chorley, un ejemplar impreso en el que se lee Liaño.
Beverley, ó el jugador ingles.-Axóvimo, de la segunda mitad del siglo XVIII.

Es traduccion del Gamester de ED. Moone.

Bien vengas mal.-Calderon. P. $\boldsymbol{X I}$., ediciones de 1691 y 1698 , en el Tom. II. de Fernández Apóntes, y en el $\boldsymbol{I V}$. de la de Keil. Con el titulo de Bien vengas mal si vienes solo, está en el Theatro hespañol de Huerta.

Vera Tásis, en el tom. I. de su coleccion de Comedias de Calderon, previuo que no era este su autor; pero reformó su juieio en el prólogo de la Novena parte.

Bizarrias (Las) de Belisa-Lope. Vega del Parnaso, y en el Tom. IX. de las Obras suellas impresas por Sancha. Tambien está en la Coleccion de las mejores comedias de Lope, Madrid, 1805. $4 .^{\circ}$, en el Tom. III. de las Comedias escogidas de este autor, Madrid, 1830, y en el II. del Tesoro del teatro español.

Blason (El) de don Ramiro, y libertad del fuero de las cien doncellas. - Lurs ue Guzmis. P. II. C. A.

En el indice de esta Parte y en los titulillos de la comedia se denomina El Fuero de tus cien doncellas, y con este único tíLulio la trae viedel

Blason (El) de los Cháves de Villalva.LOPE. P. $\boldsymbol{X}$.

En el Caltilugo del Peregrino la cila su antor con cl tínlo de Los Cháve's de Villal. $3 \prime \prime, y$ con el mismo se halla en el Indice de Hedel.

Boba (La) discreta.-Lope.

Barrera solo la cita á nombre de Cañizáres; iguoro si será la misma. Es distinta de La boba yara los olros y discrela para sí.

Boba (La) para los otros y discreta para sí.-Lope. P. XXI., en el Tom. III. de sus Comedias escogidas, Madrid, 1830, y en el II. del Tesoro del teatro español.

Medel menciona ademas otra, con igual título de Rojas, que probablemente será lit misma.

Bobo (El) del colegio.-Lope. $\boldsymbol{P} . \boldsymbol{X I V}$.

Boda (La) entre dos maridos. - LOPE. P. IV.

Bodas (Las) de Camacho.-Juan Meléndez Vildes. Obras.

Bodas entre el alma y el amor divino.Representacion moral al casamiento de Felipe III con Doña Margarita de Austria.-Lope. Lib. II. del Peregrino, y en el Tom. V. de las Obras sueltas. 
Briseida (La). Zarzuela heróica.-RAmoN DE LA CRuz. Tom. IX. de su Teatro.

Bristo. Comedia portuguesa en prosa.A stono Ferreira. Comedias de Saa de Miranda y Ferreira, 1622.

Británico. T. En prosa.-Ricise. Traducida por D. Satcrio Iacrex (D. Juan de Triguéros).

Con el misino tutulo le atribuyc Moratin otra tragedia a D. Tomas Sebastian y Latre.

\section{Bruja (La).-Lícas Feriáxnez.}

Es un Paso de su Egloga de El Nacimimto de Jesucristo, publicado por Gallardo en el núm. \& del Crilicon.

Bruto. T. - Yoltape, traducida por B. Garcí. Amsterdain, 1758. 4.

Bruto (El) de Babilonia.-Míros, Cixcer y Moneto. P. $\boldsymbol{X X X}$, C. A., y Comedias nuevas, Amsterdam, 1726.

Barrera tambien la intitula: Vabucodonosor.

Buen (El) caballero maestre de Calatrava.-Jear Bta. de Villégas. P. Fil. C. A.

Buen (EI) hijo, ó María Teresa de Austria.-Luchayo Frascisco Comella.

Buen (El) médico, ó la enferma por amor. En prosa.-Goldovi.'

No tienc el nombre del traductor.

Buen (El) pagador es Dios.-Us Irgevio DE ESTA CORTE.

Buen (El) y el mal amigo.-Gaspar Z.ABLA I ZAMORA.

Buena (La) criada.-Galdosi, traduccion de FERMIY dEL REI.

Buena (La) esposa. En un acto.-Leciaxo Fraxcisco Comelia.

Buena esposa y mejor hija.- $\mathrm{V}$. Necépsis (La).

Buena (La) guarda.-Lope. P. $\boldsymbol{X V}$.

En un manuscrito autografo del Sr. Pidal se intitula: La encomienda bien guardada.

Buena (La) madrastra. En un acto.L. A. J. M.

Es de D. Luis Moscis, segun Moratin.

Buena (La) muchacha. Primera y segunda parte. Dramajocoso en música para representarse en el nuevo teatro de la sala del duque de Gandía, en Falencia, en el carnaval de 1769.-Círtos
Goldos. Valencia, Francisco Burguete, s. a. $8 .^{\circ}$

El original italiano que se halla al frente de la traduccion castellana se intitula: La buanra finliumla. Tengo tambien Lelin de la Musica contenisla en la zarsuelu intiluluda en Idimma Italiano La buona flelinola. y en Castellano I.a buena muchacha: compuessla por Nicula piocivi, á escericion de lee que se nota com unas ** que lo es por llus Pablo Esteve y Grimau. S. l. (Madrid, 1765. $8 .{ }^{\circ}$

Buena (La) nuera.-Axóviso, de la segunda nitad del siglo XVIII.

Bueno (El) y el mal amigo.-Gispar de ZsBaLA y ŻAORA.- Y. Buen (El) y el mal amigo.

Burgalesa (La) de Lerma.-Lope. $\boldsymbol{P}$. $\boldsymbol{X}$.

Burlatlor (EI) de Sevilla y convidado de piedra.-Tirso de Molivi. P. VI. C. A., en el Tom. IV. del Tesoro del teatro español, en el volúmen de Comedias escogidas de Tirso publicado por Ilartzenbusch, en las Duze comedias de Lope y otros. Segunda parle. Barcelona, 1630 , y en el Handbuch de Lemele.

Zamora escribió otra comedia sobre este mismo asinto intitulada: To hai dereda yue no se pague, y Contriludo de piedra.

Burladora (La) burlada. Precedida de una Loa contando un estraño suceso.- $\mathrm{R}_{\mathrm{I}}$ Cardo de Tura. (E: D. Pedro Juan de Rejaule?) P. II. Poelas valencianos. $\mathrm{Se}$ reimprimió en la $B$ iblioteca de $\mathrm{R}$ badeneira.

Burlas (Las) veras.-Lope.

vo está en las Partes. yeste es el tíulo que lleva en una edicion antigua que Lit]go; Barrera añade a el: ó elt ruor inuencionero y espuñola de Florencia. porque parece que as! se adicionu en algun. edicion.

Burlas (Las) y enredos de Benito. - No sé si es de Lopé de Gósgora, pues se halla sin nombre de autor en el tomo intitulado: Quatro comedias famosas de estos dos autores, y sin embargo en niuguna parte se espresa á quién pertenece.

Buscona (La) ó el anzuelo de Fenisa.LOPE.

Este es el título que le diu Trigueros al refundirla, pues la original solo dice: $E l$ anzuclo de Fcnisa. 
Caballcro (El).-Moreto. P. II., Tom. II. de sus Comedias escogidas, 1828, P. MII. G. A., y en una XLI. estravaganle de varios.

Caballero (El) bobo.-Guillen ne Castro. P.I. Poetas ralencianos.

Caballero (El) dama.-Cristóval Moxrol y SILY.1.

La lizo Jouroi teniendo presente El Aquiles de Tir'so, segun flartzenbusch, y nor cso sin dudi le añade Barrera al lítulo: ó el Aipriles.

Caballero (EI) de Espíritu.-Gounow. sin el nombre del triductor.

Caballero (El) de Gracia.-Tinso DE Mol.1.1. P. XIII. C. A.

ifrece ol autor al fin segunda parte, que no ha publisada. Antonio burlquez limez diec (') el prohgo de sll Samsim Nazaremi). que labia escrito misa comedia con este lituln, y no hallíndose la presente en las olmas de Tirso, nu serí aventurado suproner que es realmente de aquel y no del man'slpin Tellez.

Caballero El de Illescas.-Lope. P. XIV. Caballero EI de Olmedo, T. c. - Lope. P. I.YIV. Zaragoza, 1641.

Caballero (El) de Olnedo. Burlesca linivcisco Dovteser. El mejor de los mejores libros de comedias, en las Doze comedias las mas granuliosas, y en la Biblioleca de Ribadeneira.

Caballero (EI) del milagro.-Lope. P.XV. liarrera le añade á este título: $y$ arrogante e'spunisl.

Caballero (El) del Sacramento.-Moreto. P. II. gennina de sus Comedias, Valencia, 1676 .

Esta misma romedia ha salido alguna vez con el titulo do El Eneas de Dios, y" asi se hallia con lat l'ar'te. II. espirrea de valenciu, liati, y en la XV. C. A.

Caballero (El) del Sacramento. - LoPE. P. XY.

Barrer: añade á este tilulo: y blason de los yoncallas.

Caballero (El) del Sol.-Luis VÉlez DE GLeviri.

Caballo $(\mathbf{E I})$ vos han muerto.-Lope.

Vi) estii on lis l'artes, ni la menciona Me. del. Tentro esia mismia comedia con variantes y con cl título de Si el caballo vos lum muerlo. alribuida á Vèlez de Guevara; y así es coino la trae dicho Medel. Debio de salir tambien equivocadamente á nom- bre de Calderon de la Barca, segun se colige de la nota publicada por Pera Trísis. Barrera no supo que se hubiera impreso á nombre de Lope.

Cabellos (Los) de Absalon. - Carmeron. $P$. VIII. de las ediciones de 1684, y 1726 , en el Tom. $I V$. de la de Fernández de Apóntes, en el $I V$. de la de Keil, y en las Comedias nuevas, Amsterdam, 1726.

La primera jornada de esta comedia es casi una copia literal del primer acto de la Vengansa de Tamar, segun Ilarlzenbusch.

Cada cual á su negocio.- Jerósimo DR Cuéllar. P. VI. C. $A$. y en el Indice de dicha Parte se intitula : Hacer cada cual su negocio, ó que le toca; Barrera dice: ó hacer cada uno lo que debe.

Tengo esta misına comedia sucl ta í nombre de Calderon; pero Veri Tásis ya advierte que no es snya; sin cmbargo, el Indi. ce de Nedel cita las dos como distintas y de liferentes antores.

Cada cual con su cada cual. Burlesca.Axóxino.

Algumos la alriburen á Leon Marchante y otros it Fernindez de Lcon. Ilai ediciones sueltas en las que se supone ser de un Ingenio complutense.

Cada cual lo que le toca.-Rósis ZorriI.L.T.

Medel Liae otra de Calderon, que será con toda probabilidad la misma, pirque Vera Tásis asegura que no es de este autor.

Cada loco con su tema.-Axt. Hurtado DE Mevidaz. Obras, Madrid (1728). En la primera edicion de Lisboa, $\mathbf{1 6 9 0 ,}$ no se halla esta comedia. Se reimprimió en la Biblioteca de Ribadeneira.

Barrera añade al título: ó el montañes indiano.

Cada uno con su igual.-BLAS DE MÉsA. P. XVI. C.A.

Cada uno es linaje aparte, y los Mázas de Aragon.-AFT. DE Z t MORA. Tom. II., y en la.Biblioteca de Ribadeneira.

Hedel ignoraba quien fuese el autor y la da tambien el titulo de Blason de los slizas.

Cadia uno para sí.-Caloeron. P. IX. ediciones de 1691 y 1698 , en el Tom. $\boldsymbol{I}$. de la de Fernández de Apóntes, en el $\boldsymbol{I} \boldsymbol{V}$. de la de Keil, y en la $\boldsymbol{P} . \boldsymbol{X} \boldsymbol{V}$. C. $\boldsymbol{A}$. 
Cadenas (Las) del demonio.-Calneros. $P$. VIII., ediciones de 1684 y 1726 , en el Tom. IV. de la de Fernández de A póntes, y en el $I V$. de la de Keil.

Cadmo y Ilarmonía. Fábula precedida de Loa.-Axósimo. En Vencer a Marle sin Marie.

Fajardo dice que el autor de esta pieza lo fue el I'. Pedro de Fomperosa y Quintana.

Caer para levantar.-Mítos, Cíveer y Moreto. P. XVII. C. A.

Tuve una pieza suelta $y$ anónima con igrual título; ignoro si era la misma. Medel atribuge una comedia en este tiluto á Mílos y otra á Noreto, siendo asl que solo existe una eserita por anibos en colaboracion con Cincer.

Café (E]).-Y. Comedia (La) nueva.

Cain (El) de Cataluña.-Rósas Zorralla. El mejor de los mejores libros de comedias, y en las Doze comedias las mas grandiosas.

Calanita.-Tórres Numirro. Propaladia. Reimpresa en el Teatro español anterior i Lope de Vega.

Calderro (El) de S. German, ó el mútuo agradecimiento.-G.ISP.AR DE Z Z B.IL.I Y Ziyona.

Tambien se ha publicado con solo la primera parte del título.

Califa (El) de Bagdad. Ópera cómica en un aclo y en prusa.-A Áxisio. Tom. $V$. del Teatro nuevo español.

Calisto y Melibea.- V. Celestina.

Callar hasta la ocasion.-Jusi Hertado I Cisteros. P. NX. C A.

D. Casiano Pellicer atribuye esta comedia á Alonso de Cisneros, sin dudi por 111 haberla visto y haberse fiado de alg 'III apunte que le commicarian, en el chal solo habrian puesto el viltimo apeltido de su verdadero dutor; la misma equirocicion padecio Moritin en el Catílogo de piezas \&. nimero 122: verdad es que ya confiesa 110 haberla tenido presente.

Callar siempre es lo mejor.-Mitos FrtG0so. P. I., en el Tom. I. de las Comedias escogidas de este autor, Madrid. 1828, y en la Biblioleca de Ribadeneira.

Cállate y callemos. - V. El galan secreto.

Camila. Coloquio en prosa. - LOPE DE Ruena. En sus Comedias; se Lallan reimpresos algunos Pasos en el Teatro español anterior a Lope de Vega.

Campana (La) de Aragon. - Lope. P. XVIII.

Canas (Las) en el papel, y dudoso en la venganza.-Cinderox. P. . II T. C. A.

Tor. 1.
Al mismo la atribuye Medel con solo el título de Dnudoso en la venganza, contra rl sentir de Viera Túsis. Este no le da mis ti. tulo que Las canas en el papel. Barrera dice que es de Guillen de Castro.

Canonizacion (La) de San Pascual Bailon.-Piezecita dramática gue se halla en la pág. 42 de las Demostraciones pestivas de Pedro Luis Contes, y quizás sea suya.

Canonizado (El) en vida.- Jeax FraxcisCO MAXtel.

En una impresion antigua que posec 110 lleva más tituln: Barrera aniale: y milagroso en su muerte. Sim Dipgo de dtcultí. yedel la cita anuninra con solo el título de El cunonizudio an rider.

Canto (El) junto al encanto.-Migcel le Birrios. Flor de Apolo.

Capellan (El) de la Vïrgen.- Lope. P. XVIII.

Capitan (El) Belisario.-Lope. Impresion suelta hastante antigua; segun Barrera en la $P$. $I T$ rle Comedias escogidas. Zaragoza, 16303-0̈́ y ell la $P$ : XXV. de Comedias de diferentes autores. Zaragoza, 1632, á nombre de Montalvan.

Es El ejompla manyor de lat deselirha dot tono de Comedins de las mejores ingertins,

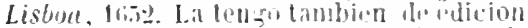
más moderna cous el tilubo de $E$ l ejo miln

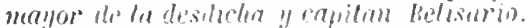

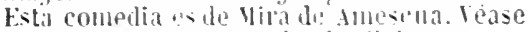

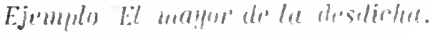

Capitan (El de Israel--I. Prodigios Los de la varn, y capilan de lsrnel.

Caprichos de anor y zelos. Joco-seria.Fervis del. Rei.

Carátula La . P. - l.ope ue Rced..

Este es al titulo fllle ha dado yoritin al segundo de los Pasios de aquel antor. ques se hallan en el foleiloso. il reimprimirlo

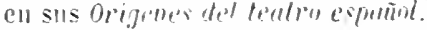

Carbonera La .-Lope. P. MIII., en las ediciones de Malrill! de Zaragoza.

Carbonero El de Lóndres. - Astosio Villomires de Sotomitor.

En mestro Catilo-in de Lundres lia en. cuention mone umintimn.

Carbonero (El) de Toledo-I. Lorenzo me llamo.

Carboneros I.os de Francia.-Miri oE Ayesci. P. MTIX. C A.

Teltwo una edicion mucho mis reciente de lit misma connedia con el litulo de Las curbomeros de Fiancia y reince se'eilla, atribuida il kujas \%orrilta.

Cárceles (Las) de Lemberg - Ivóviso de la seguuda mitad del sighlo Xlill. 
Cardenal (El) de Belen.-Lope. P. XIII. Barrera añade a este título: Luz y doctor de la Jylesia S. Jerónimo.

Cardenal Moron.-V. Milagrosa (La) eleccion.

Cárlos XII, rei de Suecia.-V. Sitiador (El) sitiado.

Cárlos el perseguido.-Lope. P. I.

Este es el tílulo que lleva en la Tabla; en la comedia sulo dice El perséguilo.

Càrlos Quinto en Francia.-Lope. P. XIX.

Cárlos Quinto sobre Dura.-GASP.1R DE Zabila y Zasion..

Cárlos Quinto sobre Túnez.-José ne CAतizínEs.

Casa con dos puertas mala es de guardar. - Clloerox. P.I., ediciones de 1636 (?), 1640, 1685 y 1726 , en el Tom. II. de las de Fernández Apóntes, en el $\boldsymbol{I}$. de la de Keil, en $\boldsymbol{e l} \boldsymbol{I I I}$. de las Comedias escogidas de Calderon. Madrid, 1831, en el III. del Tesoro del teatro español, en el Theatro hespañol de Huerta, y segun Duran en la P. XIIX. de las de á fuera. Valencia, 1636.

Casa (La) de los zelos, y selvas de Ardenia.-Cervixtes. Comedias y Entremeses.

Medel la da como anónima.

Casamiento (El) con zelos, y rei D. Pedro de Aragon. - Bartoloné Axciso. P. XXXIII. C. A.

Barrera se cquivoca al decir que por esta larte consta que el nomlire del antor es Bartolomé de Enciso, porque no solo en el título de la comedia sino en las cabezales de todas las páginas impares, se le llama Anciso.

Casamiento (EI) en la muerte, y hechos de Bernardo del Carpio.-Lope. P. I.

Con solo el título de El casamiento en lu muerle menciona ol Indice de Medel una de Lope y otra de Calderon, que probablemente serán una misma. Yela Tásis dice que no hai ninguna de Calderon. En el fragmento de una parte alesconocida de Lope que existe en la bils. del duque de osuma, se halla esta comedia con el título: La peria de Francia.

Casarse por vengarse.- Rósas Zorrilua. $\boldsymbol{P}$. I., y volúmen de Comedias escogidas, Bruselas, 1704.

Segun una nota de W. A. Duran se lalla á nombre de Calderon en la $P$. XXII. de las de á fuera, V́alencia, 1656 , y con el de Rójas en la $X X X$. de las mismas, Zaragoza, 1636 .

Castelvines y Monteses. $\boldsymbol{T}$. c. - Lope. P. $\boldsymbol{X X Y}$.
Castigando premia amor. - ANTONIo DE Zanora. Ameno jardin de Comedias de los insignes autores $D$. Antonio de Mendoza, D. Juan Bantista Diamante y $D$. Álvaro Cubillo de Aragon. Madrid, 1734.

Medel la trae aninimi.

Castigar por defender. Scria.-Rodnigo de Herrera. Flor de las mejores doce comedias.

Castigar por defender. Burlesca.-RonRIco de Herrera. P. $\boldsymbol{X} \boldsymbol{V I}$. $\boldsymbol{C}$. A.

Medel llama á este autor Francisco.

Castigo (EI) de la miseria.-JuAN DE LA Hoz. Tom. V. del Tesoro del teatro español; tambien se ha reimpreso en la Biblioteca de Ribadeneira, y en el Theatro hespañol de Huerta.

Barrera añade al título: Don Márcos Gil de Alunodóvar.

Castigo (El) del discreto.-Lope. P. FII. Castigo(El) del Penseque. Primera parte.-Tirso de Molixi. P. I., y reimpresa por Hartzenbusch en las Comedias escogidas de Tirso (Biblioteca de Ribadeneira).

Bajo este lítulo se imprimio tambien como de Calderon, y así lo aflima Medel. Vera Tísis opina que no es suya. La segundie pirte se intitula: Quien calla otirga. Doña Toresa de Guzman siguiendo su constinte unania de variar los lítulos de las comedias que daba i luz, al publicar las dos pirtes de la presente, denominu la primera, El que fuese bobo no camine, y castigo del Pense que, y la otra Segunda parte del Cusligo del. Pense que.

Castigo (El) merecido.-V. Galan (El) tramposo.

Castigo (El) sin venganza. T.-Lopk. P. XXI, en el Tom. VIII. de sus Obras sueltas, y segun dice en el Prólogo del mismo se imprimió por separado en Barcelona, Pedro la Caballeria, 1634.

Posteriormente lia recibido los títulos de Un castigo sin venganza y Cuando Lope quiere, quiere.

Castillo (El) de Lindabridis.-Calderos. $\boldsymbol{P} . \boldsymbol{I X}$, ediciones de 1691 y 1698 , en el Tom. II. de la de Fernández de Apóntes, y en el $\boldsymbol{I} \boldsymbol{V}$. de la de Keil.

En ninguna de las ediciones se encuentra al fin de la primera jornada el entremes de La Castañera, que supone Ticknor (toin. IlI. pág. 125) escribió Calderon é intercaló allí.

Castro. Tragedia en porlugues.-Antono Ferreira. Este es el único título que lleva en los Poemas lusitanes de 
este autor , edicion de Lisboa, 1309, y no Doña Ines de Castro como dice Barrera.

Castros y Andradas. - V. Desdichada (La) Estefanía.

Catalan (El) Serrallonga.-PÉrez de Mostalvax, Ayt. Coello y Rójas Zorrilla.

Asi dice ell uua edicion suelta y antigua que tengo, la cual lleva al fin el Baile de Murtinilio.

En la P. IXX. de las de a ficera, Zarago$\approx a, 1656$, se atribuye á Coello, hojas y Luis Vélez, $\mathrm{y}$ esto me parece más acertado, pues en la que yo poseo á pesar de haber sùstituido al principio el nombre de Velez por el de Moutalvan, se ha dejado subsistir el final que dice:

Desta suerte Serrallonga

el catalan bandolero

fin ha tenido, y Luis Velez

por mi, senado discreto,

os pide con los demas

sacriflcados deseos,

como perdon de las faltas,

vitores de los aciertos.

Barrera la intitula: Calalan Serrallonga y bandos th Burcelona, y yo la he tenido como de tres Ingenios:

Catalan (El) valeroso.-Y. Gallardo (El) catalan.

Catalina, ó la bella labradora.-Axóxiso. Traduccion en prosa del frances por Doña María Rosa Gílvez. Ea el Tom. V. del Teatro.nuevo español.

Catalina segunda emperatriz da Rusia.Luciavo Fraycisco Comela.

Católico (El) Recaredo.-Ait. ValladiPeES Y SoTOMaYoR.

Cautela contra cautela.-Tirso. P. II.

No es más que parcialmente de este autor, segun Hartzenbusch en las págs. $\overline{7} \bar{y}$ y 38 de los prels. del tomo de Comedias escogidas de Tirsu, donde opina que su colaborador fiue Alarcon, y que el argumento es el mismo de $E l$ Amor y el amislad, aunque manejado aquí con más tino. Tambien conviene hasta cierto punto con el argu. mento de la comedia Del enemigo el primer consejo.

Cautela (La) en la amistad -V. Cautelas son amistades y Lo que merece un soldado.

Cautelas son amistades.-Felipe GodiNEZ.

Edicion mui antigua suelta. Barrera le da tambien el titulo de Los dos Cärlos; la tengo, en la Parte XLIII. de lis de á fuera, atribuida á Yoreto con el de Lo que merece un soldudo, y es la misma que La cautela en la amistad de que poseo un análisis IS.

Cautivos (Los) de Antioquía.-Axóximo,
Inédita. EI MS. que poseo de ella está fechado en 1613.

Cautivos (Los) de Argel.-Lope. P. $\boldsymbol{X X V}$. Barrera dice que tambien se conoce por Los c'aufiurs, ó los eselumos de Argel.

Cazador (EI) más dichoso.-Diego MuXet $y$ Sol.s. Comedias y Rimas.

Vedel la cita sin nombre de autor.

Cazamento. Egloga moral, en portugues. - Francisco Mavefe de Melo. Obras mélricas.

Cecilia y Dorsan.- Vicevie Rodrígez de Arellivo. Tom. I. del Teatro nuevo español.

Esti Lomada en su fondo de la qur con el titulo de Adela y Dor'sin publicu en fran. ces Mr. Marsollier.

Céfalo y Pócris. Burlesca. - Cilderox. $\boldsymbol{P}$. $\boldsymbol{I X}$. ediciones de 1691 y 1698 , en el Tom. II. de la de Fernández de Apóntes, y en el $I V$. de la de Kicil.

Cegar para ver mejor.-A sibrosio de ArCz. P. XIII. C. A.

En las Comedias esconidas de los mas insignes poelas. S. l. ni a. se llalla con el títuln: Cigar por ver mojor y a nombre de Moreto. En un us. de la bib. del luque de Osuna en que cstí á noinbre de Arce, se intilula: Cegar para ver mejor: Sunla Luciu.

Cegries y Bencerrajes. - V. Encidia (La) de la nobleza.

Celestina, tragicomedia de Calisto y Melibea.-A vóvisı.

Lnos atribuyen su primer acto d Mexa y otros á ROnRigo Cota. el viejo, siendo su continuacion io tres cuartis parti's de ella obra de Fersaxun de liojas. Sobre sus aulores y ediciones veanse los arts. 1157 a 117 i del presente Catílogio.

Celestina.-T. Segunda comedia de Celestina y Tercera parte de la tragico. media de Celestina.

Cena (La) del rei Baltasar.-Moreto.

vo se halla en las partes de este autor. Trac el Inlice de Vyedel dos comedias con este titulo. la mude Calueron y la olia de Vorelo. Ignoro si son mula misma; pero Vera Tisis nos dice que la que se imprimio como de Calderon, no es sura. A nombre de este la ha reproducido Ludwig lemehe en su Handuach der spanichen litteralur.

Cerco de Dio. Primera y segunda parte. En portugues y castellano.-SiMiō MACHADO. Comedias.

Este altor escribió otra comedia llama. da La l'uslora Alfoa. Medel truncaudo y mezclando los títulos, y equivocando el nombre del autor, lia dicho en su Indice: Cerco de Diolo, y Pastora Alfea, de D. Bernardo Machudo. 
C.crco (El) de Numancia.-V. Numancia $\mathrm{La}$.

Cerco (El) de Pavia, y prision del rei de lrancia.-Tínecil. P. II. de Poetas valenciunos.

Cerco (El) de Ródas.-Tirnecas. P. I. de Poclus ralcneianos.

Cerco (El) de Roma jor el rei Desiderio.

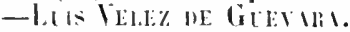

Cerco El te Santa li y ilustre lazaña de Garcilaso de la Vega.-Lork. P. I.

Esta debe ser lit misma que' on el l'ere' frino se intilula: Gurfilaso de la legen. y

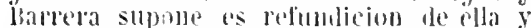
diee tiene Ms. con el tilum de Itechos de Garcilaso de la riga y Moro Turfe.

Cerco (EI) de Tagarete. Burlesca con su entremes intilulado: El Haliontento. - Fruscisco Brisurieno Qunos. P. XXIII. C.A.

Se ha publicado snelta con el seudonimo de D. liomez Yolonso.

Cerco de Viena por Cárlos V.-Lors.

vo estí en las fartes. ni la meneiona Barrera en su Culdilojo. Mi ediejon es lasstillte intigrial.

Carco (E) de Zamora.-Dinuste. P. II. Ciegos Los) y d mozo.-T. Paso de los ciegos.

Civlo (El) por los cabcllos. Santa Ines.This I Yievos. P. IL.III. C. A.

lin el bulice de fajarduse stribure esta

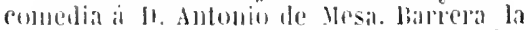
intilula: Senter Ines, la de los lintos cabellos, o el ciedo poe los cabellos.

Ciencia (La), afecto r valor forman magria jor anor, yel Ilágico en Cataluìa. Primera parle.-1. Vencen impulsos de amor los afectos delhonor y el Miigico en Cataluña, y Entre renganza y amor hullar la dicha mayor, y el Mígico en Calaluña.

Cierto (Lo) por lo dudoso.-Lorr. P. XX., y reimpresion de Felpio de 1649.

Cierto (Lo) yor lo dudoso ó la mujer firme.-D. V. R. A. D. Ficenle Rodriguez Arellano.)

En esta refumdicion de la comedia de Lope ingririo hodríguez de Arellano un trozo de Cómo hun de ser los amigos, de Tirso, segun llartzenbuseh en el Catilogo razmudo de lats obras de Fr. Gabriel Téllez.

Ciganas (As).-Gil Viceste. Obras.

farsa que está toda en castellimo como lo hablaban los gitanos de principios del siglo XYl, procedentes de Castilla.

Cinco (Las) blancas de Juan de Espera en Dios.-Ayt. ne Hoerta. P. IXXII. C. A.
Fs probablemente I). Antonio sigler de lluertil.

Ciuco venganzas en una.-Jusx ne AYAL. I'. ILIV.C.A.

Yedel equiroca el noubre del alutor il quien Hiania Maltials.

Cinua. T.-P. Convent.se, traducila del frances (jor el marques de S. Jua:ı?) (Mndrid, 1713.) 8."

Cioso (0). En porlugnes y en prosa.--

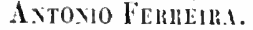

Asi se intitula, y no o Zeloso, como dice Ballreris, en liss Comedias de Sulu de Miran-

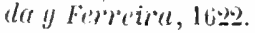

Circe (La) de dos coronas. - A xóvino.

Ciro, lijo de la perri.-V. Contra valor no hai desilicha.

Ciro ! Arpago. - Y. Contra valor no hai desilicha.

Cisma (la) de Inglaterra. - Cumnov. I. VIII., wliciones de 1684 y 1723 , en (a Tum. IV. de la de Firnánde\% de Apointes. en el $I \boldsymbol{r}$. de la de Kícil, en el III. de las Comedias escogidas de estr autor, Madrid, 1831, y en el III. del Tesoro del teatro españot.

Cindal (I.a) sin Dios.--Lonk. Edicion mui antigria y suelta.

lis lat misma que con el titulo de $\mathrm{El}$ intabediente y a nomlore de Claramonte se

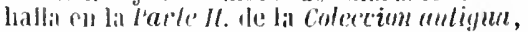
alungur hal entrimbas variantes de smma

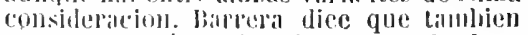
se virrilentria if nombre de Lope en la l'ar-

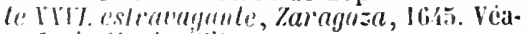
se Imbetiente (1:l).

Cl mentina. Comedia de música.-Rımon we lu Cruz. Tom. F. de su Terutro:

Clementina y Desórmes. - Mr. Movier, trallucilla ch prosa castellana por Dos

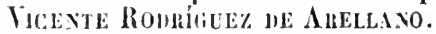

Clérigo (0) da Beira. Farsa porluguesa. - Gill Viceste. Obras.

Collicia (La) rompe el saco.-Cilderox.

Edicinn suelta de Scvilla, Francisco de Leefuluel; pero Vera Tásis niega que sea de este autor.

Coloquio alegórico, entre Castilla, Fineza, Portugal, El disimulo, La desconfianza, La cautela, La infidelidad, Música.-A xóxisı.

Esta especie de zarzuela se escribió en celebridad de haber triunfado Felipe $V$ de los que le disputaban el trono. Barrera no habla de ella.

Coloquio de Fenisa nuevamente compuesto ell Inuy gracioso estilo y muy apacible á los oyentes. -Axóximo. 
Moratin rila una rdicion de Scvilla. I.a.10, y si ha reimpreso en el mim. T del Critican de li, llarde, copiantolo de la edicion que yo le jon licelia en lalladolid, herederos

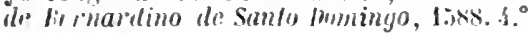
4 hinjis.

Coloquio del santo uacimicnto de nuestro Señor Jesu Cristo, entre tres pastores. -lópez le Libur. En su Cancionero, 1586.

Colopuio, en el cual se remeda el uso, trato y pláticas, que las damas en raleucia acostumbran hacer y trner en las visitas yue se hacell unàs á otras. Tiene dos principios diversos.-FerNivnez de Heremi. Obras.

Cologuio entre un alma y sus tres potencias, donde se introduce irse dellas amotinada por el mal servicio que le hacen. - Dimis IIE Vifils. Libro de poesía cristiana, y en el Tom. XIY. de la Biblioteca de Rilualencira.

Coloyuio latino-esjañol de la honra y provecho yue traen las letras. En latin y español, y en prosa y verso. - Avosiso. Sa halla en la Relricion de la fiesta de S. Ignacio por Luque Fajardo. 1610.

Cologuio pastoril con metảfora de ciertos juegos aldeanos: Drama en dos aclos. - Ai.osso ne Ledesul. P. I. de sus Conceplos cspirituales.

Cologuio pastoril, en que un pastor Hamado Torcato cuenta á otros dos pastores, llamados Filonio y Grisaldo, los amores que turo con una pastora llamada Belisia. En prosa.-Ivтомio de Torocemid. Los Colloquios saliricos.

Coloquios (Dos) entre los ermitaños Alberto y houpe.-Axóvivo. En La Juventuditriunfante.

Comedia hecha por Lic is Femrixdez. ch Inuguaje y estilo pastoril : en la rual se introducen dos pastores ! dos pastoras y un riejo, los quales son llamados Bras-Gil y Beringuella y Yliguel Turra Y Olalla: $Y$ el vicjo es llanialo Juan Beuito. En las Farsas de csto autor Salamanca, 1514, Madrid. 1867. y en el nim. T del Criticon de Gallardo.

Comedia (Ia) nueva.-Imaco Cramo. (D. Leandro Fernindez de Horatiu.)

Tambien se ha publicado bajo el tilulo de El Culé.

Comedia sin música.-Dival I Herenu.

No es drama representable. sino un dialogo en que se diseuten ilyunas matrerias politions culle rarios t'seritores y personajes distinguidos.
Comendador (EI) de Ocaña.-V. Peribañez, el comendador de Ocaña.

Comendadores (Los). Farsa. - Leis DE vit.x. El Corlesano.

Comendadores (Los) de Córdova.-Lope DF VEcil. P. II. y en el Handbuch der spanichen litleratur de Ludwig Lemekc.

Tambien se conoce con solo al titulo un los Comendadores.

Comerciante (El) ingles. En prosa.-Axó. siyo.

Tuxe una pieza de lalladires y solomaror intitulata: El fabriranle de jains $\dot{o}$ el romercianle ingles; ismor si seria la misma.

Conserciantes (Los). En prosa. - Cirlos Gothos.

lofeprea el mombre del trabluctur.

Cominge perscguido, ó sea los amores del conde de Cominge. Segunda parte. $\mathrm{N}$. $\mathrm{X}$.

l.a minera parle. que posen tambien, se intiulia: Amorevelel romele de Cominges.

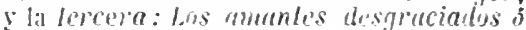
il enmer de tomingye.

Como à palle y como á rei.-Wostusis.

Vedel cita una con el título de comm madery enun rei. que atribuse a lillteron, ell In que se equiroca. La froc poien a momlore de Vontalyan estil implosin ell salamanca i menliarlos del sigho pasalo. \& conto do este se roimprimio en th Tom. II. de sus compdias escofitus. Malpinl, Isis. Yell I Bibliotece de Riluadencira.

Cono amante y como hourada.-PÉrez DB Mostilyix. Toin. II.

Cómo ha de ser el valiente.-Diego Mcxet r Sols. Comedias y Rimas.

Cómo ha de ser la amistad.-L. A. J. M. (D. Lais Moncin, serun Moratin.)

Cómo lian de ser los amigos. - Tirso. En el cuarto de sus Cigarrales.

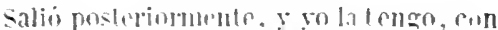

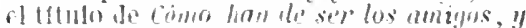

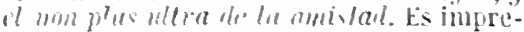

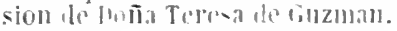

Como la luna creciente tambien tiene el sol mensuante. T.-A róviso.

Cómo luee la lealtad á vista de la traicinn.- Toy is . Forbe y Corregel.

lat longo tambion pon ol titulo arriba copiado : añade: l'o! olro lilulu la lliju th! Senesterl.

Cómo nació S. Francisco.-Rouar Moxtero y Frivcleco Villegls. Este es el titulo que lleva en la Tabla de la P. AXII.C.A.; sin cmbargo el de 
la comedia es El nacimiento de San Francisco.

Nedel la da como de dos Ingenios.

Como noble y ofendido.-Axtorio DE LA CuEN. P. XLII. C. A.

Cómo se curan los zelos y Orlando furioso. Zarzuela precedida de boa.-Bixces Cindsuo. Poesías cómicas, Tom. I.

Cómo se guarda el honor.--Moxtalvix.

Cómo se vengan los nobles.-Moreto. P. III. Valencia, 1676 y 1703, y XXIX. C. A.

Con este titulo se publici tambien $E l$ teslimorio vengado de Lope.

Cómo se rengan los nobles.-Lope. Y. Testimonio (El) vengado.

Competencia (La) de genios. Drama para poner en misica. - Nicolis Mivito. Traducido del italiano por Juax Suvistre Salyá.

Competidores y amigos.-Ait. DE IIUERT.1. Flor de las mejores doce comedias y en las Dace comedias las mas grandiosas.

Este autor es probablemente D. Antonio sigler de Huerta.

Con amor no hai amistad.-Míros. P. I. Con quien vengo, vengo. - Cuntoros. $P$. VIII., ediciones de 1684 y 1726 , en el Tom. $V$. de la de Fernández de Apóntes, en el $I V$. de la de Keil, en la P.I. C. A., en la XXXI. de las de á fuera, 1638, y en el Theatro hespañol de Huerta.

Con su pan se lo coma.-Lope. P. XVII.

Conde (EI) Alárcos.-Gullex lie Castro. P. I. y Comedias de los mejores \&., Lisboa, $16 \% 2$.

Conde (E1) Mlárcos.-Mira de Auescua. P. V.C.A., y en un tomo de comedias que, segun Mesonero, pudo ser I. Parle de las de este autor.

Conde (El) de İlos.-Guillex de Castro. $P$. $I$.

Conde $(\mathbf{E} \mathbf{l})$ de (Olsbach. Comedia en prosa, del tealro aleman, arreglada al español.-Axóxino. En el Tom. VI. del Teat ro nuevo español.

Moratin se la atribuye á D. Agustin (iar. clia de Arrieta.

Conde (El) de Saldaña. Primera parle.Cubillo de Arilgox. Suelta.

Conde (El) de Saldaña y hechos de Bernardo del Carpio. Segunda parte.Cublelo de Arafiox. P. XIII. C. A.

Conde (El) de Sex. - Axósiso. En la
Parte $X X X I$. de las de a fuera, Barcelona, 1638.

Es singular diga Barrera que precisamente enl li citada Parle XXXI. se encuentra á nombre de D. Antonio Coello. Con este mismo título se halla entre las Comedias escogidus, Bruselas, 1704; pero allí se le da por autor á Mátos Fragoso. Yo la tengo de dos distintas ediciones sueltas con el título de Dar la vida por su dama, el conde de Sex; en nua dice ser de $m$ Ingemio y en la otra de D. Luis Cocllo: á este mismo D. Luis, y no á D. Antonio se atribrye en otra impresion que poseo, en la que solo se intitula: Dar la vida por su dama.-En El Mejor de los mejores libros de comedias, Maulrid, 1655, salio con el Lítulo de La tragedia mas tastimosa de amor y á nombre de D. Antonio Coello. Ochna la ha reimpreso en el Tom. V. del Tesoro del tealro y habla en la paig. 98 en términos que suponen á la comedia Dar la vida por su dama, diversa de la del Conde de Scx, que denomima La Iragedia mas lastimosa, el conde de Sex, y la cree escrit a por Felipe IV; otros la han atribuido al conde de Lémos.-Supongo que la que Vedel scr̃ala como de Calderon, serí esta misma.

Conde (El) Don García de Castilla. T.Lorexzo María ne Villarroel. Madrid, 1778.

La tengo tambien impresa en Barcelona con el litulo de El Conde D. Garei-Scinchez de Castilla, sin nombre de autor.

Conde (El) Fernan González. T. c.-Lope. P. XIX.

Barrera añade á este título : y liberlad de Castilla.

Conde (El) Lucanor.-Caloerov. La que se publicó en la $\boldsymbol{P} . \boldsymbol{X} \boldsymbol{V} . \boldsymbol{C}$. $\boldsymbol{A}$. la reprobó por adulterada el mismo Calderon, como puede verse en el Prólogo de Vera Tásis á la Quarta parte de las Comedias de este autor, 1688 y 1731 , donde se imprimió nuui variada, y tambien en el Tom. IV. de la edicion de Fernández de Apóntes, y en el II. de la de Keil.

Conde (El) Partimúples.-Ana Caro MaLlex de Soto. P. IV.C.A.

Condenado (El) por desconfiado.-Tinso DE NIOLINA. P. II.

Hartzenbusch, que la ha reimpreso en el tomo de Comedias escogidas de Tirso, $\mathrm{y}$ Duran, opinan que es una de las cuatro de la II. Parte escritas enteramente por este autor.

Condesa (La) de Belflor. - Moreto. P. $X X Y$. C. A.

Es El perro del hortelano de Lope, que 
se publico con aquel titulo variándole el nombre del autor.

Condesa (La) de Castilla. T. - Nicasio Álvarez de Ciespoécos.

Condesa (La) de Jenovitz.-V. Rencor (El) más inhumano.

Condesa Matilde.-V. Resistencia (La) honrada.

Condesa (La) perseguida, y el capuchino escoces.- Ux Irgevio.

Firster trae una con igual titulo, que atribuye á Fr. Félix de Adsaneta.

Confesion (La) con el demonio.-FriscisCO DE la TORre. P. X LIF. C. $A$.

Confidente (EI) casual.-GisP.IR DE ZabaLA Y ZAMORA.

Confusion (La) de Hungría. - Mra dE Amescua. P. XXXY. C. A.

Se halla atribuida á Ione en un tomo colecticio de la bib. del duque de osuna.

Confusion (La) de un jardin.-Moreto. P. III. Valencia, $1676,1703, M a-$ drid, 1681, Valencia, Orga, s. a., У en el Tom. III. de las Comedias escogidas de este autor, 1831.

Confusion (La) de un papel.-Moreto. V. Engaños (Los) de un engaño del mismo.

Conquista (́La) de Cuenca y primer dedicacion de la Vírgen del Sagrario.-RoSETE Nis̃o. P. XXI. C. A.

Conquista de las Malucas.-Melciror Ferváviez de Leos. P. XLFI. C. A.

Conquista (La) de Madrid por el rei don Ramiro, y conde Fernan González.Axóviso.

Conquista (La) de Méjico.-Fersaxdo de Zarate. P. XXX. C. A.

Conquista (La) de Oran.-Lù's VÉlez DE Gevara. P. XXTV. C. A.

Barrera añade al tílulo: $\delta$ el gran Cardenal de Espiña.

Conquista (La) de Tenerifo, y conquista de Canaria, ó Nuestra S ñora de la Candelaria.-F. Guanches (Los) de Tenerife.

Conquista (La) de Valencia por el rei D. Jaime.-Uy lygexo valexciaro.

Esta serí la que Vellel menciona como anónima.

Conquista (La) del alma.-Cillderox.

Fsta comedia la tengo suelta $y$ no se halla en las ohras de este autor verdad es que él 110 la menciona ell la Memoria que envió al duque de Veragua; pern tampoco la cita Vra Tásis como atribuida falsamente á Calderon.

Constancia (La) de Arcelina.-Juax de LA Cueva. Comedias y Tragedias.
Medel llama equivocadamente al autor de esta comedia D. Francisco Antonio de la Cueva.

Constancia (La) española.-Axósiyo.

Esta es probablemente la picza que cita Moratin con el título de $L a$ conslancia es. pañoln, y silio de Cnluhorra.

Contra el amor no hai engaños.-Aviovio Exrígezz Gómez. Academias de las musas.

En la P.X.C. A. se publicó á nombre de D. Dieso Enriquez.

Contra la fé no hai respeto - Ly Irgevio, segun el epigrafe de ella ell la Parte XXXIX. C. A.; pero en la Tabla ó indice de dicha Parte se atribuye á D. Diegro Gutiẻrrez.

Barrera la da ademas el titulo de El escluvo de su padre.

Contra su suerte ninguno.-Jerósimo $\mathrm{V}_{\text {- }}$ lo de Mous.s. P. X I . C. A.

Algunos la han atribuido á Tirso, segun llartzenbusch pág. Xill. de los prels. lle las Comedias escofjilas de Tirso. En este error incurre Yedel que olvida la de Mal') de Molina.

Contra valor no hai desdicha. - Lope. P. XXIII., y en la XXXI. de las de $a$ fuera, impresa en 1638.

Barrera añade: y primero rei de Persia, suponiendo ademas que se conoce por los tllulos de Ciro hijo de la perra, y Ciro y Arpago.

Convidado (EI). - Lope dE ReEd.

Con este título ha reimpreso Yoratin en sus Origentes del Tealro, el cuarto Paso del Deleitosn de aruel autor. Tambien está on el Hrondbuch der spanichen lilteratur de Ludwig Lemeke.

Convidado de piedra.-V. Burlador (El) de Sevilla, y To hai deuda que no se pague.

Coplas donde se trata como una hermosa donzella, andando perdida por una montaña, encontró un pastor, el cua!, vista su gentileza, se enamoró de ella, Y con sus pastoriles razones la requirió de anores; á cuva requesta ella 110 quiso consentir. I despues viene un salvaje á ellos, y todos tres se conciertan de ir á una ermita que alli cerca estaba á hacer oracion á nuestra Señora. Composicion dramálica en verso. - Avóvivo. Papel suelto impreso varias vezes, y reimpreso en el Ensayo de una bib. esp. Tom. I. coluna $703 \mathrm{y}$ sigs.

Cornelia. F. - Avures Prido. Medina, 15 วัว 7 y $1603.4 .^{\circ}$ gót.

Cornudo y contento.-LOPE dE RCEDA. 
Con este nportuno titulo ha bautizado storatio el $P a * 0$ tercero del Deleiloso de aquel aulor, que ba reimpreso cu sus origenes del Tealio.

Coroma (La) en tres hermanos.-JuAx DE Vera r lillaroel. P. $\boldsymbol{X} L \boldsymbol{Y L}$. C. $A$.

Cada aclo lleva um tílulo especial que ya he colocado en ra silio que le corresponde scirtm (") irden allabelicn.

Corona (La) merecida.-Lope, P. XIV.

lit Indice de lledel meneiona otra del mismo lálulo que alribuye í Joscoso.

Corsaria catalana.- - . Cosaria catalana. Corle (La) del demonio.-Luís Yélez ne Gevira. P. XXIIII. C. A.

Wridel se equivoca en decir que es de Juan Velez.

Corle (La) en el valle.-Fraxc. de Avealtiem, Mátos Frifioso y Sebastiax Inlabiciosa. P. IXII. C. A.

Vedel lil dis sulo emmu de tres Irgenios

Cortes de Júpiter. Tragicomedia portuguesa, en la que se halla un Romance en español.-GiL lice.tTe. Obras.

Cortesana (La) en la sierra.-Thes Iygevos. P. XTVII. C. A.

El sr. Barrera posee una copia mamms. rrila antiona en la que se abribuge i Milos. Diamanle y Juan Velez de linevala. La leuso lambien con el tilulo de l.u com/l'su-

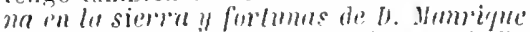
de lara, enya adicion de lltulo no se hislla

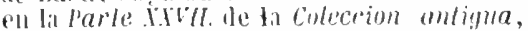
i pesar de que ol sr. Barlera parece illdi-

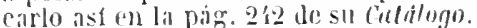

Cortesia (La) de España.-Lope. P. MII.

Cosaria (La) catalana.-Mítos Fragoso. P. XXXIX. C.A.

Creacion (La) del mundo, y primer culpa del hombre. Con una Loa sacramental al fin.-Lope. Edicion suelta ! antigua.

Es La primer culpa ded lombre de la

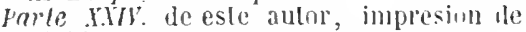
Wadrid.

Criada (La) más sagaz.-A xósino.

Criado (El) de dos amos. En prosa.-Traducida del italiano por Jost CovCIII.

Criados Los). P.-Lope ue Reed. Deleitoso.

Esle es el 1fluh que poulria laı'se, segun Barrera, a luno de los l'ases le Rueda atue olliliij Yoralin en sus Origenes ded teatro.

Crisol (EI) de la lealtal.-.-Y. Pocos bastan si son buenos, y crisol de la leallad.

Cristina de Suecia.-Lucisio Frtxcisco Comella.
Cristo (EI) de los milagros. - V. Santo Cristo de Cabrilla.

Crítica (La) del amor. - V. No hai burlas con el amor.

Cruel (La) Casandra. T-Caistóval de Virues. Obras trigicas y líricas.

Crueldad (La) por el honor. - Ruiz DE Alircox, P. II.

Cruz (La) de Caravaca.-J. B. Diaminte. P. TXVII. C. A.

Cruz (I.a) en la sepultura.-Gadoeros.

Es La Derocion de la Crus: pero con el priuter litulo y í nomlure de lopese encuentra en su $p$. Xlll. de Mulvid, y segun lurial en la rivill. de las de a fuera, 11':1'scul, 1654.

Cuadro (El). En un acto y en prosa.Axóxino, de la segunda mitad del siglo XVill., segun Moratin.

¿Cuál es afecto mayor, lealiad, ó sangre ó amory-Bixces Civnivo. Poesías cómicas, Tom. I. y P. XLVIII. C. A.

La tengo suelta con irnal totum advirtirndose que hat sido represenlada nuevamente con el de Trinmfio de Tomiris. Moraliı la cilia anónima.

Cual es el mayor aprecio del descuido de IIna dama. La Jarretiera. - Fnavc. Bíxces Caxinaro. En el Tom. II. de sus Poesías cómicas lleva el títnlo de $L a$ Jarreliera de Inglaterra, el mayor aprecio del descuido de una llama.

Cuál es la fiera mayor entre los mónstruos de amor.- V. Fieras de zelos y amor.

Crál es lo más en amor, el desprecio ó el faror. Z. - Stlvidon de lat Cueva. P. XLIII. C. A.; segun Fajardo tambíen se halla en otra Parte XLIII. de Comedias de diferentes autores, impresa en Valencia en 1660.

Cuál es mayor perfeccion? - Culneron. $P$. $V$., ediciones de 1694 y 1730 , en el Tom. IX. de la de Fernández de Apóntes, en el $\boldsymbol{I I I}$. de la de Keil, en el II. de sus Comedias escogidas. Madrid, 1828 , en la $P$. XXI. C. A. y en el Theatro hespañol de IIuerta.

En alorunas impresiones lleva el lítulo de "Crull "s mayor perfeccion, hermosmiel o iliscrecion?

Cuando Lope quiere, quiere.- V. Castigo (El) sinvenganza.

Cliando no se aguarda. - Frarcisco DB Leiva Ravírez de Arellino P. $X L$. C. A., en las Comedias de los mejores, Colonia, 1697, y en sus Comedias escogidas, Madrid, 1823 , donde tiene el titulo de Cuando no se aguarda, y 
principe tonto, como tambien en el Tom. $V$. del Tesoro del teatro español. Cuando tocas vendo, desengaños toco.V. Toquera (La) vizcaina.

Cuantas veo tantas guiero. - Seb.sstias Villaviciost y Fravisco Aveliased. P. XXV.C.A. y en la Coleccion de dramáticos posteriores $\dot{a}$ Lope de la Biblioteca de Ribadeneira.

Cuánto cabe en hora y media.-Juax DB Vera $\mathrm{x}$ Villaroel. $P$. $X L V I . C . A$.

Cuánto mienten los indicios, y el ganapan de desdiehas.-Dinmaste. P. II. y en la Coleccion de dramálicos de la $\mathrm{Bi}$ blioteca de Ribadeneira.

Medel la cita con el título de Gonapan de desdichas.

Cuánto se estima el honor.-Gulllex oE Castro. P. II.

Cuatro (Las) estrellas de Roma, y el martirio más sangriento, S. Eustaquio.Ux Ixgesio de TAlayera la Real.

Barrera indica tambien la variante en el título de el marlirio más perseguido.

Cuatro (Las) naciones, ó la viuda sutil. -Avósisio.

Es traduccion del italiano, y segun indica Moratin está hecha por D. Ant. Valladires y Sotomayor.

Cuentas (Las) del Gran Capitan.-Lope. P. XXIII.

Cuentas (Las) del Gran Capitan.-José DE Cax̃izáres.

Es diferente de la de Lope.

Cuerdo (El) en su casa.-Lope. P. VI.

Cuerdo (EI) loco.-Lope. P. XIV.

Lord Itolland posela un manuserito autógrafo, en el que se añale al título de la impresa, ó veneno saludable.

Cuerdos hacen el escarmiento.-FrixcisCO de Ylllégas. P. XXX. C. A.

Este es el título que lleva el epigrafe de la comedia y en la parte superior de las páginas pares; pero el que liene en la tabla es: Cucrdos hacen escurmicnlos.

Cuerdos hai que pareeen locos. - Jes. Zabaleta. P. XXXIII. $C$. A.

Medel cita otra de Yontalvan con igual título que tal rez sea la misma.

Cueva (La) de Salamanca.-Ruiz de Al.Arcos. P. I.

Cueva y castillo de amor.-Fraxcisco DE LeIva. P. $X L I I I$. C. A.

Culpa (La) más provechosa.-Frivicisco de Villégas. P. XX.TII. C. A.

Medel llama á pste autor Jiıan.

Cumplir á Dios la palabra.-Diamate.
Barrera añade al título: $\delta$ la hija de Jephté. Véase Cumplirle da Dios la palabra.

Cumplir con su obligacion. - PÉrEz DE Moitalyax. Tom. I. de sus Comedias, en el I. de las Fscogidas, Madrid, 1827 , yen la Biblioleca de Ribadeneira.

Cumplir dos obligariones. - Lus Vélez de Guevirt. P. VII. C. A.

Es fasi identiea i la intitulada: Obligarion a las mijeres, $\mathrm{y}$ el asunto $\mathrm{y}$ argumento igual al de Crmiplir dos obligacione's, ! duquesse de Sajomia del uismo dutor. Meilel la atribuye equivicadamente á ll. Juan Filez.

Cumplir dos obligaciones y duquesa de Sajonia.-Luss Velez de Guevars.

El asunto y argumento srin los mismos que el de las intilularlas: Cumplir ulos nbliguciones y obligacion a las mujeres, de esti: autor.

Se equivora Barrera en suponer que esta comedia es la que se halla en la l'. MII.C.A., pues la que se encuentra ell ella es la qute lleva el título pelado de cmmplir ros obligreiones. Medel la cita con solo el de Dhquesı de Srljonilı.

Cumplirle á Dios la palabra.-Dismave. P. II.

La tengo tambien suelta como de un Ingenio, Segun Fijardo se halla en una Sigumdic parte de zurios antizua eon el titulo de cuniplir is Dirs la palubia, que es al que lleva efectivamente en el lndice de la P. II. de sus Comedias.

Curioso (El) impertinente.-Gullex DE Cistro.P. I.

Custodio (El) de la Hungria, S. Juan Capistrano.-Axt. De Zinori. Tom. $I$.

Charlatan (El). Drama jocoso en música para representarse en el nuevo teatro de la sala del duque de Gandia en lalencia, el invierno de 1769.-Axovi1ro. Valencia, ciuda de José le Orga, s. a. $8^{\circ}$

El original italiano llera por tílulo $\|$ Cicurlone, y se lialla al frento de la traduc. cion east ellitha.

Charja (La) más rengativa y guapo Baltasaret.- Lx Ixigrio valicino.

Cháves (Los) de Villalba.- V. Blason (El) de los Chaves.

Chico Baturi.-Ast. de Heerta, Ciscer y Rosete. P. I. C. A.

En el Indice de este tomo se añade al lilulo antedicho:! siempre es culpat lu diesdicha no desgracin. Comn diee Batreren. Antmio Ifuertil sera sin duda Ant. Sigler de lluerta.

Chismoso (El). - Frixcisco Meseger. Tom. III. del Teatro nuevo español. 
Dama (La) boba.-Lope. P. $\boldsymbol{I X}$

Danıa (La) capitall. - DiEgo y José DE FIgenol y Córdova. P. XXíV. C. A.

Barbosa Vachado cita una con el mismo título que atribuye á llitos.

Dama (La) corregidor.-ZAB.ALETA y VILLAvitilosi. P. YII. C. A.

"iedel la atribuye ä dos Ingenios.

Dama (La) del Olivar.-Tinso. $\boldsymbol{P} . \boldsymbol{V}$.

Don Ramon Mesonero la refundio perfectamente en 1827, bajo el titulo de Lorenza lit de Estercuel.

Dama (La) doctora , ó la teología caida en la rueca. - Axóxino. Traducida del frances en prosa. Aviñon, s. a. (hácia $1750)$.

Es una pieza ridicnlizando a los jesuitas.

Dama (La) duende.-Calofroy. $P$. I., ediciones de 1636 (?), 1640,1685 y 1726 , en el Tom. III. de la de Fernández de Apóntes, en el $I$. de la de Keil, en el I. de las Comedias escogidas de este autor, Madrid, 1826, y segun nota de Duran, en la $\boldsymbol{P}$. XXIX . de las de a fuera, Valencia, 1636, y en la XXX. de las mismas, Zaragoza, 1636. Tambien está en el Thealro hespañol de IHerta.

Dama (La) melindrosa.-Lope.

Es la misma que Los Melindres de Beli$s a$ y se reimprimió en el Tom. $I V$. de sus Comedias escogidas, Madrid, 1832, y en cl II. del Tesmo det teatro español. Tengo una refundicion hecha por Trigueros con el título de La me!indrosa ó los e'selaros supuesios.

Dama (La) muda.-Lx Ixgexio.

Barrera añade $y$ lances de un broche. El Sr. Duran posera un Ms. fechado en 1713.

Dama (La) presidente.-Frtxcisco DE Leiva Risírez de Areliano. Tomo de sus Comedias escogidas, Madrid, 1833.

Dama (La) sutil.-Lucraxo Frixcisco CoMELLA.

Danza de la muerte.-V. Danza general en que entran todos los estados de gentes.

Danza de los pecados.-Diego Sívchez DE Bildsoz. Recopilacion en metro. 1554 .

Danza del santísimo Nacimiento de Nuestro Señor Jesu Cristo, al modo pastoril.-Pedro Suárez de róbles.
Moratin dice que hai edicion de Madrid, $1561 ;$ la que yo tengo es de 1606.

Danza general en que entran todos los estados de gentes. $\boldsymbol{F}$.-Axóximo de mitad del siglo XIV.

IIablan estensamente de ella Moratin en los Origenes y Martínez de la Bosa en las notas á sll Poéticr. La ha publicado integra D. Florencio Janer en Paris año 1856 , $\delta^{\circ}$ con el título de La danza de la muerte, y tambien se halla en el segundo Apéndice de la oluril de Ticknor.

Algunos hin supnesto, aunque con pocos datos, que el autor de esta pieza fué labi Sell-Tob (Don Sinto, judío de Carrion).

Dar con la misma flor.-V. Quién engaña más à quién.

Dar la vida por su dama.-V. Conde (El) de Sex.

Dar tiempo al tiempo.-Calderon. $\boldsymbol{P}$. VI., ediciones de 1683 y 1715 , en el Tomo VIII. de la le Fernandez de Apóntes, en el III. de la de Keil, en el II. de las Comedias escogidas de este autor, Madrid, 1828, en la P. XVIII. C. A. y en el Theatro hespañol de Huerta.

Hai una Loa de Salazar y Tórres para esta comedia.

Darles con la en gini la $P$. XXXI. de las de a fuera, impresa en 1638.

El Indice de Medel la atribuye á D. Lu is Belmonte y lo inismo hace Barrera: no sé la exactitud que habrí en esto; en lo que positivamente falta a ella el íltimo, es en suponer que esta comedia sea la misma que Diego Garcín de Paredes ó El valor no liene edal, como parece indicarlo en la página 515 de st Calálogo.

Darlo todo y no dar nada. - Caloeron. $P$. VII., ediciones de 1683 y 1715 , en el Tom. $\boldsymbol{X} \boldsymbol{I}$. de la de Fernández de Apóntes, en el $\boldsymbol{I V}$. de Keil y en la $\boldsymbol{P}$. VIII. C. $A$.

Darlo todo y no dar nada. Burlesca.-PEno Lanisi Stgredo. P. XXXT". C. A.

Darse zelos por vengarse. - uRIstóval Lozano, en las Persecuciones de Luzinda.

Medel la trae anónima.

David perseguido.-V. Montes (Los) do Gelboé.

De cosario á cosario.-Lope. P. XIX. reimpresion de Velpio de 1649. 
Dé cuando acá nos vino.-Lope. P. XXIV. Zaragoza, 1633.

De fuera vendrá.-Moreto. P. $I$.

Tengo una impresion suelta del siglo Xill con el titulo siguiente: De fuera vendrá quien de cusa nos pchará, y así se halla en el Theatro hespañol de Huerta. El librero Quiruga en una reinipresion de 1796 aun añadio: La lia y la sobrina, y con este largo iltulo se halla en el Tom. Il. de las Comedias escogillas de Voreto, 1828. Medel cita una picza de este autor denoninada Tia y sobrina, que sin duda es la misilia.

De los bechizos de amor la música es el mayor, y el montañes en la corte.CAX̃̄izÁRE.

Se ba impreso suelta varias vezes con este largo título, y se halla con él en el Thealro hespañol de Huerta; pero en el Tom. I. de las Comedirs escoqidus de Cañizåres, Medrill, 18\%9, solo lleva la primera parte. Barrera tambien la intitula: El wicisico por amni, ó el Monlañes en la cor!e, Don Lain de Cascajares, El Asluriarin en Madrid y Húsico pur amor, y De los encantos de amor", la misica es el mayor, os et Asturiano ch la corte, don Lain de Cascajores.

De un acaso nacen muchos.-I. A. J. II. Moratin se la atribuye á D. Luis Moncin.

De un castigo dos venganzas.-PÉrez DE Moxtalvax. Para lodos, en la P. MLIV. de las de a fuera, Zaragoza, $1652, y$ segun nola de Duran, en la XIY. de las mismas, Zaragoza, 1632 .

Se inflere del epigrafe de un soneto de D. Pedro de la Peña, que se halla en un manuscrito coetaneo que poseo, que D. Jerúnimo de Villaizan escribió otra comedia con el mismo título, que ignoro si se ha impreso, pudiendo solo decir que ni Medel ni Barrera hablan de ella. Este illtimo tambien da á la comedia de Vontalian el título de Un castigo en dos vengunisus.

De un castigo tres renganzas. - CALDERox. Seguu Duran se encuentra con este titulo en la $P$. XYVIII. de las de i fuera, Huesca, 1634.

Yo la tengo suelta. Es ln casligo en tres vengansus de calderon.

Medel trae otra á nombre de Lope que tal vez sea la unisina.

De una callsa dos efectos. - Calderor. $P$. $V$., ediciones de $169 t$ y 1730 , en el Tom. IX. de la de Fernảidez de Apóntes, y en el III. de la de Keil.

Es igual á la publicada en la $P$. Xxtrm. C. A. con el tifulo de El amor hace dis. cretos.

Decio y Eraclea. Opera, precedida de una Loa, para recitar en música.Eı. coNDE DE LAS TórRes. Madrid, (hảcia 1708). $8 .^{\circ}$

Decreto (EI) del cielo. Especie de Paso. - Castillo Solonzavo. Varios y honestos entretenimientos.

Defender à el enemigo en la traicion que es lealtad, y defensa de Carmona.D. A. R. Y.

Defensa de Barcelona por la más fuerte amazona. - FERY1Y dEL REl.

Defensa (La) de Cremona. - Y. Preso, - muerlo y vencedor.

Defensa (La) de la fé. y principe prodizioso.-Y. Príncipe (El) prodigioso.

Defensa (La) en la verdad.-Lope. Imp. suelta antigua. No está en las Partes.

En el Indice de Vedel no lleva nombre de autor. Y Rarrera solo trae mina anunima con el título Defensi de la verelail.

Defensor (El) de la fé.-V. Principe (EV) prodigioso.

Defensor (El) de su agravio.-Moreto. P.III., Valencia, 1676 y 1703, Falencia, Orga, s. a., en la $P$. M.XV. C. A., en las Comedias escogidas, Bruselas, 1701, y en sus Comedias escogidas. Madrid, 1831.

Defensor (El) del Peñon-Dinaris. P.I., yen el Ameno jardin de comedias, 1734.

Defensor (El) del Rosario-Y. Derucion (La) del Rosario de Diamante.

Defensora (La) de la reina de Hungría.Fervayo de Zarate. P. MTIX. C. A.

Degollacion (La) de los inocentes. Coloquio.-GASPAR FERIXiYdez I AVILA. Infancia de Jesucristo.

Degollado (El).-Jiri de la Cueva. Comedias y Tragedias.

Melel casi siempre equivoca el nombre "apullido we este antor, y al citar esta comedia le llana loneva.

Dejar dicha por más dicha. - Ruz DE Alareos. P. YLV.C.A.

Es la misma que Yudarse por mejuinarse de la P. CLL. de la C. A. i Por mejoria de

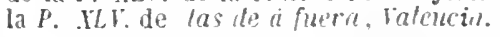

Dejar un reino por otro, y. Mártires de Madrid.-Civeer, S. De Villaviclosty Moreto. P. . ILIF. C. A.

Segun Barrera es los lo'es soles de Madril, publicada suelta a nombre de Monroi.-Barbosa cita una con el mismo titulo que supone de Vátos: lo tengo por equivocacion del bibliografo portugues. Vedel la atribuge à tres Ingenios.

Del cielo viene el buen rei.-RODRIGo DE 
IIerrers. P. VIII. C. A. Reimpresa en la Biblioleca de Ribadeneira.

Yldel llama Francison à estr antor.

Del encmigo el primer conscjo.-Tinso. P. III. y ell ol tomo de Comedias escogidas de Tirso. jublicado por Ribadeunira.

Del mal el ménos.-Tirso. F. Acerigüelo Virgas.

Fi Indires de Melel sulo menteina la de

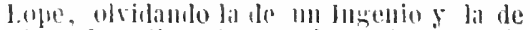
Tirso de yolina, a pesal deste las the's diripsis.

Itel mal lo ménos.-lrs Ixiexo. Parle AIIVIII. C. A.

Es distinta de la de lope ghe llova rel

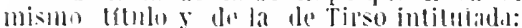

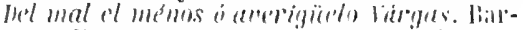

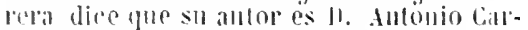
domal maripues de Castolnmol.

Del mal lo ménos.-Lope ne Veris. P. IX. y reimpresion de Velpio de 1649.

Del rei abajo ungugno. -Róss Zonralc. La P. XLII. He las de a fuera, Zaragoza, 1630 , dice ser de Caluleron; pero yalvierte lera Tásis que esto no es icierto.

Esta comedia la salido siempre á mombre de Rivias y con ef lituh de lhel rei rebujo

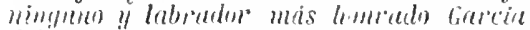

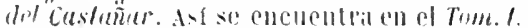
de las commedies escongedas de Bojas, Madrill, ls:- y Barreris and lo añde Conde

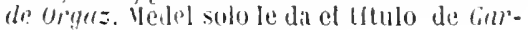
cire del crislañar.

Delincuente (El) hourado. En prosa.1). Tommo scirez ue Livgreno (Don Gaspar Mclchor de Jovellinos). En el Tom. III. de sus Obras, en el V. del Tesuro del tealro espanol, r suelta.

Delincuente (EI) sin culpa, y bastarlo ds, Iragon. - Hitus lingoso. P. XIV. C. A.

Yedel cita ma anonima con solu el lílllli) de til delincuenle sin culpa, fue probililinente seri la de Miflos.

Dulirio (El), ó las cousecueneias de un vicio. Opera cómica. En prosa y verso. - R. Sr. Cir, traducida del frances por Bertox.

bemofonte (El)-Riyiro Disz Sirigo.

yoratin menriona ma pieza con este li-

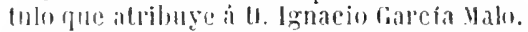

Demonio (El) en la mujer, y el rei ángel de Sicilia. Primera parie.-Rei angel de Sirilia, y' Principe demonio y diablo de Palerno. Segunda parte.-Jutr Je II)slc I. P. XLIII. de las de á fuera, Zaragoza, 16000 .
Barrera da truncado el filuto de la segundil parte, y ademas se rquivoca en suponer plue oll el $10 m 0$ impreso en Zarigoza se atriluye estil comedia í lntonio de Cas. tro: 10 que en iblice es que la represento este aclor.

Desafío (El) de Cárlos Y.-Rósus ZorriLLA.

Desagravios (Los) de Cristo.-Cubillo de Arifiox. El Enano de las Musas, y P. X.T.II, de las le i fuera, Zarago$z a, 1640$, segun los traductores de Tichnor.

Barrena añade al tínlo ímles copiado: Jernsulen destruida por Tilo y lespusiano. la l'ingan:a en el imperio.

Desconlialo (EI) -Lope. P. IIIII.

Desde Toledo á Madrid.-Tirso. P. XXVI. C. A. Si reimprimió en el Teatro anliguo español, 1S37, y por IIartzenbusch en al tomo de Comedias escogidus de Tirso, 1848.

Desden (EI) con el destlen.-Moreto. En SII P. I. Comedias escogidas. Bruselas, 170h, Comedias escogidas de los mas insignes poclas. S. l. ni a., ell sus Comedias escogidas, 1826, en el Tom. IV. del T'soro del tealro español, y en el Theatro hespañol de IInerta.

Hai un liteso burlesen imitando otro de estil commoliat, en las . Mehuyas jocosus do Alum y relisso.

Desden (EI) renegado.-Róms Zorrilat. I. XYI. C. A. Y Tom. II. de las Comedias pscogillas de este antor, $M a-$ drid, 1831 .

Fon la bihlioteea del durne de osuna piste minmseritil antógradia de lope, y flomada por eil ell lliti.

Desdicha (La) de la voz. - Carnerox. P. IH., impresa en 1683 y 1713 , en el Tom. XI. do la edicion de lernánde\% de Apontes, en el $I V$. de la de Keil, y en la $P$. XIIII. de las de áfuera, Zaragoza, $16: 30$.

Desdichada (La) Estefania. T. c.-Lope. $P$. XII , y en las Doce comedias de Lope $y$ otros. Segunda parte, Barcelo$n a, 1630$, se encilentra con la parte segunda luue intitula: El pleito por la honra.

Seguib Barrera se conoce tambien por los Custros y indradas.

Desdichado (El) en fingir.-Ruz DF ALaRcox. P. I.

Desdichados (Los) dichosos.-Calneros, segun la $P . X I I . C . A$, lo yue niega Vera Tásis; y con cfecto, se ve por su fimal en que se ofrece Segunda parte, 
que el autor verdadero es D. Antonio Manuel del Campo, no Ocampo, segun dice Medel. Este trae equivocadamente la de Calderon como distinta.

Ia Segunelu Porle, segun IBarrera, lleva el títuli di: El Condi" ile Barceloni ó la es. Irellu de Mimserrat.

Deseado (El) principe de Astúrias y Juezes de Castilla. - U'x Ixigexio.

Barrera dice que en la biblioteca del dnque de osuna exisle aulúrrafi una comedia con solo el tiflulo de El clescalo príncipe de Aslurius, i nombre de II. Juin Clablin de la Inoz y Mota, y que es la misma que la de Los Juces de Castilla, que Nedel y IJuprta atribuyen á Lanini y la Hoz bajo éste litulo, y a dos Ingenios con el de El desecado principe de Aslirias.

Desengaño de la mundana felicidad $y$ conversion de un pecador ; simbolizado en la Parábola de el llijo pródigo. O. S.-Reducido à consonancia música por el Lic. Mos. José Prims. Valencia, Antonio Bordazar, s. a. 8..$^{\circ}$ La letra será tal vez de D. José Yic. Ortí y Mayor.

Desengaño (El) dichoso. - Gchlex dE Castro. P. $I$.

Desgracia (La) renturosa.-FERrdxdo DE Z.APATE. P. XXXYII. C. A.

Es la rengenza homrosa de raspar de Aguilar.

Desgraciada (La) Raquel.-Y. Judía (La) de Toledo, de Dianuate.

Desgracias (Las) del rei D. Alfonso el Casto. Con Loa y Baile dol amor y del interes.-Avt. Mirt DF Ayescci. En la llamada $\boldsymbol{V}$. Parte de Lope $\dot{o}$ sea Flor de las comedias de España. Quinta parle, y segun Mesonero, rII un tomo de comedias rue pudo ser Parte I. de las de Mira de Amescua. Medol cita una con solo el título de Desgracias del rei $D$. Alonso, que atribuve á Lope, y que sin duda es la misma de Mira de Amescua, que como se ha visto salió en la Parte ujue se llama $\boldsymbol{V}$. de dicho Lope.

Deshonra (La) honrosa.-PÉrez. de MosTALvis. Tom. II.

Despeñado (EI).-V. Principe (El) despeñado.

Despertar (El) à quien duerme.-Lope. P. FIII. y P. XXVI. de Lope y otros, una de las estravagantes.

Desposado (EI) por fuer $\angle$ a. $-r$. Olvidar amando.

Desposorio (EI) encubierto. - LoPE.
Despreciada (La) querida.-Lope. Parte $\boldsymbol{X X I V}$. de la edicion de Madrid, y segun nota de Duran, en la $P$. XXVIII. de las de a fuera, Huesca, 1631.

Sin enbargo, Barrera dice que es de Juan Bautista Villegas, en vista de un ys. auto. grafo que poseía Duran. Armado por dicho Villegas. y fechado on Valencia i lis de mayo de 1621. Ignorando la cxistencia de este cudice la reimprimio llartzenbusch comn de Lope en el tom. Xx.lt. de la Biblioteca de Ribadeneira.

Despreciar lo que se quiere.-PÉREZ DF. Mostalyax, Tom. II.

Salio malamente en alruna edicinn á nombre de Cilleron de la liarea serun lo advierte Vera Tisis: Barrera tambien le di el lítulo de Despreciarse por quererse.

Despreciarse por quererse.-T. Despreciar lo que se quiere.

Desprecio (El) agrarlecidlo. - LOPE. $P$. XXV. enlicion de Zaragoza, en la Vega del Parnaso, $\vee$ en el Tom. I. de las Obras sueltas impresas por Sancha.

Es la misma, con alyumas lijeras varian. tes, que la dicha por el ilesprecin que lleva el nombre de liatus, lease. El desmitecin agradecido se ha publirado á nombre de este en la Biblioteca de Ribadeneira.

Desprecios (Los) en (puien ama.- Lope. Imp. suelta antigua. To está en las Partes.

Tambien se publici Ia misma pieza i nombre de Montillan.-Ambas hi tell on.

Destruccion (La) de Sagunto.-GAsptr. DE ZiB II.A I Z Yyori.

Destruccion (La) de Troya.--Cristóral de IIosrol y Sici.t.

Devocion (La) de la Cruz.-Cilneros. $P$. I. de $1636(?), 1640,1683$ y 1726. en el Tom. II. de la de Fernainder the Apóntes, en el I. de la de heil. v cu el III. del Tesoro del tealro españul.

Esta romedia solio tambien con el tilulo de la crus en la sepullura i llumbre d."

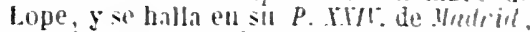

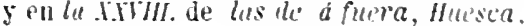
1651 .

Devocion (La) del ángel de la guarda..Mitos Frigoso. P.I.

Devocion (La) del Rosario y deroto de Maria.-DHM⿻上丨.

Vedel la trae ambuima, y barrera dice yole se eonoce por los litilus do La derocion del Rosario.-El e'selat'u de Varia y El defensor de'l Rosario.

Dia (El) de campo. Drama en "n acto.Gisptr Zubula I Zinori.

Dia (El) de campo.-R tyor HE L Ciruz. Tom. I. de su Teatro. 
Diablo (El) de Palermo y tirano de Tinacria.-M inele Pereirs.

Yedel atribuye una pieza con este título á $\mathrm{n}$. Juan de Hojica y no menciona la de pereira.

Diablo (El) está en Cantillana.-Lus Vislez. ne Guevira. P. MI'I. C. $A$.

En la Biblioteca de Ribadencira se la reimpresin con el título de El diablo esid en Cantillana. y la Inma de la Sieria. Yledel la atribuye equivocadamente il Ir. Juan Vilez.

Diablo predicador y mayor contrario amig0.- Lx ligevio. Suclta, ýá nombre de Belmonte Bermudez ell el Tom. $\boldsymbol{V}$. tlel Tesoro del teatro español, en la Biblioteca de autores españoles, y reimpresa por Mesonero.

Con igual nombre de antor, pern intitulada: El mayor contrario amigo y riablo predicador, dice Barrera se halla en la I'arle sexla de romedias de los mejores ingenios de Espuñu. Turagoza, heréderos de

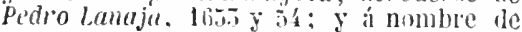
b. Franciseo rillegas en un ys. de la lib. del duque de osuma.-Tambien se halla suelta atribuida i Fr. namian Cornejo $y_{\text {il }} \mathrm{X}$. Bermudez.-D. Francisco Malaspinala refun. diu con el tilulo de La fuersa de la verilad.

Diablos son las mujeres.- $Y$. Todo es enredos amor y diablos son las mujeres.

Diablos son los alcahuetes y el espiritu Foleto.-Axтo iso de Z inori.

lis la prinera parle de Duendes son los alculutes !/ et espiritu Foleto. Medel, Ilnerta y Barrera trien anonima ma cugo título es solo Diublos son los alcalmeles.

Diadema (La) eu tres hermanos, el mayor cl más tirano y la bermana más amảnte. Primera parte del Cid.-Jose CoxCHI.

Diálogo amoroso. - Migcel de Bírios. Coro de las Musas.

Diálogo del Conexdanor Escrivi, que es una queja que da de su amiga ante el Dios de amor. Entre varios interlocutores. Se halla en el Cancionero general.

Diálogo del Santísimo Sacramento. -A vósiso.

Se representio en las Firstas del córpus hechas et año 1610 , y se halla en Ia relacion que de ellas escribio Luis de Moriles, Paimplona, 1610.

Diálogo en portugues entre un Hidalgo y un Escudero.

-Otro tambien en portugues entre un Caballero y un Doctor.

-Otro en la misma lengua entre una Regatcira y un Moço de cstribeira.
Todos tres son de Fincisco ur MoRiEs, y se hallan al lin del Tom. III. del Palmeirim de Inglaterra, edicion de 1786.

Diálogo en que se celebra la salud del conde de Oropesa. - Mrt. ne Solis. Poesias.

Diálogo entre el Anor y un Viejo.-RonRilio Cota, el tio. Se ha impreso en el Cancionero de Castillo, algunas vezes con las Coplas de Jorge Manrique, con la Celestina de Madrid, 1822, y en los Orígenes del Teatro de Moratiin a ameuce bastante nutilarlo.

Diálogo culre el Buen Gusto y el Mal Gusto.-Avóvimo. La Juventud triunfante.

Diálogo entre S. Pedro Apóstol, S. Clemente, uи Vicjo, Nicetas y Acpuila.T. Triunfos (Los) de la verdad.

Diálogo entre: Simon Mago y el apóstol S. Pedro. Especie de Auto. - Tirso. Deleitar aprovechando, lúnes por la mañana.

Diálogo entre una doncella honesta y un mancebo lascivo amante.-DAMis DE YÉGis. Libro de poesía cristiana y en el Tom. XXV. de la Biblioteca de Ribadeneira.

Diálogo militar. Picza representable.Lope. Tega del Parnaso y en el Tom.X. de las Obras sueltas.

Diálogo para cantar (entre Juan Pastor y Bras). - Lícas Pervínez. En sus Farsas 1315 y 1867 , y en el núm. 7 del Criticon de Gallardo.

Dicienbre (El) por agosto.-Juan Vílez. P. XVI. C. A.

Barrera te añade al tilıto: Nuestra Senoru de las . Niev'es.

Dicha (La) del carbonero.-V. Lorenzo me llamo.

Dicha (La) del forastero.-V. Portuguesa (La) y dicha del forastero.

Dicha (La) es la diligencia.-Toyss 0sopio. P. XLIII. C. A.

Dicha (La) por el agravio.-Dianayte. P. XXXVI. C. A.

Dicha (La) por el desprecio.-Mátos FRAgoso. Barbosa Machado la da equivocadamente el título de La desdicha por el desprecio. Se halla como de este autor en la $\boldsymbol{P}$. $\boldsymbol{X} \boldsymbol{X} \boldsymbol{X} \boldsymbol{I} \boldsymbol{X}$. C. A., en el Tom. I. de las Comedias escogidas de Mátos, Madrid, 1828, y en el Tom. IV. del Tesoro del teatro españal de Ochoa.

Ia misma comedia con alguna variante en la primera y última escena, y con el titulo de El desprecio agradecido, se publicó 
como de lopr en su P.XXV. de Zuragoza, en la Vigu ilel l'arnuso, $y$ en el Tom. X. de sus Obris sueltas.

Dicha (La) por malos medios.-Gaspar DE Ívi.t. P. III. C. A.

Dicha y desdicha del nombre.-Cilderox. $\boldsymbol{P}$. $\boldsymbol{V} I$., edicion de 1683 y 713 , en el Tom. IX. de la de Fernández de A póntes, en el III. de la de Keil, en el III. del Tesoro del teutro espariol, y en la P. XVIII. C. A.

Dichoso (El) arrepentimiento.- Lucriso Francisco Conelat.

Dichoso (El) bandolero, Frai Pedro de Mazara, capuchino.-Cis̃zires. Parte $X X X V I$. C. A.

Dichoso (EI) en Zaragoza.-Moxtalvax. P. XL.C.A.

Es idéntica í El premin en la misma pena, de Moreto, que se lialla en la $\boldsymbol{l}^{\prime}$. X.Y. La merced en el castigo, de L.opr, impresa suelta y en la P. IXVI. estrruagante de este autor, es $E l$ dichoso en Zurago:a. Por lo mismo no es fícil decidir cuill le los tres autores es el verdadero.

Dido y Enéas. - Gulluex de Castro. P. II. Difunta (La) pleiteada.-Fravcisco de Rójas Zorril.ta. P. XX. C. A.

Encuentro una de L.ope con el mismo titulo en el Catálogo de su Pereyriuo.

Dineros son calidad.-Lope. P. XXIV. Zaragoza, 1633, y en la II. estravagante. Zaragoza, 16ว̈3, segun Barrera.

Dio (Comedia de). - F. Cerco de Dio.

Dios hace justicia á todos.-Frircisco DE Ylllégas. P. XliI. C. A.

I.a misma ú otras se lan impreso tambiell á nombre de Lope $y$ de Calderon, como lo dice Iredel. Vera Túsis mo admite ninguna de Calderon bajo este título.

Dios hace reyes.-Lope. P. XXIII.

Discreta (La) enamorada.-LOPE. P. III. C. $A$.

Discreta (La) venganza.-Lope.-P. XY.

Esta misma comedia se encuentra en la P.XXXIX. C. A-donde se atribuye, sin duda injustamente, a Moreto.

Discreto (El) porfiado.- Tres Isgexios. P. X. C. A.

Ignoro si es distinta de la de Villègas que lleva el mismo titulo.

Disparate (El) creido.-JOAX dE ZıBALETA. P. XXXIV.C.A.

Es Ia misma que El embuste acreditado y disparate creidy de Luis Vélez, que se halla en la $P$. V.-Barrera dice que tambien se conoce con el título de otro demonio tenemos, y los encantos de Mlerlin.
Disputa sagrada, gustosa y moral quistion en loor de'S. Juan de Dios. Drama en un acto. - Axórimo. En los Solemnes y afectuosos obsequios a la canonizacion de este Santo. Madrid, 1692.

Divino (El) africano. T. c. - LOPE. P. XVIII.

Divino (El) calabres S. Francisco de Paula.- Iítos Frigoso y Fraxc. A veluaxEm. Se halla en el Fénix de los ingenios de Tomas de Oña.

Yedel y Barhosa citan una de Yitos con solo el titulo de S. Francisco de F'aula, y tal vez sea la misma.

Divino (El) labrador.- - Lucero (El) de Madrid y divino labrador, S. Isidro. Divino (EI) Nazareno Sanson.-Morralvix. Comedias nuevas, Amstardan, 1726 .

Tambien la tengo con solo el título de El Vazarenn Sanson.

Divino (El) portugues . S. Antonio de $\mathrm{Pa}$ dua.-IIostaliax. Tom. II. yP. ILIV. de las de á fuera, Zaragoza, 1632.

En un MS. de lit bib. de Duran. Sechado ('n 1625, se atribuye it un Bernardino do obregon.-lin las boze compdias de dife. rentes autores. Part: 1111117I. Vulencia, $16 \%$ i, se intitula San Antonis de radua, segun Barrera.

Divisa (A) da cidade de Coimbra.-GiL Vicente. Obras.

Toda está en español, sino el arsumento $y$ cl remate.

Divoreio (El) feliz, ó la marquesita.Rayor de la Crez. Tom. VII. de su Teatro.

Está sacada de ma de las novelas de Marmontel que lleva el mismo lítulo. La tengo tambien suclia y anonima.

Doctor (El) Carlino.-T. Dotor (El) Carlino.

Doleria (La) del sueño de la vida. Comedia en prosa.-Hertado de la Vera.

Nedel la atribuye equirocadamente i D. Ant. de Yendoza.

Dom Andre. En porlugues. - Axóxiso. Impreso en 1693 .

Es una farsa a pesar de intitularse nuto.

Dómine (El) Lúcas.-Lope. P. XIII.

Dónine (El) Lúcas. - Cisizires. Tom. I. de sus Comedias escogidas. Madrid, 1839, ell el $V$. del Tesoro del teatro español, en el Theatro hespañol de Huerta, y en la Coleccion de dramaticos de la Biblioteca de Ribadeneira.

Es distinta de la de Lope. 
Don Alvaro de Luna.- $\mathrm{V}$. Próspera y Adversa fortuna de D. Alvaro de Luna.

Don Beltran de Aragon.-Lope. V. Mudanzas de la fortuna.

Don Diego de Noche.-Rósis Zorrilla. P. VII. C. A., y Torn. I. de las Comedias escogidas de este autor, Madrid, 1827.

Don Domingo de D. Blas. - r. No hai mal que por bien no venga.

Don Duárdos. T. c.-GiL Yicexte, en sus Obras.

Está en castellano.

Don Enrique del Rincon.-V. Señor (El) de noches buenas.

Don Florisel de Niquea. - Moxtalyar. P. II. de sus Comedias. Poseo ademas un ejemplar suelto yue priucipia por la pág. 281 y concluye en la 328 , que sin duda será de las Doze comedias de las mas famosas, Lisboa, 1649.

Tengo esta comedia con el litulo: Pura con rodos her'manns; y amantes porra nosotros, Don Floriset de Viquea. Segun Barrera aun stzele llevar' un tercer iltulo, y es Aventuras de Grecia.

Don Gil de las calzas verdes. - Tirso. P. IV. y en el Tom. I. de las Escogidas de este autor, Madrid, 1826. Tambien en el tomo publicado por Hartzenbusch de Comedias escogidas de Tirso, en el IV. del Tesoro del tealro español, y ell el Handbuch der spanichen litteratur de Ludwig Lemeke.

Don Gonzalo de Córdora. - Lope. Parte XXIV. Zaragoza, 1641.

Viase Vhym (La) vilorit de Alemania. Barrera tambien la intitula: La meve vic. Loria de don Gonzolo de Cirvora.

Don Juan de Austria.-Y. Señor (El) Don Juan de Auslria.

Don Juan de Castro. Primera y segunda parte.-Lope. P. XIX.

Barrera dice ell la pig. 4.46 que lambien tiene por titulo: El harer bien á los muer. los. En la P. XYV. de Zaraynan se publico solo la segundu parte con el tilulo de Aventuras de don Juun de Alárcos.

Don Juan de Espina ell su patria. Primera parte.-LX INGENo.

Yedel y Barreril dicen que es de Cañizares y no la trisen eomo de un Ingenio.

Don Juan de Espina en Milan. Segunda parte.-lx IxGExo.

Vedel ni Barrera no la traen como de un Imenjo ; primero la alribuye á D. Antonio de Memloza y el segundo il Cañizáres.

Don Lope de Cardona.-Lope. P. X.
Don Pedro Miago. - Rósas Zorrilla. P. XX.C.A.

Don Quijote de la Mancha.-Gulleen de Castro. P. I.

Con este título cita Barbosa una de Mátos Fragoso.

Don Sancho el Malo y don Sancho el Bueno.-V. Travesuras son valor.

Donaires (Los) de Matico.-Lope. P. I.

En el Catálıgo prefijado al reregrino se denomina solo: El Matico.

Doncella (La) de labor. - Mostalvan. Tom. I., Tea tro antiguo español, 1837, y Duran dice que se halla en la $\boldsymbol{P} . \boldsymbol{X X X}$. de las de a fuera, Zaragoza, 1636. Ribadeneira la ha reimpreso en su Biblioteca.

Segun Barrera esta pieza con algunas variantes se publicó con el título de Marica la del puchero, y con el mismo dió á luz su refundicion Enciso y Castrillon.

Doncella (La) Teodor.-Lope. P. IX.

Doncella, viuda y casarla.-Ux Ixgenio.

Yedel cita una anónima, y lloratinmen. rioma ofra de I). Ramon de la Cruz que lleva el uismo ditulo.

Doncellas (Las) de Simancas.-Lope. No está en las Parles antiguas; pero si en el Tom. I. de la Coleccion de las mejores comedias de Lope de Vega, Madrid, 180. 4. ${ }^{\circ}$ Tambien la tengo de impresion suelta.

Donde hai agravios no hai zelos.-Rósas Zorrill. P. I. y en la P. V. C. A. Se ha reimpreso despues suelta con el título: Donde hai agravios no hai zelos, $y$ amo criado, y con el mismo en el Tom. I. de las Comedias escogidas de este autor, Madrid, 1827, en el IV. del Tesoro del tealro español, y en el Theatro hespañol de Huerta.

Donzella (Auto da) da Torre chamado Fidalgo portuguez. En castellano y portugues.-Gil Vicente. Lisboa, $1643 \mathrm{y}$ 1622 .

A pesar de intitularse aulo es una farsa. Doña Beatriz de Silva.-Tı́so. P. I $\boldsymbol{r}$.

Doña Teresa de Guzman varió el título en el de Fuborecer á lodos y ainar $d$ ninyuno.

Doña Ines de Castro. Escena trágico-lirica.-Luciano Fraxcisco Conella.

Doña Ines de Castro.-V. Castro.

Doña Ines de Castro, reina de Portugal. $\boldsymbol{T}$. c.-Lic. Mejía de la Cerda. P. III. llamada de Lope, Doze comedias de carios autores, Tortosa, 1638, y Dra- 
máticos contemporáneos á Lope en la Biblioteca de Ribadeneira.

En la segunda lista del Peregrino trae Inpe como suya una pleza con el mismo IItulo que la de Mejía, y Medel se la atribuye efectivamente.

Versan sobre este asunto las dos tragedias de Fr. Jerónimo Bermúdez y el drama de Luis Vélez de Guevara Rtinar despues de morir.

Dorotea. Accion en prosa.-Lops.

Dos (Los) aniantes del cielo, Crisanto y Daría.-Calderon. $\boldsymbol{P}$. $\boldsymbol{V}$., ediciones de 1634 y 1730 , en el Tom. IX. de la de Fernáudez de Apóntes, en el III. de Keil, y en el III. del Tesoro del teatro español.

Dos (Los) amigos, ó sea el negociante de Leon. En prosa. - A vósimo. Traduccion de D. Domisgo Bort.

Dos (Los) Cárlos. - V. Cautelas son amistades.

Dos (Los) ciegos.-V. Paso de dos ciegos.

Dos (Las) estrellas de Francia. - Leor Marchaxte y Dizgo Callejs. En el Tom. I. de las Obras poélicas de Leon Marchante se halla à nombre de estos dos autores, al paso que Medel la atribuye únicamente al primero. La tengo tambien suelta á nombre de ambos y así se balla en la $P$. $X V I I . C$. $A$.

Se promete scgunda parte.

Dos (Las) estrellas trocadas y ramilletes de Madrid.-V. Ramilletes (Los) de Madrid.

Dos (Los) filósofos de Grecia.-Fer.aydo de Zarate. P. XIX. C. A.

La tengo suelta con el titulo de Los filósofos de Grecia, Heraclito y Demócrito.

Dos (Los) jóvenes de Ignacio Poema cómico.-Francisco IsIdoro de Molisa. Se balla despues de la pág. 108 del Amphitheatro sagrado por Pedro Clemente Valdes.

Dos (Los) mejores bermanos, S. Justo y Pastor.-Leon Marchavite y Diego CaLI.EJA. 'Tom. I. de las Obras poélicas de Leon Marchante.

Moratin atribuye á D. Melchor Fernán. dez de Leon una pieza intitulada: Los dos mejores hermanos, y olra $S$. Juslo y Pas$10 r^{\circ}$ : indudablemente se equivoca en supo. ner estas piezas distintas y en adjudicárselas a Fernández de Leon. Medel trae una anónima, que probablementc será la misma, con el titulo de Dos mejores herma. nos y márlives de Alcald.

Dos (Los) monarcas de Europa.-Bırtoloyi de Salazar y Lusa, P. XXII. C. A.
Dos (Los) prodigios de Roma. - Míros Fragoso. P. XXIII, C. A.

Barbosa Machado no conoció esta comedis de Málos. Barrera añade al título: San Adrian y Santa Nalalia.

Dos (Los) soldados de Cristo. - V. Barlan y Josafat.

Dotor (El) Carlino.-Gósgora.

Esta comedia la dejó sin concluir su autor, y se balla en sus Obras.

Dotor (EI) Carlino.-Avr. DE Solis. Tomo de sus Comedias, PP. XXXV. y XLVII. $C$. A., en sus Comedias escogidas, Madrid, 1828, en el Theatro hespañol de Huerta, y en la Biblioteca de Ribadeneira.

Es distinta de la que dejó Góngora sin concluir. Medel atribuye equivocadamente esta comedia á D. Diego Muxet y Solis.

Dudoso en la venganza.-V. Canas (Las) en el papel.

Duelo (El) contra su dama. - Bírces Caxdayo. En sus Poesias cómicas Tom. II., en la $P$. XLVIII. C. A., en el tomo de sus Comedias escogidas, 1832, y en el de Dramáticos de la Biblioteca de Ribadeneira.

Duelo de honor y amistad.-Jicisto DE Herrebi. P. XXXII C. A., y en la Biblioteca de Ribadeneira.

Vedel llama al autor de esta pieza Don Francisco de Herrera. Se publicaria tam. bien como de Calderon, porque Vera Tásis la coloca entre las atribuidas falsainen le á este autor.

Duelos de amor $\mathrm{v}$ desden, en papel, cinta y retrato.- Li IXgesio c.ATALAx.

Duelos de amor $y$ lealtad. - CALDEROX. P. $I X$. de 1691 y 1698 , en el Tom. I. de la de Fernández de Apóntes, en el $I \boldsymbol{V}$. de la de beil, y en el III. del Tesoro del teatro esponiol.

Duelos de iugenio y fortuna. Precedida de Loa. - Bixices Cavoayo. Poesías comicas, Tom. I.

Duendes son alcahuetes y el espíritu Foleto. Primera parte.-Duendes son alcahuetes, alias El Foleto. Segunda parte:-Aitonio de Zayora. Tom. II.

La primeris parte la tengo impresa suel. ta con el titulo de Diablos son los alcahuetes y el espiritu Foleto.

De las dos partes de esta comedia hai en mi biblioteca una edicion que principia en la pág. $95 \mathrm{y}$ concluye en la 205 : sin duda pertenecen á una impresion del tom. II. de las Comedias de Zamora anterior á la de 1744 .

Dueño (EI) de las estrellas.-R - RIz DE Alarcos. P. II. 
Dugne El de Arjona.-Y. Lucero (El) de Custilla.

Dutue EI) (le Berganza.-Losв. Y. IIas El galun portugues.

Dulun, El) de Berganza. T. - Cunulio bl: deviux. Enano de las Musas.

Duque (El) de IIemoranci - V. Fortunas ,Las trágicas del Duque de Memoransi.

Duquar (El) de Pentiebre.-Viceste RodríGCEZ DF ARELLTYO.

Duque (EI) de Visco. Tragicomedia lastimosa.-Lore. P. II.

Duque (El) de Viseo. T.-Mincer Josí Qunsax. Tom. IV. del Teatro nuevo español.

El asumto estil sacado del drama ingrles Intitulado: El espectro de' ceastillin.
Duquesa (La) constante. Precedila de Lot - Tirrelia. P. II. de los Poetas valencianos, y en la Biblioteca de Ribadencira.

Dupuesa (La) de la Rosa. En prosa.Alosso De al Vegis. Tres famosisimas comedias. Valencia, 1566.

Moratin en los Orimnes ha reimpreso el

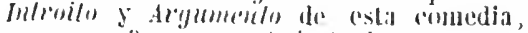
contr InI l'aso, conl e! tilnlo de amm a'engati).

Dupuesa (La) de Sajonia. - V. Cumplir dos obligaciones y duquesa de Sajonia.

Durandarte y Belerma. Burlesca.-MoSex Gullex Pieires.

lin la edicion que tonon, due es mui anligrai, no lieva mis Lítulo; Barl'rera añade ó al andin) mas nerdadero.
Eco y Narciso. - C.inderox. $P$. $I V$. de 1688 y 1731, aru el Tom. III. de la de Fernández de Apóntes, en ol $I I$. de la de Keil. y en el Thealro hespañol de Huerta.

Égloga de Plácida y Victoriano.-V. Placida y Victoriano.

Égloga interlocutoria, graciosa y por gentil estilo nuevamente trorada por DIEgo de Árila. Alcala de Henares, s. a. (intes de 1ö12). 4. 18 hojas. Se halla reimpresa en el núm. 8 del Criticon de Gallardo.

D. Fernando colon la cita en el Registro de su bibliutera talubien sin año; pero observa que es en $40^{\circ} y$ que le costio 8 maravedises en Alealit dino do 1.11 .

Égloga nuevamente compuesta en la cual se introlucen cincopersonas : un escudero llamado Estacio y un ermitaño y una moza y un diablo y dos pastores.Jeix de Palis. $1536.4^{\circ}$ gót.

Eglora ó farsa del Nacimiento de JesuCristo.-Léc is Ferxicuez, en sus Farsas y églogas.

Egloga para la noche de la Yatividad de nuestro Salvador. - Ji Ix det Excivi. Fol. $7 i$ sta. de su Cancionero, 10316. Hai otra con igual título en el fol. 79 , Y una tercera con el título de $\dot{E} g l o g a$ irocada al dorso del fol. 94. La priusera y segunda se hallan reimpresas, como si fuesen una sola, en las prágiuas 3-11 del Tealro español anterior i Lope de Vega.

Égloga para la noche postrera de Carnal, que dicen de antruejo 6 carnestollendas.-Jusx bel Excixi. Fol. 83 vta. Ile su Cancionero, 1516. Hai una segunda con el mismo título en el fol. 8̈, y esta es la reimpresa en la pág. 17 del Teatro español anterior i Lope de Vega. La primera se halla tambien en los Origenes del teatro español por Moratin.

Égloga representada en la noche de Navidai, entre cuatro rastores, Juan, Miguelejo, Rodrigacho y Andres, y un Angel.-Juax Hel Exciva. Reimpresa por Böbl de laber en la pág. 32 del Teatro español anterior a Lope de Vega.

$\dot{E}$ Eloga representada en Nảpoles delante do los ilustres caballeros y damas, de quienes habla el autor desconocido de la Cuestion de amor.-Axóxıno. Se ha. lla ell todas las ediciones de dicha obra, y la reimprimio Noratin en los Origenes del teatru español.

Égloga representidla en recuesta de unos anores ; á donde se introduce una pastorcica llamada Pascuala, que yeudo cantando con su ganado entró en la sala ả donde cl durque é la duruesa estaban, é luego despues de ella entró un pastor llamado Mingo é comen\%ó á requerilla, y estando con su recursta llegó un escuidero. que tambien preso de sus amores recuestando é altercando el uno con el otro, se la sonsacó é se tornó pastor por ella. - Jus vl: Excivi. Cancionero, 1516. fol. LXXIVI. vta. 
La reimprimio Bōhl de Faber en cl TexIro espuñiol anteriur a l.npe, pár. 22, con el título de Eyloja del cscudero quí, so tormit prostor. Timbien se lialla rn of Hrondburh

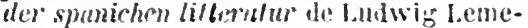
ke, y en los Origewes de Moratin.

Égloga representada por las mismas personas que en la de arriba van introd:1cidas. Eu la que Mlingo presenta á los duques la Copilacion de todas las obras de Juan de la Encina; y el escudero Gil dejó el hábito de pastor que habia traido un año, é tornose del palacio con él jumtamente la su Pascuala; y en fin Mingo è su esposa Menga viéndolos mudados del palacio crecioles rnvidia, é aunque recibieron pena de dojar los hábitos pastoriles, tambien ellos quisieron tornarsc del palacio é jrobar la vida de él.-Jors nel Excisis. Cancionero. 1516. fol. LXXXVIII.

Bōll de Fuber en su Teatro anterion $a$ Lope ha reimpreso parte de estil Eglogra con el titulo de los pastores que se, timam palacieyos.

Egloga rústica. Interlocutores : Climente, Gabriel. En portugues. Friscisco Miseel de Melo. Obras métricas.

Égloga Silviana del Galardon de amor.Luis IItrtido ne Toleno. Al fin del Epistolario de Segura y de la comedia de Preteo y Tibaldo.

Égloga trovada... en la cual se introducen tres pastores: Fileno, Zambardo é Cardonio.-Juss Der. Excrist. Cuncionero, Salamanca, 1309 . suelta de varias ediciones, y en el Tom. II. del Ensayo de una bib. esp. de Gallardo.

$\dot{\mathbf{E} g l o g a}$ trovada... sobre los infortunios de las grandes lluvias. - Jely DEL Excivi. Cancionero.

Ejemplar (El) de la devocion al Smo. Sacramento S. Pascual Bailon. O: S.Puesto en misica por 1). Pedro Furió. Valencia, Salcador Fauli, 17:0. $8^{\circ}$

Tal rez sea la letra de l). Josi Vir. (urti Mayor.

Ejemplo (El) de casadas y prueba de la paciencia. Precedida de una Loa y del Baile del Ay, ay, ay, $y$ el sotillo.Lope. P. $\boldsymbol{V} .$, scgun la llaman Nic. Alltonio y Lord Ifolland, aungue su título es el di. Flor de lits comedias de Espa$\bar{n} a d e$ diferentes autores. Quinta parte. Barcelona 1616. $4 .{ }^{\circ}$

Ejemplo (EI) en el castigo.- $r$. Tracesuras son valor.

Ejemplo (El) mayor de la desdicha. Tragicomedia lasiimosa.-Lope. Comedias de los mejores y mis insignes ingenius. Lisboa, 1632 .

Tambien la tongo de edicion mís moderna con ol título de $k$ l cjemplo mayor de la desdichn, y Canztm Brlisurin, iv de improsion utís antiorua con solo el de El Capitan Belisaris. El "jempils maym de la des. dichn, atribuida it llitos, se encurntra, segun liarrera, en lis Commedias de lis mejores y mas insignes ingentus de Esplaña. Cilonia. 1l,97.

Esta conmedia es de Mira de Anrecua comb Io procba ma ropia antegrafia de ha lib. de? duque d. ysima, on la que hai una cersista d: Lopo donde salec: rusede. se represiculur, $y$ su autor vira de Amescua obliner meves chllutsos.

El que fuere bobo no camine, y Castigo del Pense que.-Tirso.

Este es el thiuln que diis Inoña Terosa de finzman a la primera parte de El cessigo del lisise que.

Eleccion (Ia) por la virtirl.-Tirso. Parte III. Y en el Tom. III. de Escogidas de estè àtor. Malrid, 1831.

La tellzo pullicada por voña Teresa de fiuzman con ha adicion al titulo anterior de sixto quinto: E Barrera la denuinina

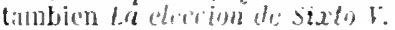

Elegir al enemiga Con Lod-da. Sila7.tr I Túnils. l'. II. Citara de Apolu. P. I.TI. C. A. $\sin$ loa. P. XLI estraragaile, de varios. ! en la Bibliotece de Ribadeneira.

Elisa Dido. T. - Cirstónal de Virces. Obras trágicas y liricas.

Elisa Dillo. reina y fumdarlora de Cartago.- H. Honestiliad $L a)$ defendida.

Ello diri.-Lope. P. III,

Embuste (El) acreditado y disparate creido-Lels Velez de Geeviri. P. F. c. A.

se publirn on liz ritrl: con el tituth ile El dispetrat: ceci to a nombre de II. Juan de

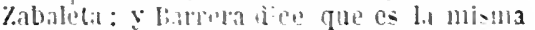
que otro demonio fencinos, o los encanlos de levtin.

Embustero (El) entañado.-L. A. J. M.

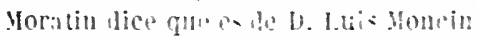

Embustes Los de Fabia.-Lort. P. X.T. Embuster (Lo do Lelauro.-1. Enridos Los de Cehuro.

Enpeños Los) de seis horas.-Cilntrox. P. FIII. C. A.: pero Vera Tasis la da por supuesta de cste autor, yoldetis, mente Barrera dice yue e's de D. 1. Lonio Coello, y yue se la condec tambian con el título de Lo que pasa an ana noche.

Eurpeños (Los) de uil dedso.-Caloehan. 
P. VI. de 1683 y 1715 , en el Tom. VIII. de la edicion de Fernández de Apóntes, ell el III. de la do Keil, en el III. de las Comedias escogidas de Calderon, Madrid, 1831, y en el Theatro hespanol de Huerta.

Es la misma que Los emperios que se ofrecen, del Mejor de los mejores libros de comedias.

Empeños (Los) de un engaño. - Ruiz ox Alarcon. P. II., XIVIII. C. A, y ell el Tom. II. de las Comedias escogidas de este antor, Madrid, 1829.

Segun Barrera y Leirado se publico con el título de Enguños de un engaño.

Empeños (Los) de un plumaje, y origen de los Guevaras.-Calderon. $P$. $\boldsymbol{X V}$. C. A.

En la Tabla de dicha parte se lee despules del titulo de la presente comedia: anmque dice de D. Pedro Calderon, es de otro ingenio de "sla corle, y del mismo sentir es Vera Tísis, contándola entre las suputes. tas de Calderon. Nilda de esto basto para sacar de error a yedel en su indice.

El autor de esta comedia promete al fin dar por mis adelante Los Blusones de Guevar'a, y no se que se haya impreso.

Empeños (Los) de una casa. Precedida de Loa y con dos Sainetes.-Soror Juava de la Cruz. Tom. II.

Empeños (Los) del mentir.-Avit. Hurtado de Mexdoza. Obras, y en la Flor de las mejores doce comedias.

Ticknor sospecha si esta comedia será la que escribio Mendoza con Quevedo para la fiesta que dio el Conde-Duque á los reyes en la noche de S. Juan de 1631 , cuyo titulo era ouien más miente medra más. Se ha reimpreso en la Biblioleca de Ribadeneira.

Empeños (Los) que se ofrecen.-CaldEnox El Mejor de los mejores libros de comedias.

Es la misma que Los Emperios de un acaso que se hilla en las obras de este autor. Medel cita otra comedia que tambien lleva el primer titulo, y se la adjudica á Montalvan. Será la de Caldesun?

Emperador (Ei) Alberto I. y la Adelina. Primera parte.-AvT. Villadires DE Sotomayor.

Inice haberla puesto en verso, exornado y arrecrlado á nuestro teatro. La sequnda parle no lleva mis titulo que La Adelina.

Emperador (El) fingido - Gabriel BocíNgel y Uxzueta. P. XLIII. C. A.

Empezar á ser amigos. - Moneto. Parle $\boldsymbol{X X X Y}, \boldsymbol{C}, \boldsymbol{A}$.
Tambien se conoce eon el titulo de $\mathrm{Ha}$ cer del contrario aıniyo, y así se publicó, seyun Barrera, en la $\boldsymbol{t}$. Illl. de Moreto, Madrid, 1681 .

En casa de nadie no se meta nadie, $\delta$ el buen marido. Zarzuela jocosa.-RAmoN De la Cruz. Tom. IX. de su Teatro.

En el engaño el remedio. - El t.ıcenciado Bano, regidor perpetuo de la villa de Lora.

En el mayor imposible nadie pierda la esperanza.-Moneto. P. III. Valencia, 1676 y 1703.

Tambien se conoce con solo el título de Nadie pierda la esperanza.

En el sueño está la muerte.-Jerón. Guedeja Quiroga. P. XIX. C. A.

Barrera la da tambien el título de $E l$ asombro de Palermo, y Morntin el de Si toda la vida es sueñi, en i't sueño cstá la muerte, $y$ el Asombro de Palermo.

En esta vida todo es verdad y todo es mentira.-Calueros. P. III. de 1664, 1687 y 1726 , en el Tom. VII. de la de Fernández de Apóntes, y en el $\boldsymbol{I}$. de la de Keil.

En la mayor lealtad mayor agravio, y favores del eielo en Portugal. - V. Lealtad (La) en el agravio.

En los indieios la culpa.-Lope. P. X.YII. edicion de Zaragoza.

En Madrid y en una casa.-Rósas ZorriLLA. P. XXXV. C. A.

La ha publicado Ilartzenbusch en el tomo de Comedias escogidas de Tirso, y pruéba que este es su autor en la pág. XlI de los prels. Medel la atribuye í Rojas, pnrque se habia publicado á su nombre, como se ha hecho en el Tealro antiguo español, 1857.

Con el tilulo de Lo que hace un manto en Madrid salió á nombre de Calderon y de Rỏjas: pero este último no hizo más que refundir $\dot{o}$ introdncir algunas variantes en la obra de Tirso. Hartzenbusch, en el tomo arriba citado, reprodujo el acto tercero de la refundicion por ser el que mayores dife. rencias ofrece.

En mujer venganza honrosa.-GaSPAR DE Montesino.

Esta comedia es del doctor Cristóval Lozano, y se encuentra en la edicion de 1658 de sus Soledades de la vida. D. Gaspar I.ozano y Montesino era sobrino suyo, y presto su nombre a las obras profanas de su tio durante la vida de este.

La comedia En mujer venganza honrosa no es la misma que Dar'se zelos por vengarse, como sospecha Barreri.

Encantada Melisendra y piscator de Toledo. - Tomas A Ñorae y Corregre. 
Encanto (EI) es la hermosura, y el hechizo sin hechiro. Precedida de Loa.Sabizar y Tórres, y concluida por Vera Tásis. Tom. II. Citara de Apolo. Se ha reimpreso en la Biblioteca de Ribadeneira.

El Sr. Duran dice que desde una parte del segundo acto hasta el fin estí escrita por Veri Tisis, y que el primer acto y la otra parte del segundo sor los de la Segunda Celestina de Snlazar.

Encanto (El) por los zelos.-Cristóval De Morroi.

Así dice en una edicion que tengro de Buryns, s. a. pero en otra que tambien posen de Serilla, Mamuel razques, s. a. el li. tuln es: El encanto por los zelos y fuente de la judiu.

Encanto (El) sin encanto. - Calderor. P. IV. de 1688 y 1731, en el Tom. III. de la edicion de Fernánilez de Apóntes, y en el II. de la de Keil.

Encantos (Los) de Medoa.-Rósas ZorriLlA. P. II., Parle sexta de comedias escogidas de los mejores ingenios. $\mathrm{Za}$ ragoza, 16303-54, y Comedias escogidas de los mas insignes poctas. S. I. ni $a$.

Encarnacion (La) del hijo de Dios. Coloquio.-Gaspar Feryírnez y Ávila. Infancia de Jesucristo.

Encomienda (La) bien guardada.- $\mathrm{F}$. Buena (La) guarda.

Encontráronse dos arrơuelos. - Joay Vélez de GuevarA. P. XXIII. C. A.

Segun indica Barrera, se conoce tambien por La boba y el vizcrimo.

Endimion y Diana. Precedida de Laa.Melchor Feriínez ne lieox. P. ILII. C. $A$.

Eneas (El) de Dios. - V. Caballero (El) del Sacramento.

Eneas (El) de la Fírgen y primer rei de Navarra. - Fraxc. Villegas y Proro F. Lavisi Sigreno. P. XLIL. C. A.

Enemiga (La) farorable. Precedida de una Loa en alabanza de las mujeres feas y el Baile de Leganitos. - Frivcisco TÁrRe(it. $P$. llamada $\boldsymbol{V}$. de Lope, en el Tom. I. del Tesoro del teatro espanol de Ochoa, y en la Biblioteca de Ribadeneira.

Jimeno no menciona esta comedia, cele. brada por Cervántes en el cap. 48 de la P. I. del Quijole, y Fuster no supo que estuviese impresa.

Medel atribuye equivocadamente una comedia con igual tutulo á Lope, sin duda por hallarse la de Tárrega en la Parte que pasa por quinta de las comedias de aquel.
Enemigos (Los) en casa.-Lope. P. XIJ.

Enemigos (LoS) hermanos.--GuILLEX DR Castro. P. II.

Enfatriōes (Os).-Lus tie Cimozis. Lisboa, 1613. Va al fin de la segunda parte de sus Rimns. Tambien se encuentra, segun Barrera, en la Primeira parte dos autos e comedias portuguesas. Lisboa, 1387. 4. $^{\circ}$

Enfermar con el remedio. - CILDeros, Luis Vélez y Cáxcer.

Vera Tásis dice lambien que solo la primera jornada es de Calderon.

Engañados (Los).-V. Engaños (Los).

Engañar á quien engaña.-Lope.

Impresion antigua: no se halla en las Par. tes ni la menciona Barrera.

Engañar con la verdad.-JERóviyo DE LA fievte. P. III. C. A.

Engañar para reinar.-Astovio Exígete Gómez.

Así dice en una edicion bastante antigua que poseo, y lo eonfirma el mismo Givuez en el priblozo de su Samson Vuzarenn. Tambien está í nombre de Enriquez, segun Barrera, en las Dise comedius de las mas frmosas. Lisbno, lij.9. 1.a tengo sue!ta á nombre de Calderon: pero ya nhsersa Vera Tásis que no es suya. Hedel supnene que tambien se inprimio atribuida á Enciso.

Al final de esta pieza adrierte el autor que es la primera que escribio.

Engañarse (El) engañando.-Grillex dE Cistro. P. II.

Engaño ,El) de unos relos.-Ronx Moxtero de Espirost. P. XLIV. C. A.

Engaños (Los). Comedia en prosa.-Lope IR RCED4. Reimpresa en los Origenes de Moratin y en el Teatro español an. terior is Lope de Vega.

En las primitivas ediciones de las Come. dicls do Rueda se intilula: Los engañados.

Engaños (Los) de un engaño - V. Empenos (Los) de un engaño.

Engaños (Los) de un engaño y confusion de un papel.-Moreto. Comedias escogidas de los mas insignes poetas. S. I. ni $a$.

yo se halla en las partes de este autor: sín embargo, la edicion que tengo es mui antigina.

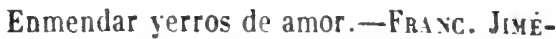
Nez ne Cistienos. P. XXYYIII. C. A.

Enredos (Los) de Celauro.-Lope. Teatro anligro español, 1837. y en el Toin. II. del Tesoro del teatro español.

Es la misma que los Embustes de Zelauro de la $P . I Y$., variada solo dicha palabra en 
el discurso de la comedia. Lope de Vega la cila con el título de Euredos de Zelauro en el Catílogo del Peregrino.

Entrada (La) del marques de los Vélez en Cataluña, rota de las tropas castellanas y asalto de Monjuich.-Aróxiso. Barcelona, 1641 y 1642.

En la primera edicion lieva ma Loi y el Entremes intitulado: Los labrudor's y $s$ oldados castellanos, con un baile al isn de Calaluña.

Entre bobos anda el juego.-Rós.ss Zorpilla. P. II., Tom. I. de sus Escogidas, Madrid, 1827, IV. del Tesoro del tealro español, en el Theatro hespañol de IIuerta, y segun Barrera, en las Doze comedias de diferentes aulores. Parte XXXXXVII. Falencia, 1646.

La tengo tambien sucita con el lítulo dr. Enlie bobos anda el juego, $)$. Licas del cigarral. La ha reimpreso Indwig Lenteke en su Handbuch der spanich'n lilteralur.

Entre el honor y el amor, el houor es 10 primero.-Avóvino.

Entre los riesgos de amor, sostenerse con honor. La Laureta.-Midis ABELLo. Impresa en Barcelona, y parece edicion de fines del siglo pasado.

Moratin la atribüc: à I. Y. Yello.

Entre venganza y amor hallar la dicha mayor, y el Mágico en Cataluña. Tercera parte.-Aróviso.

La primera warte, que tuve, se tiluta: la ciencia, afecto y vulor forman ma!jia por amor, y la seguirda que tenso : lencen impulsos de ainor los ufeclos del honor.

Entretenida (La).-Cervíxtes. Comedias $y$ entremeses, y en cl Tom. I. del Tesoro del lealro español por Ochoa.

Envidia (La) de la nobleza.-Lope. Parte $\mathrm{IXIII}$.

Segun Barrera podrá ser la misma que Cegries y Bencerrajes o La prision de las licncerrajes.

Envidias vencen fortunas.-Cristóral DE Morror y Silfa. Comedias de los mejores Ec. Lisboa, 16002.

Epitalamio para celebrar el feliz himeneo del emperador Leojoldo Ignacio con Doña Margarita de Austria.-Miguel De Bírrios. Coro de las Musas.

Ilai otrocon igual motivo, que se inti. tula: Bailele en misica, y es el quinto de la Tu!i.t.

Ermitaño (El) galan.-Zıbıieta. P. I. C. $A$.

Se equivoca Barrera en decir que esta piezil es la mistuin que La mesonera de: cielo de vira de Amescua, que va en la Parle XXXIX.
Ermitaño (EI) galan y mesonera del cielo. - Mira de Amescua. P. XXXIX. C. A.

Se publico con solo el ultulo de La mesonera del cieli: Barrera, se pquivoca en ereer que es la misma de Zabileta. Medel alribuye i Perez de fiontalviu, con el titule El ermilnino gulan, una concdia que supongo serí la de Mira de Amesena que omite.

Ermitaño (El) seglar.-Diego de Muxet Y Solls. Comedias y Rimas.

Errar principios de amor.-Pedno Rosete Yiño. Comedias de los mejores \&c. Lisboa, 16:2 y segun Barrera, en las Doze comedias de diferentes autores. Parle XXXXXVII. Valencia, 1616.

Escala (La) de la Gracia.-Fermano DE Zirite. P. XXXV.C.A.

Escándalo (El) de Grecia contra las santas imágenes.-Cabneron. P. XI. C. A.

Neclel la atribuye á Calderon; pero Vera Tísis dice que 110 es de él y solo le da cl litulo de El escándalo le Grecia; sin embargo, en la niltima cuarteda de la comedia se dice que sul aulor es Don Pedro.

Escarmientos del pecallo, ó la fuerza del desengaño, ó lo que puede un desengaño y memoria de la muerte; y justos juicios de Dios.-V. Lo que puede el desengaño y memoria de la muerte.

Escarmientos para el cuerdo. - Tirso. P. V., y en el Tom. III. de las Escogidas de este autor. Madrid, 1831.

Escarraman. Burlesca. - Moneto. Parle XXXVII. C. A.

liarrera la da tambien el litulo de Los zeLos de. Escarraman, y pregunta si la compuso con ntros.

Esclava (La) de su gaIan.-Lope. P. $\boldsymbol{X} \boldsymbol{X} \boldsymbol{V}$., Tom. I. de sus Comedias escogidas, Madrid, 1826, y en el II. del Tesoro del teatro español.

Ifedel cita tambien una de Röjas con igual titulo; sin duda será la misrna.

Esclava (La) del Negro Ponto. -Avonimo.

vo la menciona Moratin á pesar de estar impresa en 1792.

Esclavitud (La) más diclıosa, y Vírgen de los remedios.-Frixc. DE VILLEGAS y Jusepe Rojo. P. XXV. C. A.

Esclavo (El) de María.-Calderon.

Asídice en thra edicion suella y antigua que pusco; á pesar de que Vera Tásis nos isegnra que no es de este antor. Barrera no la meneiona á nombre de calderon, y sclo atribuye una con el mismo litulo á un tal D. Juan Bernardino hojo, que floreció é imprimia sus obras en el siglo Xill: sien. (d) la impresion que se halla en ini biblio. teca de mediados del siglo Xill, dtbe ser 
distinta de la citada en el Caldlogo del tca. tro anligun español.

Supone Barrera que La devocion del Bosarin de Diamante suele llevar el título de El eschmo de Maria, y en el artículo de Francisco de Villégas menciona una de este autor $y$ de Jusepe hojo que tambien se denomina El esclan de Maria.

Esclayo (El) de Ronia.-LopE. P. VIII.

Esclavo (EI) de su amor, y el ofendido vengado.- Lisa Señora die esta Corte.

Esclavo (El) de su hijo.-Moreto. V. Azote (El) de su patria y renegado Abdenaga.

Esclavo (El) del demonio.-Mira de AmesCUA. P. FI. C. A., en la $\boldsymbol{I I I}$. de Lope á quien la prohija Nic. Antonio, y segun Mesonero en un tomo de Comedias que pudiera ser I. Parte de las de Mira de Amescuo.

Esclavo (EI) del más impropio dueño y arriesgarse por aniar.-MAESTRO ROA. P. XXXI. C. A.

Esclavo (EI) en grillos de oro.-Bixces Caybayo. Tom. II. de sus Poesías cómicas, Comedias escogidas, 1832, Comedias escogidas, Bruselas, 1704, Theatro hespañol de Huerta, y tomo de Dramaticos de la Biblioteca de Ribadeneira.

Esclavos (Los) de Argel.-V. Cautivos (Los) de Argel.

Esclavos (Los) de su esclava, y hacer bien nunca se pierde.-JUAy del Castillo.

Esclavos (Los) libres.-Lope. P. XIII.

Escolástica (La) zelosa.-Lopr. P. I

Escondido (EI) y.la tapada.-Ciloeron. $\boldsymbol{P}$. VII. ediciones de 1683 y 1715 , en el Tom. $X$. de la de Fernández de Apóntes, en el IV. de la de Keil, en la $P . I X . C . A, y$ en el Theatrohespanol de Huerta.

Escrivaens (Auto dos) do Pelourinho velho.-Axósimo. Lisbla 1625.

Es una farsa portuguesa.

Escudeiro (0) surdo. Auto portugies en el que alyunos personajes hablan en castellano.-A Aórimo. Lisboa , 1634.

Es una farsa.

Escudero (El) que se torna pastor. Egloga.-V. Éloga representada en recuesta de unos amores.

Escuela (La) de los maridos.-Moliér. Traducida por Inarco Celenio (Leandro Fernaindez de Moratin).

Esforcias (Los) de Milan.-Avtosio Mar- Tíxez. P. XV. C. A.

Esmeralda (La) del amor.-V. Mudanza (La) en el amor.
Español (El) de Oran.-Miguel DB BárRios. Flor de Apolo.

Barrera dice que esta comedia se ha impreso suelta sin espresion de autor, diciendo solo De un ingenio mililar.

Español (El) Juan de Urbina.-Lic. MAiefel Goszile 7. P. IV. C. A.

De esta misma Parte saco Barrera la noticia del título de esta comedia, y no sé pur qué razon le añadió ó el cerco de Nápules.

Español (El) más amante, y desqraciado Mazías. - Tres Irgevios. P. XLFIII. C. A., yen las Poesias cómicas de Bánces Caindamo Tom. $\boldsymbol{I I}$.

En ol Prólngo de estas Poesias se asegu. ra qule uno de los tres ingenios es Bánces, y aun se quiere suponer que es él el único autor.

Española (La) de Florencia.-Calderoy. A este autor se atribuye en la $\boldsymbol{P}$. $\boldsymbol{X} \boldsymbol{I I}$. C. $A$., al mismo se adjudica en algunas ediciones sueltas que be tenido $y$ en el Indice de Medel; sin embargo, Vera Tásis dice que no es suya.

Española y enredos de Leonardo.-Axósimo. Manuscrito de principios del sisiglo $\mathrm{XVII}$.

Españoles (Los) en Chile.-Frarcisco Gorzilez de Bústos. P. IXII. C. A.

Españoles (Los) en Flándes.-Lope. Parte XIII.

Espectro (EI) del Castillo.-Rasgos y trozos traducidos en prosa castellana de esta tragedia inglesa. Tom. IV. del Teatro nuevo español. - V. Duque (El) de Viseo.

Espejo (EI) del nundo.-Lis Félez. En la Parte que Nic. Antonio llama III. de Lope, á quien supone injustamente autor de esta comedia. Tambien está en las Doce comedias de varios autores. Tortosa, 1638.

Medel se la atribuye á D. Juan Vèlez.

Espigadera(La). Primera y segunda parte.-Ramos de la CRez. Tom. IY. de sil Teatro.

En Londres tuvimos suella y anonina una pieza con jgual lltulo, que tal vez era la misma.

Esplin (El). Pieza en un acto.-Vicexts

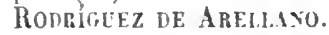

Esposa (La) y trono á un tiempo, y Mágico de Serban.-Avósimo.

Esposo (EI) fingido.-Tirrega. P. I. de los Poetas valencianos.

En los tilulithas do las pioss. de la prime. ra edicion de Valencia, dice constantemen. 
te El esposo fingido, solo en el titnlo de la comedia dice El fingido esposo.

Estados mudan costumbres. - Míros lat(i0s0. P. V.C.A., y en las Comedias de los mejores. Colonia, 1697.

Estátua (La) de Prometeo. - Calneron. $P$. VI. de 1683 y 1713 , en el Tomo VIII. de la de Fernández de Apóntes, y ell el III. de la de Keil.

Esto si qute es negociar.-Tinso. $\boldsymbol{l}$. $\boldsymbol{I I}$.

Se lua incluido en el tomo de Comedias escogidas de Tirso por IIartzenbusch, el cual piensa que esta es una de las cuiltro que le pertenecen eschusiramente. Es re. fundicion del Melancílico de la P. I.

Estrangeiros (Os). En portugues y en prosa. - SAa de Miranda. Coimbra, 1569 , en las ediciones de sus Obras, ménos en la de 1595 , y junto con las Comedias de Ferreira, 1622.

Estranjero (El). Comedia con música.Ranov de la Cruz. Tom. II. de su Teatro.

En nuestro Catílogo de Lóndres hai una anónima con igual titulo que probablemente seria la misma.

Estrella (La) de Monserrate.-Cristóval de Moríles. P. XII. C. A.

Estrella (La) de Sevilla.-Lope. Debe formar parte de algun tomo de edicion original, pues abraza los folios 99 á 120.-V. Sancho Ortiz.

Barrera no la menciona en el índice. Ludwig Lemeke la ha reimpreso en su Handbuch der spanichen litleratur.

Estrellas (Las) trocadas y ramilletes de Madrid.-Lope. P. XI.

Eufemia. En prosa.-Lope DE ROEdA. En el tomo de sus Comedias, Reimpresa en los Origenes de Moratin, en el Teatro español anterior á Lope de Vega, y en el Handbuch der spanichen lilleralur de L. Lemeke.

Eufrosina (Comedia). Porluguesa.-Jor- ge Ferreira de Vasconctillos. Coimbra, 1560, Evora, 1566 y Lisboa, 1616.

Eufrosina. Comedia en prosa no represcntable.- Ferreira de Visconcíblos, traducida al castellano por Fernando de Ballestéros y Saavedra. Madrid, 1631 y 1733.

Eugenia.-Ramon de la Gruz. Tom. III. de su Teatro.

Con igual titulo y anónima la enenentro en muestro Catálogo de Lóndres; sin duda será la misma.

Eunuco (El).-Tenencio, traducida por A bril. Comedias de Terencio.

Eurídice y Orfeo.--Ant. DE Sol.ts. Comedias, y en las PP. XVIII. y XLVII. C.A.

Nedel confundia, como ya lo hemos visto en El Dotor Carlino, á D. Antonio de Solis con D. Diego Muxet y Solis.

Para esta comedia hai una Loa de Salazar y Tórres.

Eurídice y Orfeo.-V. Marido (El) mas firme.

Exaltacion de la Cruz.-Caloeron. Parte VII., ediciones de 1683 y 1715 , en el Tom. $X$. de la de Furnánde\% de Apóntes, en el III. de la de Keil; y en la P.I. C. A.

Exámen de maridos.-Ruiz de Alarcon. P. II., Tom. I. de las Escogidas de este autor, Madrid, 1826, y III. de sus Comedias escogidas. Madrid, 1867.

Dice en el Prólogo de la parte II. intes citada, que esta pieza habia sido itribuida a otro; y efectivamente la encuentro como de Lope con muchas variantes en su P. XYIV. impresa en Zamagoza, $165 \overline{5}$ y suelta en Madrid, 1803, con el título de antes que te cases mira lo que haces, $y$ exámen de maridos.

Exhortaçāo da guerra. T. c. portuguesa.-Gil Vicente. Obras.

Expectacion (La) de Maria Santísima Coloquio. - Gaspar Fernández. y Ávila. Infancia de Jesucristo.
Fábula (La) de Perseo.-V. Perseo y Bella (La) Andrómeda.

Fajardos (Los). - V. Primer (El) $F a-$ jardo.

Falso (El) nuncio de Portugal.-Ux IvGrito.

Así dice la antigua edicion que tengo. Creo que es de Cañizúres, y Iedel se la atribuye efectivamente à este autor. Es mui singular que el Sr. Barrera no la mencione, porque es distinta de la que il trae con el título de el Nuncio falso de Portugal.

Falsos (Los) hombres de hien.-Axósimo, traduccion de D. Luciano Francisco Comelusa.

Familia (La) indigente. En un acto.-Luciano Fraxcisco Comella.

Familiar (El) sin demonio.-GASPAR DR Ávics. Flor de las mejores doce comedias. 
Famosas (Las) asturianas.-LoPE. Parte XVIII.

- Fanático (El) por la nobleza. En prosa. - Moniere, traduccion de D. Nicolas Pérez y us estranjero.

Farsa al nacimiento de nuestro redentor Jesu Cristo è de la Virgen gloriosa madre suya. - Pero López Rasjel. $4 .^{\circ} \mathrm{gót}$.

Farsa de Abraham - Diego Síxche7 de Badjoz. Recopilacion en metro. 1354.

Farsa de Isaac.-- Diego Síxciez lie BADasoz. Recopilacion en metro. 1554 .

Farsa de la fortuna ó hado. -Diego SixChez De Bapajoz. Recopilacion. 1554.

Farsa de la hechizera.-Diego Sixcinez. DE Badajoz. Recopilacion. 15ä4.

Farsa de la Iglesia.-Diego Sixciez de Badajoz. Recopilacion en melro. 15354 .

Farsa de la muerte.-Diego Sívchez De Badajoz. Recopilacion en metro. 15034 .

Farsa'de la Natividad, en la cual principalmente se disputa cuál fué mayor gozo á la Vírgen nuestra señora en la inefable concepcion ó en la gran natividad de su glorioso bijo, nuestro salvador Jesucristo ; con otras incidentes quistiones ansí moral's como teologales.-Diego Síxchez de Badajoz. Recopilacion en metro. 1554 .

Farsa de la ventera. - Diego Sivchez DE Badajoz, Recopilacion en metro. 15 ŏź.

Farsa de los Doctores en que se representa como el niño Jesus de edad dle doze años fué hallado en el templo en medio de los doctores de la lei vieja.-Diego Sischez DE Badajoz. Recopilacion en inetro. 15354 .

Farsa de matrimonio; es para representar en bodas.-Diego Síxciez. de B.1DAJOz. Recopilacion en metro. $15 \%$

La tengo tambien anónima de impresion de Medinu, 1530 , al An, $1605.40^{\circ}$ let. gót.

Farsa de Moysem.-V. Farsa en que enlran cinco figuras.

Farsa de Salomon.-Diego Síxchez DB Badsuz. Recopilacion en metro. 1553 .

Farsa de S. Pedro.-Diego Sívchez de Badajoz. Recopilacion en metro. 1554 .

Farsa de Santa Bảrbara, ell como fué llevada en juicio ante Dios. - Disgo SÁxChEZ DE B\DłJOZ. Recopilacion en metro. 135 š.

Farsa de santa Susana.-Diego Sixcuez DE Bipajoz. Recopilacion. 1303 s.

Farsa de Taniar.-Diego Sixchez IE BtDAJOz. Recopilacion en metro. 1330 i.

Farsa del Colmencro.-Diego Síxcnez DE Badajoz. Recopilacion en metro. 1530 .
Farsa del Herrero. - Drego Sixchez de BADAJ0z. Recopilacion en metro. 1554.

Farsa del Molinero... habla del santisimo Sacramento del Corpus Christi.Diego Sáxchez de Bandoz. Recopilacion en metro. 1554.

La tengo tambien suelta de edicion de Cuenca, 1603 , con el estilo algo inodernizado, y á nombre de un Diego López de Ornzco.

Farsa del mundo y moral del actor de la Real que es Fervay López de Yivicas. 1024 y $15 \% 31$.

Farsa del rei David.-Diego Síxchez DE Badajoz. Recopilacion en melro. 1554.

Se reimprimió, aunque falta de casi una mitad en el Ensayo de una bit. esp. por Gallardo. Tom. I. col. $71 \mathrm{~s}$ y sigs.

Farsa del santísimo Sacramento.-Dirgo Síxchez DE BidAjoz. Recopilacion en metro 15304.

Farsa dicba militar en que principalmente se alaba la sacra peuitencia. Represéntase en ella como los tres enemigos que tenemos, carne, mundlo, y el diablo, batallan contra las personias espirituales.-Diego Sixchez de Badajoz ó DE TILAYERt. Recopilacion en metro. 13 ว้ม

Farsa en que entran ciuco figuras... IIabla del santísimo Sacramento del Corpus Christi.-Diego Sixcilez de BidAJ0z. Recopilacion en metro. 15 ŏ 4 .

En los titulillos de las páginas se llama Far'sa de Moysem.

Farsa en que se representa la salutacion de Nuestra Señora.-Diego Sixchez dB BıDAJOz. Recopilacion en metro. 10 วัฒ.

Farsa en que se representa un juego de cañas espiritual de virtudes contra vicios.-Diego Síxchet. ite Baduoz. Recopilacion en metro. $150 \% 4$.

Farsa moral en que se representan las cuatro virtudes cardinales cómo enderezan los actos humanos.-Diego SixCHEZ DE BADAJOz. Recopilacion en metro. 1554 .

Farsa ó cuasi Comedia, en la cual se introducen tres personas, conviene á saher, una doncella, y un pastor, y un caballero (cuyos nombres ignoramos). - Lícas Fervíide7. Farsas y Églogas. Gallardo la reimprimió en el número 5 del Crilicon.

Farsa ó cuasi Consedia, en la cual se introducen cuatro personas, conviene á saber, dos pastores, é un soldado, é una pastora.-Lúcas Fervíxdez. Farsas y Églogas. 
Farsa racional del libre alvedrio en que se representa la batalla que hai entre el espíritu y la carne.-DuEgo Sivenez DE B.1najo\%. Recopilacion. 1534 .

Farsa teologal en que principalmento se tratan algunas razones de Ia Enearnacion y natividad de $\mathbf{N}$. Señor Jesurristo.-Dielo Sischez ne Brinyor. Ricopilacion en metro. $13 ̈ 3 ̆$.

Fatme y Selima. Melodrama trigico.A vóxiม.

Al fullera ol saincte l'mer congañar mugrnur'se.

Faustina (La). - Penno Nirol.s-Sticionelo, traduccion de D. Flenvir bis Rla.

Favor (El) agradecido.-Lops. $I$. $Y V$.

Favorecer á todos, y amar á ninguno, Doña Beatriz de Sitra.-Tınso.

Este es el fillulo que le puso en su cdicion (que tenuro) Donar Triésa de Glizman,

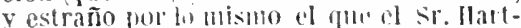
zenbusch to haya aloptiulo pll rez del de

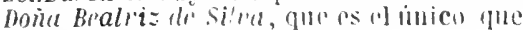
Hevil en la l'arte $1 t^{\prime}$. original.

Fayores (Los) du mundo. - Ruz de Alancox. P.I. y Tom II. de sus Comedius escogidas. Medrid, $186 \overline{7}$.

Barrera la da tamlien ol tilulo de Genar perdiendo.

Fé (La) no ha menester armas, y venida del ingles á Cádliz.-Ronnuio ne LerRERI.

Medel llama á este autor Francisen.

Fé (La) pagada. Precedida de una Lon, glosando esle pid: Que todo trabajo cuesta.-Ricinuo ne Tirs. (Es D. Pedro Juan Rejaule?) P. II. Poetas valencianos.

Fé (la) rompida.-Lope. P. IV.

Federico segundo, rei de Prusia. Primera parte.-Luciuro Friveisco Coyel.L.

Federico segundo, en el camplo de Torgau. Segunda parte.-Lucisio Frixcisco Conella.

Federico segundo en Glatz, 6 la humanidad. Tercera parte.-Lccisvo Fniscisco Coyela.

Fedra (La). T.-Axósiyo.

Felisarda (La).-Lole. P. IVI.

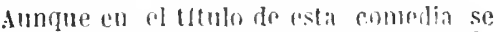
lee Filisarlu, on tolas las demas partis de clla dice Folismila.

Fenisa (Coloquio de). -A vivisio. Vailadolid 1588. 4."

Fénix (El) de Alenıania. Vida y muerte de santa Cristina. - Matos Fricioso. P. XXXIII. C. A.
Fénix (La) de Andalucía.-V. Nuestra Señora de Regla.

Fénix (El) de España, S. Francisco de Borja. - Un IxGenio lie esta Conte. P. HIIII. C. A.

Es diversa de la de $S$. Francisco de Bor. ja de firnindez de l.cen. Sermn Barrera el fugenio de la corte es el l'. biego Calteja. Mledel allobrye á dicho Calleja una con solo el litulo de El Fénix de España y otra i Cinlipror, quien no la compuso, segun Vera 'risis.

Fénix (El) de la eseritura: el glorioso san Jerónimo. - Frixc. Goxzilez Bústos. P. IL. C.A.

Fénix (EI) de los criallos, ó María Teresa de Austria.-Lucino Fnancisco CoIELLA.

Finix (El) de los hijos.-Ramov de LA Cauz. Tom. FIII. de su Teatro.

Fénix (La) de Salamanea.-Mira de Aresciv. P. III. C. A., en el Tom. I. de las Comedias escogidas de este autor, Madrid, 18:30, y ('n la Biblioteca de Ribadplicica

Fénix (La) de Tesália.-Er. masstro Roa. P. IXXVI. C. A.

Frias (Las) de Madrid. -Lops. P. II.

licrnan Mléndez I'into. Segunda parte.Lors. La tengo de impresion suelta antigua.

En la bih del duque de Osuna vi la primerll leth', tambien a nonibre de Lope y sermilia di: ma regunda parte de Antonio

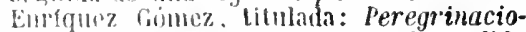
nes de Fernan Méndrs Pinlo. No he podido verifiear si es la misma que esta de lope. Barrera atribuye anbas partes á Gómez, y diep ruse se encinentran sn su Torre de $B a$ bilonia; pero no las conoció á nombre de lope.

Fianza (La) satisfecha.-Lops.

To está ro las partes. La tengo de imp. suclta y antirntil. Vara Tísis supone que existe mamuscrita í nombre de Lalderon.

Fiar de Dios.-Aytoxio Martínez y Luis Bel.moste. P. XXVI. C. A.

Fidalgo (O) aprendiz. En porlugues.liriycisco Minuel de Melo. Obras métricas.

Fiera (La), el rayo y la piedra.-CALdeRox. F. III. de 1604,1687 y 1726 , en "l Tom. VI. de la de fernández de Apóntes, y en el II. da la de Keil.

Fieris afemina amor. Precedida de una Lor. - C.unenox. P. VI. de 1683 y 1715 , en el Tom. VIII. de la de Fernánder de Apóntes, en el $I I I$. de la de Keil, y en el III. tambien del Tesoro del teatro español. 
Fieras de zilos y amor. Z. - Báxces CanD.lyo. En sus Poesías cómicas. Tom. II.

Barrera añade al titulo: $\delta$ cuál es la fiera mayor entre los mónstruos de amor.

Fijos (Los) de la Barbuda.-Luss Vícez. En la que Nic. Antonio llama $\boldsymbol{P}$. III. de Lope, á cuyo autor la atribuye indebidamente, y en la Biblioleca de Ribadeneira.

Medel se equiroca en suponerla de Juan Vèlez.

Fileno y Zambardo. Égloga.-V. Égloga trovada de Fileno y $Z$ ambardo.

Filis y Demofonte. Z.-Pedro Scorti I Agolz. Obras póstumas.

Filisarda (La).-V. Felisarda.

Filoctétes (El). T. - Sófocles.

Moratin atribuye la traduccion á un autor anónimo de la seguuda milad del siglo XVIII.

Filodemo.-Lris DE Cayoess. Al fin de la Segunda parte de sus Rimas, Lisboa, 1615. Segun Barrera se balla tambien cn la Primera parte dos autos é comedias portuguesas. Lisboa, $1587.4^{\circ}$

Filósofo (EI) casado, ó el marido avergonzado de serlo.-Axósimo.

AsI dice en la edicion de Barcelona, que tengo; pero Moratin se la atribuye á Iriarte con solo el título de El fíósofo casado.

Filósofos (Los) de Grecia, Heráclito y Demócrito.-Fersasdo Zarate.

Es la misma de la P. XIX. C. A.: Los dos filósofos de Grecia.

Fin (El) más desgraciado y fortunas de Seyano.-Pérez dr Moxitalyax. Parte $X L F . C . A$.

Es la que con el tilulo de Amor, privanza y casligo, va en ef tom. I. de las Comedias de este autor.

Fineza acreditada. - V. Infeliz ( $L a)$ A urora, y fineza acreditada.

Fineza contra fineza.-Calderox. $P . I Y$. de 1688 y. 1731 , en el Tom. II. de la de Fernández de Apóntes, y en el II. de la de Keil.

Fingida (La) Arcadia.-Moreto. P. II. de sus Comedias, y XXY. C. A.

Yedel supone que la escribio Calderon; pero Vera Tásis dice que solo es suya Ia tercera jornada, y Barrera indica si una de las otras dos podrá ser de Cáncer.

Fingida (La) Arcadia.-Tirso. P. $I I I$.

Fingido (El) esposo.-V. Esposo (El) fingido.

Fingido (Lo) verdadero. T. c.-Lope. P. XVI.
Está dirlgida al presentado Gabrlel Téllez (Tirso de Molina), cuyas comedias alaba Lope en la dedicatoria. Segun Barrera se conoce tambien por $E l$ mejor ropresentante: Vida y martirio de san Gines.

Fingir lo que puede ser. - Romix MonteRO DE Espinosa. P. II. C. A.

Fingir y amar.-Moreto. P. $\boldsymbol{X} \boldsymbol{V}$. C. A., y segun Barrera en la $\boldsymbol{P}$. IIII. de las $\boldsymbol{C o}$ medias de este autor, Valencia, Orga, s. $a$.

Firme (La) lealtad. - Dizgo Muxat de SoLis. P. II. C. A.

Firmeza, amor y venganta.-Axr. FruxCisco. P. XVIII. C. A.

Barrera sospecha si el autor de esta comedia será D. Antonio Francisco de Flóres que escribio otras dos.

Firmeza (La) en la desdicha. - LOPE. P. $X I I$.

Creo que se publicó con el titulo: La firmeza en lu desdictia y el agraviado leal.

Firmezas (Las) de Isabela.-Gósgons, en sus Obras, donde se advierte al fin de los prels. que los fines della no son de $D$. Luis, porque la acabó D. Juan de Argote su hermano. Tambien se halla en un tomo impreso con el titulo de Quatro comedias famosas de Góngora y Fega Carpio.

Físicos (0s). Farsa portuguesa, en que el Clérigo, Mestre Anrique y el Confesor hablan en castellano.-GIL ViCENTE. Obras.

In Paso, que está en castellano, se halla reimpreso en el Tealro español anterior d. Lope de Yega.

Florentina (La). En un aclo.-A xósimo. Flores (Las) de D. Juan, y pobre y rico trocados.-Lope. P. XIII, en el Tomo III. de sus Comedias escogidas, Madrid, 1830 , y en el II. del Tesoro del teal ro español por Ocboa.

Medel da a esta comedia el título de Flores de D. Jum lico.

Floresta (La) de engaños. Comedia porluguesa.-Gil Vicexite. Está casi toda en español, y se halla en sns Obras.

Florinea (La). En prosa.-BAChiller JeAs Rodrícez. Medina del Campo, 1554 . $4^{\circ}$

Formion (El).-Terescio, traducida por Abral. Comedias de Terencio.

Fortuna (La) merecida. - LoPE. P. . TI. Es distinta de la que con el misuno titulo y a nombre de Morelo se halla en su $P$. III. Madrid, 1681.

Fortuna (La) merecida.-V. Merecer para alcanzar. 
Fortunas de Andrómeda y Perseo.-CaLDERON. $P$. $F I$. de 1683 y 1715 , en el Tom. VIII. de la de Fernández. de Apóntes, en el III. de la de Keil, y en la $P$. XXI. C. A.

Vera Tísis menciona ademas entre lns Autos uno intitulado: Forlumas de Andrómeda, que no creo se haya iinpreso.

Fortunas (Las) de Isabela. - Máros FrAGoso. V. Mis (La) heroica fineza, y forlunas de Isabela, del mismo autor.

Fortunas (Las) trágicas del Duque de Memoransi.-Martis Peiroy y Querait. P. XLIV. de las de á fuera, Zarago$z a, 1652$.

Los traductores de Ticknor y Barrera dicen que en la P. XXXII. de las de á fuera, Zaragnza, 16ł0, está á nombre de Pei. ron, miéntras en una nota dada por el se. ñor Duran suponia sonaba como de Mira de Amescua.

Fragoa d'amor. T. c. porluguesa.-GiL VICENTE. Obras.

Esta casi toda en castellano.

Francesilla (La).-Lopf. P. XIIII.

Fuego de Dios en el querer bien. - Calderox. $P$. YII. de 1683 y 1715 , en el Tom. $\boldsymbol{X}$. de la de Fernández de Apóntes, en el III. de la de Keil, y en la P. XIII. C. A.

Fuente (La) de las virtudes.-Pedro CarNERERo.

Fuente ovejuna.-Lope. P. $\boldsymbol{X} \boldsymbol{I I}$.

Con este mismo título cita Medel otra de D. Crist. de Monroi y Silva.

Fuero $(\mathbf{E l})$ de las cien doncellas. - V. Blason (El) de D. Ramiro, y liberlad del fueru de las cien doncellas.

Fuerte (El), animoso, sagaz y valiente Martin López de Aivar, valenciano, teniente de maese de campo general en los estados de Flándes. - Vicesic EsQCERDo. Representóse en Valencia en 1620, segun el manuscrito original que poseo.

Fuerza (La) de la costumbre.-Gorlere de Cistro. P. II., y en la Biblioteca de autores españoles de Ribadeneira.

Fuerza (La) de la lealtad.-Ramos de LA Cruz, en el Tom. IX. de su Teatro.
Fuerza (La) de la lei.-Moneto. P. I. de sus Comedias, y VII. C. A.

Fuerza (La) de la sangre.-Guillen dB Castro. P. II.

Fuerza de la sangre, y amor hace hablar los mudos.-Tres INGenios.

En la $P$. XVII. C. A. estí a nombre de S. de Villaviciosa, Mátos y Zabaleta con. el titulo de Amor hace hablar los mudos, y tambirn la tengo como de tres Ingenios con el de El ainante mudo, la fuersia de la san. gre, $y$ amor hace hablar los mudos.

Fuerza (La) de la verdad.-Fraricisco de Malaspina. P. XIV. C. A.

En dichil Parte no lleva otro titulo; pero Barrera le añade: y Diablo predicador. Güelfos y Gibelinos, y dicc es una refundicion de El Diablo predicador. Véase.-Medel la denomina solamente Güelfos y Gibelinos.

Fuerza (La) del amor conyugal 6 Sancha, condesa de Castilla.-Misuel BelloSÁRTES.

Fuerza (La) del desengaño, ó lo que puede un desengaño, y memoria de la muerte. - V. Lo que puede el desengaño.

Fuerza (La) del interes. Precedida de Loa.-Gispir de Agullar. P. II. de los Poelas valencianos.

Nedel comete la equivocacion de llamar a Aguilar D. Francisco siempre que le menciona.

Fuerza (La) del natural-Moreto. P. II.

En el indice de lo Parte XV. de la Coleccion anligua y en el tifulo de la comedia en dicha Parte solo menciona á Moreto como autor; pero al finalizar la pieza espresa que tambien lo fué Cáncer. Tengo una impresion suelta de 1777 en la que señala a los dos como autores.

Fuerza (La) del oido.-V. Lo que puedo la aprension.

Fuerza (La) lastimosa.-Lope. P. II. y Comedias nusvas, Amstardan, 1726.

Fulgencia (La).- Vicente Rodrfiubz de Arellano. Toin. $I V$. del Teatro nuevo español.

Moratln añade á este título: $\delta$ los dos $m a$ niditicos.

Fundacion (La) de la órden de nuestra Señora de la Merced por el rei D. Jaime. Precedida de Loa. - Tárrega. P.II. de los Poetas valencianos.
Gala (La) del nadar, es saber guardar la ropa.-Moreto. P. XXXVIII. C. A.

Galan Castrucho.-Lope. P. IV.
Se ba publicado con el título de El Rufian Castrucho.

Galan (El) de la Membrilla.-Lope. P. $\boldsymbol{X}$. 
Galan (El) de su mujer. - Mítos Fragoso. P. I., en la XIV.C. A., en el Tom. I. de las Comedias escogidas de este autor, Madrid, 1828, y en la Bibliobeca de Ribadeneira.

Galan (El) fantasma. - Calderon. P. II. de 1637 (9), 1641,1686 y 1726 , en el Tom. $\boldsymbol{V}$. de la de Fernández de Apóntes, y en el $I$. de la de Keil.

Galan (EI) secreto.-Mira de Amescua. P. XXXIY.C. A.

La tengo impresa en Barcelona á Anes del siglo pasado con el Lifulo: El secreto entre dos amigos, y atribuida á Moreto. Barrera trae una de Pérez de Montalvan con el tituln: Callate y callemos, $\mathrm{y}$ dice es El galan secreto.

Galan (EI) sin dama.-Ant. Hurtado dB Mandoza. El mejor de los mejores libros de comedias.

La tengo á nombre de Calderon sin ser suya, segun lo nota Vera Tásis.

Galan (El) tramposo y pobre. - Sílas Barbadillo. Coronas del Parnaso.

Esta comedia se publicó suelta, y en el Aneno jardin de comedias, Madrid, 1734 , con el titulo de El traniposo con las damas y castigo inerecido, atribuida á Cubillo.

Galan, valiente y discreto. - MIRA DE AmESCUA, ell sus Comedias escogidas, Madrid, 1830 , en el Tom. IV. del Tesoro del teatro español, en la Parte $X X I X$. de las de áfuera, Valencia, 1636 , segun nota de Duran, y en la $B i-$ blioteca de Ribadencira.

Galardon (El) de Amor.-Y. Égloga Silviana.

Galeote (El) cautivo. - A Yónimo.

Moratln dice que es de Valladáres y So. tomayor.

Galiana (La). - V. Palacios (Los) de Galiana.

Gallarda (La) toledana.-Lope. P. XIV. Gallardo (El) catalan.-Lope. P. II.

Creo que se ha publicado con el título de El calalan valeroso.

Gallardo (El) Escarraman.-Sílas Barbadillo. El sulil cordoves Pedro de Urdemálas.

Gallardo (El) español.-Cervístes. Comedias y Entremeses.

Gallega (La) Mari-Hernández. - Tirso. $P$. I., y en el tomo de las Escrgidas del mismo por Hartzenbusch.

Tamblen se conoce con el título de $\mathrm{Ma}$. ri-Hernundez la ghólega.

Ganancia (La) por la mano.-PÉarz dr Montalvin. Tom. II.
Ganapan de desdichas. - Diamantr. V. Cuánto mienten los indicios.

Ganar amigos.-Ruiz de Acarcon. P. II., Tom. I. de las Escogidas de este autor, Madrid, 1826, y Madrid, 1867, en el IV. del Tesoro del teatro de Ochoa y en el Handbuch de Lemeke.

Tengo tamblen la publicada por Doña Teresa de Guzman intítulada: Lo que mu. cho vale mucho cuesta en ganar amigos, y la que salió en las Partes XXII. y XXIV. de Lope, ediciones de Madrid y Zaragoza á noinbre de este autor, denominada: Amor pleito y desafio. Ln más singular es que con igual título la poseyera autógrala de dicho Lope el Sr. Duran. Barrera dice que tambien se la conoce por Quien priva aconseje bien.

Ganar perdiendo.-Rurz de Alarcox. Y. Favores (Los) del mundo.

Ganar por la mano el juego.-Cubillo DB Aragon. P. XIIX. C. A.

Garcia de Parédes. - V. Falor (El) no tiene edad.

Garcia del Castañar.-Y. Del rei abajo ninguno.

Garcilaso de la Vega.-V. Cerco $(\boldsymbol{E} l)$ de Santa Fé.

Garrote (El) más bíen dado. $-\mathrm{V}$. Alcalde (El) de Zalamea.

Garza (La) de Portugal.-V. Reinar despues de morir.

Generoso (El) en España.-Diego MoxeT Y Solis. Comedias y Rimas.

Genizaro (El) de España.-V. Rayo (El) de Andalucia.

Genízaro (El) de Hungria.-Mítos FraGoso. P. $I$.

El Indice de Medel señala dos parles á esta comedia, y Barrera las menciona tam. bien al adlcionar el titulo con $y$ aleman Federico.

Ginoves (El) liberal.-LoPE. P. IF.

Gitana (La) de Mèmfis, Sta. María Egipciaca.-PÉrez dE Montalvin.

Gitana (La) melancólica. Precedida de Loa.-Gaspar Agcilar. P. I. de los Poelas valencianos. Se ha reimpreso esta comedia en la Biblioteca de Ribadeneira.

El nombre de Aguilar no es Francisco, como dice Medel.

Gitanilla (La).-PÉrez de Montal.vay.

Es distinta de la de Solis y no una mls. ma coino sospecha Barrera.

Gitanilla de Madrid.-Sous. Comedias, en las PP. XXXYII. y XLYII. C. A., en el tomo de sus Comedias escogidas, Madrid, 1828, en el Theatrohespañol 
de lluerta, y en la Biblioteca de Ribadeneira.

Vuelve aguí el indice de Vedel il confundir í D. Antonio de solis con D. Viego Muxet y solis.

Gloria (La) de Niquea y descripeion de Aranjuez. - Covie ne Villadedias. Obras.

Gloria (La) de S. Francisco.-Y. Serafin (El) humano.

Glorias de Jesus cautivo, y prodigios del rescate.-Axt. Tellez ni Aceveno.

Gloriosa (La) verge y márlir Santa Bárbara, tutelar y patrona de la iglesia parroquial de Santa María de Vallfogona. En catalan.-El loctor Viceste Giscí. Armonía del parnis. Barcelona, 1700.

En el prolugo se dice que el flnal de esta comeda y algun otro trozo no sun de Garefia.

Gobernador (El) prudente. - GaSPAR DE Xvila. P. XXI. C. A.

Golfo (El) de las sirenas. Z.-Cinnerox. $\boldsymbol{P}$. IV. de 1688 y 1731 , en el Tom. IV. de la de Fernández de Apóntes, y cn el II. de la de Kéeil.

Gombela y Suni-Ada. T. -Jusx FrixcisCO DEl PLiso. Tom. I. del Tealro nuevo español.

Grado de san Luis Gonzaga. Z.-Axósiso. Juventud triunfante.

Grado de S. Stanisha Kostka. Z.-AxóNimo. Juventud triunfanle.

Gran (El) cepitan Paréd's. - V. Valor (El) no licne edad.

Gran (La) Cenobia.-Ciloeros. P. I. de $1636^{\circ}(?), 1640,1683$ y 1726 , en el Tom. II. de la de Fernández de Apóntes, y en el $I$. de la de Keil.

Gran (EI) D Lope de Almeida.- V. A secreto agravio.

Gran (El) duque de Florencia.-Diego JIMevez Exciso. P. VI. C. A.-V. Médicis (Los) de Florencia.

Gran (El) duque de Moscovia y emperador perseguido.-LOPE. P. VIII.

Gran (El) Jorge Castrioto y príncipe Escandarbec. - Luis VELEZ. P. XLV. C. A.

En li Tabla de esta Parte se atribnye á Belujonte, y á este se lia adjudica Barrera, porque dice que suelta se lia impreso á su numbre.

Lil Seguinda parte de esta comedia es probablemente El principe esclavo, do Luis velez.

Gran (El) patriarca D. Juan de Ribera. Precedida de Loa. - Gispar Agcilar. P.II. de los Poelas valencianos.
Medel atribuye una comedia de este t1tIIIo á un Ingenio; probablemente será esta misma. Tambien comete dos equivo. caciones, cuandis citando la de Aguilar, vuelve á llamarle ll. Francisco, é intitula su comedia El Gran Palriarca de las Indias.

Gran (El) poema del mundo, rue se ha de representar é el Coliseo de Apolo en la funcion del Certámen de la Colonia de Yalencia.-Josi Casisus I Navia Oson1o, en su Viage del Parnaso.

Gran (El) principe de Fez, D. Baltasar de Loyola. - Cistorron de la Barca. P. IV. de 1688 y 1731 , en el Tom.III, de la de Fernández de Apóntes, y en el II de la de Keil.

Gran (El) rei anacoreta $S$ Onofre.-PEdro F. Lanivi Sagreno. P. XLII. C. A.

Gran (El) rei de los desiertos.-Andres DE Clarimonte. Autos sacramentales \&c. 1655.

Barrera añade al titulo San Onofre.

Gran (La) Semíramis. T.-Cristóval DB Virues. Obras trágicas y liricas.

Gran (La) sultana, doña Catalina de Oviedo.-Cenvántes. Comedias y Enlremeses.

Gran (EI) virei de Nápoles, ó duque de Osuna.-A vó:iso.

Grandezas (Las) de Alejandro. T. c.LOPE. P. XVI.

Gravedad en Yillaverde.-PÉrez de MosTAlvay P. IX. C.A.

Gridonia (La), ó cielo de amor vengado. Felix de Arteaga. (El P. Fr. Horlensio Félix Paravicino y Arteaga.) Obras póst umas.

Guanches (Los) de Tenerife y conquista de Canaria.-Lope. $\boldsymbol{P}$. $\boldsymbol{X}$.

Tambien se conoce con el título de Nues. tru Señora de la Candelaria, y segun Barrera por el de La comquisla de Tenerife $y$ contuista de Cannria ó Nuestra Señora de la Cundeluria.

Guante (El) de Doña Blanca.-Lope. Vega del Parnaso, en el Tom. IX. de las Obras suellas; segun nota de D. A. Duran en la $\boldsymbol{P}$. XXXIX. de las de a puera, Valencia, 1636 , y en la XXX. de las. mismas, Zaragoza , 1636. Barrera dice que se encuentra en la $\boldsymbol{X L I V}$. de las mismas, Zaragoza, 1652.

Guapo (El) de Andalucia, Francisco Estévan.-V. Mis (El) temido andaluz.

Guapo (EI) Julian Romero.-V. Ponerse hábilo sin pruebas.

Guarda (La) cuidadosa, precedida de una Loa En alabanza de los males, y del Baile de La Maya.-El Divivo Migurb 
Sínciez, vecino de Valladolid. Se halla en la $\boldsymbol{P}$. llamada $\boldsymbol{V}$. de Lope. La reimprimió Ochoa en el Tesoro del teatro español, y Mesonero en la Biblioteca de Ribadeneira.

En la bibli iteca del duque de 0suna existe III MS. de est't comedia á nombre de Lope, y Medel tambien se la atribuye.

Guarda (La) de sí mismo. - Caladerox. El mejor de los mejores libros de comedias, y en las Doze comedias las mas grandiosas, donde lleva este título en el índice del volúmen; pero el de $\boldsymbol{E l}$ guardarse i si mismo, al principiar la comedia.

Es El alrnide de si mesino, de la Parle VIII. de este autor.

Guardar palabra à los santos.-Sebastias de Olivíres. $P$. $\boldsymbol{X} \boldsymbol{X} . \boldsymbol{C} . \boldsymbol{A}$.

Guardar y guardarse.-Lope. P. XXIV. Zaragoza, 1641.

Guardarse (El) á si misnю.-V. Guarda (La) de sí inismo.

Guárdate de la agua mansa.-Cilderos. $P$. VIII. de 1684 y 1726 , en el Tom. $V$. de la de Fernández de Apóntes, y en el IV. de Kéfil. Tambien está en la Parte VIII. C. A. donde peladamente se intitula: Agua mansa.

Hablador (El). - A Á́siso.

Hacer (El) bien à los muertos. -V. Don Juan de Castro.

Hacer cada uno lo que debe.-Jerósino de Ceellar. P. VI. C. A., y Xlit. de las de á fuera, Zaragoza, 16ว̈n.-V. Cada cual a su negocio.

Hacer cuenta sin la buéspeda, zarzuela que se representa actualmente en Villa-Viciosa de Portugal, recreo del rei D. Pedro.-A sóvimo. Impresion de $\boldsymbol{Z} \boldsymbol{a}$ ragoza, 1704. - Segunda jornada de la zarzuela de Hacer cuenta sin la huéspeda, con Loa, y Matachines nuevos. - Axósiyo. Impresion suelta, s. l. ni a.

Barrera dice de estas dos coniposiciones: "Piececillas bien eseritas, acerbammente satíricas de la coalicion y partida. wrios del archiduque Cárlos, pretendiente wel trono español." Deben acompañarlas, aunque es dificil reunirlo, una Loa intituladil: A más linieblas mós luzes, los Matcchines para la zarzuela, el Sain'te para la misma, el entremes los vulienles de la Ampa, y la lev'cera parté cuyo título es El suevio del perro.
Güelfos y Gibelinos. - V. Fuerza (La) de la verdad y Diablo predicador.

Guerras de amor y de honor.-LOPE.

vo está en las l'urles ni la menciona Barrera con este fflulu. La impresión que tengo es suclta y mui antigna, tspresandose en ella que la representu Prado.

Guerras de zelos y amor. - Mirías DE Araba.

Medel cita ntra de D. Luis de Guzman con igual titulo.

Gustavo Adolfo, rei de Suecia.-Joas.MAsitel Martínez.

Gusto (El) del dia.-Axósino.

Moratin la atribuye á D. Anıres Miñano.

Gustos y disgustos son no más que imaginacion.-Calderox. $P$. $V$. de 1694 y 1730 , en el Tom. $\boldsymbol{X}$. de la edicion de Fernández de Apóntes, en el $\mathbf{I I I}$. de Keil, y en la $P$. VIII. C. A.

Guzman (El). T.-Axóximo.

lo sé si será esta la misma que con igual título atribuge Noratin a D. Enrique Liumos.

Guzman el Bueno. 1'-Nic. Fersididez de Moritiy.

Hacer del amor agravio.- Lx Ixúesio. P. XXY. C. A.

Esta comedia es la que conocemos con el titulo de La Baula y la flor, de Calderon.

Hacer del contrario amigo. -V. Empezar i ser amigos.

Hacer fineza el desaire.-Diego C.illeja. P. XXIII. C. A y en una estravagante que Barrera coloca como XLI. de dicha Coleccion y está impresa en Pamplona, s. a.

Hacer remedio al dolor.-Moneto y CísGER. P. II. C. A.

En una edicion molerna que poseo se dan por antores de esta comedia á Cinter, Mitos y Iforeto, y Medel la cita anúnima.

Hados y lados. hacen dichosos y desdichados.-UY IXGEYIO.

Barrera añade á este titulo: el parecido de liusia.

Hai culpa en que no hai delito.-Roy.ı Montero de Espivosi. P. Jit. C. A.

Hai verdades que en amor.-Lope. Par- 
te $X X I$., y segun Duran en la $X X I X$. de las de á fuera, Valencia, 1636.

El título de esta comedia se halla mejor espresado al fln de la nisma, donde se dice:

De las verdades de amor aquí acaba la comedia.

Halion (El) de Federico.-Lope. P. XIII. Hamete (EI) de Toledo.-Lopr. P. IX.

Hamete (El) de Toledo.-LuIS DE BeLmonte Bermúdez y Arronio Martínez. P. I. C. A., y segun Duran, en una $\boldsymbol{X} \boldsymbol{L} \boldsymbol{I}$. estravaganie de varios.

Hamete (El) de Toledo. Burlesca.-Tres Ixgenios. P. XXIX. C. A.

Hamlet. T.-Shakespeare, traducida é ilustrada con la vida del autor y notas criticas (no siempre felizes) por Inarco Celenio (D. Leandro Fernández de Moratin). Madrid, 1795. 4..$^{\circ}$ Se ha reimpreso en las ediciones de las Obras de cste autor.

El mismo Noratin en cl Catalogo de las piezas dramálicas del siglo XVill. dá conlo anonima una tragedia intitulada: Hamlel, rei de Dinamarca, que ignoro si será la que èl tradujo ú otra.

Hasta el fin nadie es dichoso.-Horeto. P. $I$.

Hasta la muerte no hai dicha. - V. No hai dicha hasta la muerte.

Hazañas (Las) del Cid. Comedia segunda.-Gull.les de Castro. P. I.

Así se intitula la segunda parte de las Mozedades del Cid en la portada de dicha Primera parte de sus comedias. Valencia, 1621 .

Hazañas de los Pizarros. - Tirso.

Con este titulo suelen comprenderse las tres comedias de la Parle IV. de este autor que tratan del D. Francisco y D. Hernando, á saber:

Todo es dar en una cosa.

Amazonas en las Indias.

La lealtad contra la envidia.

Heautontimorumenos (EI). - TERexcio, traducida por Simor Abril. Comedias de Terencio.

Hécira (La). - Terescio, traducida por Abril. Comedias de Terencio.

Héctor y Aquuiles.-Crist. de Monrol x Sil.vi.

Hécuba triste. Tragedia en prosa.-PÉREZ DE OLIVA, tomando el argumento de Euripides y mudando muchas cosas. Se balla en sus Obras y en el Tom. VI. del Parnaso español.

Hechizado (EI) por fuelza.-ANT. DE ZAmors. Tom. I., en el volúmen de las
Escogidas del mismo autor, Madrid, 1831, en el $V$. del Tesoro del teatro español, en el Theatro hespañol de Huerta y en la Biblioteca de Ribadeneira.

Hechizera (La) del cielo. - Antonio DE Navcláres. P. XXI. C. A

Barrera añade al título Santa Eufrasia. Medel apellida equivocadamente á este autor Monclares.

Hechizo (El) de Sevilla. -- Ambrosio DR Arce. P. XXXVIII. C. A.

Hechizo (El) imaginado.-Juay Zabaleta. P. XXIII. C. A.

Hechos (Los) de Garcilaso de la Vega y Moro Tarfe.-V. Cerco (El) de Sunta $\mathrm{E} e$.

Hércules (EI) de Hungría.-Asrbrosio DB Arce. P. XII. C. A.

Hércules (El) de Ocaña.-Diamante. P. $\boldsymbol{I}$.

Barbosa cita una con este titulo de Mátos Fragoso, que no creo exis ta.

Hércules furente y Oeta. Tragedia con todo el rigor del arte.-LÓPEZ DE ZARate. Obras varias, $16 \mathrm{a} 1$.

Hércules y Neso Centauro. Drama en un acto.-Axóximo.

Heredera (La) astuta, por otro título: La más sutil currutaca.-José María Mas Casellas y Exrich.

Hermanas (Las) bandoleras. - Lope. Impresion suelta y antigua.

No está en las Parles. La que lleva este titulo en el Indice de MedeI, se atribuye á Calderon, no obstante que Vera Tásis asegura que no la escribió. Barrera solo menciona Las hermanas bandoleras, ó á lo que obliga un agravio; pero la dá como anónima.

Hermano (El) de su hermana. Burlesca. -Franc. Bdo. Quiros. Obras. 1656.

Barrera añade al título $\delta$ el cerco de Zamora.

Hermanos (Los) amantes, y piedad por fuerza.-Fernando de Zarate. $\boldsymbol{P}$. $\boldsymbol{X L}$. c. $A$.

Hermanos (Los) encontrados.-Moreto.

Tengo un análisis MS. de esta comedia y con este titulo se publicó en su Parte III, Madrid, 1681, segun Barrrra. Es la nisma que el Satisfacer callando.

Hermanos más amantes.-Juan VirLégas. -V. Morica (La) garrida.

Hermosa (La) Alfreda.-Lope, P. IX.

Tambien ha solido titularse La Hermosurude Alfiedu, $\mathrm{y}$ as! se llama en el Pere. grino.

Hermosa (La) Ester. - Lope de Vega. P. X $\boldsymbol{T}$. 
Segun Barrera es La soberbia de Aman ! huinililad de Mardoqueo y lat horca para su duetio.

Hermosa (La) fea.-lope P. XXIY., $Z a-$ ragoza, 1641, en el Tom. II. de sus Comedias escogidas, Madrid, 1828, y en el II. del Tesoro del teatro español.

IIermosura (La) aborrecida.-Lope. Parte $\boldsymbol{V I I}$.

No se halla en el Indice de Vedel. Barrera añade al tftulo: $y$ desdichala frme.

Herniosura (La) le Alfreda.-V. Hermosa (La) Alfreda.

Hermosura (La) de Raquel, precedida de Loa y Baile de La Colmeneruela. Primera y segunda parte. La segunda parle lleva al principio olra Loa en prosa y el Baile de Los moriscos. LuIs VEl.f. F. Flor de las comedias de España. Quinta parle.

Barrera le da á la scrunda parte el titulo de El inds amanle Paslor y dichoso Palriarca: ignoro de dónde to ha sacado, pues en mi cjemplar en ambas partes sc denomina: La heriunsura de Raquel. Medel se equivoea en atribuir esta comedia a D. Juan Vélez.

Hermosura (La) y la desdicha.-Rós.ss Zorrilla. P. XXXV.C.A.

Hernan Cortes en Tabasco.-Fermix dec REI.

Heródes Ascalonita y la hermosa Mariana.-Gispar Lozivo Moxtesiso.

El verdadero autor de esta comedia es cl Doctor Cristóval Lozano, y se halla tam. bien en sus Soledades de la villa, cdicion de 165s: Gaspar Lozano fue sobrino suyo y prestú su nombre para las obras profanas de su tio durante la vida de este.

Heróica (La) Antona García.-CAÑızíres. Tom. II. de sus Comedias escogidas, Madrid, 1833.

Le sirvió de original la Antona Garcia de Tirso. Hartzenbusch.

Hidalgo (El) Abencerraje. -Lope. Parle XVII.

Barrera dice ser El hidalgo Ja:imin.

Hidalgo (El) Jazimin.-V. Hidalgo (El) Abencerraje.

Hidalgos (Los) del aldea.-Lope. P. XII.

Hija (La) del aire. Primera y segunda parle.-Caldenos. $P$. $\boldsymbol{H}$ II. de 1664 , 1687 y 1726 , en el Tom. VII. de la de Fernández de Apóntes, en el $\boldsymbol{I}$. de la de Keil, y en la P. X XIII. de las de á fuera, Zaragoza, 163̈0, á nonbre de Antonio Enríquez Gómez.

Hija (La) del mesonero. - DIEGo dE FiciveROA. P. XIV.C.A.

TоM. I.
La tengo suelta con el tilılo de La hija del mesonero, ó la ilustri fregona.

Hija (I.a) del senescal. - V. Corno luce la leallad.

Hijo (EI) de la molinera.-Fraxcisco DE Villég.is. P. XLII. C. A.

Esta comedia se imprimio suelta il nom. live de Lope de rega con el títuln de Más marl hai en la aldegüela de lo que se suena; y tambien se encuentra con el nombre de este autor en un .IS. de la bib. del duque de Osuna. Viedel se equiroca en llamar Juan Villeigas al autor de El hijo le la molinerel.

Hijo (El) de la piedra.-Mítos Fracoso. P. I.

La tengo tambien, publicada posterior. mente, con el tilulo de El Ilijo de la piedra y sergunelo pio r., sun Félix. Fs una imitacion de La eleccion par la virlual de Tirso, segun Hartzenbusch. Barrera la da el título de Ilijo de la pieulra: san Félix de Cantalicio, y segundo tio r.

Ilijo (El) de la virtud: san Juan Bueno. Primera y segunda parte.-FRAC. DE Llícos Vildes. P. XX. C. A.

Hijo (El) de las batallas.-Jicisto CorDERO.

La tengo stelta; pero Barrera dice que la vió en un fragmento de tomo de Comedias de este autor que parcia impreso en Valencia.

Hijo (El) de los leones.-Lope. P. IIX.

Hácia fines del siglo Xrll se reimprimio en Serilla atribuida a un Ingenio de la Corle. Jedel la trac cono diffrente de Ia de Lope, y Barrera dice pusitivamente que soul distintas: se equivoca. pnrque las he cotejalo y las encuentro identicas.

Hijo (EI) de Marco Aurelio.-Z Z B.LETA. P. I. C. A.

Dice Barrera que la refundiú con el títu. lo de El emperador" Commontro. Vedel trae otra de Moreto enri el lítulo de El hijo de Marco Aurelio, lo que seril probablemente una equirocacion.

Hijo (EI) de Reduan.-Lope. P. I.

Hijo (El) de sí mismo.-i. Hijo (El) sin padre.

Hijo (El) del águila.-Lcrs Vélez.

Barrera añade i este titulo ó Serror" D. Juan de dustria. y olserva que es la misma que existe Ms. en la bib. del duque de 0sul na intilulada: El ignila del alphes y balalla nacial de' Le'panlo.

Hijo (El) del serafin S. Pedro de Alcámara.- Iortaly. Tom. I.

Segun Barrera parece ser la misma que la de Nontilvan que solu lleva el titulo de S. Peeldo de Alecintura.

Hijo (El) del Sol, Faeton-C - Cllnerox. P. IV., ediciones de 1685 y 1731 , en 
el Tom. IV. de la de Fernández de Apóntes, y en el $\boldsymbol{I I}$. de la de Keil.

IIijo (El) obediente. Precedida de Loa.Muguel Bexeito. P. I. de los Poetas valencianos.

Vedel no meneiona esta comedia de Beneito: pero trae dos con el milismo titulo que atribuye á Voreto y á un Ingenio.

llijo (El) pródigo.--Tres Irievios.

Ilijo (EI) reconocido.-Luchano Fravisco Cosle lli.

Hijos (Los) de la Barbuda. - V. Fijos Los)

Hijos (Los) de la fortuna.-Mosrabvax.

es li misma que la de Teayénes y Clariquita que se halla en el Tomo II. de sus Comedias, y distinta de la de calderon.

llijos (Los) de la fortuna. - Culderos. P. III. de 1687 y 1726 , en el Tom. VII. de la de Fernández de Apóntes, y en el $\mathbf{I I}$. de la de Keil.

En la primera edicion (1664) de ha P.III. lleva por título: Los hijos de la forluma, Teatgénes y Cariclea.

Hijos (Los) del dolor, y Albania tiranizada.- Fraxe. de Leivi Ramírez AreLLAYO.

limenea.-Tórres Nimarro. Propaladia, Teatro español anterior a Lope de Vega, Orígenes del teatro español por Moratin, y en el Handbuch der spanichen litteratur de Ludwig Lemeke.

Historia de santa Susana.-Jia de RoDrigo Aloxso, llamado de Pepraza. S. l. 1эั\%1., Alcalá, 1 эัวั8 y Medina, $160 \%$. 4. ${ }^{\circ}$ let. gót.

Historia de Tobías.-Lope. P. $\boldsymbol{X V}$.

Hombre (El) agradecido.-Luciaxo Fraxcisco Comela.

Hombre (FI) eonvencido á la razon, ó la nujer prudente.-M. S. C.

Hombre (El) de bien.-Lope. P. VI.

Vedel cita una con irgual título de un Ingenio, que tal vez sea la misma.

Hombre (El) de bien.-Luelaxo Fraxcisco Comella.

Hombre (El) de bien, amante, casado $y$ viudo.-Fioriss, acomodada al teatro español por D. F. II. E. y C.

Hombre (El) de Portugal.-MTro. AlfaRo. P. XVI. C.A.

Hombre (EI) mejorado por sus remordinientos. En prosa.-Axósimo, traduecion de D: J. BAllY.

Hombre pobre todo es trazas.-Cilderon. P. II. de 1637 (?), 1641, 1686 y 1726 , en el Tom. FI. de la de Fernández de Apóntes, y en el I. de la de Keil.
Hombre (El) por su palabra.-Lope. Parte $X X$.

IIombre (EI) prudente. En prosa.-A sóximo, traduecion de José Coxcula.

Tambien tengo esta misna traduccion anónima.

IIonestidad (La) defendida de Elisa Dido, reina y fundadora de Cartago.-CubsLlo de Arigon. Enano de las Musas.

En el indice de Medel se encuentra con el brevisimo título de IIonestilad defendida, y tambien con el de Elisu Dirln, reina If fumbelora de Carlago. Trae ademas dicho Indice otra anónima, que denomina Lı honeslidaudefendida y porida seneclnd, que tal vez sea li misma.

Honor (El) da entendimiento y el más bobo sabe más.-Cañizíres. Tom. I. de sus Comedias escogidas, Madrid, 1829, en la Coleccion de dramáticos de la Biblioteca de autores españoles de Ribadeneira, y en el Theatro hespanol de Huerta.

Honor (El) de los Guzmanes y defensa de Tarifa.-Lus Vélez.

Es la misma que Más pesa el rei que la sangre, y bluson de: los Guzinanes. Nedel se equivoca en atribuirliá $D$. Juan Vélez.

Honor (El) en el suplicio, ó el prodigio de Cataluĩa, S. Pedro Armengol, ó los Armengoles. - V. Armengoles (Los).

Honor (EI) es lo primero. - Fraxc. DE LeIva Rivírez.

Honra (La) por la mujer.-Lope. P. XXIV. Zaragoza, 1633.

Honrado (El) hermano. T. c.-Lope. P. XVIII., y en el Tom. II. del Tesoro del teatro español por Ochoa.

Barrera pregunta si serí la misma que Los Horacios que se halıa en la lista del Peregrino.

Honrador (EI) de su padre.-Diamante. P. XI. C. A, en el Tom. V. del Tesoro del teatro español, y en la Coleccion de dramáticos de la Biblioteca de Ribadeneira.

Ilonrador (EI) de sus hijas.-Fauncisco Polo. P. XXIII. C. A.

Houras á Lope de Vega en el Parnaso.Axóxino. Fama póstuma de Lope, y en el Tom. $\boldsymbol{X X}$. de las Obras sueltas.

Fuè el antor de esta comedia D. Gabriel de Honcada.

Horacios (Los).-V. Honrado (El) hermano.

Horea (La) para su dueño.-V. Hermosa (La) Ester.

Hormesinda. T.-Nic. Fervíxnez de MoRATIN. 
Horror (El) de las montañas y portero de san Pablo.-Movrol Y SILVA.

Hortensio (L'). Comedia en prosa italiana.-A lejenjoro Piccolomins.

Ilai algunnas escenas en español.

Hospital (El) en que cura amor de amor la locura.-Diego de Tórnes y VillarroEI.. Juguetes de Thalia. Sevilla (1744).

Huérfana (La) de Barcelona y tutelar de su patria, Sta. Madrona. Comedia trágica.-A хóvimo.

Huérfano (El) ingles.-Axóxiso.

Sin duda es la que trae Moratin con el titulo de El huérfano ingles, ó el ebanisla,

İcaro y Dédalo. Precedida de Loa.-MeLchor Fervíndez de Leos. $P$. $\boldsymbol{X} L \boldsymbol{V} \boldsymbol{V} I I$. , C. $A$.

Entre la segunda y tercera jornada lleva intercalado el baile de Las aves.

Igualdad (La) en los sugetos.-Diego MUXET y Sol.Is. Comedias y Rimas.

Ilustre (La) fregona.-Lope. P. $X X I V$., Zaragoza, 1641.

Barrera adiciona al título, $y$ amanle al uso. Medel trae una de Cañizàres con jgual título, que probablemente será la misma.

Imperial (La) de Oton.-Lope. P. VIII.

Impia (La) Jezahel, mujer del infeliz Acab, ó el triunfo de Elías.-Tinso. V. Mujer (La) que manda en casa.

Imposible (La). Idilio cómico Real. Tragedia con introduccion. - Fraxcisco Minuel de Melo.

Es solo un fragmento que se balla en las obras métricas de este autor.

Imposible (El) más fácil. - Míros FRAGoso.

En mi poder existe de edicion mui an. tigua esta misma comedia a nombre de Calderon; pero con algunas supresiones sobre todo hácia el fin. Esto bastó para que Medel atribuyese una á este autor, contra el sentir de Vera Tásis.

Inclinacion (La) española.-Frava. Bixces Caxpayo.

Barrera añade al titulo $y$ musulmana nobleza.

Indicios (Los) sin culpa.-Mítos Pragoso. P. I.

Indolente (El). - A vóstyo.

Es de Luciano Franclsco Comella, segun Noratin. y atribuye á $D$. Tomas de Iriarte, $\mathbf{y}$ tal vez sea traduccion del ingles.

Huerta (La) de Juan Fernández.-Tırso. $\boldsymbol{P}$. III., y en el Tom. II. de las $\boldsymbol{E}$ scogidas de este autor, Madrid, 1823, como tambien en el tomo de Comedias escogidas de Tirso por Hartzenbusch.

Huida (La) á Egipto de nuestro Señor Jesucristo. Coloquio.- Gaspar FerváxDE7 I AvILA. Infanciai de Jesucristo.

Humildad (La) soberbia. - Guilley DE Castro. $\boldsymbol{P}$. $\boldsymbol{I}$.

Humildad (La) y la soberbia.-V. Triunfo (El)de la humildad.

Industria (La) contra el poder, y el honor contra la fuerza.-Lope. $P$. XXIV., edicion de Madrid, y segun nota de Duran en la $X X Y I I I I$. de las de a fuera, Huesca, 1634.

En la $P . I I$. de las Comedias de Calderon se encuentra esta comedia como suya con el título de Amor, honor $y$ poder, siendo lo más original que el editor de dichas comedias, Vera Tásis, la dé como verdadera con esta denominacion, y rechaze como indebidamente atribuida á Calderon $L a$ industriu conlra el poder.

Industria (La) y la suerte.-Rciz DE Alercox. $\boldsymbol{P}$. $I$.

Industrias contra finezas. - Moreto. $\boldsymbol{P}$. $\boldsymbol{I}$., y en la $\boldsymbol{X I I V}$. C. $\boldsymbol{A}$.

Ines (La). Drama sentimental. En prosa.-A.rósimo, traducida por D. M. A. IGUAL.

Inez Pereira. Farsa portuguesa. - GIL Vicentr. Obras.

Hácia el fln de esta pieza se introduce un ermitaño que representa en español.

Infamador (El).-JuAy DE LA CoEvi. Comedias y Tragedias, y en el Tom. I. del Tesorodel teatro español por Ochoa.

Medel equivoca el nombre de este autor á quien llama Antonio.

Infante en Alemania. $-V$. Victoria (La) de Norlingen.

Infanzon (El) de Illescas, ó el rei D. Pedro en Madrid. - V. Rei (El) D. Pedro en Madrid.

Infeliz (La) Aurora y fineza acreditada.-Francisco de Leiva. $\boldsymbol{P}$. XLIII. C. $\boldsymbol{A}$.

Medel la trae con el título de Fineza acreditada. 
Infelize (La) Marcela. T.-Cristóval DE Virues. Obras trágicas y líricas.

Vedel la intitula liefeliz Marcela y llama al antor el capilan Lnis virbes.

Ingratitud (La) vengada.-Lope. P. XIV.

lıgrato á quien le hizo bien.-Ux INGENio. P. XLV.C.A.

Es Et rebelde al beneficio, que i nombre de Tomas Osorio está ell la $P$. IV. y lo que le locie al valor, atribuida á llira de Amescua en le XIIIT'.

Ingrato (El) arrepentido.-LoPE. $\boldsymbol{P} . \boldsymbol{X V}$.

Ino y Neifile.-Luciano Francisco ConeL.L.1.

Ino y Temisto. T.- Luciavo Fraxcisco Conella.

Inobediente (El), ó la ciudad sin Dios.Clarayonte. P. II. C. A.

La tengo suelta de edicion mui antigua í nombre de Lope con muehas variantes. V. Ciudad (La) de' Dios.

No imenciona Pellicer esta comedia entre las que atribuye á Claramonte.

Inocencia (La) triunfante. Precedida de Loa y seguida del sainele: La burla del posadero y castigo de la estafa. Axósino.

Moratin la atribuye á José Concha.

Inocente (La) Laura.-Lope. P. XVI.

Este es el único título que lleva la co. media, sin embargo de decir al fin:

"que su autor, noble senado, "llamó La inocente Latra "II Iraiciones de Ricardo."

Iuocente (La) sangre. T.-Lope. P. XIX.

Barrera la da ademas el titulo de Los Carvajules.

Intricati (Gl').-Alyse Pisqualigo.

Comedia italiana eu la que el gracioso Calabaza habla siempre en español.

Jacinta.-Tórres Niharro. $4 .^{\circ}$ lel. gót., en la Propaladia, y en el Teatro espanol anlerior a Lope de Vega.

Jacintos (Los). - V. Jacintos (Los) y zeloso de si mismo, y Pastoral (La) de Jacinto .

Jacintos (Los) y zeloso de si mismo.LoPE. Qualro comedias famosas de Góngora y Vega Carpio.

Es la misma que La pastoral de Jacinto de la P. XVIII.; y será sin duda la ciladia con solo el título de Los Jacinlos, en El Peregrino. Nedel dice equivocadamente que st de dos Jigenios.
Introduccion en forma de coloquio, para la festividad de S. Ignacio de Loyola. -Jacivro ne Evia. Ramillete de varias fores poéticas.

Introducciones (Tres) para la comedia $y$ sarao que se hicieron á los años del conde de Salvatierra.- Praxcisco de Castro. Alegría cómica. P. II.

Invencible (La) castellana.-Josbi DE $\mathrm{CA}_{\mathrm{A}}$ ÑZÁRES.

Medel la trae anónima.

Inveucion (La) de nuestro Señor Jesucristo en el templo. Coloquio. - Gaspar fervíviez y Ävila. Infancia de Jesucristo.

Invisible (El) príncipe del baúl.-Cúbic.o de Aragor. El enano de las Musas, y en el Tom. XLVII. de la Biblioteca de Ribadeneira.

Ir por el riesgo á la dicha.-Diamante. P. II.

Íris (EI) de las pendencias.-GASPAR DE A Villa. P. XXIX. C. A.

Isabela. T.-Lupercio Lrovardo de ARGersola. La dió á luz Sedano en el Tom. VI. del Parnaso español, y la ha reimpreso Ochoa en el I. del Tesoro del leal ro español. Ludwig Lemeke ba publicacto un fragmento en su Handbuch der spanichen litteratur.

Isabela (La). Drama joco-serio.-Luciano Francisco Comela.

Isla (La) Bárbara.-Miguel Sívcirez VIDAL. Manuscrito de principios del siglo XVII., quizás autógrafo.

En el Indice de Medel se cita una comedia con este títuln; pero no se menciona el nombre del autor.

A nombre de Lope de Vega salió en las Doce comedius the varios, Torlosa 1638, segun Von Sehack.

Jacoba (La).-Luciano Fraxcisco ComeL.LA.

Jacobina (Comedia llamada) ó bendicion de Isaac.-Damax ue Végas. Libro de poesía cristiana, y en el Tom. $\boldsymbol{X X V}$. de la Biblioteca de Ribadeneira.

Jahel (La). T. -A Nóvimo.

Es de Juan López Sedano, segun Moratin.

Jardin (Fl) de Falerina.-Calderon. $\boldsymbol{P}$. $\boldsymbol{V}$. de 1694 y 1730 , en el Tom. IX. de la de Fernảnde\% de Apóntes, en el III. de la de Keil, y en el III. del Tesoro del teatro español. 
Jarretierra (La) de Inglaterra, el mayor aprecio del descrido de una dama.Bánces Cinnamo. Tom. II. de sus Pocsíus cómicas.

La tengo suelta con el titulo de Cual es el maynr aprecio del descuide de unt da. ma. La Jariclicra.

Jerjes. $T$.-A хóximo.

Job (EI) de la ley de Gracia.- Nipciso Agustin Solano y Loro.

seri distinta de la de Vidaurre, enn igual titulo cilada por ilvare\% y liaena?

Job (EI) de las mujeres.-Míros Fricioso.

\section{P. IX. C. A.}

la tengo tambien con el litulo de $E l J o b$ de lits mujeres, St"1. Isabel de Itungria.

Medel atribuye á Calderon, me parece que equivncadamente, una comedia con el titulo de El Jab de las mijeres.

Jorge Toledano.-Lope. P. XVII.

Josef (EI) de las mujeres. - Cilneron. P. VI. de 1683 y $171 \%$, en el Tom. VIII. de la de Fernándle\% de Apóntes, en el $\boldsymbol{I I I}$. de la de Keil, en la P. XIII. C. A.. y en el Tum. III. del Tesoro del teat ro espiñol.

Josef rendilo. T.-Axóxisio. Introduccion al elrama que ha de representarse en el Seminario de nobles. 1781.

Juan de Dios y Anton Martin.- Lope. P. $X$.

Tambien se titula Sin Juan de Dios.

Juan Latino.-Jistigez de Exciso. P. II. C. $A$.

Juan Sánchez de Talavera.-A Áximo. Nedel se la atribuye á Diamante.

Juanito y Coleta ó el pleito del marjuesado.-Fl.oriss, traduccion de D. F. M. E. Y C.

Jubileo (EI) de Porciúncula.-Dianaste. P. II.

Júdas Iscariote. $-Z$ anori. $\boldsymbol{T}_{0}$. $I$.

Júdas Macabeo. - Carderos. P. II. de 1637, 1641,1686 y 1726 , en el Tom. V. de la de Fernández de Apóntes, en el $I$. de la rle Keil, y en el volúmen de Comedias nuevas. Amsterdain, 1726.

En la bib. del duque de osuna cxiste una copia manuserita il nombre de kijjas Zorrilla, y Medel la trae como distinta.

Judía (La) de Toledo.-Dinaste. Parte XXVII. C. A., en el volumen de Comedias nuevas, Amsterdam, 1726 , y en la Coleccion de dramáticos le la Biblioteca de Ribadeneira.

EI Sr. Tichnor dice que esta comedia es de Niria de Anescina, porque así consta de un inanuscrito autórrafo que existia en su poder, con las licenclas para su representacion, fechadas el 10 de abrit de 160.5 . siend" el tltulo original La desgraciada Rusquel.-Lope de Vega escribio ofra pieza sobre el mismo asinto con el litulo de Las pazes we los reyes, y Judiu de Toledn; y un época más reciente I). Vicente Garcia de la fluerta compuso su linjuel, tragedia que versa tambien sohre el mismo heeho.

Judia de Toledo.-V. Pazes de los Reyes. Judit (La) castellana.-Lucino Fraxcisco Covella.

Juegos (Los) olímpicos. Con Loa.-S LLAzar y tórres. $\boldsymbol{P}$. $\boldsymbol{I}$. de su Cllara de Apolo, y en una $\boldsymbol{X} \boldsymbol{L I}$. de varjos estravagante.

Moratin mencinna otra con igual titulo como de un escritor anónimo del sigro XVIII, que tal ver sen csta misma.

Juez de su callsu - Lope. En su P. XXIV. edicion de Madrid, y P. XXVIII. de las de a fucra. Huesca, 1634.

Es la misma que El juez en su causa y El juez en su mismu causa.

Juez de su misma causa.-V. Juez (El) de su causa y Juez (El) en su causa.

Juez (El) en sucausa.-Lope. P. $\boldsymbol{M X V}$.

En la P. MIIV., edicion de Malrid, lleva por tltulo: El juez de su calcsa, y to mismo sucede, segun nota de U. Ag. Duran,

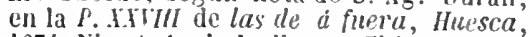
16ǰ́. Nic. Antonio la llama: El juez de su misuta culsa, y así la trae Mcdel.

Juez y reo de su causa.-Lx INGesio de LA Ċorte.

Barrera pregunta si será la de Martunez Menéses inlitulada: Pedir justicia al culpado, of juez y ren de su calusa. Las he comparado, y encuentro que tiene tintas variantes que casi parece refundicion de la de dicho Martínez

Juezes (Los) de Castilla.-Moreto. P. I. edicion de Madrid, 1677. Tambien se encuentra en la $P$. III . edicion de Valencia, 1676,1703 y Val. Orga. s. a.

ISedel cita una de Lanini Sagredo y de D. Juan de la Hoz con igual tilulo, que serun Barrera es El descisdo Principe de Ashirias, que existe lls. y autugrafa, á nombre de la lloz, en la bib. delduque de Osına.

Juicios (Los) del cielo no examinarlos y obedecerlos. - Penno Scotri Agoiz. Obras póstumas.

Juiz (0) da Beira. Farsa portuguesa.Gil Viceste. Obras.

Hai en esta pieza un zapatero que siem. pre se produce en español.

Julian Romero.-Lope. En el fragmento de una Parle que me es desconocida, y comprende desule el fol. 101 al 122. 
Barrera no hace mérito de esta comedia.

dulian y Basilisa.-Ant. de IIUerta, Rosete Nix̃o y Cáncer. P. XIII. C. A.

Los nombres de los autores constan por la Tabla del volúmen, pues al principio de la comedia $y$ en los titulillos de las píginas solo dice ser de tres lngenios.-D. Antonio Huerta serát aeiso sigler de Huerta. - Nedel la cita anónima.

Juliano apóstata.-Lus Vícez.

Asi dice en mna edicion snelta que tengo de mediados del siglo Xill:; sin embargo Barrera la atribnye ì D. Juan Crisostomo Vélez de fiuevara, hijo del D. Luis, quizás por haber copiado á INedel.

Jipiler y Semele. Z.-Dinmave. P. I.
Justicia (La) en la piedad.-Guillen DE Castro. P. II.

Es la misma que la piedad en la justicia de la $P$. XXVI. $C$. A. Se cita una pieza de este autor denominada La justicia en la verdad, que Barrera sospecha sea la misma.

Justicia (La) en la verdad.-V. Justicia (La) en la piedad.

Justina (La).-Gaspar Zabala y Zamora. Justo (El) Lot.-Álvaro Cubillo de AraGoN.

Jurentud (La) de S. Isidro.-Lope. Relacion de las fiestas de la canonizacion de S. Isidro, y en el Tom. XII. de las Obras sueltas.
I.aberinto (El) de amor.--Cervistes. Comedias y Entremeses.

Laberinto (El) de Creta. Z.-J. B. DrtMANTE. P. KYVII. C. A.

Laberinto (EI) de Creta. T. c.-Lope. P. XVI.

Labrador (EI) de Mladrid.-V. San Isidro.

Labrador (El) del Tórmes.-LOPE. Impresion suelta antigua.

to se halla en las Partes. Barrera refiriéudose á los ejemplares de Duran y llollant añade al título de la mia ó lin que puede un argravio; pero en su indice de tilulos no la trae.

Labrador (El) venturoso.-Lope. P. XXII.

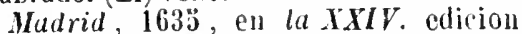
tambien de Madrid, y segun nota de D. Agustin Duran, en la XXVIII. de las de a fuera, Huesca, 1634.

Labrar flechas contra sí.-Y. Venir el amor al murdo.

Lacayo (El) fingido.-Lope. Qualro comedias famosas de Góngora y Vega Carpio.

Nedel la meneiona anónima.

Lagos (Los) de San Vicente. - Tinso. P. $V$.

ofrece Tirso una segunda parte, que no llegó á publicarse.

Lágrimas (Las) de David.-Felipe GodíNE $L$.

Medel menciona otra de Lope y una tercera de Calderon. Seria menester poder compararlas para vej si son diversas ó una misma; pero el nombre de Calderon se ha usurpado malamente á juicio de Vera Túsis: en cuanto á la de Lope puede que no exista, á no ser que sea el David perseguito di la que se refiera.

Barrera añade al títnlo de la de Godinez $\delta$ 't rei meis arrepentido.

Lances de amor, desden y zclos.-Axtonio Frunento.

Lances de amor y fortuna.-Calneron. $P$. I. de $1636,1640,1683$ y 1726 , en el Tom. III. de la de Fernández de Apóntes, en el $I$. de la de Keil, y en las Comedias de los mejores y mas insignes ingenios. Lisboa, 1652.

Laura perseguida.-Lope. P. IV.

Laurel (EI) de Apolo. Z.-Cilderos. Representose primitivamente esta composicion con motivo del nacimiento del príncipe Felipe Próspero, y posteriormente el clia del nombre de Cárlos II, aumentada con la segunda jornada y corregida la primera. Hállase en la $P$. III. de Calderon de 1664,1687 y 1726, en el Tom. VI. de la edicion de Fernández de Apóntes, y en el $\boldsymbol{I I}$. de la de Keil.

Lavandera (La) de Nápoles.-V. Mónstruo (El) de la fortuna.

Lavar sin sangre una ofensa. - Rouas Mostero de Espinosa. P. $\boldsymbol{X X I I . ~ C . ~ A . ~}$

para esta comedia eseribió el mismo autor una mojiganga intitulada: Cupidoy Vénts, que existe MS. en la bib. del duque de osuna.

Lazo (El), banda y retrato.-Andres GiL Enriquez. P. XXXIV. C. A.

Medel llama equivocadamente á este autor Diego Enriquez.

Leal (El) criado.-Lope, P. $\boldsymbol{X V}$. 
Lealtad (La) contra la envidia.-Tirso. P. IV.

Posteriormente salió con el titulo de Leallad contra la envidia, y hazaĭus de los Pizarros. Tercera parle. Véase Todo es dar en una cosa, y umazonas en las Indias.

Lealtad (La) contra su rei.-JuAx de ViLLEGAS. P. X. C. A.

Lealtad (La) en el agravio.-Lope. Parte XYII. de Zaragoza.

Barrera dice que esta comedia es la intitulada: Las quinus de forlugal en el Catálogo del Peregrino, y la que se publico suelta con el título de En la mayor leallad mayor agravio, y favores del cielo en Porlugal.

Lealtad (La) en las injurias.-DiEGo DE Figuerot y Cóndova. P. MIX. C. A.

Lealtarl (La), ó la justa desobediencia. En un acto.-GIL LORENA dE ApOZAR.

Lealtad, traicion é inocencia, ó Sífiro y Etolia.-Axósiyo.

Es de D. Ant. Valladáres y Sotomayor, segun Moratin.

Legítimo (El) bastardo. - Copistóval DE Moníles. P. XXXII. C. A.

Lego (El) de Alcalá.-Luis Vélf.7. $\boldsymbol{P}$. $\boldsymbol{I V}$. C. A.

Barrera añade al tftulo: Frui Julian. Nedel la atribuye indebidamente á Juan Vélez.

Lego (EJ) del Cármen.-Moreto. P. $\boldsymbol{I}$. edicion de Mairid, 1677.

En la de Vulencia de 1676, y en la $P$. $I$. C. A. tengo esta cousedia con el título de San Francu de Senn, y con el misno hai una Segunila parie, segun Vedel, escrita por Fr. Juan de Ribadencira.

Lei (La) ejeentada.-Lope. P. XXIV. Zaragoza, 1633 .

Lena (La). En prosa.-V. Zeluso $(\boldsymbol{E} I)$.

Leoncio y Montano.-Diego y Jose UE Figereo. P. MIV. C. A.

Letrado (EI) del cielo. - Sebistias ne Villaviciosa y Mítos fragoso. P. Mi C. A.

Libertad (La) de España por Bernardo del Carpio.-Juan de la Cueva. Comedias y Tragedias.

Medel equivoca constantemente el "1011bre de este autorá quien llama Autonio.

Libertad (La) de Roma por Nucio Escévola.- Juix de la Cieva. Comedias y Tragedias.

Como digo en el articulo anterior Nedel llama siempre á estc autor Antonio.

Jicenciado (El) Farfulla. Z. burlesca.Ramoy de la Crez. Tom. VI. de su Teatro.
Liceneiado (E1) Vidriera.-Moneto. Parte II., en el Tom. III. de las Escogidas del mismo, 1831, y en la $\boldsymbol{I}$. $\boldsymbol{V}$. C. A.

Lides de amor y desden. Z.-Diamaxte. P. II.

Limpieza (La) no manchada. - I.opr. P. XIX.

Barrera lil da tambien el titulo de Sanla Brígida.

Lina. T.-Axóxiyo.

Traduccion del frances.

Lindo (El) D. Diego.-Moreto. P. II., en la XVIII. C. A., en el Tom. I. de las Comedias escogidas de este autor, 1826 , ell el IV. del Tesoro dal tealro español, v en el Theatro hespañol de Hu'rta

Lindona (La) de Galicia. - Mostalis.

Medel \& Huerta atribuyen a lope una pieza con este lítulo. Con el de ficuhembra de Galicia se publicó la mismd á nombre de Moreto.

Lises (Las) de Francia.-Mina de Arescul. P. $X L I V . C . A .$, y segun Mesonero, en un tomo de Coinedias que pudo ser $I$. Parle de este autor.

Lo mejor es lo mejor. Precedida de Loa y seguida de tres suinetes.-A.тохо De Carnoxi y Boru. Se imprimió $S . l$. ni $a$.

Barrera cita otra edicion de Madrial, Bernardo villadiego, $16 \times 5$, en la que parece que el titnlo da la comedia es: Lo mejor es lo mejor, óntes que amor es lu patriu, y primer cerco de hinu.

Los sainctes se intitulan: La entrada de la reina.- La pragmálica de ainor.-La ronde de palacio.

Lo que es un coche en Madrid.-V. Ricsgos Los que liene un coche.

Lo que está determinado.-Lope. P. III. C. A.

Lo yue ha de ser.-Lork. PP. XXII. y X.T. ediciones de Zaragoza, en el volúmen intitulado: Coleccion de las mejores comedias de Lope, Madrid, 180̈, en el Tom. IV. a sus Comedias escogillas, Madrid, 1832, y en el II. del Tesoro del teatro español.

l.o que bace un manto en IIadrid. - V. En Madrid y en una casa.

Lo que hai ifue fiar del noundo.-Lope. P. III.

Lo que le toca al valor, y principe de Orange. - Iir. de Amesced. P.XXXIV. C. A.

El autor ofrece al fin de esta comedia una s'yumla parte que debia contener la muerte y prision de Gerardo. Es la misma que El rebelde al bencficio de Osorio, que 
se encuentra en la $P . I V . C . A .$, y el Ingrato a quien le hizo bien, que como de un Ingenio se lialla en la $X \mathbf{L} V$.

Lo que merece un soldado. - Morero. P. XLIII. de las de à fuera, Zarago$\approx a, 16 ว 0$.

Tengo tambien esta comedia con el título de Cuutelas son amistules, atribuida á Felipe Godínez. Segun Barrera se encuentra como de Moreto intitulada: La calcta (') la amistad.

Lo que mucho vale, mucho cuesta.-V. Ganar amigos.

Lo que pasa en un torno de monjas. Axóxingo.

Algunos la atribuyen á Feli pe IV, y otros al conde de Lémos. Barrera llama i esta pieza singular $y$ curiosa farsa.

Lo que pasa en una noche.-V. Empeños (Los) de scis horas.

Lo que previno el destino se logra contra la ciencia, y encantos de Rosimunda. Zarzi-comedia de música y leatro.José Vizouez de Villasinte.

Es pieza de mágia.

Lo cue puede el desengaño y memoria de la muerte.-Crist. de Mosiol y Silva.

Barrera dice que se eneuentra con el título de Escarmientos del pecado, ó la fier. za del desengaño, ó lo que puede un desengaño y memoria de la muerte; y justos juicios de Dios: y tambicn con el de La fucr:a del desengaño, ó lo pue puede un desengaño, y memoria de la muerie.

Lo que puede el oir misa. - MIR.i de Anescui. P.I. C. A.

Lo que puede la aprension. - Moneto. P. I.

Barrera tambien la da el título de $L a$ fuerza del oido.

Lo que puede la crianza.-Fraxcisco DE Villégls. P. XXY.C. A.

Barrera se equivoca en decir que tambien se halla en la P. II., y Medel en llamar al autor Juan.

Lo que puede la porfía.-Ant. Coello. Comedias de los mejores \&c. Lisboa, 16302 .

Nedel dice por error que el nombre del autor es Luis.

Lo que puede una sospecha.-MIn DE A.IEscua. P. IV. C. A., y segun Mesonero, en un tomo de Comedias que judo ser $I$. Parte de las de este autor.

Lo que son juicios del cielo.-Montalvan. Tom. I., y Comedias de los mejores \&'c. Lisboa, 1652. D. Ag. Duran dice que se halla en la $\boldsymbol{P}$. $\boldsymbol{X} \boldsymbol{X} \boldsymbol{X}$. de las de á fuera, Zaragoza, 1636.
Lo que son mujeres. - Rósas Zorrilla. P. II., y Tom. II. de sus Escogidas, Madrid, 1831.

Lo que son suegro y cuñado.-Jerós. DE Cifuéntes. $\boldsymbol{P}$. XVIII. $\boldsymbol{C}$. $\boldsymbol{A}$.

Lo que va de cetro á cetro, y crueldad de Inglaterra.-José dE CAÑ̃záres.

El sr. Barrera, refiriéndose al Catálogo de buran, dice que el autor de esta comedia es D. Pablo Rodriguez Osorio.

Lo que vale ser devotos de S. Antonio de Pádua.-Un Ingenio de esta Corte.

Medel y Barrera se la atribuyen á Cañizáres.

Loca, cuerda, enamorada, y acertar donde hai error.-JUan ANT. DE BenaviDES.

Loco (El) cuerdo, precedida de una Loa en alabanza del trabajo $y$ del Baile de los locos de Toledo.-Josi de VALDIvielso. $\boldsymbol{P}$. $\boldsymbol{V}$. de Lope que lleva por título: Flor de las comedias de España de diferentes autores. Quinta parte; y por esto sin duda le adjudica Medel á dicho Lope una comedia con este título.

Barrera añade al de la mia San Simeon, y pregunta si El loco por fuersa de los Indiees de Huerta y Medel será la misma pieza.

Loco (El) en la penitencia y tirano más impropio.- UN INGenio dE LA Corte. P. XI. C. A.

Tambien el protagonista de esta pieza es Roberto el Diablo; pero es enteramente distinta de la pieza intitulada: El loco en la penitencia, Roberlo el Diablo, de Francisco Viceno citada por Barrera.

Loco (El) por fuerza. - Lope. V. Loco (El) cuerdo.

Locos (Los) de Valencia.-Lope. P. XIIII. Coleccion de las mejores Comedias de Lope, Madrid, 1805. 4. ${ }^{\circ}$, en el Tomo IV. de las Comedias escogidas de este autor, Madrid, 1832, y ell el III. del Tesoro del teatro español.

Locos (Los) por el cielo.-Lope. P. VIII. Locura (La) por la honra.-Lope. $P$. XI.

Lograr el mayor imperio por un feliz desengaño.-Lus Movcıs.

La tuve tambien anónima.

Logrero.(El). En prosa.-Goldon, traduccion de Godomin Toibt (Domingo Botti.)

Lorenza, la de Estercuel.-V. Dama (La) del Olivar.

Lorenzo me llamo.-Mátos Fragoso. P. I. de sus Comedias, $X X V$. C. A., Come- 
dias escogidas, Bruselas, 1704, y Biblioteca de Ribadencira.

En la Parle XXVI. C. A. se halla con el título de La dicha del carbonevo y Lorenzo me llamo, en el Tom. II. de Ias Comedias escogidas de este autor, Madrid, 1833, tiene el de Lorenz) me llamo y carbonero de Tolielo, $\mathrm{y}$ bajo el nismo se ha reimpreso en el Tom. IV. del Tesoro del teatro español de 0 chna.-En las Aleluyas jocosas de Abad Velasen se halla una Relacion Irovada de la de Doña Juana de esta comedia.

Lucero (EI) de Castilla, y luna de Aragon.-LuIs VèLEz. Comedias escogidas, Bruselas, 1704, Doze comedias las mas grandiosas. Lisboa, 1653, y El mejor de los mejores libros de Comedias, donde se intitula: El privado perseguido; en estas tres obras se afirma ser su autor Luis Yélez de Guevara.

Es la misma pieza que con el título de El lucero de Caslilla y privado persequi. $d o$, formado de los dos que preceden, y como inédita, se ha impreso, á nombre de Calderon, en el Tealro umliguo españini, Mudrid, 1837. El hecho de colocarla Vera Tásis en la lista de las impresas indebidamente como de Calderon, prueba que habia ya alguna edicion antigua en que se le atribuye.-Barrera tambien la da los títulos de El paje de D. Alvaro y El duque de Arjona.

Lucero (El) de Madrid, Nuestra Señora de Atocha.-Pedro Frayc. Lavisi Sigredo. P. XLII. C. A.
Lucero (El) de Madrid y divino labrador S. Isidro.-Avt. de Zayora. Tom. II.

En nuestro Catálogo de Lòndres encuentro una comedia con igual titulo atribuida á D. Gaspar Zabala y Zamora en lo que indudablemente hai equivocacion. Medel la trae con solo el título de El divino labrador.

Lucinda perseguida.-Lope. $\boldsymbol{P}$. $\boldsymbol{X} \boldsymbol{Y I I}$.

Lucinda y Belardo. Comedia americana. - LY IYGENIO.

Lucrecia. T.-Nicolas Ferxícdez de MoRATIN.

Lucha de amor y amistad. - V. Amislad $y$ obligacion.

Luis XIV cl Grande.-Leciaso Fracisco Comella.

Luis Pérez el gallego.-Calderox. Parte VIII. de 1684 y 1726 , Tom. V. de la de Fernández de Apóntes, en el $I V$. de la de Keil, y en la P. I. C. A.

Luis Pérez el gallego. Segunda parle. Mindel de Anero Puente.

La primera parle es de Calderon.

Luna (La) de la Sagra, vida y nuerte de la santa Juana de la Cruz. - lisiscisco Bersirdo de Qciros. P. MiII. C. $A$.

Luna (La) de la sierra. - Luis Vélez. Flor de las mejores doce comedias, y Doze comedias las más grandiosas.

Nedel se equivoca en decir que es de D. Juan Vèlez.
Llave (La) de la honra.-Lope. P. III. C. $A$.

Llegar á tiempo. En prosa. - Axóvimo.
Segun Yoratin es de D. Gaspal' d+ Zabala y Zamora.

Llegar (El) en ocasion.-Lope. P. IT.
Macias el enamorado.-V. Porfiar hasta morir.

Madre (La) de la mejor.- Lope. P. $\boldsymbol{X} \boldsymbol{V} \boldsymbol{I I}$.

Maestro (El) de Alejandro.-Fersando DE Zarate. Comedias escogidas. Bruselas, 1704, y las Escogidas de este autor, Madrid, 1832; tambien está en la P. XXIV. C. A.

Maestro (El) de danzar-Lope. P. III. C. A.

Es diferente de la de Calderon.

Maestro (El) de danzar. - Cilderos. P. III. de 1664, 1687 y 1726 , Tom. VII. de la de Fernández de Apóntes, y cn el $I$. de la de Keil

Maestro (EI) de la niña. Comedia de mísica.-Rimox de la Cruz. Tom. X. de su Tealro.

Magdalena cautiva. - Ast. Viltadipes $Y$ SotomaYor.

Magdalena (La) de Roma.--Dismite.

Barrera adiciona al titulo: y bella caialina.

Mágico (El) de Salerno, Pulro Vayalarde. Primera, segunda, tercera, cuarta y quinta parte.-Juas Salvo Y Vela. 
Tambjen se ha publicado con solo el t1tulo de El mágico de Sal'rno.-Segun Barrera, III Anónimo publicó sesta parle con el litulo de El mágico de Satenno, y Espirilu Folelo, ó lambien la magia se hereda.

Mágico (EI) del Mlogol.-Axóvino.

Moratin se la alribuye á D. Antonio Valladires y Solomayol.

Mágico (El) en Cataluña.-V. Ciencia (La), afecto $y$ valor.

Mágico (El) nejicano. - Ocaspo y el Mtro. Morfio.

Barrera alribuye esta comedia únicamente a un lal Campo.

Mágrico (El) prodigioso.-Calneros. Par. te VI. de 1683 y 171 ว , Tom. VIII. de la de Fernández de Apóntes, el III. de la de Keil. P. XX. C. A., y en el $\boldsymbol{T}_{0-}$ mo III. del Tesoro del teairo español.

Mágico (El) Sigismundo. Comedia representada y cantada.- Cx Irrexlo.

Barrera no rita esta de un Ingenio y sí otra con innal tiflulis de D. Tomas Berluarlo sinchez, que quizí sea la misma, " furma primet" parte de Et gram máyico de Eurona; Sigismmmdo ol romenno: ó el lin dr llas en Culutulia: Nueslra Seño$r a$ transasa, escrild tambien por dicho sillehez.

Mil La casada.-Lope. P. XV.

Mal (lus) casados de Valencia.-Gullex ne Cistro. P. I., Tom. I. del Tesoro del teatro español, y en la Biblioteca de autores españoles de Ribadeneira.

Mal genio y buen corazon.-Axóxino.

Malgastador (E]). En vrosa.-Axósino.

to he podido rerificar si es la traduccion del frinces que lleva el mismo título, hecla por Iriarte.

Manases, rei de Judea.- Juax Orozco. Comedias nuevas, Amstardan, 1726 , ?'P. YLII. de las de a fuera, Zarago$\therefore a, 1630$.

Ilancelo (El) del camino.-J. B. DunsxTE. P. IIYI. C.A.

Mancebon (EI) de los palacios. - Juax Velez UL GUE HR. P. XXX. C. A.

Sermin Barrera, se conoce tambien con

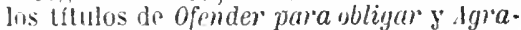
viar jara alcman. Nesoncro la la reimpreso en la biblioleca de Ribadeneira.

Nanganilla (La) de Melilla. - Ruz ne Alircox. P. II.

Manifestacion (La) de Nuestro Señor Jesucristo. Coloquio.-Gaspar Fervísidez r Ávils. Infancia de Jesucristo.

Manos (Las) blancas no ofenden.-CaLDEROx. P. VIII. de 1684 y 1726 , en el Tom. $I \boldsymbol{V}$. de la de Fernandez de Apóntes, en el $I V$. de la de Keil, y en la $\boldsymbol{P}$. IX. $C$. A. Segun Barrera, se imprimió suelta en Falencia, por José Llopis, 1699.

Mañana será otro dia.-Calneron. Parte VII. de 1683 y 1715 , en el Tomo XI. de la de Fernández de Apóntes, en el III. de la de Keil, y en El mejor de los mejores libros de comedias.

Mañanas de abril y mayo.-Calderon. P. III. de 1664,1687 y 1726 , en el Tom. VII. de la de Fernảndez de Apóntes, en el I. de la de Keil, en el I. de las Cormedias escogidas de este autor, Madrid, 1826, y en el III del Tesoro del teatro español.

Maravillas (Las) de Bahilonia.-Gúul.en DE Castro. Flor de las doce mejores comedias.

Marco Antonio y Cleopatra. Drama trágico.-Viceste Rodríguez de Areicaso.

Margarita (La) de los cielos, y más firme penitenta.-V. Santa Pelagia.

Margarita (La) preciosa.-Zabaleta, CínCer y Calderox. P. XXI. C. A.

En el indice de Medel se atribuye ínicamente i Calderon; pero Vera Tásis asegura que solo es suya la tercera jornada.

Mari-llernández la gallega.-V. Gallega (La) Mari-Hernández.

Maria Teresa de Austria en Landaw. Lucivo firiversco Covell.

Marica la del puchero.-V. Doncella (La) de labor.

Marido (EI) asigurado. Precedida de Loa. - Cirlos Boll. P. II. Puetas valencianos. La ha reimpreso con la Loa el señor Mesonero Romános en la coleccion de Dranáticos contemporáncos a Lope de Vega en la Biblioteca de autores españoles rle Ribadeneira.

Marido (EI) de su hermana. - Juiv IIE Villégas. P. V. C. A.

l)ice Barrera que es $i a$ mentirnsa verdiul de la P. AXI. de las de á fueru. Lurago: 2,1636 .

Marido (El) de su hija.-Valladáres dE SOTOMIYOR.

Marido (El) de su madre.-Mítos. P. $\boldsymbol{I}$. Barrern añade al título: Srot Gregorio.

Marido (El) hace mujer, y el trato muda costumbre. - Avtuvio llurtado de MeN10z1. Así se intitula esta pieza en la P. XXX. de las de i fiera. Zarago$z a, 1636$ (segun los traductores de Ticknor), y en la edicion segunda de las Obras de Mendoza; en la primera 
de Lisboa solo dice El trato muda costumbre. Se ha reimpreso en la Biblioteca de Ribadeneira.

Entre las poesias líricas de Mendoza hai una Loa para esta comedia.

Marido (El) más firme. T.-Lope. P. $\boldsymbol{X X}$.

Al fin se promete una segunda parte que no sé si existe. Barrera dice que esta comedia se conoce tambien por orfeo, y por Eurídice y Orfeo.

Marido (El) sofocado. Tragedia burlesca. - Ramos de la Crez. Tom. III. de su Tealro.

La tengo tambien anónima.

Mariscal (El) de Biron.-Pérez de Moxtalyan. Tom. I., P. XLIV. de las de a fuera, Zaragoza, 165. Historia trágica del duque de Biron por Mártir Rizo, . Barcelona, 1630̈, y segun nota de Duran, en la $\boldsymbol{P}$. $\boldsymbol{X X Y V}$. de las de a fuera, Zaragoza, 1632.

Mariscal (El) de Biron. Burlesca, precedida de loa. Jucas Maldosido. Parte XII. C. A.

Mármol (El) de Felisardo.-Lope. P. VI. Marques (El) de las Návas.-Lope. Parle XXII. de Zaragoza.

En la $P$. VIII. $C$. A. se encuentra á nombre de Mira de Amescua; pero lord Holland la posela aulógrafa de Lope.

Marques (El) de Mantua. T. c.-Lope. P. XII.

Marques(El) del Camarin.-Y. Amar por razon de estado.

Marques (EI) del Cigarral. - Moneto. P. III., Valencia, 1676,1703 y Valencia, Orga, s. a. La tengo de edicion mui antigua á nombre de D. Alonso de Castillo Solorzano, y lleva al fin un Romance burlesco, à la huidı que hizo la armada de Francia estando sobre Fuenterrabia. No me cabe duda que es de este autor, porque la encuentro tambien en sus Fiestas del jardin, y á su. nombre está en la $P$. X $T$ TII. C. A. y en la Coleccion de dramáticos de la Biblioteca de Ribadeneira.

Medel supone que son dos distintas comedias escrilas por diferentes autores; pero se equiroca, porque ambas son la misma.

Marquez de Mantua (Tragedia do) e do emperador Carlo Magno. En portugues.-Axósimo. Lisboa, 1664 y 1660 ö.

Es de Baltasar Diaz.

Narta imaginaria.-V. Astucias del enemigo, etc.
Marta la piadosa. - Tırso. P. F., Tomo IV. del Tesoro del teatro esp. de Ochoa, y en el de Comedias escogidas de Tirso en la Biblioteca de Ribadeneira.

Se ha publicado tambien esta comedia con el título de La beata enamornda y ha sido refundida por D. Jionisio Sulis.

Marta la Romarantina.-Ux Isgesio.

Es una de las partes del Asombro de la Franciu, de Cañizáres.

Mártir y rei de Sevilla, S. Hermenegildo.-Fericisdo de Zarate.

Barrera añade al tltulo: $\delta$ el rei más perfecio.

Miártires (Los) de Córdova.-Astoxio DE Castro. P. Xlill. de las de a fuera. Zaragoza , 16 0ั0.

Barrera añade al titulo: San Acisclo y santa Victoria. Medel la atribuye indehidamente à Guillen de Castro.

Mártires (Los) de Madrid.-Lope. Patte XXIX. de este y otros autores, Huesca, 1631. La tengo de inpresion antigua suelta.

Mártires (Los) de Toledo y tejedor Paloneque.-Eugesio Gerardo Lobo.

Barrera no la menciona con este titulo aunque la trae con el de El tejedur Palameque $y$ márlires de Toled $($ ).

Más amante pastor y dichoso patriarca. -V. Hermosura (La) de Raquel.

Más (La) constante mujer.-Mlostarix. En su Para todos, P. XLIF. de las de a fuera, Zaragoza, 1632, y ell el Tomo I. de sus Comedias escogidas, Madrid, 1827. Sezun nota de Duran se encuentra tambien eu la Parte $\mathbf{I I V}$. de las de i fuera, Zaragoza 1633. Se ha reimpreso por Mesonero ell la $\mathrm{Bi}$ blioteca de Ribadeneira.

Escribinse estit comedia en competencia de la de Sufrir más por querer mas. de li. llaizan. Asi consta por el epírafe de $16 n$ sinnoto coetáneo, que se halla ell 11 u tomo de Poesias mumuscrilas que poseo.

Más (La) constante nujer. Preculida de Loa. Burlesca. - Jcas Mildovino, DiEgo la Dieña y Jeróviho Cifcentes. P. XI.C.A.

Más (La) dichosa venganza. - A.T. DE Sols. P. XXV. C. A.

Barrera no menciona esta comedia en el artículo de D. Ant. de Solis, por haber creido malamente que era La venganza le la dumpesa de Amalfi, de Diego Muxet de solis. Medel dice, por equivocacion, que este aulor escribiu la más dichosa vengunza. 
Mảs (El) dichoso prodigio.-UN INGENio. P. XXXIII. C. A.

Más (Los) dichosos hermanos.-V. Siete (Los) durmientes.

Màs encanto es la hermosura.-DumanTE. P. I., y Ameno jardin de comedias. Madrid, 1734.

Más es el ruido que las nuezes, y el reloj toque su hora.-UN INGENio seviliaxo.

Huerta menciona una de Bánces Candamo con el lítulo de Mas es el ruido que tas muc $\approx e s, \dot{o}$ sitio y máscuras de Amiens.

Más (El) galan portugues, duque de Berganza.-Lope. P. VIII.

En una copia manuscrila que posera lord Holland, se titulaba: El duque de $\mathrm{BC}^{2}$ ganza.

Más (La) heróica espartana.-Gaspar de Zibali y Zamora.

Más (La) heroica fineza y fortunas de lsabela.-Mítos, y Diego y José Cornova y Figerenol. $P$. $X X X 71 I . C$. $\boldsymbol{A}$.

Al dar el tiluln de esta conedia Barbosa Nachado, dice Nasela en lugar de Isabela. Medel la intitula: Las fortunas de Isabela.

Más (La) heróica piedad más noblemente pagada.-Luis MIoxcix.

Moratin añade al título y el clector $d c$ Sajonia.

Más (La) heróica romana. - UN INGEnio.

Mảs (EI) heróico español, lustre de la antigiiedad. Con su Entremes y Sainete. -Josè Coxcha.

El Entremes se intitula: Por engañar engañarse y el hostelero burlado, y el Sainete: Las pruebas de un casado.

Más (El) heróico silencio.-Avt. CarnoNA. $P$. XXI. C. A.

Más (La) hidalga hermosura - Tres Ingenos. P. XLIII. de las de a fuera, Zaragoza, 1650 , y segun Fajardo en igual Parte de Valencia, 1660.

Barrera dice ser el autor Rojjas Zorrilla.

Más (La) honrosa venganza del valeroso Wifredo, y muerte de Salomon, tirano de Cataluña.-Juan Mavuel Martínez.

Más (El) ilustre frances San Bernardo. Moreto. P. XI. C. A.

Más (La) ilustre fregona. - Cax̃izíres. Tom. II. de sus Comedias escogidas, Madrid, 1833, y en la Coleccion de dramáticos de la Biblioteca de Ribadeneira.

Vís (EI) impropio verlugo por la más justa venganza.-Rósas Zorrilla. $P$. II., $P$. XLIV. de las de á fuera , Zaragoza, 1632, y volúmen de Comedias escogidas, Bruselas, 1704, en cuya Tabla se atribuye á Mátos, aunque en el titulo y titulillos de la comedia dice que es de Rójas.

Medel cita una anónima con solo la primera parte de este tilulo, y advierte que es burlesca.

Más (El) justo rei de Grecia.-Geranoo Lово.

Más la amistad que la sangre.-Andnes ne Baeza. P. XII. C. A.

Más merece quien más ama.-ANT. IIurtado de Mendoza. En las Obras, Madrid (1728), se da como suya únicamente; pero en la P. XLVI. C. A. se encuentra como de Mendoza y le D. Juan de Vera y Villaroel.

Barrera dice que con solo el nombre de Mendoza está en liss Doze comedias de Lope y otros autores. Parte segunda. Barcelona, 1650 , y que sin duda lo que hizo vera fué retocarla.

Más pesa el rei que la sangre. Al fin se halla una Loa sacramental á lo morisco. - Lole. Impresion antigua suelta.

No esta en las Partes porque tal vez sea de Luis Vẻlez, á cuyo nombre tengo un ejemplar que se titula: Más pesa el rei que la sangre y blason de los Guzmanes. En el Indice de Medel se atribuye á Rojjas; y en el de Barrera no se encuentra bajo este titulo. Es la misma que El honor de los Guzmanes y defensa de Tarifa.

Más pesa el rei que la sangre, y blason de los Guzmanes.-Luis VeLEz. Impresion suelta.

Es la misma que la anterior que lleva el nombre de Lope. Se ha reimpreso en la Biblioteca de Ribadeneira.

Más (EI) piadoso troyano. - Francisco DE VILlEGas. P. XXXII. C. A.

Barrera añade al titulo: Dido y Eneas. Nedel se equivoca en decir que es de Juan Villégas.

Más pueden zelos que amor.--Lope. Parte III. C. A.

Más sabe el loco en su casa que el cuerdo en la ajena, y el natural vizcaíno. -José de Concha.

Más (La) sutil currutaca.-V. Heredera (La) astuta.

Más (El) temido andaluz y guapo Francisco Estévan.- Un INGENio valenciano.

Barrera se la atribuye á José Valles, $\mathrm{y}$ dice que se publicaron dos partes con los titulos de El más temido andaluz, Francisco Estévan y Et guapo de Andalucia, Francisco Estévan.

Más triunfa el amor rendido.-AG. DE $\mathrm{SA}_{-}$ i,AZAR Y TórRes, y J. de Vera Tásis Y VILLARROEI. 


\section{MAY}

ÍNDICE DE TITULOS.

MAY

1521

I.a he tenido anónima.

Barrera se cquivoca en suponer que esta comedia es la inisina que Triunfo y ven. ganza de amor, de Salazar; dice tambien que se la conoce con el titulo de Sin armas vence el amor, ó el mayor triunfo de amor.

Más vale á quien Dios ayuda, Esaú y Jacob, ó el pastor más perseguido y finezas de Raquel. - Y. Pastor (El) más perseguido.

Más vale el hombre que el nombre.Bánces Candayo. Poesias cómicas, Tom. II.

Más vale tarde que nunca.-José JuLias López de Caszro.

Dice Barrera que esta comedia es notable por las chistosas y conocidas relacio. nes del gracioso Perejil.

Más (El) valiente andaluz Anton Bravo. Cristoval de Moxroi y Silva.

Matar por zelos su dama.-MTro. JuAv DE CABBZA. La tengo suelta, y tambien se halla en la I. Parte de sus Comedias. Zaragoza, 1662.

Mateo Vizconde.-Juan de Arala. Parte $X X X I I I . C . A$.

Matico (El).-Y. Donaires (Los) de Matico.

Matilde de Orleim. En prosa.-Avóvino.

Matrimonio (EI) casual.-Fancisco FlLoyevo. Manuscrita.

Moratin cita una impresa con igual título de un Anónimo de la segunda mitad del siglo XVIII.

Matrimonio (El) por razon de estado.Luciano Francisco Coyer.la.

Moralin se la atribuye á José Concha.

Matrimonio (El) secreto. Drama en música.-Asóvimo, traducido libremente del italiano por Luciano Francisco Comella.

Mayor (La) constancia de Muzio Scevola. -Franc. de Leiva Ramírez.

Mayor (El) desengaño.-Tinso. P. I., y en la XLII. de las de a fuera, Zarago$z a, 1650$.

Mayor (La) desgracia de Cárlos Y, y hechizerías de Argel.-Lope. P. $\boldsymbol{X X I V}$. Zaragoza, 1633.

Barrera dice que está en la Parle XLIII. de las de a fuera con el título de La ma. yor desgracia de Cárlos $V$. y conquista de Argel, o Hechicera de Argel.

Mayor (El) encanto amor.-CALDERox. P. II. de 1637 (?), 1641,1686 y 1726 , en el Tom. $\boldsymbol{V}$. de la de Fernández de Apóntes, y en el $I$. de la de Keil.

Mayor (La) hazaña del emperador Cár- los Quinto.-Diego JiyB́ngz de Exciso. Comedias de los mejores \& c. Lisboa, 1652 , y segun nota de D. A. Duran se halla en la $P$. XXXIII. de las de $a$ fuera, Valencia, 1642.

Medel se equiroca en decir que es de Bartolomé de Enciso; tambien me parece que anda errado en suponer que hai otra de tres Ingenios.

Mayor (El) imposible.-Lopr. P. $\boldsymbol{X} \boldsymbol{X} \boldsymbol{V}$., Tom. I. de sus Cumedias escogidas, Madrid, 1826, y II. del Tesoro del teatro español.

Mayor (El) mónstruo del mundo. $-\mathrm{V}$. Mayor (El) mónstruo los zelos.

Mayor (El) mónstruo los zelos. - CALDerox. P. $I I$., de 1637 (?), 1641, 1686 y 1726, en el Tom. $\boldsymbol{V}$. de la de Fernández de Apóntes, en el $I$. de la de Keil, y en el III. del Tesoro del teatro español. En el II. de las Comedias escogidas de este autor, Madrid, 1828, ademas del título antedicho se añade: y Tetrarca de Jerusulen.

En cl tom. II. de la edicion de 1641, lleva el de Mayor mónstruo del mundo.

Mayor (El) Palmer.-Axóxiso.

Traduccion del frances.

Mayor (La) piedad de Leopoldo el Grande.-Gaspar Zabala y Zayora.

Mayor (EI) rival de Roma, Viriato. Drama trágico.- Leciavio Fraxicisco CoMELLA.

Mayor (El) triunfo de Julio César, y batalla de Farsalia.-A.rt. DE Solis.

Barrera trae con ignal título una de D. Francisco Alcedo y Herrera impresa en 1680 ; pero no menciona la de Solis. ¿Estará tal vez equivocado el nombre del autor en la edicion que yo poseo?

Mayor (La) venganza de honor.-Cubiclo de Aragor. $P$. $\boldsymbol{X}, C$. $A$.

Barrera añade al titulo: y los comenda. dores de Córdova.

Mayor (La) virtud de un rei.-Lope. En la Vega del Parnaso y en el Tom. IX. de Obras sueltas.

Se publicó con el título de El mejor casamentero, y d nombre de Mátos Fragoso, en la P. XXXVII. C. A.

Mayor (La) vitoria.-Lope. P. $\boldsymbol{X} \boldsymbol{X I I}$. edicion de Madrid, 1635 , y en la $X X I Y$. de Zaragoza, 1633.

Es distinta de La mayor vitoria de Ale. mania.

Mayor (La) vitoria de Alemania de D. Gonzalo de Córdova. - Lope. Eu la Vega del Parnaso, y en el Tom. $\boldsymbol{X}$. 
de las Obras sueltas impresas por Sancha.

Es la misma que Don Conzalo de Cirdova de la Parte XI7F. de Zaragoza; pero es distinta de la fure solo lleva el título de la mayor viloria. Barrera la denomima tamlien La nueva vicloria de Don Gonzalo de Córdova.

Mayor (La) vitoria de Constantino Magno. - Ambrosio Arce de los Rexes. P. XIV.C.A.

Mayorazgo (EI) dudoso.-LoPE. P. II.

Mayorazgo (El) figura.-Castlllo Solorziro. Alivios de Casandra, y en la Coleccion de dramáticos de la Biblioteca de Ribadeneira.

Medel la trae anónima, y Barrera añade al título: $y$ el interes castigado.

Ma yordomo (EI) de Dios y devocion de las ánimas. - Tres Ivgevios.

Mayordomo (EI) de la dluquesa de Amalfi. LOPE. P. XI.

Muxet y Solis hizo mua continuacion á esta comedia con ol título de La venganza de la duipuesa de Amalfi.

Mayordomo (EI) feliz.-F. C. H. DE C.

Mazariegos y Monsalves.-Ant. de ZnMoRA. Tom. I. de sus Comedias, en el de las Escogidas, Madrid, 1831, y en la Biblioteca de Ribadeneira.

Médicis (Los) de Florencia.-Diego JuÉNEz Evciso. P. XVIII. C. A., en las Comedias de los mejores, Colonia, 1697, segun Barrera en las Doze comedias de Lope y otros. Segunda parle. Barcelona, 1630 , y en la Biblioteca de Ribadeneira.

En la P. II. C. A. se halia repetida con el 1 f́tulo de El gran duque de Florencia, y en III IS. que posee el Sr. Gayángos se intitula: Tragedia det primer duque de Florencia, y se atribuye en él equivocadate á U. Gabriel de Henao y Monjaraz.-Medel llama al autor Bartolomé de Enciso.

Barrera dice que la Segunda parte de esta comedia es la de Rosete: Todo sucede al reves.

Médico (El) á palos.-Ivarco Ćelenio. (Leandro Fernández de Moratin.)

Es imitacion de Moliere.

Médico (El) de su honra. - Calderon. P. II. de 1637 (?), 1641,1686 y 1720 , on el Tom. VI. de las de Fernández de Apóntes, en el I. de la de Keil, en el III. del Tesoro del teatro esp. por Ochoa, y en el Handbuch de Lemeke.

Médico pintor, san Lúcas.-Furnando DE Zarate. P. XL. C. A.

Medora. En prosa.-Lope de Rueda. Co- medias, y en el Teatro español anlerior a Lope de Vega.

Mejor (El) alcalde el rei.-Lope. P. XXI.

Mejor (El) alcalde el rei, y no hai cuenta con serranos. - Ant. Martínez. Parle XX.C.A.

En el Indice de esta Parte se advierte es diferente de la de Lope.

Mejor (El) amigo el muerto.-Belnonte, Ródas y Calueron. P. IX. C. A.

Vera Tisis confirma que la tercera jormada es de Calderon. Dice Barrera que Fajardo despues de citar esta comedia menciona El mejor testigo el muerlo, de Belmonte, Rojas y Calderon, y que Huerta atribuye $E l$ mejor anigo... á tres Ingenios, y El Mejor tesligo it Belmonte; observando por fin que sin duda son una misina.

Nejor (El) amigo el rei.-Moneto. P. I. Imitacion poco feliz de Caulcla contra cautela, comedia que se halla en la $P$. II. de las de Tirso. Hartzcnbusch.

Mejor (EI) casamentero.-Míros. Parte XXXVII. C. A.

Barbosa Machado da equivocadamenle á esta comedia el título de $E l$ mejor casamiento. Es la nisma que La mayor virtud de un rei, de Lope, publicada en la Vega del Parnaso.

Mejor (La) espigadera.-Trnso. P. III. de sus Comedias.

Tengo tambien una reimpresion de doña Teresa de Guzman con el título de La nuera más leal y mejor espigadera.

Mejor (El) esposo.-Gulllen de Castro. P. II.

Barrera añade al título San Jose; y Medel la trae tambien con el de Tránsilo de san José.

Mejor está que estaba.-Calderon. P. VI. de 1683 y 1715 , en el Tom. VIII. de la de Fernández de Apóntes, en el III. de la de Keil, en el $\boldsymbol{I V}$. de Comedias escogidas de este autor, Madrid, 1833, en la $P . I$. C. A., y en el Theatro hespañol de Huerta.

NIejor (La) flor de Sicilia, santa Rosolea. Precedida de Loa.-AG. De Salazar $\mathbf{x}$ Tórres, en el Tom. II. de su Citara de Apolo, y en la P.XLII. C. A. sin Loa.

Mejor (El) fruto de un árbol, N. Sra. de Balvarena.-UN INGE N1O.

Barrera añade al título: $y$ aurora de Rioja.

Mejor (La) luna africana.-TRes Ingenos.

No la pone así el indice de Medel, sino como de Calderon, por haber tambien salido á su nombre sill ser suya, segun lo ad- 
MEL

ÍNDICE DE TÍTULOS.

MER

vierte Vera Tásis. Barrera y Leirado dice terminantemente que la tercera jornada es de Calderon, $y$ adiciona al titulo de la mia y rei Chico de Granada.

Mejor (La) luz de Sevilla, N. Sra. de los Reyes.-Jeróniyo Guedeja 7 QuiROGA.

Alguna vez se ha citado esta comedia con solo el titulo de Vuestra Señora de las Reyes, y Moratin se equivoca en suponer que son dos piezas distintas.

Mejor (El) maestro el tiempo. - LoPE. $P$. $F I$.

Mejor (El) mozo de España. T. c.-Lope. $P . X X$

Mejor (El) padre de pobres.-Calderos. P. $\boldsymbol{X F}$. de la C. A.

Es de Pérez de Montalvan, y efectivamente Vera Tásis niega que sea de Calderon.

Mejor (El) par de los doce.-Míros y MoRETo. La tengo de una edicion de mitad del siglo XVII, y en la $P$. XXXIX. C. A.

Medel la atribuye á dos Ingenios, y ademas trae otra con igual títulin que dice es de Montalvan, en lo que quizá hàya error.

Mejor (El) rei del mundo y templo de Salomon.-Álvaro Cubillo.

Barrera no se atreve í adjudicarla decididamente á este autor: en la edicion antigura que tengo suelta, dice ser de él.

Mejor (El) representante, ó vida, muerte y martirio de $\mathrm{S}$. Gines.-LoPE.

Es, segun Barrera, Lo fingido verdadero, de la Porte fivt.

Mejor (El) representante, S. Gines Cúicer Rosete y Axt. Mintívez. Parte $X X I X . C . A$.

Mejor (El) testigo el muerto.-V. Mejor (El) amigo el muerto.

Mejor (El) tutor es Dios.-LuIs DE BELMovte. P. XXVIII. C. A.

Barrera tambien da á esta comedia el título de Buen pagador es Dins. Sin duda se habia impreso á nombre de Calderon porque á él se la adjudica Medel, que no menciona la de Belmonte.

Melaneólico (El).-Tirso. P. I.

Es el argumento de la comedia Esto sí que es negociar, eserito de primera mano. V́arios trozos de versificacion son iguales en ambas piezas. Harlzenbusch.

Melindres (Los) de Belisa.-Lope. P. IX. La tengo con el título de La dama melindrosa, y Triguéros en su refundicion la llama: La melindrosa o los esclavos supuestos.

Melindrosa (La) ó los esclavos supuestos. -LOPE.
Aś intitulo Triguéros en su refundicion la comedia conocida por los melindres de Belisa ó La dama melindrosa de Lope.

Menéchmos.-Plauto, traduccion castellana en prosa, anónirna, impresa en Anvers, 15 วัวั.

Menémnos. En prosa.-Plauto, traducida libremente por Timosedi. Se ha reimpreso en los últimos liempos en los Origenes de Moratin.

Mentir con honra, y conquista de Sevilla por san Fernando.-Y. Toma (La) de Sevilla.

Mentir por razon de estado.-Felipe MiLAS de Aragor. P. XXXI. C. A.

En el Indice de Yedel se cita equirocadamente como de Cubillo de Aragon.

Mentir y mudarse á un ticmpo.-Diego y José de Figuerol y Córdova. P. XIV̈. C. $\boldsymbol{A}$, y en la Biblioteca de Ribadeneira.

Se publicó posteriormente con el titulo de Nentir y mudarse á un liempo: el mentiroso en la corte: la tengo.

Mentirosa (La) verdad.-V. Marido (El) de su hermana.

Mentiroso (El).-Lope. Este nombre llera en una edicion mui antigua que tengo; pero Alarcon en sus Comedias la trae como suya bajo el título de $L a$ verdad sospechosa, y dice espresamente en el prólogo, que esta es una de las que andaban impresas como de otro dueño. En la $\boldsymbol{P}$. XXII de Lope, Zarago $\approx a, 1630$, ya se intituló. El mentiroso ó la verdad sospechosa.

Mercader (El) amante. Precedida de Loa. -Gaspar de Agcilir. P. II. de los Poetas ralencianos, en el Tom. I. del Tesoro del teatro español, v en la Biblioteca de Ribadeneira.

Medel yerra como siempre el nombre de este autor.

Merced (La) en el castigo. - Lope. La tengo suelta de edicion bastante antigua, y ademas parece que tambien está en la Parte XXVI., estravagante, Zaragoza, 16 í.

La presente comedia con el título de $E l$ premio en la misma pena, atribuida á Yoreto, se encuentra en la P. .Y.Y. $C$. A., y como El dichoso en Zaragoza. prohijada d Pérez de Itontalvan, se halla en la .FL. de la inisma Coleccion.

Merecer de la fortuna ensalzamientos dichos0s.-DIEgo de VERA y Jose de RIBer.A. P. XXIII. C. A.

Merecer para alcanzar. - Moreto. Parte ILIII. C. A. 
Tambien se eonoce con el título de fa forlma merecida, y es cl que lleva en la P. III. de este antor, Malrid, I68I, segun Birceril.

Mérilo (El) es la corona, y encantos de mar y amol. Con Loa.-Siltz III Y Túnllis. P. II. de su Cítara de Apolo, y en una $\boldsymbol{P}$. ILI. de varios estravagante.

llesonera (La) del cielo.-Mira DE AuEscul. P. XXXIX. C. A.

Teura esta comedia suelta eon el título del Ermilaño galan y mesonera del cielo: y esto sin duda fue lo que indujo en error i Barpera al decir, que lis comedia de llira de Amescua era la misma que se lialla en la I. I. C. A. i nombre de Zibaleta, con el título de El Ermilano gulan.

Metamoriosca. - Roueno DE Cepena. Obras, y reimpresa por Oclioa en el Tom. I. ilel Tesoro del teatro español.

Joratin en el mim. 1.il del Catílogo que va al fin de sus Origenes, la da como anonims. porque la eopia manuserita que vió, sin dudit no llevaba el nombre del intor.Iledel diee equivocalimmonte que es del 1'. Valentin de Cesperles.

Milagro (El) por los zelos. -LoPE. Impresion suelta antigua.

To esti en las Parles. Tambien se ha pnblicado con el título de El milagro por los zelos y D. Sluaro de Luna. Barrera no la pone en sullidice.

Milagros (Los) del desprecio. - Lope. P. XXVII. estracagante, Barcelona, 1633 , P. X. C. A , Tom. I. de Comedias escogidas de este autor, Madrid, 1826, y ell el II. del Tesoro del teatro español.

Se publici tambien en Sevilla por Leefdacl, bajo el nombre de un Ingenio de esla Corle.

Milagrosa (La) eleccion.-Moneto. Parte XXXIX. C. A.

El indice de dicha parte la intitula: $L a$ milagrosa eleccion de Pio $V, y$ Barrera aun parece indicar si tambien se la conoce por solo San Pio $V$, y por El cardenal Moron.

Mílite glorioso. - Plauto, traducida en prosa castellana por un autor desconocido, é impresa en Anvers, 13 ว̆.̆.

Minas (Las) de Polonia. Drama.-AxóNiso, traduccion de María Gasca y Nedrano.

Nira al fin.-U. INGesio. P. XXVIII. C. A.

Segun Duran en la Parte XXXIII. de las de if fuer $a$, Valencia, 1642, se atribuye á liosele Niño; pero Fajardo y Medel suponell que son dos piezas distintas con iguales litillos.
Mirád á quien alabais.-Iops. P. XVI., y P. VI. estravagante, Zaragoza, 1653.

Míralo (EI) todo en Castilla, en Nápoles y en Sicilia. Primera parte.-UN INGliNio SEVILLANo.

Segun Barrera sucle conocerse con solo el título de Hiralo toto, y alula á vezes umida con las piczas Felipe V. en Castilla, y Mís es el ruiulo que las nuezes.

Mirones (Los) de la Corte. Diálogo en prosa. - Súlas Barbanillo. Casa del plazer honesto.

Mirrha (La tragedia de) en la que se recuentan los infelizes amores que ouo con el rey Ziniras su padre.-Bacinluer Virlalon. Medina del Campo, 1336. $4 .^{\circ}$ gót.

Naís bien que pieza dramática es una novela en dílogo.

Misantropía (La) desvanecida. En prosa. - KotrebíE, traducida en castellano.

Este drama en un aclo es la continuacion del intitulado: Misantropia y arrepentimiento del mismo autor.

Misantropia y arrepentimiento. Drama. - Kotzerie.

Moratin se la atribuye (supongo que la traduccion) á Dionisio Solis.

Misántropo (El). - Moliere, traduccion de $D$. José Sedano.

Misas (Las) de S. Vicente Ferrer.-FerNanio de Zirate. P. XXIII. $C$. A.

Misma (La) conciencia acusa.-Moneto. P. I. de sus Comedias, VII. C. A., y vol. de Comedias escogidas, Bruselas, 1704.

Barbosa Machado atribuye equivocadamente csta comedia á Mátos.

Mitra (La) y pluma en la cruz, S. Casiano. - Tonias Manuel de Paz, P. XlVI. C. $A$.

Mitridates. T.-A vónimo.

Mocedad (La) de Roldan.-Lope. P. XIX.

Tambien se conoce, segun Barrera, por Mocedades de Roldan.

Mocedades (Las) de Bernardo del Carpio. - Lope. Impresion suelta antigua. Parte XXIX. de este y otros autores. Huesca, 1634, y P. VII. de Comedias escogidas, Zaragoza, 1633.

No está en el Índice de Barrera con este título. Acaso sea esta picza la intitulada Roncesválles en el Catálogo del Peregrino.

Mocedades (Las) de Enrique Quinto.Axóvino.

Mocedades de Roldan.-V. Mocedad (La) de Roldan. 
Mocedades (Las) del Cid. Primera y segunda parte. - GullLen DR Cistro. P. I., Biblioteca de Ribadeneira, y Lemeke en el Handbuch.

Mocedades (Las) del Cid. Burlesca.Cíncero $P, X X X I X, C . A$.

Segun Barrera, se publicó con el titulo de Las travesuras del cid, à nombre de Moreto, en su P. III., Madrid, 1681.

Mocedades (Las) del duque de Osuna.Cristóval de. Monror. Se ha reimpreso en la Coleccion de dramáticos de la Biblioteca de Ribadeneira.

Medel dice equivocadamente que el au. tor es D. Juan de Silva.

Mofina (A) Mendes. En portugues.-GIL VicenTe. Obras.

Mojigata (La).-Inarco Celenio. (Leandro Fernández de Moratin.)

Molino (EI).-LoPE. P. I., en la Coleccion de las mejores comedias de este autor. Madrid, 1803, en el Tom. IV. de las Comedias escogidas del mismo, Madrid, 1832, y en el II. del Tesoro del teatro español.

Monja (La) alférez.-Montalvan.

Menciona Castillo Solorzano en la novela El bachiller Trapaza una comedia con el mismo litulo, compuesta por Luis Belmonte; quizás sea la misma.

Mónstruo (El) de Cataluña, y peñas de Monserrate; frai Juan Garin.-Axósimo.

Móustruo (El) de la amistad. -Pedro LANINI SaGREDO.

Barrera añade al titulo y azucena de Va. lencia.

Mónstruo(El) de la fortuna.--Tres IsgeNos. P. VII. C. A.

Es La lavundera de Nópoles de Lope, que se balla en su $P$. VI.-Medel cita una con el titulo de El mónslruo de la forluma y la da como anónima.

Mónstruo (EI) de la fortuna: la lavandera de Nápoles, Felipa Catanea.-Tres INGENios.-P. XXIV. C. A.

La primera jornada es de Calderon, segun Vera Tásis: las otras dos dice Barrera पue las escribieron Montalvan y Rójas. Fajardo cita otra con el mismo título, impresa suelta, y la supone de Luis Vélez, Rojas y Coello.

Mónstruo (El) de los jardines. - Calderon. $\boldsymbol{P}$. IV. de 1688 y 1731 , en el Tum. III. de la de Fernánidez de Apóntes, y en el II. de la de Keil.

Montañes (EI) Juan Pascual, y primer asistente de Sevilla.-UN INGENio. Es de D. Juan de la Hoz y Mota, y se ha

ToM. 1. reimpreso en la Biblioteca de Ribadeneira.

Montañesa (La) de Astúrias.-Lurs VÈLEZ. P. XXX. C. A.

Medel siguiendo su casí constante error atribuye esta comedia á D. Juan Vélez.

Montería (La) de las damas y caballeros de Troya. Especie de farsa.-LuIS DE Milan. En su Corlesuno.

Monteros (Los) de Espinosa.-Axónimo.

Lope de Vega, en el Catálogo del Pere. grini, cita como suya una con el mismo título.

Montes (Los) de Gelboé y David perseguido.-LoPE. Impresion suelta y antigua.

No esta en las Partes ni en el Indice de Nedel por este tilulo. El Sr. Duran cita un manuscrito antigno en el que se intituld. ba: Las persecuciones de David. Barrera no la trae en su Índice bajo este título, aunque la menciona con el de David persegui. do y monles de Gelboé, con el cual la he tenido suelta.

Morica (La) Garrida.-Juax BTA. DE VILLÉGAS. P. VII. C. A.

Barrera añade al titulo: y hermanos amantes.

Mosquetero (El) de Flándes.-Francisco Goxzález de Bústos. P. XXXYII. C. A. Mosseh en su juventud. - Mavoet $D E$ Leon. Parece edicion de los Paises Bajos y de mediados del siglo XVII.

Barrera no silo no habla de este yanuel de Leon sino que ni aun menciona el título de esta comedia en el Índice alfabético de ellos.

Motezuma. Drama en música para representarse en el nuevo tealro de la sala del duque de Gandia en Valencia; en el otoño de 1768. - Vitorio AMEdEo Cisga-Santi. Falencia, viuda de José de Orga. $s . a .8 .^{\circ}$

El testo italiano, que va al frente de la traduccion, lleva el mismo título.

Moza (La) de cántaro.-Lope, refundida por Triguéros. 1803.

Con este mismo título la cita Medel: yo no he visto edicion alguna de la coniedia original ; pero Barrera dice que se halla en las Doce coinedias de diferentes autores. Parle XXXXXVII. (Ye choca esta manera de numerar.) Valencia, 1646.

Mozarabes (Los) de Toledo. -Joan HidalG0. P. XXXVIII. C. A.

Muchos aciertos de un yerro.-Josi DE Figueroa x Cóbdova. $\boldsymbol{P}$. $\boldsymbol{X} \boldsymbol{X} I I$. c. $\boldsymbol{A}$.

Nedel indebidamente la atribuge à D. Diego de Figueroa. 
Mudanza (La) en el amor.-Montalvan. P. XLV.C.A.

Segun Barrera, tambien se conoce por l.a esmeralda del amor, á nombre de tiójas Zorrilla.

Mudauzas de la fortuna.-V. Rigor de las desdichas.

Mudanzas de la fortuna y firmezas del amor. - Cristóval Monrol y Sillva. P. XLI. de las de á fuera, Valencia, segun Duran, y segun Barrera en las Doze comedias las mas famosas. Lisboa, 1649 .

Mudanzas de la fortuna y sucesos de D. Beltran de Aragon.-Lope. En la Parte que se denomina $\boldsymbol{I I I}$. de las suyas, sin embargo de yue solo contiene ires comedias de Lope.

Es sin duda el Don Bellran de Aragon citado en la segunda lista del Peregrino.

Mudarse por mejorarse.-Ruz de Alarcox. P.I., y Tom. II. de sus Comedias escogidas. Madrid, 1867.

Es diferente de la de Zarate que tiene igual título; pero es la misma que se publicó en la P. XLV. C. A. con cl de Dejar alicha por más dicha; y en la XLI. de las de a fuer'a intitulada: Por mejoría.

Mudarse por mejorarse. - Fervando de Zarate. P. MIX. C. A., Comedias escogidas de este autor. Malrid, 1832, Tom. V. del Tesoro del teatro español, y en la Biblioteca de Ribadeneira.

Es distinta de lia de Alarcon.

Muerta (La) por el honor.- Lx Ixigevio.

Mluerte (La) de Ayax Telamon sobre las armas de Aquíles. T. - Juan de la Cueva. Comedias y Tragedias.

Medel siempre llama á este autor Antonio.

Muerte (La) de Baldovinos. Burlesca.Ciscer. Obras varius, 1761.

Muerte (La) de Virginia y Apio Claudio. T.-Juan De la Cueva. Comedias y Tragedias.

Muerte (La) del rey Don Sancho y reto de Zamora.-Juav ne la Cueva. Comedias y Tragedias.

Nedel Ilama constantemente Antonio á este autor.-Barrera añade al título: por Don Diego Ordúnez.

Muertos vivos.-Lopk. P. XVII.

Mujer, ángel y milagro. - Nicolas DE VII.LAROEL.

La edicion que tengo, que parece de anes del sigIo XVII. hecha por Francisco Sans de Mfidrid, dice que es segunda, corregida y emmenduda por el autor.-Noratin la atribuye equivocadamente á D. Juan de Vera y Villarroel y lo mismo hace Medel; Barrera solo dice que se hallaba manuscrita en un códice de la Bib. Nac.

Mujer (La) contra el consejo.- Mátos, Ant. Mirtínez y Zabaleta. P. VII. C. A.

Barbosa Machado padece error creyendo, que el único autor de esta comedia fue Nitos: Medel solo dice que es de tres lngenios, y trae otra con el misno titulo de Luis Uiloa.

Mujer (La) de dos maridos.-D. V. R. D. A. (D. Vicente Rodriguez de Arellano.)

Mlujer, llora y vencerás. - Caldenon. $P$. V. de $169 t$ y 1730 , en el Tom. $I X$. de la de Fernández de Apóntes, en el $I I$. de Keil, y en la P. XVII. C. A.

Mujer (La) por fuerza.-Tirso. P. II. y en el Tom. II. de las Escogidas de este autor, Madrid , 1829.

Opina Ilartzenbusch que esta comedia es una de las ocho que dice Tírso no ser suyas en la $P$. II., y le parece más bien de Lope.

Mujer (La) que manda en casa.-Tirso. P. IV.

Segun Barrera tambien se conoce por el titulo de La impia Jezabel, mujer del infeliz Acab, 6 el trimfo de Elías.

Mujer (La) variable. En prosa.-Goldon.

No lleva el nombre del traductor.

Mujer (La) zelosa. - Tomada de la de Mr. Desforges, y traducida en prosa castellana por D. Julian de Velasco. Tom. VI. del Teatro nuevo español.

Mujeres (Las) sin hombres.-Lope. Parle XVI.

Segun Barrera esta comedia se conoce tambien con el nombre de Las amazonas.

Mundo(Farsa del).-V. Farsa del mundo. Munuza. T.-A Nónino.

Es de D. Gaspar Melchor de Jovellános: ell sus Obras se intitula: El Pelayo.

Muñecas (Las) de Marcela.-Cobillo DE Aragon. En El Enano de las Musas, en el volúmen de sus Comedias escogidas, Madrid, 1826, en el V. del Tesoro del teatro español, y en el Tumo XLVII. de la Biblioteca de Ribadeneira.

Muros (Los) de Jericó.-Sbbastian Oliváres. P. XXXII. C. A.

Músico (EI) por amor, ó el montañes en la Corte: Don Lain de Cascajáres.V. De los hechizos de amor. 
Músicos amo y criado, y el amor por el retrato.-Santiago Garro.

Se ha atribuido indebidamente á D. José de Cañizáres.

\section{$\mathrm{N}$}

Nabucodonosor.-V. Bruto $(E l)$ de $B a-$ bilonia.

Nacimiento (El) de Cristo.-Lope. Parte $X X I Y$. Zaragoza, 1641.

Tal vez sea la que intitula solo: $E l$ Nacimiento en el Catảlogo de su Peregrino.

Nacimiento(El) de Cristo. Z.-DiamanTE. P. II.

Nacimiento (EI) de Hércules, ó comedia Anfitrion.-V. Anfitrion.

Nacimiento (El) de la Mejor.-Valdivielso. Actos y comedias.

Nacimiento (EI) de Montesínos.-Gulillen de Castro. $\boldsymbol{P}$. $\boldsymbol{I}$.

Barrera tambien la intitula: $E l$ conde Grimáltos sin duda por ser este su principal protagonista, así es que en el final dice:

ay acabe en este contento "la historia y el nacimiento "de Grimalto y Montesínos."

Nacimiento (El) de Nuestro Señor. Coloquio en dos jornadas. - MiRA DE A MEsc0A. Autos sacramentales \&c. 1655 .

Esta misma composicion con el nombre de Auto se halla en los Aulos sacramentales, 1675 .

Nacimiento (Del santo) de Nuestro Señor Jesucristo. Coloquio entre tres pastores. - JUAN López de Úbeda, en la pág. 33 de su Cancionero, 1586.

Nacimiento (El) de Nuestro Señor Jesucristo. Auto o farsa.-Lúcas FervínDEZ. Farsas y églogas.

Nacimiento (El) de Nuestro Señor Jesucristo. Coloquio.-Gaspar Hernández Y Ávica. Infancia de Jesucristo.

Nacimiento (El) de Nuestro Señor Jesucristo. Precedida de Loa. - Sánchez Tórtoles. El entretenido, P. I.

Nacimiento (El) de S. Francisco.-Romar Montero y Franc. de Villigas. Parte $\boldsymbol{X X X I X . C . A .}$

En el Indice de los títulos de dicha parte se le da el de Cómo nació S. Francisco. - Medel la trae anónima.

Nacimiento (El) de Urson y Valentin.-V. Urson y Valentin.

Nacimiento (El) del alba.-Lope. Impresion suelta y antigua, y $P$. $X X Y I$. estravagante de Zaragoza, 164 .
Mustafá (El). Comedia heróica. - Josí Concha.

Muzárabes de Toledo. - V. Mozárabes (Los) de Toledo.

Nacimiento (E1) del Hijo de Dios. Diez diálogos pastoriles a este asunto. Juan López de Úbeda. Vergel de flores divinas.

Nacimiento del rei D. Juan III de Portugal.-Y. Visitacao.

Nadie fie su secreto.-Calderor. Parte $I X$. de 1691 y 1698 , en el Tom. $I$. de la de Fernández de Apóntes, y en el $\boldsymbol{I} \boldsymbol{V}$. de la de Keil.

Con el título de No guardas tú tu secreto se halla en la $P$. II. C. A.

Nadie pierda la esperanza.-V. En el mayor imposible nadie pierda la esperanza.

Nadie se atreva al honor.-A $\$$ BRosio DE Coesca y Argüello.

Medel llama á este autor Antonio de la Cueva.

Nadie se conoce.-Lope. P. XXII. Madrid, 1635 .

Nao d' amores. Tragicomedia portuguesa.-Gil Vicente. Obras.

Gran parte de ella está en español.

Narcete (El). T.-Axóvimo.

Moratin cita una tragedia de Josẻ Con. cha intitulada: Narseles, que ignoro si será la misma.

Narciso (El) en su opinion.-Gulllex DB Castro. P. II., y en la Biblioteca de Ribadeneira.

Parece que sirvió de modelo á Moreto para su Lindo D. Diego.

Naufragio (El) feliz.-ZABALA y ZAmora.

Nazareno (El) Sanson.-V. Divino (El) Nazareno Sanson.

Necedad (La) del discreto.-Lopr. Parte $X X Y$.

Vera Tásis la coloca entre las manuscritas que no eran de Calderon, á pesar de llevar su nombre.

Necépsis. $T$.-Axósimo.

No sé si será esta la tragedia que Mora. tin atribuye á D. Cándido Marła Triguèros con el título de Buena esposa y mejor hija, la Necépsis.

Negra (La) por el honor.-Moneto. Parte $\boldsymbol{X} X \boldsymbol{X} . C . A .$, y segun Barrera, en 
una $\boldsymbol{P}$. $\boldsymbol{I I I}$. de este autor, Valencia, Orga, s. $a$.

Negro (El) del cuerpo blanco, y el esclavo de su honra. - U. INGenio de esta Corte.

Se atribuye á D. Franc. de Leiva Ramirez de Arellano, y existe manuscrita en la bib. del duque de Osuna. La que yo tengo como de un Ingenio está impresa.

Negro (El) del mejor anio. - Mira de AuescuA. P. IV.C.A., y en un tomo de Comedias que, segun Mesonero, pudo ser I. Parte de las de este autor.

Medel trae otras dos con igual titulo, una de suan Vélez y otra de Lope, que probablemente serín la misma de liira de Amescua. Barrera indica que tambieu se conoce con el título de San Berito de Palermo.

Negro (El) más prodigioso. - Diauante. P. II.

Barbosa Machado atribuye esta comedia a Nitos sin fundamento alguno.

Negro (El) sensible. Melodrana en un acıo.-A xónino.

Moratin ia cita como de Luciano Francisco Comella.

Negro (El) valiente en Flándes.-V. Valienle (El) negro en Flándes.

Negro (EI) valiente en Flándes. Segunda parte.-Maveed Vicficte Guerrero.

La primera parle es El valicnte Negro en Flóndes, de Claramonte.

Neron cruel.-V. Roma abrasada.

Ni amor se libra de amor. - Calderon. $P$. III. de 1664,1687 y 1726 , en el Tom. VII. de la edicion de Fernández. de Apóntes, y en el $\boldsymbol{I I}$. de la de Keil.

Nieto (EI) de su padre.-Guil.Lex ne CasTro. P. X. C. A.

Niña (La) de Gómez Arias. - Lư Vélez. Nedel la cita escrita por un lugenio; probablemente será la misma.

Niña (La) de Gómez Arias. Caloneroy. $\boldsymbol{P}$. IV. de 1688 y 1731 , Tom. IV. de la de Fernández de Apóntes, en el $\boldsymbol{I I}$. de la de Keil, y en el III. del Tesoro del tealro español.

Barrera dice que esta comedia es refundicion de la de Luis Vélez.

Niña (La) de plata.-Lope. P. IX.

Salió tambien con el titulo de La niña de plata y burla vengada.

Niñez (La) de S. Isidró.-Lope. Relacion de las fiestas de la canonizacion de S. Isidro, y en el Tom. XII. de las Obras sueltas impresas por Sancha.

Niñez (La) del Padre Rójas. Primera parle.-LOPE. P. XVIII. C. A.
Niñezes (Las) de Roldan.-José Roso y Francisco Villeggas. P. $\boldsymbol{X X X I I I . ~ C . ~ A . ~}$ Medel la trae anóuima.

Niñezes (Las) y primer triunfo de David. - Manuel de Várgas. P. $\boldsymbol{X} X X V I I I$. C. $A$.

Niño (El) inocente de la Guardia.-Lopr. P. VIII.

Segun Barrora tambien lleva los titulos de El santo niño de la Guardia y El segundo Cristo.

Nise lastimosa, Doña Ines de Castro y Valladáles, princesa de Portugal. $T$. - Jenónimo Bermúdez. Primeras tragedias españolas, en el Tom. VI. del Parnaso español de Sedano, y en el I. del Tesoro del teatro español.

Sobre este asunto se halla una tragedia del Lic. Mejia de La Cerda en la P. III. de las Comedias de Lope.

Nise laureada, Doña Ines de Castro y Valladáres, princesa de Portugal. $T$. - Jerón. Beruúdez. Primeras tragedias españolas, ell el Tom. VI. del Parnaso español de Sedano, y en el I. del Tesoro del teatro español.

Niteti (La).-V. No hai en amor fineza más constanle, etc.

No amar la mayor fineza.-JUan ZibalesTA. P. XXIII. C. A.

No aspirar á merecer.-Diamante. $P$. $I$.

No cabe más en amor ni hai amor firme sin zelos.-Fraxcisco Carbonel.

No es amor como se pinta. - Tres INGENios. $P$. XVI. C. A.

No está en matar el vencer. - Mátos. P. $X X X . C . A$.

Barrera añade al titulo: el cerco de Zımora.

No guardas tú tu secreto. - Calobron. P.II. C. A.

Es Nadie fie su secrelo.

No habrá mal donde hai mujer.-CALDE RoN. Edicion suelta de Stvilla, José Padrino.

Barrera la trae á nombre de D. Antonio Grati y Alava; pero no al de Calderon.

No hai amar como fingir.-leon Marchante. Tom. I. Obras poéticas, y en la $P . X X X Y, C . A$.

En el indice del tom. I. de las obras de Leon Marcliante se corrige el error de haberla atribuido en la pág. $\mathbf{3 5 4}$ á este y á Calleja.

En las Aleluyas jocosus de Ant. Abad Velasco hai un Pasu trovado de esta comedia.

No hai amigo para amigo.-Rósas ZorrILLA. P. I. de sus Comedias. 
Barrera dice que suele citarse con el segundo tílulo de Las cairas se vuclven lansas.

No bai amor donde hai agravio. - AvroNio Hurtado de Mendoza. Obras, en la Flor de las mejures doce comedias, y segun Barrera, en las Doze comedias de diferentes autores. P. XXXXXVII. Valencia, 1646.

Medel la atribuye á D. Gaspar de Saravia y Mendoza.

No hai bien sin ajeno daño.-Avr. Sigle $\mathrm{B}$ DE LA HUERTA. Flor de las mejores doce comedias.

No hai burlas con el amor.-Calderos. $\boldsymbol{P}$. $\boldsymbol{V}$. de 1694 y 1730 , en el Tom. $I X$. de la de Fernández de Apóntes, en el III. de Keil, en el I. de las Comedias escogidas de Calderon, Madrid, 1826 , en la $P$. XLII. de las de a fuera, Zaragoza, 1630 , en las Comedias escogidas de los más insignes poetas. S. I. ni a., y en el Theatro hespañol de Huerta.

Barrera tambien le da el título de La criticn del amor.

No hai burlas con las mujeres, ó casarse y vengarse.-Mira dE AuEsCuA. $P$. $V$. C. $A$.

No hai castigo contra amor. - JoAy CABEza. La tengo suelta y tambien está en la $I$.. Parle de sus Comedias, $Z$ arago$z a, 1662$.

En el Indice de Yedel se llama á este au. tor Juan Cabezas.

No hai con la patria venganza y Temistocles en Persia.-Josè de C.tš̉lzines.

No hai contra el amor encantos.-TREs INGENIOS.

No hai contra el amor poder. -JUay V̈ÉLEZ. P. $X X Y$. C. A.

En nuestro Catálogo de Lóndres se halla suelta á nombre de Luis Vélez, y Nedel la trae al de Antonio Enríquez Gomez, confundiéndola sin duda con la de este autor intitulada: No hai contra el honor poder.

No hai contra el hado defensa y destruicion de Tébas.-Marcelo ve A rala Y Guzyix.

No hai contra el honor poder.-A.T. Exríquez Gómez. P. II. C. A., y en otra Parte II. variante que menciona Barrera.

No hai contra lealtad cautela.-Frsicisco de Leiva Ramírez de Arellayo. P. $X L$. C. A.

Medel la trae anónima.
No hai contra un padre razon.-FraxcisCO de Leiva Risírez de Arellavo.

No hai cosa buena por fierza.- lis Ivevio.

No hai cosa como callar. - Calderoy. $\boldsymbol{P}$. VII. de 1683 y $171 \mathrm{~s}$, en el Tom. $\boldsymbol{X}$. de la de Fernández de Apóntes, en el $\boldsymbol{I I I}$. de la de Keil, y en la P. XVII. C. A.

No hai culpa donde hai amor. - Jetr DF Vega Beltrax. La impresion de mi biblioteca, que es antigua, principia por la pág. 443 y concluye por la 480 , de modo que se véformaba parte de algun tomo. iSerá acaso de las Doze comedias de diferentes autores, P. X.XXXXVII. Valencia, 1646, ó de las Doze comedias de las mas famosas. Lisboa, 1649, en cuyos volúmenes dice Barrera que se encuentra?

No hai deuda que no se pague. - V. Burlador (El) de Sevilla.

No hai deuda que no se pague, y convidado de piedra. - AsT. DE Z Zirora. Tom. II., y en el de las Escogidas de este autor, Madrid, 1831 , donde lleva este largo título: No hai plazo que no se cumpla ni deuda que no se paque. El convidado de piedra. Se ha reimpreso en la Biblioteca de Ribadeneira con el de No hai plazo que no se cumpla, y convidado de piedra.

Esta comedia de Zamora es refundicion del Burlador de Serilla de Tirso.

No hai dicha hasta la muerte.- Ux Irgevo. $P . X L V . C$. A., en cuya $T$ abla se intitula: Hasta la muerte no hai dicha.

La tengo suelta con el nombre de sil autor Mira de Amescua, y con el títulis pri. miltivo de to hai dicha ni desdicha husta la muertc.

No hai dicha ni desdicha hasta la muerte. - Yira de A uEscu. Impresion suella.

Es la misma que la anterior. Barrera pregunta si es de Vira de Amescua o Ró. jas: sin duda se habrá publicado tambien i nombre de este. Se ha reimproso en la Bibliuleca de Ribaleneira.

To hai cn amor fineza más constante yue dejar por amor su mismo amante. La Niteti.-Axósisio.

Posteriormente salio con solo el tílulo de La rileti, y In ratin atribuye esta pieza d D. Francisco Mariano Nifo.

No hai gusto como la honra.-Fersisdo LUIS dE lers Y MexdozA. P. TXYI. C. A.

En el Indice de Medel se atribuye equi- 
vocadamente esta comedia a D. Antonio de Yendoza.

No hai mal que por bien no venga.-Ruz de Alarcon. P. IV. C. A., y Tom. $I$. de sus Comedias escogidas, Mallrid, $186 \%$.

La tengo snelta, edicion de Valencia, 177 , con el titulo de No hai mal que por bien no venga, D. Domingo de D. Blus; y con el mismo dice Bariera que se en. cuentra en la P. H. de Comedius éscogillas. Zarago: $a, 1655$.

Es distinca de la de Zamora.

No hai mal que por bien no venga, D. Domingo de D. Blas.-Axt. oE Z IMora. Comedias escogidas, Madrid, 1831 .

Segun Barrera se halla en el Ameno jar. din le comedias. 1754, con el título de D. Domingo de D. Blas, s no hai mal que por bien no venga.-Es distinta de la de Alarcon.

Yo hai más saber que salvarse. - Lope. Impresion suella y mui antigua.

No se encuentra en las Partes. Fl Indice de Medel solo trae una con este tílnlo de Cristoval de Monroi; de alli sin duda lo ha copiado Barrera, quieu tampoco menciona la de Lope.

No bai peor sordo.-Tinso. P. III., y en el Tom. III. de las escogillas de este autor. Madrid, 1831, donde lleva el título con que la reimprimió Doña $\mathrm{T}$. resa de Guzman de No hai peor sordo que el que no quiere oir. La ha incluido Hartzenbusch en el tomo de Comedias escogidas de Tirso.

No hai plazo que no se cumpla, y convidado de piedra, ó No hai plazo que no se cumpla ui deuda que no se pague. El convidado de piedra.-V. No hai deuda que no se pague, y convidado de piedra.

No hai roinar como vivir.-MIRI DE A uESct. P. XIII. C. A.

No hai ser padre siendo lei.-Rósas Zornilla. P. I., en la VI. C. A., y en las Comedias de los miejores. Colonia, 1697.

Ilai una Relacion lrovada de esta comsedia en las Aleluyas jocosas de Velasco.

No hai vida como la honra - Moytalvis. Para todos, en la P. $\boldsymbol{X L I V}$. de las de a fuera, Zaragoza, 1632 , en el Tom. I. de sus Comedias escogidas, Madrid, 1827, y en el IV. del Tesoro del teatro español por Ochoa. Segun Duran tambien está en la Parte $\boldsymbol{X X V}$. de las de á fuera, Zaragoza, 1632. Se ha reimpreso en la Biblioteca de Ribadeneira.

Medel atribuyc á Lope una seria y otra burlesea con jurnal lf́ulo.

No puede ser.-Moneto. P. II., Tom. II. de sus Comedias escogidas, 1828, en la P. XIV. C. A., en el Theatro hespañol de Huerta, y segun Barrera, en las Comedias de los mas insignes ingenios de España. Colonia, 1697.

La tengo suelta con el título de No puede ser cl guardar una mujer.

No se pierden las finezas.-Axdres ne BAEZA. P. XI. C. A.

No siempre lo peör es cierto.-Calneron. $P$. VIII. de 1684 y 1726 , en el Tomo IV. de la de Fernández de $\Lambda$ póntes, en el $I V$. de la de Kéli, en el $\boldsymbol{I}$. de las Comedias escogidas de Calderon, 1826, en el III. del Tesoro del tealro espanol de Ochoa, y en el Theatro hespañol de lluerta.

En la $P . I$. C. A. se encuentra con el título de Nunca lo peor es cierto.

No son todos ruiseñores.-Lope, P. XXII. Mallid, 1633 .

La lie tenido á nombre de Calderon, y es estraño que Veri Tásis no la mencione entre las supuestas.

Noche (La) de S. Juan.-Lope. P. XXI.

Noche (La) de Troya. En un acto.-V. R. A. (Viccnte Rodríguez Arellano.)

Noche (La) dia. Comedia sacramenlal.Avtovio Condino y Montesegro.

Yoche (La) toledana.-Lope. P. III., en la cual solo hai tres comedias de Lope.

Novios de IIornachuélos.-Lope. Impresion suelta y antigua.

No se lialla ell las parles.

Nuera (La) humilde. Precedida de Loa.Gispar Agullir. P. I. Poetas valencianos.

Hedel se equivoea en llamar á este autor Fiancisco.

Nuera (La) más leal, y mejor espigadera. -V. Mejor (La) espigadera.

Nuera (La) sagaz. En prosa.-A sósiso, traducida del italiano.

Moratin se la atribuye á Josẻ Concha.

Nuestra Señora de A tocha.-Rósas ZorriLLA. P. II.

La tengo suelta con el tílulo de $L a p a-$ trona de Hrulidel, Nuestra Scñora de Atocha. Medel cita una Nuestra Señora de Aiocha de D. Pedro Lanini Sagredo que tal vez sea la de Rójas.

Nuestra Scñora de la Aurora.-Moreto. 
P. III., Valencia, 1676 y 1703 , y $M a-$ drid, 1681.

Barrera dice que la escribio en colaboracion con $\mathrm{D}$. S. de Villaviciosa y Mátos; sin elubargo, yo solo encuentro a D. Jerónimo Cincer como coautor, en la $P$. XXXIV. $C$. A., donde se intitula: La Virgen de la Aurora.

Nuestra Señora de la Luz.-Franc. SalGADO. $\boldsymbol{P}, \boldsymbol{X} \boldsymbol{X} I \boldsymbol{X} . \boldsymbol{C} . \boldsymbol{A}$.

Nuestra Señora de la Vitoria, y restauracion de Málaga.-Frixc. de LEIVA. P. XLIII. C.A.

Nuestra Señora de los Reyes.-V. Mejor (La) luz de Sevilla, Nra. Sra. de los Reyes.

Nuestra Señora de Regla.-Ambrosio ne Coexca. P. XIVII. C. A.

Barrera le da tambien el título de La Fénix de Andalucia.

Nuestra Señora del Mar y conçuista de Almería.-Licenchado D. Juan Antonio Bevavídes.

Lleva al fin una dedicatoria de este dirigida á D. Juan Diego de Castro, en la que ensalza el valor de este señor el! la batalla de Villaviciosa, donde recibio tres graves heridas, y en la de Briluuega en la que tambien dio muestras de su denuedo. Si Barrera hubiera tenido á la vista este docunsento, no hubiera dudado que el licenciado D. Juan Antonio Benavídes era diferente sugeto del D. Juan de Benavídes, elogiado por Montalvan.

Nuestra Señora del Pilar.-Sebastiun Vtllaviciosa, Mátos y Moreto, $\boldsymbol{P} . \boldsymbol{V}$. C. A.

No conoció Barbosa Machado esta comedia, putes no la cita en el artículo de Mátos.

Nueva (La) ira de Dios, y gran Tamorlan de Persia.-Luis VéLez.

La lengo tambien con solo el título de El Tanorlan. Medel la atribuye equivocadamente á Juan Vélez. Sogun Barrera se halla en la P. XXXlll. de cioce comedias fa. mosas. Valeneia, 1642, donde se atribuye malamente á Lope.

Nueva (La) maravilla de la gracia.-PEdro Lavisi Sagredo. P. XLIII. C. A.
En la Tabla de dicha Parte se encuentra con este título y nombre de autor; pero en el que lleva la comedia dice: La nueva maravilla de la gracia, Juana de Jesus Maria. De D. Francisco Lanini Sagredo.

Nueva (La) vitoria de Don Gonzalo de Córdova.-V. Mayor (La) vitoria de Alemania de $D$. Gonzalo.

Nueva (La) vitoria del marques de Santa Cru\%. T. c. - Lope. P. IXV.

Nuevo (El) mundo descubierto por Cristóval Colon.- Lope. P. IV., y en el Tom. II. del Tesoro del teatro español. Nuevo (El) mundo en Castilla. - Mitos. P. XXIVII. C.A.

Barrera dice que es refundicinn de Las Baluecas del duyue de Alba de Lope.

Nuevo (El) Olimpo. Especie de Zarzuela. -Bocíngel Lizuet.. Madrid, (1649). 4.

Nulidades del amor.-Tomas DE AT̃orbe I CorRejel.

Numancia (La). T.-Cervíves. Fiaje al Parnaso edicion de Sanclia, en el Tom. $\boldsymbol{Y}$. de las Oóras eseogidas de este autor, publicadas en Paris por Arrieta, en el Tom.I. del Tesoro del teatro español, y en el Handbuch de Ludwig Lemeke.

Segun Barrera parece que se publicó con el título de El cerco de Vumancia.

Numancia destruida. T. - IGvicio López DE ArAl..

Nunca lo peor es cierto.-V. No siempre lo peor es cierto.

Nunca muclio costó poco.-Reiz de Alarcos. Tom. II. de sus Comedias escogidas, Mudrid, 1829.

Con este título y a nombre de Lope, se publicó ántes en la P. IXII. de este autor Zarago $\approx a, 16.50$.

Es la misma que los pechos privilegiados de Alarcou que se halla en su P. II.

Nuncio (El) falso de Portugal.-Tres IxGesios. P. H.IV. C. A.

Esta comedia es diferente de la que se publicó coll el título de El falso nuncio de Porlugal.
Obediencia (La) laureada y primer Cárlos de Hungría.-Lope. P. VI.

Obispo (El) de Crobia, san Estanislao.Fervindo de Zarate. P. $\boldsymbol{X} \boldsymbol{V} . \boldsymbol{C} . \boldsymbol{A}$.

Obligacion (La) á las mujeres-Luis VÉLEZ. P. II. C. A.
Medel atribuye sin razon esta comedia á Juau Vélez.-Tengo un $\| S$. de principio del siglo Xril. con influitas variantes del impreso, y en él se intitula: La obligacion de las mujeres.

Esta comedia es casi la misura que la de cumplir dos obligaciones, taubien de vi. 
lez, y distinta de la que escribió con el tltulo de Cumplir dos obligaciones y cluquesa de Sajoniu.

Obligados y ofendidos.-Rósas Zorrulla. P. $\boldsymbol{I}$.

Salio despues con el título de obligados y ofendidos, y gorron de Salamanca en la P. VI. C. A., y en la XXXII. de las de á fuera, Zaragoza, 1640 , seguu los traductores de Ticknor.

Obligar con el agravio. - Fraxcisco DE Vitoria. P. IF. C. A.

Obligar contra su sangre.-Mira de AuescoA. Scgun Mesonero tambien se encuentra cn un tomo de Comedias que pudo ser la Parte I. de las de cste autor. Se ha reimpreso en la Bibliotera de Ribadeneira.

Obras son amores.-Lope. $\boldsymbol{F}$. XI., v en el tomo impreso en Madrid, $180^{\circ}$, en 4. intitulado: Coleccion de las mejores comedias de Lope.

Dice Barrera que en la Biblioteca Nacional existe un auto sacramental con este mismo título, autógrafo de Lope.

Ocasion (La) hace el Jadron.-Moreto. P. III. Valencia, 1676,1703 y Valencia, Orga, s. a.

Se publicó más tarde con el título de $L a$ ocasion hace el ladron y el lmucque de las malelas. Se encuentra en el lom. II. de las Comedias escogidas de este autor, 1828.En la P. XXVIII. $C$ A., y en el Indice de Me. del se atribuye indebidamente a llátos.

Es una refundicion de La villana le Vallécas, de Tirso.

Ocasion (La) perdida.-Lope. P. II.

Octava (La) maravilla.-LoPE. P. $X$.

Ofender cols las finezas.-Jeróximo VILLAIZAN. $P$. XLIV. de las de á fuera, Zaragoza, 163\%2; D. Agustin Duran dice que se, halla en la $\boldsymbol{P} . \boldsymbol{X} \boldsymbol{X} \boldsymbol{X}$. de las mismas, Zaragoza, 1636. Se ha reimpreso en da Biblioteca de Ribadeneira.

Ofensor (El) de sí mismo.-Cristóval de Monkol y Silva. Se ha reimpreso en la Coleccion de dramiticos de la Biblioteca de Kihadeneira.

Olimpa y Vireno.-Montalvan. Tom. I., y segun Barrera en la $\boldsymbol{P}$. XXIX. de las de á fuera, Valencia, 1636.

Olvidar amando.-Franc. Bernirdo Quiros. P. XXXVIII. C. A.
Es de Luis Belmonte, segun Barrera, y se encuentra con el titulo de El desposado por fuerza, $y$ olvidar amando, en la Parle XLI. de las de a fuera impresa en Valencia.

Ollero (El) de Ocaña.-Luis VÉlez, en el tomo de sus Comedias escogidas, $M a$ drid, 1832. Sc ha reimpreso en la $\mathrm{Bi}$ blioteca de Ribadeneira.

Barrera añade al titulo: $\delta$ no es barro lo del puchero.

jpera (La) cómica. - Avóxino, traduccion en prosa y verso por $D$. Vicente Rodriguez de Arellano. Tom. $V$. del Teatro nuevo español.

Oponerse á las estrellas.-MÁtos, Axtonio Martícez y Moreto. P. V. C. A.

Barbosa Nachado se equivoca al suponer que esta comedia fuc escrita únicamente por Mátos, y Medel la da como anónima.

Oratorio místico y alegórico á María Sautisima del Pilar.-Gerardo Lobo. Obras Tom. II.

Oratorio sacro en que se celebra la traslacion del santísimo Sacramento à la iglesia del convento de la Enseñanza de Barcelona en 1761.-A vónivo.

Orgullosa (La). - Formada sobre la que con el mismo título escribió Mr. DesTouches, y acomodada al teatro espanol por ${ }^{~} D$. Francisco de Plano. Tomo III. del Teatro nuevo español.

Orígen de Nuestra Señora de las Angustias y rebelion de los moriscos.-ANTorio Fajardo y Acevedo. $\boldsymbol{P} . \boldsymbol{X} \boldsymbol{L} . \boldsymbol{C}$. $\boldsymbol{A}$.

Orígen, pérdida y restauracion de la Virgen del Sagrario.--Calderon. Parte II. de 1637 (?), 1641, 1686 y 1736, en el Tom. VI. de la de Fernández de Apóntes, y en el I. de la de Keil.

Tambien se ha publicado con el título de La Vírgen del sagrario, su origen, pérdida y reslauracion.

Osar morir da la vida.-Zabaleta. P. $\boldsymbol{X}$. C. $A$.

Otro demonio tenemos, y los encantos de Merlin.-V. Disparale (El) creido.

Oveja (La) contra el pastor y tirano Boleslao.-Toyas Ax̃orbe y CorrejbL.

Está sacada de la novela escrita con el mismo titulo por Saint-Pierre.

Paciencia (La) en los trabajos. - FeLIPE
Pablo y Virginia.-Juan Francisco Pasror. Toin. I. del Teatro nuevo español. 
Godinez. P. XVIII. C. A.-V. Trabajos (Los) de Job.

Padre (El) de familia. - Traducida libremente del frances en prosa por D. J. D. E. Tom. VI. del Teatro nuevo español.

Padre (El) de su enemigo.-JUAx oE VILLÉgas. P. XLIII, de las de a fuera, Zaragoza, 1650 .

Padrino (EI) desposado.-Lope. P. II .

Tambien se conoce por Argelan, rei de Alcald́.

Pagar y no pagar. P.-LOPE de RUEda. Este es el titulo que dió Moratin al Paso sesto del Dcleiluso de este autnr, al reimprimirlo en sus Origenes del teatro español.

Pagarse en la misma flor, y boda entre dos maridos. Burlesca.-FÉlIX MORENo Y Postonel.

Palabra (La) vengada.-Fervixdo de $Z_{t-}$ RATE. P. XLIV.C.A.

Palabras y plumas.-Tirso. $P$. I. Duran la reimprimió en la Talia, y Hartzenbusch en el tomo de Comedias escogidas de Tirso.

Salió posteriormente, $y$ la tengo, con el título de $E l$ petimelre con palabias y plu. mas.

Palacio (El) confuso.-LOPE. P. XXIV. de Madrid. Segun Duran en la Par. te XXVIII. de las de a fuera, Huesca, 1634, y Barrera dice en la XXFIII. de las estravagantes, 1639.

La misma comedia se halla en la Par. te XXVIII. C. A á nombre de Mira de Amescua ; sin embargo, es más probable que sea de Lope cuando se encuentra en la edicion genuina de sus obras dramáticas.

Palacios (Los) de Galiana.-LOPE. Parte XXIII.

Es La Galiuna del Catálogo de su Peregrino.

Palmerin de Oliva. - Montalyax. Parte XLIII. de las de a fuera, Zaragoza, 1630 .

Barrera se equivoca en suponer que en dicha Parte se le añade al titulo: ó la cncanladora Lucelinda.

Paloma (La) de Toledo.-Lope. De edicion antigua que parece formar parte de un tomo de Comedias de Lope. Será acaso de la $P$. XXIX. de este y otros autores, Huesca, 1634.

Paloma (La) dominica, Sta. Columba de Reati. Segunda parte.-ANr. Téllez DE Azevedo.

La primera parle se intitula Amar antes de nacer (V.). Segun Barrera hal una tercera parle del inismo autor.

Para averiguar verdades el tiempo el mejor tes tigo, ó el hijo de cuatro padres. -L. A. J. M.

El autor es D. Luis Moncin, segun Moratin.

Para con todos hermanos, y amantes para nosotros, D. Florisel de Niquea.- V. Don Florisel de Niquea.

Para conquistar desprecios más pueden zelos que amor. Comedia americana. - Axósimo.

Para obsequiọ á la deidad nunca es culto la crueldad. Z.- Axóvimó, segun un manuscrito de ella que poseo; pero Barrera dice que está escrita por González Martínez, é impresa con la adicion al título de y Ifigenia en Tracia.

Para vencer á Amor, querer vencerle.Calderon. $P$. VI. de 1683 y 1713 , en el Tóm. VII. de la de Fernández de Apóntes, en el III. de la de Keil, y en la $P$. VII. C. A. Segun Barrera se imprimio sielta en Valencia, por Lorenzo Meisnier, 1681.

Pardos (Los) de Aragon.-A vóvimo.

Moratin se la atribuye á D. Manuel Fermin de Laviano.

Parecido (El).-Мовето. P. II., у XXIII. C. $A$.

Posteriormente la refundió el mismo Mo. reto y salió con el título de $E l$ parecido en ta Corte, y con èl se halla en el tom. III. de las Comedias escogidas de este autor, 1831, y en el Thealro hespañol de Huerta.

Aprovechó Moreto en esta comedia el acto primero de El castigo del penseque de Tirso. Harlzenbusch.

Volviola á refuudir libremente D. Tomas Sebastian y Latre, imprimiéndola á continuaciou de su Ensayo sobre el lealro espeñot.

Parecido (El) en la Corte.-Y. Parecido (El).

Paredes (Las) oven.-Rcíz dE Altrcox. P. I., Tom. I. de las Escogidas de este autor, Madrid, 1826 . IV. del Tesoro del teatro espaniol, y II. de sils Comedias escogidas, Madrid, $186 \overline{7}$.

Barrera dice que suele llevar el titulo de Tambien las paredes nyen.

Pasion (La) de Cristo. Turneo.-Jory DF LEQUE. Divina poesía.

Es un diálogo entre la Justicia y la Fé.

Pasion vencida de afecto. - Disuste. P. I. y en el Ámeno jardin de comedias. 1734.

Paso de dos ciegos y uu mozo, mui gra- 
cioso, para la noche de Navidad.-TIsoxen. Le tengo at principio del Auto del Santo Nacimiento de Cristo. Alcala 1603.

Moratin diee que se halla en la Turiana, y el lo reimprinio en los Origenes del tea. tro español con el título de Los ciegos y el mo:o.

Paso cómico. - đrgel Peregrixo. La mejor guirnalda de Apolo, Tom. I.

Pasos. Se publicaron diez de Lope de Rueda en prosa, segun Moratin; pero no dice dónde se hallan. D. Juan Colon y Colon supone que son los que rontiene el Registro de representantes de Timoneda, uno de ellos es el reproducido por Noratin con el título de $\boldsymbol{E} \cdot \boldsymbol{l}$ rufian cobarde, otros dos los que seîala el mismo con los numeros 90 y 93 , $y$ los siete restantes, los que contiene El deleitoso.

Pasos jocosos parodiados de varias comedias.-A.tr. Aban Velasco en sus Aleluyas jocosas.

Pastelero (El) de Madrigal.-Ls Inciesio. segun el sr. Barrera el antor de esta comedia os Inrunimo de Cucllas.

Pastor (El) Fido.- Solis, Coello y Ciaderos. P. VIII. C. A.

Vera Tisis dice tambien que solo es de Calderno la terera jornada; Hedel la atribilye á tres Ingenios.

Pastor (El) Fido. T. c. - Guirivi, traducida en verso por Suárez de Fiunueroa. Niipoles, 1602, y Valencia, 1609.

Pastor (El) Fido.-Guarix, traducido en metro español por Doña Isabel Correa. Amberes , 1694. 8. ${ }^{\circ}$

Pastor (EI) más perseguido y finezas de Raquel.-Cristóvil de Moxinor y Silva.

sexun Barrera se publico tambien con cl título de Mus vale a yuicn Dios aynda, Esait $y$ Jacob, $\delta$ el pastor más perseguido $y$ finesas de liquel.

Pastora Alfar. Primera y segunda parte. - Simaó Machado. Comedias.

Esta en portugnes y español.

Pastoral (La) Belarda. - V. Verdadero (El) amante.

Pastoral (La) de Jacinto. - Lope. Parte XVIII.

Esta comedia se imprimió en el volúmen de Onatro comedias famosas de Gongora y Vega Carpio, con el título de Los Jacintos y zeloso de simismo; y suelta, segun Barrera, con el de La setva de Albania, $y$ zeloso de si mismo.

Pastores (Los) de Belen.-Primcro y sc- gundo coloquio.-Godisez. Aulos sacramentales \&c. 1635.

Pastores (Los) que se tornan palaciegos. Égloga.-V. Égloga reprèsentada en recuesla de unos amores.

Patron (El) de Salamanca, S. Juan do Sahagun, con Monroyes y Manzanos.Juan de Yera y Villaroel. $P$. $x L y I$. C. $A$.

Moratin atribuye á este autor una comedia intilulada: El palron de Salamanca, y otra $S$. Juan de Suhagun; me parece que solo existe una y es la que yo tengo que reune ambos titulos.

Patrona (La) de Madrid, Nuestra Señora de A tocha.-Rósas Zorril.a.

En la Parle II. de las Comedias de este antor se intitula: Nueslra Señora de Alocha.

Paulino. T. Tomas de AÑonbe y CorreJEL.

Pazes (Las) de los reyes y judía de Toledo.-LOpe. P. VIII.

Tambien se conoce con solo el título de Judia de Toledo.

Peclios (Los) privilegiados. - Ruı DE Alincon. P. II., en el Toun. II. Comedias escogidas del mismo, Madrid, 1829 , donde lleva por primer título Nunca mucho costó poco, y en el Tom. I. de sus Comedias escogidas, Madrid, 1867.

Pedir favor al contrario. - Miguel oE Barrios. Flor de Apolo.

Pedir justieia al culpado.-Ant. MartiNEZ. P. XVI. C. A.

Barrera añade: juez y reo de su causa. Con este solo título tengo á nombre de un Ingenio una especie de refundicion de la de Pelir juslicia al culpado.

Pedro Carbonero.-Lope. P. XIV.

Pedro de Urdemálas.-Cienvántes. Comedias y Entremeses.

Pedro de Urdimálas. - Un Ingenio de esta Conte.

Es diferente de la de Cervántes. No sè si será esta la refundicion de las dos anteriores, á que alude Barrera, y dice que indebidamente se ha atribuido á Cañizáres algima vez.

Pedro Vayalarde. - V. Mágico (El) de Salerno.

Pelayo (El). T.-Gaspar de Jovelláxos. Tom. VI. de sus Obras, y suelta la tengo anónima con el titulo de Munuza.

Pelayo. T.-Mavuel José Quintana.

Pelear hasta morir.-Rosete Niño. Parte XXXII. C. A.

Peligrar en los remedios.-Rósas ZoraiLL.1. P. I. 
Peligro (El) en la amistad.-CristóvaL Morááes.

Peligro (El) en mar y tierra.-Fersixdo de Giñan Y Caro.

Barrera se equivoca en llamar á este alltor Griñan y Caro: tengo la edicion de Sevilla de esta comedia à la que se reflere, y en ella se lee Giñan.

Peligros (Los) de la ausencia. - Lope. P. XXIV. Zaragoza, 1641.

Peña (La) de Francia.-Tirso. P. IV. - Loña Teresa de Guzman la publicó en el siglo pasado, y la tengo con el título de $L a$ peña de Francia y lraicion descubierla.

Peña (La) de Francia.-Lope. V. Casamiento (El) en la muerte.

Peor está que estaba.-Calderox. $P$. $I$. de 1636 (?), 1640,1683 y 1726 , en el Tom. III. de las de Fernández de Apóntes, en el $\boldsymbol{I}$. de la de Keil, y en el IV. de las Comedias escogidas de este autor, Madrid, 1833.

Es distinta de la de Mátos.

Peor está que estaba.-Mítos. Es diferente de la de Calderon.

Perderse por no perderse.-Cubilio ve Aragox. P. VIII. C. A.

Pérdida (La) de Jesucristo Nuestro Señor de doce años. Coloquio.-G.sPar FerNáxdez y ÁrILs. Infancia de Jesucristo.

Pérdida y restauracion de la Bahia de Todos santos. -Jusr Axtosio Corre. P. XXXIII. C. A.

Perfecta (La) casada, prudente, sabia y honrada.-V. Prudente, sabia y honrada.

Perfecto (El) amigo.-Gaspar Zibila $\mathrm{r}$ Zamora.

Perfeto (El) caballero.-Gullexy de Casтво. P. I., y Comedias de los mejores \&c. Lisboa, 1632 .

Peribáñez y el comendador de Ocaña. T. C.-LOPE. P. IV.

Se publicó con solo el titulo de El comendador de Ocaña.

Perico el de los palotes.-Tres Isgevios. P. XLVI. C. A.

Perla (La) de Inglaterra y peregrina de Hungría.-Us lsaesio de Silimasca.

Perla (La) del Sacramento. Comedia americana.-Asósıo.

Perro (El) del hortelano.-Lope. P. XI., en la Coleccion de sus mejores comedias, Madrid, 1803̈, cn el Tom. II. de sus Comedias escogidas, Madrid, 1828, y en el Tom. II. del Tesoro del teatro español por Ochoa.
Lord Holland poseía una copia manuscrita con el título de Amar por ver amar, y en la $P$. XYV.C. A. se supone de Moreto y denomina La condesa le Botfor.

Persecuciones (Las) de David.-Y. Montes (Los) de Gelboé y David perseguido.

Perseguida (La) Amaltea. Precedida de Loa.-Tirregs. P. I. Poetas valencianos.

P'erseguido (El).-LOPE. V. Cirlos el perseguido.

Cou el tituln soln de El perseguido la menciona el mismo Lope en el Catálogo de su Peregrino, y se imprimio en Lisbra en 1605. Medel trae la de lope y otra anoni. ma con igual título.

Perseo(El). T. c.-Lope. P. XVI.

En los tituli!los de las pígs. dice La fábula de Perseo. Se publico tambien con el 11 . tulo de La bella Andrúmeda.

Persíles y Sigismunda.-Rósıs Zorrula. P. I., y segun Duran en la XXIX. de las de a fuera, Valencia, 1636, y en la XXX. de las mismas, Zaragoza, 1636 .

Barrera añade al titulo: is hallarse para perdersc.

Petimetra (La).-Nicolas Fervixdez de Moritix.

Petimetre (El) con palabras y plumas.V. Palabras y plumas.

Petra(La) y la Juana, ó el casero prudente. Capricho dramálico. - Riyos DE la Crez. Tom. $\boldsymbol{X}$. de su Teatro.

Piadoso (El) aragones. -Lope. P. X.TI.

Piadoso (El) veneciano.-Lope. P. XXIII.

Picarillo (EI) ell España. - Chî̀zíes. Torn. I. de las Comedias escogidas de este autor, Madrid, 1829, ell el V. del Tesoro del teatro español, y cn la Coleccion de dramáticos de la Bitlioteca de Rihadeneira.

Barbosa Machado cita una de Mitos con este titulo: Medel da a la de cañizares el de El picarito én España, y Barrera lo adi. ciona: y señor de la Gran Canariu.

Picos (Los) de oro.-Rayos de la Cacz. Tom. I. de su Teatro.

Piedad (La) de un hijo vence la impiedad de un padre, y real jura de Artajérjes. -Axt. Bizo.

Piedad (La) ejecutada.-Lope. P. TrIII. Barrera dice que tal vez esta pieza sea la que con el titulo de Pimentetes y Quinsnes se anuncia en el Catálogo del Percgrino.

Piedad (La) en la justicia.-Gutulex DE Cistro. P. XIVI. C. A. y en la Biblioteca de Ribadencira. 
Es la misma que La justicia en la piedad de su $P . I I$.

Piedra (La) filosofal.-Bixces Candano. Poesíus cómicas, Tom. I.

Pimenteles y Quiñónes.-Lore. V. Piedad (La) ejeculada.

Pintor (E1) de su deshonra.-Ciborrox. P. VII. de 1683 y 1715 , en el Tom XI. de la edicion de Fernández de Apóntes, en el $\boldsymbol{I V}$. de Keil, y en la Par. te. ILII. de las de á fuera, Zaragoza, 1630 .

Pintor (El) fingido. - Viceste Rodríguez. Arellaio.

Píramo y Tishe. Burlesca.-Rosete Niño. P. XIII. C.A.

Barrera dice que tambien liene el titulo de Los dos amrulcs mäs fints; peri) yo 111 conozco con esta denominacion más que la de I). Ant. P'ablo Fernitudez.

Pilaco. T.-Nictsio Ávarez la Ciesfee(ios.

Plácida y Vitoriano. Égloga representable.-Juar nel. ExcINA. S. l. ni a. 4." let. gót.

Platero (El) del cielo.-Axt. Mísrtice\%. P. .XXI. C.A.

Barrera añade: Sitn Eloi.

Plava (La) de S. Lucar.-B.setol. Contes. P. XL.C. A.

IInerta cita La lucuña tle S. Lucar, y Ife. del La lacula de S. Lucar, ambas de Barto. lome Cortes, iserán acaso la que yo tengo?

Pleito (El) de Hernan Cortes eon Páufilo de Narvaez. - José de Cañ záress.

Pleito (El) de Inglaterra. - V. Pleitos (Los) de Inglaterra.

pleito (El) del demonio con la Vírgen.Tres J venos. P. VI. C. A.

Pleito (El) por la houra.-Lope. No está en las Partes de este antor; yo la tengo suclta, y tambien se encuentra en un tomo lle Doce comedias nuevas de Lope de Vega y olros. Segunda parte. Barcelona, 1630.

Se llama Segumla parte de esta comedia i La deselichadu Eslefania, y Barrera cree que El plecilo por la honra es la misma que Et valor de Fernandico, que se encuentra IIs. en la bib. del duque de Osuna; así parece tambien indicarlo el final donde dice:

"Señor, esclavo ne sobra

ya difunta Estefania,

de las maldicientes bocas

está segruro ini honor, que ya Fernandico sobra.»

Pleito (El) que tuvo el diablo con el cura de Madriléjos.-Luis Yésez de Guevara, Rójas y Mira de Ayescua. Flor de las mejores doce comedias.
En las Doze comedias las mas graneliosas se intitula: El pleito que puso al dinblo el cur'a de Madrilésos, y se dice en el lítulo que es de hres Ingenios; pero al principio de la primer jornutu se halla el nombre de Luis Vélez, en la segunda el de Ro. jas, y en la terceria el de Mira de Amescua. Consta anonima enliedel con bl título del Pleito del disblo con al cura de Madriléjos

Pleitos (Los) de Inglaterra.-Lope. Parle X.YIII.

Tambien El plitio de Inglalerra, segin. Barrera.

Pluma, púrpura y espada solo en Cisnéros se halla, y restauracion de Oran. Primera parte.-Ux INGexio.

La segunda murte sc intitula: El.gran cardenal de España Frai Fi'ancisco Jiménez de cisnérns.

Pobre (EI) más poderoso.-V. San Juan de Dios.

Pobreza, amor y fortuna.-Diego y José ligerro I y Córnovi. P. XIII. C. A., y Toin. V. del Tesoro del tealro español; tambien está en la Biolioteca de Ribadeneira.

stedel la atribuye solo á D. lliego.

Pobreza (La) estimada.-Lope. P. XVIII.

Pobreza no es vileza.-Lope. $\boldsymbol{P}$. XX.

Pobrezas (Las) de Reiuáldos. - Lope. Parle VII.

Poco aprovechan avisos, cuando hai mala inclinacion. - Mítos. P. MIV. C. A.

Pocos bastan si son buenos, y el erisol de la lealtad. - Mítos. P. $\boldsymbol{Y X X I V . ~}$ C. $A$.

Poder (E) de la amistad.-Moneto P. I., y en la VII. C. A.

Tengo una reimpresion suelta con el t1tulo de El poder de la amistad, y vengansa sin castigo.

Poder (El) de la razon.-Tomas de AÑonhe y Correjel.

Poder (El) vencido y amor premiado.LOPE. $P . X$.

Poder y amor compitiendo.-JUAx DE LA Chlie. P. XXYYII. C. A.

Barrera dice que es de b. Francisco de la Cille.

Pompeyo (El). T.-Caistóval de Mesa. Eclogas de Virgilio y rimas.

Poncella (La) de Orleans.-Axt. DE $\mathrm{ZA}_{\mathrm{A}}$ NorA. TOM: $I$.

Medel da comn coautor de esta comedia á D. José de Cañizúres.

Ponces (Los) de Barcelona.--Lope. P. IX . Ponerse hábito sin prucbas, y guapo Julian Romero.-CaÑ̃zíres. 
El Sr. Barrera sıpone que á vezes solo - se le ha dado el LItulo de El gruapo Julian Romero.

Póngale nombre el discreto.-FRAxc. GóME7. DE Acosta. Edicion suelta de $\mathrm{Se}$ villa hecha por Francisco de Leefiael en los primeros años vel siglo XYIII.

Por acrisolar su honor, competidor hijo y padre.-Cis̃zínes. Tom. II. de sus Comedias escogidas , Madrid, 1833, y en la Coleccion de dramaticos de la Biblioteca de Ribadeneira.

Barrera da tambien d esta comedia el tltulo de $A$ lo que obliga el honnr, y chelo conlra su padie.

Por amparar la virtud olvidar su mismo amor, ó la hidalguía de uua inglesa.Gaspar Zabala i Zayora.

Por el sótano y el torno.-Tinso. P. II., y en el Tom. I. de las Escogidas de este autor, Madrid, 1826.

Esta comedia es una de las cuatro de la $P$. $I I$. que le perteuceen por entero, segut] Hartzenbuseh, quien la incluyo en el tomo de Comedias escogidas de Tirso. La refundio D. Dionisio Salis.

Por la puente, Juana.-Lope. P. XXI, en la XXVII. estravagante, Barcelona, 1633, en el Tom. II. de sus $C_{0-}$ medias escogidas, Madrid, 1828, y en el II. del Tesoro del teatro español.

Por mejoría.- F. Mudarse por mejorarse ó Dejar dicha por más dicha.

Por oir misa y dar cebada nunca se perdió jornada.-ZAMorı. Toln. I.

Por ser leal y ser noble dar puñal contra su sangre, y la toma de Milan.-GisPAR DE ZiBALA Y ZayOR.

Por su rei y por su dama.-Bixces CAxDAmo. Tom. I. Poesías cómicas, ell la P. XLVIII. C. A., en el volúmen de sus Comedias escogidas, Madrid, 1832, en el Tom. $V$. del Tesoro del teatro español, y en el tomo de Dramaticos de la Biblioteca de Ribadeneira.

Porceles de Murcia.-Lope. P. VII.

Porcia y Tancredo. - Lois de UlloA. Parte $X \dot{L} I I I$. C. A.

Porfía (La) hasta el temor.-Lope. Parte $\boldsymbol{X X I V}$. de Madrid, y en la XXVIII. de las le a fuera, Huesca, 1631, segun notą de Duran.

Porfiando vence amor.-Lope. Fega del Parnaso, y en el Tum. IX. de las Obras sueltas, impresas por Sancha.

Con igual titulo trae otra de Calderon Medel; pero Vera Tásis dice que no es suya.

Porfiar hasta morir.-LOPE. P. XXIII.
Segun Barrera tambien se conoce por Mucíns el enamoi"adis.

Portuguesa (I,a), y dicha del forastero.I.OPE. P. III. C. A.

Tal vez sea la citada con solo el título de La dicha del forastero en la segunda lista del Peregrino.

Postrer (El) duelo de España. - Cilderor. P. IV. de 1688 y 1731, en el Tom. III. de la edicion de Feruández de Apóntes, y en el II. de la de Ĺeil.

Postrer (El) godo de España.-Lope. Parie VIII.

Se publicó en la X.XV. con el título de El último gon de España.

Prado (El) de Valencia. Con una Loa al principio y otra al fin.-Tirregs. P. $I$. Poetas valencianos, y en la Biblioteca de Ribadeneira.

Prados (Los) de Leon.-Lope. P. XYT.

Pranto de María Parda. Diálogo.-Git. Viceyte. Obras.

Uno.de los interlocutores habla en castellano; los otros lo hacen en portugues.

Premia el cielo con amor de Cataluña el valor, y glorias de Barcelona.--José Coscill.

Premiar (El) al liberal por rescatar su fortuna.-G GBRIEL DE Rol.

yedel y lluerta la traen anönima.

Premio (El) de la constancia y amor euamorado.-V. Amor (El) enamorado.

Premio (EI) de la hernosura. T. c.-Lope. $P, X V I$

Premio (EI) de la humanidad.-GısPar ZAB \LI I Z Iyor 1 .

Premio (El) de las letras por el rei D. Felipe el scgundo; precedida de una Loa en alabanza de los dedos y de un Baile pastoril.-Divis Silestio DE Poro, natural de Murcia. En la Flor de las comedias de España. Quinta parte, que se supone ser el quinto tomo de las obras dramáticas de Lope ; por esta razon sin duda se la atribuye Medel.

Premio (El) del bien hablar.-Lore. Parte $\boldsymbol{X X I}$., en la Coleccion de las mejores comedias de Lope, Madrid, 1805, en el Tom. I. de sus Comedias escogidas, Madrid, 1826, y en el II. del Tesoro del teatro espaxiol de Ochoa.

Premio (El) en la misma pena.-Horeto. P. XX. C. A.

La comedia de Lope intitulada $L a$ merced en el casligo, y la de Montalran El dichoso en Zarayosa, son las mismas que la de Ioreto; no es fácil por consiguiente el poder decidir cuil de los tres es su verdadero autor. La que lleva el nombre de Lope 
debe haberse publicado tambien con el título del Premio en la misma pena, cuando con él se la adjudica Medel.

Prendas de amor. Coloquio en verso.LOPE DE Ruena. En $E l$ deleitoso, y en los Origenes de Moratin reimpresos por Ochoa.

Presentacion (La) de Nuestro Señor Jesucristo en el templo.-Coloquio.-GASpar Fernández y Ávila. Infancia de Jesucristo.

Preso, muerto y vencedor, todos cumplen con su honor en defensa de Cremona.-AnToNio de Zayora.

Segun D. Ag. Duran se halla en una de las Partes de a fuera que él creia ser la XLI; pero Barrera dice que es en el Ameno jar. din de comedias de los insignes autores, Zamora, Diamante y Cubillo. 1754, y allí parece que solo lleva el título de La defensa de Cremona. En Medel consta anónima.

Preso (El), ó el parecido. Melodrama.Axóxisio, traducido del frances en verso y prosa por D. E. T. (Eugenio Tapia.) Tom. II. del Teatro nuevo español.

Preso (El) por amor $\delta$ el real encuentro. - Axtonio Valladínes de Sotomayor.

Presumida (La). Z.- Mor De Fúnestes. Tercera parte de sus Poesías.

Presumida (La) y la hermosa.-Fernando DE Zarate. P. XXIII. C. A., y en la $\boldsymbol{B}$ iblioteca de Ribadeneira.

Pretender (El) con pobreza.-Gulldey DE Castro. P. II.

Pretendiente (EI) al reves. - Tinso, $\boldsymbol{P}$. I., reimpresa por Duran en la Talía española, por Hartzenbusch en las Comedias escogidas de Tirso, y en el Teatro antiguo español, 1837.

Salio á nombre de Calderon á principios del siglo XVIIl. con el tílulo de El pretendiente al reves ó el rábano por las hojas, llena de erratas, faltas de sentido $\mathrm{y}$ con supresiones imperdonables.

Primer (El) blason de Israel. - PEDro Scotti de Agoiz. Obras póstumas.

Primer (El) conde de Flándes.-Fens. DE Znate. P. XXIX. C. A.

Distinta de la de Mfira de Amescua.

Primer (La) culpa del hombre.-Lope. $\boldsymbol{P}$. $\boldsymbol{X} \boldsymbol{X I V}$. de Madrid.

Se imprimíó posteriormente con el títu. lo de La creacion del mundo, y primer culpa del hombre, $\mathrm{y}$ así se halla en el volumen de Comedias nuevas. Amstardan, 1726 .

Primer (El) Fajardo.-Lope. P. VII.

Tal vez sea Los Fajardos del Catálogo del Peregrino.
Primer (El) rei de Castilla. -Lopr. Parte $X V I I$.

Primer (El) templo de amor.-Melchor FBRNÁNDEZ DE LEON. Consta en Medel anónima.

Primera (La) flor del Perú, entre penetrantes espinas, y la inocencia atribulada. Espresivos símbolos de la vida de Sta. Rosa de Lima. $O$. S.-Reducido á concento músico por el Licenciado Mosen Francisco Vicente Cervera. Valencia, Antonio Bordazar, s. a. 8.0

El autor de la letra podrá tal vez ser D. José Vic. Orlí y Mayor.

Primera (La) infornacion.-Lope. Parte $X X I I$. edicion de Madrid, 1635.

Al fin de esta comedia se advierte que es de Lope y no del Dr. Pérez de Montalvan, lo cual parece probar que se publicó alguna vez con el hombre de este último.

Primero es la honra.-Moneto. P. II., y en la $\boldsymbol{P}$. XVII. $\boldsymbol{C}$. A.

Primero es la honra que el gusto.-Rósas. Tengo un análisis MS. de esta comedia, y por él se ve que es diferente de la de Mo. reto; efectivamente, Medel menciona las dos.

Primero soi yo.-Calderon. P. VI. de 1683 y 1715 , en el Tom. FIII. de la de Fernández de Apóntes, en el III. de la de Keil, y en el Theatro hespanol de Huerta.

Princesa (La) de los montes ó los hermanos encontrados.- V. Satisfacer callando.

Princesa, ramera y mártir, santa Afra. ToMas AÑorbe Y Correjel.

Príncipe (El) constante.-Calderon. P. I. de $1636,1640,1685$ y 1726 , en el Tom. III. de la de Fernández de Apóntes, en el I. de la de Keil, $\boldsymbol{P}$. XI. C. A., y Comedias de los mejores etc. Lisboa, 1652 .

En algunas ediciones se añade al título $y$ márlir de Portugal.

Príncipe (El) de la estrella y castillo de la vida.-Ant. Martínez, Juan Zabaleta y Vicente SuÁrez. P. XLIII. C. A.

Principe $(\mathbf{E l})$ de los montes.-V.A lo hecho no hai remedio.

Principe (El) de los sabios. (Sto. Tomas de Aquíno.) Poema cómico.-Jer. MaN. DE Castilla Y MuÑı. Impreso suello.

Príncipe (El) de Marruecos.-V. Tragedia del rei $D$. Sebastian.

Príncipe (EI) despeñado.-Lope dE VEGa. P. VII. 
Tal vez sea esta la pleza El despentado que menciona Lope en El peregrino.

Principe (El) don Cárlos.-Lopr. Edicion que parece anterior á 1620 , y en la que se espresa que esta comedia la representó Olmedo.

Hai una reimpresion exacta de ella en la P. XXVIII. C. A., y alli equivocadamente se atribuye á Montalvan, confundièndola sin duda, como tambien lo ha hecho Barrera, con el Segundo Séneca de España y príncipe D. Cdrlos de dicho autor. Poseo ademas una impresion de Valencia, 1773, con el nombre de D. Diego Jiménez Enciso; pero con variaciones, adiciones y supresiones tales que puede decirse la rebizo dicho Enclso. Segun nota que tengo de Duran, esta refundicion se encuenira ya en lá Parte XXVIII. de las de á fuera, Huescu, 1634. Barrera ademas de cometer la equivocacion que arriba he indicado, no dice que esta pieza haya salido á nombre de Lope, atribuye si una que lleva el mismo título á Cañizáres; mas como no la he tenido presente ignoro si es distinta.

Principe (El) esclavo.-LuIs VÉlez DE Guevara.

Barrera añade al titulo: y hazañas de Escanderberg, observando puede tenerse por segunda parte de El gran Jorge Castrioto, que probablemente es de Belmonte. Medel se equivoca en suponerla de D. Juan Vélez.

Príncipe (EI) jardinero y fingido Cloridano.-Santiago de Pita.

Príncipe (El) perfecto. (Primera parte.) -LOPE. P. XI.

Príncipe (El) perfecto: (Segunda parte.) -LOPB. P. XVIII.

Príncipe (EI) perseguido. - Belmonte, Moreto y Ant. Martíez. En El mejor de los mejores libros de comedias, y en las Doze comedias las mas grandiosas, donde despues del título se atribuye á Moreto, miéntras en el índice del volúmen se dice que es de tres autores.

Alguna vez se ha publicado suelta como de tres Ingenios, sin espresar sus nombres, y asi la trae Medel.

Príncipe (El) prodigioso.-Máros y MoRETO. En El mejor de los mejores libros de comedias y en las Doze comedias las mas grandiosas, donde se atribuye, despues del título, solo á Mátos, y en el índice del tomo á dos autores.

A nombre de ambos la tengo suelta intitulada: El príncipe prodigioso y defensor de la fé; y con la primera parte del título hai en mi biblioteca una impresion suelta, hecha en Sevilla por Francisco Leefdael, en la que dice ser de Montalvan.
Príncipe (El) prodigioso y defensor de la fé.-V. Principe (El) prodigioso.

Príncipe (El) tirano.-JOAN de la Cueva. Comedias y Tragedias.

No es Antonio el nombre del autor como supone Medel.

Príncipe (El) tirano. T.-JuAy de LA Cueva. Comedias y Tragedias.

Es distinta de su comedia que llevd Igual título.

Príncipe (El) villano. - L tTS dE BeLmoste Bermúdez. P. XIV. C.A.

Príncipe (El) viñador.-Luıs Vélez. Parte $\boldsymbol{X X X}$. C. A.

No es de D. Juan Vélez como dice Medel.

Príncipes (Los) de la Iglesia.-Cristóval. de Monrol Y Silya. La tengo suelta sin más título.

Barrera dice que se encuentra en la Par. te sexta de comedias escogidas de los mejores Ingenios. Zaragoza, herederos de P. Lanaja, 165j-54, con el de Príncipes de la Iglesia San Pedro y San Pablo.

Prision (La) de los Bencerrajes.-V. Envidia (La) de la nobleza.

Prision (La) sin culpa.-Lope. P. FIII.

Prisionero (EI) de guerra.-Goldovi. No tiene el nombre del traductor.

Esta pieza es sin duda la misma que Mo. ratin atribuye á Fermin del Reí con el título de El prisionero de guerra, ó un curioso accidente; con el cual la tuve anó. nima.

Prisionero (El) más valiente.-V. Batalla (La) de Pavia y prision del rei Francisco, de D. Crist. de Monroi y Silva.

Privado (El) perseguido.-V. Lucero (El) de Castilla.

Privanza (La) y caida de D. Alvaro de Luna.-Damiax Salustrio de Poro. En la Parte que Nic. Antonio dice ser la III. de Lope, á quien supone injustamente autor de esta pieza: lo mismo hace Medel.

Privar contra su gusto.-Tirso. P.IF., y en el tomo de Comedias escogidas de Tirso publicado por Hartzenbusch.

Pródiga (La comedia). - Luls de Miraxd. Sevilla, 19.34. 4. ${ }^{\circ}$ let. gót.

Prodigio(El) de los montes y mártir del cielo.-Gullexi de Castro. Autos sacramentales etc. 16 วัว.

Tengo ademas una edicion suelta hecha por la viula de Leefiael en Sevilla, en que se añade al título anterior Santa Bdrbara. Barrera pregunta si será esta la Bdrbara del cielo que cita Lope como suya en el Catálogo del Peregrino. 
Prodigio (El) de Polonia.-Juan Delgafo. P. $\boldsymbol{X} X X \boldsymbol{V I}$. C. A.

Barrera añade al titulo San Jacinto.

Prodigios de amor.-Melchor de Valdes Villaviciosa.

Así se llama al autor en el título de la comedia é indice de la $P$. XXXI. C.A. donde se halla; en los epigrafes de dicha Parte se le apellida Valdes Valdivielso; y Medel le nombra Francisco Mesa y Valdivielso. El primero de todos es al verdadero, segun un MS. de la bib. del duque de Osuna.

Prodigios (Los) de la vara y capitan de Israel.-Mira de A mescua.P. XXXVII. C. A.

Medel cita de este autor El capitan de Is racl, que tal vez sea la misma.

Profeta (El) falso Mahoma.-Rójas ZorRILLA. $\boldsymbol{P}$. $\boldsymbol{I}$.

Progne y Filomena.-Gulluen de Castro. P. I.

Progne y Filomena.- Rójas Zorrilla. P. I. de sus Comedias, y VI. C. A.

Se halla refundida libremente por D. Tomas Sebastian y Latre en su Ensayo sobre cl leatro español.

Prólogos dialogísticos. - Lope. P. XVI. de sus Comedias. Es un Didlogo entre el Teatro y un Forastero; en la Parte $X I X$. hai otro entre un Poeta y el Teatro. Ambos son mui curiosos por las noticias que dan sobre el estado del teatro á principios del siglo XYII.

Pronóstico (El) de Cádiz. - Aloxso DE Osuna. P. XXXI. C. A.

Próspera fortuna de Don Álvaro de Luna, y adversa de Rui López de Ávalos. Primera purte.-Tinso. $\boldsymbol{P}$. II.

Es una de las ocho comedias de esta Parte, que Tirso solo compuso parcialmente, ayudado quizá por Alarcon, en sentir de Hartzenbusch.-Con el presente tilulo no la menciona vedel y se contenta con poner: Adversa fortuna de D. Alvaro de Luna, primera y segunda parte; siendo así que de este modo solo se denomina la Segunda yarte.

Próspera (La) fortuna de Rui López de Áralos el Bueno. - Daylay Salustrio ve Poro. P. III. de Lope, á quien la atribuye sin fundamento Nic. Antonio.

En el mismo tomo hai una Segunda par. te que se intitula: Adversa fortuna de Rui Lopez de Avalos, tambien de Poyo. Se han reimpreso ambas en la Biblioteca de Ribadeneira.

Próspera (La) fortuna del caballero del Espíritu Santo. - Lic. Juan Grajal (Grajáles?).

Nic. Antonio y Medel atribuyen falsamen- te esta pleza á Lope, sin duda por hallarse en la P. III. de sus Comedias. Es la primera parte de la Adversa fortuna del caballero del Espiritu Sanlo que se halla en la mis. ma Parte.

Prosperidad (La) de Elio Seyano. Drama para ponerlo en música. - Nicolas MINATo, traducido del italiano por Juan Silvestre Salvá.

Prudencia (La) en el castigo. - Rósas Zorrili.a. P. $\boldsymbol{X L I V}$. C. A.

En los Catálngos de Huerta y Medel se halla citada con este titulo otra que se atribuye á Lope.

Prudencia (La) en la mujer.-Tinso. Parte III., en la Talia española, en el tomo de Comedias escogidas de Tirso por Hartzenbusch, y en el IV. del Tesoro del teatro español de Ochoa. Fué tambien reimpresa suelta por doña Teresa de Guzman.

La refundió á su manera un tal Cipriano de Segura, despojándola de las bellas octavas que contiene sustituidas por un romancillo insipido y desaliñado, segun Duran.

Prudente (La) Abigail.-Ant. EnRíquez Gómez. Academias de las Musas, y Comedias nuevas. Amslardan, 1726.

Medel que la vió tambien bajo el nombre de Calderon de la Barca, atribuye á este otra con el mismo título, sin atender á lo que advierte Vera Tásis, ni reparar en que las dos no son más que una.

La tengo suelta con el título de Los irabajos de Davidy finezas de Abigail.

Prudente, sabia y honrada.-Cubillo DE Aragon. El enano de las Musas, y en la P. XII. C. A.

En el tomo de Comedias escogidas de este autnr, Madrid, 1826, lleva el título de La perfecta casada, prudenle, sabia y honrada, y lo mismo sucede en el XLVII. de la Biblioteca de Ribadeneira donde se ha reimpreso.

Prueba (La) caprichosa.-Traducida del ingles al frances por Mma. Riccoboni, y del frances en prosa castellana por D. Francisco de Paula Naranjo. Tomo. VI. del Teatro nuevo español.

Moratin la da como anónima.

Prueba (La) de las promesas.-Roiz DE Alarcon. $\boldsymbol{P}$. $\boldsymbol{I I}$.

Prueba (La) de los ingenios.-Lope. Parte IX.

Se publicó tambien con el título de $L a$ prueba de los ingenios y laberinto de amor.

Prueba (La) feliz.- Rayon DB LA Cauz. Tom. III. de su Teatro.

Psíquis y Cupido.-V. Síquis y Cupido. Puente (La) de Mantible. - Cardzron. 
P. I. de 1636 (?), $1610,168:$ y 1726 , en el Tum. II. de la de Fernández de Apóntes, y en el I. de la de Keil.

Medel atribuye á Lope indebidamente otra eon igual titulo.

Puerta (La) Macarena. Primera y segunda parte.-Mostalvay

Purgatorio (EI) dle S. Patricio.-Chlones. $P$. I. de 1636 (?), 1640,1685 y 1725 , en el Tom. II. de la de Fernáidez de Apóntes, y en el $\boldsymbol{I}$. de la de Keil.

Púrpura (La) de la rosa. Zarzuela precedida de una Loa. - C'ilnerox. P. III.

Qué (El) dirán.-Lope, segun su P. XXIV. Zaragoza, 1633. Barrera dice que tambien se encuentra cono de Lope en la $P$. XXVI. estravagante de este antor, Zaragoza, 1645 .

A pesar de esto su verdadero autor es Matlas de los Reyes, y á sil nombre se imprinió en Jaen, por perdir de la cuesta, 1629 , con el titulo del Qué dirán y donaires de Pedio Corchuelo.

Qué es la ciencia del reinar.--Dor Gircít Aznar Bélez. s. (Andres Gonzilez Bárcia). P. XLVIII. C. A.

Conociendo Barrera este anagrama, no sé porqué ha puesto entre los autores dramáticos á D. Farcía Aznar Vélez, y aun presume si la $s$ que va suelta al fln de su nombre querrá decir sacerdole ó sevillano. Medel erróneamente dice, que esta comedia es de Juan Vélez.

Quem tem farelos. Farsa porluguesa.Gil Vicente. Obras.

En esta pieza el criado ordonho babla en español.

Querer hasta morir, y amautes portugueses.-V. Amantes (Los) portugueses.

Querer la propia desdicha. -Lope. $\boldsymbol{P} . \boldsymbol{X} \boldsymbol{V}$., y reimpresion de Velpio de 1649 .

Querer por solo querer.-Antonio Hurtado de Mendoza. Obras, y en la Parte $\boldsymbol{X X X I}$. C. A. La tengo por separado impresa en Madrid, por Juan de la Cuesta , 1623. 4.

A esta edicion, ademas de una loa que tambien se encuentra en la impresion de las Obras, suele ir unida la Fiesla que se hizo en Aranjuez d los años de Felipe IIII., en la que hai una Relacion dialngada.

Querer sabiendo querer, y gran reina de Tinácria.-UN Ingenio.

Medel trae una con el solo titllto de QucTом. I. le 1664, 1687 y 1726 , en el Tom. VII. de la edicion de Fernández de A póutes, y en el $\boldsymbol{I I}$. de la de Keil.

Púsoseme el sol, salióme la luna.-Lope [IF VEGI? Impresion suelta y antigua.

No estii en las Purles verdaderus de este autor, y aunque se encuentra en lie XXVI. rslrauganle", Zaragušle, 16行, atribuida á il, Barrera la señala como de Andres de Claramonte y lo misnan hare Medel, tanto bijo el título de la que yo tengi como con el de Sanla Teodora, puisoremir el sol, silliome la luna. rer sabiendlo quever cuyo antor dice ser 1). Diego de Agulayo; comn no la he visto no sé si es la misma; Barrera dice que sí, aunque no advierte que haya salido como de 111 Ingeilio.

Quererse sin declararse. - Fervacoo nE ZiRATE. P. XXI. C.A.

Quien ama, no haga fieros.-I.ope. Part? XVIII.

Quien bien ama tarde olvida. - Lope. P. X.YIí. de Zaragoza, 1630.

Quien bien tienc y mal escoge. Coloquio en la sublevacion de Barcelona y $\mathrm{Va}$ lencia: en elogio de Felipe V.-Axóxi Mo. Impresion suelta de Madrid, 1706.

Quien calla, otorga. Segunda parte del Pense que. - Tirso. P. I., y nn el tomo de las Escogidas de Tirso por Hartzenbusch.

Ademas de esta, cita Yedel en su Indice otris d. is de igmal tituio, la una de Enciso y la otra de Calderon, que acaso serán una misma. Vera Tísis nota que á Calderon se ha atribuido equi rocadamente.

D.ña Teresa de Guzman la publicú con solo el titulo de Seginda parte del Casligo del Pense que.

Quién ellgaña más á quién. - Ruiz ne Alarcox. P. MLF. C. A., y en el Tomo II. de las Comedias escogidas de este autor, Madrid, 1829.

Segun Barrera y Leirado es la de Dar con la misma flor y refundieion hecha por el mismo Alarcon de su Desdichado en fingir.

Quién es quien premia al Amor. Precedida de Loa.-Bixces Cardaso. Poesias cómicas, Tom. I.

Quien liabla más obra ménos.-Frrxarno De Zirite. P. MLIV. C. A., Comedias escogidas de este autor. Madrid, 1832, y en la Biblioteca de Ribadeneira. 
Iuijitó en ella Zarate los dos actos primeros de lit comediil Palubras y plumas de 'Tirso, segun llarlzenbusch.

Quicn habló, pagó. - Tirso. P. II.

Es tula de las comedias de esta Parte, qu1 1 son enteramente de Tirso en sentir de Ilartzenbush.

Quien más mieute medra más. - V. $\boldsymbol{E m -}$ p'ños (Lus) del mentir.

Q:ien mis no puede.-Lope. P. TVII.

Cuicu no cae, no se levanta.-Tirso. Parte $\mathrm{r}$.

Quich prira aconseje bien.-V. Ganar amigos.
Quien todo lo quiere.-Lope. P. $X X I I$., Madrid, 1633̈.

Quinas (Las) de Portugal. -V. Leallad (La) en el agravio.

Quinta (La) de Florencia.-I.ope. P. II.

Quitar de Espraña con honra el fendo de cien doncellas. - Anronio DE $\mathbf{Z}_{\mathrm{A}}$ MORA.

Quitar el feudo á su patria Aristómenes Mesenio.-Miros, segun una edicion suelta que teigo heela en Valencia en 1761.-V. Arislómenes Mesenio.
Rábano (El) por las hojas.-V. Pretendiente (EV) al reves.

Radamislo y Zenobia. T. - Crebillon, traducida por D. A. B. N.

Radiana (Comedia intilulada).-Agustix Ortiz. S. l. ni a. $4 .^{\circ}$ gót.

Ramilletes (Los) de Madrid.-Lope. Parte $\mathrm{XI}$.

$\therefore$ punlicó suelta con el título de Las dos estrellas lrocadas y ramilleles de Ma. drid.

Ramirez (Los) de Arellano. T. c.-Lope. P. XYIV. Zaragoza, 1641.

Raipuel. T.- Yicexte Gircíl de LA HuERTr. Obras, y en el Toin. V. del Tesoro del leatro español.

Rayo (El) de Andalucia. Primera y segunda parte.-Cebilio de Arigox. La segunda lleva por tílulo El rayo de $\boldsymbol{A} n$ dalucíl, y genizaro de España. Ambas se encuentran en El Enano de las Musas.

Tambien se publicó con sola la denominacion de El genisaro de España.

Razon (La) husca venganza. - Maxued Monchox. P. $\boldsymbol{I}$. C. A.

Razon (La) hace dichosos.-Antovio MartíNe\%, Zibaleta y Cixcer. $P$. X X I I. C. A.

No dice más el título de esta comedia; pero Barrera le añade el uiltimo verso de ella ila traicion desdichados. Consta en Jedel anonima.

Razon (I.a) todo lo vence.-Luciano Frascisco Comella.

Razon (La) venceal poder.-Mátos. Parte XXIX.C. A.

Rebelde (El) al beneficio.-Tomas Osorio. P. IV.C.A.

Es la misma que Lo que le toca al valor, atribıida á Vira de Amescua en la $P . X X X I V$, y el lngrat" $a$ quien le hiso bien que como de un ingenio via en la XLV.

Reconciliacion (La), ó los dos hermanos. -Korzice, traducida en prosa por D. Vicente Rodríguez de Arellano. Tom. II. del Tealro nuevo español.

Reconciliacion (La) ó los dos hermanos. Drama en cinco actos.-Kotziüe, traducida del aleman al frances y del frances al castellano por D. F. N. de R. Es distinta version que la de Arellano.

Redentor (El) cautivo.-Mátos y Villaviciosa. P. XXIII. C. A.

Consta anonima en Nedel.

Rei (EI) ángel de Sicilia, y príncipe demonio, y diablo de Palermo.-V. Demonio (El) en la mujer.

Rei (El) doll Alfonso el Bueno.-Pedro Lavini Sagredo. P. XL. C. A.

Barrera añade al título ó la balalla de las Novas.

Rei (El) D. Alfonso el de la Mano horadada. Burlesca. - UN lngenio. P. XVIII. C. A.

Dice Barrera que en la Tabla de dicha Parte se declara ser de Luis Vélez; sin cmbarro, en 111 i ejemplar que es magniflco, completo y de la edicion de Madrid, 1662, se atribuye á un Ingenio, tanto al principio de la comedia como en el índice.

Rei (EI) D. Enrique el Tercero, llamado el Enfermo.-José de CaÑızáres.

Así dice en una edicion suelta de Salamanca que tengro: en otra de Valencia de 1768 que tambien poseo, dice el títilo: $E l$ rei Enrique el Enfermo, § se atribuye á un Ingenio.

Rei (El) don Pedro el primero de Aragon 
y de Pamplona.-Joan de Vera r VirlaBOEL.

Este es el titulo que lleva el prImer acto de su comedia La corona en lres hermanos.

Rei (El) don Pedro en Madrid y el Infanzon de Illéscas. - Tirso? La ha publicado Hartzenbusch en el tomo de $\mathrm{Co}$ medias escogidas de este autor on la Biblioleca de Ribadeneira, mui diversa de como corria impresa.

Medel la trae únicamente como de Calderon, sin duda por hallarse en una Quinta parte de este autor que salió á luz en Barculona en 1677; pero. que él rechazó como espurea. Tambien se ha alribuido á Lope por hallarse en una $P$. XXVII. suya estravagante de Barcclona, $16 \overline{33}$.

Segun dicho señor Hartzenbusch, Andres de Claramonte la refundió con el títilo de $E l$ infanzon de llléscus, $\mathrm{y}$ yoreto con el de El rei valiente $y$ justiciero $y$ rico-hombre de Alcald.

Rei (EI) don Ramiro, el Monje, y la campana de Huesca.-Joan de VraA $I$ Villarobl.

Título del tercer acto de su comedia $L a$ corona en ires hermanos.

Rei (El) D. Sebastian.-Fraxcisco de VlL.égas. P. XIX. C. A.

La tuve anónima con la adicion al titulo de y Por'tugues inds heróico.

Rei (El) Enrique el Enfermo.-SeIs IvgaNios. P. IX. C. A.

Segun Barrera, estos scis Ingenios son: Zabaleta, Martínez, Rosete, Sebastian Villaviciosa. Moreto y Cáncer. Es distinla de la que con igual trtulo se dice de un ingenio.

Rei (El) Enrique el Enfermo.-UN IxGBNio. Valencia, 1768.

Es la misina que El rei D. Enrique ol Tercero, llamado el Enferino, de Ca ñizáres.

Rei (El) sin reino. T. c.-Lope. P. $X X$.

Rei valiente y justiciero y rico-hombre de Alcalá.-V. Valiente (El) justiciero.

Rei (El) Vamba.-V. Fida y muerte de Vamba.

Reina (La) en el Buen-retiro.-Astosio Martinez. P. $\boldsymbol{X I X}$. C. A.

Reina (La) Juana de Nápoles. - Lopr. P. VI.

Tengo una edicion del siglo XYIII. con el titulo de La reina Juana de Ndpoles, y ma. rido bien ahorcado. En la $P$. VII. C. A. se publlcó con el lftulo de El niónstruo de la forluna, atribuida á tres Ingenios.

Reina (La) Maria Estuarda.-Dinyantb. P. II:

Tengo esta comedia suelta con el titulo de Religiosas constancias en las bdrbaras tragedias.
Reina (La) Sevilla.-Mira de Amescua. Este es el título que lleva en una edicion suelta y mui antigua que tengo.

En la $P . X X I X$. C. A. se intitula Los car. boneros de Francia.

Reinar despues de morir.-Lus Vélez. Comedias de los mejores etc. Lisboa, 1652, Comedias de los mejores, Colonia, 1697, volúmen de Comedias escogillas de Luis Vélez, Madrid, 1832 , en el IV. del Tesoro del teatro de Ochoa, y en la Biblioteca de Ribadeneira.

Barrera da tambien á esta comedia los titulns de boña Ines de Castro y Ln gar:a de Porlugal. Mátos escribió la ségunda par te de esta comedia con el titulo de ver y creer.

Medel la atribuye equivocadamente á Juan Vélez.

Reinar no es la mejor suerte.-U: IvGsNio. P. XXVII. $\stackrel{C}{\text {. A. }}$

Medel da el tftulo inexacto pues dice es Reinar no es la mayor suerte.

Reinar por obedecer.-DitMaxte, SEbasTiAs Vilaticiosa y Mítos. P. VIII. C. A.

La he tenido suelta como de tres Inge. nios. Medel la atribuye solo i Diamante.

Reino (El) en cortes, y rei en campaña. - Avitovio Coelco. Autos sacramentales etc. 163 ว̆.

Relacion de la fiesta de Aranjucz.-Axtonio de Mendoza. Obras.

Es un diälogo en verso.

Religiosas constancias en las bärbaras tragedias.-JoAn Biotista Diasivite.

En los titulillos que llevan las piginas pares solo dice: La reina Muriu Esluarda, y con este título se encuentra en la Parte II. de las Comedias de viamante.

Remedio (El) en el peligro.-Dityaxte. P.I., y en el Ameno jardin de comedias, 1734.

Remedio (El) en la desdicba.-Lope. Parie $X I I I$.

Comedia dedicada á su hija Doña Marcela del Carpio. ¿Será acaso la de Abiudur. raez y Narvaez citada en su lista del Peregrino?

Remedio, industria y valor.-Mostalvas. Edicion anligua.

Segun un Indice MS. de Gámez es de Vi. llaviciosa y Mátos.

Rencor (El) más inhumano de un pecho aleve y tirano ó la condesa de Jenovitz, con Loa y Sainete.-A xónimo.

El Sainete se Intitula: Los Iretnicu reales 
y la casaca. Moratin atribuye esta comedia á José Concha.

Rendirse á la obligacion. -Diego y José de Cónova y figueroa. P. XXITV. C. A. Renegada (La) de Valladolid.-Luis Bet.movte Bermúnez. $\boldsymbol{P}$. I. C. $\boldsymbol{A}$.

En rel Indiee de dicho tomo se atribnye á Belmnnte y Aut. Bermudez. Consta en Medel incinima.

Renegarlo (El) de Carmona.-U I Ivassio.

No se por que razon supone Barrera que el autor de esta conedia puede ser un tal Garefa.-Fué prohibida por el Santo ofleio.

Renegado (El) del cielo.-Carstóval de Morilles.

barrera se equiroca en suponer que esta comedia es la mistlla que Renegado, rei y márlir de este autor.

Renegado, rei y mártir.-Castóval DE Moríles.

Estil comedia es totalmente distinta de El reneyado del cielo del mismo autor; por lo tanto Barrera se equivoca cuando supone que ambas son una.

Renegado (El) Zanaga.--Bervardryo RoDríioez. Segun Von Schack se halla en las Doce comedias de varios, Torlosa, 1638

Nedel intitula esta comedia Renegado Cenaga y Barrera añade al título de la mia: y sigundo Job de Argel, efectivamente los dos últimos versos dicen:

y aqui se accuba, senado, el Job segundo de Argel.

Repelon (Aueto del) en el cual se introducen dos pastores Piernicurto y Juan Paramas. - Juan del Excivis. Fin su Cancionero, Salamanca, 1303 , y en el Tom. II. del Ensayo de una biblioleca esp. de Gallardo.

Representacion á la Pasion y Muerte de nuestro precioso Redentor.-JUAN DEI. Escisa, fol. 80 vta. de su Cancionero, y Teatro español anterior a Lope de Yega.

Representacion á la santísima Resurreccion de Cristo. - Juan del Encina, folio 82 vta. de su Cancionero.

Represeritacion de Juan dec Exciva, que se halla en el fol. 96 de su Cancionero, edicion de Zaragoza, 1316 ; reimpresa por Gallardo en el núm. 5 del Criticon con el título de El triunfo del Amor.

Representacion de la Historia evangélica del capítulo nono de San Juan.-SEusstisx dF Horozco. En su Cancionero MS. que se encuentra en la bib. Colombina é impresa en Sevilla en $1867.8 .^{\circ}$
Representacion de la parábola de San Mateo á los veinte capitulos de su sagrado Evangelio. Representada en Toledo en 1548.-Sebastian de Horozco. Se halla en su Cancionero MS. que existe en la bib. Colombina é impresa en Sevilla en 1867. 8.

Representacion panegírica.-Sous. Tomo de sus Poesías.

Es un diálogo entre cnatro personajes alegóricos en alabanza del Conde de oro. pesa.

Reprisentacion para el Carro triunfal, que cerró la Máscara de parejas, ejecutada por la Escuela de San Pablo de Búrgos, en celebridarl de la victoria conseguida por Phelipe quinto en Ios Campos de Villa-Viciosa.- Francisco Antonio de Castro.

Representacion sagrada que se supone hecha en Zaragoza con motivo de haberse hecho las pazes entre España y Francia en tiempo de Felipe II.-LOPE. Libro III. del Peregrino y en el Tomo $F$. de las Obras sueltas impresas por Sancha.

República (La) al reves. - Tirso. P. V.

Resistencia (La) hourada y condesa Matilde.-LOPE. P. II.

En el frontis de esta Parte solo dice Condesa Matilde.

Respeto (EI) en la ausencia.-GASPAR DE Avilu. P. IV. C. A.

Respuesta (La) está en la mano.- UN INGENIO.

Debió de salir tambien á nombre de Cal. deron de la Barca, pues asi lo aflrman Medel y Vera Tásis, quien asegura no ser de aquel autor. Barrera la supone de un Ingenio de Tuledo; pero en la mia dice que este es de la Corte.

Restauracion (La) de Buda. Precedida de Loa.--Bánces Candamo. Poesias cómicas. Tom. I. Barrera dice que se imprinió suelta y con esmero en Madrid, Antonio Roman, $1686.4 .^{\circ}$

Restauracion (La) de España , $\delta$ el alba y el sol.-V. Alba (El) y el sol.

Restaurar por deshonor lo perdido con rigor : la restauracion de España. En un acto.-José Concha.

Resucitar con el agua.-JosÉ Ro1z, JAcinto Hurtado de Mendoza y Pedro Francisco lanini Valencia. $\boldsymbol{P}$. $\boldsymbol{X} \boldsymbol{X} \boldsymbol{V I}$. C. A.

Barrera añade al título citado: San Pedro de Muzara.

Resurrecçāo (A). Diálogo en portugues.Gil Vicente. Obras. 
Ricahembra (La) de Galicia.-V. Lindona (La) de Galicia.

Rico (El) avariento. - Mira de Amescua. Aulos sacramentales etc. 1653 , y segun Mesonero, en un tomo de Comedias que pudo ser I. Parle de las de este autor.

Rico-hombre (El) de Alcalá.-V. Valiente (El) justiciero.

Riesgos, amor y amistad.- Jún Vét.ez. P. XXXVII. C. A.

Este es su título y no Riesgos de amor y amiclad como dicen el sr. Barrera y Medel.

Riesgos (Los) que ticne un coche.-ANtovio de Mrsdoza. P. IF. C. A.

Acaso será la misma la que salió á nombre de Calderon, de quien no es, segun Vera Tásis. Medel habla de dos, la una de Mendoza y la otra de Caldernn; con el nombre de este se encuentra en las comnedius escogidus do los mas insignes poelas. S. l. ni a.

Barrera dice que esta comedia salio taınbien con el tílulo de lo que es un coche en Mudi ill, y con el mismo dice Sedel que es de Lope.

Riesgos y alivios de un manto.- Mitos.

Rigor (EI) de las desdichas y mudanzas de la fortuna. - Cildenos. $-P$. $I X$. C. A.

Medel le señali el mismo autor coutra el sentir de Vera Tisis, quien solo la iutitula $E l$ rigor de las desdichns. La he cotejado con la de Lope: Mudanzas de lı forlumu y sucesos de D Bellran, y con las mudan. zas de la fortuna y firmezas del amor de Monroi, y es diversa.

Robo (El) de Dina.-Lope. P. XXIII.

Robo (El)de Elena.-Cristóval de Moyrol y Sit.va.

Robo (El) de las sabinas.-Juan DE CoEllo y A rias. P. $\boldsymbol{X I}$. C. A.

Roca (La) del honor.-CAI.deroy.

No es suya en sentir de Vera Tásis. Barrera la trae anonima y dice que ya se imprimió en 1672: la edicion que yo tengo es de Sevilla, viuda de Leefuael, hecha á principios del siglo XVlll.

Roma abrasada. $\boldsymbol{T}$.-Lope. P. $\boldsymbol{X} \boldsymbol{X}$.

Barrera añade $y$ crucldades de Neron, y sospecha que esta pieza sea el Neron cruel citada en el Peregrino.

Romagem de aggravados. $\boldsymbol{T}$..c. portuguesa.-Gil Vicente. Obras.

Va al flı una Canliga en español.

Romera (La) ile Santiago.-Tirso. Parte $X \boldsymbol{X} X I I I . C$. A., y en el Tom. $I V$. de las Comedias escogidas de este autor, Madrid, 1833.

I.a tengo de edicion de Valencin de 1777 con el nombre de Luis Vèlez de Guevara y algunas variantes. No estrañaria que fuese realmente de este antor; y Hartzen. busch en la pág. XLI. de los prels, del tomo de Comedias escogidas de Tirso opina, que acaso estará retocada por aquel.

Roncesvålles. - V. Mocedades (Las) de Bernardo del Carpio.

Rosa (La) Alejandrina - V. Rosa (La) de Alejandrla de Luis Vélez.

Rosa (La) de Alejandría.-Lcis Vélez. P.II. C. A. En el Indice de esta Parte tiene el título de La Rosa Alejandrina.

Se equivoca Medel en decir que es de Juan Vẻlez.

Rosa (La) de Alejandria.-Rosete Nix̃o. P. XXIF. de la C. A.

Es distinta de la de Luis Vélez. Barrera añade altftulo: Sanla Calalina.

Rosario (EI) perseguido. - Uy Ixaevio.

Barrera trae una con este titulo que atribuye a Moreto, y nada dice de la de un Ingenio. Tal vez scan ambas una misma. - Consta en Medel anónima.

Rubena. En portugues y parte en español.-Gil Vicente. Obras.

En el Teatro español anlerior d Lope de Vega se ha reimpreso una escena, que estả toda en castellano, $\mathrm{y}$ la ha repetido ochoa ell el lom. l. del Tesorit del tealro español.

Ruella (La) de la fortuna, precedida de una lod $y$ de un Baile curioso y grave. - Axt. Mira de Amescul. Flor de las comedias de España. Quinta parte, y en la Biblioteca de Ribadeneira.

Medel cila una de Lope con igual titulo; pero sin duda le indujo en esie error el liallarse en el tomo qué se reputa quinto de sus Comedias.

Rufian (El) Castrucho. - Lope. Teatro anliguo español, 1837.

Es la misma que. El galan Caslrucho de la P. IV.; pero siempre que en esta dice golun, en la otra se lee rufian. Lope la da este úlimo titulo en el Catálogo del Peregrino.

RuGian (EI) cobarde. P.-Lope de Rued.

Este títuln dió Yoratin á un Paso publicado en sus origines del lealro, el cual me parece se halla tambien en el Registro de ripresentantes que publicó Timoneda.

Rutian (El) dichoso.-Cervixtes. Comedias y Entremeses.

Ruiseñor (El) de Sevilla-Lope. P. XVII.

Rústico (El) del cielo. T. c. - Lope. Parce $X$ VIII.

Esta comedia, segun Barrera, se conoce tambien por El sunin hermumo Francisco.

Rutrvanscadt (El) ó Quijote trágico. Tragedia burlesca.-JUAY Pisor Y Víats. Edicion de Madrid, Sancha, 1786. 
Saber del mal y del bien.-Calderon. P. I. de 1636 (?), 1640,1685 y 1726 , cn el Tom. II. de la de Fernáudez de Apóntes, y ell el $I$. de la de Keil.

Saber del mayor peligro triunfar sola una nujer. La Elvira.-Ant. Valladires y SoTONiYOR.

Saber desmentir sospechas. - Calneron. P. Y. C. A., á la que copia ciegamente el Índice de Medel. Con todo Vera Tásis cuenta csta comıdia entre las que se lian atribuido indebidamente á Calderon.

Saber (El) por no saber, y vida de S. Julian de Alcalá de Henares.-Lope. Parte XXIII.

Saber premiar la inocencia y castigar la traicioll.-Ant. Valladáres y SOTOMIYYR.

Saber (El) puede dañar.-Lope. P. XXIII.

Saber ser loco es cordura.-Alonso CaresPO dE la Pixilla.

Consta anónima en Medel.

Sabia (La) Flora mal sabidilla.-Sir.as Barbidllo. Madrid, I621.8.

Especie de comedia en prosa y verso, ó novela puesta en diálogo.

Sabio (El) en su retiro.-Mátos. Parte XXXIII. C. A.

Tengo una edicion muchn más reciente en la que se le ha puesto el titulo de $E l$ sabio en su reliro y villano en su rincon, $\mathrm{y}$ he visto otra en que dice ademas Jum La brador. La lia publicado el Sr. Mesonero en la Biblioleca de Ribadeneira.

Saco (El) de Roma, y mucrte de Borbon, y corouacion de nuestro invicto emperador Cärlos V.-Juan de la Cueva. Comedias y Tragedias, y ell el Tom. I. del Tesoro del teatro español.

Medel trae una con el titulo de Saco de Roma que atribuye, á mi modo de ver equivoradamente, á un D. Antonio de la Cueva, y otra que sin duda es de Juan de la Cueva que intitula: Cerco de Rimma y muerle de Borbon, y tambien se la adjudlca al Anlonio de la Cueva.

Sacrificio (El) de Ifigenia.-CAÑżiREs.

Barrera la intitula primera parte. Sin duda Trlguérns quiso que su refundicion de la de Calderon formara la segunda.

Sagaz (EI) Estacio, marido examinado. En prosa.-Aloxso Jeróvimo dE Sílas Barbadillo. Madrid, 1620 y $\mathbf{1 6 2 1 . 1 2 0 ^ { \circ }}$

Salir el amor del mundo.-V. Venir el amor al muindo.
Salvaje. (Comedia).-Romero de Cirpeda. Obras, y en el Tom. I. del Tesoro del teatro español.

Con este titulo atribuye Medel una pie$\mathrm{za}$ al $\mathrm{P}$. Valentin de Céspedes. Barrera se equivoca en llamar á esta comedia Selvaje.

San Acisclo y Santa Victoria.-V. Mártires (Los) de Córdova.

San Alejo.-Comedia traduzida de un libro de prosa suyo en diversidad y variedad de verso castellano por LóPEZ DE Úbeda y por Cornejo ne Rójas. - Se halla en el Cancionero de libeda, 1586.

Sall Alejo.-V.Vida (La) de san Alejo.

San Antonio Abad.-Fersando de ZaraTE. P. $X X X . C A$.

San Antonio de Padua.-V. Divino (El) portugues.

San Bartolomé en Armenia.-Crisr. or Mosrol y Silva.

Medel la trae anónima y cita una Segunda purte que solo lleva el título de San Bartolomé.

San Bernardo.-V. Más (El) ilustre frances, san Bernardo.

San Bernardo Abad.-Binces Candamo. Poesias cómicus. Tom. II.; allí se dice que solo las dos primeras jornadas son de este alitor y la tercera de D. Juan de la Hoz Mota.

San Diego de Alcalá.-Lope, P. III. C A.

San Emeterio y san Celedonio, mártires de Calahorra.-V. Tres (Los) blasones de España.

San Estanislao.-V. Obispo (El) de Crobia, san Estanislao.

San Francisco de Borja, duque de Gandía - Meichor Fernandez de Leon. P. XLII. C. A.

El verdadero autor se supone ser el P. Pedro de Fomperosa y Quintana.

San Francisco de Paula.-V. Divino (El) calabres, S. Francisco de Paula.

San Franco de Sena.- V. Lego (El) del Cármen.

San Froilan.-V. Segundo (El) Moises.

San Isidro, labrador de Madrid.-LOPB. P. VII. de sus Comedias, y XXVIII. C. $\boldsymbol{A}$.

Esta comedia es diversa de las dos de Lope de S. Isldro, que se hallan en el tomo de Fiestas a su canonizacion, intituladas: Niñez y juventud de S. Isidro. Barrera cita una de este autor con solo el título de San Isidro de Madrid. 
San Jerónimo, cardenal de Belen.-V. Cardenal (El) de Belen.

San Juan Bautista.-Ceistóval dB MonRoI.

Es comedia y no auto sacramental como dice Barrera.

San Juan Bueno. - V. Hijo (El) de la virtud.

San Juan de Dios.-V. Juan de Dios y - Anton Martin.

San Juan de Sahagun.-V. Patron (El) de Salamanca.

San Juan Francisco Régis.-En obsequio de este santo hai unos poemas cantables para representarse, en el tomo de ViÑERTA, intitulado: El nuevo sol de la Francia.

San Justo y Pastor.-V. Dos (Los) mejores hermanos.

San Lázaro. - V. Fida y muerte de san Lizaro.

San Luis Bertran.-Moreto. P. XXVI. C. A.

Es de Gaspar Aguilar y se publicó en sus Fiestas áln bealificacion del sunto.

San Mateo en Etiopia.-Felipe Godívez. P. XXVIII. C. A.

El autor promete al fin una segunda parte.

San Nicolas de Tolentino,-Lope. Parte XXIF. Zaragoza, 1641.

Tambien es El sunto de los milagros, segun Barrera.

San Pedro de Alcántara.-V. $H_{i j o}(E l)$ del serafin.

Sancbo Ortiz de las Roelas. Tragedia arreglaula por TRIGUEROS.

Es una refundicion de la estrella de Sevilla de Lope de Vega. Barrera en su indice no la menciona ni bajo uno ni otro título.

Sangre (La) leal de loc montañeses de Navarra.-Tíre EGA. P. I. Poetas ralencianos, y en la Biblioteca de Ribadeneira.

Medel la intilula equivocadamente Sangre real.

Sanson.-V. Valiente (El) nazareno.

Santa Bárbara. En catalan.-V. Gloriosa (La) verge y martir.

Santa Brígida. - V. Limpieza (La) no manchuda.

Sañta Columba de Reati.-V. Amar ántes de nacer y Paloma (La) dominica.

Santa Ines, la de los lindos cabellos.-V. Cielo (El) por los cabellos.

Santa Isabel reina de Portugal.-Rójas Zorrllla. P. I.
En la $P$. XXXI. de las de d fuera, 1638, se halla anónima.

Santa (La) Juana. Primera y segunda parte.-Tinso. P. $\boldsymbol{V}$.

La tercera parte de esta comedia ofrecida por el autor al fin de la segunda, existe manuscrita original en la biblioteca del duque de Osuna, segun Hartzenbusch. En el Indice de Yedel se incluyen la t., II. y III. partes de Sanla Juana de la Cruz, y se atribuyen á Gabriel Téllez, es decir, á Tirso. Esto me prueba que tambien se imprimió la tercera parte.

Santa Juliana.-Diamaxte. P. I., y Ameno jardin de comedias. 1734.

Santa (La) Liga.-Lope. P. $X \boldsymbol{V}$.

Es sin duda La butalla naval del Pere. grino.

Santa Madrona. - V. Vida (La) y muerte de Sanla Madrona.

Santa Maria del Monte, y convento de San Juan.-Diayante. P. I.

Santa María Magdalena de Pazzi.-DiAMANTE. $P$. $I$.

Santa Olalla de Mérida. - Fraxcisco GoyzÁlez de Bístos. P. XYII. C. A.

Creo que no sea cierto el que Mátos Fragoso escribiese una con este título, segun pretende Barbosá.

Santa Pelagia.-Feriano Zarate. Parte $X L I V . C . A$.

Barrera la da tambien el tílulo de La Marrgurila de los cielos, y más firme penitencia.

Santa Rosa del Perú.-Moreto. P. II.

En la $P$. XXYYT. C. A., donde tambien se balla, dice que las dos primeras jornadas de esta comedia fueron las últimas que escribió Morelo en el discurso de su vida, y que la tercera la hizo D. Francisco Lanini Sagredo.

Santa Rosalea.-V. Mejor (La) for de Sicilia.

Santa Susana.-Y. Historia de santa Sibsana.

Santa Teresa de Jesus.-Diamixte. P. II. En las Daze commerlias de varios. Tortosa, 1658, hai una intitulada: La bichavenlura. da malie Santa Teresa de Jesus, de Luis Vélez.

Santero (El) Macario, ó el santo Macarro. P. - Lúcas Fervíidez. Paso de la égloga de $E t$ Nacimiento, reimpreso por Gallardo en el núm. $4 .^{\circ}$ del Criticon.

Santiago el Verde.-Lope. P. XIII.

Santísimo (El) Nacimiento de N. S. Jesu Cristo, al modo pastoril. Danza.-SciREZ DE Róbles. Madrid, 1606.

Ilai una edicion mucho más anligua. 
Santo (El) Cristo de Cabrilla.-Moreto. P. XXXIV. C. A.

se counce timbien con el título de $E l$ cirislo de los milayras, y así se hallia en la P. M11. de Moreto, Madrial, 1681. Vedel la intilnla mal, Santo Cristo de Culabriur.

Santo (EI) de los milagros.-- V. San Nicolas de Tolentino.

Sanlo Domingo ell Soriano.-Moxraluas. Edicion anligna.

Santo (EI) hermano Francisco.-V. Rúslico (El) del ciclo del mismo autor.

santo (El) negro Rosambuco de la ciudad de Palermo. - Lope. En la llamada III. Parle de sus Comedias.

Barresa da tambien a esta pieza el título de lida y w.n'rite del sanlo negro, llamado S. Bemilo di: Pulermo, que es el que lleva en la Trubla de dicha P. III.

Santo (El) niño de la Guardia. - V. Niño El inocente.

sainto Tonas de Villanueva.-Disurats. P. IXIII. C. A.

Santoy sastre-Tirso. P. IV.

li imlice de Vedel la trac con este titulo y con el de San Ilmmobom, y en los Lituli-

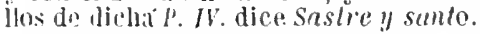

Sara Sampson. Tragedia en prosa.-A.ióviso.

Saslie (El) del Campillo.-Lope. Parle IIVII. cslraiagante. Barcelone, 1633.

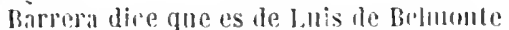
Bermuldez. Es distinta de lit que con igrul Ĺtulo escribio Báuces Cilumlantuo.

Sastre (El) del Campillo.-Bixes Cixmyo. Tom. II. de sus Obras cómicas y (ill el de sus Comedias escoyidas, $18332^{\circ}$. Tambien so imprimió en el tomo rle dramáticos de la Biblioleca de Riballeucira.

Biartera añale al tllulv el viltimo verso de la comedia, que dice: buelos de homory ve slos.

Sastre y santo.-V. Santo y saslre.

Satisfacer callando. - Moneto. Parle I.YYVII. C. A.

Segmin Barrerd is los lermanos inconbarlos de la Parle III. he dicluo Vereto, Valrid, |tisl, y limbicns intilnta: Salisfucer callando y prince'su de los montes, el mna impresion antigua y suclla que tenon,

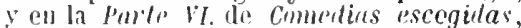
Zarajoza, lia.j, atribujendose en almbis aliciolues à lope.

Consta cumo de este antor en ol indice. de liarrera con el título: l'rincesa de los momles, i los hermamos amcomlrados.

Secreta (Ia) venganza de don lope de Almeida. - V. A secrelo agravio secre- ta venganza, o vengarse en fuego y en agua.

Secretario (El) de sí mismo.- l.ope. P. VI.

Secreto (El) á vozes.-Cithorrox. P. VI. de 1683 y 1715 , en el Tom. VIII. de la edicion de Fernáudez de Apintes, en el III. de la de Keil. con-la Parte $X \mathbf{L I I}$. le las de á fuera, Zaragoza, 1650, y en el Thealrohespañol de IJuerta

Secrelo (EI) entre dos amigos. - Moreto.

No se publicó cu las partes de este aator; sin dinda no serí silya poes en la Parle XXXV. de la Coleccim anligun estí á nombic de .lira de Ameseria con el título de El gralien secreto.

Segunda comedia de Celestina, en la cual se trata de los amores de un eaballero, llamado Félides, y de una doncella de clara sangre, llamada Polandria. $\boldsymbol{E n}$ prosu y algo de verso.-FElacilio DE Sil.vi. Medina, 15̈34, Venecin, 15336 y Amberes, s. $a$.

Segunda Celestina. - Aliustin ne Sal.AZ.1R, refundida en 1818 por... Manuscrilu.

Segunda jornada de la zarzuela de hazer cuenta sin la huéspeda. Con Loa y Matachines nuevos.-V. Hacer cuenta sin la liuéspeda.

Srgundo (El) Cristo.-V. Niño (El) inccenle.

Segundo (El) Escipion-Cildofon. Parle VII. de 1683 y 1713 , en el Tom. $X$. de la edicion de Fernández de Apóntes, en el III. da la de Keil, y segun Bariera se imprimió suelta en Nápoles, por Salvador Caslaldo, 1681.

Segundo (El) Moises, san liroilan.-Mitos. P. HIX. C. A.

Bamera se equivoca en decir que esta comedia va como de un Ingenio ell dichi larte, porque el nombre de llitus se halla al principio de la piaza y eu los litulitos que encabezan las pigs. impires. Segun dice el mismo Barrera aparece por un calílogn de la bih. de Gímez, quis Norelo luvolambica parte en su composicion.

Segundo (El) Séucea de Espaĩa, y príncipe D. Cárlos. - Mostiıvıs, en el Para todos.

La segunda parte se intitula: Séneca $(E l)$ de Españu, D. Helipe II.

Selva (La) de Albania y zeloso de sí mismo.-V. Pustoral (La) de Jacinto.

Sclva de amor y zclos.-Rósis Zorrilla. P. XXIII C.A.

Selva (La) sin amor. - Égloga pastoral. - Lope, al fin del Laurel de Apolo, y en el Tom. I. di sus Obras suellas edicion de Sancha. 
Selvajia (La). En prosa.-Alonso DE V llégas Selvago. Toledo, $155 \% 4.40^{\circ}$

Selvas y bosques de amor.-LOPr. Parte XXIV. Zaragoza, 1633.

Sembrar (El) en buena tierra. - Lope. $P$. $X$.

Semejante (EI) á sí mismo. - Rulz DE a larcon. P. $I$.

Semíramis. Tragedia en un acto.-GAsPAR Zabala Y Zamora.

Séneca (EI) de España, D. Felipe II. Segunda parte. - Mostalvas. Tom. II.

La primera parte se intitula: El segundo Séneca de España.

Séneca y Neron.-Calderon? P. X VIII. C. A.

El Indice de Medel la llama Séneca Neron y la atribuye al mismo Calderon; lo que es un error, segun Vera Tásis.

Sentencia (La) sin firma.-GasPar de ÁviLA. P. II. C. A.

Barrera añade al titulo ó $S$. Juan CapisIrano.

Señor (El) de noches buenas.-Cubillo DB Aragos. Enano de las Musas, tomo de las escogidas de este autor, Madrid, 1826 , y en el XLVII. de la Biblioleca de Ribadeneira.

Cubillo se queja en el Enano de que se hubiese impreso esta comedia á nombre de D. Antonio de Mendoza lo cual, segun él mismo dice, debio de ser malicia de algun émulo suyo.

El Indice de Medel trae la de Mendoza como distinta, y en la Flor de las doce mejores comedias es donde se encuentra con su nombre.-Barrerà la da tambien el titulo de $D$. Enrique del Rincon.

Señor (El) Don Juan de Austria.-MosTALYAs. Tom. $I$.

Señora (La) y la criada.-Calderox. Parte IX. de 1691 y 1698 , en el Tom. I. de la de Fernández de Apóntes, en $\boldsymbol{e l} \boldsymbol{I} \boldsymbol{V}$. de la de Keil, y en la $\boldsymbol{P} . \boldsymbol{X} \boldsymbol{L} \boldsymbol{V} \boldsymbol{I}$. C. $A$.

Señorita (La) displicente. En un acto. Ramon dE la Cruz.

Señorita (La) mal criada. - ToyAs DE IRIARTE.

La ture impresa en $. f a d r i d, 1788$, y ademas el plan en prosa el primer borrador en verso y la copia en limpio. La edjcion que ahora poseo techa en Barcclona solo dice que es del autor del Señorito mimado.

Ser fino y no parecerlo. -AvT. DE ZAyoRA. Tom. II.

Ser prudente y ser sufrido.-Movtalyas. Tom. 1. de sus Comedias escogidas, Madrid, 1827, y en la Biblioleca de Ribadeneira.
Será lo que Dios quisiere.-Prdro Fraxcisco Lavini Sigredo. P. $\boldsymbol{X}$ LII. C. $A$.

Serafin (El) humano.-Lope. P. $\boldsymbol{X} \boldsymbol{I} \boldsymbol{X}$.

Al tin de esta comedia dice:

"se da á la primera parle

nin del Serafin bumano.

No sé si la segunda se habrá publicado.

Barrera dice que se adiciono este títule con el nombre de San francisco, y que tal vez sea la comedia conocida por La gloria de San Francisco.

Serafina.-Tórres Niharro. Propaladia. Serafina (Comedia). En prosa.-Axóximo. Se imprimió con la Tebaida y la Hipólita en Valencia, 1521, y solo con la primera en Sevilla, 1506.

Es distinta de la de Tórres Naharro.

Serafina. Tragedia en prosa. - Alorso DB LA VEGA.

Serra da Estrella. Tragicomedia pastoril porluguesa.-GIL VICE.TE.

Barrera no la trae con este titulo que es el que lleva en la edicion de las Obras hecha en Hamburgo, sino con el de Tragicomedia al parlo de la reina.

Serrana (La) de la Yera.-Lope. P. VII. Serrana (La) de Tórmes.-Lope. P. XVI.

En la dedicatoria dice el autor, que en esta comedia probu la pluma en el principio de sus estudios.-Tengo un MS. antiguo con variantes.

Servir á buenos.-Lope. P. XXIV. Zaragoza, 1641, y en la Coleccion de las mejores comedias de Lope. Madrid, $180 \mathrm{~s}$. $4^{\circ}$

Servir á señor discreto.-Lopr. P. XI.

Servir (EI) con mala estrella. - LOPE. P. VI.

Servir más por querer más.-JERóNiyO DE Villaizay.

Servir para merecer-Diamite. $\boldsymbol{P}$. XII. C. A.

Servir sin lisonja.-GasPar dE Ávila. P. XVI. C.A.

Sesóstris , rei de Egipto. -Axósimo. Moratin atribuye á $D$. Ramon de la Cruz una tragedia con el mismo titulo.

Sí (El) de las niñas.- Ivarco Celcesio (Leandro Fernández de Moratin).

Si el caballo yos han muerto, y blason de liss Mendozas. En lenguaje antiguo.LUIS YÉLEZ.

Barrera la trae con el titulo: Si el caba. llo vos han muerto, subid, rei, en mi cabrtllo; yo la tengo con solo el de Si el caballo vos han muerio, atribuida á Lope $\mathrm{y}$ con algunas variantes.

Si no vieran las mujeres!-Lope. Vega del Parnaso, en el Tom. X. de las 
Obras sueltas, edicion de Sancha, en el III. de las Comedias escogidas de este autor, Madrid, 1830 , y en el II. del Tesoro del teatro español.

Si toda la vida es sueño, en el sueño está la muerte, y el asombro de $\mathrm{Pa}$ lermo.-V. En el sueño eslá la muerte.

Si una vez llega á querer, la más firme es la mujer- - Cañizarias.

Sibila (La) del Oriente y gran reina de Sabá. - Calderon. $P$. $V$. de 1694 y 1730 , en el Tom. IX. de la de Fernảnder. de Apontes, y en el III. de la de Keil.

Siempre ayuda la verdad.-Tirso. P. II.

No es por entero de Tirso, segun llartzenbusch, en la pág. XXXYil de los preliminares del tomo de Comedias escogidas de dicho aulor; quizas fué su colaborador Ruiz de Alarcon, $y$ á nombre de este la trae Vedel.

Siempre hai que envidiar amando. Drama con música.-ANT. DE ZAMORA. Tomo $I$.

La tengo suelta como anónima. Barrera dice que tal vez sea la de Amando siempre hai desdichas, publicada sin nombre de autor.

Siempre vence la razon. Coloquio nuevo. -Avóximo.

No la menciona Barrera. Uno de los personajes habla en portugues. Este Coloquio se escribió en la época de Felipe V. duran. te la guerra de sucesion.

Sierras (Las) de Guadalupe.-Lope. Impresion suella y antigua.

No se halla en las Partes ni la menciona Barrera en su Indice.

Siete (Los) durmientes, y más dichosos hermanos.-Moneto. P. XIX. C. A. y III. de las Comedias de este autor $\mathrm{Va}-$ lencia, Orga, 8. a.

Barrera dice que con el título de Los más dichosos hermanos se encuentra en la otra P. III., impresa en Madrid en 1681.

Siete (Las) estrellas de Francia.-Luss Beluonte. $P$. $X X I$. C. $A$.

Yo la be tenido con la adicion al tftulo; San Bruno.

Siete (Los) Infantes de Lara. T.-JoaN DE la Cueva. Comedias y Tragedias.

Sigue Medel llamando Anlonio á Juan de la Cueva.

Siete (Los) Infantes de Lara en lenguaje antiguo. Gran tragedia con Loa y un Baile curioso de Pedro de Brea.-Huntado dB Velarde (Alfonso?), vecino de Guadalajara. Se halla en la que Nicolas Antonio llama $\boldsymbol{V}$. Parte de las Co- medias de Lope, aunque lleva el título de Flor de las comedias de España de diferentes autores. Quinta parte.

Siete (Los) Infantes de Lara. - V. El bastardo Mudarra.

Siete (Los) Infantes de Lara. Comedia burlesca.-La mitad de Cáncer, y la otra de Juan Vélez de Guevara. El mejor de los mejores libros de comedias.

Silano (El). T.-ANónimo.

Silencio (El) agradecido.-Avónımo. Parte XXXI. de las de a fuera, impresa en 1638.

El Sr. Barrera dice que en un Índice moderno de la librería de Gámez, y en otro indice de la coleceion de Casal, se atribuia decididamente á Lope, y el baron de Münch Bellinghausen sospecha si será del doctor Francisco Toribio Jiménez, colector de la citada $P . X X X I$.

Silesia (La). T.-Josí López Sbdano.

Silviana (Égloga) del galardon de amor. - Luls Hurtado de Toledo. Al fin de su segunda edicion de la comedia Preteo y Tibaldo, s. a. y del Epistolario de Juan de Segura, de Alcala, 1553.

Silla (La) de S. Pedro.-Antonio MartíNEZ. P. $X I$. C. A.

Medel trae otra de Juan Vẻlez que tal vez sea la misma.

Sin armas vence el amor, $\delta$ el mayor triunfo de amor.-V. Más triunfa el amor rendido.

Sin honor no bai amistad, - Antonio GonzÁlez de GarGi-GonzÁlez.

No encuentro esta comedia citada en ningun catilogo, ni Barrera menciona el nombre de su autor, á pesar de que la edicion que yo poseo de esta pieza parece del siglo XVII.

Sin honra no hai amistad.-Rósas ZorRILLA. P. II., y segun Duran, en la $X L I$. de las de a fuera, Valencia.

Sin honra no hai valentía.-Lopr. No se halla en las Partes.

Por la antigüedad de la impresion suelta que tengo, me inclino á creer más probable sea de Lope que de Moreto, como dice en la Parte III. de este, impresa en Vatencia en 1703 , y en la $X X V$. C. A. Medel y Barrera en sus Índices solo la traen á nombre de este.

Sin honra no bai valentía. - Morero. P. III. Valencia, 1676,1703 y Orga, s. a.; tambien en la $\boldsymbol{P} . \boldsymbol{X X V}$. C. $\boldsymbol{A}$.

Es la misma que tengo á nombre de Lope.

Síquis y Cupido. Drama en un acto.Luciano Francisco Comblla.

Sirena (La) de Tinacria.-Diego de Córdova $x$ Figubroa. P. XLIV. C. A. 
Sirena (La) del Jordan.-Caistóval dB Monbol $\mathrm{Y}$ Silya. P. XLV. C. A.

En la Tabla de dicha Parte se antade al tItulo anterior $S$. Juan Bautista, y yo la tengo sucl ta con esta adiclon.

Sitiador (El) sitiado, y conquista de Stralsundo, Cárlos XII., rei de Suecia. Tercera parte.-Gaspar Zabala Y ZAMORA. Madrid, 1787.8.

La primera parte de esta comedia se in. titula: Cárlos XII, rei de Suecia, y la se. gunda: El silto de Pullov por Cários XII.

Sitio (El) de Betulia.-UN INGenio DE LA Corte. P. XXXVI. C. A., y Comedias nuevas, Amstardan, 1726.

Sitio(EI) de Breda.-Cilderon. P. $I$. de 1636 (?), 1640, 1685 y 1726 , en el Tomo III. de la de Fernández de Apóntes, en el $I$. de la de Keil, y en la Parte XXVIII. C. A.

Sitio (El) de Cales.-Lociano Francisco Comella.

Sitio (El) de Olivenza. - Uy Ivgenio. Parte $X X . Y F . C . A$.

Sitio (EI) de Pultov por Cárlos XII. Véase Sitiador (El) sitiado.

Sitio (EI) de Toro y noble Martin Abarca. -Un Ingenio.

Ignoro si será la que Moratin atribuye con este título á D. Vicente Rodriguez Arellano.

Soberana Vírgen de Guadalupe.-V. en los Autos con igual título.

Soberbia (La) de Aman y humildad de Mardoqueo.-Y. Hermosa (La) Ester.

Soberbia (La) de Nembrot.-ANT. ENriQUEz Gómez.

Entre las copias manuscritas, equivocada ó falsamente atribuidas á Lope que poseía lord Holland, estaba La soberbia de Nembrol y primero rei del nundo.

Socorro (El) de los mantos.-CÁrlos DE Arellano. P. $X X X I . C . A$.

Medel y otros atribuyen esta pieza á D. Francisco de Leiva Rainirez de Arellano.

Sol (El) á media noche y estrellas á medio dia.-JoAn Bta. Villégas. P. VII. C. $A$.

Sol (El) de el Occidente, S. Benito.Cañizáass. Tengo un manuscrito de 1697 de esta comedia, que no he visto impresa.

Sol (El) de España en su Oriente, y toledano Moises. - Axónimo.

Moratin y Barrera la atribuyen á D. Manuel Fermin de Laviano.

Sol (El) de la sierra.-Diamantr. P.I., y Ameno jardin de comedias. 1734.
Sol (El) del (Oriente, San Rasilio Magno. - Pedro Francisco de Lavisi Sagredo.

Sol (El) obediente al hombre.-Garcia Aznar Vélez s. (Andres González Barria). P. XLVIII. C. A. y Comedias nuevas. Amsterdam, 1726.

Sol (El) parado.-Lope. P. XVII.

Segun Barrera, Gómez Enriquez escribió, pero no publicó, una comedia con este mismo título, y la de Lope parece que tambien suele denominarse: Ascendencia de los macstres de Sanliago.

Soldadesca.-Tóras Nararro. Propaladia.

Soldado (El) amante.-Lope. P. $\boldsymbol{X} \boldsymbol{V I I}$.

Soldado (EI) más herido, y vivo despues de muerto, Sau Sebastian. - Pedro DESTENOZ Y LODOSA.

Este es el titulo de la comedia y el apellido de sil autor en dos ediciones que tengo, hechas en Madrid y sevilla á principios del siglo XVIIl. Barrera dice que en la l'arte XXIV. de la Coleccion antigua se intitula solo: El Soldado mús herido, y vivo despues de muerto, $y$ al autor le llama Pedro de Estenoz.

Solo el piadoso es mi hijo.- Mítos. Vıllaviciosa y Avellaseda. $P$. XXI C. $\boldsymbol{A}$.

Consta anónima en Medel.

Solo en Dios la confianza.-Rosete Nix̃o. P. XYI. C. A.

Solteron (El) y su criada. - Formada sobre la que escribió en frances Mr. Coluin D' Harleville por D. T. G. S. (D. Tomas García Suelto.) En el Tom. III. del Teatro nuevo españul.

Sombrero (El) que habla. En prosa.Asósino, traducida por D.M. A. Igual.

Sordo (El). Farsa.- Se atribuye á Lope DE Roeda. Tengo dos ediciones, una gótica de Valladolid s. a., y otra en letra redonda $s$. $l$. ni $a$.

Sordo (EI) y el montañes.-Melchor FerNÁSDEZ de LeOx. P. XLIV. C. A., en el Theatro hespañol de Huerta, y en la Biblioteca de Ribadeneira.

Sortija (La) de Florencia.-SEBastiax DB Villaviciosa. P. $\boldsymbol{X V I I} . \boldsymbol{C}$. A.

Medel atribuye csta comedia a D. Fran. císco Mesa y á Villaviciosa.

Sortija (La) del olvido.-LOPE. P. III.

Subordinacion (La). Tragicomedia en prosa.- J. M. C. B.

Sucesos (LOS) de tres horas. - LEIS DB Oviedo. P. XXVI. C. A.

Barrera presume si este autor será D. Luis Antonio de Oviedo y Herrera, conde de la Granja.

Sucesos (Los) en Oran por el marques 
de Ardáles.-Lùs Vélez. $P$. XXVII. C. $A$.

Medel la atribuye equivocadamente á D. Juan Vilez.

Sueño (El). Drama en un acto.-Axósiмo. Está traducido por D. E. F. Castrillon.

Sucño (El) del perro. Competencia de animales terrestres y volátiles. Va precedida de una Loa.-Avosino. Impresion suella.

Sueño del perro. Segunda comedia. Axóxivo. Impresion suella.

Estas dos comedias satíricas, cscritas contra los enemigns de Felipe V., forman la tercera parte de Hacer cuenla sin la hitéspeta.

Sueños hai que lecciones son, ó efectos del desengaño. Drama alegórico en prosa.-Refundido por D. M. A. Igual.

Sueños hai que son verdades, y D. Felipe V. en Estrenadura. - Axóvino. Impresion suelta de Lisboa, s. $a$.

El autor ofrece al fin una segunila parle que no sé si salio.

Sueños hai que verdades son.-V. Trabajos (Los) de Jacob.

Suerte (La) sin esperanza. Precedida de una Loa.-Gaspar Agullar. P. II. de los Poelas valencianos.

Tacaña (La) de San Lucar.-V. Playa (La) de San Lucar.

Tambien bai duelo en las danias. - CaI,DERON. P. $I I I$. de 1664,1687 y 1726 , en el Tom. VI. de la de Fernández de Apóntes, en el II. de la de Keil, y en el Theatro hespañol de Huerta.

Tambien hai duelo en los santos. - UN INGExio.

Barrera no cita ninguna comedia con este título de un lugenio; la que menciona con (il se la dtribuye á 1 . Juan Salvo y Vela, y tal vez sea la misma.

Tambien hai piedad con zelos.-Dos Garcíl A 7.sar BĖlez. s. (Andres González Barcia.) P. XLVIII. C. A.

Vedel atribuye una con igual tltulo á suan Vélez de Guevara.

Tambien la afrenta es veneno.-LuIs VElez, Coel.lo y Rósas. Comedias de los mejores. Colonia, 1697.

Consta en Medel anouima.

Tambien las paredes oyen.-Y. Paredes (Las) oyen.
El Indice de Medel llama á este autor D. Francisco.

Suertes (Las) trocadas, y torneo venturoso. Precedida de loa.-Tärrega. P. I. de los Poetas valencianos.

Sufrimiento (El) premiado.-Montalvan. Tom. II.

Sufrir más por querer más. -JERón. DE Villaizan. $P$. XLIV. de las de a fuera, Zaragoza, 1652. Segun Duran se balla tambien en la $\boldsymbol{P}$. $\boldsymbol{X X V}$. de las mismas, Zaragoza, 1632, y se ha reimpreso en la Biblioteca de Ribadeneira.

Se escribió esta comedia en competencia de la de Montalvan intitulada: La mas conslante mujer, segun consta de un soneto de D. Pedro Peña, que poseo en un volúmen MS. de 1638.

Sufrir más por querer ménos.-Rodrigo Exríouez. P. X. C. A.

Sufrir más por valer más.-Jerónımo DE la Cruz y Mexnoza. P. XXXI. C. $A$.

El Índice de VIedel atribnye una comedia con el mismo título á sor Juana Ines de la Cruz, y otia á D. Antonio de Mendoza : en ambos casos se equivoea.

Sutilezas del amor y el marques del Camarin.-Y. Amar por razon de eslado.

Tambien por la voz hai dicha.-CıN̄ıziRES.

Tambien se ama en el abismo. Con Loa. - Salazar y Tórres. P. II. de su Citara de Apolo, XXXVIII. C. A., donde se la llama fiesla de zarzuela, y en una $P$. XLI. estravagante de varios.

Jimeno dice que la tercera jornada es de D. José Orti y Nóles.

Tamorlan (El).-Luis VĖLEz.

Tambien se publicó con el titulo de Nueva (La) ira de Dios y gran Tamorlan de Persia. (Véase). - Medel la atribuye indebi damente á D. Juan Vèlez.

Tancredo (EI). T. -A Nósiso.

Tanto es lo de más como lo de ménos.Tirso. P. $I$.

Tao (EI) de S. Anton.-ANónimo. Manuscrito de principios del siglo XVII.

En el Indice general de Medel se cita una de D. Andres de Claramonte con el mismo titulo, y Barrera dice que existe Ms. en la bib. del duque de osuna. 
Teagénes y Clariquea.-V. Hijos (Los) de la fortuna, Teugines y Cariclea.

Teagénes y Clariquea.-Mostalvan. Tomo $I I$.

Posteriormente se ha reimpreso con el tItulo de Los hijos de la forlma. Es distin. ta de la de Calderon que tiene este último titulo.

Tebaida (Ĺ). En prosa y rerso.-AxóNimo. Impresa con la Hipólita y la Serafina, en Valencia, 1521, y con la segunda solamente en Sevilla, $15 \mathbf{k 6}$.

Tejedor (El) de Segovia.-Ruiz de AlarCon. P. II., y Tom. III. de sus Comedias escogidas. Madrid, 1867.

Esta es la que se denomina segunda parte del Tejedor' de Segovia en las ediciones modernas y en el tnm. II. de las Comedias escogidas de este autor, Madrid, 1829. De la primera no poseo edicion alguna antigua que lleve el nombre de Alarcon. La que tengo, en la que ya se encuentra, es de Barcelona, 1771. Ochna ha reimpreso una y otra en el lom. IV. del Tesoro del teatro españal. Ambas salieron malamente como de Calderon, segun lo previene Vera Tásis, y Alarcon se queja tambien de ser esta una de las comedias que se le Labian usurpado. Medel pone una de este autor, y las dos partes las atribuye á Calderon.

Tejedor (EI) Palomeque y mártires de Toledo.-V. Mártires (Los) de Toledo.

Telémaco en la isla de Calipso. Drama heróico en un acto.-D. J. P. D. L. C.

No sè si esta pieza seri la que Moratin atribuye á un anónimo de la segunda mitad del siglo XVIII. con solo el título de Telémaco.

Tellos (Los) de Menéses. Primera y segunda parte.-LOPE. $\boldsymbol{P}$. XXI.

Ademas las tengo de impresion suelta y antigua con el mismo titulo, $y$ und edicion más reciente de ambas partes con el de Valor, lealtad y ventura de los Tellos de Menéses: no estrañaré se haya denominado asl desde época más añeja, porque poseo otra impresion antigua de la segunda par. te con el mismo titulo.

Temperanza. Égloga moral, en portugues. - Francisco Manuel de Melo. Obras métricas.

Templarios (Los).-Mostalyax. Tom. $I$. Templo d'A pollo. Tragicomedia portuguesa.-GiL Viceste. Obras.

En esta pieza todos los personajes representan en español, mẻnos un Villano.

Tener zelos de sí mismo.-Gaspar ZabaLA I ZAMORA.

Tercera (La) de sí misma.-Calderon. P. VIII. C. A., y la XXXII. de las de a fuera. Zaragoza, 1640.
Medel tambien la alribuye á este autor: pero Vera Tásis niega que sea suya bajo el presente Litulo ó bajo el de Amor inyenio $y$ mujer, que es el otro con que se co. noce. Su verdadero autor es Mira de Ames. cua, segun lo dice en las Doze comedias de las mas fuminsas, Lisboa, 16 19 , y en un MS. de la bib. del duque de Osuna fechado en 1626 , en el que lleva el título de La tercera de símisma: amor, ingenio y mujer.

Tercera parte de. la tragicomedia de Celestina. En prosa. - Gaspar Gómez. Toledo, 1ว39. $4 .^{\circ}$ gót.

Tercero (El) de su afrenta. - A.it. MaвtiAez. P.XV.C.A., y en los Dramálicos posteriores á Lope de la Biblioteca de Ribadeneira.

En las Aleluyas jocosas de Ant. Abad l'e. lasco se halla un Paso trovulo de esta comedia.

Tesorina (Comedia intitulada). - JAIYE Guete. S. l. ni a. $4 .^{\circ} \mathrm{g} b$ t.

Testigo (EI) contra si.-LOPE. P. $\boldsymbol{V I}$.

Testimonio (EI) vengado, - LopE. P. I .

Creo que se publici tambien con el tru. lo de Cómo se vengan los nobles.

Tétis y Peleo.-José de Bolea. P. XXIX. C. A.

Es distinta de la que con igual título se encuentra en las obras de Salazar y Tórres, y por lo tanto no cabe la duda del Sr. Barrera.

Tétis y Peleo. Precedida de Loa.-SiLAzar y Tórres. Tom. II. de su Cílara de Apolo.

Es diversa de la de D. José Bolea.

Tía (La) de la menor.-Mátos. P. I.

Barrera añade al tltulo ó alld se verd.

Tia y sobrina.-V. De fuera vendrá.

Tierra (La) de Jauja. P.-Lope. Deleitoso.

Segun Barrera este es el título que pare ce debe darse á uno de los dos pasos de Rueda que dejó de incluir Moratin en sus Origenes del lealro.

Tinelaria.-Tórres Namarro. Propaladia.

Tio (El) y la tia. Z. -Rimox dE LA CRUz. Tom. $V$. de su Teairo.

Tirano (El) castigado.-Lope. P. IV.

Tirano castigado.-DiA MANTE. P. XXXVI. C. $A$.

Es distinta de la de Lope.

Tirano (El) de si propio.-Gabriel Blaxco Alvarez.

Todo cabe en lo posible.-Fersiado DE Álla. P. XXFI. C. A

Medel se equiroca en llamar Gaspar á este autor.

Todo es dar en una cosa,-Tirso, P. IY. Posteriormente saliú con el tllulo de 
Tndo es dar en una cosa, y hazañas de los Pizarros. Primera parle, y con él se encuentra en el tom. $I V$. de las Comedias escogidas de este autor, Madrid, 1853.V. Amasonas en las Indias y Lealtad contra la envidia.

Todo es enredos amor.-Dibgo dB Córdova y figueroa. P. $X X X \boldsymbol{X} I I . C . A$.

La tengo suelta con el título de Todo es enredos amor, y diablos, son las mujeres, á nombre de este mismo autor, y como de Moreto se halla en la Parte III. de sus Comedias, Valencia, 1676 y 1703 , y Vulencia, Orga, s. a. Medel la cita con el título de Diablos son las mujeres.

Todo es ventura. - Ruiz ne Alarcon. $P$. $I$.

Todo lo vence el amor.-Zamora. Tom. I.

En el tomo intitulado: Flores de el Parnaso hai un Entremes, un Baile y un Sarao para esta comedia.

Quizas ha salido tambien á nombre de Calderon cuando Medel menciona una de este autor con el mismo titulo.

Todo sucede al reves.-Rosbtr Niño. Segun Barrera está en las Doze comedias de las mas famosas. Lisboa, 1649 , y forma la segunda parte de Los Médicis de Florencia.

Tolomea. En prosa.-Alonso de la Vega. En sus Tres famosisimas comedias, Valencia, 1566.

Toma (La) de Breslall.-Gaspar Zabala Y Zamora.

Toma (La) de Sevilla por el santo rei Fernando.-Cristóval de Moráles.

Tambien lleva el título de Nentir con honra, y conquista de Sevilla por San Fernando, en un MS. citado por el Sr. Fernández-Guerra.

Toquera (La) vizcaína.-Montalvan. Tomo I. de sus Comedias. en el II. de las Escogidas, Madrid, 1831 , en el IV. del Tesoro del tealro español; segun nota de D. A. Duran, se halla en la $\boldsymbol{P}$. XXIX. de las de a fuera, Valencia, 1636 , y tambien se ha reimpreso por Mesonero en la Biblioteca de Ribadeneira.

Hai una refundicion de esta comedia que segun Barrera, se intitula: Cuando tocas vendo, desengaños toco.

Torneos (Los) de Aragon-Lope. P. IV. Trabajos (Los) de David, y finezas de Abigail.-Ant. Enriquez Gómez.

Es la misma que La prudente Abigail.

Trabajos (Los) de David, y finezas de Micol.-Gaspar Lozano Montesino. Comedias nuevas, Amstardan, 1726.

El verdadero autor es el doctor Cristóval
Lozano, y se encuentra en la ediclon de 1658 de sus Soledades de la vida.

Trabajos (Los) de Jacob. -Lopk. P. XXII. edicion de Madrid, 1635 .

En el encabezamiento de todas las hojas y aun en el de la misma comedia, despues del nombre del autor, lleva por titulo: Sueños hai que verdades son, y Barrera tambien la intitula: Tragicomedia de la salida de Eqipto. Segunda parte.

Trabajos (Los) de Job.-FeluPE Godínez. P. VI. C. A., y en la XXXI. de las de a fuera, Barcelona, 1638.

No he visto la que con el mismo titulo traen Medel y Barrera atribuida á Lope. Me inclino á creer que no existe, y que han confundido la que forma el asunto de este artículo con la de Los trabajus de Jacob, que es efectivamente de Lope. En la Parte XVIII. C. A. se halla la comedia de Godinez con el título de La paciencia en los trabajos, y Barrera (ignoro por qué) la intitula tambien Los trabajos de Job, y pruebas de la paciencia.

Trabajos (Los) de Tobías.-Rójas ZoRRIl.LA. P. II., en la XXXIII. de las de a fuera, Valencia, 1642, segun D. A. Duran, y en las Doze comedias de diferentes autores. Parte XXXXXVII. Valencia, 1646, segun Barrera.

Trabajos (Los) de Ulíses.-Luts BвцmonTE. P. XLV. C. A., y XLI. de las de $\dot{a}$ fuera, Valencia, segun Duran.

Tragedia (La) del duque de Berganza.Cubillo de Aragon. El Enano de las Musas.

Tragedia (La) del rei D. Sebastian y bautismo del príncipe de Marruécos. LOPE. P. XI.

Tambien salió con solo el título de Bautismo del principe de Marruécos; y con solo el de El principe de Marruécos la trae Lope en su Peregrino.

Tragedia (La) más lastimosa de amor.Antonio Coello. El mejor de los mejores libros de comedias, segun su Tabla, porque en la cabezal de la comedia solo se intitula: La tragedia más lastimosa y no lleva nombre de autor. Por esta razon sin duda, trae Medel una anónima con el título castrado.V. Conde (El) de Sex.

Tragicomedia del parto de la reina.- $\mathbf{V}$. Serra da estrella.

Traicion (La) bien acertada.-Lops. P. I.

Traicion (La) busca el castigo. - Rósas Zornilla. P. $I$.

Traicion (La) contra su sangre. - V. Traicion (La) en propia sangre.

Traicion (La) en propia sangre.-Dirgo dB RIBEba. P. XXXI. C. A. 
Traicion (La) en propia sangre. Burlesca. - Un Ingenio. P. XLV. C. A.

En la Tabla de dicha Parte se intitula: La traicion contra su sangre, y Barrera añade al tiluln: $y$ siete infantes de Lara.

Traiciones de Ricardo. - V. Inocenle (La) Laura.

Traidor (E) contra su sangre.-Mátos. P. I.

Se publicó suelta con el titulo de $E$ t traidor contra su sangre, $y$ siele Infanles de Lara.

Traidor (El) Tiñitas. Tragedia en un acto.-UN INGenio.

No la menciona Barrera á pesar de estar impresa en Valencia en 1718.

Tramas (Las) de Garulla. Pieza en un acto.-Avónimo.

Moratin se la atribuye á D. Gaspar de Zabala y Zamora.

Trampa adelante.-Moreto. P. I., en el Tom. I. de las Comedias escogidas del mismo, Madrid, 1826, y en el Theatro hespañol de Huerta.

Tramposo (El) con las damas, y castigo merecido. - Cublllo dE ArAgov. Así dice en una impresion suelta y antigua que tengo.

Es la misma que El galan tramposo que se halla en Ias Coronas del Parnaso de Sálas Barbadillo como de este autor.

Barrera dice que con el título de El tramposo con las dainas y como de Cubillo está en el Ameno jardin de comedias de los in. signes aulmes... Zamma, Diamante y Cubillo. Madrid, 1734 . Se ha reimpreso en la Biblioleca de Ribadeneira.

Transformaciones de amor. - Villaizan. P. XLII. de las de áfuera, Zaragoza, 1650.

Tránsito (EI) de S. José.-V. Mejor (El) esposo.

Trapero (El) de Madrid.-Ant. ValladáRES \ SOTOMAIOR.

Trato (El) de Argel.-Cervívtes. Viaje al Parnaso de la edicion de Sancba.

Algunos la han llamado Los tratos de Argel.

Trato (El) muda costumbre.-ANT. HoRTAdo DE MEndoza. Este es el título que lleva en la primera edicion de sus Obras, y en la $\boldsymbol{P}$. I. C. $\boldsymbol{A}$; pero en la segunda impresion de Madrid tiene este: $E l$ marido hace mujer, y el $t r a-$ to muda costumbre, y así se intitula tambien, segun los traductores de Ticknor, en la $\boldsymbol{P}$. $\boldsymbol{X} \boldsymbol{X} \boldsymbol{X}$. de las de $\boldsymbol{d}$ fwera, Zaragoza, 1636.

Barrera dice que á nombre de Lope se halla en la $P . X X V I I$. estravagante de este autor, Zaragoza, 1639.

Tratos (Los) de Argel.-V. Trato $(E l)$ de Argel.

Travesuras (Las) de Don Luis Cuello. Primera y segunda parte.-MARCELO DB Ayala y Guzmax.

Travesuras (Las) de Pantoja.-Moreto. P. III. Valencia, 1676,1703, y Falencia, Orga, s. a.

En la $P . X I X, C$. A. lleva el título de Las travesuras del valiente Panloja. En cl volumen de Comedias escogidas, Bruselas, 1704, se intitula: El valienle Panloja. - Promete el autor al fin segunda parle, que no ha salido.

Travesuras (Las) del Cid. Burlesca.- $\mathbf{V}$. Mocedades (Las) del Cid, de Cáncer.

Travesuras son valor.-Tres Irgevios.

Es la misma que la anónima de la $P$. VIII. C. A. Barrera dice que uno de los tres Ingenios fué Moreto, quien la refundió con buen éxito. Otro de los autores podrá ser Málos Fragoso, á quien se la atribuye Bar. bosa.

Travesuras son valor.-Avósimo. Parte VIII. C. A.

Es la misma que la anterior atribuida á tres Ingenios: Barrera supnne que uno de ellos es Moreto. Este la refundio despues y se publicó suelta con igual título.

Travesuras son valor.-Moreto. La tengo suelta impresa en 1747.

Es una refundicion, hecha por Yoreto solo, de la que se publico con igual título $\checkmark$ anónima en la $P$. VIIII. $C$. A., y como de tres Ingenios suelta. Barrera supone que tambien suele intitularse: Don Sancho el Malo y Don Sancho el Bueno y El ejemplo en el castigo, que se encuentra en la P. III. de Moreto, Valencia, Orga, s. a.

Tres (Los) afectos de amor, piedad, desmayo y valor.-Calderox. P. FIII. de 1684 y 1726 , en el $T$ om. $\boldsymbol{F}$. de la de Fernàndez de Apóntes, en el $I F$. de la de Keil, y en la $P$. $\boldsymbol{X I I I . C . A .}$

Tres (Los) blasolles de España.-Rósas Zorailla. P. II.

Se ve que D. Ant. Coello fué colaborador de Rójas por el final que dice así:

$Y$ don Antonio Coello

de su prinera jurnada

pide perdon al senado:

si eslolras dos no os agradan, hoi dun Francisco de Rojas

pide perdon por enlrambas.

Barrera da tambien á esta comedia el $t 1$. tulo de Anles de nacer muriendo, y muriendo vicloriosos, Sun Emelerio y celedonio, martires de Calahorra.

Tres (Las) coronaciones del emperador Carlos V.-Franumo Zabatz. P. XL. C. $\boldsymbol{A}$. 
Tres (Los) diamantes.-Lope. P. II.

Tres (Las) edades del mundo. - Luis VÉLEZ. P. XXXVIII. C. A.

Medel casi constantemente atribuye á D. Juan vélez las comedias de su padre D. Luis.

Tres (Las) justicias en una.-Caldenos. P. IX. de 1691 y 1698 , en el Tom. I. de la de Fernández de Apóntes, en el $\boldsymbol{I V}$. de la de Keil, y en la $\boldsymbol{P} . \boldsymbol{X V}$. C. $A$.

Tres (Los) mayores portentos en tres distintas edades. El orígen religioso y blason carmelitano.-ANr. Bızo.

Barrera trae una comedia intitulada: Los tres mayores prodigios en tres distintas edades, $y$ origen carmetitano, $\mathrm{y}$ se la atribuye à Vlelchor Fernández de Leon, corrigiendo á Moratin que se la adjudica á Bazo. Como no poseo la de leon no me es dado compararlas; pero me inclino á pensar si serán dos piezas distintas.

Tres (Los) mayores prodigios. Precedida de una Loa. - Chlneron. P. II. de 1637 (?), 1641,1686 y 1726 , en el Tom. VI. de la de Fernández de Apóntes, y en el $I$. de la de Keil.

Tres (Los) portentos de Dios. - Luis VÉLEZ.

Barrera añode al tllulo: y principe de la Iglesia.-Medel la atribuye equivocadamente á Juan Vélez.

Tres (Los) señores del mundo.-BelmovTE. P. III. C. A.

Barrera añade á este lítulo y triunvirato de Roma.

Tres (Los) soles de Madrid.-V. Dejar un reino por otro, y martires de Madrid.

Tribunal (El) de los majaderos. Diálogo en verso. - Sílas Birbadillo, en la Casa del placer honesto.

Triunfante (El) martirio y gloriosa muerte de S. Vicente, hijo de Huesca y patron de Valencia. Precedida de Loa.Ricardo de Turia. (Es D. Pedro Juan Rejaule?). P. II. Poetas valencianos.

Barrera copió el título de la Tabta de dicha P. II. é intilula esta comedia: Vida, martirio y muerie de S. Vicente Martir, patron de Valencia.

Triunfo (El) de Judit y muerte de Holofórnes.-Juan de Vera Tásis y VillaROEL.

Triunfo (EI) de la humildad y sobertia vencida.-Lope. $\boldsymbol{P}$. $\boldsymbol{X}$.

En las cabezeras dé las páginas se lee: El triunfo de la amistad y soberbia abatida. Tambien se conoce por La humitdad y la soberbia, y así dice en una copia manuscrila que poseía lord Holland.
Triunfo (El) de la lealtad. Elogio polttico y moral a Ant. Alvarez de Toledo.A Nósımo. Madrid, s. a.

Triunfo de la paz y el tiempo.-DiamanTE. P. II.

Triunfo (El) de las flores.-Penro Ruiz de Gordejuela.

Creo que esta comedia no se ha impreso; el manuscrito de ella que poseo parece ser de fines del siglo XVIl ó principios del XVIII. Barrera la menciona como anónima y añade al título: Sunta Eulalia y Santa Julia.

Triunfo (El) de los santos. Tragedia.Ignoro si es del P. Pedro de Moríles; pero se halla en el volúmen que publico intitulado: Carta... en que se da relacion de la festividad que en Méjico se hizo a la colocacion de las santas reliquias. Mejico, 1579 .

Esta composicion dramática va dividida en cinco actos, está escrila en varias clases de metros, la precede un prólogo y tiene varios coros.

Triunfo (El) del amor. Drama en un acto. -Gaspar Zabala y Zamora.

Triunfo (El) del amor.-V. Representacion de Juan del Encina.

Triunfo del amor y la amistad, Jenwal y Faustina. En prosa.-Gaspar Zabala $Y$ Zamora.

Triunfo (El) del Ave María.-Un Ingenio. Barrera crec si será de Rosele Niño. En nuestro Catálogo de Lóndres, entre las anónimas encuentro una con el mismo título.

Triunfo (El) del invierno. Tragicomedia, parte en portugues; pero lo más en castellano.-Gil Vicente. Obras. Se ha reimpreso en el Teatro español anterior a Lope de Vega un Paso que está todo en castellano.

Triunfo y venganza de amor.-Salazar $\mathbf{I}$ Tónres. Tom. II. Citara de Apolo.

Esta comedia no es la misma que Más triunfa el amor rendido de Salazar y Vera Tásis, como lo asegura Barrera.

Triunfos de amor y fortuna. Precedida de Loa $y$ seguida de tres Entremeses.Anronio DE Solss, en sus Comedias, 1681, y en las PP. XIII. y XLVII. C. A. Medel confunde á D. Antonio de Solis con D. Diego Muxet y Solis.

Triunfos de Felipe V., y efectos del rei Jacobo.-Bern. de Arteaga y MontalvaN.

Triunfos (Los) de la verdad.-Tinso.

Es una especie de auto ó diálogo entre S. Pedro Apóstol, $\mathrm{S}$. Clemente, un viejo, Aquila y Nicétas, que se halla en el Delei- 
tar aprovechando, lúnes por la mañana, y concluye ast:

\section{Conocerás en tu esposa, casta, cuerda y virtuosa, los triunfos de la verdad.}

Medel cita una anónima con el mismo tItulo.

Triunfos (Los) de S. Miguel.-Cubillo DE Aragon. El Enano de las Musas.

Triunfos de valor y ardid. Cárlos XlI, rei de Suecia. Primera parte.-GisPAR ZABALA Y Z A MORA.

No conozco la segunda parte.

Triunfos (Los) de valor y honor en la corte de Rodrigo.-Axóximo.

Segun Moratin y Barrera es de Manuel Fermin de Laviano.

Trofea.-Tórres Nabarro. Propaladia.

Ulisipo.-Comedia en prosa portuguesa. - Ferreira Vascoxcellos. Lisboa, 1618. Úlimo (EI) godo. T. c.-Lope. P. XXV. Es la misma que El postrer godo de España de la P. VIII. de dicho Lope.

Un bobo hace ciento. Con Loa.-AST. DE Solis. Tomo de sus Comedias, Partes XXXVII. y XLVII. C. A., tomo de Comedias escogidas de este autor, Madrid, 1828, en el Theatro hespañol de Huerta, y en la Biblioteca de Ribadeneira.

Medel la atribuye á Muxet y Solis.

Un castigo en dos venganzas. - V. De un castigo dos venganzas.

Un castigo en tres vengantas. - CiLneRon. P. IX. de 1691 y 1698 , en el Tono $I$. de la de Fernández de Apóntes, y en el $I V$. de la de Keil. Segun nota de Duran se publicó en la $\boldsymbol{P}$. $\boldsymbol{X} X \boldsymbol{X} \boldsymbol{V I I I}$.
Trompeta (La) del juicio.-GABriel DEL Corral. P. $\boldsymbol{X X X I . C . A .}$

Segun el Índice de Medel existe otra pieza de Bójas con igual titulo; pero comn no menciona la de Corral tal vez sea una equivocacion, ó que quizá se habrá impreso tambien á nombre de Rójas.

Troya abrasada. T.c.-Axosimo.

Me parece que no existe á nombre de Calderon ninguna pieza con este titulo como pretende Medel.

Troyanas (Las). T.-L. Av. Séseca, traduccion en verso de Jusepe Ant. González de Sálas. Nueva idea de la Tragedia antigua.

Tutor (El). - JUAN DE LA CuEva. Comedias y Tragedias.

Tuzani de las Alpujárras.-V. Amar despues de la muerte.

de las de á fuera, Huesca, 1634, con el título: De un castigo tres ve ganzas.

Un castigo sin venganza.- V. Castigo (El) sin venganza.

Un loco hace ciento. En un acto $y$ en prosa.-Dox̃a María Rosa de Gálvez. Tom. $\nabla$. del Teatro nuevo español.

Un montañes sabe bien donde el zapato le aprieta.-L. A. J. M.

Moratin dice que es de B. Luis Moncin.

Union (La) es mui poderosa, y lidio mágico Gíges. Tercera parte.-Y. Anillo (El) de Gíges.

Urson y Valentin, hijos del rei de Francia.-Lope. P.I.

En el Peregrino se menciona una segunda parle con igual titulo que quedo sin duda inédita. Barrera da á esta pieza el t1. tulo del Nacimiento de Urson y Vabentin.
Valedora (La) de los hombres. - Axósiмo. Poseo un MS. con las licencias para su represcntacion fechadas en $\mathbf{1 6 7 5}$ y 89 .

Aunque no se halla el nombre del autor en esta comedia, se ve por su final que cs parto de dos Ingenios.

Valeroso Aristómenes Mesenio.-Axóxtmo. P. XXXI. de las de á fuera. V. Aristomenes Mesenio.

Tom. I.
Valeroso (El) español y. primero de su casa.-Gaspar de Ávila. P. $X X X$. C. A.

Barrera añade al titulo: Hernan! Cortes. - Medel la trae anúnima y menciona otra de dos Ingenios que intitula solo: El vulcroso espanol.

Valiente (EI) Campuzano.-Fersardo DE Zarate. P. MIV.C. A. y Biblioteca de Ribadeneira. 
Nedel se equivoca en llamar Agustin ả este alitor.

Valiente (El) Céspedes. T. c.-Lope. ParIe XX.

Valiente (El) Juan de Heredia.-Lope.

Io se halla en las Partes. La tengo de c'dicion anliguta y suella.

Valiente (El) justiciero.-Moreto. P. II., $y$ enl $I d \boldsymbol{X} . \boldsymbol{C} \boldsymbol{A}$.

la tengo sueltia con el titulo del Valienle jusficiern, If "l Rico-hombre de Alcalá, que es el que lifira en el Tom. I. de las Comedins cecogillas de este autnr, 1826, à pesar de qule ell el Indice solo dice El Ricohombre de Alcula: as la intitula tambien Nedel. La ha reimpreso Ochoil en el Tom. IV. del Tisorn diel leatro español y Lemeke en su Homelbuch.

Esta comedia está formada sobre la de El rei Don Pedro en Madrid de Tirso, segun Hartzenbusch, páo. XI.II. de las prels. de las Comedias escoyidas de dicho antur, y ha sido refundida posteriormente yor D. Dionisio solis y despues por el Sr. Fernandez-Guerra, siendo ineditas aun ambas refundiciones.

Valiente (El) más dichoso D. Pedro Guíral.-Mostalvax. Tom. II.

Valiente (El) Nazareno. - Montalvax. Tom. II.

Suele llevar el tItulo de El valiente Nazareno Sanson, y segun Barrera solo el de Sanson.

Valiente (El) negro en Flándes.-Axpres DE Claranovte. Edicion suelta hecha en Sevilla a principios del siglo XVIII. y en la Biblioteca de Ribadeneira.

Tengo otra más moderna con el titulo de Et ne'gro v'aliente en Flandes, que tambien lleva el nombre de este autor, y en la P'arte XXXY. de las de a freera, impresa en Ifi58. se pnillentra anninima.-Ihai una segnndi larer ntilulida: Elonemra nulieule en Flánde.s p:r D. Hanuel Vicente Guerrero.

Valiente (El) Pantoja.-Moreto. Con este título se hallan Las travesuras de Pantoja en las Comedias escogidas de diferentes libros. Bruselas, 1704.

Cunsta anónima en Medel.

Valor (El) rontra fortuna.-Axdres BAEZA. P. XI. C. A.

Valor (El) de Fernandico.-V. Pleilo (El) por la honra.

Valor (El) de las mujeres.-Lope. Parte XVIII.

Valor, fortuna y lealtad.-Lope. No está en las Partes. La tengo de edicion antigua y suella.

Yo la mencinna Barrera en su Indire con Este titulo ni con el de Valor, leultud $y$ ventura de lo.s Tellos de Menéses. Segunda purte. Ignoro si existiri la Parte primera con el título de Valor, forluna y leallad; 1:il vez se encuentre con solo el de Los Tellos de Menéses como se denomina en una Primer'a parle que poseo de edicion suelta y antigua.

Valor, lealtad y ventura de los Tellos de Menéses. Primera parte.-Lope.

Es la misma que bajo el título de Los Tellns de Mcnéses se halla en su P. XXI.

\section{Segunda parte._Lope.}

En el Indice de Nedel están ambas partes con el titulo de Lns Tellos de Menéses.

Valor (El) no tiene edad. - Diamante. P. XLVIII. C. A. Se ha reimpreso en la Coleccion de dramáticos de la Biblioteca de Ribadeneira.

Tambien la tengo suelta con el título de El ralor no tiene edad, y Sanson de Estre. malurit.

Barrera la da tambien los títulos de Dicgn Garcia de Parédr's y El gran capitan Parédes.

Valor (El) nunca vencido, y hazañas de Juan de Aréyalo. - Úv INGienio andaluz.

Nedel y Barrera dicen que es de Francisco Scotti Fernández de Córdova; pero nada advierten de que se haya publicado como de un Ingenio.

Valor (El) perseguido y traicion vengada. -Montaluan.

En la bib. del dnque de 0suna existe im. presa á nombre de Lope.

Vanaglorioso (El). En prosa.-A Nósimo, traducida del frances.

No sé si será la que con igual título atribuye Moratin á D. José Clavijo y Fajardo.

Vaquero (El) de Granada. - Diamantb. P. XXVI C. A.

Vaquero (EI) de Morana.-Lope. P VIII. y reimpresa por Velpio en $\mathbf{1 6 3} 1$.

Vaquero (El) emperador-Mátos, Diamante y Aydres Gil Enríquez. Parte XXXIX. C. A.

Barrera añade al título Tamerlan de Per. sia, y Barbosa la intitula: El barquero emperador.

Varios prorligios de amor.-Rójas ZoRRILLA. P. XLII. C. A.

Varona (La) castellana.-Lope. P. IX.

La olvidó Nic. Antonio al describir esta Parte.

Vaso (El) y la piedra.-Fennando de $\mathrm{Z}_{\mathrm{A} \text { - }}$ Rate. $P . X X I X, C . A$. blo.

Rarrera añade al utulo: S. Pedro y S.Pa-

Velho $(0)$ da horta. Farsa portuguesa.GiL. Vicknte. Obras. 
Se encuentra en esta pieza un cantar en español.

Vellocino (El) de oro. Precedida de una Loa.-LOPE. P. $\boldsymbol{X I X}$.

Vellon (EI) de oro conquistado. Drama en un acto. - A Nósimo.

Venatoria (Comedia).-Góxgora. Obras.

La dejó sin concluir.

Vencedor (El) de sí mismo.-Cobillo DE Aragor.

Vencen el rigor de un parire osadía y sumision. 0 sea Franval y Emilia. $E n$ prosa.-Asósimo, traduccion de $\boldsymbol{D}$. $\boldsymbol{M}$. A. Igual.

Vencen impulsos de amor los afectos del honor y el máyico en Cataluña. Segunda parte. - A sóvimo.

La prineru parte se intitula : La ciencin afecto y valor forman mágia por amır, y el mrigico en Catoluña, y la tercera: Entre vengansa y amir hallan la dicha mayor y el mágiro en Cutaluña.

Vencer a Marte sin Marte.-V. Cadmo y Hurmonía.

Vencerse es mayor valor.-Diego y JosÉ Figueroa y Córdova. P. $\boldsymbol{I I}$. C. A.

En el litulo de esta comedia en dicha Parte se atribuye á Calderon; pero en la Tabla se corrige este error de imprenta, $y$ se dice que sus verdaderos autores son los Figuernas. De aquí vendrá la equivocacion de Medcl que trae una pieza del mismo tltulo comn escrita por Calderon. Vera Tảsis la incluyo en la nota de las comedias que habia supuesto la Coleccion anligua ser de este autor. Segun Barrera parece que tam. bien salió como de dos lngenios.

Vencimiento (EI) de Turno.-Calderor, segun la $P$. $X I I$. C. A.

Para convencerse del fundamento con que lo niega Vera Tásis, basta leer los cua. tro versos últimos de la comedia:

"Y así rindiendo al demonio "la roja sangre de Cristo, DAntonio Banuel del Campo, wda fin al Turno vencido.w

Yedel menciona la de Campo como diferente de la de Calderon, en lo que se equivota.

Tambien se conoce esta comedia con solo el titulo de Turno vencido.

Veneno (El) en la guirnalda y la triaca en la fuente.-Mecchor Ferivivdez DE LEOs. P. XLVI. C. A.

Veneno (EI) en la hermosura. $Z$. de representacion y música, precedida de Loa. - Ángel Peregrino. La mejor guirnalda de Apolo. Tom. I.

Veneno (El) para sí. - Us Isgevio. Parte XXXIX. C. A.
Por un manuscrito autógrafo que existe en la bib. del duque de Osuna, fechado en Madrid á 25 de mayo de 1656 , se ve que es de Diamante.

Yengada ántes de ofendida.-JERósıм DB Cifuéstes. P. XII. C. A.

Vengador (El) de los cielos y rapto de Elias.-Bíces Candamo. Poestas éomicas. Tom. I.

Vengadora (La) de las mujeres. - Lopr. $\boldsymbol{P}$. $\boldsymbol{X V}$., y reimpresion de Felpio de 1649.

Venganza (La) de Agamenon. Tragedia en prosa.-PEREz de OLIVA. Tomó el argumento de Sófocles. Despues de haberse impreso suelta en 1528 , se incluyó en sus Obras yen el Tom. FI. del Parnaso español.

Venganza (La) de la duquesa de Amalú. -Diego Mexet y Solis. Comedias y Rimas.

Dice el autor que esta comedia forma la continuacion de la intitulada: $E l$ mayordomo de la duquesa de Ainalfi de Lope.-Bar. rera se equivoca en suponer que esta pieza es la misma que La más dichosa vengan$\approx a$ que escribio D. Antonio de Solis.

Venganza (La) de Tamar.-Tirso P. III.

Corre con igual titulo una de Felipe Godínez, que es la misma de Tirso, suprimidos muchos versos, alterados otros y cambiado el desenlace. Hartzenbusch, pág. Xl. de lns prels. del tomo de Comedias escogidas de Tirso.

Venganta (La) en el despeño.-Mítos. P. XXXIV. C. A., y en las Comedias de los mejores. Colonia, 1697.

Posteriormente se reimprimio $\mathrm{y}$ la tengo conn el litulo de La venganza en ét despeño y tirano de Nat'arra. Tambien ba salido alguna vez con el de La venganza en el empeño: Vedel se equivoca por lo tanto cuando la da como una comedia diferente del mismo autor. En la P. AXXIV. arriba citada, ya se observa que es un error el haberla darlo este viltimo título. Tambien la trae Nedel con el de Alfonso de vavarra.

Venganza (La) en los agravios.-Thes IsGEsios.

Medel \& Barrera la citan anónima; pero no como de tres Ingenios.

Venganza (La) honrosa, precedida de Loa y el Baile de la boda de Foncarral. - Gispar Agrilar. Parte que dicen $\boldsymbol{F}$. de Lope, y en la Biblioteca de Ribadeneira.

En la Parle rXxril. C. A. se balla mal atribuida a D. Fernando de Zarate con el t1tulo de La desgracia venturosa.

Medel siguiendo su costumbre de asig. nar á Lope todas las piezas que se hallan 
en la que se considera Parte $V$. de sus Comedias, le atribnye una pieza con el tílulo de lil presente.

Venganza (La) venturosa.-Lope. $\boldsymbol{P}$. $\boldsymbol{X}$.

Vengalse cou fuego y agua.-V. A secreto agravio secreta venganza.

Venir el amor al mundo.-Melchor EERxixnez de LeOx. P. MLVIII. C. A.

Aunque esta pieza lleva cl título de Comedia fimosa no es más que una zarzucla. Segun un MS. que posee el Sr. Gayángos el titulo es: Venir el amor al mutudo, y labrar flechas contra sí, y lleva ma Introduccion que no se halla en la impresa. ¿Serí acaso la citada por Medel con el título de Salir el amor' del mundo de un Anónimo?

Ventura (La) con el nombre. - Tirso. P. IIVII. C. A., Y tomo de Comedias eacogidas de Tirso por Hartzenbusch.

Ventura (La) en la desgracia. -- LOPE. P. XIVIII. C. A.

Ventura (La) sin buscalla.-Lope. P. $\boldsymbol{X}$. Ventura te dé Dios, hijo.--Tinso. P. III. Ventura y atrevimiento.-LOPE. Edicion antigua y suelta.

No cstí en las Partes, ni en los Indices de Vedel y Barrera.

Ver ycreer. Segunda parte de Reinar despues de morir.Mímos. Tom. II. de sus Comedias escogidas, Madrid, 1833, y en la Biblioteca de Ribadeneira.

Esla es, segun queda dicho, la segunda parte de Reinor despues de morir de lélez de Guevara, y no de Doñit lnes de Castro di Yejía de la Cerda, como lo asegura Mede], annque versen las dos sobre el mismo asunto. Barrera da í esta segunda parte el título de fir y creer, el rei don Pedro de Porligul y doña lnes de Castro.

Ver y no creer.-Lope. P. XXIV. Zaragoza, 1633 .

Verdad (La) averiguada, y eugañoso casamiento.-Gullen de Cistro. P. $\boldsymbol{I I}$.

Yerdad (La) sospechosa.-Rulz de Alarcox. P. II., Tom. I de las Escogidas de cste autor, Madrid, 1826, cn el $I V$. del Tesoro del tealro español, y en el III. de sus Comedias escogidas. Madrid, 1867.

Bajo este mismo título se publico como de Lope en su Parte XXII., impresa en Zaragoza, $16 \tilde{3} 0$. V. Menliroso $(E l)$.

Verdadero (EI) amante.-Lope. P. $\boldsymbol{X I V}$.

En Londres tuvimos un manuscrito antiguo en el que esta comédia se intitulaba: El v'erdadero cimante, gran pastoral Be. larda, y Barrera la cita tambien con solo el título de La Pastoral Belarda.
Verdugo (El) de Málaga._Luis VĖlez. P. XVI. C. A.

Insiste Medel en suponer que esta comedia tambien es de Juan Vélez.

Vergonzoso (El) en palacio.-Tinso. En el Primero de sus Cigarrales, y en el Tom. I. de sus Comedias escogidas, Madrid, 1826. La ha incluido Hartzenbusch en el tomo de Comedias escogidas de Tirso.

Verse y tenerse por muertos.-MandeL Frbile de A ndrade. P. XXXIV. C. A., y en las Comedias de los mejores. Colonia, 1697.

El Sr. Barrera llama á este antor Freire de Andrade. Consta anónima en Medel.

Viajes (Los) del emperador Segismundo, 6 el escultor y el ciego. En prosa.Axónimo, traduccion de $\boldsymbol{D}$. Domingo Botti.

Vicio (El) en los estremos.-GuILIEN DE Castro. P. $\boldsymbol{I}$ I.

Victimas (Las) del amor, Ana y Sindham. - Gaspar de Zabala y Zamora.

Victoria de España y Francia.-V. Fitoria.

Victoria (La) de la honra.-LopE. V. Fitoria (La) de la honra.

Victoria de Norlingen y el infarte de Alemania.-Castillo Solonzano. Parte XXVIII. C. A.

Medel la cita con solo el título de La viccoria de Norlingen.

Victoria (La) del honor.-V. Vitoria (La) de la honra.

Victoria por el amor.-JACinto Cordero. P. XXVIII. C. A.

Tambien creo que se halla en un frag. mento de tomo de Comedias de este autor, al parecer impreso en Valencia, que existia en la bib. de Duran; y Medel cita una con el mismo título de D. Manuel Norchon, y otra de Calderon; pero no habla de la de Cordero.

Victoria (La) por la honra.-V. Vitoria de la honra.

Vida, conversion y muerte de Agueda de Acevedo, dama de Valladolid.-Lorerzo DE Avellaneda, soldado. Manuscrito de 1606 , inédito.

Vida (La) de Heródes.-Tırso. $\boldsymbol{P}$. $\boldsymbol{F}$.

En la tabla de las comedias que va al principio del tomo, se intitula La vida $y$ muerle de Heródes, y de esta manera la hallamos en los Indices de Medel y de Barrera.

Vila (La) de san Alejo.-Moneto. P. I., Valencia, 1676 , y P. X. C. A.

Vida de san Julian de Alcalà de Henáres.-V. Saber (El) por no saber. 
Vida (La) de san Pedro Nolasco.-Lope. P. XXII., Madrid, 1635.

Vida (La) dél gran Tacaño.-Cax̃izáres.

Segun un manuscrito que posee el señor Gayángos el verdadero autor de esta picza es I). Melchor Feriández de Lcon, y゙ á nombre de este la traen Medel y Barrera.

Vida (La) en el ataud. - Ródas Zorrilla. P. XXXII. C. A.

Vida (La) es sueño.-Calderos. $\boldsymbol{P}$. $\boldsymbol{I}$. de $1636,1640,1683$ y 1726 , en el Tomo II. de la de Fernández de Apóntes, en el $I$. de la de Keil; en el III. del Tesoro del teatro español; segun nota de D. A. Duran en la P. XXX. de las de a fuera, Zaragoza, 1636, en las Comedias de los mejores. Colonia, 1697, y en las Comedias escogidas de los mas insignes poetas. S. l. ni $a$.

Vida (La) es sueño, y lo que son juicios del cielo. Zarzuela espinosa, historia verdadera, representada en el gran coliseo de la Paciencia de Madrid.Axóximo. Impresion suelta de Zaragosa, 8. a.

Pieza satírico-polftica de la época de Felipe $\mathrm{V}$.

Vida, martirio y muerte de $\mathrm{S}$. Vicente Mártir, patron de Valencia.-RICARdo DE Turia. Asi se intitula en la Tabla de la P. II. de Poetas valencianos, El Triunfante martirio y gloriosa muerte de $S$. Vicente, hijò de Huesca y patron de Valencia.

Vida (La) y muerte de Heróảes. V. Fida (La) de Heródes.

Vida y muerte de la monja de Portugal. - Mira de Ayescua. P. XXXili. C. A.

Vida y muerte de $S$. Cayetano. - SEIS IXgevios. $P$. XXX VIII. $C$. A.

Parece que los seis Ingenios son: Diamante, Moreto, Sebastian de Villaviciosa, Avellineda, Mátos y D. A. re Arce.

Vida y muerte de san Lázaro. - MiRA DE Amescu. P. IX. C. A., y segun Mesonero, en un tomo de Comedias que pudo ser $I$. Parte de las de este autor.

Vida (La) y muerte de Santa IIadrona, intitulada, la viuda tirana, y conquista de Barcelona.-Axósiyo." Parte XXXI. de las de á fuera, 1638.

El Sr. baron de Münch-Bellinghausen sospeeha si el coleetnr de esta Pmite XXXI., Francisco Toribio Jimenez, serí el autor de esta comedia.

Vida y muerte de Vamba.-Lope. P. I.

Supongo seri la que se cila en al Peregrino con solo el título de El rei lamba.
Vida y muerte del Cid, y noble Martin Peláez.-Uxisgexio.

Parece un recuerdo de $E l$ cobarde mos valienle de Tirso, en opinion de Ilartzenbusch.

Vida y mucrte del Sto. Fr. Luis Bertran. Comedia con Loa.-Gaspar de AGulLAR. Fiestas a la beatificacion del Santo, pág. 31 .

En la $P . X Y Y$. C. A. se publicó indebidamente como de Yorelo con solo el título de San Luis Bertran.

Vidriana (Comedia llamada). - Jaime GïzTE. $4 .^{\circ}$ gót.

Viejo (El) enamorado.-Jeay de la Ceeva. Comedias y Tragedias.

Vuelve Yedel á llamar Antonio á este autor.

Vicjo (El) y la niña.-Ixapco Celesio (Leandro Fernindez de Moratin).

Viento es la dicha de amor. Zarzuela música.-AIT DE Ziyora. Tom. II.

Yilbalpandos (0s). En prosa portuguesa. -Franc. SaA de Mirasia. Coimbra, 1560 , en las Obras de este autor, y con las Comedias de Ferreira, 1622.

Villana (La) de Vallécas.-Tirso. P. I. Reimpresa por Hartzenbusch en el tomo de Comedias escogidas de Tirso.

La refundio hábilmente D. Diorisio Solis en $181 \%$.

Villana (La) de Jetafe.-Lope. P. XIV.

Villana (La) de la Sagra.-Tirso. P. III., yen el tomo de Comedias escogidas de Tirso por Hartzenbusch.

Villano (El) del Danubio y el buen juez no tiene patria.-Joay de la Hoz Mora. Vedel la menciona enn snlo la primera parte del lf́tul, y la atribuye equivocadamente d Cañizires.

Villano (El) en su rincon.-Lope. P. FII., Y $T L I V$. de las de á fuera, Zaragoza, 1632 .

Vinatero (El) de Míadrid.-Valcadíres de Sotomiror.

Violencias (Las) del amor.-Castóral DE Mosrot Y Silva.

Barrera añade al titulo y $D$. Belforin de Grecin. Medel cita otra con el primer lftu. lo, que atrilumbo í um ll. Juan de silva, en lo que creo se cquivoca.

Vírgen (La) de Guadalupe.-Birces CasDaso. Poesías cómicas. Tom. I.

Barrela despues de cilar esta connedia comn esclusiramente de Candamo. trae otra con igual títule que supnne escrita por este autor $\mathrm{E}$ por L. Juall de la Hoz.

Virgen (La) de la Aurora. - Moreto y Cícer. P. IIIIV.C.A. 
Como de Moreto únicamente en la $P$. III. de sus Comedias con el tílulo de Nuestra Scriora de la Aurora.

Vírgen (La) de la Fúencisla.-S. Villaviciosa, Mátos y Zabaleta. P. X XIII. C. $A$.

Barbosa titula esta comedia La rírgen de la Fuensalida.

Vírgen (La) de la Salceda.-Leox Marchante y Diego Calleja. Tom. I. Obras poéticas de Marchante, y en la Parte XXIV. C. A.

se promete segunda parte.

Vírgen de los Desamparados de Valencia• - Marco axtoxio Ortí, no Ortiz, como se lee en la $P$. XXXII. C. A.

Nedel la trae como anonima, y Jimeno dice que la tercera jormada es de Jacinto Alonso Nalvenda.-De la misma Vilgen de los Desamparados escribió uma comedia D. Franciseo de la Tórre, segun es de ver por la pág. 385 de las Real's pirslas etc. por Francisco de la Tórre. Allí solo se pone la Loa que la precedia, y en la pán. stou se da la razon de no imprimir la comedia.

Vírgen (La) del Sagrario.-V. Orígen, pérdida y restauracion de la Vírgen del Sagrario.

Virginia. $\bar{T} .-$ Moxtiano y Lurando. Discurso I. de las Tragedias españolas.

Virtud (La) aun entre persas lauros y honores grangea. T. c. Con dos Loas y dos Entremeses.-José Sivtos.

Los entremeses se intilulinn: Huypudo de Scila dio en Carbudis $\mathrm{y}$ Las caperesas de Sancho.

Virtud (La) consiste en medio. El pródigo y rico avariento.-U. IXgerio.

Refundicion antigua del Tanto es lo de más como lo de mènos de Tírso, segrun Hartzenbusch.

Virtud (La) en la indigencia.-Traluccion del frances en prosa por D. J. E. G. Tom. V. del Teatro nueco español.

Virtud, pobreza y mujer.-Lope. P. XX.

Virtud (La) premiada, ó el verdadero buen hijo.-L. A. J. M.

Segun Moratin el autor es D. Luis Moncin.

Firtudes contra les vicios (Comedia de). -LOpez de Úbeda, en su Cancionero, 1586.

Virtudes vencer señales.-Lus Vécez. Edicion del siglo YVII que principia por la pág. 91 y coucluye en la 128; por consiguiente, pertencé á una $\boldsymbol{P u r -}$ te que me es desconocida.

Segun nota de Duran, y Barrera en su caldogo, se halla esta comedia á nombre de Lope y con el tifulo de Virtudes vencen señales y negro rei bandolero en la Parte XXXII. de las de á fuera, Zaragoza, 1640 ; pero los traductores de Ticknor suponen que en dicha Parte se atribuye á Luis Vélez.

Visitaçāo que o autor fez ao parto da muito esclarecida Rainha Dona Maria, e nascimento do muito alto Principe Dom Joāo, o Terceiro em Portugal.Gil. Viceste. Obras.

Es una especie de monólogo pastoril en castellano.

Vísperas (Las) sicilianas. - Tres INGENios.

Vera Tásis la cuenla como mal atribuida á Calderon en las Partes de a fiera. Lo diflculto no obstante, porque ni Nedel ni Barrera la traen como de Calderon. El íltimo adiciona al tilulo: y venyanza en los agravios.

Viting (El). T.-Avósimo.

Vitoria de España y Francia. Precedida de Loa. - Silas Barbadillo. Coronas del Parnaso.

Vitoria (La) de la lonra.-Lope. P. XXI.

Esta será probablemente la que se llama La victoria del honor en la segunda lista del Peregrino, y tal vez la misma intitulada: Victoria por la honra, y se balla, segun Duran, en la P. XXXIII. de las de a fuera, Valencia, 1642.

Vitoria (La) del amor. - Manuel Morchov. P. IX. C. A.

Melel la intitula : Victoria por el amor.

Yiuda (La), casada y doncella.-Lope. P. VII.

Con este tftulo dice Jimeno que escribió una comedia D. Cárlos Gazulla de Ursino, la cual existia manuscrita.

Viuda (La) gaditana.-Axósimo, traduccion del ingles.

Viuda (La) generosa.-Fermir del Rei.

Viuda (La) tirana y conquista de Barcelona.-V. Vida (La) y muerte de Santa Madrona.

Viuda (La) valenciana.-Lope, P. $\boldsymbol{X I} \boldsymbol{F}$.

Viudo (El). - Gil Vicente. Obras, en el Teatro español anterior $a$ Lope de Vega, y en el Tom. I. del Tesoro del teatro español.-Está en castellano.

Vivanderas (Las) ilustres.-ANtonio YaLLIDÁRES Y SOTOMAYOR.

La he tenido anónima.

Voto (El) de Santiago, y batalla de Clavijo.-Rodnico de IIERRER. $P . X X X I I I$. C. A.

Medel se equivoca en llamar Francisco á este alltor 
Yerro (El) del entendido.-Mátos. P. I., en el Tom. I. de sus Comedias escogidas, Madrid, 1828, y en la Biblioleca de Ribadeneira.

Yo me entiendo y Dios me entiende.Cẫizáres. Suelta y en la Coleccion de dramáticos de la Biblioteca de Ribadeneira.
Ninguna de estc titulo se halla en el Indice de Medel. Vera Tásis dice que una con cl titulo de lin me entiendo salio á nounbre de Calderon, de quien no es.

Yo por vos, y vos por otro.-Moreto. P.III. Valencia, 1676 y 1703, y en la XLII. C.A.
Zafira. T.-Axósimo.

Zagales (Los) del Jenil. Zarzuela pastoral.-RAmon de la Cruz. Tom. VI. de su Teatro.

Zara. Tragedia en ménos de un acto.Ramos de la Cruz. Tom. VI. de su Teatro. .

Zelos, amor y venganza.-Ltts Vélez. P. II. C. A.

Barrera le da tambien el título de No hai mal que por bien no venga.-Medel vuelve á adjudicar al hijo D. Juan esta comedia del padre Luis.

Zelos aun del aire matan. Z.-CALderox. $\boldsymbol{P} \quad \boldsymbol{V I I}$. de 1683 y 1715 , en el Tom. $\boldsymbol{X}$. de Fernándoz dé Apóntes, en el III. de la lle Keil, en la P. XIX. C. A., y segun Duran in una de las Partes de a fuer" que supone ser lo $\boldsymbol{X} \boldsymbol{L I}$.

Zelos con zelos se curan.-Tipso. P. IV., Tomo de Comedirs escogidas publicado por Hartzenbusch, y en il Tom. I. de las Escogidas del mismo Tirso, Madrid, 1826 .

La tengo tambien á nc.mbre de Lope en el fragmento de una Parte que tal yez sea toca de Comedias de este autor: liene algunas variantes.

Zelos (Los) de Rodamonte.-Rójas ZorRILLA. $P$. $I$.

En las Doce comedias de varins. Tortosa. 1638, se encuentra una comedia con el mismo título á nombre de Vira de Amescua; asi lo dice Von Schack.

Zelos (Los) hacen estrellas, y el amor hace prodigios. - JUAX VÉlez.

Barrera la atribuyge á Juis lỉez de fuevara: en el ejemplar que tengo en mi biblioteca, que es de una edicion de mediados del siglo pasado, dice positivamente que es del Juan; pero yo la he tenido tam- bien á nombre del Luis y probablemente seril de êl.

Zelos (Los) hasta los cielos, y desdichada Estefanía.-Luis Vélez.

Se cquiroca Jedel en decir que es de Juan Vélez.

Zelos, honor y cordura.-Axóviyo. Parte $\mathbf{X X X I}$. de las de áfuera impresa en 1638.

Barrera se lâ atribuge á Ant. Coello.

Zelos no ofenden al sol-Art. Exrígeez Góyez. Doze comedias las mas grandiosas, y en la Flor de las mejores doce comedias.

La lengo suplta á nombre de Calderon y la he terijo como de un Ingenio, por lo mismo se equiroca Vedel cuando atribuse una con este títulio a cada uno de lus aulo. res mouciunados: ademas Vera Tosis va advierte que se imprimió malamente como de Calderon. Gúnez dice en el prologo de su Sumson Vazareno, que cra stry.

Zelos son bien y ventura.-Felipe GodíNEz. P. TXXŸ. C. A.

Barrera añade al titulo: San Aibano.

Zelosa (La) de sí misma.-Tirso. P. I., y en el tomo de las Esiogiuas de este autor publicado por Hartzenbusch.

Zeloso (EI). En prosa.-Alfoxso Velizoeez. de Yelasco. Se publicó en Milan en 1602 con el título de La Lenay con el de $E l$ zeloso, ! bajo cste último en Barcelona, 1613, reimpresa en el Tom. I. del Tesoro del teatro español.

Zeloso le si mismo.- V. Pastoral La) de Jucinto.

Zeloso (EI) don Lésmes.- Vicerre RodriGite7. Arellayo.

Zeloso (El) prudente.-Tirso. Quinto Cigarral.-La tengo tambien publicada 
en Madrid por Doña Teresa de Guzman con el tísulo de El zeloso prudente en el mayor aprieto de los zelos. Hartzenbusch la ha reimpreso en el tomo de Comedias escogidas de Tirso de la Biblioteca de Ribadeneira.
Barrera dice que es la que tambien se conoce con el tílulo de Al buen callar llaman Sancho.

Zeloso (El) y la tonta.-DÁmaso DE IsusQUITA.

Zoraida. T.--N. Alvárez de Cienfuégos.

\section{AUTOS.}

\section{Figuran en este índiec los Antos saeramentales, los cialogados y más de oehenta, precedidos de Loa.}

A Dios por razon de estado.-Calderon. Volúnen de Autos, Barcelona, 1701. Precedido de una Loa en el Tom. I. de los mismos de 1717, y en el II. de 1759.

A María el corazon.-Calderon de la Barca, en el volúmen de sus Autos, Barcelona, 1701. Precedido de Loa en el Tom. I. de los mismos de 1717, y en el II. de 1759 .

A tu prójimo como á tí. Precedido de loa.--Calderon. Tom. VI. Aulos de 1717 , y en el IV. de 1759.

Acreedores (Los) del hombre. - LOPE. Fiestas al Sacramento, y Tom. XVIII. Obras sueltas.

Medel trae uno con este lítulo que atribuye á Rójas Zorrilla, y no menciona el de Lope.

Adivina quién te dió. Con Loa.-Gómez Tejada de los Reyes. Noches buenas.

Alimentos (Los) del hombre. Precedido de Loa.-Calderox. Tom. II. Aulos, de 1717 , y en el $l$. de 1759 .

Alma (A). En portugues.-GiL VICEnte. Obras.

Amar y ser amado, y divina Filotea. Precedido de Loa.-Calberox. Tom. I. $\boldsymbol{A}$ ulos de 1717, y en el $\boldsymbol{I I}$. de $17 \ddot{\partial} \mathrm{J}$.

Con el título solo de La divina Filotra salió en el volúmen de Autos de este autor, impreso en Barceloma, 1701.

Amistad (La) en el peligro.-YaLdivielso. Actos y comedias.

Amor es fe.-María del Cielo ó no Ceo, traduccion de Settien. En sus Obras varias.
Barrera no hace mérito de esta version castellana, y solo cita el original portugues que supone manuscrito, lo que tengo por inexacto.

Andrómeda y Perseo. Precedido de Loa. -Calderon. Tom. IV. Autos de 1717, y eu el $I I I$. de 1759 .

Ángeles (Los) encontrados. Con Loa y Villancicos al Nacimiento del Hijo de Dios.-Antonio de Castilla, natural de Úbeda. La cdicion que tengo parece de principios del siglo XVII.

Barrera no menciona el Villancico.

Año (El) Santo de Roma. Precedido de loa.-Calderon. Tom. II. Autos de 1717, y en el I. de 1759.

Aĩo (El) Santo en Madrid. Precedido de Loa.-Calderon. Tom. II. Autos, de 1717 , y en el $I$. de 1739 .

Árbol de la vida.-José oe Vardivielso. Actos y comedias.

Árbol (EI) del mejor fruto. Precedido de Loa.-Calderos. Tom. II. Autos, de 1717 , y en el $r$. de 1759.

Árboles (Los). - Rósıs Zorrit.la. Autos sacramentales, $16 \%$.

Arca (El) de Dios cautiva. Precedido de Loa.-Cinneroy. Tom. V. Autos de 1717 , y en el VI. de 1760 .

Astucias (Las) de Luzbel, contra las divinas profecias. - A róxryo.

Este es indudablemente el Auto al Nacimiento de Nuestro Señor Jesucristo que con irual lítuloatribuye Barrera á un tal Quiroga.

Auto de la Pasion. Reprasentacion de la Pasion de Nuestro Señor Jesu-Cristo. Lúcas linánuez. Farsas y Églogas. 
Auto pastoril castelhano endereçado as matinas de Natal. - GiL Vicestr. Obras.

Está todo en castellano.

Auto pastoril portuguez.-Gil VICEste. Obras.

Autos (Cuatro) al Santísimo Sacramento.-JoAN DE LUQUR. Divina poesía.

Autos sacramentales (Tres).-DIBGo RÁmos DEL CAstrllo. Autos sacramentales, 1675.

No tienen titulo estas composiciones.

Autos (Tres) de Jorge'de Mostemayor, en los maitines de la noche de Navi-

B

Barca (La) de la Gloria.-Gil Viceste. Obras.

Está en castellano.

Barca (A) do Inferno. En portugues.GiI Vicente. Obras.

Caballero (EI) del Febo.-Rójas Zorrilla. Navidad y Córpus Cristi, 1664.

Nedel lo atribuye equivocadamente á Nontalvan.

Cananea (A). En portugues.-GIL TicesTE. Obras.

Cantares (Los).-Lope. Fiestas al Sacramento, y Tom. XVIII. Obras sueltas.

Cascabel (El) del demonio, ó sea Auto al Nacimiento de Cristo.- Lis Isgesio.

Lo tengo tambien anónimu, y Barrera dice que es de un tal Quirega.

Cautivos (Los) libres.-José de Valduvielso. Actos y comedias.

Cena (La) del rei Baltasar. Precedido de Loa. - Calderox. Tom. I. Aulos de 1717, en el II. de 17309 , en la Naridad y Córpus Cristi, 1664, y en el Tomo III. del Tesoro del teatro español.

Cetro (El) de José. Precedido de Loa.Soror JUaya Ires de lat Crez. Tom. II. Obras.

Ciento por uno. -V. Nivestra Señora del Rosario.

Colmenero (El) divino. Con Letra y Loa. - Tisso.

Tengo una impresion suelta en cuyo eplgrafe dice: Represenlole Pinedo año de dad; á cada nocturno uno. En el auto primero se introducen: Tiempo, Justicia original, Inocencia, Sensualidad, Adan, Eva, Esperanza.-En el segundo : Tiempo, Naturaleza humana, Entendimiento humano.-En el tercero: Tiempo, Viejo, Bobo, Fardina, Gil, Llorente, Gonzalo. Se hallan en las Obras de Montemayor, Anvers, $1525 \%$. $12 .^{\circ}$

Fueron desconocidos á Barrera.

Arenturas (Las) del hombre. - Lope. Fiestas al Sacramento, y Tom. XVIII. Obras sueltas.
Barca (A) do Purgatorio. En portugues. Gil Viceste. Obras.

Bodas (Las) de Bato y Menga. Auto del Nacimiento de Jesucristo.-Avósımo.

1621 ; ademas de que la edicion es de esta época, el mismo Tirso dijo al reimprimirlo en su Deleilar aprovechancio, que babia sido aplaudido años hacia en Toledo con honra y provechn de su aulor Pinedo, $y$ satisfaccion del poeta. - Medel lo trae anonimo con el titulo de Los Colmeneros divinos, $\mathbf{y}$ una comedia tambien anónima denominada El Colmenero dirino; tal vez ambas composiciones sean la misina de Tirso que, segun Barrera, se ha publicado tambien cen el titulo de El oso y la colmena.

Concepcion (La) sin mancilla. Auto en alegoría.-Diego Fervídez de Soltsi. Se halla en los Elogios de Maria de Luis de Paracuéllos.

Cordero (EI) de lsaias. Precedido de Loa. - Calderos. Tom. V. Autos de 1717, y en el VI. de 1760.

Cuatro (Los) tiempos. En castellano.Gil Vicexte. Obras, y ell el Teatro español anterior á Lopé de Vega.

Cubo (El) de la Almudena. Precerlido de loa.-Calderos. Tom. IF. Aulos de 1717. ven el III. de 1759. Tambien está en los Autos sacramentales de varios, impresos en 1650 ; perc s:n Loa.

Cura (La) y la enfernedad. Piecrcisio de loa.-Cilderox. Tom. H. sutos de 1717 , y en el IV. de 1759. 
Del pan y del palo.-Lope. Fiestas al Sacramento, y Tom. XVIII. Obras sueltas. cexclado Juax Cixesi. T'engo el MS. original firmado por el autor y con las licencias para su representacion fechadas en Mudrid en 1609.

Medel trae uno intitulado Desposorios de Ninestra Señora, anónimo.

Desposorios (Los) de Moisen. Auto en prosa, fuera del argumento que esta en verso.- Avósino. Museo literario de Tapia, Tom. I. pág. 41.

Derocion (La) de la misa. Precedido de Loa.-Calderox. Tom. III. Autos de 1717 , y en el $\boldsymbol{V}$. de 1760.

Dia do luizo. En portugues.-Avósimo, impreso en Lisboa, 1625.

Dia (El) mayor de los dias. Precedido de Loa.-Calderon. Tom. VI. Autos de 1717 , y en el $I V$. de 1739 .
Desposorios (Los) de la Vírgen.-EL LI-

Dia (El) y la noche.-V. Entre dia y noche.

Diablo (El) mudo.-Calderon, en el volúmen de sus Autos, Barcelona , 1701, y precerlido de una $L o a$, en el Tom. $\nabla I$. de los mismos de 1717, y en el IV. de 1739 .

Divina (La) Filotea.-Caldrron. Tomo de sus Autos, Barcelona, 1701. V. Amar y ser amado.

Divino (El) Jason.-Calderon. Navidad y Corpus Cristi, 1664.

Divino (E1) Orfeo. Precedido de Loa.Calneros. Tomo de sus Autos de 1677 , en $e l V I$. de 1717, y en el IV. de 1759.

Se halla una segunda parle de este auto en la Coleccion inédita de D. Juan Isidro Fajardo.

Duelo (El) de los pastores.-Calderox, segun el impreso que poseo.

Medel ni Barrera no le señalan autor.

\section{$\mathrm{E}$}

Encantos (Los) de la culpa.-Calderoy. Volúmen de sus Aulos, Barcelona, 1701. Se reimprimió con una Loa en el Tom. V. de los mismos de 1717, y ell el VI. de 1760 .

Entre dia y noche.--Valdnvielso. Navidad y Córpus Cristi, 1664.

En los titulillos de la eabecera de las pá. ginas se denomina El dia y la noche.

Escandarbech.-Moxralvax. Para todos.

Fe (La).-Gil Viceyte. Obras.

Solo la $F e$ habla en portugues, los dernas lo hacen en castellano.

Feira (A). En portugues.-GiL Viceste. Obras.

Es un auto, $\mathrm{y}$ efectivamente se encuentra entre las obras de devocion de este autor.
Es sin duda el mismo que, estropead" $\mathrm{y}$ aumentado su título, llama Medel, sin se. ñalarle autor, Escandarbeg y Clistern..

Espigas (Las) de Ruth.-Calderox. Volúmen de sus Autos, Barcelona, 1701, y precedido de una Loa, en el Tom. VI. de los mismos de 1717, y en el IV. de 1739 .

Esposa (La) en los cantares.-LOPEz DE ÚBEDA. Cancionero, 1586.

Fénix (El) de amor.--Yaldivielso. Actos $y$ comedias.

Férias (Las) del alma.-Valdivielso. Aclos y comedias.

Fiestas (Las) de los märtires.-Lors BeLMoNTE. Poseo un MS. de este auto fechado en 1639.

Lo trae Medel. 
Galan, discreto y valiente.-Rósas ZORRiLlA. Autos sacramentales, $1655 \mathrm{y}$ 1675 .

Barrera no cita con exactitud el litulo que dice ser: Galan, valiente y discrets.

Gran (La) casa de Austria y divina Margarita. - Moreto. Navidad y Córpus Cristi, 1664 .

Gran (El) mercado del mundo. Precedido de Loa.-Calderon. Tom. IV. Autos de 1717, y en el III. de 1739 .

Es el que Vera Tásis denomina $E l$ mercado del mundo.

Gran (El) palacio.-Moreto. Autos sacramentales, 1673 .

Es de Röjas Zorrilla como lo prueba el final, y á nombre de este se halla en los Autos sacramentales, 1655 , con su verdadero título: El gran palin de palacio. En el tomo de Autos de 1675 se encuentra tambien la Loa que escribió D. Jerónimo Cáncer.
Gran (El) patio de palacio. Precedido de una Loa de Cáncer.-Rójas Zorrilla. Aulos sacramentales, etc., 1630 .

En los Aulos sacramentales, 1675, se atribuye equivocadamente á Voretı y se intitula El gran palacin.

Gran (El) químico del mundo. Precedido de Loa y seguido de un Entremes.Bisces Caxdayo. Poesías cómicas, Ta mo $I I$.

Gran (El) teatro del mundo. Precedido de Loa.-Cilderos. Tom. I. de Aulos de 1717 , en el $I I$. de 1759 , y en el de Autos sacramentales de diversos, impreso en 16 ว̈ว.

En la Tabla publicada por Vera Tásis solo suena con el título de El leatro del unundo.

Fué aumentado por el imitador de Calderon D. Antonin Benito Vidaurre yorduก̃a, segun Alvarez ฐ Baena.

Heredero (El). Precedido de Loa.-Mira DE AMESCCA. Autos sacramentales, etc., $1655^{\circ}$, y en los de 1675 ; pero sin Loa.

Heredero (EI) del cielo.-Lope. Fiestas al Sacramento, y Tom. XVIII. Obras sueltas.

Hermanos (Los) parecidos. Precedido de Letra $y$ Loa.-Tirso Deleitar aprocechando, lúnes por la tarde.

Medel no menciona auto alguno ast intitulado, y sí una comedia anonima.

Hidalga (La) del valle. Precedido de Loa. - Calderos. Tom. IF. de sus Aulos de 1717, en el $I I I$. de 1759 , y en las Triunfales celebraciones del P. Paracuéllos , 1640.

Imágen (La) del Sacramento San Juan de Dios. Precedido de su Loa.-Sebastias Astovio Gadea y Oviedo. Se halla al fin del libro intitulado: Triunfales fiestas, del mismo.

Indulto (El) general. Precedido de Loa. - Calderon. Tom. II. de sus Aulos de 1717, y en el 1 . de 1759 .
Hijo (El) pródigo.-Yaldrvielso. Aclos y comedias.

Hijo pródigo.-Lope de Vega. Y. Parábola del hijo pródigo.

Historia (A) de Deos. En porlugues.GIL Viceste. Obras.

Hombre (El) encantado. - Valdivielso. Actos y comedias.

Hospital (El) de los locos.-Vildiviel.so, en sus Actos y comedias.

En los epigrafes de varins piginas se intitula: Los tocos del hispilal.

Humildad (La) coronada de-las plantas. Precedido de Loa.-Calderos. Tom. $\boldsymbol{V}$. de sus Aulos de $171 \pi$, y en el $T I$. de 1760.

Inmunidad (La) del sagrado.-Citnerox. Volúmen de sus Autos, Barcelona. 1701 , y precedido de una $L n a$, en el Tom. I. de los mismos de 1717, y en el II. de 1739 .

Inocencia y malicia. Precedido de Loa.Gómez Tejad de los Reies. Noche buena. 
Jardin (El) de Falerina.-Calderos. Yolúmen de sus Autos, Barcelona, 1701, y precedido de una Loa, en el Tom. V.

Laberinto (El) del mundo. Precedido dc Loa.-Calderon. Tom. VI. de sus Autos de 1717, y en el $I F$. de 1759.

Se halla puesto dos vezes en la Tablu de los autos publicada por Vera Tásis.

Lágrimas (Las) de Roma. - María DEL Cielo ó do Ceo, traducido por Settien. En sus Obras varias.

Barrera cita solo el original portugues y lo supone MS., en lo que creo se equiroca.

Llamados y escogidos. Precedido de Loa. - Calderon. Tom. I. de sus Autos

Madrina (La) del cielo.-Tirso. V. Nuestra Señora del Rosario.

Maestrazgo (El) del Toison. Precedido de Loa.-Calderov. Tom. III. de sus Autos de 1717, en el $\boldsymbol{V}$. de la de 1760 , y en el Xuñez Sotomayor, Descripcion panegírica, pág. 218 , donde lleva por título El maestrazgo del Tuson, y no tiene Loa.

Mártir (El) del Sacramento San Hermenegildo. Auto historial alegórico, precedido de Loa.-Soror Juana INES DE la Cruz. Tom. II. Obras.

Mas (La) hermosa Raquel, pastora de las almas. Auto alegórico. - Uv IvGesio MATRITEXSE.

Mayor desempeño.-Cubillo de Aragon.

Creo que este auto no se ha impreso nunca. J'oseo el MS. original de Cubillo fechado en franada á 31 de abril de 1657, en 10 que delje haber' equivocacion por cuanto riste mes soln tiene treinta dias.

Mayor Oneza de amor.-Manía del Cirlo de los mismos de 1717, y en el VI. de 1760 .

\section{M}

Lepra (La) de Constantino. Precedido de loa.-Calderon. Tom. IV. de sus Autos de 1717, y en el III. de 1759.

Lirio (EI) y la azuzena. Precedido de loa.-Calderon. Tom. III. de sus Autos de 1717, y en el $V$. de 1760.

Medel equivoca el título, pues pone $L y$ rio da la Azuzena.

Lo que va del hombre á Dios. Precedido de Loa.-Caluenon. Tom. III. de sus Autos de 1717, y en el $\boldsymbol{V}$. de 1760.

\section{$\mathrm{LL}$}

de 1717, y en el II. de la de 1759. Medel no lo cita en su Indice.

ó do Ceo, traducido por Settien. En sus Obras varias.

Barrera sclo cita el origina portugues y dice que está MS.: repito como he dicho que no me parece exacto.

Mayor (La) soberbia bumana de Nabucodonosor.-MIra DE A hiescua. Navidad y Córpus Cristi, 1664.

Mejor (EI) rei de los reyes.-Axónimo.

Mesa (La) redonda.-Luls Vélez. Navidad y Córpus Cristi, 1664.

Mesas (Las) de la fortuna-Bánces CanDamo. Poesias cómicas, Tom. III.

Mesías (El) verdadero. Con su Loa.Juax de Anson y Má́cas.

Como se ve, el segundo apehido de este autor no es Mayas como dice el Sr. Barrera, copiando á Medel ó á Huerta. Lo he tenido anónimo.

Misacantano (El).-Lope. Fiestas al Sacramento, y Tom. XVIII. Obras sueltas. 
Misterios (Los) de la misa.-Calderon. Yolúmen de sus Autos, Barcelona, 1701 , y precedido de una Loa, en el Tom. II. de los mismos de 1717, y en el I. de 1759 .

Mistica y real Babilonia. Precedido de loa.-Calderon. Tom. $V$. de sus Autos de 1717 , y en el VI. de 1760.
Omitido en cl Indice general, á no supo. nerse que es el que anuncia de Calderon con el estravagante tftulo de Mystica Is. rael Biblioleca.

Mónstruo (El) de la sierra, y el pastor ángel. Auto en tres jornädas. - AvóNiм0.
Nacimiento (El). - Gil Ficeste. Obras, donde se intitula Auto pastoril castelhano, en el Teatro español anterior $\dot{a}$ Lope, y en el Tom. I. del Tesoro del tea tro español.

Nacimiento (El).-Lùs Vélez. Autos sacramentales etc. 1650 .

En los de 1675 se titula El Nacintienlo de Cristo.

Nacimiento (El) de Cristo.-Lus Vélez. Autos sacramentales etc. Madrid, 1675 .

Es el mismo que el anterior.

Nacimiento (El) de Cristo. - Godínez. Autos sacramentales, $167 \%$.

Es diferente del otro del mismo autor, cuyo tftulo empieza como este.

Nacimiento (El) de Cristo nuestro bien, y sol á nedia noche.-Mira DE Ayes. cuA. Navidad y Córpus Cristi, 1664.

Nacimiento (El santo) de Cristo N. S.Juas Pastor. Alcala, 1603.

l'recede en esta edicion el Passo de los dos ciegos Anónimn que, segun Moratin, es de Juan de Timoneda.

Nacimiento (El) de Cristo, y pastores de Belen.-Gobínez. Autos sacramentales, $167 \%$.

Nacimiento (El) de Nuestro Salvador Jesucristo.-LOPE. Navidad y Córpus Cris$t i, 1664$.

Nacimiento (El) de Nuestro Señor. Auto ó farsa.-Lúc.ss Fervíxdez, en sus Farsas y Eglogas.

Nacimiento (El) de Nuestro Señor.-JosÉ DE Yaldivielso. Navidad y Córp's Cristi, 1664.

Nacimiento (EI) de Nuestro Señor.-Mar. DE AMESCUA. Autos sacramentales y al Nacimiento de Cristo. 167\%.

Nacimiento (EI) del Hijo de Dios.-AxtoNio DE Castilla. Autos sacramentales, 1675.

Este es el nombre del autor que lleva el auto al principio, añadiéndose que cra na- tural de ubeda; en el Indice se le llama Antonio del Castillo.

Nacimiento (E]) del Hijo de Dios.-Lope. V. Tirano (El) castigado.

Natividad (La) de Nuestra Señora.-Lope, segun una copia manuscrita que tengo coetánea del autor.

Tambien lo cita Medel en su Indice.

Nave (La) del mercader. Precedido de Loa.-Calderos. Volúmen de sus Autos de 1677 , en el $I$. de 1717 , en el $I I$. de 1729 , y en el III. del Tesoro del teatro español.

Niño (El) pastor.-Lope. Fiestas al Sacramento, y Tom. XVIII. Obras sueltas.

Yedel y Huerta citan una comedia del mismo Lope con este titulo; sospecho que sea equivocacion.

No hai instante $\sin$ milagro. Precedido de Loa.-Calderor. Tomo de sus Au$t o s$ de $167 \pi$, en el $V$. de 1717 , yen el VI. de 1760 .

Yo hai mas fortuna que Dios. Precedido de Loa.-Cilnenos. Tom. IV. de sus Autos de 1717, y en el III. de 1739.

El Indice de Vledel dice equirocadamente No hai más fortuma de Dios.

No le arriendo la ganancia. Precedido de Letra y Loa.-Tinso. Deleitar aprovechando, mártes por la tarde.

Nombre (El) de Jesus.-Lope. Fiestas del SSmo. Sacramento y en el IVIII. de Obras sueltas.

Nuestra Señora del Pilur.-Felepe SixCHEz. Aulos sacramentales. 1673 .

Vedel lo cita anumino.

Nuestra Señora del Rosario, ciento por uno.-Cubulo de Arigor. Navidad $y$ Córpus Cristi, 1664 .

Nuestra Señora del Rosario . la Madrina del cielo.-Tinso. Favidad y Córpus Cristi, 1664 .

Nuevo (EI) hospicio de pobres. Precedi- 
do de Loa.-Cilneron. Tomo de sus Autos de 1677, en el II. de 1717, y en el I. de $170 \% 9$.

Nuero (El) palacio del Retiro. Precedido de Loa.-Calderon. Tom. II. de sus Autos de 1717, y en el I. de $\mathbf{1 7 5 9}$.

Olvidado por Vera Tásis en la Tabla de Ins autos de Culderon.
Obra del santisimo Nacimiento de Y. S. Jesucristo. - V. Pecudor.

Obra noramente feita da muito dolorosa moite \& pairaō de nosso Senhor Iesu Cristo, conforme a escreveram os quatro Santos Eraligelistas. - Frixcisco VAz DE Guimriés.

Hai varias ediciones de los siglos XVI $\mathrm{y}$ Xrll de este aulo portngulles.

Obreros (Los) del Scñor.-Rósıs ZorriLut. Aulos sacramenlales etc. $1633 \mathrm{y}$ 1670 .

Corrió malamente como de Calderon, segun lo afiruna rera Tásis ell el prólogo del tom. I. de sus Comedias; sin embargo, Fajardo en la disertacion que precede á los

Pan (El) y el palo.-V. Del pain.

Parábola del hijo pródigo hecha en una fiesta al patron de España Santiago.Lope. Lib. IV. del Peregrino, y $T_{0-}$ mo $\boldsymbol{V}$. de las Obras suellas impresas por Sancha.

Pasion (La) de Nuestro Redentor Jesucristo-Lúcas Fervíxidz, en sus Eursas y Eglogas.

Pastor (El) Fido. Precedido de Loa.-CALDEROX. Tom. III. de sus Aulos de 17I7, y en el $V$. de 1760 .

Pastor (El) Iobo y cabaña celestial. Lope. Fiestas ai Sacramento, y Tomo XVIII. Obras sueltas.

Barrera duda si es de Lope o de Mira de Amescua; Medel lo atribuye al tiltimo.

Pecador Obra del santísimo Nacimiento de Nuestro Señor Jesu-Cristo llamada del).-Bartoloyé Apiricio. S. l. ni $a$. 4. ${ }^{\circ}$ gót. y Sevilla, 1611.

Se ha reimpreso en el Ensayo de una bib. española. Tom. I. col. 222 2 ? sigs.

Barrera cita un auto de Juan Caxesi intitulado: Obra del pecador.

Peregrino (El).-Valdivielso, en Aclos $y$ comedias.

Medel lo intiula: El peregrino del cielo, y lo mismo hace Barrera. autos ineditns que recogió de Calderon, asegura que Los O'mi'ros 's de este, que In cmmendio y lo publicó con el título de El dia mayor de los diss. Ile examinado este hecho y uo lo mencentro exacto, purque dichos antos son completimente distintos. - Los obreros es el mismo que La siem. bra del Siñor.

Örden (El) de Melquiserlec. Precedido de loa.-Chlurrox. Tom. $\boldsymbol{V}$. de sus Autos de 1717, y en el VI. de 1760.

Ordenes (Las) militares. Precedido de loa.-Calnerox. Tomo de sus Aulos, de 1677 , en el I. de 1717, y en el II. de $17 \% 9$.

Oso (El) y la colmena.-V. Colmenero (El) divino.

Piel (La) de Gedeon. Precedido de Loa. - Cumbros. Tom. III. de sus Autos de 1717, y en el $V$. dle 1760 .

Pintor (El) de su deshonra. Precedido de Loa.-Calderon. Tom. I. de sus Autos de 1717 , y en el $\boldsymbol{I I}$. de 1759 .

Plantas (Las).-Calneron. Autos sacramentales ete. $16.5 \%$

Este es uno de los autos no comprendidos en la Colection de ellos, y que Vera Túsis asegura ser de Calderon.

Pleito (El) matrimonial.-Calderox. Tomo de sus Autos, Barcelona, $1701, \mathrm{y}$ con el título de $\boldsymbol{E}$ l pleito matrimonial del cuerpo y el alma, en el de Autos sacramentales etc., de varios, impreso en 16jö: con el nismo Io anuncia Hedel.

En el tom. V1. de la Coleccion de Autos de Calderon de 1717, y en el IV. de la de 1759 , se encuentra este auto adicionado por D. Ant. de Zamora y precedido de una Loa.

Polifemo (El).-Montalyay. Para todos. Premio (El) de la humildad, y daños de la soberbia. - Felipe Sinchez CanaLERO.

Premio (El) de la limosna, y rico de Alejandría.-Felipe Gonínez. Navidad y Córpus Crisli, 1664. 
Primer (El) duelo del mundo. Precedido de Loa y seguido de Entremes (El astrólogo tunante) y Mojiganga.-Bíxces Candamo. Poesías cómicas. Tom. I.

Primer (La) flor del Carmelo. Precedido de loa.-Calderon. Tom. II. de sus Autos de 1717, en el I. de 17009, y en el III. del Tesoro del teatro español.

Primer (El) refugio del hombre y probática Piscina.-Calderos. Volúmen de sus Autos, Barcelona, 1701. Se reimprimió, precedido de una Loa, en el Tom.VI. de sus Autos de 1717, y en el IV. de 1739.

Primero y segundo Isaac. Precedido de Loa.-Calderon. Tomo de sus Autos de 1677, en el $I I$. de 1717, y en el I. de 1759.

Príncipe (El) de la Paz y trasformaciones de Celia.-LOPE, segun una copia manuscrila antigua que poseo.

Medel lo atribuye á Mira de Ámescua.

Protestacion (La) de la fe. Precedido de Loa. - Calderox. Tom. VI. Aulos, 1760.

No se encuentra en la edicion de 1717.

Quién hallará mujer fuerte? Preuedido de Loa.-Calderon. Tomo de sus Aulos

Redencion (La) de cautivos. Precedido de Loa.-Calderon. Tom. $V$. de sus $A u-$ tos de 1717, y en el VI. de 1760.

Redencion (A la) del género humano. Pleito ejecutivo entre el Género humano $\mathrm{y}$ el Castigo. Son interlocutores: Justicia, Razon, Relator, Misericordia, abogado del Género humano, y Rigor, abogado del Castigo. Diälogo.-Juay DE LUQUE. Divina poesía.

Es una especie de auto corto.

Sacro (El) Parnaso. Precedido de Loa.Caltneron. Tom. V. de sus Aulos de 1717 , en el VI. de 1760 , y en la Descripcion panegírica de Núñez Sotomayor, pág. 15̆1, sin la Loa.
Pruebas (Las) de Cristo. Precedido de Loa.-MIRa de A mescua. Autos sacramentales etc., 16 כ̆ solo el auto.

Pruebas del linaje humano, y encomienda del hombre.-Asósiso.

Tengo un $M S$. con las licencias para su representacion fechadas en 1605 .

Psiques y Cupido, Crislo y el alma.Valdivielso. Actos y comedias.

Psíquis y Cupido. Precedido de Loa.Calneros. Tom. I. de sus Autos de 1717 y 1739 .

En el tom. II. de dichas ediciones se ha. lla otro con el mismo tílulo; pero es enteramente distinto. Medel lo culoca en la S: Siquis y Cupido.

Psiquis y Cupido. Precedido de Loa.Calderon. Tom. II. de sus Autos, $171 \mathrm{~T}$ y 173 9.

Es distinto del que con igual título se halla en el torn. I.

Puente (La) del mundo.-Lope. Fieslas al Sacramento, y Tom. XVIII. Obras sueltas.

de 1677 , en el $\boldsymbol{V}$. de la edicion de 1717 , y en el VI. de 1760.

$\mathrm{R}$

Rescate (El; del hombre. Auto al Nacimiento del Hijo de Dios.-Avóxiso.

La edicion que yo tengo, que no la cren primera, estid hecha en Malbil, Antonio Sunz, $174 i$.

Residencia (La) del hombre. Dos autos con igual título. - Asóvinos. Museo literario de Tapia. pág. 100.

Reyes (Los) Mágos. En castellano.-GiL Vicevite. Obras, y en el Teatro espanol anterior á Lope de Vega.

S

San Aleiro. En portugues. - Baltasar Dias. Lisboa, 1610̈-16-2z̈ y 38 .

San Martin. En castellano.-Gil ViceyTE. Obras.

Sancta Catberina. En portuguez. - 
Baltasar Dlas. Lisboa, 1616-33-34 y 59 .

Santísimas (Las) Formas de Alcalá. Mostalvan. Navidad y Córpus Cristi, 1664.

Santo (El) Nacimiento de Cristo N. S.L. Nacimiento (El santo).

Santo (EI) rei D. Fernando. Parte primera y segunda, precedido cada uno de su Loa.-Calderon. Tomo de sus Autos de 1677, en el III. de la edicion de 1717, y en el $\boldsymbol{V}$. de la de 1760.

Medel dice que va acompañado no solo de Loa sino de Enlremeses y Bailes; 10 que no es ast en las ediciones que acabo de citar.

Segunda (La) esposa y triunfar muriendo. Precedido de Loa.-Caloenon. Tom.VI. de sus Autos de 1717, y en el IV. de 17399

Parece que deba ser el mismo á que Vera Tásis da el título pelado de Triunfar muriendo; pero en tal caso no debiera haber puesto despues como auto diverso á Lu sígunda esposa.

Segundo (El) blason del Austria. Precedido de Loa.-Calderon. Tom. IV. de sis Autos de 1717, y en el III. de 1739.

Vera Tásis coloca en la Tabla de los Autos cle Calderon á El primer blason del Austria, que no sé haya llegado á publicarse.

Semilla (La) y la zizaña. Precedido de Loa.-Caloeron. Tom. III. de sus Autos de 1717, y en el V. de 1760.

Serpiente (La) de metal. Precedido de Loa. - Cltoprov. Tom. II. de sus A $u$ tos de 1717, y en el I. de 1759.

Serrand (La) de Plasencia. - Valdivielso. Actos y comedias.

Barrera le da el títilo de La serrana de

\section{$\mathrm{T}$}

Teatro (El) del mundo.-Calderon. En un tomo de Autos impreso hácia 1640.

Tesoro (El) escondido. Precedido de Loa. - Calderos. Tom. IV. de sus Aulos de 1717, y en el III. de 17309.

Tirano (Ë) casligado.-Lope. Navidad y Córpus Cristi, 1664.

En el epfgrafe dice: Aulo famoso del $\mathrm{Na}$ cimiento del Hijo de Diss. Ei lirano casti. gado.

Tormento (El) del demonio. Auto al Nacimiento de Cristo.-Anósimo.

Torre (La) de Babilonia. Precedido de la Vera de Plusencia, y Medel lo trae anonimo con el mismo título.

Sibila (La) Casandra. - GIL Vicénte. Obras, y en el Teatro español anterior á Lope de Vega.

Está en castellano.

Siega (La).-Lope. Fiestas al Sacramento, y Tom. XVIII. Obras sueltas.

Siembra (La) del Señor. Precedido de Loa.-Calderon. Tom. VI. de sus Autos de 1717, y en el IV. de 1759.

No se halla en la Tabla de los autos de este autor que publicó Vera Tásis. En los Autos al Nacimiento, 1655 y 1675, se publicó como de liójas con el título de Los obreros del Señor.

Soberana (La) Vírgen de Guadalupe, y sus milagros y grandezas de España.Avónimo. Sevilla, 1605. 4. ${ }^{\circ}$

Ignoro que razon tuvo D. Justino Matute y Gaviria para atribuir esta pieza á Miguel de Cervántes.

Hai ediciones de Sevilla de 1615, $1617 \mathrm{y}$ 1868 en las que se intitula indebidamente Comedia.

Socorro (EI) general. Precedido de Loa. - Calderon. Tom. $\boldsymbol{V}$. de sus Autos de 1717, y en el VI. de 1760 .

Sol (El) á media noche y estrellas á medio dia.-Miri de A mescua.

Es distinto de la comedia de J. Bta. Villegas. Barrera no lo menciona ni en el Indice de los títulos de autos, ni en el articulo de Mira de Amescua.

Soldado (El). Precedido de Loa.-Gómez Tejada de los Reyes. Noche buena.

Tengo tambien suelto el mismo auto $\mathrm{y}$ loa con el título de El soldado vencedor.

Soldado (El) vencedor.-V. Soldado (El).

Sueños hai que. verdades son. Precedido de Loa.- Calderon. Tom. III. de sus $A$ utos de 1717, y en el $V$. de 1760.

Loa.-Calderon. Tom. III. de sus Autos de 1717, y en el V. de 1760.

Medel le da equivocadamente el título de La loma de Babilonia.

Tránsito (El) y Asuncion de la purísima inmaculada y humilde Vírgen María Madre de Dios, Señora y abogada nues. tra.-Anónimo. S. l. 1603 . $40^{\circ}$

Triunfo de la virtud. Con su Loa.-GóMez Tejada de los ReYes. Noches buenas.

Triunfos de misericordia, y la justicia vencida. -ANósımo. 
Vacante (La) general. Precedido de Loa. - Calderos. Tomo de sus Autos de 1677 , en el $I V$. de la edicion de 1717 , y en el III. de la de 1759.

Valle (EI) de la zarzuela. Precedido de loa.-Calderon. Tom. IV. de sus Autos de 1717, y en el III. de 1739.

Valle (El) de lágrimas convertido en risas por la Aurora Maria. Con Loa.Fr. Axtosio Amador. Fol. 82 vita. de los Elogios a María por Luis de Paracuéllos.

Veneno (El) y la triaca. Precedido de Loa.-Calderon. Tom. IV. de sus Autos de 1717, y en el III. de 17309.

No lo menciona Vera Tásis en la Tabla de los Autos de Culderon.

Verdadero (El) Dios Pan.-Calderos. Tomo de sus Autos, Barcelona, 1701, y precedido de una Loa, en el Tom. IIII. de sus Autos de 1717, y en el $V$. de 1760.

Viaje del alma. Representacion moral.Lope. Lib. I. del Peregrino en su patria, y en el Tom. F. de las Obrus sueltas, inipresas por Sancha.

Viático (El) Cordere. Precedido de Loa.Calderos. Tom. I. de sus Autos de 1717 , y II. de 1739 .

Yugo (El) de Cristo.-Lope, segun una copia que tengo con el permiso para su re-
Vida (La) es sueño. Precedido de Loa.Cilderox. Tomo de sus Autos de 1677, en el VI. de la edicion de 1717, y en el IV. de la de 1739 .

En la coleccinn de autos que reunió $\mathrm{Fa}$ jardo se halla MS. la segunda parte.

Villano (El) en su rincon.-VAldivielso. Actos y comedias.

Viña (La) del Señor. Precedido de Loa. -Calderox. Tomo de sus aulos de 1677 , en el $I V$. de la de 1717, en el III. de la de $170 \% 9$, y en el III. tambien del Tesoro del tealro español, por Ochoa. Vírgen (La) de Guadalupe. Auto en tres jornadas.-Felipe Godisez. Autos sacramentales, etc., 16303 y 1675.

Consta anónimo en Medel.

Vírgen (La) del Rosario, la amiga más verdadera.-Astosio Coello, en la Navidad y Córpus Cristi, 1664 .

Yedel llama equirocadamente Luis a este autor.

Vuelta (La) de Egipto.-Lope. Fiestas al Sacramento, y Tom. XVIII. Obras sueltas.

Consta anónimo en Medel.

Y

presentacion, dado en Alcalá en 1630. El indice de Iredel to da como anúnimo. 
LOAS.

\section{Se comprenden en ellas las Loas saeramentales, dialogadas, entremesadas, alegóricas, eriticas, famosas, euriosas, y más de doscientas sin título.}

\section{A}

A mas linieblas mas luzes, al llanto mas alegria. Loa para la zarzuela de Hacer cuenta sin la huéspeda.-Axóximo. Alma (EI) enferma.-Avósiso. Navidad y Córpus Cristi, 1664.

Antiloquio ou loa a hūa Comedia de Iob. En portugues. - Francisco MANoEL DE Melo. Obras métricas.

\section{B}

Batalla (La) naval. - Axóviso. P. III.
Arbol (El) místico. -José Vic. Orth y MAYOR.

Se encuentra sin título y como de Calderon al frente del auto La lepra de Constantino, en el Tom. V. de los suyos; pero Jimeno en su Biblioleca nos descubre el nombre de su verdadero autor, y el título que sin duda llevará en una edicion suelta de 1712 .

Comedias de Lope de Vega, etc. 1614.

G

Calidades (Las) de las mujeres.-Axóxiмо. P. III. Comedias de Lope.

Cinco (Las) reglas de contar.-Axóvimo. Nacidad y Córpus Cristi, 1664.

Colores (Los). - José Vic. Ortí y Mayor.

Se halla sin titulo, como de Calderon, para el auto La humildad coronada de las flores, en el Tom.IV. de los suyos; pero Ji- meno declara el nombre de su verdadero autor y el titulo que probablemente lleva en la edicion suelta de 1707: el asunto se relaciona á sucesos del tiempo de Felipe $V$.

Concepcion (La; le María Santísima.Soror Juava Ines ne la Cauz. Tom. II. de sus Obras.

Dia (El) y la noche, y un galan.-Avó- | Nimo. Navidad y Córpus Cristí, 1664. 
Fe (La).-Axósimo. Autos sacramenta-

Juego (El) de la pelota.-Galdoron. Ociosidad entrelenida.

Juego (Ed) del hombre.-Juax de Robles Corvalas. Al fin de un romance intilu-
Lengua (La).-Axósimo. Precede á la comedia La venganza honrosa, en la Flor de las comedias de España. Quinta parte.

Letras (Las) del A., B., C. - Axósimo. P. III. de Comedias de Lope.

Loa.-Axósimo. Precede á la Fábula ó comedia de Cadmo y Armonía, que se supone ser del P. Pedro de Fomperosa y Quintana. (V. Núm. 1488.)

Loa -Arósimo. Precede á la comedia de Juan Grajåles El bastardo de Ceuta, en la Flor de las comedias de España. Quinta parte.

Loa.-Axósimo. Precede á la conedia Desgracias del rei D. Alfonso el Casto, en la Flor de las comedias de España. Quinta parte.

Loa.-Asóvimo. Se halla al principio de la tragedia de Hurtado de Velarde Los siete infantes de Lara, en la Flor de las comedias de España Quinla parte.

Loa.-Migtel Beseito. Precede á su comedia $E l$ Hijo obediense, P. I. de los Poelas valencianos.

Loa.-José Butrov. Fa el Clarin de la fama y cilara de Apolo.

Loa.-Gullen lie Castro. Aulos sacramentales, 1675.

Está -cil la pág. 198 y no se halla en la Tabla del volumen.

Loa.-Gulles ne Castro. Al principio de sI cumedia El ainor constante, P. I. de los Poetas valencianos.

Laa.-G Gilles de Castro. Hizola la compañía de Arias en Sevilla, en los Autos sacramentales, etc., 1635 .

Loa.-Diego de Cóbdoya y Figueroa. Rasgos del ocio. les, con quatro comedias, etc. 1655.

Iado: Misterioso aparecimiento de la Cruz de Caravaca, inpreso en Madrid hácia 1685 .

Loa.-Seb. de Villaviciosa. Rasgos del ocio.

Loa á las fiestas sacramentales con que celebró la dedicacion de su templo la ciudad de Jaca en el año de 1660.Joay Alegre. En el Núnez Solomayor. Descripcion panegírica, pág. 137. (V. Núm. 1332.)

Representáronla Joseph de Prado y Mla. riana Baca.

Loa á las bodas del condestable de Castilla conl la Sra. Doña María de Benavídes.-Diamaste. P. I. de sus Comedias.

Loa á los años de la condesa de Galve. Poema encomiástico para representarse.-Soror Juana lyes de ha Crez. Tom. II. Obras.

Loa á los años de la reina Doña María Luisa de Borbon. - SOROR JUANa INES DE la Cruz. Tom. 1. Obras.

Loa á los años de la reina madre Doña Mariana de Austria. - Soror Joava INes de ha Cauz. Toin. II. de las Obras.

Loa á los años del conde de Galve. Soror JUaya INes de la Cruz. Tom.II. de las Obras.

Loa á los años del maestro Fr. Diego Velazquez de la Cadena.--SOROR JuAxa INES DE LA CRUZ. Tom. I. de sus Obras.

Loa á los felices años del conde de Parédes.-Soror Juaya Ises de la Croz. Tom. I. de sus Obras.

Loa al año que cumplió el primogénito del conde de Parédes. - SOROR JUAxA Ines ne la Crot. Tom. I. de sus Obras. Loa al Nacimiento de Nuestro Señor Jesucristo.-Sinchez Tórtoles. El Entre- 
tenido, P. I. precede á su comedia con igual título.

Loa al nacimiento del príncipe D. Luis Jacobo Primero, el Deseado.-A Ávisimo. En El clarin sonoro de la Fama, por Butron.

Loa al nombre de la reina Doña Maria Luisa de Borbou para la concdia de Ícaro y Détlalo.-Melcior Feríndez DE Lleox. $P$. XLVIII. C. A.

Loa al redentor patriarca S. Pedro Nolasco-Leos Mircinve. Tum. I. de sus Obras.

Loa al Sacramento.-Juan de Luque. Dirina poesia.

Loa al santisimo misterio del Nacimiento de N. S. Jesucristo. -A vóvino. Entremeses varios y Luas, impresos por Ant. Sanz.

Loa al Santísimo Sacramento. - Sebastiay Yillaviciosa. Ociosidad enlrelenida.

Loa alegórica para la comedia $E \boldsymbol{l}$ amor perseguido y la rirlud triunfonte.Gaspar Zabala y Zamora.

Loa breve en metáfora de Polifemo y Galatea para cualquier funcion y tiempo, principalmente para el de Navidad.Axóxsyo. Entremeses varios y Loas, impresos por Sanz.

Loa celebrando la Concepcion de María Santísima.-Soror JUANA lNes de LA Crez. Tum. II. de sus Obras.

Loa con que empezaron Rueda y Ascanio. -Quińoxes de Besiverte. Jocoseria.

Loa con que empezó en la corte Roque de Figueroa.-Quñónes de Bexatexte. Jocoseria.

Loa con que empezó Lorenzo Hırtado en Madrid la segunda vez.-Quñónes DE Benavente. Jocoseria.

Esta loa se reimprimió en la Ociosidad entretenida, solo sí que en la cabezal se puso Bermardo de Prado en lugar de Lorenso Hurlalio, y se variaron algunos de los interlocutores.

Loa con que empezó Tomas Fernández en la corte. - Quiñóses be Bexarexte. Jucoseria

Loa cou que entró á representar en Madricl la compania de rélix Pascual.Silazar y Tónres. Cilara de Apolo. Tom. II.

Loa con que cutró en la corte Beruardo de Prado.-Quiñoves de Besavente. Ociosidud enlretenida.

Loa con que se estrenó en Granada el auto de La imágen del Sacramento, San Juan de Diss.-Ganet y Ovino. l're- cede a dicho auto en Las triunfales fieslas de este autor.

Loa crítica y sucinta en que se elogia mujer de cualquier estado, nombre ú otra circunstancia, porqne es comun para todas esferas de mujeres.-AvóNimo. Entremeses varios, núm. 2.

Loa curiosa del juego del hombre.-A NóNimo. Se halla en un pliego suclto impreso en Madrid, por Francisco Sanz, s. a., cuyo título es: Misterioso aparecimienlo de la sanlisima Cruz de Caravaca. Por el Lic. Iuan de Robles Corvalan.

Loa de la comedia de Monjuich.-Axóniso. Se halla al fin de la comedia intitillada: Entrada del marques de los Vélez en Calaluña, rola de las tropas castellanas y asallo de Monjuich, en la edicion de 1641 .

Loa dialogada.-Lope. Precede á su comedia $E l$ vellocino de oro, en la $P . X I X$.

Loa donde se nombran todas las danias de Valencia.-Cír.os Borl. Precede á su comedia El marido asigurado, P. II. de los Poetas valencianos.

Loa en alabanza de la espada.-A - Á́nimo. $P$. III. de las Cumedias de Lope, y al fin de las de Simā̃ Machado, donde se atribuye resueltamente á Lope.

Loa en al̆abanza de la humildad.-AvóNivo. P. VII. de Lope.

Loa en alabanza de la vanidad.-Anóviмo. P. VIII. de Lope.

Loa en alabanza de las mujeres, en metáfora de las flores, yerbas y plantas.Axósiyo. Pliego suelto impreso en $\mathbf{V a}$ lencia, por Francisco Mestre, s. a. (Lácia 1670), intitulado: Famoso romance del arlificio de la seda, y grandezas de la airilad de Murciay su fértil vega.

Loa en alabanza de las mujeres feas.Anósimo. Por el contesto se saca que es de Francisco de ávila. Precede á la comedia La enemiga favorable, de Tárrega, en la Flor de las comedias de España. Quinla parte

Loa en las huertas donde fué á divertirse la condesa de Parédes.--Sorcr Juana Ines de la Cruz. Tom. I. de sus Ubras. Loa en vituperio de la mala leugua.Anóviyo. P. VII. de Lope.

Loa entre la Iglesia y el zelo.-Quñónss DE Bevavente. Ociosidad entretenida. Loa entre ocho personas.-Fr. Antovio Amanor. Precede á su auto $E l$ valle de ligrimas converlido en risas, que se 
balla en los Elogios de Marla, de Luis de Paracuéllos. Núm. 1339.

Loa famosa. - Axónirmo. Parece que se hizo para la primera representacion que dió en Madrid la compañía de Cintor 6 Diego Vivas, y se halla en los Autos sacramentales, etc., 1655.

I.oa famosa.-Mira de Amescus. Precede á su auto El heredero, en el tomo de Autos sacramentales, etc., 1655.

Loa famosa.-Mara de Aypscua. Precede al auto de Las pruebas de Cristo, en los Aulos sacramentates, etc., 1655.

Es diversa de la de este autor que se halla en el tomo de los impresos en 1675.

Loa famosa.-Mira dB Amescea. Aulos sacramentales, 167 .

Tambien es distinta de la del mismo, que está en los Autus de 1655.

Loa famosa.-LoPe. Autos sacramentales, elc., 165 .

Loa famosa en alabanza de los dedos.Axósimo. Precede á la comedia El premio de las letras, de Salustio de Poyo, en la Flor de las comedias de España. Quinta parte.

Loa famosa en alabanza de los males.Axósimo. Precede á la comedia $\mathbf{L a}$ guarda cuidadosa, de Miguel Sánchez, en la Flor de las comedias de España. Quinta parte.

Loa famosa en alabanza del trabajo.Asósino. Precede á la comedia El loco cuerdo, de Valdivielso, en la Flor de las comedias de España. Quinta parte.

Loa famosa entre la Iglesia y el zelo.LoIs DE Besavente. Ociosidad entretenida.

Loa famosa; hala de echar nujer y en bábito de labradora.-Anjusnn. Ya al principio de La rueda de a fortuna, de Mira de Amescua en la Flor de las comedias de Esparia. Quinta parte.

Loa mui discreta y curiosa en aplauso del gloriosisimo Patriarca S. José. - José Moraleja. El Entretenido. P. II.

Loa para el auto El colmenero divino.Tirso. Deleitar aprovechando.

Loa para el auto El mártir del Sacramento --SOROR JUaxa INES DE LA CREz. Precede á dicho auto en el Tom. II. de sus Obras.

Loa para el auto El Mesías verdadero.Juar de Assor y Mácas. Va con dicho auto.

Loa para Francisco Garcia el Pupilo.J. B. Diamìnte. Rasgos del ocio.
Loa para la comedia burlesca $E$ l mariscal de Biron.-Joan Maldonado. P. $\boldsymbol{X I I}$. C. $A$.

Loa para la comedia con que se celebró en Lima la exaltacion á la corona de España de D. Luis I.-Pedro Peralta Burvoevo, en el Elisio Peruano, de Fernández de Castro.

Loa para la comedia del Buen-Retiro, intitulada: Amor es todo invencion, Júpiter y Anfitrion.-Asósimo.

Es probablemente de Cañizáres, y se halla al principio de la citada comedia,

Loa para la comedia el Sueño del perro. - Asóvimo. Precede à dicha comedia.

Loa para la comedia Lo mejor es lo mejor.-Avtosio de Cardosa y Borja.

Loa para la comedia que se representó á sus Magestades en el palacio del BuenRetiro en celebridad de la llegada á la corte de Doña María Luisa. - Perez Mostoro. Tom. I. de sus Obras.

Loa para la coronacion del señor D. Fernando el VI.-Félix de Alarcos. En El dia de Lima.

Loa para la ónera Decio y Eraclea.-EL CONDE de las Tórrres. Precede á dicha ópera.

Loa para los años del emperador de Alemania.-Moreto. Rasgos del ocio.

Loa para tiempo de Carnestolendas.Francisco Parraga Martel de la fuenTR. En su Historia de Liseno y Fenisa.

Más bien que $L \cap a$, parece una zarzuelita representada entre varios personajes.

Loa que precede á la comedia burlesca $L a$ mas constante mujer. - Jety MaLtorido, Diego la Deeña y Jerónimo CifcexTES. P. XI. C. A.

Loa que precede à la comedia $E l$ rencor mas inhumano de un pecho aleve y tirano.-A sósilyo.

Tal veź sea de José Concha.

Loa que precede á la comedia Endimion y Dicina. - Ifelchor Fervisuet de LEOY P. YLII. C. A.

Loa rue precede á la conedia firras afemina amor. - CALDERON.

Loa que precede á la comedia Los empeños de lina casa. - SORor Jeasa INEs DB la Crcz. Tom. II, de sus Obras.

Loa que precede á la comedia Los tres mayores prodigios. - CALDEROX.

Loa que precede à la zarzaela $L a$ pirpura de la rusil - Caldenos.

Loa que representó Antonio de Prado.- 
Quiñones de Benavente. Jocoseria, y en La mejor for de entremeses.

Loa que se representó á sus Magestades en celebridad de los años de la reina Doña María Luisa esposa de Cárlos II. -Pérez Montoro. Tom. I. de sus Obras.

Loa que se representó en el cuarto centenar de la Conquista de Valencia.Makco Antovio Ortí, en su Siglo $I V$. de la Conquista de Valencia.

Loa sacramental.-Avósimo.

Till vez sea de Lope, pues se halla al fll de su comedia La Creacion del mundo" priner culpa del kombre, en una edicion anligua que poseo.

Loa sacramental á lo morisco.-LOPE? Al fill de una edicion antigua que tengo de la comedia Mas pesa el rei que la sangre, con el nombre de Lope; aunque quizá no sea este su verdadero autor.

Loa sacramental entre tres galanes.Axóvino. Navidad y Córpus Cristi, 1664.

Loa sacramental entre un galan llamado D. Cárlos, que representa la Sabiluría, y entre Bras villano, (jue representa la Iguorancia.-A xóximo. Nacidall y Córpus Cristi, 1664.

Loa sacramental para el Auto del Gran palucio.-Cárcer. Aulos sacramentales, 1630 y 1673 .

Loa sacramental que la compañía de Antonio Prado representó en el auto de La primer for del Carmelo. - A vósino. Aulos sacramentales, etc., $163 ̈ 0 ̈$.

Es distinta de la que lleva este auto en la Coleccion de los de Calderon.

Loa sacramental que la compañia de Osorio representó en el Aulo del Gran patio de Palacio, de Rójas.-Cíverer. Aulos sacramentales, ete., $16.5 \%$

Loa segunda con que volvió Roque de Figueroa á empezar en Madrid.-QusióNES DE B EXAVENTE. Jocoseria.

Loa sin título que precede al auto Los hermanos parecidos.-Tirso. Deleilar aprovechando.

Loa sin título que precede al auto No le arriendo la ganancia.-Tirso. Deleitar aprovechando.

Loas (Once) sin título. - Axóxisas. Al principio de la $\boldsymbol{P}$. $\boldsymbol{I}$. de las Comedias de Lope.

Loas (Delno) para represeutar en cualquier tiempo, fiesta ó funcion.Anóvimas. Entremeses varios y Loas, impresos por Sanz.
Loas (Dos) $\sin$ título.-Avósimas. Parte VII. de Lope.

Una de estas loas ey sobre las mujeres $\mathrm{y}$ la otra de un farsero.

Loas ('Tres) sin título.-Aronimas. Parle VIII. de Lope.

Loas. Hai e $6 \mathbf{s}$ sin título ni nombre de autor en la Navidad y Córpus Cristi, 1664.

Loas de Gaspar Agullar. T'pes al principio de sus consedias La gitana melancólica, La nuera humilde, y Los amantes de Cartago. I. I. de los Poetas valencianos; y coecedses que preceden á los de El mercader amante, La fuerza del interes, La suerte sin esperanza, y El gran palriarca Don Juan ie Ribera, P. II. de los Poelas valencianos.

Loas de D. Francisco Bínces Caxdamo. Ciseces, una para el auto El primer duelo del mundo; y cuatro para las comedias Quién es quien premia al amor, La restauracion de Buda, Cómo se curan los celos, y Duelos de ingenio y forluna. Tom. I. de sus Poesías cómicas. En el II. hai otra Loa para el auto El gran quimico del mundo.

Loas (Setenter) sin títnlo.-Calderor.

Corresponden i ignal numero de antos de los setentid y dos que comprende la $\mathrm{Co}$ leccion de este autnr en seis vols. . $^{\circ}, \mathrm{por}$ que el que precede al de La lepra de Comstanlino 'n el II. tomo, y al de La humildad coronadu de lies plinties en el V., fueron segun lo dice Jimeno escritns por $v$. José Via, Ortí y layor, é impresis por separado el primero, que es relativo is Felipe $V$., con el títuln de Los colori's, y el segundo con el de El árbol mistico.

Loas (Bos) que preceden á la prinera y segunda parte de la comedia El sanio isi I). Fernando. - Cilderox.

Loas a ars uíos de D. Cárlos II.-Soror Juna ints e la Cruz. Tom. I. de sus Obras is encuentran cemeraro, y expre en : i lle.

Loas (Doce) a yarios asuntos, alguna dialogada. - Jacinto v:" Evis. Ramillete de carias flores poétiins.

Loas (Cuata) sin título.-Gómez TEJadi de los Reyes. En la Foche-buena, y preceden á sus autos Inc cecia $y$ malicia, Allivina quién te dic $: A$ soldado, y Triunfo de la virtud.

Loas de ÄG. de Rójas.

\section{Nola de las que}

se hallan en su viaje estretenido.

Loa de la ciudad de Sevilla.

De los que entran sin pagar en la comedia. 
† Del chasco que le sucedió en Sevilla con una mujer fea.

De todo lo nuevo aplace.

De un fracaso sucedido al autor en Sevilla.

De algunas naciones del mundo, y da noticia de un cómico retirado.

De la esclavitud del autor y trabajos de esta, inferiores á los de los representantes.

De la comedia, su antigüedad, preeminencias y prerogativas.

Loa en que con alusion á las bodas de la Luna, manifiesta la dificultad de agradar al vulgo con las nuevas comedias así los autores como los actores.

De la primavera.

Loa de la ciudad de Granada.

Con motivo de una tienda que puso el autor estando en Granada.

De una hermosa mujer con la circunstancia de faltarle un ojo.

De la festividad del Córpus. y ciudad de Toledo.

En vituperio de las mujeres.

En su alabanza.

De un enigma de la mujer.

De la mosca.

De la nobilísima casa de Austria y Borgoña.

Loa de varios asuntos.

A las buenas dentaduras, circunstancias que han de tener, y medios para conservarlas.

Loa á la ciudall de Salamanca, y cuenta un gracioso caso sucedido en Valencia.

Al silencio.

Al amor.

Loa para empezar á representar en Valladolid.

A la letra $\mathbf{A}$.

A la $\mathrm{R}$.

Loa á la ciudad de Valladolid.

Al Santísimo Sacramento con alusion á unos bailes

Loa en que se da razon por qué llamaban il autor el Caballero del Milagro.

Siete luas á los siete dias de la semana.

+ Ina en alabanza de los lalirones.

l.od a la nobleza y utilidades del puerco.

A las cuatro cdades del mundo

Las dos loas que llevan t al mirgen, solo se encuentran en las primitivis ediciones.-Las escritas En vituperin y ala. bania de las mujeres, la de la lelra li, y tres d los dias de la semana, están en prosa.

Loas (Doa).- Sílas Barbadillo. Coronas del Parnaso. Una de ellas precede a la comedia Vitoria de España y Francia, la otra está dirigida $\boldsymbol{A}$ Clori, morena en el color, y en las costumbres inui libre.

Loas (Dos) para las comedias Euridice y Orfeo y Dar tiempo al tiempo.Ag. de Silazar I Tórres. Cítara do Apolo. Tom. I.

Loas (Nueve) de Agustix StlazAR Y TórRES para sus comedias Elegir al enemigo, El amor mas desqraciado, Zéfalo y Pócris, La mejor flor de Sicilia, Tambien se ama en el abismo, Los jueyos ollmpicos, $E l$ encanto es la hermosura, El mérito es la corona, y Tdtis y Peleo. En la P. II. Cítara de Apolo.

Loas (Dos) para cualquiera fiesta.--FELIPE Sí.ichez. Autos sacramentales, $16 \%$.

Loas (Dos).-José Síxtos. Preceden á su comedia La virtud aun entre persas.

Loas de D. Axtoxio de Sous. Hai $\mathbf{l o s}$, una para su comedia Triunfos de amor y forluna, y otra para Un bobo hace ciento, en el tomo de sus Comedias; y orece en el de sus Poesias, a saber: Introduccion de una fiesta que hicieron unas seglares en un concento de monjas; la de la comedia Un bobo hace ciento; otra plara la comedia de Las amazonas; dos para la de Euridice y Orfeo; otra para la de Darlo todo y no dar nada, le Calderon; olla para la de Pico y Canente, de Llloa; otra para la de Hipomene y Atalunta, de Monteser; otra para La cautiva de Falladolid; otra para una comedia doméstica que se representó en casa de los condes de Oropesa, y una para la primera comedia que representaba en cada ciudad la compañia de Prado.

Loas (Wos), una para dar principio al aìo en Barcelona la companía de Manuel Garcia. Y la olra para la zarzucla que se represcintó én casil de Doina Josefa E-mir.-Jose Tifill Y Xegrete. Rumillete poélico.

Loas de Tinaeris. remera que preceden á sus comedias $E l$ prado de $\boldsymbol{B}$ lencia, $\boldsymbol{E l}$ esposo fingido, $L a$ perseguida Amaltra, y Las suertes trocadas. P. I. Ue los Poelas valencianos. Hos que vall al principio de La duquesa 
constante y La fundacion de N. S. de la Merced.

Loas (Cuatro) á la exaltacion al trono de D. Cárlos IY.-Estevay ne TeraLIA y Lisnu. Al fin de su obra intitulada: El sol en el medio dia, 1790. $40^{\circ}$

Loas. Cum (s.o.-Ricardone Tuma (Don Juan de Rejaule y Toledo?) Se hallan en la P. II. de los Poetas valencianos, al principio de sus comedias La burladora burlada, La beligera española, La fe pagada, y El triunfante marlirio de $S$. Vicente : la primera Contando un estraño suceso; la segunda Para el primer dia que represcntó la compaña de Pórras en Valemcia; la tercera Glosando este pie, "que todo trabajo cuesta;" y la cuarta 4 S. Vicente Marlir.

Loas. - Lope? Cona al principio de su comedia El cjemplo de las casadas, en la Flor de las comedias de España, Quinta parte; doce en las Fiestas al SSmo. Sacramento; exme en los Autos sacramentales, etc., 1653; mere (que precede á la comedia El Vellocino de oro, en la $P$. $X I X$; cerretoo al fin de lis Cornedias de Simāo Machado, la primera En alabanza de la espada, que tambien se halla en la P. III.; la segunda De los memorables hechos de los romanos y griegos; la tereera Del desastrado fin de alguncs emperalores, $y$ capilanes romanos $y$ gricgos; y la cuarta sin título; y alos que preceden á las dos comedias de Lope que están en la Relacion de las fiestas a la canonizacion de S. Isidro. Loas. Dos.-Luis Velez de Guevara? Preceden á la primera y segunda parte de La hermosura de Raquel, en la Flor de las comedias de España. Quinla parle.

Loco (EI).-Aróviso. Autos sacramentales, etc., 163.
Nacimiento (El).-1rósmo. Navidad y Córpus Cristi, 1664.

Sacimiento (Loa al), para el auto de Los angeles encontrados. - A TTOMDO DE CisTiles. Va al fin de dicho auto.

Tacimiento (EI) de Cristo.-Axóxuo. Aulos sacramentales, $167 \%$.

Nacimiento (El) de Cristo Nuestro Bien. -Axóriso. Navidad y Córpus Cristi, 1664.

Nacimiento (El) de Cristo Yuestro Scñor.

Oficios (Los). Loa sacramental.-Axóxi-
- Ixóxino. Navidad y Córpus Cristi, 1664.

Sacimiento (El) del IIijo de Dios.-Axóxiso. Tacidal y Córpus Crisi 1664.

Tuestra Señora.-Cisnerox. Tardes apacibles.

Nuestra Señora. -Jein de Siy Axtovio. Autos sacramentales, 1670.

Nuestra Señora del Rosario.-Axóximo. Yavidad y Córpus Cristi, 1664.
Planetas y signos. - Leor Murcinite. Tom. I. de sus Obras poéticas, y all el Vergel de entromeses, $167 . j$, segun Barrera.
Pronóstico (El). - Axívino. A yibs sacramentules, 163:3, y en los de 1675 is la pág. 200. 


\section{$\mathrm{R}$}

Reloj (El).-Calnerox. Arcadia de entremeses, 1723, y Flores del Parnaso. Reloj (EI). - Leos Marcinste. Tom. I. de sus Obras poćlicas.
Rosario (EI). En alabanzas de Vuestra Señora. - Iróxiso. Nacidad y Córpus Cristi, 1664 .
San Pedro Nolasco.-Leox Marcinste. Tom. I. de sus Obras poélicas.

Santisimo (El) misterio del Vacimiento de Nuestro Señor Jesucristo.-Axós. Mo. Tomo de Entremeses varios y Loas. Santisimo (El) Sicramento.-Sf.b. IIE ViLLAVICIOsi Ociosidad entretenida.
Siete (Los) dias de la semana.-CilorRox. Arcadia de entremeses, 1691 y 1700 .

Siete (Los' sabios de Grecia-Cinderox. Entremeses varios. Zaragoza, s. a.

Suntuoso (EI) Escurial. - Aóxino. Purte III. de las Comedias de Lope.

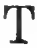

Títulos (Los) de las comedias. - Lope. Verdores del Parnaso, de Armesto y Castro.

Se publico anónima en la . Yaridady Córpus Cristi, 1 biti.

Títulos (Los) de las comedias. - Axósiuo. Autos sacramentales, ctc., 1600 .
Es diversa de la atribuida á Lope de Veşa en los verdores del P(brinsi), de armesto.

Tres (Los) sentidos corporales. - Axósso. Facidall y Córpus Cristi, 166 .

Triunfo (El) de las mrieres.-Gerunuo Lopo. Ohras. Tom. I. y en el Tom. II. de la edicion de 1730 .

\section{V}

Vaqueros (LOS) de Aranjuez.-R.syor DE LA Croz. Tom. VII. de su Teatro.

Villano (El). - Axóvirro. Autos sacra-

mentales, con quatro comedias. $163 \mathrm{~g}$. Virgen (La) del Rosario.-Avivino. En la Nacidad y Córpus Cristi, $166 \dot{ }$ 


\section{ENTREMESES, BAILES, JÁCARAS, SAINETES, MOJIGANGas, VILlaNCICOS, UNIPERSONALES, FINES DE FIESTA, SARAOS, SOLILOQUIOS,}

\section{y alguna otra composicion representable con distinta denominacion que no esté ineluida en las seceiones anteriores de este indice.}

A lo que obliga el amor. Relacion jocoseria.-Jose Moralej.. El entretenido. P. II.

Abad (El) del Campillo. E.-Leov Marcnavte. Obras poélicas. Tom. I., y en la Ociosidad entretenida.

Abadejillo (El). E.-Quišó:es de BenaveNTE. Jocoseria, y en el Festejo cómico.

Abanino (EI). B. - Pérez Movroro. Tom. I.

El Sr. Fernindez-Guerra ni eita el nombre del autor ni dice qué clase de composicion es.

Abate (EI) y albañil. S. - A xóximo.

Agente (EI) de sus negocios. S.-Rayor DE th Cruz. Toin. VIII. de su Teutro.

Aguador (El). E.-Moreto. Rasgos del ocio.

Agujetero (EI) fingido. E.-Araesto Y Castro. Verdores del Parnaso, y en sus Sainetes y entremeses, 1674 .

Alcalde (El) de Alcorcon. E.-Moreto. Tardes apacibles.

Alcalde (El) de Mairena. E.-Fernando dE Zarate. Rasgos del ocio.

El Sr. Ferníndez.Guerra lo cita suelto sin nombre de autor.

Alcalde (EI) del corral. B.-Qữ̄óngs DE Benivexte. Parnaso nuevo y amenidades del gusto.

Alcalde (El) hablando al rei. E.- VIcente Suárez de Deza. Donaires de Tersicore.

Es el mismo quej|lel alcalde villano haulando al rci, quese encuentra en las Flo- res del Parnaso y en la Arcadia de entremeses, de 1723.

Alcalde (El) haciendo audiencia. E.José Cáros Guerra. P. II. de $\boldsymbol{E} l$ entretenido, de Moraleja.

El Sr. Fernández-Guerra se lo atribuye á este.

Alcalde (El) justiciero. S.-ANónimo.

Alcalde (EI) médico. E.-José Moraleja. $\boldsymbol{P}$. II. de El entretenido.

Hluerta en su Theatro hespañol reimprlmió este entremes, anónimo, con cl título de El alcalde quimico.

Alcalde (El) por fuerza. E.-A sósimo. Entremeses varios y Loas, impresos por Antonio Sanz.

Alcalde (EI) químico. E. - V. Alcalde (El) nédico.

Alcalde (El) villano hablando al rei. $\boldsymbol{E}$. - Vic. Sitiaz de DEza. Flores del Parnaso y Arcadia de entremeses, 1723.

Es el mismo que an los Donaires de Tersicore se encuentra con el titulo de $E l$ alcalde hablando al rei.

Alcaldes (Los). Primera, segunda, tercera y cilarla parte. E.-Tinso. P.II.

En el Indice de entremests reciactado por el Sr. Fernández-Guerra, que trae Barrera, se intitula esta piececital los alcaldes encontrados, y se da como ituinla parte, inédita, la que está impresa como cuaria en la $P$. II. de Tirso, suponiencio cuarla é impresa, una que deberá sel. quinta y no se ha publicado. Habla ademas de una sesta parte que no ha visto la luz pública. 


\section{AMO}

INDICE UE TÍTULOS.

AYO

683

Huerta en su Thealro hespañol tambien denomina esta composlcion Los alcaldes encontrados; pero solo reimprimió la primera parte, anónima.

Alcaldes (Los). M. - I.eor Marchiste. Tom. I. Obras poéticas.

Alcaldes (Los) enharinados. E.-AxóriMo. Entremeses rarios, núm ?.

Alcaldito (El). E.-Axóvino. Autos sacramentales, etc., 16 วัว.

No lo encuentro en el Indice de Fernán. dez-Guerra.

Alcolea y noche de San Juan. E.-Moreтo. Parnaso nuevo y amenidades del gusto.

Este es el título que lleva en el indice, al principio de èl solo dice: Entremes para ln noche de $S$. Juan. Fernández-Guerra no lo menciona con el título de Alcolea.

Alfanje (El) y estudiantes burlones. $\boldsymbol{E}$. - Axósino. Arcadia de entremeses, 1723.

Alfiler (El). B.-Qcišóxes de Bexavexte. Autos sacramenlales, 1673 .

Alimentos (Los). Entrcmes en prosa.Axóvino. P. I. Comedias de Lope.

Almacen (El) de norias. S.-Riyos DE LA Cruz. Tom. II. de sil Teatro.

Almoneda (La). $M$-Friscisco de Castro. Alegrín cómica. P. II.

Amantes (Los) á escuras. E. A Flores del Parnaso.

Amantes (Los) de Teruel. M.-Axósiyo. Arcadic de encremeses, 1691 y 1700.

Es un estracto o compendio de los dmantesde Teruel, de Suirez de Deza.

Amigo (El) verdadero. E.-Axdres Gil. Parnaso nuevo y amenidades del gusto. Segun Barrera tambien se encuentra en la Florcsta de entremeses. $\boldsymbol{M} a$ drid, 1680.

Es el mismn que está como anónimo en el tomo de Enlremestos vios, nưm.?.

Amo y criado. S. - A Nónimo.

Amor (El)al uso E.-Qurióxes de Bexivevte. Navidad y Córpus Cristi, 1664.

Amor (El) borracho. S.-ivgel Pergeriso. La mejor guirnalda de Apolo. Tom. I.

Amer (El) buhonero. E.-Frircisco DE Castro. Alegria cómica. P. I.

Amor (El) duende. S.-Jerósimo Mosfortr y Vera. Elisio Peruano, de Fernández de Castro y Bocángel.
Amor (El) es sin razon. B.-ANT. A BAD Velasco, en sus Aleluyas jocosas.

Amor (El) sastre. B.-Fravcisgo de CAStho. Alegria cómica. P. II.

Amor $y$ desden. B.-Salazar y Tórres. Cilara de Apolo. Tom. I.

Amor (El) y el interes. B.-Axórimo. Flor de las comedias de España. Quir:ta parte. Va al principio de la comedia de Mira de Amescua Desgracias del rei D. Allonso el Casto.

Amor y zelos. B. - Agestir Saltzar y Tórres. Citara de Apolo. Tom. I.

Angulo (El). F.-Quñóxes de BevsyexTE. Nicidad y Córpus Cristi, 1664.

Antojadiza (La). E.-Lois dE BexavesTE. Tardes apacibles.

Antojero (El). B. E.-Scárez de Deza. Donaires de Tersicore.

Añasquillo. B. E.-SC.́nez. DE DEZA. Donaires de Tersicore.

Apodos (Los). E.-Ast. DE Zaxora. Segun Barrera cn el Tom. I. de sus $\mathrm{Co}$ medias, 17 ? 2 .

En el Thentro hespañl de Huerta se encuentra anónimo.

Arambeles (Los). E.-Axóviyo. Arcadia de entremeses, 1691 y 1700 .

Arrufaifa (El). B.-Axósino. Arcadia de entremeses, 1691 y 1700.

Astrólogo (El) embustero y burlado. $E$. - Aróxiso. Arcadia de entremeses. 17 ㅋ․

Astrólogo (El) tunante. Entremes para el auto. El primer duelo del mundo.Bixces Cisdayo. Poesias cómicas, Tom. $I$.

Astucia (La) de la alcarreña. S.-AxóIIyo.

Avantal (El). E.-Qcrĩóses de BexayesTE. Autos sacramentales , 1670 .

En el Fensi! amum do pnlpemeses, 1691 , se encuentril un aninimo con el mismo iftulo, segun Gallardu.

Aves (Las). B.-Melchor Fersivoez de Leox. Se halla intercalado entre la segunda y tercera jornada de su comedia Icaro y Dédalo, en la P. TLVIII. C. A.

Ay, ay, ay, y el sotillo B.-Axúviyo. Flor de ins comedias de España. Quinla parle. Está al principio de la comedia de I.ope $E$ l cjemplo de las casadas. Avo (El). E.-Moreto. Aulos sacrameniales, $167 \%$. 
Baile.-Vicrvite Sívcriez. Lira poética.

No estí en olmatice de Feruandez-Guerra.

Baile cantado. Especie de zarzuela.Gixes Cimpll.lo de Balle. Gustos y disgustos del lentiscar de Carlagena.

Tamporo lo encuentro en el Indice de Ferniutlez-Guerra.

Baile curioso y grave.-Axóxiso. Precede á La ruedi de la fortuna, de Mira de Anescua, en la Flor de las comedias de España. Quinta parte.

Tambien falta en el Indice de FernindezGuerra.

Baile para Francisco Ponze.-V. Loco (El) de amor.

Baile para los años del príncipe.- MtesTro Leox (Marcinte). Rasgos del ocio.

Con este título no se halla en el Indice de Fernandez-Guerra.

Baile pastoril. - Axósiso. Se habla al principio del Premio de las letras, de Saiustio de Poyo, en la Flor de las comedias de España. Quinta parte

Baile (El) perdido. Representacion graciosu.-A.tu. ne Solis. Poesia.

Es una repeeje de sainete.

Baile sin titulo que principia:

"Reinando en Francia

Cárlos el primero."

- Axónino. P. VIII. Comedias de Lope.

To está en el Indiec de Fernández-Guerra.

Baile y sarao que se cantó y representó en la liesta de Todo lo vence el amor. - Avir. de Ziyon. Flores del Parnaso.

No lo encuentro en el Intice de Fernández-Guerra.

Bailes.-Gonez de Tejada. Hai algunos en su Noche buena.

No los cita Fernández-Guerra.

Baladrones (Los). Entremes cantado $y$ representado.-Afyesto y Cistro. Verdores del Parnaso, y en sus Sainetes $y$ entremeses, 1674 .

Bambochos (Los)? Parece que este deba ser el título de Baile ó entremes cantado, falto de la primera hoja: la segunda lleva la sigrn. E 2 , y concluye á la cuarta hoja de dicha sign. Se halla en el Tomo le Entromeses varios y Loas, impresos por $\boldsymbol{S} a n z$.
Fernández-Guerra no cita ninguno con este titulo ni que principie: "Aqui sin dluda ha de ser."

Bandoleras (Las) del Prado. S.-Suárez DE DEzA. Donaires de Tersicore.

Bandos (Los) de Lavapies. B.-Antonio Abad Velasco. Aleluyas jocosas.

Barbas (Las) de balde. E.-Leon MarChante. Obras poéticas. Tom. I.

Barbero (El). E.-Suárez de Deza. Donaires de Tersicore.

Barberos (Los) de la Puerta del Sol. E. - Axóxiyo. En el tomo de Entremeses varios y Loas, impreso por Sanz.

Barrendero (El). M. - Frascisco de Castro. Alegría cómica. P. IIIL.

Batalla (La). B.-Frixcisco Avel.Laneda. Ociosidad entretenida.

Bobo (EI) casado. $\boldsymbol{E}$.-Axósimo. Entremeses varios, núm. 1.

Boda (La) de Foncarral. B.-Asósimo. Precede á la comedia de Aguilar La venganza honrosa, en la Flor de las comedias de España. Quinta parle.

Borla (La) de Juan Rana. E.-Cíccer. Manojilo de entremeses, y Floresta ile entremeses.

Boda de pordioseros. B.-Quevedo. En su Parnaso español, monte en dos cumbres, 1724, Tom. III. de sus Obras.

Boda (La) y los violines. E.-Francisco DE Casrro. Alegria cómica. P. $I$.

Bodas (Las) de Mengo y Camacho. Entre. mes en dos jornadas.-Castilio Solónzivo. Varios y honestos eniretenimientos.

No lo trae con este título FernándezGuerra.

Bodegon (El). E.-Joar Vélez. Tardes apacibles.

Dice el Sr. Barrera rue en la biblioteca del duque de Osuna existe in MS. original de este entremes á nombie de Luis Vélez; sin embargo, cu las Tardes umitibles se halla el de Juan su hijo.

Borracho (El). E.-Cistrilo socónzaxo. Varios y honestos entretenimiir:iss.

No consta en el Indice de Ferub́udezrilierra.

Borracho (El). E.-Quĩónes de Bentvente. Jocoseria, y en La mejor for de entremeses.

El mismo entremes anonimo se. halla en los dutos sacramentales, ete., 1655. 
Borracho (El) y Talaveron. B. - Leov Marchante. Tom. $I$. de sus Obras poéticas, y en el Parnaso nuevo y amenidades del gusto.

Borrachos (Los). B.- Quevedo. En su Parnaso español, monte en dos cumbres, 1724. Tom. III. de sus Obras.

Borrachos (Los). B. E. - Suírez de Deza. Donaires de Tersicore.

Bota (La).E.-Moreto. Tardes apacibles.

Botrro (El) Mastránzos. E. - Axóxiso. Arcadia de entremeses, 1723.

Brujas (Las). E.-Ilureto. Aulos sacramentales, $1675^{\circ}$.

Brujas (Las). Segunda parte. E.-AxóNiмo. Cómico festejo. Tom. II.

Buñuelos (Los). E.-Axósimo. Arcadia de entremeses, 1691,1700 y.1723, y Entremeses varios, núms. 1 y 2.

Burla (La) de la inocencia. E.-Suarez De Deza. Donuires de Tersicore.

Burla (La) de la sortija. E. - Friscisco de Cistro. Cómico festejo. Tom. I.

En el indice de la obra se intitula: $E l$ chasco de la sortija.

Burla (La) de los capones. E. - Aruesto y Custro. Verdores del Parnaso, y ell sus Sainetes y entremeses, 167'.

Burla (La) de los lisiados. E.-Avrosio Abid Velasco. Aleluyas jocosas.

Burla (La) de los títeres fingidos. E.Francisco de Castro. Alegria cúmica. P. III.

Burla (La) de Pantoja y el doctor. E.Moreto. Autos sagramentales, 1673.

Se equiroea Barrera en suponer que este entremes es el mismo que el atribuido á Benavente en la Vavilad y Córpus Cristi con el título: El doctor ys el enfermo.

Caballero (El). E.-Stácez yez Deza. Donaires de Tersicor..

Caballero (EI) bailarin. Ś-Sílıs BIRBaDillo. Coronas de! ! arnaso.

Caballero (El) de $\boldsymbol{W}$ : dina. S.-Axósiro. Moratin dics qle es de D. Ramon de la Cruz.

Caballero (El: je Olmedo. B.-Axósisro. $P$. TII. d. las Comedias de Lope.

Caballero, El) de Siguienza, D. Patricio Lúcas. S. -Axóximo.

C.d: illo en su casa y Dios en la de ivdos. S. - A rósimo.

Callejon (El) de la Plaza mayor. S. - AxóNimo.
Burla (La) del figonero. E.-Fauxcisco ne Cistro. Cómico feslejo. Tom. $I$.

Burla (La) del herrero. E.-A xóvino. Co. mico lestejo. Tom. II.

Burla (La) del labrador. E.-Frivcisco de Cistro. Cómico festejo. Tom. I.

Burla (La) del miserable. E.-Suife7. DE Dez.1. Donaires de Tersicore.

Burla (La) del papel. E. Frixcisco oE Cistro. Alcyria cómica. P. III.

Burla Laj del pozo. E.-P.co B.do QciRos. Obras. 1600 .

Burla (La) del ropero. E. -Friscisco ve Avellavena. Rasgos del ocio.

Burla (La) del sombrero. E.-Frixcisco DE Cistro. Alegria cónica. P. II.

Tambien se ha publicado anonimo.

Burla (La) del talego. E.-Frivisico de Cistro. Alegria cómica. P. I.

Burla (La) del vejete.-V. Duelo (El) del rejete.

Burla (La) más sazonada. E.-Cícer. Autos sacramentales, $167 \%$.

En el indice del tomo se intitula: La burla sazmaila.

Burlador (El) burlado. S. -R IMor de LA Cacr. Tom. I. de su Teatro.

Burlados (Los de Caruestolendas. E.Fansisco de Cistro. Alegriz cómica. P. III.

Burlas (Las) de Isabel. E. - Quñónes de Bersferte. Nacidad y Córpus Cristi, 166 t. $^{\prime}$.

Busca-oficios El). En prosi.-Sicis BarBadillo. Casa del plazer honesto.

El antor llama corredin á esta pieza à pesar de ser un entremes.

Calles (Las) de Madrid. E.-Qcišóxes DE Bexive.rte. Ociosidad entrelenida.

Fornindez-linerra cita un sainete con el mismo título, que principia:

"Doña Clara.-Isubela, tii en el Prado?

El de Benavente dice:

"Ah, craballero.-Es d mi?"

Campanilla (La ). E.-Moreto. Manojilo de entremeses, Entremeses varios, Zaragoza, s. a., y Floresta de entremeses. 1691.

Candil y Garabato. E.-Ivivuo. Arcadia de entremeses. 1691 y 1700 , ell el tomo de Entremeses vurios, núm. $2, y$ Thealro hespañol de Huerta. 
Es el mismo que Los ciegos Candily Garabato, con muclisimas variantes.

Cantarico (El). Sainele cantado y represenlado. - Armesto y Castro. Verdores del Parnaso, y en sus Sainetes $y$ entremeses, 1674.

Capeador (El). Entremes en prosa.-ANóNimo. P.I. Comedias de Lope.

Capeadora (La). Primera y segunda parle. E.-Quiñóses ne Benavente. Jocoseria, y en $L a$ mejor flor de entremeses.

Caperuzas (Las) de Sancho. $\boldsymbol{E}$. - José Síxos. Ya al final de la comedia $L a$ virlud aun entre persas, del mismo autor.

Capitan (El) de Samuel. E.-Axóximo. Entremeses varios, núm. 2.

Caprichoso (El) en su gusto y la dama setentona. E.-Silas Barbadillo. Casa del plazer honesto.

Es una especie de entremes, á pesar de que el autor lollama comedia.

Cárcel (La) de Sevilla. Entremes en prosa y verso.-Axóxiso? P. VII. de las Comedias de Lope.

Se la reimpreso al fin del Tom. $I$. del Ensayo de una bib. esp. por el Sr. Fernindez-Gucrra, quien supone con fundamento que el autor de esta piececita es Migruel de Cervántes.

Careo (El) de los majos. S.-Rswor DE LA Cruz. Tom. VI. de su Tealro.

Carnestolendas (Las). E. - C.r.deros. Rasgos del ocio.

Carreteros (Los). B. E.-Mitos. Manojito de entremeses, Entremeses varios, Zu: agoza, s. a., Floresta de entremeses, y Ramillete de entremeses escogidos.

Casa (La) al reves y los vocablos. B.Qunóxes de Bexiyexte. Ociosidad entrelenida.

Casa (La) de dueñas. S.-Suírez de DezA. Donaires de Tersicore.

Casa (La) de los génios y la dama general. E.-Suirez de Dez.1. Donaires de Tersicore.

Casa (La) de linajes. E.-Axóxiro. Tomo II. del Cómico festejo.

Fcrníndez-Guerra sin duda no ha logrado verlo cuando no copia el principio ni cita la obra donde se encuentra.

Casa (La) de posadas. E. -Frixcisco DE Cistro. Alegría cómica. P. $I$.

En los tonos de Entremeses varios, números 1 y 2 , se encuentra anúnimo.

Casa (La) de vecindad. E.-Seb. dE V1Llavicios.s. Rasgos del ocio.
Fernández-Guerra no trae el principio de este entremes ni dice dúnde se halle, lo que prueba que no ha logrado verlo.

Casa (La) puntual. E. - Francisco DE Castro. Alegria cómica. P. III.

Casado (El) de por fuerza. E.-Anónimo. Arcadia de entremeses, 1723.

Es diverso del de Villaviciosa.

Casado (El) por fuerza. E.-SEB. DE VILLAviciosa. Rasgos del ocio.

No lo menciona Fernández-Guerra.

Casamiento (EI) de la Calle mayor con el Prado viejo. E. C.-Quĩ̃ónes dE BEXaVENTE. Jocoseria.

Casamientos (Los). M.-Suárez de Deza. Donaires de Tersicore.

Casas (Las) de placer. E.-Francisco DE Avellaneda. Rasgos del ocio.

No consta ell el Indice de FernándezGuerra.

Casero (El) burlado. S.-Avóximo.

Ioratin dice que es de D. Ramon de la Cruz.

Caslañera (La). E.-Cistillo Solórzaxo. Avenluras del bachiller Trapaza.

Ile comparado esta piccecita con la de joulal título que se lialla en li Ociosidad entretenida a nombre de Ionteser, y encuentro que es exactamente la misma. Los Sres. Barloral y feluández-Guerra no babian podido verificarh.

Castañeras (Las) picadas. S.-Rıroy DE u Cruz. Tom. VII. de su Tealro.

Castigo (El) de un zeloso. $E$.-Axóvivo. Thealro hespañol de Iuerta.

Alvarez y Baena dice que es de José Julian Lopez de Castro, y Fernández-Guerra se lo altribuye á francisco de Castro.

Cerco (Fl) de las hembras. B.-Moneto. Parnaso nuevo y amenidades del guslo.

Cesto (El) y el sacristan. E.-Francisco de Castri Cómico festejo. Tom. I.

Segun Fornández.Guerra este entremes es en muchos pasajes fiagio del de Quevedo intitulado: Los refriches del viejo zeloso.

Cestos (Los). E. Un Ixĩenio valenciaNo. El enlrelenido, de Micsaleja. P. II.

Fernindez-Guerra lo atribugn á dicho Ioraleja.

Ciego (El) por su provecho. S.-Avbsimo.

Ciegos (Los) apaleados. E. - Axúviło. Arcadia de enlremeses, 1723, y Entremeses varios, núm. 1.

Ciegos (Los) Candil y Garabato. E.Axóvivo. Entremeses varios, númerús 1 y 2. 
Es el mismo que el intitulado: Candil y Garabato; pero tiene considerables variantes. Fernández-Guerra no lo menciona con el primer título, á no ser el que denomina: Los ciegos, y dice se encuentra en el Theatro poélico. 1658.

Cinco (Los) galanes.-V. Guardadme las es paldas.

Civilidades (Las). E.-Quñ̄óses DE BENAVENTR. Jocoseria, y en La mejor for de entremeses.

Cocinero (El) sordo fingido por el interes. S.-Sú́rbz de DezA. Donaires de Tersicore.

Cochero (El) y Monsieur Corneta. S.A Nónimo.

Coches (Los). E.-Quñónes de BenavexTR. P. II. de las Comedias de Tirso, y segun Barrera, en ios Entremeses nuevos de diferentes autores. Zaragoza, 1640.

Cochęs (Los) de Sevilla. E. - A vóviso. Flores del Parnaso.

Cochino (El) de San Anton. E.-Axóxiso. Entremeses varios, núm. 2.

Codicia (La) rompe el saco. E. -Juax DE Tapia y Ballesteros. Entremeses varios, nủms. 1 y 2.

Colmeneruela (La). B.-Axóvisso. Precede a la Primera parte de la Hermosura de Raquel, de Guevara, en la Flor de lqs comedias de España. Quinta parte.

Barrera se lo atribuye á Luis Vílez de Guevara.

Cómo (El). E.-Quros. Ociosidad entretenida.

Comparaciones (Las). $\boldsymbol{E}$.-Lope de Vega? Fieslas al Sacramento, y Tom. XVIII. Obras suelias.

Competencia (La) del portugues y frances. E.-Aryesto I Castro. Verdores del Parnaso, y en sus Saineles y entremeses, 1674 .

Conclusiones (Las). F.-Axóxiso. Theatro hespañol de Huerta.

Fernandez-Guerra i,:i'iua este entre. mes: Conclusiones nrinluras, y lo atribuye á Zamora.

Convidado (El). Relacion jocosa de figuron. - Josk Miopderja. Segunda parle de $E l$ entrritatido.

No la trae rernández-Guerra.

Convidaio (El). E.-Quĩóses de Berlvpyrk. Navidad y Córpus Cristi, 1664.

Co:'uluado (El) de Astúrias. B. E.-SuáIEZ DB DEZA. Donaires de Tersicore.

Cornudos (Los), y Juan de Aprieta. E.Axósimo. Entremeses varios, núm. 1.

El argumento de esta piececilla es el mismo que el de Juan Aprieta; pero la composicion es del todo distinla: por consiguiente, Fernández-Cuerra se equivoca cuando supone que ambos principian por el mismo verso con una pequeña variante, siendo asi que el primero de Los cormudos dice:

"Estar aqui nos tiene mala cuenta,"

y el de Juan Aprieta:

"Sepulcro de cuartillos._-iAh, gallegn!"

Cortacaras (El). E. - Moreto. Parnaso nuevo $y$ amenidades del guslo.

Es el mismo publicado como anónimn en Scuilla, que tengo en un tomn de En. tremeses varios y Loas, impresos la mayor parte por Antonio Sanz, de .Madrid.

Cortejo (El) escarmentado. S. RA roy D LA Cruz. Tom. II. de su Teatro.

Cortejo (El) fastidioso. S.-KAMoN dE LA Cruz. Tom. VIII. de su Tealro.

Cortes de los bailes. B.-Quevedo. Parnaso español, monle en dos cumbres, 1721. Tom. III. de sus Obras.

Cortesano (El). E.-Jer. Cixigr. Tardes apacibles.

Cortesías (Las). E.-Axóxiso. Impreso en Sevilla, por Diego Lnpez do Haro. Se halla en el tomo de Entreme ies v'rios y Loas, impresos la mayor parte por Ant. Sanz, de Madrid, yen el de Entremeses varios, núm. 2 .

Criadlos (Los) astutos y embrollos descubiertos. S.-Axóxiyo.

Criados (Los) y el enfermo. S.-Axóviyo.

Cuatro (Los) galanes. E.-Quĩóxes de Bevivexte. Jocaseria, en La mejor flor de entremeses, y en los Entremeses nuevos de diferenies aulores. Zaragoza, 1640 , segun Barrera.

Cuatro (Los) galanes. E.-Aróxisio. Diverso del de Benavente. Theatro hespañol, de Huerta, y suelto en los Entremeses varios, núms. 1 y 2.

Cuatro naciones, que son: españoles, negros, italianos y mejicanos. Sarao. - Soror Juara Ixes de li Crez. Ya al fin de la comedia Los empeños de una casa, en el Tom. $I I$. de sus Obras.

Cuatro (Los) toreadores. E.-Frasicisco de Castro. Alegria cómica. P. I.

Cuero (El). E.-Quras. Ociosidad entretenida.

No 10 menciona Fernindez-Guerra.

Cuero (El). E.-Axósisto, y diverso del de Quiros. Tomo de Entremeses carios y Loas impresos por Sanz, Entremeses varios, num. 2, donde lleva el título de $\boldsymbol{E l}$ cuero, ó bolero Mastránzos. 
Fernindez-Guerra "lo menciona tambien coil el de El cuero y angelitos, y Gallardo dice que en el Pensil aneno de cntremeses, 1691. se eneuentra uno con solo el t1tulo de El cucro.
Cueva (La) de Salamanca. Entremes en prosa.-Cerváxtes. Comedias y entremeses.

Cuna (La). Entremes en prosa.-Anónimo. P. I. Comedias de Lope.
Chasco (El) de la sortija. E.-V. Burla de la sorlija.

Chasco (El) del sillero. S.--V. Dia (El) de loteria.

Chico (El) y la chica. S.-Axóxiso.

Dice Moratin que es de D. Ramon de la Cinz.

Chillona (La). B. E.-Sebistian Villaviciosi. Tardes apacibles.
Chirimias (Las), ó la ladrona. E.-Anóviso. Entremeses varios, núms. 1 y 2.

Se publicó tambien anónimo con solo el título de La ladruna.

Chirivitas el yesero. S.-Axósimo.

Noratin se lo atribuye á D lamon de la cruz.

Chirlos Mirlos (Los). E.-Francisco dB Castno. Cómico festejo. Tom. I.

Especie de entrenes en elogio de Felipe Y. No está en el Indice de FernándezGuerra.

Descuidese en el rascar. E.-Movresen. Ociosidad entretenida.

Destierro (El) del hoyo. E.-Fraxcisco DE Castro. Cómico feslejo. Tom. $\boldsymbol{I}$.

Feruández-Guerra se equivoca intitulando este entremes El destierro del ocio.

Devocion (La) engañosa. S.-RAMon DE LA Cruz. Tom. II. de su Teatro.

Dia (EI) de compadres. E.-Leov MarChavite. Tom. I. Obras poéticas.

Es el mismo que á nombre de D. José de Figueroa se halla en el Munojilo y en la Floresta de entremeses.

Dia (El) de cumpadres. E.-Josí DE FIgueroa. Masmojito de entremeses, y Floresta de entremeses.

Es el citado átteriormente á nombre de Leon Marchantt.

Dia (El) de lotería. Primera parte.-Chasco del sillero, y Segunda parte del Dia de lotería. S.-Avónimos.

Diablillos (Los). E.-Francisco de CasTro. Alegría cómica. P. III.

Dicha (La) viene cuando no se aguarda. Comedia jocosa en un aclo, óllámesc fin de fiesla. - L. A. J. M.

Moratin le atribuye á D. Luis Monein.

Difunto (El). E. - Asósimo, Arcadia de entremeses, 1691 y 1700 . 
Dime con quién a ndas, direte quién eres. $\boldsymbol{E}$. A Ásimo. Se halla intercalado entre la segunda y tercera jornada de la comedia Al freir de los huevos.

Discreta (La) y la boba. S.-RAMOs DE LA Cruz. Tom. IV. de su Teatro.

Doctor (EI). E. C.-Quĩ̃óxES DE BEMAVENTE. Jocoseria, y en La mejor flor de enlremeses.

Doctor (El) Borrego. E. - A xóxiyo. Entremeses varios, núm. 1.

Doctor (El) Juan Rana. E. C.-Quisóxes DE BeNavente. Jocoseria, y en La mejor for de entremeses.

Doctor (EI) simple. Entremeses en prosa. -Avóximo. P. I. Comedias de Lope.

Doctor (EI) Soleta. E.-A xóximo. Arcadia de entremeses, 1691 y 1700 , Entremeses varios, núm. 1, y Theatro hespanol de Huerta.

Doctor (EI) y el enfermo. E.-Quišónes de Benavente. Nacidad y Córpus Cristi, 166 t.

Fs distinto de La burla de Pantoja y el doctor, de Moreto, à pesar de lo que dice Barrera.

Don Calceta. E.-Axóximo. Thealro hespañol de Huerta.

Don Estanislao. E.-F.co B.do Quiros. Obras. 16 วั6.

Don Gaiféros, con títulos de algunos romances antiguos y modernos. M.Suírez de Deza. Donaires de Tersicore.

Don Gaiféros y las busconas de Madrid. E.-Quisónes De Beyiverte. Navidad y Córpus Cristi , 1664 .

Barrera lo cita tambien con solo el titulo de Don Gaiféros, y dice que se encuentra en los Entromeses de diversos aulores. Alcalá, $16 \dot{4} \mathbf{3}$.

Don Jaime. B.-Axósimo. P. VII. Comedias de Lope.

Donde las dan las toman, los zapateros y el renegado. S.-Asósino.

Moratin dice que es de D. Ramon de la Cruz.

Doña Esquina. E. - Moreto. Parnaso nuevo y amenidades del gusto.

Fernảndez-Guerra ignora que este entremes se haya impreso y que su autor sea Moreto.
Doña Isabel la ladrona, que azotaron y cortaron las orejas en Madrid. J.Quĩónes de Benavente. Jocoseria.

Fernández-Guerra probablernente no ba logrado verla cuando no copia el principio nil dice dónde se encuentra.

Doña Mata. E.-Calderox. Parnaso nuevo y amenidades del gusto.

Doña Parva-materia. $\boldsymbol{E}$. de f.-Fravicisco ne Castro. Alegría cómica. P. III.

Doña Ventosa. E.-Silas Barbadillo. Coronas del Parnaso.

Dormilon (El). E. - Mátos. Rasgos del ocio.

Fernåndez-Guerra ignnra asimismo que este entremes se haya impreso y que su autor sea Mátos Fragoso.

Dos (Las) amigas. $\boldsymbol{E}$.-Castillo Solórzavo. Varios y honestos entrelenimientos.

Desconocido al Sr. Fernández-Guerra.

Dos áspides trae Jacinta. B.-MoNteser. Parnaso nuevo y cmenidades del gusto.

En el Vergel de entremeses se encuentra á nombre de Alonso de olmedo, segun Fer. nández-Guerra.

Dos (Los) habladores. - V. Habladores (Los).

Dos (Las) vinditas. S. - RAyoy DE LA Cruz. Tom. $V$. de su Teatro.

Dragonzillo (El). E.-Cilderox. Flores del Parnaso.

Duca (La). E. -Axóxiso. Entremeses varios, núm. 1.

Duelo (EI) del vejete. E.-Axóxisro. Cómico festejo. Tom. II.

Fernindez-Guerra dice que tambien se conoce con el títilo de l.a burla del vejete

Duende (El). E.-Axóviso. P. II. de las Comedias de Tirso.

Duende (EI) fingido y vejete burlado. $\boldsymbol{E}$. -Art. Abid Yelisco. Aleluyas jocosas.

Dueña (La). E. C.-Quiñóses dE BesiveNTE. Jocoseria, y en La mejor flor de entremeses.

Dueñas (Las). E. C.-Quĩónes de BexiVESTE. Jocoseria, y en La mejor for de entremeses.

Duque (El) de Humena. B. - Axósiro. P. VII. Comedias de Lope.
Ecos (Los). B.-Mosteser. Parnaso nuevo y amenidades del gusto.
Fernández-Guerra no ha visto sin duda tampoco este entremes cuando ignora cómo principia y el nombre de su autor. 
Eleccion (La) de los alcaldes de Daganzo. E.-Cervíntes. Comedias y entremeses.

Elementos (los). B.-Silazar y Tórres. Cílara de Apolo. Tom. I.

Embarazada (La) ridicula. S.-RAmon DE la Cruz. Tom. I. de su Teatro.

Embusteros (Los). E.-Quiros. Parnaso nuevo y amenidades del gusto.

Enamoradizo(El). E.-Quiróxes ne BeNii ENte. Naridad y Córpus Cristi, 1664.

Encantada (La). M.-Suárez de Deza. Donaires de Tersicore.

Al mencionar el Sr. Fernimdez-Guerra esta mojiganga, ni copia el primer verso ni diee donde se halla; lo hisee si cuindo cita despues otra composicion del mismo género, que equivocadanente intituliı $L a$ encontrada.

Endemoniada (La). Entremes en prosa. -Axóvino. P. I. Comedias de Lope.

Endemoniada (La) fingida y chistes de Bacallao. E.-Queveno. Al fin de la III. edicion de las Comedias de Simā Machado.

Enfermo (EI). $E$.-Quñónes de BenivenTE. Ociosidad entretenida.

Enfermo (EI) descomido. $\boldsymbol{E}$.-Axósiso. Theatro hespañol de Huerta.

Fernández-Guerra intitula esta pieza equivocadamente: El cnfermo desconocilo.

Enfermo (El) y junta de médicos. E.francisco de Castro. Alegría cómica. P. I.

Enjuga los aljófares. B.-Diamaste. Parnuso nuevo y amenidades del gusto.

Enmendador (El). E.-Axóximo. Cómico festejo. Tom. II.

Ensayo (El). E.-Axores GlL Exríquez. Ociosidal entretenida.

No sé de dónde ha sacado el Sr. Fernindez-linerra que el titulo de este entremes sea el Ensayo y. diu de comedia, ni que el primer verso diga:

"Señoras, pues á eslas horas,"

siendo así que principia:

"Deja cso con treinta dinblos.»

Entierro (El) de la compañía de Ribera. $S$ - Ramox de la Cruz. Tom. $X$. le su T'eatro.

EnIrada (La) en Madrid de la reina Doña Maria Luisa de Borbolt. S.-Avrovio ne Carnosa. Se imprimió con la comedia Lo mejor es lo mejor, del misno antor.

Entremes para la fiesta de' Todo lo vence el amor.-ANT. DE Ziyora. Flores del Parnuso.
Entremes que hizo el auctor á ruego de una monja parienta suya, evangelista, para representarse, como se representó, en un monasterio de esta cibdad dia de Salı Juan Evangelista.-Sebastian DE Horozco. En su Cancionero que está MS. en la bib. Colombina, é impreso en Sevilia, 1867. 8. ${ }^{\circ}$

Entremes y baile que se representó en el palacio del Buen-Retiro con motivo de la llegada a la corte de Doña María Luisa.-Pérez Montoro. Tom. I. de sus Obras.

El baile se intitula del Abanino. Fernández-Guerra lo cita sin el nombre del autor.

Entremeses (Dos) que cantaron Bernarda Manuela, la Grifona de Zagala y la Escamilla de Zagal.-Armesto y Castro. Verdores del Parnaso.

No se halla en el indice de FernándezGuerra más que el primero, pero no menciona el segundo cuyo primer verso dice:

"No me dirús, Menga hermosa."

Escandarbey. E.-Melgarejo. Entremeses varios, núms. 1 y 2.

Escofieteras (Las). S.--Ramon de la Cruz. Tom. $X$. de su Teatro.

Esdrújulos (Los). B. E.-Suárez ne DEza. Donaires de Tersicore.

Es distiuto del de Monteser.

Esdrújulos (Los). B.-Monteser. Ociosidad entretenida.

Espejo (El). E.-Anónımo. Theatro hespañol de Iluerta; y segun FernándezGuerra, en el Teatro poélico. 1658.

Espejo (El) y burla de Pablillos. E.Axóvimo. Arcadia de entremeses, 1723.

Espejos (Los). E. - Leon Marchante. Tom. $I$. de sus Obras poéticas.

Estafadoras(Las). B.-Quevedo. Parnaso español, monle en dos cumbres, 1724, Tom. III. de sus Obras.

Estafas (Las) en metáfora de flores. B.Suárez de DezA. Donaires de Tersicore.

Estafeta (La). E. - Leon Marciante. Tom. I. de sus Obras poéticas.

Estravagantes (Los). B. - Monteser. Ociosidad entretenida.

Estudiante (El). E.-Avósiyo. P. II. de las Comedias de Tirso.

En los titulitlos de las páginas dice: $E l$ estudirmte que se va da acostar.

Estudiante (El) marques. E.-Francisco de Cistro. Alegria cómica. P. I.

Eufrasia y Tronera.-V. Muerto (El), Eufrasia y Tronera. 
Examinador (El) Miser Palomo. Segunda parle de Miser Palomo y médico de es. píritu. E.-Antonio Hútado de MenDozA. Valencia, 1620-28. 8.
En la edicion de las Obras de Mendoza, Madrid (1728), se reimprimió la Parte primera con solo el Iftulo de Miser Falomo, y ssta es tambien la única que conoció Fernández-Guerra, que cita una impresion de Cddiz, Francisco Juan de Velasco.

Figonero (El). E.-J. B. Dhamaxtв. Rasgos del ocio.

Fernández-Guerra no parece haber visto este entremes, puesto que no copia su primer verso, ni dice quien es su autor, ni cl libro en dónde se halla.

Figuras (Las). M.-Fraxcisco de Castro. Alegría cómica. P. II.

Figuron (El). E.-Francisco de Castro. Alegria cómica. P. III.

Flema (La). E.-Frascisco de Avellane. DA. Rasgos del ocio.

No lia vislo esla piccecita el Sr. Fernández-Guerra cuando no trae su primer verso ni dice dónde se encuentra.

Flores (Las) y el Zurdillo. Jicara entremesada.-Fravcisco Avellaneda. Tardes apacibles.

Forzados (Los) de amor. E.-ARursto I Castro. Verdores del Parnaso, y en sus Sainetes y entremeses, 1674.

Frances (El). E.-CáxCer. Entremeses varios, Zaragoza, s.a., y segun Barrera se balla tambien en la Flor de entremeses, etc., 1676.

Francisco, qué tienes? E.-Frascisco DB C.sstro. Alegría cómica, P. I.

Lo he visto anónimo.

Fregona (La). E.--Mitos. Rasgos del ocio.

Principia este entremes:

"Casildilla, ya estamos en la corle;

se re pues que es el que Fernandez-Guerra trde como anonimo y del cual, segun el mismo, existe segunda parte. Vo lo tengo tambien anonino eu los Autos sacramen. tales, etc., 165.

Frioleras (Las). S.-Rimox dE la Cruz. Tom. III. de su Teatro.
Gabacho (El). E.-Axósimo. P. II. de las Comedias de Tirso.

En los titulillos de las páginas se denomina El gabacho y las lenguas ó lenguas.
Galan (EI) llevado por mal. E.-Mátos. Tardes apacibles.

Galanes (Los). E.--Moneto. Tardes apacibles. 
Galeote (El) mulato. B. E.-Soírez DE DEZA. Donaires de Tersicore.

Galeotes (Los). B.-Quevedo. Parnaso español. monte en dos cumbres, 1724. Tom. III. de sus Obras.

Galeras (Las) de la honra. E.-Moneto. Autos sacramentales, 1675.

Gallego (EI) silletero. E. - Axóximo. Cómico festejo. Tom. II.

Gallos (Los). B.-Quiñóses de BenavenTE. Ociosidad entretenida.

Gangosos (Los). E.-Axóvimo. Arcadia de entremeses, 1691 y 1700.

Estraño que no esté en el indice de Fernimdez-Guerra.

Gansos (Los). S.-Axóximo.

Es distinto del entremes que lleva el mismo título.

Gansos (Los). E.-Axóvino. Arcadia de entremeses, 1691 y 1700 .

Garañon (El). E. - Francisco de Castro. Cómico festejo, Tom. I.

Gargolla. Jácara entremesada. - LEoN Marchante. Tom. I. Obras poéticas.

Gato (El) y la montera. E.-SEb. DE VILLAVICIOSA. Rasgos del ocio, 1661.

Este nismo entremes se encuentra en el Tom. I. de las Obras poélicas de Leon Marclinute como de este autor, y en las Arcadius de entremeses, 1691 y 1700 se publico anunimo. Tengo las cuatro impresiones. Ni Barrera ni Fermindez-Guerra lo mencionan bajo el nombre de Villaviciosa que es, en mi sentir, el verdadero autor.

Girantones (Los). $\boldsymbol{E}$-Fraxcisco de Castro. Alegría cómica. P. II.

Gila y Pascual zagales. Bailete.-Suárez DE DEZi. Donaires de Tersicore.

Gitanos (Los). E.-Cáncer. Autos sacramentales, 1673.

Golosos (Los). E.-V. Perico y Marina.
Gori (El), gori. $\boldsymbol{E}$.-Anónimo. Impreso en Valencia, por Agustin Laborda, s. $a$.

Barrera dice que en la Flor de entremeses, loas y bailes, Zaragoza, 1676, se halla á nombre de Quiñónes de Benavente.

Gorronzillos (Los). E.-Suirez DE DEzA. Donaires de Tersicore.

Guarda corderos, zagala. $\boldsymbol{E}$.-A R mesto $\mathbf{Y}$ Castro. Verdores del Parnaso, y en los Sainetes y entremeses de Armesto y Castro, 1674, segun Barrera.

Guarda (La) cuidadosa. Entremes en prosa.-Cervíntes. Comedias y entremeses. Tom. I. del Tesoro del teatro español por Ochoa, y en el Handbuch de Ludwig Lemeke.

Guardadme las espaldas. $\boldsymbol{E}$-Calnbron. Tardes apacibles, y Axónimo en el tomo de Entremeses varios, núm. 1.

Tambien se ha publicado á nombre de Moreto con el titulo de Los cinco galanes, en la Flor de cutremeses, etc., Zaragoza, 1676.

Guardainfante (El). Primera y segunda parte. $\boldsymbol{E}$. C.-Quiñónes de BeNayente. Jocoseria.

Guitarra(La). E.--Anónimo. Arcadia de entremeses, 1691 y 1700 núms. 1 y 2 , y Theatro hespañol de Huerta.

Gurruminas (Las). E.-ANt. de Zamona. Tom. I. Comedias, 1722, Entremeses varios y Loas, impresos por Sanz, y en el Theatro hespañol de Huerta.

Gurruminos (Los). E.-ZAMORA. Entremeses varios y Loas, impreso por Sanz, y en el Tom. I. de sus Comedias, 1722. Huerta lo reimprimió anónimo en el Theatro hespañol.

Gusto (El) loco. B.-Monteser. Ociosidad entretenida.
Habladores (Los). Entremes en prosa $y$ verso.-Avónimo, en la $\boldsymbol{P}$. VII. de las Comedias de Lope.

Se publico en Sevilla, 1621, y on Cadis, 1646 , con el litulo de Los dos hablatores y á nombre de Niguel de Cervíntes; posteriormente se ha reimpreso con igual titulo en el Tum. X. de las Obras escugidas de este autor, publicadas en Paris por Arrieti, y en el Tom. I. del Tesoro del teatro español.

Hambriento (El). $E$-Móneto. Ailos sacramentales, 1673 .

Diverso de los otros dos del mismo título.
Hambriento (El). E.-ANónimo. Entremeses varios, núm. 2.

Distinto de los de Moreto y Villaviciosa.

Hambriento (El). E.-Seb. de Villayic10sa. Tardes apacibles.

Diverso del anónimo y del de Moreto.

Hechicera (La). E.-Lope de Vega? Fiestas al Sacramento, y Tom. XVIII. Obras sueltas.

IIcchizo (El) de los cueros. E.-Francisco de Castro. Cómico festejo. Tom. I.

Hermosura y discrecion. B.-Salazar $Y$ Tónnes. Cilara de Apolo. Tom. I. 
Herrero (El) de viejo. B.-JoAN de ZabaLETA. Ociosidad entretenida.

Fernández-Guerra no menciona este entremes con el presente titulo, que es el que lleva en su encabezamiento; pero sí con el de Hierro viejo como equivocadamente se cita en el Indice de la Ociosidad entrelenida.

Hidalga (La) E.-Moyteser. Entremeses varios, Zaragoza, s. a., y en el Laurel de entremeses, segun FernándezGuerra.

Fs el mismo que el intitulado La hidal. guia, de este autor.

Hidalgo (El) de Olias. E.-Joan ZabaleTA. Rasgos del ocio.

Fernández-Guerra no ha debido ver este entremes, aunque dice se halla en una Floresta de 1680 , cuando no menciona el nombre de su autor ni copia el principio

Hidalguía (I.a). E.-Moyteser. Manojito de entremeses, y Floresta de entremeses.

El mismo con el título de La hidalga se balla en los Entremeses varios, Zaragaza, s. $a$.

Hierro (El) viejo. B.-V. Herrero (El) de viejo.

Hija (La) del doctor. $\boldsymbol{E}$.-José de FigeERod. Manojito de entremeses, y Floresta de entremeses.

Hijito (E1) de vecino. S. -R Iyos DE IA Cruz. Tom. $X$. de su Teatro.

Hijo (EI) del zapatero y estudiante salmanquino. E.-Asósino. Arcadia de entremeses, 1723, y tomo de Entremeses varios, núm. 1.

Impulsos (Los) del placer. S. -RAyoy DE u Cruz. Tom. V. de su Teatro.

India (La). - Risios de L.l Croz, Tomo VIII. de su Teatro.

Indiano (EI). Entremes en prosa.-Axósiso. P. I. Comedias de Lope.

Infanta (La) Palancona. Entremes en forma de comedia con primera, segunda $y$ tercera parte (son jornudas).-Axónuo. Al fin de las Comedias de Simaō Macbado.

Fernindez-Gucrra dice que es de Quevedo, que se iniprimió en Madrid, por Bernardinn de Gu:mum, 1625. 4..$^{\circ}$ que despues se publicó en $8 .^{\circ}$ con el de la endemonia. da fingida, y que se encuentra cul los Entremeses nuevos. Zaragoza, 1640 , con el titulo de La infanta Palancona. Enlremes
Hijos (Los) de la paz. S.-RAmor DE LA Cruz. Tom. V. de su Teatro.

Hilo (El) de Plándes. B.-PEdro FrayCisco Lasisi. Ociosidad entretenida.

Gallardo in intitula Los hilos de Flóndes, y dice está en un tomo de Enbremeses sin portada.

Hombre (El) mujer. $E$.-Axósimo. Cómico festejo, Tom. II.

Hombre (El) solo. E.-Axósimo. Entremeses varios, núms. 1 y 2.

Fernández-Guerra sin duda nı ha con. seguido ver este entremes, cuandn no cita el verso primern ni indica si está impreso o donde se encuentra.

Hombre (El) solo á la moda. S.-Avósiмo. Manuserito.

Hombres (Los) con juicio. S.-RAMON DE la Cruz. Tom. II. de su Teatro.

Hombres (Los) solos. S.-RAMON DE LA Croz. Tom. VIII. de su Teatro.

Hospital (El) de los podridos. Entremes en prosa y versn.-Axósimo. P. VII. Comedias de Lope.

Fernández-Guerra cita una pdicion de Cádiz, por Francisco Juan de Velasco, $\mathrm{y}$ ademas lo reimprimió al fin del Tom. I. del Ensayn de unn bib. esp. de Gallardn, donde da las razones que tiene para atribuir esta composicion dramática à Viguel de Cerrintes.

Huevos (Los). E.-Axósino. P. III. Coincdias de Lope.

Huyendo de Scila dió en Caríbdis. E.Joś Sirtos. Ya al fin de la comedia La virtud aun entre persas.

grarioso eserito en disparates ridiculos, y atribuido á Fèlix Persio liertiso.

Informe (El) sin forma. E. - Axóxiso. Theatro hespañol de Huerta.

Alvarez y Baena, y Ferníndez-Guerra, dicen que es de Julian López de Castro.

Ingles (EI) bablador. E.-Fraxclsco DE Cistro. Aleyría cómica. P. I.

Instrumentos (Los). E. - Cildnerox. Tardes apacibles.

Introduccion, zarulula. baile of fin de fiesta al Sarao de los Planetas.-Jeriósho lensivoez de Cistro y Bocisgel. Elisio Peruano.

In li encuentro en el hidice de Fernin. dez-Guerra. 
Invencibles (Los) hechos de D. Quijote de la Mancha, E.-Kraveiseo DE Avita, natural de Madrid, P. VIII. de las Comedias de Lope, y en los Verdores del Parnaso salió anónimo y se dellomina mojiganga.

Jácara que cantó en la compañia de Bartolomé Romero, Francisca Paula.-QuiNónes de Besaveste. Jocoseria, y en La mejor flor de entremeses.

Es la que Fernảndez-Guerra intitula: $L a$ jacara que perlis, que es el verso por que principia.

Jácara que se cantó en la compañía de Olmedo.-Quĩóxes de Bexilvente. Jocoseria, y en La mejor flor de entremeses.

Es la que Ferníndez-Guerra pone en Entendainoms, señores, que es su primer verso.

Jácara que se cantó en la compañia de Ortegon.-Quĩóses de Besiveste. Jocoseria.

Es la que intitula Fernández-Guerra: Sin saber si la contamos, primer verso de ella.

Jácaras (Dos) que se cantaron en la compañia de Bartolomé Romero.-QulSóses de Bexaveste. Jocoseria.

io las menciona Fernindez-Giterra. La una principia: “Viéntras se viste una niña," y la otra:

"Qué tanta jácara quicres."

Jeringa (La). E.-Melgarejo, en el tomo de Entremeses varios, núm. 1.

Fernández-Guerra no menciona el nombre del antor ni cita el primer verso; tallupoco dice donde se hilla, prucbis evidentes de que no ha logrado verlo.

Jóven (El) Pedro de Guzman. Scena unipersunal.-Jose Cuxcma.

Juan de Aprieta, y chasco de la carta.
Ir á ver pártir la vieja. M. - Francisco DR Castro. Alegría cómica. P. I.

Ir por lana y volver trasquilado. $\boldsymbol{E}$. F. ${ }^{c}{ }^{\circ}$ B. ${ }^{d o}$ Quiros. Obras. 1656.

E.-Avóximo. Theatro hespañol de Huerta.

Es el misino argumento que el de Los cormudos y Juan Aprieta; pero la composicion es diversa.

Juan Rana. Entremes ó Loa.-Francisco DE Arellaneda. Floresta de entremeses, 1691, y Manojito de entremeses.

Por el titnliilo que llevan arriba las páginas en la Floresia, y por el mismo contenido, de la pieza, parece que sea más bien Loa que Entremes; y efectivamente Loct se intitula, segrun Barrera, en los Risggos del ocio. Segundin parte. 1664, donde se atribuye á Moreto.

Juan Rana, comilon. E. -Axóximo. Arcadia de entremeses, 1691 y 1700.

Júdas (El) por fuerza. E.-ANt. A bad VeLAsco, en sus Aleluyas jocosas.

Juego (EI) de trueos. B.-Fr.iva. GonzíLE7. DE Bústos. Ociosidart entretenida.

Juego (El) del ajedrez. M.-Suárez DE DEZA. Donaires de Tersicore.

Juego (El) del hombre. $\boldsymbol{E}$.-Quñónes DE Benavente. Navidad y Córpus Cristi. 1664 , y segun Barrera en los Entremeses nuevos de diferentes autores. Zaragoza, 1640.

Juego (El) del hombre. B. - Juav V'élez DE GUEvara. Tardes apacibles.

Segun Barrera se encuentra en la Flor de entremeses. Zaragoza, 1676 , á nombre de b. Pedro Frane. Lanini.

Juego (EI) del hombre. B.-Silizar Y Tórres. Citara de Apolo, Tom. I.

Juez (El) de los divorcios. Eucremes en prosa.-Cervintes. Comedir" y entremeses.

Labradores (Los) y soldados castellanos, con un baile al uso de Cataluña. Entremeses en que hai varios personajes que hablan el catalan.-Axóximo. Se imprimió á continuaciou de la comedia intitulada: La entrada del marques de los Vélez en Cataluña, 1641.

No encuentro el tituln de este entremes en el indice de Fernúndez-fiuerra.

Ladrona (La). E.-Axósimo. En el tomo 
de Entremeses varios y Loas, impreso por Sanz.

El mismu entremes se publicó con el 11 . tulo de Las chirimias o la ladrona, y lo tengo en los tomos de Entremeses, nuineros 1 y 2.

Ladrones (Los) engañados. Entremes en prosa.-Asóximo. P.I. Comedias de Lope.

Ladrones (Los), y Moro Hueco y la pariJa. E.-Quĩ̃ónes de Bevaventr. Navidad y Córpus Cristi, 1664.

Lámina (La). E.-Axóniro. Cómico festejo. Tom. II.

Lanturulu. B.-Asóvimo. Arcadia de enmeses, 1691 y 1700 .

Leganitos. B.-Axósimo. Va al principio de La enemiga facorable, de Tárrega en la Flor de las comedias de España. Quinta parte, y no en la Parte III. de Comedias de Lope y olros como dice Fernảndez-Guerra.

Lenguas (Las). E.-Cíncer. Manojito de entremeses y Floresta de entremeses.

El mismo, á nombre de Calđeron, Entremeses varios, Zaragoza, s. a.; FermindezGuerra supone que existe Mis. en la biblinteca del duque de isuma otro entremes con el mismo título, anuque distinto en su! contenido, que atribuye dubitativamente a Calderon.

Letrado (EI). E.-Lope? Fiestas al Santísimo Sacramento, y Tom. XVIII. de sus Obras sueltas, Madrid, Sanclia.

Letrado (El) de amor. B.-Monteser. Ociosidad entretenida.

Con igual título mencinna Barrera olro de Francisco Binegasi y I.ujan.

Libro (El) de, qué quieres? E.-Ciscer. Aulos sacramentales, 1673 .

Barrora solo le da el título de gyué quie. res, boca?

Licenciado (El) y el bachiller. E. C.-

\section{M}

Maestio (EI) de escuelas. Entremes en prosa.-Se halla al fin de la comedia El hijo obediente, de Beneito, de quien será con toda probabilidad.

Fernández-Guerra se equivoca en decir que el título es: El maestro de escuela y que estia piececita se halla en la $P$. II. de l'oetas valencianos, pues está en la I.

Mago (El). E. C.-Quĩónes de BexavexTE. Jocoseria.
QuiNónes de Bevauknte. Jocoseria, y en La mejor flor de entremeses.

Es singular que el Sr. Fernández-Suerra no cite sil primer verso ni diga dónde se encuentra.

Linajudos (Los). E.-Aróxımo. Arcadia de entremeses, 1723, y tomo de Entremeses varios y Loas, impresos por Sanz.

Lo que es Madrid. E.-Fraxcisco DE. Avellased. Tardes apacibles.

Lo que pasa en el rio de Madrid en et mes de julio. M.-Suarez de Deza. Donaires de Tersicore.

Lo que puede la intercesion. B.-AxósMo. Arcadia de entremeses, $1691 \mathrm{y}$ 1700.

Lo que son mujeres. E.-Frarcisco DE Cistro. Cómico festejo. Tam. I.

Locas (Las) caseras. E. - A Lovso DE OLyedo. Flores del Parnaso, y anónimo en el tomo de Entremeses varios, núniero 2.

Loco (El). E.-Juax Vélez. Rasgos del ocio.

Sin duda no lo ha visto el Sr. FernandezGuerra cuando no copia el primer verso ni cila el libro donde se encuentra.

Loco (El) de amor. B.-Movteser. Ociosidad entretenida.

Esic es el litulo que lleva en el Indice de la Ociusidud ontrelenida; al principio de èl, solo dice Baile para Francisco Pon. ce, y empieza:

$$
\text { "Eslo no liene remedio." }
$$

Locos (Los). E. - Monteser. Ociosidad cnlretenida.

Locos (Los). E. -Axósiyo. Cómico festejo. Tom. II.

Locos (Los) de Scrilla. S. -Axóxiyo.

Locos (Los) de Toledo. B. - Axóviso. Precede à El loco cuerdo, de Valdivielso, ell la Flor de las comedias de España. Quinta parte.

Maja (La) majarla. S.-Rishox de Li Cacz. Tom. III. de sll Tiatro.

Malcasado (El). E.- Scinez de DezA. Donaires de Tersicore.

Malcontenta (La). E.-Axóxiyo. P. II. de las Comedias de Tirso.

Malcontento (El). E.-Fincisco Bervirno Qciros. Se halla á continuacion de la conedia El cerco de Tayarete, del nismo autor. P. X.XIVIII. C.A. 
No lo cita el Sr. Fernández-Guerra.

Manolo. Tragedia para reir, o sainete para llorar.-Rayos de la Cruz. Tomo IV. de su Teatro, y en el $V$. del Tesoro del teatro español.

Tengo una segunda parte imipresa suelta en $\hat{1}^{\circ} \mathrm{y}$ el litulo es El Vanolo. Saincte ó tragedia burlesca. No dice quien es su autor.

Manos (Las) negras. S.-Monteser. Parnaso nuevo y amenidades del gusto.

Manos (Las) y cuajáres. E. C.-Quiñóxes DE Bevavente. Jocoseria, y en $L a$ mejor flor de entremeses.

Manta (La) E.-Fraxcisco de Quiros. Ociosidad entretenida.

Lo tengo tambien anónimo con algunas variantes, en los Entreineses varios. n. ${ }^{\circ}$, y suelto impreso en Sevilla, Vicolas Váz: quez, s. a. Con las mismas variantes y titulo de La manta $o$ el Bolique Girapliega, y tambien anónimo, lo incluyó tinterta en sil thealro hespañol. Segnu Bilrera salió á nombre de Benavente en la Flor de entremeses, loas y baites. Zaragoza, 1676.

Manzana (La). M.-Miestro Leov (MinCIIITTE). Manojito de entremeses, Entremeses varios, Zaragoza, s. a. y Floresta de entremeses.

En la bib. del duque de osmua existe Ms. esta mojiganga con el mismo título $\mathrm{y}$ a nombre de llonteser.

Maricones (Los) galanteados. E.-Anuesto y Castro. Verdores del Parnaso, y en sus Sainetes y entremeses, 1674, segun Barrera.

Marido (El) flemático. E.-Qutĩóves DE Beriverce. Nacidad y Córpus Cristi, 1664 .

Marido (El) hasta el infierno. E. -F. ${ }^{c o}$ B. do Qcinos. Obras. 1630 b.

Maridos (Los) conformes. E.-EL coNDE DE ReBOlledo, en sus Obras.

Maridos (Los) engañados y desengañados. S.-Rimox de la Groz. Tom. II. de su Teatro.

Marigüela. B. E.-Juan Vélez de Guevan. Tardes apacibles.

Fernández-Guerra lo intitula: Maricuela.

Mariones (Los). E.-Quñóses de BexaVExte. Navidad y Córpus Cristi, 1664.

Mariquita (La). E. - Moneto, tomo de Entremeses varios, Zaragoza, s. a., en el de Entremeses varios, núm. 1, y segun Barrera en la Flor de entremeses. 1676 .

Marques (EI) de Alfarache. E.-Lope? Fiestas al Sacramento, y Tom. XVIII. Obras suellas.
Martinillo. B.-Axóviso. Se halla al fin de una edicion antigua que tengo del Catalan Serrallonga.

No lo menciona el Sr. Fernández-Guerra.

Martinillo (El). Primera y segunda parte. E. C.- Quiñónes de Benatunte. Jocoseria.

Matachines (Los). E.-Axóximo. Tomos de Entremeses varios, núms. 1 y 2.

Matachines para la zarzuela de Hacer cuenta sin la huéspeda.-A Nóxiso.

Matemático (El). S.-Suárez de Deza. Donaires de Tersicore.

Maulero (El). B.- Monteser. Parnaso nuevo y amenidades del gusto.

Maya (La). B.-Axóvimo. Precede á $\boldsymbol{L a}$ guarda cuidadosa, de Miguel Sánchez, en la Flor de las comedias de España. Quinta parte.

Maya (La). E.-Quñónes de Brnavente. Jocoseria, y en La mejor flor de entremeses.

Médico (El) de amor. B.-Frixcisco DE Avellaneda. Ociosidad entretenida.

Médico (EI) del tabaco. $\boldsymbol{F}$. - No lleva nombre de autor ; pero se halla impreso á continuacion del Capitan Belisario, de Lope, en una edicion antigua que poseo.

Médico (El) sordo y el recino gangoso. E. - Tórres Y Villarroel. Tomo de Entremeses varios, núm. 2, y Axósimo en el Thealro hespañol de Huerta.

Médicos (Los) de la moda. E.-Axónimo. Theatro hespañol de Huerta.

Alvarez y Baena atribuye este entremes á José Julian Lupez de Castro, y Fernindez-Guerra con el título de Los méllicos á la mola se lo adjudica á Francisco de Castro.

Melindrosa (La), E.-Quixónes de BenaVEYTE. Entremeses varios, Zaragoza, s. a., y Ociosidad entretenida.

Melisendra. Entremes con Loa.-AxósIso. P. I. Comedias de Lope.

Melonar (El) y la respondona. E.-Axóviso. Tomo de Entremeses varios, número 2.

Ferníndez-Guerra le da tambien el titulo de Melones y respondona, ó el melonar, refriéndose á un MS. de la bib. del duque de usuna.

Melones y respondona, ó el melonar. $\boldsymbol{E}$. -V. Melonar (El) y la Respondona.

Mellado (El). J.-Cildenos. Ociosidad entretenida.

Mellado (El). Baile en jácara.-Mítos. Tardes apacibles. 
Mellado (El). B. E.-Moneto. Tardes apacibles.

Menga y Bras. B. E. Jer. Cívcer. Tardes apacibles.

Mentiras de cazadores y toreadores. $\boldsymbol{E}$. -F.co B. ${ }^{d 0}$ Quiros. Obras. 1656.

Mesonerica (La). B.-Asósımo. P. VIII. de Lope de Yega.

Mico (EI). E.-Axósimo. Entremeses varios, núm. 2.

Milazro (El). E.-Suírez de Deza. Donaires de Tersicore.

Miser Palomo. E. Primera y segunda parte.-V. Examinador (El) Miser Palomo.

Miserable (EI) y el dotor. B.-Quĩóxes DE Bevavente. Autos sacramentales, 1675.

Mochuelo (El). E.-Axóximo. Flores del Parnaso, Arcadia de entremeses, 1723, y tomo de Entremeses varios, núm. 2.

Fernández-Guerra lo intitula Pleito del Mochuclo, segun un MS. de la biblioteca del duque de osuna.

Mojiganga de fiestas, y fiesta de mojigangas.-TORRe Y SEvil. Intercalada entre la segunda y tcrcera jornada de la comedia Azucena de Etiopia.

Mojiganga que se hizo para fiesta de S. N. la reina por críados suyos.Suírez de Deza. Donaires de Tersicore.

Fernández-Guerra pone por tltulo á esta pieza

"Señor Otoñe que es su primer verso.

Mojiganga de personajes de títulos de comedias por estilo nuevo.-Sú́rEz DE Deza. Donaires de Tersicore.

Fernández-Guerra le da por título Personajes de titulos de comedias.

Moịiganga para fin de fiesta à la comedia de Al freir de los huevos.-Arósiм0. Se encuentra al final de dicha comedia.

Molinero (El). E-Axósisso. Tomo de Entremeses rarios, nums. 1 y 2 , y en el Thealro hespañol de Huerta.

Morcilla (La). E.-Axósino. Tomo de Entremeses varios, num. 2.

Morena de Manzanáres. B. - ViltaticioSA. Parnaso nuero y amenidades del gusto.

Moriscos (Los). B.-Axóximo. Precede á la II. Parle de La hermosura de Raquel, de Guevara, en la Flor de las comedias de España. Quinta parle.
Barrera se lo atribuye á dicho Luis vẻlez de Guevara.

Mortero (El) y chistes del sacristan. $\boldsymbol{E}$.Fraxcisco de Ávila. P. VIII. de I.ope.

Mozas (Las) de la galera. $\boldsymbol{B}$. $\boldsymbol{E}$.-Suirez DE DEZA. Donaires de Tersicore.

Mozas (Las) de la galera. E.-Jony Diaz DE LA FUENTE. Tardes apacibles.

En el índice de este tomo, sc llama al autor Juan Dlaz de la Calle.

Mucho te quiero, Marica. B.-PE.̃a RoJA. Ociosidad entrelenida.

Mudo (El). B.-Moxteser. Ociosidad enIretenida.

Muela (La). E.-Axóxiso. Theatro hespoñol de Huerta, y segun Fernández.Guerra en la Floresta de entremeses, 1680.

En la bib. del duque de osuna existe MS. otro entremes tambien anönimo que lleva el mismo título annque es diverso del impreso.

Muerte (La). M.-Calderor, Flores del Parnoso.

Muerte (La). E. C.-Qcišónes de BexaVESTE. Jocoseria, y en $L a$ mejor flor de entremeses.

Fernindez-liuerra ni cita el priner verso de este entremes, ni dice düde se encuen. tra.

Muerte (La) de Bigotillos. E.-Axóxмo. Tomo de Entremeses varios, número 2.

Fernínlez-Cuncra lo trae como de un ingenio de la Corte.

Muerto (El), Eufrasia y Tronera, $E$. Quiros. Parnaso nueio y amenidades del gusto.

Muerto (EI) vivo y el viro muerto, y entrambos burlados. $E$. - Arósino. $A r-$ cadia de entremeses, 1733 .

Mucrtos (Los) viros. E.-Quñoves IIE Bexivexte. Jocoseria, y cu $L a$ mojor flor de entremeses. - suprimicndo lo que cantan los músicos al fin. ýa nombre de IIoreto, se reinurinió en los Verdores del Parnaso, de Armesto. Barrera dice que tambien se encuentra con el nombre de Benarente. en la Flor de entremescs, loas y bailes. Zarano:a, 1676, y en los Verdores del Parnaso. Pamplona. 1697.

Muestra (La) de los carros del Córpus cn Madrid. E.-Iope? Fieslas del Sacramento, YTom. IVIII. de las Obras sueltas.

En el Indice de entremeses de 1. Aure. 
liano Fernández-Guerra, que trae Barrera, dice que en un cuaderno de entremeses MSS. se encuentra á nombre de Quiñones de Benavente.

Mundi novo (El). E.-Frascisco de CasTro. Cómico festejo, Tom. I.

Mundi nuevo (El). M. - Suárez de Deza. Donaires de Tersícore.
Fernández-Guerra lo intitula equivocadamente Mundi-novo.

Muñuelo (El). Tragedia por mal nombre. $S$. Ramon de la Cruz. Tom. $\boldsymbol{X}$. de su Teatro.

Murnuurador (El). E.-Quiñónes DE BEnaventb. Jocoseria, y en $L a$ mejor flor de entremeses.
Taciones (Las). E.-Axóximo. Arcadia de entremeses, 1691 y 1700 .

Es de I. Franc. Ant. de Monteser, como lo comprueba un ys. de la bib. del duque de osuna.

Nadadores (Los). B.-Queredo. Parnaso español, monte en dos cumbres. 1724, Tom. III. de sus Obras.

Negra (La). M.-Axóxino. Flores del Parnaso.

Negra (La) lectora. E.-Axóxino. Arcadia de entremeses, 1723.

Negrito (El) hablador, y sin color anda la niña. E.-Qciñóses de Bexivente. Navidad y Córpus Cristi, 1664.

Es cl mismo que el que se publicó con el título de El negro en la II. Perte de las Comedias de Tirso como si fuera de este autor.

Negro (EI). E.-Axóxisio. P. II. de las Comedias de Tirso.

Es el mismo que más tarde se publico en la Navidal y Córpus Cristi con el litulo de El negrito hablador, y sin color anda la miña, atribuido á Quiñones de Benavente.

Negros (Los). B. E.-Fraxcisco de AveLLANED.. Tardes apacibles.

Negros (Los). Introduccion y entremes. - Francisco de Cistro. Alegría cómica. P. III.

Negros (Los) de santo Tomé. Entremes en prosa.-Axósmo. P. I. Comedias de Lope.

Nigromántico (El). E. - A xóxisı. Arcadia de entremeses, 1691, $1700 \mathrm{y}$ 1723.

Niña (La) hermosa. B.-Alosso ne (UIEDo. Manojito de entremeses, Entremeses varios, Zaragoza, s. a. y Floresta de entremeses.

Niñas (Las) de la maestra. E.-Axige Peregliso. La mijor guirnalda de Apolo. Tom. I.

Niño (El) caballero. E.-Axt. de Sous.
Tomo de sus Comedias y en las Partes XIII. y XLVIII. C. A.

Los personajes que flguran en este entremes, son los mismos aclores que representaron en 1658 la comedia Triunfos de amor y fortuna.

Niño (El) de la Rollona. E.-Fancisco de Avellaneda. Manojito de entremeses, Entremeses varios, Zaragoza, s. a. Floresla de entremeses, y en el tomo de Entremescs varios, núm. 1.

Niño (El) y la mujer que acomoda amas. M. - Suárez de Deza. Donaires de Tersicore.

Niños (Los) de la inclusa. E.-Francisco de Castro. Alegría cómica. P. II.

No habia reparado. $\boldsymbol{E}$ - $-\boldsymbol{A}$ vóvimo: Tomo de Entremeses varios, núm. 2.

No hai rato mejor que el de la plaza Mayor. S.-A vóximo.

No hai tiempo que no se llegue, ni deuda que no se pague. E.-Axóxisio. Va intercalado entre la primera y segunda jornada de la comedia Al freir de los huevos, y segun Fernảndez-Guerra en el Ameno jardin de comedias.

Noche (La) buena. E. - Francisco dR C.astro. Alegría cómica. P. I.

Noche de S. Juan.-V. Alcolea y noche de S. Juan.

Noches (Las) de invierno, y perdone el enfermo. $\boldsymbol{E}$.-Fancisco de AyellaneDA. Rasgos del ocio.

Ferníndez-Guerra sin duda no lo ha vis. to euando no copia el primer verso ni dice dónde se halla.

Novelero (El). S.-A xóvivo.

Novia (La) burlada. $E$. de f.-Francisco de Cistro. Alegria cómica. P. III.

Novio (El) de la aldeana. E.-Axóximo. Arcadia de entremeses, 1723.

Tovio (El) miserable. E.-Francisco DE Cistro. Alegria cómica. P. I.

Novio (El) y el sueño del carnero. E.- 
Francisco Jerósimo de Tórres. Tomo de Entremeses varios, núms. 1 y 2.

Novios (Los). E.-Sú́rez de DeZA. Donaires de Tersicore.
Novios (Los) espantados. S.-RAyoN DE la Cruz. Tom. V. de su Teatro.

Lo tengo tambien anunimo.
Oficios (Los). B. E.-Moneto. Tardes apacibles.

Olvidos. Relacion.-José Moraleja. P. II. de $E$ l entrelenido.

Oposicion (La) á cortejo. S.-RAmox de ua Cruz. Tom. I. de su Tealro.

Lo he tenido anonimo.

Orfeo. B.-Cívcer. V. Fábula de Orfeo.

Órgano (El) y el mágico. Primera y segunda parte. $-E$. Frascisco de CasTRO. Alegria cómica. P. III.

Organos (Los). E.-Lope? Fieslas al Sacramenio, y Tom. XVIII. Obras suellas.

Barrera dice que este entremes es de Quiñónes de Benavente, aunque se atribuye á Lope. ¿Lo confundirá con el de Los organos y sacristanes que positivamente es de aquel?

Padrazo (El) y las hijazas. E.-SílAs Barbadillo. Coronas del Parnaso.

Padre (El) engañado. Entremes en prosa $y$ verso.- Axósiso. P. I. Comedias de Lope.

Padrino (El) y el pretendiente. $S$. $-R_{A-}$ MON DE LA CRCZ. Tom. VIII. de su Teatro.

Paga (La) del mundo. E. C.-Qcis̄ónes DE Benaveste. Jocoseria y en La mejor flor de entremeses.

Pagar que le descalabren. E.-Frtxcisco de Castro. Cómico feslejo. Tom. I.

Pajarillo (El). Entremes cantado y representado.-Aryesto y Castro. Verdores del Parnaso, y en sus Saineles y entremeses, 1674 .

Pájaros (Los). B. - Jacisto Malvexda. Parnaso nuevo y amenidades del gusto.

Pajes (Los) golosos. E.-Leos MarchaxTE. Tom. I. Obras poéticas.

Fs el mismo que con una pequeña va. riacion en el final, se publico despues como anunimo, y lo tengo en un tomo de Entremeses varios y loas, impresos por Sanz, y en el Thealro hespañol de Huerta.
Órganos (Los) y sacristanes $E .-Q u$ cı̃óves de Beyayeste. Verdores del Parnaso, de Armesto, y Barrera dice que tambien está en la Flor de entremeses, loas y bailes. Zaragoza, 1676, y en los Verdores del Parnaso, Pamplona, 1697. Osos (Los). E.-Axóvimo. Arcadia de entremeses, 1723.

Otros hai más locos que no nosotros. $E$. ó S.-Fraxicisco Sivitos. Gigantones de Madrid.

Io lo trae Fernández-Guerra.

Oye usted? E.-Aryesto y Castro. Verdores del Parnaso.

Segun Parrera en la pdicion de los Sainetes y entremeses de Armesto y Castro, de 167'i, el título es: Oye usted? qué dice rusted?

Segun Fernández-Guerra tambien está en la Floresta de entremeses, 1680.

Pan y Siringa. E.-Aruesto y Cistno. Verdores del Parnaso, y en sus Sainetes $y$ entremeses, 1674, segun Barrera.

Para-todas (El). E. - Scirez de Deza. Donaires de Tersicore.

Paracumbé. Baile a lo porıgues. - Axósiro. Flores del Parnaso.

Pásate acá, compadre. B. - A vóxino. Parte VIII. de Lope.

Paseo (El) del tio. F. de f.-Fraxcisco DE Cistro. Alegría cómica. P. III.

Pastelería (La) y burla de las cazuelas. E.-Francisco ne Cistro. Cómico festejo. Tom. I.

Patas (Las) de vaca. E.-Qciñóres de Besaveste. Parnaso nuevo y amenidades del gusto.

Lo he visto anonlimo.

Payos (Los) hechizados, Juanito y Juanita. S.-Axóxiyo.

yoratin lo atribuge a P. Ramon de la cruz. 
Pedidora (La). E. - Cai.deron. Tardes apacibles.

Es el mismo que á nombre de D. Jerónimo de Cáncer se balla en los Enlremeses varios. Zaragoza, s. a.

Pedro de Brea. B.-Axónisio. Precede á la Tragedia de los siele infantes de Lara, de Hurtado Velarde, en la Flor de las comedias de España. Quinla parle.

Pedro Grullo y Autor Pintado. E. AxóNiso. Cómico festejo. Tom. II.

Pedro Hernández y el corregidor. Entremes en prosa.-Axósino. P. I. Comedias dc Lope.

Pelicano y Raton. E.-Cáncer. Manojito de entremeses y Floresta de entremeses.

El mismo, con el nombre de Calderon, en los Entremeses varios. Zaragoza, s. a.

Perdone la enferma. $\boldsymbol{E}$.-José Moraleja. Segunda parte del Entretenido.

Perendeca (La). E. - Moneto. Tardes apacibles.

Perico el empedrador, ó los ciegos hipócritas y embusteros. S.-Axóviyo.

Perico y Marina, por otro título, Los golosos. E.-A xóxuno. Tomo de Entremeses varios, núm. 2.

Periquillo, non durmas. B. - Quiros. Parnaso nuevo y amenidades del gusto.

Perlático (El) fingiuo. S. - Axóxisio.

Persiano (El) fingido. $\boldsymbol{E}$. - Ariesto I Cistro. Verdores del Parnaso, y en sus Sainetes y entremeses, 1674.

Personajes de titulos de comedias. $\boldsymbol{M}$.Suíaz de Deza. Donaires de Tersicore.

Pésame (El) á la duquesa. E.-Axóvimo. Arcadia de entremeses, 1723.

Pésame (El) de la viuda. M.-Calderox. Parnaso nuevo y amenidades del gusto, y Floresta de entremeses. Madrid, 1680.

Pésame (El) de Medrano. E.-Fraxcisco bE Cistro. Alegria cómica, $\boldsymbol{P}$. $\boldsymbol{I}$.

Petimetra (La). E. - Asóxiso. Tomo de Enlremeses varios y Loas.

Fernandez-Guerra lo atribuye á un Ingenis alegre.

Petimetre (El). S.-Rayox ne ha Cruz. Tom. III. de su Tealro.

Pintas (Las). B.-Axóximo. Arcadia de entrcmeses, 1691.

To lo encuentro en el Indice del Sr. Fernández-ruerra.

Pintor (El). B. E.-Sú́rez de Deza. Donaires de Tersicore.

Planetas (Los). E. C.-Quiñóxes DE BENivexte. Jocoseria y cu La mejor flor de entremeses.
Platero (El) de amor. $\boldsymbol{B} . \boldsymbol{E} .-$ SoÁREz DR DEzA. Donaires de Tersicore.

Plazuela (La) de Sta. Cruz. E.-CaldeRON. Rasgos del ocio.

Fernández-Guerra lo cita como manuscrito.

Pleito (El) del borrico. $\boldsymbol{E}$. - Anónimo. Tomo de Entremeses varios, núm. 2.

Pleito (El) del gallego. E.-ANónımo. Entremeses varios, núm. 2.

Pleito (El) del mochuelo. E.-V. Mochuelo $(\boldsymbol{E} l)$.

Plemática (La). J.-Quiñónes dE BenavENTE. Ociosidad enlrelenida.

No Ia menciona Fernández-Guerra.

Pobres (Los) con mujer rica, ó el picapedrero. S.-Rayon de la Cruz. Tom. II. de su Teatro.

Poeta (El). Entremes en prosa y verso.Lope? Fiestas al Sacramento, y $\mathrm{To}_{0}$ mo XVIII. Obras suellas.

Poeta (El). E.-Axóximo. Theatro hespanol de Huerta.

Es distinto del de Lope.

Poeta (El) remendon. E.-F.co.B.do QuInos. Obras. 1636.

Poeta (El) y los matachines. E. - SuÁrez DE DEzA. Donaires de Tersicore.

Por engañar engañarse, y el hostelero burlado. E.-José Coxcna. Va entre el primero y segundo aeto de su comedia El más heróico español; y al fin del melodrama Falme y Selime; solo que alıí se llama sainete y va anónimo.

Porfiada (La) sangría y diserecion de un barbero. $\boldsymbol{E}$ - - in INGenio de Segovia. Tomo de Enlremeses varios, núm. 1.

Portugues (El). E.-Cíxcer. Autos sacramentales, etc., 16ว̆5. Tambien se encuentra en los Aulos sacramentales y al Nacimiento, 1673 ; pero con la denominacion de Mojiganga.

Prado (El) de Madrid y baile de la Capona. E.-Sílas Barbadillo. Coronas del Parnaso.

Pragmática (La) de amor. S.-Antonio dE Cardona. Se imprimió con la comedia Lo mejor es lo mejor, del mismo autor.

Presente (El) del romano boloñes. $\boldsymbol{E}$. A vónino. Arcadia de entremeses, 1723.

Presumida (La) burlada. S.-RAmos DB u Cruz. Tom. I. de su Teatro.

Pretendida (La). E.-JuAN VÉlez DE GueVArA. Tardes apacibles.

Pruebas (Las) de un easado. S.-Josí Coxen . Entre el segundo y tercer acto lle sul comedia $E l$ más heróico español. 
Puente (La) segoviana. Primera y segunda parle. E. C. - QUIÑOSBS DE BENAVENTE. Jocoseria.

Pulga (La) y la chispa, B. - Leon Marcmante. Tom. I. de sus Obras poélicas.

Putos (Los). E.-Cáncer. Ociosidad entrelenida.

Q

¿Qué quieres boca? B.-Cíxcer. V. Libro (El) de, qué quieres boca?

Quero (Ei). E.-Juas Vélez. Ociosidad entrelenida.

Quién masca ahi? E. -Fraxcisco de CAsTRo. Alegría cómica. P. II.

Quijada y el alcalde. E.-Axósimo. Arcadia de entremeses, 1723.
Por el primer verso que copla el Sr. Fernández-Guerra en su Indice, se ve que este entremes es el mismo que dice se halla MS. en la bib. del duque de Osuna á nombre de $\mathrm{D}$. Juan de Castro; por lo tanto se equivoca en darlos como dos diferentes piezas con iguales títulos.
Rábanos (Los) y la fiesta de toros. $E$.Fraxcisco de Avellaveda. Manojito de entremeses y Floresta de entremeses.

Refugio (EI) de los poetas. $\boldsymbol{E}$. - Leor Marchaste..Tom. I. de sus Obras poélicas, y en el Parnaso nuevo y amenidades del gusto.

Registros (Los). E.-Monteser. Parnaso nuevo $y$ amenidades del gusto.

Rei (El) Don Rodrigo y la Cava. M.-MoReto. Entremeses varios, Zaragoza, s. a., y Aulos sacramenlales, etc. 16030 . En esta última obra se llama baile entremesado.

Relacion, afirmando que hai amor.-José Moraleza. Segunda parle de El eritrelenido.

Relacion, alabando las escelencias de la espada.--Josi Moraleja. Segunda parte de $E l$ enirelenido.

Relaciones. Hai ocho jocosas y siete amorosas en la Primera parie de $\boldsymbol{E} \boldsymbol{l}$ entretenido, de Sánchez Tórtoles.

Relaciones. Se encuentran trea sin título especial en la Segunda parte de $\boldsymbol{E}$ l entretenido, por Moraleja.

Relaciones. Hai tres de D. Árger PereGRINo, en La mejor guirnalda de Apolo, Tom. I.

Relaciones burlescas representables, sacadas de varias comedias.-AvT. ABAD Velisco. Aleluyas jocosas.
Químicos (Los) fingidos. $\boldsymbol{E}$. - JUAY $D B$ Tapia ₹ Ballestéros. Tomo de Entremeses varios, núm. 1.

Fernández-Guerra no ha tenido sin dnda ocasion de ver este entremes cuando no copia el verso por que principia.
Reliquia (La). $E$.-MaLo de Mousi. $E$ ntremeses varios. Zaragoza, s. a., Floresta de entremeses, 1691, y tomo de Entremeses varios, núm. 2.

Es el mismo que con el nombre de.Voreto tengo tambien en los rer"lores slel Par. naso, de Armeslo, que segun Fernindez. Guerra se halla en el Teatro poélicu, licis, yque dice Barrera se encuentra en la Flor de entremeses, 1676 , y en el Ramillele de entremeses. Pamplona, 1700. Lo he visto suelto anónimo.

Reloj (El) y genios en la venta. E.-C.ALDERO.. Tardes apacibles.

Remediador (El). E.-LOPE? Fieslas al Sacramento y Tom. XVIII, Obras sueltas.

Este mismo entremes lo encuentro como de Quiñónes de Benavente en su Jocoseria.

Renediador (El). Entremes cantado.QCIŚÓNes DE BEXivexte, en su Jocoseria, y segun Barrera en los Entremeses de diversos aulores, Alcalá, 10013.

Este entremes se halla en las Ficstas al Sanlisimo Sacramenlo atribuido á Lope.

Renegada (La) de Vallẻcas. E.-AxóxiMo. Flores del Parnaso.

Reo (El). E.-Cíxicer. Rasgos del ocio.

Fernández-Guerra no debe haberlo visto cuando no copia su principio, ni uos da el nombre del auter, ni lice dónde se en. cuentra. 
Retablo (El) de las maravillas. Entremes en prosa.-Cervántes. Comedias y entremeses.

Retablo (El) de las maravillas. E.-QuiNónes DE Benavente. Jocoseria, y en La mejor for de entremeses.

Distinto del de Cervántes.

Reto (El). E.-Francisco de Castro. Alegria cómica. P. I.

Retrato (El) de Juan Rana. Representacion graciosa.-ANT. DE Solis. Tomo de sus Poesias.

Es una especic de sainete ó entremes.

Retrato (El) de Juan Rana. E.-SEB. DE Villaviciosa. Tardes apacibles.

Es distinto del de Solis.

Retrato (El) vivo. E.-Mовето. Rasgos del ocio.

Reverencias (Las). E.-Mítos Fragoso. Tardes apacibles.

Reverso (El) del sarao. S.-RAyon DE LA Cruz. Tom. VII. de su Tealro.

Rico (El) y el pobre. B.-Míros. Rasgos del ocio.

Es baile, y no entremes como dice Fer. nández-Guerra.
Ridículos (Los) enamorados. E.-ANóNIм0. Arcadia de entremeses, 1723.

Robo (EI) de Elena. E.-Lopr? Fiestas al Sacramento, y Tom. XVIII. Obras sueltas.

Romances (Los). E.-Avósimo. P. III. de las Comedias de Lope y otros aulores.

Ronda (La). M.-SuÁrez DE Deza. Donaires de Tersicore.

Ronda (La) de amor. B.-Francisco DE Avellaneda. Ociosidad entretenida.

Ronda (La) de palacio. S.-Antonio DE Cardona. Se imprimió con la comedia Lo mejor es lo mejor, del mismo autor.

Ropero (El) alquilon. M.-Francisco DE Castao. Alegría cómica. P. III.

Rubilla (La). B. E.-Francisco DE AveLlaNe DA. Tardes apacibles.

Rueda (La) y los buñuelos. E. - Joax Francisco de Tejera. Flores del Parnaso.

Rueda (La) y los cobielos. Segunda parte. E.-A nóviso. Cómico festejo. Tom. II.

Rufian (EI) viudo, llamado Trampágos. E.-Cervántes. Comedias y entremeses.
Sacadora. (La). E.-P. F. Lanini. Ociosidad entretenida.

Sacadoras (Las). B.-Queveno. Parnaso español, monte en dos cumbres. 1724, Tom. III. de sus Obras.

Sacamuelas (El). B. E.-Seb. DE VILlaviciosa. Tardes apacibles.

Sacas (Las). M. - A xóviso. Flores del Parnaso.

Sacristan (EI) Berengeno. E.-Akmesto r Cistro. Verdores del Parnaso. Barrera lo llama El sacrisian Berenjo, y dice que está en los Saineles y estremeses de Castro, 1674.

Sacristan (EI) Bonami. E.-Armesto Y Castro. Verdores del Parnaso, ell sus Saineles y entremeses, $1674, y$ lo tengo tambien anónimo en el tomo de Entremeses varios, núm. 2.

Sacristan (El) Cojete. E.-Avósimo. Entremeses varios, núm. 2.

Sacristan (El) Chinchilla. E.-Alosso de Olyevo. Flores del Parnaso.

No sẻ de dónde ha sacado el Sr. Fernández-Guerra que el titulo de este entre- mes es El sacrislan Chinchilla, y lirra tirra.

Sacristan (El) Chinela. E.-SвB. DE VILLAviciosa. Turdes apacibles.

Sacristan (El) encantado. E.-Frascisco JERóNimo DB TórRes, en el tomo de Entremeses varios, núm. 2.

Sacristan (EI) hechicero. E.-ANónimo. Tomos de Entremeses varios, números 1 y 2.

Fernández-Guerra dice que está en la Floresta de enlremeses, 1680 . Los dos ejemplares que tengo son de una edicion hecha en Sevilla, por Manuel Nicolus Vázquez, s. $a$.

Sacristan (El) niño. E.-Axónımo. Cómico feslejo. Tom. II.

Sacristan (El) Soguijo. E. - A Nónımo. P. III. Comedias de Lope y otros aulores.

Sacristan (El) y viejo ahorcados. E.QuiÑónbs DB Brnavente. Navidad $y$ Córpus Cristi, 1664.

Sacristanes (Los). Entremes para la fiesta en el aulo de La viña.-MIR.I DE AMES- 
CVA. Aulos sacramentales, 1630 , y Aulos sacramentales y al Nacimienlo, 1675.

Sacristanes (Los) burlados. E.-Moвrto. Parnaso nuevo y amenidades del gusto.

Sacristanes (Los) burlados. E.-Qoix̃oNBS dB BeNavente. Navidad y Córpus Cristi, 1664.

Es diverso del de Moreto $\mathrm{g}$ del de Quiros.

Sacristanes (Los) burlados. E.-F. ${ }^{c 0}$ B. do Quiros. Obras, 1656, y en el tomo de Entremeses varios, núm. 2.

Es diverso del de Quiñónes y Moreto.

Sacristaues (Los) Cosquillas y Talegote. E.-Quñónbs de BeNayente. Navidad y Corpus Cristi, 1664.

Sainete en forma de danza á los felices sucesos de Felipe V.-A Á́ximo.

No lo encuentro citado por FernándezGuerra.

Sainete para la zarzuela de Hacer cuentä sin la huéspeda. - Axóviyo. Ya unido con el entremes para la misma zarzuela intitulado: Los valientes de la Ampa, Zaragoza, 1704.

No está en el Indice de Fernảndez-Guerra.

Sainete que se ejecutará en forma de danza á los felices sucesos de nuestro gran monarca D. Felipe V.-dxóxiyo. Impreso suelto.

No lo cita Fernández-Guerra.

Sainetes. Hai dos de Soror Joaxi Ixes DR LA CRUZ intercalados entre las jornadas de su comedia Los empeños de una casa. Se intitulan: Sainete primero de palacio y Sainete segundo.

Sainete de Solss. Hai uno para la comedia de Pico y Canenie en el tomo de sus Poesias.

Salta en banco. E. y S.-ANT. DB Solis. Comedias 1681 , y en las PP. XIII. y XLVII. C. A.

Sarao (El). S.-Rayon de la Croz. Tomo VII. de su Teatro.

Sargento (El) Ganchillos. E. - Fravcisco DB Avellaneda. Parnaso nuevo y amenidades del gusto.

Sastre (El). E.-Juas Vélgz. Ociosidad entretenida.

Sentencias (Las). E.-Axóxiyo. Entremeses varios, núm. 2.

Señorías (Las) de moda. S.-RAyos DB la Cruz. Tom. I. de su Teatro.

Señorito (El) enamorado. S.-Axóvimo. Si (El). E. - Cíncrq. Aulos sacramentales, etc. 16 วัว.

Fernández-Guerra da este entremes como MS. Y no conoció el noubre de su autor.
Si el abad juega á los naipes, zno harán lo mismo los frailes? B.-Axt. ABAD Velasco en sus Aleluyas jocosas.

Fernández-Guerra no trae exacto el tilulo de esta piececita.

Sies (Los) del mayordomo D. Ciriteca. S.-Axóvimo.

Sitios (Los) de recreacion del rei. M.Calderon. Tardes apacibles.

Soldadillo (El). E.-LOPB? En las Fiestas al Sacramento y en el Tom. XFIII. de sus Obras suellas.

Lo tengo suelto anonimo de dos edicio. nes de Sevilla, la una de José Padrino (En. tremeses varins, núm. 1), y la otra de Manuel Nicolas Vdzquez, (Enlremeses varios, num. 2), ambas $s$. $a$.

Soldado (El). E. C.-QCIX̃óNes DE BEXAVENTE. Jocoseria.

Se publicó sin rombre de autor en los Entremeses varios, Zaragoza, s. a.

Soliloquio, preguntando si se debe ó no amar.-Jose Moraleja. Segunda parle de $E l$ entrelenido.

Sombra (La). E.-Axósimo. Tomo de $\boldsymbol{E}$ ntremesesvarios, núm. 2. Es el que principia:

"Benito, amigo.-

Qué hai, compadre amigo?"

Sombrerito(EI). S.-RAyox de LA Crez. Tom. III. de su Teatro.

Sones (Los). B.-SEe. DE Villaviciosa. Rasgos del ocio y Tardes apacibles.

Sopista (El) Cubilete, mágico. S.-AxóNiYo.

Sopones (Los) de Salamanca. B.-QCEVEDo. Parnaso español, monte en dos cumbres. 1724, en el Tomo III. de sus Obras.

Sorda (La). E. - Sвb. Dв Villaviciosa. Parnaso nuevo y amenidades del gusto.

Sordas (Las) vocingleras. E.-Axóviyo. Arcadia de entremeses, 1723.

Sordo y el letrado, y pleito del cebadal. E.-Axósiso. Tomo de Entremeses varios, núm. 2.

Sordo (El), y Periquii'n el de Madrid. E.-Cixcer. Aulos sacramentales, 165 J̆.

No lo menciona el sr. Fernández-Guerra.

Sotillo (El) de Manzanáres. B.-AxóxiMo. Precede á la comedia de Grajáles El baslardo de Ceula, en la Flor de las comedias de España. Quinta parte.

Sueño (El). S.-RıyoN dB la Croz. Tomo XVIII. de su Tealro.

Superfluidades (Las). S.-RAMOX DB LA Croz. Tom. I. de su Tealro. 
Tabaco (El). B.-Francisco dr AvrllaNEDA. Ociosidad entretenida.

Tabaquería (La) y las pazes. E.-Suínez DE DE7A. Donaires de Tersieore.

Tajadas (Las). E.-Axónimo. Manojilo de entremeses y Floresta de entremeses.

Talego (El). Primera y segunda parle. E. C. -Quiñones de Benavente. Jocoseria.

La segunda parte se imprimió tambien en La mejor flor de enlvemeses.

Talego (El) niño. E.-QUıX̃ónes DE BENavente. Jocoseria y en La mejor flor de entremeses.

Tembleque. E. - A Nónimo. Entremeses varíos, núm. 2.

Tertulias (Las) de Madrid. S.-Ramon de la Cruz. Tom. VIII. de su Tealro.

Testimonios (́Los). E.-Quĩ̃ónes DE BENATENTE. Rasgos del ocio.

Fernández-Guerra cita uno de Cáncer con el nismo título, que dice se halla en el Laurel at entremeses; pero como no copia el primer verso, ignoro si será el de Benavente. Barrera supone que el de Cáncer se halla tambien en el Ramillete de sainetes escogidos. Zaragoza, 1672.

Tia (La). E.-Morteskr. Entremeses varios, Zaragoza, s. a. y Tomo de $\boldsymbol{E}$ tremeses sin portada, citado por $\mathrm{Ga}$ llardo.

Tiempo (El). E. C.-Quĩónes or Benavente. Jocoseria y ell $L a$ mejor for de entremeses.

Titanes (Los). $M$. - Francisco de Castro. Alegría cómica. P. III.

No es entremes como supone FernándezGuerra.

Títeres (Los). S.-SuÁrez de DezA. Donaires de Tersicore.

Torda (La). E.-Anonimo. Tomo de $E n-$ tremeses varios, num. 1.

Fernández-Guerra lo intitula equivocadamente La Torela.

Un retrato de la señora infanta Margarita. B.-Sú́rez DB DF7.A. Donaires de Tersicore.

No consta en el Indice de FcrnándezGuerra.
Toreador (El). E.-Calderon. Tardes apacibles.

Torcador (El) D. Babilés. E. F. ${ }^{c o}$ B. do Quinos. Obras. 1656.

Segun Fernández-Guerra se imprimió tambien en Cádiz, por Francisco Juan de Velasco.

Toros (Los). B.-A Nónimo. Aulos sacramentales, 167 .

Trajes (Los). B.-Juay Vílezz de GubvaRA. Tardes apacibles, y Laurel de entremeses, segun Fernảndez-Guerra.

Tramposo (El). S.-Avónimo.

Tranca (La). E-José de Figurboa. Manojito de entremeses, Entremeses varios, $Z$ aragoza, s. a. Floresta de entremeses, y tomo de Entremeses varios, num. 2.

Lo be visto anónimo.

Treinta (Los) reales y la casaca. S.A vónimo. Se balla al fin de la comedia El rencor mas inhumano de un pecho aleve y lirano.

Atribuida por Moratin á José Concha.

Trepado (El). E.-MÁtos. Tardes apactbles.

Tribu. al (El) con uñas. E. - Avónımo. Entremeses varios, núm. 2.

Triunfo (EI) del interes. S.-RAMON DE la Cruz. Tom. IX. de su Tealro.

Trovas burlescas de un paso de la comedia: No hai amor como fingir; de otro ce la de $E l$ desden con el desden, y de otro de la de Lorenso me llamo.--ANToNio Abad Velasco. Aleluyas jocosas.

Trullo. Añadido. $\boldsymbol{E}$-A Aónimo. Tomos de Entremeses varios, núms. 1 y 2.

Turrada. E.-Quiñónes DE Benaventr. Jocoseria y en La mejor flor de entremeses.

Reimprimióse con alguna variacion al fin y con el título de El zeloso turrada en la Navidad y Córpus Cristi, 1664.

Triunfo (El) de los coches. Entremes en prosa.-Barrionuevo. P. VIII. de Lope.

Universidad (La) de amor. B.-Anónimo. Arcadia de enlremeses, 1691 y $1700, y$ Theatro hespañol de Huerta. 
Valentonas (Las) y destreza. B.-QueveDo. Parnaso español, monte en dos cumbres, 1724, Tom. III. de sus Obras.

Valiente (El). E.-SÁxchez Tórtoles. El entrecenido, Primera parle, edicion de 1701 : en la de 1729 dice Barrera que el entremes que contiene se intilula: Las Gurruminas.

Valientes (Los) de la Ampa, y fanfarron de la Europa. Entremeses para la zarzuela de Hacer cuenla sin la Huéspeda. Va unido á un sainete para la misma zarzuela.-Axósimo. Zaragoza, 1704.

Valientes (Los) encamisados. E.-FrisCISCO DE la Calle. Ociosidad entretenida, y segun Barrera en el Ramillete de saineles, Zaragoza, 1672.

Valientes y Tamayonas. B. -Quevedo. Parnaso español, monle en dos cumbres. 1724.

Fernández-Guerra lo intitula: Valentones $y$ Tomajones, y dice se halla en el Tom. III. de las Obras de Quevedo.

Vejete (El) enamorado. E.-Fraxcisco de Castro. Alegría cómica, P. II., y en la Areadia de entremeses, 1793.

Hai muchas variantes entre los dos. Tambien ha salido anónimo.

Vendederas (Las) en la puerta del Rastro. E.-Aryesto y Castro. Verdores del Parnaso y ell sus Sainetes y entremeses, 1674.

Venta (La). E.-Ax́́xiso. P. II. de las Comedias de Tirso.

Como de Quevedo lo publicó su sobrino en Las tres musas ultimas castellanas. 1670.

Ventas (Las) del Puerto. E.-P. FR. MIGOEL DE Moliya. Fol. 99 rta. de los Elogios de Maria, por Luis de Paracuéllos.

No habla de él Fernández-Guerra.

Verdad (La). E. C.-Quĩ̄ónes de Bexa-
VE.TtE. Jocoseria, y en La mejor for de entremeses.

Viejo (El) zeloso. Entremeses en prosa.Cervistes. Comedias y entremeses.

Visiones (Las). E. - Axóvimo. Aulos sacramentales, elc., $165 \%$.

No lo menciona Fernández-Guerra.

Visiones (Las). E. - Bixces Caxdayo. Tom. II de sus Obras cómicas, y en las Flores del Parnaso.

Parece una parndia del anonimo que con igual título se halla en el tomo de Autos sacramentales, etc., 1655.

Visita (La) de duelo. S.-RAmoy DE LA Croz. Tom. VIII. de su Teatro.

Visita (La) de la cárcel. E. C.-Quriónes DE Benavente. Jocoseria.

Fernández-Guerra dice equivocadamen. te que el título es Visita de carcel.

Visita (La) de los locos. Sainete primero y segundo.-Axóximos. En Vencer á Marle $\sin M a r i e$. Son los dos que cita Fernández-Guerra en su Índice con este títnlo.

Puede que el autor de estos sainetes sea el P. Pedro Fomperosa y Quintana á quien atribuye Fajardo el Vencer ds Marte.

Yisita (La) y pleito de la liebre. $E$. Frascisco de Castro. Alegria cómica. P. I.

Fernández-Guerra intitula equirocadamente La vista y pleilo de la liebre.

Yisitas (Las). E.-Seb. de Vhlaviciosa. Tardes apacibles.

Fiuda (La) hipócrita. S.-RAyor DE LA Crez. Tom. VII. de su Teatro.

Viudas (Las). E.-Axósiro. P. II. de las Comedias de Tirso.

Viudos (Los) al uso. E. -F.co B.do QciROs, Obras. 16 ŏ 6.

Vizcaino (El) fingido. Entremes en prosa. - Cervántes. Comedias y entremeses.
Yo lo vi. E.-Cíxcer. Manojito de entremeses y Floresta de eniremeses.
Yo me muero, y no sé cómo. B. -Jự V'é1.87. Parnaso nuevo y amenidades del guslo.

Toм. 1. 
Zagal (El) agradecido. E.-Armesto X Castro. Verdores del Parnaso y en sus Sainetes $y$ entremeses, 1674, segun Barrera.

Zalıorí (El). E.-Avósimo. Tomo de $\boldsymbol{E}_{n-}$ tremes varios, núm. 1.

Este cutremes es de D. Francisco Benegyilsi y Lujan, y se halla, segun Barrera, 'Il el tomo de sus Obras métricas. Madrid, 1714.

Zahori (El). B.-Axóvıno. Arcadia de entremeses, 1691 y 1700 .

Fernández-Cinerra no ha dibido verlo cuando no cita el primer verso. Es distinto del entremes de Benegasi que lleva el mismo título.

Zamalandrana (La) bermana. B.-Moneto. Parnaso nuevo y amenidades del gusto.

Zaparrastrones (Los). B. - Bena Vente. Parnaso nuevo y amenidades del gusio.

Zapatero (El). E.-Fernando de ZiRate. Rasgos del ocio.

No esta en cl İndice de Fernández-Gucrra. Zapatero (EI) sordo. E.-Axósimo. En el tomo de Entremeses varios y Loas.

Zeloso (El) Turrada. E.-V. Turrada. 


\section{NÚMER0 DE PIEZAS}

\section{DE QUE CONSTA EL INDICE DE ESTA SEGUNDA DIVISION.}

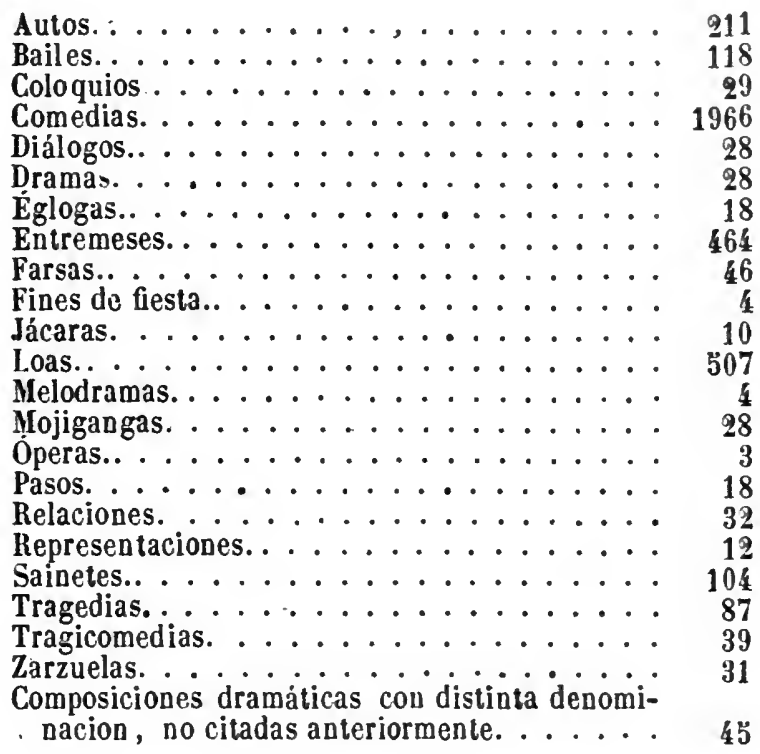

Este breve resúmen de la segunda division de la Seccion Dramitica, patentiza la riqueza del Teatro español, y el distinguido lugar que ocupa en mi Biblioteca.

El número de piezas asciende aproximadamente ả tres mil ochocientas treinta. 
230911

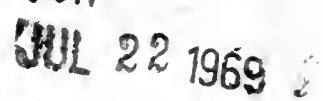


(4) 


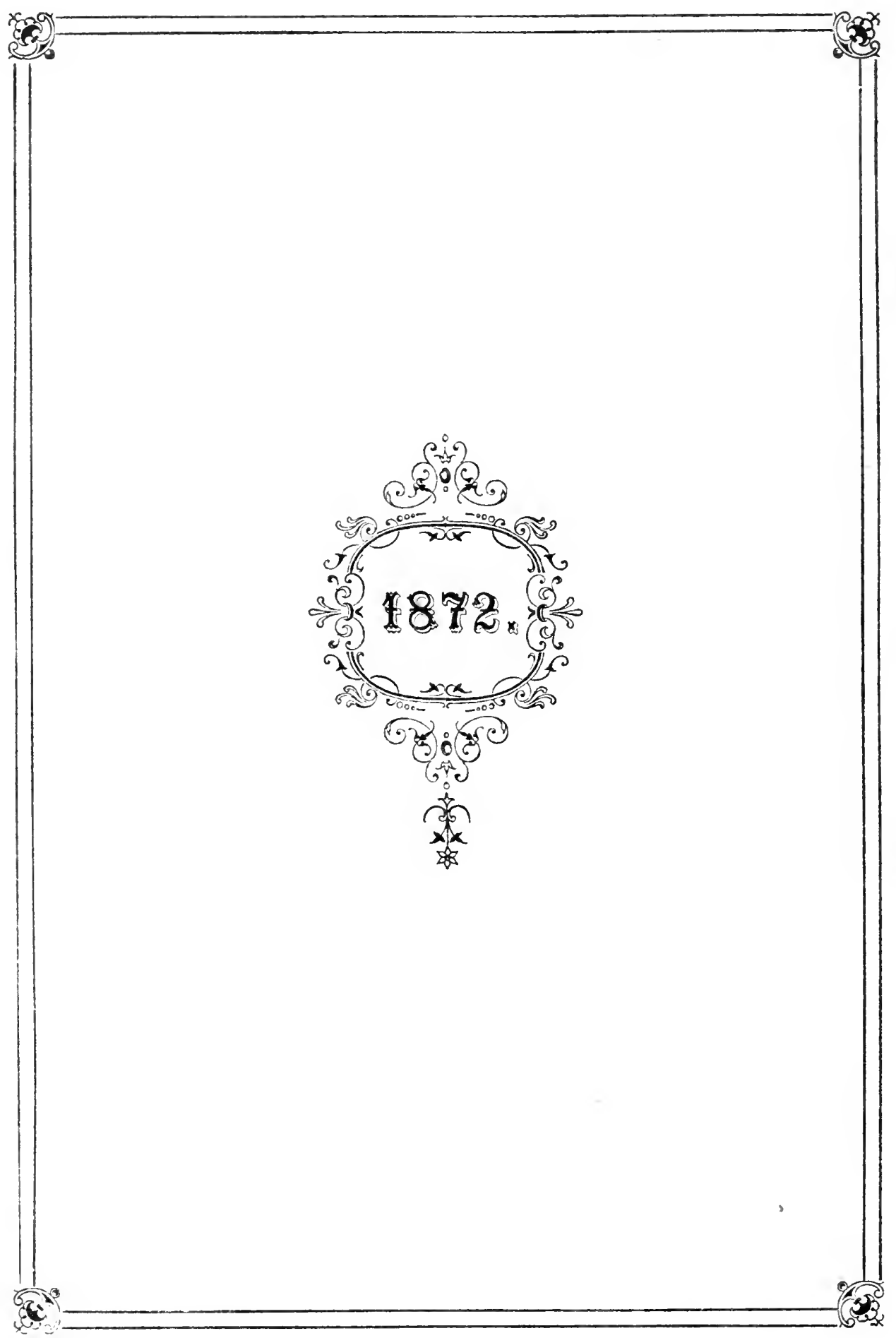



Z

997

53

$\mathrm{v} \cdot 1$

c.2
Vicente, S. P.

Catalogo de la biblioteca de Salva

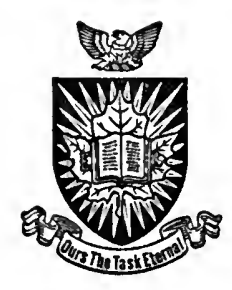

CARLETON

UNIVERSITY

LIBRARY

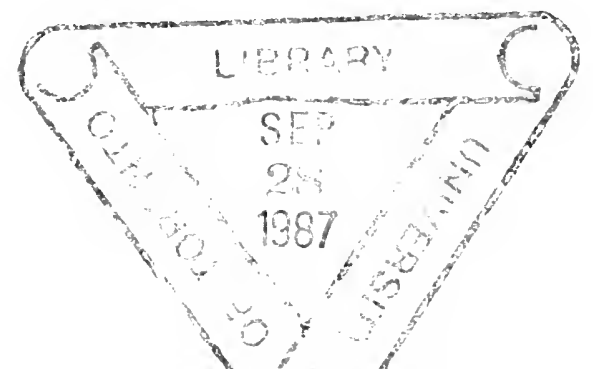




.


